\title{
National Water Summary 1990-91 Hydrologic Events and Stream Water Quality
}

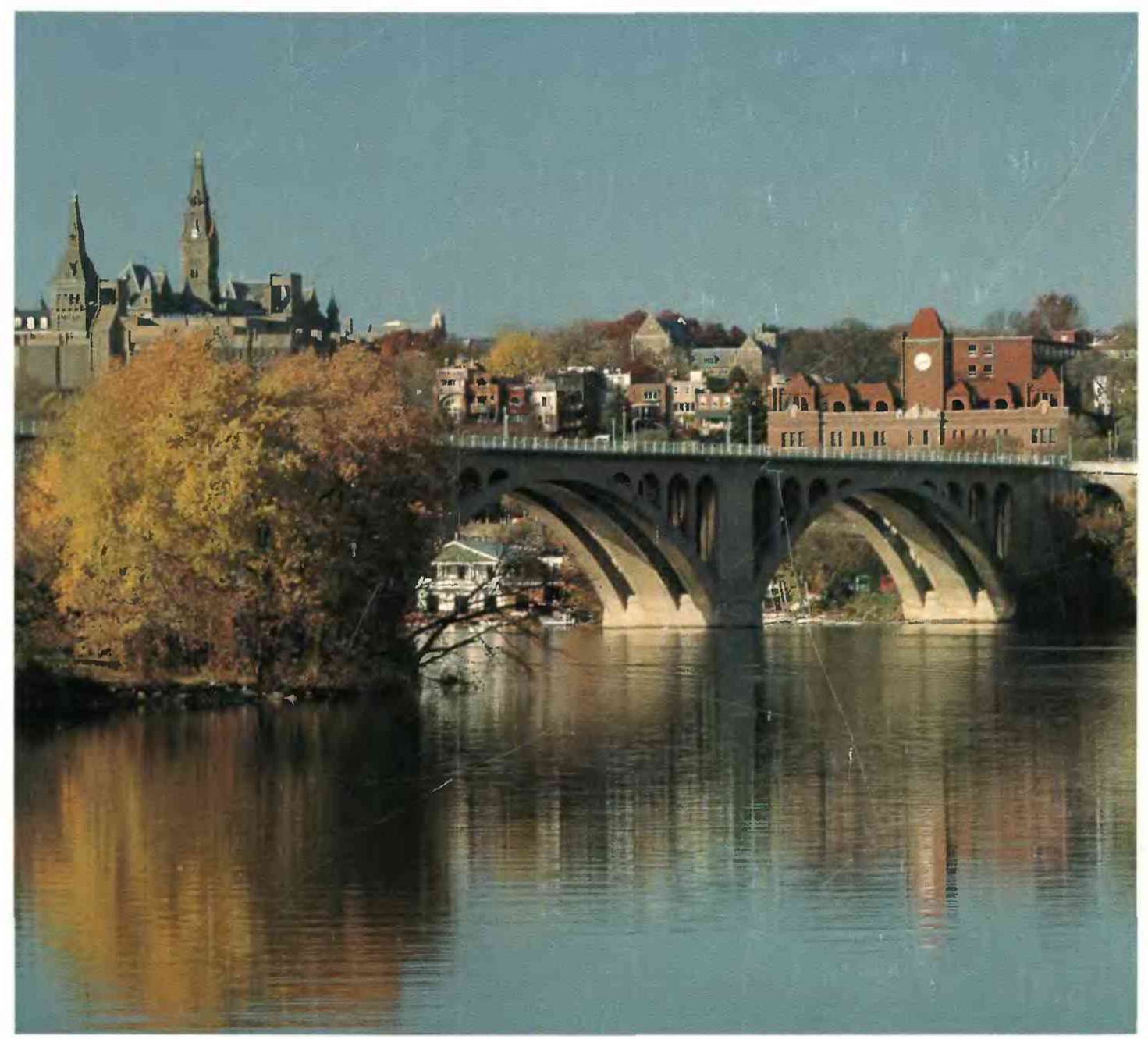

United States Geological Survey Water-Supply Paper 2400 


\section{NATIONAL WATER SUMMARY -}

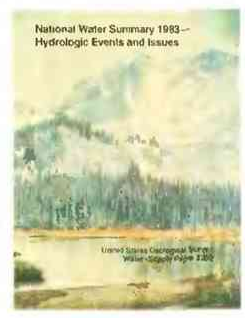

$$
\begin{aligned}
& 1983 \text { - Hydrologic Events and Issues } \\
& \text { (U.S. Geological Survey } \\
& \text { Water-Supply Paper 2250) }
\end{aligned}
$$

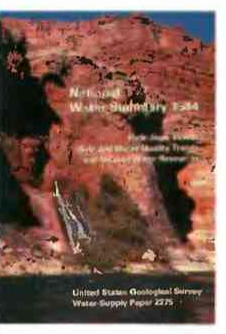

1984 - Hydrologic Events, Selected Water-Quality Trends, and

Ground-Water Resources

(U.S. Geological Survey

Water-Supply Paper 2275)

1986 - Hydrologic Events and Ground-Water Quality (U.S. Geological Survey Water-Supply Paper 2325)

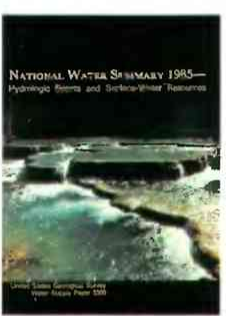

1985 - Hydrologic Events and Surface-Water Resources (U.S. Geological Survey Water-Supply Paper 2300)

\section{7- Hydrologic Events and Water Supply and Use (U.S. Geological Survey Water-Supply Paper 2350)}

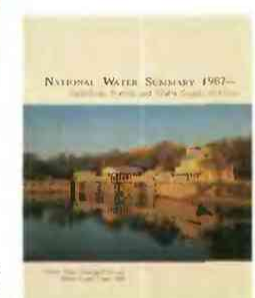

1988-89 - Hydrologic Events and Floods and Droughts (U.S. Geological Survey Water-Supply Paper 2375)

Suggestions about themes for future National Water Summary reports and comments regarding this series are most welcome.

Remarks should be addressed to: Chief Hydrologist, U.S. Geological Survey, 409 National Center, Reston, VA 22092

Front Cover: Upstream (northwest view) of the Potomac River, a principal source of water for the Washington, D.C., metropolitan area, from Theodore Roosevelt Island, showing Francis Scott Key Bridge, part of the Georgetown waterfront, and towers of Georgetown University.

Back cover: Downstream (southeast) view of the Potomac River, Key Bridge, and Roosevelt Island from Georgetown University south tower, 1934 and 1992.

(Color photographs, David F. Usher, U.S. Geological Survey; black and white photograph, Historical Society of Washington, D.C., photograph collection, number 6968) 


\section{NATIONAL WATER SUMMARY 1990-91}

Hydrologic Events and Stream Water Quality

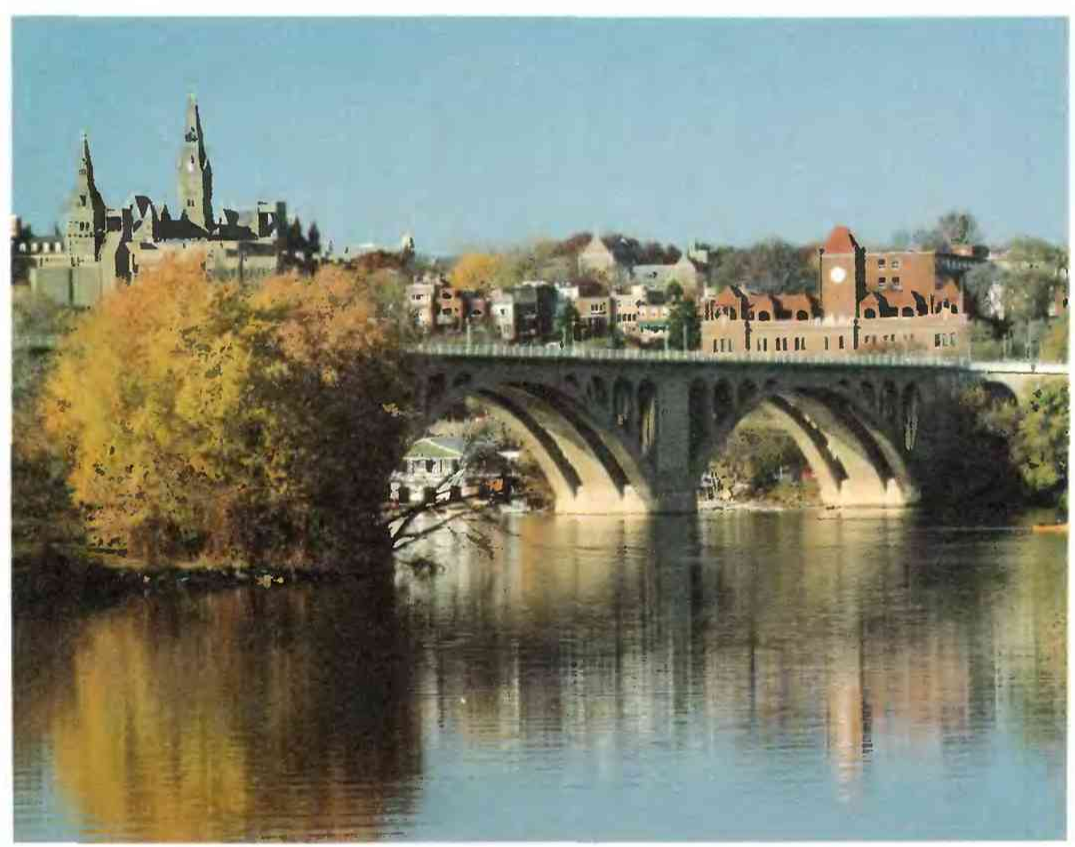

By U.S. Geological Survey

Richard W. Paulson, Edith B. Chase, John S. Williams, and David W. Moody, Compilers

United States Geological Survey Water-Supply Paper 2400 
U.S. DEPARTMENT OF THE INTERIOR BRUCE BABBITT, Secretary

U.S. GEOLOGICAL SURVEY

Dallas L. Peck, Director

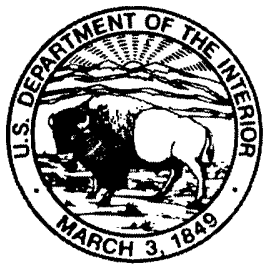

UNITED STATES GOVERNMENT PRINTING OFFICE: 1993

For sale by the U.S. Government Printing Office

Superintendent of Documents, M.S. SSOP, Washington, D.C. 20402-9328

United States Geological Survey

National Water Summary

ISSN 0892-3469 


\section{FOREWORD}

$N$

ational Water Summary 1990-91-Hydrologic Events and Stream Water Quality is the seventh in a series of reports that describe the conditions, trends, availability, quality, and use of the water resources of the United States. This volume continues a discussion on surfacewater resources begun in the 1985 National Water Summary by assembling information on water-quality conditions and determining water-quality trends during the past decade. The topic of the present volume is particularly timely because the U.S. Congress is considering reauthorization of the Clean Water Act.

The U.S. Geological Survey (USGS) interest in water quality can be traced to 1879 when it first reported analyses of natural waters. Between 1884 and 1901, the USGS published 25 reports containing information on the geologic control and the chemical and physical properties of water. Given an increase in the demand for water-quality information, the USGS established the Division of Hydro-Economics in 1902 to review and extract information contained in existing board-of-health reports and from other sources that could be used to describe ambient water quality. Despite some controversy, M.O. Leighton, chief of the new unit and later Chief Hydrographer, directed that pollution studies were a proper component of the USGS inventory of water resources because sewage and industrial wastes degraded the quality of water for many uses. Much of the effort during this time was devoted to differentiating between "normal" and "polluted" water and determining the degradation of municipal water supplies caused by municipal and industrial wastes.

The first USGS systematic nationwide monitoring program for assessing the mineral character of streams and lakes was begun in 1905 and continued until 1907. Two USGS water-supply papers, one published in 1909- "The Quality of Surface Waters in the United States-Part 1, Analyses of Waters East of the One Hundredth Meridian" by R.B. Dole - and the other published in 1911 - "Some Stream Waters of the Western United States, with chapters on Sediment Carried by the Rio Grande and the Industrial Application of Water Analyses" by Herman Stabler-have become classic reference volumes. They also provided the historical data used in one of the articles in this volume, "Factors Affecting Stream Water Quality, and Water-Quality Trends in Four Drainage Basins in the Conterminous United States, 1905-90." These

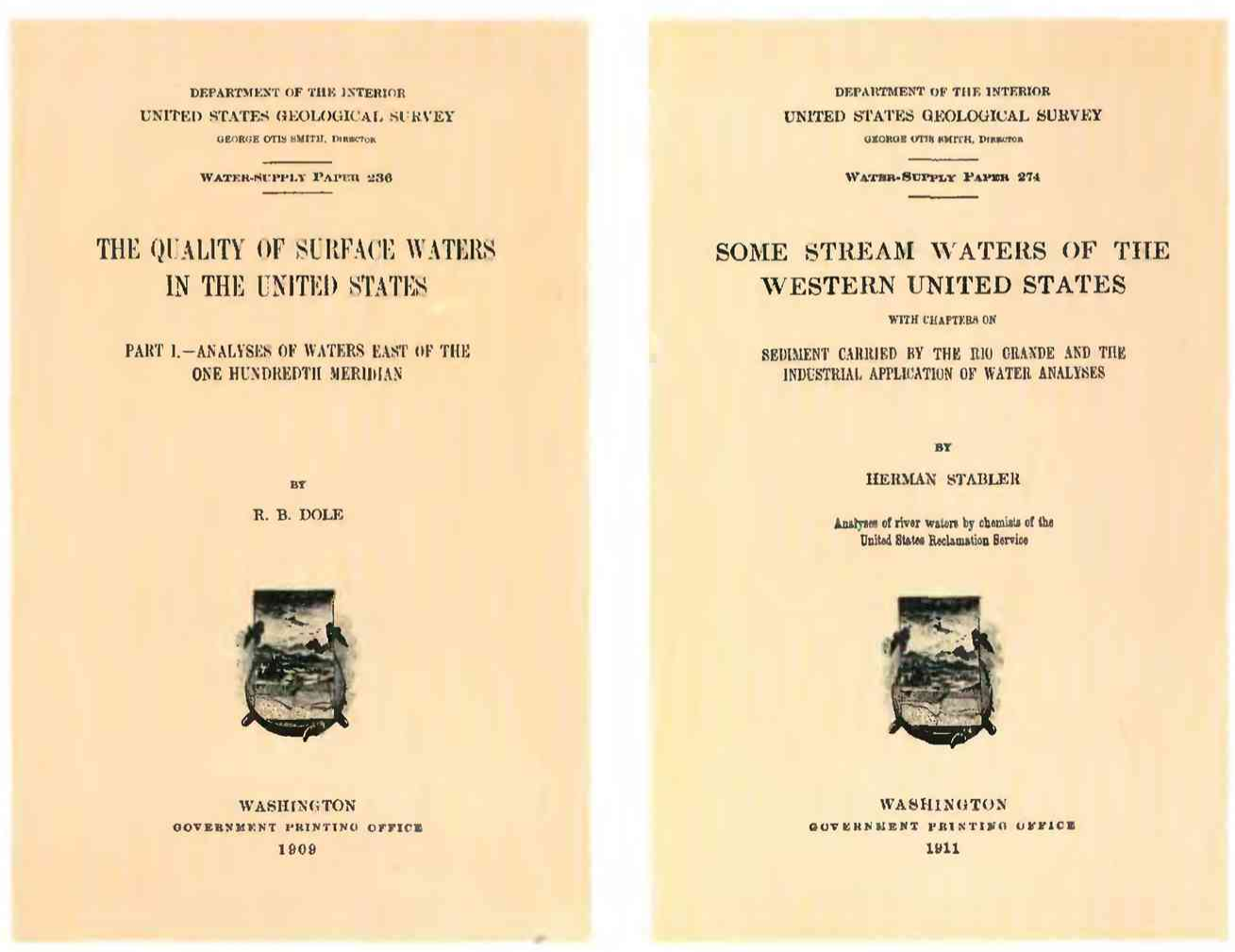


and other studies of the period provided the first scientific estimates of the amounts of dissolved solids and sediment transported by the Nation's rivers to the oceans. Contamination studies continued to be a major component of the USGS water-quality program until 1912, when Congress established the U.S. Public Health Service with the mandate to study sanitary water quality.

During the intervening years, the USGS continued to publish much information about the suitability of the Nation's water supplies for public use and for agricultural and industrial purposes. However, it wasn't until the 1960's that water-quality programs of the USGS again addressed the effects of contaminants on water resources. With the passage of the Water Quality Act of 1965 and the Clean Water Act of 1972, the need to assess the quality of the Nation's water resources became apparent. The USGS established several nationwide networks of stations to evaluate trends in water quality over time; however, the data are limited because the stations are limited in number and the measurements do not include the toxic and ecological indicators that have emerged in the past decade as major environmental issues.

Decisionmakers now recognize that the available information is insufficient for sound environmental decisions and national water-quality policy. However, a number of programs recently implemented or planned by the USGS and by other agencies, such as the U.S. Environmental Protection Agency (EPA), the U.S. Fish and Wildlife Service, the National Oceanic and Atmospheric Administration, and many State agencies, will do much to provide the information needed for future decisions and policy. For example, the USGS recently established the National Water Quality Assessment Program (NAWQA) to help close the gap in understanding the degree to which the surface- and ground-water resources of the country are contaminated and to monitor water-quality change over time. Full-scale implementation of NAWQA began in fiscal year 1991 with the investigation of the first 20 of 60 stream basins that eventually will be included in the program. These 60 basin assessments, which in aggregate represent about 45 percent of the land area and 70 percent of the population and water use in the United States, together with the national syntheses that will generalize the results of these studies to other stream basins in the country, will do much to support future national, regional, and local water-quality-management decisions.

The USGS also is coordinating the water-information activities of the Federal Government, as part of the responsibilities of the Water Information Coordination Program (WICP), which was delegated to the USGS by the Federal Office of Management and Budget. WICP has established the Intergovernmental Task Force on Monitoring Water Quality under its Interagency Advisory Committee on Water Data. The task force, which consists of representatives of Federal, State, and interstate agencies and is chaired by the EPA, has the ambitious goal of developing a nationwide strategic plan to meet the country's water-quality information requirements more effectively and economically. This goal will be achieved by improving the comparability of information collected by Federal, State, and local agencies, Indian tribes, and the private sector; by improving the accessibility to existing information; and by building a framework within which to integrate and coordinate existing monitoring efforts on a State-by-State and stream-basin basis.

By the end of the decade the United States will have much-improved documentation of crucial environmental and statistical trends in water quality.

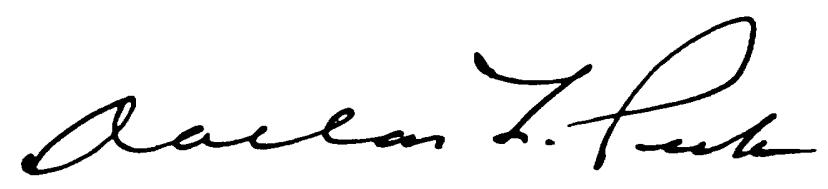

DIRECTOR 


\section{CONTENTS}

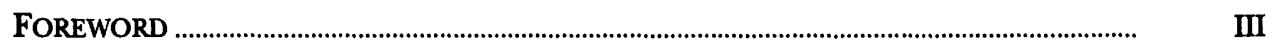

OVERVIEW AND INTRODUCTION .........................................................................................

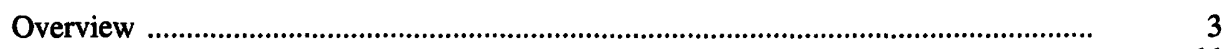

Introduction

Hydrologic Conditions ANd Water-Related Events, WATER YeARs 1990-91 13

Water year 1990-

Review of water year 1990 hydrologic conditions and water-related events G.J. McCabe, Jr., J.D. Fretwell, and E.B. Chase ...............................

Seasonal summaries of hydrologic conditions, water year 1990

G.J. McCabe, Jr., W.O. Brown, and R.R. Heim, Jr. ........................

Water year 1991-

Review of water year 1991 hydrologic conditions and water-related events G.J. McCabe, Jr., J.D. Fretwell, and E.B. Chase ..............................

Seasonal summaries of hydrologic conditions, water year 1991 R.R. Heim, Jr., G.J. McCabe, Jr., and W.O. Brown ......................... 56

Hydrologic PERSPECTIVES ON WATER ISSUES ............................................................... 65

Introduction

Hydrology of stream water quality-

Factors affecting stream water quality, and water-quality trends in four drainage basins in the conterminous United States, 1905-90

J.D. Hem

Statistical analysis of water-quality data

D.R. Helsel

Assuring the reliability of water-quality data

L.C. Friedman.

Stream water quality in the conterminous United States-Status and trends of selected indicators during the 1980 's

R.A. Smith, R.B. Alexander, and K.J. Lanfear

Institutional and management aspects-

Nationwide water-quality reporting to the Congress as required under section 305(b) of the Clean Water Act

A.E. Mayio and G.H. Grubbs. 
State Summaries of STream Water Qual.tTy...

Introduction to State summaries of stream water quality

\begin{tabular}{|c|c|}
\hline Alabama ........................ & 155 \\
\hline 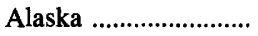 & 163 \\
\hline 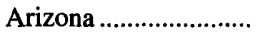 & 171 \\
\hline Arkansas .......................... & 179 \\
\hline California ...................... & 187 \\
\hline 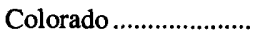 & 197 \\
\hline Connecticut ................. & 207 \\
\hline Delaware ..................... & 215 \\
\hline 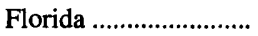 & 221 \\
\hline Georgia ......................... & 231 \\
\hline 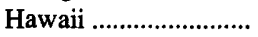 & 239 \\
\hline 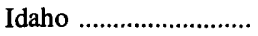 & 247 \\
\hline Illinois ........................... & 255 \\
\hline 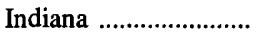 & 263 \\
\hline Iowa & 269 \\
\hline 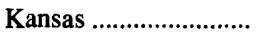 & 277 \\
\hline 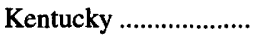 & 285 \\
\hline Louisiana ......................... & 293 \\
\hline
\end{tabular}

\begin{tabular}{|c|c|}
\hline Maine ............................ & 301 \\
\hline $\begin{array}{c}\text { Maryland and District of } \\
\text { Columbia ................ }\end{array}$ & 309 \\
\hline Massachusetts ............ & 317 \\
\hline Michigan ....................... & 325 \\
\hline Minnesota ..................... & 335 \\
\hline Mississippi ................. & 343 \\
\hline Missouri ...................... & 351 \\
\hline Montana ......................... & 361 \\
\hline Nebraska ...................... & 371 \\
\hline Nevada ....................... & 379 \\
\hline New Hampshire ......... & 387 \\
\hline New Jersey .................. & 395 \\
\hline New Mexico ................. & 403 \\
\hline New York ................... & 413 \\
\hline North Carolina ........... & 421 \\
\hline North Dakota ............... & 429 \\
\hline 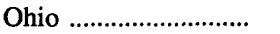 & 437 \\
\hline
\end{tabular}

$\begin{array}{lr}\text { Oklahoma ................ } & 445 \\ \text { Oregon .................. } & 455 \\ \text { Pennsylvania ............ } & 463 \\ \text { Puerto Rico ............. } & 471 \\ \text { Rhode Island ............ } & 477 \\ \text { South Carolina .......... } & 485 \\ \text { South Dakota ............ } & 491 \\ \text { Tennessee ................. } & 499 \\ \text { Texas ...................... } & 507 \\ \text { Utah ........................ } & 517 \\ \text { Vermont ................... } & 525 \\ \text { Virginia .................... } & 531 \\ \text { Washington ............... } & 539 \\ \text { West Virginia ............ } & 547 \\ \text { Western Pacific } & \\ \text { Islands ................... } & 555 \\ \text { Wisconsin ................... } & 561 \\ \text { Wyoming .................. } & 569\end{array}$

Glossary

Water-quality equivalents and conversion factors

Hydrologic unit maps-

Water-resources regions

Water-resources subregions

Cataloging units and hierarchy of hydrologic units

\section{FIGURES}

1. Maps showing streamflow and precipitation in the United States and Puerto

Rico, water year 1990 .

2-3. Graphs showing-

2. Monthly discharges for selected major rivers of the United States and Puerto Rico, water years 1989 and 1990

3. Month-end storage of selected reservoirs in the United States, water years 1989 and 1990

4-9. Maps showing-

4. Location or extent of significant hydrologic and water-related events in the United States, October 1989 through

September 1990

5-8. Seasonal hydrologic conditions, water year $1990-$

5. Fall season

6. Winter season

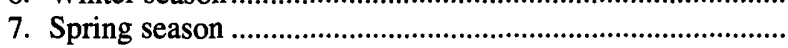

8. Summer season

9. Streamflow and precipitation in the United States and Puerto Rico, water year 1991 
FIGURES-Continued

10-11. Graphs showing-

10. Monthly discharges for selected major rivers of the United States, water years 1990 and 1991

11. Month-end storage of selected reservoirs in the United States,

12-16. Maps showing -

12. Location or extent of significant hydrologic and water-related events in the United States and Puerto Rico, October 1990 through September 1991

13-16. Seasonal hydrologic conditions, water year 1991-

13. Fall season

14. Winter season

15. Spring season

16. Summer season

17. Graph showing schematic circulation of nutrient elements

18. Drainage basins of four water-quality stations used to determine selected long-term water-quality trends

19. St. Lawrence River, N.Y., near outlet of Lake Ontario and location of sampling stations

20. Graph showing annual sulfate yields of the St. Lawrence River at Cornwall, Ontario, Canada, 1906-90

21. Map showing the Columbia and Snake Rivers, Washington and Oregon, and location of sampling stations

22-23. Graphs showing-

22. Sulfate concentrations at Northport on the Columbia River, Wash., 1910-85.

23. Annual sulfate yield at Northport, Wash., 1910-81.

24. Map showing Allegheny River, Pa., and location of sampling stations

25. Graphs showing sulfate concentration and $\mathrm{pH}$ of the Allegheny River at New Kensington, Pa., 1948-89

26. Map of the lower Mississippi River, La., and location of sampling stations ....

27-28. Graphs showing-

27. Dissolved sulfate of the Mississippi River at New Orleans, La. 1905-6 and near St. Francisville, La., 1955-89

28. Distribution of normal and skewed data

29-33. Plots showing -

29. Box-plot components

31. Simple, standard, and truncated box plots

32. Truncated box plots used in the State summaries of stream water quality

33. Minimum reporting limits in box plots

34. Graph showing scatter plot without and with a superimposed LOWESS smoothed line

35. Example of map showing results of trend analyses as used in the State summaries of stream water quality

36. Graphs showing how water-quality data are adjusted to remove the variability of streamflow 


\section{FIGURES-Continued}

37. Map showing land-use classification devised from hydrologic cataloging units to provide a basis for analyzing stream water-quality indicators

38-43. Maps and graphs showing concentrations and trends in stream water quality in the conterminous United States for-

38. Dissolved oxygen, 1980-89

39. Fecal coliform bacteria, $1980-89$

40. Dissolved solids, $1980-89$

41. Nitrate, 1980-89

42. Total phosphorus, $1982-89$

43. Suspended sediment, 1980-89

44-45. Maps and tabulations showing yield and percentage change in yield of nitrate, total phosphorus, and suspended sediment transported-

44. From 14 water-resources regions, 1980-89

45. According to land use, $1980-89$

46. Map and graphs showing water quality of tributaries to selected reservoirs in the conterminous United States, 1980-89

ap and tabulation showing load, yield, and percentage change in load and yield of nitrate, total phosphorus, and suspended sediment in six coastal segments of the conterminous United States, 1980-88

48. Maps showing surface-water withdrawals, 1985 , and graphs showing water quality in basins used as sources of domestic, industrial, and irrigation water uses, 1980-89

49. Graphs showing national trends in selected toxic trace elements and organic compounds in finfish tissue, 1970-86

50-51. Maps showing -

50. Herbicide concentrations in streams in a 10-State agricultural area of the Midwest during 1989

51. Atrazine loads contributed by the Mississippi River drainage basin to the Gulf of Mexico, spring 1991

52-54. Graphs showing percentage of-

52. Total waterbodies in the United States assessed by reporting States and the percentage meeting designated water uses

53. Assessed waterbodies that reporting States identified as impaired, by type of contaminant or process, in their 305(b) reports for 1990

54. Assessed waterbodies that reporting States identified as impaired, by source of contaminant, in their 305(b) report for 1990 ............

55-56. Graphs showing most-cited-

55. Ground-water contaminants, as reported by 42 States in their 305(b) reports for 1990

56. Sources of ground-water contaminants, as reported by 42 States in their 305(b) reports for 1990

57. Graph showing increase in total river length assessed by reporting States in their 305(b) reports, 1984-90.

58. Map showing location of water-quality monitoring stations in the United States and Puerto Rico from which data were used for analysis of water quality in the State summaries in this volume 
FIGURES-Continued

In "State Summaries of Stream Water Quality"-

Each State summary has maps and diagrams showing-

1. Land use, physiography, and population.

2. Selected water-quality monitoring stations, types of statistical analysis, and geographic features.

3. Water-quality conditions, water years 1987-89.

4. Trends in water quality, selected water years.

Some State summaries have photographs showing related stream water quality information.

\section{TABLES}

1. Chronology of significant hydrologic and water-related events,

October 1989 through September 1990

2. Chronology of significant hydrologic and water-related events, October 1990 through September 1991

3. Chemical composition of water and related data for the St. Lawrence River, representing outflow from Lake Ontario, selected years 1906-90

4. Change in major cation and anion concentrations in the St. Lawrence River outflow from Lake Ontario, between 1906-7 and 1977

5. Estimated annual yield of constituents, in tons per square mile, St. Lawrence River outflow from Lake Ontario, selected years 1906-90

6. Chemical composition and constituent annual yield of water and related data for the Columbia River at and near Northport, Wash., and The Dalles, Oreg., and the Snake River near its mouth, selected years 1910-68

7. Chemical composition of water and related data for the Allegheny River at and near Kittanning, Pa., selected years 1906-89

8. Chemical composition of water and related data for the Kiskiminetas River at Vandergrift, Pa., at times of low flow, 1947 and 1976

9. Chemical composition of water and related data for the Mississippi River at New Orleans, La., 1905-6, and near St. Francisville, La., water years 1966 and 1989

10. Sources and environmental significance of selected water-quality constituents

11. Summary, by State, as documented in the State summaries in this volume, of selected water-quality constituents or properties statistically analyzed to determine conditions and trends in stream water quality .....

In "State Summaries of Stream Water Quality"-

Each State summary has a table 1 that lists the water-quality constituents discussed in the State summary and describes the sources and environmental significance of each constituent. 


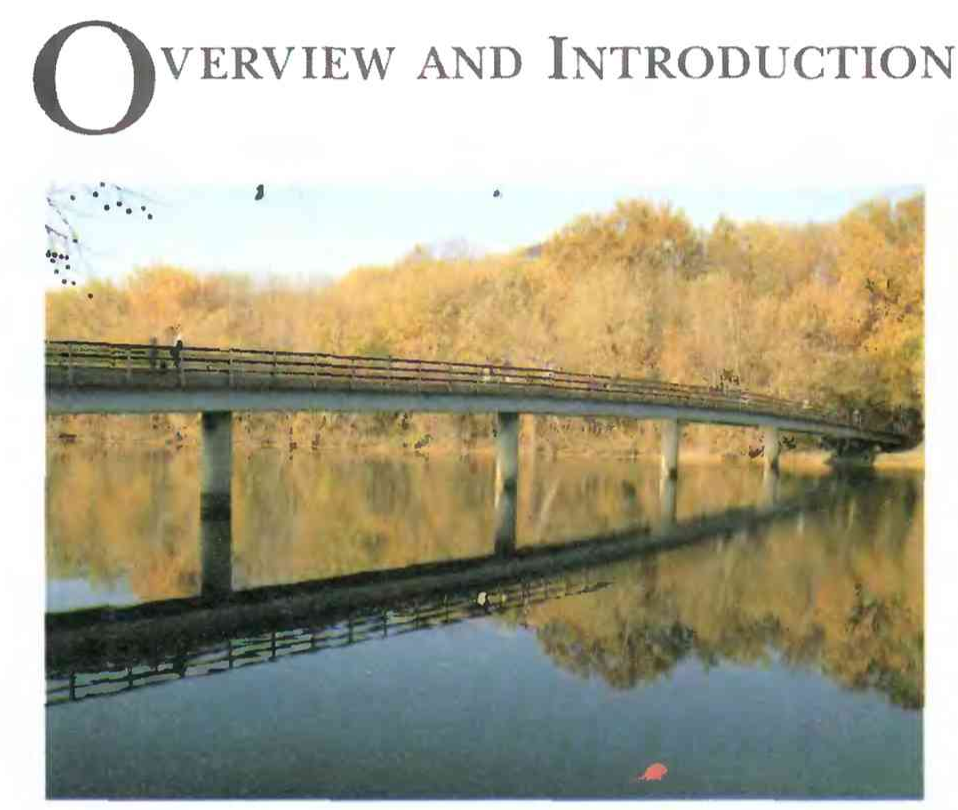

Footbridge to Theodore Roosevelt Island in the Potomac River. The island, named for the 26th president of the United States, is a peaceful nature-study area in the Washington, D.C., area. (David F. Usher, U.S. Geological Survey) 


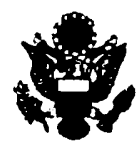

Public Law 92-500

92nd Congress, S. 2770

October 18, 1972

\section{An Act}

To amend the Federal Water Pollution Control Act.

Be it enacted by the Senate and House of Representatives of the United States of America in Congress assembled, That this Act may be Federal water cited as the "Federal Water Pollution Control Act Amendments of Pollution Con1972".

Sec. 2. The Federal Water Pollution Control Act is amended to read as follows:

\section{“TITIE I-RESEARCH AND RELATED PROGRAMS} trol Act Amend-

ments of 1972 . 84 Stat. 91. 33 USC 1151 "DECLAR.1TION OF GOALS IND POLICY

"SEc. 101. (a) The objective of this Act is to restore and maintain the chemical, physical, and biological integrity of the Nation's waters. In order to achieve this objective it is hereby declared that, consistent with the provisions of this Act-

"(1) it is the national goal that the discharge of pollutants into the navigable waters be eliminated by 1985 ;

"(2) it is the national goal that wherever attainable, an interim goal of water quality which provides for the protection and propagation of fish, shellfish, and wildlife and provides for recreation in and on the water be achieved by July 1, 1983;

"(3) it is the national policy that the discharge of toxic pollutants in toxic amounts be prohibited;

" $(4)$ it is the national policy that Federal financial assistance be provided to construct publicly owned waste treatment works;

"(5) it is the national policy that areawide waste treatment management planning processes be developed and implemented to assure adequate cont rol of sources of pollutants in each State; and

“(6) it is the national policy that a major research and demonstration effort be made to develop technology necessary to eliminate the discharge of pollutants into the navigable waters, waters of the contiguous zone, and the oceans.

"(b) It is the policy of the Congress to recognize, preserve, and protect the primary responsibilities and rights of States to prevent. leduce, and eliminate pollution, to plan the development and use (including restoration. preservation. and enhancement) of land and water resources, and to consult with the Administrator in the exercise of his authority under this Act. It is further the policy of the Congress to support and aid research relating to the prevention, reduction, and elimination of pollution. and to provide Federal technical services and financial aid to State and interstate agencies and municipalities in connection with the prevention, reduction. and elimination of pollution.

"(c) It is further the policy of Congress that the President, acting through the Secretary of State and such national and international organizations as he determines appropriate, shall take such action as may be necessary to insure that to the fullest extent possible all foreign countries shall take meaningful action for the prevention, reduction, and elimination of pollution in their waters and in international waters and for the achievement of goals regarding the elimination of lischarge of pollutants and the improvement of water quality to at least the same extent as the United States does under its laws.

"(d) Except as otherwise expressly provided in this Act. the Ad- Administration. ministrator of the Environmental Protection Agency (hereinafter in this Act called 'Administrator') shall administer this Act. 


\section{Overview}

N

ational Water Summary 1990-91Hydrologic Events and Stream Water Quality was planned to complement existing Federal-State water-quality reporting to the U.S. Congress that is required by the Clean Water Act of 1972. This act, formally known as the Federal Water Pollution Control Act Amendments of 1972 (Public Law 92-500), and its amendments in 1977, 1979, 1980, 1981, 1983, and 1987, is the principal basis for Federal-State cooperation on maintaining and reporting on water quality in the United States. Under section 305(b) of the Clean Water Act, the States must designate uses for waterbodies, biennially assess whether the waterbodies meet designated uses, and report to the U.S. Environmental Protection Agency (EPA), which in turn summarizes the findings of the State assessments in a biennial National Water Quality Inventory report to the Congress.

This volume of the National Water Summary uses a nationally consistent data base and methods of statistical analysis to document stream water quality in the United States, Puerto Rico, and the Western Pacific Islands. As a basis for preparation of this report, the U.S. Geological Survey (USGS) created a data base of waterquality data from about 2,900 stream water-quality monitoring stations in the United States (Lanfear, 1993). These data, which were extracted primarily from the USGS National Water Information System (NWIS) and supplemented with data from the EPA national data base known as STORET, consisted mostly of water-chemistry and physical-sediment data. About 1,400 of these stations met a criterion, used in this volume for trends analysis of data, of having a period of record that began before water year 1980. (A water year is the period from October 1 through September 30 and is identified by the calendar year at the end of the period.) Inasmuch as the determination of trends requires about 10 years of data, few biological data were suitable for trends analysis because biological indicators of water quality were not being collected extensively by water year 1980 . Also, because of the lack of long-term data, an assessment of the water quality of lakes and reservoirs is not included in this National Water Summary. Constituent and waterproperty data were selected from this data base and analyzed with statistical techniques that have been used extensively by the USGS to summarize conditions and trends in water quality. (Throughout the remainder of this article, the term "constituent" is used also to represent water properties, such as $\mathrm{pH}$ and alkalinity.) Selected results from this analysis are presented graphically, both by State and nationally, in this volume.

The data base created for preparation of this volume and the resulting nationally consistent statistical analysis of these data provide a unique opportunity to compare and contrast stream water-quality conditions and trends nationally and State by State. Because of the complexity of water quality and the natural seasonal and diurnal variations in the concentrations of waterquality constituents, the determination of trends in water quality requires a relatively long period of record. Trends in constituent concentrations in the State summaries in this volume were calculated for one or more of four periods-water years $1970-89,1975-89,1980-$
89, and 1982-89. Unfortunately, few water-quality monitoring stations have periods of record of more than 10 or 15 years, and therefore most analyses in the State summaries were done for 8- or 10-year periods. Although interest in water quality has continued to heighten since passage of the Clean Water Act, funds for support of data-collection programs are limited and data records of many of the constituents now of current concern, especially organic constituents, do not exist or are less than 10-years long; consequently only a modest number of organic constituents are presented in this volume. Discussion of conditions and trends in water quality in this National Water Summary also draw upon information about land use, population, water use, application of agricultural chemicals in rural areas, the siting of industrial facilities, and other ancillary information. Because the results of analysis of a restricted number of constituents are presented in this volume, State 305(b) reports also are cited in the discussion of water quality in each State.

The following discussion is an overview of the three parts of this 1990-91 National Water Summary"Hydrologic Conditions and Water-Related Events, Water Years 1990-91," "Hydrologic Perspectives on Water Issues," and "State Summaries of Stream Water Quality."

\section{HYDROLOGIC CONDITIONS AND WATER- RELATED EVENTS, WATER YEARS 1990-91}

Data on national hydrologic conditions and water-related events during water years 1990 and 1991 are presented in a format that is consistent with previous volumes of the National Water Summary to maintain the continuity of the description of hydrologic conditions and events. During these water years, one of the most persistent weather conditions in the United States was the drought in parts of the West. Although intense precipitation in California in March 1991 provided temporary relief, some parts of California were subjected to a continuing drought that began in 1987. Drought also persisted in the northern and western parts of Nevada, which, except for near-average conditions in 1989, also have suffered drought since 1987.

\section{WATER YEAR 1990}

Annual precipitation was near average and temperatures were above average for water year 1990 for much of the country because of a northward displacement of the jetstream during much of the year. As a result, storm tracks were displaced somewhat north of normal, and weather systems moved more rapidly from west to east. This trend was reflected in below-median streamflow for most of the West, as in California, for example, where precipitation was less than half of average in the central southern part of the State and streamflow was accordingly low. Streamflow also was below median in a large part of the North-Central States and in northern and central Florida. In contrast, precipitation in parts of the Southwest, central Rocky Mountains, southern Great Plains, middle Mississippi Valley, and the lower Great Lakes region was above average for

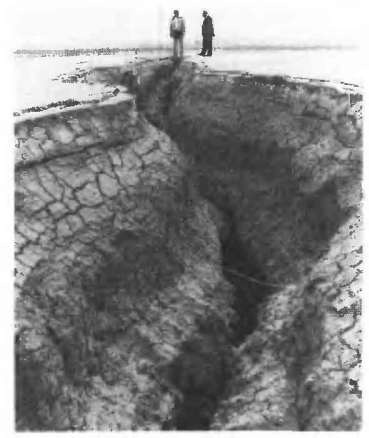


the year. This increase resulted in above-median combined flow for the Mississippi, St. Lawrence, and Columbia Rivers - the three largest rivers in the conterminous United States.

Drought in the West and parts of the Southeast continued to spread during the water year. Water levels were below median in Folsom Lake in California, the Rye Patch Reservoir in Nevada, the San Carlos Reservoir in Arizona, and the Colorado-Big Thompson Project in Colorado; and by the end of the year the Rye Patch Reservoir was down to 1 percent of capacity.

To compound the effects of drought in many areas of the country, annual average temperatures were above normal, and 779 new daily maximum temperature records were set during June to September. Temperatures were above to much above average along the southern Atlantic Coast and in the central Appalachian Mountains, southern California, the Southwest, the Pacific Northwest, the central and northern Rocky Mountains, and the northern Great Plains.

\section{WATER YEAR 1991}

Stronger-than-average anticyclonic conditions prevailing over the conterminous United States during water year 1991 resulted in the continuation of drought conditions and above-average temperatures from the previous year in several western areas of the country. Below-average precipitation occurred in northern California and parts of the Pacific Northwest, western Arizona, and the central Great Plains. South-central Noith Dakota, northwestern South Dakota, and most of the Middle Atlantic Coast States also experienced below-average precipitation. Temperatures slightly above average occurred from the Cascade Mountains in Washington to central Oregon, in the Southwest, and from the northern Great Plains southeastward toward the central Gulf Coast. Temperatures much above average occurred from Florida to the lower Great Lakes. Streamflow was below median for northern California, most of Nevada, southern Idaho, and southern Oregon, as well as most of Kansas, much of North Dakota, northeastern South Dakota, and northwestern Minnesota.

In other areas of the country, precipitation was above average. Streamflow for the year also was above median in the lower Mississippi Valley northward into the western and eastern parts of the Ohio Valley and from the Texas Panhandle into central New Mexico, eastern Arizona, and southern Colorado. The combined flow of the three largest rivers in the conterminous United States-the Mississippi, St. Lawrence, and Columbiawas 17 percent above the median.

The continued drought in the West resulted in below-median reservoir levels in that area. The levels of Pine Flat Lake in California, the Fort Peck Lake in Montana, and the Conchas Lake in New Mexico were much below median for water year 1991. Lake Tahoe, which is on the California-Nevada boundary, had no usable storage during the entire water year.

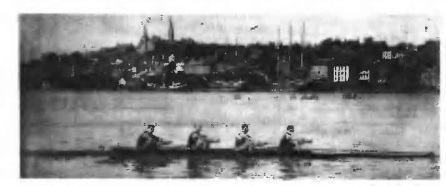

\section{HYDROLOGIC PERSPECTIVES ON WATER ISSUES}

The "Hydrologic Perspectives on Water Issues" part of this volume consists of two sections-"Hydrol- ogy of Stream Water Quality" and "Institutional and Management Aspects." Collectively, the five articles in this part provide information about stream water quality in the United States and water-quality assessment and reporting by the States and the Federal Government; they also provide background information for understanding the State-by-State summaries in the "State Summaries of Stream Water Quality" part of this volume.

\section{HydRology of StREAM Water Quality}

Variations across the United States of climate, geology, soils, topography, patterns of naturally occurring vegetation, and other natural factors affect stream water quality. As a result, stream water quality was highly variable across the continent even before the growth of population, agriculture, and industry during the last 2 centuries. As streams became extensively used for domestic, commercial, industrial, and agricultural water supply, they received point-source contaminants from irrigation-system return flows, municipal and industrial wastewater-treatment facilities, and nonpointsource contaminants from urban and agricultural areas. Additionally, the construction of dams, reservoirs, diversion canals, and other civil engineering works, drainage of wetlands, deforestation, urbanization, air pollution, and the results of other human activities have affected the flow and water-quality characteristics of streams. In recent decades, the continued growth of population and industrial and agricultural activities, and floods and droughts increased pressure on water resources to the point where numerous waterbodies became temporarily or permanently unsuitable for human use and as wildlife habitats.

\section{Geographicai Variations and Temporal Trends in Stream Water Quality}

Streams convey a dynamic mixture of water, dissolved constituents, and particulate matter under the influence of gravity across the Earth's surface. As a result, streams convey dissolved constituents and particulate matter to the oceans from a variety of sources, which can be considered as reservoirs, that consist of the atmosphere, the solid rocks of the Earth's surface (the lithosphere), all of the plants and animals at or near the surface of the Earth (the biosphere), and soils. Oceans also are reservoirs. Because these reservoirs are not uniformly distributed and they vary in time, the mixture of water, dissolved constituents, and particulate matter in streams can be highly nonuniform.

Little scientific evidence exists about stream water quality in the United States before the 20th century. From the spring of 1905 until the spring of 1907 , the USGS conducted a program of systematic once-daily sampling and chemical analysis of composites of the daily samples of principal streams in the United States. The analytical results of sampling for about 100 waterquality stations on streams east of the 100th Meridian in 1906-7 and another for 55 stations in the West in 1905-7 were documented by Dole (1909) and Stabler (1911), respectively. Perhaps reflective of the expansionist attitude of the time, Dole stated that the program of sampling and analysis was undertaken to support "a detailed study of the quality of industrial water supplies, 
both surface and underground, and it became advisable during this investigation to procure information regarding the chemical composition of the waters and of the lakes and streams of the United States."

Although other scientific and anecdotal information exists about the status of stream water quality in particular streams or restricted geographical areas at particular times, little other systematic scientific evidence is available about overall water quality in the United States in the early part of the 20th century. The article Factors Affecting Stream Water Quality, and Water-Quality Trends in Four Drainage Basins in the Conterminous United States, 1905-90 in this volume discusses the natural circulation mechanisms and rates of carbon, sulfur, chlorine, and nitrogen between streams and the reservoirs cited above, describes human-induced circulation of these elements, and contrasts selected data collected in the early 1900 's with more recently collected data for four reaches of streams in the conterminous States to determine what changes occurred in their drainage basins during the century. The reaches are the St. Lawrence River near Ogdensburg, N.Y., in the Great Lakes basin; the Columbia River near The Dalles, Oreg., in the Columbia River basin; the Allegheny River upstream from Pittsburgh, $\mathrm{Pa}$., in the Allegheny River basin; and the Mississippi River at and near New Orleans, La., in the Mississippi River basin. Because stream water quality varies from year to year due to variations in weather and stream discharge, even if all other factors remain constant, interpretation of 1 year of data collected almost 90 years ago must be done cautiously.

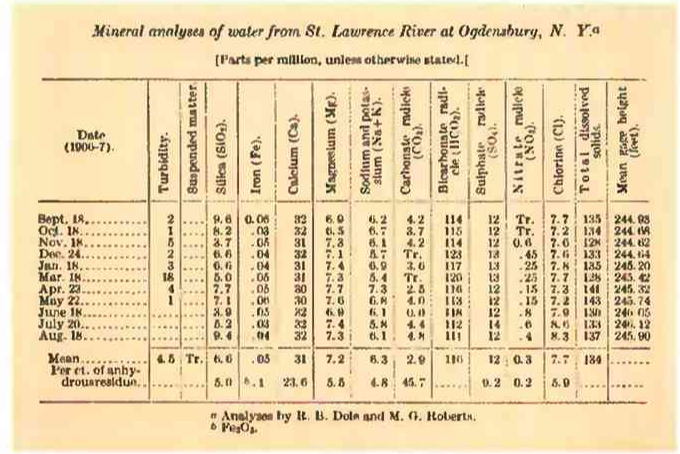

Water quality of the St. Lawrence River at Ogdensburg, N.Y., 1906-7, as documented by Dole in 1909

The yield of sulfate in the St. Lawrence River apparently has increased from about 10 tons per square mile per year during the early part of this century to about 25 tons per square mile per year in 1980, at which time it seems to have become more constant. This increase was caused primarily by increased atmospheric sulfur deposition on the Great Lakes drainage, and the leveling off of the sulfate yields indicates that the discharge of sulfate by the St. Lawrence River has come into equilibrium with the human-induced atmospheric loading on the drainage area.

Although the average annual discharge of the Columbia River at The Dalles, Oreg., approximates the average annual discharge of the St. Lawrence River at Cornwall, Ontario, Canada, the concentration and yield of sulfate in the Columbia River have changed less during the century than in the St. Lawrence. Human- induced effects at Northport, Wash., in the upper part of the basin are minor, which also is true to a lesser degree at The Dalles, Oreg.

Runoff of acid mine drainage from coal mines caused the concentration of sulfate in the Allegheny River in the reach immediately downstream from Kittanning, $\mathrm{Pa}$., to increase from about $17 \mathrm{mg} / \mathrm{L}$ (milligrams per liter) in the early 1900 's to about $200 \mathrm{mg} / \mathrm{L}$ in 1947; additional effects of acid drainage from the Kiskiminetas River also were found in the Allegheny downstream from the confluence of the rivers below Kittanning. Use of water-storage reservoirs to provide dilution during periods of low flow and other remedial measures provided substantial improvement in water quality between 1947 and 1989 .

Concentrations of sulfate in the lower Mississippi River appear to have about doubled since 1905-6 and, similar to the Great Lakes drainage, have leveled off in recent years, indicating that the transport of sulfate by the river to the ocean could have come to equilibrium with regard to human-induced loading of sulfate. Because the amount of data is modest and there are many uncertainties in quantifying human-induced loading in the Mississippi River basin and in understanding the response of the basin to these loads, the foregoing findings are tentative. Much additional work is needed to quantify and understand elemental circulation rates and to understand the effects of a century of development on these basins and the Nation as a whole.

Although numerous water-quality data-collection programs have come into existence during the last decades of the 20th century, few have been national in scope. The USGS Hydrologic Bench-Mark Network (Leopold, 1962) and the USGS National Stream Quality Accounting Network (NASQAN) (Ficke and Hawkinson, 1975) were established only in the 1960's and 1970's, respectively. The Hydrologic Bench-Mark Network, which began in 1964, monitors 55 of the Nation's streams that are minimally affected by human influence. NASQAN, which began in 1973 and which monitors the quantity and quality of water that flows from the Nation's major drainage basins, increased from an original set of 50 water-quality monitoring stations in 1973 to a maximum of 518 stations in 1979 , and then it declined to 410 stations in 1992. The Federal-State Cooperative Program (Gilbert and Mann, 1990), operated by the USGS in cooperation with about 1,000 State and local agencies, supports the operation of additional water-quality stations in the United States, but most of them have relatively short periods of record. As a result, data from water-quality monitoring stations that are suitable for analysis of trends in concentrations of water-quality constituents infrequently exceed $10-15$ years in length, and some stations are no longer in operation.

Comparability of data from different data-collection networks is highly problematical. Data from the Hydrologic Bench-Mark Network and NASQAN and data collected under the USGS Federal-State Cooperative Program generally are comparable because standard methods of data collection and analysis were used. However, because State agencies operate their own datacollection networks, with resulting differences in sampling methods, preservation and shipment of samples, and laboratory analysis, use of State-based data might not be comparable from State to State for regional or national analysis and thus cannot be used. 


\section{Statistical Analysis and Quality Assurance of Water-Quality Data}

Interpreting water-quality data is challenging. The concentrations of water-quality constituents are variable in time and throughout a particular waterbody, and errors- - even unavoidably small errors - are made in sampling and in the shipment and chemical analysis of samples. Such natural and human-induced influences add uncertainty to data.

Statistics is the science that deals with uncertainty. It strives to separate patterns, such as a change in the concentration of a constituent over time, from the uncertainty inherent in all observations of natural systems. When applied to water-quality data, the separation of patterns from uncertainty generally is accomplished by describing data characteristics such as the average, determining the variation of the constituent over time, and comparing data collected at two or more locacions. The article Statistical Analysis of WaterQuality Data in this volume discusses the characteristics of water-quality data, appropriate statistical and graphical methods of representing water-quality data distributions, and the determination of trends in waterquality data.

Water-quality data have characteristics that make them inappropriate for analysis by some statistical techniques. Data sets of other natural variables can have a so-called normal distribution, which is a symmetrical distribution having a particular set of mathematical properties. However, water-quality data usually are not normally distributed, are never less than zero, and cannot be known below the minimum reporting limit of the method of measurement. Water-quality data sets also contain outliers, which are data of considerably higher or lower value than most of the data.

The article discusses non-normal distributions of water-quality data and the attributes of box plotswhich are graphical representations of data distributions - and discusses how outliers and data below a minimum reporting limit are represented in box plots. Box plots are used extensively to represent data distributions of selected constituents for water years 198789 in the State summaries.

The article also describes the seasonal Kendall test, which is a statistical method for determining the existence of trends in the concentration of water-quality constituents. It is called a "seasonal" test because it takes into consideration the natural seasonal variation in water quality by making comparisons of data only from like seasons. Thus, data from all of the winter seasons in a water-quality station record are compared to determine trends. Indications of trends for all of the seasons then are aggregated to determine if an overall trend exists. The seasonal Kendall test was applied extensively in the State summaries, and the results are displayed graphically.

One of the potential pitfalls in the determination of trends in water quality is that the concentration of a water-quality constituent tends to vary with streamflow, and, thus, the effects of streamflow must be determined and concentration data adjusted for it. The article "Statistical Analysis of Water-Quality Data" describes the basis for determining the effects of streamflow and adjusting concentration data for the effects.
The article Assuring the Reliability of WaterQuality Data in this volume describes the obstacles to collection of water-quality data, quality-assurance techniques to minimize the effects of these obstacles, and the quality-assurance programs of the USGS. Analysis of water-quality data is based on the assumption that the data accurately represent the waterbody of interest, within an acceptable margin of error. Unfortunately, data collected for one purpose can have a level of uncertainty that is appropriate for the purpose for which the data were collected but that might not be appropriate for other purposes. An approach to solving this problem is to maintain quality-assurance programs that assure that the collection, shipment, and laboratory analysis of water samples and the documentation of the data are done to carefully defined standards.

Assuring the quality of water-quality data is much more challenging than assuring the quality of a manufactured item, because the specifications of the latter are known to a great degree of certitude whereas it is not possible to know beforehand the exact mixture of water, dissolved constituents, and particulate matter that is collected in a water sample. Additionally, more than one sample could be needed to characterize the status of a waterbody. Even when a representative sample is collected, there is always the risk that the sample could be contaminated by the method of collection, the container in which it is stored before analysis, and by handling during analysis. This is particularly problematic for collection of trace-element constituents, such as lead, mercury, and other metals, which by their nature are present in water in very small concentrations.

Because water from streams is a complex mixture and it is not possible to know before analysis what it contains, the analysis for a constituent using a particular laboratory method or machine could be interfered with by the presence of another, unsuspected constituent. Moreover, errors can occur if operators are improperly trained, laboratory equipment and chemicals are not to standard, and documentation is improper.

By their very nature, national water-quality data-collection programs cover large geographical areas and operate for many years. Because of the large geographic extent, personnel from widely separated locations operate elements of the program and can be unaware of the effects of any errors that they might commit, and, moreover, personnel change during the long time periods of the program. Additionally, new methods of data collection and laboratory procedures might be adopted. Since no two methods are exactly alike, the adoption of new methods by a program adds risk that an apparent change in value of a constituent could be caused by a change in the method instead of by a change in the concentration of the constituent in streams. Finally, if data-collection methods are not adequately documented, it is not possible to analyze historical data and determine the circumstances under which they were collected.

The USGS has been collecting water-quality data almost from its inception in 1879 . Over the years, the USGS has developed a data-collection quality-assurance program that defines standards for data collection, analysis, and documentation; developed programs to 
aSsure that USGS personnel are adequately trained; and established standard reference samples for laboratory analysis.

The article Stream Water Quality in the Conterminous United States-Status and Trends of Selected Indicators During the 1980's in this volume describes analyses of water-quality data from Federal and State monitoring programs. Data are selected to provide a national and regional description of water-quality conditions and trends to assist decisionmakers and the public in assessing progress toward water-quality goals. The data sources examined are (1) USGS data on traditional indicators of chemical and sanitary conditions in streams collected at 313 to 424 stations in the conterminous United States from 1980 to 1989, (2) U.S. Fish and Wildlife Service (FWS) data on concentrations of pesticides and trace elements in finfish tissue collected at 113 station on major rivers in the conterminous United States and the Great Lakes between 1970 and 1986, and (3) USGS data collected from 1989 to 1991 for selected herbicides in 149 streams in a 10-State area of the agricultural Midwest and at locations on the Mississippi River and its major tributaries.

The most plentiful water-quality data for analysis of conditions and trends of the Nation's streams exist for traditional chemical and sanitary indicators. Analyses of selected indicators, based on USGS data for streams of the conterminous United States, are a major component of the article. The article begins with a presentation of six sets of maps that show the range of concentrations and trends in concentration of six traditional indicators of water quality-dissolved oxygen, fecal coliform bacteria, dissolved solids, nitrate, total phosphorus, and suspended sediment; box plots that show the average concentration of the constituents in stream basins that are predominately of one of four land-use types (agricultural, urban, forest, and range); and graphs that show trends in concentration in these indicators nationally and by land use.

Concentrations of several of the traditional water-quality indicators decreased during the 1980's and, collectively, provide evidence of progress in pollution control during the decade. The most notable improvements occurred in concentrations of fecal coliform bacteria, an important indicator of the suitability of stream water for contact recreation, and total phosphorus, which usually is the nutrient controlling the process of eutrophication in freshwater. However, despite widespread declines in these indicators, more than a third of the streams sampled in 1989 had annual average concentrations of total phosphorus and fecal coliform bacteria that exceeded desirable limits. Thus, waterquality goals for these indicators are not yet being met in a significant percentage of streams.

Trends in other traditional indicators provide evidence of slight improvement or little change in stream water quality during a decade when the economy and population showed significant growth. For example, dissolved-oxygen concentrations nationally changed little from 1980 to 1989 , but streams in urban areas showed slight improvement in dissolvedoxygen conditions, possibly reflecting the effect of improving point-source controls. Similarly, nitrate concentrations remained nearly constant nationally, which represents a significant departure from the pattern of widespread increases in nitrate reported for 1974-81 at
USGS stream water-quality stations.

The article also describes the transport of nitrate, total phosphorus, and suspended sediment from large land areas of the conterminous United States as defined by 14 water-resources regions and hydrologic cataloging units classified according to major land uses. Estimates of yield and change in yield during the 1980's are presented for these constituents and land areas. The geographic variation in yields of these constituents results from differences in the land-use characteristics of the regions. Yields are highest in the Ohio-Tennessee and Upper Mississippi regions, for example, due to the combined influence of agricultural activity and population density. Yields of nitrate and total phosphorus are lowest in forest and range basins where cultural sources of nutrients are small.

The transport of these constituents can influence the ecological health of lakes, reservoirs, estuaries, and other coastal waters through the accumulation of nutrients and sediment-attached contaminants in the plants and animals of the waterbody. The deposition of sediment also can have costly effects on the waterbodies by reducing reservoir storage or clogging navigable channels. For the conterminous United States, the article describes the transport of total phosphorus and suspended sediment to a selected set of 85 large reservoirs, and the transport of nitrate, total phosphorus, and suspended sediment to 6 coastal segments. During the 1980's, widespread declines occurred in the loads of total phosphorus transported to these waterbodies, whereas loads of suspended sediment either declined slightly or remained the same for most of the waterbodies. Loads of nitrate transported to the Gulf of Mexico decreased, but they increased or remained the same in other coastal segments.

Also discussed is water quality in stream basins where there is significant domestic, industrial, and irrigation water use. Results of the analysis are displayed graphically and show the percentage of stations in basins having significant domestic, industrial, and irrigation water use where the annual average concentration of selected indices and constituents exceeded particular limits.

Few regional and national stream water-quality data exist for toxic trace elements and for organic compounds such as herbicides and pesticides. Selected findings from two of the more geographically comprehensive data sources are summarized in the article. The first provides national-level information on trends in toxic trace elements and pesticides in finfish tissue in major rivers of the United States and the Great Lakes as compiled by the Fws. Contaminant concentrations in finfish tissue are integrative measures of water quality and can reflect long-term average contaminant concentrations in stream water and sediment. Since the 1970 's, these data show declines in concentrations of the toxic trace elements arsenic, cadmium, and lead and the organic compounds chlordane, dieldrin, DDT, toxaphene, and total PCB's.

The second data source, consisting of recent USGS studies of herbicide concentrations in streams in a large agricultural area of the Midwest, provides important regional information on the magnitude and distribution of herbicides in streams. The concentrations of four herbicides - alachlor, atrazine, cyanazine, and simazine-are summarized in the article. Samples col- 
lected during the spring and early summer of 1989 following herbicide application show, for example, that concentrations of atrazine and cyanazine exceeded applicable EPA drinking-water criteria at approximately one-half of the sites. Additional data collected in the spring of 1991 on atrazine in the Mississippi River and several of its major tributaries quantify the amounts of atrazine transported to the Mississippi River by major rivers and discharged to the Gulf of Mexico.

\section{Federal-State Water-Quality Assessment and Reporting}

Before the 1972 Clean Water Act, State and Federal agencies and private parties collected information on water-quality conditions and progress on restoring water quality on an as-needed basis. The article Nationwide Water-Quality Reporting to the Congress as Required Under Section 305(b) of the Clean Water Act in this volume describes the background to reporting before the passage of the act, the evolution of the reporting process during the last 20 years, and selected findings from the 1990 National Water Quality Inventory report to the Congress.

During the first 10 years of State reporting under section 305(b), EPA had difficulty in aggregating Statebased water-quality assessments because the reports, known as State 305(b) reports, were inconsistent. Beginning in 1983, EPA issued comprehensive guidelines to the States on report content and format (U.S. Environmental Protection Agency, 1983). These guidelines were based on recommended assessment measures developed by the EPA in cooperation with the Association of State and Interstate Water Pollution Control Administrators (Association of State and Interstate Water Pollution Control Administrat,ors, 1984). These guidelines recommended that the States report the sum of the areas of surface waterbodies that support, to varying degrees, the waterbodies' designated use; the extent to which dischargers cause waterbodies to not support their designated use; relative rankings of water contaminants; and the relative ranking and sources of ground-water contaminants. The article also discusses subsequent refinements of the guidelines to include reporting on wetlands and estuaries and to increase report consistency.

Despite the improvement of 305(b) report consistency in recent years, the article notes that it is still impossible to aggregate information from the reports and define national trends in water quality for the following reasons. The States use different criteria in defining the geographical extent and designated uses of the waterbodies; design and operate their own data-collection programs to monitor their particular water-quality problems, and hence interpret a wide variety of data to assess the waterbodies; use their own criteria to determine whether the waterbodies meet designated uses; and inconsistently follow EPA guidelines in preparing their reports.

Finally, the article cites the findings from the 1990 Water Quality Inventory Report to the Congress (U.S. Environmental Protection Agency, 1992) and notes the assessed waterbodies that support their designated uses -70 percent of assessed river lengths, 60 percent of assessed lake areas, and 67 percent of assessed estuarine areas. Most of the States reported that nutrients were among the top contributors to nonsupport of waterbody designated use, and toxic substances-such as metals, pesticides, and organic chemicals - cause severe problems where they occur, but they are less widely reported.

\section{STATE SUMMARIES OF STREAM WATER QUALITY}

The "State Summaries of Stream Water Quality" part of this 1990-91 National Water Summary describes water-quality conditions and trends in each State, the District of Columbia (combined with Maryland), Puerto Rico, and the Western Pacific Islands. Each State summary contains the following information:

- Overview of stream water quality,

- Discussion of water-quality monitoring,

- Description of water-quality conditions, as represented by statistical summaries of data on concentrations of a maximum of 8 water-quality constituents at a maximum of 10 selected water-quality monitoring stations, during water years 1987-89,

- Description of trends in concentrations of as many as 8 water-quality constituents for one or more of four periods - water years 1970-89, 1975-89, 1980-89, and 1982-89 - at a maximum of 20 water-quality monitoring stations (trend analysis was not possible for the Western Pacific Islands because of insufficient data),

- Description of water-quality management, and

- Selected references-State, local, and general-on stream water quality.

Each State summary also includes a table and four multicolor illustrations (the same table and figure numbers are used for each State) that show:

- Selected water-quality constituents and their source and environmental significance (table 1),

- Land use, physiography, and population (fig. 1),

- Location of selected water-quality monitoring stations, type of statistical analysis performed on station data, and geographic features mentioned in the text (fig. 2),

-Water-quality conditions of selected streams during water years 1987-89 (fig. 3; see example on page 9), and

- Trends in water quality of selected streams as reflected by selected constituents during one or more of four periods - water years 1970-89, 1975-89, 1980-89, and 1982-89 (fig. 4; see example on page 9).

Interpretation of the analysis of constituent data for water-quality conditions is by stream basin, whereas the interpretation of trends is by constituent. This interpretation is facilitated by maps of land use, physiography, and population and other ancillary reports or data that are available for each State. The distribution and trends in constituent concentration are influenced by a wide range of natural and human-induced changes within a stream basin. These changes include relatively long-term fluctuations in streamflow, precipitation, and temperature and changes in agricultural and industrial activities, construction of waste-treatment plans, urbanization, and other land uses. If sufficient ancillary information or published references were available to interpret water-quality conditions or trends, State-summary authors attribute a cause-and-effect basis for the waterquality characteristics.

Stream water quality is influenced by land use and human activities more often within stream basin rather than within a State boundary. However, analysis of 

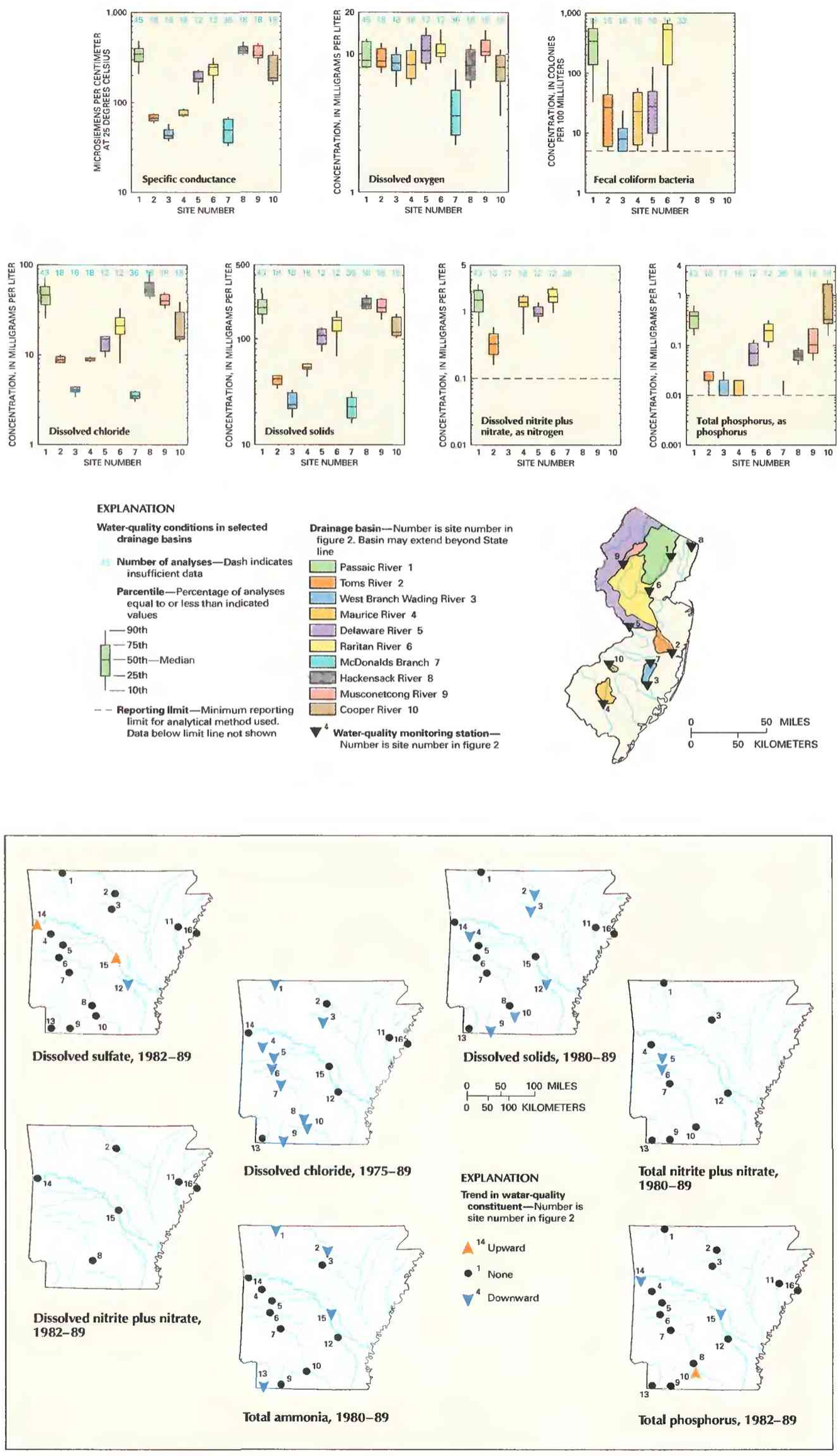

Example of figure 3 used in each State summary in this volume of the National Water Summary to show water-quality conditions for selected streams.
Example of figure 4 used in each State summary in this volume of the National Water Summary to show water-quality trends for selected streams. 
stream water quality was done by State and not by basin boundary in this volume to facilitate comparison of the State summaries of stream water quality with State summaries on other water-resources topics in previously published volumes of the National Water Summary. Accordingly, no attempt was made to duplicate the analysis of data on the basis of national or regional stream basins of like land or water use that was undertaken in the article Stream Water Quality in the Conterminous United States-Status and Trends of Selected Indicators During the 1980's wherein national and regional displays of conditions and trends of selected water-quality constituents are given. For every State, except Delaware, data for dissolved solids and nitrate plus nitrite (as nitrogen) were analyzed because these constituents have an extensive data base and are broad indicators of the effect of natural and human-induced processes on water. In Delaware, these data were not available; however, total-nitrate data were available and were analyzed as a surrogate for nitrate plus nitrite. Most States analyzed for dissolved oxygen (31 States), fecal coliform bacteria (38), phosphorus (25), and suspended sediment (31), and the conditions and trends of these constituents in the State summaries can, in general, be compared to the national analysis discussed in the article cited above.

Only selected findings from State 305(b) reports are cited in the State summaries because the length of the summaries was limited. However, the 305(b) reports are a major source of information on stream water quality in most States.

The results displayed in the State summaries and the article Stream Water Quality in the Conterminous United States-Status and Trends of Selected Indicators During the 1980's represent the findings of a nationally consistent and scientifically rigorous analysis of water quality in the United States. The statistical methods of analysis and display of results provide an opportunity to compare and contrast water quality State by State and nationally. Such analyses will be more comprehensive when data consistently collected from a broader range of constituents over a longer period of time become available.

\section{REFERENCES CITED}

Association of State and Interstate Water Pollution Control Administrators, 1984, America's clean water-The States' evaluation of progress, 1972-1982: Washington, D.C., Association of State and Interstate Water Pollution Control Administrators, $16 \mathrm{p}$.

Dole, R.B., 1909, The quality of surface waters in the United States-Part 1, Analyses of waters east of the one hundredth meridian: U.S. Geological Survey Water-Supply Paper 236, 123 p.

Ficke, J.F., and Hawkinson, R.O., 1975, The national stream quality accounting network (NASQAN)-Some questions and answers: U.S. Geological Survey Circular $719,23 \mathrm{p}$.

Gilbert, B.K., and Mann, W.B., IV, 1990, The U.S. Geological Survey Federal-State cooperative water-resources program-Fiscal year 1989: U.S. Geological Survey Open-File Report 90-353, 49 p.

Lanfear, K.J., 1993, Hydrologic data-collection stations whose stream water quality data were available to prepare the 1990-91 national water summary on stream water quality: U.S. Geological Survey Open-File Report 93-29, $48 \mathrm{p}$.

Leopold, L.B., 1962, A national network of hydrologic bench marks: U.S. Geological Survey Circular 460-B, 4 p.

Stabler, Herman, 1911, Some stream waters of the western United States, with chapters on Sediment carried by the Rio Grande and the industrial application of water analyses: U.S. Geological Survey Water-Supply Paper 274, $188 \mathrm{p}$.

U.S. Environmental Protection Agency, 1983, Guidelines for the preparation of the 1984 State water quality assessment (305(b) report): Washington, D.C., U.S. Environmental Protection Agency, Office of Water, $20 \mathrm{p}$.

1992, National water quality inventory, 1990 report to Congress: Washington, D.C., U.S. Environmental Protection Agency, Office of Wetlands, Oceans, and Watersheds, EPA 503/9-92/006, 236 p. 


\section{INTRODUCTION}

his volume, National Water Summary 1990 91-Hydrologic Events and Stream Water Quality, is organized into three parts, following the format of the six previous volumes in the National Water Summary series (see inside front cover for previous volumes). The first part, "Hydrologic Conditions and Water-Related Events, Water Years 1990-91," provides a synopsis of the Nation's water-resources conditions during the 1990 and 1991 water years (October 1, 1989, through September 30, 1990, and October 1, 1990, through September 30, 1991). A brief review of each water year is supplemented by maps of annual streamflow and precipitation and a chronological list of significant floods, droughts, and other waterrelated events and by seasonal summaries that contain maps of streamflow, precipitation, temperature, and upperair atmospheric-pressure patterns.

The second part, "Hydrologic Perspectives on Water Issues," contains articles on the hydrologic and institutional and management aspects of stream water quality. These articles deal with the availability of stream waterquality data and their suitability for national assessment, the limits of what can be determined about water-quality conditions and trends from available data, and statistical methods to use in the analysis and quality assurance of water-quality data. Additionally, one article discusses the role of the States and the Federal Government in biennial assessments of water quality and in reporting these assessments to the Congress.

The third part, "State Summaries of Stream Water Quality," describes water quality in each State, the District of Columbia (combined with Maryland), Puerto Rico, and the Western Pacific Islands. The description of water quality is based on the statistical analysis of data on water-quality constituents and properties that were derived from a data base prepared specifically for this National Water Summary and created from the U.S. Geological Survey (USGS) National Water Information System and the U.S. Environmental Protection Agency (EPA) storage and retrieval system (STORET). Because biological indicators of water quality have not been collected extensively, virtually all the data included in the data base are water-chemistry data. See the article "Introduction to State Summaries of Stream Water Quality" in this volume for information about the contents of the State summaries.

The basis for any assessment of the highly variable water quality in the United States is nationally consistent data. Water quality is highly variable because of climate, geology, topography, soils, land cover, and other natural factors that vary across the continent. In the more than 200 years since its foundation, the United States has become a technologically advanced nation with large industrial, agricultural, and urban areas, all of which are highly dependent on withdrawals of surface and ground water. These human uses of land and water also affect the quality and quantity of ground- and surface-water resources and, in some locations, have seriously degraded the resources. Nationally consistent data by which to assess the Nation's water resources and evaluate the effects of natural and human-induced factors are relatively sparse, and only during the last two decades have data been collected specifically to evaluate the changes from earlier times to the present.

From the spring of 1905 until the spring of 1907, the USGS conducted a program of systematic once-daily sampling and chemical analysis of weekly composites of the daily samples of principal streams in the United States. During sampling in 1906-7 and 1905-7, about 100 waterquality stations on streams east of the 100th Meridian and 55 stations in the western part of the country were documented by Dole (1909) and Stabler (1911), respectively. Although other scientific and anecdotal information exists about the status of stream water quality in particular streams or restricted geographical areas at particular times, little other systematic scientific evidence is available about overall water quality in the United States in the early part of the 20 th century.

National water-quality monitoring networks such as the USGS Hydrologic Bench-Mark Network (Leopold, 1962) and the National Stream Quality Accounting Network (NASQAN) (Ficke and Hawkinson, 1975) were established in the 1960's and 1970's, respectively. The Hydrologic Bench-Mark Network monitors the quality of 55 streams that are minimally affected by human influence. NASQAN monitors the Nation's major drainage basins; it started with 50 water-quality monitoring stations in 1973, increased to 518 stations by 1979 , and then decreased to 410 stations in 1992. Additional water-quality monitoring stations have been operated by the USGS as part of the Federal-State Cooperative Program (Gilbert and Mann, 1990). These stations, which are operated by the USGS in cooperation with many of the 1,000 State and local agencies that participate in the program, have relatively short periods of records (rarely exceeding 10-15 years) and some are no longer operational.

In 1972, passage of the Clean Water Act, formally known as the Federal Water Pollution Control Act Amendments of 1972 (Public Law 92-500), and its subsequent amendments, provided the legislative foundation of much of EPA's water-pollution-control activities. The act also defined the State's roles in identifying waterbodies, assigning designated uses, and establishing water-quality standards. Because the act gave the States the responsibility for monitoring, States operate many data-collection programs and draw upon a wide variety of information in assessing whether waterbodies meet designated uses. However, much of the data are not comparable from State to State because there are no national data-collection standards under which the State monitoring programs operate.

Since the U.S. Water Resources Council's Second National Water Assessment was published in 1978 (U.S. Water Resources Council, 1978), few efforts have been made to document stream water quality on a national scale. However, beginning in 1974, the EPA has prepared a series of biennial National Water Quality Inventory reports to Congress (see for example, U.S. Environmental Protection Agency, 1992), which are based on individual reports prepared by the States as required by section 305 (b) of the Clean Water Act. In 1984, the Association of State and Interstate Water Pollution Control Administrators developed a set of uniform responses from the States to a set of questions about the status of waterbodies so that progress in pollution control could be measured in terms of river lengths or lake areas that meet designated uses (Association of State and Interstate Water Pollution Control Administrators, 1984); the Association plans a revised assessment of progress made by the States during the last 20 years.

Several other assessment programs have periodically reviewed the status of water quality nationwide. In particular, the U.S. Forest Service (1981) and the U.S. Department of Agriculture (1982) assessments of soil, 
water, forest, rangeland, and related resources have drawn on existing reports and data sources.

Although the lack of national data sets has severely constrained the preparation of national assessments, a number of recent attempts have been made to evaluate water quality of specific river basins and draw general conclusions from the results. Patrick (1992) reviewed information from the Delaware River, the Neches Estuary, and the Flint River and concluded that significant progress had been made in the past 20 years to reduce the discharge of many wastes and nutrients to these waterbodies and to improve their oxygen content. Toxic metals have been reduced in the water but have accumulated in sedimentsa potentially major future problem. Becker and Neitzel (1992) have compiled a set of reports on human modifications of 12 river ecosystems in North America. Those reports give graphic evidence of the ways in which human activities affect river basins. Finally, in an attempt to provide an assessment of global freshwater quality, Meybeck and others (1989), under the auspices of the United Nations Global Monitoring system, reviewed information on pollution issues and presented a synoptic view of the environmental situation in several waterbodies, such as the River Danube, the Great Lakes, and Lake Nasser. All these studies note the lack of information and the need to improve water-quality monitoring before problems can be assessed and the effects of pollution-control policies evaluated.

\section{Acknowledgments}

Preparation of the National Water Summary requires the compilation of material from many individuals within the USGS and various other Federal and State agencies. This 1990-91 National Water Summary is the seventh in the series of USGS Water-Supply Papers prepared under the direction of Philip Cohen, Chief Hydrologist. The compilers gratefully acknowledge the assistance of State agencies in preparing and reviewing the State summaries. In addition, the following Federal agencies provided information:

\section{U.S. DEPARTMENT OF COMMERCE}

NATIONAL OCEANIC AND ATMOSPHERIC ADMINISTRATION NATIONAL ENVIRONMENTAL SATELLITE, DATA, AND INFORMATION SERVICE NATIONAL WEATHER SERVICE

U.S. DEPARTMENT OF DEFENSE, ARMY CORPS OF ENGINEERS U.S. DEPARTMENT OF TRANSPORTATION, COAST GUaRd, NATIONAL RESPONSE CENTER

U.S. ENVIRONMENTAL Protection AGENCY

Although individual acknowledgment is not feasible for all who participated in the preparation of this report, their cooperation and many contributions made publication of this report possible. The following persons, however, deserve special mention.

The authors of the individual articles and the State summaries, who adhered to strict guidelines and whose names appear on the articles. Kenneth J. Lanfear, who developed the water-quality data base used in the preparation of this National Water Summary and the computer software that made it possible to derive the nationally consistent analysis of stream water-quality conditions and trends used extensively in the State summaries, and Kathleen K. Fitzgerald, who retrieved data from USGS computers nationwide. Gail E. Mallard, Robert C.
Bubeck, George A. Irwin, Donald A. Goolsby, and Wayne E. Webb, who provided expertise and coordination of the analysis of stream water quality, and Jerri V. Davis, Anne B. Hoos, Rick T. Iwatsubo, and Robert J. Rogers, who assisted by preparing prototype State summaries. Eugene R. Hampton, who provided technical editorial review; Robert S. Roberts, Mary A. Kidd, Hyla H. Strickland, Diane Shugrue, Elizabeth E. Enright, and Jack H. Green, who provided editorial review and editorial assistance in preparing the State summaries; and Linda J. Jacobsen, who assisted with editorial review. Patricia S. Greene, Phillip J. Redman, Robert J. Olmstead, Gregory J. Allord, and Edward J. Swibas, who assisted with the design, coordination, and layout of the report; David Carlson, who assisted with the development and preparation of computer-generated illustrations; and Gina P. Barker, Jennifer S. Norton, Gary D. Latzke, Timothy D. Covington, James O. Whitmer, and Leslie J. Robinson, who assisted with the graphics. Jamaica Pettit, who typeset the State summaries; and Janet N. Arneson, who provided administrative assistance.

\section{REFERENCES CITED}

Association of State and Interstate Water Pollution Control Admin istrators, 1984, America's clean water-The States' evaluation of progress, 1972-1982: Washington, D.C., Association of State and Interstate Water Pollution Control Administrators, $16 \mathrm{p}$.

Becker, C.D., and Neitzel, D.A., eds., 1992, Water quality in North American river systems: Columbus, Ohio, Battelle Press, $304 \mathrm{p}$.

Dole, R.B., 1909, The quality of surface waters in the United States-Part 1, Analyses of waters east of the one hundredth meridian: U.S. Geological Survey Water-Supply Paper 236, $123 \mathrm{p}$.

Ficke, J.F., and Hawkinson, R.O., 1975, The national stream quality accounting network (NASQAN)-Some questions and answers: U.S. Geological Survey Circular 719, 23 p.

Gilbert, B.K., and Mann, W.B., IV, 1990, The U.S. Geological Survey Federal-State cooperative water-resources program-Fiscal year 1989: U.S. Geological Survey Open-File Report 90-353, $49 \mathrm{p}$.

Leopold, L.B., 1962, A national network of hydrologic bench marks: U.S. Geological Survey Circular 460-B, 4 p

Meybeck, Michel, Chapman, D.V., and Helmer, Richard, 1989, Global freshwater quality-A first assessment: Cambridge, Mass., World Health Organization and the United Nations Environment Programme, Basil Blackwell, Inc., 306 p.

Patrick, Ruth, 1992, Surface water quality-Have the laws been successful: Princeton, N.J., Princeton University Press, $198 \mathrm{p}$.

Stabler, Herman, 1911, Some stream waters of the western United States, with chapters on Sediment carried by the Rio Grande and the industrial application of water analyses: U.S. Geological Survey Water-Supply Paper 274, $188 \mathrm{p}$.

U.S. Department of Agriculture, 1982, Soil, water, and related resources in the United States-Status, conditions, and trends, 1980 appraisal: Washington, D.C., U.S. Department of Agriculture, 2 vols., variously paginated.

U.S. Environmental Protection Agency, 1992, National water quality inventory, 1990 report to Congress: Washington, D.C., U.S. Environmental Protection Agency, Office of Wetlands, Oceans, and Watersheds, EPA 53/9-92/006, 236 p.

U.S. Forest Service, 1981, An assessment of the forest and rangeland situation in the United States: U.S. Forest Service Report 22, $352 \mathrm{p}$.

U.S. Water Resources Council, 1978, The Nation's water resources-1975-2000: Washington, D.C., U.S. Government Printing Office, 4 vols., variously paginated. 


\section{Hydrologic Conditions and WATER-RELATED EVENTS, WATER YeARs 1990-91}

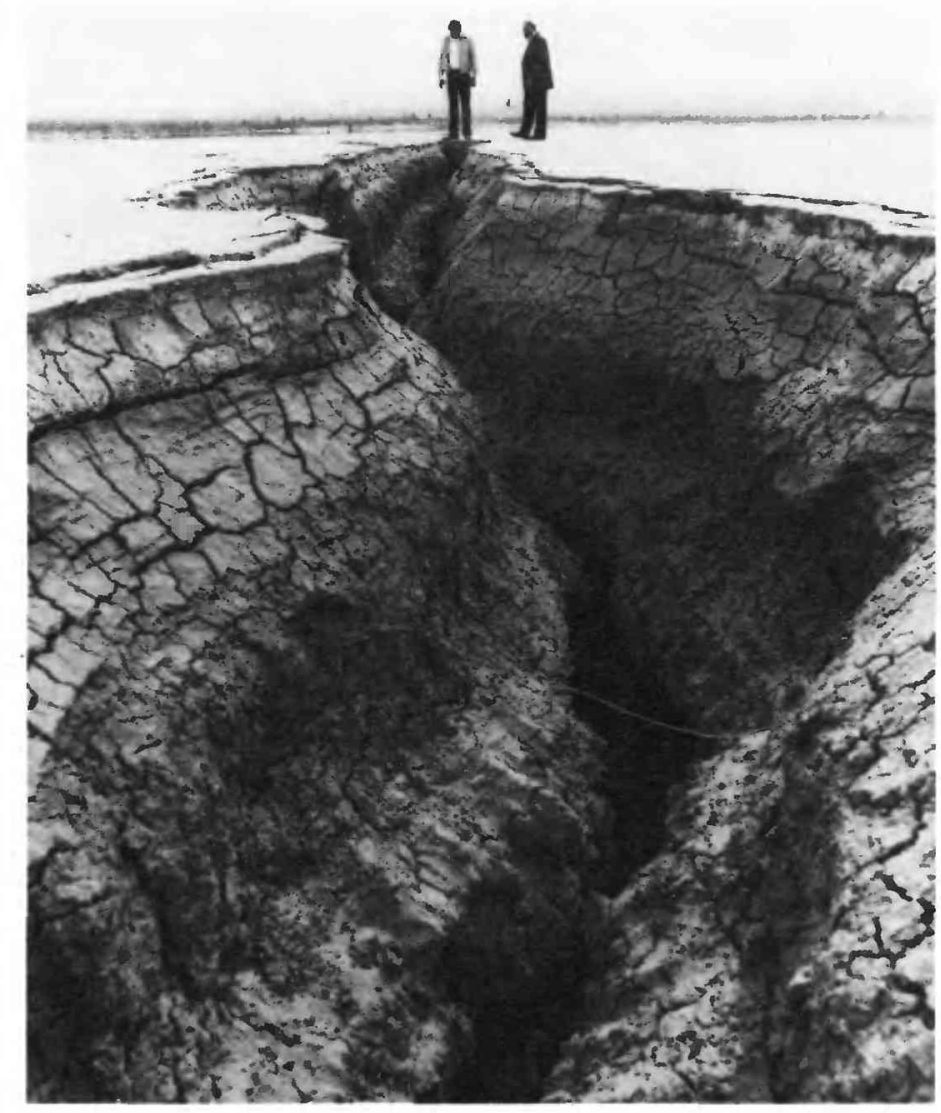

Subsidence of the land surface resulting from ground-water depletion created a fissure one-half mile long and 12-feet deep on a runway on Rogers Dry Lake at Edwards Air Force Base, California. (Anne Gordon, Edwards Air Force Base) 


\title{
Review of Water Year 1990 Hydrologic Conditions AND Water-RELATED EVENTS
}

\author{
By Gregory J. McCabe, Jr., Judy D. Fretwell, and Edith B. Chase
}

\begin{abstract}
Surface-water hydrologic conditions and many water-related events are controlled primarily by meteorologic and climatic factors. The following annual and seasonal summaries of hydrologic conditions for water year 1990, therefore, are described in a climatic context. Streamflow, which is expressed as a percentage of median streamflow for the reference period 1951-80, and precipitation, which is expressed as a percentage of average annual precipitation for the reference period 1931-90, are depicted on maps (fig. 1)
\end{abstract} to provide an overview of the water year. Quarterly streamflow and precipitation data also are presented (figs. $5 A, B ; 6 A, B ; 7 A, B ; 8 A, B$ ) in the "Seasonal Summaries" section and are accompanied by maps showing temperature as a departure from average 1931-90 reference-period conditions (figs. 5C, $6 C$, $7 C, 8 C$ ) and atmospheric-pressure conditions near 10,000 feet (about 3,048 meters) as compared to average 1948-70 reference-period conditions (figs. $5 D$, $6 D, 7 D, 8 D$ ). Departure from the average temperature is depicted in terms of standard deviations, which is a statistical measure of the dispersion of values around an average. The distribution of high- and low-pressure areas across the United States at about 10,000 feet, which are recorded in terms of the 700-millibar pressure surface, or height field, influences the distribution of surface temperature, precipitation, and, thus, streamflow. Usually, excessive precipitation and droughts that persist throughout a season will be observed in conjunction with persistent low- and highpressure conditions in the upper atmosphere. Because these maps depict conditions averaged over a 3-month period, ephemeral events, such as a single flood resulting from an individual storm, might not be associated easily with the general upper-level circulation.

The data used in preparing these summaries were taken from the following publications: the National Oceanic and Atmospheric Administration's (NOAA) "Climate Impact Assessment, United States"; "Daily

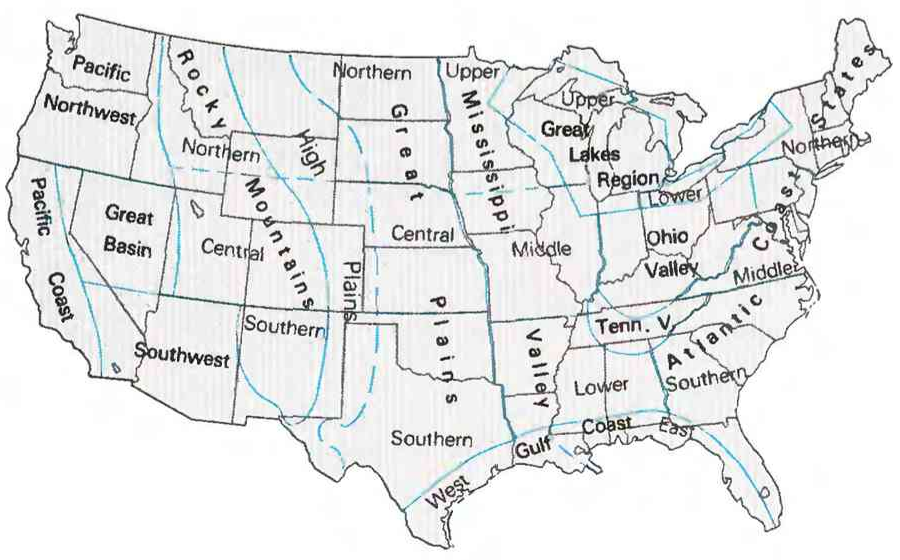

Weather Maps, Weekly Series"; "Monthly and Seasonal Weather Outlook"; "Storm Data"; and "Weekly Weather and Crop Bulletin" (the last publication is prepared and published jointly by NOAA and the U.S. Department of Agriculture); and the U.S. Geological Survey's (USGS) monthly "National Water Conditions" reports. Geographic designations in this article generally conform to those used in the "Weekly Weather and Crop Bulletin" (see map showing geographic designations).

For water year 1990, streamflow was above median for a large part of the Southeastern States (fig. 1A) and in isolated sections of the Northeastern States; it was below median for most of the Western States and in a large part of the North-Central States and north and central Florida. Although a large area of the country had below-median streamflow during water year 1990, the combined flow of the three largest rivers in the conterminous United States- the Mississippi, St. Lawrence, and Columbia-was 15 percent above median. Annual flow of the St. Lawrence River was 1 percent below median, flow of the Mississippi River was 25 percent above median, and flow of the Columbia River was 7 percent below median.

Annual precipitation for water year 1990 was near average for much of the country (fig. $1 B$ ). However, in California and in parts of the Pacific Northwest, the central Rocky Mountains, the upper Mississippi Valley, and the southern Atlantic Coast States, the annual precipitation was below average. In the Tennessee Valley, the Middle Atlantic Coast States, and the Gulf Coast. precipitation was slightly below average. Central southern California received less than half the average precipitation for the water year. In contrast, parts of the Southwest, central Rocky Mountains, southern Great Plains, middle Mississippi Valley, and the lower Great Lakes region received above-average precipitation for the water year.

Temperatures for water year 1990 were above average for most of the country. Along the southern Atlantic Coast, and in the central Appalachian Mountains, southern California, the Southwest, the Pacific Northwest, the central and northern Rocky Mountains, and the northern Great Plains, temperatures were above to muchabove average. In central Washington and Oregon, and southern Nevada. temperatures were at least 2 standard deviations above the average. Only the lower Great Lakes region, Ohio Valley, central Tennessee Valley, central Gulf Coast, west-central Texas, and northern New England had temperatures that were cooler than average. Nationally, water year 1990 was one of the warmest years on record. During the late spring and summer of 1990, oppressive heat in many parts of the country was the result of higher-than-average atmospheric pressures. In all, 779 new daily maximum temperature records were set between June and September 1990. 

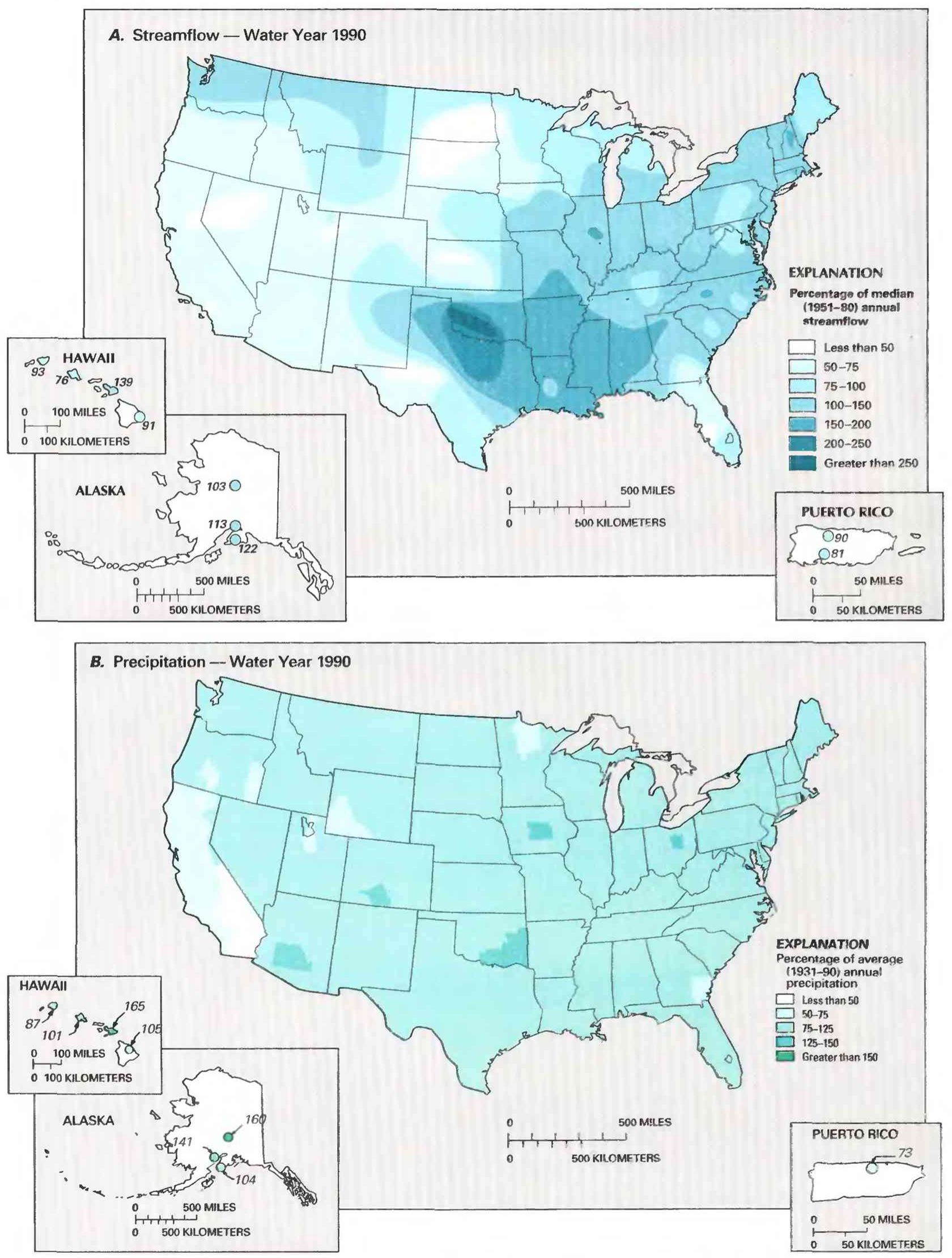

Figure 1. Streamflow $(A)$ and precipitation $(B)$ in the United States and Puerto Rico in water year 1990. Streamflow is shown as a percentage of median, and precipitation as a percentage of average. (Sources: A. Data from U.S. Geological Survey. B, Data from the National Oceanic and Atmospheric Administration, National Climatic Data Center.) 

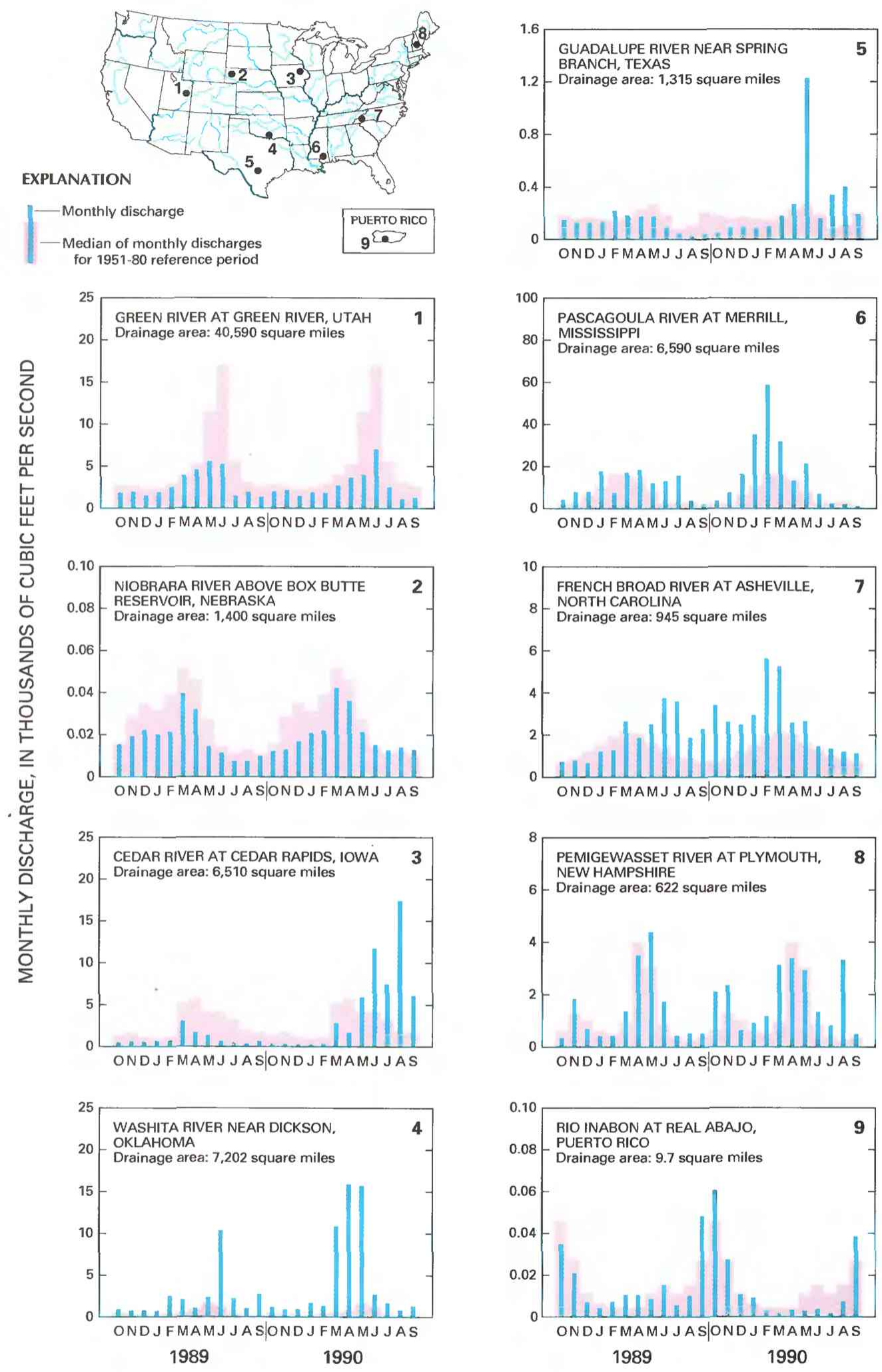

Figure 2. Monthly discharges for selected major rivers of the United States and Puerto Rico for water years 1989 and 1990 compared with monthly median discharges for the reference period water years 1951-80. (Source: Data from U.S. Geological Survey files.) 

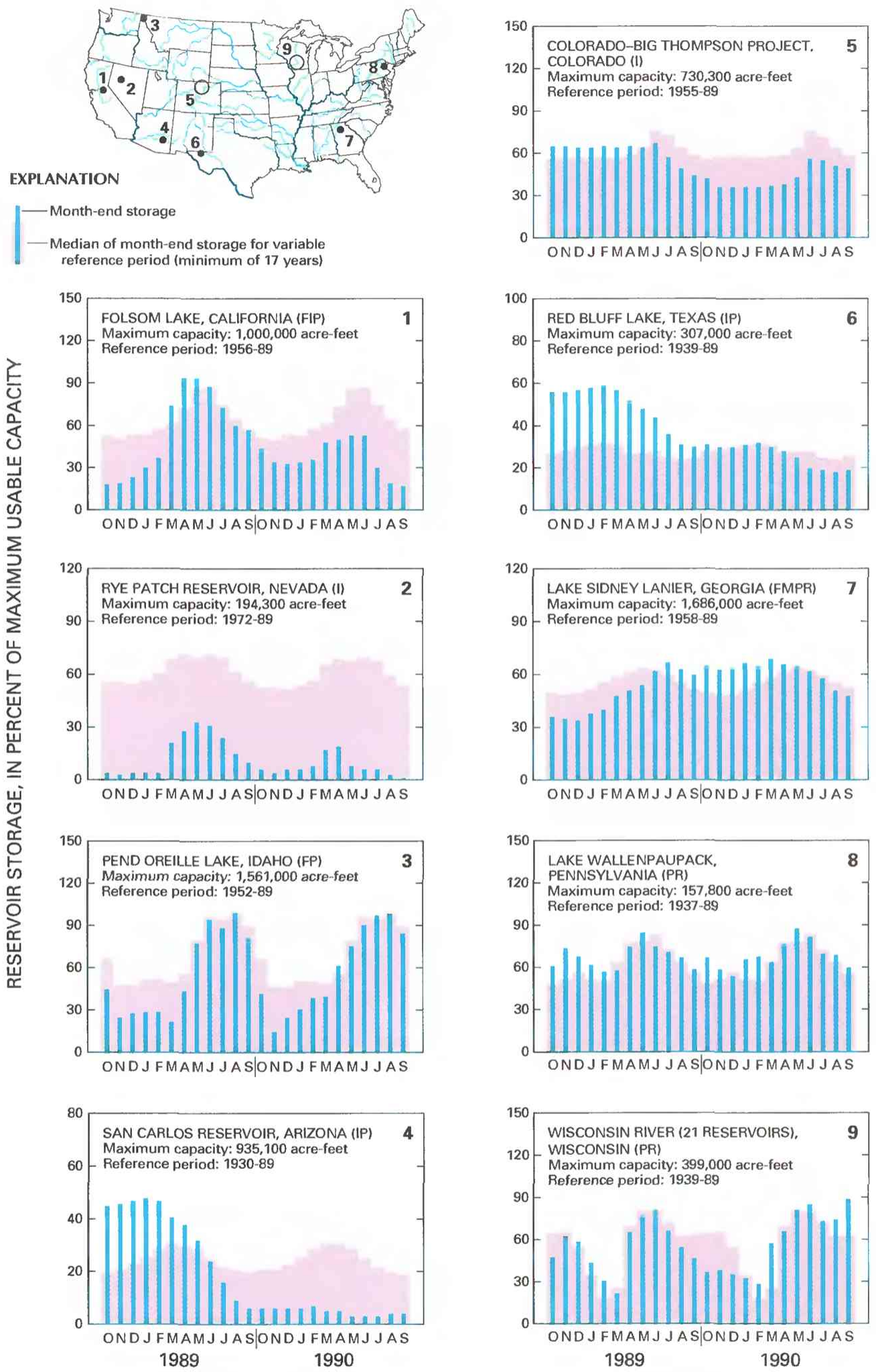

Figure 3. Month-end storage of selected reservoirs in the United States for water years 1989 and 1990 compared with median of month-end storage for reference period. The reference period, which varies but is a minimum of 17 years, for each reservoir or reservoir system is shown on the graph; the beginning year for a reservoir system is the year records began for the newest reservoir in the system. The location of individual reservoirs is shown on the map by a black dot; the general location of reservoir systems (multi-reservoirs) is shown by an open circle. Principal reservoir and water uses are shown in parentheses: $F$, flood control; I, irrigation; M, municipal; P, power; and R, recreation. (Source: Data from U.S. Geological Survey files.) 
Below-average precipitation and above-average temperatures prevailed over the United States during water year 1990 in response to the northward displacement of the jetstream during most of the year. When the jetstream is located more northward than normal, storm tracks also are displaced somewhat north of normal and weather systems generally move more rapidly from west to east. The situation also produces above-average atmospheric pressures, which cause above-average temperatures.

Drought conditions continued to spread in the Western States and in parts of the Southeast. California entered the fourth consecutive year of drought. In Florida, the drought also intensified; southwestern Florida had a second consecutive year of drought. Drought that began during fall 1987 continued in areas in central North Dakota.

The regional and local patterns of hydrologic conditions can be seen in the graphs of monthly discharges for selected rivers (fig. 2) and storage of selected reservoirs (fig. 3). The drought that prevailed in the Western States during water year 1990 is illustrated by the monthly discharge of the Green River at Green River, Utah (fig. 2). Discharge of the Green River, as well as other western rivers, was below median for the entire water year. In contrast to the drought in the Western States, the effects of above-average precipitation in areas in the Southeastern States and parts of the Ohio Valley are seen in the monthly discharge of selected rivers. For example, monthly discharges of the Pascagoula River at Merrill, Miss., and the French Broad River at Asheville, N.C., were above median for most of the water year.

The drought in the Western States also is illustrated by the month-end reservoir storage of Folsom Lake in California, Rye Patch Reservoir in Nevada, San Carlos Reservoir in Arizona, and the Colorado-Big Thompson Project in Colorado (fig. 3). Storage was below median for the entire water year in each of these reservoirs. Storage in Rye Patch Reservoir was less than
10 percent of maximum usable capacity for most of the water year. By the end of water year 1990 the storage of Rye Patch Reservoir was 1 percent of maximum capacity, and storage of the San Carlos Reservoir was 4 percent of maximum capacity.

During the 1990 water year, many significant water-related events, both natural and human induced, occurred throughout the United States. A representative set of these events is listed chronologically in table 1 , and their geographic location is plotted in figure 4 . Table 1 represents a culling of some hundreds of these hydrologic occurrences, generally omitting, for example, floods whose recurrence interval is less than 10 years, toxic spills that involve less than 2,500 gallons, and fishkills of less than 5,000 fish. The selection of events for inclusion in table 1 was affected to some extent by the degree of media coverage, including National Weather Service and USGS periodicals, and by communications from USGS field offices alerting the national office that significant hydrologic events had occurred. Toxic-spill data were provided by the U.S. Coast Guard National Response Center. Reporting of weather-related events and damage estimates is subjective. Therefore, table 1 might be inconsistent with other national compilations of hydrologic events, such as the annual flooddamage report to the Congress by the U.S. Army Corps of Engineers (1990). Weather-related events (excluding drought, storm surges, and coastal flooding) were estimated to have caused damage in excess of $\$ 2.5$ billion. Of this amount, flood damage was about $\$ 1.6$ billion (U.S. Army Corps of Engineers, 1990).

\section{REFERENCE CITED}

U.S. Army Corps of Engineers, 1990, Annual flood-damage report to Congress, fiscal year 1990: U.S. Army Corps of Engineers report prepared in cooperation with the National Weather Service. [Available from the U.S. Army Corps of Engineers, Engineering Division, Washington, D.C.] 


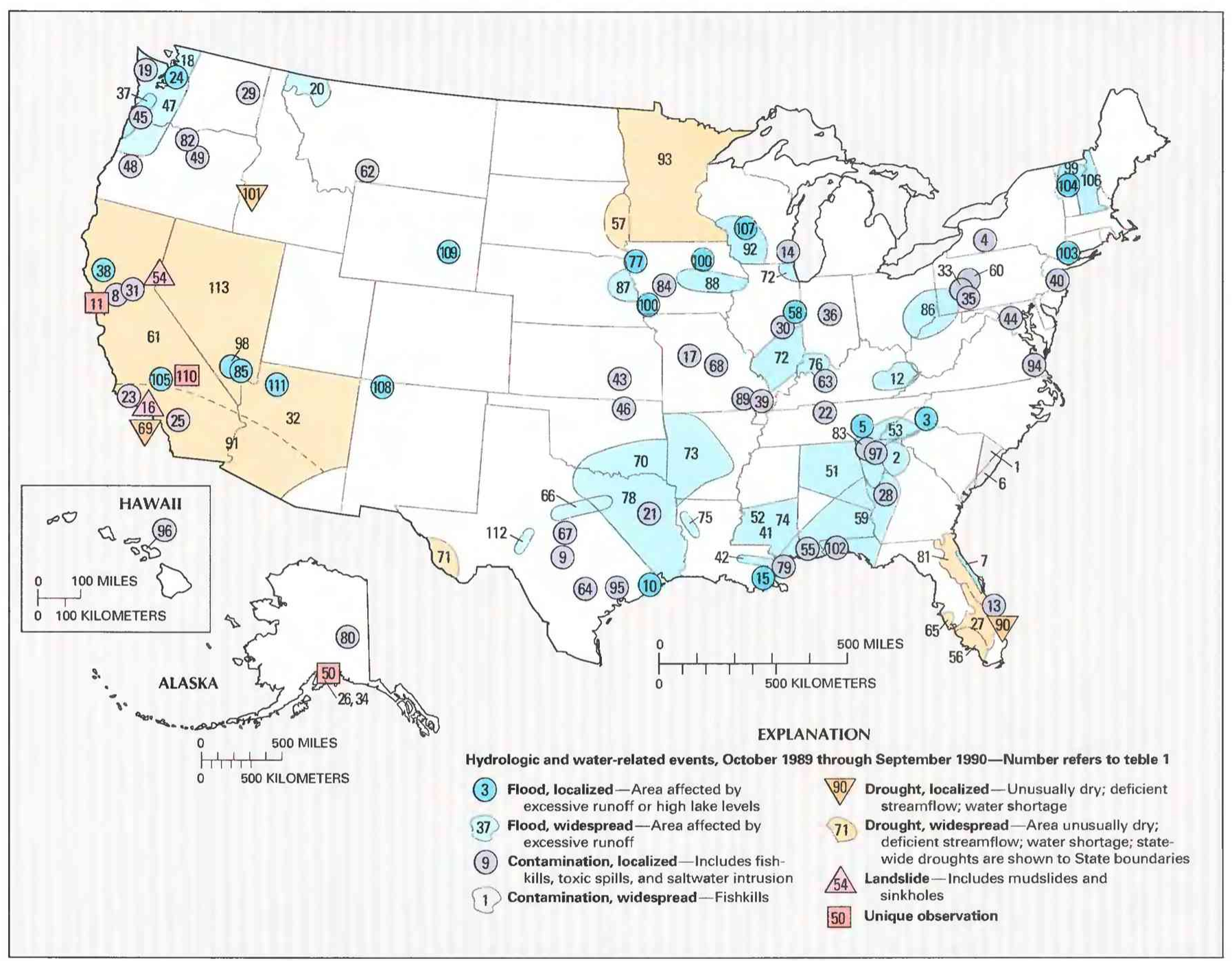

Figure 4. Location or extent of significant hydrologic and water-related events in the United States, October 1989 through September 1990 , as documented in table 1. 
Table 1. Chronology of significant hydrologic and water-related events, October 1989 through September 1990

[The events described are representative examples of hydrologic and water-related events that occurred during water year 1990 . Toxic-spill data were provided by the U.S. Coast Guard National Response Center. Fishkill data generally were provided by the U.S. Environmental Protection Agency on the basis of reports transmitted by State agencies. Meteorological data are mostly from reports of the National Oceanic and Atmospheric Administration. Abbreviations used: $\mathrm{t}^{3} / \mathrm{s}=\mathrm{cubic}$ feet per second; $\mathrm{mi}^{2}=$ square miles; $\mathrm{mph}=$ miles per hour; $\mathrm{mg} / \mathrm{L}=$ =milligrams per liter; Mgal/d=million gallons per day; ppm=parts per $\mathrm{million}$ ]

1 In late September and early October, in the aftermath of Hurricare Hugo, about 5 million fish died in lakes and streams in the eastern third of South Carolina. Areas affected were the Santee Cooper lakes, the Santee, Black, Lynches, and Little Pee Dee Rivers, oxbow lakes along these rivers, small streams and lakes, and some farm ponds. The fish deaths occurred when organic material and untreated sewage were washed into the water from land or when water stirred the organic material on the river bottom and depleted the oxygen to levels that affected all species of fish.

Severe flooding in northeastern and north-central Georgia followed intense rains on September 30 and October 1. On September 30, more than 4 inches of rain fell in 6 hours and flooded creeks, including Sweetwater Creek (tributary to the Chattahoochee River) near Atlanta and the Toccoal Ocoee River on the Tennessee-Georgia line. Rainfall exceeded 10 inches for the week in some parts of the State. Recurrence intervals were less than 10 years except at three streamflow stations - Broad River near Bell, Kettle Creek near Washington, and Sope Creek near Marietta-where peak discharges had recurrence intervals of 50 years. In Atlanta, where a wastewater-treatment plant was flooded, 200 million gallons of raw sewage was discharged into the Chattahoochee River. Damage to the treatment plant was estimated at $\$ 1$ million. In Paulding County, northwest of Atlanta, a small bridge collapsed and was washed away. In northern Georgia, flooding and mudslides caused many road closings. In Putnam County, the Little River reached a record height of 28.7 feet on October 2, breaking the 1971 record by 0.3 foot, and flooded houses and covered bridges. The Little and Etowah Rivers in Cherokee County crested above flood stage as did the Flint River in Clayton County, the Yellow River in Newton County, and the Ocmulgee River in Bibb County. Allatoona and Lake Lanier Reservoirs were both above average October levels after the rains. Two deaths were attributed to flooding. Several tornadoes touched the ground during the storms.

Rainfall during September 29 to October 1 in much of North Carolina caused local flooding of roads, homes, and croplands as creeks overflowed their banks and drainage systems became plugged. In Henderson County, crop damage to vegetables was estimated at $\$ 6$ million. About half of the hay and vegetable crops in Transylvania County were damaged.

On October 1, a pipe ruptured at a pig farm and discharged about 5,000 gallons of pig manure into Cryder Creek, which flows into the Genesee River near Wellsville, N.Y. Because the Genesee River is the source of the town's water supply, residents were asked to conserve water for a few days until the waste dissipated and pumping could be resumed.

As a result of intense rain on September 29 and 30, rivers and creeks in Bledsoe County, Tenn., reached flood stage. Three people drowned because their car was swept off a bridge on October 2 . The creek level was 2 feet above the bridge at the time of the accident.

On October 3, shellfishing was temporarily banned along the South Carolina coast because waste was being discharged into rivers and carried to the coast from 10 major sewage- treatment plants in the Charleston area. The plants were not yet fully operational because of damage by Hurricane Hugo in late September.

7 Along the east coast of Florida, urban areas were flooded between Melbourne (Brevard County) and St. Augustine (St. Johns County) on October 9 and 10. A stalled weather front produced 11.17 inches of rain at Rockledge and Cocoa (Brevard County) in just 12 hours on October 9 and 10. The most rain ever recorded in St. Augustine for a 24-hour period occurred October 10, with a total of 16.08 inches in 14 hours. The previous 24 -hour record was 9.52 inches on September 18, 1963. Many roads into downtown St. Augustine and a bridge to Anastasia Island were closed to traffic because of washouts and flooding. On the west side of town, 4 feet of water covered many roads, and in the historic district, streets were covered with 1.5 to 2 feet of water. Many buildings and homes also were flooded. At the closest gaging station (Moultrie Creek, drainage area $19.8 \mathrm{mi}^{2}$, about 5 miles southwest of St. Augustine) peak discharge was $194 \mathrm{ft}^{3} / \mathrm{s}$; the 2-year recurrence interval flood for this site is $351 \mathrm{ft}^{3} / \mathrm{s}$.

8 On October 13, the California Department of Fish and Game announced that about 150,000 steelhead trout had died within a few weeks at the Mokelumne River fish hatchery, due to the quality of water released from an upstream reservoir. Water released from the reservoir contained hydrogen sulfide (a natural byproduct of decaying material in the bottom of the reservoir) and silt, which denied oxygen to the fish.

9 On October 14, a fishkill was reported in the Colorado River upstream from its confluence with the San Saba River between San Saba and Mills Counties, in central Texas. Thousands of dead fish were reported along the banks of the river. State biologists blamed the kill on an alga (Prymnesium parvum) known as golden alga, because of the coloring it imparts to water. The alga, which can produce several toxins that are lethal to fish but not to other aquatic life, is found in water having salinity equal to that released from the E.V. Spencer Reservoir upstream from the kill. The kill included yellow and channel catfish, buffalo carp, and other fish that ranged from 4 to 40 pounds in weight. Similar fishkills were reported on August 12 and September 28 along the Colorado River as the alga moved downstream from the reservoir. The fishkill began in late August near Ballinger in Runnels County and moved downstream until it arrived at Shaw Bend in mid-October. Tens of thousands of fish were estimated to have been killed.

10 On October 15, Hurricane Jerry crossed the Texas coast during the time of the highest predicted tides of the year and caused flooding of coastal areas. The hurricane, which had average winds of $85 \mathrm{mph}$ and gusts to $100 \mathrm{mph}$, came ashore 10 miles southwest of Galveston Island. Tides were 6 to 7 feet above normal; however, only 1.46 inches of rain fell. Three people died in a pickup truck that was swept off a seawall. Damage was estimated at $\$ 8.25$ million.

The Loma Prieta earthquake, magnitude 7.1 on the Richter scale, shocked the San Francisco, Calif., area on October 17. The epicenter was located about 8 miles northeast of 
Table 1. Chronology of significant hydrologic and water-related events, October 1989 through September 1990-continued

\begin{tabular}{|c|c|}
\hline $\begin{array}{c}\text { No. } \\
\text { (fig. 4) }\end{array}$ & NOVEMBER 1989 (con.) \\
\hline 23 & $\begin{array}{l}\text { In November, saltwater was detected in a new weil at Port } \\
\text { Hueneme (near Oxnard), in southern California at depths } \\
\text { where freshwater has long been believed to be unaffected } \\
\text { by the ocean. Preliminary testing of water from depths of } \\
700 \text { to } 800 \text { feet showed a chloride concentration in excess } \\
\text { of } 7,000 \mathrm{mg} / \mathrm{L} \text {, well above the U.S. Environmental Pro- } \\
\text { tection Agency drinking-water limit of } 250 \mathrm{mg} / \mathrm{L} \text {. }\end{array}$ \\
\hline
\end{tabular}

DECEMBER 1989

24

A 3-day storm in early December produced as much as 8 inches of rain in parts of western Washington and caused severe flooding. More than 500 people (including all the residents of Hamilton) were evacuated from their homes on December 4 after a dike broke and the Skagit River overflowed its banks. One State highway and many county roads were closed because of high water and mudslides. Southeast of Seattle, the floods caused one death when a car was driven off a road into the Green River. In a separate incident, a driver was rescued from the Tolt River near Carnation more than 1 hour after the driver's car was swept from the road by floodwaters.

25 AMission Viejo, Calif., wastewater-treatment plant was closed on December 5, when an estimated 100 to 500 gallons of acetone contaminated the wastewater system and killed microorganisms that are an integral part of the system. Ten days after the contamination, wastewater samples showed $45 \mathrm{ppm}$ acetone. Cost to repair the system was estimated at $\$ 40,000$ to $\$ 50,000$.

26

On December 14, Redoubt Volcano erupted after 23 years of quiescence. The enuption was preceded by only 24 hours of intense seismic activity. The eruption-generated volcaniclastic flow eroded snow and ice from Drift Glacier and flooded the Drift River valley. An oil-storage facility on the banks of Drift River was not damaged by this flow, which was estimated to be between 600,000 and $700,000 \mathrm{ft}^{3} / \mathrm{s}$.

Because rainfall was as much as 13 inches less than average in many areas of southern Florida, which is at the 100 -year recurrence interval for western Palm Beach County, the governing board of the South Florida Water Management District imposed mandatory restrictions for water use on south Florida water users, effective December 18. These were the first-ever restrictions for the 4 million residents on the lower east coast of Florida. Water utilities reduced line pressure because of declining ground-water levels. Water levels in Lake Okeechobee were 2 feet lower than average for the first week in December.

During the first 3 weeks of December, more than 40,000 fish died in a newly impounded 195-acre public fishing facility at the Big Lazer Creek Wildlife Management Area, near Talbotton, Ga. Dissolved oxygen depletion in the water, which could be partly attributed to rapidly changing temperatures, caused the fish to die. The most affected species was bluegill. Other affected species were shellcracker, largemouth bass, and catfish.

\section{EVENT}

DeCEMBER 1989 (con.)

ery waters and put into $36^{\circ} \mathrm{F}$ river water and according to officials at Eastern Washington University, the trout died as a result of temperature shock. The fish were planted in the pens on December 22, and the first deaths were noticed December 25. The deaths continued for 6 to 10 days.

Between December 30 and 31, in east-central Illinois, an estimated 750,000 gallons of water containing benzene, toluene, styrene, and nephthalene spilled from a broken pipeline leading from a chemical company sludge pit. The spill flowed overland to a drainage ditch, which carried it to the Kaskaskia River upstrearn from several water-supply intakes. The river supplies water for the communities of Tuscola and Arcola, and the chemical company, and all three water supplies were contaminated. Residents were warned not to drink or cook with the water and the watersupply treatment and distribution systems were flushed to remove the contaminants. Another 855,000 gallons of partly treated water was discharged from the sludge pit on January 8 and 9 . These discharges did not further contaminate water supplies because river intake pumps had remained closed since the December spill. Effects of the spill and discharge on plant and fish life are unknown and no plans were made to clean up the river.

31 In December, scientists on the California Central Valley Regional Water Quality Control Board reported a link between farm runoff contaminated with pesticides and a precipitous decline in the Sacramento River striped bass fishery. Striped bass reproduction was at an all-time low in the Sacramento-San Joaquin River Delta. Prized as a game fish, the bass have value as an indicator of the estuary's biological health. The pesticides linked to the drainage from the Sacramento Valley rice fields are carbofuran, methyl parathion, and malathion.

\section{JANUARY 1990}

As of January 1, according to the U.S. Soil Conservation Service, Arizona had the least reservoir storage since 1978, due to deficient precipitation in all but southeastern Arizona. Precipitation in the last quarter of 1989 was 25 percent of average in the northwest Colorado River watershed, 50 percent of average in the Gila River watershed, and about 81 percent of average in the Santa Cruz and San Pedro watersheds. The drought cycle started about 2 years earlier.

33 About 10,000 gallons of unleaded gasoline spilled into the Monongahela River upstream from Pittsburgh, Pa., on January 1 after a barge hit a bridge and ruptured. The barge was one of about 50 that broke loose from their moorings by ice and rushing water. Rising waters caused by warming temperatures also forced about 200 people from their homes near Maxwell Dam in Fayette County, where about 30 of the barges were jammed.

34 Redoubt Volcano in Alaska erupted on January 2 and filled more than 20 miles of stream channels with viscous mud. The volcano triggered the largest flooding in the century along the Drift River when volcaniclastic flows incorporated great quantities of ice and snow from Drift Glacier. The flow was estimated to be between 350,000 and $2,000,000 \mathrm{ft}^{3} / \mathrm{s}$. In turn, the flooding damaged a riverside oil facility about 20 miles downstream and 90 miles south-

net pens in the reservoir just above Little Falls Dam, Wash.,
nat 50 and 90 percent of 30,00 rainbow trout died in on the Spokane River, a tributary to the Columbia River. The fish had been taken from relatively warm $\left(48^{\circ} \mathrm{F}\right)$ fish- 
Table 1. Chronology of significant hydrologic and water-related events, October 1989 through September 1990-continued

\begin{tabular}{|c|c|c|}
\hline \multirow{2}{*}{$\begin{array}{c}\text { No. } \\
\text { (fig. 4) }\end{array}$} & \multicolumn{2}{|c|}{ EVENT } \\
\hline & OCTOBER 1989 (con.) & NOVEMBER 1989 (con.) \\
\hline
\end{tabular}

Santa Cruz. It was the largest earthquake to occur in the San Francisco area since the great earthquake of 1906 . One section of a fault that extended 12 miles deep moved horizontally about 5 feet. Damage was extensive and 66 people died. The earthquake and rainfall that followed on October 23 caused some landslides in the Santa Cruz area and flooding and landslides blocked some streets. Despite the rain, many Santa Cruz mountain residents were without water for several weeks, because of ruptured pipes and cracked reservoirs that serve small subdivisions. The earthquake also damaged some private wells in the area.

12 Remnants of Hurricane Jerry produced 4 to 6 inches of rain in 12 hours in eastern Kentucky and western Virginia on October 17 and 18 , and caused flood damage estimated at $\$ 11.4$ million in Kentucky and \$3 million in Virginia. Hundreds of families were evacuated, more than 600 homes and a school were damaged or destroyed, and hundreds of bridges and roads were washed out by flooding in Pike, Floyd, Clay, Letcher, Leslie, and Jackson Counties in Kentucky and Buchanan County in Virginia. In Kentucky, several hundred students were temporarily stranded when the Frasure and Left Beaver Creeks spilled over their banks into one of the school buildings. Other Kentucky counties affected by the floods were Knott, Magoffin, Owsley, and Perry. The 10 counties in Kentucky were declared disaster areas by the Governor.

13 Thousands of fish died in Palm Beach County, Fla., on October 21 and 22, due to a sudden drop in temperature that lowered the oxygen level in ponds and suffocated the fish. In all, 18 fishkills $(10-1,000$ fish each) were reported. Among the dead fish were largemouth bass, speckled perch, bluegill, and sunfish.

About 100,000 fish were found dead in the Burnham Canal of the Menomonee River, Wis., on October 23. The massive fishkill (mostly gizzard shad) was blamed on low dissolved-oxygen levels. Other fish killed included channel catfish, walleye, northern pike, alewives, crappies, and panfish.

\section{NOVEMBER 1989}

In Jefferson Parish, La. (near New Orleans), 15 to 16 inches of rain fell on November 6 and flooded homes and roads. Hundreds of residents were forced from their homes, and school children were temporarily stranded; one death was reported. In St. Charles Parish, nearly 2,000 homes were flooded and damage was estimated at $\$ 7.4$ million.

On November 7, a landslide blocked the Pacific Coast Highway in Pacific Palisades near Los Angeles, Calif. The slide was blamed on water that seeped from a natural spring beneath a mansion on a bluff 150 feet above the highway and destabilized the bluff. The highway remained completely closed for almost 2 days. The cost of repair was $\$ 100,000$.

A major fishkill (more than 18,000 fish worth about $\$ 20,000$ ) occurred along a 14-mile stretch of Muddy Creek (tributary to the Lamine River) and its tributary Long Branch in Johnson County western Missouri, when ammonia laden chicken-manure effluent (used to irrigate nearby farmland) flowed into the creek from a poultry farm as a result of a spraying machine malfunction. Ammonia killed some fish directly and others indirectly by oxygen depletion of the water. Most fish killed were catfish and carp. Also killed were crayfish, black bass, crappies, flatheads, bullheads, sunfish, and suckers. The kill was discovered November 8 but had probably begun a few days earlier.

In northwestern Washington, record rainfalls drenched Whatcom County on November 9 . Two days of warm rains melted snow on the flanks of Mount Baker and fed the Nooksack River's three forks. In Acme, water from the South Fork ran several feet deep over Highway 9. An 80foot section of a bridge over the Nooksack River at Nugent's Corner was washed away by floodwaters. The North Cascades Highway was closed November 9 after a slide deposited tons of rocks and debris on the highway. Other slides closed Mount Baker Highway. More than 7 inches of rain fell near Snoqualmie Pass in 24 hours. In Whatcom County, 12 homes sustained major structural damage and 50 sustained minor damage. Both pink and spring Chinook salmon populations in the Nooksack River basin system were devastated as a result of high water Damage estimates in Whatcom County alone were $\$ 5.3$ million (excluding repair to the bridge at Nugents Corner, which was $\$ 2$ to $\$ 3$ million). Flood damage in Skagit County was estimated at $\$ 1.4$ million. Damage to roads and other facilities in the extreme northern part of the Mount Baker-Snoqualmie National Forest was estimated at $\$ 2.5$ million.

19 Bleach was poured into the Quileute Tribal Hatchery's water supply in LaPush, Wash., on November 10 or 11 and killed 60,000 to 80,000 newly hatched summer run Chinook salmon, valued at $\$ 18,000$. The fish were to be released into the Quileute River. The act was thought to have been deliberate.

20 Within 48 hours between November 10 and 12 , extensive rainfall (4.98 inches on Marias Pass) caused flooding in northwestern (Lincoln and Flathead Counties) Montana. Rivers and creeks reached flood stage on November 12, due to the intense rains and out-of-season snowmelt runoff. As a result of the flooding, a hunter's trailer was washed into the Flathead River near Columbia Falls, a few homes were damaged in the West Glacier area, two bridges over Sullivan and Soldier Creeks on the west side of Hungry Horse Reservoir were destroyed, and a house was washed a few hundred feet down Libby Creek near Libby in Lincoln County. A few sections of the Middle Fork Flathead River flooded roadways on the Nyack Flats in Flathead County and damaged parts of the Lybeck dike near Evergreen. The Burlington Northern Railroad line was closed because of two large washouts and widespread damage to railroad embankments along the Middle Fork.

About 250 barrels of crude oil spilled into the Sabine River just south of White Oaks, Tex., on November 17. The spill was caused by a leaking or broken pipeline. Longview, which uses the river as a source of drinking water, temporarily deferred use of the river water until it was declared safe.

An overturned truck leaked 8,600 gallons of gasoline into a creek adjacent to Interstate 40 in Nashville, Tenn., on November 22. Because gasoline also flowed into a culvert under the highway, the interstate was closed for several hours, homes and businesses were evacuated, and a kindergarten was closed and students moved to a nearby elementary school. 
Table 1. Chronology of significant hydrologic and water-related events, October 1989 through September 1990—continued

No

(fig. 4)

EVENT

JANUARY 1990 (con.)

JANUARY 1990 (con.)

west of Anchorage. The flood changed the course of the Drift River, causing it to flow on the back side of the oil facility.

On January 8, thousands of dead alewifes (small fish similar to minnows) were found in the Youghiogheny River about 25 miles below the dam in Connellsville (Fayette County), $\mathrm{Pa}$. About 350 walleyes, some crappies, and bluegills also died. The first dead fish were noticed December 27. The fish were believed to have been sucked into the intake pipes of a new powerplant (opened December 7, 1989), which occurred concurrently with the release of large volumes of water from the dam.

About January 9, a ruptured valve at an agricultural chemical firm caused about 7,500 gallons of 28-percent nitrogen fertilizer to spill into a small tributary that flows into White Lick Creek (a tributary of the White River) in southern Boone County, Ind., near the Hendricks County line. Thousands of fish, some large, died in 13.5 stream miles as a result of the spill.

Three rainstorms, the last and most severe (100-year recurrence interval) of which occurred on January 9, caused flooding in an area extending from Seattle, Wash., to Tillamook, Oreg. Many rainfall records were set during these storms, which also brought large quantities of snow to the mountains (28 inches at Stevens Pass the night of January 9). Hundreds of people were evacuated from Centralia, Wash., when a dike was breached by the Skookumchuck River. In all, flooding caused about 3,000 people to flee their homes in Washington. The storms caused four people to drown in Washington and three deaths in weather-related accidents in Oregon. Mudslides and flooding forced the closing of many roads. Washouts and fallen trees along rail lines near Vader, Wash., suspended rail service between Seattle and Portland for several days. In Washington, damage was estimated at $\$ 17$ million for roads, sewers, and other public facilities. In Oregon, initial estimates placed damage at $\$ 15.5$ million in Tillamook County alone (including $\$ 2.5$ million in publicly owned facilities losses, $\$ 1$ million in agricultural losses, and $\$ 4.2$ million in dairyfarm losses). Peaks of record were exceeded at six streamflow stations, including two at which the flood had a recurrence interval of 100 years-Puyallup River near Electron, Wash., and Nehalem River near Foss, Oreg. Peak discharges at the other four sites (on the Chehalis and Willapa Rivers in Washington) had recurrence intervals of 25 to 75 years.

On January 12 , roads were flooded locally when the Sacramento, Calif., area received a record 2.53 inches of rainfall in 24 hours. The rainfall broke the previous record for January 12 of 1.65 inches, set in 1906 . Before the rainfall, runoff in the area had been only 35 percent of average. The rainfall helped to temporarily alleviate conditions of a 2-year-long drought. Several auto accidents that caused four deaths were attributed to the weather. Rains associated with the same storm caused several mudslides in Los Angeles County and closed the San Francisquito Canyon Road near Lake Elizabeth.
A massive fishkill was reported on January 12 at No. Seven Wildlife Area near Charleston, Mo. About 209,000 fish were killed in a 2-mile stretch. Most of the fish were small shad, but some fish were estimated to weigh 6 pounds. Bass, bluegill, sunfish, crappie, catfish, drum, gar, and min- nows also died. Shallow water covered by ice is suspected as the cause of the kill.

Several thousand fish were killed on January 14, when a nuclear powerplant in New Jersey, shut down for safety tests. The shutdown caused a 20 -degree decrease in water temperature adjacent to the plant.

In a 24-hour period beginning on the morning of January 24 4 to 10 inches of rain fell in the southern half of Mississippi and caused flooding. The Pearl River near Monticello, the Bogue Chitto near Tylertown, and the Buffalo River near Woodville each had a peak discharge that had recurrence intervals of about 25 years. At $23 \mathrm{gag}$ ing stations in south Mississippi, peak discharges exceeded a 2-year recurrence interval.

About January 27, flooding forced the closing of more than 30 roads and highways in southeastern Louisiana after a week of rain. In the Denham Springs area, 850 homes ( 350 in East Baton Rouge Parish and 500 in Livingston Parish) were damaged by rising waters. Rivers contributing to flooding were the Comite River, the Pearl River near Slidell, and the Bogue Chitto near Franklinton. On January 27, the gaging station Amite River near Darlington (about 35 miles northeast of Baton Rouge, La.) had a record peak discharge of $104,000 \mathrm{ft}^{3} / \mathrm{s}$ (recurrence interval greater than 50 years), which exceeded the old maximum of 76,400 $\mathrm{ft}^{3} / \mathrm{s}$. The station Amite River near Denham Springs, about 15 miles east of Baton Rouge, had a peak discharge of $96,600 \mathrm{ft}^{3} / \mathrm{s}$, which also had a recurrence interval greater than 50 years. Peak discharges of other streams in southeastern Louisiana had recurrence intervals of about 10 years. Flood damage was estimated at $\$ 80$ million to $\$ 100$ million.

43 About January 29, thousands of fish died when Muddy Creek Lake, about 25 miles southeast of Wichita and 6 miles northeast of Douglas, Kans., was drained. Although the reason for draining the lake was unknown, it was theorized that someone drained the lake to make it unsuitable as a beaver habitat.

On January 30, the National Park Service reported thousands of dead fish in the Chesapeake and Ohio Canal in a section from Old Angler's Inn, in Maryland, to Georgetown, in Washington, D.C. Carp, catfish, smallmouth bass, and bluegill died of suffocation. Because repairs were being made to the canal floor, the water level of the canal had been lowered and the water froze to a depth of 9 inches, which left little dissolved oxygen in the water for the fish to breathe.

In Washington County, Oreg., 4 million gallons of raw sewage flowed into the Tualatin River in Tualatin on January 30 and 31 because grease and plastic foam combined to clog a 30-inch sewer line and force sewage to overflow into the river.

Between 3,000 and 10,000 dead fish were discovered on January 31 in a 5-mile stretch of West Branch Creek, a tributary of the Verdigris River, which flows into Lake Oologah about 25 miles northeast of Tulsa, Okla. The dead fish included carp and bullhead and the game fish crappie and bass. According to a game ranger with the Oklahoma Department of Wildlife Conservation, the fish had been dead for several days. The deaths seemed to be related to a spill 
Table 1. Chronology of significant hydrologic and water-related events, October 1989 through September 1990—continued

No.

EVENT

(fig. 4)

JANUARY 1990 (con.)

FEBRUARY 1990 (con.)

from a sewage-treatment plant 5 to 6 miles west of the creek. The spill affected the water supply of at least 6,000 Nowata County residents; however, the spill was not considered to be dangerous to humans.

FEBRUARY 1990

In early February, warm, intense rain contributed to flooding and mudslides in Washington and Oregon. In Washington, a nursing home and about 100 other homes in Centralia were evacuated on February 10, when the Skookumchuck River reached a peak stage more than 1 foot higher than during the January flood. In Lewis County, high water and mudslides closed about 15 roads, mostly south and east of Chehalis. Twenty miles east of Naselle, on February 11, a 300-foot section of State Highway 4 collapsed. A mudslide swept away 300 yards of Ocean Beach Highway (State Route 4) at KM Mountain about 4.5 miles northwest of Skamokawa. Slides also buried U.S. Highway 2 with as much as 50 feet of mud near Stevens Pass. State Highway 112 was destroyed at Deep Creek just west of Twin Rivers and about 20 miles west of Joyce when a slide washed away about 200 feet of the road. In Oregon, overflow of the Nehalem and Wilson Rivers caused mudslides and minor flooding. One lane of U.S. Highway 101 was closed because it was covered by 6 to 8 inches of water. Flooding and slides were also reported throughout Clatsop County.

In Douglas County, Oreg., an electrical outage caused a spill of about 120,000 gallons of untreated sewage into Elk Creek on February 7. Douglas County Health Department warned residents not to drink inadequately treated water from Elk Creek or the downstream Umpqua River.

On February 8, a tanker truck overturned, spilling 3,500 to 5,000 gallons of hydrochloric acid into Camas Creek near Ukiah, Oreg. The creek flows into the North Fork John Day River, which is tributary to the Columbia River. The spill killed fish in a 12-mile stretch of the North Fork and people were warned not to fish or eat fish from a 50-mile stretch of the river from its confluence with Camas Creek to below Spray in Wheeler County. Residents were also warned to keep livestock away from the spill. Most of the 20,000 to 100,000 fish killed were nongame fish such as dace, suckers, squawfish, and shiners. However, about 4,700 were game fish: 1,700 juvenile Chinook salmon, 2,300 juvenile steelhead, 400 whitefish, and 300 bull trout. Also killed were 10,000 Pacific lamprey eels, a ceremonial and subsistence food of local Indians.

In Alaska, the February 15 eruption of Redoubt Volcano caused the second largest mudflow down the Drift River since the volcano's eruptions began in December 1989. Volcaniclastic flows eroded less snow and ice from Drift Glacier, which had been heavily eroded by the January 2 eruption, and the peak discharge was estimated to be between 350,000 and $900,000 \mathrm{ft}^{3} / \mathrm{s}$. Channel filling near the Drift River Oil Terminal caused the flow to breach containment dikes around the oil storage tanks.

As much as 8.5 inches of rain fell in a 48-hour period (February 15 and 16) and caused flooding in north and west-central Alabama. Less than 1 inch of rain fell in the southern half of the State during the same period. Many roads and bridges were washed out by floodwaters and many schools were closed. Lake Purdy was above its capacity and spilled water over the Cabaha River Dam. Flooding was reported throughout the Birmingham area and all along the Coosa, Black Warrior, and Tallapoosa Rivers in northern Alabama. Flooding also occurred along the Sucarnoochee River in Sumter County, the Tennessee River in Morgan County, and the Alabama and Cahaba Rivers in Selma. Floods affected virtually every major river in the State. Peak flows of record were established at gages on several streams having less than $300 \mathrm{mi}^{2}$ of drainage area. Recurrence intervals for peak discharges ranged from about 5 years to more than 100 years. Discharge exceeded both the 100 -year flood and the previous peak of record (since 1900) on Mulberry Fork near Garden City (about 30 miles north of Birmingham) on February 16, where the peak discharge was 66,500 $\mathrm{ft}^{3} / \mathrm{s}$ at a gage height of 25.04 feet. As of February 19, floods had caused three deaths. State officials estimated damage from the floods at $\$ 2.5$ million. Six counties (Bibb, Greene, Russell, Shelby, Talladega, and Tuscaloosa) were declared disaster areas by the President.

Between February 15 and 20, intense rainfall of 4 to 9 inches in a 48-hour period caused flooding in Mississippi; 2 deaths were attributed to the floods. Flash flooding along a creek in Mendenhall forced 250 to 400 people from their homes on February 15. On February 19 and 20, more than 100 people were forced from their homes in Shubuta, Clarke County, by flooding along the Chickasawhay River. Recurrence intervals ranged from 10 years to slightly more than 25 years on most streams from the southwest to the east-central part of the State; no record-breaking peaks were reported.

53 Between February 16 and 19, storms caused major flooding in Georgia, Tennessee, and North Carolina. In Georgia, as many as 1,000 people were evacuated from their homes in Trion, in the northwestern part of the State, after as much as 12 inches of rain fell on February 15-16, causing the Chattooga River to overflow its banks. On the Chattooga River at Summerville (53 years of record), the peak discharge of $30,100 \mathrm{ft}^{3} / \mathrm{s}$ exceeded the 1951 peak of record by about 25 percent and was equal to the discharge of the 100 year flood. Three storm-related deaths occurred. The mayor of Trion estimated damage to the high school and an elementary school alone to be $\$ 1$ million. In McCaysville, in extreme northern Georgia on the Georgia-Tennessee boundary, flooding of the Toccoa/Ocoee River forced 500 people from their homes. Damage to municipal buildings in McCaysville was estimated at $\$ 1.6$ million. The town of Resaca, Ga., on the Oostanaula River suffered its worst flooding in 40 years according to the National Weather Service. On the Oostanaula River, peak discharge was the second highest in 97 years of record at Resaca and the fourth highest in 51 years of record at Rome. The Conasauga River near Eton (33 years of record) peaked at 33,200 $\mathrm{ft}^{3} / \mathrm{s}$ on February 16 , equal to the discharge of a 100 -year recurrenceinterval flood and about 30 percent greater than the previous peak discharge in 1973. Peak discharges of two tributaries of Conasauga River-Mill Creek near Crandall (5 years of record) and Holly Creek near Chatsworth ( 30 years of record)-also exceeded previous peak discharges of record by 150 and 125 percent, respectively. Recurrence intervals on the two creeks were 50 years and 2.1 times the 100 -year flood, respectively. Weather (including tornadoes) caused an estimated $\$ 15.7$ million in damage in nine counties (Carroll, Chattooga, Cobb, Douglas, Fannin, Gilmer, Gordon, Murray, and Walker). 
Table 1. Chronology of significant hydrologic and water-related events, October 1989 through September 1990-continued

\begin{tabular}{|c|c|}
\hline $\begin{array}{l}\text { No. } \\
\text { (fig. 4) }\end{array}$ & FEBRUARY 1990 (con.) \\
\hline & $\begin{array}{l}\text { In Tennessee, Copperhill (Polk County), which is just across } \\
\text { the river from McCaysville, was completely under water. } \\
\text { Damage to Polk County was estimated at } \$ 5.3 \text { million. } \\
\text { Flooding on the Ocoee River in Tennessee came close to } \\
\text { the records set in } 1906 \text {. Parts of Highway } 64 \text { were washed } \\
\text { out through Ocoee Gorge, and the Ocoee Power Plant was } \\
\text { extensively damaged. Several Tennessee Valley Author- } \\
\text { ity workers at the plant were airlifted to safety. More than } \\
200 \text { people evacuated homes in Chattanooga and East } \\
\text { Ridge, as the Chickamauga and Spring Creeks rose and the } \\
\text { Tennessee River flooded. Near-record flow occurred at } \\
\text { South Chickamauga Creek near Chickamauga, Tenn., be- } \\
\text { tween February } 17 \text { and } 18 \text {. Many homes and businesses } \\
\text { were damaged, roads were flooded, bridges were washed } \\
\text { out, and mudslides and rockslides were reported in the } \\
\text { mountains. }\end{array}$ \\
\hline
\end{tabular}

In North Carolina, in associated flooding, one person drowned on February 16 in the French Broad River after being swept away from a fish hatchery in Transylvania County. More than 200 people were evacuated from their homes in lowlying areas, mostly in Macon, Jackson, Clay, and Cherokee Counties in the southwestern part of the State. The roof of a science building at the University of North Carolina at Asheville collapsed, apparently from the weight of water that collected on the roof. Agricultural officials reported that flood damage in North Carolina was in the millions of dollars. Non-agricultural damage from flooding was expected to exceed $\$ 1$ million. Preliminary estimates of road and bridge damage totaled $\$ 1.81$ million.

On February 18, as much as 6 feet of snow fell in the Sierra Nevada and contributed to a mudslide that closed more than 85 miles of Interstate Highway 80 from the Nevada border to Applegate in northern California. This was one of the most severe storms on record for this area. Precipitation at Sacramento on February 16 ( 2.05 inches) exceeded the 1986 record of 1.84 inches. The storm even produced snowflakes in Sacramento, a rare occurrence. Snowstorms also closed Interstate Highway 5 through the Grapevine, which links the northern and southern sections of the State. In related storms in southern California, tons of mud and rock rolled onto Malibu Canyon Road, forcing its closure to the Ventura Freeway near Los Angeles.

Temporarily closed oyster beds in Mobile, Ala., were closed indefinitely, on February 21, by State health officials because fresh floodwaters entering the saltwater oyster beds were contaminated with human and animal fecal bacteria.

By the end of February as the drought of 1989 continued into 1990 , half of southwest Florida was under Phase I wateruse restrictions and the area around Bonita Springs and north Naples was under Phase II water-use restrictions. Phase I restrictions allow watering and car washing only from 4:00 a.m. to 8:00 a.m. 3 days a week, and Phase II restrictions allow those activities only 2 days a week. Precipitation was 15-16 inches below average in 1988 and 67 inches below average in 1989. All artesian aquifers in southwestern Florida were extremely low or at all-time record low water levels. In the Hawthorn aquifer, used by three water companies in Lee County to provide water after reverse osmosis treatment, water levels had declined 5 feet since October 1, 1989, after declining almost 20 feet in the year prior to October 1 . Chloride concentrations in monitoring wells in the Lower Tamiami aquifer in the Bonita Springs area had slowly increased, leading water
EVENT management officials to be concerned about saltwater intrusion.

57 By the end of February, streamflow in eastern South Dakota was beginning to be severely affected by the less-than-average precipitation received during the preceding 2 years. At the Big Sioux River near Castlewood gaging station, in the upstream part of the basin, no flow had been recorded since early January 1990. Expected discharge for this time of year is about $10 \mathrm{ft}^{3} / \mathrm{s}$. The recurrence interval for no flow for a 60-day period during this time of year is greater than 100 years. Downstream from the Big Sioux River at Sioux Falls gaging station, streamflow averaged $12 \mathrm{ft}^{3} / \mathrm{s}$ from December 1 to February 28 . The recurrence interval for this discharge for a 90 -day period is about 30 years.

MARCH 1990

58 Rains exceeding 3.6 times average in February and near average in March falling in east-central Illinois caused severe flooding in Danville, when the Vermilion River overtopped the water-treatment plant below Lake Vermilion causing the suspension of water service for nearly a week. A peak discharge of $20,100 \mathrm{ft}^{3} / \mathrm{s}$ occurred on the North Fork Vermilion River at Bismarck on March 11 and had a recurrence interval of greater than 100 years. The resultant flooding necessitated the evacuation of people living along the river and caused \$1 million in property damage to homes and businesses.

Seven to 16 inches of rain beginning on March 15 and continuing through March 20, caused severe flooding in parts of Alabama, Florida, and Georgia. Peak discharges at some gaging stations exceeded those for both the period of record and the 100 -year flood. Recurrence intervals of peak discharges on the Pea, Choctawhatchee, and Blackwater Rivers ranged from 1.2 to 2.1 times those for the 100 -year flood. Recurrence intervals were greatest on streams having drainage areas of less than $500 \mathrm{mi}^{2}$.

In Alabama, predominantly in the southeastern part, property damage was extensive and many bridges and roads were flooded. At least 11 people drowned, most of them in cars that went through barricades on flooded roads and were swept away by floodwaters. Elba, Ala., along the Pea River (about 70 miles southeast of Montgomery), received the greatest damage. It was submerged under 12 feet of water after an earthen levee collapsed. Emergency management officials said that flooding did more than $\$ 100$ million damage in the State.

In Florida, about 1,200 people in the northwestern part of the State were evacuated from low-lying areas. Most were from the town of Caryville, where the entire population of 630 residents was evacuated because of flooding by the Choctawhatchee River. Flooding also caused evacuations along the Apalachicola River near Blountstown, the Escambia River near Cantonement, and the Blackwater River near Milton. A record-breaking peak discharge occurred on the Yellow River at Milligan, where both the peak discharge of $51,500 \mathrm{ft}^{3} / \mathrm{s}$, which had a recurrence interval of 100 years, and the peak stage of 19.00 feet exceeded those for the 1975 record discharge of $38,600 \mathrm{ft}^{3} / \mathrm{s}$ and stage of $17.71 \mathrm{ft}$. Peak discharges on other streams had recurrence intervals of 50 years or less. Three flood-related deaths occurred. 
Table 1. Chronology of significant hydrologic and water-related events, October 1989 through September 1990—continued

EVENT

No

(fig. 4)

MARCH 1990 (con.)

APRIL 1990 (con.)

In Georgia, flooding was worst in the northwestern and westcentral parts of the State. The most severe flooding occurred on Upatoi Creek near Columbus where the recordbreaking peak discharge of $46,300 \mathrm{ft}^{3} / \mathrm{s}$ was 3.1 times the discharge of the 100-year flood. Other severe flooding occurred on the Yellow River, Chatahoochee River, Kinchafoonee Creek, and in the upper Flint River basins. Flood-related traffic accidents claimed four lives, with several million dollars in damages to roads, bridges, and personal property reported.

Flooding also occurred in Jackson County, Miss., on March 20 after 14 inches of rain fell in 2 days. About 35 homes were flooded and several roads were washed out.

About 80,000 gallons of diesel fuel, gasoline, and kerosene spilled into a tributary of the Allegheny River when a pipeline split on March 31 as the result of a landslide in Freeport, Pa. (35 miles north of Pittsburgh). The petroleum products mixed with water as it poured over six dams between Freeport and Pittsburgh. The 41-mile long slick caused as many as seven communities, which normally draw water from the river, to temporarily discontinue using the river for public supply. Several communities had no running water and were supplied water from portable tankers; others were forced to draw water from other sources. Conservation was urged in areas where the stored supply was insufficient. In all, 11 communities and as many as 1 million people were affected by the spill. As of April 6 clean up was completed.

APRIL 1990

In California, the Metropolitan Water District (a six-county agency in the southern part of the State) warned governments and businesses on April 4 that it might no longer be able to provide a limitless supply of water, because California was then in its second-longest sustained drought of record. Restrictions were placed on sources of water to the north, the Sierra Nevada mountains, and the Colorado River. Supplies to the Metropolitan Water District were expected to be cut by one-third from the Colorado River and 60 percent from Mono Basin and Owens Valley in the Sierras. Only 50 percent of the usual agricultural allotment from the California State Water Project from the north would be available. The District also predicted a 5- to 10percent reduction in allotments to urban users. Southern California farmers had begun to drill wells after being notified that they would receive only half their usual water allotment from the north. Water-supply conditions were even worse in other parts of the State. During the coming summer, the San Francisco Bay area and central California were projected to experience severe shortages of water and would be implementing water-rationing programs. Some water districts in the central valley and central coast had cut agricultural allotments to zero, forcing farmers to use ground water or shift what little water they had to longterm crops such as fruit trees.

On April 16, the Montana Water Quality Bureau reported a fuel leak from underground tanks used to store fuel for underground nuclear fallout shelters of the Church Universal and Triumphant in Corwin Springs, Mont. The underground complex is on church property, bordering the north edge of Yellowstone National Park near the Yellowstone River.
During the preceding winter, 35 tanks having a combined capacity of 635,000 gallons were installed and filled with diesel fuel and gasoline. An estimated 31,000 gallons had leaked into soils surrounding the complex, which is several hundred yards from Mol Heron Creek, an important cutthroat trout spawning stream that flows into the Yellowstone River. The church had the tanks pumped and excavated for repair.

On April 23, a tank barge struck a submerged object in the Ohio River at Owensboro, Ky., and spilled 18,000 gallons of unleaded gasoline. No cleanup was feasible because the gasoline rapidly dissipated.

On April 24, as a result of a pipeline rupture, 50,000 gallons of crude oil spilled into Millsap Lake in Millsap, Tex. Millsap continued drawing water for public supply by lowering the intake from 30 to 48 inches below lake level and by drawing the water through particulate filters and carbon-bed absorbers. Intense rain and local flooding hampered recovery efforts and caused some oil and absorbent pads to be washed into the Brazos River.

On April 25, the Southwest Florida Water Management District imposed a 3-month cap on water permits in an 800$\mathrm{mi}^{2}$ area in southern Hillsborough and Manatee Counties, where the water table had dropped below sea level and allowed seawater to seep inland. Under this measure, the District would issue no new permits to pump water from the aquifer. About 80 percent of the permitted water use in this area is for crop irrigation.

Six people drowned as a result of flash flooding from Brownwood to Dallas, following a series of thunderstorms and tornadoes in central and northern Texas on April 25. Authorities said that flooding was the worst in the Brownwood area since 1954. As much as 16 inches of rain fell in 24 hours. About 1,300 people were evacuated from the low-lying areas of Brownwood, in Brown County, and rural parts of Parker County as waters continued to rise on April 26. Recurrence intervals of the floods were greater than 100 years at gaging stations on Pecan Bayou at Brownwood and Pecan Bayou near Mullin, both in the Colorado River basin. A flow of $30,000 \mathrm{ft}^{3} / \mathrm{s}$ was the largest of record at the Leon River near DeLeon in the Brazos River basin (previous record of 7,540 $\mathrm{ft}^{3} / \mathrm{s}$ was set in 1968). A four-lane bridge on U.S. Highway 377 , about 15 miles southwest of Roanoke in Denton County, was closed because of high-water damage. Water was 7.4 feet above the Lake Brownwood spillway on April 26, a record for the 80year-old dam. In Wise County, Lake Bridgeport was at its highest level ever on April 29, and water was released at a record rate of $14,000 \mathrm{ft}^{3} / \mathrm{s}$ into the West Fork Trinity River. Parker County, battered by tornadoes, floods, and an oil spill, was declared a disaster area by the Governor. Overall damage estimate was in the millions of dollars.

67 On April 26, a pipeline ruptured and 294,000 gallons of crude oil spilled into the Sabana River near Gorman, Tex. Although cleanup efforts were hampered by intense rain and accompanying flooding, 42,000 gallons of oil were recovered as the floodwaters receded. The oil threatened water supplies of communities in Erath and Comanche Counties, which take their drinking water from Proctor Lake about 10 miles downstream from the spill. Local pasture lands along the flood plain of the river were contaminated with the oil. 
Table 1. Chronology of significant hydrologic and water-related events, October 1989 through September 1990-continued

\begin{tabular}{|c|c|c|}
\hline \multirow{2}{*}{$\begin{array}{c}\text { No. } \\
\text { (fig. 4) }\end{array}$} & \multicolumn{2}{|c|}{ EVENT } \\
\hline & APRIL 1990 (con.) & MAY 1990 (con.) \\
\hline
\end{tabular}

68 More than 43,000 mostly nongame fish died in Cedar Creek near Frankenstein in Osage County, Mo., between April 28 and 30 , when 1.5 miles of the creek were polluted with hog manure. The dead fish included sunfish, bass, bullshead, minnows, suckers, darters, and madtoms.

\section{MAY 1990}

On May 2, the mayor of Los Angeles, Calif., announced a mandatory water-conservation program, the first in the city in 12 years. The conservation measures involved reducing 1986 water-use levels by 10 percent. The program was the result of 4 years of drought in the area.

Intense rains on May 1-3, caused severe flooding May 3-6 in the southeastern part of Oklahoma as the State experienced the wettest January-April period since 1892. Five gaging stations reported peak discharges that exceeded previous records and recurrence intervals greater than 100 yearsMuddy Boggy near Unger ( 8 years of record) and near Farris (54 years of record), Wishita River near Dickinson ( 62 years of record), Kiamichi River near Clayton ( 9 years of record) and Canadian River near Whitefield (52 years of record). Other gaging stations that had peak discharges that exceeded previous records were Baron Fork at Eldon (42 years of record) and Kiamichi River near Antlers (18 years of record). On May 3, the water level at Lake Eufaula in eastern Oklahoma reached a record high of 599.72 feet above sea level, and authorities released a record 230,000 $\mathrm{ft}^{3} / \mathrm{s}$ of water through floodgates. Lake Texoma reached a record level of 27 feet above flood stage. This was the first time since 1957 that water had flowed over the spillway at Lake Texoma Dam. Several bridges were washed out or damaged and one flood-related death was reported. In Marshall County alone, officials estimated $\$ 3$ million in damage. Federal disaster assistance was requested by 39 counties.

71 Despite floods in northern and eastern Texas, western Texas entered its fourth drought-like year by May 8 with deficient rainfall of 2 to 4 inches. Increased pumping from the Edwards aquifer drew down the water table and flow of the San Marcos and Comal Springs, which receive water from the Edwards aquifer. Some perennial creeks in Presidio that recharge the aquifer had not flowed in 2 to 3 years.

Extensive rains caused flooding in Illinois in early May. Rainfall of 3 to 4 inches over Lake, Cook, and DuPage Counties on May 9 and 10 produced substantial flooding in parts of northeastern Illinois. New peak gage heights for the period of record were established at 11 gaging stations. As much as 6 inches of rain, in the 48 hours ending May 17, fell on already saturated soil and caused severe flooding in localized areas of central and southern Illinois. Discharges were a record maximum at six gaging stations. At two of those stations-Skillet Fork at Wayne City in the Wabash River basin and Whitley Creek near Allenville in the Kaskaskia River basin-peak discharges had a recurrence interval that exceeded 100 years.

Floods, mainly in the Arkansas River basin and along the Red River, occurred in Arkansas during early May. However, flooding also was significant in the Ouachita River basin in the vicinity of Hot Springs later in the month. Over- night rainfall of 3 to 5 inches on May 2 to 3 in the northwest quarter of Arkansas caused flooding that resulted in many road closures. The Arkansas River at Little Rock peaked at about $400,000 \mathrm{ft}^{3} / \mathrm{s}$, the greatest discharge since navigation began in the 1970's. Damage to roads and bridges was estimated at $\$ 7$ million in the Fort Smith area. More than 300 families were forced from their homes in central Arkansas owing to the worst flooding since 1957. Thirty-three counties were declared disaster areas. Discharge of the Red River near Index equaled the 100-year recurrence interval. Rainfall of 12.97 inches in less than 24 hours, May 19 and 20, caused severe flooding in Hot Springs. Downtown Hot Springs, which lies in a steep valley, was flooded when runoff overwhelmed the drainage systems. City officials in Hot Springs estimated damage at $\$ 5.3$ million. Peak discharge on the Ouachita River at Malvern (about 20 miles southeast of Hot Springs), broke the previous record discharge set in May 1923. The American Red Cross estimated that 335 homes in Hot Springs and Garland County were flooded.

$74 \quad$ From May 12 to 13, a storm swept through south Mississippi and produced more than 8 inches of rain, almost all of which fell in an 18-hour period beginning at noon on May 12. As a result of the intense rainfall, substantial flooding occurred. Bouie Creek near Hattiesburg and White Sand Creek near Oak Vale experienced the largest floods since 1974. Five had peak discharges that exceeded a 15 -year recurrence interval. In all, 25 gaging stations experienced floods that had a recurrence interval greater than 2 years. Estimated damages exceeded $\$ 800,000$.

75 Flooding on the Red River, with recurrence intervals of 25 to 50 years, occurred between Shreveport and Alexandria, La., between May 15 and 22 following intense rainfalls. Flooding affected as much as $600 \mathrm{mi}^{2}$ and about 80,000 acres of crops and pasture. Agricultural damage was estimated at $\$ 7$ million, not including the cost of rebuilding and replanting.

76 As much as 15 inches of rain about May 19 in south-central Indiana caused flooding in southern Indiana and forced dozens of people from their homes. As a result of flooding along the White River and smaller tributaries, the Petersburg water main was severed, leaving the mining and farming community without freshwater for 2 weeks. Flooding of small basins was the most severe since 1979, and mainstem flows were the greatest since 1961. Flooding was the most severe in the French Lick and English areas. As a result, the Governor declared southern Indiana as eligible for State disaster assistance.

77 Intense rains on May 19 in Iowa caused the most severe flooding in 40 years in Sioux City along Perry Creek, where the peak discharge was estimated at $8,670 \mathrm{ft}^{3} / \mathrm{s}$. Seventeen homes were destroyed, another 256 had major damage, and 201 had minor damage. More than 50 business establishments were affected by the floods, but none were destroyed.

The second most intense rainfall in Texas since 1898, when records began, caused severe flooding in May. On April $28,6.5$ inches of rain in 36 hours in Wichita Falls contributed to May flooding on the Red River. By May 3, about 2,300 homes had sustained damage as a result of 2 weeks of rainfall. Record flows occurred at 12 gaged streams, and record stages occurred at nine reservoirs between May 
Table 1. Chronology of significant hydrologic and water-related events, October 1989 through September 1990—-continued

No. (fig. 4)
EVENT

MAY 1990 (con.)
MAY 1990 (con.)
2 and May 21. Recurrence intervals were greater than 100 years at six sites in the Red and Trinity River basins: Little Wichita River above Henrietta (in the Red River basin), Red River at Denison Dam near Denison, Red River at Arthur City, West Fork Trinity River at Grand Prairie, East Fork Trinity River near Crandall, and West Fork Trinity River near Boyd. Six flood-related fatalities were confirmed. On May 10, the Trinity River near Crockett had a record discharge, and flooding on the Trinity River was the most severe in 80 years. Forty-six counties qualified for Federal assistance for flooding that occurred in late April and May. More than 1,500 people were forced from their homes because of flooding of the Trinity River, mostly south of Dallas. Texas received 4 to 5 inches of rain on May 12, as flooding continued along the Trinity River below Oakwood. The contents and stage of the Livingston Reservoir on the Trinity River, reached record maximums for the period of record, which began in 1968. Officials released a record $108,000 \mathrm{ft}^{3} / \mathrm{s}$ of water through floodgates on May 17. A flow of $20,000 \mathrm{ft}^{3} / \mathrm{s}$ can cause flooding. About 380 people were evacuated from homes below the dam. As of May 9, estimated damage to roads and bridges in the State was $\$ 7$ million. Damage to agriculture was $\$ 500-700$ million and damage to residences in northern, northeastern, eastern, and central Texas (along the Red and Trinity rivers) was $\$ 60$ million. As of May 8 , according to the National Weather Service, the flooding was the most severe since 1908 .

On May 24, a freighter struck the Jackson Avenue Ferry Landing near the French Quarter (at Algiers Point) in New Orleans, La. and then collided with some barges. The accident, which occurred about 8:25 p.m., ripped three holes in the freighter and ruptured several tanks. As a result, an estimated 40,000 gallons of No. 6 fuel oil spilled into the Mississippi River and caused a slick that stretched 60 miles downstream. The leading edge of the slick was at Point Sulphur by noon on May 25. The spill threatened the water supply for the town of Pointe a la Hache, which has an intake from the river. About 140 cubic yards of contaminated debris and 3,000 gallons of oil and water mixture were recovered. Damage to the ferry landing was an estimated $\$ 200,000$.

On May 29, about 150,000 gallons of fuel spilled into the Goldstream Creek valley when a tanker train of the Alaska Railroad derailed about 40 miles south of Fairbanks, Alaska. Fuel apparently drained into Goldstream Creek, which flows into one of the richest waterfowl nesting areas on the North American coast. Officials of the Alaska Department of Environmental Conservation and the railroad were quickly on site to contain the fuel.

At the end of May, after several months of deficient rainfall, ground-water levels and spring discharges were at record minimums in parts of northeastern Florida. All-time low water levels of 53.12 feet and 33.01 feet below land surface were measured at two representative wells in the Floridan aquifer system in Seminole County. These levels were 1.20 and 0.94 foot lower, respectively, than previous record-minimum measurements made in 1989. Records at the two wells began in October 1951 and November 1985 , respectively. In addition, May discharges were the lowest of twice-yearly collected data (May and September) since 1961 at two of the six artesian springs measured in Seminole County. Discharge of the other four springs was at or near the lowest measured since 1980 , the

time of the previous lows. Before 1961, the six springs were measured only during the high-flow period (September) in most years back to 1930. Because of low water levels on May 30, the St. John's Water Management District imposed water-use restrictions in Seminole County, bringing the number of counties in northeast Florida under mandatory restrictions to 12 .

82

In May, several hundred thousand steelhead smolt were killed by gas supersaturation below John Day Dam on the Columbia River, Oreg. Gas supersaturation can occur below Columbia River dams when water is spilled from the reservoir.

JUNE 1990

83 On June 3, more than 7,700 dead fish were found in a 30-mile section of Tar Creek, Drowning Bear Creek, and the Conasauga River near Dalton in Whitfield County, Ga. An industrial pollutant, a form of 1-Tridecanol that is used as a wetting agent, caused the deaths. More than half of the fishkill was game or commercial species. Fish killed in largest numbers included sunfish, bluegill, drum, shad, stonerollers, catfish, crappie, redhorse, carp, bullhead, minnows, shinners, bass, mosquitofish, and warmouth.

In early June, spring rains washed large amounts of nitrates from farm fields into several river systems used for municipal water supplies in Iowa. Iowa City uses the lowa River and the city of Des Moines uses the Des Moines and Raccoon Rivers as sources of surface water. The two cities blended their surface water with ground water to keep nitrate concentrations within allowable levels for their municipal water supplies. On June 9, the nitrate level in the Iowa City drinking water was $10.2 \mathrm{mg} / \mathrm{L}$, which exceeded Federal standards for drinking water of $10 \mathrm{mg} / \mathrm{L}$. Iowa City issued an alert to advise that children less than 6 months old and pregnant women should not drink the water and provided bottled water from ground-water supplies. The city of Des Moines also alerted their customers.

Flash floods in Las Vegas, Nev., caused two deaths on June 10. Maximum reported rainfall was about 1.5 inches in a 1-hour period at several locations, which caused peak flows having recurrence intervals equal to or less than 10 years. Total damage was estimated at $\$ 2.6$ million.

On June 14-15, flash flooding occurred in Belmont, Harrison, and Jefferson Counties in Ohio, in an area adjacent to the West Virginia panhandle. The flooding was caused by 3 to 5 inches of rain within 3 hours on the evening of June 14 ; most damage occurred on Wegee and Pipe Creeks in Belmont County, where 26 people were killed and 58 homes and trailers were destroyed. Homes were swept off foundations, and cars were washed away. Both creeks flow through steep, narrow valleys and drain into the Ohio River. In Harrison and Jefferson Counties, floods on Short Creek and its tributaries damaged adjacent towns. Peak discharge at the gaging station Short Creek at Dillonvale (48 years of record) had a recurrence interval that exceeded 100 years and was greater than the previous record set in 1945. The previous peak of record also was exceeded on Wheeling Creek near Blaine ( 7 years of record). The three counties were declared Federal disaster areas. Damage in the Pipe and Wegee Creek basins was estimated at about $\$ 2$ mil- 
Table 1. Chronology of significant hydrologic and water-related events, October 1989 through September 1990-continued

No.

EVENT

(fig. 4)

JUNE 1990 (con.)

JUNE 1990 (con.)

lion. Lesser flooding caused by the same storm occurred across a wide area of central and eastern Ohio, northern West Virginia, and western Pennsylvania.

As much as 11 inches of rain fell during June 13 to 16 in northeastern Nebraska and caused major flooding along Shell Creek in the Platte River basin and along Maple Creek and Union Creek in the Elkhorn River basin. On June 17, the peak discharge of $8,000 \mathrm{ft}^{3} / \mathrm{s}$ at a stage of $22.76 \mathrm{feet}$ at Shell Creek near Columbus ( 40 years of record), broke the previous record and exceeded the 100 -year recurrence interval. On June 16, the peak discharge of $15,100 \mathrm{ft}^{3} / \mathrm{s}$ at a stage of 25.72 feet at Union Creek at Madison (12 years of record) broke the previous record and had a recurrence interval of 60 years. Peak discharges on June 17 were $23,000 \mathrm{ft}^{3} / \mathrm{s}$ at a stage of $23.90 \mathrm{feet}$ at Pebble Creek at Scribner (12 years of record) and $11,600 \mathrm{ft}^{3} / \mathrm{s}$ at a stage of 16.30 feet at Maple Creek near Nickerson (39 years of record). Both discharges had recurrence intervals of 50 years and broke previous records. Much of the peak flow bypassed the gaging station near Nickerson after breaking through dikes upstream from the gage. The six counties of Platte, Colfax, Dodge, Madison, Stanton, and Cuming were declared disaster areas by the State. Damage was estimated at $\$ 50$ million for these six counties alone. One death was attributed to the flooding.

Intense rainfall contributed to flooding during June 17 to 22 in central Iowa. Peak discharges exceeding the 100-year recurrence interval set records on June 17 at seven gaging stations: Wapsipinicon River near DeWitt in east-central Iowa (56 years of record); Crow Creek at Bettendorf in east-central Iowa (13 years of record); Clear Creek near Coralville in east-central Iowa ( 38 years of record); Squaw Creek at Ames in central Iowa (32 years of record); North River near Norwalk ( 50 years of record); South River near Ackworth in central Iowa (50 years of record); and Boyer River at Logan in west-central Iowa (58 years of record). Record peak discharge of Old Mans Creek near Iowa City in east-central Iowa ( 18 years of record) had a recurrence interval that was between 50 and 100 years. Recurrence intervals of other flooded streams ranged from 2 to about 25 years. Forty-one counties were declared disaster areas by the State and 18 were declared eligible for Federal assistance. Two people were killed and damage was estimated at $\$ 83$ million.

On June 19, an industrial discharge of an ammonium refrigerant entered McKenzie Creek in the St. Francis River basin near Greenville in Wayne County, Mo., and killed 27,000 fish. All fish including minnows, darters, sculpins, sunfish, suckers, bullhead, bass, and shad as well as tadpoles were killed in a 1-mile section of the creek.

On June 22, the water level of Lake Okeechobee in Florida was at 10.47 feet above sea level, about 2.7 feet below average for that time of year. The record low of 9.75 feet was set on July 26, 1981. The lake reaches a critical level at about 10.5 feet, wherein there is little pressure to push the freshwater southward to the coast to replenish ground water and to keep saltwater from moving up canals, thus threatening well fields. The lake continued to lose water through evaporation, withdrawals for the irrigation of sugar cane and vegetable fields south of the lake, and withdrawals for the saw grass marshes of Everglades National Park As of late June, the Lake Okeechobee region had received only 55 percent of the average precipitation for the month.
91

On June 26, southern California's leading water agency, the Metropolitan Water District (MWD), signed a landmark agreement to pay for conservation measures in one farming district (the Imperial Irrigation District) and send the water saved to urban customers. The MWD agreed to pay for flow-regulating reservoirs and improved canal lining, and to provide more flow monitors in return for the 106,000 acre-feet of water that would be saved annually at a cost of $\$ 225$ million. The measure was spurred by the continuing 4-year drought, which was the most severe in 60 years. At the end of the 1990 rainy season, California had received only 65 percent of average precipitation, and 400 local water agencies had imposed restrictions. State-aquaduct water allotments to agriculture, which uses about 80 percent of the available water, were decreased severely. Some of the deficit could be overcome by pumping ground water at increased costs. In Santa Barbara, some residents spray painted their dead lawns green. Water levels in reservoirs continued to fall as maximum temperatures exceeded $100^{\circ} \mathrm{F}$ and set new records in much of southern California and Arizona. These conditions only aggravated the forest fire situation in the two States. Eleven deaths were blamed on the heat and fires. The summer fire threat was very high to extreme throughout the Southwest. Temperatures exceeded operational limits of aircraft used to fight forest fires and aircraft were grounded on June 26 as temperatures exceeded $115^{\circ} \mathrm{F}$ at 2 p.m. in Phoenix.

92 On June 28-29, severe storms and flooding caused an estimated \$13 million in damage in seven southwestern Wisconsin counties. On June 30 , the Governor declared a state of emergency in 13 counties affected by severe weather since June 22. Most of the damage was to crops, bridges, and roadways. One person was killed by flooding in the Green Bay area.

93 A 100-year rainfall record for June was broken when 9.82 inches was recorded at the Minneapolis-St. Paul airport during the month, thus ending a 3-year drought in Minnesota. June rainfall was only 1.4 inches less than average for June, July, and August. Streamflow was deficient for most of the State in April, but was excessive in most of the central half of the State in June.

\section{JULY 1990}

On July 1, a major petroleum spill into the Chesapeake Bay occurred near Hampton Roads, Va., when two containerized cargo vessels collided. About 35,300 gallons of No. 4 fuel oil flowed from one of the ships. The oil affected public beaches at Ocean View in Norfolk, a marsh area in Lynnhaven inlet, and the banks of the Elizabeth River near the confluence of the southern and eastern branches. Cleanup of the beaches was completed by July 9 . Cleanup of the shore and facilities in the Elizabeth River continued until July 27. About 10,400 gallons of oil and 3 tons of oiled sea grass were recovered.

95 The explosion and fire of a waste tank containing benzene, styrene, crude feed stock oil, and methyl tert-butylethene on Saturday, July 7, in Channelview, Tex., killed 14 people. A resultant major chemical spill (quantity unknown) into the San Jacinto River forced its closure to marine traffic. Most of the spilled product burned or evaporated; some was 
Table 1. Chronology of significant hydrologic and water-related events, October 1989 through September 1990—continued

\begin{tabular}{ccc}
\hline \multirow{2}{*}{$\begin{array}{c}\text { No. } \\
\text { (fig. } 4)\end{array}$} & EVENT & JULY 1990 (con.) \\
\hline
\end{tabular}

secured with booms and a dike. The spilled material that was not contained was expected to dissipate rapidly, aided by high air temperatures. The river was re-opened on Sunday.

In an unnamed pond in Wailuku, Maui, Hawaii, 60,000 common tilapia (fish) died in early July as a result of the death of algae and low dissolved-oxygen concentrations in the pond.

On July 11 , more than 13,000 fish were killed when ammonia laden swine feedlot wastes entered Fausett Creek near Whitestone in Gilmer County, Ga. The fish died in a 4-mile stretch of the creek. About 16 percent of the fish were game or commercial species. Among the species killed in largest numbers were stonerollers, Notropis, hogsucker, bass, sunfish, shiner, redhorse, darter, sculpin, and minnows.

In the early morning of July 16 , more than 2 inches of rain from a storm centered in the Flamingo Wash basin west of Las Vegas, Nev., caused the highest floods in the wash in 20 years. One fatality resulted from the flood. Damage exceeded the $\$ 2.6$ million caused by the flood of June 10 , 1989.

On July 4 and 23 , intense rainfall caused by severe localized thunderstorms caused flash flooding in the high elevations across north-central Vermont. Six counties (Franklin, Chittenden, Lamoille, Caledonia, Washington, and Orange) were declared a Federal disaster area on July 25. Damage was primarily confined to public facilities such as roads, bridges, and culverts and totaled an estimated $\$ 2.6$ million.

In late July, intense rainfall flooded parts of southwestern and northeastern Iowa. On July 27, the Nishnabotna River near Hamburg reached a peak stage of 28.06 feet, just 0.21 foot below the record set in September 1989. Many roads were closed and agricultural areas flooded. Flooding occurred in the Cedar River basin in northeastern Iowa on July 29. Most residents of Finchford, about 15 miles northwest of Waterloo, were evacuated during flooding along the West Fork Cedar River. A new maximum stage of 18.45 feet at the gaging station on the West Fork Cedar River at
Finchford ( 45 years of record) exceeded the old record of $17.25 \mathrm{feet}$ set in 1951 . The peak discharge of $23,300 \mathrm{ft}^{3} / \mathrm{s}$, however, was less than the $31,900 \mathrm{ft}^{3} / \mathrm{s}$ that also occurred in 1951.

101 Low streamflow and above-average temperatures throughout July caused numerous fishkills in the Snake River in Idaho from Swan Falls Dam to Brownlee Reservoir. Abundant whitefish and several large sturgeon, as well as large quantities of nongame fish, died. Among 28 dead sturgeon, some were as much as 8 feet long and about 50 years old.

$$
\text { AUGUST } 1990
$$

Between August 3 and 13, about 1 million fish died in the Mulatto Bayou near Milton in Santa Rosa County, Fla. Cause of the kill is uncertain but industrial discharges were suspected. Ninety-five percent of the dead fish were Menhaden, a commercial species. Other species killed included spot, croaker, speckled trout, and sea robins.

In early August, rainfall caused localized flooding and a mudslide in Putnam County in southeastern N.Y., near Carmel and Kent. Peekskill Hollow Creek near Tompkins Corners, (drainage area of $14.9 \mathrm{mi}^{2}$ ), about 5 to 10 miles west of maximum flooding and the mudslide, had a record peak flow of $1,050 \mathrm{ft}^{3} / \mathrm{s}$ and accompanying gage height of 4.77 feet on August 7. This represents a 25 -year recurrence-interval flood. Records began at this site in 1975.

104 Minor flooding accompanied a frontal system that moved through New England in early August. Generally only small streams and urban areas were flooded and only for short periods of time. However, on August 6, several engines and cars on a freight train were derailed in Vermont when a section of track washed out due to flooding associated with intense rain (as much as 2 inches overnight).

On the evening of August 6, storm cells over the Mojave Desert, Calif., caused at least one flash flood. On that date, the stage was 8.3 feet (about $10,000 \mathrm{ft}^{3} / \mathrm{s}$ ) on the Mojave River at Lower Narrows near Victorville. The next day 
Table 1. Chronology of significant hydrologic and water-related events, October 1989 through September 1990—continued

\begin{tabular}{|c|c|c|}
\hline \multirow{2}{*}{$\begin{array}{c}\text { No. } \\
\text { (fig. 4) }\end{array}$} & \multicolumn{2}{|c|}{ EVENT } \\
\hline & August 1990 (con.) & SEPTEMBER 1990 \\
\hline
\end{tabular}

the stage was 4.3 feet (about $88 \mathrm{ft}^{3} / \mathrm{s}$ ) as water infiltrated almost immediately into the dry stream channel.

106

A series of storm events produced heavy precipitation from August 7 to 11 throughout the central and northern parts of New Hampshire. Eight of New Hampshire's ten counties (Coos, Grafton, Carroll, Sullivan, Merrimack, Belknap, Cheshire, and Hillsborough) were declared a Federal disaster area on August 29. Damage caused by flash flooding was principally confined to the steep upland areas. Total storm damages were estimated at $\$ 1.2$ million and were primarily to public facilities such as roads, bridges, and culverts.

107 Tomah in Monroe County, Wis., received more than 8 inches of rain on August 17 and 18, which caused flooding that forced 1,500 residents from their homes and threatened the Lake Tomah Dam on the Lemonweir River. Losses of personal property and damage to city streets were estimated at about $\$ 3$ to 5 million. However, no serious injuries or deaths were reported.

Intense rains on August 20 near the Colorado-New Mexico line destroyed a gaging station on the La Plata River near Farmington, N. Mex. The estimated stage of 12.5 feet is the maximum for the 51 years of record.

In Wyoming, intense thunderstorms southwest of Wheatland caused extreme flooding of Sybille Creek and its tributaries on August 20. Discharge was determined indirectly at three sites; one to aid in the evaluation of bridge scour. The peak discharge at one gage was $19,900 \mathrm{ft}^{3} / \mathrm{s}$, which is nearly six times the discharge having a recurrence interval of 100 years.

USGS personnel in California documented a substantial rate of subsidence in Antelope Valley: an average annual rate of 0.1 foot with elevation differences of as much as 5 feet in some places. An intense desert rainstorm and the resultant erosion and runoff on the evening of August 17 produced numerous new fissures at the land surface and obvious subsidence in a broad area south of the main playa runway used for space shuttle landings.
111

On September 3, intense rains caused severe flooding in the Havasu Creek Canyon, about 80 miles northwest of Flagstaff, Ariz. In Supai Village, home of about 800 Havasupai Indians, about 60 tourists and 100 Supai residents were airlifted to safety before the village was inundated by an estimated 14-foot wall of water. A few injuries and severe damage to homes and crops resulted from the flooding. The peak discharge near the mouth of the Colorado River was estimated at $20,300 \mathrm{ft}^{3} / \mathrm{s}$. Many cottonwood and ash trees that lined the banks of the Havasu Creek were swept into the Colorado River. The Governor declared a state of emergency for the area on September 4.

Rainfall during the latter part of September produced flooding in several areas of Texas. The city of Menard was flooded September 17 for the fifth time during the year as a result of 5 to 6 inches of rainfall upstream near Eldorado. At 4 p.m. the stage of the San Saba River at Menard rose to 19.4 feet, which corresponds to a discharge of $66,000 \mathrm{ft}^{3} / \mathrm{s}$. This stage was less than the maximum discharge for the period of record of $130.000 \mathrm{ft}^{3} / \mathrm{s}$ with a stage of $22.2 \mathrm{feet}$, which occurred in July 1938. Maverick (between Bronte and Ballinger) received 9 inches of rain, which caused the Colorado River near Ballinger to peak at 27.5 feet on the morning of September 20 (equal to the maximum gage height of record at this site). After 6 to 8 inches of rain fell on the upper watershed, the South Concho River at Christoval crested at a stage of 14.1 feet (the highest since 1962) on September 23 and had a discharge of $24,300 \mathrm{ft}^{3} / \mathrm{s}$. The maximum stage ever recorded at this gaging station was 20.5 feet in 1936.

The 1990 water year was the fourth consecutive drought year in northern and western Nevada. Streamflow ranged from about 40 to 50 percent of average in streams draining the east flank of the Sierra Nevada and in the Humboldt River basin. The Lake Tahoe level fell below the rim in September for the first time since 1978. Water-use restrictions in the Reno-Sparks area were implemented. - Irrigators relying on reservoir storage were particularly hard hit by the cumulative effects of the drought. 


\title{
Seasonal Summaries of Hydrologic Conditions, WATER YeAR 1990
}

\author{
By Gregory J. McCabe, Jr., ${ }^{1}$ William O. Brown, ${ }^{2}$ and Richard R. Heim, Jr. ${ }^{2}$
}

FALL 1989
Streamflow for fall 1989 was above median in the Southeast, near to above median in the Northeast, and near to below median in the Plains States, the Rocky Mountains, and the Western States (fig. 5A) The combined flow of the three largest rivers in the conterminous States - the Mississippi, St. Lawrence, and Columbia-was near median having discharges that ranged from 21 percent above median during October to 19 percent below median in December.

The southeastern region, from North Carolina to Louisiana (except for west-central Florida), was wetter than average, and parts of this area received more than 150 percent of average precipitation (fig. $5 B$ ). As a result, severe flooding occurred in parts of northern Georgia between September 30 and October 1 when intense rainfall occurred. More than 4 inches of rain fell during a 6-hour period in some areas (table 1, event 2). On October 9-10, 11.17 inches of rain fell at Rockledge and Cocoa in Brevard County, Fla., in just 12 hours (table 1, event 7). On October 10, more than 16 inches of rain fell in 14 hours at St. Augustine, St. Johns County, Fla. (table 1, event 7). These intense rainfalls were the result of a stalled cold front that moved slowly through the area and then reversed direction and moved back through the area as a warm front. Many streets were flooded by as much as 4 feet of water, but no major damage was reported. The previous maximum 24hour rainfall (9.52 inches) at St. Augustine was recorded on September 18, 1963.

Areas in eastern Kentucky also received intense rainfall during October, and, for the season, this region along with central and southern West Virginia reported more than 100 percent of the average rainfall. On October $17-18$, remnants of Hurricane Jerry produced as much as 6 inches of rain in parts of eastern Kentucky, causing flooding, more than $\$ 11$ million in damage, and the evacuation of hundreds of people (table 1, event 12). Despite these rainfall amounts, eastern Texas averaged only 57 percent of average October-December precipitation. Parts of the central and northern Great Plains and High Plains, however, received precipitation amounts in excess of 150 percent of average, the only such values west of the Mississippi River (fig. 5B).

Conditions in the West were drier than normal (fig. $5 B$ ), except for central and eastern Montana, the western

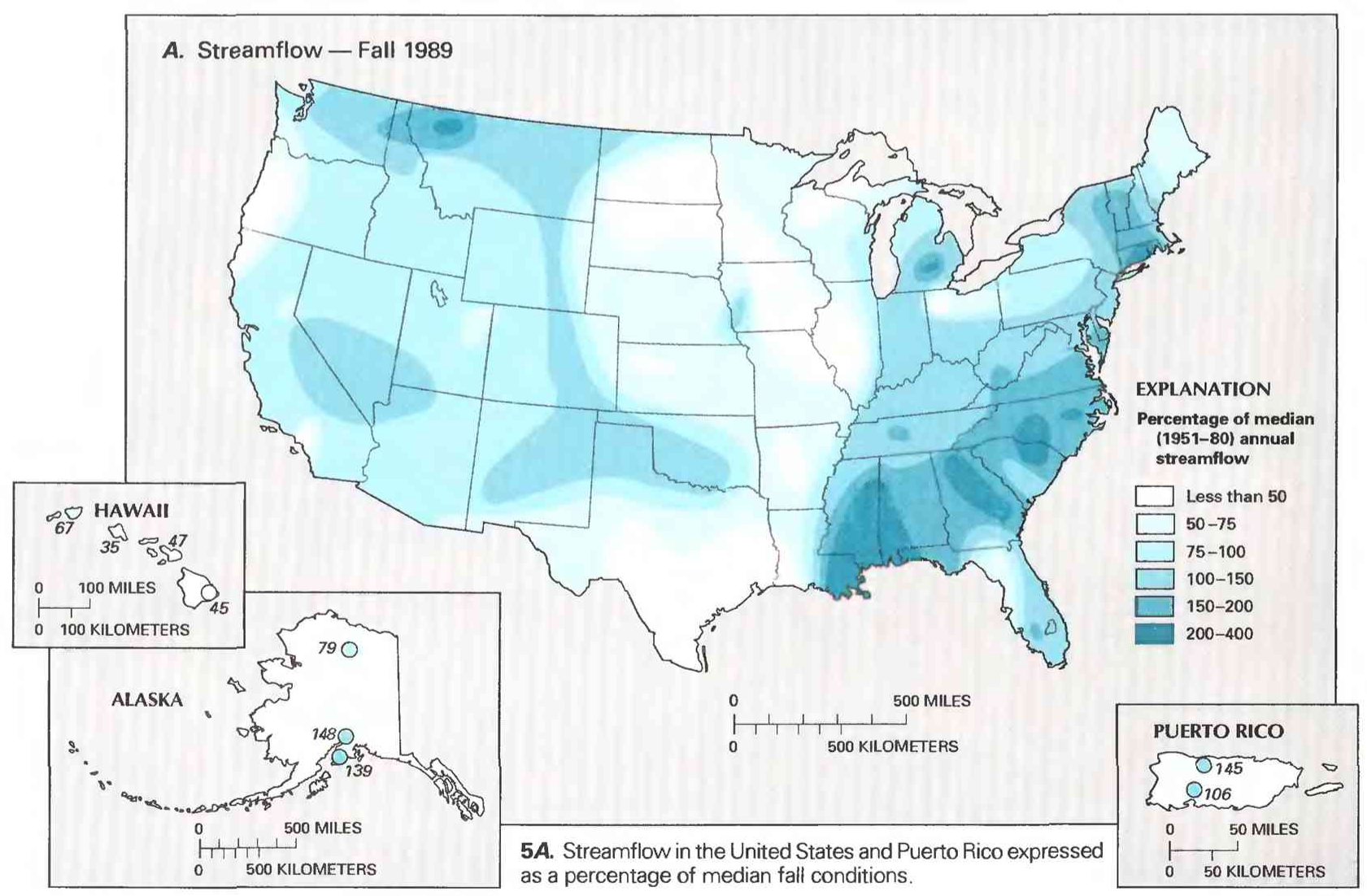

Figure 5. Hydrologic conditions during the fall (October-December 1989) of water year 1990. (Sources: Streamflow data from the U.S Geological Survey; meteorological data from the National Oceanic and Atmospheric Administration, Climate Analysis Center and National Climatic Data Center.)

${ }^{1}$ U.S. Geological Survey. ${ }^{2}$ National Oceanic and Atmospheric Administration, National Climatic Data Center. 
Dakotas, and northern Wyoming; most of the remainder of the West received significantly less than the average precipitation. Southern California, southern Nevada, the panhandles of Texas and Oklahoma, northwestern Iowa, southwestern Kansas, and northwestern Arkansas received less than 25 percent of the average seasonal rainfall, and the Southwest region had the third driest November on record. Low reservoir storage in the Western States was indicative of the dry conditions. At the end of December, Lake Tahoe, which is on the California-Nevada border, had no usable storage, and both the Rye Patch Reservoir in Nevada and the San Carlos Reservoir in Arizona had only 6 percent of maximum storage. In southern Florida, the South Florida Water Management District imposed water-use restrictions during December. In many areas of southern Florida, rainfall was as much as 13 inches below average (table 1, event 27).

Precipitation was low during November from the Southwest through the southern Plains to the central Mississippi Valley. This was the result of a ridge of high pressure over the Gulf of Alaska, which blocked Pacific storms from the west, and a strong west or northwest flow of air over the Plains, which kept Gulf moisture eastward so that it was not pulled into storm systems until they reached the Southeastern States, where above-average precipitation occurred. This above-average precipitation was further enhanced by southerly air flow on the western side of a ridge of high pressure over the western Atlantic Ocean and the Eastern States. For example, 15 to 16 inches of rain fell in Jefferson Parish, La., on November 6 and nearly 2,000 homes were flooded (table 1 , event 15 ).

Temperatures across the conterminous United States reflected the fall 1989 ridge-trough pattern of atmospheric circulation (fig. $5 C, D$ ). From the Pacific, eastward to the eastern slopes of the Rocky Mountains, temperature departures were mostly positive. Fall temperatures generally were much-above average over southern Nevada and north-western Arizona, central Washington, and north-central Idaho. At the same time, temperatures generally were much-below average ( 0.5 to 1.28 standard deviations) across much of the eastern half of the country (fig. 5C). The central Ohio valley, western Virginia, most of New England, the western mid-Atlantic region, and the Mississippi Gulf coast all recorded temperature departures in excess of 2 standard deviations below the average. December was especially cold for points east of the Mississippi. For the Nation, it was the fourth coldest December since 1895, and at least 592 daily record-low temperatures were established. At one time in December, more than 50 percent of the Nation was covered by at least 1 inch of snow, and parts of the Southeast had their first white Christmas ever-southeastern North Carolina had as much as 19 inches of snow December 22-24.

5B. Precipitation in the conterminous United States expressed as a percentage of average fall total precipitation. 5C. Temperature in the conterminous United States expressed as a departure from average fall conditions. (Much above, at least 1.28 standard deviations above the average; above, between 0.52 and 1.28 standard deviations above the average; near average, between -0.52 and 0.52 standard deviations from the average; below, between 0.52 and 1.28 standard deviations below the average; much below, at least 1.28 standard deviations below the average.)

5D. Average height of 700-millibar pressure surface (blue line) over North America and departure from average (1948-70) fall conditions (black dashed line). Data in meters.
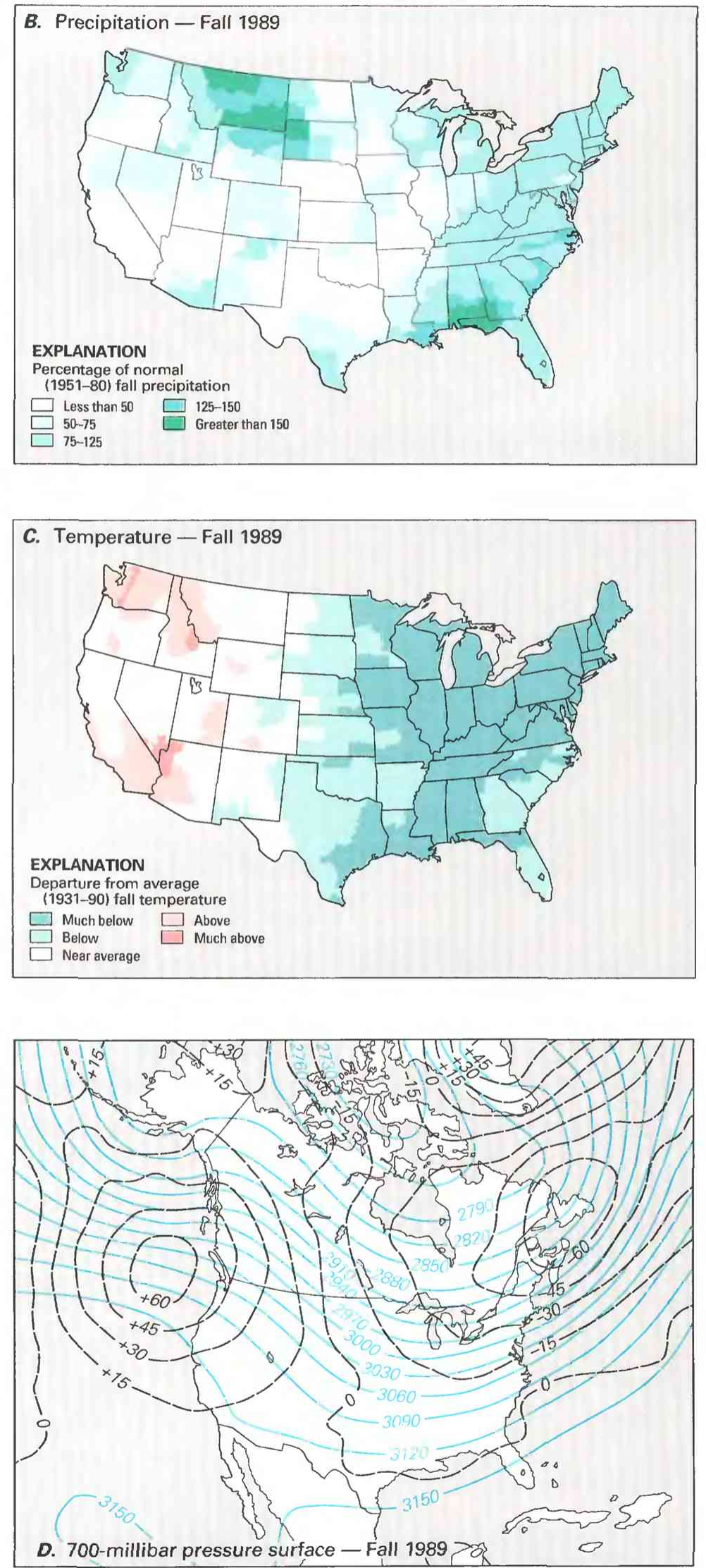

Figure 5. Continued. 
The spatial distribution of streamflow across the conterminous United States for winter 1990 was not much different from that which occurred during fall 1989 (compare figs. $5 A$ and $6 A$ ). Streamflow was near to above median for the eastern third of the country and the southern Plains, near to below median for the central and northern Plains, and below median for most of the Western States with areas of near-median streamflow in the Northwest and the Great Basin. The combined flow of the 3 largest rivers-the Mississippi, St. Lawrence, and Columbia-was 11 percent above median in January, 41 percent above median in February, and 29 percent above median in March.

In January, as a result of intense rainfall, flooding occurred in areas from Seattle, Wash., to Tillamook, Oreg. (table 1, event 37). Peaks of record were exceeded at six gaging stations, including two at which the 100 -year flood was equaled (Puyallup River near Electron, Wash., and Nehalem River near Foss, Oreg.). Flood damage was estimated to be $\$ 17$ million in Washington and more than $\$ 15$ million in Oregon. Near Sacramento, Calif., 2.53 inches of rain fell on January 12 and broke the previous January 12 rainfall record of 1.65 inches that was set in 1906 (table 1, event 38 ). In southeastern Louisiana, flooding caused by several days of rain duriing the last week of January resulted in damage of $\$ 80$ million to $\$ 100$ million (table 1 , event 42).

Intense rainfall also produced flooding in parts of the Southeast during February and March. In February, rainfall caused severe flooding in Georgia, Tennessee, and North Carolina (table 1, event 53). In some streams in northwest Georgia, peak discharges exceeded both the peaks of record and the 100-year floods. About 1,000 people were evacuated from their homes in Trion, Ga., when as much as 12 inches of rain fell on February 15-16 and the Chattooga River overflowed its banks (table 1, event 53). Also on February 15-16, as much as 8.5 inches of rain fell in northern Alabama causing flooding, and one stream (Mulberry Fork near Garden City) reached a peak discharge in excess of the 100-year flood; six counties were declared disaster areas by the President (table 1, event 51). During the same time period, 4 to 9 inches of rain fell in east-central Mississippi causing flooding but no record-breaking peak discharges (table 1, event 52).

In March, intense rainfall again caused flooding in Georgia and Alabama and in some parts of Florida and Mississippi. Peak discharges at some gaging stations in northwestern and west-central Georgia, southeastern Alabama, and northwestern Florida exceeded both the record and 100 year flood. In Alabama, property damage was extensive, and about 1,200 people in northwestern Florida were evacuated from low-lying areas. Flood damage was estimated to be as much as $\$ 100$ million in Alabama alone (table 1 , event 59).

Precipitation generally was above average from the Gulf Coast to the southern Great Plains to the Great Lakes (fig. $6 \mathrm{~B}$ ). Atmospheric circulation around the western margins of a strengthening Bermuda High brought warm, moist air into the southeastern and central United States (fig. $6 D$ ). Alabama, Louisiana, and Oklahoma had the wettest or second wettest winter on record, and winter 1990 was the seventh wettest winter on record for the conterminous 48 States. The dry pattern from the fall season, however, continued across most of the West as higher-than-average atmospheric pressures persisted in association with a ridge

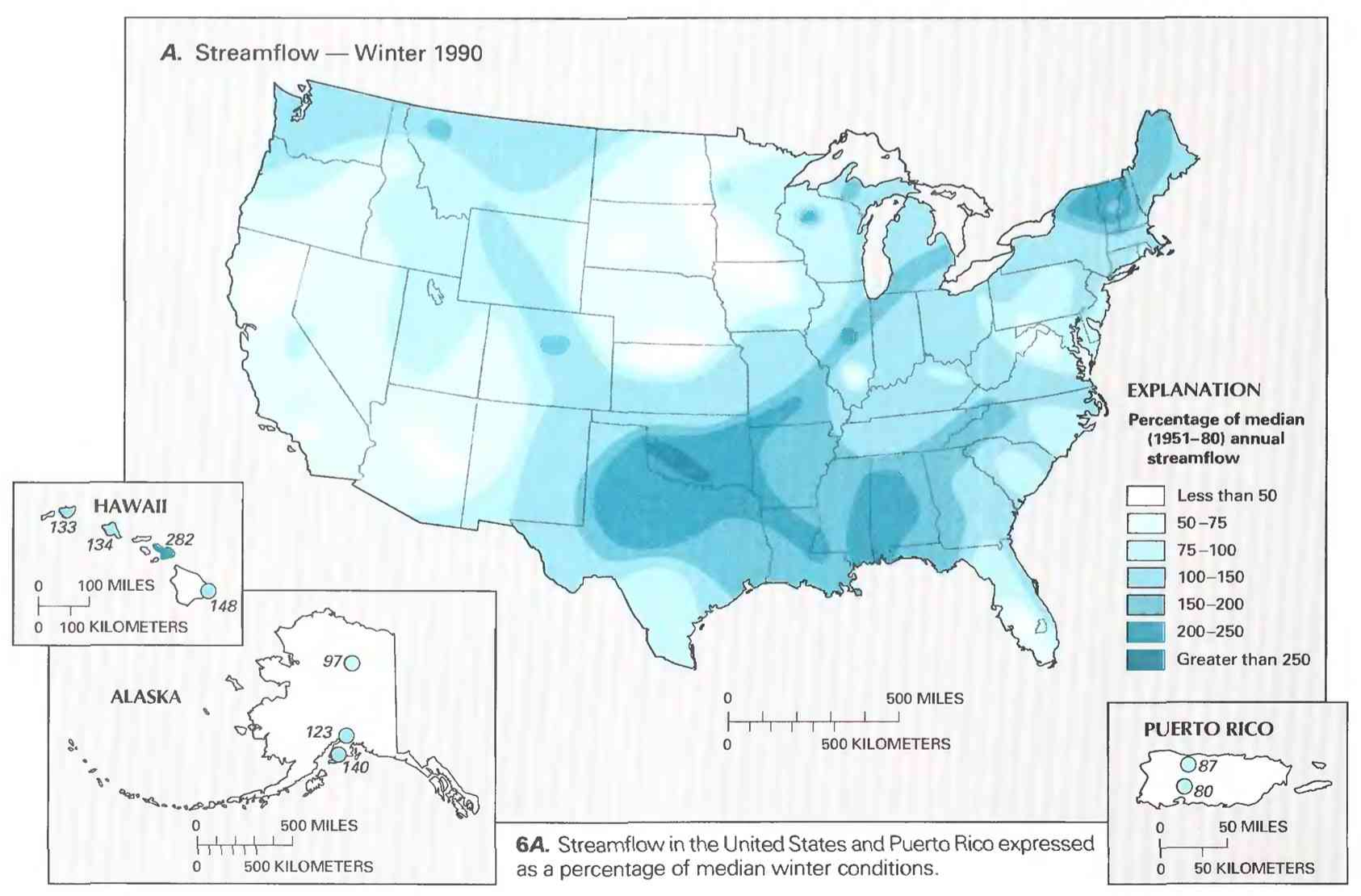

Figure 6. Hydrologic conditions during the winter (January-March 1990) of water year 1990. (Sources: Streamflow data from the U.S. Geological Survey; meteorological data from the National Oceanic and Atmospheric Administration, Climate Analysis Center and National Climatic Data Center.) 
over the Western States (fig. 6D). Much of the western third of the country, from the eastern Rocky Mountains and the northern Great Plains to the Pacific coast recorded less than average precipitation for the season (fig. $6 B$ ). By the end of winter 1990, Lake Tahoe on the California-Nevada border had no usable storage for four consecutive months, and the contents of the Rye Patch Reservoir in Nevada and the San Carlos Reservoir in Arizona had been below 20 percent and 10 percent of maximum capacity, respectively, for four consecutive months. In January, the U.S. Soil Conservation Service stated that reservoir storage in Arizona was the lowest since 1978 (table 1 , event 32). In southern Florida, dry conditions continued and water levels in all artesian aquifers in southwest Florida were extremely low or at all-time record lows (table 1, event 56).

During most of winter 1990, the atmospheric circulation did not exhibit pronounced troughs and ridges, and intrusions of cold Arctic air into the United States were infrequent (fig. $6 D$ ). For the conterminous States, this winter had the second warmest January on record since national statistics began in 1895 . There were no reports of new daily record-low temperatures for the entire month. However, at least 250 new daily record highs were set in the conterminous States. Nationally, February was the 15 th warmest February, and March was the 10th warmest March on record. At least 211 new daily record highs were reported in February and 377 in March. February also had 60 new daily record low temperatures whereas March had only 13 . The only parts of the country having slightly below-average temperatures for the season were extreme southern Arizona and southwestern New Mexico, along with northcentral and central coastal California. At the other extreme, the northeastern quarter of the country, except for Maine (fig. 6C), had winter temperature departures of 2 to 3 standard deviations above the average, which is a very rare occurrence.
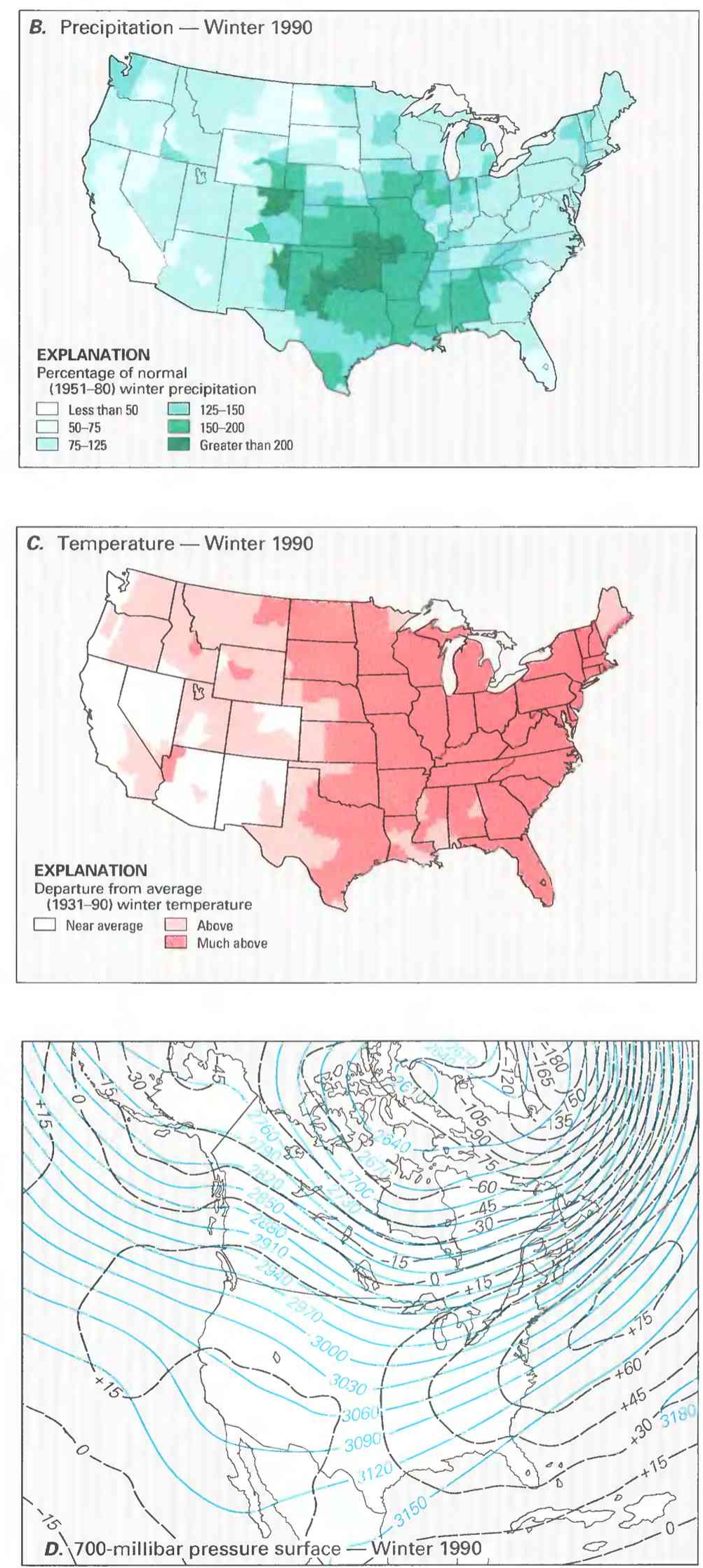

Figure 6. Continued.
6B. Precipitation in the conterminous United States expressed as a percentage of average winter total precipitation.

6C. Temperature in the conterminous United States expressed as a departure from average winter conditions. (Much above, at least 1.28 standard deviations above the average; above, between 0.52 and 1.28 standard deviations above the average; near average, between -0.52 and 0.52 standard deviations from the average; below, between 0.52 and 1.28 standard deviations below the average; much below, at least 1.28 standard deviations below the average.)

6D. Average height of 700-millibar pressure surface (blue line) over North America and departure from average (1948-70) winter conditions (black dashed line). Data in meters. 
SPRING 1990
Streamflow for spring 1990 was above median for the middle and lower Mississippi Valley and southern Great Plains and below median for Florida and most of the West (fig. 7A). A strong ridge of high pressure developed over Alaska and Canada that prevented any significant intrusions of relatively cool, moist Pacific air into the Western States (fig. $7 D$ ), which resulted in a generally warm spring for the West (fig. 7C). The flow of the three largest riversthe Mississippi, St. Lawrence, and Columbia - was near to above median throughout the season.

Precipitation was below average for the western Great Plains, parts of the Gulf Coast, the eastern slopes of the Appalachians, and much of the Southeast (fig. $7 B$ ). Isolated pockets of subnormal precipitation also occurred in the California deserts, central Oregon, northern Minnesota, and the central parts of the mid-Atlantic States. The remainder of the country had above-average precipitation, and many areas received in excess of 150 percent of average. These areas included the middle Mississippi Valley, eastern South Dakota, southeastern Oklahoma, northwestern Arkansas, the eastern slopes of the southern Rocky Mountains, south-central Nevada, the northern California coast, and northern Washington. On a national scale, spring 1990 had the 4th wettest May, 18th driest June, and 8th wettest April-May period on record.

Intense rainfall occurred in Illinois, Iowa, and the south-central States from mid-April through mid-May. Between April 15 and May 19, as much as 24 inches fell in the area between the Gulf Coast and Lake Michigan (table 1 , events $66,70,72-78$ ). Severe flooding occurred and peak discharges at many gaging stations in Oklahoma, Arkan- sas, Texas, Illinois, and Iowa exceeded previous records or the 100-year flood (table 1, events 66, 70, 72, 73, 77, and 78). In Wichita Falls, Tex., on April 28, 6.5 inches of rain fell in 36 hours, which was the second most intense rainfall on record (table 1, event 78). Peak discharges exceeded the 100-year recurrence interval at six sites in the Red and Trinity River basins. More than 2,300 homes sustained damage, and flooding along the Trinity River was the worst in 80 years. Estimated damage was $\$ 500-700$ million to agriculture and $\$ 60$ million to residences; 46 counties qualified for Federal assistance. In June, intense rainfall occurred again in areas of Nebraska, Iowa, and Ohio. Discharges from some streams in these areas exceeded previous record flows and 100-year floods (table 1 , events $86,87,88$ ). Some flooding also occurred in Nevada (table 1 , event 85 ). On June 14-15, severe floods occurred in Belmont, Harrison, and Jefferson Counties, Ohio; about 3 to 5 inches of rain fell in a 3-hour period during the evening of June 14 (table 1 , event 86). Peak discharges at some stations exceeded the peak of record, and peak discharge at the Short Creek gaging station at Dillonvalle, Ohio, exceeded the 100 -year recurrence interval, as well as the previous peak of record (set in 1945). The three counties were declared Federal disaster areas.

As much as 11 inches of rain in a 4-day period, June 13-16, fell in northeastern Nebraska and caused major flooding (table 1, event 87). Six counties were declared State disaster areas (Platte, Colfax, Dodge, Madison, Stanton, and Cuming). Peak discharges exceeded the previous peaks of record at two gaging stations and the 100year recurrence interval at one site. Estimated damage for

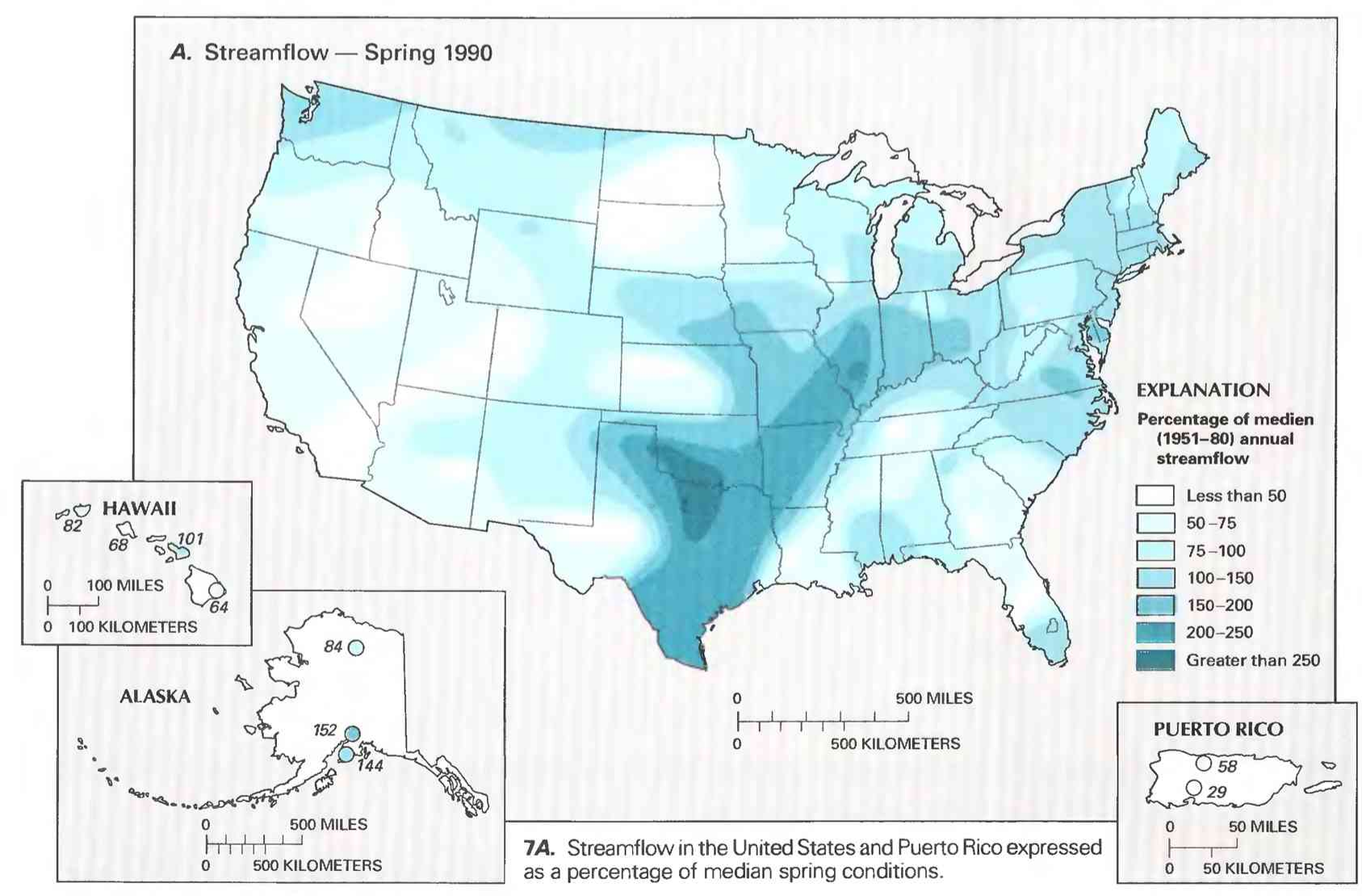

Figure 7. Hydrologic conditions during the spring (April-June 1990) of water year 1990. (Sources: Streamflow data from the U.S. Geological Survey; meteorological data from the National Oceanic and Atmospheric Administration, Climate Analysis Center and National Climatic Data Center.) 
the six counties exceeded $\$ 50$ million.

On June 17-22, severe flooding occurred in parts of Iowa; 41 counties were declared disaster areas by the State and 18 were declared eligible for Federal assistance. Estimated damage was $\$ 83$ million. Peak discharges exceeding the 100-year recurrence interval were measured at seven gaging stations on June 17 (table 1, event 88). On June 28-29, severe storms and flooding caused an estimated $\$ 13$ million in damage in seven southwestern Wisconsin counties. On June 30, the Governor declared a state of emergency in 13 counties (table 1 , event 92).

Although several areas received large amounts of rainfall during the spring, most of the rain fell in areas already saturated, and little fell in drought-stricken areas. Dry conditions continued in the West, and severe to extreme drought spread in areas west of the Mississippi, in Florida, Wisconsin, Michigan, the Dakotas, and adjacent parts of Montana and Minnesota (fig. 7A). By the end of June, a quarter of the conterminous United States was in severe to extreme long-term drought. In California, drought intensified through the spring, and streamflow decreased to levels below 40 percent of median. In the area of California's central coast, runoff decreased to only 10 percent of median; it had been only 20 percent of median during the previous 3 years. Reservoir contents also continued to be low in the West. Contents at the San Carlos Reservoir in Arizona dropped to 3 percent of maximum usable capacity in May. In Florida, water-use restrictions were in effect by May 30 for 12 counties (Seminole, Volusia, Marion, Flagler, St. Johns, Clay, Nassau, Duval, Bradford, Putnam, Baker, and Alachua), and voluntary water-use restrictions were called for in Orange, northern Osceola, Brevard, Lake, Polk, Indian River, and Okeechobee counties (see also table 1, event 81 ).

Temperatures in the eastern half of the country were cooler than average, and in the Ohio and Tennessee Valleys temperatures averaged at least 1 standard deviation below average (fig. $7 \mathrm{C}$ ). At the same time, temperatures in the West were above normal. These temperature departures reflected the persistence of a strong ridge of high pressure over Alaska and western Canada and the formation of a trough over the eastern United States during spring 1990 (fig. 7D).

April had 78 new daily record-low temperatures along with 178 daily record-high temperatures. Nationally, May 1990 was the 15 th coldest on record; 47 daily recordlow temperatures were set. May temperatures for the country as a whole were cooler than average as a result of the formation of a stronger-than-average trough over the central United States during May that produced widespread precipitation and northerly air flow from Canada. June was the 15th warmest June on record; 174 daily record-high temperatures were set.

7B. Precipitation in the conterminous United States expressed as a percentage of average spring total precipitation.

7C. Temperature in the conterminous United States expressed as a departure from average spring conditions. (Much above, at least 1.28 standard deviations above the average; above, between 0.52 and 1.28 standard deviations above the average; near average, between -0.52 and 0.52 standard deviations from the average; below, between 0.52 and 1.28 standard deviations below the average; much below, at least 1.28 standard deviations below the average.) 7D. Average height of 700-millibar pressure surface (blue line) over North America and departure from average (194870) spring conditions (black dashed line). Data in meters.
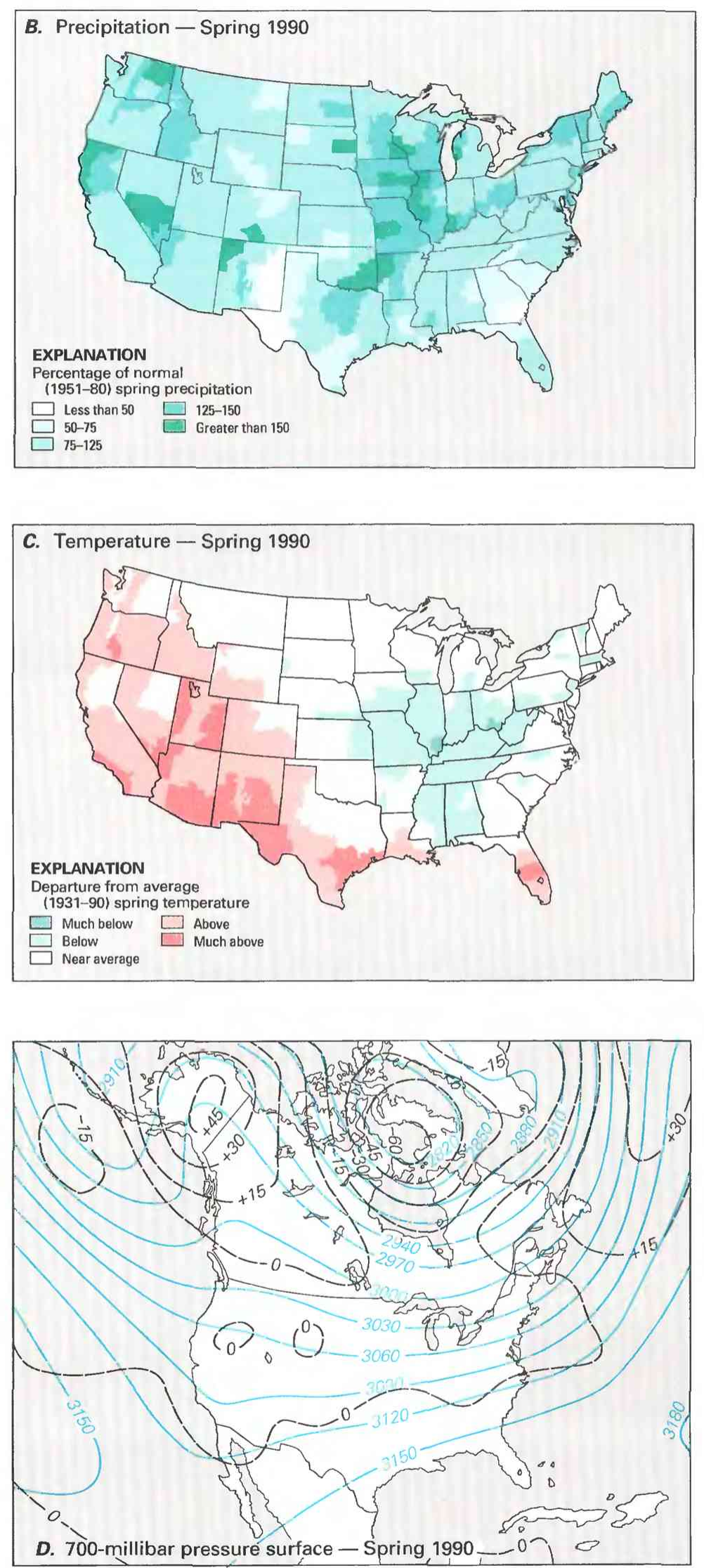

Figure 7. Continued. 
SUMMER 1990
Streamflow during summer 1990 was above median in the northern parts of the Ohio and Mississippi Valleys and below median in the Southwest and Southeast (fig. 8A). The combined flow of the three largest rivers continued in the near to above-median range. Much of the West and some areas in Georgia, South Carolina, Florida, and the northern Great Plains remained in extreme drought during the summer months.

Atmospheric pressure generally was higher than average for most of the United States (fig. $8 D$ ), and produced higher-than-average temperatures for much of the country, although a weak trough was present just off the West Coast. Temperatures were below average for the northeastern quarter of the country except for parts of New England, where temperatures were above average (fig. $8 C$ ). A triangular area from central Texas to eastern Colorado to southern Arizona also had below-average temperatures. Temperatures for much of the remainder of the country generally were warmer than average, with muchabove-average temperatures in the northwestern quarter of the country and much of Florida (1.28 standard deviations or warmer). In the extreme coastal areas of Washington, central Oregon, and west-central Idaho, temperatures were very warm and generally were 3 standard deviations above average. On a statistical basis, a +3 standardized departure can be expected, on average, less than once every 100 years.

Because of higher-than-average atmospheric pressures, oppressive heat covered many parts of the country. On July 2, Valentine, Neb., recorded a new all-time record-high temperature of $114^{\circ} \mathrm{F}$. During August,
Medford, Oreg., had 10 consecutive days of temperatures equal to or greater than $100^{\circ} \mathrm{F}$, and Sacramento, Calif., recorded 7 consecutive days of temperatures equal to or greater than $105^{\circ} \mathrm{F}$. During the latter part of August, temperatures in Kansas averaged $12^{\circ} \mathrm{F}$ above average. During September, temperatures were $9-12^{\circ} \mathrm{F}$ above average in the central Great Plains and the middle Mississippi Valley. Several high-temperature records were set in areas of the Great Basin, Rocky Mountains, the Great Plains, and the Southeast. In contrast, abnormally cool air moved into the north-central and northeastern States during August and September. In September, 24 low-temperature records were broken or equaled from Michigan to southern New England and in North Carolina. In total, 159 new daily record-high temperatures were set nationwide in July, 172 in August, and 274 in September. At the other extreme, 92 new daily record lows were set in July, 99 in August, and 74 in September.

Rainfall was below average for the southeastern quarter of the country, except for the central Appalachian region and south-coastal Florida (fig. $8 B$ ). The northern and eastern part of the Great Plains, the central Rocky Mountains, parts of the Great Basin, central California, and parts of the Pacific Northwest also reported a deficit in rainfall. Most of these areas received from one-half to three-quarters the average rainfall for the period, and southwestern North Dakota, southeastern Montana, south-central Idaho, and coastal Washington received less than one-half the average summer rainfall. Isolated pockets of excess rainfall also were reported. In contrast, the central and eastern parts of the Ohio Valley received in

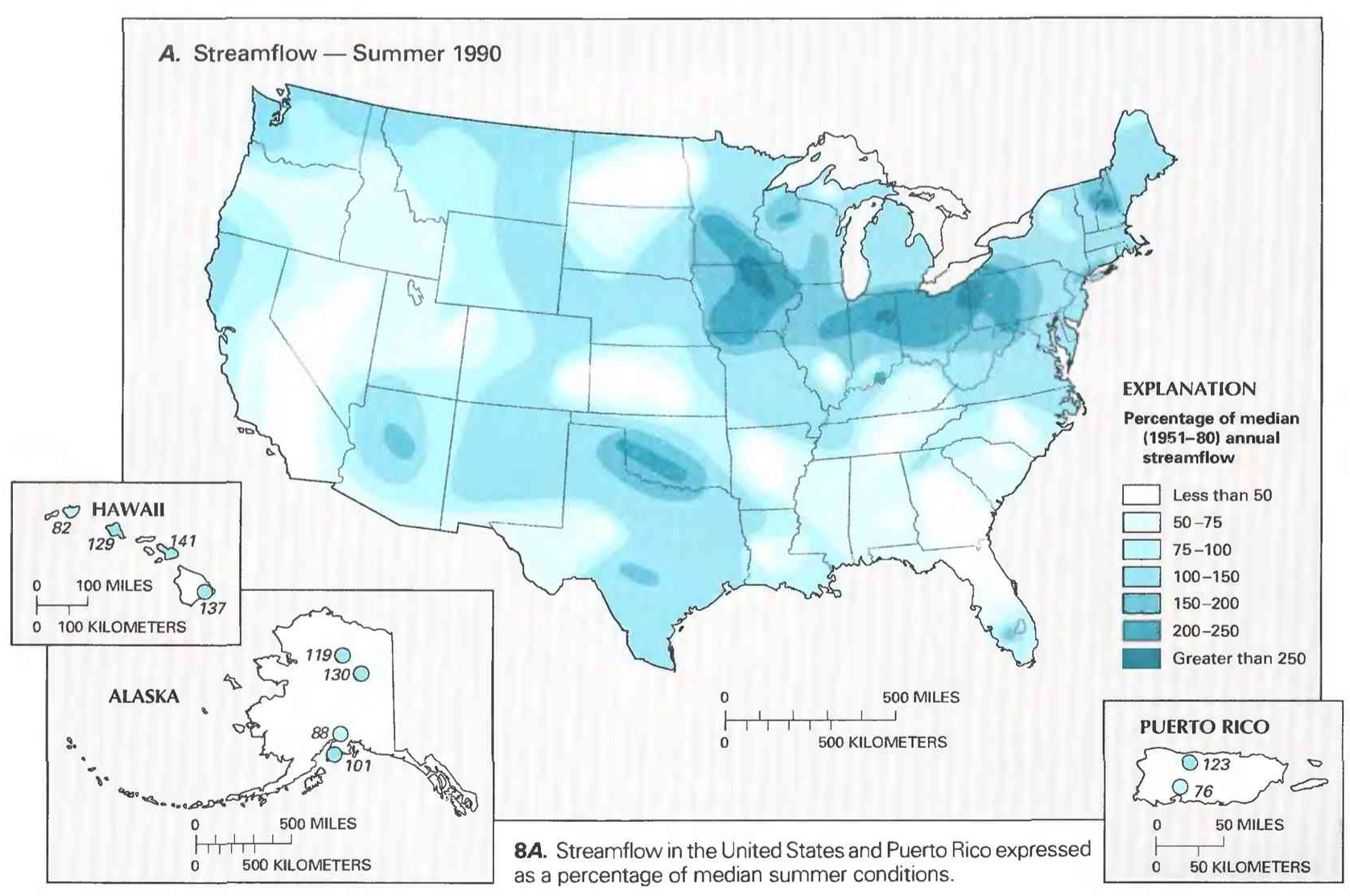

Figure 8. Hydrologic conditions during the summer (July-September 1990) of water year 1990. (Sources: Streamflow data from the U.S. Geological Survey; meteorological data from the National Oceanic and Atmospheric Administration, Climate Analysis Center and National Climatic Data Center.) 
excess of 150 percent of average summer rainfall as did south-central Washington, extreme northeastern California, southeastern Wyoming, south-central Colorado, and southern Nevada. The Big Bend area of western Texas and south-central Arizona recorded in excess of 200 percent of the average summer rainfall.

In various parts of the country during the summer season, extremes in rainfall occurred. On July 16 , intense rains fell west of Las Vegas, Nev., and caused the highest floods of the last 20 years in the Flamingo Wash drainage basin (table 1, event 98). Also in July, intense rains in northeastern Iowa caused severe flooding, which resulted in the evacuation of residents living along the West Fork Cedar River in Finchford, Iowa (table 1, event 100). During August, stagnant weather systems brought 4 to 12 inches of rainfall to areas along the Atlantic Coast, and thunderstorms caused intense rainfall in much of the Great Plains and upper Ohio and Mississippi Valleys. Although much of the Southwest continued to suffer extreme drought, some areas received local excessive rainfall. For example, on August 14, Desert Hill, Ariz., received 3.42 inches of rain in less than 2 hours.
8B. Precipitation in the conterminous United States expressed as a percentage of average summer total precipitation.

8C. Temperature in the conterminous United States expressed as a departure from average summer conditions. (Much above, at least 1.28 standard deviations above the average; above, between 0.52 and 1.28 standard deviations above the average; near average, between -0.52 and 0.52 standard deviations from the average; below, between 0.52 and 1.28 standard deviations below the average; much below, at least 1.28 standard deviations below the average.)

$\mathbf{8 D}$. Average height of 700 -millibar pressure surface (blue line) over North America and departure from average (1948-70) summer conditions (black dashed line). Data in meters.
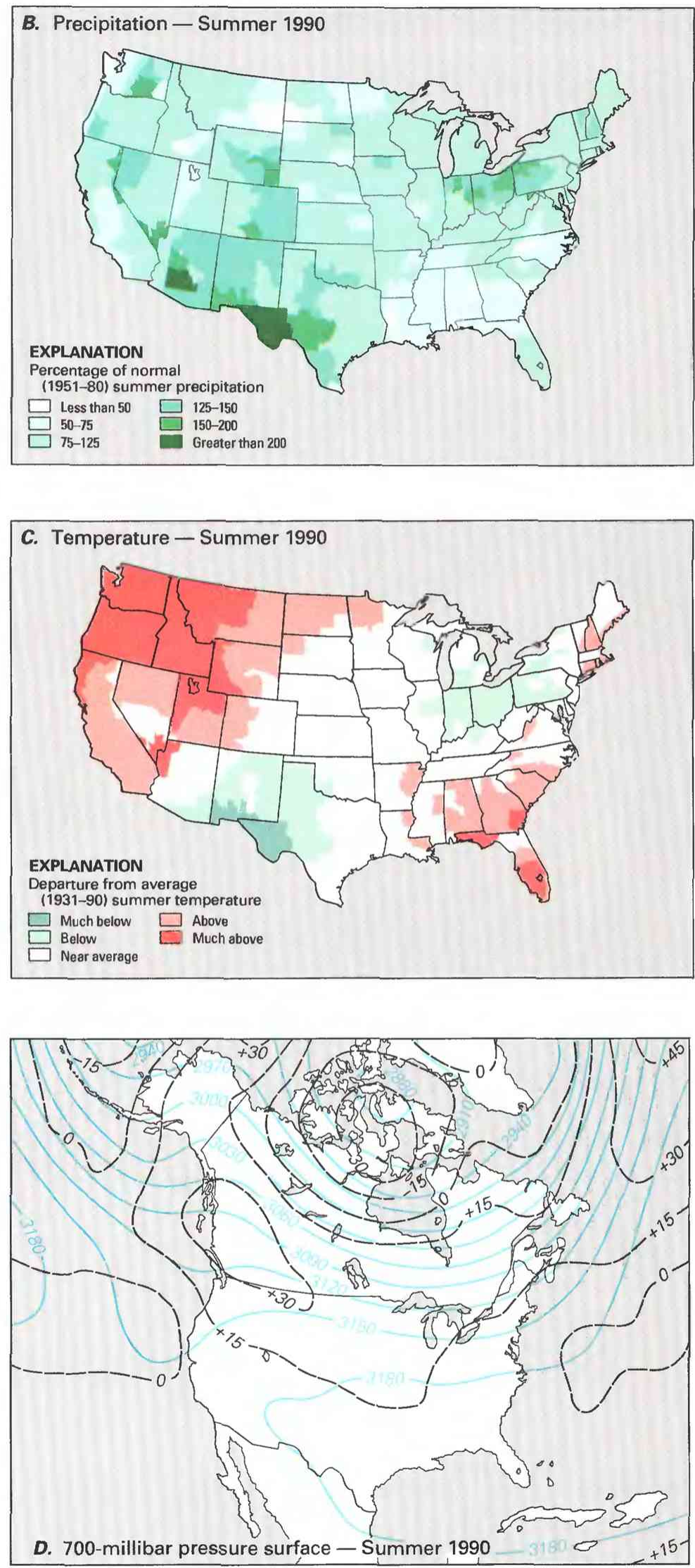

Figure 8. Continued. 


\title{
Review of Water Year 1991 Hydrologic Conditions AND WATER-RELATED EVENTS
}

\author{
By Gregory J. McCabe, Jr., Judy D. Fretwell, and Edith B. Chase
}

\begin{abstract}
Surface-water hydrologic conditions and many water-related events are controlled primarily by meteorologic and climatic factors. The following annual and seasonal summaries of hydrologic conditions for water year 1991, therefore, are described in a climatic context. Streamflow, which is expressed as a percentage of median streamflow for the reference period 1951-80, and precipitation, which is expressed as a percentage of average precipitation for the reference period 1931-90, are depicted on maps (fig. 9) to provide an overview of the water year. Quarterly streamflow and precipitation data also are presented (figs. 13A, $B ; 14 A, B ; 15 A, B ; 16 A, B$ ) in the "Seasonal
\end{abstract} Summaries" section and are accompanied by maps showing temperature as departure from average 193190 reference-period conditions (figs. $13 C, 14 C, 15 C$, $16 C)$ and atmospheric-pressure conditions near 10,000 feet (about 3,048 meters) as compared to average 194870 reference-period conditions (figs. 13D, 14D, 15D, $16 D$ ). Departure from average temperature is depicted in terms of standard deviations, which is a statistical measure of the dispersion of values around an average. The distribution of high- and low-pressure areas across the United States at about 10,000 feet, which are recorded in terms of the 700-millibar pressure surface, or height field, influences the distribution of surface temperature, precipitation, and, thus, streamflow. Usually, excessive precipitation and droughts that persist throughout a season will be observed in conjunction with persistent low- and high-pressure conditions in the upper atmosphere. Because these maps depict conditions averaged over a 3-month period, ephemeral events, such as a single flood resulting from an individual storm, might not be associated easily with the general upperlevel circulation.

The data used in preparing these summaries were taken from the following publications: the National Oceanic and Atmospheric Administration's (NOAA) "Climate Impact Assessment, United States"; "Daily Weather Maps, Weekly Series"; "Monthly and Seasonal

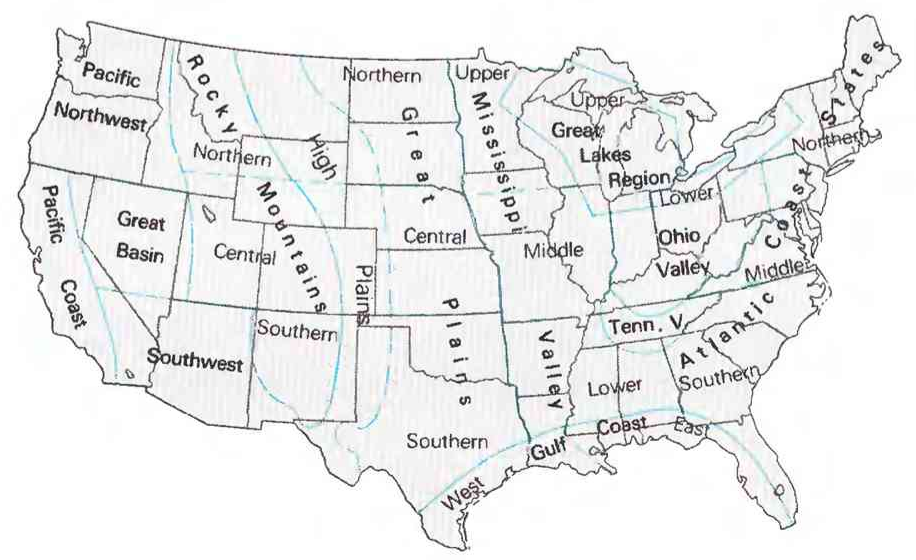

Weather Outlook"; "Storm Data"; and "Weekly Weather and Crop Bulletin" (the last publication is prepared and published jointly by NOAA and the U.S. Department of Agriculture); and the U.S. Geological Survey's (USGS) monthly "National Water Conditions" reports. Geographic designations in this article generally conform to those used in the "Weekly Weather and Crop Bulletin" (see map showing geographic designations).

Streamflow for water year 1991 was above median in parts of the upper Mississippi Valley, throughout the lower Mississippi Valley westward through the Texas Panhandle into central New Mexico, southern Colorado, and eastern Arizona, in parts of the Tennessee and Ohio Valleys, and in south-central Georgia and north-central Florida (fig. 9A). It was below median for northern California, most of Nevada, southern Idaho, and southern Oregon, as well as most of Kansas and adjacent States, much of North Dakota, northeastern South Dakota, northwestern Minnesota, and southwestern Texas. The combined flow of the three largest rivers in the conterminous United States-the Mississippi, St. Lawrence, and Columbia-was 17 percent above median. Annual flow of the St. Lawrence River was 4 percent above median, flow of the Mississippi River was 28 percent above median, and flow of the Columbia River was 4 percent above median.

Annual precipitation for water year 1991 was about average for a large part of the country. However, in northern California and parts of the Pacific Northwest, the Southwest, and the central Great Plains, precipitation was below average (fig. $9 B$ ). Slightly below-average precipitation occurred in south-central North Dakota, northwestern South Dakota, and most of the Middle Atlantic Coast States. In the remainder of the country, precipitation was above average. In western Texas, parts of northern and extreme southern Louisiana, northeastern Mississippi, east-central Georgia, and central South Carolina, precipitation was greater than 150 percent of average.

Annual-average-temperature departures for water year 1991 reflected a classic trough-ridge pattern that caused below-average temperatures in the central and southern Rocky Mountains, southern Great Plains, the Pacific Northwest, and central California. Temperatures were slightly above average from the Cascade Mountains in Washington to central Oregon, in the Southwest, and from the northern Great Plains southeastward toward the central Gulf Coast. From Florida to the lower Great Lakes region, temperatures averaged at least 2 standard deviations above the average.

The spring was especially warm in the Eastern States. In April alone, 219 new maximum-daily-temperature records were set. Nationally, the January-May period was the seventh warmest on record. Because of the unusually warm conditions in the East, nearly 700 tornadoes were reported during March through May, more than twice the average for that period. In the 

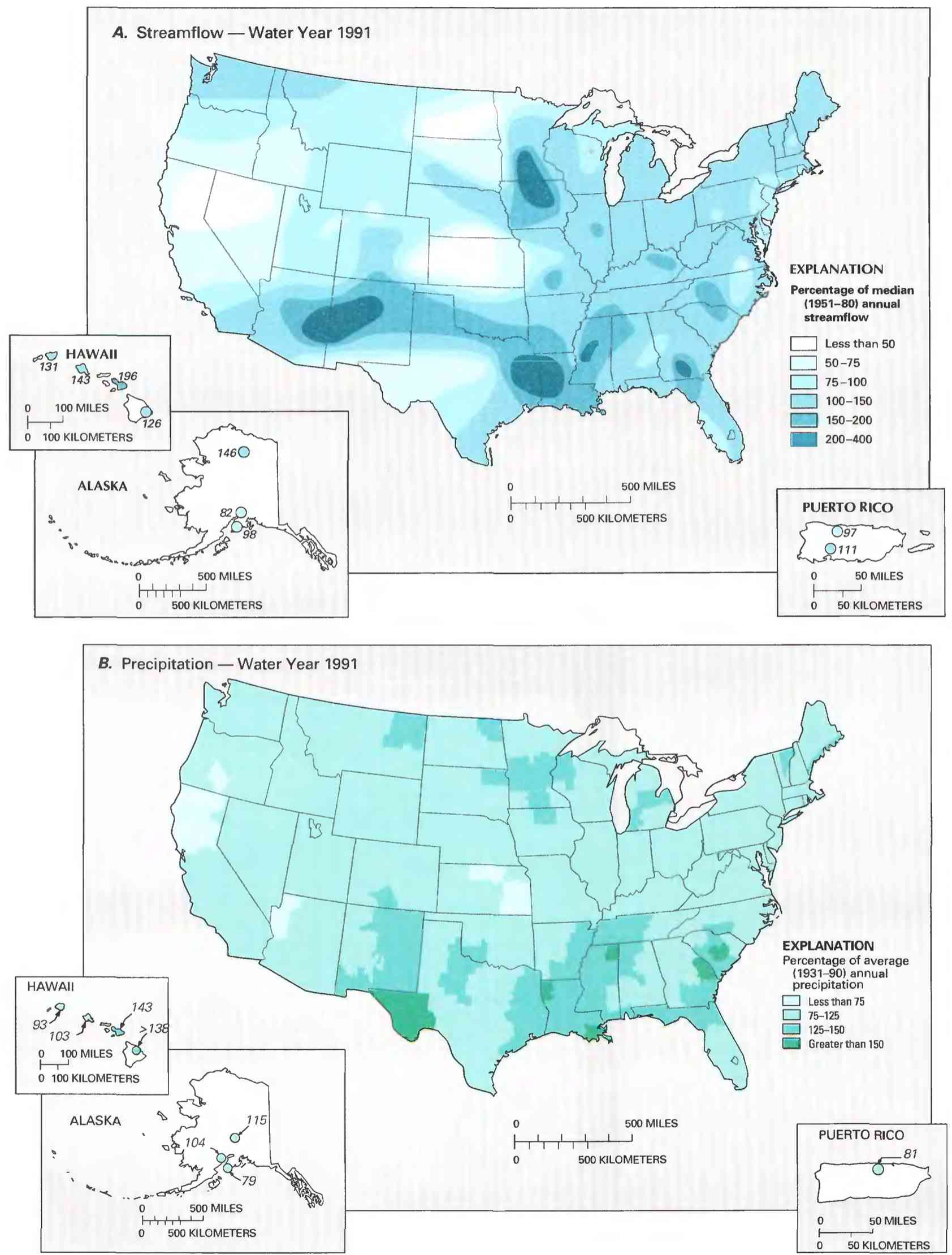

Figure 9. Streamflow $(A)$ and precipitation $(B)$ in the United States and Puerto Rico in water year 1991. Streamflow is shown as a percentage of median, and precipitation as a percentage of average. (Sources: A, Data from U.S. Geological Survey. B, Data from the National Oceanic and Atmospheric Administration, National Climatic Data Center.) 

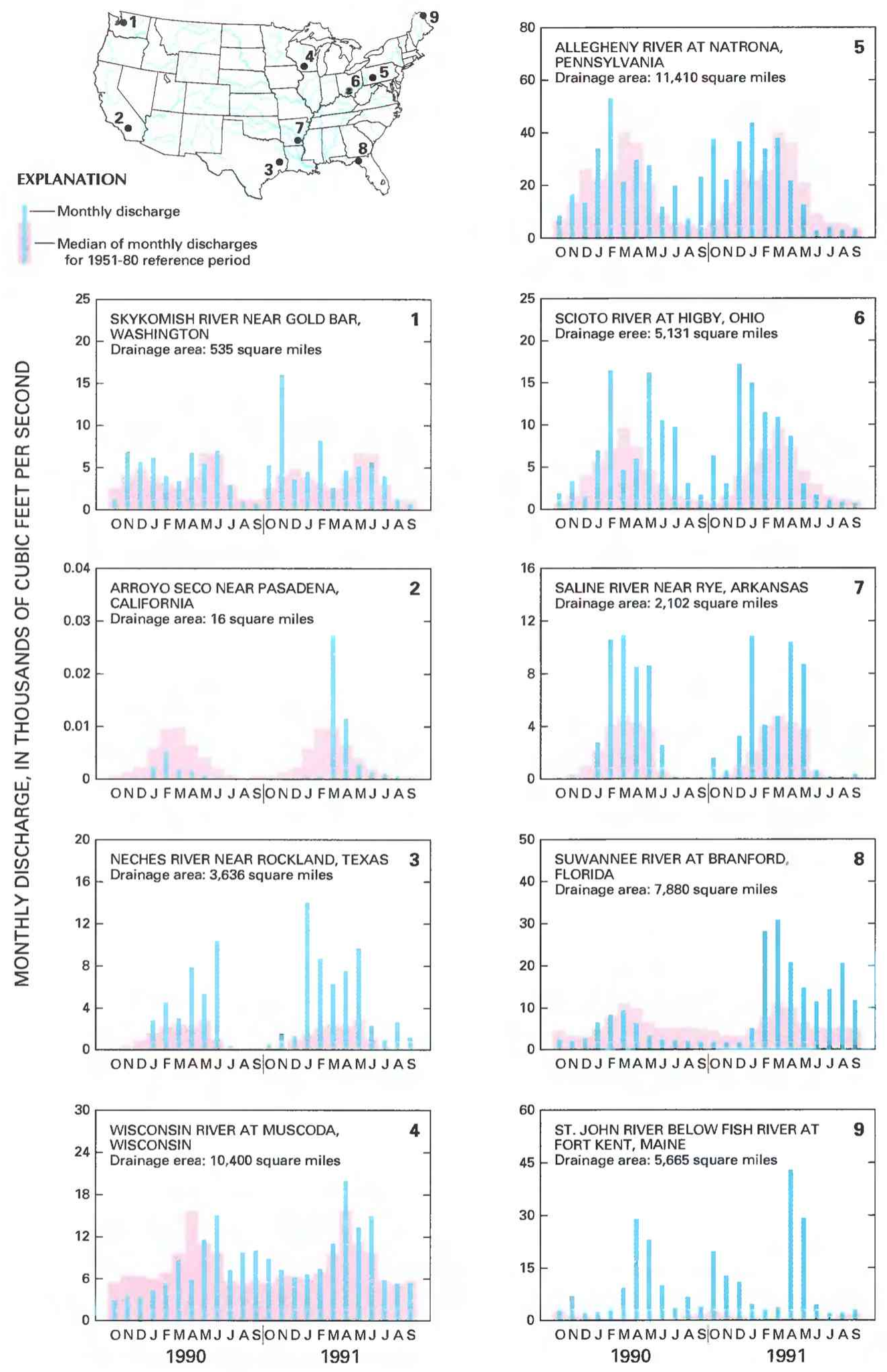

Figure 10. Monthly discharges for selected major rivers of the United States for water years 1990 and 1991 compared with monthly median discharges for the reference period water years 195180. (Source: Data from U.S. Geological Survey files.) 

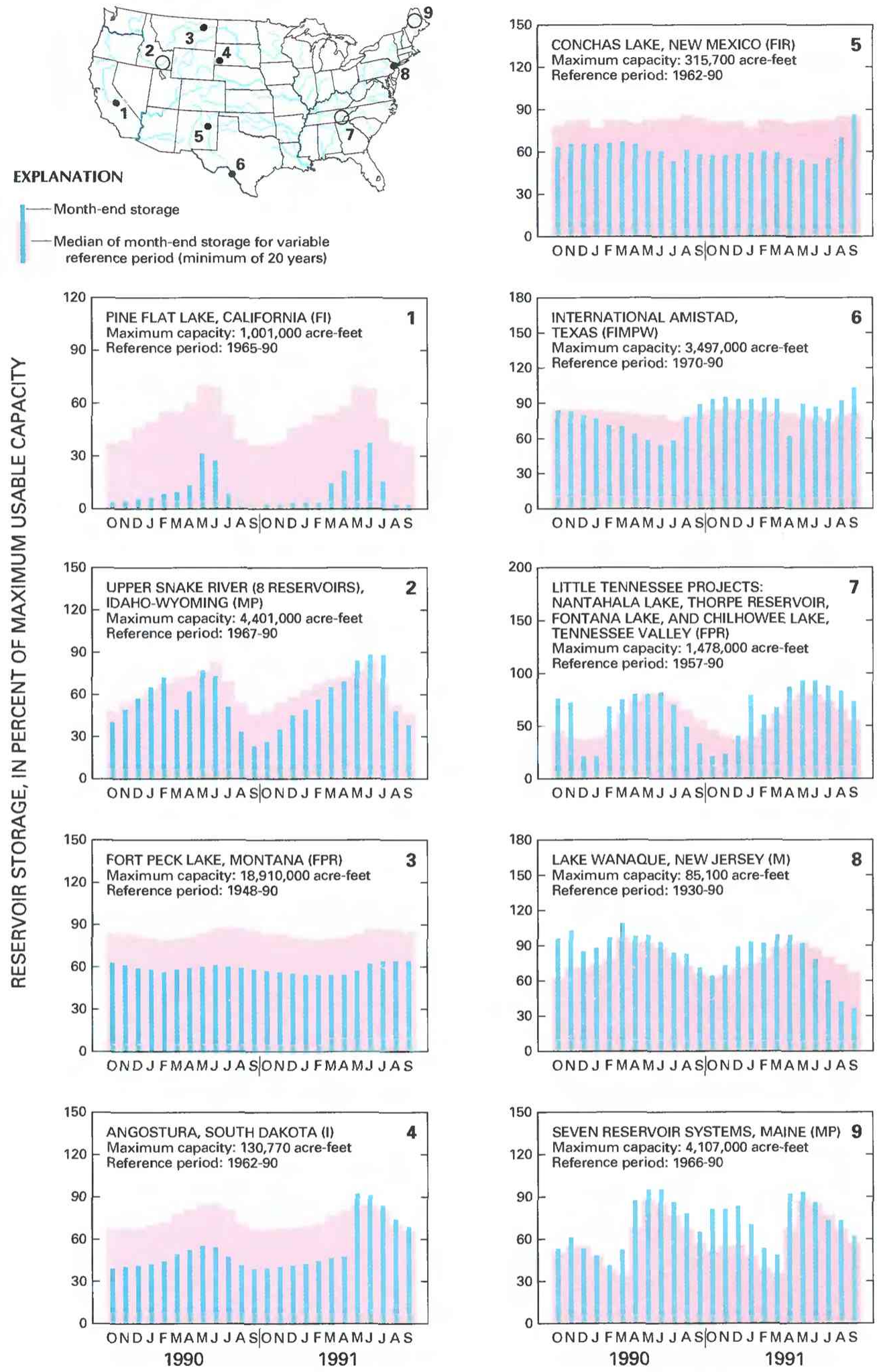

Figure 11. Month-end storage of selected reservoirs in the United States for water years 1990 and 1991 compared with median of month-end storage for reference period. The reference period, which varies but is a minimum of 20 years, for each reservoir or reservoir system is shown on the graph; the beginning year for a reservoir system is the year records began for the newest reservoir in the system. The location of individual reservoirs is shown on the map by a black dot; the general location of reservoir systems (multi-reservoirs) is shown by an open circle. Principal reservoir and water uses are shown in parentheses: F, flood control; I, irrigation; M, municipal; P, power; R, recreation; and W, industrial. (Source: Data from U.S. Geological Survey files.) 
Southeastern States, not only were temperatures high, but precipitation was much above average in many locations due to the flow of warm, moist air from the Gulf of Mexico into the Southeastern States. For water year 1991, one of the largest rainfall totals ever measured in any major American city was $\mathbf{1 1 0 . 9 3}$ inches at New Orleans; the average annual-January through December-total is 59.74 inches.

Stronger-than-average anticyclonic conditions prevailed over the conterminous States during water year 1991 and resulted in above-average temperatures and drought conditions in several areas of the country. California and much of the Western States had the fifth consecutive year of significant precipitation deficit. In addition to the drought in the West, the persistence of an upper-air ridge over the Northeastern States during the spring and summer contributed to drought in some areas of the Ohio Valley and Middle Atlantic Coast States. The only hurricane to hit the United States during water year 1991 was Hurricane Bob, which developed in the northern Bahamas and struck eastern Long Island, N.Y., and New England on August 19. It produced 3 to 9 inches of rain and was accompanied by wind gusts of as much as 120 miles per hour. Total damage caused by Hurricane Bob was estimated to be $\$ 1.5$ billion.

The regional and local patterns of hydrologic conditions can be seen in the graphs of monthly discharges for selected rivers (fig. 10) and storage of selected reservoirs (fig. 11). The monthly discharge of rivers illustrates regional hydrologic conditions. For example, the drought conditions that affected the Middle Atlantic Coast region in the latter part of the water year are illustrated by the monthly discharge of the Allegheny River at Natrona, Pa., and by the Scioto River at Higby, Ohio. During the spring and summer, the discharge of these rivers was below median. In the west, intense rainfall in California relieved the drought for a short period in March. The effects of the March rainfall are shown by the discharge of the Arroyo Seco near Pasadena, Calif. (fig. 10). The monthly discharge of this river was below median during the entire 1990 water year and the first part of water year 1991. After March, discharge of this river exceeded the median monthly values for two consecutive months.

The continued drought in the Western States is illustrated by the month-end reservoir storage of selected reservoirs (fig. 11). For example, the storage of Pine Flat Lake in California, Fort Peck Lake in Montana, and Conchas Lake in New Mexico were much below me- dian for water years 1990 and 1991. The contents of Conchas Lake was just above median during September 1991. Lake Tahoe, which is on the California-Nevada boundary, had no usable storage during the entire water year. The monthly storage of the Wanaque Reservoir in New Jersey reflects the drought that affected the Middle Atlantic Coast States during the spring and summer. In contrast to the drought-affected areas, the month-end reservoir storage of the Little Tennessee Projects (Nantahala Lake, Thorpe Reservoir, Fontana Lake, and Chilhowee Lake) and the International Amistad Reservoir in Texas illustrates the effects of above-average precipitation in the Southeast during water year 1991 .

During water year 1991, many significant waterrelated events, both natural and human induced, occurred. A representative set of these events is listed chronologically in table 2 , and their geographic location is plotted in figure 12. Table 2 represents a culling of some hundreds of these hydrologic occurrences, generally omitting, for example, floods whose recurrence interval is less than 10 years, toxic spills that involve less than 2,500 gallons, and fishkills of less than 5,000 fish. The selection of events for inclusion in table 2 was affected to some extent by the degree of media coverage, including National Weather Service and USGS periodicals, and by communications from USGS field offices alerting the national office that significant hydrologic events had occurred. Toxic-spill data were provided by the U.S. Coast Guard National Response Center. Reporting of weather-related events and damage estimates is subjective; therefore, table 2 might be inconsistent with other national compilations of hydrologic events, such as the annual flood-damage report to the Congress by the U.S. Army Corps of Engineers (1991). Weather-related events (excluding drought, storm surges, and coastal flooding) were estimated to have caused damage in excess of $\$ 4.3$ billion. Of this amount, flood damage was about $\$ 1.7$ billion (U.S. Army Corps of Engineers, 1991).

\section{REFERENCE CITED}

U.S. Army Corps of Engineers, 1991, Annual flood-damage report to Congress for fiscal year 1991: U.S. Army Corps of Engineers report prepared in cooperation with the National Weather Service. [Available from the U.S. Army Corps of Engineers, Engineering Division, Washington, D.C.] 


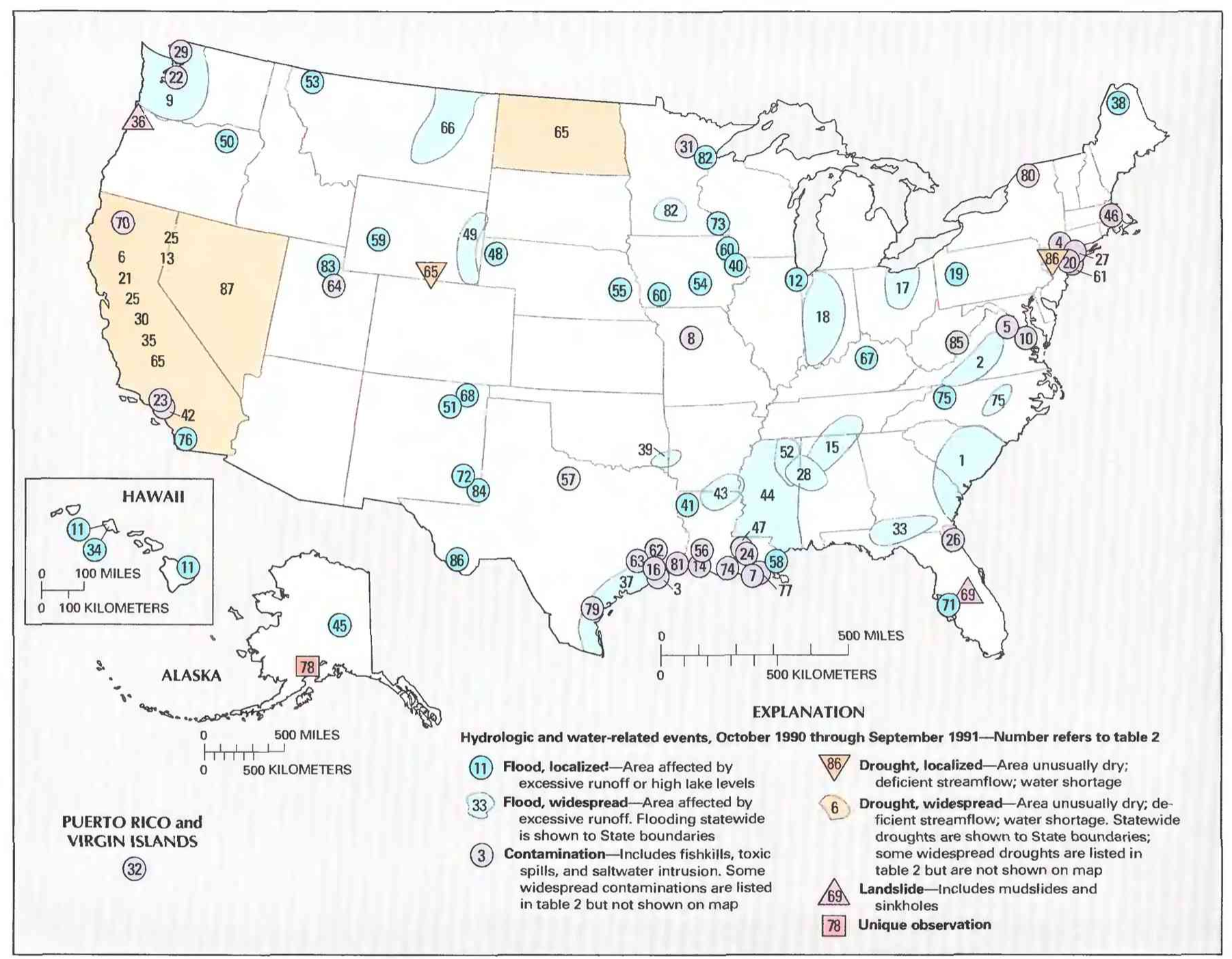

Figure 12. Location or extent of significant hydrologic and water-related events in the United States and Puerto Rico, October 1990 through September 1991, as documented in table 2. Some events listed in table 2 are not shown in figure 12 because of the areal extent of the event. 
Table 2. Chronology of significant hydrologic and water-related events, October 1990 through September 1991

[The events described are representative examples of hydrologic and water-related events that occurred during water year 1991. Toxic-spill data were provided by the U.S. Coast Guard National Response Center. Fishkill data generally were provided by the U.S. Environmental Protection Agency on the basis of reports transmitted by State agencies. Meteorological data are mostly from reports of the National Oceanic and Atmospheric Administration. Abbreviations used: $\mathrm{ft}^{3} / \mathrm{s}=\mathrm{cubic}$ feet per second: $\mathrm{mi}^{2}=$ =square miles; $\mathrm{mph}=$ miles per hour; $\mathrm{mg} / \mathrm{L}=$ milligrams per liter; Mgal/d=million gallons per day; ppm=parts per million; USGS=U.S. Geological Surveyl

No.

EVENT

(fig. 12)

OCTOBER 1990 (con.)

(not shown) During late September and early October, new minimum records for stream discharges, ground-water levels, and lake levels were established after several months of deficient rainfall from Jacksonville to Pensacola in northern Florida and from Savannah westward across southern Georgia. Total rainfall at Jacksonville airport for the 1990 water year was 25.53 inches below average. In Florida, new minimum stream discharges occurred at 8 of 40 USGS gaging stations; drought recurrence intervals at some sites exceeded 50 years. Ground-water levels were record minimums in 16 of 29 wells completed in the Upper Floridan aquifer; the levels ranged from about 0.1 to 2.6 feet below previous lows of record. Water levels at 5 of 7 lakes in the area also were at record lows, ranging from about 0.6 to 4.2 feet lower than previous records. In Georgia, minimum-stream-discharge records were set or equaled at 5 of 20 USGS gaging stations; at some sites drought recurrence intervals exceeded 50 years. Record minimum groundwater levels were reported in 13 of 32 wells completed in the Upper Floridan aquifer. Levels ranged from about 0.1 to 5.6 feet below previous lows of record. Drought conditions in the area were alleviated somewhat by intense rainfall during mid-October.

Tropical storm Klaus caused severe flooding, deaths, and millions of dollars in damage in parts of South Carolina and Georgia during mid-October. In localized areas in South Carolina, rainfall was intense between October 10 and 12. As much as 8 inches fell in 6 hours near Sumter, S.C., and parts of Orangeburg, Sumter, and Kershaw Counties received about 12 inches within 24 hours. The rainfall intensity had a recurrence interval of about 100 years. Peak discharges at 10 gaging stations exceeded both the 100 year recurrence interval and previous peaks of record. Four people were killed when a stranded car was swept off U.S. Highway 1 after failure of the dam on Kendall Lake near Camden (about 25 miles northeast of Columbia), S.C. On October 11, caskets were carried by floodwaters out of a cemetery at Rafting Creek Baptist Church near Sumter in Sumter County.

In Georgia, rainfall ranged from 7 to 10 inches in the eastern and central parts of the State. Local flooding was severe on small streams in the Augusta area, where about 8.5 inches of rain fell within 24 hours. About 9.5 to 10 inches of rain fell in Thurman and Modoc. Four people drowned in rising floodwaters in the flood-effected area. One person was swept away during an attempt to leave a stranded car at a flooded railroad crossing and three people drowned in Jefferson County, about 50 miles southwest of Augusta. At many gaging stations, discharge exceeded peaks of record and the 100-year recurrence interval. Recurrence intervals for the peak discharges were 50 years or less on streams having drainage areas less than $200 \mathrm{mi}^{2}$. Limited flooding occurred on the Savannah River near Augusta. The city of Augusta and nine counties in Georgia were declared Federal disaster areas. Flood damage was estimated to be $\$ 40$ million in the vicinity of Augusta. A3-day maximum total rainfall of 19.9 inches at Louisville set a new record for the State.
2 Between October 11 and 23, two periods of flooding occurred in Virginia, primarily along the eastern slope of the Blue Ridge Mountains. The first period, October 11 to 15, resulted in peak discharges having recurrence intervals of less than 2 years, except in the Rappahannock River basin where recurrence intervals were 5 to 10 years. During the second period, on October 21 to 23 , discharges were greater. Recurrence intervals were about 2 years in the Shenandoah River basin, 2 to 5 years in the Rappahannock and middle James River basins, and 2 to 10 years in the Roanoke River basin. Monthly average flows in the Rappahannock and James River basins were the greatest for October since 1980. Along the mainstem Dan River, flows were the greatest since 1960. On the lower Roanoke River, at Randolph, the flow set a new record for October for the period of record (1928-90).

3 On October 14, about 11,500 gallons of No. 2 fuel oil spilled into the Galveston Bay at Texas City, Tex., during the repair of a 20-inch pipeline. About 6,300 gallons of the spill was recovered in cleanup operations.

4 About 164,000 gallons of kerosene spilled into the Hudson River on October 26, when a tank barge became grounded on Diamond Reef near New Hamberg, N.Y. A total of 30,000 gallons was recovered.

5 On October 26, about 250,000 gallons of petroleum products was discovered in the ground water at a tank terminal in Fairfax, Va., and in a nearby stream. An estimated 18 feet of petroleum products was floating on the ground water; the exact areas affected were undefined. The spill, which extended under about 250 homes, was potentially dangerous as it could cause explosions if the petroleum products seeped into basements. An underground pipeline leak is suspected as the source. Above-ground storage tanks in the area hold gasoline, diesel, and aviation fuel. Oil was recovered through 91 wells and removed from Crook Branch Creek. The spill was expected to be contained by February 1992, but could take as long as 10 years for final cleanup.

6 The drought continued in California. October precipitation at 207 reporting stations averaged 69 percent below the longtime average for the month. Average storage in 155 reservoirs was at 34 percent of capacity at the end of the month (60 percent of the long-term October month-end average). Storage was 24 percent less than at the end of October 1989.

\section{NOVEMBER 1990}

On November 2, a tank barge ran aground in the Gulf Intracoastal Waterway near Houma, La., and spilled 85,000 gallons of crude oil. A 5-mile stretch of the waterway was closed to vessel traffic, and a containment boom was deployed. An estimated 52,000 gallons of oil was recovered as of November 8 when the waterway was partly reopened. As of November 15, all the spilled oil had been recovered and the waterway had been reopened to unrestricted traffic. 
Table 2. Chronology of significant hydrologic and water-related events, October 1990 through September 1991-continued

No.

(fig. 12)

EVENT

NOVEMBER 1990 (con.)

NOVEMBER 1990 (con.)

On November 5, about 300,000 gallons of crude oil spilled near Ethel, Mo., when a 12-inch pipeline ruptured. A 10-acre field was saturated and an unknown quantity of oil entered Turkey Creek and migrated to the Chariton River, a tributary to the Missouri River. After containment, a slight sheen was observed on the Missouri River.

$9 \quad$ The "Pineapple Express," a name given by the National Weather Service to the fall storm route from Hawaii to the Pacific Northwest, brought two major tropical storms into Washington on November 9 and 24 . As a result, a wide area of western Washington and part of eastern Washington were flooded. During the first storm, intense rainfall and warm temperatures caused snowmelt, which contributed to major flooding in most basins draining high elevations north and west of Seattle. Flooding also occurred in lowland areas of the drainage basins of the Snoqualmie, Snohomish, Stillaguamish, Skagit, and Nooksack Rivers north of Tacoma and also to the west in the Skokomish and Queets basins in the less populated Olympic Peninsula. During the second storm, record rainfalls and snowmelt caused by high temperatures produced high water in most river basins east and west of the Cascade Range. A record 24-hour rainfall of 5.82 inches occurred in Olympia and a November 24-hour record of 3.56 inches occurred at the Seattle-Tacoma International Airport. Flooding was widespread in western Washington, from the Canadian border to south of the Columbia River. In eastern Washington, flooding was confined to the Stehekin, Wenatchee, and Yakima River basins. The Puget Sound area was the hardest hit, with major flooding from the Nooksack basin north of Bellingham to the Chehalis basin south of Chehalis. Flows were peaks of record at eight stations, with recurrence intervals ranging from 25 to about 100 years. Peaks of record in excess of the 100-year recurrence interval were recorded at three gaging stations in the Wenatchee River basin-at Plain, Peshastin, and Monitor. One person drowned after being swept into the Snoqualmie River near Duvall while attempting to leave a stalled automobile on a flooded county road. An old pontoon bridge linking Seattle with its eastern suburbs sank and severed cables anchoring the new seven-lane I-90 bridge to the lake bottom. Total damage for the two storms was estimated at $\$ 100$ million. A total of 17 counties were declared disaster areas by the Governor.

On November 17, about 94,000 gallons of asphalt flux petroleum product was spilled into Piney Point Creek (tributary to the Potomac River) near Piney Point, Md. A boom deployed just downstream from the spill site contained the spilled product. Cleanup was completed as of December 14.
Flooding on Oahu, Hawaii, on November 20 followed a week of steady rainfall that ended with a sudden thunderstorm that left more than 9 inches of rain in 2 hours near Waimea. A USGS gaging-station shelter on Kamananui Stream at Maunawai was swept downstream, but the digital recorder was recovered. The last punched gage height of 12.70 feet at 8:00 a.m. has a corresponding discharge of $10,500 \mathrm{ft}^{3} / \mathrm{s}$ and recurrence interval of 100 years. Because the peak flow was estimated to have occurred at about 9:30 a.m., the actual peak discharge likely had a recurrence interval greater than 100 years. The previous peak of record had a recurrence interval of about 50 years. At Hilo, on the is- land of Hawaii, 23.10 inches of rain fell during the same week; maximum intensity was 10.63 inches in 24 hours.

Between 3 and 5 inches of rain fell on November 26 and 27 in Cook, Will, and DuPage Counties in Illinois and contributed to flooding in northeastern and central parts of the State on November 28 and 29. The flooding was most significant in northeastern Illinois, south of Chicago. Peak flows at gaging stations on Butterfield Creek at Flossmoor and the Little Calumet River at South Holland had respective recurrence intervals of 17 and 20 years. In Matteson, one person drowned while trying to drive an automobile through flood water.

13 At the end of November, a 4-year drought continued unabated in California and northern Nevada. During the month, precipitation lagged far behind average throughout California. In the Sacramento basin, precipitation was about 25 percent of average for the water year. At Lake Tahoe, on the California-Nevada border, the water surface was about 1.0 foot below the natural rim, the lowest level since the winter of 1934-35, when the lake surface was 1.26 feet below the rim.

\section{DECEMBER 1990}

On December 16, a 4-inch pipeline, damaged by a passing vessel, spilled 20,400 gallons of crude oil into Black Lake in Hackberry, La. About 12,600 gallons had been recovered by January 4 , when cleanup operations ceased.

Several days of steady rain on saturated soil caused flooding on December 20 to 30 in the northern and western parts of Alabama and the south-central part of Tennessee. Continuing showers the following week exacerbated the flooding in many areas. In Alabama, Huntsville had 7.7 inches of rain and Muscle Shoals, 10.7 inches. Similar quantities fell across Tennessee. The peak stage of record was exceeded at the gaging station on the Tombigbee River at Bevill Lock and Dam near Pickensville, Ala., on December 26. The maximum stage of 144.05 feet was 2.00 feet above the previous peak of May 23,1983. The corresponding discharge was $160,000 \mathrm{ft}^{3} / \mathrm{s}$ (discharge for the 1983 peak was $130,000 \mathrm{ft}^{3} / \mathrm{s}$ ). Peak discharges equaled or exceeded those having recurrence intervals of 100 years at four gaging stations near Huntsville-Paint Rock River near Woodville, Flint River near Chase, Cotaco Creek near Athens, and Big Nance Creek at Courtland. Peak flows also were recorded at gaging stations on Luxapallila Creek at Millport (in the Mobile River basin, about 50 miles west of Birmingham) and West Fork Flint Creek near Oakville (in the Tennessee River basin about 35 miles southwest of Huntsville). Peaks of record or 100 -year recurrence intervals were exceeded at three stations in south-central Tennessee-Sequatchie River near Whitwell, East Fork Mulberry Creek at Lynchburg, and Elk River above Fayetteville.

On December 27, a 6-inch underground pipeline was discovered to be leaking at a pumping station in Baytown, Tex. Before the leak was secured, about 14,600 gallons of crude oil was released. Of the total, about 8,400 gallons spilled into Goose Creek; some of the oil reached Hog Island Beach and the mainland shore. An estimated 10,000 gal- 
Table 2. Chronology of significant hydrologic and water-related events, October 1990 through September 1991—continued

No.

(fig. 12)

DECEMBER 1990 (con.)

EVENT

DECEMBER 1990 (con.) lons of the product had been recovered from the beach as of December 31.

Two to three inches of rain falling on snow-covered ground caused flooding in many areas of Ohio during the period December 28-31. Flooding conditions were exacerbated by significantly above-average precipitation earlier in the month. Average precipitation in Ohio for the month of December was 7.78 inches (5.20 inches above the long-term average), making it the wettest December in more than 100 years of record keeping. Flooding was reported in at least 20 counties spread throughout Ohio. Rising flood waters forced the evacuation of residents in Butler, Cuyahoga, Franklin, Marion, and Pickaway Counties. County commissioners declared Marion County a disaster area. Peak discharges recorded at gaging stations in the Lake Erie basin had recurrence intervals that generally ranged from 10 to 25 years. In contrast, peak discharges recorded at gaging stations in the Ohio River basin had associated recurrence intervals that generally ranged from 2 to 10 years.

18 Widespread flooding in Indiana resulted from 3 to 6 inches of rainfall on December 28 to 30 . The rain melted snow cover having depths of 2 to 9 inches. Because rainfall was steady and of limited intensity, peak flows in small drainage basins were broad and sustained. Flows of most small rivers had peaked and were receding by December 31 . However, as of January 3, flows of the major rivers including the Wabash, White, and Kankakee Rivers, were still rising in the middle and lower reaches. Low-lying areas along these rivers and the cities of Noblesville, Indianapolis, Columbus, and Terre Haute were most seriously affected by the flooding. Between 3,000 and 4,000 people were displaced by the floods. The White River at Noblesville had the peak discharge of record $\left(27,000 \mathrm{ft}^{3} / \mathrm{s}\right.$, a recurrence interval of 40 years). The Tippecanoe River near Ora peaked at a stage of 15.10 feet ( 0.02 foot below the previous maximum) on January 1. Discharge on the Tippecanoe River was about $7,000 \mathrm{ft}^{3} / \mathrm{s}$, which had a 15 -year recurrence interval. The State asked the Federal Government to declare 40 of the State's 92 counties as disaster areas.

On December 30, one person drowned and another was rescued from the floodwaters of Buffalo Creek in Butler County, Pa. The high water was the result of rains and snowmelt in the western part of the State. Streamflow at the gaging station near Freeport had a recurrence interval of about 11 years.

On December 30, more than 1 million gallons of sludge seeped into New York Harbor after a municipal barge collided with a ship carrying molasses. The sludge leaked from a hole below the barge's waterline. No molasses was spilled.

(not shown) At the end of December, much of Florida continued to have record or near-record minimum streamflow, lake levels, and ground-water levels. Water levels in 10 percent of more than 300 wells in southwest Florida were at all-time lows.

Drought continued in California in December despite some relief from month-end snowfall and rains. During the week of December 16 to 22, Santa Maria reported its first snowfall since weather records began in 1942. However, in the mountains, snowfall had little water content (about onefourth of average). Precipitation in the northern Sierra Nevada was the fourth lowest in 70 years, according to the California Department of Water Resources. As of Janu- ary 1 , statewide runoff was 20 percent of average. Statewide reservoir storage at 155 major reservoirs was about 54 percent of average.

\section{JANUARY 1991}

22 On January 6, oil was discovered seeping from a cracked pipe under the Tacoma tidal flats in Washington. The pipeline carries crude oil nearly a mile from the Blair waterfront to a refinery. An estimated 483,000 gallons of crude oil was spilled. Most of the oil was contained in a drainage ditch by a hastily constructed earthen dam that apparently saved Commencement Bay and Puget Sound from major environmental damage. A relatively small quantity of oil (200 to 500 gallons) flowed into Blair Waterway, which is connected to Commencement Bay, where it was contained by a boom. Most of the environmental damage was to the soils and to water in an aquifer immediately beneath the drainage ditch, where the water table is only 1 to 2 feet below land surface. Fortunately, no drinking water is drawn from the aquifer.

23 On January 8, about 13,000 gallons of No. 6 oil was spilled as a result of overfilling of the cargo tank of a freight ship in the East Basin Channel in Long Beach, Calif. Subsequent rainfall helped to flush oil from under piers. Establishment of a safety zone temporarily prohibited vessels from using the East Basin Channel, where the patches of oil were greatest. Oil also affected the Cerritos Channel and the Los Angeles breakwater. Several oiled birds were observed in the spill area. An estimated 4,926 gallons of oil had been recovered by April 18, when cleanup was discontinued.

24 On January 9 , a tank barge carrying about 440,000 gallons of $1,1,1$ trichloroethane collided with a tugboat in the lower Mississippi River near Baton Rouge, La., causing a spill into the river. Sampling indicated $125 \mathrm{ppm}$ of the product in the water. As a precaution, drinking-water intakes between Baton Rouge and New Orleans were closed and traffic on the Mississippi River was temporarily halted.

(not shown) January streamflow from north-central to west-central South Dakota was uncommonly low, owing to dry conditions. Reaches of the Moreau River, the Grand River at Little Eagle, and the Belle Fourche River near Elm Springs became dry. The average monthly flow at Elm Springs is 31 $\mathrm{ft}^{3} / \mathrm{s}$. The Cheyenne River at Cherry Creek (average monthly discharge of $112 \mathrm{ft}^{3} / \mathrm{s}$ ) had a discharge of 5.61 $\mathrm{ft}^{3} / \mathrm{s}$, and the White River near Oacoma (average monthly discharge of $62 \mathrm{ft}^{3} / \mathrm{s}$ ) flowed at $0.05 \mathrm{ft}^{3} / \mathrm{s}$ on January 7 and $0.38 \mathrm{ft}^{3} / \mathrm{s}$ on January 14 .

At the end of January, the California State Water Project had declared the harshest restrictions in its 30-year history by ordering an immediate decrease in water deliveries to its farm customers and by warning urban users that they might receive only one-half the normal supply. The State Water Project is the major provider of irrigation water to farmers in the southwest San Joaquin Valley and to cities in southern California. California, in its fifth year of drought, had generally received only 25 percent of average precipitation. Runoff was about 20 percent of average, and storage in $\mathbf{1 5 5}$ reservoirs decreased to 54 percent of average. Water level in Lake Tahoe was 1.30 feet below the natural rim elevation, the lowest level of record dating back to 1900 . The drought also continued in northern Nevada and was espe- 
Table 2. Chronology of significant hydrologic and water-related events, October 1990 through September 1991—continued (fig. 12)

JANUARY 1991 (con.)

cially severe in the Sierra Nevada basins. By the end of January, spring and summer flow projections ranged from 15 to 20 percent of average.

(not shown) Drought continued in parts of Florida during January. Much of the State had record or near-record minimum streamflow, lake levels, and ground-water levels.

\section{FEBRUARY 1991}

About 900,000 gallons of No. 5 jet fuel was spilled on February 10 when a storage tank was overfilled at Cecil Air Field Naval Air Station near Jacksonville, Fla. Most of the fuel reached the St. Johns River and Sal Taylor Creek, a tributary to Yellow Water Creek. About 680,000 gallons of the fuel had been recovered by February 19.

On February 15, about 11,000 gallons of No. 4 fuel oil spilled from an underground storage tank into a sewer system that emptied into the east branch of Stamford Harbor, near Stamford, Conn. Cleanup efforts were discontinued on June 25.

In parts of Mississippi and Alabama, intense rainfall in February resulted in flooding. In Mississippi, recurrence intervals for peak discharges generally were about 10 years. In Alabama, several streams flooded when about 6 inches of rain fell between February 18 and 22. On February 23, the peak of record was exceeded in the Mobile River basin at the gaging station Tombigbee River at Bevill Lock and Dam near Pickensville (11 years of record), which is about 40 miles west of Tuscaloosa, Ala. The maximum stage of 44.30 feet was 0.25 foot above the previous record peak of December 26, 1990. The February peak discharge of $180,000 \mathrm{ft}^{3} / \mathrm{s}$ was $20,000 \mathrm{ft}^{3} / \mathrm{s}$ greater than during December 1990 .

On February 22, the casing of a pipeline booster pump burst during transfer operations from a tank ship near Fidalgo Bay, Anacortes, Wash. About 210,000 gallons of crude oil was spilled of which about 17,600 gallons flowed through a series of ditches and culverts into Fidalgo Bay. Washington State Fish and Wildlife personnel recovered 113 dead birds and reported 100 more in distress from the spill. About 300,000 gallons of oily water had been recovered as of March 4. Cleanup efforts were discontinued on June 12.

Rain finally fell in California in February- 3 to 5 inches along the coast and as much as 15 inches in the mountains-and brought some short-term relief from the drought. The duration and intensity of rainfall did not do much to offset the long-term effects of a 5-year water shortage. Through the end of February, the water year was the third driest on record, after 1977 and 1924. At month's end, the State's reservoir storage was 48 percent of average and runoff was 15 percent of average. The drought was being called the worst water crisis in the history of southern California. The Federal Government announced plans to drain the California reservoirs under its jurisdiction to meet minimum needs of urban and farm customers. A huge fissure had closed a runway on the 44-mi ${ }^{2}$ Rogers Dry Lake at Edwards Air Force Base. The half-mile long, 12-foot deep fissure, which could be the largest in the State, was a surface manifestation of a system being extensively stressed by ground-
E VEN T

FEBRUARY 1991 (con.) water pumping. Smaller, but extensive ground fissuring also was documented in Lancaster. By the end of February, streamflows were at record lows at two-thirds of the USGS index gaging stations in the State. Contents of 90 percent of the index reservoirs were below average, and usable storage in Lake Tahoe was zero for the sixth consecutive month. A new low, 1.35 feet below the rim, was reached in February. Also, water levels in index wells in alluvial basins were at new record monthly lows.

(not shown) In Florida, water levels in many wells in the Upper Floridan aquifer reached new February lows. The ground-water conditions were caused by long-term drought in the State.

\section{MARCH 1991}

On March 3, rupture of a 34-inch pipeline near Grand Rapids, Minn., caused a major oil spill. Five acres of frozen marsh was covered by 1.7 million gallons of crude oil having an estimated thickness of 7 to 12 inches. An unknown quantity of oil flowed through a storm sewer into the frozen Prairie River. Oil was flowing both above and below the ice surface. Most of the oil had been recovered from the river when cleanup was discontinued on April 25.

On March 6, a tank barge sank in 1,800 feet of water about 30 miles east of St. Kitts, West Indies. The sunken barge released an estimated 500,000 gallons of bunker oil, a fuel used by ships and boats. Although much of the fuel evaporated soon after the spill, the residue spread across 300 miles of the Caribbean, fouling tourist beaches on the principal islands of Puerto Rico and the U.S. Virgin Islands (St. Thomas, St John, and St. Croix). More than 500 workers used small shovels and garbage bags to remove tar balls from the island beaches. Beach contamination was greatest on the northeastern side of St. John. Minor coastal contamination by tar balls was reported on St. Croix, St. Thomas, the east side of Saba Island, and Culebra, Puerto Rico. As of March 28, this oil continued to affect both Puerto Rico and the U.S. Virgin Islands. Most cleanup operations were discontinued April 17.

Because of intense rainfall, areas of northern Florida and southern Georgia were flooded during the week of March 3. In Florida, rainfall in excess of 7 inches within 24 hours caused flooding on many major streams and creeks in Calhoun and Jackson Counties and along Munson Slough in Leon Courty. Peak flows had recurrence intervals of about 25 years. In Georgia, on March 7, the Satilla River at Waycross crested at 21.52 feet, which is almost 1 foot below the record stage of April 1948. Fifteen counties in southern Georgia were declared Federal disaster areas.

Three storms hit the Hawaiian islands between March 19 and 23. Intense rains caused severe flooding, mudslides, and a power outage that lasted for several hours on the island of Oahu. Rainfall ranged from 9 inches along the Waianae leeward coast - the normally dry side of Oahu - to about 34 inches at Waiahole close to the mountains near the north end of Kaneohe Bay. As much as 19 inches of rain was recorded during 24 hours on the northern part of the island. Property damage due to flooding was estimated at $\$ 20$ million. A USGS gaging station on Punaluu Stream near Punaluu was washed away. Peak discharges exceeded those of record at two gaging stations. Discharge of Kipapa 
Table 2. Chronology of significant hydrologic and water-related events, October 1990 through September 1991—continued

\begin{tabular}{ccc}
\hline \multirow{2}{*}{$\begin{array}{c}\text { No. } \\
\text { (fig.12) }\end{array}$} & EVENT & \\
\cline { 2 - 4 } & MARCH 1991 (con.) & APRIL 1991 (con.) \\
\hline
\end{tabular}

Stream near Wahiawa ( 35 years of record), on March 20 , was $6,400 \mathrm{ft}^{3} / \mathrm{s}$, which has a recurrence interval of about 75 years, at a stage of 12.67 feet. The peak was $720 \mathrm{ft}^{3} / \mathrm{s}$ greater and 0.38 foot higher than the 1963 peak of record. Discharge of Punaluu Stream near Punaluu (39 years of record), on March 21, was 7,180 ft $3 / \mathrm{s}$, which has a recurrence interval of 1.29 times that of the 100 -year event, at a stage of 8.34 feet. The peak was $1,480 \mathrm{ft}^{3} / \mathrm{s}$ greater and 0.74 foot higher than the 1974 peak of record.

March precipitation in California resulted in an addition of 2 million acre-feet of water to its largest reservoirs. Nearly 7 inches of precipitation fell on Sacramento during the first week of March (average March precipitation is 1.8 inches). Although some precipitation fell in the northern part of the State, the greatest effect was in the central and southern parts. Water-use limitations set earlier in the month by officials of drought-stricken cities were reevaluated. However, the need for conservation practices remained because, despite the precipitation, the contents of most large reservoirs was still at only 50 percent of average. Although 40 inches of snow fell at Donner Summit in the Sierra Nevada, the moisture content ( 41 percent) was less than average. Nevertheless, March precipitation brought some relief from the 5 consecutive years of drought.

APRIL 1991

Intense rainfall along the Oregon coast, on April 4, caused about 1 million cubic yards of debris to break loose from an active slide area at mile post 31 of Oregon Highway 6. The slide closed the highway and created a landslide dam across the Devils Fork Wilson River 4 miles upstream from its confluence with the South Fork. About 800 people were evacuated from the area downstream from the dam. The Wilson River was about 3 feet above flood stage and still rising when the evacuation was ordered. However, the emergency was downgraded when the river was discovered to be draining around one side of the dam. The highway was closed for about 7 weeks until a single-lane roadway could be cleared through the slide.

Spring thunderstorms produced rain across the southern onethird of Texas during the latter part of the first week of April, as a strong onshore flow of moist air collided with a front stalled over eastern Texas. As much as 19 inches of rain inundated the southern tip of the State, while more than 12 inches deluged Victoria. Rain fell at the rate of 3 inches an hour at some locations. As much as 13 inches of rain fell within 24 hours in Brownsville, forcing closure of the airport. Wind gusts of $70 \mathrm{mph}$ accompanied a storm that moved through Houston. Another storm left as much as 6 inches of hail near Marfa. Widespread flash flooding along the Texas Gulf Coast from Houston to Brownsville forced the closure of numerous roads near Houston and the evacuation of residents in Harlingen (just northeast of Brownsville). The San Bernard River overflowed its banks near Brazoria, and the Guadalupe River rose 15 feet in 5 hours.

On April 9, warm weather combined with intense rain to produce ice-jam flooding on the St. John River in Aroostook County in northern Maine. The flooding forced the evacuation of nearly 200 people near Dickey.
The ice jam was nearly 20 feet deep near the town and nearly 30 feet deep in other places. Depth of water near one gage was almost 40 feet. The ice jam destroyed two bridges and two USGS gaging stations and damaged 130 homes as it moved downstream. The county was declared a Federal disaster area on April 19. Damage was estimated at \$14 million.

In Arkansas and Oklahoma, storms brought intense rains of short duration that caused local flash flooding from April 11 to 14 . Highway 71 near Mena, in the west-central part of Arkansas, was closed after 3 feet of water covered the road. River flooding generally was minor and limited to lowlands adjacent to the river. Flooding also washed out a bridge in Antlers in the southeastern part of Oklahoma, after 4 inches of rain fell in 6 hours.

40 On April 12, three people drowned in Durango, in Dubuque County in the north-east part of Iowa, as a result of flooding of the Little Maquoketa River. The victims were attempting to drive across a water-covered bridge on Paradise Valley county road just south of U.S. Highway 52 when the car stalled. Two victims were swept away in the car and the third was swept from the roof of the vehicle. The peak discharge of $21,400 \mathrm{ft}^{3} / \mathrm{s}$, the fourth largest of record at the gaging station on the Little Maquoketa River near Durango, had a recurrence interval of 35 to 40 years (record began in 1934). The greatest 24-hour precipitation associated with the flooding was 4 inches at a station several miles from the gaging station.

41 Shreveport and Bossier City, La., were flooded on April 12 after numerous storms brought 80 -mph winds and a record 12hour rainfall of 10.42 inches on already saturated ground. In Shreveport, as much as 3 inches of rain fell within 2 hours. The flooding caused two persons to drown and damaged 500 homes. Total damage was estimated at $\$ 5$ million.

42 On April 23, failure of a flange gasket on an 8-inch pipeline at a facility in Los Angeles Harbor, Calif., caused 11,300 gallons of gasoline to spill into a storm drain that flows into the harbor. Cleanup was completed on May 3 with the recovery of about 1,260 gallons.

Storms of April 28 to 29, which produced 6 to 11 inches of rain in 48 hours, caused severe flooding in southern Arkansas and northern Louisiana. In Arkansas, the peak discharge of $24,300 \mathrm{ft}^{3} / \mathrm{s}$ at the gaging station on Smackover Creek near Smackover in the south-central part of the State exceeded the 40-year recurrence interval on April 29 but was less than the peak of record $\left(52,700 \mathrm{ft}^{3} / \mathrm{s}\right.$ on June 8,1974$)$. The peak stage of 25.25 feet on Bayou Bartholomew near McGehee, in southeastern Arkansas, was the second highest stage since at least 1930; the highest stage occurred on May 11, 1958. In Arkansas, one life was lost and 100 people were evacuated from their homes because of the flooding. Estimated damage to roads, bridges, and culverts was $\$ 3.5$ million in Ashley and Union Counties. In Louisiana, flooding was especially severe along the Ouachita River through Morehouse Parish. At many locations, stages were 4 to 5 feet above previous records. On April 30, in the north-central part of the State, Bayou D'Arbonne Lake at Farmerville had a gage height of 50.38 feet (4.95 feet above the previous record) and Lake Claiborne near Aycock had a gage height of 16.00 feet (4.00 feet above the previous record). 
Table 2. Chronology of significant hydrologic and water-related events, October 1990 through September 1991—continued

\begin{tabular}{ccc}
\hline \multirow{2}{*}{\begin{tabular}{c} 
No. \\
\cline { 2 - 3 } (fig. 12)
\end{tabular}} & EVENT & \\
\hline
\end{tabular}

44

Rainfall during the month of April was excessive in Mississippi. April 1991 was the wettest month on record at 18 precipitation stations and it was the wettest April on record at 56 precipitation stations. The rainfall totals for the State ranged from 6.5 inches at Merrill to 23 inches at Rolling Fork. As a result of the record rainfall, flooding occurred in all the river basins in the State, and in the Delta Region of northwestern Mississippi, about 2 million acres of land was underwater. Dollar estimates of the total damage caused by this flood were in the hundreds of millions.

A record accumulated winter snowfall of 147.6 inches (having a water content of 12 inches) in the Chena River basin and other local basins in Alaska began to melt about April 21. Because of limited drainage, runoff from the snowmelt began flooding basements and first floors of more than 300 homes in communities southeast of Fairbanks during the last week in April. Regulated flow of the Chena River at the Moose Creek Dam (releases of 7,500 to $8,000 \mathrm{ft}^{3} / \mathrm{s}$ throughout the week) combined with flow from the Little Chena River to create a discharge of $11,550 \mathrm{ft}^{3} / \mathrm{s}$. The combined streamflow was the greatest since May 1975, which was 5 years before the first operation of the Moose Creek Dam. Areas just downstream from the dam on the Chena River had minor flooding when ice jams formed on bridge crossings. Also, about 40 homes in the Rosie Creek subdivision, southwest of Fairbanks, were flooded when a 3-mile long ice jam created backwater on the Tanana River. Residents were evacuated by boat. Several flooded locations were declared disaster areas by the State. Damage was about $\$ 2$ million.

\section{MAY 1991}

On May 3, mooring operations at Braintree, Mass., caused a tank vessel to spill about 16,000 gallons of No. 2 diesel oil into the Weymouth Fore River. Most of the spilled oil was contained with a boom and an estimated 14,000 gallons of oily water was removed.

Two tugs collided on the lower Mississippi River north of Baton Rouge, La., on May 5. The result was a spillage of about 47,000 gallons of toluene.

On May 10, as much as 7 inches of rain produced extreme flooding along the White River in northwestern Nebraska. At the gaging station White River at Crawford, the peak stage was 16.3 feet, 8.6 feet greater than the previous maximum which occurred in 1958. Peak discharge was based on slope-area and road-overflow measurements and was determined to be $13,300 \mathrm{ft}^{3} / \mathrm{s}, 4$ times the 100 -year recurrence interval. Flooding caused extensive damage to railroad tracks and destroyed Crawford's water system, a new $\$ 1$ million golf course scheduled to open the next day, a camping area at a State park, a mobile home park, and a cattle sale barn. Damage was estimated to be as much as $\$ 15$ million. One person died when the mobile home park was flooded.

In the Upton-Osage area of Wyoming, torrential rains caused the highest peak flow since 1978 on Beaver Creek near Newcastle on May 14. A measurement made on June 1 showed a peak discharge of $4,130 \mathrm{ft}^{3} / \mathrm{s}$, a recurrence inter$\mathrm{val}$ of 25 years. As much as 5 inches of rain reported in the Glenrock-Douglas area during May 15 and 16 (3.5 inches within 24 hours) caused some flooding along tributaries to the North Platte River. Peak flow at Bed Tick Creek south of Douglas was $3,300 \mathrm{ft}^{3} / \mathrm{s}$ on May 15, a recurrence interval of 50 years. Significant flooding also occurred along Crow Creek in the southeastern corner of the State during the first few days in June. Also, spring snowfalls of 110 to 130 percent of average for this time of year relieved the concern for drought that had prevailed earlier in the year. However, in southern and eastern Wyoming, snowpack was still only 70 to 90 percent of average.

50 On May 19, intense rain and full storage of McKay Reservoir upstream from Pendleton, Oreg., combined to force the evacuation of more than 100 families from low-lying areas along McKay Creek and the Grande Ronde River. Record inflows (peak estimated at $5,010 \mathrm{ft}^{3} / \mathrm{s}$ ) to the reservoir (73 years of record) resulted in record outflow $(3,500$ $\mathrm{ft}^{3} / \mathrm{s}$ ) from the reservoir. These flows represent recurrence intervals of 25 and 100 years, respectively. The previous peak discharge of $3,250 \mathrm{ft}^{3} / \mathrm{s}$ was recorded in February 1921.

51 Flooding of headwater streams in the Sangre de Cristo Mountains between Santa Fe and Taos, N. Mex. occurred during May 21-22 with reported property damage in the thousands of dollars. Atmospheric conditions held intense thunderstorms stationary over this areas resulting in 24-hour rainfalls of more than 2 inches in the foothills to more than 3 inches in the mountains. In some streams, peak discharges exceeded the 50-year recurrence interval for flood flows.

For the second consecutive month, record amounts of rain fell in Mississippi. May 1991 was the wettest month on record at 4 precipitation stations and the wettest May on record at 22 precipitation stations. Rainfall totals for the month ranged from 5.9 inches at Clarksdale to 23.4 inches at Guntown. From May 25 to 27, 8 to 12 inches of rain fell in the northeastern corner of the State, which resulted in extreme flooding in the Tombigbee River basin. Four gaging stations had peak discharges, which had recurrence intervals of about 100 years. Twentymile Creek near Guntown had a peak discharge that greatly exceeded the 100-year recurrence interval.

53 In much of northwestern Montana, intense rainfall during May caused streamflows having recurrence intervals of 2 to 5 years. Peak discharge of $3,180 \mathrm{ft}^{3} / \mathrm{s}$ at the gaging station Tobacco River near Eureka was the maximum of record, which spanned 33 years. Peak discharges in the North Fork Sun River and Badger Creek basins had recurrence intervals of 25 years.

JUNE 1991

54 Thunderstorms on June 3 and 4 produced as much as 6 inches of rain in the central part of Iowa. The rainfall caused flooding of Indian Creek near Mingo in Jasper County. A stage of 19.16 feet was the highest since May 1944 when the stage was 21.4 feet.

55 Flooding in east-central Nebraska resulted from 4 to 7 inches of rainfall on June 4. Colfax and Dodge Counties received the most rain. Howells, a town located in Colfax County, received 7 inches of rain in 1 hour. Floodwaters topped a 15-foot high dike and flooded downtown Howells to a depth 
Table 2. Chronology of significant hydrologic and water-related events, October 1990 through September 1991-continued

No

(fig. 12)
EVENT

JUNE 1991 (con.)
JUNE 1991 (con.) of 4 feet. On June 5, at Pebble Creek at Scribner located in Dodge County, the peak stage was 24.15 feet, 0.25 foot higher than the peak stage established just the previous year, and the discharge of $27,900 \mathrm{ft}^{3} / \mathrm{s}$ broke the previous record that had been established in 1990. The flooding closed U.S. Highway 275 near Scribner for about 11 miles. The library housed in the Community Center lost all but 300 of its 12,300 books. One man, who refused to leave his home, died when the walls of his basement collapsed. Damage was estimated at \$28 million.

On June 4, No. 2 diesel oil was released when the flange on a 6inch bunker pipeline began leaking at a fuel dock in Westlake, $\mathrm{La}$. and an estimated 14,500 gallons of fuel was spilled into the Calcasieu River. The Calcasieu Ship Channel on the north side of Clooney Island was closed to vessel traffic until June 7. Cleanup was discontinued on June 11.

On June 7, a 10-inch pipeline ruptured in the Brazos River near Seymour, Tex., and caused a major spill of an estimated 630,000 gallons of light crude oil. The oil was widely distributed in flood-plain areas over 150 river miles. A light sheen and oiled debris were sighted 176 miles downstream at Possum Kingdom Lake. However, the oil that reached the lake was not of sufficient quantity to threaten the lake. Most of the oil was not recoverable because of rapid dispersion and dissipation in the rain-swollen river.

Two days of intense rain on June 10 and 11 flooded streets and houses, interrupted transit service, and closed the City Hall in New Orleans, La. Two children drowned in rain-swollen ditches. One precipitation gage in the middle of town recorded 9.85 inches of rain in 6 hours on June 10, 6 inches of which fell within 2 hours. Rainfall in some areas exceeded 12 inches. The 6-month precipitation in New Orleans of 71.22 inches far exceeded the average annual precipitation of 59.74 inches.

Widespread flooding occurred during early June in the Wind River basin, Wyo., as a result of snowmelt runoff augmented by rainfall. Floods at gaging stations generally had peak discharges with recurrence intervals of 15 to 50 years. Record peak discharges of $14,300 \mathrm{ft}^{3} / \mathrm{s}$ and $2,230 \mathrm{ft}^{3} / \mathrm{s}$ occurred June 13 on the Wind River at Crowheart and South Fork Little Wind River above Washakie Reservoir, near Fort Washakie, respectively. Recurrence intervals were 50 and 40 years, respectively.

On June 14 and 15, locally intense rainfall of 6 to 13 inches flooded much of Iowa. Flooding was extensive in the East Nishnabotna River basin in southwestern Iowa. In northeastern Iowa, flood stages exceeded those of record at three stations in the Turkey River basin on June 14 and 15: Turkey River at Garber (78 years of record), Roberts Creek above Saint Olaf ( 6 years of record), and Silver Creek near Luana (6 years of record). Flow of the Turkey River at Garber had a recurrence interval greater than 100 years. Flooding of the Turkey River and its tributaries destroyed several bridges and flooded several towns. Clayton County was declared a disaster area by the Governor. Between mid-June and mid-July the U.S. Secretary of Agriculture had declared 94 of Iowa's 99 counties agricultural disaster areas. By mid-July, flooding caused the President to declare 13 counties as Federal disaster areas.

Two spills were reported within 2 days in the Kill Van Kull between New York and New Jersey. On June 17, about

21,000 gallons of acetone was spilled after a tug collided with a barge at Bayonne, N.J. The acetone dissipated quickly and was unrecoverable. On June 18 , about 17,000 gallons of No. 2 fuel oil spilled from a tank barge when a tank was overfilled during loading operations. The spill was immediately contained by a boom and the affected areas cleaned by June 20 .

On June 20 , about 9,000 gallons of crude oil overran a containment wall and spilled into Goose Lake and Goose Creek near Baytown, Tex. Heavy oil affected 1 mile of beach on the north side of Goose Creek. Cleanup was discontinued on July 1.

On June 25 , an estimated 124,000 gallons of waste oil was spilled at a tank farm in Houston, Tex. About 30,000 gallons escaped containment and affected 20 acres of land and marsh. Of that quantity, 21,000 gallons entered the San Jacinto River.

A pipeline rupture on June 27 spilled crude oil in Park City, Utah. More than 92,000 gallons of oil spilled into Silver Creek and the Weber River and about 34,000 gallons went into nearby wetlands and irrigation ditches. Standing oil was removed by controlled burns. An estimated 71,000 gallons was recovered by flushing the creek and diverting oil to collection points.

65 As of June 30, drought continued to be widespread in the West. Califomia, the most severely affected of the Western States, set a record for the driest 5-year period of record. The total rainfall for the 5-year period ending June 30 totaled 77.43 inches ( 75 percent of average), which was 1.32 inches less than the former mark of 78.75 inches set from July 1 , 1929 , to June 30,1934 . California reservoirs were at their lowest levels since 1977; inflow was only 50 percent of average. North Dakota was still in extreme drought conditions despite some rainfall. Water levels in several wells near Mountain Home, Wyo., had become dry because water levels had dropped below the depth of the wells.

(not shown) Herbicides were detected in the Mississippi River and several major tributaries throughout April, May, and June. The herbicide atrazine was detected in each of 146 water samples collected at eight locations on the Mississippi, Ohio, and Missouri Rivers and on three smaller tributaries-the Illinois, Platte, and White Rivers. More than three-fourths of these samples also contained the herbicides alachlor, cyanazine, and metolachlor. Atrazine concentrations exceeded the U.S. Environmental Protection Agency's Maximum Contaminant Level for public water supplies continuously for several weeks in rivers as large as the Missouri and Mississippi. These rivers drain areas of more than $500,000 \mathrm{mi}^{2}$. The increase in concentrations was coincident with the application of herbicides to croplands in April and May. The increases likely were caused by late spring and early summer rainfall washing some of the herbicides into the streams. However, these samples were collected before treatment, whereas the Maximum Contaminant Levels apply to water supplied to users after treatment.

(not shown) On June 28, Pennsylvania issued a drought warning for 33 counties in the Susquehanna River basin and a drought watch in 22 counties in the Ohio River basin and 7 counties in the middle and upper Delaware River basins. Only five counties in the State escaped drought designations. 
Table 2. Chronology of significant hydrologic and water-related events, October 1990 through September $1991 \longrightarrow$ continued

\begin{tabular}{lll}
\hline \multirow{2}{*}{$\begin{array}{c}\text { No. } \\
\text { (fig. 12) }\end{array}$} & EVENT & \\
\cline { 2 - 3 }
\end{tabular}

The smallest June discharge recorded in 97 years of record occurred at the gaging station Susquehanna River at Williamsport this month. Second, third, and sixth smallest discharges occurred at three other stations in the basin having records ranging from 52 to 101 years.

$$
\text { JULY } 1991
$$

High water from widespread showers from June 20 to July 2 washed out roads and topped gaging stations from Fort Peck to Miles City, Mont., an area that normally is arid. The Frenchman River, Porcupine Creek, Rock Creek, Deep Creek, Cherry Creek, and the Milk River were most affected. For example, the Frenchman River at the international boundary had a peak discharge of $2,820 \mathrm{ft}^{3} / \mathrm{s}$, the largest recorded peak flow since 1954. On June 21, streamflow of Razor Creek, south of Roundup, swept across U.S. Highway 87; one motorist who was caught in the floodwaters died. This flood peak from a drainage area of only $17 \mathrm{mi}^{2}$, was calculated by indirect measurement to be $6,330 \mathrm{ft}^{3} / \mathrm{s}$.

In Kentucky, as much as 6 inches of rain fell during the first week of July. The resulting flooding damaged several homes in Compton, caused extensive damage to the water plant in Scott County (north of Lexington), and closed several roads in Frankfort that were under as much as 6 feet of water.

Three inches of rainfall during the first week of July caused flooding that necessitated the closing of Interstate Highway 25 near Springer, N. Mex. During the same storm, 6 inches of hail accumulated on the ground in the area between Maxwell and Raton.

On July 12, after intense rains, a house in Frostproof, Fla., collapsed into a sinkhole. Rainfall of 5.5 inches in Polk County probably triggered the development of this and five other small sinkholes in the county.

On July 14, a major inland chemical spill occurred 8 miles north of Dunsmuir, in northern California. A seven-car train derailment resulted in the release of about 19,500 gallons of metham sodium (a weed and tree killer) from a tank car into the Sacramento River. The river empties into Lake Shasta, the State's largest reservoir and a major source for area drinking water. More than 70 people were treated for headaches, dizziness, nausea, and eye irritation that were caused by a noxious cloud of gas (hydrogen sulfide and methylisothiocyanate) that resulted from the spill. Flow of the river was decreased within the affected areas, and diversion dams were constructed to force the remaining flow through spillways lined with activated charcoal. Where the chemical concentrated in pools, the pools were pumped. The product also was diluted by aeration in the spill area. By July 24 , the metham sodium had broken down into methylisothiocyanate, a pesticide that has the same toxicity as metham sodium. The product had stratified on a thermal layer below the river surface and had not dispersed as expected. The concentration was not harmful to humans but was harmful to aquatic life. More than 100,000 fish were killed along a 45-mile stretch of the river. Insects and birds along the river also were killed, and cedar and maple trees turned yellow. When the river became safe, the California Fish and Game Department released hatchery fish into the river, which is habitat for osprey who feed along it.
71 Torrential weekend rains of 4 to 6 inches in west-central Florida on July 13 and 14 caused flooding of the Little Manatee and Alafia Rivers in Hillsborough County. On July 15, the Alafia River crested at 16.8 feet, almost 4 feet above flood level. On the same date the Little Manatee River crested at 14.5 feet, more than 3 feet above flood stage.

During July 14-15, flooding occurred in the Pecos River near Roswell, N. Mex., as a result of intense local rainfall. Roswell received 5.35 inches of rain during these 2 days. The streamflow in the Pecos River locally peaked at more than $8,000 \mathrm{ft}^{3} / \mathrm{s}$, which is 5 times the previous maximum flow for the month of July, and exceeded the flood flow with a 10-year recurrence interval.

73 On July 21, flash flooding in Garvin Brook inundated the small community of Stockton, Minn., about 4 miles southwest of Winona. The flood resulted from a 1-hour rainfall of 6 inches (about twice the 100-year, 1-hour rainfall) in the area. Virtually the whole town was under about 5 feet of water within hours of the rainfall. More than 90 of the 100 homes in Stockton were damaged and two were destroyed. Damage was severe to crops, farming equipment, and farmrelated buildings. At the gaging station on Garvin Brook near Minnesota City, about 4 miles downstream from Stockton, stage of the river rose 17 feet and the gage shelter was destroyed.

(not shown) On July 22, the collision of a Chinese freight vessel with a Japanese fishing vessel caused a major oil spill 20 miles west of Cape Flattery, Wash., in Canadian waters. The fishing vessel, which contained 364,000 gallons of fuel, sank in 90 fathoms of water. A slick 500 yards wide and 5.7 miles long quickly formed from the leaking sunken vessel and drifted southeast into U.S. waters. By July 24 , a slick 4 miles wide and 10 miles long and another slick were spotted east and north of the wreck. Skimming operations recovered about 36,600 gallons of oily water and 34,200 bags of oily waste. By August 2 , the leading edge of slick was 10 miles south of Grays Harbor, and oil affected beaches 2 miles south of La Push. By August 8, the spill affected shores south of Sand Point, north of Saddle Rock, and at Cape Alava. On August 15, the Canadian Coast Guard reported that pumping from the sunken vessel had begun. By August 16, 12,500 gallons had been recovered from the vessel. Bioremediation was rejected because of possible adverse effects on natural resources in the area. Hundreds of birds died as a result of the spill.

74 A spill of 11,500 gallons of crude oil occurred in Bayou Sorrel, La., on July 22 . About 10,500 gallons of oil was recovered from the water by July 27 , when cleanup was discontinued.

(not shown) On July 24, the Governor declared a drought emergency in 67 counties of Pennsylvania. The area encompassed the entire Susquehanna and Potomac River basins, the northern Delaware River basin, and two counties in the Ohio River basin. Water restrictions were implemented in 39 counties in central Pennsylvania, where officials declared the drought to be the worst in 60 years. Several streams in the area were flowing at 70 percent below average.

During the last week in July, several storms caused flooding in North Carolina. On July 27, as much as 4 inches of rain fell within 1 hour in Avery County, N.C., and caused mudslides and flash flooding. Three days of intermittent 
Table 2. Chronology of significant hydrologic and water-related events, October 1990 through September 1991—continued

No.

\section{EVENT}

$$
\text { JULY } 1991 \text { (con.) }
$$

August 1991 (con.) but locally severe thunderstorms between July 29 and 31 produced more than 10 inches of rain in parts of Wilson, Wayne, Johnston, and Sampson Counties. In Rockridge, 7 inches of rain fell in 3.5 hours and washed out sections of State Road 1123. Dozens of other roads were flooded, several bridges and culverts were destroyed, residents of low-lying areas were evacuated, and hundreds of acres of cropland were inundated as a result of the runoff.

Rare summer thunderstorms and showers set records and caused flooding in southern California. Flash flooding in LaMesa forced the evacuation of 24 people from a trailer park. July monthly rainfall in San Diego and Los Angeles set new records.

On July 31 , about 12,600 gallons of crude oil spilled from a leaking pipeline into the lower Mississippi River at Norco, La. Most oil pooled along the west bank along a 5-mile stretch of the river, and two of three water intake tanks at the St. Charles Parish Water Facility were contaminated. The third tank was drawn down to the 5-foot level, which introduced sediment into the public supply system; a public notice was issued to users to not consume the water. On August 2, absorbent booms and various filtration techniques were used to control the level of contamination at the plant, and users were warned of possible drinking water contamination.

\section{AUGUST 1991}

On August 11 and 12, a glacial-outburst flood occurred from Strandline Lake, about 70 miles west of Anchorage, Alaska. Strandline Lake is dammed by the Triumvirate Glacier, which originates in the Tordrillo Mountains. Outbursts from Strandline Lake occur at intervals of about every 1 to 5 years. Previous outbursts occurred when the Triumvirate Glacier was floated by the lake.

(not shown) On August 16, 16 counties in Pennsylvania were added to the 39 already designated by the Governor as drought emergency areas. Only a few counties in the southwestern part of the State remained unaffected by the drought conditions. Departures from average precipitation ranged from 4 to 8.5 inches, and streamflow generally was only 50 percent of average for this time of year. Ground-water levels also were reported to be below average in 26 counties. Two water companies in Cameron County began rationing supplies to customers.

(not shown) Hurricane Bob, which developed as a tropical depression northeast of the Bahamas on August 16, grazed the North Carolina coast and caused damage from New York to Maine before moving into southeastern Canada as it weakened. Wind gusts of as much as $120 \mathrm{mph}$ and 3 to 9 inches of rain were deposited by the storm. The hurricane, which came ashore along the coast of Rhode Island and Connecticut on August 19, and associated thunderstorms, produced as much as five times the average rainfall in New England. In Westerly, R.I., 200 coastal homes and businesses were flooded. Intense rains in Goreham, Maine, washed out five bridges and flooded many roads. However, as a result of the dry antecedent conditions, peak flows of New England rivers had recurrence intervals only in the 1 - to 7 -year range. Urban runoff contributed to the highest flows. The rainfall (an August record of 15.22 inches in Portland, Maine) ended the extreme low-flow conditions that existed in Maine before the storm. Total hurricane damage was estimated to be $\$ 1.5$ billion.

(not shown) On August 21, Louisiana State and Federal environmental officials reported that a chemical used by sugar-cane growers to control pests had caused the deaths of about 750,000 fish in southern Louisiana waterways during the summer. Intense rains contributed to the massive kills by washing azinphosmethyl into rivers and bayous before it could decompose. In one incident, all aquatic life along nearly a 10-mile stretch of Bayou Lafourche was killed. The chemical had been applied extensively because mild winter weather had led to infestations of the sugar-cane borer, an insect that can severely damage crops.

On August 24, about 10,500 gallons of No. 6 fuel oil was spilled in the Corpus Christi Inner Harbor, Tex. All free-floating oil was recovered, and minor shoreline cleanup was completed. River after a boat carrying 2.4 million gallons of the prod- 
Table 2. Chronology of significant hydrologic and water-related events, October 1990 through September 1991—continued

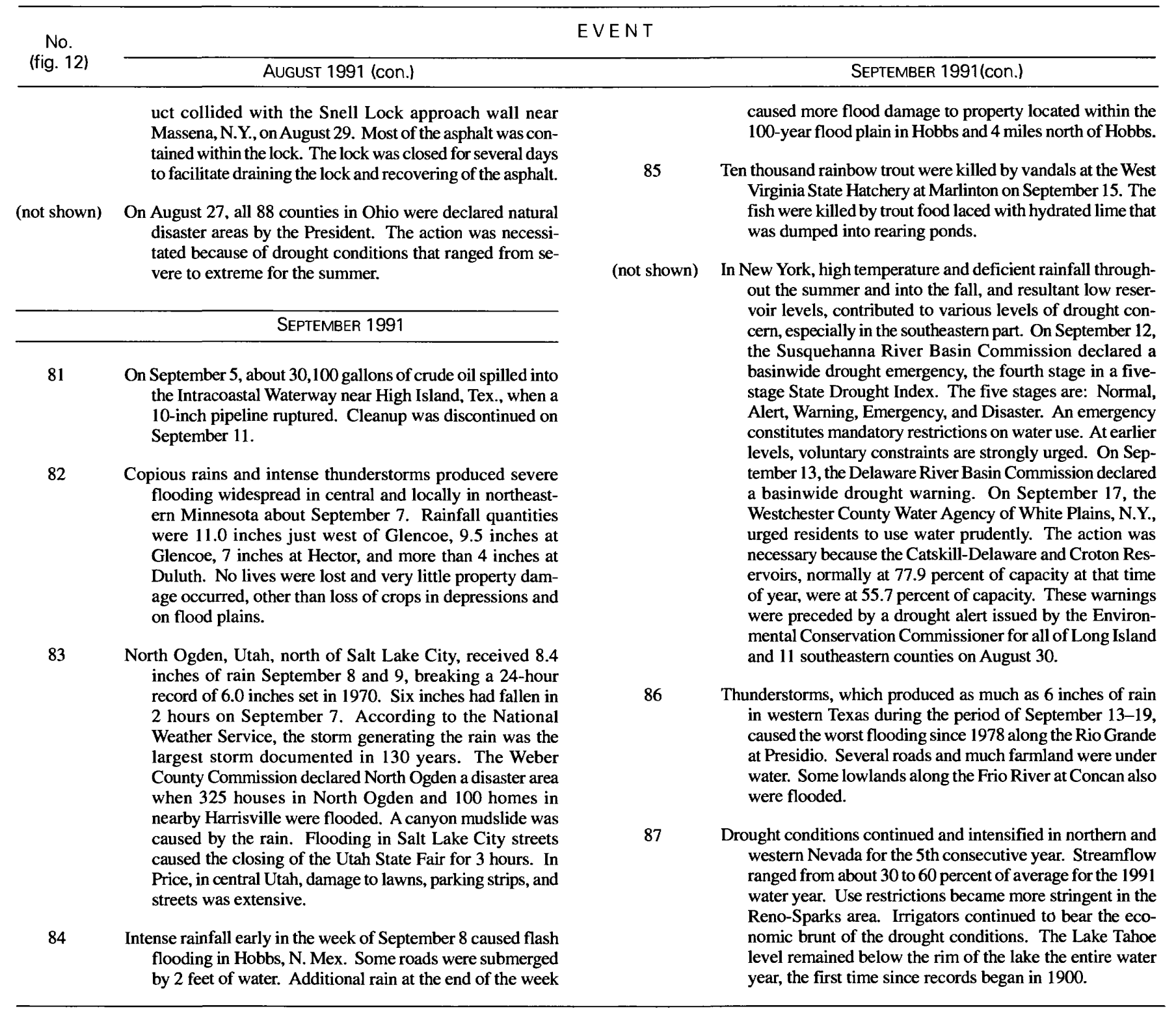




\title{
Seasonal Summaries of Hydrologic Conditions, WATER YEAR 1991
}

\author{
By Richard R. Heim, Jr., ${ }^{1}$ Gregory J. McCabe, Jr., ${ }^{2}$ and William O. Brown ${ }^{1}$
}

FALL 1990
Streamflow for fall 1990 was above median for most of the area between the lower Mississippi Valley and northern Maine and below median for a large part of the West, the central and northern Great Plains, and part of the Southeast (fig. 13A). Drought in the West and parts of the Southeast and northern Great Plains continued from the summer into the fall. During October, precipitation in California generally was 69 percent below the average for the month; at month end storage in 155 reservoirs averaged 34 percent of capacity, which is 40 percent below average for the end of October (table 2, event 6). By the end of the fall, reservoir storage remained well below median and precipitation remained well below average in California. For locations from northern to southern California, the fall precipitation ranged from 48 to 100 percent below average.

In Florida, several record low discharges and water levels in wells occurred as a result of deficient rainfall. By the end of December, about 10 percent of the wells in southwest Florida had all-time low-water levels. Although drought conditions persisted in parts of the West and Southeast, the combined flow of the three largest rivers in the conterminous States - the Mississippi, St. Lawrence, and Columbia - was above median for the entire fall season.
Precipitation was below average for a large part of the country (fig. 13B) in response to above-average atmospheric pressures (fig. 13D). Except for northwestern Washington, northern Idaho, northwestern Montana, and the central and southern Rocky Mountains, precipitation in the area from the eastern Great Plains to the Pacific was average to below average, with parts of southern California and southern Nevada receiving less than 25 percent of average fall precipitation (fig. 13B). All of California, most of Nevada, southern Oregon, and the eastern two-thirds of North Dakota had precipitation values at least 50 percent below average. The water level of Lake Tahoe on the California-Nevada border was the lowest since the winter of 1934-35 (table 2, event 13). From central Texas eastward along the Gulf Coast, including all of Florida, precipitation generally was about 80 percent of average for the fall. In contrast, the southern shore of Lake Michigan and central South Carolina received more than twice the average rainfall for this period. From eastern Texas northeastward to Maine (except for coastal Virginia, Maryland, and Delaware), most precipitation values were well above average with large parts of the area reporting at least 150 percent of average.

During mid-October, tropical storm Klaus moved

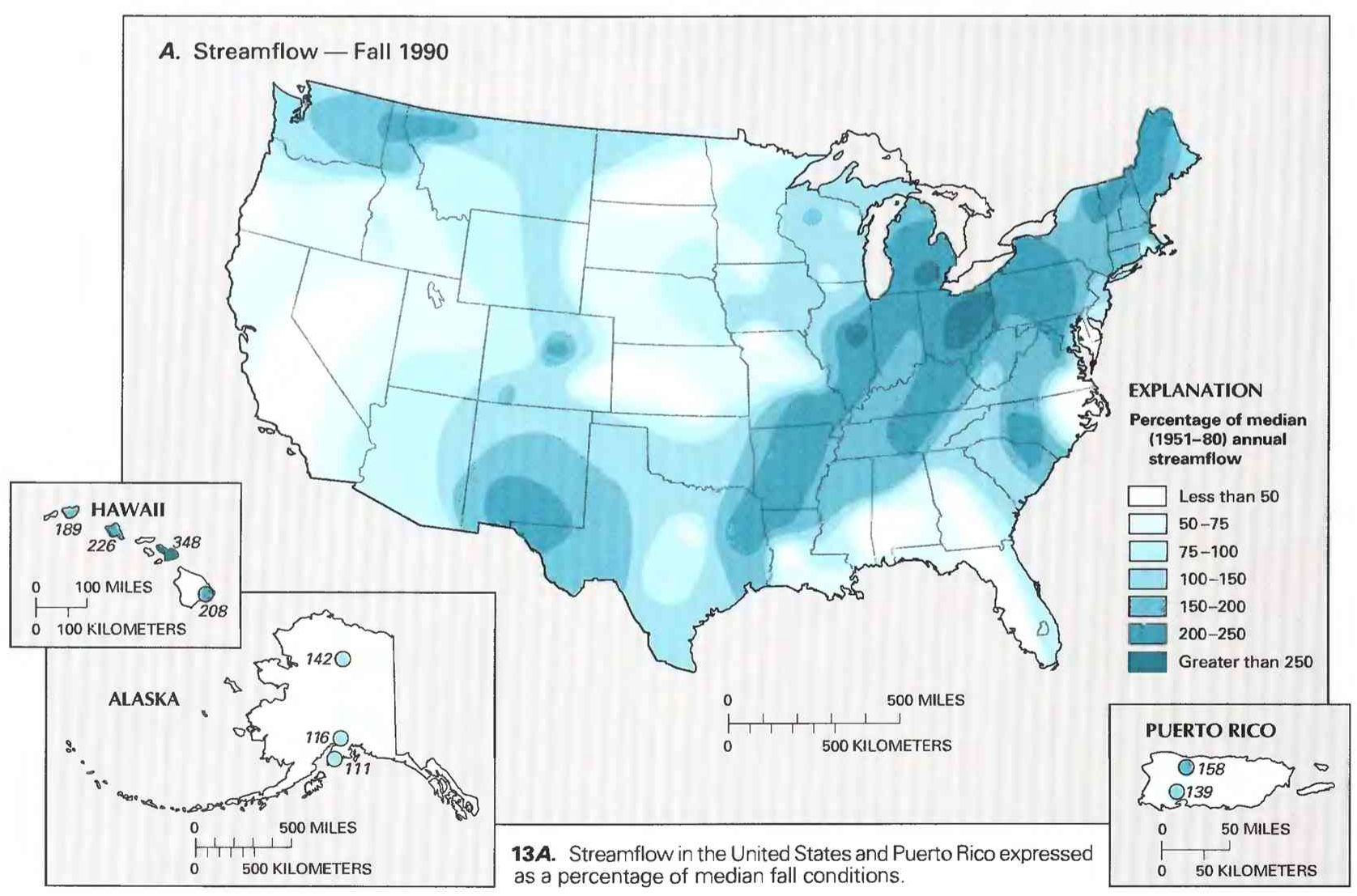

Figure 13. Hydrologic conditions during the fall (October-December 1990) of water year 1991. (Sources: Streamflow data from the U.S. Geological Survey; meteorological data from the National Oceanic and Atmospheric Administration, Climate Analysis Center and National Climatic Data Center.)

${ }^{1}$ National Oceanic and Atmospheric Administration, National Climatic Data Center. ${ }^{2}$ U.S. Geological Survey. 
through the Southeast producing intense rainfall and flooding in parts of South Carolina and Georgia (table 2, event 1). Peak discharges at 10 stations exceeded previous peaks of record and the 100 -year recurrence interval. Some areas of South Carolina received about 12 inches of rain in a 24-hour period.

During November, two severe storms from the Pacific brought intense precipitation and severe flooding to Washington (table 2, event 9). The first storm moved into northwestern Washington on November 9 and produced flooding in a wide area of western Washington and a part of eastern Washington; on November 24, another storm brought warm temperatures as well as intense precipitation. Warmer-thanaverage temperatures and record rainfall caused snow to melt in the Cascade Mountains, which contributed to greater flooding. A record 24-hour rainfall of 5.82 inches was recorded in Olympia, and a November 24-hour record rainfall of 3.56 inches was recorded at the Seattle-Tacoma International Airport. Peak discharges at eight stations exceeded previous records, and recurrence intervals ranged from 25 to 100 years. Total damage from the two storms was estimated to be more than $\$ 100$ million, and 17 counties were declared State disaster areas. Also in November, intense rainfall and severe flooding occurred in Hawaii (table 2, event 11). On November 20 , a week of steady rain ended with a strong thunderstorm that dropped more than 9 inches of rain in 2 hours in northern Oahu. Peak discharge on the Kamananui Stream at Maunawai had at least a 100-year recurrence interval. In Hilo, on the island of Hawaii, 23.10 inches of rain fell during the same period-10.63 inches of which fell in a 24-hour period. In Tennessee and the northern and western parts of Alabama, late-December floods resulted from several days of steady rain falling on saturated soils. The 100 -year recurrence interval or peak of record was exceeded by peak discharges at three stations in Tennessee and five in Alabama (table 2, event 15). Widespread flooding also occurred in Indiana when 3 to 6 inches of rain fell during December 28 30 (table 2, event 18). The rainfall and melting snow combined to produce flooding that caused 3,000 to 4,000 people to be evacuated in Noblesville, Indianapolis, Columbus, and Terre Haute.

The fall 1990 temperature pattern consisted of aboveaverage departures for the East and below-average departures for the West (fig. 13C). These temperature departures resulted from higher-than-average atmospheric pressures over the East and slightly lower-than-average atmospheric pressures over much of the West (fig. 13 D). Much of the Atlantic Coast had much-above-average temperatures. In the West, temperatures were slightly above average across parts of Arizona and New Mexico; however, temperatures were as much as 2 standard deviations below the average in parts of western Oregon. For the season, at least 686 new daily record-high temperatures were set and 374 daily record lows occurred. Nationally, November 1990 ranked as the sixth warmest November on record, and December ranked as the nineteenth coldest December.

13B. Precipitation in the conterminous United States expressed as a percentage of average fall total precipitation. 13C. Temperature in the conterminous United States expressed as a departure from average fall conditions. (Much above, at least 1.28 standard deviations above the average; above, between 0.52 and 1.28 standard deviations above the average; near average, between -0.52 and 0.52 standard deviations from the average; below, between 0.52 and 1.28 standard deviations below the average; much below, at least 1.28 standard deviations below the average.)

13D. Average height of 700-millibar pressure surface (blue line) over North America and departure from average (1948-70) fall conditions (black dashed line). Data in meters.
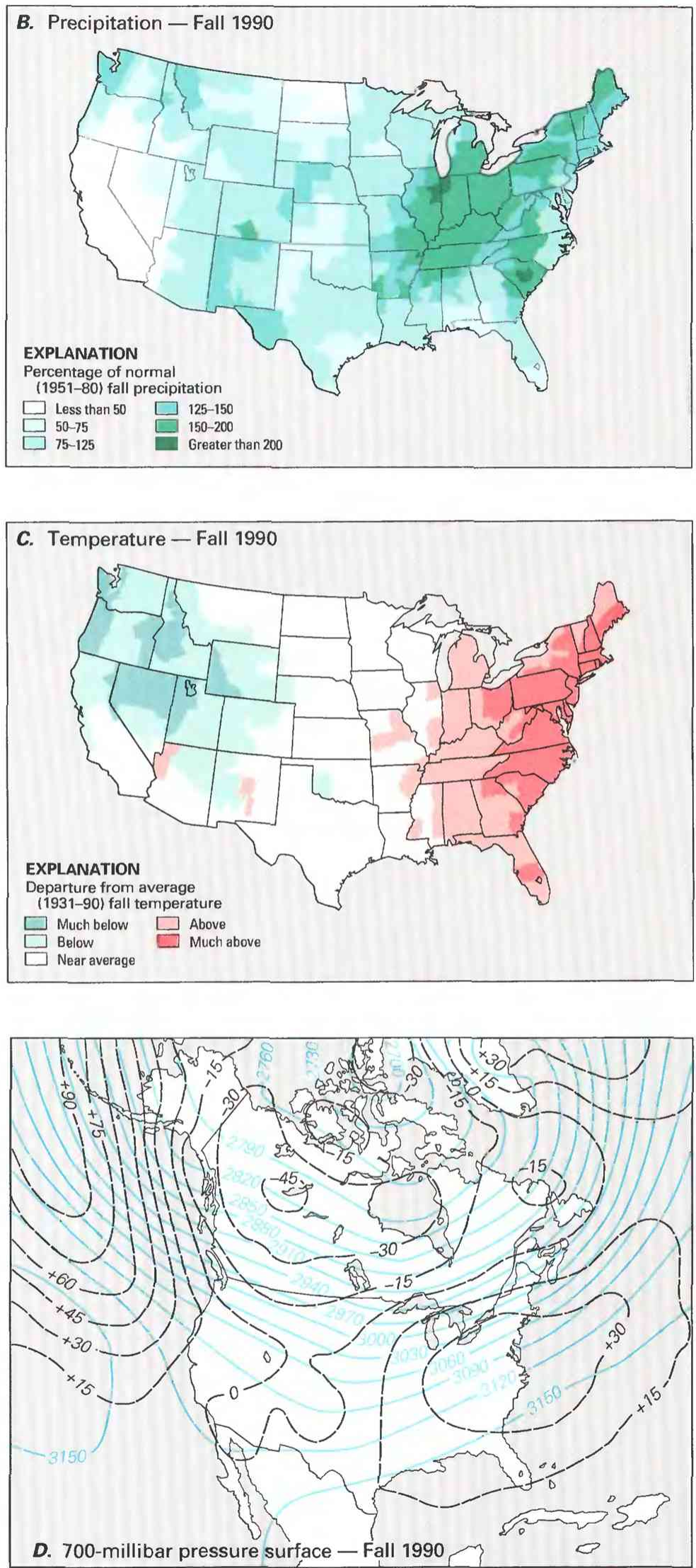

Figure 13. Continued. 
Streamflow for winter 1991 was below median for much of the West and the central and northern Great Plains, and above median for areas from western Arizona across New Mexico, Texas, and southern Oklahoma to western Mississippi, from southeastern Missouri northeastward to the Great Lakes, in north-central Iowa, northwestern Wisconsin, and north-central Florida (fig. 14A). The combined flow of the three largest rivers in the conterminous United States-the Mississippi, St. Lawrence, and Columbia--was above median for the entire winter season. In January, the flow of the Mississippi River was a record high.

Although a large part of the country had above-median streamflow, California and parts of Florida still were affected by severe to extreme drought. By the end of January, the California State Water Project cut water deliveries to farmers and warned urban users that water supplies could be cut 50 percent. The water level of Lake Tahoe continued to drop, to the lowest level on record ( 1.35 feet below the natural rim elevation) (table 2, event 30 ). At the end of February, a major storm system brought much needed rain to parts of California, however, the general conditions were still extremely dry. The period of October 1990 to February 1991 ranked as the third driest October-February period on record for California. By the end of February, there had been no usable storage in Lake Tahoe for six consecutive months (table 2 , event 30 ). This was the beginning of the fifth consecutive dry water year for California. Also by the end of February, the Metropolitan Water District, which serves 15 million customers in southern California, reduced water supplies by 50 percent to agricultural users and by 20 percent to residential customers. In the Central Valley, where irrigation is extensive, water deliveries were cut 75 to 100 percent as a precaution in case the drought continued into a sixth year.

In March, California received some relief from drought as precipitation in California was almost 3 times the monthly average, increasing the seasonal precipitation from 35 to 75 percent of average statewide and increasing streamflow to near the median. In addition, reservoir storage in the State increased from 48 to 60 percent of average. By the end of the winter, streamflow conditions in Florida also had increased to the near-median and even above-median range.

During the first part of March a trough developed over the West Coast and produced a strong onshore flow of moisture laden air from the subtropical South Pacific. This situation often is termed the "Pineapple Express" and is the wettest possible atmospheric circulation pattern for California. The result was much-above-average precipitation in California. Later in March, a ridge developed in the Gulf of Alaska that disrupted the "Pineapple Express," and replaced the flow of maritime tropical air into California with the flow of maritime pacific air. The result was a continuation of much-aboveaverage precipitation.

Although California had a month of extreme precipitation, in general, extreme precipitation events were not as common during winter 1991 as they were during fall 1990 . During February 18 to 22 , however, intense rains fell in the Southeast, particularly in Mississippi and Alabama (table 2, event 28). In general the peak discharges of streams were close to the 10-year recurrence interval. One peak of record was measured on the Tombigbee River at Bevill Lock and Dam, near Pickensville, Ala. During the first week of March, intense rainfall in southern Georgia and northern Florida caused flooding. In Florida, rainfall intensities were as much as 7 inches in a 24-hour period (table 2, event 33 ).

During March 19 to 23, intense rains in Hawaii caused severe floods, mudslides, a power outage on the island of Oahu, and millions of dollars of damage (table 2, event 34). Peak discharges exceeded record peaks at two gaging stations on Oahu. Over Oahu, the rainfall varied from 9 inches along

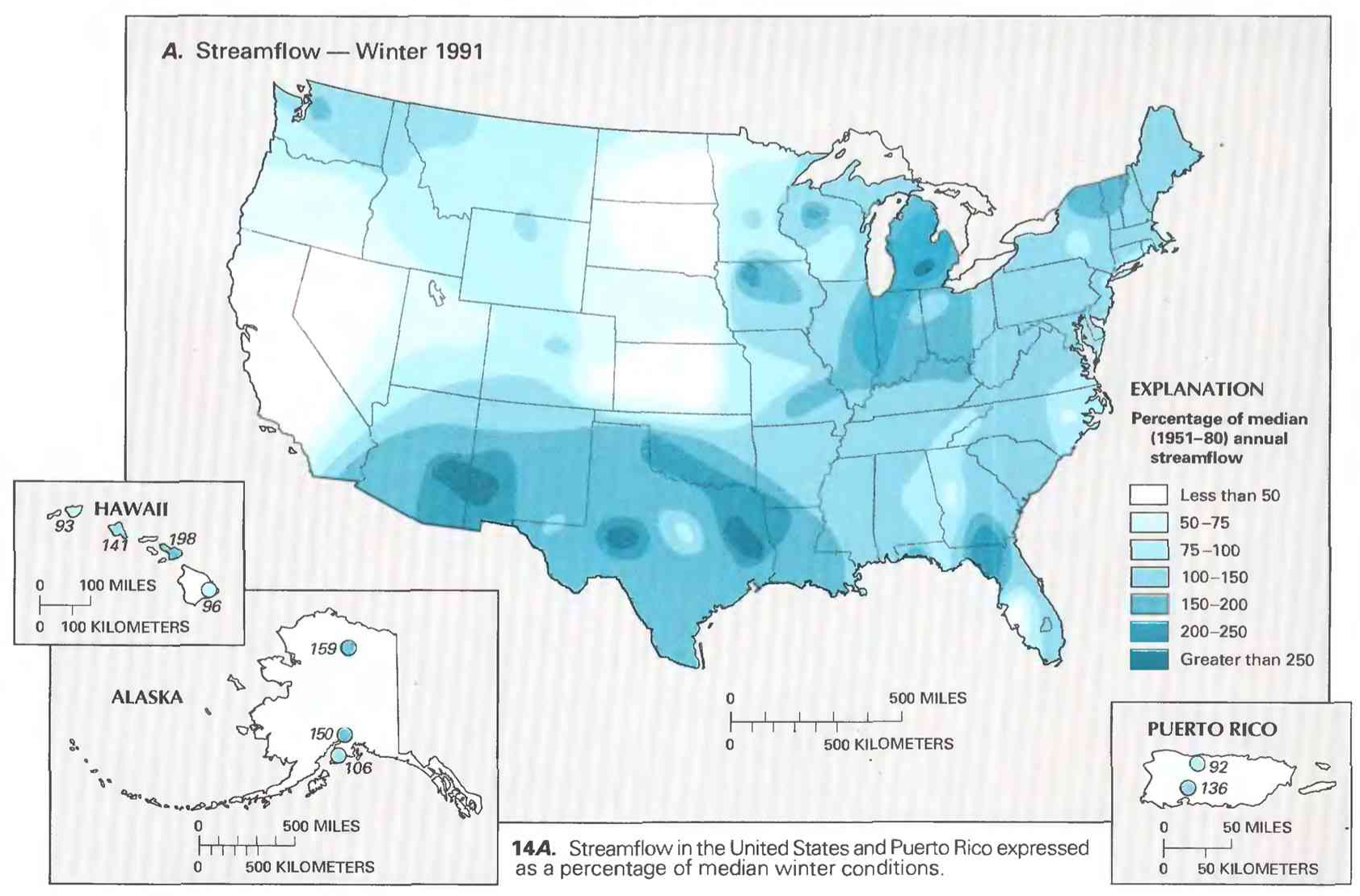

Figure 14. Hydrologic conditions during the winter (January-March 1991) of water year 1991. (Sources: Streamflow data from the U.S. Geological Survey; meteorological data from the National Oceanic and Atmospheric Administration, Climate Analysis Center and National Climatic Data Center.) 
the Waianae leeward coast, which is normally the dry side of the island, to 34 inches at Waiahole close to the mountains near the north end of Kaneohe Bay. The rainfall came in three different periods. The first and most severe episode started during the afternoon of March 19 and continued into the early morning of March 20. Moisture was brought from the tropical oceans by southeasterly winds. The rains from this episode primarily affected the windward side of the islands. The Ahuimanu Loop rain gage near Kahaluu on Central Kaneohe Bay recorded 14.27 inches of precipitation in 13 hours. The second period of rain occurred during the early morning of March 21. A stationary storm cell remained over the islands for several hours and caused intense rainfall. No rain gage was in the area of most intense rain, but it is believed that as much as 10 inches of rain fell in a 3-hour period in some areas. On March 21, the peak discharge of Punaluu Stream near Punaluu was about 1.29 times the 100 -year flood. The third episode occurred on March 23 when a band of intense showers moved from the south.

For the season, precipitation was average to below average for much of the northern two-thirds of the country except for the middle Mississippi Valley (fig. 14B). In parts of central North Dakota, southwestern Wyoming, northern Oklahoma, and southern Kansas, precipitation was as much as 50 percent below average. Isolated pockets of below-average precipitation occurred in south-central Indiana, northern South Carolina, extreme southern Texas, and the Florida Keys. Precipitation was above average over the remainder of the country and as much as twice the average over central Arizona and the panhandle of Florida and southern Georgia. The remainder of the Gulf Coast region received more than 150 percent of the average winter precipitation, as did southern California, southern Arizona, and west-central Iowa.

Temperature departures were fairly uniform across the country for winter 1991 (fig. 14C). Above average temperatures prevailed in response to above average atmospheric pressures (fig. 14D), and only the central Rocky Mountains had slightly below average temperatures. Temperature departures in the High and Great Plains, central Washington, central Oregon, southern Florida, and the middle and northern Atlantic Coast, except for Maine, averaged at least one standard deviation above average.

The winter temperature and precipitation patterns reflect the winter atmospheric circulation. In general, the mean winter atmospheric circulation exhibited higher-than-average pressures over the western Atlantic Ocean and over the Gulf of Alaska. Flow along the western margins of the strong Bermuda High generated higher-than-average temperatures in the Central and Eastern United States (fig. 14D). In addition, this flow enhanced the transport of warm, moist air from the Gulf of Mexico into the Southeastern United States and produced higher-than-average precipitation in the southern Mississippi and Ohio Valleys. The tendency for ridges to develop near the Pacific Northwest prevented the intrusion of Pacific moisture and produced generally dry conditions in the West for the fifth consecutive year.

14B. Precipitation in the conterminous United States expressed as a percentage of average winter total precipitation.

14C. Temperature in the conterminous United States expressed as a departure from average winter conditions. (Much above, at least 1.28 standard deviations above the average; above, between 0.52 and 1.28 standard deviations above the average; near average, between -0.52 and 0.52 standard deviations from the average; below, between 0.52 and 1.28 standard deviations below the average; much below, at least 1.28 standard deviations below the average.)

14D. Average height of 700-millibar pressure surface (blue line) over North America and departure from average (1948-70) winter conditions (black dashed line). Data in meters.
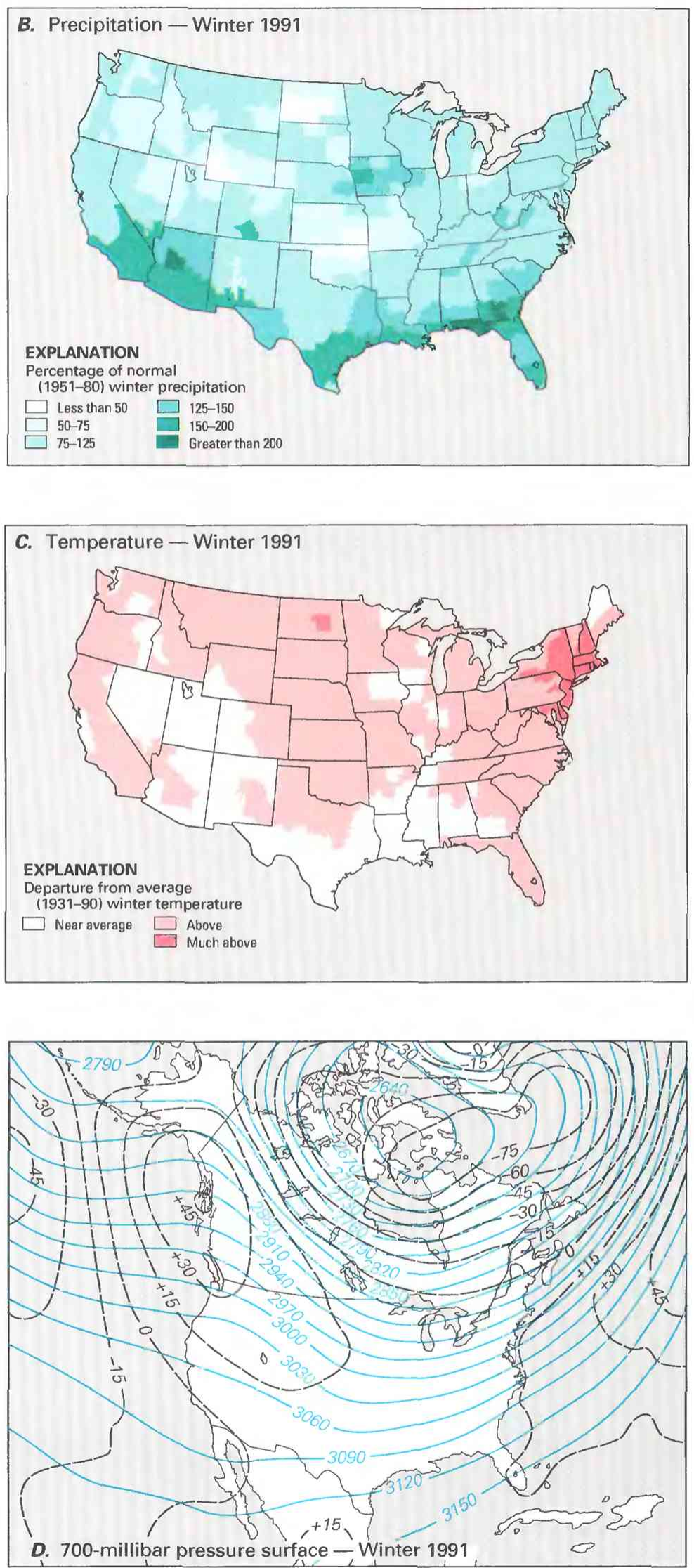

Figure 14. Continued. 
SPRING 1991
Streamflow during spring 1991 remained near to below median in a large part of the West and was below median in much of the Northeast (fig. 15A). Below-median streamflow also occurred in isolated areas of the Great Plains. Abovemedian streamflow occurred along the Gulf Coast and northward through the Mississippi Valley and westward through Texas, Oklahoma, New Mexico, and Arizona. The combined flow of the three largest rivers in the conterminous Statesthe Mississippi, St. Lawrence, and Columbia-was above median for the entire season.

Precipitation varied significantly across the conterminous States-generally wet conditions in the Northwest and Southeast and dry conditions elsewhere (fig. 15B). From the Pacific Northwest eastward to the central Great Lakes region precipitation was above average; eastern Montana, most of South Dakota, and southern Wyoming received in excess of 150 percent of average. In northern and eastern Oregon precipitation was 150 percent of average. The Southeastern region from central Texas through central North Carolina had in excess of 100 percent of the average rainfall, and rainfall along the Gulf Coast was 150 percent of average (fig. $15 B$ ). The wettest area of the country for the spring season was the lower Mississippi Valley where more than twice the average rainfall occurred. In contrast, precipitation in California, the desert Southwest, the southern Rocky Mountains, the Ohio Valley, and the middle and northern Atlantic Coast was below average. Central Pennsylvania, southern California, and Arizona received less than 50 percent of average rainfall.

During April 1991, roughly one-sixth of the country experienced much wetter-than-average conditions and oneseventh experienced much drier-than-average conditions. However, much of the above-average precipitation occurred in areas that generally receive intense rainfall in the spring. $\mathrm{Na}$ tionally, April 1991 was the third wettest April on record. May 1991 ranked as the eighth wettest May on record.
The October 1990 to April 1991 period was the 19th driest October-to-April period on record for California. Reservoir storage in California remained so low that campgrounds at State parks began charging 25 cents for 5 minutes of water at public showers. At the end of June, San Francisco had experienced its driest 5 -year period ever. The 5-year rainfall ending on June 30,1991, totaled 77.43 inches, which is less than the former driest 5-year total of 78.75 set during July 1 , 1929, to June 30, 1934 (table 2, event 65). Similarly, in Pennsylvania, drought warnings were declared in 33 counties in the Susquehanna River basin, and drought watches were declared in 22 counties in the Ohio River basin and in 7 counties in the middle and upper Delaware River basin. The lowest June discharge in the last 97 years was recorded on the Susquehanna River at Williamsport.

While the drought continued in California and other parts of the West, the lower Mississippi Valley and much of the Southeast received large amounts of rain. During the first week of April, thunderstorms produced intense rainfall over southern Texas (table 2, event 37) where as much as 19 inches of rain fell in some areas at rates as much as 3 inches per hour, and caused widespread flashflooding. The Guadalupe River rose 15 feet in just 5 hours. In Louisiana, Shreveport and Bossier City had intense rainfall and subsequent flooding on April 12 (table 2, event 41). The flooding damaged 500 homes. During April 28 to 29, rainfall of 6 to 11 inches in southern Arkansas and northern Louisiana produced flooding that caused people to be evacuated from their homes (table 2, event 43). Flood stages along the Ouachita River in Morehouse Parish, La., were 4 to 5 feet above previous records. In northwestern Louisiana as much as 30 inches of rain fell between April 12 and 20.

In northwestern Nebraska, as much as 7 inches of rain fell on May 10 (table 2, event 48). Peak discharge of the White River at Crawford was estimated to be 4 times the 100-year

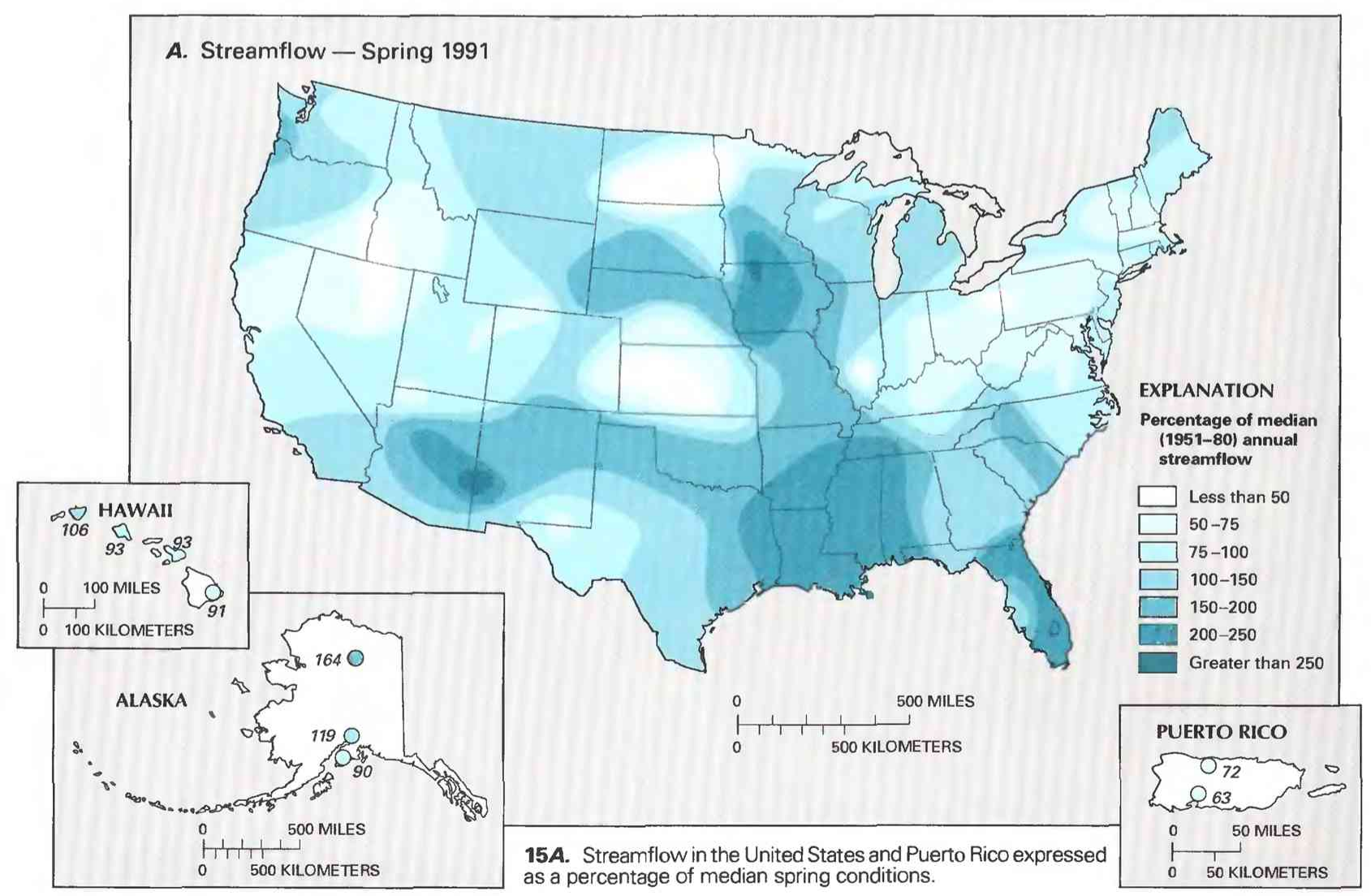

Figure 15. Hydrologic conditions during the spring (April-June 1991) of water year 1991. (Sources: Streamflow data from the U.S. Geological Survey; meteorological data from the National Oceanic and Atmospheric Administration, Climate Analysis Center and National Climatic Data Center.) 
recurrence interval. Intense rainfall also occurred in parts of the Northwest. Parts of Wyoming received as much as 3.5 inches of rainfall in a 24-hour period from a storm during May 15-16, and intense rain in northwestern Montana produced a peak of record on the Tobacco River (table 2, event 53). On May 19, intense rains near Pendleton, Oreg., and a full reservoir combined to force the evacuation of residents living in low-lying areas along McKay Creek and the Grande Ronde River (table 2, event 50). Outflows from the McKay Reservoir produced peak discharges equal to the 100 -year recurrence interval.
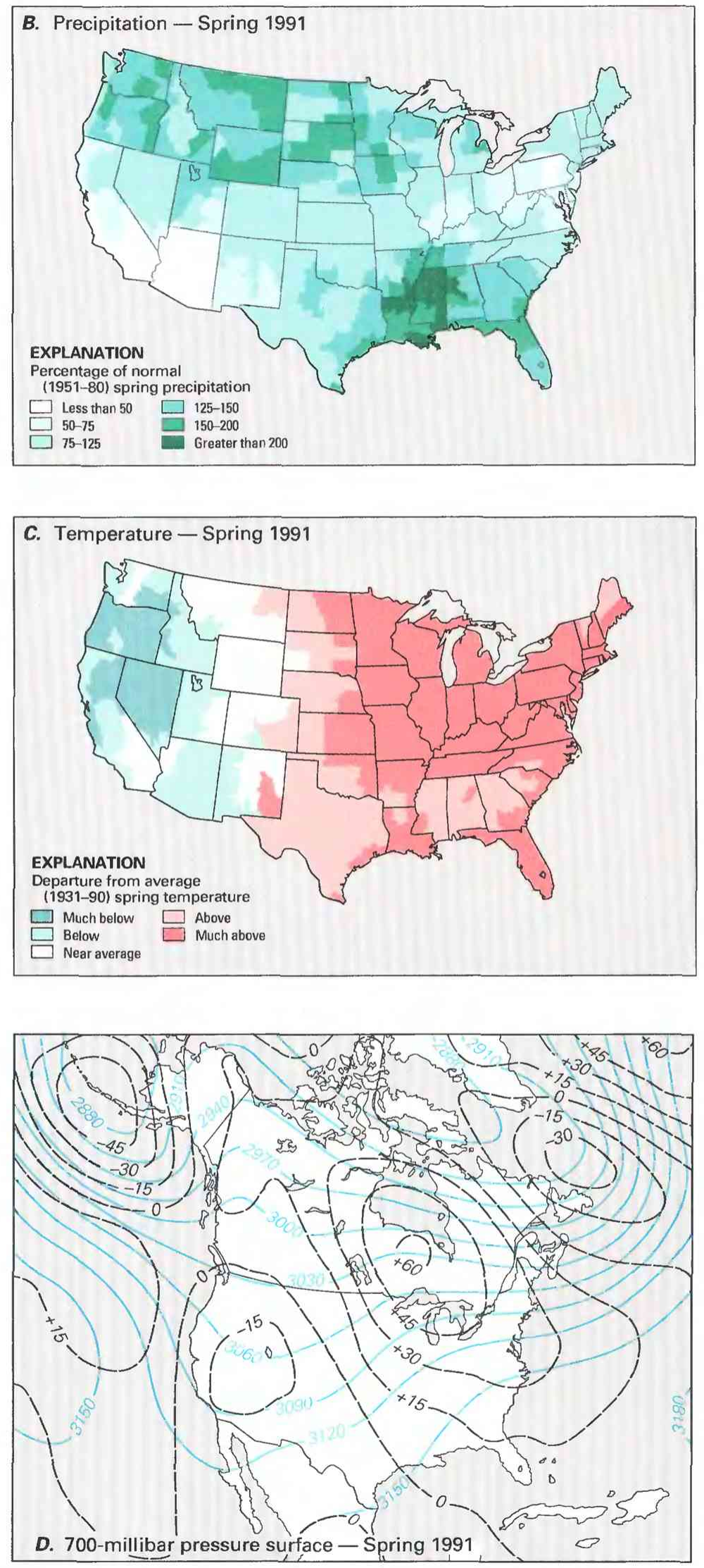

Figure 15. Continued.
15B. Precipitation in the conterminous United States expressed as a percentage of average spring total precipitation.

15C. Temperature in the conterminous United States expressed as a departure from average spring conditions. (Much above, at least 1.28 standard deviations above the average; above, between 0.52 and 1.28 standard deviations above the average; near average, between -0.52 and 0.52 standard deviations from the average; below, between 0.52 and 1.28 standard deviations below the average; much below, at least 1.28 standard deviations below the average.)

15D. Average height of 700-millibar pressure surface (blue line) over North America and departure from average (1948-70) spring conditions (black dashed line). Data in meters. 
Streamflow was below median for a large part of the country during summer 1991 (fig. 16A). In July, streamflow generally declined for most of the country; and in August, for the first time in several months, the combined flow of the three largest rivers in the conterminous United States-the Mississippi, St. Lawrence, and Columbia - was below median. The flow of these rivers continued to decline into September when the combined flow was again below median.

For much of summer 1991, the mean 700-millibar atmospheric circulation was characterized by higherthan-average pressures over the central United States (fig. $16 D$ ), which led to warmer-than-average temperatures in many areas of the western and eastern States (fig. $16 C$ ). Flow on the western margins of the Bermuda High continued to bring warm, moist air from the Gulf of Mexico into the Southeastern States and produced above average rainfall (fig. $16 B$ ). The summer monsoon in the Southwest, which was confined to areas east of the Rocky Mountains, caused frequent summer showers in Colorado, Texas, and New Mexico.

During July, the Southeastern United States continued to receive above average rainfall. New Orleans received another 13.15 inches in July to bring the yearto-date total rainfall to 85 inches. Columbia, S. C., received 17.46 inches in July and Appalachicola, Fla., received 17.40 inches. In contrast, conditions remained relatively dry from northern Virginia northward. It was the driest July on record in Caribou, Maine. In Pennsylvania, the Governor declared a drought emergency in 67 counties, and water restrictions were implemented in 39 counties. Some officials declared the drought in Pennsylvania the worst in 60 years. Several streams were flowing at 70 percent below median in July and only 50 percent of median by the end of August. In August, 16 more counties were declared drought-emergency areas. Drought also was progressing in Ohio. By the end of August, the President declared all 88 counties in Ohio drought-disaster areas.

During August, Hurricane Bob brought rains to parts of the Northeastern States, which eased some of the dry conditions; no significant floods were caused by the hurricane. However, the hurricane produced 3 to 9 inches of rain in some areas, and it was accompanied by wind gusts as much as $\mathbf{1 2 0}$ miles per hour. Hurricane Bob produced 7.83 inches of rain in Portland, Maine, which pushed Portland's total August precipitation to a new record. On August 19, rainfall from thunderstorms associated with the hurricane pushed August rainfall in New England up to five times the average. Estimated damage caused by the hurricane was $\$ 1.5$ billion.

In August, areas in the Southeast continued to receive large amounts of rainfall. By the end of August, the year-to-date rainfall in New Orleans rose to 92.23 inches; the average annual total is 59.74 inches. Drought in the Northeast continued, as reflected by the contents of the New York City reservoirs. Contents of these reservoirs fell to 64 percent of capacity during August. As August ended, Raleigh, N.C., had experienced its 20th consecutive month of warmer-than-average temperatures.

Precipitation for the summer season was below average for a large part of the country (fig. 16B). The

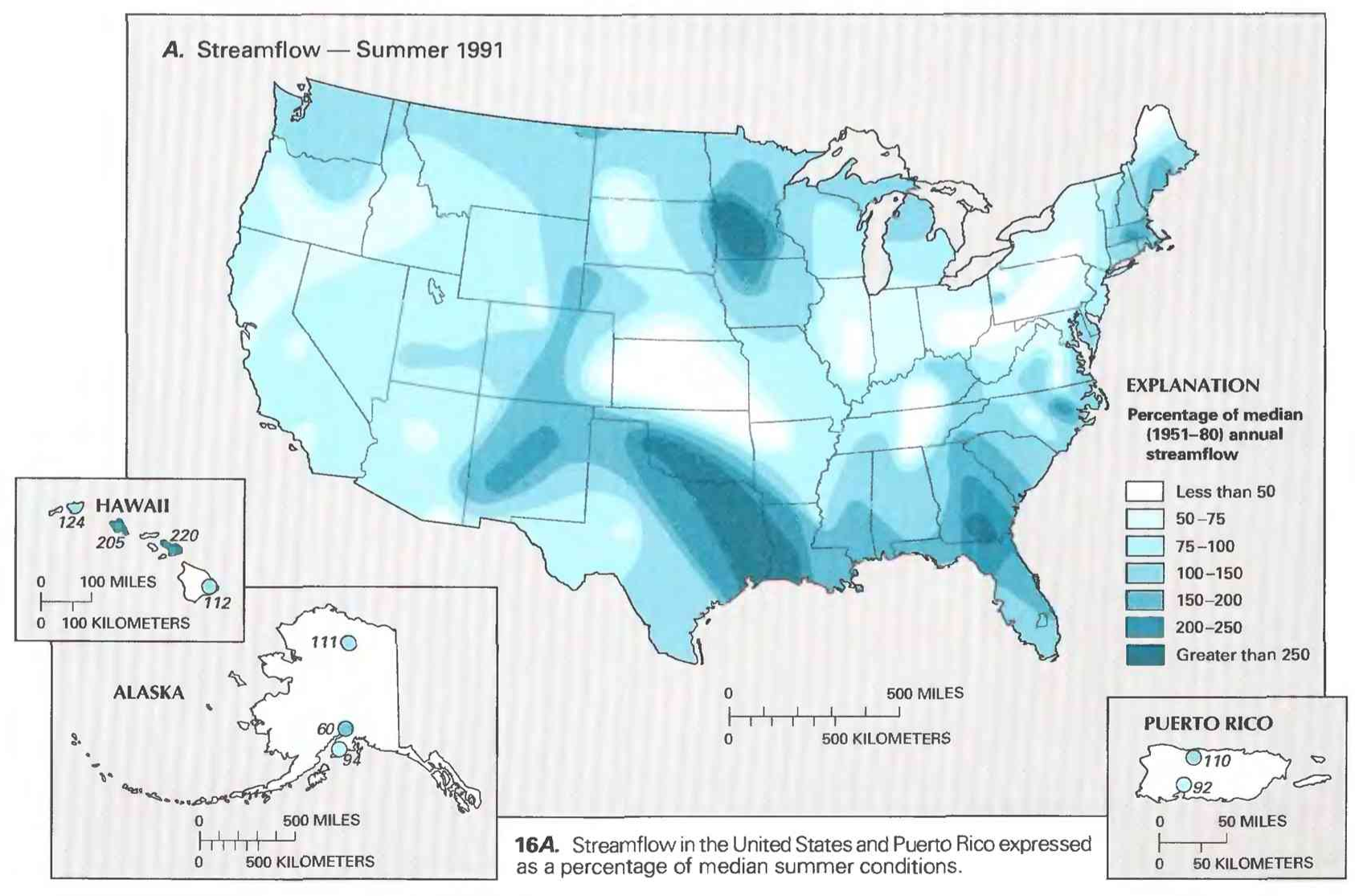

Figure 16. Hydrologic conditions during the summer (July-September 1991) of water year 1991. (Sources: Streamflow data from the U.S. Geological Survey; meteorological data from the National Oceanic and Atmospheric Administration, Climate Analysis Center and National Climatic Data Center.) 
Southwest deserts, California, the Pacific Northwest (except for northwest Washington), and the northern Rocky Mountains were all below average; extreme southwest Arizona, central California, northern Oregon, northeastern Kansas, and north-central Idaho averaged less than 50 percent of average precipitation. Parts of the central Plains, Great Lakes region, Ohio and Tennessee Valleys, and the mid-Atlantic region also had a deficit in summer precipitation. At the other extreme, southeastern New Mexico had more than twice the average summer rainfall, while the Texas panhandle, northeastern California, east-central Georgia, central South Carolina, and the coastal areas of New England had in excess of 150 percent of the average rainfall for July through September.

A patchwork temperature-departure pattern occurred in the Central and Eastern United States during summer 1991 (fig. 16C). Temperatures in southwestern and northeastern New Mexico generally were 2 standard deviations below average. Temperatures in the northwestern third of the country (from central coastal California through the southern Rocky Mountains to the northern Great Plains) generally were above average. Central Oregon and central Washington had positive temperature departures of more than 2 standard deviations.

16B. Precipitation in the conterminous United States expressed as a percentage of average summer total precipitation.

16C. Temperature in the conterminous United States expressed as a departure from average summer conditions. (Much above, at least 1.28 standard deviations above the average; above, between 0.52 and 1.28 standard deviations above the average; near average, between -0.52 and 0.52 standard deviations from the average; below, between 0.52 and 1.28 standard deviations below the average; much below, at least 1.28 standard deviations below the average.)

16D. Average height of 700-millibar pressure surface (blue line) over North America and departure from average (1948-70) summer conditions (black dashed line). Data in meters.

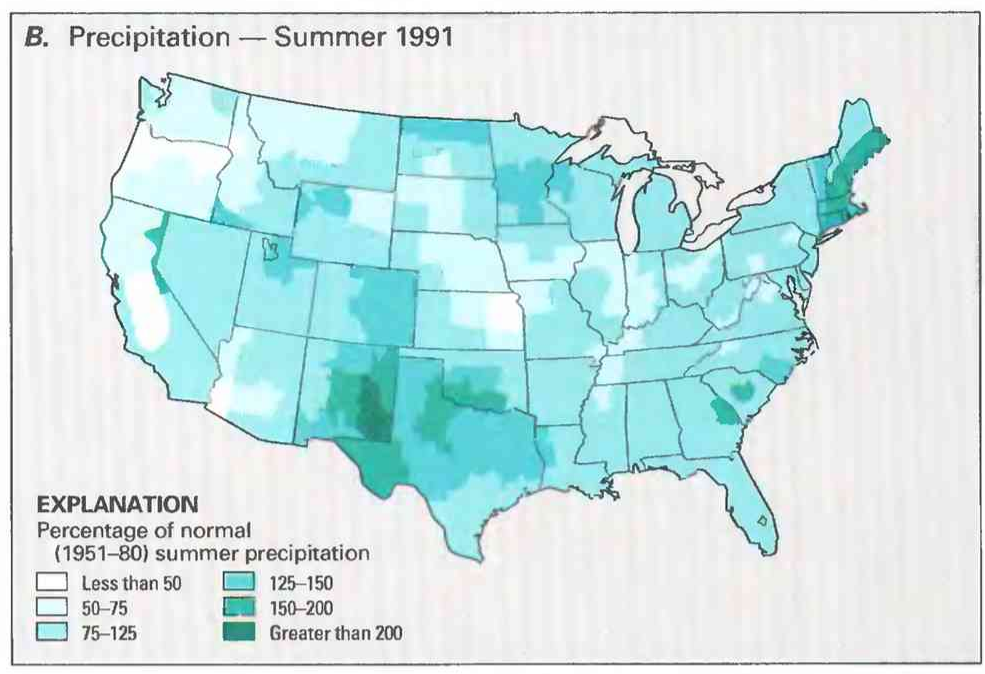

C. Temperature - Summer 1991
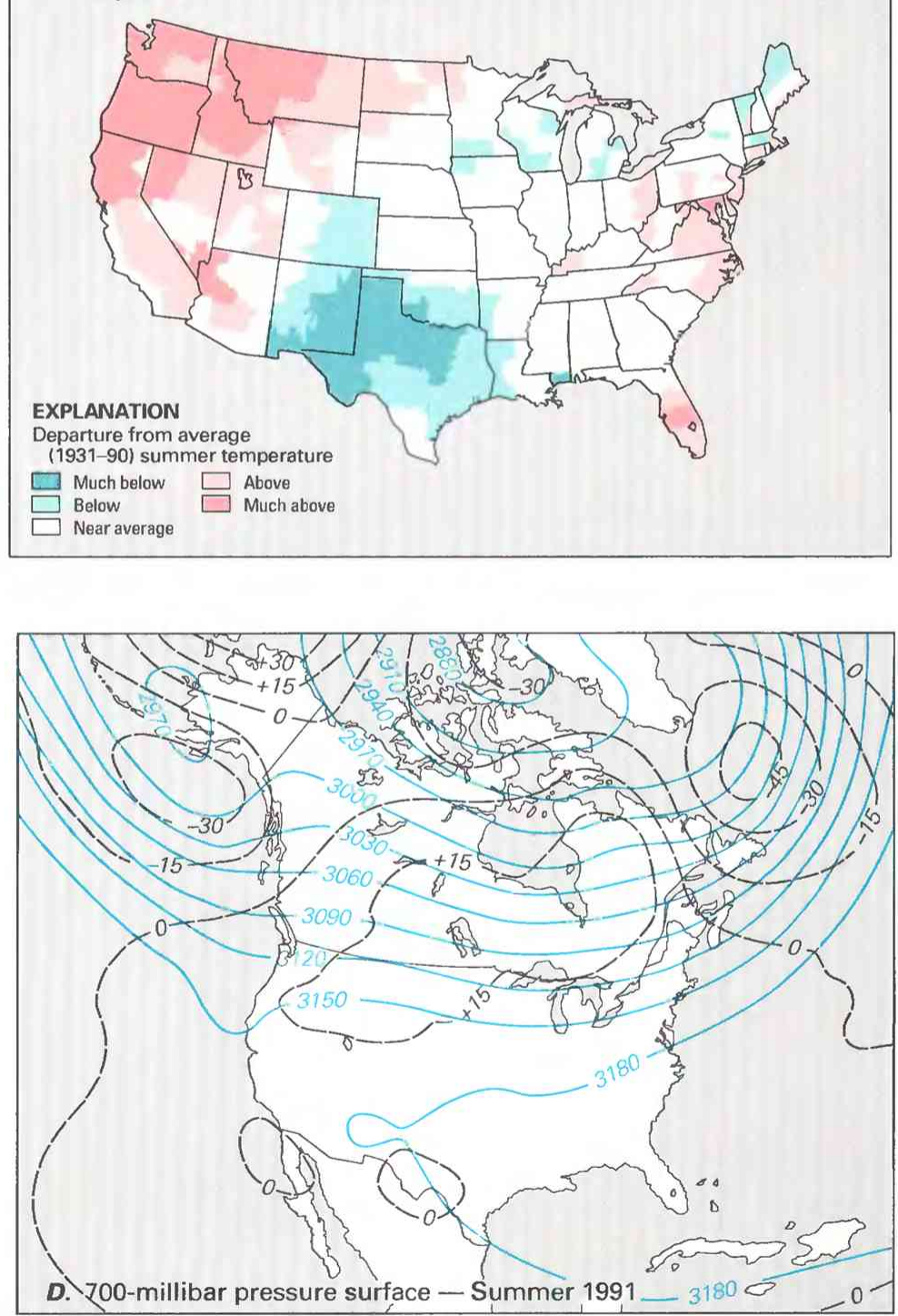

Figure 16. Continued. 
U.S. Geological Survey Water-Supply Paper 2400 

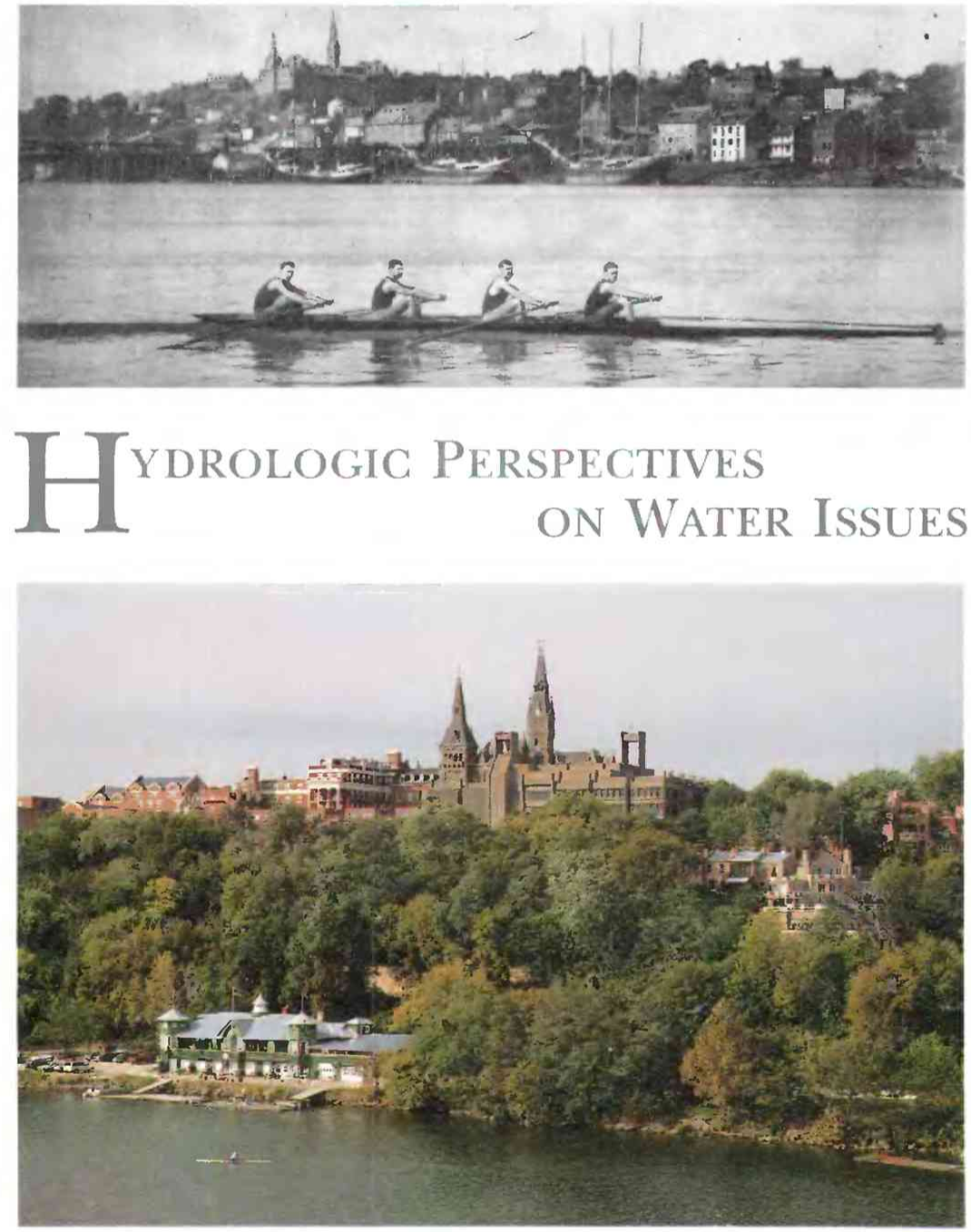

Recreational use of the Potomac River at Washington, D.C., circa 1885 (black and white) and 1992 (color). Both photographs show the Georgetown waterfront. (Black-and-white photograph, Historical Society of Washington, D.C., photograph collection, number 3093; color photograph, David F. Usher, U.S. Geological Survey) 


\section{INTRODUCTION}

The "Hydrologic Perspectives on Water Issues" part of this 1990-91 National Water Summary contains five articles; the first four articles concern the hydrology of stream water quality, specifically conditions and trends of water quality in the United States and water-quality data collection and analysis, and the fifth article concerns water-quality reporting by the States and the Federal Government. The first article discusses the limited data that are available for the determination of national long-term water-quality conditions and trends and presents the results and interpretation of the analysis of these limited data. The second article discusses the characteristics of stream water quality and the statistical techniques that were used to summarize water-quality data in this National Water Summary. The third article discusses quality assurance in collecting water-quality data and describes quality-assurance programs of the U.S. Geological Survey. The fourth article discusses a national assessment of water quality in the 1980's. The fifth article describes biennial reporting of water quality to the U.S. Congress by the States through the U.S. Environmental Protection Agency as required by section 305(b) of the Clean Water Act and presents findings of the 1990 biennial report to the Congress. A synopsis of each article is given below.

HYDROLOGY

OF STREAM

WATER QUALITY
INSTITUTIONAL AND MANAGEMENT ASPECTS
"Factors Affecting Stream Water Quality, and Water-Quality Trends in Four Drainage Basins in the Conterminous United States, 1905-90" describes the elements usually found in freshwater streams and the circulation of these elements between freshwater streams and the atmosphere, lithosphere, soils, biosphere, and the oceans. The article discusses the geochemical controls on the circulation of several of the elements and the natural and humaninduced processes that affect their concentrations in streams. Based on limited data from a year-long national waterquality data-collection program begun in the spring of 1905 by the U.S. Geological Survey, the article compares the concentrations, loads, and yields of selected water-quality constituents in the beginning of the 20th century with more recently collected data in stream reaches in four river basins in the conterminous United States. The comparison of data indicates that the effects of human activities, not surprisingly, have affected concentrations of some elements over the course of the century, but not uniformly in each basin, and that consequently there have been changes in water quality.

"Statistical Analysis of Water-Quality Data" describes the characteristics of water quality and statistical measures that are effective in representing data distribution and trends in concentrations of water-quality constituents. It describes typical statistical distributions of constituents found in water and the use of box plots to graphically and compactly portray the distributions. The article also discusses the variation of water-quality data over time and with streamflow, a technique to remove the effect of streamflow on the analysis of temporal trends in waterquality data, and the seasonal Kendall test, which is the statistical test used to detect trends in concentrations of water-quality constituents.

"Assuring the Reliability of Water-Quality Data" discusses the obstacles to assuring the reliability of waterquality data and the programs that have been designed to minimize such obstacles. These obstacles impede the collection of representative water samples from waterbodies, the collection and shipment of water samples to a laboratory for analysis without contaminating the sample, the analysis of samples within the error bounds of the analytical method used, and the recording and documenting of data with ancillary information that characterizes methods of data collection and analysis. The article describes training programs, standards of data collection, analysis, and documentation as elements in assuring the reliability of water-quality data.

"Stream Water Quality in the Conterminous United States-Status and Trends of Selected Indicators During the 1980's" discusses the types and geographic distribution of data that are ideal for an assessment of national water quality. Although available data are far from ideal, the article assesses water quality in the conterminous United States as represented by six common water-quality indicators-dissolved oxygen, fecal coliform bacteria, dissolved solids, nitrate, total phosphorus, and suspended sediment-and estimates loads and (or) yields of nitrate, total phosphorus, and suspended sediment in stream basins by land use, in large regional water-resources regions, and in drainage to selected reservoirs and the coasts. Analyses of water quality in basins having significant domestic, industrial, and irrigation water uses, trends in concentrations of selected toxic trace elements and organic compounds in finfish tissue, and concentrations of herbicides in agricultural areas of the Midwest also are presented.

Until the latter part of this century, societal interest in water quality had been local or regional and focused on improving the degraded condition of particular waterbodies and stream basins. As a result, few national programs of water-quality data collection and reporting existed. The passage of the Clean Water Act in 1972 defined the Federal and State roles in water-quality protection. The article "Nationwide Water-Quality Reporting to the Congress as Required Under Section 305(b) of the Clean Water Act" describes water-quality reporting by the States under section 305(b) of the act and also presents the findings from the most recent, 1990, U.S. Environmental Protection Agency report to the Congress. 


\title{
Factors Affecting Stream Water Quality, and Water-Quality Trends in Four Drainage Basins in the Conterminous United StaTes, 1905-90
}

\author{
By John D. Hem
}

\section{INTRODUCTION}

A major area of interest in recent studies of stream water quality is the evaluation of trends over time in certain constituent concentrations that can be attributed to human activities, such as the disposal of waste, use of fertilizers, burning of fossil fuels, control of streamflow, irrigation, clearing of forests, and the deicing of roads. To better control these sources of contamination, it is important to know the influences of natural processes on water that is thought to be natural or in pristine condition. Thus, the objectives of this article are to (1) review modes of expression of chemical analyses and some general principles of stream water geochemistry, (2) provide some insights as to hydrologic and geochemical controls of the chemical composition of stream water and the ways some chemical constituents can be influenced by human activities, and (3) demonstrate cause-and-effect relations for differing natural and human-influenced processes on stream water quality using long-term records for four drainage basins in the conterminous United States.

Concerns about water contamination are not new. English poet Samuel Taylor Coleridge (1772-1834) pondered the effect of a German city on the Rhine River in his "Ode to the City of Cologne":

In Köln, a town of monks and bones,

And pavements fang'd with murderous stones,

And rags and hags and hideous wenches,

I counted two-and-seventy stenches;

All well defined and several stinks!

Ye nymphs that reign o'er sewers and sinks,

The river Rhine, it is well known,

Doth wash your city of Cologne;

But tell me, nymphs, what power divine

Shall henceforth wash the river Rhine?

Concern for the Rhine River has been particularly strong among water users in the lower reaches of the river, where during the 150 years in which chemical analyses of the water have been made, the records show large increases in sulfate and chloride concentrations. It has been estimated (Drever, 1982, p. 195) that by 1980 more than 90 percent of the chloride and 75 percent of the sulfate carried to the North Sea by the Rhine was contributed by human activities. These and other constituents and their relation to human activities are as much a concern in the United States as they are in Europe.

\section{FACTORS AFFECTING STREAM WATER QUALITY}

\section{General Principles of Stream WATER GEOCHEMISTRY}

The composition of pristine stream water can range from nearly that of rainwater, which is a very dilute solution containing a few tens of milligrams per liter of dissolved material, to concentrations of as much as several thousand milligrams per liter, which usually are found in semiarid regions where saline springs contribute chemical constituents derived from readily soluble rock strata. In general, however, the dissolvedsolids concentrations of principal streams in humid and subhumid regions of the conterminous United States have a narrower range. Analyses (Hem and others, 1990) showing maximum and minimum concentrations for a recent 3-year period for 29 stream-sampling sites in the United States recently were published. Seven of these sites had maximum total dissolved-solids concentrations greater than $1,000 \mathrm{mg} / \mathrm{L}$ (milligrams per liter); these high concentrations are attributable to saline inflows, and human activities probably intensified their effects.

Chemical analyses of stream water that have been published since the early years of this century generally include determinations for four positively charged ions (cations) - calcium $\left(\mathrm{Ca}^{2+}\right)$, magnesium $\left(\mathrm{Mg}^{2+}\right)$, sodium $\left(\mathrm{Na}^{+}\right)$, and potassium $\left(\mathrm{K}^{+}\right)$- and five negatively charged ions (anions) - bicarbonate $\left(\mathrm{HCO}_{3}^{-}\right)$, sulfate $\left(\mathrm{SO}_{4}^{2-}\right)$, chloride $\left(\mathrm{Cl}^{-}\right)$, fluoride $\left(\mathrm{F}^{-}\right)$, and nitrate $\left(\mathrm{NO}_{3}^{-}\right)$- and uncharged dissolved silicic acid (generally reported in terms of silica, $\mathrm{SiO}_{2}$ ). These are the major constituents in most natural stream water and are those considered in this article. Minor constituents, present at concentrations substantially less than $1 \mathrm{mg} / \mathrm{L}$, include a wide variety of inorganic and organic constituents and, although these constituents commonly are influenced by human activities, they are not considered in this article because few historical data are available.

\section{Chemical Reactions that Govern Stream Composition}

Weathering is a general term for mechanical and chemical alteration of rock minerals that are exposed to the atmosphere and circulating water at and near the land 
surface. Chemical reactions that occur during weathering produce both water soluble and non-water soluble products; those that are water soluble are transported from the reaction site in surface runoff. To a certain extent, at least, the concentrations of dissolved elements would be expected to reflect the relative abundance of the elements in the rocks exposed at the reaction site. Such a broad generalization has some validity for silicon ( $\mathrm{Si}$ ) and the four elements that form the major cations of most natural stream water. These five elements are among the eight most abundant elements, with oxygen being the most abundant, in igneous and sedimentary rocks of the Earth's outer crust. The other two of the most abundant elements-aluminum (Al) and iron (Fe) - form oxides or hydroxides of very low solubility during normal rock weathering and, therefore, generally are not present in large amounts in stream water. On the other hand, major anions in stream water display a more complex relation to rock composition. In the average stream-water sample, the five most abundant anions represent the nonmetallic elements carbon, sulfur, chlorine, fluorine, and nitrogen. Also, oxygen is included in three of the anions of these elements.

Oxygen is by far the most abundant element in crustal rocks, composing 46.6 percent of the lithosphere (Goldschmidt, 1954, p. 512). In rock-mineral structures, the predominant anion is $\mathrm{O}^{2-}$, and water $\left(\mathrm{H}_{2} \mathrm{O}\right)$ itself is almost 90 percent oxygen by weight. The nonmetallic elements fluorine, sulfur, carbon, nitrogen, chlorine, and phosphorus are present in lesser amounts in the lithosphere. These elements all play essential roles in life processes of plants and animals, and, except for phosphorus and fluorine, they commonly occur in earthsurface environments in gaseous form or as dissolved anions.

In a very broad general sense then, the major cationic constituents of stream water tend to reflect the composition of associated rocks and the relative resistance of the rock minerals to weathering. The anions, which must be present in these water solutions in electrochemical balance with the cations, tend to reflect the influence of various chemical and biochemical processes that have broken down the rock minerals as well as the chemical, biochemical, and physical processes taking place in the aquatic and surrounding environments. The predominance of bicarbonate anions in most stream water is related to cycling of carbon dioxide $\left(\mathrm{CO}_{2}\right)$ from air and to biological processes in soil. Dissolution of carbon dioxide in water produces carbonic acid $\left(\mathrm{H}_{2} \mathrm{CO}_{3}\right)$ that attacks rock minerals. Bicarbonate anions are formed in solutions participating in such reactions in amounts equivalent to the amount of cations that are released.

Sulfur and nitrogen participate in biologically mediated oxidation reactions producing hydrogen ions $\left(\mathrm{H}^{+}\right)$ that become available for weathering of rock minerals. For example, pyrite $\left(\mathrm{FeS}_{2}\right)$ can be converted to dissolved ferrous iron and sulfate as a result of oxidation of sulfur by dissolved oxygen, and the hydrogen ion is a major byproduct. Carbonate or sulfate in sedimentary rocks (limestone and gypsum, for example) can be taken directly into solution and can add substantially to the bicarbonate and sulfate contents in water that is in contact with such rocks.

Chlorine plays a less significant role in chemical weathering processes than do sulfur and carbon. Most geochemists believe that much, or most, of the chloride in stream water in coastal areas is derived from sea salt that is carried landward or deposited by rainfall. Farther inland, however, a major part of the chloride loads in streams is the result of human activities.

The final composition of stream water is the product of the weathering reactions and related processes outlined above. However, the chemical processes are influenced and controlled by an intricate combination of environmental factors that are characteristic for each drainage system. Therefore, the composition of the bedrock in an area and the residual material left at the surface as soil and subsoil exert a strong influence on the chemical composition of runoff from the area. The reactions of water with this material are the ultimate geological control and are the source of soluble weathering products.

Most igneous and metamorphic rocks are composed predominantly of alumino-silicate minerals, including feldspar such as albite $\left(\mathrm{NaAlSi}_{3} \mathrm{O}_{8}\right)$ or anorthite $\left(\mathrm{CaAl}_{2} \mathrm{Si}_{2} \mathrm{O}_{8}\right)$, and crystalline forms of silica such as quartz $\left(\mathrm{SiO}_{2}\right)$. Various mixed metal-plus-silicon oxides such as olivine $\left[(\mathrm{Mg}, \mathrm{Fe})_{2}\left(\mathrm{SiO}_{4}\right)\right]$ and pyroxene $\left[\mathrm{Mg}_{2}\left(\mathrm{SiO}_{3}\right)_{2}\right]$ can be major constituents in darker colored igneous rocks that are relatively low in total silicon.

Rocks that were deposited as sediment can consist of unaltered fragments of a precursor rock body (resistates, as described by Hem, 1985, p. 6) and are represented by sandstone and conglomerate. The finer grained sedimentary rocks, such as shale or siltstone, also can contain some unaltered particles but also usually have high proportions of slightly soluble alteration products, such as clay minerals, formed during weathering of resistant silicate minerals. Such rocks are classified as hydrolyzates. Another class of sedimentary rock of major importance is the precipitates, such as limestone and dolomite, which are predominantly composed of calcium carbonate and calcium plus magnesium carbonate, respectively. Evaporites are sedimentary rocks produced by extensive evaporation of water from weathering solutions. Common examples are gypsum and anhydrite, primarily composed of calcium sulfate, or halite (rock salt), primarily composed of sodium chloride. Obviously the more readily soluble minerals of evaporite or precipitate rocks can dissolve rapidly when exposed to circulating water. Carbonates also can act as cementing material between the mineral grains of resistate and hydrolyzate rocks.

The extent to which minerals are attacked and dissolved from igneous and metamorphic terranes depends in large part on the availability of reaction sites on solid surfaces and the length of time the solution-solid contact is maintained. The effects of weathering are controlled by kinetic factors, such as the rates of the chemical reactions and the general rates of water and sediment movement, and biologic factors that include the effects of biotic growth in the weathering zone. Also, the hydrologic properties of the drainage system (precipitation, evaporation, runoff, slope of the area), the relative permeability of rocks and soils, and the degree to which the surface drainage system is coupled to the ground-water reservoirs are important modulating forces. In rocks that contain more soluble minerals such as calcite, the degree to which solids are dissolved and carried off in the runoff is more likely to be governed by chemical thermodynamic factors, and in carbonate 
systems a state of chemical equilibrium could be closely approached.

Mineral-dissolution reactions of importance generally require a continuous supply of hydrogen ions in the incoming solution. To some degree reacting hydrogen ions are supplied from the water itself, which always includes, to some extent, water molecules that have broken apart (dissociated) into hydrogen and hydroxide ions. Under standard conditions $\left[25^{\circ} \mathrm{C}\left(77^{\circ} \mathrm{F}\right)\right.$ and 1 atmosphere pressure], the effective concentration of hydrogen ions in pure water is $10^{-7.00}$ moles per liter. (A mole of a chemical element is a quantity in grams numerically equal to the atomic weight. For hydrogen, $10^{-7.00}$ moles per liter is equivalent to $0.1 \mathrm{mg} / \mathrm{L}$ ).

The $\mathrm{pH}$ scale commonly used to express acidity is defined as the negative base-10 logarithm of the effective concentration (activity) of hydrogen ions in a solution. At neutrality under the conditions defined in the preceding paragraph, the $\mathrm{pH}$ therefore will be 7.00 . A change of $1 \mathrm{pH}$ unit represents a tenfold change in hydrogen-ion activity. The activity of a dissolved ion is exactly equal to its concentration only in very dilute solutions. This topic has been discussed and explained more extensively by $\operatorname{Hem}(1985$, p. 14-17).

In natural systems the most effective sources of hydrogen ions generally are chemical reactions involving dissolved constituents. An important source is carbon dioxide gas, which is present in weathering solutions as a result of contact with air; it is produced in larger quantities by plant-root respiration and decay of soil organic matter and by the metabolic processes of various organisms in water and sediment. Equation 1 shows that some of the carbon dioxide that dissolves forms carbonic acid (note that in the following equations the arrows indicate the direction in which the reaction normally proceeds; reactants are on the left side and products on the right; double arrows indicate that reactions can proceed in either direction) -

$$
\underset{\text { carbon dioxide }}{\mathrm{CO}_{2}}+\underset{\text { water }}{\mathrm{H}_{2} \mathrm{O}} \rightarrow \underset{\text { carbonic acid }}{\mathrm{H}_{2} \mathrm{CO}_{3}}
$$

Equation 2 shows that the acid dissociates to form bicarbonate ions and hydrogen ions-

$$
\underset{\text { carbonic acid }}{\mathrm{H}_{2} \mathrm{CO}_{3}} \rightleftarrows \underset{\text { bicarbonate }}{\mathrm{HCO}_{3}^{-}}+\underset{\text { hydrogen }}{\mathrm{H}^{+}}
$$

and carbonate anions can be formed in a second dissociation step (equation 3 ) -

$$
\underset{\text { bicarbonate }}{\mathrm{HCO}_{3}^{-}} \underset{\text { carbonate }}{\mathrm{CO}_{3}^{2-}}+\underset{\text { hydrogen }}{\mathrm{H}^{+}}
$$

The $\mathrm{H}^{+}$that is supplied by reactions in equations 2 and 3 can react with silicate minerals such as the sodiumbearing form of feldspar (equation 4) -

$$
\begin{gathered}
\underset{\text { albite }}{2 \mathrm{NaAlSi}_{3} \mathrm{O}_{8}}+\underset{\text { hydrogen }}{2 \mathrm{H}^{+}}+\underset{\text { water }}{9 \mathrm{H}_{2} \mathrm{O}} \rightarrow \\
\underset{2}{\mathrm{Al}_{2} \mathrm{Si}_{2} \mathrm{O}_{5}(\mathrm{OH})_{4}}+\underset{\text { kaolinite }}{4 \mathrm{H}_{4} \mathrm{SiO}_{4} \mathrm{aq}}+\underset{\text { silicic acid }}{2}+\underset{\text { sodium }}{2 \mathrm{Na}^{+}}
\end{gathered}
$$

to produce the clay mineral kaolinite, undissociated silicic acid $\left(\mathrm{H}_{4} \mathrm{SiO}_{4}\right.$ which also can be written as $\left.\mathrm{SiO}_{2}\right)$, and sodium ions. This is essentially an irreversible process (note the single arrow) in that albite is not readily synthesized from the reaction products under ordinary natural weathering conditions, and the reaction will continue to proceed to the right as long as reactants are available.
The hydrogen-ion flux that is provided by carbonic acid dissociation also can attack calcite $\left(\mathrm{CaCO}_{3}\right)$ (equation 5) -

$$
\underset{\text { calcite }}{\mathrm{CaCO}_{3}}+\underset{\text { hydrogen }}{\mathrm{H}^{+}} \stackrel{\underset{\text { bicarbonate }}{\mathrm{HCO}_{3}^{-}}}{\rightarrow}+\underset{\text { calcium }}{\mathrm{Ca}^{2+}}
$$

This reaction is relatively fast and readily reversible so that in drainage basins in carbonate-dominated terranes the stream water commonly will have near-equilibrium concentrations of hydrogen, bicarbonate, and calcium ions. At equilibrium, the rates of forward and reverse processes represented in equation 5 are equal.

In effect, the forward progress of reactions such as is shown in equations 4 and 5 will be controlled by the availability of hydrogen ions, but the final result, as indicated by the chemical composition of stream water from any given drainage basin, will be influenced by a complicated set of interrelated physical factors that influence the volume and rate of water movement, ecologic and climatic factors that control the type and density of plant and bacterial growth and soil development, and the human development of water and land resources. Thus, the geochemistry of stream water in any given drainage basin is unique to that basin. The historical record of water chemistry in a specific basin cannot be interpreted without giving proper attention to the way various hydrologic and other environmental factors in the basin have influenced the chemical composition of the water. An extensive body of research on the topic of global streamwater geochemistry is summarized by Meybeck and Helmer (1989), who agree with the need expressed in this paragraph for a broad consideration of cause and effect when evaluating stream-water chemistry.

\section{Effects of Human Activities}

A considerable part of the currently existing motivation for organized long-term water-quality studies has been public concern that human activities in many drainage basins have induced destructive changes in stream water quality. From examples cited in this article, such effects can indeed be documented in some basins. Also, in some basins water-quality management has succeeded in correcting some of the human-caused deterioration and is substantially restoring the quality of the water. The concept of sustainability is relevant, and the development goal for drainage systems is to maintain suitable water quality while permitting levels of water use that will sustain the basin's existing and reasonable future economic development.

Human activities that alter streamflow characteristics, and thus cause water-quality changes, include the building of structures that impound or regulate rates of streamflow, diversion of water from one drainage basin to another, irrigation of land adjacent to streams, and lowering of tributary ground-water tables by pumping from wells. Waste disposal, directly or indirectly, into streams also influences water quality by adding chemicals and suspended matter. Disposal of untreated organic waste into streams was common in urban and rural areas of the Nation until the early 20th century. Besides pathogenic bacteria in the waste, large amounts of organic chemicals and suspended material depleted the dissolved oxygen of receiving waters and killed much of the aquatic biota in some streams. Thus, 
the concentration of dissolved oxygen in stream water also is considered a contamination index. Normally, the dissolved-oxygen content is near the saturation level that can be calculated for water that is in contact with air at ambient temperature, but oxidizable material in solution, especially organic waste, can substantially deplete the dissolved-oxygen content. Additionally, phosphate $\left(\mathrm{PO}_{4}{ }^{3-}\right)$ concentrations are indicative of contamination from waste sources. Phosphate is a constituent of domestic and industrial waste, in part, because of the widespread use of phosphate compounds as detergent additives.

Land-use changes and related developments also can affect stream water quality. Examples include urbanization, clearing of forests, various agricultural practices, such as use of fertilizers and pesticides and return flow of drainage water from irrigated fields, and industrialization. Urbanization and industrialization lead to various side effects. Mining for coal and metals generally contaminates water during and after the mining activity. The smelting of ores to recover metals and the burning of coal to generate power release pollutants into the

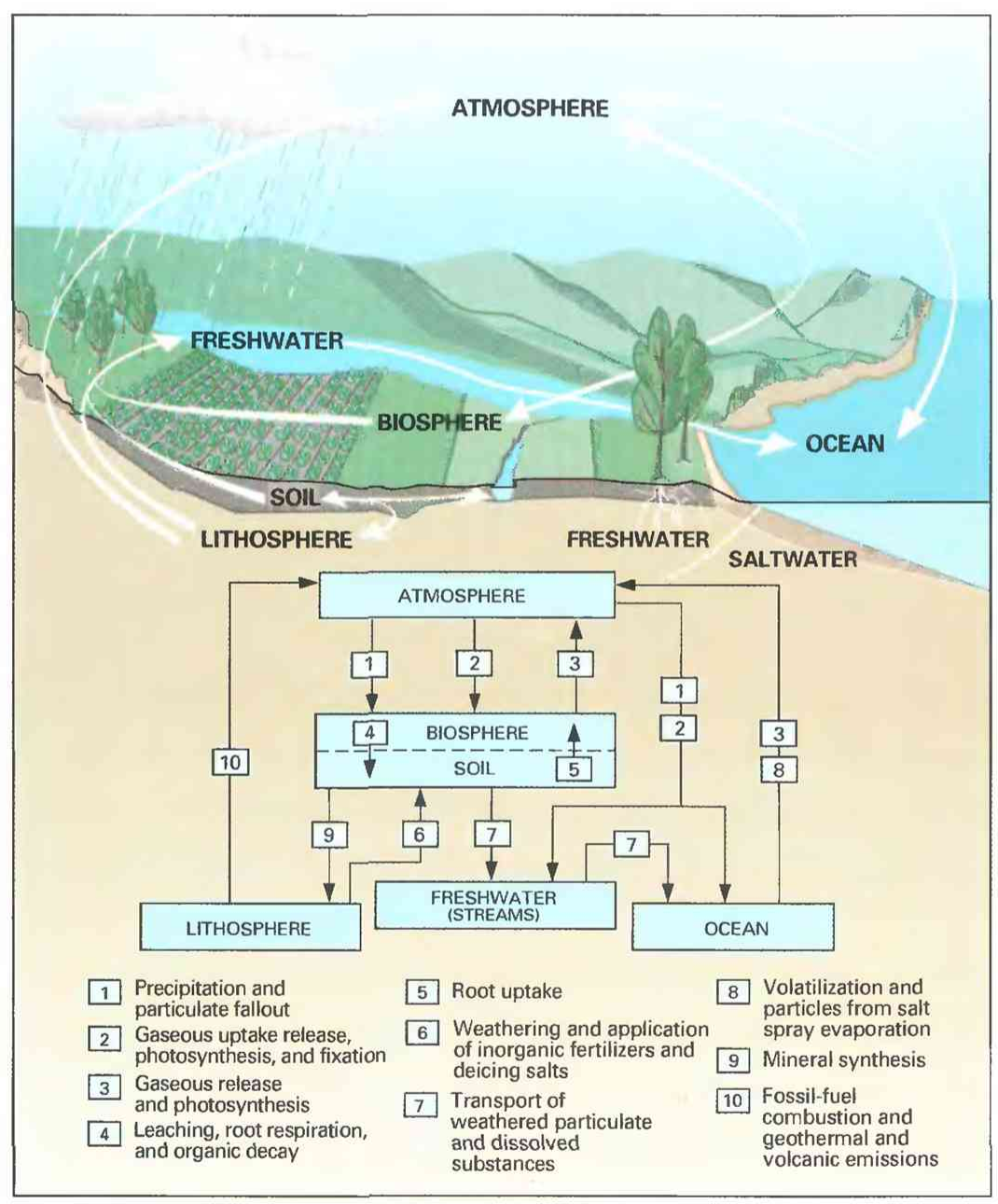

Figure 17. Generalized cycle of the various reservoirs and transport mechanisms and pathways involved in the circulation of nutrient elements. The numbered arrows repre sent processes by which elements transfer among the reservoirs. Processes shown are those considered to have the most important influence on stream water quality. (Source: Modified from Meybeck, 1983.) air, and eventually these pollutants find their way into water supplies. Metal ores, coal, and other organic fuels commonly contain, or are associated with, reduced sulfur. Oxidation of the sulfur by burning the fuel and smelting the ores, and oxidation in the mines or in waste dumps when sulfides are exposed to air, constitute major sources of sulfate in stream water. High metal concentrations commonly are found in streams draining metal-mining areas, and sodium chloride and calcium chloride are dispersed widely by salt and sand mixtures used to melt ice from highways.

\section{CiRCULATION RATES OF ElEMENTS}

The concept of cyclic circulation of individual elements, in part coupled to the hydrologic cycle, has been developed and quantified over the past half century. Besides the total quantities of the elements present in various reservoirs-bedrock (the lithosphere), soils, all forms of living matter (the biosphere), the oceans, the atmosphere, and freshwater-the rates of exchange and mechanisms of movement from one reservoir to another are considered in the cycle. This concept is highly relevant in considering stream-water geochemistry and related elemental fluxes.

A simplified diagram representing the various reservoirs and transport mechanisms and pathways involved in the circulation cycles of nutrient elements at and above the surface of the Earth is given in figure 17. The processes are those considered to be the most important in the context of this article, but others of lesser significance can be postulated. For some of the elements, notably carbon, sulfur, chlorine, and nitrogen, considerable research has been done to evaluate (quantitatively) the amount of the various elements in the reservoirs and the rates of transfer. Each of these elements is expanded on in the following discussions.

\section{Carbon}

Most of the Earth's supply of carbon is stored in carbonate rocks in the lithosphere. Normally the circulation rate for lithospheric carbon is slow compared with that of carbon between the atmosphere and biosphere. The carbon cycle has received much attention in recent years as a result of research into the possible relation between increased atmospheric carbon dioxide concentration, most of which is produced by combustion of fossil fuel, and the "greenhouse effect" or global warming. Extensive research has been done on the rate at which carbon dioxide might be converted to cellulose and other photosynthetically produced organic compounds by various forms of natural and cultivated plants. Estimates also have been made of the rate at which carbon dioxide is released to soil under optimum conditions by various kinds of plant cover, such as temperate-zone deciduous forests, cultivated farm crops, prairie grassland, and desert vegetation.

The efficiency of the weathering of rocks in using carbonic acid produced in the carbon cycle is affected by various hydrologic, environmental, and cultural controls. The fact that the principal anion in fresh surface water worldwide almost always is bicarbonate attests to the overriding importance of this process. Exceptions are 
systems in which evaporite minerals are available for dissolution by ground water, or where human activities are major sources of sulfate or chloride inflow.

Quantitative estimates of the magnitude of the carbon cycle (Hem, 1985, p. 108), based mainly on a compilation by Lieth (1963), suggest that the total amount of carbon dioxide converted to organic matter during a year might be as great as 7 to 9 tons per acre in midlatitude deciduous forests and about a tenth that amount in native grassland. Cultivated farm crops presumably convert somewhat more carbon dioxide per unit area than might be expected in native grassland. Respiration of carbon dioxide by plant roots is at a rate equal to about 25 percent of the total carbon dioxide used by the plants, and the potential supply of carbon dioxide from vegetation for weathering rock is about 1.65 tons / acre/yr (tons per acre per year) on the average, over the whole land area of the Earth (Lieth, 1963). This is equivalent to about 1,060 tons $/ \mathrm{mi}^{2} / \mathrm{yr}$ (tons per square mile per year) of carbon dioxide. If all this carbon dioxide were dissolved in water, and the resulting carbonic acid reacted with silicate minerals to maintain near-neutral $\mathrm{pH}$, the annual bicarbonate yield could be as great as 1,200 tons $/ \mathrm{mi}^{2}$. Adrainage basin in a limestone terrane theoretically could produce bicarbonate at an even higher rate, as the reaction between dissolved carbon dioxide and solid carbonate minerals produces two bicarbonate ions per reacting dissolved carbon dioxide molecule.

As might be expected, the average rates of bicarbonate yield in drainage basins of the world are far below these numbers, as only a relatively small proportion of the carbon dioxide released in soil is likely to participate in rock weathering. A general indication of the role of dissolved carbon dioxide in weathering processes in streams can be obtained by calculating the average annual bicarbonate yield from average concentration of dissolved bicarbonate, average water discharge, and drainage-basin area. Examples of this type of calculation can be obtained from published literature. Peters (1984) studied 56 drainage basins in the conterminous United States and Hawaii to determine the relative importance of stream temperature, population density, atmospheric precipitation, and three rock types that represent extremes in the range of type and quality of chemical-weathering products expected in streamflow (limestone, 19 basins; sandstone, 12 basins; and crystalline rock, 25 basins) as controls of constituent yield. Of the limestone basins, the Kalamazoo River at Saugatuck, Mich., had the maximum annual bicarbonate yield, which was about 324 tons $/ \mathrm{mi}^{2}$; the population density for this drainage basin was 183 persons $/ \mathrm{mi}^{2}$, runoff was $14.1 \mathrm{in} / \mathrm{yr}$ (inches per year), and total precipitation was $34.0 \mathrm{in} / \mathrm{yr}$. In the other 18 limestone-dominated drainage basins, annual bicarbonate yields were substantially lower-15 had less than 225 tons $/ \mathrm{mi}^{2}$, and the average yield for the 19 basins was 114 tons $/ \mathrm{mi}^{2}$.

In general, bicarbonate yields reported by Peters (1984) were much smaller for basins in crystalline (noncarbonate) rock terranes than for those in limestone or sandstone terranes. Most of the drainage basins in crystalline rock had bicarbonate yields of less than 91 tons $/ \mathrm{mi}^{2}$; however, his data showed that bicarbonate yields could be substantial under some conditions. For example, a small igneous-rock drainage basin on the island of Hawaii, which had $180 \mathrm{in} / \mathrm{yr}$ of precipitation, $147.8 \mathrm{in} / \mathrm{yr}$ of runoff, and no human occupants, had an annual bicarbonate yield of 235 tons $/ \mathrm{mi}^{2}$. Other investigators also have reported relatively large bicarbonate yields for certain igneous terranes. For example, Dethier (1986) reported large bicarbonate yields from igneous drainage basins in the Pacific Northwest. Among studies referred to by Dethier is a study by Reynolds and Johnson (1972) for a basin having an active glacier in the northern Cascade Mountains of Washington. In this basin, the annual bicarbonate yield was near or slightly greater than 100 tons $/ \mathrm{mi}^{2}$.

The high bicarbonate yield in some of the Pacific Northwest streams could be the result of glacial action and mechanical erosion of rock material in basins having steep slopes that produce large amounts of relatively freshly fractured and fine-grained sediment that would participate readily in dissolution and alteration reactions. The rate at which such reactions would proceed is a function of net surface area of sediment available per unit volume of runoff and the length of time such material was exposed to water in the runoff process. Therefore, the efficiency of solvent erosion under conditions in the Pacific Northwest region could be considerably increased by such factors.

Apparent trends in dissolved carbon dioxide and bicarbonate and carbonate ions in water-quality records are difficult to evaluate. For more than a century the standard laboratory procedure for determining bicarbonate and carbonate concentrations has been the titration of a measured portion of the water sample with dilute sulfuric acid of known strength to end points at two selected $\mathrm{pH}$ values. The usual end point for the determination of carbonate is near $\mathrm{pH} 8.3$ and for bicarbonate near $\mathrm{pH} 4.5$. These end points represent hydrogen-ion activities at which the reactions shown in equations 3 and 2 , respectively, have been displaced to the left, and negligible amounts of carbonate or bicarbonate remain. Results of the titration commonly are expressed in terms of concentration of bicarbonate ions, or of both carbonate and bicarbonate. In a more strict sense, the titration data represent the acid-neutralizing capacity, or alkalinity, of the water, and assignment of the alkalinity solely to bicarbonate and carbonate is an arbitrary assumption. In this sense, the alkalinity is a property of the solution and not a simple constituent concentration. Although some other constituents can contribute to alkalinity, in streams not significantly affected by human activities, the assignment to bicarbonate and carbonate generally is correct.

The proper end point $\mathrm{pH}$ of the alkalinity determination depends to some extent on total dissolved-constituent concentrations and other factors. Modern titration and $\mathrm{pH}$ measuring equipment can correct for such effects, but in past years colored indicator dyes were used that did not allow for such corrections. For these and other reasons, apparent differences in alkalinity over time at a given sampling point are not always easily interpreted. A discussion of the chemistry of alkalinity determinations and references to pertinent literature are given in Hem (1985, p. 106-109).

\section{Sulfur}

The cycle of sulfur in weathering environments is affected by a more diverse set of reactions than for carbon. As is the case with carbon, most of the Earth's 
supply of sulfur is stored in the lithosphere (Hem, 1985, p. 113). Although some sulfur actually is taken up by vegetation, the growth and decay of plants does not tie up large proportions of the total sulfur supply. The element's geochemical behavior in the environment is summarized by Nriagu (1978). In igneous and metamorphic rocks, sulfur generally is present in the chemically reduced sulfide form $\left(\mathrm{S}^{2-}\right)$ and commonly is associated with metals. Polysulfide minerals in which the nominal valence of sulfur is between -2 and 0 also are common. An example is pyrite $\left(\mathrm{FeS}_{2}\right)$, which commonly occurs in association with coal seams and other sediments laid down under conditions where free oxygen was not available.

In weathering environments where oxygen is continuously available, negatively charged reduced forms of sulfur are converted to positively charged oxidized forms such as sulfate $\left(\mathrm{SO}_{4}^{2-}\right)$ in which the sulfur is in the fully oxidized $\left(\mathrm{S}^{6+}\right)$ state. Oxidation and reduction reactions of sulfur commonly are bacterially mediated. The calcium sulfate minerals gypsum $\left(\mathrm{CaSO}_{4} \cdot\right.$ $\left.2 \mathrm{H}_{2} \mathrm{O}\right)$ and anhydrite $\left(\mathrm{CaSO}_{4}\right)$ are common constituents of evaporite rocks, and, in semiarid regions where such rocks are near the land surface, stream water can contain substantial concentrations of sulfate. However, streams in humid regions generally carry relatively low concentrations of sulfate unless human activities have intervened. Weathering reactions that involve oxygen are important in the development of soils, especially in humid and subhumid climates. Commonly, oxygen is in relatively short supply at shallow depths in the soil zone, having been depleted by oxidation of organic matter. In wetland soil and submerged sediments, oxygen can be in very short supply and sulfur is in reduced form. However, as noted by Nyborg (1978) and Fitzgerald (1978), the sulfur in aerated soil is principally a component of organic compounds. In any event, any reduced species of sulfur may be converted to sulfate by oxidation when wetlands are drained or soils are converted from their natural state to agricultural cropland. All these processes can increase the availability of sulfate for transport by streams and cause increased sulfate loads in areas affected by development.

Geochemical studies of sulfate in streams have been approached in various ways. Berner (1971), for example, reviewed literature on sources of sulfate in the dissolved loads of streams, especially in areas where development effects are likely to be strong. He concluded that for North America as much as 60 percent of the average yield of sulfate carried to the ocean is related to human activities. He assigned a higher proportion of the total yield of sulfate in European streams to human sources, but for other continents he thought the effects of human activities to be relatively minor.

Some of the compounds produced in the sulfur cycle are gases. For example, combustion of fossil fuels, especially coal, produces sulfur dioxide gas $\left(\mathrm{SO}_{2}\right)$, which is further oxidized in the atmosphere to sulfur trioxide $\left(\mathrm{SO}_{3}\right)$ that combines with water to form sulfuric acid $\left(\mathrm{H}_{2} \mathrm{SO}_{4}\right)$. Reduction of sulfate in anaerobic soils and sediment produces hydrogen sulfide $\left(\mathrm{H}_{2} \mathrm{~S}\right)$ gas that also is reoxidized to sulfate in the presence of air. As a result, precipitation from the atmosphere is a major source of sulfate in streams in parts of North America and Europe. The estimate by Berner (1971) for human sources includes both sulfur dioxide and hydrogen sul- fide reaction pathways. A compilation by the U.S. Environmental Protection Agency (1984), summarizing research on acidic deposition, quoted estimates and measurements of "excess sulfate" yields in precipitation and in lakes and streams in the northeastern United States and southeastern Canada. Among measured data cited was a wet-plus-dry annual sulfate deposition rate for a site in the Adirondacks that ranged from 8.2 to about 16 tons $/ \mathrm{mi}^{2}$. Although a wide range of values was observed, these rates probably can be considered reasonable for much of the eastern half of the United States. The term "excess sulfate" is defined as the amount "over and above that supplied by sea salt cycling." Peters (1984) estimated that, on average, 60 percent of the sulfate yields observed for the stream basins he studied was assignable to atmospheric sources.

Another source of sulfur in the global hydrologic cycle that is not related to human activities is gaseous emission of hydrogen sulfide and sulfur dioxide from volcanoes and other geothermal sources. Although effects of these emissions can be locally intense, they generally are thought to be much less significant on a global scale than the human sources.

Sulfate concentration in streams, and changes over time, are discussed later in this article as one of the principal indices of human influences on stream-water composition. Also, it will be shown that differences and similarities in sulfate yields help in attaining a reasonable perspective on the importance of various hydrologic and geochemical characteristics of individual drainage systems.

\section{Chlorine}

Nearly all chlorine compounds are readily soluble in water. As a result, the major reservoir for this element in figure 17 is the ocean (Hem, 1985, p. 117). Chloride, as noted earlier, is naturally present at low levels in rain and snow, especially over and near the oceans. Widespread increases in chloride concentration in runoff in much of the United States can be attributed to the extensive use of sodium chloride and calcium chloride for deicing of streets and highways. Bubeck and others (1971) pointed out the importance of the increased use of deicing salt as a cause of increased chloride concentrations in streams of the northeastern United States and the role of this factor in the chloride trends in Lake Ontario. Increases in chloride concentration also can occur as a result of disposal of sewage, oil-field brines, and various kinds of industrial waste. Thus, chlorideconcentration trends also can be considered as an index of the alteration of stream-water chemistry by human development in the industrialized sections of the world. Although chlorine is an essential element for animal nutrition, it is of less importance for other life forms.

\section{Nitrogen}

About three-fourths of the Earth's nitrogen is present in the atmosphere as nitrogen gas. Because of its importance as an essential element in plant and animal nutrition, nitrogen, in its various oxidation states and its yield and concentration, is of considerable interest in studies of human influences on stream-water composition. Certain small and medium-sized streams in the intensively developed agricultural areas of the United 
States have been strongly affected by nitrogen-bearing runoff from fertilized soil. However, because of its use by aquatic vegetation, the amount and form of nitrogen tends to be seasonally variable, and, especially for larger streams, it is more difficult to use than sulfate or chloride as an index of human effects on water composition. Although nitrate concentrations are reported in some of the streams evaluated in this article, no attempt at interpretation of the nitrogen chemistry is made here; however, Turner and Rabalais (1991), using mainly U.S. Geological Survey (USGS) data, have evaluated nitrogen trends since 1905 in the Mississippi River at St. Francisville, La.

Trends in concentrations of nitrate plus nitrite, which represent the total of dissolved $\mathrm{N}^{5+}$ and $\mathrm{N}^{3+}$ species, are given in the State summaries in this volume (1990-91 National Water Summary). This determination commonly is used as an index of water contamination from human sources. The nitrite concentration generally is much smaller than the nitrate concentration in this combined determination because nitrite is readily converted to nitrate in oxygenated water.

\section{STREAM WATER-QUALITY TRENDS IN FOUR DRAINAGE BASINS}

\section{BACKGROUND}

The first comprehensive nationwide study of the chemical composition of surface water in the United States was begun by the USGS in 1905 . This program received cooperative support from State agencies in Illinois, Minnesota, Kansas, California, Oregon, and Washington and entailed collection of daily samples of water at or near gaging-station sites on principal streams for a period of about 1 year. The daily samples were combined into 10-day composites, which were filtered to remove suspended material and analyzed for principal dissolved constituents. As a result of decreased funding and related factors, this work was substantially curtailed after 1907; however, the studies did produce compilations of analyses for about 100 stream-sampling sites east of the 100th Meridian (Dole, 1909) and for about another 55 sites in the western part of the country (Stabler, 1911). Somewhat more detailed reports for each of the six cooperating States also were issued in the USGS Water-Supply Paper series, and Clarke (1924) used many of the analyses from the program in his summary of the composition of river and lake waters of the United States.

During most of the 1920's and 1930's very few detailed studies of stream water quality were made by the USGS. Beginning in the 1940's, a renewal of interest and activity gradually developed, and an annual series of Water-Supply Papers was begun in 1941 under the general title "Quality of Surface Water of the United States (year)." Growth of the surface-water-quality program can be seen in the growth of the number of pages in this annual report series from 74 pages in 1941 to 1,413 pages in $1950,2,160$ pages in 1960 , and 5,259 pages in 1970. Since 1971, these records have been published in the annual series "U.S. Geological Survey Water Resources Data for (State and water year)." Collectively, these publications form a major data base that can be used to compare early and recent observations at the same or nearby sampling sites.
Stream water quality commonly varies greatly in response to water discharge; thus, a single year of record is not adequate for reliable extrapolation, and, in any exacting comparison of historical data, this factor needs to be taken into account. From the beginning, it has been a general policy in the USGS surface-water-quality program to locate sampling sites at or near gaging stations where records of streamflow are obtained. Until about 1970 , many of the USGS water-quality records were based on daily sampling, generally with determinations of specific electrical conductance (an indicator of total cation and anion concentration) on each sample, but with extensive analyses performed only on composited daily samples. Composites usually contained 10 daily samples. However, where stream discharge and other factors caused substantial day-to-day changes in specific conductance, the composite period was shortened to prevent mixing of chemically dissimilar samples and to give a clearer indication of the stream-chemistry variability. Annual averages of these analyses, weighted by time or discharge, were used to summarize the records. After 1970 , complete analyses were done on single samples collected at various time intervals ranging from semimonthly to quarterly, and analyses of composite samples were no longer made. Analytical procedures changed from time to time as improved instrumentation and techniques became available. (See article "Assuring the Reliability of Water-Quality Data" in this volume.) In 1973, a comprehensive USGS program for stream water-quality studies, the National Stream Quality Accounting Network (NASQAN) was begun (Ficke and Hawkinson, 1975); it was designed to give a national water-quality data base that would be uniform in terms of sample-collection methods and analytical procedures and that could be examined by relatively refined statistical procedures.

It is instructive to identify and consider the importance of the various sources and controlling factors that operate in specific drainage basins in the United States to produce water having hydrochemical properties that are characteristic of each basin. To that end, four drainage basins having long-term hydrologic and water-chemistry records were chosen for study in this article-the Great Lakes-Upper St. Lawrence River at and near Ogdensburg, N.Y., and Cornwall, Ontario, Canada; the Columbia River at and upstream from The Dalles, Oreg.; the Allegheny River upstream from Pittsburgh, $\mathrm{Pa}$; and the lower Mississippi River at and upstream from New Orleans, La.

The historical records mentioned above are compared with more recent data for each of the drainage basins in order to detect and explain major differences between water composition observed early in the 20th century and that observed more recently. Sulfate, as mentioned earlier, is one of the principal indicators of the effects of human activities on stream-water composition, and it is the principal indicator used in the following discussions. The records selected for study display general trends in concentrations and yields that appear to be wellenough defined to outweigh the influences of different sampling frequencies and changing compositing practices. Trends that can be detected in the data collected in the past 20 years generally are too subtle to be evaluated closely by the methods used in this article and are more appropriately studied by the more sophisticated procedures used in the State summaries in this volume, which are described by Smith and others (1987) and in 


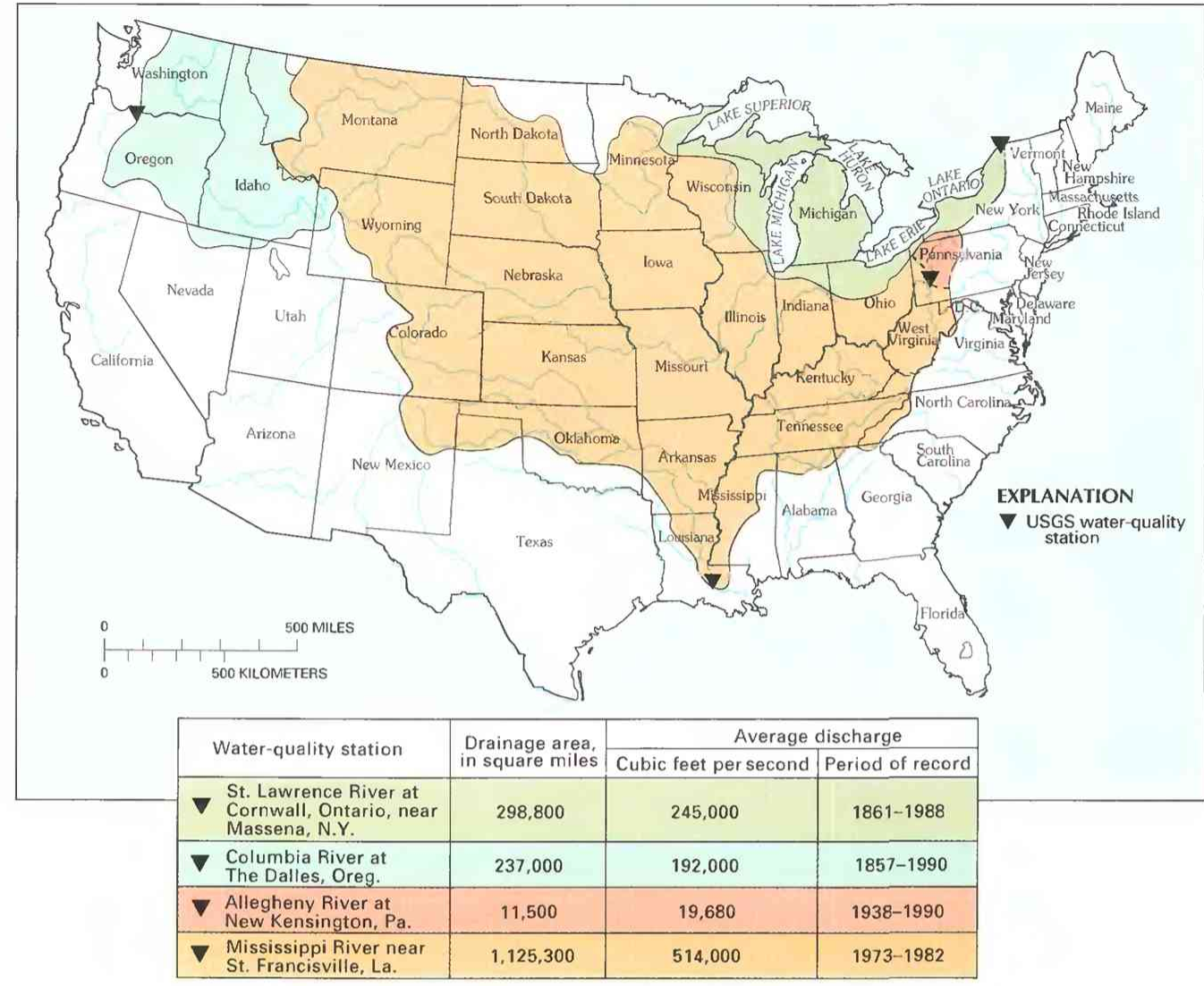

Figure 18. Drainage basins and related data of the four water-quality stations from which data were obtained for determining selected long-term water-quality trends. See figures $19,21,24$, and 26 for a detailed map of each area. [Source: Drainage area and discharge data from U.S. Geological Survey, 1989 (St. Lawrence River): 1991a (Columbia River); 1991c (Allegheny River); 1984 and 1991d (Mississippi River).]

two articles in this volume ("Statistical Analysis of Water-Quality Data"; "Stream Water Quality in the Conterminous United States-Status and Trends of Selected Indicators During the 1980's") and in the references cited therein.

Selected analytical and related data for the drainage basins are given in tables 3-9. The location of these basins is shown in figure 18 , and the study areas are shown in figures 19,21,24, and 26. Apparent trends with time are evaluated by various means described in the text. The annual minimum and average constituent concentrations and annual yields of sulfate in tons per unit area of drainage basin are the focus of the discussion.

Descriptions of sampling and analytical procedures for the early uSGs data suggest that, in general, the results for major constituents should be comparable in precision and accuracy with those given in later records. However, in some respects the procedures used in the early work may have introduced inaccuracy and bias. The daily samples were collected in 120-mL (milliliter) capacity soft-glass bottles, which limited the volume of water for analysis. The rather low sensitivity of some of the procedures available at that time probably affected the analytical accuracy for constituents present at small concentrations. Analyses reported by Stabler(1911) for stations in the West give only bicarbonate, chloride, and total dissolved-solids concentrations for the individual samples and weekly composites. Methods used to prepare composite samples for more complete analysis for these stations were inconsistent and introduced substantial bias, hence cationic compositions given for these waters probably are not geochemically useful.

Analyses given by Dole (1909) represent composites of equal volumes of daily samples. Generally there were three composites for each month. The complete analyses for these stations are much more reliable than those given by Stabler (1911) as indicators of the actual water composition, but some bias is introduced by compositing equal volumes for each day when stream discharge was variable.

Both Dole (1909) and Stabler (1911) reported difficulties in removing suspended sediment from the composite samples before the analyses of dissolved concentrations were started. It is evident from the reported concentrations that the various filtration and pretreatment methods used sometimes left particulate material in the samples and caused improbably high determined concentrations for iron, silica, and possibly some other solutes. Also, Dole (1909, p. 23) noted that the reported values for nitrate concentrations were possibly not representative of conditions in the stream at the time of sample collection. A storage time of 3 to 8 weeks generally intervened before analyses were performed, and some changes in nitrate concentrations might have occurred. A similar uncertainty applies to most reported nitrate concentrations in USGS sampling programs before about 1970 and is one reason long-term trends in this constituent are not evaluated in this article. 


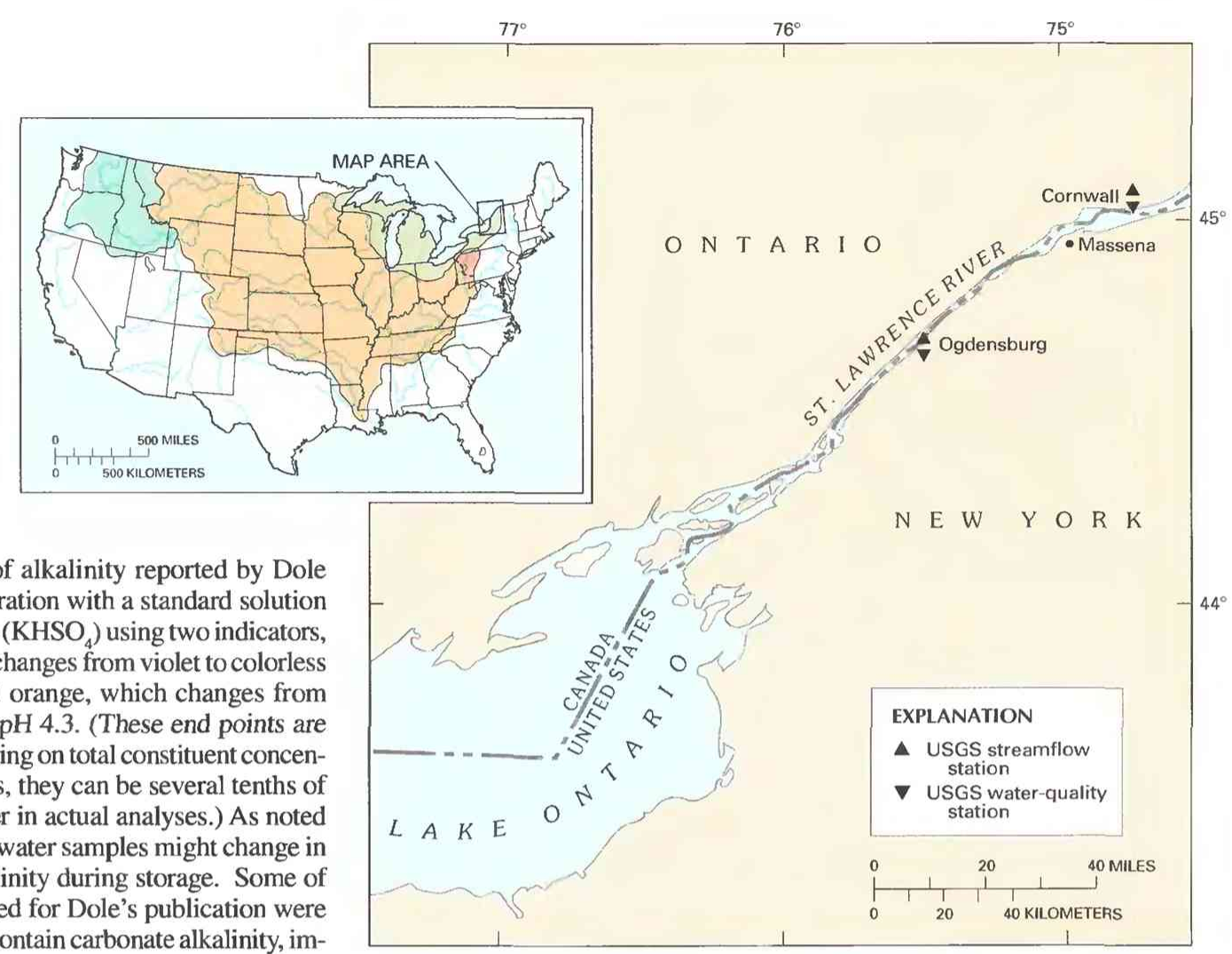

(1909) were made by titration with a standard solution of potassium acid sulfate $\left(\mathrm{KHSO}_{4}\right)$ using two indicators, phenolphthalein, which changes from violet to colorless near $\mathrm{pH} 8.2$ and methyl orange, which changes from yellow to pink at about $\mathrm{pH} 4.3$. (These end points are approximate, and depending on total constituent concentrations and other factors, they can be several tenths of a $\mathrm{pH}$ unit higher or lower in actual analyses.) As noted by Barnes (1964), some water samples might change in $\mathrm{pH}$ and possibly in alkalinity during storage. Some of the water sources sampled for Dole's publication were consistently reported to contain carbonate alkalinity, implying a $\mathrm{pH}$ above 8.2 at the time of analysis. Measurements of $\mathrm{pH}$ as such were not made on any of these samples, as the $\mathrm{pH}$ concept had not yet been developed. Whether any significance can be attached to the fact that almost all samples from the lower four Great Lakes and the St. Lawrence River analyzed for the Dole study contained detectable concentrations of carbonate is impossible to decide. More modern analyses show no consistent occurrence of carbonate alkalinity for these sources.

Water analyses traditionally have included a summarizing value termed "total dissolved solids." A determined value specified as "residue on evaporation" (ROE) is obtained by evaporating a measured volume of the water sample to dryness in a dish whose weight is known exactly, drying the residue at a specified temperature (in USGS practice at $180^{\circ} \mathrm{C}$ for 1 hour), and weighing the dish and its contents after cooling in a moisture-free atmosphere. The more modern analyses also include electrical conductance, which is related to the total concentration of dissolved cations and anions, and electronic determination of $\mathrm{pH}$, which is a measure of the acidity or hydrogen-ion $\left(\mathrm{H}^{+}\right)$activity. Although this ROE procedure appears to be simple and direct, it has complicating factors. The bicarbonate in solution in the original sample is converted to carbonate by drying, with loss of an equivalent amount of carbon dioxide gas. However, some types of water, such as those having high concentrations of dissolved calcium and sulfate, can deposit residues that contain water incorporated in crystalline minerals such as gypsum $\left(\mathrm{CaSO}_{4} \cdot 2 \mathrm{H}_{2} \mathrm{O}\right)$. To avoid this problem, a calculated total dissolved solids (SUM) commonly is reported for water containing more than about $1,000 \mathrm{mg} / \mathrm{L}$ total constituent concentration. The SUM calculation is made by adding reported concentrations for all the major constituents, with a correction factor converting dissolved bicarbonate to an equivalent car-

Figure 19. Sampling stations on the St. Lawrence River at Cornwall, Ontario, Canada, and Ogdensburg, N.Y., from which data were obtained for determining selected long-term water-quality trends.

bonate content of the dried residue. In the State summaries in this volume, trends in dissolved-solid concentrations are based on ROE analyses.

\section{GREAT LAKES -UPPER ST. LAWRENCE RIVER}

The St. Lawrence River, at the outlet of Lake Ontario, represents the drainage from the Great Lakes basin and has a relatively constant chemical composition, owing to the large storage capacity of the lakes and their efficiency as mixing basins for inflow. The water surface of the Great Lakes makes up a substantial fraction of the basin area. The basin also has a relatively constant water discharge. These characteristics make it a good site for study of water-quality trends. Data from two water-quality sampling and streamflow-gaging stations - Cornwall, Ontario, Canada, and Ogdensburg, N.Y. (40 miles upstream from Cornwall)-are used to show constituent change over time. Although the two stations are 40 miles apart (fig. 19) and there is a small amount of tributary inflow between them, the chemical composition of the water at the sites does not differ significantly and thus can be used for comparison of data over time. At Cornwall, the drainage area of the St. Lawrence River is $298,800 \mathrm{mi}^{2}$ and the long-term average discharge is $245,000 \mathrm{ft}^{3} / \mathrm{s}$ (cubic feet per second) (U.S. Geological Survey, 1989) (fig. 18).

Data from these stations are summarized briefly in table 3, where each of the columns represents data for a particular year progressing from $1906-7$ to 1990 . The 
Table 3. Chemical composition of water and related data for the St. Lawrence River, representing outflow from Lake Ontario, selected years 1906-90

[Concentration values are in milligrams per liter unless otherwise noted. Data from the Ogdensburg, N.Y., and Cornwall, Ontario, Canada, stations are considered equivalent. Sources: Column 1, Dole (1909); columns 2-4, Leverin (1942); column 5, U.S. Geological Survey (1960); column 6, U.S. Geological Survey (1974); columns 7, 8, Hem and others (1990); column 9, U.S. Geological Survey district office (written commun., 1991). -.data not available or not retrieved]

\begin{tabular}{|c|c|c|c|c|c|c|c|c|c|}
\hline \multirow{3}{*}{$\begin{array}{l}\text { Constituent, property, } \\
\text { and related data }\end{array}$} & \multirow{2}{*}{\begin{tabular}{|c|}
$\begin{array}{c}\text { Ogdensburg, } \\
\text { N.Y. }\end{array}$ \\
${ }^{1} 1906-7$ \\
\end{tabular}} & \multicolumn{3}{|c|}{$\begin{array}{c}\text { Cornwall, } \\
\text { Ontario, Canada }\end{array}$} & \multicolumn{2}{|c|}{$\begin{array}{l}\text { Ogdensburg, } \\
\text { N.Y. }\end{array}$} & \multicolumn{3}{|c|}{$\begin{array}{l}\text { Cornwall, } \\
\text { Ontario, Canada }\end{array}$} \\
\hline & & ${ }^{2} 1935$ & ${ }^{2} 1937$ & ${ }^{2} 1940$ & ${ }^{3} 1956$ & ${ }^{4} 1969$ & ${ }^{2} 1977$ & ${ }^{2} 1980$ & ${ }^{5} 1990$ \\
\hline & 1 & 2 & 3 & 4 & 5 & 6 & 7 & 8 & 9 \\
\hline Silica $\left(\mathrm{SiO}_{2}\right)$ & 6.6 & 6.9 & 1.0 & 4.1 & 3.5 & 0.6 & 0.2 & 0.5 & $-\cdots$ \\
\hline Calcium (Ca) & 31 & 33 & 36 & 36 & 36 & 39 & 38 & 36 & $\ldots$ \\
\hline Magnesium (Mg) & 7.2 & 7.9 & 9.0 & 8.5 & 8.2 & 7.3 & 8.0 & 7.8 & $\cdots$ \\
\hline Sodium (Na) & \multirow{2}{*}{${ }^{6} 6.3$} & \multirow{2}{*}{${ }^{6} 7.3$} & \multirow{2}{*}{${ }^{6} 10$} & \multirow{2}{*}{${ }^{6} 7.5$} & 9.7 & 12 & 13 & 13 & $\cdots$ \\
\hline Potassium (K) & & & & & 1.5 & 1.3 & 1.6 & 1.4 & $\cdots$ \\
\hline $\begin{array}{l}\text { Alkalinity as bicarbonate } \\
\left(\mathrm{HCO}_{3}\right) \text { (property) }\end{array}$ & 122 & 110 & 113 & 97 & 112 & 110 & 110 & 99 & $\cdots$ \\
\hline Sulfate $\left(\mathrm{SO}_{4}\right)$ & 12 & 19 & 22 & 21 & 25 & 28 & 27 & 26 & 27 \\
\hline Chloride (Cl) & 7.7 & 15 & 16 & 16 & 21 & 26 & 27 & 26 & $\ldots$ \\
\hline Fluoride (F) & $\cdots$ & $\cdots$ & $\cdots$ & $\cdots$ & .1 & .1 & .1 & .2 & $\cdots$ \\
\hline Nitrate $\left(\mathrm{NO}_{3}\right)$ & .3 & .6 & .4 & 1.0 & 1.0 & 3 & .53 & .49 & $-\cdot$ \\
\hline Dissolved solids & 134 & 156 & 160 & 158 & 179 & 169 & ${ }^{\urcorner} 169$ & ${ }^{8} 160$ & $\cdots$ \\
\hline $\begin{array}{l}\text { Specific conductance, in micro- } \\
\text { siemens at } 25^{\circ} \mathrm{C} \text { (property) }\end{array}$ & $\cdots$ & -. & $\cdots$ & $\cdots$ & 299 & 314 & 370 & 270 & 300 \\
\hline pH units (property) & $\cdots$ & 8.0 & 7.9 & 8.0 & $6.8-7.9$ & $7.3-8.0$ & 7.8 & 7.1 & $\ldots$ \\
\hline $\begin{array}{l}\text { Drainage area, in } \\
\text { square miles }\end{array}$ & 295,200 & 298,800 & 298,800 & 298,800 & 295,200 & 295,200 & 298,800 & 298,800 & 298,800 \\
\hline $\begin{array}{l}\text { Average discharge, in cubic } \\
\text { feet per second }\end{array}$ & 242,300 & 192,000 & 204,000 & 226,000 & 257,000 & 270,000 & 250,000 & 296,000 & 264,800 \\
\hline
\end{tabular}

1 Average of 11 monthly samples, September 1906-January 1907, March-August 1907.

2 Single sample collected on Aug. 30, 1935 (col. 2), Dec. 20, 1937 (col. 3), Aug. 22, 1940 (col. 4), June 27, 1977 (col. 7), and Sept. 29, 1980 (col. 8).

3 Average of 10-day composite samples collected daily during water year 1956

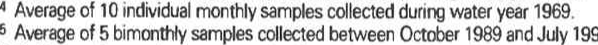

${ }^{6}$ Sodium and potassium not determined separately; total is equivalent amount of sodium.

7 Maximum total dissolved solids for period $1977-80$

8 Minimum total dissolved solids for period $1977-80$.

data show that major dissolved-ion concentrations in the river were nearly constant during the period $1968-80$ and that most of the change occurred between 1907 and 1955. Data for some major ions for samples from Lake Ontario that were presented by Weiler and Chawla (1969) indicate that relatively continuous increases occurred until the 1960's. An illustration in Hem and others (1990) based on a graph from Dobson (1967) suggests that sulfate concentration in Lake Ontario steadily increased from 12 to $14 \mathrm{mg} / \mathrm{L}$ in 1906 to 28 to $30 \mathrm{mg} / \mathrm{L}$ in the 1970's. However, during the 1980's, the sulfate concentration in the lake as represented by the St. Lawrence River at Cornwall did not show any further upward trend, and it seems likely that the sulfate concentration had stabilized. NASQAN samples taken at 1or 2-month intervals during water years 1981-85 had sulfate concentrations of $28 \mathrm{mg} / \mathrm{L}$ or more on $11 \mathrm{occa}-$ sions. During water years $1986-90$ no sulfate concentrations greater than $27 \mathrm{mg} / \mathrm{L}$ were observed at Cornwall. Possible factors explaining these observations are discussed in the section "Comparison of Results."

Behavior of chloride concentration during the period of record was somewhat similar to that of sulfate-about a threefold increase compared to the doubling of sulfate. Weiler (1981) noted that calcium and sodium concentrations in Lake Ontario increased during the $1906-80$ period by about 8 and $6 \mathrm{mg} / \mathrm{L}$, respectively. Although Weiler did not report a significant trend for bicarbonate, he did note a seasonal variation that he attributed to photosynthesis by aquatic biota. The average alkalinity reported by Dole (1909) for 11 monthly samples was $122 \mathrm{mg} / \mathrm{L}$ as bicarbonate (table 3 , col. 1). In their discussion of hydrogeochemistry of
North American surface waters, Hem and others (1990) noted that the maximum and minimum concentrations of bicarbonate observed in the river at Cornwall during water years $1977-80$ were 110 and $99 \mathrm{mg} / \mathrm{L}$, respectively (table 3 , cols. 7,8 ). These data indicate that a long-term decrease in bicarbonate of 10 to $20 \mathrm{mg} / \mathrm{L}$ is a reasonable estimate.

Table 4 summarizes the change in major ion concentrations in the outflow from Lake Ontario between 1907 and 1977 in terms of gains and losses in milliequivalents per liter (meq/L). Milliequivalent units are calculated from concentrations in milligrams per liter by multiplying the latter by a conversion factor (Hem, 1985 , p. 56) that takes into account the atomic or ionic weight and electrical charge of each constituent. Because the totals of milliequivalent concentrations of anions must equal the total for cations, analytical data expressed in this form give a clearer picture of the relative magnitudes and chemical factors involved in gains and losses of individual dissolved constituents than would the simple gravimetric state of milligrams per liter.

Column 1 of table 4 gives average values in milliequivalents per liter for calcium, magnesium, sodium plus potassium, bicarbonate, sulfate, and chloride for the St. Lawrence River at Ogdensburg for 1906-7, and column 2 gives values for constituents in the sample collected at Cornwall on June 27, 1977. From these data, most of the change in the cations is in calcium and sodium, and, for the anions, increases in sulfate and chloride are partly balanced by a loss of bicarbonate.

Dobson (1967) and Weiler (1981) attribute the historical changes in water composition of the Great Lakes to human activities, which have increased as the 
Table 4. Change in major cation and anion concentrations in the St. Lawrence River outflow from Lake Ontario, between 1906-7 and 1977

IConcentration values are in milliequivalents per liter. Sources: Column 1. Dole (1909, p. 98); column 2, Hem and others (1990); column 3 calculated from columns 1 and 2 l

\begin{tabular}{|c|c|c|c|}
\hline \multirow{3}{*}{$\begin{array}{l}\text { Constituent } \\
\text { or property }\end{array}$} & $\begin{array}{c}\text { Ogdensburg. } \\
\text { N.Y. } \\
\end{array}$ & $\begin{array}{c}\text { Cornwall, } \\
\text { Ontario, } \\
\text { Canada }\end{array}$ & \multirow{2}{*}{$\begin{array}{l}\text { Change in } \\
\text { concentration }\end{array}$} \\
\hline & '1906 & ${ }^{2} 1977$ & \\
\hline & 1 & 2 & 3 \\
\hline \multicolumn{4}{|l|}{ Cations: } \\
\hline Calcium (Ca) & 1.547 & 1.896 & +0.349 \\
\hline Magnesium (Mg) & .592 & .658 & +.066 \\
\hline $\begin{array}{l}\text { Sodium (Na) and } \\
\text { potassium (K) as } \mathrm{Na}\end{array}$ & .274 & .607 & +.333 \\
\hline Total & 2.413 & 3.161 & +.748 \\
\hline \multicolumn{4}{|l|}{ Anions: } \\
\hline $\begin{array}{l}\text { Alkalinity, as bicarbonate } \\
\left(\mathrm{HCO}_{3}\right) \text { (property) }\end{array}$ & 1.998 & 1.803 & -.195 \\
\hline Sulfate $\left(\mathrm{SO}_{4}\right)$ & .250 & .562 & +.312 \\
\hline Chloride (CI) & .217 & .762 & +.545 \\
\hline Total & 2.465 & 3.127 & +.662 \\
\hline
\end{tabular}

' Average of 11 monthly samples, September 1906-January 1907, March-August 1907 2 Single sample collected on June 27, 1977.

population of the drainage basins of the lower four lakes has increased since the beginning of the 20th century. Industrial waste and incompletely treated sewage are thought to be major sources of sulfate and chloride. Other nonpoint sources are agricultural fertilizers and fossil-fuel combustion and urban runoff that add sulfate and sodium and calcium chlorides used for deicing highways. The decrease in alkalinity of the water leaving Lake Ontario can possibly be explained as a direct consequence of the low $\mathrm{pH}$ of rain that falls on all the lakes. However, because the loss of bicarbonate alkalinity is only about two-thirds as great as the gain in sulfate, the observed changes cannot be simply assigned to sulfuric acid in this rainfall. It seems more likely that some of the acidity in the rain that falls over the tributary drainage is neutralized by reaction with sedimentaryrock minerals, as calcium and sodium show increases.

During the 1960's there was much concern about the eutrophication of Lake Erie. The limiting nutrient for aqueous microbiota in the Great Lakes was perceived to be phosphorus (Weiler, 1981), and household synthetic detergents containing sodium phosphate were thought to be an important source. Consequently, a concerted effort was made to decrease the sale of detergents containing phosphate and to improve sewagetreatment processes. By the 1980's, some declines in phosphate concentration had occurred in Lake Ontario (Weiler, 1981).

An accompanying effect of eutrophication that is more readily observable in table 3 is a decrease in silica concentration in Lake Ontario. Some decline in dissolved silica apparently has occurred in all of the lakes except Lake Superior. This decline is brought about by the growth of diatoms, a species of aquatic microorganisms in the upper layers of lake water that is widespread in all types of water impoundments where the water is clear and exposed to the sun. The silica is used by these microorganisms to form their skeletons and is later precipitated and becomes part of the bed sediment.

Silica determinations on the 1906-7 St. Lawrence samples (table 3, col. 1) might have been affected by inadequate filtration, and possibly some silica was dissolved from the glass sample bottles during storage be- fore analysis. Thus, the average silica concentration of $6.6 \mathrm{mg} / \mathrm{L}$ might be too high. However, a rather welldefined downward trend is observable in more recent silica-concentration records for the St. Lawrence at Ogdensburg and Cornwall that has greater experimental certainty. Determinations of dissolved silica on individual samples collected during water year 1956 ranged from 1.1 to $6.8 \mathrm{mg} / \mathrm{L}$ (U.S. Geological Survey, 1960). A record of once-monthly samples from water year 1969 (U.S. Geological Survey, 1974) shows silica concentration that ranged from a low of 0.0 (below the minimum reporting limit) to a maximum of $1.9 \mathrm{mg} / \mathrm{L}$. Samples taken during water years $1977-80$ show concentrations of 0.2 and $0.5 \mathrm{mg} / \mathrm{L}$ (table 3 , cols. 7, 8).

The Lake Superior drainage basin is underlain predominantly by metamorphic and igneous rocks, whereas most of the Great Lakes drainage area eastward to the outlet of Lake Ontario is underlain by carbonaterich sediment. It would be expected, therefore, that the water of Lake Superior would have different chemical characteristics than those of the other Great Lakes because it has a different set of geochemical controls. Also, the major ion composition of water in Lake Superior has not changed significantly during the period of record.

Because carbonate minerals are readily available in all the lake drainage basins except that of Lake Superior, the effect of acid rain and human-introduced contaminants is reflected in the increases in sulfate, chloride, calcium, and sodium concentrations in the other lakes and the outflow into the St. Lawrence River. The system is dynamic, and the outflow concentrations of these ions also are influenced by the rate of water discharge. Thus, a decrease in concentration, for example, as indicated in table 3 (cols. 7, 8) for bicarbonate between the June 1977 and September 1980 samples, could be a dilution effect because the discharge on the 1980 date was about 18 percent higher than that on the earlier sampling date. The apparent leveling off of chloride and sulfate concentrations in the 1980 's decade might be attributable to above-average rainfall and runoff during some of that period.

Additional insight into changes in dissolved material flowing from the lakes over time can be obtained by calculating average annual yields of major constituents observed in the Great Lakes-St. Lawrence basin. Thus, annual yields of the five constituents in the St. Lawrence that have been shown to be affected most strongly by human activities in the Great Lakes basins are given in table 5 .

Table 5. Estimated annual yield of constituents, in tons per square mile, St. Lawrence River outflow from Lake Ontario, selected years $1906-90$

[Calculated from data in table 3 using equation: tons per square mile $=$ [annual average constituent concentration (milligrams per liter) $x$ annual average stream discharge (cubic feet per second) $\times$ conversion factor $(0.9844) \div$ drainage area charge (cubic feet per second) $\times$ conversion factor $(0.9844) \div$ drainage area
(square miles).] Column numbers are those used in table $3 . \cdots$, data not avaitable for calculation]

\begin{tabular}{l|c|c|c|c|c|c|c}
\hline \multirow{2}{*}{$\begin{array}{c}\text { Constituent } \\
\text { or property }\end{array}$} & $\begin{array}{c}\text { Ogdensburg. } \\
\text { N.Y. }\end{array}$ & $\begin{array}{c}\text { Cornwall, } \\
\text { Ontario, } \\
\text { Canada }\end{array}$ & \multicolumn{2}{|c|}{$\begin{array}{c}\text { Ogdensburg, } \\
\text { N.Y. }\end{array}$} & \multicolumn{3}{|c}{$\begin{array}{c}\text { Comwall, Ontario, } \\
\text { Canada }\end{array}$} \\
\cline { 2 - 9 } & $1906-7$ & 1937 & 1956 & 1969 & 1977 & 1980 & 1990 \\
\cline { 2 - 9 } & 1 & 3 & 5 & 6 & 7 & 8 & 9 \\
\hline Calcium (Ca) & 25.0 & 24.2 & 30.9 & 35.1 & 31.3 & 35.1 & $\ldots$ \\
Sodium $(\mathrm{Na})$ & 15.1 & 16.7 & 8.3 & 10.8 & 10.7 & 12.7 & $\ldots-$ \\
Bicarbonate $\left(\mathrm{HCO}_{3}\right)$ & 98.6 & 75.9 & 96.0 & 99.0 & 90.6 & 96.5 & $\ldots$ \\
Sulfate $\left(\mathrm{SO}_{4}\right)$ & 9.7 & 14.8 & 21.4 & 25.2 & 22.2 & 25.4 & 23.6 \\
Chloride (Cl) & 6.2 & 10.8 & 18.0 & 23.4 & 22.2 & 25.4 & $\ldots$ \\
\hline
\end{tabular}

'Equivalent amount of sodium from combined sodium and potassium. 
Peters (1984) calculated the annual yields of major constituents for 56 drainage basins and evaluated the degree of correlation with four environmental factors-bedrock type, annual precipitation, population density, and average stream temperature. His study shows that in basins dominated by limestone bedrock, the average annual yield for calcium was 36.0 tons $/ \mathrm{mi}^{2}$ and for bicarbonate was 114.2 tons $/ \mathrm{mi}^{2}$. Calcium yields listed in table 5 for the $1956-80$ period are close to the averages reported by Peters and are significantly higher than yields for 1906-7. However, the bicarbonate yields indicated in table 5 are lower than the average reported by Peters and show no well-defined trend. Eight of the 56 streams studied by Peters are tributaries of the Great Lakes-St. Lawrence system, and the average of the annual sulfate yield reported for these eight streams was 28.5 tons $/ \mathrm{mi}^{2}$. This finding agrees approximately with the sulfate yield of 25.4 tons $/ \mathrm{mi}^{2}$ given in table 5 (col. 8 ) for Cornwall during water year 1980 , considering the rather wide range of annual sulfate yields in the eight basins that were selected by Peters.

A further indication of the influence of carbonate geochemistry on the Great Lakes is noted by Weiler (1981). He stated that calcite supersaturation occurs in the lower lakes at times and noted that the solubility limit for calcite as indicated by $\mathrm{pH}$, bicarbonate, and calcium concentrations commonly was exceeded in near-surface water in all of the lakes except Superior; satellite imagery at times provided evidence of calcium carbonate precipitating in the lake water.

Although the substantial effects of human activities on the composition of the Great Lakes water is well documented by the data cited here, the system as a whole has shown a substantial ability to maintain a relatively high degree of chemical stability. The effect of acidic precipitation, for example, has not significantly depleted the capacity of the system to neutralize acid as has occurred in smaller lakes and streams in noncarbonate terranes in other parts of the northeastern United States. Although further increases in sulfate concentration in the lower Great Lakes have been predicted by various investigators (Weiler, 1981), the concentrations of sulfate and chloride in the St. Lawrence River just downstream

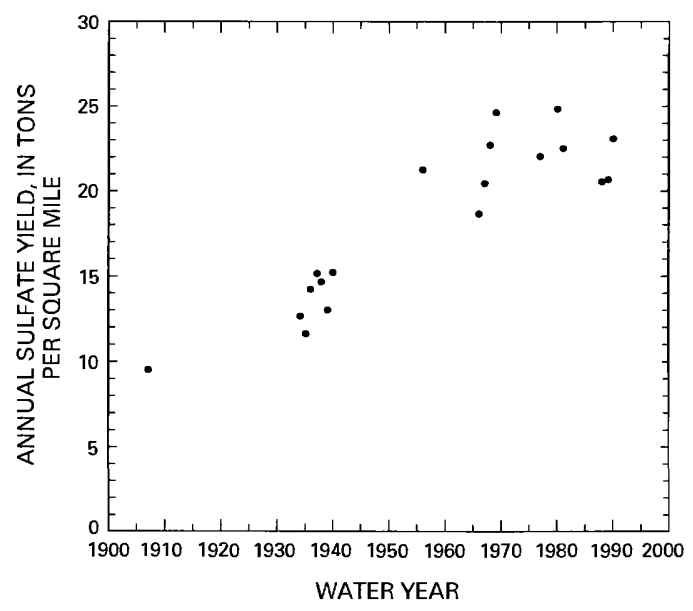

Figure 20. Annual sulfate yields of the St. Lawrence River at Cornwall, Ontario, Canada, 1906-90. (Source: Calculated from data in U.S. Geological Survey water-resources records and Leverin (1942).) from the outlet of Lake Ontario appear from NASQAN data to have remained the same or perhaps declined slightly since about 1980 .

The annual yields of sulfate during 1906-90 for the St. Lawrence-Great Lakes basin (fig. 20) are influenced considerably by differences in water discharge from year to year. The maximum values of about 25 tons $/ \mathrm{mi}^{2}$ in 1969 and 1980 and 23 tons $/ \mathrm{mi}^{2}$ in 1990 represent discharges substantially above the long-term average. The minimum yield for 1960-70, 18.8 tons $/ \mathrm{mi}^{2}$, occurred in 1966 , a year that had belownormal discharge. However, the yield more than doubles between 1906 and 1956 and has an upward trend through about 1970 .

\section{COLUMBIA RIVER UPSTREAM FROM THE DALLES, OREGoN}

Another major river drainage system shared by the United States and Canada is that of the Columbia River. The total drainage area of the Columbia at its mouth is $258,200 \mathrm{mi}^{2}$, and its long-term average discharge is $281,200 \mathrm{ft}^{3} / \mathrm{s}$ (Leifeste, 1974). Six stationsfour on the Columbia and two on the Snake River, a major tributary to the Columbia - are used in this discussion to show constituent changes over time. On the Columbia River, data from stations at Northport, Wash., and Cascade Locks, The Dalles, and Rufus, Oreg., are used; the data from the three Oregon stations are considered equivalent. On the Snake River, the data from Clarkston and Ice Harbor in Washington are considered equivalent. The major downstream station used in this discussion is The Dalles, which is about 80 miles upstream from the city of Portland and has a continuous water-quality record from 1950 to 1982 . However, in some years only specific-conductance data were obtained. Additionally, about 40 miles downstream from The Dalles about 2 years of intensive sampling was done at Cascade Locks, near and upstream from the present site of Bonneville Dam, during 1910-12 (Van Winkle, 1914). The long-term average discharge at The Dalles is $192,000 \mathrm{ft}^{3} / \mathrm{s}$ (U.S. Geological Survey 1991a), and the drainage area upstream from the sampling station is $237,000 \mathrm{mi}^{2}$ (fig.18). Locations of these sampling stations and tributary basins are shown in figure 21 .

Although the drainage basin of the Columbia is very different in many respects from that of the St. Lawrence above Cornwall, the basins are similar in size, discharge, and total runoff. The area drained by the St. Lawrence above Cornwall is about 1.26 times greater than that of the Columbia above The Dalles, and the average discharge of the St. Lawrence River at Cornwall is about 1.27 times greater than that of the Columbia at The Dalles (fig. 18). Hence, the runoff per square mile in the two systems is nearly the same.

Within the United States, the station farthest upstream on the Columbia is at Northport, Wash., about 8 miles from the United States-Canada International Boundary (fig. 21). Water-quality records for this station cover most of the period 1952-90, although for some years the information obtained was minimal. In addition, Van Winkle (1914) includes complete analyses for major components in 10-day composites of daily samples collected from February 1, 1910, to January 31, 1911. The drainage area of the Columbia at Northport 

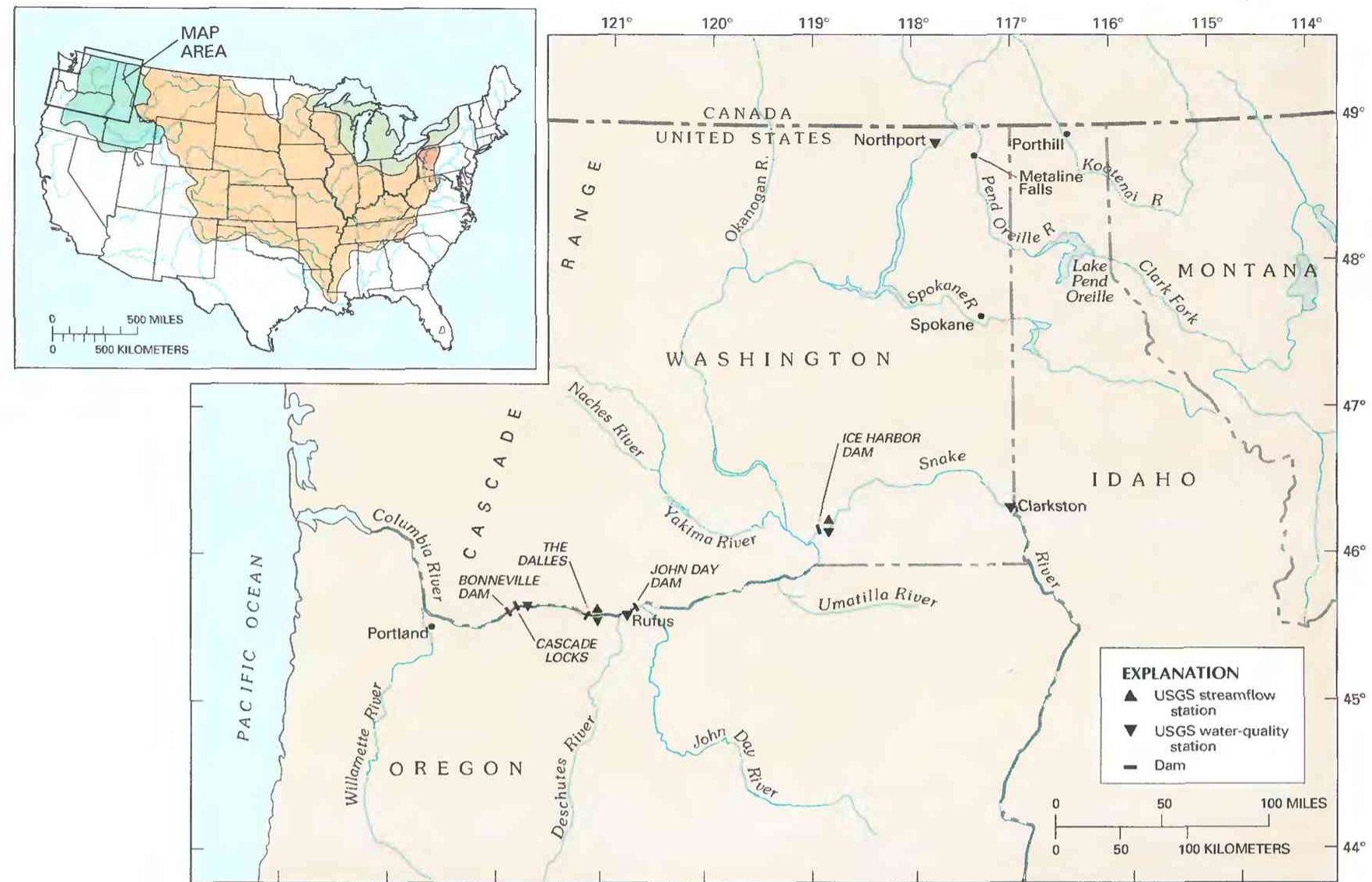

WASH I N G TO N

Figure 21. Sampling stations on the Columbia and Snake Rivers, Washington and Oregon, from which data were obtained for determining selected long-term water-quality trends.

is $59,700 \mathrm{mi}^{2}$. However, not all of this area is in Canada, as the Pend Oreille and Kootenai rivers that drain more than $25,000 \mathrm{mi}^{2}$ of western Montana and northern Idaho join the Columbia a few miles north of the International Boundary. The average discharge of the Columbia at Northport for 54 years of record ending in 1991 is 99,870 $\mathrm{ft}^{3} / \mathrm{s}$ (U.S. Geological Survey, 1992).

The water contributed by the Snake River, the principal tributary in the reach between Northport and The Dalles, is about 54 percent of the gain in discharge of the Columbia at The Dalles. The remaining inflow is contributed by smaller tributaries such as the Okanogan, Spokane, Yakima, Umatilla, John Day, and Deschutes Rivers. Irrigation is extensive in most of the tributary basins, especially along the Snake River. Much of the area of the Columbia drainage basin south of the International Boundary, however, contributes very little direct surface runoff. In Idaho, for example, large areas are underlain by basalt and, although this terrane transmits ground water readily, the stream drainage patterns are poorly developed. Also, precipitation at lower elevations in most of eastern Washington and Oregon is too low to contribute much runoff because moisture in air masses from the west is removed by their passage over the mountains in western Washington and Oregon (U.S. Geological Survey, 1991b, p. 459-460, 551-552).

A general indication of the chemical characteristics of the stream water in the Columbia River system is shown in table 6. Data for Northport (table 6, cols. 1, 3, 6) for several years show that all constituents with the exception of silica are at similar concentrations, although the discharge in 1968, the year of lowest discharge, was about 78 percent of that in 1954 (U.S. Geological Survey, $1959,1973)$. Records for this station show that although the annual maximum discharge during the 1950's and 1960 's commonly was as much as 10 times as great as the annual minimum discharge, the maximum annual sulfate concentrations were only about twice as great as the annual minimum sulfate concentrations. These relations suggest that strong homogenizing forces are at work. Three such forces are (1) the mixing effect of a large volume of naturally stored surface water, such as in the Great Lakes, can dampen out fluctuations in concentration related to dilution by runoff or snowmelt, (2) regulation of flow by storage reservoirs impounded by dams can contribute to decreases in the range between yearly maximum and minimum concentrations, as demonstrated by records for the Colorado River below Hoover Dam (Hem and others, 1990, p. 227), and (3) the chemical interaction between runoff and surficial material, especially where there is a large volume of streamflow of which a considerable part is contributed by ground water, can prevent extensive chemical variations. The third factor probably is important in the area of the Columbia basin upstream from Northport.

Changes in concentration between Northport and The Dalles (as determined at Rufus, Oreg., about 20 miles upstream from The Dalles) that occurred in water year 1954 are shown in columns 3 and 5 of table 6 . The greatest increases in concentration are in silica, sodium, and chloride. The increased concentrations observed at The Dalles (table 
Table 6. Chemical composition and constituent annual yield of water and related data for the Columbia River at and near Northport, Wash., and The Dalles, Oreg., and the Snake River near its mouth, selected years 1910-68

[Concentration values are in milligrams per liter unless otherwise noted; annual yields in tons per square mile. Data from the Cascade Locks, Rufus, and The Dalles, Oreg., stations on the Columbia River are considered equivalent as are data from lce Harbor and Clarkston, Wash., stations on the Snake River. Sources: Concentration values in columns 1, 2, Van Winkle (1914); columns 3-5, U.S. Geological Survey (1959); columns 6-8, U.S. Geological Survey (1973). Yields are calculated from concentration values and discharge data. ---, data not (1914); columns $3-5$, U.S.
available or not computed]

\begin{tabular}{|c|c|c|c|c|c|c|c|c|c|c|c|c|c|c|c|c|}
\hline \multirow{5}{*}{$\begin{array}{l}\text { Constituent, } \\
\text { property, } \\
\text { and related data }\end{array}$} & \multicolumn{6}{|c|}{ Columbia River } & \multirow{2}{*}{\multicolumn{2}{|c|}{$\begin{array}{c}\text { Snake River } \\
\begin{array}{c}\text { Clarkston, } \\
\text { Wash. }\end{array}\end{array}$}} & \multicolumn{4}{|c|}{ Columbia River } & \multirow{2}{*}{\multicolumn{2}{|c|}{$\begin{array}{c}\text { Snake River } \\
\begin{array}{l}\text { Ica Harbor, } \\
\text { Wash. }\end{array}\end{array}$}} & \multirow{2}{*}{\multicolumn{2}{|c|}{$\begin{array}{c}\text { Columbia River } \\
\text { The Dalles, } \\
\text { Oreg. }\end{array}$}} \\
\hline & \multirow{2}{*}{\multicolumn{2}{|c|}{$\begin{array}{c}\begin{array}{c}\text { Northport, } \\
\text { Wash. }\end{array} \\
1910-11\end{array}$}} & \multicolumn{2}{|c|}{$\begin{array}{c}\text { Cascade Locks, } \\
\text { Oreg. }\end{array}$} & \multicolumn{2}{|c|}{$\begin{array}{l}\text { Northport, } \\
\text { Wash. }\end{array}$} & & & \multicolumn{2}{|c|}{$\begin{array}{l}\text { Rufus, } \\
\text { Oreg. }\end{array}$} & \multicolumn{2}{|c|}{$\begin{array}{l}\text { Northport, } \\
\text { Wash. }\end{array}$} & & & & \\
\hline & & & \multicolumn{2}{|c|}{1910} & \multicolumn{2}{|c|}{1954} & \multicolumn{2}{|c|}{1954} & \multicolumn{2}{|c|}{1954} & \multicolumn{2}{|c|}{1968} & \multicolumn{2}{|c|}{1968} & \multicolumn{2}{|c|}{1968} \\
\hline & $\begin{array}{l}\text { Concen- } \\
\text { tration }\end{array}$ & Yield & $\begin{array}{c}\text { Concen- } \\
\text { tration }\end{array}$ & Yield & $\begin{array}{l}\text { Concen- } \\
\text { tration }\end{array}$ & Yield & $\begin{array}{c}\text { Concen- } \\
\text { tration }\end{array}$ & Yield & $\begin{array}{l}\text { Concen- } \\
\text { tration }\end{array}$ & Yield & $\begin{array}{c}\text { Concen- } \\
\text { tration }\end{array}$ & Yield & $\begin{array}{l}\text { Concen- } \\
\text { tration }\end{array}$ & Yield & $\begin{array}{c}\text { Concen- } \\
\text { tration }\end{array}$ & Yield \\
\hline & \multicolumn{2}{|c|}{1} & \multicolumn{2}{|c|}{2} & \multicolumn{2}{|c|}{3} & \multicolumn{2}{|c|}{4} & \multicolumn{2}{|c|}{5} & \multicolumn{2}{|c|}{6} & \multicolumn{2}{|c|}{7} & \multicolumn{2}{|c|}{8} \\
\hline Silica $\left(\mathrm{SiO}_{2}\right)$ & 8.7 & 15.9 & 13 & 11.5 & 6.3 & 13.6 & 20 & 9.4 & 11 & 9.6 & 4.8 & 8.1 & 16 & 6.0 & 11 & 7.6 \\
\hline Calcium (Ca) & 18 & 32.9 & 16 & 14.2 & 21 & 45.1 & 22 & 10.3 & 19 & 16.5 & 22 & 37.0 & 21 & 7.9 & 20 & 13.8 \\
\hline Magnesium (Mg) & 4.7 & 8.6 & 4.2 & 3.7 & 5.0 & 10.8 & 7.9 & 3.7 & 4.9 & 4.3 & 4.4 & 7.4 & 7.6 & 2.8 & 5.1 & 3.5 \\
\hline Sodium (Na) & \multirow{2}{*}{$' 4.7$} & \multirow{2}{*}{${ }^{1} 8.6$} & \multirow{2}{*}{$' 7.1$} & \multirow{2}{*}{${ }^{\prime} 6.3$} & 1.6 & 3.4 & 18 & 8.4 & 6.3 & 5.5 & 1.7 & 2.9 & 19 & 7.1 & 6.3 & 4.3 \\
\hline Potassium (K) & & & & & 8 & 1.7 & 2.3 & 1.1 & 2.1 & 1.8 & .7 & 1.2 & 2.5 & .94 & 1.6 & 1.1 \\
\hline $\begin{array}{l}\text { Alkalinity, as bicarbonate } \\
\qquad\left(\mathrm{HCO}_{3}\right) \text { (property) }\end{array}$ & 73 & 134 & 67 & 59.3 & 75 & 161 & 103 & 48.2 & 78 & 67.7 & 74 & 124 & 106 & 39.6 & 78 & 53.8 \\
\hline Sulfate $\left(\mathrm{SO}_{4}\right)$ & 12 & 22.0 & 13 & 11.5 & 12 & 25.8 & 27 & 12.6 & 14 & 12.2 & 14 & 23.5 & 27 & 10.1 & 19 & 13.1 \\
\hline Chloride (CI) & 6 & 1.1 & 2.0 & 1.8 & .9 & 1.9 & 9.5 & 4.5 & 3.2 & 2.8 & .4 & .67 & 8.8 & 3.3 & 3.9 & 2.7 \\
\hline Fluoride (F) & $\cdots$ & $\cdots$ & $\cdots$ & $\cdots$ & $\cdots$ & $\ldots$ & $\cdots$ & ... & .2 & $\cdots$ & .2 & $\cdots$ & .4 & ... & $\cdots$ & $\ldots$ \\
\hline Nitrate $\left(\mathrm{NO}_{3}\right)$ & .23 & $\ldots$ & .43 & $\ldots$ & .7 & ... & 1.3 & -.. & 1.0 & ... & .5 & ... & 1.1 & -.. & $\ldots$ & -.. \\
\hline Dissolved solids & 84 & 154 & 89 & 78.7 & 85 & 183 & 159 & 74.4 & 103 & 89.5 & 88 & 148 & 160 & 59.8 & 102 & 70.3 \\
\hline $\begin{array}{l}\text { Specific conductance, in micro- } \\
\text { siemens at } 25^{\circ} \mathrm{C} \text { (property) }\end{array}$ & $\cdots$ & $\cdots$ & $\cdots$ & $\cdots$ & 147 & $\cdots$ & 247 & $\cdots$ & 167 & -.. & 149 & $\cdots$ & 252 & $\cdots$ & 167 & $\cdots$ \\
\hline $\begin{array}{l}\text { Drainage area, in } \\
\text { square miles }\end{array}$ & \multicolumn{2}{|c|}{59,700} & 237, & & & & & & & & & & & & & \\
\hline $\begin{array}{l}\text { Average discharge, in cubic } \\
\text { feet per second }\end{array}$ & ${ }^{2} 111$ & & 213 & & & & & & & & & & & & & \\
\hline $\begin{array}{l}\text { Dissolved solids load, in } \\
\text { million tons per year }\end{array}$ & 9 . & & 18 & & & & & & & & & & & & & \\
\hline
\end{tabular}

1 Sodium and potassium not determined separately, total is eqiuvalent amount of sodium

2 Average discharge was estimated by assuming that the ratio of the 1910 value to the long-term average discharge was the same for the river at Northport as it was at The Dalles.

6, col. 8) possibly are the result of the relatively large silica and sodium concentrations in the Snake River as determined at Clarkston, Wash. (table 6, col. 4), which is the farthest downstream station on the Snake River. Annual yields of the major constituents also are given in table 6 for each of the sampling stations; however, the yields at Northport in 1910-11 (table 6, col. 1) are based on estimated discharge inasmuch as no measured-discharge data are available for that year. The yields for the Cascade Locks station (table 6, col. 2) are much lower than those for the Northport station, which reflects the fact that much of the tributary drainage area between the stations is effectively noncontributing. Water-quality data for the Columbia at The Dalles after the early 1970's are sparse for most years.

Trend lines for the annual maximum and minimum sulfate concentrations observed at Northport rep-

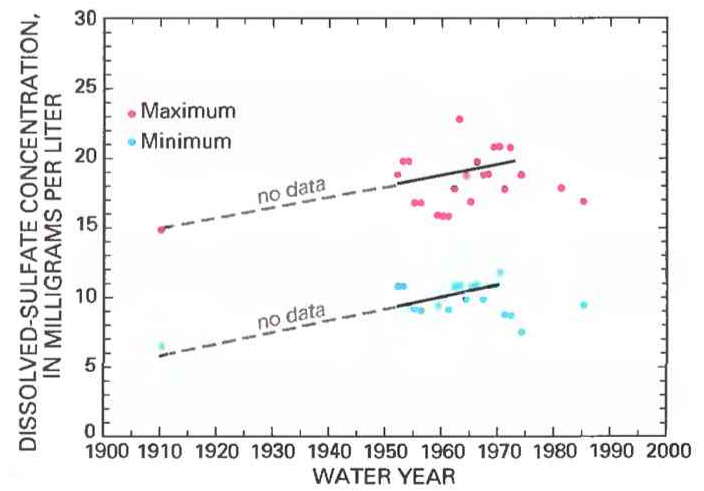

Figure 22. Annual maximum and minimum dissolvedsulfate concentrations of the Columbia River at Northport, Wash., 1910-85. (Source: U.S. Geological Survey records of water-quality data.) resent the optimum least-squares fit of all the values from 1910 to 1970 to a straight line (fig. 22). The significance of the apparent upward trend in sulfate concentration is uncertain because of the long gap in records between 1910 and 1952. If the trend lines are calculated for the $1952-70$ values only, ignoring the 1910 values, and then are extrapolated linearly to 1910 , they intersect the 1910 coordinate at $9.2 \mathrm{mg} / \mathrm{L}$ for the minimum sulfate concentration and $16 \mathrm{mg} / \mathrm{L}$ for the maximum. These values are close enough to the recorded 1910 values of 6.7 and 15 for the minimum and maximum sulfate concentrations to lend support for the reality of the trend. Although not shown here, the annual minimum and maximum sulfate concentrations for the Columbia River at The Dalles do not show well-defined trends, and a possible explanation is given in the section "Comparison of Results."

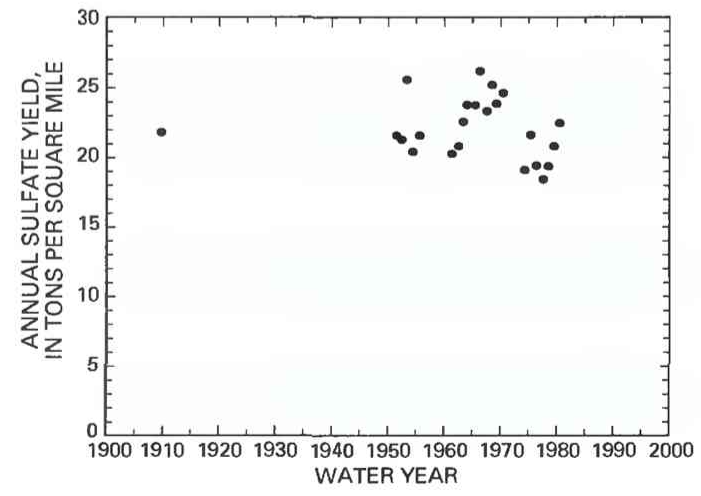

Figure 23. Annual sulfate yield of the Columbia River at Northport, Wash., 1910-81. (Source: Calculated from U.S. Geological Survey water-resources records.) 
The historical increases in sulfate concentration shown in figure 22 are much smaller in an absolute as well as in a relative sense than the increases observed in the St. Lawrence from 1906 to the 1970's. The average sulfate concentration in the St. Lawrence increased from 12 to $28 \mathrm{mg} / \mathrm{L}$ between 1906 and 1969 (table 3), an increase of more than 130 percent. For the Columbia at Northport, the increase in average sulfate concentration was from $12 \mathrm{mg} / \mathrm{L}$ in 1910 to $14 \mathrm{mg} / \mathrm{L}$ in 1968 (table 6), an increase of about 17 percent.

In contrast to the apparent upward trend for the annual minimum and maximum sulfate concentrations (fig.22), it is evident that the annual sulfate yields (fig. 23) for the drainage basin of the Columbia River at Northport do not show any clearly defined trend. However, the sulfate yields have fluctuated between about 18 and about 26 tons $/ \mathrm{mi}^{2}$ for the years of record up to 1981 , and this fluctuation could be interpreted as representing a rather poorly defined decreasing trend from 1960 to the 1980 's. At The Dalles, the sulfate yields are only about half as great, and possible explanations are given in the section "Comparison of Results."

\section{Allegheny River Near PItTSburgh, PENNSYLVANIA}

The Allegheny River drains an area of about $11,500 \mathrm{mi}^{2}$ in southwestern New York and western Pennsylvania, and the long-term average discharge is $19,680 \mathrm{ft}^{3} / \mathrm{s}$ (fig. 18). At Pittsburgh, the Allegheny joins the Monongahela River to form the Ohio River. Four stations (fig. 24) are used in this discussion to show constituent changes over time. In downstream order these are Kittanning, which is on the Allegheny about 40 miles upstream from Pittsburgh and about 12 miles upstream from the confluence of the Allegheny and the Kiskiminetas River; Vandergrift on the Kiskiminetas about 12 miles upstream from its confluence with the Allegheny, which is about 28 miles above the confluence of the Allegheny and the Monongahela; and
New Kensington and Sharpsburg, data from which are equivalent, downstream from the confluence of the Kiskiminetas with the Allegheny.

In the Allegheny drainage basin, the bedrock is sandstone, shale, and limestone and contains extensive deposits of bituminous coal (McCarren, 1967). Exploitation of petroleum and natural gas has produced some stream contamination through release of saline ground water associated with the petroleum. For about 70 miles upstream from Pittsburgh, the Allegheny receives drainage from many active and abandoned coal mines that has been affected by oxidation products of pyrite and related sulfide minerals that accompany the coal. This drainage is a solution of sulfuric acid and commonly carries high concentrations of iron and other cations. The Allegheny provides a part of the water for the city of Pittsburgh, and the deterioration of water quality in the river has been a matter of considerable concern for many years.

The station at Kittanning, Pa., has the only analytical data for the Allegheny River recorded during the early 1900's (Dole, 1909). As shown in table 7 (col. 1), the time-weighted average sulfate concentration for

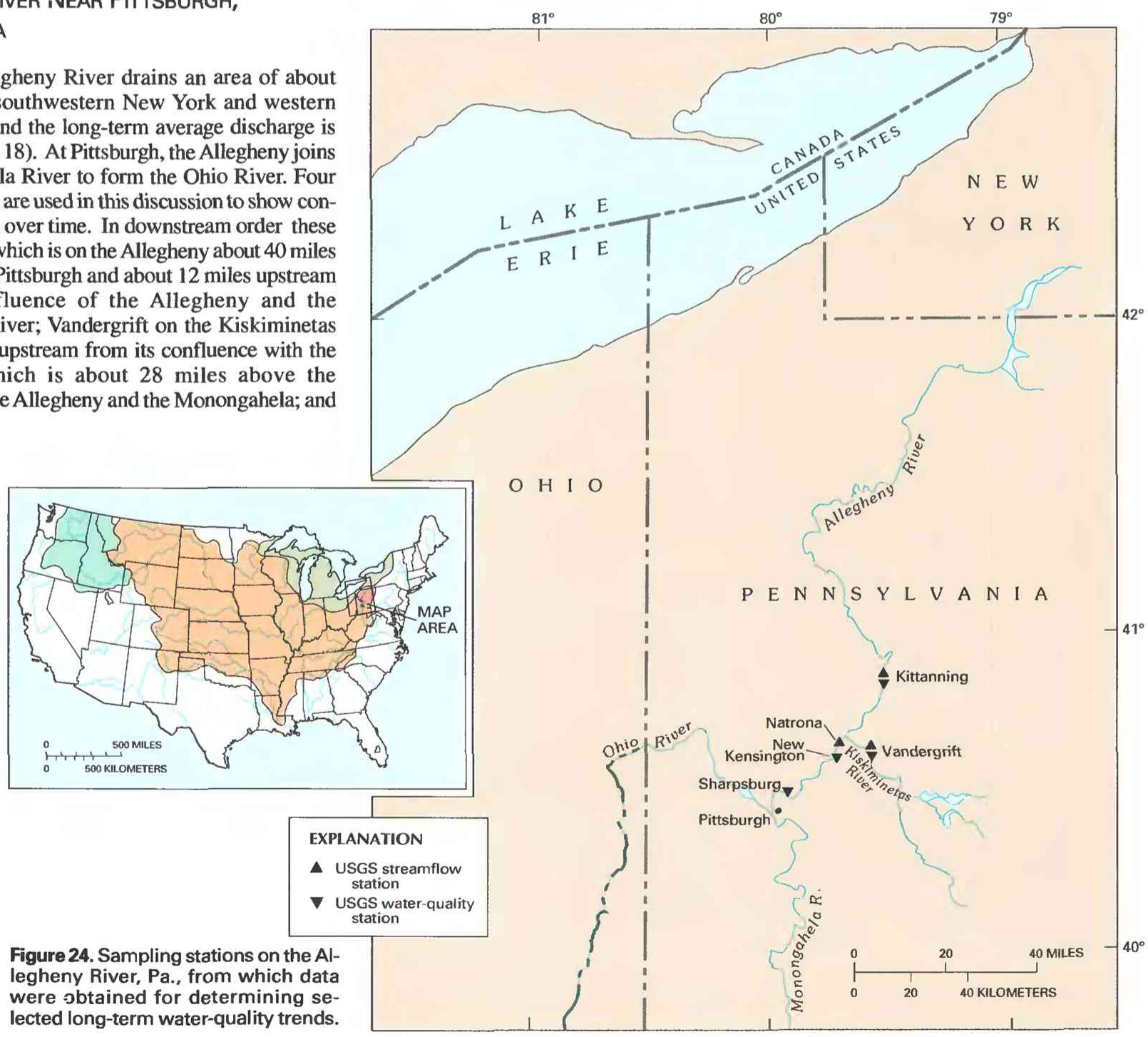

Figure 24. Sampling stations on the Allegheny River, $\mathrm{Pa}$., from which data were sbtained for determining selected long-term water-quality trends. 
1906-7 was $17 \mathrm{mg} / \mathrm{L}$. In contrast, McCarren (1967, a study of water-quality records of the Allegheny and its tributaries up to about 1965) reported that the average sulfate concentration for water year 1962 was $48 \mathrm{mg} / \mathrm{L}$. Although this is a substantial increase, even larger sulfate and hydrogen-ion contributions to the river are received farther downstream. Among other aspects of the water-quality problems in the lower part of the Allegheny basin, McCarren noted the large inflow of acid mine drainage carried by the Kiskiminetas River. He mentioned that a plan for improvement of the water quality in the lower Allegheny River was being implemented. In general, the flood-control and multipurpose reservoirs that had been constructed, or were planned for construction in the Allegheny basin, were to be operated in such a way as to increase water-discharge rates in the lower Allegheny at times of natural low flow. By providing dilution water for such times, the effect of acid mine drainage from streams such as the Kiskiminetas River would be eased. At the same time, efforts to clean up abandoned mines and waste-disposal sites, and decreasing contamination from other sources, would continue.

Some effects of flow-management and other contamination-abatement measures on water composition in the Kiskiminetas River are indicated by data in table 8. The composite sample for November 1120,1947 (table 8, col. 1) represents an average discharge about three-fifths as great as that for the 1976 sample (table 8, col. 2). The smaller sulfate concentration in the 1976 sample was mainly the result of dilution, as the daily sulfate loads were about the same. However, the $\mathrm{pH}$ values show a hundredfold decrease in acidity in the 1976 sample. This demonstrates the

Table 7. Chemical composition of water and related data for the Allegheny River at and downstream from Kittanning. Pa., selected years 1906-89

[Concentration values are in mil ligrams per liter unless otherwise noted. Data from the New Kensington and Sharpsburg stations are considered equivalent. Sources: Column 1, Dole (1909); column 2, U.S. Geological Surver (1953): column 3. U.S. Geological Survey (1976); column 4, U.S. Geological Survey (1991c). .-., data not available]

\begin{tabular}{|c|c|c|c|c|}
\hline \multirow{4}{*}{$\begin{array}{l}\text { Constituent, property, } \\
\text { and related data }\end{array}$} & \multicolumn{4}{|c|}{ Allegheny Fiver, Pa., at or near- } \\
\hline & \multirow{2}{*}{$\begin{array}{c}\text { Kittanning } \\
\text { '1906-7 } \\
\end{array}$} & \multirow{2}{*}{\begin{tabular}{|c|} 
Sharpsburg \\
${ }^{2} \uparrow 947$ \\
\end{tabular}} & \multicolumn{2}{|c|}{ New Kensington } \\
\hline & & & ${ }^{3} 1975$ & ${ }^{3} 1989$ \\
\hline & 1 & 2 & 3 & 4 \\
\hline Silica $\left(\mathrm{SiO}_{2}\right)$ & 7.9 & $\cdots$ & 4.1 & 3.5 \\
\hline Calcium (Ca) & 14 & $-\cdots$ & 33 & 38 \\
\hline Magnesium (Mg) & 3.0 & -- & 7.3 & 10 \\
\hline Sodium (Na) & ${ }^{4} 11$ & $\cdots$ & 14 & 23 \\
\hline Potassiur $\langle K\rangle$ & & $\cdots$ & 2.6 & 2.3 \\
\hline $\begin{array}{l}\text { Alkalinity, as bicarbonate } \\
\text { (HCO } \text { (property) }\end{array}$ & 38 & 0 & 24 & 40 \\
\hline Sulfate $\left(\mathrm{SO}_{4}\right)$ & 17 & $193-200$ & 110 & 110 \\
\hline Chloride (CI) & 14 & 46-49 & 14 & 24 \\
\hline Fluoride (F) & $\cdots$ & - - & .4 & 2 \\
\hline Nitrate $\left(\mathrm{NO}_{3}\right)$ & .7 & $4.1-5.4$ & 2.2 & 2.2 \\
\hline Dissolved solids & 87 & - - & 224 & 232 \\
\hline $\begin{array}{l}\text { Specific conductance, in micro- } \\
\text { siemens at } 25^{\circ} \mathrm{C} \text { (property) }\end{array}$ & & $609-625$ & 350 & $\cdots$ \\
\hline pH units (property) & -- & $4.0-4.2$ & 6.7 & 7.5 \\
\hline $\begin{array}{l}\text { Drainage area, in } \\
\text { square miles }\end{array}$ & 8.973 & 11,410 & 11,500 & 11,500 \\
\hline $\begin{array}{l}\text { Average discharge, in cubic } \\
\text { feet per second }\end{array}$ & - - & 3,700 & 3,740 & 3,580 \\
\hline
\end{tabular}

' Time-weighted average.
${ }^{2}$ Range of values for 4 cross-section samples on Nov. 10, 1947

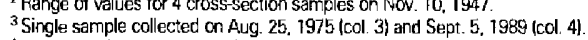

${ }^{4}$ Sodium and potassium not determined separately; total is equivalent amount of sodium.
Table 8. Chemical composition of water and related data for the Kiskiminetas River at Vandergrift, Pa., at times of low flow, 1947 and 1976

IConcentration values are in milligrams per liter unless otherwise noted. Sources: Column 1, U.S. Geological Survey (1953); column 2. U.S. Geological Survey (1977). -.-, data not availablel

\begin{tabular}{|c|c|c|}
\hline \multirow{3}{*}{$\begin{array}{l}\text { Constituent, property, } \\
\text { and related data }\end{array}$} & \multicolumn{2}{|c|}{$\begin{array}{l}\text { Kiskirtinetas Fiver at } \\
\text { Vandergrift, } \mathrm{Pa} \text {. }\end{array}$} \\
\hline & ${ }^{1} 1947$ & ${ }^{2} 1976$ \\
\hline & 1 & 2 \\
\hline Silica $\left(\mathrm{SiO}_{2}\right)$ & $\cdots$ & $\cdots$ \\
\hline Calcium (Ca) & -- & 43 \\
\hline Magnesium (Mg) & $-\cdots$ & 16 \\
\hline Sodium (Na) & $\cdots$ & --- \\
\hline Potassium (K) & $\cdots$ & -- \\
\hline $\begin{array}{l}\text { Alkalinity, as bicarbonate } \\
\left(\mathrm{HCO}_{3}\right) \text { (property) }\end{array}$ & 0 & 0 \\
\hline Sulfate $\left(\mathrm{SO}_{4}\right)$ & $360\left({ }^{3} 1,027\right)$ & $225\left\langle^{3} 1,086\right\}$ \\
\hline Chloride (CI) & 12 & 21 \\
\hline Fluoride (F) & $\cdots$ & .2 \\
\hline Nitrate $\left(\mathrm{NO}_{3}\right)$ & -- & - - \\
\hline Dissolved solids & -- & 325 \\
\hline $\begin{array}{l}\text { Specific conductance, in micro- } \\
\text { siemens at } 25^{\circ} \mathrm{C} \text { (property) }\end{array}$ & 981 & 700 \\
\hline $\mathrm{pH}$ units (property) & 3.2 & 5.2 \\
\hline $\begin{array}{l}\text { Drainage area, in } \\
\text { square miles }\end{array}$ & 1,825 & 1,825 \\
\hline $\begin{array}{l}\text { Average discharge, in cubic } \\
\text { feet per second }\end{array}$ & 1,058 & 1,790 \\
\hline
\end{tabular}

1 Composite sample, Nov. 11-20, 1947.

2 Single sample, Jan. 22, 1976.

${ }^{3}$ Sulfate load, in tons per day.

fact that the diluting water contained bicarbonate alkalinity that reacted to neutralize the acid, and the effect is not simply a matter of dilution.

In addition to the 1906-7 data mentioned above, table 7 gives analyses for three samples from the Allegheny below the Kiskiminetas-one from Sharpsburg (November 10, 1947, col. 2) and two from New Kensington (August 25, 1975, col. 3; September 5, 1989, col. 4). Water discharge rates were about the same for all three samples. However, the proportion of flow coming from the Kiskiminetas probably was greater at the time of the 1947 sampling than it was for the later sampling dates because flow control became more extensive after 1950 (McCarren, 1967, p. 66). The waterquality records for New Kensington indicate, in general, an upward trend in alkalinity.

Figure 25 shows the dissolved-sulfate concentration and $\mathrm{pH}$ of samples collected from the Allegheny River below the Kiskiminetas at low-flow stages during the period of record for water years 1948-89. The values represent single samples that were collected about once a month, and the sample used for each year was the one having the lowest reported stream discharge. No special effort seems to have been made to collect samples at minimum flow stages. However, for nearly all the years of record, a reasonably representative sample was obtained for low-flow conditions. In the 1948-52 period, the stream discharges for samples represented in figure 25 ranged from $1,580 \mathrm{ft}^{3} / \mathrm{s}$ in 1948 to $2,500 \mathrm{ft}^{3} / \mathrm{s}$ in 1949 . After 1965, the discharges for most of the plotted data values were considerably higher, although in 1967 the flow was $2,960 \mathrm{ft}^{3} / \mathrm{s}$ and in 1982 was $2,920 \mathrm{ft}^{3} / \mathrm{s}$. The $\mathrm{pH}$ values measured in monthly samples from New Kensington before 1970 were as high as 6.2 but only 


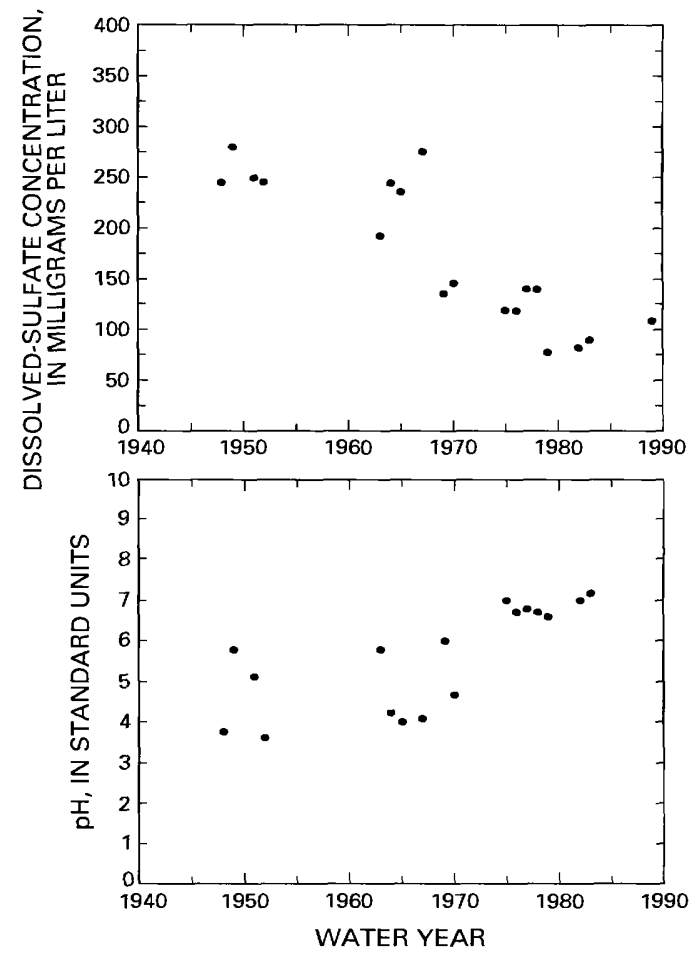

Figure 25. Dissolved-sulfate concentration and $\mathrm{pH}$ of the Allegheny River at New Kensington, Pa., 1948-89. Annual values shown were measured in samples collected at the lowest discharge rate for each water year. (Source: U.S. Geological Survey records of water-quality data.)

when stream discharges exceeded $5,000 \mathrm{ft}^{3} / \mathrm{s}$. In the 1980 's, the $\mathrm{pH}$ of the water was above 6.5 at all sampling times, although discharges reported at those times were as low as $2,920 \mathrm{ft}^{3} / \mathrm{s}$.

The improvement in water quality in the Allegheny River at low flow during the time period covered by figure 25 is rather dramatic. Data in table 7 indicate a nearly 50-percent decrease in sulfate concentration at low flow in the 1975 and 1989 data compared to the 1947 data. The fact that discharge rates were about the same for all three sampling dates means that the actual sulfate loads at low flow in 1975 and 1989 were only about half that observed in 1947.

\section{LOWER MISSISSIPPI RIVER, LOUISIANA}

The Mississippi River is the largest North American river in terms of both drainage area and discharge, and the possible existence of long-term historical trends in the chemical composition of the river is of great interest. The water composition of the lower Mississippi near its mouth reflects the effects of human activities in the entire Mississippi drainage basin, and data collected since 1954 at the St. Francisville, La., water-quality sampling station (figs.18, 26), along with data collected in 1905-6 near New Orleans, La., are used in this discussion. The contributing drainage area of the river near St. Francisville is about $1,125,300 \mathrm{mi}^{2}$, and the average discharge, which was determined from the nearest upstream gaging stations (Tarbert Landing, Miss., and Red River Landing, La.; fig. 26), is $514,000 \mathrm{ft}^{3} / \mathrm{s}$ for the years 1973 82 (U.S. Geological Survey, 1984).

The earliest water-quality records for the Mississippi near its mouth (Dole, 1909) are for the New Orleans public-water utility intake for the period April 29, 1905, to April 28, 1906; a shortcoming of the New Orleans record is a lack of discharge data (table 9, col. 1). Detailed chemical-quality sampling on the lower Mississippi was not undertaken by the USGS until 1954 . The sampling station, which later became a part of the NASQAN sampling network, was located at a highway ferry crossing 2 miles southwest of St. Francisville, about 35 miles upstream from Baton Rouge and more than 160 miles upstream from the New Orleans sampling station. Beginning in 1957, these records were supplemented by a daily sampling program at the Luling-to-Destrehan ferry crossing, 17 miles west of and upstream from New Orleans. However, the difference in drainage area between the St. Francisville station and the Luling-toDestrehan ferry crossing is considered to be insignificant, and, therefore, except for possible effects of industrial activity and waste disposal at and near Baton Rouge, the records for New Orleans and the Luling-toDestrehan ferry crossing should be essentially the same as those for St. Francisville. Where data were obtained at the two stations simultaneously, the sulfate and chloride concentrations at the downstream stations generally were slightly higher than those at St. Francisville, but the differences are mainly within analytical uncertainty. Because the data from the St. Francisville station are more complete, they are used here as the basis for investigating historical changes in water composition.

As with all delta formation, the discharge channels of the Mississippi River delta continually migrate. As sediment builds up in one channel, it eventually forces the river to abandon that route and find another. An example of the process can be seen in the development of the Atchafalaya River. This stream probably was first formed by ancient floods near the confluence of the Red and Mississippi Rivers, and by the 19th century discharge from the Mississippi River through the Old River into the Atchafalaya River, later aided by navigation channel-clearing improvements and flood-control activities had become significant (Shlemon, 1972). To prevent the abandonment of the main Mississippi channel through New Orleans, which had been predicted as a possibility by 1975 (Wells, 1980, p. 6), the U.S. Army Corps of Engineers designed and, by 1963, had installed the Old River Control Structure (fig. 26). Since July 1963, the Old River Control Structure has been operated to divert variable amounts of flow from the Mississippi into the Atchafalaya. The amount of this diversion is required to be at least 30 percent of the total flow of the Atchafalaya, which also carries the entire discharge of the Red River from a drainage area of $87,570 \mathrm{mi}^{2}$ (U.S. Geological Survey, 1981). As a result of the diversion by the control structure, the average flow of the Mississippi at Tarbert Landing is decreased by about 20 percent compared to the discharge upstream from the diversion point (Wells, 1980). This would not be expected to influence significantly the dissolved-sulfate or chloride concentrations in the river near St. Francisville, but it does influence calculation of yields of dissolved constitu- 


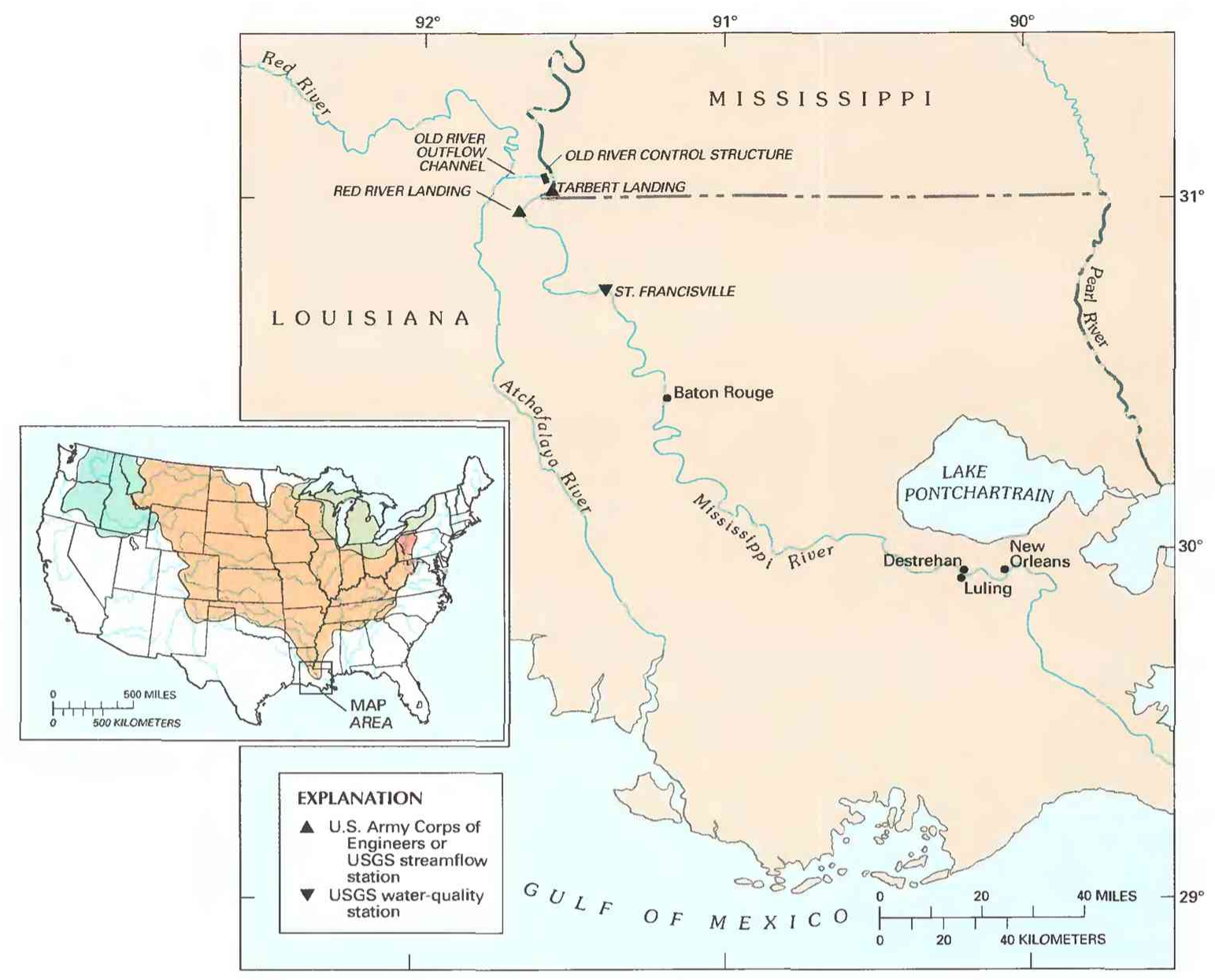

Figure 26. Sampling stations on the lower Mississippi River, La., from which data were obtained for determining selected long-term water-quality trends.

ents because the effective drainage area upstream from Tarbert Landing cannot be exactly determined due to the variable amounts of flow routed down the Atchafalya River.

Many other factors complicate the interpretation of changes that have taken place in water composition above New Orleans since 1906. In addition to many cultural changes, agricultural and industrial development changes, dams and reservoirs, channel controls, the effects of variable rainfall and runoff in the basin upstream, and the possible effects of the Atchafalaya diversion, there have been various changes in sampling protocol over the years of record. A once-daily sampling schedule prevailed in New Orleans in 1905-6, but each composite covered only 1 week. In the years from 1955 to 1968 , daily sampling continued but generally with a standard 10-day equal-volume composite period. Some composites, however, contained a month of daily samples if day-to-day variation was small. Beginning in 1969 , the practice of compositing daily samples to provide a sufficient volume of water for chemical analysis was discontinued, and complete analyses were subsequently made on single larger samples collected during flow measurements in a cross section according to NASQAN procedures to ensure reliable representations of conditions. The sampling frequency generally was about once a month, but in some years it was two or three times a month, and in a few years it was less than once a month. For most years, daily average values of specific conductance and temperature were taken from on-site recorded data, and for some years other properties or constituents, including sulfate and chloride, were measured daily. The number of determinations of sulfate available per year ranged from 365 to as few as 6 . The approximation of historical sulfate concentration in the Mississippi River made by Hem and others (1990) was based on selecting from each water-year's data the complete analysis that showed the lowest total constituent concentration (as indicated by total dissolved solids or specific conductance) and using the sulfate concentration in that analysis to represent that year. When plotted against time, these values yielded what appeared to be a consistent upward trend over the period 1906-80. For each of the years of record (1905-89), the average, minimum, and maximum sulfate values were plotted (fig. 27). Trials of various curve-fitting procedures appeared to give the most reasonable results when a straight-line least-squares fit was applied to the data up through 1967. Although the degree of correlation is not extremely high, it is better than the one reported by Hem and others (1990) that included values from 1968 to 1981 . For at least the daily samples and 10-day composites, sulfate seems to show a consistent upward trend with time. Subsequent to about 1970, the 
Table 9. Chemical composition of water and related data for the Mississippi River at New Orleans, La., 1905-6, and near St. Francisville, La., water years 1966 and 1989

[Concentration values are in milligrams per liter unless otherwise noted. Sources: Column 1, Dole (1909); column 2, U.S. Geological Survey (1971): column 3, U.S. Geological Survey (1990). ---, data not available]

\begin{tabular}{|c|c|c|c|c|c|c|c|c|c|}
\hline \multirow{4}{*}{$\begin{array}{c}\text { Constituent, } \\
\text { property, } \\
\text { and related data }\end{array}$} & \multirow{2}{*}{\multicolumn{3}{|c|}{$\begin{array}{c}\text { New Orleans Water Works Intake } \\
1905-6\end{array}$}} & \multicolumn{6}{|c|}{ Mississippi River near St. Francisville } \\
\hline & & & & \multicolumn{3}{|c|}{${ }^{4}$ Water year 1966} & \multicolumn{3}{|c|}{${ }^{7}$ Water year 1989} \\
\hline & $\begin{array}{c}\text { 'July 30-Aug. } 5 \text {, } \\
1905\end{array}$ & $\begin{array}{c}{ }^{3} \mathrm{Feb} .4-10 \\
1906\end{array}$ & $\begin{array}{c}\text { Annual } \\
\text { average }\end{array}$ & $\begin{array}{l}{ }^{5} \text { Dec. 1-10, } \\
1965\end{array}$ & $\begin{array}{c}{ }^{6} \mathrm{Feb} .12-20 \\
1966\end{array}$ & $\begin{array}{c}\text { Annual } \\
\text { average }\end{array}$ & $\begin{array}{l}{ }^{8} \text { Nov. 14, } \\
1988\end{array}$ & $\begin{array}{c}{ }^{9} \text { Mar. } 14 \\
1989\end{array}$ & $\begin{array}{c}\text { Annual } \\
\text { average }\end{array}$ \\
\hline & & 1 & & & 2 & & & 3 & \\
\hline Silica $\left(\mathrm{SiO}_{2}\right)$ & 13 & 7.8 & 11 & 7.8 & 8.4 & 7.6 & 4.1 & 5.4 & 5.0 \\
\hline Calcium (Ca) & 33 & 28 & 32 & 44 & 36 & 43 & 40 & 24 & 33 \\
\hline Magnesium (Mg) & 8.5 & 6.8 & 8.4 & 22 & 9.3 & 13 & 19 & 6.6 & 11 \\
\hline Sodium (Na) & \multirow{2}{*}{${ }^{10} 21$} & \multirow{2}{*}{${ }^{10} 7.8$} & \multirow{2}{*}{${ }^{10} 13$} & 28 & 17 & 21 & 34 & -.. & 22 \\
\hline Potassium (K) & & & & 3.4 & 2.0 & 3.1 & 4.1 & $\cdots$ & 3.0 \\
\hline $\begin{array}{l}\text { Alkalinity, as bicarbonate } \\
\left(\mathrm{HCO}_{3}\right) \text { (property) }\end{array}$ & 116 & 91 & 111 & 168 & 116 & 145 & 162 & 77 & 115 \\
\hline Sulfate $\left(\mathrm{SO}_{4}\right)$ & "36 & ${ }^{12} 17$ & 24 & "87 & ${ }^{12} 38$ & 59 & "76 & ${ }^{12} 29$ & 44 \\
\hline Chloride (CI) & 10 & 6.3 & 9.7 & 28 & 21 & 22 & 27 & 9.2 & 19 \\
\hline Fluoride (F) & $\cdots$ & $\cdots$ & $\cdots$ & .4 & .2 & .3 & $\cdots$ & $\cdots$ & .2 \\
\hline Nitrate $\left(\mathrm{NO}_{3}\right)$ & 2.7 & 2.5 & 2.5 & 1.8 & 3.6 & 1.7 & 2.6 & 4.2 & 3.9 \\
\hline Dissolved solids & 195 & 130 & 166 & 320 & 201 & 250 & $\cdots$ & $-\cdots$ & 200 \\
\hline $\begin{array}{l}\text { Specific conductance, in micro- } \\
\text { siemens at } 25^{\circ} \mathrm{C} \text { (property) }\end{array}$ & $\cdots$ & $\cdots$ & $\cdots$ & 511 & 337 & 413 & 507 & 228 & 349 \\
\hline pH units (property) & $\cdots$ & $\cdots$ & $\cdots$ & 7.6 & 7.6 & 7.4 & 7.7 & 7.5 & 7.6 \\
\hline $\begin{array}{l}\text { Drainage area, in } \\
\text { square miles }\end{array}$ & \multicolumn{3}{|c|}{$1,243,700$} & \multicolumn{3}{|c|}{$1,125,300$} & \multicolumn{3}{|c|}{$1,125,300$} \\
\hline $\begin{array}{l}\text { Average discharge, in cubic } \\
\text { feet per second }\end{array}$ & $\cdots$ & $\ldots$ & $\cdots$ & ${ }^{13} 224,000$ & ${ }^{13} 601,000$ & ${ }^{13} 337,000$ & ${ }^{13} 145,000$ & ${ }^{13} 1,120,000$ & ${ }^{13} 569,000$ \\
\hline
\end{tabular}

1 Analyses of weekly composites of daily samples, April 29, 1905-April 28, 1906.

2 Composite sample having the maximum dissolved-sulfate concentration during the $1905-6$ period.

${ }^{3}$ Composite sample having the minimum dissolved-sulfate concentration during the $1905-6$ period.

${ }^{4}$ Analyses of 10-day composites of daily samples, water year 1966 .

${ }^{5}$ Composite sample having the maximum dissolved-sulfate concentration during water year 1966.

${ }^{6}$ Composite sample having the minimum dissolved-sulfate concentration during water year 1966.

Analyses of single monthly samples, water year 1989.

${ }^{8}$ Monthly daily sample having the maximum dissolved-sulfate concentration during water year 1989.

9 Monthly daily sample having the minimum dissolved-sulfate concentration during water year 1989.

${ }^{10}$ Total sodium plus potassium as equivalent amount of sodium

12 Maximum dissolved sulfate for that yea

2 Minimum dissolved sulfate for that year

13 Discharge at Tarbert Landing. Miss., for sampling dates.

values do not show a clear trend, and the linear leastsquares calculation yields a nearly level straight line for all three sets of data.

Some evidence of the composition of the Mississippi River water at New Orleans during the long gap between 1906 and 1955 can be obtained from reports by Collins and others (1934) and Lohr and Love (1954) on quality of public water supplies in the United States. The data given by Lohr and Love are for the chemical quality of the Mississippi River at the New Orleans watersupply intake and include maximum, minimum, and average total hardness values for the year 1950. A rather well-defined linear relation between sulfate concentrations and hardness can be developed from the analytical data for St. Francisville in the 1950's over the range in total hardness from 80 to $125 \mathrm{mg} / \mathrm{L}$. If applied to the minimum and average hardness values reported by Lohr and Love (1954) for the untreated water at New Orleans during 1950, calculated sulfate concentrations for 1950 are $30 \mathrm{mg} / \mathrm{L}$ for the minimum hardness and $44 \mathrm{mg} / \mathrm{L}$ for the average hardness. These values are very close to the trend lines in figure 27. The sulfate concentration given by Collins and others (1934) for the 1931 sample furnished by the New Orleans Water Utility is $42 \mathrm{mg} / \mathrm{L}$. It is not clear, however, whether this is an average value for the entire year, and it lies somewhat above the average line in figure 27.

The most likely cause of the upward sulfate concentration trend from 1906 to 1967 in the Mississippi River would seem to be the contamination of the river and its tributaries by human activities, paralleling, as it does, the upward trend in sulfate in the St. Lawrence River and the lower Great Lakes during the same period. However, factors other than simple waste-disposal practices might be responsible. For example, the records for the Allegheny River above Pittsburgh demonstrate ef-

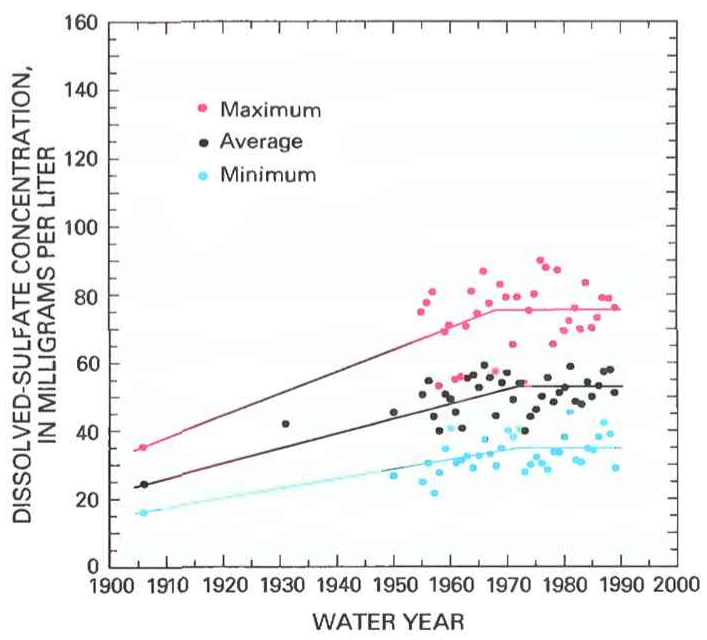

Figure 27. Annual maximum, average, and minimum dissolved-sulfate concentration of the Mississippi River at New Orleans, La., 1905-6, and near St. Francisville, La., 1955-89. (Sources: Refined from Hemand others (1990); data from Dole (1909) and other U.S. Geological Survey data compilations.) 
fects of human activities that modified flow patterns by releasing, during periods of low flow, water stored in reservoirs during high-flow stages in order to dilute what would normally have been a low flow having a high sulfate concentration. Some of the sulfate behavior in the Mississippi could possibly be ascribed to the holding back of dilute flood water in storage facilities upstream and releasing them at later times. The general effect of storage on water quality at downstream points is to decrease the variability of constituent concentrations.

Annual maximum, average, and minimum concentrations of sulfate in the Mississippi all increased until 1980; therefore, the changes are probably not simply related to flow control. The apparent disappearance of the increasing trend during the 1980's could also be explained as a long-term climatic effect, as some years in the 1980's did have high rainfall and runoff rates. However, there also were years of very low runoff in that decade. Sulfate in the St. Lawrence also showed an apparent leveling off of the increasing trend at about the same time.

It also should be noted that beginning in 1968 there were changes in sampling protocol. The practice of compositing samples taken on different dates was disconiinued, and most of the subsequent data represent single samples collected at monthly intervals, although in some years sampling was more trequent. In 1970 and again from 1975 through 1978, sulfate was determined on a daily basis. These differences inject uncertainty into statistical interpretations.

The records for the Mississippi near St. Francisville also show a substantial increase in chloride concentration since 1906. For the April 15-21, 1906, New Orleans sample, which is not shown in table 9, the minimum chloride concentration was $4.8 \mathrm{mg} / \mathrm{L}$. Between 1955 and 1975, the annual minimums observed near St. Francisville generally were between 11 and 15 $\mathrm{mg} / \mathrm{L}$, but no well-defined trend was discernible. From 1975 to 1989 annual minimums ranged from $9.0 \mathrm{mg} / \mathrm{L}$ in 1979 to $17 \mathrm{mg} / \mathrm{L}$ in 1986 and 1987 . The maximum chloride concentration for 1906 at New Orleans was 17 $\mathrm{mg} / \mathrm{L}$. Records for St. Francisville in the $1955-75$ period show that annual maximum chloride concentrations generally were nearly double the 1906 New Orleans maximum. From 1975 to 1989 , only 1 year (1986) had a maximum chloride concentration as high as $28 \mathrm{mg} / \mathrm{L}$. In general, the records cited here imply a general upward trend in chloride concentration in the Mississippi River near St. Francisville and at New Orleans from 1906 to about 1975, but most of the change was in place by the mid-1950's. More complete data consisting of daily chloride determinations are available for the St. Francisville sampling station for the period 1974-89, in contrast to the monthly samples or 10-day composites analyzed in previous years.

Table 9 gives an indication of the over-all change in composition of the water of the lower Mississippi during the 60 years following the 1905-6 record published by Dole (1909). As noted in the discussion of figure 27, the slopes of the fitted straight-line trends appear to change at or shortly after 1967. Interestingly, the average discharge for the minimum dissolved-sulfate concentration in water year 1989 was nearly eight times as great as the discharge for the maximum dis- solved-sulfate concentration sample in that year. Also, the average discharge for water year 1989 was near the long-term average for the station (fig. 18).

In general, the historical data for the Mississippi near St.Francisville show that minimum values for sulfate and chloride concentrations occur during high-flow periods and maximum values occur at low flow, but the relation of discharge and concentration is poorly defined. In summary, a very large amount of data that suggests water-quality changes have occurred in the lower Mississippi is available. However, interpretation of these data in order to closely define the causes of the trends is still rather uncertain.

\section{COMPARISON OF RESULTS}

The sensitivity of a drainage system to humaninduced water-quality degradation is a function of numerous physical properties of the system relating to climate, bedrock geology, and rate of water circulation or residence time. The interaction of these factors from the time water reaches the land surface as precipitation until it flows as runoff into a drainage channel leaves a characteristic imprint on the amount and chemistry of the stream water. The runoff per square mile, on a longterm average basis, is an important factor affecting water composition.

The three most abundant anions in most stream water are bicarbonate, sulfate, and chloride. All of these constituents influence geochemical and biochemical processes that occur during the passage of water from the precipitation stage to the point of discharge as stream flow at a drainage-basin outlet. Sulfur appears to be particularly sensitive to various kinds of human activities, and the tendency for it to be circulated into the atmosphere in both oxidized and reduced forms lends mobility to sulfate in the stream-water part of the hydrologic cycle.

The St. Lawrence River at the outlet of the Great Lakes system shows a well-defined upward trend in sulfate concentrations between 1906-7 and 1980 (table 3). The trend is less masked by seasonal or short-term variability than for most other streams in the conterminous United States because of the large volume of water stored in the lakes and the effectiveness of seasonal mixing that occurs in all of them. Also, the sedimentary rocks and the glacial drift derived from them that underlie the four lowermost lake basins provide carbonate to neutralize acid precipitation, and ample precipitation sustains a large outflow.

The hypothesis that the doubling of the sulfate concentration in the St. Lawrence River near the outlet of Lake Ontario since 1906-7 was caused primarily by increased atmospheric sulfur contributions to the Great Lakes drainage basin appears to be reasonable. Table 4 shows that changes in cation and anion concentrations between 1906-7 and 1977 fit the assumption that the hydrogen ion contributed by precipitation is being neutralized by reactions between the hydrogen ion and solid-rock minerals as well as with dissolved alkalinity in the Great Lakes. The increase in annual sulfate yield between 1906 and the average value for the 1969-80 period is about $14.3 \pm 1.5$ tons $/ \mathrm{mi}^{2}$ (table 5). Although some of the sulfate yield in 1906 could have been 
caused by atmospheric sulfur, the concentrations of sulfate in Lake Ontario that were determined at that time (12 $\mathrm{mg} / \mathrm{L}$ ) were thought by Weiler (1981) to represent the natural condition extending back into the 19 th century. Calculated sulfate yields for the St. Lawrence at Cornwall (fig. 20) and dissolved-sulfate data in table 3 indicate that the drainage system ultimately will reach a steady-state sulfate concentration at the outlet if the sulfate loading stabilizes. However, a considerable lag period would seem likely before the drainage basin response becomes stable. It appears from the sulfateyield data that the Great Lakes-St. Lawrence basin has reached a relatively steady condition, having a human-induced annual sulfate loading in the vicinity of 14 tons $/ \mathrm{mi}^{2}$ added to natural loading of about 10 tons $/ \mathrm{mi}^{2}$. These figures agree with other estimates of atmospheric pollution-related sulfate deposition in the Northeast, such as the range of 8.2 to 16 tons $/ \mathrm{mi}^{2}$ quoted above (U.S. Environmental Protection Agency, 1984) and the conclusion by Peters (1984) that about 60 percent of the sulfate yield of streams in the United States was from atmospheric sources.

The average annual discharge for the Columbia River at The Dalles, Oreg. (fig. 18), is about the same as that of the St. Lawrence River at Cornwall, Ontario, Canada, but many of the other physical, hydrologic, and geochemical characteristics of the two systems are very different. A large part of the Columbia drainage in eastern Washington and Oregon and in adjacent areas of Idaho has a semiarid climate and contributes little direct runoff to the Columbia. Although the Columbia and its tributaries have some large natural lakes and many reservoirs created by dams, the area of water surface in the Columbia River basin is not nearly as large as the area of the Great Lakes.

The bedrock in much of the Columbia drainage basin that is in the United States is of volcanic origin, mostly basaltic lava flows. Those lava flows in the Snake River drainage are capable of transmitting ground water, both vertically and laterally, at a relatively rapid rate. This could be a significant factor in the stream water quality of the lower part of the Columbia River drainage, especially with respect to the hydrogeochemistry of water from the Snake River.

The average concentration of sulfate in the Columbia River at Northport, Wash., in 1910 was $12 \mathrm{mg} / \mathrm{L}$. In all subsequent years for which enough measurements were made to permit calculation of a meaningful average (requires at least one sample per month for this sampling point), the annual average sulfate concentration ranged from a low of $11 \mathrm{mg} / \mathrm{L}$ to a high of $14 \mathrm{mg} / \mathrm{L}$, and the sulfate concentration was inversely related to discharge. As a consequence, a fairly constant annual yield of sulfate in tons per square mile was observed over the entire period of record (fig. 23). Although discharge was not measured at Northport in 1910 , a reasonable estimate of the average flow for that year can be computed by assuming that the ratio of the 1910 discharge value to the longterm average was the same for the Northport station as it was for the station at The Dalles. The estimated average discharge obtained by this calculation is 111,000 $\mathrm{ft}^{3} / \mathrm{s}$, and the estimated sulfate yield is 22 tons $/ \mathrm{mi}^{2}$. This yield is similar to the values of 25.8 and $23.5 \mathrm{tons} / \mathrm{mi}^{2}$ calculated for water years 1954 and 1968 (table 6).
Changes in human contributions to the sulfate yield at Northport during the period of record apparently are a minor part of the total.

A substantial part of the discharge of the Columbia at Northport is contributed by the two major tributaries that drain areas of western Montana and northern Idaho- the Clark Fork-Pend Oreille and the Kootenai. The Kootenai River also drains a substantial area in southeastern British Columbia. Both streams join the Columbia a short distance north of the U.S.-Canada boundary. Although historical water-quality records for both streams are rather limited, they do provide a basis for estimating sulfate yields.

A daily sampling record for the Kootenai River at Porthill, Idaho, for water year 1950 (U.S. Geological Survey, 1954) gave a calculated annual sulfate yield of 17.7 tons $/ \mathrm{mi}^{2}$. A calculation for the Pend Oreille at Metaline Falls, Wash., based on daily sampling during the same water year (U.S. Geological Survey, 1954) gave a sulfate yield of 14.2 tons $/ \mathrm{mi}^{2}$. The average water discharge for these two tributaries in 1950 was $60,900 \mathrm{ft}^{3} / \mathrm{s}$, which is more than one-half of the 1950 average discharge of the Columbia at Northport, Wash. (111,000 $\left.\mathrm{ft}^{3} / \mathrm{s}\right)$. Water-quality records were not obtained at that station in 1950. However, the sulfate yield in water year 1952 was 21.8 tons $/ \mathrm{mi}^{2}$ (U.S. Geological Survey, 1957) and, as shown in figure 23 , generally has ranged from about 22 to about 25 tons $/ \mathrm{mi}^{2}$. In order for annual sulfate yields to be this high at Northport, the annual sulfate yield for the Columbia basin upstream from the Kootenai and Pend Oreille sampling stations must be substantially greater than 30 tons $/ \mathrm{mi}^{2}$. Using the 1950 and 1952 data quoted above, the calculated annual sulfate yield for the $20,800 \mathrm{mi}^{2}$ of the Columbia basin that is upstream from the two tributaries is 33.8 tons $/ \mathrm{mi}^{2}$. Records for 1980 89 are incomplete, but generally they support this estimate.

Mineral and thermal springs are among possible sources of sulfate in the Canadian part of the Columbia drainage basin. As noted by Van Everdingen (1972), some of the springs in this region yield water having a large enough sulfate concentration to approach saturation with respect to gypsum. Extensive exposures of sedimentary rock in the southern Rocky Mountains of Canada, described by Norford (1969), could also yield sulfate to weathering solutions.

Measurements of sulfate concentrations at four sampling stations on the Columbia River (P.H. Whitfield, Environment Canada, written commun., August 1991) from 1985 to 1991 provide some additional insights into sulfate sources. The data for a station that is upstream from natural lakes and artificial storage reservoirs show that annual minimum sulfate concentrations near $10 \mathrm{mg} / \mathrm{L}$ are reached in most years during June or July, when flow is augmented by melting snow. During the fall and winter seasons, sulfate concentrations commonly are in the range of 25 to 40 $\mathrm{mg} / \mathrm{L}$, and a maximum concentration of $53.5 \mathrm{mg} / \mathrm{L}$ was reported on February 11, 1986.

These sulfate concentrations are substantially more variable and reach higher values than any at downstream stations on the Columbia. The highest sulfate concentration observed at The Dalles in the 1951-74 period was $34 \mathrm{mg} / \mathrm{L}$, which occurred in 1972 . The higher 
maximums observed at the Canadian site suggest that the high sulfate yield could come from ground-water inflows and dissolution of sedimentary-rock minerals in the upper part of the Columbia drainage basin.

In general, the human-induced effects on the composition of flow in the Columbia at Northport probably are relatively minor and are mostly masked by the large amount of runoff available and by the effects of storage and mixing in lakes and reservoirs. To a somewhat lesser degree, the same is true of the flow at The Dalles. At that site, the human effects are more significant, but they are far less evident than those in the lower part of the Great Lakes-St. Lawrence basin.

The average runoff of the Allegheny River basin above New Kensington is $1.72 \mathrm{ft}^{3} / \mathrm{s} / \mathrm{mi}^{2}$, which is nearly the same as the water yield of the Columbia basin above Northport. However, the average discharge of the Allegheny is only about 19 percent of that of the Columbia at Northport. Hence, one could predict the higher sensitivity to point sources of contamination in the Allegheny that is demonstrated by the data for various sampling stations in the Allegheny basin. The average of the data published by Dole (1909) for the Allegheny shows a relatively pristine condition in 1906-7 at the Kittanning, Pa., sampling station (table 7). Minimum and maximum sulfate concentrations reported by Dole for the year were $10 \mathrm{mg} / \mathrm{L}$ and $35 \mathrm{mg} / \mathrm{L}$, respectively. McCarren's (1967) analytical data for that station for 1961-62 show a range of sulfate concentrations from a minimum of $32 \mathrm{mg} / \mathrm{L}$ to a maximum of $67 \mathrm{mg} / \mathrm{L}$. These data are substantial evidence of sulfate contamination at Kittanning, and the contamination can be attributed to atmospheric fallout. McCarren (1967) indicated that most of the coal-mining activity was downstream from the Kittanning station.

Major sources of mine-drainage and industrialwaste contamination of the Allegheny River immediately upstream from Pittsburgh are located on the Kiskiminetas River. As shown in table 8, during the period November 11-20,1947, the sulfate load in the Kiskiminetas was 1,027 tons/day at an average discharge of $1,058 \mathrm{ft}^{3} / \mathrm{s}$. On January 22,1976 , at an average discharge of $1,790 \mathrm{ft}^{3} / \mathrm{s}$, the sulfate load was 1,086 tons/day. The similarity of sulfate loads for these two sampling periods contrasts with the decrease in sulfate concentration from $360 \mathrm{mg} / \mathrm{L}$ in 1947 to $225 \mathrm{mg} / \mathrm{L}$ in 1976 . This decrease in concentration can be attributed to dilution brought about by release of water from upstream storage reservoirs. The hundredfold decrease in hydrogenion activity indicated by the concurrent increase in $\mathrm{pH}$ in the 1976 sample indicates the diluting water had a substantial acid-neutralization capacity.

An indication of the relative contamination sensitivity of the Allegheny compared to the Columbia can be gained by considering daily sulfate loads. The Columbia at Northport in 1968 (table 6, col. 6) had an average sulfate concentration of $14 \mathrm{mg} / \mathrm{L}$ and an average discharge of $102,000 \mathrm{ft}^{3} / \mathrm{s}$, which represents an average daily sulfate load of 3,850 tons. If the 1,027 tons/day sulfate load equal to that of the Kiskiminetas was added to the Northport sulfate load at a discharge of $1,058 \mathrm{ft}^{3} / \mathrm{s}$, the average sulfate concentration at Northport would increase to $18 \mathrm{mg} / \mathrm{L}$. The complete analytical data for 1968 for this station (U.S. Geological Survey, 1973) show a minimum average discharge of $40,500 \mathrm{ft}^{3} / \mathrm{s}$ for the composite sample representing January 1-20 and a sulfate concentration of $19 \mathrm{mg} / \mathrm{L}$. Here, the addition of $1,058 \mathrm{ft}^{3} / \mathrm{s}$ of discharge carrying 1,027 tons/ day of sulfate would have given a final sulfate concentration of $28 \mathrm{mg} / \mathrm{L}$. Although the effect on sulfate concentration at low flow would be significant, the effect at the annual average discharge rate is only a little greater than the analytical uncertainty in the sulfate determinations.

A much more obvious effect of discharge on sulfate concentration can be seen for the Allegheny River. From tables 7 and 8 it can be calculated that the sulfate concentration in the Allegheny upstream from the Kiskiminetas at low flow in November 1947 would have been about $136 \mathrm{mg} / \mathrm{L}$. As the data in column 2 of table 7 show, the sulfate concentration was about $200 \mathrm{mg} / \mathrm{L}$ after receiving discharge from the Kiskiminetas. At a near-average discharge of $19,640 \mathrm{ft}^{3} / \mathrm{s}$ and a typical sulfate concentration of $40 \mathrm{mg} / \mathrm{L}$ in the Allegheny upstream from the Kiskiminetas, the effect of the inflow at the rate of $1,058 \mathrm{ft}^{3} / \mathrm{s}$ and a sulfate concentration of $360 \mathrm{mg} / \mathrm{L}$ would be to increase the sulfate concentration of the Allegheny below the river confluence to $57 \mathrm{mg} / \mathrm{L}$.

Additional data in table 7 (cols. $2,3,4$ ) show that for similar flow stages in the Allegheny below the Kiskiminetas, there was indeed a substantial improvement in water quality between November 1947 and September 1989. The sulfate concentration decreased by about one-half and $\mathrm{pH}$ increased from near 4.0 to 7.5. Data in figure 25 indicate that most of the decrease in sulfate and increase in $\mathrm{pH}$ at low flow had taken place by 1975 . Flow augmentation by timed reservoir releases and related remedial measures have had an obvious beneficial effect on the quality of the Allegheny at New Kensington.

In the lower Mississippi River, data on concentrations of sulfate and changes between 1905-6 and 1989 (fig. 27) show an approximate doubling of annual minimum, maximum, and average concentrations. Most of the change occurred before 1980 . The calculation of sulfate yield for the whole Mississippi drainage basin is fraught with many uncertainties, owing to the complex nature of flow-control and water-diversion efforts and incomplete discharge and water-quality data. However, a rough approximation of sulfate yield can be made using discharge data from the Tarbert Landing station and the rather arbitrary contributing area assigned in USGS water-data compilations of $1,125,300 \mathrm{mi}^{2}$ for the Tarbert Landing station. The results obtained using the annual average sulfate concentration for each year indicate that for most of the years from 1964 to 1989 the annual yield was between 20 and 25 tons $/ \mathrm{mi}^{2}$. The 5 years in which the yield was below 20 tons $/ \mathrm{mi}^{2}$ were years of low mean discharge.

These estimated annual sulfate yields are similar in magnitude to those calculated for that general time period for the Great Lakes-St. Lawrence basin (table 5). However, if it could be estimated, the gain in yield between $1905-6$ and the $1964-89$ period is a more meaningful figure. The discharge of the river at the New Orleans sampling site during the 1905-6 period was not measured. A further uncertainty relates to the amount of flow that might have left the main river at the site of the present Old River Control Structure. If it is assumed 
this was a minor effect in 1905-6, the long-term average discharge (about $570,000 \mathrm{ft}^{3} / \mathrm{s}$ ) given by Wells (1980) for the measuring point at Vicksburg, Miss., about 140 river miles upstream from the Old River Control Structure, could perhaps be assumed to approximate the 1905-6 average for the Mississippi at New Orleans. The average sulfate concentration of $24 \mathrm{mg} / \mathrm{L}$ given for that period leads to a calculated annual yield of 12 tons $/ \mathrm{mi}^{2}$ of sulfate for the drainage basin.

Although this estimate has a substantial uncertainty, the indicated increase in annual yield of sulfate since 1906 is about 9 to 14 tons $/ \mathrm{mi}^{2}$. This increase is equivalent to the increase calculated for the Great LakesSt. Lawrence system from 1906 to the 1970's and 1980's (fig. 20) and could be considered as possibly explainable by an increase in atmospheric contributions of sulfate. It also appears from the relatively minor changes that have occurred during the 1970's and 1980's that the river has reached an approximate steady state with respect to present-day sulfate contributions from the drainage basin and effective transport of sulfate out of the basin to the ocean. Continuing efforts to control sulfur releases to the atmosphere and hydrosphere in the drainage basin could eventually decrease the sulfate concentrations and yields observed at St. Francisville to an extent that will be more obvious.

Much more study of the historical data for the Mississippi River system is needed before these tentative conclusions can be either verified or rejected. The challenge presented by such studies is a major one, but the increased understanding of the geochemistry of a major river that would result is a worthy goal.

\section{SUMMARY}

Under pristine conditions, that is, in the absence of human civilization and development, the chemical composition of stream and lake waters is, ideally, controlled by the alteration of rock minerals through chemical weathering processes, which liberate soluble products. These processes, in turn are controlled or influenced by climatic factors such as rainfall, air temperature, and evaporation, and by associated biological or biochemical processes, such as photosynthesis and transpiration by plants, decay of vegetative debris, and the effects of aquatic-life processes. Circulation of essential nutrient elements, including carbon, sulfur, chlorine, and nitrogen, generally is bound to elemental oxygen from the atmosphere and provides most anionic species occurring in natural water, such as bicarbonate, sulfate, chloride, and nitrate. Other constituents of natural surface waters, including calcium, magnesium, sodium, and potassium, can be correlated in general with the chemical composition of rocks and soils in a given drainage basin and are found as major cationic species and are in electrochemical balance with anions in these waters.

The influence of human activities in a stream drainage basin can be relatively simple and direct, as in the disposal of soluble organic and inorganic waste, or more subtle and complex, as in the conversion of prairie or forest land to agricultural use. Such effects can be expected to increase as population density and agri- cultural, industrial, and mining activities increase. However, the detection of long-term trends in surface-water chemistry that can be expected to occur as a result of human activities is difficult and uncertain for much of the United States. Part of this difficulty is related to the availability and reliability of the base historical surfacewater-chemistry data. However, another factor affecting studies of surface-water chemistry is the intricate nature of the interactions among the various hydrogeochemical factors that are active in controlling water composition. Because of this complexity, the study of long-term water-quality trends in any river or lake drainage system requires an organized evaluation of the specific hydrologic properties of the system. It seems that most systems have rather unique characteristics that are not exactly duplicated in any other.

The earliest nationwide program for determining in detail the chemical composition of surface waters in the United States was operated by the USGS from about 1905 to 1907 . It involved collection of once-daily samples at about 155 sampling points for a period of 1 year. Analyses for major cations and anions were performed on 10-day filtered composites of the daily samples. After the termination of this program, the collection of surface-water chemical-composition data by the USGS was done at only a few scattered sites, and it was not until the early 1960 's that anything approaching the intensity level of the early studies was attained. As a result, for most sampling points there is a 30-year or longer time gap with few or no data available between the early and more recent data.

Because of changes in methods of sample collection, transport, preservation, and laboratory chemical analysis, the 1905-7 data may not be totally comparable with more recently obtained data. However, the results of the early work were carefully evaluated at that time for accuracy, and it appears that results for the major constituents-calcium, magnesium, sodium, sulfate, and chloride - and probably also bicarbonate plus carbonate alkalinity should be rather directly comparable with more recent data. The most reliable values in the 19057 data probably are those for sulfate and chloride. For the purpose of this article it should be recognized that such uncertainty as may be present in the data for the major ions is not a major obstacle to making or trying to make serious use of the data. (See article "Assuring the Reliability of Water-Quality data" in this volume for more information on quality assurance.)

For the detailed comparison of stream-water chemistry in the early years of the 20th century with more modern conditions, four drainage basins having diverse hydrologic characteristics were selected for study. They were the Great Lakes-Upper Saint Lawrence River basin (near the outlet of Lake Ontario), the Columbia River basin (upstream from the Dalles, Oreg.), the Allegheny River basin (upstream from Pittsburgh, Pa.), and the Mississippi River basin (upstream from New Orleans, La.). Principal attention was given to sulfate concentrations and annual yields in tons per square mile, the reason being that major quantities of sulfate are released to the atmosphere by fossil-fuel combustion and various industrial activities, and the sulfate is brought to the land surface in rain and dry fallout. 
In the Great Lakes-Upper St. Lawrence River basin, for example, the yield of sulfate in tons per square mile per year in the St. Lawrence River nearly doubled between 1905 and 1956 and continued to increase, but at a lesser rate, until about 1970 , when the yield leveled off or perhaps even declined slightly. The continuing yield of between about 19 to 25 tons $/ \mathrm{mi}^{2}$ indicates that the basin may have reached a steady state between the natural and human-induced loading of sulfur to the basin and its removal by the St. Lawrence River. In contrast, sulfate concentrations in the upper Columbia River basin at Northport, Wash., show less clearly defined trends in sulfate concentrations and yields during the century. These data indicate that human-induced effects are largely masked by the large amount of runoff available in the Columbia River basin and by the effects of storage and mixing in lakes and reservoirs.

Coal mining was extensive in the Allegheny River drainage basin in Pennsylvania in this century, and sulfate concentrations in the river near Pittsburgh increased substantially between the early 1900's and 1962 as a result of drainage from many active and abandoned coal mines. The operation of flood-control and multipurpose reservoirs in the basin has caused a nearly 50percent decline in sulfate concentration in the Allegheny River near Pittsburgh at low flow, as shown in analysis of samples collected in 1947 and compared to samples collected in 1975 and 1989. This flow augmentation by timed reservoir releases has had a beneficial effect on the quality of the Allegheny River.

The Mississippi River drains more than 1,125,000 $\mathrm{mi}^{2}$ of the conterminous United States and integrates the effect on stream water quality of a large range of human activities across a large continental area. The calculation of sulfate yield in the basin has many uncertainties because water-quantity and water-quality data are incomplete, and the effects of flow control and water diversions are difficult to measure. However, from the available data it can be estimated that sulfate concentrations in the lower Mississippi River at and upstream from New Orleans, La., probably have doubled between 1905-6 and 1989; most of this increase seems to have occurred before 1980. Estimates of the increase in annual sulfate yield due to human activities since 1905 ranging from about 9 to about 14 tons $/ \mathrm{mi}^{2}$ are consistent with the increase in sulfate yields in the Great LakesSt. Lawrence River system. In both instances, yields seem to have leveled off around 1970 or 1980 and to have remained fairly stable since. Possibly, both drainage systems have reached a steady state, and the natural and human-induced sulfate loading to the basins, much of it from atmospheric deposition, is now stable.

The study of the trends of stream water quality is important because changes in certain constituent concentrations can be attributed to human activities and because the 20th century has been a time of great population growth and development of agriculture, industry, and water-control facilities in the United States. Intuitively, one can anticipate that these factors have had a nonuniform and frequently significant effect on stream water quality. The sparse record of water-quality data collected early in the century provides some-but far from complete-insight into these effects. Although it is not possible to compensate for the lack of plentiful water-quality data from early in the century, the increased collection of water-quality data in more recent times will be a valuable legacy to future generations that seek to understand the effect of human activities on national stream water quality.

\section{Acknowledgments}

The help of Adrian Demayo and other officials of Environment Canada in furnishing water chemistry data is gratefully acknowledged. In particular, information concerning chemistry of the St. Lawrence River and Lake Ontario was furnished by Daniel Cluis, David Lam, Melanie Neilson, and Aline Sylvestre; data for sampling stations on the Columbia River in British Columbia were furnished by Paul Whitfield. Colleagues Robert C. Bubeck and Donald A. Goolsby provided helpful technical reviews of the manuscript.

\section{REFERENCES CITED}

Barnes, Ivan, 1964, Field measurement of alkalinity and $\mathrm{pH}$ : U.S. Geological Survey Water-Supply Paper 1535-H, $17 \mathrm{p}$.

Berner, R.A., 1971, Worldwide sulfur pollution of rivers: Journal of Geophysical Research, v. 76, p. 6597-6600.

Bubeck, R.C., Diment, W.H., Deck, B.L., Baldwin, A.L., and Lipton, S.D., 1971, Runoff of deicing salt-Effect on Irondequoit Bay, Rochester, New York: Science, v. 172, p. $1128-1132$.

Clarke, F.W., 1924, The composition of the river and lake waters of the United States: U.S. Geological Survey Professional Paper 135, $199 \mathrm{p}$.

Collins, W.D., Lamar, W.L., and Lohr, E.W., 1934, Industrial utility of public water supplies in the United States, 1932: U.S. Geological Survey Water-Supply Paper 658, $135 \mathrm{p}$.

Dethier, D.P., 1986, Weathering rates and the chemical flux from catchments in the Pacific Northwest, U.S.A., in Colman, S.M., and Dethier, D.P., eds., Rates of chemical weathering of rocks and minerals: Orlando, Fla., Academic Press Inc., p. 503-530.

Dobson, H.F.H., 1967, Principal ions and dissolved oxygen in Lake Ontario, in Proceedings of the 10th Conference on Great Lakes Research, Toronto, Canada, 1967: Ann Arbor, Mich. International Association for Great Lakes Research, p. 337-356.

Dole, R.B., 1909, The quality of surface waters in the United States-Part 1, Analyses of waters east of the one hundredth meridian: U.S. Geological Survey Water-Supply Paper 236, $123 \mathrm{p}$.

Drever, J.L., 1982, The geochemistry of natural waters: Englewood Cliffs, N.J., Prentice Hall Inc., 388 p.

Ficke, J.F., and Hawkinson, R.O., 1975, The national stream quality accounting network (NASQAN)-Some questions and answers: U.S. Geological Survey Circular 719, $23 \mathrm{p}$.

Fitzgerald, J.W., 1978, Naturally occurring organosulfur compounds in soil, in Nriagu, J.O., ed., Sulfur in the environment-Part II, Ecological impacts: New York, Wiley-Interscience, p. 391-443.

Goldschmidt, V.M., 1954, Geochemistry: Oxford, England, Clarendon Press, $730 \mathrm{p}$

Hem, J.D., 1985, Study and interpretation of the chemical characteristics of natural water (3d ed.): U.S. Geological Survey Water-Supply Paper 2254, $264 \mathrm{p}$.

Hem, J.D., Demayo, Adrian, and Smith, R.A., 1990 Hydrogeochemistry of rivers and lakes, in Riggs, H.C., 
and Wolman, M.G., eds., Surface water hydrology: Boulder, Colo., Geological Society of America, The Geology of North America, v. O-1, p. 189-231.

Leifeste, D.K., 1974, Dissolved-solids discharge to the oceans from the conterminous United States: U.S. Geological Survey Circular 685, $8 \mathrm{p}$.

Leverin, H.A., 1942, Industrial waters of Canada-Report on investigations 1934 to 1940: Canada Department of Mines and Resources, Bureau of Mines Report 807,61 p.

Lieth, Helmut, 1963, The role of vegetation in the carbon dioxide content of the atmosphere: Journal of Geophysical Research, v. 68, no. 13, p. 3887-3898.

Lohr, E.W., and Love, S.K., 1954, Industrial utility of public water supplies in the United States 1952-Part 2, States west of the Mississippi River: U.S. Geological Survey Water-Supply Paper 1300, $462 \mathrm{p}$.

McCarren, E.F., 1967, Chemical quality of surface water in the Allegheny River basin, Pennsylvania and New York U.S. Geological Survey Water-Supply Paper 1835, $74 \mathrm{p}$

Meybeck, Michel, 1983, Atmospheric inputs and river transport of dissolved substances, in Symposium on dissolved loads of rivers and surface water quantity/quality relationships, August 1983, Hamburg, Germany: International Association of Hydrological Sciences Bulletin, 141, p. 173-192.

Meybeck, Michel, and Helmer, Richard, 1989, The quality of rivers-From pristine stage to global pollution: Palaeogeography, Palaeoclimatalogy, Palaeoecology (Global and Planetary Change Section), v. 75, p. 283309.

Norford, B.S., 1969, Ordovician and Silurian stratigraphy of the southern Rocky Mountains: Geological Survey of Canada Bulletin 176, $90 \mathrm{p}$.

Nriagu, J.O., 1978, ed., Sulfur in the environment-Part II, Ecological impacts: New York, Wiley-Interscience, $482 \mathrm{p}$.

Nyborg, Marvin, 1978, Sulfur pollution in soils, in Nriagu, J.O., ed., Sulfur in the environment-Part II, Ecological impacts: New York, Wiley-Interscience, p. 359-390

Peters, N.E., 1984, Evaluation of environmental factors affecting yields of major dissolved ions of streams in the United States: U.S. Geological Survey Water-Supply Paper 2228, $39 \mathrm{p}$

Reynolds, R.C., Jr., and Johnson, N.M., 1972, Chemical weathering in the temperate glacial environment of the northern Cascade Mountains: Geochimica et Cosmochimica Acta, v. 36, p. 537-554.

Shlemon, R.J., 1972, Development of the Atchafalaya DeltaHydrologic and geologic studies of coastal Louisiana: Baton Rouge, La., Louisiana State University, Coastal Research Unit, $51 \mathrm{p}$.

Smith, R.A., Alexander, R.B., and Wolman, M.G., 1987, Analysis and interpretation of water-quality trends in major U.S. rivers, 1974-81: U.S. Geological Survey Water-Supply Paper 2307, 25 p

Stabler, Herman, 1911, Some stream waters of the western United States, with chapters on Sediment carried by the Rio Grande and the industrial application of water analyses: U.S. Geological Survey Water-Supply Paper 274 $188 \mathrm{p}$.

Turner, R.E., and Rabalais, N.N., 1991, Changes in Mississippi River water quality in this century-Implications for coastal food webs: BioScience, v. 41, no. 3, p. 140147.

U.S. Environmental Protection Agency, 1984, Effects sciences, v. 2 of The acidic deposition phenomenon and its effect-Critical assessment review papers: U.S.Environmental Protection Agency Report EPA 600/ 9-83-016AF, p. 4-11.

U.S. Geological Survey, 1953, Quality of surface waters of the United States, 1948-Parts 1-6: U.S. Geological Survey Water-Supply Paper $1132,515 \mathrm{p}$
- 1954, Quality of surface waters of the United States, 1950--Parts 9-14: U.S. Geological Survey Water-Supply Paper $1189,158 \mathrm{p}$.

1957, Quality of surface waters of the United States, 1952-Parts 9-14: U.S. Geological Survey Water-Supply Paper 1253,344 p.

- 1959, Quality of surface waters of the United States, 1954-Parts 9-14: U.S. Geological Survey Water-Supply Paper $1353,426 \mathrm{p}$.

- 1960, Quality of surface waters of the United States, 1956-Parts 1-4: U.S. Geological Survey Water-Supply Paper $1450,603 \mathrm{p}$.

_ 1971, Quality of surface waters of the United States, 1966-Parts 7-8: U.S. Geological Survey Water-Supply Paper 1994, 815 p.

-1973, Quality of surface waters of the United States, 1968-Parts 12-16: U.S. Geological Survey WaterSupply Paper $2100,464 \mathrm{p}$.

-1974, Quality of surface waters of the United States 1969-Parts 4-5: U.S. Geological Survey Water-Supply Paper 2144, $367 \mathrm{p}$.

1976, Water resources data for Pennsylvania-volume 3, Ohio River and St. Lawrence River basins-Water year 1975: U.S. Geological Survey Water Data Report PA-75-3 [Springfield, Va., National Technical Information Service PB261438], 209 p.

1977, Water resources data for Pennsylvania-volume 3, Ohio River and St. Lawrence River basins-Water year 1976: U.S. Geological Survey Water Data Report PA-76-3 [Springfield, Va., National Technical Information Service PB272094], $270 \mathrm{p}$.

1981, Water resources data for Louisiana-volume 2, Southern Louisiana-Water year 1980: U.S. Geological Survey Water Data Report LA-80-2 [Springfield, Va., National Technical Information Service PB81186033], $371 \mathrm{p}$.

1984, Water resources data for Louisiana-volume 2 Southern Louisiana-Water year 1983: U.S. Geological Survey Water Data Report LA-83-2 [Springfield, Va. National Technical Information Service PB85-128007, $360 \mathrm{p}$.

1989, Water resources data for New York-volume 1, Eastern New York excluding Long Island-Water year 1988: U.S. Geological Survey Water Data Report NY88-1 [Springfield, Va., National Technical Information Service PB90-183096], 259 p.

-1990, Water resources data for Louisiana - Water year 1989: U.S. Geological Survey Water Data Report LA89-1 [Springfield, Va., National Technical Information Service PB90-230962], 395 p.

- 1991a, Water resources data for Oregon-volume 1 , Eastern Oregon-Water year 1990: U.S. Geological Survey Water Data Report OR-90-1 [Springfield, Va. National Technical Information Service PB91-204677], $193 \mathrm{p}$.

1991b, National water summary 1988-89-Hydrologic events and floods and droughts: U.S. Geological Survey Water-Supply Paper 2375, $591 \mathrm{p}$

-1991c, Water resources data for Pennsylvania — volume 3, Ohio River and St. Lawrence River basins-Water year 1990: U.S. Geological Survey Water Data Report PA-90-3 [Springfield, Va., National Technical Information Service PB91-204826], $153 \mathrm{p}$.

-1991d, Water resources data for Louisiana-Water year 1990: U.S. Geological Survey Water Data Report LA90-1 [Springfield, Va., National Technical Information Service PB91-226829], 419 p.

— 1992, Water Resources data for Washington-Water year 1991: U.S. Geological Survey Water Data Report WA91-1 [Springfield, Va., National Technical Information Service PB 92-220409], $470 \mathrm{p}$ 
92 National Water Summary 1990-91-Stream Water Quality: HYDROLOGIC PERSPECTIVES ON WATER ISSUES

Van Everdingen, R.O., 1972, Thermal and mineral springs in the Southern Rocky Mountains of Canada: Ottawa Canada, Environment Canada, Water Management Service, $149 \mathrm{p}$.

Van Winkle, Walton, 1914, Quality of the surface waters of Washington: U.S. Geological Survey Water-Supply Paper 339, $105 \mathrm{p}$.

Wells, F.C., 1980, Hydrology and water quality of the lower Mississippi River: Louisiana Department of Transportation and Development, Office of Public Works, Water Resources Technical Report no. 21, 83 p. (in cooperation with the U.S. Geological Survey).

Weiler, R.R., 1981, Chemistry of the North American Great Lakes: Verhandlungen der Internationalen Vereinigung fur Theoretische und Angewandte Limnologie, v. 21, p. 1681-1694.

Weiler, R.R., and Chawla, V.K., 1969, Dissolved mineral quality of Great Lakes waters, in Proceedings of the 12th Conference on Great Lakes Research, Ann Arbor, Mich., 1969: Ann Arbor, Mich., International Association for Great Lakes Research, p. 801-818.

\section{FOR ADDITIONAL INFORMATION}

John D. Hem, U.S. Geological Survey, 345 Middlefield Road, Menlo Park, CA 94025 


\title{
Hydrology of Stream Water Quality
}

\section{Statistical Analysis of Water-Quality Data}

\author{
By Dennis R. Helsel
}

\section{INTRODUCTION}

Statistics is the science that deals with uncertainty. It strives to separate patterns, such as a change in some measured variable over time, from the uncertainty inherent in all observations of natural systems. When applied to water-quality data, separating patterns from uncertainty is accomplished in three primary activities:

- Describe data characteristics, such as the mean or the median chemical concentration,

- Model the relations between two or more measured variables, such as chemical-concentration changes with time, and

- Compare groups of data, such as chemical concentration at two or more locations.

Assumptions about the characteristics of data are inherent to statistical procedures. Therefore, the usefulness of a procedure can be judged by how well its assumptions match the characteristics of the data being analyzed. The commonly observed characteristics of stream water-quality data and the statistical procedures used in a nationally consistent analysis of stream water quality in the State summaries of this volume-National Water Summary 1990-91-Hydrologic Events and Stream Water Quality - are presented in this article.

\section{COMMON CHARACTERISTICS OF WATER-QUALITY DATA}

Water-quality data have several characteristics that are significant to statistical analyses:

A base limit of zero.-Chemical concentrations cannot be negative.

Presence of outliers.-Outliers are data of considerably higher or lower value than most of the data. These occur infrequently but regularly, and high outliers are more common.

Nonstandard distributions.-The data distribution shows the frequency with which given values occur. One common type of distribution found in some types of data sets is the normal distribution-the socalled bell-shaped curve-shown in figure 28 . This distribution is symmetrical and follows a pattern represented by a particular mathematical equation. (Some data sets can have a symmetrical distribution that is not a normal distribution.) Many water-quality data sets are not symmetrical, however, and look more like the bars of figure 28. The data are skewed, meaning that the right and left halves of their distribution are not symmetrical. Skewness is a direct result of the first two characteristics - the data cannot include negative values and can include outliers. Erroneous results may occur if statistical procedures that assume a normal data distribution are applied to data that follow the distribution represented by the bars in figure 28 .

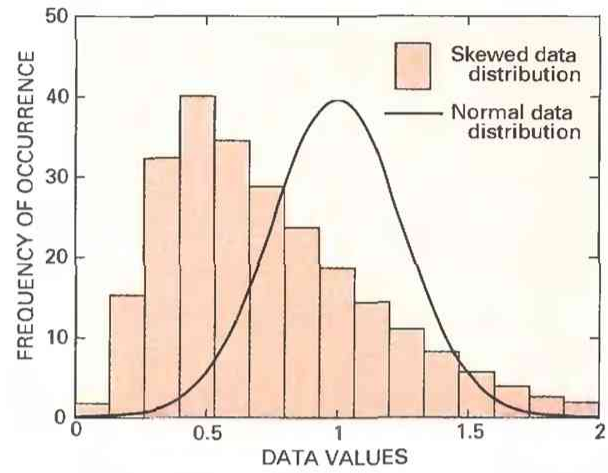

Figure 28. Example of normal data distribution curve superimposed on skewed data distribution.

Data values below a minimum reporting limit.Chemicals in water samples can be present in trace amounts that a laboratory might not report because the analytical procedure used is not sensitive enough to measure very small concentrations. Instead, the laboratory reports only that a concentration is below some reporting limit, such as less than one $(<1)$ part per million. This type of value is difficult to incorporate into traditional statistical tests.

Human and natural influences.-Water quality is strongly affected by human-induced and naturally occurring processes. These processes, such as changes in upstream land use over time or the effects of a prolonged drought, may be of interest to the investigator. Alternatively, the processes may be of little interest in themselves, but they produce variations in data that must be accounted for before correctly discerning the effects that are of interest. The strong dependence of waterquality concentrations on streamflow is one example. Concentration variations due to short-term changes in streamflow need to be considered before testing for longterm trends in concentration.

Statistical methods described in the subsequent sections, and used to analyze data for the State summaries, were designed to work well with data having the characteristics listed above.

\section{GRAPHICAL METHODS FOR ANALYSIS OF DATA}

Large amounts of data can be understood much more quickly if they are presented in graphical form rather than in tabular form. Therefore, graphs are an important and efficient way to gain insight into the data being investigated. Two types of graphs are used in this volume - box plots and smoothed-line scatter plots. Although both types are becoming more common in scientific literature, they are not as familiar to the general 
public. As explained below, box plots effectively describe the characteristics of single groups of data and reveal differences between groups. Smoothed-line scatter plots display the relation between two variables.

\section{BOX PLOTS}

Box plots of a data set provide concise visual summaries of the-

- center value (median) of the data,

- variation in the middle half of the data, and

- skewness of the data.

Some types of box plots also show-

- presence or absence of unusual values.

The components of box plots are shown in figure 29 and are described here for two hypothetical data sets. The box of a box plot displays percentiles of a data set. The middle horizontal line within the box is the median, or 50th percentile. By definition, one-half of the data values are equal to or less than the median, and onehalf are equal to or greater. The median splits the box into two segments representing equal proportions ( 25 percent) of the data set, but the segments are often of unequal height.

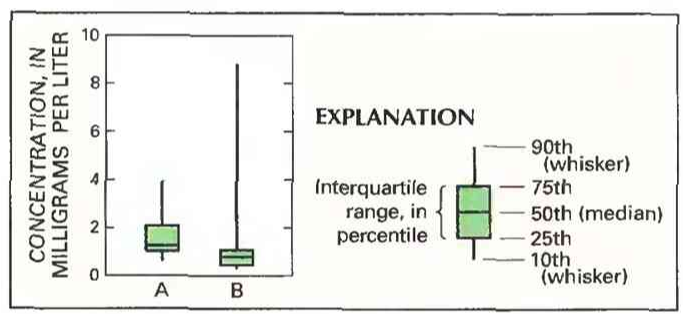

Figure 29. Hypothetical box plots showing the components of a box plot.

The 25th and 75th percentiles of the data, respectively, form the top and bottom lines of the box. Therefore, by definition, 25 percent of the data have a value equal to or less than the bottom line of the box, and 75 percent have a value equal to or less than the top line of the box. For example, the 25th percentile in case A of figure 29 is $1.0 \mathrm{mg} / \mathrm{L}$ (milligram per liter), which indicates that 25 percent of the data are equal to or less than this value; and the 75th percentile of the A data is 2.1 $\mathrm{mg} / \mathrm{L}$, which indicates that 75 percent of the data are equal to or less than this value. The range in concentration between the 25 th and 75 th percentile-the height of the box-is called the interquartile range. For case A the interquartile range is 1.1 (2.1 minus 1.0$)$ and for case $\mathrm{B}$ the interquartile range is 0.6 ( 1.1 minus 0.5 ).

Lines called whiskers extend vertically from the top and bottom of each box out to the 10th and 90th percentiles of the data. Therefore, the 10 percent of the observations that lie above the end of the upper whisker and the 10 percent that lie below the end of the lower whisker are not shown on the plot. Upper and lower whiskers of unequal length give further evidence that the data represented by a box plot follow a skewed distribution. This is the case with the B data set's extended upper whisker, which is caused by a single outlier.

The data of figure 29 are somewhat skewed, as shown by the unequal size of the segments of box $A$ and by the unequal whisker lengths for both boxes. A symmetric distribution would instead have a box with segments of similar size and have whiskers of similar length. Because the data of figure 29 are not symmetrical, application of statistical tests that assume a symmetrical data distribution might produce inaccurate results.

A more traditional alternative to box plots for portraying water-quality data is dot-and-line plots, which can obscure important characteristics of the data. Figure 30 displays the data from figure 29 as a dot-and-line plot.

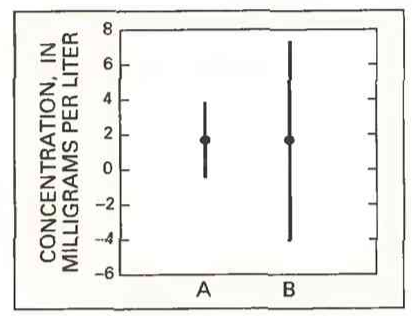

Figure 30. Example of dot-andline plot using hypothetical data of figure 29 .

In such plots, the mean data value is plotted as a dot, and the variability of the data is shown by a vertical line that extends plus and minus 2 standard deviations (or standard errors) above and below the mean, respectively. Dot-and-line plots would be appropriate if the data were symmetrical and had no outliers, but environmental data usually do not have these characteristics. Note that figure 30 does not show the skewness of the data. Also note that the large standard deviation for case $\mathrm{B}$ is the result of the one outlier, whereas the small interquartile range of figure 29 clearly shows this variation to be uncharacteristic of most of the data. Finally, the negative concentrations are impossible.

\section{Types of Box Plots}

Although there are a number of types of box plots, the three most common versions are the simple, standard, and truncated (Helsel and Hirsch, 1992), and they differ only in how data outside the boxes are shown (fig. 31). In the simple box plot, whiskers are drawn outward from the box to the maximum and minimum data values. In the standard box plot, the whiskers are shortened, and outliers are shown as distinct values. For the trun-

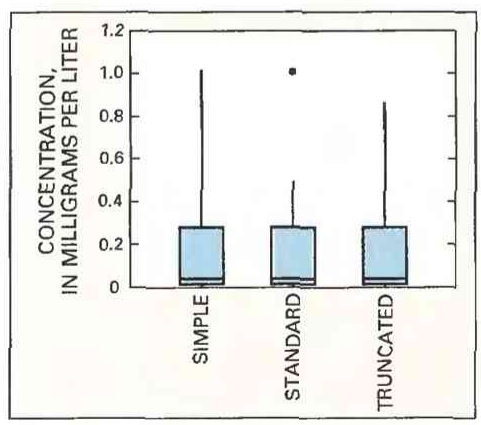

Figure 31. Three common versions (simple, standard, and truncated) of the box plot. Each box plot represents the same data. 

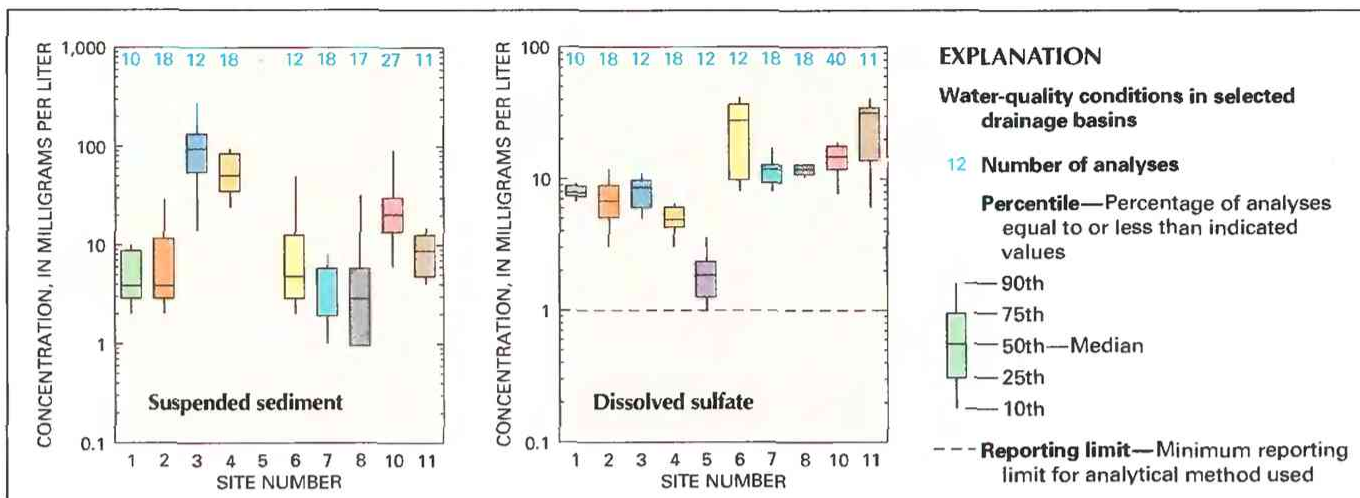

Figure 32. Example of truncated box plots used in the State summaries of this volume of the National Water Summary. (Site 9 not used for this analysis.)

cated box plot, the highest and lowest 10 percent of the data are not represented, and whiskers are drawn to the 10th and 90th percentiles of the data (this is the type shown in figure 29). Truncation allows the majority of the data to be plotted without compressing the scale of the box to show extreme outliers.

Truncated box plots are most appropriate when the extremes are of less interest than is the majority of the data. That is true of the data used in this volume, and therefore truncated box plots are used in the State summaries. Figure 32 is an example of the truncated box plots used in the State summaries to show water-quality conditions in selected drainage basins. This type of box plot also was used to represent ground-water quality throughout the Nation in the 1986 National Water Summary (U.S. Geological Survey, 1988). Further information about the various types of box plots can be found in Chambers and others (1983) and McGill and others (1978).

Data that exhibit skewness often are plotted on a logarithmic scale, a scale commonly used for scientific data covering a wide range of magnitudes. Figure 32 is one example. A logarithmic scale compresses the locations of upper data values by plotting multiples of 10 as adjacent tick marks on the vertical axis. Box plots of skewed data often appear relatively symmetric when plotted on a logarithmic scale.

\section{Box Plots for Data Sets Containing Values Below a Reporting Limit}

Data sets that include values that are known only to be below a reporting limit also can be shown effectively by box plots. Because there is no way of knowing what the actual values are, no values below the reporting limit value are actually shown. A line is drawn across the graph at the reporting limit value, and the portion of the whisker and box segment below the reporting limit is masked. The resulting appearance is one of box plots rising over a horizon. The proportion of the box and whiskers seen above the reporting limit is in direct relation to the amount of data whose values are greater than the reporting limit value.

Figure 33 illustrates how box plots are modified if they represent data that include values below a minimum reporting limit. The data are dissolved-solids con- centrations displayed as box plots for seven long-term surface-water sampling sites along the Colorado River. The (hypothetical) reporting limit of $600 \mathrm{mg} / \mathrm{L}$ is seen as a horizontal dashed line across the entire figure. The degree to which box plots are seen above this line is related directly to the percentage of data at each site below the reporting limit. For example, fewer than 10 percent of data at the Hoover Dam through Morelos Dam sites are below $600 \mathrm{mg} / \mathrm{L}$, so that the reporting-limit line is below the lower whisker. The box and whiskers are completely portrayed. For the Colorado-Utah State line and the Cisco sites, between 25 and 50 percent of the data are below the reporting limit, so that the horizontal line cuts off everything below part of the central box. At the Lees Ferry site between 75 and 90 percent of the

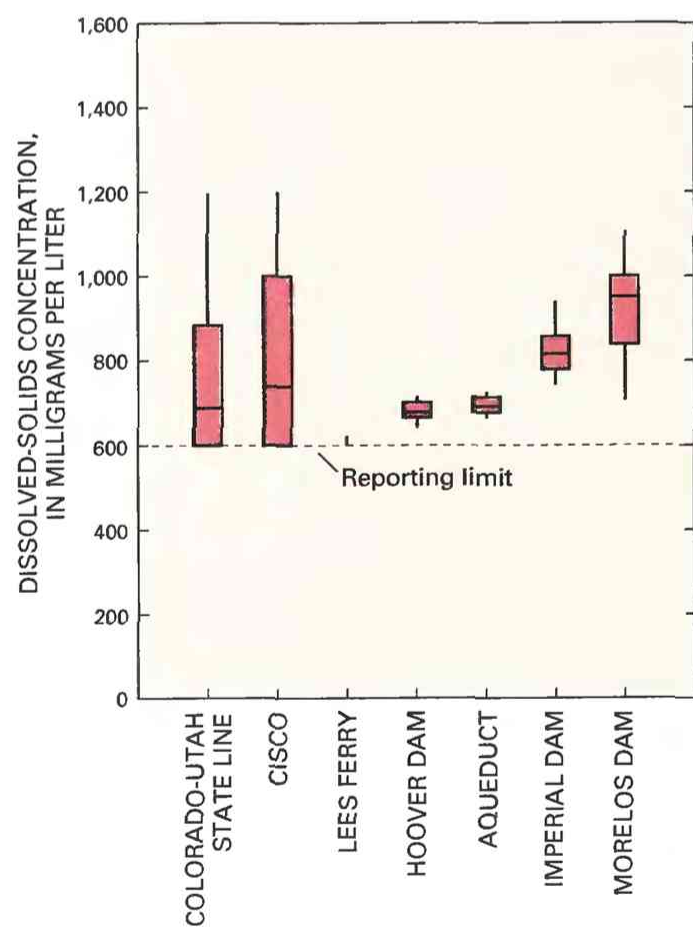

\section{EXPLANATION}

Percentile-Percentage of analyses equal to or less than indicated values

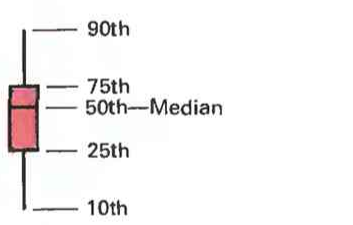

$$
\text { UPSTREAM } \longrightarrow \text { DOWNSTREAM }
$$

Figure 33. Examples of box plots that show the effect of a minimum reporting limit for the data. 
data are below the reporting limit, so that the entire box and part of the upper whisker are obscured. For each site, these box plots accurately portray both the distribution of data above the reporting limit and the percentage of data below.

\section{SCATter Plots ANd SmoOthed Lines}

Scatter plots are perhaps the most common type of graph used in scientific applications. Data are defined by two variables $(x, y)$ that are plotted to illustrate the relation between the variables. The range and trend of the data are easily comprehended from the plot, but details about the center- the pattern of how the $y$ value varies with the $x$ value - are much more difficult to see.

For example, the scatter plot in figure $34 A$ shows the relation between the sand load transported by the Colorado River at Lees Ferry, Colo., by a wide magnitude of streamflow. Whether a straight or curved relation better fits this data is difficult to determine by eye. Because subtle changes in the slope of a line often are difficult to see objectively, and to better judge patterns of data without being strongly influenced by outliers, a
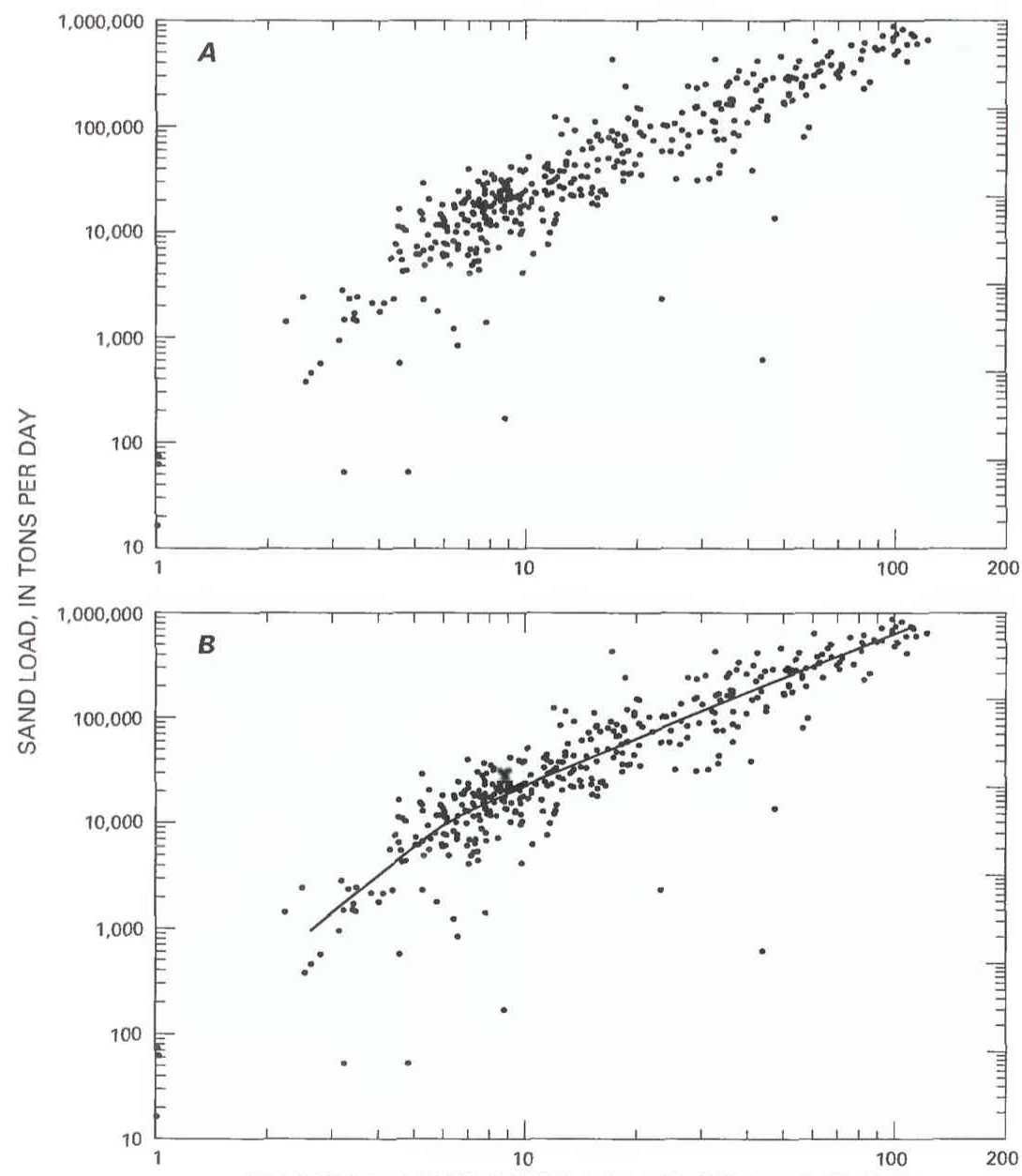

STREAMFLOW, IN THOUSANDS OF CUBIC FEET PER SECOND

Figure 34. Example of scatter plot $(A)$ and a scatter plot with superimposed LOWESS smoothed line $(B)$. Note that scales are logarithmic, a common representation when scientific data cover a large range of magnitudes. smoothed center line whose direction and slope vary locally in response to the data themselves can be fitted mathematically within the data. Thus, if the data are in a straight line, the mathematically computed center line will be a straight line. If the data are in a curved line, the computed center line also will curve. Many mathematical methods are available for constructing this type of center line-probably the most familiar is the moving average. The method discussed here, and used in the State summaries of this volume, is called LOWESS, or Locally Weighted Scatterplot Smoothing, and is described in detail by Cleveland and McGill (1984) and Cleveland (1985).

In figure $34 B$, a LOWESS smoothed line is superimposed on the Lees Ferry data scatter plot of figure $34 \mathrm{~A}$. The left side of the line shows a slight break in the slope, verifying that a straight line would not fit the data accurately over the full range of the data. The rate of increase in sand transport slows above 7,000 cubic feet per second. This curvature is much easier to see after superimposing the smoothed line over the data. The greatest strength of a LOWESS smoothed line is that no particular form of the relation (straight line or other) is assumed before computation. The smoothed line can be curved or straight, taking any form that the data dictate. As such, smoothed lines help the eye discern the pattern of relation between variables. Smoothed lines are used in the State summaries of this volume to illustrate the relation between constituent concentrations and time.

LOWESS is complex to compute. The method is called locally weighted because nearby data to the left and right of the point on the line to be estimated will affect the value of the smoothed line more than those farther away. Because the smoothed line is less affected by vertical outliers than by data more toward the center of the pattern, the method is called robust in the statistical literature.

The smoothness of the line can be varied by altering the proportion of data used in computing the value of the smoothed line at each location; as more data are included, the line becomes less sensitive to local fluctuations, and therefore smoother. Selection of the proportion of data used is determined subjectively according to the purpose for which the analysis is made. In the State summaries in this volume, relatively large proportions of data were used, so that the resulting lines show overall patterns that have little local variation.

Smoothed lines also are used in trend analyses to model the effect of streamflow on concentration of suspended sediment or dissolved constituents. The departures from the smoothed line are tested for trend, as explained in the next section.

\section{TESTING FOR TRENDS}

Trend analysis is the determination of whether values of a particular variable have changed over time. One of the primary uses for statistical tests in water quality is to determine whether constituent concentrations are changing consistently over time; for example, whether nitrate concentration generally is increasing in a stream over a 10-year period. A test for trend will determine if such a trend can be detected against the background variability of the data. In the State summaries in this volume, 
the trend test used is the seasonal Kendall test (Hirsch and others, 1982).

\section{Seasonal Kendall Test}

The seasonal Kendall test is a nonparametric (or distribution free) test for trend. It makes very few assumptions about the characteristics of the data. As such it is applicable to data that have the characteristics described above in the section "Common Characteristics of Water-Quality Data." In particular, it does not assume that the data follow a normal or other symmetrical distribution, as do parametric statistical tests. Inlike parametric tests, nonparametric tests easily and correctly handle skewed data and data having outliers. Therefore, nonparametric tests are more generally applicable to a wider variety of data than are parametric tests.

The test also allows for seasonal differences in water quality. Data in one season are compared only to data in the same season in later years. In this way, variations in concentrations throughout the year do not add to the uncertainty of the data. which must be overcome before a trend can be discerned. A complete discussion of the advantages of nonparametric tests as applied to environmental data is given by Helsel and Hirsch (1992).

The common parametric test for trend is a linear regression, which is computed by determining whether the straight line that best fits the data differs from a horizontal line. Concentration is the response $(y)$ variable, and time is the explanatory $(x)$ variable. If the line is level, no change has occurred. If the line slopes upward or downward, the concentration is changing. Linear regression assumes that-

- $y$ and $x$ are related in a straight line,

- the distribution of data around the line follows a normal distribution, and

- the variability of data around the line is constant over the range of data.

When many hundreds of sites and many constituent concentrations are to be tested, as in the State summaries in this volume, verifying whether the three above assumptions are met for each equation can be very difficult and time consuming. Consequently, the use of procedures having fewer underlying assumptions, such as nonparametric methods, has great advantages.

In contrast, the seasonal Kendall test does not require the three above assumptions in order to test for trend. It tests for a monotonic (increasing or decreasing, but not necessarily straight line) relation between concentration and time. For data not fitting the assumptions of regression, the nonparametric test will have a greater ability to detect trends when they exist, while not falsely declaring them to be present when they are not. Because the seasonal Kendall test is so generally applicable, the same test can be applied to all constituents and sites, regardless of the distribution of the data. This makes it ideal for repeated use in comparing trends at a wide variety of sites.

\section{KENDALL'S TAU}

The seasonal Kendall test is based on the nonparametric correlation coefficient tau $(\tau)$ (Kendall,1938), which measures the strength of any monotonic relation between variables and thus is well suited for variables that exhibit skewness and do not have a normal distribution. Tau is computed by first ordering all data pairs by increasing time. If a constituent concentration is correlated positively with time, the concentration will increase more often than decrease as time increases. For a negative correlation, the concentration will decrease more often than increase. If no correlation exists, the concentration will increase and decrease at about the same frequency. Tau is computed by counting the number of increases and decreases. Its significance is tested by determining whether more increases or decreases in concentration occur than would be expected by chance alone.

Any statistical procedure compares the patterns found in the data to those expected to occur merely by chance. Kendall's tau is no exception. The natural variability of data can produce some imbalance between increases and decreases in concentration without implying that a trend has occurred. To be considered significant, test results used for the State summaries in this volume must have been extreme enough that there would be less than a 5-percent chance of getting the observed value of tau when there was no trend, but only natural variability. This is the meaning of the statistical statement that the probability must be less than an aipha of 0.05 . Alpha is the probability chosen as the cutoff above which the test results are declared to be indistinguishable from natural variability. Results having a 10 - or 15 percent probability of being produced by chance alone, for example, would be declared as having no trend in the State summaries.

Another implication of an alpha of 5 percent is that about 5 percent of all tests (all combinations of sites and chemical constituents tested) can be expected to result in a false declaration of trend. Unfortunately, there is no way to determine which of the declared trends are actually in this category. When a trend is found, an estimate of the rate of change in concentration over time also is possible, although these are not shown in the State summaries. The nonparametric estimate related to tau is called a Kendall's slope estimate. Computation methods are described by Hirsch and others (1982).

\section{USE of IDENTICAL TIME PeRIOdS}

Whenever concentration trends are computed at more than one location, the time period used for the tests must be identical in order to compare the concentration trends among the various sites. Trend is not a static phenomenon. Concentrations might generally increase for 10 years, for example, followed by a decrease over the next 10 years. For the entire 20-year span there might then be no overall trend. Comparisons among sites in which data represent different parts of this period could result in citing increases at one site and decreases or no trend at another site due solely to differences in the time period examined. Therefore, trends during four consistent and distinct time periods-1970-89, 1975-89, $1980-89,1982-89$ - are used in the State summaries. Trends in the concentration of a constituent are not compared across these time periods. Figure 35 is an example of maps used in the State summaries to show these trends. 


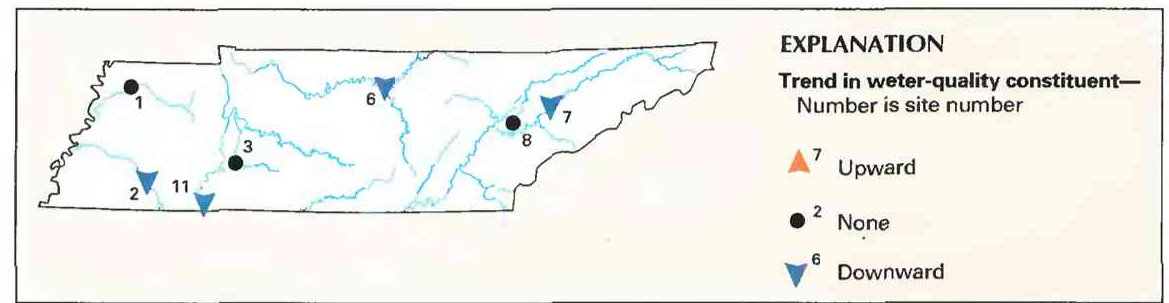

Figure 35. Example of maps used in the State summaries in this volume of the National Water Summary to show results of trend analyses. Note: Numbers refer to site numbers used in other illustrations in the State summaries, and not all trend symbols appear on every trend map.

\section{COMPENSATING FOR SEASONALITY}

Seasonal Variation Trend

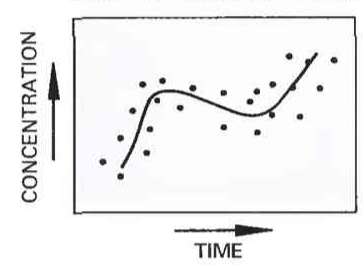

Seasonal changes in environmental conditions are a major source of variation in water quality. By removing or compensating for short-term seasonal variation, any trend in constituent concentration over longer time periods is more easily seen. For the seasonal Kendall test, compensation for seasonality is accomplished by performing tests on data from the same seasons, and each month can be considered a season. For example, January concentrations are compared only with January concentrations from other years, February only with February, and so on, until 12 trend tests are performed. No comparisons are made across seasonal boundaries. A test statistic is computed for each season, and then the 12 tests are combined to form an overall test for trend. An overall estimate of the rate of change in concentration (the slope) also can be computed without crossing seasonal boundaries.

Trend tests were computed for 12 seasons in the State summaries. If there were insufficient samples to do this, 2-month or 3-month seasons were used. In this way, sufficient data were available within each season to compute a separate test for trend.

Box plots such as those shown in figure 32 were used in the State summaries only when the data represented all the seasons of the year. In this way no seasonal patterns, such as concentrations that were consistently higher in the spring, would be over- or under-represented in the box plots and therefore be misleading as to characteristics expected year-round.

\section{ADJUSTMENT FOR STREAMFLOW}

Variables other than time and season often have considerable control on stream water quality. Some of these variables are natural and random phenomena such as rainfall, temperature, or streamflow. The fluctuations over time in these natural variables can make any trend in water quality difficult to detect. For the seasonal Kendall test, variation in concentration due solely to streamflow can be removed by first computing a LOwESS smoothed line of concentration versus streamflow (Hirsch and others, 1991). For example, figure $36 \mathrm{~A}$ is a scatter plot of the concentration of a hypothetical waterquality constituent versus time that may or may not be affected by changes in streamflow. Figure $36 B$ is a scatter plot and superimposed LOWESS curve of the concentration of the constituent versus streamflow. Because there is an obvious relation between streamflow and constituent concentration--concentrations are clearly higher at higher streamflow-a more accurate portrayal of trends in concentration can be seen if the fluctuation in streamflow is removed. Figure $36 C$ shows the residual values of constituent concentration after the concentration that was expected at the streamflow level at the time of data collection is subtracted from each observed value. The residual values in figure $36 C$ clearly show an upward trend. In the State summaries, concentrations were similarly adjusted for streamflow whenever possible.

As long as the relation between concentration and streamflow has not changed over the period of the trend test, a trend in the residuals implies a trend in concentration (fig. 36). If the relation has changed, as when the trend period spans the construction of a major reservoir project or new diversion, the results are less clear. A trend in the residuals for this situation might not be due to a trend in concentration, but to the changes in streamflow which have altered the relation to concentration during the period. Controlling variables such as streamflow must be free from changes caused by human influence, or that influence must be constant, over the period tested for trend. When it is impossible to adjust for streamflow due to changing human influence, rainfall data often are used as a surrogate for streamflow, although this has not been done in the State summaries. There also is some indication that prolonged drought may alter the relation between concentration and discharge, resulting in a trend due to what may be natural causes.

Use of Seasonal Kendall Test for Data Sets Containing Values Below a RePORTING LIMIT

Because tau depends only on whether constituent concentration increases or decreases with time, and not on the magnitude of concentration, it can be computed even in cases when some of the data are known only as less than a reporting limit. This is not true for regression and most other parametric methods (Helsel, 1990).

The seasonal Kendall test can be used without any difficulty when only one reporting limit exists. Comparisons are then possible between all pairs of observations. All values reported as less than the reporting limit can be compared to values above the reporting limit. Difficulties arise when the reporting limit changes with time. This can be expected to occur as a consequence of the introduction of more sensitive chemical-analytical procedures during a long-term water-quality data-collection program. For example, if a procedure that determines discrete constituent-concentration values above a mini- 


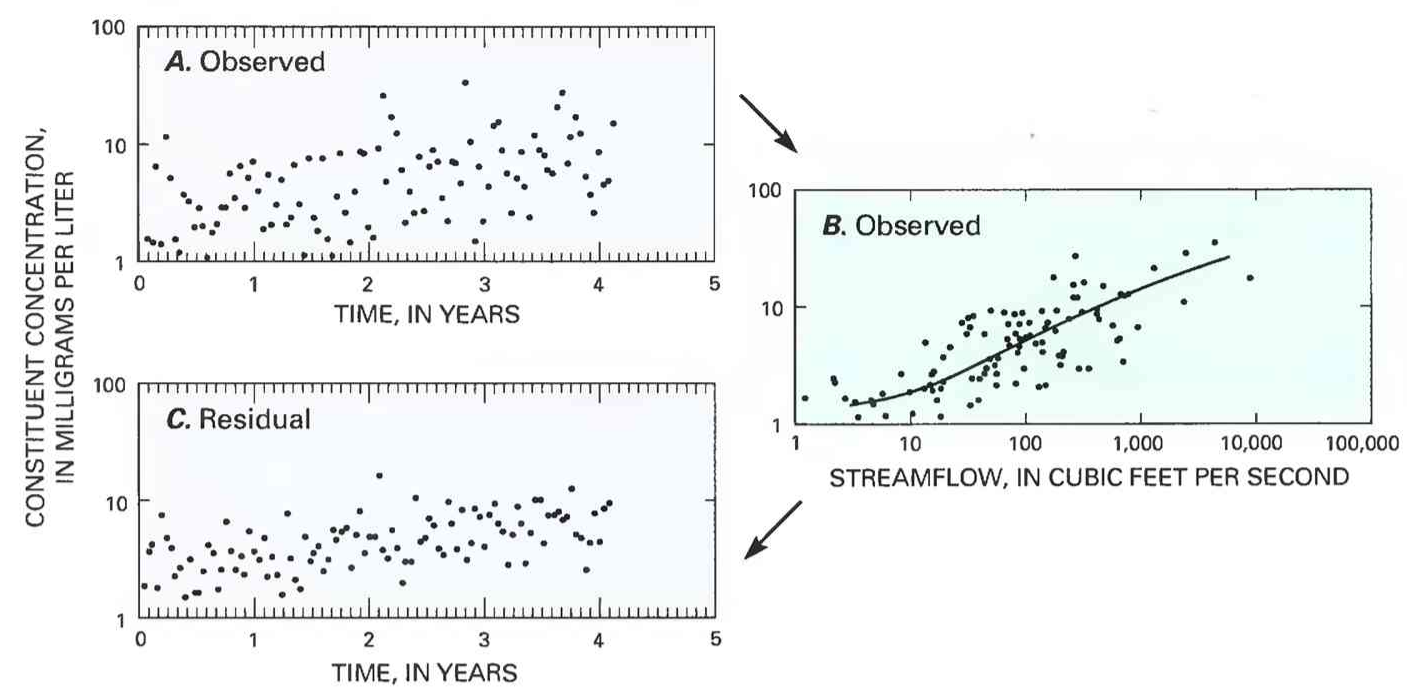

Figure 36. Hypothetical water-quality data that are adjusted to remove the variability of streamflow. A. Scatter plot of observed constituent concentration versus time. B. Scatter plot of constituent concentration versus streamflow and a superimposed LOWESS line that quantifies the relation of constituent concentration with streamflow. $C$. Scatter plot of residual constituent concentration versus time, where the residual concentration is the difference between the observed value of constituent concentration and the expected value of constituent concentration, based on streamflow at the time of observed data collection. Note that the scale for the constituent concentration is logarithmic.

mum reporting limit of $5 \mathrm{mg} / \mathrm{L}$ is replaced with a procedure that determines values above $1 \mathrm{mg} / \mathrm{L}$ during a datacollection program, a data set that contains the values $<5,7,<1,3$, and $<1$ could result (the more sensitive procedure was introduced after the $<5$ and before the first $<1$ values were collected). There is no way to compare $\mathrm{a}<5$ with $\mathrm{a}<1$ and determine which one was higher or whether they were the same. These ambiguities make the seasonal Kendall test difficult to compute; the only way to use the test in this situation is to convert all values lower than the highest reporting limit to a less-than value. The resulting data set of $<5,7,<5,<5$, and $<5$ loses information as a result, and the ability to detect a trend decreases. However, few other methods are valid for dealing with such data, and, in the State summaries, this adjustment was performed to data sets that had more than one level of less-than values.

\section{SUMMARY}

Graphs can illustrate a great deal more information about data than a single numerical statistic, and they more clearly portray information than do tables of numbers. Box plots and smoothed-line scatter plots are the graphical methods used in this 1990-91 National Water Summary. Box plots allow easy comparisons of important features among several groups of data. They show the center, variation, and symmetry of the data. Smoothed-line scatter plots, similar in function to a moving average, show the central pattern of the relation between two variables. Both types of graphs allow the data to determine their shape, rather than imposing predetermined assumptions about symmetry and linearity.

Nonparametric tests generally are applicable to a wide variety of types of data, including that of stream water quality. Their use avoids problems found with parametric tests, which depend on some aspect of the data following a particular distribution such as the normal (bell-shaped) distribution. The seasonal Kendall test for trend is a nonparametric test that compensates for differences in concentration due to seasonality and streamflow. Thus, it focuses on the item of interestchanges in constituent concentration over time. The use of box plots, smoothed-line scatter plots, and the seasonal Kendall test has enabled the Nation's stream water quality to be uniformly reported and interpreted in this volume of the National Water Summary.

\section{REFERENCES CITED}

Chambers, J. M., Cleveland, W.S., Kleiner, Beat, and Tukey, P.A., 1983, Graphical methods for data analysis: Boston, Mass., PWS-Kent Publishing Co., 395 p.

Cleveland, W.S., 1985, The elements of graphing data: Monterey, Calif., Wadsworth Books, 323 p.

Cleveland, W.S., and McGill, Robert, 1984, The many faces of a scatterplot: Journal of the American Statistical Association, v. 79 , no. 388 , p. 807-822.

Helsel, D.R., 1990, Less than obvious-Statistical treatment of data below the detection limit: Environmental Science and Technology, v. 24, no. 12, p. 17661774.

Helsel, D.R., and Hirsch, R. M., 1992, Statistical methods in water resources: Amsterdam, Elsevier Publishers, $522 \mathrm{p}$.

Hirsch, R.M., Alexander, R.B., and Smith, R.A., 1991, Selection of methods for the detection and estimation of trends in water quality: Water Resources Research, v. 27 , no. 5 , p. $803-813$.

Hirsch, R.M., Slack, J.R., and Smith, R.A., 1982, Techniques of trend analysis for monthly water quality data: Water Resources Research, v. 18, no. 1, p. 107121. 
Kendall, M.G., 1938, A new measure of rank correlation: Biometrika, v. 30, p. 81-93.

McGill, Robert, Tukey, J.W., and Larsen, W.A., 1978, Variations of box plots: The American Statistician, v. 32 , no. 1, p. 12-16.

U.S. Geological Survey, 1988, National water summary 1986-Hydrologic events and ground-water quality:
U.S. Geological Survey Water-Supply Paper 2325, $560 \mathrm{p}$.

\section{FOR ADDITIONAL INFORMATION}

Dennis R. Helsel, U.S. Geological Survey, 413 National Center, Reston, VA 22092 
By Linda C. Friedman

\section{INTRODUCTION}

One of the most important challenges to organizations that regulate and manage the Nation's water resources is to obtain reliable water-quality data. Concepts of assuring the reliability of water-quality data are discussed in this article. Information on the quality-assurance program of the U.S. Geological Survey (USGS), the agency within the Federal Government that has the principal responsibility for providing hydrologic information about the Nation's water resources, also is provided.

The term "water quality" commonly has a connotation related to human consumption and domestic water use. However, knowledge about water quality also is essential for industrial, agricultural, and recreational uses. Thus, the collection of water-quality data is a major public concern and one in which all levels of government - town, county, State, and Federal-actively participate. In the last few decades, people in the United States (and in the rest of the world) have grown increasingly aware of protecting the environment and, in conjunction with this awareness, have grown increasingly concerned about human influence on the Nation's water resources, as reflected by the water-quality laws passed by the Congress.

Federal laws passed between 1965 and 1987 (such as Public Law 89-234, the Water-Quality Act of 1965; Public Law 92-500, the Federal Water-Pollution Control Act Amendments of 1972, and its subsequent amendments in 1977, 1979, 1980, 1981, 1983, and 1987) have fostered the involvement of all levels of government in the quality of water by, for example, giving the States authority to establish standards for water quality and by providing funds for construction of municipal sewage-treatment plants, and so forth. (See article
"Nationwide Water-Quality Reporting to the Congress as Required Under Section 305(b) of the Clean Water Act" in this volume.) These laws, along with those passed by other levels of government, and the increased concern of the public have led to the expenditure of billions of dollars to protect and improve water quality. Thus, Ember (1992, p. 18) notes, "Since***1972, the Environmental Protection Agency estimates the U.S. has spent nearly $\$ 590$ billion (in 1990 dollars) on water pollution control."

To support the expenditure of this money and to meet the information needs required to regulate and manage our water resources, vast amounts of waterquality data are being collected by governments at all levels and by private-sector organizations. It is essential that these data be reliable. However, determining the reliability of water-quality data is difficult because of the many factors that affect reliability.

\section{QUALITY ASSURANCE}

\section{General CONCEPTS}

Quality assurance can be described as programs and sets of procedures, including but not limited to quality-control procedures, that are necessary to assure product quality or data reliability. Inherent in the concept of quality assurance is the attempt to assure that the quality of a product is "good." However, the terms "good quality data" and "poor quality data" can be misleading unless the intended use of the data also is considered. As Taylor (1985a, p. 67) notes, “Absolutes do not exist, and judgments of quality often must be made on an individual basis. What is good quality in one situation

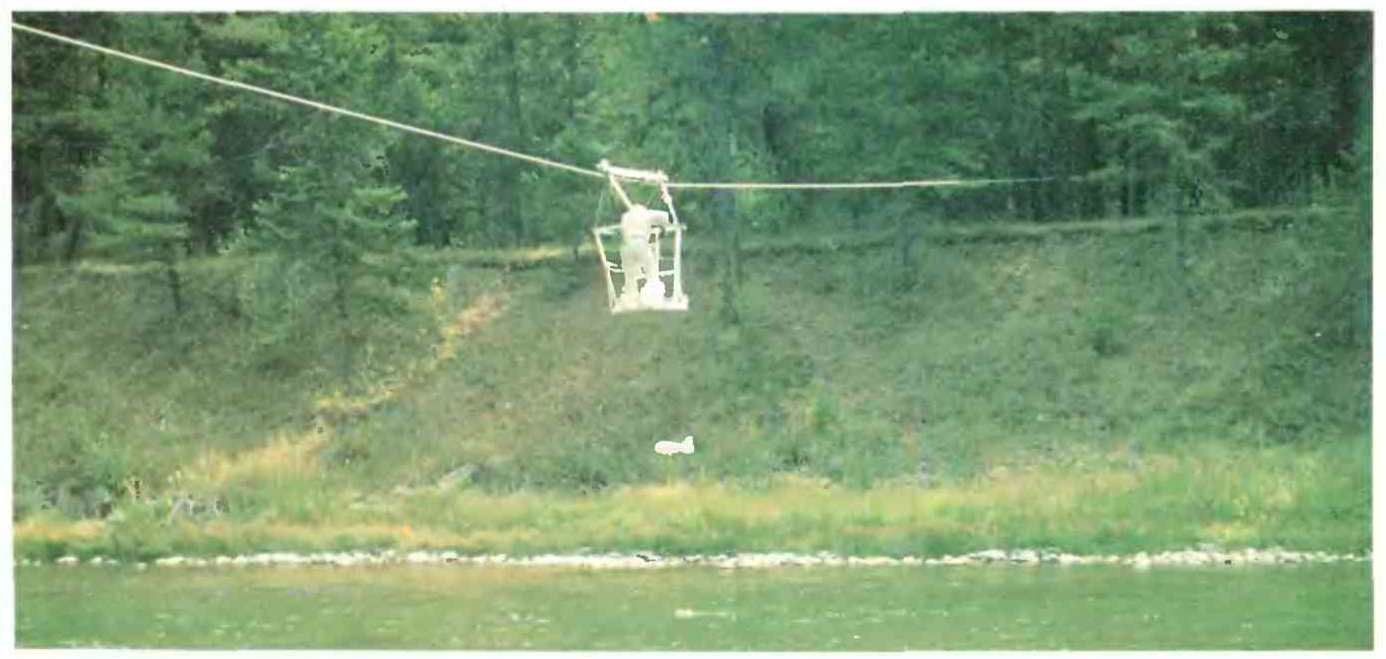

USGS hydrologist collects water-quality samples of the Blackfoot River, Mont., to determinine contamination from mine tailings. (K.J. Lanfear, U.S. Geological Survey) 
or even in one person's perception could be considered poor or inadequate quality in another case. Evaluation of quality thus depends on the intended use of the product or service and a judgment as to whether expectations have been realized." Similarly, McCully and Lee (1980, p. 57) note that quality assurance "could be defined as producing the best product (analytical result) possible. However, this would probably lead to the analyst producing very few analytical results since the best analytical result possible was the objective. Therefore, from a practical point of view, the quality of the analytical results should be defined according to the use intended rather than the best possibie."

Because water-chemistry and physical sediment data are the most abundant water-quality data that have been collected in recent decades, the State summaries of water quality in this volume are based largely on these data. Although many of the quality-assurance principles and programs discussed in this article are general and pertain to all kinds of water-quality data, some are specific to water-chemistry data and not to other data types such as biological data, which are being used increasingly to characterize water quality. For additional information on quality assurance of biological data, see Ohio Environmental Protection Agency (1989) and U.S. Environmental Protection Agency (1978).

\section{WATER-QUALITY DATA}

To determine trends in water quality over a period of time or to correlate data from different areas of the country, water-quality data must be comparable, regardless of when the samples were collected, where the samples were analyzed, and what methodology and specialized techniques were used to collect and analyze the samples. Fundamental to the concept of making measurements is that measurements can be only estimates of the properties being measured.

Fortunately, inasmuch as all water-quality data are obtained from some form of physical, chemical, or biological measurement and measurements are always subject to uncertainty, the data can be used without the user knowing the values measured with infinite certainty. In order to use or make water-resources management decisions based on the data, data users can rely on the data if they are confident that the data represent the portion or entire waterbody of concern and that the data can be compared to an analytical standard and (or) to each other.

\section{OBSTACLES TO ASSURING THE RELI- ABILITY OF WATER-QUALITY DATA}

Assuring the reliability of water-quality data (or other environmental data) involves difficulties that usually do not exist in assuring the quality of manufactured products or of nonenvironmental data. For example, in developing and applying quality-assurance practices to an industrial process, an important tenet is that accuracy - which is the degree of agreement of the measured value with the true or accepted value — can be measured and specified. Thus, when a product is being manufactured, design specifications are set and the product is expected to meet the specifications within certain lim- its. These limits are set by determining what the consequences would be if the product deviates from the specifications. Procedures for quality control and quality assurance are established to measure specifications of the product and to assure that they stay within the limits. The specifications, and type and degree of procedures that are applied, typically are the result of some compromise with costs, which may be measured in terms of lives as well as dollars.

In contrast, the collection of environmental data deals with unknowns. It is not possible to measure the closeness of the collected data to an accepted value without first knowing the accepted value. For example, when analyzing a water sample, chemical measurements are reported relative to analytical standards; and the chemical analyses are verified, where appropriate, using reference materials, which are stable homogeneous materials, having one or more known or experimentally determined chemical or physical properties. However, because standards and reference materials are unlikely to be prepared using the exact environmental matrix of the sample and because the environmental-sample matrix could significantly affect the analytical results, some uncertainty in the analytical results will remain.

Although employee training is a concept central to quality-control and quality-assurance programs and is essential to producing good water-quality data, one cannot always presume that the use of well-trained personnel will result in accurate water-quality data. Although the accuracy of a trained individual in analyzing a standard sample can be determined because the standard sample has been prepared to have predetermined concentrations of constituents, the accuracy of that individual in analyzing a particular field sample will be uncertain because concentrations of constituents in the field sample are unknown. Furthermore, whereas the trained individual's analysis of the field sample can be compared with the analysis produced by others, some uncertainty of the accuracy of reported values will remain-even if the results from all analysts are the same--because one can never be certain that the consensus represents the "true" concentration.

As can be readily discerned from the article "Factors Affecting Stream Water Quality, and WaterQuality Trends in Four Drainage Basins in the Conterminous United States, 1905-90" in this volume, natural waters are very complex mixtures. Surface water, in particular, usually is not homogeneous. However, to determine the water quality of a large body of water, such as a lake or stream, it is necessary to assume that the measurements that are taken and samples of water that are collected and analyzed are representative of the entire body, or that portion of the waterbody that is of concern. As Hem (1985, p. 42) points out, this is an intrinsic problem that faces anyone collecting water-quality data: "Sampling is a vital part of studies of natural-water composition and is perhaps the major source of error in the whole process of obtaining water-quality information***. In any type of study in which only small samples of the whole substance under consideration may be examined, there is inherent uncertainty because of possible sampling error."

Assuming that a representative sample is collected, some of the other factors that can adversely affect data reliability, such as contamination of the sample, can be avoided or at least minimized if everyone in- 


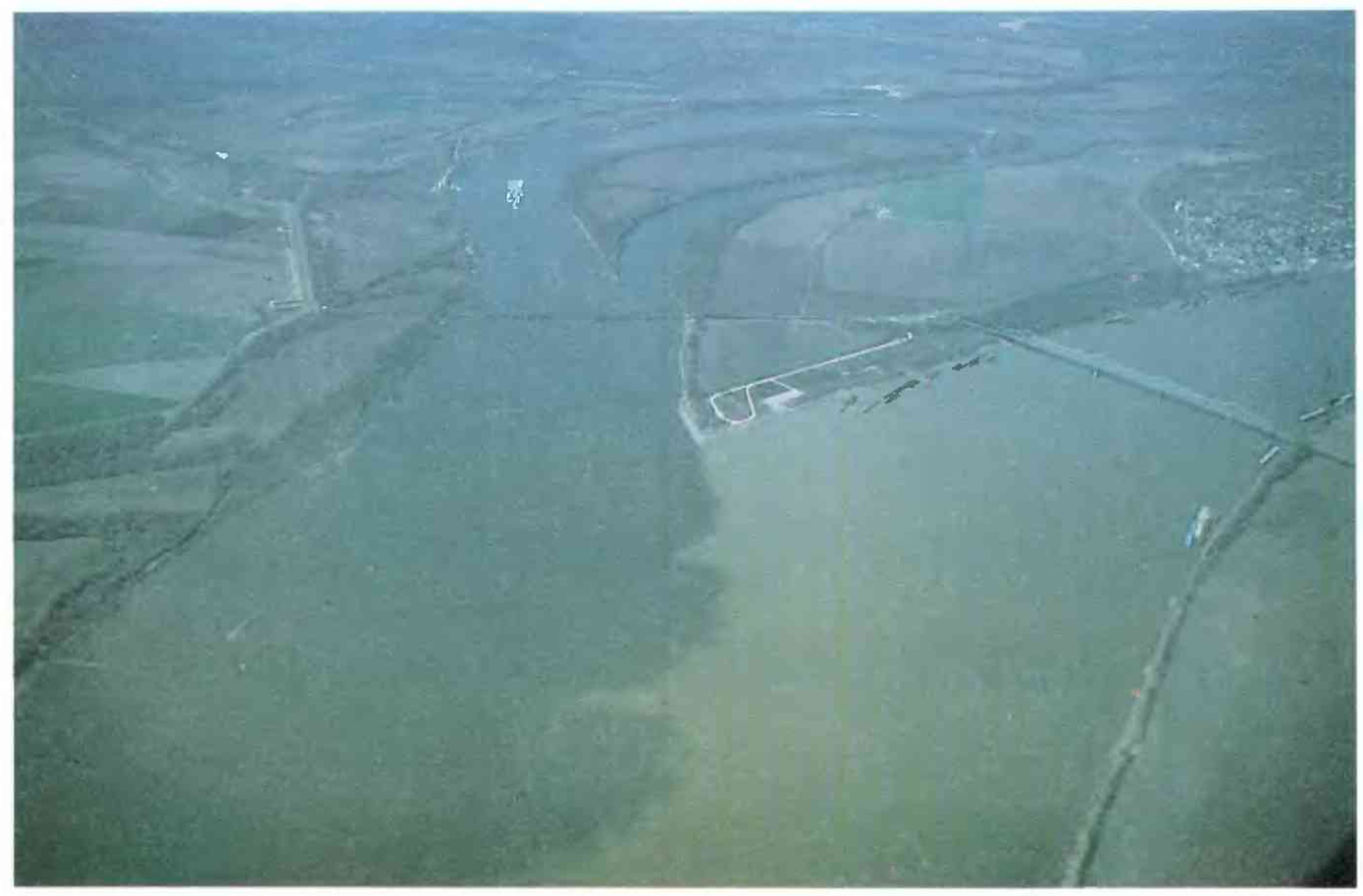

Confluence of the Ohio and Mississippi Rivers at Cairo, III. Note the contrast in the appearance of the rivers. (R.H. Meade, Jr., U.S. Geological Survey)

volved in collection and analysis of the water sample is sufficiently trained, properly equipped, and careful. But still other factors, such as an undetermined compound that causes an unsuspected analytical interference, can be subtle and difficult to detect.

Increases in the size of the data-collection area and the length of time during which data are collected also tend to aggravate reliability problems. However, the study of larger water-resources systems is inevitable as emphasis on studying nonpoint-source pollution continues to increase. Rickert (1991, p. 19) points out that past expenditures have "abated the worst of gross pointsource pollution" but further states, "The Nation faces a new water-quality challenge in the 1990 's - how to reduce contamination from potentially toxic trace elements and manmade trace organic substances that enter surface and ground water largely from nonpoint sources***." Extending the size of a study area to determine contamination from nonpoint sources, as well as increasing the duration of data collection, will increase the number of variables (including people). Minor differences in sample collection and analysis can therefore be magnified.

The proliferation of regional and multiagency data-collection programs in recent years also has added to the problem of assuring data quality. Farland (1980, p. vii) notes, "Traditionally, the basis for evaluation of data quality has been the reputation of the principal investigator responsible for the measurement program. Today, many***measurement programs involve many individuals or several organizations. So usually it is not possible for a principal investigator to control personally all aspects of the data process; data from such programs can no longer be judged solely on the reputation of the investigator."

\section{SOURCES OF ERROR}

\section{GENERAL}

Although quality-assurance programs are designed to increase the reliability of water-quality data, they will not eliminate all data variability and sources of error. Understanding the sources of data uncertainty provides insight into the problems of collecting and using water-quality data. For example, Robertson's (1976, p. 808) observations substantiate why the determination of trace elements in natural water continues to be particularly difficult even though analytical sensitivity has improved significantly over the last decade: "First, the concentrations of most trace elements are present in most natural waters near or below***detection sensitivities of many of the popular analytical techniques presently in use. Secondly, at these extremely low concentrations contamination problems are often overwhelming; and thirdly, natural waters are so complex in their physicochemical and biological makeup that very subtle partitioning among biotic and abiotic fractions greatly complicates storage and analysis of these waters."

As described below, errors and differences in data comparability can be introduced when the sample is collected, transported, or stored, when analyses of the sample are made, or when the resulting data are recorded or stored. Although the following discussion is not exhaustive, it identifies many of the sources of data uncertainty.

\section{Collection of SAmples}

The need for and the inherent difficulties in obtaining representative water samples from a heterogeneous surface-water body have been mentioned. 


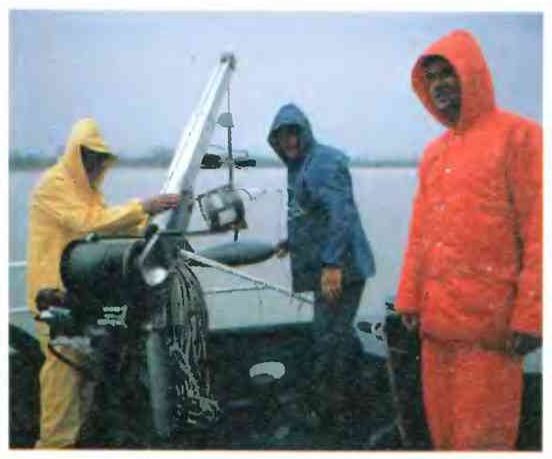

USGS hydrologists and chemists prepare to collect depth-integrated samples of the Mississippi River. (R.H. Meade, Jr., U.S. Geological Survey)
Sampling sites must be sufficient in number and be positioned so that the samples will represent the entire waterbody. Sometimes, the position of sites must be made to meet multiple study objectives. For example, one study might require that samples be collected near public water-supply intakes, whereas another study might require that samples be collected near suspected contamination sources. Also, because concentrations of constituents vary vertically and horizontally in a waterbody, water samples ideally are collected in increments across a waterbody using methods designed to ensure that the samples are depth integrated. However, there is a limit to what can be done. As Hem (1985, p. 43) notes, "The more portions taken, the more nearly the sample represents the whole. The sample error would reach zero when the size of the sample became equal to the original volume of material being sampled, but for obvious reasons this method of decreasing sampling error has practical limits." Although practical limits dominate sampling decisions, sampling density generally is determined by the amount of heterogeneity of a waterbody.

Deciding when to collect samples is analogous to deciding where to collect them. Concentrations of many constituents in surface water vary with the time of year because of factors such as seasonal differences in the volume of water in a waterbody, seasonal differences in amounts of herbicides applied to surrounding land, and so forth. Some constituents, such as dissolvedoxygen concentration, even vary with the time of day. Inasmuch as it is not practical to collect samples continuously, decisions about when to collect them are very important.

\section{DIVISION OF SAMPLES}

Sampling problems are not limited to those related to collecting the original water samples from a large body of water. Immediately after field collection, the samples usually are divided (subsampled) into smaller portions, some of which also might be filtered to remove sediment, and then are further divided either in the field or more often in a laboratory into portions on which actual analyses are done. Thus, for those samples that are not filtered, a complex heterogeneous mixture of water and sediment is divided and subdivided to obtain many samples that are intended to represent the body of water, but often do not because of the uneven distribution of sediment among the samples. For samples that have been filtered, hetereogeneity might not be a problem, but other problems, such as contamination, adsorption, and variability in concentration caused by the use of filters of different pore size and diameter, are more likely to occur.

\section{Alteration OF SAMPLES by Contamination OR LOSS OF CONSTITUENTS}

Water samples can be contaminated in many ways. Samples in the field or laboratory can be contaminated by fingers or by dust. A detected element or compound can leach into the sample from the container material, particularly if the container was cleaned improperly or is made of inappropriate material (for example, using an inappropriate plastic container to collect a sample for organic analysis). Preservatives, which sometimes must be added to a sample to prevent changes in the concentration of the constituent being determined (by acting as bactericides or by preventing precipitation, for example) might not be sufficiently pure. Samples also can be contaminated by the ambient air as, for example, by vehicle fumes, which in recent years were a major source of lead contamination in water samples. Volatile preservatives used in one sample might migrate into another sample through the container walls. Even if contamination of a sample is avoided during its collection, preservation, and analysis, contamination of a laboratory reagent or standard sample also can contribute to erroneous data.

In addition to changes caused by contamination, the concentration of a constituent in a water sample can decrease as the constituent is lost because of bacterial action or volatilization, adsorbtion (onto filters, containers, and so forth), or precipitation. Such losses can occur during sample collection, preservation, transport, storage, and analysis. To reduce such losses, it is important that the sample be preserved adequately, whether by the addition of chemicals (for example, nitric acid to keep trace metals in solution) or by physical means (for example, chilling to reduce bacterial action). Organic compounds particularly are subject to loss during analysis. For example, before determining specific organic compounds in a water sample, an organic solvent is used to extract (separate) the organic compounds from the water. However, because part of any organic compound being determined is likely to remain in the water phase of the sample, even after multiple extractions, the determined concentration usually will be less than the true concentration.

Although the likelihood for contamination or loss of constituents increases as the amount of samplehandling increases, considerable manipulation cannot be avoided for most samples. As noted above, samples usually are divided into smaller samples and, depending on the analyses to be made, may be filtered and (or) preserved. Analysis is almost certain to necessitate further handling of the sample. Unless extreme care is taken during each step, a portion or all of the water originally collected can undergo some contamination or constituent loss.

\section{ANALYTICAL INTERFERENCES}

As used here, the term "interferences" pertains to constituents in a natural waterbody that can interfere with the determination of other constituents in a water sample, rather than to contaminants added during sample collection and handling. Chemically, the word "water" represents the hydrogen and oxygen compound, $\mathrm{H}_{2} \mathrm{O}$; however, in reality the Nation's water resources are stud- 
ied to determine what is dissolved and suspended in $\mathrm{H}_{2} \mathrm{O}$. If only one or two simple compounds were involved, the study of water would be relatively simple. However, surface water (and ground water) is an extremely complex mixture and many of the constituents that are dissolved or suspended in a sample have the potential to interfere with the determination of other constituents in the sample.

The degree to which there is an interference in making an analysis depends on many factors, including the amount of the interfering substance relative to the amount of the substance being determined and the analytical method used. An interference can result in the reporting of a value that is too high (positive interference) or too low (negative interference) relative to the true or accepted value. It also can result in the false detection of a compound that is not in the water or the lack of detection of a compound that is in the water. Robertson (1976, p. 814) notes that, "For essentially every measurement technique there exists some type of chemical interference which can affect the accuracy."

For example, constituents other than the one of interest can inhibit a chemical reaction necessary for the determination of the constituent being measured or they can react with a reagent to form an apparent excess of the constituent. An interfering constituent can produce an electronic signal in an instrument that alters the electronic signal that results from measurement of the concentration of the constituent of interest. Color and turbidity also are two interferences, particularly important in spectrophotometric or colorimetric analyses, that physically interfere with analyses, usually resulting in concentration determinations that are higher than they should be. The amount of dissolved solids in a sample or the $\mathrm{pH}$ of the sample also can interfere with some analytical methods.

For common interferences, compensatory techniques often are allowed for in the analytical method. Because they are costly and time-consuming, other techniques designed to compensate for less common interferences are unlikely to be used, unless the interferences are suspected or detected. When developing a new instrument or analytical method, it is impractical, if not impossible, to test for interferences from all possible substances and at all levels of concentration. Instead, knowledge of the theory behind the instrument or method, along with knowledge of similar instruments or methods, is used to focus on those substances that are likely to interfere. Thus, undetected interferences can contribute to errors in water-quality data. If, eventually, the interference is discovered, the feasibility of reviewing the data and correcting or compensating for the interference might not be possible.

\section{Changes in Methods and Equipment}

Three factors that can vary with analytical methods and instruments are (a) analytical bias, which is a specific positive or negative deviation of the value from the true or accepted value, (b) precision, which is the degree of agreement of repeated measurements and is expressed in terms of dispersion of the values obtained about the average value, and (c) the lowest concentration that can be detected. Because data records incorporate artifacts of the instruments used to obtain data, data from different types of instruments and different methods may not be comparable even if all instructions are carefully followed and instruments are properly calibrated and maintained. As instruments become obsolete and are replaced by instruments of new design, the lack of data comparability can become a serious problemeven if the new instruments are more precise, have lower detection limits, and are less subject to interference.

Water-quality data variability attributable to new analytical methods probably began to increase markedly in the 1960's when, in parallel with increasing interest in collecting water-quality data, the variety of new types of analytical instruments designed to analyze waterquality samples also increased. For that reason, waterquality data records can be difficult to interpret because it often is not possible to separate the data peculiarities of an analytical method from the natural variability of a constituent.

Long-term data-collection programs are particularly subject to data-interpretation problems that result from changing analytical methods. Therefore, managers of such programs must determine the circumstances under which a method should be changed. Relevant questions are: Should a method be used even if the resulting data are no longer the best that can be determined? If a method currently being used is subject to interferences not present in a newer method, which method should be selected? What if neither method has interferences, but the constituent of interest can be detected at a much smaller concentration by the newer method? If a new method is not adopted now, does this mean that the current method should be used for another 50 or 100 years even though future methods are likely to yield data that are many times more accurate?

Instruments and analytical methods will continue to evolve, and analysts

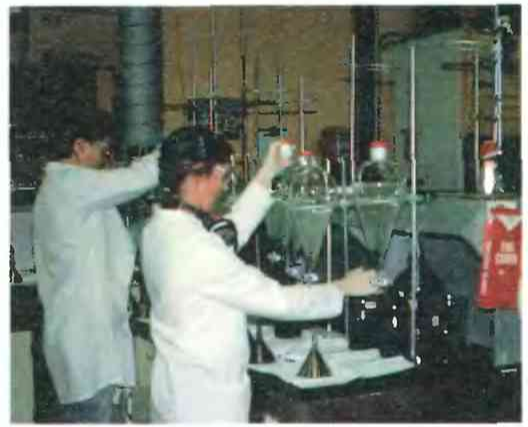

USGS chemists perform water-quality analyses at the Survey's National WaterQuality Laboratory near Denver, Colo. (Carlos Arozarena, U.S. Geological Survey) seeking to obtain and provide the best data possible will be inclined to select the newer instruments and methods. Quality-assurance programs must assure comparability of future, present, and historical water-quality data. Every change must be documented with regard to the type of change and the date of initial use of a new method or instrument. Samples must be analyzed for a specific period of time by the method being replaced and by the method being adopted and the data compared. Note that it is not necessary to require that the two methods produce identical data, but rather that the methods produce data that can be compared. Nonetheless, it must be recognized that it is virtually impossible to always assure that two very different analytical techniques will give comparable results for all water-quality samples.

\section{Changes in Personnel}

The number and type of personnel involved in collecting and analyzing water-quality data vary with the purpose and size of the data-collection project. For example, in a research project or in a project that is short term, localized, or both, personnel are few and the same people generally stay with the project until it is com- 
pleted. In contrast, a large-scale long-term project involves many people. In some long-term programs, few, if any, of the people involved will stay with the project from start to finish.

Taylor (1985b, p. 34) notes, "By the laws of probability, the chance of faulty data will increase rapidly as the number of participants increases." In one sense, the fact that people seek to produce high-quality work is part of the problem: "Doing what 'seems to be right' at a given moment is a practice characterized by frequent changes and often by overcompensation, resulting in outputs that are difficult to evaluate statistically" (Taylor, 1985a, p. 70). In contrast, human complacency about maintaining the high quality of data becomes more prevalent when, as the number of people involved in collection and analysis grows larger, individual staff members lose sight of how the data are to be used. Although it is impossible to limit the number of people involved in a widespread data-collection activity or eliminate the turnover of people involved in longterm programs, their adverse effect on the data can be minimized to some extent by ensuring that everyone is adequately trained and that all changes in personnel, collection techniques, and methods are adequately documented.

One way to increase confidence in water-quality data is to have several individuals simultaneously collect water samples from the same site. If analyses then are repeated many times using different analytical instruments and methods, perhaps also using different laboratories, and if all answers agree one can make the assumption that the data are accurate. The assumption is a good one, even if potentially erroneous because, as noted earlier, one cannot be certain that the consensus represents the true value. However, such time-consuming and costly procedures usually are practical only in small research projects and not in large environmental data-collection programs.

\section{DOCUMENTATION INADEQUACIES}

Many problems associated with interpretation of water-quality data could be eliminated and some errors even corrected if data-collection and analysis records included sufficient ancillary data. Along with the water-quality data, all information related to sample collection procedures, analytical methods, and personnel changes should be recorded, and each person involved in a project should be careful to document even minor deviations from normal procedures. In discussing medical records, Hicks and others (1978, p. 279) note, "The fundamental role of the record cannot be overemphasized. When the subject, the requesting authority, and the analyst have all departed from the scene, nothing remains but the record, which has a permanent intrinsic value - if its data are valid."

One challenge in comparing historical water-quality data with data obtained today is that of determining which methods were used to collect and analyze the samples. Although, ideally, records should be kept of the procedures that were used in sample collection and analyses, Taylor (1985b, p. 10-11) notes, "When methods are repeatedly used, there is incentive to write them up in a formal manner, but those used on an infrequent basis are often based on an analyst's 'know-how'***. The practice of using unwritten methods should be discouraged. Docu- mentation of what was done is almost always needed. When the writing is done after-the-fact, it is likely to be brief and sketchy and possibly inaccurate. Describing a method before its use is part of planning and should be done with as much care as that used for all other aspects of a chemical analysis."

The advent of the computer has both simplified and complicated data collection and interpretation. One problem that develops when data are stored, particularly in a computerized data base, is that the original purpose for collecting the data might not be documented in the data base. Large computerized data bases contain enormous amounts of data in an easily retrievable form; however, most of the data bases contain only analytical data, and information about the purpose and techniques used in sample collection and analyses normally are unavailable. Such unannotated data from computer files might not be a problem or might be only a minor problem in studies that are relatively short term and limited in scope, inasmuch as written or oral supporting documentation probably can be obtained with relative ease. However, the use of unannotated data becomes more of a problem as studies encompass larger areas and longer time periods or when an attempt is made to use data from studies that have been completed more than a few years previously. Increasingly, efforts are being made to incorporate significant changes, such as a change in analytical method, into computerized data bases. However, documentation of minor changes, such as a change in the strength of an oxidant, which might make major differences in the data, seems unlikely to be included in computer data bases in the near future. Because incorporation of ancillary data into water-quality data bases is not yet practical, gaining access to the information is costly even when such data have been recorded.

Quality-assurance programs should require periodic review of all field and laboratory records, including documentation of standard-solution preparation, instrument calibration, and reference-material analyses. Furthermore, before a data record is stored, a graphical representation or mathematical analysis of all data for a sample should be made by at least one person familiar with the sampling site to see if the data make sense. As Naus $(1975$, p. 3$)$ notes, "For a given data set, there is always information to help spot errors. There are known constraints on the values of variates. There is historical experience on likely ranges of values. The experience may consist of values (sometimes ratios or differences) that are deemed 'acceptable.' The experience may draw on a variety of sources, including judgment of analysts***." Although careful review can eliminate some errors from the permanent record, it is important that data not be rejected simply because they do not meet preconceived notions. Thus, an extreme reported concentration for a constituent could be either the result of an error or it could represent an extreme actual value.

\section{QUALITY ASSURANCE OF USGS WATER- QUALITY DATA}

\section{BACKGROUND}

Water-quality data collected by the USGS are stored nationally in the USGS National Water Data Storage and Retrieval System (WATSTORE) and in the U.S. Environmental Protection Agency's data base known as 
STORET; the data also are stored in each USGS field office in computerized files known as the National Water Information System. These data, which are available to and used by other agencies in their water-resources management and regulation function, also can be accessed by the public (Edwards, 1987). Because the growth of USGS quality-assurance programs and the growth of its water-quality programs are related, the reliability of USGS water-quality records is inevitably linked to the quality-assurance history of obtaining those records.

The USGS has been involved with the collection of water-quality data almost from its inception on March 3,1879 , and has long been aware that the quality of its data is of paramount importance. In summarizing the USGS water-quality activities during the years 1879 to 1973, Durum (1978, p. 3) notes, "The Survey's waterquality activity can be traced ${ }^{* * *}$ to 1879 when the first chemical quality of water resources information was made available" and also comments (p. 13) that, "Historically, the hallmark of Geological Survey analysts is reliable data."

Durum (1978) reports the establishment of the Division of Quality of Water as an independent unit within the Water Resources Branch of the USGS in January 1918. Durum details the increase in the number of USGS laboratories from 1 laboratory in 1918 to 2 in 1937 , and to 22 in 1967 . He also notes the subsequent decline in the number of USGS laboratories located in field offices, beginning in the 1970's as analyses were increasingly automated and laboratories were centralized. Today (1992), although some water-quality analyses are done at the sample-collection site or in USGS field offices, most are done under the control of the USGS National Water-Quality Laboratory, near Denver, Colo. Durum notes that early USGS analyses were directed primarily at major cations and anions, analytical methods were essentially limited to gravimetric, colorimetric, or titrimetric procedures before 1950 , and early analyses led to the development of relations that became the basis for some of the first techniques used in the quality assurance of water-quality analyses. These early techniques, which involved applying criteria developed from relations between dissolved solids and the constituents dissolved in the water (Howard, 1933) and achieving a balance between cations and anions, remain in use today as part of the analytical review process. Currently, computer programs are used to apply such criteria (Friedman and Erdmann, 1982) in checking analytical reports before the data are stored.

In the 1960's and 1970's, analytical capabilities advanced, and the USGS added organic, biological, and radiochemical determinations to an expanding list of inorganic determinations as the number of samples collected throughout the Nation increased. In response to the proliferation of synthetic chemicals that have the potential for contaminating water resources, the variety of organic determinations continues to increase. New agricultural and industrial chemicals are being added on a continuing basis to the list of determinations made by the USGS National Water-Quality Laboratory. Increasing public awareness that low concentrations of contaminants can affect human health and otherwise adversely affect our Nation's water, plus the availability of more sophisticated instrumentation, has led to the development of analytical methods that are increasingly aimed at detecting lower and lower concentrations of constituents. Although past practices still apply to today's quality-assurance efforts, the list of and need for additional quality-assurance practices continues to grow as more samples are collected for an expanding list of determinations and are analyzed by increasingly sensitive analytical methods.

\section{QuALITY AsSURANCE IN THE 1990's}

Some of the more important quality-assurance practices of the USGS in the 1990's include the use of standard methods of data collection and analysis, analysis of reference samples, and staff training. Additionally, the USGS cooperates with other laboratories in the analysis of reference samples.

\section{Standard Practices}

Laboratory quality-control practices, such as careful standard-sample preparation, instrument maintenance, and complete documentation, are essential to any good laboratory and are enumerated in the National Handbook of Recommended Methods for Water-Data Acquisition (U.S. Geological Survey, Office of Water Data Coordination, 1982). Such practices have been and are standard in the USGS. Durum (1978, p. 14) notes "Standard solutions were prepared by experienced chemists and compared against solutions of known reliability. Laboratory and portable field instruments were inspected and calibrations checked at regular intervals in accordance with manufacturers specifications***. Rechecks of suspect analysis and second analyst approval were standard procedure in all laboratories." Early USGS publications presented the analytical methods used, in addition to the study results (for example, Dole, 1909). Documents on methods such as that of Collins (1928) were published by the USGS and were available together with internal documents that summarized analytical procedures, although Durum (1978,p. 13) indicates that "the first attempt to standardize procedures in the ***laboratories" was not made until 1950. Currently (1992), the USGS requires the use of documented analytical methods such as those described by Britton and Greeson (1987), Fishman and Friedman, (1989), and Wershaw and others (1987).

Each USGS water-resources field office is required to use approved collection techniques (for example, Ward and Harr, 1990), to follow specific instructions for cleaning sample bottles, selecting and cleaning filtering equipment, and so forth, and to ensure that instruments are properly calibrated. Each office is required to maintain an up-to-date quality-assurance plan (for example, Knapton and Nimick, 1991) and to conduct timely reviews of all of its water-quality data. For example, the requesting USGS field office must review the data obtained from the National Water-Quality Laboratory within 30 days. If, during this time, the field office believes the analytical results are in error, it can request reanalyses of samples (Jones, 1987); after 30 days, the laboratory may discard the samples. Water-quality activities in each field office undergo formal technical reviews by the USGS Office of Water Quality (the successor of the Division of Quality of Water), which is responsible for for the development of techniques for the collection, 
analysis, and interpretation of water-quality data. Such formal reviews, begun in 1968 with, as Durum notes, a desire for improved quality control, are a key component of USGS quality-assurance activities.

\section{Reference Samples}

The USGS also relies on its Standard Reference Water Sample (SRWS) program (Janzer, 1985; Long and Farrar, 1992; Malo and others, 1978; and Schroder and others, 1980), and it cooperates with other laboratories in conducting laboratory quality-control and qualityassurance activities. Begun in 1962, the program is unlike reference-sample programs that are based on distilled or deionized water in that, since 1966 , it has usually used filtered natural surface water as the base from which to prepare reference materials. A benefit of the program is that users have detected analytical problems that are not always apparent in reference-sample programs that are based on a distilled or deionized water matrix. Therefore, USGS and all laboratories working cooperatively with the USGS are required to participate in the SRWS program.

In addition to using the SRWS reference samples, USGS analysts use other reference samples and participate in appropriate interlaboratory performance tests conducted by other government agencies (for example, those conducted by the U.S. Environmental Protection Agency). Analysts at the National Water-Quality Laboratory routinely analyze SRWS and other reference samples along with appropriate standards. If necessary (for example, to analyze samples in which an interference is suspected or in determining organic constituents), analysts "spike" samples with known concentrations of the constituent of interest to verify the analysis. Control charts are kept, and the laboratory analysts reanalyze samples when reference-sample data indicate that there might be a problem.

As part of a self-imposed quality check, the chief of the National Water-Quality Laboratory submits reference samples to the laboratory on a daily basis. In addition, the USGS Branch of Quality Assurance, which is organizationally distinct from the laboratory, sends reference samples to the National Water-Quality Laboratory; these reference samples, which are often mixtures of SRWS, are disguised to look like routine field samples and thus are not given special attention by the laboratory. Further discussion of these and other USGS qualitycontrol and quality-assurance procedures are given in Jones (1987) and Friedman and Erdmann (1982).

\section{Training}

As stated in the National Handbook of Recommended Methods for Water-Data Acquisition (U.S. Geological Survey, Office of Water Data Coordination, 1982, p. 5-191), "The quality-control plan should provide for a periodic assessment of training needs and should describe the scope and manner in which training is to be accomplished. New employees should not be allowed to work alone until their work is at least equivalent to existing employees'. Meetings and workshops should be scheduled to exchange information and maintain high levels of skill." Training always has been a key part of USGS activities, and on-the-job training is conducted in every office. Further, in addition to meetings and workshops, the USGS has held formal water-quality training courses for more than 30 years. These courses are now taught routinely at the USGS National Training Center in Colorado. Within the past few years, the USGS also has begun training its personnel in the concepts of a management style known as "total quality management"; in this management style, all employees in an organization, including those in top management, are committed to improvement and to producing quality products.

In recent years, the increasing use of total quality management throughout the Nation reflects the growing awareness of the importance of assuring quality and the realization that top management must participate. The theory behind the phrase entails having everyone in an organization aware of and involved in assuring quality. In such organizations, employees and managers work together, in a continuous team effort, to improve products of the organization.

As noted by Juran (1974, p. 18-3), "Many managers believe that the company's quality problems could be solved by the operators [although] overwhelming evidence is that operator-controllable defects generally are less than $20 \%$ of the total" and that (p. 18-46) "most quality problems are management-controllable," and "upper management participation is $* * *$ the real index of the importance of the quality function***."

Reid (1990), in discussing what he terms "employee involvement (EI) techniques," indicates that drastic changes in management attitude are often needed to provide a background where such techniques can work. He states (p. 164), "Quality Circles. Brainstorming. Task forces. Teamwork Training. They're all useful EI formats. But they are only formats. Unless these programs are provided in a nurturing organizational climate, their benefits will soon be snuffed out by the existing bureaucratic, authoritarian structure and mind-sets. Trying to change human behavior in an unsympathetic environment is an exercise in futility."

Organizations that have embraced the total quality management concepts are recognized to have greatly improved product quality. As a result, the concept is spreading throughout government agencies. The emphasis now being placed on management training and team development is an investment that, for water-quality data, can be expected to further enhance data reliability in the future.

\section{USGS DATA IN THE STATE SUMMARIES IN THIS VOLUME}

Quality-control and quality-assurance practices have been an integral part of USGS history, and the majority of USGS data are reliable. Nevertheless, during the preparation of the State summaries in this volumeNational Water Summary 1990-91-Hydrologic Events and Stream Water Quality-some USGS water-quality data were found to be unsuitable for use in long-term trend analyses because of problems of contamination or bias. (For more details, see article "Introduction to State Summaries of Stream Water Quality" in this volume.) Also, sporadic reports (for example, Shiller and Boyle, 1987; Windom and others, 1991) have suggested that some USGS trace-metal data are unreliable. Investigation of these problems by the USGS has suggested that some of the problems with the data could be the result of in- 
sufficiently documented changes of analytical method and (or) reporting criteria, whereas other problems are believed to be the result of sample contamination, particularly during sample collection.

In general, errors in USGS water-quality data have been detected through the application of quality-control practices, the reasons for the errors investigated by the USGS, and the data not incorporated in USGS data bases. Some difficulty in data interpretation has occurred because data collected for different purposes have been combined in computerized data bases and, as explained in the section "Documentation Inadequacies," the original intended use of data is not known. Although the need to examine all data carefully before they are used can never be eliminated, the USGS has placed an increased emphasis on the need for documentation of analyticalmethod changes and is designing a data base that will incorporate such documentation.

The USGS data that were found to be unsuitable for determining long-term trends were, in general, valid as originally used to report the quality of a waterbody. Furthermore, although, as noted, some water samples collected for analyses of trace elements apparently were contaminated, the reported concentrations generally were below recommended health or other water-quality limits and, because the samples were contaminated, the actual values were even smaller.

\section{CONCLUSION}

All public and private organizations that collect data on the Nation's water resources need to operate effective quality-assurance programs that are supported by all levels of management. As Taylor (1985a, p. 75) notes, "Quality assurance [QA] is more than a program; it is a philosophy, a way of life. As a program, QA is doomed to failure. As a philosophy there is a chance for success. When QA is approached as both a program and a philosophy, the chances for producing high quality data are excellent."

Although costs associated with assuring the reliability of water-quality data (for complete and careful training of personnel, the collection and analyses of field samples, preparation and analysis of reference materials, review of activities and data, design of computer systems that can store more than just analytical results, and so forth) can be considerable, they are far less than the billions being spent to collect water-quality data and they are necessary to assure useful data. Without effective quality-assurance programs and the resulting highquality data, our society will not have the data needed to assure human health and safety, to document whether water-quality improvement programs are successful, and to determine the status of the Nation's environment.

\section{REFERENCES CITED}

Britton, L.J., and Greeson, P.E., eds., 1987, Methods for collection and analysis of aquatic biological and microbiological samples: U.S. Geological Survey Techniques of Water-Resources Investigations, book 5 , chap. A4, $363 \mathrm{p}$

Collins, W.D., 1928, Notes on practical water analysis: U.S. Geological Survey Water Supply Paper 596-H, $266 \mathrm{p}$

Dole, R.B., 1909, The quality of surface-waters in the United States-Part 1, Analysis of waters east of the one hun- dredth meridian: U.S. Geological Survey Water-Supply Paper 236, $123 \mathrm{p}$.

Durum, W.H., 1978, Historical profile of quality of water laboratories and activities, 1879-1973: U.S. Geological Survey Open-File Report 78-432, 235 p.

Edwards, M.D., 1987, NAWDEX-A key to finding water data: U.S. Geological Survey general interest publication, $15 \mathrm{p}$.

Ember, L.R., 1992, Clean water act is sailing a choppy course to renewal: Chemical and Engineering News, v. 70, no. 7, p. $18-24$.

Farland, R.J., 1980, Data quality assurance guidelines for marine environment programs: Office of Ocean Engineering, Rockville, Md., National Oceanic and Atmospheric Administration, $101 \mathrm{p}$.

Fishman, M.J., and Friedman, L.C., eds., 1989, Methods for determination of inorganic substances in water and fluvial sediments: U.S. Geological Survey Techniques of Water-Resources Investigations, book 5, chap. A1, $545 \mathrm{p}$.

Friedman, L.C., and Erdmann, D.E., 1982, Quality assurance practices for the chemical and biological analysis of water and fluvial sediments: U.S. Geological Survey Techniques of Water-Resources Investigations, book 5 , chap. A6, $181 \mathrm{p}$.

Hem, J.D., 1985, Study and interpretation of the chemical characteristics of natural water (3d ed): U.S. Geological Survey Water-Supply Paper 2254, 263 p.

Hicks, G.P., Kreig, A.F., and Thiers, R.E., 1978, Data transmission, in Inhorn, S.L., ed., Quality assurance practices for health laboratories: Washington, D.C., American Public Health Association, p. 273-294.

Howard, C.S., 1933, Determination of total dissolved solids in water analysis: Industrial and Engineering Chemistry, v. 5, no. 1, p. 4-6.

Janzer, V.J., 1985, The use of natural waters as U.S. Geological Survey reference samples, in Quality assurance for environmental monitoring: American Society of Testing Materials, Special Technical Testing Publication 867, p. 319-333.

Jones, B.E., 1987, Quality control manual of the U.S. Geological Survey's National Water Quality Laboratory: U.S. Geological Survey Open-File Report 87-457, 17 p.

Juran, J.M., 1974, Motivation, in Juran, J.M., Gryna, F.M., Jr., and Bingham, R.S., Jr., eds., Quality control handbook: New York, McGraw-Hill, p. 18-1-18-52.

Knapton, J.R., and Nimick, D.A., 1991, Quality assurance for water-quality activities of the U.S. Geological Survey in Montana: U.S. Geological Survey Open-File Report 91-216, $41 \mathrm{p}$.

Long, H.K. and Farrar, J.W., 1992, Report on the U.S. Geological Survey's evaluation program for standard reference samples distributed in April 1992- T-119 (trace constitutents), M-122 (major constituents), N-34 (nutrients), N-35 (nutrients), and $\mathrm{Hg}-14$ (mercury): U.S. Geological Survey Open-File Report 92-164, 100 p.

Malo, B.A., Beetem, W.A., Friedman, L.C., and Erdmann, D.E., 1978, The quality assurance program of a National Laboratories System, in Proceedings of the 4th Joint Conference on Sensing of Environmental Pollutants, New Orleans, La., November 6-11, 1967: Washington, D.C., American Chemical Society, p. 345-347

McCully, K.A., and Lee, J.G., 1980, Quality assurance of sample analysis in the chemical laboratory, in Garfield, F.M., Palmer, Nancy, and Schartzman, George, eds., Optimizing chemical laboratory performance through the application of quality assurance principles, Proceedings of symposium, Association of Official Analytical Chemists, 94th annual meeting, Washington, D.C., October 1980:: Arlington, Va., Association of Official Analytical Chemists, p. 57-86.

Naus, J.I., 1975, Data quality control and editing: New York, Marcel Decker, Inc., 202 p. 
Ohio Environmental Protection Agency, 1989, Standardized biological field sampling and laboratory methods for assessing fish and macroinvertebrate communities, v. 3 of Biological criteria for protection of aquatic life: $\mathrm{Co}-$ lumbus, Ohio Environmental Protection Agency, Division of Water Quality Planning and Assessment, Surface Water Section, $58 \mathrm{p}$.

Reid, P.C., 1990, Well made in America: New York, McGrawHill Publishing Company, $226 \mathrm{p}$.

Rickert, D.A., 1991, A perspective for the 1990's, in United States Geological Survey Yearbook Fiscal Year 1990: U.S. Geological Survey annual report, p. 19-24.

Robertson, D.E., 1976, Analytical chemistry of natural waters: U.S. National Bureau of Standards Special Publication 422 , v. 2, p 805-836.

Shiller, A.M., and Boyle, E.A., 1987, Variability of dissolved trace metals in the Mississippi River: Geochimica et Cosmochimica Acta, v. 51, p. 3273-3277.

Schroder, L.J., Fishman, M.J., Friedman, L.C., and Darlington, G.W., 1980, The use of standard reference water samples by the U.S. Geological Survey: U.S. Geological Survey Open-File Report 80-738, 11 p.

Taylor, J.K., 1985a, The quest for quality assurance: American Laboratory, v. 17, no. 10, p. 67-76.

$1985 \mathrm{~b}$, Principals of quality assurance of chemical measurements: U.S. National Bureau of Standards NBSIR 85-3105, $71 \mathrm{p}$.

U.S. Environmental Protection Agency, 1978, Quality assurance guidelines for biological testing: U.S. Environmen- tal Protection Agency (Office of Research and Development, Environmental Monitoring and Support Laboratory, Las Vegas, Nev.), Environmental Monitoring Series, EPA-600/4-78-043, 474 p.

U.S. Geological Survey, Office of Water Data Coordination, 1982 , Chemical and physical quality of water and sediment, Chap. 5 of National Handbook of Recommended Methods for Water-Data Acquisition: Reston, Va., U.S. Geological Survey, p. 5-1-5-194.

Ward, J.R., and Harr, C.A., eds., 1990, Methods for collection and processing of surface-water and bed-material samples for physical and chemical analyses: U. S. Geological Survey Open-File Report 90-140, 75 p.

Wershaw, R.L., Fishman, M.J., Grabbe, R.R., and Lowe, L.E. eds., 1987, Methods for determination of organic substances in water and fluvial sediments: U.S. Geological Survey Techniques of Water-Resources Investigations, book 5 , chap. A3, 80 p.

Windom, H.L., Byrd, J.T., Smith, R.G., Jr., and Huan, Feng, 1991, Inadequacy of NASQAN data for assessing metal trends in the Nation's rivers: Environmental Science and Technology, v. 25, no. 6, p. 1137-1142.

\section{FOR ADDITIONAL INFORMATION}

Linda C. Friedman, U.S. Geological Survey, 436 National Center, Reston, VA 22092 


\title{
HYDROLOGY OF STREAM WATER QUALTY
}

\section{STREAM WATER QUALITY IN THE CONTERMINOUS UNITED States-STATUS AND TRENDS OF SElECTEd INDiCATORS DURING THE 1980's}

\author{
By Richard A. Smith, Richard B. Alexander, and Kenneth J. Lanfear
}

\section{INTRODUCTION}

In the years since enactment of the Clean Water Act, formally known as the Federal Water Pollution Control Act Amendments of 1972 (Public Law 92-500), and its subsequent amendments in 1977, 1979, 1980, 1981,1983 , and 1987, major changes have taken place in the sources of water contaminants and in the efforts to control them. Population distribution, land use, industrial activity, agricultural practices, and pollution-control strategies have all changed significantly. The effects of these changes on water quality and the consequences on human and ecological health and the use of water resources are of major economic and social importance. Thus, the early 1990's are an appropriate time to examine national water-quality conditions and trends.

In contrast to the State summaries in this volume that portray water-quality conditions and trends within State boundaries, this article presents a summary of national water quality in the conterminous United States, represented by the status and trends of selected indicators. This article is based on water-quality data from Federal and State monitoring programs, generally from 1980 to 1989 , and is intended to provide decisionmakers and the public with information on the progress being made toward water-quality goals. By necessity, the analyses presented in this article were compiled from a variety of data sources that, collectively, only partially address the diverse water-quality issues currently of interest. The major component of this article is an analysis of U.S. Geological Survey (USGS) monitoring data on several indicators of chemical and sanitary conditions in streams; secondary components are analyses of U.S. Fish and Wildlife Service (FWS) finfish-tissue data and analyses of USGS herbicide data from streams that drain agricultural areas in the Midwest.

This article is organized into three major sections, and much of the water-quality summary information is presented graphically. Thus, the following descriptions of the sections emphasize those illustrations.

1. The characteristics and limitations of existing national water-quality data.

2. The water-quality data selected for analysis and the geographic characteristics of the data. Because interpretation of water quality in the subsequent section is, in part, made on the basis of land use, this section introduces a land-use classification that is used in this article and shown in figure 37.

3. A national summary of conditions and trends in stream water quality as represented by:

- Figures 38-43, which show concentrations of six frequently measured indicators of chemical and sanitary conditions in streams and their relation to land use,
- Figures 44-45, which show yields of nitrate, total phosphorus, and suspended sediment transported from large water-resources regions (fig. 44) and according to land use (fig. 45),

- Figure 46 , which shows water quality of tributaries to selected reservoirs,

- Figure 47, which shows loads and yields of nitrate, total phosphorus, and suspended sediment transported to coastal waters,

- Figure 48, which shows water quality in basins used as sources of domestic, industrial, and irrigation water uses,

- Figure 49, which shows national trends in pesticides and toxic trace elements in finfish tissue, and

- Figures 50-51, which show herbicide concentrations in streams in agricultural areas of the Midwest.

\section{CHARACTERISTICS AND LIMITATIONS OF EXISTING NATIONAL WATER-QUALITY DATA}

\section{National WATER-QUALITY MONITORING}

Comprehensive and consistent data on nearly all aspects of environmental conditions at the national level currently are on the frontier of Federal statistical reporting. Therefore, some limitations are inherent in compiling a statistical description of national water-quality conditions and trends because reliable national data do not yet exist for many aspects of water quality. The primary reason for the lack of data is that water-quality monitoring is technically demanding and expensive, as are most types of environmental monitoring. Moreover, as monitoring programs have evolved over the past 20 years, ideas have changed about which water-quality indicators are important and how to measure them. As a result, long periods have elapsed between recognition of water-quality problems and the availability of national-level data that describe their occurrence, severity, and trends over time. Also, in conducting a statistically based analysis of water-quality trends, as many as 10 consecutive years of water-quality data commonly are needed to help distinguish short-term variability from long-term changes. (See article "Statistical Analysis of Water-Quality Data" in this volume for a discussion of statistical techniques of water-quality analysis.)

Currently (1992), two Federal water-quality monitoring programs are being implemented that will greatly enhance national water-quality data bases for future analyses-the USGS National Water Quality Assessment Program (Hirsch and others, 1988; Leahy and others, 1990) and the U. S. Environmental Protection 
Agency (EPA) Environmental Monitoring and Assessment Program (U.S. Environmental Protection Agency, 1990a). Together, these national programs are designed to monitor a wide variety of biological, chemical, and physical indicators. However, nearly a decade will be required to amass the quantity of data needed to document environmentally and statistically significant trends. In the meantime, descriptions of national water-quality conditions and trends must be based on data from numerous separate, less comprehensive monitoring programs.

\section{STREAM WATER-QUALITY INDICATORS}

Within Federal, State, and local monitoring programs, many water-quality indicators are used to describe different aspects of water quality. Indicators range from those that are specific and narrowly focused, such as individual chemical or bacterial concentrations, to those that are integrative and broadly focused, such as indices of biological community health. In the middle of this spectrum lie water-quality indices combining two or more chemical concentrations and bioassays in which the toxicity of a water sample is tested on living organisms. Narrowly focused indicators tend to be more precisely defined and methodologically standardized and are more easily related to specific causes and sources of contamination. Integrative indicators, in contrast, are more broadly defined and tend to relate more directly to the consequences of water quality in terms of water use and human and ecological health.

Ideally, a national summary of stream water quality would include analysis of data from a mix of indicators chosen from this broad spectrum. For several reasons, however, the range in indicators from existing national data bases is severely limited.

Biological indicators.-Perhaps the major limitation is a shortage of nationally representative biological data. In recent years, interest in the use of biological indicators rather than single chemical indicators has increased because they integrate many aspects of, and are more directly related to, human and ecological health. Most State governments monitor some biological aspects of water quality, and a few, such as Ohio, have large bioassessment programs (Ohio Environmental Protection Agency, 1987, 1992). However, because scientific consensus is lacking on the validity of any single biological indicator of streams, few national biological data bases exist.

Use support.-Support of waterbody designated use is an integrative water-quality indicator that refers to the degree to which the quality of a waterbody is sufficient to support State-designated water uses, such as fishing and swimming. An EPA national data base exists for this indicator because section 305(b) of the Clean Water Act requires States to make a biennial, statewide assessment of designated-use support and to submit the findings to the EPA, which in turn submits a national water-quality report to the U.S. Congress. (See article "Nationwide Water Quality Reporting to the Congress as Required Under Section 305(b) of the Clean Water Act" in this volume for a more detailed discussion of State reporting of water quality.) State officials determine the degree of support of designated use on the basis of formally adopted State-specific standards and criteria and then describe the water quality of a waterbody as either fully supporting, partially supporting, or not supporting the designated use. However, two major difficulties preclude the analysis of use-support data for determining national water-quality conditions and trends. First, State-to-State differences in the standards and criteria used to determine use support make it difficult to interpret regional patterns in water quality; and, second, methodological changes over the history of the 305(b) program preclude any analysis of trends.

Chemical indicators.-Despite considerable interest and some recent progress in collecting biological and integrative indicators of water quality, the majority of water-quality data that are available for analysis of conditions and trends of the Nation's streams are relatively specific, predominantly chemical data. These include measures of sanitary conditions, plant nutrients, and the concentrations of other commonly occurring substances. Even within the category of specific chemical indicators, however, existing national data bases fall far short of covering the spectrum of current interest.

Toxic chemicals.-A serious deficiency in chemical data is the nearly complete lack of national toxic-contaminant data bases. Organic and inorganic toxic compounds enter streams from many sources. A significant source of potentially toxic organic chemicals is pesticides. The number of agriculturally and domestically applied pesticides has increased over the past two decades and now includes hundreds of chemicals (U.S. Environmental Protection Agency, 1990b). From 1975 to 1980, regular sampling for 22 organochlorine and organophosphate pesticides occurred in a nationwide network of about 170 stations (Gilliom and others, 1985), but no nationally organized, long-term pesticide monitoring in streams has been undertaken since that time. As presented below in the section "Concentration and Transport of Herbicides in Agricultural Areas in the Midwest," however, data from recent short-term regional monitoring of selected pesticides are now available. Also, the Fws as part of its National Contaminant Biomonitoring Program (NCBP) has compiled a data base of analyses of trace-element and organic-compound concentrations in finfish that were collected periodically between 1970 and 1986. (Lowe and others, 1985; Schmitt and Brumbaugh, 1990; Schmitt, Zajicek, and Peterman, 1990; and Schmitt, Zajicke, and Ribick, 1985). Data through 1986 are summarized below in the section " $\mathrm{Na}$ tional Trends in Pesticides and Toxic Trace Elements in Finfish Tissue." Although the NCBP is the only one of its kind, only a small fraction of the pesticides and other toxic substances currently released to streams is monitored.

Toxic organic substances used by industry also are known to enter streams. These compounds include volatile organic degreasing agents, polychlorinated biphenyls (PCB's), and polycyclic aromatic hydrocarbons from the chemical manufacturing and petroleum industries. Unfortunately, no nationally organized stream monitoring for any of these substances has ever occurred, and no national-level data are available.

Some stream monitoring for toxic inorganic substances has occurred, but reliable national data are lacking for arsenic, cadmium, chromium, copper, lead, mercury, and most other trace elements. Federal, State, and local governments routinely have monitored trace-element concentrations in streams for more than a decade, but several recent studies have concluded that traditional 
techniques of sample collection and analysis have seriously overestimated the concentration of dissolved trace elements in streams (Flegal and Coale, 1989; Shiller and Boyle, 1987; Windom and others, 1991). Based on the findings reported in these studies, the relatively abundant national trace-element data are not reliable for statistical summarization.

\section{SELECTED WATER-QUALITY DATA}

From among the available water-quality indicators, three types of nationally or regionally available water-quality data were selected for analysis. The types of data are (a) selected chemical, physical, and sanitary constituents or properties (nationwide), (b) toxic trace elements and pesticides in finfish tissues (nationwide), and (c) herbicides (localized in the Midwest). The indicators selected, the rationale for their selection, and the geographic characteristics of the data are discussed in this section.

\section{INDICATORS}

Chemical, physical, and sanitary indicators.Constituents and properties that traditionally have served as indicators of the chemical, physical, and sanitary conditions of streams were selected for analysis. For the national overview of stream conditions and trends, six constituents-dissolved oxygen, fecal coliform bacteria, dissolved solids, dissolved nitrite plus nitrate (referred to as nitrate in this article and expressed as nitrate-nitrogen), total phosphorus, and suspended sediment-were selected for analysis. Three of these-nitrate, total phosphorus, and suspended sediment-also were used for analysis of stream transport of nutrients and suspended sediment. For the analysis of water quality in areas of significant domestic, industrial, and irrigation water use, five indicators-alkalinity, calcium concentration, hardness, $\mathrm{pH}$, and temperature-were selected. Data for these indicators that were suitable for trends testing were obtained from about 1,400 water-quality monitoring stations that were in a data base compiled for preparation of this National Water Summary. For a more complete description of this data base, see section "Geographic Characteristics" below and the article "Introduction to State Summaries of Stream Water Quality" in this volume.

Toxic trace elements and pesticides in finfish tissue.-The FWS NCBP stands as an exception to the lack of national-level information on both the biological and toxicological aspects of water quality. The data base consists of analyses of concentrations of selected toxic trace elements and organic compounds in whole finfish; the fish were collected periodically between calendar years 1970 and 1986 from a national network of 117 stations located on major rivers and in the Great Lakes (113 stations in the conterminous United States). A recent study (Schmitt and Finger, 1987) indicates that trace-element concentrations measured in this program do not generally suffer from the over-estimation problem cited above for dissolved trace elements in water samples (see previous discussion under "Toxic Chemicals"). Although selected results of statistical analyses of data from the program have been published in several articles (Lowe and others, 1985; Schmitt and
Brumbaugh, 1990; Schmitt, Zajicek, and Peterman, 1990; and Schmitt, Zajicke, and Ribick, 1985), no comprehensive summary of the findings has been published to date. Collectively, the data provide valuable information on national trends in trace-element, pesticide, and other contaminant concentrations in finfish tissue. In this article, trend information from the NCPB is summarized for four trace elements - arsenic, cadmium, lead, and mercury-and for five organic compounds-DDT and related compounds, dieldrin, total PCB's, toxaphene, and chlordane and related compounds.

Herbicides in agricultural areas of the Midwest.-Recent investigations of stream concentrations of herbicides have been completed for a 10-State agricultural region in the Midwest, where a majority of herbicide use in the United States occurs, and for the Mississippi River and its major tributaries that drain this region. Analyses were made of 13 organic compounds (herbicides and their metabolites) in water samples taken from streams throughout the study area during 1989 (samples were taken during March-April, May-June, and October-November) and 1990 (samples were taken during March-April and May-June) (Goolsby, Thurman, and Kolpin, 1991; Thurman and others, 1991). A subsequent study by Goolsby, Coupe, and Markovchick (1991) analyzed five herbicides collected at sites on the Mississippi River and its major tributaries during April-June 1991. Collectively, these studies provide the best-available information on the distribution of herbicides in streams in agricultural areas during preplanting, postplanting, and harvesting periods of the year. Selected results of these investigations for four herbicides-alachlor, atrazine, cyanazine, and simazine-are presented in this article.

\section{Geographic Characteristics}

\section{National Analyses}

Obtaining a geographically representative description of water-quality indicators for streams in the conterminous United States requires more than simply compiling all the available data from existing monitoring networks. Even when data are collected in a standardized manner at each sampling station, the characteristics of the stations can result in a biased picture of national conditions. For example, if a disproportionate number of stations are located on streams that drain densely populated, heavily industrialized, or intensively cultivated drainage basins, the data likely will present a poorer picture of water quality than actually exists nationally.

Ideally, the best method of obtaining a geographically representative sample of the Nation's streams is through a randomized process of selecting the sample locations. In addition to being statistically unbiased, the uncertainty of statistical estimates based on a random sampling design can be stated explicitly. However, because statistical summarization of national conditions has not been the primary objective of monitoring, national water-quality monitoring networks were not established in this randomized manner. Most existing sampling stations, including those operated by Federal, State, and local governments, purposefully are located to monitor the effects of specific sources of contamination to better understand those effects and to efficiently man- 
age water quality. Although such "targeted" sampling is a logical and necessary component of monitoring programs, it results in an unrepresentative sample of national conditions and thus complicates the problem of statistically describing water-quality conditions.

Chemical, physical, and sanitary indicators.-For the purpose of presenting a national overview of chemical, physical, and sanitary stream water-quality conditions and trends, a geographically representative subset of stations was selected for each indicator from the set of about 1,400 water-quality monitoring stations cited in the section "Indicators" above. A station was selected if it (a) had sufficient data (8 or 10 years) for trend analysis for that indicator (Lanfear and Alexander, 1990), (b) was the most downstream station in a given stream basin, and (c) was not located within 25 miles of any other station. The stream-basin units used in this analysis are USGS hydrologic cataloging units (fig. 37; see also map in Supplemental Information part of this volume). A cataloging unit is a geographic area representing part or all of a drainage basin, a combination of drainage basins, or a distinct hydrologic feature (Seaber and others, 1987). Because of station-to-station differences in constituents sampled at the water-quality monitoring stations, the number of stations meeting these criteria ranged, for the six constituents used in the national overview of conditions and trends, from 313 to 424 .

The geographic representativeness of the selected stations was evaluated by comparing land-cover and population characteristics of the cataloging units containing the selected stations with the same characteristics collectively for all the cataloging units in the conterminous United States. The comparison for one constituent, dissolved solids, with the conterminous United States is shown below.

Among the six constituents, the land-cover and population characteristics of the selected cataloging units were virtually identical. Also, the land-cover characteristics of the selected cataloging units closely resemble those for the conterminous United States as a whole, but the population density of the selected cataloging units is slightly higher than for the Nation. Although there are 2,111 cataloging units in the conterminous United States, land-cover data were not available for 3 of the cataloging units; in addition, 9 of the units are lakes that have only water as the land cover. Therefore, all land-cover and population analyses for this article were done on

\begin{tabular}{|c|c|c|c|c|}
\hline \multirow{2}{*}{\multicolumn{2}{|c|}{$\begin{array}{l}\text { Comparison of selected } \\
\text { characteristics } \\
\text { (population density, in persons per } \\
\text { square mile; land-cover category, in } \\
\text { percentage of total land area) }\end{array}$}} & \multicolumn{3}{|c|}{$\begin{array}{l}\text { Cataloging-unit } \\
\text { percentile }\end{array}$} \\
\hline & & 25th & 50th & 75th \\
\hline \multicolumn{5}{|c|}{ CONTERMINOUS UNITED STATES $-2,099$ cataloging units } \\
\hline \multicolumn{2}{|c|}{ Population density } & 4.4 & 24.8 & 72.9 \\
\hline \multirow[t]{3}{*}{ Land cover: } & Urban & 0.7 & 1.8 & 4.0 \\
\hline & Crop and pasture & 6.5 & 15.3 & 37.3 \\
\hline & Forest & 2.2 & 17.4 & 52.6 \\
\hline \multicolumn{5}{|c|}{ DISSOLVED-SOLIDS ANALYSIS -340 cataloging units } \\
\hline \multicolumn{2}{|c|}{ Population density } & 11.8 & 39.7 & 114.0 \\
\hline \multirow[t]{3}{*}{ Land cover: } & Urban & 1.1 & 2.4 & 5.6 \\
\hline & Crop and pasture & 6.5 & 15.4 & 35.8 \\
\hline & Forest & 6.5 & 23.4 & 56.2 \\
\hline
\end{tabular}

2,099 cataloging units. The population data are from U.S. Bureau of the Census (1991), and the land-cover data are from K.D. Cavett (U.S. Department of Agriculture, National Agricultural Statistics Service, written commun., 1990) and the U.S. Soil Conservation Service (1989).

Also, to provide a basis for analyzing the chemical, physical, and sanitary indicators by land use in this article, the cataloging units were grouped into four major land uses-agriculture (which is subdivided into wheat, corn and soybeans, and mixed), urban, forest, and range. This land-use classification was based on population density, land-cover characteristics, crop type, and total surface- and ground-water withdrawals for domestic use (fig. 37). Stations in cataloging units not meeting the criteria for any of the land-use classes were not included in these analyses. Note that this land-use classification is unique to this article and does not parallel the land-use classification used in the State summaries in this volume.

Toxic trace elements and pesticides in finfish tissue.-The stations where finfish were collected by the FWs for analysis are located on the Great Lakes and major rivers of the United States and generally are representative of stream basins larger than about 5,000 square miles. In this article, concentrations data for selected trace element and organic compounds are summarized for the 113 monitoring stations in the conterminous United States and the Great Lakes.

\section{Regional Analyses}

Often the sources or consequences of stream contamination are strongly associated with a specific region of the country. The region of interest can comprise adjacent or connected stream basins in a single geographic area or can be geographically disjointed and comprise stream basins having similar land-use or water-use characteristics. In this article, in addition to presenting national analyses, the results of both types of regional analyses are presented.

Regional analyses of chemical, physical, and sanitary indicators include comparisons of (a) the concentrations of dissolved oxygen, fecal coliform bacteria, dissolved solids, nitrate, total phosphorus, and suspended sediment in stream basins classified by land use, (b) the load of nitrate, total phosphorus, and suspended sediment transported to reservoirs and coastal waters from large regions and from basins classified by land use, and (c) the concentrations of chloride, sulfate, and hardness and an index of corrosivity (based on $\mathrm{pH}$, temperature, alkalinity, and calcium) in stream basins classified according to domestic, industrial, and irrigation water use. These regional analyses are based on data from one station per cataloging unit from the set of about 1,400 water-quality monitoring stations referred to above in the section "National Analyses." The information on nitrate, totalphosphorus, and suspended-sediment loads is presented for 14 regions compiled from the 18 water-resources regions in the conterminous United States. (For maps showing the 18 water-resources regions, see Seaber and others, 1987, and the "Supplemental Information" part of this volume.) A regional analysis also is presented for herbicide concentrations in a 10-State agricultural region of the Midwest and for herbicide transport for the Mississippi River and its major tributaries. 


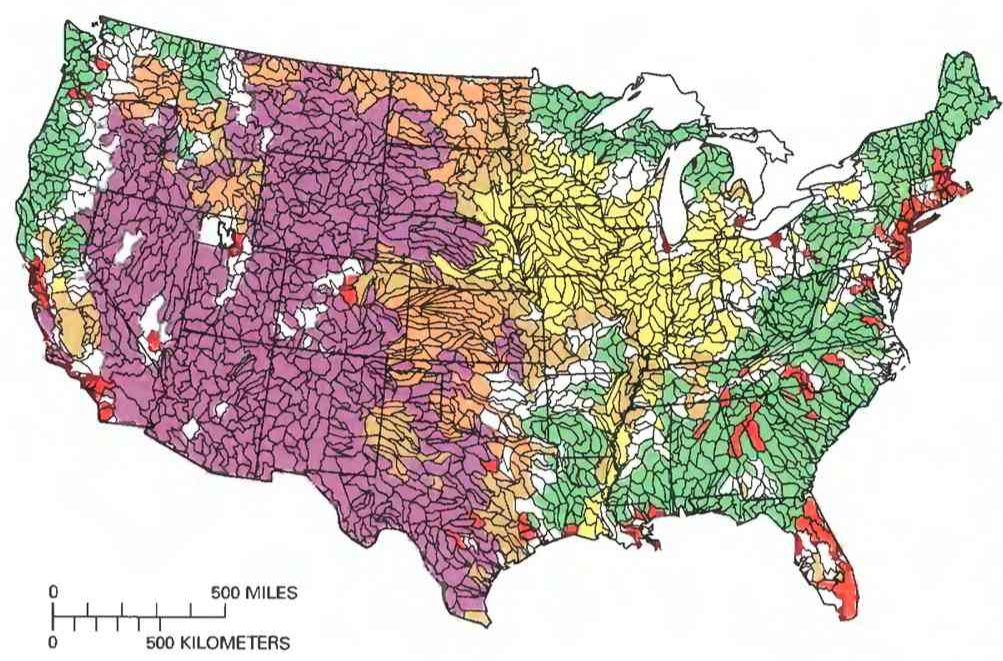

\section{EXPLANATION}

\begin{tabular}{|c|c|c|}
\hline \multirow{2}{*}{ 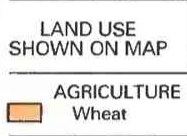 } & \multicolumn{2}{|c|}{$\begin{array}{l}\text { CRITERIA FOR DETERMINING LAND USE } \\
\text { (Land cover, in percent; crop type, in percent; population density, in persons per } \\
\text { square mile; total water withdrawals for domestic use, in million gallons per day) }\end{array}$} \\
\hline & $\begin{aligned} \text { Land cover: } & >40 \text { crop and pasture } \\
& <40 \text { forest } \\
& <10 \text { urban }\end{aligned}$ & $\begin{aligned} \text { Crop type: } & >50 \text { wheat } \\
& <20 \text { corn and soybeans }\end{aligned}$ \\
\hline $\begin{array}{l}\text { Corn and } \\
\text { soybeans }\end{array}$ & $\begin{aligned} \text { Land cover: } & >40 \text { crop and pasture } \\
& <40 \text { forest } \\
& <10 \text { urban }\end{aligned}$ & $\begin{aligned} \text { Crop type: } & >50 \text { corn and soybeans } \\
& <20 \text { wheat }\end{aligned}$ \\
\hline Mixed & $\begin{aligned} \text { Land cover: } & >40 \text { crop and pasture } \\
& <40 \text { forest } \\
& <10 \text { urban }\end{aligned}$ & $\begin{array}{c}\text { Crop type: }<50 \text { wheat and corn } \\
\text { and soybeans }\end{array}$ \\
\hline URBAN & $\begin{array}{l}\text { Land cover: }<30 \text { crop and pasture } \\
\text { Population: }>100\end{array}$ & $\begin{array}{l}\text { Total water withdrawals } \\
\text { for domestic use: }>6\end{array}$ \\
\hline$\square$ FOREST & $\begin{aligned} \text { Land cover: }>50 \text { forest } & <40 \text { agricul } \\
& <10 \text { urban }\end{aligned}$ & \\
\hline$\square$ RANGE & $\begin{array}{c}\text { Land cover: }>50 \text { range and barren la } \\
<40 \text { agriculture }\end{array}$ & and $\begin{array}{l}<0 \text { forest } \\
<10 \text { urban }\end{array}$ \\
\hline$\square$ OTHER & All land cover not meeting any of & above criteria \\
\hline
\end{tabular}

Figure 37. Land-use classification of hydrologic cataloging units, as used in this article, in the conterminous United States. The classification was derived as follows: agriculture land use by type of land cover and the crops grown; urban land use by type of land cover, population density, and total surface- and ground-water withdrawals for domestic use; forest and range land use by type of land cover. For the range land use, the aggregate landcover percentages for agriculture, forest, and urban cannot exceed 50 percent. >, greater than; <, less than. (Sources: Criteria for determining land use-landcover and crop data from U.S. Soil Conservation Service, 1989, and K.D. Cavett, U.S. Department of Agriculture, National Agricultural Statistics Service, written communication, 1990; population data from U.S. Bureau of the Census, 1991; water-withdrawal data from U.S. Geological Survey files. Hydrologic cataloging units modified from Seaber, 1987; see also map in "Supplemental Information" part of this volume.)

\section{NATIONAL SUMMARY OF CONDITIONS AND TRENDS IN STREAM WATER QUALITY}

\section{CONCENTRATIONS OF SIX COMMON WATER- QUALITY CONSTITUENTS}

Of the six constituents statistically analyzed, five (dissolved oxygen, fecal coliform bacteria, dissolved solids, nitrate, and suspended sediment) were analyzed for water years 1980-89; the sixth (total phosphorus) was analyzed for water years $1982-89$ because data from 1980 and 1981 were unsuitable for analysis. (A water year is the 12 -month period from October 1 through September 30 and is identified by the calendar year in which it ends.) The results of the analyses are shown in figures 38-43. Each figure represents one constituent and contains the following five components $A-E$. (Because some cataloging units do not qualify for the land uses shown in the box plots in component $B$ and graphs in component $E$, the total number of stations represented is less than the number of stations plotted in maps in components $A$ and $C$, and in graphs in component $D$ in each figure.)

A. Map of the conterminous United States showing average concentration and the percentage of samples (frequency of occurrence) at each water-quality station in which concentrations were greater than or less than the selected concentration thresholds at each station (figs. 38A-43A). These thresholds represent either EPA recommended concentration limits (U.S. Environmental Protection Agency, 1976, 1986) or other arbitrarily defined thresholds chosen to separate high and low concentrations.

$B$. Box plot showing average station concentrations of the constituent, by land use (figs. $38 B-43 B$ ).

$C$. Map of the conterminous United States showing the trend in concentration, which was derived from applying the seasonal Kendall test to the constituentconcentration records at each station (figs. $38 C$ $43 C$ ). For stations with sufficient concentration and streamflow data, concentration records were flow adjusted before trend testing. About 86 percent of the stations were flow adjusted. (See article "Statistical Analysis of Water-Quality Data" in this volume for more discussion of the seasonal Kendall test.)

$D$. Graph showing the percentage of stations where the annual average concentration was greater than or less than selected concentration thresholds (figs. $38 D-43 D$ ).

$E$. Graph showing the percentage of the stations where the annual average concentration was greater than or less than selected concentration thresholds, by land use (figs. $38 E-43 E$ ). 


\section{Dissolved Oxygen}

Dissolved oxygen is essential to the respiration of aquatic organisms, and its concentration in streams is a major determinant of the species composition of biota in the water and underlying sediments. Moreover, the dissolved oxygen in streams has a profound effect on the biochemical reactions that occur in water and sediments, which in turn affect numerous aspects of water quality, including the solubility of many toxic elements and esthetic qualities of odor and taste. For these reasons, dissolved oxygen historically has been one of the most frequently measured indicators of water quality (Hem, 1985).

In the absence of substances that cause its depletion, the dissolved-oxygen concentration in stream water approximates the saturation level for oxygen in water in contact with the atmosphere and decreases with increasing water temperature from about $14 \mathrm{mg} / \mathrm{L}$ (milligrams per liter) at freezing to about $7 \mathrm{mg} / \mathrm{L}$ at $86^{\circ} \mathrm{F}$ $\left(30^{\circ} \mathrm{C}\right)$. For this reason, in ecologically healthy streams, the dissolved-oxygen concentration depends primarily on temperature, which varies with season and climate.

Criteria for defining desirable dissolved-oxygen concentration often are differentiated as applicable to cold-water biota, such as trout and their insect prey, and the more low-oxygen-tolerant species of warm-water ecosystems. Moreover, because of the critical respiratory function of dissolved oxygen in aquatic animals, criteria often are expressed in terms of the short-term duration and frequency of occurrence of minimum concentrations rather than long-term average concentrations. Studies cited by the EPA (1986) of the dependence of freshwater biota on dissolved oxygen suggest that streams in which the concentration is less than $6.5 \mathrm{mg} / \mathrm{L}$ for more than about 20 percent of the time generally are not capable of supporting trout or other cold-water fish, and such concentrations could impair population growth among some warm-water game fish, such as largemouth bass. Furthermore, streams in which the dissolved-oxygen-deficit concentration is greater than $4 \mathrm{mg} / \mathrm{L}$ for more than 20 percent of the time generally cannot support either coldor warm-water game fish. Dissolved-oxygen deficit refers to the difference between the saturation and measured concentrations of dissolved oxygen in a water sample and is a direct measure of the effects of oxygendemanding substances on dissolved oxygen in streams.

Major sources of substances that cause depletion of dissolved oxygen in streams are discharges from municipal and industrial wastewater-treatment facilities; leaks and overflows from sewage lines and septic tanks; stormwater runoff from agricultural and urban land; and decaying vegetation, including aquatic plants from the stream itself and detrital terrestrial vegetation. Dissolved oxygen is added to stream water by the process of aeration (waterfalls, ripples) and the photosynthesis of aquatic plants.

Figure $38 \mathrm{~A}$ shows the average concentration of dissolved oxygen and the percentage of samples (frequency of occurrence) of concentrations less than 6.5 $\mathrm{mg} / \mathrm{L}$ at each of 424 selected stations. One readily apparent feature of the map is a climate-related pattern of decreasing average dissolved-oxygen concentration from north to south, which reflects the greater capacity of colder water to contain dissolved oxygen. The lowest average concentrations (less than $8.0 \mathrm{mg} / \mathrm{L}$ ) and the highest frequencies of concentrations less than $6.5 \mathrm{mg} / \mathrm{L} \mathrm{oc}$ curred in the Southeast where high temperatures and a larger than average burden of decaying vegetation are natural constraints on dissolved-oxygen concentration. Disrupting this pattern, however, are a few stations in the northern tier of States and numerous stations in the central States at which the average concentrations were less than $8.0 \mathrm{mg} / \mathrm{L}$ and where concentrations less than 6.5 $\mathrm{mg} / \mathrm{L}$ occurred for more than 20 percent of the samples. Among the four land-use types, the average concentrations of dissolved oxygen were the lowest at stations in urban areas (fig. 38B).

Upward trends ( 38 stations) in dissolved-oxygen concentration outnumbered downward trends (26 stations), as shown in figure $38 \mathrm{C}$. In general, increases in dissolved oxygen represent an improvement in water quality. Concentration increases were especially numerous in the central States where at many stations concentration levels were less than the $6.5 \mathrm{mg} / \mathrm{L}$ criterion for more than 20 percent of the samples. Nationally, the percentage of stations having more than 20 percent of concentrations less than $6.5 \mathrm{mg} / \mathrm{L}$ remained nearly constant at about 20 percent. Similarly, the percentage of stations having more than 20 percent of dissolved-oxygen-deficit concentrations greater than $4.0 \mathrm{mg} / \mathrm{L} \mathrm{re}$ mained constant at about 9 percent (fig. 38D). In urban areas, however, the percentage of stations having more than 20 percent of dissolved-oxygen concentrations less than $6.5 \mathrm{mg} / \mathrm{L}$ decreased from 42 in 1981 to 21 percent in 1989 (fig. 38E).

Changes in dissolved-oxygen concentrations in the Nation's streams during the 1980's are of particular interest given the large public and private capital investments made to control point-source pollution during the decade. It is estimated that between 1980 and $1989, \$ 126$ billion was spent to upgrade municipal treatment facilities, and $\$ 68$ billion was spent by private industry to reduce point-source biochemical-oxygen-demand loads (U. S. Environmental Protection Agency, 1990c). Increased dissolved-oxygen concentration in streams in urban areas may reflect investments in point-source pollution control.

At the national level, however, part of the explanation for the lack of change in dissolved-oxygen concentration could be that much of the investment in pointsource pollution controls simply has served to keep pace with population increases and economic development. Oxygen-demanding waste loads declined substantially in the 1970's but were nearly stable during the 1980's (U. S. Environmental Protection Agency, 1990c). Despite point-source control expenditures, the loads did not decline in the 1980's, because during that decade the population increased by 10 percent and the real gross national product increased by 30 percent (U.S. Bureau of the Census, 1990). The maintenance of nearly constant dissolved-oxygen concentration in streams during this period of increased pollution generation represents an important environmental benefit of pollution controls. 


\section{Average concentration}

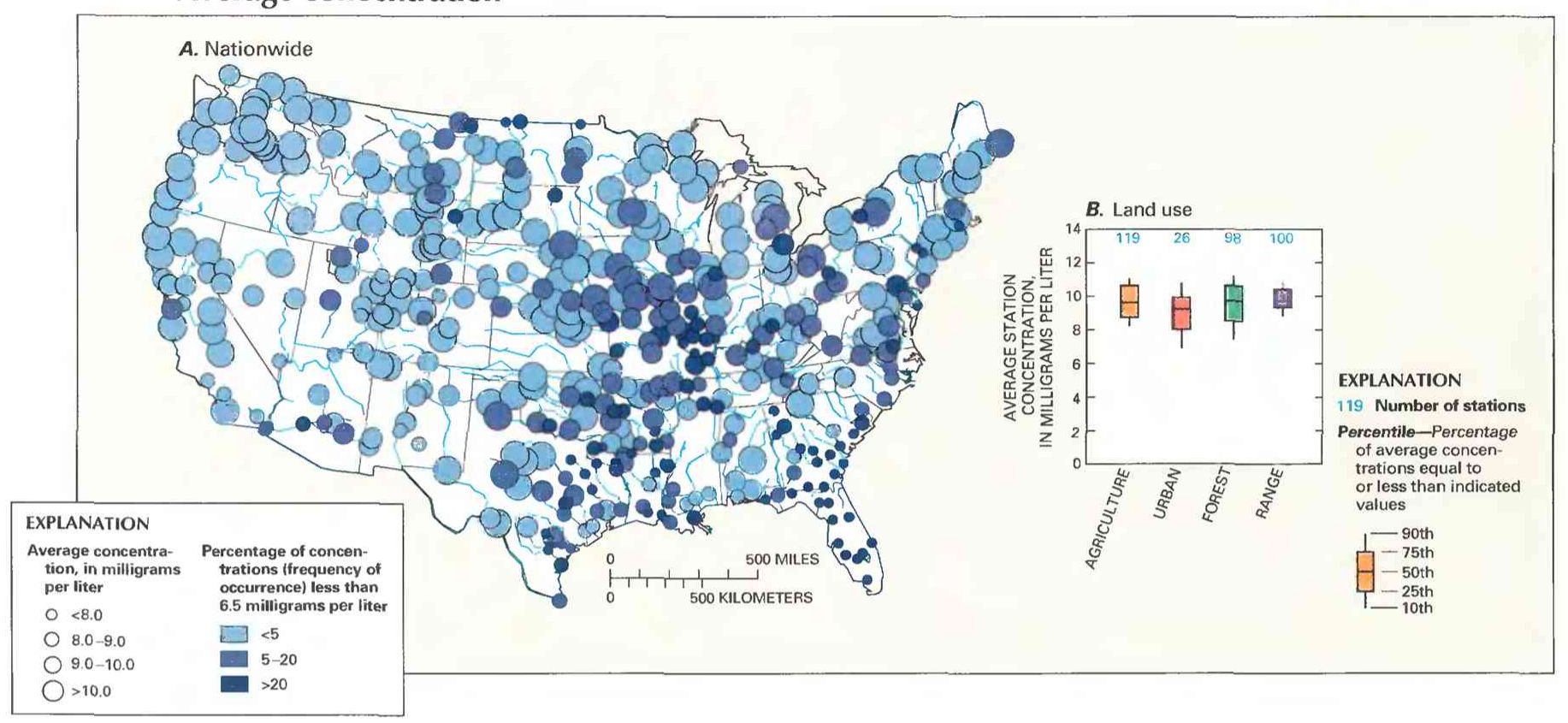

\section{Trends in concentration}

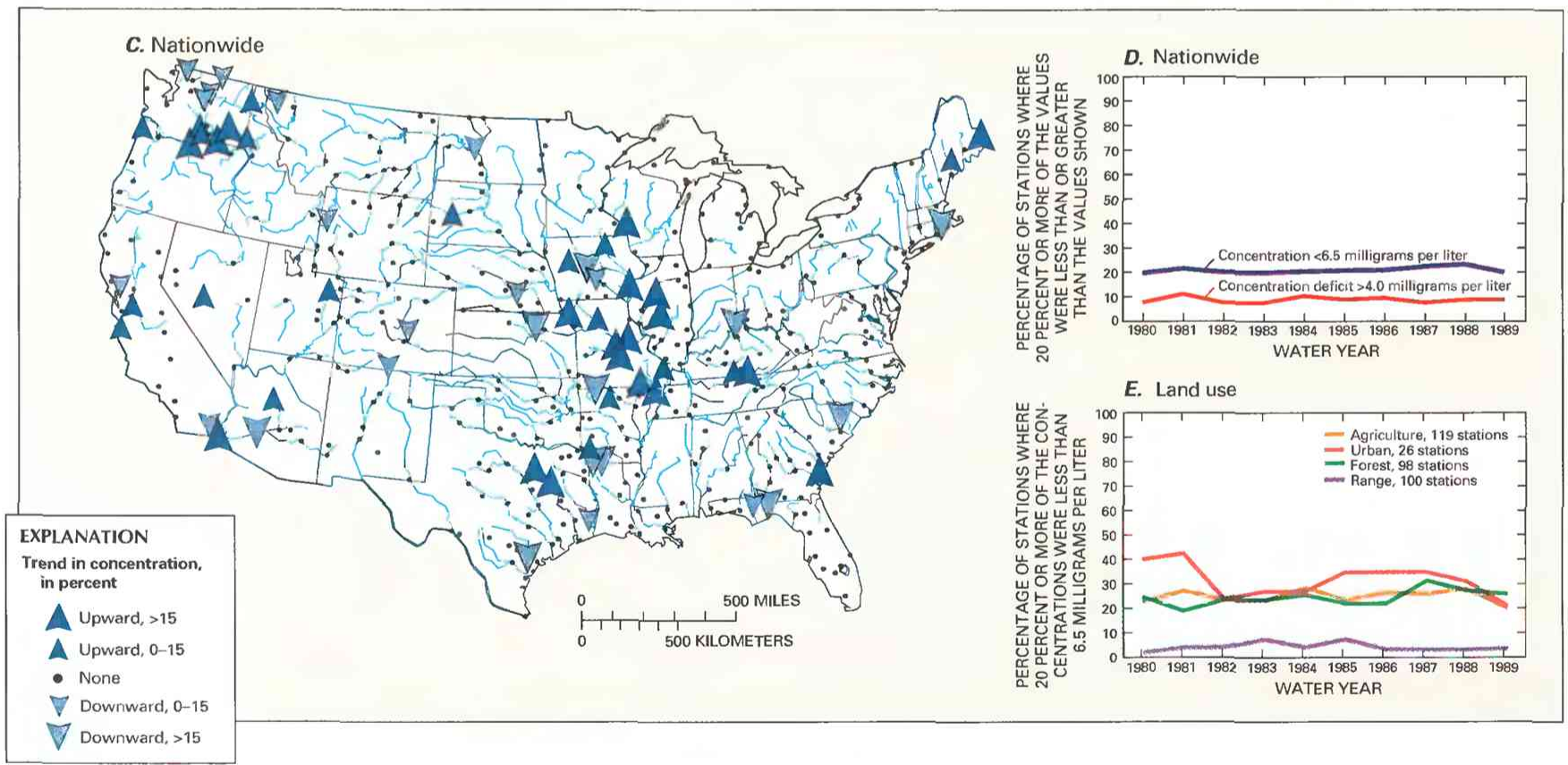

Figure 38. Concentration and trends in dissolved oxygen in stream water at 424 selected water-quality monitoring stations in the conterminous United States, water years 1980-89. (Because some cataloging units do not qualify for the land uses shown in $B$ and $E$, the total number of stations represented is less than the 424 stations used to compute $A, C$, and $D$.) $A$, Average concentration and percentage of concentrations less than $6.5 \mathrm{mg} / \mathrm{L}$ (milligrams per liter) nationwide. $B$, Average concentration, by land use. $C$, Trends in concentration nationwide. $D$, Percentage of stations nationwide where 20 percent or more of the dissolved-oxygen concentrations were less than $6.5 \mathrm{mg} / \mathrm{L}$ and 20 percent or more of the dissolved-oxygen-deficit concentrations were greater than $4.0 \mathrm{mg} / \mathrm{L}$. E, Percentage of stations where 20 percent or more of the dissolved-oxygen concentrations were less than $6.5 \mathrm{mg} / \mathrm{L}$, by land use. >, greater than; <, less than. (Source: Data from U.S. Geological Survey files.) 


\section{Fecal Coliform Bacteria}

Historically, the concentration of fecal coliform bacteria has been considered an important indicator of water quality because the presence of these organisms in streams is a reliable indicator of fecal contamination from warm-blooded animals (U.S. Environmental Protection Agency, 1976). The presence of fecal material in water where humans swim or where shellfish are harvested presents a significant risk of infection from pathogenic organisms associated with fecal coliform bacteria (U.S. Environmental Protection Agency, 1986). The correlation between documented cases of infectious disease and selected species of fecal coliform bacteria such as Escherichia coli is well established, but total concentrations of the fecal coliform group are easier to measure than selected species and, thus, have been widely used as an indicator for many years. A concentration of 200 bacterial colonies $/ 100 \mathrm{~mL}$ (colonies per 100 milliliters) of water has long been considered the acceptable limit for fecal-coliform density in waters where human contact occurs (U.S. Environmental Protection Agency, 1976). In addition to this limit, an arbitrary threshold of 1,000 bacterial colonies $/ 100 \mathrm{~mL}$ was selected for this article to categorize high fecal-coliform concentrations. The major sources of fecal coliform bacteria are untreated sewage, effluent from sewage-treatment plants, and runoff from pastures, feedlots, and urban areas.

Figure 39 indicates that concentrations of fecal coliform bacteria greater than 200 colonies $/ 100 \mathrm{~mL}$ were widespread and frequent in the Nation's streams during the 1980 's, but that gradual progress was made in reduc- ing bacterial concentrations over the course of the decade. Fecal-coliform concentrations of 200 colonies $/ 100$ $\mathrm{mL}$ or greater occurred in at least 20 percent of the samples at a significant majority of the 313 stations shown in figure 39A. Fecal-coliform concentrations were highest in the agricultural areas of the midwestern and south-central parts of the country and in several tributaries to the eastern Great Lakes. At many stations in the agricultural areas, average bacterial concentrations were greater than 1,000 colonies $/ 100 \mathrm{~mL}$. In agricultural and urban areas, average concentrations of fecal coliform bacteria were greater than those in forested and range areas (fig 39B); this is expected because the former areas are known to contain point and nonpoint sources of fecal bacteria.

Downward trends in fecal-coliform concentrations (fig. 39C) occurred at 40 stations and upward trends at 10 stations. Concentration decreases were especially common in the central part of the country, and they occurred in cataloging units that had significant urban, agricultural, or range land use. The percentage of stations nationwide where the annual average concentration was greater than 1,000 colonies $/ 100 \mathrm{~mL}$ decreased from 18 to 13 percent, and the percentage of stations having annual average concentrations greater than 200 colonies $/ 100 \mathrm{~mL}$ decreased from 52 to 35 percent (fig. 39D.) From 1980 to 1989 , in all land-use areas except forested areas, the percentage of stations in which the annual average concentration was greater than 200 colonies $/ 100 \mathrm{~mL}$ decreased (fig. $39 E$ ). All of these trends suggest that control of point and nonpoint sources of fecal coliform bacteria improved over the course of the decade. 


\section{Fecal coliform bacteria}

$1980-89$

\section{Average concentration}

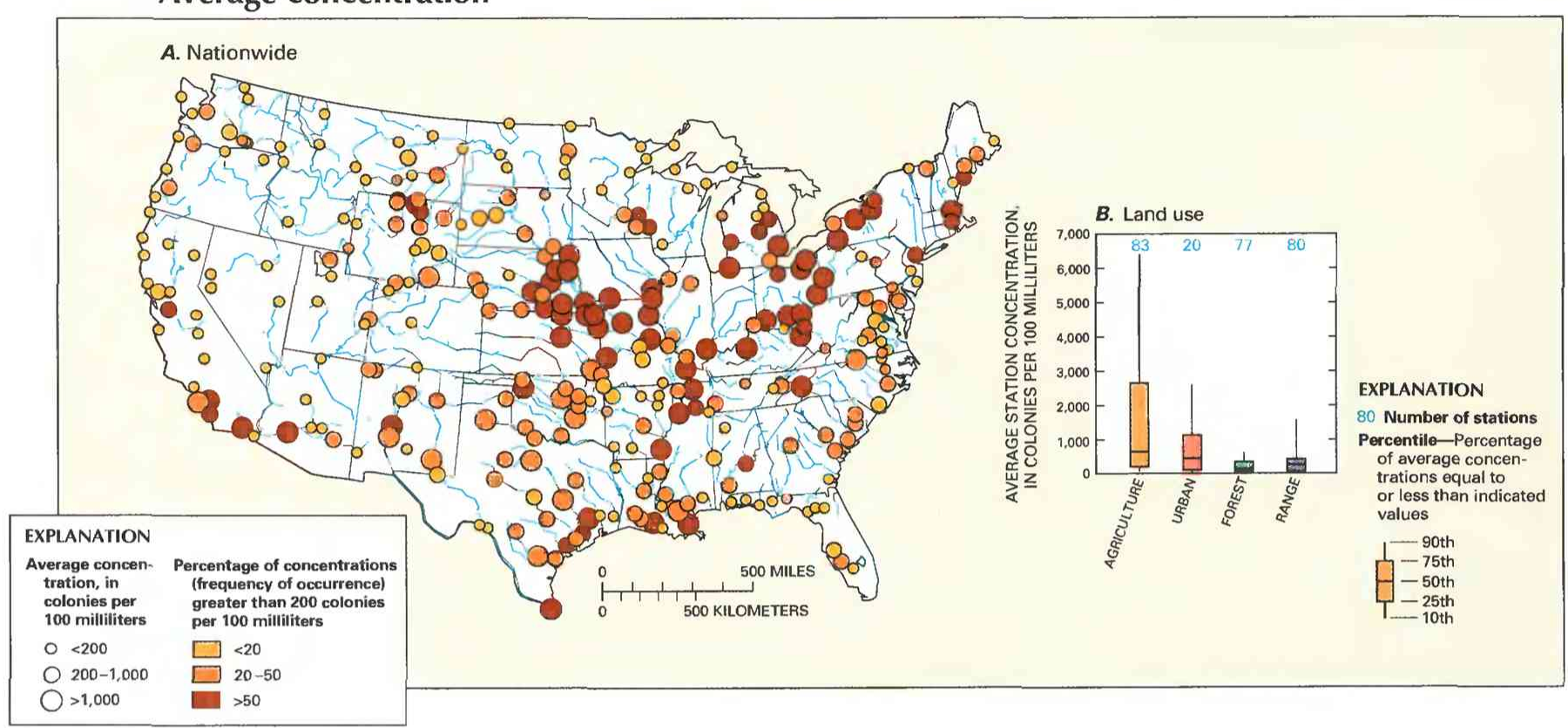

\section{Trends in concentration}

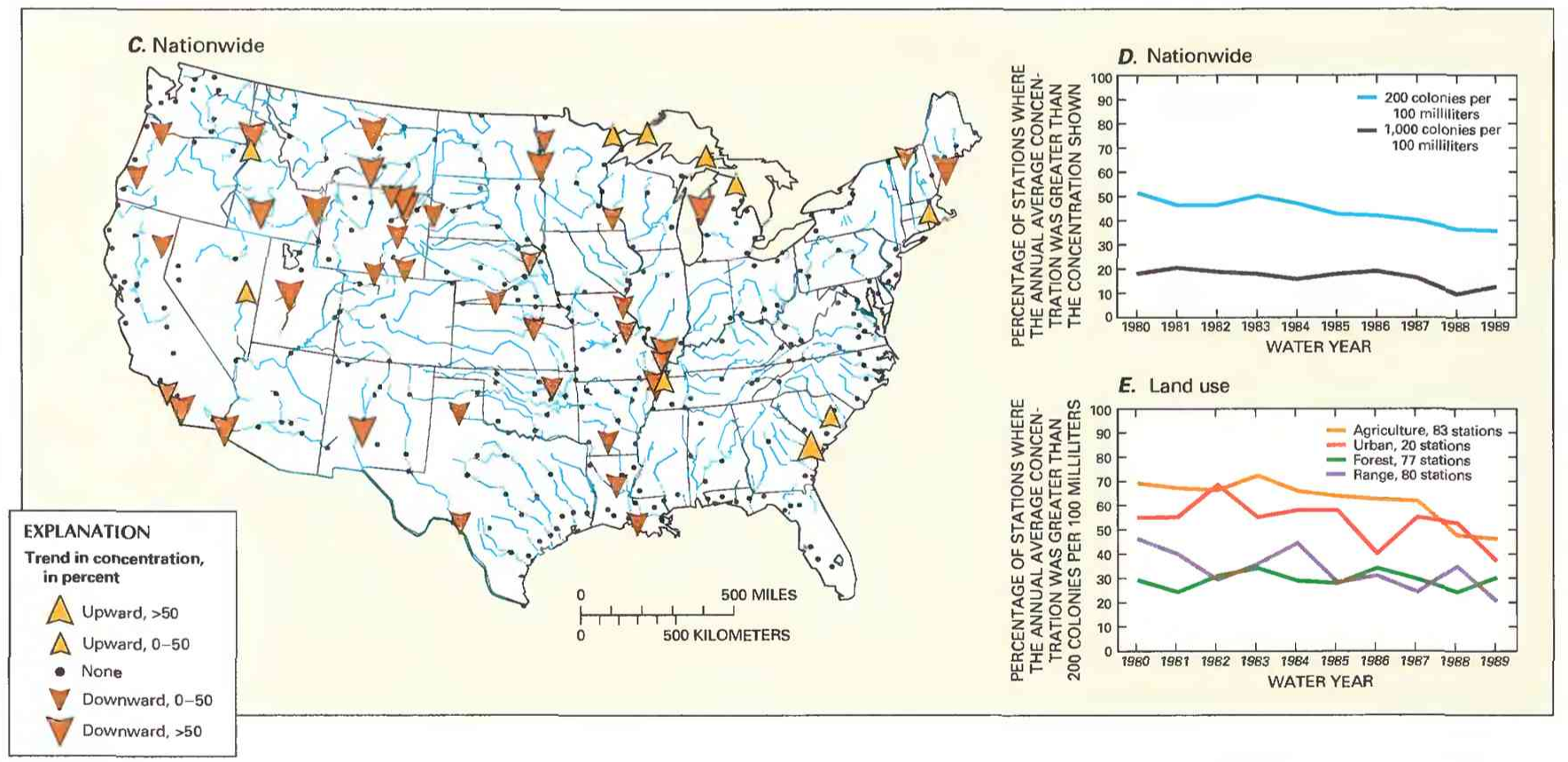

Figure 39. Concentration and trends in fecal coliform bacteria in stream water at 313 selected water-quality monitoring stations in the conterminous United States, water years 1980-89. (Because some cataloging units do not qualify for the land uses shown in $B$ and $E$, the total number of stations represented is less than the 313 stations used to compute $A$, $C$, and $D$.) $A$, Average concentraíion and percentage of concentrations greater than 200 colonies per 100 milliliters nationwide. B. Average concentration, by land use. $C$. Trends in concentration nationwide. $D$, Percentage of stations nationwide where the annual average concentration was greater than 200 or 1,000 colonies per milliliter. $E$, Percentage of stations where the annual average concentration was greater than 200 colonies per 100 milliliters, by land use. >, greater than; <, less than. (Source: Data from U.S. Geological Survey files.) 


\section{Dissolved Solids}

Dissolved solids refers to the sum of all dissolved constituents in a water sample. In most streams the major components of dissolved solids are the ions of calcium, magnesium, sodium, potassium, bicarbonate, sulfate, and chloride. The significance of these constituents in streams is related mostly to the potential limitations that large dissolved-solids concentrations impose on certain domestic, industrial, and irrigation water uses rather than to their ecological significance. In this article, dissolved-solids concentrations are classified arbitrarily as low (less than $100 \mathrm{mg} / \mathrm{L}$ ), medium (100 to $500 \mathrm{mg} / \mathrm{L}$ ), high (500 to $1,000 \mathrm{mg} / \mathrm{L}$ ), and very high (greater than $1,000 \mathrm{mg} / \mathrm{L}$ ). A more detailed discussion of the effects of dissolved solids on the suitability of water for societal use is discussed in the section "Water Quality in Areas of Selected Water Use."

In most streams the major source of dissolved solids is the dissolution of minerals naturally found in soil and rock. (See article "Factors Affecting Stream Water Quality, and Water-Quality Trends in Four Drainage Basins in the Conterminous United States, 190590 " in this volume for discussion of mineral dissolution.) Because of the wide variation in the solubility of different minerals, and in the amount of precipitation available to dissolve them, the concentration of dissolved solids in streams nationwide ranges from only a few milligrams per liter to several thousand milligrams per liter. Within this broad range, the highest dissolvedsolids concentrations (greater than $500 \mathrm{mg} / \mathrm{L}$ ) are found in the arid Southwest, where high rates of evaporation and transpiration tend to concentrate dissolved solids. Concentrations are medium to high (greater than 100 $\mathrm{mg} / \mathrm{L}$ ) in parts of the midwestern States, where soluble carbonates are abundant, and they are lowest (less than $100 \mathrm{mg} / \mathrm{L}$ ) in the eastern and northwestern parts of the United States, where high precipitation rates dilute dis- solved constituents (fig. 40A). Average concentrations were lowest in forested areas and highest in range areas, which reflect the more arid areas of the country (fig. $40 B$ ).

Human activities contribute significantly to dissolved-solids concentrations in most regions, however. A moderate correlation between population and dissolved-solids concentration in streams has long been noted (Peters, 1984) for much of the eastern and northwestern United States, where point-source municipal and industrial effluents typically have higher dissolved-solids concentrations than their receiving streams. Also, land disturbance associated with mining and agriculture increases the exposure of mineral deposits to precipitation and increases the nonpoint-source load of dissolved solids. In recent years, the correlation between population and dissolved-solids concentrations has been strengthened by the increased dissolved salts in streams as a result of the increased use of highway deicing salt (Smith and others, 1987). In addition, in arid regions, reservoirs have increased evaporation rates, which result in higher stream concentrations of dissolved solids (Paulson and Bakers, 1983).

Nationwide trends in dissolved-solids concentration varied throughout the 1980-89 period, and downward trends (46 stations) outnumbered upward trends (28 stations) among a total of 340 stations (fig. $40 \mathrm{C}$ ). Downward trends were especially common in the central part of the country, the Pacific Northwest, and far southwestern United States, whereas upward trends were most common in drainage to the Gulf of Mexico and Atlantic Ocean. Nationally, the percentage of stations having average concentration greater than 100,500 , and $1,000 \mathrm{mg} / \mathrm{L}$ remained approximately constant at 75,25 , and 12 percent, respectively (fig. $40 \mathrm{D}$ ). Moreover, among specific land-use classes, the percentage of stations exceeding the $500 \mathrm{mg} / \mathrm{L}$ threshold remained nearly constant (fig. $40 E$ ). 


\section{Dissolved solids}

\section{Average concentration}

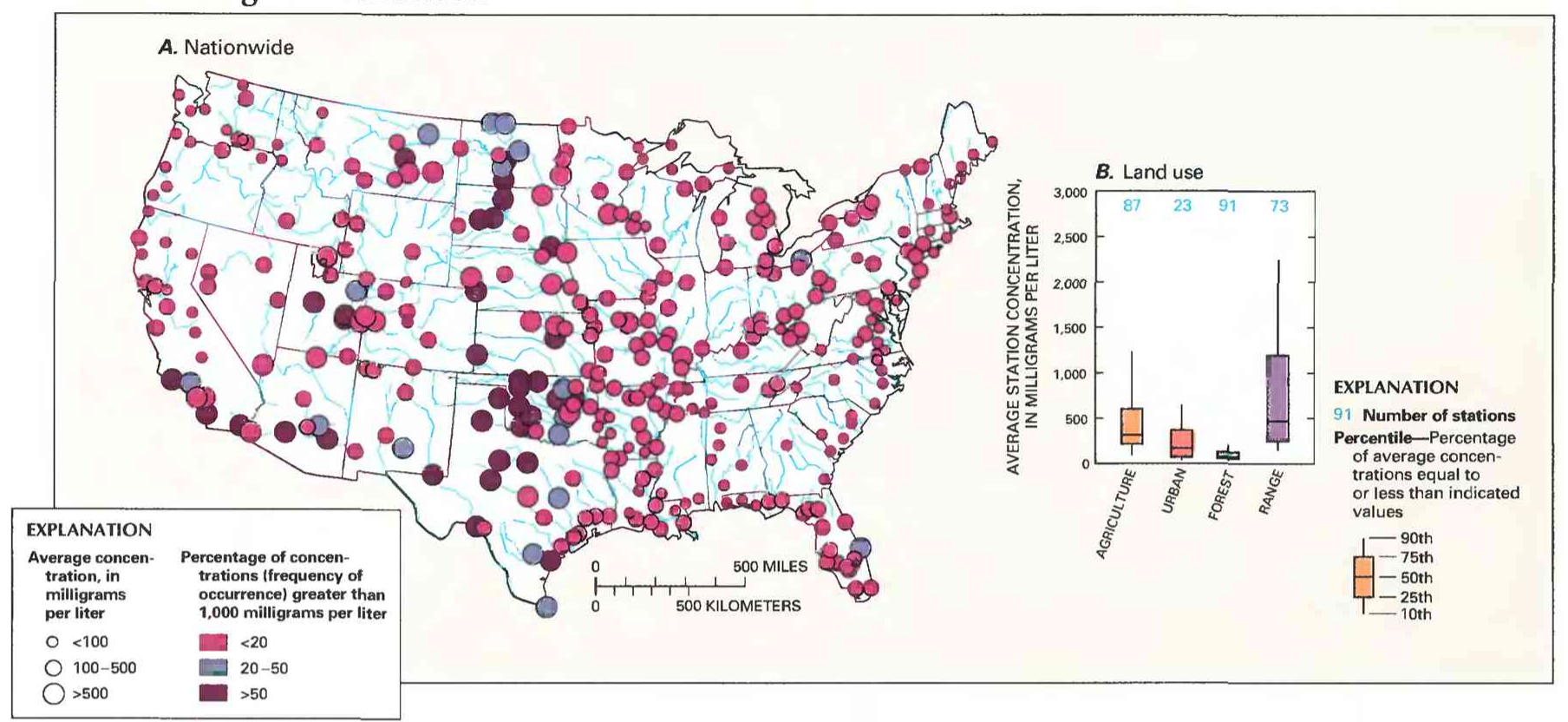

\section{Trends in concentration}

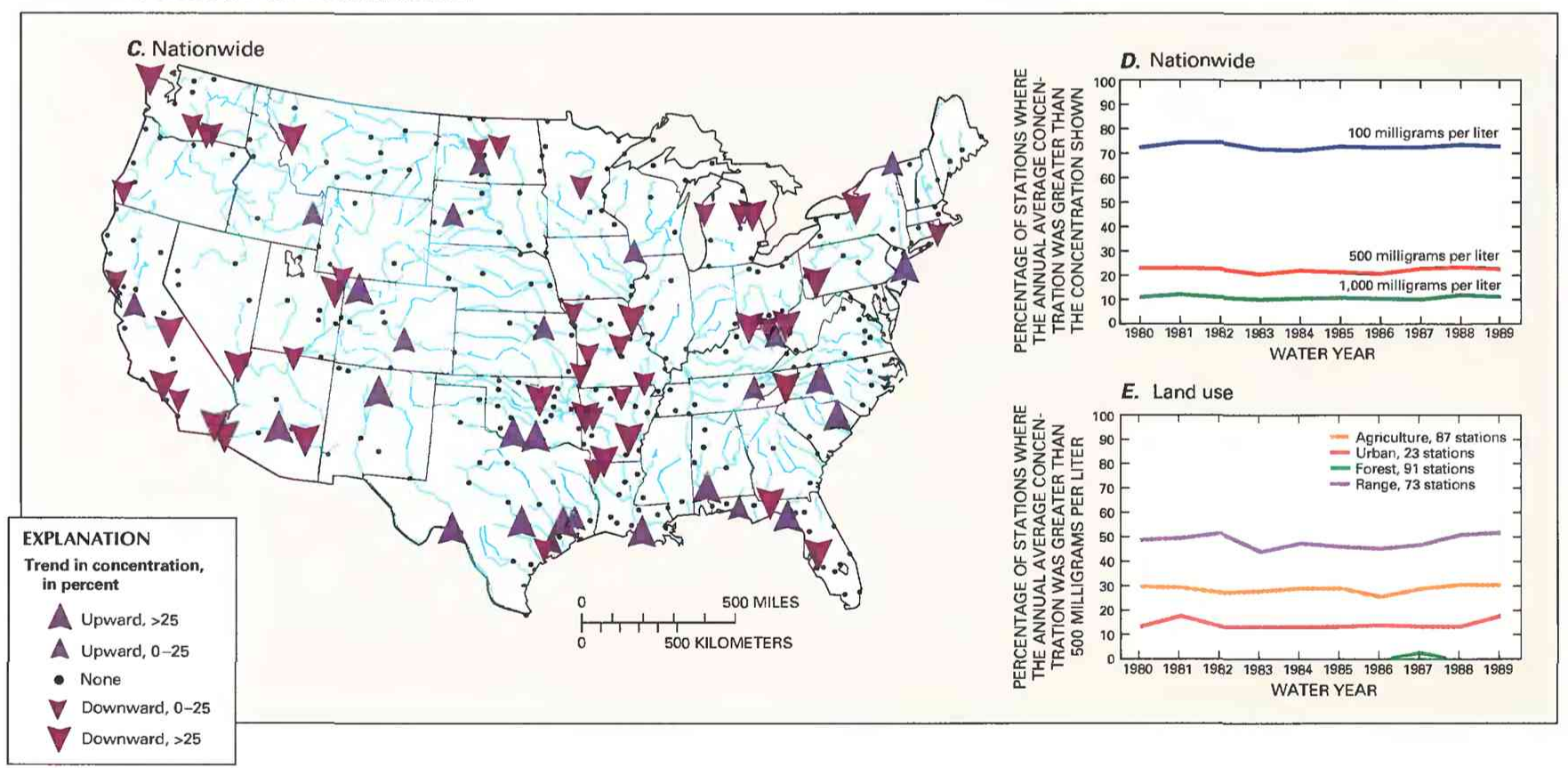

Figure 40. Concentration and trends in dissolved solids in stream water at 340 selected water-quality monitoring stations in the conterminous United States, water years 1980-89. (Because some cataloging units do not qualify for the land uses shown in $B$ and $E$, the total number of stations represented is less than the 340 stations used to compute $A, C$, and $D$.) $A$, Average concentration and percentage of concentrations greater than $1,000 \mathrm{mg} / \mathrm{L}$ (milligrams per liter) nationwide. $B$. Average concentration, by land use. $C$, Trends in concentration nationwide. $D$, Percentage of stations nationwide where the annual average concentration was greater than 100,500, or 1,000 mg/L. $E$, Percentage of stations where the annual average concentration was greater than $500 \mathrm{mg} / \mathrm{L}$, by land use. >, greater than; <, less than. (Source: Data from U.S. Geological Survey files.) 


\section{Nitrate}

High nitrate concentrations in streams can have serious toxicological and ecological effects. The most clearly established human-health hazard of high nitrate concentrations in drinking water is that of methemoglobinemia, a potentially fatal disease primarily of infants (U.S. Environmental Protection Agency, 1986). The almost universally applied threshold concentration for nitrate in water supplies to protect against the disease is $10 \mathrm{mg} / \mathrm{L}$ expressed as nitrogen. Nitrate concentrations rarely exceed that level in streams, but they frequently do exceed it in shallow ground water in agricultural areas where animal wastes and nitrogen fertilizers are concentrated.

Ecological concern about high concentrations of nitrate in streams stems from its potential for contributing to eutrophication, which is the excessive growth of aquatic plants that can impart unpleasant odors and tastes to water and reduce its clarity, and, upon dying, can lower the dissolved-oxygen concentrations (National Academy of Sciences, 1969). It has not been possible, however, to establish a nationally applicable threshold concentration for nitrate to protect against eutrophication because effects of nitrate concentrations are highly variable from place to place and are greatest in coastal waters that are far removed from inland nitrate sources. Historically, government standards and eutrophication-control strategies for inland waters have focused on phosphorus concentration rather than on nitrate concentration because phosphorus usually is depleted more rapidly by the growth of aquatic plants than is nitrate, and, therefore, frequently is the limiting factor in eutrophication. Increasingly, however, it is recognized that control of estuarine and coastal eutrophication will require control of nitrate from inland sources.

Major sources of nitrate in streams are municipal and industrial wastewater discharge and agricultural and urban runoff. Deposition from the atmosphere of the nitrogenous material in automobile exhaust and industrial emissions also is a source.
For purposes of this article, nitrate concentrations are arbitrarily grouped into three concentration classesless than $1 \mathrm{mg} / \mathrm{L}, 1$ to $3 \mathrm{mg} / \mathrm{L}$, and greater than $3 \mathrm{mg} / \mathrm{L}$. Figure $41 A$ shows that average nitrate concentrations were greater than $3 \mathrm{mg} / \mathrm{L}$ at several stations in the midwestern and southwestern United States. The concentrations ranged from 1 to $3 \mathrm{mg} / \mathrm{L}$ at many other stations in those areas, as well as in the mid-Atlantic States and the lower Mississippi River basin. Throughout much of the rest of the Nation, nitrate concentrations averaged less than $1 \mathrm{mg} / \mathrm{L}$. At stations in agricultural and urban areas, average concentrations of nitrate were much greater than concentrations at stations in forested and range areas (fig. $41 B$ ).

Significant trends in nitrate concentration (fig. $41 C$ ) were nearly equally divided between upward ( 22 stations) and downward ( 27 stations) trends among a total of 344 stations. Downward trends occurred predominately in the eastern, south-central, and southeastern United States, whereas upward trends were geographically scattered. Nationally, the percentage of stations having average concentrations greater than 1 $\mathrm{mg} / \mathrm{L}$ remained constant at about 20 percent (fig. $41 D$ ). There is some evidence of success in reducing nitrate levels in streams having very high concentrations because the percentage of stations nationwide having annual average concentrations greater than $3 \mathrm{mg} / \mathrm{L}$ decreased from about 6.5 to 4.0 percent. In agricultural areas, the percentage of stations where the annual average concentration was greater than $1 \mathrm{mg} / \mathrm{L}$ reached a peak of 46 percent in 1984 and then declined to 34 percent by 1989 (fig. $41 E$ ).

These 1980-89 trends in nitrate concentration represent a noteworthy change from the period 1974 81 , when increases in nitrate were widespread and appeared related to large increases in nitrogen-fertilizer use through 1981 (Smith and others, 1987). The lack of a nationwide trend in nitrate concentration in streams during the 1980's, therefore, is consistent with the fact that nitrogen fertilizer use peaked in 1981 and has remained approximately at that level since (Alexander and Smith, 1990). 
Average concentration

Nitrate

1980-89

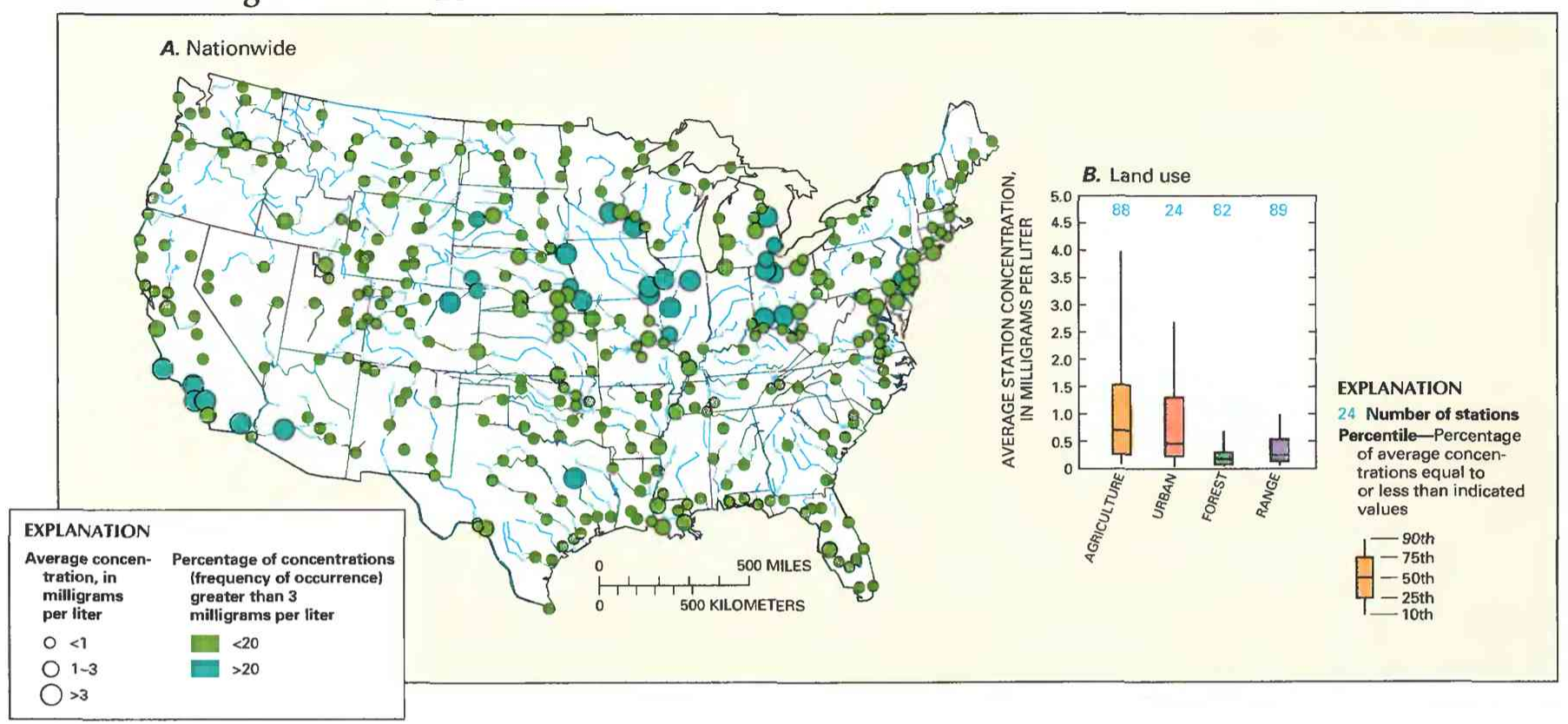

\section{Trends in concentration}

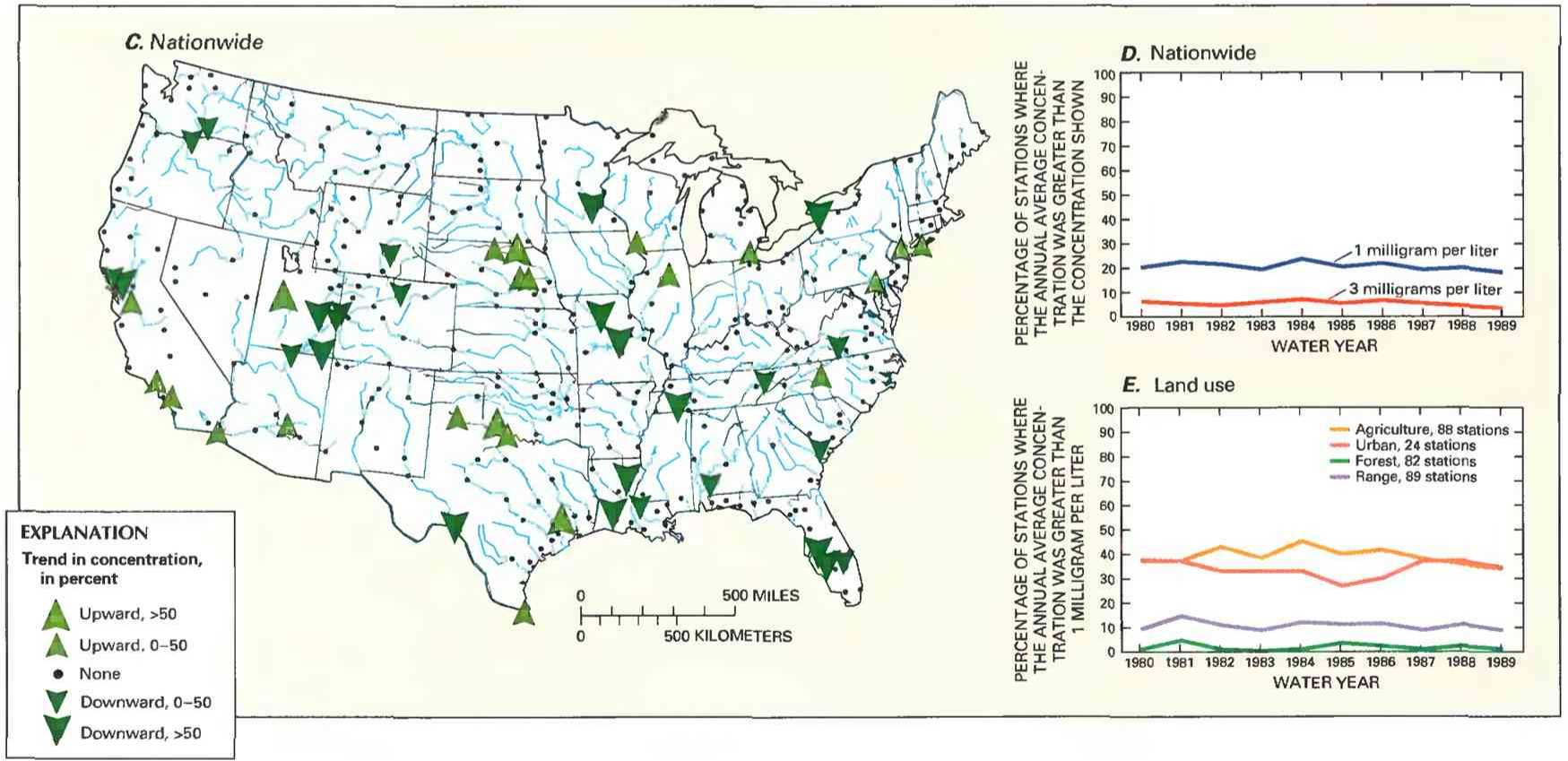

Figure 41. Concentration and trends in nitrate in stream water at 344 selected water-quality monitoring stations in the conterminous United States, water years 1980-89. (Because some cataloging units do not qualify for the land uses shown in $B$ and $E$, the total number of stations represented is less than the 344 stations used to compute $A, C$, and $D$.) $A$, Average concentration and percentage of concentrations greater than $3 \mathrm{mg} / \mathrm{L}$ (milligrams per liter) nationwide. $B$, Average concentration, by land use. $C$, Trends in concentration nationwide. $D$, Percentage of stations where the annual average concentration was greater than 1 or $3 \mathrm{mg} / \mathrm{L}$. E, Percentage of stations where the annual average concentration was greater than $1 \mathrm{mg} / \mathrm{L}$, by land use. >, greater than; <, less than. (Source: Data from U.S. Geological Survey files.) 


\section{Total Phosphorus}

In streams, phosphorus occurs primarily as phosphate and can be either dissolved, incorporated in organisms, or attached to particles in the water or in bottom sediments. Total phosphorus refers to the sum of all forms of phosphorus in a water sample and is reported in terms of elemental phosphorus.

Phosphorus is a particularly important nutrient in freshwater ecosystems because, as discussed above in the nitrate section, phosphorus usually is the nutrient in shortest supply and its availability often controls the rate of eutrophication. When human activities make phosphorus available in larger quantities, the accelerated growth of algae and other aquatic plants in streams can cause eutrophication, which depletes dissolved oxygen, imparts undesirable tastes and odors in the water, and clogs water-supply intakes. To protect against eutrophication, the EPA (1986) recommends an upper limit of 0.1 $\mathrm{mg} / \mathrm{L}$ as the standard for total phosphorus in streams. For this article, a threshold of $0.1 \mathrm{mg} / \mathrm{L}$ and an arbitrary threshold of $0.5 \mathrm{mg} / \mathrm{L}$ were selected for analysis of total-phosphorus concentrations in streams. Several characteristics of eutrophication in lakes and reservoirs, such as algal biomass, water clarity, and dissolved-oxygen depletion rate, have been found to be strongly correlated with the loading rate of total phosphorus (Rast and others, 1983). Estimates of phosphorus loading for a national sample of reservoirs are discussed in the section "Transport to Selected Reservoirs."

Sources of phosphorus are the decomposition of organic matter and inorganic phosphate minerals that are mined and incorporated in fertilizers, detergents, and other commodities. Thus, major point sources of phosphorus to streams are waste discharges from sewagetreatment and food-processing plants and other industrial facilities. Nonpoint sources of phosphorus include agricultural and urban runoff and, in certain regions, the runoff and ground-water flow from areas that contain natural deposits of phosphate minerals (Hem, 1985).

As discussed in the article "Introduction to State Summaries of Stream Water Quality" in this volume, apparent bias in the analysis of total phosphorus by the USGS in water years 1980 and 1981 made analysis of trends in total phosphorus unsuitable for those years. Consequently, all analyses for total phosphorus in this article are reported for water years 1982-89, a period for which no measurement bias is known to exist.

Average total-phosphorus concentrations were $0.1 \mathrm{mg} / \mathrm{L}$ or greater at most of the 410 stations shown in fig. $42 \mathrm{~A}$. Concentrations greater than $0.5 \mathrm{mg} / \mathrm{L}$ were especially common at stations in the central and southcentral part of the country where extensive agricultural use of phosphorus and highly erodible soils combine to create large nonpoint-source loads of phosphorus. Average total-phosphorus concentrations for the 1982-89 period show a higher concentration in agricultural areas but show a wider range of concentrations in urban areas (fig. 42B). Total-phosphorus concentrations are high in urban areas, where streams are influenced by a combination of point and nonpoint sources, and in west-central Florida, where there are large deposits of phosphate minerals.

Nationally, downward trends (92 stations) in total phosphorus (fig. 42C) occurred very widely and outnumbered upward trends (19 stations) by a factor of almost 5 to 1 . Downward trends occurred in all regions but occurred most frequently in the central States and the Great Lakes region. Upward trends occurred most frequently in the southeastern States. Nationally, the percentage of stations having annual average total-phosphorus concentrations greater than $0.1 \mathrm{mg} / \mathrm{L}$ decreased gradually from 54 to 42 percent between 1982 and 1989 (fig. $42 D$ ). A decrease in the percentage of water-quality monitoring stations having annual average concentrations greater than $0.1 \mathrm{mg} / \mathrm{L}$ occurred in all land-use categories with the exception of heavily forested areas, where the concentrations were more constant (fig. 42E).

The widespread pattern of a decline in total-phosphorus concentrations during the 1980's appears to represent the geographic expansion of a pattern begun in the 1970's (Smith and others, 1987) when downward trends were only slightly more numerous than upward trends, and occurred mostly in the Great Lakes area and the upper Mississippi River basin. Upward trends occurred most frequently in the Southeast. It is likely that widespread declines in total-phosphorus concentrations during the 1980's reflect significant reductions in pointsource loads that occurred during the period and some reduction in nonpoint-source loads. In addition to the previously described improvements in municipal- and industrial-wastewater treatment, the decrease since 1971 in phosphorus content of detergents helped reduce pointsource loads by an estimated 15 to 20 percent (U.S. Environmental Protection Agency, 1990b). The reasons for changes in nonpoint-source loads of phosphorus are more difficult to determine, but phosphorus-fertilizer use has declined more than 20 percent since 1979 (Alexander and Smith, 1990), and phosphorus contributions from livestock waste declined about 10 percent from 1982 to 1987 (U.S. Bureau of the Census, 1989; U.S. Soil Conservation Service, 1992). 


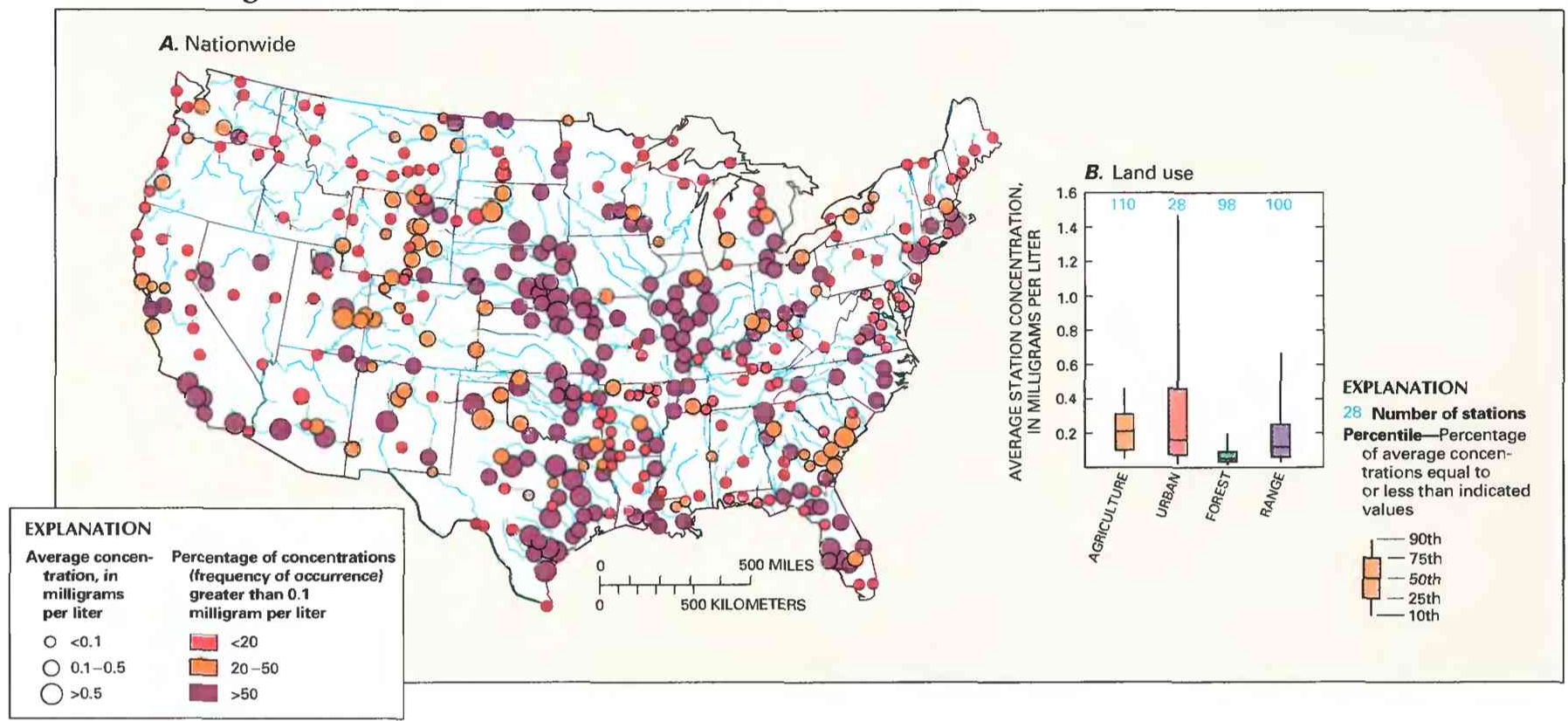

\section{Trends in concentration}

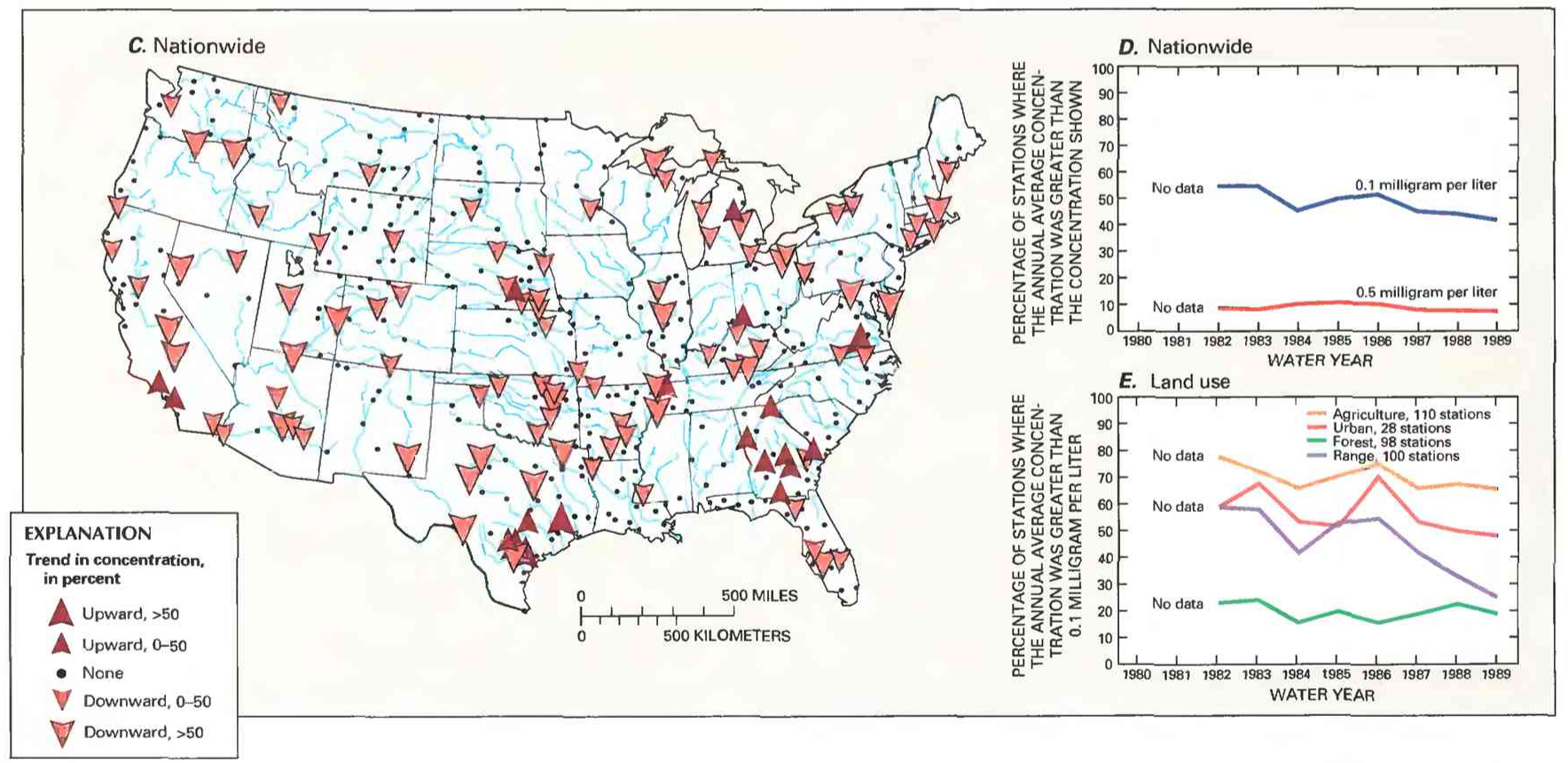

Figure 42. Concentration and trends in total phosphorus in stream water at $\mathbf{4 1 0}$ selected water-quality monitoring stations in the conterminous United States, 1982-89. (Because some cataloging units do not qualify for the land uses shown in $B$ and $E$, the total number of stations represented is less than the 410 stations used to compute $A, C$, and $D$.) $A$, Average concentration and percentage of concentrations greater than $0.1 \mathrm{mg} / \mathrm{L}$ (milligram per liter) nationwide. $B$, Average concentration, by land use. $C$, Trends in concentration nationwide. $D$, Percentage of stations where the annual average concentration was greater than 0.1 or $0.5 \mathrm{mg} / \mathrm{L}$. $E$, Percentage of stations where the annual average concentration was greater than $0.1 \mathrm{mg} / \mathrm{L}$, by land use. >, greater than; <, less than. (Source: Data from U.S. Geological Survey files.) 


\section{Suspended Sediment}

The suspended-sediment concentration of streams consists of the total quantity of suspended organic and inorganic particulate matter in water and has an important influence on aspects of water use and ecosystem health. High concentrations of suspended sediment in streams diminish the recreational use of streams because pathogens and toxic substances commonly associated with suspended sediment are threats to public health. High concentrations also reduce water clarity, thereby affecting the esthetic appeal of streams. They also are detrimental to stream biota because they inhibit respiration and feeding, diminish the transmission of light needed for plant photosynthesis, promote infections (U.S. Environmental Protection Agency, 1986), andwhen the sediment is deposited-can suffocate benthic organisms, especially in the embryonic and larval stages. Most sediment must be removed from water that is withdrawn for human use, and high sediment concentrations add significantly to the cost of treatment. Additionally, suspended sediment can cause significant wear to bridge footings and other stream structures, and, as it accumulates in a reservoir, it decreases the storage capacity of the reservoir. Nationally, such damage accounts for fully 30 percent of the estimated $\$ 3$ billion annual "off farm" cost of soil erosion (Clark and others, 1985).

The source of most suspended sediment is soil erosion. Although organic particles frequently form an important component of suspended sediment, most is inorganic by weight. Rates of soil erosion vary widely and depend on such factors as soil characteristics, precipitation frequency and intensity, slope of the land surface, and the nature and extent of land disturbance from agriculture, mining, and construction. Because the quantities of sediment entering streams depend greatly on natural factors, it is difficult to establish national criteria for suspended-sediment concentration. In many western areas, for example, stream ecosystems are naturally adapted to suspended-sediment concentrations that periodically are many times greater than those that are detrimental in other areas. Rather than establish national criteria for suspended-sediment concentration, the EPA has recommended that light penetration in water not be reduced by suspended material by more than 10 percent from its natural level (U.S. Environmental Protection Agency, 1986). In this article, average suspended-sediment concentrations for this study period are arbitrarily grouped into three concentration classes-less than 100 $\mathrm{mg} / \mathrm{L}, 100$ to $500 \mathrm{mg} / \mathrm{L}$, and greater than $500 \mathrm{mg} / \mathrm{L}$.

Suspended-sediment concentrations at the 324 stations shown in figure $43 \mathrm{~A}$ were highest in the westcentral part of the country, where many water-quality monitoring stations had average concentrations greater than $500 \mathrm{mg} / \mathrm{L}$ and some had concentrations greater than $1,000 \mathrm{mg} / \mathrm{L}$. By contrast, average concentrations only rarely were $100 \mathrm{mg} / \mathrm{L}$ or greater at stations in the north Atlantic and south Atlantic States, Great Lakes, and Pacific Northwest. Throughout much of the central part of the United States, average concentrations were in the $100-500 \mathrm{mg} / \mathrm{L}$ range. High suspended-sediment concentrations tended to occur in streams in areas dominated by range and agricultural land due to the high erodibility of soils in these areas (fig 43B).

Downward trends ( 37 stations) in suspendedsediment concentration, which greatly outnumbered upward trends (5 stations), occurred mostly at stations in the south-central part of the country and along the Gulf Coast (fig. 43C). Nationally, the percentage of stations having annual average concentrations greater than 100 $\mathrm{mg} / \mathrm{L}$ declined from 37 to 31 percent (fig. $43 D$ ). The steepest declines in the percentage of stations having annual average concentrations greater than $500 \mathrm{mg} / \mathrm{L}$ occurred in areas dominated by range and agricultural land (fig. 43E), and it is likely that increased efforts in soil conservation during 1980-89 contributed at least in part to these trends. The U.S. Soil Conservation Service (1989) estimates that sheet and rill erosion on rural land, a category that includes crop and range land cover, decreased by 13 percent between 1982 and 1987. 


\section{Suspended sediment}

Average concentration

1980-89

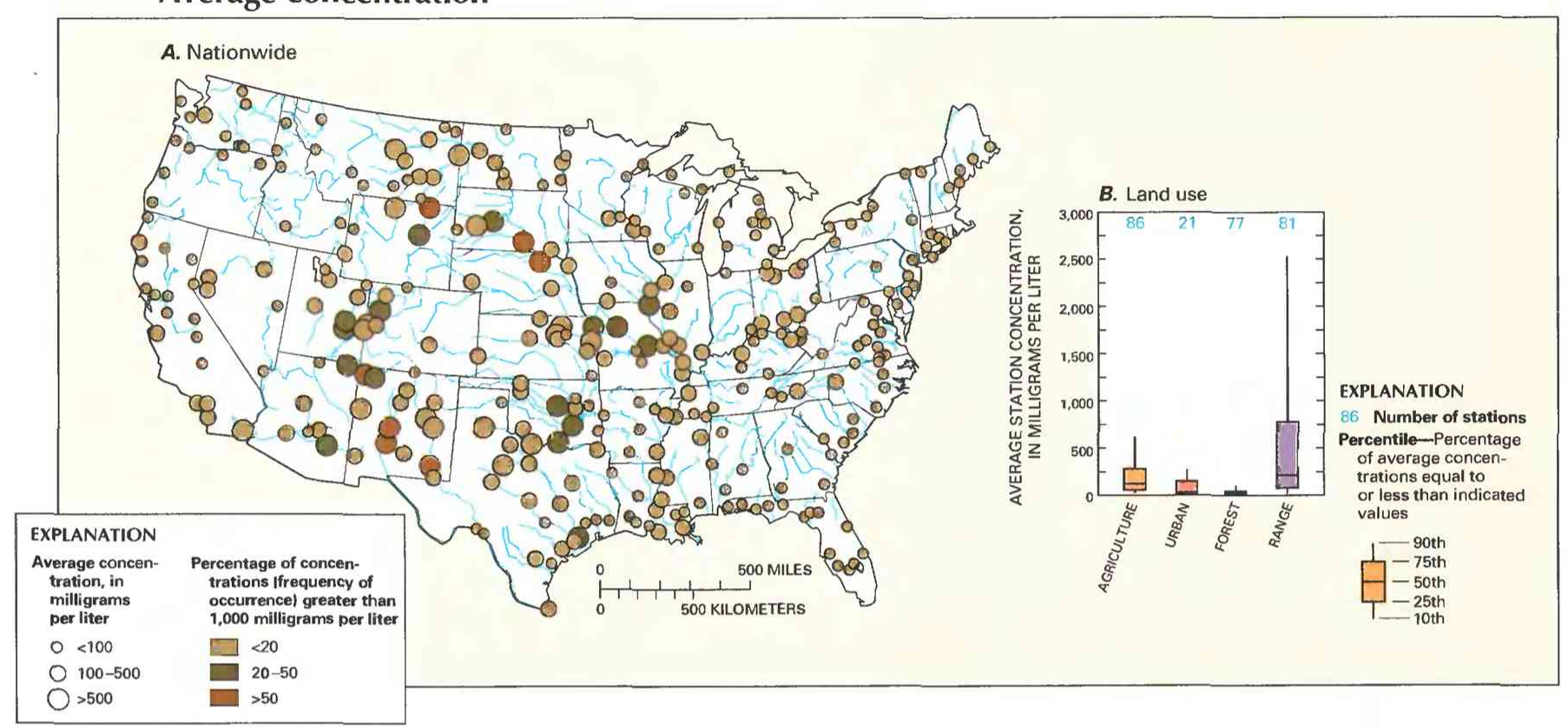

\section{Trends in concentration}

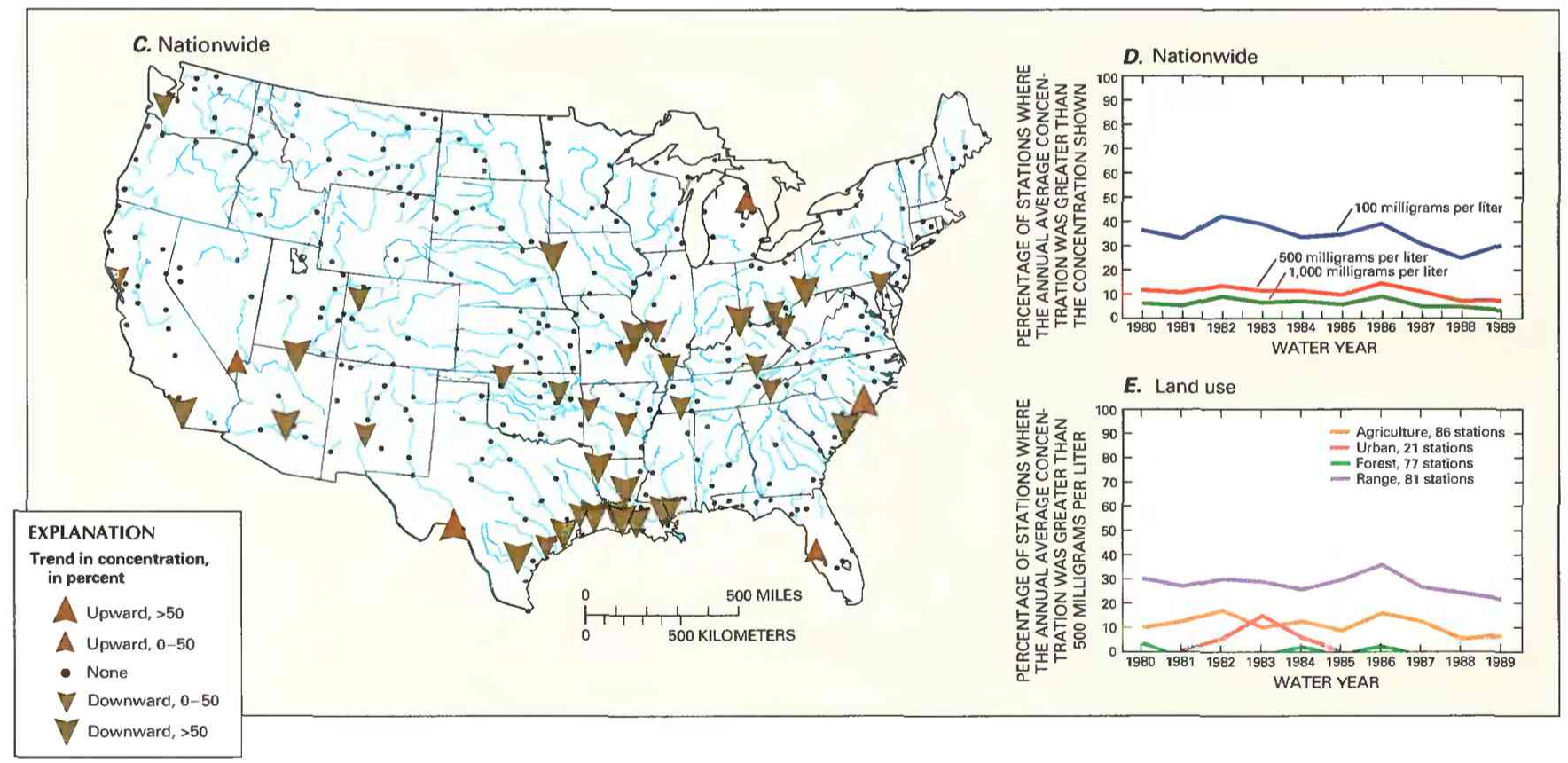

Figure 43. Concentration and trends in suspended sediment in stream water at 324 selected water-quality monitoring stations in the conterminous United States, water years 1980-89. (Because some cataloging units do not qualify for the land uses shown in $B$ and $E$, the total number of stations represented is less than the 324 stations used to compute $A, C$, and $D$.) $A$, Average concentration and percentage of concentrations greater than $1,000 \mathrm{mg} / \mathrm{L}$ (milligrams per liter) nationwide. $B$, Average concentration, by land use. $C$, Trends in concentration nationwide. $D$, Percentage of stations where the annual average concentration was greater than 100,500 , or $1,000 \mathrm{mg} / \mathrm{L}$. $E$, Percentage of stations where the annual average concentration was greater than $500 \mathrm{mg} / \mathrm{L}$, by land use. $>$, greater than; <, less than. (Source: Data from U.S. Geological Survey files.) 
TRANSPORT OF NitRate, TOTAL PHOSPHORUS, AND SUSPENDED SEDIMENT IN STREAMS

The transport of contaminants in streams from their sources, point and nonpoint, to downstream destinations is a water-quality issue of national concern. Even when constituent concentrations in a stream are within desirable limits, large quantities of contaminants can be transported downstream to more sensitive environments where they can accumulate through sedimentation, evaporation, or biological uptake. The quantity of a constituent carried by a stream is defined as "load" or "yield." Load is the quantity of the constituent transported during a specified time period, such as tons per year, and is equal to the constituent concentration times the stream discharge. Yield, which is the quantity of the constituent transported during a given time divided by unit drainage area, such as tons per year per square mile, provides a useful measure for comparing loads among basins of differing size.

Lakes, reservoirs, and estuaries and other coastal waters are particularly affected by stream-transported constituents. The important common feature of these waterbodies is that they can accumulate harmful amounts of nutrients, toxic substances, suspended sediment, and other contaminants. For example, nutrients can stimulate excessive plant growth and cause eutrophication, and benthic organisms can ingest or absorb toxic organic and inorganic constituents that can enter the food chain. In addition to the effects of toxic contaminants on animal and plant communities, the economic effects of resulting bans on eating finfish and shellfish are of considerable national importance. Also, some nutrients and toxic substances can be adsorbed by suspended sediment, and the sediment serves as an agent for the transport, deposition, and retention of these contaminants in waterbodies. Finally, the deposition of sediment in waterbodies also has a direct and costly effect on the physical characteristics of the waterbodies, such as reduction of reservoir storage or clogging of navigable channels.

The following discussion of the transport of nitrate, total phosphorus, and suspended sediment is organized into four sections. The first two sections describe the transport of these constituents from 14 water-resources regions and from cataloging units that have been classified into the four land uses defined in figure 37. The last two describe their transport to large reservoirs and coastal areas. Because of the large influence of yearto-year variations in streamflow on the transport of nutrients and suspended sediment, all estimates of load in the following sections were flow adjusted.

\section{Transport from Water-Resources Regions}

The 14 water-resources regions used in this article are shown in figure 44 . For each region, the average of the 8- or 10-year median flow-adjusted station yield and the annual percentage change in yields are shown for nitrate, total phosphorus, and suspended sediment.

Yields of nitrate and total phosphorus were highest in the Upper Mississippi and Ohio-Tennessee regions and lowest in the Souris-Red-Rainy and Texas-GulfRio Grande regions. The geographic pattern of nutrient yields reflects regional differences in land use and runoff, and it differs from the geographic pattern of nutri- ent concentrations shown in figures $41 A$ and $42 A$. For example, total-phosphorus concentrations were high in the streams draining the Texas-Gulf-Rio Grande region, whereas total-phosphorus yields were low because of low average runoff.

Suspended-sediment yields followed a geographic pattern similar to that of nitrate and total phosphorus; high yields occurred in the Ohio-Tennessee and Upper and Lower Mississippi regions. Additionally, high suspended-sediment yields occurred throughout the Colorado region. Also note that suspended-sediment yields are much greater than nutrient yields.

Figure 44 also summarizes trends in nitrate and suspended-sediment yields for water years 1980-89 and in total-phosphorus yields for water years 1982-89. Trends in yield, expressed as annual percentage change, were determined for each station using the seasonal Kendall test (Hirsch and others, 1982), and the median trend for each region is shown. The use of the annual percentage change in yield allows the difference in number of years used to be disregarded and allows the yields of the three constituents to be directly compared.

Nitrate yields changed little during the 1980-89 period, a result that stands in stark contrast to the 1974 81 period during which widespread increases in nitrate were reported by Smith and others (1987). The largest change in nitrate yield decreased 1.6 percent per year, resulting in a 16-percent decrease over the course of the decade.

With the exception of the South Atlantic-Gulf region, where the annual change in total-phosphorus yield was an increase of 0.1 , annual changes in totalphosphorus yields decreased at least slightly in all regions between 1982 and 1989 and decreased substantially in the Great Lakes, Arkansas-White-Red, and Lower Mississippi regions. The pattern of widespread decreases in total-phosphorus yield is consistent with the pattern of concentration trends (fig. $42 \mathrm{C}$ ) and possibly is the result of the combined effects of improved municipal- and industrial-wastewater treatment, reduced phosphate content of detergents, reduced fertilizer use, and reduced quantities of livestock wastes (see previous discussion of total phosphorus in the section "Concentrations of Six Common Water-Quality Constituents.")

Suspended-sediment yields decreased slightly in all regions except the Souris-Red-Rainy, Great Lakes, and South Atlantic-Gulf regions, where yields increased slightly. As noted in the earlier discussion of concentration trends, the national trend toward moderate decreases in suspended-sediment yields during the 1980's is the result, in part, of increased soil-conservation efforts.

\section{Transport According to Land Use}

Much of the geographic variation in nitrate, total-phosphorus, and suspended-sediment yields seen in figure 44 results from differences in the land use of the regions. For example, yields in the Ohio-Tennessee and Upper Mississippi regions are due to the combined influence of extensive agricultural activity and relatively high population density. Figure 45 shows the average of the 8- or 10-year median flow-adjusted station yields of nitrate, total phosphorus, and suspended sediment for four land-use classes (see classification criteria shown in figure 37 and the earlier section "Selected WaterQuality Data”). 


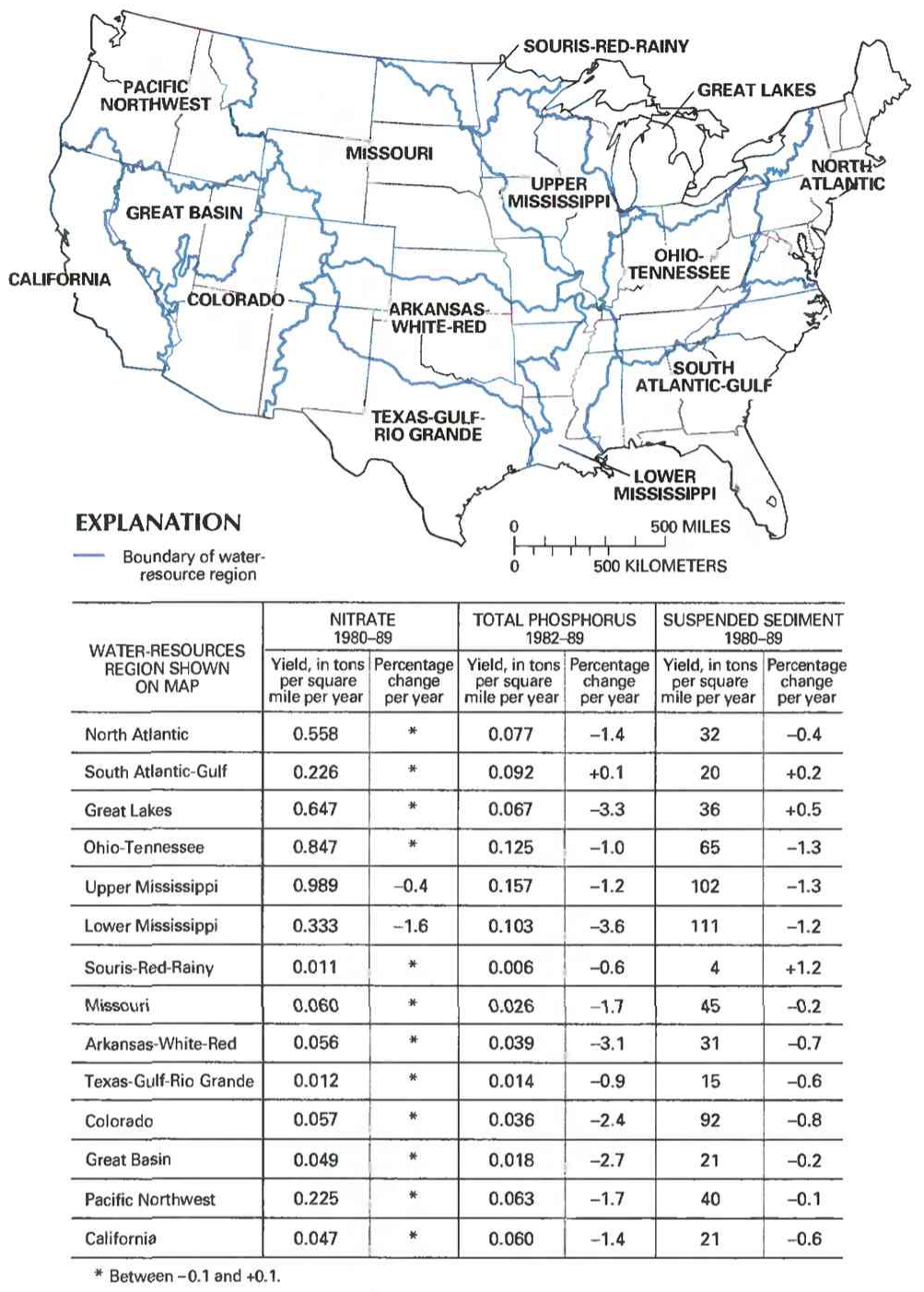

Figure 44. Yield and percentage change in yield of nitrate, total phosphorus, and suspended sediment in 14 water-resources regions of the conterminous United States. (Source: Data from U.S. Geological Survey files; water-resources regions modified from Seaber and others, 1987.)

One noteworthy feature of figure 45 is that in agricultural areas, yields of nitrate, total phosphorus, and suspended sediment were all highest in cataloging units under corn and soybean cultivation, lowest in cataloging units under wheat cultivation, and moderate to high in cataloging units dominated by mixed agriculture (wheat and corn and soybeans). The differences in yield among the agriculture categories result from crop-related factors, such as fertilizer composition and application rates, tillage practices, climate, and soil characteristics that have an influence on either nutrient and suspendedsediment availability or on runoff.

Not surprisingly, yields of nitrate and total phosphorus were high in urban cataloging units, due to large point-source contributions of the nutrients to streams. In contrast, nitrate and total phosphorus were low in cataloging units having forest and range land use, where cultural sources of nutrients are small. The factors that limit yields in forest and range-land categories, where nonagricultural forms of vegetation are dominant, are that soil erosion is controlled by forest cover and that precipitation rates are low in western range land.

Possible causes of changes in yield during the 1980 's can be determined by examining yield changes in relation to land use. As noted in the previous section "Transport from Water-Resources Regions," few trends in nitrate yield occurred during the $1980-89$ period, a noteworthy change from the previous decade when nitrate increases were widespread. One likely reason for the absence of major changes in nitrate yields in agricultural basins during the 1980's is a leveling off in the quantities of nitrogen fertilizer used nationally since 1981 (Alexander and Smith, 1990).

Total-phosphorus yields decreased at least slightly in all land-use classes, a result that is consistent with the regional pattern of yield changes described previously. Decreases in total-phosphorus yield were greatest in the agricultural and range land-use areas. Phosphorus-fertil- 


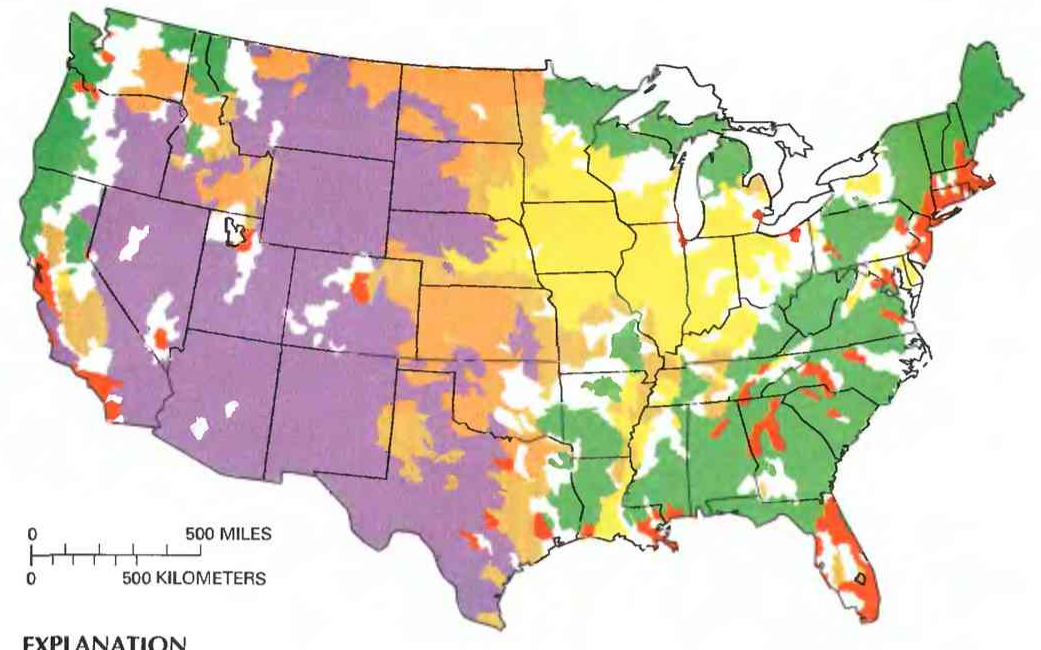

EXPLANATION

\begin{tabular}{l|c|c|c|c|c|c}
\hline \multirow{2}{*}{$\begin{array}{c}\text { LAND USE } \\
\text { SHOWN ON MAP }\end{array}$} & \multicolumn{2}{|c|}{$\begin{array}{c}\text { NITRATE } \\
1980-89\end{array}$} & \multicolumn{2}{c|}{ TOTAL PHOSPHORUS } & \multicolumn{2}{c}{$\begin{array}{c}\text { SUSPENDED SEDIMENT } \\
1982-89\end{array}$} \\
\cline { 2 - 8 } & $\begin{array}{c}\text { Yield, in tons } \\
\text { per square } \\
\text { mile per year }\end{array}$ & $\begin{array}{c}\text { Percentage } \\
\text { change } \\
\text { per year }\end{array}$ & $\begin{array}{c}\text { Yield, in tons } \\
\text { per square } \\
\text { mile per year }\end{array}$ & $\begin{array}{c}\text { Percentage } \\
\text { change } \\
\text { per year }\end{array}$ & $\begin{array}{c}\text { Yield, in tons } \\
\text { per square } \\
\text { mile per year }\end{array}$ & $\begin{array}{c}\text { Percentage } \\
\text { change } \\
\text { per year }\end{array}$ \\
\hline $\begin{array}{c}\text { AGRICULTURE } \\
\text { Wheat }\end{array}$ & 0.032 & $*$ & 0.010 & -2.8 & 10 & +0.8 \\
\hline$\square \quad$ Corn and soybeans & 0.932 & $*$ & 0.163 & -2.1 & 100 & -1.0 \\
\hline$\square \quad$ Mixed & 0.304 & $*$ & 0.066 & -1.6 & 79 & -0.7 \\
\hline$\square$ URBAN & 0.547 & +0.2 & 0.119 & -0.6 & 23 & -0.6 \\
\hline$\square$ FOREST & 0.255 & $*$ & 0.063 & -0.8 & 31 & -0.3 \\
\hline RANGE & 0.031 & $*$ & 0.017 & -1.9 & 33 & -0.2 \\
\hline
\end{tabular}

Figure 45. Yield and percentage change in yield of nitrate, total phosphorus, and suspended sediment in hydrologic cataloging units in the conterminous United States that are classified as having agricultural (wheat, corn and soybeans, and mixed ), urban, forest, and range land use. See figure 37 for explanation of land-use classification and hydrologic cataloging units. (Source: Data from U.S. Geological Survey files.)

izer use decreased nationally by 16 percent during 1980 85 (Alexander and Smith, 1990). A possible additional factor in the decline in total-phosphorus yields in agricultural areas is the general trend toward declining erosion rates and suspended-sediment yields in rural areas (U.S. Soil Conservation Service, 1989). Soil-erosion rates have a potentially important influence on nonpointsource yields of total phosphorus due to a strong tendency for phosphorus to adsorb to soil particles.

Probably the greatest contribution to the decrease in total-phosphorus yield in urban areas resulted from reductions in point-source loads brought about by more complete treatment of municipal and industrial wastewater, decreased industrial water use, and by the widespread removal of phosphate from detergents. The 33-percent decrease in yield in the Great Lakes region during water years 1982-89 (fig. 44), where point-source phosphorus control has been especially stringent (International Joint Commission, 1989), is noteworthy in this regard.

Suspended-sediment yields in most land-use areas reached peak values early in the 1980's and decreased substantially by the end of the decade. Only the yields in areas dominated by wheat cultivation showed an increase. It is possible that decreases in suspendedsediment yield in streams are a reflection of decreases in soil-erosion rates as reported by the U.S. Soil Conservation Service (1989) for several of their categories of rural land use for 1982-87. The increased use of conservation tillage practices also supports the conclusion that erosion rates on agricultural land declined during the 1980's. A comparison of survey data for 1982 and 1988 (Conservation Technology Information Center, 1982, 1988) shows that the percentage of cropland under conservation tillage increased from 18 to 42 percent for the Northeast, 34 to 42 percent in the Great Lakes and Midwest, and 10 to 23 percent in the southern Great Plains. These areas correspond to parts of the Missouri, Upper Mississippi, Ohio-Tennessee, and North Atlantic waterresources regions (fig. 44), where decreases in suspended-sediment yields occurred.

\section{Transport to Selected Reservoirs}

It is evident from studies of nitrate, total-phosphorus, and suspended-sediment loads in large river basins (see, for example, Jaworski and others, 1992) that a large percentage of the particulate material that streams transport from higher elevations in the interior of the continent is removed before the streams reach coastal waters. Biological uptake is primarily responsible for the removal of nitrate, whereas reservoirs are major repositories for phosphorus and sediment.

The accumulation of phosphorus and sediment in reservoirs is a significant national water-quality problem. As discussed earlier, phosphorus usually is the plant nutrient in shortest supply in freshwater, and its abundance commonly regulates algal growth in reservoirs and lakes. High concentrations of algae reduce water clarity and cause taste and odor problems; upon settling, decaying algal cells deplete dissolved oxygen and recycle phosphorus to the bottom water, which becomes available for renewed phytoplankton growth when vertical mixing of the water occurs in the spring. In addition to reducing water clarity, sediment suspended in streams that enter reservoirs tends to settle out and accumulate, gradually diminishing the reservoir storage capacity.

Total-phosphorus and suspended-sediment loads were calculated for water years 1982-89 and 1980-89, respectively, for water-quality monitoring stations located within 25 miles upstream of reservoirs having a normal storage capacity of greater than 5,000 acre-feet. The 85 stations that met the above criteria (fig. 46A) have a geographic distribution similar to that of large reservoirs throughout the conterminous United States (Ruddy and Hitt, 1990).

More than 20 years of intensive research has established the strong correlation between the loads of total phosphorus transported to reservoirs and lakes to several important indicators of eutrophication, such as phytoplankton density, water clarity, and dissolved-oxygendepletion rate. This research has lead to the development of reliable indices for predicting eutrophic conditions in lakes and reservoirs on the basis of total-phosphorus load. The most widely used is the Vollenweider index (Vollenweider, 1975), which is calculated from the load of total phosphorus to a lake or reservoir, the volume of the waterbody, and the residence time or amount of time needed for streams to provide inflow equal to the volume of the waterbody.

In theory, the value of the index for a given reservoir is equal to the average steady-state total-phosphorus concentration of the reservoir. Index values between $0.05 \mathrm{mg} / \mathrm{L}$ and $0.3 \mathrm{mg} / \mathrm{L}$ indicate moderately eutrophic conditions; in this range, a submerged black and white disk that is used to measure water clarity is visible to a 
depth of about 3 to 6 feet. Index values greater than 0.3 $\mathrm{mg} / \mathrm{L}$ indicate highly eutrophic conditions; disk visibility is less than 3 feet.

Trends in Vollenweider index values for the 85 reservoirs over water years 1982-89 are summarized in figure $46 B$. The percentage of reservoirs having index values exceeding the lower threshold $(0.05 \mathrm{mg} / \mathrm{L})$ of the moderately eutrophic range decreased from 67 to 57 percent, but the percentage having index values greater than the threshold for highly eutrophic conditions (greater than $0.3 \mathrm{mg} / \mathrm{L}$ ) increased slightly from about 11 to about 15 percent. The increase in the percentage of reservoirs with high index values is in contrast to the general pattern of moderate decreases in total-phosphorus concentrations and loads nationally.

The accumulation of sediments in reservoirs causes the loss of water-storage capacity that eventually must be remedied through dredging or construction of new reservoirs. Nationally, the total annual cost of replacing lost reservoir storage capacity is estimated to range from $\$ 80$ to $\$ 700$ million in 1985 dollars (Clark and others, 1985). An index of the sediment-accumulation rate in a reservoir is obtained by dividing the incoming suspended-sediment load by the reservoir area. Annual sediment-accumulation rates for the 85 reservoirs ranged from less than one-tenth to more than 10 pounds per square foot; the median was 1.2 pounds per square foot. The percentage of the reservoirs having accumulation rates greater than 2 pounds per square foot per year decreased slightly during 1980-89 (fig. 46C). For sediment having a typical density of about 1 ounce per cubic inch, an accumulation rate of 2 pounds per square foot per year would lead to an average loss of reservoir depth of about 0.2 inch per year.

\section{Transport to Coastal Waters}

Estimated loads of nitrate, total phosphorus, and suspended sediment transported in streams to coastal waters of the conterminous United States are summarized in figure 47. Coastal-load estimates were based on methods described in Cohn and others (1989). To determine these estimates, it is necessary to use daily streamflow data for each water year. Because streamflow data were unavailable for 1989 , the period 1980-88 was used for nitrate and suspended sediment and 1982-88 was used for total phosphorus. For this discussion, coastal segments are identified as North Atlantic, South Atlantic, Gulf of Mexico, Great Lakes, Pacific Northwest, and California, and their extent is shown in figure 47 . For each coastal segment, annual loads for ungaged drainage areas were computed by multiplying the computed yield for the gaged drainage area by the area of the ungaged area; this load was then added to the computed load for the gaged area to derive the load for the segment. The average of the annual load estimates for the indicated time periods are shown in figure 47. Note that computations for the Great Lakes drainage do not include loads from Canadian streams, and those for the Gulf of Mexico do not include loads from Mexican streams. The annual percentage change in load shown in figure 47 was estimated by applying the Sen slope estimator (Sen, 1968) to the series of annual loads. The statistical significance of the percentage-change estimates was determined by applying the Kendall test for trend (Kendall, 1975).

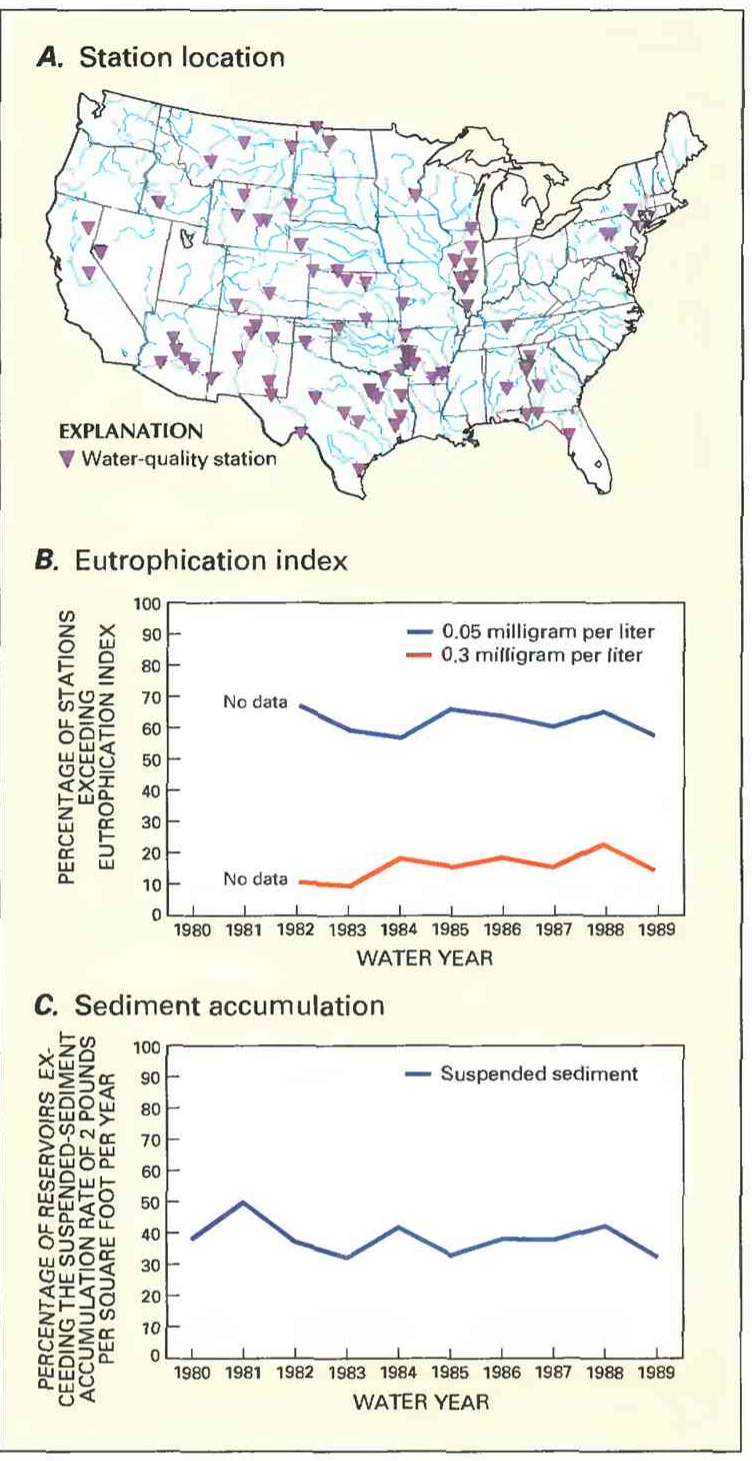

Figure 46. Water quality of tributaries to 85 selected large reservoirs, $1980-89$. A, Location of water-quality monitoring stations. $B$, Percentage of stations exceeding eutrophication index values of $0.05 \mathrm{mg} / \mathrm{L}$ (milligrams per liter) and $0.3 \mathrm{mg} / \mathrm{L}$. C, Percentage of reservoirs whose suspended-sediment accumulation exceeded 2 pounds per square foot per year. (Source: Data from U.S. Geological Survey files.)

The Gulf of Mexico receives drainage from about 60 percent of the land area of the conterminous States and receives the highest percentage of nitrate, total-phosphorus, and suspended-sediment loads of the six coastal segments -70 percent of nitrate, 65 percent of total phosphorus, and 62 percent of suspended sediment. However, when the coastal-segment yields-determined by dividing load by drainage area-are compared, differences between the segments become apparent. The Great Lakes and North Atlantic have the highest yields of nitrate, for example, due to the combined effects of municipal and industrial point sources, atmospheric deposition, and significant application of nitrogen-based fertilizers. Coastal yields of total phosphorus and suspended sediment, by contrast, are highest in the California segment where torrential spring runoff carries high 


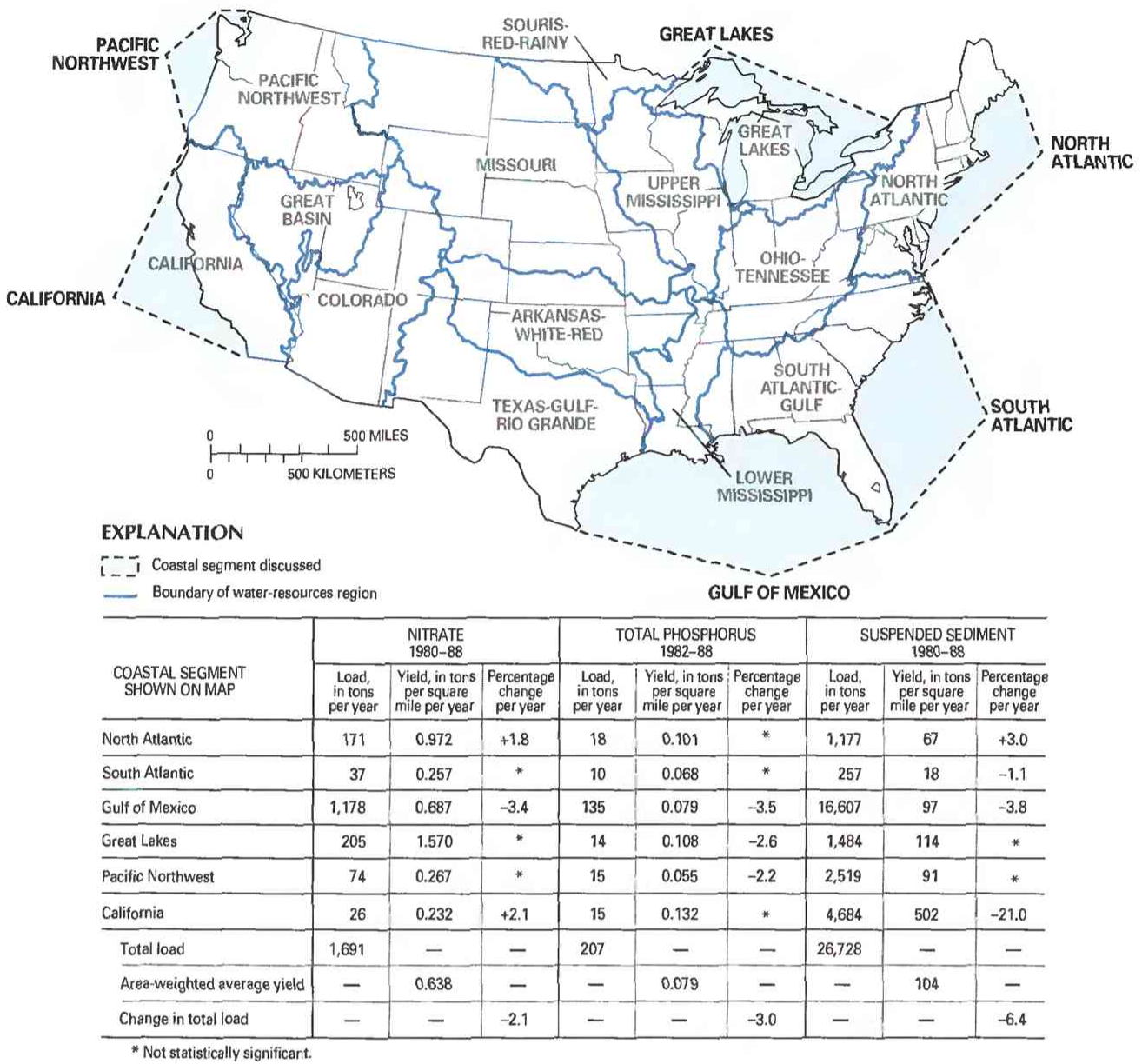

Figure 47. Load, yield, and percentage change in load and yield of nitrate, total phosphorus, and suspended sediment in six coastal segments of the conterminous United States. Note: Computations for the Great Lakes drainage do not include loads from Canadian streams, and those for the Gulf of Mexico do not include loads from Mexican streams. (Source: Data from U.S. Geological Survey files; water-resources regions modified from Seaber and others, 1987.)

sediment loads from the steep slopes of coastal mountains in the northern part of the State. Also, in California, suspended-sediment loads are especially high in areas where timber-harvesting practices have exposed soil to erosion. Finally, yields of nitrate, total phosphorus, and suspended sediment are comparatively low in the South Atlantic coastal segment because extensive areas of forested wetland and many large reservoirs in the drainage to the South Atlantic and Gulf of Mexico segments trap the particulate material.

Consistent with the general pattern of yield trends in interior basins, the predominant direction of change in coastal loads of nitrate, total phosphorus, and suspended sediment was downward during the periods studied. For the conterminous States, the decrease in total coastal loads of the three constituents was 2.1,3.0, and 6.4 percent per year, respectively. This downward trend in total coastal loads was influenced greatly by the decreases in the delivery of the three constituents to a single coastal segment-the Gulf of Mexico. Significant decreases in loads of two of the constituents - total phosphorus and suspended sediment-also occurred in the Great Lakes and Pacific Northwest segments and the
South Atlantic and California segments, respectively. In contrast, nitrate loads to all coastal segments except the Gulf of Mexico either increased or showed no statistically significant trend.

\section{Water Quality In AREAS of Selected WATER USE}

Water quality affects water use. If the quality of available water is not suitable for its intended use, users must choose between treating the water or finding alternative sources, which can have an effect on the cost of providing usable water. The following discussion focuses on surface-water withdrawals and on the concentrations of several dissolved constituents or combinations of dissolved constituents that impair water use and require that the water receive chemical treatment before it can be used for domestic and industrial purposes and for irrigation of crops. In addition to dissolved solids, which has been discussed above, the discussion below focuses on chloride, sodium, and sulfate, and on indices that are computed from concentrations of these and other water-quality constituents and properties. 
Figure $48 \mathrm{~A}$ shows cataloging units having high surface-water withdrawals for domestic, industrial, and irrigation use. High surface-water withdrawals in cataloging units are defined as those having 1985 surfacewater withdrawals (Solley and others, 1988) for a given water-use category within the upper 25 percent of all cataloging units--for domestic use, the surface-water withdrawal was greater than $2.3 \mathrm{Mgal} / \mathrm{d}$ (million gallons per day); for industrial use, it was greater than $2 \mathrm{Mgal} / \mathrm{d}$; and for irrigation use, it was greater than $13 \mathrm{Mgal} / \mathrm{d}$. Note that many cataloging units are identified as having high surface-water withdrawals for more than one water use. Additionally, data from water-quality monitoring stations in the cataloging units that are aggregated by water-use category are summarized in figures $48 B-D$ to show trends in water quality in terms of chemical criteria relevant to water use. These criteria are discussed below, along with the results of the analysis.

\section{Domestic Water Use}

Water for domestic use often requires treatment to adjust the concentrations of several common constituents. Dissolved solids in drinking water become detectable to a majority of people at a concentration of about $500 \mathrm{mg} / \mathrm{L}$, which currently is the EPA secondary maximum contaminant level (SMCL), although certain individual constituents, such as chloride and sulfate, can affect taste at concentrations well below this level. For example, EPA recommends an SMCL of $250 \mathrm{mg} / \mathrm{L}$ for chloride to protect the taste of drinking water and 250 $\mathrm{mg} / \mathrm{L}$ for sulfate to protect against laxative effects (U.S. Environmental Protection Agency, 1979, 1986).

In cataloging units having high domestic surfacewater withdrawals, the percentage of water-quality stations having annual average dissolved-solids concentrations greater than $500 \mathrm{mg} / \mathrm{L}$ fluctuated around 17 percent between 1980 and 1989 . However, the percentage of stations having annual average chloride and sulfate concentrations greater than $250 \mathrm{mg} / \mathrm{L}$ decreased slightly or remained the same (fig. $48 B$ ).

Throughout much of the United States, water for domestic use is treated to reduce the amount of calcium and magnesium, the principal components of the soapconsuming property of water that commonly is termed "hardness." A decrease in soap cleansing becomes noticeable when hardness, usually expressed as an equivalent concentration of calcium carbonate, is greater than about $100 \mathrm{mg} / \mathrm{L}$. An additional reason for treating hard water is that calcium and magnesium-which are relatively insoluble-form scale or mineral deposits that clog plumbing and appliances. At more moderate levels of hardness, however, calcium and magnesium form a thin layer over chemically sensitive metallic surfaces that serves to protect plumbing and appliances against corrosion. Water having a hardness concentration greater than $180 \mathrm{mg} / \mathrm{L}$ is considered very hard and 300 $\mathrm{mg} / \mathrm{L}$ is considered extremely hard (U.S. Environmental Protection Agency, 1976). In cataloging units having high domestic surface-water withdrawals, the percentage of water-quality monitoring stations having annual average hardness greater than $300 \mathrm{mg} / \mathrm{L}$ increased from about 15 percent in water year 1980 to 18 percent in water year 1989.

Corrosion of pipes and solder joints can contribute lead or other toxic materials to water that is used for domestic as well as industrial use, in addition to reducing the useful life of plumbing and appliances. Several indices of the corrosive capacity of water have been devised (Singley, 1981), and most assume that an optimal balance between the corrosive and scale-forming properties of water lies at about the saturation point for calcium carbonate. The most widely used index, that of Langelier (1936), is a function of $\mathrm{pH}$, temperature, alkalinity, calcium concentration, and ionic strength. Positive values of the index indicate scale-forming conditions and negative values indicate corrosive conditions. Values less than about -2 generally are considered highly corrosive. In cataloging units having high domestic surface-water withdrawals, the percentage of water-quality monitoring stations having an annual average Langelier saturation index value less than -2 decreased from 22 to 14 percent (fig. $48 B$ ) from water year 1980 to 1989 .

\section{Industrial Water Use}

The dissolved-solids concentration of water is important for industrial use because of its effects on corrosion and scale formation in pipes, rate of chemical reactions, taste in foods and beverages, and product color control, to name only a few. The dissolved-solids concentration of process water can be reduced through deionization, but the quality of available water can be an important factor in industrial siting.

Maximum acceptable dissolved-solids concentrations in untreated water for industrial use are variable, ranging from $150 \mathrm{mg} / \mathrm{L}$ for textile manufacturing, through a few thousand milligrams per liter in the chemical and petroleum industries, to $35,000 \mathrm{mg} / \mathrm{L}$ for boiler makeup (U.S. Environmental Protection Agency, 1986). In cataloging units having significant industrial surfacewater withdrawals, the percentage of water-quality monitoring stations having an annual average dissolvedsolids concentration greater than $1,000 \mathrm{mg} / \mathrm{L}$ remained nearly constant during the 1980's at about 4 percent (fig. $48 C)$.

Limits on hardness in raw water supplies for industry also are variable. The hardness requirement for process water in industries is essentially zero, a level that can be achieved through treatment. In cataloging units having significant industrial surface-water withdrawals, the percentage of water-quality stations having an annual average hardness of greater than $300 \mathrm{mg} / \mathrm{L}$ increased from 9 to about 12 percent during water years $1980-89$ (fig. 48C).

As with water for domestic water use, the corrosivity of some industrial water supplies requires adjustment to avoid costly damage to pipes and other equipment. In cataloging units having large industrial surface-water withdrawals, the percentage of stations having an annual average Langelier saturation index less than -2 decreased from 29 to 22 percent during water years 1980-89 (fig. 48C).

\section{Irrigation Water Use}

A primary consideration in evaluating the quality of water for irrigation is the concentration of dissolved solids that can interfere with osmotic plant uptake of water and nutrients and with soil structure stemming from imbalances in certain cation concentrations. In 
general, harmful osmotic effects on sensitive crops begin to appear when the dissolved-solids concentration is greater than about $500 \mathrm{mg} / \mathrm{L}$, and many crops are damaged by concentrations greater than $1,000 \mathrm{mg} / \mathrm{L}$ (Federal Water Pollution Control Administration, 1968). Among cataloging units having significant irrigation surface-water withdrawals, the percentage of water-quality monitoring stations having annual average dissolvedsolids concentrations greater than $500 \mathrm{mg} / \mathrm{L}$ increased slightly during the $1980-89$ period from 30 to 33 percent (fig. 48D).

In addition to contributing to osmotic pressure, sodium in sufficient concentrations is toxic to certain fruits and other plants, and, when present in high concen- trations relative to the concentrations of cations having a positive charge of 2, can adversely affect soil structure and infiltration and permeability rates (U.S. Environmental Protection Agency, 1976). The sodium-adsorption ratio (SAR) of irrigation water is a frequently used index of sodium concentration in relation to calcium and magnesium. When SAR values exceed about 4 , sensitive fruits can be damaged; when it exceeds about 13, many crops can be damaged (Federal Water Pollution Control Administration, 1968). The percentage of water-quality monitoring stations in cataloging units having significant irrigation surface-water withdrawals with annual average SAR values greater than 4 increased from 9 to 16 percent during 1980-89 (fig. 48D).
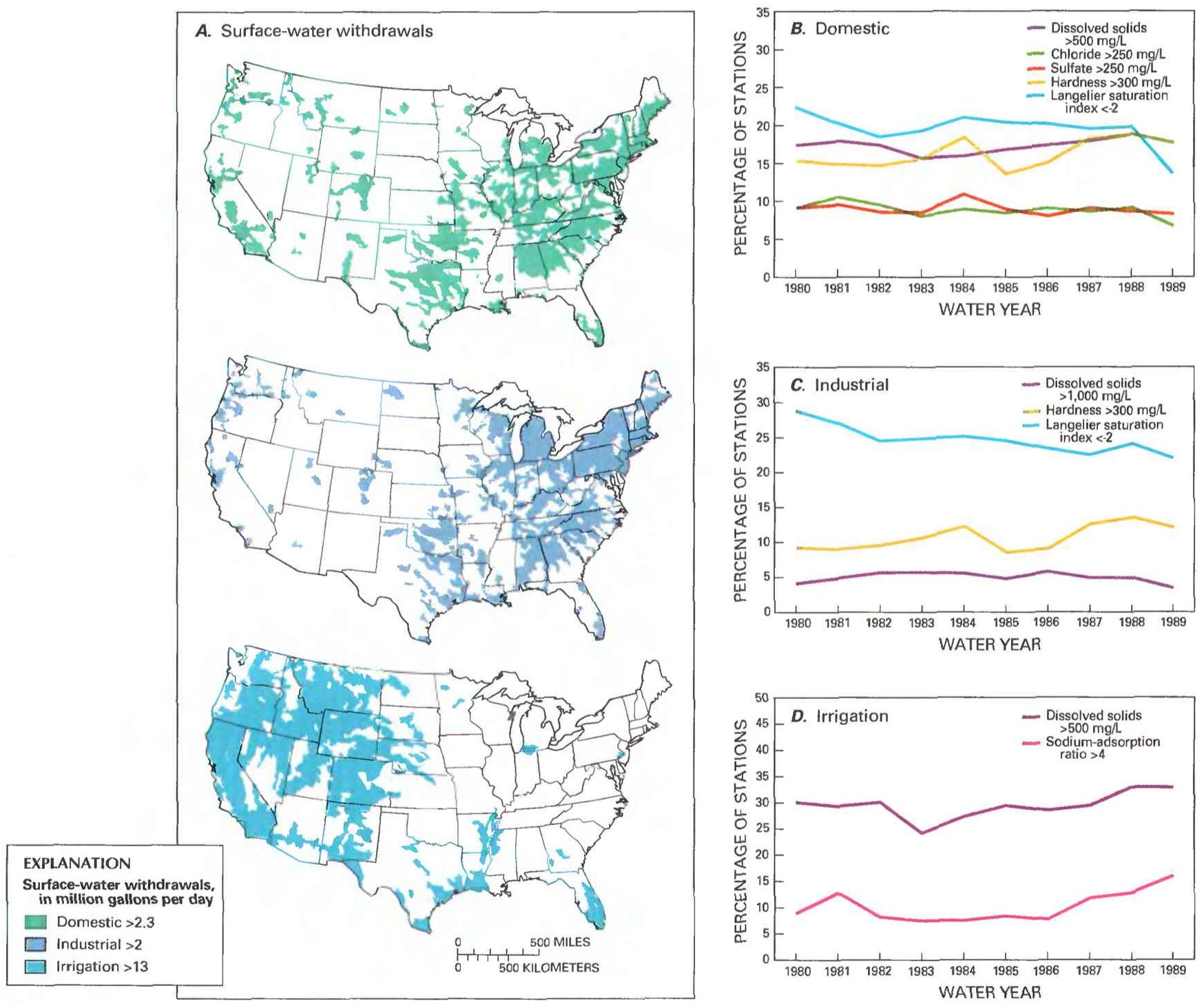

Figure 48. Surface-water withdrawals in the conterminous United States for three water-use categories, 1985; and trends in water quality, by water-use category, 1980-89. A, Hydrologic cataloging units with surface-water withdrawals greater than $2.3 \mathrm{Mgal} / \mathrm{d}$ (million gallons per day) for domestic use, greater than $2 \mathrm{Mgal} / \mathrm{d}$ for industrial use, and greater than $13 \mathrm{Mgal} / \mathrm{d}$ for irrigation use; these values are the thresholds used for selecting the upper 25 percent of the cataloging units. $B$, Trends in water quality in cataloging units in the upper 25 percent of surface-water withdrawals for domestic use. $C$, Trends in water quality in cataloging units in the upper 25 percent of surface-water withdrawals for industrial use. $D$, Trends in water quality in cataloging units in the upper 25 percent of surface-water withdrawals for irrigation use. Cataloging units are shown in figure 37. >, greater than; <, less than. (Source: Data from U.S. Geological Survey files.) 


\section{National Trends in Pesticides and Toxic TRACE ELEMENTS IN FINFISH TISSUE}

An exception to the general lack of national-level information on both the biological and toxicological aspects of water quality is a data base compiled by the FWS in its NCBP. Figure 49, which is based on data from Christopher Schmitt (U.S. Fish and Wildlife Service, written commun., 1992), shows the locations where fish were collected for analysis (fig. 49A), the changes over time in concentration of several trace elements (fig. 49B), and organic compounds in whole finfish (fig. 49C). Geometric-annual-average concentrations shown in figure 49 are computed for two species of fish-one bottom feeding and one predator species - at each station. Concentrations of three of the four toxic elements measured - arsenic, cadmium, and lead - showed decreases ranging from 50 to 63 percent between calendar years 1976 and 1986; concentrations of the fourth element, mercury, remained nearly constant. Fish-tissue concentrations of DDT and related compounds, dieldrin, and total PCB's decreased by more than 60 percent between 1970 and 1986. Between 1976 and 1986, toxaphene concentrations decreased by 65 percent, and chlordane and related compounds decreased by 32 percent from their peak in 1978.

In theory, contaminant concentrations in finfish tissue are integrative measures of water quality and can reflect long-term average contaminant concentrations in one or more aspects of the stream environment. Depending on the chemical nature of the contaminant in question and the age and species of fish sampled, contaminant concentrations in fish tissue could be indicative of contaminant levels in either the living or nonliving components of either the stream water or sediments. Moreover, data on contaminant levels in fish tissue provide information on the health risks of the human consumption of fish from the locality where the fish samples were collected. However, there are several difficulties in interpreting the toxicological significance of contaminantconcentration measurements made in the NCBP. First, contaminant concentrations in the NCBP are measured in whole fish as opposed to the more edible portions of fish, whereas U.S. Food and Drug Administration criteria for evaluating the safety of fish for human consumption are based on contaminant concentrations in fish fillets. Second, organic chemical analyses in the NCBP are not specific for the toxic components of certain classes of contaminants such as PCB's but, instead, refer to the total concentration of all compounds in the class. Nevertheless, NCBP data provide a useful summary of nationaland regional-level trends in the occurrence of historically important toxic contaminants in fish tissues.

\section{CONCENTRATION AND TRANSPORT OF HERBI- CIDES IN AGRICULTURAL AREAS IN THE MIDWEST}

\section{Concentration of Herbicides}

In the United States, the application of herbicides before crops and weeds start to grow (preemergent) increased rapidly during the 1970 's, reflecting changes in tillage practices (National Research Council, 1989). As noted above, an exception to the general lack of information on pesticide concentrations in streams is a recent study of herbicide occurrence in a random sample of 149

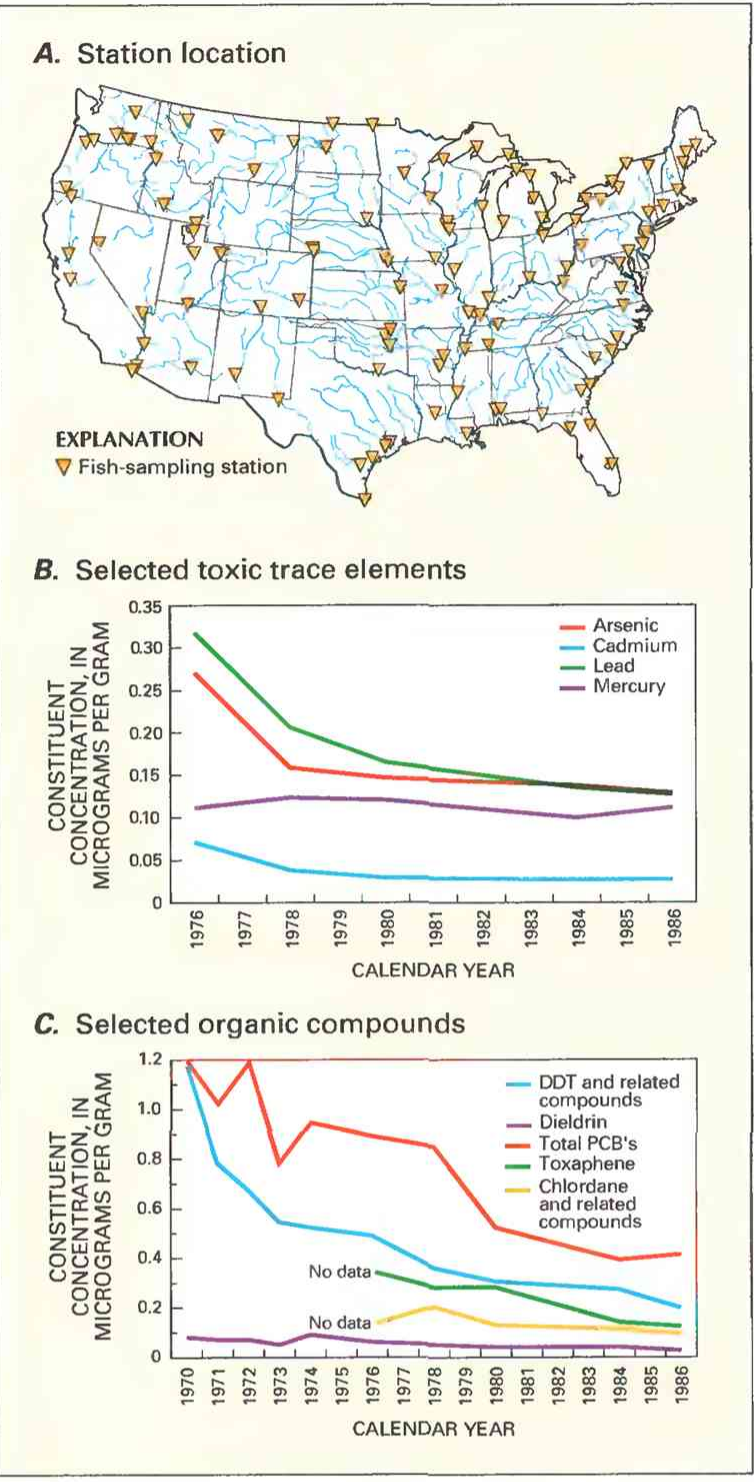

Figure 49. Trends in concentration (geometric-annual average, all in wet weight) of selected constituents in finfish tissue collected at 113 stations on major rivers in the conterminous United States and the Great Lakes for selected years. $A$, Location of fish-sampling stations. $B$, Trends in selected toxic trace elements, 1976-86. C, Trends in selected organic compounds, 1970-86. (Source: Based on data from Christopher Schmitt, U.S. Fish and Wildilife Service, written communication, 1992.)

streams draining agricultural basins in a 10-State region of the Midwest (Goolsby, Thurman, and Kolpin, 1991; Thurman and others, 1991). Although this study is regional rather than national in scope, approximately threequarters of all preemergent herbicides used in the United States are applied to row crops in the study region. The study area and the concentrations of selected herbicides in streams are shown in figure 50 . The herbicide concentrations reported below are for untreated stream water, whereas the EPA maximum contaminant levels (MCL's) and lifetime health-advisory levels apply to treated water. It is noteworthy, however, that conventional water-supply treatment processes generally do not 

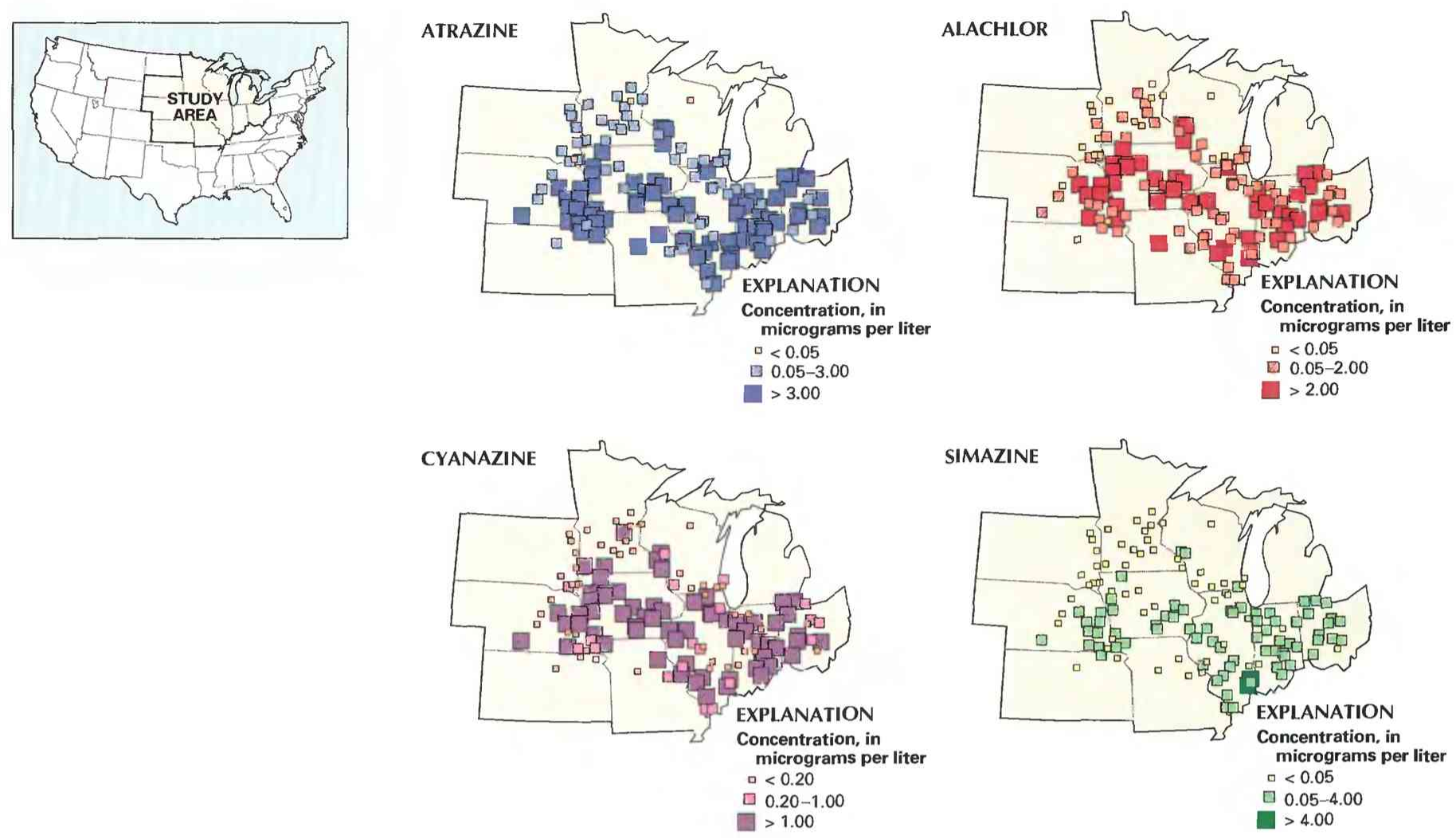

Figure 50. Concentrations of selected herbicides collected during the first runoff after application in the spring of 1989 in streams that drain agricultural areas in a 10-State area in the Midwest. Highest concentration interval in each map is the U.S. Environmental Protection Agency drinking-water criterion. >, greater than; <. less than. (Source: Data from U.S. Geological Survey files.)

remove these herbicides from water (Miltner and others, 1989). About 18 million people in the drainage basins within the 10-State area rely on surface-water withdrawals for drinking-water supplies. [Note: The EPA MCL's used in this article were promulgated in July of 1991 for atrazine and alachlor and in July of 1992 for simazine. Only the MCL for simazine differs from that used by Goolsby, Thurman, and Kolpin (1991). The lifetime health-advisory limit for cyanazine differs from the limit used by Goolsby, Thurman, and Kolpin (1991).]

Results of the reconnaissance suggest that detectable concentrations of atrazine, one of the most commonly used herbicides for weed control in corn and sorghum production, occurred year-round in a majority of the streams sampled. During the first runoff after application in 1989 , a majority ( 52 percent) of the streams sampled had atrazine concentrations exceeding $3 \mu / \mathrm{L}$ (micrograms per liter), the EPA MCL recommended for drinking water (fig. 50). During the spring and early summer period following herbicide application, atrazine concentrations increased by as much as two orders of magnitude and then decreased to preapplication levels by fall during low-streamflow conditions. Because of the random design of the sampling, these results are believed to be typical of streams throughout the study region.

For three other herbicides (alachlor, cyanazine, and simazine) the number of sampling locations having concentrations exceeding the EPA drinking-water criteria during the immediate postapplication period ranged from 2 to 49 percent. Concentrations of alachlor exceeded the EPA MCL for drinking water of $2 \mu / \mathrm{L}$ at 32 percent of the streams sampled (Goolsby, Thurman, and Kolpin, 1991). When compared with the most recent EPA drinking-water criteria, concentrations of cyanazine exceeded the lifetime health-advisory level of $1 \mu / \mathrm{L}$ at 49 percent of the streams sampled, whereas concentrations of simazine exceeded the EPA MCL of $4 \mu / \mathrm{L}$ at only 2 percent of the streams sampled.

\section{Occurrence and Transport of Herbicides in the Mississippi River and its Major Tributaries}

The widespread occurrence of herbicides in medium-sized streams in the Midwest prompts questions about the magnitude and distance of transport of these compounds in the large rivers that drain the region. A number of major cities, including Cincinnati, Ohio; Louisville, Ky.; Omaha, Neb.; Kansas City and St. Louis, Mo.; Minneapolis-St. Paul, Minn.; and New Orleans, La., withdraw water directly from either the Ohio, Missouri, or Mississippi Rivers for public supplies.

As a follow-up to the 1989 and 1990 survey described above, sampling for five herbicides in the Mississippi River and several of its major tributaries was initiated by the USGS in the spring of 1991 (Goolsby, Coupe, and Markovchick, 1991). The estimates of atrazine loads determined by this survey are summarized in figure 51 . 


\section{EXPLANATION}

\begin{tabular}{c|c|c|c}
\hline \multicolumn{1}{c|}{$\begin{array}{c}\text { SOURCE OF ATRAZINE, } \\
\text { BY DRAINAGE } \\
\text { BASIN SHOWN ON MAP }\end{array}$} & \multicolumn{2}{c|}{$\begin{array}{c}\text { DRAINAGE } \\
\text { AREA IN } \\
\text { SQUARE MILES }\end{array}$} & \multicolumn{2}{c}{ ATRAZINE LOAD } \\
Pounds & Percent \\
\hline$\square \quad \begin{array}{l}\text { Mississippi River basin above } \\
\text { Clinton, lowa }\end{array}$ & 85,600 & 24,900 & 4.8 \\
\hline$\square \quad \begin{array}{l}\text { Missouri River basin above } \\
\text { Hermann, Mo. }\end{array}$ & 524,000 & 131,600 & 25.4 \\
\hline$\square \quad \begin{array}{l}\text { Ohio River basin above } \\
\text { Grand Chain, III. }\end{array}$ & 203,100 & 95,500 & 18.5 \\
\hline $\begin{array}{l}\text { Other tributary inflow, } \\
\text { Clinton, lowa, to Thebes, III. }\end{array}$ & 103,600 & 189,700 & 36.7 \\
\hline $\begin{array}{l}\text { Other tributary inflow, Thebes, } \\
\text { III., to Baton Rouge, La. }\end{array}$ & 208,700 & 75,300 & 14.6 \\
\hline$\square \begin{array}{l}\text { Mississippi River basin above } \\
\text { Baton Rouge, La.(includes load } \\
\text { diverted into the Atchafalaya River } \\
\text { above Baton Rouge, La.) }\end{array}$ & $1,125,000$ & 517,000 & 100.0 \\
\hline
\end{tabular}

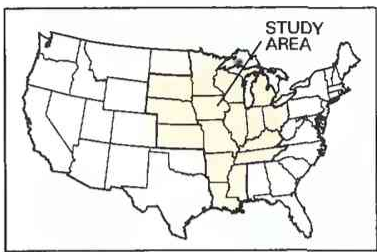

Kans.

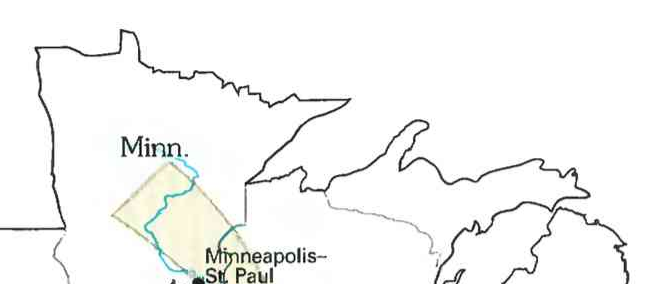

Wis.

Neb.

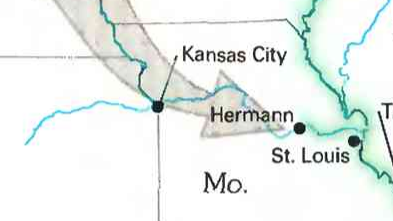

IIl.
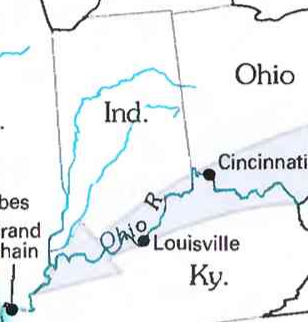

Figure 51. Atrazine loads, by pounds and percentage of total load, contributed to the Mississippi River drainage basin from Clinton, lowa, to Baton Rouge, La., April-June, 1991. (Source: Modified from Goolsby, Coupe, and Markovchick, 1991.)

One or more herbicides were detected in every sample collected during the April to June period. Atrazine was detected most frequently, followed by cyanazine, alachlor, and simazine. Concentrations of two herbicides, atrazine and alachlor, occasionally exceeded MCL's for drinking water. Atrazine exceeded the MCL in 27 percent of the samples, including one sample from the Mississippi River at Baton Rouge, La., hundreds of miles from the major source of atrazine in the Midwest. Alachlor exceeded the MCL in 4 percent of the samples, but only in the smaller tributaries.

Load calculations were made for atrazine to determine the predominant source areas for this widely used herbicide. The calculations indicate that the largest percentage (about 37 percent) of the atrazine discharged from the Mississippi River into the Gulf of Mexico entered the river from streams draining Iowa and Illinois. The second largest source area was the Missouri River basin, which contributed about 25 percent of the atrazine entering the Gulf. The atrazine discharged to the Gulf of Mexico during April, May, and June 1991 was estimated to be 517,000 pounds. This quantity represents slightly less than 1 percent of the amount of atrazine applied annually to cropland in the Mississippi basin.

\section{SUMMARY}

Statistical summaries of national water-quality conditions and trends provide decisionmakers and the public with objective measures of progress towards water-quality goals. Ideally, the data for national waterquality summaries should (a) be geographically representative, (b) include a variety of chemical and biological indicators, and (c) provide a basis for determining water-quality trends. Existing water-quality data fall short of this ideal in several respects. First, due to a lack of scientific consensus on the nationwide validity of any single biological indicator in streams, few national-level data exist to describe biological conditions. Second, 
there are few national-level data on toxic contaminants in streams, such as pesticides, industrial organic compounds, and toxic trace metals. Finally, State reporting of water quality that is mandated by section $305(\mathrm{~b})$ of the Clean Water Act to assess whether waterbodies support designated uses contains methodological inconsistencies from State to State and in time. These inconsistencies make it impossible to summarize national water-quality conditions and trends from State reporting of water quality.

The most abundant data for describing national stream water-quality conditions and trends are traditional sanitary and chemical water-quality indicators such as dissolved oxygen, fecal coliform bacteria, nutrients (nitrate and total phosphorus), and suspended sediment. Concentrations of several of these water-quality indicators decreased during the 1980's and, collectively, provide evidence of progress in pollution control during the decade. The most notable improvements occurred in concentrations of fecal coliform bacteria, an important indicator of the suitability of stream water for contact recreation, and total phosphorus, which usually is the nutrient controlling the process of eutrophication in freshwater. Nationally, the percentage of water-quality monitoring stations having fecal coliform bacteria and total phosphorus concentrations greater than desirable limits decreased substantially during the 1980's. Widespread declines also occurred in the load of total phosphorus transported to large reservoirs and coastal waters, where the accumulation of phosphorus can lead to persistent eutrophication problems. However, despite widespread declines in these indicators, more than a third of the streams sampled in 1989 had annual average concentrations of total phosphorus and fecal coliform bacteria that exceeded desirable limits. Thus, water-quality goals are not yet being met in a significant percentage of streams.

Trends in other traditional indicators provide evidence of slight improvement or little change in stream water quality during a decade when the economy and population showed significant growth. For example, dissolved-oxygen concentrations nationally changed little from 1980 to 1989 , but streams in urban areas showed slight improvement in dissolved-oxygen conditions, possibly reflecting the effect of improving pointsource controls. Similarly, nitrate concentrations and yields remained nearly constant nationally, but they declined in a number of streams draining agricultural areas where nitrate levels have been historically high. This general tendency toward constant or declining nitrate concentrations represents a significant departure from the pattern of trends for 1974-81, when widespread increases in nitrate were reported. Also, the quantity of nitrate transported to coastal waters, where nitrogen plays an important role in eutrophication, decreased in the Gulf of Mexico area but increased somewhat in the North Atlantic and California coastal segments during the 1980's. Suspended-sediment concentrations and yields decreased slightly in most of the country, and the quantity of suspended sediment transported to coastal segments decreased or remained the same in all but the North Atlantic region.

Finally, little change was noted in the concentrations of most major dissolved constituents that have economic significance through their effects on the esthetic characteristics of drinking water, the chemical character- istics of industrial process water, or the salinity of irrigation water. Annual average concentrations of dissolved constituents exceeded desirable limits at a third or fewer of the streams sampled for each constituent. The most noteworthy changes were substantial decreases in the chemical corrosivity of stream water used for domestic and industrial water supplies.

National-level information documenting trends in the toxicological aspects of water quality is limited to data on toxic contaminants in finfish tissue in major rivers and the Great Lakes compiled by the Fws between 1970 and 1986. Contaminant concentrations in finfish tissue are integrative measures of water quality and can reflect long-term average contaminant concentrations in stream water and sediment. The data show that since the 1970's, concentrations of the toxic elements arsenic, cadmium, and lead and the organic compounds chlordane (and related compounds), dieldrin, DDT (and related compounds), toxaphene, and total PCB's declined significantly. However, the concentrations of mercury remained nearly constant during the time period.

Although national-level information on trends in pesticides in stream water is not available, recent studies of herbicide concentrations in streams in agricultural areas of the midwestern United States from 1989 to 1991 provide important regional information on the magnitude and distribution of herbicides in streams. These studies show that, during the first runoff in 1989 following herbicide application, atrazine exceeded applicable EPA drinking-water criteria at 52 percent of the streams sampled; for alachlor, cyanazine, and simazine, the number of streams sampled that exceeded the criteria ranged from 2 to 49 percent. Substantially lower, but detectable, concentrations of these herbicides persisted throughout the year in many of the streams in the region. Additional sampling for these herbicides in the Mississippi River and its major tributaries showed that alachlor and atrazine occasionally exceeded EPA drinking-water criteria and that substantial quantities of these herbicides are transported by major rivers over long distances.

In sum, stream water quality in the conterminous United States either improved or remained about the same during the 1980's as shown by most available measures. Although modest improvements in water quality during this period of economic growth represent a significant achievement in pollution control, much remains to be done to reach existing water-quality goals for the indicators currently monitored at the national level. Moreover, the fragmentary nature of data on the biological and toxicological aspects of stream water quality leaves largely unanswered the question of progress in these areas. Recently initiated Federal monitoring programs eventually will provide data for a more comprehensive view of water-quality conditions and trends that will show whether there is continued progress towards national water-quality goals.

\section{REFERENCES CITED}

Alexander, R.B., and Smith, R.A., 1990, County level estimates of nitrogen and phosphorus fertilizer use in the United States, 1945 to 1985: U.S. Geological Survey Open-File Report 90-130, 12 p.

Clark, E.H., Haverkamp, J.A., and Chapman, William, 1985, Eroding soils-The off-farm impacts: Washington, D.C., The Conservation Foundation, 252 p. 
Cohn, T.A., DeLong, L.L., Gilroy, E.J., Hirsch, R.M., and Wells, D.K., 1989, Estimating constituent loads: Water Resources Research, v. 25, no. 5, p. 937-942.

Conservation Technology Information Center, 1982, 1982 National survey-Conservation tillage practices-Executive summary: West Lafayette, Ind., National Association of Conservation Districts, 83 p.

1988, 1988 National survey - Conservation tillage practices-Executive summary: West Lafayette, Ind., National Association of Conservation Districts, $7 \mathrm{p}$.

Federal Water Pollution Control Administration, 1968, Water quality criteria-Report of the National Technical Advisory Committee to the Secretary of the Interior: Washington, D.C., U.S. Department of Interior, 234 p.

Flegal, A.R., and Coale, K.H., 1989, Discussion-Trends in lead concentration in major U.S. rivers and their relation to historical changes in gasoline-lead consumption: Water Resources Bulletin, v. 25, no. 6, p. 1275-1277.

Gilliom, R.J., Alexander, R.B., and Smith, R.A., 1985, Pesticides in the Nation's rivers, 1975-1980, and implications for future monitoring: U.S. Geological Survey WaterSupply Paper 2271, $26 \mathrm{p}$.

Goolsby, D.A., Coupe, R.C., and Markovchick, D.J., 1991, Distribution of selected herbicides and nitrate in the Mississippi River and its major tributaries, April through June 1991: U. S. Geological Survey Water-Resources Investigations Report $91-4163,35 \mathrm{p}$.

Goolsby, D.A., Thurman, E.M., and Kolpin, D.W., 1991, Geographic and temporal distribution of herbicides in surface waters of the upper midwestern United States, 1989-90, in Mallard, G.E., and Aronson, D.A., eds, U.S. Geological Survey toxic substances hydrology program-Proceedings of the technical meeting, Monterey, Calif., March 11-15, 1991: U.S. Geological Survey Water-Resources Investigations Report 91-4034, p. 183188.

Hem, J.D., 1985, Study and interpretation of the chemical characteristics of natural water (3d ed.): U.S. Geological Survey Water-Supply Paper 2254, $263 \mathrm{p}$.

Hirsch, R.M., Alley, W.M., and Wilber, W.G., 1988, Concepts for a national water-quality assessment program: U.S. Geological Survey Circular 1021, 42 p.

Hirsch, R.M., Slack, J.R., and Smith, R.A., 1982, Techniques of trend analysis for monthly water-quality data: Water Resources Research, v. 18, no. 1, p. 107-121.

International Joint Commission, 1989, 1989 report on Great Lakes water quality: Windsor, Ontario, Canada, International Joint Commission, Great Lakes Water Quality Board, $127 \mathrm{p}$.

Jaworski, N.A., Groffman, P.M., Keller, A.A., and Prager, J.C., 1992, A watershed nitrogen and phosphorus balanceThe upper Potomac River basin: Estuaries, v. 15, no. 1, p. 83-95.

Kendall, M.G., 1975, Rank correlation methods, London, Charles Griffin and Co., Ltd., $202 \mathrm{p}$.

Lanfear, K.J., and Alexander, R.B., 1990, Methodology to derive water-quality trends for use by the national water summary program of the U.S. Geological Survey: U.S. Geological Survey Open-File Report 90-359, 10 p.

Langelier, W.F., 1936, The analytical control of anti-corrosion water treatment: American Water Works Association Journal, v. 28 , no. 10 , p. 1500-1521.

Leahy, P.P., Rosenshein, J.S., and Knopman, D.S., 1990, Implementation plan for the national water-quality assessment program: U.S. Geological Survey Open-File Report 90-174, $10 \mathrm{p}$.

Lowe, T.P., May, T.W., Brumbaugh, W.G., and Kane, D.A., 1985, National contaminant biomonitoring programConcentrations of seven elements in freshwater fish, 1978-1981: Archives of Environmental Contamination and Toxicology, v. 14, p. 363-388.

Miltner, R.J., Baker, D.B., Speth, T.F., and Fronk, C.A., 1989, Treatment of seasonal pesticides in surface waters:
American Water Works Journal, v. 81, no. 1, p.43-52. National Academy of Sciences, 1969, EutrophicationCauses, consequences, correctives-Proceedings of international symposium on eutrophication, Madison, Wis., June 11-15, 1967: Washington, D.C., National Academy of Sciences, $661 \mathrm{p}$.

National Research Council, Board of Agriculture, Committee on the Role of Alternative Farming Methods in Modern Production Agriculture, 1989, Alternative agriculture: Washington, D.C., National Academy Press, $448 \mathrm{p}$.

Ohio Environmental Protection Agency, 1987, The role of biological data in water-quality assessment, v. 1 of Biological criteria for the protection of aquatic life: Columbus, Ohio Environmental Protection Agency, Division of Water Quality Monitoring and Assessment, Surface Water Section, $50 \mathrm{p}$.

1992, Summary, status, and trends, v. 1 of Ohio water resource inventory: Columbus, Ohio Environmental Protection Agency, Division of Water Quality Planning and Assessment, Ecological Assessment Section, $183 \mathrm{p}$.

Paulson, L.J., and Bakers, J.R., 1983, The effects of impoundments on salinity in the Colorado River, in Adams, V.D., and Lamarra, V.A., eds., Aquatic resources management of the Colorado River ecosystem-Proceedings of symposium of the aquatic resources management of the Colorado River ecosystem, Las Vegas, Nev., November 16-18, 1981: Ann Arbor, Mich., Ann Arbor Science Publishers, $679 \mathrm{p}$.

Peters, N.E., 1984, Evaluation of environmental factors affecting yields of major dissolved ions of streams in the United States: U.S. Geological Survey Water-Supply Paper 2228, $39 \mathrm{p}$.

Rast, W.R., Jones, A.R., and Lee, G.F., 1983, Predictive capability of U.S. OECD phosphorus loading-eutrophication response models: Water Pollution Control Federation Journal, v. 55, no. 7, p. 990-1003.

Ruddy, B.C., and Hitt, K.J., 1990, Summary of selected characteristics of large reservoirs in the United States and Puerto Rico, 1988: U.S. Geological Survey Open-File Report 90-163, 295 p.

Schmitt, C.J., and Brumbaugh, W.G., 1990, National contaminant biomonitoring program-Concentrations of arsenic, cadmium, copper, lead, mercury, selenium, and zinc in U.S. freshwater fish, 1976-1984: Archives of Environmental Contamination and Toxicology, v. 19, p. 731-747.

Schmitt, C.J., and Finger, S.E., 1987, The effects of sample preparation on measured concentrations of eight elements in edible tissues of fish from streams contaminated by lead mining: Archives of Environmental Contamination and Toxicology, v. 16, p.185-207.

Schmitt, C.J., Zajicek, J.L., and Peterman, P.H., 1990, National contaminant biomonitoring program-Residues of organochlorine chemicals in U.S. freshwater fish, 19761984: Archives of Environmental Contamination and Toxicology, v. 19, p. 748-781.

Schmitt, C.J., Zajicek, J.L., and Ribick, M.A., 1985, National pesticide monitoring program-Residues of organochlorine chemicals in freshwater fish, 1980-81: Archives of Environmental Contamination and Toxicology, v. 14, p. 225-260.

Seaber, P.R., Kapinos, F.P., and Knapp, G.L., 1987, Hydrologic unit maps: U.S. Geological Survey Water-Supply Paper 2294, 63 p.

Sen, P.K., 1968, Estimates of the regression coefficient based on Kendall's tau: American Statistical Association Journal, v. 63, p. 1379-1389.

Shiller, A.M., and Boyle, E.A., 1987, Variability of dissolved trace metals in the Mississippi River: Geochimica et Cosmochimica. Acta, v. 51, p. 3273-3277.

Singley, J.E., 1981, The search for a corrosion index: Ameri- 
can Water Works Association Journal, v. 73, no. 11, p. 579-582.

Smith, R.A., Alexander, R.B., and Wolman, M.G., 1987, Water-quality trends in the Nation's rivers: Science, v. 235 , no. 4796 , p. $1607-1615$.

Solley, W.B., Merk, C.F., and Pierce, R.R., 1988, Estimated use of water in the United States in 1985: U.S. Geological Survey Circular 1004, $82 \mathrm{p}$.

Thurman, E.M., Goolsby, D.A., Meyer, M.T., and Kolpin, D.W., 1991, Herbicides in surface waters of the midwestern United States-The effect of spring flush: Environmental Science and Technology, v. 25, no. 10, p. 1794-1796.

U.S. Bureau of the Census, 1989, Census of agriculture 1987, final county file-Technical documentation AG-87-2: Washington, D.C., U.S. Bureau of the Census [machine readable data file].

1990, Statistical abstracts of the United States-The national data book (110th ed.): Washington, D.C., U.S. Government Printing Office, 991 p.

1991, Census of population and housing 1990-Public Law 94-71 Data on CD-ROM: Washington, D.C., U.S. Bureau of the Census [machine-readable data files].

U.S. Environmental Protection Agency, 1976, Quality criteria for water: Washington, D.C., U.S. Environmental Protection Agency, $256 \mathrm{p}$.

1979, Part 143 - National secondary drinking water regulations: Federal Register, v. 44, no. 140, p. 4219542202.

1986, Quality criteria for water 1986: Washington, D.C., U.S. Environmental Protection Agency, Office of Water, EPA 440/5-86-001[variously paginated]. 1990a, Design report for EMAP [Environmental
Monitoring and Assessment Program]: Washington, D.C., U.S. Environmental Protection Agency, Office of Research and Development, EPA/600/3-91/053 [variously paginated].

1990b, Toxic chemical release inventory reporting package for 1990: Cincinnati, Ohio, U.S. Environmental Protection Agency EPA 560/4-90-001 [variously paginated].

-1990c, Environmental investments-The cost of a clean environment: Washington, D.C., U.S. Environmental Protection Agency EPA-230/11-90-083 [variously paginated].

U.S. Soil Conservation Service, 1989, Summary report 1987-National resources inventory: U.S. Soil Conservation Service Statistical Bulletin no. 790, 37 p.

1992, Agricultural waste characteristics in Agricultural waste management field handbook, part 651 of National engineering handbook: Washington, D.C., U.S. Soil Conservation Service chap. 4, p. 4-1-4-23.

Vollenweider, R.A., 1975, Input-out models with special reference to the phosphorus loading concept in limnology: Swiss Journal of Hydrology, v. 37, no. 1, p. 53-84.

Windom, H.L., Byrd, J.T., Smith, R G., Jr., and Huan, Feng, 1991, Inadequacy of NASQAN data for assessing metal trends in the nation's rivers: Environmental Science and Technology, v. 25, no. 6, p. 1137-1142.

\section{FOR ADDITIONAL INFORMATION}

Richard A. Smith and Richard B. Alexander, U.S. Geological Survey, 410 National Center, and Kenneth J. Lanfear, 407 National Center, Reston, VA 22092 
Institutional and Managhaien! Aspecis

\title{
Nationwide Water-Quality Reporting to the Congress as ReQuired Under Section 305(b) of the Clean Water Act
}

\author{
By Alice E. Mayio' and Geoffrey H. Grubbs ${ }^{1}$
}

\section{INTRODUCTION}

Section 305(b) of the Clean Water Act requires all States, the District of Columbia, Puerto Rico, and the U.S. Virgin Islands to report biennially to the U.S. Environmental Protection Agency (EPA) an assessment of the quality of their surface waters. EPA is required to summarize the findings of these assessments in a biennial National Water Quality Inventory report to the Congress. These assessment reports, commonly referred to as 305(b) reports, are the prime means by which the States (herein including the District of Columbia, Puerto Rico, and the U.S.Virgin Islands) and EPA communicate information to the public and to the Congress on the results of State water-quality-monitoring activities and the progress made in implementing water-pollution-control programs. The reports provide estimates not only of the current status of water quality and the uses States make of their waters, but also of the source of the contaminants that continue to affect water quality and water uses. As analytical and reporting consistency has improved in recent years, the assessments increasingly are being used as water-planning and decisionmaking tools nationally as well as within individual States.

This article discusses the background of the water-quality reporting process under section 305 (b), some of the findings published in the 1990 National Water Quality Inventory report to the Congress, and the progress EPA and the States have made in continuing to refine the process. Information on the quality of lakes, estuaries, and ground water as well as on streams is given in the 1990 findings included in this article; however, only stream water quality is discussed in the State summaries in this U.S. Geological Survey (USGS) National Water Summary volume (National Water Summary 1990-91-Hydrologic Events and Stream Water Quality). The USGS State summaries reference the 305(b) reports. Several key terms-designated use, water-quality criteria, water-quality standards, and water-qualitylimited waterbodies - used frequently in the following discussion and in the 305(b) reports are defined in the glossary at the end of this volume.

\section{BACKGROUND OF THE 305(b) PROCESS}

The Clean Water Act, formally known as the Federal Water Pollution Control Act Amendments of 1972 (Public Law 92-500), and its subsequent amendments in 1977, 1979, 1980,1981, 1983, and 1987, are the legislative foundation of much of EPA's water-pollution-control activities. Passed by the Congress to address wide-scale pollution problems in the Nation's sur- face waters, the Act established comprehensive programs to identify, control, and prevent pollution of surface waters. The 1977 and 1987 amendments to the Act expanded these programs to include lakes, estuaries, ground water, wetlands, and other aspects of water quality and water-quality monitoring. Before 1972, States, Federal agencies, and private parties collected information on water-quality conditions and progress on restoring water quality on an as-needed basis. In section 305(b), the Clean Water Act introduced regular reporting by States on water issues of concern to the public, the Congress, and EPA. Specifically, section 305(b) calls for-

- A description of the quality of navigable waters (that is, all surface waters) in each State as measured against EPA's water-quality criteria;

- An analysis of the extent to which all navigable waters meet the goals of the Clean Water Act to ensure a level of water quality that provides for the protection and propagation of a balanced population of finfish, shellfish, and wildlife and that allows recreation in and on the water;

- An analysis of the extent to which eliminating the discharge of contaminants has contributed to achieving the goals of the Act;

- A set of recommendations for additional actions needed to meet the goals of the Act and identification of those waterbodies - individual stream segments, lakes, and estuaries-for which additional actions are necessary;

- An estimate of the environmental effects and the economic and social costs and benefits of achieving the goals of the Act; and

- A description of the nature and extent of nonpoint sources of pollution and of the programs and costs necessary to control them.

Between 1974, when the first precursor to the 305(b) reports was published, and 1982, the States prepared their reports without significant guidance from EPA. Consequently, the summary reports to Congress aggregated widely varying State information. For example, the first report to Congress in 1974 (U.S. Environmental Protection Agency, 1974) focused on conditions in 22 major waterways that were selected by EPA on the basis of length, volume, or proximity to major cities. It also summarized chemical and physical water data, which are stored in EPA's computerized data system known as STORET, for the period 1963-72. Subsequent reports to Congress focused on general water-quality measures such as the number of water-quality-problem areas cited by States or the number of basins affected by point or nonpoint sources of pollution. Special EPA studies often supplemented the State-reported data.

In 1983, EPA issued its first comprehensive guidelines to the States on 305(b) content and format (U.S.

${ }^{1}$ U.S. Environmental Protection Agency. 


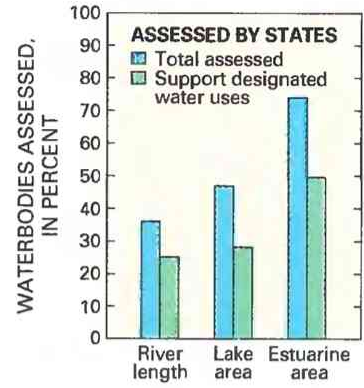

Figure 52. Percentage of total waterbodies assessed by reporting States and the percentage meeting designated water uses. Total river length, 1.8 million miles; lake area, 39.4 million acres; and estuarine area, 36,000 square miles. (Sources: Assessed data, U.S. Environmental Protection Agency, 1992; total mileage and acreage, U.S. Environmental Protection Agency files.)
Environmental Protection Agency, 1983). These guidelines recommended assessment measures developed by EPA in cooperation with the Association of State and Interstate Water Pollution Control Administrators (ASIWPCA) in 1982 for publication in the States' Evaluation of Progress report (Association of State and Interstate Water Pollution Control Administrators, 1984). Among the measures introduced in the 1983 guidelines were-

For surface water

- The sum of the areas of waterbodies that fully support, partially support, and do not support designated uses, such as fishing and swimming;

- The extent to which sources such as municipal and industrial dischargers cause waterbodies to not fully support designated uses;

- A relative ranking of contaminants of concern; and

- A discussion of public-health and aquatic-life concerns, such as fishing advisories and bathing-area closures.

For ground water

- A relative ranking of contaminants and sources of contamination.
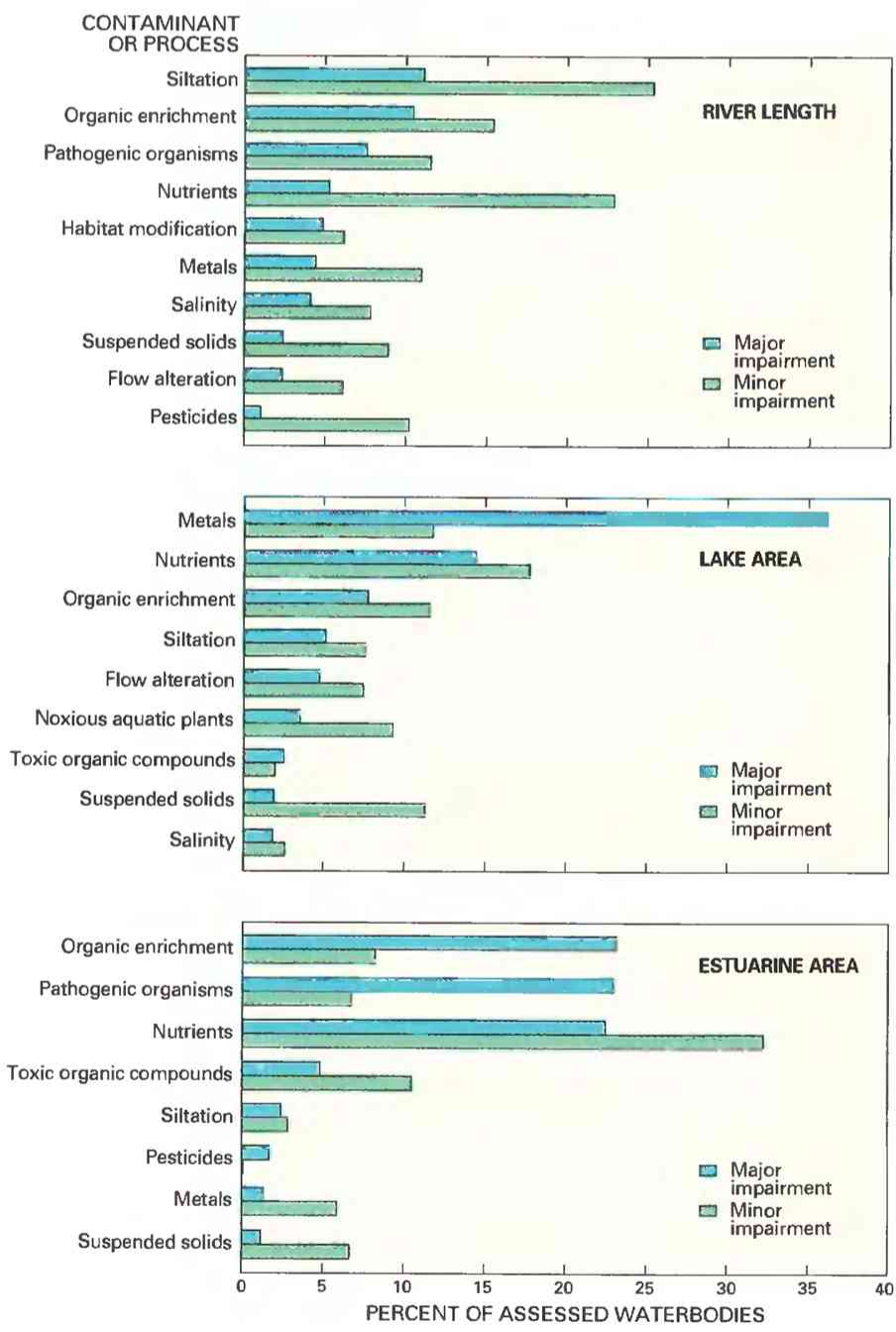

Figure 53. Percentage of assessed waterbodies that reporting States identified as impaired, by type of contaminant or process and in order of major impairment, in their 305(b) reports for 1990 . (Source: Modified from U.S. Environmental Protection Agency, 1992.)
These measures, which have been refined and expanded since 1983, became the standard measures of today's water-quality assessment process.

\section{PRESENT 305(b) PROCESS}

Beginning with the 1984 reporting cycle, EPA developed biennial reporting guidelines for the States to use in preparing their water-quality assessments under section 305(b) (U.S. Environmental Protection Agency, 1983, 1985a, 1987a, 1989, 1991a). These guidelines specify a format for reporting and discussing specific water-quality measures, and also provide recommendations for assessment methods. States review and comment on the guidelines before they are issued in final form. Once the guidelines are issued, EPA 305(b) coordinators in each of the EPA regions and other EPA staff help the States analyze their water-quality data and prepare their assessments.

The primary purpose of EPA's guidance to the States is to encourage consistency in the reporting of key water-quality measures. To do this, increased specificity was introduced to the reporting measures originally developed with ASIWPCA in 1982. For example, for the 1992 reporting cycle, States were asked to report on waterbodies that fully support, partially support, and do not support specific uses such as aquatic-life support, swimming, or drinking-water supply. However, as noted in the section "Limitations on the Use of 305(b) Data," States may still define these terms differently, and therefore such data cannot yet be used to compare specifically the status of waters among States.

For the 1990 and 1992 reporting cycles, the guidelines also reflect additional information needs arising from the 1987 amendments to the Clean Water Act. For example, the 1987 amendments expanded reporting requirements for water-quality conditions in lakes, lake-pollution-abatement programs, and lakerestoration activities. EPA has asked the States to use their 305(b) reports to update nonpoint-source assessments and to identify water-quality-limited waterbodies, particularly those that have been affected by toxic substances. These new reporting requirements reflect a growing awareness of the value of the 305(b) waterquality process in helping decisionmakers understand where water-quality problems exist, how extensive and severe those problems are, and what progress is being made to control them. In so doing, the water-quality information provided by the 305 (b) reporting process is a base from which State and Federal managers can work to set priorities for future pollution-control actions.

\section{FINDINGS OF THE 1990 NATIONAL WATER QUALITY INVENTORY REPORT}

Since 1974 and as required by the Clean Water Act, EPA has submitted to Congress a National Water Quality Inventory that summarizes the State 305(b) reports (U.S.Environmental Protection Agency, 1974, 1975, 1976, 1978, 1984, 1985b, 1987b, 1990, 1992). Selected findings from the 1990 report (U.S. Environmental Protection Agency, 1992), which summarizes the State 305 (b) reports for 1988-89, are given below. These findings are just a snapshot of water-quality conditions of both surface and ground water because some incon- 
sistency still exists in State reporting on many components requested in the guidelines (see section "Limitations on the Use of 305(b) Data").

\section{Surface-water findings}

- Most assessed waterbodies support their designated uses -70 percent of assessed river lengths, 60 percent of assessed lake areas, and 67 percent of assessed estuarine areas (fig. 52).

- Various contaminants of primarily nonpoint origin are the most commonly reported problems in the Nation's assessed waterbodies (fig. 53).

- Nutrients, such as phosphorus and nitrogen, are reported by the States to be among the top contributors to nonsupport of uses in all types of surface waters. Excess levels of these nutrients contribute to oxygen deficiencies and organic enrichment of water; the latter also is reported among the top causes of impairment. The other most widespread contaminants or processes contributing to contamination, as judged by the State administrators, are siltation, pathogenic organisms, and metals.

- In general, toxic substances, such as metals, pesticides, and organic chemicals, tend to cause severe water-quality problems where they occur, but they are less widely reported. It should be noted that in most States, analyzing water samples for toxic substances is done less frequently than for other contaminants because such analyses are expensive and the States have funding limitations.

- State administrators reported that the leading source of water-quality contamination in streams and lakes is runoff from agricultural activities, such as crop production and grazing (fig. 54). In estuaries, discharges from municipal sewage-treatment plants are cited as the leading source. Other leading sources are runoff from storm sewers and urban areas; hydrologic and habitat modifications, such as the channelization of streams; waste disposal on land, primarily leakage from septic systems; and resource extraction, such as mining or oil drilling.

- Restrictions on fish consumption were reported by 47 States for a total of 1,000 advisories and 50 bans. The most commonly identified contaminants causing the restrictions were $\mathrm{PCB}$ 's, pesticides, dioxin, organic chemicals, and mercury and other metals. Sources contributing these contaminants included industrial discharges, runoff from storm sewers and urban areas, and agricultural activities.

- Pollution-caused fishkills were reported by 42 States for a total of 1,365 incidents. Pesticides, organic enrichment, and oil and gas were cited as the leading causes, primarily from industrial, agricultural, and municipal sources.

- Contaminated sediment in waterbodies was reported by 33 States for a total of 384 incidents. Leading contaminants include metals, PCB's, pesticides, and dioxin.

- Shellfish-harvesting restrictions affecting 2,018 square miles of estuarine waterbodies were reported by 20 States. Discharges from municipal treatment plants, runoff from storm sewers and urban areas, and leakage from septic systems were cited as the main
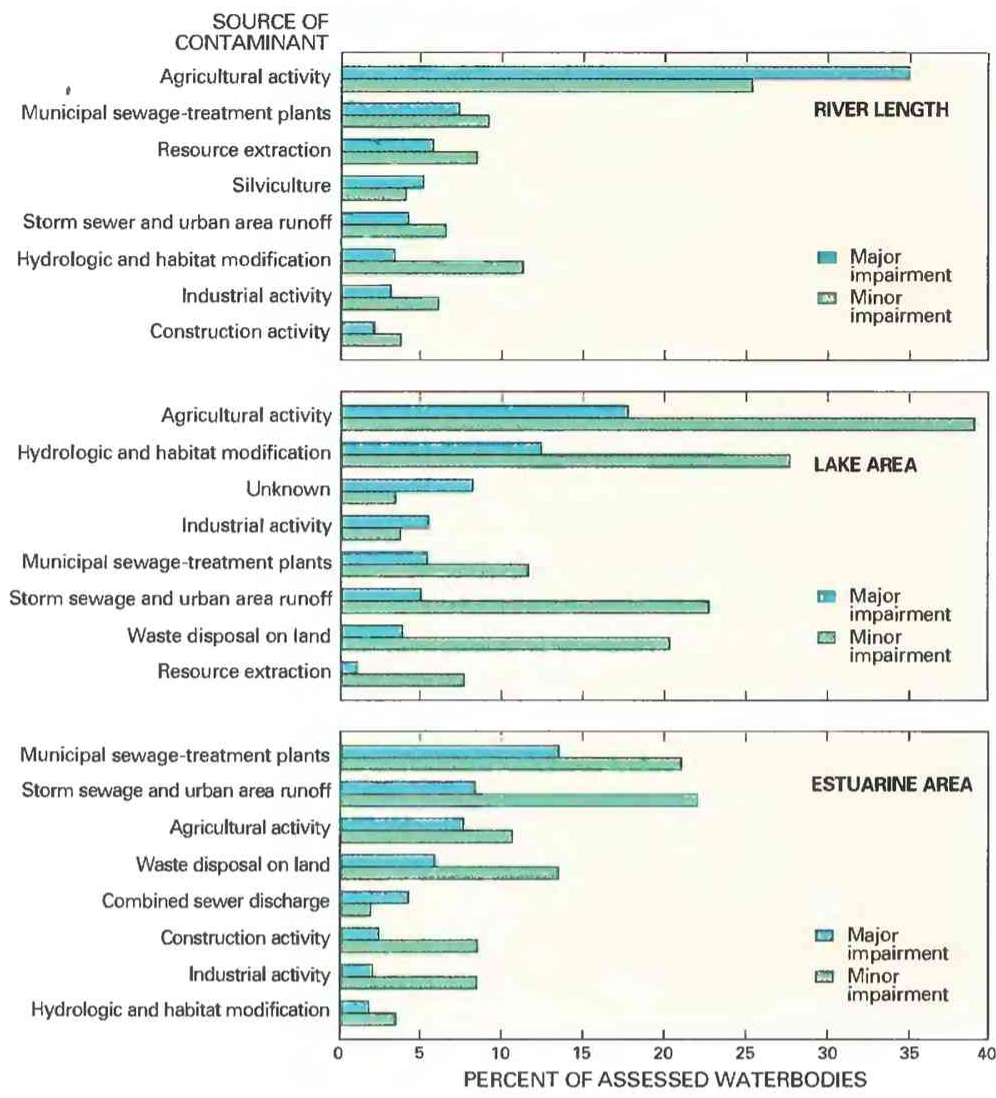

Figure 54. Percentage of assessed waterbodies that reporting States identified as impaired, by source of contaminant and in order of major impairment, in their 305(b) reports for 1990. (Source: Modified from U.S. Environmental Protection Agency, 1992.)

sources of contaminants (primarily pathogenic organisms) leading to restrictions.

\section{Ground-water findings}

- The quality of the Nation's ground water in general is good to excellent. However, State administrators reported an increasing number of incidents of contamination affecting both public water supplies and private wells.

- State administrators believe that the most prevalent contaminants in ground water nationwide are nitrates, metals, pesticides, petroleum products, and volatile organic compounds (fig. 55).

- The source of ground-water contamination most frequently cited by the States is leaking underground storage tanks (fig. 56)-39 States ranked it as a source of ground-water contamination and 21 States ranked it as the most important source of contamination. Also widely cited were leakage from septic systems, municipal landfills, and abandoned hazardouswaste sites and runoff from agricultural activities.

\section{LIMITATIONS ON THE USE OF 305(b) DATA}

There are two major limitations on the use of 305(b) data- the data cannot be used to estimate national water-quality trends over time, and they cannot be used 


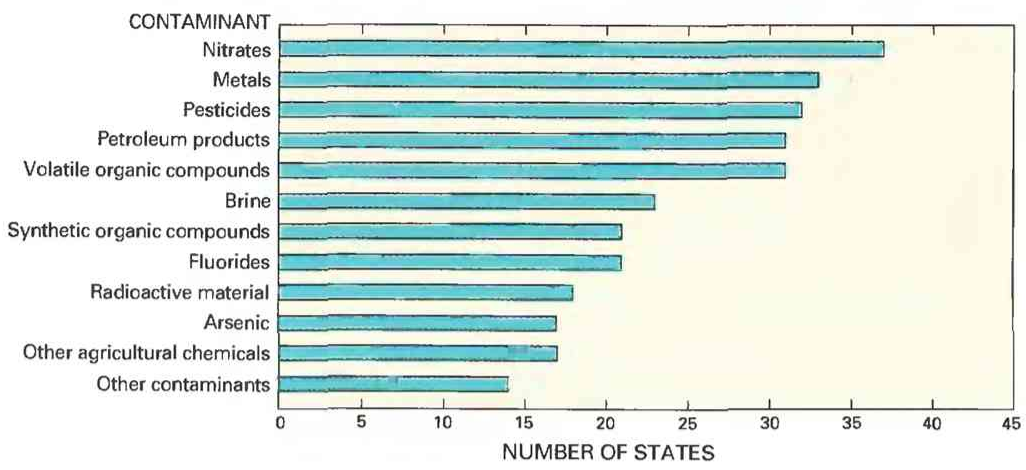

Figure 55. Most-cited ground-water contaminants, as reported by 42 States in their 305(b) reports for 1990. (Source: Modified from U.S. Environmental Protection Agency, 1992.)

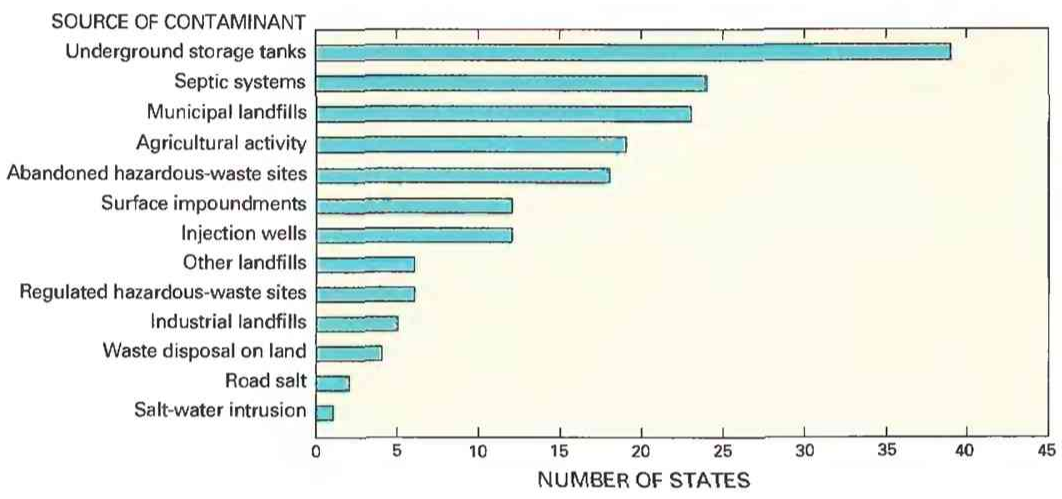

Figure 56. Most-cited sources of ground-water contaminants, as reported by 42 States in their 305(b) reports for 1990. (Source: Modified from U.S. Environmental Protection Agency, 1992.)

to compare the status of waters among States. Three factors contribute to these limitations:

- The 305(b) State reports are based on information provided by individual States. Although Federal laws provide guidance, each State manages its own pollution-control programs and conducts its own monitoring. State monitoring activities, which are funded partially through grants from EPA (provided by the Clean Water Act) and are subject to EPA review, often are managed with a significant amount of autonomy to meet the particular needs of the State. As a result, State monitoring programs vary in comprehensiveness, have different objectives, and produce different types of water-quality data and assessment reports. For example, some States almost exclusively monitor water chemistry at fixed sampling stations in their major waterbodies. Other States supplement their water-chemistry data with more integrative biological assessments of the health of aquatic communities and the integrity of aquatic habitats. Toxicological tests and special intensive surveys also are used to varying degrees by States. In addition, many States supplement their monitoring information with citizen-collected data or less rigorous evaluative approaches such as questionnaires sent to fish and game biologists. EPA's 305(b) guidelines distinguish between these types of data and encourage States to use as much data as possible in making assessment decisions.

- Water-quality standards vary among States. In order to determine if its waters are impaired, each State must compare all monitoring data to water-quality criteria and standards that it developed and that were approved by EPA. However, if its criteria and standards are different from those of other States, assessment results might not be comparable across State lines. In addition, data within given States might not be directly comparable over time because criteria and standards are reviewed and updated on a regular basis as improved scientific methods become available. States also continuously work to improve their monitoring capabilities and therefore to increase the number and type of contaminant problems detected.

- Not all States follow EPA's 305(b) guidelines, inasmuch as there is no legal requirement that they do so. Specific definitions and analytical approaches generally are decided by the States. As a result, reporting formats, attention to recommended measures, and analytical approaches have varied greatly over the years.

\section{IMPROVING THE CONSISTENCY OF THE 305(b) REPORTS}

The 305 (b) process is dynamic. The consistency and comprehensiveness of State water-quality reporting have improved as the result of two Federal activities-the development of a computerized data base, known as the Section 305(b) Waterbody System, to manage the 305(b) assessment information; and the establishment of a work group of interested State and Federal water-quality representatives. The States also are making significant progress with each biennial cycle. For example, more States are assessing more waterbodies (fig. 57), and the reporting on many water-quality measures has improved. The water-quality assessment data base and the Consistency Work Group to eliminate inconsistencies are discussed below.

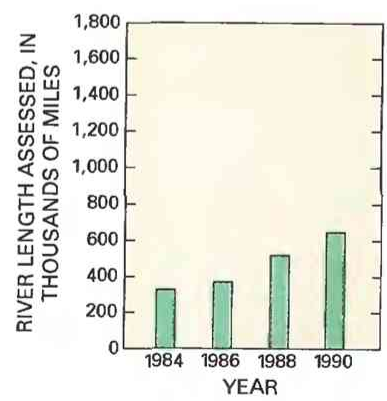

Figure 57. Increase in total river lengths assessed by reporting States in their 305 (b) reports, 1984-90. (Source: Data from U.S. Environmental Protection Agency, 1992.) 


\section{SECTION 305(b) WATERBODY SYSTEM}

Akey tool in improving the water-quality-reporting process is EPA's computerized water-quality assessment data base, the Waterbody System (WBS). The WBS, which was developed by EPA in 1985 and adopted by States beginning in 1988, allows analysts to organize their data on the basis of individual waterbodies and thus, to better manage the results of their assessments. For each waterbody entered in the data base, States provide key information such as the identification number of the waterbody; the area that fully supports, partially supports, or does not support designated uses; the area affected by specific contaminants; and the area affected by specific sources of contaminants. The wBS provides a standard format for entering this information and it also provides computer programs for adding and editing data, generating reports, and transferring data between personal-computer and mainframe-computer data bases.

Once information is entered into the data base, standardized statewide summary reports that meet the requirements of section 305 (b) can be generated easily by the WBS. EPA assists States in entering data and using the data base, and it has updated a data-base user's guide (U.S. Environmental Protection Agency, 1991b). During the 1990 reporting cycle, 40 States used the wBS to manage at least some of their waterbody information. As more and more States use the wBS, it will become possible to track changes in the condition of individual waterbodies over time.

One of the strengths of the wBS is its ability to be linked to a computerized locational data base known as the River Reach File, which assigns unique identifiers to hydrologic features, such as streams and lakes, that have been compiled from USGS topographic maps. Reach File 3, which is the most recent and comprehensive version of the River Reach File, is based on 7.5-minute quadrangle maps at a scale of $1: 24,000$. The file contains about 3 million hydrologic features and identifies stream reaches as short as 0.1 mile and lakes of less than 1 acre. As of June 1, 1992, 100 percent of the hydrologic features on the 7.5-minute quadrangle maps had been incorporated into Reach File 3 for 45 of the 48 conterminous States. Completion of Reach File 3 and its linkage with the WBS will provide an unprecedented capability for precision mapping, calculating stream length and lake area, and connecting 305(b) assessment data to other types of information such as the location of point-source dischargers.

\section{CONSISTENCY WORK GROUP}

In April 1990, EPA convened a Consistency Work Group to investigate inconsistencies in the 305(b) process and to develop recommendations to eliminate the inconsistencies. The work group consisted of 6 State representatives, 10 EPA regional 305 (b) coordinators, and a USGS representative. The work group identified two major inconsistencies - accounting of total waterbodies within each State (for example, total river lengths, lake areas, or coastal shoreline lengths) and methods of determining support of designated uses. To reduce the inconsistencies, the work group made recommendations, which, after review by a larger group of EPA regional and
State 305(b) coordinators, ultimately were incorporated into the 305(b) guidelines for the 1992 reporting cycle. EPA has convened an expanded work group to address the guidelines for the 1994 report.

\section{FUTURE OF THE 305(b) PROCESS}

The roles, objectives, and responsibilities of the many organizations that monitor water quality have not been clearly defined as part of an integrated national framework. For example, in addition to State monitoring, which results in data for the 305(b) reports, and State decisionmaking, various Federal agencies such as the Department of Commerce and the Department of the Interior maintain other monitoring programs; private and local facilities monitor compliance with permit limits; some public-interest groups conduct monitoring and maintain water-quality data bases; and private citizens engage in water-quality monitoring, often through Stateapproved programs. Inconsistencies among these monitoring programs make it difficult to integrate data for interpretation and decisionmaking and to compare water-quality conditions from place to place and over time.

These problems are shared by the 305 (b) process. Although progress is being made in improving the consistency and comprehensiveness of 305(b) reporting, a greater effort must be made to improve the Nation's monitoring program as a whole and to develop waterquality information of greater value to decisionmakers. To accomplish this, EPA and the USGS have taken the initiative with the States and seven other key Federal monitoring agencies to establish an Intergovernmental Task Force on Monitoring Water Quality. The goals of this task force are to-

- Develop a strategy for water-quality monitoring and assessment that will use monitoring resources more effectively and improve information on the surface- and ground-water quality of the Nation;

- Develop environmental indicators-standard descriptors of aquatic conditions-that agencies can use to report national, regional, and local water-quality status and trends and to measure progress toward achieving established waterquality goals;

- Use comparable data-collection methods where possible in the field and the laboratory and recommend standard data qualifiers that allow data with known levels of confidence to be shared; and

- Improve information-sharing mechanisms that will result in a linked nationwide water-information network providing access to and supporting the sharing and integration of information collected by Federal, State, local, and private organizations.

In coming years, the 305 (b) process will continue to evolve as the Consistency Work Group and the Intergovernmental Task Force on Monitoring Water Quality develop and implement specific recommendations to improve the scope of the water-quality monitoring program and its linkage to other monitoring and assessment activities. EPA looks forward to continuing to work with its Federal, State, local, and private partners on these 
initiatives and to improving the 305(b) process to enable it to better serve the needs of water-resources decisionmakers, Congress, and the public.

\section{REFERENCES CITED}

Association of State and Interstate Water Pollution Control Administrators, 1984, America's clean water-The States' evaluation of progress, 1972-1982: Washington, D.C., Association of State and Interstate Water Pollution Control Administrators, $16 \mathrm{p}$.

U.S. Environmental Protection Agency, 1974, National water quality inventory, 1974 report to Congress: Washington, D.C., U.S. Environmental Protection Agency, Office of Water Planning and Standards, EPA 440/9-74-001, 305 p. -1975, National water quality inventory, 1975 report to Congress: Washington, D.C., U.S. Environmental Protection Agency, Office of Water Planning and Standards, EPA 440/9-75-014, 133 p.

1976, National water quality inventory, 1976 report to Congress: Washington, D.C., U.S. Environmental Protection Agency, Office of Water Planning and Standards, EPA 440/9-76-024, 236 p.

1978, National water quality inventory, 1977 report to Congress: Washington, D.C., U.S. Environmental Protection Agency, Office of Water Planning and Standards, EPA 440/4-78-001, $165 \mathrm{p}$.

1983, Guidelines for the preparation of the 1984 State water quality assessment (305(b) report): Washington, D.C., U.S. Environmental Protection Agency, Office of Water, $20 \mathrm{p}$.

1984 , National water quality inventory, 1982 report to Congress: Washington, D.C., U.S. Environmental Protection Agency, Office of Water Regulations and Standards, EPA 440/2-84-006, 63 p.

1985a, Guidelines for the preparation of the 1986 State water quality assessment (305(b) report): Washington, D.C., U.S. Environmental Protection Agency, Office of Water, $26 \mathrm{p}$. 1985b, National water quality inventory, 1984 report to Congress: Washington, D.C., U.S. Environmental Protection Agency, Office of Water Regulations and Standards, EPA 440/4-85-029, 111 p.

$1987 \mathrm{a}$, Guidelines for the preparation of the 1988 State water quality assessment (305(b) report): Washington, D.C., U.S. Environmental Protection Agency, Office of Water, $32 \mathrm{p}$.

1987b, National water quality inventory, 1986 report to Congress: Washington, D.C., U.S. Environmental Protection Agency, Office of Water, EPA 440/8-87. 105 p.

1989 , Guidelines for the preparation of the 1990 State water quality assessment (305(b) report): Washington, D.C. , U.S. Environmental Protection Agency, Office of Water, $36 \mathrm{p}$.

1990, National water quality inventory, 1988 report to Congress: Washington, D.C., U.S. Environmental Protection Agency, Office of Water, EPA 440-4-90-003, $226 \mathrm{p}$.

1991a, Guidelines for the preparation of the 1992 State water quality assessment (305(b) report): Washington, D.C., U.S. Environmental Protection Agency, Office of Water, $39 \mathrm{p}$.

1991b, PC waterbody system user's guide, Version 3.0, November 1, 1991: Washington, D.C., U.S. Environmental Protection Agency, Office of Water, $250 \mathrm{p}$.

1992 , National water quality inventory, 1990 report to Congress: Washington, D.C., U.S. Environmental Protection Agency, Office of Wetlands, Oceans, and Watersheds, EPA 503/9-92/006, 236 p.

\section{FOR ADDITIONAL INFORMATION}

305(b) Coordinator, U.S. Environmental Protection Agency Assessment and Watershed Protection Division (WH553) Washington, D.C. 20460 


\section{State Summaries of \\ $\infty$ Stream Water Quality}

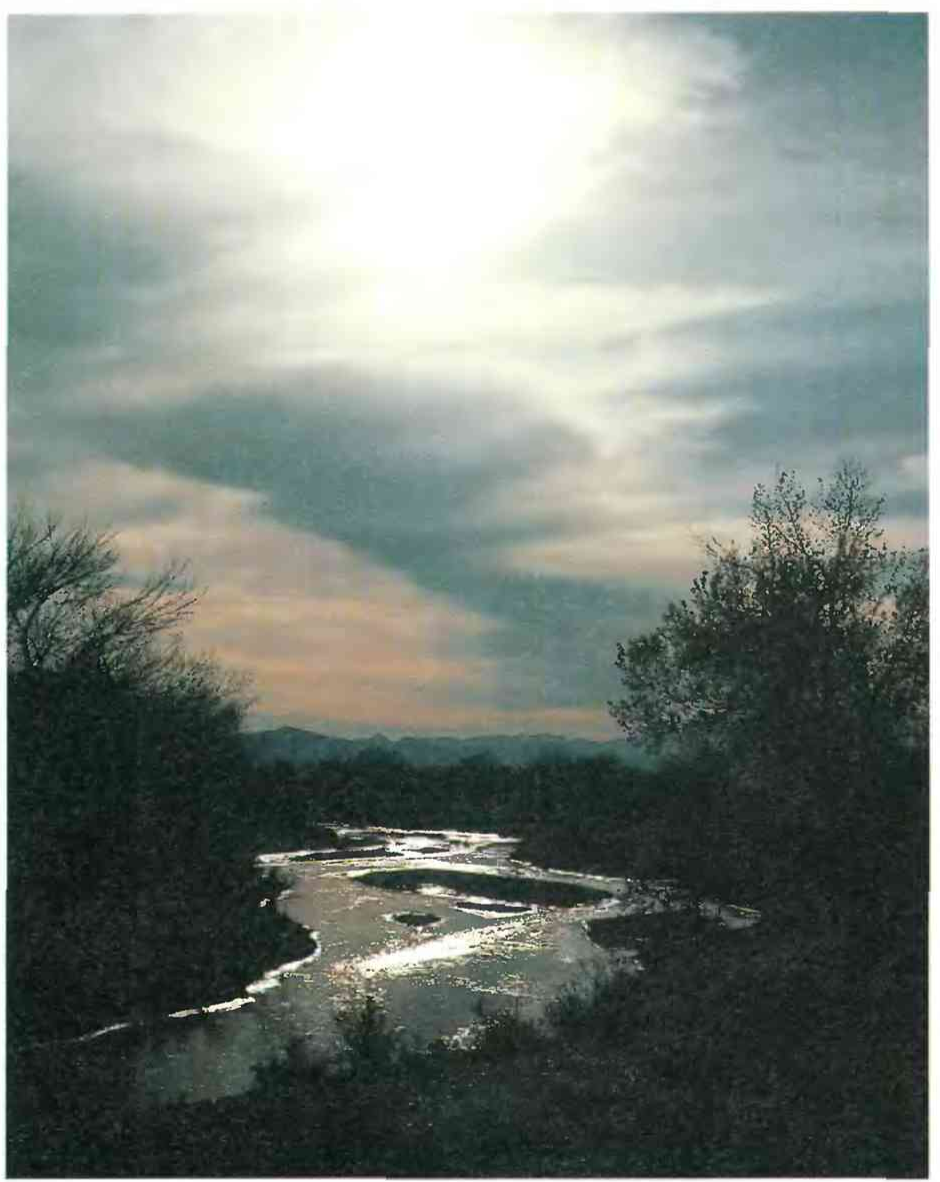

Walker River near Wabuska, Nev., near the site of a U.S. Geological Survey hydrologic datacollection station. (Steve VanDenburgh, U.S. Geological Survey) 


\section{Introduction to State Summaries of Stream Water Quality}

\begin{abstract}
"State Summaries of Stream Water Quality" in this 1990-91 National Water Summary describes ambient stream water-quality conditions and trends in each State, the District of Columbia (combined with Maryland), Puerto Rico, and the Western Pacific Islands. (The term "State" is used in the following discussion for all of these geographic areas.) The contents of the State summaries and the methods used to represent water-quality data presented in the summaries are described below; note that data on lakes and reservoirs are not included. Hydrologic terms, along with other selected terms, are defined in the glossary at the end of the volume, and some of them are expanded on in this discussion. Additionally, in the discussion below, the term "water-quality constituent" is used inclusively to include properties of water.
\end{abstract}

Each State summary contains the following information:

- Overview of stream water quality,

- Discussion of water-quality monitoring,

- Description of water-quality conditions, as represented by statistical summaries of data on concentrations of a maximum of 8 water-quality constituents at a maximum of 10 selected waterquality monitoring stations, during water years $1987-89$,

- Description of trends in concentrations of as many as 8 waterquality constituents for one or more of four periods - water years 1970-89, 1975-89, 1980-89, and 1982-89-for selected constituents, at a maximum of 20 water-quality monitoring stations (note that for the Western Pacific Islands summary, the analysis of water-quality trends was not possible because of insufficient data),

- Description of water-quality management, and

- Selected references-State, local, and general—on stream water quality.

Each State summary also includes a table and four multicolor illustrations (the same table and figure numbers are used for each State) that show:

- Selected water-quality constituents and their source and environmental significance (table 1),

- Land use, physiography, and population (fig. 1),

- Location of selected water-quality monitoring stations, type of statistical analysis performed on station data, and geographic features mentioned in the text (fig. 2),

- Water-quality conditions of selected streams during water years 1987-89 (fig. 3), and

- Trends in water quality of selected streams as reflected by selected constituents during one or more of four periods-water years $1970-89,1975-89,1980-89$, and 1982-89 (fig. 4).

\section{WATER-QUALITY MONITORING}

\section{SOURCES OF DATA AND TECHNIOUES USED}

Systematic monitoring of stream water quality in the Nation is relatively recent and, as discussed in the article "Factors Affecting Stream Water Quality, and Water-Quality Trends in Four Drainage Basins in the Conterminous United Sates, 1905-90" in this volume, national stream water-quality data were collected for only a relatively brief period early in the 20 th century. Although regional water-quality monitoring networks were established to monitor the results of particular river-basin water-quality improvement programs in later years, national water-quality monitoring networks such as the U.S. Geological Survey (USGS) Hydrologic Bench-Mark Network (Leopold, 1962) and National Stream Quality Accounting Network (NASQAN) (Ficke and Hawkinson, 1975) began to be established only in the 1960's and 1970's, respectively. The Hydrologic
Bench-Mark Network, which began in 1964, monitors the Nation's streams that are minimally affected by human influence and has maintained a constant network of 55 water-quality monitoring stations since it was established. NASQAN, which began in 1973 and monitors the quantity and quality of water that flows from the Nation's major drainage basins, increased from an original set of $\mathbf{5 0}$ water-quality monitoring stations in 1973 to a maximum of 518 stations in 1979, and then it declined to 410 stations by 1992 (T.L. Miller, U.S. Geological Survey, oral commun., 1992). Additional water-quality monitoring stations have been operated by the USGS as part of the Federal-State Cooperative Program (Gilbert and Mann, 1990). These stations are operated by the USGS in cooperation with many of the 1,000 State and local agencies that participate in the program. However, most of those stations have relatively short periods of records that infrequently exceed $10-15$ years in length; also, some of those stations are no longer operational. Water-quality monitoring station data records from the NASQAN, Hydrologic Bench-Mark, and Federal-State Cooperative programs and other USGS water-data records are stored in the computer-based USGS National Water Information System (NWIS) and the U.S. Environmental Protection Agency (EPA) national water data base known as STORET. State water-resources agencies also use STORET as a repository of their water-resources data.

Data analyzed in the State summaries reflect only ambient stream water quality; that is, the data do not consist of measurements of municipal or industrial effluent quality. Additionally, constituentconcentration data were derived from analyses of composite water samples collected along the cross section of each stream. Composited samples are more representative of the stream cross section than any single-point sample because water-quality concentrations frequently are nonuniformly distributed in stream cross sections. Two types of constituent concentrations were used-dissolved concentrations, which were derived from analysis of water samples from which sediment had been filtered, and total (dissolved plus particulate) concentrations, which were derived from analysis of water samples and their suspended sediment. In a few locations where a stream is very well mixed and water quality is uniform along its cross section, data for dissolved-constituent concentrations were derived from an analysis of water samples taken at a single location in the stream cross section.

Data from the analysis of water samples were used only if the data had been derived using standard methods approved by the USGS or by using equivalent methods. If a method of sample collection or analysis changed over time, data from an analysis were included in the evaluation of recent stream water quality or stream waterquality trends only if the change in method did not affect the comparability of the data.

Only data from water-quality monitoring stations that had been sampled at relatively uniform time intervals, without consideration of streamflow, have been used for the analyses shown in the summaries. The intent of such sampling is to obtain unbiased water-quality data representative of the full range of streamflow variability at the stations, a factor that is especially important when analyzing for trends. Additionally, instantaneous stream-discharge estimates were available for all water-quality data that were statistically analyzed. These discharges were required if flow-adjusted constituent concentrations were used in the computations of water-quality trends. (See article "Statistical Analysis of Water-Quality Data" in this volume for a discussion of removing the effects of streamflow in computing trends of water-quality constituents.)

The following criteria for frequency of data collection at water-quality monitoring stations were used to assure that sufficient data were available for analysis of water-quality conditions or trends. In the evaluation of water-quality conditions, data normally must 
have been available for at least 10 of the 12 quarters of water years 1987-89. However, if data for 10 quarters were not available, authors of the State summaries were permitted to use fewer than 10 quarters if the data were not seasonally biased. In the evaluation of water-quality trends, data must have spanned the period under evaluation-water years 1970-89, 1975-89, 1980-89, and 1982-89-with a total of no more than 2 years of data missing at the beginning or end of the period and with a substantial amount of data collected in the first and the last thirds of the period of analysis. Lanfear and Alexander (1990) discuss the detailed criteria for data availability for statistical analysis in the State summaries.

Data from about 2,900 water-quality monitoring stations were extracted from the NWIS and STORET data bases and used to create a data base specifically for the preparation of this National Water Summary. All these stations met the criteria for cross-sectional sampling; however, only about 1,400 of the stations met the criteria for trend testing-frequency-of-data collection, period of record, and having one or more constituents that qualified for trend testing. This data base represented most of the relatively long-term (greater than 10 years) ambient stream water-quality data available for the Nation before water year 1990 that were electronically transferable. Virtually all the data are water-chemistry and physical-sediment data because biological-indicator data of water quality have been collected only in recent years. Stations that were used in the State summaries are shown in figure 58, and a complete listing of the stations by State is included in Lanfear (1993).

Each State summary was restricted to data from no more than 30 water-quality monitoring stations, and those stations were selected to represent water quality in representative drainage areas in the State. However, most States had data records available from far fewer than 30 water-quality monitoring stations. In presenting data for the two types of statistical analyses-water-quality conditions and waterquality trends - data from a maximum of 10 stations were used to represent water-quality conditions, and data from a maximum of 20 stations were used to represent water-quality trends. For some States, data from some stations were used to analyze both water-quality conditions and trends.

\section{WATER-Quality CONSTITUENTS}

General.-All water-quality constituents for which data are summarized in one or more of the State summaries are listed in table 10 ; also given are the sources of the constituent and its environmental significance. The order of this listing is consistent with the order of constituent listing in USGS hydrologic-data reports (Novak, 1985). The constituents discussed in each of the State summaries are summarized by State in table 11. For every State, except Delaware, dissolved solids and nitrate plus nitrite data (as nitrogen) were analyzed because these constituents have an extensive data base and are broad indicators of the effect of natural and human-induced processes on water. In Delaware, these data were not available; however, total nitrate data were available and were analyzed as a surrogate for nitrate plus nitrite. Data for dissolved-oxygen concentration (31 States), fecal coliform bacteria (38), sulfate (47), and suspended sediment (31) also were analyzed for most States, and specific conductance (18), phosphorus (25), alkalinity (14), and phosphate (12) were analyzed for many States.

The constituents discussed in this National Water Summary are relatively few in comparison to the number and types of waterquality constituents presently analyzed for by the USGS and other Federal, State, and local agencies. In recent years, increased public awareness and environmental legislation have resulted in an increase in the number of water-quality monitoring programs that collect data for stream water-quality analysis. However, for trend analysis in particular, data records were not considered for analysis in the State summaries if their periods of collection did not span the period

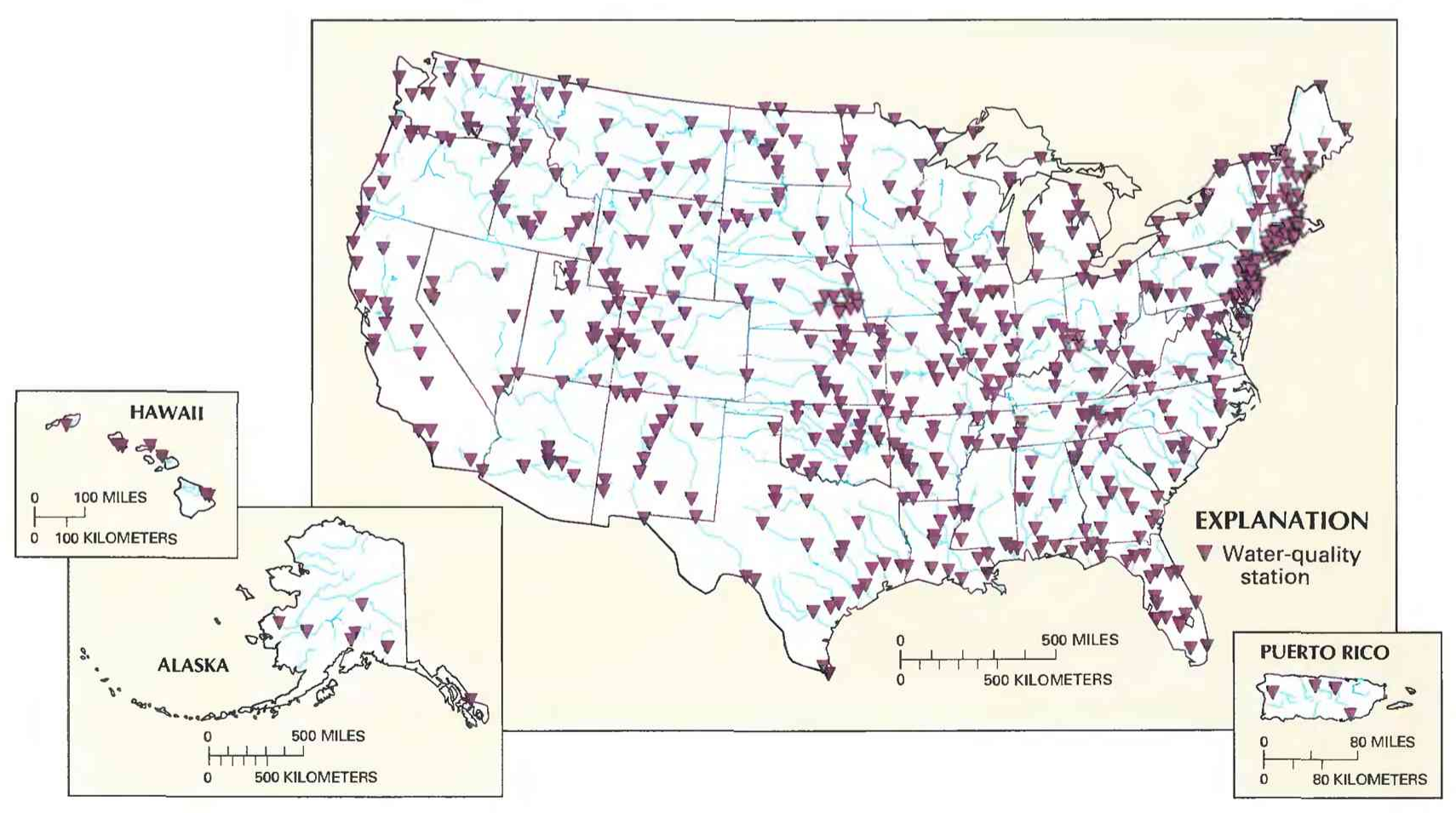

Figure 58. Water-quality monitoring stations in the United States and Puerto Rico from which data were used for analysis of water quality for use in the State summaries of the National Water Summary 1990-91-Hydrologic Events and Stream Water Quality. Eight water-quality monitoring stations in the Western Pacific Islands are not shown. (See Lanfear, 1993, for a complete listing of station names.) 
Table 10. Sources and environmental significance of selected water-quality constituents [Source: Compiled by the U.S. Geological Survey, Office of Water Quality]

\begin{tabular}{|c|c|c|}
\hline Constituent or property & Common sources & Environmental significance \\
\hline Specific conductance (property) & $\begin{array}{l}\text { A measure of the electrical conductivity of water; var- } \\
\text { ies with the quantity of dissolved solids and is } \\
\text { used to approximate the dissolved-solids content. }\end{array}$ & $\begin{array}{l}\text { Dissolved solids can cause water to be unsuitable } \\
\text { for public supply, agriculture, and industry; can } \\
\text { harm aquatic organisms. }\end{array}$ \\
\hline pH (property) & $\begin{array}{l}\text { A measure of hydrogen-ion activity (acidity or alkalin- } \\
\text { ity); can be affected by geologic setting, biological } \\
\text { activity, municipal and industrial wastewater dis- } \\
\text { charge, and atmospheric deposition. }\end{array}$ & $\begin{array}{l}\text { Acidic water can corrode pipes and equipment; can } \\
\text { cause the release of lead and other metals from } \\
\text { distribution systems to drinking water; can affect } \\
\text { wastewater-treatment processes and taste of water }\end{array}$ \\
\hline Turbidity (property) .................. & $\begin{array}{l}\text { Caused by natural or human-induced suspended mat- } \\
\text { ter; components include clay, silt, fine organic and } \\
\text { inorganic matter, soluble colored organic com- } \\
\text { pounds, and microscopic aquatic organisms. }\end{array}$ & $\begin{array}{l}\text { Can be detrimental to aquatic organisms; can cause } \\
\text { water to be unsuitable for recreation, industry, and } \\
\text { public supply. }\end{array}$ \\
\hline Dissolved oxygen ...................... & $\begin{array}{l}\text { Introduced from the atmosphere; also a byproduct of } \\
\text { aquatic plant life. }\end{array}$ & $\begin{array}{l}\text { Necessary for aquatic life; deficiency can result from } \\
\text { assimilation of organic wastes and decay of algae. }\end{array}$ \\
\hline Fecal coliform bacteria .............. & $\begin{array}{l}\text { Sources include effluent from sewage-treatment } \\
\text { plants and runoff from pastures, feedlots, and } \\
\text { urban areas. }\end{array}$ & $\begin{array}{l}\text { Presence indicates contamination of water by wastes } \\
\text { from humans or other warm-blooded animals. }\end{array}$ \\
\hline $\begin{array}{l}\text { Fecal streptococcal bacteria; } \\
\text { includes fecal enterococcal } \\
\text { bacteria. }\end{array}$ & 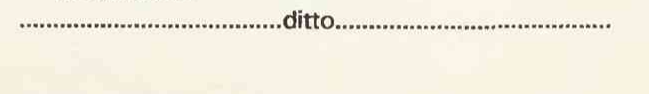 & Ditto. \\
\hline Hardness (property) ................... & $\begin{array}{l}\text { A characteristic of water primarily related to the } \\
\text { concentrations of calcium and magnesium. }\end{array}$ & $\begin{array}{l}\text { Hardness causes the formation of an insoluble } \\
\text { residue when used with soap, and scale in } \\
\text { vessels in which water has been allowed to } \\
\text { evaporate. }\end{array}$ \\
\hline 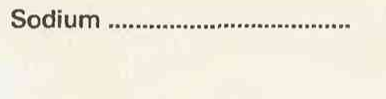 & $\begin{array}{l}\text { Occurs in some igneous rocks, evaporite deposits, } \\
\text { and sediments; also in oil-field brines, road de- } \\
\text { icers, and irrigation return flow. }\end{array}$ & $\begin{array}{l}\text { Can cause water to be unsuitable for public supply, } \\
\text { agriculture, and industry. }\end{array}$ \\
\hline 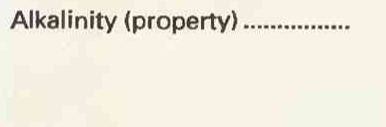 & $\begin{array}{l}\text { A measure of the quantity of acid-neutralizing sub- } \\
\text { stances; can be affected by geologic setting, in- } \\
\text { dustrial wastewater discharge, waste gases, } \\
\text { and runoff from surface mining. }\end{array}$ & $\begin{array}{l}\text { Sufficiently alkaline water can be unsuitable for } \\
\text { drinking and some agricultural and industrial } \\
\text { uses. }\end{array}$ \\
\hline 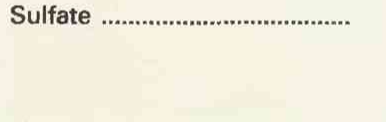 & $\begin{array}{l}\text { Occurs in some rocks; also in mine runoff, industrial } \\
\text { wastewater discharge, and atmospheric deposi- } \\
\text { tion. }\end{array}$ & $\begin{array}{l}\text { Concentrations exceeding a natural, background } \\
\text { level indicate contamination from human activity; } \\
\text { in excess, can cause water to be unsuitable for } \\
\text { public supply; can harm aquatic organisms. }\end{array}$ \\
\hline
\end{tabular}

1980-89 for most constituents and 1982-89 for selected constituents, as discussed below. As a result of the relatively recent onset of data collection for many constituents, the State summaries do not include data on pesticides and other agricultural and industrial chemicals and a wide variety of biological indicators of stream health. For some agricultural and industrial chemicals, collection methods and laboratory analysis are evolving and comparability of data over time could be problematic. Finally, as described in more detail below, an evaluation of the comparability of data in the $\mathrm{Na}$ tional Water Summary data base determined that some data should not be included in the State summaries or should be analyzed for trends during 8 water years (water years 1982-89) instead of 10 years (water years 1980-89).

Trace elements.--Improvements in methods for the collection and analysis of dissolved trace elements and other water-quality constituents have lowered the minimum reporting limits (MRL's) for many constituents. MRL's are concentrations below which the sample collection, processing, and laboratory analytical methods that are used to measure constituent concentrations are considered not effective. For example, if the MRL for a constituent is $1 \mu / \mathrm{L}$ (microgram per liter), some entries of that constituent in the data base would be shown as $<1 \mu / \mathrm{L}$ to indicate that the constituent concentration was less than that value. As a result of improved methods and the lowering of MRL's over time, concentrations of some constituents that were reported in the past as being below the MRL might in recent years be assigned a distinct concentration. Increasing interest in the quality of data has fostered more refined quality-assurance procedures for the evaluation of sources of contamination that occur in water samples during their collection and analysis. The collection and analysis of quality-control samples have revealed that some data in the historical data base were influenced by contamination introduced during data collection and analysis and are therefore unsuitable for trend analysis. For example, although data for many of the dissolved trace elements, such as cadmium, chromium, copper, and lead are found in data bases of the USGS and other agencies, recent quality-control data indicate that an unquantified portion of these historical data could represent contamination introduced during sample collection and analysis and would thus not be valid measures of ambient water quality (Shiller and Boyle, 1987; Windom and others, 1991; T.L. Miller, U.S. Geological Survey, written commun., 1992). Consequently, data for these dissolved trace elements, many of which are environmentally significant, were considered unsuitable for analysis in the State summaries and therefore were not included. Fortunately, these recent investigations indicate that the ambient values are relatively low for most of these dissolved trace elements-some of which are toxic. Special collection and analytical procedures were followed to avoid contamination of the water samples analyzed for trace metals in more recent investigations, leading to the conclusion that the historical ambient levels in the sampled streams could well have been far lower than formerly thought. See article "Assuring the Reliability of Water-Quality Data" in this volume for more information on quality assurance.

Sulfate-Studies of sulfate analyses made by USGS waterquality laboratories indicate that a positive bias, which indicates that the results are reported consistently too high, is likely in some sulfate data for the 1982-89 period (D.A. Rickert, U.S. Geological 
Table 10.--Sources and environmental significance of water-quality constituents-continued

\begin{tabular}{|c|c|c|}
\hline Constituent or property & Common sources & Environmental significance \\
\hline 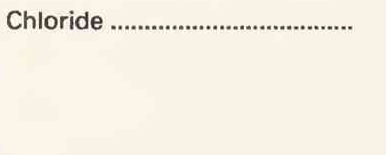 & $\begin{array}{l}\text { Occurs in some rocks and ground-water discharge; } \\
\text { also in road deicers, industrial and urban waste- } \\
\text { water discharge, and atmospheric deposition. }\end{array}$ & $\begin{array}{l}\text { Concentrations exceeding a natural, background level } \\
\text { indicate contamination from human activities; } \\
\text { can cause water to be unsuitable for public } \\
\text { supply, agriculture, and industry; can harm } \\
\text { aquatic organisms. }\end{array}$ \\
\hline Silica & Is derived from the decomposition of silicate minerals. & $\begin{array}{l}\text { Can cause water to be unsuitable for some industrial } \\
\text { applications such as boiler feed water; forms hard } \\
\text { scale. }\end{array}$ \\
\hline 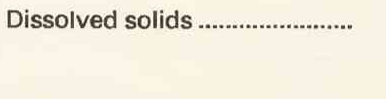 & $\begin{array}{l}\text { A result of rock weathering; also in agricultural runoff } \\
\text { and industrial discharge. }\end{array}$ & $\begin{array}{l}\text { In excess, can cause water to be unsuitable for public } \\
\text { supply, agriculture, and industry; can harm } \\
\text { aquatic organisms. }\end{array}$ \\
\hline $\begin{array}{l}\text { Nitrite plus nitrate; } \\
\text { total nitrate. }\end{array}$ & $\begin{array}{l}\text { Nonpoint sources are agricultural and urban runoff; } \\
\text { a major point source is wastewater discharge. }\end{array}$ & $\begin{array}{l}\text { Plant nutrient that, in excess, can cause algal blooms } \\
\text { and excessive growth of higher aquatic plants in } \\
\text { bodies of water; can cause water to be unsuitable } \\
\text { for public supply. }\end{array}$ \\
\hline 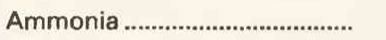 & 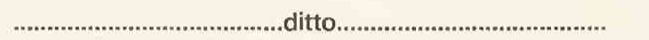 & Ditto. \\
\hline Ammonia plus organic nitrogen & 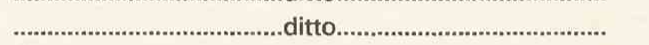 & Ditto. \\
\hline 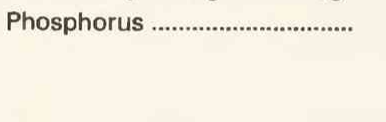 & $\begin{array}{l}\text { Occurs in some rocks and sediments; also in runoff } \\
\text { and seepage from phosphate-rock mines, agri- } \\
\text { cultural and urban runoff, and industrial and } \\
\text { municipal wastewater discharge. }\end{array}$ & $\begin{array}{l}\text { Plant nutrient that, in excess quantity, can cause algal } \\
\text { blooms and excessive growth of higher aquatic } \\
\text { plants in bodies of water. }\end{array}$ \\
\hline 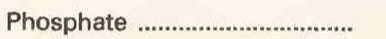 & 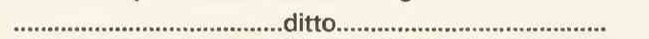 & Ditto. \\
\hline 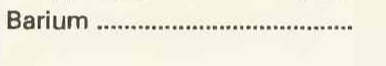 & $\begin{array}{l}\text { Occurs in some rocks; also in mine runoff and waste- } \\
\text { water discharge. }\end{array}$ & $\begin{array}{l}\text { Toxic in larger than trace concentrations; can cause } \\
\text { water to be unsuitable for public supply. }\end{array}$ \\
\hline Iron & $\begin{array}{l}\text { Occurs from the decomposition of some rocks; also } \\
\text { in mine runoff. }\end{array}$ & $\begin{array}{l}\text { Can affect the suitablitiy of water for public and } \\
\text { industrial water supply and can harm aquatic } \\
\text { organisms. }\end{array}$ \\
\hline 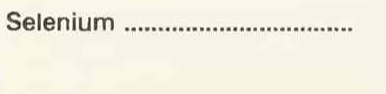 & $\begin{array}{l}\text { Occurs in some rocks and soils; can be leached from } \\
\text { arid lands by irrigation. }\end{array}$ & $\begin{array}{l}\text { Toxic in larger than trace concentrations; can cause } \\
\text { water to be unsuitable for public supply; can } \\
\text { harm aquatic organisms. }\end{array}$ \\
\hline Suspended sediment ................ & $\begin{array}{l}\text { A result of rock erosion; also induced by disturbances } \\
\text { of land cover due to fires, floods, and human } \\
\text { activities such as mining, logging, construction, } \\
\text { and agriculture. }\end{array}$ & $\begin{array}{l}\text { Can be detrimental to aquatic organisms; can fill res- } \\
\text { ervoirs and impair recreational use of water. }\end{array}$ \\
\hline
\end{tabular}

Survey, written commun., 1990). The suspected bias is associated with the use of a turbidimetric technique for sulfate analysis that was adopted by the laboratories in 1982 . The suspected bias results from uncorrected analysis of samples that could have been colored by natural or human-induced contaminants that could have interfered with the turbidimetric estimate of sulfate in concentrations of less than about $75 \mathrm{mg} / \mathrm{L}$ (milligrams per liter). Although review of corrected and uncorrected analyses of water samples in 1989 indicate that the median bias is about $2 \mathrm{mg} / \mathrm{L}$, the bias for some samples was much greater. Consequently, the State summaries do not present results of analysis of sulfate data if water samples in a State commonly were colored by natural or human-induced contaminants and more than 25 percent of water-sample concentrations were reported as less than $75 \mathrm{mg} / \mathrm{L}$. Additionally, trends in sulfate concentration were determined for water years 1982-89, rather than water years $1980-89$, in order to avoid reporting a possible trend caused by a change in methodology in 1982.

Total phosphorus and ammonia plus organic nitrogen.Studies by Alexander and others (R.B. Alexander, U.S. Geological Survey, written commun., 1992) of quality-assurance data indicate that a positive bias is likely in total phosphorus and total ammonia plus organic nitrogen in the early 1980's for all analyses that were done by the USGS water-quality laboratory near Denver, Colo. Because the laboratory at that time was providing water-quality analyses typically for States west of the Mississippi River, this bias is found generally in those States. As a result, all trend analyses for these two constituents in selected State summaries are reported for water years $1982-89$, a period for which no bias is known to exist.
Dissolved solids.-Studies by Alexander and others (R.B. Alexander, U.S. Geological Survey, written commun., 1992) of quality-assurance data on the residue-on-evaporation (ROE) analysis of dissolved solids by USGS water-quality laboratories indicate that changes occurred in the measurement bias of dissolved-solids concentration data for water years 1981-89. A change in laboratory operations in 1986 accounts for small trends in measurement bias over this period. Unfortunately, it is difficult to apply the results of the analysis by Alexander and others to the more than 400 stations from which dissolved-solids data were analyzed for the State summaries. Therefore, a conservative screening of all dissolved-solids trends was conducted; all up or down trends in dissolved solids that were less than the observed magnitude of change -2 percent per year in the quality-assurance data-were converted to no trends in figure 4 in each State summary. Although this action is likely to result in the loss of some small but valid trends in dissolved solids in the State summaries, it reduces the likelihood that any remaining up or down trends result from laboratory-method biases. No adjustments were made to the dissolved-solids data for analysis of waterquality conditions for water years 1987-89 in the summaries because the effects of the measurement bias for this time period is negligible.

\section{WATER-QUALITY CONDITIONS}

Water-quality conditions discussed in the State summaries under the heading "Water-Quality Conditions" are based on an interpretation of the statistical analysis of water-quality constituent- 
Table 11. Summary, by State, of selected water-quality constituents or properties statistically analyzed to determine conditions and trends in stream water quality in the 1990-91 National Water Summary

[Source: Compiled from State summaries, 1990-91 National Water Summary]

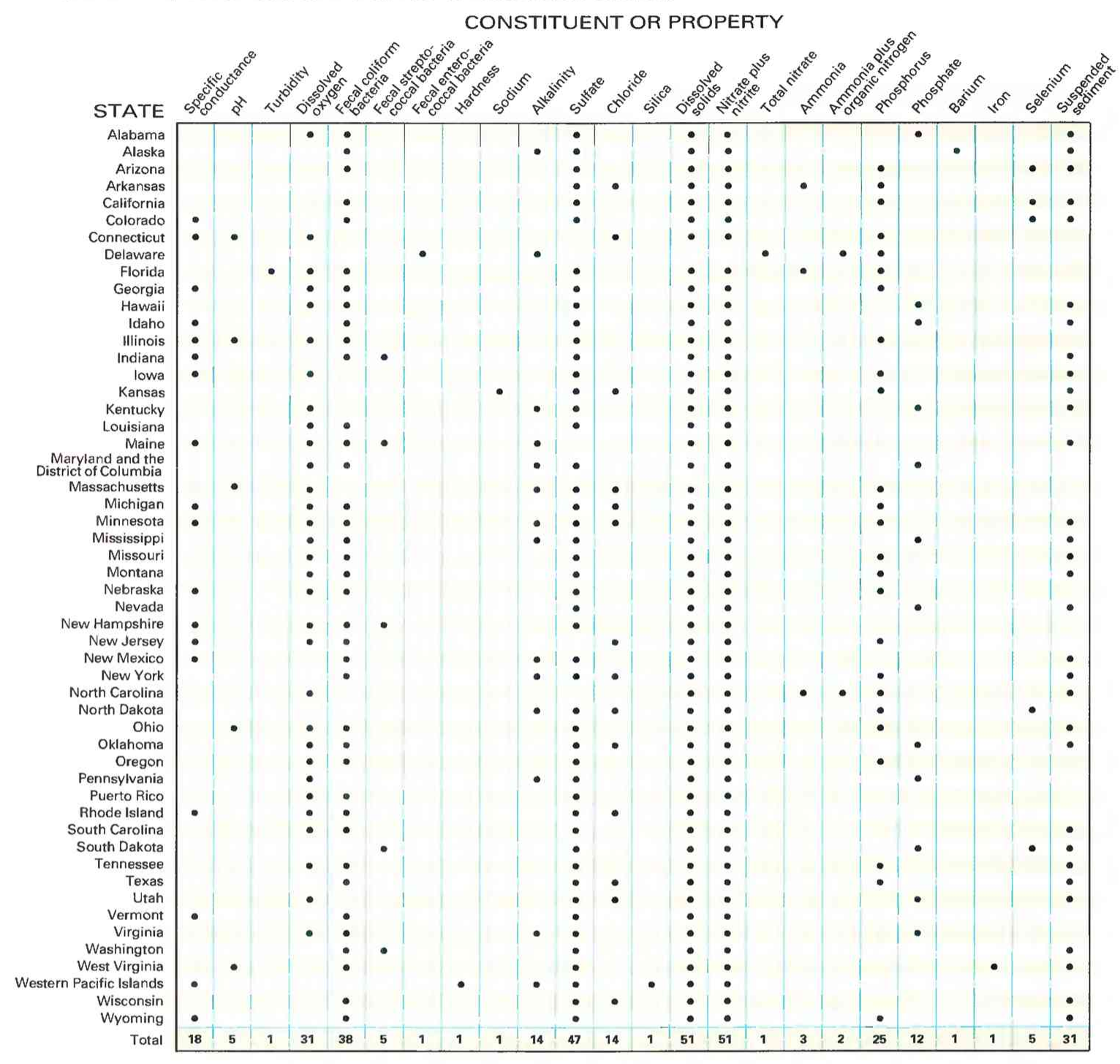

concentration data collected at a maximum of 10 water-quality monitoring stations in the State during water years 1987-89. These statistical analyses are presented in figure 3 in each summary as a series of box plots that represent the statistical analysis of a maximum of 8 constituents. For example, the accompanying box plot illustrates the statistical distribution of dissolved-solids data at 10 waterquality monitoring stations in Tennessee. The site number of each

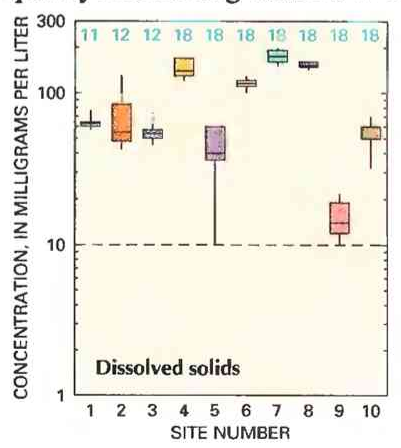
station is shown at the bottom of the box plot, and the number of samples statistically represented at each site is shown at the top. The units of measurement of the constituent are shown at the left in a logarithmic scale. Where applicable, a horizontal dashed line at the concentration that represents the MRL of the analytical method used appears in a box plot, and no data are represented below the line; the MRL in the ex- ample box plot is $10 \mathrm{mg} / \mathrm{L}$. (See article "Statistical Analysis of WaterQuality Data" in this volume for more information about graphical representation of statistical data.) Each State figure 3 also includes a map that shows the drainage area of the water-quality monitoring stations. The water-quality data are discussed in terms of these river basins and the data are interpreted after consideration of the basin land use, physiography, and population density as shown in each State figure 1. If two or more basins have similar attributes and their waterquality conditions are similar, they are described together. Because the summaries are brief descriptions of water quality in the States, only limited interpretation of water-quality conditions was possible. Where feasible, sources of natural or human-induced contamination are identified, and the effect of the contaminants on stream water quality is described.

Additional sources of water-quality information cited in the summaries are reports on water quality by State agencies, as required under the Clean Water Act. These reports, known as 305(b) reports, document the designated use of waterbodies in the States and the degree to which the waterbodies meet their designated uses. The State summaries in this volume extensively reference the 305 (b) 
reports, and concentrations of water-quality constituents are compared with the designated uses of State waterbodies and the degree to which the waterbodies are reported to support their designated uses. (See article "Nationwide Water-Quality Reporting to the Congress as Required Under Section 305(b) of the Clean Water Act" in this volume for more information on the 305 (b) reports.)

State stream water-quality standards are referenced frequently in the discussions of constituent concentrations. Unfortunately for the purposes of comparing water-quality data with State water-quality standards, it usually was not possible to graphically represent water-quality standards on box plots such as those in figure 3 . Although the States can opt to select a single concentration level of a constituent as a standard, which would be a straightforward concept to represent on a box plot, some States adopt standards by designated use or geographic area. Displaying such multiple levels of a standard could be confusing on a box plot, whose purpose is to summarize the concentration of one constituent from as many as 10 water-quality monitoring stations in many geographic areas of the State. For some constituents, standards vary seasonally or might not be represented as a single number, but rather as an exceedance in which the concentration of a constituent may not exceed a particular level more than a specified percentage of the time. Therefore, no attempt was made to annotate the box plots with State stream water-quality standards because of the dynamic nature and complexity of water-quality standards.

\section{WATER-QUALITY TRENDS}

Water-quality trends discussed in the State summaries under the heading "Water-Quality Trends" are based upon an interpretation of the statistical analysis of selected constituent-concentration data collected at as many as 20 water-quality monitoring sites in the States during four selected periods-water years 1970-89, 1975-89, 1980-89, and 1982-89. These trends are presented in figure 4 in each State summary on a series of maps of the State - one map for each of a maximum of 8 constituents - on which the stream-drainage network, major waterbodies, and the location of each waterquality monitoring site are shown. For example, the accompanying map of Virginia, which is representative of the figure 4 in each summary, show trends in dissolved solids at the 5 selected monitoring sites for water years 1975-89. The small circle represents no trend in the concentration at a site, an up symbol represents an upward trend, and a down symbol represents a downward trend. Additionally, the numbers identify the stations shown and described in each State figure 2.

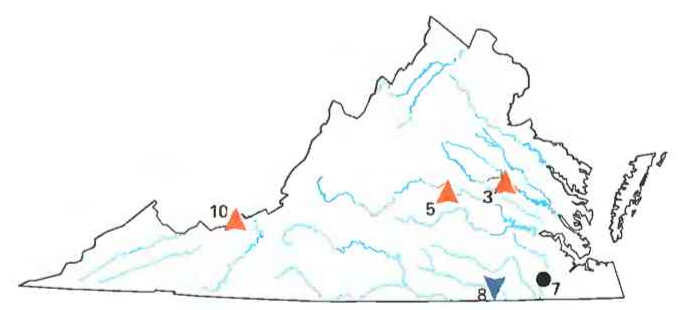

Dissolved solids, $1975-89$

Trends in concentrations of water-quality constituents were determined by a statistical method known as the seasonal Kendall test (Hirsch and others, 1982), which is used extensively by the USGS. If possible, constituent-concentration data were adjusted for changes in streamflow to preclude identifying a trend in concentration that was caused only by a trend in streamflow. Two factors can prevent this technique from being used-if more than 10 percent of the samples had concentrations less than the MRL for the analytical method used, or if the streamflow was substantially controlled by human activities. When the concentration data could not be adjusted for streamflow, trends were determined directly from the concentration data. A significance level of 0.05 was used in applying the seasonal Kendall test. Therefore, as many as 5 percent of the declared trends may be incorrectly identified because of statistical uncertainty. See Lanfear and Alexander (1990) and the article "Statistical Analysis of Water-Quality Data" in this volume for more information on the seasonal Kendall test.

State-summary authors had computer access to individual data records in the data base created specifically for preparation of the National Water Summary and were able to graphically portray the records as part of their quality assurance and analysis of the records. One graphic that they used extensively was the scatter plot, which showed the concentration and time of data collection of each data value in a data record that was used for trend analysis. Superimposed on the plot of the concentration data was a smooth line that represented the inferred trend. The scatter plot and smooth line provide insight into the range and distribution of the concentration and assist in visualizing the trend. (See article "Statistical Analysis of Water-Quality Data" in this volume for more information about scatter plots and smoothed trend lines.) One scatter plot is included in each State summary. The accompanying scatter plot, shown as an example, displays the concentration of dissolved sulfate during water years 1975-89 at water-quality monitoring site 2 in the Nebraska State summary.

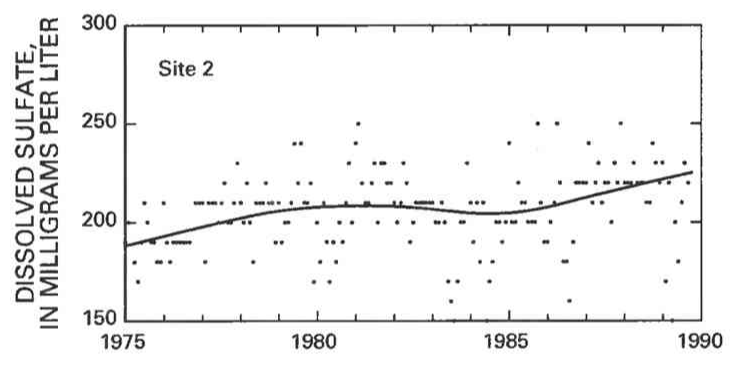

Authors of each State summary relied greatly on their knowledge of land use, population distribution, urbanization, industrial and agricultural activities, and other available ancillary information to interpret trends in concentrations of water-quality constituents. Documented data sets, 305(b) reports, and other scientific literature about factors that influence stream water quality also were referenced. Because many factors influence water quality, authors of the State summaries were not always able to identify the cause of water-quality conditions and trends.

Stream water quality is influenced more by land use and human activities within stream-basin boundaries than within political boundaries. However, analysis of stream water quality was done by State and not basin boundary in this volume to facilitate comparison of the State summaries of stream water quality with State summaries on other water-resources topics in previously published volumes of the National Water Summary. Accordingly, no attempt was made in the State summaries to duplicate the analysis of data on the basis of national or regional stream basins of similar land or water use such as in the article "Stream Water Quality in the Conterminous United States-Status and Trends of Selected Indicators During the 1980's" in this volume.

\section{WATER-QUALITY MANAGEMENT}

In implementing the Clean Water Act, States are assigned many responsibilities. These responsibilities include designating the uses of waterbodies, establishing water-quality standards, monitoring stream water quality and point and nonpoint sources of contamination, reporting the status of water quality, and other facets of 
water-quality management. (See article "Nationwide Water-Quality Reporting to the Congress as Required Under Section 305(b) of the Clean Water Act" in this volume for more information on the 305(b) program.) Additionally, many State laws have been enacted to address local concerns. The State agencies that are responsible for water-quality management and preparation of the 305(b) reports and their enacted State legislation are discussed in each State summary under the heading "Water-Quality Management."

\section{REFERENCES CITED}

Ficke, J.F., and Hawkinson, R.O., 1975, The national stream quality accounting network (NASQAN) - Some questions and answers: U.S. Geological Survey Circular 719, 23 p.

Gilbert, B.K., and Mann, W.B., IV, 1990, The U.S. Geological Survey Federal-State cooperative water-resources program-Fiscal year 1989: U.S. Geological Survey Open-File Report 90-353, 49 p.

Hirsch, R.M., Slack, J.R., and Smith, R.A., 1982, Techniques of trend analy- sis for monthly water quality data: Water Resources Research, v. 18, no. 1, p. 107-121.

Lanfear, K.J., 1993, Hydrologic data-collection stations whose stream water quality data were available to prepare the 1990-91 national water summary on stream water quality: U.S. Geological Survey Open-File Report 93-29, $48 \mathrm{p}$.

Lanfear, K. J., and Alexander, R. B., 1990, Methodology to derive water-quality trends for use by the national water summary program of the U.S. Geological Survey: U.S. Geological Survey Open-File Report 90-359, $10 \mathrm{p}$.

Leopold, L.B., 1962, A national network of hydrologic bench marks: U.S. Geological Survey Circular 460-B, 4 p.

Novak, C. E., 1985, WRD [Water Resources Division] data reports preparation guide-1985 edition: U.S. Geological Survey Open-File Report 85$480,199 \mathrm{p}$.

Shiller, A.M., and Boyle, E.A., 1987, Variability of dissolved trace metals in the Mississippi River: Geochimica et Cosmochimica Acta, v.51, p. 3273-3277.

Windom, H.L., Byrd, J.T., Smith, R.G., Jr., and Huan, Feng, 1991, Inadequacy of NASQAN data for assessing metal trends in the Nation's rivers: Environmental Science and Technology, v. 25, no. 6, p.1137-1142. 


\section{Alabama Stream Water Quality}

Precipitation in Alabama averages about 55 inches per year and ranges from about 50 inches per year in the central and westcentral parts of the State to about 65 inches per year near the Gulf of Mexico (U.S. Geological Survey, 1986, p. 131). This precipitation provides runoff for 40,600 miles of streams and rivers within the State (Alabama Department of Environmental Management, 1990, p. 1). In most streams, the water is suitable for State-designated uses such as public, domestic, commercial, and industrial supply; livestock watering; irrigation; aquaculture; navigation; wildlife; and recreation (Alabama Department of Environmental Management, 1990, p. 6). These use classifications are assigned for purposes of water-pollution control. The relative importance placed on each designated use differs within and among river basins.

Offstream surface-water withdrawals in 1985 averaged 8.250 $\mathrm{Mgal} / \mathrm{d}$ (million gallons per day) or 96 percent of the combined offstream surface- and ground-water use. The major offstream uses were thermoelectric power generation $(6,920 \mathrm{Mgal} / \mathrm{d})$, industrial supply (804 Mgal/d), and public supply (442 Mgal/d) (U.S. Geological Survey, 1990, p. 145). Surface water is the principal source for public supply for most of the large cities in Alabama. Ground-water supplies are available in most locations but often are inadequate.

The quality of Alabama's surface-water resources is affected by land use in many parts of the State. Land uses (fig. $1 A$ ) are deter- mined, in part, by physiography. The broad flood plains and rolling hills in the Interior Low Plateaus and Coastal Plain (fig. $1 B$ ) lend themselves to cropland and pasture, but there also are large areas of woodland and forest. The physiography in the Appalachian Plateaus, Valley and Ridge, and Piedmont provinces is less conducive to cropland and pasture; nonetheless, these areas contain some of both.

The Tennessee, Black Warrior, Tombigbee, Alabama, Mobile, Coosa, Tallapoosa, and Chattahoochee Rivers are the major streams in Alabama. Surface-water resources in all the major streams have been extensively developed by reservoirs that provide flood control, navigation, electric power, and water supplies for an increasing population. Population centers (fig. $1 C$ ) along these rivers have ample water supplies and are served by commercial navigation routes. The State's 1990 population was 4 million-a 3.8-percent increase since 1980 (U.S. Bureau of the Census 1990 decennial census files).

\section{WATER-QUALITY MONITORING}

Water-quality data obtained from analyses of water samples collected at monitoring stations are stored in the U.S. Geological Survey's (USGS) National Water Information System and the U.S. Environmental Protection Agency's (EPA) national data base known as STORET. Water-quality and streamflow data are reported by water year-the 12 months from October 1 through September 30. A water year is identified by the calendar year in which it ends. For example, water year 1991 comprises October 1, 1990, through September 30, 1991.

The data used in this summary of Alabama's stream water quality were obtained from water samples collected at 10 monitoring stations at which data collection is systematic and continuing (fig. 2). Analyses of water samples collected at all 10 stations are the basis for the discussion and graphic summary (fig. 3) of stream water-quality conditions during water years $1987-89$, and data from 9 stations are the basis for the discussion and graphic summary (fig. 4) of stream waterquality trends. Water samples were collected and analyzed by using standard methods approved by the USGS (Britton and Greeson, 1987; Fishman and Friedman, 1989; Ward and Harr, 1990) or by using equivalent methods. If a method for sample collection or analysis changed over time, data from an analysis were included in the evaluation of recent stream water quality or of stream waterquality trends only if the change in method did not affect the comparability of the data.
Figure 1. Land use, physiography, and population in Alabama. A, Major land uses. B, Physiographic divisions. C. Population distribution in 1990. (Sources: A, Major land uses modified from Anderson, 1967: B, Physiographic divisions from Fenneman, 1946; landforms from Thelin and Pike, 1990. C. Data from U.S. Bureau of the Census 1990 decennial census files.) 


\section{WATER-QUALITY CONDITIONS}

Water in Alabama streams generally is suitable for most purposes; only 38 stream segments totaling 391 miles do not meet Federal standards for fish and wildlife (James McIndoe, Alabama Department of Environmental Management, oral commun., 1990). These stream segments represent less than 1 percent of the 40,600 miles of waterways in Alabama. Substandard wastewater-treatment facilities are one cause of degraded water quality in some stream segments. According to the Alabama Department of Environmental Management, 45 of 252 publicly owned wastewater-treatment facilities failed to comply with Federal guidelines by the July 1, 1988, deadline - a substantial decrease from 115 facilities that failed to comply in 1985 (James McIndoe, Alabama Department of Environmental Management, oral commun., 1990). Other factors affecting stream water quality are nonpoint sources such as agricultural activities, mining, and urban runoff.

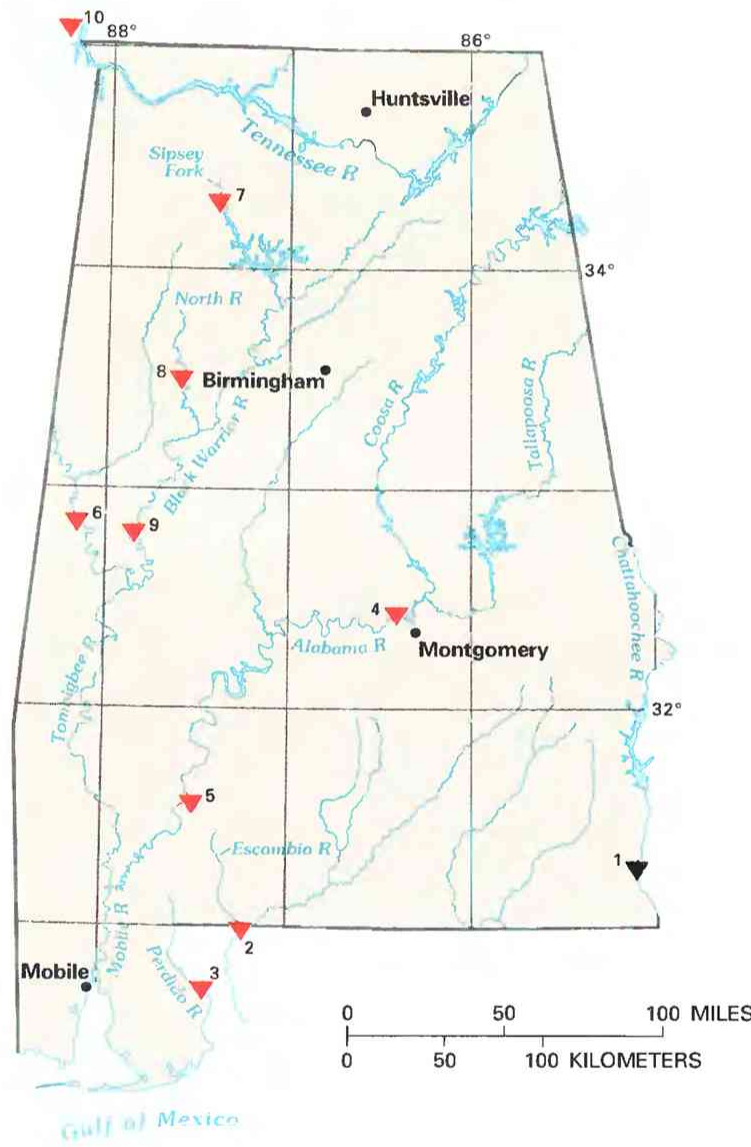

The following discussion of stream water quality in Alabama is organized by river basin (fig. 3). Where physiographic and landuse characteristics in different basins are similar, the discussion of those basins is combined. Graphs in figure 3 summarize certain aspects of stream water quality in the basins for water years 1987-89. The graphs show frequency distributions of data values that represent concentrations of selected stream-water constituents. These constituents are dissolved oxygen, fecal coliform bacteria, dissolved sulfate, dissolved solids, dissolved nitrite plus nitrate (as nitrogen), dissolved phosphate (as phosphorus), and suspended sediment. The data are reported in milligrams per liter $(\mathrm{mg} / \mathrm{L})$ and colonies per 100 milliliters. Sources and environmental significance of each constituent are described in table 1.

Water quality at each monitoring station is the result of geological, chemical, biological, and hydrologic processes that occur over a large area. Water-quality problems that affect aquatic life or public health only locally are not fully represented in this summary.

\section{CHATTAHOOCHEE RIVER}

The Chattahoochee River forms the southern one-half of the eastern boundary of Alabama. The headwaters of the Chattahoochee River are in the Piedmont province in Georgia, an area underlain by metamorphosed sedimentary and igneous rocks. Soils in the basin are relatively thin in most areas. Major land uses are cropland and forest, except for the urban area in and near Atlanta, Ga., through which the Chattahoochee River flows. The river then flows into the Coastal Plain, where the terrain is flatter and the soils are thicker, allowing more agricultural land use. Seven dams regulate the river upstream from site 1. The Chattahoochee River has been the subject of numerous water-quality studies, particularly near Atlanta, Ga.

Concentrations of most water-quality constituents at site 1 were within the range of concentrations for the other nine monitoring stations (fig. 3). Nitrite plus nitrate concentrations at site 1 commonly

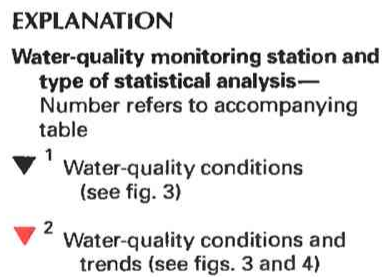

\begin{tabular}{|c|c|c|c|}
\hline $\begin{array}{l}\text { Site no. } \\
\text { on map }\end{array}$ & $\begin{array}{l}\text { USGS station } \\
\text { name and no. }\end{array}$ & $\begin{array}{l}\text { Drainage area } \\
\text { (square miles) }\end{array}$ & $\begin{array}{l}\text { Major land use } \\
\text { (see fig. 1) }\end{array}$ \\
\hline 1 & 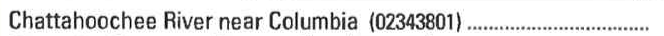 & 8,210 & Cropland with pasture, woodland, and forest. \\
\hline 2 & 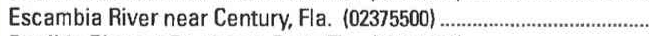 & 3,817 & Ditto. \\
\hline 3 & Perdido River at Barrineau Park, Fla. $(02376500)$ & 394 & Grazed forest and woodland. \\
\hline 4 & 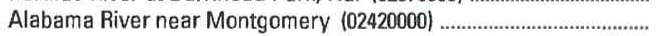 & 15,087 & Cropland with pasture, woodland, and forest. \\
\hline 5 & Alabama River near Claiborne $(02429500)$ & 21,967 & Ditto. \\
\hline 6 & Tombigbee River at Gainesville $(02449000)$ & 8,632 & Ditto. \\
\hline 7 & Sipsey Fork near Grayson (02450250) & 92 & Forest and woodland. \\
\hline 8 & North River near Samantha $(02464000)$ & 223 & Grazed forest and woodland. \\
\hline 9 & Black Warrior River at Selden Lock and Dam near Eutaw (02466031) & 5,810 & Ditto. \\
\hline 10 & Tennessee River at Pickwick Landing, Tenn. (03593005) ..................... & 38,820 & Cropland with pasture, woodland, and forest. \\
\hline
\end{tabular}

Figure 2. Selected water-quality monitoring stations, type of statistical analysis, and geographic features in Alabama. (Sources: Major land uses modified from Anderson, 1967; other data from U.S. Geological Survey files.) 
were higher than most during water years $1987-89$, possibly owing to wastewater discharge into the river from municipalities along the waterway.

\section{ESCAMBIA AND PERDIDO RIVERS}

The Escambia and Perdido Rivers are entirely within the Coastal Plain and drain a large part of south-central Alabama. Sediments in the drainage basins are mostly sand, gravel, and clay. There is a mixture of cropland, pasture, and forest throughout both basins.

At site 2 on the Escambia River, the median suspended-sediment concentration $(31 \mathrm{mg} / \mathrm{L})$ was as high as that at any other monitoring station (fig. 3). The sources of the suspended sediment probably were streambed and flood-plain sediments and agricultural runoff.

At site 3 on the Perdido River, median sulfate and dissolvedsolids concentrations $(4.3 \mathrm{mg} / \mathrm{L}$ and $22 \mathrm{mg} / \mathrm{L})$ were the lowest during water years 1987-89, and the median suspended-sediment concentration $(11 \mathrm{mg} / \mathrm{L})$ was lower than most. Forest covers a large part of the basin upstream from site 3 , and the land surface is less disturbed by agricultural activities than in the Escambia River basin. Additionally, parts of the drainage area upstream from site 3 have soils consisting mostly of well-sorted quartzite sands, which contribute little dissolved solids or suspended sediment to streams unless the land surface is disturbed by agricultural activities or timber harvesting.

\section{ALABAMA RIVER}

The rivers that join the Alabama River upstream from sites 4 and 5 drain different physiographic provinces. Site 4 is in the Coastal Plain, but most of the upstream drainage is in the Piedmont and Valley and Ridge provinces. The Piedmont province is underlain by metamorphosed sedimentary and igneous rocks. The Valley and Ridge province is underlain primarily by limestone, shale, sandstone, and chert. Cropland and pasture occupy much of the valleys and other flat areas in the drainage upstream from site 4 . The ridges and mountains are densely forested except in areas that have been harvested for timber. Eight reservoirs upstream from site 4 trap much of the
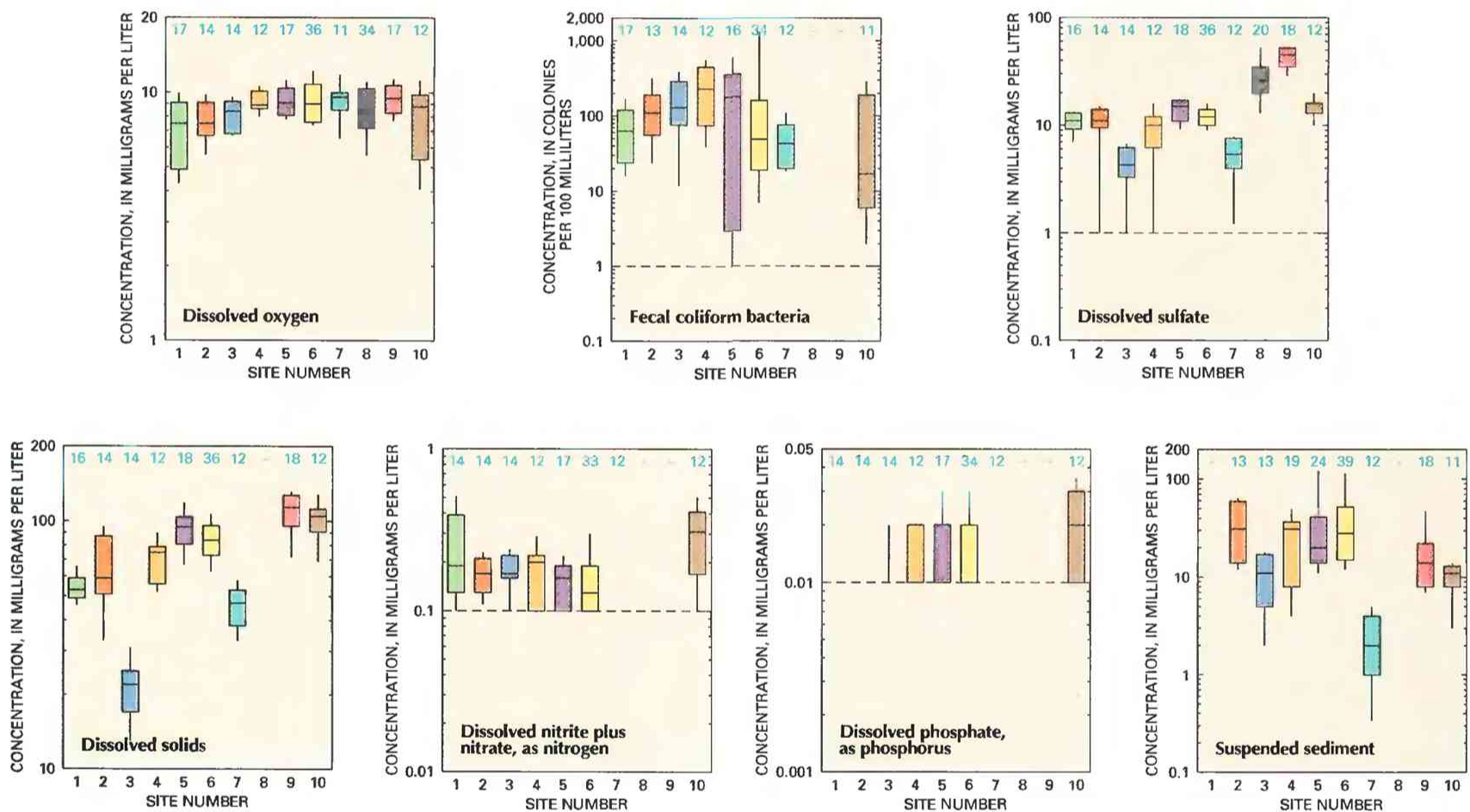

\section{EXPLANATION}

Water-quelity conditions in selected
drainage besins
Number of anelyses-Dash indicates
insufficient data
Percentile-Percentage of analyses
equal to or less than indicated
values
-90th
-75th
- 50th-Median
- 10th
- Reporting limit-Minimum reporting
limit for analytical method used.
Data below limit line not shown

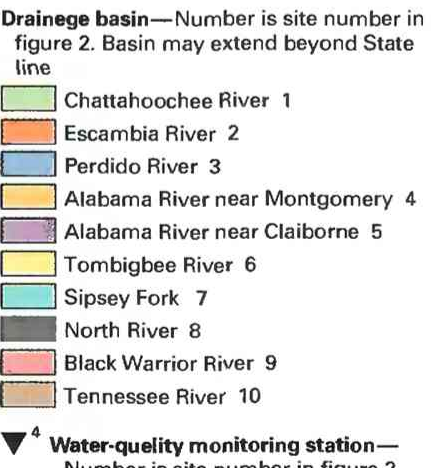
Number is site number in figure 2

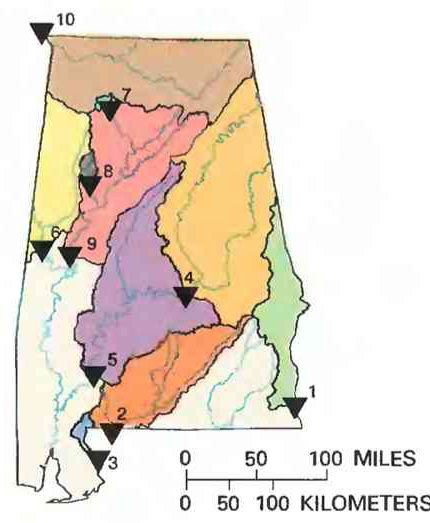

Figure 3. Water quality of selected streams in Alabama, water years 1987-89. (Source: Data from U.S. Geological Survey files.) 
Table 1. Sources and environmental significance of selected water-quality constituents [Source: Compiled by the U.S. Geological Survey, Office of Water Quality]

\begin{tabular}{|c|c|c|}
\hline Constituent & Common sources & Environmental significance \\
\hline 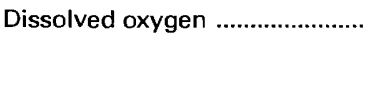 & $\begin{array}{l}\text { Introduced from the atmosphere; also a byproduct of } \\
\text { aquatic plants. }\end{array}$ & $\begin{array}{l}\text { Necessary for aquatic life; deficiency can result from } \\
\text { assimilation of organic wastes or rapid growth } \\
\text { and decay of algae. }\end{array}$ \\
\hline Fecal coliform bacteria ................ & $\begin{array}{l}\text { Sources include effluent from sewage-treatment } \\
\text { plants and runoff from pastures, feedlots, and ur- } \\
\text { ban areas. }\end{array}$ & $\begin{array}{l}\text { Presence indicates contamination of water by wastes } \\
\text { from humans and other warm-blooded animals. }\end{array}$ \\
\hline Sulfate & $\begin{array}{l}\text { Occurs in some rocks; also in mine runoff, industrial } \\
\text { wastewater discharge, and atmospheric deposi- } \\
\text { tion. }\end{array}$ & $\begin{array}{l}\text { Concentrations exceeding a natural, background } \\
\text { level indicate contamination from human activity; } \\
\text { in sufficient quantity, can cause water to be } \\
\text { unsuitable for public supply; can harm aquatic } \\
\text { organisms. }\end{array}$ \\
\hline Dissolved solids ............................ & $\begin{array}{l}\text { A result of rock weathering; also in agricultural runoff } \\
\text { and industrial discharge. }\end{array}$ & $\begin{array}{l}\text { In sufficient quantity, can cause water to be unsuitable } \\
\text { for public supply, agriculture, and industry; can } \\
\text { harm aquatic organisms. }\end{array}$ \\
\hline 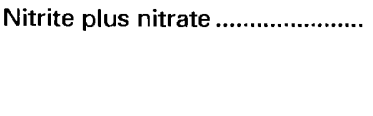 & $\begin{array}{l}\text { Nonpoint sources are agricultural and urban runoff; } \\
\text { a major point source is wastewater discharge. }\end{array}$ & $\begin{array}{l}\text { Plant nutrient that, in sufficient quantity, can cause } \\
\text { algal blooms and excessive growth of higher } \\
\text { aquatic plants in bodies of water; can cause water } \\
\text { to be unsuitable for public supply. }\end{array}$ \\
\hline 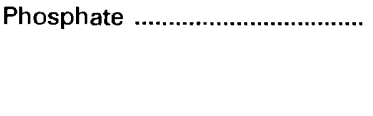 & $\begin{array}{l}\text { Occurs in some rocks and sediments; also in runoff } \\
\text { and seepage from phosphate-rock mines, agri- } \\
\text { cultural and urban runoff, and industrial and } \\
\text { municipal wastewater discharge. }\end{array}$ & $\begin{array}{l}\text { Plant nutrient that, in sufficient quantity, can cause } \\
\text { algal blooms and excessive growth of higher } \\
\text { aquatic plants in bodies of water. }\end{array}$ \\
\hline Suspended sediment ................ & $\begin{array}{l}\text { A result of rock erosion; also induced by disturbances } \\
\text { of land cover due to fires, floods, and human } \\
\text { activities such as mining, logging, construction, } \\
\text { and agriculture. }\end{array}$ & $\begin{array}{l}\text { Can be detrimental to aquatic organisms; can fill res- } \\
\text { ervoirs and impair recreational use of water. }\end{array}$ \\
\hline
\end{tabular}

suspended sediment in the river; nonetheless, the median concentration of suspended sediment at site $4(31 \mathrm{mg} / \mathrm{L})$ was equal to those for site 2 and higher than those for all of the other monitoring stations (fig. 3).

Between sites 4 and 5, the drainage area is entirely within the Coastal Plain and is underlain mostly by sand, gravel, and clay deposits. Three dams regulate steamflow between sites 4 and 5 . Within the Coastal Plain, the Alabama River basin is extensively farmed.

Concentrations of most water-quality constituents were similar at sites 4 and 5 and met State water-quality criteria. The Alabama River basin has no apparent, persistent, widespread water-quality problems.

\section{TOMBIGBEE RIVER}

The Tombigbee River basin lies entirely within the Coastal Plain. The basin is underlain by unconsolidated deposits of sand, gravel, and clay that are easily eroded. The river has been extensively dammed for navigation. Forest, woodland, cropland, and pasture are the predominant land uses in the basin. The median concentration of suspended sediment at site $6(28 \mathrm{mg} / \mathrm{L})$ was higher than that at the other monitoring stations except sites 2 and 4 (fig. 3), which also are in the Coastal Plain. The median nitrite plus nitrate concentration at site $6(0.13 \mathrm{mg} / \mathrm{L})$ was lower than those at all of the monitoring stations except site 7 .

In the future, the greatest threat to water quality in the Tombigbee River probably will be industrial development along the waterway. The water quality of the river has not yet been substantially degraded. However, the limited quantity of water available in the river for dilution already has caused some concern in the upper end of the basin in Mississippi. Industrial discharges and increased barge traffic could have detrimental effects on water quality in the basin.

\section{SIPSEY FORK}

The Sipsey Fork basin lies entirely within the Appalachian Plateaus province, and most of the drainage basin is undisturbed and densely forested. Much of the basin has been designated a National
Wilderness Area; however, timber is harvested in parts of the basin. Because the stream is underlain by sandstone and shale, and because land in the basin is little disturbed, median concentrations of nitrite plus nitrate (less than $0.10 \mathrm{mg} / \mathrm{L}$ ) and suspended sediment $(2.0$ $\mathrm{mg} / \mathrm{L}$ ) at site 7 were the lowest for any monitoring station (fig. 3). The median dissolved-sulfate concentration $(5.4 \mathrm{mg} / \mathrm{L})$ was lower than those for all stations except site 3 .

\section{NORTH AND BLACK WARRIOR RIVERS}

The drainage basin of the North River upstream from site 8 lies entirely within the Appalachian Plateaus. Upstream from site 9, the drainage basin of the Black Warrior River is mostly in the Appalachian Plateaus; only a small area of the basin upstream from site 9 is in the Coastal Plain. Streams draining the Appalachian Plateaus are underlain by sandstone and shale and, under natural conditions, generally have low concentrations of dissolved minerals. However, surface and subsurface coal mining and forestry are important activities throughout much of the Black Warrior River basin. Surface mining creates spoil material that erodes easily and contributes sediment to streams. Further, runoff from spoils can add highly mineralized and acidic water to streams. Extensive timber harvesting can contribute sediment to streams through increased erosion. The Black Warrior River is regulated by four dams upstream from site 9 , and there is a dam between site 8 on the North River and its confluence with the Black Warrior River upstream from site 9.

Water quality in the North and Black Warrior Rivers has been affected by surface coal mining. Median sulfate concentrations were higher for sites 8 and $9(26$ and $45 \mathrm{mg} / \mathrm{L})$ than those for the other monitoring stations (fig. 3 ). The dissolved-solids concentration at site 9 (median, $114 \mathrm{mg} / \mathrm{L}$ ) also was the highest in the State.

\section{TENNESSEE RIVER}

The Tennessee River enters Alabama from Tennessee, where the river basin is underlain primarily by sandstone, shale, and limestone. About midway across northern Alabama, the river enters the Interior Low Plateaus. This area is characterized by wide alluvial flood plains and upland formations of sandstone, chert, and limestone. 
Cropland is extensive in the flood plain of the Tennessee River main stem, whereas the headwater area is more densely forested. The river is regulated by several dams.

The median dissolved-solids concentration for site $10(105$ $\mathrm{mg} / \mathrm{L}$ ) was higher than those for most other monitoring stations (fig. 3 ), and the median nitrite plus nitrate concentration at site 10 $(0.31 \mathrm{mg} / \mathrm{L})$ was higher than that for any other station. These high concentrations possibly were due to agricultural activity in the basin and to wastewater discharge from numerous cities.

\section{WATER-QUALITY TRENDS}

Trend analysis is a statistical procedure used to detect changes in stream water quality at a monitoring station over time. For this report, water-quality data from nine monitoring stations (fig. 2) were analyzed for trends by using the seasonal Kendall test (Hirsch and others, 1982), a method used extensively by the USGS. The graph (shown below) of the dissolved-sulfate concentration in the Black Warrior River at site 9 illustrates the trend inferred from the concentration data and demonstrates the variation in water quality that is common in streams.

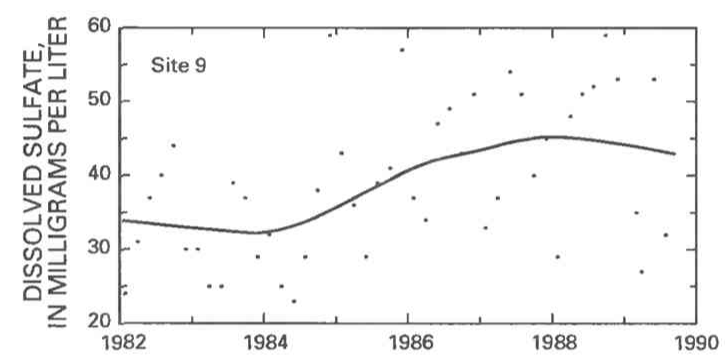

When possible, constituent-concentration data were adjusted for changes in streamflow to preclude identifying a trend in concentration that was caused only by a trend in streamflow. The data were not adjusted when (1) more than 10 percent of the samples had concentrations lower than the minimum reporting limit for the analytical method used or (2) streamflow was controlled substantially by human activities. When the concentration data could not be adjusted for streamflow, trends were determined directly from the concentration data.
Statewide trends in concentrations of selected stream-water constituents are shown on maps in figure 4. On each map, a trend is indicated at a monitoring station only if the data from that station were suitable for use in the trend analysis. For more information on the suitability criteria and on the trend-analysis procedure used for this report, see Lanfear and Alexander (1990).

\section{DISSOLVED OXYGEN}

The dissolved-oxygen concentration in a stream is controlled by several factors, including water temperature, air temperature and pressure, hydraulic characteristics of the stream, photosynthetic or respiratory activity of stream biota, and the quantity of organic material present. A trend in dissolved-oxygen concentrations commonly is directly or indirectly the result of human activities. Generally, an upward trend in dissolved-oxygen concentrations indicates improving stream water-quality conditions and a downward trend indicates deteriorating conditions. Dissolved-oxygen concentrations had no trend at any of the monitoring stations during 1980-89.

\section{FECAL COLIFORM BACTERIA}

Fecal coliform bacteria are used as indicators of fecal contamination from humans and other warm-blooded animals. Such contamination can introduce disease-causing viruses and bacteria into a stream.

Concentrations of fecal coliform bacteria had no trend at the seven monitoring stations that had sufficient data for trend analysis. Although treatment of waste at sewage-treatment plants improved during this period, bacterial concentration in the streams did not decrease. Apparently, in streams affected by municipal wastewatertreatment-plant discharge, urban runoff, or runoff from livestockholding areas or pastures, improved waste treatment was offset by increasing contamination from one or more of these sources.

\section{DISSOLVED SULFATE}

The major natural sources of sulfate in streams are rock weathering,volcanoes, and biochemical processes (Hem, 1985, p. 113). Human activities such as mining, waste discharge, and fossil-fuel combustion also can be important sources. A shortened trend-analysis period was used for sulfate because data before water year 1982 are not comparable to data from subsequent years.

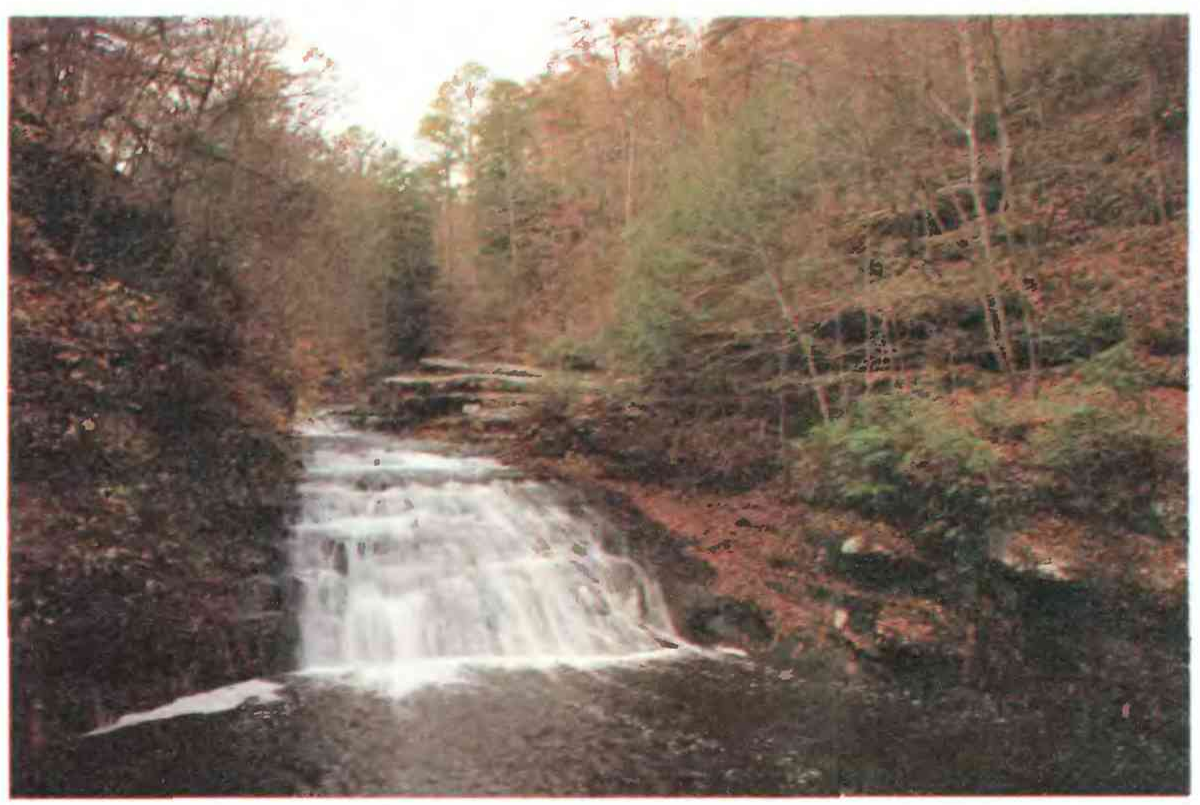

Tributary of the Sipsey Fork. The Sipsey Fork drains a National Wilderness Area; basin streams are minimally affected by human activities. (John S. Williams, U.S. Geological Survey.) 


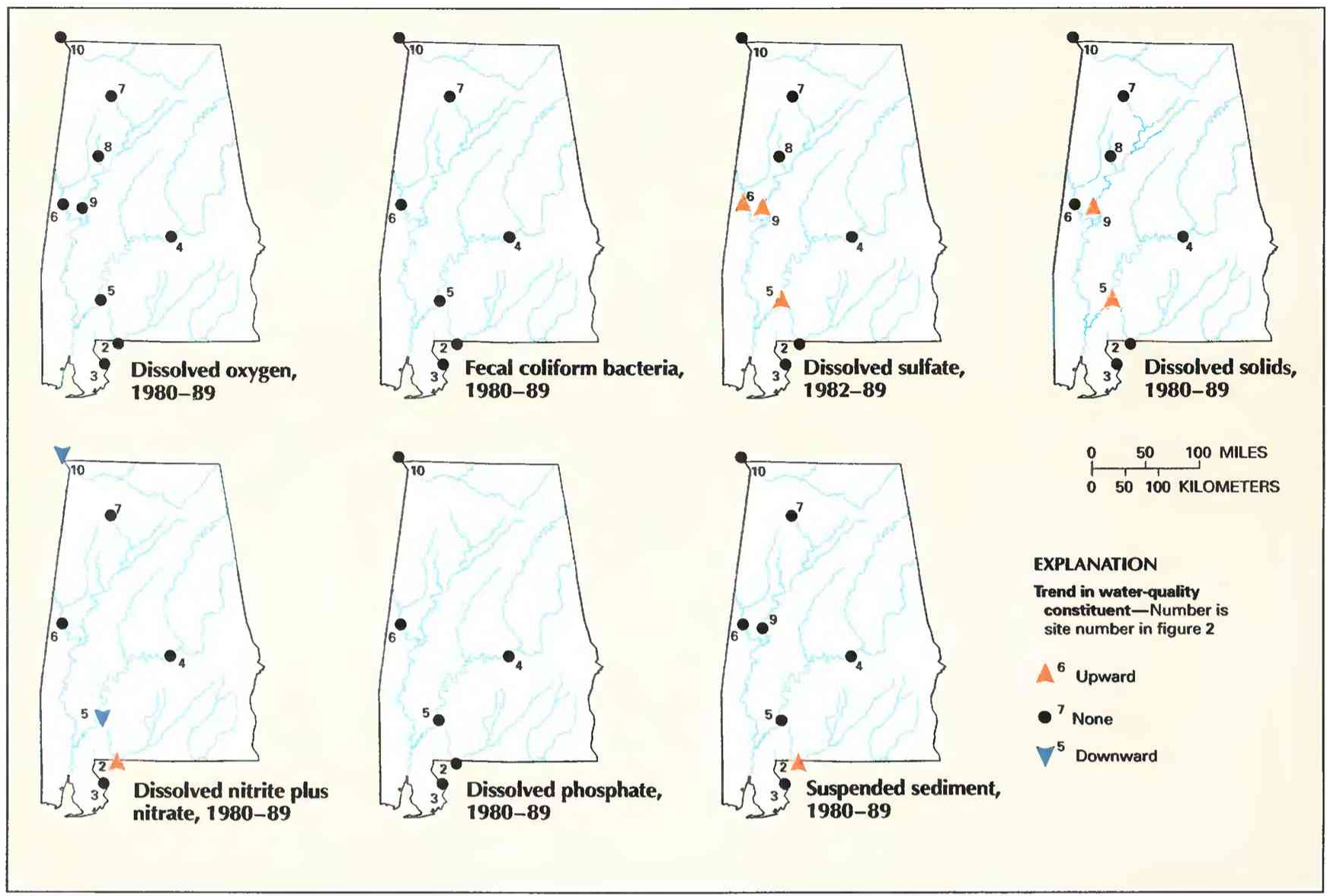

Figure 4. Trends in water quality of selected streams in Alabama, by water years. (Source: Data from U.S. Geological Survey files.)

A possible source of sulfate in streams other than mining activity and waste discharge is atmospheric deposition. However, upward trends in sulfate concentrations in Alabama drainage basins unaffected by mining or waste discharges do not correlate well with trends in sulfur dioxide emissions (Brand Niemann, U.S. Environmental Protection Agency, oral commun., 1989), atmospheric concentrations of sulfate (U.S. Environmental Protection Agency, 1989), or sulfate deposition (Schertz and Hirsch, 1985). However, the increases in sulfate concentrations in the Alabama River at site 5 and the Tombigbee River at site 6, which occurred despite decreases in sulfate deposition, might represent a delayed response that corresponds to the time of travel from the point of deposition to the stream channel (M. Robbins Church, U.S. Environmental Protection Agency, oral commun., 1990). Also, in many States in the Southeast, the sulfate adsorption capacity of soils has been reduced as a result of decades of deposition and retention of large quantities of sulfate in these basins (Church and others, 1990).

Mining activity in the Black Warrior River basin peaked in the early 1980's, but sulfate concentrations continued to increase. Concentrations of sulfate and other constituents in streams that drain mined areas are expected to increase for $8-10$ years after mining has ceased; then, sulfate concentrations probably will decrease as runoff to the streams gradually becomes less mineralized (Puente and others, 1982, p. 34).

\section{DISSOLVED SOLIDS}

Dissolved solids in stream water result primarily from rock weathering but also can be introduced as a byproduct of human activities (table 1). Concentrations generally are greatest in streams draining basins underlain by rocks and soils that contain easily dissolved minerals.

The upward trend in the dissolved-solids concentration at site 5 might have been caused by increasing industrial and agricultural activity in the Alabama River basin. The upward trend at site 9 on the Black Warrior River can be attributed in large part to the increase in surface coal mining in the basin.

\section{DISSOLVED NITRITE PLUS NITRATE}

Nitrite and nitrate are oxidized forms of nitrogen that together constitute most of the dissolved nitrogen in well-aerated streams. $\mathrm{Ni}$ trite readily oxidizes to nitrate in natural waters; therefore, nitrate generally is by far the more abundant of the two (Hem, 1985, p. 124). Natural sources of nitrogen in stream water include the atmosphere and biological activity by certain microorganisms. Nitrogen also can enter streams as a result of human activities (table 1). No definite causes are known for the upward trend in nitrite plus nitrate concentrations in the Escambia River at site 2 or the downward trends in the Alabama River at site 5 and the Tennessee River at site 10.

\section{DISSOLVED PHOSPHATE}

Phosphate is the oxidized form of phosphorus and the only form of significance in most natural waters. Small quantities of dissolved phosphate commonly are present in streams as a result of rock weathering. Normally, concentrations are no more than a few tenths of a milligram per liter (Hem, 1985, p. 126) and usually are much lower. Higher concentrations can indicate contamination from human activities (table 1). 
Phosphate concentrations had no trend at the six monitoring stations from which data met the criteria for trend analysis. Agricultural runoff is a major source of phosphorus in rivers; however, phosphorus-fertilizer use in the basins upstream from the six sites has remained nearly constant from 1980 to 1989 (Tennessee Valley Authority, 1989).

\section{SUSPENDED SEDIMENT}

Suspended sediment is a product of erosion. The erosion can be either natural or the result of land-cover disturbances related to human activities (table 1). Suspended-sediment concentrations had an upward trend in the Escambia River at site 2, possibly as a result of increasing agricultural activity.

\section{WATER-QUALITY MANAGEMENT}

Water-quality standards are set and enforced by Federal, State, and local government agencies. The EPA has the primary responsibility for establishing and enforcing water-quality regulations. The adoption of water-quality standards is a State responsibility that is overseen by EPA. The Alabama Department of Environmental Management is the permitting authority under the National Pollutant Discharge Elimination System and also is responsible for preparing a biennial water-quality-assessment report (Alabama Department of Environmental Management, 1990) mandated by section 305(b) of the Federal Clean Water Act that is submitted to EPA and the U.S. Congress. Two agencies regulate resource-extraction activities that can adversely affect water quality - the Alabama Surface Mining Reclamation Commission and the State Oil and Gas Board. The Alabama Department of Conservation and Natural Resources regulates activities that can affect water quality in wildlife refuges and game-management areas.

During the 1988 session, the Alabama Legislature passed several new acts related to water. The Alabama Agricultural Nonpoint Source Financial Assistance Act of 1988 assists in controlling contamination of Alabama's lakes, streams, rivers, aquifers, and estuaries. The act provides for the State Soil and Water Conservation Districts to administer a Federal cost-sharing program that was established by the legislature in 1986 . The program provides financial assistance to land users for controlling soil erosion, preventing water pollution, and improving forests.

Owing to their extensive network of reservoirs in Alabama, the Tennessee Valley Authority and the U.S. Army Corps of Engineers have significant water-quality-management responsibilities. Both Federal agencies conduct water-quality monitoring and assessment programs, and both consider water quality in their reservoir operations

\section{SELECTED REFERENCES}

Alabama Department of Environmental Management, 1990, Water quality report to Congress for calendar years 1988 and 1989-The 305(b) re- port: Montgomery, Alabama Department of Environmental Management, $88 \mathrm{p}$.

Anderson, J.R., 1967, Major land uses in the United States, in U.S. Geological Survey, 1970, National atlas of the United States of America: Washington, D.C., U.S. Geological Survey, p. 158-159.

Britton, L.J., and Greeson, P.E., eds., 1987, Methods for collection and analysis of aquatic biological and microbiological samples: U.S. Geological Survey Techniques of Water-Resources Investigations, book 5, chap. A4, $363 \mathrm{p}$.

Church, M.R., Shaffer, P.W., Eshleman, K.N., and Rochelle, D.P., 1990, Potential future effects of current levels of sulfur deposition on stream chemistry in the Southern Blue Ridge Mountains, United States: Journal of Water, Air, and Soil Pollution, v. 50, p. 39-48.

Fenneman, N.M., 1946, Physical divisions of the United States: U.S. Geological Survey special map, scale 1:7,000,000.

Fishman, M.J., and Friedman, L.C., eds., 1989, Methods for the determination of inorganic substances in water and fluvial sediments: U.S. Geological Survey Techniques of Water-Resources Investigations, book 5, chap. A1, 545 p.

Hem, J.D., 1985, Study and interpretation of the chemical characteristics of natural water ( $3 d$ ed.): U.S. Geological Survey Water-Supply Paper 2254, $263 \mathrm{p}$.

Hirsch, R.M., Slack, J.R., and Smith, R.A., 1982, Techniques of trend analysis for monthly water quality data: Water Resources Research, v. 18, no. 1, p. 107-121.

Lanfear, K.J., and Alexander, R.B., 1990, Methodology to derive water-quality trends for use by the National Water Summary Program of the U.S. Geological Survey: U.S. Geological Survey Open-File Report 90-359, $10 \mathrm{p}$.

Puente, Celso, Newton, J.G., and Bingham, R.H., 1982, Assessment of hydrologic conditions in potential coal-lease tracts in the Warrior coal field, Alabama: U.S. Geological Survey Open-File Report 81-540, 43 p.

Schertz, T.L., and Hirsch, R.M., 1985, Trend analysis of weekly acid rain data--1978-83: U.S. Geological Survey Water-Resources Investigations Report 85-4211, 64 p.

Tennessee Valley Authority, 1989, Unpublished data in the computer files of the National Fertilizer Development Center of the Tennessee Valley Authority, Muscle Shoals, Alabama.

Thelin, G.P., and Pike, R.J., 1990, Digital shaded relief map of the conterminous United States: Menlo Park, Calif., U.S. Geological Survey digital image processing, scale 1:3,500,000.

U.S. Environmental Protection Agency, 1989, Unpublished data in computer files of the U.S. Environmental Protection Agency Aerometric Information Retrieval System, Research Triangle Park, North Carolina.

U.S. Geological Survey, 1986, National water summary 1985-Hydrologic events and surface-water resources: U.S. Geological Survey WaterSupply Paper $2300,506 \mathrm{p}$.

1990, National water summary 1987-Hydrologic events and water supply and use: U.S. Geological Survey Water-Supply Paper 2350 $553 \mathrm{p}$.

Ward, J.R., and Harr, C.A., eds., 1990, Methods for collection and processing of surface-water and bed-material samples for physical and chemical analyses: U.S. Geological Survey Open-File Report 90-140, 71 p. 
162 National Water Summary 1990-91-Stream Water Quality: STATE SUMMARIES

Prepared by Will S. Mooty

FOR ADDITIONAL INFORMATION: District Chief, U.S. Geological Survey, 520 19th Avenue, Tuscaloosa, AL 35401 


\section{Alaska Stream Water Quality}

Alaska constitutes about 16 percent of the total land area of the United States and contains about 40 percent of the Nation's surface-water resources (U.S. Geological Survey, 1986, p. 137). The Yukon, Kuskokwim, and Copper Rivers are among the 10 largest rivers in the United States (U.S. Geological Survey, 1990, p. 149). Annual precipitation ranges from about 5 inches on the Arctic Coastal Plain to about 300 inches in southeastern Alaska; much of the precipitation falls as snow. Glaciers and ice fields cover nearly 5 percent of the State (Post and Mayo, 1971).

Surface-water withdrawals in 1985 averaged 334 million gallons per day, which was 82.2 percent of the total offstream water use. Ground water supplied the remaining 17.8 percent. Most of the surface water was used for agriculture (43.9 percent) and industry and mining (37.5 percent). Fish hatcheries are the major agricultural users. Public water supply accounted for only 10.5 percent of offstream surface-water use (U.S. Geological Survey, 1990, p. 150, 154). Instream water is used mostly for commercial and recreational fisheries.
Surface-water quality can be affected by land use. Most of Alaska is covered by forest, woodland, tundra, and muskeg (fig. 1A); physiography (fig. $1 B$ ) and climate have limited human activity and its potential effects on water quality. Population in the State is sparse (fig. $1 C$ ); therefore, most of Alaska's streams are little affected by the point- and nonpoint-source pollution commonly associated with urban areas. Alaska's population increased from about 402,000 in 1980 to about 550,000 in 1990 (U.S. Bureau of the Census 1990 decennial census files). Increases were greatest in Fairbanks, Anchorage, and the Matanuska-Susitna Valley north of Anchorage.

Most of Alaska's streams contain water that is of suitable quality for all beneficial uses designated by the State for purposes of water-pollution control (Alaska Department of Environmental Conservation, 1990, p. 5), but glacier-fed streams can require treatment to remove suspended sediment. Also, local water-quality degradation caused by human activity or by natural causes can make water in some streams unsuitable for many uses.

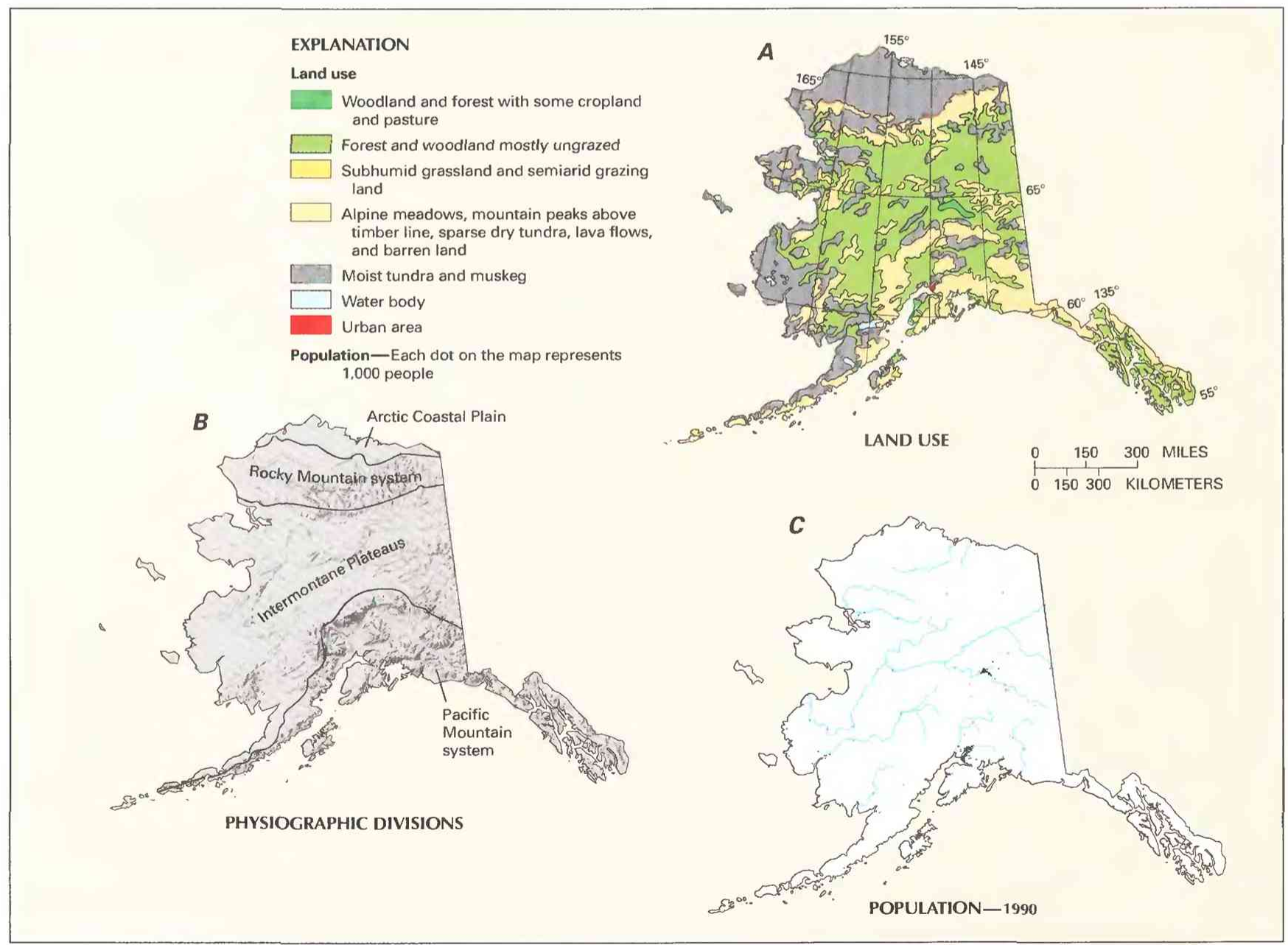

Figure 1. Land use, physiography, and population in Alaska. A, Major land uses. B, Physiographic divisions. C, Population distribution in $1990 . \quad$ (Sources: A, Major land uses modified from Anderson, 1967. B, Physiographic diagram from Harrison, 1969; divisions from Wahrhaftig. 1965; landforms from Thelin and Pike, 1990. C, Data from U.S. Bureau of the Census 1990 decennial census files.) 


\section{WATER-QUALITY MONITORING}

Water-quality data obtained from analyses of water samples collected at monitoring stations are stored in the U.S. Geological Survey's (USGS) National Water Information System and the U.S. Environmental Protection Agency's (EPA) national data base known as STORET. Water-quality and streamflow data are reported by water year-the 12 months from October 1 through September 30. A water year is identified by the calendar year in which it ends. For example, water year 1991 comprises October 1, 1990, through September 30 , 1991.

No long-term water-quality monitoring stations are operated on the Arctic Coastal Plain, in southwestern Alaska, on the Aleutian Islands, or near the major population centers of Anchorage, Fairbanks, or Juneau. The U.S. Geological Survey, as well as other Federal, State, and private agencies, collects water-quality data throughout Alaska for specific hydrologic investigations, which usually are of short duration. High costs associated with water-quality monitoring in Alaska are a major factor affecting the scope of longterm collection of data.

The data used in this summary of Alaska's stream water quality were obtained from water samples collected at six monitoring stations at which data collection is systematic and continuing (fig. 2). All stations were sampled at approximately uniform time intervals when weather permitted; from late fall to early spring, dangerous ice conditions and extreme weather make it impossible to collect waterquality and streamflow data safely from most of Alaska's large rivers. Analyses of water samples collected at the six stations are the basis for the discussion and graphic summary (fig. 3) of stream waterquality conditions during water years 1987-89 and for the discussion and graphic summary (fig. 4) of stream water-quality trends. Water samples were collected and analyzed by using standard methods approved by the USGS (Britton and Greeson, 1987; Fishman and Friedman, 1989; Ward and Harr, 1990) or by using equivalent methods. If a method of sample collection or analysis changed over time, data from an analysis were included in the evaluation of recent stream

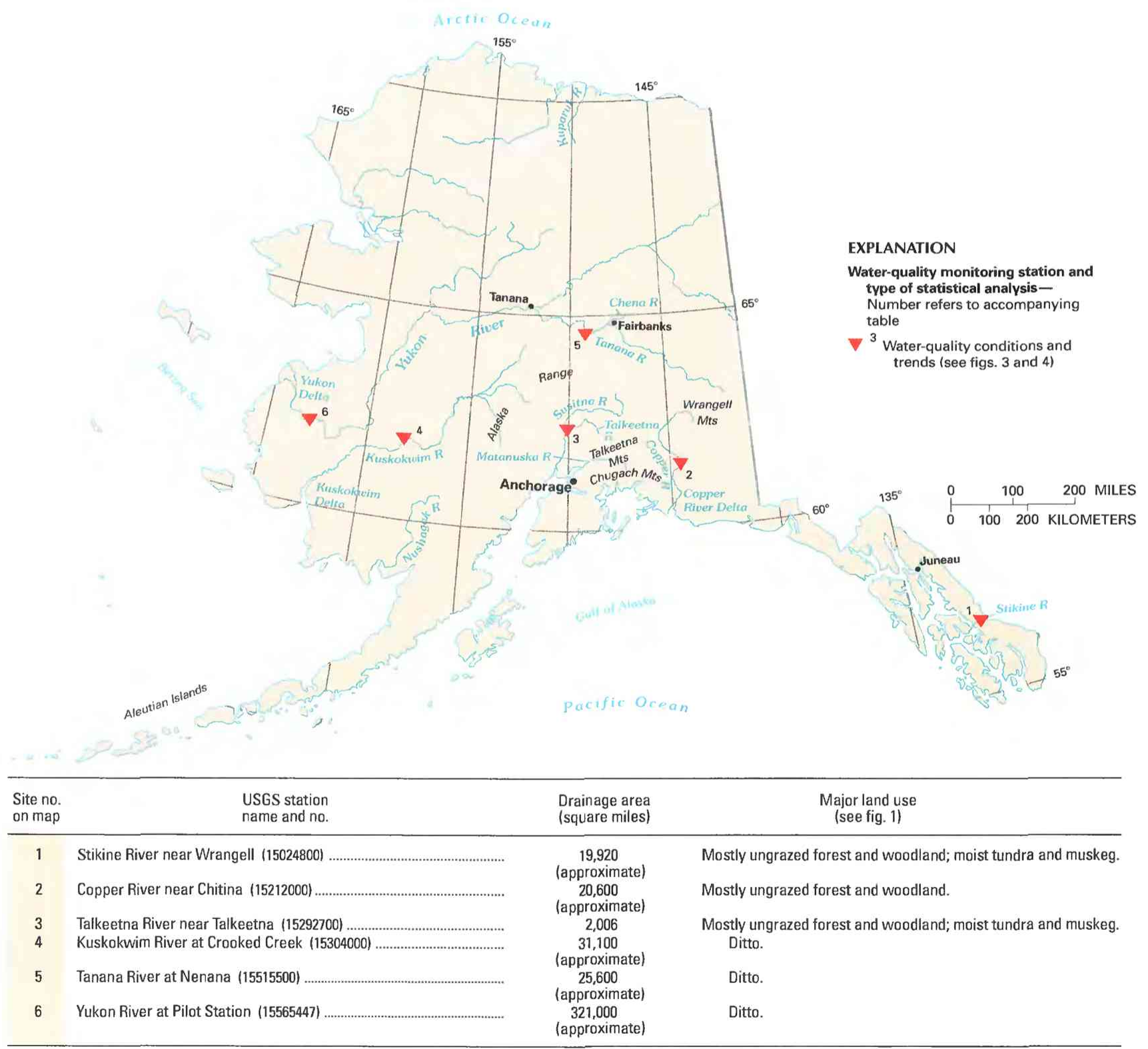

Figure 2. Selected water-quality monitoring stations, type of statistical analysis, and geographic features in Alaska. (Sources: Major land uses modified from Anderson, 1967; other data from U.S. Geological Survey files.) 
water quality or of stream water-quality trends only if the change in method did not affect the comparability of the data.

\section{WATER-QUALITY CONDITIONS}

Water quality has been identified as "impaired" in 29 streams and is "suspected of being affected" in 122 streams by point- and nonpoint-pollution sources (Alaska Department of Environmental Conservation, 1990). Major pollution sources include urban development, mining, oil and gas development and transportation, and timber harvesting. The six rivers discussed in this report are not on the Department's "impaired" list, but many of the tributaries to these rivers are on the list.

The following discussion of stream water quality in Alaska is organized by river basin (fig. 3). Graphs in figure 3 summarize certain aspects of stream water quality in the basins for water years 1987-89. The graphs show frequency distributions of data values that represent concentrations of selected constituents in stream water and measurements of selected physical properties of stream water. These constituents and properties are fecal coliform bacteria, alkalinity (as calcium carbonate), dissolved sulfate, dissolved solids, dissolved nitrite plus nitrate (as nitrogen), dissolved barium, and suspended sediment. The data are reported in colonies per 100 milliliters (col/ $100 \mathrm{~mL})$, milligrams per liter $(\mathrm{mg} / \mathrm{L})$, and micrograms per liter $(\mu \mathrm{g} /$ L). Sources and environmental significance of each constituent and property are described in table 1 .

Water quality at each monitoring station is the result of geological, chemical, biological, and hydrologic processes that occur over a large area. Water-quality problems that affect aquatic life or public health only locally are not fully represented in this summary.

All concentrations of dissolved sulfate, dissolved solids, dissolved nitrite plus nitrate, and dissolved barium at the six monitoring stations met State water-quality standards. State standards require that suspended-sediment concentrations not exceed those of "natural conditions" (Alaska Department of Environmental Conservation, 1989). Suspended-sediment concentrations can differ markedly among reaches of the same river and are affected by tributary inflow and degree of mixing. The concentrations also can differ seasonally, especially in glacier-fed rivers, where suspended-sediment concentrations are much higher in summer than in winter. Because of these factors, natural conditions are difficult to determine and must be established on a case-by-case basis (Mary Maurer, Alaska Division of Geological and Geophysical Surveys, oral commun., 1991). Natural conditions have not been determined for reaches upstream from the six monitoring stations identified in this report, but water-quality conditions in those reaches probably approximate natural conditions because the drainage basins upstream from these stations are large and mostly undisturbed.

\section{STIKINE RIVER}

The Stikine River originates in British Columbia, Canada, and flows through southeastern Alaska to the Pacific Ocean; more than 95 percent of the drainage basin is in Canada. For much of its length, the Stikine River flows over volcanic and intrusive rocks. Forest, woodland, moist tundra, and muskeg cover most of the basin upstream from site 1; glaciers cover about 10 percent. The basin is sparsely populated. Some mining and logging activity in the upper basin may adversely affect tributary streams, but these streams contribute only a small fraction of the total streamflow at site 1 .

Median values of alkalinity $(45 \mathrm{mg} / \mathrm{L})$, sulfate $(11 \mathrm{mg} / \mathrm{L})$, dissolved solids $(58 \mathrm{mg} / \mathrm{L})$, and nitrite plus nitrate $(0.10 \mathrm{mg} / \mathrm{L})$ for site 1 were among the smallest for the six monitoring stations (fig. 3 ). The small concentrations of dissolved minerals are characteristic of most water from regions underlain by intrusive and volcanic rocks (Davis and DeWiest, 1966) and also reflect the limited effects of human activity in the Stikine River basin.

\section{COPPER RIVER}

The Copper River, which originates in the Alaska Range and the Chugach and Wrangell Mountains, flows southward to the Gulf of Alaska. The river is fed by several glaciers and flows across diverse volcanic and sedimentary rocks and loess deposits. Glaciers cover about 17 percent of the basin upstream from site 2 . At least eight glacier-dammed lakes larger than $0.04 \mathrm{mi}^{2}$ (square mile) and numerous smaller lakes are located upstream from site 2 (Post and Mayo, 1971). Frequent lake-outburst floods result in channel scour and significantly increased sediment loads (Emery and others, 1985). Population in the basin is sparse, and there are only a few small towns. The Copper River Delta is an important nesting area for many species of migratory waterfowl, including trumpeter swans and Canada geese.

The median concentration of suspended sediment at site 2 (555 $\mathrm{mg} / \mathrm{L}$ ) was the second largest for the six monitoring stations (fig. 3). Sediment sources include mass movement of steep mountain slopes, glaciolacustrine deposits (Reimnitz, 1966, p. 43), sudden release of glacier-dammed lakes, and sliding of lacustrine deposits as a result of earthquakes (S.H. Jones, U.S. Geological Survey, written commun., 1991). Another major source of suspended sediment is glacier-fed streams. As glaciers move, they grind and pulverize rocks and assimilate much of the resulting fine particulate matter. As the glacial ice melts, the sediments are released to the streams.

\section{TALKEETNA RIVER}

The Talkeetna River originates in the Talkeetna Mountains and is tributary to the Susitna River. The basin lies within the Pacific Mountain System. Volcanic, intrusive, and sedimentary rocks underlie the Talkeetna River basin. Most of the basin is covered by forest, woodland, moist tundra, and muskeg. Although there are no towns or villages upstream from site 3, the river has extensive summer recreational use. Site 3 is part of the U.S. Geological Survey's Hydrologic Bench-Mark Network. This nationwide monitoring network provides reliable baseline data on hydrologic and water-quality conditions in representative undeveloped watersheds that can be used to compare and contrast conditions in basins more obviously affected by human activities.

Median values of alkalinity $(31 \mathrm{mg} / \mathrm{L})$, sulfate $(8.3 \mathrm{mg} / \mathrm{L})$, dissolved solids $(58 \mathrm{mg} / \mathrm{L})$, and barium $(10 \mu \mathrm{g} / \mathrm{L})$ for water samples collected from the Talkeetna River at site 3 were as small or smaller than those for the other monitoring stations (fig. 3). The small concentrations are to be expected because human activity is much less in the Talkeetna River basin upstream from site 3 than in the other five river basins discussed in this report. The median nitrite plus nitrate concentration $(0.16 \mathrm{mg} / \mathrm{L})$ was the largest of those for the six monitoring stations but still was very small. The basin contains numerous bogs and small, shallow lakes that have no obvious inlets or outlets (Dean, 1980, p. 6) and that may contribute nitrite and nitrate to the Talkeetna River through ground-water seepage.

\section{KUSKOKWIM RIVER}

The Kuskokwim River originates in the Alaska Range (fig. 2) and flows southwestward to the Bering Sea. The river flows through forest, woodland, moist tundra, and muskeg of the Intermontane Plateaus, which are underlain by diverse sedimentary and intrusive rocks and alluvial deposits. Glaciers occupy less than 2 percent of the basin. The inhabitants of the several small towns and villages on the banks of the Kuskokwim River upstream from site 4 depend on the river for transportation and subsistence fishing. Some placer mining occurs in the upper river basin. The Kuskokwim Delta is a prime waterfowl habitat and, combined with the Yukon Delta, is third on the U.S. Fish and Wildlife Service's "major concern" list for the Nation's waterfowl nesting grounds (Tiner, 1984). 
The median concentration of fecal coliform bacteria in the Kuskokwim River at site $4(15 \mathrm{col} / 100 \mathrm{~mL})$ was the largest for the six monitoring stations (fig. 3). Most villages in this region and elsewhere have no sewage-treatment facilities. Human waste is disposed of in the river, on the land surface, or in shallow lagoons that serve as holding rather than treatment facilities (Alaska Department of Environmental Conservation, 1990, p. 58). Several tributaries upstream from site 4 are on the "impaired" or "suspected" list of streams affected by point- and nonpoint-source pollution (Alaska Department of Environmental Conservation, 1990, apps. I and II). The median barium concentration at site $4(41 \mu \mathrm{g} / \mathrm{L})$ was among the largest of those for the six monitoring stations. Barium concentrations were larger in the river basins having substantial alluvial and glacial deposits (sites 4, 5, and 6) but nonetheless were far lower than the State dissolved-barium standard of $1,000 \mu \mathrm{g} / \mathrm{L}$ (Alaska Department of Environmental Conservation, 1989). The median concentration of suspended sediment at site $4(103 \mathrm{mg} / \mathrm{L})$ was the smallest of those for the six monitoring stations. Much of the inflow upstream from site 4 is not directly derived from glacial meltwater, so the suspended- sediment contribution is small. The Kuskokwim River has the smallest stream gradient (1.14 feet per mile) of the six rivers discussed here; consequently, it is least able to transport coarse sediment.

\section{TANANA RIVER}

The Tanana River flows from the Alaska Range and several smaller mountain ranges within the Intermontane Plateaus and joins the Yukon River near the village of Tanana. The Tanana River basin is underlain by alluvial, glacial, and eolian deposits and igneous and metamorphic rocks. Forest, woodland, moist tundra, and muskeg cover most of the basin; glaciers occupy about 6 percent. Fairbanks and several small villages lie along the Tanana River upstream from site 5. Placer mining, gravel extraction, agriculture, land developmeni, and runoff from roads have degraded the water quality of several tributaries sufficiently to warrant their placement on the "impaired" or "suspected" list of streams affected by point- and nonpoint-source pollution (Alaska Department of Environmental Conservation, 1990). The Chena River (tributary to the Tanana) is
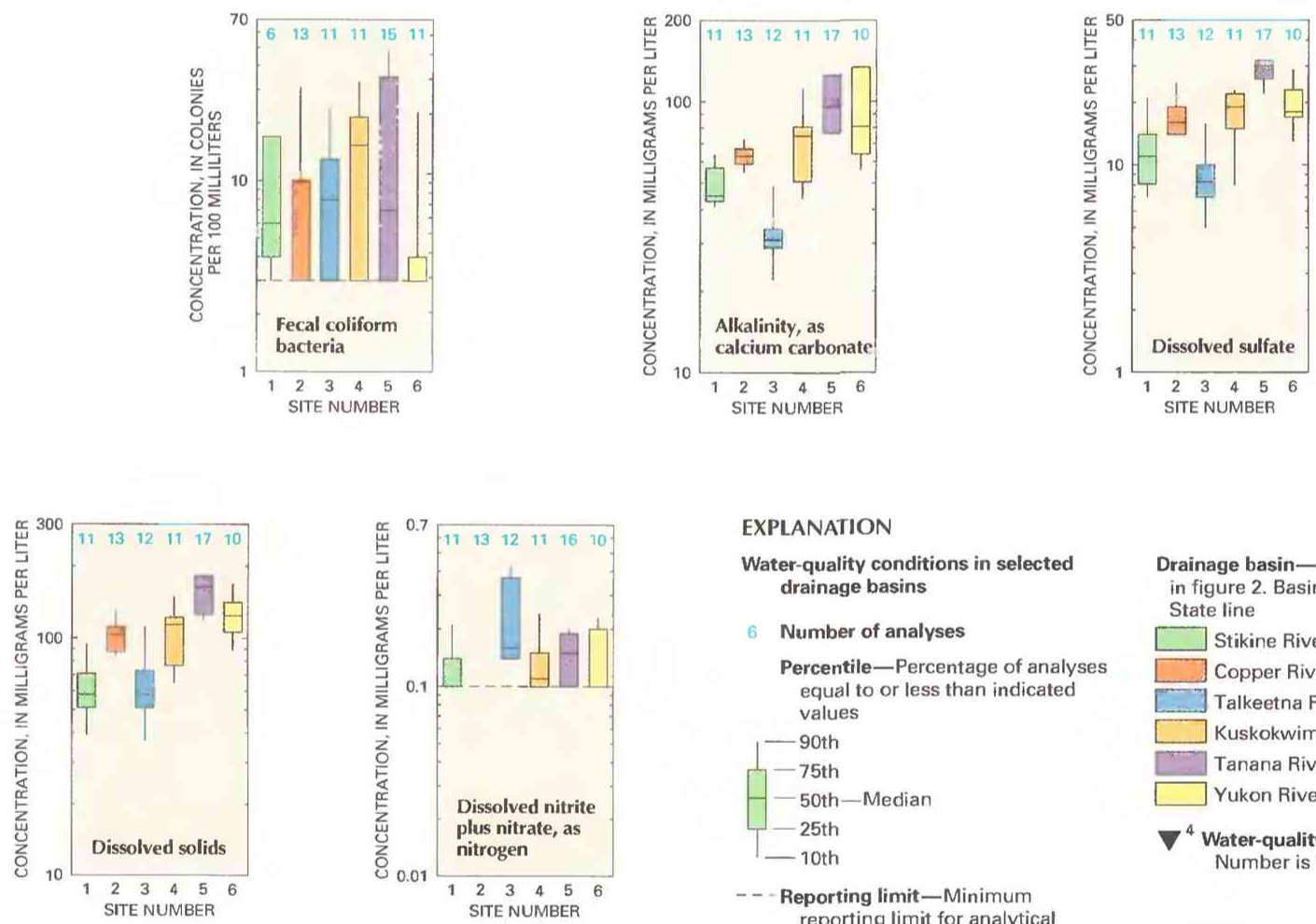

\section{EXPLANATION}

\begin{tabular}{|c|c|}
\hline & $\begin{array}{l}\text { ter-quality conditions in selected } \\
\text { drainage basins }\end{array}$ \\
\hline 6 & Number of analyses \\
\hline & $\begin{array}{l}\text { Percentile-Percentage of analyses } \\
\text { equal to or less than indicated } \\
\text { values }\end{array}$ \\
\hline & -90 th \\
\hline & -75 th \\
\hline & -50th-Median \\
\hline & -25 th \\
\hline & -10 th \\
\hline & $\begin{array}{l}\text { Reporting limit-Minimum } \\
\text { reporting limit for analytical } \\
\text { method used. Data below limit } \\
\text { line not shown }\end{array}$ \\
\hline
\end{tabular}

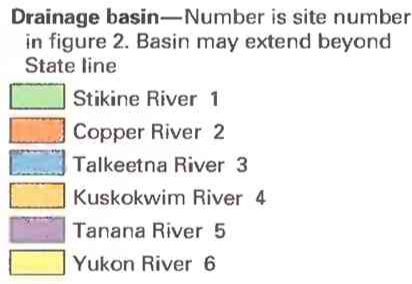

$\nabla^{4}$ Water-quality monitoring stationNumber is site number in figure 2

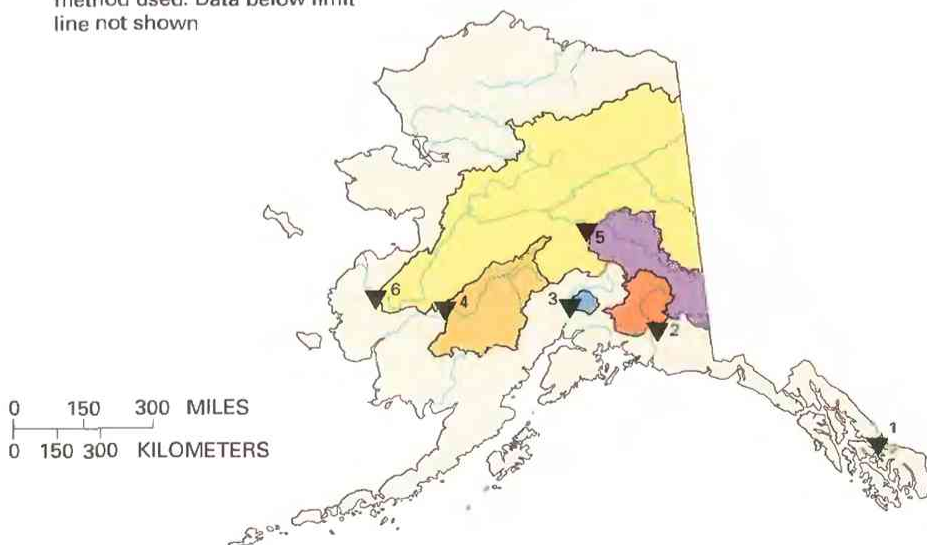

Figure 3. Water quality of selected streams in Alaska, water years 1987-89. (Source: Data from U.S. Geological Survey files.) 
listed as "impaired" in Fairbanks because of pollution from several sources.

Median values of alkalinity $(96 \mathrm{mg} / \mathrm{L})$, sulfate $(30 \mathrm{mg} / \mathrm{L})$, dissolved solids ( $163 \mathrm{mg} / \mathrm{L})$, nitrite plus nitrate $(0.15 \mathrm{mg} / \mathrm{L})$, barium $(40 \mu \mathrm{g} / \mathrm{L})$, and suspended sediment $(602 \mathrm{mg} / \mathrm{L})$ in the Tanana River at site 5 were the largest or among the largest for the six monitoring stations (fig. 3). Large alkalinity values are directly related to the geology of the basin, which is underlain by limestone and calciumrich metamorphic rocks. Large sulfate concentrations probably result naturally from oxidation of sulfide minerals but also might have resulted from placer mining and land-development activities. The large nitrite plus nitrate concentrations could have resulted from agricultural runoff but also might be natural. Large concentrations of nitrate have been found in ground water in nonagricultural areas near Fairbanks (Johnson and others, 1978). Large suspended-sediment concentrations in the Tanana River are caused primarily by melting glaciers.

\section{YUKON RIVER}

The Yukon River, which originates in Canada and flows to the Bering Sea, is the longest river in Alaska and the third longest in the United States. The river drains about $321,000 \mathrm{mi}^{2}$ upstream from site 6 . The complex geology of the Yukon River basin includes a variety of intrusive, volcanic, metamorphic, and sedimentary rocks and alluvial and glacial deposits. Forest, woodland, dry and moist tundra, and muskeg cover most of the basin; glaciers occupy less than 2 percent. The Canadian towns of Dawson and Whitehorse, as well as Fairbanks and many villages, are located along either the Yukon River or its tributaries. Residents depend on the river for transportation and subsistence fishing. Several tributaries upstream from site 6 are on the "impaired" or "suspected" list of streams affected by point- and nonpoint-source pollution (Alaska Department of Environmental Conservation, 1990, apps. I and II). Pollution sources include placer mining, gravel extraction, urban runoff, land development. and agriculture.

Median concentrations of fecal coliform bacteria $(3 \mathrm{col} / 100$ $\mathrm{mL})$ and nitrite plus nitrate $(0.10 \mathrm{mg} / \mathrm{L})$ in the Yukon River at site 6 were among the smallest of those for the six monitoring stations (fig. 3). The Tanana River, a major tributary, had large median con- centrations of these constituents but accounts for only about 11 percent of the streamflow at site 6 . The median barium concentration $(44 \mu \mathrm{g} / \mathrm{L})$ was the largest for the six monitoring stations but was much smaller than the State dissolved-barium standard of $1,000 \mu \mathrm{g} / \mathrm{L}$.

\section{WATER-QUALITY TRENDS}

Trend analysis is a statistical procedure used to detect changes in stream water quality at a monitoring station over time. For this report, water-quality data from six monitoring stations (fig. 2) were analyzed for trends by using the seasonal Kendall test (Hirsch and others, 1982), a method used extensively by the USGS. The graph (shown below) of the dissolved-barium concentration in the Yukon River at site 6 illustrates the trend inferred from the concentration data.

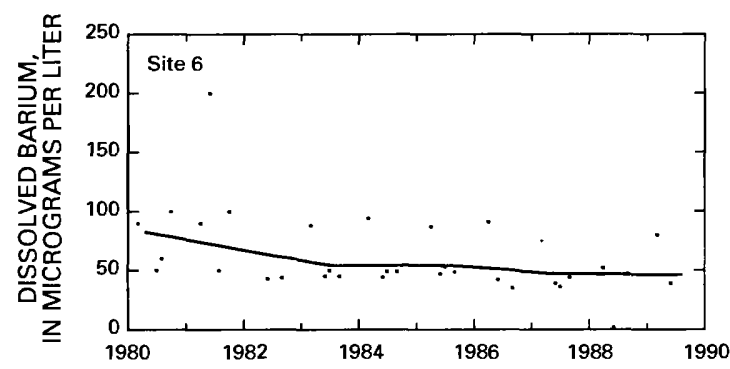

When possible, constituent-concentration data were adjusted for changes in streamflow to preclude identifying a trend in concentration that was caused only by a trend in streamflow. The data were not adjusted when (1) more than 10 percent of the samples had concentrations less than the minimum reporting limit for the analytical method used or (2) the streamflow was controlled substantially by human activities. When the concentration data could not be adjusted for streamflow, trends were determined directly from the concentration data.

Statewide trends in concentrations of selected constituents in stream water and in measurements of selected physical properties of stream water are shown on maps in figure 4. On each map, a trend

Table 1. Sources and environmental significance of selected water-quality constituents and properties

[Source: Compiled by the U.S. Geological Survey, Office of Water Quality]

Constituent or property Common sources Environmental significance

\begin{abstract}
Fecal coliform bacteria .............. Sources include effluent from sewage-treatment plants and runoff from pastures, feedlots, and urban areas.

Alkalinity (property) ................. A measure of the quantity of acid-neutralizing substances; can be affected by geologic setting, industrial wastewater discharge, waste gases, and runoff from surface mining.

Sulfate

Occurs in some rocks; also in mine runoff, industrial wastewater discharge, and atmospheric deposition.
\end{abstract}

Dissolved solids

Nitrite plus nitrate

A result of rock weathering; also in agricultural runoff and industrial discharge.

Nonpoint sources are agricultural and urban runoff; a major point source is wastewater discharge.

Barium .

Suspended sediment
Occurs in some rocks; also in mine runoff and wastewater discharge.

A result of rock erosion; also induced by disturbances of land cover due to fires, floods, and human activities such as mining, logging, construction, and agriculture.
Presence indicates contamination of water by wastes from humans and other warm-blooded animals.

Sufficiently alkaline water can be unsuitable for some agricultural and industrial uses.

Concentrations exceeding a natural, background level indicate contamination from human activity; in sufficient quantity, can cause water to be unsuitable for public supply; can harm aquatic organisms.

In sufficient quantity, can cause water to be unsuitable for public supply, agriculture, and industry; can harm aquatic organisms.

Plant nutrient that, in sufficient quantity, can cause algal blooms and excessive growth of higher aquatic plants in bodies of water; can cause water to be unsuitable for public supply.

Toxic in larger than trace concentrations; can cause water to be unsuitable for public supply.

Can be detrimental to aquatic organisms; can fill reservoirs and impair recreational use of water. 

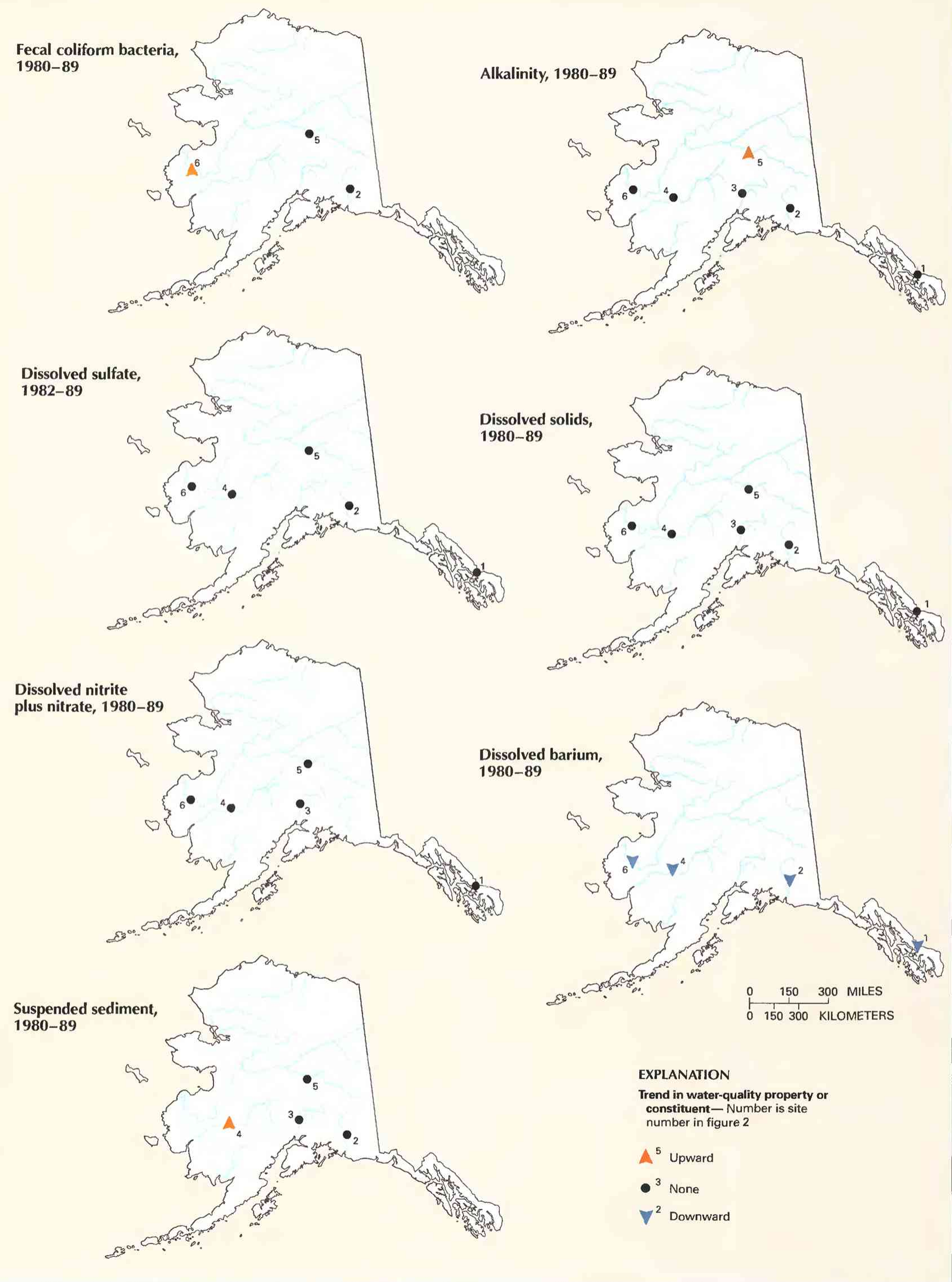

Figure 4. Trends in water quality of selected streams in Alaska, by water years. (Source: Data from U.S. Geological Survey files.) 
is indicated at a monitoring station only if the data from that station were suitable for use in the trend analysis. For more information on the suitability criteria and on the trend-analysis procedure used for this report, see Lanfear and Alexander (1990).

\section{FECAL COLIFORM BACTERIA}

Fecal coliform bacteria are used as indicators of fecal contamination from humans and other warm-blooded animals. Such contamination can introduce disease-causing viruses and bacteria into a stream.

The upward trend in fecal coliform bacteria concentrations at site 6 might be attributable to a population increase in villages along the Yukon River; little was done to improve wastewater treatment during the 1980-89 period (Alaska Department of Environmental Conservation, 1990). However, reliable population-change data are not available owing to changes in census boundaries. The trend probably was not caused by additional pollution from Fairbanks because no significant increase was detected in the Tanana River downstream from Fairbanks at site 5.

\section{ALKALINITY}

Alkalinity is a measure of the capacity of the substances dissolved in water to neutralize acid. In most natural waters, alkalinity is produced mainly by bicarbonate and carbonate (Hem, 1985, p. 106), which are ions formed when carbon dioxide or carbonate rock dissolves in water. Alkalinity had an upward trend for 1980-89 in the Tanana River at site 5 (fig. 4) for unknown reasons.

\section{DISSOLVED SULFATE}

The major natural sources of sulfate in streams are rock weathering, volcanoes, and biochemical processes (Hem, 1985, p. 113). Human activities such as mining, waste discharge, and fossil-fuel combustion also can be important sources. A shortened trend-analysis period was used for sulfate because data from analyses performed before water year 1982 are not comparable to data from subsequent years.

Sulfate concentrations had no trend at the five monitoring stations from which data were suitable for trend analysis (fig. 4). The principal factor affecting sulfate concentration in the five rivers is the geology of the drainage basins.

\section{DISSOLVED SOLIDS}

Dissolved solids in stream water result primarily from rock weathering but also can be introduced as a byproduct of human activities (table 1). Concentrations generally are greatest in streams draining basins underlain by rocks and soils that contain easily dissolved minerals.

Dissolved-solids concentrations had no trend for $1980-89$ at the six monitoring stations having data that were suitable for trend anlysis (fig. 4). Concentrations of selected major inorganic constituents of dissolved solids (calcium, magnesium, sodium, chloride, potassium, and silica) also had no trend at any of the six stations (trends analyzed but not shown).

\section{DISSOLVED NITRITE PLUS NITRATE}

Nitrite and nitrate are oxidized forms of nitrogen that together normally constitute most of the dissolved nitrogen in well-aerated streams. Nitrite readily oxidizes to nitrate in natural waters; therefore, nitrate generally is by far the more abundant of the two (Hem, 1985, p. 124).

Nitrite plus nitrate concentrations had no trend for $1980-89$ at the five monitoring stations having data that were suitable for trend analysis (fig. 4). The Tanana River at site 5 had no trend despite a decrease in crop production in the basin. Concentrations in the remaining four rivers probably were near natural, background concentrations because of substantial dilution by water unaffected by human activity.

\section{DISSOLVED BARIUM}

Barium, a common constituent of igneous rock, is the only trace metal that had concentrations greater than its minimum reporting limit $(2 \mu \mathrm{g} / \mathrm{L})$ at all six monitoring stations (fig. 3). Barium concentrations had downward trends for 1980-89 in the Stikine River at site 1, the Copper River at site 2, the Kuskokwim River at site 4, and the Yukon River at site 6 (fig. 4). However, the magnitude of the trend was small at each monitoring station. The reason for these downward trends is not known.

\section{SUSPENDED SEDIMENT}

Suspended sediment is a product of erosion. The erosion can be either natural or the result of land-cover disturbances related to human activities (table 1). In Alaska, glaciers are major agents of erosion.

Suspended-sediment concentrations trended upward during 1980-89 in the Kuskokwim River at site 4 (fig. 4). The small increase in concentrations might have been caused by increased mining activity and receding glaciers in the Kuskokwim River basin.

\section{WATER-QUALITY MANAGEMENT}

The Alaska Department of Environmental Conservation (ADEC) enforces the water-quality standards established in Title 18, Chapter 70 of the Alaska Administrative Code (Alaska Department of Environmental Conservation, 1989). The standards identify the limits of allowable pollutant concentrations for the designated uses of drinking water, food processing, agriculture, aquaculture, industry, water recreation, wildlife, and growth and propagation of fish, shellfish, and other aquatic life. State water-quality standards differ among designated uses, but State law requires that stream water be maintained for all uses. Designated-use categories are designed so that specific water bodies can be reclassified to exclude other uses. This provision is necessary to allow uses such as placer mining (David Sturdevant, Alaska Department of Environmental Conservation, oral commun., August 1990). The Alaska Department of Fish and Game, through Alaska Statutes 16.05.840 and 16.05.870, has permit jurisdiction over activities that could affect fish (Alaska Department of Fish and Game, 1990).

The ADEC prepares a water-quality assessment report (Alaska Department of Environmental Conservation, 1990) that is submitted biennially to the EPA and the U.S. Congress pursuant to section 305(b) of the Federal Clean Water Act. The ADEC also is responsible for developing the Alaska Nonpoint Source Pollution Assessment and Management Program.

The USGS maintains the only long-term stream water-qualitymonitoring network in Alaska. This network is confined to the larger rivers and does not monitor local sources of pollution. The network has declined in size because data collection at monitoring stations on the Susitna, Nushagak, and Kuparuk Rivers has been discontinued owing to budgetary constraints. The USGS, in cooperation with the U.S. Forest Service, has recently (1985 to the present) increased water-quality monitoring in streams affected by mine drainage near Juneau and in other streams in southeastern and south-central Alaska.

\section{SELECTED REFERENCES}

Alaska Department of Environmental Conservation, 1989, Water quality standards, 18-AAC-70 [Alaska]: Juneau, Alaska Department of Environmental Conservation, $37 \mathrm{p}$. 
1990, Alaska water quality assessment 1990 - Section 305(b) report to the Environmental Protection Agency: Juneau, Alaska Department of Environmental Conservation, $125 \mathrm{p}$.

Alaska Department of Fish and Game, 1990, Fish habitat permit (AS 16.05.840 and AS 16.05.70) [Alaska]: Juneau, Alaska Department of Fish and Game, Habitat Division, 1 p.

Anderson, J.R., 1967, Major land uses in the United States, in U.S. Geological Survey, 1970, National atlas of the United States of America: Washington, D.C., U.S. Geological Survey, p. 158-159.

Britton, L.J., and Greeson, P.E., eds., 1987, Methods for collection and analysis of aquatic biological and microbiological samples: U.S. Geological Survey Techniques of Water-Resources Investigations, book 5, chap. A4, $363 \mathrm{p}$

Davis, S.N., and DeWiest, R.J.M., 1966, Hydrogeology: New York, Wiley, $463 \mathrm{p}$.

Dean, K.G., 1980, Surficial geology of the Susitna-Chulitna River area, Alaska - part I, text: Fairbanks, University of Alaska, 35 p.

Emery, P.A., Jones, S.H., and Glass, R.L., 1985, Water resources of the Copper River basin, Alaska: U.S. Geological Survey Hydrologic Investigations Atlas HA-686, scale 1:1,000,000.

Fishman, M.J., and Friedman, L.C., eds., 1989, Methods for the determination of inorganic substances in water and fluvial sediments: U.S. Geological Survey Techniques of Water-Resources Investigations, book 5, chap. A1, 545 p.

Harrison, R.E., 1969, Shaded relief map of Alaska, in U.S. Geological Survey, 1970, National atlas of the United States of America: Washington, D.C., U.S. Geological Survey, p. 58.

Hem, J.D., 1985, Study and interpretation of the chemical characteristics of natural water (3d ed.): U.S. Geological Survey Water-Supply Paper 2254 , $263 \mathrm{p}$.

Hirsch, R.M., Slack, J.R., and Smith, R.A., 1982, Techniques of trend analysis for monthly water quality data: Water Resources Research, v. 18 , no. 1, p. 107-121.
Johnson, P.R., Wilcox, D.E., Morgan, W.D., and others, 1978, Arsenic, nitrate, iron, and hardness in ground water, Fairbanks area, Alaska: U.S. Geological Survey Open-File Report 78-1034.

Lanfear, K.J., and Alexander, R.B., 1990, Methodology to derive water-quality trends for use by the National Water Summary Program of the U.S. Geological Survey: U.S. Geological Survey Open-File Report 90-359, $10 \mathrm{p}$.

Post, Austin, and Mayo, L.R., 1971, Glacier dammed lakes and outburst floods in Alaska: U.S. Geological Survey Hydrologic Investigations Atlas HA455 , scale $1: 1,000,000$.

Reimnitz, Erk, 1966, Late Quaternary history and sedimentation of the Copper River Delta and vicinity, Alaska: San Diego, University of California, Ph.D. dissertation, $160 \mathrm{p}$.

Thelin, G.P., and Pike, R.J., 1990, Digital shaded relief map of the conterminous United States: Menlo Park, Calif., U.S. Geological Survey digital image processing, scale 1:3,500,000.

Tiner, R.W., Jr., 1984, Wetlands of the United States - Current status and recent trends: Newton Corner, Mass., U.S. Fish and Wildlife Service, National Wetlands Inventory, $57 \mathrm{p}$.

U.S. Geological Survey, 1986, National water summary 1985-Hydrologic events and surface-water resources: U.S. Geological Survey Water-Supply Paper 2300, 506 p.

1990, National water summary 1987 - Hydrologic events and water supply and use: U.S. Geological Survey Water-Supply Paper 2350, $553 \mathrm{p}$.

Wahrhaftig, Clyde, 1965, Physiographic divisions of Alaska: U.S. Geological Survey Professional Paper 482, 52 p.

Ward, J.R., and Harr, C.A., eds., 1990, Methods for collection and processing of surface-water and bed-material samples for physical and chemical analyses: U.S. Geological Survey Open-File Report 90-140, 71 p.

Prepared by Ronald L. Rickman

FOR ADDITIONAL INFORMATION: District Chief, U.S. Geological Survey, 4230 University Drive, Suite 201, Anchorage, AK $99508-4664$ 


\section{ARIZONA Stream Water Quality}

Surface water is one of Arizona's most valuable natural resources. Adequate water supplies of acceptable quality are essential to the State's economy. The principal water use in Arizona is irrigation. About 87 percent of the total freshwater withdrawals from surface-water and ground-water supplies is used to irrigate nearly 1 million acres of crops in the southern and western parts of the State (Valley National Bank of Arizona, 1989, p. 43; fig. 1A). In the Tucson and Phoenix metropolitan areas, public and industrial water uses predominate.

In 1985, surface water supplied about 52 percent $(3,330$ million gallons per day) of total freshwater withdrawals. Of the surface water used, about 92 percent was used for agriculture and about 7 percent for public supply (U.S. Geological Survey, 1990, p. 159).

Annual precipitation ranges from about 5 inches in the Basin and Range Lowlands water province of southern Arizona (fig. $1 B$ ) to about 25 inches in the mountains of the Central Highlands water province (Sellers and Hill, 1974). More than 95 percent of the precipitation that falls on the State evaporates or is transpired by plants (Harshbarger and others, 1966, p. 5). Because precipitation varies greatly geographically and from year to year, annual streamflow volumes also are variable.

The demand for water differs among areas and by type of water use. Arizona has developed a system of reservoirs, canals, and aqueducts for the storage and transfer of surface water to meet seasonal water demands and to decrease the volume of ground water pumped in the central parts of the State.
In 1990, the population of Arizona was 3.7 million-an increase of about 35 percent since 1980 (U.S. Bureau of the Census 1990 decennial census files). Most of the population is concentrated in Phoenix and Tucson (figs. $1 C$ and 2). About 1.2 million people relied on surface-water sources for their water supply in 1985 (Solley and others, 1988). As Arizona's population continues to increase, so will the demand for water of suitable quality for municipal and industrial supplies.

\section{WATER-QUALITY MONITORING}

Water-quality data obtained from analyses of water samples collected at monitoring stations are stored in the U.S. Geological Survey's (USGS) National Water Information System and the U.S. Environmental Protection Agency's (EPA) national data base known as STORET. Water-quality and streamflow data are reported by water year - the 12 months from October I through September 30. A water year is identified by the calendar year in which it ends. For example, water year 1991 comprises October 1, 1990, through September 30, 1991.

The data used in this summary of Arizona's stream water quality were obtained from water samples collected at 13 monitoring stations at which data collection is systematic and continuing (fig. 2 ). Analyses of water samples collected at 10 stations are the basis for the discussion and graphic summary (fig. 3) of stream waterquality conditions during water years $1987-89$, and data from all 13

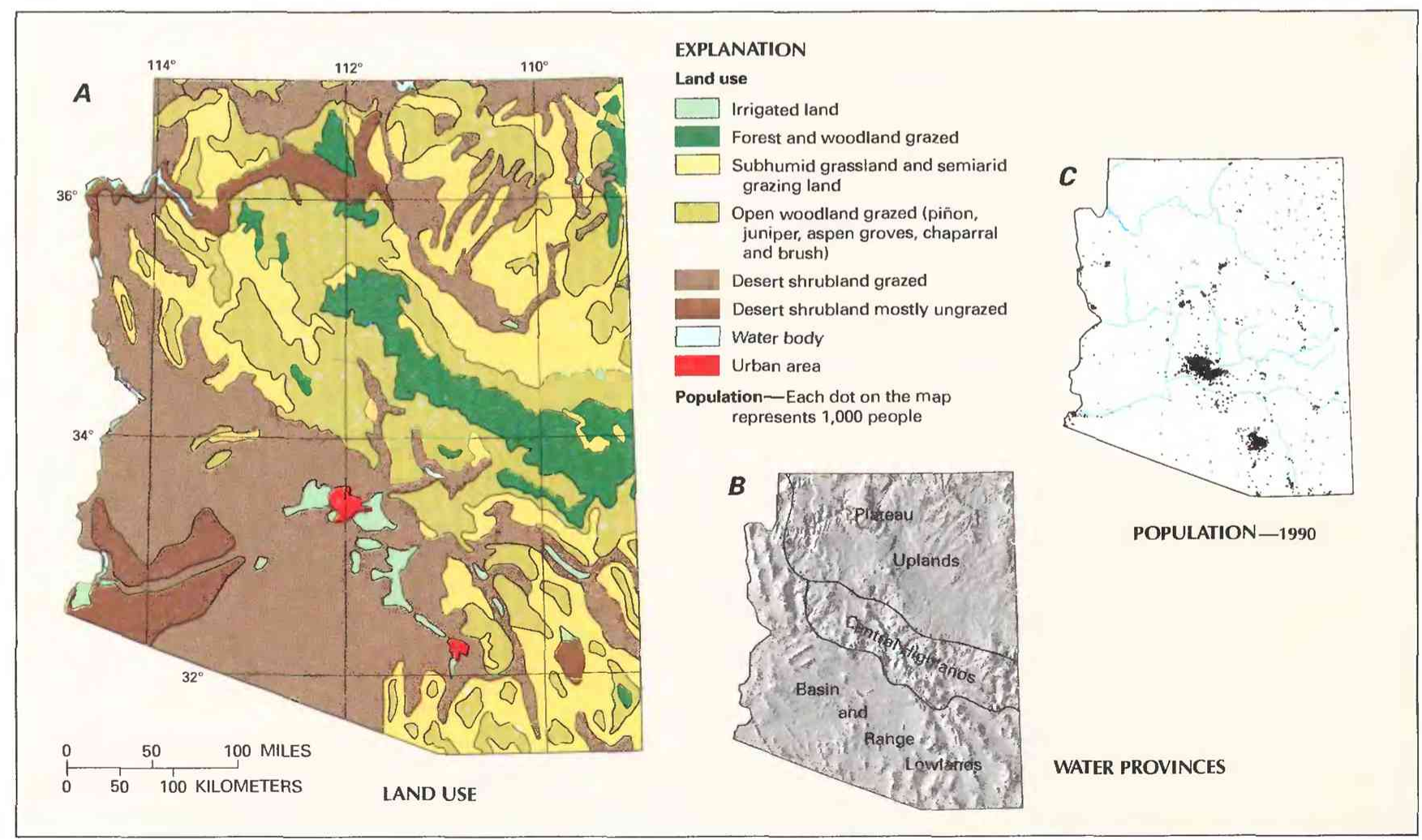

Figure 1. Land use, physiography, and population in Arizona. A, Major land uses. B, Water provinces. C, Population distribution in 1990. (Sources: A. Major land uses modified from Anderson, 1967. B, Water provinces from White and others, 1961; landforms from Thelin and Pike, 1990. C, Data from U.S. Bureau of the Census 1990 decennial census files.) 
stations are the basis for the discussion and graphic summary (fig. 4) of stream water-quality trends. Water samples were collected and analyzed by using standard methods approved by the USGS (Britton and Greeson, 1987; Fishman and Friedman, 1989; Ward and Harr, 1990 ) or by using equivalent methods. If a method of sample collection or analysis changed over time, data from an analysis were included in the evaluation of recent stream water quality or of stream water-quality trends only if the change in method did not affect the comparability of the data.

\section{WATER-QUALITY CONDITIONS}

Water quality can determine the potential uses of water and can be as important as the quantity of the supply for municipal, industrial, and certain agricultural uses. Arizona's rivers originate in mountains and provide water suitable for most uses, although human activities have adversely affected the quality of surface water in parts of the State. In 1989, the State delineated 380 miles of streams in Arizona where toxic substances were identified or probable (Arizona Department of Environmental Quality, 1990, p. 26). Drainage from irrigated croplands, mining operations, and urban runoff is the source of pollution (Baldys, 1990, p. 2).

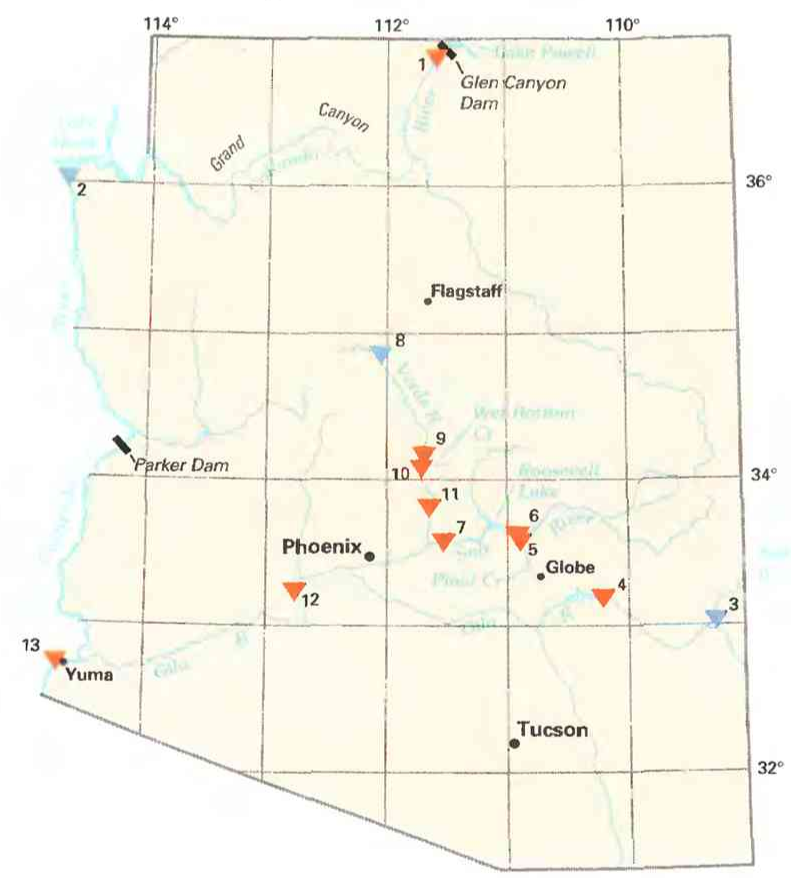

The following discussion of stream water quality in Arizona is organized by river basin (fig. 3). Graphs in figure 3 summarize certain aspects of stream water quality in the basins for water years 1987-89. The graphs show frequency distributions of data values that represent concentrations of selected stream-water constituents. These constituents are fecal coliform bacteria, dissolved sulfate, dissolved solids, dissolved nitrite plus nitrate (as nitrogen), total phosphorus (as phosphorus), dissolved selenium, and suspended sediment. The data are reported in colonies per 100 milliliters $(\mathrm{col} / 100 \mathrm{~mL})$, milligrams per liter $(\mathrm{mg} / \mathrm{L})$, and micrograms per liter. Sources and environmental significance of each constituent are described in table 1.

Water quality at each monitoring station is the result of geological, chemical, biological, and hydrologic processes that occur over a large area. Water-quality problems that affect aquatic life or public health only locally are not fully represented in this summary.

\section{COLORADO RIVER}

The Colorado River flows from the Upper Colorado River Basin and enters Arizona at Lake Powell. From Lake Powell, the river flows southwestward through the Grand Canyon into Lake Mead and then southward to form Arizona's western border. Land use upstream from site 1 is mainly livestock grazing in desert shrubland, grassland, and woodland.

Daily variations in the release of water for hydroelectric-power generation at Glen Canyon Dam result in fluctuations in discharge at site 1 . The fluctuations are of concern to those attempting to preserve the trout fishery downstream from the dam and to recreational users of the river between the dam and Lake Mead. Erosion of beaches and sandbars along the river in the Grand Canyon is a major environmental concern.

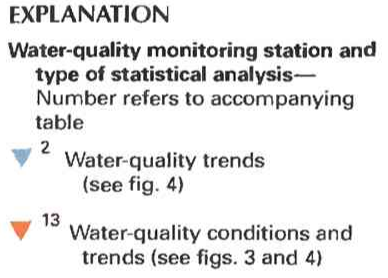

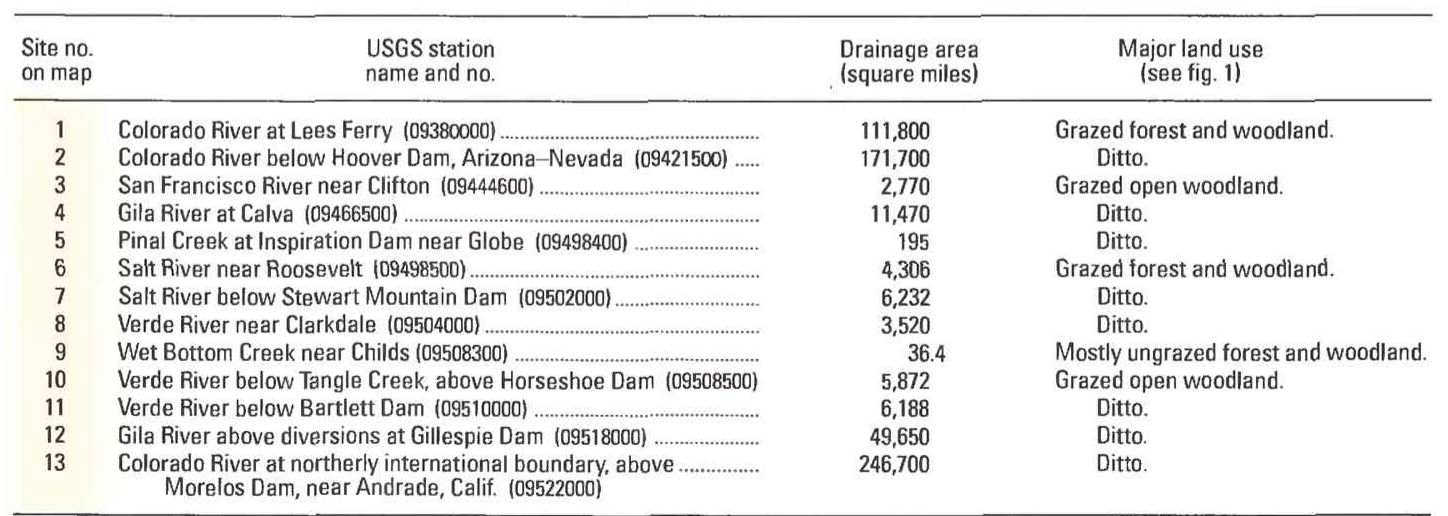

Figure 2. Selected water-quality monitoring stations, type of statistical analysis, and geographic features in Arizona. (Sources: Major land uses modified from Anderson, 1967; other data from U.S. Geological Survey files.) 
The median (50th-percentile) dissolved-solids concentration of $492 \mathrm{mg} / \mathrm{L}$ at site 1 (fig. 3) was the fourth lowest in water samples collected at the 10 monitoring stations. The median suspended-sediment concentration ( $4 \mathrm{mg} / \mathrm{L})$ at site 1 was the second lowest; the small magnitude is related to sediment trapping in the upstream reservoir, Lake Powell (Williams and Wolman, 1986, p. 83).

Increases in dissolved-solids concentrations are of concern to all downstream water users in the United States and Mexico (Radtke and others, 1988, p. 3). At site 13, the median dissolved-solids concentration of $730 \mathrm{mg} / \mathrm{L}$ was substantially higher than the median concentration of $492 \mathrm{mg} / \mathrm{L}$ at site 1 . The increase in dissolved solids in the lower Colorado River results mainly from irrigation return flow from cropland adjacent to the river downstream from Parker Dam.

\section{GILA RIVER}

The Gila River drains most of the southern part of the State. Land use upstream from site 4 is mainly grazing in open woodlands. Irrigation return flows and mine drainage might affect water quality at site 4 .
The median concentrations of fecal coliform bacteria ( 51 $\mathrm{col} / 100 \mathrm{~mL})$, nitrite plus nitrate $(0.69 \mathrm{mg} / \mathrm{L})$, and phosphorus $(0.09$ $\mathrm{mg} / \mathrm{L}$ ) at site 4 were the second highest for the 10 monitoring stations. The median suspended-sediment concentration $(307 \mathrm{mg} / \mathrm{L})$ was the highest.

Land use upstream from site 12 is mainly grazing in open woodlands; however, water quality at site 12 is affected by municipal and agricultural sources. Upstream from site 12, sewage discharge and irrigation return flow affect stream water quality. The State has identified the reach of the Gila River from west of Phoenix to site 12 as effluent dominated because sewage-treatment-plant effluent sustains perennial flow in that reach. Boron concentrations at site 12 commonly exceed allowable limits for agricultural irrigation (Arizona Secretary of State, 1987).

At site 12, median concentrations of fecal coliform bacteria $(490 \mathrm{col} / 100 \mathrm{~mL})$, nitrite plus nitrate $(8.7 \mathrm{mg} / \mathrm{L})$, and phosphorus $(2.3$ $\mathrm{mg} / \mathrm{L})$ were the highest for the 10 monitoring stations. Median sulfate $(480 \mathrm{mg} / \mathrm{L})$ and dissolved-solids $(2,250 \mathrm{mg} / \mathrm{L})$ concentrations were the second highest.
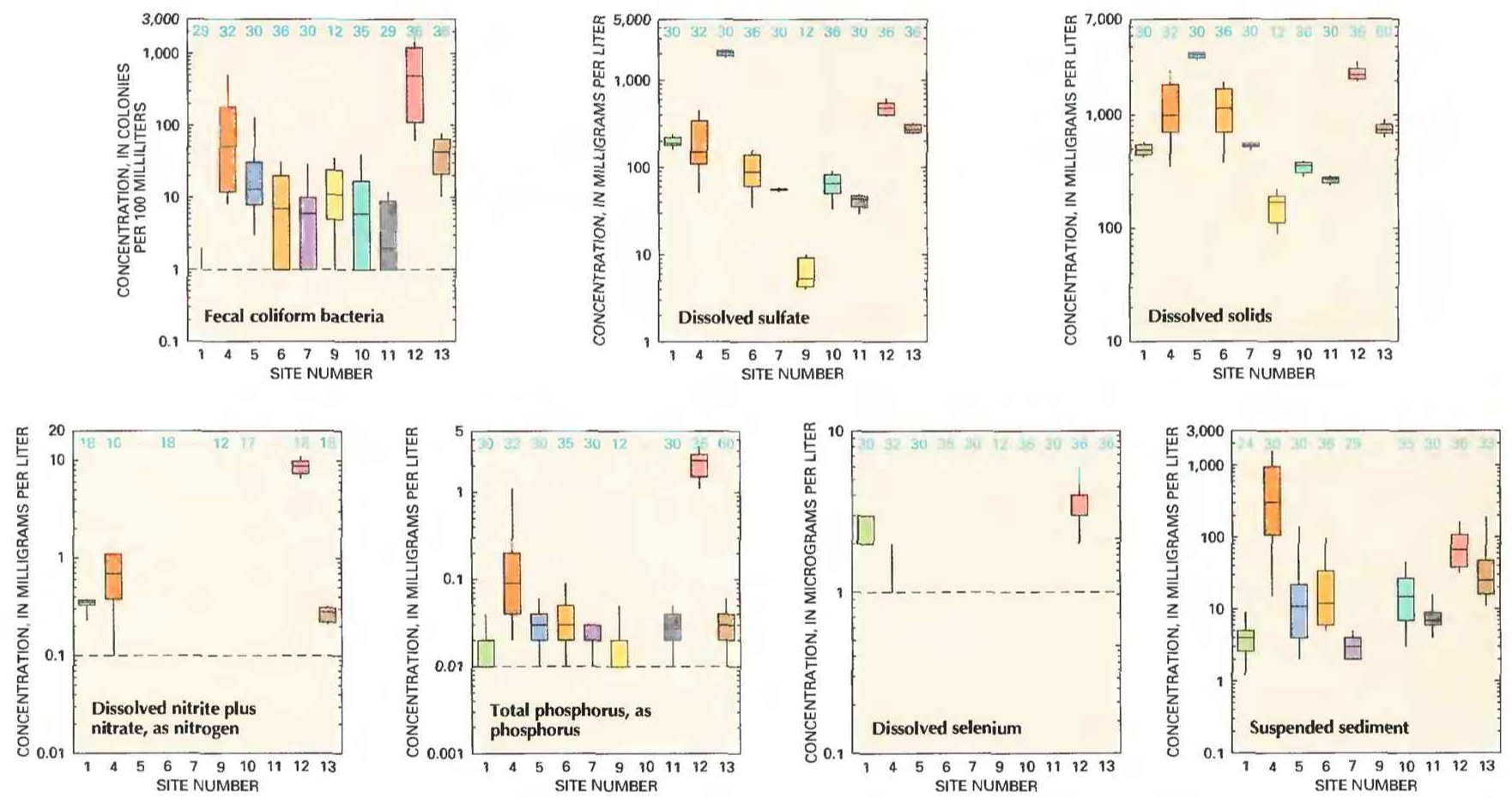

\section{EXPLANATION}

Water-quality conditions in selected
drainage basins
Number of analyses-Dash indicates
insufficient data
Percentile-Percentage of analyses
equal to or less than indicated
values
-90th
- 75th
- 50th-Median
- 25th
10th
limit for analytical method used.
Data below limit line not shown

Drainage basin-Number is site number in figure 2. Basin may extend beyond State line

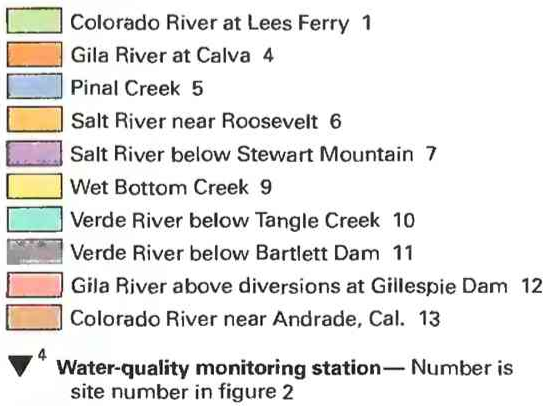

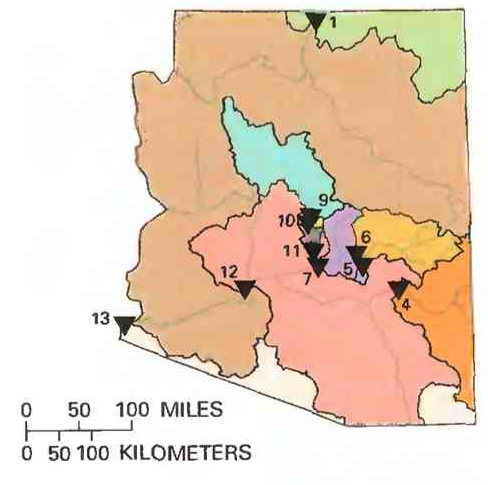

Figure 3. Water quality of selected streams in Arizona, water years 1987-89. (Source: Data from U.S. Geological Survey files.) 


\section{PINAL CREEK}

Pinal Creek is a small Salt River tributary that drains the north slope of the mountains east of Roosevelt Lake. Upstream from site 5 , the principal land use is grazing of open woodland and copper mining near Globe.

At site 5 , median concentrations of sulfate $(2,100 \mathrm{mg} / \mathrm{L})$ and dissolved solids $(3,380 \mathrm{mg} / \mathrm{L})$ were the highest for the 10 monitoring stations. Drainage from active and inactive copper mines caused the high concentrations.

\section{SALT RIVER}

The Salt River drains the central and eastern parts of the Plateau Uplands water province. Upstream from sites 6 and 7, the principal land cover is forest and woodland in which livestock graze. Upstream from site 6, the Salt River receives inflow of saline water from springs. East of Phoenix, between sites 6 and 7, water of the Salt River is stored in a series of reservoirs.

At sites 6 and 7, median dissolved-solids concentrations were $1,140 \mathrm{mg} / \mathrm{L}$ and $537 \mathrm{mg} / \mathrm{L}$, respectively (fig. 3 ). The high concentration at site 6 was the result of the contribution of the saline springs during base flow. The lower concentration downstream at site 7 was caused by dilution mainly from seasonal snowmelt and tributary inflow to Roosevelt Lake from the northwest.

\section{WET BOTTOM CREEK}

Wet Bottom Creek is a tributary to the Verde River that drains a remote part of central Arizona and is within a U.S. Forest Service roadless wilderness area. Forest and woodland cover most of the basin upstream from site 9 . The basin is underlain by relatively insoluble igneous and volcanic rocks. Because the basin is remote, it is only slightly affected by human activities. At site 9 , median concentrations of sulfate $(5.3 \mathrm{mg} / \mathrm{L})$, dissolved solids $(170 \mathrm{mg} / \mathrm{L})$, nitrite plus nitrate (less than $1 \mathrm{mg} / \mathrm{L}$ ), phosphorus $(0.01 \mathrm{mg} / \mathrm{L}$ ), and selenium (less than $1 \mathrm{mg} / \mathrm{L}$ ) were among the lowest for the 10 monitoring stations.

\section{VERDE RIVER}

The Verde River drains the western part of the Plateau Uplands water province of central Arizona. Land use in the basin is mostly grazing. Only small quantities of water are diverted upstream from site 10 to irrigate crops in the Verde River valley. At site 10, median concentrations of dissolved solids $(358 \mathrm{mg} / \mathrm{L})$ and nitrite plus nitrate (less than $0.1 \mathrm{mg} / \mathrm{L}$ ) - constituents commonly associated with irrigation runoff - were among the lowest median concentrations for water samples collected at the 10 monitoring stations (fig. 3).

Median concentrations of fecal coliform bacteria, sulfate, and suspended sediment at sites 10 and 11 were similar to or smaller than those in samples collected at most of the other monitoring stations. Median concentrations of fecal coliform bacteria, sulfate, dissolved solids, and suspended sediment were slightly smaller at site 11 than at site 10 . The decrease probably resulted from dilution by tributary inflow between the sites.

\section{WATER-QUALITY TRENDS}

Trend analysis is a statistical procedure used to detect changes in stream water quality at a monitoring station over time. For this report, water-quality data from 13 monitoring stations (fig. 2) were analyzed for trends by using the seasonal Kendall test (Hirsch and others, 1982), a method used extensively by the USGS. The graph (shown below) of the dissolved-sulfate concentration in Pinal Creek at site 5 illustrates the trend inferred from the concentration data and demonstrates the variation in water quality that is common in streams.

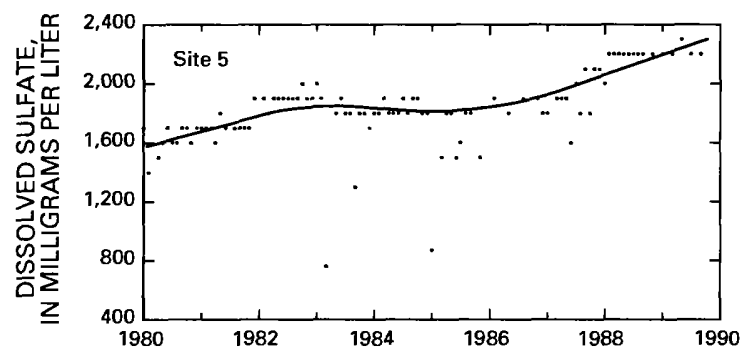

Table 1. Sources and environmental significance of selected water-quality constituents [Source: Compiled by the U.S. Geological Survey, Office of Water Quality]

\begin{tabular}{|c|c|c|}
\hline Constituent & Common sources & Environmental significance \\
\hline Fecal coliform bacteria ................ & $\begin{array}{l}\text { Sources include effluent from sewage-treatment } \\
\text { plants and runoff from pastures, feedlots, and ur- } \\
\text { ban areas. }\end{array}$ & $\begin{array}{l}\text { Presence indicates contamination of water by wastes } \\
\text { from humans and other warm-blooded animals. }\end{array}$ \\
\hline Sulfate & $\begin{array}{l}\text { Occurs in some rocks; also in mine runoff, industrial } \\
\text { wastewater discharge, and atmospheric deposi- } \\
\text { tion. }\end{array}$ & $\begin{array}{l}\text { Concentrations exceeding a natural, background } \\
\text { level indicate contamination from human activity; } \\
\text { in sufficient quantity, can cause water to be } \\
\text { unsuitable for public supply; can harm aquatic } \\
\text { organisms. }\end{array}$ \\
\hline Dissolved solids .......................... & $\begin{array}{l}\text { A result of rock weathering; also in agricultural runoff } \\
\text { and industrial discharge. }\end{array}$ & $\begin{array}{l}\text { In sufficient quantity, can cause water to be unsuitable } \\
\text { for public supply, agriculture, and industry; can } \\
\text { harm aquatic organisms. }\end{array}$ \\
\hline Nitrite plus nitrate ....................... & $\begin{array}{l}\text { Nonpoint sources are agricultural and urban runoff; } \\
\text { a major point source is wastewater discharge. }\end{array}$ & $\begin{array}{l}\text { Plant nutrient that, in sufficient quantity, can cause } \\
\text { algal blooms and excessive growth of higher } \\
\text { aquatic plants in bodies of water; can cause water } \\
\text { to be unsuitable for public supply. }\end{array}$ \\
\hline 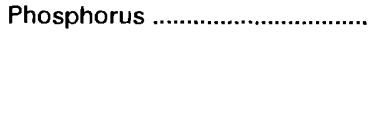 & $\begin{array}{l}\text { Occurs in some rocks and sediments; also in runoff } \\
\text { and seepage from phosphate-rock mines, agri- } \\
\text { cultural and urban runoff, and industrial and } \\
\text { municipal wastewater discharge. }\end{array}$ & $\begin{array}{l}\text { Plant nutrient that, in sufficient quantity, can cause } \\
\text { algal blooms and excessive growth of higher } \\
\text { aquatic plants in bodies of water. }\end{array}$ \\
\hline Selenium ......................................... & $\begin{array}{l}\text { Occurs in some rocks and soils; can be leached from } \\
\text { arid lands by irrigation. }\end{array}$ & $\begin{array}{l}\text { Toxic in larger than trace concentrations; can cause } \\
\text { water to be unsuitable for public supply; can } \\
\text { harm aquatic organisms. }\end{array}$ \\
\hline Suspended sediment ................. & $\begin{array}{l}\text { A result of rock erosion; also induced by disturbances } \\
\text { of land cover due to fires, floods, and human } \\
\text { activities such as mining, logging, construction, } \\
\text { and agriculture. }\end{array}$ & $\begin{array}{l}\text { Can be detrimental to aquatic organisms; can fill res- } \\
\text { ervoirs and impair recreational use of water. }\end{array}$ \\
\hline
\end{tabular}


When possible, constituent-concentration data were adjusted for changes in streamflow to preclude identifying a trend in concentration that was caused only by a trend in streamflow. The data were not adjusted when (1) more than 10 percent of the samples had concentrations lower than the minimum reporting limit for the analytical method used or (2) streamflow was controlled substantially by human activities. When the concentration data could not be adjusted for streamflow, trends were determined directly from the concentration data.

Statewide trends in concentrations of selected stream-water constituents are shown on maps in figure 4. On each map, a trend is indicated at a monitoring station only if the data from that station were suitable for use in the trend analysis. For more information on the suitability criteria and on the trend-analysis procedure used for this report, see Lanfear and Alexander (1990).

\section{FECAL COLIFORM BACTERIA}

Fecal coliform bacteria are used as indicators of fecal contamination from humans and other warm-blooded animals. Such contamination can introduce disease-causing viruses and bacteria into a stream.

Concentrations of fecal coliform bacteria decreased at site 13 on the lower Colorado River and had no trend at nine stations. The decrease in concentrations of fecal coliform bacteria may have been the result of dilution from increased streamflow in the Upper Colorado River Basin during 1983-87 concurrent with a reduction in the part of the flow that results from irrigation return flow.

\section{DISSOLVED SULFATE}

The major natural sources of sulfate in streams are rock weathering, volcanoes, and biochemical processes (Hem, 1985, p. 113). Human activities such as mining, waste discharge, and fossil-fuel combustion also can be important sources.

The upward trend in sulfate concentrations in Pinal Creek at site 5 is attributable to a gradual arrival in the stream of ground water contaminated by acidic mine drainage (Eychaner, 1988). Sulfate constituted about 60 percent of the dissolved-solids load at site 5 in 1988 (Eychaner, 1988, p. 570). Sulfate concentrations decreased at sites 1,2, and 13 on the Colorado River, site 4 on the lower Gila River, site 6 on the lower Salt River, and site 10 on the lower Verde River. Sulfur emissions from reduced copper-smelter operations in central Arizona decreased during the trend-analysis period (Valley National Bank of Arizona, 1989, p. 41).

\section{DISSOLVED SOLIDS}

Dissolved solids in stream water result primarily from rock weathering but also can be introduced as a byproduct of human activities (table 1). Concentrations generally are greater in streams draining basins underlain by rocks and soils that contain easily dissolved minerals.

The upward trend in dissolved-solids concentrations at site 7 may have resulted from the concentration of dissolved solids by evaporation from the Salt River reservoir system during dry years near the end of the trend-analysis period. The downward trend in the

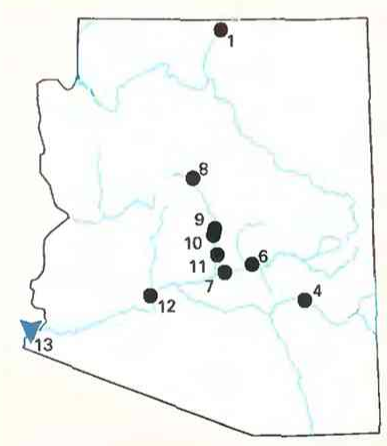

Fecal coliform bacteria, 1980-89

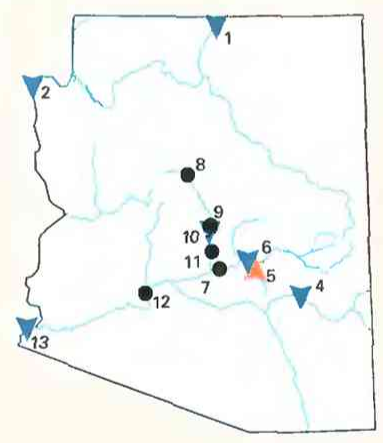

Dissolved sulfate, $1980-89$

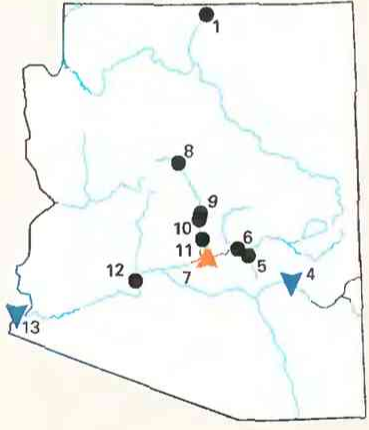

Dissolved solids, 1980-89

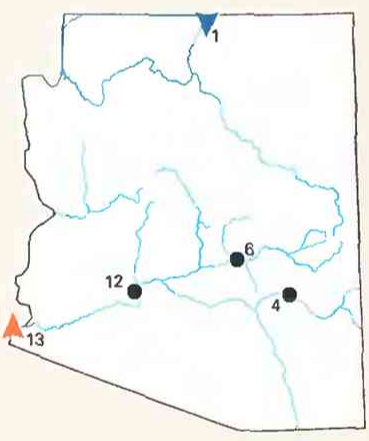

Total nitrite plus nitrate, 1975-89

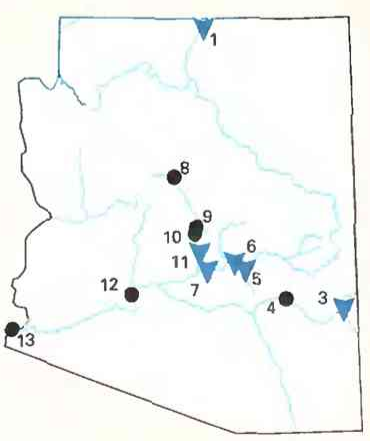

Total phosphorus, $1982-89$

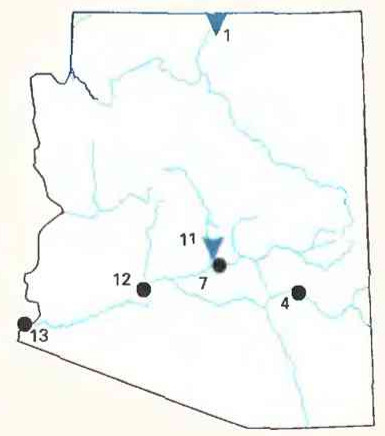

Dissolved selenium, 1980-89

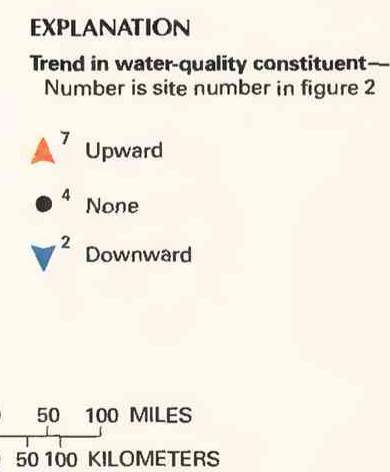

$0 \quad 50100$ KILOMETERS

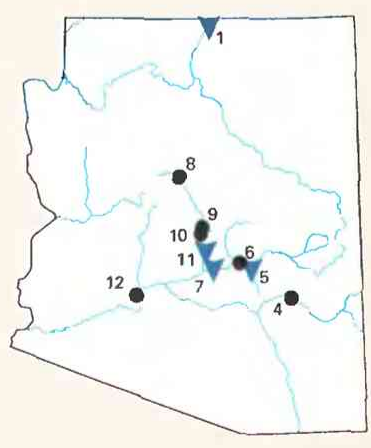

Suspended sediment, 1980-89

Figure 4. Trends in water quality of selected streams in Arizona, by water years. (Source: Data from U.S. Geological Survey files.) 
Gila River at site 4 may have resulted from dilution during 198387, a period of greater than average precipitation and runoff (U.S. Geological Survey, 1984-88). Dilution during the same wet years caused the downward trend in the Colorado River at site 13.

\section{DISSOLVED NITRITE PLUS NITRATE}

Nitrite and nitrate are oxidized forms of nitrogen that together normally constitute most of the dissolved nitrogen in well-aerated streams. Nitrite readily oxidizes to nitrate in natural waters; therefore, nitrate generally is by far the more abundant of the two (Hem, 1985, p. 124).

A cause for the increasing nitrite plus nitrate concentration in the Colorado River at site 13 is not known. The decreasing concentration in the Colorado River at site 1 probably was the result of dilution by increased runoff from the Upper Colorado River Basin during 1983-87.

\section{TOTAL PHOSPHORUS}

The total phosphorus concentration of a water sample is a measure of the concentration of all forms of phosphorus present in the sample, dissolved and particulate. Human activities (table 1) can be important sources of phosphorus in streams. A shortened trendanalysis period was used for phosphorus because data from analyses performed before water year 1982 are not comparable to data for subsequent years.

Phosphorus concentrations decreased at site 1 on the Colorado River, site 3 on the San Francisco River, site 5 on Pinal Creek, sites 6 and 7 on the Salt River, and site 11 on the Verde River and had no trend at six other stations (fig. 4). The downward trend in phosphorus concentrations at site 1 might have been the result of dilution from greater than average precipitation and runoff in the Upper Colorado River Basin during 1983-87. The causes of the slightly decreasing phosphorus concentrations at sites $3,5,6,7$, and 11 are not known. However, improved agricultural practices and a reduction in the use of phosphate-based detergents might have caused the downward trends.

\section{DISSOLVED SELENIUM}

Selenium exists in nature generally as a trace element, but soils in some arid and semiarid regions of the Western United States contain more than trace amounts. Dilution by greater than average precipitation and runoff in the upper Colorado River probably caused the downward trend in selenium concentrations at site 1 . The cause for the decreasing selenium concentration at site 11 on the Verde River is not known.

\section{SUSPENDED SEDIMENT}

Suspended sediment is a product of erosion. The erosion can be either natural or the result of land-cover disturbances related to human activities (table 1).

The downward trend in suspended-sediment concentrations at site 1, located about 16 miles downstream from Glen Canyon Dam on the Colorado River, is the result of sediment trapping in Lake Powell behind Glen Canyon Dam. The decreasing suspended-sediment concentrations in the Salt River at site 7 and in the Verde River at site 11 also probably resulted from sediment trapping in large upstream reservoirs. Sediment trapping in large reservoirs greatly reduces suspended-sediment loads downstream from the dams and can affect the downstream environment for long periods after dam construction (Williams and Wolman, 1986, p. 84). A cause for the downward trend in Pinal Creek at site 5 is not known.

\section{WATER-QUALITY MANAGEMENT}

Stream water quality is regulated by the Arizona Department of Environmental Quality (ADEQ), which was established by the Arizona Environmental Quality Act of 1986 to administer the State's programs for management of water quality, air quality, solid wastes, and hazardous wastes. Within $A D E Q$, the Office of Water Quality assesses waterborne threats to human health and the environment and is updating water-quality standards for surface water. When implemented, these revised standards will set limits on the concentrations of many additional pollutants, including toxic substances.

The ADEQ monitors the quality of surface water throughout Arizona by activities of its staff and through agreements with local, State, and Federal agencies. The USGS, the Arizona Department of Water Resources, and the ADEQ cooperate in the collection of streamflow and water-quality data at many stations in the State.

The ADEQ implements water-quality programs mandated by State and Federal authorities. Pursuant to section 305(b) of the Federal Clean Water Act, the ADEQ prepares and submits biennial reports to the EPA and the U.S. Congress that document Arizona's progress in implementing the goals and objectives of the act.

Arizona cooperates with the Federal Government and six other States in managing dissolved-solids concentrations in the Colorado River. In 1973, Arizona, California, Colorado, Nevada, New Mexico, Utah, and Wyoming created the Colorado River Basin Salinity Forum to address problems of excessive dissolved-solids concentrations. In 1975, with EPA approval, the seven States adopted numerical standards for dissolved-solids concentrations in the Colorado River. These standards are maintained through a joint State-Federal program authorized by Congress in 1974 and amended in 1984 under the Colorado River Basin Salinity Control Act.

\section{SELECTED REFERENCES}

Anderson, J.R., 1967, Major land uses in the United States, in U.S. Geological Survey, 1970, National atlas of the United States of America: Washington, D.C., U.S. Geological Survey, p. 158-159.

Arizona Department of Environmental Quality, 1990, Annual report, fiscal year 1989: Phoenix, Arizona Department of Environmental Quality, 39 p.

Arizona Secretary of State, 1987, Water quality, boundaries and standards, title 18, R-18-101 through 304: Phoenix, Arizona Secretary of State report, p. 1-37.

Baldys, Stanley, III, 1990, Trend analysis of selected water-quality constituents in the Verde River basin, central Arizona: U.S. Geological Survey Water-Resources Investigations Report 90-4128, $55 \mathrm{p}$.

Britton, L.J., and Greeson, P.E., eds., 1987, Methods for collection and analysis of aquatic biological and microbiological samples: U.S. Geological Survey Techniques of Water-Resources Investigations, book 5, chap. A4, $363 \mathrm{p}$.

Eychaner, J.H., 1988, Movement of inorganic contaminants in acidic water near Globe, Arizona, in Millard, G.E., and Ragone, S.E., eds., U.S. Geological Survey Toxic Substances Hydrology Program-Proceedings of the technical meeting, Phoenix, Arizona, September 26-30, 1988: U.S. Geological Survey Water-Resources Investigations Report 88-4220, p. 567-575.

Fishman, M.J., and Friedman, L.C., eds., 1989, Methods for the determination of inorganic substances in water and fluvial sediments: U.S. Geological Survey Techniques of Water-Resources Investigations, book 5, chap. Al, $545 \mathrm{p}$.

Harshbarger, J.W., Lewis, D.D., Skibitzke, H.E., and others, 1966, Arizona water: U.S. Geological Survey Water-Supply Paper 1648, 85 p.

Hem, J.D., 1985, Study and interpretation of the chemical characteristics of natural water (3d ed.): U.S. Geological Survey Water-Supply Paper 2254, $263 \mathrm{p}$.

Hirsch, R.M., Slack, J.R., and Smith, R.A., 1982, Techniques of trend analysis for monthly water-quality data: Water Resources Research, v. 18, no. 1, p. 107-121. 
Lanfear, K.J., and Alexander, R.B., 1990, Methodology to derive water-quality trends for use by the National Water Summary Program of the U.S. Geological Survey: U.S. Geological Survey Open-File Report 90-359, $10 \mathrm{p}$.

Radtke, D.B., Kepner, W.G., and Effertz, R.J., 1988, Reconnaissance investigation of water quality, bottom sediment, and biota associated with irrigation drainage in the lower Colorado River valley, Arizona, California, and Nevada, 1986-87: U.S. Geological Survey Water-Resources Investigations Report 88-4002, 77 p.

Sellers, W.D., and Hill, R.H., eds., 1974, Arizona climate 1931-1972: Tucson, University of Arizona Press, $616 \mathrm{p}$.

Solley, W.B., Merk, C.F., and Pierce, R.R., 1988, Estimated use of water in the United States in 1985: U.S. Geological Survey Circular 1004, 82 p.

Thelin, G.P., and Pike, R.J., 1990, Digital shaded relief map of the conterminous United States: Menlo Park, Calif., U.S. Geological Survey digital image processing, scale 1:3,500,000.

U.S. Geological Survey, 1984-88, Water resources data for Arizona, water years 1983-87: U.S. Geological Survey Water-Data Report AZ-83-1 to $A Z-87-1$ (published annually).
1990, National water summary 1987-Hydrologic events and water supply and use: U.S. Geological Survey Water-Supply Paper 2350, $553 \mathrm{p}$.

Valley National Bank of Arizona, 1989, Arizona statistical review: Phoenix, Valley National Bank of Arizona, Economic Planning Division, 45th edition, $93 \mathrm{p}$.

Ward, J.R., and Harr, C.A., eds., 1990, Methods for collection and processing of surface-water and bed-material samples for physical and chemical analyses: U.S. Geological Survey Open-File Report 90-140, 71 p.

White, N.D., Stulik, R.S., Morse, E.K., and others, 1961, Annual report on ground water in Arizona, spring 1960 to spring 1961: Phoenix, Arizona State Land Department, Water Resources Report 10,93 p.

Williams, G.P., and Wolman, M.G., 1986, Effects of dams and reservoirs on surface-water hydrology-Changes in rivers downstream from dams, in U.S. Geological Survey, National water summary 1985-Hydrologic events and surface-water resources: U.S. Geological Survey Water-Supply Paper 2300, p. 83-88. 
178 National Water Summary 1990-91-Stream Water Quality: STATE SUMMARIES

Prepared by Herbert H. Schumann, U.S. Geological Survey; “Water-Quality Management” section by Edwin Swanson, Arizona Department of Environmental Quality

FOR ADDITIONAL INFORMATION: District Chief, U.S. Geological Survey, 375 S. Euclid Avenue, Tucson, AZ 85719 


\section{ARKANSAS Stream Water Quality}

Arkansas has abundant surface water of suitable quality for most uses. Most perennial streams are in the Springfield-Salem Plateaus, the southern one-half of the Ouachita Mountains, and the northern one-half of the West Gulf Coastal Plain (Hunrichs, 1983; U.S. Geological Survey, 1986, p. 151). Streams and lakes are the sources for public water supplies that serve about one-half of the population. Offstream surface-water withdrawals in 1985 averaged 2,100 $\mathrm{Mgal} / \mathrm{d}$ (million gallons per day), about 36 percent of the combined offstream surface- and ground-water withdrawals. The major offstream surface-water uses were thermoelectric power generation (1.090 Mgal/d), agriculture (739 Mgal/d), and public water supply (156 Mgal/d) (U.S. Geological Survey, 1990, p. 166). Surface-water withdrawals are greatest in the west-central part of Arkansas.

Streams also are an important recreational resource in Arkansas. Per capita participation in fishing, pleasure boating, water skiing, and canoeing in Arkansas substantially exceeds the national average. Per capita boat ownership in Arkansas is second in the Nation (Arkansas Department of Parks and Tourism, 1985).

Owing partly to the abund...nce of water, Arkansas is primarily an agricultural State. Land use (fig. $1 A$ ) is influenced, in part, by physiography; the flat, alluvial plains are more suitable for large farming operations, and the hilly and mountainous regions are more

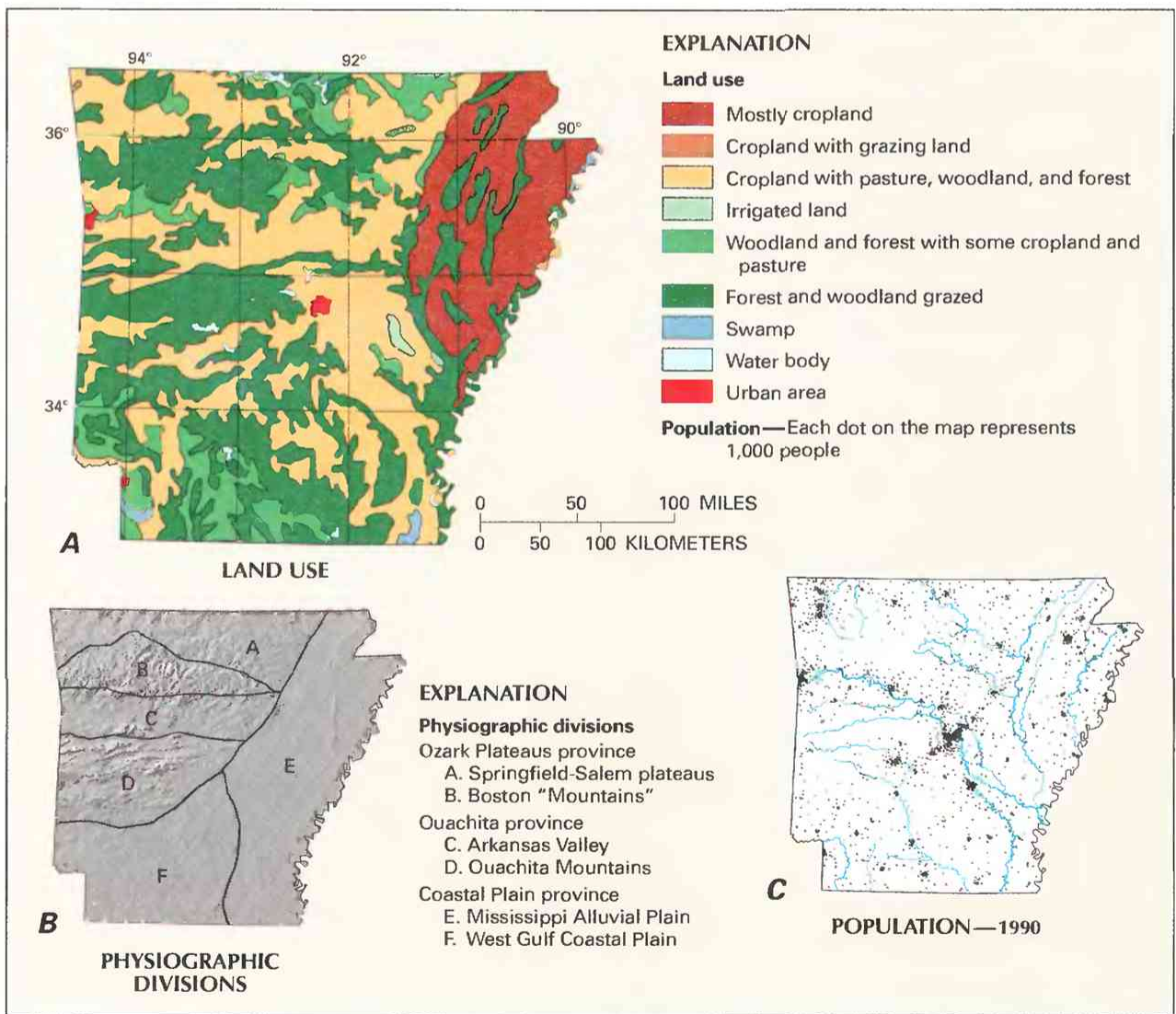

Figure 1. Land use, physiography, and population in Arkansas. A, Major land uses. B, Physiographic divisions. C. Population distribution in 1990. (Sources: A, Major land uses modified from Anderson, 1967. B. Physiographic divisions from Fenneman, 1946; landforms from Thelin and Pike, 1990. C. Data from U.S. Bureau of the Census 1990 decennial census files.) suitable for timber harvesting, small farms, and livestock production. Cropland is the dominant land use in the flat Mississippi Alluvial Plain (fig. $1 B$ ), and land use in the rest of the State is primarily forest or forest mixed with cropland and pasture. Some of these land uses can have a substantial effect on stream water quality.

Most of the State's population centers are along the Arkansas River or in northwestern Arkansas (fig. $1 C$ ). The fastest growing areas of the State are in central and northwestern Arkansas. The State's 1990 population was 2.4 million, which is 2.8 percent greater than in 1980 (U.S. Bureau of the Census 1990 decennial census files).

\section{WATER-QUALITY MONITORING}

Water-quality data obtained from analyses of water samples collected at monitoring stations are stored in the U.S. Geological Survey's (USGS) National Water Information System and the U.S. Environmental Protection Agency's (EPA) national data base known as STORET. Water-quality and streamflow data are reported by water year - the 12 months from October 1 through September 30. A water year is identified by the calendar year in which it ends. For example, water year 1991 comprises October 1, 1990, through September 30, 1991.

The data used in this summary of Arkansas' stream water quality were obtained from water samples collected at 16 monitoring stations operated by the USGS and the Arkansas Department of Pollution Control and Ecology (fig. 2). These monitoring stations are part of a network of stations at which data collection is systematic and continuing. Analyses of water samples collected at 10 stations are the basis for the discussion and graphic summary (fig. 3) of stream water-quality conditions during water years 1987-89, and data from all 16 stations are the basis for the discussion and graphic summary (fig. 4) of stream water-quality trends. Water samples were collected and analyzed by using standard methods approved by the USGS (Britton and Greeson, 1987; Fishman and Friedman, 1989; Ward and Harr, 1990) or by using equivalent methods. If a method of sample collection or analysis changed over time, data from an analysis were included in the evaluation of recent stream water quality or of stream water-quality trends only if the change in method did not affect the comparability of the data. 


\section{WATER-QUALITY CONDITIONS}

The following discussion of stream water quality in Arkansas is organized by river basin (fig. 3). Where physiographic and landuse characteristics in different basins are similar, the discussion of those basins is combined. Graphs in figure 3 summarize certain aspects of stream water quality in the basins for water years 1987-89. The graphs show frequency distributions of data values that represent concentrations of selected stream-water constituents. These constituents are dissolved sulfate, dissolved chloride, dissolved solids, total and dissolved nitrite plus nitrate (as nitrogen), total ammonia (as nitrogen), and total phosphorus (as phosphorus). The data are reported in milligrams per liter $(\mathrm{mg} / \mathrm{L})$. Sources and environmental significance of each constituent are described in table 1.

Water quality at each monitoring station is the result of geological, chemical, biological, and hydrologic processes that occur over a large area. Water-quality problems that affect aquatic life or public health only locally are not fully represented in this summary. A report by the Arkansas Department of Pollution Control and Ecol- ogy (1990) discusses these problems more fully. That report indicates that about 35 percent of the stream miles assessed in Arkansas are not impaired for any use and that about 80 percent of the stream miles meet water-quality goals for fishing and swimming.

One of the more widely known stream water-quality issues in Arkansas is a commercial-fishing ban and fish-consumption health advisory on Bayou Meto because of dioxin contamination. A fishconsumption health advisory was also issued in April 1990 by the Arkansas Department of Health for reaches of the Arkansas River near Pine Bluff and the Red River near Ashdown because of excessive dioxin concentrations in fish (T.C. McChesney, Arkansas Department of Health, written commun., 1990). Another widely publicized issue has been the effect of sewage-treatment-plant effluent from Fayetteville on the White River and Beaver Lake. However, imprcvements of the treatment facility have substantially decreased the effect of the effluent on the river. These issues are discussed in the report by the Arkansas Department of Pollution Control and Ecology (1990).

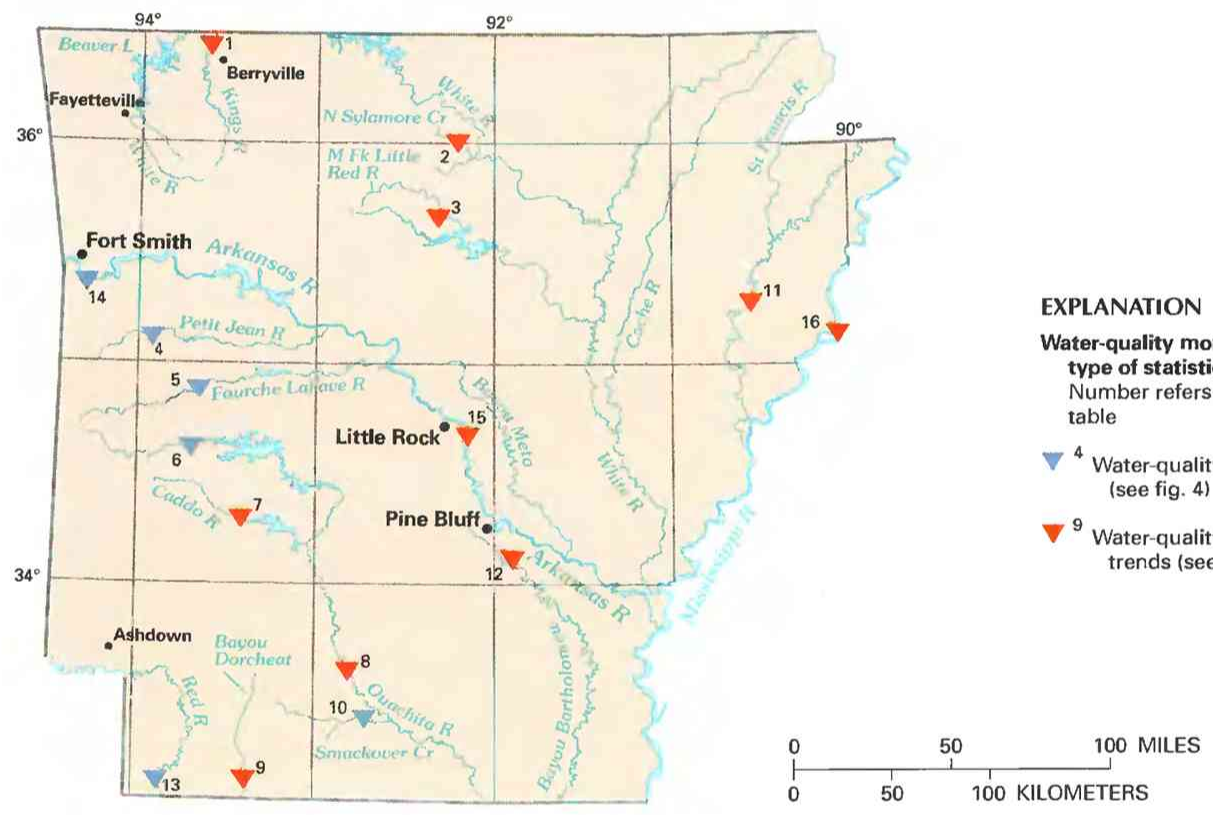

\begin{tabular}{|c|c|c|c|}
\hline $\begin{array}{l}\text { Site no. } \\
\text { on map }\end{array}$ & $\begin{array}{l}\text { USGS station } \\
\text { name and no. }\end{array}$ & $\begin{array}{l}\text { Drainage area } \\
\text { (square miles) }\end{array}$ & $\begin{array}{l}\text { Major land use } \\
\text { (see fig. 1) }\end{array}$ \\
\hline 1 & Kings River near Berryville ${ }^{1}(07050500)$ & 527 & Cropland with pasture, woodland, and forest. \\
\hline 2 & North Sylamore Creek near Fifty Six $(07060710)$ & 58.1 & Forest and woodland. \\
\hline 3 & 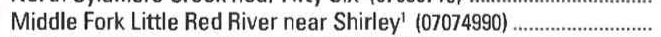 & 265 & Grazed forest and woodland. \\
\hline 4 & Petit Jean River near Booneville $(07258500)$ & 241 & Ditto. \\
\hline 5 & 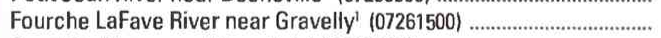 & 410 & Ditto. \\
\hline 6 & Ouachita River near Mount Ida $(07356000)$ & 414 & Ditto. \\
\hline 7 & Caddo River near Amity' $(07359770)$ & 291 & Ditto. \\
\hline 8 & Ouachita River at Camden $(07362000)$ & 5,357 & Ditto. \\
\hline 9 & Bayou Dorcheat near Taylor' (07348650) & 389 & Ditto. \\
\hline 10 & Smackover Creek north of Smackover ${ }^{1}(07362110)$ & 411 & Ditto. \\
\hline 11 & St. Francis River at Parkin $(07047800)$ & 6,475 & Mostly cropland. \\
\hline 12 & Bayou Bartholomew near Ladd' $(07364115)$ & 115 & Cropland with pasture, woodland, and forest. \\
\hline 13 & Red River near Spring Bank' $(07344350)$ & 56,909 & Ditto. \\
\hline 14 & $\begin{array}{l}\text { Arkansas River at James W. Trimble Lock and Dam, near } \\
\text { Van Buren }(07250550)\end{array}$ & 150,547 & Ditto. \\
\hline 15 & $\begin{array}{l}\text { Arkansas River at David D. Terry Lock and Dam, below Little Rock } \\
\text { (07263620) }\end{array}$ & 158,288 & Ditto. \\
\hline 16 & 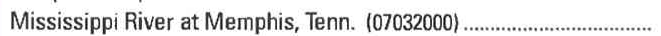 & 932,800 & Ditto. \\
\hline
\end{tabular}

'Station operated by Arkansas Department of Pollution Control and Ecology.

Figure 2. Selected water-quality monitoring stations, type of statistical analysis, and geographic features in Arkansas. (Sources: Major land uses modified from Anderson, 1967; other data from U.S. Geological Survey files.) 


\section{KINGS RIVER AND NORTH SYLAMORE CREEK}

Nearly all of the drainage basins of the Kings River and North Sylamore Creek lie within the Springfield-Salem Plateaus physiographic section of the Ozark Plateaus. The basins are underlain by limestone and dolomite; as a result, stream water in this area generally is hard (hardness of greater than $120 \mathrm{mg} / \mathrm{L}$ as calcium carbonate) and well buffered (Petersen, 1988). Well-buffered streams are resistant to change in $\mathrm{pH}$ caused by acidic precipitation, biological activities, and runoff.

Land use in the Kings River basin upstream from site 1 primarily is cropland with pasture, woodland, and forest. The median concentrations of most water-quality constituents in water samples collected at this site were within the range of those for the other monitoring stations (fig. 3). However, the median total nitrite plus nitrate concentration $(0.44 \mathrm{mg} / \mathrm{L})$ was the highest. Site 1 is several miles downstream from the sewage-treatment plant at Berryville. Also, chickens, pigs, and cattle are raised in the basin. These kinds of point and nonpoint sources typically contribute nitrogen, phosphorus, and other contaminants to streams.

The North Sylamore Creek basin upstream from site 2 is covered almost entirely by forest and woodland and is about 1 percent pasture (R.A. Mills, U.S. Forest Service, written commun., 1990). The basin is undisturbed except by recreational activities and nonintensive timber management. Land adjacent to North Sylamore Creek and upstream from site 2 is restricted to recreational use. As a result of this lack of disturbance, median concentrations of chloride $(2.0 \mathrm{mg} / \mathrm{L}$ ), dissolved nitrite plus nitrate (less than $0.10 \mathrm{mg} / \mathrm{L}$ ), and phosphorus (less than $0.03 \mathrm{mg} / \mathrm{L}$ ) for site 2 were lower than those for the other monitoring stations (fig. 3).

\section{MIDDLE FORK LITTLE RED RIVER}

Nearly all of the Middle Fork Little Red River basin upstream from site 3 lies within the Boston "Mountains" physiographic section of the Ozark Plateaus. Land use in the basin primarily is grazed
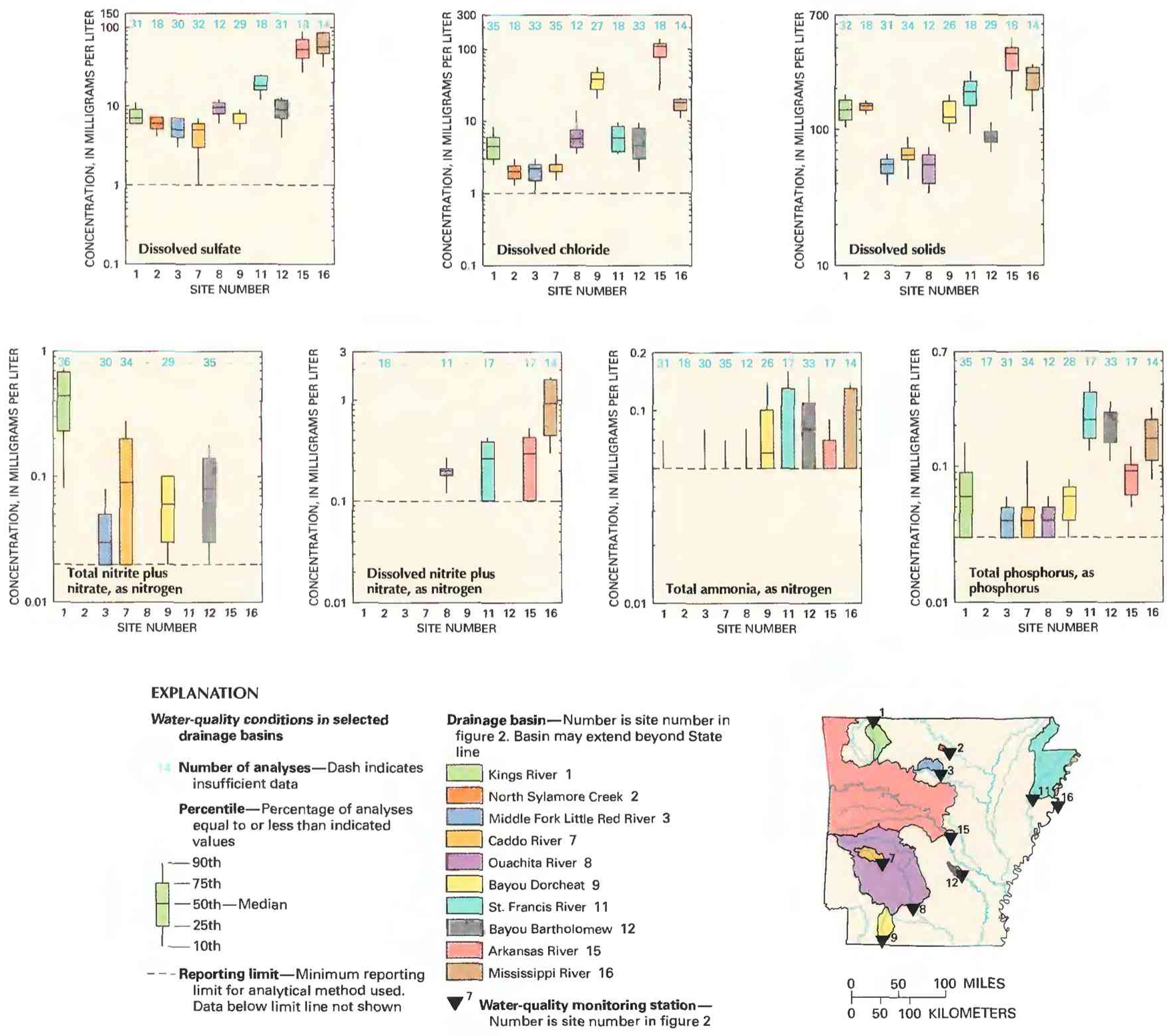

Figure 3. Water quality of selected streams in Arkansas, water years 1987-89. (Source: Data from U.S. Geological Survey and Arkansas Department of Pollution Control and Ecology files.) 
Table 1. Sources and environmental significance of selected water-quality constituents [Source: Compiled by the U.S. Geological Survey, Office of Water Quality]

\begin{tabular}{|c|c|c|}
\hline Constituent & Common sources & Environmental significance \\
\hline 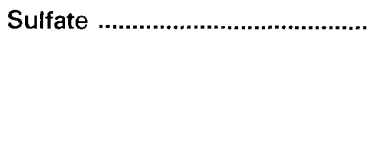 & $\begin{array}{l}\text { Occurs in some rocks; also in mine runoff, industrial } \\
\text { wastewater discharge, and atmospheric deposi- } \\
\text { tion. }\end{array}$ & $\begin{array}{l}\text { Concentrations exceeding a natural, background } \\
\text { level indicate contamination from human activity; } \\
\text { in sufficient quantity, can cause water to be } \\
\text { unsuitable for public supply; can harm aquatic } \\
\text { organisms. }\end{array}$ \\
\hline Chloride .......................................... & $\begin{array}{l}\text { Occurs in some rocks and ground-water discharge; } \\
\text { also in road deicers, industrial and urban waste- } \\
\text { water discharge, and atmospheric deposition. }\end{array}$ & $\begin{array}{l}\text { Concentrations exceeding a natural, background level } \\
\text { can cause water to be unsuitable for public supply, } \\
\text { agriculture, and industry; can harm aquatic or- } \\
\text { ganisms. }\end{array}$ \\
\hline Dissolved solids ......................... & $\begin{array}{l}\text { A result of rock weathering; also in agricultural runoff } \\
\text { and industrial discharge. }\end{array}$ & $\begin{array}{l}\text { In sufficient quantity, can cause water to be unsuitable } \\
\text { for public supply, agriculture, and industry; can } \\
\text { harm aquatic organisms. }\end{array}$ \\
\hline Nitrite plus nitrate ........................ & $\begin{array}{c}\text { Nonpoint sources are agricultural and urban ruroff; } \\
\text { a major point source is wastewater discharge. }\end{array}$ & $\begin{array}{l}\text { Plant nutrient that, in sufficient quantity, can cause } \\
\text { algal blooms and excessive growth of higher } \\
\text { aquatic plants in bodies of water; can cause water } \\
\text { to be unsuitable for public supply. }\end{array}$ \\
\hline 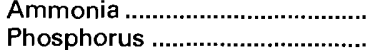 & Occurs in some rocks and sediments; also in runoff & $\begin{array}{l}\text { Ditto. } \\
\text { Plant nutrient that, in sufficient quantity, can cause }\end{array}$ \\
\hline & $\begin{array}{l}\text { Occurs in some rocks and sediments; also in runoff } \\
\text { and seepage from phosphate-rock mines, agri- } \\
\text { cultural and urban runoff, and industrial and } \\
\text { municipal wastewater discharge. }\end{array}$ & $\begin{array}{l}\text { Plant nutrient that, in sufficient quantity, can cause } \\
\text { algal blooms and excessive growth of higher } \\
\text { aquatic plants in bodies of water. }\end{array}$ \\
\hline
\end{tabular}

forest and woodland. Stream water in this area generally is soft (hardness less than $60 \mathrm{mg} / \mathrm{L}$ as calcium carbonate) and weakly buffered (Petersen, 1988) because the basin is underlain by shale and sandstone. Median concentrations of sulfate $(5.0 \mathrm{mg} / \mathrm{L})$, chloride $(2.2$ $\mathrm{mg} / \mathrm{L})$, dissolved solids $(55 \mathrm{mg} / \mathrm{L})$, total nitrite plus nitrate $(0.03$ $\mathrm{mg} / \mathrm{L})$, and phosphorus $(0.04 \mathrm{mg} / \mathrm{L})$ for site 3 were lower than those for most other monitoring stations (fig. 3).

\section{CADDO RIVER}

The Caddo River basin upstream from site 7 lies within the Ouachita Mountains. Land use in the basin is primarily grazed forest and woodland. The basin is underlain mostly by shale and sandstone. As a result, stream water in this area generally is soft and weakly buffered (Petersen, 1988). Median concentrations of sulfate (5.0 $\mathrm{mg} / \mathrm{L})$, chloride $(2.5 \mathrm{mg} / \mathrm{L})$, dissolved solids $(65 \mathrm{mg} / \mathrm{L})$, and phosphorus $(0.04 \mathrm{mg} / \mathrm{L})$ for site 7 were lower than those for most other monitoring stations (fig. 3).

\section{OUACHITA RIVER}

The Ouachita River basin upstream from site 8 lies within the West Gulf Coastal Plain and Ouachita Mountains. Land use in the basin primarily is grazed forest and woodland. The West Gulf Coastal Plain is underlain by sand, silt, clay, and lignite, and the Ouachita Mountains are underlain primarily by shale and sandstone. Stream water in this part of the State generally is soft and weakly buffered (Petersen, 1988). Median concentrations of dissolved solids (55 $\mathrm{mg} / \mathrm{L})$ and phosphorus $(0.04 \mathrm{mg} / \mathrm{L})$ for site 8 were lower than those for most other monitoring stations (fig. 3).

\section{BAYOU DORCHEAT}

The Bayou Dorcheat basin upstream from site 9 lies within the West Gulf Coastal Plain. Land use in the basin primarily is grazed forest and woodland. The West Gulf Coastal Plain is underlain by sand, silt, clay, and lignite. Stream water in this area generally is soft and weakly buffered (Petersen, 1988). The median concentration of chloride $(39 \mathrm{mg} / \mathrm{L})$ for site 9 was higher than those for most other monitoring stations (fig. 3). Activities related to petroleum extraction affect water quality in some parts of the West Gulf Coastal Plain (Arkansas Department of Pollution Control and Ecology, 1990, p. 2), which might explain the relatively high chloride concentrations.

\section{ST. FRANCIS RIVER AND BAYOU BARTHOLOMEW}

Most of the St. Francis River and Bayou Bartholomew basins lie within the Mississippi Alluvial Plain, which is underlain by sand and clay. Stream water in these areas varies from hard and well buffered to soft and weakly buffered (Petersen, 1988).

Land in the St. Francis River basin upstream from site 11 is used mostly for crop production. The Bayou Bartholomew basin upstream from site 12 has cropland with pasture, woodland, and forest. Median concentrations of sulfate for sites 11 and 12 (18 and 9.0 $\mathrm{mg} / \mathrm{L}$, respectively) were higher than those for most other monitoring stations. The median concentrations of ammonia for site 12 $(0.08 \mathrm{mg} / \mathrm{L})$ and phosphorus for sites 11 and $12(0.22 \mathrm{mg} / \mathrm{L}$ for both) were higher than those for any other monitoring station. Extensive fertilizer use in the counties drained by these streams (Arkansas Agricultural Statistics Service, 1990) might be a cause for these high ammonia and phosphorus concentrations.

\section{ARKANSAS AND MISSISSIPPI RIVERS}

The Arkansas and Mississippi Rivers have basins exceeding 150,000 square miles, most of which lies outside of Arkansas. The water in these large rivers is hard and well buffered (Petersen, 1988).

Land use in both basins in Arkansas mostly is cropland with pasture, woodland, and forest. In the Arkansas River at site 15 and the Mississippi River at site 16, median concentrations of sulfate (53 and $57 \mathrm{mg} / \mathrm{L}$, respectively), chloride (110 and $18 \mathrm{mg} / \mathrm{L}$ ), dissolved solids ( 363 and $260 \mathrm{mg} / \mathrm{L})$, dissolved nitrite plus nitrate $(0.29$ and $0.93 \mathrm{mg} / \mathrm{L})$, and phosphorus ( 0.09 and $0.16 \mathrm{mg} / \mathrm{L})$ were higher than those for most other monitoring stations (fig. 3). Because of their large drainage areas, these two rivers are affected by many geological, industrial, agricultural, and municipal sources of these constituents. Most of the chloride in the Arkansas River is contributed by naturally occurring brine deposits in Kansas and Oklahoma.

\section{WATER-QUALITY TRENDS}

Trend analysis is a statistical procedure used to detect changes in stream water quality at a monitoring station over time. For this report, water-quality data from 16 monitoring stations (fig. 2) were analyzed for trends by using the seasonal Kendall test (Hirsch and others, 1982), a method used extensively by the USGS. The graph (at right) of the dissolved-solids concentration in Smackover Creek 


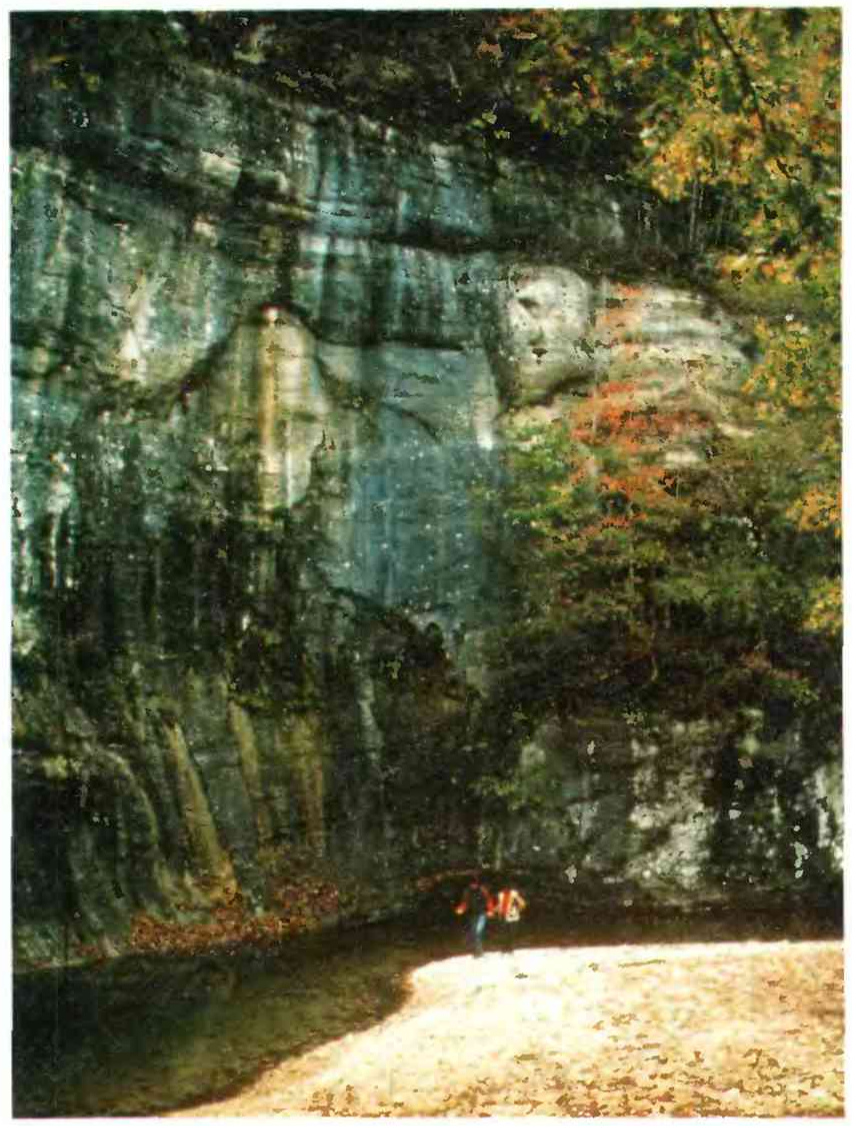

North Sylamore Creek in the Ozark Plateaus of northern Arkansas. The major human activities in this small basin-recreation and nonintensive timber management-have had little effect on water quality. (Courtesy of Robyn Horn, Arkansas Department of Parks and Tourism.)

at site 10 illustrates the trend inferred from the concentration data and demonstrates the variation in water quality that is common in streams.

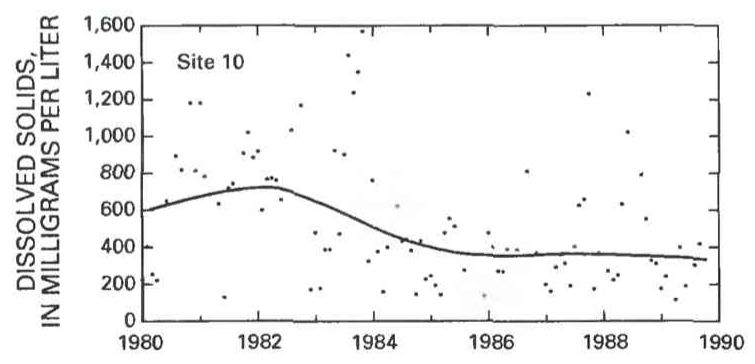

When possible, constituent-concentration data were adjusted for changes in streamflow to preclude identifying a trend in concentration that was caused only by a trend in streamflow. The data were not adjusted when (1) more than 10 percent of the samples had concentrations lower than the minimum reporting limit for the analytical method used or (2) the streamflow was controlled substantially by human activities. When the concentration data could not be adjusted for streamflow, trends were determined directly from the concentration data.

Statewide trends in concentrations of selected stream-water constituents are shown on maps in figure 4. On each map, a trend is indicated at a monitoring station only if the data from that station were suitable for use in the trend analysis. For more information on the suitability criteria and on the trend-analysis procedure used for this report, see Lanfear and Alexander (1990).

\section{DISSOLVED SULFATE}

The major natural sources of sulfate in streams are rock weathering, volcanoes, and biochemical processes (Hem, 1985, p. 113). Human activities such as mining, waste discharge, and fossil-fuel combustion also can be important sources. A shortened trend-analysis period was used for sulfate because data from analyses performed before water year 1982 are not comparable to data for subsequent years.

Sulfate concentrations had an upward trend in the Arkansas River at sites 14 and 15 . Because of the large magnitude of these increases and the absence of upward trends at sites where the ambient sulfate concentration is smaller, atmospheric deposition probably was not the cause of the trends. However, industrial- and sewagetreatment-plant effluents are potential sources of sulfate and might have been responsible for the increasing concentration. Sulfate concentrations decreased in Bayou Bartholomew at site 12 for unknown reasons.

\section{DISSOLVED CHLORIDE}

Chloride is present in all natural waters but usually in low concentrations (Hem, 1985, p. 118). Except in streams that receive ground-water discharge high in chloride, concentrations of greater than a few milligrams per liter generally are the result of human activities (table 1).

The cause of the downward trend in chloride concentrations at nine monitoring stations is unknown; however, sites 9 and 10 (on Bayou Dorcheat and Smackover Creek) are in areas where improvements in oil-field brine management practices might have contributed to the decreasing chloride concentration at those monitoring stations. Concentrations trended downward at most sites in the Ozark Plateaus and Ouachita provinces (where median chloride concentrations commonly are less than $5 \mathrm{mg} / \mathrm{L})$.

\section{DISSOLVED SOLIDS}

Dissolved solids in stream water result primarily from rock weathering but also can be introduced as a byproduct of human activities (table 1). Concentrations generally are greatest in streams draining basins underlain by rocks and soils that contain easily dissolved minerals.

The dissolved-solids concentration decreased in five streams, but causes of the trends are unknown. However, two of the streams in which concentrations decreased (Bayou Dorcheat at site 9 and Smackover Creek at site 10) are in areas where improvements in oilfield brine management might have had an effect on dissolved-solids concentrations.

\section{TOTAL AND DISSOLVED NITRITE PLUS NITRATE}

Nitrite and nitrate are oxidized forms of nitrogen that together normally constitute most of the dissolved nitrogen in well-aerated streams. Nitrite readily oxidizes to nitrate in natural waters; therefore, nitrate generally is by far the more abundant of the two (Hem, 1985, p. 124).

Total nitrite plus nitrate concentrations had no trend at 8 of the 10 monitoring stations from which data were suitable for trend analysis. The downward trends in total nitrite plus nitrate concentrations in the Fourche LaFave River at site 5 and the Ouachita River at site 6 have no readily apparent cause. Dissolved nitrite plus nitrate concentrations had no trend at the six monitoring stations from which data were suitable for trend analysis. 


\section{TOTAL AMMONIA}

Ammonia in stream water oxidizes to nitrate under aerobic conditions (Hem, 1985, p. 126). Although small quantities of ammonia can be present in unpolluted stream water, the presence of high concentrations commonly indicates contamination from agricultural or urban sources.

Improvement in sewage-treatment-plant and industrial discharge upstream from site 13 on the Red River and site 15 on the Arkansas River is a potential cause of the downward trend in ammonia concentrations at those locations, whereas improvement in sewage-treatment-plant discharges and livestock operations upstream from site 1 on the Kings River might have caused the decrease there. A cause for the downward trend at site 2 on North Sylamore Creek, which is in a relatively undisturbed basin, is unknown.

\section{TOTAL PHOSPHORUS}

The total-phosphorus concentration of a water sample is a measure of the concentration of all forms of phosphorus present in the sample, dissolved and particulate. Human activities (table 1) can be important sources of phosphorus in streams. A shortened trendanalysis period was used for phosphorus because data for water years $1980-81$ are not comparable to data for subsequent years. Although the causes of the upward trend in Smackover Creek at site 10 and the downward trend in the Arkansas River at sites 14 and 15 are not certain, changing phosphorus loads from sewage-treatment plants could have affected concentrations in receiving streams.

\section{WATER-QUALITY MANAGEMENT}

The Arkansas Department of Pollution Control and Ecology, created by the State Legislature through Act 472 of 1949, administers, manages, and enforces laws and regulations that provide for the protection of the physical, chemical, and biological properties of all waters of the State. Act 472 also designates the Department as the agency of the State responsible for activities required by the Federal Water Pollution Control Act. The Clean Water Act of 1972 is an amendment to this law. Pursuant to section 305(b) of the act, the Department prepares a biennial water-quality-assessment report (Arkansas Department of Pollution Control and Ecology, 1990) that is submitted to the EPA and the U.S. Congress.

The primary regulatory and management document of the Department is "Regulation No. 2-Regulation Establishing Water Quality Standards for Surface Water of the State of Arkansas" (Arkansas Department of Pollution Control and Ecology, 1988). This document, in accordance with the provision of Act 472 and the Clean Water Act, classifies all waters of the State according to their attainable beneficial uses including ecological, recreational, water-supply (domestic, agriculture, industrial), and navigational uses. The regulation also establishes specific criteria for certain contaminants in order to protect the designated uses. The waters of the State recently

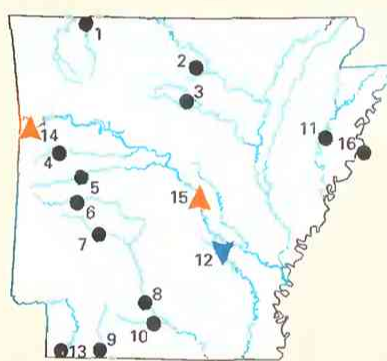

Dissolved sulfate, $1982-89$

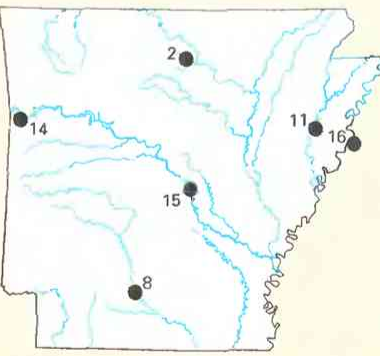

Dissolved nitrite plus nitrate, 1980-89

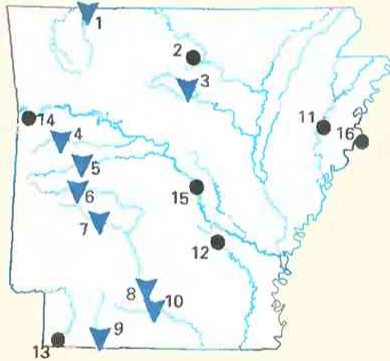

Dissolved chloride, 1975-89

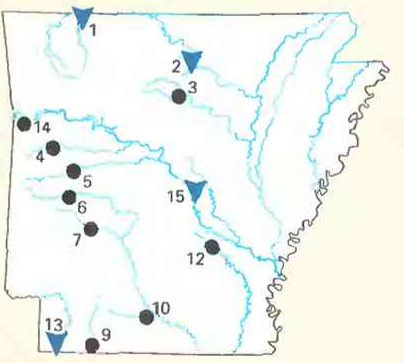

Total ammonia, 1980-89

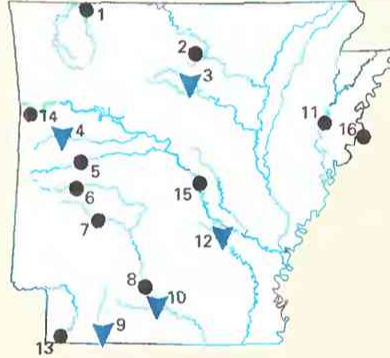

Dissolved solids, $1980-89$
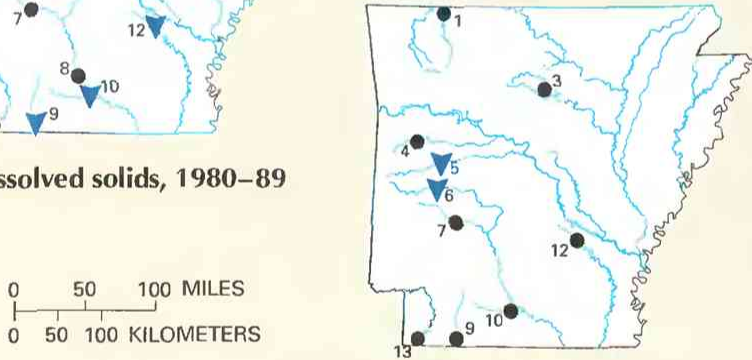

Total nitrite plus nitrate, 1982-89

\section{EXPLANATION}

Trend in water-quality constituent-Number is site number in figure 2

$A^{14}$ Upward

- ${ }^{1}$ None

$\nabla^{4}$ Downward

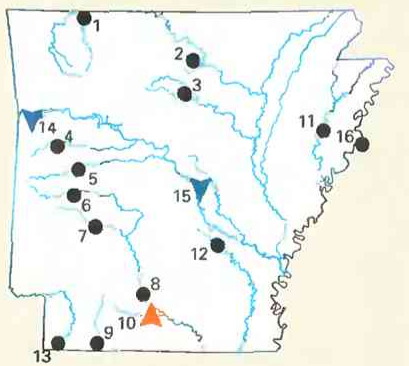

Total phosphorus, 1982-89

Figure 4. Trends in water quality of selected streams in Arkansas, by water years. (Source: Data from U.S. Geological Survey and Arkansas Department of Pollution Control and Ecology files.) 
have been divided into six ecological regions according to their physical, chemical, and biological characteristics. The ecological uses of water bodies are defined by their characteristic fish communities, and the protective criteria are unique to each region. Water-quality standards are reviewed triennially.

State water-quality standards composed of protective criteria for designated beneficial uses are the regulatory basis for most of these surface-water-quality management programs:

- Issuing point-source-discharge permits in which contaminantconcentration limits are established to prevent violation of specific contaminant criteria.

- Directing the primary emphasis of nonpoint-source-pollution control programs through assessments of water bodies contaminated by nonpoint sources.

- Developing of management plans and implementation of "best land-management practices" to control adverse effects from these sources currently (1990) delegated to the Arkansas Soil and Water Conservation Commission.

- Guiding certification decisions associated with issuance of permits to discharge dredge-and-fill material into waters of the State (Clean Water Act Section 404 permitting process). Such activities must not result in impairment of designated uses or in the degradation of water quality in any water body.

- Evaluating data supplied by the statewide ambient water-quality monitoring network. This network includes almost 150 stations at which water samples are routinely collected and analyzed for numerous physical, chemical, or biological parameters. These stations monitor least-disturbed water bodies, areas of point-source or nonpoint-source pollution, and results of pollution-abatement activities.

- Determining short-term water-quality changes and long-term trends.

Because water-quality standards are based on existing, least degraded surface-water-quality conditions by ecological region, these conditions become the baseline for measuring future conditions.

\section{SELECTED REFERENCES}

Anderson, J.R., 1967, Major land uses in the United States, in U.S. Geological Survey, 1970, National atlas of the United States of America: Washington, D.C., U.S. Geological Survey, p. 158-159.

Arkansas Agricultural Statistics Service, 1990, Arkansas agricultural statistics 1989: Arkansas Agricultural Experiment Station Report Series 316, $56 \mathrm{p}$.
Arkansas Department of Parks and Tourism, 1985, Statewide comprehensive outdoor recreation plan: Little Rock, Arkansas Department of Parks and Tourism, $131 \mathrm{p}$.

Arkansas Department of Pollution Control and Ecology, 1988, Regulation no. 2, as amended, regulations establishing water quality standards for surface waters of the State of Arkansas: Little Rock, Arkansas Department of Pollution Control and Ecology, 77 p.

1990, Arkansas water quality inventory report 1990: Little Rock, Arkansas Department of Pollution Control and Ecology, 353 p.

Britton, L.J., and Greeson, P.E., eds., 1987, Methods for collection and analysis of aquatic biological and microbiological samples: U.S. Geological Survey Techniques of Water-Resources Investigations, book 5, chap. A4, $363 \mathrm{p}$.

Fenneman, N.M., 1946, Physical divisions of the United States: Washington, D.C., U.S. Geological Survey special map, scale 1:7,000,000.

Fishman, M.J., and Friedman, L.C., eds., 1989, Methods for the determination of inorganic substances in water and fluvial sediments: U.S. Geological Survey Techniques of Water-Resources Investigations, book 5, chap. Al, $545 \mathrm{p}$.

Hem, J.D., 1985, Study and interpretation of the chemical characteristics of natural water ( $3 \mathrm{~d}$ ed.): U.S. Geological Survey Water-Supply Paper $2254,263 \mathrm{p}$.

Hirsch, R.M., Slack, J.R., and Smith, R.A., 1982, Techniques of trend analysis for monthly water quality data: Water Resources Research, v. 18, no. 1 , p. 107-121.

Hunrichs, R.A., 1983, Identification and classification of perennial streams of Arkansas: U.S. Geological Survey Water-Resources Investigations Report 83-4063, scale 1:500,000.

Lanfear, K.J., and Alexander, R.B., 1990, Methodology to derive water-quality trends for use by the National Water Summary Program of the U.S. Geological Survey: U.S. Geological Survey Open-File Report 90-359, $10 \mathrm{p}$.

Petersen, J.C., 1988, Statistical summary of selected water-quality data (water years 1975 through 1985) for Arkansas rivers and streams: U.S. Geological Survey Water-Resources Investigations Report 88-4112, $189 \mathrm{p}$.

Thelin, G.P., and Pike, R.J., 1990, Digital shaded relief map of the conterminous United States: Menlo Park, Calif., U.S. Geological Survey digital image processing, scale 1:3,500,000.

U.S. Geological Survey, 1986, National water summary 1985-Hydrologic events and surface-water resources: U.S. Geological Survey WaterSupply Paper 2300, 506 p.

1990, National water summary 1987--Hydrologic events and water supply and use: U.S. Geological Survey Water-Supply Paper 2350, $553 \mathrm{p}$.

Ward, J.R., and Harr, C.A., eds., 1990, Methods for collection and processing of surface-water and bed-material samples for physical and chemical analyses: U.S. Geological Survey Open-File Report 90-140, 71 p. 
Prepared by James C. Petersen and W. Reed Green, U.S. Geological Survey; "Water-Quality Management" section by William E. Keith, Arkansas Department of Pollution Control and Ecology

FOR ADDITIONAL INFORMATION: District Chief, U.S. Geological Survey, 2301 Federal Office Building, 700 West Capitol, Little Rock, AR 72201 


\section{CALIFORNIA Stream Water Quality}

For more than 40 years, California has led the Nation in offstream surface-water withdrawals, primarily used for the irrigation of millions of acres of agricultural land (fig. 1A). Surface-water sources supplied 60 percent (22,600 million gallons per day) of the freshwater used in 1985 . Of that surface water, 90 percent was used for agriculture, 7 percent for public supply, and 3 percent for thermoelectric power generation, self-supplied industry and mining, and domestic and commercial use (U.S. Geological Survey, 1990, p. 178).
In much of the State, irrigation is the principal water use; in densely populated areas, however, public water supply is predominant.

Precipitation runoff during winter and spring is the primary source of fresh surface water. Most precipitation in the State falls in the northern Coast Range, Klamath Mountains, Southern Cascade Range, and northern Sierra Nevada physiographic sections (fig. $1 B$ ). The resultant stream runoff differs greatly with location and season.

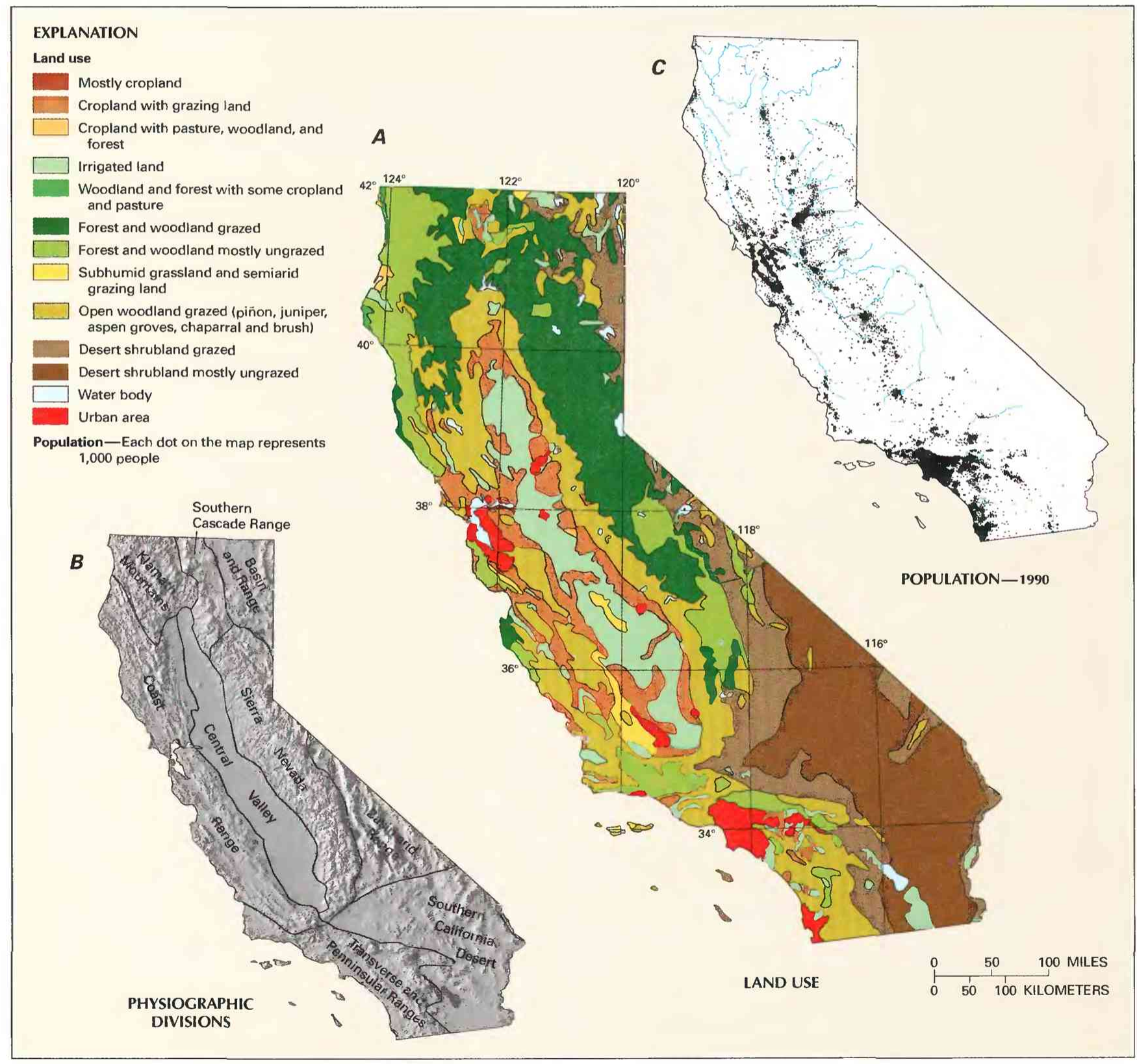

Figure 1. Land use, physiography, and population in California. A, Major land uses. B, Physiographic divisions. C, Population distribution in 1990. (Sources: A, Major land uses modified from Anderson, 1967. B, Physiographic divisions modified from Fenneman, 1946; landforms from Thelin and Pike, 1990. C. Data from U.S. Bureau of the Census 1990 decennial census files.) 


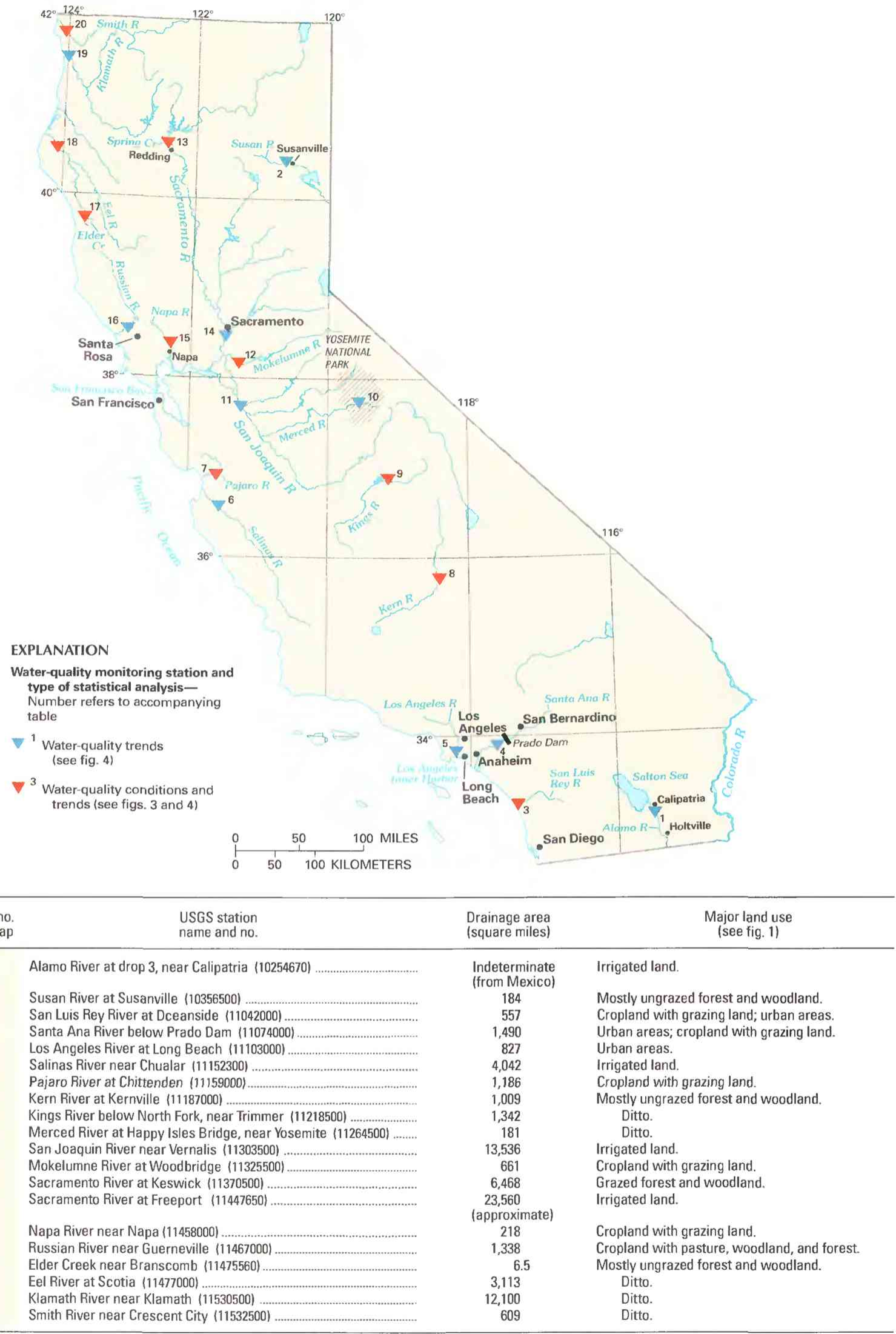

Figure 2. Selected water-quality monitoring stations, type of statistical analysis, and geographic features in California. (Sources: Major land uses modified from Anderson, 1967; other data from U.S. Geological Survey files.) 
The 1990 population of California was 29.8 million-an increase of 25.7 percent since 1980 (U.S. Bureau of the Census 1990 decennial census files). More than 17.7 million people rely on surface-water sources for supply. As the population of California (fig. $1 C$ ) continues to increase, so will the demand for usable water.

The demand for freshwater differs by season, area, and type of water use. Demand for irrigation water is greatest from mid-April through October, whereas the demand for freshwater in areas of largest population is continuous (U.S. Geological Survey, 1986, p. 157). The demand for water is greatest in the dry regions of the State. Because of this seasonal and geographical mismatch between supply and demand, California has developed an extensive system of reservoirs and aqueducts for the storage and transfer of surface water.

Water quality can limit the use of water as much as water availability. The quality of most stream water in California is adequate to support the beneficial uses designated by the State; in some places, however, human activities have affected the quality. Agriculture, abandoned and active mines, and urban runoff are sources of pollution (California State Water Resources Control Board, 1990, p. vii).

\section{WATER-QUALITY MONITORING}

Water-quality data obtained from analyses of water samples collected at monitoring stations are stored in the U.S. Geological Survey's (USGS) National Water Information System and the U.S. Environmental Protection Agency's (EPA) national data base known as STORET. Water-quality and streamflow data are reported by water year-the 12 months from October 1 through September 30. A water year is identified by the calendar year in which it ends. For example, water year 1991 comprises October 1, 1990, through September 30, 1991.

The data used in this summary of California's stream water quality were obtained from water samples collected at 20 monitoring stations at which data collection is systematic and continuing (fig. 2). Analyses of water samples collected at 10 stations are the basis for the discussion and graphic summary (fig. 3) of stream water-quality conditions during water years $1987-89$, and data from all 20 stations are the basis for the discussion and graphic summary (fig. 4) of stream water-quality trends. Water samples were collected and analyzed by using standard methods approved by the USGs (Britton and Greeson, 1987; Fishman and Friedman, 1989: Ward and Harr, 1990) or by using equivalent methods. If a method of sample collection or analysis changed over time, data from an analysis were included in the evaluation of recent stream water quality or of stream water-quality trends only if the change in method did not affect the comparability of the data.

\section{WATER-QUALITY CONDITIONS}

In 1990, the California State Water Resources Control Board (1990, p. vi) assessed 896 streams, whose lengths total more than 14,200 stream miles. Designated beneficial-use criteria were not met in about 11 percent of the stream miles assessed. The principal pollution sources for streams are agriculture, abandoned and active mines, urban runoff, erosion, individual domestic-sewage-disposal systems, and animal grazing. Additional pollution comes from point sources, from natural or unknown sources, and from Mexico in streams that flow across the international border (California State Water Resources Control Board, 1990, p. vii).

The following discussion of stream water quality in California is organized by river basin (fig. 3). Where physiographic and landuse characteristics in different basins are similar, the discussion of those basins is combined. Graphs in figure 3 summarize certain aspects of stream water quality in the basins for water years 1987-89. The graphs show frequency distributions of data values that repre- sent concentrations of selected stream-water constituents. These constituents are fecal coliform bacteria, dissolved sulfate, dissolved solids, dissolved nitrite plus nitrate (as nitrogen), dissolved phosphorus (as phosphorus), dissolved selenium, and suspended sediment. The data are reported in colonies per 100 milliliters $(\mathrm{col} / 100 \mathrm{~mL})$, milligrams per liter $(\mathrm{mg} / \mathrm{L})$, and micrograms per liter $(\mu \mathrm{g} / \mathrm{L})$. Sources and environmental significance of each constituent are described in table 1.

Water quality at each monitoring station is the result of geological, chemical, biological, and hydrologic processes that occur over a large area. Water-quality problems that affect aquatic life or public health only locally are not fully represented in this summary.

\section{ALAMO RIVER}

The Alamo River flows from Mexico to the Salton Sea. Streamflow at the international border generally is less than $5 \mathrm{ft}^{3} / \mathrm{s}$ (cubic feet per second) and increases to about $700 \mathrm{ft}^{3} / \mathrm{s}$ at site 1 . Most of the water in the Alamo River is imported from the Colorado River. Irrigated land is the principal land use upstream from site 1, and agricultural drainage, one of the major sources of pollutants, substantially increases the streamflow from the international border to site 1 .

At site 1, the median (50th-percentile) concentrations of fecal coliform bacteria $(5,000 \mathrm{col} / 100 \mathrm{~mL})$, sulfate $(770 \mathrm{mg} / \mathrm{L})$, dissolved solids $(2,200 \mathrm{mg} / \mathrm{L})$, nitrite plus nitrate $(6.4 \mathrm{mg} / \mathrm{L})$, selenium $(8$ $\mu \mathrm{g} / \mathrm{L}$ ), and suspended sediment ( $532 \mathrm{mg} / \mathrm{L}$ ) were the highest for the 10 monitoring stations (fig. 3). Ninety percent of fecal coliform bacteria concentrations exceeded $2,000 \mathrm{col} / 100 \mathrm{~mL}$, all sulfate and dissolved-solids concentrations exceeded 600 and $1,000 \mathrm{mg} / \mathrm{L}$, respectively, and 90 percent of the selenium concentrations exceeded $5 \mu \mathrm{g} / \mathrm{L}$. The entire California reach of the Alamo River has been classified as a Water Quality Limited Segment by the California State Water Resources Control Board (1990, app. B) because of the presence of toxic chemicals and pesticides. A Water Quality Limited Segment defines a stream reach that presently does not support designated beneficial uses and is not expected to fully support these uses in the future even after the application of required technology-based treatment.

\section{SUSAN AND MERCED RIVERS}

The Susan and Merced Rivers originate in the Sierra Nevada, where surface drainage is rapid and streams generally have low dissolved-solids concentrations. Forest and woodland cover most of the two drainage basins upstream from sites 2 and 10. Site 2 on the Susan River is upstream from Susanville, and site 10 is on the Merced River in Yosemite National Park, where numerous hiking trails cross the area.

At sites 2 and 10, median concentrations of the selected waterquality constituents generally were the lowest for the 10 monitoring stations (fig. 3). Upstream from both stations, the water is suitable for all designated beneficial uses (California State Water Resources Control Board, 1988a, app. A). Downstream from these sites, however, human activities have adversely affected stream quality. The California State Water Resources Control Board (1988a; 1990) has classified a 14-mile reach of the Susan River, downstream from site 2, as a Water Quality Limited Segment because of high concentrations of heavy metals, dissolved solids, and boron. Agricultural drainage and urban runoff (including runoff from an industrial area and airport), domestic-wastewater discharge, and geothermal discharge are sources of pollutants. Downstream from site 10 , streamflow in the Merced River is regulated by dams, diversions, channel alterations, and pumping for irrigation. Downstream increases in dissolved solids are the result of increasing irrigation drainage (Sorenson, 1982, p. 26). 


\section{SANTA ANA RIVER}

Urban areas and grazed cropland are major land uses upstream from site 4 on the Santa Ana River. From the headwaters to San Bernardino, streamflow is intermittent. Discharge of treated wastewater results in perennial streamflow downstream from San Bernardino. Farther downstream, but still upstream from site 4, water imported from northern California is released into the stream. In the Anaheim area, streamflow recharges the ground-water system through percolation ponds, supplying water for later use by the residents of Orange County (California State Water Resources Control Board, 1988a, p. 72).

In the Santa Ana River at site 4, median concentrations of fecal coliform bacteria $(290 \mathrm{col} / 100 \mathrm{~mL})$, dissolved solids $(627 \mathrm{mg} / \mathrm{L})$, and nitrite plus nitrate $(5.8 \mathrm{mg} / \mathrm{L})$ were the second highest for the 10 monitoring stations (fig. 3), and phosphorus $(2.7 \mathrm{mg} / \mathrm{L})$ was the highest. The California State Water Resources Control Board (1990, app. B) has classified 49 miles of the Santa Ana River (about 37 miles upstream and 12 miles downstream from site 4) as a Water Quality Limited Segment because of high concentrations of bacteria, dissolved solids, and nitrogen. Municipal wastewater discharges, urban runoff, and agricultural drainage are sources of pollutants (California State Water Resources Control Board, 1988a,b; 1990).

\section{LOS ANGELES RIVER}

The Los Angeles River flows through the extensively urbanized Los Angeles-Long Beach area. In the lower part of the drainage basin, the stream channel is lined with concrete. Most of the streamflow upstream from site 5 is from industrial and urban runoff.

In the Los Angeles River at site 5, nearly 90 percent of the dissolved-solids concentrations exceeded $500 \mathrm{mg} / \mathrm{L}$ (fig. 3). Los Angeles Inner Harbor is classified as a Water Quality Limited Segment because of the presence of toxic metals and organic chemicals from nonpoint-source pollution (California State Water Resources Control Board, 1988a; 1990).
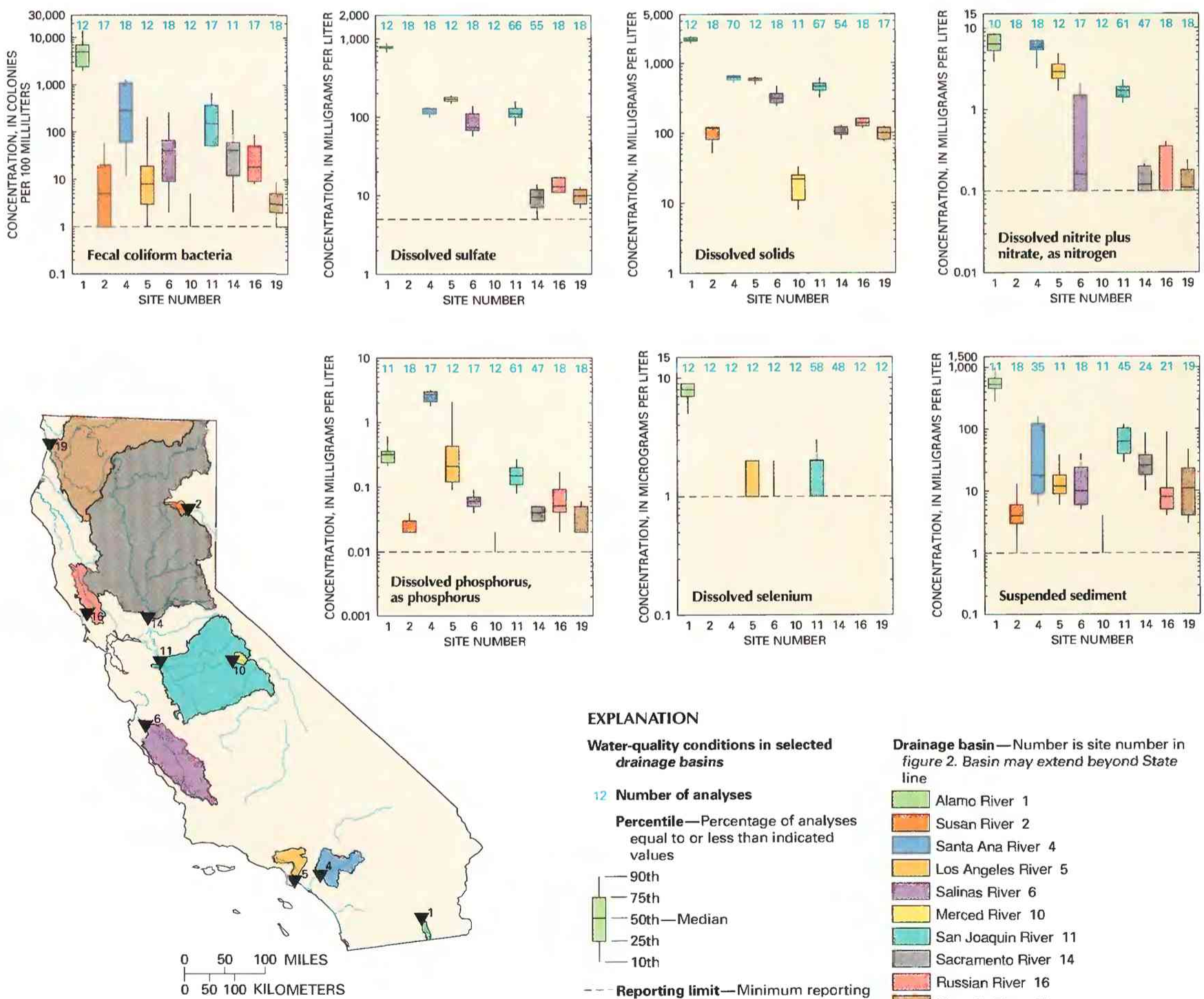

\section{EXPLANATION}

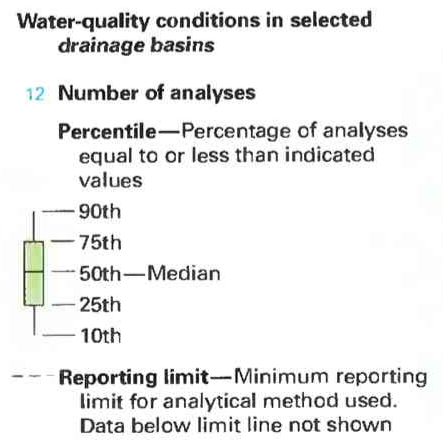

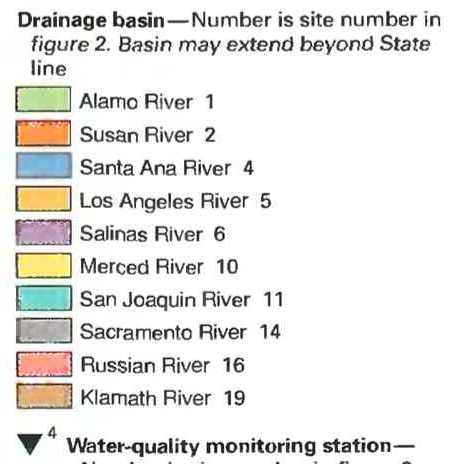

Figure 3. Water quality of selected streams in California, water years 1987-89. (Source: Data from U.S. Geological Survey files.) 


\section{SALINAS RIVER}

The Salinas River enters the Pacific Ocean about 80 miles south of San Francisco. Upstream from site 6, irrigated agriculture, mainly year-round row-crop farming, is the principal land use. Most water for irrigation is pumped from wells rather than directly from the river. Releases from three reservoirs upstream from site 6 provide ground-water recharge.

In the Salinas River at site 6, dissolved-solids concentrations generally were lower than $500 \mathrm{mg} / \mathrm{L}$, and suspended-sediment concentrations generally were lower than $50 \mathrm{mg} / \mathrm{L}$ (fig. 3). Although the California State Water Resources Control Board (1988a; 1990) has not designated any Water Quality Limited Segments along the Salinas River, a 30-mile reach of the river has been assessed as being affected by organic chemicals from agriculture and other nonpoint sources of pollution.

\section{SAN JOAQUIN RIVER}

The San Joaquin River is the second largest river that flows into San Francisco Bay. Irrigated agriculture is the principal land use upstream from site 11 . The basin includes the most extensively cultivated, irrigated, and chemically treated land in the State. Stream water quality generally deteriorates downstream as stream water is reused and dissolved-solids concentrations increase. However, near site 11 , stream water quality improves because of dilution by tributaries that drain the western slopes of the Sierra Nevada (Clifton and Gilliom, 1989, p. 23).

In the San Joaquin River at site 11, most dissolved-solids concentrations were lower than $500 \mathrm{mg} / \mathrm{L}$ (fig. 3). Median concentrations of fecal coliform bacteria $(150 \mathrm{col} / 100 \mathrm{~mL})$ and suspended sediment $(63 \mathrm{mg} / \mathrm{L})$ were the third and second highest, respectively, for the 10 monitoring stations (fig. 3). Two samples contained selenium concentrations that equaled or exceeded $5 \mu \mathrm{g} / \mathrm{L}$ (not shown in fig. 3). The California State Water Resources Control Board (1990, table VIII) has designated a 100-mile segment of the river as Water Quality Limited. Efforts are continuing through Federal and State legislation to mitigate pollution from agricultural drainage, particularly discharges that contain selenium. In addition, the State is as- sessing the potential for the occurrence of trihalomethanes and other disinfection byproducts in the lower reaches of the river.

\section{SACRAMENTO RIVER}

The Sacramento River, which has the largest drainage area of any river in the State, flows into San Francisco Bay. Irrigated land is the principal land use in the basin. Numerous storage reservoirs, diversions, and an extensive system of levees regulate the river. During floods, water diverted through bypasses upstream from Sacramento is not sampled at site 14 .

In the Sacramento River at site 14, median concentrations of most selected constituents were low relative to those in other streams (fig. 3), and the water quality is suitable for all designated beneficial uses. However, Spring Creek, a tributary to the Sacramento River, has been classified by the California State Water Resources Control Board (1990, app. B) as a Water Quality Limited Segment because of acidic mine drainage. The EPA is funding a project to eliminate pollution from this tributary. In November 1988, a health-hazard warning was issued that advises against consumption of trout caught in the Sacramento River from Redding to 60 miles downstream. In that stream reach, the California Department of Health Services has found dioxin concentrations that exceed Federal standards. The State also is assessing the potential for occurrence of trihalomethanes and other disinfection byproducts in the lower reaches of the river.

\section{RUSSIAN AND KLAMATH RIVERS}

The Russian and Klamath Rivers flow into the Pacific Ocean in northwestern California. Upstream from site 16 on the Russian River, cropland, pasture, woodland, and forest are the major land uses. Two reservoirs upstream from the monitoring station store water for agricultural and municipal needs and for flood control. Headwaters of the Klamath River originate in agricultural areas of Oregon. Upstream from site 19 on the Klamath River in California, grazed forest and woodland cover the basin.

In the Russian River at site 16 and the Klamath River at site 19 , concentrations of most selected constituents were low relative to those in most other streams (fig. 3). Water quality in the Russian

Table 1. Sources and environmental significance of selected water-quality constituents |Source: Compiled by the U.S. Geological Survey, Office of Water Qualityl

\begin{tabular}{|c|c|c|}
\hline Constituent & Common sources & Environmental significance \\
\hline Fecal coliform bacteria ............... & $\begin{array}{l}\text { Sources include effluent from sewage-treatment } \\
\text { plants and runoff from pastures, feedlots, and ur- } \\
\text { ban areas. }\end{array}$ & $\begin{array}{l}\text { Presence indicates contamination of water by wastes } \\
\text { from humans and other warm-blooded animals. }\end{array}$ \\
\hline 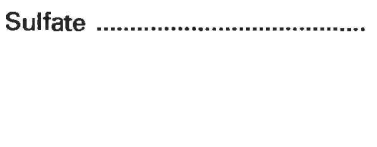 & $\begin{array}{l}\text { Occurs in some rocks; also in mine and agricultural } \\
\text { runoff, industrial wastewater discharge, and } \\
\text { atmospheric deposition. }\end{array}$ & $\begin{array}{l}\text { Concentrations exceeding a natural, background } \\
\text { level indicate contamination from human activity; } \\
\text { in sufficient quantity, can cause water to be } \\
\text { unsuitable for public supply; can harm aquatic } \\
\text { organisms. }\end{array}$ \\
\hline Dissolved solids .......................... & $\begin{array}{l}\text { A result of rock weathering; also in agricultural runoff } \\
\text { and industrial discharge. }\end{array}$ & $\begin{array}{l}\text { In sufficient quantity, can cause water to be unsuitable } \\
\text { for public supply, agriculture, and industry; can } \\
\text { harm aquatic organisms. }\end{array}$ \\
\hline Nitrite plus nitrate ........................ & $\begin{array}{l}\text { Nonpoint sources are agricultural and urban runoff; } \\
\text { a major point source is wastewater discharge. }\end{array}$ & $\begin{array}{l}\text { Plant nutrient that, in sufficient quantity, can cause } \\
\text { algal blooms and excessive growth of higher } \\
\text { aquatic plants in bodies of water; can cause water } \\
\text { to be unsuitable for public supply. }\end{array}$ \\
\hline 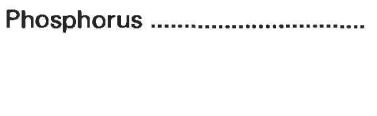 & $\begin{array}{l}\text { Occurs in some rocks and sediments; also in runoff } \\
\text { and seepage from phosphate-rock mines, agri- } \\
\text { cultural and urban runoff, and industrial and } \\
\text { municipal wastewater discharge. }\end{array}$ & $\begin{array}{l}\text { Plant nutrient that, in sufficient quantity, can cause } \\
\text { algal blooms and excessive growth of higher } \\
\text { aquatic plants in bodies of water. }\end{array}$ \\
\hline 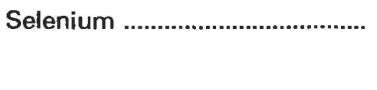 & $\begin{array}{l}\text { Occurs in some rocks and soils; can be leached from } \\
\text { arid lands by irrigation. }\end{array}$ & $\begin{array}{l}\text { Toxic in larger than trace concentrations; can cause } \\
\text { water to be unsuitable for public supply; can } \\
\text { harm aquatic organisms. }\end{array}$ \\
\hline Suspended sediment ................. & $\begin{array}{l}\text { A result of rock erosion; also induced by disturbances } \\
\text { of land cover due to fires, floods, and human } \\
\text { activities such as mining, logging, construction, } \\
\text { and agriculture. }\end{array}$ & $\begin{array}{l}\text { Can be detrimental to aquatic organisms; can fill res- } \\
\text { ervoirs and impair recreational use of water. }\end{array}$ \\
\hline
\end{tabular}


and Klamath Rivers is suitable for all designated beneficial uses, and no Water Quality Limited Segments have been identified (California State Water Resources Control Board, 1990, app. B). In 1980, the Klamath River was added to the Federal Wild and Scenic Rivers System.

\section{WATER-QUALITY TRENDS}

Trend analysis is a statistical procedure used to detect changes in stream water quality at a monitoring station over time. For this report, water-quality data from 20 monitoring stations (fig. 2) were analyzed for trends by using the seasonal Kendall test (Hirsch and others, 1982), a method used extensively by the USGS. The graph (shown below) of the dissolved-solids concentration in the Alamo River at site 1 illustrates the trend inferred from the concentration data and demonstrates the variation in water quality that is common in streams.

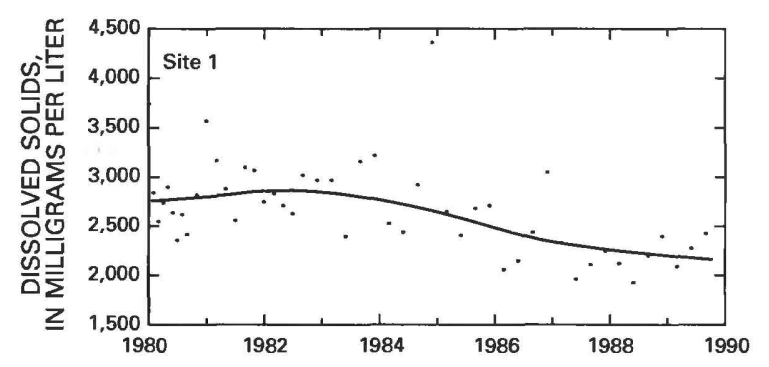

When possible, constituent-concentration data were adjusted for changes in streamflow to preclude identifying a trend in concentration that was caused only by a trend in streamflow. The data were not adjusted when (1) more than 10 percent of the samples had concentrations lower than the minimum reporting limit for the analytical method used or (2) streamflow was controlled substantially by human activities. When the concentration data could not be adjusted for streamflow, trends were determined directly from the concentration data.

Statewide trends in concentrations of selected stream-water constituents are shown on maps in figure 4. On each map, a trend is indicated at a monitoring station only if the data from that station were suitable for use in the trend analysis. For more information on the suitability criteria and on the trend-analysis procedure used for this report, see Lanfear and Alexander (1990).

\section{FECAL COLIFORM BACTERIA}

Fecal coliform bacteria are used as indicators of fecal contamination from humans and other warm-blooded animals. Such contamination can introduce disease-causing viruses and bacteria into a stream.

No explanation is readily apparent for the downward trend in fecal coliform bacteria concentrations in the Susan River at site 2 (fig. 4). Bacteria concentrations at this location already were low; 75 percent of the concentrations in samples collected during 198789 were less than $20 \mathrm{col} / 100 \mathrm{~mL}$ (fig. 3). In the San Luis Rey River at site 3 , the downward trend in fecal coliform bacteria concentrations was related to improvements in municipal-wastewater discharges and to the implementation of regulatory policies on dairy wastewater discharges (California State Water Resources Control Board, 1988a, p. 77). Improvements in sewage-treatment practices also could be the reason for the decreases in fecal coliform bacteria in the Los Angeles River at site 5.

\section{DISSOLVED SULFATE}

The major natural sources of sulfate in streams are rock weathering, volcanoes, and biochemical processes (Hem, 1985, p. 113).
Human activities such as mining, agriculture, waste discharge, and fossil-fuel combustion also can be important sources. A shortened trend-analysis period was used for sulfate because data from analyses performed prior to water year 1982 are not comparable to data from subsequent years.

In the San Joaquin River at site 11 and the Mokelumne River at site 12 , the upward trends in sulfate concentrations probably were the result of decreased precipitation and runoff during the drought of the late 1980's (U.S. Geological Survey, 1991, p. 197-206). The increasing sulfate concentration at site 11 also might be related to increasing irrigation return flow. No cause is known for the increasing sulfate concentration at site 19 , which monitors drainage from a forested basin; however, the trend probably was not related to decreased streamflow because there was no associated upward trend in dissolved-solids concentrations.

The decreasing sulfate concentrations in the Alamo River at site 1 and the Santa Ana River at site 4 primarily were due to improvement in wastewater discharges from Holtville, Calipatria, and San Bernardino (California State Water Resources Control Board, 1988a, p. 70). At site 1, the downward trend also was due to dilution by imported water.

\section{DISSOLVED SOLIDS}

Dissolved solids in stream water result primarily from rock weathering but also can be introduced as a byproduct of human activities (table 1). Concentrations generally are greatest in streams draining basins underlain by rocks and soils that contain easily dissolved minerals.

The downward trend in dissolved-solids concentrations in the Alamo River at site 1 was primarily the result of construction, improvement, or expansion of municipal wastewater-treatment facilities in Holtville and Calipatria (California State Water Resources Control Board, 1988a). The downward trend also was the result of dilution of water imported from the Colorado River. Increasing streamflow in the Alamo River has caused the water level of the Salton Sea to rise and damage agricultural, recreational, and residential property along its shore (California Department of Water Resources, 1987, p. 106). A cause for the downward trend in the Kings River at site 9 is not known.

\section{DISSOLVED NITRITE PLUS NITRATE}

Nitrite and nitrate are oxidized forms of nitrogen that together constitute most of the dissolved nitrogen in well-aerated streams. Nitrite readily oxidizes to nitrate in natural waters; therefore, nitrate generally is by far the more abundant of the two (Hem, 1985, p. 124).

In the Santa Ana River at site 4, the upward trend in nitrite plus nitrate concentrations (fig. 4) was associated with population growth and attendant increasing municipal-wastewater discharge, urban runoff, and dairy operations (California State Water Resources Control Board, 1988a,b; 1989). Upstream from site 11 on the San Joaquin River, increasing irrigation return flow and runoff from dairies and feedlots were the primary reasons for the upward trend (California State Water Resources Control Board, 1988a,b). In addition, the increasing nitrite plus nitrate concentration can be related to decreased streamflow.

The decreasing nitrite plus nitrate concentrations at sites 15 and 16 on the Napa and Russian Rivers were associated with the construction, improvement, or expansion of municipal wastewatertreatment facilities in Napa and Santa Rosa (California State Water Resources Control Board, 1988a; 1989). The principal land use upstream from the monitoring stations is agriculture.

\section{DISSOLVED PHOSPHORUS}

Small quantities of dissolved phosphorus-most of it in the oxidized form, phosphate-commonly are present in streams as a 


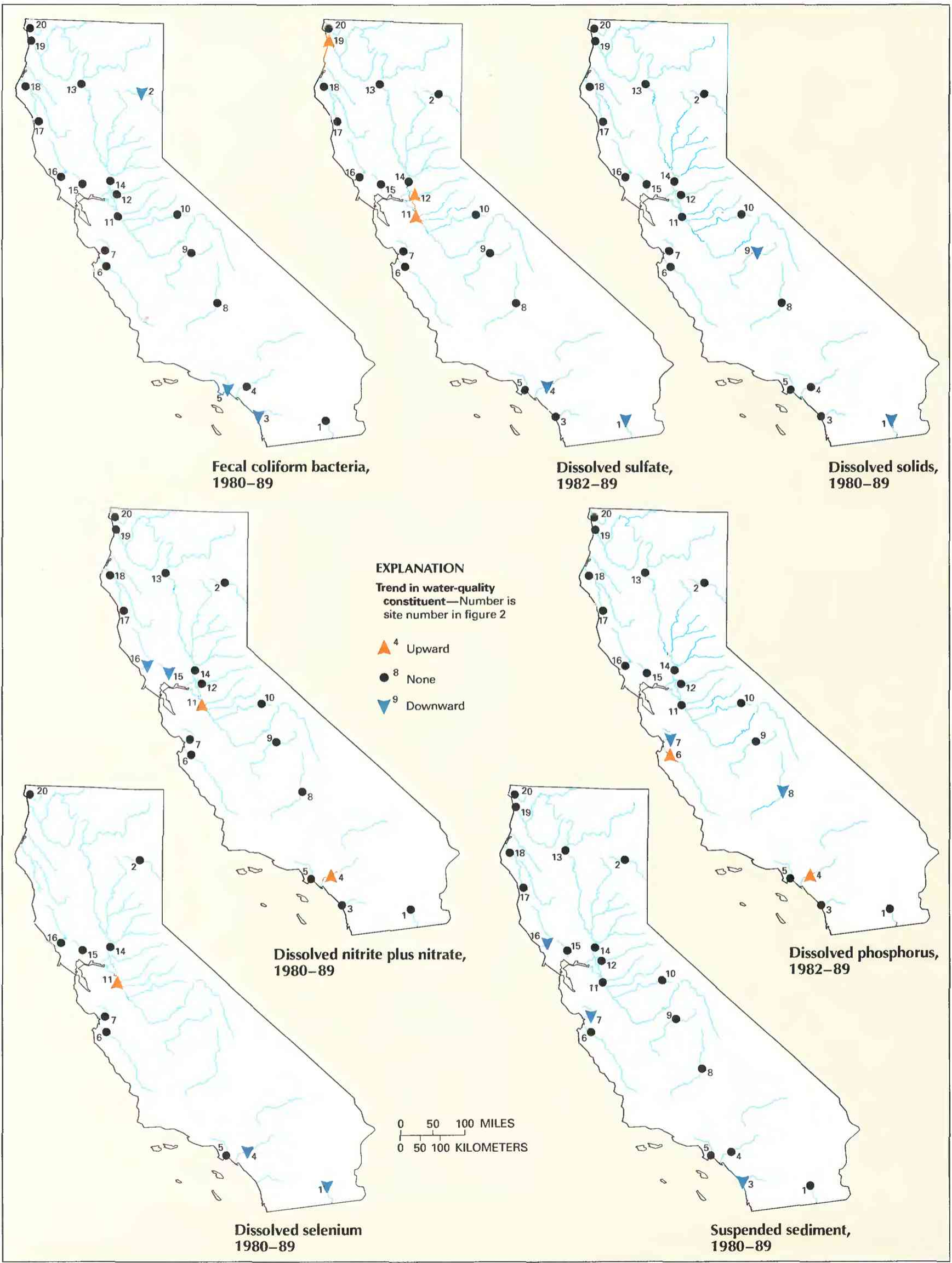

Figure 4. Trends in water quality of selected streams in California, by water years. (Source: Data from U.S. Geological Survey files.) 


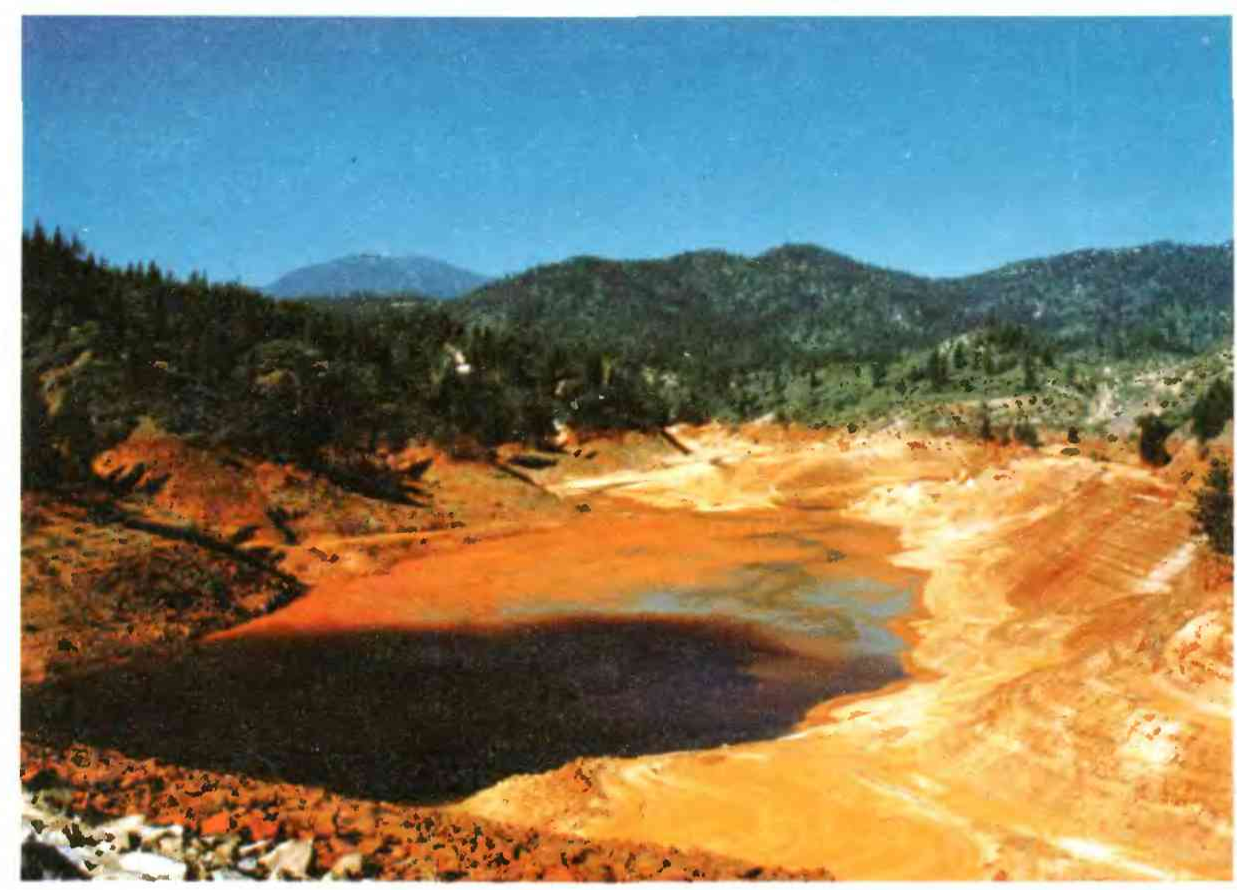

Spring Creek Reservoir just upstream from the confluence of Spring Creek with the Sacramento River near Redding, Calif. The water is colored by acidic drainage from several inactive copper mines and their associated wastes. (Dennis A. Wentz, U.S. Geological Survey.)

result of rock weathering. Concentrations of dissolved phosphorus in natural water normally are no more than a few tenths of a milligram per liter (Hem, 1985, p. 126) and are usually much lower. Higher concentrations can indicate contamination from human activities (table 1). A shortened trend-analysis period was used for phosphorus because data from analyses performed in water years 1980 81 are not comparable to data from subsequent years.

Upstream from site 4 on the Santa Ana River, population growth has increased municipal wastewater discharge and urban runoff. The upward trend in phosphorus concentrations at site 4 (fig. 4) can be attributed to increasing wastewater discharges, which currently do not meet State standards and make the river unsuitable for swimming (California State Water Resources Control Board, 1989, p. 16). The increasing phosphorus concentration in the Salinas River at site 6 can be attributed to agricultural activities - in particular, increases in the use of phosphorus-based fertilizers (California Department of Food and Agriculture, 1980-89). In the Pajaro River at site 7 and the Kern River at site 8, the decreasing phosphorus concentrations were related to the State's continuing effort to improve agricultural and timber-harvesting practices and to minimize degradation of stream quality by domestic wastes (including encouraging use of smaller quantities of phosphate-based detergents) and urban runoff (California State Water Resources Control Board, 1989).

\section{DISSOLVED SELENIUM}

Selenium exists in nature generally as a trace element, but soils in some arid and semiarid regions of the Western United States contain more than trace amounts. In some dry agricultural areas of California, water from irrigation leaches selenium from the soil and into ground water and streams. Although selenium has been a waterquality problem in a few areas, concentrations in most streams rarely exceed State water-quality objectives.

The upward trend in selenium concentrations in the San Joaquin River at site 11 (fig. 4) is attributable to increases in irrigation return flow (California State Water Resources Control Board, 1988a,b) and to decreases in streamflow. Dilution by imported water caused the downward trend in the Alamo River at site 1 . The cause of the downward trend in the Santa Ana River at site 4 is not known. Most selenium concentrations at site 4 were at or less than the minimum reporting limit of $1 \mu \mathrm{g} / \mathrm{L}$ (fig. 3).

\section{SUSPENDED SEDIMENT}

Suspended sediment is a product of erosion. The erosion can be either natural or the result of land-cover disturbances related to human activities (table 1).

In the Russian River at site 16, the decreasing suspended-sediment concentration was primarily the result of sediment trapping and channel adjustment following construction of a reservoir on the river in 1983. The effects of newly constructed reservoirs on suspendedsediment concentrations can be noticeable downstream for extended periods after construction (Smith and others, 1987, p. 13). Downward trends in suspended-sediment concentrations in the San Luis Rey River at site 3, the Pajaro River at site 7, and the Russian River at site 16 could have been the result of decreasing cropland erosion as agricultural lands become urban areas (California State Water Resources Control Board, 1989).

\section{WATER-QUALITY MANAGEMENT}

Stream water quality is regulated by the California State Water Resources Control Board (State Board) in conjunction with nine California Regional Water Quality Control Boards (Regional Boards). The Porter-Cologne Water Quality Control Act established the State and Regional Boards in 1967 and vested them with the authority to coordinate water-rights, water-pollution, and water-quality functions of the State government. In addition, the State Board implements the Federal Clean Water Act in California.

Section 305(b) of the Federal Clean Water Act requires States to submit biennial water-quality-assessment reports to the EPA. The 
State Board has the responsibility of preparing and submitting these reports (California State Water Resources Control Board, 1988a; 1990), which document progress in implementing the goals and objectives of the Clean Water Act. Currently (1990), the State Board is implementing a Clean Water Strategy Program to address waterquality issues throughout the State.

The Regional Boards have the responsibility for preparing and updating regional water-quality control plans that are used in stream water-quality management. Included in these plans are water-quality objectives for streams and other water resources of each region. The Regional Boards issue discharge permits in accordance with the National Pollutant Discharge Elimination System, which is based on water-quality objectives established through basin plans. As the foundation of the State's Clean Water Strategy Program, water-quality assessments are made by each Regional Board to describe waterquality conditions of water bodies in each region.

The California Department of Water Resources (DWR) has statutory authority to assess the quality of the State's water resources in coordination with the State and Regional Boards. The USGS, the DWR, and the State and Regional Boards cooperate in monitoring streamflow and water quality at numerous stations within the State. In addition, all agencies cooperate on water-quality assessments.

California cooperates with the Federal Government and with other States in managing salinity in the Colorado River, which borders California on the southeast. In 1973, the Colorado River Basin Salinity Control Forum was created by the seven States that contain land drained by the Colorado River to address water-quality problems in the basin. In 1975, the basin States adopted, and the EPA approved, numerical salinity standards for the river. These standards are being maintained through a joint Federal-State program authorized by Congress in 1974 by means of the Colorado River Basin Salinity Control Act.

\section{SELECTED REFERENCES}

Anderson, J.R., 1967, Major land uses in the United States, in U.S. Geological Survey, 1970, National atlas of the United States of America: Washington, D.C., U.S. Geological Survey, p. 158-159.

Britton, L.J., and Greeson, P.E., eds., 1987, Methods for collection and analysis of aquatic biological and microbiological samples: U.S. Geological Survey Techniques of Water-Resources Investigations, book 5, chap. A4, $363 \mathrm{p}$.

California Department of Food and Agriculture, 1980-89, Fertilizing materials: California Department of Food and Agriculture Tonnage Report 1980-89 [published quarterly], variously paginated.

California Department of Water Resources, 1987, California water, looking to the future: California Department of Water Resources Bulletin 160$87,123 \mathrm{p}$.
California State Water Resources Control Board, 1988a, Water quality assessment for water years 1986 and 1987: Sacramento, California State Water Resources Control Board, Water Quality Monitoring Report 88-1WQ, $107 \mathrm{p}$.

$1988 \mathrm{~b}$, Nitrate in drinking water, report to the legislature: Sacramento, California State Water Resources Control Board, Water Quality Monitoring Report 88-11WQ, $149 \mathrm{p}$.

1989, Water: Sacramento, California State Water Resources Control Board, $28 \mathrm{p}$.

1990, 305(b) Water quality report for water years 1988-1989: Sacramento, California State Water Resources Control Board, Water Quality Monitoring Report 90-6WQ, $33 \mathrm{p}$.

Clifton, D.G., and Gilliom, R.J., 1989, Sources and concentrations of dissolved solids and selenium in the San Joaquin River and its tributaries, California, October 1985 to March 1987: U.S. Geological Survey WaterResources Investigations Report 88-4217, 33 p.

Fenneman, N.M., 1946, Physical divisions of the United States: Washington, D.C., U.S. Geological Survey special map, scale 1:7,000,000.

Fishman, M.J., and Friedman, L.C., eds., 1989, Methods for the determination of inorganic substances in water and fluvial sediments: U.S. Geological Survey Techniques of Water-Resources Investigations, book 5, chap. A1, 545 p.

Hem, J.D., 1985, Study and interpretation of the chemical characteristics of natural water (3d ed.): U.S. Geological Survey Water-Supply Paper 2254, $263 \mathrm{p}$.

Hirsch, R.M., Slack, J.R., and Smith, R.A., 1982, Techniques of trend analysis for monthly water-quality data: Water Resources Research, v. 18, no. 1, p. 107-121.

Lanfear, K.J., and Alexander, R.B., 1990, Methodology to derive water-quality trends for use by the National Water Summary Program of the U.S. Geological Survey: U.S. Geological Survey Open-File Report 90-359, $10 \mathrm{p}$.

Smith, R.A., Alexander, R.B., and Wolman, M.G., 1987, Analysis and interpretation of water-quality trends in major United States rivers, 1974-81: U.S. Geological Survey Water-Supply Paper 2307, 25 p.

Sorenson, S.K., 1982, Water-quality assessment of the Merced River, California: U.S. Geological Survey Open-File Report 82-450, 46 p.

Thelin, G.P., and Pike, R.J., 1990, Digital shaded relief map of the conterminous United States: Menlo Park, Calif., U.S. Geological Survey digital image processing, scale 1:3,500,000.

U.S. Geological Survey, 1986, National water summary 1985-Hydrologic events and surface-water resources: U.S. Geological Survey Water-Supply Paper 2300, $506 \mathrm{p}$.

1990, National water summary 1987-Hydrologic events and water supply and use: U.S. Geological Survey Water-Supply Paper 2350, $553 \mathrm{p}$.

1991, National water summary 1988-89--Hydrologic events and floods and droughts: U.S. Geological Survey Water-Supply Paper 2375, $591 \mathrm{p}$.

Ward, J.R., and Harr, C.A., eds., 1990, Methods for collection and processing of surface-water and bed-material samples for physical and chemical analyses: U.S. Geological Survey Open-File Report 90-140, 71 p. 
Prepared by Rick T. Iwatsubo, U.S. Geological Survey; "Water-Quality Management” section by Richard Woodard, California Department of Water Resources

FOR ADDITIONAL INFORMATION: District Chief, U.S. Geological Survey, Federal Building, Room W-2234, 2800 Cottage Way, Sacramento, CA 95825 


\section{COLORADO Stream Water Quality}

Four major rivers - the Colorado, South Platte, Arkansas, and Rio Grande-have their headwaters in the Rocky Mountains of Colorado. Colorado is the source of about 13 million acre-feet of water per year for other States. Eighty-eight percent of Colorado's exported stream water is derived from precipitation, most of which falls as snow in the mountainous western one-half of the State. Only 12 percent of the water leaving the State is the result of surface-water inflow from outside of Colorado (U.S. Geological Survey, 1990, p. 183).

Surface water accounts for 12.6 million acre-feet per year, or 83 percent of the water used annually in Colorado. Agriculture, the State's leading water use, accounts for 92 percent of the surface water used. Most of the irrigated acreage is in the eastern one-half of the State (fig. 1A). Domestic and commercial supply, industry and mining, and thermoelectric power generation account for the remaining 8 percent of surface-water use. Most of these activities also are in the eastern one-half of the State. Three-quarters of Colorado's available surface-water resources are located west of the Great Plains (fig. $1 B$ ), but only about one-tenth of the State's population resides there (fig. $1 C$ ). About four-fifths of the State's population is concentrated along the eastern edge of the Rocky Mountains (U.S. Geological Survey, 1990, p. 185). Colorado's 1990 population was 3.3 million (U.S. Bureau of the Census 1990 decennial census files).

The quality of the State's water is important to all water users. Stream water flowing from the mountains can be degraded by natural sources and human activities. Soluble salts and minerals contained in some geologic formations substantially increase the dissolvedsolids concentration of the water in some parts of the State (Warner and others, 1985 , p. 12). The dissolved-solids concentration frequently is referred to as the salinity of the water. Excessive salinity is a major concern of agricultural, industrial, and domestic watersupply users (Warner and others, 1985, p. 2). Irrigation return flows are an important source of dissolved solids in some streams (Moody and Mueller, 1984, p. 2). Farming and ranching can be significant sources of increased nutrient loading to the streams. Urban areas contribute waste discharges and storm runoff that adversely affect water quality as streams and rivers pass through. In some mountain areas, water from melting snow is degraded almost immediately by the effects of current and historical metal mining in the State (Wentz, 1974, p. 6). Deterioration of stream water quality can result from the addition of acidic water that contains large concentrations of trace elements from abandoned mines, old tailing piles, and discontinued milling operations. As a result, much of the water can become unsuitable for fishery, irrigation, industrial, and domestic uses.

\section{WATER-QUALITY MONITORING}

Water-quality data obtained from analyses of water samples collected at monitoring stations are stored in the U.S. Geological Survey's (USGS) National Water Information System and the U.S. Environmental Protection Agency's (EPA) national data base known as STORET. Water-quality and streamflow data are reported by water year-the 12 months from October 1 through September 30. A water year is identified by the calendar year in which it ends. For example, water year 1991 comprises October 1, 1990, through September 30, 1991.

Land use, physiography, and population in Colorado. A Major land uses. $B$, Physic divisions. C, Population distribution in 1990. (Sources: A, Major land uses modified from Anderson, 1967. B, Physiographic divisions from Fenneman, 1946; landforms from Thelin and Pike, 1990. C. Data from U.S. Bureau of the Census 1990 decennial census files.) 
The data used in this summary of Colorado's stream water quality were obtained from water samples collected at 14 monitoring stations at which data collection is systematic and continuing (fig. 2). Analyses of water samples collected at 10 stations are the basis for the discussion and graphic summary (fig. 3) of stream water-quality conditions during water years $1987-89$, and data from 13 stations are the basis for the discussion and graphic summary (fig. 4) of stream water-quality trends. Water samples were collected and analyzed by using standard methods approved by the USGS (Britton and Greeson, 1987; Fishman and Friedman, 1989; Ward and Harr, 1990) or by using equivalent methods. If a method of sample collection or analysis changed over time, data from an analysis were included in the evaluation of recent stream water quality or of stream water-quality trends only if the change in method did not affect the comparability of the data.

\section{WATER-QUALITY CONDITIONS}

All of Colorado's major drainage basins are affected to some degree by nonpoint-source pollution (Colorado Water Quality Control Division, 1989, p. 12). The historic mining districts, located mostly in the Rocky Mountains, contribute toxic trace elements to more than 1,300 miles of rivers and streams. Sediment is the most prevalent nonpoint-source pollutant and affects 2,154 miles of streams in the mountains and plains areas. Nutrients affect 743 miles (Colorado Water Quality Control Division, 1989, p. 16). Of the 31,470 miles of streams in Colorado, 28,105 miles meet water-quality criteria for fishing, whereas 572 miles do not. The remaining 2,793 miles have not been assessed. Colorado has 9,062 miles of streams that have swimming as a designated beneficial use, and only 254 miles do not meet quality criteria for that classification (Colorado Water Quality Control Division, 1990, p. ix).

The following discussion of stream water quality in Colorado is organized by river basin (fig. 3). Where physiographic and landuse characteristics in different basins are similar, the discussion of those basins is combined. Graphs in figure 3 summarize certain aspects of stream water quality in the basins for water years 1987-89. The graphs show frequency distributions of data values that represent measurements of selected physical properties of stream water and concentrations of selected constituents in stream water. These properties and constituents are specific conductance, fecal coliform bacteria, dissolved sulfate, dissolved solids, dissolved nitrite plus nitrate (as nitrogen), dissolved selenium, and suspended sediment. The data are reported in microsiemens per centimeter at 25 degrees

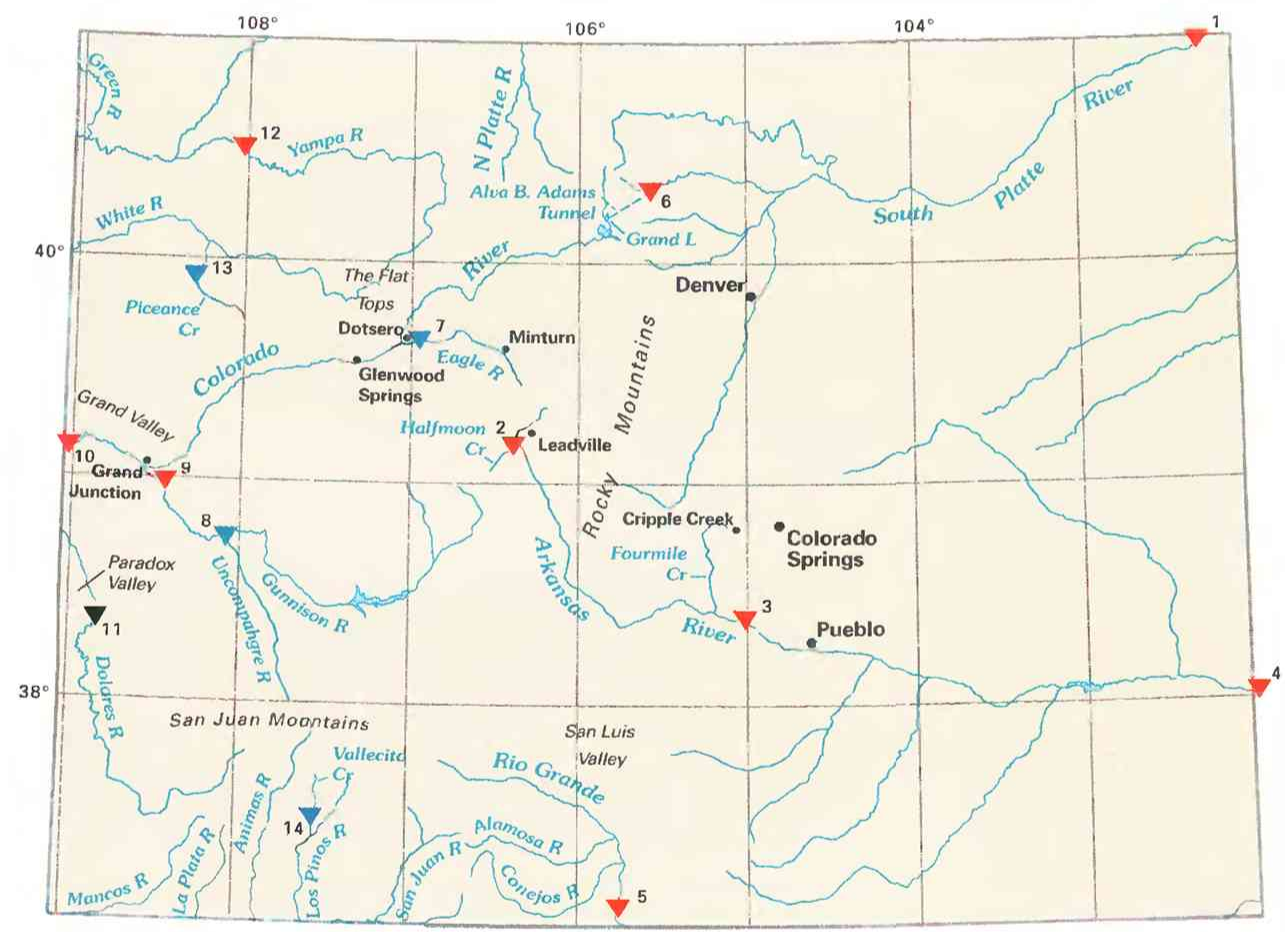

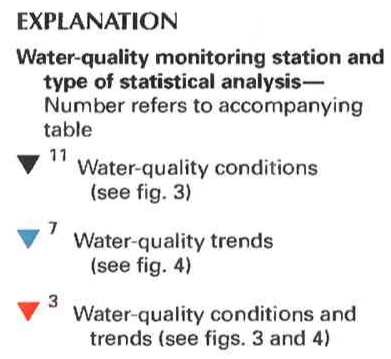

EXPLANATION

ater-quality monitoring station and type of statistical analysisNumber refers to accompanying ality condition ater-quality trends Water-quality conditions and
trends (see figs. 3 and 4 )

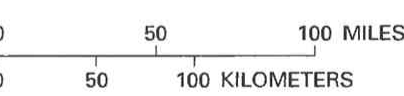

\begin{tabular}{|c|c|c|c|}
\hline $\begin{array}{l}\text { Site no. } \\
\text { on map }\end{array}$ & $\begin{array}{l}\text { USGS station } \\
\text { name and no. }\end{array}$ & $\begin{array}{l}\text { Drainage area } \\
\text { (square miles) }\end{array}$ & $\begin{array}{l}\text { Major land use } \\
\text { (see fig. 1) }\end{array}$ \\
\hline 1 & South Platte River at Julesburg $(06764000)$ & 23,193 & Mostly cropland; irrigated land. \\
\hline 2 & Halfmoon Creek near Malta $(07083000)$ & 23.6 & Grazed forest and woodland. \\
\hline 3 & Arkansas River at Portland $(07097000)$ & 4,024 & Subhumid grassland and semiarid grazing land; irrigated land. \\
\hline 4 & 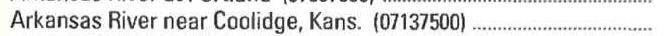 & 25,410 & Subhumid grassland and semiarid grazing land; mostly cropland. \\
\hline 5 & Rio Grande near Lobatos (08251500) & 7,700 & Irrigated land; subhumid grassland and semiarid grazing land. \\
\hline 6 & Alva B. Adams Tunnel at East Portal, near Estes Park (09013000) ..... & Indeterminate & Grazed forest and woodland. \\
\hline 7 & Eagle River at Gypsum (09069000) & 944 & Ditto. \\
\hline 8 & Uncompahgre River at Delta $(09149500)$ & 1,115 & Grazed open woodland; irrigated land. \\
\hline 9 & 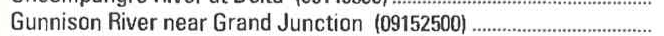 & 7,928 & Grazed desert shrubland; grazed open woodland. \\
\hline 10 & 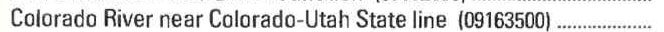 & 17,843 & Ditto. \\
\hline 11 & Dolores River near Bedrock $(09171100)$ & 2,145 & Grazed open woodland. \\
\hline 12 & 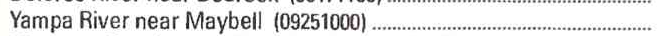 & 3,410 & Cropland with pasture, woodland, and forest; grazed desert shrubland. \\
\hline 13 & Piceance Creek below Ryan Gulch, near Rio Blanco (09306200) ....... & 506 & Grazed open woodland. \\
\hline 14 & 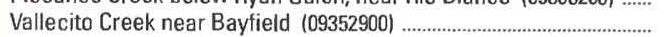 & 72.1 & Grazed forest and woodland. \\
\hline
\end{tabular}

Figure 2. Selected water-quality monitoring stations, type of statistical analysis, and geographic features in Colorado. (Sources: Major land uses modified from Anderson, 1967; other data from U.S. Geological Survey files.) 
Celsius $(\mu \mathrm{S} / \mathrm{cm})$, colonies per 100 milliliters, milligrams per liter $(\mathrm{mg} / \mathrm{L})$, and micrograms per liter $(\mu \mathrm{g} / \mathrm{L})$. Sources and environmental significance of each property and constituent are described in table 1 .

Water quality at each monitoring station is the result of geological, chemical, biological, and hydrologic processes that occur over a large area. Water-quality problems that affect aquatic life or public health only locally are not fully represented in this summary.

\section{SOUTH PLATTE RIVER}

The South Platte River and its tributaries constitute the major river system of northeastern Colorado, draining nearly one-fifth of the State. The South Platte River originates in the center of the State and flows northeastward for about 270 miles before entering Nebraska (U.S. Geological Survey, 1986, p. 168). Most of the water in this river comes from the eastern slope of the Rocky Mountains. About 370 million gallons per day is imported into the basin from the Colorado, Arkansas, and North Platte River basins. Water in the upper South Platte River basin provides habitat for aquatic life and is suitable for most uses.
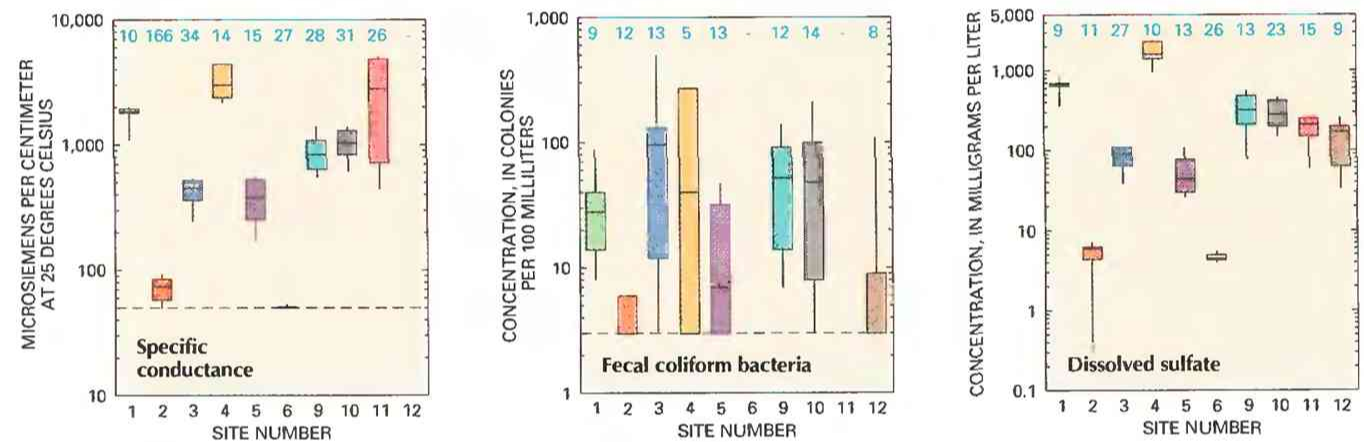
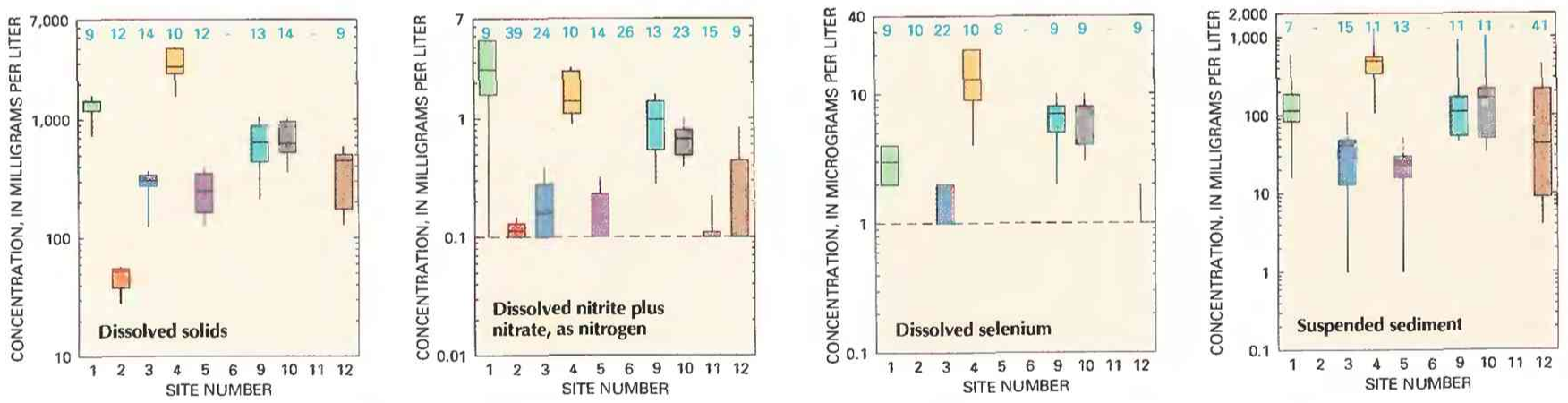

\section{EXPLANATION}

Water-quality conditions in selected dreinage basins

10 Number of analyses-Dash indicates insufficient data

Percentile-Percentage of analyses equal to or less than indicated values

-90th

-75 th

- -50 th-Median

-25 th

-10th

-..-Reporting limit-Minimum reporting limit for analytical method used. Data below limit line not shown
When the South Platte River and its tributaries reach the Great Plains, the waters are degraded by the State's largest population centers. About two-thirds of the State's population lives in the South Platte River basin (Colorado Water Quality Control Division, 1989, p. 50), mostly in the urban-industrial corridor in and north of Denver. As it flows through this area, the river assimilates wastes from municipal and industrial discharge and urban runoff. Several important recreational reservoirs in the Denver metropolitan area are subject to accelerated eutrophication caused by increased nutrient loading from their basins. Concentrations of dissolved oxygen, fecal coliform bacteria, ammonia, and trace elements frequently do not meet the State's water-quality standards (Colorado Water Quality Control Division, 1990, p. 15). However, the effects of urbanization on water quality in the basin, such as excessive fecal coliform bacteria concentrations, decrease downstream from the Denver metropolitan area owing to dilution. The South Platte River flows through one of Colorado's major agricultural areas (figs. $1 A$ and 2 ). The area economy depends largely on irrigated agriculture and livestockfeeding operations, both of which can affect water quality.

Values for several properties and constituents in samples collected at site 1 during 1987-89 were among the largest for any of 


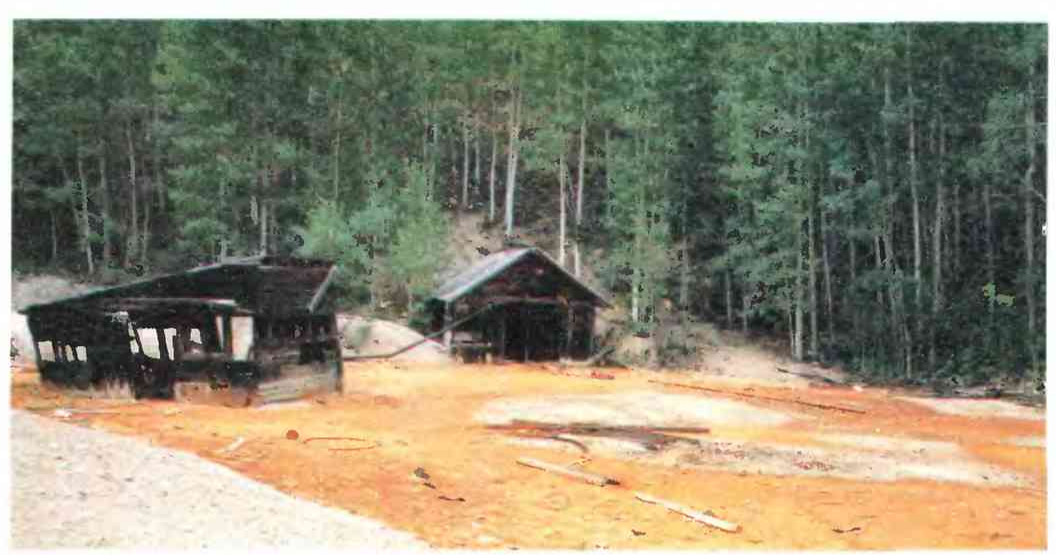

Acidic drainage from abandoned mines, such as this one in the Animas River basin, can degrade the water quality of mountain streams. (Robert F. Middelburg, U.S. Geological Survey.)

the 10 monitoring stations (fig. 3). Owing to runoff from agricultural areas, specific conductance, sulfate, dissolved solids, nitrite plus nitrate, selenium, and suspended sediment were at levels larger than would be expected in a natural stream in the South Platte River basin.

\section{ARKANSAS RIVER BASIN}

The Arkansas River is Colorado's largest basin and drains about one- quarter of the State's $104,247-\mathrm{mi}^{2}$ (square mile) area. The river system contains 5,159 miles of streams, which is 16 percent of the State's total stream miles. Originating in the central part of the State, the river flows eastward for about 235 miles before entering Kansas. About 20 percent of the State's population resides in the Arkansas River basin, mostly in the Colorado Springs and Pueblo areas (Colorado Water Quality Control Division, 1990, tables 1 and 2). Although water in most of the basin is of a quality suitable for most uses, mining in the headwater areas and irrigation in the primarily agricultural lower basin have substantially degraded water quality in many reaches of the Arkansas River system.

Halfmoon Creek is a small headwater tributary to the Arkansas River. The creek basin is forested, and the major land use is grazing. Water quality at site 2 is representative of that of minimally contaminated snowmelt from the eastern Rocky Mountains. Concentrations of all dissolved constituents were small in samples collected during 1987-89 (fig. 3). Near Leadville, extensive mining activities have significantly degraded water quality in the Arkansas River main stem and several headwater tributaries. Downstream, Fourmile Creek, which drains the Cripple Creek mining district, also is strongly affected by mine runoff. These effects are apparent in the Arkansas River main stem just downstream at site 3 , where the median sulfate concentration increased from a natural background level of $6 \mathrm{mg} / \mathrm{L}$ at site 2 to $91 \mathrm{mg} / \mathrm{L}$ at site 3 and the median dissolved-solids concentration increased from $52 \mathrm{mg} / \mathrm{L}$ at site 2 to $306 \mathrm{mg} / \mathrm{L}$ at site 3 . Concentrations of fecal coliform bacteria were much larger at site 3 than at site 2, probably because of runoff from livestock grazing areas and sewage effluent that enter the river downstream from site 2 .

Farther downstream, where agriculture is the predominant land use, large increases in dissolved-solids concentrations recorded at site 4 indicate deterioration of water quality caused by agricultural activities. At site 4, just downstream from the Colorado State line, the median dissolved-solids concentration was $2,790 \mathrm{mg} / \mathrm{L}$, about 9 times the concentration at site 3 and about 53 times the concentration at site 2 (fig. 3).

Much of the Arkansas River basin between the Rocky Mountains and the Kansas State line is underlain by shale formations that contain selenium. When the soil derived from these formations is irrigated, selenium and other elements are mobilized and can be trans- ported to the river in runoff. The mobilization of selenium in the basin is evident by the thirteenfold increase in the median selenium concentrations between site 3 and site 4 . Selenium concentrations have been as large as $52 \mu \mathrm{g} / \mathrm{L}$ in surface water, $29 \mu \mathrm{g} / \mathrm{L}$ in alluvial ground water, and 5.4 parts per million in bottom sediments. Tissue samples from aquatic life, fish, and birds in this area have greater than normal selenium levels, although not to an extent that causes deformities or reproductive failures (Mueller and others, 1991).

\section{RIO GRANDE BASIN}

The Rio Grande originates in the southern Colorado mountains and flows southward for about 130 miles before entering New Mexico (U.S. Geological Survey, 1986, p. 168). In Colorado, the Rio Grande system has 2,118 miles of streams, which is 6.7 percent of the State's total stream miles. About 1 percent of the State's population resides in the basin (Colorado Water Quality Control Division, 1990, tables 1 and 2). Forest covers much of the mountainous parts of the basin, but agriculture and mining activities have some effect on the water quality of the river.

Water from most of the Rio Grande basin is suitable for most uses. However, in short reaches of the headwaters and near the mouth of the Conejos River, excessive trace-metal concentrations impair irrigation use (U.S. Geological Survey, 1986, p. 168). The Alamosa River, a major tributary, has large concentrations of toxic trace metals that have eliminated aquatic life in much of its upper reaches (Colorado Water Quality Control Division, 1989, p. 114). Excessive tracemetal concentrations in much of the Alamosa River have been attributed to localized geologic conditions, such as weathering of iron pyrite, rather than to mining. However, mining has degraded the water quality of some smaller tributaries. Extensive irrigation in the lower reaches of the Rio Grande basin of Colorado can account at least partly for elevated dissolved-solids and suspended-sediment concentrations; however, the levels of these constituents currently are not large enough to be a concern.

The closed basin of the Rio Grande drainage lies in the northern part of the San Luis Valley. The closed basin is separated from the Rio Grande by a low topographic divide and a ground-water divide (Hearne and Dewey, 1988, p. 42). Normally, water in the basin does not discharge across the divides, although both divides can be breached. Here, as a result of metal mining, many of the upper reaches of streams draining into the closed basin exceed the Colorado basic stream standards for aquatic-life protection and agricultural uses (Colorado Water Quality Control Division, 1989, p. 116).

Site 5 is located on the Rio Grande main stem near the New Mexico border. Water quality of the Rio Grande at that monitoring station is essentially the same as that of the river as it flows across the border into New Mexico. At site 5, values for all properties and constituents were similar to or less than those at monitoring stations on streams that drain areas not solely in the mountains (fig. 3) and are representative of a stream that is minimally contaminated, either by natural or human-related causes.

\section{COLORADO RIVER}

The Colorado River system drains nearly two-fifths of the State. In Colorado, this drainage has three major subbasins: the Colorado River main-stem system, which drains west-central Colorado and includes the Gunnison and Dolores River systems; the San Juan River system, which drains southwestern Colorado; and the WhiteYampa River systems, which drain northwestern Colorado. The San Juan and the White-Yampa Rivers join the Colorado River in Utah. Three-quarters of the State's available water is in these rivers, but 
Table 1. Sources and environmental significance of selected water-quality properties and constituents [Source: Compiled by the U.S. Geological Survey, Office of Water Quality]

\begin{tabular}{|c|c|c|}
\hline Property or constituent & Common sources & Environmental significance \\
\hline $\begin{array}{l}\text { Specific conductance .......................... } \\
\text { (property) }\end{array}$ & $\begin{array}{l}\text { A measure of the electrical conductivity of water; var- } \\
\text { ies with the quantity of dissolved solids and is } \\
\text { used to approximate the dissolved-solids content. }\end{array}$ & $\begin{array}{l}\text { Dissolved solids can cause water to be unsuitable for } \\
\text { public supply, agriculture, and industry; can harm } \\
\text { aquatic organisms. }\end{array}$ \\
\hline Fecal coliform bacteria ................ & $\begin{array}{l}\text { Sources include effluent from sewage-treatment } \\
\text { plants and runoff from pastures, feedlots, and ur- } \\
\text { ban areas. }\end{array}$ & $\begin{array}{l}\text { Presence indicates contamination of water by wastes } \\
\text { from humans and other warm-blooded animals. }\end{array}$ \\
\hline Sulfate & $\begin{array}{l}\text { Occurs in some rocks; also in mine runoff, industrial } \\
\text { wastewater discharge, and atmospheric deposi- } \\
\text { tion. }\end{array}$ & $\begin{array}{l}\text { Concentrations exceeding a natural, background } \\
\text { level indicate contamination from human activity; } \\
\text { in sufficient quantity, can cause water to be un- } \\
\text { suitable for public supply; can harm aquatic } \\
\text { organisms. }\end{array}$ \\
\hline 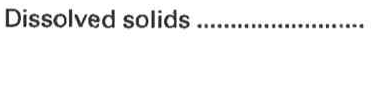 & $\begin{array}{l}\text { A result of rock weathering; also in agricultural runoff } \\
\text { and industrial discharge. }\end{array}$ & $\begin{array}{l}\text { In sufficient quantity, can cause water to be unsuitable } \\
\text { for public supply, agriculture, and industry; can } \\
\text { harm aquatic organisms. }\end{array}$ \\
\hline Nitrite plus nitrate & $\begin{array}{l}\text { Nonpoint sources are agricultural and urban runoff; } \\
\text { a major point source is wastewater discharge. }\end{array}$ & $\begin{array}{l}\text { Plant nutrient that, in sufficient quantity, can cause } \\
\text { algal blooms and excessive growth of higher } \\
\text { aquatic plants in bodies of water; can cause water } \\
\text { to be unsuitable for public supply. }\end{array}$ \\
\hline Selenium & $\begin{array}{l}\text { Occurs in some rocks and soils; can be leached from } \\
\text { arid lands by irrigation. }\end{array}$ & $\begin{array}{l}\text { Toxic in larger than trace concentrations; can cause } \\
\text { water to be unsuitable for public supply; can } \\
\text { harm aquatic organisms. }\end{array}$ \\
\hline Suspended sediment .................. & $\begin{array}{l}\text { A result of rock erosion; also induced by disturbances } \\
\text { of land cover due to fires, floods, and human } \\
\text { activities such as mining, logging, construction, } \\
\text { and agriculture. }\end{array}$ & $\begin{array}{l}\text { Can be detrimental aquatic organisms; can fill res- } \\
\text { ervoirs and impair recreational use of water. }\end{array}$ \\
\hline
\end{tabular}

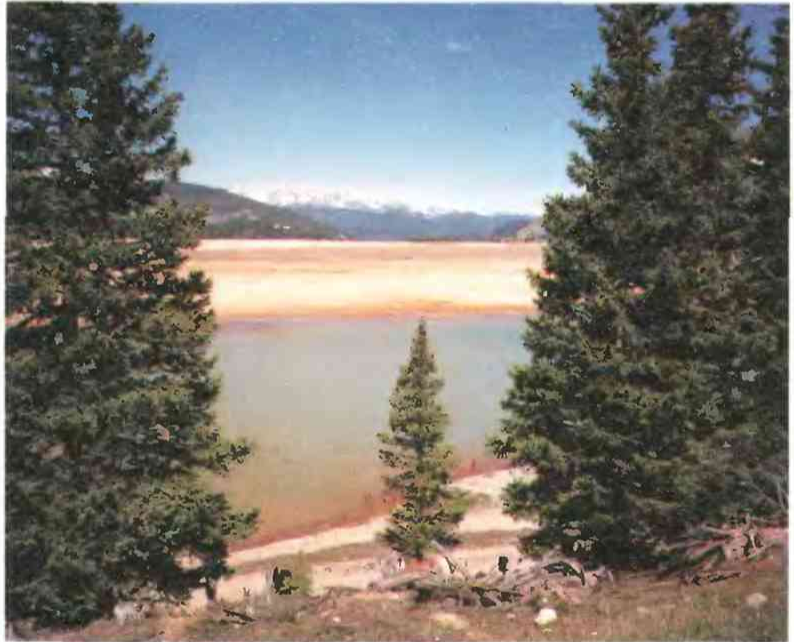

Tailings from a molybdenum mine near the Continental Divide create a lake in the headwaters of a stream in the Colorado River basin. Metals mining is a significant source of water-quality degradation in the Rocky Mountains. (Robert F. Middelburg, U.S. Geological Survey.)

only about one-tenth of the population resides in the basin. The mismatch of supply and demand allows about $448 \mathrm{Mgal} / \mathrm{d}$ of water to be exported annually from the Colorado River basin to the Rio Grande, Platte, and Arkansas River basins to the east (U.S. Geological Survey, 1986, p. 171).

The Colorado River main-stem system originates in the central and southwestern mountains of the State and flows westward into Utah. The Dolores River joins the Colorado River in Utah but herein is considered part of the Colorado River main-stem system. The system has a drainage area of $22,200 \mathrm{mi}^{2}$, or 21 percent of the State. Water quality has been assessed in essentially all of the basin's 6,833 miles of streams (Colorado Water Quality Control Division, 1990, p. 7). Water quality in this basin generally is satisfactory for most uses, although runoff from agricultural areas, abandoned mines, and naturally occurring saline ground-water discharge causes some lo- calized problems (Colorado Water Quality Control Division, 1989, p. 129).

The mountainous headwater area of the Colorado River main stem is popular for year-round recreation. Many ski resorts are located there, and the area's population increases considerably in the winter. Technologically advanced wastewater-treatment facilities help maintain the quality of area streams. These streams are the source of most transmountain diversion water conveyed to the east. The Alva B. Adams Tunnel diverts water from Grand Lake to the South Platte River basin on the eastern slope of the Rocky Mountains. Site 6, which is 700 feet downstream from the east portal of the tunnel, monitors water that comes mainly from snowmelt. Water in Grand Lake is low in dissolved solids, as indicated by the small specific-conductance values during water years 1987-89 (fig. 3), and is subject to minimal contamination.

Metal and energy-related mining over much of the region affects the water quality of some basin streams. Currently (1991), water in some parts of the lower reach of the Eagle River is acutely and chronically toxic to aquatic life owing to cadmium, copper, lead, manganese, and zinc in concentrations that frequently exceed State agriculture and drinking-water criteria. One of the main sources of these trace elements is a mine and its tailings piles upstream from Minturn. The mine, now inactive, is undergoing remediation through the Comprehensive Environmental Response, Compensation, and Liability Act. Runoff from the mine affects water quality in the Eagle River to its confluence with the Colorado River near Dotsero (Colorado Water Quality Control Division, 1989, p. 137).

Hot springs in the Glenwood Springs and Dotsero areas are major contributors of salinity to the Colorado River. An estimated 534,000 tons per year of salt enters the river in this reach-nearly 20 percent of the base-flow salt load that exits Colorado at the Utah State line (Warner and others, 1985, p. 30).

Downstream from Glenwood Springs, the Colorado River main stem flows through an area of energy-related mining and agriculture. In this section the river is affected by sediment and salinity from these activities, as well as from natural sources (Colorado Water Quality Control Division, 1989, p. 140). The Grand Valley near Grand Junction is the largest population center in the basin and is a major agricultural area. The base-flow salt load from the Grand Valley is estimated to be 755,000 tons per year, or 28 percent of the total salt 
load in the Colorado River where it enters Utah (Warner and others, 1985, p. 51). In the Paradox Valley of the Dolores River basin, naturally saline ground water enters the Dolores River. The Paradox Valley contributes an estimated 152,000 tons per year, or 52 percent of the salt load from the Dolores River basin. An increase in the median specific conductance for water years 1987-89 from 690 $\mu \mathrm{S} / \mathrm{cm}$ at a monitoring station 7.9 miles upstream from site 11 (not shown) to $2,800 \mu \mathrm{S} / \mathrm{cm}$ at site 11 (fig. 3) illustrates the localized effect of the saline Paradox Valley ground water.

Irrigation return flows in the Gunnison River basin have increased selenium concentrations in basin streams. Selenium concentrations at site 9 were significantly larger than background levels, but concentrations in 90 percent of the samples collected during water years 1987-89 did not exceed the State standard of $10 \mathrm{mg} / \mathrm{L}$ for drinking-water supply.

\section{WHITE AND YAMPA RIVERS}

The White and Yampa Rivers drain the sparsely populated northwestern part of the State. Both rivers are part of the Colorado River drainage but join the Green River before it enters the Colorado River in Utah. The basin has major reserves of coal and oil shale. All of the 6,114 miles of streams in the White and Yampa River basins have been assessed (Colorado Water Quality Control Division, 1990, p. 7). Water quality in these two river basins and their tributaries meet all State water-quality criteria (Colorado Water Quality Control Division, 1990. p. 35).

The Yampa River originates in the north-central mountains of Colorado and flows westward for about 165 miles before joining the Green River. Water in the basin is used principally for irrigation of hay meadows. The major water-quality issues of the basin are salinity and trace-element contamination resulting from coal mining. However, neither appreciably affected water quality in the river at site 12 during 1987-89 (fig. 3).

The White River originates in The Flat Tops mountains and flows parallel to the Yampa River. The river flows westward for about 120 miles before joining the Green River in Utah. The principal water use in the basin is irrigation of hay meadows. The major water-quality issues of the basin, in addition to salinity and trace-metal contamination from coal mining, are the potential effects of shale-oil development in the Piceance Creek basin (Tobin and others, 1985, p. 78). At present (1991), only limited test mining of the oil shale has occurred and only minor effects of the mining have been measured in streams.

\section{SAN JUAN RIVER BASIN}

The San Juan River system is located in southwestern Colorado. Major rivers in the basin are the San Juan, Los Pinos, Animas, La Plata, and Mancos Rivers: all emanate from the San Juan Mountains. Water quality of all 2,428 miles of streams in the basin has been assessed (Colorado Water Quality Control Division, 1990, p. 7). Agriculture, mining, and tourism are the activities that have the greatest potential to affect the basin's water quality. The area is sparsely populated, but an increase in tourism is placing demands on the water resources of the basin, particularly the western part.

Water quality in the San Juan River basin is suitable for most uses, except in some reaches of the Animas River near its headwaters. Previous mining activities have resulted in high trace-metal concentrations that have affected the river's ability to support aquatic life (Colorado Water Quality Control Division, 1990, p. 35).

\section{WATER-QUALITY TRENDS}

Trend analysis is a statistical procedure used to detect changes in stream water quality at a monitoring station over time. For this

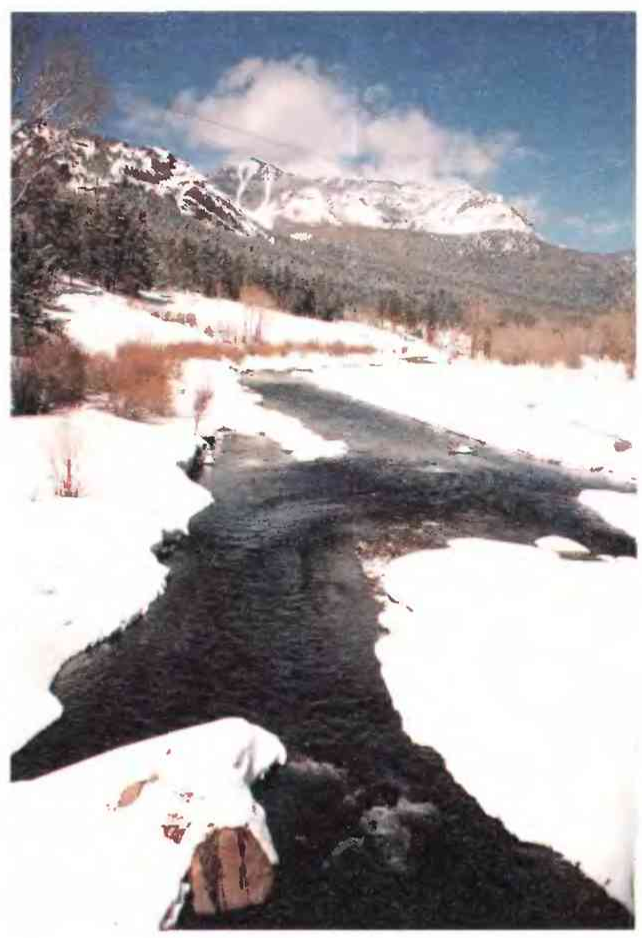

San Juan River near its headwaters. Snowmelt in the Rocky Mountains is the principal source of water for Colorado streams. Headwater streams are pristine in areas where human activities, such as mineral extraction, are minimal. (Robert F. Middelburg, U.S. Geological Survey.)

report, water-quality data from 13 monitoring stations (fig. 2) were analyzed for trends by using the seasonal Kendall test (Hirsch and others, 1982), a method used extensively by the USGS. The graph (shown below) of the dissolved-sulfate concentration in the Yampa River at site 12 illustrates the trend inferred from the concentration data and demonstrates the variation in water quality that is common in streams.

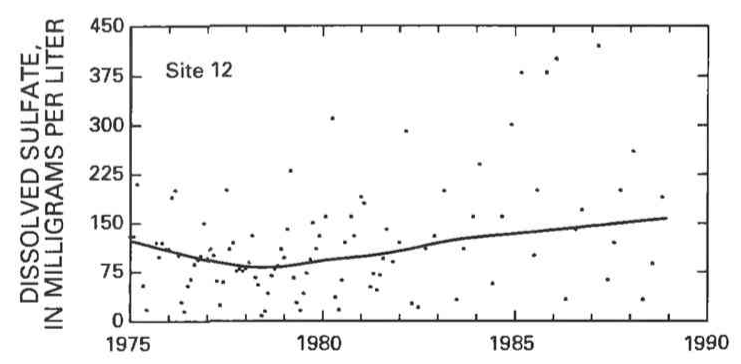

When possible, constituent-concentration data were adjusted for changes in streamflow to preclude identifying a trend in concentration that was caused only by a trend in streamflow. The data were not adjusted when (1) more than 10 percent of the samples had concentrations lower than the minimum reporting limit for the analytical method used or (2) streamflow was controlled substantially by human activities. When the concentration data could not be adjusted for streamflow, trends were determined directly from the concentration data.

Statewide trends in measurements of selected physical properties of stream water and concentrations of selected constituents in stream water are shown on maps in figure 4. On each map, a trend is 
indicated at a monitoring station only if the data from that station were suitable for use in the trend analysis. For more information on the suitability criteria and on the trend-analysis procedure used for this report, see Lanfear and Alexander (1990).

\section{SPECIFIC CONDUCTANCE}

Specific conductance is a measure of the ability of a sample of water to conduct electricity. Because specific conductance and the

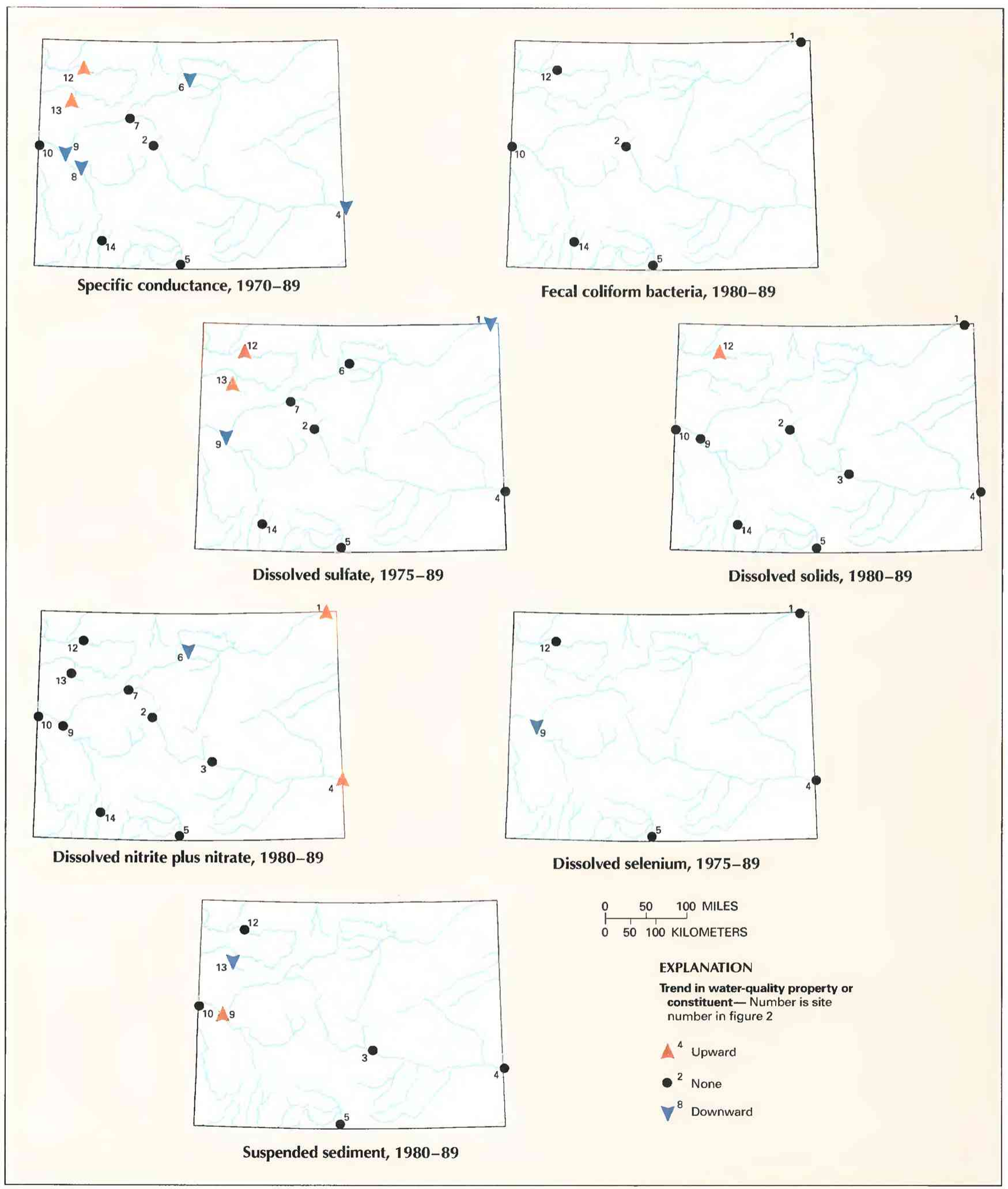

Figure 4. Trends in water quality of selected streams in Colorado, by water years. (Source: Data from U.S. Geological Survey files.) 
dissolved-solids concentration are roughly proportional in most natural waters, the specific-conductance value often can be used to estimate the dissolved-solids concentration (Hem, 1985, p. 66-68). Specific conductance was chosen for discussion in this report because long-term data are available from more monitoring stations than for dissolved solids.

Specific conductance had upward trends at site 12 on the Yampa River and site 13 on Piceance Creek, both in the northwestern part of the State. Neither stream is substantially regulated. The upward trends are attributable to a combination of decreasing streamflow during the later years of the trend-analysis period and increased grazing, which allows more of the naturally occurring salts in the soil to enter the streams in runoff. The upward trend in Piceance Creek at site 13 also is attributable to the discharge of water having a large dissolved-solids concentration to the creek as a result of oilshale test-mine dewatering (Tobin and others, 1985, p. 10).

Changes in water-management practices in the lower Arkansas River basin and improved irrigation practices probably caused the downward specific-conductance trend at site 4 . There was a downward trend recorded at this monitoring station for the period 1968-82 in another study (U.S. Geological Survey, 1985, p. 83). The cause for the downward trend at site 6 at the east portal of the Alva B. Adams Tunnel is not known. The downward trends at site 8 on the Uncompahgre River and site 9 on the Gunnison River were the result of changing irrigation practices in the basin and possibly also were a result of the U.S. Bureau of Land Management salinity-control demonstration projects in the Uncompahgre River basin (Colorado Water Quality Control Division, 1989, p. 147).

\section{FECAL COLIFORM BACTERIA}

Fecal coliform bacteria are used as indicators of fecal contamination from humans and other warm-blooded animals. Such contamination can introduce disease-causing viruses and bacteria into a stream. Concentrations of fecal coliform bacteria had no significant trend at any of the six stations tested during the period 1980-89.

\section{DISSOLVED SULFATE}

The major natural sources of sulfate in streams are rock weathering, volcanoes, and biochemical processes (Hem, 1985, p. 113). Human activities such as mining, waste discharge, and fossil-fuel combustion also can be important sources.

Upward trends were detected at site 12 on the Yampa River and site 13 on Piceance Creek. These stations monitor areas of oilshale and coal mining. Such mining can cause significant increases in sulfate concentrations. Analysis of data collected at site 12 on the Yampa River indicate that the upward trend was caused by decreasing discharge during the later years of the trend-analysis period. The upward trend at site 13 might have been associated with dewatering of oil-shale test mines, the result of which is the discharge of sulfateenriched water into Piceance Creek.

The two stations at which trends were downward, site 1 on the South Platte River and site 9 on the Gunnison River, monitor areas of extensive agricultural activity. No definite cause for the downward trends is known, although improvements in agricultural practices, such as decreased use of sulfur products associated with fertilizers, soil amenders, and fungicides, would cause sulfate to decrease. A third station, site 4 on the Arkansas River near the Kansas border, also monitors an area of extensive agricultural activity, but sulfate concentrations at that site had no trend. Streamflow upstream from sites 1,9 , and 4 is extensively regulated, and differences in reservoir releases of less contaminated water from the mountains might explain the difference in trend at the stations monitoring areas having the same general land use.

There were no trends in sulfate concentrations at site 2 on Halfmoon Creek, site 6 at the Alva B. Adams Tunnel, or site 14 on Vallecito Creek. These streams are representative of the pristine and weakly buffered water originating from precipitation in the Rocky Mountains and are potentially susceptible to contamination from acid rain and snow. The lack of trend at these stations indicates that the atmospheric contributions of sulfate have not changed significantly.

\section{DISSOLVED SOLIDS}

Dissolved solids in stream water result primarily from rock weathering but also can be introduced as a byproduct of human activities (table 1). Concentrations generally are greatest in streams draining basins underlain by rocks and soils that contain easily dissolved minerals. A decrease in precipitation and runoff in the late 1980 's and the associated lessened dilution of the more mineralized ground-water contribution to streamflow is the probable cause for the upward trend in dissolved-solids concentrations at site 12 on the Yampa River (fig. 4).

\section{DISSOLVED NITRITE PLUS NITRATE}

Nitrite and nitrate are oxidized forms of nitrogen that together normally constitute most of the dissolved nitrogen in well-aerated streams. Nitrite readily oxidizes to nitrate in natural waters; therefore, nitrate generally is by far the more abundant of the two (Hem, 1985, p. 124).

The two stations at which there were upward trends, site 1 on the South Platte River and site 4 on the Arkansas River, monitor agricultural areas in Colorado as does the Gunnison River station (site 9), at which there was no trend. Whether the difference in trend was due to differences in agricultural practices or to the effects of steamflow regulation by upstream dams is not clear.

Of the three stations that monitor pristine waters that originate in the Rocky Mountains-site 2 on Halfmoon Creek, site 6 at the Alva B. Adams Tunnel, and site 14 on Vallecito Creek-only concentrations at site 6 had a downward trend. The slight downward trend was more likely the result of natural limnological cycles in the reservoir from which the transmountain diversion water is drawn than of changes in atmospheric-deposition rates. Because of the small nitrite plus nitrate concentrations (between 0.1 and $0.2 \mathrm{mg} / \mathrm{L}$ ) recorded at the three monitoring stations and the short trend-analysis period (1980-89), further study is needed to determine the significance of the trend information.

\section{DISSOLVED SELENIUM}

Selenium exists in nature generally as a trace element, but soils in some arid and semiarid regions of the Western United States contain more than trace amounts. Selenium concentrations had a downward trend at site 9 on the Gunnison River during 1975-89. The source of selenium is irrigation return flow from cropland in an area of highly erodible shale formations containing selenium. A recently implemented salinity-control project of the U.S. Bureau of Land Management designed to alleviate the salinity problem in the basin might account for the downward trend (Colorado Water Quality Control Division, 1989, p. 147).

\section{SUSPENDED SEDIMENT}

Suspended sediment is a product of erosion. The erosion can be either natural or the result of land-cover disturbances related to human activities (table 1). Colorado has identified suspended sediment as a nonpoint-source pollution problem in many reaches of streams throughout the State (Colorado Water Quality Control Division, 1989, p. 13). However, federally conducted suspendedsediment monitoring has decreased because of budgetary constraints. As a result, available data are limited, and few of the 13 stations had sufficient data for trend analysis.

Concentrations of suspended sediment at site 9 on the Gunnison River had an upward trend, probably owing to increasing run- 
off from agricultural areas in the lower part of the basin (Colorado Water Quality Control Division, 1989, p. 147). The decrease at site 13 on Piceance Creek might have been the result of dilution by dewatering activities at oil-shale test-mining areas. Such activities add water low in suspended sediment to the local streams (Tobin and others, 1985, p. 10).

\section{WATER-QUALITY MANAGEMENT}

"Water quality management in Colorado has evolved from a technology based program into one which relates specific control actions to water quality problems. Expected measurable improvements or maintenance of existing water quality is the goal," states the Colorado Department of Health in their 1990 State water-qualityassessment report (Colorado Water Quality Control Division, 1990, p. 45), which is submitted biennially to the EPA and the U.S. Congress pursuant to section 305(b) of the Clean Water Act. According to the report, the State is achieving that goal, even with a reduction in their stream-quality monitoring program. In 1979, the State had more than 150 water-quality monitoring stations. Currently (1990), the number of stations has decreased to 100 ; however, monitoring at two-thirds of those stations is frequent and systematic. The present water-quality monitoring emphasis is on identifying areas where specific or potential problems exist because of population growth or land-use changes. The State relies primarily on State-collected waterquality information and other-agency data obtained from STORET; most of the other-agency data are collected by the USGS.

The Water Quality Control Division of the Colorado Department of Health has the primary responsibility for implementing water-quality programs as defined under the Colorado Water Quality Control Act (section 25-8-101). Water-quality standards are established by the Water Quality Control Commission, a nine-member board appointed by the Governor to serve as the regulatory and policy-setting entity of the State for water-quality issues.

State nonpoint-source issues are managed by the Colorado Nonpoint Source Task Force, which was formed in 1987. Four subcommittees address various concerns of nonpoint-source pollution related to agriculture/silviculture, urban and construction runoff, mining, and hydrologic modification.

Colorado is a member of the Colorado River Basin Salinity Control Forum and the Colorado River Basin Salinity Control Advisory Council, which are interstate organizations that have been formed by the seven Colorado River Basin States. The States work with the Federal Government in implementing salinity-control measures in the basin. The Forum was established in 1973 under Public Law 92-500 to develop water-quality standards. The Advisory Council, created in 1974 under Public Law 93-320, coordinates State actions and advises the Federal Government of the Council's views on issues affecting water-quality standards and ways to meet those standards. The resources of the U.S. Department of the Interior (including the USGS), the EPA, and the U.S. Department of Agriculture are coordinated through an Interagency Salinity Control Committee. Colorado supports the salinity-control program through waterquality-management plans, effluent-discharge control, and education about the control of salinity.

\section{SELECTED REFERENCES}

Anderson, J.R., 1967, Major land uses in the United States, in U.S. Geological Survey, 1970, National atlas of the United States of America: Washington, D.C., U.S. Geological Survey, p. 158-159.
Britton, L.J., and Greeson, P.E., eds., 1987, Methods for collection and analysis of aquatic biological and microbiological samples: U.S. Geological Survey Techniques of Water-Resources Investigations, book 5, chap. A4, $363 \mathrm{p}$.

Colorado Water Quality Control Division, 1989, Colorado Nonpoint Source Assessment Report, 1989 Addendum: Denver, Colorado Department of Health, $189 \mathrm{p}$.

1990, Water quality in Colorado, 305(b) Report, 1990: Denver, Colorado Department of Health, variously paginated.

Fenneman, N.M., 1946, Physical divisions of the United States: Washington, D.C., U.S. Geological Survey map, scale 1:7,000,000.

Fishman, M.J., and Friedman, L.C., eds., 1989, Methods for the determination of inorganic substances in water and fluvial sediments: U.S. Geological Survey Techniques of Water-Resources Investigations, book 5 , chap. A1, $545 \mathrm{p}$.

Hearne, G.A., and Dewey, J.D., 1988, Hydrologic analysis of the Rio Grande Basin north of Embudo, New Mexico, Colorado and New Mexico: U.S. Geological Survey Water-Resources Investigations Report 86-4113, $244 \mathrm{p}$.

Hem, J.D., 1985, Study and interpretation of the chemical characteristics of natural water (3d ed.): U.S. Geological Survey Water-Supply Paper 2254, $263 \mathrm{p}$.

Hirsch, R.M., Slack, J.R., and Smith, R.A., 1982, Techniques of trend analysis for monthly water quality data: Water Resources Research, v. 18, no. 1, p. 107-121.

Lanfear, K.J., and Alexander, R.B., 1990, Methodology to derive water-quality trends for use by the National Water Summary Program of the U.S. Geological Survey: U.S. Geological Survey Open-File Report 90-359, $10 \mathrm{p}$.

Moody, C.D., and Mueller, D.K., 1984, Water quality of the Colorado River system-Historical trends in concentration, load, and mass fraction of inorganic solutes: U.S. Bureau of Reclamation, REC-ERC 84-9, 60 p.

Mueller, D.K., DeWeese, L.R., Garner, A.J., and Spruill, T.B., 1991, Reconnaissance investigation of water quality, bottom sediment, and biota associated with irrigation drainage in the middle Arkansas River basin, Colorado and Kansas: U.S. Geological Survey Water-Resources Investigations Report 91-4060, 84 p.

Thelin, G.P., and Pike, R.J., 1990, Digital shaded relief map of the conterminous United States: Menlo Park. Calif., U.S. Geological Survey digital image processing, scale 1:3,500,000.

Tobin, R.L., Stranathan, H.E., and Covay, K.J., 1985, Water-quality characteristics of streams in the Piceance Creek and Yellow Creek drainage basins, northwestern Colorado, water years 1977-81: U.S. Geological Survey Water-Resources Investigations Report 84-4261, 80 p.

U.S. Geological Survey, 1985, National water summary 1984 -Hydrologic events, selected water-quality trends, and ground-water resources: U.S. Geological Survey Water-Supply Paper 2275, 467 p.

1986 , National water summary 1985 - Hydrologic events and surfacewater resources: U.S. Geological Survey Water-Supply Paper 2300, $506 \mathrm{p}$.

1990, National water summary 1987-Hydrologic events and water supply and use: U.S. Geological Survey Water-Supply Paper 2350, $553 \mathrm{p}$.

Ward, J.R., and Harr, C.A., eds., 1990, Methods for collection and processing of surface-water and bed-material samples for physical and chemical analyses: U.S. Geological Survey Open-File Report 90-140, 71 p.

Warner, J.W., Heimes, F.J., and Middelburg, R.F., 1985, Ground-water contribution to the salinity of the Upper Colorado River Basin: U.S. Geological Survey Water-Resources Investigations Report 84-4198, $113 \mathrm{p}$.

Wentz, D.A., 1974, Effect of mine drainage on the quality of streams in Colorado, 1971-72: Colorado Water Resources Circular 21, $117 \mathrm{p}$. 
206 National Water Summary 1990-91-Stream Water Quality: STATE SUMMARIES

Prepared by Robert F. Middelburg, U.S. Geological Survey

FOR ADDITIONAL INFORMATION: District Chief, U.S. Geological Survey, Building 53, Mail Stop 415, Denver Federal Center, Lakewood, CO 80225 


\section{Connecticut Stream Water Quality}

Connecticut has more than 8,400 miles of streams and 6,000 lakes (U.S. Geological Survey, 1986, p. 175). These waters have been, and will continue to be, an important factor in the growth and development of the State. Industrial, commercial, and domestic users in Connecticut rely on surface water for most freshwater needs. In 1985 , surface water supplied on average 1,060 million gallons per day, which accounted for 88 percent of all offstream freshwater withdrawals in the State (U.S. Geological Survey, 1990, p. 196). Ground water supplied the remaining 12 percent. Although surface water is plentiful in Connecticut, the State is densely populated and heavily industrialized. These factors combine to create major demands on water resources for supply, waste assimilation, and recreation. The goal of the State is to accommodate these activities while maintaining or achieving water quality suitable to support a healthy aquatic habitat (Connecticut Department of Environmental Protection, 1988. p. 6).

Most of Connecticut is covered by woodland, forest, pasture, and cropland, but there are large urban areas located predominantly in industrialized regions of the State (fig. 1A). Connecticut is in the Taconic and New England Upland sections of the New England physiographic province (fig. $1 B$ ).

Surface water is evenly distributed across the State, but population is not. The southwestern and central parts of the State have the greatest population density, whereas the northwestern and northeastern parts are the least populated (fig. 1C). The 1990 population of the State was 3.3 million (U.S. Bureau of the Census 1990 decennial census files), for an average density of about 677 people per $\mathrm{mi}^{2}$ (square mile). Between 1970 and 1990, the statewide population increased by 8.4 percent; the greatest increase was in southwestern Connecticut.

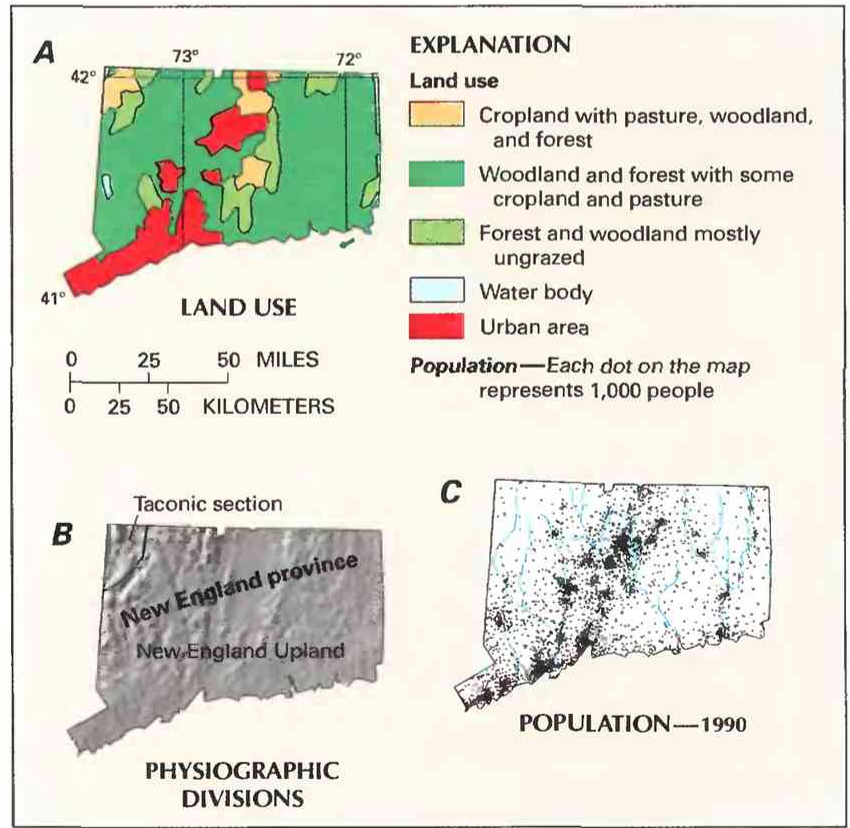

Figure 1. Land use, physiography, and population in Connecticut. A, Major land uses. B, Physiographic divisions. $C$, Population distribution in 1990. (Sources: A, Major land uses modified from Anderson, 1967. $B$. Physiographic divisions from Fenneman, 1946; landforms from Thelin and Pike, 1990. C, Data from U.S. Bureau of the Census 1990 decennial census files.)

\section{WATER-QUALITY MONITORING}

Water-quality data obtained from analyses of water samples collected at monitoring stations are stored in the U.S. Geological Survey's (USGS) National Water Information System and the U.S. Environmental Protection Agency's (EPA) national data base known as STORET. Water-quality and streamflow data are reported by water year-the 12 months from October 1 through September 30. A water year is identified by the calendar year in which it ends. For example, water year 1991 comprises October 1, 1990, through September 30, 1991.

The data used in this summary of Connecticut's stream water quality were obtained from water samples collected monthly, every 2 months, or quarterly at 10 monitoring stations at which data collection is systematic and continuing (fig. 2). Analyses of water samples collected at these stations are the basis for the discussion and graphic summary (fig. 3) of stream water-quality conditions during water years 1987-89, and for the discussion and graphic summary (fig. 4) of stream water-quality trends. Water samples were collected and analyzed by using standard methods approved by the USGS (Britton and Greeson, 1987; Fishman and Friedman, 1989; Ward and Harr, 1990) or by using equivalent methods. If a method of sample collection or analysis changed over time, data from an analysis were included in the evaluation of recent stream water quality or of stream water-quality trends only if the change in method did not affect the comparability of the data.

\section{WATER-QUALITY CONDITIONS}

In 1988, the Connecticut Department of Environmental Protection (DEP) assessed the water quality of 880 miles of the major rivers and streams in the State and reported that 66 percent fully supported DEP water-quality goals (Connecticut Department of Environmental Protection, 1988, p. 1). Another 27 percent supported some DEP goals, such as providing a healthy aquatic habitat, but was not recommended for swimming. The remaining 7 percent of the stream miles assessed did not support designated water uses other than limited aquatic habitat maintenance, navigation, and some industrial activities. Most of the major sources of water-quality degradation in the larger rivers and streams in the State are point sources, whereas the degradation of water quality in smaller streams stems mainly from nonpoint-source contamination. Major point sources are municipal sewage-treatment-plant discharge, industrial discharge, and combined municipal- and storm-sewer overflow. The primary nonpoint sources are septic systems; runoff from road surfaces, land development, agricultural areas, and lawns; and natural processes (Connecticut Department of Environmental Protection, 1989, p. 2).

A persistent and widespread water-quality problem in Connecticut is contaminated stream and lake-bottom sediments (C.G. Fredette, Connecticut Department of Environmental Protection, oral commun., August 1990). The primary sources of contamination were the numerous metal finishing, textile, and paper mills that characterized industry in New England from the late 1700's through the mid-1900's. The contaminants found in the bottom sediments include metals, organic compounds, and solid residuals from paper and textile mills.

The following discussion of stream water quality in Connecticut is organized by river basin (fig. 3). Where physiographic and landuse characteristics in different basins are similar, the discussion of 
those basins is combined. Graphs in figure 3 summarize certain aspects of stream water quality in the basins for water years 1987-89. The graphs show frequency distributions of data values that represent measurements of selected physical properties of stream water and concentrations of selected constituents in stream water. These properties and constituents are specific conductance, $\mathrm{pH}$, dissolved oxygen, dissolved chloride, dissolved solids, dissolved nitrite plus nitrate (as nitrogen), and total phosphorus (as phosphorus). The data are reported in microsiemens per centimeter at 25 degrees Celsius, standard $\mathrm{pH}$ units, and milligrams per liter $(\mathrm{mg} / \mathrm{L})$. Sources and environmental significance of each property and constituent are described in table 1.

Water quality at each monitoring station is the result of geological, chemical, biological, and hydrologic processes that occur over a large area. Water-quality problems that affect aquatic life or public health only locally are not fully represented in this summary.

\section{SHETUCKET AND QUINEBAUG RIVERS}

The Shetucket and Quinebaug Rivers are the major streams in the Thames River basin, which drains most of eastern Connecticut and a small part of Massachusetts (fig. 2). The drainage basins of both rivers are predominantly rural, and small mill towns and agricultural communities serve as centers of commerce and industry. Woodland and forest cover most of the two basins, but there is some cropland and pasture as well.

The drainage basins of the Shetucket and Quinebaug Rivers are underlain by crystalline (metamorphic and igneous) bedrock and the glacial drift (stratified drift and till) derived from it. The minerals in these materials have little solubility in water, as indicated by the low dissolved-solids concentrations in most streams in these basins (Thomas and others, 1967, p. 40; Randall and others, 1966, p. 36).

Water quality of most streams in the two river basins has been described as "good to excellent"; iron and manganese are the only constituents that commonly exceed recommended limits for domestic and industrial use (Thomas and others, 1967; Randall and others, 1966). Notable problem areas are the Little River at Versailles Pond in the Shetucket River basin, where mercury contamination from an industrial discharge has caused the State to issue a fish consumption advisory (Connecticut Department of Environmental Protection, 1988, p. 33), and the French River in the Quinebaug River basin, where bottom sediments have been contaminated by past industrial and municipal discharges. Impounded reaches of the Quinebaug River frequently exhibit algal blooms and low dissolved-oxygen concentrations in bottom water. The nutrients causing these conditions are derived from sewage-treatment plants and nonpoint sources in the basin (C.G. Fredette, Connecticut Department of Environmental Protection, oral commun., February 1991).

The median dissolved-solids concentration of samples collected during 1987-89 was $62 \mathrm{mg} / \mathrm{L}$ in the Shetucket River at site 1 and $72 \mathrm{mg} / \mathrm{L}$ in the Quinebaug River at site 2 (fig. 3). These low concentrations reflect the low solubility of the rocks underlying the basin. The median phosphorus concentration at site 2 on the Quinebaug River was $0.07 \mathrm{mg} / \mathrm{L}$, which exceeds the EPA (1986) suggested maximum concentration of $0.05 \mathrm{mg} / \mathrm{L}$ for water entering a lake or reservoir. This standard is intended to prevent the excessive growth of nuisance aquatic vegetation and to control accelerated or cultural eutrophication. None of the other properties or constituents at sites 1 and 2 had unusually high concentrations during 1987-89 (fig. 3).

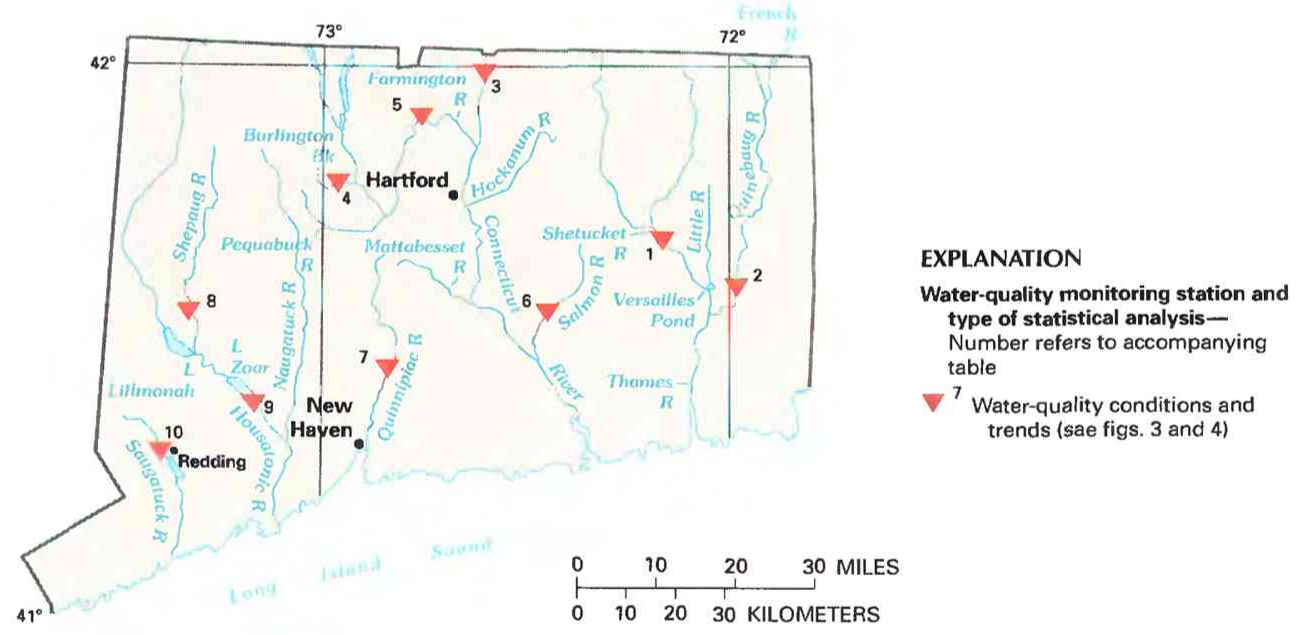

\begin{tabular}{|c|c|c|c|}
\hline $\begin{array}{l}\text { Site no. } \\
\text { on map }\end{array}$ & $\begin{array}{l}\text { USGS station } \\
\text { name and no. }\end{array}$ & $\begin{array}{l}\text { Drainage area } \\
\text { (square miles) }\end{array}$ & $\begin{array}{l}\text { Major land use } \\
\text { (see fig. 1) }\end{array}$ \\
\hline 1 & Shetucket River at South Windham $(01122610)$ & 408 & Woodland and forest with some cropland and pasture. \\
\hline 2 & 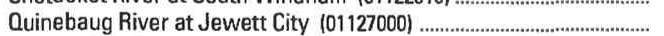 & 713 & Ditto. \\
\hline 3 & 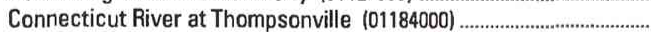 & 9,660 & Urban areas; cropland with pasture, woodland, and forest. \\
\hline 4 & 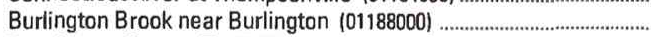 & 4.1 & Woodland and forest with some cropland and pasture. \\
\hline 5 & 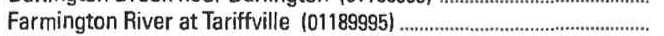 & 577 & Ditto. \\
\hline 6 & 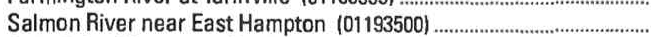 & 100 & Mostly ungrazed forest and woodland. \\
\hline 7 & Quinnipiac River at Wallingford $(01196500)$ & 115 & Urban areas; woodland and forest with some cropland and pasture. \\
\hline 8 & 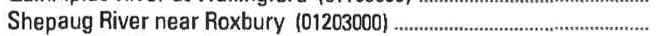 & 132 & Woodland and forest with some cropland and pasture. \\
\hline 9 & 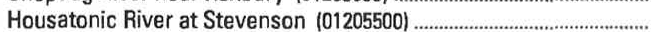 & 1,544 & Ditto. \\
\hline 10 & 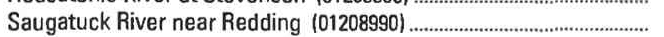 & 21 & Ditto. \\
\hline
\end{tabular}

Figure 2. Selected water-quality monitoring stations, type of statistical analysis, and geographic features in Connecticut. (Sources: Major land uses modified from Anderson, 1967; other data from U.S. Geological Survey files.) 


\section{CONNECTICUT RIVER}

The Connecticut River drains $11,260 \mathrm{mi}^{2}$ and is the largest stream in New England. The river originates near the Canadian border and flows southward through Vermont, New Hampshire, Massachusetts, and Connecticut to Long Island Sound. Cropland, pasture, woodland, and forest cover most of the basin, but there are several large urban and suburban areas that have a substantial effect on water quality. Also, the basin has several industrial and commercial areas.

The Connecticut River in central Massachusetts and northcentral Connecticut flows through a broad lowland underlain by sedimentary rocks (sandstone, siltstone, and shale) that are interbedded with igneous rocks (basalt) that form prominent ridges. Elsewhere, the basin is underlain by crystalline bedrock. Glacial drift, largely derived from local bedrock, discontinuously covers bedrock throughout the basin. The sedimentary rocks and associated glacial drift are composed of more soluble minerals than the crystalline bedrock and drift in other parts of the basin. Consequently, naturally derived dissolved-solids concentrations during low flow are larger in streams in north-central Connecticut than in streams draining areas underlain by crystalline rocks (Ryder and others, 1981, p. 44).

The water of most streams in the Connecticut part of the basin is suitable for most uses, except in the Hockanum and Mattabesset Rivers, which flow through large urban'and suburban areas. The Hockanum River is degraded by municipal waste and urban runoff, and the Mattabesset River is degraded by combined-sewer overflows, urban runoff. and landfills (Connecticut Department of Environmental Protection, 1988, p. 88). Overflow from combined municipal and storm sewers during periods of excessive runoff is the most frequent cause of water-quality problems in the Connecticut River. Of 54 miles of the river assessed by the DEP in 1988,8 miles fully supported wateruse goals, and the remaining 46 miles partially supported the goals (Connecticut Department of Environmental Protection, 1988, p. 88).

The median dissolved-solids concentration in samples collected during 1987-89 at site 3 on the Connecticut River was 73 $\mathrm{mg} / \mathrm{L}$, reflecting the low solubility of the crystalline bedrock and drift underlying most of its drainage. The values for the other properties and constituents are characteristic of water that has not been substantially contaminated.

\section{FARMINGTON RIVER AND BURLINGTON BROOK}

The Farmington River, a major tributary to the Connecticut River, drains $601 \mathrm{mi}^{2}$ in north-central Connecticut. Woodland and forest cover most of the basin along with some cropland and pasture. The geology of the basin consists of crystalline and sedimentary bedrock overlain by glacial drift.

Water quality of streams in the basin is satisfactory for most uses, particularly in the less developed upper basin where there are several large public water-supply impoundments. The DEP assessed 54 miles of the Farmington River main stem in 1988 and found that all fully supported water-use goals (Connecticut Department of Environmental Protection, 1988, p. 88). However, in the more developed, lower part of the Farmington River basin, water quality of some streams is degraded by human activities. The Pequabuck River, a tributary that drains an urban industrialized area in the lower basin, is degraded by municipal- and industrial-waste discharge and urban runoff. Of the 13 miles of the Pequabuck River assessed by the DEP in 1988,6 miles partially supported and 7 miles did not support wateruse goals (Connecticut Department of Environmental Protection, 1988, p. 88).

Burlington Brook is a small tributary to the upper Farmington River in an area relatively unaffected by human activities. The absence of significant development is reflected in the comparatively low constituent concentrations in samples collected from Burlington Brook during 1987-89. At site 4, samples had median chloride, dis- solved-solids, and phosphorus concentrations of $13 \mathrm{mg} / \mathrm{L}, 57 \mathrm{mg} / \mathrm{L}$, and $0.02 \mathrm{mg} / \mathrm{L}$, respectively. The median $\mathrm{pH}$ was 6.8 .

Site 5 is on the Farmington River main stem downstream from the confluence with the Pequabuck River. Low concentrations of constituents in water samples collected at this site during 1987-89 (fig. 3) are indicative of relatively uncontaminated water, except for high phosphorus concentrations, which had a median of $0.12 \mathrm{mg} / \mathrm{L}$. The source of the phosphorus probably was municipal sewagetreatment facilities located on the Pequabuck River and upstream from site $\mathbf{5}$ on the Farmington River (Ernest Pizzuto, Jr., Connecticut Department of Environmental Protection, oral commun., February 1991).

\section{SALMON RIVER}

The Salmon River is a major tributary to the Connecticut River and drains $150 \mathrm{mi}^{2}$ of predominantly forest and woodland in eastcentral Connecticut. The basin is underlain by crystalline bedrock that is largely covered by glacial drift. Because the materials that make up the bedrock and drift have low solubility in water, concentrations of dissolved solids and other constituents derived from rock weathering are low in most streams in the basin. As a result, many of the streams have little buffering capacity, which makes them susceptible to acidification by atmospheric deposition of sulfuric and nitric acids. The State has designated the Salmon River basin a priority watershed to monitor for possible detrimental effects from acid precipitation (Connecticut Department of Environmental Protection, 1989, p. 55).

The uncontaminated water of streams in the Salmon River basin is an important factor in the current effort to restore Atlantic salmon to some of their historical habitat in New England. The Salmon River basin was selected as one of the key basins in this program for the development of hatchery and rearing facilities and for natural spawning areas. The primary water-quality concern in the basin, along with acidification, is potential nonpoint-source contamination from residential and commercial development.

The Salmon River at site 6 during 1987-89 had median chloride, dissolved-solids, and phosphorus concentrations of $15 \mathrm{mg} / \mathrm{L}$, $67 \mathrm{mg} / \mathrm{L}$, and $0.01 \mathrm{mg} / \mathrm{L}$, respectively (fig. 3). These values are characteristic of a stream that is relatively unaffected by human activities.

\section{QUINNIPIAC RIVER}

The Quinnipiac River drains $166 \mathrm{mi}^{2}$ of south-central Connecticut. Principal land cover in the basin is woodland and forest, with some cropland, pasture, and urban areas. The urban areas are densely populated and industrialized. The basin is underlain by interbedded sedimentary and igneous rocks that are largely covered by glacial drift.

The water quality of several streams in the basin is affected by human activities. Of the 23 miles of the Quinnipiac River assessed by the DEP in 1988, 20 miles partially supported and 3 miles did not support water-use goals (Connecticut Department of Environmental Protection, 1988, p. 89). The primary sources of contamination in the basin are industrial and municipal discharge, storm sewers, and landfills. Treated sewage effluent from upstream communities constitutes more than one-half of the streamflow of the river at site 7 during low streamflow conditions (Lee Dunbar, Connecticut Department of Environmental Protection, written commun., October 1990).

The median concentrations of chloride $(31 \mathrm{mg} / \mathrm{L})$ and dissolved solids (196 mg/L) at site 7 on the Quinnipiac River during 1987-89 were the highest for any of the 10 monitoring stations (fig. 3). Although soluble sedimentary rocks underlying the basin contribute in part to the high concentrations of these constituents, particularly during low-flow periods, industries and urban areas are the major sources. The high specific-conductance, nitrite plus nitrate, 
and phosphorus values in samples from the Quinnipiac River at site 7 during 1987-89 (fig. 3) are indicative of contamination.

\section{HOUSATONIC AND SHEPAUG RIVERS}

The Housatonic River originates in western Massachusetts and flows southward through western Connecticut to Long Island Sound, draining $1,950 \mathrm{mi}^{2}$. Woodland and forest cover most of the basin, but there is some cropland and pasture, along with several densely populated and industrialized urban areas. The bedrock consists of metamorphosed carbonate rocks (marble) in part of the Housatonic River valley and several tributary valleys and crystalline rocks elsewhere in the basin. Discontinuous deposits of glacial drift overlie the bedrock. The dissolution of carbonate rocks results in higher $\mathrm{pH}$ and higher concentrations of dissolved solids in several streams (Cervione and others, 1972, p. 24). The effect of carbonate rocks was evident in the data collected during 1987-89 at site 9 on the Housatonic River, where the median $\mathrm{pH}$ was 7.9 , the highest $\mathrm{pH}$ for any station, and the median dissolved-solids concentration was $133 \mathrm{mg} / \mathrm{L}$ (fig. 3 ).
The main stem of the Housatonic River in Connecticut is regulated by a series of hydroelectric powerplants. In the lower reaches of the river, the dams at these plants form several large impoundments including Lakes Lillinonah and Zoar. Water quality in these lakes is degraded by nutrient enrichment from sewage-treatment plants and various nonpoint sources, resulting in summer algal blooms. A widespread problem in the river is polychlorinated biphenyl (PCB) contamination. The PCB's, derived from a manufacturing facility in Massachusetts, have accumulated in the bottom sediments of the river, primarily in impounded reaches (Frink and others, 1982). Because some fish from the river contain PCB concentrations that exceed U.S. Food and Drug Administration tolerance levels for human consumption, the Connecticut reach of the river upstream from site 9 has been under a State health advisory since 1977 that recommends against the consumption of fish. However, since 1979, the concentrations of PCB in fish and sediment have decreased (Connecticut Department of Environmental Protection, 1988, p. 33).

The largest tributaries to the Housatonic River in Connecticut are the Naugatuck (310-mi drainage) and the Shepaug $\left(148 \mathrm{mi}^{2}\right)$
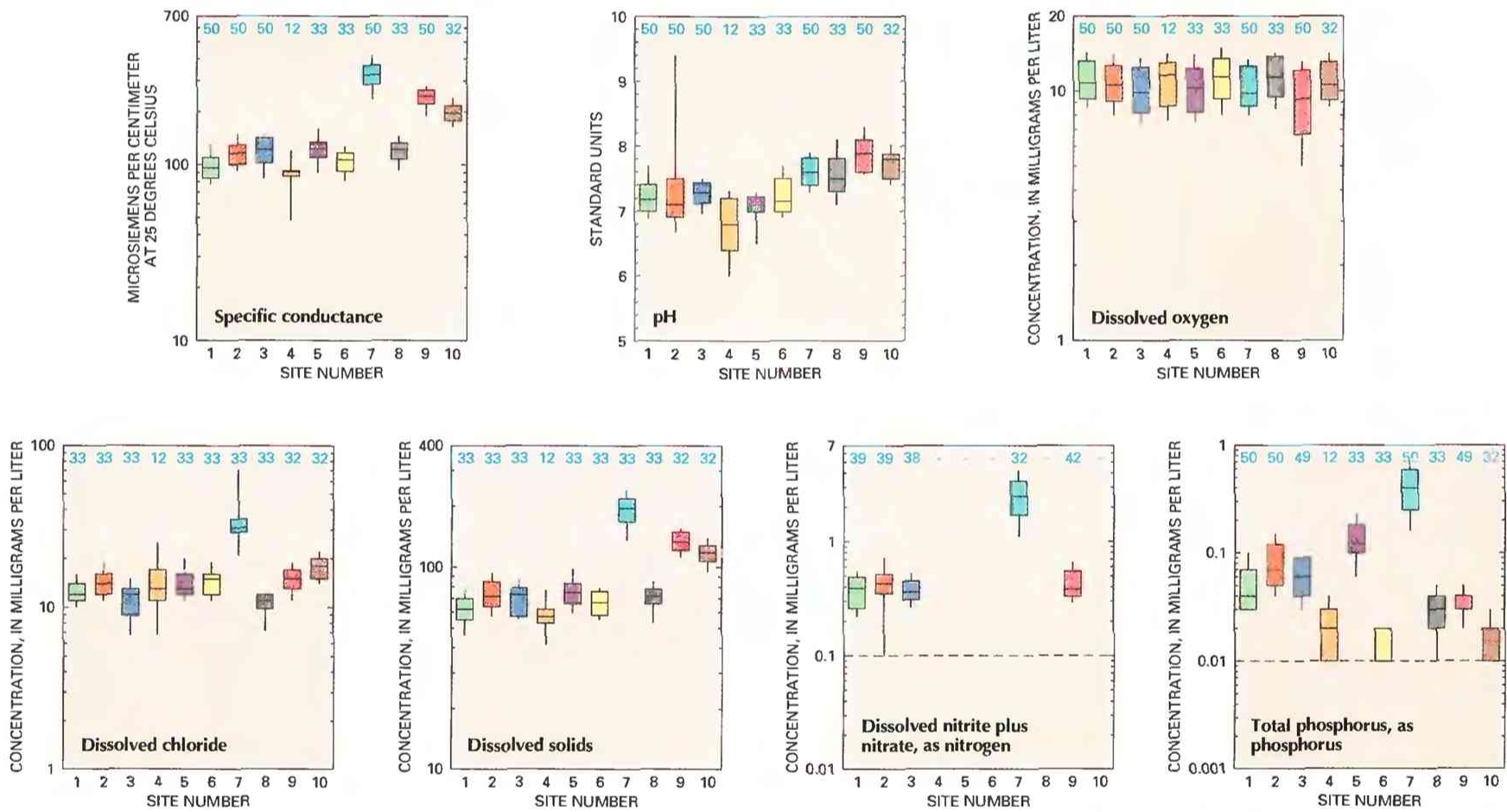

\section{EXPLANATION}

Water-quality conditions in selected
drainage basins
50 Number of analyses-Dash indicates
insufficient data
Percentile-Percentage of analyses
equal to or less than indicated
values
-90th
-75th
- 50th-Median
- 10th
- Reporting limit-Minimum reporting
limit for analytical method used.
Data below limit line not shown

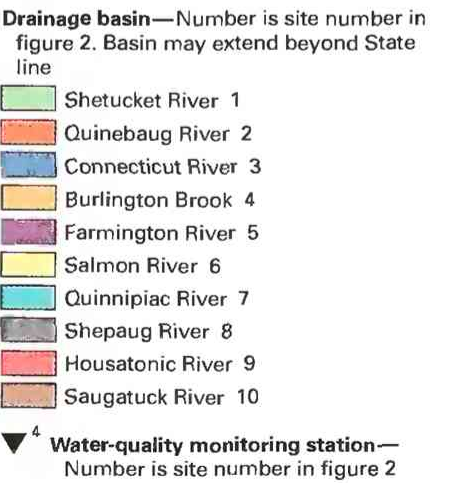

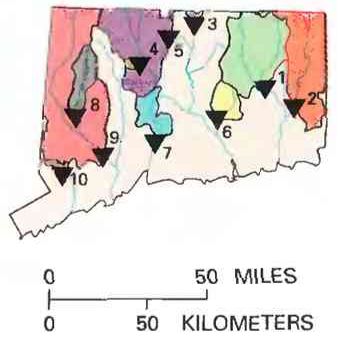

Figure 3. Water quality of selected streams in Connecticut, water years 1987-89. (Source: Data from U.S. Geological Survey files.) 
Table 1. Sources and environmental significance of selected water-quality properties and constituents [Source: Compiled by the U.S. Geological Survey, Office of Water Quality]

\begin{tabular}{|c|c|c|}
\hline Property or constituent & Common sources & Environmental significance \\
\hline $\begin{array}{l}\text { Specific conductance .................. } \\
\quad \text { (property) }\end{array}$ & $\begin{array}{l}\text { A measure of the electrical conductivity of water; var- } \\
\text { ies with the quantity of dissolved solids and is } \\
\text { used to approximate the dissolved-solids content. }\end{array}$ & $\begin{array}{l}\text { Dissolved solids can cause water to be unsuitable for } \\
\text { public supply, agriculture, and industry; can harm } \\
\text { aquatic organisms. }\end{array}$ \\
\hline 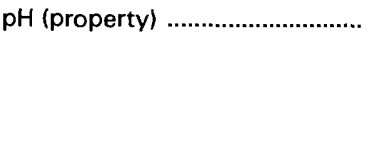 & $\begin{array}{l}\text { A measure of hydrogen-ion activity (acidity or alkalin- } \\
\text { ity); can be affected by geologic setting, biological } \\
\text { activity, municipal and industrial wastewater dis- } \\
\text { charge, and atmospheric deposition. }\end{array}$ & $\begin{array}{l}\text { Acidic water can corrode pipes and equipment; can } \\
\text { cause the release of lead and other metals from } \\
\text { distribution systems to drinking water; can affect } \\
\text { wastewater-treatment processes and taste of } \\
\text { water. }\end{array}$ \\
\hline Dissolved oxygen ......................... & $\begin{array}{l}\text { Introduced from the atmosphere; also a byproduct of } \\
\text { aquatic plants. }\end{array}$ & $\begin{array}{l}\text { Necessary for aquatic life; deficiency can result from } \\
\text { assimilation of organic wastes or rapid growth } \\
\text { and decay of algae. }\end{array}$ \\
\hline Chloride .......................................... & $\begin{array}{l}\text { Occurs in some rocks and ground-water discharge; } \\
\text { also in road deicers, industrial and urban waste- } \\
\text { water discharge, and atmospheric deposition. }\end{array}$ & $\begin{array}{l}\text { Concentrations exceeding a natural, background level } \\
\text { can cause water to be unsuitable for public supply, } \\
\text { agriculture, and industry; can harm aquatic or- } \\
\text { ganisms. }\end{array}$ \\
\hline 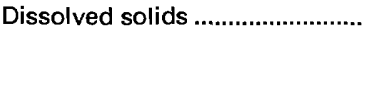 & $\begin{array}{l}\text { A result of rock weathering; also in agricultural runoff } \\
\text { and industrial discharge. }\end{array}$ & $\begin{array}{l}\text { In sufficient quantity, can cause water to be unsuitable } \\
\text { for public supply, agriculture, and industry; can } \\
\text { harm aquatic organisms. }\end{array}$ \\
\hline Nitrite plus nitrate .......................... & $\begin{array}{l}\text { Nonpoint sources are agricultural and urban runoff; } \\
\text { a major point source is wastewater discharge. }\end{array}$ & $\begin{array}{l}\text { Plant nutrient that, in sufficient quantity, can cause } \\
\text { algal blooms and excessive growth of higher } \\
\text { aquatic plants in bodies of water; can cause water } \\
\text { to be unsuitable for public supply. }\end{array}$ \\
\hline Phosphorus .................................. & $\begin{array}{l}\text { Occurs in some rocks and sediments; also in runoff } \\
\text { and seepage from phosphate-rock mines, agri- } \\
\text { cultural and urban runoff, and industrial and } \\
\text { municipal wastewater discharge. }\end{array}$ & $\begin{array}{l}\text { Plant nutrient that, in sufficient quantity, can cause } \\
\text { algal blooms and excessive growth of higher } \\
\text { aquatic plants in bodies of water. }\end{array}$ \\
\hline
\end{tabular}

Rivers. The Naugatuck River flows through a series of industrialized cities and towns, and water quality is degraded by municipal and industrial sources. Of 43 miles of the river assessed by the DEP in 1988, 1 mile fully supported, 19 miles partially supported, and 23 miles did not support water-use goals (Connecticut Department of Environmental Protection, 1988, p. 90). The Shepaug River drains a relatively undeveloped basin and is little affected by human activities. The comparative lack of contamination is apparent in the low median concentrations of chloride $(11 \mathrm{mg} / \mathrm{L})$, dissolved solids $(72$ $\mathrm{mg} / \mathrm{L})$, and phosphorus $(0.03 \mathrm{mg} / \mathrm{L})$ for samples collected during 1987-89 at site 8 (fig. 3). In 1988, the DEP assessed 27 miles of the river and found that all fully supported water-use goals (Connecticut Department of Environmental Protection, 1988, p. 90).

\section{SAUGATUCK RIVER}

The Saugatuck River drains $93 \mathrm{mi}^{2}$ in southwestern Connecticut and flows into Long Island Sound. The upper part of the basin is rural, whereas the lower basin is densely populated and developed. Land cover in the basin is woodland and forest along with cropland, pasture, and suburban areas. The basin is underlain by crystalline bedrock that includes metamorphosed carbonate rocks (marble) near the headwaters. Glacial drift generally overlies the bedrock. The basin contains several large reservoirs that supply water to about one-half the population of southwestern Connecticut. The DEP reports that landfills are a potential source of contamination to some streams in the basin (Connecticut Department of Environmental Protection, 1988 , p. 90). However, the water quality of most streams in the ba$\sin$ is relatively unaffected by human activities. The relatively high median $\mathrm{pH}$ (7.8) and median dissolved-solids concentration (118 $\mathrm{mg} / \mathrm{L}$ ) of samples collected during $1987-89$ at site 10 on the Saugatuck River probably resulted from the carbonate rocks in the basin; the low concentrations of phosphorus (median $0.01 \mathrm{mg} / \mathrm{L}$ ) reflect the limited effect of human activities in the upper basin.

\section{WATER-QUALITY TRENDS}

Trend analysis is a statistical procedure used to detect changes in stream water quality at a monitoring station over time. For this report, water-quality data from 10 monitoring stations (fig. 2) were analyzed for trends by using the seasonal Kendall test (Hirsch and others, 1982), a method used extensively by the USGS. The graph (shown below) of the dissolved-chloride concentration in the Saugatuck River at site 10 illustrates the trend inferred from the concentration data and demonstrates the variation in water quality that is common in streams.

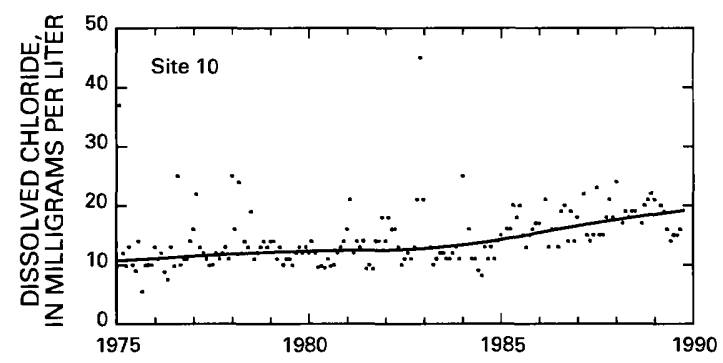

When possible, constituent-concentration data were adjusted for changes in streamflow to preclude identifying a trend in concentration that was caused only by a trend in streamflow. The data were not adjusted when (1) more than 10 percent of the samples had concentrations lower than the minimum reporting limit for the analytical method used or (2) streamflow was controlled substantially by human activities. When the concentration data could not be adjusted for streamflow, trends were determined directly from the concentration data.

Statewide trends in measurements of selected physical properties of stream water and on concentrations of selected constituents in stream water are shown on maps in figure 4. On each map, a trend is indicated at a monitoring station only if the data from that station were suitable for use in the trend analysis. For more information on the suitability criteria and on the trend analysis procedure used for this report, see Lanfear and Alexander (1990).

\section{SPECIFIC CONDUCTANCE}

Specific conductance is a measure of the ability of a sample of water to conduct electricity. Because specific conductance and the 
dissolved-solids concentration are roughly proportional in most natural waters, the specific-conductance value often can be used to estimate the dissolved-solids concentration (Hem, 1985, p. 66-68). Population growth and the resulting increase in wastewater discharge and use of deicing salt probably caused the increasing specific conductance in six streams (fig. 4).

$\mathrm{pH}$

The $\mathrm{pH}$ of a sample of water is a measure of its hydrogen-ion activity (effective concentration). An increase in hydrogen-ion content causes water to become more acidic but results in a lower measured $\mathrm{pH}$ value because the units of $\mathrm{pH}$ are inversely related to hydrogen-ion activity. Both natural processes and human activities (table 1) can affect $\mathrm{pH}$. The $\mathrm{pH}$ of river water in most areas not affected by pollution is between about 6.5 and 8.5 (Hem, 1985, p. 64).

The cause of the increasing $\mathrm{pH}$ in seven streams (fig. 4) is not known but might have been related to improved wastewater treatment. State-mandated improvements in the treatment of industrial waste, including the neutralization of acids, decreased the quantity of acids discharged to streams in industrialized basins. In some areas, population growth has caused increases in the quantity of effluent discharged from sewage-treatment plants to streams. This effluent usually contains alkaline, neutralizing constituents that increase the $\mathrm{pH}$ in receiving waters (C.G. Fredette, Connecticut Department of Environmental Protection, oral commun., September 1990). Two of the streams in which $\mathrm{pH}$ did not have a trend, Burlington Brook (at site 4) and the Salmon River (at site 6), have drainage basins that are relatively undeveloped and little affected by changes in wastewater treatment.

\section{DISSOLVED OXYGEN}

The dissolved-oxygen concentration in a stream is controlled by several factors, including water temperature, air temperature and pressure, hydraulic characteristics of the stream, photosynthetic or respiratory activity of stream biota, and the quantity of organic material present. A trend in dissolved-oxygen concentrations commonly is directly or indirectly the result of human activities. Generally, an upward trend in dissolved-oxygen concentrations indicates im- proving stream water-quality conditions and a downward trend indicates deteriorating conditions.

The increasing dissolved-oxygen concentration in eight streams (fig. 4) might have been the result of the installation or upgrading of sewage-treatment plants and improved treatment of industrial waste discharge. These changes occurred after the passage of Connecticut's Clean Water Act in 1967 and the Federal Water Pollution Control Act Amendments of 1972 (Federal Clean Water Act). As a result of improved treatment, discharge of waste that created an oxygen demand on receiving waters has been decreased or eliminated.

\section{DISSOLVED CHLORIDE}

Chloride is present in all natural waters but usually in low concentrations (Hem, 1985, p. 118). Except in streams that receive ground-water discharge high in chloride, concentrations of greater than a few milligrams per liter generally are the result of human activities (table 1).

The widespread upward trend in chloride concentration (fig. 4) probably was the result of increasing population and development. Chloride-containing salts are used for many domestic and industrial applications; as the population increases, it is likely that the quantity of salt used increases proportionately. Development of many previously wooded or agricultural areas accompanied the population increase. Development included the construction of roads, parking areas, and sidewalks. During the winter, salt is applied to many of these areas for deicing purposes, and it subsequently dissolves and is carried to nearby streams by surface runoff and groundwater discharge.

The time-series graph of chloride concentration near the beginning of the Water-Quality Trends section illustrates the increasing concentration of chloride at site 10 (near Redding). From 1970 to 1989 , the town of Redding, which occupies much of the Saugatuck River basin, grew in population by approximately 27 percent. During the winter of 1976-77, 533 tons of salt was used for deicing in the town (Bingham and Rolston, 1978); by the winter of 1989-90, salt usage had increased to 930 tons (M.A. Weisner, Comptroller, Town of Redding, oral commun., October 1990).

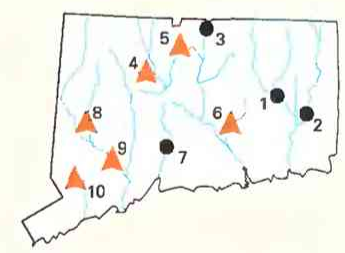

Specific conductance, 1975-89

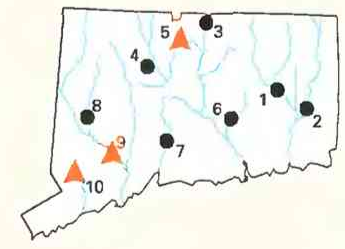

Dissolved solids, 1975-89

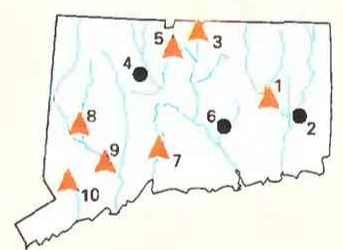

pH, 1975-89

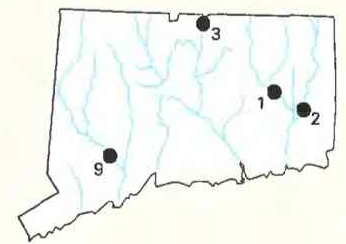

Dissolved nitrite plus nitrate, 1980-89

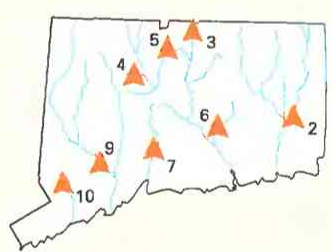

Dissolved oxygen, 1970-89

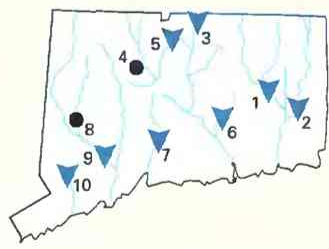

Total phosphorus, 1975-89

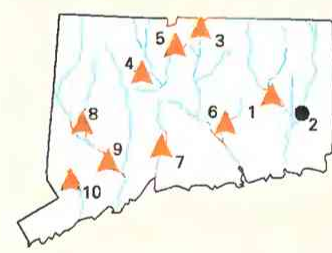

Dissolved chloride, 1975-89

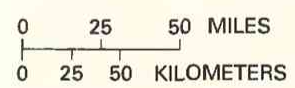

\section{EXPIANATION}

Trend in water-quelity property or constituent-Number is site number in figure 2

$A^{5}$ Upward

${ }^{2}$ None

$\nabla^{3}$ Downward

Figure 4. Trends in water quality of selected streams in Connecticut, by water years. (Source: Data from U.S. Geological Survey files.) 


\section{DISSOLVED SOLIDS}

Dissolved solids in stream water result primarily from rock weathering but also can be introduced as a byproduct of human activities (table 1). Concentrations generally are greatest in streams draining basins underlain by rocks and soils that contain easily dissolved minerals. The upward trends in dissolved-solids concentrations in the Farmington River at site 5, the Housatonic River at site 9, and the Saugatuck River at site 10 (fig. 4) probably were the result of increased population and development in these basins.

\section{DISSOLVED NITRITE PLUS NITRATE}

Nitrite and nitrate are oxidized forms of nitrogen that together constitute most of the dissolved nitrogen in well-aerated streams. Nitrite readily oxidizes to nitrate in natural waters; therefore, nitrate generally is by far the more abundant of the two (Hem, 1985, p. 124). Nitrite plus nitrate concentrations had no trend during 1980-89 at the four monitoring stations from which data met the criteria for trend analysis (fig. 4).

\section{TOTAL PHOSPHORUS}

The total phosphorus concentration of a water sample is a measure of the concentration of all forms of phosphorus present in the sample, dissolved and particulate. Human activities (table 1) can be important sources of phosphorus in streams.

The downward trends in phosphorus concentrations in eight streams probably can be attributed to several causes. Decreasing agricultural land use; improved agricultural practices that include changes in fertilizer application, animal-waste control, and erosion and sedimentation control; and a continuing effort to control other nonpoint sources of contamination have reduced the phosphorus concentrations in many streams. Point-source-contamination controls, such as the installation and improvement of sewage-treatment plants, also have reduced the quantity of phosphorus discharged to streams. Trends in phosphorus concentrations were absent in Burlington Brook at site 4 and in the Shepaug River at site 8 because both streams have predominantly wooded drainage basins that are minimally affected by human activities.

\section{WATER-QUALITY MANAGEMENT}

The mission of the Connecticut water-quality management program is to protect ground water, surface water, and water-related resources in the State to ensure adequate public water supply and protect human health and safety. The program also is intended to preserve and enhance recreation, propagation of fish and aquatic life, the natural character of water bodies, and the economic well-being of the State. Relative to stream water quality, these goals are achieved through:

- Development of water-quality standards and criteria and sitespecific stream classifications,

- Regulation of discharge to and withdrawal from surface water and ground water,

- Regulation of construction on and adjacent to inland water resources,

- Monitoring and assessment of water quality,

- Environmental planning, and

- Engineering and financial management of contamination abatement or prevention projects.

The water-quality management agency in Connecticut is the DEP. The DEP manages water quality in streams through State and Federal water-quality and water-resource management legislation, which originated in 1967 with the passage of the Connecticut Clean Water Act. The 1972 Federal Water Pollution Control Act added au- thorities and resources for stream water-quality management. State water-resource legislation also provides for management and protection of water quality in inland wetlands and watercourses, flood plains, and streams tributary to public water-supply reservoirs. Statutory authorities for municipalities include specific provisions for control of nonpoint sources of contamination related to land use. Examples of these provisions include protection of public water-supply reservoirs, regulation of land uses that may affect inland wetlands and watercourses, and control of erosion and sedimentation at construction sites.

The DEP monitors and assesses the water quality of streams through several programs. Two cooperative monitoring programs with the USGS are an ambient water-quality program and a streamflow monitoring program. State programs include ambient biological monitoring, fish-tissue monitoring, ambient toxicity monitoring, and short-term water-quality and biological surveys. Water-quality monitoring of Connecticut streams increased greatly during the 1970 's but has remained at a constant level from 1980 until the present (1990).

Interstate water-quality management is coordinated through direct contact with the adjacent States of New York, Massachusetts, and Rhode Island and by participation in the New England Interstate Water Pollution Control Commission and the New England Governors' Conference. The DEP prepares a biennial water-qualityassessment report to the EPA and the U.S. Congress (Connecticut Department of Environmental Management, 1988) as mandated by section 305(b) of the Federal Clean Water Act.

\section{SELECTED REFERENCES}

Anderson, J.R., 1967, Major land uses in the United States, in U.S. Geological Survey, 1970, National atlas of the United States of America: Washington, D.C., U.S. Geological Survey, p. 158-159.

Bingham, J.W., and Rolston, J.L., 1978, Road-salt storage and road network in Connecticut: U.S. Geological Survey Miscellaneous Field Studies Map MF-981-A, scale 1:125,000.

Britton, L.J., and Greeson, P.E., eds., 1987, Methods for collection and analysis of aquatic biological and microbiological samples: U.S. Geological Survey Techniques of Water-Resources Investigations, book 5, chap. A4, $363 \mathrm{p}$.

Cervione, M.A., Jr., Mazzaferro, D.L., and Melvin, R.L., 1972, Water resources inventory of Connecticut, part 6, upper Housatonic River basin: Hartford, Connecticut Water Resources Bulletin 21, $84 \mathrm{p}$.

Connecticut Department of Environmental Protection, 1988, State of Connecticut 1988 water quality report to Congress: Hartford, Connecticut Department of Environmental Protection Water Compliance Unit, 100 p. 1989, Nonpoint source pollution-An assessment and management plan: Hartford, Connecticut Department of Environmental Protection Water Compliance Unit, $129 \mathrm{p}$.

Fenneman, N.M., 1946, Physical divisions of the United States: Washington, D.C., U.S. Geological Survey special map, scale 1:7,000,000.

Fishman, M.J., and Friedman, L.C., eds., 1989, Methods for the determination of inorganic substances in water and fluvial sediments: U.S. Geological Survey Techniques of Water-Resources Investigations, book 5, chap. A1, $545 \mathrm{p}$.

Frink, C.R., Sawhney, B.L., Kulp, K.P., and Fredette, C.G., 1982, Polychlorinated biphenyls in Housatonic River sediments in Massachusetts and Connecticut; determination, distribution, and transport: New Haven, Connecticut Agricultural Experiment Station Bulletin 800, 20 p.

Hem, J.D., 1985, Study and interpretation of the chemical characteristics of natural water (3d ed.): U.S. Geological Survey Water-Supply Paper 2254, $263 \mathrm{p}$.

Hirsch, R.M., Slack, J.R., and Smith, R.A., 1982, Techniques of trend analysis for monthly water quality data: Water Resources Research, v. 18, no. 1, p. 107-121.

Lanfear, K.J., and Alexander, R.B., 1990, Methodology to derive water-quality trends for use by the National Water Summary Program of the U.S. Geological Survey: U.S. Geological Survey Open-File Report 90-359, $10 \mathrm{p}$.

Randall, A.D., Thomas, M.P., Thomas, C.E., Jr., and Baker, J.A., 1966, Water resources inventory of Connecticut, part 1, Quinebaug River basin: Hartford, Connecticut Water Resources Bulletin 8, 102 p. 
Ryder, R.B., Thomas, M.P., and Weiss, L.A., 1981, Water resources inventory of Connecticut, part 7, upper Connecticut River basin: Hartford. Connecticut Water Resources Bulletin 24, 78 p.

Thelin, G.P., and Pike, R.J., 1990, Digital shaded relief map of the conterminous United States: Menlo Park, Calif., U.S. Geological Survey digital image processing, scale 1:3,500,000.

Thomas, M.P., Bednar, G.A., Thomas, C.E., Jr., and Wilson, W.E., 1967, Water resources inventory of Connecticut, part 2, Shetucket River basin: Hartford, Connecticut Water Resources Bulletin 11, $96 \mathrm{p}$.

U.S. Environmental Protection Agency, 1986, Quality criteria for water, 1986: Washington, D.C., U.S. Environmental Protection Agency Report EPA 440/5-86-001, unpaginated.
U.S. Geological Survey, 1986, National water summary 1985-Hydrologic events and surface-water resources: U.S. Geological Survey Water-Supply Paper 2300, $506 \mathrm{p}$.

1990, National water summary 1987-_Hydrologic events and water supply and use: U.S. Geological Survey Water-Supply Paper 2350, $553 \mathrm{p}$.

Ward, J.R., and Harr, C.A., eds., 1990, Methods for collection and processing of surface-water and bed-material samples for physical and chemical analyses: U.S. Geological Survey Open-File Report 90-140, 71 p.

Prepared by K.P. Kulp and J.R. Bohr, U.S. Geological Survey; “Water-Quality Management” section by F.S. Banach, Connecticut Department of Environmental Protection

FOR ADDITIONAL INFORMATION: Office Chief, U.S. Geological Survey, Federal Building, 450 Main Street, Room 525, Hartford, CT 06103 


\section{DELAWARE Stream Water Quality}

Delaware has abundant stream-water resources that are of a quality suitable for most uses including public, agricultural, and industrial supply; maintenance of aquatic life and wildlife; and recreation. In 1985, stream water supplied about 43 percent or 60 $\mathrm{Mgal} / \mathrm{d}$ (million gallons per day) of the estimated $139 \mathrm{Mgal} / \mathrm{d}$ of freshwater used in the State. About 82 percent of stream water withdrawn was used for public supply, 13 percent for agriculture, and 5 percent for industrial purposes (U.S. Geological Survey, 1990, p. 204). Most stream water used for public supply in Delaware is withdrawn and distributed in New Castle County, the northernmost county of the State, where surface water supplies an estimated 275,000 users (Martin W. Wollaston, Water Resources Agency for New Castle County, oral commun., May 1991). Excluding the Delaware River, which is brackish in the reach along the eastern boundary of the State, Brandywine, Red Clay, and White Clay Creeks and the Christina, St. Jones, and Nanticoke Rivers are the principal streams in the State. Brandywine Creek, which originates in Pennsylvania, is the largest source of fresh stream water in Delaware and is the primary source of water supply for Wilmington. Hoopes Reservoir, on a tributary to Red Clay Creek, is used for water supply when diminished flow or unacceptable quality limits the use of Brandywine Creek. Streams have not been developed appreciably for water supply in the central and southern parts of the State. However, streams in these areas are potential sources of small freshwater supplies in their nontidal reaches.

Delaware is in the northeastern part of the Delmarva Peninsula, which is bounded on the west by the Chesapeake Bay and on

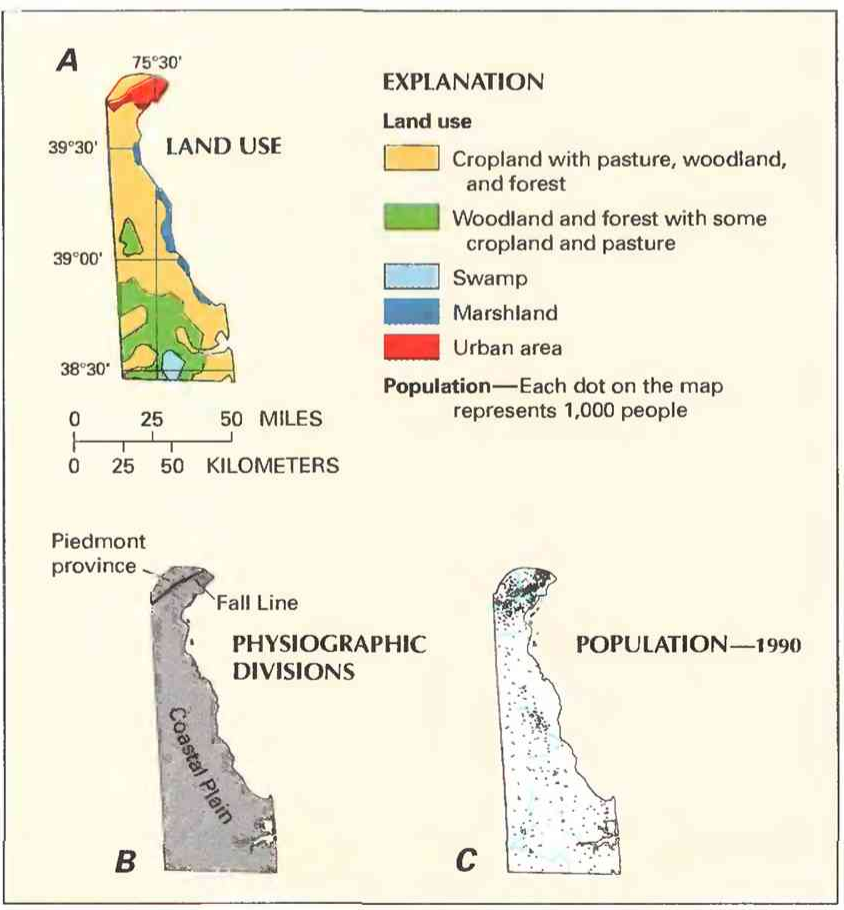

Figure 1. Land use, physiography, and population in Delaware. A, Major land uses. B, Physiographic divisions. C, Population distribution in 1990. (Sources: A. Major land uses modified from Anderson, 1967. B, Physiographic divisions from Fenneman, 1946; landforms from Thelin and Pike, 1990. C. Data from U.S. Bureau of the Census 1990 decennial census files.) the east by the Delaware River and Atlantic Ocean. Streams that flow into the Delaware River and Atlantic Ocean are affected by tides in their lower reaches. Saline water in the tidal reaches limits water use because the water is unsuitable for human consumption, irrigation of crops, and many industrial purposes. Streams in the western part of the State that drain into the Chesapeake Bay contain freshwater except for the Nanticoke River downstream from Seaford and Broad Creek downstream from Laurel, where dredged navigation channels permit tidal movement of saline water into the upper reaches of the deepened channels.

Farming is a major industry in Delaware, and the central and southern parts of the State support the greatest concentration of agricultural activity (fig. $1 A$ ). Most urban and suburban areas are in northern Delaware. Cypress Swamp, an area of about $50 \mathrm{mi}^{2}$ (square miles), straddles Delaware's southern boundary with Maryland.

Delaware is situated in two contrasting physiographic provinces - the Piedmont and the Coastal Plain (fig. $1 B$ ). These provinces are separated by the Fall Line, which is marked by rapids and falls in stream channels and extends northeastward through Newark and Wilmington. The Piedmont province, which constitutes 6 percent of the State's area, lies north of the Fall Line and is characterized by a rolling terrain of hills, moderately deep valleys, and rapidly flowing streams. The Coastal Plain province, south of the Fall Line, is characterized by level terrain and streams with gentle slopes, meandering channels, and extensive contiguous wetland areas (U.S. Geological Survey, 1986, p. 181).

From 1980 to 1990 , Delaware's population increased from 594,338 to 666,168 (U.S. Bureau of the Census 1990 decennial census files). Most Delawareans live in or near cities and towns having populations of 2,500 or more, and the majority reside in the Wilmington metropolitan area (figs. $1 C$ and 2). As the population continues to increase, so too will the demand for safe, dependable water supplies.

\section{WATER-QUALITY MONITORING}

The water-quality data on which this report is based resulted from analysis of samples collected at monitoring stations operated by the Delaware Department of Natural Resources and Environmental Control (DNREC). These stations are part of a statewide network operated since 1970 for the collection of stream water-quality data in an ongoing, systematic manner. The water-quality data are stored in STORET, the U.S. Environmental Protection Agency's (EPA) national data base. The streamflow data used to prepare parts of this report were collected by the U.S. Geological Survey (USGS). Water-quality and streamflow data are reported by water year-the 12-month period from October 1 through September 30 . A water year is identified by the calendar year in which it ends. For example, water year 1991 comprises October 1, 1990, through September 30, 1991.

The data used in this summary of Delaware's stream water quality were obtained from water samples collected at nine monitoring stations at which data collection is systematic and continuing (fig. 2). Analyses of water samples collected at all nine stations are the basis for the discussion and graphic summary (fig. 3) of stream water-quality conditions during water years 1987-89, and data from seven stations are the basis for the discussion and graphic summary (fig. 4) of stream water-quality trends. Because the monitored streams generally are well mixed, total-constituent concentrations were derived from the analysis of water samples that were collected at a 
single point in the streams. The samples were analyzed by using standardized methods approved by the EPA or by using equivalent methods. If a method of sample collection or analysis changed over time, data were included in the evaluation of stream water-quality conditions or of stream water-quality trends only if the change in methodology did not affect the comparability of the data. Finally, water samples at all stations included in the evaluation were collected at relatively uniform time intervals, without consideration of streamflow. This sampling results in water-quality data that are representative of the full range of streamflow variability at the stations.

\section{WATER-QUALITY CONDITIONS}

Twenty-three percent of the stream miles assessed during 1988-89 by the DNREC (1990a, p. 2) supported all uses designated by the DNREC for purposes of water-quality monitoring and protection; 78 percent of the stream miles supported well-balanced and healthy populations of fish, shellfish, and wildlife; and 19 percent of the stream miles supported primary-contact recreation. The most widespread water-quality problem is excessive concentrations of enterococcal bacteria; these bacteria, which belong to the fecal streptococcal bacteria group, indicate the possible presence of pathogens introduced by fecal contamination. From the standpoint of human health, the most serious water-quality problem is that of toxic substances (organic compounds and trace elements), which are present in about 10 percent of the assessed stream lengths in the State (Delaware Department of Natural Resources and Environmental Control, 1990a, p. 3). Investigations by the DNREC have identified several potential sources of bacterial and chemical contamination including point-source discharges and runoff from agricultural and urban areas.

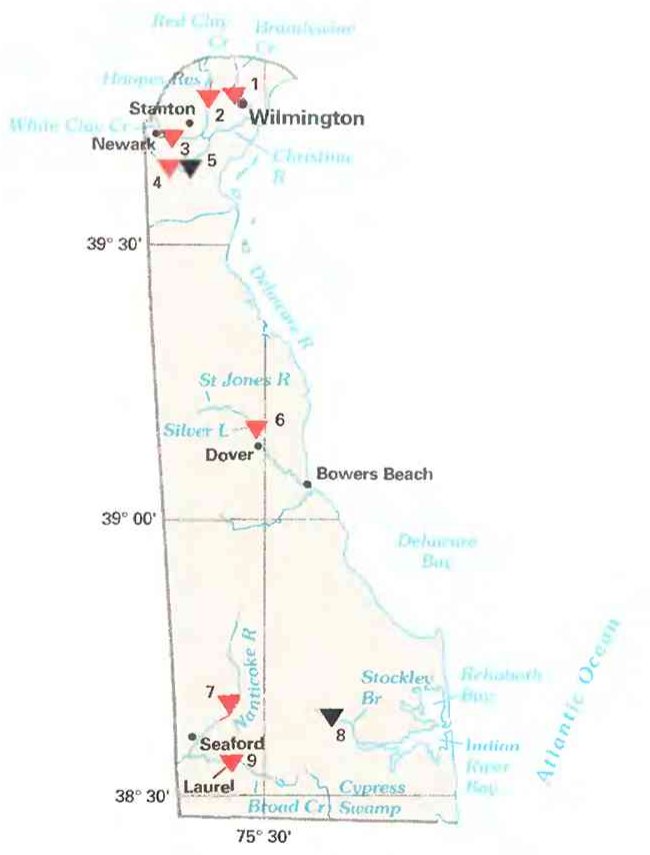

The following discussion of stream water quality in Delaware is organized by river basin (fig. 3). Where physiographic and landuse characteristics in different basins are similar, the discussion of those basins is combined. Graphs in figure 3 summarize certain aspects of stream water quality in the basins for water years 1987-89. The graphs show frequency distributions of data values that represent concentrations of selected constituents in stream water and measurements of selected physical properties of stream water. These constituents and properties are enterococcal bacteria, alkalinity (as calcium carbonate), total nitrate (as nitrogen), total ammonia plus organic nitrogen (as nitrogen), and total phosphorus (as phosphorus). The data are reported in colonies per 100 milliliters $(\mathrm{col} / 100 \mathrm{~mL}$ ) and milligrams per liter $(\mathrm{mg} / \mathrm{L})$. Sources and environmental significance of each constituent and property are described in table 1 .

Water quality at each monitoring station is the result of geological, chemical, biological, and hydrologic processes that occur over a large area. Water-quality problems that affect aquatic life or public health only locally are not fully represented in this summary.

\section{BRANDYWINE, RED CLAY, AND WHITE CLAY CREEKS AND CHRISTINA RIVER}

A substantial quantity of freshwater in Delaware drains from the Piedmont province through streams in the northern part of the State. The principal streams are Brandywine, Red Clay, and White Clay Creeks and the Christina River. Together, these streams drain about $568 \mathrm{mi}^{2}$ in northern Delaware and southeastern Pennsylvania. Most of the basin is in Pennsylvania; only 25 percent of the total drainage area is in Delaware (Rasmussen and others, 1957, p. 35).

The nontidal reach of Brandywine Creek supports the maintenance and propagation of 26 species of fish. However, because enterococcal bacteria concentrations in the stream water sometimes exceed the State standard of $100 \mathrm{col} / 100 \mathrm{~mL}$, the reach does not fully support primary contact recreation (Delaware Department of Natural Resources and Environmental Control, 1990b, p. 20-21). The quality of water in Red Clay Creek in Delaware also has been de-

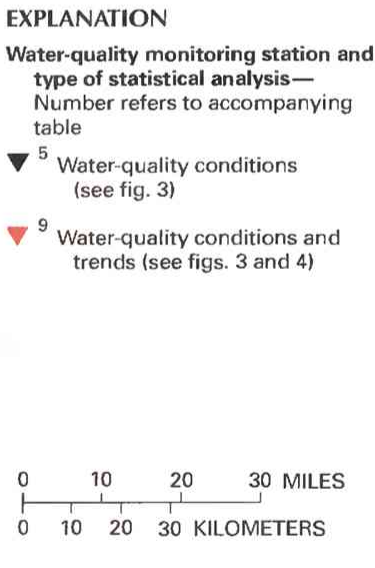

\section{LANATION}

Number refers to accompanying

table

Water-quality conditions

Water-quality conditions and

$10 \quad 20 \quad 30$ KILOMETERS

\begin{tabular}{|c|c|c|c|}
\hline $\begin{array}{l}\text { Site no. } \\
\text { on map }\end{array}$ & $\begin{array}{l}\text { USGS station } \\
\text { name and no. }\end{array}$ & $\begin{array}{l}\text { Drainage area } \\
\text { (square miles) }\end{array}$ & $\begin{array}{l}\text { Major land use } \\
\text { (see fig. 1) }\end{array}$ \\
\hline 1 & Brandywine Creek at Wilmington' $(01481500)$ & 314 & Cropland with pasture, woodland, and forest; urban areas. \\
\hline 2 & Red Clay Creek at Wooddale $1(01480000)$ & 47.0 & Ditto. \\
\hline 3 & 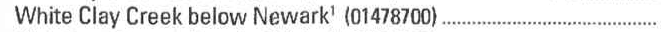 & 71.5 & Ditto. \\
\hline 4 & Christina River at Coochs Bridge' $(01478000)$ & 20.5 & Ditto. \\
\hline 5 & Christina River near Bear ${ }^{1}(01478040)$ & 40.6 & Ditto. \\
\hline 6 & St. Jones River at Dover ${ }^{1}(01483700)$ & 31.9 & Cropland with pasture, woodland, and forest. \\
\hline 8 & Stockley Branch at Stockley' $(01484500)$ & 5.24 & Ditto. \\
\hline 9 & Broad Creek at Laurel $\left.\right|^{1}(01487450)$ & 90.8 & Ditto. \\
\hline
\end{tabular}

${ }^{1}$ Water-quality station operated by the Delaware Department of Natural Resources and Environmental Control.

Figure 2. Selected water-quality monitoring stations, type of statistical analysis, and geographic features in Delaware. (Sources: Major land uses modified from Anderson, 1967; other data from U.S. Geological Survey files.) 
graded by bacteria and by toxic substances, including zinc. At site 2 during water years $1987-89$, the median concentration of enterococcal bacteria $(210 \mathrm{col} / 100 \mathrm{~mL})$ was among the highest for the nine water-quality conditions monitoring stations, and concentrations higher than $100 \mathrm{col} / 100 \mathrm{~mL}$ were common. Because of contamination in the water, sediment, and fish tissue, Red Clay Creek presently is not approved for swimming or fishing (Delaware Department of Natural Resources and Environmental Control, 1990c).

Water from Brandywine Creek (site 1) and Red Clay Creek (site 2) is similar in chemical character and reflects the combined effects of basin geology and human activities on stream water quality. Discharges of municipal and industrial wastewater and runoff from agricultural and urban areas have a significant effect on water quality at both sites. Median values of alkalinity at site $1(54 \mathrm{mg} / \mathrm{L})$ and site $2(58 \mathrm{mg} / \mathrm{L})$ were among the highest for the monitoring stations (fig. 3) and represent natural contributions from weathering of soils and rocks, along with contributions from wastewater discharges and agricultural activities. Median concentrations of nitrate in water from site $1(2.3 \mathrm{mg} / \mathrm{L})$ and site $2(3.2 \mathrm{mg} / \mathrm{L})$ were among the highest for the nine monitoring stations (fig. 3). Concentrations of total ammonia plus organic nitrogen at both sites were mostly less than 1 $\mathrm{mg} / \mathrm{L}$. The median concentration of phosphorus at site $2(0.24$ $\mathrm{mg} / \mathrm{L}$ ) was the highest for stations in the monitoring network, and the median concentration at site 1 was only slightly lower.

In the White Clay Creek basin, agriculture and, to a lesser extent, urban development are the principal human activities affecting stream water quality. Overall, water in White Clay Creek is of a quality suitable for most uses, although excessive concentrations of zinc have been detected occasionally at Newark and Stanton. Fishing is fully supported in the reach from the Pennsylvania-Delaware State line to the confluence with the Christina River. However, White Clay Creek does not fully support primary-contact recreation because enterococcal bacteria, the greatest water-quality problem, often are present at site 3 and other locations in concentrations exceeding the State standard (Delaware Department of Natural Resources and Environmental Control, 1990d).
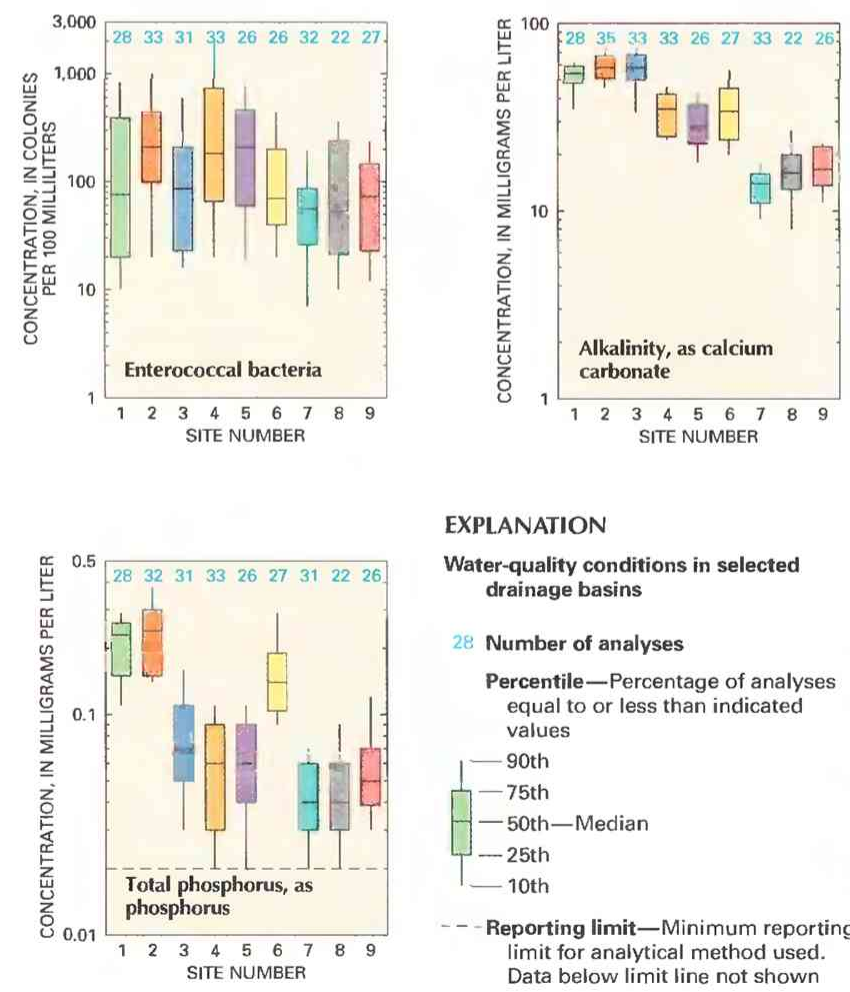

\section{EXPLANATION}

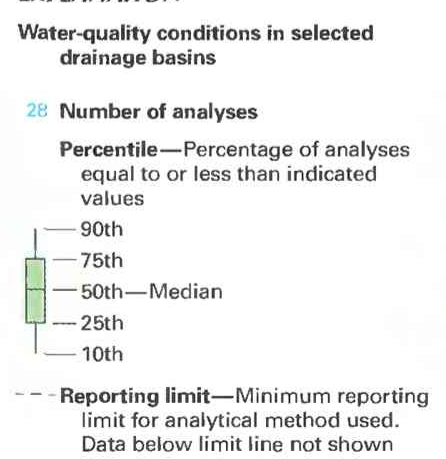

The median alkalinity of stream water from site $3(58 \mathrm{mg} / \mathrm{L})$ was one of the highest for the monitoring stations (fig. 3 ) and reflected contributions from various natural sources and human activities. The median concentration of nitrate $(3.2 \mathrm{mg} / \mathrm{L})$ in water from site 3 was among the highest and reflected contributions from extensive agricultural operations in the basin. The median concentration of ammonia plus organic nitrogen $(0.37 \mathrm{mg} / \mathrm{L})$ was the lowest, and that of phosphorus $(0.07 \mathrm{mg} / \mathrm{L})$ was about average for stations in the monitoring network.

Because of consistently high concentrations of enterococcal bacteria, the Christina River does not fully support primary contact recreation (Delaware Department of Natural Resources and Environmental Control, 1990e). Median concentrations of enterococcal bacteria in water from site $4(183 \mathrm{col} / 100 \mathrm{~mL})$ and site $5(210 \mathrm{col} /$ $100 \mathrm{~mL}$ ) were among the highest for the network stations. The principal sources of enterococcal bacteria are discharges from a municipal wastewater-treatment plant, agricultural and urban runoff, and overflows from combined sewers carrying domestic wastewater and storm runoff. Except for the relatively high concentrations of enterococcal bacteria, constituent concentrations in water from the Christina River at sites 4 and 5 were in the middle range among those for the nine monitoring stations in the network. Compared to site 4 , the smaller median alkalinity concentration $(28 \mathrm{mg} / \mathrm{L})$ at site 5 reflects increasing contributions to streamflow of less alkaline water from the Coastal Plain in the lower part of the Christina River basin. Median concentrations of nitrate decreased downstream from 1.5 $\mathrm{mg} / \mathrm{L}$ at site 4 to $0.93 \mathrm{mg} / \mathrm{L}$ at site 5 . Ammonia plus organic nitrogen concentrations were similar at both sites, as were phosphorus concentrations.

\section{ST. JONES AND NANTICOKE RIVERS, STOCKLEY BRANCH, AND BROAD CREEK}

Streams in the Coastal Plain are not used appreciably for water supply, mainly because abundant ground-water supplies are readily accessible.Water use also is limited by the relatively small discharges
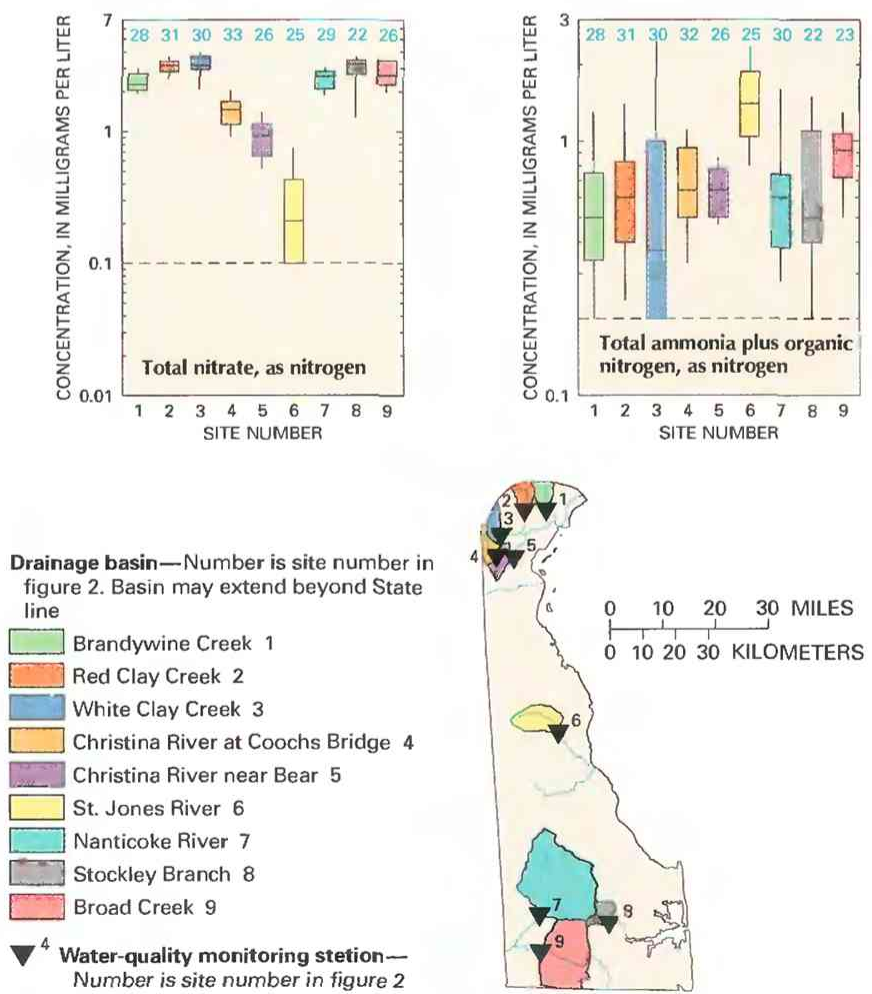

Figure 3. Water quality of selected streams in Delaware, water years 1987-89. (Source: Data from U.S. Geological Survey, U.S. Environmental Protection Agency, and Delaware Department of Natural Resources and Environmental Control files.) 
Table 1. Sources and environmental significance of selected water-quality constituents and properties [Source: Compiled by the U.S. Geological Survey, Office of Water Quality]

\begin{tabular}{|c|c|c|}
\hline Constituent or property & Common sources & Environmental significance \\
\hline Enterococcal bacteria ................... & $\begin{array}{l}\text { Sources include effluent from sewage-treatment } \\
\text { plants and runoff from pastures, feedlots, and ur- } \\
\text { ban areas. }\end{array}$ & $\begin{array}{l}\text { Presence indicates contamination of water by wastes } \\
\text { from humans and other warm-blooded animals. }\end{array}$ \\
\hline Alkalinity (property) .................... & $\begin{array}{l}\text { A measure of the quantity of acid-neutralizing sub- } \\
\text { stances; can be affected by geologic setting, in- } \\
\text { dustrial wastewater discharge, waste gases, and } \\
\text { runoff from surface mining. }\end{array}$ & $\begin{array}{l}\text { Sufficiently alkaline water can be unsuitable for some } \\
\text { agricultural and industrial uses. }\end{array}$ \\
\hline 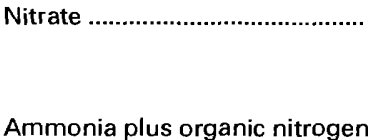 & $\begin{array}{l}\text { Nonpoint sources are agricultural and urban runoff; } \\
\text { a major point source is wastewater discharge. }\end{array}$ & $\begin{array}{l}\text { Plant nutrient that, in sufficient quantity, can cause } \\
\text { algal blooms and excessive growth of higher } \\
\text { aquatic plants in bodies of water; can cause water } \\
\text { to be unsuitable for public supply. } \\
\text { Ditto. }\end{array}$ \\
\hline 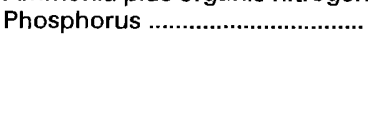 & $\begin{array}{l}\text { Occurs in some rocks and sediments; also in runoff } \\
\text { and seepage from phosphate-rock mines, agri- } \\
\text { cultural and urban runoff, and industrial and } \\
\text { municipal wastewater discharge. }\end{array}$ & $\begin{array}{l}\text { Plant nutrient that, in sufficient quantity, can cause } \\
\text { algal blooms and excessive growth of higher } \\
\text { aquatic plants in bodies of water. }\end{array}$ \\
\hline
\end{tabular}

of Delaware's Coastal Plain streams, saline-water encroachment in the tidal reaches of the streams, and the often substantial distances between the streams and points of intended use. The St. Jones and Nanticoke Rivers are the principal streams draining the Coastal Plain of Delaware. Stockley Branch is typical of the many small streams draining to Rehoboth and Indian River Bays. Broad Creek is a major tributary of the Nanticoke River.

The St. Jones River basin in central Delaware contains numerous branches, tributaries, and drainage ditches. The river flows from the northwest to the southeast and passes through Dover, the largest municipality in the basin. Although the St. Jones River basin is the most urbanized and industrialized large drainage basin in central Delaware, nearly one-half of the land in the basin remains in agricultural use. In the Nanticoke River and Broad Creek basins in southwestern Delaware, land is covered primarily by crops and forest. Land use in the Stockley Branch basin in southeastern Delaware includes rural residential areas, scattered forests, agricultural operations, and extensive poultry and livestock operations.

The quality of water in the St. Jones and Nanticoke Rivers, Stockley Branch, and Broad Creek reflects the combined effects of natural factors in human activities. However, because natural concentrations of stream-water constituents are low in many Coastal Plain streams, input from human activities can have a substantial effect on the chemical characteristics of water in the streams. Specific water-quality problems in the St. Jones and Nanticoke River, Stockley Branch, and Broad Creek basins have restricted certain designated uses of these waters. Contamination by organic compounds (particularly polychlorinated biphenyls) and pesticides has rendered the St. Jones River from Dover to Bowers Beach unsuitable for fishing (Delaware Department of Natural Resources and Environmental Control, 1990f). Median concentrations of enterococcal bacteria at sites 7,8 , and 9 were among the lowest for the nine monitoring stations, yet primary-contact recreation in the Nanticoke River, Stockley Branch, and Broad Creek is not fully supported because of occasionally excessive concentrations of these bacteria at several locations (Delaware Department of Natural Resources and Environmental Control, $1990 \mathrm{~g}, \mathrm{~h}, \mathrm{i})$.

At site 6 on the St. Jones River, the median concentration of nitrate $(0.21 \mathrm{mg} / \mathrm{L})$ was the lowest among those for the nine monitoring stations, whereas the median concentration of ammonia plus organic nitrogen $(1.40 \mathrm{mg} / \mathrm{L})$ was the highest. The distribution of these concentrations indicates the presence of ground-water inflow containing little or no dissolved oxygen mainly from poorly drained parts of the upper St. Jones River basin. The distribution also might signify that Silver Lake, a eutrophic water body immediately upstream from site 6 , has a major effect on the form of nitrogen prevalent in the river by limiting the oxidation of ammonia and organic nitrogen to nitrate. Median concentrations of nitrate in water from the Nanticoke River at site $7(2.6 \mathrm{mg} / \mathrm{L})$, Stockley Branch at site 8 $(3.2 \mathrm{mg} / \mathrm{L})$, and Broad Creek at site $9(2.7 \mathrm{mg} / \mathrm{L})$ were among the highest for the monitoring stations. These concentrations reflect substantial contributions of shallow ground-water inflow containing nitrate from fertilizers and onsite septic systems and, to a lesser extent, nonpoint source runoff from agricultural areas. Nutrient concentrations in the Nanticoke River also are affected by point-source discharge of wastewater from municipal and industrial operations. At sites 7, 8, and 9 median concentrations of phosphorus were the lowest among the monitoring stations. Median alkalinity concentrations ranged from $14 \mathrm{mg} / \mathrm{L}$ at site 7 to $34 \mathrm{mg} / \mathrm{L}$ at site 6 and reflected small chemical contributions from the relatively insoluble sediments of the Coastal Plain.

\section{WATER-QUALITY TRENDS}

Trend analysis is a statistical procedure used to detect changes in stream water quality at a monitoring station over time. For this report, water-quality data from seven monitoring stations (fig. 2) were analyzed for trends by using the seasonal Kendall test (Hirsch and others, 1982), a method used extensively by the USGS. The graph (shown below) of the total nitrate concentration in Red Clay Creek at site 2 illustrates the trend inferred from the concentration data and demonstrates the variation in water quality that is common in streams.

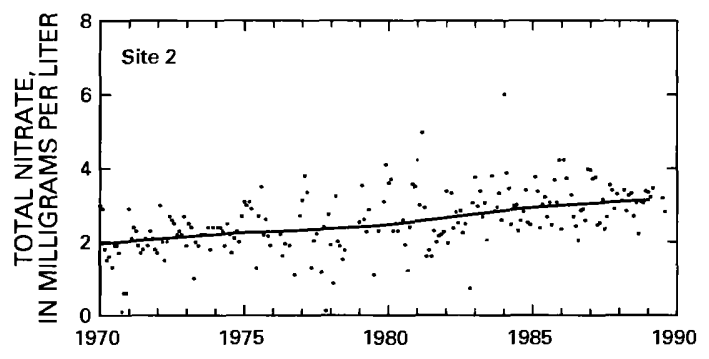

When possible, constituent-concentration data were adjusted for changes in streamflow to preclude identifying a trend in concentration that was caused only by a trend in streamflow. The data were not adjusted when (1) more than 10 percent of the samples had concentrations lower than the minimum reporting limit for the analytical method used or (2) streamflow was controlled substantially by human activities. When the concentration data could not be adjusted for streamflow, trends were determined directly from the concentration data.

Statewide trends in measurements of selected physical properties of stream water and concentrations of selected constituents in stream water are shown on maps in figure 4. On each map, a trend is 


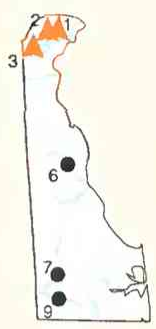

Alkalinity, 1970-88

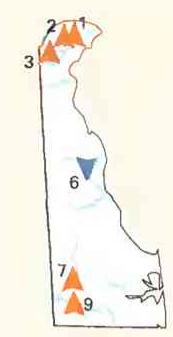

Total nitrate, 1970-88

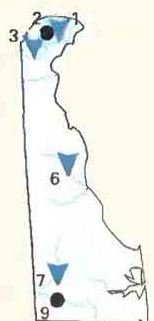

Total ammonia plus organic nitrogen, 1970-88

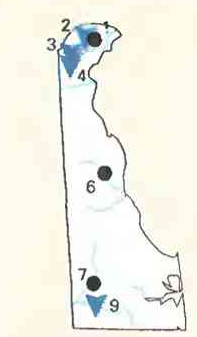

\section{EXPLANATION}

Trend in water-quality property or constituent - Number is site number in figure 2

$A^{1}$ Upward

- ${ }^{2}$ None

$\nabla^{4}$ Downward

Total phosphorus, 1980-88

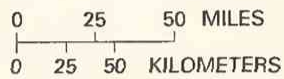

Figure 4. Trends in water quality of selected streams in Delaware, by water years. (Source: Data from U.S. Geological Survey, U.S. Environmental Protection Agency, and Delaware Department of Natural Resources and Environmental Control files.)

indicated at a monitoring station only if the data from that station were suitable for use in the trend analysis. Trends in enterococcal bacteria concentrations are not shown because the length of the data record was insufficient for trend analysis. For more information on the suitability criteria and on the trend-analysis procedure used for this report, see Lanfear and Alexander (1990).

Since 1946, information on the chemical quality of stream water in Delaware has been collected for various purposes. During that time, increased population and urbanization, along with changes in land use, agricultural practices, and wastewater-collection and treatment procedures, have affected the chemical character of the water. This report discusses changes in some aspects of water quality that have occurred from 1970 to recently (1990). McKenzie (1979) reported changes in water quality in Brandywine Creek at Wilmington during 1946-72, the St. Jones River at Dover during 195972 , and the Nanticoke River near Bridgeville during 1957-72 and noted increasing concentrations of major inorganic chemical constituents over time in Brandywine Creek and the St. Jones River. No distinct trends in constituent concentrations were observed in water from the Nanticoke River.

\section{ALKALINITY}

Alkalinity is a measure of the capacity of the substances dissolved in water to neutralize acid. In most natural waters, alkalinity is produced mainly by bicarbonate and carbonate (Hem, 1985, p. 106), which are ions formed when carbon dioxide or carbonate rock dissolves in water.

Upward trends in alkalinity were detected at sites 1, 2, and 3, which are in basins that drain areas of the Piedmont underlain chiefly by crystalline rocks and, to a lesser extent, carbonate rocks. Although the relative importance of different sources is unknown, the upward trends probably resulted from increasing alkalinity contributions from municipal wastewater discharges and runoff from urban areas. No trend was recorded at sites 6,7 , and 9 , which are in basins that drain the unconsolidated sediments of the Coastal Plain.

\section{TOTAL NITRATE}

Nitrogen from point and nonpoint sources can be introduced into streams in several forms; nitrate is the end product of their oxidation. Upward trends in nitrate concentrations at sites 1,2, and 3 in northern Delaware (fig. 4) probably resulted from population growth and attendant increases in municipal wastewater discharge and runoff from agricultural and urban areas, mainly in parts of the basins in Pennsylvania. Point-source discharges in northern Delaware are small and intermittent and would not be expected to have a pronounced effect on trends. The increasing nitrate concentration in the Nanticoke River at site 7 probably resulted from increasing discharge of municipal and industrial wastewater and from increasing concentrations in surface runoff from fertilized cropland. Fertilizers also contribute nitrogen to shallow ground water that flows into the Nanticoke River. Site 9 on Broad Creek also is in an agricultural basin where fertilizer application has led to gradual increases in nitrate concentration in stream water. The decreasing nitrate concentration in the St. Jones River at site 6 might have resulted from increasing aquatic plant growth in Silver Lake and from reduction of nonpointsource nitrogen contributions as land in the basin is converted from agricultural to nonagricultural uses.

\section{TOTAL AMMONIA PLUS ORGANIC NITROGEN}

Ammonia and organic nitrogen oxidize to nitrate in well-aerated streams. The presence of substantial quantities of either ammonia or organic nitrogen can indicate contamination from nearby urban or agricultural sources.

Downward trends in concentrations of ammonia plus organic nitrogen in Brandywine Creek at site 1, White Clay Creek at site 3, and the Nanticoke River at site 7 (fig. 4) probably reflect improvements in wastewater-treatment processes and reduction of nitrogen concentrations in ground-water inflow from areas where regional sewers have replaced septic tanks. The trend in concentrations at site 6 also was downward for water years 1970-88, although concentrations increased gradually in the later part of the trend period.

\section{TOTAL PHOSPHORUS}

The total phosphorus concentration of a water sample is a measure of the concentration of all forms of phosphorus present in the sample, dissolved and particulate. Human activities (table 1) can be important sources of phosphorus in streams.

In the Red Clay Creek, White Clay Creek, and Christina River basins, municipal wastewater discharges, fertilizers, and nonpointsource urban runoff are the major sources of phosphorus in stream water. Although not presented in this report, the data on which the trend analyses were performed indicate significant decreases in phosphorus concentrations from the early 1980 's to 1983 , followed by a period of relatively low, stable concentrations. Specific causes for the decreasing concentrations at site 2 on Red Clay Creek, site 3 on White Clay Creek, and site 4 on the Christina River (fig. 4) have not been documented; however, the trends could be related to the replacement of high-phosphate detergents with low-phosphate or phosphate- 
free detergents and to improvements in wastewater-treatment processes. The decreasing concentration in Broad Creek at site 9 could have resulted in part from reduced concentrations in wastewater discharged to the shallow ground-water system through septic tanks. The ground water, which eventually discharges to streams, constitutes a major component of streamflow in the Coastal Plain.

\section{WATER-QUALITY MANAGEMENT}

The DNREC, Division of Water Resources, is responsible for managing programs to protect water resources and control water pollution. The Delaware Environmental Protection Act of 1974 and Regulations Governing the Control of Water Pollution (1974) authorize the DNREC to administer the National Pollutant Discharge Elimination System program and to regulate wastewater-treatment facilities. The Division of Water Resources performs numerous regulatory, monitoring, and enforcement functions, including developing water-quality standards and criteria, assessing of stream water quality to determine compliance with effluent and water-quality standards, monitoring waste discharges and ambient water-quality conditions, and issuing permits to discharge wastewater. The Division also prepares a biennial water-quality assessment submitted to the U.S. Congress and the EPA, as required by section 305(b) of the Federal Clean Water Act (Delaware Department of Natural Resources and Environmental Control, 1990a-i).

Several water-resources management issues in Delaware require interagency cooperation. For example, the Division of Public Health, within the Delaware Department of Health and Social Services, is responsible for posting swimming advisories and regulating shellfish-harvesting areas. The Divisions of Water Resources and Public Health conduct water-quality monitoring activities in support of these programs. The Governor's Environmental Council assists the DNREC in identifying environmental matters of public concern, including water-resources issues, and addresses these concerns through appropriate policies and programs.

The State of Delaware is a charter member of the Delaware River Basin Commission, an interstate agency concerned with basinwide water-resources evaluation, planning, and management. Representatives from the DNREC participate in many of the special water-quality committees of the Commission.

Since 1970, the Division of Water Resources has operated a statewide stream water-quality monitoring program. Although the level of monitoring has remained relatively constant, the types of monitoring have changed to meet evolving needs. The most significant changes have been the addition of biological monitoring and toxics assessment to the regular stream water-quality program, and special surveys to evaluate specific water-quality problems.

To help improve the quality of surface-water resources in the State, volunteers from the Delaware Stream Watch Program, a surveillance conducted by concerned individuals, regularly visit selected streams and perform routine monitoring activities including visual surveys, physical and chemical water-quality measurements, and biological surveys. Stream Watch volunteers report their findings and any water-quality problems directly to the DNREC.

\section{SELECTED REFERENCES}

Anderson, J.R., 1967, Major land uses in the United States, in U.S. Geological Survey, 1970, National atlas of the United States of America: Washington, D.C., U.S. Geological Survey, p. 158-159.

Delaware Department of Natural Resources and Environmental Control, 1990a, 1990 Delaware water quality inventory 305(b) report, volume I-Summary: Dover, Delaware Department of Natural Resources and Environmental Control. $72 p$.

1990b. 1990 Delaware water quality inventory 305(b) report, volume II-Basin assessment information for Brandywine River: Dover, Delaware Department of Natural Resources and Environmental Control, p. 17-21.

1990c, 1990 Delaware water quality inventory 305(b) report, volume II - Basin assessment information for Red Clay Creek: Dover, Delaware Department of Natural Resources and Environmental Control, 21 p.

1990d, 1990 Delaware water quality inventory 305(b) report, volume II-Basin assessment information for White Clay Creek: Dover, Delaware Department of Natural Resources and Environmental Control, 32 p.

$1990 \mathrm{e}, 1990$ Delaware water quality inventory 305(b) report, volume II-Basin assessment information for Christina River: Dover, Delaware Department of Natural Resources and Environmental Control, 54 p.

1990f, 1990 Delaware water quality inventory 305(b) report, volume II-Basin assessment information for St. Jones River: Dover, Delaware Department of Natural Resources and Environmental Control, 38 p.

$1990 \mathrm{~g}, 1990$ Delaware water quality inventory 305(b) report, volume II-Basin assessment information for Nanticoke River: Dover, Delaware Department of Natural Resources and Environmental Control, 51 p.

$1990 \mathrm{~h}, 1990$ Delaware water quality inventory 305 (b) report, volume II-Basin assessment information for Indian River Bay: Dover, Delaware Department of Natural Resources and Environmental Control, $81 \mathrm{p}$.

1990i, 1990 Delaware water quality inventory 305(b) report, volume II-Basin assessment information for Broad Creek: Dover, Delaware Department of Natural Resources and Environmental Control, $41 \mathrm{p}$.

Fenneman, N.M., 1946, Physical divisions of the United States: Washington, D.C., U.S. Geological Survey special map, scale 1:7,000,000.

Hirsch, R.M., Slack, J.R., and Smith, R.A., 1982, Techniques of trend analysis for monthly water quality data: Water Resources Research, v. 18, no. 1, p. 107-121.

Lanfear, K.J., and Alexander, R.B., 1990, Methodology to derive water-quality trends for use by the National Water Summary Program of the U.S. Geological Survey: U.S. Geological Survey Open-File Report 90-359, $10 \mathrm{p}$.

McKenzie, S.W., 1979, Long-term chemical-quality changes in selected Delaware streams: Delaware Geological Survey Report of Investigations no. $34,41 \mathrm{p}$.

Rasmussen, W.C., Groot, J.J., Martin, R.O.R., and others, 1957, The water resources of northern Delaware: Delaware Geological Survey Bulletin no. 6 , v. 1,223 p.

Thelin, G.P., and Pike, R.J.., 1990, Digital shaded relief map of the conterminous United States: Menlo Park, Calif., U.S. Geological Survey digital image processing, scale 1:3,500,000.

U.S. Department of Commerce, Bureau of the Census, 1982, Census of population (1980), number of inhabitants: Washington, D.C., U.S. Government Printing Office, $84 \mathrm{p}$.

U.S. Geological Survey, 1986, National water summary 1985-Hydrologic events and surface-water resources: U.S. Geological Survey Water-Supply Paper 2300, $506 \mathrm{p}$.

1990, National water summary 1987-Hydrologic events and water supply and use: U.S. Geological Survey Water-Supply Paper 2350, $553 \mathrm{p}$.

Prepared by Gary N. Paulachok and Joel D. Blomquist, U.S. Geological Survey; "Water-Quality Management" section by John F. Davis, Delaware Department of Natural Resources and Environmental Control

FOR ADDITIONAL INFORMATION: Hydrologist in Charge, U.S. Geological Survey, Federal Building, Room 1201, 300 S. New Street, Dover, DE 19901 


\section{FLORIDA}

\section{Stream Water Quality}

Florida has an area of $59,390 \mathrm{mi}^{2}$ (square miles), of which more than 17,800 $\mathrm{mi}^{2}$ are wetlands, lakes, and streams (Fernald, 1981, p. 163). Surface-water resources are vast, consisting of more than 1,700 streams and rivers measuring 12,700 stream miles and 7,700 lakes covering 3,280 $\mathrm{mi}^{2}$ (Florida Department of Environmental Regulation, 1988a, p. 6). The principal land covers are forest and woodland $\left(23,700 \mathrm{mi}^{2}\right)$, and the principal land uses (fig. $1 A$ ) are related to agriculture $\left(13,100 \mathrm{mi}^{2}\right)$. Urban and associated areas compose about 5 percent $\left(3,300 \mathrm{mi}^{2}\right)$ of the State (Fernald, 1981, p. 163).

Florida is in the Coastal Plain physiographic province (fig. $1 B$ ), where stream features are the result of subtropical climate, abundant annual rainfall, relatively flat terrain, and permeable soils and underlying rock (U.S. Geological Survey, 1986, p. 187). Annual rainfall in the State is about 53 inches, but quantities range from 52 inches in the central part to 60 inches in the southeast to 64 inches in the northwest. Annual runoff ranges from about 5 inches in the Florida Keys to 40 inches in northwestern Florida (U.S. Geological Survey, 1986, p. 187).

Total fresh surface water withdrawn for offstream uses in 1985 was $2,230 \mathrm{Mgal} / \mathrm{d}$ (million gallons per day) (U.S. Geological Survey, 1990 , p. 209). Fresh surface water was used mainly for irrigation $(1,330 \mathrm{Mgal} / \mathrm{d})$, thermoelectric power generation $(630 \mathrm{Mgal} / \mathrm{d})$, public supply (185 Mgal/d), and commercial and industrial supply (77 $\mathrm{Mgal} / \mathrm{d}$ ). About 10 percent of Florida's population uses surface water for its freshwater needs.

Florida's natural environment is enriched with abundant water resources that enhance the quality of life for its residents and sustain a significant recreation-based economy. The quality of most streams in Florida meets State standards established for water-pollution control, but some environmental stress has been caused by population

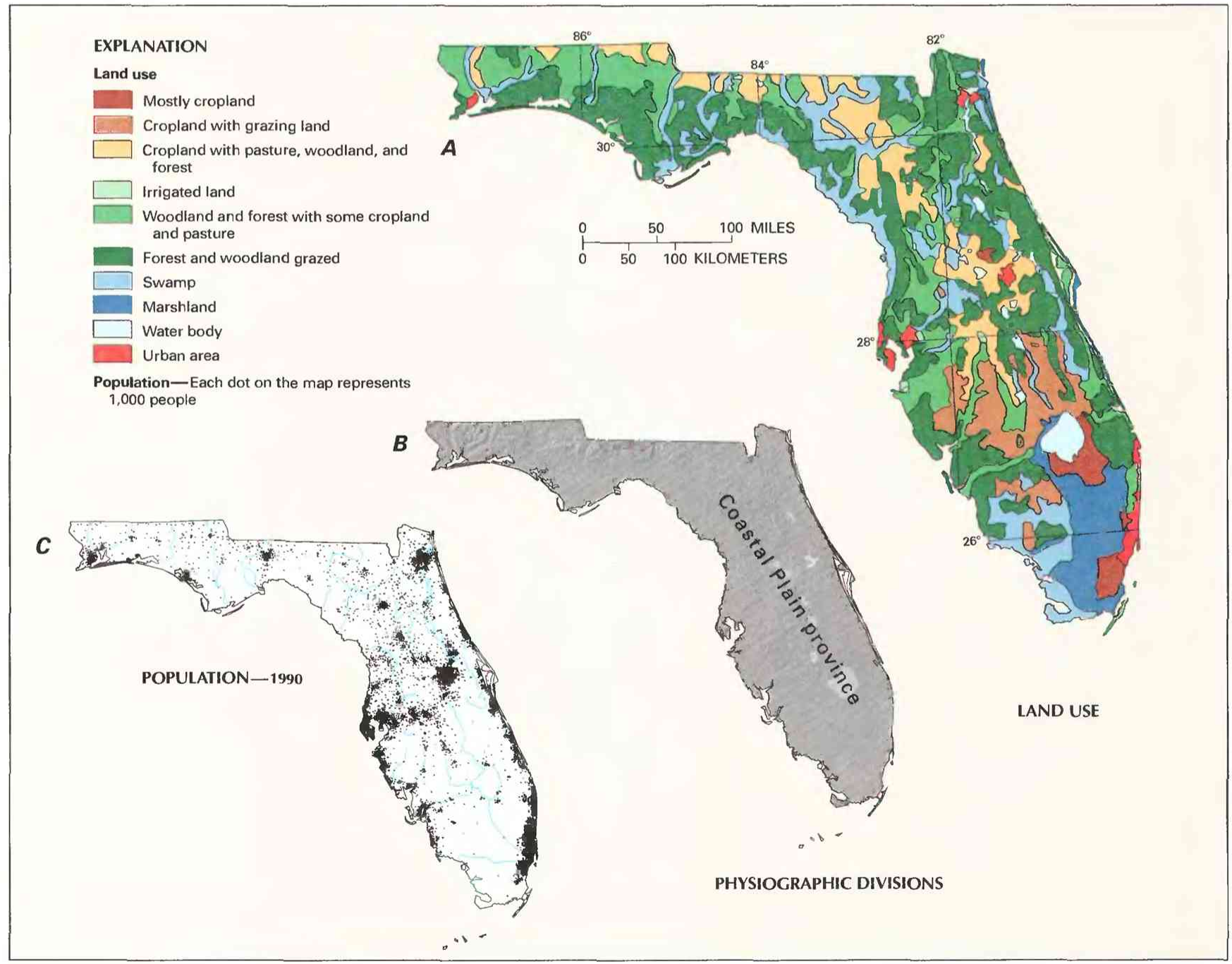

Figure 1. Land use, physiography, and population in Florida. A, Major land uses. B, Physiographic divisions. C, Population distribution in 1990. (Sources: A. Major land uses modified from Anderson, 1967. B, Physiographic divisions from Fenneman, 1946; landforms from Thelin and Pike, 1990. C, Data from U.S. Bureau of the Census 1990 decennial census files.) 
growth. The distribution of water-quality problems approximates the distribution of population (fig. $1 C$ ), which has increased 33 percent from about 9.7 million in 1980 to 12.9 million in 1990 (U.S. Bureau of the Census 1990 decennial census files). Water quality of streams in the sparsely populated northwestern and west-central parts of the State usually meets regulatory standards; however, water-quality problems are evident in densely populated urban areas such as Jacksonville, Orlando, Tampa, and the southeastern coast (Florida Department of Environmental Regulation, 1988a, p. 1).

\section{WATER-QUALITY MONITORING}

Water-quality data obtained from analyses of water samples collected at monitoring stations are stored in the U.S. Geological Survey's (USGS) National Water Information System and the U.S. Environmental Protection Agency's (EPA) national data base known as STORET. Water-quality and streamflow data are reported by water year-the 12 months from October 1 through September 30. A water year is identified by the calendar year in which it ends. For example, water year 1991 comprises October 1, 1990, through September 30, 1991.

The data used in this summary of Florida's stream water quality were obtained from water samples collected at 25 monitoring stations at which data collection is systematic and continuing (fig. 2). Analyses of water samples collected at 10 stations are the basis for the discussion and graphic summary (fig. 3 ) of stream water-quality conditions during water years 1987-89, and data from 20 stations are the basis for the discussion and graphic summary (fig. 4) of stream water-quality trends. Water samples were collected and analyzed by using standard methods approved by the USGS (Britton and Greeson, 1987; Fishman and Friedman, 1989; Ward and Harr, 1990) or by using equivalent methods. If a method for sample collection or analysis changed over time, data from an analysis were included in the evaluation of recent stream water quality or of stream water-quality trends only if the change in method did not affect the comparability of the data.

\section{WATER-QUALITY CONDITIONS}

Florida's surface-water quality is assessed biennially by the Florida Department of Environmental Regulation (DER) in accordance with the Federal Clean Water Act. The assessment for 1988 determined that 92 percent of the stream reaches either fully or partially supported their designated uses, and 8 percent did not (Florida Department of Environmental Regulation, 1988a, p. 12). Most streams are classified as Class III waters, which are designated for recreation and the propagation and management of a well-balanced fish and wildlife population (Florida Department of Environmental Regulation, 1990). Organic enrichment, deficient dissolved-oxygen concentrations, and excessive nutrient concentrations were the primary conditions cited in the $900-1,000$ miles of streams that did not meet designated-use guidelines (Florida Department of Environmental Regulation, 1988a, p. 12). Most of the adverse conditions were ascribed to nonpoint runoff from agricultural and urban areas, which are increasing in size throughout the State. A recent reduction in point-source contamination is attributable to improvement in wastetreatment processes (Florida Department of Environmental Regulation, 1988a, p. 3).

The following discussion of stream water quality in Florida is organized by river basin (fig. 3). Where physiographic and landuse characteristics in different basins are similar, the discussion of those basins is combined. Graphs in figure 3 summarize certain aspects of stream water quality in the basins for water years 1987-89. The graphs show frequency distributions of data values that represent measurements of selected physical properties of stream water and concentrations of selected constituents in stream water. These properties and constituents are turbidity, dissolved oxygen, dissolved sulfate, dissolved solids, dissolved nitrite plus nitrate (as nitrogen), dissolved ammonia (as nitrogen), and dissolved phosphorus (as phosphorus). The data are reported in nephelometric turbidity units and milligrams per liter $(\mathrm{mg} / \mathrm{L})$. Sources and environmental significance of each property and constituent are described in table 1 .

Water quality at each monitoring station is the result of geological, chemical, biological, and hydrologic processes that occur over a large area. Water-quality problems that affect aquatic life or public health only locally are not fully represented in this summary.

\section{ST. JOHNS AND OKLAWAHA RIVERS}

The St. Johns River originates in an expansive marshy area northeast of Lake Okeechobee and drains 9,168 $\mathrm{mi}^{2}$ (U.S. Geological Survey, .1986 , p. 188). The river lies almost entirely in coastal lowlands and flows parallel to the coast for 273 miles and into the Atlantic Ocean near Jacksonville. More than 60 percent of the flood plain in the upper drainage basin of the St. Johns River has been ditched, diked, and drained for various agricultural uses (U.S. Geological Survey, 1986, p. 188). Cropland and pasture cover much of the upper basin. but the percentage of forest increases downstream. Urban development is extensive in Orlando and Jacksonville, the largest cities in the basin.

Water quality in the upper reaches of the St. Johns River generally meets State water-pollution-control criteria (Florida Department of Environmental Regulation, 1988b, p. 225). Dissolvedoxygen concentrations, however, have been lower than optimal in some reaches because of sluggish flow and possible organic enrichment from agricultural runoff. In the Orlando area, discharges to several tributaries of the St. Johns River from wastewater-treatment facilities have decreased dissolved-oxygen concentrations and increased nutrient and bacteria concentrations. Downstream at site 1, however, dissolved-oxygen concentrations were higher than 5.0 $\mathrm{mg} / \mathrm{L}$ in at least 75 percent of the measurements made during water years 1987-89, and nitrite plus nitrate and phosphorus concentrations were similar in magnitude to those in most other streams (fig. 3 ). The somewhat higher sulfate and dissolved-solids concentrations at site 1 , relative to those at other monitoring stations, were likely the result of discharge from moderately saline springs that flow into the river (Dysart and Goolsby, 1977).

The Oklawaha River, which is the largest tributary to the St. Johns River, drains $2,769 \mathrm{mi}^{2}$ or about one-third of the St. Johns River basin (U.S. Geological Survey, 1986, p. 188) and lies mainly in the highlands (Fernald, 1981, p. 17). Upstream from site 2, land use is principally agricultural (Florida Department of Environmental Regulation, 1988b, p. 151). Flow in the upper basin is regulated by numerous water-control structures and canals. About one-half of the stream discharge at site 2 comes from Silver Springs.

Stream water in the Oklawaha River basin ranges in quality from pristine to the most polluted in the State (Florida Department of Environmental Regulation, 1988b, p. 151). Most of the waterquality problems are in the southern reaches, where water is contaminated by both point and nonpoint sources. Decreased dissolvedoxygen concentrations and increased nutrient concentrations have been reported. At site 2 , dissolved-oxygen concentrations were lower than $5.0 \mathrm{mg} / \mathrm{L}$ in nearly 50 percent of the measurements made during 1987-89, and nitrite plus nitrate concentrations were higher than those at most of the other monitoring stations (fig. 3).

\section{KISSIMMEE RIVER}

The Kissimmee River is the principal tributary to Lake Okeechobee, the largest freshwater lake in Florida (U.S. Geological Survey, 1986, p. 188), and drains about 2,900 $\mathrm{mi}^{2}$. The upper part of the basin is in upland plains, but near the lake the basin consists of 


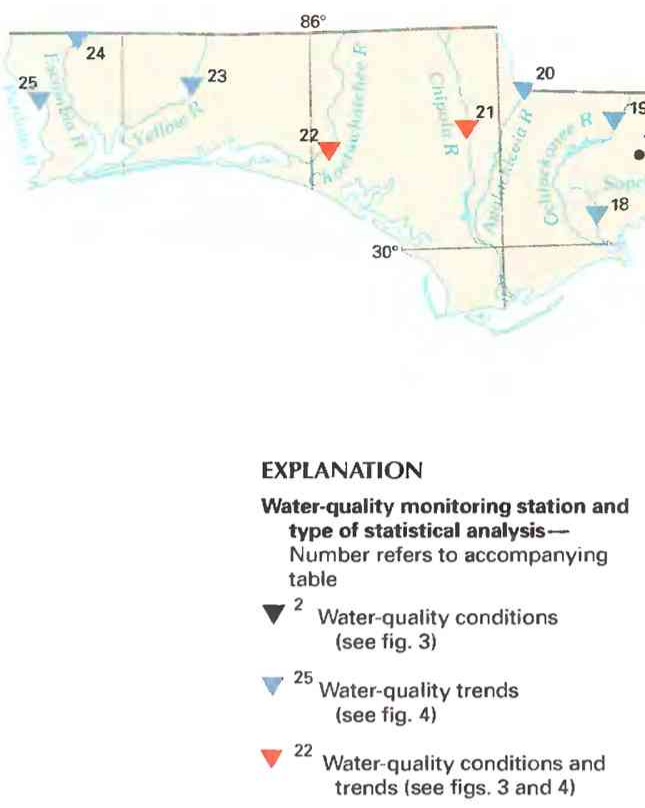

\section{EXPLANATION}

ion an pe of statistical analysis(see fig. 4) trends (see figs. 3 and 4)

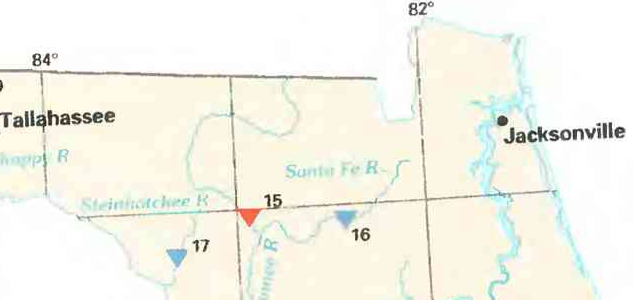

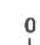

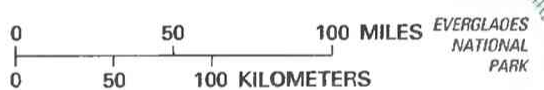

50100 KILOMETERS

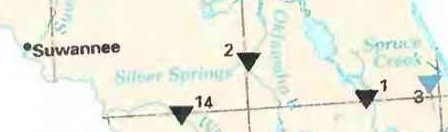


coastal lowlands (Fernald, 1981, p. 17). South of Orlando, the upper basin is densely urbanized but gradually changes downstream to rangeland and cropland and then to wetlands at site 6 near Lake Okeechobee (fig. 1A). A large part of the natural drainage of the Kissimmee River has been channelized and dammed.

The primary water-quality issue upstream from Lake Tohopekaliga is nutrient and organic enrichment from urban and agricultural sources. The downstream reach of the Kissimmee River has been channelized. As a result, runoff from agricultural areas and rangeland can flow rapidly to Lake Okeechobee with little opportunity for natural assimilation by flood-plain vegetation (Florida Department of Environmental Regulation, 1988b, p. 110). At site 6, dissolved-oxygen concentrations lower than $5.0 \mathrm{mg} / \mathrm{L}$ in about 25 percent of the measurements made during water years 1987-89 (fig. 3) might have been caused by organic enrichment.

\section{MIAMI CANAL AND CALOOSAHATCHEE RIVER}

The Miami Canal and the Caloosahatchee River are the principal southern outlets from Lake Okeechobee. The Miami Canal, which drains into Biscayne Bay, is one of five major canals that dis-
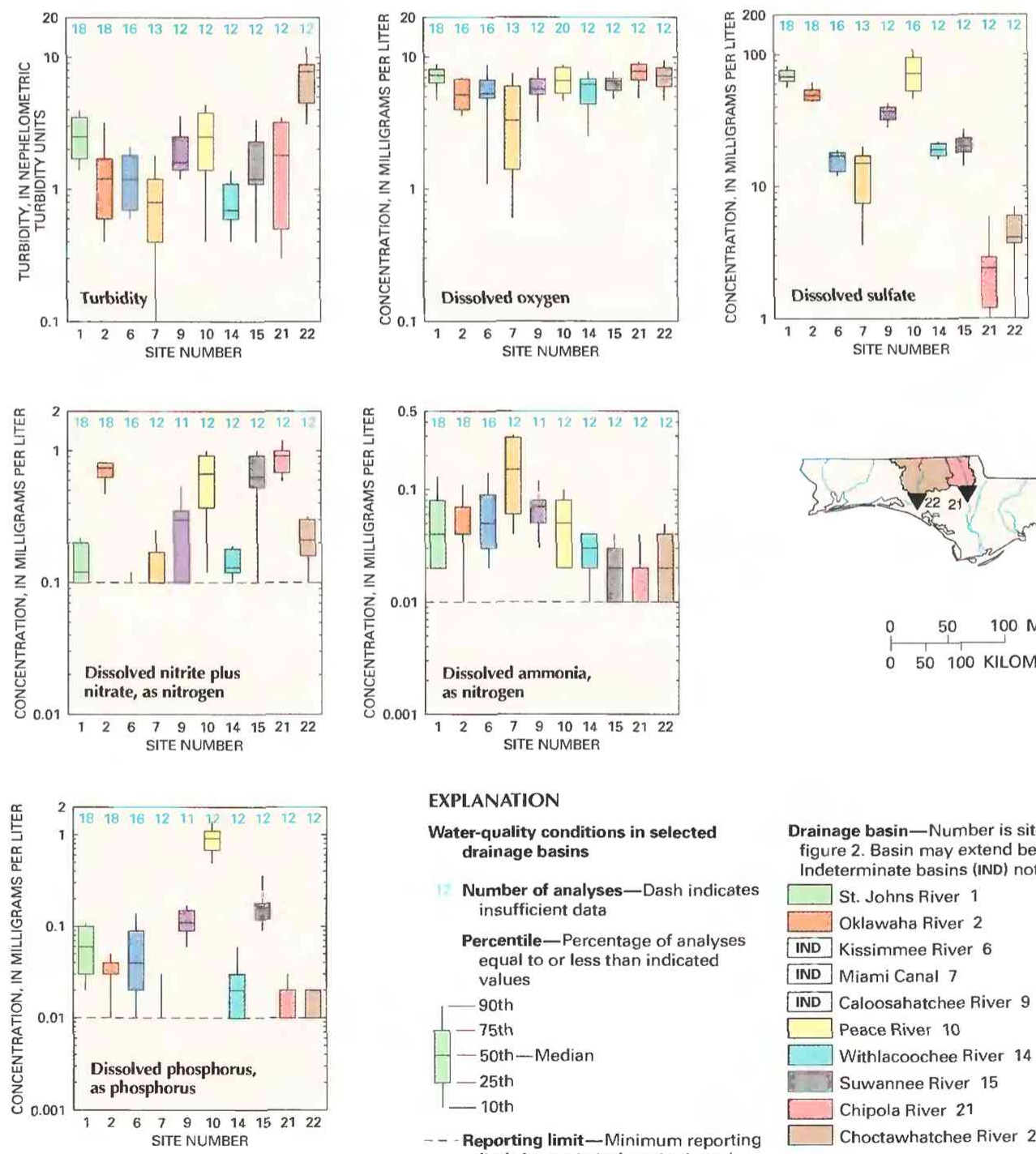

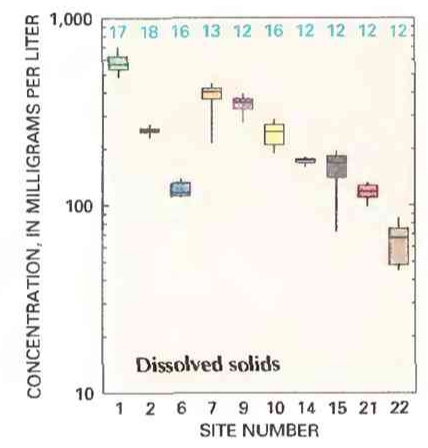

tribute water from Lake Okeechobee to densely populated areas along the southeastern coast of Florida. In the area of the upper reach, near the lake, the major land-use activities are agricultural. In the middle reach, native wetlands remain as part of water-conservation efforts for Everglades National Park. The area near site 7, on the downstream reach of the Miami Canal, is densely urbanized.

Water quality of the Miami Canal is adversely affected by agricultural and urban runoff and by sewage effluent (Florida Department of Environmental Regulation, 1988b, p. 194). Decreased dissolved-oxygen concentrations and increased bacteria, nutrient, and pesticide concentrations have been reported for parts of the canal. The median dissolved-oxygen concentration at site $7(3.3 \mathrm{mg} / \mathrm{L})$ was the lowest for the 10 monitoring stations (fig. 3), and median ammonia concentrations generally were higher than for the other stations. However, other nutrient concentrations were low; nitrite plus nitrate and phosphorus concentrations were among the lowest for the 10 stations.

The Caloosahatchee River originates at the western part of Lake Okeechobee and flows about 75 miles to the Gulf of Mexico near Fort Myers. Upstream from site 9, the river is named the Caloosahatchee Canal. In the upper reaches, rangelands and wetlands
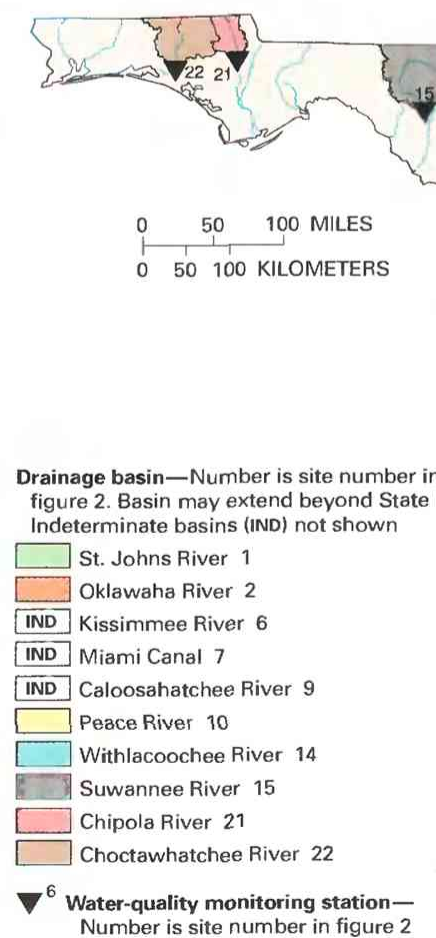

Figure 3. Water quality of selected streams in Florida, water years 1987-89. (Source: Data from U.S. Geological Survey files.) 
Table 1. Sources and environmental significance of selected water-quality properties and constituents [Source: Compiled by the U.S. Geological Survey, Office of Water Quality]

\begin{tabular}{|c|c|c|}
\hline Property or constituent & Common sources & Environmental significance \\
\hline Turbidity (property) .................... & $\begin{array}{l}\text { Caused by natural or human-induced suspended mat- } \\
\text { ter; components include clay, silt, fine organic and } \\
\text { inorganic matter, soluble colored organic com- } \\
\text { pounds, and microscopic aquatic organisms. }\end{array}$ & $\begin{array}{l}\text { Can be detrimental to aquatic organisms; can cause } \\
\text { water to be unsuitable for recreation, industry, and } \\
\text { public supply. }\end{array}$ \\
\hline Dissolved oxygen ........................ & $\begin{array}{l}\text { Introduced from the atmosphere; also a byproduct of } \\
\text { aquatic plants. }\end{array}$ & $\begin{array}{l}\text { Necessary for aquatic life; deficiency can result from } \\
\text { assimilation of organic wastes or rapid growth } \\
\text { and decay of algae. }\end{array}$ \\
\hline Fecal coliform bacteria ................ & $\begin{array}{l}\text { Sources include effluent from sewage-treatment } \\
\text { plants and runoff from pastures, feedlots, and ur- } \\
\text { ban areas. }\end{array}$ & $\begin{array}{l}\text { Presence indicates contamination of water by wastes } \\
\text { from humans and other warm-blooded animals. }\end{array}$ \\
\hline Sulfate & $\begin{array}{l}\text { Occurs in some rocks; also in mine runoff, industrial } \\
\text { wastewater discharge, and atmospheric deposi- } \\
\text { tion. }\end{array}$ & $\begin{array}{l}\text { Concentrations exceeding a natural, background } \\
\text { level indicate contamination from human activity; } \\
\text { in sufficient quantity, can cause water to be } \\
\text { unsuitable for public supply; can harm aquatic } \\
\text { organisms. }\end{array}$ \\
\hline Dissolved solids ............................ & $\begin{array}{l}\text { A result of rock weathering; also in agricultural runoff } \\
\text { and industrial discharge. }\end{array}$ & $\begin{array}{l}\text { In sufficient quantity, can cause water to be unsuitable } \\
\text { for public supply, agriculture, and industry; can } \\
\text { harm aquatic organisms. }\end{array}$ \\
\hline 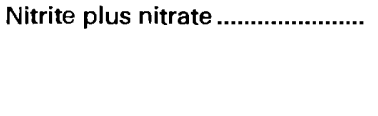 & $\begin{array}{l}\text { Nonpoint sources are agricultural and urban runoff; } \\
\text { a major point source is wastewater discharge. }\end{array}$ & $\begin{array}{l}\text { Plant nutrient that, in sufficient quantity, can cause } \\
\text { algal blooms and excessive growth of higher } \\
\text { aquatic plants in bodies of water; can cause water } \\
\text { to be unsuitable for public supply. }\end{array}$ \\
\hline 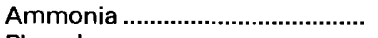 & . ditto & Ditto. \\
\hline 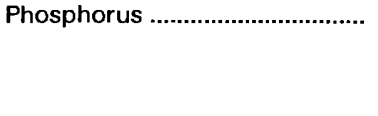 & $\begin{array}{l}\text { Occurs in some rocks and sediments; also in runoff } \\
\text { and seepage from phosphate-rock mines, agri- } \\
\text { cultural and urban runoff, and industrial and } \\
\text { municipal wastewater discharge. }\end{array}$ & $\begin{array}{l}\text { Plant nutrient that, in sufficient quantity, can cause } \\
\text { algal blooms and excessive growth of higher } \\
\text { aquatic plants in bodies of water. }\end{array}$ \\
\hline
\end{tabular}

predominate, but there is some agricultural land near the lake. The river quality generally meets designated-use criteria, but decreased biological diversity and dissolved oxygen have been reported for some reaches (Florida Department of Environmental Regulation, 1988b, p. 39). At site 9 , the median dissolved-oxygen concentration was $5.7 \mathrm{mg} / \mathrm{L}$, and in about 25 percent of the measurements, concentrations were equal to or lower than $5.0 \mathrm{mg} / \mathrm{L}$ (fig. 3).

\section{PEACE RIVER}

The Peace River originates in the Green Swamp in central Florida and flows southwestward, emptying into the Gulf of Mexico at Charlotte Harbor, and drains about 2,400 $\mathrm{mi}^{2}$ (Conover and Leach, 1975). The upper drainage basin, a major recharge area for the Floridan aquifer system, lies in the central highlands. The middle part of the basin is in upland plains. The lower basin, downstream from site 10, is in coastal lowlands (Fernald, 1981, p. 17). Land use in the basin upstream from site 10 mostly is agricultural, although some land is barren as a result of extensive phosphate mining (Florida Department of Environmental Regulation, 1988b, p. 159). Urban areas upstream from site 10 include Lakeland, Winter Haven, and Bartow.

Water-quality concerns in the Peace River include discharge from wastewater-treatment facilities, phosphate mines, and citrusprocessing plants and runoff from urban, agricultural, and mined areas (Florida Department of Environmental Regulation, 1988b, p. 159). The most serious water-quality conditions that have been reported generally relate to lakes that receive sewage-treatment-plant effluent and parts of the river that receive nutrients from phosphate mining and fertilizer production. At site 10 , the high median nitrite plus nitrate concentration of $0.67 \mathrm{mg} / \mathrm{L}$ and median phosphorus concentration of $0.91 \mathrm{mg} / \mathrm{L}$ during water years $1987-89$ (fig. 3) likely reflect the basinwide effects of land-use practices.

\section{WITHLACOOCHEE RIVER}

The Withlacoochee River originates in the Green Swamp of central Florida and drains $2,020 \mathrm{mi}^{2}$, most of which is coastal lowlands (Fernald, 1981, p. 17). Along much of its course, the river is hydraulically connected to the Floridan aquifer system (U.S. Geological Survey, 1986, p. 191). The river receives considerable drainage from wetlands (Florida Department of Environmental Regulation, 1988b, p. 278). Land cover upstream from site 14 mostly consists of agricultural areas, forest, and swamp.

The water in the Withlacoochee River is suitable for the designated use of the stream, although local problems have existed, mainly in downstream reaches. Much of the river has a low dissolvedoxygen concentration at times because of drainage from swamps (Florida Department of Environmental Regulation, 1988b, p. 278). Although the median dissolved-oxygen concentration at site 14 during water years $1987-89$ was $6.2 \mathrm{mg} / \mathrm{L}$, about 10 percent of the dissolved-oxygen concentrations were equal to or lower than 2.5 $\mathrm{mg} / \mathrm{L}$ (fig. 3).

\section{SUWANNEE RIVER}

The Suwannee River, which drains $9,950 \mathrm{mi}^{2}\left(4,260 \mathrm{mi}^{2}\right.$ in Florida), has its headwaters in the Okefenokee Swamp in Georgia. The river flows southward, emptying into the Gulf of Mexico near Suwannee (U.S. Geological Survey, 1986, p. 191). In Florida, the upper part of the drainage basin is in highlands, and the lower part is in coastal lowlands (Fernald, 1981, p. 17). Much of the river's flow is from tributary springs (U.S. Geological Survey, 1986, p. 191). The drainage basin is forested, but agricultural land is common.

The water quality of the Suwannee River meets most State standards, although phosphorus concentrations have increased owing to drainage from phosphate mines (Florida Department of Environmental Regulation, 1988 b, p. 254). At site 15 , the median phosphorus concentration of $0.16 \mathrm{mg} / \mathrm{L}$ was exceeded only by that for the Peace River at site 10 (fig. 3), which also is in a phosphate-mining area. Dissolved-oxygen concentrations at site 15 generally exceeded 5.0 $\mathrm{mg} / \mathrm{L}$.

\section{CHIPOLA RIVER}

The Chipola River originates in Alabama and drains $1,237 \mathrm{mi}^{2}$, of which $1,020 \mathrm{mi}^{2}$ is in Florida (Conover and Leach, 1975). The drainage basin lies in highlands and coastal lowlands (Fernald, 1981, 
p. 17). Population in the basin is sparse, and land cover upstream from site 21 mostly is woodland and forest.

Water quality of the Chipola River generally meets State standards, although runoff from agricultural lands and discharge from wastewater-treatment facilities have caused some water-quality problems (Florida Department of Environmental Regulation, 1988b, p. 52). Undesirable values of nitrate, biochemical oxygen demand, and siltation, all predominantly from agricultural and silvicultural nonpoint sources, have been identified. At site 21 , the median nitrite plus nitrate concentration was $0.91 \mathrm{mg} / \mathrm{L}$, considerably higher than those at the other monitoring stations (fig. 3). Turbidity values at site 21 , however, were similar to those at most of the other stations.

\section{CHOCTAWHATCHEE RIVER}

The Choctawhatchee River is in northwestern Florida in an area that has an annual rainfall of about 64 inches (U.S. Geological Survey, 1986, p. 192). The river drains $4,646 \mathrm{mi}^{2}$, of which 1.538 $\mathrm{mi}^{2}$ is in Florida (Conover and Leach, 1975). Although much of the upper drainage basin in Alabama and Florida is in highlands, the river flows mostly through coastal lowlands (Fernald, 1981, p. 17). Land cover upstream from site 22 consists mostly of forest and agricultural land.

The water quality of the Choctawhatchee River generally meets State standards, but this river basin has more water-quality problem areas than other sparsely populated basins in northwestern Florida (Florida Department of Environmental Regulation, 1988b, p. 62). Agriculture and logging, along with several small wastewatertreatment facilities, have caused increased concentrations of nutrients and suspended sediment. At site 22 , however, nitrite plus nitrate and phosphorus concentrations in water samples collected during water years $1987-89$ were similar to or lower than those at other monitoring stations, and dissolved-oxygen concentrations were higher than $5.0 \mathrm{mg} / \mathrm{L}$ most of the time.

\section{WATER-QUALITY TRENDS}

Trend analysis is a statistical procedure used to detect changes in stream water quality at a monitoring station over time. For this report, water-quality data from 20 monitoring stations (fig. 2) were analyzed for trends by using the seasonal Kendall test (Hirsch and others, 1982), a method used extensively by the USGS. The graph (above right) of the dissolved-solids concentration in the Alafia River at site 12 illustrates the trend inferred from the concentration data and demonstrates the variation in water quality that is common in streams.

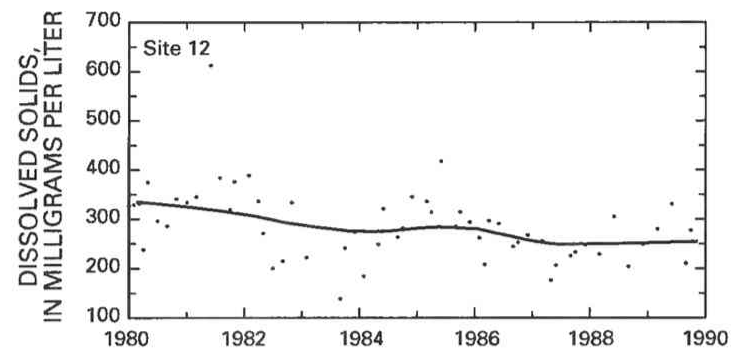

When possible, constituent-concentration data were adjusted for changes in streamflow to preclude identifying a trend in concentration that was caused only by a trend in streamflow. The data were not adjusted when (1) more than 10 percent of the samples had concentrations lower than the minimum reporting limit for the analytical method used or (2) streamflow was controlled substantially by human activities. When the concentration data could not be adjusted for streamflow, trends were determined directly from the concentration data.

Statewide trends in measurements of selected physical properties of stream water and in concentrations of selected constituents in stream water are shown on maps in figure 4. On each map, a trend is indicated at a monitoring station only if the data from that station were suitable for use in the trend analysis. For more information on the suitability criteria and on the trend-analysis procedure used for this report, see Lanfear and Alexander (1990).

\section{TURBIDITY}

Turbidity is a measure of the light-absorbing and scattering capacity of a sample of water. Stream water that appears "cloudy" or "muddy" would have a higher measured turbidity value than water that appears clear. The major source of turbidity in stream water is suspended matter, which can enter the stream as a result of either natural processes or human activities (table 1).

The upward turbidity trend in the Steinhatchee River at site 17 (fig. 4) likely was due to silviculture. Turbidity problems in the

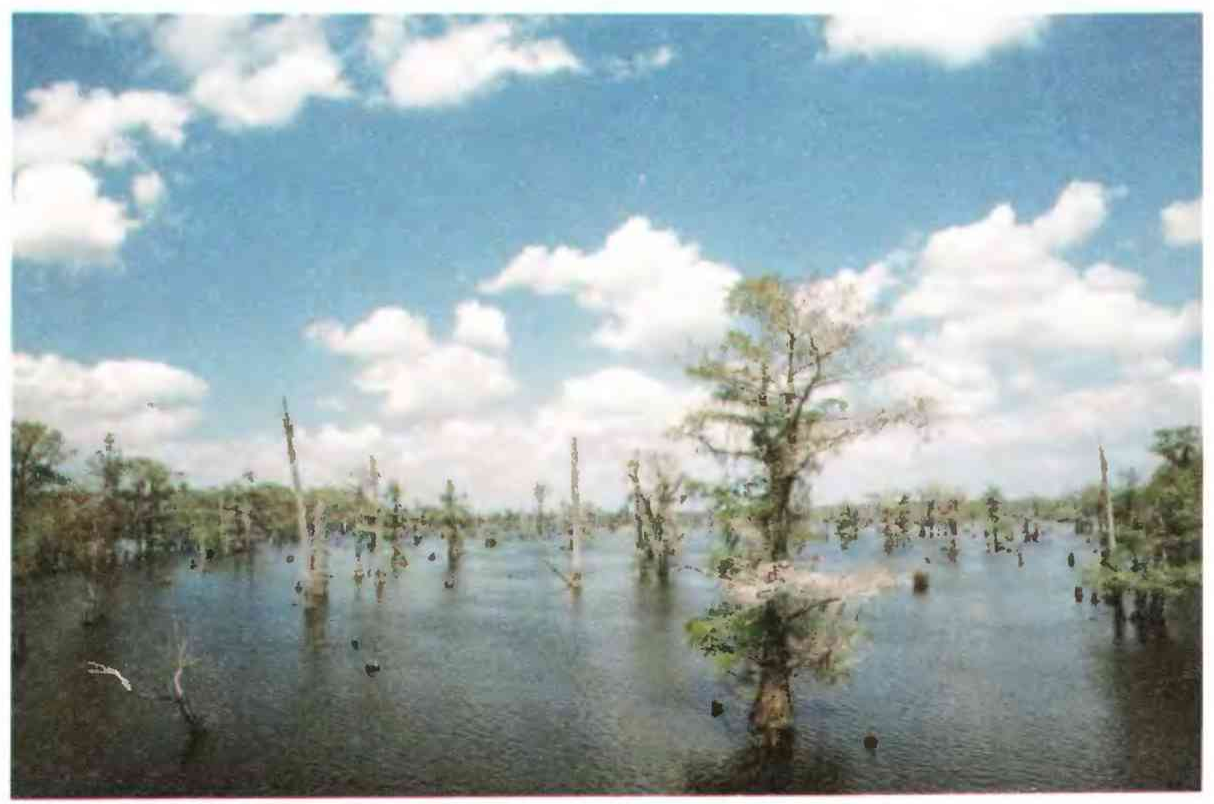

Part of a reservoir on the lower Chipola River in northwestern Florida. Although the Chipola River meets State water-quality standards, in some reaches agricultural runoff causes elevated nitrogen concentrations and sedimentation. (George A. Irwin, U.S. Geological Survey.) 


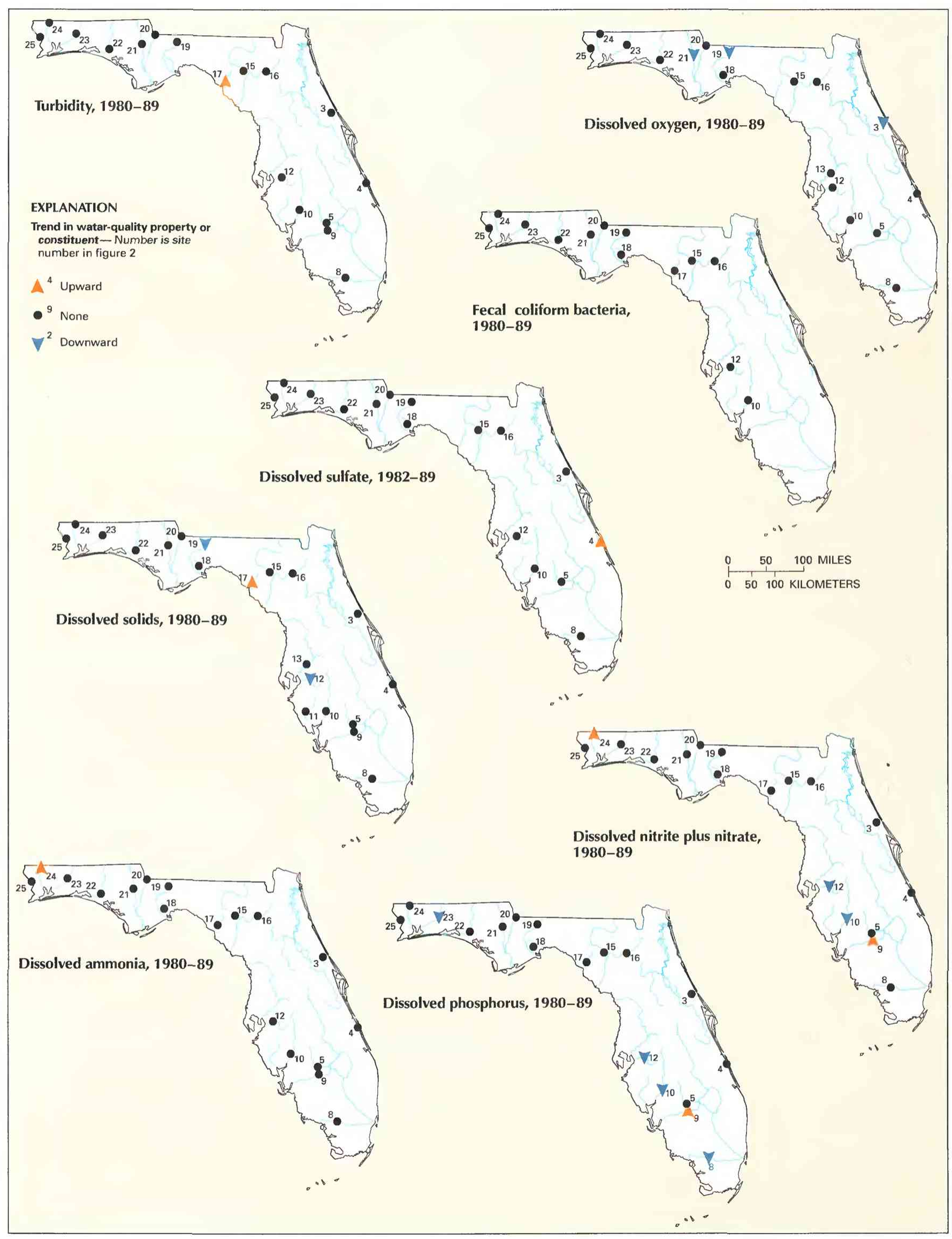

Figure 4. Trends in water quality of selected streams in Florida, by water years. (Source: Data from U.S. Geological Survey files.) 
basin have'been reported by the Florida Department of Environmental Regulation (1988b, p. 246).

\section{DISSOLVED OXYGEN}

The dissolved-oxygen concentration in a stream is controlled by several factors, including water temperature, air temperature and pressure, hydraulic characteristics of the stream, photosynthetic or respiratory activity of stream biota, and the quantity of organic material present. A trend in dissolved-oxygen concentrations commonly is either directly or indirectly the result of human activities. Generally, an upward trend in dissolved-oxygen concentrations indicates improving stream water-quality conditions and a downward trend indicates deteriorating conditions.

A reason for the downward trends in dissolved-oxygen concentration in Spruce Creek at site 3, the Ochlockonee River at site 19, and the Chipola River at site 21 (fig. 4) is not known. Despite the decreases, median concentrations were higher than $5.0 \mathrm{mg} / \mathrm{L}$ at the three monitoring stations during water years $1987-89$ (fig. 3).

\section{FECAL COLIFORM BACTERIA}

Fecal coliform bacteria are used as indicators of fecal contamination from humans and other warm-blooded animals. Such contamination can introduce disease-causing viruses and bacteria into a stream.

Fecal coliform bacteria concentrations had no trend at the 13 monitoring stations from which data met the criteria for trend analysis. The absence of any significant change in the concentration of fecal coliform bacteria indicates that the input to streams of inadequately treated sewage or runoff from urban areas, feedlots, and pastures did not change substantially during the trend-analysis period.

\section{DISSOLVED SULFATE}

The major natural sources of sulfate in streams are rock weathering, volcanoes, and biochemical processes (Hem, 1985, p. 113). Human activities such as mining, waste discharge, and fossil-fuel combustion also can be important sources. The increasing sulfate concentration in the Main Canal at site 4 likely was due to consistently below-average streamflow in conjunction with agricultural runoff during the late 1980 's.

\section{DISSOLVED SOLIDS}

Dissolved solids in stream water result primarily from rock weathering but also can be introduced as a byproduct of human activities (table 1). Concentrations generally are greatest in streams draining basins underlain by rocks and soils that contain easily dissolved minerals.

The upward trend in dissolved-solids concentrations in the Steinhatchee River at site 17 likely was due to consistently lower than average streamflow during the latter part of the analysis period. Forest logging and planting, which are reported to cause recurring turbidity problems (Florida Department of Environmental Regulation, 1988b, p. 246), also might have contributed to the increasing dissolved-solids concentration at site 17 .

The downward trend in dissolved-solids concentrations in the Alafia River at site 12 might have been the result of improved runoffmanagement practices for phosphate mining and processing. The reason for the decreasing dissolved-solids concentration in the Ochlockonee River at site 19 is not known.

\section{DISSOLVED NITRITE PLUS NITRATE}

Nitrite and nitrate are oxidized forms of nitrogen that together constitute most of the dissolved nitrogen in well-aerated streams. $\mathrm{Ni}$ - trite readily oxidizes to nitrate in natural waters; therefore, nitrate generally is by far the more abundant of the two (Hem, 1985, p. 124).

The small increase in nitrite plus nitrate concentration in the Caloosahatchee River at site 9 likely was attributable to agricultural runoff near Lake Okeechobee (Florida Department of Environmental Regulation, 1988b, p. 39). Hammett (1988, p. 87) also reported a substantial increase in nitrate concentrations from 1966 to 1985 in the Caloosahatchee River near Olga that was attributed to wastewatertreatment effluent and agricultural runoff. The upward trend in nitrite plus nitrate concentrations in the Escambia River at site 24 could have been the result of wastewater-treatment and paper-mill discharge or effluent (Florida Department of Environmental Regulation, 1988b, p. 83).

The decreasing nitrite plus nitrate concentration in the Alafia River at site 12 could be attributable to improved wastewater treatment and mining practices. In the Peace River at site 10, the downward trend could have been the result of recently improved mining practices (Florida Department of Environmental Regulation, 1988b, p. 160). However, a similar trend for nitrate did not occur in the Peace River during 1957-85, according to another study (Hammett, 1988, p. 86).

\section{AMMONIA}

Ammonia in stream water oxidizes to nitrate under aerobic conditions (Hem, 1985, p. 126). Although small quantities of ammonia can be present in unpolluted stream water, the presence of high concentrations commonly indicates contamination from agricultural or urban sources. The upward trend in ammonia concentrations in the Escambia River at site 24 could be attributable to increased discharge from a paper mill near the Alabama State line and from wastewater-treatment facilities (Florida Department of Environmental Regulation, 1988b, p. 83).

\section{DISSOLVED PHOSPHORUS}

Small quantities of dissolved phosphorus-most of it in the oxidized form, phosphate_commonly are present in streams as a result of rock weathering. Concentrations of dissolved phosphorus in natural water normally are no more than a few tenths of a milligram per liter (Hem, 1985, p. 126) and are usually much lower. Higher concentrations can indicate contamination from human activities (table 1).

The upward trend in phosphorus concentrations in the Caloosahatchee River at site 9 likely was due to increased agricultural runoff (Florida Department of Environmental Regulation, 1988b, p. 39; Hammett, 1988, p. 84). Substantial increases in total phosphorus and orthophosphorus concentrations during 1966-85 in the Caloosahatchee River at Olga, caused by agricultural runoff and wastewater-treatment effluent, were reported by Hammett (1988, p. 87).

The downward trends in the Peace River at site 10 and the Alafia River at site 12 might reflect changes in land use and wastewater-disposal practices, particularly in phosphate mining and processing areas. According to Hammett $(1988$, p. 98), a decrease in total phosphorus of 6 percent per year occurred in the Peace River at site 10 during 1957-85. Decreases in phosphorus concentrations also have been reported by the Florida Department of Environmental Regulation (1988b, p. 82) for several reaches of the Peace and Alafia Rivers. A cause for the downward trends in the Tamiami Canal at site 8 and the Yellow River at site 23 is not known; concentrations at both monitoring stations were near the limit of analytical detection.

\section{WATER-QUALITY MANAGEMENT}

The Florida DER, created by the Florida Environmental Reorganization Act of 1975, is the primary State agency responsible for 
Prepared by George A. Irwin, U.S. Geological Survey; "Water-Quality Management" section by Thomas M. Swihart, Florida Department of Environmental Regulation

FOR ADDITIONAL INFORMATION: District Chief, U.S. Geological Survey, 227 North Bronough Street, Suite 3015, Tallahassee, FL 32301 
water-quality program management. The Department's authority to preserve the State's environmental integrity and water quality is based on regulatory programs for permitting and enforcement. The State's regulatory program is designed to coordinate citizen complaints, Departmental investigations, water analysis, and planning and management programs. Permitting is the major tool used in the regulatory program and is administered chiefly through district offices of the Department located throughout the State. Polluting, operating without a permit, or violating permit conditions can, under Florida law, be grounds for enforcement action by the DER.

The Florida DER prepares a biennial water-quality-assessment report (Florida Department of Environmental Regulation, 1988a; 1988 b) submitted to the EPA and the U.S. Congress in accordance with section 305(b) of the Federal Clean Water Act. The primary objective of the report is to evaluate the quality of Florida's surface waters with regard to their suitability for designated uses. Almost all streams in Florida are classified as Class III waters, designated for "Recreation and Propagation and Management of a WellBalanced Population of Fish and Wildlife" (Florida Department of Environmental Regulation, 1990). Water-quality data used for the 305(b) assessments are generated by State and Federal agencies; however, sampling by these agencies has decreased substantially since the 1970's because of budget constraints.

The Florida Game and Fresh Water Fish Commission is responsible for fishery management, and the Florida Department of Natural Resources has separate responsibilities for recreation, parks, and endangered species management. Water-quantity management, under the Florida Water Resources Act of 1972, is the primary responsibility of five Water Management Districts that are funded by property taxes.

The State of Florida has maintained a large land-acquisition program for stream protection during the last 20 years and has spent more than $\$ 1$ billion to purchase important natural-resource lands. The program has included major purchases along the Apalachicola, Suwannee, Kissimmee, and Loxahatchee Rivers. The Surface Water Improvement and Management program, created in 1988, allocates about $\$ 15$ million annually for special restoration and preservation of critical water resources. Larger scale, special-restoration programs, such as a \$250-million program to partly dechannelize the Kissimmee River, are planned.

Governors of Florida, Georgia, and Alabama appoint members to the Apalachicola-Chattahoochee-Flint Rivers Interstate Coordinating Council, whose function is to improve the management of that large river system. The council resolves conflicts among the States and various users concerning issues such as proper allocation of water between upstream and downstream users and the effects of operation and maintainence of the navigation channel on the Apalachicola River-Bay system.

\section{SELECTED REFERENCES}

Anderson, J.R., 1967, Major land uses in the United States, in U.S. Geological Survey, 1970, National atlas of the United States of America: Washington, D.C., U.S. Geological Survey, p. 158-159.
Britton, L.J., and Greeson, P.E., eds., 1987, Methods for collection and analysis of aquatic biological and microbiological samples: U.S. Geological Survey Techniques of Water-Resources Investigations, book 5 , chap. A4, $363 \mathrm{p}$.

Conover, C.S., and Leach, S.D., 1975, River basin and hydrologic unit map of Florida: Florida Geological Survey, Map Series 72.

Dysart, J.E., and Goolsby, D.A., 1977, Dissolved-solids concentrations and loads in Florida surface waters: Florida Geological Survey, Map Series 77.

Fenneman, N.M., 1946, Physical divisions of the United States: Washington, D.C., U.S. Geological Survey special map, scale 1:7,000,000.

Fernald, E.A., ed., 1981, Atlas of Florida: Tallahassee, Institute of Science and Public Affairs, Florida State University, 276 p.

Fishman, M.J., and Friedman, L.C., eds., 1989, Methods for the determination of inorganic substances in water and fluvial sediments: U.S. Geological Survey Techniques of Water-Resources Investigations, book 5, chap. A1, 545 p.

Florida Department of Environmental Regulation, 1988a, Water quality assessment for the State of Florida: Tallahassee, Florida Department of Environmental Regulation, 105 p.

1988b, 1988 Florida water quality assessment 305(b) technical appendix: Tallahassee, Florida Department of Environmental Regulation, $289 \mathrm{p}$.

1990, Water-quality standards, in Administrative Code: Florida Department of Environmental Regulation, Tallahassee, chap. 17-3, 88 p.

Hammett, K.M., 1988, Land use, water use, streamflow, and water-quality characteristics of the Charlotte Harbor inflow area, Florida: U.S. Geological Survey Open-File Report 87-474, 104 p.

Hem, J.D., 1985, Study and interpretation of the chemical characteristics of natural water (3d ed.): U.S. Geological Survey Water-Supply Paper 2254, $263 \mathrm{p}$.

Hirsch, R.M., Slack, J.R., and Smith, R.A., 1982, Techniques of trend analysis for monthly water quality data: Water Resources Research, v. 18, no. 1, p. 107-121.

Lanfear, K.J., and Alexander, R.B., 1990, Methodology to derive water-quality trends for use by the National Water Summary Program of the U.S. Geological Survey: U.S. Geological Survey Open-File Report 90-359, $10 \mathrm{p}$.

Thelin, G.P., and Pike, R.J., 1990, Digital shaded relief map of the conterminous United States: Menlo Park, Calif., U.S. Geological Survey digital image processing, scale 1:3,500,000.

U.S. Geological Survey, 1986, National water summary 1985-Hydrologic events and surface-water resources: U.S. Geological Survey Water-Supply Paper 2300, 506 p.

1990, National water summary 1987-Hydrologic events and water supply and use: U.S. Geological Survey Water-Supply Paper 2350, $553 \mathrm{p}$.

Ward, J.R., and Harr, C.A., eds., 1990, Methods for collection and processing of surface-water and bed-material samples for physical and chemical analyses: U.S. Geological Survey Open-File Report 90-140, 71 p. 


\section{GEORGIA Stream Water Quality}

Nearly all of Georgia's surface water originates within its borders. A statewide annual precipitation of 50 inches (U.S. Geological Survey, 1986) ranks Georgia sixth among the contiguous 48 States in annual precipitation (National Oceanic and Atmospheric Administration, 1988). However, occasional droughts serve as a reminder that water resources are limited and that maintenance of acceptable stream water quality is a priority.

Surface water was withdrawn from Georgia's streams, rivers, and reservoirs at a rate of $4,370 \mathrm{Mgal} / \mathrm{d}$ (million gallons per day) in 1985, which represented 81.3 percent of the water withdrawn in the State (U.S. Geological Survey, 1990, p. 216). Ground water accounted for the remaining 18.7 percent. Most surface water was used for thermoelectric power generation $(3,280 \mathrm{Mgal} / \mathrm{d})$, followed by public water supply (634 Mgal/d), self-supplied industrial and mining facilities (288 Mgal/d), agricultural activities (166 Mgal/d), and selfsupplied domestic and commercial use (4 Mgal/d) (U.S. Geological Survey, 1990, p. 220). The southern part of the State is primarily agricultural (fig. $1 A$ ) and relies mainly on ground water. Surface-water use is greatest in the northern part of the State, where urban areas and industry located in the Piedmont, Blue Ridge, and Valley and Ridge physiographic provinces (figs. $1 B$ and $1 C$ ) rely almost entirely on surface water as a source of supply.

Fifty-two percent of the people in Georgia depended on surface water for supply in 1980 (U.S. Geological Survey, 1986); that percentage increased to approximately 56 percent in 1989 (J.L. Fanning, U.S. Geological Survey, Doraville, Ga., written commun., 1990). The State's population increased from 5.5 million in 1980 to 6.5 million in 1990 (U.S. Bureau of the Census 1990 decennial census files).

\section{WATER-QUALITY MONITORING}

Water-quality data obtained from analyses of water samples collected at monitoring stations are stored in the U.S. Geological Survey's (USGS) National Water Information System and the U.S. Environmental Protection Agency's (EPA) national data base known as STORET. Water-quality and streamflow data are reported by water year-the 12 months from October 1 through September 30. A water year is identified by the calendar year in which it ends. For example, water year 1991 comprises October 1, 1990, through September 30, 1991.

The data used in this summary of Georgia's stream water quality were obtained from water samples collected at 18 monitoring stations at which data collection is systematic and continuing (fig. 2). Analyses of water samples collected at 10 stations are the basis for the discussion and graphic summary (fig. 3) of stream water-quality conditions during water years 1987-89, and data from 16 stations are the basis for the discussion and graphic summary (fig. 4) of stream

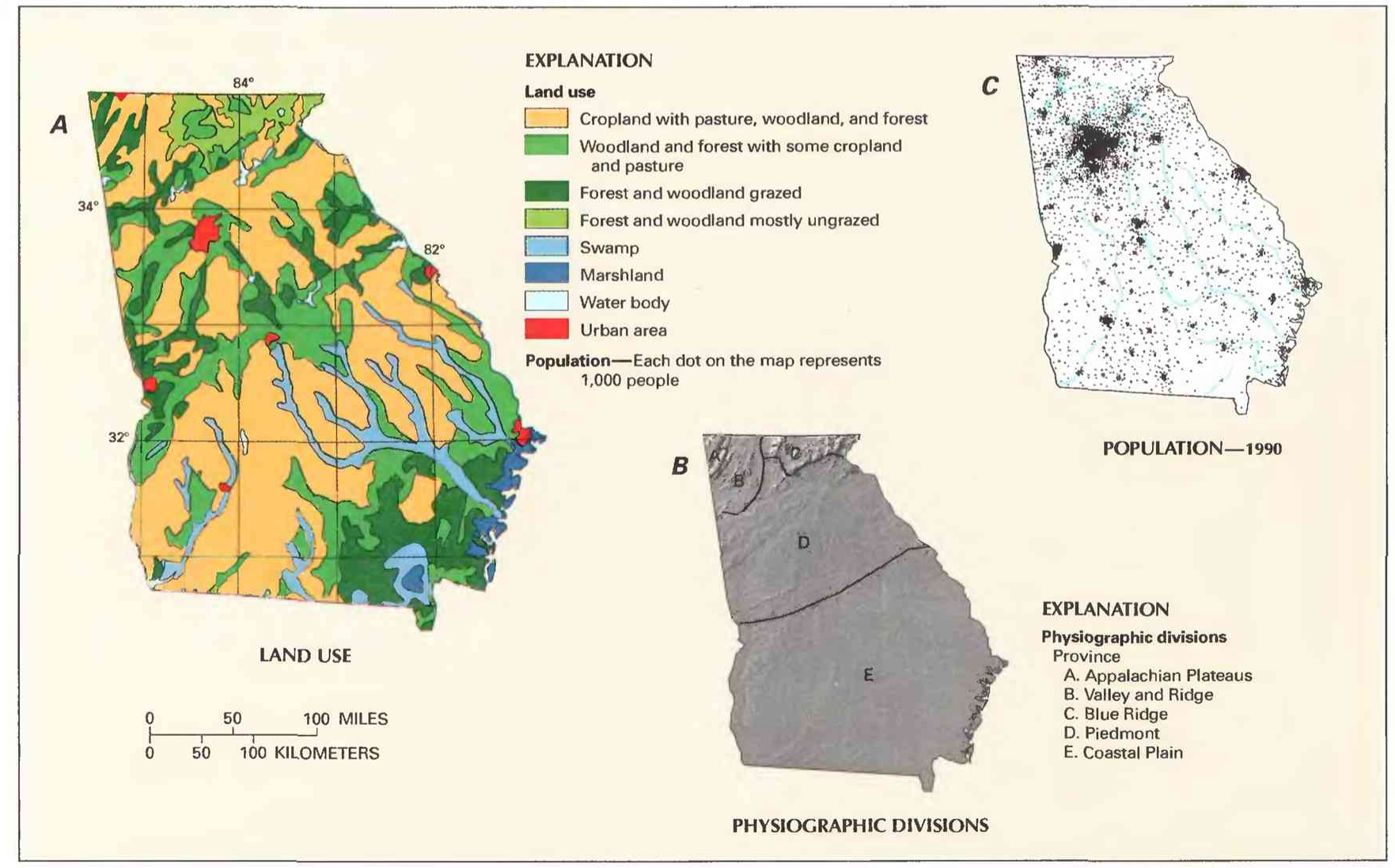

Figure 1. Land use, physiography, and population in Georgia. A, Major land uses. B, Physiographic divisions. $C$, Population distribution in 1990. (Sources: A, Major land uses modified from Anderson, 1967. B. Physiographic divisions from Fenneman, 1946; landforms from Thelin and Pike, 1990. C, Data from U.S. Bureau of the Census 1990 decennial census files.) 
water-quality trends. Water samples were collected and analyzed by using standard methods approved by the USGS (Britton and Greeson, 1987; Fishman and Friedman, 1989; Ward and Harr, 1990) or by using equivalent methods. If a method of sample collection or analysis changed over time, data from an analysis were included in the evaluation of recent stream water quality or of stream water-quality trends only if the change in method did not affect the comparability of the data.

\section{WATER-QUALITY CONDITIONS}

The Environmental Protection Division (EPD) of the Georgia Department of Natural Resources has established water-use classi- fications based on designated beneficial uses for streams and has assigned specific water-quality standards to support each water-use classification (Georgia Department of Natural Resources, 1990a). An assessment of the State's streams in 1988-89 indicated that 97 percent of the 20,000 stream miles evaluated supported the designated uses (Georgia Department of Natural Resources, 1990b, p. 8). Nonpoint sources (64 percent of the time) and point sources from municipalities ( 16 percent of the time) and industry ( 20 percent of the time) were identified as the specific causes for less-than-full support of the designated uses. Of concern are discharges of nutrients (nitrogen and phosphorus), toxic substances (organic compounds and trace metals), and fecal coliform bacteria and the effect of these contaminants on the aquatic life of the receiving streams and reservoirs

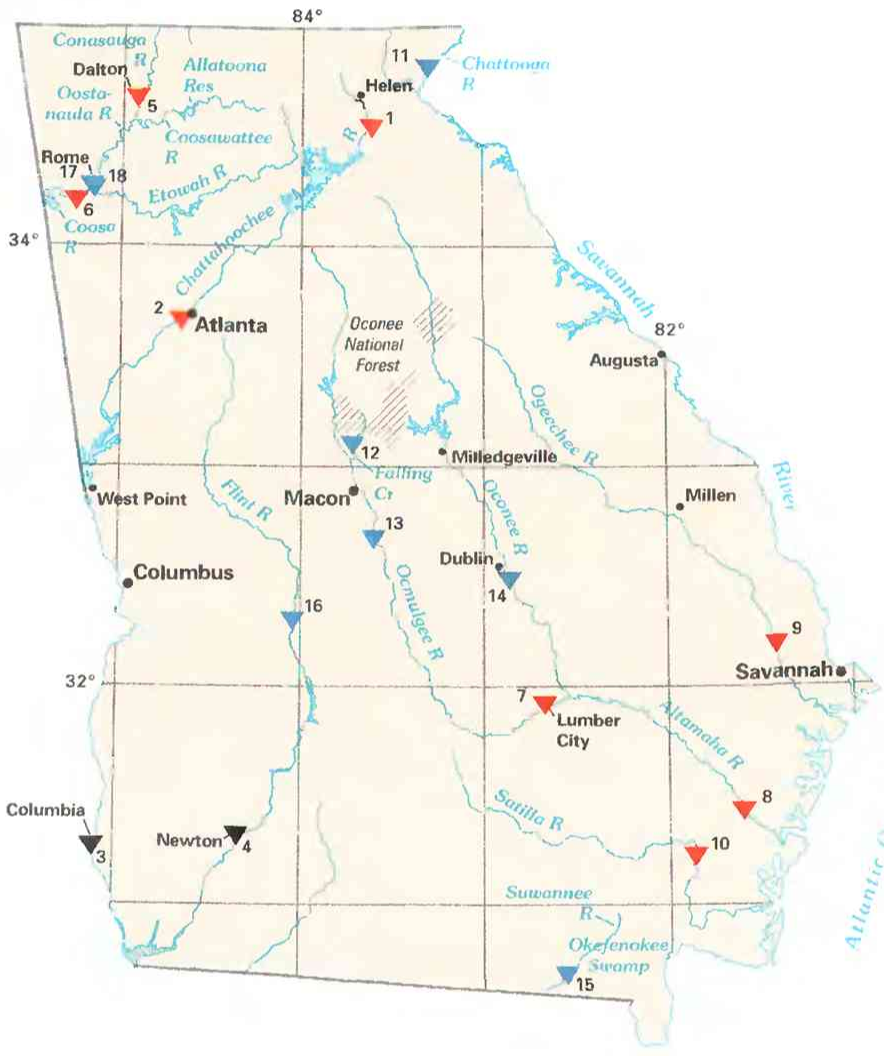

\section{EXPLANATION}

Water-quality monitoring station and type of statistical analysisNumber refers to accompanying table

$\nabla^{3}$ Water-quality conditions (see fig. 3)

v ${ }^{13}$ Water-quality trends (see fig. 4)

$\nabla^{9}$ Water-quality conditions and trends (see figs. 3 and 4)

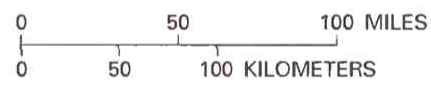

\begin{tabular}{|c|c|c|c|}
\hline $\begin{array}{l}\text { Site no. } \\
\text { on map }\end{array}$ & $\begin{array}{l}\text { USGS station } \\
\text { name and no. }\end{array}$ & $\begin{array}{l}\text { Drainage area } \\
\text { (square miles) }\end{array}$ & $\begin{array}{l}\text { Major land use } \\
\text { (see fig. 1) }\end{array}$ \\
\hline 1 & Chattahoochee River near Cornelia $(02331600)$ & 315 & Woodland and forest with some cropland and pasture. \\
\hline 2 & 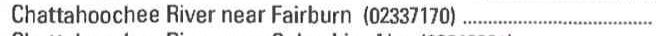 & 2,060 & Cropland with pasture, woodland, and forest; urban areas. \\
\hline 3 & Chattahoochee River near Columbia, Ala. (02343801) ........... & 8,210 & $\begin{array}{l}\text { Grazed forest and woodland; cropland with pasture, woodland, and } \\
\text { forest. }\end{array}$ \\
\hline 4 & Flint River at Newton $(02353000)$ & 5,740 & Cropland with pasture, woodland, and forest. \\
\hline 5 & Conasauga River at Tilton $(02387000)$ & 687 & Cropland with pasture, woodland, and forest; urban areas. \\
\hline 6 & 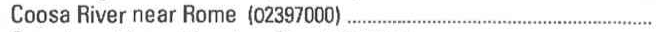 & 4,040 & Cropland with pasture, woodland, and forest. \\
\hline 7 & Ocmulgee River at Lumber City $(02215500)$ & 5,180 & Ditto. \\
\hline 8 & 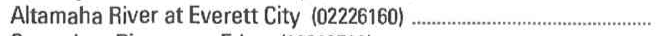 & 14,000 & Woodland and forest with some cropland and pasture; swamp. \\
\hline 9 & 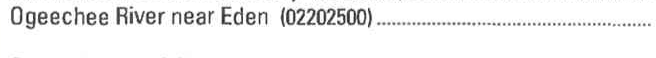 & 2,650 & $\begin{array}{l}\text { Grazed forest and woodland; cropland with pasture, woodland, and } \\
\text { forest, swamp. }\end{array}$ \\
\hline 10 & Satilla River at Atkinson $(02228000)$ & 2,790 & Grazed forest and woodland; swamp. \\
\hline 11 & Chattooga River near Clayton $(02177000)$ & 207 & Ungrazed forest and woodland. \\
\hline 12 & 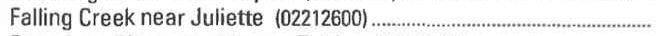 & 72 & Grazed forest and woodland. \\
\hline 13 & Dcmulgee River near Warner Robins $(02213700) \ldots . . . .$. & 2,690 & Cropland with pasture, woodland, and forest; urban areas. \\
\hline 14 & 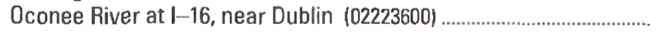 & 4,400 & Ditto. \\
\hline 15 & Suwannee River at Fargo $(02314500)$ & 1,260 & Marshland; swamp. \\
\hline 16 & Flint River at Montezuma $(02349500)$ & 2,900 & Cropland with pasture, woodland, and forest. \\
\hline 17 & Oostanaula River at Rome $(02388520)$ & 2,150 & Cropland with pasture, woodland, and forest, urban areas. \\
\hline 18 & Etowah River at Rome $(02396000)$ & 1,820 & Ditto. \\
\hline
\end{tabular}

Figure 2. Selected water-quality monitoring stations, type of statistical analysis, and geographic features in Georgia. (Sources: Major land uses modified from Anderson, 1967; other data from U.S. Geological Survey files.) 
and on public health. Important issues and challenges for the future include controlling toxic substances, erosion and sedimention, and urban runoff (Georgia Department of Natural Resources, 1990b).

The following discussion of stream water quality in Georgia is organized by river basin (fig. 3). Where physiographic and landuse characteristics in different basins are similar, the discussion of those basins is combined. Graphs in figure 3 summarize certain aspects of stream water quality in the basins for water years 1987-89. The graphs show frequency distributions of data values that represent measurements of selected physical properties of water and concentrations of selected constituents in stream water. These properties and constituents are specific conductance, dissolved oxygen, dissolved sulfate, dissolved solids, total and dissolved nitrite plus nitrate (as nitrogen), and total phosphorus (as phosphorus). The data are reported in microsiemens per centimeter at 25 degrees Celsius $(\mu \mathrm{S} / \mathrm{cm})$ and milligrams per liter $(\mathrm{mg} / \mathrm{L})$. Sources and environmental significance of each property and constituent are described in table 1 .

Water quality at each monitoring station is the result of geological, chemical, biological, and hydrologic processes that occur over a large area. Water-quality problems that might affect aquatic life or public health only locally are not fully represented in this summary.

\section{CHATTAHOOCHEE RIVER}

The Chattahoochee River headwaters are in the Blue Ridge mountains of northeastern Georgia; the river flows southwestward through the Piedmont province to near West Point, then southward along the Georgia-Alabama border to Florida. Water quality is affected by geology, land use, and eight major (5,000 acre-feet or larger) impoundments in Georgia.

The Chattahoochee River basin upstream from Cornelia (site 1) lies within the Blue Ridge province. Streams draining the headwater area contact nearly insoluble rocks and therefore are naturally low in mineral content (Cherry, 1961, p. 26). Land use primarily is forest with small areas of cropland and pasture; the basin is sparsely populated.

The concentrations of dissolved oxygen, dissolved solids, and phosphorus at site 1 reflect the minimal effect of human activity in
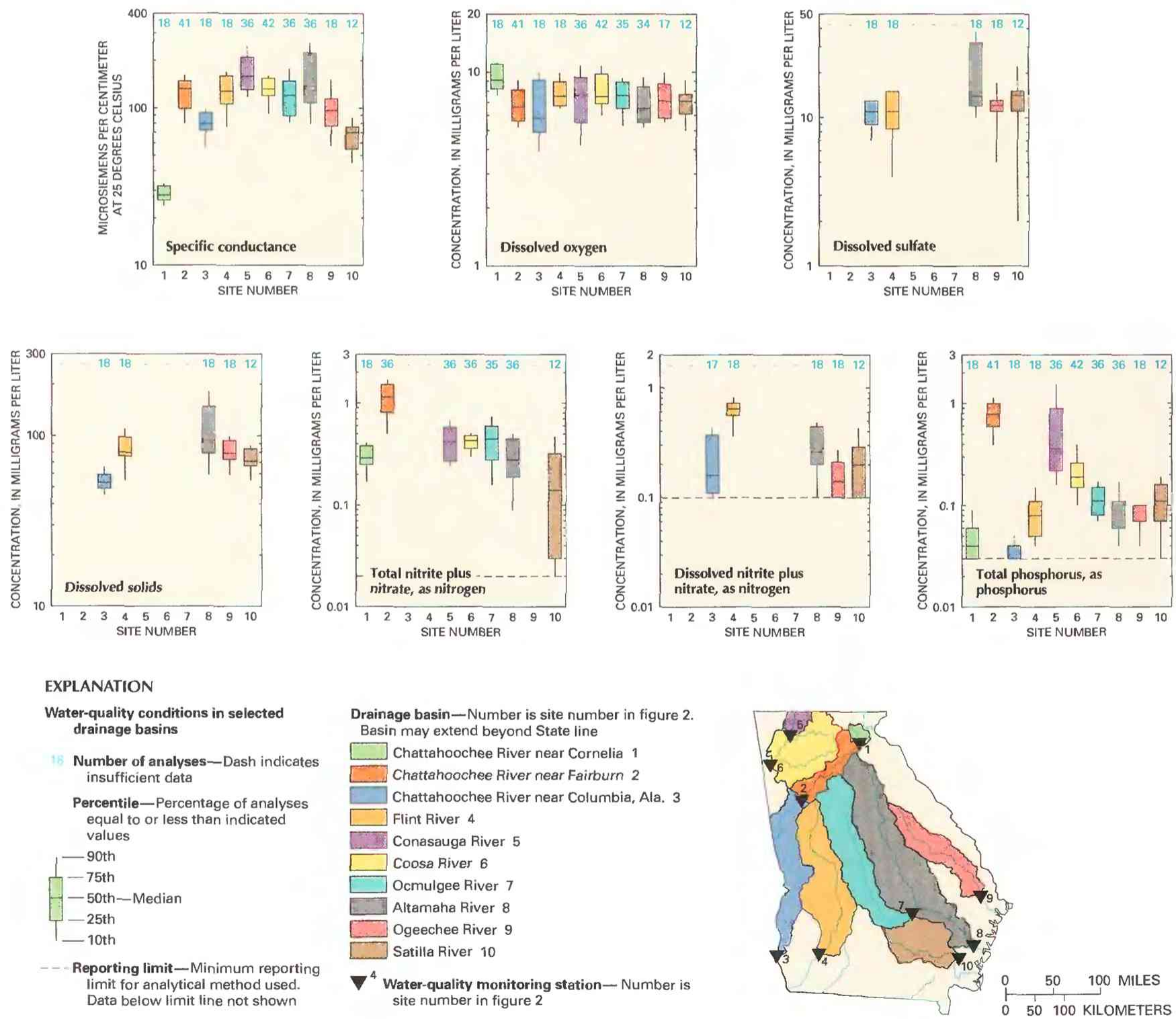

Figure 3. Water quality of selected streams in Georgia, water years 1987-89. (Source: Data from U.S. Geological Survey files.) 
Table 1. Sources and environmental significance of selected water-quality properties and constituents [Source: Compiled by the U.S. Geological Survey, Office of Water Quality]

\begin{tabular}{|c|c|c|}
\hline Property or constituent & Common sources & Environmental significance \\
\hline $\begin{array}{l}\text { Specific conductance } . . . . . . . . . . . . . . . \\
\text { (property) }\end{array}$ & $\begin{array}{l}\text { A measure of the electrical conductivity of water; var- } \\
\text { ies with the quantity of dissolved solids and is } \\
\text { used to approximate the dissolved-solids content. }\end{array}$ & $\begin{array}{l}\text { Dissolved solids can cause water to be unsuitable for } \\
\text { public supply, agriculture, and industry; can harm } \\
\text { aquatic organisms. }\end{array}$ \\
\hline Dissolved oxygen ........................ & $\begin{array}{l}\text { Introduced from the atmosphere; also a byproduct of } \\
\text { aquatic plants. }\end{array}$ & $\begin{array}{l}\text { Necessary for aquatic life; deficiency can result from } \\
\text { assimilation of organic wastes or rapid growth } \\
\text { and decay of algae. }\end{array}$ \\
\hline Fecal coliform bacteria ............... & $\begin{array}{l}\text { Sources include effluent from sewage-treatment } \\
\text { plants and runoff from pastures, feedlots, and ur- } \\
\text { ban areas. }\end{array}$ & $\begin{array}{l}\text { Presence indicates contamination of water by wastes } \\
\text { from humans and other warm-blooded animals. }\end{array}$ \\
\hline 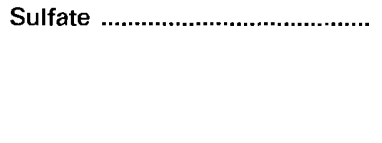 & $\begin{array}{l}\text { Occurs in some rocks; also in mine runoff, industrial } \\
\text { wastewater discharge, and atmospheric deposi- } \\
\text { tion. }\end{array}$ & $\begin{array}{l}\text { Concentrations exceeding a natural, background } \\
\text { level indicate contamination from human activity; } \\
\text { in sufficient quantity, can cause water to be } \\
\text { unsuitable for public supply; can harm aquatic } \\
\text { organisms. }\end{array}$ \\
\hline Dissolved solids ........................... & $\begin{array}{l}\text { A result of rock weathering; also in agricultural runoff } \\
\text { and industrial discharge. }\end{array}$ & $\begin{array}{l}\text { In sufficient quantity, can cause water to be unsuitable } \\
\text { for public supply, agriculture, and industry; can } \\
\text { harm aquatic organisms. }\end{array}$ \\
\hline Nitrite plus nitrate & $\begin{array}{l}\text { Nonpoint sources are agricultural and urban runoff; } \\
\text { a major point source is wastewater discharge. }\end{array}$ & $\begin{array}{l}\text { Plant nutrient that, in sufficient quantity, can cause } \\
\text { algal blooms and excessive growth of higher } \\
\text { aquatic plants in bodies of water; can cause water } \\
\text { to be unsuitable for public supply. }\end{array}$ \\
\hline Phosphorus .................................... & $\begin{array}{l}\text { Occurs in some rocks and sediments; also in runoff } \\
\text { and seepage from phosphate-rock mines, agri- } \\
\text { cultural and urban runoff, and industrial and } \\
\text { municipal wastewater discharge. }\end{array}$ & $\begin{array}{l}\text { Plant nutrient that, in sufficient quantity, can cause } \\
\text { algal blooms and excessive growth of higher } \\
\text { aquatic plants in bodies of water. }\end{array}$ \\
\hline
\end{tabular}

the basin. A low concentration of dissolved solids at site 1 is indicated by a median value for specific conductance (related to the concentration of dissolved solids or mineral content) of $28 \mu \mathrm{S} / \mathrm{cm}$, which is the lowest median specific-conductance value for any of the 10 monitoring stations (fig. 3). The concentrations of dissolved oxygen (median, $9.1 \mathrm{mg} / \mathrm{L}$ ) and phosphorus (median, $0.04 \mathrm{mg} / \mathrm{L}$ ) at site 1 are among the highest and lowest concentrations, respectively, for the 10 monitoring stations.

Near Atlanta, the water quality of the river is degraded by contributions from nonpoint sources, water-pollution control facilities, and combined storm- and municipal-sewer overflows that originate primarily in the densely populated Atlanta metropolitan area. In samples collected during water years $1987-89$, median values of specific conductance (site $1,28 \mu \mathrm{S} / \mathrm{cm}$; site $2,132 \mu \mathrm{S} / \mathrm{cm}$ ) and median concentrations of total nitrite plus nitrate (site $1,0.29 \mathrm{mg} / \mathrm{L}$; site 2, $1.1 \mathrm{mg} / \mathrm{L}$ ) and phosphorus (site $1,0.04 \mathrm{mg} / \mathrm{L}$; site 2, $0.78 \mathrm{mg} / \mathrm{L}$ ) were higher at site 2 , the downstream monitoring station, than at site 1 (fig. 3). Median dissolved-oxygen concentrations were substantially lower at site $2(6.6 \mathrm{mg} / \mathrm{L})$ than at site $1(9.1 \mathrm{mg} / \mathrm{L})$. Although pointand nonpoint-source contributions degrade the water quality at site 2 , the median concentration of dissolved oxygen exceeded the 5.0 $\mathrm{mg} / \mathrm{L}$ (daily average) standard established by the EPD to protect warmwater fisheries.

Inflow between site 2 and site 3 also has a marked effect on the water quality of the river. From Columbus, Ga., to Columbia, Ala. (site 3), the river flows through the upper Coastal Plain. Land use is predominantly cropland with smaller areas of pasture, woodland, and forest. Streams tributary to the river are exposed to nearly insoluble deposits of clay, sand, and gravel and have a small mineral content (Cherry, 1961, p. 28-29). In this reach, dilution tends to decrease the concentration of dissolved solids, as indicated by the lower median value for specific conductance of $79 \mu \mathrm{S} / \mathrm{cm}$ at site 3 compared to 132 $\mu \mathrm{S} / \mathrm{cm}$ at site 2 (fig. 3). Dilution also decreases phosphorus concentrations between sites 2 and 3 . The median phosphorus concentration decreased from $0.78 \mathrm{mg} / \mathrm{L}$ at site 2 to $0.03 \mathrm{mg} / \mathrm{L}$ at site 3 . The median concentration of dissolved oxygen at site $3(5.8 \mathrm{mg} / \mathrm{L})$ was lower than that at site $2(6.6 \mathrm{mg} / \mathrm{L})$. The decrease probably was caused by water that has low concentrations of dissolved oxygen released through dams from the depths of upstream reservoirs and by increased loads of oxygen-demanding materials entering the river downstream from Columbus.

\section{FLINT RIVER}

The Flint River orginates in an area of crystalline rocks near Atlanta and flows southward through rural, agricultural areas of the Piedmont and Coastal Plain provinces. Flow is regulated upstream from Newton (site 4) by two dams.

Concentrations of dissolved solids (median, $80 \mathrm{mg} / \mathrm{L}$ ) and sulfate (median, $11 \mathrm{mg} / \mathrm{L}$ ) in the Flint River at site 4 were similar to the concentrations for sites 3 and 8-10 in the Piedmont or Coastal Plain provinces, except for the dissolved solids at Columbia, Ala. (site 3) (fig. 3). Concentrations of dissolved oxygen at site 4 (median, 7.5 $\mathrm{mg} / \mathrm{L}$ ) exceeded the established warm-water fishery standard of 5.0 $\mathrm{mg} / \mathrm{L}$ (daily average). Concentrations of dissolved nitrite plus nitrate (median, $0.64 \mathrm{mg} / \mathrm{L}$ ) and phosphorus (median, $0.08 \mathrm{mg} / \mathrm{L}$ ) at site 4 were among the highest and lowest concentrations, respectively, at any of the 10 monitoring stations. The high concentrations of dissolved nitrite plus nitrate compared to phosphorus indicates contributions from nonpoint sources, possibly runoff from farmland, rather than from point sources, such as treated sewage effluent from wastewater-treatment plants, which generally has large concentrations of both constituents.

\section{COOSA RIVER}

The Coosa River, which is formed by the confluence of the Oostanaula and Etowah Rivers at Rome, flows westward into Alabama. Flow in Georgia is regulated by three dams. The Conasauga and Coosawattee Rivers, which join to form the Oostanaula River, and the Etowah River originate in areas underlain by crystalline rocks and have little dissolved mineral content. In the lower parts of their basins, the Conasauga, Coosawattee, and Etowah Rivers contact more soluble carbonate rocks and the water increases in mineral content (Cherry, 1961, p. 24).

The median specific-conductance value for the Conasauga River at Tilton (site 5) was $159 \mu \mathrm{S} / \mathrm{cm}$, the highest for any of the monitoring stations (fig. 3). The high specific-conductance value was due to both natural and human-related causes. Upstream from site 5 , the river receives nonpoint-source discharges from the Dalton area, which includes the city of Dalton and a large textile industrial complex. Concentrations of dissolved oxygen, however, were not appreciably affected by these discharges during water years $1987-89$, as 
indicated by a median concentration of $7.6 \mathrm{mg} / \mathrm{L}$, which exceeds warm-water fishery standard of $5.0 \mathrm{mg} / \mathrm{L}$ (daily average).

Inflow from tributaries between sites 5 and 6 dilutes the concentration of dissolved solids as indicated by lower specific-conductance values at site 6 (median, $132 \mu \mathrm{S} / \mathrm{cm}$ ) compared to those at site 5 (median, $159 \mu \mathrm{S} / \mathrm{cm}$ ) (fig. 3). Inflow between sites 5 and 6 also dilutes the concentration of phosphorus (median of $0.36 \mathrm{mg} / \mathrm{L}$ at site $5 ; 0.19 \mathrm{mg} / \mathrm{L}$ at site 6 ); however, the total nitrite plus nitrate concentrations at sites 5 and 6 were similar. The median concentration of dissolved oxygen of $7.5 \mathrm{mg} / \mathrm{L}$ at site 6 is greater than the $5.0 \mathrm{mg} / \mathrm{L}$ (daily average) warm-water fishery standard.

\section{OCMULGEE AND ALTAMAHA RIVERS}

The Altamaha River is formed by the junction of the Ocmulgee and Oconee Rivers at Lumber City. The Altamaha River basin is the largest drainage lying wholly within the State. The Altamaha basin is underlain by igneous and metamorphic rocks, clay, and sand in the Piedmont province and sedimentary rocks, clay, and sand in the Coastal Plain (Lamar, 1944).

Land use in this drainage basin is diverse. Large urban and industrial centers are located in the headwater areas of the Ocmulgee and Oconee Rivers; forest, pasture, and cropland dominate the central part of the basin; swampy areas are common in the lower part of the basin.

The median concentrations of sulfate $(14 \mathrm{mg} / \mathrm{L})$, dissolved solids $(94 \mathrm{mg} / \mathrm{L})$, nitrite plus nitrate $(0.26 \mathrm{mg} / \mathrm{L})$, and phosphorus $(0.09 \mathrm{mg} / \mathrm{L}$ ) at site 8 on the Altamaha River (fig. 3) indicate no significant degradation of water quality from human activities. The median value for specific conductance at site $8(138 \mu \mathrm{S} / \mathrm{cm}) \mathrm{com}-$ pared to that at site 7 upstream on the Ocmulgee River $(120 \mu \mathrm{S} / \mathrm{cm})$ indicates a small increase in the concentration of dissolved solids between these locations; however, the median total nitrite plus nitrate concentration decreased from $0.45 \mathrm{mg} / \mathrm{L}$ at site 7 to $0.28 \mathrm{mg} / \mathrm{L}$ at site 8 , and the median total phosphorus concentration decreased from $0.11 \mathrm{mg} / \mathrm{L}$ at site 7 to $0.09 \mathrm{mg} / \mathrm{L}$ at site 8 .

\section{OGEECHEE AND SATILLA RIVERS}

The Ogeechee River originates in the Piedmont province and flows about 245 miles to the Atlantic Ocean. The lower reach (about 44 miles) is affected by tides. From near the town of Millen to the Atlantic Ocean, the flood plain is largely a swamp. The Satilla River originates in the Coastal Plain province and flows 256 miles to the Atlantic Ocean. The reach of this stream affected by tides extends about 67 miles upstream from the mouth. The downstream area in much of the Satilla River basin also is swampy. Land use in both drainage basins is primarily a mix of cropland and pasture, woodland, and forest. The basins generally are rural and sparsely populated.

The effect of human activities on the water quality of the basins is minimal. Median concentrations of dissolved solids at sites 9 and 10 were less than $80 \mathrm{mg} / \mathrm{L}$, median concentrations of sulfate were less than $15 \mathrm{mg} / \mathrm{L}$, median concentrations of dissolved nitrite plus nitrate were less than $0.3 \mathrm{mg} / \mathrm{L}$, median concentrations of dissolved oxygen were about $7 \mathrm{mg} / \mathrm{L}$, and the median concentrations of phosphorus were less than $0.12 \mathrm{mg} / \mathrm{L}$ (fig. 3).

\section{WATER-OUALITY TRENDS}

Trend analysis is a statistical procedure used to detect changes in stream water quality at a monitoring station over time. For this report, water-quality data from 16 monitoring stations (fig. 2) were analyzed for trends by using the seasonal Kendall test (Hirsch and others, 1982), a method used extensively by the USGS. The graph (above right) of specific conductance in the Chattahoochee River at site 2 illustrates the trend inferred from the data and demonstrates the variation in water quality that is common in streams.

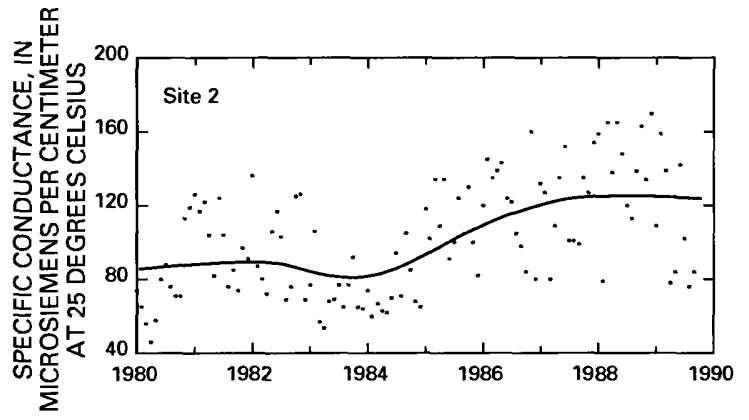

When possible, constituent-concentration data were adjusted for changes in streamflow to preclude identifying a trend in concentration that was caused only by a trend in streamflow. The data were not adjusted when (1) more than 10 percent of the samples had concentrations lower than the minimum reporting limit for the analytical method used or (2) streamflow was controlled substantially by human activities. When the concentration data could not be adjusted for streamflow, trends were determined directly from the concentration data.

Statewide trends in measurements of selected physical properties of stream water and in concentrations of selected constituents in stream water are shown on maps in figure 4. On each map, a trend is indicated at a monitoring station only if the data from that station were suitable for use in the trend analysis. Fecal coliform bacteria have been substituted for sulfate in the discussion and graphic presentation because insufficient sulfate data were suitable for trend analysis. For more information on the suitability criteria and on the trend-analysis procedure used for this report, see Lanfear and Alexander (1990).

\section{SPECIFIC CONDUCTANCE}

Specific conductance is a measure of the ability of a sample of water to conduct electricity. Because specific conductance and the dissolved-solids concentration are roughly proportional in most natural waters, the specific-conductance value often can be used to estimate the dissolved-solids concentration (Hem, 1985, p. 66-68).

Specific-conductance values increased at 11 monitoring stations, indicating increasing dissolved-solids concentrations (fig. 4). An increase in nonpoint-source contributions from growth and development near Helen and from an increase in livestock production in the upper part of the Chattahoochee River basin during 1980-89 possibly contributed to the upward trend in specific-conductance values at site 1 (fig. 4). Rapid growth and land development in the Atlanta area and diversion of treated wastewater from the Ocmulgee River basin in 1985 (water originally withdrawn from the Chattahoochee River basin) likely contributed to the upward trend at site 2 downstream from metropolitan Atlanta. Upward trends in the Coosa River at site 6 and the Etowah River at site 18 were a result of urban growth in the Rome area and decreased flow from Allatoona Reservoir during drought in 1985-88 (U.S. Geological Survey, 1991, p. 239-246). The upward trend in the Ocmulgee River at site 13 likely is attributable to increased loads of dissolved solids from point- and nonpoint-source discharges to the river in the Macon area. Upward trends in the Ocmulgee, Altamaha, Ogeechee, Oconee, and Flint Rivers at sites 7-9, 14, and 16 also probably resulted from urban development in the basins, even though these monitoring stations are farther downstream from developed parts of their basins than are sites 2 and 13. Upward trends in specific conductance might also have resulted from the drought of 1985-88, except at sites $1,9,15$, and 16 , where the data were flow adjusted. A probable cause for the upward trend in the Suwannee River at site 15 is not readily apparent. 


\section{DISSOLVED OXYGEN}

The dissolved-oxygen concentration in a stream is controlled by several factors, including water temperature, air temperature and pressure, hydraulic characteristics of the stream, photosynthetic or respiratory activity of stream biota, and the quantity of organic material present. A trend in dissolved-oxygen concentrations commonly is directly or indirectly the result of human activities. Generally, an upward trend in dissolved-oxygen concentrations indicates improving stream water-quality conditions and a downward trend indicates deteriorating conditions.
Increasing point- and nonpoint-source-pollutant inputs to the Chattahoochee River possibly contributed to the downward dissolved-oxygen trend at site 2 downstream from Atlanta (fig. 4); however, the moderate-to-severe drought of 1985-88 compounded the decrease. In addition to the growth and development of metropoli$\tan$ Atlanta, diversion of treated wastewater from the Ocmulgee River basin in 1985 (water originally withdrawn from the Chattahoochee River basin) has increased waste quantities discharged into the river. However, even though waste loads to the river have increased, the concentrations of dissolved oxygen usually meet water-quality standards established for this reach of the river.

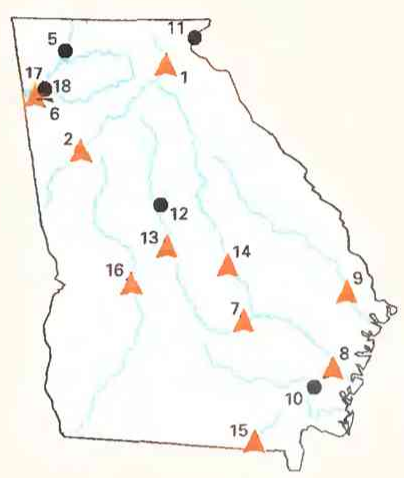

Specific conductance, 1980-89

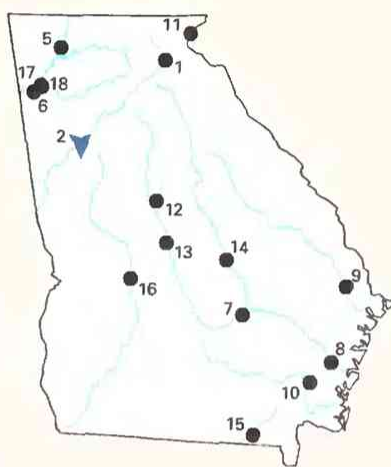

Dissolved oxygen, 1980-89

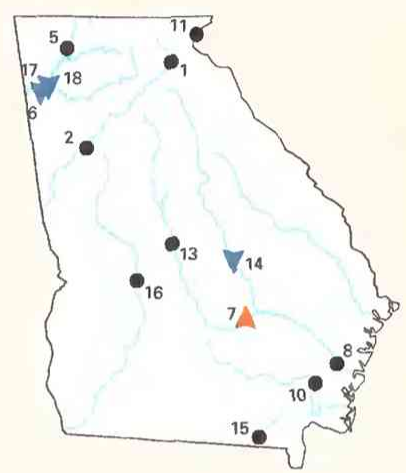

Fecal coliform bacteria, 1980-89

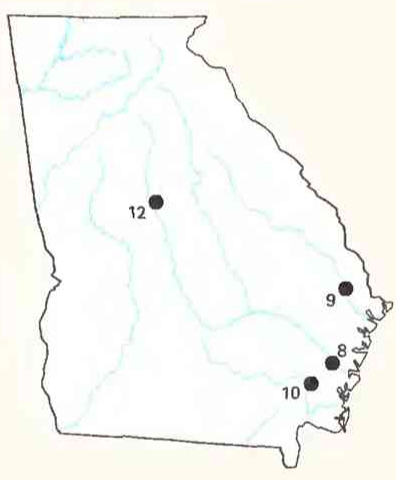

Dissolved solids, 1980-89

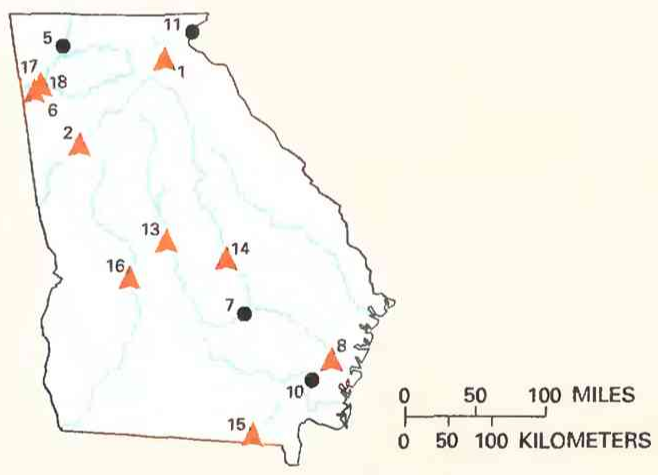

Dissolved nitrite plus nitrate, 1980-89

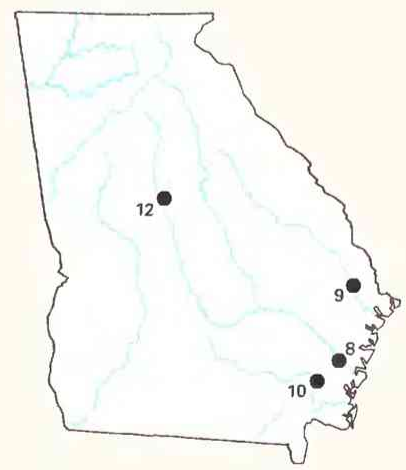

Total nitrite plus nitrate, 1980-89

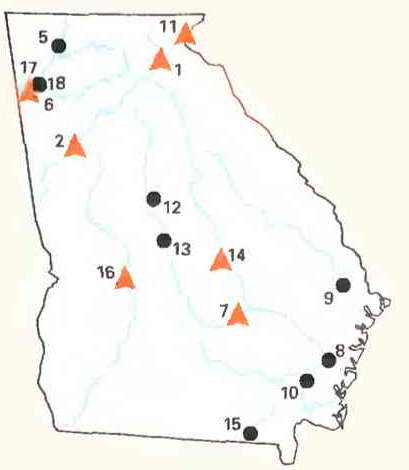

Total phosphorus, 1980-89
EXPLANATION

Trend in water-quality property or constituent-Number is site number in figure 2

$A^{1}$ Upward

- ${ }^{9}$ None

$\nabla^{2}$ Downward

Figure 4. Trends in water quality of selected streams in Georgia, by water years. (Source: Data from U.S. Geological Survey files.) 


\section{FECAL COLIFORM BACTERIA}

Fecal coliform bacteria are used as indicators of fecal contamination from humans and other warm-blooded animals. Such contamination can introduce disease-causing viruses and bacteria into a stream.

Causes for the upward trend in fecal coliform bacteria concentrations in the Ocmulgee River at site 7 (fig. 4) are not apparent. The downward trends in the Coosa River at site 6, the Oostanaula River at site 17, the Etowah River at site 18, and the Oconee River at site 14 probably were due to improvements of nearby water-pollution control facilities.

\section{DISSOLVED SOLIDS}

Dissolved solids in stream water result primarily from rock weathering but also can be introduced as a byproduct of human activities (table 1). Concentrations generally are greatest in streams draining basins underlain by rocks and soils that contain easily dissolved minerals.

Concentrations of dissolved solids at the four monitoring stations from which data were suitable for trend analysis had no trend during water years $1980-89$ (fig. 4). Monitoring stations on the Altamaha River (site 8) and the Ogeechee River (site 9) are in basins where development is occurring in the headwater areas; however, the monitoring stations are many miles downstream from developing urban and industrial areas, and any effects on the concentration of dissolved solids were not apparent. The Satilla River at Atkinson (site 10) is in a basin that has grown moderately in some areas, but the basin is not yet densely populated. Falling Creek near Juliette (site 12) is in the Oconee National Forest where no basin disturbances have occurred in recent times.

\section{TOTAL AND DISSOLVED NITRITE PLUS NITRATE}

Nitrite and nitrate are oxidized forms of nitrogen that together constitute most of the dissolved nitrogen in well-aerated streams. Nitrite readily oxidizes to nitrate in natural waters; therefore, nitrate generally is by far the more abundant of the two (Hem, 1985, p. 124).

Upward trends in total nitrite plus nitrate concentrations in the Chattahoochee River at site 1 , the Chattahoochee River at site 2, the Coosa River at site 6, the Ocmulgee River at site 13, the Oostanaula River at site 17, and the Etowah River at site 18 (fig. 4) were caused by increased point- and nonpoint-source discharges associated with urban growth. Increases in concentrations probably were augmented by reduced dilution caused by drought during 1985-88. The town of Helen, located upstream from site 1, has undergone recreationrelated growth and development. Point-source contributions from Helen, however, are minimized by land application of treated wastewater. The Atlanta metropolitan area, which is upstream from site 2, has grown extensively in the last decade. Rome, which is upstream from site 6 and surrounds sites 17 and 18, and Macon, which is upstream from site 13, also had substantial urban growth. The upward trend in total nitrite plus nitrate concentrations in the Oconee River at site 14 might have been related to urban growth in Milledgeville and Dublin, nonpoint-source runoff from areas recently clearcut for timber harvest, or nonpoint-source runoff from agricultural areas.

Causes, other than drought, for the upward trends in the Altamaha River at site 8 , the Suwannee River at site 15 , and the Flint River at site 16 are not apparent. Human activities are minimal in the Suwannee River basin upstream from site 15. The Okefenokee Swamp is in the headwaters of this basin. Population growth in the lower Altamaha and middle Flint River drainages was minimal during $1980-89$.

\section{TOTAL PHOSPHORUS}

The total phosphorus concentration of a water sample is a measure of the concentration of all forms of phosphorus present in the sample, dissolved and particulate. Human activities (table 1) can be important sources of phosphorus in streams.

The upward trend in total phosphorus concentrations in the Chattahoochee River at site 2 (fig. 4), downstream from Atlanta, resulted from increased point- and nonpoint-source discharges, including the diversion of treated sewage effluent from the Ocmulgee River basin to the Chattahoochee River beginning in 1985. Upward trends in the Chattahoochee River at site 1, the Coosa River at site 6 , the Oconee River at site 14, and the Flint River at site 16 were the result of a combination of urban point- and agricultural nonpointsource effects. The absence of a trend in the Ocmulgee River at site 13, which is a short distance downstream from Macon, and the upward trend in the Ocmulgee River at site 7, farther downstream, indicate that the increase at site 7 was caused primarily by nonpointsource agricultural runoff to the river between sites 7 and 13. Causes for the increase in the Chattooga River at site 11 are not apparent.

\section{WATER-QUALITY MANAGEMENT}

The Georgia Department of Natural Resources, EPD, is responsible for environmental protection, management, regulation, permitting, and enforcement in Georgia. The Water Protection Branch of the Georgia EPD manages all aspects of water-pollution control. Water-pollution control activities include:

- Monitoring streams, lakes, and estuaries for water-quality trends and toxic substances;

- Conducting intensive water-quality surveys and performing aquatic biomonitoring tests;

- Mathematically modeling water quality and determining wasteload allocations;

- Managing nonpoint-source runoff;

- Planning basin development;

- Establishing water-quality standards;

- Administering the loan process for funding construction of municipal water-pollution control facilities;

- Managing the National Pollutant Discharge Elimination System permit and enforcement program for municipal and industrial pointsource discharges;

- Training operators of water-pollution control facilities; and

- Managing industrial pretreatment and the land application of treated wastewater and sludge.

The Water Protection Branch also is responsible for preparing the biennial water-quality-assessment report that documents progress in implementing the goals and objectives of the Federal Clean Water Act (Georgia Department of Natural Resources, 1990b); the report is submitted to the EPA and the U.S. Congress pursuant to section 305(b) of the act.

Water-quality monitoring is an important part of waterpollution control activities in Georgia. The Georgia EPD and the USGS cooperate in monitoring streamflow and water quality at many stations in the State.

The Georgia EPD is responsible for implementing federally mandated standards intended to improve the quality of water in the United States. More stringent fecal coliform bacteria standards were adopted in December 1989 to support the EPA requirement that States protect all water for the use of primary-contact recreation. Also, numeric standards for toxic substances were adopted to comply with 1987 amendments to the Federal Clean Water Act that established criteria for concentration of toxic substances in order to protect aquatic life and human health. 


\section{SELECTED REFERENCES}

Anderson, J.R., 1967, Major land uses in the United States, in U.S. Geological Survey, 1970, National atlas of the United States of America: Washington, D.C., U.S. Geological Survey, p. 158-159.

Britton, L.J., and Greeson, P.E., eds., 1987, Methods for collection and analysis of aquatic biological and microbiological samples: U.S. Geological Survey Techniques of Water-Resources Investigations, book 5, chap. A4, $363 \mathrm{p}$.

Cherry, R.N., 1961, Chemical quality of water of Georgia streams, 1957-58: Atlanta, Georgia State Division of Conservation, Department of Mines, Mining, and Geology, The Geological Survey Bulletin no. 69, 100 p.

Fenneman, N.M., 1946, Physical divisions of the United States: Washington, D.C., U.S. Geological Survey special map, scale 1:7,000,000.

Fishman, M.J., and Friedman, L.C., eds., 1989, Methods for the determination of inorganic substances in water and fluvial sediments: U.S. Geological Survey Techniques of Water-Resources Investigations, book 5 , chap. A1, 545 p.

Georgia Department of Natural Resources, 1990a, Georgia rules and regulations for water quality control; Chapter 391-3-6, Revised March 1990: Atlanta, Environmental Protection Division, p. 701-795.

1990b, Water-quality control in Georgia, 1988-1989: Atlanta, Environmental Protection Division, $74 \mathrm{p}$.

Hem, J.D., 1985, Study and interpretation of the chemical characteristics of natural water (3d ed.): U.S. Geological Survey Water-Supply Paper 2254, $263 \mathrm{p}$.

Hirsch, R.M., Slack, J.R., and Smith, R.A., 1982, Techniques of trend analy- sis for monthly water quality data: Water Resources Research, v. 18, no. 1, p. 107-121.

Lamár, W.L., 1944, Chemical character of surface waters of Georgia: U.S Geological Survey Water-Supply Paper 889-E, p. 317-380.

Lanfear, K.J., and Alexander, R.B., 1990, Methods to derive water-quality trends for use by the National Water Summary Program of the U.S. Geological Survey: U.S. Geological Survey Open-File Report 90-359, $10 \mathrm{p}$.

National Oceanic and Atmospheric Administration, 1988, State, regional, and national monthly and annual precipitation weighted by area for the contiguous United States, January 1931-December 1987: Asheville, N.C., National Climatic Data Center, Historical Climatology Series 4-2, 72 p.

Thelin, G.P., and Pike, R.J., 1990, Digital shaded relief map of the conterminous United States: Menlo Park, Calif., U.S. Geological Survey digital image processing, scale 1:3,500,000.

U.S. Geological Survey, 1986, National water summary 1985-Hydrologic events and surface-water resources: U.S. Geological Survey Water-Supply Paper 2300, 506 p.

1990, National water summary 1987-Hydrologic events and water supply and use: U.S Geological Survey Water-Supply Paper 2350, 553 p.

1991, National water summary 1988-89-Hydrologic events and floods and droughts: U.S. Geological Survey Water-Supply Paper 2375, $591 \mathrm{p}$.

Ward, J.R., and Harr, C.A., eds., 1990, Methods for collection and processing of surface-water and bed-material samples for physical and chemical analyses: U.S. Geological Survey Open-File Report 90-140, 71 p.

Prepared by J.B. McConnell and G.R. Buell, U.S. Geological Survey; "Water-Quality Management” section by W.M. Winn, Georgia Department of Natural Resources, Environmental Protection Division

FOR ADDITIONAL INFORMATION: District Chief, U.S. Geological Survey, Peachtree Business Center, Suite 130, 3039 Amwiler Road, Atlanta, GA 30360-2824 


\section{HAWAII Stream Water Quality}

Hawaii has more rainfall than any other State in the Nation. Average annual rainfall is about 70 inches, or $22,000 \mathrm{Mgal} / \mathrm{d}$ (million gallons per day); rainfall is the State's only source of freshwater (U.S. Geological Survey, 1990, p. 223). Surface water supplied about 48 percent $(613 \mathrm{Mgal} / \mathrm{d})$ of the freshwater used in 1985 . Nearly all of the surface water withdrawn, 93 percent ( $573 \mathrm{Mgal} / \mathrm{d})$, was used for agriculture. In 1985, the island of Maui was the largest user of surface water for irrigation (309 Mgal/d) in the State.

Landforms in Hawaii are mostly the result of volcanic activity followed by periods of erosion and sedimentation. The State consists of 132 islands, shoals, and reefs. The eight major islandsHawaii, Maui, Oahu, Kauai, Molokai, Lanai, Niihau, and Kahoolawe - have a total land area of about 6,450 square miles and are the tops of mostly submerged volcanic mountains. Volcanic activity during the past 8 years has enlarged the island of Hawaii.

The quality of Hawaii's streams is determined largely by the geology, land use (fig. 1A), and population distribution (fig. $1 B$ ) in each stream basin. There are 376 perennial streams in the State $(\mathrm{Ha}-$ waii Commission on Water Resource Management, 1990, p. 5). Average discharge rates of these streams differ geographically owing to islandwide rainfall distributions that range from about 11 inches per year in the dry leeward coastal areas to about 300 inches per year along the high windward slopes (Giambelluca and others, 1986). The island of Hawaii has the largest acreage under cultivation but used the least amount of water for irrigation in 1985 (52 Mgal/d). This is because the large acreages of sugarcane on the island of Hawaii are

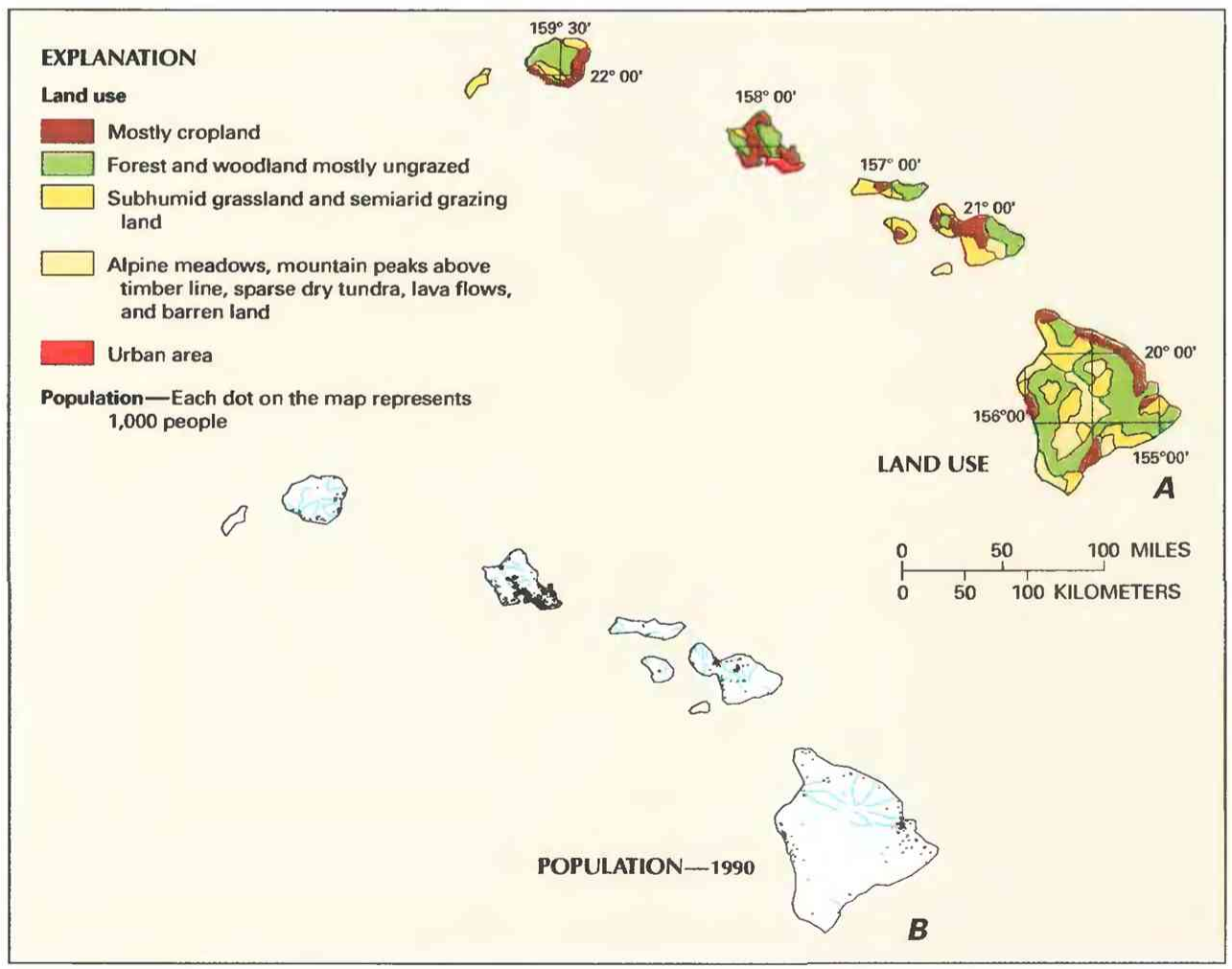

Figure 1. Land use and population in Hawaii. A, Land use. B, Population distribution in 1990. (Sources: A, Anderson, 1967. B, Data from U.S. Bureau of the Census 1990 decennial census files.) in areas that receive ample rainfall and require little or no irrigation (U.S. Geological Survey, 1990, p. 227).

The State of Hawaii's population reached 1.1 million in 1990 (U.S. Bureau of the Census 1990 decennial census files), an increase of 44 percent since 1970 . Oahu is the most densely populated island (fig. $1 B$ ). As the population of the State continues to increase, so will the demand for usable water.

\section{WATER-QUALITY MONITORING}

Water-quality data obtained from analyses of water samples collected at monitoring stations are stored in the U.S. Geological Survey's (USGS) National Water Information System and the U.S. Environmental Protection Agency's (EPA) national data base known as STORET. Water-quality and streamflow data are reported by water year - the 12 months from October I through September 30. A water year is identified by the calendar year in which it ends. For example, water year 1991 comprises October 1, 1990, through September 30, 1991.

The data used in this summary of Hawaii's stream water quality were obtained from water samples collected every 2 months or quarterly at seven monitoring stations at which data collection is systematic and continuing (fig. 2). Analyses of water samples collected at these stations are the basis for the discussion and graphic summary (fig. 3) of stream water-quality conditions during water years 1987-89 and for the discussion and graphic summary (fig. 4) of stream water-quality trends. Water samples were collected and analyzed by using standard methods approved by the USGS (Britton and Greeson, 1987; Fishman and Friedman, 1989; Ward and Harr, 1990) or by using equivalent methods. If a method of sample collection or analysis changed over time, data from an analysis were included in the evaluation of recent stream water quality or of stream water-quality trends only if the change in method did not affect the comparability of the data.

\section{WATER-QUALITY CONDITIONS}

The following discussion of stream water quality in Hawaii is organized by river basin (fig. 3 ). Where physiographic and land-use characteristics in different basins are similar, the discussion of those basins is combined. Graphs in figure 3 summarize certain aspects of stream water quality in the basins for water years 1987-89. The graphs show frequency distributions of data values that represent concentrations of selected streamwater constituents. These constitu- 
ents are dissolved oxygen, fecal coliform bacteria, dissolved sulfate, dissolved solids, dissolved nitrite plus nitrate (as nitrogen), dissolved phosphate (as phosphorus), and suspended sediment. The data are reported in milligrams per liter $(\mathrm{mg} / \mathrm{L})$ and colonies per 100 milliliters $(\mathrm{col} / 100 \mathrm{~mL})$. Sources and environmental significance of each constituent are described in table 1.

Water quality at each monitoring station is the result of geological, chemical, biological, and hydrologic processes that occur over a large area. Water-quality problems that affect aquatic life or public health only locally are not fully represented in this summary. One such local problem has been incidences of leptospirosis infections (caused by spirochete bacteria in overland runoff), which reportedly affect swimmers and agricultural workers engaging in waterrelated activities following storms (Hawaii Department of Health, 1990b, p. 67).

Fujioka and others $(1988$, p. 1) reported high concentrations of fecal coliform bacteria in streams on Oahu, and these concentrations increased as the streams flowed through urban areas. In 1990. the Hawaii Department of Health replaced fecal coliform bacteria standards with enterococcal bacteria standards for marine recreational waters (Hawaii Department of Health, 1990a, p. 52), and the enterococcal standards for stream waters are being evaluated.

\section{WAIMEA RIVER}

The Waimea River is on the leeward side of Mt. Waialeale, Kauai. The mountain's summit area is reported to be one of the wettest areas on Earth. Median annual rainfall in the Waimea River basin ranges from about 300 inches at the headwaters to about 20 inches at site 1 (Giambelluca and others, 1986, p. 86). Upstream from site 1, the Waimea River basin is mostly undeveloped, and the land cover is forest and woodland conservation reserves. Water quality in the basin has been affected only minimally by human activity; however, grazing cattle are a source of fecal coliform bacteria.

During water years 1987-89, relatively high fecal coliform bacteria concentrations (median, $720 \mathrm{col} / 100 \mathrm{~mL}$ ) were a result of runoff from grazed land. However, sulfate concentrations were lower than $20 \mathrm{mg} / \mathrm{L}$, and dissolved-solids concentrations did not exceed
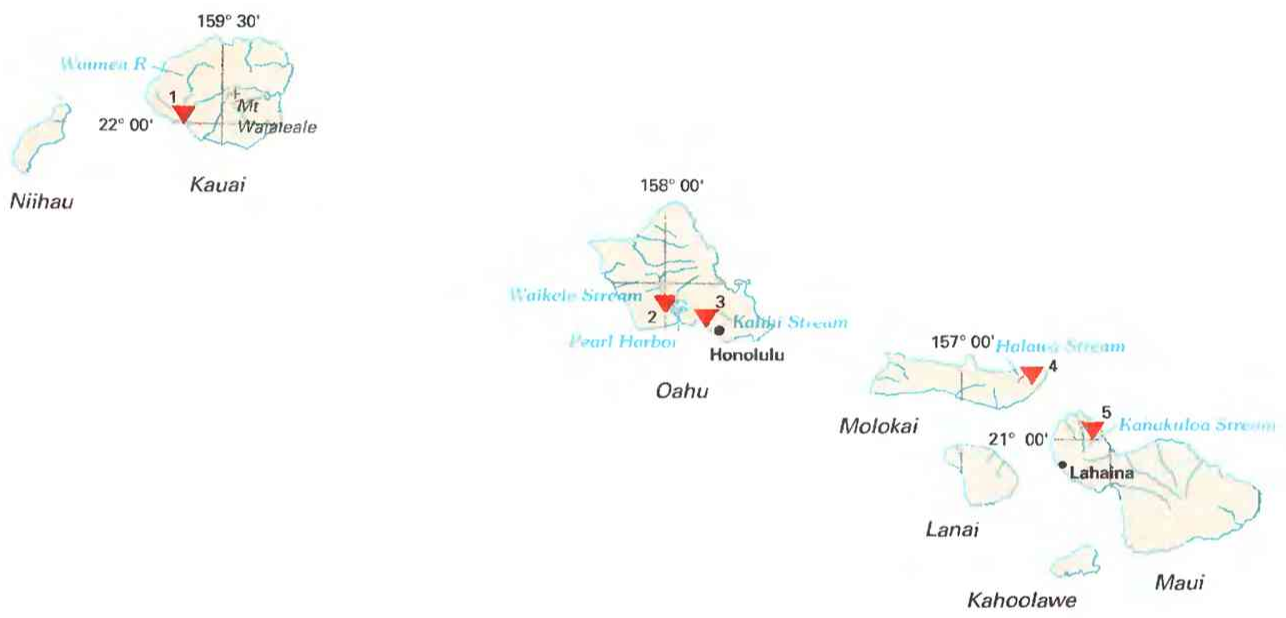

EXPLANATION

Water-quality monitoring station and type of statistical analysisNumber refers to accompanying table

$\nabla^{3}$ Water-quality conditions and trends (see figs. 3 and 4)

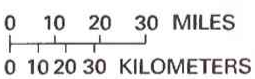

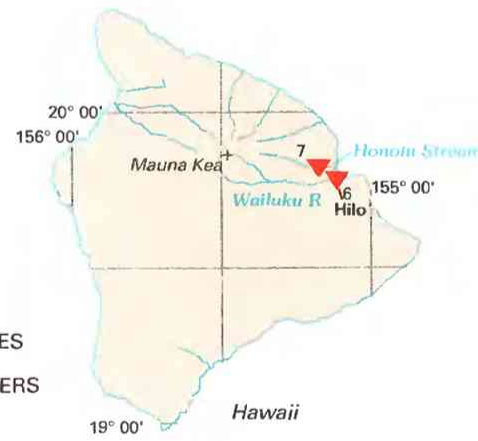

\begin{tabular}{|c|c|c|c|}
\hline $\begin{array}{l}\text { Site no. } \\
\text { on map }\end{array}$ & $\begin{array}{l}\text { USGS station } \\
\text { name and no. }\end{array}$ & $\begin{array}{l}\text { Drainage area } \\
\text { (square miles) }\end{array}$ & $\begin{array}{l}\text { Major land use } \\
\text { (see fig. 1) }\end{array}$ \\
\hline 1 & Waimea River near Waimea, Kauai $(16031000)$ & 57.8 & $\begin{array}{l}\text { Mostly ungrazed forest and woodland; subhumid grassland and } \\
\text { semiarid land. }\end{array}$ \\
\hline 2 & Waikele Stream, Waipahu, Dahu $(16213000) \ldots$ & 45.7 & Cropland; urban areas. \\
\hline 3 & Kalihi Stream at Kalihi, Oahu $(16229300)$ & 5.18 & Urban areas. \\
\hline 4 & Halawa Stream near Halawa, Molokai $(16400000)$ & 4.62 & Mostly ungrazed forest and woodland. \\
\hline 5 & 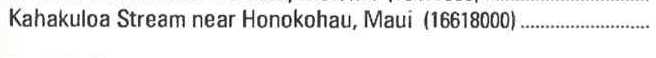 & 3.47 & $\begin{array}{l}\text { Mostly ungrazed forest and woodland; subhumid grassland and } \\
\text { semiarid grazing land. }\end{array}$ \\
\hline 6 & Wailuku River at Hilo, Hawaii $(16713000)$ & 256 & $\begin{array}{l}\text { Mostly ungrazed forest and woodland; subhumid grassland and } \\
\text { semiarid grazing land; cropland. }\end{array}$ \\
\hline 7 & 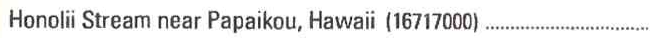 & 11.6 & Mostly ungrazed forest and woodland. \\
\hline
\end{tabular}

Figure 2. Selected water-quality monitoring stations, type of statistical analysis, and geographic features in Hawaii. (Sources: Major land uses modified from Anderson, 1967; other data from U.S. Geological Survey files.) 
$100 \mathrm{mg} / \mathrm{L}$ during water years 1987-89. Median concentrations of nitrite plus nitrate (less than $0.1 \mathrm{mg} / \mathrm{L}$ ) and phosphate (less than 0.01 $\mathrm{mg} / \mathrm{L}$ ) were among the lowest for the seven monitoring stations.

\section{WAIKELE STREAM}

The Waikele Stream drains south-central Oahu and flows into the West Loch of Pearl Harbor. Median annual rainfall ranges from about 275 inches at the headwaters to about 25 inches near the mouth (Giambelluca and others, 1986, p. 73). The drainage area upstream from site 2 is substantially affected by agriculture and urban development. Sediment from streams, stormwater outfalls, and nonpoint sources have contributed to siltation in Pearl Harbor; ship channels must be dredged about every 6 years (Stephanie Aschmann, U.S. Navy, oral commun., Oct. 1990). Ground water that has high dissolved-solids concentrations and discharges into the stream above site 2 also affects stream water quality.

The median dissolved-oxygen concentration $(7.2 \mathrm{mg} / \mathrm{L})$ was the lowest for the seven monitoring stations (fig. 3). The median concentrations of fecal coliform bacteria $(5,700 \mathrm{col} / 100 \mathrm{~mL})$, sulfate $(17$ $\mathrm{mg} / \mathrm{L})$, dissolved solids $(225 \mathrm{mg} / \mathrm{L})$, nitrite plus nitrate $(0.99 \mathrm{mg} / \mathrm{L})$, phosphate $(0.11 \mathrm{mg} / \mathrm{L})$, and suspended sediment $(11 \mathrm{mg} / \mathrm{L})$ were among the highest for the seven monitoring stations.

\section{KALIHI STREAM}

The Kalihi Stream upstream from site 3 drains a small area in southeastern Oahu. Median annual rainfall ranges from about 200 inches at the headwaters to about 25 inches near the mouth (Giambelluca and others 1986, p. 73). The basin upstream from site 3 is extensively urbanized. The effects of urban development on stream water quality are significant because the stream flows through a densely populated area of Honolulu.

The adverse effects of urbanization are evident in the concentrations of the selected stream-water constituents at site 3 during water years 1987-89. The dissolved-oxygen concentration $(8.0$ $\mathrm{mg} / \mathrm{L}$ ) was the second lowest and the median fecal coliform bacteria concentration $(9,100 \mathrm{col} / 100 \mathrm{~mL})$ was the highest for the seven monitoring stations (fig. 3). The bacteria concentrations exceeded the Hawaii Department of Health's criterion of $200 \mathrm{col} / 100 \mathrm{~mL}$ for
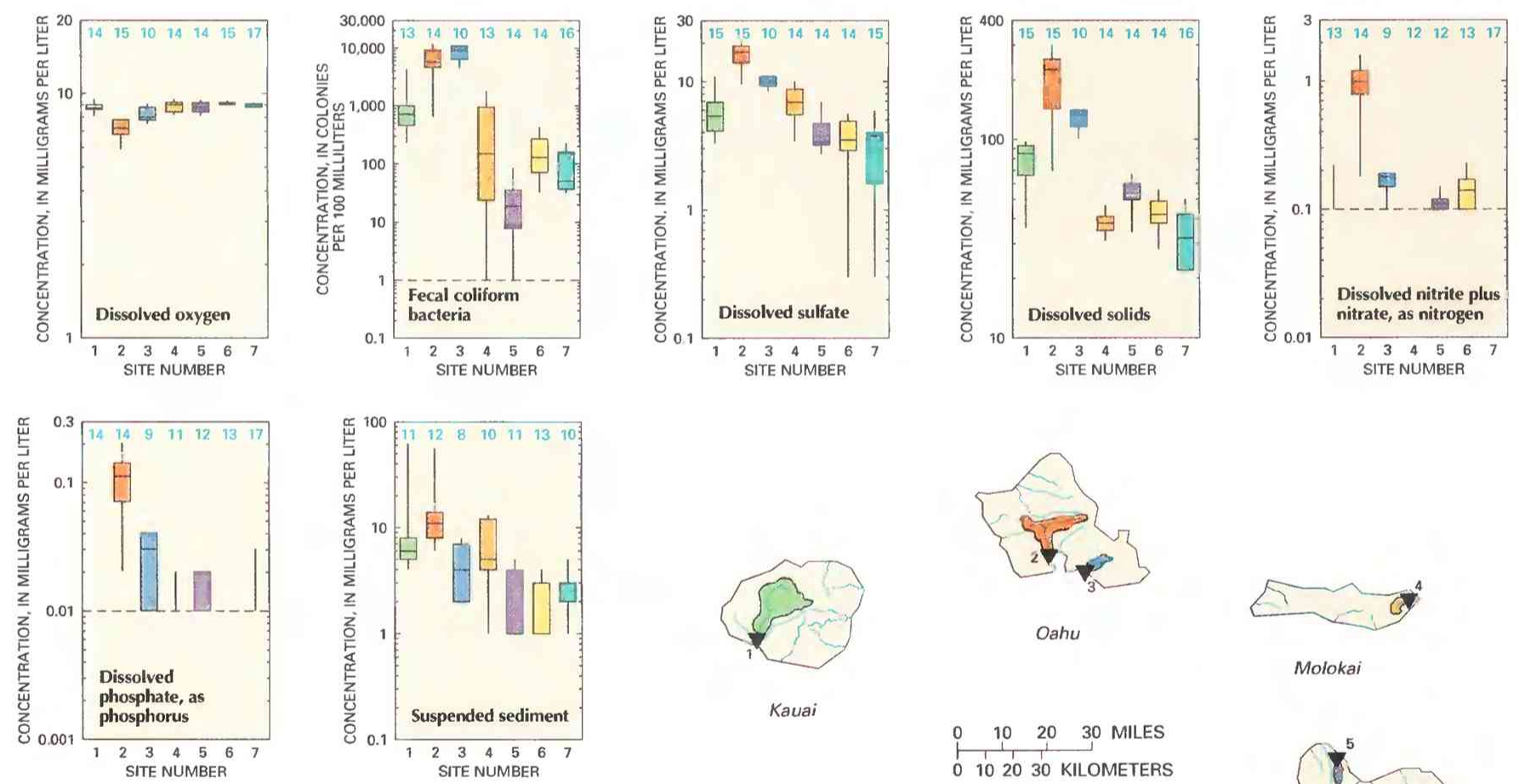

Oahu

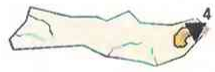

Molokai

Kauai

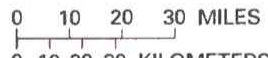

$\begin{array}{lllll}1 & 10 & 20 & 30 & \text { KILOMETERS }\end{array}$

\section{EXPLANATION}

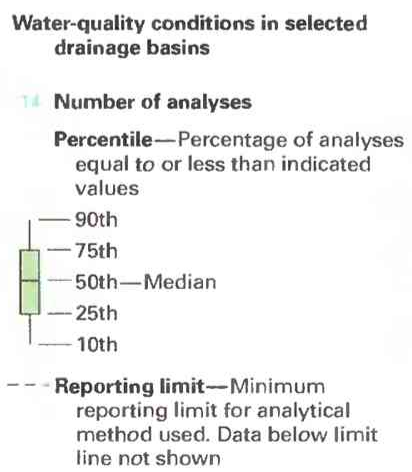

Drainage basin - Number is site number in figure 2. Basin may extend beyond State line

$\square$ Waimea River 1

Waikele Stream 2

Kalihi Stream 3

Halawa Stream 4

Kahakuloa Stream 5

Wailuku River 6

Honolii Stream 7

$\nabla^{4}$ Water-quality monitoring stationNumber is site number in figure 2

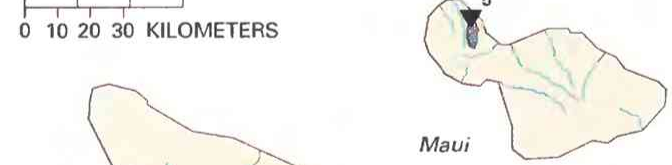

Figure 3. Water quality of selected streams in Hawaii, water years 1987-89. (Source: Data from U.S. Geological Survey files.) 
recreational use of surface water (Hawaii Department of Health, 1990a, p. 52). The State's criterion, however, is based on geometric mean values determined from 10 or more samples collected during any 30-day period. The median concentrations of sulfate $(10$ $\mathrm{mg} / \mathrm{L})$, dissolved solids $(133 \mathrm{mg} / \mathrm{L})$, nitrite plus nitrate $(0.18 \mathrm{mg} / \mathrm{L})$, and phosphate $(0.03 \mathrm{mg} / \mathrm{L})$ were second highest among data from the seven monitoring stations.

\section{HALAWA STREAM}

The Halawa Stream basin is on the eastern end of Molokai island and drains relatively undeveloped land upstream from site 4. Median annual rainfall in the basin ranges from about 163 inches at the headwaters to about 41 inches near the mouth (Giambelluca and others, 1986, p. 125). Upstream from site 4, most of the land is either forested or supports woodland conservation reserves. Concentrations of most selected stream-water constituents in samples collected during water years 1987-89 reflect the scarcity of contamination sources.

\section{KAHAKULOA STREAM}

Kahakuloa Stream is located on the northeastern part of the island of Maui. Median annual rainfall in the basin ranges from about 200 inches at the headwaters to 40 inches near the mouth (Giambelluca and others, 1986, p. 112). The major land cover upstream from site 5 is forest and woodland conservation reserves. The water quality of Kahakuloa Stream during water years 1987-89 (fig. 3) reflects the relative absence of contamination sources in the basin.

\section{WAILUKU RIVER AND HONOLII STREAM}

The Wailuku River and Honolii Stream drain the eastern slope of Mauna Kea volcano on the island of Hawaii. Median annual rainfall on the eastern slope ranges from 20 inches at the summit $(13,796$ feet) of Mauna Kea to 300 inches in an area situated at an altitude of 2,000-3,000 feet (Giambelluca and others, 1986, p. 99). Rainfall at the mouth of the Wailuku River in Hilo is about 128 inches. Land cover upstream from site 6 on the Wailuku River is woodland, forest, cropland, and pasture. Honolii Stream basin upstream from site 7 is entirely within forest and woodland conservation reserves. Site 7 is one of 57 USGS Hydrologic Bench-Mark Network stations nationwide that monitor streams in basins in which human activities are minimal.

Water at sites 6 and 7 is suitable for most uses. Median concentrations of all constituents were among the lowest. At both locations, at least 50 percent of the concentrations of sulfate were 3.8 $\mathrm{mg} / \mathrm{L}$ or lower; of nitrite plus nitrate were $0.14 \mathrm{mg} / \mathrm{L}$ or lower; of dissolved solids were $42 \mathrm{mg} / \mathrm{L}$ or lower; and of phosphate were lower than $0.01 \mathrm{mg} / \mathrm{L}$. Median dissolved-oxygen concentrations $(9.1$ $\mathrm{mg} / \mathrm{L}$ at site 6 , and $9.0 \mathrm{mg} / \mathrm{L}$ at site 7) were as high as those for any of the seven monitoring stations.

\section{WATER-QUALITY TRENDS}

Trend analysis is a statistical procedure used to detect changes in stream water quality at a monitoring station over time. For this report, water-quality data from seven monitoring stations (fig. 2) were analyzed for trends by using the seasonal Kendall test (Hirsch and others, 1982), a method used extensively by the USGS. The graph (shown below) of the dissolved sulfate concentration in Halawa Stream, Molokai, at site 4 illustrates the trend inferred from the concentration data and demonstrates the variation in water quality that is common in streams.

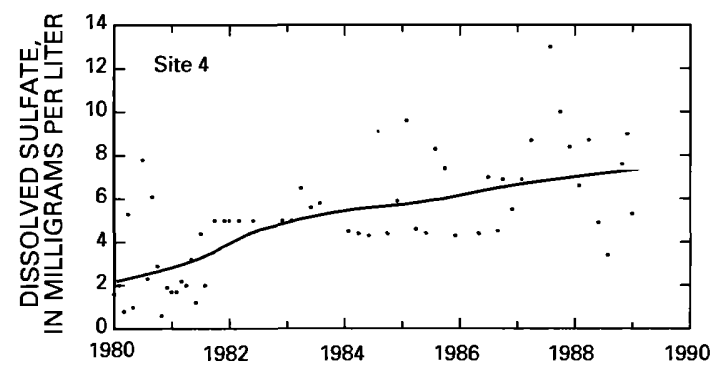

When possible, constituent-concentration data were adjusted for changes in streamflow to preclude identifying a trend in concentration that was caused only by a trend in streamflow. The data were

Table 1. Sources and environmental significance of selected water-quality constituents

[Source: Compiled by the U.S. Geological Survey, Office of Water Quality]

Constituent Common sources Environmental significance

Dissolved oxygen ..................... Introduced from the atmosphere; also a byproduct of aquatic plants.

Fecal coliform bacteria

Sources include effluent from sewage-treatment plants and runoff from pastures, feedlots, and urban areas.

Sulfate

Occurs in some rocks; also in mine runoff, industrial wastewater discharge, and atmospheric deposition.

Dissolved solids

A result of rock weathering; also in agricultural runoff and industrial discharge.

Nitrite plus nitrate.

Phosphate

Suspended sediment
Occurs in some rocks and sediments; also in runoff and seepage from phosphate-rock mines, agricultural and urban runoff, and industrial and municipal wastewater discharge.

Nonpoint sources are agricultural and urban runoff; a major point source is wastewater discharge.

A result of rock erosion; also induced by disturbances of land cover due to fires, floods, and human activities such as mining, logging, construction, and agriculture.
Necessary for aquatic life; deficiency can result from assimilation of organic wastes or rapid growth and decay of algae.

Presence indicates contamination of water by wastes from humans and other warm-blooded animals.

Concentrations exceeding a natural, background level indicate contamination from human activity; in sufficient quantity, can cause water to be unsuitable for public supply; can harm aquatic organisms.

In sufficient quantity, can cause water to be unsuitable for public supply, agriculture, and industry; can harm aquatic organisms.

Plant nutrient that, in sufficient quantity, can cause algal blooms and excessive growth of higher aquatic plants in bodies of water; can cause water to be unsuitable for public supply.

Plant nutrient that, in sufficient quantity, can cause algal blooms and excessive growth of higher aquatic plants in bodies of water.

Can be detrimental aquatic organisms; can fill reservoirs and impair recreational use of water. 
not adjusted when (1) more than 10 percent of the samples had concentrations lower than the minimum reporting limit for the analytical method used or (2) streamflow was controlled substantially by human activities. When the concentration data could not be adjusted for streamflow, trends were determined directly from the concentration data.

Statewide trends in concentrations of selected stream-water constituents are shown on maps in figure 4. On each map, a trend is indicated at a monitoring station only if the data from that station were suitable for use in the trend analysis. For more information on the suitability criteria and on the trend-analysis procedure used for this report, see Lanfear and Alexander (1990).

\section{DISSOLVED OXYGEN}

The dissolved-oxygen concentration in a stream is controlled by several factors, including water temperature, air temperature and pressure, hydraulic characteristics of the stream, photosynthetic or respiratory activity of stream biota, and the quantity of organic material present. A trend in dissolved-oxygen concentrations commonly is directly or indirectly the result of human activities. Generally, an upward trend in dissolved-oxygen concentrations indicates improving stream water-quality conditions and a downward trend indicates deteriorating conditions.
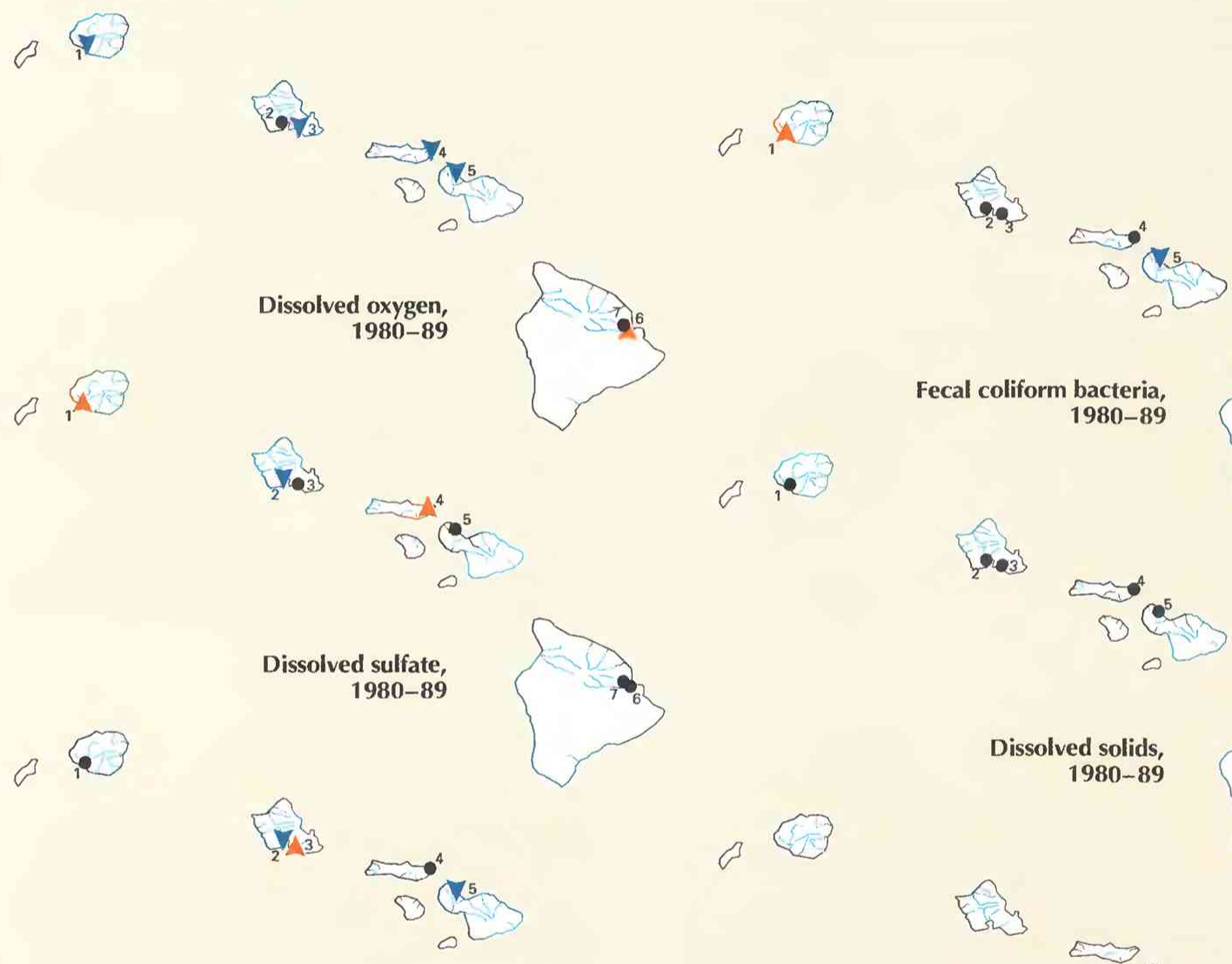

Fecal coliform bacteria, 1980-89
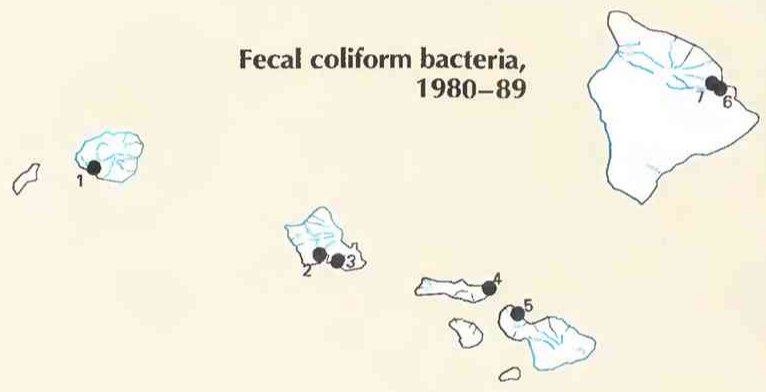

Dissolved solids, 1980-89

Dissolved nitrite plus nitrate, 1980-89
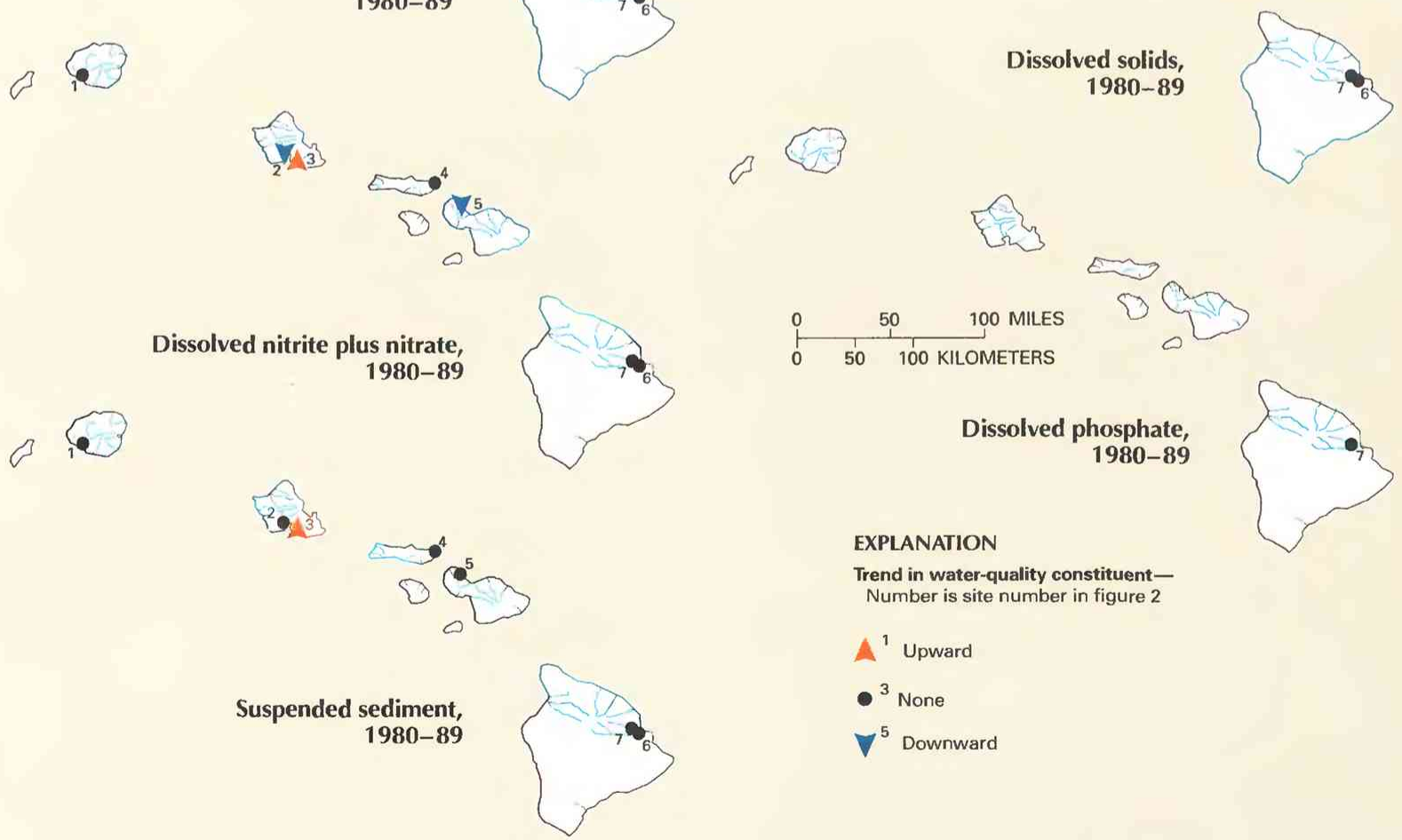

Trend in water-quality constituent-
$\mathbf{A}^{1}$ Upward
${ }^{3}$ Non
$\nabla^{5}$ Downward

Figure 4. Trends in water quality of selected streams in Hawaii, by water years. (Source: Data from U.S. Geological Survey files.) 
The downward trends in dissolved-oxygen concentrations in the Waimea River at site 1, Kahili Stream at site 3, Halawa Stream at site 4, and Kahakuloa Stream at site 5 can be attributed to decreased streamflow as the result of drought conditions during 1983-86 (U.S. Geological Survey, 1991, p. 247-254). A cause for the upward trend in the Wailuku River at site 6 is not known.

\section{FECAL COLIFORM BACTERIA}

Fecal coliform bacteria are used as indicators of fecal contamination from humans and other warm-blooded animals. Such contamination can introduce disease-causing viruses and bacteria into a stream.

The upward trend in fecal coliform bacteria concentrations in the Waimea River at site 1 possibly was caused by either increasing numbers of cattle in the basin or increasing runoff from grazing land during the trend-analysis period. The downward trend in Kahakuloa Stream at site 5 possibly resulted from reduced runoff during the 1983-86 drought.

\section{DISSOLVED SULFATE}

The major natural sources of sulfate in streams are rock weathering, volcanoes, and biochemical processes (Hem, 1985, p. 113). Human activities such as mining, waste discharge, and fossil-fuel combustion also can be important sources.

Causes for the upward trends in sulfate concentrations in the Waimea River at site 1 and Halawa Stream at site 4 are not known. However, atmospheric deposition of sulfate as a result of continuous volcanic activity on the island of Hawaii might have affected sulfate concentrations in streams. The downward trend at site 2 is a result of the elimination of treated sewage discharged into Waikele Stream (Hawaii Department of Health, 1990b, p. 30).

\section{DISSOLVED SOLIDS}

Dissolved solids in stream water result primarily from rock weathering but also can be introduced as a byproduct of human activities (table 1). Concentrations generally are greatest in streams draining basins underlain by rocks and soils that contain easily dissolved minerals. Dissolved-solids concentrations had no significant trend at the seven monitoring stations (fig. 4).

\section{DISSOLVED NITRITE PLUS NITRATE}

Nitrite and nitrate are oxidized forms of nitrogen that together normally constitute most of the dissolved nitrogen in well-aerated streams. Nitrite readily oxidizes to nitrate in natural waters; therefore, nitrate generally is by far the more abundant of the two (Hem. 1985 , p. 124).

The upward nitrite plus nitrate trend at site 3 on Kalihi Stream. Oahu, might have been the result of increasing urban stormwater runoff. The downward trend at site 2 can be attributed to a decrease in treated sewage discharged to Waikele Stream as a result of improved treatment facilities and reuse of the effluent for sugar cane and golf-course irrigation. The decreasing nitrite plus nitrate concentration in Kahakuloa Stream at site 5 possibly resulted from decreased runoff during the 1983-86 drought from small areas of grazing land in the basin.

\section{DISSOLVED PHOSPHATE}

Phosphate is the oxidized form of phosphorus and the only form of significance in most natural waters. Small quantities of dissolved phosphate commonly are present in streams as a result of rock weathering. Normally, concentrations are no more than a few tenths of a milligram per liter (Hem, 1985, p. 126) and usually are much lower. Higher concentrations can indicate contamination from human activities (table 1). Phosphate concentrations had no trend in Honolii Stream at site 7, the only monitoring station from which data were suitable for trend analysis.

\section{SUSPENDED SEDIMENT}

Suspended sediment is a product of erosion. The erosion can be either natural or the result of land-cover disturbances related to human activities (table 1). The upward trend in suspended-sediment concentrations in Kalihi Stream at site 3 might have been caused by increasing volumes of storm runoff from a growing urban area.

\section{WATER-QUALITY MANAGEMENT}

To balance the demands on freshwater from a growing population and a viable agricultural industry and to ensure the minimum streamflow required to maintain Hawaii's fragile stream ecosystem, the Hawaii State Water Commission adopted administrative rules in 1988 to regulate and manage the State's water resources (Hawaii Commission on Water Resource Management, 1988). Critical watercontrol areas have been designated for parts of Oahu (Pearl Harbor) and Maui (Lahaina), where all water withdrawals are regulated by permits.

The Hawaii Department of Health (DOH) is the agency designated by the Governor of Hawaii to manage the State's water quality. As directed by State statute, "The director of DOH is to prevent, control, and abate water pollution within the State. Through its Environmental Management Division, DOH administers programs and policies to protect and preserve Hawaii's health and environment" (Hawaii Department of Health, 1989, p. ix-1). The DOH prepares a biennial water-quality-assessment report that is submitted to the EPA and the U.S. Congress. The report (Hawaii Department of Health, $1990 \mathrm{~b}$ ) documents the State's progress in implementing the goals and objectives of the Federal Clean Water Act as mandated by section 305(b) of the act.

Hawaii's water-quality standards are contained in the Administrative Rules, Title 11, Chapter 54. This chapter establishes State policy on the quality of streams, lakes, estuaries, coastal waters, and wastewater-receiving ocean waters. Rules for wastewater treatment and disposal are established in the Administrative Rules, Title 11, Chapter 62 (Hawaii Department of Health, 1988, p. 22) to ensure that disposal of wastewater does not contaminate or pollute any valuable water resources.

The surface and coastal water-quality monitoring program in Hawaii was established and has been maintained by the DOH since enactment of the Federal Water Pollution Control Act of 1965. The State's monitoring program focuses on beach and nearshore receiving waters, and more than 340 coastal sites have been monitored since 1971 (Hawaii Department of Health, 1990b, p. 55).

Stream water quality is monitored by the USGS as part of the National Stream Quality Accounting Network and Hydrologic Bench-Mark programs. The Hawaii Department of Transportation has a cooperative agreement with the USGS to monitor streamflow and water quality affected by construction of a major highway on Oahu. The Hawaii Department of Land and Natural Resources and city and county of Honolulu have had joint projects during past stream water-quality assessments.

\section{SELECTED REFERENCES}

Anderson, J.R., 1967, Major land uses in the United States, in U.S. Geological Survey, 1970, National atlas of the United States of America: Washington, D.C., U.S. Geological Survey, p. 158-159.

Britton, L.J., and Greeson, P.E., eds., 1987, Methods for collection and analysis of aquatic biological and microbiological samples: U.S. Geological Survey Techniques of Water-Resources Investigations, book 5, chap. A4, 363 p. 
Fishman, M.J., and Friedman, L.C., eds., 1989, Methods for the determination of inorganic substances in water and fluvial sediments: U.S. Geological Survey Techniques of Water-Resources Investigations, book 5 , chap. A1, $545 \mathrm{p}$.

Fujioka, R.S., Tenno, Kenneth, and Kansako, Sidney, 1988, Naturally occurring fecal coliforms and fecal streptococci in Hawaii's streams in Proceedings of the First Biennial Water Quality Symposium: Microbiological Aspects, Banff, Alberta, Canada, 17 p.

Giambelluca, T.W., Nullet, M.A., and Schroeder, T.A., 1986, Rainfall atlas of Hawaii: Honolulu, Hawaii Department of Land and Natural Resources, Division of Water and Land Development Report R76, 267 p.

Hawaii Commission on Water Resource Management, 1988, Administrative rules of the state water code, chapter $174 \mathrm{C}$, Hawaii revised statutes: Honolulu, Hawaii Department of Land and Natural Resources, 95 p. 1990, Hawaii stream assessment - Hawaii's streams and their instream and riparian resources, a conservation point of view, draft 1990: Honolulu, Hawaii Department of Land and Natural Resources and the National Park Service, $329 \mathrm{p}$.

Hawaii Department of Health, 1988, Hawaii administrative rules, title 11, chapter 62-Wastewater systems: Honolulu, Hawaii Department of Health, $22 \mathrm{p}$.

1989, Hawaii's nonpoint source water pollution management plan: Honolulu, Hawaii Department of Health, 75 p.

1990a, Hawaii administrative rules, title 11, chapter 54 - Water quality standards: Honolulu, Hawaii Department of Health, 67 p. 1990b, 305(b) Report on water quality-Report for the year ending December 31, 1989: Honolulu, Hawaii Department of Health, 71 p.

Hem, J.D., 1985, Study and interpretation of the chemical characteristics of natural water (3d ed.): U.S. Geological Survey Water-Supply Paper 2254, $263 \mathrm{p}$.

Hirsch, R.M., Slack, J.R., and Smith, R.A., 1982, Techniques of trend analysis for monthly water quality data: Water Resources Research, v. 18, no. 1, p. 107-121.

Lanfear, K.J., and Alexander, R.B., 1990, Methodology to derive water-quality trends for use by the National Water Summary Program of the U.S. Geological Survey: U.S. Geological Survey Open-File Report 90-359, $10 \mathrm{p}$.

U.S. Geological Survey, 1986, National water summary 1985-Hydrologic events and surface-water resources: U.S. Geological Survey WaterSupply Paper 2300, $506 \mathrm{p}$.

1990, National water summary 1987-Hydrologic events and water supply and use: U.S. Geological Survey Water-Supply Paper 2350, $553 \mathrm{p}$.

1991, National water summary 1988-89-Hydrologic events and floods and droughts: U.S. Geological Survey Water-Supply Paper 2375, $591 \mathrm{p}$.

Ward, J.R., and Harr, C.A., eds., 1990, Methods for collection and processing of surface-water and bed-material samples for physical and chemical analyses: U.S. Geological Survey Open-File Report 90-140, 71 p. 
246 National Water Summary 1990-91-Stream Water Quality: STATE SUMMARIES

Prepared by Johnson J.S. Yee and Marty G. Lum

FOR ADDITIONAL INFORMATION: District Chief, U.S. Geological Survey, 677 Ala Moana Blvd., Suite 415, Honolulu, HI 96813 


\section{IDAHO Stream Water Quality}

The major drainage basins in Idaho are those of the Snake, Salmon, Kootenai, Clearwater, Pend Oreille, and Spokane Rivers, which ultimately discharge to the Columbia River in Oregon, and that of the Bear River, which drains the southeastern part of the State and flows into northwestern Utah (U.S. Geological Survey, 1986, p. 207-214). Total surface-water inflow to Idaho is about 32,900 $\mathrm{Mgal} / \mathrm{d}$ (million gallons per day), and total surface-water outflow is about $69,700 \mathrm{Mgal} / \mathrm{d}$ (U.S. Geological Survey, 1990, p. 229). Streamflow is maintained by precipitation (mostly snow) that averages 22 inches per year and ranges from 8 inches in southern Idaho to 60 inches in the mountains of the central part of the State (U.S. Geological Survey, 1986, p. 207, 209).

Stream water quality in Idaho is affected by land use, which is determined, in part, by physiography. Agricultural, urban, and industrial activities and livestock grazing (fig. $1 A$ ) affect stream water quality in the Columbia Plateaus and Basin and Range (fig. 1B), whereas logging and mining are prevalent in the Northern Rocky Mountains.
From 1980 to 1990 , the population of Idaho (fig. $1 C$ ) increased 6.6 percent to about 1,007,000 (U.S. Bureau of the Census 1990 decennial census files). The greatest increases were in and near Boise (population of 336,700 ) in southwestern Idaho, Idaho FallsPocatello $(234,800)$ in eastern Idaho, Twin Falls-Burley $(136,800)$ in southern Idaho, and Lewiston-Coeur d'Alene $(203,000)$ in northern Idaho. As the population of Idaho continues to increase, so will the demand for usable water. Water uses such as agriculture and hydroelectric power generation could conflict with growing demand for water of suitable quality for domestic consumption and recreation.

\section{WATER-QUALITY MONITORING}

Water-quality data obtained from analyses of water samples collected at monitoring stations are stored in the U.S. Geological Survey's (USGS) National Water Information System and the U.S. Environmental Protection Agency's (EPA) national data base known as STORET. Water-quality and streamflow data are reported by water

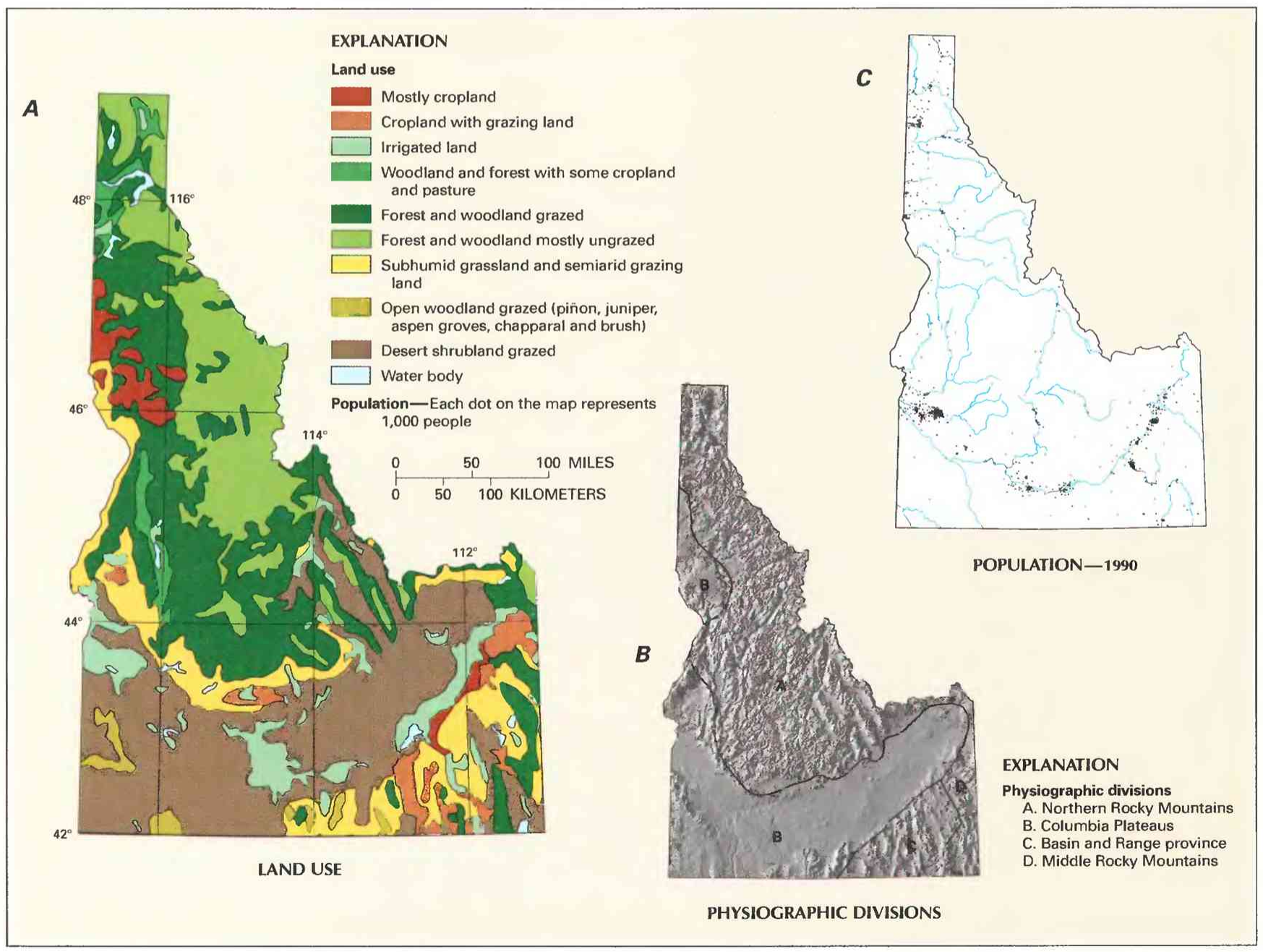

Figure 1. Land use, physiography, and population in Idaho. A, Major land uses. B, Physiographic divisions. C, Population distribution in 1990. (Sources: A, Major land uses modified from Anderson, 1967. B, Physiographic divisions from Fenneman, 1946; landforms from Thelin and Pike, 1990. C, Data from U.S Bureau of the Census 1990 decennial census files.) 
year - the 12 months from October 1 through September 30. A water year is identified by the calendar year in which it ends. For example, water year 1991 comprises October 1, 1990, through September 30, 1991.

The data used in this summary of Idaho's stream water quality were obtained from water samples collected at 20 monitoring stations at which data collection is systematic and continuing (fig. 2). Of those monitoring stations, six are part of the Geological Survey's National Stream Quality Accounting Network (NASQAN), and the remainder are part of Idaho's streamflow gaging-station network. Analyses of water samples collected at six stations are the basis for

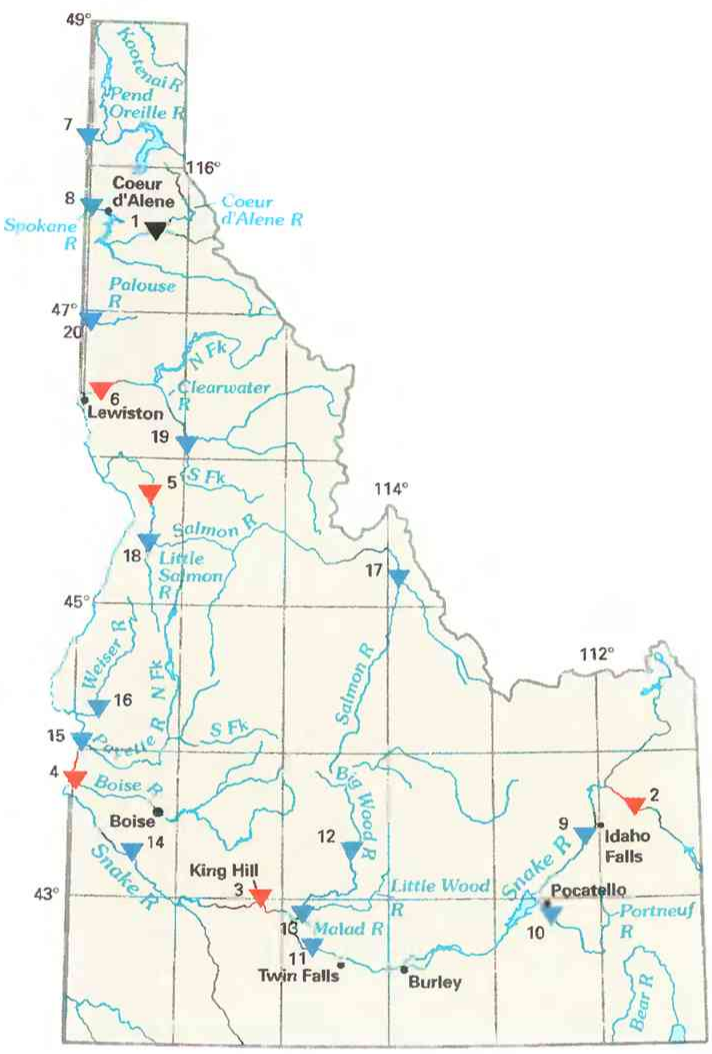

the discussion and graphic summary (fig. 3) of stream water-quality conditions during water years 1987-89, and data from 19 stations are the basis for the discussion and graphic summary (fig. 4) of stream water-quality trends. Water samples were collected and analyzed by using standard methods approved by the USGS (Britton and Greeson, 1987; Fishman and Friedman, 1989; Ward and Harr, 1990) or by using equivalent methods. If a method of sample collection or analysis changed over time, data from an analysis were included in the evaluation of recent stream water quality or of stream water-quality trends only if the change in method did not affect the comparability of the data.

\author{
EXPLANATION \\ Water-quality monitoring station and \\ type of statistical analysis- \\ Number refers to accompanying \\ table \\ $\nabla^{1}$ Water-quality conditions \\ (see fig. 3) \\ $\nabla^{7}$ Water-quality trends \\ (see fig. 4) \\ $\nabla^{2}$ Water-quality conditions and \\ trends (see figs. 3 and 4)
}

\begin{tabular}{|c|c|c|c|}
\hline $\begin{array}{l}\text { Site no. } \\
\text { on map }\end{array}$ & $\begin{array}{l}\text { USGS station } \\
\text { name and no. }\end{array}$ & $\begin{array}{l}\text { Drainage area } \\
\text { (square miles) }\end{array}$ & $\begin{array}{l}\text { Major land use } \\
\text { (see fig. 1) }\end{array}$ \\
\hline 1 & Coeur d'Alene River at Cataldo $(12413500)$ & 1,223 & Mostly ungrazed forest and woodland. \\
\hline 2 & 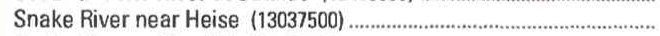 & 5,752 & Irrigated land; cropland with grazing land. \\
\hline 3 & Snake River at King Hill $(13154500)$ & 35,800 & Irrigated land; grazed desert shrubland. \\
\hline 4 & Boise River near Parma (13213000) & 3,970 & Irrigated land; urban areas. \\
\hline 5 & Salmon River at White Bird $(13317000)$ & 13,550 & $\begin{array}{l}\text { Woodland and forest with some cropland and pasture; grazed forest } \\
\text { and woodland. }\end{array}$ \\
\hline 6 & Clearwater River at Spalding $(13342500)$ & 9,570 & Grazed forest and woodland; cropland. \\
\hline 7 & 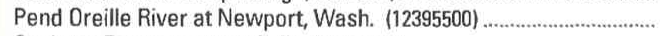 & 24,200 & Woodland and forest with some cropland and pasture. \\
\hline 8 & Spokane River near Post Falls $(12419000)$ & 3,840 & $\begin{array}{l}\text { Woodland and forest with some cropland and pasture; grazed forest } \\
\text { and woodland. }\end{array}$ \\
\hline 9 & Snake River near Shelley $(13060000)$ & 9,790 & Irrigated land; cropland; urban areas. \\
\hline 10 & Portneuf River at Pocatello $(13075500)$ & 1,250 & Ditto. \\
\hline 11 & Snake River near Buhl $(13094000)$ & $\begin{array}{l}17,500 \\
\text { (approximate) }\end{array}$ & Irrigated land; grazed desert shrubland; urban areas. \\
\hline 12 & Big Wood River near Bellevue $(13141000)$ & 824 & Irrigated land; grazed desert shrubland. \\
\hline 13 & Malad River near Gooding $(13152500)$ & 2,990 & Ditto. \\
\hline 14 & Snake River near Murphy (13172500) & 41,900 & Grazed desert shrubland. \\
\hline 15 & 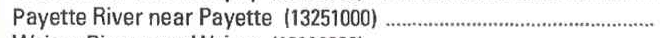 & 3,240 & Irrigated land. \\
\hline 16 & Weiser River near Weiser (13266000) & 1,460 & Irrigated land; grazed desert shrubland. \\
\hline 17 & Salmon River at Salmon (13302500) & 3,760 & Grazed forest and woodland; grazed desert shrubland. \\
\hline 18 & Little Salmon River at Riggins $(13316500)$ & 576 & Grazed forest and woodland. \\
\hline 19 & South Fork Clearwater River at Stites $(13338500)$ & 1,150 & Mostly ungrazed forest and woodland. \\
\hline 20 & Palouse River near Potlatch $(13345000)$ & 317 & Cropland; grazed forest and woodland. \\
\hline
\end{tabular}

Figure 2. Selected water-quality monitoring stations, type of statistical analysis, and geographic features in Idaho. ISources: Major land uses modified from Anderson, 1967; other data from U.S. Geological Survey files.) 


\section{WATER-QUALITY CONDITIONS}

During 1988, the Idaho Department of Health and Welfare (1989) assessed the water quality of about 50 percent of the State's stream miles and concluded that about 7 percent of the stream miles assessed were adversely affected by point sources and about 57 percent were affected by nonpoint sources. The major point sources of pollution were facilities for municipal sewage treatment, food processing, ore processing, livestock confinement, and aquaculture (fish hatcheries). The major nonpoint sources of pollution were agriculture, livestock grazing, logging and related activities, road building, and mining. About 83 percent of the stream miles either partially supported or fully supported beneficial uses designated by the State for purposes of water-pollution control. The remaining streams did not support at least one of the beneficial uses protected by Idaho's water-quality standards.

The following discussion of stream water quality in Idaho is organized by river basin (fig. 3). Where physiographic and land-use characteristics in different basins are similar, the discussion of those basins is combined. Graphs in figure 3 summarize certain aspects of stream water quality in the basins for water years $1987-89$. The graphs show frequency distributions of data values that represent measurements of selected physical properties of stream water and concentrations of selected constituents in stream water. These properties and constituents are specific conductance, fecal coliform bacteria, dissolved sulfate, dissolved solids, dissolved nitrite plus nitrate (as nitrogen), dissolved phosphate (as phosphorus), and suspended sediment. The data are reported in colonies per 100 milliliters and milligrams per liter. Sources and environmental significance of each property and constituent are described in table 1.

Water quality at each monitoring station is the result of geological, chemical, biological, and hydrologic processes that occur over a large area. Water-quality problems that affect aquatic life or public health only locally are not fully represented in this summary.

\section{COEUR D'ALENE AND CLEARWATER RIVERS}

Water in northern Idaho generally contains low concentrations of dissolved chemical constituents compared to elsewhere in the State because the rocks in this region are more resistant to weathering. Consequently, smaller quantities of chemical constituents dissolve from the rocks and enter the streams. Dissolved-solids concentrations at sites 1 and 6 on the Coeur d'Alene and Clearwater Rivers were the lowest at the six monitoring stations (fig. 3). Likewise, sulfate concentrations at site 6 were low.

Logging and mining are the activities that most affect water quality in the Coeur d'Alene and Clearwater Rivers (Idaho Department of Health and Welfare, 1989, p. 74-75, 90). The Coeur d'Alene mining district in the Coeur d'Alene River basin is one of the Nation's leading producers of silver, lead, copper, gold, antimony, and zinc. Site 1 is downstream from extensively mined areas. Nonetheless, at site 1 , concentrations of dissolved solids and suspended sediment, which often are present in runoff from mines, were among the lowest of those at the six monitoring stations. At site 6, downstream from extensively logged areas, the suspended-sediment concentrations were lower than those at most of the other monitoring stations. The lower constituent concentrations at sites 1 and 6 probably were the result of containment of mine drainage in treatment ponds, reduction of ore-processing activity in the mining area, and dilution by runoff from larger tributary basins where mining and logging are less common.

Fecal coliform bacteria, nitrite plus nitrate, and phosphate concentrations at sites 1 and 6 also were among the lowest at the six
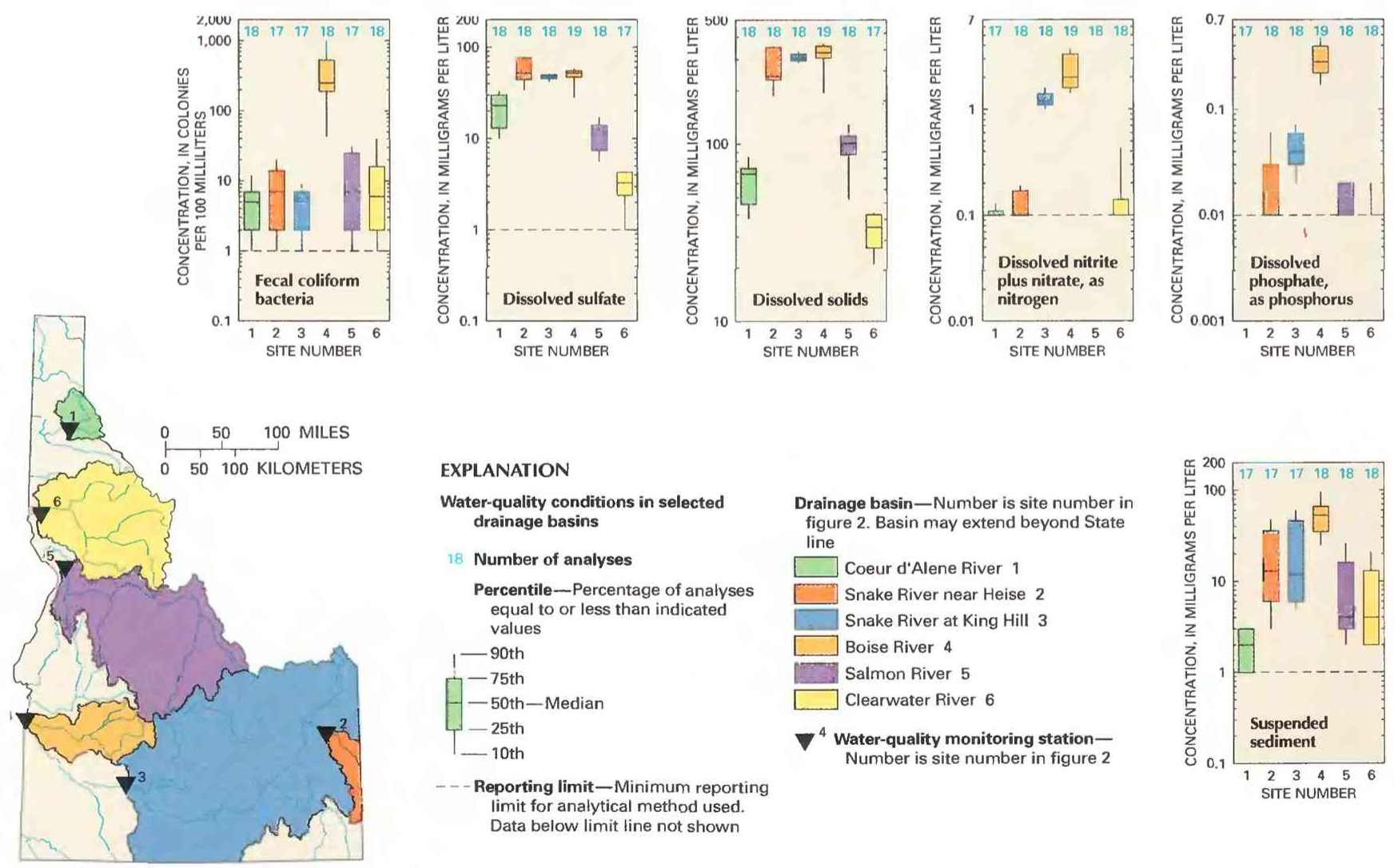

Figure 3. Water quality of selected streams in Idaho, water years 1987-89. (Source: Data from U.S. Geological Survey files.) 
monitoring stations. These low concentrations indicate that livestock grazing, urban activities, and agriculture in the two basins have not affected water quality substantially.

\section{SNAKE RIVER}

The predominant land and water uses that affect water quality in the upper Snake River basin are irrigated agriculture, food processing, aquaculture, hydroelectric power projects, livestock grazing, and urban development, mostly along the main stem of the Snake River between sites 2 and 3 . The overall water quality at site 2 was rated "good" by the Idaho Department of Health and Welfare (1989, p. 28), but because of excessive toxic trace-metal concentrations, that aspect of the water quality was rated "fair." At site 3, overall water quality was rated "fair" by the Idaho Department of Health and Welfare $(1989$, p. 32) because of high concentrations of nutrients, trace metals, and suspended sediment.

During 1988, about 5,700 stream miles in the Snake River basin were assessed for nonpoint-source pollution (Idaho Department of Health and Welfare, 1989, p. 26-43). Runoff from irrigation drainage and soil erosion adversely affected some aspect of water quality in 2,900 of the stream miles assessed. Runoff, primarily from irrigation drainage, adversely affected salmonid spawning and support of cold-water biota in about 2,100 stream miles. Stream-channel and streambank alteration also affected those uses in about 1,800 stream miles.

The increases in dissolved-solids, nitrite plus nitrate, and phosphate concentrations in the Snake River between sites 2 and 3 probably were the result of effluent discharges from point sources and of agricultural runoff containing nitrogen and phosphorus fertilizers. The higher sulfate concentrations at sites 2 and 3 compared to those at the other monitoring stations probably reflect the dissolution of naturally occurring sulfate from rocks.

\section{BOISE RIVER}

Twenty-five percent of Idaho's population resides in the lower Boise River basin. Urban, industrial, agricultural, and food-processing activities have had a major effect on water quality in the basin. Water quality at site 4 has been rated "poor" by the Idaho Department of Health and Welfare (1989, p. 46) because of high concentrations of nutrients, bacteria, and suspended sediment. Median fecal coliform bacteria, dissolved solids, nitrite plus nitrate, phosphate, and suspended-sediment concentrations were highest at site 4 (fig. 3 ).

\section{SALMON RIVER}

Some of the largest designated wilderness areas in the United States are within the 13,550-square mile Salmon River basin; however, logging, livestock grazing, mining, and recreation could affect water quality in the basin. Water quality at site 5 , near the mouth of the Salmon River (fig. 3), has been rated "fair" by the Idaho Department of Health and Welfare $(1989$, p. 63) because of large suspendedsediment loads during spring runoff. Sulfate, dissolved-solids, phosphate, and suspended-sediment concentrations at site 5 were among the lowest, and nitrite plus nitrate concentrations were the lowest of those at the six monitoring stations. Although suspended-sediment concentrations were low, the total quantity of suspended sediment carried by the river can be large when streamflow is great. The low constituent concentrations at site 5 indicate that the predominant land uses in the basin have not degraded water quality substantially.

\section{WATER-QUALITY TRENDS}

Trend analysis is a statistical procedure used to detect changes in stream water quality at a monitoring station over time. For this report, water-quality data from 19 monitoring stations (fig. 2) were analyzed for trends by using the seasonal Kendall test (Hirsch and others, 1982), a method used extensively by the USGS. The graph (shown below) of specific-conductance values in the Snake River at site 9 illustrates the trend inferred from the data and demonstrates the variation in water quality that is common in streams.

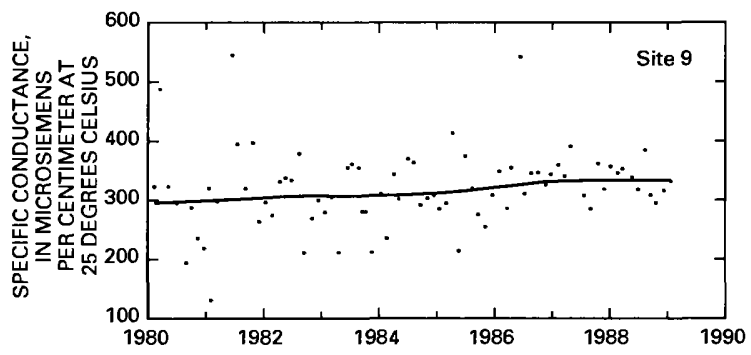

When possible, constituent-concentration data were adjusted for changes in streamflow to preclude identifying a trend in concentration that was caused only by a trend in streamflow. The data were not adjusted when (1) more than 10 percent of the samples had concentrations lower than the minimum reporting limit for the analytical method used or (2) the streamflow was controlled substantially by human activities. When the concentration data could not be adjusted for streamflow, trends were determined directly from the concentration data.

Statewide trends in measurements of selected physical properties of stream water and in concentrations of selected constituents in stream water are shown on maps in figure 4. On each map, a trend is indicated at a monitoring station only if the data from that station were suitable for use in the trend analysis. For more information on the suitability criteria and on the trend-analysis procedure used for this report, see Lanfear and Alexander (1990).

\section{SPECIFIC CONDUCTANCE}

Specific conductance is a measure of the ability of a sample of water to conduct electricity. Because specific conductance and the dissolved-solids concentration are roughly proportional in most natural waters, the specific-conductance value often can be used to estimate the dissolved-solids concentration (Hem, 1985, p. 66-68).

The upward trend in specific-conductance values in the Snake River at site 9 could have been the result of increased urban runoff and sewage effluent associated with increasing population in the Idaho Falls area. The absence of a trend at the other monitoring stations might reflect the State's efforts to control nonpoint sources of pollution such as agriculture, livestock grazing, logging, and mining.

\section{FECAL COLIFORM BACTERIA}

Fecal coliform bacteria are used as indicators of fecal contamination from humans and other warm-blooded animals. Such contamination can introduce disease-causing viruses and bacteria into a stream.

The downward trend in the Snake River at sites 2 and 3 (fig. 4) might have been the result of improved quality of irrigation drainage owing to changes in irrigation methods and to a decrease in the volume of drainage. The downward trend at site 3 also might have been the result of improvements in municipal wastewater-treatment facilities upstream on the Snake River, as might the downward trend at site 6 on the Clearwater River. 
Table 1. Sources and environmental significance of selected water-quality properties and constituents [Source: Compiled by the U.S. Geological Survey, Office of Water Quality]

\begin{tabular}{|c|c|c|}
\hline Property or constituent & Common sources & Environmental significance \\
\hline Sulfate & $\begin{array}{l}\text { Occurs in some rocks; also in mine runoff, industrial } \\
\text { wastewater discharge, and atmospheric deposi- } \\
\text { tion. }\end{array}$ & $\begin{array}{l}\text { Concentrations exceeding a natural, background } \\
\text { level indicate contamination from human activity; } \\
\text { in sufficient quantity, can cause water to be } \\
\text { unsuitable for public supply; can harm aquatic } \\
\text { organisms. }\end{array}$ \\
\hline 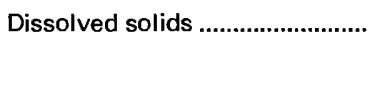 & $\begin{array}{l}\text { A result of rock weathering; also in agricultural runoff } \\
\text { and industrial discharge. }\end{array}$ & $\begin{array}{l}\text { In sufficient quantity, can cause water to be unsuitable } \\
\text { for public supply, agriculture, and industry; can } \\
\text { harm aquatic organisms. }\end{array}$ \\
\hline 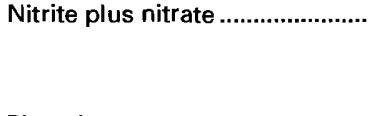 & $\begin{array}{l}\text { Nonpoint sources are agricultural and urban runoff; } \\
\text { a major point source is wastewater discharge. }\end{array}$ & $\begin{array}{l}\text { Plant nutrient that, in sufficient quantity, can cause } \\
\text { algal blooms and excessive growth of higher } \\
\text { aquatic plants in bodies of water; can cause water } \\
\text { to be unsuitable for public supply. }\end{array}$ \\
\hline
\end{tabular}

\section{DISSOLVED SULFATE}

The major natural sources of sulfate in streams are rock weathering, volcanoes, and biochemical processes (Hem, 1985, p. 113). Human activities such as mining, waste discharge, and fossilfuel combustion also can be important sources.

Sulfate concentrations had no trend at the four monitoring stations from which data were suitable for trend analysis (fig. 4). Sources of sulfate in the drainage basins monitored by these stations are fertilizers, sewage effluent, naturally occurring minerals in the rocks, and mine drainage. The absence of a trend at sites 2 and 3 on the Snake River, which receives agricultural runoff, might indicate little increase in the use of fertilizers, soil amendments, and fungicides in agricultural practices. Concentrations in the Salmon River at site 5 and the Clearwater River at site 6 might have had no trend because land-use activities that could affect sulfate concentrations, such as mining and livestock grazing, are widely dispersed and localized.

\section{DISSOLVED SOLIDS}

Dissolved solids in stream water result primarily from rock weathering but also can be introduced as a byproduct of human activities (table 1). Concentrations generally are greatest in streams draining basins underlain by rocks and soils that contain easily dissolved minerals.

Dissolved-solids concentrations had no trend at the four monitoring stations from which data were suitable for trend analysis (fig. 4). The absence of a trend at site 3 probably was due to dilution. Upstream from site 3, a large volume of ground water discharges to the Snake River and improves water quality. About 6,000 cubic feet per second was discharged to the Snake River between Twin Falls and King Hill in 1980 (Kjelstrom, 1986).

\section{DISSOLVED NITRITE PLUS NITRATE}

Nitrite and nitrate are oxidized forms of nitrogen that together normally constitute most of the dissolved nitrogen in well-aerated streams. Nitrite readily oxidizes to nitrate in natural waters; there- fore, nitrate generally is by far the more abundant of the two (Hem, 1985, p. 124).

Nitrite plus nitrate concentrations in the Snake River at sites 2 and 3, the Salmon River at site 5, and the Clearwater River at site 6 had no trend (fig. 4). Although irrigation is extensive in the Snake River basin between sites 2 and 3, the absence of a trend might indicate that nitrogen concentrations in irrigation runoff were unchanged as a result of little change in nitrogen-fertilizer use during the trendanalysis period. There was no trend in nitrogen-fertilizer use on a State level during 1980-85 (Alexander and Smith, 1990). From 1979 to 1985 , the number of acres in the Snake River basin irrigated by sprinkler systems increased by about 7 percent (D.C. Larsen, University of Idaho, oral commun., 1990). Although part of the increase can be attributed to newly irrigated land, most of the increase is attributable to conversion from flood to sprinkler irrigation. The change in irrigation method results in a lower volume of drainage that might offset the effects of increases in irrigated acreage. Nitrite plus nitrate concentrations at sites 5 and 6 might have had no trend because land uses that can affect nitrogen concentrations, such as livestock grazing, are widely dispersed and localized in the drainage basins of the Salmon and Clearwater Rivers.

\section{DISSOLVED PHOSPHATE}

Phosphate is the oxidized form of phosphorus and the only form of significance in most natural waters. Small quantities of dissolved phosphate commonly are present in streams as a result of rock weathering. Normally, concentrations are no more than a few tenths of a milligram per liter (Hem, 1985, p. 126) and are usually much lower. Higher concentrations can indicate contamination from human activities (table 1). A shortened trend-analysis period was used for phosphate because data for water years 1980-81 are not comparable to data for subsequent years.

The downward trend in phosphate concentrations in the Salmon River at site 5 and the Clearwater River at site 6 , as well as the absence of a trend in the Snake River at sites 2 and 3, probably was, at least in part, the result of Idaho's efforts during the 1980's to upgrade municipal primary and secondary sewage-treatment facilities to meet secondary-treatment standards. The absence of a trend 


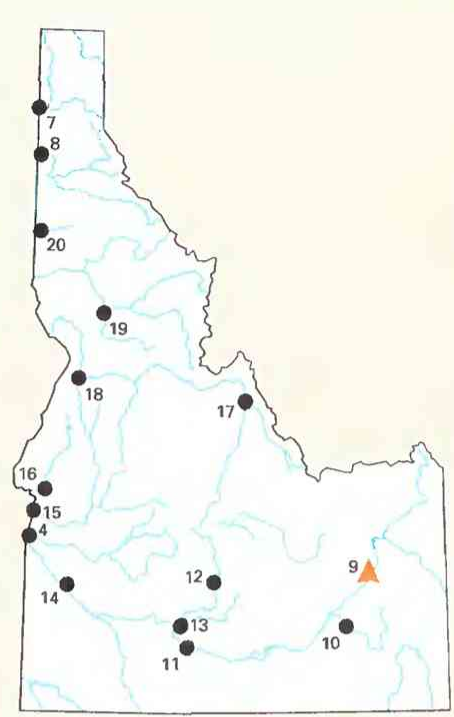

Specific conductance, $1980-89$

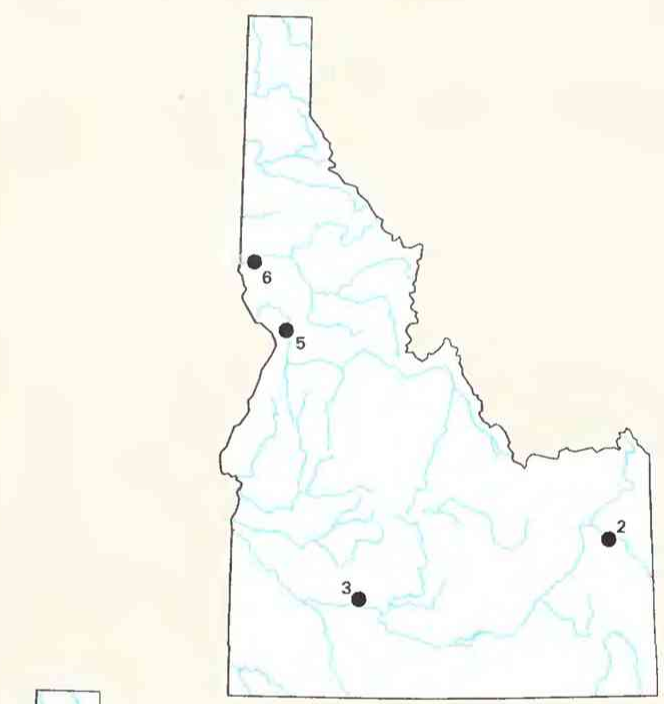

Dissolved solids, 1980-89

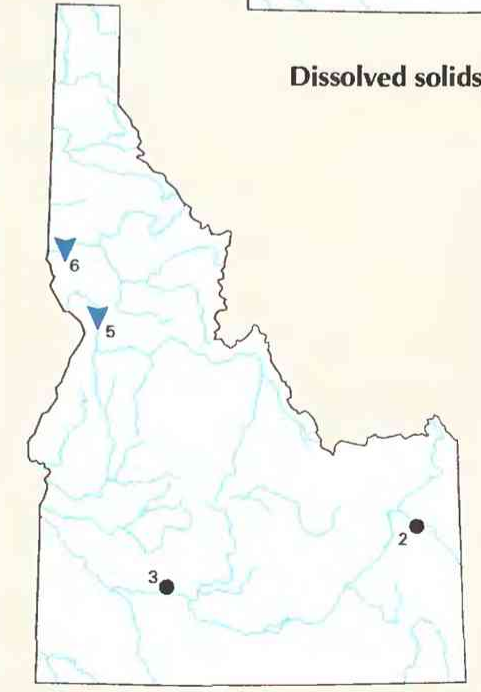

Dissolved phosphate, 1982-89

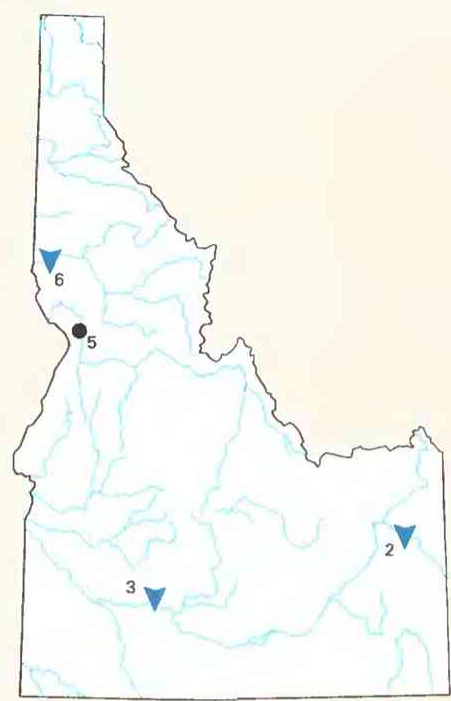

Fecal coliform bacteria, 1980-89

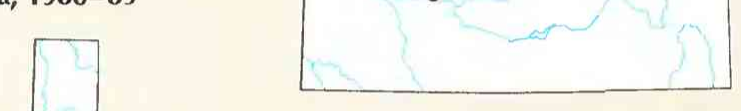

Dissolved sulfate, 1980-89

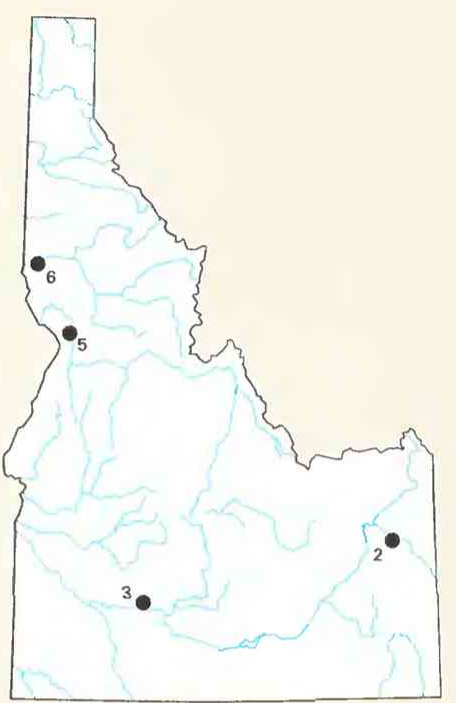

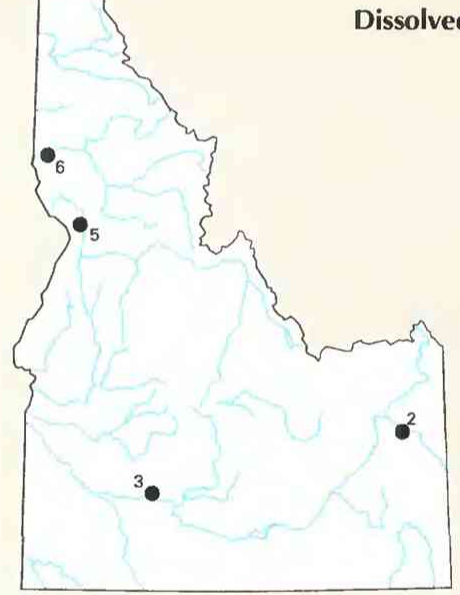

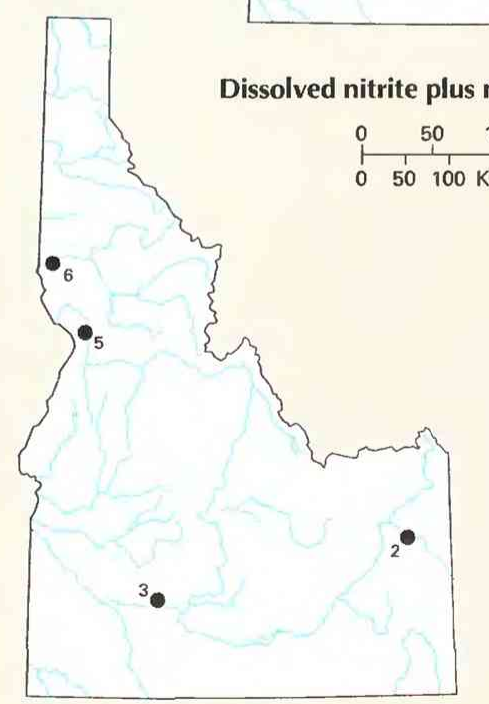

\section{EXPLANATION}

Trend in water-quality property or constituent - Number is site number in figure 2

A9 Upward

- ${ }^{3}$ None

$\nabla^{5}$ Downward

Figure 4. Trends in water quality of selected streams in Idaho, by water years. (Source: Data from U.S. Geological Survey files.) 


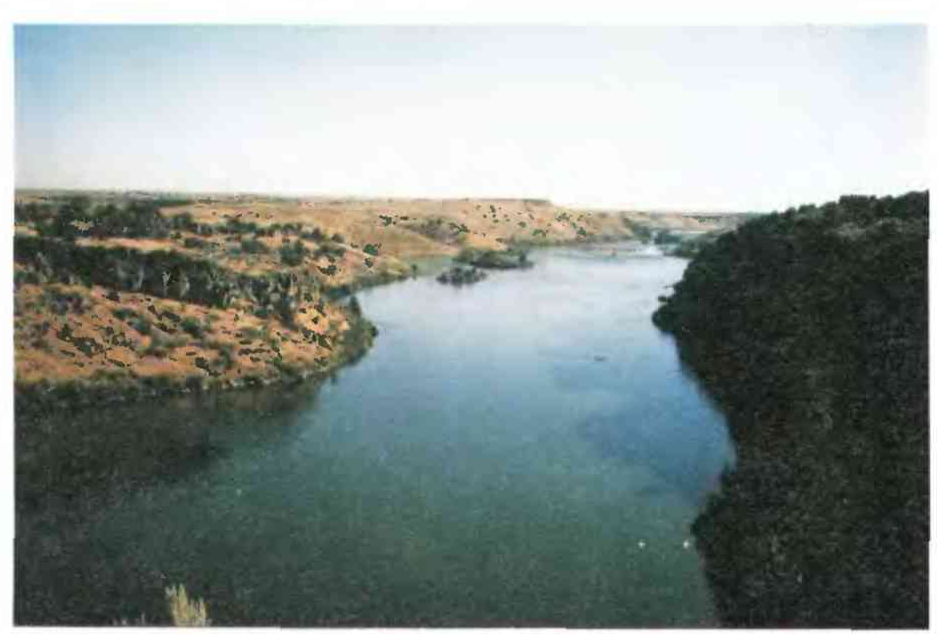

Snake River in southeastern Idaho. The Snake River is a significant source of irrigation water across southern Idaho. Irrigation return flow affects the water quality of the river. (Walton H. Low, U.S. Geological Survey.)

in the Snake River also might have been the result of little-changing phosphate-fertilizer use in the basin during müch of the trend-analysis period. There was no trend in phosphorus-fertilizer use on a State level during 1980-85 (Alexander and Smith, 1990).

\section{SUSPENDED SEDIMENT}

Suspended sediment is a product of erosion. The erosion can be either natural or the result of land-cover disturbances related to human activities (table 1).

Concentrations of suspended sediment had no trend at four monitoring stations. Within the drainage basins of the Snake and Clearwater Rivers (sites 2, 3, and 6), large water-storage reservoirs trap most suspended sediment that otherwise would be transported to the monitoring stations, thus masking any trends that might have occurred upstream from the reservoirs.

\section{WATER-QUALITY MANAGEMENT}

Stream water quality in Idaho is managed primarily by the Division of Environmental Quality of the Idaho Department of Health and Welfare, pursuant to sections 304(i), 305(b), 314, and 319 of the Federal Clean Water Act. Pursuant to section 305(b) of the act, the Division prepares a biennial water-quality-assessment report (Idaho Department of Health and Welfare, 1989) that is submitted to the EPA and the U.S. Congress. Other State agencies involved in managing stream water quality include the Idaho Department of Lands and the Idaho Department of Water Resources. Idaho's Water Pollution Control Program consists of several surface- and ground-water programs. Many of these programs are managed under the authority of Idaho's Environmental Protection and Health Act, Forest Practices Act, Water-Quality Standards and Wastewater Treatment Requirements, Surface Mining Act, Dredge and Placer Mining Act, Stream Channel Alteration Act, and Ground-Water Quality Protection Act, as well as Federal legislation. The water-supply program authorized under the Federal Safe Drinking Water Act also is a major part of the overall State water-quality program.

Idaho's agricultural water-quality program goal is to reduce the adverse effects of agricultural and related practices on water quality. The program is guided by the Agricultural Pollution Abatement Plan (Idaho Soil Conservation Commission, 1979), which provides for management of agriculture-related sources of water-quality degradation such as soil erosion and sedimentation, livestock grazing, runoff of agricultural chemicals, and livestock-confinement areas on about 14.4 million acres of irrigated and nonirrigated cropland, pasture, and rangeland.

The Forest Practices Water-Quality Management Plan regulates forest practices that create the potential for environmental damage on about 22 million acres of Federal, State, and private lands (Idaho Department of Health and Welfare, 1988). The plan is administered by the Idaho Department of Health and Welfare.

Mining activities on State and private lands are overseen by the Idaho Department of Lands under the authority of the Dredge and Placer Mining Act, the Surface Mining Act, and the Oil and Gas Wells-Geologic Information and Prevention of Waste Act. Regulation of discharges from mining and cyanide-leaching facilities is the responsibility of the Idaho Department of Health and Welfare.

Point-source pollution control is administered by the EPA. Public water supply, municipal wastewater-treatment construction grants, sewage-sludge management, lake management, water-quality monitoring, water-quality standards, and ground-water management are overseen by the Idaho Department of Health and Welfare. Major water-quality activities implemented since 1987 are a statewide assessment of nonpoint pollution sources (Idaho Department of Health and Welfare, 1989) and the development and implementation of a nonpoint-source management plan (Bauer, 1989), an antidegradation policy (Clark, 1990), and a ground-water-quality program.

\section{SELECTED REFERENCES}

Alexander, R.B., and Smith, R.A., 1990, County-level estimates of nitrogen and phosphorus fertilizer use in the United States, 1945 to 1985: U.S. Geological Survey Open-File Report 90-130, 12 p.

Anderson, J.R., 1967, Major land uses in the United States, in U.S. Geological Survey, 1970, National atlas of the United States of America: Washington, D.C., U.S. Geological Survey, p. 158-159.

Bauer, S.B., 1989, Idaho nonpoint source management program 1989: Boise, Idaho Department of Health and Welfare, Division of Environmental Quality, Water Quality Bureau, 195 p.

Britton, L.J., and Greeson, P.E., eds., 1987, Methods for collection and analysis of aquatic biological and microbiological samples: U.S. Geological Survey Techniques of Water-Resources Investigations, book 5, chap. A4, $363 \mathrm{p}$.

Clark, W.H., 1990, Coordinated nonpoint source water quality program for Idaho: Boise, Idaho Department of Health and Welfare, Division of Environmental Quality, Water Quality Bureau, 139 p.

Fenneman, N.M., 1946, Physical divisions of the United States: Washington, D.C., U.S. Geological Survey special map, scale 1:7,000,000.

Fishman, M.J., and Friedman, L.C., eds.,1989, Methods for the determination of inorganic substances in water and fluvial sediments: U.S. Geological Survey Techniques of Water-Resources Investigations, book 5 , chap. A1, 545 p.

Hem, J.D., 1985, Study and interpretation of the chemical characteristics of natural water (3d ed.): U.S. Geological Survey Water-Supply Paper 2254. 263 p.

Hirsch, R.M., Slack, J.R., and Smith, R.A., 1982, Techniques of trend analysis for monthly water quality data: Water Resources Research, v. 18, no. 1, p. 107-121.

Idaho Department of Health and Welfare, 1988, State of Idaho forest practices water quality management plan: Boise, Division of Environmental Quality, Water Quality Bureau, 133 p.

1989 , Idaho water quality status report and nonpoint source assessment, 1988: Boise, Division of Environmental Quality, Water Quality Bureau, 170 p.

Idaho Soil Conservation Commission, 1979, Idaho agricultural pollution abatement plan: Boise, Idaho Soil Conservation Commission, $77 \mathrm{p}$.

Kjelstrom, L.C., 1986, Flow characteristics of the Snake River and water budget for the Snake River Plain, Idaho and eastern Oregon: U.S. Geological Survey Hydrologic Investigations Atlas HA-680, scale 1:1,000,000.

Lanfear, K.J., and Alexander, R.B., 1990, Methodology to derive water-quality trends for use by the National Water Summary Program of the U.S. 
254 National Water Summary 1990-91-Stream Water Quality: STATE SUMMARIES

Geological Survey: U.S. Geological Survey Open-File Report 90-359, $10 \mathrm{p}$.

Thelin, G.P., and Pike, R.J., 1990, Digital shaded relief map of the conterminous United States: Menlo Park, Calif.. U.S. Geological Survey digital image processing, scale 1:3,500,000.

U.S. Geological Survey, 1986, National water summary 1985-Hydrologic events and surface-water resources: U.S. Geological Survey Water-Supply Paper 2300, 506 p.
1990, National water summary 1987-Hydrologic events and water supply and use: U.S. Geological Survey Water-Supply Paper 2350, $553 \mathrm{p}$.

Ward, J.R., and Harr, C.A., eds., 1990, Methods for collection and processing of surface-water and bed-material samples for physical and chemical analyses: U.S. Geological Survey Open-File Report 90-140, 71 p.

Prepared by Walton H. Low

FOR ADDITIONAL INFORMATION: District Chief, U.S. Geological Survey, 230 Collins Road, Boise, ID 83702 


\section{ILLINOIS Stream Water Quality}

Illinois has abundant surface-water resources, including about 14,100 miles of streams in or bordering the State $(13,200$ miles of interior streams and 880 miles of border streams) (Illinois Environmental Protection Agency, 1990, p. 2). The Illinois River and its major tributaries form the largest drainage basin in Illinois (U.S. Geological Survey, 1986, p. 216). Other major rivers include the Rock, Kaskaskia, Big Muddy, Embarras, and Little Wabash.

Offstream surface-water withdrawals in Illinois in 1985 averaged $13,500 \mathrm{Mgal} / \mathrm{d}$ (million gallons per day), or 93.6 percent of total offstream withdrawals (U.S. Geological Survey, 1990, p. 235). The largest offstream surface-water uses were thermoelectric power generation (11,700 Mgal/d), public supply $(1,320 \mathrm{Mgal} / \mathrm{d})$, and industry and mining (438 Mgal/d). Instream uses include hydroelectric power generation, maintenance of fish and other aquatic life, navigation, and recreation.

Land use can substantially affect the quality of water. Cropland or cropland mixed with pasture, woodland, and forest cover much of Illinois; the State also has several large urban areas (fig. 1A). Cropland predominates in the Central Lowland (fig. $1 B$ ); woodland and forest cover much of the Ozark Plateaus, Interior Low Plateaus, and Coastal Plain; and additional woodland areas border the major streams. The largest urban areas are the greater Chicago metropolitan area, Joliet, Aurora, Rockford, Rock Island-Moline, East St. Louis, Peoria, Springfield, and Champaign-Urbana (fig. IC and 2). Illinois' population (11.4 million) remained essentially unchanged from 1980 to 1990 (U.S. Bureau of the Census 1990 decennial census files).

Contaminated stream water can directly affect the health of the population that obtains its drinking water from surface-water sources. Contaminated stream water also can affect the economy of an area by restricting recreational uses of water bodies. Stream waterquality problems in Illinois have numerous point and nonpoint sources. Point sources include municipal and industrial wastewatertreatment facilities and combined-sewer overflows; nonpoint sources include agricultural runoff, urban runoff, surface mining, and channelization (Illinois Environmental Protection Agency, 1990, p. 18). These sources contribute nutrients, chemicals, and suspended sediment that affect the quality of surface water.

\section{WATER-QUALITY MONITORING}

Water-quality data obtained from analyses of water samples collected at monitoring stations are stored in the U.S. Geological Survey's (USGS) National Water Information System and the U.S. Environmental Protection Agency's (EPA) national data base known as STORET. Water-quality and streamflow data are reported by water year-the 12 months from October 1 through September 30. A water year is identified by the calendar year in which it ends. For example, water year 1991 comprises October 1, 1990, through September 30, 1991.

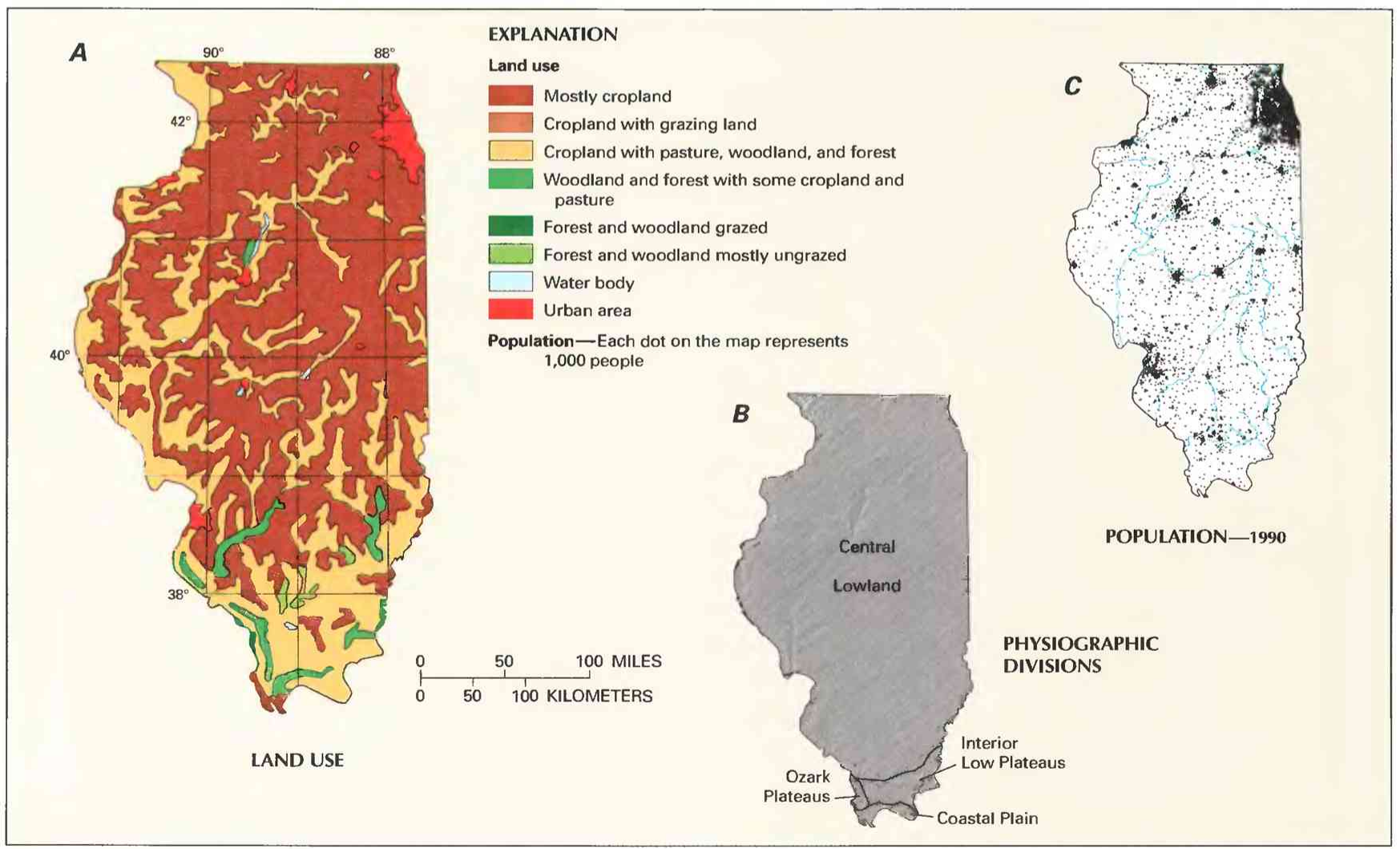

Figure 1. Land use, physiography, and population in Illinois. A, Major land uses. B. Physiographic divisions. $C$, Population distribution in 1990. (Sources: A, Major land uses modified from Anderson, 1967. B. Physiographic divisions from Fenneman, 1946; landforms from Thelin and Pike, 1990. C. Data from U.S. Bureau of the Census 1990 decennial census files.) 
The data used in this summary of Illinois' stream water quality were obtained from water samples collected at intervals of 4-6 weeks at 20 monitoring stations at which data collection is systematic and continuing (fig. 2). Analyses of water samples collected at 10 stations are the basis for the discussion and graphic summary (fig. 3) of stream water-quality conditions during water years 1987-

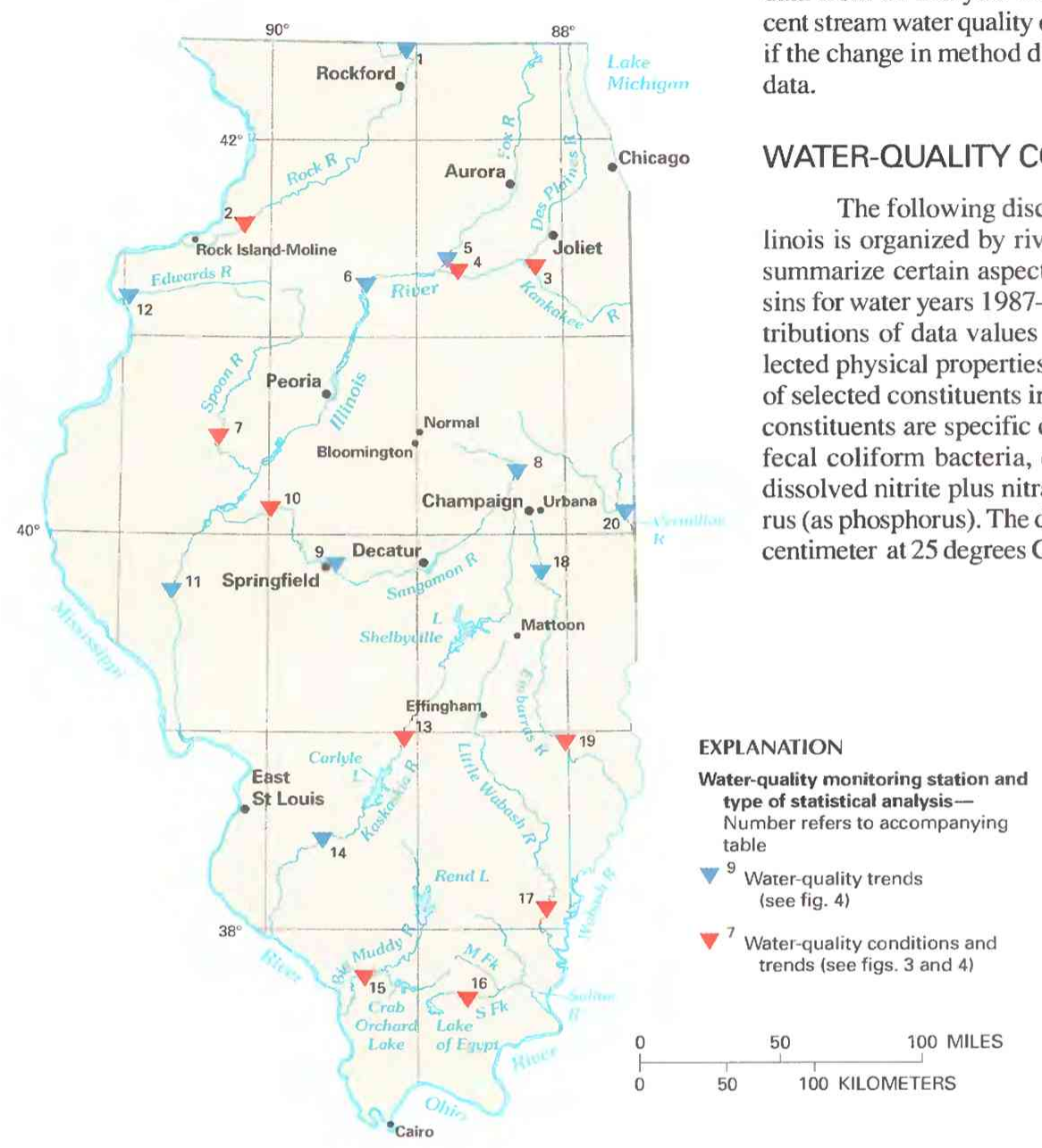

89 , and data from all 20 stations are the basis for the discussion and graphic summary (fig. 4) of stream water-quality trends. Water samples were collected and analyzed by using standard methods approved by the USGS (Britton and Greeson, 1987; Fishman and Friedman, 1989; Ward and Harr, 1990) or by using equivalent methods. If a method of sample collection or analysis changed over time, data from an analysis were included in the evaluation of recent stream water quality or of stream water-quality trends only if the change in method did not affect the comparability of the

CONDITIONS rects of stream water quality in the bains for water years $1987-89$. The graphs show frequency dis-

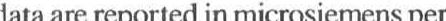
entimes

\begin{tabular}{|c|c|c|c|}
\hline $\begin{array}{l}\text { Site no. } \\
\text { on map }\end{array}$ & $\begin{array}{l}\text { USGS station } \\
\text { name and no. }\end{array}$ & $\begin{array}{l}\text { Drainage area } \\
\text { (square miles) }\end{array}$ & $\begin{array}{l}\text { Major land use } \\
\text { (see fig. 1) }\end{array}$ \\
\hline 1 & Rock River at Rockton $(05437500)$... & 6,363 & Mostly cropland. \\
\hline 2 & 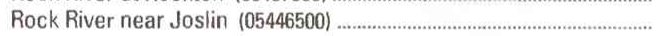 & 9,549 & Ditto. \\
\hline 3 & Kankakee River near Wilmington $(05527500)$... & 5,150 & Cropland with pasture, woodland, and forest. \\
\hline 4 & Illinois River at Marseilles (05543500) & 8,259 & Mostly cropland; urban areas. \\
\hline 5 & Fox River at Dayton (05552500) & 2,642 & Ditto. \\
\hline 6 & Illinois River at Hennepin $(05556200)$ & 12,756 & Mostly cropland. \\
\hline 7 & Spoon River at Seville $(05570000)$ & 1,636 & Cropland with pasture, woodland, and forest. \\
\hline 8 & Sangamon River at Fisher $(05570910)$ & 240 & Mostly cropland. \\
\hline 9 & Sangamon River at Riverton $(05576500) \ldots \ldots \ldots . .$. & 2,618 & Ditto. \\
\hline 10 & 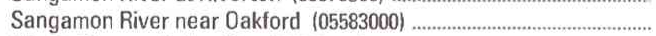 & 5,093 & Mostly cropland; urban areas. \\
\hline 11 & Illinois River at Valley City $(05586100)$ & 26,742 & Mostly cropland. \\
\hline 12 & Edwards River near New Boston (05466500) & 445 & Cropland with pasture, woodland, and forest. \\
\hline 13 & Kaskaskia River at Vandalia $(05592500)$ & 1,940 & Mostly cropland. \\
\hline 14 & 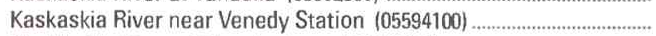 & 4,393 & Cropland with pasture, woodland, and forest. \\
\hline 15 & 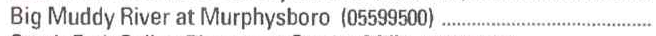 & 2,169 & Ditto. \\
\hline 16 & South Fork Saline River near Carrier Mills $(03382100)$ & 147 & Ditto. \\
\hline 17 & Little Wabash River at Main Street at Carmi (03381495) ..................... & 3,088 & Ditto. \\
\hline 18 & Embarras River at Camargo (03343395) & 180 & Mostly cropland. \\
\hline 19 & Embarras River at Ste. Marie $(03345500)$ & 1,516 & Cropland with pasture, woodland, and forest. \\
\hline 20 & Vermilion River near Danville $(03339000)$.... & 1,290 & Ditto. \\
\hline
\end{tabular}

Figure 2. Selected water-quality monitoring stations, type of statistical analysis, and geographic features in Illinois. (Sources: Major land uses modified from Anderson, 1967; other data from U.S. Geological Survey files.) 
per liter $(\mathrm{mg} / \mathrm{L})$, and colonies per 100 milliliters $(\mathrm{col} / 100 \mathrm{~mL})$. Sources and environmental significance of each property and constituent are described in table 1.

Water quality at each monitoring station is the result of geological, chemical, biological, and hydrologic processes that occur over a large area. Water-quality problems that affect aquatic life or public health only locally are not fully represented in this summary.

Water-quality conditions are referenced to water uses and water-quality standards designated by the Illinois Environmental Protection Agency (IEPA) (1990, p. 4 and 7). The IEPA has applied ratings to streams based on a stream's ability to support aquatic life. The ratings include (1) full-aquatic-life use support, (2) partial support with minor use impairment, (3) partial support with moderate-use impairment, and (4) nonsupport. Specific IEPA standards for generaluse purposes are as follows: $\mathrm{pH}$ (in standard units), 9.0 maximum, 6.5 minimum; dissolved oxygen, $5.0 \mathrm{mg} / \mathrm{L}$ minimum; fecal coliform bacteria, $200 \mathrm{col} / 100 \mathrm{~mL}$ maximum; dissolved sulfate, $500 \mathrm{mg} / \mathrm{L}$ maximum; dissolved solids, 1,000 mg/L maximum; and total phosphorus, $0.05 \mathrm{mg} / \mathrm{L}$ maximum.

\section{ROCK RIVER}

The Rock River originates in Wisconsin and flows to the Mississippi River. One-third of the drainage area is in Illinois. In the Illinois part of the basin, the surficial geology comprises mostly glacial drift and outwash deposits overlying dolomite, shale, limestone, and coal. Land use in the basin is mostly cropland. Reservoirs formed by seven of eight low-hydraulic-head dams, which originally were constructed for hydroelectric power generation, are now used for recreation (U.S. Geological Survey, 1986, p. 216). Agricultural runoff and wastewater-treatment-plant effluent are potential sources of contamination.

The IEPA (1990, p. 31, fig. 8) has classified the Rock River as having minor use impairment because of excessive phosphorus in discharge from wastewater-treatment plants and in agricultural runoff. At site 2 , the median concentration of phosphorus $(0.23 \mathrm{mg} / \mathrm{L})$ (fig. 3) was almost five times the IEPA standard. Coal in the basin has had little effect on water quality; the median sulfate concentration $(40 \mathrm{mg} / \mathrm{L})$ at site 2 was the lowest for the 10 monitoring stations and was well below the IEPA standard.

\section{KANKAKEE RIVER}

The Kankakee River originates in Indiana and joins the Des Plaines River downstream from site 3 to form the Illinois River. The river has been extensively channelized in Indiana but is relatively unmodified in Illinois. In the Illinois part of the basin, the surficial geology comprises mostly lakebed and glacial moraine deposits overlying dolomite and coal. Land use in the basin is predominantly cropland with some pasture and woodland. Livestock raising is an important activity, and coal is strip mined near the western edge of the basin. Agricultural and coal-mine runoff are potential sources of contamination.

The main stem of the Kankakee River in Illinois upstream from site 3 has been rated by the IEPA as having full aquatic-life-use support; however, nutrients and silt result in minor use impairment owing to agricultural runoff to one of the smaller tributaries (Illinois Environmental Protection Agency, 1990, p. 34, fig. 9). Many samples from site 3 (fig. 3 ) exceeded the IEPA standards for fecal coliform bacteria and total phosphorus concentrations, probably because of agricultural runoff.

\section{ILLINOIS RIVER}

The Illinois River originates at the confluence of the Des Plaines and Kankakee Rivers and is augmented with diversions from Lake Michigan. Seventy-five percent of the Illinois River basin is in Illinois. The river system drains the heavily industrialized area in the northeastern part of the State. Commerce along the river is made possible by a series of locks and dams. The basin's surficial geology comprises mostly glacial-drift and moraine deposits overlying dolomite, limestone, shale, and coal. Land uses in the basin are mostly agricultural and urban. Wastewater-treatment-plant effluent and urban and agricultural runoff are potential sources of stream contamination.

The Illinois River upstream from site 4 has minor use impairment because of industrial-and municipal-wastewater discharges and soil erosion (Illinois Environmental Protection Agency, 1988, p. 29, fig. 8). Barge traffic on the river contributes to the problem by resuspending sediments and increasing wave action that causes bank erosion. The median concentrations of dissolved solids $(474 \mathrm{mg} / \mathrm{L})$ and phosphorus $(0.43 \mathrm{mg} / \mathrm{L}$ ) at site 4 (fig. 3 ) were the highest for the 10 monitoring stations; phosphorus concentrations exceeded the IEPA standard, and probably resulted from the large volume of wastewatertreatment-plant effluent.

\section{SPOON RIVER}

The Spoon River flows into the Illinois River in west-central Illinois. The surficial geology of the basin comprises mostly glacial drift overlying limestone, shale, and coal. Cropland, pasture, and woodland cover most of the basin, and there are several active and abandoned coal strip mines.

The quality of stream water in the basin slightly impairs aquatic-life maintenance because of turbidity and, to a lesser degree, because of nutrients from agricultural runoff, coal mining, and municipal-wastewater effluent (Illinois Environmental Protection Agency, 1990, p. 38, fig. 10). Few fecal coliform bacteria samples exceeded the IEPA standard, and the median nitrite plus nitrate concentration was low (fig. 3). These concentrations probably were low because of the sparse population in the river basin. The median phosphorus concentration $(0.14 \mathrm{mg} / \mathrm{L})$ at site 7 (fig. 3 ) exceeded the IEPA standard yet was one of the lowest for the 10 monitoring stations.

\section{SANGAMON RIVER}

The Sangamon River joins the Illinois River in central Illinois. The river is extensively channelized along its lower reach; less channelization has taken place along the upper reaches. The basin contains five major reservoirs. In most of the basin, glacial drift overlies limestone, shale, and coal. Land use is predominantly cropland, but there is some oil production, and coal has been deep-shaft mined. Agricultural runoff, urban runoff, and municipal-wastewater effluent are potential sources of contamination.

Wastewater-treatment-plant effluent and urban runoff from the large communities of Decatur, Bloomington-Normal, and Springfield impair aquatic-life maintenance in the Sangamon River (Illinois Environmental Protection Agency, 1990, p. 42, fig. 11). During water years $1987-89$, the median concentration of phosphorus $(0.34$ $\mathrm{mg} / \mathrm{L}$ ) at site 10 (fig. 3 ) and some concentrations of fecal coliform bacteria exceeded the IEPA standards for general-use purposes. The high concentrations probably were the result of large volumes of wastewater-treatment-plant effluent.

\section{KASKASKIA RIVER}

The Kaskaskia River originates near Champaign and empties into the Mississippi River. Streamflow in the river is partially regulated by dams that form Lake Shelbyville and Carlyle Lake. The surficial geology comprises mostly glacial drift overlying limestone, shale, and coal. Land uses are mostly agricultural. Agricultural runoff and chemical-plant effluent are potential sources of contamination. 
The Kaskaskia River upstream from site 13 is capable of full aquatic-life-use support except for a 17.6-mile reach downstream from a chemical plant; aquatic-life maintenance in the reach was partially impaired by organic contaminants (Illinois Environmental Protection Agency, 1990, p. 46, fig. 12). Organic pesticides (chlordane, dieldrin, and heptachlor epoxide) were present in the stream sediment upstream from Lake Shelbyville. During water years $1987-$ 89 , some fecal coliform bacteria samples and the median phosphorus concentration $(0.15 \mathrm{mg} / \mathrm{L})$ at site 13 (fig. 3 ) exceeded the IEPA standards. The high concentrations probably were the result of agricultural runoff.

\section{BIG MUDDY RIVER}

The Big Muddy River flows through southern Illinois to the Mississippi River. Six dams regulate streamflow in the Big Muddy River basin; Rend and Crab Orchard Lakes are the largest reservoirs. The drainage basin is underlain mostly by glacial drift that overlies limestone, shale, and coal. Cropland, pasture, woodland, and forest are the major land uses, but there is some coal and oil production.
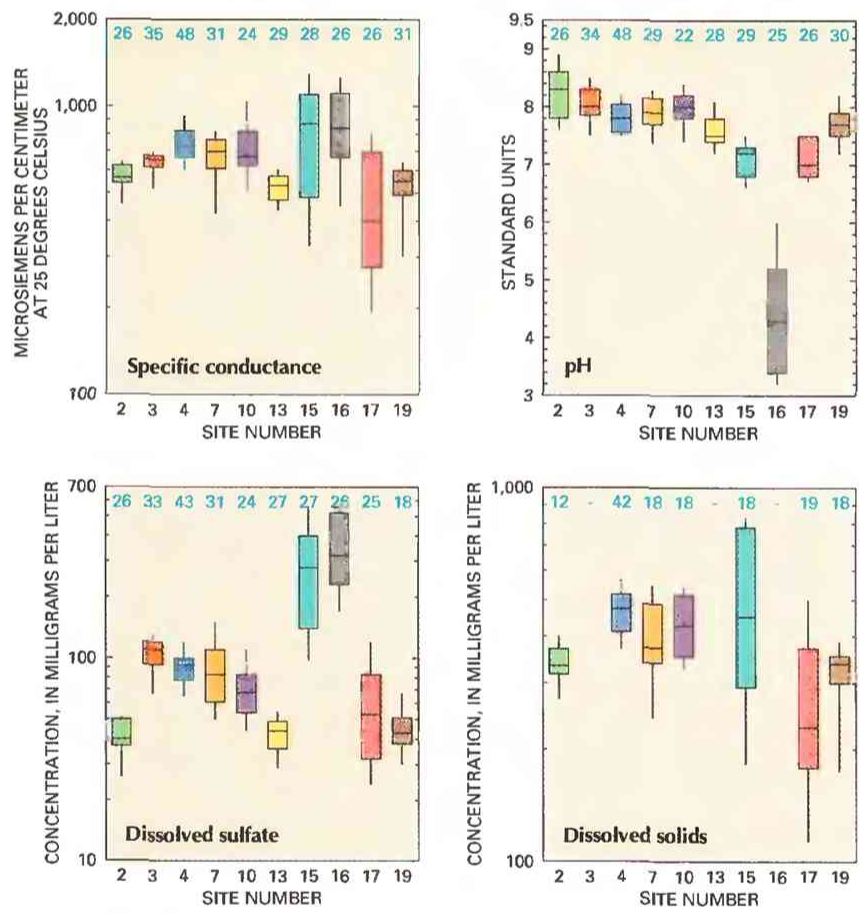

\section{EXPLANATION}
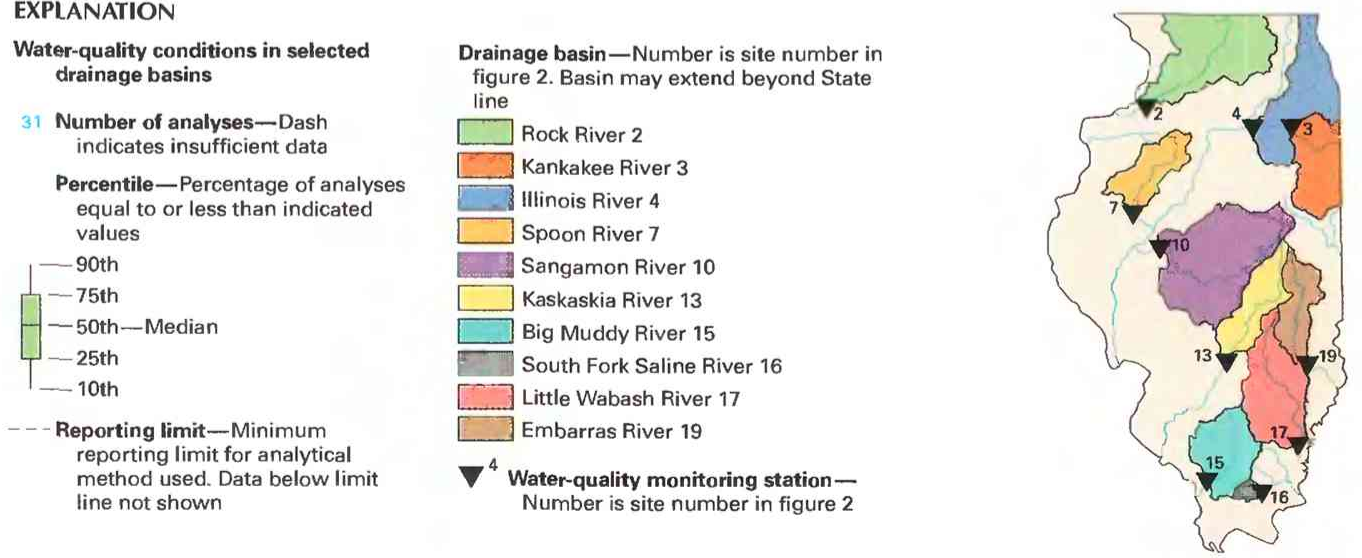
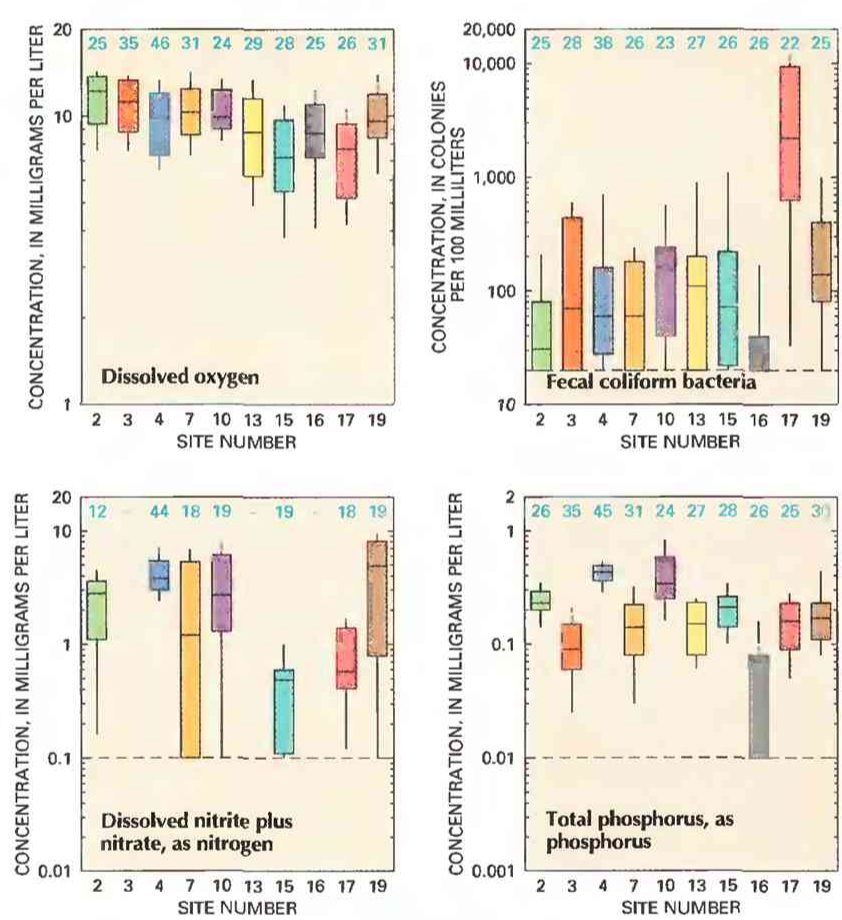

Agricultural runoff, coal mining, and wastewater-treatment-plant effluent are potential sources of contamination.

The main stem of the Big Muddy River has received a minor use-impairment rating as a result of agricultural runoff, coal-mine runoff, and municipal wastewater-treatment-plant effluent; the exception is a full-use rating for a 0.7 -mile reach downstream from Rend Lake (Illinois Environmental Protection Agency, 1990, p. 56, fig. 14). Some fecal coliform bacteria concentrations and all phosphorus concentrations at site 15 (fig. 3) exceeded the IEPA standards. The source of contamination probably was agricultural runoff and wastewater fhe median sulfate concentration $(280 \mathrm{mg} / \mathrm{L})$ was the $\mathrm{sec}-$ 列 10 monitoring stations and reflects the extensive coal mining in the basin that exposes sulfur-bearing minerals to weathering.

\section{SOUTH FORK SALINE RIVER}

The South Fork Saline River originates in southern Illinois, joins the Middle Fork Saline River, and empties into the Ohio River. The South Fork Saline River is regulated by the dam that forms Lake

$0 \quad 50100$ KILOMETERS

Figure 3. Water quality of selected streams in Illinois, water years 1987-89. (Sources: Data from U.S. Geological Survey files.) 
of Egypt. The surficial geology of the basin comprises mostly glacial-drift and lakebed deposits overlying limestone, shale, and coal. Cropland, pasture, woodland, and forest cover most of the basin, and there has been extensive strip and deep-shaft coal mining.

Most of the South Fork Saline River upstream from site 16 has been given a full aquatic-life-use support rating; however, the 9mile reach just upstream from the monitoring station has a non-support-use rating (Illinois Environmental Protection Agency, 1990, p. 60, fig. 15). Acid runoff from an inactive coal mine in the basin causes low $\mathrm{pH}$ values and has adversely affected the river. The median $\mathrm{pH}$ value (4.3) at site 16 (fig. 3 ) was much less than the minimum IEPA standard of 6.5 . The $\mathrm{pH}$ value and the median sulfate concentration were the lowest and highest, respectively, for the 10 monitoring stations and were directly related to coal mining. In contrast, the median concentrations of fecal coliform bacteria and total phosphorus were the lowest, probably because the basin is sparsely populated, and possibly also because the acidity kills the bacteria.

\section{LITTLE WABASH RIVER}

The Little Wabash River originates near Mattoon and flows to the Wabash River. Eleven water-supply reservoirs have been built in the drainage basin; the largest of these is near Effingham. Glacialdrift and lakebed deposits overlie limestone, shale, and coal in most of the basin. Land uses are predominantly agricultural, but there also is oil and gas production (U.S. Geological Survey, 1986, p. 221). Wastewater-treatment-plant effluent is a source of stream contamination.

The Little Wabash River upstream from site 17 has been rated as having minor use impairment except for a 4-mile reach near Mattoon that has been adversely affected by wastewater-treatmentplant effluent (Illinois Environmental Protection Agency, 1990, p. 52, fig. 13). The median concentration of fecal coliform bacteria $(2,200$ $\mathrm{col} / 100 \mathrm{~mL}$ ) at site 17 (fig. 3) was the highest for the 10 monitoring stations and exceeded the IEPA standard; some samples exceeded $10,000 \mathrm{col} / 100 \mathrm{~mL}$. Phosphorus concentrations in all samples collected at site 17 exceeded the IEPA standard. The high concentrations of fecal coliform bacteria and phosphorus probably were the result of wastewater-treatment-plant effluent.

\section{EMBARRAS RIVER}

The Embarras River originates near Urbana and flows to the Wabash River. In most of the basin, glacial drift overlies limestone, shale, and coal. Land uses in the basin are cropland, pasture, woodland, and forest, but oil is produced as well. Municipal wastewatertreatment-plant effluent and agricultural and oil-field runoff are potential sources of contamination in the basin.

About 43 percent of the Embarras River system has been rated as having minor use impairment (because of channelization and agricultural and oil-field runoff), about 5 percent as having moderateuse impairment, and less than 1 percent as being nonsupportive of aquatic life (Illinois Environmental Protection Agency, 1990, p. 51, fig. 13). Phosphorus concentrations at site 19 (fig. 3) exceeded the IEPA standard. The high concentrations probably were the result of wastewater effluent and agricultural runoff.

\section{WATER-QUALITY TRENDS}

Trend analysis is a statistical procedure used to detect changes in stream water quality at a monitoring station over time. For this report, water-quality data from 20 monitoring stations (fig. 2) were analyzed for trends by using the seasonal Kendall test (Hirsch and others, 1982), a method used extensively by the USGS. The graph (next page) of the dissolved-sulfate concentration in the Sangamon River at site 10 illustrates the trend inferred from the concentration data and demonstrates the variation in water quality that is common in streams.

Table 1. Sources and environmental significance of selected water-quality properties and constituents [Source: Compiled by the U.S. Geological Survey, Office of Water Quality]

\begin{tabular}{|c|c|c|}
\hline Property or constituent & Common sources & Environmental significance \\
\hline $\begin{array}{l}\text { Specific conductance } \\
\quad \text { (property) }\end{array}$ & $\begin{array}{l}\text { A measure of the electrical conductivity of water; var- } \\
\text { ies with the quantity of dissolved solids and is } \\
\text { used to approximate the dissolved-solids content. }\end{array}$ & $\begin{array}{l}\text { Dissolved solids can cause water to be unsuitable for } \\
\text { public supply, agriculture, and industry; can harm } \\
\text { aquatic organisms. }\end{array}$ \\
\hline 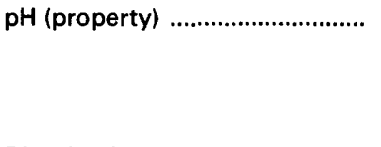 & $\begin{array}{l}\text { A measure of hydrogen-ion activity (acidity or alkalin- } \\
\text { ityl; can be affected by geologic setting, biological } \\
\text { activity, municipal and industrial wastewater dis- } \\
\text { charge, and atmospheric deposition. }\end{array}$ & $\begin{array}{l}\text { Acidic water can corrode pipes and equipment; can } \\
\text { cause the release of lead and other metals from } \\
\text { distribution systems to drinking water; can affect } \\
\text { wastewater-treatment processes and taste of } \\
\text { water. }\end{array}$ \\
\hline Dissolved oxygen .......................... & $\begin{array}{l}\text { Introduced from the atmosphere; also a byproduct of } \\
\text { aquatic plants. }\end{array}$ & $\begin{array}{l}\text { Necessary for aquatic life; deficiency can result from } \\
\text { assimilation of organic wastes or rapid growth } \\
\text { and decay of algae. }\end{array}$ \\
\hline Fecal coliform bacteria ............... & $\begin{array}{l}\text { Sources include effluent from sewage-treatment } \\
\text { plants and runoff from pastures, feedlots, and ur- } \\
\text { ban areas. }\end{array}$ & $\begin{array}{l}\text { Presence indicates contamination of water by wastes } \\
\text { from humans and other warm-blooded animals. }\end{array}$ \\
\hline 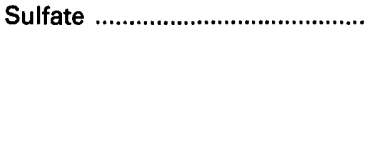 & $\begin{array}{l}\text { Occurs in some rocks; also in mine runoff, industrial } \\
\text { wastewater discharge, and atmospheric deposi- } \\
\text { tion. }\end{array}$ & $\begin{array}{l}\text { Concentrations exceeding a natural, background } \\
\text { level indicate contamination from human activity; } \\
\text { in sufficient quantity, can cause water to be } \\
\text { unsuitable for public supply; can harm aquatic } \\
\text { organisms. }\end{array}$ \\
\hline Dissolved solids ............................ & $\begin{array}{l}\text { A result of rock weathering; also in agricultural runoff } \\
\text { and industrial discharge. }\end{array}$ & $\begin{array}{l}\text { In sufficient quantity, can cause water to be unsuitable } \\
\text { for public supply, agriculture, and industry; can } \\
\text { harm aquatic organisms. }\end{array}$ \\
\hline Nitrite plus nitrate ........................... & $\begin{array}{l}\text { Nonpoint sources are agricultural and urban runoff; } \\
\text { a major point source is wastewater discharge. }\end{array}$ & $\begin{array}{l}\text { Plant nutrient that, in sufficient quantity, can cause } \\
\text { algal blooms and excessive growth of higher } \\
\text { aquatic plants in bodies of water; can cause water } \\
\text { to be unsuitable for public supply. }\end{array}$ \\
\hline 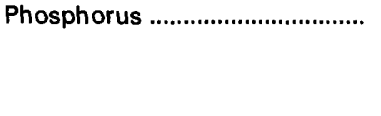 & $\begin{array}{l}\text { Occurs in some rocks and sediments; also in runoff } \\
\text { and seepage from phosphate-rock mines, agri- } \\
\text { cultural and urban runoff, and industrial and } \\
\text { municipal wastewater discharge. }\end{array}$ & $\begin{array}{l}\text { Plant nutrient that, in sufficient quantity, can cause } \\
\text { algal blooms and excessive growth of higher } \\
\text { aquatic plants in bodies of water. }\end{array}$ \\
\hline
\end{tabular}




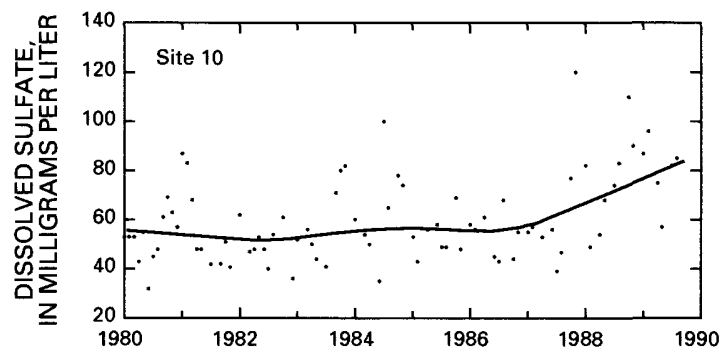

When possible, constituent-concentration data were adjusted for changes in streamflow to preclude identifying a trend in concentration that was caused only by a trend in streamflow. The data were not adjusted when (1) more than 10 percent of the samples had concentrations lower than the minimum reporting limit for the analytical method used or (2) streamflow was controlled substantially by human activities. When the concentration data could not be adjusted for streamflow, trends were determined directly from the concentration data.

Statewide trends in measurements of selected physical properties of stream water and in concentrations of selected constituents in stream water are shown on maps in figure 4 . On each map, a trend is indicated at a monitoring station only if the data from that station were suitable for use in the trend analysis. For more information on the suitability criteria and on the trend-analysis procedure used for this report, see Lanfear and Alexander (1990).

\section{SPECIFIC CONDUCTANCE}

Specific conductance is a measure of the ability of a sample of water to conduct electricity. Because specific conductance and the dissolved-solids concentration are roughly proportional in most natural waters, the specific-conductance value often can be used to estimate the dissolved-solids concentration (Hem, 1985, p. 66-68).

Increasing wastewater discharges and urban runoff in conjunction with less than average precipitation and resulting decreased dilution during 1987-89 probably caused the increasing specific conductance in the Fox River at site 5 and the Edwards River at site 12. Cropland and pasture are the major land uses in the drainage basins of the Kaskaskia and Embarras Rivers; a decrease in runoff containing agricultural chemicals, owing to the less than average precipitation of $1987-89$, probably caused the decreasing specific conductance at sites 14 and 19.

$\mathrm{pH}$

The $\mathrm{pH}$ of a sample of water is a measure of its hydrogen-ion activity (effective concentration). An increase in hydrogen-ion content causes water to become more acidic but results in a lower measured $\mathrm{pH}$ value because the units of $\mathrm{pH}$ are inversely related to hydrogen-ion activity. Both natural processes and human activities (table 1) can affect $\mathrm{pH}$. The $\mathrm{pH}$ of river water in most areas not affected by pollution is between about 6.5 and 8.5 (Hem, 1985, p. 64).

Changes in $\mathrm{pH}$ were small at the monitoring stations where trends were detected, and the values at most of the monitoring stations were within the IEPA standards. Less than average precipitation during 1987-89 and the resulting decrease in dilution of wastewatertreatment-plant discharge probably caused the upward trends in the Illinois River at site 4 and in the Sangamon River at site 10. Coalmine reclamation activities in the South Fork Saline River basin probably decreased acidic drainage to the river and allowed the increasing $\mathrm{pH}$ at site 16 , but values remained too low to meet the IEPA standards.

Decreasing $\mathrm{pH}$ in the Spoon, Edwards, and Embarras Rivers at sites 7,12 , and 19 probably resulted in part from the less than average precipitation and runoff during 1987-89. Acidic ground water, which can result from contact with coal deposits and from contamination with oil-field brines, became a larger component of streamflow owing to the diminished precipitation. Also, decreasing use of agricultural lime (University of Illinois College of Agriculture, 1990 , p. 51, fig. 10.3) in conjunction with the decrease in precipitation and runoff probably reduced the quantity of acid-neutralizing lime that entered the streams.

\section{DISSOLVED OXYGEN}

The dissolved-oxygen concentration in a stream is controlled by several factors, including water temperature, air temperature and pressure, hydraulic characteristics of the stream, photosynthetic or respiratory activity of stream biota, and the quantity of organic material present. A trend in dissolved-oxygen concentrations commonly is directly or indirectly the result of human activities. Generally, an upward trend in dissolved-oxygen concentrations indicates improving stream water-quality conditions and a downward trend indicates deteriorating conditions. Reductions in quantities of oxygen-depleting matter discharged by sewage-treatment plants in the Chicago metropolitan area and at Decatur probably caused the upward dissolved-oxygen trends in the Illinois River at site 4 and the Sangamon River at site 9 .

\section{FECAL COLIFORM BACTERIA}

Fecal coliform bacteria are used as indicators of fecal contamination from humans and other warm-blooded animals. Such contamination can introduce disease-causing viruses and bacteria into a stream.

Fecal coliform bacteria concentrations had no trend at any of the monitoring stations from which data met the criteria for trend analysis. These bacteria are short lived in well-oxygenated streams. If a monitoring station is too distant from a pollution source to obtain live bacteria for culturing, trends in bacteria numbers might not be detected.

\section{DISSOLVED SULFATE}

The major natural sources of sulfate in streams are rock weathering, volcanoes, and biochemical processes (Hem, 1985, p. 113). Human activities such as mining, waste discharge, and fossil-fuel combustion also can be important sources.

Coal is, or has been, mined in the four basins that had upward trends in sulfate concentrations; however, the increasing concentrations do not necessarily indicate increases in coal mining. Rather, the upward trends in the Rock, Kankakee, and Sangamon Rivers at sites $2,3,9$, and 10 might have been caused by a proportionately greater contribution of ground water-which traveled through the sulfur-rich coal deposits and coal-mine spoils-to streamflow during the 1987-89 drought. Coal-mine reclamation in the South Fork Saline River basin probably resulted in the decreasing sulfate concentration at site 16 .

\section{DISSOLVED SOLIDS}

Dissolved solids in stream water result primarily from rock weathering but also can be introduced as a byproduct of human activities (table 1). Concentrations generally are greatest in streams draining basins underlain by rocks and soils that contain easily dissolved minerals.

Dissolved-solids concentrations had no significant trend at any of the five sites from which data were suitable for trend analysis. Relatively unchanging wastewater treatment and land-use practices in the five river basins probably were the reasons for the absence of trends. 


\section{DISSOLVED NITRITE PLUS NITRATE}

Nitrite and nitrate are oxidized forms of nitrogen that together constitute most of the dissolved nitrogen in well-aerated streams. Nitrite readily oxidizes to nitrate in natural waters; therefore, nitrate generally is by far the more abundant of the two (Hem, 1985, p. 124).

Increased wastewater discharges and urban runoff in the Chicago metropolitan area probably caused the increasing nitrite plus nitrate concentration in the Illinois River at site 4. Cropland is a major land use in the basin; fertilizers applied to fields also are a potential source of nutrients, which can be transported to streams in runoff.

\section{TOTAL PHOSPHORUS}

The total phosphorus concentration of a water sample is a measure of the concentration of all forms of phosphorus present in the sample, dissolved and particulate. Human activities (table 1) can be important sources of phosphorus in streams. Improvements in
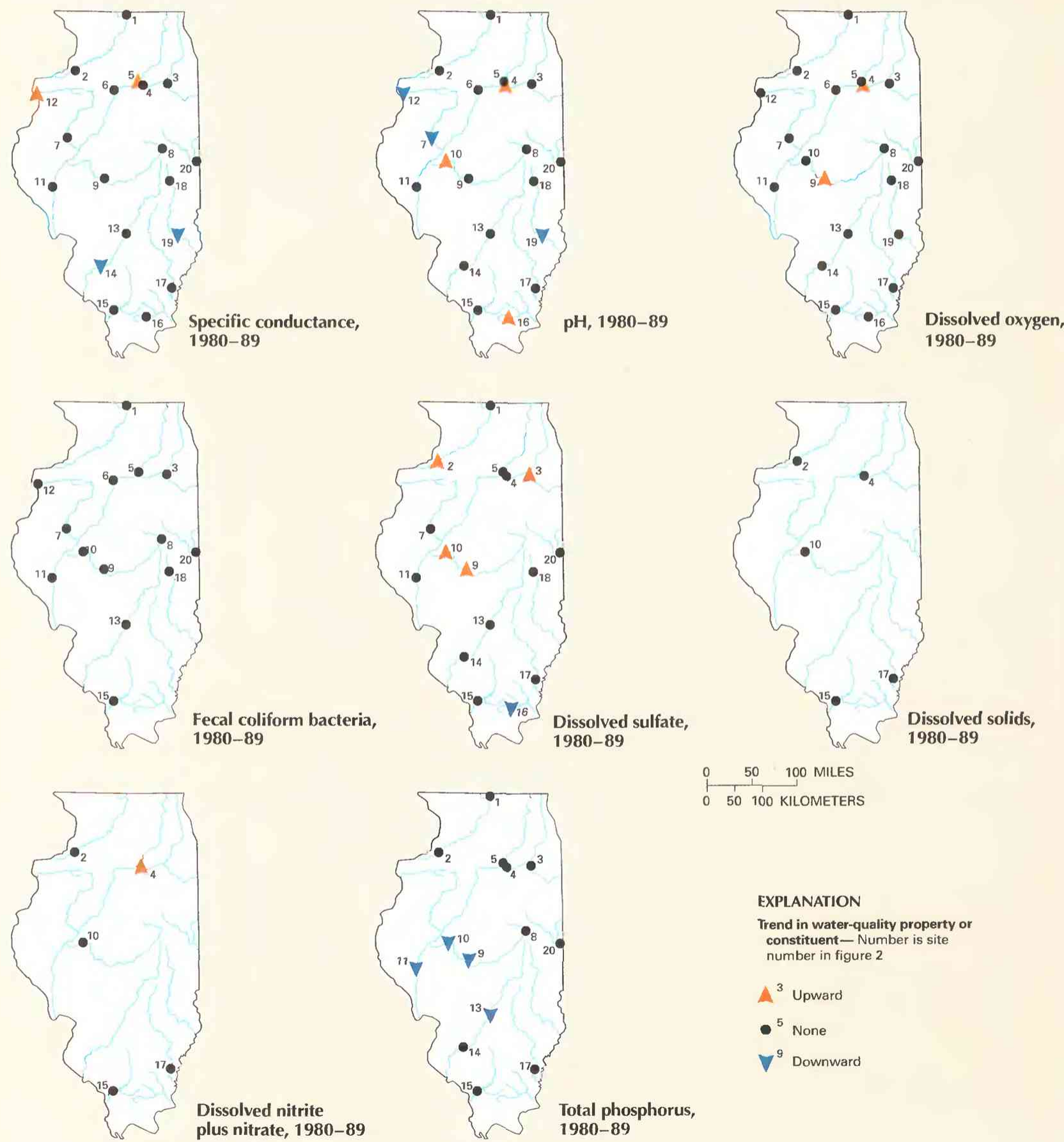

$\stackrel{50}{0} \quad 100$ MILES

Dissolved nitrite

plus nitrate, $1980-89$

Total phosphorus,

\section{EXPLANATION}

Trend in water-quality property or constituent - Number is site number in figure 2
$\AA^{3}$ Upward
${ }^{5}$ None
$\nabla^{9}$ Downward

Figure 4. Trends in water quality of selected streams in Illinois, by water years. (Sources: Data from U.S. Geological Survey files.) 
municipal wastewater-treatment-plant discharges and decreases in urban and agricultural runoff probably caused the decreasing phosphorus concentrations in the Sangamon River at sites 9 and 10, in the Illinois River at site 11, and in the Kaskaskia River at site 13.

\section{WATER-QUALITY MANAGEMENT}

The Illinois Environmental Protection Act of 1970 assigned a seven-member Pollution Control Board the responsibility of establishing the basic regulations and standards necessary for the preservation of the environment. The act also created and established the IEPA as the principal State agency for the implementation of environmental programs. This includes activities such as monitoring, planning, permitting, financial assistance administration, compliance assurance, and program management that are conducted to prevent, control, and abate water pollution in Illinois. The IEPA is responsible for the maintenance and updating of the State Water Quality Management Plan that identifies the State's goals and objectives pertaining to activities that may degrade water quality. The State's General Assembly designated the IEPA as the State Water Pollution Control Agency for all purposes of the Federal Clean Water Act. The Illinois Environmental Protection Act further established the Department of Energy and Natural Resources as the research and education arm of the State's environmental protection apparatus.

Illinois established the State Water Plan Task Force in 1980 to provide a means of coordinating the activities of State agencies responsible for water-resource management and water-pollution control. An overall State Water Plan was submitted to the Governor and legislature in January 1984, and the task force monitors the plan's implementation.

The IEPA participates in water-resource-management activities of the Association of State and Interstate Water Pollution Control Administrators, International Joint Commission of the Great Lakes Water Quality Board, Ohio River Valley Sanitation Commission, Upper Mississippi River Conservation Committee, and other interstate committees and commissions.

The IEPA has maintained an effective and efficient surfacewater-monitoring and assessment program since its inception in 1970. Adjustments and additions to the monitoring effort have been undertaken to keep pace with technological advances and broadening environmental concerns. Monitoring activities focus on water and sediment chemistry as well as on physiological and biological data (aquatic invertebrates, fisheries, and habitat). A comprehensive Surface Water Monitoring Strategy outlines monitoring programs, quality-assurance activities, laboratory-support needs, and data-management procedures. Results from each of the monitoring elements are used in a comprehensive report (Illinois Environmental Protection
Agency, 1988; 1990) prepared pursuant to section 305(b) of the Federal Clean Water Act, which requires that States submit biennial water-quality assessments to the EPA and the U.S. Congress (Joel Cross, Illinois Environmental Protection Agency, written commun., 1990).

\section{SELECTED REFERENCES}

Anderson, J.R., 1967, Major land uses in the United States, in U.S. Geological Survey, 1970, The National atlas of the United States of America: Washington, D.C., U.S. Geological Survey, p. 158-159.

Britton, L.J., and Greeson, P.E., eds., 1987, Methods for collection and analysis of aquatic biological and microbiological samples: U.S. Geological Survey Techniques of Water-Resources Investigations, book 5, chap. A4, $363 \mathrm{p}$.

Fenneman, N.M., 1946, Physical divisions of the United States: U.S. Geological Survey special map, scale 1:7,000,000.

Fishman, M.J., and Friedman, L.C., eds., 1989, Methods for the determination of inorganic substances in water and fluvial sediments: U.S. Geological Survey Techniques of Water-Resources Investigations, book 5, chap. A1, 545 p.

Hem, J.D., 1985, Study and interpretation of the chemical characteristics of natural water (3d ed.): U.S. Geological Survey Water-Supply Paper 2254, $263 \mathrm{p}$.

Hirsch, R.M., Slack, J.R., and Smith, R.A., 1982, Techniques of trend analysis for monthly water quality data: Water Resources Research, v. 18, no. 1. p. 107-121.

Illinois Environmental Protection Agency, 1988, Illinois water quality report 1986-1987: Springfield, Illinois Environmental Protection Agency, Division Water Pollution Control, IEPA/WPC/88-002, 305 p. 1990, Illinois water quality report 1988-1989: Springfield, Illinois Environmental Protection Agency, Division Water Pollution Control, IEPA/ WPC/90-160, $352 \mathrm{p}$.

Lanfear, K.J., and Alexander, R.B., 1990, Methodology to derive water-quality trends for use by the National Water Summary Program of the U.S. Geological Survey: U.S. Geological Survey Open-File Report 90-359, $10 \mathrm{p}$.

Thelin, G.P., and Pike, R.J., 1990, Digital shaded relief map of the conterminous United States: Menlo Park, Calif., U.S. Geological Survey digital image processing, scale 1:3,500,000.

U.S. Geological Survey, 1986, National water summary 1985-Hydrologic events and surface-water resources: U.S. Geological Survey Water-Supply Paper 2300, $506 \mathrm{p}$.

1990, National water summary 1987-Hydrologic events and water supply and use: U.S. Geological Survey Water-Supply Paper 2350, $553 \mathrm{p}$.

University of Illinois College of Agriculture, 1990, Illinois agronomy handbook-1991-1992: Urbana-Champaign, University of Illinois, Cooperative Extension Service Circular 1311, $126 \mathrm{p}$.

Ward, J.R., and Harr, C.A., eds., 1990, Methods for collection and processing of surface-water and bed-material samples for physical and chemical analyses: U.S. Geological Survey Open-File Report 90-140, 71 p.

Prepared by G.O. Balding and R.H. Coupe

FOR ADDITIONAL INFORMATION: District Chief, U.S. Geological Survey, 102 E. Main Street. 4th floor, Urbana. IL 61801 


\section{INDIANA Stream Water Quality}

Indiana is a water-rich agricultural and industrial State that has approximately 20,000 miles of rivers and streams large enough to support aquatic life throughout most of the year (Indiana Department of Environmental Management, undated, p. 2). Streams, rivers, and lakes supplied 93.2 percent (an average of 8,720 million gallons per day) of the water withdrawn for use in Indiana during 1985 (U.S. Geological Survey, 1990, p. 244). Ground water supplied the remaining 6.8 percent. Surface water was used for thermoelectric power generation (66.2 percent), industrial and mining applications (30.2 percent), public water supply ( 3.5 percent), and agriculture $(0.1$ percent) (U.S. Geological Survey, 1990, p. 247).

Water-quality standards have been adopted by the State to protect legally designated water uses. Nearly all rivers and streams in Indiana are designated for full-body-contact recreation and for aquatic-life uses (327 Indiana Administrative Code 2-1-3). Other

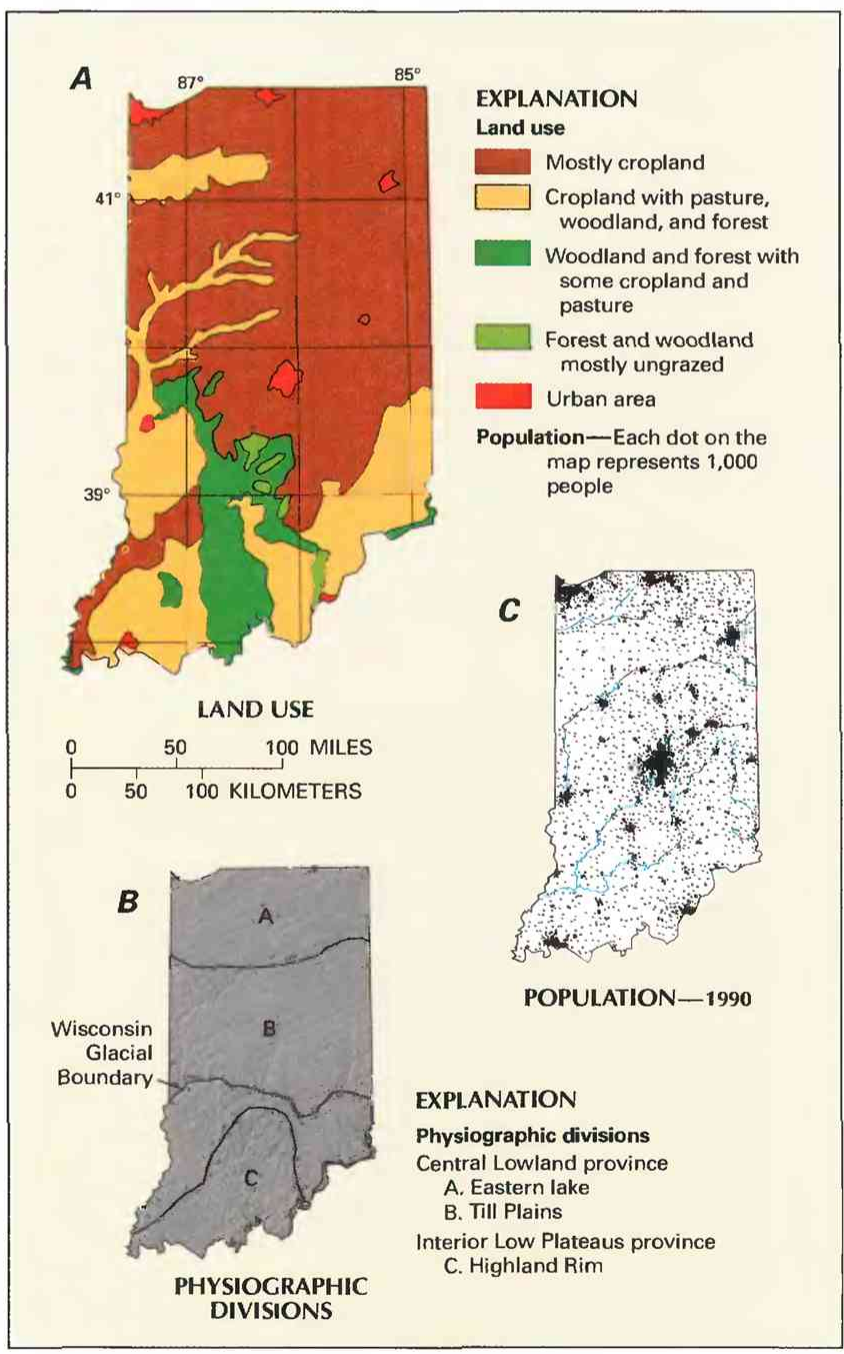

Figure 1. Land use, physiography, and population in Indiana. $A$ Major land uses. B. Physiographic divisions. C. Population distribution in 1990. ISources: A, Major land uses modified from Anderson, 1967. B, Physiographic divisions from Fenneman, 1946; landforms from Thelin and Pike, 1990 C. Data from U.S. Bureau of the Census 1990 decennial census files.) legally designated uses include public water supply, industrial water supply, agricultural use, limited use, and exceptional use (327 Indiana Administrative Code 2-1-3). Water bodies designated for limited use are those characterized by naturally poor physical or chemical quality or by irreversible human-caused conditions. Water bodies designated for exceptional use are those that provide unusual aquatic habitat, support unique aquatic organisms, or are of exceptional natural beauty. Many streams have multiple-use designations and the most protective water-quality standards apply.

Land use can substantially affect stream water quality. Approximately 70 percent of the land in Indiana is used for agriculture (Indiana Department of Environmental Management, undated, p. 1) (fig. 1A). Most of the land used for row crops (principally corn and soybeans) is on gently rolling glacial deposits in the Central Lowland (fig. $1 B$ ) and on flood plains along rivers and streams in the Interior Low Plateaus. Forest and pasture are the principal land uses in the unglaciated Interior Low Plateaus. Most of the population (fig. $1 C$ ) lives in cities and towns located on major rivers and streams. The population of Indiana was 5.5 million in 1990 (U.S. Bureau of the Census 1990 decennial census files), an increase of 6.7 percent from 1970.

Annual precipitation ranges from 36 inches in northeastern Indiana to 44 inches in the south-central part of the State. Precipitation is distributed throughout the year, but the greatest amounts typically fall in March through July (U.S. Geological Survey, 1986, p. 223). Annual runoff ranges from about 10 inches in northeastern Indiana to 18 inches in the south-central part of the State (Crawford and Mansue, 1988, p. 10). Streamflow is well sustained in the glaciated northern and central parts of the State but is poorly sustained in the southern, unglaciated region where many streams typically are dry during late summer or fall.

\section{WATER-QUALITY MONITORING}

Water-quality data obtained from analyses of water samples collected at monitoring stations are stored in the U.S. Geological Survey's (USGS) National Water Information System and the U.S. Environmental Protection Agency's (EPA) national data base known as STORET. Water-quality and streamflow data are reported by water year-the 12 months from October 1 through September 30. A water year is identified by the calendar year in which it ends. For example, water year 1991 comprises October 1, 1990, through September 30, 1991.

The data used in this summary of Indiana's stream water quality were obtained from water samples collected at six monitoring stations at which data collection is systematic and continuing (fig. 2). Data are collected at sites 1,2, and 4 to support national water-quality programs of the USGS. Sites 1 and 4 are maintained as part of the National Stream Quality Accounting Network, which supplies information concerning the physical and chemical properties of regional watersheds to resource managers. Site 2 is part of the Hydrologic Bench-Mark Network, a collection of stations used to monitor the flow and water quality in streams that are known to be minimally affected by human activity. Data are collected at sites 3, 5, and 6 to support local water-quality assessment projects.

Analyses of water samples collected at all six stations are the basis for the discussion and graphic summary (fig. 3) of stream waterquality conditions during water years 1987-89, and data from site 2 are the basis for the discussion and graphic summary (fig. 4) of stream 
water-quality trends. Water samples were collected and analyzed by using standard methods approved by the USGS (Britton and Greeson, 1987; Fishman and Friedman, 1989; Ward and Harr, 1990) or by using equivalent methods. If a method of sample collection or analysis changed over time, data from an analysis were included in the evaluation of recent stream water quality or of stream water-quality trends only if the change in method did not affect the comparability of the data.

\section{WATER-QUALITY CONDITIONS}

Approximately one-fourth of Indiana's 20,000 miles of streams that are potentially suitable for fishing and swimming were assessed in 1986 and 1987 for the degree of support of their legally designated use(s). Sixty-eight percent of the stream miles fully met the requirements for their designated use, 19 percent partially supported their designated use, and 13 percent did not support their designated use (Indiana Department of Environmental Management, undated, p. 5). Contamination attributed to overflows from combined septic and storm sewers, municipal and industrial wastewater discharges, and agricultural runoff accounted for the water-quality problems in most of the stream miles that failed to support their designated use (Indiana Department of Environmental Management, undated, p. 9, 11). The causes for nonsupport of designated uses most frequently identified were organic compounds [mostly polychlori-

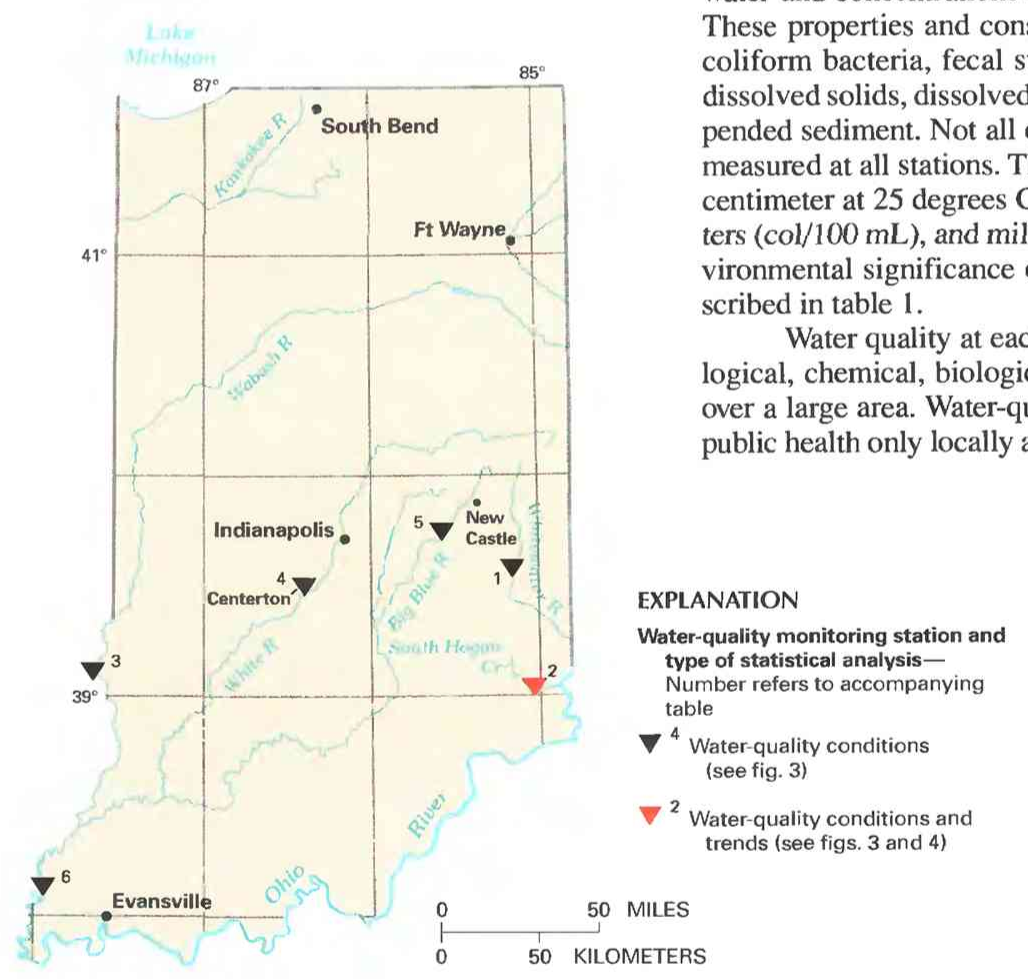

\begin{tabular}{|c|c|c|c|}
\hline $\begin{array}{l}\text { Site no. } \\
\text { on map }\end{array}$ & $\begin{array}{l}\text { USGS station } \\
\text { name and no. }\end{array}$ & $\begin{array}{l}\text { Drainage area } \\
\text { (square miles) }\end{array}$ & $\begin{array}{l}\text { Major land use } \\
\text { (see fig. 1) }\end{array}$ \\
\hline 1 & Whitewater River near Alpine $(03275000)$ & 522 & Cropland with pasture, woodland, and forest; urban areas. \\
\hline 3 & 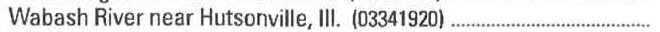 & 12,986 & Ditto. \\
\hline 4 & White River near Centerton (03354000) & 2,444 & Mostly cropland; urban areas. \\
\hline 5 & Big Blue River at Carthage $(03361000)$ & 184 & Mostly cropland. \\
\hline 6 & Wabash River at New Harmony $(03378500)$ & 29,234 & Ditto. \\
\hline
\end{tabular}

Figure 2. Selected water-quality monitoring stations, type of statistical analysis, and geographic features in Indiana. (Sources: Major land uses modified from Anderson, 1967; other data from U.S. Geological Survey files.) nated biphenyls (PCB's)], fecal coliform bacteria, biochemical oxygen demand, low concentrations of dissolved oxygen, organochlorine pesticides, and ammonia (Indiana Department of Environmental Management, undated, p. 9).

Fish-tissue samples and stream-bottom sediment samples from 2,306 stream miles were analyzed for selected synthetic organic compounds, metals, and other trace elements. Of the 2,306 stream miles assessed, 922 miles either contained fish whose tissues had concentrations of toxic compounds that exceeded U.S. Food and Drug Administration action levels or had concentrations of toxic compounds in bottom sediments that exceeded background concentrations (Indiana Department of Environmental Management, undated, p. 15, $44-46)$. On the basis of the fish-tissue analysis, a fish-consumption advisory was issued for 585 stream miles because of excessive concentrations of PCB's, chlordane, dieldrin, or heptachlor (Indiana Department of Environmental Management, undated, p. 31-34). Eighty-seven fishkills were reported during 1986-87; 31 percent of the fishkills were attributed to contamination caused by agricultural activities (Indiana Department of Environmental Management, undated, p. 21).

The following discussion of stream water quality in Indiana is organized by river basin (fig. 3). Graphs in figure 3 summarize certain aspects of stream water quality in the basins for water years 1987-89. The graphs show frequency distributions of data values that represent measurements of selected physical properties of stream water and concentrations of selected constituents in stream water. These properties and constituents are specific conductance, fecal nitrite plus nitrate (as nitrogen), and susCelsius $(\mu \mathrm{S} / \mathrm{cm})$, colonies per 100 millilice of each property and constituent are de-

Water quality at each monitoring station is the result of geoogical, chemical, biological, and hydrologic processes that occur over a large area. Water-quality problems that affect aquatic life or public health only locally are not fully represented in this summary. oring station

Number refers to accompanyin

(see fig. 3)

Water-quality co

50 MILES

KILOMETERS 


\section{WHITEWATER RIVER}

The Whitewater River is in the Till Plains; land use in the basin is primarily cropland with pasture, woodland, forest, and some urban areas. The concentrations of fecal coliform bacteria (median, 290 $\mathrm{col} / 100 \mathrm{~mL}$ ) and nitrite plus nitrate (median, $3.6 \mathrm{mg} / \mathrm{L}$ ) at site 1 (fig. 3) indicate contamination from sources that could include runoff from feedlots, runoff from land application of animal waste, urban runoff and combined-sewer overflows, or malfunctioning individual septic systems. Of the suspended-sediment samples collected at three sites, those collected at site 1 had the highest median concentration ( $23 \mathrm{mg} / \mathrm{L})$, which might have been caused by erosion of cropland.

South Hogan Creek is in the Till Plains in southern Indiana; land use in the basin is primarily forest, pasture, and cropland. Of the samples collected, those collected at site 2 had the lowest median values of specific conductance $(427 \mu \mathrm{S} / \mathrm{cm})$, dissolved solids $(248 \mathrm{mg} / \mathrm{L})$, nitrite plus nitrate $(0.1 \mathrm{mg} / \mathrm{L})$, and suspended sediment $(9 \mathrm{mg} / \mathrm{L})$ (fig. 3). However, water samples from site 2 had the highest median concentration of fecal streptococcal bacteria $(470 \mathrm{col} / 100$
$\mathrm{mL}$ ). The relatively low concentrations of most constituents probably can be attributed to the large area of forest and the small degree of agricultural and urban development in the basin. The high concentrations of fecal streptococcal bacteria (median, $470 \mathrm{col} / 100 \mathrm{~mL}$ ) and the occasionally high fecal coliform bacteria concentrations (75th percentile, $780 \mathrm{col} / 100 \mathrm{~mL}$ ) may have been caused by runoff from feedlots upstream from the monitoring station.

\section{SOUTH HOGAN CREEK}

South Hogan Creek is in the Till Plains in southern Indiana; land use in the basin is primarily forest, pasture, and cropland. Of the samples collected, those collected at site 2 had the lowest median values of specific conductance $(427 \mu \mathrm{S} / \mathrm{cm})$, dissolved solids (248 $\mathrm{mg} / \mathrm{L})$, nitrite plus nitrate $(0.1 \mathrm{mg} / \mathrm{L})$, and suspended sediment ( $9 \mathrm{mg} / \mathrm{L}$ ) (fig. 3). However, water samples from site 2 had the highest median concentration of fecal streptococcal bacteria $(470 \mathrm{col} / 100$ $\mathrm{mL}$. The relatively low concentrations of most constituents probably can be attributed to the large area of forest and the small degree of
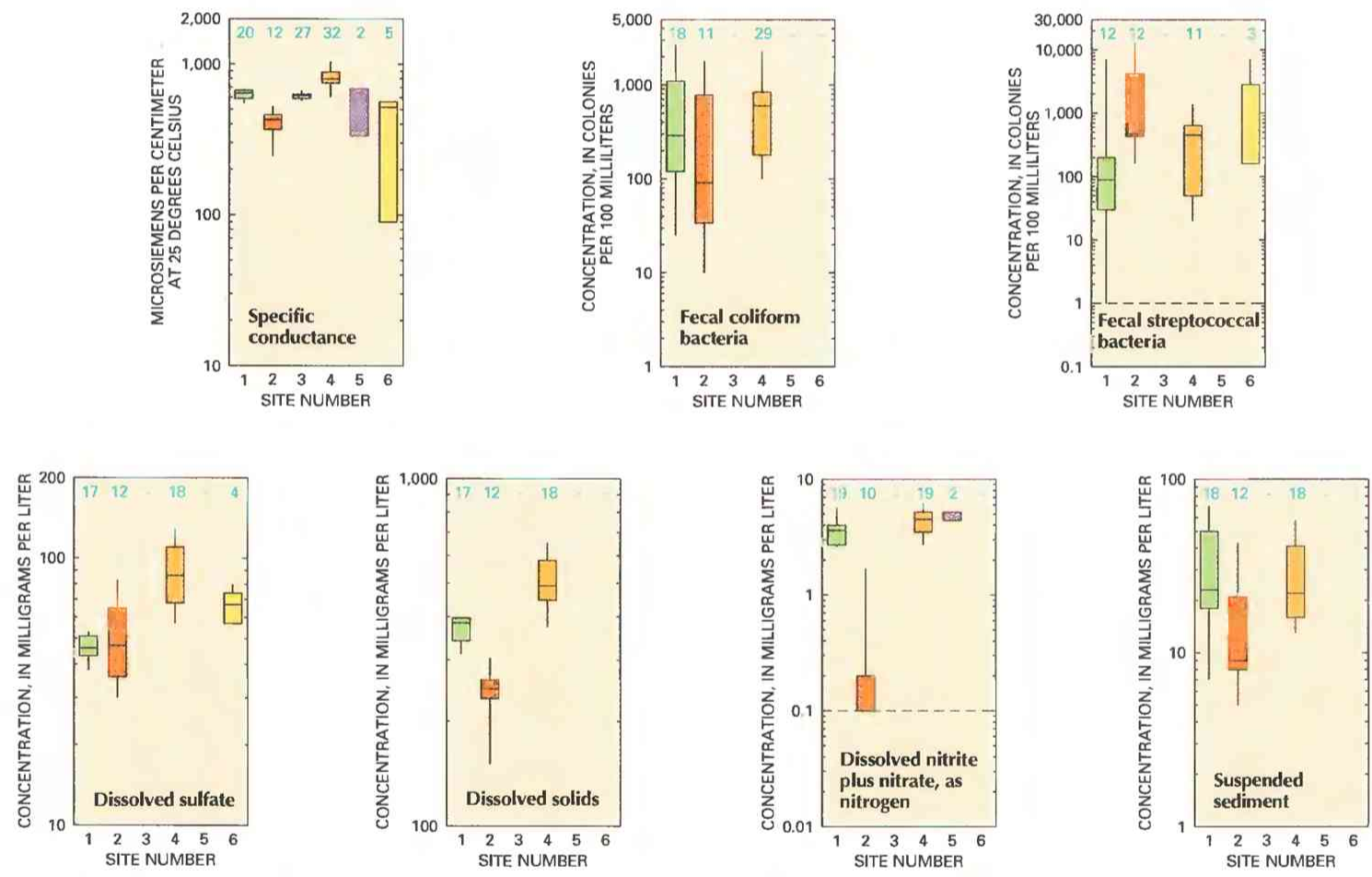

\section{EXPLANATION}
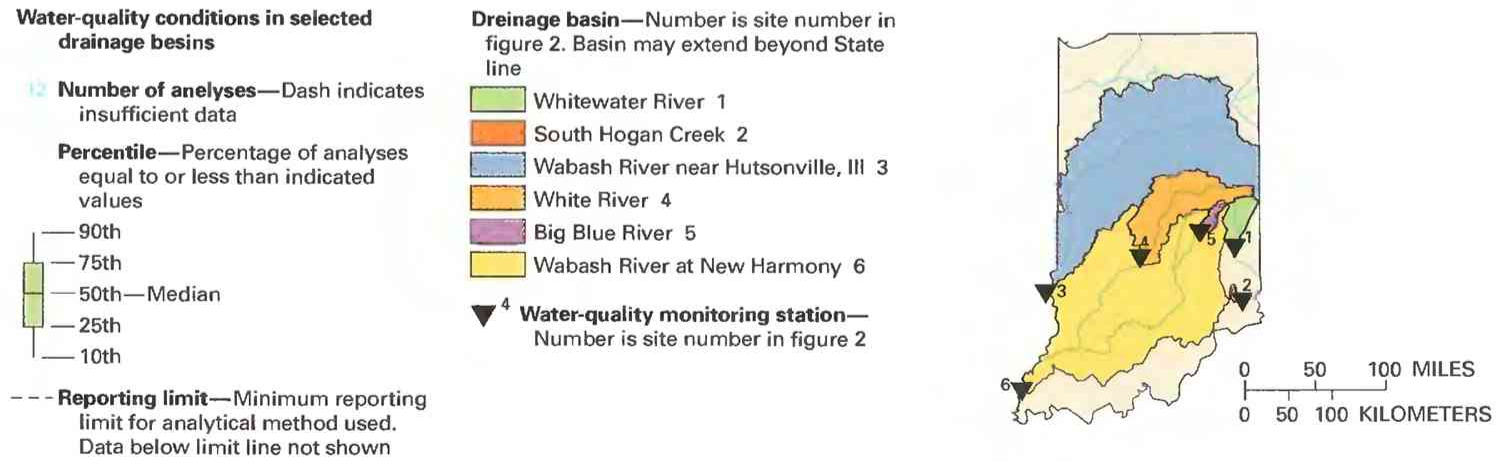

Figure 3. Water quality of selected streams in Indiana, water years 1987-89. (Source: Data from U.S. Geological Survey files.) 
Table 1. Sources and environmental significance of selected water-quality properties and constituents [Source: Compiled by the U.S. Geological Survey, Office of Water Quality]

\begin{tabular}{|c|c|c|}
\hline Property or constituent & Common sources & Environmental significance \\
\hline $\begin{array}{l}\text { Specific conductance } \\
\text { (property) }\end{array}$ & $\begin{array}{l}\text { A measure of the electrical conductivity of water; var- } \\
\text { ies with the quantity of dissolved solids and is } \\
\text { used to approximate the dissolved-solids content. }\end{array}$ & $\begin{array}{l}\text { Dissolved solids can cause water to be unsuitable for } \\
\text { public supply, agriculture, and industry; can harm } \\
\text { aquatic organisms. }\end{array}$ \\
\hline $\begin{array}{l}\text { Fecal coliform and fecal ............. } \\
\text { streptococcal bacteria }\end{array}$ & $\begin{array}{l}\text { Sources include effluent from sewage-treatment } \\
\text { plants and runoff from pastures, feedlots, and ur- } \\
\text { ban areas. }\end{array}$ & $\begin{array}{l}\text { Presence indicates contamination of water by wastes } \\
\text { from humans and other warm-blooded animals. }\end{array}$ \\
\hline 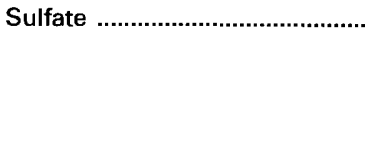 & $\begin{array}{l}\text { Occurs in some rocks; also in mine runoff, industrial } \\
\text { wastewater discharge, and atmospheric deposi- } \\
\text { tion. }\end{array}$ & $\begin{array}{l}\text { Concentrations exceeding a natural, background } \\
\text { level indicate contamination from human activity; } \\
\text { in sufficient quantity, can cause water to be } \\
\text { unsuitable for public supply; can harm aquatic } \\
\text { organisms. }\end{array}$ \\
\hline Dissolved solids .............................. & $\begin{array}{l}\text { A result of rock weathering; also in agricultural runoff } \\
\text { and industrial discharge. }\end{array}$ & $\begin{array}{l}\text { In sufficient quantity, can cause water to be unsuitable } \\
\text { for public supply, agriculture, and industry; can } \\
\text { harm aquatic organisms. }\end{array}$ \\
\hline Nitrite plus nitrate ......................... & $\begin{array}{l}\text { Nonpoint sources are agricultural and urban runoff; } \\
\text { a major point source is wastewater discharge. }\end{array}$ & $\begin{array}{l}\text { Plant nutrient that, in sufficient quantity, can cause } \\
\text { algal blooms and excessive growth of higher } \\
\text { aquatic plants in bodies of water; can cause water } \\
\text { to be unsuitable for public supply. }\end{array}$ \\
\hline Suspended sediment .................. & $\begin{array}{l}\text { A result of rock erosion; also induced by disturbances } \\
\text { of land cover due to fires, floods, and human } \\
\text { activities such as mining, logging, construction, } \\
\text { and agriculture. }\end{array}$ & $\begin{array}{l}\text { Can be detrimental to aquatic organisms; can fill res- } \\
\text { ervoirs and impair recreational use of water. }\end{array}$ \\
\hline
\end{tabular}

agricultural and urban development in the basin. The high concentrations of fecal streptococcal bacteria (median, $470 \mathrm{col} / 100 \mathrm{~mL}$ ) and the occasionally high fecal coliform bacteria concentrations (75th percentile, $780 \mathrm{col} / 100 \mathrm{~mL}$ ) may have been caused by runoff from feedlots upstream from the monitoring station.

\section{WABASH RIVER}

All four monitoring stations on Wabash River basin streams (sites 3-6) are in the Till Plains. Land use in these drainage basins primarily is cropland, but there is substantial urbanization along the White River upstream from Centerton (site 4). Site 4 is approximately 28 miles downstream from Indianapolis. The White River receives treated municipal wastewater from the city's two wastewater-treatment plants as well as from other treatment plants upstream.

Compared to all samples, those collected from the White River at site 4 had the highest median values of specific conductance (797 $\mu \mathrm{S} / \mathrm{cm})$, fecal coliform bacteria $(600 \mathrm{col} / 100 \mathrm{~mL})$, sulfate $(86$ $\mathrm{mg} / \mathrm{L})$, dissolved solids $(491 \mathrm{mg} / \mathrm{L})$, and nitrite plus nitrate $(4.5$ $\mathrm{mg} / \mathrm{L}$ ) (fig. 3). High concentrations of these constituents in this basin have human-related sources, which include industrial and municipal wastewater, combined-sewer overflows, and urban and agricultural runoff.

Samples collected from the Big Blue River at site 5 had relatively high concentrations of nitrite plus nitrate (median, $4.4 \mathrm{mg} / \mathrm{L}$ ) (fig. 3). The high concentrations probably were caused by runoff from agricultural land or from the discharge of treated municipal wastewater. Near New Castle, the Big Blue River is contaminated with metals from the discharge of two steel mills (Indiana Department of Environmental Management, undated, p. 137). The Wabash River between sites 3 and 6 , and several miles upstream from site 3, fully supports aquatic life and recreational uses (Indiana Department of Environmental Management, undated, p. 113).

\section{WATER-QUALITY TRENDS}

Trend analysis is a statistical procedure used to detect changes in stream water quality at a monitoring station over time. For this report, water-quality data were analyzed for trends by using the seasonal Kendall test (Hirsch and others, 1982), a method used extensively by the USGS. Water-quality data sufficient for trend analysis were available only for South Hogan Creek at site 2 (fig. 2). The longest period of record available for each property or constituent was used for trend analysis. The graph (shown below) of dissolved-sulfate concentrations in South Hogan Creek st site 2 illustrates the trend inferred from the concentration data and demonstrates the variation in water quality that is common in streams.

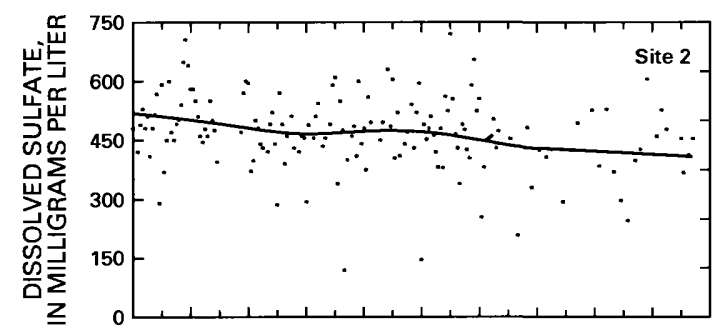

When possible, constituent-concentration data were adjusted for changes in streamflow to preclude identifying a trend in concentration that was caused only by a trend in streamflow. The data were not adjusted when (1) more than 10 percent of the samples had concentrations lower than the minimum reporting limit for the analytical method used or (2) streamflow was controlled substantially by human activities. When the concentration data could not be adjusted for streamflow, trends were determined directly from the concentration data.

Statewide trends in measurements of selected physical properties of stream water and in concentrations selected constituents in stream water are shown on maps in figure 4 . On each map, a trend is indicated at a monitoring station only if the data from that station were suitable for use in the trend analysis. For more information on the suitability criteria and on the trend-analysis procedure used for this report, see Lanfear and Alexander (1990).

\section{SPECIFIC CONDUCTANCE}

Specific conductance is a measure of the ability of a sample of water to conduct electricity. Because specific conductance and the dissolved-solids concentration are roughly proportional in most natural waters, the specific-conductance value commonly can be used to estimate the dissolved-solids concentration (Hem, 1985, p. 66-68). The downward trend in specific conductance in South Hogan Creek at site 2 (fig. 4) might have been the result of improvements in wastewater treatment during 1970-89 upstream from the monitoring station. 


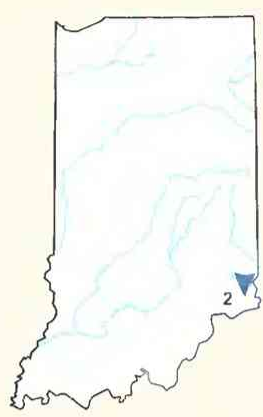

Specific conductance, 1970-89

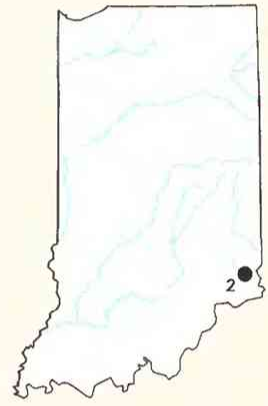

Dissolved solids, 1970-89

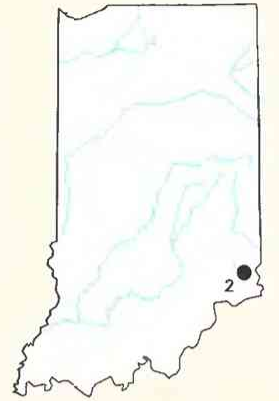

Fecal coliform bacteria, 1980-89

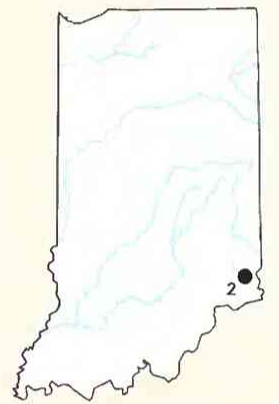

Dissolved nitrite plus nitrate, 1980-89

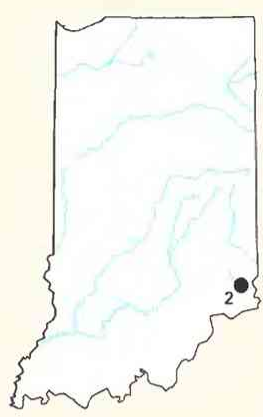

Fecal streptococcal bacteria, 1975-89

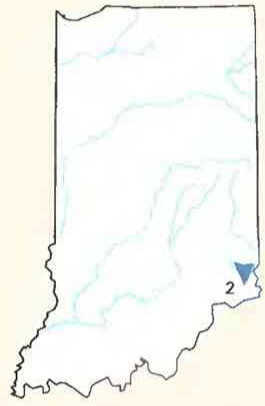

Suspended sediment, 1980-89

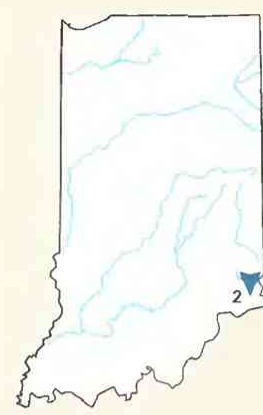

Dissolved sulfate, 1970-89

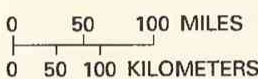

EXPLANATION

Trend in water-quality property or constituent- Number is site number in figure 2

${ }^{2}$ None

$\nabla^{2}$ Downward

Figure 4. Trends in water quality of selected streams in Indiana, by water years. (Source: Data from U.S. Geological Survey files.)

\section{FECAL COLIFORM AND FECAL STREPTOCOCCAL BACTERIA}

Fecal coliform bacteria and fecal streptococcal bacteria are used as indicators of fecal contamination from humans and other warm-blooded animals. Such contamination can introduce diseasecausing viruses and bacteria into a stream.

The concentration of fecal coliform bacteria at site 2 did not change significantly during $1980-89$ (fig. 4). Also, the concentration of fecal streptococcal bacteria at site 2 did not change significantly during 1975-89 (fig. 4).

\section{DISSOLVED SULFATE}

The major natural sources of sulfate in streams are rock weathering, volcanoes, and biochemical processes (Hem, 1985, p. 113). Human activities such as mining, waste discharge, and fossil-fuel combustion also can be important sources. The downward trend in sulfate concentrations at site 2 for water years 1970-89 (fig. 4) might indicate improvement in the quality of wastewater discharge upstream from the monitoring station.

\section{DISSOLVED SOLIDS}

Dissolved solids in stream water result primarily from rock weathering but also can be introduced as a byproduct of human activities (table 1). Concentrations generally are greatest in streams draining basins underlain by rocks and soils that contain easily dissolved minerals. The absence of a trend in dissolved-solids concentration at site 2 (fig. 4) indicates that the processes contributing dissolved solids to the stream or transporting dissolved solids in the stream did not change during 1970-89.

\section{DISSOLVED NITRITE PLUS NITRATE}

Nitrite and nitrate are oxidized forms of nitrogen that together normally constitute most of the dissolved nitrogen in well-aerated streams. Nitrite readily oxidizes to nitrate in natural waters; therefore, nitrate generally is by far the more abundant of the two (Hem, 1985 , p. 124). The absence of a trend in nitrite plus nitrate concentrations at site 2 (fig. 4) indicates either that the processes contributing nitrite plus nitrate to the stream or transporting nitrite plus nitrate in the stream did not change significantly during $1980-89$ or that changes in the processes contributing or transporting nitrite plus nitrate have been masked by changes in streamflow (Hirsch and others, 1982, p. 120).

\section{SUSPENDED SEDIMENT}

Suspended sediment is a product of erosion. The erosion can be either natural or the result of land-cover disturbances related to human activities (table 1). The downward trend in suspendedsediment concentrations at site 2 (fig. 4) might have been the result of a decrease in row-crop farming in the basin or successful application of erosion control measures.

\section{WATER-QUALITY MANAGEMENT}

Indiana statutes IC 13-1 and IC 13-7 provide legal authority to the Indiana Department of Environmental Management and the Water Pollution Control Board to regulate and manage the water quality of Indiana's lakes, rivers, streams, and other water bodies. The Water Pollution Control Board, which consists of four ex-officio 
members and five members appointed by the Governor of Indiana, is given authority to adopt rules to protect, maintain, and enhance the quality of Indiana's water bodies. These rules, which have the force of law, govern various aspects of water-quality management including State water-quality standards, National Pollutant Discharge Elimination System permits, construction permits, and land application of wastes. The Indiana Department of Environmental Management is responsible for implementing and enforcing the rules of the Water Pollution Control Board.

The Indiana Department of Environmental Management also is responsible for preparing a biennial State water-quality report to the U.S. Congress and the EPA (Indiana Department of Environmental Management, undated). This report, mandated by section 305(b) of the Federal Clean Water Act, summarizes various State waterquality programs and activities and assesses water-quality conditions and trends. Indiana, represented by the Indiana Department of Environmental Management, is a member of several interstate or international organizations that work to maintain and improve water quality. Among these are the Ohio River Valley Sanitation Commission, the International Joint Commission, the Association of State and Interstate Water Pollution Control Administrators, and the Great Lakes Governors' Task Force.

Since the early 1970 's, water-quality monitoring by the State has increased substantially in Indiana. The number of fixed waterquality monitoring stations at which monthly water samples are collected and analyzed has increased, and the number of parameters examined also has increased. Samples for detection of toxic organic compounds now are collected quarterly at selected stations. Monitoring of toxic substances in fish tissue and sediments in selected streams began in 1979 and has been expanded to include many other Indiana streams and lakes. The State now periodically monitors for toxic substances in addition to conducting routine sampling inspections at sewage-treatment plants and industries. The State also conducts bioassay studies on the effluent of a variety of dischargers.

The Indiana Department of Environmental Management uses water-quality and sediment data collected by the USGS when applicable to State surveys or studies. Streamflow data collected and published by the USGS are used for several purposes by the Indiana Department of Environmental Management.

\section{SELECTED REFERENCES}

Anderson, J.R., 1967, Major land uses in the United States, in U.S. Geological Survey, 1970, National atlas of the United States of America: Washington, D.C., U.S. Geological Survey, p. 158-159.

Britton, L.J., and Greeson, P.E., eds., 1987, Methods for collection and analysis of aquatic biological and microbiological samples: U.S. Geological Survey Techniques of Water-Resources Investigations, book 5, chap. A4, $363 \mathrm{p}$.

Crawford, C.G., and Mansue, L.J., 1988, Suspended-sediment characteristics of Indiana streams, 1952-84: U.S. Geological Survey Open-File Report $87-527,79 \mathrm{p}$.

Fenneman, N.M., 1946, Physical divisions of the United States: Washington, D.C., U.S. Geological Survey special map, scale 1:7,000,000.

Fishman, M.J., and Friedman, L.C., eds., 1989, Methods for the determination of inorganic substances in water and fluvial sediments: U.S. Geological Survey Techniques of Water-Resources Investigations, book 5, chap. Al, 545 p.

Hem, J.D., 1985, Study and interpretation of the chemical characteristics of natural water (3d ed.): U.S. Geological Survey Water-Supply Paper 2254, $263 \mathrm{p}$.

Hirsch, R.M., Slack, J.R., and Smith, R.A., 1982, Techniques of trend analysis for monthly water quality data: Water Resources Research, v. 18, no. 1 , p. $107-121$.

Indiana Department of Environmental Management, undated, Indiana 305(b) report, 1986-87: Indianapolis, Indiana Department of Environmental Management, $231 \mathrm{p}$.

Lanfear, K.J., and Alexander, R.B., 1990, Methodology to derive water-quality trends for use by the National Water Summary Program of the U.S. Geological Survey: U.S. Geological Survey Open-File Report 90-359, $10 \mathrm{p}$.

Thelin, G.P., and Pike, R.J., 1990, Digital shaded relief map of the conterminous United States: Menlo Park, Calif., U.S. Geological Survey digital image processing, scale 1:3,500,000.

U.S. Geological Survey, 1986, National water summary 1986-Hydrologic events and surface-water resources: U.S. Geological Survey WaterSupply Paper 2300, 506 p.

1990, National water summary 1987-Hydrologic events and water supply and use: U.S. Geological Survey Water-Supply Paper 2350, $553 \mathrm{p}$.

Ward, J.R., and Harr, C.A., eds., 1990, Methods for collection and processing of surface-water and bed-material samples for physical and chemical analyses: U.S. Geological Survey Open-File Report 90-140, 71 p.

Prepared by E.R. Bayless and J.D. Martin, U.S. Geological Survey; “Water-Quality Management” section by D.E. Clark, Indiana Department of Environmental Management

FOR ADDITIONAL INFORMATION: District Chief, U.S. Geological Survey, 5957 Lakeside Boulevard, Indianapolis, IN 46278 


\section{IowA}

\section{Stream Water Quality}

The landscape of Iowa reflects a history of glaciation (Prior, 1976 , p. 22) and is characterized by numerous rivers, fertile soils, moderate relief, and gently inclined strata. Land use is predominantly agriculture, mostly cropland (fig. $1 A$ ), and has been determined in large part by physiography (fig. $1 B$ ).

About one-quarter of Iowa's population (fig. $1 C$ ) is served by public water supplies from surface-water sources (Clark and Thamke, 1988 , p. 27). The State's population in 1990 was 2.9 million, a 4.7percent decrease since 1980 (U.S. Bureau of the Census 1990 decennial census files).

Surface-water uses in Iowa are many and include public, rural, and industrial supply; livestock watering; irrigation; mining; energy production; wastewater disposal; habitat for fish and other biota; esthetics; recreation; and navigation. Surface water withdrawn for offstream uses during 1985 averaged 2,090 Mgal/d (million gallons per day), or about 76 percent of the total offstream use in Iowa (U.S. Geological Survey, 1990, p. 254). Most offstream surface-water withdrawals were used for thermoelectric power generation $(1,800$
$\mathrm{Mgal} / \mathrm{d})$, water supply for industry and mining (138 Mgal/d), and public water supply $(91 \mathrm{Mgal} / \mathrm{d})$.

The statewide annual precipitation is 32 inches. Ninety-two percent of that quantity is rain, which falls mostly during summer and early fall (U.S. Geological Survey, 1986, p. 229). About 26 inches is lost annually to evapotranspiration; the greatest loss is during the summer growing season. During periods of less than normal precipitation, surface-water supplies can become critically deficient, particularly in western and south-central Iowa. Reservoir storage is an alternative by which water is stored and made available for use.

\section{WATER-QUALITY MONITORING}

To many users, the quality of water in Iowa's streams and rivers can be as important as the quantity. Federal and State agencies monitor Iowa's waters to obtain data useful in protecting the quality of those waters for instream and offstream uses. Water-quality data obtained from analyses of water samples collected at monitoring stations are stored in the U.S. Geological Survey's (USGS) National Water Information System and the U.S. Environmental Protection Agency's (EPA) national data base known as STORET. Water-quality and streamflow data are reported by water year-the 12 months from October 1 through September 30. A water year is identified by the calendar year in which it ends. For example, water year 1991 comprises October 1, 1990, through September 30, 1991.

The data used in this summary of Iowa's stream water quality were obtained from water samples collected at 14 monitoring stations at which data collection is systematic and continuing (fig. 2). Analyses of water samples collected at 7 stations are the basis for the discussion and graphic summary (fig. 3) of stream waterquality conditions during water years 1987-89, and data from 12 stations are the basis for the discussion and graphic summary (fig. 4) of stream water-quality trends. Water samples were collected and analyzed by using standard methods approved by the USGS (Britton and Greeson, 1987; Fishman and Friedman, 1989; Ward and Harr, 1990) or by using equivalent methods. If a method of sample collection or analysis changed over time, data from an analysis were included in the evaluation of recent stream water quality or of stream
Figure 1. Land use, physiography, and population in lowa. A, Major land uses. B, Physiographic divisions. C, Population distribution in 1990. (Sources: A, Major land uses modified from Anderson, 1967. B, Physiographic divisions from Prior, 1976; landforms from Thelin and Pike, 1990. C, Data from U.S. Bureau of the Census 1990 decennial census files.)

\section{EXPLANATION}

A. Northwest lowa Plain

C. Missouri Alluvial Plain

D. Des Moines Lobe

F. Iowan Surface

G.Paleozoic Platea

H. Mississippi Alluvial Plain

PHYSIOGRAPHIC DIVISION 
water-quality trends only if the change in method did not affect the comparability of the data.

\section{WATER-QUALITY CONDITIONS}

For purposes of water-quality monitoring and protection, State water-quality standards have been established for designated uses in 18,300 stream miles, 48,970 lake acres, 31,700 reservoir acres, and 36,850 wetland acres (Iowa Department of Natural Resources, 1990). Of the 7,155 stream miles assessed during water years $1988-89$ by the Iowa Department of Natural Resources (IDNR), 7 percent were described as not supporting designated uses, 92 percent as partially supporting designated uses, and 1 percent as fully supporting designated uses but threatened (Iowa Department of Natural Resources, 1990). Sediment, nutrients, and pesticides, primarily attributed to agricultural nonpoint sources, were identified as affecting 99 percent of the stream miles that did not fully support designated uses. Metals, including mercury and copper, were identified as having an effect on about 6 percent of the stream miles that did not fully support designated uses. Sources of metals include industrial and municipal point sources and naturally occurring soils and rock formations. Fecal coliform bacteria affected 6 percent of the miles designated for swimming, water skiing, and other contact recreation. Agricultural nonpoint sources and discharges from municipal wastewater-treatment facilities are sources of fecal coliform bacteria.
A review of water-quality data by the IDNR (1989) indicated that the frequency of water-quality-standards violations for dissolved oxygen, $\mathrm{pH}$, and ammonia nitrogen commonly increases during periods of low water levels and increased water temperatures. However, concentrations of fecal coliform bacteria, nitrates, and suspended sediment commonly decreased in periods of little runoff resulting from drought during 1988-89. Precipitation and runoff during the drought were near record lows (U.S. Geological Survey, 1988$89 ; 1991$, p. 279-286).

Iowa is the second-largest user of pesticides in the Nation (Iowa Department of Natural Resources, 1987, p. 17). Pesticides were identified as having minor to moderate effects on 91 percent of the stream miles assessed during 1988-89, reflecting the widespread use of pesticides in the State (Iowa Department of Natural Resources, 1990). The pesticides most frequently detected in Iowa surface water are alachlor, atrazine, cyanazine, metolachlor, and metribuzin (U.S. Geological Survey, 1988-89). Pesticide concentrations exceeded EPA health advisories or proposed maximum contaminant levels for alachlor $[2 \mu \mathrm{g} / \mathrm{L}$ (micrograms per liter)], atrazine $(3 \mu \mathrm{g} / \mathrm{L})$, or cyanazine $(10 \mu \mathrm{g} / \mathrm{L})$ in water samples collected by the USGS at 16 of 19 sampling sites during spring runoff periods in 1989 (Don Goolsby, U.S. Geological Survey, written commun., November 1989).

The following discussion of stream water quality in Iowa is organized by river basin (fig. 3). Where physiographic and land-use characteristics in different basins are similar, the discussion of those

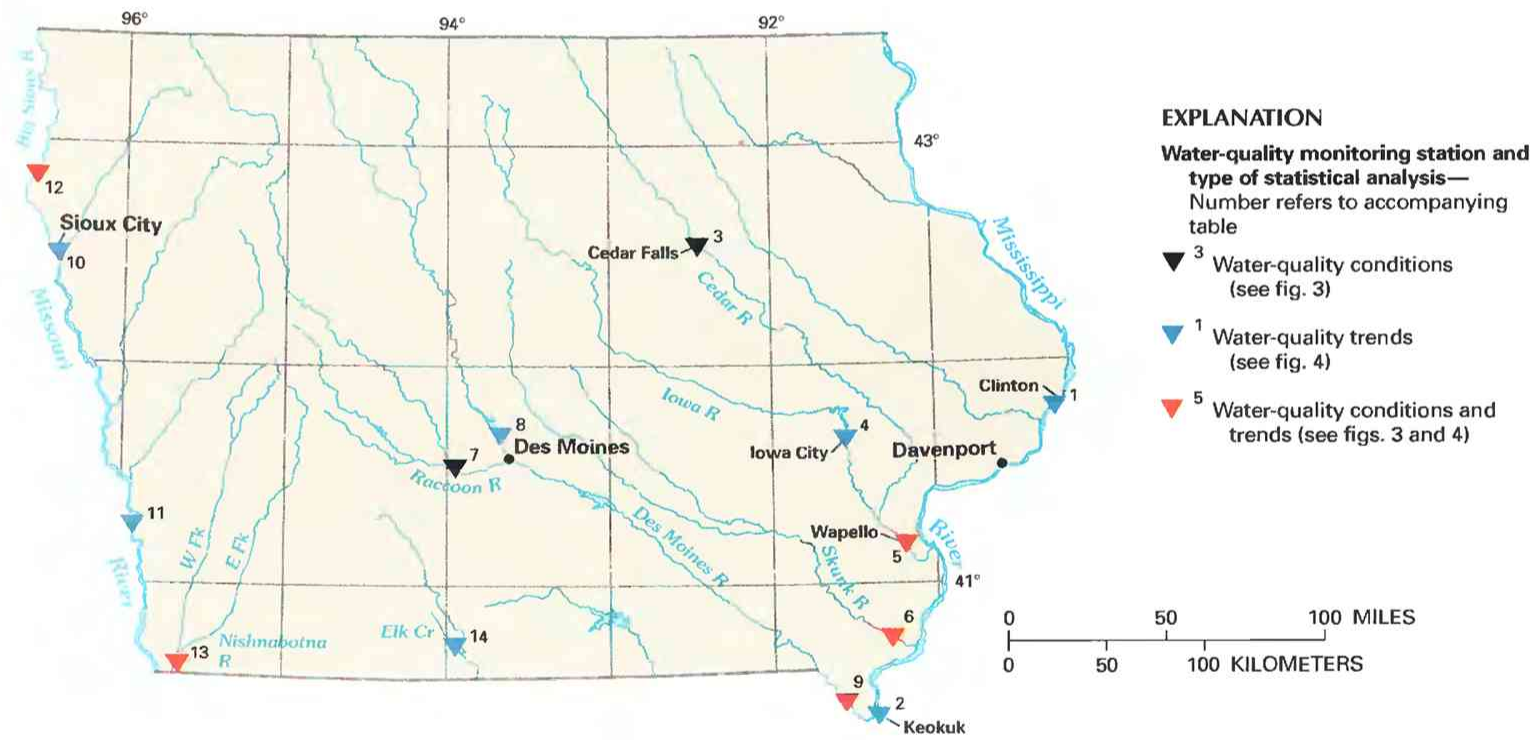

\begin{tabular}{|c|c|c|c|}
\hline $\begin{array}{l}\text { Site no. } \\
\text { on map }\end{array}$ & $\begin{array}{l}\text { USGS station } \\
\text { name and no. }\end{array}$ & $\begin{array}{l}\text { Drainage area } \\
\text { (square miles) }\end{array}$ & $\begin{array}{l}\text { Major land use } \\
\text { (see fig. 1) }\end{array}$ \\
\hline 1 & 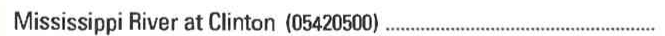 & 85,600 & Cropland with pasture, woodland, and forest. \\
\hline 2 & 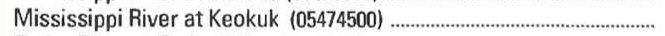 & 119,000 & Mostly cropland. \\
\hline 3 & Cedar River at Cedar Falls (05463050) & 4,734 & Ditto. \\
\hline 4 & lowa River at lowa City (05454500) & 3,271 & Ditto. \\
\hline 5 & lowa River at Wapello $(05465500)$ & 12,499 & Ditto. \\
\hline 6 & Skunk River at Augusta $(05474000)$ & 4,303 & Ditto. \\
\hline 7 & Raccoon River at Van Meter $(05484500)$ & 3,441 & Ditto. \\
\hline 8 & 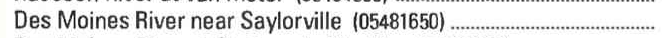 & 5,841 & Ditto. \\
\hline 9 & 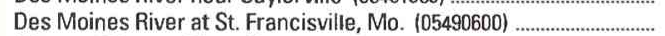 & 14,300 & Ditto. \\
\hline 10 & Missouri River at Sioux City (06486000) & 314,600 & Subhumid grassiand and semiarid grazing land; mostly cropland. \\
\hline 11 & 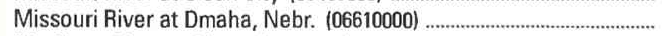 & 322,800 & Ditto. \\
\hline 12 & Big Sioux River at Akron $(06485500)$ & 8,424 & Mostly cropland. \\
\hline 13 & 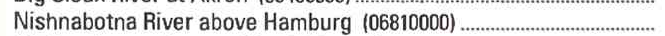 & 2,806 & Ditto. \\
\hline 14 & Elk Creek near Decatur City (06897950) & 53 & Ditto. \\
\hline
\end{tabular}

Figure 2. Selected water-quality monitoring stations, type of statistical analysis, and geographic features in lowa. (Sources: Major land uses modified from Anderson, 1967; other data from U.S. Geological Survey files.) 
basins is combined. Graphs in figure 3 summarize certain aspects of stream water quality in the basins for water years $1987-89$. The graphs show frequency distributions of data values that represent measurements of selected physical properties of stream water and concentrations of selected constituents in stream water. These properties and constituents are specific conductance, dissolved oxygen, dissolved sulfate, dissolved solids, dissolved nitrite plus nitrate (as nitrogen), dissolved phosphorus (as phosphorus), and suspended sediment. The data are reported in microsiemens per centimeter at 25 degrees Celsius $(\mu \mathrm{S} / \mathrm{cm})$ and milligrams per liter $(\mathrm{mg} / \mathrm{L})$. Sources and environmental significance of each property and constituent are described in table 1.

Water quality at each monitoring station is the result of geological, chemical, biological, and hydrologic processes that occur over a large area. Water-quality problems that affect aquatic life or public health only locally are not fully represented in this summary.

\section{CEDAR AND IOWA RIVERS}

The Cedar and Iowa Rivers drain a large part of central and eastern Iowa. The Cedar River joins the Iowa River just upstream from the Iowa River's confluence with the Mississippi River. The upper part of the basin is level to gently rolling and has long slopes and low relief. Slopes are steeper near large river valleys in the southern part of the basin (Prior, 1976, p. 45-50). Flow of the Iowa River is regulated by a multipurpose reservoir 67 miles upstream from site 5. Numerous low-head dams have been constructed on the Cedar River, but they have little effect on streamflow (U.S. Geological Survey, 1986, p. 230). The basin contains numerous small towns and several large population centers. Large stream segments of the $\mathrm{Ce}$ dar and Iowa Rivers are affected by discharge from municipal wastewater-treatment facilities and urban runoff (Iowa Department of Natural Resources, 1988). Agriculture is the principal land use in the basin-more than 93 percent of the land area is suitable for cultivation (U.S. Geological Survey, 1986, p. 230). Agricultural runoff has a substantial effect on the water quality in the basin, especially in the Iowa River. Nutrients, sediment, and pesticides are carried from farm fields to streams in surface runoff, and increased concentrations of these constituents consistently have been measured following periods of rainfall (McDonald and Splinter, 1982).

The median concentrations of phosphorus $(0.05 \mathrm{mg} / \mathrm{L})$ and suspended sediment $(37 \mathrm{mg} / \mathrm{L})$ in the Cedar River at site 3 were among the smallest for the seven monitoring stations (fig. 3). However, the median concentrations of phosphorus $(0.15 \mathrm{mg} / \mathrm{L})$ and sus-
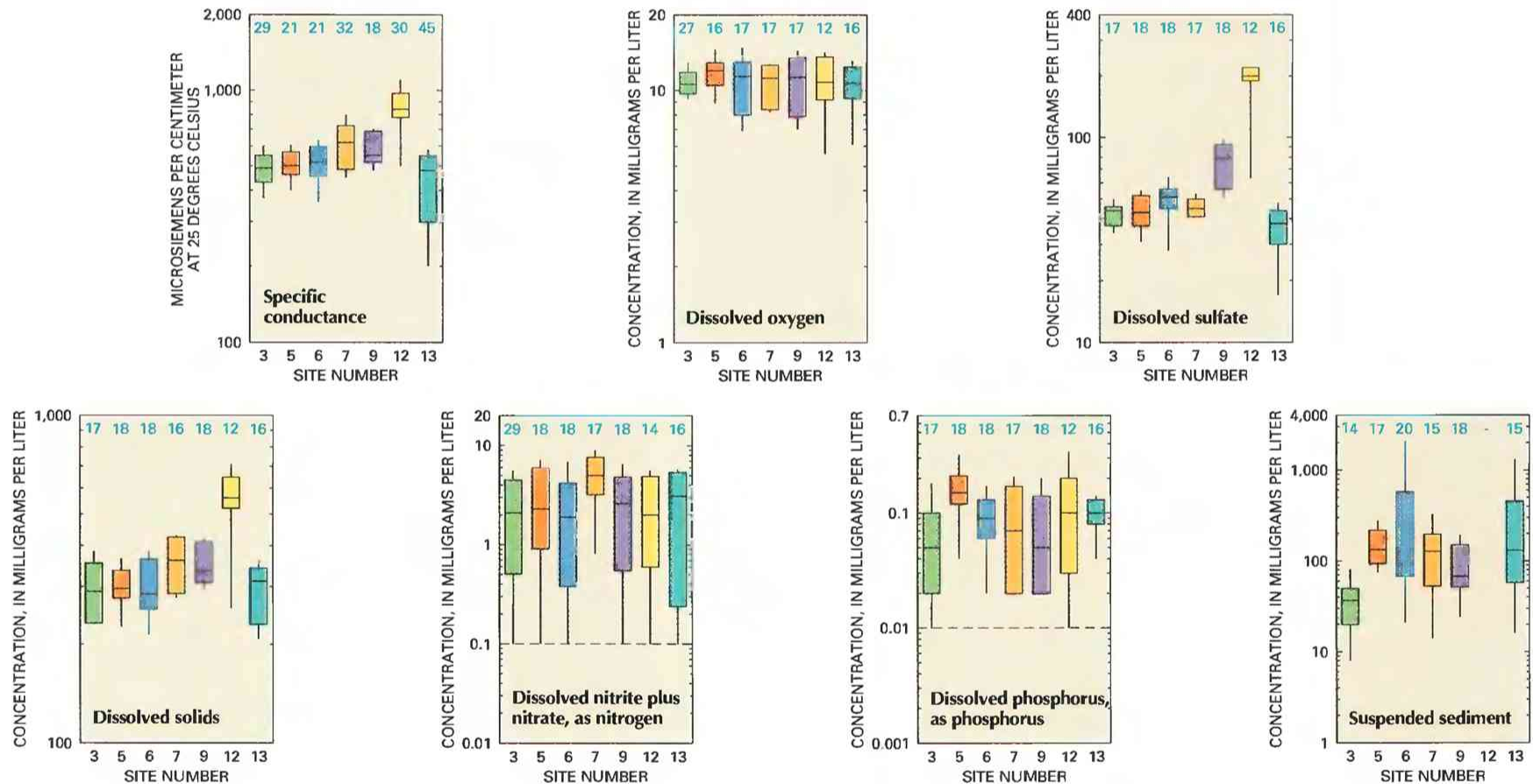

\section{EXPLANATION}
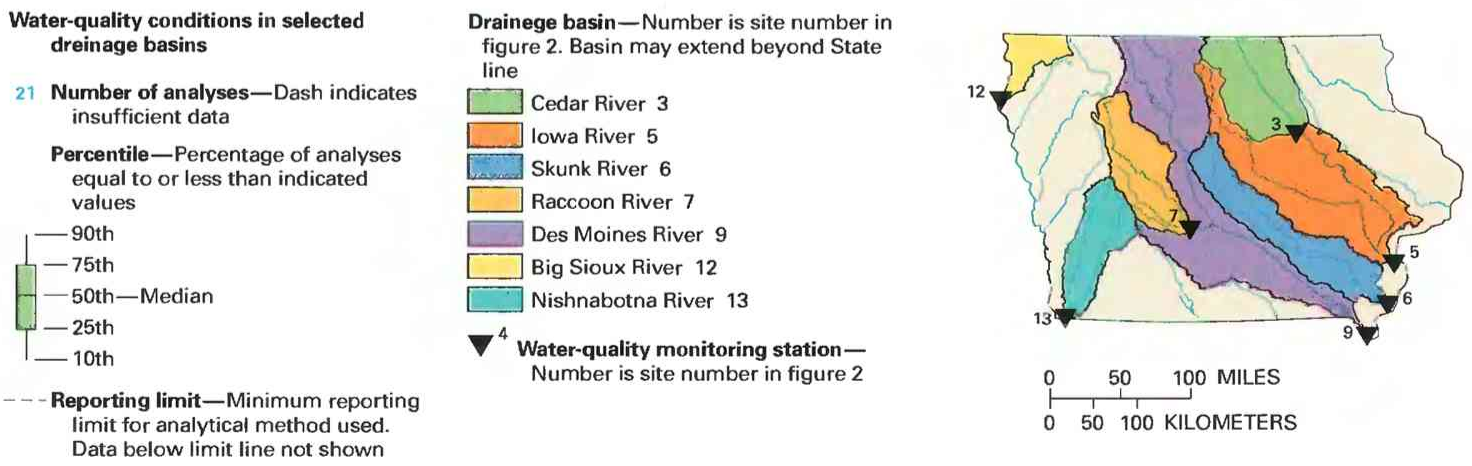

Figure 3. Water quality of selected streams in lowa, water years 1987-89. (Source: Data from U.S. Geological Survey files.) 
pended sediment $(134 \mathrm{mg} / \mathrm{L})$ were larger in the Iowa River at site 5 than in the other six streams. Nonetheless, the total quantity of sediment transported annually by the river in water years 1988 and 1989 was the smallest of record at this site as a result of low-flow conditions during drought. Nitrite plus nitrate concentrations in both rivers met the State standard for untreated potable water supply.

\section{SKUNK RIVER}

Most of the Skunk River basin lies in the Southern Iowa Drift Plain. Much of the terrain consists of flat, tablelike uplands with steep, hilly slopes near the margins of the stream valleys. Flat, bottomland terrain is minimal in comparison with the extensive uplands (Prior, 1976 , p. 45). The area is underlain by glacial deposits, including weathered drift and moderate to thick loess. The principal land use is agriculture, and water quality in the basin is affected by agricultural runoff, particularly in the spring and summer. The basin is predominantly rural, and only small segments of the river are affected by municipal and industrial wastewater discharge.

During water years 1987-89, the median dissolved-solids concentration $(285 \mathrm{mg} / \mathrm{L})$ in the Skunk River at site 6 was the smallest for any of the seven monitoring stations (fig. 3), probably in part because there are few wastewater facilities on the river. The median nitrite plus nitrate concentration at site $6(1.9 \mathrm{mg} / \mathrm{L})$ was the smallest for the seven monitoring stations. However, the 10th- to 90 th-percentile range of nitrite plus nitrate concentrations $(0.1-6.9 \mathrm{mg} / \mathrm{L})$ was large in this basin owing to seasonal differences in runoff. Although suspended-sediment concentrations at site 6 occasionally were large, the total quantity of sediment transported annually by the Skunk River during water years 1987-89 was less than average for the period of record at this site, probably as a result of less than normal runoff during drought.

\section{RACCOON AND DES MOINES RIVERS}

The Raccoon-Des Moines River basin lies almost entirely within the Des Moines Lobe. The Raccoon River flows along the southern terminus of the former glacial ice lobe. Glacial till is de- posited over much of the area. The principal land use in the basin is agriculture. The Raccoon River is the primary source of public water supply for the metropolitan area of Des Moines, downstream from site 7. Urban runoff and municipal wastewater-treatment-plant discharge affect segments of the Raccoon and Des Moines Rivers, primarily downstream from Des Moines (Iowa Department of Natural Resources, 1990).

Agricultural runoff affects water quality in the basins. The median nitrite plus nitrate concentration in the Raccoon River at site $7(5.0 \mathrm{mg} / \mathrm{L})$ was the largest for any of the seven monitoring stations, and the median at site 9 on the Des Moines River $(2.6 \mathrm{mg} / \mathrm{L})$ was the third largest (fig. 3). Median values of specific conductance, sulfate, and dissolved solids also were larger at sites 7 and 9 than at most of the other stations, probably because of the relatively large soluble-mineral content of the soils and dissolved-mineral content of ground water in the basin. Although large relative to those at most of the other monitoring stations, the values for properties and constituents at sites 7 and 9 were within State water-quality standards.

\section{BIG SIOUX RIVER}

The Big Sioux River forms part of the western boundary of the State and borders the Northwest Iowa Plains. Moderate to thick loess deposits overlie glacial till. Land in the basin is used predominantly for cropland and livestock production. There are several population centers in South Dakota upstream from site 12. Sources of contaminants in the Big Sioux River include municipal wastewater-treatment-plant discharge and agricultural activities in the basin (Iowa Department of Natural Resources, 1990).

Median values of specific conductance $(840 \mu \mathrm{S} / \mathrm{cm})$, sulfate (200 mg/L), and dissolved solids ( $560 \mathrm{mg} / \mathrm{L}$ ) were substantially larger in the Big Sioux River at site 12 than in the other six streams (fig. 3). The large concentrations were mainly from natural sources. Soils and ground water derived from this glacial terrain are typically rich in calcium, magnesium, carbonate, and sulfate (Wahl and others, 1982, p. 45). Water from alluvial aquifers contributes most of the river's base flow during low-flow conditions. Fertilizers probably produced the elevated dissolved-phosphorus concentrations at site 12 .

Table 1. Sources and environmental significance of selected water-quality properties and constituents [Source: Compiled by the U.S. Geological Survey, Office of Water Quality]

\begin{tabular}{|c|c|c|}
\hline Property or constituent & Common sources & Environmental significance \\
\hline $\begin{array}{l}\text { Specific conductance .................. } \\
\quad \text { (property) }\end{array}$ & $\begin{array}{l}\text { A measure of the electrical conductivity of water; var- } \\
\text { ies with the quantity of dissolved solids and is } \\
\text { used to approximate the dissolved-solids content. }\end{array}$ & $\begin{array}{l}\text { Dissolved solids can cause water to be unsuitable for } \\
\text { public supply, agriculture, and industry; can harm } \\
\text { aquatic organisms. }\end{array}$ \\
\hline Dissolved oxygen ......................... & $\begin{array}{l}\text { Introduced from the atmosphere; also a byproduct of } \\
\text { aquatic plants. }\end{array}$ & $\begin{array}{l}\text { Necessary for aquatic life; deficiency can result from } \\
\text { assimilation of organic wastes or rapid growth } \\
\text { and decay of algae. }\end{array}$ \\
\hline 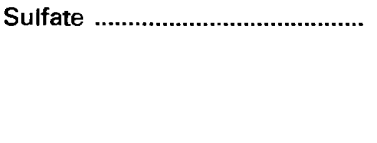 & $\begin{array}{l}\text { Occurs in some rocks; also in mine runoff, industrial } \\
\text { wastewater discharge, and atmospheric deposi- } \\
\text { tion. }\end{array}$ & $\begin{array}{l}\text { Concentrations exceeding a natural, background } \\
\text { level indicate contamination from human activity; } \\
\text { in sufficient quantity, can cause water to be } \\
\text { unsuitable for public supply; can harm aquatic } \\
\text { organisms. }\end{array}$ \\
\hline Dissolved solids ........................... & $\begin{array}{l}\text { A result of rock weathering; also in agricultural runoff } \\
\text { and industrial discharge. }\end{array}$ & $\begin{array}{l}\text { In sufficient quantity, can cause water to be unsuitable } \\
\text { for public supply, agriculture, and industry; can } \\
\text { harm aquatic organisms. }\end{array}$ \\
\hline Nitrite plus nitrate ........................... & $\begin{array}{l}\text { Nonpoint sources are agricultural and urban runoff; } \\
\text { a major point source is wastewater discharge. }\end{array}$ & $\begin{array}{l}\text { Plant nutrient that, in sufficient quantity, can cause } \\
\text { algal blooms and excessive growth of higher } \\
\text { aquatic plants in bodies of water; can cause water } \\
\text { to be unsuitable for public supply. }\end{array}$ \\
\hline Phosphorus ................................... & $\begin{array}{l}\text { Occurs in some rocks and sediments; also in runoff } \\
\text { and seepage from phosphate-rock mines, agri- } \\
\text { cultural and urban runoff, and industrial and } \\
\text { municipal wastewater discharge. }\end{array}$ & $\begin{array}{l}\text { Plant nutrient that, in sufficient quantity, can cause } \\
\text { algal blooms and excessive growth of higher } \\
\text { aquatic plants in bodies of water. }\end{array}$ \\
\hline Suspended sediment ................... & $\begin{array}{l}\text { A result of rock erosion; also induced by disturbances } \\
\text { of land cover due to fires, floods, and human } \\
\text { activities such as mining, logging, construction, } \\
\text { and agriculture. }\end{array}$ & $\begin{array}{l}\text { Can be detrimental to aquatic organisms; can fill res- } \\
\text { ervoirs and impair recreational use of water. }\end{array}$ \\
\hline
\end{tabular}




\section{NISHNABOTNA RIVER}

The Nishnabotna River lies within the Southern Iowa Drift Plain, Western Loess Hills, and Missouri Alluvial Plain. The basin is predominantly rural. Some farms and public suppliers withdraw from surface-water sources because dependable ground-water supplies are scarce. More than 90 percent of the land is used for agriculture, although less acreage is devoted to row crops than in most areas of Iowa, and there are fewer agricultural drainage-tile systems in this part of the State (U.S. Geological Survey, 1986, p. 234). These drainage systems increase the rate and volume of agricultural runoff to streams.

The Nishnabotna River at site 13 had the smallest median values of specific conductance $(480 \mu \mathrm{S} / \mathrm{cm})$ and sulfate $(38 \mathrm{mg} / \mathrm{L})$ for any of the seven monitored streams (fig. 3). Ground water generally contains larger concentrations of dissolved minerals than does stream water. The ground-water contribution to the streamflow of the Nishnabotna River is minimal because deposits underlying the stream channel have relatively little permeability, and the small contribution of ground water probably accounts for the small specific-conductance values. Runoff from cropland and pastures carries nitrogen compounds and sediment to the river. The maximum nitrite plus nitrate and suspended-sediment concentrations at site 13 (7.0 and $6,480 \mathrm{mg} / \mathrm{L}$, not shown in fig. 3 ) were the largest for any monitoring station during water years 198789.

\section{WATER-QUALITY TRENDS}

Trend analysis is a statistical procedure used to detect changes in stream water quality at a monitoring station over time. For this report, water-quality data from 12 monitoring stations (fig. 2) were analyzed for trends by using the seasonal Kendall test (Hirsch and others, 1982), a method used extensively by the USGS. The graph (shown below) of the dissolved nitrite plus nitrate concentration in the Des Moines River at site 9 illustrates the trend inferred from the concentration data and demonstrates the variation in water quality that is common in streams.

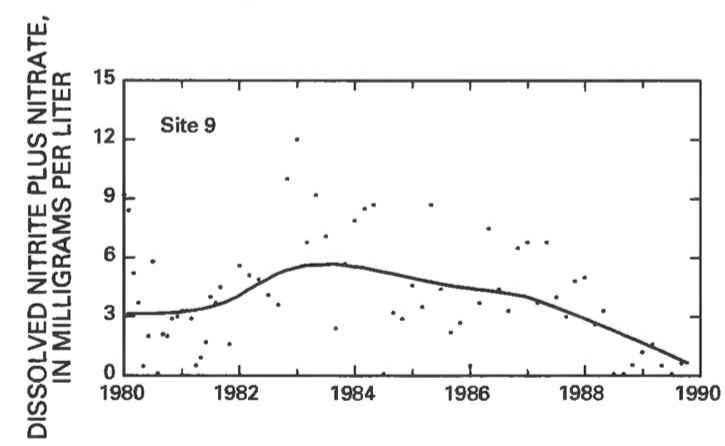

When possible, constituent-concentration data were adjusted for changes in streamflow to preclude identifying a trend in concentration that was caused only by a trend in streamflow. The data were not adjusted when (1) more than 10 percent of the samples had concentrations lower than the minimum reporting limit for the analytical method used or (2) streamflow was controlled substantially by human activities. When the concentration data could not be adjusted for streamflow, trends were determined directly from the concentration data.

Statewide trends in measurements of selected physical properties of stream water and in concentrations of selected constituents in stream water are shown on maps in figure 4. On each map, a trend

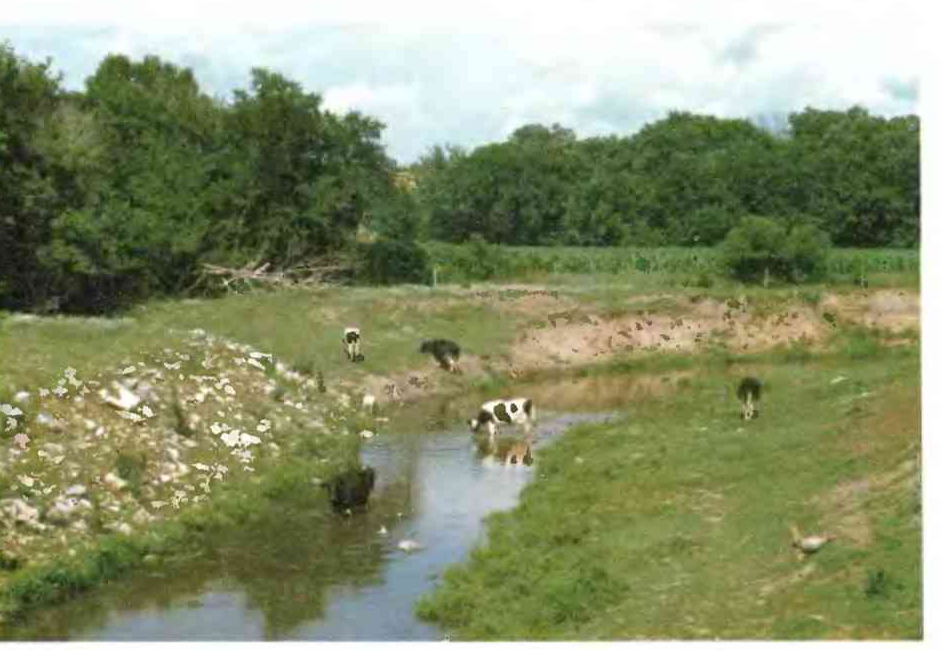

asture along a northeastern lowa stream. Cattle are a source of nutrients and colal contanation in streams draining grazed land. (Dana W. Kolpin, U.S. Geological

is indicated at a monitoring station only if the data from that station were suitable for use in the trend analysis. For more information on the suitability criteria and on the trend-analysis procedure used for this report, see Lanfear and Alexander (1990).

\section{SPECIFIC CONDUCTANCE}

Specific conductance is a measure of the ability of a sample of water to conduct electricity. Because specific conductance and the dissolved-solids concentration are roughly proportional in most natural waters, the specific-conductance value often can be used to estimate the dissolved-solids concentration (Hem, 1985 , p. $66-68$ ).

Specific conductance had upward trends in the Mississippi River at sites 1 and 2 and a downward trend in the Missouri River at site 10 (fig. 4). Because of the size and diversity of these drainage basins, it is difficult to define specific causes for the trends.

\section{DISSOLVED OXYGEN}

The dissolved-oxygen concentration in a stream is controlled by several factors, including water temperature, air temperature and pressure, hydraulic characteristics of the stream, photosynthetic or respiratory activity of stream biota, and the quantity of organic material present. A trend in dissolved-oxygen concentrations commonly is directly or indirectly the result of human activities. Generally, an upward trend in dissolved-oxygen concentrations indicates improving stream water-quality conditions and a downward trend indicates deteriorating conditions. The increasing dissolved-oxygen concentration in the Iowa River at site 5 might have been the result of decreased streamflow and increased photosynthetic activity owing to unusually large algal populations in the Iowa River during water years 1988 and 1989 (McDonald and Johnson, 1989).

\section{DISSOLVED SULFATE}

The major natural sources of sulfate in streams are rock weathering, volcanoes, and biochemical processes (Hem, 1985, p. 113). Human activities such as mining, waste discharge, and fossil-fuel combustion also can be important sources. A shortened trend-analysis period was used for sulfate because data from analyses performed prior to water year 1982 are not comparable to data from subsequent years.

Sulfate concentrations had no trend at six monitoring stations during 1982-89 (fig. 4). Sulfate trends commonly are associated with 
surface mining of coal (Smith and others, 1987, p. 8). Less than 0.2 percent of the total land area in lowa has active or abandoned mine sites. Surface mining has not resulted in major statewide nonpointsource pollution in Iowa because most mining operations are small and scattered (Iowa Department of Natural Resources, 1988). However, mining activities can cause localized water-quality problems.

\section{DISSOLVED SOLIDS}

Dissolved solids in stream water result primarily from rock weathering but also can be introduced as a byproduct of human ac- tivities (table 1). Concentrations generally are greatest in streams draining basins underlain by rocks and soils that contain easily dissolved minerals. A cause for the downward trend in dissolved-solids concentrations at site 9 (fig. 4) during water years $1980-89$ is unknown.

\section{DISSOLVED NITRITE PLUS NITRATE}

Nitrite and nitrate are oxidized forms of nitrogen that together normally constitute most of the dissolved nitrogen in well-aerated streams. Nitrite readily oxidizes to nitrate in natural waters; there-

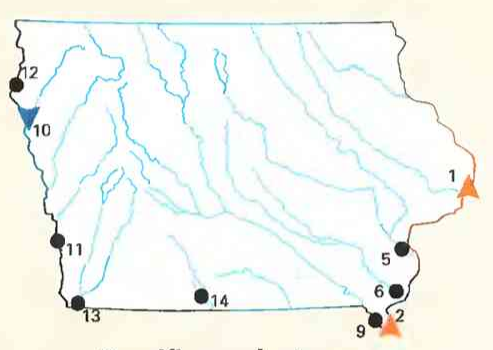

Specific conductance, 1980-89

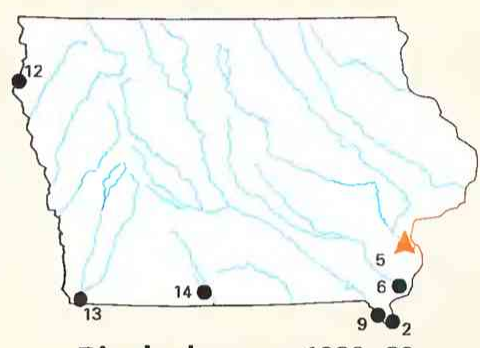

Dissolved oxygen, 1980-89

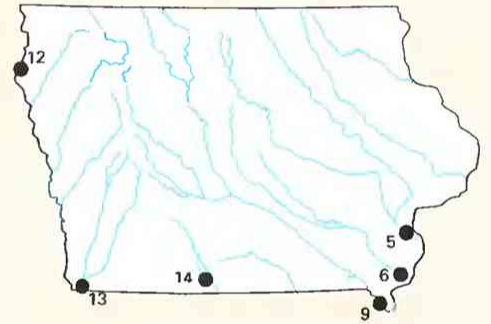

Dissolved sulfate, 1982-89

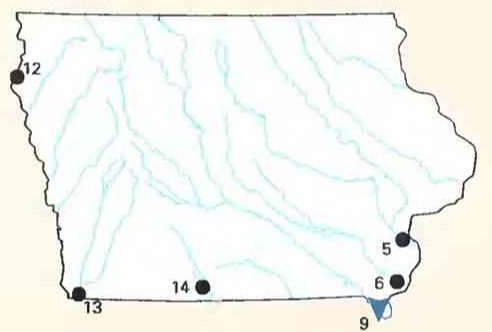

Dissolved solids, 1980-89

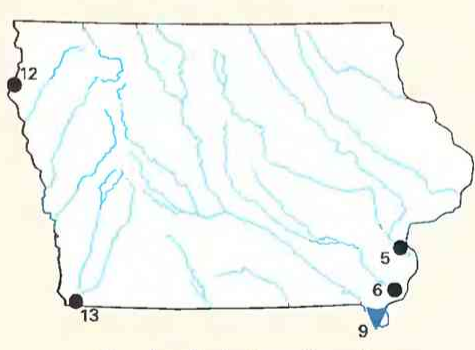

Dissolved nitrite plus nitrate, 1980-89

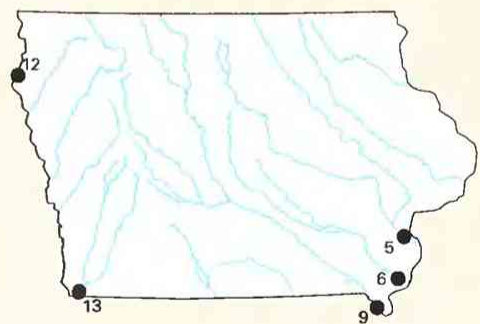

Dissolved phosphorus, 1980-89

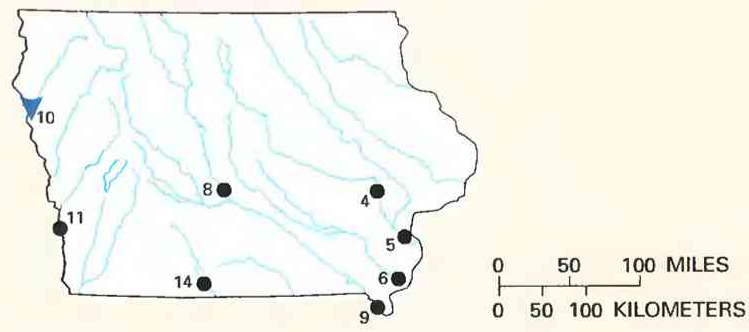

\section{EXPLANATION}

Trend in water-quality property or constituent-Number is site number in figure 2
A $^{1}$ Upward
- ${ }^{5}$ None
$\nabla^{9}$ Downward

Suspended sediment, 1980-89

Figure 4. Trends in water quality of selected streams in lowa, by water years. (Source: Data from U.S. Geological Survey files.) 
fore, nitrate generally is by far the more abundant of the two (Hem, 1985 , p. 124).

The typical sources of nitrogen to cropland in Iowa include fertilizer, manure, nitrogen-fixing legumes, precipitation, and soil. More than 1 million tons of nitrogen fertilizer are applied to Iowa fields annually, making Iowa the second largest user in the Nation. Nitrogen fertilizer use significantly increased during 1970-85 (Iowa Department of Natural Resources, 1987, p. 13), then decreased. The downward trend in the Des Moines River at site 9 (fig. 4) is attributable primarily to decreased runoff and increased algal utilization of nitrite plus nitrate (Baumann and others, 1989) during water years 1988-89.

\section{DISSOLVED PHOSPHORUS}

Small quantities of dissolved phosphorus-most of it in the oxidized form, phosphate-commonly are present in streams as a result of rock weathering. Concentrations of dissolved phosphorus in natural water normally are no more than a few tenths of a milligram per liter (Hem, 1985, p. 126) and are usually much lower. Higher concentrations can indicate contamination from human activities (table 1). A shortened trend-analysis period was used for phosphorus because data from analyses performed in water years 1980-81 are not comparable to data from subsequent years. Phosphorus concentrations had no trend at five monitoring stations during 1982-89 (fig. 4).

\section{SUSPENDED SEDIMENT}

Suspended sediment is a product of erosion. The erosion can be either natural or the result of land-cover disturbances related to human activities (table 1).

Sediment is the largest pollutant by volume in Iowa. Sediment was identified as having a major effect on 91 percent and a moderate or minor effect on 7 percent of the stream miles assessed by the IDNR during water years 1988-89 (Iowa Department of Natural Resources, 1990). Decreased runoff during water years 1988-89 probably produced the downward trend in suspended-sediment concentrations in the Missouri River at site 10 (fig. 4).

\section{WATER-QUALITY MANAGEMENT}

Chapter 455B of the Code of Iowa designates the IDNR as the State agency responsible for management of stream water quality in Iowa. The IDNR sets and enforces ambient water-quality standards for streams and sets and enforces effluent standards for all wastewater dischargers through the National Pollutant Discharge Elimination System. The IDNR regulates the design, construction, and operation of industrial and municipal wastewater-treatment systems and oversees the financing of municipal wastewater-treatment systems. The Environmental Protection Division of the IDNR prepares a biennial water-quality assessment report for the EPA and the U.S. Congress (Iowa Department of Natural Resources, 1988; 1990) in compliance with section 305(b) of the Federal Clean Water Act.

The IDNR participates in several interstate associations whose activities concern water-quality issues: the Association of State and Interstate Water Pollution Control Administrators, the Upper Mississippi River Basin Association, and the Upper Missouri River Basin Association. The IDNR also participates in water-quality monitoring activities on the Mississippi River along the Iowa border as part of the long-term resource-monitoring activities of the Federal Upper Mississippi River Environmental Management Program.

The number of water-quality monitoring stations and water samples collected from interior Iowa streams has remained relatively constant since monitoring began in the early 1970's. To meet data needs more effectively, especially with regard to determining trends in water quality, the IDNR's routine water-quality sampling schedule was altered in 1986 to increase the number of monthly samples collected and decrease the number of quarterly samples collected.

The IDNR receives water-quality information from special studies and monitoring programs conducted on Iowa streams by other agencies. The University of Iowa Hygienic Laboratory, under contract with the IDNR, has conducted several special studies of water quality to determine the effects of municipal wastewater-treatmentplant discharges on the water quality of Iowa streams. Annual fishcontaminant monitoring in Iowa is a cooperative effort with the EPA Region VII office. The U.S. Army Corps of Engineers sponsors water-quality monitoring on the Des Moines, Raccoon, and Iowa Rivers in and near Federal flood-control reservoirs. Data from the USGS National Stream Quality Accounting Network stations supplement other water-quality monitoring data and are used to assess water quality for the biennial 305(b) water-quality-assessment reports. The IDNR also uses streamflow data from USGS gaging stations to interpret water-quality data, to determine wasteload allocations, and to determine the appropriate designated uses for Iowa streams.

\section{SELECTED REFERENCES}

Anderson, J.R., 1967, Major land uses in the United States, in U.S. Geological Survey, 1970, National atlas of the United States of America: Washington, D.C., U.S. Geological Survey, p. 158-159.

Baumann, E.R., Lutz, D.S., and Yager, T.K., 1989, Water quality studiesRed Rock and Saylorville Reservoirs, Des Moines River, Iowa, January 26, 1988-September 27, 1988: Ames, Iowa State University, Department of Civil Engineering, 320 p.

Britton, L.J., and Greeson, P.E., eds., 1987, Methods for collection and analysis of aquatic biological and microbiological samples: U.S. Geological Survey Techniques of Water-Resources Investigations, book 5, chap. A4, $363 \mathrm{p}$.

Clark, M.L., and Thamke, J.N., 1988, Estimated water use in Iowa, 1985: U.S. Geological Survey Open-File Report 87-704, 28 p.

Fishman, M.J., and Friedman, L.C., eds., 1989, Methods for the determination of inorganic substances in water and fluvial sediments: U.S. Geological Survey Techniques of Water-Resources Investigations, book 5, chap. A1, $545 \mathrm{p}$.

Hem, J.D., 1985, Study and interpretation of the chemical characteristics of natural water (3d ed.): U.S. Geological Survey Water-Supply Paper 2254, $263 \mathrm{p}$.

Hirsch, R.M., Slack, J.R., and Smith, R.A., 1982, Techniques of trend analysis for monthly water quality data: Water Resources Research, v. 18 , no. 1, p. 107-121.

Iowa Department of Natural Resources, 1987, Iowa groundwater protection strategy: Des Moines, Iowa, Environmental Protection Commission, $106 \mathrm{p}$.

1988, Water quality in Iowa during 1986 and 1987: Des Moines, Iowa Department of Natural Resources, Environmental Protection Division, Water Quality Planning Section, variously paginated.

1989, Water quality in Iowa, 1989 update to the 305(b) report: Des Moines, Iowa Department of Natural Resources, Environmental Protection Division, Water Quality Planning Section, variously paginated.

1990, Water quality in Iowa during 1988 and 1989: Des Moines, Iowa Department of Natural Resources, Environmental Protection Division, Water Quality Planning Section, variously paginated.

Lanfear, K.J., and Alexander, R.B., 1990, Methodology to derive water-quality trends for use by the National Water Summary Program of the U.S. Geological Survey: U.S. Geological Survey Open-File Report 90-359, $10 \mathrm{p}$.

McDonald, D.B., and Johnson, J.K., 1989, Coralville Reservoir water quality study, February 1988-November 1988: Iowa City, Iowa Institute of Hydraulic Research, University of Iowa, $54 \mathrm{p}$.

McDonald, D.B., and Splinter, R.C., 1982, Long term trends in nitrate concentration in Iowa water supplies: Journal of the American Water Works Association, v. 74, no. 8, p. 437-440.

Prior, J.C., 1976, A regional guide to Iowa landforms: Iowa City, Iowa Geological Survey Educational Series 3, $72 \mathrm{p}$.

Smith, R.A., Alexander, R.B., and Wolman, M.G., 1987, Analysis and interpretation of water-quality trends in major United States rivers, 1974 81: U.S. Geological Survey Water-Supply Paper 2307, 25 p. 
Thelin, G.P., and Pike, R.J., 1990, Digital shaded relief map of the conterminous United States: Menlo Park, Calif., U.S. Geological Survey digital image processing, scale 1:3,500,000.

U.S. Geological Survey, 1986, National water summary 1985-Hydrologic events and surface-water resources: U.S. Geological Survey Water-Supply Paper 2300, 506 p.

1988-90, Water resources data for Iowa, water years 1987-89, volume 1: U.S. Geological Survey Water-Data Reports IA-87-1 to IA-891 (published annually).

1990, National water summary 1987-Hydrologic events and water supply and use: U.S. Geological Survey Water-Supply Paper 2350, $553 \mathrm{p}$.
1991, National water summary 1988-89-Hydrologic events and floods and droughts: U.S. Geological Survey Water-Supply Paper 2375, $591 \mathrm{p}$.

Wahl, K.D., Meyer, M.J., and Karsten, R.K., 1982, Hydrology of the surficial aquifer in the Floyd River basin, Iowa: Iowa City, Iowa Geological Survey, Water Supply Bulletin 12, 53 p.

Ward, J.R., and Harr, C.A., eds., 1990, Methods for collection and processing of surface-water and bed-material samples for physical and chemical analyses: U.S. Geological Survey Open-File Report 90-140, 71 p.

Prepared by Melanie L. Clark, U.S. Geological Survey; "Water-Quality Management" section by John R. Olson, Iowa Department of Natural Resources

FOR ADDITIONAL INFORMATION: District Chief, U.S. Geological Survey, Federal Building, Room 69, 400 S. Clinton Street, Iowa City, IA 52244 


\section{KANSAS Stream Water Quality}

Surface-water resources are distributed unevenly in Kansas (U.S. Geological Survey, 1986, p. 237). In areas of the State that have little available ground water, streams and lakes are the primary sources of supply. The quality of these surface waters is important for public water supply, agriculture, industry, recreation, and aquatic life.

Offstream surface-water withdrawals in 1985 averaged 866 million gallons per day. Surface water provides about one-half of the State's public water supply and virtually all water required for thermoelectric power generation (U.S. Geological Survey, 1990, p. 264).

Land use can substantially affect the quality of water. Cropland and grazing are the predominant land uses in Kansas (fig. 1A). Land-use potential is determined largely by physiography and the distribution of water resources. The State's topography ranges from generally flat terrain in the Great Plains of western Kansas (fig. $1 B$ ) to gently rolling hills in the Central Lowland of eastern Kansas and the Ozark Plateaus in extreme southeastern Kansas. Annual precipitation ranges from 16 inches in the west to 40 inches in the southeast (U.S. Geological Survey, 1986, p. 237).

Western Kansas, where large-scale farming is common, has few cities with populations of more than 10,000. Ground-water sources provide most of the water used for irrigation and public supply in this part of the State, where surface-water supplies are neither abundant nor dependable. Most Kansas residents live in urban areas of the eastern and south-central parts of the State (fig. $1 C$ ). In these areas, streams and reservoirs are important sources of water for public supply, industry, and power generation. Ground water is abundant only in large river valleys and in localized areas. From 1970 to 1980 , the urban population in Kansas increased by 6.1 percent, while the rural population, which commonly derives domestic supplies from ground water, increased by only 3.4 percent (Institute for Public Policy and Business Research, 1990). The 1990 population of Kansas was 2.5 million, a 4.8-percent increase from 1980 (U.S. Bureau of the Census 1990 decennial census files).

\section{WATER-OUALITY MONITORING}

Water-quality data obtained from analyses of water samples collected at monitoring stations are stored in the U.S. Geological Survey's (USGS) National Water Information System and the U.S. Environmental Protection Agency's (EPA) national data base known as STORET. Water-quality and streamflow data are reported by water year-the 12 months from October 1 through September 30. A water year is identified by the calendar year in which it ends. For example, water year 1991 comprises October 1, 1990, through September 30, 1991.
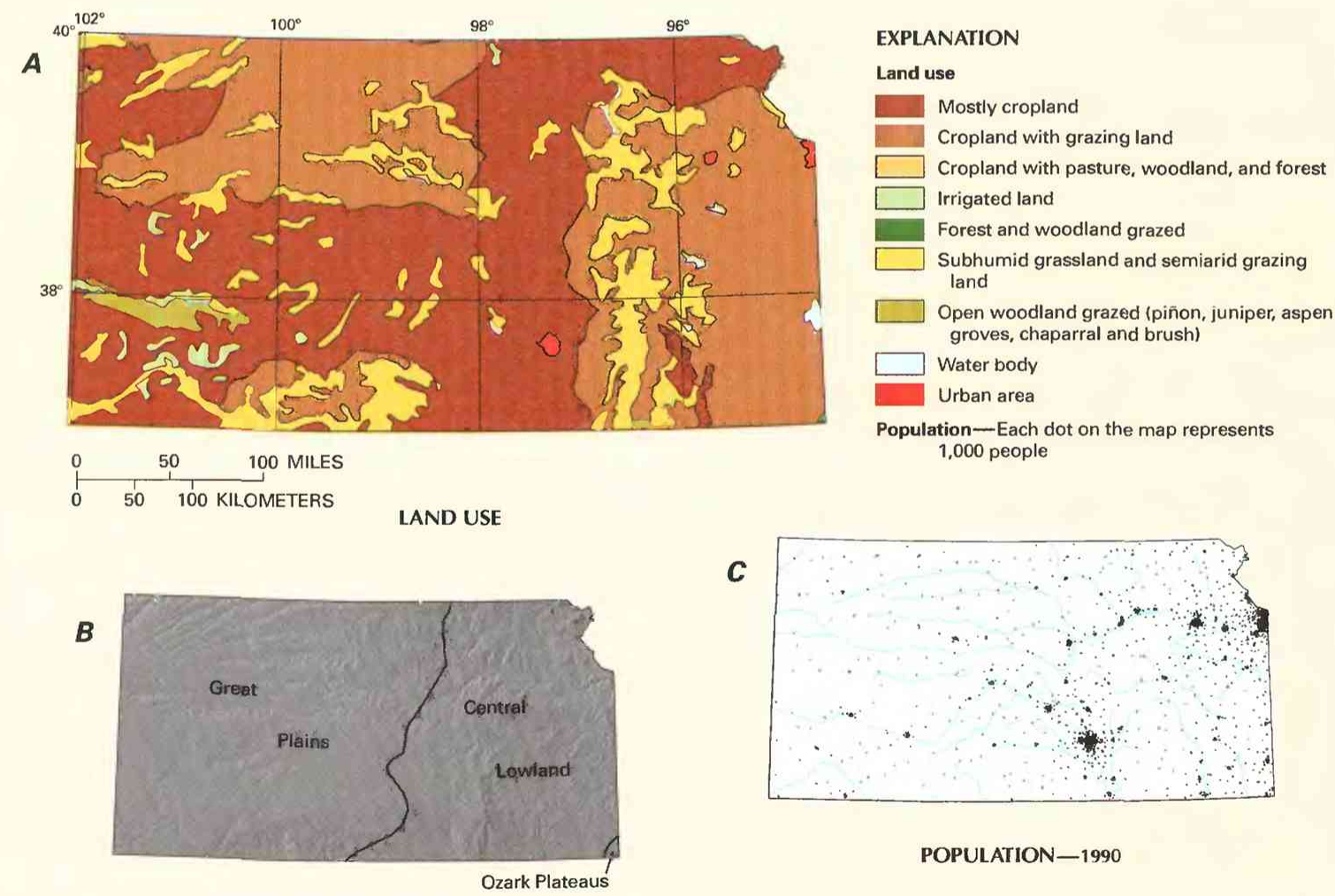

PHYSIOGRAPHIC DIVISIONS

POPULATION-1990

Figure 1. Land use, physiography, and population in Kansas. A, Major land uses. B. Physiographic divisions. $C$, Population distribution in 1990. (Sources: A, Major land uses modified from Anderson, 1967. B, Physiographic divisions from Fenneman, 1946; landforms from Thelin and Pike, 1990. C, Data from U.S. Bureau of the Census 1990 decennial census files.) 
The data used in this summary of Kansas' stream water quality were obtained from water samples collected at least quarterly at 15 monitoring stations at which data collection is systematic and continuing (fig. 2). Analyses of water samples collected at 10 stations are the basis for the discussion and graphic summary (fig. 3) of stream water-quality conditions during water years 1987-89, and data from all 15 stations are the basis for the discussion and graphic summary (fig. 4) of stream water-quality trends. Water samples were collected and analyzed by using standard methods approved by the USGS (Britton and Greeson, 1987; Fishman and Friedman, 1989; Ward and Harr, 1990) or by using equivalent methods. If a method of sample collection or analysis changed over time, data from an analysis were included in the evaluation of recent stream water quality or of stream water-quality trends only if the change in method did not affect the comparability of the data.

\section{WATER-QUALITY CONDITIONS}

Runoff from agricultural land is a major cause of stream waterquality degradation in Kansas. In more than one-half of the stream miles assessed by the Kansas Department of Health and Environment (KDHE) in 1988-89, nonsupport of uses designated by the State for purposes of water-quality monitoring and protection was the result of organic enrichment from cropland runoff (Kansas Department of Health and Environment, 1990). Pesticide residues in surface water are another major consequence of agricultural activity in the State. Atrazine, a herbicide used to control broadleaf and grassy weeds in corn, sorghum, and rangeland, is the pesticide most often detected in Kansas streams and lakes (Kansas Department of Health and Environment, 1989). Other pesticides frequently detected are alachlor, metolachlor, metribuzin, and 2,4-D (Kansas Department of Health and Environment, 1988).

Evaluation of clean water goals by the KDHE (1990) concluded that goals pertaining to the suitability of streams for fishing were not met in 8 percent of assessed stream miles because of exceedances of Food and Drug Administration Action Levels for chlordane in fish tissue (U.S. Food and Drug Administration, 1984). This extensively used pesticide was banned for agricultural use in 1978, but use continued for home and garden insect control until 1988 (U.S. Environmental Protection Agency, 1990). Excessive chlordane concentrations in fish tissue have been a continuing problem downstream from large urban areas (Kansas Department of Health and Environment, 1987). In addition, goals pertaining to the suitability of streams for swimming were not attained in 82 percent of assessed stream miles because of exceedances of Kansas water-quality criteria for fecal coliform bacteria. Primary sources of this contamination are non-disinfected municipal wastewater-treatment-plant effluents and runoff from livestock confinement areas (Donald H. Snethen, Kansas Department of Health and Environment, written commun., October 1990).

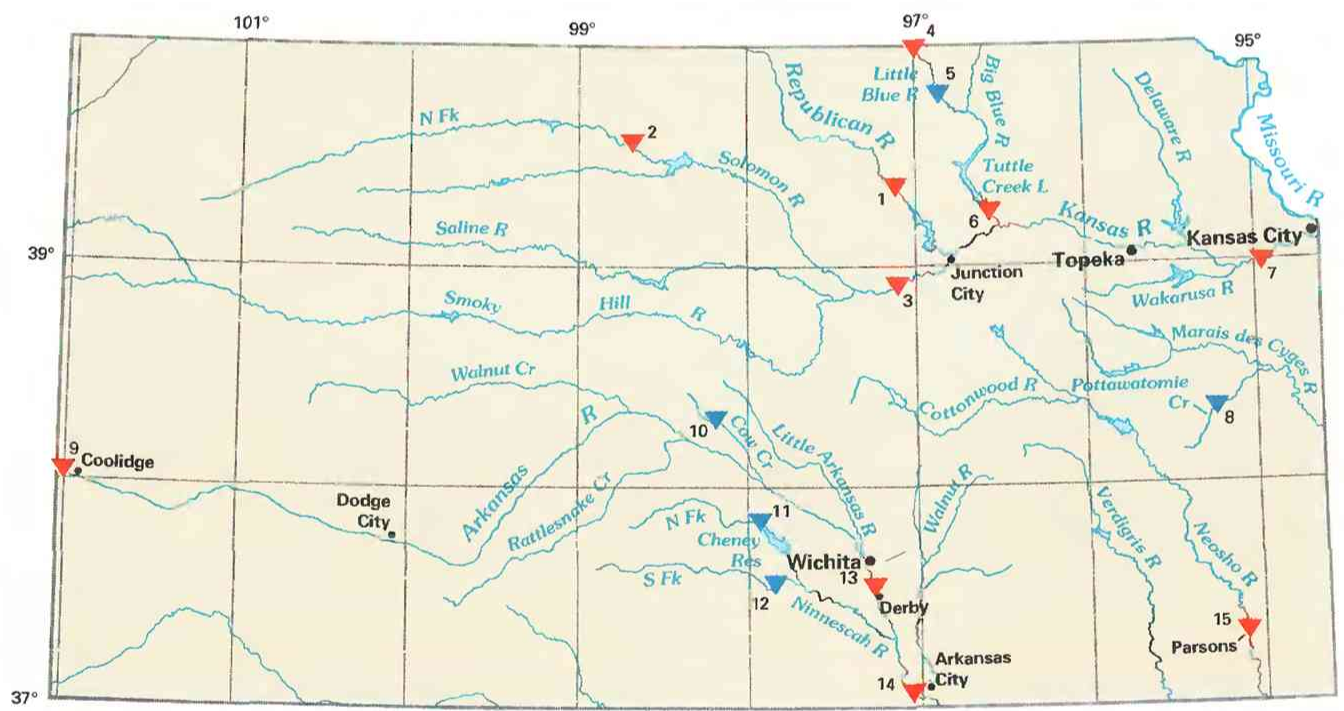

\author{
EXPLANATION \\ Water-quality monitoring station and \\ type of statistical analysis- \\ Number refers to accompanying \\ table \\ $\nabla^{5}$ Water-quality trends \\ (see fig. 4) \\ $\nabla^{6}$ Water-quality conditions and \\ trends (see figs. 3 and 4)
}

\begin{tabular}{|c|c|c|c|}
\hline $\begin{array}{l}\text { Site no. } \\
\text { on map }\end{array}$ & $\begin{array}{l}\text { USGS station } \\
\text { name and no. }\end{array}$ & $\begin{array}{l}\text { Drainage area } \\
\text { (square miles) }\end{array}$ & $\begin{array}{l}\text { Major land use } \\
\text { (see fig. 1) }\end{array}$ \\
\hline 1 & Republican River at Clay Center (06856600) & 24,542 & Cropland with grazing land. \\
\hline 2 & North Fork Solomon River at Portis $(06872500)$ & 2,315 & Ditto. \\
\hline 3 & Smoky Hill River at Enterprise $(06877600)$ & 19,260 & Cropland with grazing land; mostly cropland. \\
\hline 4 & Little Blue River at Hollenberg (06884025) & 2,752 & Mostly cropland. \\
\hline 5 & 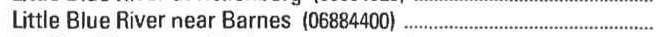 & 3,324 & Ditto. \\
\hline 6 & Big Blue River near Manhattan (06887000) & 9,640 & Ditto. \\
\hline 7 & Kansas River at DeSoto $(06892350)$ & 59,756 & Cropland with grazing land; mostly cropland. \\
\hline 8 & Pottawatomie Creek near Garnett $(06914000)$ & 334 & Cropland with grazing land. \\
\hline 9 & Arkansas River near Coolidge $(07137500)$ & 25,410 & Subhumid grassland and semiarid grazing land; irrigated land. \\
\hline 10 & Cow Creek near Lyons $(07143300)$ & 728 & Mostly cropland. \\
\hline 11 & North Fork Ninnescah River above Cheney Reservoir $(07144780)$.... & 787 & Ditto. \\
\hline 12 & South Fork Ninnescah River near Murdock $(07145200)$........................ & 650 & Ditto. \\
\hline 13 & Arkansas River at Derby ${ }^{1}(07144550)$ & 40,830 & Ditto. \\
\hline 14 & Arkansas River at Arkansas City ${ }^{1}(07146500)$ & 43,713 & Ditto. \\
\hline 15 & Neosho River near Parsons (07183500) & 4,905 & Cropland with grazing land. \\
\hline
\end{tabular}

'Water-quality data supplied by Kansas Department of Health and Environment.

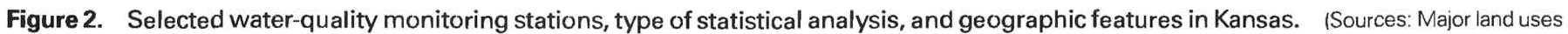
modified from Anderson, 1967; other data from U.S. Geological Survey files.) 
The following discussion of stream water quality in Kansas is organized by river basin (fig. 3). Where physiographic and landuse characteristics in different basins are similar, the discussion of those basins is combined. Graphs in figure 3 summarize certain aspects of stream water quality in the basins for water years 1987-89. The graphs show frequency distributions of data values that represent concentrations of selected stream-water constituents. These constituents are dissolved sodium, dissolved sulfate, dissolved chloride, dissolved solids, dissolved nitrite plus nitrate (as nitrogen), total phosphorus (as phosphorus), and suspended sediment. The data are reported in milligrams per liter $(\mathrm{mg} / \mathrm{L})$. Sources and environmental significance of each constituent are described in table 1.

Water quality at each monitoring station is the result of geological, chemical, biological, and hydrologic processes that occur over a large area. Water-quality problems that affect aquatic life or public health only locally are not fully represented in this summary.

Kansas surface-water-quality standards and suggested limits apply to some of the constituents shown in the graphs. State standards (Kansas Department of Health and Environment, 1986a) for sulfate $(250 \mathrm{mg} / \mathrm{L})$, chloride $(250 \mathrm{mg} / \mathrm{L})$, dissolved solids (500 $\mathrm{mg} / \mathrm{L})$, and nitrate $(10 \mathrm{mg} / \mathrm{L})$ are based on national drinking-water regulations established by the U.S. Environmental Protection Agency $(1986 a, b)$. In Kansas, these standards are intended to protect streams for all designated uses: drinking-water supply, irrigation, livestock watering, body-contact recreation, noncontact recreation, and aquatic life (Kansas Department of Health and Environment, 1990). The suggested limit for sodium $(100 \mathrm{mg} / \mathrm{L})$ is based on dietary restrictions for people susceptible to high blood pressure; the suggested limit for total phosphorus $(5 \mathrm{mg} / \mathrm{L})$ is based on concentrations that indicate contamination from human or animal wastes (Kansas Department of Health and Environment, 1986b).

\section{REPUBLICAN, NORTH FORK SOLOMON, AND SMOKY HILL RIVERS}

The Republican River originates in southwestern Nebraska and northeastern Colorado; the headwaters of its tributary, the Smoky Hill River, are in eastern Colorado. The Solomon and Saline Rivers
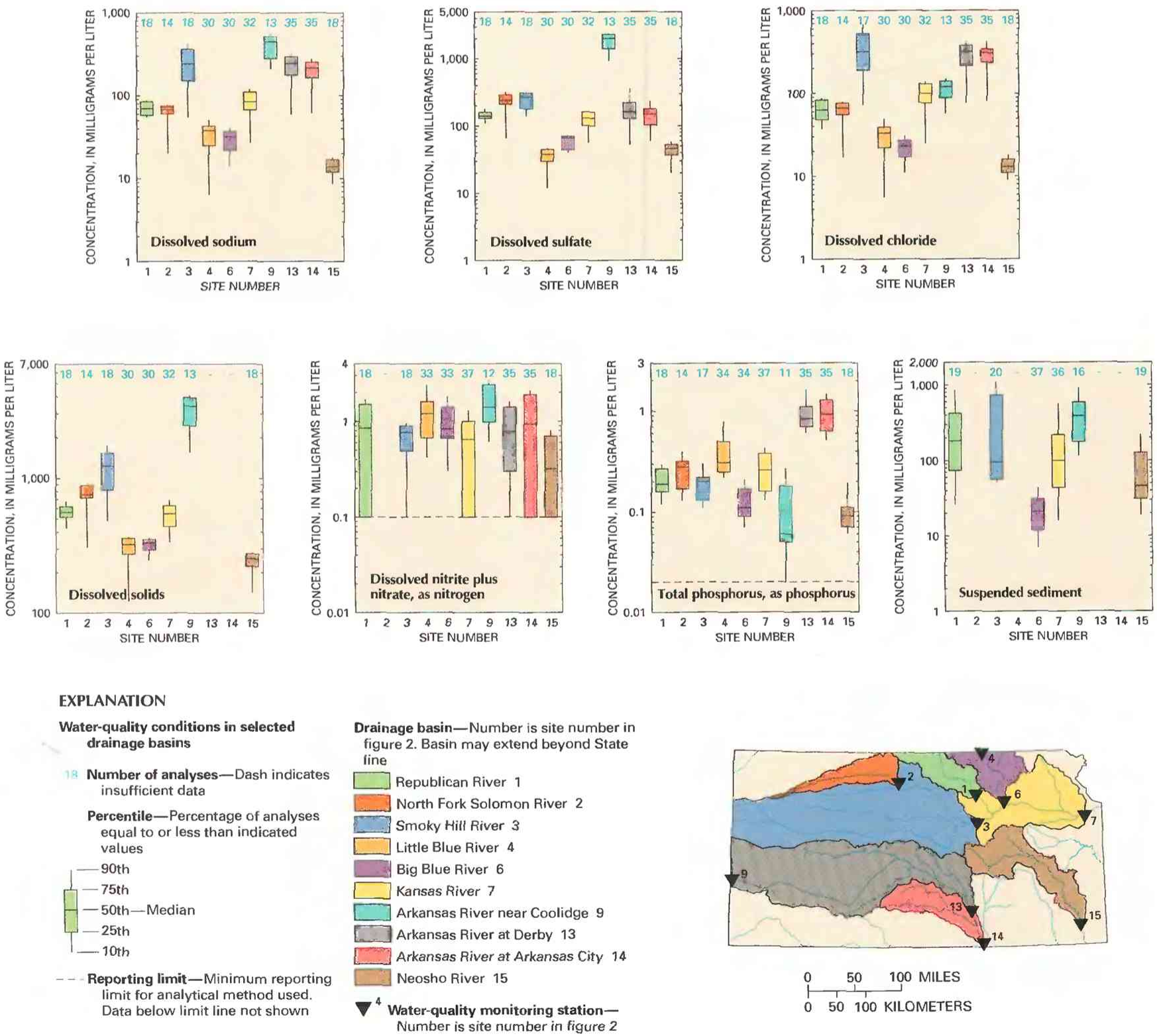

Figure 3. Water quality of selected streams in Kansas, water years 1987-89. (Source: Data from U.S. Geological Survey and Kansas Department of Health and Environment files.) 
Table 1. Sources and environmental significance of selected water-quality constituents

[Source: Compiled by the U.S. Geologıcal Survey, Office of Water Quality]

\begin{tabular}{|c|c|c|}
\hline Constituent & Common sources & Environmental significance \\
\hline Sodium & $\begin{array}{l}\text { Occurs in some igneous rocks, evaporite deposits, and } \\
\text { sediments; also in oil-field brines, road deicers, and } \\
\text { irrigation return flow. }\end{array}$ & $\begin{array}{l}\text { Can cause water to be unsuitable for public supply, } \\
\text { agriculture, and industry. }\end{array}$ \\
\hline Sulfate & $\begin{array}{l}\text { Occurs in some rocks; also in mine runoff, industrial } \\
\text { wastewater discharge, and atmospheric deposi- } \\
\text { tion. }\end{array}$ & $\begin{array}{l}\text { Concentrations exceeding a natural, background } \\
\text { level indicate contamination from human activity; } \\
\text { in sufficient quantity, can cause water to be } \\
\text { unsuitable for public supply; can harm aquatic } \\
\text { organisms. }\end{array}$ \\
\hline Chloride & $\begin{array}{l}\text { Occurs in some rocks and ground-water discharge; } \\
\text { also in road deicers, industrial and urban waste- } \\
\text { water discharge, and atmospheric deposition. }\end{array}$ & $\begin{array}{l}\text { Concentrations exceeding a natural, background level } \\
\text { can cause water to be unsuitable for public supply, } \\
\text { agriculture, and industry; can harm aquatic or- } \\
\text { ganisms. }\end{array}$ \\
\hline Dissolved solids ............................ & $\begin{array}{l}\text { A result of rock weathering; also in agricultural runoff } \\
\text { and industrial discharge. }\end{array}$ & $\begin{array}{l}\text { In sufficient quantity, can cause water to be unsuitable } \\
\text { for public supply, agriculture, and industry; can } \\
\text { harm aquatic organisms. }\end{array}$ \\
\hline Nitrite plus nitrate .......................... & $\begin{array}{l}\text { Nonpoint sources are agricultural and urban runoff; } \\
\text { a major point source is wastewater discharge. }\end{array}$ & $\begin{array}{l}\text { Plant nutrient that, in sufficient quantity, can cause } \\
\text { algal blooms and excessive growth of higher } \\
\text { aquatic plants in bodies of water; can cause water } \\
\text { to be unsuitable for public supply. }\end{array}$ \\
\hline 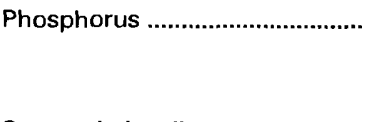 & $\begin{array}{l}\text { Occurs in some rocks and sediments; also in runoff } \\
\text { and seepage from phosphate-rock mines, agri- } \\
\text { cultural and urban runoff, and industrial and } \\
\text { municipal wastewater discharge. }\end{array}$ & $\begin{array}{l}\text { Plant nutrient that, in sufficient quantity, can cause } \\
\text { algal blooms and excessive growth of higher } \\
\text { aquatic plants in bodies of water. }\end{array}$ \\
\hline Suspended sediment ....................... & $\begin{array}{l}\text { A result of rock erosion; also induced by disturbances } \\
\text { of land cover due to fires, floods, and human } \\
\text { activities such as mining, logging, construction, } \\
\text { and agriculture. }\end{array}$ & $\begin{array}{l}\text { Can be detrimental to aquatic organisms; can fill res- } \\
\text { ervoirs and impair recreational use of water. }\end{array}$ \\
\hline
\end{tabular}

are tributary to the Smoky Hill River. All of these rivers drain land that is used predominantly for agriculture. Soils in these basins are easily eroded by wind and water.

The quality of stream water in downstream reaches of the Smoky Hill, Solomon, and Saline Rivers is adversely affected by discharge of mineralized ground water containing large concentrations of sodium, sulfate, chloride, and dissolved solids. This problem becomes more severe during periods of low flow and impairs use of the water for public supply. Sources of the mineralized water are naturally occurring salt formations and brines associated with petroleum production (Gogel, 1981). Irrigation return flows also have caused increased concentrations of sodium, sulfate, chloride, and dissolved solids in ground water and base flows of the Republican and Smoky Hill River valleys (Spruill, 1985).

During water years 1987-89, median concentrations of dissolved solids consistently exceeded the Kansas water-quality standard of $500 \mathrm{mg} / \mathrm{L}$ in the Republican River at site 1, the North Fork Solomon River at site 2, and the Smoky Hill River at site 3 (fig. 3). At sites 2 and 3, median sulfate concentrations were near the State standard of $250 \mathrm{mg} / \mathrm{L}$. At site 3 , the median concentration of sodium $(240 \mathrm{mg} / \mathrm{L}$ ) exceeded the State's suggested limit of $100 \mathrm{mg} / \mathrm{L}$, and the median concentration of chloride $(320 \mathrm{mg} / \mathrm{L})$ exceeded the Kansas water-quality standard of $250 \mathrm{mg} / \mathrm{L}$. Agricultural runoff contributes large concentrations of sediment to streams in the Republican and Smoky Hill River basins. Concentrations of suspended sediment were relatively large at sites 1 and 3 during water years 1987-89.

\section{KANSAS, LITTLE BLUE, AND BIG BLUE RIVERS}

The Kansas River is formed by the confluence of the Republican and Smoky Hill Rivers and flows eastward to join the Missouri River. The Big Blue and Little Blue Rivers, major tributaries to the Kansas River, drain cropland in Nebraska and northeastern Kansas. Large, multipurpose reservoirs have been constructed on the Big Blue River and on two other major tributaries to the Kansas River, the
Delaware and Wakarusa Rivers, which also drain agricultural land. Water from these reservoirs and from the Kansas River supplies many of the municipal and industrial needs of the large populations living in the urban corridor from Junction City to Kansas City.

Stream water quality in the Kansas River and its tributaries is affected by agricultural runoff, industrial and municipal effluents, and urban runoff. During water years $1987-89$, the median concentration of dissolved solids in water from the Kansas River at site 7 $(545 \mathrm{mg} / \mathrm{L}$ ) exceeded the State water-quality standard of $500 \mathrm{mg} / \mathrm{L}$ primarily because there were large concentrations of sodium (median, $84 \mathrm{mg} / \mathrm{L}$ ), sulfate (median, $130 \mathrm{mg} / \mathrm{L}$ ), and chloride (median, $100 \mathrm{mg} / \mathrm{L}$ ), which are major constituents of dissolved solids. The median concentrations were substantially larger than those at sites 4 and 6 on the tributary streams. However, nitrite plus nitrate concentrations generally were larger in the Big Blue River at site 6 (median, $0.83 \mathrm{mg} / \mathrm{L}$ ) and in the Little Blue River at site 4 (median, 1.2 $\mathrm{mg} / \mathrm{L}$ ) than at site 7 on the Kansas River (median, $0.65 \mathrm{mg} / \mathrm{L}$ ). These data indicate that agricultural sources of nitrite and nitrate (fertilizers and animal wastes) had a greater effect on stream water quality in the Kansas River basin during 1987-89 than did urban sources, such as wastewater-treatment-plant effluent. Suspended-sediment concentrations were much larger in the Kansas River at site 7 (median, 100 $\mathrm{mg} / \mathrm{L}$ ) than in the Big Blue River at site 6 (median, $21 \mathrm{mg} / \mathrm{L}$ ) because site 6 is only 2.5 miles downstream from Tuttle Creek Lake, a reservoir that traps most of the sediment (P.R. Jordan, U.S. Geological Survey, written commun., August 1990).

Atrazine is detected most frequently and in the largest concentrations in eastern Kansas, where this herbicide commonly is applied. Also, greater precipitation in that part of the State causes more runoff from cropland. Results from a recent study of water quality in the lower Kansas River basin indicated that atrazine concentrations are largest during spring and summer and frequently exceed the EPA's Maximum Contaminant Level of 3.0 micrograms per liter (Stamer and others, 1990, p. 26). Atrazine is not appreciably removed during conventional water-treatment processes unless activated-carbon filtering is used (Miltner and others, 1989). 


\section{ARKANSAS RIVER}

The Arkansas River basin spans six States. The river flows through Kansas from Colorado to Oklahoma. Water in the western reaches of the river typically contains large concentrations of sodium, sulfate, chloride, and dissolved solids because of the continual reuse of the water for irrigation in eastern Colorado and western Kansas. Concentrations of dissolved constituents are increased in irrigation return flows because of evaporation and leaching of salts from the soil. Irrigation return flows have the greatest effect on the quality of water in the Arkansas River during periods of little precipitation when the source of most streamflow is tailwater from irrigated fields and ground-water return flow (Cain, 1985).

Concentrations of sodium (median, $450 \mathrm{mg} / \mathrm{L}$ ), sulfate (median, 2,000 mg/L), and dissolved solids (median, 3,410 mg/L) at site 9 were the largest at any of the 10 monitoring stations. However, the median phosphorus concentration at site $9(0.06 \mathrm{mg} / \mathrm{L})$ was the smallest for any of the sampling sites; there is no readily apparent reason for the unexpectedly small concentrations. Suspended sediment, which is transported by irrigation tailwater, generally had the largest concentrations at site 9 (median, $389 \mathrm{mg} / \mathrm{L}$ ).

In downstream reaches of the Arkansas River, where larger populations and more industry are located, water quality is affected by tributary inflow and discharges from municipalities and industries. Dilution causes concentrations of some dissolved constituents in the Arkansas River to decrease between the upstream monitoring station at Coolidge (site 9) and downstream stations at Derby and Arkansas City (sites 13 and 14). The median sulfate concentration decreased from $2,000 \mathrm{mg} / \mathrm{L}$ at site 9 to less than $200 \mathrm{mg} / \mathrm{L}$ at sites 13 and 14. Median sodium and nitrite plus nitrate concentrations also were smaller at the downstream sites than at the upstream site. However, median chloride and phosphorus concentrations were larger at the downstream sites. Discharge of saline water to the Arkansas River is the primary cause of the larger concentration of chloride, which increased from a median of $120 \mathrm{mg} / \mathrm{L}$ at site 9 to medians of 317 $\mathrm{mg} / \mathrm{L}$ at site 13 and $305 \mathrm{mg} / \mathrm{L}$ at site 14 . The median phosphorus concentration increased from $0.06 \mathrm{mg} / \mathrm{L}$ at site 9 to $0.84 \mathrm{mg} / \mathrm{L}$ at site 13 and $0.92 \mathrm{mg} / \mathrm{L}$ at site 14 , most likely because of increased municipal and industrial discharges to downstream reaches of the Arkansas River.

In Kansas, the Arkansas River is not used for public supply because of unsuitable quality. About 40 percent of the public supply for Wichita is from Cheney Reservoir on the North Fork Ninnescah River, a tributary of the Arkansas River that has usable quality water. Other tributaries, such as Cow Creek, Rattlesnake Creek, and the South Fork Ninnescah River, are unusable in some reaches owing to natural saline ground-water discharge.

\section{NEOSHO RIVER}

The Neosho River drains agricultural land used for grazing and crops. Water tends to be very hard but is suitable for most uses throughout the basin. Surface water is used for most municipal and industrial supplies. At site 15 on the Neosho River near Parsons, sodium, sulfate, chloride, dissolved solids, nitrite plus nitrate, and phosphorus concentrations were substantially smaller than the State surface-water quality standards or suggested limits. Median concentrations of all constituents at site 15 were either the smallest or among the smallest of those at any of the 10 monitoring stations (fig. 3).

Some tributaries to the Neosho River drain land that has been mined for coal, lead, and zinc. Mining caused lasting disturbance to the land and to the hydrology of the area. As a result, runoff and ground water contribute large concentrations of dissolved solids, sulfate, toxic metals, and acidity to streams (Bevans, 1980; Spruill, 1987). The affected streams drain into the Neosho River downstream from site 15 .

\section{WATER-QUALITY TRENDS}

Trend analysis is a statistical procedure used to detect changes in stream water quality at a monitoring station over time. For this report, water-quality data from 15 monitoring stations (fig. 2) were analyzed for trends by using the seasonal Kendall test (Hirsch and others, 1982), a method used extensively by the USGS. The graph (shown below) of the dissolved nitrite plus nitrate concentration in the $\mathrm{Ar}$ kansas River at site 13 illustrates the trend inferred from the concentration data and demonstrates the variation in water quality that is common in streams.

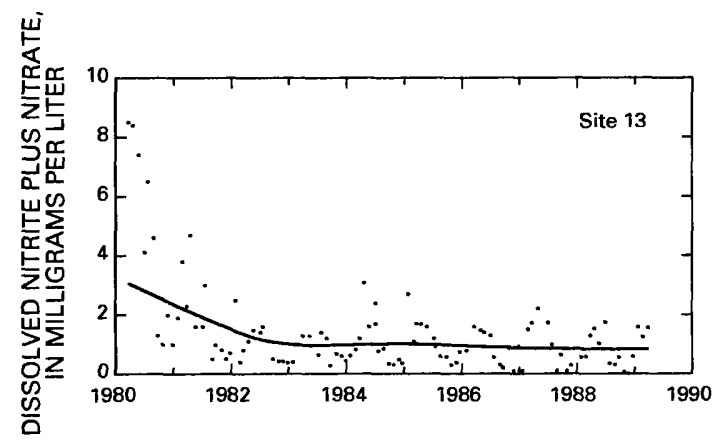

When possible, constituent-concentration data were adjusted for changes in streamflow to preclude identifying a trend in concentration that was caused only by a trend in streamflow. The data were not adjusted when (1) more than 10 percent of the samples had concentrations lower than the minimum reporting limit for the analytical method used or (2) streamflow was controlled substantially by human activities. When the concentration data could not be adjusted for streamflow, trends were determined directly from the concentration data.

Statewide trends in concentrations of selected stream-water constituents are shown on maps in figure 4 . On each map, a trend is indicated at a monitoring station only if the data from that station were suitable for use in the trend analysis. For more information on the suitability criteria and on the trend-analysis procedure used for this report, see Lanfear and Alexander (1990).

\section{DISSOLVED SODIUM}

Sodium can enter streams as a consequence of natural processes or human activities. Once in solution, sodium tends to remain in that state; therefore the potential range of sodium concentration in streams is great (Hem, 1985, p. 100, 101).

The upward trend in sodium concentrations in the Big Blue River at site 6 possibly was the result of an increase in irrigated acreage in the drainage basins of the Big Blue and Little Blue Rivers. In 1982 , about 21 percent $(1,307,400$ acres $)$ of the drainage area was irrigated cropland; in 1987 , about 24 percent $(1,465,600$ acres $)$ was irrigated (L.J. Kuder, U.S. Soil Conservation Service, written commun., August 1990; C.A. Miller, U.S. Soil Conservation Service, written commun., September 1990). Drainage from irrigated land commonly contains larger concentrations of dissolved ions, such as sodium, sulfate, and chloride, than the applied water (L.R. Petri, U.S. Geological Survey, written commun., June 1968).

\section{DISSOLVED SULFATE}

The major natural sources of sulfate in streams are rock weathering, volcanoes, and biochemical processes (Hem, 1985, p. 113). Human activities such as mining, waste discharge, and fossil-fuel combustion also can be important sources. The decreasing sulfate concentration at site 15 possibly was related to less than average 
streamflow and resulting large concentrations of dissolved substances during $1980-81$ followed by a return to more normal streamflow and concentrations during succeeding years of the trend-analysis period.

\section{DISSOLVED CHLORIDE}

Chloride is present in all natural waters but usually in low concentrations (Hem, 1985, p. 118). Except in streams that receive ground-water discharge high in chloride, concentrations of greater than a few milligrams per liter generally are the result of human activities (table 1).
The upward trend in chloride concentrations in the Big Blue River at site 6 possibly was the result of the increase in irrigated acreage in the Big Blue River and Little Blue River basins in Kansas and Nebraska. The downward trend in chloride concentrations in the Neosho River at site 15 probably had the same cause as the decreasing sulfate concentration at that location.

\section{DISSOLVED SOLIDS}

Dissolved solids in stream water result primarily from rock weathering but also can be introduced as a byproduct of human ac-

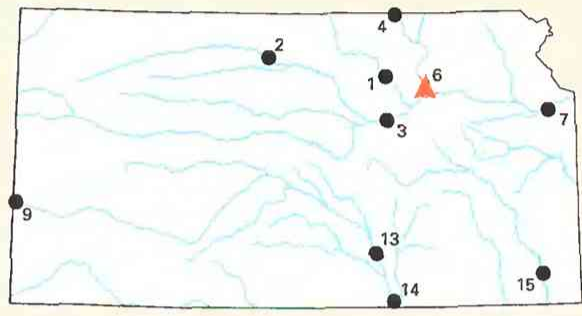

Dissolved sodium, 1980-89

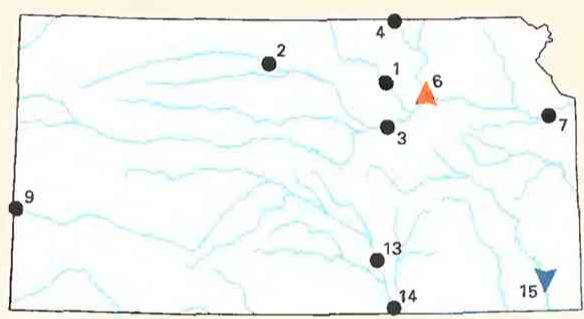

Dissolved chloride, 1980-89

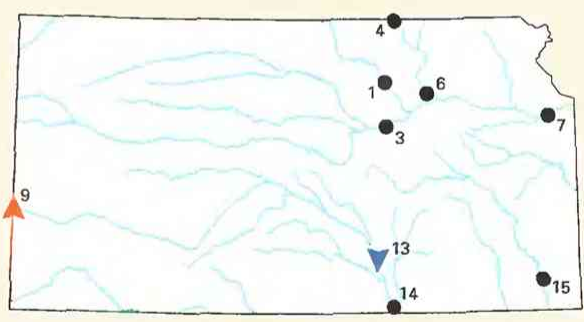

Dissolved nitrite plus nitrate, $1980-89$

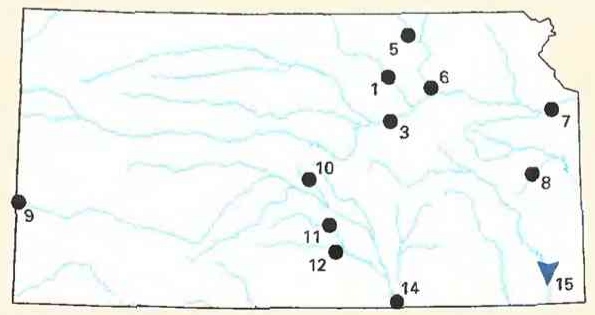

Suspended sediment, 1980-89

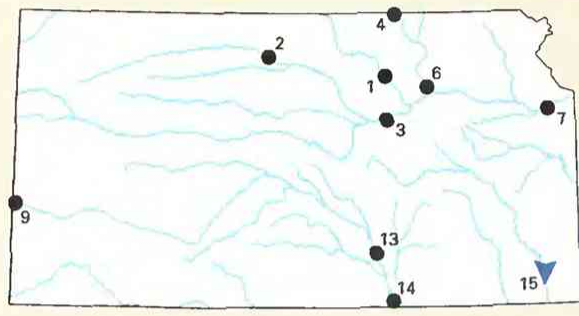

Dissolved sulfate, 1980-89

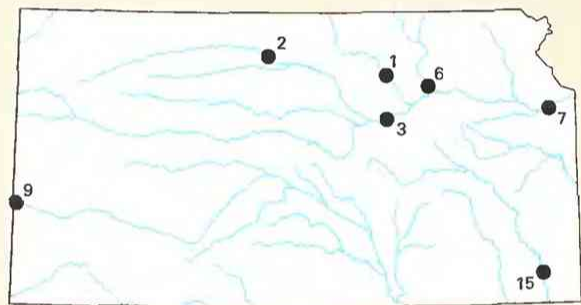

Dissolved solids, 1980-89

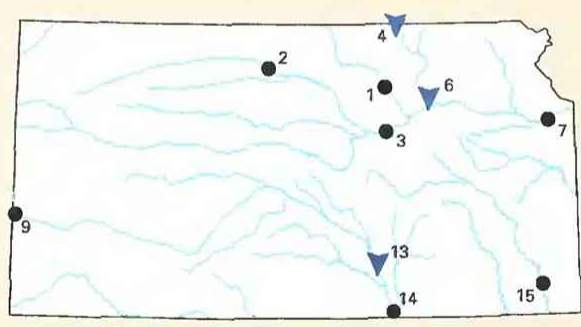

Total phosphorus, 1980-89

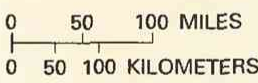

\section{EXPLANATION}

Trend in water-quality constituentNumber is site number in figure 2

$$
\begin{aligned}
& \Delta^{9} \text { Upward } \\
& { }^{3} \text { None } \\
& \nabla^{6} \text { Downward }
\end{aligned}
$$

Figure 4. Trends in water quality of selected streams in Kansas, by water years. (Source: Data from U.S. Geological Survey and Kansas Department of Health and Environment files.) 
tivities (table 1). Concentrations generally are greatest in streams draining basins underlain by rocks and soils that contain easily dissolved minerals. Dissolved-solids concentrations had no significant trend at the seven monitoring stations during water years 1980-89.

\section{DISSOLVED NITRITE PLUS NITRATE}

Nitrite and nitrate are oxidized forms of nitrogen that together normally constitute most of the dissolved nitrogen in well-aerated streams. Nitrite readily oxidizes to nitrate in natural waters; therefore, nitrate generally is by far the more abundant of the two (Hem, 1985 , p. 124).

The increasing nitrite plus nitrate concentrations in the Arkansas River at site 9 could be related to an increase in the amount of nitrogen-containing fertilizers used upstream from this site, in Colorado. Between 1986 and 1989, fertilizer use in the four eastern Colorado counties bordering the Arkansas River increased by 35 percent (Bill Lawson, Colorado Department of Agriculture, written commun., 1990). The decreasing nitrite plus nitrate concentrations in the Arkansas River at site 13 resulted from the upgrading in the early 1980's of all sewage-treatment facilities in south Wichita, several miles upstream from Derby. All sewage now receives at least secondary treatment in which nutrients such as nitrogen and phosphorus are more effectively removed.

\section{TOTAL PHOSPHORUS}

The total phosphorus concentration of a water sample is a measure of the concentration of all forms of phosphorus present in the sample, dissolved and particulate. Human activities (table 1) can be important sources of phosphorus in streams.

Both site 4 on the Little Blue River and site 6 on the Big Blue River monitor drainage from primarily agricultural land, mostly in Nebraska. About 95 percent of phosphate-fertilizer use in the drainage basins of the Little Blue and Big Blue Rivers occurs in Nebraska (Ron Zelt, U.S. Geological Survey, written commun., 1990). From 1981 to 1989, phosphate-fertilizer applications in Nebraska declined from about 40,000 tons to 11,000 tons (Nebraska Department of Agriculture, 1990). The decreasing phosphorus concentrations at sites 4 and 6 are most likely related to this decrease in fertilizer use. In the Arkansas River at site 13, decreases in phosphorus concentrations correspond to improvement in wastewater treatment in Wichita during the early 1980 's.

\section{SUSPENDED SEDIMENT}

Suspended sediment is a product of erosion. The erosion can be either natural or the result of land-cover disturbances related to human activities (table 1).

The decreasing suspended-sediment concentrations in the Neosho River at site 15 might have resulted from decreased erosion in the drainage basin. Improved land-use practices, retention of runoff in ponds and reservoirs, and a decrease in the occurrence of intense storms can decrease rates of overland runoff and quantities of sediment carried into streams.

\section{WATER-QUALITY MANAGEMENT}

The KDHE, Division of Environment, has the primary responsibility for administering provisions of Federal water-pollution-control statutes. The Division is responsible for protection of drinkingwater supplies, regulation of wastewater discharges, control of nonpoint-source pollution, and reclamation of mined land. The Division also monitors and assesses the quality of the State's surfaceand ground-water resources and establishes water-quality standards (Kansas Department of Health and Environment, 1986a).
The Division of Environment prepares a biennial waterquality-assessment report (Kansas Department of Health and Environment, 1990) that is submitted to the U.S. Congress and the EPA pursuant to section 305(b) of the Federal Clean Water Act. In preparing the report, the Division relies extensively on physical and chemical monitoring conducted at its network of fixed and rotational stations, lake and reservoir surveys, a stream-macroinvertebrate sampling network, effluent-quality monitoring, effluent-toxicity testing, fish-tissue monitoring (a cooperative venture with Region VII of the EPA), and special investigations. Since the early 1970 's, water-quality monitoring conducted by the KDHE has increased substantially in number of sites sampled and the substances monitored.

The Kansas nonpoint-source pollution-control program is the most recent State water-quality-management initiative. The 1987 amendments to the Federal Clean Water Act require States to assess water-quality effects of nonpoint pollutant sources and to develop a corrective-action program. The Kansas program also seeks to protect existing undamaged water quality. The KDHE is responsible for maintaining and coordinating the nonpoint-source pollution-control program among numerous State, Federal, and local agencies.

\section{SELECTED REFERENCES}

Anderson, J.R., 1967, Major land uses in the United States, in U.S. Geological Survey, 1970, National atlas of the United States of America: Washington, D.C., U.S. Geological Survey, p. 158-159.

Bevans, H.E., 1980, A procedure for predicting concentrations of dissolved solids and sulfate ion in streams draining areas strip mined for coal: U.S. Geological Survey Water-Resources Investigations, Open-File Report $80-764,17 \mathrm{p}$.

Britton, L.J., and Greeson, P.E., eds., 1987, Methods for collection and analysis of aquatic biological and microbiological samples: U.S. Geological Survey Techniques of Water-Resources Investigations, book 5, chap. A4, $363 \mathrm{p}$.

Cain, Doug, 1985, Quality of the Arkansas River and irrigation-return flows in the lower Arkansas River valley, Colorado: U.S. Geological Survey Water-Resources Investigations Report 84-4273, 85 p.

Fenneman, N.M., 1946, Physical divisions of the United States: Washington, D.C., U.S. Geological Survey special map, scale 1:7,000,000.

Fishman, M.J., and Friedman, L.C., eds., 1989, Methods for the determination of inorganic substances in water and fluvial sediments: U.S. Geological Survey Techniques of Water-Resources Investigations, book 5 , chap. A1, 545 p.

Gogel, Tony, 1981, Discharge of saltwater from Permian rocks to major streamaquifer systems in central Kansas: Kansas Geological Survey Chemical Quality Series 9,60 p.

Hem, J.D., 1985, Study and interpretation of the chemical characteristics of natural water (3d ed.): U.S. Geological Survey Water-Supply Paper 2254, $263 \mathrm{p}$.

Hirsch, R.M., Slack, J.R., and Smith, R.A., 1982, Techniques of trend analysis for monthly water quality data: Water Resources Research, v. 18, no. 1, p. 107-121.

Institute for Public Policy and Business Research, 1990, Kansas statistical abstract 1988-89: Lawrence, University of Kansas, 298 p.

Kansas Department of Health and Environment, 1986a, Kansas surface-water quality standards: Topeka, Kansas Department of Health and Environment, Kansas Administrative Regulations 28-16-28e, p. 7.

$1986 \mathrm{~b}$, Explanation of your drinking water analysis: Topeka, Kansas Department of Health and Environment, pamphlet.

1987, Water quality implications of chlordane in Kansas: Topeka, Kansas Department of Health and Environment, Bureau of Water Protection, Division of Environment, $25 \mathrm{p}$.

1988, Kansas water quality assessment 1986-1987, 305(b) report: Topeka, Kansas Department of Health and Environment, Bureau of Water Protection, 144 p.

1989, Atrazine in Kansas: Topeka, Kansas Department of Health and Environment, Bureau of Water Protection, Division of Environment, $29 \mathrm{p}$.

1990, Kansas water quality 1988-1989, draft 305(b) report: Topeka, Kansas Department of Health and Environment, Bureau of Environmental Quality, Division of Environment, $50 \mathrm{p}$. 
Lanfear, K.J., and Alexander, R.B., 1990, Methodology to derive water-quality trends for use by the National Water Summary Program of the U.S. Geological Survey: U.S. Geological Survey Open-File Report 90-359, $10 \mathrm{p}$.

Miltner, R.J., Baker, D.B., Speth, T.F., and Fronk, C.A., 1989, Treatment of seasonal pesticides in surface waters: Journal of the American Water Works Association, v. 81, no. 1, p. 43-52.

Nebraska Department of Agriculture, 1990, 1989 Nebraska agricultural statistics: Lincoln, Nebraska Agricultural Statistics Service, $154 \mathrm{p}$.

Spruill, T.B., 1985, Statistical evaluation of the effects of irrigation on chemical quality of ground water and base flow in three river valleys in northcentral Kansas: U.S. Geological Survey Water-Resources Investigations Report 85-4156, $64 \mathrm{p}$.

1987, Assessment of water resources in lead-zinc mined areas in Cherokee County, Kansas, and adjacent areas: U.S. Geological Survey WaterSupply Paper 2268, $68 \mathrm{p}$.

Stamer, J.K., Pope, L.M., and Zelt, R.B., 1990, Occurrence and distribution of pesticides in the lower Kansas River basin in Kansas and Nebraska: Manhattan, Kans., Water and the Future of Kansas Conference, March 7-8, 1990, Proceedings, p. 25-26.

Thelin, G.P., and Pike, R.J., 1990, Digital shaded relief map of the conterminous United States: Menlo Park, Calif., U.S. Geological Survey digital image processing, scale 1:3,500,000.
U.S. Environmental Protection Agency, 1986a, Maximum contaminant levels (subpart B of part 141, National interim primary drinking-water regulations): U.S. Code of Federal Regulations, Title 40, parts 100 to 149 , revised as of July 1, 1986, p. 524-528.

1986b, Secondary maximum contaminant levels (section 143.3 of part 143, National secondary drinking-water regulations): U.S. Code of Federal Regulations, Title 40, parts 100 to 149, revised July 1, 1986, p. 587590.

1990, Suspended, cancelled, and restricted pesticides: Washington, D.C., U.S. Government Printing Office, no pagination.

U.S. Food and Drug Administration, 1984, Action levels for poisonous or deleterious substances in human food and animal feed: Washington, D.C., U.S. Government Printing Office, 14 p.

U.S. Geological Survey, 1986, National water summary 1985-Hydrologic events and surface-water resources: U.S. Geological Survey Water-Supply Paper 2300, $506 \mathrm{p}$.

1990, National water summary 1987-Hydrologic events and water supply and use: U.S. Geological Survey Water-Supply Paper 2350, $553 \mathrm{p}$.

Ward, J.R., and Harr, C.A., eds., 1990, Methods for collection and processing of surface-water and bed-material samples for physical and chemical analyses: U.S. Geological Survey Open-File Report 90-140, 71 p.

Prepared by Joan F. Kenny, U.S. Geological Survey; "Water-Quality Management" section by Donald H. Snethen, Kansas Department of Health and Environment

FOR ADDITIONAL INFORMATION: District Chief, U.S. Geological Survey, 4821 Quail Crest Place, Lawrence, KS 66049 


\section{KENTUCKY Stream Water Quality}

Kentucky has abundant water resources. Precipitation ranges from 40 inches per year in the northernmost part of the State to 52 inches in the southern part. Precipitation is least during August, September, and October (U.S. Geological Survey, 1986, p. 245). Seasonal or long-term variation in precipitation can affect streamflow and use of the resource; therefore, reservoirs commonly are used to augment streamflow during periods of little flow.

In 1985 , surface water accounted for 95.1 percent of the 4,200 million gallons per day of freshwater withdrawn for offstream use in Kentucky. Of the surface-water withdrawals, 84.4 percent was used for thermoelectric power generation; 8.9 percent was used for public supply; 5.3 percent was used for self-supplied domestic, commercial, industrial, and mining puposes; and 1.4 percent was used for agriculture (U.S. Geological Survey, 1990, p. 272).

Most Kentucky streams fully support uses designated by the State for purposes of water-pollution control. However, some streams do not support or only partially support designated uses because of fecal coliform bacteria contamination, organic enrichment, or siltation (Kentucky Natural Resources and Environmental Protection Cabinet, 1990a, p. 1). A stream in Kentucky can be designated for one or more of the following uses: warm-water aquatic habitat, coldwater aquatic habitat, domestic water supply, primary-contact recreation, secondary-contact recreation, and outstanding-resource waters (Kentucky Natural Resources and Environmental Protection Cabinet, 1990b).

The availability of reliable water-supply and navigation systems on the larger rivers contributes to the State's diverse land uses (fig. 1A). The construction of reservoirs, some with lock systems for barge traffic, has resulted in the continued inland development of the

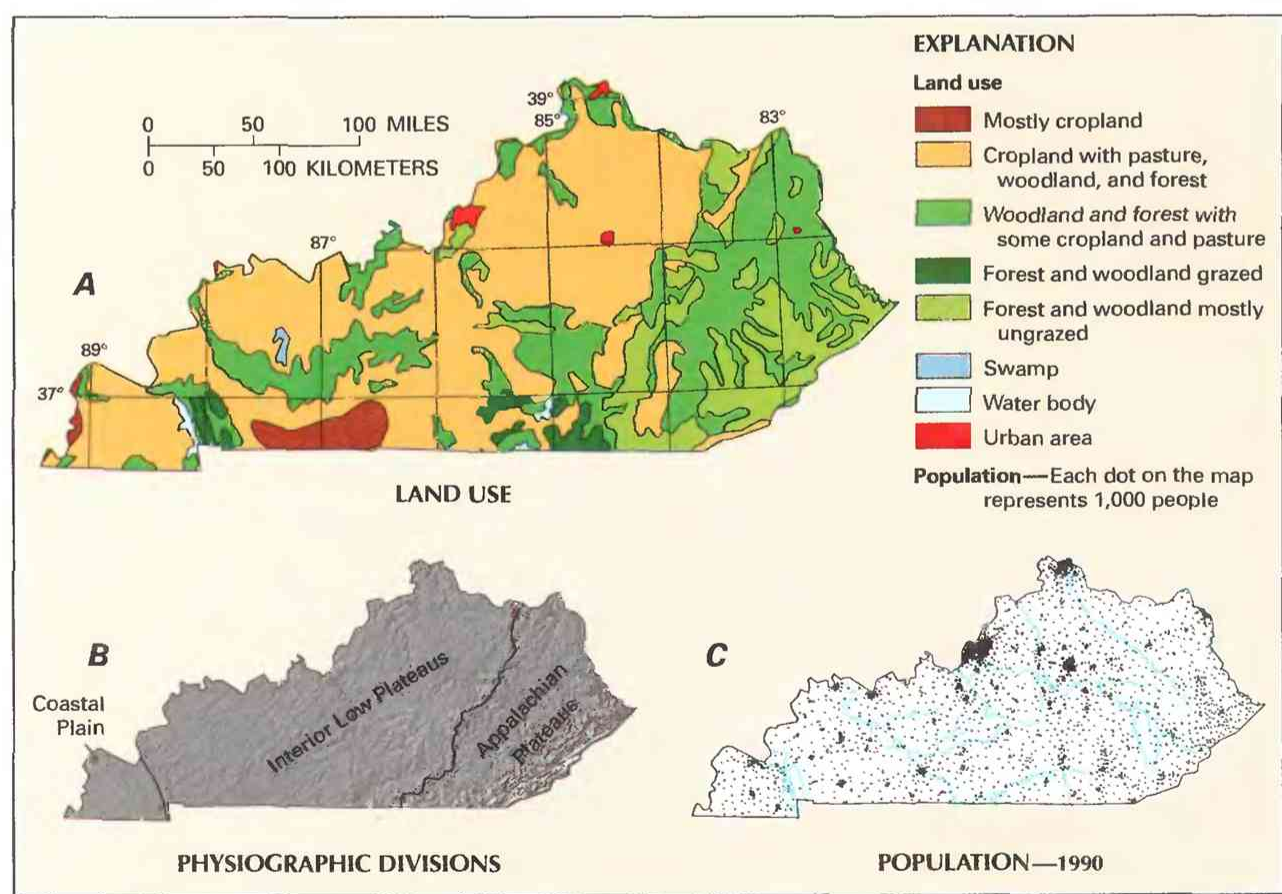

Figure 1. Land use, physiography, and population in Kentucky. A, Major land uses. B, Physiographic divisions. C, Population distribution in 1990. (Sources: A, Major land uses modified from Anderson, 1967. B, Physiographic divisions from Fenneman, 1946; landforms from Thelin and Pike, 1990. C, Data from U.S. Bureau of the Census 1990 decennial census files.)
Interior Low Plateaus and the Coastal Plain (fig. 1B). The reservoirs also provide flood control, electric-power generation, water supply, and recreation. The rich soils and accessibility of the flat to rolling hills characteristic of the Interior Low Plateaus and the Coastal Plain support agricultural, urban, and industrial growth. Poor soils and accessibility problems associated with the rugged, steep, and narrow valleys of the Appalachian Plateaus restrict economic development in eastern Kentucky. In that physiographic province, coal, oil, and natural gas extraction is the principal industry.

Distribution of Kentucky's 3.7 million population (U.S. Bureau of the Census 1990 decennial census files) reflects the topography and resource potentials of the three physiographic provinces. The greatest population densities (fig. $1 C$ ) are along major rivers (Ohio, Kentucky, Green, and Barren Rivers), where the availability of water supports the growth of urban centers.

\section{WATER-QUALITY MONITORING}

Water-quality data obtained from analyses of water samples collected at monitoring stations are stored in the U.S. Geological Survey's (USGS) National Water Information System and the U.S. Environmental Protection Agency's (EPA) national data base known as STORET. Water-quality and streamflow data are reported by water year-the 12 months from October 1 through September 30. A water year is identified by the calendar year in which it ends. For example, water year 1991 comprises October 1, 1990, through September 30, 1991.

The data used in this summary of Kentucky's stream water quality were obtained from water samples collected at 11 monitoring stations at which data collection was systematic (fig. 2). Analyses of water samples collected at 10 stations are the basis for the discussion and graphic summary (fig. 3) of stream water-quality conditions during water years $1987-89$, and data from 10 stations are the basis for the discussion and graphic summary (fig. 4) of stream waterquality trends. Water samples were collected and analyzed by using standard methods approved by the USGS (Britton and Greeson, 1987; Fishman and Friedman, 1989; Ward and Harr, 1990) or by using equivalent methods. If a method of sample collection or analysis changed over time, data from an analysis were included in the evaluation of recent stream water quality or of stream water-quality trends only if the change in method did not affect the comparability of the data.

\section{WATER-QUALITY CONDITIONS}

Of 10,221 stream miles assessed by the Kentucky Natural 
Resources and Environmental Protection Cabinet (KNREPC), 6,630 miles supported designated uses, 1,613 miles only partially supported designated uses, and 1,978 miles did not support designated usesspecifically warm-water aquatic habitat and primary-contact recreation uses. The major causes of nonsupport were fecal coliform bacteria contamination, which affected primary-contact recreation use, and organic enrichment and siltation, which impaired warm-water aquatic habitat use. The main sources of fecal coliform bacteria contamination were municipal wastewater-treatment plant discharges and agricultural runoff. Municipal point sources caused organic enrichment, whereas surface mining and agricultural nonpoint sources were the major sources of siltation (Kentucky Natural Resources and Environmental Protection Cabinet, 1990a, p. 1).

In 1989, the KNREPC assessed nonpoint-source contamination and concluded that agriculture adversely affected about 50 percent of the streams and lakes assessed. Twenty-four percent of the streams and lakes assessed were contaminated by resource extraction (primarily coal, oil, and gas). Other nonpoint sources included silviculture; construction; urban runoff; hydrologic-habitat modifications, such as dredge and fill operations; and land disposal of waste (Kentucky Natural Resources and Environmental Protection Cabinet, 1989 , p. vi).

The following discussion of stream water quality in Kentucky is organized by river basin (fig. 3). Where physiographic and landuse characteristics in different basins are similar, the discussion of those basins is combined. Graphs in figure 3 summarize certain aspects of stream water quality in the basins for water years 1987-89. The graphs show frequency distributions of data values that represent concentrations of selected constituents in stream water and measurements of selected physical properties of stream water. These con- stituents and properties are dissolved oxygen, alkalinity (as calcium carbonate), dissolved sulfate, dissolved solids, dissolved nitrite plus nitrate (as nitrogen), dissolved phosphate (as phosphorus), and suspended sediment. The data are reported in milligrams per liter $(\mathrm{mg} / \mathrm{L})$. Sources and environmental significance of each constituent and property are described in table 1 .

Water quality at each monitoring station is the result of geological, chemical, biological, and hydrologic processes that occur over a large area. Water-quality problems potentially affecting aquatic life and public health associated with the consumption of water and fish contaminated with toxic constituents have been reported by the KNREPC $(1988,1989,1990 a)$ in specific stream reaches; however, discussion of such local problems is beyond the scope of this report.

\section{BIG SANDY RIVER}

The Big Sandy River basin lies in the rugged mountains of the Appalachian Plateaus in eastern Kentucky, Virginia, and West Virginia. The basin is underlain by sandstone, shale, and coal. The excessively drained, shallow soils of the upland areas are suitable only for forest, which supports small silviculture operations. Agricultural development is limited to the valleys. The principal industry in the basin is the extraction of coal and, to a lesser degree, oil and natural gas. The major sources of stream contamination in the basin are resource extraction (acidic drainage, sulfate, iron, chloride, toxic metals, and sediment); silviculture (sediment); onsite and municipal wastewater-treatment systems (decomposable organic matter, nutrients, and pathogens); and landfills (metals, sediment, and pathogens) (Kentucky Natural Resources and Environmental Protection Cabinet, 1989, p. 15; 1990a, p. 18).

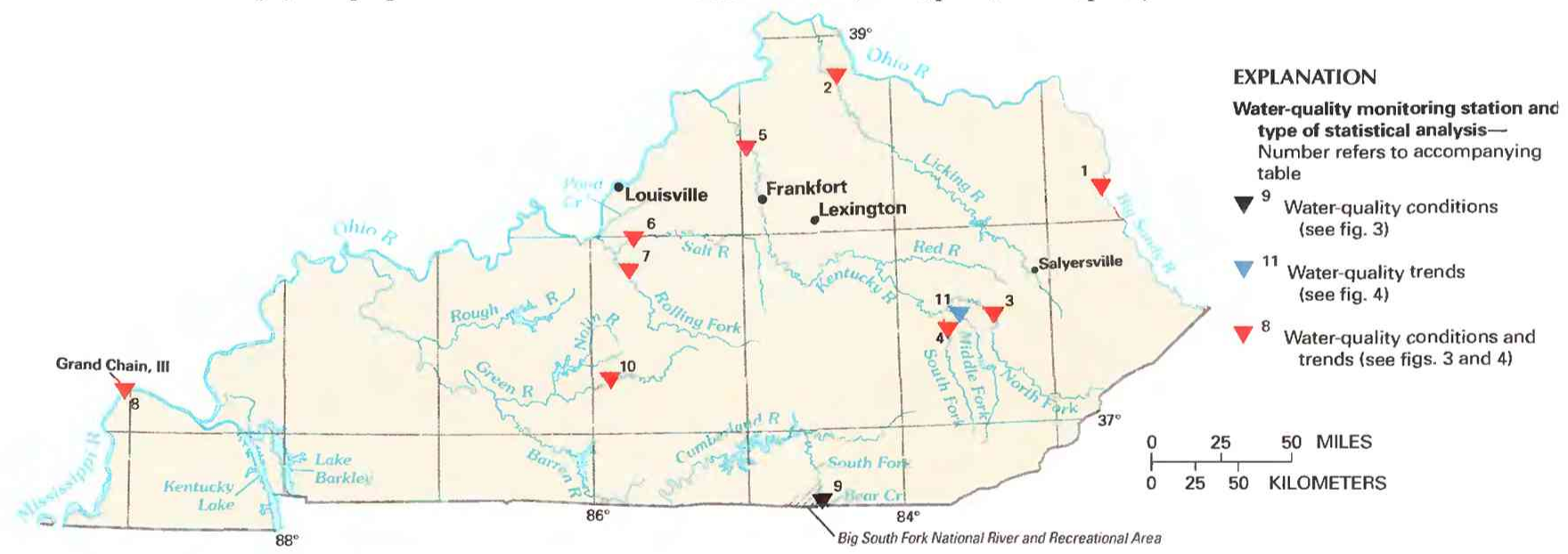

\begin{tabular}{|c|c|c|c|}
\hline $\begin{array}{l}\text { Site no. } \\
\text { on map }\end{array}$ & $\begin{array}{l}\text { USGS station } \\
\text { name and no. }\end{array}$ & $\begin{array}{l}\text { Drainage area } \\
\text { (square miles) }\end{array}$ & $\begin{array}{l}\text { Major land use } \\
\text { (see fig. 1) }\end{array}$ \\
\hline 1 & Big Sandy River at Louisa (03215000) & 3,897 & $\begin{array}{l}\text { Mostly ungrazed forest and woodland; woodland and forest with } \\
\text { some cropland and pasture. }\end{array}$ \\
\hline 2 & Licking River at Butler $(03254000)$ & 3,375 & Cropland with pasture, woodland, and forest. \\
\hline 3 & 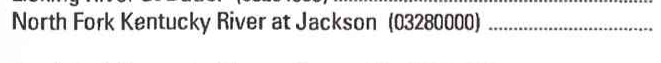 & 1,101 & $\begin{array}{l}\text { Mostly ungrazed forest and woodland; woodland and forest with } \\
\text { some cropland and pasture. }\end{array}$ \\
\hline 4 & 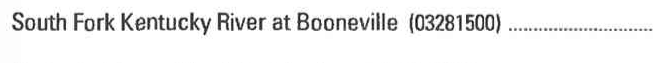 & 722 & $\begin{array}{l}\text { Woodland and forest with some cropland and pasture; mostly } \\
\text { ungrazed forest and woodland. }\end{array}$ \\
\hline 5 & Kentucky River at Lock 2, at Lockport $(03290500)$ & 6,180 & Cropland with pasture, woodland, and forest; urban areas. \\
\hline 6 & Salt River at Shepherdsville $(03298500)$ & 1,197 & Cropland with pasture, woodland, and forest. \\
\hline 7 & 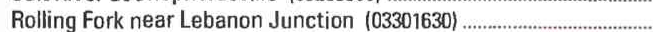 & 1,375 & Ditto. \\
\hline 8 & Ohio River at Lock and Dam 53, near Grand Chain, III. (03612500) ..... & 203,100 & Ditto. \\
\hline 9 & 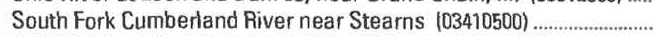 & 954 & Grazed forest and woodland. \\
\hline 10 & Green River at Munfordville $(03308500)$ & 1,673 & Cropland with pasture, woodland, and forest. \\
\hline 11 & Middle Fork Kentucky River at Tallega (03281000) & 537 & $\begin{array}{l}\text { Woodland and forest with some cropland and pasture; mostly } \\
\text { ungrazed forest and woodland. }\end{array}$ \\
\hline
\end{tabular}

Figure 2. Selected water-quality monitoring stations, type of statistical analysis, and geographic features in Kentucky. (Sources: Major land uses modified from Anderson, 1967; other data from U.S. Geological Survey files.) 
Concentrations of dissolved solids and suspended sediment at site 1 on the Big Sandy River were among the highest recorded at the 10 monitoring stations (fig. 3). The median (50th percentile) sulfate concentration of $120 \mathrm{mg} / \mathrm{L}$ was two to seven times the median concentrations reported at all stations except site 3 . These data support the KNREPC's conclusions concerning major contamination sources in the basin. Mining activities have exposed soils that are readily leached and transported by runoff. Brines associated with oil extraction have increased dissolved-solids concentrations through runoff, leaking brine pits, and direct discharge to streams.

\section{LICKING RIVER}

The headwaters of the Licking River are located in the Appalachian Plateaus; the lower basin lies in the Interior Low Plateaus. The diverse topography of the basin ranges from rugged mountains underlain by sandstone, shale, and coal in areas drained by the headwaters to highly dissected areas and gently rolling hills underlain by limestone and shale in the Interior Low Plateaus. Dissolution of limestone increases the concentration of dissolved minerals and alkalinity in basin streams. Land-use activities, which also are diverse in the basin, include resource extraction in the upper basin and agriculture and heavy industry in the lower basin. Major sources of stream contamination in the basin are agriculture (sediment, nutrients, pesticides, and pathogens); onsite and municipal wastewater-treatment systems (decomposable organic material, nutrients, and pathogens); resource extraction (chlorides, sediment, and sulfate); open dumps (sediment, toxic metals, and pathogens); silviculture (sediment); and urban stormwater runoff (nutrients, toxic metals, and sediment) (Kentucky Natural Resources and Environmental Protection Cabinet, 1989. p. 19; 1990a, p. 19-20).

During water years 1987-89, dissolved-solids concentrations were relatively low at site 2 (fig. 3 ). However, oil-field brine has contaminated drinking-water supplies for cities such as Salyersville (Kentucky Natural Resources and Environmental Protection Cabinet, 1988, p. 117). The high median suspended-sediment concentration $(31 \mathrm{mg} / \mathrm{L})$, relative to those for most of the other monitoring stations, likely was the result of resource extraction in the upper basin and agricultural activities in the lower basin.

\section{KENTUCKY RIVER}

The main stem of the Kentucky River is formed by the confluence of the North Fork, Middle Fork, and South Fork Kentucky Rivers. The river then flows about 250 miles to the Ohio River. The upper Kentucky River basin, which drains areas of the Appala-
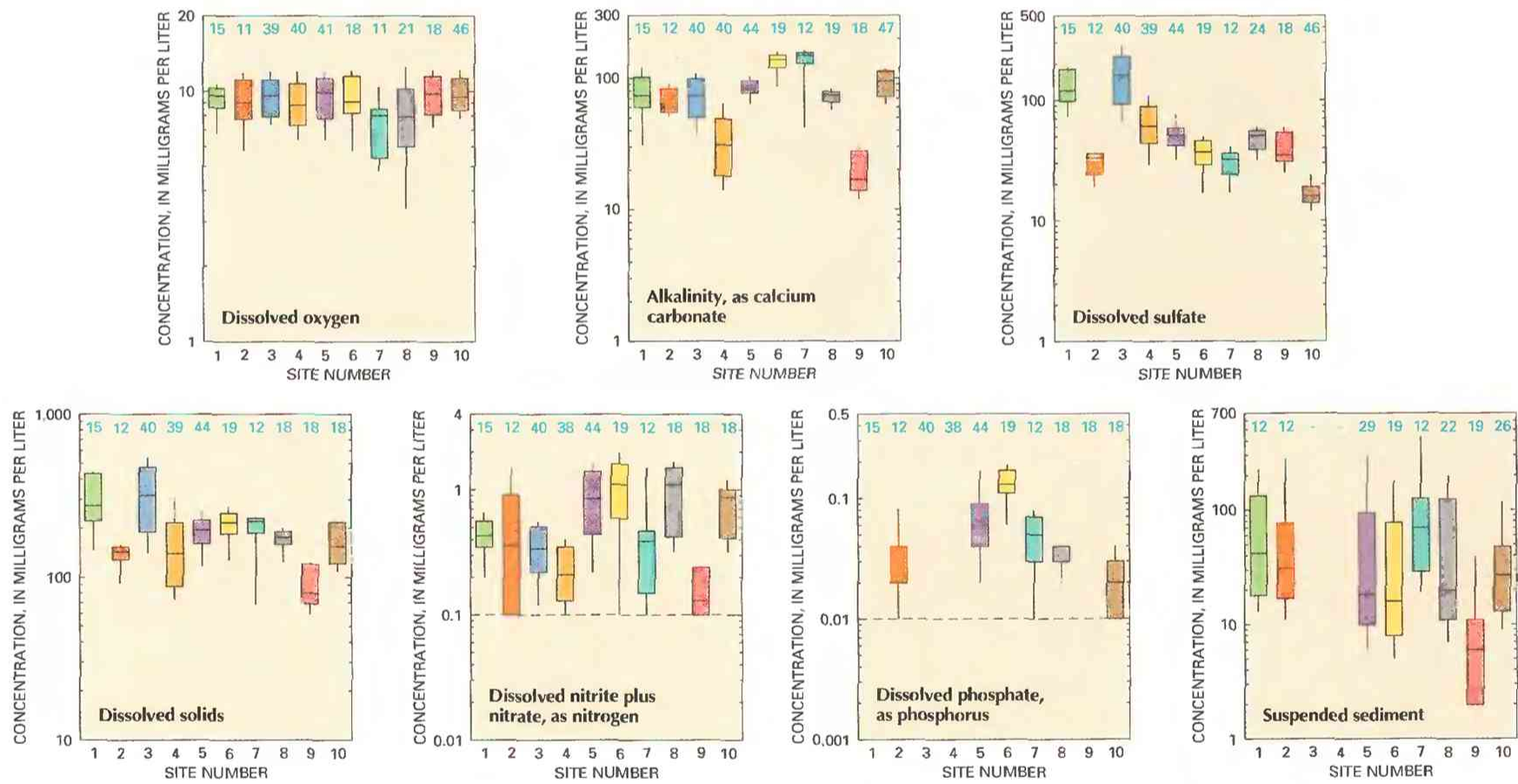

\section{EXPLANATION}

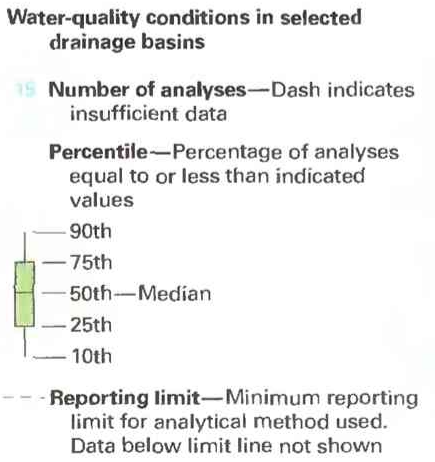
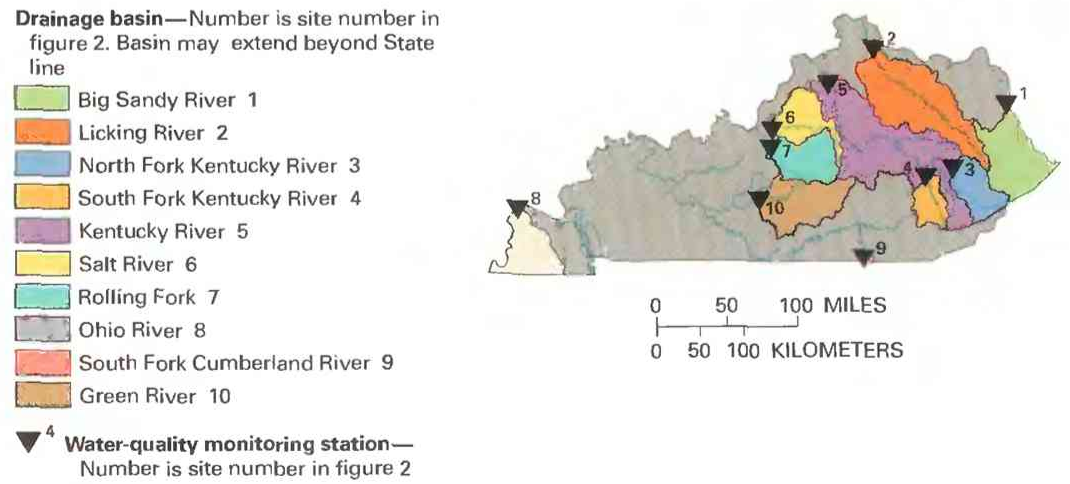

Figure 3. Water quality of selected streams in Kentucky, water years 1987-89. (Source: Data from U.S. Geological Survey files.) 
chian Plateaus, is underlain by sandstone, shale, and coal. In the upper basin, which is characterized by rugged topography and steep stream slopes, land disturbance caused by surface and underground coal mining substantially affects water-quality conditions (Smoot and others, 1991). The annual sediment yield for the North Fork, which has about 4 percent of its drainage area disturbed by mining, is about 1,500 tons per square mile, or about 15 times the yield per square mile of the Kentucky River basin as a whole. About 60 percent of the sulfate load in the Kentucky River basin originates in the upper basin (Smoot and others, 1991). Increased water-quality constituent concentrations and sediment loads in the North Fork Kentucky River basin have eliminated all but the most tolerant species of aquatic biota in many streams (Bradfield and Porter, 1990, p. 7).

The median concentrations of sulfate $(160 \mathrm{mg} / \mathrm{L})$ and dissolved solids $(319 \mathrm{mg} / \mathrm{L})$ in the North Fork Kentucky River at site 3 were higher than those for any of the other monitoring stations and were more than twice the median concentrations at site 4 on the South Fork Kentucky River (61 and $140 \mathrm{mg} / \mathrm{L}$, respectively) (fig. 3). These results reflect the greater extent and effect of coal mining in the North Fork Kentucky River basin. In contrast, the median concentrations of nitrite plus nitrate and phosphate at both sites were among the lowest for the 10 monitoring stations. The limited agricultural activity and population in the basin may account for these low concentrations.

The middle Kentucky River basin, which drains areas of the Interior Low Plateaus, is underlain mostly by limestone and shale. The basin is characterized by conical hills that are erosional remnants of the surrounding uplands. Soils are shallow, poorly drained, and not well suited to agriculture. The middle basin has contrasting waterquality conditions. Reaches of the Red River, a tributary of the Kentucky River, are classified as an outstanding-resource water, the KNREPC's most restrictive classification (Kentucky Natural Resources and Environmental Protection Cabinet, 1990b, p. 8). The Red River supports a large, diversified biological community. In contrast, an area of extensive oil and gas production substantially affects the quality of water in several nearby streams; dissolved solids, barium, sodium, chloride, bromide, and other dissolved-constituent concentrations have increased as a result of brine discharges from oil-production activities. As a result, some stream reaches draining active oil and gas fields support only a few tolerant aquatic organisms. About 90 percent of the chloride load in the entire Kentucky River basin originates from oil and gas activities in the upper and middle parts of the basin (Smoot and others, 1991).

The lower Kentucky River basin is underlain by limestone and has a gently rolling terrain composed of ridges and hills. The lower basin has soils that were derived mainly from phosphatic limestone and that are well suited to farming and pasture. Agriculture, including the thoroughbred horse industry and tobacco production, and urbanization are major land uses. Because of agricultural activities and urbanization, the inputs of nitrogen and phosphorus into streams within the Kentucky River basin, including about 76 percent of the annual load of ammonia and organic nitrogen, are largest in the lower basin. Nearly 80 percent of the total ammonia and nitrogen transported in the lower Kentucky River can be attributed to nonpoint sources (Smoot and others, 1991). Suspended-sediment loads are high in streams draining agricultural land and, in certain basins, approach those in mining areas of the upper basin. Biological communities in some stream reaches draining urban areas have been substantially affected by low concentrations of dissolved oxygen and high concentrations of trace metals and other constituents resulting from wastewater discharge and nonpoint-source runoff (Smoot and others, 1991).

Site 5 is near the mouth of the Kentucky River. Nitrite plus nitrate and phosphate concentrations at site 5 were among the highest for the 10 monitoring stations (fig. 3). The high concentrations are attributable primarily to agricultural and urban runoff. Other water-quality problems in the lower basin are more localized and, therefore, are not reflected in the data from site 5. These local problems are not easily detected at a main-stem monitoring station because of natural water-quality improvement due to instream processes such as dilution, reaeration, and sedimentation.

\section{SALT RIVER AND ROLLING FORK}

The Salt River is a tributary of the Ohio River that drains part of the Interior Low Plateaus. The Salt River's principal tributary is the Rolling Fork. The Salt River basin is underlain primarily by limestone and shale; the topography ranges from irregular, steeply sloped

Table 1. Sources and environmental significance of selected water-quality constituents and properties [Source: Compiled by the U.S. Geological Survey, Office of Water Quality]

\begin{tabular}{|c|c|c|}
\hline Constituent or property & Common sources & Environmental significance \\
\hline Dissolved oxygen .......................... & $\begin{array}{l}\text { Introduced from the atmosphere; also a byproduct of } \\
\text { aquatic plants. }\end{array}$ & $\begin{array}{l}\text { Necessary for aquatic life; deficiency can result from } \\
\text { assimilation of organic wastes or rapid growth } \\
\text { and decay of algae. }\end{array}$ \\
\hline Alkalinity (property) ................... & $\begin{array}{l}\text { A measure of the quantity of acid-neutralizing sub- } \\
\text { stances; can be affected by geologic setting, in- } \\
\text { dustrial wastewater discharge, waste gases, and } \\
\text { runoff from surface mining. }\end{array}$ & $\begin{array}{l}\text { Sufficiently alkaline water can be unsuitable for some } \\
\text { agricultural and industrial uses. }\end{array}$ \\
\hline Sulfate & $\begin{array}{l}\text { Occurs in some rocks; also in mine runoff, industrial } \\
\text { wastewater discharge, and atmospheric deposi- } \\
\text { tion. }\end{array}$ & $\begin{array}{l}\text { Concentrations exceeding a natural, background } \\
\text { level indicate contamination from human activity; } \\
\text { in sufficient quantity, can cause water to be } \\
\text { unsuitable for public supply; can harm aquatic } \\
\text { organisms. }\end{array}$ \\
\hline Dissolved solids ........................... & $\begin{array}{l}\text { A result of rock weathering; also in agricultural runoff } \\
\text { and industrial discharge. }\end{array}$ & $\begin{array}{l}\text { In sufficient quantity, can cause water to be unsuitable } \\
\text { for public supply, agriculture, and industry; can } \\
\text { harm aquatic organisms. }\end{array}$ \\
\hline Nitrite plus nitrate ............................ & $\begin{array}{l}\text { Nonpoint sources are agricultural and urban runoff; } \\
\text { a major point source is wastewater discharge. }\end{array}$ & $\begin{array}{l}\text { Plant nutrient that, in sufficient quantity, can cause } \\
\text { algal blooms and excessive growth of higher } \\
\text { aquatic plants in bodies of water; can cause water } \\
\text { to be unsuitable for public supply. }\end{array}$ \\
\hline 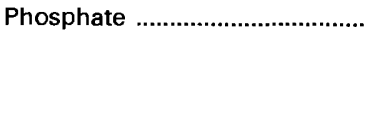 & $\begin{array}{l}\text { Occurs in some rocks and sediments; also in runoff } \\
\text { and seepage from phosphate-rock mines, agri- } \\
\text { cultural and urban runoff, and industrial and } \\
\text { municipal wastewater discharge. }\end{array}$ & $\begin{array}{l}\text { Plant nutrient that, in sufficient quantity, can cause } \\
\text { algal blooms and excessive growth of higher } \\
\text { aquatic plants in bodies of water. }\end{array}$ \\
\hline Suspended sediment ................. & $\begin{array}{l}\text { A result of rock erosion; also induced by disturbances } \\
\text { of land cover due to fires, floods, and human } \\
\text { activities such as mining, logging, construction, } \\
\text { and agriculture. }\end{array}$ & $\begin{array}{l}\text { Can be detrimental to aquatic organisms; can fill res- } \\
\text { ervoirs and impair recreational use of water. }\end{array}$ \\
\hline
\end{tabular}


hills and narrow valleys to gently rolling hills dissected by streams having broad flood plains. Agriculture, urbanization, forest, and woodlands are major land uses. The KNREPC has reported that major sources of stream contamination in the basin are agriculture (sediment, nutrients, pesticides, and pathogens); silviculture (sediment); urban stormwater runoff (toxic metals, nutrients, and sediment); and municipal wastewater-treatment systems (decomposable organic material, nutrients, and pathogens). Sedimentation caused by streambank erosion has been identified as the primary nonpoint source of contamination of the Rolling Fork. Urban stormwater runoff from the Louisville metropolitan area has degraded Pond Creek, a tributary of the Salt River (Kentucky Natural Resources and Environmental Protection Cabinet, 1989, p. 37; 1990a, p. 25-26).

The median nitrite plus nitrate concentration at site $6(1.1$ $\mathrm{mg} / \mathrm{L}$ ) was equal to or higher than those for the other monitoring stations; the median phosphate concentration $(0.13 \mathrm{mg} / \mathrm{L})$ was the highest (fig. 3). Point and nonpoint sources of contamination contributed to the high nutrient concentrations; however, dissolution of the underlying phosphatic limestone also could be a source of the phosphate. The limestone terrane also accounted for high alkalinity values. Although soils in the basin can be easily eroded because of extensive agricultural activities, the median suspended-sediment concentration was among the lowest for any monitoring station.

Water-quality conditions in the Rolling Fork are different from those in the Salt River. Concentrations of dissolved oxygen were lower than those in the main stem of the Salt River. Compared to the main stem of the Salt River, sulfate, nitrite plus nitrate, and phosphate concentrations at site 7 were low. The median suspended-sediment concentration at site 7 was the highest for any monitoring station, supporting the KNREPC's observations concerning nonpointsource-related sediment problems in the Rolling River basin. The KNREPC has reported that urban stormwater runoff and municipal wastewater-treatment systems are the major sources of contamination in the Rolling Fork, which accounts for the lower concentrations of dissolved oxygen (Kentucky Natural Resources and Environmental Protection Cabinet, 1990a, p. 26).

\section{OHIO RIVER}

The Ohio River forms the northern boundary of Kentucky for a distance of 664 stream miles. The river system drains an area of $204,000 \mathrm{mi}^{2}$ (square miles) in 14 States and 33,300 mi in Kentucky (about 82 percent of the State). Identifying sources of contamination in such a large basin is difficult. The Ohio River Valley Water Sanitation Commission is responsible for evaluating water quality in the main stem. On the basis of 1989 data from the Commission, the KNREPC issued a fish consumption advisory for Kentucky's part of the main stem owing to large concentrations of polychlorinated biphenyl and chlordane in fish-tissue samples (Kentucky Natural Resources and Environmental Protection Cabinet, 1990a, p. 34).

Site 8 is near the confluence of the Ohio and Mississippi Rivers. The median concentrations of alkalinity, sulfate, dissolved solids, phosphate, and suspended sediment at site 8 were within the range of those for the 10 monitoring stations (fig. 3). The median nitrate concentration at site $8(1.1 \mathrm{mg} / \mathrm{L})$ was equal to or higher than those for the other monitoring sites.

\section{SOUTH FORK CUMBERI AND RIVER}

The South Fork Cumberland River drains part of the Appalachian Plateaus. The basin, characterized by rugged mountains, is underlain by sandstone, shale, and coal. The economy of the basin relies mostly on resource extraction and silviculture. Site 9 is downstream from the Big South Fork National River and Recreation Area in southeastern Kentucky and northeastern Tennessee. Before the area was so designated, its coal and timber resources were extensively developed. Acidic drainage from mines is a major problem in the basin (Kentucky Natural Resources and Environmental Protection Cabinet, 1989, p. 32). Bear Creek, which joins the South Fork Cumberland River just upstream from site 9, was shown by Rikard and others $(1986$, p. 44) to be one of the most polluted tributaries of the river. That study indicated that the water in Bear Creek had virtually no alkalinity, was acidic $(\mathrm{pH}, 4.2)$, and had a median sulfate concentration in excess of $80 \mathrm{mg} / \mathrm{L}$. At site 9 , the effects of Bear Creek are somewhat attenuated. Alkalinity during water years $1987-$ 89 (median, $17 \mathrm{mg} / \mathrm{L}$ ) (fig. 3) was considerably higher than that in Bear Creek (not shown), and the median sulfate concentration (35 $\mathrm{mg} / \mathrm{L}$ ) was less than one-half that in Bear Creek. Concentrations of other constituents (except dissolved oxygen) were generally lower than those at the other monitoring stations.

\section{GREEN RIVER}

The Green River basin contains about one-fourth of the State's land area and is the largest drainage basin in the State. Reservoirs have been constructed by the U.S. Army Corps of Engineers on the Rough, Nolin, and Barren Rivers, as well as on the main stem of the Green River in the upper basin. The topography in this section of the Interior Low Plateaus is characterized by gently rolling terrain underlain by limestone in the upper basin and hills and broad flood plains underlain by sandstone, shale, and coal in the lower basin. Land uses in the upper basin include agriculture, urban areas, and resource extraction. Major sources of stream contamination in the upper basin are agriculture (sediment, nutrients, pesticides, and pathogens); resource extraction (chloride); onsite and municipal wastewater-treatment systems (decomposable organic matter, nutrients, and pathogens); and urban stormwater runoff (toxic metals, nutrients, and sediment) (Kentucky Natural Resources and Environmental Protection Cabinet, 1989, p. 43; 1990a, p. 26-27).

Concentrations of chloride in the Green River at site 10 , which are higher than those recorded at other locations in the basin, have been associated with brines from oil production (Leist, 1986, p. 46); however, dissolved-solids concentrations at site 10 were not high relative to those in other streams discussed in this report (fig. 3). Concentrations of sulfate, another major component of dissolved solids, likewise were low in samples collected during 1987-89. The relatively high median concentrations of nitrite plus nitrate $(0.87 \mathrm{mg} / \mathrm{L})$ and suspended sediment $(27 \mathrm{mg} / \mathrm{L})$ were among the highest for the 10 monitoring stations; the high values possibly were due to agricultural and urban runoff and municipal point sources.

\section{WATER-QUALITY TRENDS}

Trend analysis is a statistical procedure used to detect changes in stream water quality at a monitoring station over time. For this report, water-quality data from 10 monitoring stations (fig. 2) were analyzed for trends by using the seasonal Kendall test (Hirsch and others, 1982), a method used extensively by the USGS. The graph (shown below) of the dissolved-sulfate concentration in the Green River at site 10 illustrates the trend inferred from the concentration data and demonstrates the variation in water quality that is common in streams.

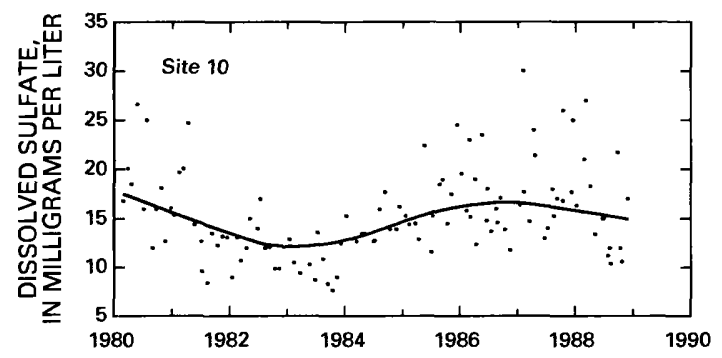


When possible, constituent-concentration data were adjusted for changes in streamflow to preclude identifying a trend in concentration that was caused only by a trend in streamflow. The data were not adjusted when (1) more than 10 percent of the samples had concentrations lower than the minimum reporting limit for the analytical method used or (2) streamflow was controlled substantially by human activities. When the concentration data could not be adjusted for streamflow, trends were determined directly from the concentration data.

Statewide trends in measurements of selected physical properties of stream water and in concentrations of selected constituents in stream water are shown on maps in figure 4. On each map, a trend is indicated at a monitoring station only if the data from that station were suitable for use in the trend analysis. Trend maps are not shown for dissolved oxygen and dissolved phosphate because data for those constituents from most monitoring stations did not meet suitability criteria for trend analysis. For more information on the suitability criteria and on the trend-analysis procedure used for this report, see Lanfear and Alexander (1990).

\section{ALKALINITY}

Alkalinity is a measure of the capacity of the substances dissolved in the water to neutralize acid. In most natural waters, alkalinity is produced mainly by bicarbonate and carbonate (Hem, 1985, p. 106), which are ions formed when carbon dioxide or carbonate rock dissolves in water.
Alkalinity had upward trends in the North Fork and South Fork Kentucky Rivers at sites 3 and 4 during water years 1980-89. Increasing alkalinity, at a rate of 3.5 percent per year, also was noted by Smoot and others (1991) for the North Fork Kentucky River during water years 1976-86. The increasing alkalinity at sites 3 and 4 might have been a result of improvement in the control of acidic drainage from mines in the two basins. The cause of the decrease in alkalinity in the Salt Fork at site 6 is unknown.

\section{DISSOLVED SULFATE}

The major natural sources of sulfate in streams are rock weathering, volcanoes, and biochemical processes (Hem, 1985, p. 113). Human activities such as mining, waste discharge, and fossil-fuel combustion also can be important sources. A shortened trendanalysis period was used for sulfate because data from analyses performed before water year 1982 are not comparable to data for subsequent years.

Sulfate concentrations had upward trends in the Big Sandy River at site 1 and in the Green River at site 10. The upward trends at these stations might have been associated with resource-extraction activities in the basins.

\section{DISSOLVED SOLIDS}

Dissolved solids in stream water result primarily from rock weathering but also can be introduced as a byproduct of human ac-

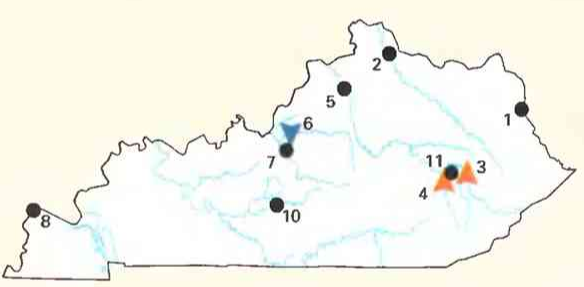

Alkalinity, 1980-89

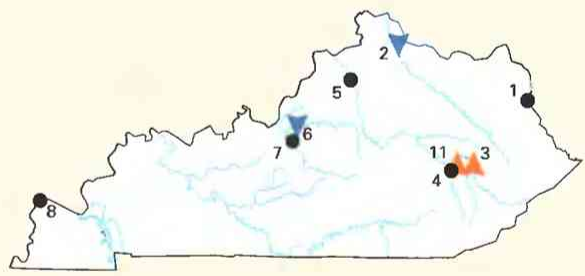

Dissolved solids, 1980-89

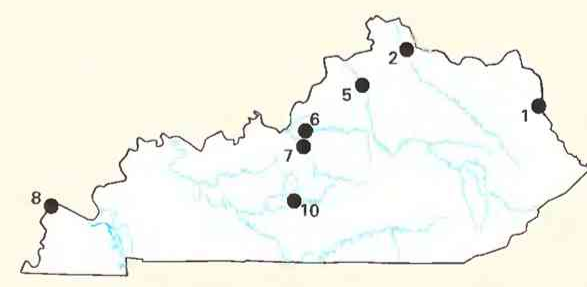

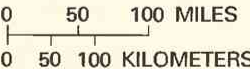

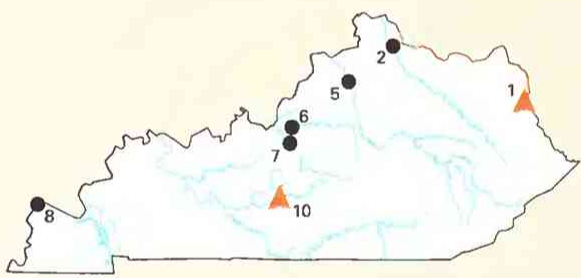

Dissolved sulfate, 1982-89

Suspended sediment, $1980-89$

\section{EXPLANATION}

Trend in water-quality property or constituent-Number is site number in figure 2

${ }^{3}$ Upward

- ${ }^{5}$ None

$\nabla^{6}$ Downward

Figure 4. Trends in water quality of selected streams in Kentucky, by water years. (Source: Data from U.S. Geological Survey files.) 
tivities (table 1). Concentrations generally are greatest in streams draining basins underlain by rocks and soils that contain easily dissolved minerals.

Upward trends in dissolved-solids concentrations were detected in the North Fork Kentucky River at site 3 and the Middle Fork Kentucky River at site 11. The economy in these basins depends on resource extraction. Runoff of highly mineralized water associated with increased production of coal, oil, and gas during 1976-86 was possibly a cause of the upward trends in dissolved-solids concentrations in the North Fork and Middle Fork Kentucky Rivers (Smoot and others, 1991). A cause for the downward trends in dissolvedsolids concentrations in the Licking River at site 2 and the Salt River at site 6 is not known.

\section{DISSOLVED NITRITE PLUS NITRATE}

Nitrite and nitrate are oxidized forms of nitrogen that together constitute most of the dissolved nitrogen in stream water. Nitrite readily oxidizes to nitrate in natural waters; therefore, nitrate generally is by far the more abundant of the two (Hem, 1985, p. 124). No trends in nitrite plus nitrate concentrations were detected at the six monitoring stations from which data were sufficient for trend analysis.

\section{SUSPENDED SEDIMENT}

Suspended sediment is a product of erosion. The erosion can be either natural or the result of land-cover disturbances related to human activities (table 1). Suspended-sediment concentrations had no trend at the seven monitoring stations having sufficient data for trend analysis.

\section{WATER-QUALITY MANAGEMENT}

Under the authority of Kentucky Revised Statutes 224 and 151, the KNREPC, Division of Water, is responsible for the protection and management of the water resources of Kentucky. As the lead enforcement agency in the State for the Federal Clean Water Act, the Division directs, programs, and staffs efforts in policy development, regulation, permitting, inspection, enforcement, management, and investigation.

The Division administers the Kentucky Pollutant Discharge Elimination System (KPDES) Program. This program requires that permits be issued for the discharge of pollutants from any point source into waters of the State. The Division also has developed a nonpointsource control program with the assistance of an interagency Nonpoint Source Advisory Committee, of which the USGS is a member. To determine the overall effectiveness of such programs, the $\mathrm{Di}$ vision maintains a statewide surface-water monitoring network of 45 stations. The USGS, under the Federal-State Cooperative Program, participates in the State's monitoring program by collecting streamflow data. The information from the program is used to evaluate stream conditions, identify priority streams for more intensive investigation, determine appropriate water-quality classifications and standards for streams, develop wasteload allocations, and designate streams for the State's Wild Rivers Program. During 1988-89, the Division conducted nine studies to determine whether priority streams were supporting their designated use classifications (Kentucky Natural Resources and Environmental Protection Cabinet, 1990a, p. 12)

As mandated by section 305(b) of the Federal Clean Water Act, the Division prepares and submits a biennial report on Kentucky's water quality to the EPA and the U.S. Congress (Kentucky National Resources and Environmental Protection Cabinet, 1988; 1990a). In addition to presenting stream and lake water-quality conditions and trends, the report discusses special concerns and offers recommendations for achieving the goals and objectives mandated by the Clean Water Act. The report also summarizes the status of wetlands, ground-water quality, and the State water-quality protection programs.

Several agencies outside of the KNREPC cooperate in the programs of the Kentucky Division of Water. The Kentucky Environmental Quality Commission provides guidance to the Governor and the KNREPC in the development of environmental policy for the State. The EPA provides grant funds to the Division for the administration of numerous programs such as the KPDES, nonpoint source, public drinking water, ground-water protection, monitoring, and municipal wastewater-treatment-plant construction programs.

In 1948, the Ohio River Valley Water Sanitation Commission, an interstate compact agency, was established for pollution abatement in the Ohio River valley. As a member, Kentucky coordinates its water-quality programs and actions relevant to the Ohio River with that agency. Kentucky is also 1 of 13 States eligible for assistance from the Appalachian Regional Commission for infrastructure construction projects. The State also participates as a member of the Water Management Subcommittee of the National Governors' Association and the Association of State and Interstate Water Pollution Control Administrators.

\section{SELECTED REFERENCES}

Anderson, J.R., 1967, Major land uses in the United States, in U.S. Geological Survey, 1970, National atlas of the United States of America: Washington, D.C., U.S. Geological Survey, p. 158-159.

Bradfield, A.D., and Porter, S.D., 1990, Summary of biological investigations relating to surface-water quality in the Kentucky River basin, Kentucky: U.S. Geological Survey Water-Resources Investigations Report 904051, $63 \mathrm{p}$.

Britton, L.J., and Greeson, P.E., eds., 1987, Methods for collection and analysis of aquatic biological and microbiological samples: U.S. Geological Survey Techniques of Water-Resources Investigations, book 5, chap. A4, $363 \mathrm{p}$.

Fenneman, N.M., 1946, Physical divisions of the United States: Washington, D.C., U.S. Geological Survey special map, scale 1:7,000,000.

Fishman, M.J., and Friedman, L.C., eds., 1989, Methods for the determination of inorganic substances in water and fluvial sediments: U.S. Geological Survey Techniques of Water-Resources Investigations, book 5, chap. A1, $545 \mathrm{p}$

Hem, J.D., 1985, Study and interpretation of the chemical characteristics of natural water ( $3 \mathrm{~d}$ ed.): U.S. Geological Survey Water-Supply Paper 2254 $263 \mathrm{p}$.

Hirsch, R.M., Slack, J.R., and Smith, R.A., 1982, Techniques of trend analysis for monthly water quality data: Water Resources Research, v. 18 , no. 1 , p. 107-121.

Kentucky Natural Resources and Environmental Protection Cabinet, 1988, Kentucky report to Congress on water quality: Frankfort, Division of Water, $155 \mathrm{p}$.

1989, Kentucky nonpoint source pollution assessment report: Frankfort, Division of Water, $98 \mathrm{p}$.

$1990 a$, Kentucky report to Congress on water quality: Frankfort, Division of Water, $187 \mathrm{p}$.

1990b, Classification of waters, Kentucky Administrative Regulations, Title 401, Chapter 5, Section 26: Frankfort, Division of Water, 22 p.

Lanfear, K.F., and Alexander, R.B., 1990, Methodology to derive water-quality trends for use by the National Water Summary Program of the U.S. Geological Survey: U.S. Geological Survey Open-File Report 90-359, $10 \mathrm{p}$.

Leist, D.W., 1986, An evaluation of water-quality data from hydrologic accounting unit 051100, Green River Basin, Kentucky: U.S. Geological Survey Water-Resources Investigations Report 85-4208, 49 p.

Rikard, Michael, Kunkle, Sam, and Wilson, Juliette, 1986, Big South Fork National River and Recreation Area water quality report 1982-1984: Fort Collins, Colo., National Park Service Water Resources Report 86-7, $150 \mathrm{p}$.

Smoot, J.L., Liebermann, T.D., Evaldi, R.D., and White, K.D., 1991, Surface water-quality assessment of the Kentucky River Basin, Kentucky: Analy- 
sis of available water-quality data through 1986: U.S. Geological Survey Open-File Report 90-360, 209 p.

Thelin, G.P., and Pike, R.J., 1990, Digital shaded relief map of the counterminous United States: Menlo Park, Calif., U.S. Geological Survey digital image processing, scale 1:3,500,000.

U.S. Geological Survey, 1986, National water summary 1985-Hydrologic events and surface-water resources: U.S. Geological Survey Water-Supply Paper 2300, $506 \mathrm{p}$.

1990, National water summary 1987-Hydrologic events and water supply and use: U.S. Geological Survey Water-Supply Paper 2350, $553 \mathrm{p}$.
1991, National water summary 1988-89-Hydrologic events and floods and droughts: U.S. Geological Survey Water-Supply Paper 2375, $591 \mathrm{p}$.

Ward, J.R., and Harr, C.A., eds., 1990, Methods for collection and processing of surface-water and bed-material samples for physical and chemical analyses: U.S. Geological Survey Open-File Report 90-140, 71 p.

Prepared by Rene Garcia and Lloyd H. Woosley, Jr.

FOR ADDITIONAL INFORMATION: District Chief, U.S. Geological Survey, 2301 Bradley Avenue, Louisville, KY 40217 


\section{LOUISIANA Stream Water Quality}

Water of good quality is vital to Louisiana. The State's streams, rivers, lakes, and wetlands support productive freshwater and estuarine ecosystems that provide recreation and a livelihood for many citizens of the State. The economic importance of Louisiana's fishing industry cannot be overestimated; each year, more fish and shellfish are shipped throughout the Nation from Louisiana than from any other State (U.S. Army Corps of Engineers, 1988, p. 2). Water withdrawn from streams, rivers, and lakes in Louisiana is used for public and industrial supplies and for agriculture. In 1985, offstream fresh surface-water withdrawals in Louisiana averaged $8,470 \mathrm{Mgal} / \mathrm{d}$ (million gallons per day) (U.S. Geological Survey, 1990, p. 275).

Annual precipitation that ranges from 48 inches in the northern part of the State to 64 inches in the southern part (U.S. Geological Survey, 1986, p. 253) provides abundant water to streams and rivers that flow through or border the State. The largest is the Mississippi River, which drains more than 40 percent of the conterminous United States. The average annual discharge of the Mississippi River at Tarbert Landing, Miss., is 514,200 cubic feet per second, or 332,300 Mgal/d (U.S. Geological Survey, 1986, p. 253).

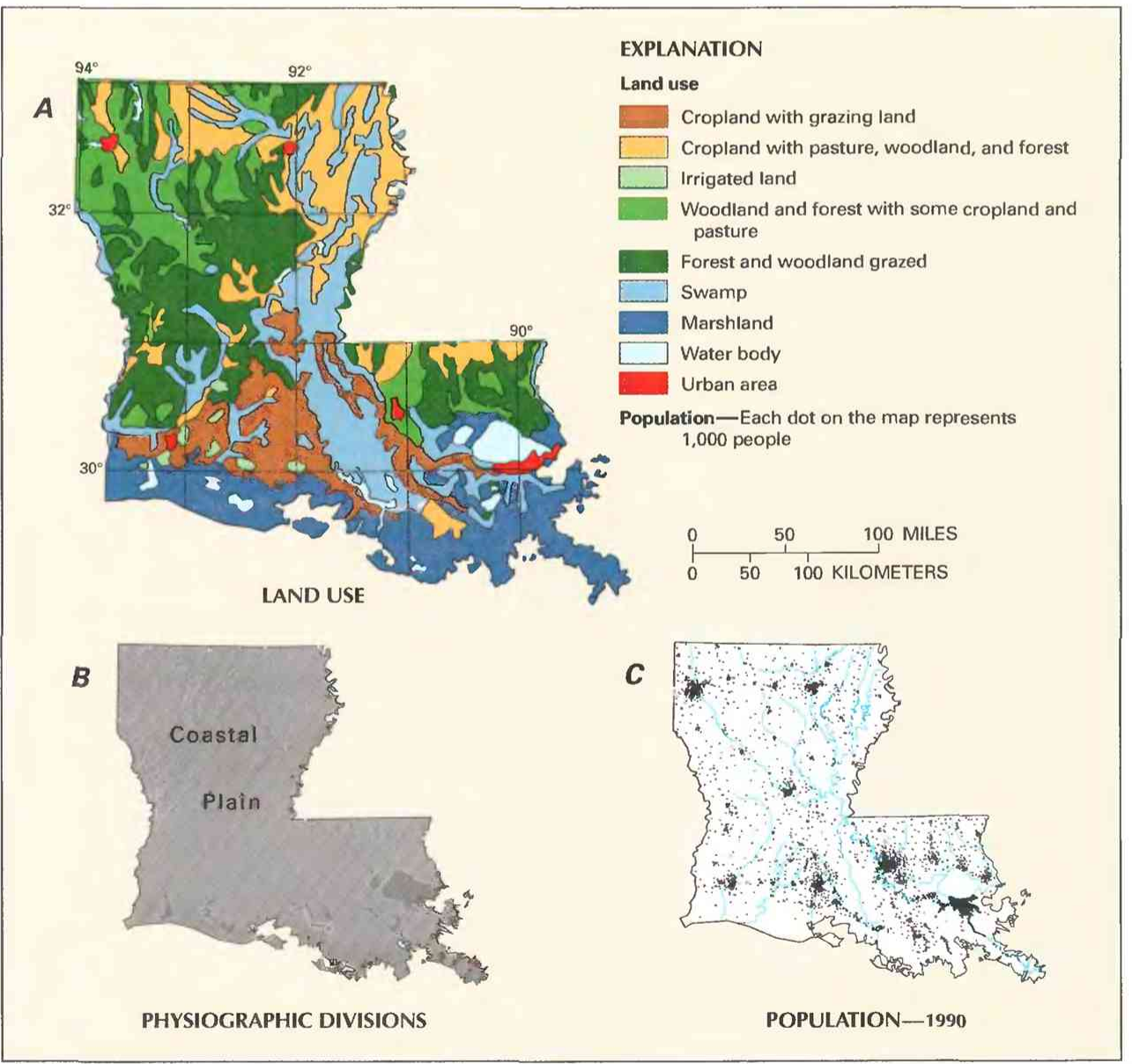

Figure 1. Land use, physiography, and population in Louisiana. A, Major land uses. B, Physiographic divisions. C, Population distribution in 1990. (Sources: A, Major land uses modified from Anderson, 1967. B, Physiographic divisions from Fenneman, 1946; landforms from Thelin and Pike, 1990. C, Data from U.S. Bureau of the Census 1990 decennial census files.)
The quality of Louisiana's streams and rivers depends in large part on the uses of the land they drain. Land use in the State (fig. 1A) has been determined mostly by climate and physiography. Louisiana lies wholly within the Coastal Plain (fig. $1 B$ ), which generally has low relief and is well suited to agricultural uses. In terms of area, forest, cropland, grazing land, and wetlands are the major land uses. However, some of the areas that are indicated as swamps and marshes in figure $1 A$ support oil and gas production and aquaculture. Industries and population centers (fig. $1 C$ ) along the Mississippi River and other large streams use streams as sources of water as well as for wastewater disposal and as a means of transportation. About 43 percent of Louisiana's population relied on surface water for its water supply in 1985 (Solley and others, 1988). The State's 1990 population was 4.2 million (U.S. Bureau of the Census 1990 decennial census files).

\section{WATER-QUALITY MONITORING}

Water-quality data obtained from analyses of water samples collected at monitoring stations are stored in the U.S. Geological Survey's (USGS) National Water Information System and the U.S. Environmental Protection Agency's (EPA) national data base known as STORET. Water-quality and streamflow data are reported by water year-the 12 months from October 1 through September 30. A water year is identified by the calendar year in which it ends. For example, water year 1991 comprises October 1, 1990, through September 30, 1991.

The data used in this summary of Louisiana's stream water quality were obtained from water samples collected monthly, every 2 months, or quarterly at 10 monitoring stations at which data collection is systematic and continuing (fig. 2). Analyses of water samples collected at 7 stations are the basis for the discussion and graphic summary (fig. 3) of stream water-quality conditions during water years 1987-89, and data from all 10 stations are the basis for the discussion and graphic summary (fig. 4) of stream waterquality trends. Water samples were collected and analyzed by using standard methods approved by the USGS (Britton and Greeson, 1987; Fishman and Friedman, 1989; Ward and Harr, 1990) or by using equivalent methods. If a method of sample collection or analysis changed over time, data from an 
analysis were included in the evaluation of recent stream water quality or of stream water-quality trends only if the change in method did not affect the comparability of the data.

\section{WATER-QUALITY CONDITIONS}

For purposes of water-quality monitoring and protection, the State has designated beneficial uses for Louisiana waters, some or all of which apply to a particular stream. These designated uses are primary-contact recreation, secondary-contact recreation, fish and wildlife propagation, and, if appropriate, public water supply. An assessment of the State's surface water indicated that, of the assessed water bodies, 59 percent fully supported designated uses, 26 percent partially supported designated uses, 5 percent did not support designated uses, and 10 percent was rated "unknown" because of insufficient information (Louisiana Department of Environmental Quality, 1990, p. 1).

Land use, municipal and industrial wastewater discharges, and seasonal variation in precipitation and runoff are the primary influences on stream water quality in Louisiana. Statewide water-quality concerns include high iron concentrations and pesticide residues in water and trace insecticide residues in bottom material. A noteworthy local concern is toxic organic constituents in bottom material and fish tissue in the lower Calcasieu River near Lake Charles (Pereira and others, 1988, p. 772).

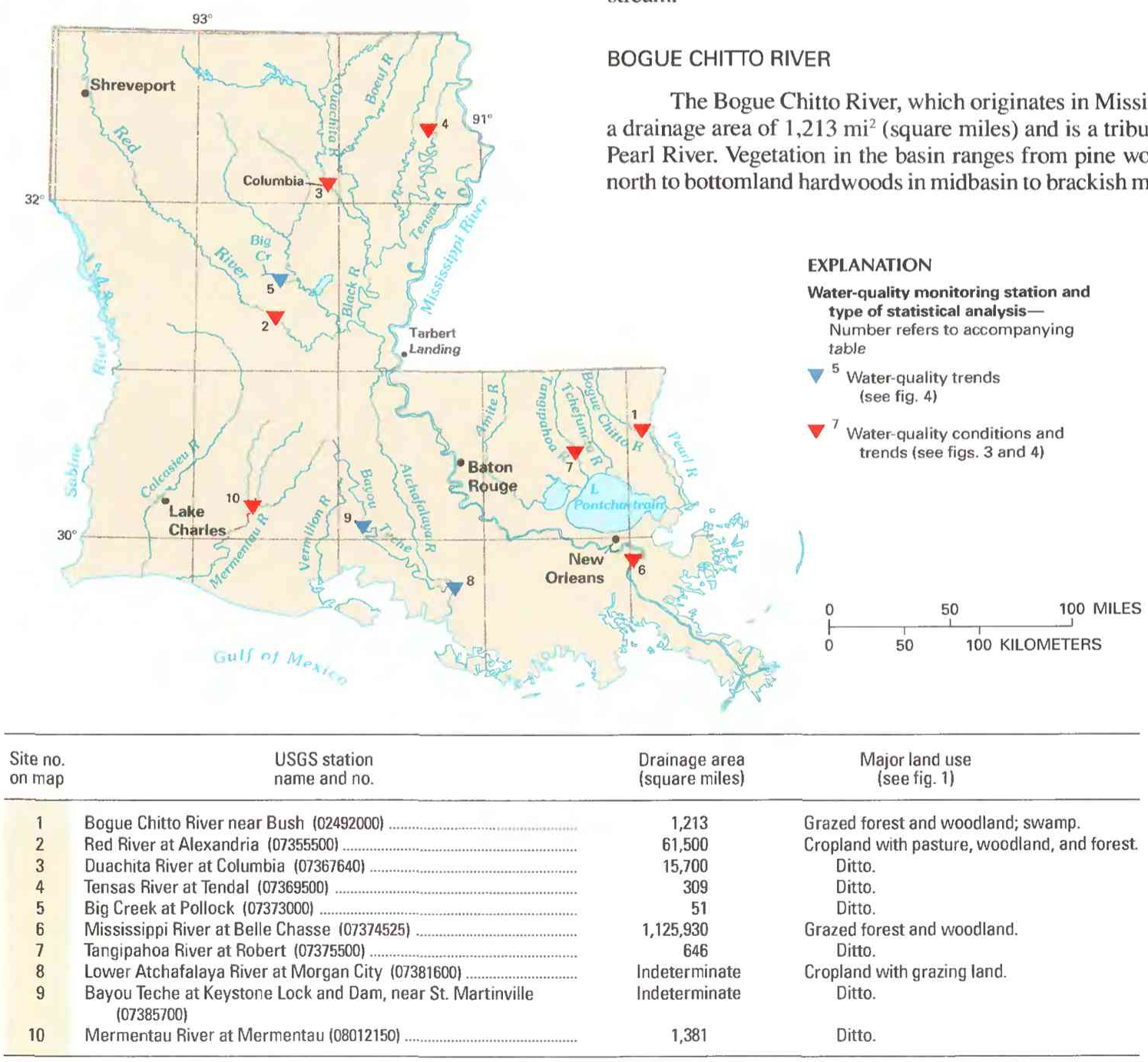

The following discussion of stream water quality in Louisiana is organized by river basin (fig. 3). Graphs in figure 3 summarize certain aspects of stream water quality in the basins for water years 1987-89. The graphs show frequency distributions of data values that represent concentrations of selected stream-water constituents. These constituents are dissolved oxygen, fecal coliform bacteria, dissolved sulfate, dissolved solids, and dissolved nitrite plus nitrate (as nitrogen). The data are reported in milligrams per liter ( $\mathrm{mg} / \mathrm{L}$ ) and colonies per 100 milliliters (col/100 mL). Sources and environmental significance of each constituent are described in table 1 .

Water quality at each monitoring station is the result of geological, chemical, biological, and hydrologic processes that occur over a large area. Water-quality problems that affect aquatic life or public health only locally are not fully represented in this summary.

State water-quality standards established by the Louisiana Department of Environmental Quality (LDEQ) differ among stream basins (Louisiana Department of Environmental Quality, 1989). For streams discussed in this report, the maximum allowable concentration for dissolved solids ranges from 105 to $1,000 \mathrm{mg} / \mathrm{L}$ and for total (dissolved plus suspended) sulfate from 10 to $150 \mathrm{mg} / \mathrm{L}$. Standards for nitrite plus nitrate have not been established. The State standard for fecal coliform concentrations for primary-contact recreation is a five-sample logarithmic mean of $200 \mathrm{col} / 100 \mathrm{~mL}$ of not fewer than five samples collected within a 30 -day period. The dissolved-oxygen standard is 4.0 or $5.0 \mathrm{mg} / \mathrm{L}$. depending on the designated uses of the stream.

\section{BOGUE CHITTO RIVER} poods in the orth to bottomland hardwoods in midbasin to brackish marsh in the

Figure 2. Selected water-quality monitoring stations, type of statistical analysis, and geographic features in Louisiana. (Sources: Major land uses modified from Anderson, 1967; other data from U.S. Geological Survey files.) 
south. The LDEQ considers the river to fully support its designated uses; however, that status is threatened by occasional exceedances of the fecal coliform bacteria standard and high concentrations of suspended solids that are caused by livestock grazing along the river's banks and by sand and gravel mining in streams (Louisiana Department of Environmental Quality, 1990, p. I-14).

During water years 1987-89, dissolved-oxygen concentrations in the Bogue Chitto River at site 1 were acceptable by State standards and had a median concentration of $8.8 \mathrm{mg} / \mathrm{L}$ (fig. 3). The median sulfate concentration $(3.5 \mathrm{mg} / \mathrm{L})$ was the second lowest for the seven monitoring stations, and the median dissolved-solids concentration $(34 \mathrm{mg} / \mathrm{L})$ was the lowest.

\section{RED RIVER}

The Red River, which originates in eastern New Mexico, enters northwestern Louisiana from Arkansas. The Red River fully supports its designated uses, but that status is threatened by an increase in fecal coliform bacteria, dissolved solids, and nutrients (Louisiana Department of Environmental Quality, 1990, p. B-26). Many of the water-quality problems in the basin are caused by municipal and industrial wastewater discharges, agricultural runoff, oil and gas operations, and naturally occurring salt springs.

During water years 1987-89, the Red River at site 2 had dissolved-oxygen concentrations (median, $8.0 \mathrm{mg} / \mathrm{L}$ ) that were well within the State minimum standard, and at leasi 90 percent of fecal coliform bacteria concentrations were below $200 \mathrm{col} / 100 \mathrm{~mL}$ (fig. 3). Median concentrations of sulfate $(87 \mathrm{mg} / \mathrm{L})$ and dissolved solids $(435$ $\mathrm{mg} / \mathrm{L}$ ) were the highest for any of the seven monitoring stations, whereas the median concentration of nitrite plus nitrate $(0.1 \mathrm{mg} / \mathrm{L})$ was among the lowest.

\section{OUACHITA RIVER}

The Ouachita River system extends from west-central Arkansas near the Oklahoma border to east-central Louisiana and joins the
Tensas River to form the Black River, which empties into the Red River: Much of the $15,700 \mathrm{mi}^{2}$ basin of the Ouachita River upstream from site 3 at Columbia consists of fertile alluvial plains planted in cotton and soybeans. Upland areas of the basin are forested in hardwood and pine (Louisiana Department of Environmental Quality, 1990, p. A-7). The Ouachita River generally supports its designated uses, but potential problems include excessive concentrations of nutrients, pathogen indicators, and pesticides (Louisiana Department of Environmental Quality, 1990, p. B-21). Sources of these contaminants include urban and agricultural nonpoint source runoff.

Water quality at the Ouachita River at site 3 generally is suitable for most purposes. During water years 1987-89, the median fecal coliform concentration of $6 \mathrm{col} / 100 \mathrm{~mL}$ was the lowest for any of the seven monitoring stations (fig. 3). However, dissolved-oxygen concentrations (10th percentile, $5.1 \mathrm{mg} / \mathrm{L}$ ) occasionally decreased to near the State standard of $5.0 \mathrm{mg} / \mathrm{L}$, probably owing to the low aeration rates of this sluggish river. Concentrations of sulfate (median, $17 \mathrm{mg} / \mathrm{L}$ ) and dissolved solids (median, $84 \mathrm{mg} / \mathrm{L}$ ) were not excessive, nor were those of nitrite plus nitrate (median, less than $0.1 \mathrm{mg} / \mathrm{L}$ ) when compared to those in other basins in the State.

\section{TENSAS RIVER}

The Tensas River basin and the adjacent Bouef River basin formerly consisted of large tracts of bottomland hardwoods but now are primarily used for agriculture. During the last 30 years, a variety of pesticides has been used in the basin to control crop pests, and pesticides in surface-water bodies are a problem (Louisiana Department of Transportation and Development, 1984, p. 206).

At site 4, dissolved oxygen had a median concentration of 7.8 $\mathrm{mg} / \mathrm{L}$ (fig. 3), which is well within State standards. However, fecal coliform bacteria concentrations in 25 percent of the water samples collected at site 4 equaled or exceeded $200 \mathrm{col} / 100 \mathrm{~mL}$. The relatively high concentrations of dissolved solids (median, $233 \mathrm{mg} / \mathrm{L}$ ) and nitrite plus nitrate (75th percentile, $0.6 \mathrm{mg} / \mathrm{L}$ ) reflect extensive agricultural land use in this area.
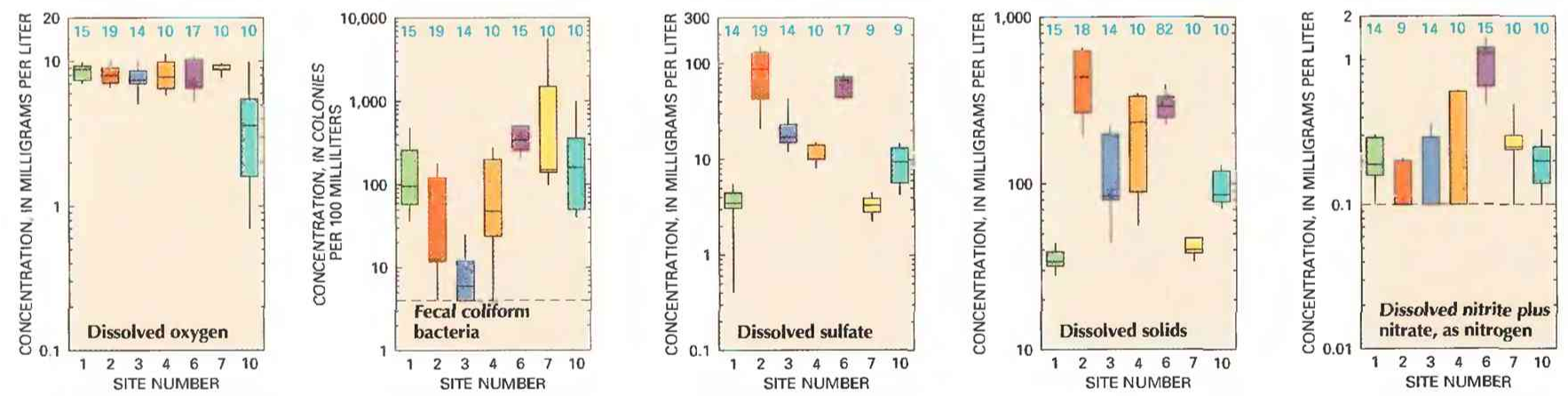

\section{EXPLANATION}

Water-quality conditions in selected
drainage basins
15 Number of analyses
$\begin{aligned} & \text { Percentile-Percentage of analyses } \\ & \text { equal to or less than indicated } \\ & \text { values }\end{aligned}$
-90th
-75 th
-50 th-Median
25th
10th
Reporting limit-Minimum
reporting limit for analytical
method used. Data below limit
line not shown

Drainage basin-Number is site number in figure 2. Basin may extend beyond State line

7 Bogue Chitto River 1 Red River 2 Ouachita River 3 Tensas River 4 Mississippi River 6 Tangipahoa River 7 $\square$ Mermentau River 10

$\nabla^{4}$ Water-quality monitoring stationNumber is site number in figure 2

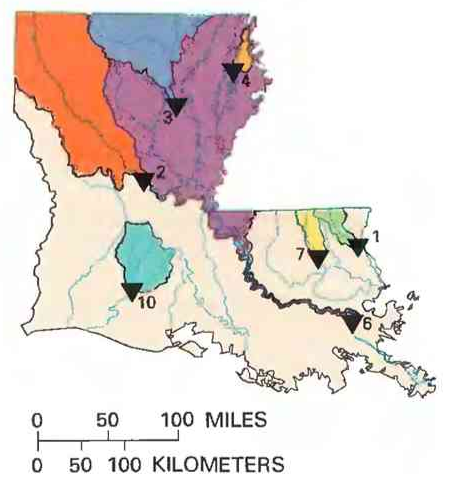

Figure 3. Water quality of selected streams in Louisiana, water years 1987-89. (Source: Data from U.S. Geological Survey files.) 
Table 1. Sources and environmental significance of selected water-quality constituents [Source: Compiled by the U.S. Geological Survey, Office of Water Quality]

\begin{tabular}{|c|c|c|}
\hline Constituent & Common sources & Environmental significance \\
\hline 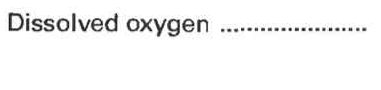 & $\begin{array}{l}\text { Introduced from the atmosphere; also a byproduct of } \\
\text { aquatic plants. }\end{array}$ & $\begin{array}{l}\text { Necessary for aquatic life; deficiency can result from } \\
\text { assimilation of organic wastes or rapid growth } \\
\text { and decay of algae. }\end{array}$ \\
\hline Fecal coliform bacteria ................ & $\begin{array}{l}\text { Sources include effluent from sewage-treatment } \\
\text { plants and runoff from pastures, feedlots, and ur- } \\
\text { ban areas. }\end{array}$ & $\begin{array}{l}\text { Presence indicates contamination of water by wastes } \\
\text { from humans and other warm-blooded animals. }\end{array}$ \\
\hline Sulfate & $\begin{array}{l}\text { Occurs in some rocks; also in mine runoff, industrial } \\
\text { wastewater discharge, and atmospheric deposi- } \\
\text { tion. }\end{array}$ & $\begin{array}{l}\text { Concentrations exceeding a natural, background } \\
\text { level indicate contamination from human activity; } \\
\text { in sufficient quantity, can cause water to be } \\
\text { unsuitable for public supply; can harm aquatic } \\
\text { organisms. }\end{array}$ \\
\hline 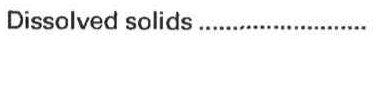 & $\begin{array}{l}\text { A result of rock weathering; also in agricultural runoff } \\
\text { and industrial discharge. }\end{array}$ & $\begin{array}{l}\text { In sufficient quantity, can cause water to be unsuitable } \\
\text { for public supply, agriculture, and industry; can } \\
\text { harm aquatic organisms. }\end{array}$ \\
\hline Nitrite plus nitrate ............................ & $\begin{array}{l}\text { Nonpoint sources are agricultural and urban runoff; } \\
\text { a major point source is wastewater discharge. }\end{array}$ & $\begin{array}{l}\text { Plant nutrient that, in sufficient quantity, can cause } \\
\text { algal blooms and excessive growth of higher } \\
\text { aquatic plants in bodies of water; can cause water } \\
\text { to be unsuitable for public supply. }\end{array}$ \\
\hline
\end{tabular}

\section{MISSISSIPPI RIVER MAIN STEM}

The Mississippi River is used for navigation and assimilation of municipal and industrial wastewater discharges as well as for public supply. In Louisiana, the Mississippi River partially supports its designated uses. Water-quality concerns include toxic organic compounds and exceedances of the fecal coliform bacteria standard. Possible sources of these problems are industrial, municipal, and agricultural discharges; chemical spills; and urban runoff (Louisiana Department of Environmental Quality, 1990, p. B-19).

At Belle Chasse, 16 river miles downstream from New Orleans, fecal coliform concentrations at site 6 exceeded $200 \mathrm{col} / 100$ $\mathrm{mL}$ in 90 percent of the samples (fig. 3 ). The median concentrations of sulfate $(66 \mathrm{mg} / \mathrm{L})$ and nitrite plus nitrate $(1.1 \mathrm{mg} / \mathrm{L})$ were among the highest for the seven monitoring stations. The median concentration of dissolved solids at site 6 during water years 1987-89 (289 $\mathrm{mg} / \mathrm{L}$ ) was exceeded by the median for only one other station. Saltwater intrusion during a nationwide drought in 1988 (U.S. Geological Survey, 1991) caused a maximum dissolved-solids concentration of $20,000 \mathrm{mg} / \mathrm{L}$ (not shown in fig. 3). These relatively high constituent concentrations were the result of input from diverse point and nonpoint sources.

\section{TANGIPAHOA RIVER}

The Tangipahoa, Amite, and Tchefuncta Rivers are the three major tributaries to Lake Pontchartrain. The rivers are in southeastern Louisiana, and their drainages are bounded by the Bogue Chitto River basin to the east and the Mississippi River basin to the west. Overall water quality in these basins partially supports designated uses, although excessive counts of fecal coliform bacteria and excessive concentrations of ammonia, trace metals, and suspended sediments have been recorded. Possible sources of these problems are municipal and industrial discharges, agricultural runoff from dairy pastureland and animal holding operations, surface mining, and unsewered waste discharges (Louisiana Department of Environmental Quality, 1990, p. B-10). The Tangipahoa River was a popular recreational stream before issuance by the State of an advisory against primary contact recreation in 1987 . No water-quality advisories have been issued for the Amite and Tchefuncta Rivers.

In the Tangipahoa River at site 7 during 1987-89, dissolvedoxygen concentrations (median, $8.8 \mathrm{mg} / \mathrm{L}$ ) were relatively high (fig. 3 ) and of a magnitude considered fully supportive of aquatic life. Concentrations of most dissolved constituents were low compared to those at most of the other monitoring stations. However, fecal coliform bacteria concentrations frequently were high; concentrations were higher than $1,500 \mathrm{col} / 100 \mathrm{~mL}$ in 25 percent of the water samples collected at site 7 .

\section{MERMENTAU RIVER}

The Mermentau River is one of many southern Louisiana rivers, including the Atchafalaya, Vermilion, Calcasieu, and Sabine Rivers and Bayou Teche, that flow directly into the Gulf of Mexico. These rivers differ in streamflow and water-quality characteristics, basin development, and water-quality problems.

The Mermentau River basin is a predominantly agricultural area of southwestern Louisiana and encompasses the region of the State covered by prairie and coastal wetlands. Agricultural runoff from irrigation has a major effect on water quality in all receiving streams (Jan Boydstun, Louisiana Department of Environmental Quality, written commun., September 1989). Streams in the area also have dissolved-oxygen deficiencies, excessive fecal coliform bacteria concentrations, and excessive turbidity caused primarily by agricultural runoff from eroding cropland and pastureland (Louisiana Department of Transportation and Development, 1984, p. 393394).

At site 10 during water years $1987-89$, the median concentration of dissolved oxygen (3.6 mg/L) (fig. 3) was lower than the State standard of $5 \mathrm{mg} / \mathrm{L}$ and very low for a large river. The median concentration of nitrite plus nitrate $(0.2 \mathrm{mg} / \mathrm{L})$ was lower than might have been expected considering the many sources of nitrogen con-

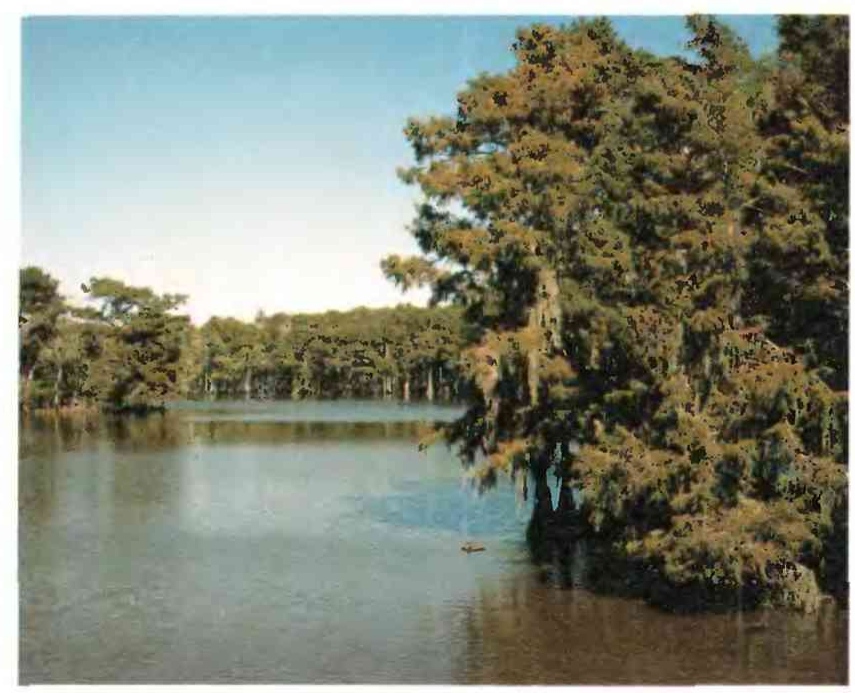

Tributary of the Mermentau River. Southern Louisiana streams typically are slow flowing and turbid. Streams in the Mermentau River basin are adversely affected by agricultural runoff. (Dennis K. Demcheck, U.S. Geological Survey.) 
tamination and probably reflects the effects of dilution and assimilation by phytoplankton and other aquatic vegetation. The dissolvedoxygen deficiency and fecal coliform concentrations that frequently exceeded $200 \mathrm{col} / 100 \mathrm{~mL}$ indicate that the upper basin has been adversely affected by agricultural runoff.

\section{WATER-QUALITY TRENDS}

Trend analysis is a statistical procedure used to detect changes in stream water quality at a monitoring station over time. For this report, water-quality data from 10 monitoring stations (fig. 2) were analyzed for trends by using the seasonal Kendall test (Hirsch and others, 1982), a method used extensively by the USGS. The graph (shown below) of the dissolved-solids concentration in the Red River at site 2 illustrates the trend inferred from the concentration data and demonstrates the variation in water quality that is common in streams.

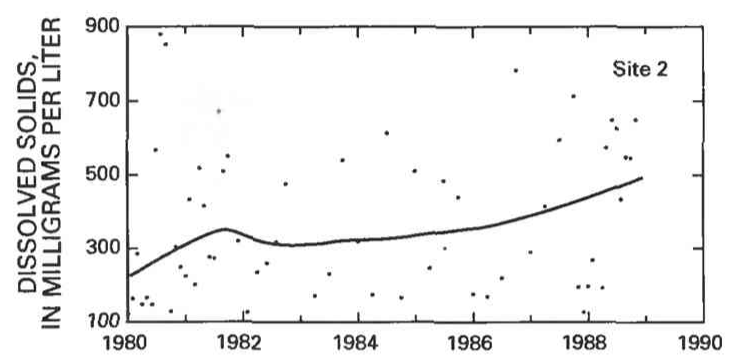

When possible, constituent-concentration data were adjusted for changes in streamflow to preclude identifying a trend in concen- tration that was caused only by a trend in streamflow. The data were not adjusted when (1) more than 10 percent of the samples had concentrations lower than the minimum reporting limit for the analytical method used or (2) streamflow was controlled substantially by human activities. When the concentration data could not be adjusted for streamflow, trends were determined directly from the concentration data.

Statewide trends in concentrations of selected stream-water constituents are shown on maps in figure 4. On each map, a trend is indicated at a monitoring station only if the data from that station were suitable for use in the trend analysis. For more information on the suitability criteria and on the trend-analysis procedure used for this report, see Lanfear and Alexander (1990).

\section{DISSOLVED OXYGEN}

The dissolved-oxygen concentration in a stream is controlled by several factors, including water temperature, air temperature and pressure, hydraulic characteristics of the stream, photosynthetic or respiratory activity of stream biota, and the quantity of organic material present. A trend in dissolved-oxygen concentrations commonly is directly or indirectly the result of human activities. Generally, an upward trend in dissolved-oxygen concentrations indicates improving stream water-quality conditions and a downward trend indicates deteriorating conditions.

Dissolved-oxygen concentrations had no trend at any monitoring station. Most of the slow-moving, warm streams in Louisiana have naturally low concentrations of dissolved oxygen. However, in all but one of the streams discussed previously, median dissolvedoxygen concentrations were above the State's standard of $5.0 \mathrm{mg} / \mathrm{L}$ during 1987-89.

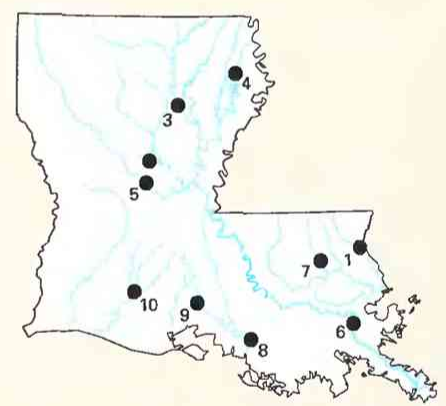

Dissolved oxygen, 1980-89

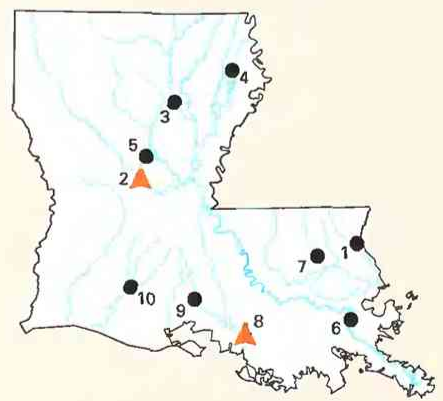

Dissolved solids, 1980-89

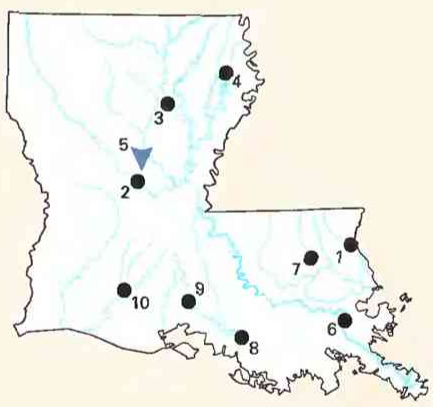

Fecal coliform bacteria, 1980-89

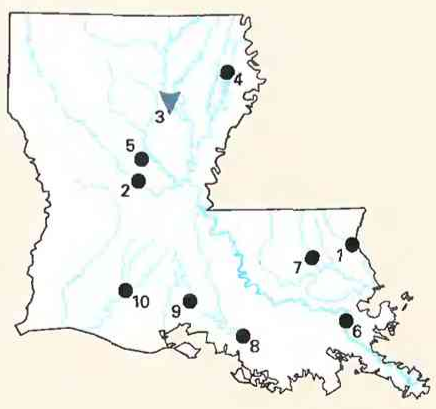

Dissolved nitrite plus nitrate, 1980-89

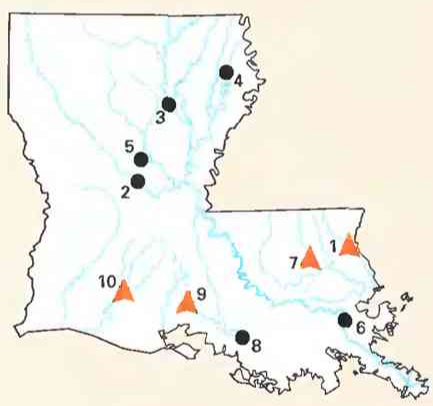

Dissolved sulfate, 1980-89

\section{EXPLANATION}

Trend in water-quality constituentNumber is site number in figure 2

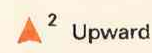

- ${ }^{4}$ None

$\nabla^{5}$ Downward

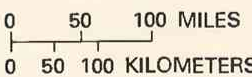




\section{FECAL COLIFORM BACTERIA}

Fecal coliform bacteria are used as indicators of fecal contamination from humans and other warm-blooded animals. Such contamination can introduce disease-causing viruses and bacteria into a stream.

Fecal-coliform concentrations had a downward trend in Big Creek at site 5 and had no trend at the other nine monitoring stations. Upgrades of many municipal wastewater-treatment plants throughout Louisiana during this period possibly caused reduced fecal coliform bacteria inputs to streams; however, many of the monitoring stations might not have been located close enough to point sources to detect these concentration changes. In addition, increases in nonpoint-source bacterial contamination might have obscured decreases in point-source contamination.

\section{DISSOLVED SULFATE}

The major natural sources of sulfate in streams are rock weathering, volcanoes, and biochemical processes (Hem, 1985, p. 113). Human activities such as mining, waste discharge, and fossil-fuel combustion also can be important sources.

The increasing sulfate concentrations in the Bogue Chitto River at site 1 , in the Tangipahoa River at site 7 , in Bayou Teche at site 9, and in the Mermentau River at site 10, all of which have relatively small drainage basins that are almost entirely in southern Louisiana, might have been caused by paper-mill operations and fossil-fuel-burning power-generating plants that began operating in southern Louisiana during the trend-analysis period (1980-89). Paper-mill and fossil-fuel-burning power-generating plants are sources of atmospherically deposited sulfates.

The absence of upward trends in sulfate concentrations at site 2 on the Red River, site 6 on the Mississippi River, and site 8 on the Atchafalaya River probably was due to the large drainage basins of these rivers and the large volume of water available for dilution. No trends were detected at the three northernmost stations (sites 3, 4, and 5). These basins are primarily rural and agricultural areas, but they contain paper mills.

\section{DISSOLVED SOLIDS}

Dissolved solids in stream water result primarily from rock weathering but also can be introduced as a byproduct of human activities (table 1). Concentrations generally are greatest in streams draining basins underlain by rocks and soils that contain easily dissolved minerals.

The upward trends in dissolved-solids concentrations in the Red River at site 2 and the Atchafalaya River at site 8 might have been caused by drought in 1988. Reduced surface runoff during drought causes a larger proportion of streamflow to be composed of ground-water discharge, which has a larger dissolved-solids concentration than surface runoff. Streamflow in the Red and Atchafalaya Rivers is composed partly of flow from saltwater springs in northeastern Texas and southwestern Arkansas.

The absence of downward trends in dissolved-solids concentrations in the other streams, despite increased control of point-source discharge, probably is related to several factors. These factors might include the distribution of point sources within the basin, increases of nonpoint loading from agriculture and urban runoff that offset any decreases in loading from municipal wastewater-treatment facilities, and the effects of droughts during the trend-analysis period.

\section{DISSOLVED NITRITE PLUS NITRATE}

Nitrite and nitrate are oxidized forms of nitrogen that together normally constitute most of the dissolved nitrogen in well-aerated streams. Nitrite readily oxidizes to nitrate in natural waters; therefore, nitrate generally is by far the more abundant of the two (Hem, 1985, p. 124).

The most likely cause of the decreasing nitrite plus nitrate concentration in the Ouachita River at site 3 is a reduction in nitrogen loads that has resulted from improved municipal sewage treatment. Other monitoring stations might not have been close enough to treatment-plant outfalls to detect significant changes in nitrite plus nitrate concentrations. Also, reductions in point-source inputs might have been obscured by increases in nonpoint-source inputs such as agricultural and urban runoff.

\section{WATER-QUALITY MANAGEMENT}

The LDEQ supervises the administration and regulation of water-quality policies in the State. The agency supports the EPA National Pollutant Discharge Elimination System program to monitor and regulate municipal and industrial wastewater discharges. The LDEQ monitors ambient water quality as well as specific events such as petroleum or chemical spills. The agency also prepares a biennial water-quality assessment report submitted to the EPA and the U.S. Congress in compliance with section 305(b) of the Federal Clean Water Act (Louisiana Department of Environmental Quality, 1990). The LDEQ issues discharge permits and reviews permits related to hydrologic alterations such as dredging. Other State agencies having responsibilities for the quality of water in Louisiana's streams are the Department of Health and Hospitals, which monitors surface water for bacteria, and the Department of Agriculture, which monitors for pesticides.

\section{SELECTED REFERENCES}

Anderson, J.R., 1967, Major land uses in the United States, in U.S. Geological Survey, 1970, National atlas of the United States of America: Washington, D.C., U.S. Geological Survey, p. 158-159.

Britton, L.J., and Greeson, P.E., eds., 1987, Methods for collection and analysis of aquatic biological and microbiological samples: U.S. Geological Survey Techniques of Water-Resources Investigations, book 5, chap. A4, $363 \mathrm{p}$.

Fenneman, N.M., 1946, Physical divisions of the United States: Washington, D.C., U.S. Geological Survey special map, scale 1:7,000,000.

Fishman, M.J., and Friedman, L.C., eds., 1989, Methods for the determination of inorganic substances in water and fluvial sediments: U.S. Geological Survey Techniques of Water-Resources Investigations, book 5, chap. A1, 545 p.

Hem, J.D., 1985, Study and interpretation of the chemical characteristics of natural water (3d ed.): U.S. Geological Survey Water-Supply Paper 2254, $263 \mathrm{p}$.

Hirsch, R.M., Slack, J.R., and Smith, R.A., 1982, Techniques of trend analysis for monthly water quality data: Water Resources Research, v. 18, no. 1, p. 107-121.

Lanfear, K.J., and Alexander, R.B., 1990, Methodology to derive water-quality trends for use by the National Water Summary Program of the U.S. Geological Survey: U.S. Geological Survey Open-File Report 90-359, $10 \mathrm{p}$.

Louisiana Department of Environmental Quality, 1989, Louisiana surface water quality standards: Baton Rouge, Louisiana Administrative Code, title 33, Environmental Quality, part IX, Water Quality Regulations, chap. 11, unnumbered.

1990, Louisiana water quality inventory 1990: Baton Rouge, Louisiana Department of Environmental Quality, $61 \mathrm{p}$.

Louisiana Department of Transportation and Development, 1984, The Louisiana Water Resources Study Commission's report to the 1984 legislature: Baton Rouge, Office of Public Works, Draft report, 438 p.

Pereira, W.E., Rostad, C.E., Chiou, C.T., and others, 1988, Contamination of estuarine water, biota, and sediment by halogenated organic compounds-A field study: Environmental Science and Technology, v. 22, no. 7 , p. 772-778.

Solley, W.B., Merk, C.F., and Pierce, R.R., 1988, Estimated use of water in the United States in 1985: U.S. Geological Survey Circular 1004, 82 p. 
Thelin, G.P., and Pike, R.J., 1990, Digital shaded relief map of the counterminous United States: Menlo Park, Calif., U.S. Geological Survey digital image processing, scale 1:3,500,000.

U.S. Army Corps of Engineers, 1988, Crisis on Louisiana's coast-America's loss: U.S. Army Corps of Engineers, New Orleans District, 13 p.

U.S. Geological Survey, 1986, National water summary 1985-Hydrologic events and surface-water resources: U.S. Geological Survey Water-Supply Paper 2300, 506 p.

1990, National water summary 1987-Hydrologic events and water supply and use: U.S. Geological Survey Water-Supply Paper 2350, $553 \mathrm{p}$.
1991, National water summary 1988-89-Hydrologic events and floods and droughts: U.S. Geological Survey Water-Supply Paper 2375, $591 \mathrm{p}$.

Ward, J.R., and Harr, C.A., eds., 1990, Methods for collection and processing of surface-water and bed-material samples for physical and chemical analyses: U.S. Geological Survey Open-File Report 90-140, 71 p. 
Prepared by J. Josh Gilbert

FOR ADDITIONAL INFORMATION: District Chief, U.S. Geological Survey, 6554 Florida Blvd., Baton Rouge, LA 70896 
MAINE

\section{Stream Water Quality}

Maine has abundant surface-water resources, including about 31,700 miles of rivers and streams and 5,780 lakes and ponds (Maine Department of Environmental Protection, 1990, p. 5). These resources, suitable for most uses, have attracted industrial, municipal, and recreational development.

Surface water provided an average of $783 \mathrm{Mgal} / \mathrm{d}$ (million gallons per day) for offstream use in 1985 . About 69 percent of the surface water withdrawn $(540 \mathrm{Mgal} / \mathrm{d})$ was used for industrial and mining activities, about 13 percent $(102 \mathrm{Mgal} / \mathrm{d})$ was used for thermoelectric power generation, and about 11 percent $(86 \mathrm{Mgal} / \mathrm{d})$ was used for public supply (U.S. Geological Survey, 1990, p. 285). Other uses of surface water include hydroelectric power generation, livestock watering, irrigation, maintenance of aquatic life, and recreation.

Stream water quality can be affected substantially by land use. Land use in Maine (fig. 1A) is determined in part by physiography,

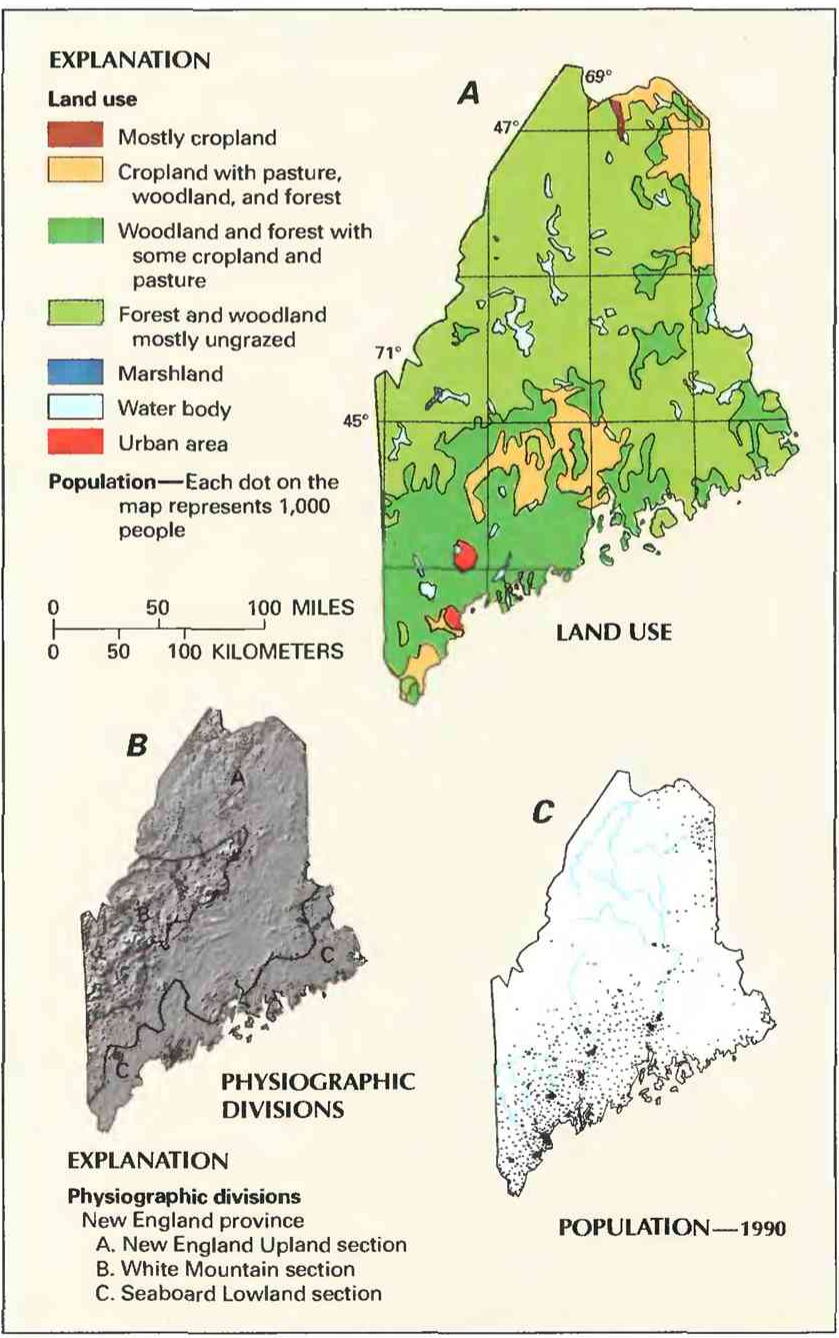

Figure 1. Land use, physiography, and population in Maine. $A$ Major land uses. $B$, Physiographic divisions. $C$, Population distribution in 1990. (Sources: A, Major land uses modified from Anderson, 1967. B, Physiographic divisions from Fenneman, 1946; landforms from Thelin and Pike, 1990. C. Data from U.S. Bureau of the Census 1990 decennial census files.) which ranges from the mountains of the White Mountain section in northwestern Maine (fig. $1 B$ ) to the gently rolling terrain of the Seaboard Lowland section along the coast. Most of the State is forested, but some areas in the New England Upland and Seaboard Lowland sections are used for cropland and pasture.

Maine's population in 1990 was 1.2 million (U.S. Bureau of the Census 1990 decennial census files), an increase of about 9.2 percent from the 1980 population. Southern Maine, in which most of the State's population resides (fig. $1 C$ ), accounts for most of this growth. Throughout the State, increasing demand for water makes protection of Maine's water resources a vital objective of Federal, State, and regional water-management agencies.

\section{WATER-QUALITY MONITORING}

Water-quality data obtained from analyses of water samples collected at monitoring stations are stored in the U.S. Geological Survey's (USGS) National Water Information System and the U.S. Environmental Protection Agency's (EPA) national data base known as STORET. Water-quality and streamflow data are reported by water year-the 12 months from October 1 through September 30. A water year is identified by the calendar year in which it ends. For example, water year 1991 comprises October 1, 1990, through September 30, 1991.

The data used in this summary of Maine's stream water quality were obtained from water samples collected at eight monitoring stations at which data collection is systematic and continuing (fig. 2). Analyses of water samples collected at these stations are the basis for the discussion and graphic summary (fig. 3) of stream waterquality conditions during water years 1987-89 and for the discussion and graphic summary (fig. 4) of stream water-quality trends. Water samples were collected and analyzed by using standard methods approved by the USGS (Britton and Greeson, 1987; Fishman and Friedman, 1989; Ward and Harr, 1990) or by using equivalent methods. If a method of sample collection or analysis changed over time, data from an analysis were included in the evaluation of recent stream water quality or of stream water-quality trends only if the change in method did not affect the comparability of the data.

\section{WATER-QUALITY CONDITIONS}

Most of Maine's surface waters meet State designated-use criteria that have been established for purposes of water-pollution control. On the basis of criteria presented in the Federal Clean Water Act, 93.1 percent of the total stream miles of Maine's major rivers and 99.7 percent of minor rivers, streams, and brooks are suitable for recreation (Maine Department of Environmental Protection, 1990, table 12). Water of this quality is an improvement on conditions of 15 years ago, when streams were adversely affected by untreated or inadequately treated wastewater from municipalities and from pulp and paper, textile, and other mills.

Since the mid-1970's, new and upgraded wastewater-treatment facilities have significantly improved water quality. Nevertheless, dioxin in wastewater from numerous pulp and paper mills and bacteria in untreated municipal wastewater from combined sewer overflows continue to be serious problems in some reaches of Maine's rivers (Maine Department of Environmental Protection, 1990). Other waterquality problems result from acid rain, construction, agriculture, 
animal grazing, timber harvesting, and waste disposal, although all these problems are not fully described in this report.

Water-quality criteria adopted by the State may differ depending on the State's classification of a river. The criteria for class $\mathrm{A}, \mathrm{B}$, and $\mathrm{C}$ waters require that the water be suitable for fishing, navigation, recreational use, industrial use, and hydroelectric power generation. In addition to these criteria, class A waters are suitable for drinking after disinfection and have aquatic-life habitat characterized as natural. Class B waters are suitable for drinking after treatment and fully support aquatic life. Class $\mathrm{C}$ waters also are suitable for drinking after treatment; however, the discharges into class $\mathrm{C}$ waters may cause changes to aquatic-life habitat, providing that all indigenous fish species and the resident biological community are supported (Maine Department of Environmental Protection, 1987, p. 13 14). The Wild River at Gilead (site 5) and the Saco River at Cornish (site 8 ) are class A. The Penobscot River at Eddington (site 3) and the Kennebec River at North Sidney (site 4) are class B. The remaining rivers discussed in this report are class $\mathrm{C}$ at the location of the monitoring stations.

The following discussion of stream water quality in Maine is organized by river basin (fig. 3). Graphs in figure 3 summarize certain aspects of stream water quality in the basins for water years 1987-89. The graphs show frequency distributions of data values that

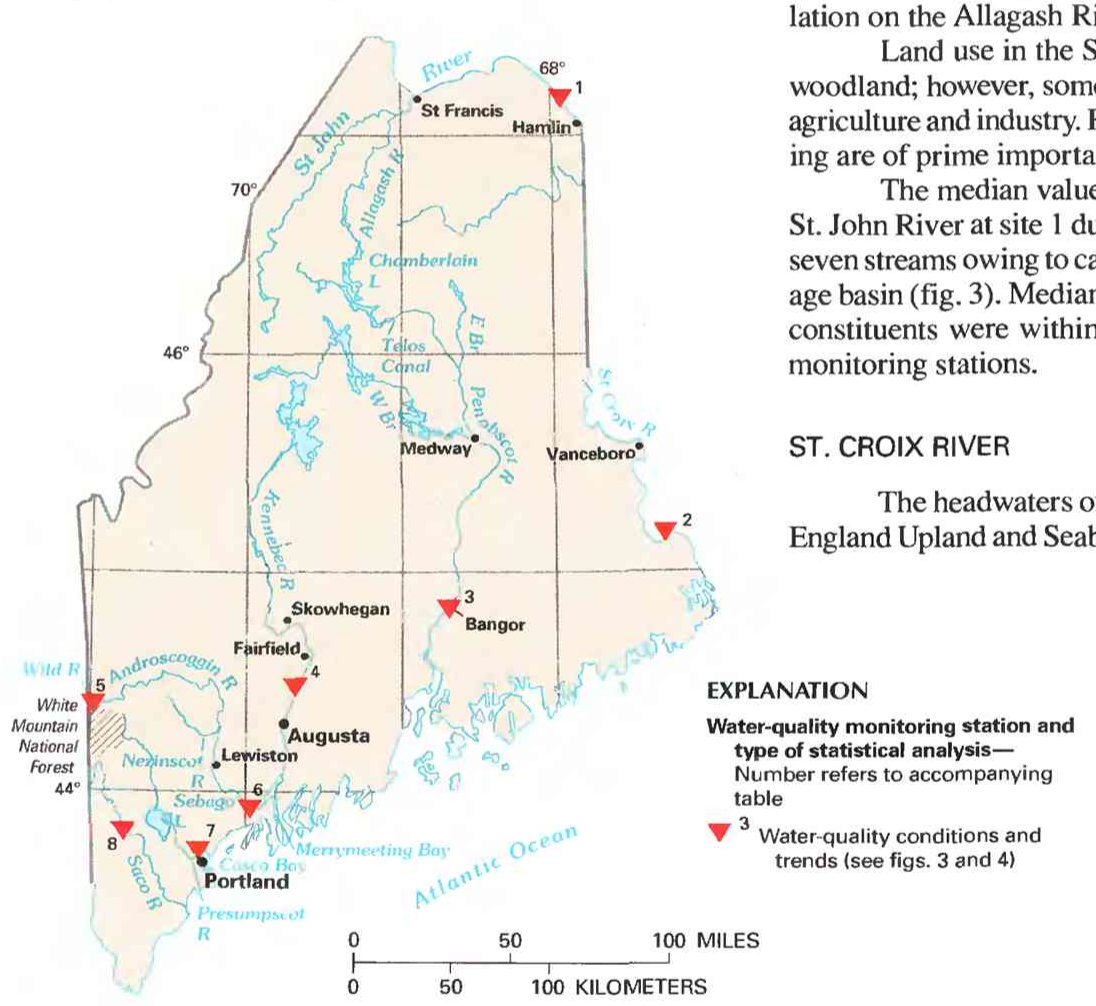

represent measurements of selected physical properties of stream water and concentrations of selected constituents in stream water. These properties and constituents are specific conductance, dissolved oxygen, fecal coliform bacteria and fecal streptococcal bacteria, alkalinity (as calcium carbonate), dissolved solids, dissolved nitrite plus nitrate (as nitrogen), and suspended sediment. The data are reported in microsiemens per centimeter at 25 degrees Celsius $(\mu \mathrm{S} / \mathrm{cm})$, milligrams per liter $(\mathrm{mg} / \mathrm{L})$, and colonies per 100 milliliters $(\mathrm{col} / 100$ $\mathrm{mL}$ ). Sources and environmental significance of each property and constituent are described in table 1 .

Water quality at each monitoring station is the result of geological, chemical, biological, and hydrologic processes that occur over a large area. Water-quality problems that affect aquatic life or public health only locally are not fully represented in this summary.

\section{ST. JOHN RIVER}

The St. John River drains Maine's New England Upland physiographic section. The headwaters are in northwestern Maine. The river flows northeastward to form the boundary between the United States and Canada for about 100 miles between St. Francis and Hamlin and then enters Canada. Upstream from site 1, the river system is essentially unregulated except for minor streamflow regulation on the Allagash River for recreational purposes.

Land use in the St. John River basin is primarily forest and Lowe hower, some areas upstream from site 1 are devoted to agriculture and industry. Recreational uses such as canoeing and fish-

The median value of alkalinity $(34 \mathrm{mg} / \mathrm{L})$ was higher in the St. John River at site 1 during water years $1987-89$ than in the other seven streams owing to carbonate bedrock in the St. John River drainage basin (fig. 3). Median values of the other selected properties and constituents were within the range of median values for the eight

The headwaters of the St. Croix River drain areas of the New oard Lowland physiographic sections. The

\begin{tabular}{|c|c|c|c|}
\hline $\begin{array}{l}\text { Site no. } \\
\text { on map }\end{array}$ & $\begin{array}{l}\text { USGS station } \\
\text { name and no. }\end{array}$ & $\begin{array}{l}\text { Drainage area } \\
\text { (square miles) }\end{array}$ & $\begin{array}{l}\text { Major land use } \\
\text { (see fig.1) }\end{array}$ \\
\hline 1 & St. John River at Van Buren (01015000) & 8,174 & $\begin{array}{l}\text { Mostly ungrazed forest and woodland; cropland with pasture, } \\
\text { woodland, and forest. }\end{array}$ \\
\hline 2 & 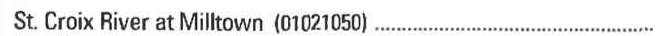 & 1,460 & Mostly ungrazed forest and woodland. \\
\hline 3 & Penobscot River at Eddington (01036390) & 7,764 & Mostly ungrazed forest and woodland; cropland and forest. \\
\hline 4 & 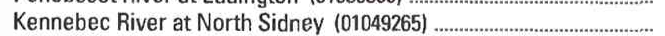 & 5,403 & Woodland and forest with some cropland and pasture. \\
\hline 5 & Wild River at Gilead $(01054200)$ & 69.6 & Mostly ungrazed forest and woodland. \\
\hline 7 & Presumpscot River near West Faimouth $(01064140)$ & 598 & Ditto. \\
\hline 8 & Saco River at Cornish $(01066000)$ & 1,293 & Ditto. \\
\hline
\end{tabular}

Figure 2. Selected water-quality monitoring stations, type of statistical analysis, and geographic features in Maine. (Sources: Major land uses modified from Anderson, 1967; other data from U.S. Geological Survey files.) 
river flows southward through densely forested land and forms the border between the United States and Canada from Vanceboro to the Atlantic Ocean. Streamflow in the St. Croix River is regulated for hydroelectric power generation and industrial use.

The St. Croix River at site 2 had no high concentrations of the selected properties and constituents during water years 1987-89 (fig. 3). At Milltown (site 2), the St. Croix River has been designated as class C. However, the Maine Department of Environmental Protection (1990, app. I, p. 99) determined that, owing to dioxin found in industrial sludge, this river segment did not meet class $\mathrm{C}$ standards.

\section{PENOBSCOT RIVER}

The East and West Branches of the Penobscot River combine at Medway to form the Penobscot River. The headwaters of the West Branch are in the White Mountain physiographic section. The West Branch flows eastward through several dams that regulate streamflow for hydroelectric power generation. The smaller East Branch originates in the New England Upland physiographic section and includes
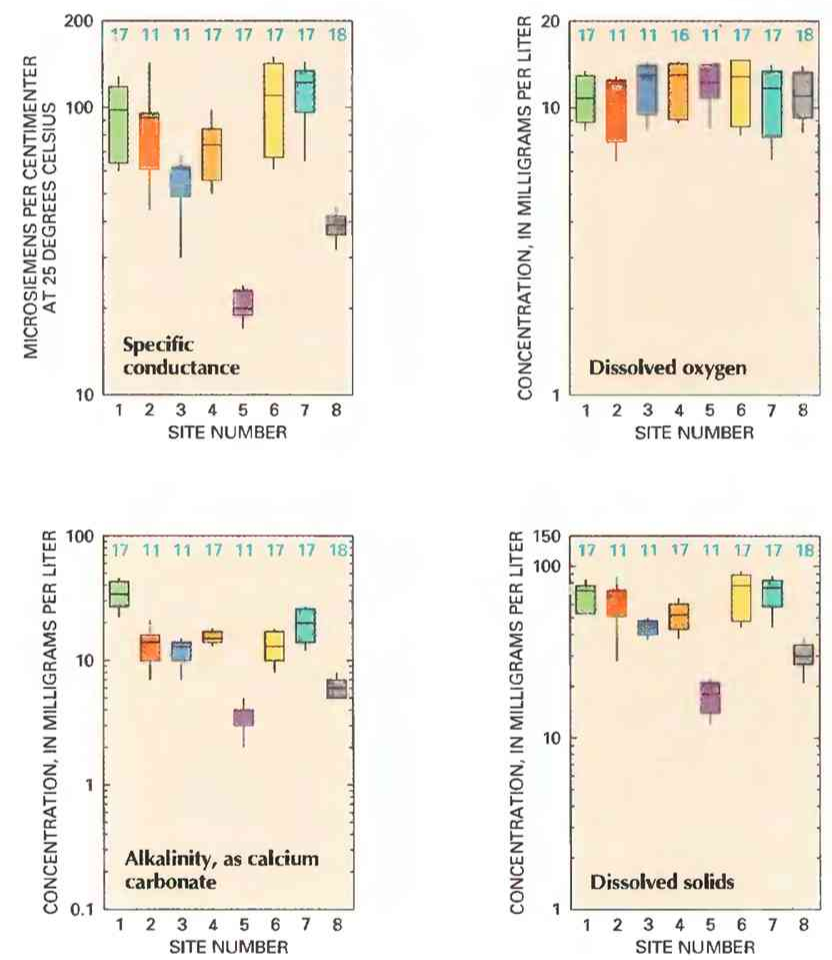

the 249-square-mile drainage area of Chamberlain Lake and its tributaries, formerly in the St. John River basin, but now diverted to the Penobscot River basin through the Telos Canal. The main stem of the Penobscot River flows southward through the New England Upland and Seaboard Lowland physiographic sections to the Atlantic Ocean.

Water uses along the Penobscot River are diverse. Recreation is important in the upper reaches of the East and West Branches, where fishing and white-water rafting are popular. Hydroelectric power generation and municipal and industrial uses are common throughout the remainder of the basin. Woodland and forest cover most of the upper basin, but there is some cropland and pasture near site 3 .

Median concentrations of the selected constituents in water samples collected at site 3 during water years 1987-89 were within the distribution of median values for each constituent (fig. 3); however, the discovery of dioxin in fish from the Penobscot River has raised water-quality concerns. Municipal and industrial wastewatertreatment facilities have improved water quality in recent years, but
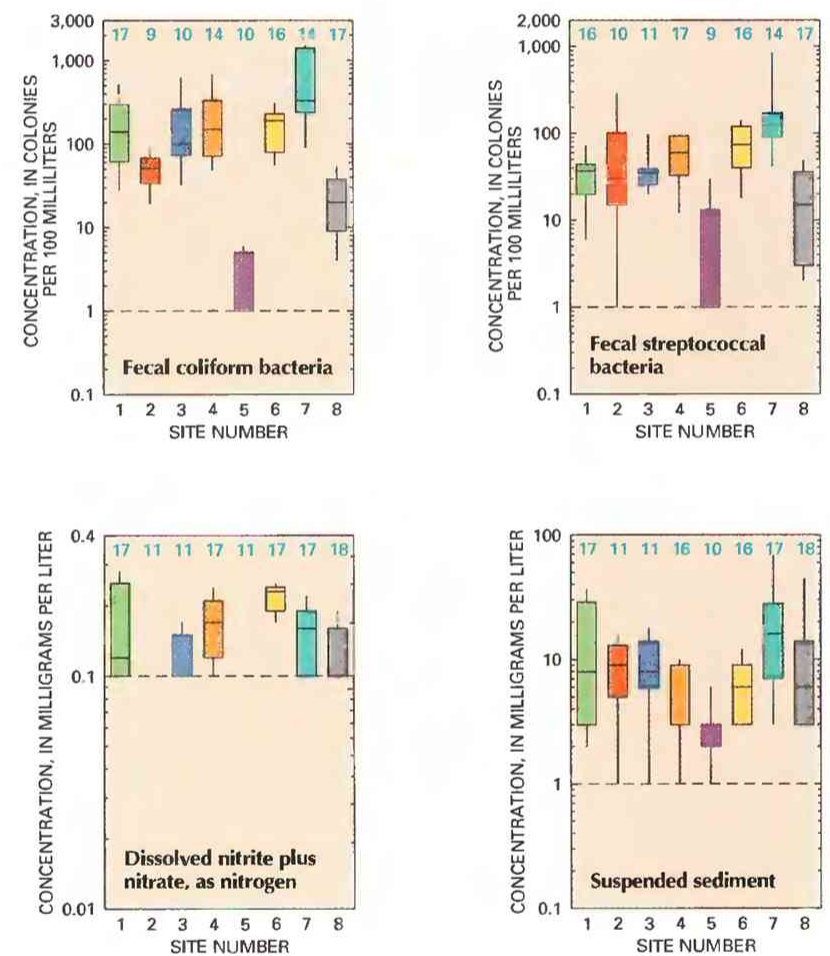

\section{EXPLANATION}

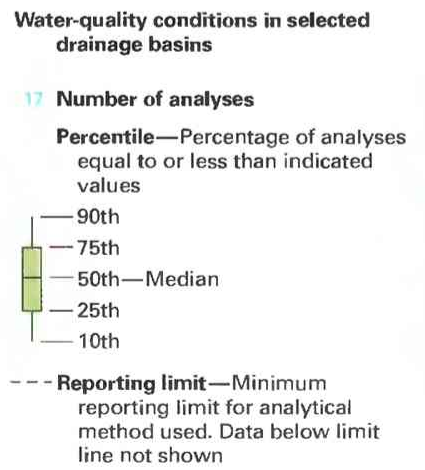

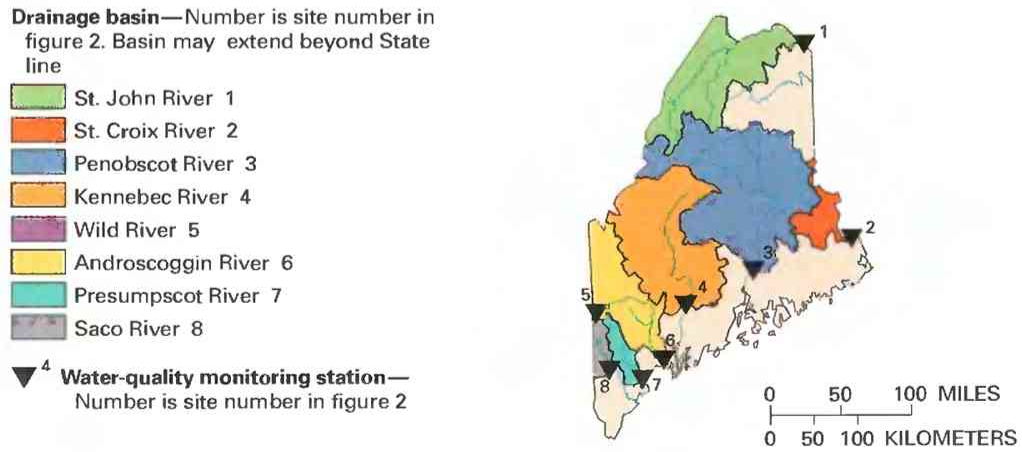

Figure 3. Water quality of selected streams in Maine, water years 1987-89. (Source: Data from U.S. Geological Survey files.) 
dioxin from industrial point sources and bacteria from untreated municipal wastewater are a continuing problem (Maine Department of Environmental Protection, 1990, app. I, p. 60-62).

\section{KENNEBEC RIVER}

The headwaters of the Kennebec River are in the White Mountain physiographic section. Similar to the headwaters of most rivers in Maine, the headwaters of the Kennebec are pristine. The river flows southward through the New England Upland and Seaboard Lowland sections and joins the Androscoggin River in Merrymeeting Bay before emptying into the Atlantic Ocean. Numerous dams regulate the Kennebec River's flow for hydroelectric power generation. The basin is covered primarily by woodland and forest with some cropland and pasture.

Water in the Kennebec River is adequate for most uses. Fishing and recreation are important uses in the upper part of the basin, whereas municipal and industrial uses are important along the main stem of the river. Municipal sewer overflows and industrial wastewater discharges prevent some reaches downstream from the towns of Skowhegan and Fairfield from meeting water-quality criteria for the river's class B designation (Maine Department of Environmental Protec-

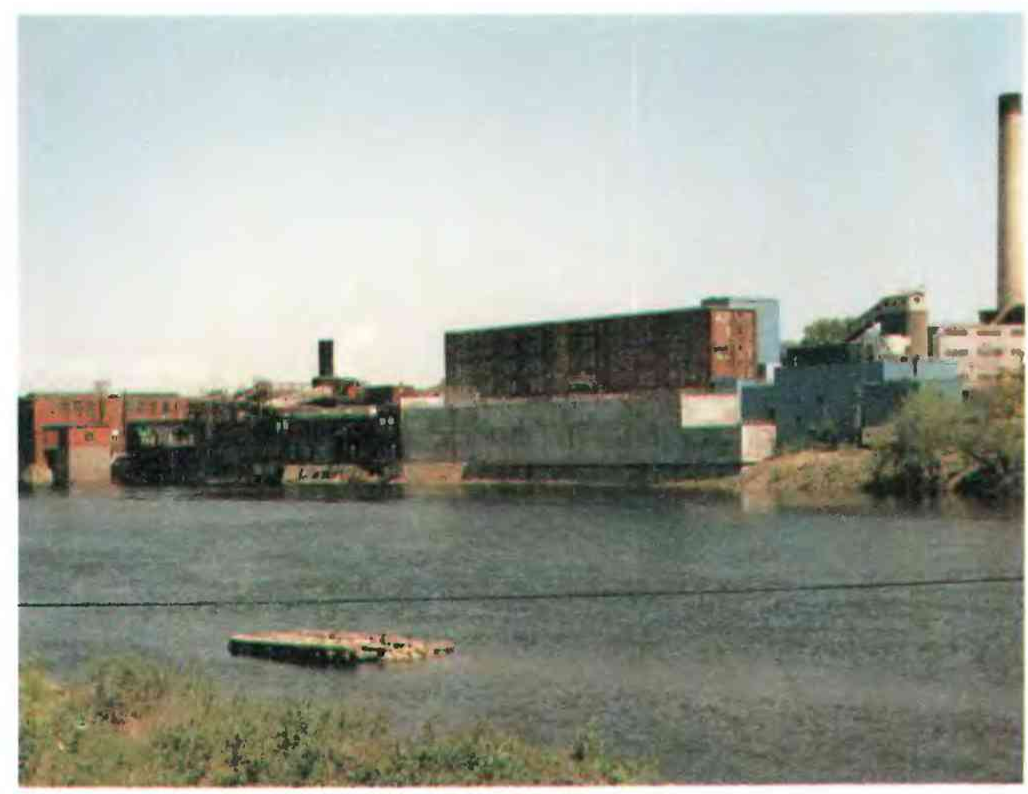

Paper mill on the Kennebec River. Maine sets water-quality standards that ensure the suitability of stream water for all users, including industries such as this paper mill. (Scott A. Olson, U.S. Geological Survey.)

tion, 1990, app. I, p. 81-83). Nonetheless, median concentrations of the selected properties and constituents in water samples taken from site 4 during water years $1987-89$ were within the range of median values for the eight monitoring stations (fig. 3) and within waterquality criteria adopted by the State.

\section{WILD RIVER}

The Wild River basin lies within the White Mountain physiographic section. Most of the drainage area of the Wild River upstream from site 5 is in the White Mountain National Forest. Site 5 is about 2,000 feet upstream from the confluence of the Wild and Androscoggin Rivers. Most of the basin is covered by open woodland and forest.

Site 5 on the Wild River at Gilead is part of the USGS Hydrologic Bench-Mark Network. Bench-mark stations provide hydrologic data, including water-quality data, for basins affected principally by natural conditions. The network allows comparisons between conditions in undeveloped watersheds and conditions in basins affected by human activities.

The entire length of the Wild River is pristine. The median values of all properties and constituents in water samples from site 5 , except dissolved oxygen, were lower than median values for any of the other seven monitoring stations (fig. 3 ).

\section{ANDROSCOGGIN RIVER}

The headwaters of the Androscoggin River, which are within the White Mountain physiographic section, drain mountainous areas in northwestern Maine near the New Hampshire border. The river then flows southeastward through the New England Upland and Seaboard Lowland physiographic sections to the Atlantic Ocean. Numerous dams regulate the river's flow for hydroelectric power generation. Woodland and forest cover much of the basin, along with some cropland and pasture.

Industrial development along the main stem of the Androscoggin River has degraded water quality. The river was once considered one of the Nation's 10 most polluted rivers (Maine Department of Environmental Protection, 1990, p. 23). Conditions have im- proved; however, bacteria and dioxin are still major water-quality concerns. Much of the Androscoggin River is unsuitable for recreation and fishing and does not meet class $\mathrm{C}$ criteria. Furthermore, the Androscoggin River from the confluence with the Nezinscot River to Great Falls in Lewiston has been classified as a Water Quality Limited Segment - a reach having water quality that presently and in the future will not support the river's designated uses even with appropriate treatment (Maine Department of Environmental Protection, 1990, app. I, p. 94-96).

Median concentrations of dissolved solids $(77 \mathrm{mg} / \mathrm{L})$ and nitrite plus nitrate $(0.23 \mathrm{mg} / \mathrm{L})$ in water samples from site 6 were higher than those for any other monitoring station (fig. 3). Median concentrations of fecal coliform bacteria $(190 \mathrm{col} / 100 \mathrm{~mL})$ and fecal streptococcal bacteria $(74 \mathrm{col} / 100 \mathrm{~mL})$ were among the highest.

\section{PRESUMPSCOT RIVER}

The Presumpscot River, which lies within the Seaboard Lowland physiographic section, originates at the outlet of Sebago Lake in southern Maine. The river flows southeastward to Casco Bay and is regulated by Sebago Lake Dam and dams for several small powerplants. The basin is covered primarily by woodland and forest, but some land is used for cropland and pasture.

The water quality of Sebago Lake is among the best in Maine, and the lake is used as the primary water supply for the Portland Water District. The water quality of the Presumpscot River at the Sebago Lake outlet meets State standards; however, just upstream from site 7 , the river is degraded by urban and industrial point sources and other nonpoint sources (Maine Department of Environmental Protection, 1990 , app. I, p. 118). The median values of specific conductance (122 $\mu \mathrm{S} / \mathrm{cm})$, fecal coliform bacteria $(330 \mathrm{col} / 100 \mathrm{~mL})$, fecal streptococcal bacteria $(130 \mathrm{col} / 100 \mathrm{~mL})$, and suspended sediment $(16 \mathrm{mg} / \mathrm{L})$ were higher for water samples collected at site 7 than for samples from the other monitoring stations (fig. 3).

\section{SACO RIVER}

The Saco River originates in eastern New Hampshire and flows southeastward into Maine. The river drains parts of the White 
Mountain, New England Upland, and Seaboard Lowland physiographic sections and then empties into the Atlantic Ocean. There is little streamflow regulation upstream from Cornish.

Principal water uses of the Saco River include hydroelectric power generation, municipal and industrial water supply, and recreation. The Saco River is considered to have more canoe traffic than any other New England river (Land and Water Resources Center, 1984).

Water quality of the Saco River is suitable for most uses. Measurements of the selected properties and concentrations of the selected constituents at site 8 were, for the most part, lower than at the other monitoring stations except site 5 on the Wild River (fig. 3 ).

\section{WATER-QUALITY TRENDS}

Trend analysis is a statistical procedure used to detect changes in stream water quality at a monitoring station over time. For this report, water-quality data from eight monitoring stations (fig. 2) were analyzed for trends by using the seasonal Kendall test (Hirsch and others, 1982), a method used extensively by the USGS. The graph (shown below) of alkalinity values in the St. John River at site 1 illustrates the trend inferred from the concentration data and demonstrates the variation in water quality that is common in streams.

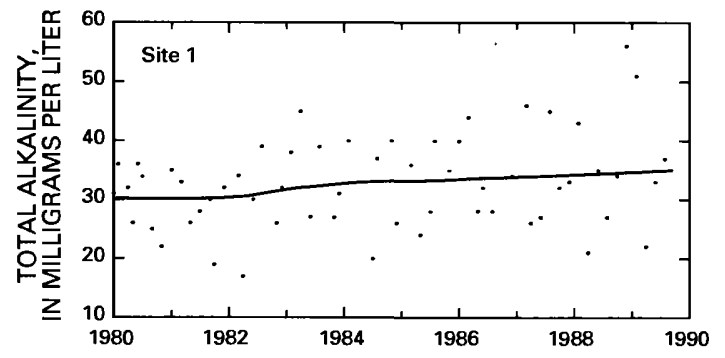

When possible, constituent-concentration data were adjusted for changes in streamflow to preclude identifying a trend in concentration that was caused only by a trend in streamflow. The data were not adjusted when (1) more than 10 percent of the samples had concentrations lower than the minimum reporting limit for the analytical method used or (2) streamflow was controlled substantially by human activities. When the concentration data could not be adjusted for streamflow, trends were determined directly from the concentration data.

Statewide trends in measurements of selected physical properties of stream water and in concentrations of selected constituents in stream water are shown on maps in figure 4. On each map, a trend is indicated at a monitoring station only if the data from that station were suitable for use in the trend analysis. For more information on the suitability criteria and on the trend-analysis procedure used for this report, see Lanfear and Alexander (1990).

\section{SPECIFIC CONDUCTANCE}

Specific conductance is a measure of the ability of a sample of water to conduct electricity. Because specific conductance and the dissolved-solids concentration are roughly proportional in most natural waters, the specific-conductance value often can be used to estimate the dissolved-solids concentration (Hem, 1985, p. 66-68).

Specific-conductance values measured at the eight monitoring stations during water years $1980-89$ had no trends (fig. 4). Only minor development occurred upstream from most of the monitoring stations during the analysis period, which might account for the absence of trends.

\section{DISSOLVED OXYGEN}

The dissolved-oxygen concentration in a stream is controlled by several factors, including water temperature, air temperature and pressure, hydraulic characteristics of the stream, photosynthetic or respiratory activity of stream biota, and the quantity of organic material present. A trend in dissolved-oxygen concentrations commonly is directly or indirectly the result of human activities. Generally, an upward trend in dissolved-oxygen concentrations indicates improving stream water-quality conditions and a downward trend indicates deteriorating conditions.

Dissolved-oxygen concentrations had upward trends in the Kennebec River at site 4 and in the Presumpscot River at site 7 for water years 1980-89 (fig. 4). Dissolved-oxygen concentrations at the other six monitoring stations had no trends. More upward trends were expected owing to significant efforts to improve Maine's water qual-

Table 1. Sources and environmental significance of selected water-quality properties and constituents

[Source: Compiled by the U.S. Geological Survey. Office of Water Quality]

\begin{tabular}{|c|c|c|}
\hline Property or constituent & Common sources & Environmental significance \\
\hline $\begin{array}{l}\text { Specific conductance } \\
\text { (property) }\end{array}$ & $\begin{array}{l}\text { A measure of the electrical conductivity of water; var- } \\
\text { ies with the quantity of dissolved solids and is } \\
\text { used to approximate the dissolved-solids content. }\end{array}$ & $\begin{array}{l}\text { Dissolved solids can cause water to be unsuitable for } \\
\text { public supply, agriculture, and industry; can harm } \\
\text { aquatic organisms. }\end{array}$ \\
\hline Dissolved oxygen ....................... & $\begin{array}{l}\text { Introduced from the atmosphere; also a byproduct of } \\
\text { aquatic plants. }\end{array}$ & $\begin{array}{l}\text { Necessary for aquatic life; deficiency can result from } \\
\text { assimilation of organic wastes or rapid growth } \\
\text { and decay of algae. }\end{array}$ \\
\hline $\begin{array}{l}\text { Fecal coliform and fecal .............. } \\
\text { streptococcal bacteria }\end{array}$ & $\begin{array}{l}\text { Sources include effluent from sewage-treatment } \\
\text { plants and runoff from pastures, feedlots, and ur- } \\
\text { ban areas. }\end{array}$ & $\begin{array}{l}\text { Presence indicates contamination of water by wastes } \\
\text { from humans and other warm-blooded animals. }\end{array}$ \\
\hline Alkalinity (property) ................... & $\begin{array}{l}\text { A measure of the quantity of acid-neutralizing sub- } \\
\text { stances; can be affected by geologic setting, in- } \\
\text { dustrial wastewater discharge, waste gases, and } \\
\text { runoff from surface mining. }\end{array}$ & $\begin{array}{l}\text { Sufficiently alkaline water can be unsuitable for some } \\
\text { agricultural and industrial uses. }\end{array}$ \\
\hline Dissolved solids .......................... & $\begin{array}{l}\text { A result of rock weathering; also in agricultural runoff } \\
\text { and industrial discharge. }\end{array}$ & $\begin{array}{l}\text { In sufficient quantity, can cause water to be unsuitable } \\
\text { for public supply, agriculture, and industry; can } \\
\text { harm aquatic organisms. }\end{array}$ \\
\hline Nitrite plus nitrate ......................... & $\begin{array}{l}\text { Nonpoint sources are agricultural and urban runoff; } \\
\text { a major point source is wastewater discharge. }\end{array}$ & $\begin{array}{l}\text { Plant nutrient that, in sufficient quantity, can cause } \\
\text { algal blooms and excessive growth of higher } \\
\text { aquatic plants in bodies of water; can cause water } \\
\text { to be unsuitable for public supply. }\end{array}$ \\
\hline Suspended sediment .................. & $\begin{array}{l}\text { A result of rock erosion; also induced by disturbances } \\
\text { of land cover due to fires, floods, and human } \\
\text { activities such as mining, logging, construction, } \\
\text { and agriculture. }\end{array}$ & $\begin{array}{l}\text { Can be detrimental to aquatic organisms; can fill res- } \\
\text { ervoirs and impair recreational use of water. }\end{array}$ \\
\hline
\end{tabular}


ity from 1975 to 1985 . Before 1975 , untreated or inadequately treated wastewater from numerous pulp and paper mills put large biochemical oxygen demand (BOD) loadings on Maine rivers. The building of many secondary wastewater-treatment facilities greatly decreased the BOD loadings. Construction of numerous municipal wastewater-treatment facilities further improved conditions (Maine Department of Environmental Protection, 1990, p. 26). More upward trends might have been detected if the water-quality data base from 1975 to 1989 had been comprehensive enough to enable a statewide trend analysis for this longer period.

\section{FECAL COLIFORM AND FECAL STREPTOCOCCAL BACTERIA}

Fecal coliform bacteria and fecal streptoccocal bacteria are used as indicators of fecal contamination from humans and other warm-blooded animals. Such contamination can introduce diseasecausing viruses and bacteria into a stream.

Fecal coliform bacteria concentrations had a downward trend in the St. John River at site 1 for water years 1980-89 (fig. 4). Fecal streptococcal bacteria concentrations in water samples from the eight monitoring stations had no trends for water years 1980-89. More downward trends in bacteria concentrations were expected because of the numerous municipal wastewater-treatment facilities built since the mid-1970's. The near absence of decreases in bacteria during water years $1980-89$ might have been due to most water-quality improvement having occurred before 1980 and fewer large municipal wastewater-treatment facilities having been built in the 1980's than in the 1970 's.

\section{ALKALINITY}

Alkalinity is a measure of the capacity of the substances dissolved in the water to neutralize acid. In most natural waters, alkalinity is produced mainly by bicarbonate and carbonate (Hem, 1985 , p. 106), which are ions formed when carbon dioxide or carbonate rock dissolves in water.

The alkalinity in the St. John River at site 1 increased during water years 1980-89 (fig. 4). The cause of the upward trend in the St. John River, where alkalinity values were already large because of basin geology, is unknown.
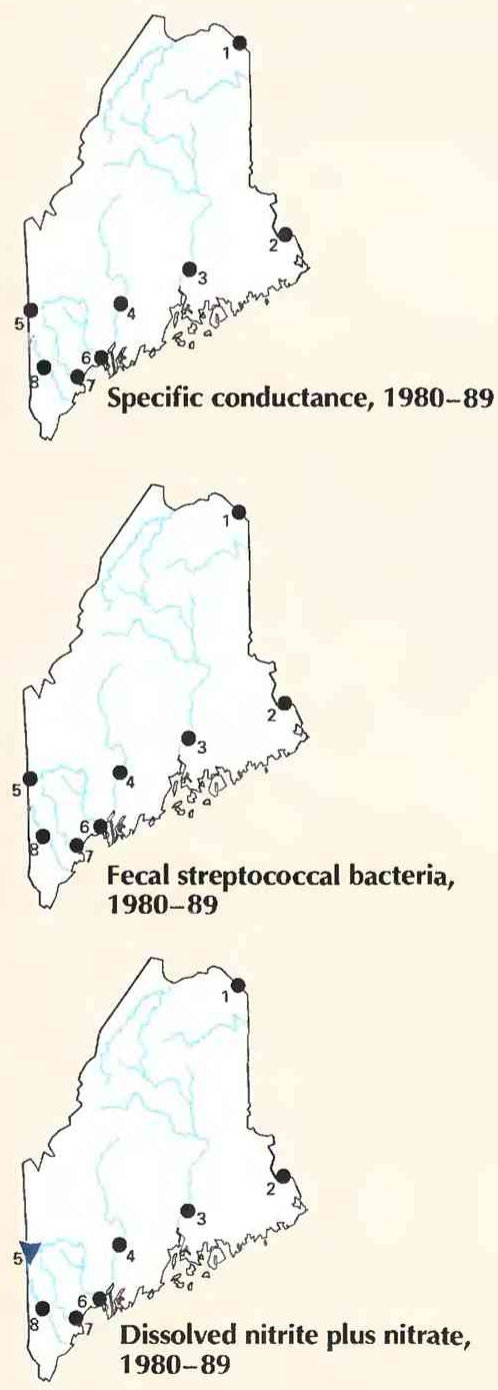
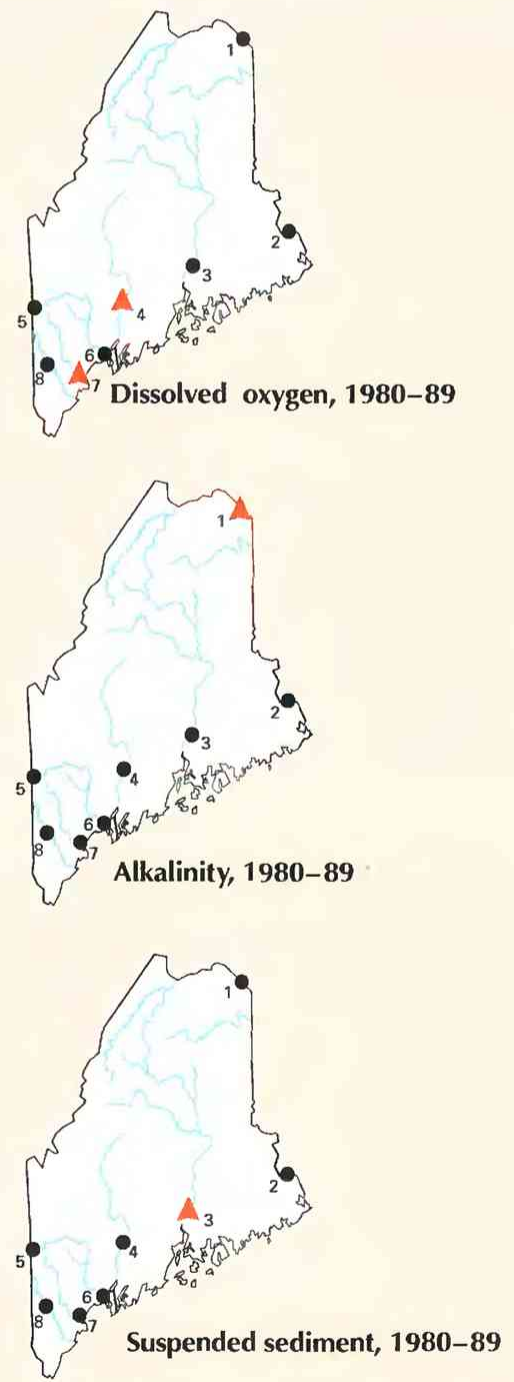
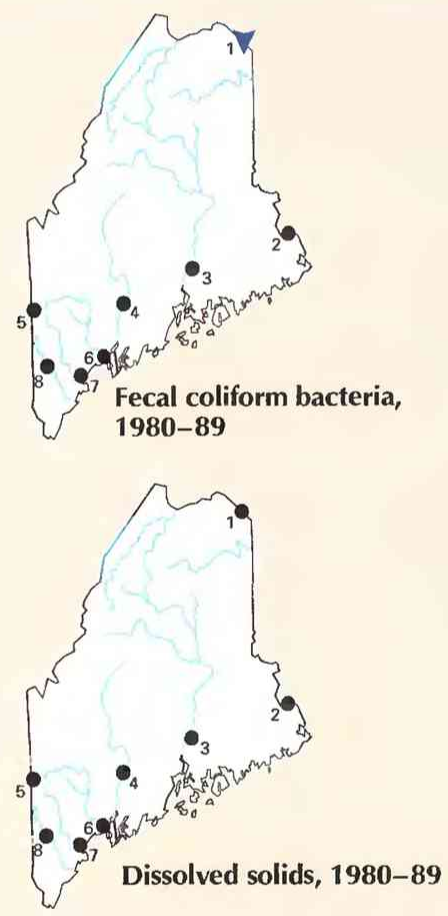

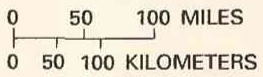

EXPLANATION

Trend in water-quality property or constituent- Number is site number in figure 2

$$
\begin{aligned}
& \triangle^{4} \text { Upward } \\
& { }^{3} \text { None } \\
& \nabla^{5} \text { Downward }
\end{aligned}
$$

Figure 4. Trends in water quality of selected streams in Maine, by water years. (Source: Data from U.S. Geological Survey files.) 


\section{DISSOLVED SOLIDS}

Dissolved solids in stream water result primarily from rock weathering but also can be introduced as a byproduct of human activities (table 1). Concentrations generally are greatest in streams draining basins underlain by rocks and soils that contain easily dissolved minerals.

Dissolved-solids concentrations in water samples from eight monitoring stations had no trends for water years 1980-89 (fig. 4). The reason for the absence of trends might be that only minor development occurred upstream from most of the monitoring stations during the analysis period.

\section{DISSOLVED NITRITE PLUS NITRATE}

Nitrite and nitrate are oxidized forms of nitrogen that together constitute most of the dissolved nitrogen in stream water. Nitrite readily oxidizes to nitrate in natural waters; therefore, nitrate generally is by far the more abundant of the two (Hem, 1985, p. 124).

Nitrite plus nitrate concentrations decreased slightly in water samples from the Wild River at site 5 during water years 1980-89 (fig. 4). The cause of the downward trend on the Wild River, where concentrations were already small, is unknown.

\section{SUSPENDED SEDIMENT}

Suspended sediment is a product of erosion. The erosion can be either natural or the result of land-cover disturbances related to human activities (table 1).

Water samples from site 3 on the Penobscot River had a slight increase in suspended-sediment concentrations (fig. 4) for reasons that are not readily apparent. Regardless, suspended sediment is not a major concern in the Penobscot River basin. The absence of upward trends in suspended sediment at the other monitoring stations might have been due to only minor development occurring upstream from most of the monitoring stations and to a decrease in agricultural activities in many areas of the State.

\section{WATER-QUALITY MANAGEMENT}

Water-quality classification and protection of the State's rivers and lakes are the responsibility of the Maine Department of Environmental Protection (MDEP). The MDEP licenses waste dischargers and monitors the licensees and receiving waters to ensure that waterquality standards and license requirements are met. The MDEP also is the lead agency for the development and implementation of Maine's nonpoint-source management plan.

Section 305(b) of the Federal Clean Water Act requires States to submit biennial water-quality-assessment reports to the U.S. Congress and the EPA. The MDEP Bureau of Water Quality Control has this responsibility for Maine. The 305(b) report (Maine Department of Environmental Protection, 1990) describes current water-quality conditions of surface-water bodies and documents progress in implementing the goals and objectives of the Clean Water Act.

The MDEP also licenses hydroelectric power-generating facilities, manages construction grants for municipal wastewater-treatment plants, and issues water-quality certification for water-related development, such as stream alteration and wetlands dredging and filling. The EPA issues separate Federal wastewater-discharge permits under the National Pollutant Discharge Elimination System.

The Maine Departments of Inland Fisheries and Wildlife and Marine Resources manage and protect fish populations in streams. The Department of Inland Fisheries and Wildlife reviews applications that involve alteration of streambeds and streamflows upstream from the limit of tidal influence; the Department of Marine Resources reviews development in tidal streams, estuaries, and upland streams having anadromous fish populations.

The Maine Department of Human Services regulates the use of surface water for public-supply purposes. The Department of Human Services reviews water-supply development plans, establishes water-supply quality standards, and monitors the quality of water delivered to consumers to ensure that standards are met.

The Governor's Land and Water Resources Council and State Planning Office promote interagency coordination in implementing programs related to surface-water quality. Representatives of State, Federal, and regional agencies and the University of Maine constitute the council. The State also participates in the New England Governor's Conference, the New England-New York Water Council, the St. John River Basin Board, and the St. Croix River Board of Control. A primary goal of these groups is the improvement of surface-water quality. As a result of interagency cooperation, waterquality monitoring has increased significantly during the last two decades.

The USGS has cooperative agreements with the Maine Geological Survey, five regional planning agencies, the International Joint Commission, and the Federal Energy Regulatory Commission. The agreements enable the systematic collection of water-quality and streamflow data at more than 50 sites in Maine.

\section{SELECTED REFERENCES}

Anderson, J.R., 1967, Major land uses in the United States, in U.S. Geological Survey, 1970, National atlas of the United States of America: Washington, D.C., U.S. Geological Survey, p. 158-159.

Britton, L.J., and Greeson, P.E., eds., 1987, Methods for collection and analysis of aquatic biological and microbiological samples: U.S. Geological Survey Techniques of Water-Resources Investigations, book 5, chap. A4, $363 \mathrm{p}$.

Fenneman, N.M., 1946, Physical divisions of the United States: Washington, D.C., U.S. Geological Survey special map, scale 1:7,000,000.

Fishman, M.J., and Friedman, L.C., eds., 1989, Methods for the determination of inorganic substances in water and fluvial sediments: U.S. Geological Survey Techniques of Water-Resources Investigations, book 5, chap. A1, 545 p.

Hem, J.D., 1985, Study and interpretation of the chemical characteristics of natural water (3d ed.): U.S. Geological Survey Water-Supply Paper 2254 , $263 \mathrm{p}$.

Hirsch, R.M., Slack, J.R., and Smith, R.A., 1982, Techniques of trend analysis for monthly water quality data: Water Resources Research, v. 18, no. 1, p. $107-121$.

Knox, C.E., and Nordenson, T.J., 1955, Average annual runoff and precipitation in the New England-New York area: U.S. Geological Survey Hydrologic Investigations Atlas HA-7, scale 1:1,000,000.

Land and Water Resources Center, 1984, Maine rivers and streams: University of Maine at Orono, $12 \mathrm{p}$.

Lanfear, K.J., and Alexander, R.B., 1990, Methodology to derive water-quality trends for use by the National Water Summary Program of the U.S. Geological Survey: U.S. Geological Survey Open-File Report 90-359, $10 \mathrm{p}$.

Maine Department of Environmental Protection, 1987, Water classification program: Augusta, Maine Department of Environmental Protection Report, Title 38, Article 4-A, 51 p.

1990 , State of Maine 1990 water quality assessment: Augusta, Bureau of Water Quality Control, $234 \mathrm{p}$.

Thelin, G.P., and Pike, R.J., 1990, Digital shaded relief map of the conterminous United States: Menlo Park, Calif., U.S. Geological Survey digital image processing, scale 1:3,500,000.

U.S. Geological Survey, 1990, National water summary 1987-Hydrologic events and water supply and use: U.S. Geological Survey Water-Supply Paper 2350, $553 \mathrm{p}$.

Ward, J.R., and Harr, C.A., eds., 1990, Methods for collection and processing of surface-water and bed-material samples for physical and chemical analyses: U.S. Geological Survey Open-File Report 90-140, 71 p. 
308 National Water Summary 1990-91-Stream Water Quality: STATE SUMMARIES

Prepared by Scott A. Olson and Derrill J. Cowing

FOR ADDITIONAL INFORMATION: Office Chief, U.S. Geological Survey, 26 Ganneston Drive, Augusta, ME 04330 


\section{Maryland AND THE District of Columbia Stream Water Quality}

Maryland and the District of Columbia have abundant and economically important surface-water resources. Annual precipitation in these two areas is about 42 inches (U.S. Geological Survey, 1990 , p. 291). In addition, an average of 30,000 million gallons per day enters the streams of Maryland and the District of Columbia from adjacent States. In 1985, surface-water withdrawals supplied public water-supply needs for 68 percent of the population of Maryland and 100 percent of the population of the District of Columbia (U.S. Geological Survey, 1990, p. 291). In addition to public supply, the streams and estuaries in the area also provide transportation, recreation, and scenic beauty. Water quality in most of the 93,000 miles of streams has been described as "good and stable," although problems exist locally (Maryland Department of the Environment, 1988, p. 5).

Land use (fig. $1 A$ ) and physiography (fig. $1 B$ ) affect the use and quality of stream water. Land in Maryland is about 11 percent urban, 41 percent agricultural, 44 percent forest, and 4 percent wetland (Maryland Department of the Environment, 1988, p. 16). Areas of the State that are drained by surface water are mostly cropland, pasture, woodland, and forest; woodland and forest cover most of the land in the larger river basins that have substantial out-of-State drainage. The State contains parts of five physiographic provincesCoastal Plain, Piedmont, Blue Ridge, Valley and Ridge, and Appalachian Plateaus. Surface water is the major source of water supply in the four more densely populated provinces north and west of the Fall Line (the boundary separating the Coastal Plain and Piedmont provinces) because the consolidated rock that underlies the area has limited ground-water storage capacity.

The combined 1990 population of Maryland and the District of Columbia was 5.4 million (U.S. Bureau of the Census 1990 decennial census files). Population is centered mainly in the Baltimore and Washington, D.C., metropolitan areas (figs. $1 C$ and 2). Many urban areas had a substantial decline in population from 1970 to 1990 , whereas rural areas had rapid growth and development. Most of this significant growth and urban development has been in central Maryland near Baltimore and Annapolis, and Washington, D.C. (U.S. Bureau of the Census decennial census files).

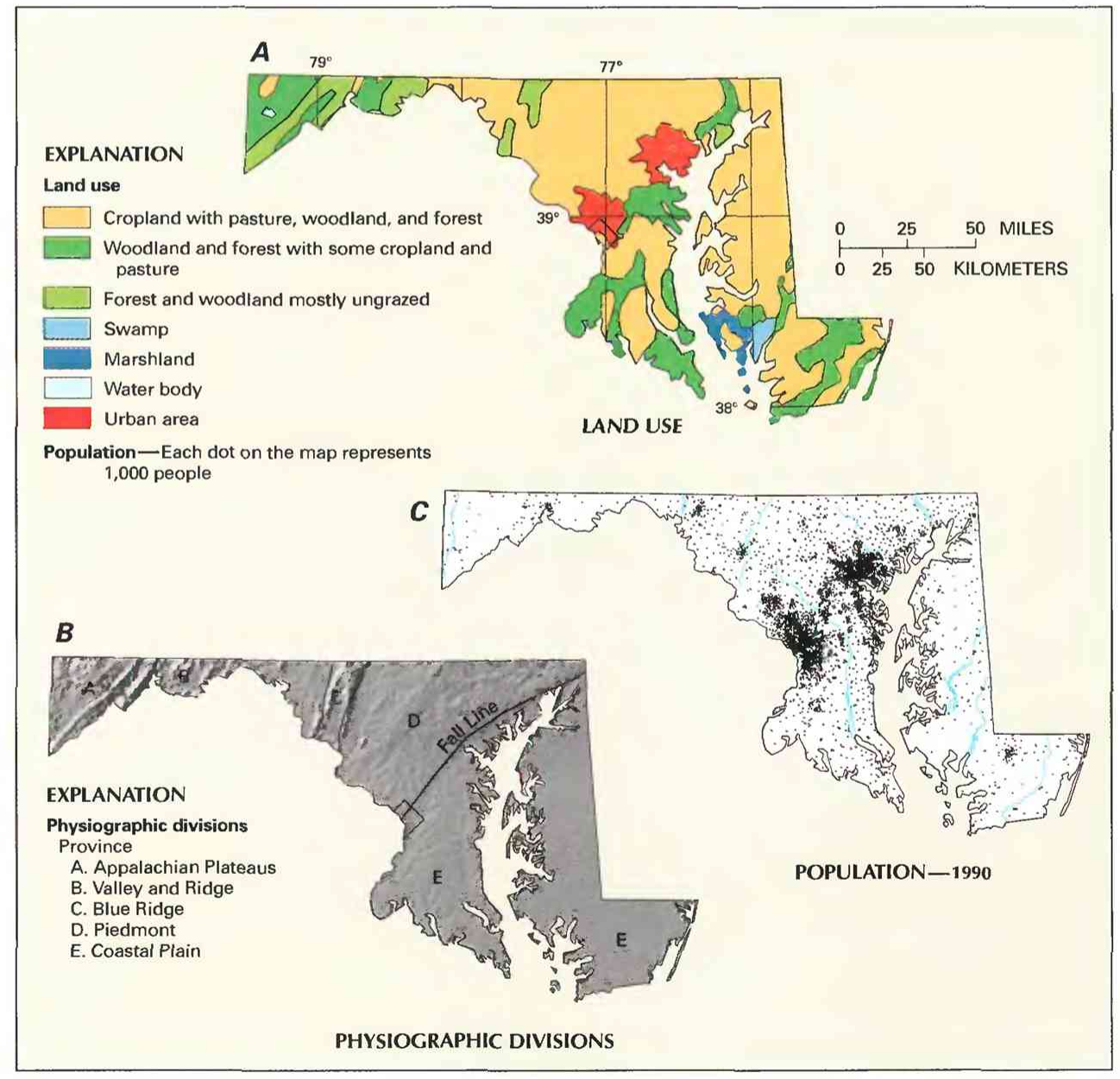

Figure 1. Land use, physiography, and population in Maryland and the District of Columbia. A, Major land uses. B, Physiographic divisions. C. Population distribution in 1990. (Sources: A, Major land uses modified from Anderson, 1967. B. Physiographic divisions from Fenneman, 1946; landforms from Thelin and Pike, 1990. C, Data from U.S. Bureau of the Census 1990 decennial census files.)

\section{WATER-QUALITY MONITORING}

Water-quality data obtained from analyses of water samples collected at monitoring stations are stored in the U.S. Geological Survey's (USGS) National Water Information System and the U.S. Environmental Protection Agency's (EPA) national data base known as STORET. Water-quality and streamflow data are reported by water year - the 12 months from October 1 through September 30. A water year is identified by the calendar year in which it ends. For example, water year 1991 comprises October 1, 1990, through September 30, 1991.

The data used in this summary of stream water quality in Maryland and the District of Columbia were obtained from water samples collected at six monitoring stations at which data collection is systematic and continuing (fig. 2). Analyses of water samples collected at these stations are the basis for the discussion and graphic summary (fig. 3 ) of stream water-quality conditions during water years 1987-89 and for the discussion and graphic summary (fig. 4) of stream water-quality trends. Water samples were collected and analyzed by using standard methods approved by the USGS (Britton and Greeson, 1987; Fishman and Friedman, 1989; 
Ward and Harr, 1990) or by using equivalent methods. If a method of sample collection or analysis changed over time, data from an analysis were included in the evaluation of recent stream water quality or of stream water-quality trends only if the change in method did not affect the comparability of the data.

In addition to monitoring the quality of streams and reservoirs for public-supply withdrawals and instream fisheries, the USGS and the Maryland Department of the Environment (MDE) monitor stream water where it reaches the Chesapeake Bay estuary. The River Input Program (formerly Fall Line monitoring) is a cooperative data-collection program conducted by these two agencies. The purpose of the program is to monitor the flow of nutrients from major tributaries to the bay. Sampling stations for this program are located near the "hydrologic fall line," where the streams become affected by tides. This point is often near the Fall Line, where the Piedmont meets the Coastal Plain.

\section{WATER-QUALITY CONDITIONS}

In 1988 , the MDE $(1988$, p. 95$)$ assessed the quality of the State's streams. About 93 percent of the stream miles fully supported, 5.4 percent partially supported, and 1.7 percent did not support the uses designated by the State for purposes of water-pollution control and monitoring. Common causes for use impairment were excessive concentrations of nutrients, sediment, and bacteria from agricultural and urban runoff, mining, municipal discharges, land disposal, and industrial discharges. Other important water-quality concerns in the State are stream acidification in western Maryland due to mine drainage and acid precipitation, pesticides such as chlordane in agricultural runoff, and the effects of organic and trace-metal toxic substances from industrial sources.

The following discussion of stream water quality in Maryland and the District of Columbia is organized by river basin (fig. 3). Where physiographic and land-use characteristics in different basins are similar, the discussion of those basins is combined. Graphs in figure 3 summarize certain aspects of stream water quality in the basins for water years 1987-89. The graphs show frequency distributions of data values that represent concentrations of selected constituents in stream water and measurements of selected physical properties of stream water. These constituents and properties are dissolved oxygen, fecal coliform bacteria, total alkalinity (as calcium carbonate), dissolved sulfate, dissolved solids, dissolved nitrite plus nitrate (as nitrogen), and dissolved phosphate (as phosphorus). The data are reported in milligrams per liter $(\mathrm{mg} / \mathrm{L})$ and colonies per 100 milliliters $(\mathrm{col} / 100 \mathrm{~mL})$. Sources and environmental significance of each constituent and property are described in table 1 .

Water quality at each monitoring station is the result of geological, chemical, biological, and hydrologic processes that occur over a large area. Water-quality problems that affect aquatic life or public health only locally are not fully represented in this summary.

\section{CHOPTANK RIVER}

The Choptank River drains a large part of the Coastal Plain on the Delmarva Peninsula. This area consists of uplands having soils that range from poorly drained to well drained (Hamilton and others, 1989). Land cover in the drainage basin is mainly cropland, woodland, pasture, and forest. Average discharge of the Choptank River at site 1, which is near the hydrologic fall line of the river, is about $130 \mathrm{ft}^{3} / \mathrm{s}$ (cubic feet per second). The effects of agriculture (primarily excessive bacteria and nitrogen in runoff) on the stream and downstream estuary are the primary water-quality concerns in this basin.

The sedimentary deposits underlying the Choptank River are composed of sand and clay that are not readily dissolved. Thus, median concentrations of alkalinity $(12 \mathrm{mg} / \mathrm{L}$ ) and dissolved solids ( 96 $\mathrm{mg} / \mathrm{L}$ ) at site 1 were the lowest for any of the six monitoring stations. Low alkalinity values reflect the susceptibility of the Choptank

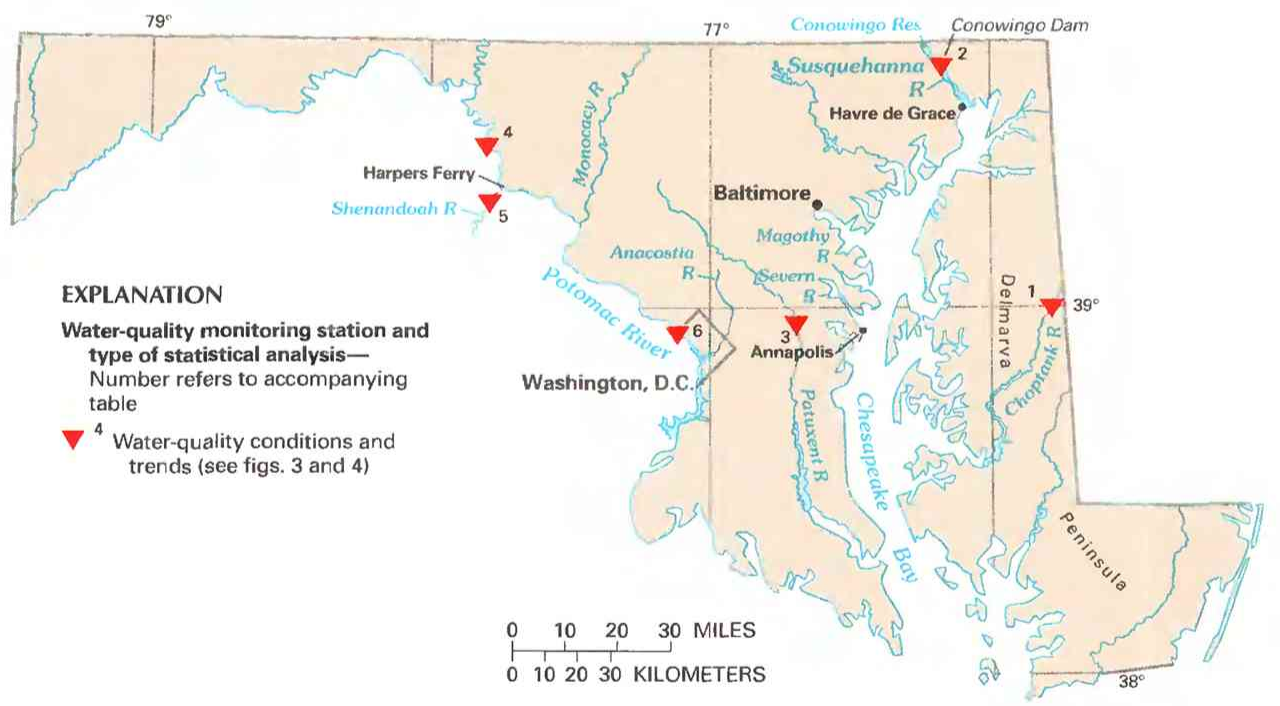

\begin{tabular}{|c|c|c|c|}
\hline $\begin{array}{l}\text { Site no. } \\
\text { on map }\end{array}$ & $\begin{array}{l}\text { USGS station } \\
\text { name and no. }\end{array}$ & $\begin{array}{l}\text { Drainage area } \\
\text { (square miles) }\end{array}$ & $\begin{array}{l}\text { Major land use } \\
\text { (see fig. 1) }\end{array}$ \\
\hline 1 & Choptank River at Greensboro $(01491000)$ & 113 & Cropland with pasture, woodland, and forest. \\
\hline 2 & 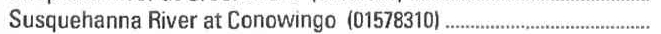 & 27,100 & Woodland and forest with some cropland and pasture. \\
\hline 3 & Patuxent River near Bowie (01594440) ............................................. & 348 & Cropland with pasture, woodland, and forest. \\
\hline 4 & Potomac River at Shepardstown, W. Va. (01618000) & 5,936 & Mostly ungrazed forest and woodland. \\
\hline 5 & Shenandoah River at Millville, W. Va. (01636500) & 3,040 & Ditto. \\
\hline 6 & Potomac River at Chain Bridge at Washington, D.C. $(01646580)$........ & 11,570 & Ditto. \\
\hline
\end{tabular}

Figure 2. Selected water-quality monitoring stations, type of statistical analysis, and geographic features in Maryland and the District of Columbia. (Sources: Major land uses modified from Anderson, 1967; other data from U.S. Geological Survey files.) 
River to acidification; the $\mathrm{pH}$ at site 1 had a median value of 6.5 , which was less than those at all other sites. Acidic precipitation often causes a temporary decline in the stream-water $\mathrm{pH}$ and an increase in dissolved-aluminum concentrations. Concentrations of other constituents at site 1 were characteristic of a stream that is little contaminated.

\section{SUSQUEHANNA RIVER}

The Susquehanna River system extends throughout central Pennsylvania and New York; drains the Piedmont, Valley and Ridge, and Appalachian Plateaus provinces; and transports more freshwater into Maryland and the Chesapeake Bay (average discharge of 41,000 $\mathrm{ft}^{3} / \mathrm{s}$ ) than any other source. Agriculture, mining, and urbanization are the primary activities that affect water quality in the basin. In Maryland, the Susquehanna River supplies the cities of Havre de Grace and Baltimore and is expected to supply the increasing demand for water needed to support growth in northeastern and central Maryland. The Susquehanna River, the largest river on the East Coast, is known for its fisheries and serves as spawning grounds for a variety of fish. Storm runoff causes increased suspended-sediment concentrations that result in reservoir siltation and inhibit aquatic life by increasing turbidity. Extreme storm runoff (greater than about $400,000 \mathrm{ft}^{3} / \mathrm{s}$ ) scours the reservoirs and redeposits the sediment in the upper Chesapeake Bay. In addition, contamination of water and sediment by toxic chemicals has recently become an important topic because of the scarcity of data concerning these materials and their possible effects on the Chesapeake Bay.

Site 2 is located at the outflow of the Conowingo Dam. During low flow, dissolved-oxygen concentrations commonly decrease to critical levels downstream from the dam. However, dam operators attempt to maintain sufficient flow to prevent this depletion. The median dissolved-oxygen concentration at site 2 was $11.3 \mathrm{mg} / \mathrm{L}$, but 10 percent of the samples had concentrations of less than $4.4 \mathrm{mg} / \mathrm{L}$, which is less than the State standard of $5.0 \mathrm{mg} / \mathrm{L}$ for water-contact recreation, aquatic life, and water supply (Maryland Department of the Environment, 1989, p. 5). Concentrations of fecal coliform bacteria at site 2 (median, $15 \mathrm{col} / 100 \mathrm{~mL}$ ) were the lowest at any of the six stations. The median nitrite plus nitrate concentration (1.2 $\mathrm{mg} / \mathrm{L}$ ) was the second highest in samples from the six stations, and
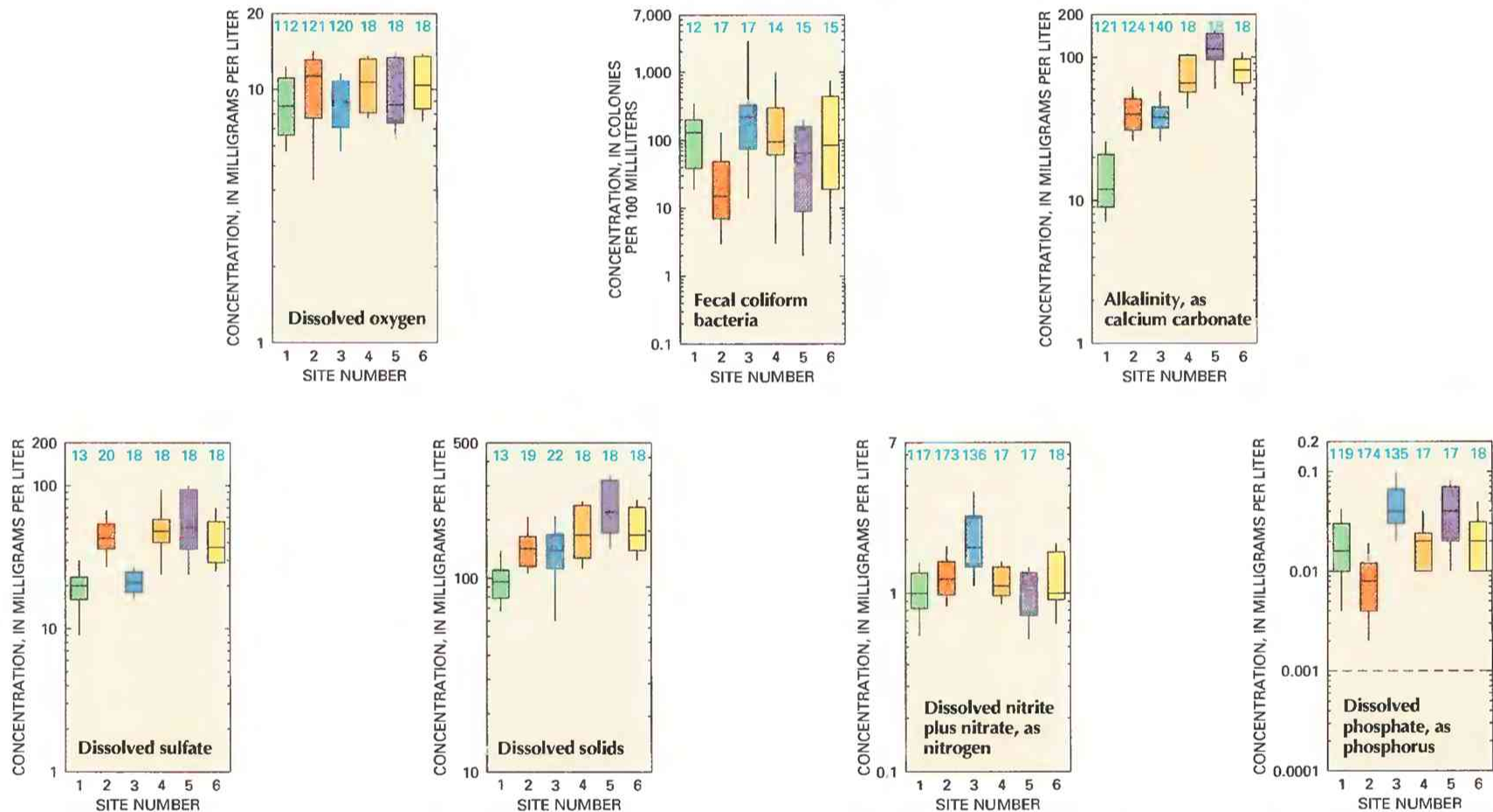

\section{EXPLANATION}
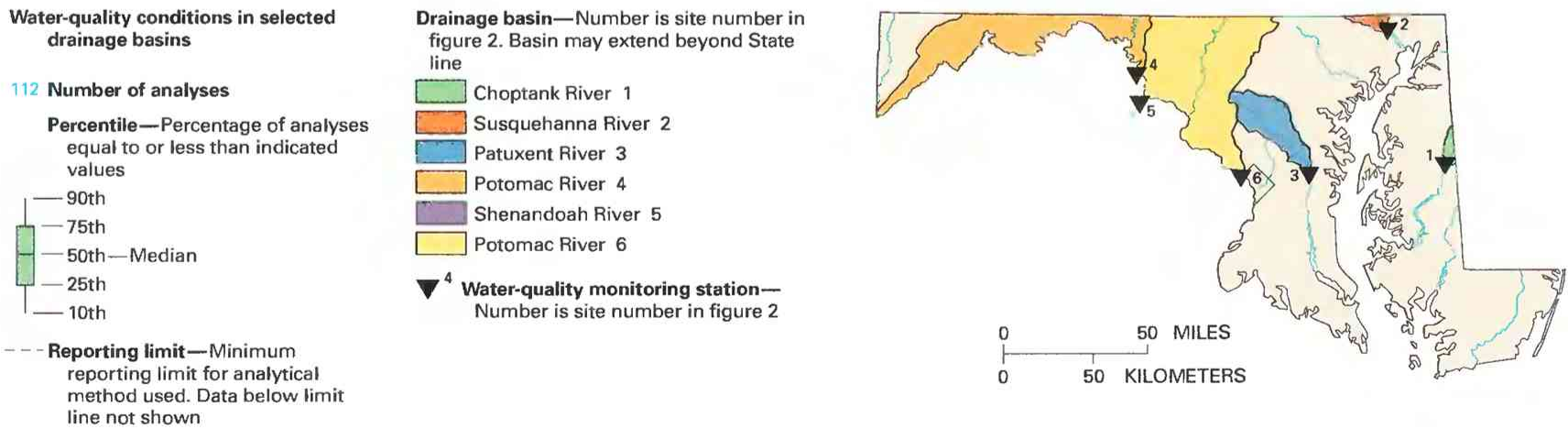

Figure 3. Water quality of selected streams in Maryland and the District of Columbia, water years 1987-89. (Source: Data from U.S. Geological Survey files.) 
Table 1. Sources and environmental significance of selected water-quality constituents and properties [Source: Compiled by the U.S. Geological Survey, Office of Water Quality]

\begin{tabular}{|c|c|c|}
\hline Constituent or property & Common sources & Environmental significance \\
\hline Dissolved oxygen & $\begin{array}{l}\text { Introduced from the atmosphere; also a byproduct of } \\
\text { aquatic plants. }\end{array}$ & $\begin{array}{l}\text { Necessary for aquatic life; deficiency can result from } \\
\text { assimilation of organic wastes or rapid growth } \\
\text { and decay of algae. }\end{array}$ \\
\hline Fecal coliform bacteria .................. & $\begin{array}{l}\text { Sources include effluent from sewage-treatment } \\
\text { plants and runoff from pastures, feedlots, and ur- } \\
\text { ban areas. }\end{array}$ & $\begin{array}{l}\text { Presence indicates contamination of water by wastes } \\
\text { from humans and other warm-blooded animals. }\end{array}$ \\
\hline 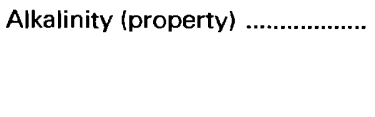 & $\begin{array}{l}\text { A measure of the quantity of acid-neutralizing sub- } \\
\text { stances; can be affected by geologic setting, in- } \\
\text { dustrial wastewater discharge, waste gases, and } \\
\text { runoff from surface mining. }\end{array}$ & $\begin{array}{l}\text { Sufficiently alkaline water can be unsuitable for some } \\
\text { agricultural and industrial uses. }\end{array}$ \\
\hline 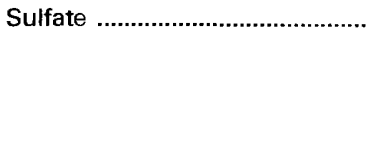 & $\begin{array}{l}\text { Occurs in some rocks; also in mine runoff, industrial } \\
\text { wastewater discharge, and atmospheric deposi- } \\
\text { tion. }\end{array}$ & $\begin{array}{l}\text { Concentrations exceeding a natural, background } \\
\text { level indicate contamination from human activity; } \\
\text { in sufficient quantity, can cause water to be } \\
\text { unsuitable for public supply; can harm aquatic } \\
\text { organisms. }\end{array}$ \\
\hline 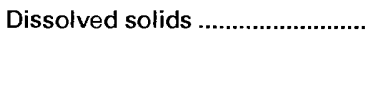 & $\begin{array}{l}\text { A result of rock weathering; also in agricultural runoff } \\
\text { and industrial discharge. }\end{array}$ & $\begin{array}{l}\text { In sufficient quantity, can cause water to be unsuitable } \\
\text { for public supply, agriculture, and industry; can } \\
\text { harm aquatic organisms. }\end{array}$ \\
\hline Nitrite plus nitrate & $\begin{array}{l}\text { Nonpoint sources are agricultural and urban runoff; } \\
\text { a major point source is wastewater discharge. }\end{array}$ & $\begin{array}{l}\text { Plant nutrient that, in sufficient quantity, can cause } \\
\text { algal blooms and excessive growth of higher } \\
\text { aquatic plants in bodies of water; can cause water } \\
\text { to be unsuitable for public supply. }\end{array}$ \\
\hline 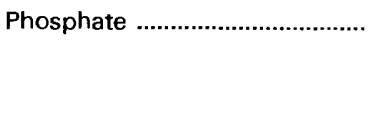 & $\begin{array}{l}\text { Occurs in some rocks and sediments; also in runoff } \\
\text { and seepage from phosphate-rock mines, agri- } \\
\text { cultural and urban runoff, and industrial and } \\
\text { municipal wastewater discharge. }\end{array}$ & $\begin{array}{l}\text { Plant nutrient that, in sufficient quantity, can cause } \\
\text { algal blooms and excessive growth of higher } \\
\text { aquatic plants in bodies of water. }\end{array}$ \\
\hline
\end{tabular}

the median phosphate concentration $(0.008 \mathrm{mg} / \mathrm{L})$ was the lowest. With the exception of dissolved oxygen, the constituent concentrations at site 2 indicate that water quality in the main stem of the Susquehanna River has been little degraded by activities in the drainage basin.

\section{PATUXENT RIVER}

The Patuxent River drains parts of the Piedmont province in central Maryland. The long-term average discharge as of 1989 was $362 \mathrm{ft}^{3} / \mathrm{s}$ at site 3 . Site 3 is near the hydrologic fall line and monitors little drainage from the Coastal Plain. The major land uses in the basin are agricultural, but water quality in the river also is affected by urban development. Water-use classification for the Patuxent River is water-contact recreation, aquatic life, and shellfish harvesting in the estuarine part of the river (Maryland Department of the Environment, 1988 , p. 225). The primary reasons for impairment of these uses are eutrophication and bacterial contamination. Eutrophication occurs when large concentrations of nutrients and organic matter encourage rapid algal growth, which increases turbidity and causes oxygen depletion when algae and other aquatic vegetation die and decompose. Primary sources of nutrients and bacteria are municipal discharge, agricultural and urban runoff, and waste disposal.

During 1987-89, fecal coliform bacteria had a median concentration of $220 \mathrm{col} / 100 \mathrm{~mL}$ and had several occurrences of concentrations greater than $1,000 \mathrm{col} / 100 \mathrm{~mL}$. Concentrations frequently did not meet State standards for water-contact recreation, aquatic life, and water supply (Maryland Department of the Environment, 1989, p. 5). Median nitrite plus nitrate $(1.8 \mathrm{mg} / \mathrm{L})$ and phosphate $(0.04$ $\mathrm{mg} / \mathrm{L}$ ) concentrations at site 3 were the highest or among the highest for the six monitoring stations (fig. 3). The concentrations of the selected water-quality constituents recorded at site 3 are greater than would be expected in an uncontaminated stream.

\section{POTOMAC AND SHENANDOAH RIVERS}

The Potomac River, which is the second largest tributary to the Chesapeake Bay, drains 11,570 square miles of diverse physiography. Geology and land use in the basin are important contributors to water-quality characteristics of the river. In the Potomac River ba- sin, three water-quality monitoring stations (sites 4-6) were used to assess water-quality conditions during 1987-89. Site 4 monitors drainage from the upper part of the Potomac River basin, including drainage from the Appalachian Plateaus and Valley and Ridge provinces. Major water-quality issues in the upper basin are coal mining, forestry, raw- and treated-sewage effluent, acid precipitation, and toxic substances such as dioxin from paper mills. Site $\mathbf{5}$ is on the Shenandoah River in West Virginia. The Shenandoah River drains the eastern part of the Valley and Ridge province and joins the Potomac River at Harpers Ferry, W. Va. Water quality in the Shenandoah River greatly affects water quality in the Potomac River in Maryland. Site 6 is downstream from sites 4 and 5 and monitors additional drainage from areas of the Piedmont and Blue Ridge provinces. The largest Maryland stream in the drainage area upstream from site 6 and downstream from the mouth of the Shenandoah River is the Monocacy River, which drains the Piedmont province in central Maryland west of the Patuxent River basin.

Of samples collected at the three monitoring stations, those from site 5 had the highest median concentration of alkalinity (114 $\mathrm{mg} / \mathrm{L}$ ), sulfate (51 mg/L), and dissolved solids (219 mg/L) (fig. 3). The magnitude of these concentrations is due primarily to the dissolution of easily weathered limestone and dolomite in the Shenandoah River basin. At site 4, the median concentrations of alkalinity (66 $\mathrm{mg} / \mathrm{L}$ ), sulfate (48 mg/L), and dissolved solids ( $167 \mathrm{mg} / \mathrm{L}$ ) were characteristic of drainage from the three western Maryland physiographic provinces. Downstream at site 6 , less mineralized water from the Piedmont and Blue Ridge provinces mixes with streamflow from upstream (sites 4 and 5). This dilution yielded median sulfate (37 $\mathrm{mg} / \mathrm{L})$ and dissolved-solids $(167 \mathrm{mg} / \mathrm{L})$ concentrations at site 6 that were lower than would have resulted from mixing drainage from basins upstream at sites 4 and 5 . Alkalinity concentrations at site 6 , however, indicate that the Potomac River maintains its buffering capacity at this downstream monitoring station.

Median nitrite plus nitrate concentrations were nearly equal at sites 4-6, although higher concentrations were more common at site 6. Agricultural runoff from the Piedmont province and municipal discharges from the Washington, D.C., metropolitan area are probable sources of the higher nitrite plus nitrate concentrations at site 6 . Bacterial contamination continues to be a concern in the basin. Median concentrations of fecal coliform bacteria were less than 
$100 \mathrm{col} / 100 \mathrm{~mL}$ at sites $4-6$. However, 25 percent of the samples had concentrations larger than $300 \mathrm{col} / 100 \mathrm{~mL}$ at site 4 and $440 \mathrm{col} /$ $100 \mathrm{~mL}$ at site 6 and occasionally exceeded the State standard for water-contact recreation, aquatic life, and water supply. Constituent concentrations at these three stations reflect water quality that is substantially affected by geology and human activities.

\section{WATER-QUALITY TRENDS}

Trend analysis is a statistical procedure used to detect changes in stream water quality at a monitoring station over time. For this report, water-quality data from six monitoring stations (fig. 2) were analyzed for trends by using the seasonal Kendall test (Hirsch and others, 1982), a method used extensively by the USGS. The graph (shown below) of the dissolved nitrite plus nitrate concentration in the Susquehanna River at site 2 illustrates the trend inferred from the concentration data and demonstrates the variation in water quality that is common in streams.

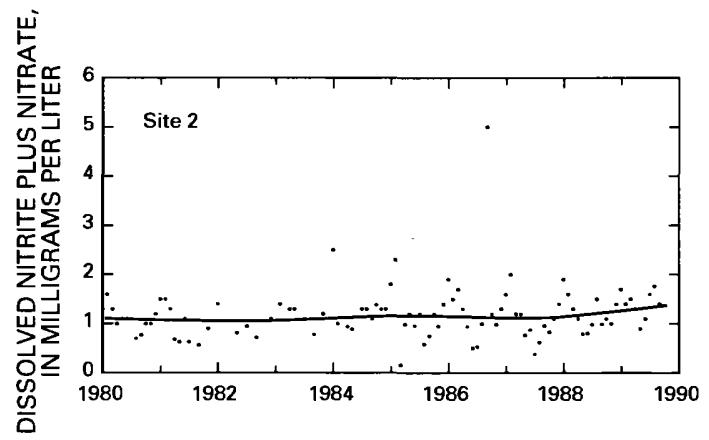

When possible, constituent-concentration data were adjusted for changes in streamflow to preclude identifying a trend in concentration that was caused only by a trend in streamflow. The data were not adjusted when (1) more than 10 percent of the samples had concentrations lower than the minimum reporting limit for the analytical method used or (2) streamflow was controlled substantially by human activities. When the concentration data could not be adjusted for streamflow, trends were determined directly from the concentration data.

Statewide trends in concentrations of selected constituents in stream water and in measurements of selected physical properties of stream water are shown on maps in figure 4. On each map, a trend is indicated at a monitoring station only if the data from that station were suitable for use in the trend analysis. For more information on the suitability criteria and on the trend-analysis procedure used for this report, see Lanfear and Alexander (1990).

\section{DISSOLVED OXYGEN}

The dissolved-oxygen concentration in a stream is controlled by several factors, including water temperature, air temperature and pressure, hydraulic characteristics of the stream, photosynthetic or respiratory activity of stream biota, and the quantity of organic material present. A trend in dissolved-oxygen concentrations commonly is directly or indirectly the result of human activities. Generally, an upward trend in dissolved-oxygen concentrations indicates improving stream water-quality conditions and a downward trend indicates deteriorating conditions.

No trend in dissolved-oxygen concentrations was detected in data from the six monitoring stations (fig. 4). Dissolved-oxygen concentrations at all monitoring stations, with the exception of occasional measurements at site 2, were acceptable by State standards during 1980-89. However, Bahner and others (1990, p. 1) reported an apparent long-term (1950-89) decline in dissolved-oxygen concentrations in the Chesapeake Bay, although no recent trends were discernible. Continued efforts to decrease nutrient loads in stream water might result in future increases in dissolved-oxygen concentrations at the six monitoring stations as well as in the Chesapeake Bay.

\section{FECAL COLIFORM BACTERIA}

Fecal coliform bacteria are used as indicators of fecal contamination from humans and other warm-blooded animals. Such contamination can introduce disease-causing viruses and bacteria into a stream.

No trend in fecal coliform bacteria concentrations was detected in data from the six monitoring stations (fig. 4). Bacteria concentrations in stream water might have been expected to decrease as a result of nutrient-management practices such as controls on animal waste in runoff and improvement in wastewater-treatment facilities. However, the effects of these practices might not yet be apparent at these monitoring stations.

\section{ALKALINITY}

Alkalinity is a measure of the capacity of the substances dissolved in the water to neutralize acid. In most natural waters, alkalinity is produced mainly by bicarbonate and carbonate (Hem, 1985, p. 106), which are ions formed when carbon dioxide or carbonate rock dissolves in water.

Urban and industrial development has increased as a result of population growth in the Patuxent River basin during 1980-89. Larger quantities of urban runoff, industrial discharges, and municipal wastewater-treatment-plant effluent resulting from this development are probable causes of increasing alkalinity at site 3 (fig. 4).

\section{DISSOLVED SULFATE}

The major natural sources of sulfate in streams are rock weathering, volcanoes, and biochemical processes (Hem, 1985, p. 113). Human activities such as mining, waste discharge, and fossil-fuel combustion also can be important sources. A shortened trend-analysis period was used for sulfate because data from analyses performed prior to water year 1982 are not comparable to data from subsequent years.

No trend in dissolved-sulfate concentrations was detected at any of the six monitoring stations during 1982-89 (fig. 4). Although the State has administered two programs since 1977 to reclaim abandoned mining operations and to regulate discharges from existing mine operations that are known sources of sulfate in the upper Potomac River basin (Maryland Department of the Environment, 1988, p. 50), no downward trend was detected at either site 4 or site 6 on the Potomac River.

\section{DISSOLVED SOLIDS}

Dissolved solids in stream water result primarily from rock weathering but also can be introduced as a byproduct of human activities (table 1). Concentrations generally are greatest in streams draining basins underlain by rocks and soils that contain easily dissolved minerals.

Possible reasons for the upward trend in the dissolved-solids concentration in the Patuxent River at site 3 (fig. 4) are increased contaminant loads in runoff as a result of urbanization and agricultural practices and increased discharges from municipal and industrial facilities. The drainage area upstream from site 3 is much smaller than that of other basins where urban development might affect dissolved-solids concentration; thus, the effects of localized changes might be more apparent at site 3 than at other sites.

\section{DISSOLVED NITRITE PLUS NITRATE}

Nitrite and nitrate are oxidized forms of nitrogen that together constitute most of the dissolved nitrogen in stream water. Nitrite 


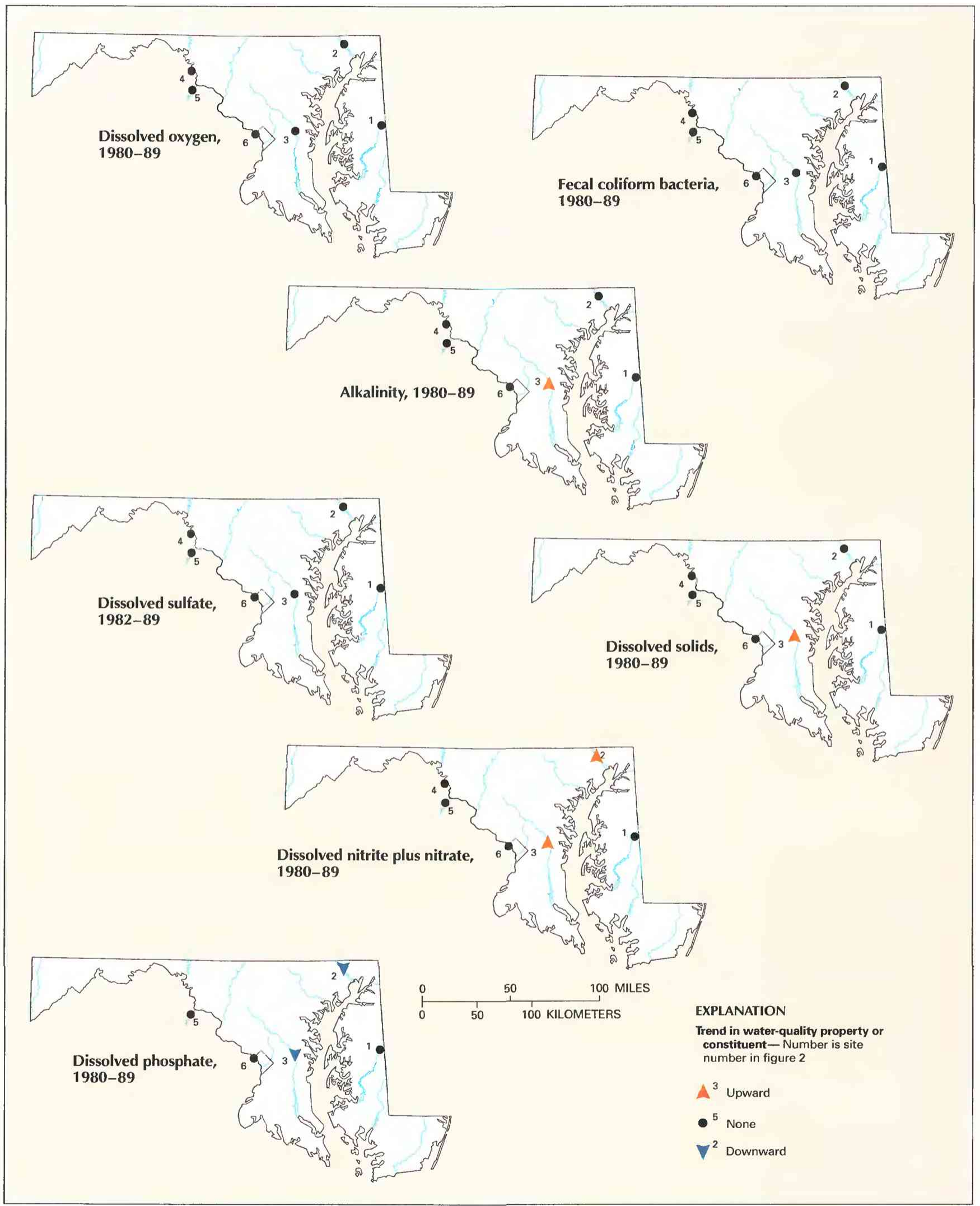

Figure 4. Trends in water quality of selected streams in Maryland and the District of Columbia, by water years. (Source: Data from U.S. Geological Survey files.) 
readily oxidizes to nitrate in natural waters; therefore, nitrate generally is by far the more abundant of the two (Hem, 1985, p. 124).

Sources of nitrite and nitrate include fertilizers and animal wastes in agricultural runoff, atmospheric deposition, and discharges from municipal wastewater-treatment facilities. In 1985, Maryland, Virginia, and Pennsylvania entered into the Chesapeake Bay Agreement, which stated that those States would decrease the quantity of nutrients entering the Chesapeake Bay by 40 percent. Management programs are being implemented by each State to meet this waterquality goal. However, these programs had not been in place long enough to prevent the upward trends in nitrite plus nitrate concentrations during 1980-89 at sites 2 and 3 on the Susquehanna and Patuxent Rivers (fig. 4), whose drainage basins are affected by runoff from urban and agricultrural areas.

\section{DISSOLVED PHOSPHATE}

Phosphate is the oxidized form of phosphorus and the only form of significance in most natural waters. Small quantities of dissolved phosphate commonly are present in streams as a result of rock weathering. Normally, concentrations are no more than a few tenths of a milligram per liter (Hem, 1985, p. 126) and usually are much lower. Higher concentrations can indicate contamination from human activities (table 1).

In an effort to decrease the nutrient input to the Chesapeake Bay, Maryland issued a statewide ban in 1985 on the sale and use of phosphate-based detergents. The decrease in phosphate concentration in the Patuxent River at site 3 (fig. 4), downstream from several municipal wastewater-treatment-plant discharges, is attributable to the ban. The decreasing phosphate concentration in the Susquehanna River at site 2 is not obviously attributable to the ban because most of the drainage basin is outside the State and is not directly affected by the legislation. Also, the Susquehanna River basin is much less urbanized. However, concentrations might have decreased because the distribution areas for sale of nonphosphate-based detergents extend into adjacent States that have not banned use of phosphate-based detergents. Improved agricultural practices that require less use of phosphate fertilizer throughout Maryland and Pennsylvania also might have contributed to the downward trend. Streams that had no trend in phosphate concentrations are in drainage basins that are less affected by agriculture and urban development than those of the Susquehanna and Patuxent Rivers.

\section{WATER-QUALITY MANAGEMENT}

Stream water quality is regulated primarily by MDE, although the Departments of Agriculture and Natural Resources have limited water-quality management authority in agricultural areas and in wetlands and scenic-river corridors, respectively. The MDE establishes water-quality standards; performs regulatory, enforcement, and inspection activities for point and nonpoint sources of pollution; and coordinates water-quality programs of other State agencies. This authority is provided through various water-pollution articles in the Code of Maryland regulations. In addition, the MDE is responsible for implementing the Federal Clean Water Act in Maryland and for writing a biennial water-quality-assessment report (Maryland Department of the Environment, 1988) that is submitted to the EPA and the U.S. Congress in accordance with section 305(b) of the Federal Clean Water Act.

Several statewide and regional advisory panels, composed of citizens and professionals, advise the State on stream water-quality matters. Statewide panels include the MDE State Water Quality Advisory Committee, the Coastal Advisory Committee, and the Scenic and Wild Rivers Review Board of the Department of Natural Resources. Regional advisory panels are usually associated with specific watersheds. These panels include the Monocacy River Commission, the Patuxent River Commission, and the Severn River Commission. Other local or special-interest advisory groups include the Anacostia River Advisory Board, the Magothy River Commission, Trout Unlimited, and Save Our Streams.

Maryland cooperates with other States and their governments on regional water-quality management issues through the following interstate commissions: the Chesapeake Bay Commission, the Interstate Commission on the Potomac River Basin, the Susquehanna River Basin Commission, and the Ohio River Sanitation Commission. All but the Interstate Commission on the Potomac River Basin have Federal participants.

Water-quality monitoring, which has increased since the early 1970 's as a direct result of the Clean Water Act, provides information for management purposes. The Chesapeake Bay Monitoring Program provides baseline information as well as data about the management of the bay and its tributaries. The USGS stream waterquality monitoring program has provided long-term information about constituent loads and trends for several of the largest tributaries to the Chesapeake Bay.

The District of Columbia Water Pollution Control program is administered by the Water Resources Management Division (WRMD) of the Environmental Regulation Administration in the Department of Consumer and Regulatory Affairs. This agency acts as the primary regulatory agency for enforcing Federal and District laws and regulations related to water pollution control. The program functions include: setting water-quality standards, monitoring water-quality and reporting water-quality trends, certifying National Pollutant Discharge Elimination System permits, and planning and environmental review of water pollution control (Mohnsin Siddique, Water Resources Management Division, written commun., 1992).

The WRMD also cooperates with many local and regional agencies to develop regional strategies for water pollution monitoring and assessment and participates in restoration efforts of the Chesapeake Bay. Many of these programs, which respond to different management control strategies, focus on the Potomac Estuary and its tributaries (District of Columbia Government, 1992, p. 8).

\section{SELECTED REFERENCES}

Anderson, J.R., 1967, Major land uses in the United States, in U.S. Geological Survey, 1970, National atlas of the United States of America: Washington, D.C., U.S. Geological Survey, p. 158-159.

Bahner, L.H., Reynolds, R.C., and Batiuk, R.A., 1990, Volumetric analysis of dissolved oxygen trends in the Chesapeake Bay-Preliminary findings: Annapolis, Md., Chesapeake Bay Program, unpaginated.

Britton, L.J., and Greeson, P.E., eds., 1987, Methods for collection and analysis of aquatic biological and microbiological samples: U.S. Geological Survey Techniques of Water-Resources Investigations, book 5, chap. A4, $363 \mathrm{p}$.

District of Columbia Government, 1992, The District of Columbia waterquality assessment: Washington, D.C., 140 p.

Fenneman, N.M., 1946, Physical divisions of the United States: Washington, D.C., U.S. Geological Survey special map, scale 1:7,000,000.

Fishman, M.J., and Friedman, L.C., eds., 1989, Methods for the determination of inorganic substances in water and fluvial sediments: U.S. Geological Survey Techniques of Water-Resources Investigations, book 5 , chap. A1, 545 p.

Hamilton, P.A., Shedlock, R.J., and Phillips, P.J., 1989, Ground-water-quality assessment of the Delmarva Peninsula, Delaware, Maryland, and Virginia-Analysis of available water-quality data through 1987: U.S. Geological Survey Open-File Report 89-34, 71 p.

Hem, J.D., 1985, Study and interpretation of the chemical characteristics of natural water (3d ed.): U.S. Geological Survey Water-Supply Paper 2254, $263 \mathrm{p}$.

Hirsch, R.M., Slack, J.R., and Smith, R.A., 1982, Techniques of trend analysis for monthly water quality data: Water Resources Research, v. 18, no. 1 , p. 107-121.

Lanfear, K.J., and Alexander, R.B., 1990, Methodology to derive water-quality trends for use by the National Water Summary Program of the U.S. 
Geological Survey: U.S. Geological Survey Open-File Report 90-359, $10 \mathrm{p}$.

Maryland Department of the Environment, 1988, 1985-1987 Maryland water quality inventory: Baltimore, Maryland Department of the Environment, various pagination.

1989. Code of Maryland Regulations 26.08.02 Water Quality: Baltimore, Maryland Department of the Environment, 32 p.

Thelin, G.P., and Pike, R.J., 1990, Digital shaded relief map of the conterminous United States: Menlo Park, Calif., U.S. Geological Survey digital image processing, scale 1:3,500,000.
U.S. Geological Survey, 1990, National water summary 1987-Hydrologic events and water supply and use: U.S. Geological Survey Water-Supply Paper $2350,553 \mathrm{p}$.

Ward, J.R., and Harr, C.A., eds., 1990, Methods for collection and processing of surface-water and bed-material samples for physical and chemical analyses: U.S. Geological Survey Open-File Report 90-140, 71 p.

Prepared by Joel D. Blomquist, U.S. Geological Survey; “Water-Quality Management” section by J. Shermer Garrison, Maryland Department of the Environment

FOR ADDITIONAL INFORMATION: District Chief, U.S. Geological Survey, 208 Carroll Building, 8600 LaSalle Road, Towson, MD 21204 


\section{MASSACHUSETTS Stream Water Quality}

An annual precipitation of 45 inches provides Massachusetts streams with a plentiful supply of water for public use, industry, and thermoelectric power generation. In 1985, surface water supplied 95 percent, or 5,940 million gallons per day, of the total freshwater used offstream in the State. Of the surface water withdrawn, 85 percent was used for thermoelectric power generation; 13 percent was used for public supply, domestic, and commercial purposes; and 2 percent was used for industry and mining (U.S. Geological Survey, 1990, p. 303).

The quality of the State's surface water is affected by land use (fig. $1 A$ ) and population distribution. More than 75 percent of Massachusetts' population resides in urban centers within the Seaboard Lowland and in the Coastal Plain (figs. $1 B$ and $1 C$ ). Smaller population centers are located in the Connecticut River valley in the New England Upland. Vegetable and dairy farming are major land uses in this area and, to a lesser extent, in the valleys of the Taconic and Green Mountain physiographic sections to the west. Cranberry production is predominant in the Coastal Plain and Seaboard Lowland to the southeast.

The population of Massachusetts in 1990 was 6 million, a 4.9percent increase since 1980 (U.S. Bureau of the Census 1990 decennial census files). Although surface water is the major source of supply for large urban areas of the State and is relatively plentiful, its

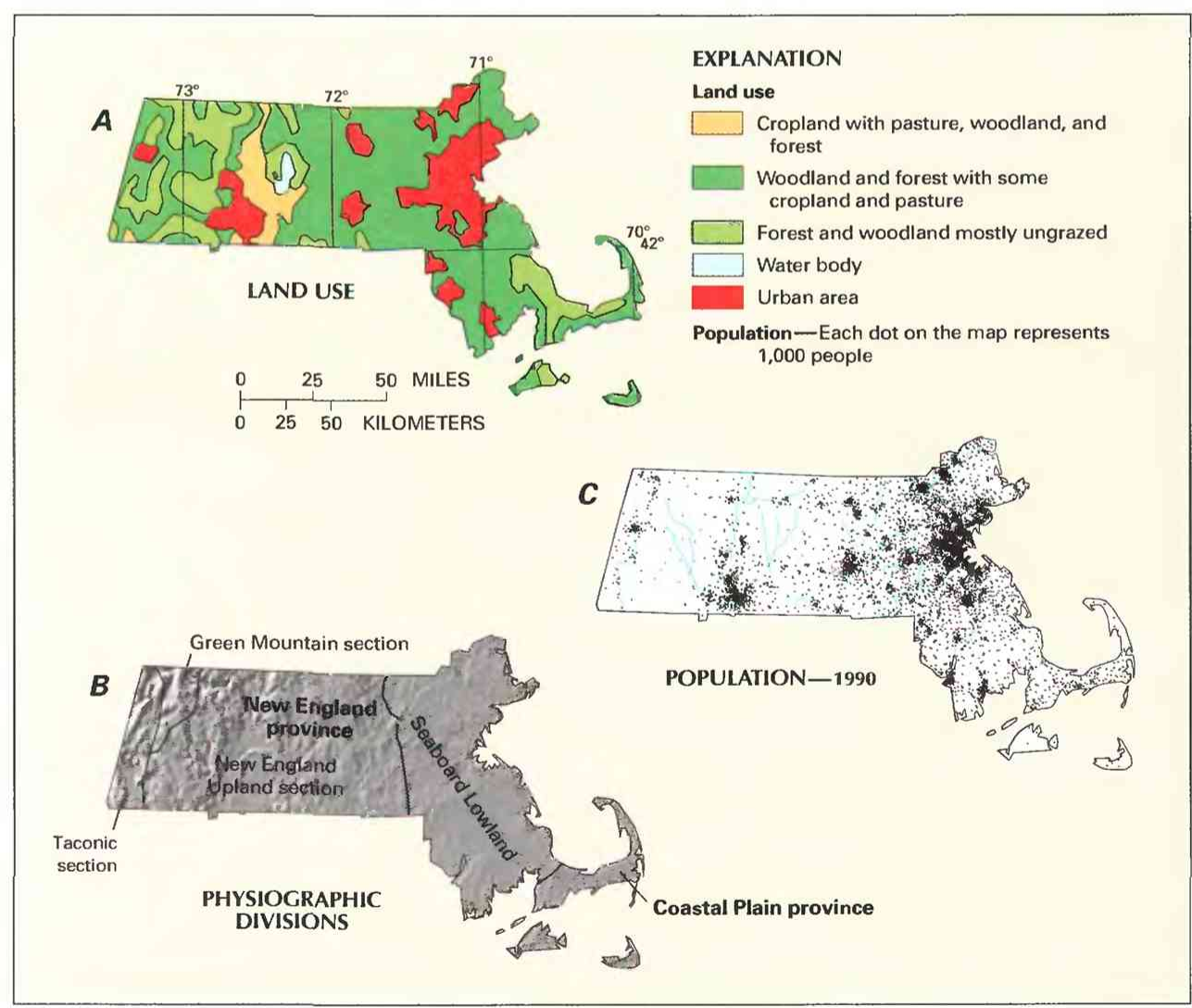

Figure 1. Land use, physiography, and population in Massachusetts. A, Major land uses. B, Physiographic divisions. C. Population distribution in 1990. (Sources: A. Major land uses modified from Anderson, 1967. B, Physiographic divisions from Fenneman, 1946; landforms from Thelin and Pike, 1990. C. Data from U.S. Bureau of the Census 1990 decennial census files.) distribution does not coincide with that of the population. The greater Boston area on the east coast accounts for about one-half the State's surface-water usage, but the water comes from Quabbin and Wachusett Reservoirs in the central uplands.

For purposes of water-pollution control, the Massachusetts Department of Environmental Protection (DEP) has designated three classes of stream-water use: drinking water, contact recreation, and noncontact recreation. Each class has specific numeric water-quality standards. Monitoring showed, as of 1990, 35 percent of assessed miles of streams and rivers fully supported, 29 percent partially supported, and 36 percent did not support their designated use (Massachusetts Department of Environmental Protection, 1990).

Installation of wastewater-treatment plants statewide beginning in 1967 has markedly improved water quality. Biochemical oxygen demand (BOD), a quantifier of stream pollutant loads, and nutrients have been reduced by about one-half, and concentrations of ammonia and suspended solids that exceed water-quality criteria have been nearly eliminated. Remaining causes of water-quality problems are predominantly bacterial contamination and small dissolved-oxygen concentrations caused by urban runoff (Massachusetts Department of Environmental Quality Engineering, 1988a).

\section{WATER-QUALITY MONITORING}

Water-quality data obtained from analyses of water samples collected at monitoring stations are stored in the U.S. Geological Survey's (USGS) National Water Information System and the U.S. Environmental Protection $\mathrm{Ag}$ ency's (EPA) national data base known as STORET. Water-quality and streamflow data are reported by water year-the 12 months from October 1 through September 30. A water year is identified by the calendar year in which it ends. For example, water year 1991 comprises October 1, 1990, through September 30, 1991.

The data used in this summary of Massachusetts' stream water quality were obtained from water samples collected at four monitoring stations at which data collection is systematic and continuing (fig. 2). Analyses of water samples collected at these stations are the basis for the discussion and graphic summary (fig. 3) of stream water-quality conditions during water years 1987-89 and for the discussion and graphic summary (fig. 4) of stream water-quality trends. Water samples were collected and analyzed by using standard methods approved by the 
USGS (Britton and Greeson, 1987; Fishman and Friedman, 1989; Ward and Harr, 1990) or by using equivalent methods. If a method of sample collection or analysis changed over time, data from an analysis were included in the evaluation of recent stream water quality or of stream water-quality trends only if the change in method did not affect the comparability of the data.

\section{WATER-QUALITY CONDITIONS}

The primary causes of degraded water quality in Massachusetts streams are urban runoff, combined storm- and domestic-sewer overflows, and wastewater-treatment-plant discharges. Urban runoff causes increased concentrations of nutrients (nitrogen and phosphorus), oil and grease, and toxic metals and decreased concentrations of dissolved oxygen. Combined-sewer overflows cause excessive concentrations of fecal coliform bacteria, and wastewater-treatment-plant discharges cause excessive concentrations of nutrients such as ammonia nitrogen. Contamination of streambed sediments from toxic metals and chlorinated hydrocarbons has become a more prominent issue since wastewater treatment has reduced oxygendeficiency and sedimentation problems (Massachusetts Department of Environmental Quality Engineering, 1988a).

The following discussion of stream water quality in Massachusetts is organized by river basin (fig. 3). Where physiographic and land-use characteristics in different basins are similar, the discussion of those basins is combined. Graphs in figure 3 summarize certain aspects of stream water quality in the basins for water years 1987-89. The graphs show frequency distributions of data values that represent measurements of selected physical properties of stream water and concentrations of selected constituents in stream water. These properties and constituents are $\mathrm{pH}$, dissolved oxygen, alkalinity (as calcium carbonate), dissolved sulfate, dissolved chloride, dissolved solids, dissolved nitrite plus nitrate (as nitrogen), and total phosphorus (as phosphorus). The data are reported in standard $\mathrm{pH}$ units and milligrams per liter ( $\mathrm{mg} / \mathrm{L}$ ). Sources and environmental significance of each property and constituent are described in table 1.

Water quality at each monitoring station is the result of geological, chemical, biological, and hydrologic processes that occur over a large area. Water-quality problems that affect aquatic life or public health only locally are not fully represented in this summary.

\section{CONNECTICUT RIVER}

In Massachusetts, 24 percent of the Connecticut River basin lies within the New England Upland. The basin is underlain by sandstone and shale, basalt flows, and crystalline metamorphic and ig neous rocks, all of which are covered by a discontinuous mantle of glacial till and stratified drift.

Water quality in the upper Connecticut River basin north of Springfield has improved substantially since the late 1970's when wastewater-treatment plants were constructed (Massachusetts Department of Environmental Quality Engineering, 1988b, p. 6). Water quality in the lower Connecticut River basin south of Springfield has been degraded mostly by combined-sewer overflows and overland runoff from agricultural and urban areas. The Millers River basin shows some of the greatest effects of acidic precipitation in the State (Ruby and others, 1988, p. 24) owing to the predominance of granitic bedrock (Zen, 1983) and glacial drift, which contribute little to the buffering capacity of streams. No monitoring stations in the Connecticut River basin in Massachusetts had sufficient data for a graphic summary of recent water-quality conditions.

\section{MERRIMACK RIVER}

The Merrimack River drains northeastern Massachusetts and flows into the Atlantic Ocean. The basin is underlain by crystalline metamorphic and igneous rocks that are covered by till and stratified drift. In Massachusetts, the Merrimack River receives drainage from the Sudbury, Assabet, Concord, and Nashua Rivers. For the past century, these rivers have received large quantities of contaminants that cause BOD, primarily from paper and textile manufacturing, and the basins have undergone considerable residential, commercial, and light industrial development during the past 10 years. However, dilution of contaminants has prevented severe BOD loading, and installation of wastewater-treatment plants since the mid-1970's has improved water-quality conditions in the Merrimack River basin. In the

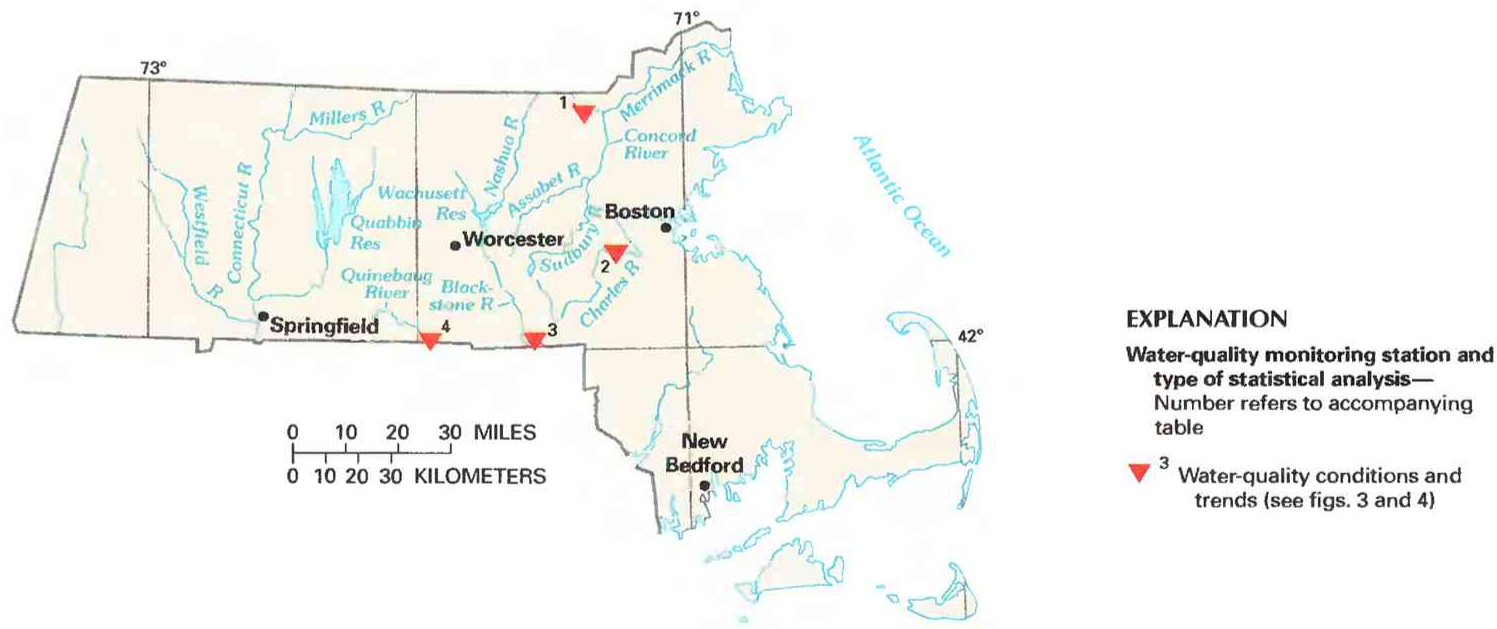

\begin{tabular}{|c|c|c|c|}
\hline $\begin{array}{l}\text { Site no. } \\
\text { on map }\end{array}$ & $\begin{array}{l}\text { USGS station } \\
\text { name and no. }\end{array}$ & $\begin{array}{l}\text { Drainage area } \\
\text { (square miles) }\end{array}$ & $\begin{array}{l}\text { Major land use } \\
\text { (see fig. 1) }\end{array}$ \\
\hline 1 & Merrimack River above Lowell (01096550) & 3,900 & Woodland and forest with some cropland and pasture; urban areas. \\
\hline 2 & Charles River at Dover $(01103500)$ & 183 & Urban areas. \\
\hline 3 & Blackstone River at Millville $(01111230)$ & 277 & Woodland and forest with some cropland and pasture. \\
\hline 4 & Quinebaug River at Quinebaug, Conn. (01124000) & 155 & Ditto. \\
\hline
\end{tabular}

Figure 2. Selected water-quality monitoring stations, type of statistical analysis, and geographic features in Massachusetts. (Sources: Major land uses modified from Anderson, 1967; other data from U.S. Geological Survey files.) 
upper Sudbury River basin, mercury from a hazardous waste site has contaminated streambed sediments in some places.

The low median concentrations of sulfate $(12 \mathrm{mg} / \mathrm{L})$, chloride $(19 \mathrm{mg} / \mathrm{L})$, dissolved solids $(71 \mathrm{mg} / \mathrm{L})$, nitrite plus nitrate $(0.31$ $\mathrm{mg} / \mathrm{L}$ ), and phosphorus (less than $0.20 \mathrm{mg} / \mathrm{L}$ ) at site 1 (fig. 3 ) are indicative of the improved quality of water in the main stem of the Merrimack River. The median values of $\mathrm{pH}(6.8)$, dissolved oxygen $(8.9 \mathrm{mg} / \mathrm{L})$, and alkalinity $(12 \mathrm{mg} / \mathrm{L})$ also indicate that the assimilative capacity of streams in the basin has helped to maintain adequate water quality.

\section{CHARLES RIVER}

The Charles River basin lies within the Seaboard Lowland. The basin is underlain by igneous and metamorphic rocks on the western side and by metamorphosed sedimentary and volcanic rocks on the eastern side, and is mantled by unconsolidated glacial till and stratified drift throughout. Much of the Charles River upstream from site 2 flows through small residential communities; extensive riverine wetlands cover nearly 10 percent of the basin (Massachusetts Department of Environmental Quality Engineering, 1988b).

Wastewater-treatment-plant discharge commonly increases concentrations of most water-quality constituents to levels greater than those of natural conditions in Massachusetts streams and might
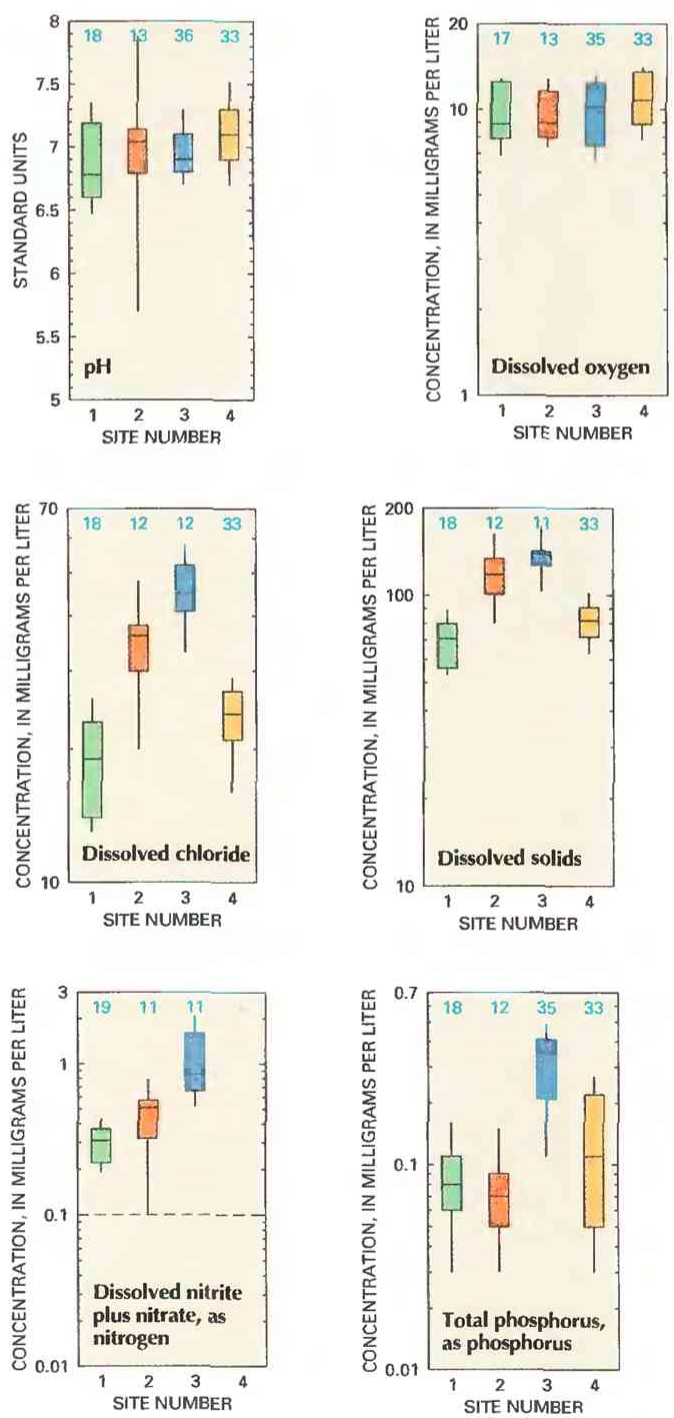

have contributed to the greater than natural concentrations of chloride (median, $36 \mathrm{mg} / \mathrm{L}$ ) and dissolved solids (median, $118 \mathrm{mg} / \mathrm{L}$ ) at site 2 (fig. 3). However, the oxygen demand of the treatment-plant discharges and seasonal effects of wetlands in the basin, which produce runoff having lower dissolved-oxygen concentrations during the summer, failed to reduce the median dissolved-oxygen concentration to less than $9.0 \mathrm{mg} / \mathrm{L}$, and concentrations rarely were less than $7.0 \mathrm{mg} / \mathrm{L}$.

\section{BLACKSTONE AND QUINEBAUG RIVERS}

The drainage basins of the Blackstone and Quinebaug Rivers lie within the New England Upland and are underlain by crystalline igneous and metamorphic bedrock that is covered by unconsolidated glacial till and stratified drift. Large areas of the two river basins were developed for residential use in the 1980 's, and the rest remains mostly woodland and forest. Wastewater-treatment-plant discharges constitute a substantial part of the total discharge of the Blackstone River-often more than one-half during summer low-flow periods (Massachusetts Department of Environmental Quality Engineering, 1988b). Water quality of the Blackstone River noticeably reflects this condition; concentrations of many constituents in wastewater-treatment-plant discharges exceed those found in natural stream water.
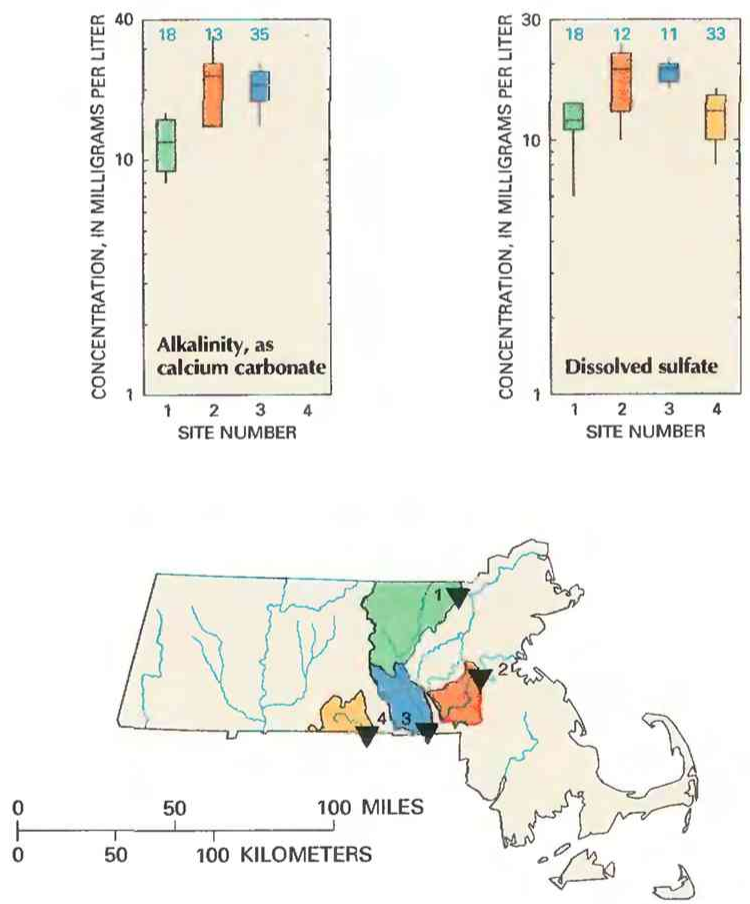

\section{EXPLANATION}

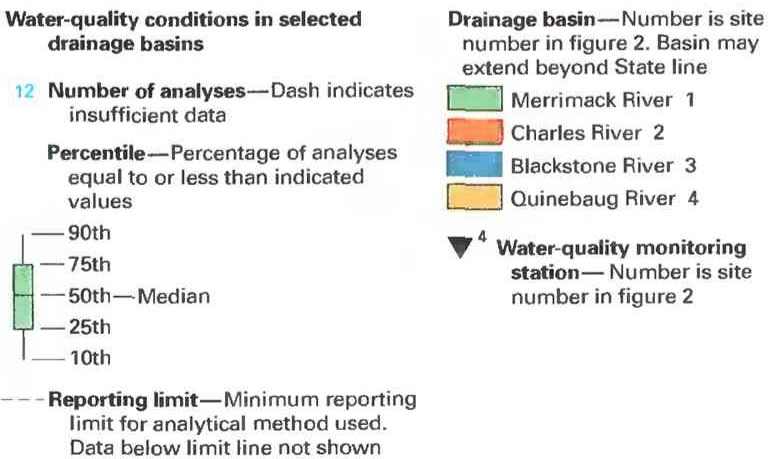

Figure 3. Water quality of selected streams in Massachusetts, water years 1987-89. (Source: Data from U.S. Geological Survey files.) 
Median sulfate, chloride, dissolved solids, nitrite plus nitrate, and phosphorus concentrations for site 3 on the Blackstone River were larger than median concentrations of those constituents for site 4 on the Quinebaug River (fig. 3). These differences might reflect the effects of increased urbanization in the Blackstone River basin. especially the wastewater-treatment discharge that constitutes a large proportion of the streamflow throughout low-flow periods, producing greater contaminant concentrations than in natural stream water.

\section{WATER-QUALITY TRENDS}

Trend analysis is a statistical procedure used to detect changes in stream water quality at a monitoring station over time. For this report, water-quality data from four monitoring stations (fig. 2) were analyzed for trends by using the seasonal Kendall test (Hirsch and others, 1982), a method used extensively by the USGS. The graph (shown below) of the dissolved-chloride concentration in the Merrimack River at site 1 illustrates the trend inferred from the concentration data and demonstrates the variation in water quality that is common in streams.

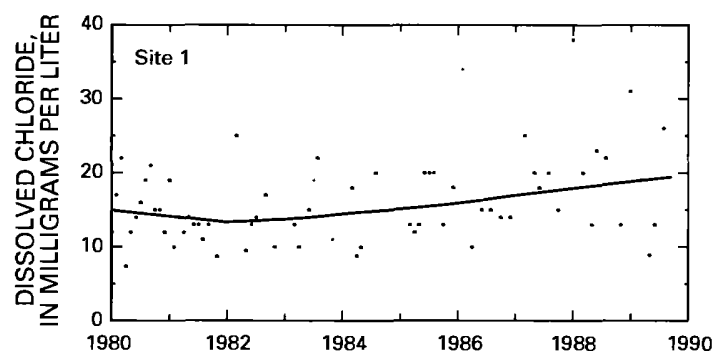

When possible, constituent-concentration data were adjusted for changes in streamflow to preclude identifying a trend in concen- tration that was caused only by a trend in streamflow. The data were not adjusted when (1) more than 10 percent of the samples had concentrations lower than the minimum reporting limit for the analytical method used or (2) the streamflow was controlled substantially by human activities. When the concentration data could not be adjusted for streamflow, trends were determined directly from the concentration data.

Statewide trends in measurements of selected physical properties of stream water and in concentrations of selected constituents in stream water are shown on maps in figure 4. On each map, a trend is indicated at a monitoring station only if the data from that station were suitable for use in the trend analysis. For more information on the suitability criteria and on the trend-analysis procedure used for this report, see Lanfear and Alexander (1990).

$\mathrm{pH}$

The $\mathrm{pH}$ of water is a measure of its hydrogen-ion activity (effective concentration). An increase in hydrogen-ion content causes water to become more acidic but results in a lower measured $\mathrm{pH}$ value because the units of $\mathrm{pH}$ are inversely related to hydrogen-ion activity. Both natural processes and human activities (table 1) can affect $\mathrm{pH}$. The $\mathrm{pH}$ of river water in most areas not affected by pollution is between about 6.5 to 8.5 (Hem, 1985, p. 64).

The upward $\mathrm{pH}$ trends in the Charles, Blackstone, and Quinebaug Rivers at sites 2,3, and 4 probably were a result of increasing wastewater-treatment-plant discharges. These discharges commonly are more strongly buffered, producing higher than natural $\mathrm{pH}$ values in stream water.

\section{DISSOLVED OXYGEN}

The dissolved-oxygen concentration in a stream is controlled by several factors, including water temperature, air temperature and

Table 1. Sources and environmental significance of selected water-quality properties and constituents

[Source: Compiled by the U.S. Geological Survey, Office of Water Quality]

Property or constituent Common sources Environmental significance

$\mathrm{pH}$ (property)

A measure of hydrogen-ion activity (acidity or alkalinity); can be affected by geologic setting, biological activity, municipal and industrial wastewater discharge, and atmospheric deposition.

Dissolved oxygen

Alkalinity (property)

Sulfate troduced from the atmosphere; also a byproduct of aquatic plants.

A measure of the quantity of acid-neutralizing substances; can be affected by geologic setting, industrial wastewater discharge, waste gases, and runoff from surface mining.

Occurs in some rocks; ałso in mine runoff, industrial wastewater discharge, and atmospheric deposition.

Chloride

Occurs in some rocks and ground-water discharge; also in road deicers, industrial and urban wastewater discharge, and atmospheric deposition.

Dissolved solids

A result of rock weathering; also in agricultural runoff and industrial discharge.

Nitrite plus nitrate

Nonpoint sources are agricultural and urban runoff; a major point source is wastewater discharge.

Phosphorus

Occurs in some rocks and sediments; also in runoff and seepage from phasphate-rock mines, agricultural and urban runoff, and industrial and municipal wastewater discharge.
Acidic water can corrode pipes and equipment; can cause the release of lead and other metals from distribution systems to drinking water; can affect wastewater-treatment processes and taste of water.

Necessary for aquatic life; deficiency can result from assimilation of organic wastes or rapid growth and decay of algae.

Sufficiently alkaline water can be unsuitable for some agricultural and industrial uses.

Concentrations exceeding a natural, background level indicate contamination from human activity; in sufficient quantity, can cause water to be unsuitable for public supply; can harm aquatic organisms.

Concentrations exceeding a natural, background level can cause water to be unsuitable for public supply, agriculture, and industry; can harm aquatic organisms.

In sufficient quantity, can cause water to be unsuitable for public supply, agriculture, and industry; can harm aquatic organisms.

Plant nutrient that, in sufficient quantity, can cause algal blooms and excessive growth of higher aquatic plants in bodies of water; can cause water to be unsuitable for public supply.

Plant nutrient that, in suffidient quantity, can cause algal blooms and excessive growth of higher aquatic plants in bodies of water. 
pressure, hydraulic characteristics of the stream, photosynthetic or respiratory activity of stream biota, and the quantity of organic material present. A trend in dissolved-oxygen concentrations commonly is directly or indirectly the result of human activities. Generally, an upward trend in dissolved-oxygen concentrations indicates improving stream water-quality conditions and a downward trend indicates deteriorating conditions.

The improved dissolved-oxygen conditions in the Blackstone River at site 3 might be attributable to improved treatment at several wastewater-treatment plants in the Blackstone River basin. Earlier discharges of untreated or less adequately treated wastewater probably had larger BOD loads that caused smaller dissolved-oxygen concentrations.

\section{ALKALINITY}

Alkalinity is a measure of the capacity of the substances dissolved in the water to neutralize acid. In most natural waters, alkalinity is produced mainly by bicarbonate and carbonate (Hem, 1985, p. 106), which are ions formed when carbon dioxide or carbonate rock dissolves in water. Alkalinity had no trend at the two monitoring stations from which data were suitable for trend analysis.

\section{DISSOLVED SULFATE}

The major natural sources of sulfate in streams are rock weathering, volcanoes, and biochemical processes (Hem, 1985, p. 113).

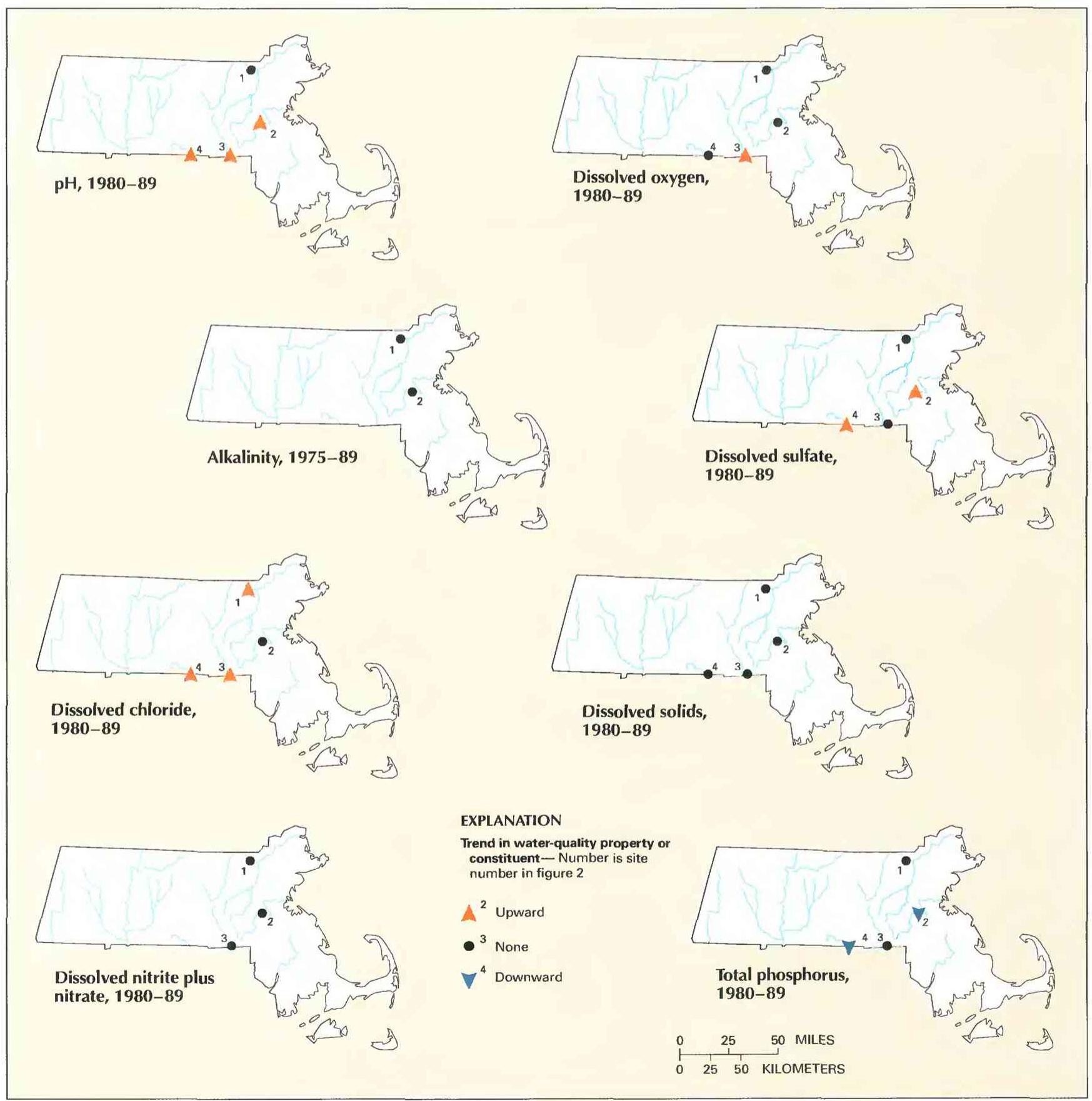

Figure 4. Trends in water quality of selected streams in Massachusetts, by water years. (Source: Data from U.S. Geological Survey files.) 
Human activities such as mining, waste discharge, and fossil-fuel combustion also can be important sources. Upward trends in sulfate concentrations in the Charles River at site 2 and the Quinebaug River at site 4 might have been the result of an increasing proportion of wastewater-treatment-plant discharges in streamflow, as well as of increasing surface runoff from growing residential areas in both river basins.

\section{DISSOLVED CHLORIDE}

Chloride is present in all natural waters but usually in low concentrations (Hem, 1985, p. 118). Except in streams that receive ground-water discharge high in chloride, concentrations of greater than a few milligrams per liter generally are the result of human activities (table 1). The upward trends in chloride concentrations in the Merrimack, Blackstone, and Quinebaug Rivers at sites 1, 3, and 4 might have been the result of increased applications of highway deicing salts but also might have been caused by increasing wastewatertreatment-plant discharges.

\section{DISSOLVED SOLIDS}

Dissolved solids in stream water result primarily from rock weathering but also can be introduced as a byproduct of human activities (table 1). Concentrations generally are greatest in streams draining basins underlain by rocks and soils that contain easily dissolved minerals. Dissolved-solids concentrations had no trend at the four monitoring stations from which data were suitable for trend analysis (fig. 4).

\section{DISSOLVED NITRITE PLUS NITRATE}

Nitrite and nitrate are oxidized forms of nitrogen that together normally constitute most of the dissolved nitrogen in well-aerated streams. Nitrite readily oxidizes to nitrate in natural waters; therefore, nitrate generally is by far the more abundant of the two (Hem. 1985 , p. 124). Nitrite plus nitrate concentrations had no trend at the three monitoring stations from which data were suitable for trend analysis.

\section{TOTAL PHOSPHORUS}

The total phosphorus concentration of a water sample is a measure of the concentration of all forms of phosphorus present in the sample, dissolved and particulate. Human activities (table 1) can be important sources of phosphorus in streams. Causes for the downward trend in the Charles River at site 2 and the Quinebaug River at site 4 are not apparent from available data on land use and agricultural practices that might ordinarily cause such a trend.

\section{WATER-QUALITY MANAGEMENT}

The DEP administers the State's regulatory programs for the protection of water resources and has three priority concerns: resource protection, waste prevention, and waste-site cleanup. Divisions within the DEP include Water Pollution Control, Water Supply, Wetland and Waterways, Hazardous Waste, and Solid Waste. The DEP prepares a biennial water-quality-assessement report (Massachusetts Department of Environmental Protection, 1990) for the EPA and the U.S. Congress in compliance with section 305(b) of the Federal Clean Water Act. The Division of Water Pollution Control administers a water-resources inventory and water-quality research program in cooperation with universities and USGS. The DEP's Bureau of $\mathrm{Mu}-$ nicipal Facilities provides funds for the constructing or upgrading of wastewater-treatment facilities and sewer-system components. The
DEP issues permits for all discharges to surface water within the State and provides grants or loans to municipalities for operating environmental-protection facilities. The DEP Regulatory Program is responsible for enforcement of DEP regulations.

The DEP manages nonpoint-source contamination through a program established by section 319 of the Water Quality Act of 1987, which addresses mitigation of known nonpoint-source problems. The program funds research projects that examine water-quality effects of structures and activities such as detention beds, sand filters, streambank stabilization, underground storage, and nutrient loading; the program also funds the use of a Rapid Biological Assessment method in previously uninvestigated waters to complement an ongoing monitoring program.

Other intrastate organizations that address water-quality concerns include numerous watershed associations. Twenty-one of these operate in individual watersheds of the 27 watersheds delineated by the State. Interstate water-quality issues are addressed by the New England Interstate Water Pollution Control Commission. The Commission coordinates interstate water-pollution control efforts, educates and trains personnel for careers in water-pollution control, and informs the public of water-quality issues. The Commission also conducts legislation and regulation review, provides a forum for discussing or resolving interstate concerns or disputes, carries out special projects, and approves interstate water classifications.

\section{SELECTED REFERENCES}

Anderson, J.R., 1967, Major land uses in the United States, in U.S. Geological Survey, 1970, National atlas of the United States of America: Washington, D.C., U.S. Geological Survey, p. 158-159.

Britton, L.J., and Greeson, P.E., eds., 1987, Methods for collection and analysis of aquatic biological and microbiological samples: U.S. Geological Survey Techniques of Water-Resources Investigations, book 5, chap. A4, $363 \mathrm{p}$.

Fenneman, N.M., 1946, Physical divisions of the United States: Washington, D.C., U.S. Geological Survey special map, scale 1:7,000,000.

Fishman, M.J., and Friedman, L.C., eds., 1989, Methods for the determination of inorganic substances in water and fluvial sediments: U.S. Geological Survey Techniques of Water-Resources Investigations, book 5 , chap. A1, 545 p.

Hem, J.D., 1985, Study and interpretation of the chemical characteristics of natural water (3d ed.): U.S. Geological Survey Water-Supply Paper 2254, $263 \mathrm{p}$.

Hirsch, R.M., Slack, J.R., and Smith, R.A., 1982, Techniques of trend analysis for monthly water quality data: Water Resources Research, v. 18, no. 1 , p. 107-121.

Lanfear. K.J., and Alexander, R.B., 1990, Methodology to derive water-quality trends for use by the National Water Summary Program of the U.S. Geological Survey: U.S. Geological Survey Open-File Report 90-359, $10 \mathrm{p}$.

Massachusetts Department of Environmental Protection, 1990, Commonwealth of Massachusetts summary of water quality: Westborough, Massachusetts Department of Environmental Protection, 88 p.

Massachusetts Department of Environmental Quality Engineering, 1988a, Commonwealth of Massachusetts summary of water quality: Westborough, Massachusetts Department of Environmental Quality Engineering, $66 \mathrm{p}$.

$1988 \mathrm{~b}$, Commonwealth of Massachusetts summary of water quality, Appendix III, basin/segment information: Westborough, Massachusetts Department of Environmental Quality Engineering, $177 \mathrm{p}$.

Ruby, Armand, III, Godfrey, P.J., and Zajicek, O.T, 1988, The Massachusetts acid rain monitoring project, phase II: Amherst, University of Massachusetts, Water Resources Research Center Publication no. 159, 47 p.

Thelin. G.P., and Pike, R.J., 1990. Digital shaded relief map of the conterminous United States: Menlo Park. Calif., U.S. Geological Survey digital image processing, scale 1:3,500,000.

U.S. Geological Survey, 1990, National water summary 1987--Hydrologic events and water supply and use: U.S. Geological Survey Water-Supply Paper 2350, 553 p. 
Ward, J.R., and Harr, C.A., eds., 1990, Methods for collection and processing of surface-water and bed-material samples for physical and chemical analyses: U.S. Geological Survey Open-File Report 90-140, 71 p.
Zen, E-an, ed., 1983, Bedrock geologic map of Massachusetts: U.S. Geological Survey State geologic map, scale 1:250,000. 
324 National Water Summary 1990-91-Stream Water Quality: STATE SUMMARIES

Prepared by Jeffrey L. Strause

FOR ADDITIONAL INFORMATION: District Chief, U.S. Geological Survey, 28 Lord Road, Suite 280, Marlborough, MA 01752 


\section{MiCHIGAN Stream Water Quality}

Michigan's location and 32 inches per year of precipitation provide the State with plentiful freshwater resources. Lakes Superior, Michigan, Huron, and Erie, which contain 5,080 cubic miles of water (U.S. Geological Survey, 1990, p. 305), border Michigan on the north, west, and east. Most of the State's 36,350 miles of streams and rivers flow into the four lakes, and most of those streams and rivers contain water that is suitable for most uses. The water quality of only 4 percent (1,361 miles) of Michigan's stream miles is considered degraded, according to the Michigan Department of Natural Resources (1990a, p. 29).

In 1985, surface water constituted about 95 percent or 10,800 $\mathrm{Mgal} / \mathrm{d}$ (million gallons per day) of freshwater withdrawals for offstream use in Michigan (U.S. Geological Survey, 1990, p. 310) and supplied about two-thirds of the State's population with potable water in 1985 (Solley and others, 1988). In 1980, about 65,000
Mgal/d or 101,000 ft $3 / \mathrm{s}$ (cubic feet per second) of instream water generated power at 82 dams (U.S. Geological Survey, 1986, p. 277).

The quality of Michigan's stream water can be affected by several factors, of which land use is one of the more significant. Land use in the State ranges from croplands in southern Michigan to forests in the north (fig. 1A). The State occupies parts of two physiographic provinces: the Superior Upland and Central Lowland (fig. 1B). Physiographic diversity has contributed to the different land-use and settlement patterns. Michigan's population is concentrated in the southern one-half of the Lower Peninsula (fig. $1 C$ ).

\section{WATER-QUALITY MONITORING}

Water-quality data obtained from analyses of water samples collected at monitoring stations are stored in the U.S. Geological

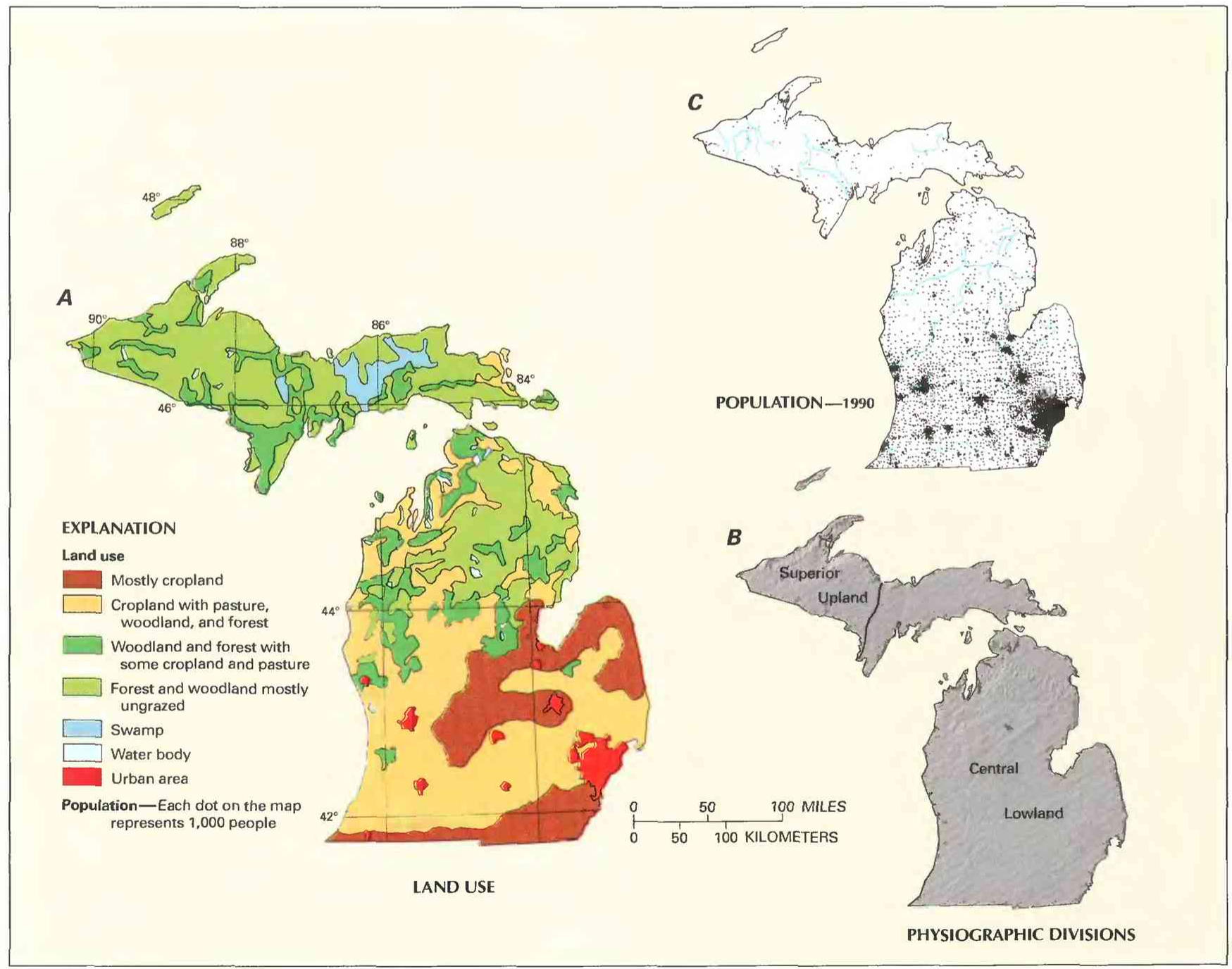

Figure 1. Land use, physiography, and population in Michigan. $A$, Major land uses. B, Physiographic divisions. $C$, Population distribution in 1990. (Sources: A, Major land uses modified from Anderson, 1967. B, Physiographic divisions from Fenneman, 1946; landforms from Thelin and Pike, 1990. C, Data from U.S. Bureau of the Census 1990 decennial census files.) 
Survey's (USGS) National Water Information System and the U.S. Environmental Protection Agency's (EPA) national data base known as STORET. Water-quality and streamflow data are reported by water year-the 12 months from October 1 through September 30. A water year is identified by the calendar year in which it ends. For example, water year 1991 comprises October 1, 1990, through September 30, 1991.

\section{EXPLANATION}

Water-quality monitoring station and type of statistical analysis-

Number refers to accompanying table

$\nabla^{9}$ Water-quality trends (see fig. 4)

$\nabla^{7}$ Water-quality conditions and trends (see figs. 3 and 4 )

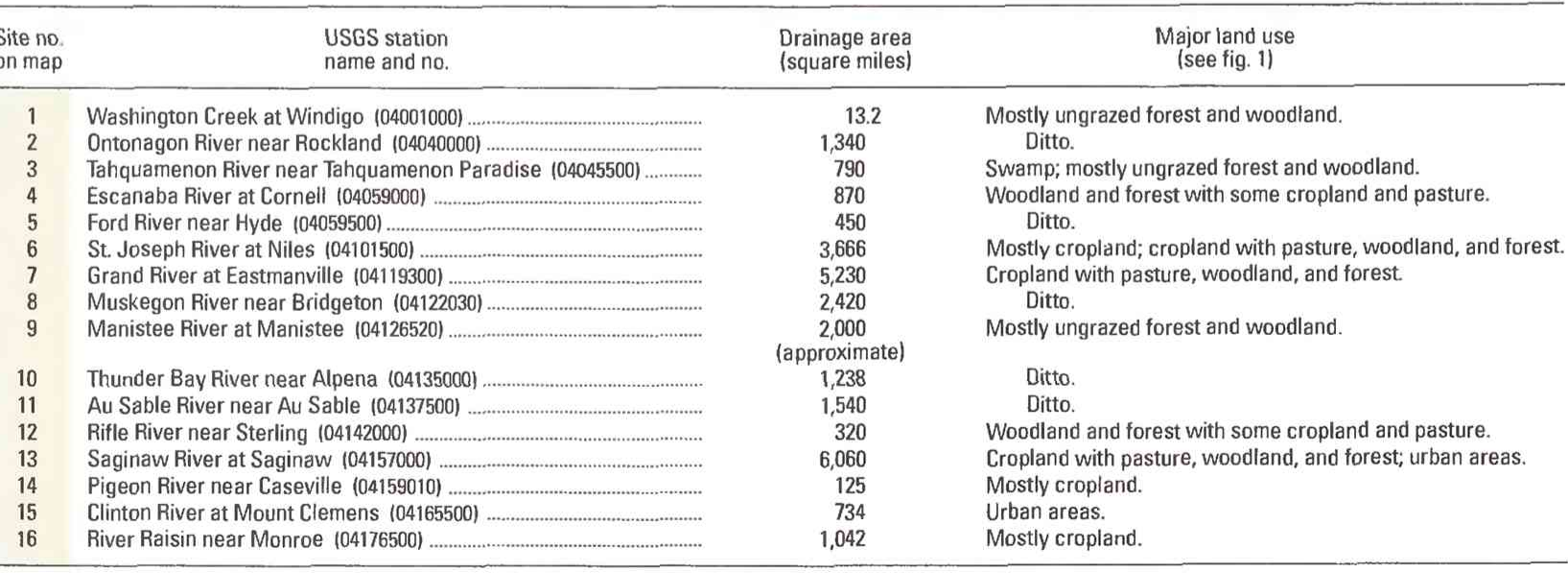

Figure 2. Selected water-quality monitoring stations, type of statistical analysis, and geographic features in Michigan. ISources: Major land uses modified from Anderson, 1967; other data from U.S. Geological Survey files.) 
The data used in this summary of Michigan's stream water quality were obtained from water samples collected every 2 months or quarterly at 16 monitoring stations at which data collection is systematic and continuing (fig. 2). Analyses of water samples collected at 10 stations are the basis for the discussion and graphic summary (fig. 3) of stream water-quality conditions during water years 198789 , and data from all 16 stations are the basis for the discussion and graphic summary (fig. 4) of stream water-quality trends. Water samples were collected and analyzed by using standard methods approved by the USGS (Britton and Greeson, 1987; Fishman and Friedman, 1989; Ward and Harr, 1990) or by using equivalent methods. If a method of sample collection or analysis changed over time, data from an analysis were included in the evaluation of recent stream water quality or of stream water-quality trends only if the change in method did not affect the comparability of the data.

\section{WATER-QUALITY CONDITIONS}

The Great Lakes basin has 43 designated Areas of Concern in which water use is adversely affected (G.W. Goudy, Michigan Department of Natural Resources, written commun., July 1991). Fourteen of these areas affect Michigan's waters; they generally are restricted to the lower reaches of rivers and the receiving bay or harbor of the affected Great Lake. Water-quality degradation in these areas and others has affected Michigan's fish populations. In 1990, the Michigan Department of Public Health issued advisories against consumption of fish obtained from the Great Lakes and connecting channels within the State, 12 inland lakes, and 21 streams (Michigan Department of Natural Resources, 1990a, p. 59). The advisories include specific or all species and recommend limited or no consumption because of toxic contaminants. Although numerous toxic contaminants are listed as the cause of the advisories, the primary contaminants are mercury and polychlorinated biphenyls. About 1.6 percent of the State's stream miles is affected by the advisories (Michigan Department of Natural Resources, 1990a, p. 59).

The following discussion of stream water quality in Michigan is organized by river basin (fig. 3). Where physiographic and land-use characteristics in different basins are similar, the discussion of those basins is combined. Graphs in figure 3 summarize certain aspects of stream water quality in the basins for water years 1987 89. The graphs show frequency distributions of data values that represent measurements of selected physical properties of stream water and concentrations of selected constituents in stream water. These properties and constituents are specific conductance, dissolved oxygen, fecal coliform bacteria, dissolved sulfate, dissolved chloride, dissolved solids, dissolved nitrite plus nitrate (as nitrogen), and total phosphorus (as phosphorus). The data are reported in microsiemens per centimeter at 25 degrees Celsius, milligrams per liter $(\mathrm{mg} / \mathrm{L})$, and colonies per 100 milliliters $(\mathrm{col} / 100 \mathrm{~mL}$ ). Sources and environmental significance of each property and constituent are described in table 1 .

Water quality at each monitoring station is the result of geological, chemical, biological, and hydrologic processes that occur over a large area. Water-quality problems that affect aquatic life or public health only locally are not fully represented in this summary.

\section{ONTONAGON RIVER}

The Ontonagon River basin is located in the Superior Upland, which is characterized by thin glacial deposits overlying igneous and metamorphic rocks. The terrain ranges from hilly to mountainous, and swamps and lakes are numerous. The river flows northwestward into Lake Superior. Hardwood forest covers most of the basin, and the major land use is timber harvesting. The basin is sparsely populated and little developed. Red clay in the basin contributes to turbidity in streams; however, the high suspended-sediment concentrations in this basin are unusual for Upper Peninsula streams.
Specific-conductance values and sulfate, chloride, and dissolved-solids concentrations at site 2 are low (fig. 3) because the basin is underlain by resistant, crystalline igneous and metamorphic bedrock. The water is soft as a result of the low concentrations of dissolved minerals. The median dissolved-oxygen concentration was $11.8 \mathrm{mg} / \mathrm{L}$, which is higher than the water-quality standard of 7 $\mathrm{mg} / \mathrm{L}$ as a minimum (Michigan Department of Natural Resources, 1990a, p. 19) for cold-water streams. The low concentrations of fecal coliform bacteria, nitrite plus nitrate, and phosphorus reflect the absence of contamination from urban and agricultural sources.

\section{TAHQUAMENON RIVER}

The Tahquamenon River basin is located in the Central Lowland. The land is flat and has extensive swampy lowlands. The river flows nor theastward into Lake Superior. The basin is extensively forested, undeveloped, and sparsely populated. Timber harvesting is the major land use. Unlike most Michigan streams, the Tahquamenon River has a light-brown color caused by tannic acid that is leached from the bark of cedar trees in swamps. Suspended-sediment concentrations in the river are low.

During water years $1987-89$, the median dissolved-solids concentration in the Tahquamenon River at site 3 was $108 \mathrm{mg} / \mathrm{L}$ (fig. 3). Concentrations of sulfate and chloride, both of which are components of dissolved solids, were correspondingly low. Wastewater discharge and agriculture in the basin are minimal; consequently, the median fecal coliform bacteria, nitrite plus nitrate, and phosphorus concentrations were low- $11 \mathrm{col} / 100 \mathrm{~mL}, 0.1 \mathrm{mg} / \mathrm{L}$, and $0.02 \mathrm{mg} / \mathrm{L}$, respectively.

\section{FORD RIVER}

The Ford River basin is located in the Central Lowland. The basin is mostly forested but has some agricultural land in the central part. Farming and timber harvesting are the major land uses. The Ford River flows southeastward into Lake Michigan.

Dissolved-solids concentrations in samples collected from the Ford River at site 5 during 1987-89 were about twice those at sites 2 and 3, the other two monitoring stations in the Upper Peninsula (fig. 3). Whether the higher specific-conductance values and dissolved-solids concentrations are caused by natural conditions or are related to agricultural activity in the basin is not known. However, the low nitrite plus nitrate and phosphorus concentrations probably indicate that agricultural runoff is not a serious problem upstream from site 5 .

\section{ST. JOSEPH AND GRAND RIVERS}

The St. Joseph and Grand River basins are located in the Central Lowland. Both rivers flow westward and into Lake Michigan. Relatively thick glacial deposits underlie the basins. In terms of area, the major land uses in both basins are agricultural. However, the Grand River basin is more densely populated and industrialized than the St. Joseph River basin and contains the cities of Grand Rapids, Lansing, and Jackson, which have a combined population of more than 600,000 . Water quality is generally degraded downstream from Grand Rapids, Lansing, and Jackson (Michigan Deparment of Natural Resources, 1990a, p. 46).

The high sulfate, chloride, dissolved-solids, and nitrite plus nitrate concentrations in the St. Joseph and Grand Rivers, relative to those in most of the other 10 streams (fig. 3), reflect the agricultural and urban development in the basins. Although the median fecal coliform bacteria concentration for the St. Joseph River at site $6(980$ $\mathrm{col} / 100 \mathrm{~mL}$ ) was higher than that for the Grand River at site $7(280$ $\mathrm{col} / 100 \mathrm{~mL}$ ), the difference might be more a function of samplingsite location with respect to wastewater-treatment plants than a measure of the basin water quality. The Grand River basin has more 

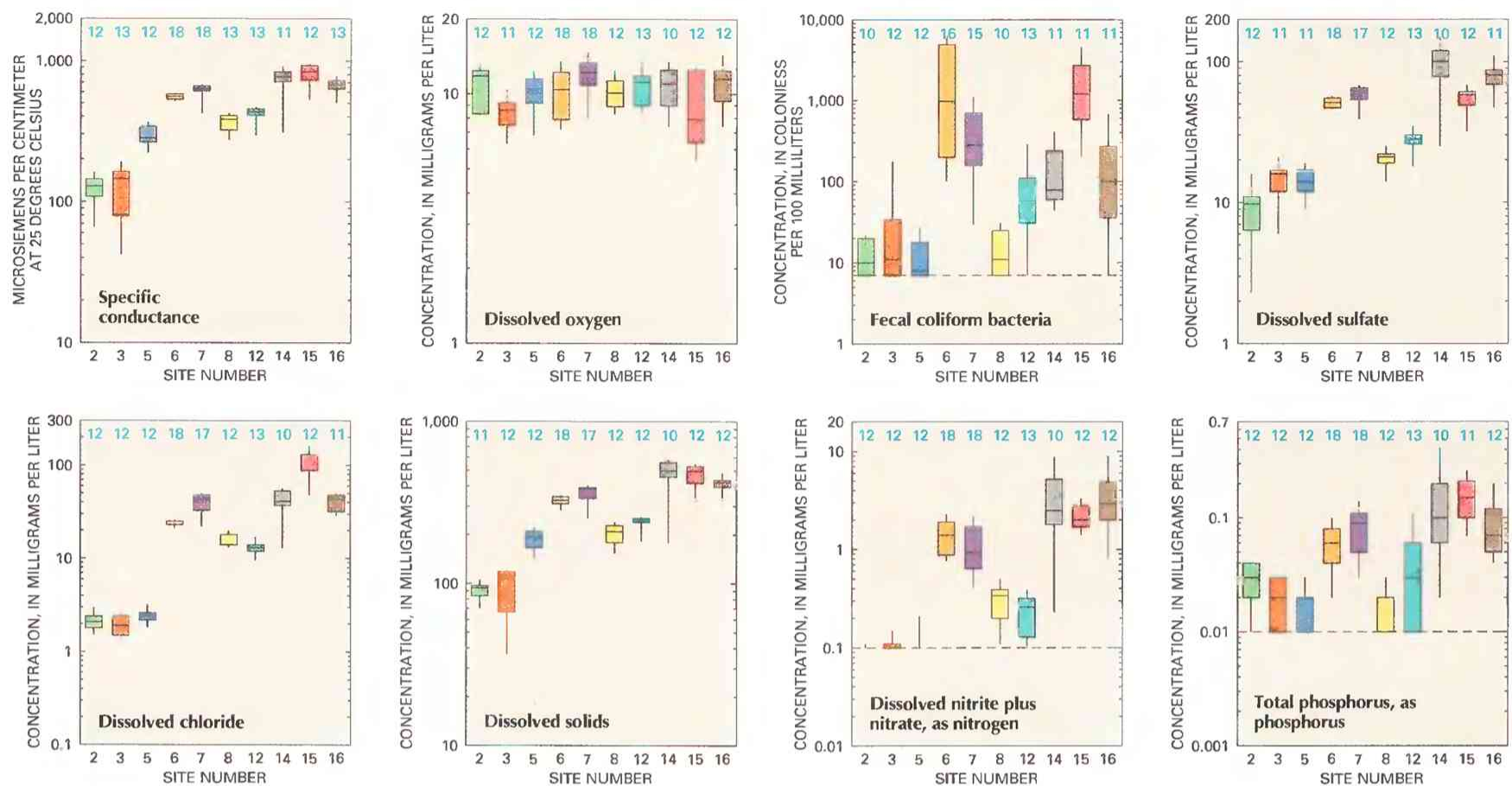

\section{EXPLANATION \\ Water-quality conditions in selected drainage basins \\ Number of analyses \\ Percentile-Percentage of analyses equal to or less than indicated values \\ -90th \\ -75 th \\ - 50th-Median \\ -25 th \\ -- Reporting limit-Minimum reporting limit for analytical method used. Data below limit line not shown}
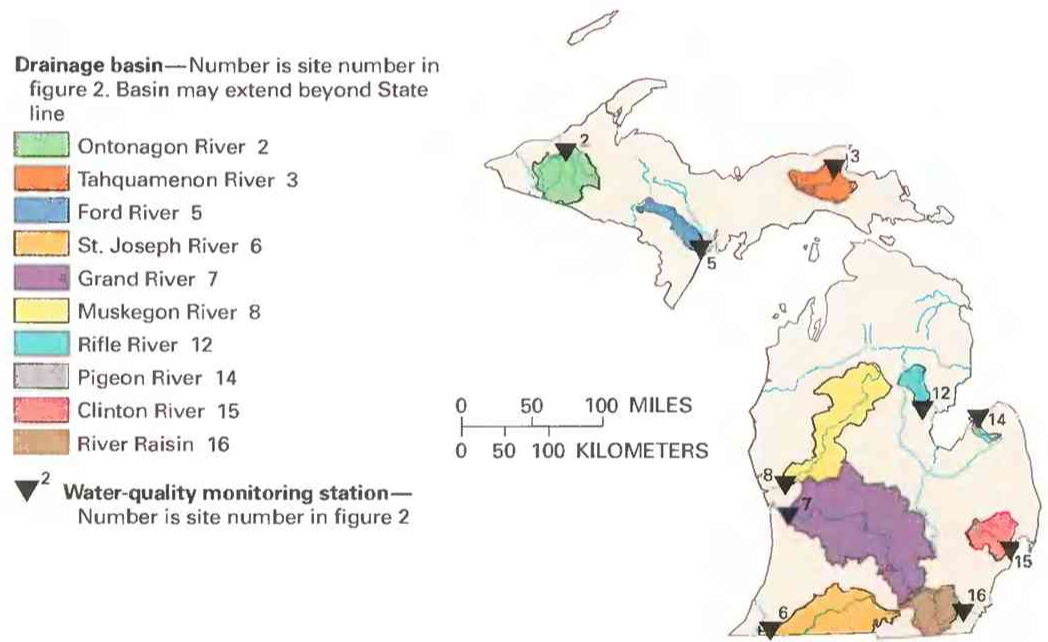

Figure 3. Water quality of selected streams in Michigan, water years 1987-89. (Source: Data from U.S. Geological Survey files.)

wastewater-treatment plants, which are sources of fecal contamination in streams. At sites 6 and 7, nitrite plus nitrate and phosphorus concentrations were higher than those in the Upper Peninsula and in the northern Lower Peninsula. However, at the mouth of the Grand River, phosphorus loads have decreased 83 percent since 1970 (Michigan Department of Natural Resources, 1990a, p. 46).

\section{MUSKEGON AND RIFLE RIVERS}

The Muskegon and Rifle River basins are located in the Central Lowland. The Muskegon River flows into Lake Michigan and the Rifle River flows into Lake Huron. The geology of the Muskegon River basin is characterized by relatively thick, glacial deposits and some bedrock outcrops. The Rifle River basin is hilly and has sandy soils and glacial moraine deposits in the upper part and bedrock outcrops in the lower part. Both basins contain large forested areas; agriculture is a secondary land use. Neither basin is densely populated. The Muskegon and Rifle River basins are used intensively for recreation, and fisheries protection is a priority. Oil and gas resources have been developed in both basins, and development is continuing. The effect this development is having on the water quality at sites 8 and 12 is not known. Studies in a nearby basin indicate that although oil wells were contaminating the stream, the degree of contamination was insufficient to disrupt biological communities (Michigan Department of Natural Resources, 1990a, p. 48).

Sulfate, chloride, dissolved-solids, and nitrite plus nitrate concentrations were similar at sites 8 and 12 (fig. 3). The concentrations of these constituents were lower than for the more agricultural and industrial basins farther south.

\section{PIGEON RIVER}

The Pigeon River basin is located in the Central Lowland. The basin is characterized by flat terrain, lack of industry, and sparse population. The Pigeon River flows northwestward into Saginaw Bay. Most cropland is drained by subsurface tiles. Tiled drainage either enters auxiliary surface drains that carry the discharge to streams or enters a stream directly. Base flow during the summer is low, often 
Table 1. Sources and environmental significance of selected water-quality properties and constituents [Source: Compiled by the U.S. Geological Survey, Office of Water Quality]

\begin{tabular}{|c|c|c|}
\hline Property or constituent & Common sources & Environmental significance \\
\hline $\begin{array}{l}\text { Specific conductance ...................... } \\
\text { (property) }\end{array}$ & $\begin{array}{l}\text { A measure of the electrical conductivity of water; var- } \\
\text { ies with the quantity of dissolved solids and is } \\
\text { used to approximate the dissolved-solids content. }\end{array}$ & $\begin{array}{l}\text { Dissolved solids can cause water to be unsuitable for } \\
\text { public supply, agriculture, and industry; can harm } \\
\text { aquatic organisms. }\end{array}$ \\
\hline Dissolved oxygen ........................ & $\begin{array}{l}\text { Introduced from the atmosphere; also a byproduct of } \\
\text { aquatic plants. }\end{array}$ & $\begin{array}{l}\text { Necessary for aquatic life; deficiency can result from } \\
\text { assimilation of organic wastes or rapid growth } \\
\text { and decay of algae. }\end{array}$ \\
\hline Fecal coliform bacteria ................ & $\begin{array}{l}\text { Sources include effluent from sewage-treatment } \\
\text { plants and runoff from pastures, feedlots, and ur- } \\
\text { ban areas. }\end{array}$ & $\begin{array}{l}\text { Presence indicates contamination of water by wastes } \\
\text { from humans and other warm-blooded animals. }\end{array}$ \\
\hline 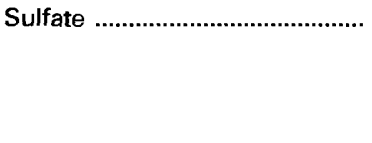 & $\begin{array}{l}\text { Occurs in some rocks; also in mine runoff, industrial } \\
\text { wastewater discharge, and atmospheric deposi- } \\
\text { tion. }\end{array}$ & $\begin{array}{l}\text { Concentrations exceeding a natural, background } \\
\text { level indicate contamination from human activity; } \\
\text { in sufficient quantity, can cause water to be } \\
\text { unsuitable for public supply; can harm aquatic } \\
\text { organisms. }\end{array}$ \\
\hline 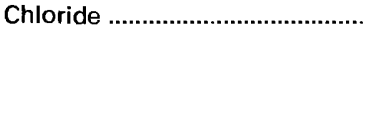 & $\begin{array}{l}\text { Occurs in some rocks and ground-water discharge; } \\
\text { also in road deicers, industrial and urban waste- } \\
\text { water discharge, and atmospheric deposition. }\end{array}$ & $\begin{array}{l}\text { Concentrations exceeding a natural, background level } \\
\text { can cause water to be unsuitable for public supply, } \\
\text { agriculture, and industry; can harm aquatic or- } \\
\text { ganisms. }\end{array}$ \\
\hline Dissolved solids .......................... & $\begin{array}{l}\text { A result of rock weathering; also in agricultural runoff } \\
\text { and industrial discharge. }\end{array}$ & $\begin{array}{l}\text { In sufficient quantity, can cause water to be unsuitable } \\
\text { for public supply, agriculture, and industry; can } \\
\text { harm aquatic organisms. }\end{array}$ \\
\hline Nitrite plus nitrate ........................ & $\begin{array}{l}\text { Nonpoint sources are agricultural and urban runoff; } \\
\text { a major point source is wastewater discharge. }\end{array}$ & $\begin{array}{l}\text { Plant nutrient that, in sufficient quantity, can cause } \\
\text { algal blooms and excessive growth of higher } \\
\text { aquatic plants in bodies of water; can cause water } \\
\text { to be unsuitable for public supply. }\end{array}$ \\
\hline 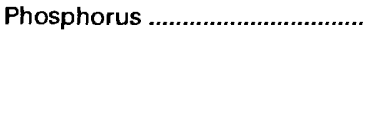 & $\begin{array}{l}\text { Occurs in some rocks and sediments; also in runoff } \\
\text { and seepage from phosphate-rock mines, agri- } \\
\text { cultural and urban runoff, and industrial and } \\
\text { municipal wastewater discharge. }\end{array}$ & $\begin{array}{l}\text { Plant nutrient that, in sufficient quantity, can cause } \\
\text { algal blooms and excessive growth of higher } \\
\text { aquatic plants in bodies of water. }\end{array}$ \\
\hline
\end{tabular}

less than $5 \mathrm{ft}^{3} / \mathrm{s}$ at site 14 . Increased tillage and improved drainage have caused the rapid transport of excess agricultural fertilizer applications to basin streams. In 1985, the estimated farm-applied nitrogen fertilizer in Huron County - the county in which the Pigeon River basin is located-was 11.3 million kilograms, the most for any Michigan county (Alexander and Smith, 1990).

Concentrations of most constituents in samples collected from the Pigeon River at site 14 were high relative to those in most of the other nine streams (fig. 3). Runoff from agricultural areas was the primary cause of the higher concentrations (Michigan Department of Natural Resources, 1990a, p. 50).

\section{CLINTON RIVER AND RIVER RAISIN}

The Clinton River and River Raisin basins are located in the Central Lowland. The Clinton River flows eastward to Lake St. Clair, and the River Raisin flows eastward to Lake Erie. The land adjacent to Lake St. Clair and Lake Erie is underlain by mineralized shale and sandstone (Rheaume, 1991). Most communities in the basins rely on Lakes Huron and Erie for their drinking-water supply. Both basins are adjacent to the densely urbanized and industrialized Detroit area. The Clinton River basin is predominantly urban, whereas the River Raisin basin is predominantly agricultural. Water quality of the Clinton River is affected by combined storm- and municipal-sewer outflows and urban runoff from Pontiac to its mouth (Michigan Department of Natural Resources, 1988, p. 32). Parts of the River Raisin basin also are affected by combined-sewer overflows (Michigan Department of Natural Resources, 1988, p. 34).

The abundance of point and nonpoint pollution sources in the Clinton River and River Raisin basins is reflected in the high concentrations of most constituents (fig. 3). The median fecal coliform bacteria concentration for site 15 was $1,200 \mathrm{col} / 100 \mathrm{~mL}$, which exceeds the State standard for recreational waters (Michigan Department of Natural Resources, 1990a, p. 19). High chloride concentrations at site 15 (median, $130 \mathrm{mg} / \mathrm{L}$ ) probably are at least partly the result of road deicing-salt application in the densely urbanized Clinton River basin. The median dissolved-solids concentration in the Clinton River at site $15(495 \mathrm{mg} / \mathrm{L})$ was the second highest for the 10 monitoring stations. The State standard for dissolved solids is $500 \mathrm{mg} / \mathrm{L}$ as a monthly average (Michigan Department of Natural Resources, 1990 a, p. 18). Nitrite plus nitrate concentrations were higher at sites 15 and 16 than at most of the other monitoring stations. The frequency distribution of nitrite plus nitrate concentration for site 16 is similar to that for the agricultural Pigeon River basin (site 14). Phosphorus concentrations were higher at sites 15 and 16 than at most of the other monitoring stations. The sources of phosphorus likely are urban in the Clinton River basin and agricultural in the River Raisin basin.

\section{WATER-QUALITY TRENDS}

Trend analysis is a statistical procedure used to detect changes in stream water quality at a monitoring station over time. For this report, water-quality data from 16 monitoring stations (fig. 2) were analyzed for trends by using the seasonal Kendall test (Hirsch and others, 1982), a method used extensively by the USGS. The graph (shown below) of the total-phosphorus concentration in the River Raisin at site 16 illustrates the trend inferred from the concentration data and demonstrates the variation in water quality that is common in streams.

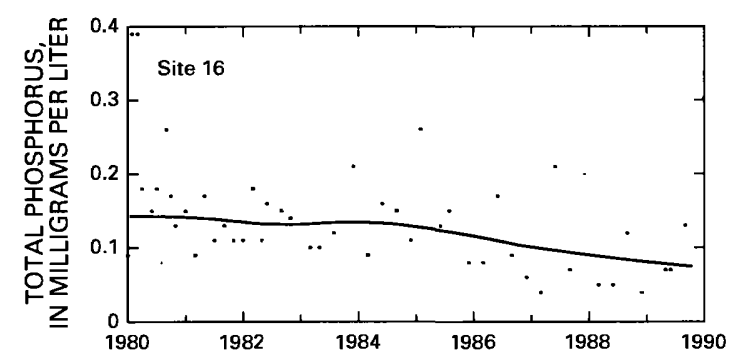

When possible, constituent-concentration data were adjusted for changes in streamflow to preclude identifying a trend in concen- 
tration that was caused only by a trend in streamflow. The data were not adjusted when (1) more than 10 percent of the samples had concentrations lower than the minimum reporting limit for the analytical method used or (2) streamflow was controlled substantially by human activities. When the concentration data could not be adjusted for streamflow, trends were determined directly from the concentration data.

Statewide trends in measurements of selected physical properties of stream water and in concentrations of selected constituents in stream water are shown on maps in figure 4. On each map, a trend is indicated at a monitoring station only if the data from that station were suitable for use in the trend analysis. For more information on the suitability criteria and on the trend-analysis procedure used for this report, see Lanfear and Alexander (1990).

\section{SPECIFIC CONDUCTANCE}

Specific conductance is a measure of the ability of a sample of water to conduct electricity. Because specific conductance and the dissolved-solids concentration are roughly proportional in most natural waters, the specific-conductance value often can be used to estimate the dissolved-solids concentration (Hem, 1985, p. 66-68).

The upward specific-conductance trend in the Escanaba River at site 4 is the result of an increase in dissolved solids. Dissolvedsolids concentrations have increased steadily since 1975 in the Escanaba River at site 4. The Escanaba River drains an area of extensive iron-ore mining in the central part of the Upper Peninsula, and the upward trend probably was related to mining. A cause for the upward specific-conductance trend at site 12 on the Rifle River near Sterling is not readily apparent but probably was related to runoff from agricultural areas. The salt and chemical industries in the Manistee area historically have been the cause of contamination from chloride and other dissolved constituents in the lower reaches of the Manistee River (Great Lakes Basin Commission. 1975, p. 76). The decreasing specific conductance at site 9 probably was the result of gradual reductions in discharge from those industries.

\section{DISSOLVED OXYGEN}

The dissolved-oxygen concentration in a stream is controlled by several factors, including water temperature, air temperature and pressure, hydraulic characteristics of the stream, photosynthetic or respiratory activity of stream biota, and the quantity of organic material present. A trend in dissolved-oxygen concentrations commonly is directly or indirectly the result of human activities. Generally, an upward trend in dissolved-oxygen concentrations indicates improving stream water-quality conditions and a downward trend indicates deteriorating conditions. Dissolved-oxygen concentrations had no significant trend at 15 monitoring stations during water years 1980 89.

\section{FECAL COLIFORM BACTERIA}

Fecal coliform bacteria are used as indicators of fecal contamination from humans and other warm-blooded animals. Such contamination can introduce disease-causing viruses and bacteria into a stream.

A cause for the upward trends in fecal coliform bacteria concentrations in the undeveloped Washington Creek basin (site 1) and predominantly rural Tahquamenon and Thunder Bay River basins (sites 3 and 10) is not readily apparent. The increases were slight. The small downward trend at site 9 probably was the result of wastewater-treatment-plant improvements. The absence of a significant downward trend at numerous sites was unexpected, considering the $\$ 3.5$ billion that has been spent on about 1,100 municipal wastewater-treatment improvements in the State since 1972 (Michigan De- partment of Natural Resources, 1990a, p. 221). However, any substantial reductions resulting from these improvements might have occurred before the trend-analysis period. Also, the absence of trend could be a function of sampling-site location with respect to the point source. Fecal coliform bacteria do not survive long in the stream environment.

\section{DISSOLVED SULFATE}

The major natural sources of sulfate in streams are rock weathering, volcanoes, and biochemical processes (Hem, 1985, p. 113). Human activities such as mining, waste discharge, and fossil-fuel combustion also can be important sources. A shortened trend-analysis period was used for sulfate because data from analyses performed prior to water year 1982 are not comparable to data from subsequent years.

A cause for the upward trends in sulfate in the Ford River at site 5 and the St. Joseph River at site 6 is not known, but the increasing concentrations might be attributable in part to atmospheric deposition. Although sulfur dioxide emissions from industrial sources in the State have been reduced by 60 percent (Michigan Department of Natural Resources, 1990b, p. 26), northeasterly winds probably carry contaminants from population centers outside of Michigan.

\section{DISSOLVED CHLORIDE}

Chloride is present in all natural waters but usually in low concentrations (Hem, 1985, p. 118). Except in streams that receive ground-water discharge high in chloride, concentrations of greater than a few milligrams per liter generally are the result of human activities (table 1).

A cause for the upward trend in chloride concentrations in the Escanaba River at site 4 is not known. Chloride is a major component of the dissolved-solids concentration in the Clinton River, and salt used for road deicing during the winter probably is a major source of the chloride. The upward trend at site 15 probably was due to increasing application of road salt in the basin. During 1975-89, Macomb County, which is almost entirely in the Clinton River basin and includes northeastern Detroit, steadily increased salt use from 28,000 to 42,000 tons per year (R.M. Morisette, Macomb County Road Commission, written commun., October 1990). The downward trend in the Manistee River at site 9 corresponds to a reduction in industrial discharges (see the discussion of specific-conductance trends). The decreasing concentration in the Rifle River at site 12 might seem not to compare well with the upward trend in specific conductance or the absence of trend in dissolved solids; however, the chloride concentration (median, $13 \mathrm{mg} / \mathrm{L}$ during water years $1987-89$ ) at site 12 is too low to be a major component of the dissolved-solids concentration.

\section{DISSOLVED SOLIDS}

Dissolved solids in stream water result primarily from rock weathering but also can be introduced as a byproduct of human activities (table 1). Concentrations generally are greatest in streams draining basins underlain by rocks and soils that contain easily dissolved minerals.

The upward trend in dissolved solids in the Escanaba River at site 4 probably was related to iron-ore mining, as discussed under specific conductance. High dissolved-solids concentrations in the Clinton River at site 15, caused by combined-sewer overflows and urban runoff in northwestern Detroit (Michigan Department of Natural Resources, 1986, p. 19), have been a continual problem. Substantial population increases in the Clinton River basin upstream from Mount Clemens during the 1970's and 1980's contributed to the upward trend in dissolved-solids concentrations at site 15 . 


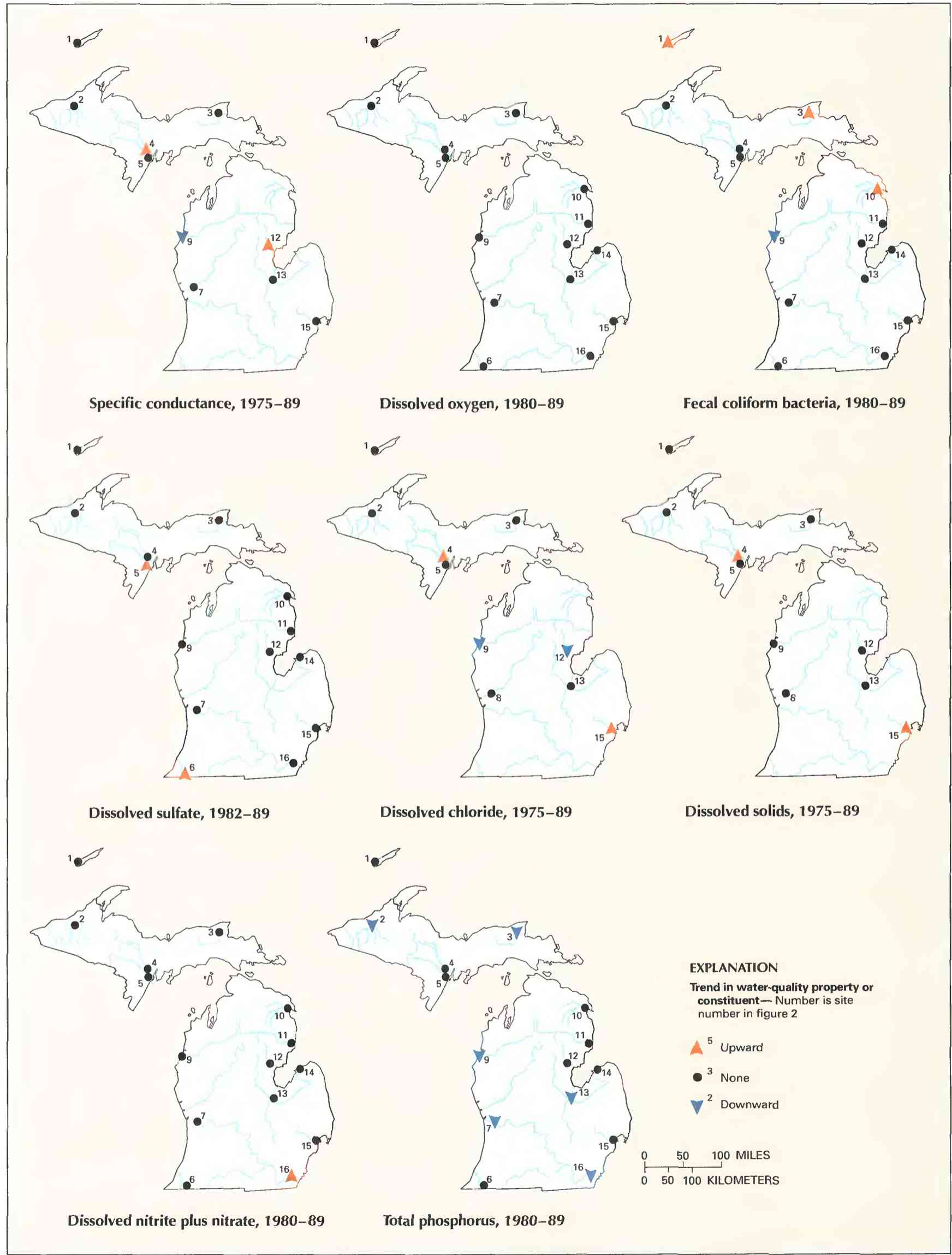

Figure 4. Trends in water quality of selected streams in Michigan, by water years. (Source: Data from U.S. Geological Survey files.) 


\section{DISSOLVED NITRITE PLUS NITRATE}

Nitrite and nitrate are oxidized forms of nitrogen that together normally constitute most of the dissolved nitrogen in well-aerated streams. Nitrite readily oxidizes to nitrate in natural waters; therefore, nitrate generally is by far the more abundant of the two (Hem, 1985 , p. 124). The increasing nitrite plus nitrate concentrations in the River Raisin at site 16 upstream from Monroe might have been the result of increasing nitrogen-fertilizer use in the basin. Nitrogenfertilizer use increased in Michigan between 1980 and 1985, the latest period for which data were available for this study (Alexander and Smith, 1990).

\section{TOTAL PHOSPHORUS}

The total phosphorus concentration of a water sample is a measure of the concentration of all forms of phosphorus present in the sample, dissolved and particulate. Human activities (table 1) can be important sources of phosphorus in streams.

The downward trends in phosphorus concentrations at six monitoring stations correspond closely to improved wastewater treatment (Michigan Department of Natural Resources, 1990a, p. 12). The 1977 ban on the use of phosphorus detergents (Michigan Department of Natural Resources, 1988, p. 29) also contributed to decreases in the early 1980's. Downward trends in primarily agricultural basins might also have been the result of a decreased use of phosphorus fertilizers in Michigan between 1980 and 1985, the latest period for which data were available for this study (Alexander and Smith, 1990).

\section{WATER-QUALITY MANAGEMENT}

The Michigan Department of Natural Resources is responsible for protecting the quality of Michigan's environment and managing the State's natural resources. The Department's Surface Water Quality Division is responsible for protecting stream water quality in the State. The principal regulatory tool to control discharge of pollutants to stream water is the National Pollutant Discharge Elimination System permit program. The program currently administers about 1,400 discharge permits (Michigan Department of Natural Resources, 1990a, p. 218).

The Surface Water Quality Division prepares a biennial waterquality assessment report mandated by section $305(\mathrm{~b})$ of the Federal Clean Water Act that is submitted to the EPA and the U.S. Congress (Michigan Department of Natural Resources, 1990a). The Division also monitors chemical and biological quality of the State's surface water, sets water-quality standards and waste-load allocations, prepares discharge permits, monitors industrial and municipal discharge-permit compliance, administers a nonpoint-source pollution program, and supports enforcement actions and water-quality planning (Michigan Department of Natural Resources, 1990a, p. 7).

The Water Resources Commission Act (Michigan Public Act 245 of 1929, as amended in November 1986) is Michigan's basic water-pollution control legislation. This legislation established the Michigan Water Resources Commission, which is authorized to promulgate water-quality standards for Michigan waters. The purposes of the water-quality standards are to establish water-quality requirements applicable to the Great Lakes, their connecting waterways, and all other surface water in the State; to protect public health and welfare; to enhance and maintain the quality of water; to protect the State's natural resources; and to serve the purposes of the Michigan Water Resource Commission Act, the Federal Clean Water Act, and the United States-Canada Great Lakes Water Quality Agreement (Michigan Department of Natural Resources, 1990a, p. 17).

In 1986, updated water-quality standards were promulgated that mandated improved water quality in the State. Some of Michigan's related water-quality-management goals are increased dis- solved oxygen in rivers, control of nonpoint sources of pollution, implementation of watershed plans that transcend political boundaries, and protection of high-quality waters (Michigan Department of Natural Resources, 1988, p. xiii-xiv). The surface water monitored by the Michigan Department of Natural Resources has included rivers tributary to the Great Lakes; natural, urban, and degraded areas; and drinking-water intakes. Because of changing program priorities and budget reductions, the number of stations sampled decreased from 599 in 1973 to 64 at the beginning of 1990 (Michigan Department of Natural Resources, 1990a, p. 245). However, during 1990, the number of monitoring stations increased to about 100 (G.W. Goudy, Michigan Department of Natural Resources, written commun., July 1991).

The protection of waters common to the United States and Canada is the charge of the International Joint Commission. Established jointly by the United States and Canada (Boundary Waters Treaty of 1909), the Commission addresses the rights and responsibilities of both countries in issues affecting the Great Lakes and connecting channels. Numerous task forces, boards, committees, and subcommittees perform the duties of the Commission. The Great Lakes Regional Office of the International Joint Commission is in Windsor, Ontario.

\section{SELECTED REFERENCES}

Alexander, R.B., and Smith, R.A., 1990, County-level estimates of nitrogen and phosphorus fertilizer use in the United States, 1945 to 1985: U.S. Geological Survey Open-File Report 90-130, 12 p.

Anderson, J.R., 1967, Major land uses in the United States, in U.S. Geological Survey, 1970, National atlas of the United States of America: Washington, D.C., U.S. Geological Survey, p. 158-159.

Britton, L.J., and Greeson, P.E., eds., 1987, Methods for collection and analysis of aquatic biological and microbiological samples: U.S. Geological Survey Techniques of Water-Resources Investigations, book 5, chap. A4, $363 \mathrm{p}$.

Fenneman, N.M., 1946, Physical divisions of the United States: Washington, D.C., U.S. Geological Survey special map, scale 1:7,000,000.

Fishman, M.J., and Friedman, L.C., eds., 1989, Methods for the determination of inorganic substances in water and fluvial sediments: U.S. Geological Survey Techniques of Water-Resources Investigations, book 5, chap. Al, 545 p.

Great Lakes Basin Commission, 1975. Great Lakes basin framework study, Appendix 7, Water quality: Water Quality Work Group, Public Information Office, Great Lakes Commission, Ann Arbor, Mich., 228 p.

Hem, J.D., 1985, Study and interpretation of the chemical characteristics of natural water (3d ed.): U.S. Geological Survey Water-Supply Paper 2254, $263 \mathrm{p}$.

Hirsch, R.M., Slack, J.R., and Smith, R.A., 1982, Techniques of trend analysis for monthly water quality data: Water Resources Research, v. 18, no. 1 , p. 107-121.

Lanfear, K.J., and Alexander, R.B., 1990, Methodology to derive water-quality trends for use by the National Water Summary Program of the U.S. Geological Survey: U.S. Geological Survey Open-File Report 90-359, $10 \mathrm{p}$.

Michigan Department of Natural Resources, 1986, Water quality and pollution control in Michigan, the 1986 305(b) report: Lansing, Michigan Department of Natural Resources, Surface Water Quality Division, $132 \mathrm{p}$.

1988, Water quality and pollution control in Michigan, the 1988 305(b) report: Lansing, Michigan Department of Natural Resources, Surface Water Quality Division, 234 p.

$1990 \mathrm{a}$, Water quality and pollution control in Michigan, the 1990 305(b) report: Lansing, Michigan Department of Natural Resources, Surface Water Quality Division, 274 p.

$1990 \mathrm{~b}$, Winds of change-A special report: Michigan Natural Resources Magazine, v. 59, no. 4, p. 19-34.

Rheaume, S.J., 1991, Hydrologic provinces of Michigan: U.S. Geological Survey Water-Resources Investigations Report 91-4120, 73 p.

Solley, W.B., Merk, C.F., and Pierce, R.R., 1988, Estimated use of water in the United States in 1985: U.S. Geological Survey Circular 1004, 82 p. 
Thelin, G.P., and Pike, R.J., 1990, Digital shaded relief map of the conterminous United States: Menlo Park, Calif., U.S. Geological Survey digital image processing, scale 1:3,500,000.

U.S. Geological Survey, 1986, National water summary 1985-Hydrologic events and surface-water resources: U.S. Geological Survey Water-Supply Paper 2300, $506 \mathrm{p}$.
1990, National water summary 1987-Hydrologic events and water supply and use: U.S. Geological Survey Water-Supply Paper 2350, 553 p. Ward, J.R., and Harr, C.A., eds., 1990, Methods for collection and processing of surface-water and bed-material samples for physical and chemical analyses: U.S. Geological Survey Open-File Report 90-140, 71 p. 
334 National Water Summary 1990-91-Stream Water Quality: STATE SUMMARIES

Prepared by Stephen P. Blumer

FOR ADDITIONAL INFORMATION: District Chief, U.S. Geological Survey, 6520 Mercantile Way, Suite 5, Lansing, MI 48911 


\section{MinNESOTA Stream Water Quality}

Known widely as the Land of 10,000 Lakes, Minnesota actually has 12,034 lakes and about 90.000 miles of rivers and streams (Minnesota Pollution Control Agency, 1990). Although water is abundant in Minnesota, there is little surplus; average annual runoff ranges from about 2 inches in the west to about 14 inches in the northeast (U.S. Geological Survey, 1986, p. 287).

The quality of Minnesota's surface water can be substantially affected by land use. Land use in the State (fig. $1 A$ ) ranges from dense forests in the northeast to heavily tilled cropland throughout the western and southern parts of the State. An intervening transition zone has mixed cropland, woodland, and pasture. Land use generally is affected by physiography, from thin-soiled, crystalline bedrock of the Superior Upland (fig. $1 B$ ) to the rich prairie soils in the till and outwash plains of the Central Lowland.

The population (fig. 1C) of Minnesota, 4.4 million in 1990, is 7.3 percent greater than that in 1980 (U.S. Bureau of the Census 1990 decennial census files). Substantial increases have occurred in and near the Minneapolis-St. Paul metropolitan area, which uses more surface water than any other area of the State. Both cities obtain most of their water for municipal supply from the Mississippi River and discharge waste to the Mississippi and Minnesota Rivers.

\section{WATER-QUALITY MONITORING}

Water-quality data obtained from analyses of water samples collected at monitoring stations are stored in the U.S. Geological Survey's (USGS) National Water Information System and the U.S. Environmental Protection Agency's (EPA) national data base known as STORET. Water-quality and streamflow data are reported by water year-the 12 months from October 1 through September 30. A water year is identified by the calendar year in which it ends. For example, water year 1991 comprises October 1, 1990, through September 30 . 1991.

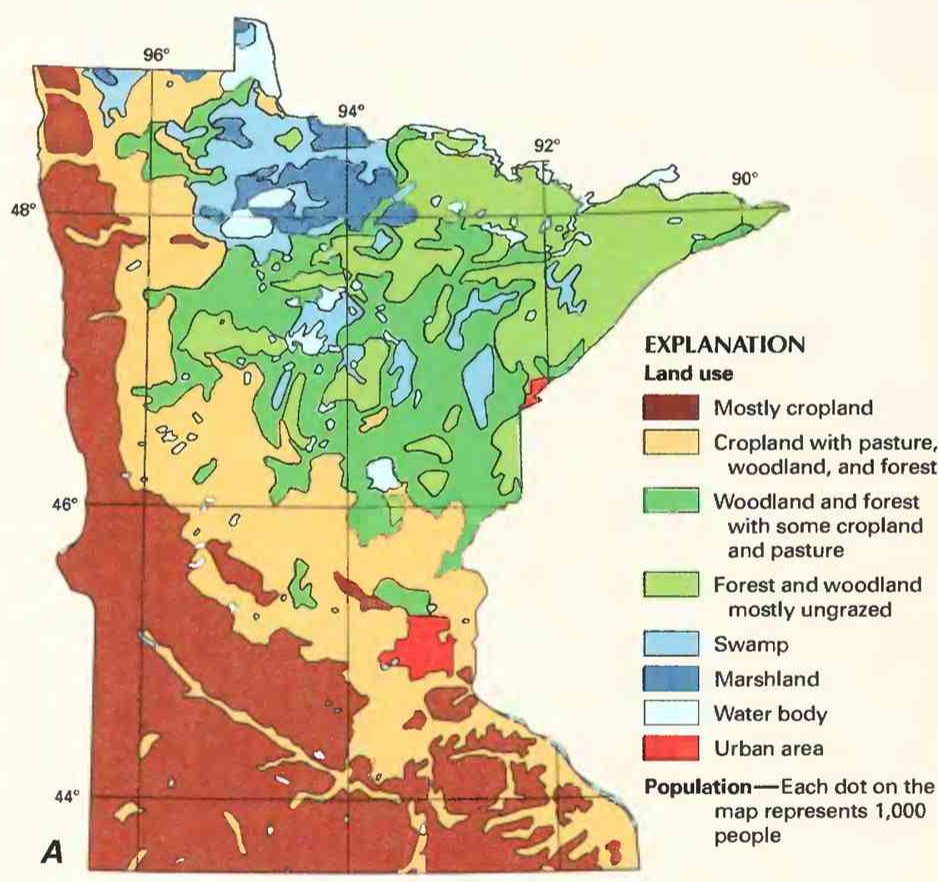

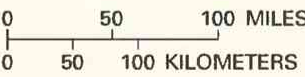

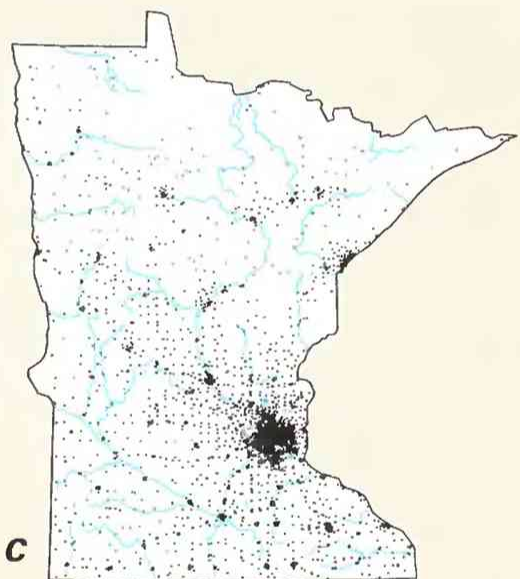

POPULATION-1990

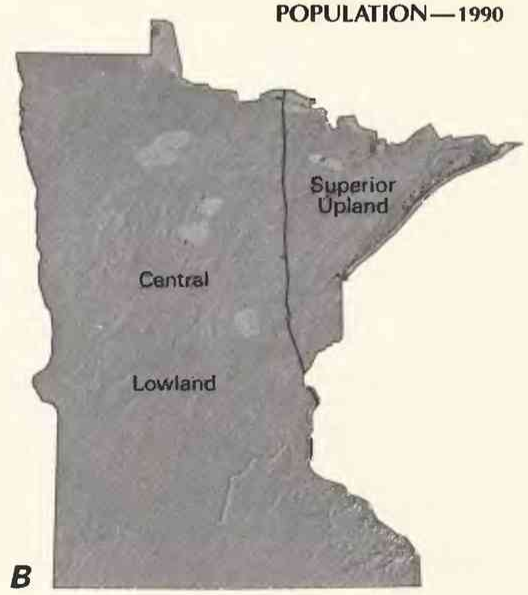

PHYSIOGRAPHIC DIVISIONS

Figure 1. Land use, physiography, and population in Minnesota. A, Major land uses. B, Physiographic divisions. C, Population distribution in 1990. (Sources: A, Major land uses modified from Anderson, 1967. B. Physiographic divisions from Fenneman, 1946; landforms from Thelin and Pike, 1990. C. Data from U.S. Bureau of the Census 1990 decennial census files.) 
Surface-water samples are collected throughout Minnesota by Federal, State, and local agencies. The data used in this summary of Minnesota's stream water quality were obtained from water samples collected at 10 monitoring stations at which data collection is systematic and continuing (fig. 2). Analyses of water samples collected at these stations are the basis for the discussion and graphic summary (fig. 3) of stream water-quality conditions during water years 198789 and for the discussion and graphic summary (fig. 4) of stream water-quality trends. Water samples were collected and analyzed by using standard methods approved by the USGS (Britton and Greeson, 1987; Fishman and Friedman, 1989; Ward and Harr, 1990) or by using equivalent methods. If a method of sample collection or analysis changed over time, data from an analysis were included in the evaluation of recent stream water quality or of stream water-quality trends only if the change in method did not affect the comparability of the data.

\section{WATER-QUALITY CONDITIONS}

The following discussion of stream water quality in Minnesota is organized by river basin (fig. 3). Where physiographic and land-use characteristics in different basins are similar, the discussion of those basins is combined. Graphs in figure 3 summarize certain aspects of stream water quality in the basins for water years 198789. The graphs show frequency distributions of data values that represent measurements of selected physical properties of stream water

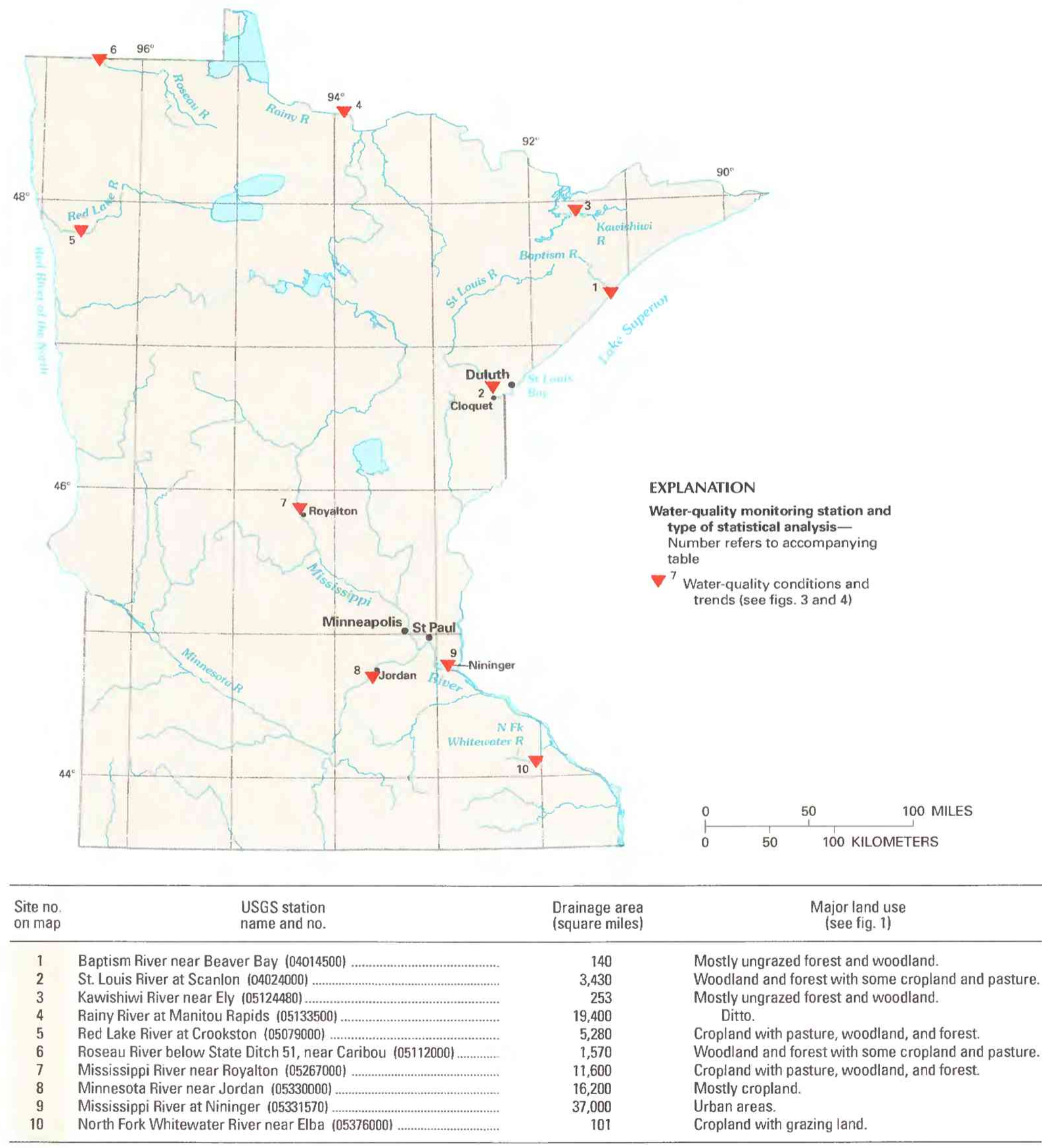

Figure 2. Selected water-quality monitoring stations, type of statistical analysis, and geographic features in Minnesota. (Sources: Major land uses modified from Anderson, 1967; other data from U.S. Geological Survey files.) 
and concentrations of selected constituents in stream water. These properties and constituents are specific conductance, fecal coliform bacteria, alkalinity (as calcium carbonate), dissolved sulfate, dissolved chloride, dissolved solids, dissolved nitrite plus nitrate (as nitrogen), and suspended sediment. The data are reported in microsiemens per centimeter at 25 degrees Celsius, colonies per 100 milliliters, and milligrams per liter ( $\mathrm{mg} / \mathrm{L})$. Sources and environmental significance of each property and constituent are described in table 1 .

Water quality at each monitoring station is the result of geological, chemical, biological, and hydrologic processes that occur over a large area. Water-quality problems that affect aquatic life or public health only locally are not fully represented in this summary.

\section{BAPTISM, ST. LOUIS, KAWISHIWI, AND RAINY RIVERS}

The Baptism, St. Louis, Kawishiwi, and Rainy Rivers drain part of northeastern Minnesota. This area of the State has crystalline
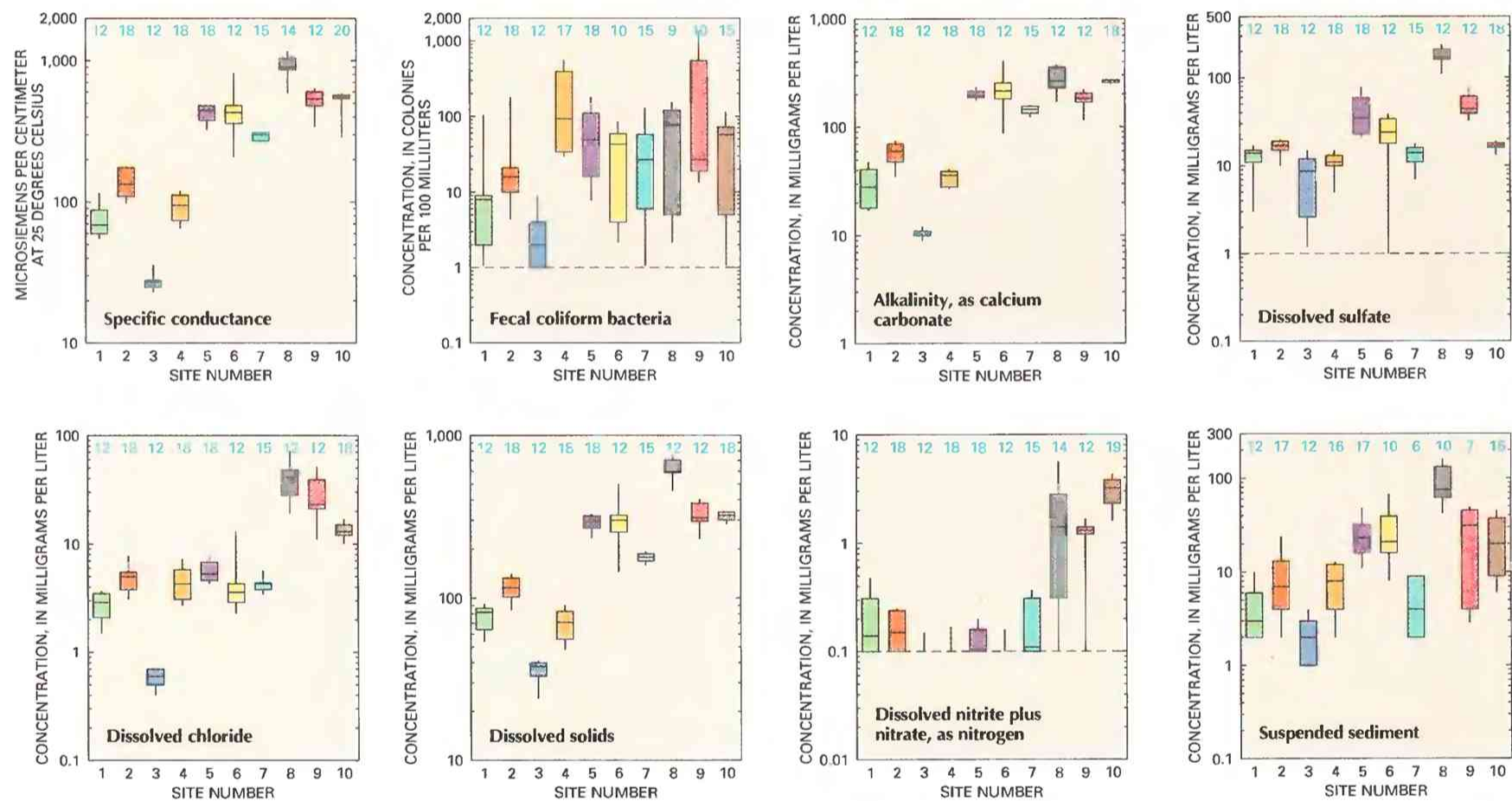

Alkalinity values of less than $80 \mathrm{mg} / \mathrm{L}$ and dissolved-solids concentrations of less than $150 \mathrm{mg} / \mathrm{L}$ at sites $1-4$ (fig. 3) were a result of low solubility of the soils and bedrock that underlie the basins. The weakly buffered surface waters in this part of the State make them susceptible to the effects of acid precipitation. Sulfate concentrations, however, were not excessive; median concentrations at all four sites were less than $20 \mathrm{mg} / \mathrm{L}$. Nitrite plus nitrate, chloride, and suspendedsediment concentrations at sites $1-4$ also were among the lowest in the State and reflect the near-pristine character of streams in these basins.

Urban centers and wood-processing facilities upstream from sites 2 and 4 have caused increased concentrations of several constituents in the St. Louis and Rainy Rivers. The Minnesota Pollution Control Agency (1990) considers the State-designated beneficial uses of these rivers to be impaired by point-source discharges. Specific-conductance, fecal coliform bacteria, alkalinity, sulfate, chloride, dissolved-solids, and suspended-sediment values were
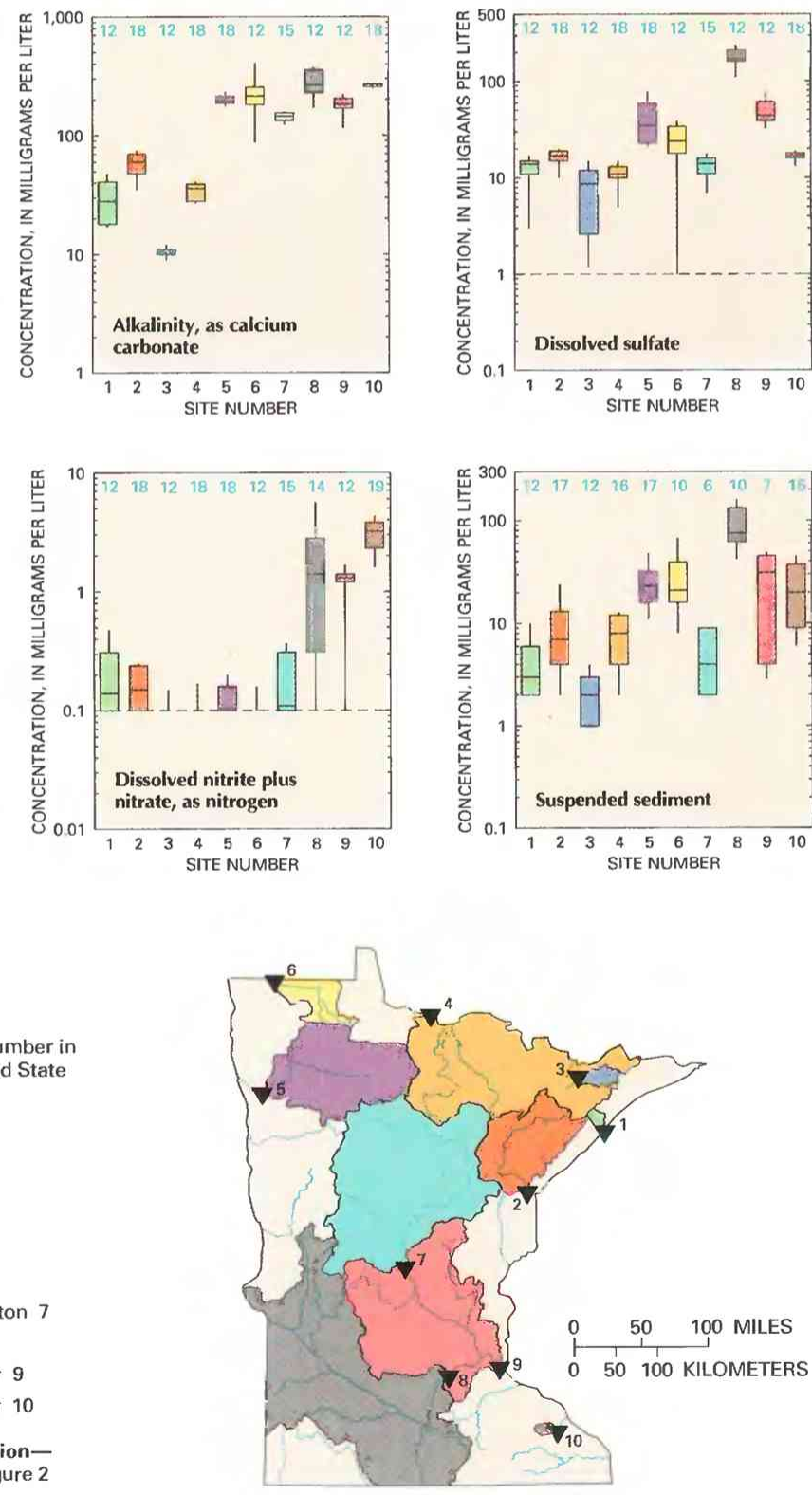

\section{EXPLANATION}

Water-quality conditions in selected
drainage basins
Number of analyses
Percentile-Percentage of analyses
equal to or less than indicated
values
-90th
-75 th
-50 th-Median
- 25th
10th
reporting limit for analytical
method used. Data below limit
line not shown

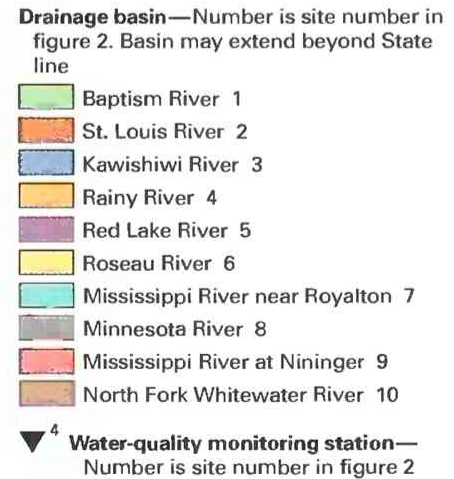

Figure 3. Water quality of selected streams in Minnesota, water years 1987-89. (Source: Data from U.S. Geological Survey files.) 
Table 1. Sources and environmental significance of selected water-quality properties and constituents [Source: Compiled by the U.S. Geological Survey, Office of Water Quality]

\begin{tabular}{|c|c|c|}
\hline Property or constituent & Common sources & Environmental significance \\
\hline $\begin{array}{l}\text { Specific conductance } \\
\text { (property) }\end{array}$ & $\begin{array}{l}\text { A measure of the electrical conductivity of water; var- } \\
\text { ies with the quantity of dissolved solids and is } \\
\text { used to approximate the dissolved-solids content. }\end{array}$ & $\begin{array}{l}\text { Dissolved solids can cause water to be unsuitable for } \\
\text { public supply, agriculture, and industry; can harm } \\
\text { aquatic organisms. }\end{array}$ \\
\hline Dissolved oxygen ........................ & $\begin{array}{l}\text { Introduced from the atmosphere; also a byproduct of } \\
\text { aquatic plants. }\end{array}$ & $\begin{array}{l}\text { Necessary for aquatic life; deficiency can result from } \\
\text { assimilation of organic wastes or rapid growth } \\
\text { and decay of algae. }\end{array}$ \\
\hline Fecal coliform bacteria ................ & $\begin{array}{l}\text { Sources include effluent from sewage-treatment } \\
\text { plants and runoff from pastures, feedlots, and ur- } \\
\text { ban areas. }\end{array}$ & $\begin{array}{l}\text { Presence indicates contamination of water by wastes } \\
\text { from humans and other warm-blooded animals. }\end{array}$ \\
\hline Alkalinity (property) ........................ & $\begin{array}{l}\text { A measure of the quantity of acid-neutralizing sub- } \\
\text { stances; can be affected by geologic setting, in- } \\
\text { dustrial wastewater discharge, waste gases, and } \\
\text { runoff from surface mining. }\end{array}$ & $\begin{array}{l}\text { Sufficiently alkaline water can be unsuitable for some } \\
\text { agricultural and industrial uses. }\end{array}$ \\
\hline Sulfate & $\begin{array}{l}\text { Occurs in some rocks; also in mine runoff, industrial } \\
\text { wastewater discharge, and atmospheric deposi- } \\
\text { tion. }\end{array}$ & $\begin{array}{l}\text { Concentrations exceeding a natural, background } \\
\text { level indicate contamination from human activity; } \\
\text { in sufficient quantity, can cause water to be } \\
\text { unsuitable for public supply; can harm aquatic } \\
\text { organisms. }\end{array}$ \\
\hline Chloride & $\begin{array}{l}\text { Occurs in some rocks and ground-water discharge; } \\
\text { also in road deicers, industrial and urban waste- } \\
\text { water discharge, and atmospheric deposition. }\end{array}$ & $\begin{array}{l}\text { Concentrations exceeding a natural, background level } \\
\text { can cause water to be unsuitable for public supply, } \\
\text { agriculture, and industry; can harm aquatic or- } \\
\text { ganisms. }\end{array}$ \\
\hline Dissolved solids ........................... & $\begin{array}{l}\text { A result of rock weathering; also in agricultural runoff } \\
\text { and industrial discharge. }\end{array}$ & $\begin{array}{l}\text { In sufficient quantity, can cause water to be unsuitable } \\
\text { for public supply, agriculture, and industry; can } \\
\text { harm aquatic organisms. }\end{array}$ \\
\hline 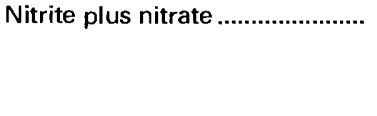 & $\begin{array}{l}\text { Nonpoint sources are agricultural and urban runoff; } \\
\text { a major point source is wastewater discharge. }\end{array}$ & $\begin{array}{l}\text { Plant nutrient that, in sufficient quantity, can cause } \\
\text { algal blooms and excessive growth of higher } \\
\text { aquatic plants in bodies of water; can cause water } \\
\text { to be unsuitable for public supply. }\end{array}$ \\
\hline 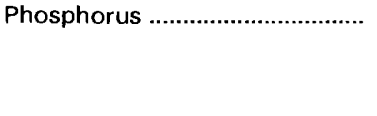 & $\begin{array}{l}\text { Occurs in some rocks and sediments; also in runoff } \\
\text { and seepage from phosphate-rock mines, agri- } \\
\text { cultural and urban runoff, and industrial and } \\
\text { municipal wastewater discharge. }\end{array}$ & $\begin{array}{l}\text { Plant nutrient that, in sufficient quantity, can cause } \\
\text { algal blooms and excessive growth of higher } \\
\text { aquatic plants in bodies of water. }\end{array}$ \\
\hline Suspended sediment ................... & $\begin{array}{l}\text { A result of rock erosion; also induced by disturbances } \\
\text { of land cover due to fires, floods, and human } \\
\text { activities such as mining, logging, construction, } \\
\text { and agriculture. }\end{array}$ & $\begin{array}{l}\text { Can be detrimental to aquatic organisms; can fill res- } \\
\text { ervoirs and impair recreational use of water. }\end{array}$ \\
\hline
\end{tabular}

slightly higher at sites 2 and 4 than in the Baptism River at site 1 and the Kawishiwi River at site 3.

\section{RED LAKE AND ROSEAU RIVERS}

The Red Lake and Roseau Rivers drain into the Red River of the North in northwestern Minnesota. Glacial and lacustrine deposits are 200-300 feet thick in this part of the State. From west to east, sandy soils rich in clay and silt give way to poorly drained organic soils and peat near the basin headwaters. Population in the basins is sparse, and land use is predominantly agricultural. The high specificconductance, alkalinity, sulfate, and dissolved-solids values at sites 5 and 6 relative to those at most other monitoring stations (fig. 3) are mainly a result of the geology of northwestern Minnesota (Maclay and others, 1967). High sulfate concentrations, which constituted a large portion of the dissolved-solids concentrations, probably resulted from discharge of ground water having a high concentration of calcium sulfate (Maclay and others, 1967). Although runoff from tilled fields causes higher suspended-sediment concentrations in streams of northwestern Minnesota than in those of the northeastern part of the State, low nitrite plus nitrate concentrations at sites 5 and 6 indicate that runoff of agricultural chemicals currently is not a problem.

\section{MISSISSIPPI, MINNESOTA, AND WHITEWATER RIVERS}

The Mississippi, Minnesota, and Whitewater Rivers drain about two-thirds of the State. Land cover in the basins ranges from dense forest in the north to intensively cultivated soils in the south and west. Runoff from agricultural areas along the Minnesota River, which flows into the Mississippi River near Minneapolis and St. Paul, is of particular concern because of contamination from sediment and agricultural chemicals.

Because of mixing, constituent concentrations at site 9 on the Mississippi River at Nininger generally were intermediate to those at site 7 on the Mississippi River at Royalton upstream from site 9 and at site 8 on the Minnesota River near Jordan (fig. 3). The Minnesota River joins the Mississippi River upstream from site 9. During 1987-89, median dissolved-solids concentrations in these basins ranged from about $200 \mathrm{mg} / \mathrm{L}$ in the Mississippi River at site 7 to nearly $600 \mathrm{mg} / \mathrm{L}$ in the Minnesota River at site 8 . Concentrations of sulfate and chloride, major components of dissolved solids, also were highest in the Minnesota River basin. High specific-conductance, alkalinity, and dissolved-solids values in the Minnesota River probably are caused by highly mineralized ground water. Ground water near the headwaters has high concentrations of sulfate and chloride (Cotter and Bidwell, 1968). Substantially greater runoff in the Mississippi River basin probably causes the water at site 7 to be more dilute. Median concentrations of suspended sediment in the drainage basins of the Mississippi and Minnesota Rivers ranged from 4 $\mathrm{mg} / \mathrm{L}$ at site 7 in the Mississippi River headwaters to $75 \mathrm{mg} / \mathrm{L}$ in the Minnesota River at site 8.

Alkalinity values had similar distributions at sites 7-10. However, the range was least in the North Fork Whitewater River at site 10 , where discharge of water from carbonate rocks is the predominant source of flow.

Differences in agricultural and urban development in the basins caused nitrite plus nitrate concentrations to differ greatly among them. The headwaters of the Mississippi River drain an area that has 
little agriculture and had low nitrite plus nitrate concentrations during water years 1987-89; only about one-half of the water samples at site 7 had detectable levels. Areas that are more agricultural, such as the Minnesota and Whitewater River basins (sites 8 and 10), had higher concentrations (greater than $4 \mathrm{mg} / \mathrm{L}$ ). However, no concentrations exceeded the $10-\mathrm{mg} / \mathrm{L}$ limit for untreated drinking-water supplies (Minnesota Pollution Control Agency, 1988).

\section{WATER-QUALITY TRENDS}

Trend analysis is a statistical procedure used to detect changes in stream water quality at a monitoring station over time. For this report, water-quality data from 10 monitoring stations (fig. 2) were analyzed for trends by using the seasonal Kendall test (Hirsch and others, 1982), a method used extensively by the USGS. The graph (shown below) of the total-phosphorus concentration in the St. Louis River at site 2 illustrates the trend inferred from the concentration data and demonstrates the variation in water quality that is common in streams.

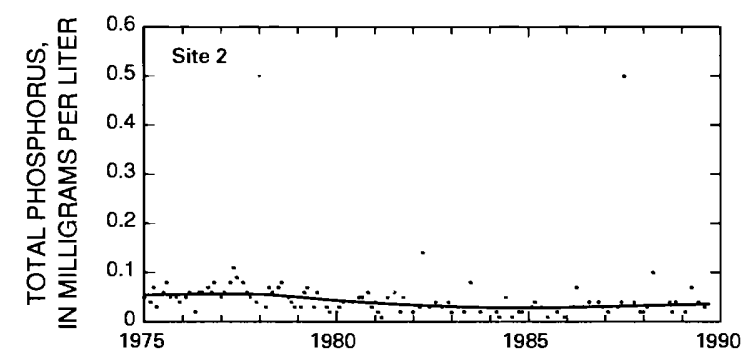

When possible, constituent-concentration data were adjusted for changes in streamflow to preclude identifying a trend in concentration that was caused only by a trend in streamflow. The data were not adjusted when (1) more than 10 percent of the samples had concentrations lower than the minimum reporting limit for the analytical method used or (2) streamflow was controlled substantially by human activities. When the concentration data could not be adjusted for streamflow, trends were determined directly from the concentration data.

Statewide trends in concentrations of selected stream-water constituents are shown on maps in figure 4. On each map, a trend is indicated at a monitoring station only if the data from that station were suitable for use in the trend analysis. For more information on the suitability criteria and on the trend-analysis procedure used for this report, see Lanfear and Alexander (1990).

The data for dissolved oxygen and total phosphorus (as phosphorus) contain trends that are noteworthy owing to the location of the monitoring stations at which the trends were detected. Those constituents were substituted for specific conductance and alkalinity trends in the following discussion and graphic presentation.

\section{DISSOLVED OXYGEN}

The dissolved-oxygen concentration in a stream is controlled by several factors, including water temperature, air temperature and pressure, hydraulic characteristics of the stream, photosynthetic or respiratory activity of stream biota, and the quantity of organic material present. A trend in dissolved-oxygen concentrations commonly is directly or indirectly the result of human activities. Generally, an upward trend in dissolved-oxygen concentrations indicates improving stream water-quality conditions and a downward trend indicates deteriorating conditions.

Dissolved-oxygen concentrations trended upward during 1975-89 in the Mississippi River at site 9 and in the North Fork Whitewater River at site 10 (fig. 4). The increasing dissolved-oxygen concentration at site 9 probably resulted from reduced input of oxygen-demanding substances from the Minneapolis-St. Paul metropolitan area because of improved sewage treatment and better control of nonpoint urban runoff. The Minnesota Pollution Control Agency (1990) classified the designated uses of the Mississippi River in the vicinity of site 9 as impaired because of sewage effluent. The upward trend in the North Fork Whitewater River at site 10 could have been due to decreased nonpoint inputs of oxygen-demanding substances; the major reduction probably was in agricultural runoff.

\section{FECAL COLIFORM BACTERIA}

Fecal coliform bacteria are used as indicators of fecal contamination from humans and other warm-blooded animals. The presence of these bacteria in a stream can signal the presence of pathogenic viruses and bacteria that also are of fecal origin.

Fecal coliform bacteria concentrations had a downward trend in the St. Louis River at site 2 (fig. 4). Diversion of sewage effluent to a treatment facility near Duluth probably caused the trend.

\section{DISSOLVED SULFATE}

The major natural sources of sulfate in streams are rock weathering, volcanoes, and biochemical processes (Hem, 1985, p. 113). Human activities such as mining, waste discharge, and fossil-fuel combustion also can be important sources. Sulfate is a constituent of acid precipitation and has been of particular concern because of its potential effect on lakes and streams in northeastern Minnesota. These waters are in drainage basins that have thin soils overlying crystalline bedrock and consequently are weakly buffered and susceptible to degradation from acid precipitation.

During 1975-89, sulfate concentrations in northeastern Minnesota streams for which sufficient data were available for trend analysis had no significant change, nor did those in the southeastern part of the State (fig. 4). However, upward trends in sulfate concentrations were detected in the Red Lake River at site 5, the Roseau River at site 6, and the Mississippi River at site 7 in the northwestern and central parts of the State. These trends probably were the result of human activity and could have resulted from atmospheric deposition. However, the streams are well buffered and can resist the changes in $\mathrm{pH}$ associated with high rates of acidic atmospheric deposition.

\section{DISSOLVED CHLORIDE}

Chloride is present in all natural waters but usually in low concentrations (Hem, 1985, p. 118). Except in streams that receive ground-water discharge high in chloride, concentrations of greater than a few milligrams per liter generally are the result of human activities (table 1). High chloride concentrations in Minnesota streams usually result from the application of salt for road deicing or runoff from storage areas.

Upward trends in chloride concentrations were detected in the Minnesota River at site 8 and in the North Fork Whitewater River at site 10 (fig. 4). The increasing chloride concentrations probably indicates that more road salt or chloride from other sources related to human activities has entered the two streams. Increased wastewater discharges associated with population increases near the headwaters of the Whitewater River could have contributed to the increase in chloride concentration in the river.

The decreasing chloride concentration in the St. Louis River at site 2 likely was the result of diversion of sewage to a treatment plant near Duluth and the closure of wood-pulp-processing plants in Cloquet, upstream from site 2. Chlorine-containing compounds often are used as bleaching agents during paper manufacture. The decreasing chloride concentration in the Kawishiwi River at site $\mathbf{3}$ is 
difficult to explain because that stream is not substantially affected by human activities. Although most of Minnesota experienced drought during the late 1980's (U.S. Geological Survey, 1991, p. 345-
352), the northeastern part of the State had greater than average precipitation, and the resulting runoff might have diluted chloride concentrations in the Kawishiwi River.

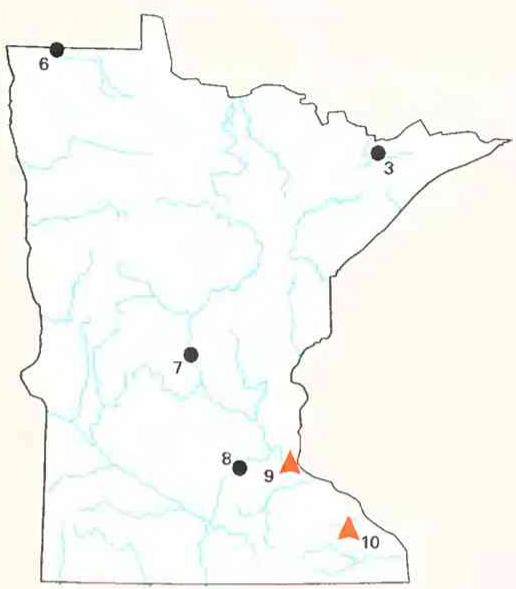

Dissolved oxygen, 1975-89

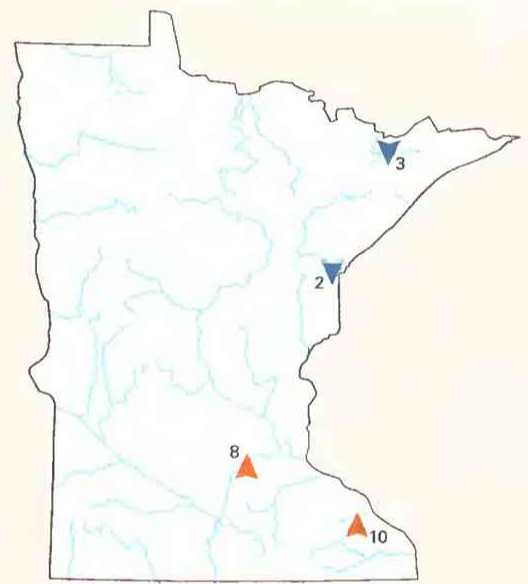

Dissolved chloride, 1970-89

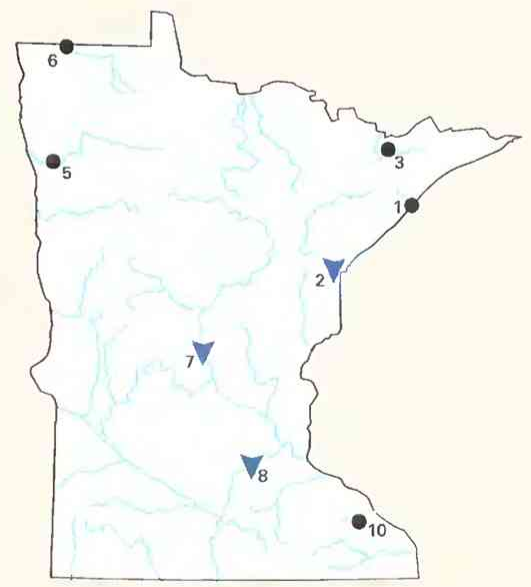

Total phosphorus, 1975-89

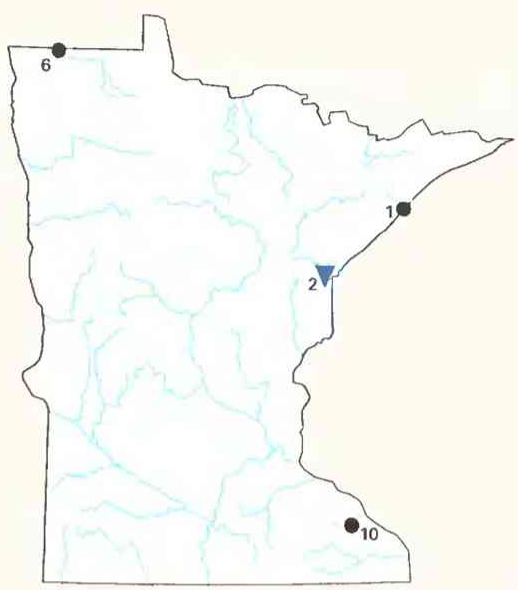

Fecal coliform bacteria, 1975-89

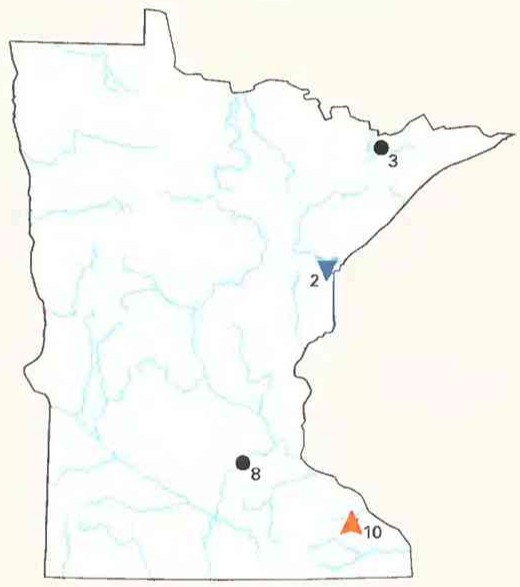

Dissolved solids, 1970-89

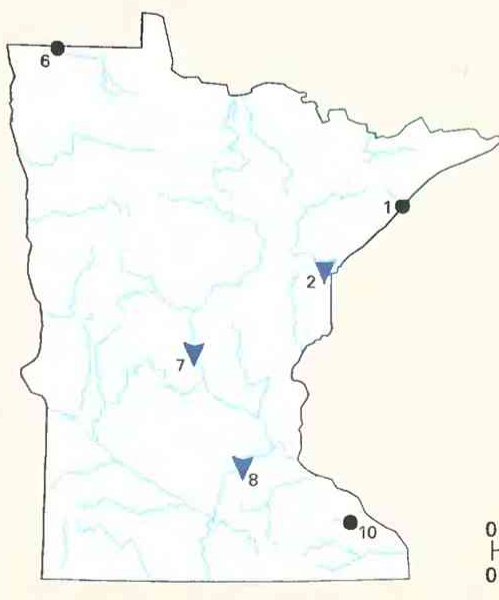

Suspended sediment, 1975-89

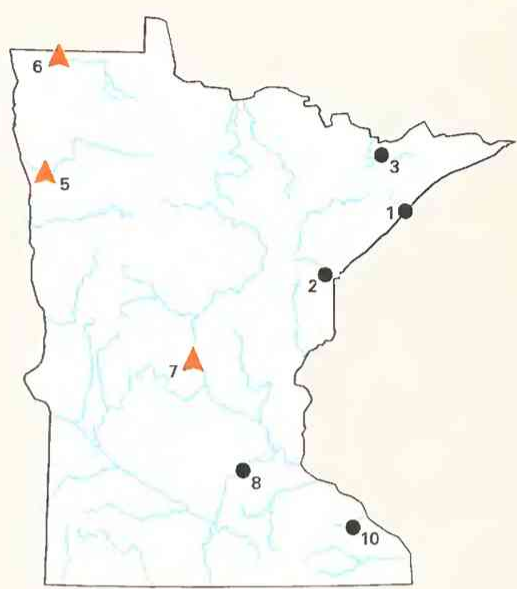

Dissolved sulfate, $1975-89$

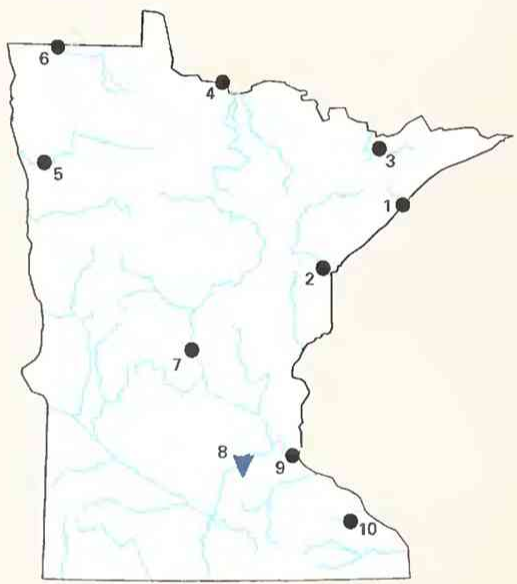

Dissolved nitrite plus nitrate, 1980-89

\section{EXPLANATION}

Trend in water-quality constituentNumber is site number in figure 2
${ }^{8}$ Upward
${ }^{3}$ None
$\nabla^{2}$ Downward

Figure 4. Trends in water quality of selected streams in Minnesota, by water years. (Source: Data from U.S. Geological Survey files.) 


\section{DISSOLVED SOLIDS}

Dissolved solids in stream water result primarily from rock weathering but also can be introduced as a byproduct of human activities (table 1). Concentrations generally are greatest in streams draining basins underlain by rocks and soils that contain easily dissolved minerals.

Dissolved-solids concentrations trended upward during 197089 in the North Fork Whitewater River at site 10 (fig. 4). Drought in the late 1980's might have resulted in less runoff and a dominance of ground-water input to streams. Ground water generally has higher concentrations of dissolved solids. The trend also might have been the result of increased urban development and agriculture in the Whitewater River basin.

The downward trend in the St. Louis River at site 2 probably resulted from the closing of wood-pulp-processing plants in Cloquet. The incorporation of Cloquet into the Western Lake Superior Sanitary District, which routes sewage to a treatment plant on St. Louis Bay near Duluth, also probably helps reduce quantities of dissolved solids in the river.

\section{DISSOLVED NITRITE PLUS NITRATE}

Nitrite and nitrate are oxidized forms of nitrogen that together normally constitute most of the dissolved nitrogen in well-aerated streams. Nitrite readily oxidizes to nitrate in natural waters; therefore, nitrate generally is by far the more abundant of the two (Hem, 1985, p. 124).

Nitrite plus nitrate concentrations had a downward trend in the Minnesota River at site 8 for $1980-89$ (fig. 4). The trend probably was the result of reduced runoff from agricultural areas during the drought of the late 1980's.

\section{TOTAL PHOSPHORUS}

The total-phosphorus concentration of a water sample is a measure of the concentration of all forms of phosphorus present in the sample, dissolved and particulate. Human activities (table 1) can be important sources of phosphorus in streams. Runoff from agricultural areas and effluent from sewage-treatment plants are the main sources of phosphorus contamination in Minnesota streams. Because much of the phosphorus from those sources is in particulate form, total-phosphorus concentrations were used in the trend analysis.

Decreasing inputs from wood-pulp-processing plants and the diversion of sewage to treatment plants near Duluth probably caused the downward phosphorus-concentration trend in the St. Louis River at site 2. The downward trends in the Mississippi River at site 7 and the Minnesota River at site 8 probably were the result of reduced inputs from sewage-treatment plants or from nonpoint sources such as runoff from agricultural areas.

\section{SUSPENDED SEDIMENT}

Suspended sediment is a product of erosion. The erosion can be either natural or the result of land-cover disturbances related to human activities (table 1). Suspended-sediment concentrations trended downward in the St. Louis River at site 2, the Mississippi River at site 7, and the Minnesota River at site 8, possibly as a result of improved controls on runoff from urban and agricultural sources.

\section{WATER-QUALITY MANAGEMENT}

The Minnesota Pollution Control Agency (MPCA) is responsible for maintaining the quality of streams in Minnesota. The MPCA implements the Federal Clean Water Act in the State and submits biennial water-quality-assessment reports (Minnesota Pollution Con- trol Agency, 1990) to the U.S. Congress and the EPA in compliance with section 305(b) of the act.

The MPCA works with EPA to maintain the quality of Minnesota's streams and issues permits to pollutant dischargers in accordance with the National Pollutant Discharge Elimination System on the basis of State water-quality goals. These permits allow the MPCA to monitor and restrict effluent discharges to streams. The MPCA also has authority to regulate nonpoint sources affecting the State's waters.

Data-collection and regulatory efforts of various Federal, State, and local units of government are coordinated with those of the MPCA. Agencies cooperating with the MPCA include the Minnesota Department of Natural Resources, the Minnesota Department of Health, the Minnesota Department of Agriculture, the USGS, the U.S. Fish and Wildlife Service, the U.S. Soil Conservation Service, the Metropolitan Council of the Twin Cities Area, the Metropolitan Waste Control Commission, and many soil and water conservation districts and watershed boards throughout Minnesota.

The MPCA manages the recently implemented Clean Water Partnership program. This program provides funding and technical assistance to local governments to study pollution problems and implement efforts to control sources.

With funding from the Legislative Commission on Minnesota Resources, the MPCA is the lead agency in the Minnesota River Assessment Program, a study that evaluates nonpoint-source pollution entering the Minnesota River. The USGS also is involved in the effort to identify affected reaches of the Minnesota River and the tributaries that are major carriers of nonpoint-source pollution to the river. This information will allow regulatory agencies to concentrate their resources on those drainage basins that have the greatest effect on water quality of the Minnesota River.

\section{SELECTED REFERENCES}

Anderson, J.R., 1967, Major land uses in the United States, in U.S. Geological Survey, 1970, National atlas of the United States of America: Washington, D.C., U.S. Geological Survey, p. 158-169.

Britton, L.J., and Greeson, P.E., eds., 1987, Methods for collection and analysis of aquatic biological and microbiological samples: U.S. Geological Survey Techniques of Water-Resources Investigations, book 5, chap. A4, $363 \mathrm{p}$.

Cotter, R.D., and Bidwell, L.E., 1968, Water resources of the Lac Qui Parle River watershed, southwestern Minnesota: U.S. Geological Survey Hydrologic Investigations Atlas HA-269, scale 1:250,000.

Fenneman, N.M., 1946, Physical divisions of the United States: Washington, D.C., U.S. Geological Survey special map, scale 1:7,000,000.

Fishman, M.J., and Friedman, L.C., eds., 1989, Methods for the determination of inorganic substances in water and fluvial sediments: U.S. Geological Survey Techniques of Water-Resources Investigations, book 5, chap. A1, 545 p.

Hem, J.D., 1985, Study and interpretation of the chemical characteristics of natural water (3d ed.): U.S. Geological Survey Water-Supply Paper 2254, $263 \mathrm{p}$.

Hirsch, R.M., Slack, J.R., and Smith, R.A., 1982, Techniques of trend analysis for monthly water-quality data: Water Resources Research, v. 18, no. 1, p. 107-121.

Lanfear, K.J., and Alexander, R.B., 1990, Methodology to derive water-quality trends for use by the National Water Summary Program of the U.S. Geological Survey: U.S. Geological Survey Open-File Report 90-359, $10 \mathrm{p}$.

Maclay, R.W., Winter, T.C., and Pike, G.M., 1967, Water resources of the Two Rivers watershed, northwestern Minnesota: U.S. Geological Survey Hydrolgic Investigations Atlas HA-237, scale 1:250,000.

Minnesota Pollution Control Agency, 1988, Standards for the protection of the quality and purity of the waters of the State: Minnesota Pollution Control Agency, Minnesota Rules Chapter 7050, 58 p.

1990 , Minnesota water quality $1988-89$, The 1990 report to the Congress of the United States: Minnesota Pollution Control Agency, 66 p. 
Thelin, G.P., and Pike, R.J., 1990, Digital shaded relief map of the conterminous United States: Menlo Park, Calif., U.S. Geological Survey digital image processing, scale 1:3,500,000.

U.S. Geological Survey, 1986, National water summary 1985--Hydrologic events and surface-water resources: U.S. Geological Survey WaterSupply Paper 2300,506 p.
1991, National water summary 1988-89-Hydrologic events and floods and droughts: U.S. Geological Survey Water-Supply Paper 2375, $591 \mathrm{p}$.

Ward, J.R., and Harr, C.A., eds., 1990, Methods for collection and processing of surface-water and bed-material samples for physical and chemical analyses: U.S. Geological Survey Open-File Report 90-140, 71 p.

Prepared by Lan $\mathrm{H}$. Tornes

FOR ADDITIONAL INFORMATION: District Chief, U.S. Geological Survey, 702 Post Office Building, St. Paul, MN 55101 


\section{MISSISSIPPI \\ Stream Water Quality}

Abundant precipitation (about 56 inches annually) endows Mississippi with a large supply of stream water. Practically all the State's streams fully or partially support uses designated by the State for purposes of water-pollution control (Mississippi Department of Environmental Quality, 1990a, p. 2). Maintenance of fish and other aquatic-life populations in streams is a priority in Mississippi, as indicated by the fact that almost 93 percent of the State's approximately 15,622 miles of streams and rivers have a minimum designated use of Fish and Wildlife (Mississippi Department of Environmental Quality, 1990a, table II-1). The remaining 7 percent are designated Recreation, Domestic Water Supply, and Ephemeral.

Land use (fig. $1 A$ ) is determined in part by physiography (fig. $1 B$ ) and can affect water quality. Mississippi is an agricultural State. The Delta, a 7,000-mi ${ }^{2}$ (square mile) area of alluvial plain in the northwestern part of the State (essentially the western one-half of the Yazoo River basin) contains about 50 percent of the State's cropland and receives most of the agricultural chemicals used in the State (U.S. Geological Survey, 1988, p. 326).

The Yazoo, Big Black, Pearl, Pascagoula, and Tombigbee Rivers are the major streams that flow through Mississippi. Surface-

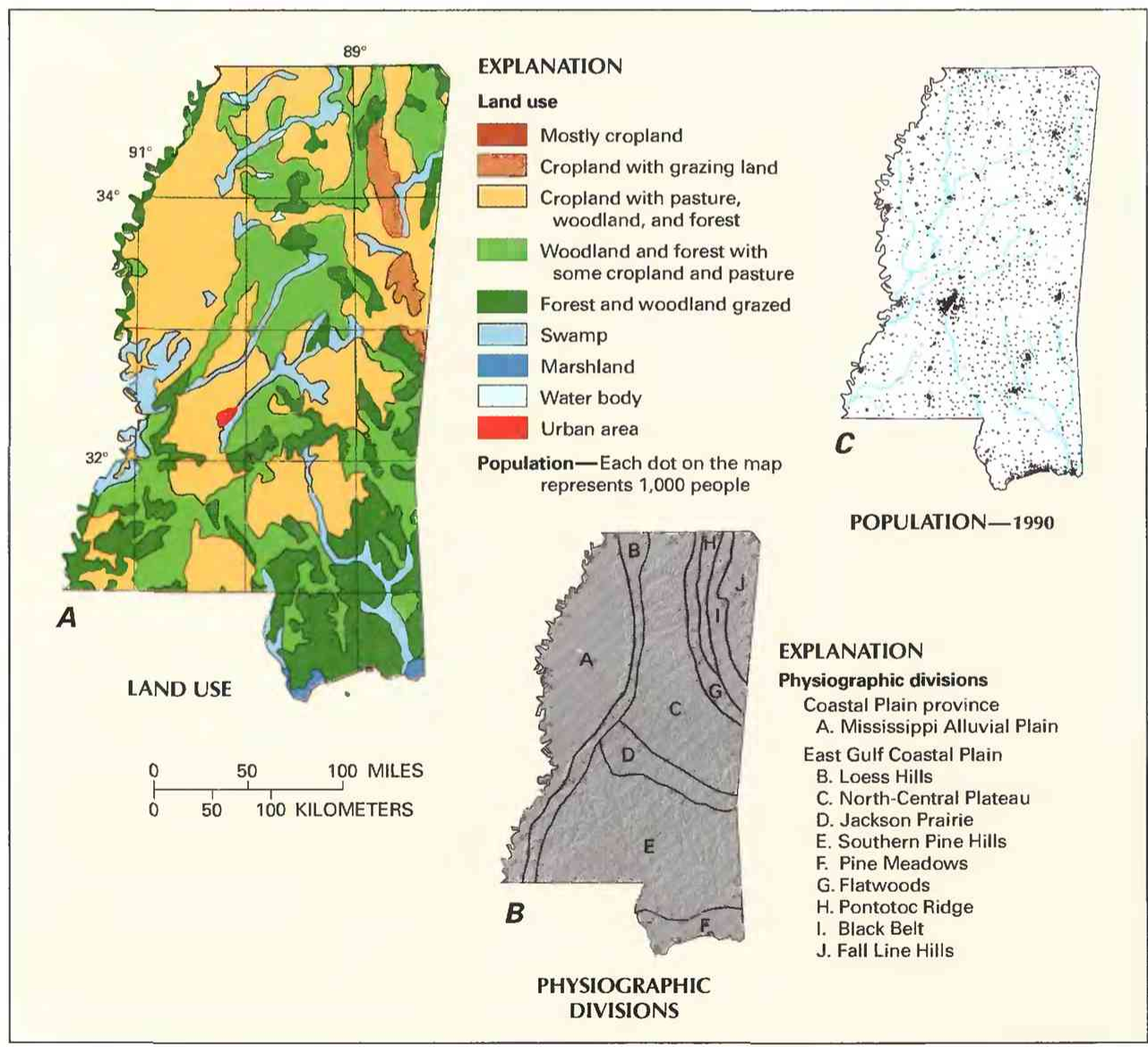

Figure 1. Land use, physiography, and population in Mississippi. A, Major land uses. B, Physiographic divisions. C. Population distribution in 1990. (Sources: A. Major land uses modified from Anderson, 1967. B. Physiographic divisions modified from Fenneman, 1946; landforms from Thelin and Pike, 1990. C. Data from U.S. Bureau of the Census 1990 decennial census files.) water outflow from these streams is about $50,200 \mathrm{Mgal} / \mathrm{d}$ (million gallons per day). The Mississippi River forms the western boundary of the State. Population centers (fig. $1 C$ ) along these rivers generally have ample water supplies, although most use ground water. The State's 1990 population is 2.6 million-a 2.1-percent increase since 1980 (U.S. Bureau of the Census 1990 decennial census files).

Offstream surface-water withdrawals in 1980 averaged 1,400 $\mathrm{Mgal} / \mathrm{d}$, or about 48 percent of the total offstream water withdrawals in the State. Most of the surface-water withdrawals were used for thermoelectric power generation and industry $(1,200 \mathrm{Mgal} / \mathrm{d})$ and irrigation (130 Mgal/d); only about $42 \mathrm{Mgal} / \mathrm{d}$ was used for public supply (U.S. Geological Survey, 1986, p. 295). By 1985 surfacewater use in the State had decreased substantially, largely as a result of decreases in water used for thermoelectric power generation. Offstream surface-water withdrawals in 1985 averaged 736 $\mathrm{Mgal} / \mathrm{d}$, or about 32 percent of the total offstream water use. Most of those withdrawals were used for thermoelectric power generation (430 Mgal/d), agriculture (173 Mgal/d), and industry (97 Mgal/d) (U.S. Geological Survey, 1990, p. 325).

Surface water accounted for about $36 \mathrm{Mgal} / \mathrm{d}$ (less than 12 percent) of the water used for public supply in Mississippi in 1985. Surface water is the principal source for public supply in Jackson, the State's capital and largest city, which withdrew $31 \mathrm{Mgal} / \mathrm{d}$ from the Pearl River and less than $3 \mathrm{Mgal} / \mathrm{d}$ from ground water (U.S. Geological Survey, 1990, p. 323 $325)$. Meridian and Columbus are the only other municipalities in the State that use surface water for public supply. As in Jackson, these systems use surface water conjunctively with ground water.

\section{WATER-QUALITY MONITORING}

Water-quality data obtained from analyses of water samples collected at monitoring stations are stored in the U.S. Geological Survey's (USGS) National Water Information System and the U.S. Environmental Protection Agency's (EPA) national data base known as STORET. Water-quality and streamflow data are reported by water year-the 12 months from October 1 through September 30. A water year is identified by the calendar year in which it ends. For example, water year 1991 comprises October 1, 1990, through September 30, 1991. 
The data used in this summary of Mississippi's stream water quality were obtained from water samples collected at seven monitoring stations at which data collection is systematic and continuing (fig. 2). Analyses of water samples collected at all seven stations are the basis for the discussion and graphic summary (fig. 3) of stream water-quality conditions during water years 1987-89, and data from six stations are the basis for the discussion and graphic summary (fig. 4) of stream water-quality trends. Water samples were collected and analyzed by using standard methods approved by the USGS (Britton and Greeson, 1987; Fishman and Friedman, 1989; Ward and Harr, 1990) or by using equivalent methods. If a method of sample collection or analysis changed over time, data from an analysis were included in the evaluation of recent stream water quality or of stream water-quality trends only if the change in method did not affect the comparability of the data.

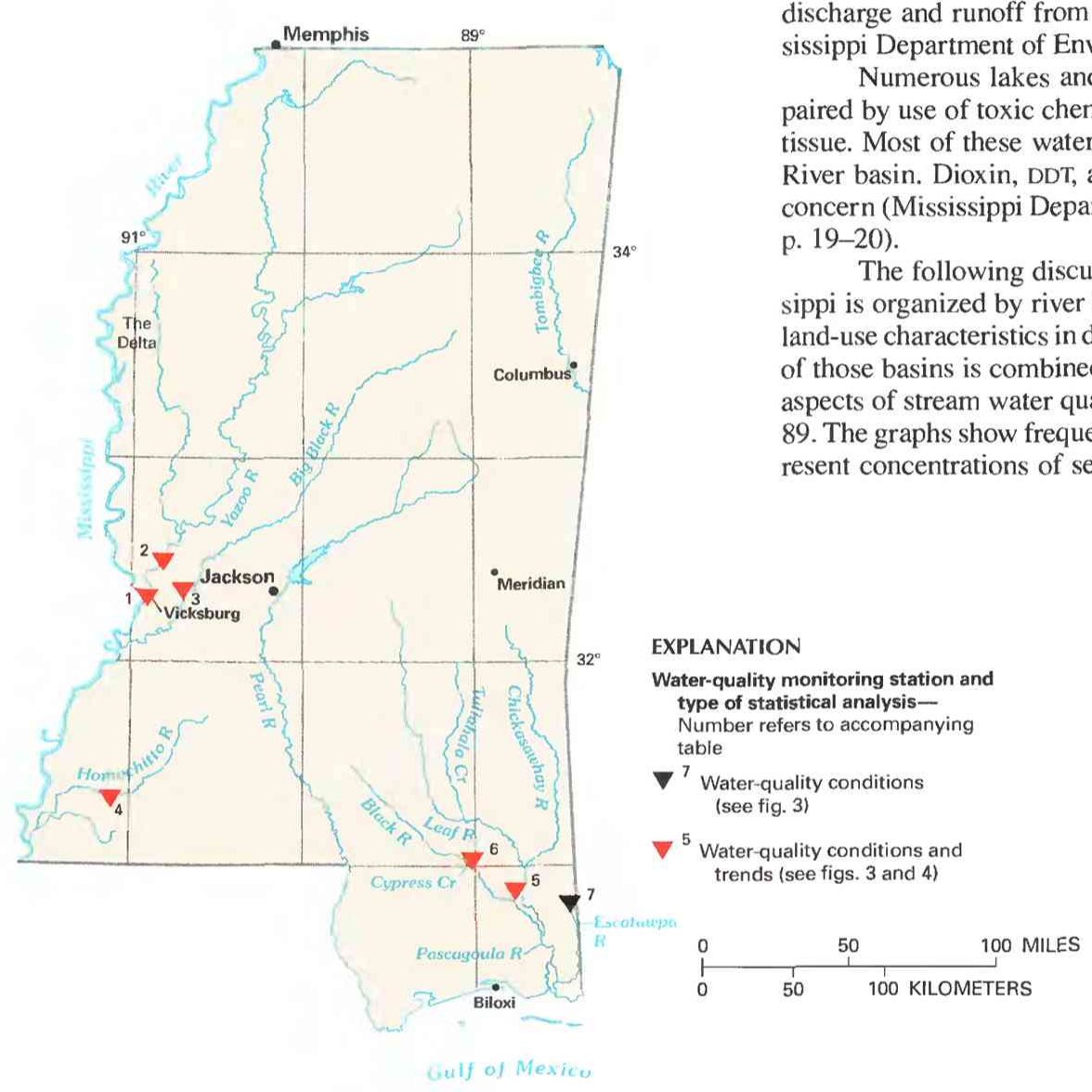

\section{WATER-QUALITY CONDITIONS}

About 7,592 miles of the State's 15,622 miles of streams and rivers fully support designated uses, 413 miles fully support the uses but are threatened, and 7,293 miles partially support the uses (Mississippi Department of Environmental Quality, 1990a, table III-1). Most of the streams that do not fully support designated uses have been degraded by nutrients and siltation, whereas the remainder have been contaminated by pesticides, priority organic chemicals (organic compounds included in the EPA's current list of "priority pollutants"), metals, chlorine, organic enrichment, suspended solids, and salinity (Mississippi Department of Environmental Quality, 1990b, p. 17). No incidences of waterborne diseases have been attributed to surface water (Mississippi Department of Environmental Quality, 1990a, p. 23). Nonpoint agricultural runoff is a major cause of degraded water quality; lesser causes are industrial and municipal point-source discharge and runoff from nonagricultural nonpoint sources (MisEuality, 1990a, p. 18).

Numerous lakes and streams in Mississippi have been imchemicals, which have been detected in fish Dioxin, DDT, and mercury are the chemicals of major concern (Mississippi Department of Environmental Quality, 1990a, The following discussion of stream water quality in Mississippi is organized by river basin (fig. 3). Where physiographic and land-use characteristics in different basins are similar, the discussion of those basins is combined. Graphs in figure 3 summarize certain aspects of stream water quality in the basins for water years 198789 . The graphs show frequency distributions of data values that represent concentrations of selected constituents in stream water and

\begin{tabular}{|c|c|c|c|}
\hline $\begin{array}{l}\text { Site no. } \\
\text { on map }\end{array}$ & $\begin{array}{l}\text { USGS station } \\
\text { name and no. }\end{array}$ & $\begin{array}{l}\text { Drainage area } \\
\text { (square miles) }\end{array}$ & $\begin{array}{l}\text { Major land use } \\
\text { (see fig. 1) }\end{array}$ \\
\hline 1 & Mississippi River at Vicksburg $(07289000)$ & $\begin{array}{c}1,140,500 \\
\text { (approximate) }\end{array}$ & Urban areas; cropland with pasture, woodland, and forest. \\
\hline 2 & Yazoo River at Redwood $(07288800)$ & 12,603 & Cropland with pasture, woodland, and forest. \\
\hline 3 & Big Black River near Bovina $(07290000)$ & $\begin{array}{c}2,810 \\
\text { (approximate) }\end{array}$ & Ditto. \\
\hline 4 & Homochitto River at Rosetta $(07292500)$ & $\begin{array}{c}750 \\
\text { (approximate) }\end{array}$ & $\begin{array}{l}\text { Woodland and forest with some cropland and pasture; grazed forest } \\
\text { and woodland. }\end{array}$ \\
\hline 5 & 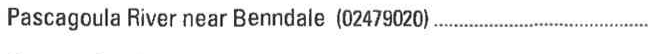 & 6,680 & $\begin{array}{l}\text { Grazed forest and woodland; woodland and forest with some cropland } \\
\text { and pasture. }\end{array}$ \\
\hline 6 & 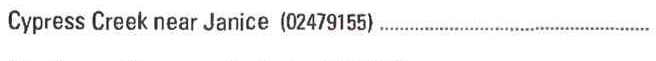 & $\begin{array}{c}53 \\
\text { (approximate) }\end{array}$ & Forest and woodland. \\
\hline 7 & Escatawpa River near Agricola $(02479560)$ & 562 & $\begin{array}{l}\text { Woodland and forest with some cropland and pasture; grazed forest } \\
\text { and woodland. }\end{array}$ \\
\hline
\end{tabular}

Figure 2. Selected water-quality monitoring stations, type of statistical analysis, and geographic features in Mississippi. (Sources: Major land uses modified from Anderson, 1967; other data from U.S. Geological Survey files.) 
measurements of selected physical properties of stream water. These constituents and properties are dissolved oxygen, fecal coliform bacteria, alkalinity (as calcium carbonate), dissolved sulfate, dissolved solids, dissolved nitrite plus nitrate (as nitrogen), dissolved phosphate (as phosphorus), and suspended sediment. The data are reported in milligrams per liter (mg/L) and colonies per 100 milliliters (col/100 $\mathrm{mL}$ ). Sources and environmental significance of each property and constituent are described in table 1 .

Water quality at each monitoring station is the result of geological, chemical, biological, and hydrologic processes that occur over a large area. Water-quality problems that affect aquatic life or public health only locally are not fully represented in this summary.

\section{MISSISSIPPI RIVER}

The Mississippi River has an average daily discharge (through 1989) of $312,000 \mathrm{Mgal} / \mathrm{d}$ at Memphis, Tenn., and $377,000 \mathrm{Mgal} / \mathrm{d}$ at Vicksburg, Miss. The river drains about $1,140,500 \mathrm{mi}^{2}$ of land having a diversity of uses-from industrialized urban areas to cropland,
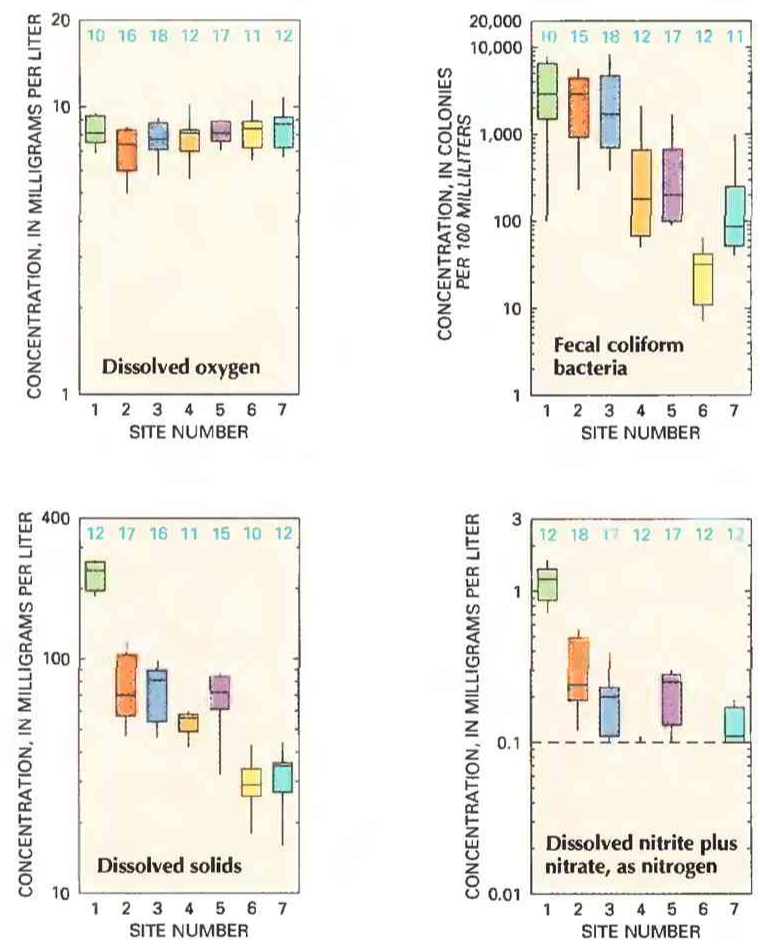

pasture, woodland, and forest. The river is a major artery of waterborne commerce.

Although the quality of water in the Mississippi River is suitable for most uses, the only significant offstream water use in Mississippi is for cooling at thermoelectric plants. However, the quality of water in the river is important to the State because (1) backwater flooding along the tributaries affects agricultural interests in the area (U.S. Geological Survey, 1986, p. 295), and (2) about $390 \mathrm{Mgal} / \mathrm{d}$ (35 percent) of the ground-water withdrawals from the Mississippi River alluvial aquifer for irrigation and catfish farming in the Delta is derived from recharge from the Mississippi River (Sumner and Wasson, 1984, p. 4).

Samples collected at site 1 on the Mississippi River during water years 1987-89 had median concentrations of alkalinity (106 $\mathrm{mg} / \mathrm{L})$, sulfate $(55 \mathrm{mg} / \mathrm{L})$, dissolved solids $(239 \mathrm{mg} / \mathrm{L})$, and nitrite plus nitrate $(1.2 \mathrm{mg} / \mathrm{L})$ several times larger than those for the other six monitoring stations (fig. 3). Nevertheless, the values at site 1 were relatively small-much less than the State and Federal criteria for sulfate $(250 \mathrm{mg} / \mathrm{L})$, dissolved solids $(500 \mathrm{mg} / \mathrm{L})$, and nitrate (10
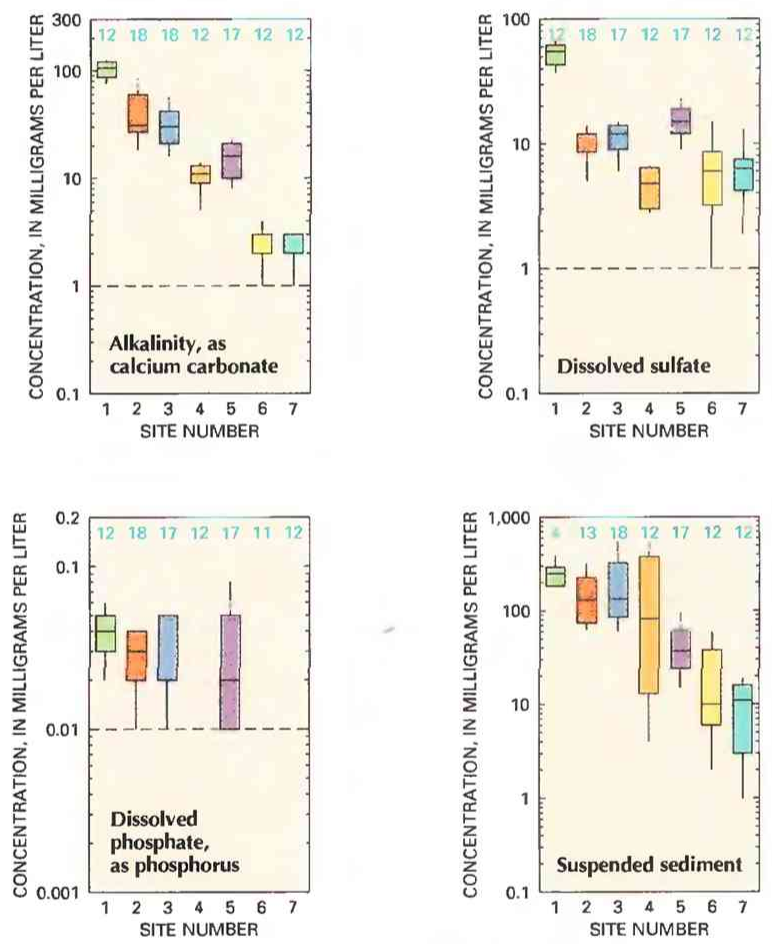

\section{EXPLANATION}

Water-quality conditions in selected
drainage basins
Number of anelyses
Percentile-Percentage of analyses
equal to or less than indicated
values
-90 th
-75 th
-50 th-Median
-25 th
10th
Reporting limit-Minimum
reporting limit for analytical
method used. Data below limit
line not shown

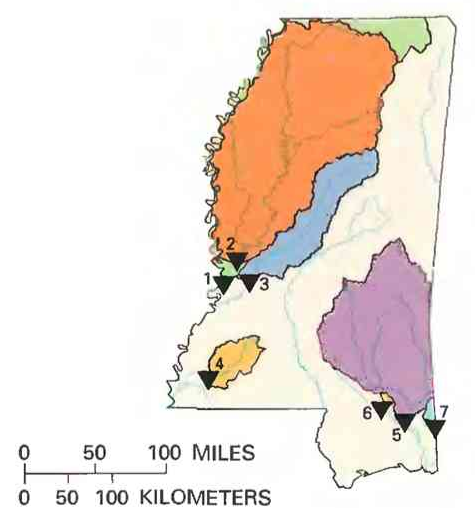

Figure 3. Water quality of selected streams in Mississippi, water years 1987-89. (Source: Data from U.S. Geological Survey files.) 
$\mathrm{mg} / \mathrm{L}$, as nitrogen) for untreated drinking water supplies (Mississippi Department of Environmental Quality, 1990b, p. 9-10; U.S. Environmental Protection Agency, 1986; U.S. Geological Survey, 1988, p. 553). About one-half of the sulfate in the Mississippi River is due to runoff over weathered rock and the other one-half is due to biochemical processes and human activities (Hem, 1985, p. 113). The water has a median hardness of $160 \mathrm{mg} / \mathrm{L}$ (about three times larger than that at the other stations). The median fecal coliform bacteria concentration $(2,900 \mathrm{col} / 100 \mathrm{~mL})$ exceeded the State standard for public water supply and water-contact recreation (Mississippi Department of Environmental Quality, 1990b, p. 9). Runoff from nonpoint sources probably contributed most of the bacteria. The quality of the Mississippi River is not substantially affected by sources in Mississippi, except possibly by sediment and agricultural chemicals from the Yazoo River basin (Mississippi Department of Environmental Quality, 1990a, p. 37).

\section{YAZOO RIVER}

The Yazoo River basin, the largest river basin completely within the State, drains about $14,000 \mathrm{mi}^{2}$ of northwestern Mississippi. The basin includes hilly upland in north-central Mississippi and the 7,000- $\mathrm{mi}^{2}$ flat lowlands of the Delta. Surface water in the Yazoo River basin generally has small dissolved-solids concentrations and is suitable for most uses; however, in extensively farmed areas, particularly in the lower part of the basin, streams receive large quantities of sediment and agricultural chemicals. The Yazoo River at site 2 only partially supports the Fish and Wildlife classification owing to degradation by pesticides, nutrients, suspended solids, and organic enrichment from agricultural nonpoint sources and municipal point sources (Mississippi Department of Environmental Quality, 1990a, p. 48). Although the median fecal coliform bacteria concentration $(2,900 \mathrm{col} / 100 \mathrm{~mL})$ was the largest for any monitoring station on an interior drainage during water years $1987-89,90$ percent of the dissolved-oxygen measurements had concentrations that equaled or exceeded $5.0 \mathrm{mg} / \mathrm{L}$ and exceeded the instantaneous minimum of 4.0 $\mathrm{mg} / \mathrm{L}$ required by the State for all waters (Mississippi Department of Environmental Quality, 1990a, p. 3). Furthermore, median values for alkalinity $(31 \mathrm{mg} / \mathrm{L})$, sulfate $(12 \mathrm{mg} / \mathrm{L})$, dissolved solids $(70$ $\mathrm{mg} / \mathrm{L})$, nitrite plus nitrate $(0.24 \mathrm{mg} / \mathrm{L})$, and phosphate $(0.03 \mathrm{mg} / \mathrm{L})$ were small (fig. 3 ). The median suspended-sediment concentration $(130 \mathrm{mg} / \mathrm{L})$ for site 2 , however, was the second largest for any interior site.

\section{BIG BLACK RIVER}

The Big Black River originates in north-central Mississippi and flows southwestward to the Mississippi River. The Big Black River drains a 3,500- $\mathrm{mi}^{2}$ area that has no major tributaries; many of the small tributaries in the upper part of the basin are perennial. The basin is sparsely populated and the terrain is hilly to gently rolling and largely forested. Cattle ranching and farming are prevalent land uses (U.S. Geological Survey, 1986, p. 296). Surface water in the Big Black River basin generally has a small dissolved-solids concentration and is suitable for most uses; however, in the areas of extensive farming, particularly in the lower part of the basin, streams receive large quantities of sediment and agricultural chemicals. The 90th-percentile suspended-sediment concentration $(545 \mathrm{mg} / \mathrm{L}$ ) for the Big Black River at site 3 during water years 1987--89 was the largest for any of the monitoring stations; the median suspended-sediment concentration (133 mg/L) was the largest for any interior site (fig. 3). Owing to contamination primarily from agricultural nonpoint sources, water quality of the Big Black River at site 3 only partially supports the Fish and Wildlife classification (Mississippi Department of Environmental Quality, 1990a, p. 34). As would be expected because of the similarity of land use in the Big Black and Yazoo River basins, the median values for alkalinity $(30 \mathrm{mg} / \mathrm{L})$, sulfate $(12$ $\mathrm{mg} / \mathrm{L})$, dissolved solids $(81 \mathrm{mg} / \mathrm{L})$, nitrite plus nitrate $(0.20 \mathrm{mg} / \mathrm{L})$, and phosphate $(0.02 \mathrm{mg} / \mathrm{L})$ at site 3 were similar to those for site 2 (fig. 3).

Table 1. Sources and environmental significance of selected water-quality constituents and properties [Source: Compiled by the U.S. Geological Survey, Office of Water Quality]

\begin{tabular}{|c|c|c|}
\hline Constituent or property & Common sources & Environmental significance \\
\hline 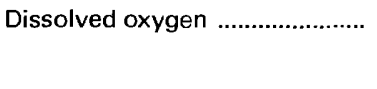 & $\begin{array}{l}\text { Introduced from the atmosphere; also a byproduct of } \\
\text { aquatic plants. }\end{array}$ & $\begin{array}{l}\text { Necessary for aquatic life; deficiency can result from } \\
\text { assimilation of organic wastes or rapid growth } \\
\text { and decay of algae. }\end{array}$ \\
\hline Fecal coliform bacteria ................ & $\begin{array}{l}\text { Sources include effluent from sewage-treatment } \\
\text { plants and runoff from pastures, feedlots, and ur- } \\
\text { ban areas. }\end{array}$ & $\begin{array}{l}\text { Presence indicates contamination of water by wastes } \\
\text { from humans and other warm-blooded animals. }\end{array}$ \\
\hline Alkalinity (property) ...................... & $\begin{array}{l}\text { A measure of the quantity of acid-neutralizing sub- } \\
\text { stances; can be affected by geologic setting, in- } \\
\text { dustrial wastewater discharge, waste gases, and } \\
\text { runoff from surface mining. }\end{array}$ & $\begin{array}{l}\text { Sufficiently alkaline water can be unsuitable for some } \\
\text { agricultural and industrial uses. }\end{array}$ \\
\hline Sulfate & $\begin{array}{l}\text { Occurs in some rocks; also in mine runoff, industrial } \\
\text { wastewater discharge, and atmospheric deposi- } \\
\text { tion. }\end{array}$ & $\begin{array}{l}\text { Concentrations exceeding a natural, background } \\
\text { level indicate contamination from human activity; } \\
\text { in sufficient quantity, can cause water to be } \\
\text { unsuitable for public supply; can harm aquatic } \\
\text { organisms. }\end{array}$ \\
\hline Dissolved solids .............................. & $\begin{array}{l}\text { A result of rock weathering; also in agricultural runoff } \\
\text { and industrial discharge. }\end{array}$ & $\begin{array}{l}\text { In sufficient quantity, can cause water to be unsuitable } \\
\text { for public supply, agriculture, and industry; can } \\
\text { harm aquatic organisms. }\end{array}$ \\
\hline Nitrite plus nitrate ........................ & $\begin{array}{l}\text { Nonpoint sources are agricultural and urban runoff; } \\
\text { a major point source is wastewater discharge. }\end{array}$ & $\begin{array}{l}\text { Plant nutrient that, in sufficient quantity, can cause } \\
\text { algal blooms and excessive growth of higher } \\
\text { aquatic plants in bodies of water; can cause water } \\
\text { to be unsuitable for public supply. }\end{array}$ \\
\hline 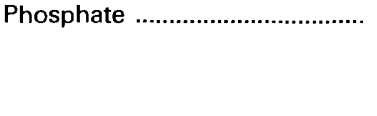 & $\begin{array}{l}\text { Occurs in some rocks and sediments; also in runoff } \\
\text { and seepage from phosphate-rock mines, agri- } \\
\text { cultural and urban runoff, and industrial and } \\
\text { municipal wastewater discharge. }\end{array}$ & $\begin{array}{l}\text { Plant nutrient that, in sufficient quantity, can cause } \\
\text { algal blooms and excessive growth of higher } \\
\text { aquatic plants in bodies of water. }\end{array}$ \\
\hline Suspended sediment ................. & $\begin{array}{l}\text { A result of rock erosion; also induced by disturbances } \\
\text { of land cover due to fires, floods, and human } \\
\text { activities such as mining, logging, construction, } \\
\text { and agriculture. }\end{array}$ & $\begin{array}{l}\text { Can be detrimental to aquatic organisms; can fill res- } \\
\text { ervoirs and impair recreational use of water. }\end{array}$ \\
\hline
\end{tabular}




\section{HOMOCHITTO RIVER}

The Homochitto River drains a $1,200-\mathrm{mi}^{2}$ area in southwestern Mississippi and empties into the Mississippi River. Most of the basin is in a region underlain by clay, sand, and gravel that are easily eroded during floods. Streamflow characteristics of the Homochitto River differ from those of most other Mississippi streams largely because of its shifting, sandy channel (Wilson, 1979, p. 3). The basin is mostly forested but supports oil and gas production. Grazing and agriculture are minor activities.

The median values for alkalinity $(11 \mathrm{mg} / \mathrm{L})$, sulfate $(4.8$ $\mathrm{mg} / \mathrm{L}$ ), dissolved solids $(56 \mathrm{mg} / \mathrm{L})$, nitrite plus nitrate (less than 0.10 $\mathrm{mg} / \mathrm{L}$ ), and phosphate (less than $0.01 \mathrm{mg} / \mathrm{L}$ ) during water years 1987 89 were small (fig. 3). However, as a result of contamination from organic enrichment and nutrients from unknown sources, water quality of the Homochitto River at site 4 only partially supports the Fish and Wildlife classification (Mississippi Department of Environmental Quality, 1990a, p. 43). Furthermore, because the basin is underlain by easily erodible material, the 90 th-percentile suspended-sediment concentration $(544 \mathrm{mg} / \mathrm{L})$ at site 4 was the second largest for the seven monitoring stations.

\section{PASCAGOULA RIVER, CYPRESS CREEK, AND ESCATAWPA RIVER}

The Pascagoula River system drains about $8,900 \mathrm{mi}^{2}$ of southeastern Mississippi and about $600 \mathrm{mi}^{2}$ of southwestern Alabama. The Pascagoula River, formed by the confluence of the Chickasawhay and Leaf Rivers, flows southward for about 80 river miles before emptying into the Gulf of Mexico. Cypress Creek, located entirely in Mississippi, is a small, nearly undisturbed tributary to the Pascagoula River. The monitoring station at site 6 on Cypress Creek is a USGS Hydrologic Bench-Mark Network station, which monitors relatively undeveloped basins. The Escatawpa River, located mostly in Alabama, flows into the Pascagoula River about 7 miles upstream from its mouth. The Pascagoula River basin is densely forested, but supports silviculture, paper-production, shipbuilding, and oil and gas development activities.

Stream water quality in the Pascagoula River basin generally meets Mississippi standards (Mississippi Department of Environmental Quality, 1990a, p. 39); however, recent analyses have detected dioxin in fish tissue downstream from two pulp mills (H.G. Folmar, Mississippi Department of Environmental Quality, Office of Pollution Control, oral commun., January 1991). On the basis of these data, the Leaf River from Tallahala Creek to the Pascagoula River and the Escatawpa River from Interstate Highway 10 to the Pascagoula River only partially support designated uses and are currently (January 1991) under fish consumption advisories. The upper part of the Escatawpa River fully supports designated uses but is subject to low $\mathrm{pH}$ values that are attributable to natural sources; the lower part only partially supports designated uses because of toxic chemicals from industrial point sources. In addition, nutrients and organic enrichment, largely from agricultural nonpoint and industrial point sources, have been detected. Water quality of Cypress Creek fully supports the Fish and Wildlife classification (Mississippi Department of Environmental Quality, 1990a, p. 39).

Concentrations of the selected water-quality constituents in the Pascagoula River at site 5 during water years $1987-89$ were neither the largest nor the smallest for the seven monitoring stations (fig. 3). However, median concentrations of fecal coliform bacteria, alkalinity, dissolved solids, and suspended sediment were smaller in Cypress Creek at site 6 and in the Escatawpa River at site 7 than at any of the other monitoring stations. Median concentrations of sulfate, nitrite plus nitrate, and phosphate were smaller at sites 6 and 7 than at most of the other monitoring stations, probably because there is less farming in the Cypress Creek and Escatawpa River basins than in the other basins.

\section{WATER-QUALITY TRENDS}

Trend analysis is a statistical procedure used to detect changes in stream water quality at a monitoring station over time. For this report, water-quality data from six monitoring stations (fig. 2) were analyzed for trends by using the seasonal Kendall test (Hirsch and others, 1982), a method used extensively by the USGS. The graph (shown below) of the dissolved-solids concentration in the Big Black River at site 3 illustrates the trend inferred from the concentration data and demonstrates the variation in water quality that is common in streams.

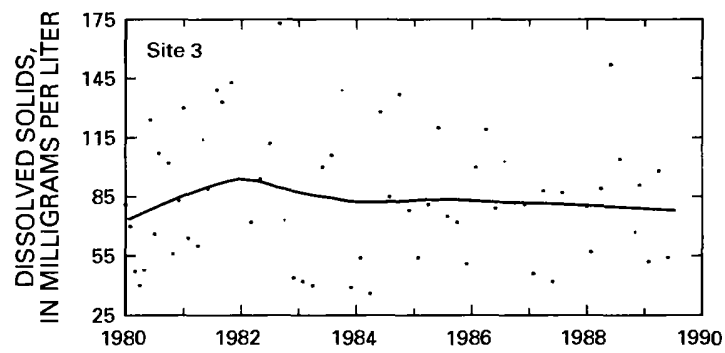

When possible, constituent-concentration data were adjusted for changes in streamflow to preclude identifying a trend in concentration that was caused only by a trend in streamflow. The data were not adjusted when (1) more than 10 percent of the samples had concentrations less than the minimum reporting limit for the analytical method used or (2) the streamflow was controlled substantially by human activities. When the concentration data could not be adjusted for streamflow, trends were determined directly from the concentration data.

Statewide trends in concentrations of selected constituents in stream water and in measurements of selected physical properties of stream water are shown on maps in figure 4. On each map, a trend is indicated at a monitoring station only if the data from that station were suitable for use in the trend analysis. For more information on the suitability criteria and on the trend-analysis procedure used for this report, see Lanfear and Alexander (1990).

\section{DISSOLVED OXYGEN}

The dissolved-oxygen concentration in a stream is controlled by several factors, including water temperature, air temperature and pressure, hydraulic characteristics, photosynthetic or respiratory activity of stream biota, and the quantity of organic pollution present. A trend in dissolved-oxygen concentration commonly is either directly or indirectly the result of human activities. Generally, an upward trend in dissolved-oxygen concentrations indicates improving stream water-quality conditions and a downward trend indicates deteriorating conditions.

The dissolved-oxygen concentration in the Big Black River at site 3 had a downward trend (fig. 4); however, the change was not substantial. The small decrease at site 3 and the absence of upward trends for the other monitoring stations despite stricter point-source standards could be attributable to the already large concentrations of dissolved oxygen at all the monitoring stations (fig. 3). Also, increases in dissolved-oxygen concentrations resulting from decreases in oxygen-demanding effluent from point sources could have been offset by decreases in dissolved-oxygen concentrations caused by increases in nonpoint source pollution.

\section{FECAL COLIFORM BACTERIA}

Fecal coliform bacteria are used as indicators of fecal contamination from humans and other warm-blooded animals. Such contami- 
nation can introduce disease-causing viruses and bacteria into a stream. The upward trends in fecal coliform bacteria concentrations in the Mississippi, Yazoo, and Big Black Rivers at sites 1, 2, and 3 (and no trends at the other monitoring stations despite more stringent point-source controls) might have been the result of increased inputs from nonpoint sources.

\section{ALKALINITY}

Alkalinity is a measure of the capacity of the substances dissolved in the water to neutralize acid. In most natural waters, alkalinity is produced mainly by bicarbonate and carbonate (Hem, 1985, p. 106), which are ions formed when carbon dioxide or carbonate rock dissolves in water.
Alkalinity had an upward trend in the Pascagoula River at site 5 and a downward trend in Cypress Creek at site 6 (fig. 4). Both monitoring stations are in the densely forested Pascagoula River basin; however, site 6 is downstream from a relatively undisturbed area, whereas site 5 is downstream from more densely populated areas and receives agricultural runoff and industrial and municipal wastetreatment plant effluents. The alkalinity changes at both monitoring stations were small.

\section{DISSOLVED SULFATE}

The major natural sources of sulfate in streams are rock weathering, volcanoes, and biochemical processes (Hem, 1985, p. 113). Human activities such as mining, waste discharge, and fossil-fuel
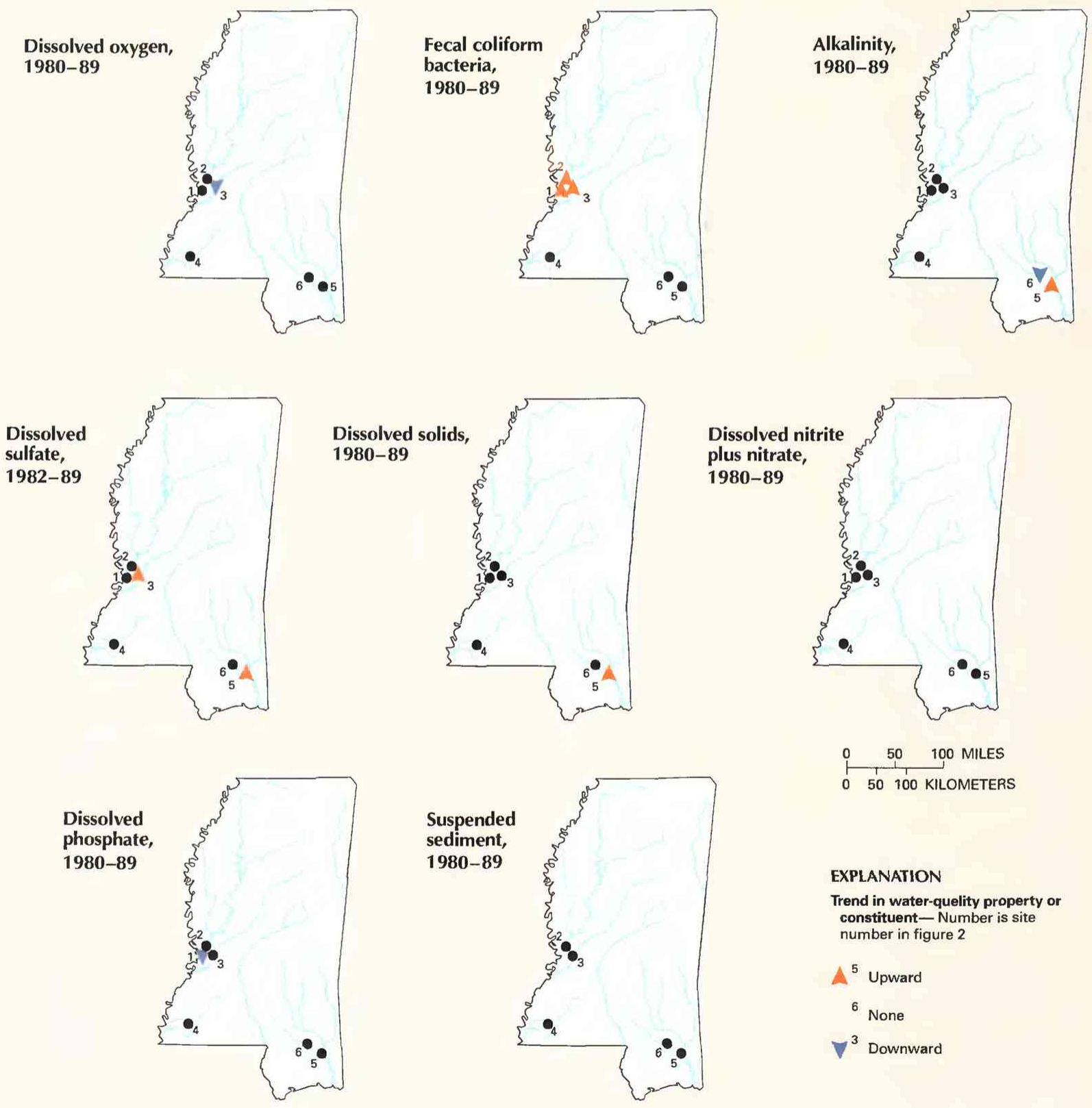

\section{EXPLANATION}

Trend in water-quelity property or constituent- Number is site number in figure 2

$$
\begin{aligned}
& A^{5} \text { Upward } \\
& { }^{6} \text { None } \\
& \nabla^{3} \text { Downward }
\end{aligned}
$$

Figure 4. Trends in water quality of selected streams in Mississippi, by water years. (Source: Data from U.S. Geological Survey files.) 
combustion also can be important sources. A shortened trend-analysis period was used for sulfate because data from analyses performed before water year 1982 are not comparable to data for subsequent years.

The cause for the upward trend in sulfate concentration in the Big Black River at site 3 (fig. 4) is unknown. Industrial wastewater discharge is the most likely source of the increasing concentration in the Pascagoula River at site 5. The 50th- and 75th-percentile sulfate concentrations in rainfall collected at site 6 during 1982-87 were 1.4 and $2.2 \mathrm{mg} / \mathrm{L}$, respectively (Bednar and Grantham, 1989, p. 15); consequently, rainfall is not considered to be a major source of sulfate in the Pascagoula River basin.

\section{DISSOLVED SOLIDS}

Dissolved solids in stream water result primarily from rock weathering but also can be introduced as a byproduct of human activities (table 1). Concentrations generally are greatest in streams draining basins underlain by rocks and soils that contain easily dissolved minerals.

The upward trend in dissolved-solids concentrations in the Pascagoula River at site 5 (fig. 4) probably was caused by increasing industrial wastewater discharges. The absence of downward trends in dissolved-solids concentrations at the other monitoring stations, despite enforcement of stricter standards for a major point source-effluent from sewage-treatment plants - might be attributable to one or more of the following: (1) the dissolved-solids concentrations at all the monitoring stations were already relatively small-much less than the State and Federal criterion of $500 \mathrm{mg} / \mathrm{L}$ for drinking water (Mississippi Department of Environmental Quality, 1990b, p. 9; U.S. Environmental Protection Agency, 1986), (2) the monitoring stations might be too distant from point sources to detect the effects of wasteload changes, or (3) decreases in loads from point sources might have been offset by increases in loads from nonpoint sources.

\section{DISSOLVED NITRITE PLUS NITRATE}

Nitrite and nitrate are oxidized forms of nitrogen that together constitute most of the dissolved nitrogen in well-aerated streams. Nitrite readily oxidizes to nitrate in natural waters; therefore, nitrate generally is by far the more abundant of the two (Hem, 1985, p. 124).

The absence of downward trends for nitrite plus nitrate concentrations (fig. 4) in streams in the interior of the State, despite enforcement of stricter standards for sewage-treatment-plant effluent, might be attributable to the already small concentrations of nitrite plus nitrate in those streams (fig. 3). Although concentrations in the Mississippi River were large, the river is large enough to mask increases by dilution. Also, the effects of waste load changes or decreases in loads from point sources could have been masked by increases from nonpoint sources.

\section{DISSOLVED PHOSPHATE}

Phosphate is the oxidized form of phosphorus and the only form of significance in most natural waters. Small quantities of dissolved phosphate commonly are present in streams as a result of rock weathering. Normally, concentrations are no more than a few tenths of a milligram per liter (Hem, 1985, p. 126) and usually are much lower. Higher concentrations can indicate contamination from human activities (table 1). The cause of the small decrease in phosphate concentration in the Mississippi River at site 1 is unknown.

\section{SUSPENDED SEDIMENT}

Suspended sediment is a product of erosion. The erosion can be either natural or the result of land-cover disturbances related to human activities (table 1).
Concentrations of suspended sediment had no trend during $1980-89$ at any of the five monitoring stations from which data met the criteria for trend analysis (fig. 4). Although the Mississippi Soil and Water Conservation Commission has held "Hold Our Topsoil" field days in all 82 counties to demonstrate the importance of erosion control and maintenance of good water quality, these and other educational programs that encourage installation of Best Management Practices have not been in place long enough to have had a noticeable effect on the State's surface-water quality.

\section{WATER-QUALITY MANAGEMENT}

The Mississippi Department of Environmental Quality, Office of Pollution Control (formerly Bureau of Pollution Control), administers programs and policies to secure, protect, and preserve the right of citizens to unpolluted waters. The Mississippi Air and Water Pollution Control Law enables the Office to administer the National Pollutant Discharge Elimination System program and to inspect and regulate wastewater-treatment facilities. The Office performs specific regulatory, enforcement, and monitoring activities. These activities include developing water-quality standards and criteria, issuing permits to wastewater dischargers, reviewing the operation and maintenance of municipal and nonmunicipal waste-treatment facilities, and monitoring to determine ambient water-quality conditions and compliance with effluent limits and water-quality standards.

The Office of Pollution Control prepares a biennial waterquality assessment (Mississippi Department of Environmental Quality, 1990a,b) submitted to the EPA and the U.S. Congress as mandated by section 305(b) of the Federal Clean Water Act. The Office also reviews and certifies Federal permits related to hydrologic modifications and issues State permits for nondischarge wastewater systems.

The Office of Pollution Control is the lead agency for the development of Mississippi's nonpoint-source water-pollution management plan that was adopted in 1989. The Office also participates in interagency work groups and interstate organizations, including the Tennessee Valley Authority Land and Water 201 Project, Gulf of Mexico Program, and the Association of State and Interstate Water Pollution Control Administrators.

The Mississippi Commission on Environmental Quality, composed of seven members appointed by the Governor, oversees the State water-management program. One commissioner is selected from each of Mississippi's five congressional districts, and two commissioners are selected from the public.

\section{SELECTED REFERENCES}

Anderson, J.R., 1967, Major land uses in the United States, in U.S. Geological Survey, 1970, National atlas of the United States of America: Washington, D.C., U.S. Geological Survey, p. 158-159.

Bednar, G.A., and Grantham, P.E., 1989, Precipitation-quality monitoring in southern Mississippi, 1982-87: U.S. Geological Survey Open-File Report 89-266, 33 p.

Britton, L.J., and Greeson, P.E., eds., 1987, Methods for collection and analysis of aquatic biological and microbiological samples: U.S. Geological Survey Techniques of Water-Resources Investigations, book 5, chap. A4, $363 \mathrm{p}$.

Fenneman, N.M., 1946, Physical divisions of the United States: U.S. Geological Survey special map, scale 1:7,000,000.

Fishman, M.J., and Friedman, L.C., eds., 1989, Methods for the determination of inorganic substances in water and fluvial sediments: U.S. Geological Survey Techniques of Water-Resources Investigations, book 5, chap. A1, 545 p.

Hem, J.D., 1985, Study and interpretation of the chemical characteristics of natural water (3d ed.): U.S. Geological Survey Water-Supply Paper 2254 $263 \mathrm{p}$.

Hirsch, R.M., Slack, J.R., and Smith, R.A., 1982, Techniques of trend analysis for monthly water quality data: Water Resources Research, v. 18, no. 1, p. 107-121. 
Lanfear, K.J., and Alexander, R.B., 1990, Methodology to derive water-quality trends for use by the National Water Summary Program of the U.S. Geological Survey: U.S. Geological Survey Open-File Report 90-359, $10 \mathrm{p}$.

Mississippi Department of Environmental Quality, 1990a, Mississippi water quality report, 1990 -Pursuant to section 305(b) of the Clean Water Act: Jackson, Mississippi Department of Environmental Quality, Bureau of Pollution Control, $116 \mathrm{p}$.

$1990 \mathrm{~b}$, Water quality criteria for intrastate, interstate and coastal waters [adopted March 22, 1990]: Jackson, Mississippi Department of Environmental Quality, Office of Pollution Control, $21 \mathrm{p}$.

Sumner, D.M., and Wasson, B.E., 1984, Summary of results of an investigation to define the geohydrology and simulate the effects of large groundwater withdrawals on the Mississippi River alluvial aquifer in northwestern Mississippi: U.S. Geological Survey Water-Resources Investigations Report $84-4343,17 \mathrm{p}$.

Thelin, G.P., and Pike, R.J., 1990, Digital shaded relief map of the conterminous United States: Menlo Park, Calif., U.S. Geological Survey digital image processing, scale 1:3,500,000.
U.S. Environmental Protection Agency, 1986, Quality criteria for water, 1986: U.S. Environmental Protection Agency, EPA-440/5-86-001, variously paginated.

U.S. Geological Survey, 1986, National water summary 1985-Hydrologic events and surface-water resources: U.S. Geological Survey WaterSupply Paper 2300, 506 p.

1988, National water summary 1986 -Hydrologic events and groundwater quality: U.S. Geological Survey Water-Supply Paper 2325, 560 p. 1990, National water summary 1987-Hydrologic events and water supply and use: U.S. Geological Survey Water-Supply Paper 2350, $553 \mathrm{p}$.

Ward, J.R., and Harr, C.A., eds., 1990, Methods for collection and processing of surface-water and bed-material samples for physical and chemical analyses: U.S. Geological Survey Open-File Report 90-140, 71 p.

Wilson, K.V., 1979, Changes in channel characteristics, 1938-74, of the Homochitto River and tributaries, Mississippi: U.S. Geological Survey Open-File Report 79-554, 18 p.

Prepared by Larry J. Slack, U.S. Geological Survey; “Water-Quality Management” section by Randy Reed, Mississippi Department of Environmental Quality, Office of Pollution Control

FOR ADDITIONAL INFORMATION: District Chief, U.S. Geological Survey, Federal Building, 100 W. Capitol Street, Suite 710, Jackson, MS 39269 


\section{MisSOURI Stream Water Quality}

Missouri has abundant surface-water resources. Two of the largest rivers in the Nation, the Mississippi and Missouri, drain the State. Streamflows are sustained by an annual precipitation that ranges from 36 inches in the northwest to about 48 inches in the southeast and by more than 1.000 springs. which are located predominantly in the southern one-half of the State (U.S. Geological Survey, 1986, p. 301).

During 1985, an estimated 5,470 Mgal/d (million gallons per day) was withdrawn from streams in Missouri, representing 89.5 percent of freshwater withdrawals. Most surface water was used for thermoelectric power generation (4,885 Mgal/d) and public supply (476 $\mathrm{Mgal} / \mathrm{d}$ ). Irrigation, industrial, and mining uses together accounted for $109 \mathrm{Mgal} / \mathrm{d}$ (U.S. Geological Survey, 1990, p. 334). North of the Missouri River and in western Missouri, ground water commonly is saline; therefore, surface water is the preferred water source in these areas.

Land use can substantially affect the quality of stream water. Land-use patterns in Missouri (fig. $1 A$ ) coincide with three major physiographic divisions (fig. $1 B$ ). The extensively farmed plains of the Central Lowland include the glaciated area north of the Missouri River (Dissected Till Plains) and an area south of the river in the western part of the State (Osage Plains). In these areas, wide, flat valleys are eroded by meandering streams that are not well sustained during droughts. The region of the State having the most springs is the wooded, hilly Ozark Plateaus, which consists of two physiographically distinct regions, the Salem and Springfield Plateaus. The deep, narrow valleys and sharp ridges of the Salem Plateau are covered predominantly by forest interspersed with cropland and pasture. Gentler slopes and wider valleys in the Springfield Plateau allow diversified agricultural activity. The Mississippi Alluvial Plain was once swampland, but extensive drainage and removal of the forest have allowed conversion of the area into cropland.

The population of Missouri in 1990 was 5.1 million (U.S. Bureau of the Census 1990 decennial census files), an increase of 9.4 percent since 1970. In 1985, about one-half of the State's population depended on surface water for domestic water supply (Solley and others, 1988). Although more municipalities in the State use ground water than surface water as a source of public supply, the major population centers are located along the Mississippi and Missouri Rivers (figs. $1 C$ and 2 ) and use these rivers as the principal publicsupply source.

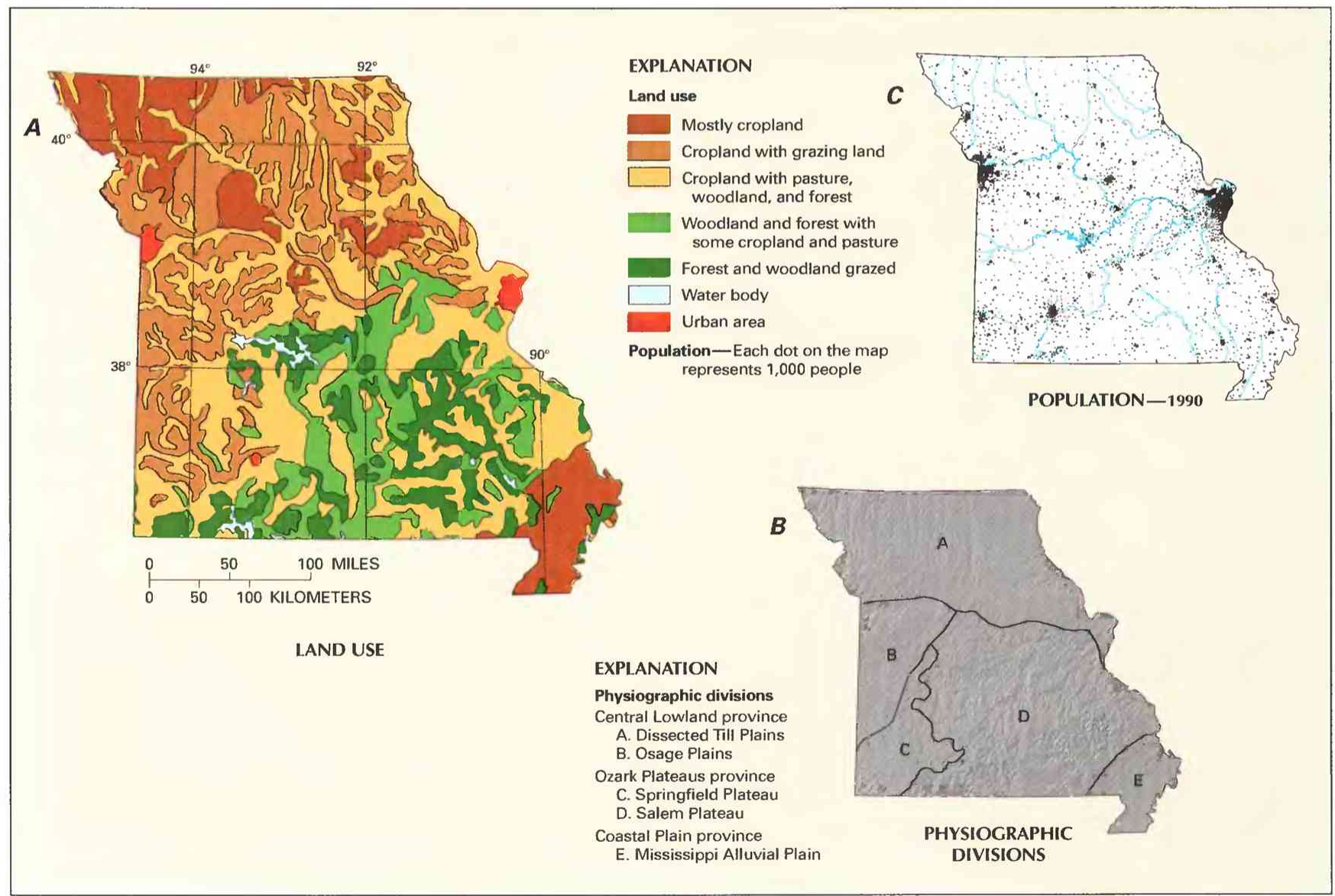

Figure 1. Land use, physiography, and population in Missouri. $A$, Major land uses. B, Physiographic divisions. $C$, Population distribution in 1990. (Sources: A, Major land uses modified from Anderson, 1967. B. Physiographic divisions from Fenneman, 1946; landforms from Thelin and Pike, 1990. C, Data from U.S. Bureau of the Census 1990 decennial census files.) 


\section{WATER-QUALITY MONITORING}

Water-quality data obtained from analyses of water samples collected at monitoring stations are stored in the U.S. Geological Survey's (USGS) National Water Information System and the U.S. Environmental Protection Agency's (EPA) national data base known as STORET. Water-quality and streamflow data are reported by water year-the 12 months from October 1 through September 30. A water year is identified by the calendar year in which it ends. For example, water year 1991 comprises October I, 1990, through September 30, 1991.
The data used in this summary of Missouri's stream water quality were obtained from water samples collected at 19 monitoring stations at which data collection is systematic and continuing (fig. 2). Analyses of water samples collected at 10 stations are the basis for the discussion and graphic summary (fig. 3 ) of stream water-quality conditions during water years 1987-89, and data from all 19 stations are the basis for the discussion and graphic summary (fig. 4) of stream water-quality trends. Water samples were collected and analyzed by using standard methods approved by the USGS (Britton and Greeson, 1987; Fishman and Friedman, 1989; Ward and Harr, 1990) or by using equivalent methods. If a method of sample collection or analy-

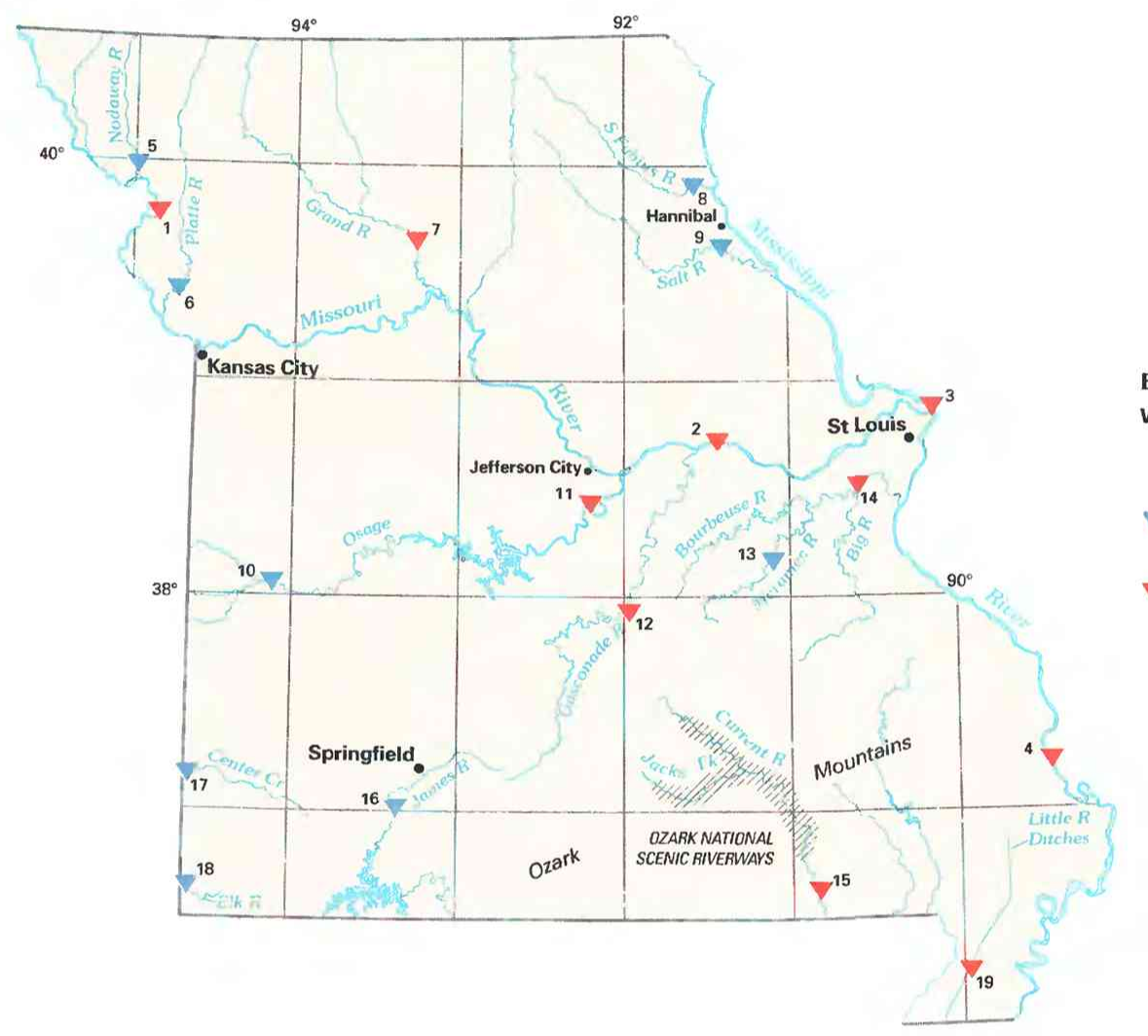

\section{EXPLANATION}

Water-quality monitoring station and type of statistical analysis-

Number refers to accompanying table

${ }^{6}$ Water-quality trends (see fig. 4)

$\nabla^{7}$ Water-quality conditions and trends (see figs. 3 and 4 )

\begin{tabular}{|c|c|c|c|}
\hline $\begin{array}{l}\text { Site no. } \\
\text { on map }\end{array}$ & $\begin{array}{l}\text { USGS station } \\
\text { name and no. }\end{array}$ & $\begin{array}{l}\text { Drainage area } \\
\text { (square miles) }\end{array}$ & $\begin{array}{l}\text { Major land use } \\
\text { (see fig. 1) }\end{array}$ \\
\hline 1 & Missouri River at St. Joseph $(06818000)$..... & 420,300 & Mostly cropland. \\
\hline 2 & Missouri River at Hermann (06934500) & 524,200 & $\begin{array}{l}\text { Cropland with grazing land; cropland with pasture, woodland, } \\
\text { and forest. }\end{array}$ \\
\hline 3 & Mississippi River below Alton, III. (05587550).. & 171,500 & Cropland with pasture, woodland, and forest. \\
\hline 4 & Mississippi River at Thebes, III. (07022000) .......... & 713,200 & Cropland with pasture, woodland, and forest; mostly cropland. \\
\hline 5 & Nodaway River near Dregon $(06817800)$ & 1,640 & Mostly cropland. \\
\hline 6 & Platte River at Sharps Station (06821190) & 2,380 & Mostly cropland; cropland with grazing land. \\
\hline 7 & Grand River near Sumner $(06902000)$ & 6,880 & Ditto. \\
\hline 8 & 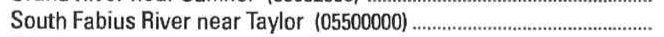 & 620 & Cropland with pasture, woodland, and forest. \\
\hline 9 & Salt River near New London (05508000) ....................... & 2,480 & Ditto. \\
\hline 10 & 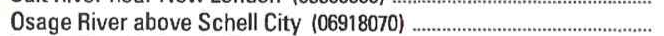 & 5,410 & Cropland with grazing land. \\
\hline 11 & Osage River below St. Thomas $(06926510)$.......... & 14,500 & Cropland with pasture, woodland, and forest. \\
\hline 12 & 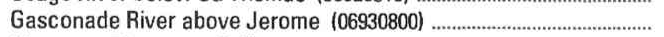 & 2,570 & Woodland and forest with some cropland and pasture. \\
\hline 13 & Meramec River near Sullivan (07014500) & 1,475 & $\begin{array}{l}\text { Grazed forest and woodland; cropland with pasture, woodland, } \\
\text { and forest. }\end{array}$ \\
\hline 14 & 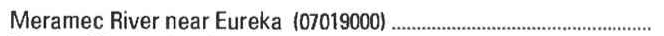 & 3,788 & Ditto. \\
\hline 15 & Current River at Doniphan $(07068000)$ & 2,038 & Ditto. \\
\hline 16 & James River near Boaz (07052250) & 462 & Cropland with pasture, woodland, and forest. \\
\hline 17 & Center Creek near Smithfield (07186480) & 297 & Ditto. \\
\hline 18 & 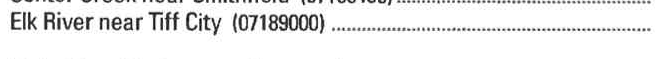 & 872 & $\begin{array}{l}\text { Grazed forest and woodland; cropland with pasture, woodland, } \\
\text { and forest. }\end{array}$ \\
\hline 19 & 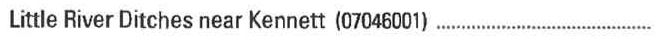 & 1,318 & Mostly cropland. \\
\hline
\end{tabular}

Figure 2. Selected water-quality monitoring stations, type of statistical analysis, and geographic features in Missouri. (Sources: Major land uses modified from Anderson, 1967; other data from U.S. Geological Survey files.) 
sis changed over time, data from an analysis were included in the evaluation of recent stream water quality or of stream water-quality trends only if the change in method did not affect the comparability of the data.

\section{WATER-QUALITY CONDITIONS}

During 1990, the Missouri Department of Natural Resources (1990, p. 1) assessed the quality of 21,063 miles of streams classified for uses designated by the State for purposes of water-quality monitoring and protection. Designated uses for streams in Missouri are protection of aquatic life and fishing, drinking-water supply, irrigation, livestock and wildlife watering, industrial process and cooling water, limited-water-contact recreation, and whole-body-contact recreation. About 9,826 miles of streams-primarily in northern and western Missouri-had partial use impairment because of excessive turbidity and sediment deposition caused by natural soil erosion and erosion from agricultural land, extensive stream channelization, and evaporation during dry weather. Soil characteristics, topography, and hydrology prevent about 8,400 of the 9,826 miles of streams from ever reaching full-use status. Seventeen miles of streams did not support designated beneficial uses primarily because of nonpoint-source mine runoff and municipal wastewater-treatment-plant discharge. Additional sources of stream pollution were urban runoff, industrial effluent, individual wastewater-disposal systems, and animal grazing.

The following discussion of stream water quality in Missouri is organized by river basin (fig. 3). Where physiographic and landuse characteristics in different basins are similar, the discussion of those basins is combined. Graphs in figure 3 summarize certain aspects of stream water quality in the basins for water years 1987-89. The graphs show frequency distributions of data values that represent concentrations of selected stream-water constituents. These constituents are dissolved oxygen, fecal coliform bacteria, dissolved sulfate, dissolved solids, dissolved nitrite plus nitrate (as nitrogen), total phosphorus (as phosphorus), and suspended sediment. The data are reported in milligrams per liter $(\mathrm{mg} / \mathrm{L})$ and colonies per $100 \mathrm{mil}-$ liliters $(\mathrm{col} / 100 \mathrm{~mL})$. Sources and environmental significance of each constituent are described in table 1.

Water quality at each monitoring station is the result of geological, chemical, biological, and hydrologic processes that occur over a large area. Water-quality problems that affect aquatic life or public health only locally are not fully represented in this summary.

Two issues of statewide concern not addressed in this report are contamination of surface waters by agricultural chemicals and of fish by chlordane. Herbicides have been detected in streams in northern Missouri (D.A. Goolsby, U.S. Geological Survey, written commun., January 1990) and in the Mississippi Alluvial Plain (Mesko and Carlson, 1988, p. 11). Excessive concentrations of chlordane in fish have resulted in advisories against the consumption of fish taken from 207 miles of streams (Missouri Department of Natural Resources, 1990, p. 59). The geographic distribution of chlordane contamination indicates that urban runoff was the major source. Chlordane was used primarily for termite control until 1988, when it was banned for all uses by the EPA.

\section{MISSOURI RIVER}

The Missouri River and its tributaries drain an area of 529,000 square miles, which includes all or parts of 10 States and a small part of Canada. The river, which drains one-half of Missouri, is regulated by dams that create reservoirs used for flood control, irrigation, public water supply, and navigation (U.S. Army Corps of Engineers, 1981, p. 1,7). Upstream from sites 1 and 2, the basin is used predominantly as semiarid grazing land and cropland in the upper part of the Missouri River basin and cropland with some grazing land within Missouri.
Suspended-sediment concentrations in the Missouri River historically have been large, in presettlement days because of erosion from sparsely vegetated arid lands and more recently because of agricultural practices and channelization. As a result of reservoir construction, suspended-sediment concentrations in the Missouri River have decreased (Ford, 1982, p. 2). Despite this decrease, the median suspended-sediment concentration at site $1(490 \mathrm{mg} / \mathrm{L})$ was largest for the 10 monitoring stations (fig. 3). Median sulfate (180 $\mathrm{mg} / \mathrm{L}$ and dissolved-solids ( $485 \mathrm{mg} / \mathrm{L}$ ) concentrations also were largest at site 1 . As the Missouri River flows from site 1 to site 2, tributaries contribute water that is less mineralized and less turbid as evidenced by the smaller median concentrations of sulfate $(120$ $\mathrm{mg} / \mathrm{L}$ ), dissolved solids ( $388 \mathrm{mg} / \mathrm{L}$ ), and suspended sediment (155 $\mathrm{mg} / \mathrm{L}$ ) at site 2 .

Small dissolved-oxygen concentrations and bacterial contamination of the river were documented as early as 1913 (Ford, 1982, p. 7, 13). During high flows, dissolved-oxygen concentrations can decrease to less than $3.0 \mathrm{mg} / \mathrm{L}$ in response to oxygen-demanding materials washed into the river by surface runoff or resuspended from the streambed (Ford, 1982, p. 14). Dissolved-oxygen concentrations at sites 1 and 2, however, were greater than the minimum standard of $5.0 \mathrm{mg} / \mathrm{L}$ for the protection of warm- and cool-water fisheries (Missouri Department of Natural Resources, 1991). Median fecal coliform bacteria concentrations were $1,600 \mathrm{col} / 100 \mathrm{~mL}$ at site 1 and $270 \mathrm{col} / 100 \mathrm{~mL}$ at site 2 .

\section{MISSISSIPPI RIVER}

The Mississippi River system drains the entire State. Land use in the basin is predominantly agriculture. Upstream from St. Louis, 29 locks and dams have been constructed and the river has been extensively channelized for navigation and flood control. Between Hannibal and St. Louis, four locks and dams impound the river.

The median nitrite plus nitrate concentration $(1.6 \mathrm{mg} / \mathrm{L})$ was larger for site 3 than for any other monitoring station (fig. 3). Agricultural land and fertilizer and food-processing industries in southern Iowa and in Missouri are believed to be the major sources of nitrite and nitrate (Missouri Department of Natural Resources, 1984, v. 1, p. 7). The median phosphorus concentration $(0.24 \mathrm{mg} / \mathrm{L})$ was larger for site 4 than for any other monitoring station. The large phosphorus concentrations were the result of agricultural land use and the large suspended-sediment concentrations. Most phosphorus in streams is associated with particulate matter. The effects of the Missouri River and the St. Louis urban area on water quality between sites 3 and 4 are apparent from increases in median concentrations of fecal coliform bacteria from $24 \mathrm{col} / 100 \mathrm{~mL}$ at site 3 to $1,500 \mathrm{col} / 100 \mathrm{~mL}$ at site 4 and sulfate from $43 \mathrm{mg} / \mathrm{L}$ at site 3 to $85 \mathrm{mg} / \mathrm{L}$ at site 4 .

Because of the agricultural land use and channelization, suspended-sediment concentrations in the Mississippi River can be large. However, the median suspended-sediment concentration was only $32 \mathrm{mg} / \mathrm{L}$ at site 3 , the result of sediment trapping by the locks and dams (Missouri Department of Natural Resources, 1984, v. 1, p. 7). At site 4, which is downstream from the confluence with the Missouri River, the median suspended-sediment concentration increased to $131 \mathrm{mg} / \mathrm{L}$.

\section{GRAND RIVER}

The Grand River basin upstream from site 7 lies entirely within the Dissected Till Plains. Except for small areas where streams incise consolidated rock, glacial till overlies loess in the basin. Because of the clayey till and underlying shale and coal beds, infiltration of water into the subsurface is minimal. Almost all water movement in the basin is through the surface-stream network. and streamflow is not sustained by ground water during dry weather. 
Extensive agricultural land use and channelization, which result in soil and streambank erosion, and water loss during dry weather are the primary factors affecting water quality in the basin (Missouri Department of Natural Resources, 1984, v. 3, p. 22). Erosion causes stream turbidity and sedimentation, which are major impediments to attainment of aquatic-life protection and fishing designated uses. Runoff containing animal wastes to streams frequently causes fecal coliform bacteria concentrations in basin streams to exceed the State standard for whole-body-contact recreation (median at site 7, 420 $\mathrm{mg} / \mathrm{L}$ for water years $1987-89$ ). The standard requires that, when a stream or lake is not affected by stormwater runoff, the fecal coliform bacteria count should not exceed $200 \mathrm{col} / 100 \mathrm{~mL}$ during the recreational season from April 1 to October 31 in waters designated for whole-body-contact recreation (Missouri Department of Natural Resources, 1991).

\section{OSAGE RIVER}

The upper two-thirds of the Osage River system drains the Osage Plains, which is underlain by alternating sequences of sand- stone, limestone, shale, and coal. The large quantity of impermeable shale present throughout the bedrock ensures that almost all water movement in this part of the basin is through the surface-stream network. Land use in the upper Osage River basin is mostly agricultural, but surface and subsurface coal mining also are important activities. Surface mining creates spoil material that erodes easily and produces mineralized and acidic runoff. About 15 miles of tributary streams in the Osage River basin of Missouri have partial or nonattainment of designated beneficial uses as a direct result of coal-mine drainage (Missouri Department of Natural Resources, 1990, p. 21).

The lower one-third of the Osage River basin lies within the Ozark Plateaus. Tributary streams draining the Springfield Plateau are underlain by limestone, and those draining the Salem Plateau are underlain by dolomite and sandstone. Base flows are sustained by springs. Agricultural land use in the lower Osage River basin is less prevalent than in the upper basin, and woodland and forest predominate.

Although extensive agricultural and mining activities in the upper Osage River basin could detrimentally affect the water quality in the lower part of the basin, the data collected at site 11 do not
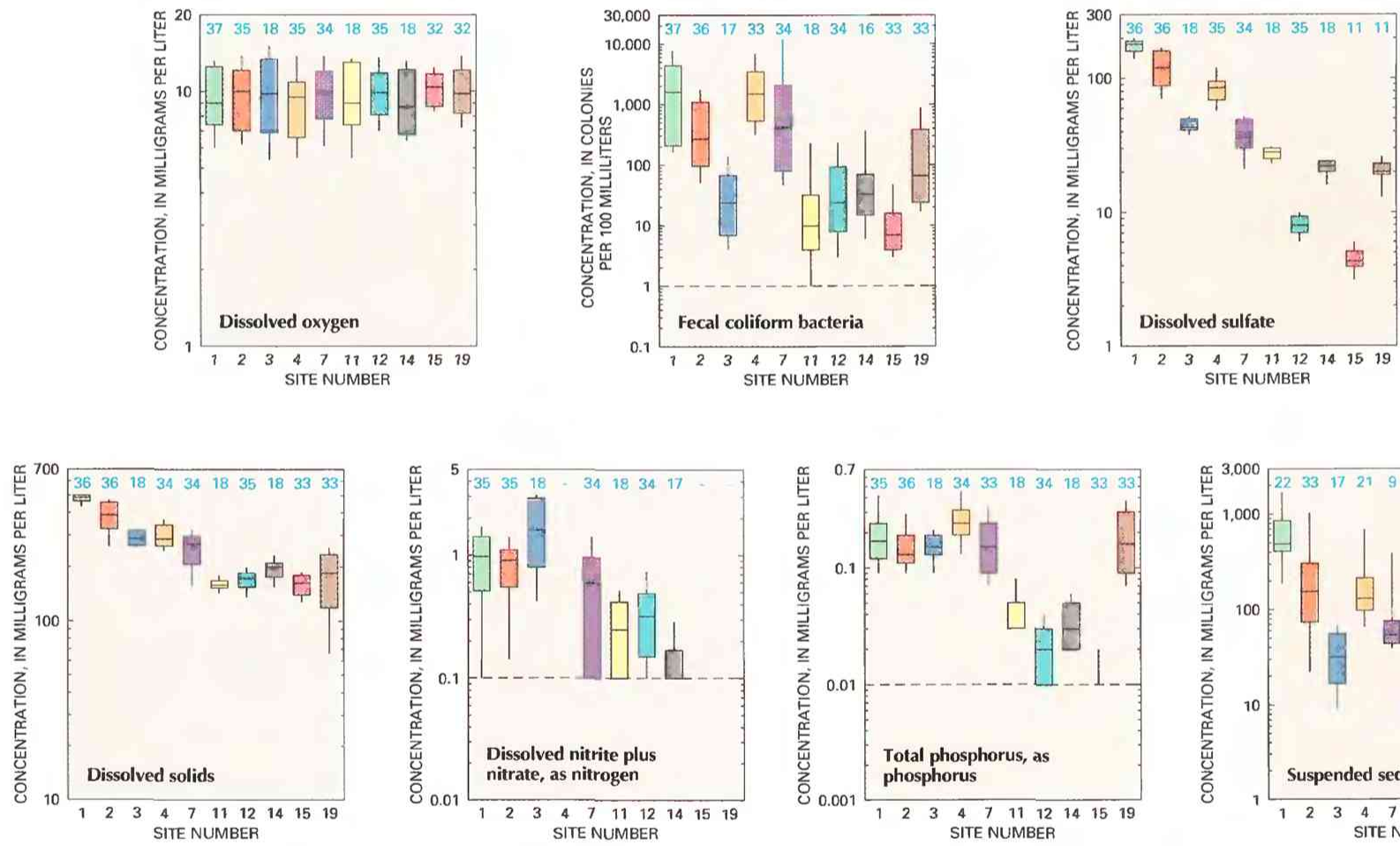

\section{EXPLANATION}

Water-quality conditions in selected
drainage basins
37 Number of analyses - Dash indicates
insufficient data
Percentile_-Percentage of analyses
equal to or less than indicated
values
-90th
-75 th
-50 th-Median
- 25th
10th
Reporting limit-Minimum reporting
limit for analytical method used.
Data below limit line not shown

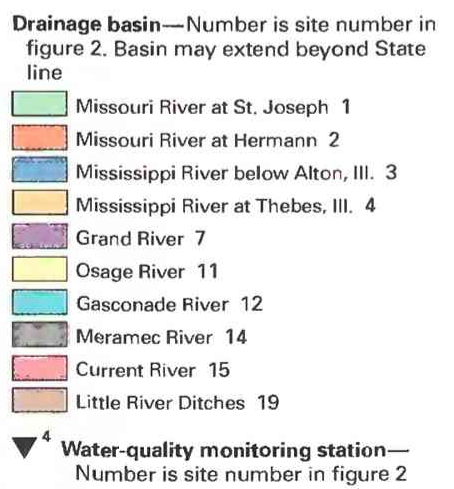

Drainage basin-Number is site number in figure 2. Basin may extend beyond State

Missouri River at Hermann 2

Mississippi River below Alton, III. 3

Mississippi River at Thebes, III. 4

Grand River 7

Osage River 11

Gasconade River 12

Meramec River 14

Current River 15

Little River Ditches 19

Number is site number in figure 2

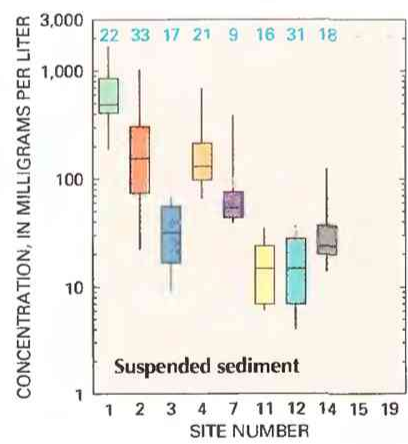

Figure 3. Water quality of selected streams in Missouri, water years 1987-89. (Source: Data from U.S. Geological Survey files.) 
indicate substantial adverse effects from these sources. Water quality at site 11 is affected by reservoirs upstream and by dilution from tributaries draining the Ozark Plateaus, which generally have small dissolved-solids and suspended-sediment concentrations. Reservoirs trap sediment and constituents such as phosphorus that adsorb to sediment particles. With the exception of sulfate, median concentrations of the stream-water constituents at site 11 were among the smallest for the 10 monitoring stations (fig. 3). When compared to data from monitoring stations on other streams draining the Ozark Plateaus (sites 12 and 15) the median sulfate concentration (28 $\mathrm{mg} / \mathrm{L}$ ) is large. This probably is the result of runoff from coal mines and oxidation of naturally occurring sulfide minerals associated with the shale and coal beds in the rocks underlying the upper two-thirds of the basin.

\section{GASCONADE, MERAMEC, AND CURRENT RIVERS}

The entire Gasconade, Meramec, and Current River basins lie within the Salem Plateau. Dissolution of dolomite in these basins results in stream water that generally contains large concentrations of calcium and bicarbonate. Numerous springs sustain base flows. With the exception of the lower Meramec River basin, which flows through urban areas near St. Louis, these basins are predominantly forested but have some cropland and pasture. Unlike basins in the Dissected Till Plains, Osage Plains, and Mississippi Alluvial Plain, soil erosion is minimal and does not adversely affect water quality.

The Gasconade River has been considered for inclusion in the Wild and Scenic Rivers System, but because of shoreline developments and transportation corridors, some segments of the river did not meet the eligibility criteria (Bureau of Outdoor Recreation, 1973, p. 6). Sand and gravel quarrying, livestock grazing, and municipal point-source discharges are potential threats to water quality in the basin. However, constituent concentrations at site 12 (except for dissolved oxygen) were among the smallest for the 10 monitoring stations (fig. 3).

The Meramec River basin includes the main-stem Meramec River and two major tributaries, the Bourbeuse River on the north and the Big River on the south. Land use on the gently rolling terrain of the Bourbeuse River basin is predominantly agricultural, whereas the areas near the main-stem Meramec River and the Big River basin are substantially forested. Concentrations of most streamwater constituents were larger at site 14 on the Meramec River than at the other two monitoring stations in the Salem Plateau-site 12 on the Gasconade River and site 15 on the Current River-where upstream agricultural land use is minimal. Of water samples from the three monitoring stations, those from site 14 also had the largest median sulfate concentration $(22 \mathrm{mg} / \mathrm{L})$. The source of sulfate is abandoned lead-zinc and barite mines in the Big River basin. About 15 miles of streams in the Big River basin have partial or nonattainment of designated beneficial uses because of past mining activities (Missouri Department of Natural Resources, 1990, p. 24). Downstream from site 14, the Meramec River has been designated as a "water-quality-limited" stream because numerous point and nonpoint sources of pollution preclude its meeting water-quality standards at all times (Missouri Department of Natural Resources, 1984, v. 5, p. 63).

During 1974, 134 miles of the Current River and its principal tributary, Jacks Fork, and about 65,000 acres of adjoining land were designated as the Ozark National Scenic Riverways (Barks, 1978, p. 1). The Current River basin, which is the most undeveloped of the three Salem Plateau stream basins, is substantially forested. Median concentrations of fecal coliform bacteria $(7 \mathrm{col} / 100 \mathrm{~mL})$, sulfate $(4.3$ $\mathrm{mg} / \mathrm{L}$ ), dissolved solids ( $163 \mathrm{mg} / \mathrm{L}$ ), and phosphorus (less than 0.01 $\mathrm{mg} / \mathrm{L}$ ) at site 15 were the smallest or among the smallest for the 10 monitoring stations, and the median concentration of dissolved oxygen $(10.4 \mathrm{mg} / \mathrm{L})$ was the largest. All classified streams in the basin have full beneficial-use attainment (Missouri Department of Natural Resources, 1990, p. 29). Potential threats to water quality in this basin are sand and gravel quarrying, livestock grazing, municipal point-source discharges, and contamination of the ground-water system that supplies base flow to the Current River.

\section{LITTLE RIVER DITCHES}

The Little River Ditches are part of an extensive system of canals that has changed much of southeastern Missouri from swamp to cropland (Luckey and Fuller, 1984, p. 7). The water quality of the Little River Ditches is affected primarily by nonpoint sources related to agricultural runoff and channelization (Missouri Department of Natural Resources, 1984, v. 6, p. 24). With the exception of those at site 1 on the Missouri River and site 4 on the Mississippi River, the median phosphorus concentration at site $19(0.16 \mathrm{mg} / \mathrm{L})$ was equal to or larger than those at any other monitoring station (fig. 3). Because the area has little topographic relief, sediment transport by runoff to streams in the Mississippi Alluvial Plain is relatively slight compared to other agricultural areas of the State despite the abundance of tilled cropland. The Little River Ditches generally are turbid, however, because virtually the entire basin has been channelized.

\section{WATER-QUALITY TRENDS}

Trend analysis is a statistical procedure used to detect changes in stream water quality at a monitoring station over time. For this report, water-quality data from 19 monitoring stations (fig. 2) were analyzed for trends by using the seasonal Kendall test (Hirsch and others, 1982), a method used extensively by the USGS. The graph (shown below) of the dissolved-sulfate concentration in Center Creek at site 17 illustrates the trend inferred from the concentration data and demonstrates the variation in water quality that is common in streams.

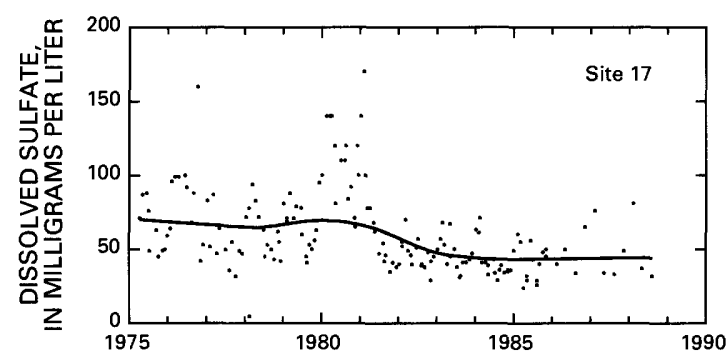

When possible, constituent-concentration data were adjusted for changes in streamflow to preclude identifying a trend in concentration that was caused only by a trend in streamflow. The data were not adjusted when (1) more than 10 percent of the samples had concentrations lower than the minimum reporting limit for the analytical method used or (2) streamflow was controlled substantially by human activities. When the concentration data could not be adjusted for streamflow, trends were determined directly from the concentration data.

Statewide trends in concentrations of selected stream-water constituents are shown on maps in figure 4 . On each map, a trend is indicated at a monitoring station only if the data from that station were suitable for use in the trend analysis. For more information on the suitability criteria and on the trend-analysis procedure used for this report, see Lanfear and Alexander (1990).

\section{DISSOLVED OXYGEN}

The dissolved-oxygen concentration in a stream is controlled by several factors, including water temperature, air temperature and pressure, hydraulic characteristics of the stream, photosynthetic or 
respiratory activity of stream biota, and the quantity of organic material present. A trend in dissolved-oxygen concentrations commonly is directly or indirectly the result of human activities. Generally, an upward trend in dissolved-oxygen concentrations indicates improving stream water-quality conditions and a downward trend indicates deteriorating conditions.

Widely distributed upward trends in dissolved-oxygen concentrations (fig. 4) were the result of a combination of factors, including the construction, improvement, or expansion of municipal wastewater-treatment facilities (John Ford, Missouri Department of Natural Resources, Division of Environmental Quality, oral commun., June 1990), declining livestock numbers, and improved containment of confined-animal waste.

\section{FECAL COLIFORM BACTERIA}

Fecal coliform bacteria are used as indicators of fecal contamination from humans and other warm-blooded animals. Such contamination can introduce disease-causing viruses and bacteria into a stream.

A reason for the slight upward trend in fecal coliform bacteria concentrations in the Osage River at site 10 is not known. However, because of flow regulation upstream from site 10 , fecal coliform bacteria concentrations were not flow adjusted before trend analysis. Increases in flow caused by surface runoff often result in increases in fecal coliform bacteria concentrations, and greater than normal precipitation during water years $1981-88$ could account for the trend.

Increasing treatment of municipal wastewater and recently required disinfection of wastewater in Illinois, Iowa, and Nebraska could account for the decreasing fecal coliform bacteria concentrations in the Missouri River at sites 1 and 2 and the Mississippi River at site 4 (John Ford, Missouri Department of Natural Resources, Division of Environmental Quality, oral commun., June 1990). At site 19 on the Little River Ditches, the downward trend in fecal coliform bacteria concentrations also is associated with improvements in municipal wastewater treatment. Although the South Fabius River basin upstream from site 8 is sparsely populated, decreasing livestock numbers and improved containment of confined-animal wastes could have resulted in the downward trend (John Ford, Missouri Depart- ment of Natural Resources, Division of Environmental Quality, oral commun., June 1990)

\section{DISSOLVED SULFATE}

The major natural sources of sulfate in streams are rock weathering, volcanoes, and biochemical processes (Hem, 1985, p. 113). Human activities such as mining, waste discharge, and fossil-fuel combustion also can be important sources.

Sulfate concentrations had a downward trend at site 17 on Center Creek for water years 1975-89 (fig. 4). Since the cessation of extensive lead-zinc mining activities in the Center Creek basin in the early 1960 's, existing mine tailings have been disturbed only minimally. The removal of easily oxidized sulfide minerals from the existing tailings has resulted in decreasing sulfate concentrations (Davis and Schumacher, 1992, p. 83).

\section{DISSOLVED SOLIDS}

Dissolved solids in stream water result primarily from rock weathering but also can be introduced as a byproduct of human activities (table 1). Concentrations generally are greatest in streams draining basins underlain by rocks and soils that contain easily dissolved minerals. Dissolved-solids concentrations had no trend at the 10 monitoring stations from which data were suitable for trend analysis (fig. 4).

\section{DISSOLVED NITRITE PLUS NITRATE}

Nitrite and nitrate are oxidized forms of nitrogen that together normally constitute most of the dissolved nitrogen in well-aerated streams. Nitrite readily oxidizes to nitrate in natural waters; therefore, nitrate generally is by far the more abundant of the two (Hem, 1985 , p. 124). Nitrogen fertilizer and livestock waste are major sources of nitrite and nitrate in streams.

Nitrite plus nitrate concentrations had downward trends in the Grand River at site 7 and the Osage River at site 11 (fig. 4). During 1980-89, nitrogen-fertilizer use in the drainage basins of the Grand and Osage Rivers was relatively constant (University of Missouri,

Table 1. Sources and environmental significance of selected water-quality constituents

[Source: Compiled by the U.S. Geological Survey, Office of Water Quality]

\begin{tabular}{lll}
\hline Constituent $\quad$ Common sources & Environmental significance
\end{tabular}

$\begin{array}{cc}\text { Dissolved oxygen ...................... } & \begin{array}{c}\text { Introduced from the atmosphere; also a byproduct of } \\ \text { aquatic plants. }\end{array} \\ \text { Fecal coliform bacteria ............... } & \begin{array}{c}\text { Sources include effluent from sewage-treatment } \\ \text { plants and runoff from pastures, feedlots, and ur- } \\ \text { ban areas. }\end{array} \\ \text { Sulfate ................................... } & \begin{array}{c}\text { Occurs in some rocks; also in mine runoff, industrial } \\ \text { wastewater discharge, and atmospheric deposi- } \\ \text { tion. }\end{array}\end{array}$

Dissolved solids

Nitrite plus nitrate

Phosphorus

Suspended sediment
A result of rock weathering; also in agricultural runoff and industrial discharge.

Nonpoint sources are agricultural and urban runoff: a major point source is wastewater discharge.

Occurs in some rocks and sediments; also in runoff and seepage from phosphate-rock mines, agricultural and urban runoff, and industrial and municipal wastewater discharge.

A result of rock erosion; also induced by disturbances of land cover due to fires, floods, and human activities such as mining, logging, construction and agriculture.
Necessary for aquatic life; deficiency can result from assimilation of organic wastes or rapid growth and decay of algae.

Presence indicates contamination of water by wastes from humans and other warm-blooded animals.

Concentrations exceeding a natural, background level indicate contamination from human activity; in sufficient quantity, can cause water to be unsuitable for public supply; can harm aquatic organisms.

In sufficient quantity, can cause water to be unsuitable for public supply, agriculture, and industry; can harm aquatic organisms.

Plant nutrient that, in sufficient quantity, can cause algal blooms and excessive growth of higher aquatic plants in bodies of water; can cause water to be unsuitable for public supply.

Plant nutrient that, in sufficient quantity, can cause algal blooms and excessive growth of higher aquatic plants in bodies of water.

Can be detrimental to aquatic organisms; can fill reservoirs and impair recreational use of water. 
published annually). During the same time period, however, the number of cattle and hogs declined by 39 percent in the Grand River basin and by 22 percent in the Osage River basin (Missouri Agricultural Statistics Office, 1989, p. 40). The downward trends at sites 7 and 11 could have resulted from this decline.

\section{TOTAL PHOSPHORUS}

The total phosphorus concentration of a water sample is a measure of the concentration of all forms of phosphorus present in the sample, dissolved and particulate. Human activities (table 1) can be important sources of phosphorus in streams.
The upward trend in phosphorus concentrations in the Elk River at site 18 (fig. 4) could be attributed primarily to substantial growth within the basin of the confined-animal and poultry industries during the 1980's (John Ford, Missouri Department of Natural Resources, Division of Environmental Quality, oral commun., June 1991). Decreasing phosphorus concentrations in the Missouri River at sites 1 and 2, the South Fabius River at site 8, and the Little River Ditches at site 19 could be the result of several factors, including the decreased use of phosphate fertilizers and phosphate-based detergents, declining livestock numbers, improved containment of confined-animal wastes, and improved municipal-wastewater treatment. For $1975-81$, a statewide average of 193,000 tons of phosphate fer-

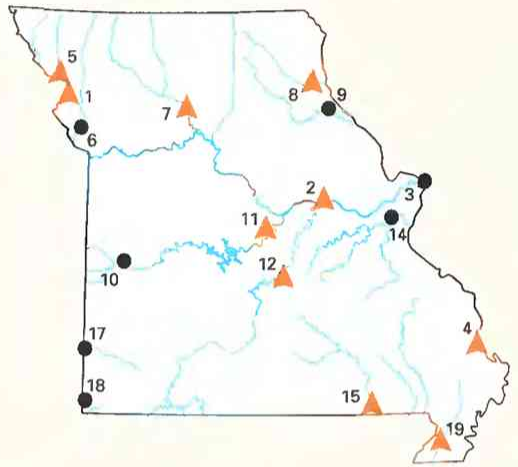

Dissolved oxygen, 1980-89

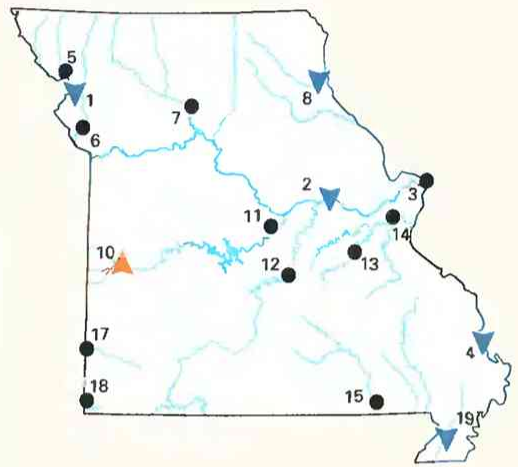

Fecal coliform bacteria, 1980-89

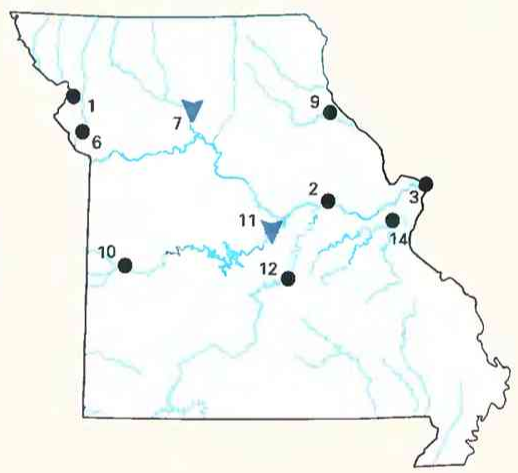

Dissolved nitrite plus nitrate, 1980-89

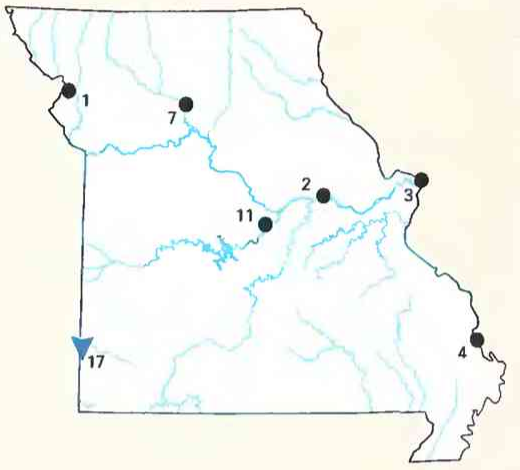

Dissolved sulfate, $1975-89$

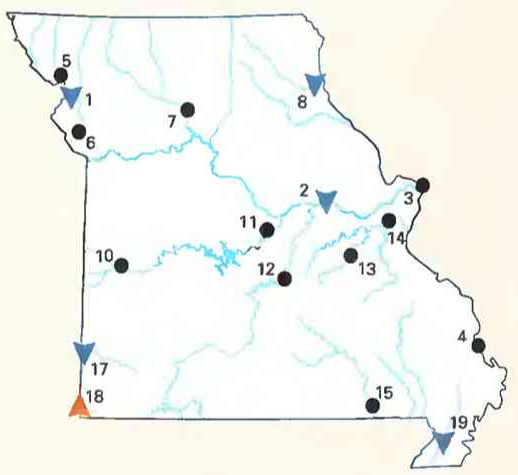

Total phosphorus, 1982-89

Dissolved solids, 1975-89

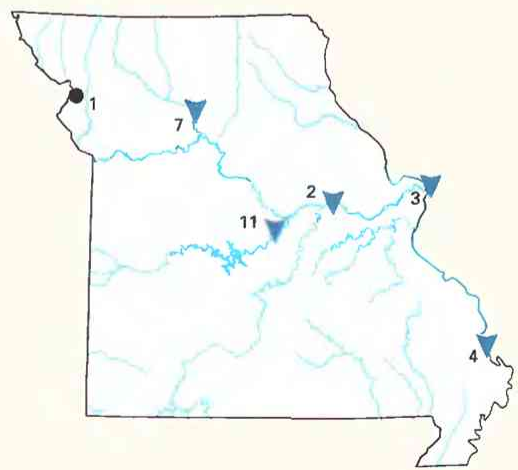

\section{EXPLANATION}

Trend in water-quality constituentNumber is site number in figure 2
$A^{1}$ Upward
- ${ }^{3}$ None
$\nabla^{2}$ Downward

Suspended sediment, $1975-89$

Figure 4. Trends in water quality of selected streams in Missouri, by water years. (Source: Data from U.S. Geological Survey files.) 
tilizer was used per year, but this quantity decreased during 198289 to an average of 154,000 tons per year (Missouri Agricultural Statistics Office, 1989, p. 36). The total number of cattle and hogs in Missouri declined by about 31 percent (about 10.7 to 7.4 million) during the same period (Missouri Agricultural Statistics Office, 1989, p. 40).

In the upper Center Creek basin, runoff from a large pile of phospho-gypsum, which is the waste from phosphate-fertilizer manufacturing, frequently has been the cause of large phosphorus concentrations in Center Creek. Because no new material has been added to the phospho-gypsum pile since the early 1970 's, decreasing phosphorus concentrations in pile leachate have resulted in a downward trend in phosphorus concentrations at site 17 (Davis and Schumacher, 1992, p. 88).

\section{SUSPENDED SEDIMENT}

Suspended sediment is a product of erosion. The erosion can be either natural or the result of land-cover disturbances related to human activities (table 1).

The downward trends in suspended-sediment concentrations in the Missouri River at site 2, the Mississippi River at sites 3 and 4, and the Grand River at site 7 (fig. 4) can be attributed to the adoption of improved agricultural management practices. The Conservation Reserve Program (CRP), conservation tillage, and conventional tillage in combination with the construction of terraces, diversions, waterways, and water-control structures minimize erosion of agricultural lands. The CRP requires that highly erodible cropland be planted in a permanent cover for 10 years. Of the estimated 14.5 million acres of cropland in Missouri, 6.25 million acres are considered highly erodible. Since 1985, about 1.5 million acres of highly erodible cropland in Missouri have been removed from production and placed in the CRP, which means that nearly one-quarter of the State's most erodible land has been taken out of production for at least 10 years (Randy Freeland, U.S. Soil Conservation Service, oral commun., June 1990). During the early to mid-1970's, conservation-tillage methods were promoted in Missouri as an alternative to conventional tillage, and by the early 1980 's some progress had been made in converting cropland to conservation tillage (John McCarthy, U.S. Soil Conservation Service, oral commun., June 1990). From 1986 through 1989, notill acreage increased from 436,000 to 821,000 acres, and total conservation-tillage acreage increased from 3.05 to 3.70 million acres (Lyn Kirschner, Conservation Technology Information Center, written commun., June 1990).

The downward trend in suspended-sediment concentrations in the Osage River at site 11 can be attributed to reservoir construction in the late 1960's and the 1970's. The effects of reservoirs on suspended-sediment concentrations may be observed for long periods of time after construction as a new equilibrium between sediment transport and deposition in the channel is establisned (Smith and others, 1987, p. 13).

\section{WATER-QUALITY MANAGEMENT}

The Water Pollution Control Program of the Missouri Department of Natural Resources' (MDNR) Division of Environmental Quality, and the policy-making Clean Water Commission (CWC) are responsible for enforcement of State laws and regulations concerning standards and management of stream and lake water quality. The Missouri Clean Water Law (Chapter 644) designated the CWC as the State's water-pollution-control agency and empowered the CWC to implement Federal water-pollution-control acts, including but not limited to those concerning water-quality standards, discharge permits, and construction grants.

Section 305(b) of the Federal Clean Water Act requires States to submit biennial water-quality assessment reports to the U.S. Con- gress and the EPA. The MDNR's Water Pollution Control Program is responsible for preparing and submitting these reports (Missouri Department of Natural Resources, 1986: 1990) to document progress in implementing the goals of the Clean Water Act.

The Missouri Water-Quality Coordinating Committee (MWQCC) was organized in 1989 to provide a forum for communication between State and Federal agencies that have water-quality interests. This interagency group chaired by the MDNR comprises the EPA: U.S. Department of Agriculture's Soil Conservation Service, Agricultural Stabilization and Conservation Service, and Forest Service; U.S. Department of the Interior's Fish and Wildlife Service and USGS; U.S. Army Corps of Engineers; Missouri Departments of Agriculture, Conservation, and Health; and the University of Missouri College of Agriculture and Extension. The MWQCC participates in the review and prioritization of nonpoint-source-pollution management projects.

Staff members of the MDNR's Water Resources Program participate in interagency work groups and interstate organizations, including the Missouri Basin States Association, the Upper Mississippi River Basin Association, and the Arkansas-White-Red River Basins Interagency Council. These organizations review Federal projects, negotiate issues that sometimes involve water quality, and coordinate collective efforts among States that contain parts of the organizations' namesake river basins.

The MDNR's surface-water-quality monitoring program has the objectives of defining regional water quality and long-term waterquality trends and identifying and understanding instream waterquality problems so that water resources can be managed effectively and efficiently. The first objective has been met with an ambientwater-quality monitoring necwork operated by the MDNR and the USGS. The second objective is met by special studies that range from longterm chemical and biological studies of specific stream segments to short-term visual assessment and qualitative benthic sampling at many sites.

\section{SELECTED REFERENCES}

Anderson. J.R., 1967, Major land uses in the United States, in U.S. Geological Survey, 1970, National atlas of the United States of America: Washington, D.C., U.S. Geological Survey, p. 158-159.

Barks, J.H., 1978, Water quality in the Ozark National Scenic Riverways, Missouri: U.S. Geological Survey Water-Supply Paper 2048, 57 p.

Britton, L.J., and Greeson, P.E., eds., 1987, Methods for collection and analysis of aquatic biological and microbiological samples: U.S. Geological Survey Techniques of Water-Resources Investigations, book 5, chap. A4, $363 \mathrm{p}$.

Bureau of Outdoor Recreation, 1973, The Gasconade River-A summary of the Federal-State team findings: Ann Arbor, Mich., Bureau of Outdoor Recreation, Lake Central Region, 25 p.

Davis, J.V., and Schumacher, J.G., 1992, Water-quality characterization of the Spring River basin in southwestern Missouri and southeastern Kansas: U.S. Geological Survey Water-Resources Investigations Report 90$4176,112 \mathrm{p}$.

Fenneman, N.M., 1946, Physical divisions of the United States: Washington, D.C., U.S. Geological Survey special map. scale 1:7,000,000.

Fishman, M.J., and Friedman, L.C., eds., 1989, Methods for the determination of inorganic substances in water and fluvial sediments: U.S. Geological Survey Techniques of Water-Resources Investigations, book 5, chap. Al, $545 \mathrm{p}$.

Ford, J.C., 1982, Water quality of the lower Missouri River, Gavins Point Dam to mouth: Missouri Department of Natural Resources, Division of Environmental Quality, $35 \mathrm{p}$.

Goolsby, D.A.. Coupe, R.C., and Markovchick, D.J., 1991, Distribution of selected herbicides and nitrate in the Mississippi River and its major tributaries, April through June 1991: U.S. Geological Survey WaterResources Investigations Report 91-4163, 35 p.

Hem, J.D., 1985, Study and interpretation of the chemical characteristics of natural water (3d ed.): U.S. Geological Survey Water-Supply Paper 2254, $263 \mathrm{p}$. 
Hirsch, R.M., Slack, J.R., and Smith, R.A., 1982, Techniques of trend analysis for monthly water quality data: Water Resources Research, v. 18, no. 1, p. 107-121.

Lanfear, K.J., and Alexander, R.B., 1990, Methodology to derive water-quality trends for use by the National Water Summary Program of the U.S. Geological Survey: U.S. Geological Survey Open-File Report 90-359, $10 \mathrm{p}$.

Luckey, R.R., and Fuller, D.L., 1984, Water resources of the Southeast Lowlands, Missouri: U.S. Geological Survey Water-Resources Investigations Report 84-4277, 78 p.

Mesko, T.O., and Carlson, G.M., 1988, Occurrence of pesticides, nitrate, volatile organic compounds, and trace elements in ground water and streams, southeastern Missouri, 1986-87: U.S. Geological Survey Open-File Report 88-495, 73 p.

Missouri Agricultural Statistics Office, 1989, Missouri farm facts: Columbia, Missouri Department of Agriculture, Agricultural Statistics Office, 67 p.

Missouri Department of Natural Resources, 1984, Missouri water quality basin plans, v. 1-8: Jefferson City, Division of Environmental Quality, variously paginated.

1986, Missouri water quality report 1986: Jefferson City, Missouri Department of Natural Resources, Water Pollution Control Program, $70 \mathrm{p}$. 1990, Missouri water quality report 1990: Jefferson City, Missouri Department of Natural Resources, Water Pollution Control Program, 71 p. 1991, Missouri water quality standards-Chapter 7, Water quality: Jefferson City, Missouri Department of Natural Resources, Clean Water Commission, 30 p.
Smith, R.A., Alexander, R.B., and Wolman, M.G., 1987, Analysis and interpretation of water-quality trends in major United States rivers, 1974 81: U.S. Geological Survey Water-Supply Paper 2307, 25 p.

Solley, W.B., Merk, C.F., and Pierce, R.R., 1988, Estimated use of water in the United States in 1985: U.S. Geological Survey Circular 1004, 82 p.

Thelin, G.P., and Pike, R.J., 1990, Digital shaded relief map of the conterminous United States: Menlo Park, Calif., U.S. Geological Survey digital image processing, scale 1:3,500,000.

U.S. Army Corps of Engineers, 1981, Missouri River corridor inventory: Kansas City District, 43 p.

U.S. Geological Survey, 1986, National water summary 1985-Hydrologic events and surface-water resources: U.S. Geological Survey Water-Supply Paper 2300, 506 p.

1990, National water summary 1987-Hydrologic events and water supply and use: U.S. Geological Survey Water-Supply Paper 2350, $553 \mathrm{p}$.

University of Missouri, published annually, Missouri fertilizer tonnage report: Columbia, Agricultural Experiment Station, pamphlet.

Ward, J.R., and Harr, C.A., eds., 1990, Methods for collection and processing of surface-water and bed-material samples for physical and chemical analyses: U.S. Geological Survey Open-File Report 90-140, 71 p. 
Prepared by Jerri V. Davis, U.S. Geological Survey; “Water-Quality Management” section by John R. Howland, Missouri Department of Natural Resources

FOR ADDITIONAL INFORMATION: District Chief, U.S. Geological Survey, 1400 Independence Road, Mail Stop 200, Rolla, MO 65401 


\section{MONTANA Stream Water Quality}

Montana streams range in water quality from that of nearly pure rainwater in some of the western mountains to that exceeding the salinity of seawater at locations in the eastern part of the State. Montana's large rivers originate in mountains and provide abundant, dependable supplies of water suitable for nearly all uses. Some smaller streams, particularly in the eastern one-half of the State, do not provide dependable supplies because of limitations in quantity and quality.

Surface-water sources provided almost 98 percent of total freshwater withdrawals in Montana in 1985 . Of the $8,450 \mathrm{Mgal} / \mathrm{d}$ (million gallons per day) of surface-water withdrawals, about 98 percent $(8,260 \mathrm{Mgal} / \mathrm{d})$ was used for agriculture, the major land use in the State (fig. 1A) (U.S. Geological Survey, 1990, p. 338). The second largest use of surface water was public supply, which accounted for $96 \mathrm{Mgal} / \mathrm{d}$ or 1.1 percent of total surface-water use.

Sources of water for Montana streams include direct runoff of rainfall and snowmelt and water that discharges from aquifers. Peak flows occur from late winter to late spring. The western and south- central parts of the State, which are in the Northern and Middle Rocky Mountains physiographic provinces (fig. $1 B$ ), receive annual precipitation that ranges from about 6 inches in the driest valleys to about 100 inches in the high mountains. Eastern Montana is in the northern Great Plains physiographic province, where precipitation ranges from about 12 to 30 inches annually (U.S. Soil Conservation Service, 1981).

In 1990, Montana had a population of 799,000 (U.S. Bureau of the Census 1990 decennial census files), most of which is concentrated in the western and south-central parts of the State (fig. 1C). The 1990 population represents an increase of 1.6 percent since 1980 .

\section{WATER-OUALITY MONITORING}

Water-quality data obtained from analyses of water samples collected at monitoring stations are stored in the U.S. Geological Survey's (USGS) National Water Information System and the U.S. Environmental Protection Agency's (EPA) national data base known as

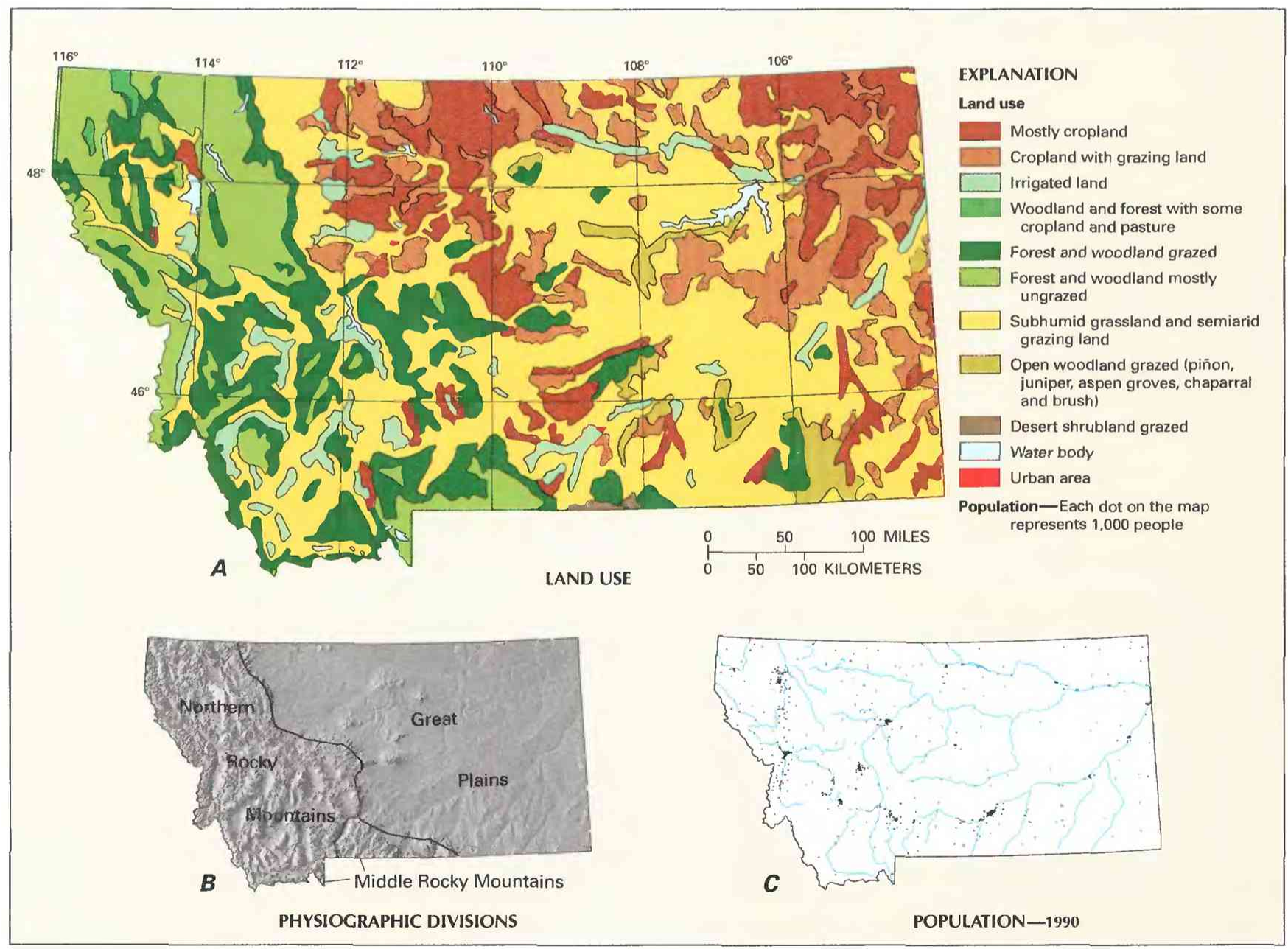

Figure 1. Land use, physiography, and population in Montana. A, Major land uses. B. Physiographic divisions. C, Population distribution in 1990. (Sources: A, Major land uses modified from Anderson, 1967. B. Physiographic divisions from Fenneman, 1946; landforms from Thelin and Pike, 1990. C, Data from U.S. Bureau of the Census 1990 decennial census files.) 
STORET. Water-quality and streamflow data are reported by water year - the 12 months from October 1 through September 30. A water year is identified by the calendar year in which it ends. For example, water year 1991 comprises October 1, 1990, through September 30, 1991.

The data used in this summary of Montana's stream water quality were obtained from water samples collected either every 2 months or quarterly at 16 monitoring stations at which data collection is systematic and continuing (fig. 2). Analyses of water samples collected at 10 stations are the basis for the discussion and graphic summary (fig. 3) of stream water-quality conditions during water years 1987-89, and data from all 16 stations are the basis for the discussion and graphic summary (fig. 4) of stream water-quality trends. Water samples were collected and analyzed by using standard methods approved by the USGS (Britton and Greeson, 1987; Fishman and Friedman, 1989; Ward and Harr, 1990) or by using equivalent methods. If a method of sample collection or analysis changed over time, data from an analysis were included in the evaluation of recent stream water quality or of stream water-quality trends only if the change in method did not affect the comparability of the data.

\section{WATER-QUALITY CONDITIONS}

The Montana Department of Health and Environmental Sciences (1988) reported that about 80 percent (20,500 miles) of Montana's stream miles have been evaluated for water-quality conditions.
Of the evaluated stream miles, 63 percent fully supported designated uses, 34 percent partially supported designated uses, and 3 percent did not support designated uses. Three categories of toxic contaminants of most concern to public health and aquatic life in Montana are toxic trace elements, chlorine and ammonia, and chlorinated hydrocarbons. About 890 stream miles had concentrations of toxic trace elements in excess of background values. Nontoxic contaminants that cause persistent problems are sediments, salts, and nutrients. These contaminants originate predominantly from agriculture, resource extraction, forestry practices, and natural processes.

The following discussion of stream water quality in Montana is organized by river basin (fig. 3). Where physiographic and landuse characteristics in different basins are similar, the discussion of those basins is combined. Graphs in figure 3 summarize certain aspects of stream water quality in the basins for water years 1987-89. The graphs show frequency distributions of data values that represent concentrations of selected stream-water constituents. These constituents are dissolved oxygen, fecal coliform bacteria, dissolved sulfate, dissolved solids, dissolved nitrite plus nitrate (as nitrogen), total phosphorus (as phosphorus), and suspended sediment. The data are reported in milligrams per liter $(\mathrm{mg} / \mathrm{L})$ and colonies per $100 \mathrm{milli}-$ liters $(\mathrm{col} / 100 \mathrm{~mL})$. Sources and environmental significance of each constituent are described in table 1.

Water quality at each monitoring station is the result of geological, chemical, biological, and hydrologic processes that occur

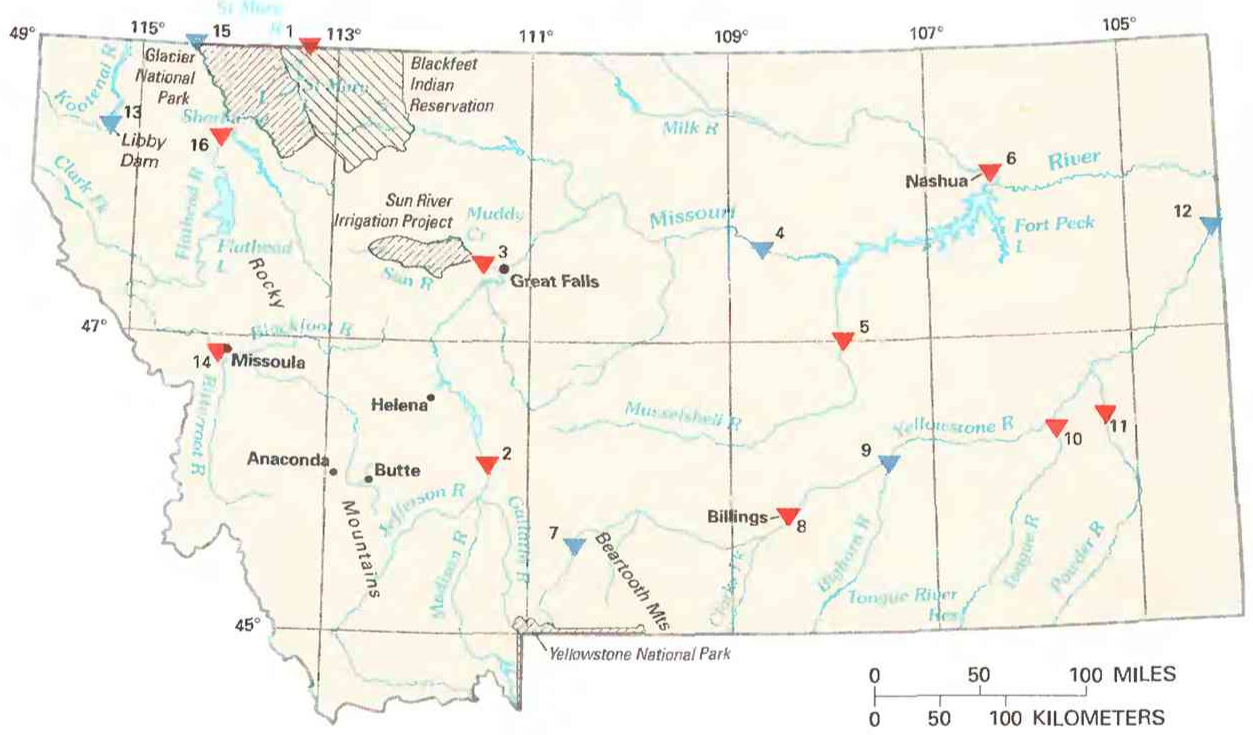

\section{EXPLANATION}

Water-quality monitoring station and type of statistical analysisNumber refers to accompanying table

${ }^{4}$ Water-quality trends (see fig. 4)

$\nabla^{5}$ Water-quality conditions and trends (see figs. 3 and 4)

\begin{tabular}{|c|c|c|c|}
\hline $\begin{array}{l}\text { Site no. } \\
\text { on map }\end{array}$ & $\begin{array}{l}\text { USGS station } \\
\text { name and no. }\end{array}$ & $\begin{array}{l}\text { Drainage area } \\
\text { (square miles) }\end{array}$ & $\begin{array}{l}\text { Major land use } \\
\text { (see fig. 1) }\end{array}$ \\
\hline 1 & St. Mary River at international boundary $(05020500)$ & 465 & Mostly ungrazed forest and woodland. \\
\hline 2 & Missouri River at Toston $(06054500)$ & 14,669 & Subhumid grassland and semiarid grazing land. \\
\hline 3 & 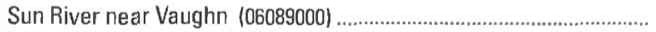 & 1,854 & Irrigated land. \\
\hline 4 & 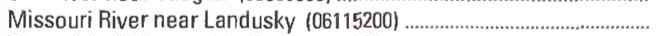 & 40,987 & Subhumid grassland and semiarid grazing land. \\
\hline 5 & 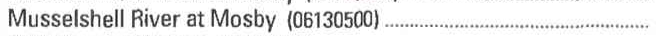 & 7,846 & Ditto. \\
\hline 6 & Milk River at Nashua $(06174500)$ & 22,332 & Mostly cropland. \\
\hline 7 & 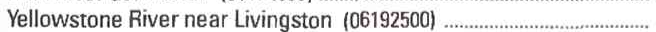 & 3,551 & Mostly ungrazed forest and woodland. \\
\hline 8 & Yellowstone River at Billings $(06214500)$ & 11,795 & Ditto. \\
\hline 9 & Bighorn River at Bighorn $(06294700)$ & 22,885 & Subhumid grassland and semiarid grazing land. \\
\hline 10 & Tongue River at Miles City $(06308500)$ & 5,379 & Ditto. \\
\hline 11 & Powder River near Locate $(06326500)$ & 13,194 & Ditto. \\
\hline 12 & Yellowstone River near Sidney (06329500) & 69,103 & Ditto. \\
\hline 13 & Kootenai River below Libby Dam, near Libby (12201933) ...................... & 8,985 & Mostly ungrazed forest and woodland. \\
\hline 14 & Clark Fork below Missoula $(12353000)$ & 9,003 & Grazed forest and woodland. \\
\hline 15 & Flathead River at Flathead, British Columbia $(12355000)$ & 427 & Mostly ungrazed forest and woodland. \\
\hline 16 & Flathead River at Columbia Falls $(12363000)$ & 4,464 & Ditto. \\
\hline
\end{tabular}

Figure 2. Selected water-quality monitoring stations, type of statistical analysis, and geographic features in Montana. (Sources: Major land uses modified from Anderson, 1967; other data from U.S. Geological Survey files.) 
over a large area. Water-quality problems that affect aquatic life or public health only locally are not fully represented in this summary.

\section{ST. MARY RIVER}

The St. Mary River, which has 70 percent of its Montana drainage in Glacier National Park and the remainder in the Blackfeet Indian Reservation, flows northward across the international boundary into Canada. The high mountains of Glacier National Park consist of resistant sedimentary rocks of Precambrian age that provide little mineralization to runoff from snowmelt and rainfall. More soluble shale and sandstone of Cretaceous age form the lower, gentle slopes in the park and are exposed at land surface in the reservation (Ross and others, 1955). St. Mary Lake, Lower St. Mary Lake, and Lake Sherburne retain and mix runoff water, which results in smaller annual fluctuation in concentrations of dissolved constituents than in other basins.

Population in the basin is sparse, and wastewater discharges are few and minor (Montana Department of Health and Environmental Sciences, 1986, p. 168). The primary land use outside of Glacier National Park is grazing. The median dissolved-solids concentration in water samples collected during $1987-89$ at site 1 was $107 \mathrm{mg} / \mathrm{L}$, the second smallest median concentration for the 10 monitored basins (fig. 3). Likewise, concentrations of other dissolved and suspended constituents, except for dissolved oxygen, were small compared to those at other stations (fig. 3). Dissolved-oxygen concentrations are greater in a natural, healthy stream.

\section{UPPER MISSOURI RIVER}

The Jefferson, Madison, and Gallatin Rivers, which form the Missouri River at their confluence, drain southwestern Montana and northwestern Yellowstone National Park. The area is characterized by mountain ranges separated by broad valleys that are extensively irrigated. Geology is varied. The mountains consist of relatively insoluble crystalline rocks and sedimentary formations of Precambrian and Paleozoic age (Ross and others, 1955).

Although fecal coliform bacteria, dissolved-solids, nitrite plus nitrate, and suspended-sediment concentrations in the Missouri River at site 2 were smaller than those in most other basins (fig. 3), local and basinwide water-quality problems exist. Irrigation, overgrazing, logging, hydroelectric power impoundments, and residential and
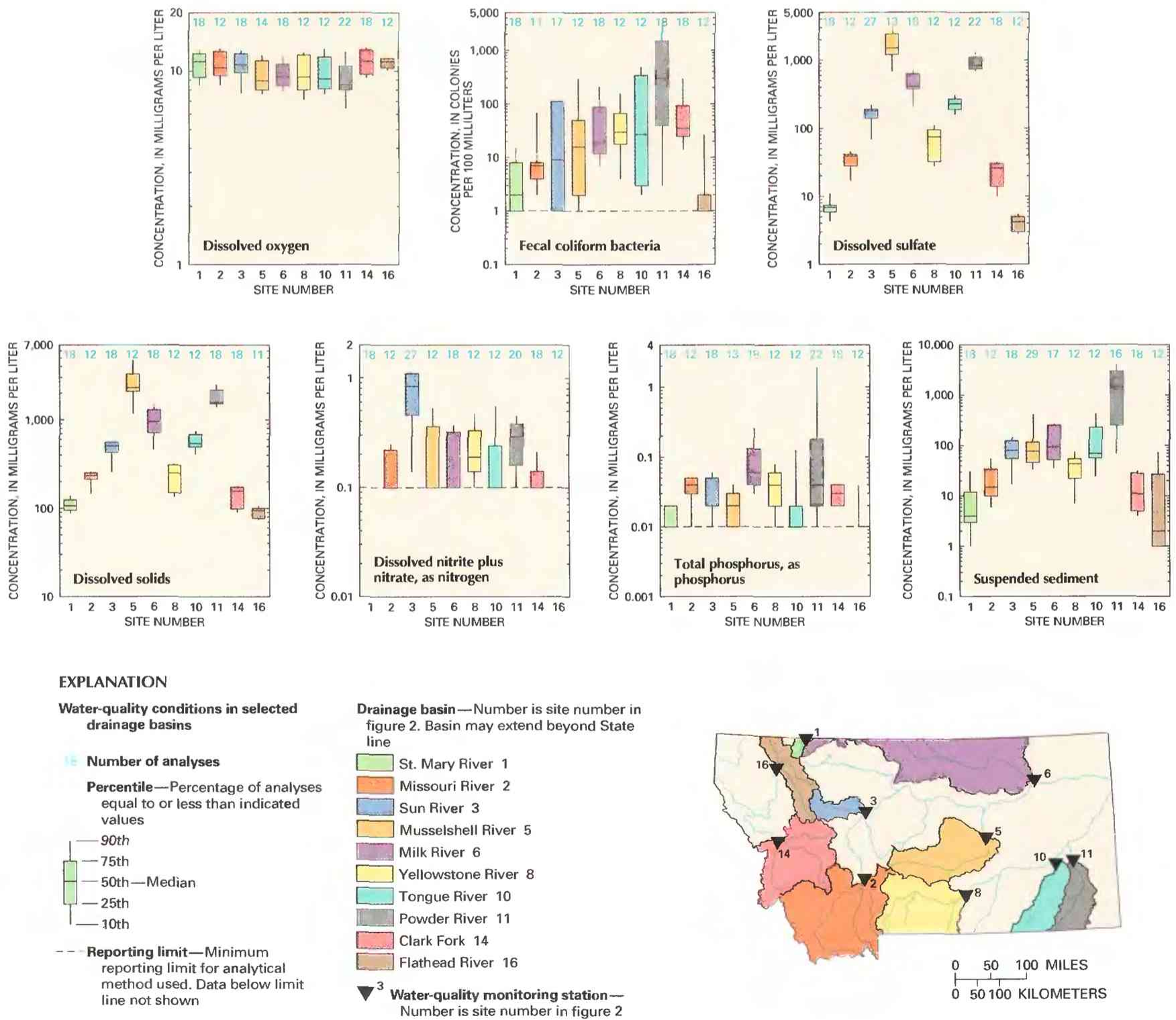

Figure 3. Water quality of selected streams in Montana, water years 1987-89. (Source: Data from U.S. Geological Survey files.) 
commercial development are important factors that affect water quality in the basin (Montana Department of Health and Environmental Sciences, 1986, p. 170). Effects of these factors are illustrated by phosphorus concentrations, which had a median $(0.04 \mathrm{mg} / \mathrm{L})$ that was among the largest for all basins and is sufficient to cause major algal blooms and nuisance aquatic-plant growth in reservoirs both upstream and downstream from site 2 .

Enriched geothermal waters within Yellowstone National Park contribute arsenic to tributaries of the Madison River (Stauffer and others, 1980). Arsenic concentrations in the river, as it flows from the park, are in the range of $140-360 \mathrm{mg} / \mathrm{L}$ (Knapton and Brosten, 1989). Tributary inflows progressively dilute arsenic concentrations as the water flows downstream. However, during periods of maximum irrigation, inflowing water to the Madison and Missouri Rivers can be substantially decreased, causing arsenic concentrations to increase significantly. Because water downstream from site 2 is used extensively for potable supplies, the Montana Department of Health and Environmental Sciences has requested instream-flow reservations on several tributaries to maintain dilution (A.A. Horpestad, Montana Department of Health and Environmental Sciences, oral commun., 1990).

\section{SUN RIVER}

The Sun River forms along the eastern slopes of the Rocky Mountains and flows through the plains to its confluence with the Missouri River. The mountains consist of resistant Precambrian and Paleozoic limestone, sandstone, and shale (Ross and others, 1955) that contribute water having small concentrations of dissolved constituents. However, less-resistant Cretaceous shale and Pleistocene glaciolacustrine deposits, which are present in much of the middle and lower basin, are major downstream sources of mineralized water and suspended sediment. As a consequence, water at site 3 had a median dissolved-solids concentration $(507 \mathrm{mg} / \mathrm{L})$ that is near the established criterion set by the State of Montana for public water supplies and a median suspended-sediment concentration (80 $\mathrm{mg} / \mathrm{L}$ ) that ranks third largest among those in the 10 basins (fig. 3 ).

The predominant water use in the basin is irrigation, largely in the Sun River Irrigation Project, which has 91,000 acres of irrigated land. Within the project, nitrogen residue from fertilizer is

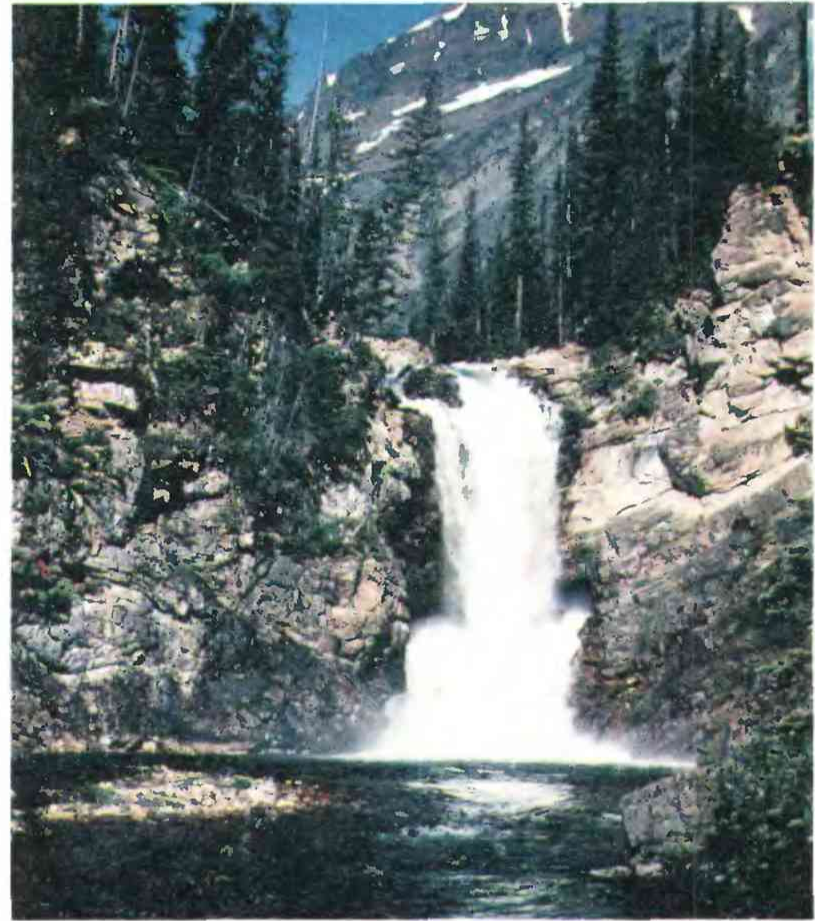

Headwater stream in the upper Missouri River basin. Streams draining the eastern slopes of northern Montana's Rocky Mountains carry pristine water to users downstream. (John H. Lambing. U.S. Geological Survey.)

leached from the soil and carried to the river by surface and subsurface return flows. Although concentrations were moderate compared with those of many other streams in the Nation that are affected by agriculture, nitrite plus nitrate concentrations (median, $0.84 \mathrm{mg} / \mathrm{L}$ ) at site 3 were the largest in any of the Montana basins described (fig. 3). Lower basin sediment problems result from a combination of natural characteristics and agricultural practices. Muddy Creek, a tributary that enters the Sun River 3.7 miles upstream from site 3, receives much of the return flow from the Sun River Irrigation

Table 1. Sources and environmental significance of selected water-quality constituents [Source: Compiled by the U.S. Geological Survey, Office of Water Quality]

\begin{tabular}{|c|c|c|}
\hline Constituent & Common sources & Environmental significance \\
\hline Dissolved oxygen ......................... & $\begin{array}{l}\text { Introduced from the atmosphere; also a byproduct of } \\
\text { aquatic plants. }\end{array}$ & $\begin{array}{l}\text { Necessary for aquatic life; deficiency can result from } \\
\text { assimilation of organic wastes or rapid growth } \\
\text { and decay of algae. }\end{array}$ \\
\hline Fecal coliform bacteria ................ & $\begin{array}{l}\text { Sources include effluent from sewage-treatment } \\
\text { plants and runoff from pastures, feedlots, and ur- } \\
\text { ban areas. }\end{array}$ & $\begin{array}{l}\text { Presence indicates contamination of water by wastes } \\
\text { from humans and other warm-blooded animals. }\end{array}$ \\
\hline 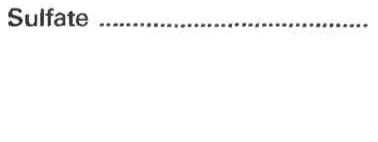 & $\begin{array}{l}\text { Occurs in some rocks; also in mine runoff, industrial } \\
\text { wastewater discharge, and atmospheric deposi- } \\
\text { tion. }\end{array}$ & $\begin{array}{l}\text { Concentrations exceeding a natural, background } \\
\text { level indicate contamination from human activity; } \\
\text { in sufficient quantity, can cause water to be } \\
\text { unsuitable for public supply; can harm aquatic } \\
\text { organisms. }\end{array}$ \\
\hline Dissolved solids .............................. & $\begin{array}{l}\text { A result of rock weathering; also in agricultural runoff } \\
\text { and industrial discharge. }\end{array}$ & $\begin{array}{l}\text { In sufficient quantity, can cause water to be unsuitable } \\
\text { for public supply, agriculture, and industry; can } \\
\text { harm aquatic organisms. }\end{array}$ \\
\hline Nitrite plus nitrate ....................... & $\begin{array}{l}\text { Nonpoint sources are agricultural and urban runoff; } \\
\text { a major point source is wastewater discharge. }\end{array}$ & $\begin{array}{l}\text { Plant nutrient that, in sufficient quantity, can cause } \\
\text { algal blooms and excessive growth of higher } \\
\text { aquatic plants in bodies of water; can cause water } \\
\text { to be unsuitable for public supply. }\end{array}$ \\
\hline 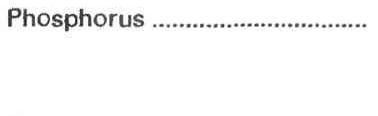 & $\begin{array}{l}\text { Occurs in some rocks and sediments; also in runoff } \\
\text { and seepage from phosphate-rock mines, agri- } \\
\text { cultural and urban runoff, and industrial and } \\
\text { municipal wastewater discharge. }\end{array}$ & $\begin{array}{l}\text { Plant nutrient that, in sufficient quantity, can cause } \\
\text { algal blooms and excessive growth of higher } \\
\text { aquatic plants in bodies of water. }\end{array}$ \\
\hline Suspended sediment ................... & $\begin{array}{l}\text { A result of rock erosion; also induced by disturbances } \\
\text { of land cover due to fires, floods, and human } \\
\text { activities such as mining, logging, construction, } \\
\text { and agriculture. }\end{array}$ & $\begin{array}{l}\text { Can be detrimental to aquatic organisms; can fill res- } \\
\text { ervoirs and impair recreational use of water. }\end{array}$ \\
\hline
\end{tabular}


Project. Extensive bank erosion and subsequent transport of suspended sediment to the Sun River and then to the Missouri River are reasons for Muddy Creek to be designated as one of Montana's "worst water-quality problems" (Montana Department of Health and Environmental Sciences, 1984, p. 51).

\section{MUSSELSHELL RIVER}

The Musselshell River of central Montana has its headwaters in the Northern Rocky Mountains and flows eastward into the northern Great Plains. Except in some mountainous headwater areas, rock formations consist mostly of nonresistant, moderately soluble shale, siltstone, and sandstone of Mesozoic and Cenozoic age (Ross and others, 1955). These formations and their associated soils contribute mineralized water to mountain runoff and caused dissolved-solids concentrations at site 5 (median, $2,300 \mathrm{mg} / \mathrm{L}$ ) to be the largest of those in the 10 basins (fig. 3). Sodium and sulfate are the dominant constituents in the water.

The Musselshell River basin is sparsely populated and land use is mostly agricultural, although some timber is harvested in headwater areas. Irrigation is the basin's largest use of water; about 103,000 acres are irrigated upstream from site 5. Salinity and sedimentation are considered to be the basin's major water-quality problems (Montana Department of Health and Environmental Sciences, 1986, p. 114). These problems stem from natural basin characteristics but are augmented by irrigated farming and other land uses. Irrigation return flow contributes additional quantities of dissolved solids to the river, and streambed erosion results from stock watering and grazing in stream riparian zones. The median suspended-sediment concentration in the Musselshell River at site 5 was $77 \mathrm{mg} / \mathrm{L}$, the fourth largest median concentration in the 10 basins (fig. 3 ).

\section{MILK RIVER}

The Milk River, which has its headwaters in Glacier National Park, flows into Canada then back into Montana and eventually enters the Missouri River downstream from Fort Peck Lake. During the irrigation season (March through September), water from the St. Mary River basin is diverted into the Milk River to supplement irrigation supplies. Water quality in the basin is affected mostly by the last major geologic event-continental glaciation-which disrupted formations of Cenozoic age and changed drainage patterns (Alden, 1932). Much of the basin has a mantle of glacial moraine that is a source of salts and sediments to the Milk River. The median concentrations of dissolved solids $(953 \mathrm{mg} / \mathrm{L})$ and suspended sediment $(93 \mathrm{mg} / \mathrm{L}$ ) at site 6 were among the largest for the 10 basins (fig. 3 ).

Agriculture, the primary land use, consists of irrigated farming, dryland farming, and livestock grazing. About 140,000 acres are irrigated upstream from site 6 . Fertilizers are widely used on cropland in the basin, and irrigation return flow, along with natural runoff, carries residues of nitrogen and phosphorus to the river. Nitrite plus nitrate concentrations were similar to those in other Montana streams affected by irrigation (fig. 3), but the median total-phosphorus concentration $(0.06 \mathrm{mg} / \mathrm{L})$ ranks as the largest for all basins. Phosphorus, through adsorptive processes, has an affinity for the clay particles that are abundant in the sediment transported by the Milk River. Also, at several locations, industries and livestock operations discharge wastewater to the river; at least a dozen municipalities do so as well (Montana Department of Health and Environmental Sciences, 1986, p. 116).

\section{UPPER YELLOWSTONE RIVER}

The Yellowstone River flows from mountain headwaters in Yellowstone National Park in Wyoming onto the Montana plains. Along the way, the river has tributary inflow of pristine waters from the Beartooth Mountains. Geology of the headwaters area consists of a complex of nearly insoluble crystalline rock, limestone, and sandstone in combination with younger, more soluble formations and valley fill (Ross and others, 1955). The diversity of rock types often causes water in tributaries to differ in chemical character. In addition to water-quality variability owing to rock type, mineralized water from geothermal springs within and near Yellowstone National Park also affects the quality of the Yellowstone River. Concentrations of trace elements such as arsenic are still large as far downstream as site 8.

Land use in the upper Yellowstone River valley is primarily agriculture, which consists of irrigated and dryland farming and livestock grazing. About 350,000 acres are irrigated upstream from site 8. Billings, the largest urban and industrial center in Montana, has three petroleum refineries, two major municipal-wastewater discharges, a sugar-beet refinery, and a powerplant with a heated discharge (Montana Department of Health and Environmental Sciences, 1986 , p. 190). The most severe water-quality problems in the basin are in the Clarks Fork Yellowstone River and result from both natural conditions and agricultural practices. This tributary enters the main stem about 10 miles upstream from site 8 . A substantial part of salinity, nutrient, and suspended-sediment concentrations measured at site 8 can be attributed to the Clarks Fork Yellowstone River. Despite these contributions, concentrations of most constituents measured at site 8 rank favorably with water from some of the least affected basins in Montana (fig. 3).

\section{TONGUE AND POWDER RIVERS}

The Tongue and the Powder Rivers originate in the Bighorn Mountains in Wyoming, enter the northern Great Plains, and flow northward to their confluences with the Yellowstone River in Montana. Except for the headwaters area, where the rocks are older and less soluble, most of the basins are underlain by moderately soluble sandstone, siltstone, and shale that are a source of dissolved solids dominated by sodium and sulfate (Ross and others, 1955). Dissolvedsolids concentrations in the Tongue River at site 10 were smaller than those in the Powder River at site 11 partly because the Tongue River has less drainage area in the plains. In the Powder River, oil-field production waters discharged from the upstream, Wyoming part of the basin contribute sodium, chloride, and sulfate (Montana Department of Health and Environmental Sciences, 1986, p. 81). The Powder River at site 11 had the largest median concentration of fecal coliform bacteria $(300 \mathrm{col} / 100 \mathrm{~mL})$ and the second largest median concentration of nitrite plus nitrate $(0.29 \mathrm{mg} / \mathrm{L})$ among the basins. Irrigation accounts for most water use; about 100,000 acres are irrigated in each basin.

Formations of easily eroded rock are sources of sediment that can enter the streams during snowmelt and rainfall runoff. About 30 percent ( 3.77 million tons) of the annual suspended-sediment load at the mouth of the Yellowstone River is from the Powder River, yet the Powder River accounts for less than 5 percent of the discharge (U.S. Geological Survey, published annually). The median suspended-sediment concentration $(1,450 \mathrm{mg} / \mathrm{L})$ at site 11 was the largest in any basin, and phosphorus, which has an affinity for clay particles, had a median concentration of $0.04 \mathrm{mg} / \mathrm{L}$-among the largest. Much of the sediment load in the Tongue River is deposited in the Tongue River Reservoir near the Montana-Wyoming border.

\section{CLARK FORK}

The upper Clark Fork basin lies within the Northern Rocky Mountains. The main stem and tributaries are surrounded by mountains formed of nearly insoluble crystalline rock, limestone, quartzite, and argillite of Precambrian age (Ross and others, 1955). Moderately soluble Tertiary formations that commonly are overlain by 
glacial deposits and alluvium lie beneath the valleys. Besides natural processes, the water quality is affected by mining and ancillary operations, forestry practices, agriculture, industry, and municipal discharges (Johnson and Schmidt, 1988). Site 14 is downstream from two major tributaries, the Blackfoot and Bitterroot Rivers, that dilute the more mineralized water of the Clark Fork. Concentrations of dissolved solids were substantially larger upstream from the confluence with these tributaries. Conversely, fecal coliform bacteria and phosphorus values were larger at site 14 than upstream because of effects from the city of Missoula and the surrounding area.

Water-quality and other environmental problems prevail throughout the upper Clark Fork basin. The EPA has designated four Superfund sites in the basin, including the largest in the Nation. Most of the water-quality problems can be traced to mining and related activities in the Butte-Anaconda area during the past 100 years. Extensive mine tailings in headwater areas were eroded, carried downstream, and deposited on flood plains and in impounded water upstream from dams. Thus, a nearly unlimited source of toxic trace elements exists that can be mobilized by overland runoff and bank erosion. The trace elements of most concern are arsenic, cadmium, copper, lead, and zinc.

\section{UPPER FLATHEAD RIVER}

Site 16 is downstream from the confluence of the three streams that form the Flathead River and upstream from Flathead Lake, the largest natural freshwater lake in the Western United States. Most of the basin consists of national forest and the western and southern parts of Glacier National Park. The terrain consists predominantly of mountains and intermontane valleys. The mountains are formed mostly of Precambrian limestone, quartzite, and argillite (Ross and others, 1955); runoff from the mountains provides a calcium bicarbonate-type water having small concentrations of dissolved solids (fig. 3).

Water quality in the basin upstream from site 16 is affected by logging and road building, tourism, and a small, year-round population. The small median dissolved-solids concentration $(95 \mathrm{mg} / \mathrm{L}$ ) indicates that water from the upper Flathead River basin is the least mineralized of that in the 10 river basins described (fig. 3). Other constituents, with the exception of dissolved oxygen, also had their smallest median concentrations at site 16 . Streams in this basin have been assigned by the State of Montana an A1 classification, which is the category of least impairment for all open waters (Montana Department of Health and Environmental Sciences, 1988, p. 6).

The Flathead basin is more populated downstream from site 16 than upstream. Therefore, the effects of population on water quality are greatest in the downstream part of the river and in the lake. A major water-quality concern to the State of Montana is eutrophication of the pristine waters of Flathead Lake from upstream and nearshore nutrient sources. Information from a study being conducted by the Montana Department of Health and Environmental Sciences and the University of Montana will be used to devise a plan for the control of nutrient discharge (Montana Department of Health and Environmental Sciences, 1988, p. 72).

\section{WATER-QUALITY TRENDS}

Trend analysis is a statistical procedure used to detect changes in stream water quality at a monitoring station over time. For this report, water-quality data from 16 monitoring stations (fig. 2) were analyzed for trends by using the seasonal Kendall test (Hirsch and others, 1982), a method used extensively by the USGS. The graph (above right) of the fecal coliform bacteria concentration in the Yellowstone River at site 8 illustrates the trend inferred from the concentration data and demonstrates the variation in water quality that is common in streams.

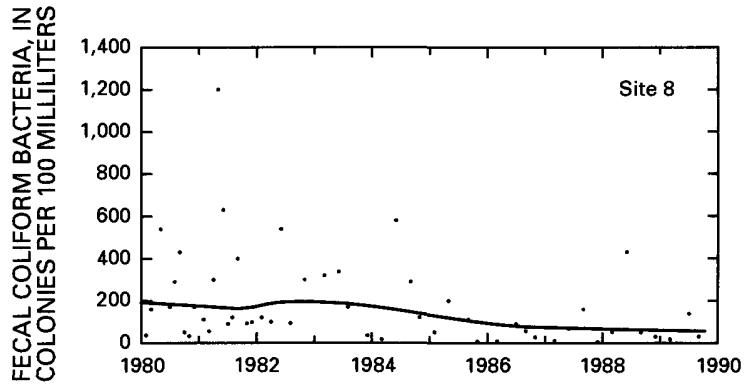

When possible, constituent-concentration data were adjusted for changes in streamflow to preclude identifying a trend in concentration that was caused only by a trend in streamflow. The data were not adjusted when (1) more than 10 percent of the samples had concentrations lower than the minimum reporting limit for the analytical method used or (2) streamflow was controlled substantially by human activities. When the concentration data could not be adjusted for streamflow, trends were determined directly from the concentration data.

Statewide trends in concentrations of selected stream-water constituents are shown on maps in figure 4. On each map, a trend is indicated at a monitoring station only if the data from that station were suitable for use in the trend analysis. For more information on the suitability criteria and on the trend-analysis procedure used for this report, see Lanfear and Alexander (1990).

\section{DISSOLVED OXYGEN}

The dissolved-oxygen concentration in a stream is controlled by several factors, including water temperature, air temperature and pressure, hydraulic characteristics of the stream, photosynthetic or respiratory activity of stream biota, and the quantity of organic material present. A trend in dissolved-oxygen concentrations commonly is directly or indirectly the result of human activities.

Dissolved-oxygen concentrations had a downward trend in the Koontenai River at site 13 for the 1980-89 trend-analysis period (fig. 4). At the beginning of the period, dissolved-oxygen supersaturation was common at site 13 , which is located downstream from Libby Dam. Subsequent powerhouse modifications resulted in smaller, more natural dissolved-oxygen concentrations at the station later in the analysis period (G. Singleton, U.S. Army Corps of Engineers, oral commun., 1990).

\section{FECAL COLIFORM BACTERIA}

Fecal coliform bacteria are used as indicators of fecal contamination from humans and other warm-blooded animals. Such contamination can introduce disease-causing viruses and bacteria into a stream.

Concentrations of fecal coliform bacteria trended downward in the Missouri River at site 4 and in the Yellowstone River at site 8 (fig. 4). The reason for the downward trend at site 4 is unknown. The municipal wastewater-treatment plant for Billings and some other major effluent sources are downstream from site 8 . However, smaller communities and livestock operations upstream from site 8 contribute point- and nonpoint-source waste discharges. Regulatory efforts to control cattle feedlots and upgrading of community waste treatment probably account for the downward trend (J. Burns, Montana Department of Health and Environmental Sciences, oral commun., 1990).

\section{DISSOLVED SULFATE}

The major natural sources of sulfate in streams are rock weathering, volcanoes, and biochemical processes (Hem, 1985, p. 113). 
Human activities such as mining, waste discharge, and fossil-fuel combustion also can be important sources.

Sulfate concentrations had a downward trend in the Sun River at site 3 (fig. 4), probably because of recent modifications in irrigation practices (J. Nypen, Greenfield Irrigation Project, oral commun., 1990). Water-conservation methods have improved, which makes less water available for leaching of sulfate salts from soil. At the remaining eight monitoring stations, sulfate was one of the dominant constituents. The absence of a trend in sulfate concentrations at these stations corresponds to the absence of a trend in dissolved-solids concentrations; sulfate is a major component of dissolved solids.

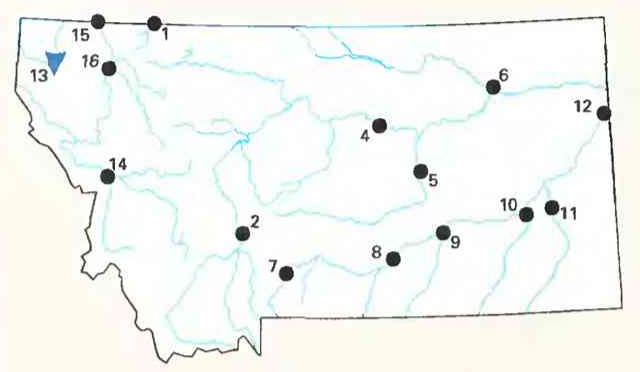

Dissolved oxygen, 1980-89

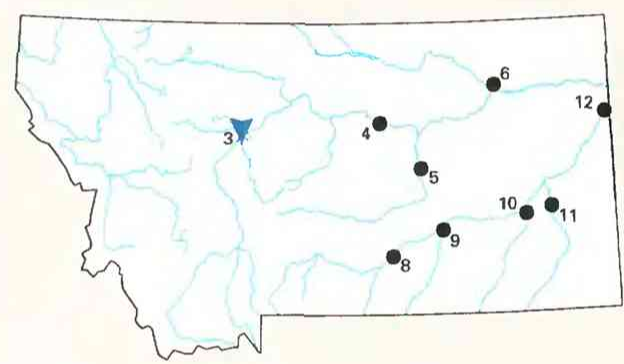

Dissolved sulfate, 1980-89

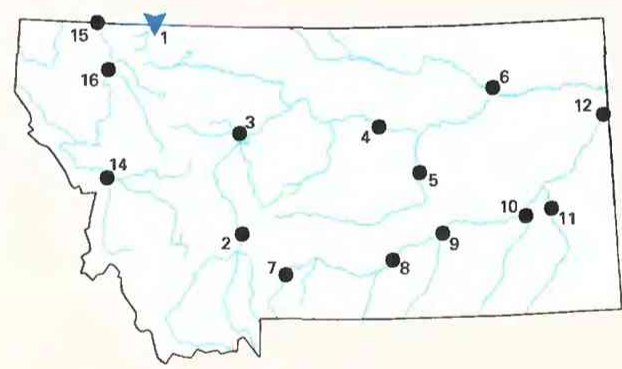

Dissolved nitrite plus nitrate, 1980-89

\section{EXPLANATION}

Trend in water-quality constituent-

Number is site number in figure 2

$$
\begin{aligned}
& { }^{5} \text { None } \\
& \nabla^{1} \text { Downward }
\end{aligned}
$$

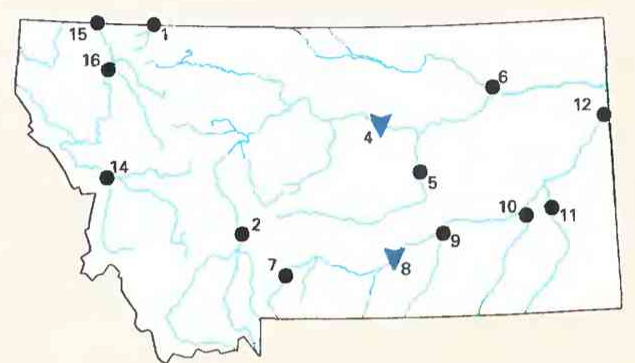

Fecal coliform bacteria, 1980-89

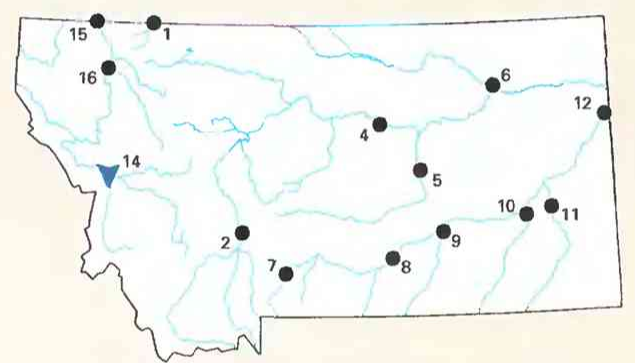

Dissolved solids, 1980-89

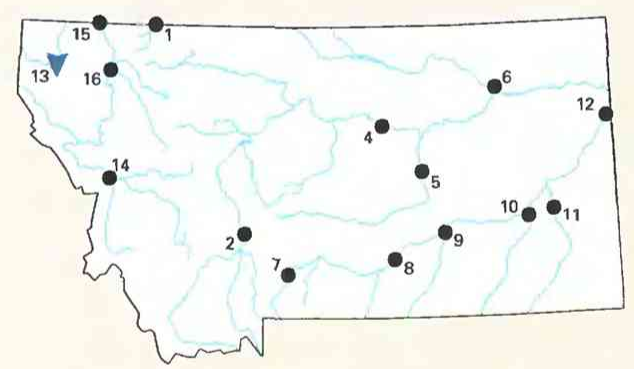

Total phosphorus, 1982-89

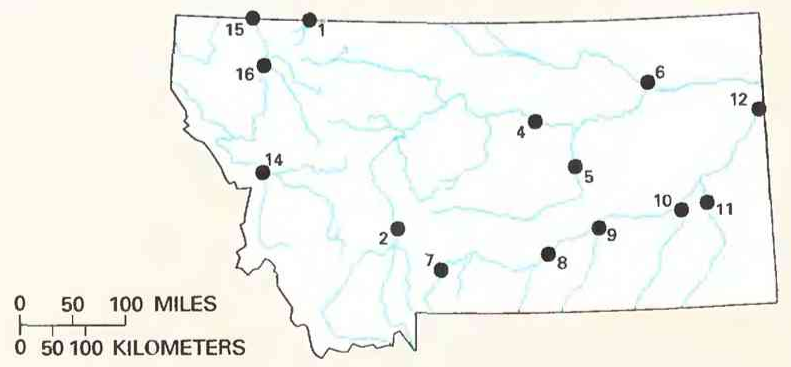

Suspended sediment, 1980-89

Figure 4. Trends in water quality of selected streams in Montana, by water years. (Source: Data from U.S. Geological Survey files.) 


\section{DISSOLVED SOLIDS}

Dissolved solids in stream water result primarily from rock weathering but also can be introduced as a byproduct of human activities (table 1). Concentrations generally are greatest in streams draining basins underlain by rocks and soils that contain easily dissolved minerals.

The decrease in surface runoff and in dilution of streamflows that resulted from drought in the late 1980's (U.S. Geological Survey, 1991, p. 369-376) might have been expected to cause upward trends in dissolved-solids concentrations. However, the years of drought were interspersed with periods of nearly average streamflow, and no upward trends were detected for 1980-89. The downward trend in the Clark Fork at site 14 (fig. 4) might have been caused by cessation of, or changes in, mining or related activities in the ButteAnaconda headwaters areas. The Montana Department of Health and Environmental Sciences, the principal State regulatory agency, attributes the decreasing concentration, at least in part, to runoff patterns in the drainage during the latter part of the trend-analysis period (G. Ingman, Montana Department of Health and Environmental Sciences, oral commun., 1990). Runoff of mineralized water from the headwater drainage was less than average, whereas dilute tributary inflows were about average.

\section{DISSOLVED NITRITE PLUS NITRATE}

Small quantities of nitrite and nitrate in natural waters are contributed from atmospheric nitrogen and dissolution of rocks and soils. These sources can be augmented by decaying animal and vegetable matter, crop fertilizers, and municipal and industrial wastes.

The absence of a trend in nitrite plus nitrate concentrations at 14 monitoring stations (fig. 4) indicates that any modification in the use of crop fertilizers or in waste disposal was insufficient to cause a trend at those stations. The quantity of nitrogen fertilizers sold in Montana during 1983-88 averaged about 112,400 tons per year and was essentially constant during the period (Montana Agricultural Statistics Service, 1989). The reason for the downward trend in the St. Mary River at site 1 is unknown. Nitrite plus nitrate concentrations at this site commonly are near the minimum reporting limit and are little affected by crop fertilizers or municipal waste. The principal source of nitrite plus nitrate for this drainage probably is the atmosphere.

\section{TOTAL PHOSPHORUS}

The total-phosphorus concentration of a water sample is a measure of the concentration of all forms of phosphorus present in the sample, dissolved and particulate. Human activities (table 1) can be important sources of phosphorus in streams. A shortened trendanalysis period was used for phosphorus because data from analyses performed in water years $1980-81$ are not comparable to data from subsequent years.

The downward trend in phosphorus concentrations in the Koontenai River at site 13 probably relates to improvement in the quality of industrial discharges upstream. The sampling site is downstream from a large reservoir that extends into Canada. In the past, phosphorus input to the reservoir from industrial sources was sufficiently large to be of concern (Bonde and Bush, 1982). More recently, phosphorus loading to the reservoir has decreased markedly (U.S. Geological Survey, published annually).

Phosphate, the oxidized form of phosphorus, is a component of some fertilizers. Phosphorus-concentration trends in streams might be expected to correspond to phosphate-fertilizer purchases in agricultural areas where irrigation runoff occurs. Records of phosphatefertilizer purchases in Montana during 1983-88 indicate random sales patterns (no trend), including substantial increases in 1983 and de- creases in 1985 and 1986 (Montana Agricultural Statistics Service, 1989). Phosphorus concentrations in basins having extensive farming likewise had no trend.

\section{SUSPENDED SEDIMENT}

Suspended sediment is a product of erosion. The erosion can be either natural or the result of land-cover disturbances related to human activities (table 1).

Suspended-sediment concentrations had no trend at any monitoring station. The absence of a trend indicates that land-use practices remained essentially unchanged during the trend-analysis period.

\section{WATER-QUALITY MANAGEMENT}

The Montana Department of Health and Environmental Sciences, Water Quality Bureau, administers programs and policies to protect, maintain, and improve the quality and potability of water for all beneficial uses. The Montana Water Quality Act (Montana Code Annotated 75-5-101) and the Federal Clean Water Act require the Bureau to promulgate rules and to perform specific regulatory, monitoring, and enforcement activities. These activities include developing water-quality standards for surface water and ground water, issuing permits to wastewater dischargers, reviewing the operation and maintenance of municipal and industrial wastewater-treatment facilities, and monitoring wastewater discharges and ambient waterquality conditions.

The Water Quality Bureau prepares a biennial water-quality assessment report (Montana Department of Health and Environmental Sciences, $1984 ; 1986 ; 1988$ ) that is submitted to the EPA and Congress pursuant to section 305(b) of the Federal Clean Water Act. The Bureau also has responsibility for toxic-substances control under the act; reviews and certifies Federal permits for hydrologic modifications; issues State permits for feedlots and for instream-construction activities; and reviews plans for subdivisions and mining and logging operations for compliance with the State Sanitation in Subdivisions Act, Nondegradation Rule, and Water Quality Standards.

The Water Quality Bureau is the lead agency for developing and implementing Montana's nonpoint-source water-pollution management plan. The Bureau participates in interagency work groups and interstate organizations, including the Flathead Basin Commission, the Clark Fork/Lake Pend Oreille Steering Committee, the Western States Water Council, the Association of State and Interstate Water Pollution Control Administrators, the Groundwater Task Force, and the Nonpoint-Source Task Force.

The Montana Board of Health and Environmental Sciences adopts the rules and water-quality standards that the Water Quality Bureau administers, issues orders to prevent pollution, and holds hearings on petitions for exemption from the Nondegradation Rule. The Bureau receives policy guidance and direction from the Water Pollution Control Advisory Council.

The Water Quality Bureau conducts or sponsors intensive surveys at specific sites in addition to fixed-station water-quality monitoring at 30 sites in the Clark Fork basin and 7 sites in the Flathead River basin, including Flathead Lake. These monitoring networks were established after 1980. The Bureau relies on the USGS to provide stream-discharge data at many of the Bureau's ambientwater-quality monitoring stations. The Bureau also uses data collected by the USGS and other agencies to determine water-quality conditions and trends throughout Montana.

Because about one-fourth of the land area of Montana is under Federal ownership, the U.S. Forest Service, the National Park Service, and the U.S. Bureau of Land Management also have significant water-quality management responsibilities. As a result of extensive agricultural production in the State, the programs and activities of 
the U.S. Soil Conservation Service, Agricultural Stabilization and Conservation Service, and Cooperative Extension Service are key components of Montana's nonpoint-source water-pollution management plan.

\section{SELECTED REFERENCES}

Alden, W.C., 1932, Physiography and glacial geology of eastern Montana and adjacent areas: U.S. Geological Survey Professional Paper 174, 133 p.

Anderson, J.R., 1967, Major land uses in the United States, in U.S. Geological Survey, 1970, National atlas of the United States of America: Washington, D.C., p. 158-159.

Bonde, T.J.H., and Bush, R.M., 1982, Limnological investigations-Lake Koocanusa, Montana, Part I-Pre-impoundment study, 1967-1972: Seattle, Wash., U.S. Army Corps of Engineers Special Report 82-21, $184 \mathrm{p}$.

Britton, L.J., and Greeson, P.E., eds., 1987, Methods for collection and analysis of aquatic biological and microbiological samples: U.S. Geological Survey Techniques of Water-Resources Investigations, book 5, chap. A4, $363 \mathrm{p}$.

Fenneman, N.M., 1946, Physical divisions of the United States: Washington, D.C., U.S. Geological Survey special map, scale 1:7,000,000.

Fishman, M.J., and Friedman, L.C., eds., 1989, Methods for the determination of inorganic substances in water and fluvial sediments: U.S. Geological Survey Techniques of Water-Resources Investigations, book 5 , chap. A1, $545 \mathrm{p}$.

Hem, J.D., 1985, Study and interpretation of the chemical characteristics of natural water (3d ed.): U.S. Geological Survey Water-Supply Paper 2254, $263 \mathrm{p}$.

Hirsch, R.M., Slack, J.R., and Smith, R.A., 1982, Techniques of trend analysis for monthly water quality data: Water Resources Research, v. 18 no. 1, p. 107-121.

Johnson, H.E., and Schmidt, C.L., 1988, Clark Fork basin project draft status report and action plan: Helena, Office of the Governor, Clark Fork Basin Project, $226 \mathrm{p}$.

Knapton, J.R., and Brosten, T.M., 1989, Arsenic and chloride data for five stream sites in the Madison River drainage, Montana, 1988: U.S. Geological Survey Open-File Report 88-722, 12 p.
Lanfear, K.J., and Alexander, R.B., 1990, Methodology to derive water-quality trends for use by the National Water Summary Program of the U.S. Geological Survey: U.S. Geological Survey Open-File Report 90-359, $10 \mathrm{p}$.

Montana Agricultural Statistics Service, 1989, Montana agricultural statistics, 1989: Helena, v. 26, 81 p.

Montana Department of Health and Environmental Sciences, 1984, Montana water quality, 1984 - The 1984 305(b) report: Helena, Environmental Sciences Division, Water Quality Bureau, $128 \mathrm{p}$.

1986, Montana water quality, 1986-The 1986 305(b) report: Helena, Environmental Sciences Division, Water Quality Bureau, 198 p. 1988, Montana water quality, 1988-The 1988 305(b) report: Helena, Environmental Sciences Division, Water Quality Bureau, $80 \mathrm{p}$

Ross, C.P., Andrews, D.A., and Witkind, I.J., 1955, Geologic map of Montana: U.S. Geological Survey, scale 1:500,000.

Stauffer, R.E., Jenne, E.A., and Bell, J.W., 1980, Chemical studies of selected trace elements in hot-spring drainages of Yellowstone National Park: U.S. Geological Survey Professional Paper 1044-F, 20 p.

Thelin. G.P., and Pike, R.J., 1990, Digital shaded relief map of the conterminous United States: Menlo Park, Calif., U.S. Geological Survey digital image processing, scale 1:3,500,000.

U.S. Geological Survey, published annually, Water resources data, Montana: Helena, U.S. Geological Survey Water Data Report.

1990, National water summary 1987-Hydrologic events and water supply and use: U.S. Geological Survey Water-Supply Paper 2350, $553 \mathrm{p}$.

1991, National water summary 1988-89-Hydrologic events and floods and droughts: U.S. Geological Survey Water-Supply Paper 2375 $591 \mathrm{p}$.

U.S. Soil Conservation Service, 1981, Average annual precipitation, Montana, based on 1941-1970 base period: Bozeman, U.S. Soil Conservation Service, $13 \mathrm{p}$.

Ward, J.R., and Harr, C.A., eds., 1990, Methods for collection and processing of surface-water and bed-material samples for physical and chemical analyses: U.S. Geological Survey Open-File Report 90-140, 71 p. 
370 National Water Summary 1990-91-Stream Water Quality: STATE SUMMARIES

Prepared by J.R. Knapton, U.S. Geological Survey; “Water-Quality Management” section by L.L. Bahls, Montana Department of Health and Environmental Sciences

FOR ADDITIONAL INFORMATION: District Chief, U.S. Geological Survey, 428 Federal Building, 301 South Park, Helena, MT 59626-0076 


\section{NEBRASKA Stream Water Quality}

Water quality is one of the most important issues facing $\mathrm{Ne}$ braska, according to the Nebraska Water Conference Council. The Council, composed of representatives from approximately 90 groups, is a forum for discussion of vital statewide water issues by its members as well as by Nebraska citizens. Reliable information on the status of and trends in the water quality of Nebraska streams is essential to optimal use and management of valuable water resources.

Nebraska is a leading agricultural State owing in large part to an abundant supply of water available from both surface- and groundwater sources. Surface water accounted for 44.3 percent, or an average of 4,450 million gallons per day, of the total offstream use in Nebraska in 1988 (U.S. Geological Survey, 1990, p. 345, 349). Agriculture accounted for most of the offstream surface-water use (47.3 percent), followed by thermoelectric power generation (31.3 percent), nuclear power generation (17.8 percent), and industry and mining (2.7 percent). Water uses accounting for less than 1 percent of total offstream surface-water use included livestock and public supply. In most areas of Nebraska, irrigation is the predominant water use; cropland covers much of the State (fig. $1 A$ ), and approximately 7.5 million acres are irrigated (U.S. Geological Survey, 1990, p. 350).

Snowmelt in the spring and runoff from thunderstorms in the spring and early summer are the primary sources of fresh surface water in Nebraska. Annual rainfall ranges from about 14 inches in the west to about 35 inches in the southeast (U.S. Geological Survey, 1986).
Nebraska is physiographically diverse. The eastern one-fourth of the State lies in the Dissected Till Plains section in the Central Lowlands physiographic province (fig. $1 B$ ). This part of Nebraska is characterized by deposits of glacial drift as much as 200 feet thick overlain by loess. Most of the remainder of the State is in the Great Plains, the majority of which is composed of dissected plains, high plains, and sandhills. The Sand Hills, which are sand dunes stabilized by native grasses, are a major physiographic feature of Nebraska that covers about one-fifth of the State.

The Missouri, Platte, Republican, Niobrara, Loup, Big Blue, and Elkhorn Rivers are the major streams in Nebraska, and they provide surface-water supplies for irrigation, wildlife, fish and other aquatic life, industry, recreation, and other uses. Population centers (fig. $1 C$ ) along these rivers have ample water supplies. The State's 1990 population was 1.6 million-an increase of 0.6 percent since 1980 (U.S. Bureau of the Census 1990 decennial census files).

\section{WATER-QUALITY MONITORING}

Water-quality data obtained from analyses of water samples collected at monitoring stations are stored in the U.S. Geological Survey's (USGS) National Water Information System and the U.S. Environmental Protection Agency's (EPA) national data base known as STORET. Water-quality and streamflow data are reported by water year-the 12 months from October 1 through September 30. A water

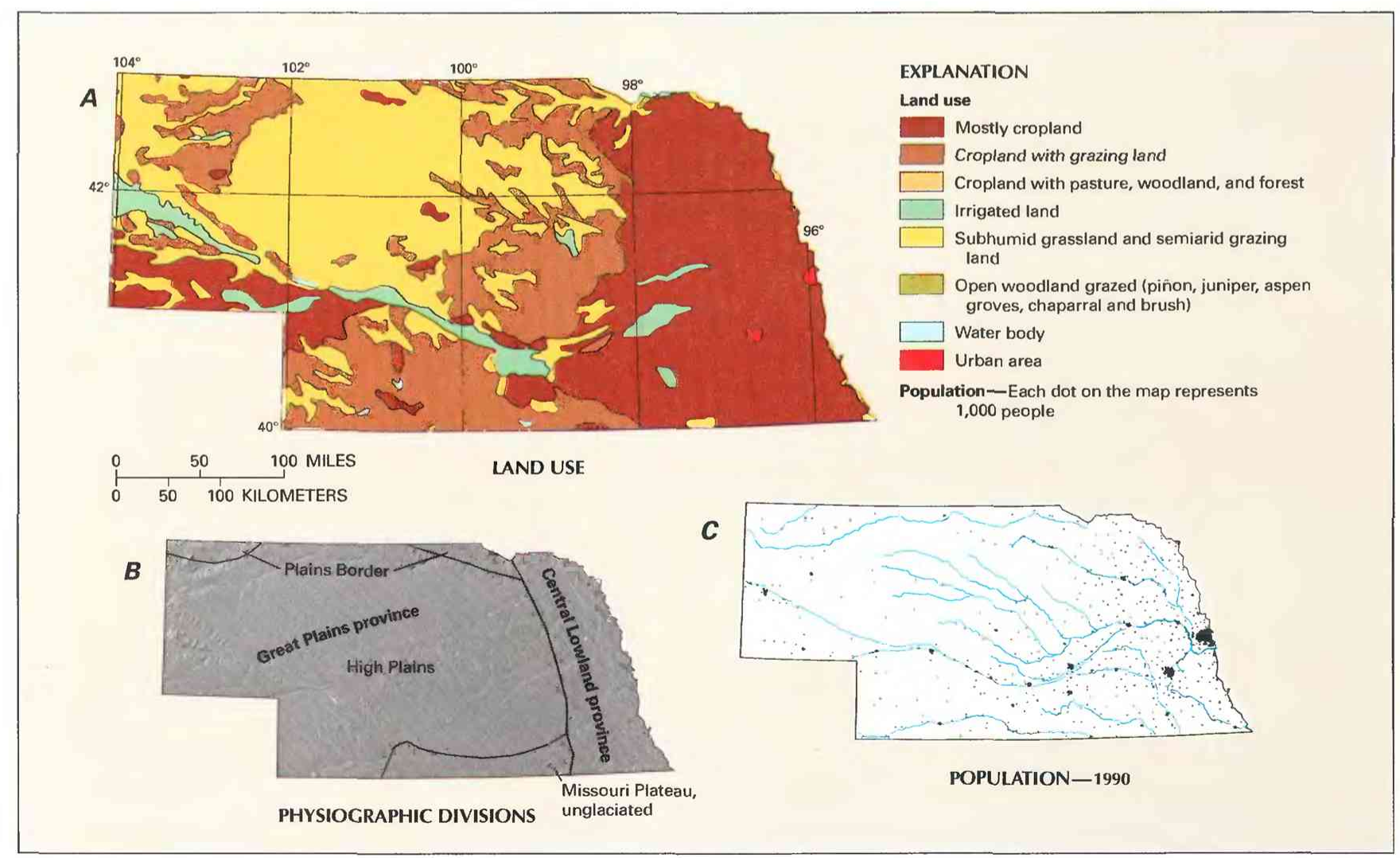

Figure 1. Land use, physiography, and population in Nebraska. A, Major land uses. B, Physiographic divisions. $C$, Population distribution in 1990. (Sources: A, Major land uses modified from Anderson, 1967. B. Physiographic divisions from Fenneman, 1946. C, Data from U.S. Bureau of the Census 1990 decennial census files.) 
year is identified by the calendar year in which it ends. For example, water year 1991 comprises October 1, 1990, through September 30, 1991.

The data used in this summary of Nebraska's stream water quality were obtained from water samples collected at 16 monitoring stations at which data collection is systematic and continuing (fig. 2). Analyses of water samples collected at 10 stations are the basis for the discussion and graphic summary (fig. 3) of stream water-quality conditions during water years $1987-89$, and data from all 16 stations are the basis for the discussion and graphic summary (fig. 4) of stream water-quality trends. Water samples were collected and analyzed by using standard methods approved by the USGS (Britton and Greeson, 1987; Fishman and Friedman, 1989; Ward and Harr, 1990) or by using equivalent methods. If a method of sample collection or analysis changed over time, data from an analysis were included in the evaluation of recent stream water quality or of stream water-quality trends only if the change in method did not affect the comparability of the data.

\section{WATER-QUALITY CONDITIONS}

In 1990, the Nebraska Department of Environmental Control (NDEC) assessed 1,111 stream segments totaling more than 13,000 miles (Nebraska Department of Environmental Control, 1991).
Water-quality indexes were calculated for 3,510 stream miles. Water quality was rated by the NDEC as excellent in 21 percent ( 737 miles), good in 74 percent (2,597 miles), and fair in 5 percent ( 176 miles) of the rated streams. No stream segments were rated as having poor water quality. Nevertheless, beneficial use was impaired to some degree in 3.308 miles of streams.

Nonpoint-source contamination was responsible for 71 percent of stream water-quality degradation (Nebraska Department of Environmental Control, 1991). The principal nonpoint contamination source in Nebraska is agricultural runoff, which increases levels of fecal coliform bacteria, suspended solids, and some pesticides. Other contamination sources are septic tanks ( 7 percent), industrial point sources ( 2 percent), habitat modifications ( 2 percent), hydrologic modifications (dams and canals) (2 percent), and natural conditions or unknown causes ( 16 percent), all of which have adversely affected the biota of some streams.

In 1989, water from 11 stream sites sampled during storm runoff in late June, after herbicides had been applied to crops, had large concentrations of atrazine, alachlor, or both. Concentrations of atrazine exceeded the EPA (1990) Lifetime Health Advisory level of $3.0 \mu \mathrm{g} / \mathrm{L}$ (micrograms per liter) in more than two-thirds of the samples. Alachlor, cyanazine, and simazine also exceeded EPA proposed Maximum Contaminant Levels (MCL) in some samples (D.A. Goolsby and E.M. Thurman, U.S. Geological Survey, written

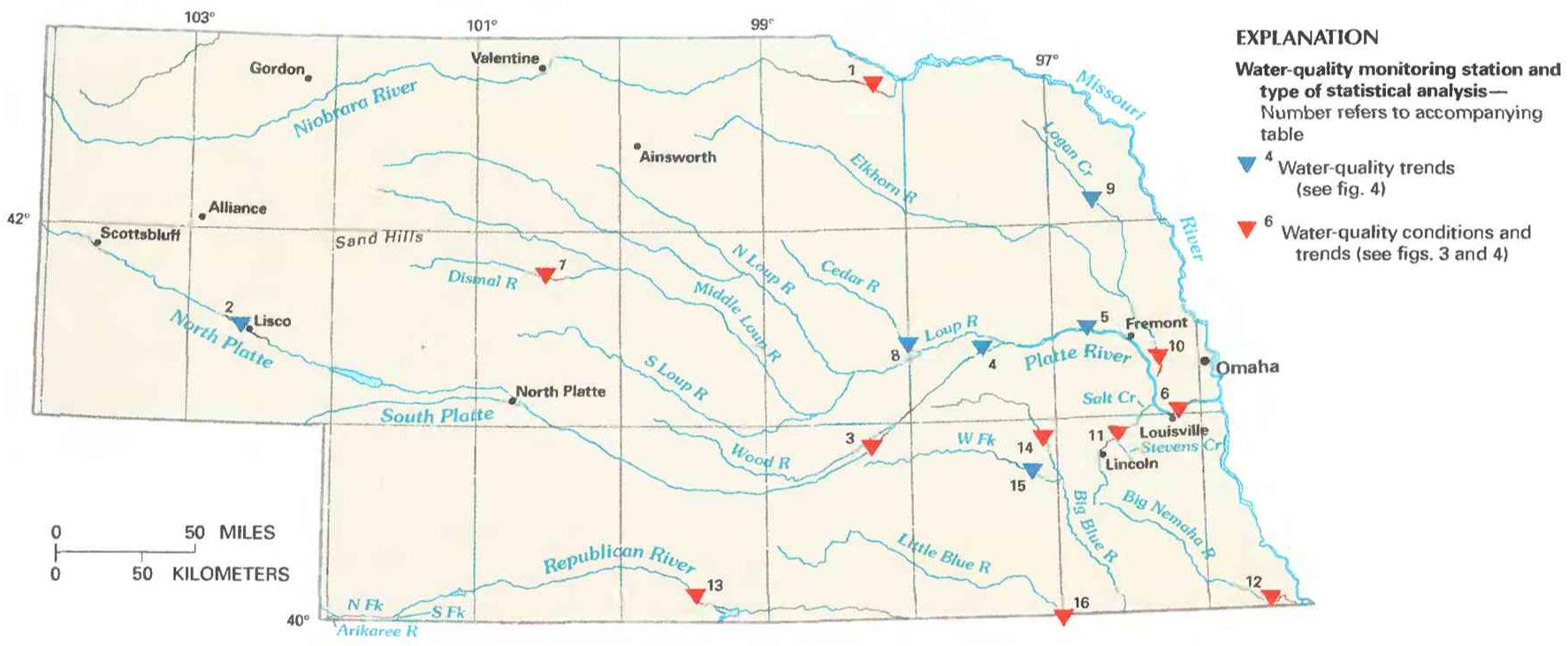

\begin{tabular}{|c|c|c|c|}
\hline $\begin{array}{l}\text { Site no, } \\
\text { on map }\end{array}$ & $\begin{array}{l}\text { USGS station } \\
\text { name and no. }\end{array}$ & $\begin{array}{l}\text { Drainage area } \\
\text { (square miles) }\end{array}$ & $\begin{array}{l}\text { Major land use } \\
\text { (see fig. 1) }\end{array}$ \\
\hline 1 & 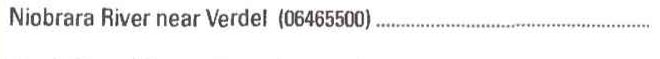 & 12,600 & $\begin{array}{l}\text { Subhumid grassland and semiarid grazing land; cropland with } \\
\text { grazing land. }\end{array}$ \\
\hline 2 & North Platte River at Lisco $(06686000)$ & 26,700 & $\begin{array}{l}\text { Subhumid grassland and semiarid grazing land; grazed desert } \\
\text { shrubland; irrigated land. }\end{array}$ \\
\hline 3 & Platte River near Grand Island (06770500) & 58,800 & $\begin{array}{l}\text { Mostly cropland; subhumid grassland and semiarid grazing land; } \\
\text { irrigated land. }\end{array}$ \\
\hline 4 & Platte River near Duncan (06774000) & 60.900 & $\begin{array}{l}\text { Subhumid grassland and semiarid grazing land; mostly cropland; } \\
\text { irrigated land. }\end{array}$ \\
\hline 5 & Platte River at North Bend $(06796000)$ & 77,100 & Ditto. \\
\hline 6 & Platte River at Louisville $(06805500) \ldots \ldots \ldots . . . .$. & 85,800 & Ditto. \\
\hline 7 & Dismal River near Thedford $(06775900) \ldots . . .$. & $960^{-}$ & Subhumid grassland and semiarid grazing land. \\
\hline 8 & Cedar River near Fullerton $(06792000)$ & 1,220 & Cropland with grazing land. \\
\hline 9 & Logan Creek at Pender (06799450) & 731 & Mostly cropland. \\
\hline 10 & Elkhorn River at Waterloo (06800500) & 6,900 & Ditto. \\
\hline 11 & 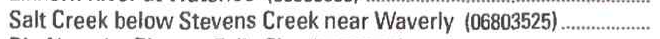 & 815 & Mostly cropland; urban areas. \\
\hline 12 & Big Nemaha River at Falls City $(06815000)$ & 1,340 & Mostly cropland. \\
\hline 13 & 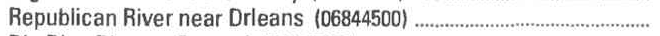 & 15,640 & Cropland with grazing land. \\
\hline 14 & Big Blue River at Seward (06880500) & 1,099 & Mostly cropland. \\
\hline 15 & 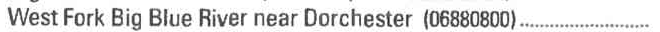 & 1,206 & Ditto. \\
\hline 16 & 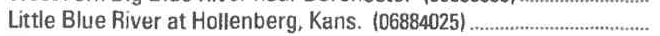 & 2,752 & Ditto. \\
\hline
\end{tabular}

Figure 2. Selected warer-quality monitoring stations, type of statistical analysis, and geographic features in Nebraska. ISources: Major land uses modified from Anderson, 1967; other data from U.S. Geological Survey files.) 
commun., March 1990). Concentrations of toxic trace elements in the surface-water samples generally did not exceed the MCL. However, toxic contaminants such as arsenic, cadmium, chromium, lead, mercury. and selenium have been detected in the tissues of fish from the Platte River (Timothy E. Fannin, U.S. Fish and Wildlife Service, written commun.. January 1991).

Natural streamflows are maintained by surface-water runoff and ground-water discharge. The mineral composition of geologic formations, therefore, affects stream water quality. The formations in Nebraska are consolidated rocks and unconsolidated or semi-consolidated deposits consisting principally of sand, gravel, sandy silt and clay, sandstone, shale, limestone, dolomite, and volcanic ash. In general, most ground water in Nebraska is of the calcium bicarbonate type.

The following discussion of stream water quality in Nebraska is organized by river basin (fig. 3). Graphs in figure 3 summarize certain aspects of stream water quality in the basins for water years 1987-89. The graphs show frequency distributions of data values that represent measurements of selected physical properties of stream water and concentrations of selected constituents in stream water. These properties and constituents are specific conductance, dissolved oxygen, fecal coliform bacteria, dissolved sulfate, dissolved solids, dissolved nitrite plus nitrate (as nitrogen), and total phosphorus (as phosphorus). The data are reported in microsiemens per centimeter at 25 degrees Celsius $(\mu \mathrm{S} / \mathrm{cm})$, milligrams per liter $(\mathrm{mg} / \mathrm{L})$, and colonies per 100 milliliters $(\mathrm{col} / 100 \mathrm{~mL})$. Sources and environmental significance of each property and constituent are described in table 1 .

Water quality at each monitoring station is the result of geological, chemical, biological, and hydrologic processes that occur over a large area. Water-quality problems that affect aquatic life or public health only locally are not fully represented in this summary.

\section{NIOBRARA RIVER}

The Niobrara River has its headwaters in the tablelands of eastern Wyoming and flows eastward through a long, narrow drainage basin that lies mostly along the northern border of Nebraska. The river also drains parts of South Dakota. In Nebraska, the Niobrara River extends about 300 miles from the Wyoming border to the confluence with the Missouri River. Approximately 75 percent of the basin is rangeland or pasture and 20 percent is cropland. Population centers in the basin include Alliance, Valentine, Ainsworth, and Gordon.

Most of the Niobrara River basin is in the Sand Hills (fig. 2). Streamflow is derived mostly from ground-water seepage (Engberg, 1983 , p. 11). The general water quality for stream reaches in the Niobrara River basin has been rated by the NDEC (1991) as excellent ( 55 percent) to good (45 percent).

The overall quality of water at site 1 was second only to that at site 7 on the Dismal River, a stream that is generally regarded as pristine. Median values for specific conductance $(274 \mu \mathrm{S} / \mathrm{cm})$, fecal coliform bacteria $(89 \mathrm{col} / 100 \mathrm{~mL})$, sulfate $(18 \mathrm{mg} / \mathrm{L})$, dissolved solids $(191 \mathrm{mg} / \mathrm{L})$, nitrite plus nitrate $(0.76 \mathrm{mg} / \mathrm{L})$, and phosphorus $(0.21$ $\mathrm{mg} / \mathrm{L}$ ) at this site were among the smallest for the 10 monitoring stations (fig. 3 ).

\section{PLATTE RIVER}

The Platte River, which is formed by the confluence of the North Platte and the South Platte Rivers near North Platte, flows 310 miles eastward across central Nebraska into the Missouri River. The principal land uses in the Platte River basin are agricultural.

Site 3 is in the middle Platte River basin. At site 3, the median sulfate concentration $(250 \mathrm{mg} / \mathrm{L})$ was larger than that for any other monitoring station (fig. 3). Sulfate concentrations were larger in the South Platte River than in the North Platte River (not shown in fig. 3); therefore, the sulfate probably originates in bedrock upstream in Wyoming and Colorado. The median dissolved-oxygen concentration $(10.5 \mathrm{mg} / \mathrm{L})$ was the second largest, the median fecal coliform bacteria concentration $(89 \mathrm{col} / 100 \mathrm{~mL})$ was the second smallest, and the median phosphorus concentration $(0.17 \mathrm{mg} / \mathrm{L})$ was the smallest among those at the 10 sites. The NDEC (1991) rated general water quality for the middle Platte basin as good.

At site 6, which is in the lower Platte River basin, the large median concentrations of dissolved solids $(486 \mathrm{mg} / \mathrm{L})$ and nitrite plus nitrate $(0.79 \mathrm{mg} / \mathrm{L})$ (fig. 3$)$ indicate that upstream agricultural activities have had a substantial effect on water quality. The median specific-conductance value at site $6(648 \mu \mathrm{S} / \mathrm{cm})$ was smaller than at site 3, and the median concentration of dissolved oxygen at site 6 $(11.8 \mathrm{mg} / \mathrm{L})$ was slightly larger. These differences might have been due to dilution by the Loup and Elkhorn Rivers, which generally have a lower specific conductance and larger dissolved-oxygen concentration. Median concentrations of fecal coliform bacteria (240 $\mathrm{col} / 100 \mathrm{~mL}$ ) and phosphorus $(0.35 \mathrm{mg} / \mathrm{L})$ at site 6 were more than twice the concentrations at site 3 , probably because of inflow from the Elkhorn River, which commonly has a larger concentration of those constituents. The NDEC (1991) rated water quality in the lower Platte River basin as good ( 86 percent) to fair (14 percent).

\section{DISMAL RIVER}

The Dismal River, which originates in the Sand Hills, is one of the major tributaries of the Loup River. The monitoring station on the Dismal River near Thedford (site 7) is part of a network of USGS Hydrologic Bench-Mark Network stations that monitor undeveloped watersheds throughout the United States. Streamflow in the Dismal River is maintained by water from the High Plains aquifer, which underlies the Sand Hills. Because there are small amounts of overland runoff and uniform base flow in the basin, streamflows vary little. Mineralization of water in the Dismal River is slight. Median concentrations of most of the selected water-quality constituents at site 7 were among the smallest for all of the monitoring stations (fig. 3 ). Upstream from the site, general water quality has been rated as good by the NDEC (1991).

\section{ELKHORN RIVER}

The Elkhorn River basin extends from the Sand Hills in northcentral Nebraska to the eastern part of the State, where the Elkhorn River flows into the Platte River. The western part of the drainage basin, which constitutes about one-third of the total drainage area, is sandhills. The rest of the basin lies mostly within the glaciated part of Nebraska, which is characterized by rolling hills formed by deposits of glacial drift overlain by loess. Cropland is the principal land use in the basin; more than 50 percent of the area is cultivated. Livestock production also is a leading industry.

Base flows in the upper part of the Elkhorn River basin are uniform because of the continual contribution of water from sand and gravel aquifers in the Sand Hills. Flows in the lower basin are more variable owing to less permeable soils and greater surface runoff.

The median concentrations of fecal coliform bacteria $(1,200$ col/100 mL), dissolved solids $(348 \mathrm{mg} / \mathrm{L})$, nitrite plus nitrate $(2.0$ $\mathrm{mg} / \mathrm{L})$, and phosphorus $(0.45 \mathrm{mg} / \mathrm{L})$ in the Elkhorn River at site 10 were the largest or second largest for the 10 monitoring stations (fig. 3). Site 10 is only 3 miles downstream from the outfall of the Fremont sewage-treatment plant, and that close proximity probably accounts for the large values. Nonetheless, the general water quality in the Elkhorn River basin has been rated by the NDEC (1991) as good (87 percent) to fair (13 percent).

\section{SALT CREEK}

Salt Creek enters the Platte River about 10 miles upstream from Louisville. Major land uses upstream from site 11 are cropland and urban areas. Streamflow is composed of ground-water seepage, treated sewage effluent from Lincoln, and surface runoff. Saline seepage is the primary cause of the highly mineralized water in Salt 
Creek. During periods of low flow in the Platte River, water from Salt Creek degrades the quality of water in the downstream reach of the river (Engberg, 1983, p. 163). The NDEC (1991) rated the general water quality in the lower reaches of Salt Creek as fair, which was the worst overall rating in the State. A median specific conductance of $4,140 \mu \mathrm{S} / \mathrm{cm}$ at site 11 , primarily the result of the natural mineralization, was the largest for the 10 monitoring stations (fig. 3 ). This value exceeds the standard of $2,000 \mu \mathrm{S} / \mathrm{cm}$ for class A agricultural use of surface water in Nebraska (Nebraska Department of Environmental Control, 1991). The effect of effluent from the Lincoln sewage-treatment plant on Salt Creek also can be seen in figure 3. Median concentrations of fecal coliform bacteria $(25,000 \mathrm{col} / 100$ $\mathrm{mL}$ ) and phosphorus $(1.5 \mathrm{mg} / \mathrm{L})$ were the largest for the 10 monitoring stations. In addition, large concentrations of sulfate (median, $230 \mathrm{mg} / \mathrm{L}$ ) and nitrite plus nitrate (median, $1.7 \mathrm{mg} / \mathrm{L}$ ) limit the beneficial water uses of Salt Creek. Probable causes of these larger concentrations are runoff from urban and agricultural nonpoint sources, municipal and industrial point sources, and channelization. Even though the median dissolved-oxygen concentration $(8.0 \mathrm{mg} / \mathrm{L})$ is small compared to that for other monitoring stations, it is not small enough to create water-quality problems in Salt Creek.

\section{BIG NEMAHA RIVER}

The Big Nemaha River drains directly into the Missouri River. The entire drainage basin lies within the glaciated part of the State. Because soils in the basin are moderately to poorly permeable and the topography is mainly rolling hills, streamflow consists, in large part, of overland runoff. Cropland is the major land use; about 70 percent of the land is cultivated, and about 20 percent is rangeland or pasture. There is some degradation of the water quality in this river from agricultural nonpoint sources. However, the NDEC (1991) rated the general water quality of the Big Nemaha River as good. Site 12 (at Falls City) is near the mouth of the Big Nemaha River; therefore, the quality of water at the monitoring station results from the mixing of water from the entire basin. The median values for specific conductance $(668 \mu \mathrm{S} / \mathrm{cm})$, fecal coliform bacteria $(130 \mathrm{col} / 100 \mathrm{~mL})$, dissolved sulfate $(76 \mathrm{mg} / \mathrm{L})$, and phosphorus $(0.21 \mathrm{mg} / \mathrm{L})$ at site 12
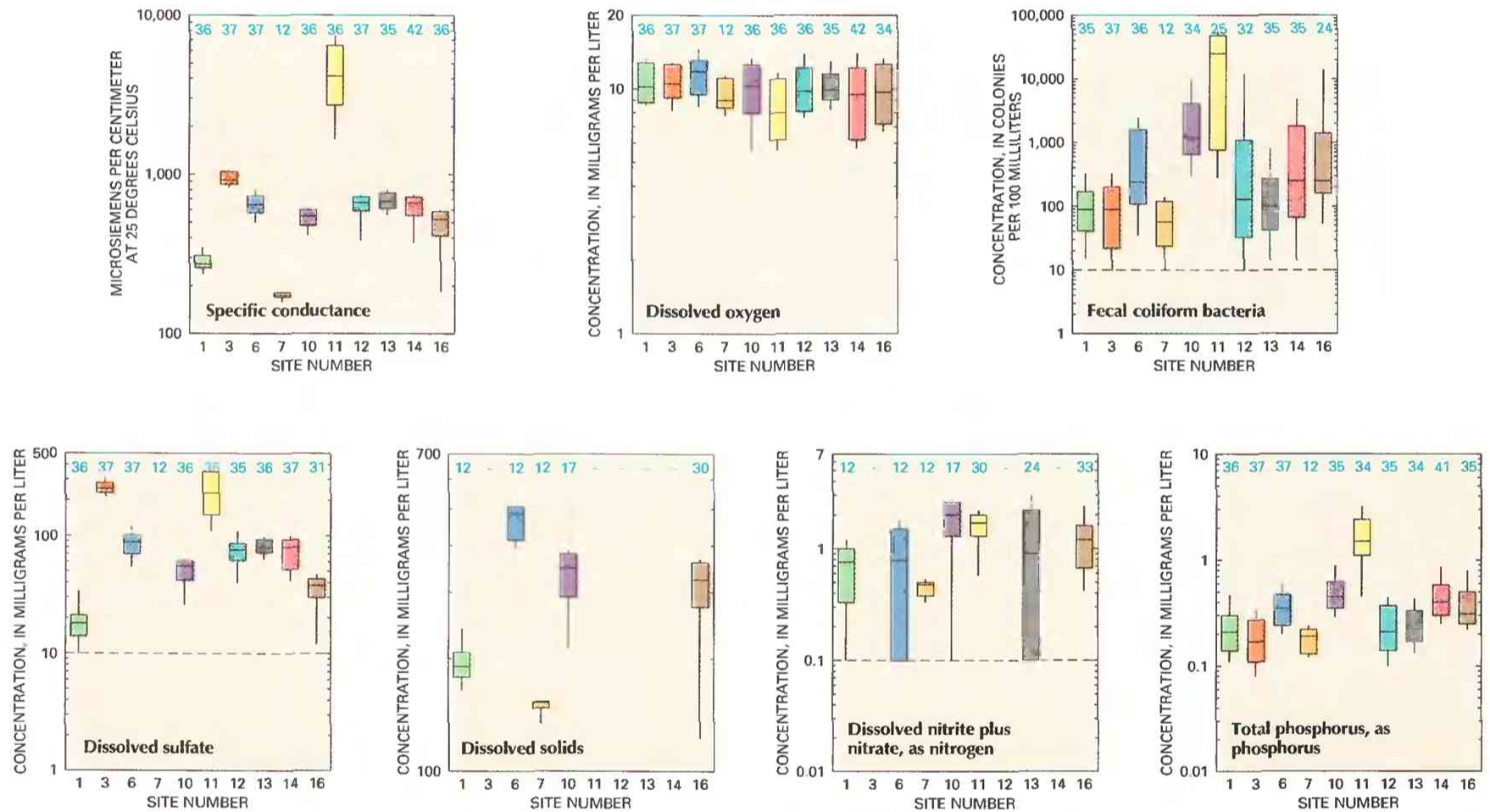

\section{EXPLANATION}
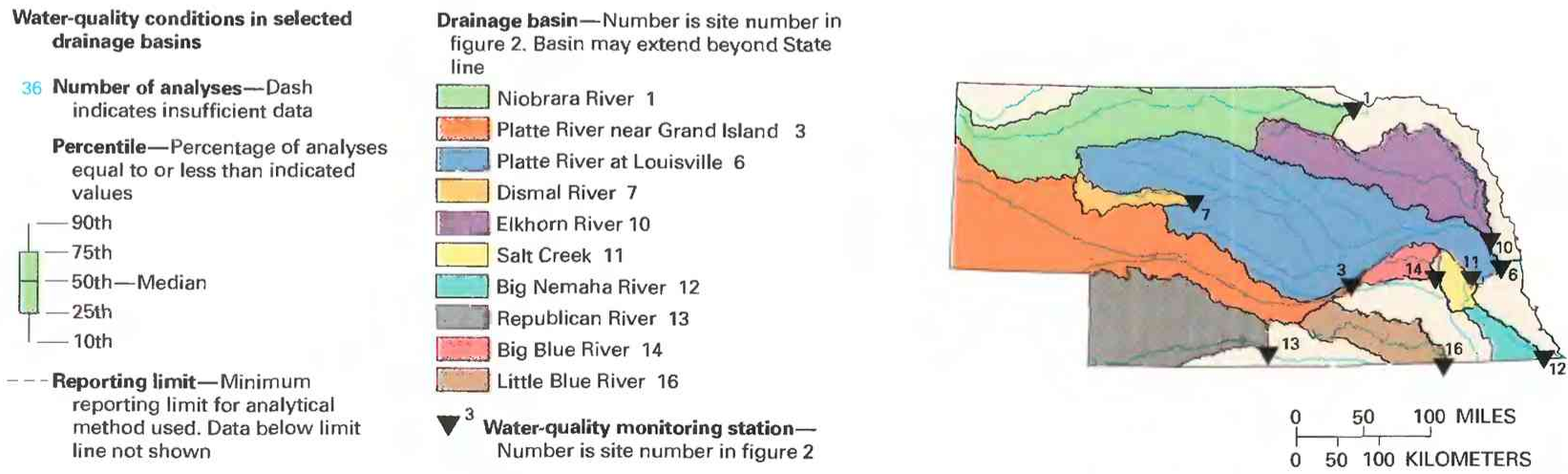

Figure 3. Water quality of selected streams in Nebraska, water years 1987-89. (Source: Data from U.S. Geological Survey files.) 
Table 1. Sources and environmental significance of selected water-quality properties and constituents [Source: Compiled by the U.S. Geological Survey, Office of Water Quality]

\begin{tabular}{|c|c|c|}
\hline Property or constituent & Common sources & Environmental significance \\
\hline $\begin{array}{l}\text { Specific conductance ...................... } \\
\text { (property) }\end{array}$ & $\begin{array}{l}\text { A measure of the electrical conductivity of water; var- } \\
\text { ies with the quantity of dissolved solids and is } \\
\text { used to approximate the dissolved-solids content. }\end{array}$ & $\begin{array}{l}\text { Dissolved solids can cause water to be unsuitable for } \\
\text { public supply, agriculture, and industry; can harm } \\
\text { aquatic organisms. }\end{array}$ \\
\hline Dissolved oxygen ............................. & $\begin{array}{l}\text { Introduced from the atmosphere; also a byproduct of } \\
\text { aquatic plants. }\end{array}$ & $\begin{array}{l}\text { Necessary for aquatic life; deficiency can result from } \\
\text { assimilation of organic wastes or rapid growth } \\
\text { and decay of algae. }\end{array}$ \\
\hline Fecal coliform bacteria ................... & $\begin{array}{l}\text { Sources include effluent from sewage-treatment } \\
\text { plants and runoff from pastures, feedlots, and ur- } \\
\text { ban areas. }\end{array}$ & $\begin{array}{l}\text { Presence indicates contamination of water by wastes } \\
\text { from humans and other warm-blooded animals. }\end{array}$ \\
\hline Sulfate & $\begin{array}{l}\text { Occurs in some rocks; also in mine runoff, industrial } \\
\text { wastewater discharge, and atmospheric deposi- } \\
\text { tion. }\end{array}$ & $\begin{array}{l}\text { Concentrations exceeding a natural, background } \\
\text { level indicate contamination from human activity; } \\
\text { in sufficient quantity, can cause water to be } \\
\text { unsuitable for public supply; can harm aquatic } \\
\text { organisms. }\end{array}$ \\
\hline 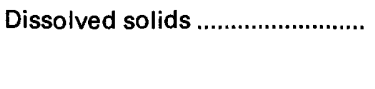 & $\begin{array}{l}\text { A result of rock weathering; also in agricultural runoff } \\
\text { and industrial discharge. }\end{array}$ & $\begin{array}{l}\text { In sufficient quantity, can cause water to be unsuitable } \\
\text { for public supply, agriculture, and industry; can } \\
\text { harm aquatic organisms. }\end{array}$ \\
\hline Nitrite plus nitrate & $\begin{array}{l}\text { Nonpoint sources are agricultural and urban runoff; } \\
\text { a major point source is wastewater discharge. }\end{array}$ & $\begin{array}{l}\text { Plant nutrient that, in sufficient quantity, can cause } \\
\text { algal blooms and excessive growth of higher } \\
\text { aquatic plants in bodies of water; can cause water } \\
\text { to be unsuitable for public supply. }\end{array}$ \\
\hline 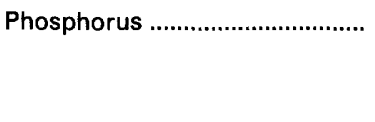 & $\begin{array}{l}\text { Occurs in some rocks and sediments; also in runoff } \\
\text { and seepage from phosphate-rock mines, agri- } \\
\text { cultural and urban runoff, and industrial and } \\
\text { municipal wastewater discharge. }\end{array}$ & $\begin{array}{l}\text { Plant nutrient that, in sufficient quantity, can cause } \\
\text { algal blooms and excessive growth of higher } \\
\text { aquatic plants in bodies of water. }\end{array}$ \\
\hline
\end{tabular}

were moderate compared with those for other monitoring stations (fig. 3).

\section{REPUBLICAN RIVER}

The Republican River is formed by the confluence of the North Fork Republican and Arikaree Rivers about 6 miles east of the Colorado-Nebraska border in southwestern Nebraska and flows through southern Nebraska into Kansas. Land uses in the drainage basin are agricultural; within the State, 50 percent of the basin is cultivated cropland and 45 percent is rangeland or pasture.

Water resources of the Republican River basin have been the most extensively developed of those in any basin in the State. Upstream from site 13, four major reservoirs for flood control and irrigation were constructed between 1949 and 1961 on the main stem and on tributaries. The NDEC (1991) rated general water quality for streams in the Republican River basin as good ( 82 percent) to fair (18 percent).

The median specific conductance in the Republican River at site $13(678 \mu \mathrm{S} / \mathrm{cm})$ was third largest among those at the 10 monitoring stations (fig. 3 ). The mineralization could have been the result of return flow of diverted surface water used for irrigation (Engberg, 1983, p. 206). However, the influence of irrigation return flow might have been reduced somewhat by reservoir releases that dilute the more mineralized water. Median concentrations of nitrite plus nitrate $(0.90 \mathrm{mg} / \mathrm{L})$ and phosphorus $(0.24 \mathrm{mg} / \mathrm{L})$ were moderate, possibly indicating that the reservoirs reduce nutrient concentrations (Engberg, 1983, p. 206). The median fecal coliform bacteria count was 100 $\mathrm{col} / 100 \mathrm{~mL}$, indicating that the stream receives little waste material from agricultural or urban areas.

\section{BIG BLUE RIVER}

The Big Blue River basin is in southeastern Nebraska. Cropland is the principal land use. Upstream from site 14, more than 80 percent of the land is cultivated. Base flows of most streams in the Big Blue River basin are low owing to flat topography in the upper part of the basin and streambeds that are only minimally incised into the sand and gravel aquifer. Therefore, streamflow in the basin is mainly the result of direct surface runoff. General water quality for all streams in the basin has been rated by the NDEC (1991) as good (85 percent) to fair (15 percent).
Successful implementation of the Construction Grants Program (U.S. Environmental Protection Agency, 1984), conservation practices, and feedlot controls, all of which reduced adverse effects on surface-water quality in the basin, could be credited for an improvement of stream water quality with regard to dissolved oxygen, fecal coliform bacteria, and phosphorus concentrations. A major emphasis of the Construction Grants Program has been the achievement of secondary treatment as a minimum standard, which has led to the establishment of centralized collection and treatment of municipal wastes for the first time in many communities.

The median concentrations of dissolved oxygen $(7.6 \mathrm{mg} / \mathrm{L})$, fecal coliform bacteria $(2,800 \mathrm{col} / 100 \mathrm{~mL})$, and phosphorus $(0.83$ $\mathrm{mg} / \mathrm{L}$ ) for 1973-78 (Engberg, 1983, p. 226), compared to $9.5 \mathrm{mg} / \mathrm{L}$, $250 \mathrm{col} / 100 \mathrm{~mL}$, and $0.40 \mathrm{mg} / \mathrm{L}$, respectively, for $1987-89$ (fig. 3), indicate substantial improvement in water quality at site 14 that has resulted from the Construction Grants Program. However, median sulfate concentrations of $0.83 \mathrm{mg} / \mathrm{L}$ for $1973-78$ and $80 \mathrm{mg} / \mathrm{L}$ for 1987-89 probably resulted from an increasing input of sulfate from nonpoint agricultural sources.

\section{LITTLE BLUE RIVER}

The Little Blue River drains an intensively cultivated area. Most of the drainage basin is composed of flatlands underlain by loess-covered sand and gravel deposits. Streamflow is maintained mostly by ground-water discharge supplemented by overland runoff in the upstream part of the basin. General water quality for all streams in the basin has been rated as good by the NDEC (1991).

The relatively large median dissolved-solids concentration at site $16(325 \mathrm{mg} / \mathrm{L}$ ) (fig. 3) probably resulted from seepage of highly mineralized water from bedrock in the lower part of the basin (Engberg, 1983, p. 240). The median nitrite plus nitrate concentration $(1.2 \mathrm{mg} / \mathrm{L})$ also was large compared to those at most other monitoring stations, probably owing to runoff from nonpoint agricultural sources.

\section{WATER-QUALITY TRENDS}

Trend analysis is a statistical procedure used to detect changes in stream water quality at a monitoring station over time. For this report, water-quality data from 16 monitoring stations (fig. 2) were analyzed for trends by using the seasonal Kendall test (Hirsch and 
others, 1982), a method used extensively by the USGS. The graph (shown below) of the dissolved-sulfate concentration in the North Platte River at site 2 illustrates the trend inferred from the concentration data and demonstrates the variation in water quality that is common in streams.

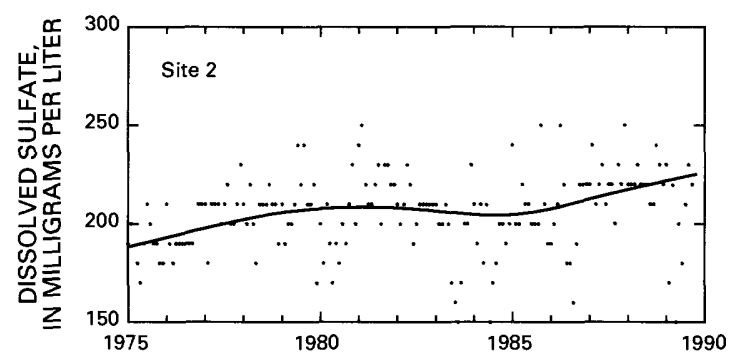

When possible, constituent-concentration data were adjusted for changes in streamflow to preclude identifying a trend in concentration that was caused only by a trend in streamflow. The data were not adjusted when (1) more than 10 percent of the samples had concentrations lower than the minimum reporting limit for the analytical method used or (2) streamflow was controlled substantially by human activities. When the concentration data could not be adjusted for streamflow, trends were determined directly from the concentration data.

Statewide trends in measurements of selected physical properties of stream water and in concentrations of selected constituents in stream water are shown on maps in figure 4 . On each map, a trend is indicated at a monitoring station only if the data from that station were suitable for use in the trend analysis. For more information on the suitability criteria and on the trend-analysis procedure used for this report, see Lanfear and Alexander (1990).

\section{SPECIFIC CONDUCTANCE}

Specific conductance is a measure of the ability of a sample of water to conduct electricity. Because specific conductance and the dissolved-solids concentration are roughly proportional in most natural waters, the specific-conductance value often can be used to estimate the dissolved-solids concentration (Hem, 1985, p. 66-68).

Specific-conductance values trended upward in the Platte River at site 3, the Elkhorn River at site 10 and its tributary Logan Creek at site 9, and the West Fork Big Blue River at site 15 (fig. 4). The increases could have been the result of increased irrigation return flow and runoff from feedlots. Declining precipitation runoff caused by drought during the late 1980's (U.S. Geological Survey, 1991 , p. 377-384) might have been a reason for the upward trends as well. In addition to agricultural activity and drought, increasing specific conductance in Salt Creek at site 11 could have been caused by runoff from areas of increasing population in and near Lincoln.

\section{DISSOLVED OXYGEN}

The dissolved-oxygen concentration in a stream is controlled by several factors, including water temperature, air temperature and pressure, hydraulic characteristics of the stream, photosynthetic or respiratory activity of stream biota, and the quantity of organic material present. A trend in dissolved-oxygen concentrations commonly is directly or indirectly the result of human activities. Generally, an upward trend in dissolved-oxygen concentrations indicates improving stream water-quality conditions and a downward trend indicates deteriorating conditions.

The increasing dissolved-oxygen concentrations in Logan Creek at site 9 and in the West Fork Big Blue River at site 15 (fig. 4) were associated with construction, improvement, or expansion of municipal wastewater-treatment facilities in many small communities along these rivers (John Bender, Nebraska Department of Envi- ronmental Control, oral commun., October 1990). Conservation practices initiated by the Upper Big Blue and Lower Big Blue Natural Resources Districts, such as reuse pits or ponds to reduce runoff from irrigation, also might have contributed to the reduction of organic matter in the Big Blue River, thereby increasing dissolved-oxygen concentrations.

The downward trends in the Platte River at site 3 and the Republican River at site 13 could have been the result of increased irrigation return flow and runoff from feedlots. A decline in streamflow during the drought of the late 1980's was also a likely cause of the trend. The cause for the downward trend in the Dismal River at site 7 is not known.

\section{FECAL COLIFORM BACTERIA}

Fecal coliform bacteria are used as indicators of fecal contamination from humans and other warm-blooded animals. Such contamination can introduce disease-causing viruses and bacteria into a stream.

In Salt Creek at site 11, the increasing fecal coliform bacteria concentration (fig. 4) could have been a result of population growth and effluent from a wastewater-treatment plant in operation since 1979 upstream from the monitoring station (John Bender, Nebraska Department of Environmental Control, oral commun., October 1990). From October to March, effluent from the plant is discharged without chlorination. Although fecal coliform bacteria die quickly in streams, the short distance between the treatment plant and the monitoring station likely allows the detection of waste-load changes. There is no readily apparent explanation for the decreases in fecal coliform bacteria in the Platte River at site 3, Logan Creek at site 9, Elkhorn River at site 10, Big Nemaha River at site 12, and Republican River at site 13.

\section{DISSOLVED SULFATE}

The major natural sources of sulfate in streams are rock weathering, volcanoes, and biochemical processes (Hem, 1985, p. 113). Human activities such as mining, waste discharge, and fossil-fuel combustion also can be important sources.

Sulfate concentrations had upward trends in the North Platte River at site 2, the Platte River at site 3, the Cedar River at site 8, the Elkhorn River at site 10, Salt Creek at site 11, and the Republican River at site 13 (fig. 4). These streams are in areas of extensive agricultural activity. The increases at all the monitoring stations were related primarily to the increasing use of ammonium-sulfate fertilizer and to the 1988-89 drought. The sale of ammonium sulfate in Nebraska increased from 5,000 tons in 1975 to 16,000 tons in 1988 (Nebraska Department of Agriculture, 1975-88). Nonetheless, sulfate concentrations at sites 4,5, and 6 on the Platte River downstream from sites 2 and 3 had no detectable trend, probably owing to dilution from inflow of the Wood, Loup, and Elkhorn Rivers. In addition to agricultural runoff, the upward trend at site 11 probably also was due to increasing urban runoff from Lincoln.

\section{DISSOLVED SOLIDS}

Dissolved solids in stream water result primarily from rock weathering but also can be introduced as a byproduct of human activities (table 1). Concentrations generally are greatest in streams draining basins underlain by rocks and soils that contain easily dissolved minerals.

The North Platte River valley from the Wyoming border to Lisco is irrigated extensively with diverted surface water. The upward trend in the dissolved-solids concentration in the North Platte River at site 2 (fig. 4) can be attributed to increasing input of irrigation water that returns to the river in the form of ground-water seepage and direct runoff (Engberg, 1983). Streamflow is maintained by controlled releases of water from several reservoirs in Wyoming. 
Snowmelt runoff from the Rocky Mountains was less than normal during 1987-89, so releases from upstream reservoirs that dilute the irrigation return flow also were less. Less than average precipitation and runoff in Nebraska during the 1988-89 drought probably contributed to the increasing dissolved-solids concentration as well.

\section{DISSOLVED NITRITE PLUS NITRATE}

Nitrite and nitrate are oxidized forms of nitrogen that together constitute most of the dissolved nitrogen in well-aerated streams. Nitrite readily oxidizes to nitrate in natural waters; therefore, nitrate generally is by far the more abundant of the two (Hem, 1985, p. 124).

Sources of nitrite plus nitrate in rivers include agricultural runoff (fertilizers and feedlot animal wastes), wastewater-treatmentplant discharges, and atmospheric deposition (Smith and others,
1987). Contrary to the upward trends at sites 1,4 , and 8 (fig. 4), nitrogen fertilizer use decreased 43 percent during 1980-89 in the drainage basins of the Niobrara, Loup, and middle Platte Rivers. However, the total number of livestock placed on grain feed increased threefold in the Niobrara River basin and was 1.4 times greater in the middle Platte and Loup River basins during the same period (Nebraska Department of Agriculture, 1975-88). Therefore, runoff from feedlots could have caused the increasing nitrite plus nitrate concentration at sites 1,4 , and 8 .

\section{TOTAL PHOSPHORUS}

The total phosphorus concentration of a water sample is a measure of the concentration of all forms of phosphorus present in the sample, dissolved and particulate. Human activities (table 1) can

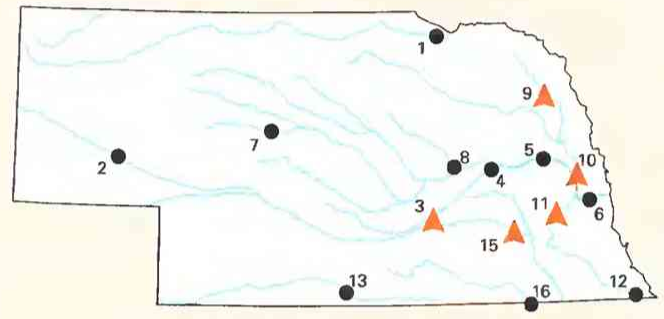

Specific conductance, $1975-89$

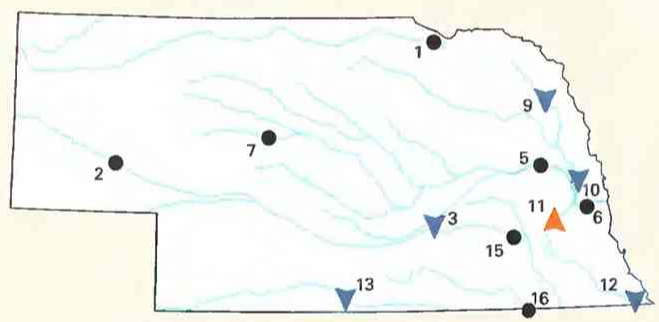

Fecal coliform bacteria, 1975-89

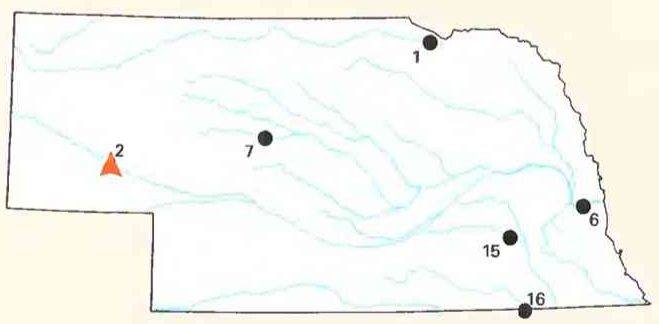

Dissolved solids, 1975-89

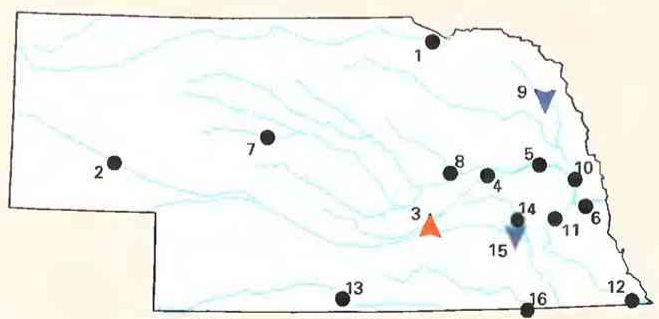

Total phosphorus, 1982-89

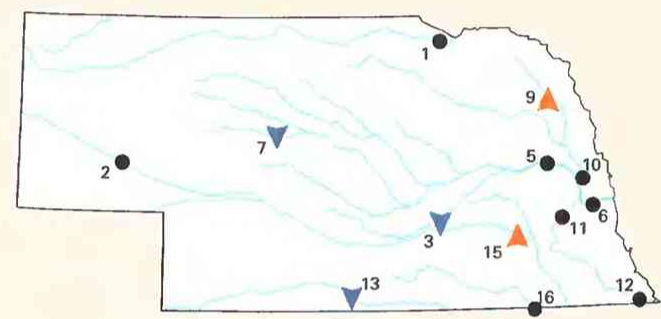

Dissolved oxygen, 1975-89

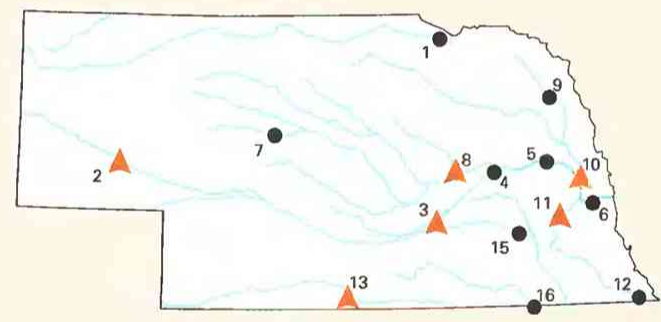

Dissolved sulfate, 1975-89

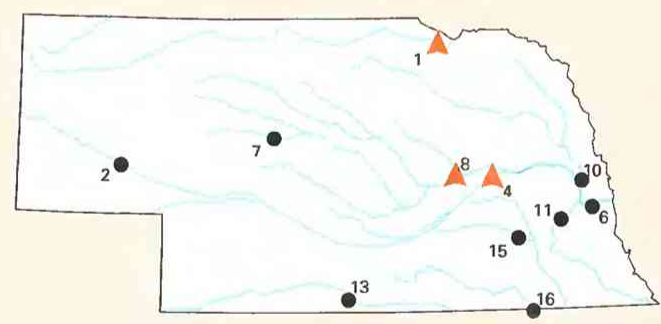

Dissolved nitrite plus nitrate, 1980-89

\section{EXPLANATION}

Trend in water-quality property or constituent- Number is site number in figure 2

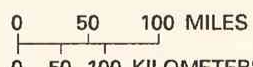
$A^{3}$ Upward
${ }^{2}$ None
$V^{7}$ Downward

Figure 4. Trends in water quality of selected streams in Nebraska, by water years. (Source: Data from U.S. Geological Survey files.) 
be important sources of phosphorus in streams. A shortened trendanalysis period was used for phosphorus because data from analyses performed in water years 1980-81 are not comparable to data from subsequent years.

No cause is apparent for the upward trend in phosphorus concentrations in the Platte River at site 3 (fig. 4). Because agricultural runoff is the major source of phosphorus in Nebraska rivers, changes in phosphate-fertilizer application could be expected to cause changes in phosphorus concentrations. Use of phosphate fertilizer decreased from 30,000 tons in 1982 to 10,000 tons in 1988 (Nebraska Department of Agriculture, 1975-88), which probably caused the downward trend in Logan Creek at site 9 and in the West Fork Big Blue River at site 15 .

\section{WATER-QUALITY MANAGEMENT}

The NDEC administers and enforces the provisions of the Nebraska Environmental Protection Act, which was passed in 1971. The act declared that it is the public policy of the State of Nebraska to conserve water and to protect and improve the quality of water for human consumption, wildlife, fish and other aquatic life, industry, recreation, and other productive, beneficial uses.

The NDEC is also the State water-pollution control agency for all purposes of the Federal Clean Water Act. Among its specific responsibilities are the development and enforcement of water-quality standards, water-quality management planning, water-quality monitoring and reporting, approval of the design of treatment and disposal systems, issuance and enforcement of discharge permits, and assurance that treatment facilities are properly operated and maintained. These activities are carried out by the NDEC's Water Quality Division. All of these activities, except water-quality-management planning, monitoring, and reporting, are governed by specific rules and regulations promulgated by the NDEC's governing body, the Environmental Control Council.

As part of its water-quality-management planning activities, the NDEC serves as the lead agency for the Nebraska Nonpoint Source Management Program. The NDEC brought together several State, Federal, and local agencies to cooperate in this program as the Nebraska Nonpoint Source Governmental Committee. Implementation of the program began in February 1990.

The NDEC is responsible for preparing Nebraska's biennial water-quality report (Nebraska Department of Environmental Control, 1991), which is submitted to the EPA and the U.S. Congress in compliance with section 305(b) of the Clean Water Act. The NDEC reviews projects requiring Federal permits or licenses for compliance with water-quality standards and issues water-quality certification for these projects under section 401 of the Clean Water Act. Point-source discharges are regulated by the NDEC under the National Pollutant Discharge Elimination System permit program (section 402 of the Clean Water Act). All municipal wastewater-treatment facilities have been upgraded to secondary treatment standards, many as a result of the NDEC's administration of the Construction Grants Program under Title II of the Clean Water Act.

Water-quality-monitoring activities conducted by the NDEC have become more diverse during the 1980 's. A network of several hundred fixed water-quality-monitoring stations, some of which were operated in cooperation with the USGS, has become a monitoring network composed of 21 fixed water-quality-monitoring stations, a rotating network of fish-tissue-analysis stations, and a rotating network of several hundred biological-monitoring stations. Special studies are performed to gather data when needed. These studies have allowed the NDEC to optimize water-quality-monitoring efforts, which have been limited by reduced funding.

\section{SELECTED REFERENCES}

Anderson, J.R., 1967, Major land uses in the United States, in U.S. Geological Survey, 1970, National atlas of the United States of America: Washington, D.C., U.S. Geological Survey, p. 158-159.

Britton, L.J., and Greeson, P.E., eds., 1987, Methods for collection and analysis of aquatic biological and microbiological samples: U.S. Geological Survey Techniques of Water-Resources Investigations, book 5, chap. A4, 363 p.

Engberg, R.A., 1983, A statistical analysis of the quality of surface water in Nebraska: U.S. Geological Survey Water-Supply Paper 2179, 252 p.

Fenneman, N.M., 1946, Physical divisions of the United States: Washington, D.C., U.S. Geological Survey special map, scale 1:7,000,000.

Fishman, M.J., and Friedman, L.C., eds., 1989, Methods for the determination of inorganic substances in water and fluvial sediments: U.S. Geological Survey Techniques of Water-Resources Investigations, book 5 , chap. A1, 545 p.

Hem. J.D., 1985, Study and interpretation of the chemical characteristics of natural water (3d ed.): U.S. Geological Survey Water-Supply Paper 2254, $263 \mathrm{p}$.

Hirsch, R.M., Slack, J.R., and Smith, R.A., 1982, Techniques of trend analysis for monthly water quality data: Water Resources Research, v. 18, no. 1, p. 107-121.

Lanfear, K.J., and Alexander, R.B., 1990, Methodology to derive water-quality trends for use by the National Water Summary Program of the U.S. Geological Survey: U.S. Geological Survey Open-File Report 90-359, $10 \mathrm{p}$.

Nebraska Department of Agriculture, 1975-88, Nebraska agricultural statistics, annual reports: Lincoln, Nebraska Agricultural Statistics Service.

Nebraska Department of Environmental Control, 1991, 1990 Nebraska water quality report: Lincoln, Nebraska Department of Environmental Control, $288 \mathrm{p}$.

Smith, R.A., Alexander, R.B., and Wolman, M.G., 1987, Analysis and interpretation of water-quality trends in major United States rivers, 1974 81: U.S. Geological Survey Water-Supply Paper 2307, 25 p.

Thelin, G.P., and Pike, R.J., 1990, Digital shaded relief map of the conterminous United States: Menlo Park, Calif., U.S. Geological Survey digital inage processing, scale 1:3,500,000.

U.S. Environmental Protection Agency, 1984, The cost of clean air and water report to Congress 1984: Washington, D.C., EPA-230/05-84 008, 21 p. 1990, Drinking water regulations and health advisories: Washington, D.C., April 1990

U.S. Geological Survey, 1986. National water summary 1985-Hydrologic events and surface-water resources: U.S. Geological Survey WaterSupply Paper 2300, 506 p.

1990, National water summary 1987--Hydrologic events and water supply and use: U.S. Geological Survey Water-Supply Paper 2350, $553 \mathrm{p}$.

1991, National water summary 1988-89-Hydrologic events and floods and droughts: U.S. Geological Survey Warer-Supply Paper 2375, $591 \mathrm{p}$.

Ward, J.R., and Harr, C.A., eds., 1990, Methods for collection and processing of surface-water and bed-material samples for physical and chemical analyses: U.S. Geological Survey Open-File Report 90-140, 71 p.

Prepared by Abraham H. Chen and Carol G. Hoy, U.S. Geological Survey; "Water-Quality Management" section by John F. Bender, Nebraska Department of Environmental Control

FOR ADDITIONAL INFORMATION: District Chief, U.S. Geological Survey, 406 Federal Building, 100 Centennial Mall, North, Lincoln, NE 68508 


\section{NEVADA Stream Water Quality}

Good-quality stream water is important to Nevada because of the scarcity of surface-water resources. Nevada is the most arid State in the Nation, according to Geraghty and others (1973, pl. 3). Surface water has been fully appropriated for many years; most priority water rights in the major river basins were established before 1900 (U.S. Geological Survey, 1986, p. 328).

In 1985, surface-water withdrawals in Nevada averaged about 2,830 million gallons per day and accounted for 75.8 percent of the freshwater used statewide (U.S. Geological Survey, 1990, p. 357). Most of the surface water withdrawn (92.5 percent) was used for irrigation. Surface-water withdrawals for public supply (6.8 percent of total withdrawals) served about 579,000 people in Nevada or about 60 percent of the State's population (Solley and others, 1988, p. 13).

Land use can substantially affect water quality. In 1988, about 576,000 acres in Nevada were used for irrigated cropland (U.S. Bureau of the Census, 1990, p. 4); however, most of Nevada is desert (fig. 1A), much of which is used for livestock grazing. Eighty-six percent of Nevada is owned and administered by the Federal Government (Nevada Division of Water Planning, 1980, p. 3).

Most of Nevada is in the Basin and Range physiographic province (fig. $1 B$ ), which is characterized by narrow, north-south-trending mountain ranges with intervening broad, flat valley floors. Extreme northeastern Nevada is in the Columbia Plateaus province, and a small area near Lake Tahoe is in the Cascade-Sierra Mountains province.

The population of Nevada in 1990 was 1.2 million, an increase of 50 percent from 1980 (U.S. Bureau of Census 1990 decennial census files). The largest population centers (fig. $1 C$ ) are the Las Vegas area, which withdraws most of its water from the Colorado River, and the Reno-Sparks area, which derives most of its supply from the Truckee River. As the population continues to increase, available surface-water resources will be increasingly stressed because they constitute the principal source of water in the areas of greatest population growth.

Demand for surface water to maintain aquatic habitats- particularly lakes and wetland areas in closed drainage basins-is increasing. Federal, and State agencies and private organizations are purchasing local water rights to increase freshwater inflow to Stillwater Marsh because irrigation return flow has contaminated wildlife areas in the marsh with selenium and arsenic (Hoffman and others, 1990, p. 1).

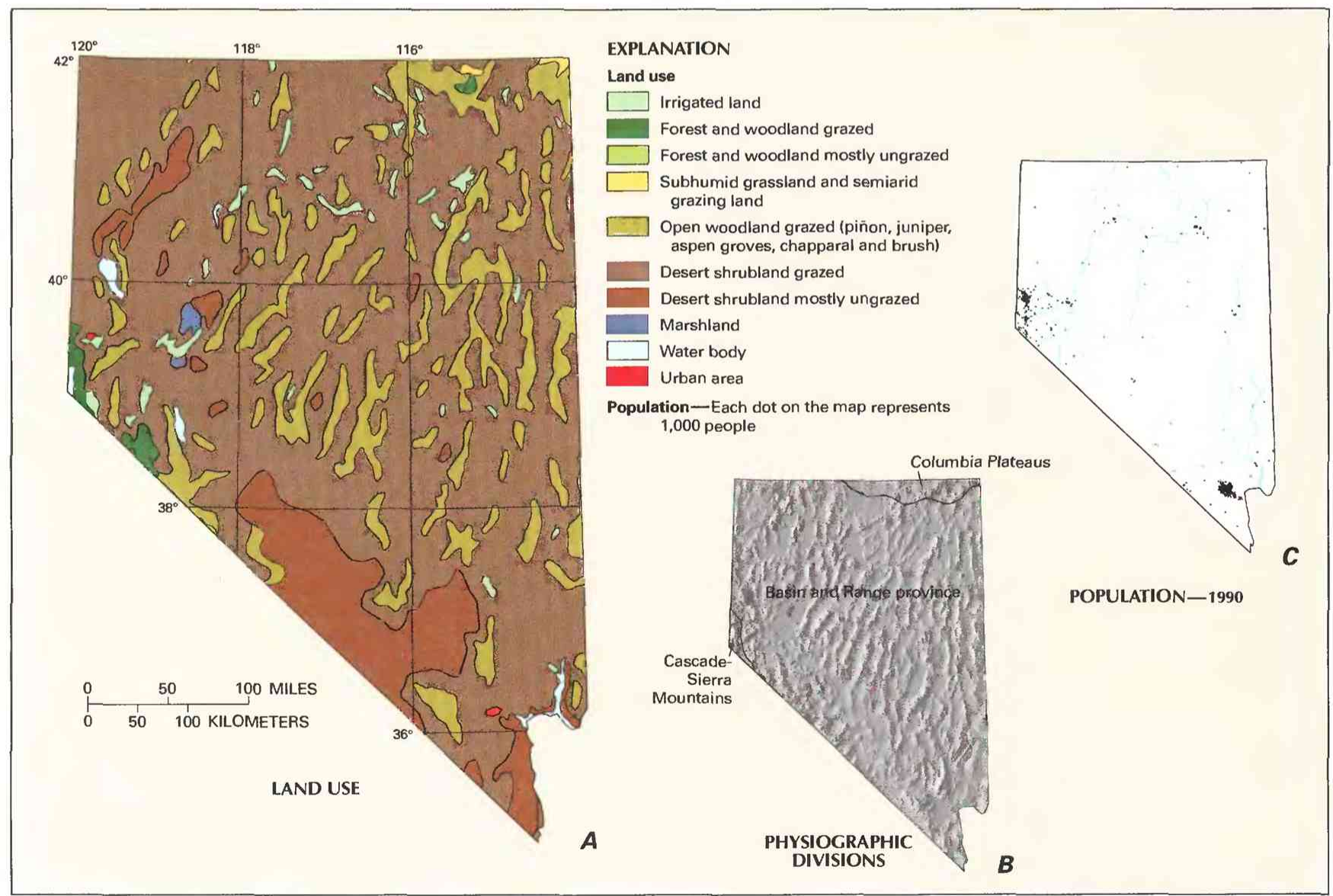

Figure 1. Land use, physiography, and population in Nevada. A, Major land uses. B. Physiographic divisions. $C$, Population distribution in 1990. (Sources: A, Major land uses modified from Anderson, 1967. B. Physiographic divisions from Fenneman, 1946; landforms from Thelin and Pike, 1990. C, Data from U.S. Bureau of the Census 1990 decennial census files.) 


\section{WATER-QUALITY MONITORING}

Water-quality data obtained from analyses of water samples collected at monitoring stations are stored in the U.S. Geological Survey's (USGS) National Water Information System and the U.S. Environmental Protection Agency's (EPA) national data base known as STORET. Water-quality and streamflow data are reported by water year-the 12 months from October 1 through September 30. A water year is identified by the calendar year in which it ends. For example, water year 1991 comprises October 1, 1990, through September 30, 1991.

The data used in this summary of Nevada's stream water quality were obtained from water samples collected at eight monitoring stations at which data collection is systematic and continuing (fig. 2). Analyses of water samples collected at all eight stations are the basis for the discussion and graphic summary (fig. 3) of stream waterquality conditions during water years 1987-89, and data from seven stations are the basis for the discussion and graphic summary (fig. 4) of stream water-quality trends. Water samples were collected and analyzed by using standard methods approved by the USGS (Britton and Greeson, 1987; Fishman and Friedman, 1989; Ward and Harr,

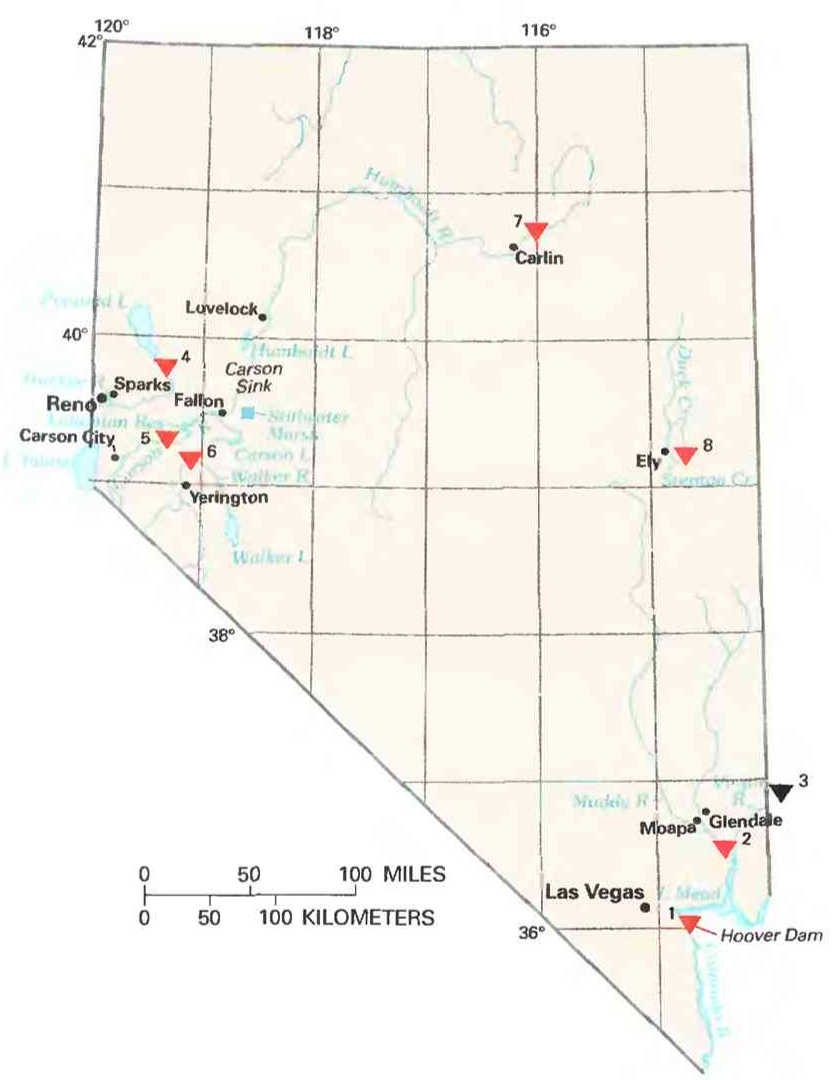

1990 ) or by using equivalent methods. If a method of sample collection or analysis changed over time, data from an analysis were included in the evaluation of recent stream water quality or of stream water-quality trends only if the change in method did not affect the comparability of the data.

\section{WATER-QUALITY CONDITIONS}

The hydrology and geology of many river basins in Nevada have a larger effect on water quality than do human activities. Water quality naturally deteriorates as streams flow from the mountains and cross the valley floors. Evaporation and water consumption by plants along the river causes the dissolved-solids concentration to increase. Concentrations of sulfate and arsenic increase as rivers receive inflow from sedimentary deposits and rocks containing these constituents. Even nitrate may be contributed to surface water by naturally occurring deposits. Sodium-nitrate deposits, found in desert regions, have been reported in northern Nevada (Hurlbut, 1971). Also, Patt and Hess (1976) reported that buried organic material might contribute to nitrate contamination of ground water near Las Vegas.

The following discussion of stream water quality in Nevada is organized by river basin (fig. 3). Where physiographic and landuse characteristics in different basins are similar, the discussion of those basins is combined. Graphs in figure 3 summarize certain aspects of stream water quality in the basins for water years 1987-89. The graphs show frequency distributions of data values that represent concentrations of selected stream-water constituents. These constituents are dissolved sulfate, dissolved solids, dissolved nitrite plus nitrate (as nitrogen), dissolved phosphate (as phosphorus), and suspended sediment. The data are reported in milligrams per liter (mg/L). Sources and environmental significance of each constituent are described in table 1 .

Water quality at each monitoring station is the result of geological, chemical, biological, and hydrologic processes that occur over a large area. Water-quality problems that affect aquatic life or public health only locally are not fully represented in this summary.

\section{COLORADO RIVER}

The Colorado River flows from the Rocky Mountains in Colorado to the Sea of Cortez in Mexico, a distance of about 1,450 miles.

\begin{tabular}{|c|c|c|c|}
\hline $\begin{array}{l}\text { Site no. } \\
\text { on map }\end{array}$ & $\begin{array}{l}\text { USGS station } \\
\text { name and no. }\end{array}$ & $\begin{array}{l}\text { Drainage area } \\
\text { (square miles) }\end{array}$ & $\begin{array}{l}\text { Major land use } \\
\text { (see fig. 1) }\end{array}$ \\
\hline 1 & Colorado River below Hoover Dam, Arizona-Nevada $(09421500)$...... & 171,700 & Mostly ungrazed desert shrubland. \\
\hline 2 & Muddy River above Lake Mead, near Overton (09419515) ................... & 8,310 & Grazed desert shrubland. \\
\hline 3 & Virgin River at Littlefield, Ariz. (09415000) & 5,090 & Ditto. \\
\hline 4 & Truckee River near Nixon (10351700) & 1,827 & Grazed forest and woodland. \\
\hline 5 & Carson River near Fort Churchill $(10312000)$ & 1,302 & Grazed desert shrubland. \\
\hline 6 & Walker River near Wabuska $(10301500)$ & 2,600 & Grazed forest and woodland. \\
\hline 7 & 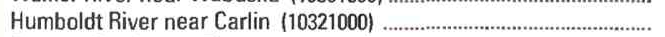 & 4,310 & Grazed desert shrubland. \\
\hline 8 & Steptoe Creek near Ely $(10244950)$ & 11 & Grazed open woodland. \\
\hline
\end{tabular}

Figure 2. Selected water-quality monitoring stations, type of statistical analysis, and geographic features in Nevada. (Sources: Major land uses modified from Anderson, 1967; other data from U.S. Geological Survey files.) 
Streamflow of the Colorado River at site 1 is regulated by Hoover Dam, which impounds Lake Mead.

Water quality in the Colorado River has been affected by agricultural runoff, runoff from naturally saline springs and soils, and discharge from municipal wastewater-treatment plants. The median concentrations of sulfate $(210 \mathrm{mg} / \mathrm{L})$ and dissolved solids (541 $\mathrm{mg} / \mathrm{L}$ ) were among the largest for the eight monitoring stations (fig. 3). Sulfate and dissolved solids are associated with runoff from agricultural areas and ground-water inflows from gypsum-bearing deposits. The median nitrite plus nitrate concentration $(0.34 \mathrm{mg} / \mathrm{L})$ was the second largest at any of the monitoring stations. The large nitrogen concentration is associated with discharge from wastewatertreatment plants and runoff from agricultural areas. Median concentrations of phosphate (less than $0.01 \mathrm{mg} / \mathrm{L}$ ) and suspended sediment ( $3 \mathrm{mg} / \mathrm{L}$ ) were among the smallest for the eight monitoring stations. Settling of sediment in Lake Mead causes the small suspended-sediment concentrations at site 1 .

\section{MUDDY RIVER}

The Muddy River originates from large springs in an area near Moapa and flows southward to Lake Mead. Upstream from Glendale, water is diverted from the river for use as coolant in a powerplant, and, downstream from Glendale, water is diverted for agricultural use. Site 2 is about 13 miles downstream from Glendale, near Lake Mead.

Water quality in the Muddy River basin is affected by geology and agriculture. Discharge from springs passes through and over gypsum deposits. Most of the river's total flow is withdrawn for irrigation; at site 2, most of the flow is from irrigation return. As a result, the median concentrations of sulfate $(950 \mathrm{mg} / \mathrm{L})$, dissolved solids $(2,100 \mathrm{mg} / \mathrm{L})$, nitrite plus nitrate $(0.18 \mathrm{mg} / \mathrm{L})$, phosphate $(0.07$ $\mathrm{mg} / \mathrm{L})$, and suspended sediment $(305 \mathrm{mg} / \mathrm{L})$ were among the largest for the eight monitoring stations (fig. 3).
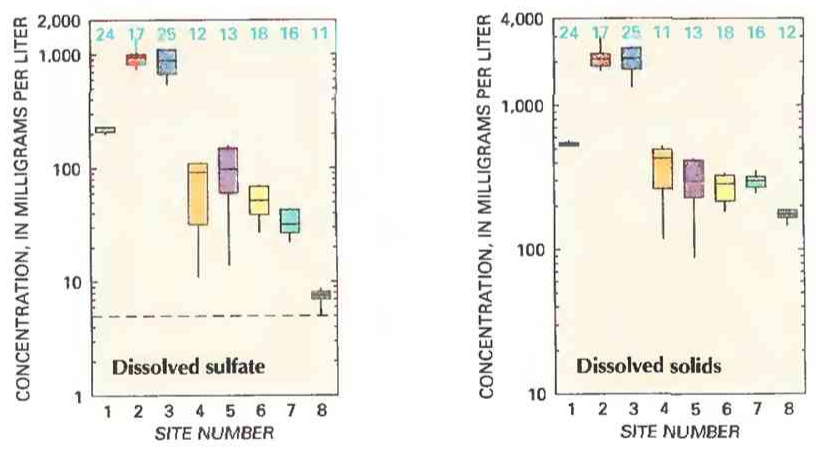

EXPLANATION

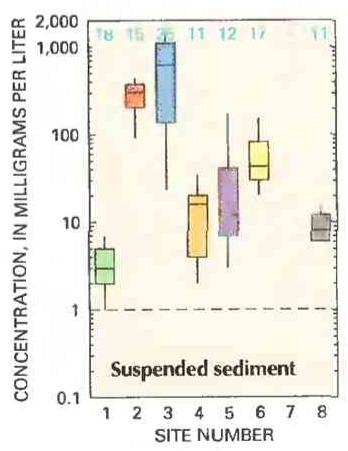

\section{VIRGIN RIVER}

The Virgin River flows from southern Utah through Arizona and Nevada into Lake Mead. Site 3 is in Arizona, 7 miles east of the Nevada State line and about 35 miles upstream from Lake Mead.

Water quality in the basin is affected by climate and geology. Evaporation, dissolution of minerals from rocks and sedimentary deposits, and inflows of saline ground water result in stream water having large concentrations of dissolved constituents. The median concentrations of sulfate $(890 \mathrm{mg} / \mathrm{L})$, dissolved solids $(2,130 \mathrm{mg} / \mathrm{L})$, nitrite plus nitrate $(0.66 \mathrm{mg} / \mathrm{L})$, and suspended sediment $(621$ $\mathrm{mg} / \mathrm{L}$ ) were among the largest for the eight monitoring stations (fig. 3). The sulfate is derived from inflow of ground water from gypsum-bearing sedimentary deposits and rocks, and the nitrite plus nitrate might have come from agricultural runoff. Suspended-sediment concentrations were large because runoff from intense thunderstorms over the arid basin carries large quantities of sediment into the river.

\section{TRUCKEE RIVER}

The Truckee River, which flows from Lake Tahoe to Pyramid Lake, is the major source of water for Reno and Sparks. Site 4 is about 50 miles downstream from Reno and Sparks. Much of the river's flow is diverted to Lahontan Reservoir in the adjacent Carson River basin for agricultural use near Fallon.

Major sources of contamination in the Truckee River are runoff from agricultural and urban areas and discharges from municipal wastewater-treatment plants, all of which are potential sources of nutrient contamination. A transcontinental railroad line runs parallel to a 44-mile reach of the Truckee River in Nevada. In 1989, the State of Nevada began administrative proceedings to prevent intransit dumping of raw sewage from the passenger trains because of pos-
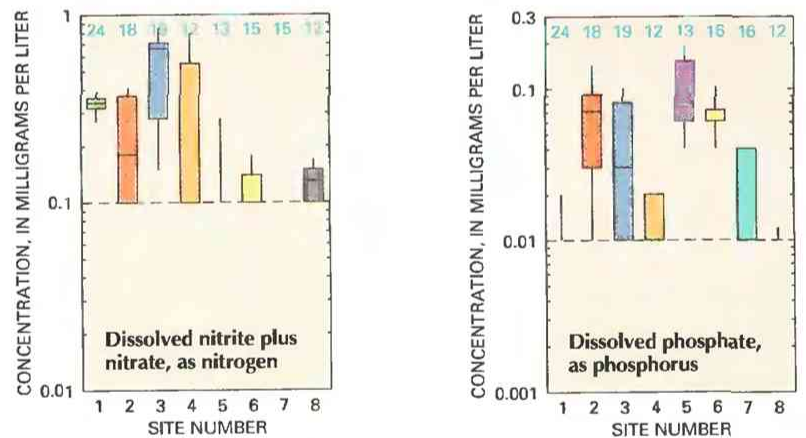

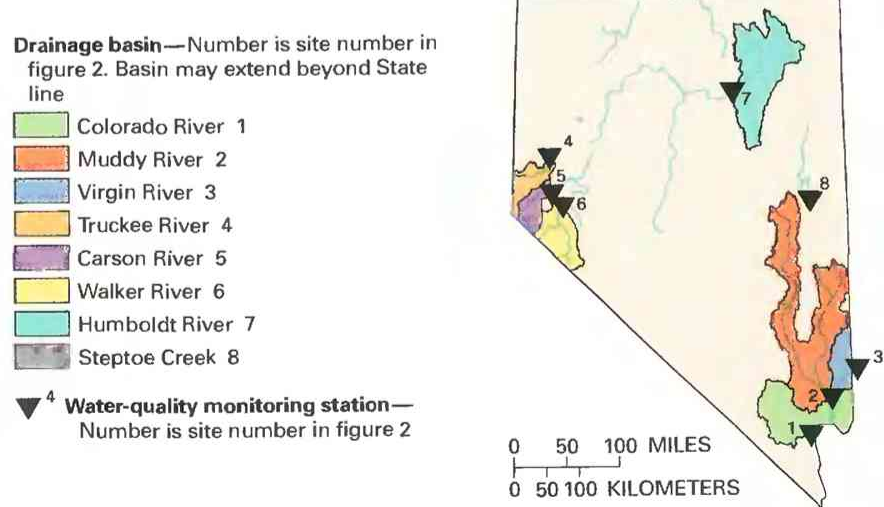

Figure 3. Water quality of selected streams in Nevada, water years 1987-89. (Source: Data from U.S. Geological Survey files.) 
Table 1. Sources and environmental significance of selected water-quality constituents [Source: Compiled by the U.S. Geological Survey, Office of Water Quality]

\begin{tabular}{|c|c|c|}
\hline Constituent & Common sources & Environmental significance \\
\hline Sulfate & $\begin{array}{l}\text { Occurs in some rocks; also in mine runoff, industrial } \\
\text { wastewater discharge, and atmospheric deposi- } \\
\text { tion. }\end{array}$ & $\begin{array}{l}\text { Concentrations exceeding a natural, background } \\
\text { level indicate contamination from human activity; } \\
\text { in sufficient quantity, can cause water to be } \\
\text { unsuitable for public supply; can harm aquatic } \\
\text { organisms. }\end{array}$ \\
\hline Dissolved solids .............................. & $\begin{array}{l}\text { A result of rock weathering; also in agricultural runoff } \\
\text { and industrial discharge. }\end{array}$ & $\begin{array}{l}\text { In sufficient quantity, can cause water to be unsuitable } \\
\text { for public supply, agriculture, and industry; can } \\
\text { harm aquatic organisms. }\end{array}$ \\
\hline Nitrite plus nitrate ......................... & $\begin{array}{l}\text { Nonpoint sources are agricultural and urban runoff; } \\
\text { a major point source is wastewater discharge. }\end{array}$ & $\begin{array}{l}\text { Plant nutrient that, in sufficient quantity, can cause } \\
\text { algal blooms and excessive growth of higher } \\
\text { aquatic plants in bodies of water; can cause water } \\
\text { to be unsuitable for public supply. }\end{array}$ \\
\hline 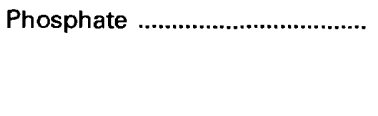 & $\begin{array}{l}\text { Occurs in some rocks and sediments; also in runoff } \\
\text { and seepage from phosphate-rock mines, agri- } \\
\text { cultural and urban runoff, and industrial and } \\
\text { municipal wastewater discharge. }\end{array}$ & $\begin{array}{l}\text { Plant nutrient that, in sufficient quantity, can cause } \\
\text { algal blooms and excessive growth of higher } \\
\text { aquatic plants in bodies of water. }\end{array}$ \\
\hline Suspended sediment .................. & $\begin{array}{l}\text { A result of rock erosion; also induced by disturbances } \\
\text { of land cover due to fires, floods, and human } \\
\text { activities such as mining, logging, construction, } \\
\text { and agriculture. }\end{array}$ & $\begin{array}{l}\text { Can be detrimental to aquatic organisms; can fill res- } \\
\text { ervoirs and impair recreational use of water. }\end{array}$ \\
\hline
\end{tabular}

sible effects on stream water quality. In 1990, the U.S. Congress protected the train operator from such legal actions, nationwide, but required installation of full-retention toilet systems in the rail passenger cars by late 1996 (Brian V. Chally, Deputy Nevada Attorney General, oral commun., 1991). Siltation and turbidity also have been problems in the Truckee River; as a result, local governments now regulate gravel-mining operations and urban construction projects to mitigate the sediment load in runoff from these activities.

The median concentration of nitrite plus nitrate in the Truckee River at site $4(0.10 \mathrm{mg} / \mathrm{L})$ was among the smallest (fig. 3$)$, although the range of concentrations was the greatest for any of the monitoring stations. The variability was caused by changes in wastewater-treatment methods at the Reno-Sparks plant and flow-related variations in the capacity of the river to assimilate nitrogen. At low flow, nitrogen in effluent is fully assimilated; at intermediate flows, the nitrogen may not be fully assimilated because water is moving faster. Large concentrations of phosphate in wastewater-treatmentplant effluent have been a chronic problem in the Truckee River; in 1982, however, the Reno-Sparks wastewater-treatment plant began removing phosphorus from municipal wastewater. As a result, more than 95 percent of the phosphorus is now removed (Nevada Division of Environmental Protection, 1988, p. 28). The small median phosphate concentration $(0.01 \mathrm{mg} / \mathrm{L})$ in water samples collected during 1987-89 reflects the success of the phosphorus-removal effort.

\section{CARSON RIVER}

The Carson River flows from the Sierra Nevada to Carson Lake, Carson Sink, and Stillwater Marsh near Fallon. Site 5 is about 35 miles northeast of Carson City. Irrigation is the principal use of surface water withdrawn from the river.

Sources of contamination in the Carson River include sewage effluent from wastewater-treatment plants, ore-mill wastes, and agricultural runoff. A reach of the river east of Carson City was added to the EPA Superfund list for priority cleanup because of mercury contamination of bottom sediment and fish (Reno Gazette-Journal, Reno, Nev., August 29, 1990). About 14 million pounds of mercury was released into streams of the middle Carson River basin during the milling of gold and silver ores in the 1800 's, according to Smith (1943, p. 25). A health advisory concerning fish consumption was issued in 1986 as the result of a study by Cooper and others (1985) that reaffirmed earlier reports of large mercury concentrations in river sediment, water, and fish.
The small median nitrite plus nitrate concentration at site 5 (less than $0.10 \mathrm{mg} / \mathrm{L}$ )—among the smallest for the eight monitoring stations (fig. 3) -indicates rapid uptake of the nutrient by aquatic vegetation. The median concentration of phosphate $(0.08 \mathrm{mg} / \mathrm{L})$ was the largest for any of the monitoring stations. Sources of phosphate include runoff from agricultural areas and discharge from sewagetreatment plants. In the past, phosphate concentrations substantially exceeded standards in the river; consequently, several treatment plants have been required to stop discharging treated effluent to the Carson River and instead use land disposal (Nevada Division of Environmental Protection, 1988, p. 47).

\section{WALKER RIVER}

The Walker River flows from the Sierra Nevada to Walker Lake. Site 6 is downstream from irrigated land in the Walker River valley, about 15 miles north of Yerington. Irrigation is the major use of river water.

Agricultural runoff is the primary source of contamination in the Walker River basin. Phosphorus and nitrate from agricultural runoff are known water-quality problems in the river, and the U.S. Bureau of Indian Affairs has reported that boron also might be a problem (Nevada Division of Environmental Protection, 1988, p. 70). Suspended sediment in water applied to irrigated crops has affected soil characteristics and has reduced crop yield in irrigated areas along the river (Nevada Division of Environmental Protection, 1988, p. 78).

The small median nitrite plus nitrate concentration at site 6 $(0.10 \mathrm{mg} / \mathrm{L})$ (fig. 3) indicates either that dilution has substantially decreased the concentrations contributed by agricultural runoff or that the nutrients have been assimilated by algae or other aquatic plants. The relatively large median concentration of phosphate $(0.06$ $\mathrm{mg} / \mathrm{L}$ ), however, indicates that neither of those mechanisms decreased phosphate concentrations appreciably. The median concentration of suspended sediment ( $43 \mathrm{mg} / \mathrm{L}$ ), another problem constituent in the basin, was the third largest for any of the monitoring stations.

\section{HUMBOLDT RIVER}

The Humboldt River originates in northern Nevada and flows to Humboldt Lake in western Nevada. Site 7 is near Carlin. Irrigation is the major use of river water.

Agricultural runoff is the primary source of contamination in the Humboldt River basin. Point-source contamination has been greatly reduced without substantial improvement of river water qual- 


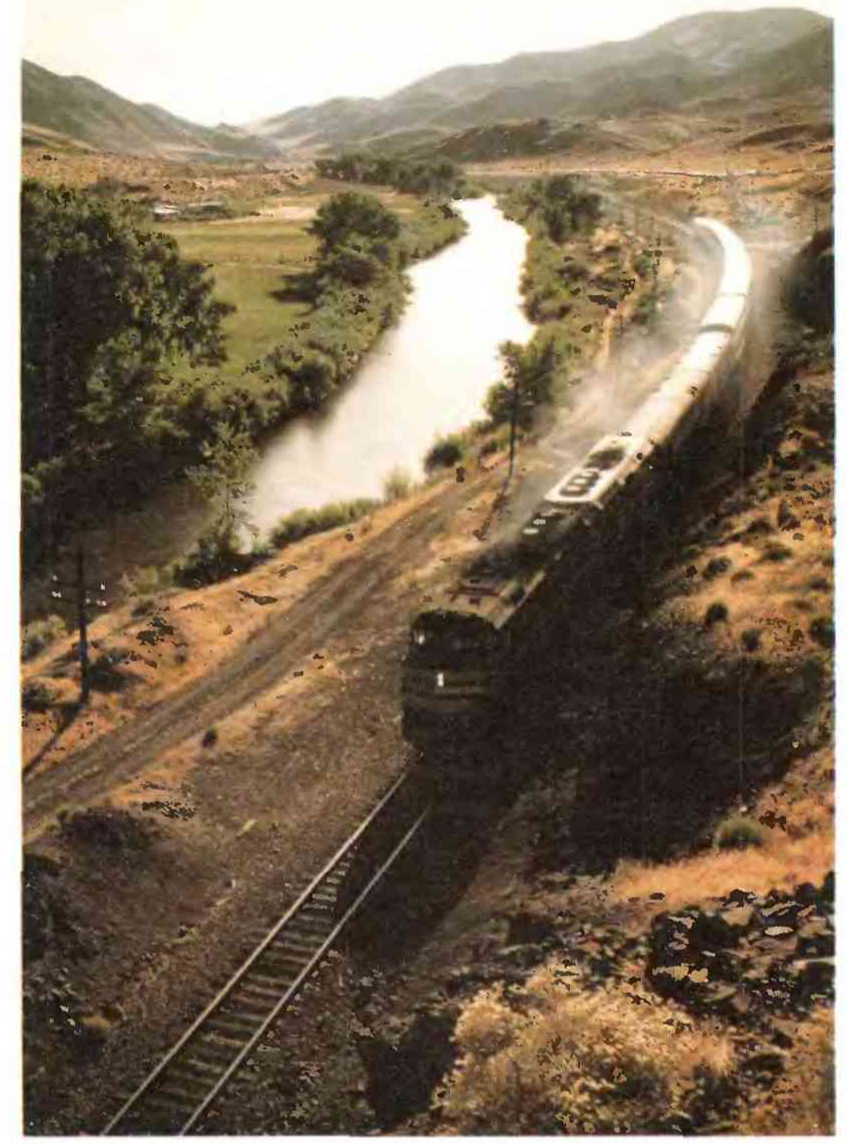

Lower Truckee River, 25 miles east of Reno, Nev. Photo site is downstream from major flow diversions for agricultural and municipal use, and principal contaminant contributions from urban areas. (A.S. VanDenburgh, U.S. Geological Survey.)

ity (Nevada Division of Environmental Protection, 1988, p. 88). This apparent lack of improvement indicates that nonpoint sources of contaminants are important causes of water-quality degradation. Withdrawal of water from the river for irrigation near Lovelock and subsequent return flow has caused water-quality problems in Humboldt Lake, a wildlife-management area that is an important stop for migratory birds along the Pacific flyway. The dissolved-solids concentration in the lake exceeds $3,000 \mathrm{mg} / \mathrm{L}$, and potentially harmful quantities of selenium and arsenic have been found in birds studied there (Hoffman and others, 1990, p. 64, 69).

The median nitrite plus nitrate concentration (less than 0.10 $\mathrm{mg} / \mathrm{L}$ ) was among the smallest for the monitoring stations (fig. 3). Rapid uptake of nitrogen by aquatic plants might result in small nitrite plus nitrate concentrations even though the river receives agricultural runoff. Dissolved solids (median concentration, $301 \mathrm{mg} / \mathrm{L}$ ) are not a water-quality problem at site 7 but become a concern at the terminus of the river near Lovelock.

\section{STEPTOE CREEK}

Steptoe Creek originates in the mountains of eastern Nevada and flows to its confluence with Duck Creek near Ely. Upstream from site 8 , the spring-fed stream drains a small area that is largely unaffected by human activities.

The median concentrations of sulfate $(7.6 \mathrm{mg} / \mathrm{L})$ and dissolved solids $(176 \mathrm{mg} / \mathrm{L})$ were the smallest for any of the monitoring sta- tions (fig. 3). The median concentration of phosphate (less than 0.01 $\mathrm{mg} / \mathrm{L}$ ) was among the smallest. The small concentrations reflect the geochemistry of the creek basin upstream from site 8 , as well as the relatively undisturbed nature of the basin.

\section{WATER-QUALITY TRENDS}

Trend analysis is a statistical procedure used to detect changes in stream water quality at a monitoring station over time. For this report, water-quality data from seven monitoring stations (fig. 2) were analyzed for trends by using the seasonal Kendall test (Hirsch and others, 1982), a method used extensively by the USGS.

When possible, constituent-concentration data were adjusted for changes in streamflow to preclude identifying a trend in concentration that was caused only by a trend in streamflow. The data were not adjusted when (1) more than 10 percent of the samples had concentrations lower than the minimum reporting limit for the analytical method used or (2) streamflow was controlled substantially by human activities. When the concentration data could not be adjusted for streamflow, trends were determined directly from the concentration data.

Statewide trends in concentrations of selected stream-water constituents are shown on maps in figure 4. On each map, a trend is indicated at a monitoring station only if the data from that station were suitable for use in the trend analysis. For more information on the suitability criteria and on the trend-analysis procedure used for this report, see Lanfear and Alexander (1990).

\section{DISSOLVED SULFATE}

The major natural sources of sulfate in streams are rock weathering, volcanoes, and biochemical processes (Hem, 1985, p. 113). Human activities such as mining, waste discharge, and fossil-fuel combustion also can be important sources.

Causes of the upward trend in sulfate concentrations in the Truckee River at site 4 and the downward trend in the Walker River at site 6 (fig. 4) are not known. However, the difference in the trends could be related to land use. Both rivers originate in the Sierra Nevada, but the Truckee River passes through an urban area and the Walker River through a rural area. The downward trend at site 1 on the Colorado River probably was the result of dilution by 5 consecutive years of greater than average streamflow into Lake Mead.

\section{DISSOLVED SOLIDS}

Dissolved solids in stream water result primarily from rock weathering but also can be introduced as a byproduct of human activities (table 1). Concentrations generally are greatest in streams draining basins underlain by rocks and soils that contain easily dissolved minerals.

A cause for the upward trend in dissolved-solids concentration in the Truckee River at site 4 (fig. 4) is unknown, but the discussion of the upward trends in sulfate concentrations also applies to dissolved solids. As with sulfate, the net downward trend in dissolved-solids concentrations in the Colorado River at site 1 probably was due to dilution. The graph of dissolved-solids concentrations at site 1 (next page), however, indicates that the concentration has been increasing since 1987, probably because runoff from the upper basin during drought in the late 1980's (U.S. Geological Survey, 1991, p. 385-392) was less than the long-term average. When precipitation is less than average, dissolved-solids concentration commonly increases because ground water, typically more mineralized than runoff from precipitation, constitutes a greater proportion of streamflow. 


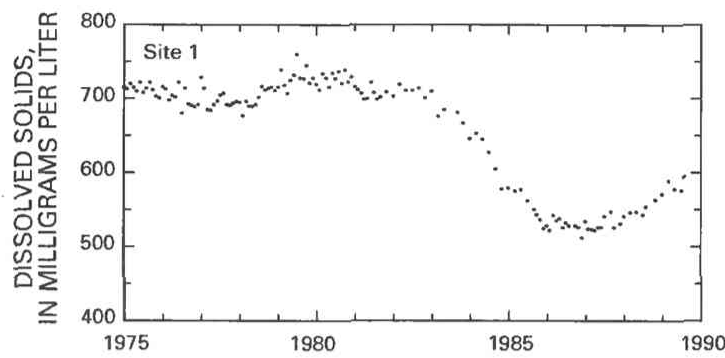

\section{DISSOLVED NITRITE PLUS NITRATE}

Nitrite and nitrate are oxidized forms of nitrogen that together normally constitute most of the dissolved nitrogen in well-aerated streams. Nitrite readily oxidizes to nitrate in natural waters; therefore, nitrate generally is by far the more abundant of the two (Hem, 1985 , p. 124)

Concentrations of nitrite plus nitrate had no significant trends at any of the monitoring stations during 1980-89 (fig. 4). However, at site 1 on the Colorado River, during 1970-80 (not shown in fig. 4), the nitrite plus nitrate concentration decreased by about 50 percent. Since 1980, the concentration there has been stable. The decreasing nitrite plus nitrate concentration might reflect a change in the form of nitrogen in the water rather than a decrease in the total concentration of nitrogen. Although incomplete, the data for all forms of nitrogen at site 1 indicate that the total nitrogen concentration has remained constant or has increased.

\section{DISSOLVED PHOSPHATE}

Phosphate is the oxidized form of phosphorus and the only form of significance in most natural waters. Small quantities of dissolved phosphate commonly are present in streams as a result of rock weathering. Normally, concentrations are no more than a few tenths of a milligram per liter (Hem, 1985, p. 126) and usually are much lower. Higher concentrations can indicate contamination from human activities (table 1). A shortened trend-analysis period was used for phosphate because data for water years 1980-81 are not comparable to data for subsequent years.

The downward trend in phosphate concentrations in the Truckee River at site 4 (fig. 4 ) was related primarily to improved sewage treatment. The reason for the decrease in the Humboldt River at site 7 is not known. At site 5 on the Carson River, there was no trend for 1982-89; however, changes in effluent-disposal practices, such as land application of the effluent, have recently been instituted at some sewage-treatment plants to reduce the phosphate concentration in the Carson River.

\section{SUSPENDED SEDIMENT}

Suspended sediment is a product of erosion. The erosion can be either natural or the result of land-cover disturbances related to human activities (table 1).

The upward trend in the suspended-sediment concentration in the Colorado River at site 1 (fig. 4) is not fully understood; however, the increase was small. Suspended-sediment concentrations had

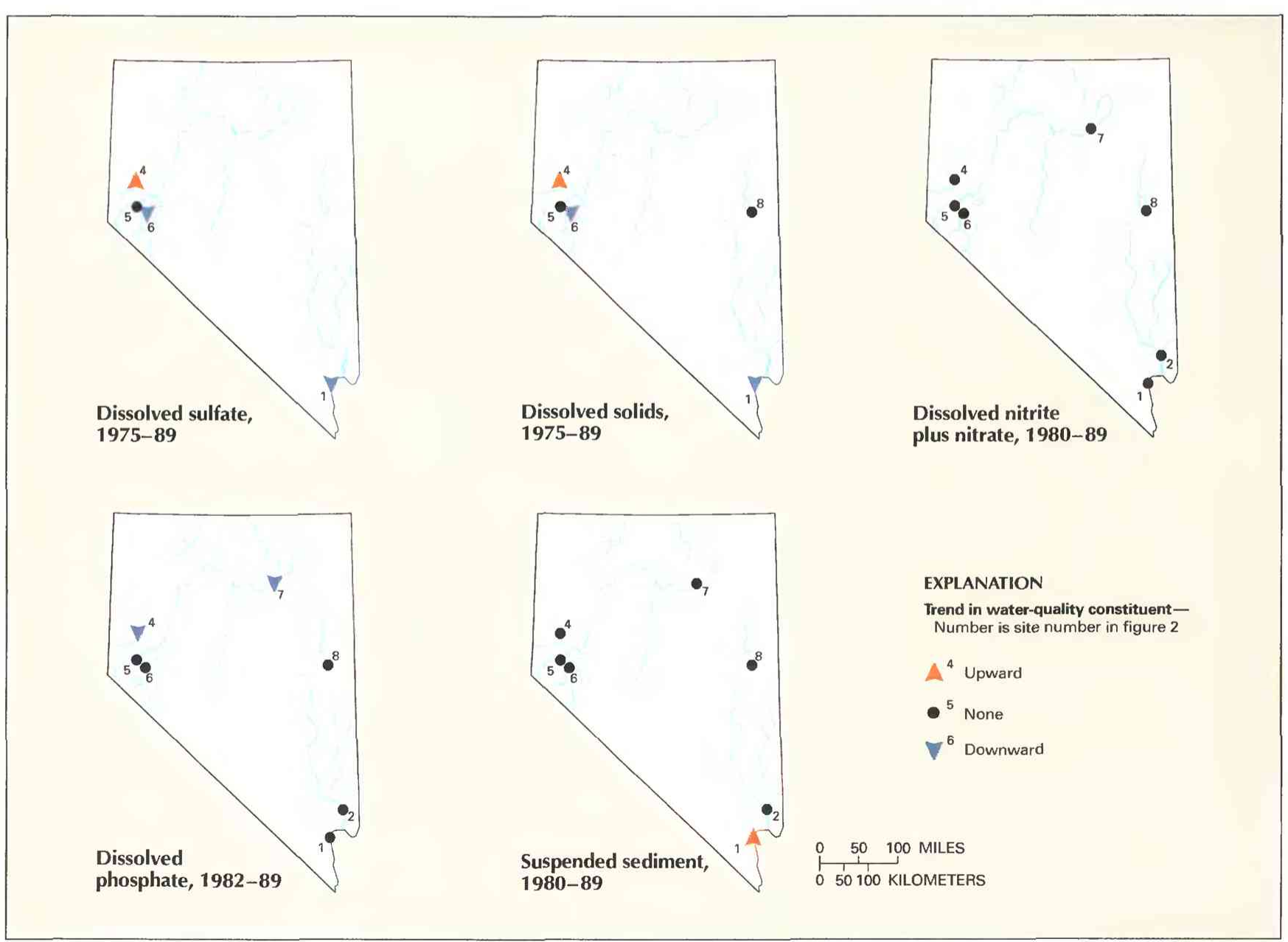

Figure 4. Trends in water quality of selected streams in Nevada, by water years. (Source: Data from U.S. Geological Survey files.) 
a downward trend during 1970-80 (not shown in fig. 4) at site 4 on the Truckee River. The trend probably resulted from improvement of urban land-management practices that decreased erosion by minimizing land disruption. Since 1980, suspended-sediment concentrations at site 4 have been stable.

\section{WATER-QUALITY MANAGEMENT}

Water quality in Nevada streams is regulated by the Nevada Division of Environmental Protection (NDEP). The NDEP was established in 1977 and is responsible for monitoring compliance with statutory and regulatory provisions for water-pollution control and hazardous-waste management. The NDEP implements the Federal Clean Water Act in Nevada and prepares a water-quality assessment report (Nevada Division of Environmental Protection, 1988) submitted biennially to EPA and the U.S. Congress pursuant to section 305(b) of the Clean Water Act.

The USGS, NDEP, Nevada Division of Water Resources, Nevada Department of Wildlife, Desert Research Institute, and several municipal and county agencies cooperate in monitoring streamflow and water quality at numerous stations in Nevada. The number of waterquality monitoring stations on Nevada streams has increased from about 50 in 1970 to 88 in 1989 (Janice Carr, Nevada Division of Enivironmental Protection, oral commun., 1990).

In 1975, the seven States within the Colorado River drainage basin, with approval from the EPA, adopted numerical standards for salinity in the Colorado River. Nevada cooperates with the Federal Government and other States in managing salinity in the Colorado River, which borders Nevada on the southeast. The standards are being enforced through a joint Federal-State program under the Colorado River Basin Salinity Control Act of 1974.

\section{SELECTED REFERENCES}

Anderson, J.R., 1967, Major land uses in the United States, in U.S. Geological Survey, 1970, National atlas of the United States of America: U.S. Geological Survey, p. 158-159.

Britton, L.J., and Greeson, P.E., eds., 1987, Methods for collection and analysis of aquatic biological and microbiological samples: U.S. Geological Survey Techniques of Water-Resources Investigations, book 5, chap. A4, $363 \mathrm{p}$.

Cooper, J.J., Thomas, R.O., and Reed, S.M., 1985, Total mercury in sediment, water, and fishes in the Carson River drainage, west-central Nevada: Carson City, Nevada Division of Environmental Protection report, 96 p.

Fenneman, N.M., 1946, Physical divisions of the United States: Washington, D.C., U.S. Geological Survey special map, scale 1:7,000,000.

Fishman, M.J., and Friedman, L.C., eds., 1989, Methods for the determination of inorganic substances in water and fluvial sediments: U.S. Geological Survey Techniques of Water-Resources Investigations, book 5 , chap. A1, 545 p.
Geraghty, J.J., Miller, D.W., Van Der Leeden, Frits, and Troise, F.L., 1973, Water atlas of the United States: Port Washington, N.Y., Water Information Center, $122 \mathrm{pl}$.

Hem, J.D., 1985, Study and interpretation of the chemical characteristics of natural water (3d ed.): U.S. Geological Survey Water-Supply Paper 2254, $263 \mathrm{p}$.

Hirsch, R.M., Slack, J.R., and Smith, R.A., 1982, Techniques of trend analysis for monthly water quality data: Water Resources Research, v. 18, no. 1, p. 107-121.

Hoffman, R.J., Hallock, R.J., Rowe, T.G., and others, 1990, Reconnaissance investigation of water quality, bottom sediment, and biota associated with irrigation drainage in and near Stillwater Wildlife Management Area, Churchill County, Nevada: U.S. Geological Survey Water-Resources Investigations Report 89-4105, $150 \mathrm{p}$.

Hurlbut, C.S., Jr., 1971, Dana's manual of mineralogy, 18th edition: New York, John Wiley, $579 \mathrm{p}$.

Lanfear, K.J., and Alexander, R.B., 1990, Methodology to derive water-quality trends for use by the National Water Summary Program of the U.S. Geological Survey: U.S. Geological Survey Open-File Report 90-359, $10 \mathrm{p}$.

Nevada Division of Environmental Protection, 1988, Nevada water quality assessment (305b) report: Nevada Division of Environmental Protection report, $139 \mathrm{p}$.

Nevada Division of Water Planning, 1980, Nevada water facts: Nevada Division of Water Planning, Water Planning Bulletin 1, $74 \mathrm{p}$.

Patt, R.O., and Hess, J.W., 1976, Characterization of nitrogen sources contaminating shallow ground water in an arid basin, Las Vegas area, Nevada: Las Vegas, University of Nevada, Desert Research Institute, Hydrology and Water Resources Publication 26, 44 p.

Smith, G.H., 1943, The history of the Comstock Lode, 1850-1920: Las Vegas, University of Nevada Bulletin, Geology and Mining Series 37, $305 \mathrm{p}$.

Solley, W.B., Merk, C.F., and Pierce, R.F., 1988, Estimated use of water in the United States in 1985: U.S. Geological Survey Circular 1004, 82 p.

Thelin, G.P., and Pike, R.J., 1990, Digital shaded relief map of the conterminous United States: Menlo Park, Calif., U.S. Geological Survey digital image processing, scale 1:3,500,000.

U.S. Bureau of the Census, 1990, 1988 Farm and ranch irrigation survey: U.S. Government Printing Office, $114 \mathrm{p}$.

U.S. Geological Survey, 1986, National water summary 1985-Hydrologic events and surface-water resources: U.S. Geological Survey WaterSupply Paper $2300,506 \mathrm{p}$.

1990 , National water summary 1987-Hydrologic events and water supply and use: U.S. Geological Survey Water-Supply Paper 2350, $553 \mathrm{p}$.

1991, National water summary 1988-89-1Hydrologic events and floods and droughts: U.S. Geological Survey Water-Supply Paper 2375, $591 \mathrm{p}$.

Ward, J.R., and Harr, C.A., eds., 1990, Methods for collection and processing of surface-water and bed-material samples for physical and chemical analyses: U.S. Geological Survey Open-File Report 90-140, 71 p. 
Prepared by Ralph L. Seiler

FOR ADDITIONAL INFORMATION: District Chief, U.S. Geological Survey, Federal Building, 333 W. Nye Lane, Carson City, NV 89706 


\section{New HAMPshiRe Stream Water Quality}

New Hampshire has an annual precipitation that averages about 42 inches and ranges from 34 inches in the Connecticut River valley to 89 inches in the White Mountains (National Oceanic and Atmospheric Administration, 1982). Consequently, the State has an abundance of freshwater. Most streams are suitable for recreational use (New Hampshire Department of Environmental Services, 1990) and, after treatment, for human consumption.

Offstream surface-water withdrawals in 1985 averaged 603 $\mathrm{Mgal} / \mathrm{d}$ (million gallons per day). The largest offstream users were thermoelectric power generation (336 Mgal/d), industry (205 $\mathrm{Mgal} / \mathrm{d}$ ), and public suppliers (61 Mgal/d). Surface water serves about two-thirds of the State's population (U.S. Geological Survey, 1990, p. 362,363 ).

The quality of surface water can be directly affected by land use. Land use in New Hampshire (fig. 1A) is determined in part by the State's physiography. The New England Upland and Seaboard Lowland sections of the New England physiographic province (fig. $1 B)$ are characterized by small mountains, many hills, rolling low-

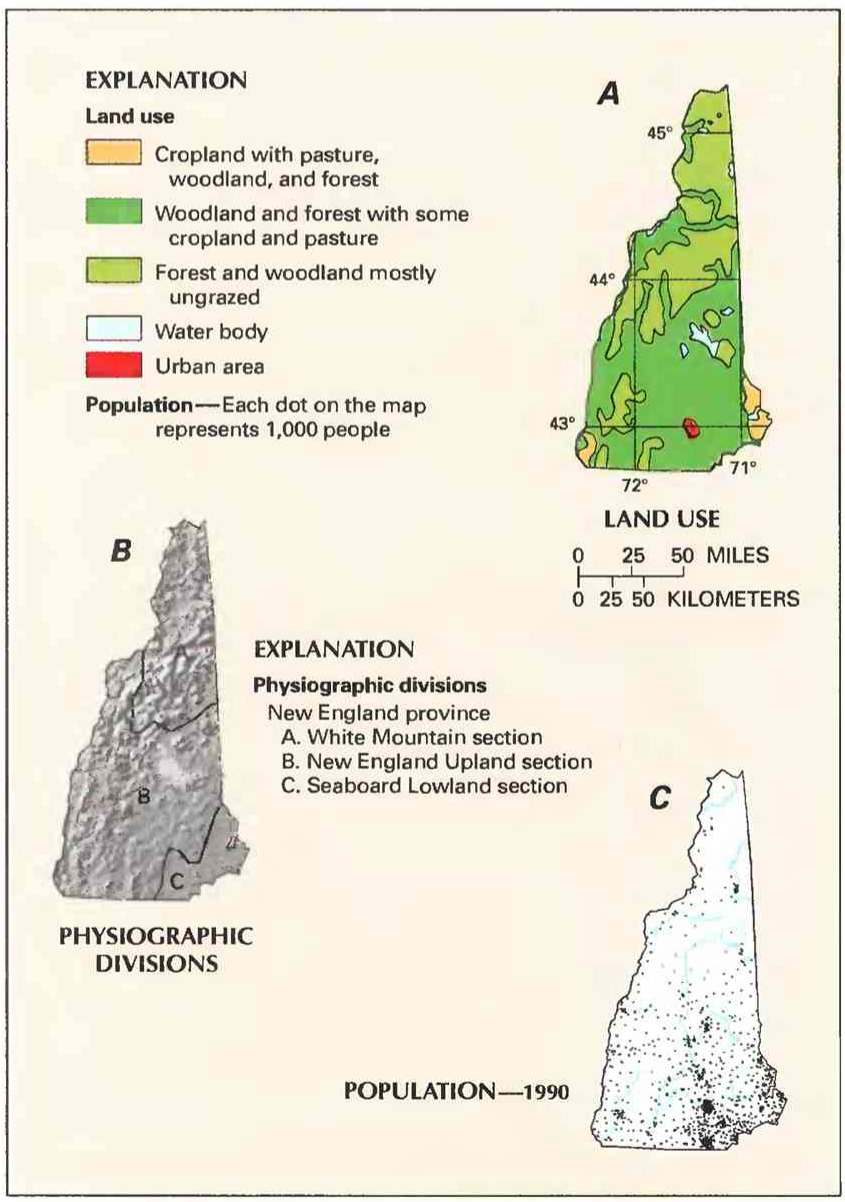

Figure 1. Land use, physiography, and population in New Hampshire. A, Major land uses. B. Physiographic divisions. C, Population distribution in 1990. (Sources: A. Major land uses modified from Anderson, 1967. B Physiographic divisions from Fenneman, 1946; landforms from Thelin and Pike, 1990. C, Data from U.S. Bureau of the Census 1990 decennial census files.) lands, flood plains, and coastal plains that support most of the State's agricultural activity. The White Mountain section primarily is mountainous terrain covered mostly by forest and woodland.

The principal river basins in New Hampshire are the Merrimack, Connecticut, Saco, and Androscoggin subregions (Seaber and others, 1984). Surface-water development in most basins consists primarily of reservoirs designed for flood control and hydroelectric power generation.

About one-half of New Hampshire's population is located in the southeastern part of the State (fig. 1C). The State's 1990 population was 1.1 million - a 20-percent increase from 1980 (U.S. Bureau of the Census 1990 decennial census files).

\section{WATER-QUALITY MONITORING}

Water-quality data obtained from analyses of water samples collected at monitoring stations are stored in the U.S. Geological Survey's (USGS) National Water Information System and the U.S. Environmental Protection Agency's (EPA) national data base known as STORET. Water-quality and streamflow data are reported by water year - the 12 months from October 1 through September 30. A water year is identified by the calendar year in which it ends. For example, water year 1991 comprises October 1, 1990, through September 30, 1991.

The data used in this summary of New Hampshire's stream water quality were obtained from water samples collected at monitoring stations at which data collection is systematic and continuing (fig. 2). Site 1 on the Merrimack River and site 5 on the Connecticut River are part of the U.S. Geological Survey's National Stream Quality Accounting Network (NASQAN). There are no NASQAN sites in the other major basins of the State; therefore, this report contains chemical and biological data indicative of conditions within only these two New Hampshire basins. Currently, only specific conductance and water temperature are monitored by the USGS in other basins of the State.

Water samples were collected and analyzed by using standard methods approved by the USGS (Britton and Greeson, 1987; Fishman and Friedman, 1989; Ward and Harr, 1990) or by using equivalent methods. If a method of sample collection or analysis changed over time, data from an analysis were included in the evaluation of recent stream water quality or of stream water-quality trends only if the change in method did not affect the comparability of the data.

\section{WATER-QUALITY CONDITIONS}

The State of New Hampshire water-resources-management program, owing to budgetary constraints, historically has focused on water-quality problems rather than on routine water-quality monitoring, although approximately 36 stations were sampled twice in 1989. In 1988-89, the New Hampshire Department of Environmental Services (NHDES) assessed 1,348 river miles that had known or potential water-quality problems. Stream-water samples were analyzed for several properties or constituents, including specific conductance, $\mathrm{pH}$, dissolved oxygen, biochemical oxygen demand, bacteria, hardness, alkalinity, chloride, dissolved solids, nutrients, and toxic metals, to assess conformance with Federal Clean Water Act goals. This assessment represented about 9 percent of New Hampshire's total river miles. Although the remaining 13,196 river miles were not monitored or evaluated in $1988-89$, water quality in them was assumed to meet 
State standards (New Hampshire Department of Environmental Services, 1990, p. III-1-3).

Eighty-nine percent of stream miles assessed by the NHDES in 1988-89 were suitable for swimming (Class A or B), more than 96 percent were suitable for fishing (Class A, B, or C), and about 4 percent did not meet at least Class $\mathrm{C}$ goals (New Hampshire Department of Environmental Services, 1990, p. III-1-3). In addition to stream miles directly assessed, the NHDES estimated that 857 stream miles (about 6 percent of total New Hampshire stream miles) contained toxic metals (New Hampshire Department of Environmental Services, 1990, p. III-2-2). Excessive concentrations of bacteria in reaches downstream from municipal wastewater-treatment plants and untreated discharges were a point-source problem in many stream segments that did not support designated uses [Classes A (suitable for untreated water supply), B, and C]. The major nonpoint sources of bacterial contamination are domestic sewage-disposal systems, animal wastes, and wastewater discharge from boats (New Hampshire Department of Environmental Services, 1990, p. I-1).

The following discussion of stream water quality in New Hampshire is organized by river basin (fig. 3). Graphs in figure 3

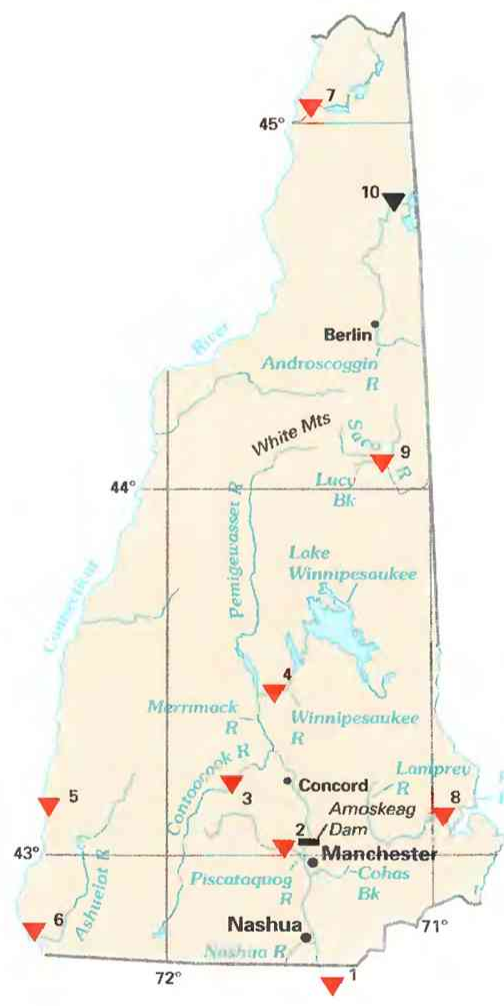

summarize certain aspects of stream water quality in the basins for water years 1987-89. The graphs show frequency distributions of data values that represent measurements of selected physical properties of stream water and concentrations of selected constituents in stream water. These properties and constituents are specific conductance, dissolved oxygen, fecal coliform bacteria, fecal streptococcal bacteria, dissolved sulfate, dissolved solids, and dissolved nitrite plus nitrate (as nitrogen). The data are reported in microsiemens per centimeter at 25 degrees Celsius $(\mu \mathrm{S} / \mathrm{cm})$, milligrams per liter, or colonies per 100 milliliters (col/100 mL). Sources and environmental significance of each property and constituent are described in table 1 .

Water quality at each monitoring station is the result of geological, chemical, biological, and hydrologic processes that occur over a large area. Water-quality problems that affect aquatic life or public health only locally are not fully represented in this summary.

\section{MERRIMACK RIVER}

The Merrimack River in central New Hampshire is formed by the confluence of the Pemigewasset and Winnipesaukee Rivers and flows southward into Massachusetts. The river is regulated for hydroelectric power generation and flood control. The basin is underlain by crystalline bedrock that consists of granite, gneiss, and schist covered by a discontinuous mantle of glacial till and stratified drift. Land cover in the basin primarily is woodland and forest with some cropland and pasture. Concord, Manchester, and Nashua are the major industrialized areas and population centers along the river. Because of improved water quality along the Merrimack River, several surface-water intakes have been proposed to supplement existing surface-water supplies for Manchester and Nashua.

The NHDES (1990) assessed 488 stream miles in the Merrimack River basin in New Hampshire during 1988-89. Seventy-eight percent (380 miles) of those assessed fully supported beneficial uses designated by the State for purposes of water-quality monitoring and protection (pollutants are not found at levels of concern and quality criteria are met), 14 percent ( 71 miles) partially supported designated

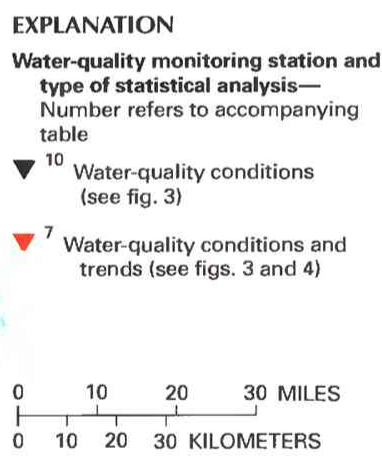

\begin{tabular}{|c|c|c|c|}
\hline $\begin{array}{l}\text { Site no. } \\
\text { on map }\end{array}$ & $\begin{array}{l}\text { USGS station } \\
\text { name and no. }\end{array}$ & $\begin{array}{l}\text { Drainage area } \\
\text { (square miles) }\end{array}$ & $\begin{array}{l}\text { Major land use } \\
\text { (see fig. 1) }\end{array}$ \\
\hline 1 & 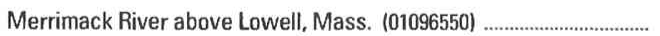 & 3,900 & Woodland and forest with some cropland and pasture. \\
\hline 3 & $\begin{array}{l}\text { Contoocook River below Hopkinton Dam, at West Hopkinton } \\
(01085500)\end{array}$ & 427 & Ditto. \\
\hline 4 & Winnipesaukee River at Tilton $(01081000)$ & 471 & Mostly ungrazed forest and woodland. \\
\hline 5 & 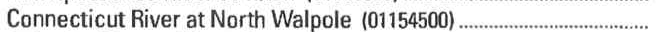 & 5,493 & Woodland and forest with with some cropland and pasture. \\
\hline 7 & Connecticut River below Indian Stream, near Pittsburg (01129200). & 254 & Mostly ungrazed forest and woodland. \\
\hline 8 & Lamprey River near Newmarket $(01073500)$ & 183 & Woodland and forest with some cropland and pasture. \\
\hline 9 & Lucy Brook near North Conway (01064400) & 4.68 & Mostly ungrazed forest and woodland. \\
\hline 10 & Androscoggin River at Errol $(01053500)$ & 1,046 & Woodland and forest with some cropland pasture. \\
\hline
\end{tabular}

Figure 2. Selected water-quality monitoring stations, type of statistical analysis, and geographic features in New Hampshire. (Sources: Major land uses modified from Anderson, 1967; other data from U.S. Geological Survey files.) 
uses (pollutants are not found at levels of concern but sources are present), and 8 percent ( 37 miles) did not support designated uses (pollutants are found at levels of concern and use is likely to be impaired). Excessive concentrations of bacteria from municipal discharges and onsite wastewater-treatment systems were the principal causes of nonsupport of designated uses. In New Hampshire, the Merrimack River is designated by the State Legislature as Class B except for the section from the Amoskeag Dam to Cohas Brook in Manchester, which is designated Class C. Most tributaries in the New Hampshire part of the basin are classified as either A or B (New Hampshire Department of Environmental Services, 1990, p. II-2).

Site 1 on the Merrimack River is located about 5 miles south of the New Hampshire border just upstream from Lowell, Mass. Water quality at site 1 is substantially affected by industrial-, municipal-, and domestic-waste discharges in the lower basin in New Hampshire and Massachusetts. Densely populated and industrialized areas of northeastern Massachusetts also affect the water quality of the Nashua River, a major tributary of the lower Merrimack River. During water years 1987-89, dissolved-solids concentrations were low at site 1 owing to the low solubility of rocks that underlie the basin and to the small volumes of municipal and industrial discharges to the Merrimack River in most of the basin. Nonetheless, the median specific conductance in the lower Merrimack River at site 1 (115 $\mu \mathrm{S} / \mathrm{cm}$ ) was nearly twice the value for stations upstream (sites 2,3 , and 4). The effects of municipal and domestic waste also are evidenced by the large concentrations of fecal coliform bacteria (median, $440 \mathrm{col} / 100 \mathrm{~mL}$ ).

\section{CONNECTICUT RIVER}

The Connecticut River forms the boundary between New Hampshire and Vermont. The basin is underlain by crystalline rocks that are covered by a discontinuous mantle of glacial till and stratified drift. Land cover in the basin primarily is woodland and forest with some cropland and pasture. The Connecticut River headwaters are in primarily mountainous terrain, and the main stem flows through rolling hills in southern New Hampshire. The Connecticut River is regulated by several hydroelectric power dams that create a series of reservoirs upstream from site 5. Dairy farming is the major agricultural activity throughout the basin. The basin mostly is rural; only the towns of Claremont, Lebanon, and Keene, all located in the southern one-half of the basin, have populations of more than 10,000 .
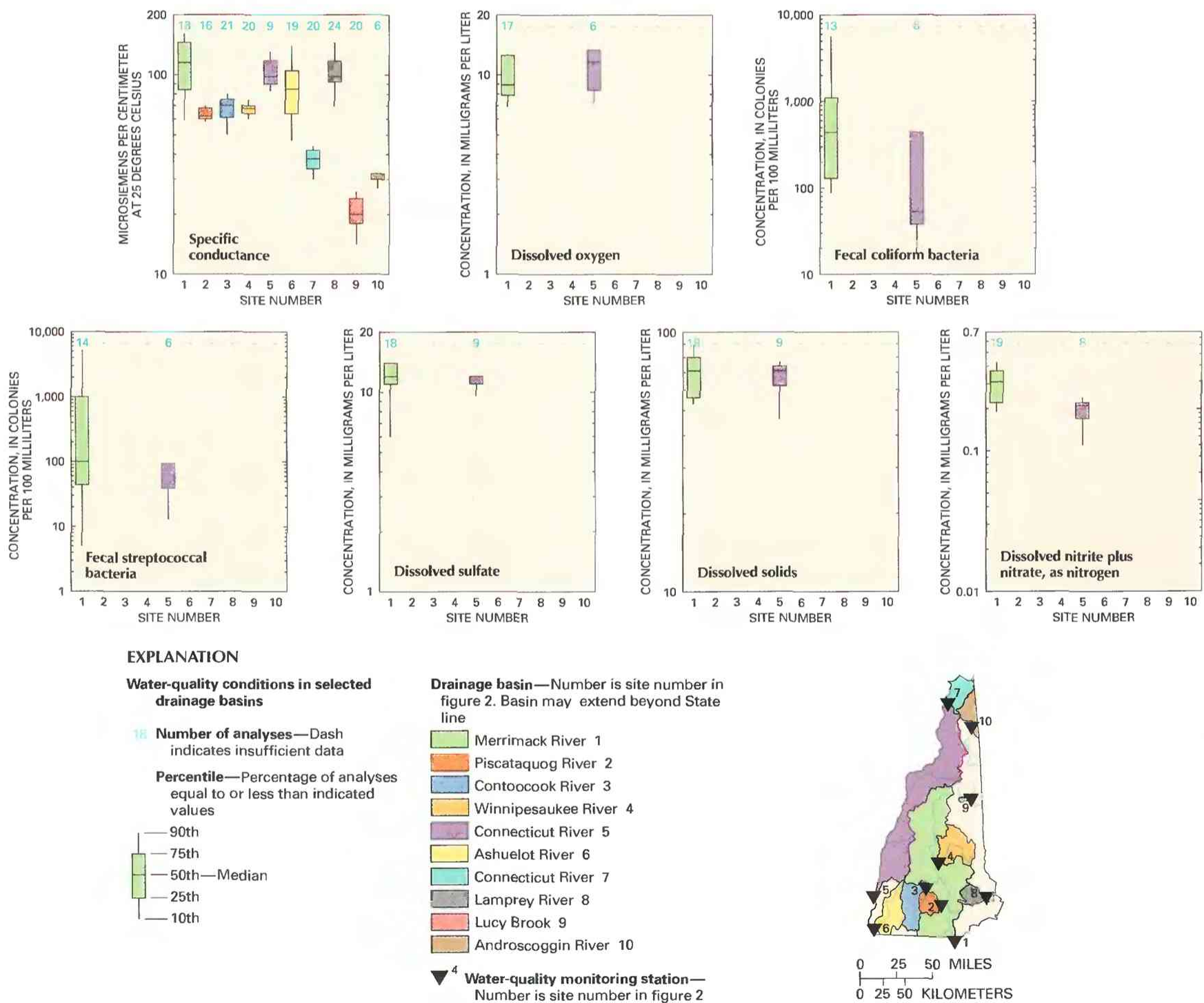

Figure 3. Water quality of selected streams in New Hampshire, water years 1987-89. (Source: Data from U.S. Geological Survey files.) 
Table 1. Sources and environmental significance of selected water-quality properties and constituents [Source: Compiled by the U.S. Geological Survey, Office of Water Quality]

\begin{tabular}{|c|c|c|}
\hline Property or constituent & Common sources & Environmental significance \\
\hline $\begin{array}{l}\text { Specific conductance ................. } \\
\quad \text { (property) }\end{array}$ & $\begin{array}{l}\text { A measure of the electrical conductivity of water; var- } \\
\text { ies with the quantity of dissolved solids and is } \\
\text { used to approximate the dissolved-solids content. }\end{array}$ & $\begin{array}{l}\text { Dissolved solids can cause water to be unsuitable for } \\
\text { public supply, agriculture, and industry; can harm } \\
\text { aquatic organisms. }\end{array}$ \\
\hline 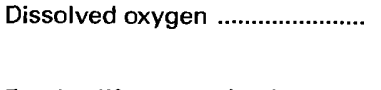 & $\begin{array}{l}\text { Introduced from the atmosphere; also a byproduct of } \\
\text { aquatic plants. }\end{array}$ & $\begin{array}{l}\text { Necessary for aquatic life; deficiency can result from } \\
\text { assimilation of organic wastes or rapid growth } \\
\text { and decay of algae. }\end{array}$ \\
\hline $\begin{array}{l}\text { Fecal coliform and fecal .............. } \\
\text { streptococcal bacteria }\end{array}$ & $\begin{array}{l}\text { Sources include effluent from sewage-treatment } \\
\text { plants and runoff from pastures, feedlots, and ur- } \\
\text { ban areas. }\end{array}$ & $\begin{array}{l}\text { Presence indicates contamination of water by wastes } \\
\text { from humans and other warm-blooded animals. }\end{array}$ \\
\hline Sulfate & $\begin{array}{l}\text { Occurs in some rocks; also in mine runoff, industrial } \\
\text { wastewater discharge, and atmospheric deposi- } \\
\text { tion. }\end{array}$ & $\begin{array}{l}\text { Concentrations exceeding a natural, background } \\
\text { level indicate contamination from human activity; } \\
\text { in sufficient quantity, can cause water to be } \\
\text { unsuitable for public supply; can harm aquatic } \\
\text { organisms. }\end{array}$ \\
\hline 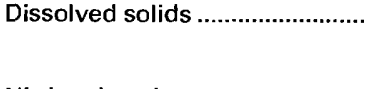 & $\begin{array}{l}\text { A result of rock weathering; also in agricultural runoff } \\
\text { and industrial discharge. }\end{array}$ & $\begin{array}{l}\text { In sufficient quantity, can cause water to be unsuitable } \\
\text { for public supply, agriculture, and industry; can } \\
\text { harm aquatic organisms. }\end{array}$ \\
\hline Nitrite plus nitrate ............................. & $\begin{array}{l}\text { Nonpoint sources are agricultural and urban runoff; } \\
\text { a major point source is wastewater discharge. }\end{array}$ & $\begin{array}{l}\text { Plant nutrient that, in sufficient quantity, can cause } \\
\text { algal blooms and excessive growth of higher } \\
\text { aquatic plants in bodies of water; can cause water } \\
\text { to be unsuitable for public supply. }\end{array}$ \\
\hline
\end{tabular}

The NHDES (1990) assessed 477 stream miles in the Connecticut River basin during 1988-89. Forty-six percent (219 miles) of those stream miles assessed fully supported State-designated uses, 42 percent ( 200 miles) partially supported designated uses, and 12 percent ( 58 miles) did not support designated uses. Streams that did not support designated uses were affected primarily by municipal, domestic, and agricultural sources of bacteria. The main stem of the Connecticut River is designated Class B by the State Legislature (New Hampshire Department of Environmental Services, 1990, p. II-2).

Median concentrations of dissolved constituents in the Connecticut River at site 5 (fig. 3 ) generally were within acceptable limits for aquatic-life protection. Specific-conductance and, hence, dissolved-solids values are low throughout the Connecticut basin owing to the relative insolubility of rocks that underlie the basin and the small volumes of municipal and industrial discharge to the Connecticut River. Nonetheless, median specific-conductance values more than doubled from site 7 in the mostly rural headwater area to site 5 in the more densely populated, small urban and industrialized areas of the watershed in southern New Hampshire.

\section{LAMPREY RIVER}

The Lamprey River is a large tributary to the Piscataqua River, which drains southeastern New Hampshire. Land cover in the Piscataqua River basin is woodland and forest with some cropland and pasture in hilly to coastal-plain terrain. The basin is underlain by metamorphic rocks - including gneiss, slate, schist, quartzite, and metavolcanic rocks--that are covered by a discontinuous mantle of glacial till and stratified drift. Water samples from site 8 on the Lamprey River had a median specific-conductance value of $98 \mu \mathrm{S} / \mathrm{cm}$ (fig. 3), which is typical of most of the State's surface water.

The NHDES (1990) assessed 183 stream miles in the Piscataqua River drainage during 1988-89. Forty-five percent ( 83 miles) of those assessed fully supported State-designated uses, 25 percent ( 45 miles) partially supported designated uses, and 30 percent ( 55 miles) did not support designated uses. Excessive bacteria concentrations were a major cause of degraded water quality in streams that did not support designated uses. The Piscataqua River basin is legislatively designated as both Class A and B by the State (New Hampshire Department of Environmental Services, 1990, p. II-2).

\section{LUCY BROOK}

Lucy Brook is a small headwater tributary to the Saco River, which drains east-central New Hampshire. The basin is underlain by crystalline bedrock that consists primarily of granite covered by a discontinuous mantle of glacial till and stratified drift. Land cover in the Saco River drainage is forest and woodland in mountainous or hilly terrain. The Lucy Brook basin is largely unaffected by human activities. Water samples from site 9 on Lucy Brook had a low median specific-conductance value $(20 \mu \mathrm{S} / \mathrm{cm})($ fig. 3$)$, reflecting the pristine nature of the basin.

The NHDES (1990) assessed 94 stream miles in the Saco River drainage during 1988-89. All 94 stream miles fully supported the designated uses. The Saco River in New Hampshire is legislatively designated as Class B throughout most of its main stem. Some tributaries that are used primarily for drinking-water supply are designated Class A.

\section{ANDROSCOGGIN RIVER}

The Androscoggin River basin is primarily rural in character and drains the eastern one-half of northern New Hampshire. Land cover consists mostly of woodland and forest in a mountainous terrain. The low median specific-conductance value of $30 \mu \mathrm{S} / \mathrm{cm}$ at site 10 (fig. 3) results from the relative insolubility of rocks that underlie the basin and the pristine nature of the headwaters of the river, which are minimally affected by human activity.

The NHDES (1990) assessed 78 stream miles in the Androscoggin River basin during 1988-89. Seventy-six percent (59 miles) of those assessed fully supported the designated uses, and 24 percent (19 miles) supported designated uses at least partially. Waters that only partially supported designated uses were affected primarily by bacteria from municipal point sources. In New Hampshire, the Androscoggin River is classified by the State Legislature as Class $\mathrm{B}$ in the headwater area and Class $\mathrm{C}$ in the more urban areas from Berlin to the Maine border (New Hampshire Department of Environmental Services, 1990, p. II-2).

\section{WATER-QUALITY TRENDS}

Trend analysis is a statistical procedure used to detect changes in stream water quality at a monitoring station over time. For this report, water-quality data from nine monitoring stations (fig. 2) were analyzed for trends by using the seasonal Kendall test (Hirsch and others, 1982), a method used extensively by the USGS. The graph (next page) of the specific conductance in the Contoocook River at site 3 illustrates the trend inferred from the data and demonstrates the variation in water quality that is common in streams. 


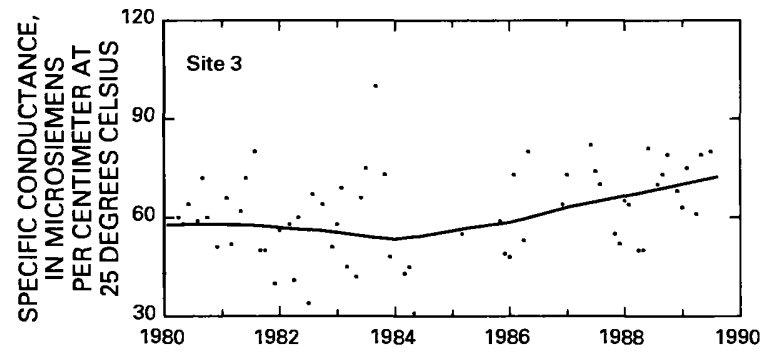

When possible, constituent-concentration data were adjusted for changes in streamflow to preclude identifying a trend in concentration that was caused only by a trend in streamflow. The data were not adjusted when (1) more than 10 percent of the samples had concentrations lower than the minimum reporting limit for the analytical method used or (2) streamflow was controlled substantially by human activities. When the concentration data could not be adjusted for streamflow, trends were determined directly from the concentration data.

Statewide trends in measurements of selected physical properties of stream water and in concentrations of selected constituents in stream water are shown on maps in figure 4 . On each map, a trend is indicated at a monitoring station only if the data from that station were suitable for use in the trend analysis. For more information on the suitability criteria and on the trend-analysis procedure used for this report, see Lanfear and Alexander (1990). Of the data from nine stations, only those from site 1 on the Merrimack River and site 5 on the Connecticut River were sufficient for trend analysis of dissolved constituents and bacteria.

\section{SPECIFIC CONDUCTANCE}

Specific conductance is a measure of the ability of a sample of water to conduct electricity. Because specific conductance and the dissolved-solids concentration are roughly proportional in most natural waters, the specific-conductance value often can be used to estimate the dissolved-solids concentration (Hem, 1985, p. 66-68).

The upward trends in specific conductance at sites $1-3$ and 8 (fig. 4) in the Merrimack and Piscataqua River basins likely resulted from increased application of highway-deicing chemicals and increased municipal, industrial, and domestic sewage effluents. The upward trends were detected at monitoring stations in densely populated areas in the southeastern part of the State that are experiencing rapid growth.

Specific-conductance values from site 6 on the Ashuelot River at Hinsdale in southwestern New Hampshire had a downward trend. The trend probably was a result of decreasing input of dissolved solids from industrial sources in the Ashuelot River basin.

Specific-conductance values at four stations that monitor other major drainage basins in the State had no trend. In those basins, growth and development are slow and input from human-related sources of dissolved solids did not increase significantly.

\section{DISSOLVED OXYGEN}

The dissolved-oxygen concentration in a stream is controlled by several factors, including water temperature, air temperature and pressure, hydraulic characteristics of the stream, photosynthetic or respiratory activity of stream biota, and the quantity of organic material present. A trend in dissolved-oxygen concentrations commonly is directly or indirectly the result of human activities. Generally, an upward trend in dissolved-oxygen concentrations indicates improving stream water-quality conditions and a downward trend indicates deteriorating conditions.

Concentrations of dissolved oxygen had no trend at sites 1 and 5 (fig. 4). The absence of a trend indicates that there was little change in biochemical oxygen demand from chemical or organic materials in wastewater discharge or runoff upstream.

\section{FECAL COLIFORM AND FECAL STREPTOCOCCAL BACTERIA}

Fecal coliform and fecal streptococcal bacteria are used as indicators of fecal contamination from humans and other warmblooded animals. Such contamination can introduce disease-causing viruses and bacteria into a stream. Fecal coliform bacteria are short-lived in the stream environment, and their numbers diminish with distance from a source.

Fecal coliform bacteria concentrations had no trend at sites 1 and 5 (fig. 4). Municipal and agricultural sources of fecal coliform bacteria have changed little within these basins-at least in the vicinity of the monitoring stations.

Fecal streptococcal bacteria concentrations also had no trend at sites 1 and 5 (fig. 4). The absence of a trend might indicate that there has been no change in the quantity of effluent discharged by sewage-treatment plants or in the volume of runoff containing bacteria in the vicinity of the monitoring stations.

\section{DISSOLVED SULFATE}

The major natural sources of sulfate in streams are rock weathering, volcanoes, and biochemical processes (Hem, 1985, p. 113). Human activities such as mining, waste discharge, and fossil-fuel combustion also can be important sources. A shortened trend-analysis period was used for sulfate because data from analyses performed before water year 1982 are not comparable to data for subsequent years.

Sulfate concentrations had no trend at site 1 or at site 5 (fig. 4). The Merrimack River basin upstream from site 1 contains several urban areas, including Concord, Manchester, and Nashua. Several of these cities have improved their sewage-treatment facilities that discharge effluent to the Merrimack River. The absence of a trend in sulfate concentrations at site 1 , despite increasing population, could have been a result of these improvements. The Connecticut River drains a forested and agricultural area. Population growth in the Connecticut River basin generally is the slowest in New Hampshire. No city in the basin is large enough to be a source of substantial waterquality degradation from industrial-wastewater discharge. The absence of a trend in sulfate at site 5 is likely a result of the slow population and industrial growth in the basin.

\section{DISSOLVED SOLIDS}

Dissolved solids in stream water result primarily from rock weathering but also can be introduced as a byproduct of human activities (table 1). Concentrations generally are greatest in streams draining basins underlain by rocks and soils that contain easily dissolved minerals.

Dissolved-solids concentrations had no trend at site 1 or at site 5 (fig. 4), indicating that changes in agricultural or industrial activities in the past 10 years have had little effect on dissolved-solids concentrations in these basins. The Merrimack and Connecticut Rivers contain low dissolved-solids concentrations, as do most rivers in New Hampshire. Sodium, bicarbonate, and chloride ions constitute most of the dissolved-solids concentration at sites 1 and 5 .

\section{DISSOLVED NITRITE PLUS NITRATE}

Nitrite and nitrate are oxidized forms of nitrogen that together constitute most of the dissolved nitrogen in stream water. Nitrite readily oxidizes to nitrate in natural waters; therefore, nitrate generally is by far the more abundant of the two (Hem, 1985, p. 124).

Nitrite plus nitrate concentrations had no trend at site 1 or at site 5 (fig. 4). The most significant sources of nitrate in New Hamp- 


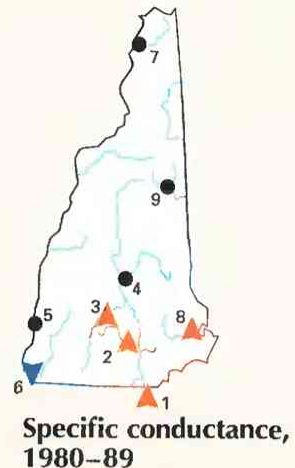
1980-89

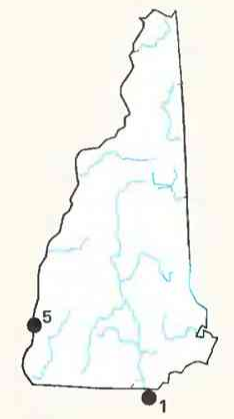

Dissolved sulfate, 1982-89

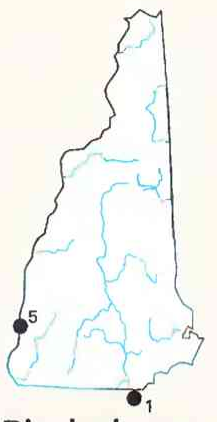

Dissolved oxygen, 1980-88

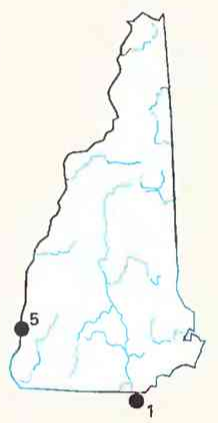

Dissolved solids, 1980-89
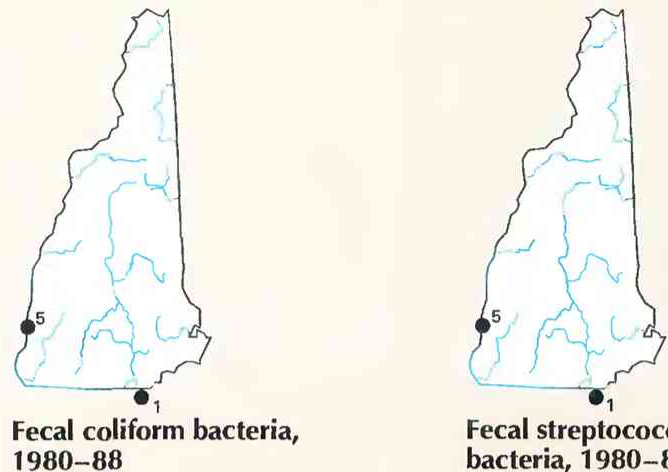

Fecal streptococcal bacteria, 1980-88

\section{EXPLANATION}

Trend in water-quelity property or

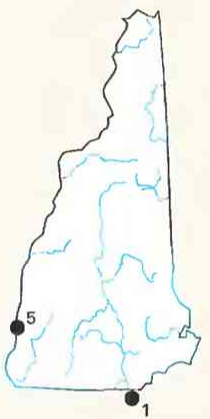

constituent- Number is site number in figure 2

$\mathbf{A}^{1}$ Upward

- None

$\nabla^{6}$ Downward

$025 \quad 50$ MILES

02550 KILOMETERS

Dissolved nitrite plus

nitrate, 1980-89

Figure 4. Trends in water quality of selected streams in New Hampshire, by water years. (Source: Data from U.S. Geological Survey files.)

shire streams are agricultural runoff, municipal sewage effluent, and leachate from domestic septic systems. The absence of a trend probably was due to a lack of change in the combined volume of these sources. Median concentrations of nitrite plus nitrate were low $(0.2-$ 0.3 milligram per liter) at both monitoring stations (fig. 3 ). These low concentrations are indicative of the relatively small quantities of nitrogenous compounds contributed by human-related activities in the Merrimack and Connecticut River basins and rapid assimilation of nitrite and nitrate by plants and algae.

\section{WATER-QUALITY MANAGEMENT}

The Department of Environmental Services is the agency responsible for water and waste management in New Hampshire. Four divisions within the Department are Water Supply and Pollution Control Division (WSPCD), Waste Management Division, Water Resources Division, and Air Resources Division. The WSPCD has overall responsibility for water-quality aspects of surface water and ground water in New Hampshire and administers surface-waterquality and ground-water-quality protection programs as set forth in State Revised Statutes Annotated 131, 148, and 485A. The WSPCD enforces the State Ground-Water Protection Rules (Ws410) and Surface-Water-Quality Standards (Ws431). The Waste Management Division, in coordination with the WSPCD, is responsible for selecting sites and issuing permits for all new facilities for solid-and hazardous-waste disposal in New Hampshire.

The WSPCD submits a biennial water-quality assessment report (New Hampshire Department of Environmental Services, 1990) to the EPA and the U.S. Congress pursuant to section 305(b) of the
Federal Clean Water Act. The report documents progress in implementation of the goals and objectives of the act. The primary management objective for water-quality improvements is attainment of legislative and Clean Water Act goals, as well as the maintenance and protection of the State's waters in which water quality currently meets these goals.

\section{SELECTED REFERENCES}

Anderson, J.R., 1967, Major land uses in the United States, in U.S. Geological Survey, 1970, National atlas of the United States of America: Washington, D.C., U.S. Geological Survey, 427 p.

Britton, L.J., and Greeson, P.E., eds., 1987, Methods for collection and analysis of aquatic biological and microbiological samples: U.S. Geological Survey Techniques of Water-Resources Investigations, book 5, chap. A4, $363 \mathrm{p}$.

Fenneman, N.M., 1946, Physical divisions of the United States: Washington, D.C., U.S. Geological Survey special map, scale 1:7,000,000.

Fishman, M.J., and Friedman, L.C., eds., 1989, Methods for the determination of inorganic substances in water and fluvial sediments: U.S. Geological Survey Techniques of Water-Resources Investigations, book 5, chap. A1, 545 p.

Hem, J.D., 1985, Study and interpretation of the chemical characteristics of natural water (3d ed.): U.S. Geological Survey Water-Supply Paper 2254, $263 \mathrm{p}$.

Hirsch, R.M., Slack, J.R., and Smith, R.A., 1982, Techniques of trend analysis for monthly water-quality data: Water Resources Research, v. 18, no. 1, p. 107-121.

Lanfear, K.J., and Alexander, R.B., 1990, Methodology to derive water-quality trends for use by the National Water Summary Program of the U.S. Geological Survey: U.S. Geological Survey Open-File Report 90-359, $10 \mathrm{p}$. 
National Oceanic and Atmospheric Administration, 1982, Monthly normals of temperature, precipitation, and heating and cooling degree days 195180, New Hampshire: Asheville, N.C., Climatography of the United States, no. 81.

New Hampshire Department of Environmental Services, 1990, New Hampshire water-quality report to Congress 305 (b): Concord, N.H., Water Supply and Pollution Control Division, $69 \mathrm{p}$.

Seaber, P.R., Kapinos, F.P., and Knapp, G.L., 1984, State hydrologic unit maps: U.S. Geological Survey Open-File Report 84-708, 198 p.
Thelin, G.P., and Pike, R.J., 1990, Digital shaded relief map of the conterminous United States: Menlo Park, Calif., U.S. Geological Survey digital image processing, scale 1:3,500,000.

U.S. Geological Survey, 1990, National water summary 1987-Hydrologic events and water supply and use: U.S. Geological Survey Water-Supply Paper 2350, $553 \mathrm{p}$.

Ward, J.R., and Harr, C.A., eds., 1990, Methods for collection and processing of surface-water and bed-material samples for physical and chemical analyses: U.S. Geological Survey Open-File Report 90-140, 71 p. 
394 National Water Summary 1990-91-Stream Water Quality: STATE SUMMARIES

Prepared by Kenneth W. Toppin

FOR ADDITIONAL INFORMATION: District Chief, New Hampshire-Vermont, U.S. Geological Survey, 525 Clinton Street, Bow, NH 03304 


\section{NEW JERSEY Stream Water Quality}

New Jersey is a water-rich State as a result of precipitation that averages about 45 inches annually. The State contains numerous urban, industrial, and agricultural areas (fig. $1 A$ ) that rely on surface- and ground-water supplies. In 1985, about 1,630 Mgal/d (million gallons per day) was withdrawn from surface water, and about $600 \mathrm{Mgal} / \mathrm{d}$ was withdrawn from ground water (U.S. Geological Survey, 1990, p. 367). Forty-three percent of all freshwater withdrawn was used for public supply, which provided water to 89 percent of the State's population. More than one-half of this public supply was derived from surface-water sources (U.S. Geological Survey, 1990, p. 369). Although the State receives abundant rainfall, an increasing population has led to serious water-supply shortages during droughts because of inadequate water-storage facilities.

Hydrologic characteristics differ greatly between the Coastal Plain and the physiographic regions north of the Fall Line (fig. $1 B$ ).

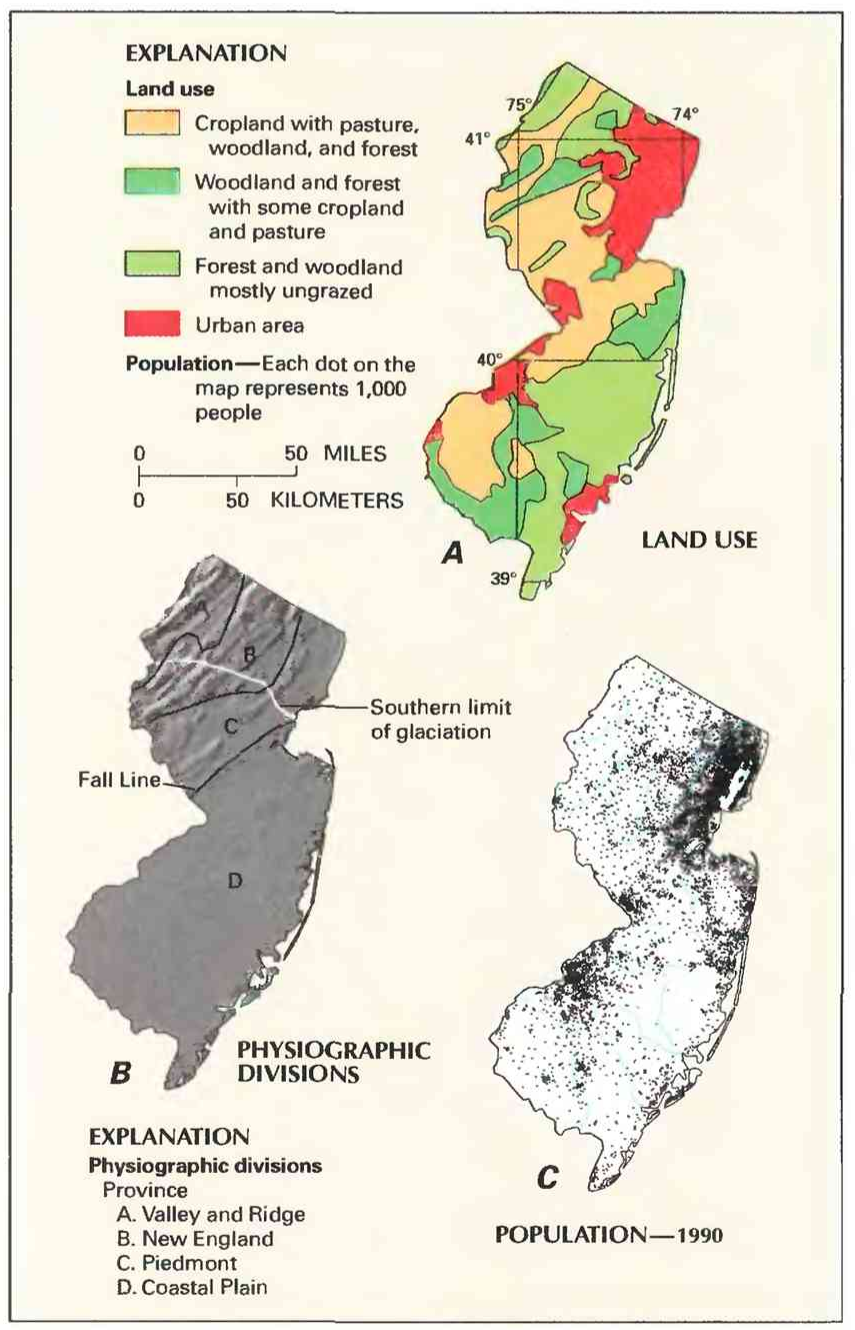

Figure 1. Land use, physiography, and population in New Jersey. A, Major land uses. B, Physiographic divisions. C, Population distribution in 1990. (Sources: A, Major land uses modified from Anderson, 1967. B, Physiographic divisions from Fenneman, 1946; landforms from Thelin and Pike, 1990. C, Data from U.S. Bureau of the Census 1990 decennial census files.)
Streamflow in the Coastal Plain consists predominantly of groundwater discharge and therefore is less responsive to variations in rainfall than in streams north of the Fall Line (U.S. Geological Survey, 1986, p. 335). Variations in streamflow can have a significant effect on stream water quality.

New Jersey is the most densely populated State in the Nation and has more than 1,000 people per square mile (fig. $1 C$ ). New Jersey had about 7.7 million residents in 1990, an increase of about 5 percent since 1980 (U.S. Bureau of the Census 1990 decennial census files). Population growth in the State during that time was greatest in formerly agricultural areas near urban centers.

Urbanization, industry, and agriculture have caused numerous water-quality problems throughout the State. The New Jersey Department of Environmental Protection (1990, p. III-6), which has recently been renamed the New Jersey Department of Environmental Protection and Energy, reported in a 1990 assessment of the quality of surface waters in New Jersey that primary-contact recreation was supported in 30 percent and the maintenance and propagation of fisheries was supported in 77 percent of the freshwater bodies evaluated. Concentrations of nutrients and fecal bacteria exceeding State surface-water-quality criteria were found in stream water throughout most of the State, along with occasional large quantities of oxygendemanding substances and metals. Municipal and industrial wastewater discharges, urban and agricultural runoff, and land disturbances are considered to be the major sources of water-quality degradation in the State (New Jersey Department of Environmental Protection, 1990, p. III-16).

\section{WATER-QUALITY MONITORING}

Water-quality data obtained from analyses of water samples collected at monitoring stations are stored in the U.S. Geological Survey's (USGS) National Water Information System and the U.S. Environmental Protection Agency's (EPA) national data base known as STORET. Water-quality and streamflow data are reported by water year-the 12 months from October 1 through September 30. A water year is identified by the calendar year in which it ends. For example, water year 1991 comprises October 1, 1990, through September 30, 1991.

The data used in this summary of New Jersey's stream water quality were obtained from water samples collected monthly, every 2 months, or quarterly at 21 monitoring stations at which data collection is systematic and continuing (fig. 2). Analyses of water samples collected at 10 stations are the basis for the discussion and graphic summary (fig. 3) of stream water-quality conditions during water years 1987-89, and data from 20 stations are the basis for the discussion and graphic summary (fig. 4) of stream water-quality trends.

Sites 1 through 6, from the USGS National Stream-Quality Accounting Network (NASQAN), are sampled four or six times annually; site 7, part of the USGS National Hydrologic Bench-Mark Network, is sampled monthly; and sites 8 through 21 , part of a cooperative network between the New Jersey Department of Environmental Protection and Energy and the USGS, are presently sampled five times annually. Site 1 also is part of a network maintained by the USGS in cooperation with the North Jersey District Water Supply Commission.

Water quality at the NASQAN and Bench-Mark Network monitoring stations was monitored at uniform time intervals without con- 
sideration of streamflow to obtain water-quality data that were not biased to specific streamflow conditions. Some of the data collected for the NASQAN program at site 1 (Passaic River at Little Falls) were collected to represent water quality during storms. Water quality at site 1 also is monitored during low-flow periods for the North Jersey District Water Supply Commission.

Water samples were collected and analyzed by using standard methods approved by the USGS (Britton and Greeson, 1987; Fishman and Friedman, 1989; Ward and Harr, 1990) or by using equivalent methods. If a method of sample collection or analysis changed over time, data from an analysis were included in the evaluation of recent stream water quality or of stream water-quality trends only if the change in method did not affect the comparability of the data.
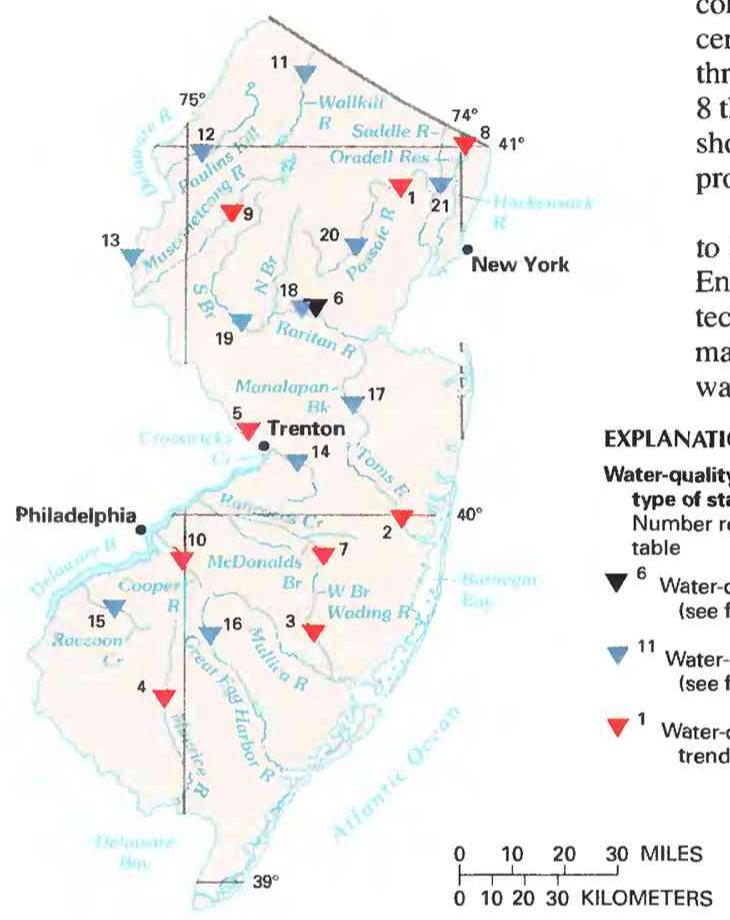

\begin{tabular}{|c|c|c|c|}
\hline $\begin{array}{l}\text { Site no. } \\
\text { on map }\end{array}$ & $\begin{array}{l}\text { USGS station } \\
\text { name and no. }\end{array}$ & $\begin{array}{l}\text { Drainage area } \\
\text { (square miles) }\end{array}$ & $\begin{array}{l}\text { Major land use } \\
\text { (see fig. 1) }\end{array}$ \\
\hline 1 & Passaic River at Little Falls $(01389500) \ldots$. & 762 & Urban areas. \\
\hline 2 & 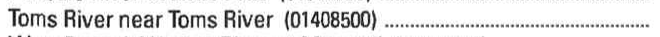 & 123 & Woodland and forest with some cropland and pasture. \\
\hline 3 & 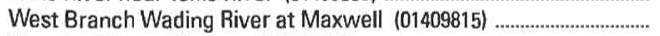 & 85.9 & Mostly ungrazed forest and woodland. \\
\hline 4 & Maurice River at Norma $(01411500)$ & 112 & Woodland and forest with some cropland and pasture. \\
\hline 5 & Delaware River at Trenton $(01463500)$ & 6,780 & Cropland with pasture, woodland, and forest. \\
\hline 6 & 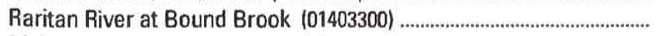 & 804 & Ditto. \\
\hline 7 & McDonalds Branch in Lebanon State Forest $(01466500)$ & 2.4 & Mostly ungrazed forest and woodland. \\
\hline 8 & Hackensack River at Rivervale $(01377000)$ & 58 & Urban areas. \\
\hline 9 & 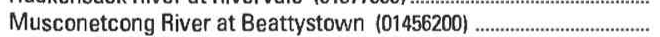 & 90.3 & Woodland and forest with some cropland and pasture. \\
\hline 10 & Cooper River at Lawnside $(01467140)$ & 12.7 & Urban areas. \\
\hline 11 & Wallkill River near Sussex $(01367770)$ & 60.8 & Cropland with pasture, woodland, and forest. \\
\hline 12 & Paulins Kill at Blairstown $(01443500)$ & 126 & Ditto. \\
\hline 13 & Delaware River at Easton, $\mathrm{Pa} .(01447000)$ & 4,717 & Ditto. \\
\hline 14 & Crosswicks Creek at Extonville $(01464500)$ & 81.5 & Ditto. \\
\hline 15 & Raccoon Creek near Swedesboro (01477120) & 26.9 & Ditto. \\
\hline 16 & 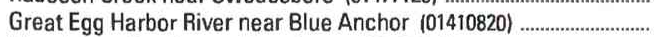 & 37.3 & Woodland and forest with some cropland and pasture. \\
\hline 17 & 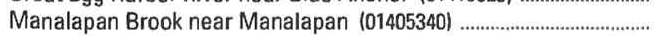 & 20.9 & Cropland with pasture, woodland, and forest. \\
\hline 18 & Raritan River at Manville $(01400500)$ & 490 & Ditto. \\
\hline 19 & South Branch Raritan River at Three Bridges (01397400) ................... & 181 & Ditto. \\
\hline 20 & Passaic River near Chatham $(01379500)$ & 100 & Woodland and forest with some cropland and pasture. \\
\hline 21 & Saddle River at Lodi $(01391500)$ & 54.6 & Urban areas. \\
\hline
\end{tabular}

Figure 2. Selected water-quality monitoring stations, type of statistical analysis, and geographic features in New Jersey. (Sources: Major land uses modified from Anderson, 1967; other data from U.S. Geological Survey files.)

\section{WATER-QUALITY CONDITIONS}

The following discussion of stream water quality in New Jersey is organized by river basin (fig. 3). Where physiographic and land-use characteristics in different basins are similar, the discussion of those basins is combined. Graphs in figure 3 summarize certain aspects of stream water quality in the basins for water years 1987 89 . The graphs show frequency distributions of data values that represent measurements of selected physical properties of stream water and concentrations of selected constituents in stream water. These properties and constituents are specific conductance, dissolved oxygen, fecal coliform bacteria, dissolved chloride, dissolved solids, dissolved nitrite plus nitrate (as nitrogen), and total phosphorus (as phosphorus). The data are reported in microsiemens per centimeter at 25 degrees Celsius ( $\mu \mathrm{S} / \mathrm{cm})$, milligrams per liter $(\mathrm{mg} / \mathrm{L})$, and colonies per 100 milliliters (col/100 mL). Fecal coliform bacteria concentrations were measured in colonies per 100 milliliters for sites 1 through 7 and in most probable number per 100 milliliters for sites 8 through 21 ; most probable number per 100 milliliters data are not shown in figure 3 . Sources and environmental significance of each property and constituent are described in table 1 .

Where possible, constituent-concentration data are compared to State surface-water-quality criteria (New Jersey Department of Environmental Protection, 1989). These criteria are designed to protect in-stream designated uses, such as fisheries propagation and maintenance, primary-contact recreation, and potable and industrial water supplies.

\section{PLANATION}

of statistical analysis -

ater-quality conditions

see fig. 3) fig. 4) is (see figs. 3 and 4 ) 
Water quality at each monitoring station is the result of geological, chemical, biological, and hydrologic processes that occur over a large area. Water-quality problems that affect aquatic life or public health only locally are not fully represented in this summary.

\section{PASSAIC RIVER}

The Passaic River and its tributaries drain much of northeastern New Jersey. Upstream from site 1 at Little Falls, the Passaic River drains $762 \mathrm{mi}^{2}$ (square miles) and is affected by large areas of wetlands, upstream urbanization, and numerous permitted wastewater discharges. Urbanization has caused increased flooding and associated water-quality problems in the basin.

Median concentrations of dissolved constituents, such as chloride (46 mg/L), dissolved solids ( $197 \mathrm{mg} / \mathrm{L})$, and nitrite plus nitrate $(1.5 \mathrm{mg} / \mathrm{L})$, were high compared to median concentrations for the other nine monitoring stations (fig. 3). These high concentrations were likely due to the extensive urbanization and large number of wastewater-treatment facilities in the basin. The median concentration of dissolved oxygen for site 1 was $9.0 \mathrm{mg} / \mathrm{L}$, although concentrations of dissolved oxygen lower than the State surface-waterquality criterion of $4.0 \mathrm{mg} / \mathrm{L}$ have been reported at locations upstream from site 1 (New Jersey Department of Environmental Protection, $1987 \mathrm{a}$ and 1988). Median concentrations of phosphorus (0.39 $\mathrm{mg} / \mathrm{L})$ and fecal coliform bacteria $(340 \mathrm{col} / 100 \mathrm{~mL})$ were higher than State surface-water-quality criteria $(0.1 \mathrm{mg} / \mathrm{L}$ for total phosphorus and $200 \mathrm{col} / 100 \mathrm{~mL}$ for fecal coliform bacteria) (New Jersey Department of Environmental Protection, 1989). The sources of these constituents are similar to those described for the dissolved constituents. Water-quality data collected during five storms at site 1 in water year 1987 were similar to routine monitoring data.
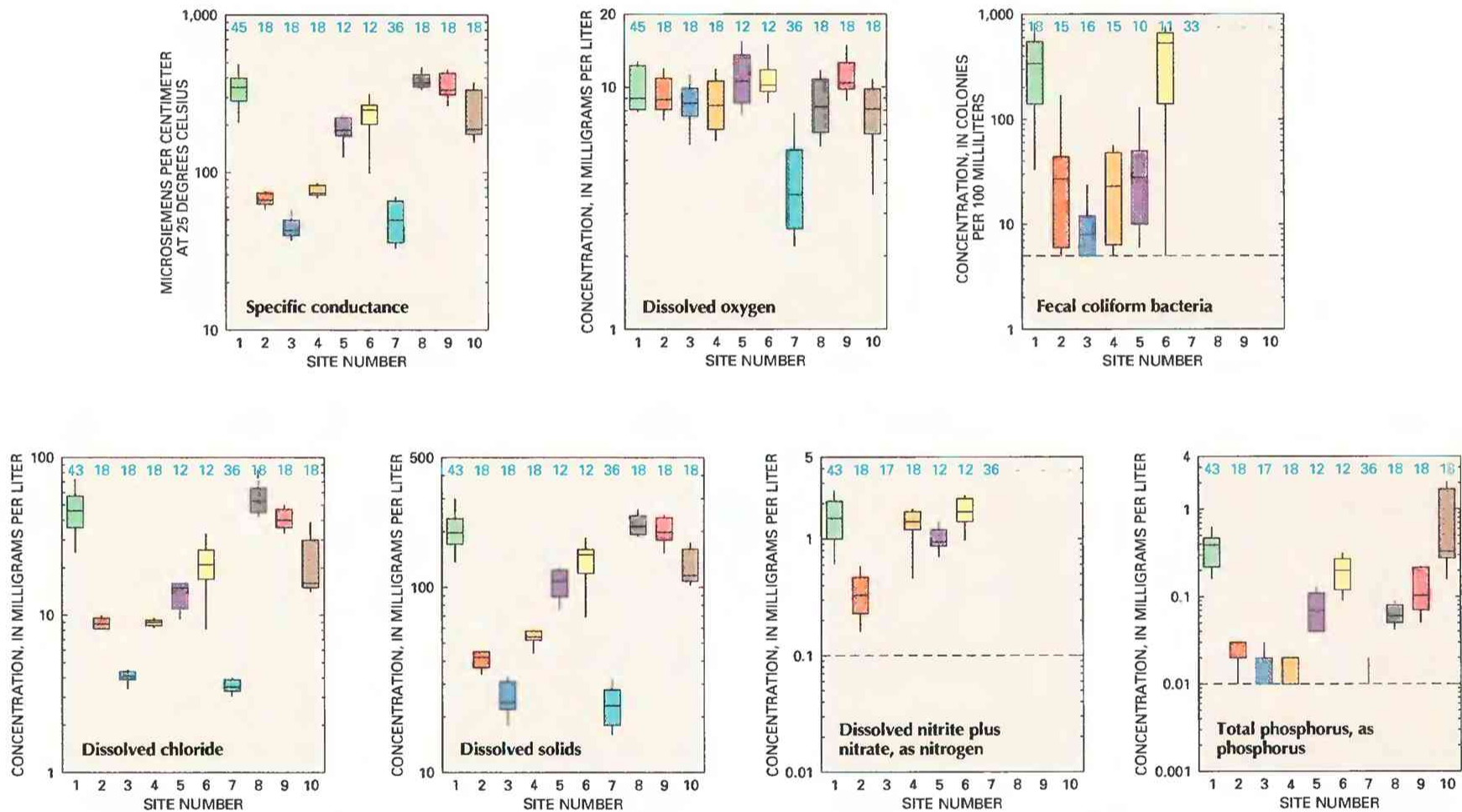

\section{EXPLANATION}

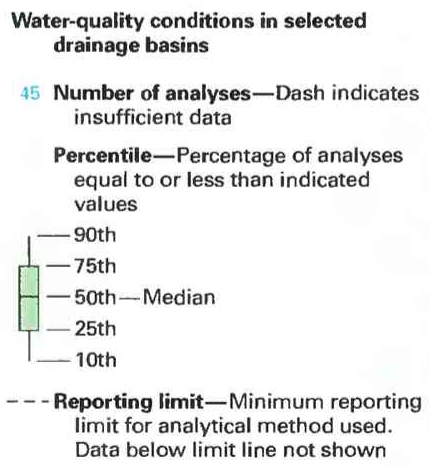

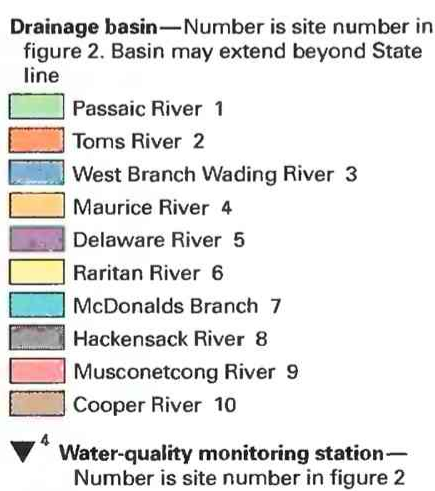

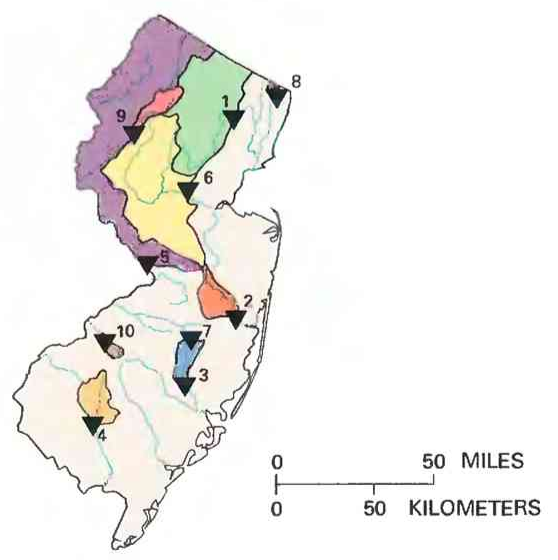

Figure 3. Water quality of selected streams in New Jersey, water years 1987-89. (Source: Data from U.S. Geological Survey files.) 
Table 1. Sources and environmental significance of selected water-quality properties and constituents [Source: Compiled by the U.S. Geological Survey, Office of Water Quality]

\begin{tabular}{|c|c|c|}
\hline Property or constituent & Common sources & Environmental significance \\
\hline $\begin{array}{l}\text { Specific conductance ...................... } \\
\quad \text { (property) }\end{array}$ & $\begin{array}{l}\text { A measure of the electrical conductivity of water; var- } \\
\text { ies with the quantity of dissolved solids and is } \\
\text { used to approximate the dissolved-solids content. }\end{array}$ & $\begin{array}{l}\text { Dissolved solids can cause water to be unsuitable for } \\
\text { public supply, agriculture, and industry; can harm } \\
\text { aquatic organisms. }\end{array}$ \\
\hline Dissolved oxygen ......................... & $\begin{array}{l}\text { Introduced from the atmosphere; also a byproduct of } \\
\text { aquatic plants. }\end{array}$ & $\begin{array}{l}\text { Necessary for aquatic life; deficiency can result from } \\
\text { assimilation of organic wastes or rapid growth } \\
\text { and decay of algae. }\end{array}$ \\
\hline Fecal coliform bacteria ............... & $\begin{array}{l}\text { Sources include effluent from sewage-treatment } \\
\text { plants and runoff from pastures, feedlots, and ur- } \\
\text { ban areas. }\end{array}$ & $\begin{array}{l}\text { Presence indicates contamination of water by wastes } \\
\text { from humans and other warm-blooded animals. }\end{array}$ \\
\hline Chloride ............................................ & $\begin{array}{l}\text { Occurs in some rocks and ground-water discharge; } \\
\text { also in road deicers, industrial and urban waste- } \\
\text { water discharge, and atmospheric deposition. }\end{array}$ & $\begin{array}{l}\text { Concentrations exceeding a natural, background level } \\
\text { can cause water to be unsuitable for public supply, } \\
\text { agriculture, and industry; can harm aquatic or- } \\
\text { ganisms. }\end{array}$ \\
\hline 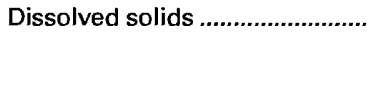 & $\begin{array}{l}\text { A result of rock weathering; also in agricultural runoff } \\
\text { and industrial discharge. }\end{array}$ & $\begin{array}{l}\text { In sufficient quantity, can cause water to be unsuitable } \\
\text { for public supply, agriculture, and industry; can } \\
\text { harm aquatic organisms. }\end{array}$ \\
\hline Nitrite plus nitrate ....................... & $\begin{array}{l}\text { Nonpoint sources are agricultural and urban runoff; } \\
\text { a major point source is wastewater discharge. }\end{array}$ & $\begin{array}{l}\text { Plant nutrient that, in sufficient quantity, can cause } \\
\text { algal blooms and excessive growth of higher } \\
\text { aquatic plants in bodies of water; can cause water } \\
\text { to be unsuitable for public supply. }\end{array}$ \\
\hline 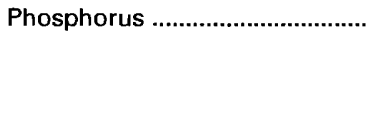 & $\begin{array}{l}\text { Occurs in some rocks and sediments; also in runoff } \\
\text { and seepage from phosphate-rock mines, agri- } \\
\text { cultural and urban runoff, and industrial and } \\
\text { municipal wastewater discharge. }\end{array}$ & $\begin{array}{l}\text { Plant nutrient that, in sufficient quantity, can cause } \\
\text { algal blooms and excessive growth of higher } \\
\text { aquatic plants in bodies of water. }\end{array}$ \\
\hline
\end{tabular}

\section{TOMS AND MAURICE RIVERS}

The Toms and Maurice Rivers drain parts of the Coastal Plain and flow into Barnegat Bay and Delaware Bay, respectively. Both basins are underlain by sandy soils and are covered primarily by pineoak woodland vegetation intermixed with cropland, pasture, and urban areas. The Toms River lies primarily in east-central New Jersey, where population has increased rapidly since the early 1970 's.

Both streams contained low concentrations of fecal coliform bacteria, dissolved solids, and phosphorus (fig. 3). Concentrations of nitrite plus nitrate in the Maurice River at site 4 were high compared to concentrations in the Toms River at site 2. Agricultural activities and wastewater from a sewage-treatment facility upstream from site 4 could have caused the high concentrations of nitrite plus nitrate.

\section{WEST BRANCH WADING RIVER AND MCDONALDS BRANCH}

The drainage basins of the West Branch Wading River and McDonalds Branch are predominantly in State-owned forestland. Both streams are in the Pinelands National Planning Reserve, a 1.1million-acre area covered by scrub pine and oak in southeastern New Jersey, and drain sandy soils that are acidic and have little buffering capacity. Water quality at sites 3 and 7 is representative of the generally undisturbed conditions in the Pinelands region.

Median concentrations of fecal coliform bacteria, dissolved solids, and phosphorus were low and consistently met State stream water-quality criteria. The median dissolved-oxygen concentration of $3.6 \mathrm{mg} / \mathrm{L}$ at site 7 on McDonalds Branch (fig. 3) was lower than the State criterion of $4.0 \mathrm{mg} / \mathrm{L}$, possibly as a result of limited reaeration and of natural chemical and biological activity in the stream.

\section{DELAWARE RIVER}

Upstream from site 5 at Trenton, the Delaware River drains nearly $6,800 \mathrm{mi}^{2}$ of western New Jersey, eastern Pennsylvania, and south-central New York. Land cover in most of the basin is cropland and woodland. The basin is a major source of municipal water supply for New York City, Philadelphia, and other cities in the region. The Delaware River Basin Commission rates water quality in the vi- cinity of Trenton as good (Delaware River Basin Commission, 1990, p. 21).

During 1987-89, the median specific conductance at site 5 was $186 \mu \mathrm{S} / \mathrm{cm}$, and the median dissolved-solids concentration was 108 $\mathrm{mg} / \mathrm{L}$ (fig. 3). The median concentration of nitrite plus nitrate was $0.94 \mathrm{mg} / \mathrm{L}$, and that of phosphorus was $0.07 \mathrm{mg} / \mathrm{L}$. Dissolved-oxygen concentrations were consistently higher than the $4.0-\mathrm{mg} / \mathrm{L}$ criterion designed for the protection of fisheries.

\section{RARITAN RIVER}

Until the early 1980 's, the Raritan River had substantial waterquality problems (New Jersey Department of Environmental Protection, 1986, p. V-153). Elimination of a major source of industrial wastewater discharge and improvements in municipal wastewatertreatment practices have improved the quality of the river's water since the early 1980 's; however, at site 6 during water years 1987 89 , the Raritan River contained fecal coliform bacteria and total-phosphorus concentrations that were about twice the State surface-waterquality criterion for each. Fecal coliform bacteria concentrations commonly were higher than $500 \mathrm{col} / 100 \mathrm{~mL}$, and the median phosphorus concentration was nearly $0.20 \mathrm{mg} / \mathrm{L}$ (fig. 3 ). The median chloride concentration was $21 \mathrm{mg} / \mathrm{L}$; this concentration was lower than those found in other urbanized stream basins in the State. The median nitrite plus nitrate concentration $(1.7 \mathrm{mg} / \mathrm{L})$ was the highest for the seven monitoring stations for which sufficient nitrite plus nitrate data were available for the frequency analysis. The source of the nitrogen likely was wastewater discharge.

\section{HACKENSACK RIVER}

The Hackensack River drains $58 \mathrm{mi}^{2}$ of northeastern New Jersey and parts of southern New York upstream from site 8. The Oradell Reservoir downstream from site 8 serves as a source of potable water for the area. Parts of the basin contain protected watershed lands, but much of the basin is urbanized.

During water years 1987-89, samples collected from the Hackensack River at site 8 had among the highest median values of specific conductance $(372 \mu \mathrm{S} / \mathrm{cm})$, chloride $(53 \mathrm{mg} / \mathrm{L})$, and dissolved solids $(213 \mathrm{mg} / \mathrm{L})$ for the 10 monitoring stations (fig. 3). A cause for 
the high values is not known. Dissolved-oxygen concentrations generally were higher than $8.0 \mathrm{mg} / \mathrm{L}$; no values were less than the 4.0 $\mathrm{mg} / \mathrm{L}$ State surface-water-quality criterion. The median phosphorus concentration was $0.06 \mathrm{mg} / \mathrm{L}$, near the average for all sites, but at a concentration large enough to contribute to eutrophication in lakes and impoundments. Eutrophication is a natural aging process in water bodies, but increased nutrients and organic materials can accelerate this process. A lake having excessive plant growth is an example of a eutrophic water body.

\section{MUSCONETCONG RIVER}

The Musconetcong River upstream from site 9 drains a narrow, $90-\mathrm{mi}^{2}$ valley in western New Jersey. Predominant land uses include woodlands on slopes and ridgetops, agriculture in the valley, and scattered population centers. The New Jersey Department of Environmental Protection (1988, p. III-101) classified the water quality in the Musconetcong River as good to fair; however, conditions deteriorate downstream.

At site 9, the Musconetcong River contained adequate dissolved oxygen for trout maintenance during water years $1987-89$ but had moderately excessive total-phosphorus concentrations (median concentration $0.10 \mathrm{mg} / \mathrm{L}$ ) (fig. 3). The median specific-conductance value $(333 \mu \mathrm{S} / \mathrm{cm})$, median chloride concentration $(40 \mathrm{mg} / \mathrm{L})$, and median dissolved-solids concentration $(198 \mathrm{mg} / \mathrm{L})$ were among the highest for the streams assessed. These high concentrations may have been due to permitted wastewater discharges upstream from the monitoring station.

\section{COOPER RIVER}

The New Jersey Department of Environmental Protection (1990, p. III-140) described the 16-mile-long Cooper River as having stream water quality that is among the poorest in the State. Upstream from site 10 , the stream drains $13 \mathrm{mi}^{2}$ of an extensively urbanized and industrialized region of southwestern New Jersey. The stream historically has received large quantities of municipal and industrial wastewater. The State of New Jersey imposed a fishing ban for the downstream part of the stream in 1979 because of chlordane contamination of fish and sediments.

The median dissolved-oxygen concentration at site 10 on the Cooper River was $8.1 \mathrm{mg} / \mathrm{L}$ during water years $1987-89$ (fig. 3), although values occasionally were lower than the State surface-waterquality criterion of $4.0 \mathrm{mg} / \mathrm{L}$. These lower dissolved-oxygen concentrations normally occur during summer. The median concentration of dissolved solids was $116 \mathrm{mg} / \mathrm{L}$ and of dissolved chloride was 16 $\mathrm{mg} / \mathrm{L}$; the median specific-conductance value was $188 \mu \mathrm{S} / \mathrm{cm}$. These values were lower than those found in rivers that drain the other urbanized basins assessed, the Passaic and Hackensack Rivers (sites 1 and 8). Concentrations of phosphorus at site 10 were higher than those at most of the other monitoring stations; the median concentration of $0.33 \mathrm{mg} / \mathrm{L}$ was three times the State surface-water-quality criterion of $0.10 \mathrm{mg} / \mathrm{L}$. Such concentrations of phosphorus indicate substantial nutrient inputs, much of which originated from permitted wastewater discharges.

\section{WATER-QUALITY TRENDS}

Trend analysis is a statistical procedure used to detect changes in stream water quality at a monitoring station over time. For this report, water-quality data from 20 monitoring stations (fig. 2) were analyzed for trends by using the seasonal Kendall test (Hirsch and others, 1982), a method used extensively by the USGS. The graph (above right) of specific conductance in the Cooper River at site 10 illustrates the trend inferred from the data and demonstrates the variation in water quality that is common in streams.

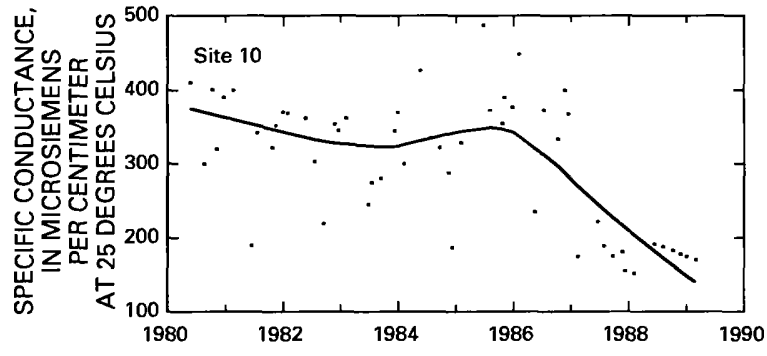

When possible, constituent-concentration data were adjusted for changes in streamflow to preclude identifying a trend in concentration that was caused only by a trend in streamflow. The data were not adjusted when (1) more than 10 percent of the samples had concentrations lower than the minimum reporting limit for the analytical method used or (2) streamflow was controlled substantially by human activities. When the concentration data could not be adjusted for streamflow, trends were determined directly from the concentration data.

Statewide trends in measurements of selected physical properties of stream water and in concentrations of selected constituents in stream water are shown on maps in figure 4. On each map, a trend is indicated at a monitoring station only if the data from that station were suitable for use in the trend analysis. For more information on the suitability criteria and on the trend-analysis procedure used for this report, see Lanfear and Alexander (1990).

\section{SPECIFIC CONDUCTANCE}

Specific conductance is a measure of the ability of a sample of water to conduct electricity. Because specific conductance and the dissolved-solids concentration are roughly proportional in most natural waters, the specific-conductance value often can be used to estimate the dissolved-solids concentration (Hem, 1985, p. 66-68).

Increases in specific conductance occurred more frequently in the northern part of the State (fig. 4). Hay and Campbell (1990) reported similar results in their assessment of water-quality trends in New Jersey streams. Upward trends at sites 1, 2, 7, 8, 9, 15, 18, and 19 probably relate to the urbanization of areas that were previously agricultural. The downward trend in specific-conductance values in the Cooper River (site 10) might be related to the completion of a regional wastewater-treatment facility in 1988 , which replaced many antiquated treatment facilities upstream from site 10.

\section{DISSOLVED OXYGEN}

The dissolved-oxygen concentration in a stream is controlled by several factors, including water temperature, air temperature and pressure, hydraulic characteristics of the stream, photosynthetic or respiratory activity of stream biota, and the quantity of organic material present. A trend in dissolved-oxygen concentrations commonly is directly or indirectly the result of human activities. Generally, an upward trend in dissolved-oxygen concentrations indicates improving stream water-quality conditions and a downward trend indicates deteriorating conditions.

Many factors contribute to the quantity of dissolved oxygen in surface water. Substantial oxygen demand by sediment in urban streams can continue to affect dissolved-oxygen concentrations even after the quality of discharges from municipal wastewater-treatment facilities has improved or facilities have been closed (New Jersey Department of Environmental Protection, 1987a, p. VI-88; 1987b, p. 112).

Biochemical-oxygen-demand removal rates at municipal wastewater-treatment facilities have increased, or municipal treatment-facilities have been regionalized, in all three basins that had 
upward dissolved-oxygen trends (sites 1, 10, and 11) (fig. 4); however, other streams whose basins contain new or updated treatment facilities had no change. The cause of the downward trend in Raccoon Creek at site 15 is not known.

In another study of water-quality trends in New Jersey, Hay and Campbell (1990) found a similar proportion of upward and downward trends. The New Jersey Department of Environmental Protection (1986, p. II-16) reported that significant increases in dissolvedoxygen concentration were found in 40 percent of the streams evaluated.

\section{FECAL COLIFORM BACTERIA}

Fecal coliform bacteria are used as indicators of fecal contamination from humans and other warm-blooded animals. Such contamination can introduce disease-causing viruses and bacteria into a stream.

Concentrations of fecal coliform bacteria had little change in New Jersey streams during water years $1980-89$ (fig. 4). Concentrations at one monitoring station on the Passaic River (site 20) had an upward trend and at 13 other stations had no trend. The near absence of change in concentrations of fecal coliform bacteria state- wide might indicate that improvements in municipal wastewatertreatment facilities have not affected this measure of water quality or that other sources of fecal coliform bacteria are counteracting the improvements in wastewater treatment.

\section{DISSOLVED CHLORIDE}

Chloride is present in all natural waters but usually in low concentrations (Hem, 1985, p. 118). Except in streams that receive ground-water discharge high in chloride, concentrations of greater than a few milligrams per liter generally are the result of human activities (table 1). Greater rates of human- and animal-waste input to streams, as well as increasing use of road-deicing salt, might be the primary sources of the many upward trends in dissolved-chloride concentrations (fig. 4). Increasing population in formerly rural areas has resulted in additional sewers and onsite waste-disposal systems. The New Jersey Department of Transportation's use of roaddeicing salt, primarily sodium chloride and calcium chloride, increased during 1976-87 (Alfred Woodrow, New Jersey Department of Transportation, written commun., August 1989). Although no data are readily available, the use of road salt by local government agencies probably increased during 1980-89. Increasing chloride concen-

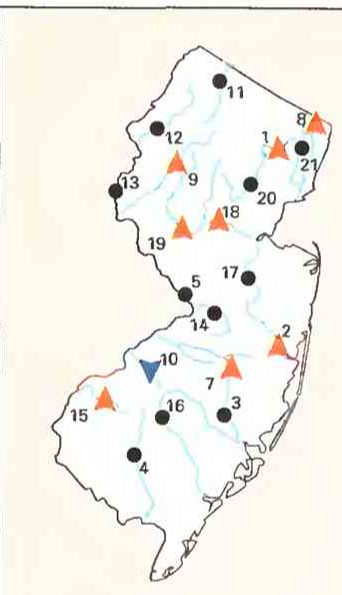

Specific conductance, 1980-89

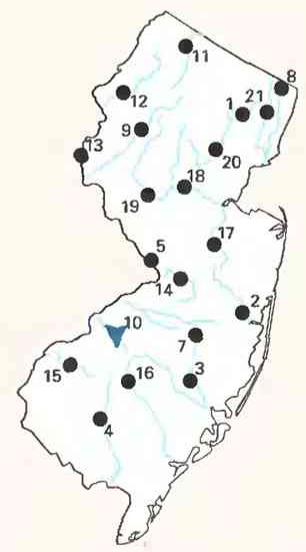

Dissolved solids, 1980-89

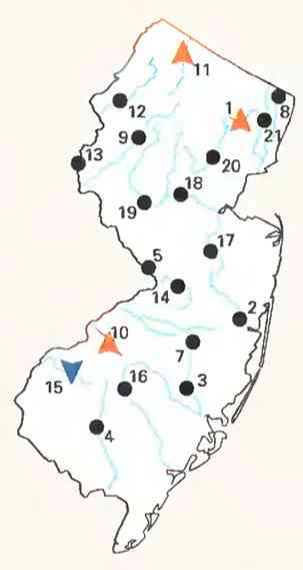

Dissolved oxygen, 1980-89

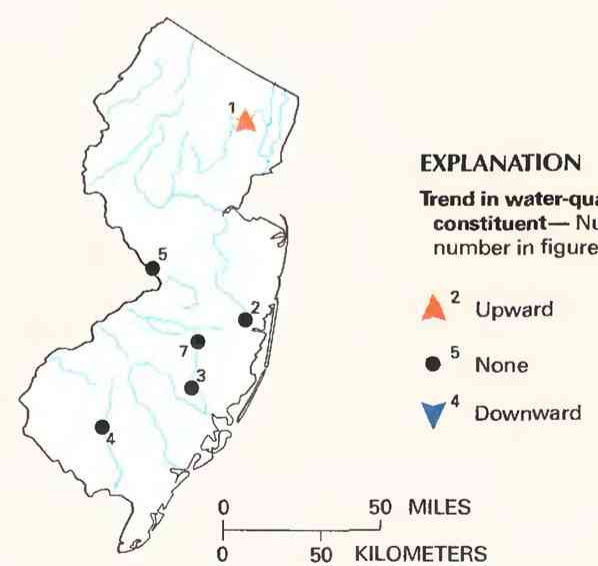

Dissolved nitrite plus nitrate, 1980-89

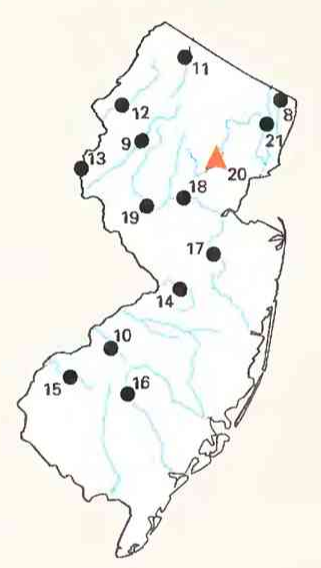

Fecal coliform bacteria, 1980-89

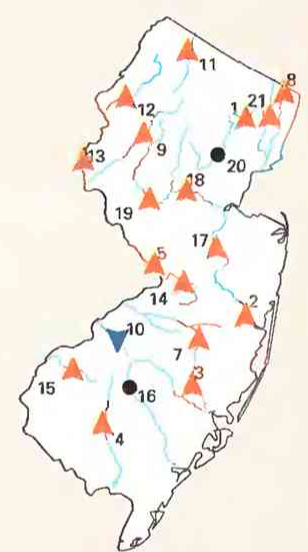

Dissolved chloride, 1980-89

Figure 4. Trends in water quality of selected streams in New Jersey, by water years. (Source: Data from U.S. Geological Survey files.) 
trations also were reported by Hay and Campbell (1990) for streams statewide and by Smith and others $(1987$, p. 5) for streams nationwide.

\section{DISSOLVED SOLIDS}

Dissolved solids in stream water result primarily from rock weathering but also can be introduced as a byproduct of human activities (table 1). Concentrations generally are greatest in streams draining basins underlain by rocks and soils that contain easily dissolved minerals.

Improvement in municipal wastewater treatment likely resulted in the downward trends in dissolved-solids concentrations in the Cooper River (site 10) and Great Egg Harbor River (site 16). Dissolved-solids concentrations had no trend at the remaining 19 monitoring stations from which data were suitable for trend analysis (fig. 4).

\section{DISSOLVED NITRITE PLUS NITRATE}

Nitrite and nitrate are oxidized forms of nitrogen that together normally constitute most of the dissolved nitrogen in well-aerated streams. Nitrite readily oxidizes to nitrate in natural waters; therefore, nitrate generally is by far the more abundant of the two (Hem, 1985 , p. 124).

An upward trend for the Passaic River at site 1 was the only trend detected in nitrite plus nitrate concentrations at the six monitoring stations from which data were suitable for trend analysis (fig. 4). The trend could have been caused by increasing wastewater discharge or urban runoff.

\section{TOTAL PHOSPHORUS}

The total-phosphorus concentration of a water sample is a measure of the concentration of all forms of phosphorus present in the sample, dissolved and particulate. Human activities (table 1) can be important sources of phosphorus in streams.

In addition to an upward trend in total-phosphorus concentrations at site 19 on the South Branch Raritan River (fig. 4), specific-conductance values and chloride concentrations also increased. These trends might have been the result of recent urban development and the presence of permitted wastewater discharges in the basin that are not in compliance with their State discharge permit (New Jersey Department of Environmental Protection, 1988, p. III-198). Phosphorus concentrations in the Delaware River at site 13 also had an upward trend, but the cause of the trend is not known.

All four stations at which concentrations of total phosphorus decreased (sites 2, 4, 10, and 16) are in the Coastal Plain. Decreasing concentrations at site 10 on the Cooper River and site 16 on the Great Egg Harbor River probably were the result of improved wastewater-treatment facilities. Possible causes of the downward trends at the other stations are not known.

As with fecal coliform bacteria, the few downward trends in phosphorus concentrations might indicate that municipal wastewatertreatment facilities are not the primary source of this constituent in surface water. The scarcity of improvement also might indicate that municipal wastewater-treatment practices have not substantially reduced the total quantity of phosphorus contributed by treatment facilities.

\section{WATER-QUALITY MANAGEMENT}

The New Jersey Department of Environmental Protection and Energy has the primary responsibility for administering Federal and State water-pollution-control laws. The principal State statutes for stream water-quality management are the New Jersey Water Pollution Control Act and the New Jersey Water Quality Planning Act.
Numerous additional State and Federal laws regulate a wide range of specific sources of surface-water contamination, such as landfills, hazardous-waste sites, soil erosion, and construction activities in the floodway.

The New Jersey Department of Environmental Protection and Energy conducts and oversees statewide and areawide water-qualitymanagement planning activities and prepares the biennial statewide water-quality inventory report for the EPA and the U.S. Congress mandated by section 305(b) of the Federal Clean Water Act (New Jersey Department of Environmental Protection, 1986; 1988; 1990). The Department generates the State's stream water-quality standards and establishes effluent limitations and total maximum daily loads for water bodies in the State.

All dischargers to the State's surface and ground water are regulated by the New Jersey Pollutant Discharge Elimination System program. Statutory authority for the program comes from the Federal Clean Water Act and the New Jersey Water Pollution Control Act. The State statute has broader authority by overseeing discharges to both surface and ground water and from both point and nonpoint sources.

The New Jersey Department of Environmental Protection and Energy has a Clean Water Council that advises the Commissioner of the Department on matters that relate to water-quality management. New Jersey participates in three interstate organizations that are involved with water quality and water-resource management: the Delaware River Basin Commission, the Interstate Sanitation Commission (which includes border waters of New Jersey, New York, and Connecticut), and the National Estuary Program for New York Harbor and Delaware Bay.

Three surface-water-quality monitoring networks exist for sampling freshwater in New Jersey. The New Jersey Department of Environmental Protection and Energy and the USGS cooperate in the operation of a network of 79 stations that are sampled five times annually. The USGS also operates six sites in New Jersey as part of NASQAN and one site as part of the National Hydrologic Bench-Mark Network. During the 1980 's, however, stream water-quality monitoring in the State declined owing to budgetary restrictions.

\section{SELECTED REFERENCES}

Anderson, J.R., 1967, Major land uses in the United States, in U.S. Geological Survey, 1970, National atlas of the United States of America: Washington, D.C., U.S. Geological Survey, p. 158-159.

Britton, L.J., and Greeson, P.E., eds., 1987, Methods for collection and analysis of aquatic biological and microbiological samples: U.S. Geological Survey Techniques of Water-Resources Investigations, book 5, chap. A4, $363 \mathrm{p}$.

Delaware River Basin Commission, 1990, Delaware River and Bay water quality assessment, 1988-1989 305(b) report: West Trenton, N.J., Delaware River Basin Commission, 66 p.

Fenneman, N.M., 1946, Physical divisions of the United States: Washington, D.C., U.S. Geological Survey special map, scale 1:7,000,000.

Fishman, M.J., and Friedman, L.C., eds., 1989, Methods for the determination of inorganic substances in water and fluvial sediments: U.S. Geological Survey Techniques of Water-Resources Investigations, book 5, chap. A1, 545 p.

Hay, L.E., and Campbell, J.P., 1990, Water-quality trends in New Jersey streams: U.S. Geological Survey Water-Resources Investigations Report $90-4046,297 \mathrm{p}$.

Hem, J.D., 1985, Study and interpretation of the chemical characteristics of natural water (3d ed.): U.S. Geological Survey Water-Supply Paper 2254, 263 p.

Hirsch, R.M., Slack, J.R., and Smith, R.A., 1982, Techniques of trend analysis for monthly water quality data: Water Resources Research, v. 18, no. 1, p. 107-121.

Lanfear, K.J., and Alexander, R.B., 1990, Methodology to derive water-quality trends for use by the National Water Summary Program of the U.S. Geological Survey: U.S. Geological Survey Open-File Report 90-359, $10 \mathrm{p}$. 
New Jersey Department of Environmental Protection, 1986, New Jersey 1986 State water quality inventory report-A report on the status of water quality in New Jersey pursuant to the New Jersey Water Pollution Control Act and Section 305(b) of the Federal Clean Water Act: Trenton, New Jersey Department of Environmental Protection, Division of Water Resources, 298 p.

1987a, Passaic River water quality management study: Trenton, New Jersey Department of Environmental Protection, Division of Water Resources, special report, $249 \mathrm{p}$.

1987b, Upper Millstone River water quality management study: Trenton, New Jersey Department of Environmental Protection, Division of Water Resources, special report, $148 \mathrm{p}$.

1988 , New Jersey 1988 State water quality inventory report-A report on the status of water quality in New Jersey pursuant to the New Jersey Water Pollution Control Act and Section 305(b) of the Federal Clean Water Act: Trenton, New Jersey Department of Environmental Protection, Division of Water Resources, $360 \mathrm{p}$.

1989, Surface water quality standards-N.J.A.C. 7:9-4.1 et seq.: Trenton, New Jersey Department of Environmental Protection, Division of Water Resources, 118 p.
1990 , New Jersey 1990 State water quality inventory report-A report on the status of water quality in New Jersey pursuant to the New Jersey Water Pollution Control Act and Section 305(b) of the Federal Clean Water Act: Trenton, New Jersey Department of Environmental Protection, Division of Water Resources, $360 \mathrm{p}$.

Smith, R.A., Alexander, R.B., and Wolman, M.G., 1987, Analysis and interpretation of water-quality trends in major United States rivers, 197481: U.S. Geological Survey Water-Supply Paper 2307, 25 p.

Thelin, G.P., and Pike, R.J., 1990, Digital shaded relief map of the conterminous United States: Menlo Park, Calif., U.S. Geological Survey digital image processing, scale 1:3,500,000.

U.S. Geological Survey, 1986, National water summary 1985-Hydrologic events and surface-water resources: U.S. Geological Survey WaterSupply Paper 2300, 506 p.

1990, National water summary 1987-Hydrologic events and water supply, and use: U.S. Geological Survey Water-Supply Paper 2350, $553 \mathrm{p}$.

Ward, J.R., and Harr, C.A., eds., 1990, Methods for collection and processing of surface-water and bed-material samples for physical and chemical analyses: U.S. Geological Survey Open-File Report 90-140, 71 p.

Prepared by Keith W. Robinson and Connie Pak, U.S. Geological Survey; "Water Quality Management" section by Kevin Berry and William Minervini, New Jersey Department of Environmental Protection and Energy

FOR ADDITIONAL INFORMATION: District Chief, U.S. Geological Survey, 810 Bear Tavern Road, Suite 206, West Trenton, NJ 08628 


\section{New MeXICO Stream Water Quality}

Because New Mexico is mostly arid or semiarid, the State's supply of surface water is limited; therefore, water quality is an important aspect of supply. This limited supply has been almost completely allocated through legal compacts and water-rights agreements. Many reservoirs have been constructed on major rivers in the State. These reservoirs capture and regulate limited and seasonally variable streamflows primarily for irrigation use and flood control (U.S. Geological Survey, 1986, p. 341-346). Significant quantities of water are lost to the atmosphere because evaporation from open-water sur- faces greatly exceeds precipitation statewide (New Mexico State Engineer Office, 1967, p. 280-281). Water use and land use in New Mexico (fig. $1 A$ ) are determined, in part, by precipitation patterns that result from physiography (fig. $1 B$ ). Annual precipitation ranges from 8 inches in flat, arid areas of the State to 24 inches in the higher mountains (U.S. Geological Survey, 1986, p. 343).

Irrigation is the principal surface-water use. During 1985 , about 95 percent of an estimated 1,780 million gallons of surface water withdrawn per day was used for irrigation, mostly of land along

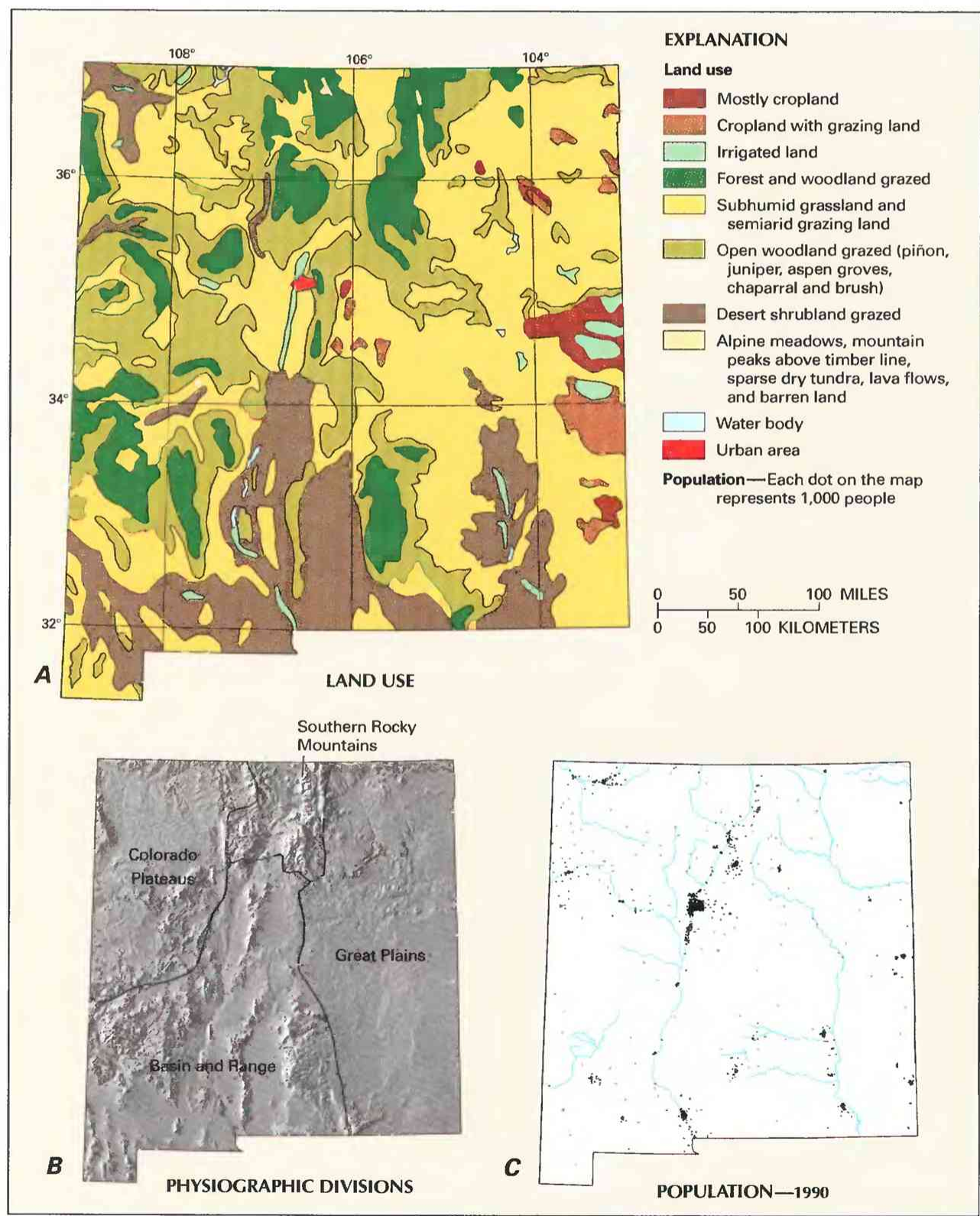

Figure 1. Land use, physiography, and population in New Mexico. A, Major land uses. B, Physiographic divisions. C, Population distribution in 1990. (Sources: A, Major land uses modified from Anderson, 1967. B, Physiographic divisions from Fenneman, 1946; landforms from Thelin and Pike, 1990. C. Data from U.S. Bureau of the Census 1990 decennial census files.) rivers (fig. 1A). The remaining 5 percent was used for thermoelectric power generation ( 2.7 percent), public water supplies (1.6 percent), and mining operations ( 0.7 percent) (U.S. Geological Survey, 1990, p. 379)

The primary instream uses of surface water are maintaining fisheries, providing aquatic recreation (New Mexico Water Quality Control Commission, 1988, p. 1), and supporting riparian areas and associated wildlife. The Rio Grande from near Lobatos in southern Colorado to near Taos in northern New Mexico is one of the original eight river segments in the Nation protected under the Federal Wild and Scenic Rivers Act of 1968.

Population centers typically are located along the State's major rivers (fig. $1 C$ ). However, nearly all of New Mexico's large cities, including Albuquerque, the State's largest, withdraw their public supplies from ground-water sources. Santa Fe and Farmington are two of the State's few large cities that rely on surface water for public supply. New Mexico's 1990 population of 1.5 million (U.S. Bureau of the Census 1990 decennial census files) represents a 48-percent increase since 1970 . The commercial, industrial, and agricultural activities that accompanied that population growth are potential stresses on the water quality of all of the State's rivers.

\section{WATER-QUALITY MONITORING}

Water-quality data obtained from analyses of water samples collected at monitoring stations are stored in the U.S. Geological Survey's (USGS) National Water Infor- 
mation System and the U.S. Environmental Protection Agency's (EPA) national data base known as STORET. Water-quality and streamflow data are reported by water year-the 12 months from October 1 through September 30. A water year is identified by the calendar year in which it ends. For example, water year 1991 comprises October 1, 1990, through September 30, 1991.

The data used in this summary of New Mexico's stream water quality were obtained from water samples collected at 17 monitoring stations at which data collection is systematic and continuing (fig. 2). These stations are part of the USGS's National Stream-Quality Accounting Network, Hydrologic Bench-Mark Network, or New Mexico Water-Quality Surveillance Network. Data for the WaterQuality Surveillance Network were collected in cooperation with the New Mexico Interstate Stream Commission. Analyses of water samples collected at 10 stations are the basis for the discussion and graphic summary (fig. 3) of stream water-quality conditions during water years 1987-89, and data from all 17 stations are the basis for the discussion and graphic summary (fig. 4) of stream water-quality trends. Water samples were collected and analyzed by using standard methods approved by the USGS (Britton and Greeson, 1987;

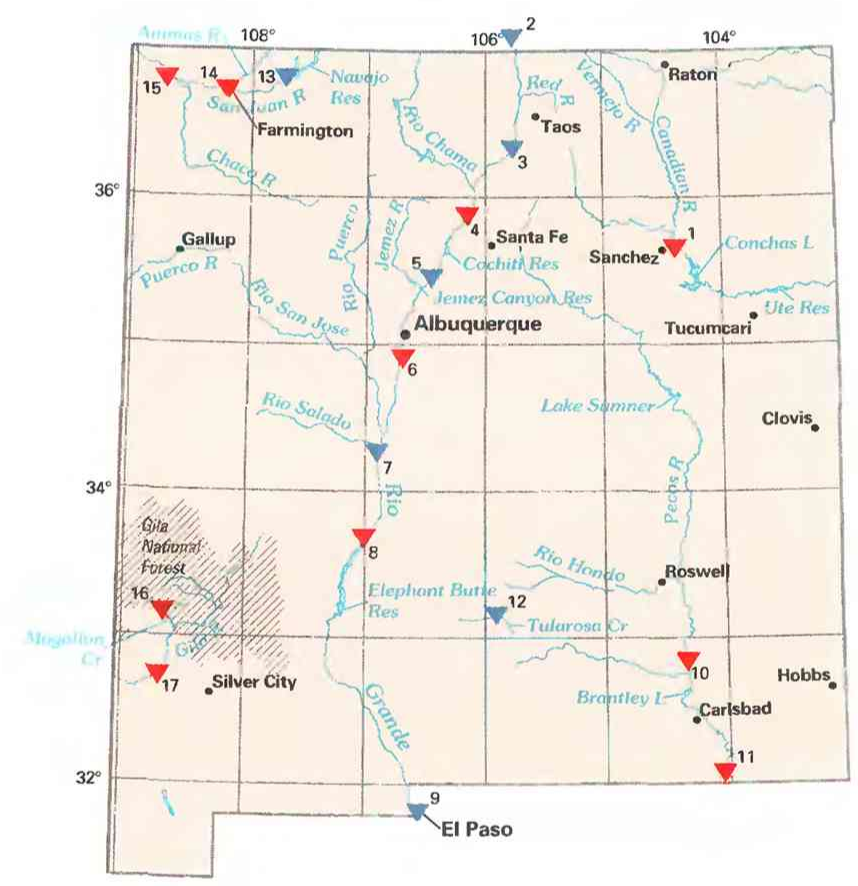

Fishman and Friedman, 1989; Ward and Harr, 1990) or by using equivalent methods. If a method of sample collection or analysis changed over time, data from an analysis were included in the evaluation of recent stream water quality or of stream water-quality trends only if the change in method did not affect the comparability of the data.

\section{WATER-QUALITY CONDITIONS}

The State's major concern regarding the quality of New Mexico's limited surface-water supply is that contamination from nonpoint sources impairs the use of many river segments and lake areas for at least one of the instream or offstream uses designated by the State for purposes of water-quality monitoring and protection. Impairment is based on exceedance of State water-quality standards adopted for those river segments (New Mexico Water Quality Control Commission, 1988). The New Mexico Water Quality Control Commission (NMWQCC) $(1990$, p. 3, 27, 35) determined that 3,117 of the 3,500 stream miles and 115,598 of the 132,000 acres of lake surface in the State do not fully support designated uses.

Sources of contaminants include runoff from grazing lands, mining areas, urban drainage areas, construction sites, and irrigated fields. Surveys of selected stream segments and lakes conducted during 1988-89 in New Mexico indicated that degraded water quality in many river segments and lakes is caused by suspended sediment, plant nutrients, and heavy metals such as cadmium, copper, iron, lead, and mercury (New Mexico Water Quality Control Commission, 1990 , p. 205-252). These surveys also indicated that pesticides

\section{EXPLANATION}

Water-quality monitoring station and
type of statistical analysis-
Number refers to accompanying
table
$\nabla^{2}$ Water-quality trends
(see fig. 4$)$
$\nabla^{8}$ Water-quality conditions and
trends (see figs. 3 and 4$)$

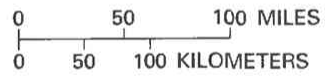

\begin{tabular}{|c|c|c|c|}
\hline $\begin{array}{l}\text { Site no. } \\
\text { on map }\end{array}$ & $\begin{array}{l}\text { USGS station } \\
\text { name and no. }\end{array}$ & $\begin{array}{l}\text { Drainage area } \\
\text { (square miles) }\end{array}$ & $\begin{array}{l}\text { Major land use } \\
\text { (see fig. 1) }\end{array}$ \\
\hline 1 & Canadian River near Sanchez (07221500) & 6,020 & Subhumid grassland and semiarid grazing land. \\
\hline 2 & Rio Grande near Lobatos, Colo. (08251500) & 7,700 & Irrigated land. \\
\hline 3 & Rio Grande below Taos Junction Bridge, near Taos (08276500) .......... & 9,730 & Subhumid grassland and semiarid grazing land. \\
\hline 4 & 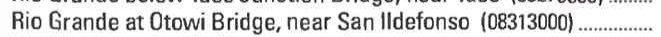 & 14,300 & Ditto. \\
\hline 5 & Rio Grande at San Felipe $(08319000)$ & 16,100 & Ditto. \\
\hline 6 & Rio Grande at Isleta (08331000) & 18,100 & Ditto. \\
\hline 7 & Rio Grande at San Acacia $(08355000)$ & 26,770 & Ditto. \\
\hline 8 & Rio Grande at San Marcial (08358500) & 27,700 & Ditto. \\
\hline 9 & Rio Grande at EI Paso, Tex. $(08364000)$ & 32,210 & Ditto. \\
\hline 10 & 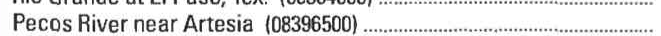 & 15,300 & Ditto. \\
\hline 11 & 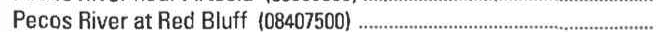 & 19,540 & Ditto. \\
\hline 12 & Tularosa Creek near Bent $(08481500)$ & 120 & Grazed forest and woodland. \\
\hline 13 & San Juan River near Archuleta (09355500) & 3,260 & Ditto. \\
\hline 14 & Animas River at Farmington (09364500) & 1,360 & Ditto. \\
\hline 15 & San Juan River at Shiprock $(09368000)$ & 12,900 & Subhumid grassland and semiarid grazing land. \\
\hline 16 & Mogollon Creek near Cliff (09430600) & 69 & Grazed forest and woodland. \\
\hline 17 & Gila River near Redrock $(09431500)$ & 2,830 & Ditto. \\
\hline
\end{tabular}

Figure 2. Selected water-quality monitoring stations, type of statistical analysis, and geographic features in New

Mexico. (Sources: Major land use modified from Anderson, 1967; other data from U.S. Geological Survey files.) 
caused contamination intermittently in the Rio Grande downstream from Cochiti Reservoir.

Ephemeral channels (arroyos) are not discussed in this report because discharges into arroyos usually disappear rapidly by infiltrating into the underlying shallow alluvial aquifers. However, uranium and other radioactive elements have been spilled accidentally during mining and milling operations into ephemeral channels such as the Puerco River near Gallup (fig. 2) in the western part of the State (New Mexico Water Quality Control Commission, 1990, p. 72).

The following discussion of stream water quality in New Mexico is organized by river basin (fig. 3). Where physiographic and land-use characteristics in different basins are similar, the discussion of those basins is combined. Graphs in figure 3 summarize certain aspects of stream water quality in the basins for water years 198789. The graphs show frequency distributions of data values that represent measurements of selected physical properties of stream water and concentrations of selected constituents in stream water. These properties and constituents are specific conductance, fecal coliform bacteria, alkalinity (as calcium carbonate), dissolved sulfate. dissolved solids, dissolved nitrite plus nitrate (as nitrogen), and suspended sediment. The data are reported in microsiemens per centimeter at 25 degrees Celsius, colonies per 100 milliliters $(\mathrm{col} / 100 \mathrm{~mL})$, and milligrams per liter (mg/L). Sources and environmental significance of each property and constituent are described in table 1 .

Average streamflows during water years 1987-89 were near long-term averages. However, in the Canadian River at site 1, the average for water year 1987 was substantially greater than the longterm average, whereas the average for water years 1988-89 was substantially smaller than the long-term average.

Water quality at each monitoring station is the result of geological, chemical, biological, and hydrologic processes that occur over a large area. Water-quality problems that affect aquatic life or public health at upstream localities that are distant from these monitoring stations are not fully represented in this summary.

\section{CANADIAN RIVER}

The Canadian River flows southward to Conchas Lake from its origin in northeastern New Mexico. Upstream from site 1 near Sanchez, the basin is sparsely populated. In most of the basin, woodland and semiarid grazing land overlie mostly unconsolidated Cretaceous deposits (New Mexico State Engineer Office, 1967, p. 16). Small tonnages of coal are produced in the Vermejo River basin west of Raton. Flood plains of the perennial tributaries that flow from the mountains bordering the western part of the basin support small patches of irrigated cropland. The average streamflow for water years $1987-89$ at site 1 was $207 \mathrm{ft}^{3} / \mathrm{s}$ (cubic feet per second).

The wide range of fecal coliform bacteria concentrations at site 1 (fig. 3) indicates an intermittent source of bacteria, such as moving herds of grazing livestock. The median alkalinity $(151 \mathrm{mg} / \mathrm{L})$ is typical of natural surface water in chemical equilibrium with calcium carbonate in soils and with atmospheric carbon dioxide (Hem, 1985, p. 109); calcium carbonate often is found in arid soils as caliche deposits. Large concentrations of sulfate (median, $430 \mathrm{mg} / \mathrm{L}$ ) and dissolved solids (median, $807 \mathrm{mg} / \mathrm{L}$ ) in water from site 1 indicate contact with soluble sediments.

Downstream from site 1 the quality of water from Conchas Lake is suitable for a large irrigation project near Tucumcari. Also, the water from Ute Reservoir (fig. 2) is suitable, following conventional water-supply treatment, for a proposed public supply for Clovis and Hobbs (New Mexico State Engineer Office, 1967, p. 59).

\section{RIO GRANDE}

The Rio Grande flows from Colorado to the Gulf of Mexico and drains 26,295 $\mathrm{mi}^{2}$ (square miles) of New Mexico. The Rio Grande basin is a geologically complex area having outcrops of sedimentary, igneous, and metamorphic rocks. The basin is a deep trough that is filled with sediments that were transported by water and wind. The average streamflow of the Rio Grande at site 4 for water years 198789 was $1,690 \mathrm{ft}^{3} / \mathrm{s}$. Streamflow is augmented by transmountain diversion of water into the Rio Chama from the San Juan River in Colorado (U.S. Geological Survey, 1986, p. 342). About 60 percent of New Mexico's population lives in the Rio Grande basin. Land-use activities in the Rio Grande basin that can affect water quality upstream from site 4 include small communities, ski resorts, summerhome developments, timber harvesting, cattle ranching, molybdenum mining, and irrigated agriculture. Nearly 700,000 acres, mostly in Colorado, are irrigated upstream from site 4.

The small median concentrations of fecal coliform bacteria (32 col $/ 100 \mathrm{~mL})$, sulfate $(56 \mathrm{mg} / \mathrm{L})$, dissolved solids $(240 \mathrm{mg} / \mathrm{L})$, and nitrite plus nitrate $(0.10 \mathrm{mg} / \mathrm{L})$ relative to those for most other monitoring stations (fig. 3) indicate that human activities and water uses upstream have had little effect on the water quality at site 4; however, nearby human activities and water uses have affected the water quality in streams locally (New Mexico Water Quality Control Commission, 1990, p. 208-218). The wide range of suspended-sediment concentrations reflects the intermittent input of sediment from nonpoint sources such as runoff from semiarid grazing lands (New Mexico Water Quality Control Commission, 1990, p. 208-218).

Downstream, between site 4 and site 6, the Rio Grande basin contains Santa $\mathrm{Fe}$ and metropolitan Albuquerque, the most densely populated areas in the State (fig. $1 C$ ). The Rio Grande's average streamflow at site 6 for water years $1987-89$ was $1,570 \mathrm{ft}^{3} / \mathrm{s}$ and was regulated upstream by Cochiti Reservoir. Croplands are irrigated on both sides of the Rio Grande by several river-diversion structures.

The sources upstream from site 6 of fecal coliform bacteria (median concentration, $240 \mathrm{col} / 100 \mathrm{~mL}$ ) and nitrite plus nitrate (median concentration, $0.47 \mathrm{mg} / \mathrm{L}$ ) are discharges from wastewater-treatment facilities and runoff from dairy farms, grazing lands, and urban areas (New Mexico Water Quality Control Commission, 1990, p. 206). The narrower suspended-sediment concentration range in water from site 6 compared to the range at site 4 was due to the settling and retention of sediments in Cochiti Reservoir, Jemez Canyon Reservoir, and several smaller reservoirs on ephemeral tributaries. The Jemez River, a perennial tributary, contains large arsenic concentrations (U.S. Geological Survey, 1976-90) that are associated with natural geothermal water (Hem, 1985, p. 144).

From site 6 to site 8 , the Rio Grande basin is drained by the Rio Puerco, the Rio San Jose, and the Rio Salado, which are intermittent streams that drain semiarid lands underlain by unconsolidated sediments. The average streamflow for water years $1987-89$ at site 8 was $1,520 \mathrm{ft}^{3} / \mathrm{s}$. Uranium mining activities in the Rio San Jose subbasin of the Rio Puerco basin might introduce to the Rio Grande heavy metals adsorbed to suspended sediments in runoff (Brandvold and others, 1984). Irrigation drainage is returned to the river through a complex network of drainage canals.

A 75-mile-long conveyance channel was constructed in 1958 to minimize evapotranspiration from the wide natural channel of the Rio Grande by conveying all flows of less than $2,000 \mathrm{ft}^{3} / \mathrm{s}$ into Elephant Butte Reservoir. The data in figure 3 for site 8 are a composite of the data collected from the river and the conveyance channel. The median alkalinity for site $8(154 \mathrm{mg} / \mathrm{L})$ is typical of surface water in equilibrium with calcium carbonate minerals in soils and atmospheric carbon dioxide (Hem, 1985, p. 109). Median concentrations of sulfate $(140 \mathrm{mg} / \mathrm{L})$ and dissolved solids $(458 \mathrm{mg} / \mathrm{L})$ were nearly twice those in water from site 4 . The great range of nitrite plus nitrate concentrations at site 8 was caused by seasonally variable drainage from grazing lands and fertilized fields. Although the largest suspended-sediment concentration shown in figure 3 is the 90 thpercentile concentration of $6,020 \mathrm{mg} / \mathrm{L}$ for water years $1987-89$, suspended-sediment concentrations can be as large as 200,000 $\mathrm{mg} / \mathrm{L}$ at the mouth of the Rio Puerco (U.S. Geological Survey, 197690 ) because of runoff from the semiarid lands underlain by unconsolidated sediments. 


\section{PECOS RIVER}

The Pecos River flows from northeast of Santa Fe southward for almost 300 miles into Texas and drains $19,540 \mathrm{mi}^{2}$ of eastern New Mexico. The Pecos River basin is underlain by limestone and evaporite deposits (U.S. Geological Survey, 1985, p. 319-320). Gypsum, a sulfate mineral, and other soluble minerals in the soils of the basin were derived from these formations. About 75 percent of the Pecos River drainage area in the State is upstream from site 10 . The average streamflow at site 10 for water years $1987-89$ was $247 \mathrm{ft}^{3} / \mathrm{s}$. Several dams on the river impound irrigation-supply water; the largest areas irrigated with surface water are between Lake Sumner and Roswell. Timber is harvested from the forests along the northern and western basin margins, and cattle and sheep graze throughout the basin.

Wastewater-treatment plant effluent and livestock grazing are sources of fecal coliform bacteria. The wide range of fecal coliform bacteria concentrations in water from site 10 (fig. 3) can be attributed to intermittent runoff from grazing lands. The large median sulfate concentration $(960 \mathrm{mg} / \mathrm{L})$ indicates stream contact with sulfate minerals or streamflow mixing with ground-water seepage. $\mathrm{Al}$ - though dissolved-solids concentrations in water were not determined at site 10 , the median dissolved-solids concentration estimated from specific conductance was $3,360 \mathrm{mg} / \mathrm{L}$. The wide range in suspendedsediment concentrations is the result of erosion from agricultural areas and of natural erosion, usually during intense summer rainstorms, in arid parts of the drainage basin. The median suspendedsediment concentration $(1,480 \mathrm{mg} / \mathrm{L})$ was the largest for all $10 \mathrm{moni}-$ toring stations and primarily reflects natural runoff.

The drainage basin of the Pecos River between sites 10 and 11 is mostly desert shrubland used for grazing and includes large tracts near Carlsbad that are irrigated with both surface water and ground water. The average streamflow at site 11 was $145 \mathrm{ft}^{3} / \mathrm{s}$ for water years 1987-89. At site 11, concentrations of fecal coliform bacteria were smaller than those at site 10 , possibly because site 11 is farther from wastewater-treatment-plant discharges and large numbers of grazing livestock. Fecal coliform bacteria generally are shortlived in streams. Brines seep into this segment of the Pecos River from underlying evaporite deposits of halite, resulting in large dissolved-solids concentrations. At site 11 , the median concentrations of sulfate $(1,700 \mathrm{mg} / \mathrm{L})$ and dissolved solids $(6,010 \mathrm{mg} / \mathrm{L})$ were the largest for any monitoring station and represent substantial increases
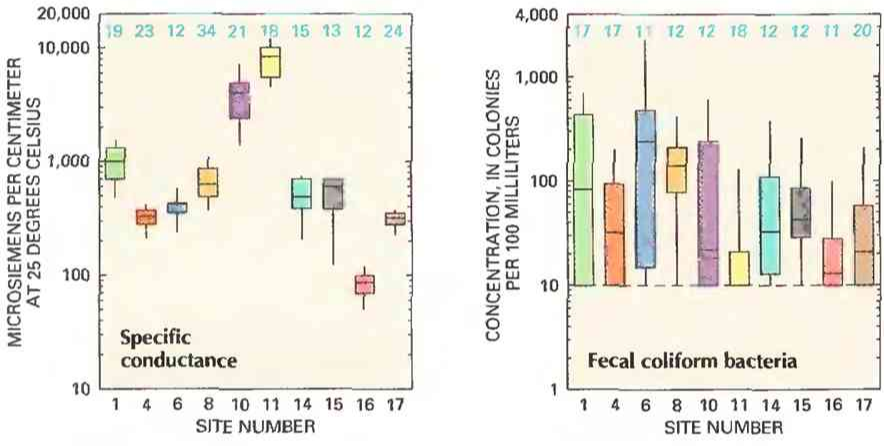

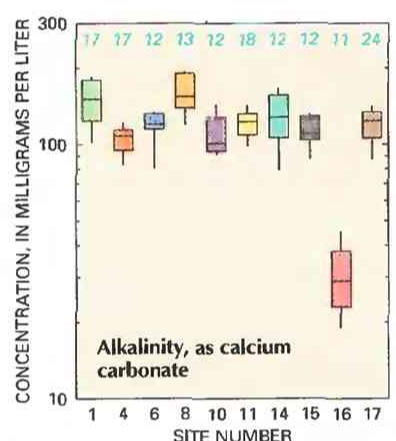

SITE NUMBER
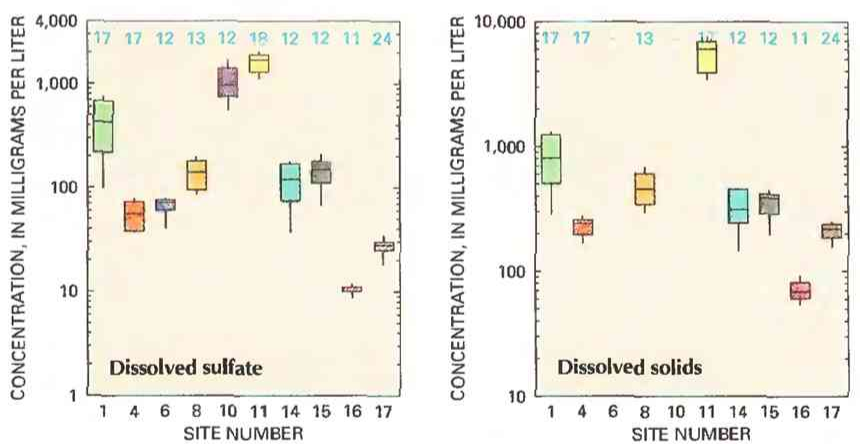
SITE NUMBER
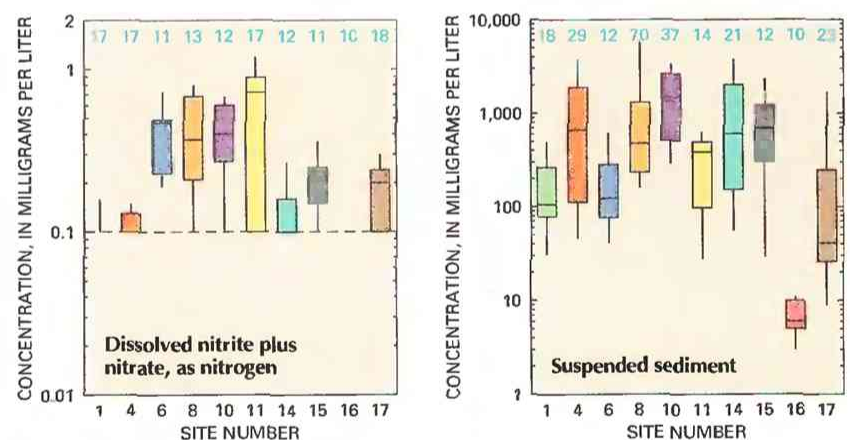

\section{EXPLANATION}

Water-quality conditions in selected drainage basins

Number of analyses-Dash
indicates insufficient data
Percentile-Percentage of analyses
equal to or less than indicated
values
-90 th
-75 th
-50 th-Median
-25 th
10th
- Reporting limit-Minimum
reporting limit for analytical
method used. Data below limit
line not shown

Drainage basin-Number is site number in figure 2. Basin may extend beyond State line

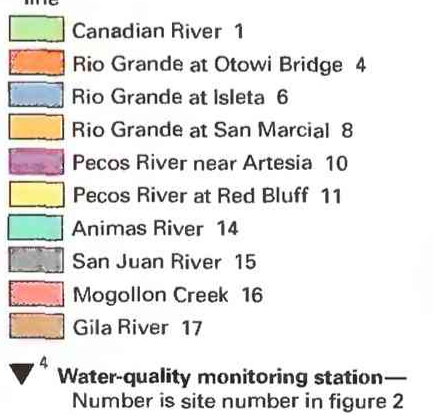

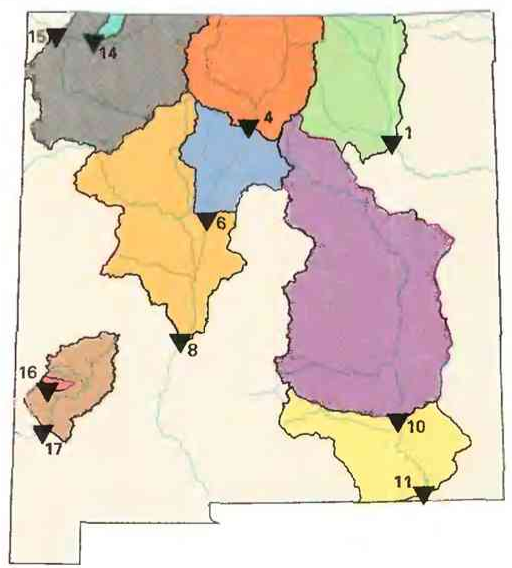

$0 \quad 50 \quad 100$ MILES

$\begin{array}{llll}0 & 50 & 100 & \text { KILOMETERS }\end{array}$

Figure 3. Water quality of selected streams in New Mexico, water years 1987-89. (Source: Data from U.S. Geological Survey files.) 
Table 1. Sources and environmental significance of selected water-quality properties and constituents

[Source: Complled by the U.S. Geologıcal Survey, Office of Water Quality]

\begin{tabular}{|c|c|c|}
\hline Property or constituent & Common sources & Environmental significance \\
\hline $\begin{array}{l}\text { Specific conductance ...................... } \\
\text { (property) }\end{array}$ & $\begin{array}{l}\text { A measure of the electrical conductivity of water; var- } \\
\text { ies with the quantity of dissolved solids and is } \\
\text { used to approximate the dissolved-solids content. }\end{array}$ & $\begin{array}{l}\text { Dissolved solids can cause water to be unsuitable for } \\
\text { public supply, agriculture, and industry; can harm } \\
\text { aquatic organisms. }\end{array}$ \\
\hline Fecal coliform bacteria ................. & $\begin{array}{l}\text { Sources include effluent from sewage-treatment } \\
\text { plants and runoff from pastures, feedlots, and ur- } \\
\text { ban areas. }\end{array}$ & $\begin{array}{l}\text { Presence indicates contamination of water by wastes } \\
\text { from humans and other warm-blooded animals. }\end{array}$ \\
\hline Alkalinity (property) ....................... & $\begin{array}{l}\text { A measure of the quantity of acid-neutralizing sub- } \\
\text { stances; can be affected by geologic setting, in- } \\
\text { dustrial wastewater discharge, waste gases, and } \\
\text { runoff from surface mining. }\end{array}$ & $\begin{array}{l}\text { Sufficiently alkaline water can be unsuitable for some } \\
\text { agricultural and industrial uses. }\end{array}$ \\
\hline Sulfate & $\begin{array}{l}\text { Occurs in some rocks; also in mine runoff, industrial } \\
\text { wastewater discharge, and atmospheric deposi- } \\
\text { tion. }\end{array}$ & $\begin{array}{l}\text { Concentrations exceeding a natural, background } \\
\text { level indicate contamination from human activity; } \\
\text { in sufficient quantity, can cause water to be } \\
\text { unsuitable for public supply; can harm aquatic } \\
\text { organisms. }\end{array}$ \\
\hline Dissolved solids ............................ & $\begin{array}{l}\text { A result of rock weathering; also in agricultural runoff } \\
\text { and industrial discharge. }\end{array}$ & $\begin{array}{l}\text { In sufficient quantity, can cause water to be unsuitable } \\
\text { for public supply, agriculture, and industry; can } \\
\text { harm aquatic organisms. }\end{array}$ \\
\hline Nitrite plus nitrate ........................... & $\begin{array}{l}\text { Nonpoint sources are agricultural and urban runoff; } \\
\text { a major point source is wastewater discharge. }\end{array}$ & $\begin{array}{l}\text { Plant nutrient that, in sufficient quantity, can cause } \\
\text { algal blooms and excessive growth of higher } \\
\text { aquatic plants in bodies of water; can cause water } \\
\text { to be unsuitable for public supply. }\end{array}$ \\
\hline Suspended sediment ...................... & $\begin{array}{l}\text { A result of rock erosion; also induced by disturbances } \\
\text { of land cover due to fires, floods, and human } \\
\text { activities such as mining, logging, construction, } \\
\text { and agriculture. }\end{array}$ & $\begin{array}{l}\text { Can be detrimental to aquatic organisms; can fill res- } \\
\text { ervoirs and impair recreational use of water. }\end{array}$ \\
\hline
\end{tabular}

from site 10 . The wide range of nitrite plus nitrate concentrations can be attributed to seasonally variable drainage from fertilized and irrigated fields. The smaller median suspended-sediment concentration for site $11(387 \mathrm{mg} / \mathrm{L})$ compared to that for site $10(1,480$ $\mathrm{mg} / \mathrm{L}$ ) is a result of sediment retention in reservoirs between these two sites.

\section{SAN JUAN AND ANIMAS RIVERS}

The San Juan River flows westward for 90 miles in New Mexico and drains $9,725 \mathrm{mi}^{2}$ of the State. Ephemeral tributaries join the river from the south, and perennial tributaries, of which the Animas River is the largest, flow into the river from the north. The drainage basin is underlain mostly by unconsolidated sedimentary deposits (New Mexico State Engineer Office, 1967, p. 185-197).

The Animas River flows into the San Juan River at Farmington 1.5 miles downstream from site 14. Croplands are irrigated in the basin in New Mexico and upstream in Colorado. Coal, uranium, and heavy metals are mined in Colorado, and oil and gas are produced in both States. Other developments in the basin include small communities, ski resorts, mountain homes, and timber harvesting. The average streamflow at site 14 for water years $1987-89$ was $871 \mathrm{ft}^{3} / \mathrm{s}$. Flow is diverted through riverbank structures for irrigation and public water supplies for Farmington and small communities.

During water years $1987-89$, concentrations of dissolved stream-water constituents at site 14 were similar to or smaller than those at other monitoring stations (fig. 3). All concentrations met criteria for untreated water intended for drinking-water supply (U.S. Environmental Protection Agency, 1988a,b). The sources of fecal coliform bacteria were wastewater-treatment plants and runoff from grazing lands. The wide range of suspended-sediment concentrations in water from site 14 can be attributed to seasonal variations in natural erosion, runoff from grazing lands, and runoff from areas of mineralresource development.

The San Juan River flows from the State near site 15 . The average streamflow at site 15 for water years $1987-89$ was $2,120 \mathrm{ft}^{3} / \mathrm{s}$ and was regulated by Navajo Reservoir and by bank structures that divert streamflow to several large irrigation projects and to two coalfired electric powerplants. Coal is surface mined from Cretaceous formations east of and parallel to the ephemeral Chaco River. Irri- gation drainage and industrial wastewater enter the river from tributaries such as the Animas and Chaco Rivers. Farmington and several small communities discharge treated wastewater directly into the San Juan River.

Concentrations of water-quality properties and constituents at site 15 were similar to those at site 14 during water years 1987-89 (fig. 3). The slightly smaller alkalinity values at site 15 (median, 110 $\mathrm{mg} / \mathrm{L}$ ) compared to those at site 14 (median, $128 \mathrm{mg} / \mathrm{L}$ ) possibly indicate that acidity was contributed to the river by wastewater discharges, lowering the alkalinity when the acid was neutralized. Suspended-sediment retention in Navajo Reservoir resulted in a smaller range of suspended-sediment concentrations at site 15 compared to site 14 .

\section{GILA RIVER AND MOGOLLON CREEK}

The Gila River flows from its source in the mountains southwestward for about 90 miles into Arizona, draining 3,500 $\mathrm{mi}^{2}$ of the Basin and Range province in southwestern New Mexico. The mountains, which occupy a large part of the drainage area, are composed of Tertiary igneous and metamorphic rocks. In 1924, approximately the northern two-thirds of this basin was included in the federally designated Gila Wilderness, the first such official wilderness-preservation area in the Nation (University of New Mexico School of Law, 1989). A large open-pit copper mine is operated in the lower basin southwest of Silver City.

Mogollon Creek is one of many small mountain creeks that flow into the Gila River. Site 16 on Mogollon Creek is a USGS Hydrologic Bench-Mark Network station, where the water quality represents that of stream water minimally disturbed by human activity. The average discharge at site 16 for water years $1987-89$ was 18 $\mathrm{ft}^{3} / \mathrm{s}$. All dissolved-constituent concentrations at site 16 were the smallest or among the smallest in samples from the 10 monitoring stations (fig. 3). These small concentrations are characteristic of a basin underlain by resistant rocks. Livestock and wildlife in the basin are sources of fecal coliform bacteria, although concentrations were smaller at site 16 than at most other monitoring stations.

The average streamflow of the Gila River at site 17 for water years $1987-89$ was $217 \mathrm{ft}^{3} / \mathrm{s}$. Small areas in the sparsely populated Gila River valley are irrigated upstream from site 17 . The larger 
median dissolved-solids concentration $(218 \mathrm{mg} / \mathrm{L})$ compared to that for site $16(69 \mathrm{mg} / \mathrm{L})$ (fig. 3 ) is attributable to the greater proportion of runoff in contact with sedimentary deposits in the Gila River valley. The wide ranges in concentrations of fecal coliform bacteria, nitrite plus nitrate, and suspended sediment at site 17 resulted from seasonally variable storm runoff from grazed forest and woodlands.

\section{WATER-QUALITY TRENDS}

Trend analysis is a statistical procedure used to detect changes in stream water quality at a monitoring station over time. For this report, water-quality data from 17 monitoring stations (fig. 2) were analyzed for trends by using the seasonal Kendall test (Hirsch and others, 1982), a method used extensively by the USGS. The graph (shown below) of the dissolved-sulfate concentration in Mogollon Creek at site 16 illustrates the trend inferred from the concentration data and demonstrates the variation in water quality that is common in streams.

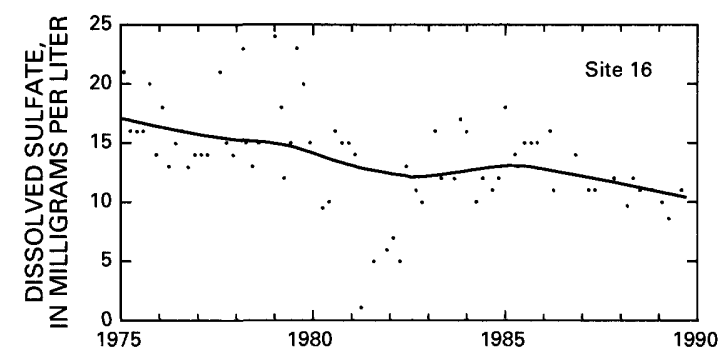

When possible, constituent-concentration data were adjusted for changes in streamflow to preclude identifying a trend in concentration that was caused only by a trend in streamflow. The data were not adjusted when (1) more than 10 percent of the samples had concentrations smaller than the minimum reporting limit for the analytical method used or (2) the streamflow was controlled substantially by human activities. When the concentration data could not be adjusted for streamflow, trends were determined directly from the concentration data. Flows in the Rio Grande, Pecos River, and San Juan River are controlled by releases from reservoirs (fig. 2), withdrawals for irrigation, and irrigation-return flows; therefore, the water-quality data for these rivers were not adjusted for changes in streamflow.

Statewide trends in measurements of selected physical properties of stream water and in concentrations of selected constituents in stream water are shown on maps in figure 4 . On each map, a trend is indicated at a monitoring station only if the data from that station were suitable for use in the trend analysis. For more information on the suitability criteria and on the trend-analysis procedure used for this report, see Lanfear and Alexander (1990).

The installation or improvement of wastewater-treatment facilities in the State since the enactment of the Federal Clean Water Act in 1972 and regulatory compliance by these facilities have decreased the concentrations of contaminants that are discharged into rivers from these point sources (New Mexico Water Quality Control Commission, 1990, p. 4). Streamflow trends during water years 1975 89 , together with the decrease of contaminants that have been discharged from wastewater-treatment plants, have resulted in many of the downward trends depicted in figure 4.

\section{SPECIFIC CONDUCTANCE}

Specific conductance is a measure of the ability of a sample of water to conduct electricity. Because specific conductance and the dissolved-solids concentration are roughly proportional in most natural waters, the specific-conductance value commonly can be used to estimate the dissolved-solids concentration (Hem, 1985, p. 66-68).

The upward trend in specific-conductance values in the $\mathrm{Ca}$ nadian River at site 1 (fig. 4) is a result of less than average stream- flow for most years during 1979-89. The downward trends at sites 4-11, 13, and 15 resulted from increased releases from reservoirs filled largely with snowmelt runoff upstream from those monitoring stations during much of the 1980 's. The downward trend in Tularosa Creek at site 12 was due to dilution effects of larger natural streamflows and to increasing discharge from a small community wastewater-treatment facility. This community uses water from mountain springs and discharges wastewater that contains dissolvedsolids concentrations that are smaller than the natural streamflow in Tularosa Creek. The downward trend in the Gila River at site 17 can be attributed to dilution by increasing snowmelt runoff from the mountainous Gila Wilderness following the end of drought in 1979 (U.S. Geological Survey, 1991, p. 409-414). Rocks and sediments in the mountains contain only small quantities of soluble minerals.

\section{FECAL COLIFORM BACTERIA}

Fecal coliform bacteria are used as indicators of fecal contamination from humans and other warm-blooded animals. Such contamination can introduce disease-causing viruses and bacteria into a stream.

The upward trend in fecal coliform bacteria concentrations in the Rio Grande at site 5 (fig. 4) resulted from the effects of a growing rural population upstream from the monitoring station. Downward trends in the Rio Grande at sites 4 and 6 indicate decreasing fecal coliform bacteria concentrations in discharges from wastewater-treatment plants. The downward trend in the Rio Grande at site $8 \mathrm{might}$ have been the result of decreasing numbers of bacteria in runoff from grazing land.

\section{ALKALINITY}

Alkalinity is a measure of the capacity of the substances dissolved in the water to neutralize acid. In most natural waters, alkalinity is produced mainly by bicarbonate and carbonate (Hem, 1985, p. 106), which are ions formed when carbon dioxide or carbonate rock dissolves in water.

The upward alkalinity trend in Mogollon Creek at site 16 (fig. 4) is consistent with the downward trend in sulfate concentrations and can be attributed to decreased acidity associated with decreasing atmospheric deposition of sulfate as sulfuric acid. Sulfur dioxide gas reacts with atmospheric water to form the sulfuric acid. Natural alkalinity is substantially larger in the Gila River (site 17) than in Mogollon Creek (site 16) (fig. 3), and the decreased acidity associated with decreasing atmospheric deposition of sulfate was insufficient to result in a detectable trend in alkalinity values at site 17 . The reason for the downward trend in the Rio Grande at site 9 is unknown, but increased urbanization in the vicinity of El Paso, Texas, might have been a factor.

\section{DISSOLVED SULFATE}

The major natural sources of sulfate in streams are rock weathering, volcanoes, and biochemical processes (Hem, 1985, p. 113). Human activities such as mining, waste discharge, and fossil-fuel combustion also can be important sources.

The downward trends in sulfate concentrations for 1975-89 at sites $6,8-11$, and 15 probably were related to dilution by releases during 1979-87 from reservoirs that frequently were filled to capacity with snowmelt runoff. The downward trends in Tularosa Creek at site 12 and the Animas River at site 14 were caused by the dilution effect of natural runoff of larger snowmelt volumes during the latter part of the analysis period. The downward trends in Mogollon Creek at site 16 and the Gila River at site 17 could have been a result of decreasing atmospheric sulfur-dioxide concentrations following compliance with more stringent air-quality regulations and decreased production in nearby copper smelters (G.A. Bacigalupa, New Mexico Air Quality Bureau, oral commun., January 1990). 


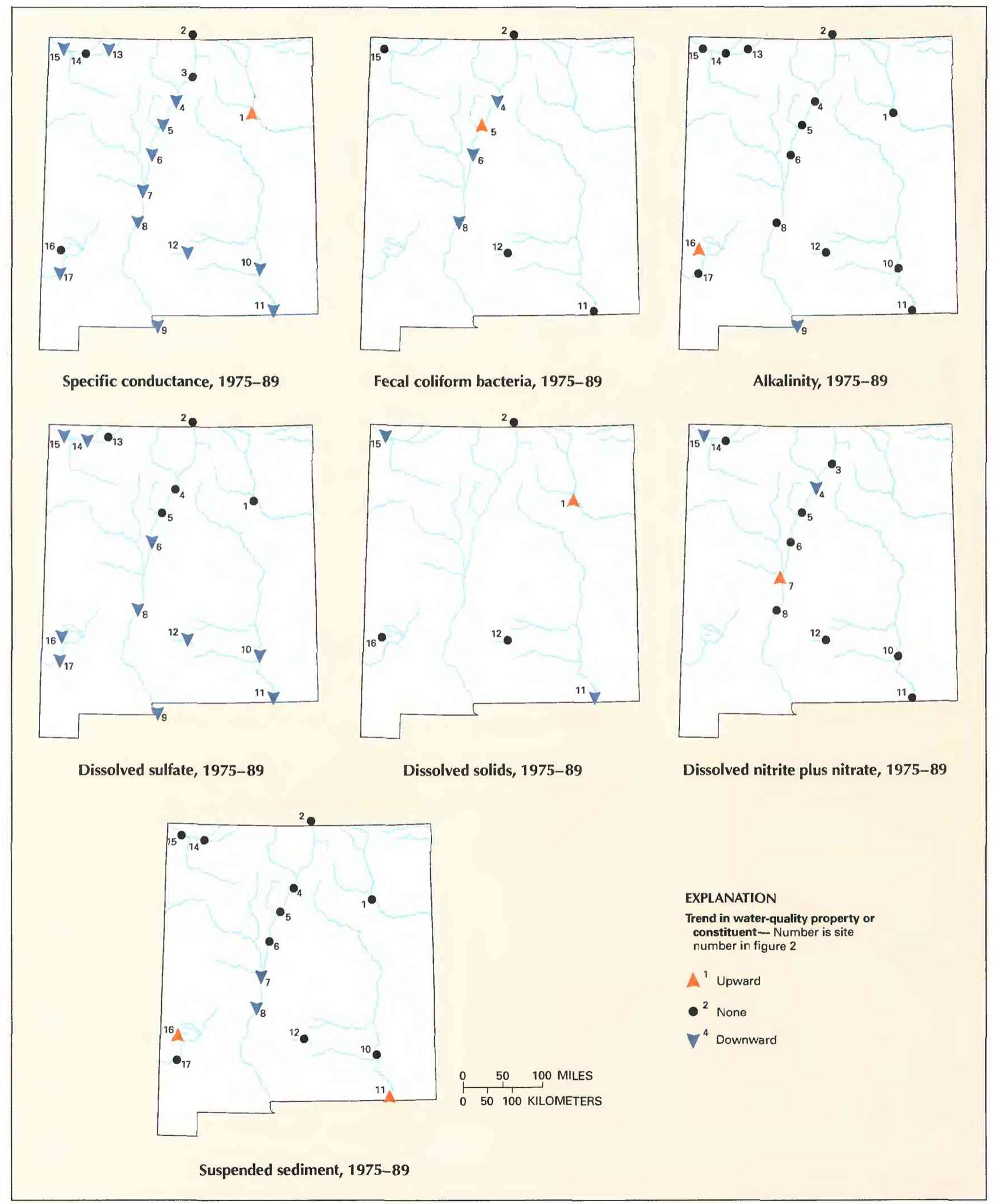

Figure 4. Trends in water quality of selected streams in New Mexico, by water years. (Source: Data from U.S. Geological Survey files.) 


\section{DISSOLVED SOLIDS}

Dissolved solids in stream water result primarily from rock weathering but also can be introduced as a byproduct of human activities (table 1). Concentrations generally are greatest in streams draining basins underlain by rocks and soils that contain easily dissolved minerals.

Data were sparse for dissolved-solids concentration as determined by the residue-on-evaporation method (Hem, 1985, p. 157) on which this trend analysis is based; thus trends were analyzed for only six monitoring stations (fig. 4). Upward or downward trends are shown for three stations. Because dissolved-solids concentrations are related to specific conductance, the causes of trends in dissolvedsolids concentrations at the three stations are the same as those given in the Specific Conductance section.

\section{DISSOLVED NITRITE PLUS NITRATE}

Nitrite and nitrate are oxidized forms of nitrogen that together normally constitute most of the dissolved nitrogen in well-aerated streams. Nitrite readily oxidizes to nitrate in natural waters; therefore, nitrate generally is by far the more abundant of the two (Hem, 1985, p. 124).

The upward trend in nitrite plus nitrate concentrations in the Rio Grande at site 7 is attributable to population growth in small communities and rural areas south of Albuquerque. Downward trends in the Rio Grande at site 4 and the San Juan River at site 15 indicate improved wastewater-treatment-plant performance upstream during water years 1975-89 (New Mexico Water Quality Control Commission, 1990, p. 4).

\section{SUSPENDED SEDIMENT}

Suspended sediment is a product of erosion. The erosion can be either natural or the result of land-cover disturbances related to human activities (table 1).

The upward trend in suspended-sediment concentrations in Mogollon Creek at site 16 was caused by increased natural erosion in the small Mogollon Creek watershed owing to increased numbers of summer storms during 1979-89 (U.S. Geological Survey, 197690). The reason for the upward trend in the Pecos River at site 11 is not known; however, the increasing suspended-sediment concentration in the river during water years 1986-89 might have been caused by construction of the Brantley Lake dam. The downward trends at the two Rio Grande stations downstream from the mouth of the Rio Puerco (sites 7 and 8) indicate improving range-management practices, which have reduced soil erosion (Bob McQueen, State Resource Conservationist, U.S. Soil Conservation Service, oral commun., March 1990).

\section{WATER-QUALITY MANAGEMENT}

The State of New Mexico is the primary legal authority for the protection of surface-water quality and acts through the NMWQCC, which was established by the New Mexico Water Quality Act of 1967. The NMWQCC consists of the head (or designee) of eight State agencies and a public representative appointed by the Governor (New Mexico Water Quality Control Commission. 1990, p. 86). The eight State agencies are the New Mexico Environment Department (NMED), State Engineer-Interstate Stream Commission, Oil Conservation Division, Park and Recreation Division, Game and Fish Department, Department of Agriculture, Soil and Water Conservation Bureau, and Bureau of Mines and Mineral Resources. The NMWQCC also is the primary legal authority for the protection of ground-water quality.

The NMWQCC has adopted a basic framework for water-quality management that includes a continuing planning process, the State water-quality management plan, surface-water-quality standards, regulations for discharge to surface waters, loan regulations for construction of wastewater facilities, and a nonpoint-source pollutionmanagement plan (New Mexico Water Quality Control Commission, 1990, p. 85). Surface-water-quality standards adopted by the NMWQCC under the State's Water Quality Act include general standards that are applicable to all surface waters that can support designated uses and meet numerical standards, based upon designated uses, for specific river segments (New Mexico Water Quality Control Commission, 1988). The NMWQCC submits a biennial water-quality assessment report to the U.S. Congress and the EPA (New Mexico Water Quality Control Commission, 1990) as mandated by section 305(b) of the Federal Clean Water Act.

The primary administrative responsibility and enforcement authority for surface-water-quality regulations are delegated to the NMED, and member agencies of the NMWQCC have coordinating roles for activities related to their respective agency mission. Under a contractual agreement with the EPA, the NMED has the responsibility to coordinate the administration of the National Pollutant Discharge Elimination System permit program (New Mexico Water Quality Control Commission, 1990, p. 87). The NMED determines the attainment of surface-water-quality standards and measures the progress made in meeting the water-quality goals of the Federal Clean Water Act. The NMED is aided in this effort by the water-quality data collected by the USGS at long-term surface-water-quality monitoring stations (New Mexico Water Quality Control Commission, 1990, p. 15).

The USGS will begin implementation of a comprehensive, continuing water-quality study of the Rio Grande valley in 1991 as part of the National Water-Quality Assessment Program (Leahy and others, 1990). This study will significantly increase the amount of waterquality data available for the Rio Grande basin in New Mexico.

\section{SELECTED REFERENCES}

Anderson, J.R., 1967, Major land uses in the United States, in U.S. Geological Survey, 1970, National atlas of the United States of America: Washington, D.C., U.S. Geological Survey, p. 158-159.

Brandvold, D.K., Popp, C.J., Lynch, T.K., and Brandvold, L.A., 1984, Heavy metals and pesticides in water, sediments, and biota in the middle Rio Grande in Stone, W.J., comp., Selected papers on water quality and pollution in New Mexico: Proceedings of symposium on water quality and pollution in New Mexico, April 12, 1984, New Mexico Bureau of Mines and Mineral Resources Hydrologic Report 7, p. 14-23.

Britton, L.J., and Greeson, P.E., eds., 1987, Methods for collection and analysis of aquatic biological and microbiological samples: U.S. Geological Survey Techniques of Water-Resources Investigations, book 5, chap. A4, $363 \mathrm{p}$.

Fenneman. N.M.. 1946, Physical divisions of the United States: Washington. D.C., U.S. Geological Survey special map, scale 1:7,000,000.

Fishman, M.J., and Friedman, L.C., eds., 1989, Methods for the determination of inorganic substances in water and fluvial sediments: U.S. Geological Survey Techniques of Water-Resources Investigations, book 5, chap. A1, 545 p.

Hem, J.D., 1985, Study and interpretation of the chemical characteristics of natural water (3d ed.): U.S. Geological Survey Water-Supply Paper 2254 . $263 \mathrm{p}$.

Hirsch, R.M., Slack, J.R., and Smith, R.A., 1982, Techniques of trend analysis for monthly water quality data: Water Resources Research, v. 18, no. 1, p. 107-121.

Lanfear, K.J., and Alexander, R.B., 1990, Methodology to derive water-quality trends for use by the National Water Summary Program of the U.S. Geological Survey: U.S. Geological Survey Open-File Report 90-359, $10 \mathrm{p}$.

Leahy, P.P.. Rosenshein, J.S., and Knopman, D.S., 1990, Implementation plan for the National Water-Quality Assessment Program: U.S. Geological Survey Open-File Report 90-174, 10 p.

New Mexico State Engineer Office, 1967, Water resources of New MexicoOccurrence, development and use: Santa Fe, New Mexico State Planning Office, $321 \mathrm{p}$. 
New Mexico Water Quality Control Commission, 1988, Water quality standards for interstate and intrastate streams in New Mexico: Santa Fe, New Mexico Water Quality Control Commission, WQCC 88-1, April 25, 1988,48 p.

1990, Water quality and water pollution control in New Mexico-1990: Santa Fe, New Mexico Water Quality Control Commission, EID/WPC90/1, $289 \mathrm{p}$.

Thelin, G.P., and Pike, R.J., 1990, Digital shaded relief map of the conterminous United States: Menlo Park, Calif., U.S. Geological Survey digital image processing, scale 1:3,500,000.

U.S. Environmental Protection Agency, 1988a, Maximum contaminant levels (subpart B of part 141, National revised drinking-water regulations): U.S. Code of Federal Regulations. Title 40, parts 100 to 149 , revised as of July 1,1988 , p. $530-533$.

1988b, Secondary maximum contaminant levels (section 143.3 of part 143 , National secondary drinking-water regulations): U.S. Code of Federal Regulations, Title 40, parts 100 to 149 , revised as of July 1, 1988, p. 608.

U.S. Geological Survey, 1976-90, Water resources data for New Mexico, water years 1975-89, v. 1: U.S. Geological Survey Water-Data Reports NM75-1 to NM-89-1 (published annually).
1985, National water summary 1984-Hydrologic events, selected water-quality trends, and ground-water resources: U.S. Geological Survey Water-Supply Paper 2275, $467 \mathrm{p}$.

1986, National water summary 1985-Hydrologic events and surfacewater resources: U.S. Geological Survey Water-Supply Paper 2300, $506 \mathrm{p}$.

1990, National water summary 1987 - Hydrologic events and water supply and use: U.S. Geological Survey Water-Supply Paper 2350, $553 \mathrm{p}$.

1991, National water summary 1988-89-Hydrologic events and floods and droughts: U.S. Geological Survey Water-Supply Paper 2375, $591 \mathrm{p}$.

University of New Mexico School of Law, 1989, Wilderness-Past, present. and future: Albuquerque Natural Resources Journal, v. 29, no. 1, 328 p.

Ward, J.R., and Harr, C.A., eds., 1990, Methods for collection and processing of surface-water and bed-material samples for physical and chemical analyses: U.S. Geological Survey Open-File Report 90-140, 71 p. 
Prepared by Kim Ong and Richard L. Lepp, U.S. Geological Survey; "Water-Quality Management" section prepared in consultation with Jim Piatt, New Mexico Environment Department

FOR ADDITIONAL INFORMATION: District Chief, U.S. Geological Survey, 4501 Indian School Rd. NE, Suite 200, Albuquerque, NM 871103929 


\section{NEW YORK Stream Water Quality}

New York's surface-water resources comprise more than 70,000 miles of streams and 3.5 million acres of lakes (U.S. Geological Survey, 1986, p. 347). Surface water is the source of supply for about two-thirds of New York State's 18 million residents. In 1985, surface-water withdrawals for public supply, industry, mining, thermoelectric power generation, and agriculture accounted for 7,950 million gallons per day or about 88 percent of the total offstream water use (U.S. Geological Survey, 1990, p. 388).

Land use (fig. $1 A$ ) and population density affect water quality, and both vary across New York as a consequence of physiography (fig. $1 B$ ) and the location of waterways. Most major population centers (fig. $1 C$ ) are located on major lakes and rivers and rely on surface water as their principal source of supply. All but 350,000 of New York City's 8 million people rely on surface water from southeastern New York, and as population continues to increase to the north of New York City, so will demands on water resources in southeastern New York. Surface water provides a major source of recreation in many parts of the State, especially in the Finger Lakes region and the Adirondack and Catskill Mountains.

\section{WATER-QUALITY MONITORING}

Water-quality data obtained from analyses of water samples collected at monitoring stations are stored in the U.S. Geological Survey's (USGS) National Water Information System and the U.S. Environmental Protection Agency's (EPA) national data base known as STORET. Water-quality and streamflow data are reported by water year-the 12 months from October 1 through September 30. A water year is identified by the calendar year in which it ends. For example, water year 1991 comprises October I, 1990, through September 30, 1991.

The data used in this summary of New York's stream water quality were obtained from water samples collected at 15 monitoring stations at which data collection is systematic and continuing (fig. 2). Analyses of water samples collected at 10 stations are the basis for the discussion and graphic summary (fig. 3) of stream water-quality conditions during water years 1987-89, and data from 14 stations are the basis for the discussion and graphic summary (fig. 4) of stream water-quality trends. Water samples were collected

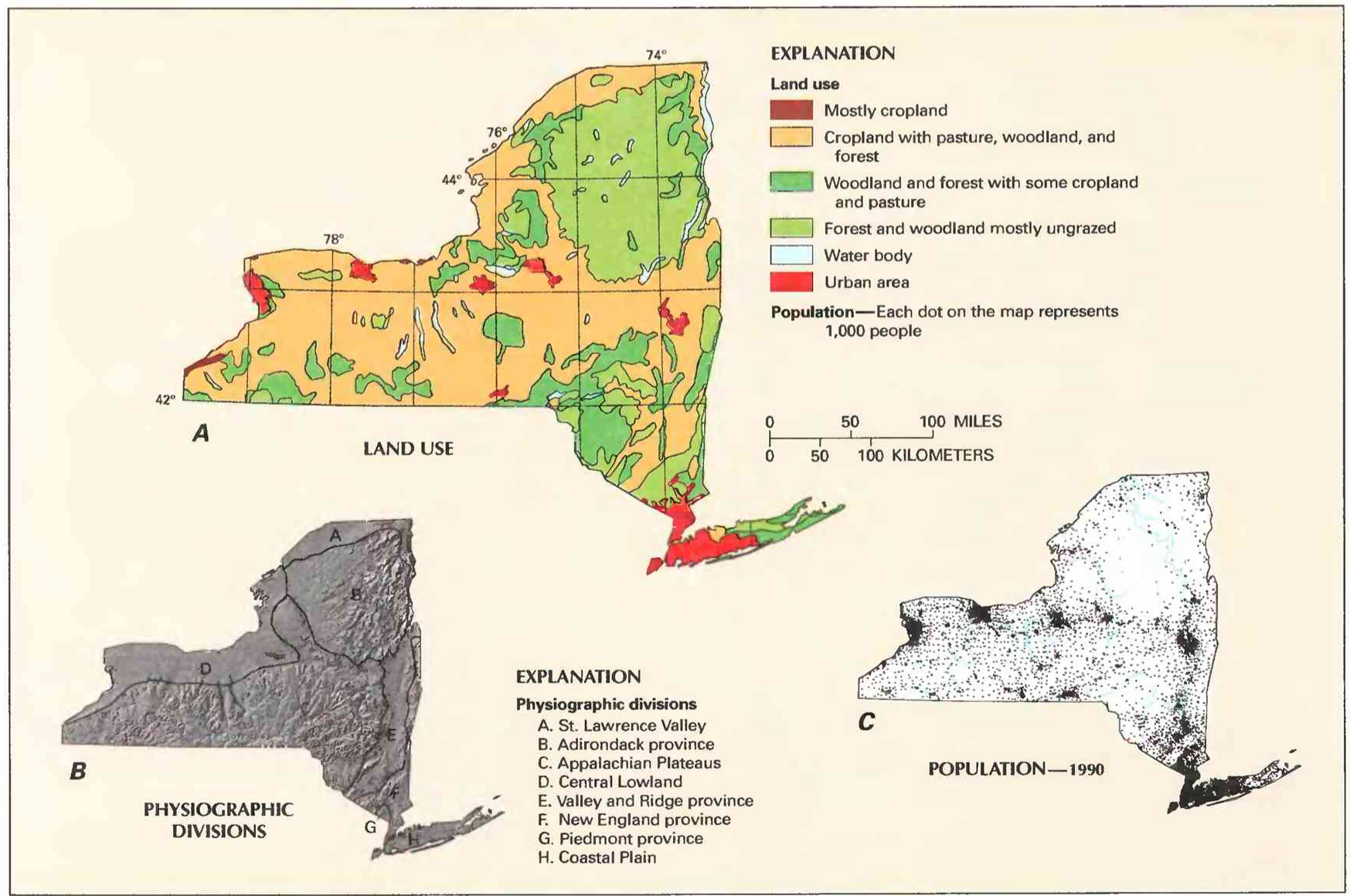

Figure 1. Land use, physiography, and population in New York. A, Major land uses. B, Physiographic divisions. $C$, Population distribution in 1990. (Sources: A, Major land uses modified from Anderson, 1967. B, Physiographic divisions from Fenneman, 1946; landforms from Thelin and Pike, 1990. C, Data from U.S. Bureau of the Census 1990 decennial census files.) 
and analyzed by using standard methods approved by the USGS (Britton and Greeson, 1987; Fishman and Friedman, 1989; Ward and Harr, 1990) or by using equivalent methods. If a method of sample collection or analysis changed over time, data from an analysis were included in the evaluation of recent stream water quality or of stream water-quality trends only if the change in method did not affect the comparability of the data.

\section{WATER-QUALITY CONDITIONS}

As of 1990, the water quality in 76 percent of New York's stream miles met State-established standards, which differ among streams (New York State Department of Environmental Conservation, 1986; 1990, p. 1). Two major problems in New York are acid rain and contaminated stream-bottom sediments. Acid rain has adversely affected surface water in several areas of the State. Streams are most sensitive to acid rain in their headwaters. The effects of acid rain have been documented in the Adirondack Mountains, where populations of fish and other biota in lakes and streams have declined or disappeared (Schindler and others, 1989). Similar effects have been observed in parts of the Catskill Mountains (P.S. Murdoch and C.R. Barnes, U.S. Geological Survey, written commun., April 1990).

Contaminated stream-bottom sediments are a serious problem in several parts of the State where toxic compounds from sediment have accumulated in fish, prompting fish-consumption advisories for more than 40 water bodies in 1990 (New York State Department of Environmental Conservation, 1990, table 20). Sediment contamination by polychlorinated biphenyls (PCB's) is the most common cause of such advisories.

The following discussion of stream water quality in New York is organized by river basin (fig. 3). Graphs in figure 3 summarize certain aspects of stream water quality in the basins for water years

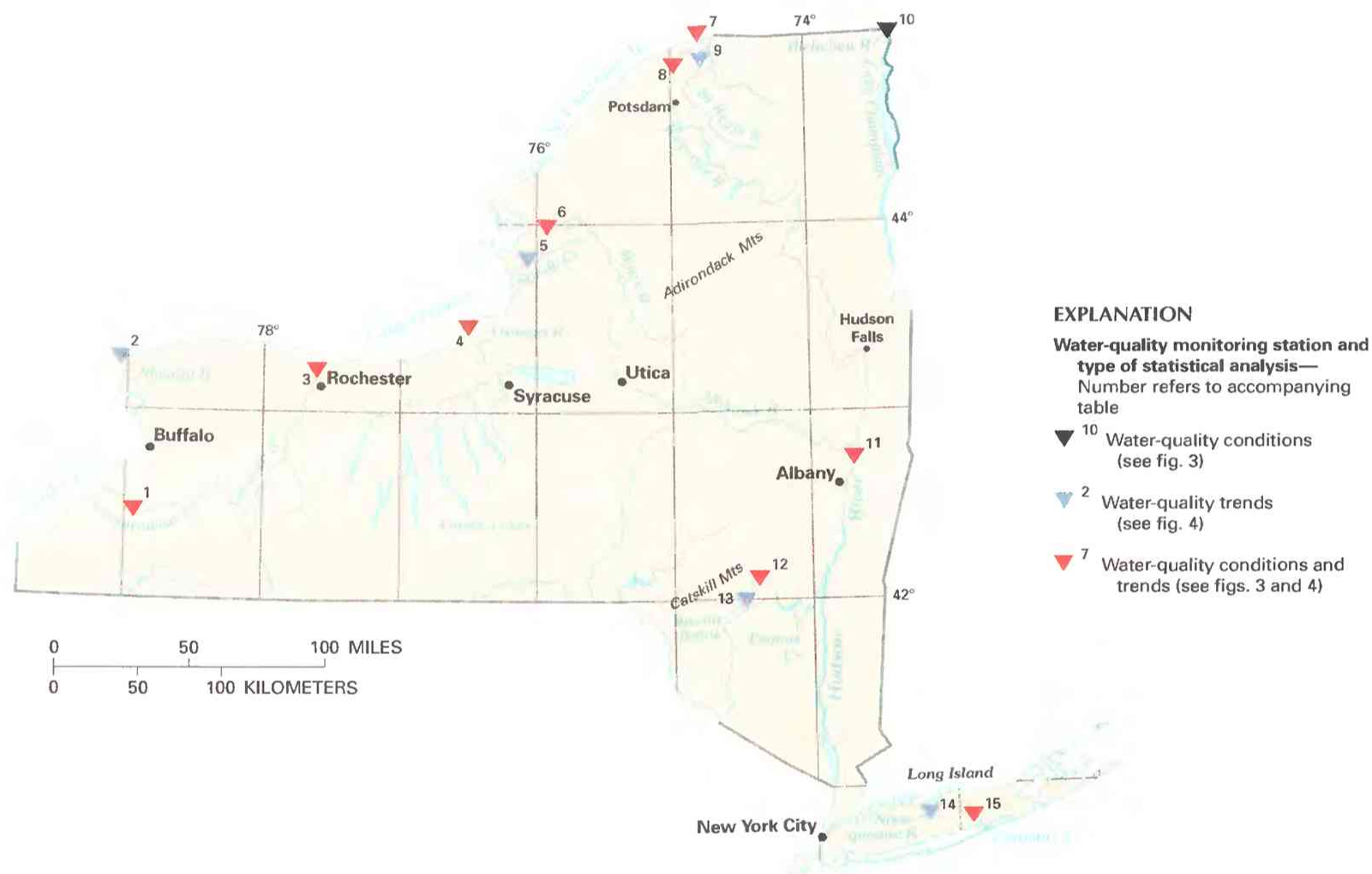

\begin{tabular}{|c|c|c|c|}
\hline $\begin{array}{l}\text { Site no. } \\
\text { on map }\end{array}$ & $\begin{array}{l}\text { USGS station } \\
\text { name and no. }\end{array}$ & $\begin{array}{l}\text { Drainage area } \\
\text { (square miles) }\end{array}$ & $\begin{array}{l}\text { Major land use } \\
\text { (see fig. 1) }\end{array}$ \\
\hline 1 & Cattaraugus Creek at Gowanda $(04213500)$ & 436 & Cropland with pasture, woodland, and forest. \\
\hline 2 & Niagara River at Fort Niagara $(04219640)$ & 265,000 & Cropland with pasture, woodland, and forest; urban areas. \\
\hline 3 & Genesee River at Rochester $(04232006)$ & 2,472 & Cropland with pasture, woodland, and forest. \\
\hline 4 & Oswego River at Oswego $(04249000)$ & 5,100 & Ditto. \\
\hline 5 & 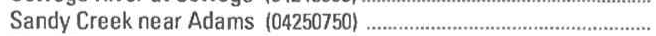 & 128 & Ditto. \\
\hline 6 & Black River at Watertown $(04260500)$ & 1,864 & Woodland and forest with some cropland and pasture. \\
\hline 7 & 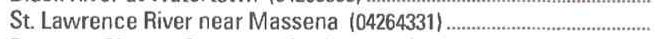 & 298,800 & Cropland with pasture, woodland, and forest. \\
\hline 8 & Raquette River at Raymondville $(04268000)$ & 1,125 & Mostly ungrazed forest and woodland. \\
\hline 9 & St. Regis River at Brasher Center (04269000) & 612 & Ditto. \\
\hline 10 & Richelieu River at Rouses Point $(04235000\}$ & 8,277 & Woodland and forest with some cropland and pasture. \\
\hline 11 & Hudson River at Green Island $(01358000)$ & $\begin{array}{c}8,090 \\
\text { (approximate) }\end{array}$ & Cropland with pasture, woodland, and forest; urban areas. \\
\hline 12 & Esopus Creek at Shandaken $(01362198)$ & 59.5 & Mostly ungrazed forest and woodland. \\
\hline 13 & Biscuit Brook at Frost Valley $(01434025)$ & 3.8 & Ditto. \\
\hline 14 & Nissequogue River near Smithtown $(1304000)$....... & $\begin{array}{c}27 \\
\text { (approximate) }\end{array}$ & Urban areas. \\
\hline 15 & Carmans River at Yaphank $(01305000)$ & $\begin{array}{c}71 \\
\text { (approximate) }\end{array}$ & Ditto. \\
\hline
\end{tabular}

Figure 2. Selected water-quality monitoring stations, type of statistical analysis, and geographic features in New York. (Sources Major land uses modified from Anderson, 1967; other data from U.S. Geological Survey files ! 
1987-89. The graphs show frequency distributions of data values that represent concentrations of selected constituents in stream water and measurements of selected physical properties of stream water. These constituents and properties are fecal coliform bacteria, alkalinity (as calcium carbonate), dissolved sulfate, dissolved chloride, dissolved solids, dissolved nitrite plus nitrate (as nitrogen), total phosphorus (as phosphorus), and suspended sediment. The data are reported in colonies per 100 milliliters $(\mathrm{col} / 100 \mathrm{~mL})$ and milligrams per liter $(\mathrm{mg} / \mathrm{L})$. Sources and environmental significance of each constituent and property are described in table 1 .

The USGS Office of Water Quality has determined that, for stream water from some parts of the United States, sulfate concentrations lower than $75 \mathrm{mg} / \mathrm{L}$ measured by the Survey's National Water Quality Laboratory between 1982 and 1989 have a median positive bias of $2 \mathrm{mg} / \mathrm{L}$ above the true value. Sulfate data for all monitoring stations except site 13 (fig. 2) might contain this bias.

Water quality at each monitoring station is the result of geological, chemical, biological, and hydrologic processes that occur over a large area. Water-quality problems that affect aquatic life or public health only locally are not fully represented in this summary.
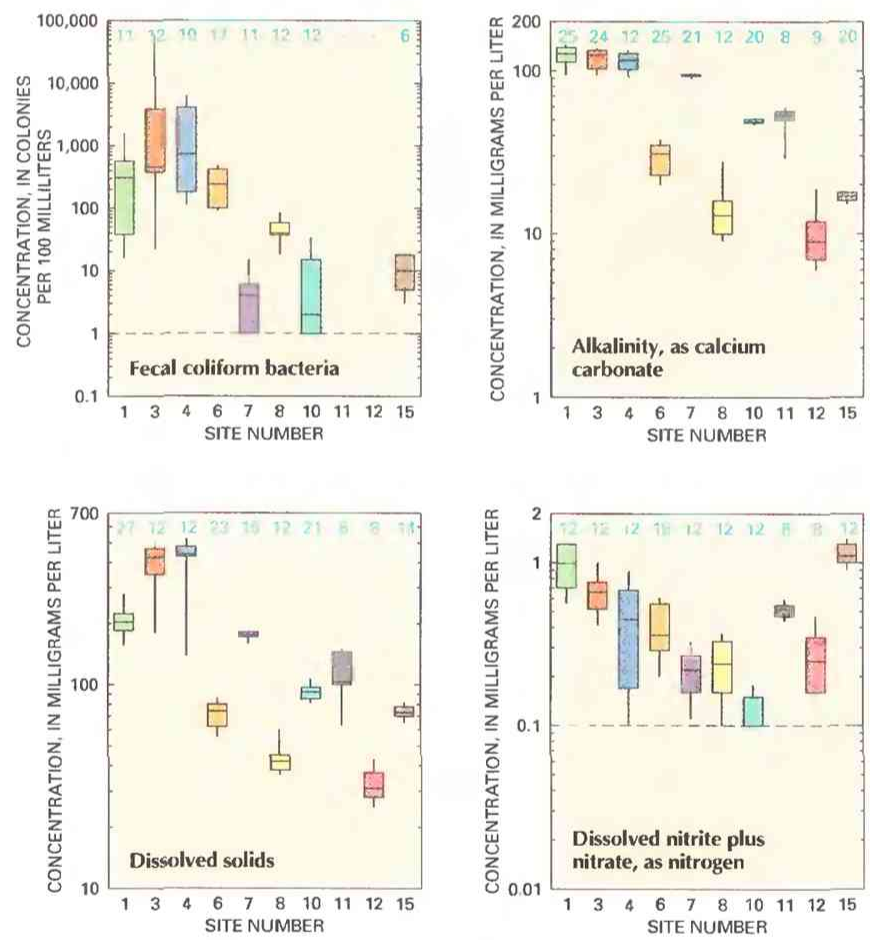

\section{EXPLANATION}

Water-quality conditions in selected
drainage basins
Number of analyses-Dash indicates
insufficient data
Percentile-Percentage of analyses
equal to or less than indicated
values
90th
-75th
-50th - Median
25th
10th
Reporting limit-Minimum reporting
limit for analytical method used.
Data below limit line not shown
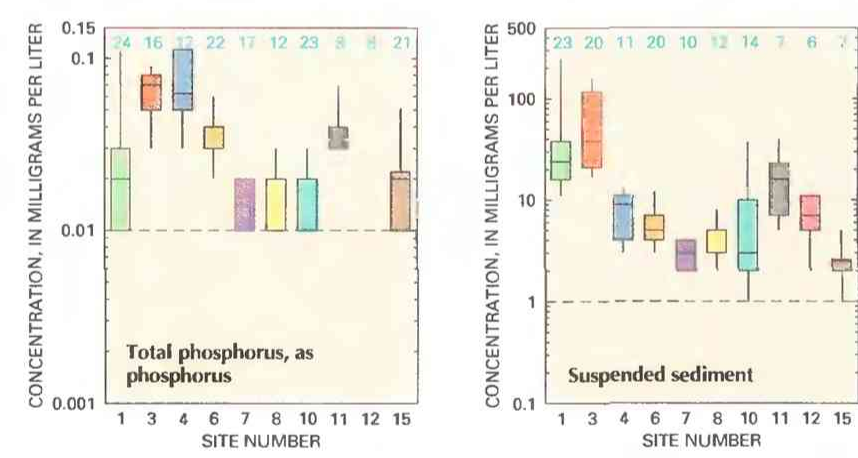

\section{CATTARAUGUS CREEK}

Cattaraugus Creek drains into the eastern end of Lake Erie. The basin is underlain by shale and siltstone, and land use is primarily woodland, forest, pasture, and cropland. Municipalities in the basin are small. Treated municipal wastewater discharges into the creek at several locations upstream from site 1 .

Water samples collected at site 1 had the highest median alkalinity $(127 \mathrm{mg} / \mathrm{L})$ for any of the 10 monitoring stations, and the median nitrite plus nitrate concentration $(0.99 \mathrm{mg} / \mathrm{L})$ was the second highest (fig. 3). The high nitrite plus nitrate concentrations indicate local water-quality degradation by agricultural runoff and municipal wastewater discharges.

\section{GENESEE RIVER}

The Genesee River originates in Pennsylvania and drains a large area of western New York before emptying into Lake Ontario. Upper parts of the drainage basin are underlain by shale and siltstone and the lower parts by shale, carbonate rock, gypsum, and halite.
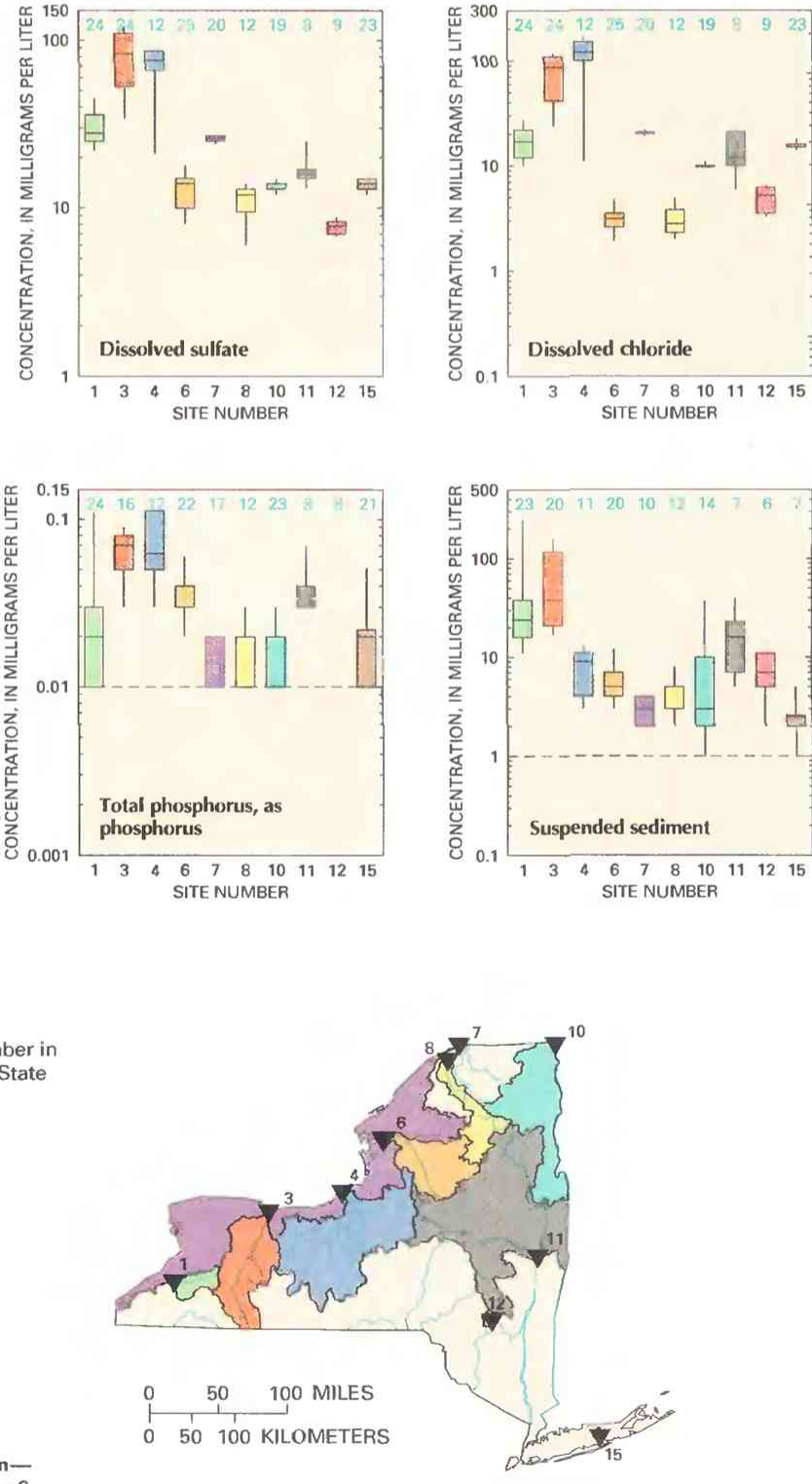

Figure 3. Water quality of selected streams in New York, water years 1987-89. (Source: Data from U.S. Geological Survey files.) 
Most of the basin is rural, and agriculture is the principal land use upstream from site 3 . Rochester, a major population and industrial center, is at the downstream end of the basin.

Water in the upper part of the Genesee River basin generally is suitable for most uses, but that in the Rochester area has been degraded by contaminants from point and nonpoint sources. However, major progress in water-pollution abatement in this area has been made in recent years (New York State Department of Environmental Conservation, 1990, p. A-26).

Fecal coliform bacteria in the Genesee River at site 3, possibly in part from combined storm- and municipal-sewer overflows (New York State Department of Environmental Conservation, 1990, p. A-26), had concentrations that were among the highest in the 10 streams (fig. 3). Water samples collected at site 3 also had among the highest median concentrations of alkalinity $(125 \mathrm{mg} / \mathrm{L})$, sulfate $(83 \mathrm{mg} / \mathrm{L})$, chloride $(87 \mathrm{mg} / \mathrm{L})$, and dissolved solids $(423 \mathrm{mg} / \mathrm{L})$. The alkalinity, sulfate, chloride, and dissolved solids are derived from soluble bedrock underlying the drainage basin. High concentrations of nitrite plus nitrate (median, $0.66 \mathrm{mg} / \mathrm{L}$ ), phosphorus (median, 0.07 $\mathrm{mg} / \mathrm{L}$ ), and suspended sediment (median, $38 \mathrm{mg} / \mathrm{L}$ ) at site 3 indicate water-quality degradation caused by agricultural runoff.

\section{OSWEGO RIVER}

The Oswego River drains a large area of north-central New York and empties into Lake Ontario. The bedrock of the drainage basin is similar to that of the Genesee River basin. The western part of the basin contains the Finger Lakes, and land use principally is a mixture of pasture, cropland, forest, and woodland. The eastern part of the basin contains less agriculture and more woodland. Syracuse is the largest population and industrial center in the basin and is upstream from site 4.

Water throughout most of the Oswego River basin is suitable for most uses. Local degradation has been noted in the Syracuse metropolitan area as a consequence of past and present municipal and industrial discharges and nonpoint sources of contaminants (New York State Department of Environmental Conservation, 1990, p. A-43).

The median concentrations of fecal coliform bacteria $(730$ $\mathrm{col} / 100 \mathrm{~mL})$, chloride $(120 \mathrm{mg} / \mathrm{L})$, and dissolved solids $(438 \mathrm{mg} / \mathrm{L})$ at site 4 were the highest for the 10 monitoring stations, and median concentrations of sulfate $(76 \mathrm{mg} / \mathrm{L})$ and phosphorus $(0.05 \mathrm{mg} / \mathrm{L})$ were the second highest (fig. 3). High concentrations of sulfate, chloride, and dissolved solids result primarily from the dissolution of bedrock. The high concentrations of bacteria and phosphorus are human induced.

\section{BLACK RIVER}

The Black River drains a large area of the Adirondack Mountains and empties into eastern Lake Ontario. Most of the drainage basin is underlain by insoluble metamorphic bedrock, but the lower parts contain limestone. The headwaters are heavily forested, and population in that part of the basin is sparse. The lower part of the basin, which has most of the population, contains pulp mills and agriculture. Acid precipitation threatens fish survival in upper parts of the basin (New York State Department of Environmental Conservation, 1990, p. A-51).

Low concentrations of sulfate (median, $14 \mathrm{mg} / \mathrm{L}$ ), chloride (median, $3.1 \mathrm{mg} / \mathrm{L}$ ), and dissolved solids (median, $74 \mathrm{mg} / \mathrm{L}$ ) at site 6 (fig. 3) reflect the insolubility of the bedrock. Higher than natural concentrations of fecal coliform bacteria (median, $240 \mathrm{col} / 100 \mathrm{~mL}$ ), nitrite plus nitrate (median, $0.36 \mathrm{mg} / \mathrm{L}$ ), and phosphorus (median, $0.30 \mathrm{mg} / \mathrm{L}$ ) indicate some water-quality degradation from agricultural runoff and wastewater discharge.

\section{ST. LAWRENCE RIVER}

The St. Lawrence River is the outflow from the Great Lakes and drains a vast section of the United States and Canada. The drain-

Table 1. Sources and environmental significance of selected water-quality constituents and properties

[Source: Compiled by the U.S. Geological Survey, Office of Water Quality]

Constituent or property Common sources Environmental significance

Fecal coliform bacteria .............. Sources include effluent from sewage-treatment plants and runoff from pastures, feedlots, and urban areas.

Alkalinity (property) ................. A measure of the quantity of acid-neutralizing substances; can be affected by geologic setting, industrial wastewater discharge, waste gases, and runoff from surface mining.

Sulfate

Occurs in some rocks; also in mine runoff, industrial wastewater discharge, and atmospheric deposition.

Chloride

Dissolved solids

Nitrite plus nitrate.

Phosphorus

Suspended sediment
Occurs in some rocks and ground-water discharge; also in road deicers, industrial and urban wastewater discharge, and atmospheric deposition.

A result of rock weathering; also in agricultural runoff and industrial discharge.

Nonpoint sources are agricultural and urban runoff; a major point source is wastewater discharge.

Occurs in some rocks and sediments; also in runoff and seepage from phosphate-rock mines, agricultural and urban runoff, and industrial and municipal wastewater discharge.

A result of rock erosion; also induced by disturbances of land cover due to fires, floods, and human activities such as mining, logging, construction, and agriculture.
Presence indicates contamination of water by wastes from humans and other warm-blooded animals.

Sufficiently alkaline water can be unsuitable for some agricultural and industrial uses.

Concentrations exceeding a natural, background level indicate contamination from human activity; in sufficient quantity, can cause water to be unsuitable for public supply; can harm aquatic organisms.

Concentrations exceeding a natural, background level can cause water to be unsuitable for public supply, agriculture, and industry; can harm aquatic organisms.

In sufficient quantity, can cause water to be unsuitable for public supply, agriculture, and industry; can harm aquatic organisms.

Plant nutrient that, in sufficient quantity, can cause algal blooms and excessive growth of higher aquatic plants in bodies of water; can cause water to be unsuitable for public supply.

Plant nutrient that, in sufficient quantity, can cause algal blooms and excessive growth of higher aquatic plants in bodies of water.

Can be detrimental to aquatic organisms; can fill reservoirs and impair recreational use of water. 
age basin supports a variety of land uses. Water quality of the St. Lawrence River at site 7 is suitable for most uses, and concentrations of most constituents were average to low for the State (fig. 3). Nonetheless, fishing advisories are currently (1990) in effect along several reaches (New York State Department of Environmental Conservation, 1990, p. A-60).

\section{RAQUETTE RIVER}

The Raquette River drains a large area of the Adirondack Mountains and empties into the St. Lawrence River. The drainage basin is underlain by sandstone and metamorphic bedrock. The upper part of the basin is heavily forested; the lower part supports some agriculture. Acid precipitation, a major water-quality problem in the basin, threatens fish survival in headwater streams and lakes (New York State Department of Environmental Conservation, 1990, p. A-59).

Water in the Raquette River basin is suitable for most uses. Values of alkalinity (median, $13 \mathrm{mg} / \mathrm{L}$ ), sulfate (median, $12 \mathrm{mg} / \mathrm{L}$ ), chloride (median, $2.8 \mathrm{mg} / \mathrm{L}$ ), and dissolved solids (median, 42 $\mathrm{mg} / \mathrm{L}$ ) at site 8 were among the lowest for the 10 monitoring stations (fig. 3) as a result of the insolubility of the bedrock. Concentrations of nitrite plus nitrate (median, $0.24 \mathrm{mg} / \mathrm{L}$ ) and phosphorus (median, less than $0.01 \mathrm{mg} / \mathrm{L}$ ) also were among the lowest.

\section{RICHELIEU RIVER}

The Richelieu River flows northward from Lake Champlain into Canada. Much of the drainage basin is underlain by metamorphic rocks, but smaller areas are underlain by clastic sedimentary and carbonate rocks. Land use in the basin is forest at higher altitudes and agriculture in the lowlands. Several small cities are located on Lake Champlain and discharge wastewater to the lake. Acid precipitation threatens fish survival in headwater lakes and streams, and agricultural runoff degrades water quality in some tributary streams (New York State Department of Environmental Conservation, 1990, p. A-69).

Water from the Richelieu River at site 10 is suitable for most uses. Nitrite plus nitrate concentrations (median, $0.10 \mathrm{mg} / \mathrm{L}$ ) were the lowest for the 10 monitoring stations, and concentrations of phosphorus (median, less than $0.10 \mathrm{mg} / \mathrm{L}$ ) and fecal coliform bacteria (median, $2 \mathrm{col} / 100 \mathrm{~mL}$ ) also were lower than for most other stations (fig. 3).

\section{HUDSON RIVER}

Upstream from site 11 north of Albany, the Hudson River System drains two basins of about equal size - those of the upper Hudson and Mohawk Rivers (fig. 2). The Hudson River originates in the Adirondack Mountains. The drainage basin is underlain primarily by metamorphic rocks and is little developed in all but the lower 50 miles upstream from site 11. The Mohawk River, which enters the Hudson River about 2 miles north of site 11, drains the more developed of the two basins and has population and industrial centers along its length. Bedrock underlying the basin is primarily sedimentary, and the principal land use is agriculture.

The Hudson River is nearly pristine north of about 50 miles upstream from site 11. Downstream from that point, wastewater discharges and runoff from communities along the river cause some contamination. The most serious water-quality problem is PCB contamination of sediment downstream from Hudson Falls (New York State Department of Environmental Conservation, 1990, p. A-77). The Mohawk River basin historically has been contaminated by agricultural runoff and industrial discharges, but conditions have improved considerably in recent years (New York State Department of Environmental Conservation, 1990, p. A-84).

\section{ESOPUS CREEK}

Site 12 on Esopus Creek is near the stream's headwaters in the Catskill Mountains. The drainage basin is small, underlain by sandstone, mostly forested, and contains several small communities. Esopus Creek empties into one of the large reservoirs that serve New York City.

The water quality in Esopus Creek at site 12 reflects the undeveloped nature of the basin and the insolubility of the bedrock. Median concentrations of alkalinity $(9.0 \mathrm{mg} / \mathrm{L})$, sulfate $(7.8 \mathrm{mg} / \mathrm{L})$, and dissolved solids $(31 \mathrm{mg} / \mathrm{L})$, were the lowest for the 10 monitoring stations (fig. 3). Median total phosphorus concentration (not shown) was also low (less than $0.01 \mathrm{mg} / \mathrm{L}$ ).

\section{CARMANS RIVER}

The Carmans River drains a small basin on Long Island. Direct surface runoff on Long Island is minimal; at least 90 percent of streamflow is contributed by a shallow aquifer (Ragone, Gurrera, and Flipse, 1976). Consequently, stream water quality is determined largely by shallow ground-water quality. The low concentrations of dissolved solids (median, $73 \mathrm{mg} / \mathrm{L}$ ) at site 15 (fig. 3) reflect the insoluble nature of the aquifer materials.

Land use in the basin is largely residential with some commercial use; population density is high. Use of septic tanks and lawn fertilizers has caused increased concentrations of nitrate in ground water (Flipse and others, 1984), and the Carmans River had the highest median nitrite plus nitrate concentration $(1.1 \mathrm{mg} / \mathrm{L})$ for the 10 monitoring stations.

\section{WATER-QUALITY TRENDS}

Trend analysis is a statistical procedure used to detect changes in stream water quality at a monitoring station over time. For this report, water-quality data from 14 monitoring stations (fig. 2) were analyzed for trends by using the seasonal Kendall test (Hirsch and others, 1982), a method used extensively by the USGS. The graph (shown below) of the dissolved-chloride concentration in the St. Lawrence River at site 7 illustrates the trend inferred from the concentration data and demonstrates the variation in water quality that is common in streams.

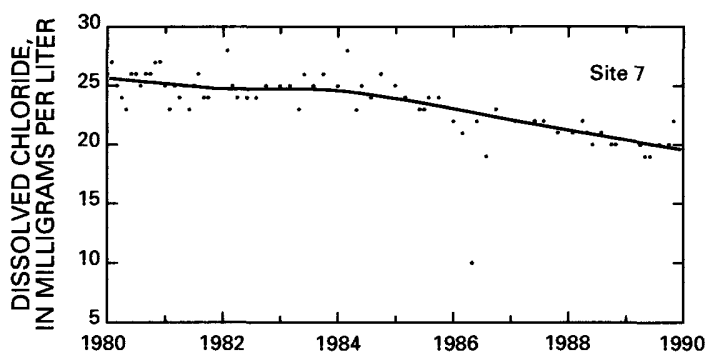

When possible, constituent-concentration data were adjusted for changes in streamflow to preclude identifying a trend in concentration that was caused only by a trend in streamflow. The data were not adjusted when (1) more than 10 percent of the samples had concentrations lower than the minimum reporting limit for the analytical method used or (2) streamflow was controlled substantially by human activities. When the concentration data could not be adjusted for streamflow, trends were determined directly from the concentration data. For more information on how the seasonal Kendall test was used in this report, see Lanfear and Alexander (1990).

Statewide trends in concentrations of selected constituents in stream water and in measurements of selected physical properties 
of stream water are shown on maps in figure 4. On each map, a trend is indicated at a monitoring station only if the data to be tested met criteria for the length of the period of record and the frequency of water-sample collection.

\section{FECAL COLIFORM BACTERIA}

Fecal coliform bacteria are used as indicators of fecal contamination from humans and other warm-blooded animals. Such contamination can introduce disease-causing viruses and bacteria into a stream. The decreasing fecal coliform bacteria concentration in the Raquette River at site 8 (fig. 4) occurred primarily in the early 1980's and probably was the result of improved sewage treatment by the town of Potsdam beginning in 1983 (Howard Lent, U.S. Geological Survey, oral commun., May 1990).

\section{ALKALINITY}

Alkalinity is a measure of the capacity of the substances dissolved in the water to neutralize acid. In most natural waters, alkalinity is produced primarily by bicarbonate and carbonate (Hem, 1985 , p. 106), which are ions formed when carbon dioxide or carbonate rock dissolves in water. A cause for the upward alkalinity trend in the St. Lawrence River at site 7 (fig. 4) is not known.

\section{DISSOLVED SULFATE}

The major natural sources of sulfate in streams are rock weathering, volcanoes, and biochemical processes (Hem, 1985, p. 113). Human activities such as mining, waste discharge, and fossil-fuel combustion also can be important sources. A shortened trend-analysis period was used for sulfate because data from analyses performed before water year 1982 are not comparable to data from subsequent years.

Biscuit Brook is a 3.8-square-mile, pristine, headwater basin in which water has low sulfate concentrations (median for 1987-89. $6.5 \mathrm{mg} / \mathrm{L}$ at site 13). More than one-half the sulfate in Biscuit Brook is derived from atmospheric sources (Murdoch, 1991); consequently, the downward trend in sulfate concentrations probably was caused by decreasing atmospheric deposition of sulfur. Smith and Alexander (1983) reported that sulfate concentrations decreased during 196580 in nearby Esopus Creek at site 12 and related the decrease to decreasing emissions of atmospheric sulfur dioxide.

\section{DISSOLVED CHLORIDE}

Chloride is present in all natural waters but usually in low concentrations (Hem, 1985, p. 118). Except in streams that receive ground-water discharge high in chloride, concentrations of more than a few milligrams per liter generally are the result of human activities (table 1).

Increasing chloride concentrations were common in streams throughout the Northeast during 1974-81 and were strongly associated with increased use of highway deicing salt and less strongly, but nonetheless significantly, associated with population increases (Smith and others, 1987). Use of highway deicing salt probably was the cause of most of the upward trends in chloride concentrations for 1980-89 (fig. 4). The increase in the Carmans River at site 15 on Long Island probably was related to deterioration of ground-water quality owing to increasing urbanization (U.S. Geological Survey, 1988, p. 390).

The decrease in chloride concentrations in the Oswego River at site 4 is attributable to the elimination of chloride-rich industrial discharges in 1986. A cause for the decreasing chloride concentrations in the Niagara River at site 2 and the St. Lawrence River at site 7 is not known.

\section{DISSOLVED SOLIDS}

Dissolved solids in stream water result primarily from rock weathering but also can be introduced as a byproduct of human activities (table 1). Concentrations generally are greatest in streams draining basins underlain by rocks and soils that contain easily dissolved minerals. The downward trend in dissolved-solids concentrations at site 4 on the Oswego River (fig. 4) was principally the result of decreases in dissolved sodium, calcium, and chloride since 1986, when a chemical plant near Syracuse that discharged waste into a tributary of the Oswego River was closed.

\section{DISSOLVED NITRITE PLUS NITRATE}

Nitrite and nitrate are oxidized forms of nitrogen that together constitute most of the dissolved nitrogen in well-aerated streams. Nitrite readily oxidizes to nitrate in natural waters; therefore, nitrate generally is by far the more abundant of the two (Hem, 1985, p. 124).

The increasing nitrite plus nitrate concentrations in Long Island streams - Nissequogue River at site 14 and Carmans River at site 15 (fig. 4) —resulted from deterioration of ground-water quality owing to increasing urbanization (U.S. Geological Survey, 1988, p. 390). These increases have been documented by Koch (1970) and Ragone, Lindner, and Oaksford (1976). A cause for the decreasing concentration in the Niagara River at site 2 is not known.

\section{TOTAL PHOSPHORUS}

The total phosphorus concentration of a water sample is a measure of the concentration of all forms of phosphorus present in the sample, dissolved and particulate. Human activities (table 1) can be important sources of phosphorus in streams.

The basins of the Genesee and Oswego Rivers are largely agricultural and have a history of water-quality degradation from agricultural runoff (New York State Department of Environmental Conservation, 1990, p. A-26 and A-43). The downward trends in phosphorus concentrations in those streams at sites 3 and 4 (fig. 4 ) probably were related to decreased phosphorus-fertilizer use in the basins and improvements in municipal wastewater treatment during the 1980's (New York State Department of Environmental Conservation, 1990). The decreasing phosphorus concentration in the St. Lawrence River at site 7 is related to a downward trend in phosphorus concentrations in Lake Ontario beginning in 1973 (George K. Hansen, New York State Department of Environmental Conservation, written commun., May 1990). Owing to the large area drained by tributaries to Lake Ontario, the downward trend cannot be ascribed to decreasing phosphorus inputs from specific sources.

\section{SUSPENDED SEDIMENT}

Suspended sediment is a product of erosion. The erosion can be either natural or the result of land-cover disturbances related to human activities (table 1). The absence of trends in suspendedsediment concentrations (fig. 4) indicates that any changes in agriculture, logging, mining, and construction have not appreciably affected sediment concentrations in the drainage basins.

\section{WATER-QUALITY MANAGEMENT}

Surface-water quality in New York State is regulated and managed by the Water Division of the New York State Department of Environmental Conservation (DEC). The DEC is responsible for administering the State's environmental quality and natural-resource programs, including those related to the control of water pollution and management of water resources. Major elements of the water program include establishment of water-quality standards, water- 
quality monitoring, issuance of State Pollutant Discharge Elimination System effluent-discharge permits, administration of municipal and industrial wastewater-treatment programs, management of nonpoint-pollution source spill-prevention and control programs, and granting of State revolving loans for construction of municipal waterpollution-control facilities.
The authority to adopt water-quality standards and classifications is stated in Title 3 of Article 17 (Water Pollution Control) of the State's Environmental Conservation Law and Title III of the Federal Clean Water Act. The State's classifications and standards are promulgated in Title 6, Chapter X, Parts 700-705 of the State's codes, rules, and regulations.

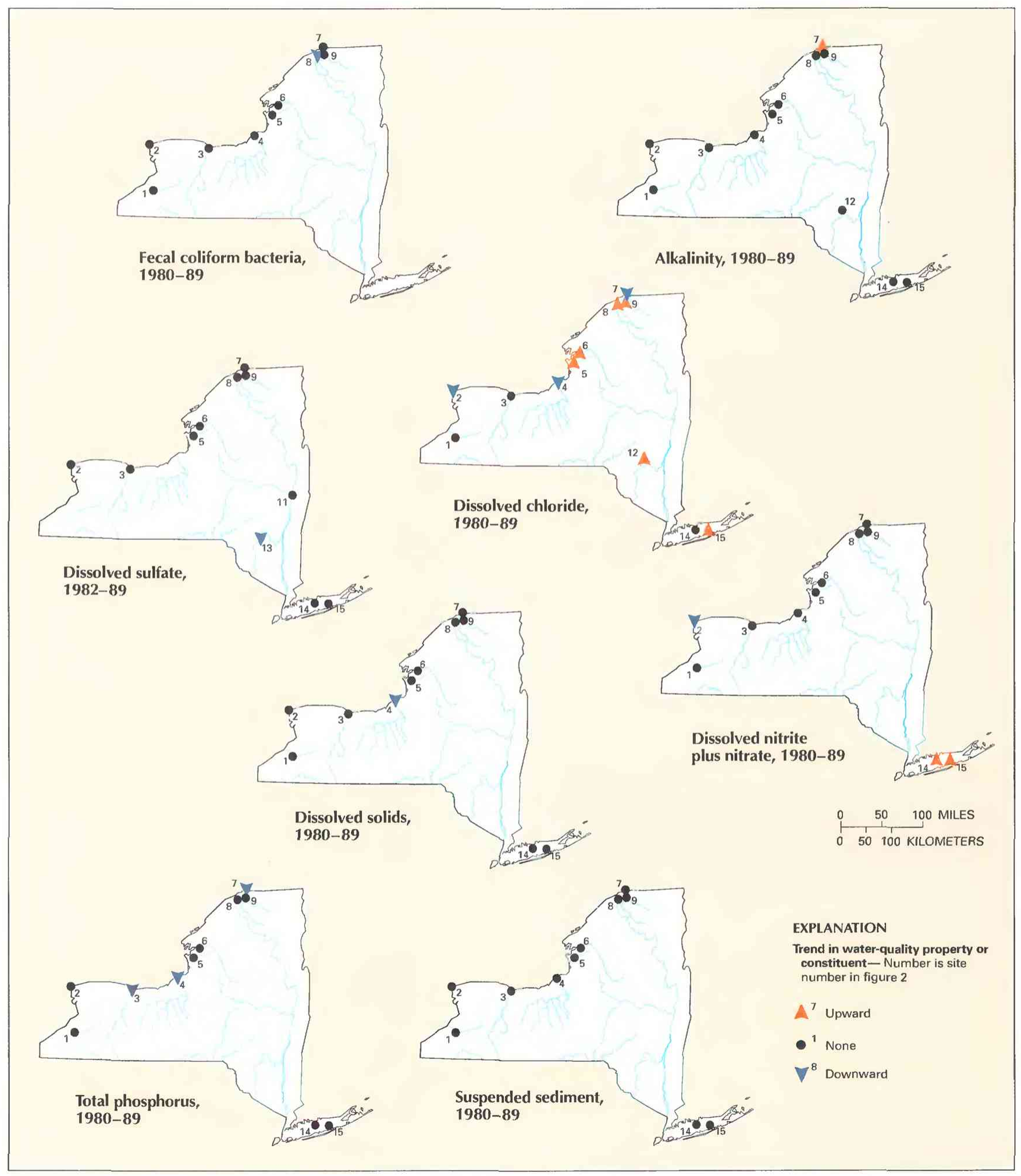

Figure 4. Trends in water quality of selected streams in New York, by water years. (Source: Data from U.S. Geological Survey files.) 
New York adopted a system of water-quality classifications and standards in 1949 and began an effort to classify some 70,000 miles of rivers and streams and 7,500 lakes and ponds. The State has continued to update and reclassify water segments for increased uses in response to water-quality improvements and public demand. The State's water-quality standards also have been revised and expanded over the years, and more than 250 substances are regulated by waterquality standards or guidance values, including most of the EPA's priority pollutants.

Current water-quality planning efforts by the DEC include the Long Island Sound and New York-New Jersey Harbor National Estuary Programs, the statewide nonpoint-source assessment and management plans, and Great Lakes management plans for the Niagara River and Lake Ontario. Also included are inland-lake water-quality assessment, toxics-management strategies, and the wellheadprotection program. The DEC is responsible for preparation of the biennial statewide water-quality assessment report to the EPA and the U.S. Congress (New York State Department of Environmental Conservation, 1990) required by section 305(b) of the Clean Water Act.

The DEC is guided in its development of water programs by the Water Management Advisory Committee, a group formed by its Water Division in 1980. The committee is composed of individuals representing public, academic, environmental, business, governmental, recreational, professional, and civic groups. The State participates in several international and interstate agencies involved with water management. They include the International Joint Commission, Great Lakes Commission, Ohio River Valley Water Sanitation Commission, Susquehanna River Basin Commission, Delaware River Basin Commission, Interstate Sanitation Commission, and the Association of State and Interstate Water Pollution Control Administrators.

\section{SELECTED REFERENCES}

Alexander, R.B., and Smith, R.A., 1990, County-level estimates of nitrogen and phosphorus fertilizer use in the United States, 1945 to 1985: U.S. Geological Survey Open-File Report 90-130, 12 p.

Anderson, J.R., 1967, Major land uses in the United States, in U.S. Geological Survey, 1970, National atlas of the United States of America: Washington, D.C., U.S. Geological Survey, p. 158-159.

Britton, L.J., and Greeson, P.E., eds., 1987, Methods for collection and analysis of aquatic biological and microbiological samples: U.S. Geological Survey Techniques of Water-Resources Investigations, book 5, chap. A4, $363 \mathrm{p}$.

Fenneman, N.M., 1946, Physical divisions of the United States: Washington, D.C., U.S. Geological Survey special map, scale 1:7,000,000.

Fishman, M.J., and Friedman, L.C., eds., 1989, Methods for the determination of inorganic substances in water and fluvial sediments: U.S. Geological Survey Techniques of Water-Resources Investigations, book 5, chap. A1, 545 p.

Flipse, W.J., Katz, B.G., Lindner, J.B., and Markel, Richard, 1984, Sources of nitrate in ground water in a sewered housing development, central Long Island, New York: Ground Water, v. 22, no. 4. p. 418-426.
Hem, J.D., 1985, Study and interpretation of the chemical characteristics of natural water: U.S. Geological Survey Water-Supply Paper 2254, 263 p.

Hirsch, R.M., Slack, J.R., and Smith, R.A., 1982, Techniques of trend analysis for monthly water quality data: Water Resources Research, v. 18, no. 1, p. 107-121.

Koch, Ellis, 1970, Effects of urbanization on the quality of selected streams in southern Nassau County, Long Island, New York, in Geological Survey Research, 1970: U.S. Geological Survey Professional Paper 700-C. p. 189-192.

Lanfear, K.J., and Alexander, R.B., 1990, Methodology to derive water-quality trends for use by the National Water Summary Program of the U.S. Geological Survey: U.S. Geological Survey Open-File Report 90-359, $10 \mathrm{p}$.

Murdoch, P.S., 1991, Chemical budgets and stream-chemistry dynamics of a headwater stream in the Catskill Mountains, New York, October 1, 1983 through September 30, 1985: U.S. Geological Survey Water-Resources Investigations Report 88-4035, $67 \mathrm{p}$.

New York State Department of Environmental Conservation, 1986, Water Quality Regulations, New York State Codes, Rules and Regulations Title 6, Chapter X, Parts 700-705: Albany, New York State Department of Environmental Conservation, Division of Water, variously paginated. 1990, New York State water quality 1990: Albany, New York State Department of Environmental Conservation, Bureau of Monitoring and Assessment, Division of Water, variously paginated.

Ragone, S.E., Gurrera, A.A., and Flipse, W.J., Jr., 1976, Change in methylene blue active substances and chloride levels in streams in Suffolk County, New York, 1961-1976: U.S. Geological Survey Open-File Report $76-600,94 \mathrm{p}$.

Ragone, S.E., Lindner, J.B., and Oaksford, E.T., 1976, Chemical constituents of water from streams in Nassau and Suffolk Counties, Long Island, New York: 1966 through 1975: U.S. Geological Survey Open-File Report. $107 \mathrm{p}$.

Schindler, D.W., Kaslan, S.E.M., and Hesslein, R.H., 1989, Biological impoverishment in lakes of the midwestern and northeastern United States from acid rain: Environmental Science and Technology, v. 23, no. 5, p. 573-580.

Smith, R.A., and Alexander, R.B., 1983, Evidence for acid-precipitation-induced trends in stream chemistry at hydrologic benchmark stations: U.S. Geological Survey Circular 910, 12 p.

Smith, R.A., Alexander, R.B., and Wolman, M.G., 1987, Analysis and interpretations of water-quality trends in major United States rivers, 1974 81: U.S. Geological Survey Water-Supply Paper 2307, 25 p.

Thelin, G.P., and Pike, R.J., 1990, Digital shaded relief map of the conterminous United States: Menlo Park, Calif., U.S. Geological Survey digital image processing, scale 1:3,500,000.

U.S. Geological Survey, 1986, National water summary 1985-Hydrologic events and surface-water resources: U.S. Geological Survey WaterSupply Paper 2300, $506 \mathrm{p}$.

1988, National water summary 1986-Hydrologic events and groundwater quality: U.S. Geological Survey Water-Survey Water-Supply Paper $2325,560 \mathrm{p}$.

1990, National water summary 1987-Hydrologic events and water supply and use: U.S. Geological Survey Water Supply Paper 2350, 553 p.

Ward, J.R., and Harr, C.A., eds., 1990, Methods for collection and processing of surface-water and bed-material samples for physical and chemical analyses: U.S. Geological Survey Open-File Report 90-140, 71 p.

Prepared by Robert J. Rogers, U.S. Geological Survey; “Water-Quality Management” section by George K. Hansen, New York State Department of Environmental Conservation

FOR ADDITIONAL INFORMATION: District Chief, U.S. Geological Survey, James T. Foley U.S. Courthouse, 445 Broadway, Albany, NY 12201 


\section{North Carolina Stream Water Quality}

Annual precipitation of about 50 inches provides North Carolina with an abundance of surface water. Surface-water sources supplied more than 2.6 million people or about 42 percent of the State's total population in 1985 (Solley and others, 1988). Offstream surface-water withdrawals in 1985 averaged 7,450 Mgal/d (million gallons per day) or 94.5 percent of the total water use. Most of this surface water was used for thermoelectric power generation $(6,400$ $\mathrm{Mgal} / \mathrm{d})$, public water supply (507 Mgal/d), and industrial and mining water supply (410 Mgal/d) (U.S. Geological Survey, 1990, p. 393-400). Surface water is the source for most municipal, industrial, and agricultural supplies in the western two-thirds of the State.

Although the State experienced drier than normal conditions in the middle to late 1980's (U.S. Geological Survey, 1991, p. 425434), in most areas of North Carolina the quality of surface water is a more immediate concern than the quantity. Most streams and rivers contain water that fully or at least partially supports uses designated by the State for purposes of water-quality monitoring and protection. These uses include water supply, propagation and maintenance of fish and aquatic life, and swimming and secondary recreational uses (North Carolina Department of Natural Resources and Community Development, 1988). In addition, North Carolina has designated five supplemental classifications: trout waters, swamp waters, nutrientsensitive waters, outstanding-resource waters, and high-quality waters. The relative importance assigned to each designated-use classification differs within and among river basins.

Land use can affect water quality substantially. Land use in North Carolina (fig. $1 A$ ) has been determined in part by the State's physiography. The eastern part of the Coastal Plain (fig. $1 B$ ) has low relief and little drainage; swamps and hardwood swampland forests dominate the landscape. Land use in the western part of the Coastal Plain is predominantly agriculture. The Piedmont province supports a mix of agriculture, woodland, pasture, and densely populated urban areas. The mountainous terrain of the Blue Ridge province is dominated by oak and hickory forests and woodlands; boreal conifers grow at altitudes of 4,500 feet and higher.

The population of the State in 1990 was 6.6 million, a 12.7 percent increase from 1980 (U.S. Bureau of the Census 1990 decennial census files). The most striking feature of the population distribution in North Carolina is a crescent-shaped series of urban areas that extends from Charlotte to Raleigh (fig. $1 C$ and 2). These areas are among the most rapidly growing in the State, along with coastal recreational and shipping communities such as Wilmington.

\section{WATER-QUALITY MONITORING}

Water-quality data obtained from analyses of water samples collected at monitoring stations are stored in the U.S. Geological Survey's (USGS) National Water Information System and the U.S. Environmental Protection Agency's (EPA) national data base known as STORET. Water-quality and streamflow data are reported by water year - the 12 months from October 1 through September 30. A water year is identified by the calendar year in which it ends. For example, water year 1991 comprises October 1, 1990, through September 30, 1991.

The data used in this summary of North Carolina's stream water quality were obtained from water samples collected at nine monitoring stations at which data collection is systematic and continuing (fig. 2). Analyses of water samples collected at all nine sta-
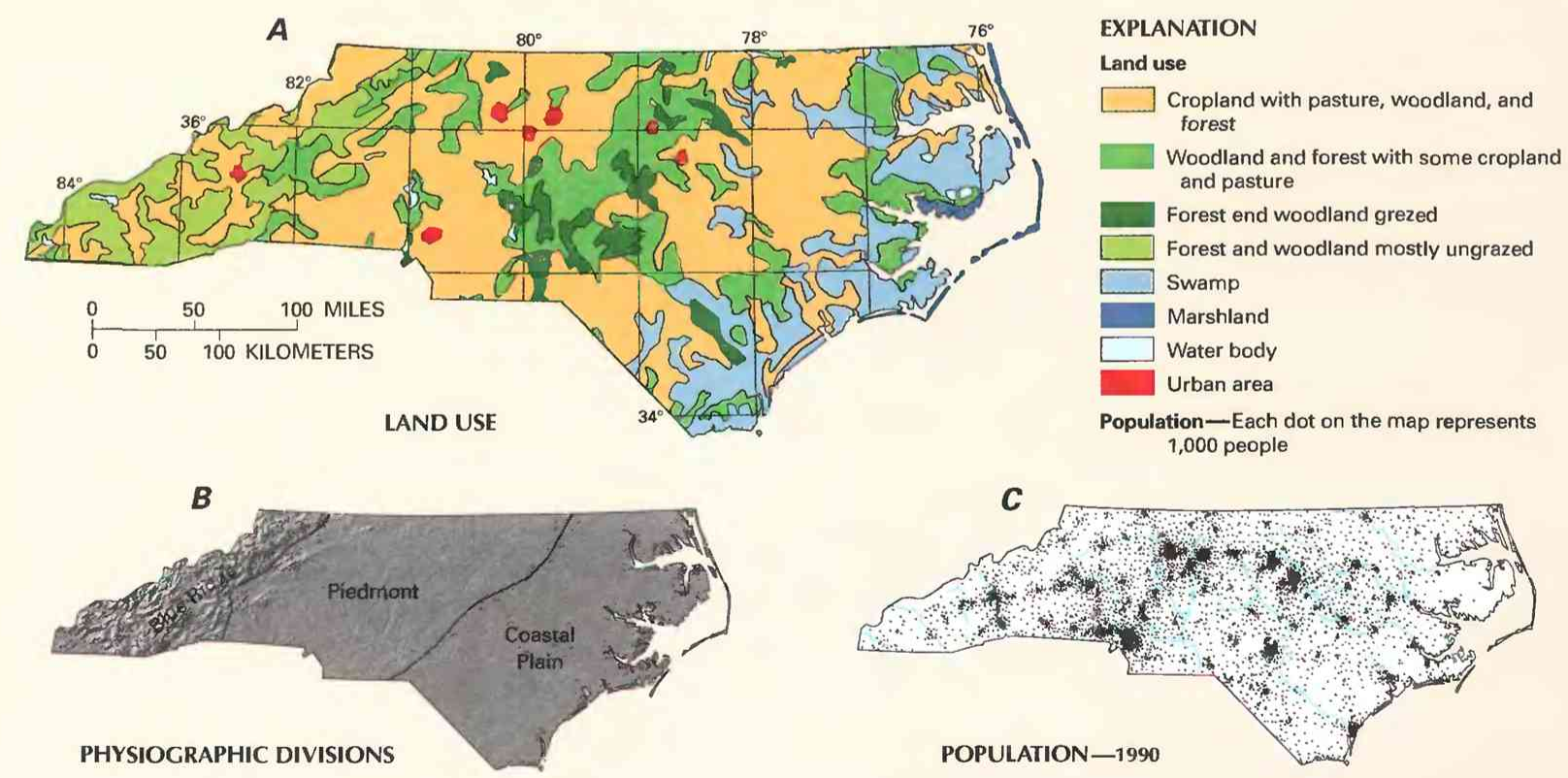

Figure 1. Land use, physiography, and population in North Carolina. A, Major land uses. B, Physiographic divisions. C, Population distribution in 1990. (Sources: A, Major land uses modified from Anderson, 1967. B, Physiographic divisions from Fenneman, 1946; landforms from Thelin and Pike, 1990. C, Data from U.S. Bureau of the Census 1990 decennial census files.) 
tions are the basis for the discussion and graphic summary (fig. 3) of stream water-quality conditions during water years 1987-89, and data from eight stations are the basis for the discussion and graphic summary (fig. 4) of stream water-quality trends. Water samples were collected and analyzed by using standard methods approved by the USGS (Britton and Greeson, 1987; Fishman and Friedman. 1989: Ward and Harr, 1990) or by using equivalent methods. If a method of sample collection or analysis changed over time, data from an analysis were included in the evaluation of recent stream water quality or of stream water-quality trends only if the change in method did not affect the comparability of the data.

\section{WATER-QUALITY CONDITIONS}

A $1988-89$ assessment showed that water in 6.0 percent of almost 37,000 miles of freshwater streams and rivers did not support designated uses (North Carolina Department of Environment, Health, and Natural Resources, 1990). River basins located in mountains typically had the greatest percentage of use-supporting streams, wheras the greatest percentage of use-impaired streams was in the northeastern Coastal Plain. In general, the major causes of impaired use were nonpoint sources such as agricultural runoff, urban runoff, and construction. Point sources accounted for only 3.0 percent of the total use impairment. At least 30 percent of the streams assessed as not supporting designated uses were reported to be affected by excessive sedimentation, and approximately 8 percent were reported to be degraded by low dissolved-oxygen concentrations. In more than 50 percent of the State's use-impaired streams, the exact cause of the degradation has not been determined.

The following discussion of stream water quality in North Carolina is organized by river basin (fig. 3). Where physiographic and land-use characteristics in different basins are similar, the discussion of those basins is combined. Graphs in figure 3 summarize certain aspects of stream water quality in the basins for water years 1987-89. The graphs show frequency distributions of data values that represent concentrations of selected stream-water constituents. These constituents are dissolved oxygen, dissolved solids, dissolved nitrite plus nitrate (as nitrogen), dissolved ammonia (as nitrogen), total ammonia plus organic nitrogen (as nitrogen), total phosphorus (as phosphorus), and suspended sediment. The data are reported in milligrams per liter $(\mathrm{mg} / \mathrm{L})$. Sources and environmental significance of each constituent are described in table 1.

Water quality at each monitoring station is the result of geological, chemical, biological, and hydrologic processes that occur over a large area. Water-quality problems that affect aquatic life or public health only locally are not fully represented in this summary.

\section{ROANOKE RIVER}

The Roanoke River basin extends from the foothills of the Blue Ridge physiographic province through the Piedmont province to the Coastal Plain, where the river empties into Albemarle Sound. The basin is extensively developed, and streamflow is regulated by six dams. Although land use in the basin upstream from site 1 is primarily forest (66 percent) and agriculture ( 24 percent), reservoirs, which store more than one-half the average annual flow, might have the greatest effect on water quality. The attenuating effect of the reservoirs is indicated by the small variances in dissolved-solids concentrations and by the low concentrations of nutrients and suspended sediment compared to those in the other Coastal Plain rivers (fig. 3). Removal of nutrients by either sedimentation or biological utilization in the reservoirs accounts for the low median concentrations of

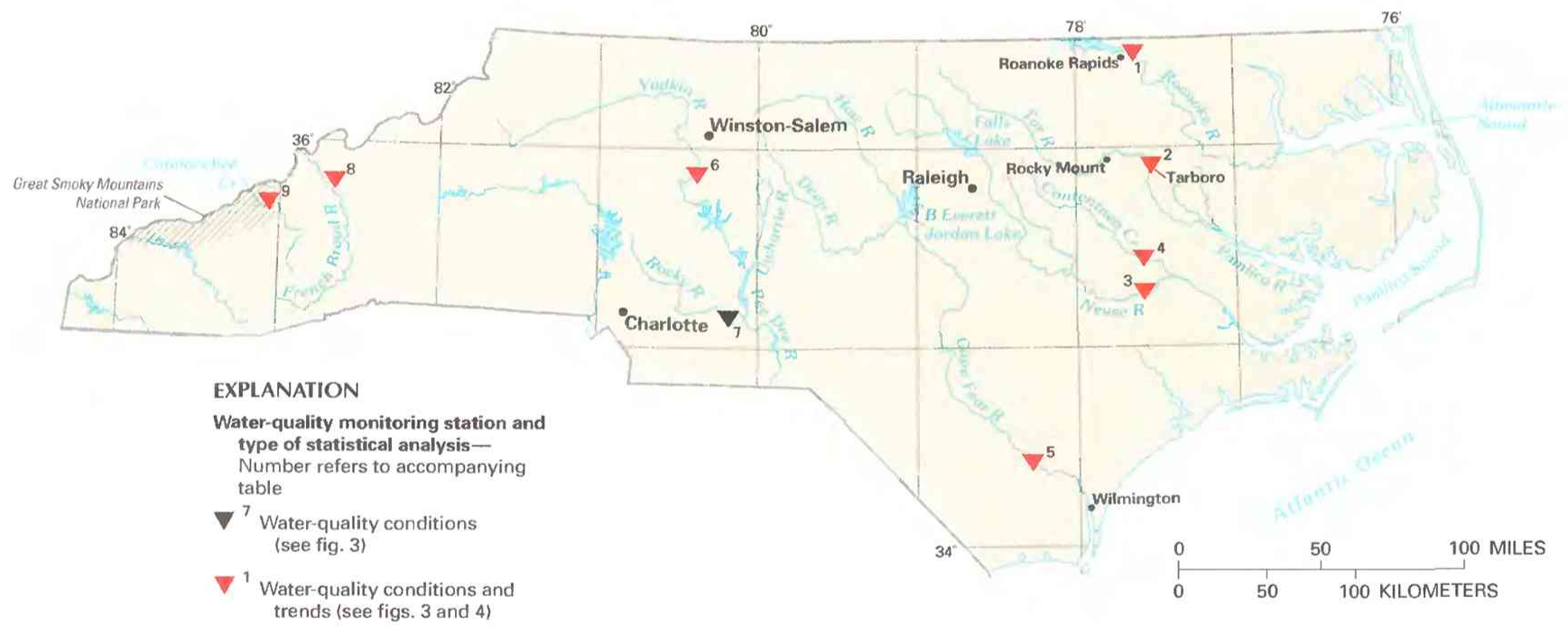

\begin{tabular}{|c|c|c|c|}
\hline $\begin{array}{l}\text { Site no, } \\
\text { on map }\end{array}$ & $\begin{array}{l}\text { USGS station } \\
\text { name and no. }\end{array}$ & $\begin{array}{l}\text { Drainage area } \\
\text { (square miles) }\end{array}$ & $\begin{array}{l}\text { Major land use } \\
\text { (see fig. 1) }\end{array}$ \\
\hline 1 & Roanoke River at Roanoke Rapids (02080500). & 8,384 & Woodland and forest with some cropland and pasture. \\
\hline 2 & 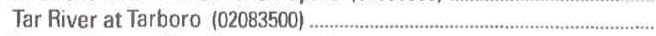 & 2,183 & Cropland with pasture, woodland, and forest. \\
\hline 3 & Neuse River at Kinston $(02089500)$ & 2,692 & Ditto. \\
\hline 4 & Contentnea Creek at Hookerton $(02091500)$ & 729 & Ditto. \\
\hline 5 & Cape Fear River at Lock 1, near Kelly (02105769) .......... & 5,255 & Woodland and forest with some cropland and pasture. \\
\hline 6 & Yadkin River at Yadkin College $(02116500)$ & 2,280 & Cropland with pasture, woodland, and forest. \\
\hline 7 & Rocky River near Norwood $(02126000)$ & 1,372 & Ditto. \\
\hline 8 & 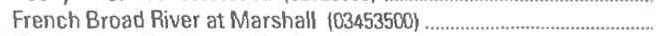 & 1,332 & Mostly ungrazed forest and woodland. \\
\hline 9 & Cataloochee Creek near Cataloochee $(03460000)$ & 49 & Ditto. \\
\hline
\end{tabular}

Figure 2. Selected water-quality monitoring stations, type of statistical analysis, and geographic features in North Carolina. ISources: Major land uses modified from Anderson, 1967; other data from U.S. Geological Survey files.) 
nitrite plus nitrate $(0.17 \mathrm{mg} / \mathrm{L})$, ammonia $(0.04 \mathrm{mg} / \mathrm{L})$, ammonia plus organic nitrogen $(0.40 \mathrm{mg} / \mathrm{L})$, and phosphorus $(0.02 \mathrm{mg} / \mathrm{L})$ (fig. 3 ). Downstream from site 1 at Roanoke Rapids, runoff from nonpoint sources, mainly agriculture, and discharges from point sources, such as a large paper mill, contribute to the nutrient enrichment of Albemarle Sound (North Carolina Department of Environment, Health, and Natural Resources, 1990).

\section{TAR, NEUSE, AND CAPE FEAR RIVERS}

The Tar, Neuse, and Cape Fear Rivers originate in the Piedmont province and flow southeastward through the Coastal Plain. Land use in these basins is similar-a mixture of agricultural areas and forest. Agricultural activity is greatest in the Coastal Plain part of the three basins. Each basin has urban areas that affect water quality; urban areas account for 2 percent of the Tar River basin, 6 percent of the Neuse River basin, and 14 percent of the Cape Fear River basin.

Possibly as a result of the similarities in physiography and land use, concentrations of several of the water-quality constituents summarized in figure 3 for site 2 on the Tar River, site 3 on the Neuse River, and site 5 on the Cape Fear River were similar. The Tar, Neuse, and upper Cape Fear Rivers are classified as nutrient-sensitive waters-waters having or subject to excessive growths of microscopic or macroscopic vegetation (North Carolina Department of Environment, Health, and Natural Resources, 1990).

The Tar River, which becomes the Pamlico River downstream from site 2, differs from the Neuse and Cape Fear Rivers in that it does not have significant flow regulation in the upper basin, and the water-quality monitoring station at site 2 is closer to upstream urban areas than are the stations in the other two basins. Median concentrations of most nutrients (nitrite plus nitrate, ammonia plus organic nitrogen, and phosphorus) at site 2, however, were lower than the medians in the Neuse and Cape Fear Rivers (fig. 3). Nonetheless, eutrophication is a problem in the lower parts of the Tar-Pamlico River basin; 33 percent of the algal blooms investigated by the State during 1988 and 1989 were in that basin (North Carolina Department of Environment, Health, and Natural Resources, 1990).

The Neuse River basin contains 14 percent of the State's population. Flow from the upper 30 percent of the basin is regulated; Falls Lake, first filled in 1983, is used for flood control, streamflow augmentation, water supply, and recreation. Water quality in the Neuse basin generally is acceptable, but eutrophication in Falls Lake and the lower Neuse River is a major concern. Median concentrations of
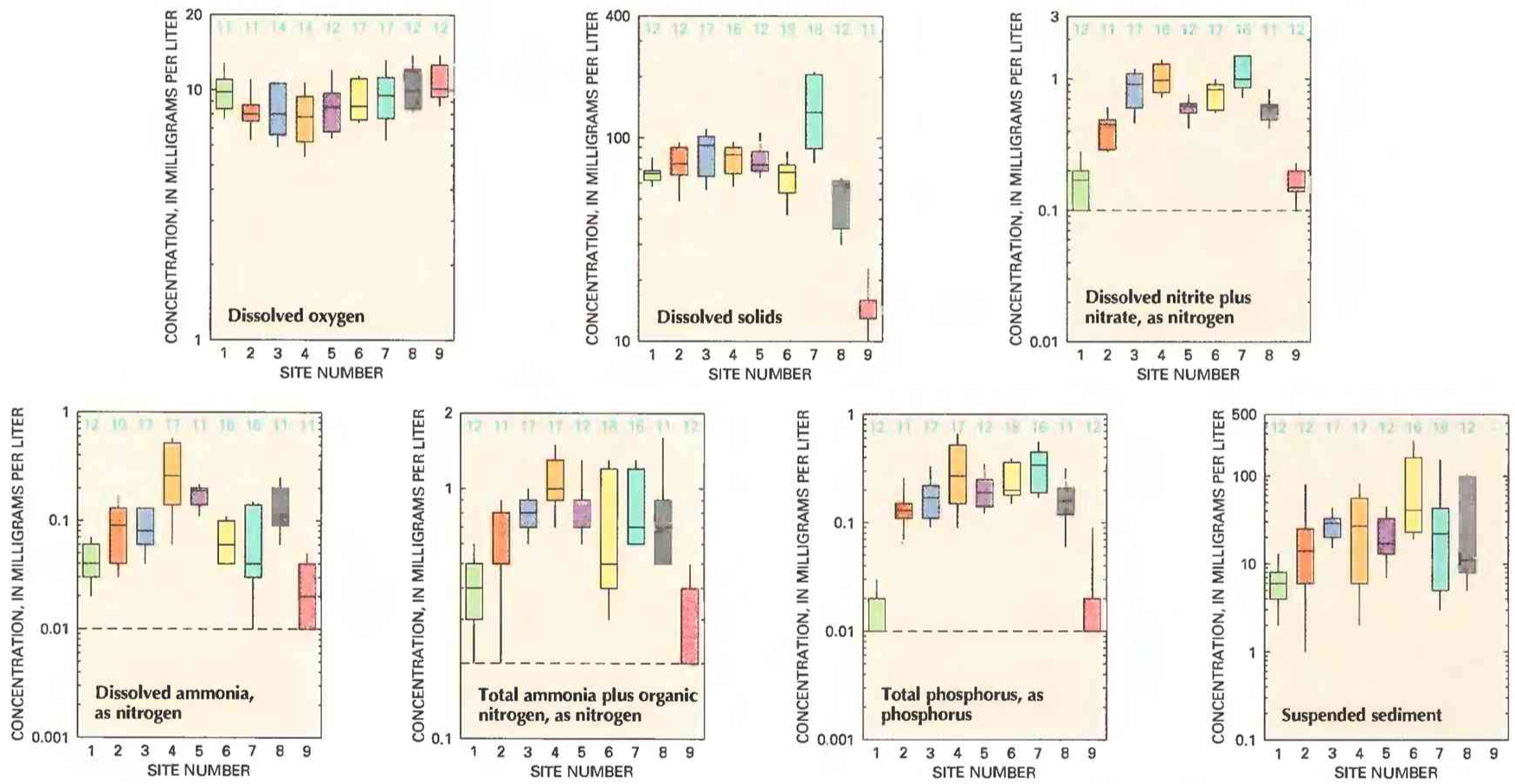

\section{EXPLANATION}

Water-quelity conditions in selected
drainage basins
Number of anelyses-Dash indicates
insufficient data
Percentile-Percentage of analyses
equal to or less than indicated values
-90th
-75th
- 50th-Median
- 25 th
- Reporth
limit for analytical method used.
Data below limit line not shown

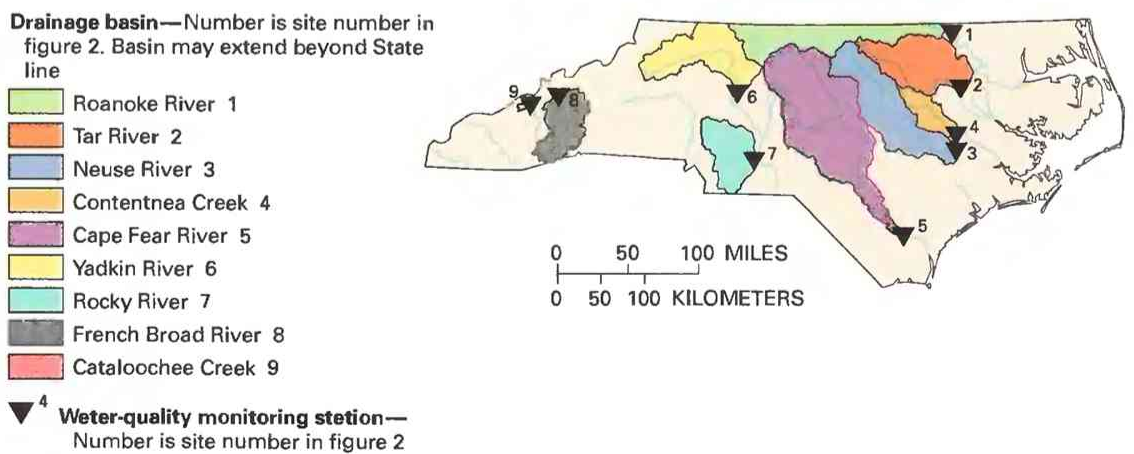

Figure 3. Water quality of selected streams in North Carolina, water years 1987-89. (Source: Data from U.S. Geological Survey files.) 
Table 1. Sources and environmental significance of selected water-quality constituents [Source: Compiled by the U.S. Geological Survey, Office of Water Quality]

\begin{tabular}{|c|c|c|}
\hline Constituent & Common sources & Environmental significance \\
\hline Dissolved oxygen ......................... & $\begin{array}{l}\text { Introduced from the atmosphere; also a byproduct of } \\
\text { aquatic plants. }\end{array}$ & $\begin{array}{l}\text { Necessary for aquatic life; deficiency can result from } \\
\text { assimilation of organic wastes or rapid growth } \\
\text { and decay of algae. }\end{array}$ \\
\hline 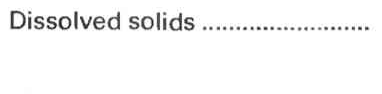 & $\begin{array}{l}\text { A result of rock weathering; also in agricultural runoff } \\
\text { and industrial discharge. }\end{array}$ & $\begin{array}{l}\text { In sufficient quantity, can cause water to be unsuitable } \\
\text { for public supply, agriculture, and industry; can } \\
\text { harm aquatic organisms. }\end{array}$ \\
\hline Nitrite plus nitrate ......................... & $\begin{array}{c}\text { Nonpoint sources are agricultural and urban runoff; } \\
\text { a major point source is wastewater discharge. }\end{array}$ & $\begin{array}{l}\text { Plant nutrient that, in sufficient quantity, can cause } \\
\text { algal blooms and excessive growth of higher } \\
\text { aquatic plants in bodies of water; can cause water } \\
\text { to be unsuitable for public supply. }\end{array}$ \\
\hline 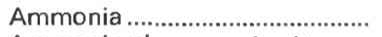 & 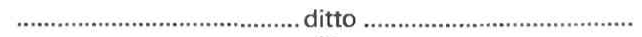 & Ditto. \\
\hline Ammonia plus organic nitrogen & . ditto & Ditto. \\
\hline 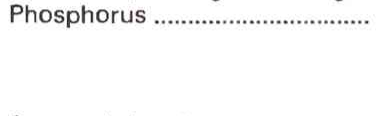 & $\begin{array}{l}\text { Occurs in some rocks and sediments; also in runoff } \\
\text { and seepage from phosphate-rock mines, agri- } \\
\text { cultural and urban runoff, and industrial and } \\
\text { municipal wastewater discharge. }\end{array}$ & $\begin{array}{l}\text { Plant nutrient that, in sufficient quantity, can cause } \\
\text { algal blooms and excessive growth of higher } \\
\text { aquatic plants in bodies of water. }\end{array}$ \\
\hline Suspended sediment .................. & $\begin{array}{l}\text { A result of rock erosion; also induced by disturbances } \\
\text { of land cover due to fires, floods, and human } \\
\text { activities such as mining, logging, construction, } \\
\text { and agriculture. }\end{array}$ & $\begin{array}{l}\text { Can be detrimental to aquatic organisms; can fill res- } \\
\text { ervoirs and impair recreational use of water. }\end{array}$ \\
\hline
\end{tabular}

nitrite plus nitrate $(0.91 \mathrm{mg} / \mathrm{L})$ and phosphorus $(0.17 \mathrm{mg} / \mathrm{L})$ (fig. 3 ) indicate the potential for high algal productivity at site 3 , although the dissolved-oxygen concentration during water years 1987-89 (median, $8.0 \mathrm{mg} / \mathrm{L}$ ) is not symptomatic of eutrophic conditions.

The Cape Fear River is the largest river entirely within North Carolina and is the only major stream in the State directly tributary to the Atlantic Ocean. About 27 percent of North Carolina's population and much of its industry are in the drainage basins of the Haw and Deep Rivers in the headwaters of the Cape Fear River. B. Everett Jordan Lake (completed in 1981) is a multipurpose reservoir that receives inflow from about one-third of the basin upstream from site 5. Nutrient loading from upstream municipal and industrial wastewater discharges might affect the water quality of the river and lake, and the State has classified the lake as nutrient sensitive (North Carolina Department of Natural Resources and Community Development, 1988). Median concentrations of nitrite plus nitrate $(0.62 \mathrm{mg} / \mathrm{L})$, ammonia $(0.19 \mathrm{mg} / \mathrm{L})$, and phosphorus $(0.19 \mathrm{mg} / \mathrm{L})$ at site 5 (fig. 3) indicate a high to very high potential for algal productivity (Crawford, 1985). Currently, however, algal blooms in the Cape Fear River are not as common as in the Tar and Neuse Rivers.

\section{CONTENTNEA CREEK}

Contentnea Creek is tributary to the Neuse River in the upper tidal reach of the Neuse. The stream has no significant upstream regulation and is the only basin discussed in this report that is mostly in the Coastal Plain. Agricultural land accounts for about 40 percent of the basin. The effect that agricultural activity has on the water quality of this low-gradient stream is indicated by the nutrient and suspended-sediment concentrations. Concentrations of nutrients generally were higher at site 4 than at the other monitoring stationsmedian concentrations were $0.98 \mathrm{mg} / \mathrm{L}$ for nitrite plus nitrate, 0.26 $\mathrm{mg} / \mathrm{L}$ for ammonia, $1.0 \mathrm{mg} / \mathrm{L}$ for ammonia plus organic nitrogen, and $0.27 \mathrm{mg} / \mathrm{L}$ for phosphorus. The relatively high median suspendedsediment concentration $(27 \mathrm{mg} / \mathrm{L})$ for site 4 exceeded that for all but two of the other stations.

\section{YADKIN AND ROCKY RIVERS}

The Yadkin River originates in the Blue Ridge province but is predominantly a Piedmont province river. The Yadkin River is one of the most regulated rivers in North Carolina, having seven reservoirs originally built for hydroelectric power generation but now serving as multipurpose impoundments. Downstream from its confluence with the Uwharrie River, the stream is known as the Pee Dee River. Rocky River, which lies entirely within the Piedmont province, is a major tributary to the Pee Dee River. Surface-water concerns in the Yadkin and Rocky River basins relate mainly to lake eutrophication and sedimentation (U.S. Geological Survey, 1986).

Site 6 on the Yadkin River is upstream from most flow regulation and 20 miles downstream from Winston-Salem, one of the larger urban areas of the State. Short-term changes in water quality at site 6, the result of storm runoff from the Winston-Salem metropolitan area, have been observed (Harned and Meyer, 1983). During water years $1987-89$, median nutrient concentrations at site 6 -nitrite plus nitrate, $0.83 \mathrm{mg} / \mathrm{L}$, and phosphorus, $0.20 \mathrm{mg} / \mathrm{L}$ (fig. 3)-were similar to those for other monitoring stations in areas where eutrophication is a concern. Soils in this region of the State are highly erodible, and increased agricultural and urban development upstream from site 6 resulted in a higher median suspended-sediment concentration $(41 \mathrm{mg} / \mathrm{L})$ than that for other stations.

The western part of the Rocky River basin drains the rapidly developing suburban area around Charlotte, the State's largest city. Also, most of the basin is in a geochemical zone of easily dissolved metamorphic rock (Simmons and Heath, 1982). Both these factors might have contributed to the high median concentration of dissolved solids for site 7 (134 mg/L) (fig. 3). The median phosphorus concentration $(0.34 \mathrm{mg} / \mathrm{L})$ also was the highest for any of the nine monitoring stations.

\section{FRENCH BROAD RIVER AND CATALOOCHEE CREEK}

The French Broad River and Cataloochee Creek basins are entirely within the Blue Ridge physiographic province and are tributary to the Tennessee River in Tennessee. Stream gradients are steep. and altitudes in each basin exceed 6,100 feet. On the basis of topography, geology, and climate, the basins are hydrologically similar; however, these basins have substantial differences in land use.

The French Broad River drains the most industrialized basin in North Carolina's mountain region. Although most of the basin is forested, discharges from numerous municipal and industrial point sources affect water quality substantially (Daniel and others, 1982). In addition, the recent completion of two interstate highways through the basin has resulted in increased tourism and recreational development. By comparison, the Cataloochee Creek basin is entirely within the Great Smoky Mountains National Park. Except for a onelane access road and a sparse network of hiking and equestrian trails, the basin is undeveloped. 
Water quality at site 8 on the French Broad River is comparable to that at stations in the Piedmont and Coastal Plain provinces. However, differences between water quality at site 8 and the background water quality for a Blue Ridge province stream, such as that at site 9 on Cataloochee Creek, are substantial. At site 9, median concentrations of all constituents but dissolved oxygen were lower than or equal to those at site 8 (fig. 3 ). Dissolved-oxygen concentrations characteristically are higher in streams that have less nutrient contamination. At site 9 , median concentrations of ammonia plus organic nitrogen $(0.2 \mathrm{mg} / \mathrm{L})$ and phosphorus $(0.01 \mathrm{mg} / \mathrm{L})$ were at or below the minimum reporting limit.

\section{WATER-QUALITY TRENDS}

Trend analysis is a statistical procedure used to detect changes in stream water quality at a monitoring station over time. For this report, water-quality data from eight monitoring stations (fig. 2) were analyzed for trends by using the seasonal Kendall test (Hirsch and others, 1982), a method used extensively by the USGS. The graph (shown below) of the dissolved-solids concentration in the Yadkin River at site 6 illustrates the trend inferred from the concentration data and demonstrates the variation in water quality that is common in streams.

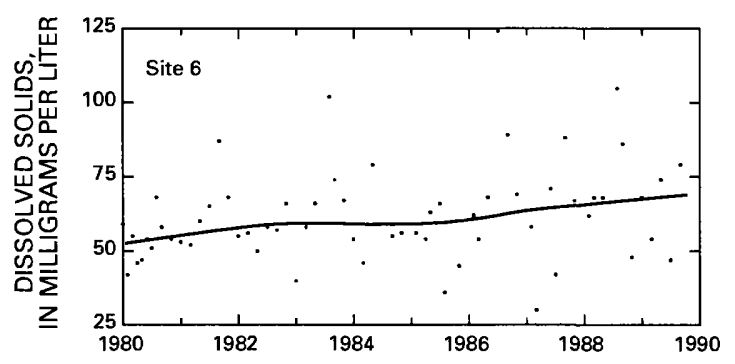

When possible, constituent-concentration data were adjusted for changes in streamflow to preclude identifying a trend in concentration that was caused only by a trend in streamflow. The data were not adjusted when (1) more than 10 percent of the samples had concentrations less than the minimum reporting limit for the analytical method used or (2) the streamflow was controlled substantially by human activities. When the concentration data could not be adjusted for streamflow, trends were determined directly from the concentration data.

Statewide trends in concentrations of selected stream-water constituents are shown on maps in figure 4. On each map, a trend is indicated at a monitoring station only if the data from that station were suitable for use in the trend analysis. For more information on the suitability criteria and on the trend-analysis procedure used for this report, see Lanfear and Alexander (1990).

\section{DISSOLVED OXYGEN}

The dissolved-oxygen concentration in a stream is controlled by several factors, including water temperature, air temperature and pressure, hydraulic characteristics, photosynthetic or respiratory activity of stream biota, and the quantity of organic pollution present. A trend in dissolved-oxygen concentrations commonly is either directly or indirectly the result of human activities. Generally, an upward trend in dissolved-oxygen concentrations indicates improving stream water-quality conditions and a downward trend indicates deteriorating conditions. Dissolved-oxygen concentrations had no trend at any of the eight monitoring stations for 1980-89 (fig. 4).

\section{DISSOLVED SOLIDS}

Dissolved solids in stream water result primarily from rock weathering but also can be introduced as a byproduct of human ac- tivities (table 1). Concentrations generally are greatest in streams draining basins underlain by rocks and soils that contain easily dissolved minerals.

Dissolved-solids concentrations had an upward trend in the Yadkin River at site 6, a downward trend in the French Broad River at site 8, and no trend at six stations for 1980-89 (fig. 4). These results represent improvement because 15- and 20-year trends (not shown in fig. 4) indicate an increasing concentration at four of five of the eastern North Carolina monitoring stations and no significant change at site 8 . Earlier studies have indicated increased dissolvedsolids concentrations in the Neuse (Harned, 1982), Yadkin (Harned and Meyer, 1983), and Cape Fear Rivers(Crawford, 1985). Daniel and others (1982) reported a decrease in dissolved-solids concentration in the mid-1970's for the French Broad River.

\section{DISSOLVED NITRITE PLUS NITRATE}

Nitrite and nitrate are oxidized forms of nitrogen that together constitute most of the dissolved nitrogen in well-aerated streams. Nitrite readily oxidizes to nitrate in natural waters; therefore, nitrate generally is by far the more abundant of the two (Hem, 1985, p. 124).

Increased fertilizer application and increased rates of cropland erosion in the Piedmont province, along with the growth of urban areas upstream, could account for the increase in nitrite plus nitrate concentration in the Yadkin River at site 6 (fig. 4). A cause for the downward trend in concentrations in Contentnea Creek at site 4 is not known.

Rates of atmospheric-nitrate deposition (from fossil-fuel combustion) generally exceed natural basin yield in North Carolina, and precipitation could account for nearly all nitrate in some major river basins. However, concentrations of nitrate in precipitation had no obvious trends during the 1980's (National Atmospheric Deposition Program, 1989).

Although no trends in nitrite plus nitrate concentrations were detected for water years 1980-89 at most monitoring stations. Crawford (1985) reported an increase in nitrite plus nitrate concentrations in the Cape Fear River at site 5. The increase was better correlated with population and employment trends than with agricultural activities. Also, Smith and others (1987) reported a 28-percent increase in nitrate load to Albemarle and Pamlico Sounds between 1974 and 1981.

\section{DISSOLVED AMMONIA}

Ammonia in stream water oxidizes to nitrate under aerobic conditions (Hem, 1985, p. 126). Although small quantities of ammonia can be present in unpolluted stream water, the presence of a high concentration commonly indicates contamination from agricultural or urban sources.

Upward trends in ammonia concentrations in the Tar River at site 2 and the Neuse River at site 3 (fig. 4) probably were related to nearby municipal wastewater discharge or livestock-related nonpoint sources. Site 2 on the Tar River at Tarboro is a short distance downstream from Rocky Mount, but no sizable municipalities are directly upstream from site 3 on the Neuse River. Although increasing, concentrations of ammonia in the Tar and Neuse Rivers were lower than those in Contentnea Creek (site 4) and in the Cape Fear River (site 5) (fig. 3), which drain similar but less urban basins.

\section{TOTAL AMMONIA PLUS ORGANIC NITROGEN}

Organic nitrogen oxidizes to nitrate in well-aerated stream water (Hem, 1985, p. 124). As is true of ammonia, a high organicnitrogen concentration can indicate contamination from nearby agricultural or urban sources.

Ammonia plus organic nitrogen concentrations had upward trends during 1980-89 in the Neuse River at site 3, Contentnea Creek 
at site 4, and the Cape Fear River at site 5 (fig. 4). These streams drain the most extensively farmed area of the State, and the trends could have been related to an increase in nitrogen-fertilizer use in North Carolina from 1980-85 (Alexander and Smith, 1990). Harned and Davenport (1990) reported an increase in ammonia plus organic nitrogen concentrations in Coastal Plain reaches of several streams tributary to Albemarle and Pamlico Sounds.

\section{TOTAL PHOSPHORUS}

The total-phosphorus concentration of a water sample is a measure of the concentration of all forms of phosphorus present in the sample, dissolved and particulate. Human activities (table 1) can be important sources of phosphorus in streams.

Phosphorus concentrations had no trend at any monitoring station during 1980-89 (fig. 4). On the basis of data collected at sites $1,2,3$, and 4, Smith and others (1987) noted no increase in phosphorus loading to Albemarle and Pamlico Sounds during 1974-81.
However, upward trends in phosphorus concentrations at several locations in the Pamlico River downstream from site 2 have been reported for 1945-88 by Harned and Davenport (1990). In 1988, a phosphate-detergent ban was implemented in North Carolina. Effects of that ban on phosphorus concentrations in these large streams were not yet evident in data collected near the end of the trend-analysis period.

\section{SUSPENDED SEDIMENT}

Suspended sediment is a product of erosion. The erosion can be either natural or the result of land-cover disturbances related to human activities (table 1). Suspended sediment is the water-quality constituent most frequently cited as the cause for nonsupport of designated uses in North Carolina streams.

Suspended-sediment concentrations had upward trends in the Cape Fear River at site 5 and in Cataloochee Creek at site 9 (fig. 4). The increase in the Cape Fear River might have been related to ex-

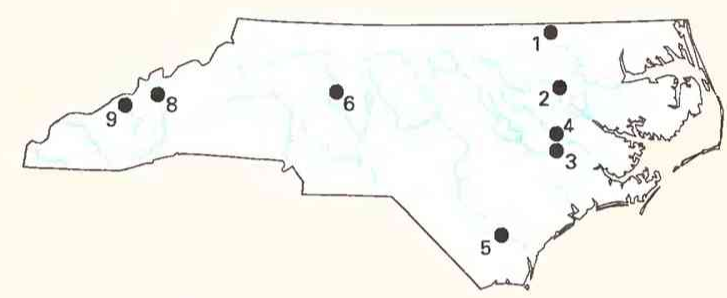

Dissolved oxygen, 1980-89

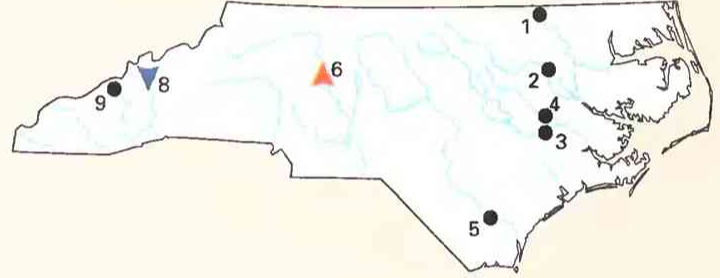

Dissolved solids, 1980-89

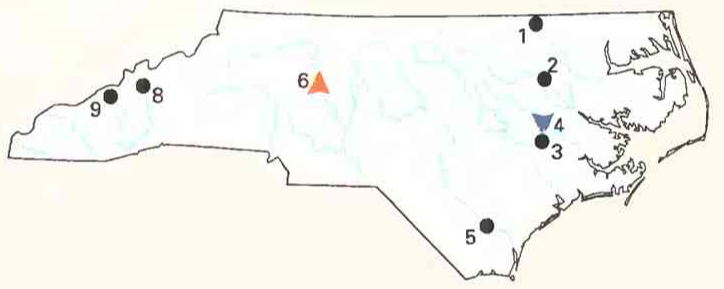

Dissolved nitrite plus nitrate, $1980-89$

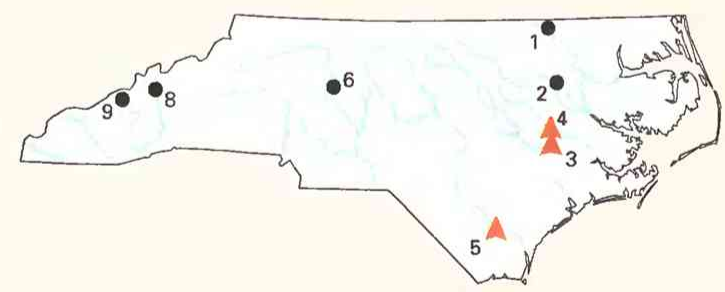

Total ammonia plus organic nitrogen, 1980-89

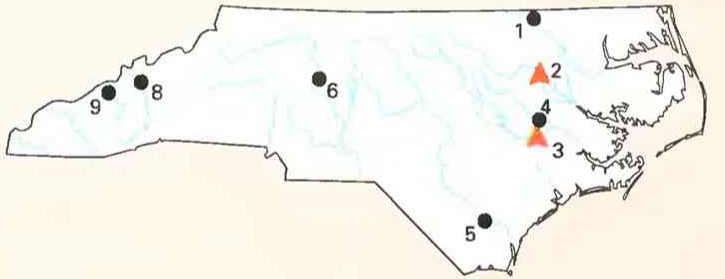

Dissolved ammonia, 1980-89

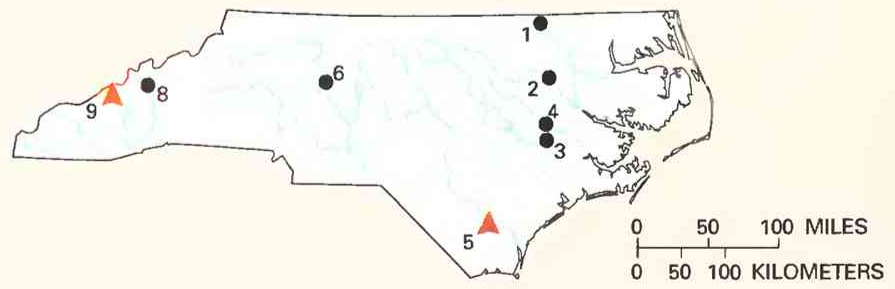

\section{EXPLANATION}

Trend in weter-quality constituent-

Number is site number in figure 2

$A^{3}$ Upward

- ${ }^{5}$ None

$\nabla^{8}$ Downward

Suspended sediment, 1980-89

Figure 4. Trends in water quality of selected streams in North Carolina, by water years. (Source: Data from U.S. Geological Survey files.) 
tensive agricultural or construction activities upstream. Although no probable cause is known, the increasing suspended-sediment concentration in Cataloochee Creek might have been due to erosion resulting from increased recreational activity, including hiking and horseback riding, in the small basin. Reservoirs can reduce sediment loads in rivers for several years following their construction (Williams and Wolman, 1984). However, the results of this trend analysis indicate that completion of Falls Lake and B. Everett Jordan Lake reservoirs on the Neuse and Cape Fear Rivers in the early 1980's had little effect on suspended-sediment concentrations at sites 3 and 5 , possibly because much of the sediment load at sites 3 and 5 enters the rivers downstream from the dams.

\section{WATER-QUALITY MANAGEMENT}

The North Carolina Department of Environment, Health, and Natural Resources administers programs and policies to protect and enhance the quality of the State's water resources. The Department's Division of Environmental Management (DEM) performs regulatory, enforcement, and monitoring functions intended to limit the detrimental effects of point and nonpoint sources on water quality.

Since 1972, North Carolina has had an extensive program to control point-source waste discharge through the National Pollutant Discharge Elimination System program. Standards for waste discharges are based on wasteload-allocation modeling by the DEM. By the end of $1989,3,310$ point sources discharged to surface water in North Carolina (North Carolina Department of Environment, Health, and Natural Resources, 1990). Of these, 123 were large municipal plants, 79 were large industrial discharge sites, and 47 were Federal facilities. The remainder were considered minor dischargers. Recent efforts by the State to decrease the effect of point sources include increased toxicity monitoring and expansion of controls on nutrient discharges in designated nutrient-sensitive waters.

The North Carolina Nonpoint-Source Management Program was developed by the DEM (North Carolina Department of Environment, Health, and Natural Resources, 1989). The program outlines a 4-year plan to implement controls on the following categories of nonpoint-source pollution: agriculture, urban runoff, construction, onsite wastewater disposal, solid-waste disposal, forestry, mining, and hydrologic modifications. Land-use control and technologybased management practices are the tools most widely selected for controlling nonpoint-source pollution and protecting designated uses of water bodies.

North Carolina has a water-quality monitoring network of about 340 stations. Numerous aquatic faunal and floral surveys, algal-bloom investigations, and bioassay tests are performed by the DEM. The DEM also conducts special studies to obtain specific information at locations not monitored by the existing network. Such studies are prompted by the need to assess the effects of particular discharges, investigate water-quality problems along a stream segment, or respond to short-term contamination problems such as spills. In addition to other publications, the DEM prepares a biennial waterquality-assessment report (North Carolina Department of Environment, Health, and Natural Resources, 1990) for the EPA and the U.S. Congress in compliance with section 305(b) of the Federal Clean Water Act.

Because of the large number of reservoirs in North Carolina and their effect on water quality, the U.S. Army Corps of Engineers and, to a lesser extent, the Tennessee Valley Authority also have significant water-quality management responsibilities. These Federal agencies conduct water-quality monitoring and assessment programs and consider water quality in their reservoir operations.

\section{SELECTED REFERENCES}

Alexander, R.B., and Smith R.A., 1990, County-level estimates of nitrogen and phosphorus fertilizer use, 1945 to 1985: U.S. Geological Survey Open-File Report 90-130, 12 p.
Anderson, J.R., 1967, Major land uses in the United States, in U.S. Geological Survey, 1970, National atlas of the United States of America: Washington, D.C., U.S. Geological Survey, p. 158-159.

Britton, L.J., and Greeson, P.E., eds., 1987, Methods for collection and analysis of aquatic biological and microbiological samples: U.S. Geological Survey Techniques of Water-Resources Investigations, book 5, chap. A4, $363 \mathrm{p}$.

Crawford, J.K., 1985, Water-quality characteristics for selected sites on the Cape Fear River, North Carolina, 1955-80-Variability, loads, and trends of selected constituents, in Water quality of North Carolina streams: U.S. Geological Survey Water-Supply Paper 2185-F, 44 p.

Daniel, C.C., III, Wilder, H.B., and Weiner, M.S., 1982, Water quality of the French Broad River, North Carolina-An analysis of data collected at Marshall, 1958-77, in Water quality of North Carolina streams: U.S. Geological Survey Water-Supply Paper 2185-C, 28 p.

Fenneman, N.M., 1946, Physical divisions of the United States: Washington, D.C., U.S. Geological Survey special map, scale 1:7,000,000.

Fishman, M.J., and Friedman, L.C., eds., 1989, Methods for the determination of inorganic substances in water and fluvial sediments: U.S. Geological Survey Techniques of Water-Resources Investigations, book 5 , chap. A1, 545 p.

Harned, D.A., 1982, Water quality of the Neuse River, North Carolina-Variability, pollution loads, and long-term trends, in Water quality of North Carolina streams: U.S. Geological Survey Water-Supply Paper 2185$\mathrm{D}, 44 \mathrm{p}$.

Harned, D.A., and Davenport, M.S., 1990, Water-quality trends and basin activities and characteristics for the Albemarle-Pamlico estuarine system, North Carolina and Virginia: U.S. Geological Survey Open-File Report 90-398, 164 p.

Harned, D.A., and Meyer, Dann, 1983, Water quality of the Yadkin-Pee Dee River system, North Carolina--Variability, pollution loads, and longterm trends, in Water quality of North Carolina Streams: U.S. Geological Survey Water-Supply Paper 2185-E, 71 p.

Hem, J.D., 1985, Study and interpretation of the chemical characteristics of natural water: U.S. Geological Survey Water-Supply Paper 2254, 263 p.

Hirsch, R.M., Slack, J.R., and Smith, R.A., 1982, Techniques of trend analysis for monthly water-quality data: Water Resources Research, v. 18, no. 1, p. 107-121.

Lanfear, K.J., and Alexander, R.B., 1990, Methodology to derive water-quality trends for use by the National Water Summary Program of the U.S. Geological Survey: U.S. Geological Survey Open-File Report 90-359, $10 \mathrm{p}$.

National Atmospheric Deposition Program, 1989, NADP/NTN annual data summary-Precipitation chemistry in the United States, 1988: Fort Collins, National Resource Ecology Laboratory, Colorado State University, $379 \mathrm{p}$.

North Carolina Department of Environment, Health, and Natural Resources, 1989, North Carolina nonpoint source management program: Raleigh, North Carolina Department of Environment, Health, and Natural Resources Report 89-02, 323 p.

1990 , Water quality progress in North Carolina, 1988-89, 305 (b) report: Raleigh, North Carolina Department of Environment, Health, and Natural Resources Report 90-07, 303 p.

North Carolina Department of Natural Resources and Community Development, 1988, Water quality progress in North Carolina, 1986-87, 305(b) report: Raleigh, North Carolina Department of Natural Resources and Community Development Report no. 88-02, 312 p.

Simmons, C.E., and Heath, R.C., 1982, Water quality of North Carolina streams - Water-quality characteristics of streams in forested and rural areas of North Carolina: U.S. Geological Survey Water-Supply Paper 2185-B, 33 p.

Smith, R.A., Alexander, R.B., and Wolman, M.G., 1987, Water-quality trends in the Nation's rivers: Science, v. 235, p. 1,607-1,615.

Solley, W.B., Merk, C.F., and Pierce, R.R., 1988, Estimated use of water in the United States in 1985: U.S. Geological Survey Circular 1004, 82 p.

Thelin, G.P., and Pike, R.J., 1990, Digital shaded relief map of the counterminous United States: Menlo Park, Calif., U.S. Geological Survey digital image processing, scale 1:3,500,000.

U.S. Geological Survey, 1986, National water summary 1985-Hydrologic events and surface-water resources: U.S. Geological Survey Water-Supply Paper 2300, 506 p.

1990, National water summary 1987-Hydrologic events and water supply and use: U.S. Geological Survey Water-Supply Paper 2350, $553 \mathrm{p}$. 
1991, National water summary 1988-89-Hydrologic events and floods and droughts: U.S. Geological Survey Water-Supply Paper 2375 , $591 \mathrm{p}$.

Ward, J.R., and Harr, C.A., eds., 1990, Methods for collection and processing of surface-water and bed-material samples for physical and chemical analyses: U.S. Geological Survey Open-File Report 90-140, 71 p.
Williams, G.P., and Wolman, M.G., 1984, Downstream effects of dams on alluvial rivers: U.S. Geological Survey Professional Paper 1286, 83 p.

Prepared by Charles R. Barnes and Marjorie S. Davenport

FOR ADDITIONAL INFORMATION: District Chief, U.S. Geological Survey, 3916 Sunset Ridge Road, Raleigh, NC 27607 


\section{NoRTH DAKOTA Stream Water Quality}

Surface water is an important resource in North Dakota. In 1985, surface-water sources supplied 1,040 Mgal/d (million gallons per day) or 89.1 percent of the freshwater withdrawn in the State. Of the surface-water withdrawals, 85.9 percent was used for thermoelectric power generation, 9.5 percent was used for agriculture, 3.8 percent was used for public supply, and 0.7 percent was used for industry and mining. Surface water accounted for $39.1 \mathrm{Mgal} / \mathrm{d}$ or 56.7 percent of the water used for public supply in 1985 (U.S. Geological Survey, 1990, p. 405). The remainder came from ground water. The three largest cities in North Dakota (Fargo, Grand Forks, and Bismarck) obtain their supplies solely from surface-water sources (U.S. Geological Survey, 1986, p. 361). Because many people in the State rely upon surface water for their drinking supply, it is important that surface-water quality be maintained at its present level.

Surface-water quality can be substantially affected by land use. Agriculture is the predominant land use in North Dakota (fig. $1 A$ ). Differences in types of agricultural activities correspond to differing physiography. North Dakota has two major physiographic provinces, the Central Lowland in the east and the Great Plains in the west (fig. 1B). The Central Lowland consists mainly of rolling, glaciated plains. More than 80 percent of the area is gently sloping, and local relief is less than 100 feet (Fenneman, 1931). Large areas have poorly

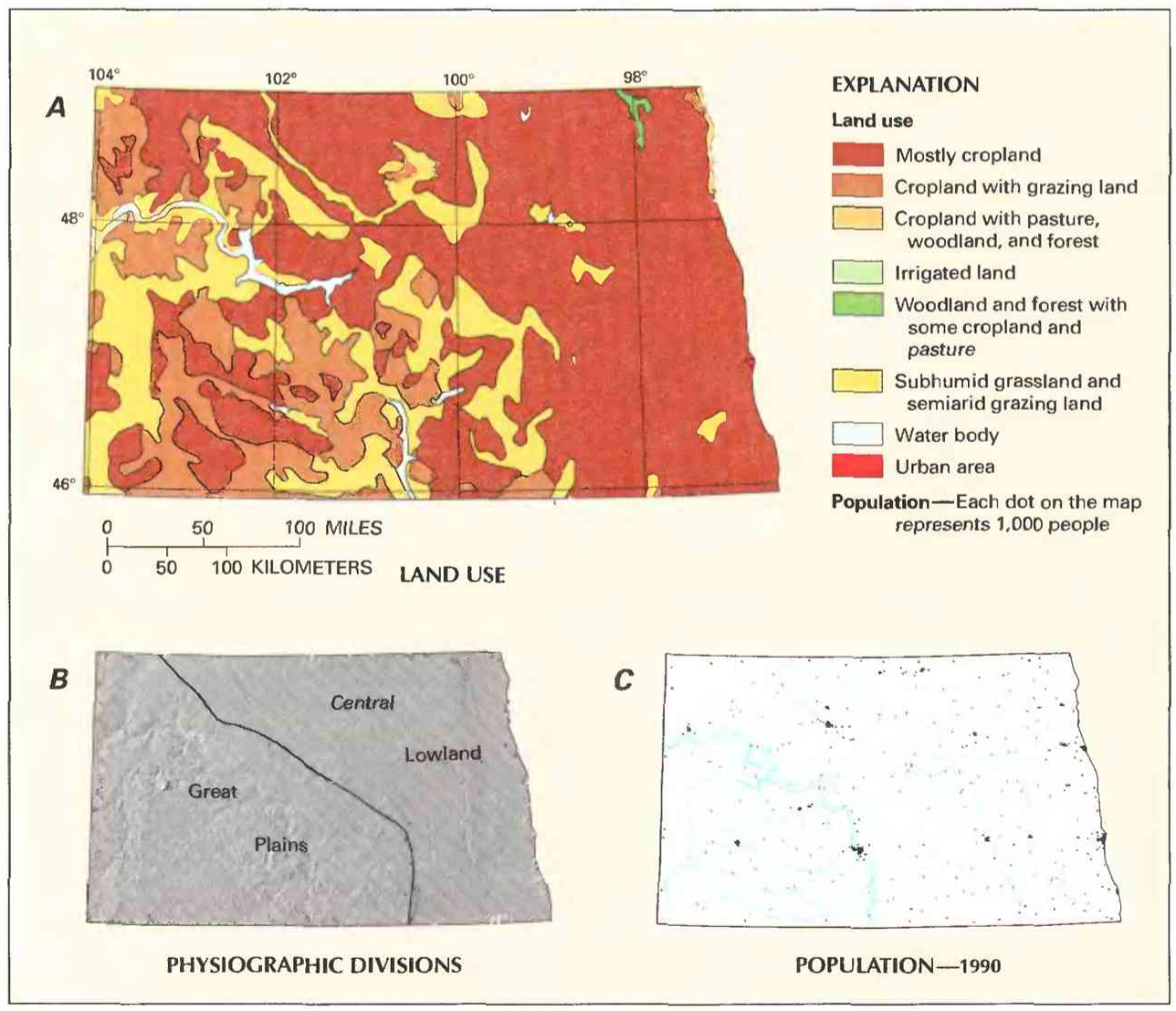

Figure 1. Land use, physiography, and population in North Dakota. A, Major land uses. B, Physiographic divisions. C. Population distribution in 1990. (Sources: A. Major land uses modified from Anderson, 1967. B, Physiographic divisions from Fenneman, 1946; landforms from Thelin and Pike, 1990. C. Data from U.S. Bureau of the Census 1990 decennial census files.) defined drainage patterns and do not contribute to surface runoff received by streams and rivers. Cultivation of small grains and other row crops is the predominant land use in the Central Lowland. The Great Plains consists mainly of rolling to hilly plains with gentle slopes. Local relief generally ranges from 300 to 500 feet (Bluemle, 1977). Most of this physiographic province has well-defined waterways. Livestock grazing is the predominant land use in the Great Plains.

The 1990 population of North Dakota was 638,800 (U.S. Bureau of the Census 1990 decennial census files). About one-half of the population lives in urban settings (figs. $1 C$ and 2). Most of the major urban centers are located near or adjacent to major rivers.

\section{WATER-QUALITY MONITORING}

Water-quality data obtained from analyses of water samples collected at monitoring stations are stored in the U.S. Geological Survey's (USGS) National Water Information System and the U.S. Environmental Protection Agency's (EPA) national data base known as STORET. Water-quality and streamflow data are reported by water year-the 12 months from October 1 through September 30. A water year is identified by the calendar year in which it ends. For example, water year 1991 comprises October 1, 1990, through September 30, 1991 .

The data used in this summary of North Dakota's stream water quality were obtained from water samples collected either every 2 months or quarterly at 14 monitoring stations at which data collection is systematic and continuing (fig. 2). Analyses of water samples collected at 10 stations are the basis for the discussion and graphic summary (fig. 3) of stream water-quality conditions during water years 1987-89, and data from all 14 stations are the basis for the discussion and graphic summary (fig. 4) of stream water-quality trends. Water samples were collected and analyzed by using standard methods approved by the USGS (Britton and Greeson, 1987; Fishman and Friedman, 1989; Ward and Harr, 1990) or by using equivalent methods. If a method of sample collection or analysis changed over time, data from an analysis were included in the evaluation of recent stream water quality or of stream water-quality trends only if the change in method did not affect the comparability of the data. 


\section{WATER-QUALITY CONDITIONS}

For purposes of water-pollution control, streams and rivers in North Dakota have been classified according to uses designated by the North Dakota State Department of Health and Consolidated Laboratories (NDSDHCL), and enforceable water-quality standards for several stream-water constituents are defined for each classification (North Dakota State Department of Health and Consolidated Laboratories, 1989). This Department also has adopted nonenforceable interim guidelines for other constituents, such as nitrogen and phosphorus.

In 1988-89, the NDSDHCL assessed water quality in 9,173 miles of the State's 11,868 miles of classified streams and rivers in fulfillment of the requirements of section 305(b) of the Federal Clean Water Act. Of the assessed streams and rivers, 6,889 miles (75 percent) were determined to fully support designated uses, and 2,284 miles ( 25 percent) were determined to partially support designated uses (North Dakota State Department of Health and Consolidated Laboratories, 1990, p. 12). Major contaminants identified by the NDSDHCL were nutrients (nitrogen and phosphorus), sediment, dissolved solids, toxic trace metals, and pathogens from fecal contamination. The major sources of contaminants were nonpoint, primarily runoff from nonirrigated cropland, pastureland, and feedlots. Natural sources of contamination affected 1,579 miles ( 17 percent) of the assessed streams and rivers. These natural sources include runoff from bare, erodible soils in the southwestern part of the State and ground-water seeps that contribute large quantities of dissolved sol- ids to tributaries draining into the Red River of the North downstream from Grand Forks.

The following discussion of stream water quality in North Dakota is organized by river basin (fig. 3). Graphs in figure 3 summarize certain aspects of stream water quality in the basins for water years 1987-89. The graphs show frequency distributions of data values that represent measurements of selected physical properties of stream water and concentrations of selected constituents in stream water. These properties and constituents are alkalinity (as calcium carbonate), dissolved sulfate, dissolved chloride, dissolved solids, dissolved nitrite plus nitrate (as nitrogen), total phosphorus (as phosphorus), and dissolved selenium. The data are reported in milligrams per liter (mg/L) and micrograms per liter. Sources and environmental significance of each property and constituent are described in table 1 .

Water quality at each monitoring station is the result of geological, chemical, biological, and hydrologic processes that occur over a large area. Water-quality problems that affect aquatic life or public health only locally are not fully represented in this summary.

\section{SHEYENNE RIVER}

Water quality of the Sheyenne River at site 2 is affected by agricultural activities and streamflow regulation. Land in the Sheyenne River basin upstream from site 2 is used predominantly for cropland. Flow in the river is regulated by dams that form Lake Ashtabula and several smaller reservoirs. Lake Ashtabula affects the
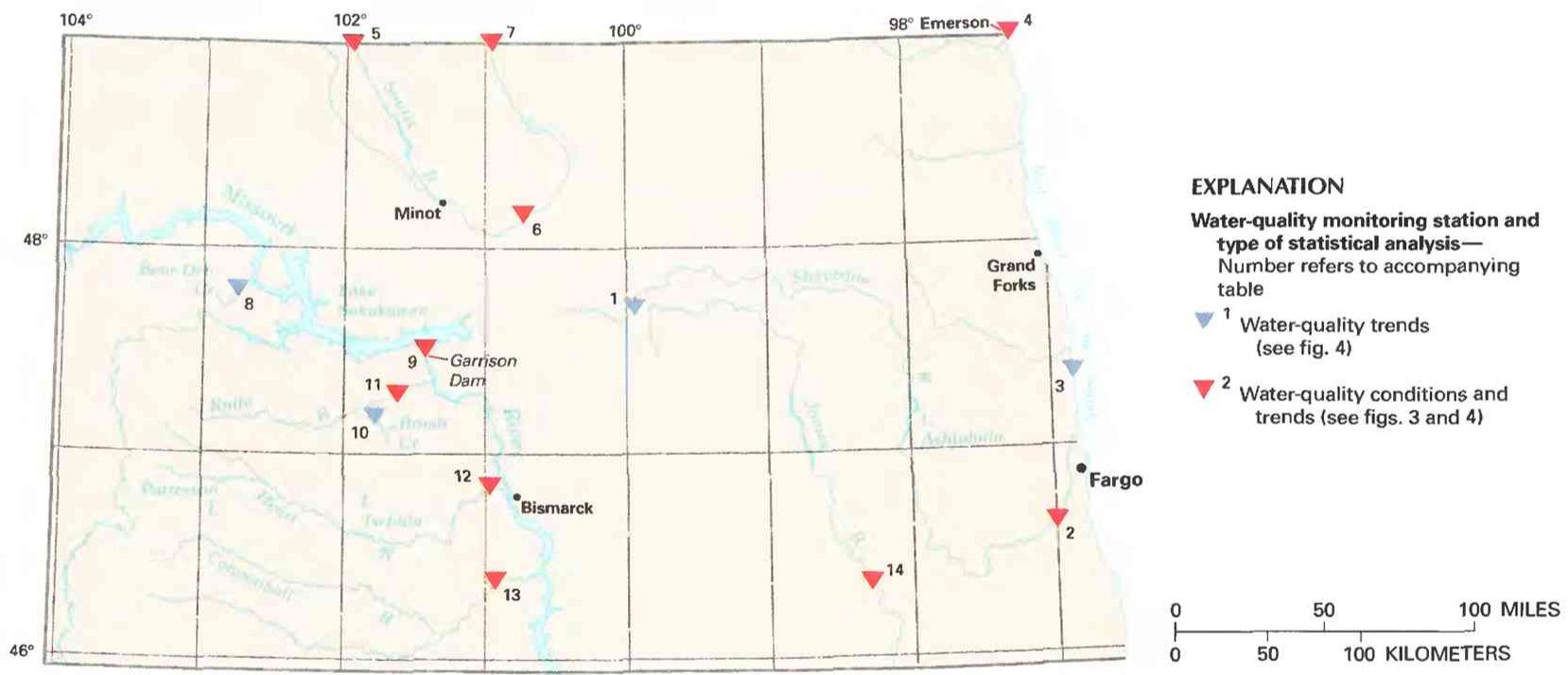

\begin{tabular}{|c|c|c|c|}
\hline $\begin{array}{l}\text { Site no. } \\
\text { on map }\end{array}$ & $\begin{array}{l}\text { USGS station } \\
\text { name and no. }\end{array}$ & $\begin{array}{l}\text { Drainage area } \\
\text { (square miles) }\end{array}$ & $\begin{array}{l}\text { Major land use } \\
\text { (see fig. 1) }\end{array}$ \\
\hline 1 & Sheyenne River above Harvey $(05054500)$ & 424 & Mostly cropland. \\
\hline 2 & 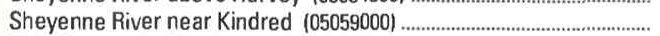 & 8,800 & Ditto. \\
\hline 3 & Red River of the North at Halstad, Minn. (05064500) & 21,800 & Ditto. \\
\hline 4 & Red River of the North at Emerson, Manitoba (05102500) .................... & 40,200 & Ditto. \\
\hline 5 & Souris River near Sherwood $(05114000)$ & 8,940 & Ditto. \\
\hline 6 & Souris River near Verendrye $(05120000)$ & 11,300 & Ditto. \\
\hline 7 & Souris River near Westhope $(05124000)$ & 16,900 & Ditto. \\
\hline 8 & 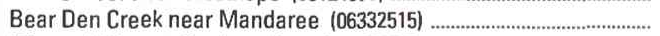 & 74 & Cropland with grazing land. \\
\hline 9 & 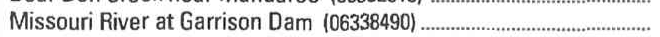 & 181,400 & Mostly cropland. \\
\hline 10 & Brush Creek near Beulah (06339560) & 23.9 & Cropland with grazing land. \\
\hline 11 & Knife River at Hazen $(06340500)$ & 2,240 & Ditto. \\
\hline 12 & 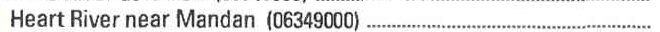 & 3,310 & Ditto. \\
\hline 13 & Cannonball River at Breien $(06354000)$ & 4,100 & Subhumid grassland and semiarid grazing land. \\
\hline 14 & James River at LaMoure $(06470500)$ & 4,390 & Mostly cropland. \\
\hline
\end{tabular}

Figure 2. Selected water-quality monitoring stations, type of statistical analysis, and geographic features in North Dakota. (Sources: Major land uses modified from Anderson, 1967; other data from U.S. Geological Survey files.) 
quality of water in the Sheyenne River by mixing snowmelt runoff with base flows. Thus, releases from the reservoir generally have similar quality throughout the year. For example, alkalinity, sulfate, chloride, and dissolved-solids concentrations in water at site 2 had little variability for water years $1987-89$ (fig. 3).

All nitrite plus nitrate concentrations were smaller than the State nonenforceable interim guideline of $1.0 \mathrm{mg} / \mathrm{L}$ (as nitrogen) (North Dakota State Department of Health and Consolidated Laboratories, 1989). However, about 75 percent of the samples collected at site 2 during water years 1987-89 had total-phosphorus concentrations larger than the State nonenforceable interim guideline of 0.10 $\mathrm{mg} / \mathrm{L}$ (as phosphorus) (North Dakota State Department of Health and Consolidated Laboratories, 1989). Chemical fertilizers applied to the land probably are the source of the large total-phosphorus concentrations.

\section{RED RIVER OF THE NORTH}

The Red River of the North forms the boundary between North Dakota and Minnesota. The river flows northward, which tends to synchronize basin flooding with the northward progression of spring thaw (Erickson and others, 1980). Tributaries in Minnesota contribute most of the flow to the river (Miller and Frink, 1984). Land use in the basin is cropland in North Dakota, whereas forest covers most of the eastern parts of the basin in Minnesota. Two of the major urban areas of North Dakota, Fargo and Grand Forks, are located on this river. The monitoring station on the Red River of the North at Emerson, Manitoba (site 4), was established to monitor the quantity and quality of streamflow crossing the international boundary between the United States and Canada.

In water samples collected during water years 1987-89, median values of alkalinity $(217 \mathrm{mg} / \mathrm{L})$, sulfate $(110 \mathrm{mg} / \mathrm{L})$, and dissolved solids $(485 \mathrm{mg} / \mathrm{L})$ at site 4 were among the smallest for any of the 10 monitoring stations (fig. 3 ), probably because of dilution from surface runoff that is greater in this basin than in other basins in North Dakota. Also, the sulfate content of soils in eastern North Dakota is smaller than that of the soils in western North Dakota (Deutschman and Ell, 1986), and this difference can partly account for the smaller sulfate concentrations in the river.
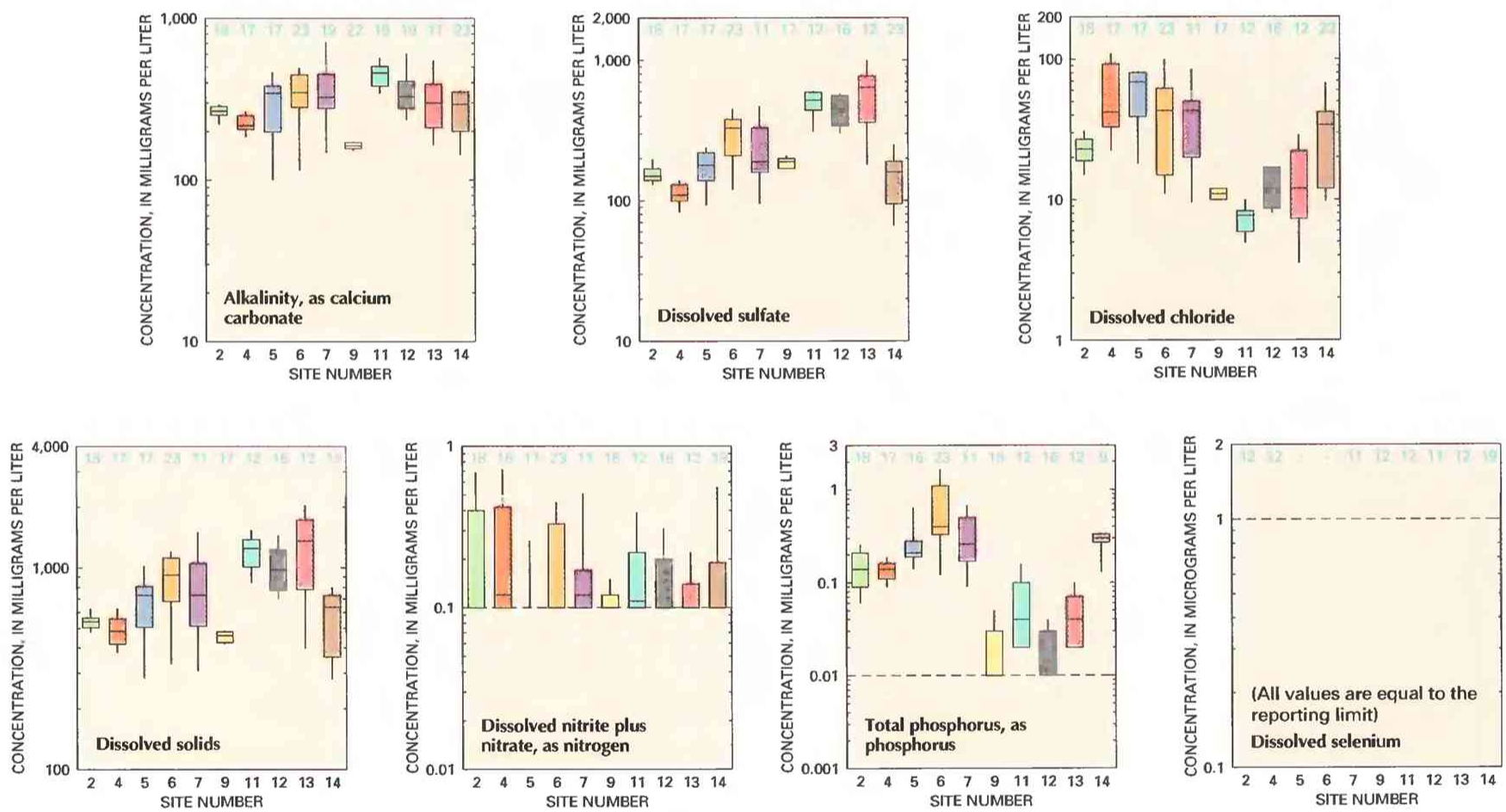

\section{EXPLANATION}

\begin{tabular}{|c|c|}
\hline $\begin{array}{l}\text { Water-quality conditions in selected } \\
\text { drainage basins }\end{array}$ & $\begin{array}{l}\text { Drainage basin-Number is site number in } \\
\text { figure } 2 \text {. Basin may extend beyond State } \\
\text { line }\end{array}$ \\
\hline Number of analyses-Dash indicates & $\square$ Sheyenne River 2 \\
\hline & Red River of the North 4 \\
\hline $\begin{array}{l}\text { Percentile-Percentage of analyses } \\
\text { equal to or less than indicated }\end{array}$ & Souris River near Sherwood 5 \\
\hline values & Souris River near Verendrye 6 \\
\hline -90th & Souris River near Westhope 7 \\
\hline $1-75$ th & Missouri River 9 \\
\hline -50th-Median & Knife River 11 \\
\hline-25 th & Heart River 12 \\
\hline - 10th & Cannonball River 13 \\
\hline $\begin{array}{l}\text {-Reporting limit-Minimum reporting } \\
\text { limit for analytical method used. } \\
\text { Data below limit line not shown }\end{array}$ & $\begin{array}{l}\square \text { James River } 14 \\
\nabla 4 \text { Water-quality monitoring station- } \\
\text { Number is site number in figure } 2\end{array}$ \\
\hline
\end{tabular}

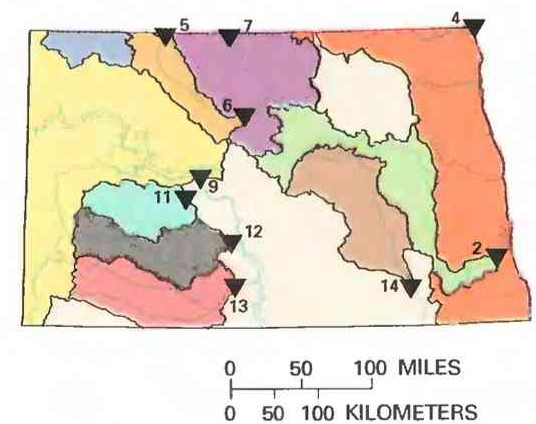

Figure 3. Water quality of selected streams in North Dakota, water years 1987-89. (Source: Data from U.S. Geological Survey files.) 
Table 1. Sources and environmental significance of selected water-quality properties and constituents [Source: Compiled by the U.S. Geological Survey, Office of Water Quality]

\begin{tabular}{|c|c|c|}
\hline Property or constituent & Common sources & Environmental significance \\
\hline Alkalinity (property) .................... & $\begin{array}{l}\text { A measure of the quantity of acid-neutralizing sub- } \\
\text { stances; can be affected by geologic setting, in- } \\
\text { dustrial wastewater discharge, waste gases, and } \\
\text { runoff from surface mining. }\end{array}$ & $\begin{array}{l}\text { Sufficiently alkaline water can be unsuitable for some } \\
\text { agricultural and industrial uses. }\end{array}$ \\
\hline Sulfate & $\begin{array}{l}\text { Occurs in some rocks; also in mine runoff, industrial } \\
\text { wastewater discharge, and atmospheric deposi- } \\
\text { tion. }\end{array}$ & $\begin{array}{l}\text { Concentrations exceeding a natural, background } \\
\text { level indicate contamination from human activity; } \\
\text { in sufficient quantity, can cause water to be } \\
\text { unsuitable for public supply; can harm aquatic } \\
\text { organisms. }\end{array}$ \\
\hline Chloride ....................................... & $\begin{array}{l}\text { Occurs in some rocks and ground-water discharge; } \\
\text { also in road deicers, industrial and urban waste- } \\
\text { water discharge, and atmospheric deposition. }\end{array}$ & $\begin{array}{l}\text { Concentrations exceeding a natural, background level } \\
\text { can cause water to be unsuitable for public supply, } \\
\text { agriculture, and industry; can harm aquatic or- } \\
\text { ganisms. }\end{array}$ \\
\hline 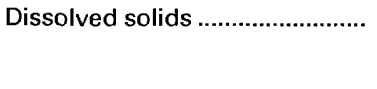 & $\begin{array}{l}\text { A result of rock weathering; also in agricultural runoff } \\
\text { and industrial discharge. }\end{array}$ & $\begin{array}{l}\text { In sufficient quantity, can cause water to be unsuitable } \\
\text { for public supply, agriculture, and industry; can } \\
\text { harm aquatic organisms. }\end{array}$ \\
\hline Nitrite plus nitrate ....................... & $\begin{array}{l}\text { Nonpoint sources are agricultural and urban runoff; } \\
\text { a major point source is wastewater discharge. }\end{array}$ & $\begin{array}{l}\text { Plant nutrient that, in sufficient quantity, can cause } \\
\text { algal blooms and excessive growth of higher } \\
\text { aquatic plants in bodies of water; can cause water } \\
\text { to be unsuitable for public supply. }\end{array}$ \\
\hline 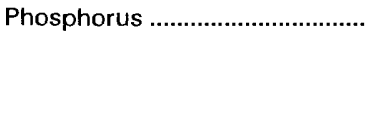 & $\begin{array}{l}\text { Occurs in some rocks and sediments; also in runoff } \\
\text { and seepage from phosphate-rock mines, agri- } \\
\text { cultural and urban runoff, and industrial and } \\
\text { municipal wastewater discharge. }\end{array}$ & $\begin{array}{l}\text { Plant nutrient that, in sufficient quantity, can cause } \\
\text { algal blooms and excessive growth of higher } \\
\text { aquatic plants in bodies of water. }\end{array}$ \\
\hline Selenium & $\begin{array}{l}\text { Occurs in some rocks and soils; can be leached from } \\
\text { arid lands by irrigation. }\end{array}$ & $\begin{array}{l}\text { Toxic in larger than trace concentrations; can cause } \\
\text { water to be unsuitable for public supply; can } \\
\text { harm aquatic organisms. }\end{array}$ \\
\hline
\end{tabular}

During low-flow conditions, when ground water contributes much of the streamflow of the river, ground water having a substantial chloride content seeps into the Red River of the North and its tributaries in the northern part of the basin and causes large chloride concentrations in stream water (Michael J. Ell, North Dakota State Department of Health and Consolidated Laboratories, oral commun., July 1990). During water years 1987-89. chloride concentrations at site 4 were among the largest for the 10 monitoring stations (fig. 3).

During water years $1987-89$, nitrite plus nitrate concentrations were smaller than the State guideline of $1.0 \mathrm{mg} / \mathrm{L}$. However. more than 75 percent of the samples collected at site 4 during water years 1987-89 had total-phosphorus concentrations greater than the State nonenforceable interim guideline of $0.10 \mathrm{mg} / \mathrm{L}$. Chemical fertilizers from cropland and municipal wastewater from urban areas along the river probably were the sources of the large phosphorus concentrations.

\section{SOURIS RIVER}

Water-quality data were collected at three monitoring stations on the Souris River. Site 5 is on the international boundary with Canada and monitors water entering the United States, site 6 is midway along the Souris River reach in the United States, and site 7 is on the international boundary with Canada and monitors water leaving the United States. Cropland is the predominant land use in the North Dakota part of the basin. Reservoirs in Canada regulate flow upstream from site 5, and reservoirs in the United States regulate flow upstream from sites 6 and 7.

Generally, constituent concentrations increased from site 5 to site 6 , then decreased from site 6 to site 7 during water years 1987 89 (fig. 3). The decrease between sites 6 and 7 indicates that tributaries and ground-water discharge downstream from site 6 contribute water that has smaller concentrations of dissolved minerals to the river.

Alkalinity, sulfate, and dissolved-solids concentrations are larger in the Souris River basin than in the Sheyenne River and Red River of the North basins because during much of the year ground water that contains larger concentrations of sulfate and bicarbonate contributes to the flow of the Souris River. Also, evaporation from the numerous small reservoirs on the Souris River concentrates dissolved minerals.

Site 5 had the largest median chloride concentration (69 $\mathrm{mg} / \mathrm{L}$ ) for the 10 monitoring stations. Natural sources possibly caused the large concentrations, but other unknown sources in Canada also could be contributing.

Nitrite plus nitrate concentrations at sites 5, 6, and 7 were smaller than the State nonenforceable interim guideline of 1.0 $\mathrm{mg} / \mathrm{L}$. However, almost all total-phosphorus concentrations at all three monitoring stations were larger than the State guideline of 0.10 $\mathrm{mg} / \mathrm{L}$. The median phosphorus concentration at site $6(0.40 \mathrm{mg} / \mathrm{L})$ was the largest for any of the 10 monitoring stations. Chemical fertilizers in runoff from cropland and municipal wastewater from Minot probably are important sources of phosphorus upstream from site 6.

\section{MISSOURI RIVER}

The Missouri River drains parts of Montana, Wyoming, North Dakota, and Canada. Site 9 is located at the outflow from Garrison Dam. Lake Sakakawea, which was formed by Garrison Dam, fills mainly with snowmelt runoff, and release water is used for hydroelectric power generation and downstream navigation. Water in the Missouri River released through Garrison Dam has a consistent quality throughout the year; water samples from site 9 had the least concentration variance for almost all constituents (fig. 3). Median concentrations of alkalinity ( $163 \mathrm{mg} / \mathrm{L}$ ), dissolved solids (461 $\mathrm{mg} / \mathrm{L})$, and phosphorus $(0.01 \mathrm{mg} / \mathrm{L})$ were the smallest for any of the 10 monitoring stations. These small concentrations were the result of dilution from snowmelt.

\section{KNIFE RIVER}

Land use in the Knife River basin upstream from site 11 is predominantly cropland and grazing land; coal mining also is common. These activities potentially affect the water quality of the river, although basin geology has the most significant effect. 
Alkalinity, sulfate, and dissolved-solids concentrations in water from site 11 were among the largest of those for the 10 monitoring stations (fig. 3). The median alkalinity concentration (460 $\mathrm{mg} / \mathrm{L}$ ) was the largest for the 10 monitoring stations. The large alkalinity probably was due to natural causes. Nearly 75 percent of the sulfate concentrations for the Knife River were larger than the State water-quality standard of $450 \mathrm{mg} / \mathrm{L}$ (North Dakota State Department of Health and Consolidated Laboratories, 1989). Soils in the western one-half of the State have a larger sulfate content than those in the eastern one-half (Deutschman and Ell, 1986) and probably contribute to the large sulfate concentrations in this basin.

All nitrite plus nitrate concentrations were smaller than the State nonenforceable interim guideline of $1.0 \mathrm{mg} / \mathrm{L}$, probably because few chemical fertilizers are used in this basin. Only 25 percent of the phosphorus concentrations at site 11 were larger than the State nonenforceable interim guideline of $0.10 \mathrm{mg} / \mathrm{L}$.

\section{HEART RIVER}

The predominant land uses in the Heart River basin upstream from site 12 are cropland and grazing land. The Heart River is regulated by dams that formed Patterson Lake and Lake Tschida; water from these reservoirs is used for irrigation. Regulation and irrigation might affect water quality in the basin by increasing the dissolved-mineral content in the river; however, basin geology probably has the most significant effect.

Concentrations of sulfate (median, $450 \mathrm{mg} / \mathrm{L}$ ) and dissolved solids (median, $978 \mathrm{mg} / \mathrm{L}$ ) were large in samples collected at site 12 (fig. 3); 50 percent of the sulfate concentrations for the Heart River were larger than the State water-quality standard of $450 \mathrm{mg} / \mathrm{L}$. Soils in the western one-half of the State have a substantial sulfate content (Deutschman and Ell, 1986), which probably contributes to the large sulfate concentrations in this basin.

Nitrite plus nitrate and phosphorus concentrations were small, indicating that agricultural chemicals were not an important pollutant in this basin during water years 1987-89. All the total-phosphorus values were smaller than the State nonenforceable interim guideline of $0.10 \mathrm{mg} / \mathrm{L}$.

\section{CANNONBALL RIVER}

Land use in the Cannonball River basin upstream from site 13 is predominantly subhumid grassland and semiarid grazing land. The median concentrations of sulfate $(640 \mathrm{mg} / \mathrm{L})$ and dissolved solids $(1,360 \mathrm{mg} / \mathrm{L})$ were the largest for the 10 monitoring stations (fig. 3). More than 50 percent of the sulfate concentrations for the Cannonball River were larger than the State water-quality standard of 450 $\mathrm{mg} / \mathrm{L}$. The large sulfate concentrations were caused by leaching of soils, which have a substantial sulfate content in the western part of the State (Deutschman and Ell, 1986).

Nitrite plus nitrate and phosphorus concentrations were small, indicating that agricultural chemicals were not an important source of stream water contamination in the basin during 1987-89. Almost all phosphorus values were smaller than the State nonenforceable interim guideline of $0.10 \mathrm{mg} / \mathrm{L}$.

\section{JAMES RIVER}

Cropland is the predominant land use in the James River basin upstream from site 14. Numerous small reservoirs on the James River regulate flow and also are used for waterfowl nesting and resting areas. Water quality in the river is affected by agricultural runoff and waterfowl. During 1987-89, nitrite plus nitrate concentrations were smaller than the State nonenforceable interim guideline of $1.0 \mathrm{mg} / \mathrm{L}$. However, all phosphorus concentrations were larger than the State nonenforceable interim guideline of $0.10 \mathrm{mg} / \mathrm{L}$. Run- off containing chemical fertilizers probably is a major source of phosphorus in basin streams.

\section{WATER-QUALITY TRENDS}

Trend analysis is a statistical procedure used to detect changes in stream water quality at a monitoring station over time. For this report, water-quality data from 14 monitoring stations (fig. 2) were analyzed for trends by using the seasonal Kendall test (Hirsch and others, 1982), a method used extensively by the USGS. The graph (shown below) of the dissolved-sulfate concentration in Brush Creek at site 10 illustrates the trend inferred from the concentration data and demonstrates the variation in water quality that is common in streams.

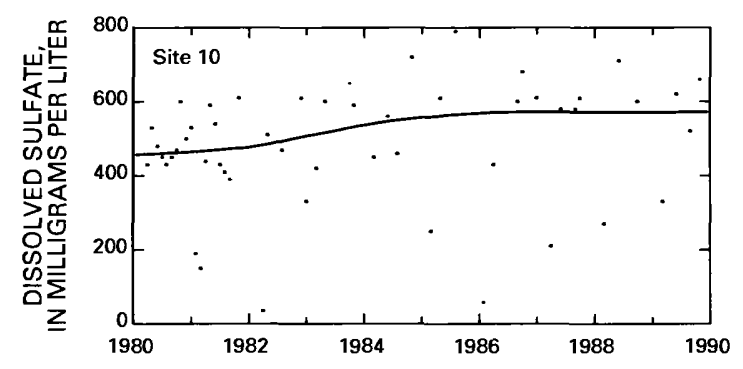

When possible, constituent-concentration data were adjusted for changes in streamflow to preclude identifying a trend in concentration that was caused only by a trend in streamflow. The data were not adjusted when (1) more than 10 percent of the samples had concentrations lower than the minimum reporting limit for the analytical method used or (2) streamflow was controlled substantially by human activities. When the concentration data could not be adjusted for streamflow, trends were determined directly from the concentration data.

Statewide trends in measurements of selected physical properties of stream water and concentrations of selected constituents in stream water are shown on maps in figure 4 . On each map, a trend is indicated at a monitoring station only if the data from that station were suitable for use in the trend analysis. For more information on the suitability criteria and on the trend-analysis procedure used for this report, see Lanfear and Alexander (1990).

\section{ALKALINITY}

Alkalinity is a measure of the capacity of the substances dissolved in the water to neutralize acid. In most natural waters, alkalinity is produced mainly by bicarbonate and carbonate (Hem, 1985, p. 106), which are ions formed when carbon dioxide or carbonate rock dissolves in water. Causes are not known for the upward alkalinity trends in the Missouri River at site 9 and in the Knife River at site 11 or for the downward trend in the Sheyenne River at site 1.

\section{DISSOLVED SULFATE}

The major natural sources of sulfate in streams are rock weathering, volcanoes, and biochemical processes (Hem, 1985, p. 113). Human activities such as mining, waste discharge, and fossil-fuel combustion also can be important sources.

The upward sulfate trends in Brush Creek at site 10 and in the Heart River at site 12 could have been caused by the drought of 1988 89 (U.S. Geological Survey, 1991, p. 435 442). Decreased precipitation during drought reduces runoff that dilutes the more mineralized stream water in years having normal to greater than normal precipitation. Evaporation and irrigation return flow further increase concentrations of dissolved minerals. A cause for the downward trend in the Missouri River at Garrison Dam (site 9) is not known. 


\section{DISSOLVED CHLORIDE}

Chloride is present in all natural waters but usually in low concentrations (Hem, 1985, p. 118). Except in streams that receive ground-water discharge high in chloride, concentrations of greater than a few milligrams per liter generally are the result of human activities (table 1).

Chloride concentrations had an upward trend in the Souris River at site 5 and a downward trend in Bear Den Creek at site 8. Causes for the trends are not known.

\section{DISSOLVED SOLIDS}

Dissolved solids in stream water result primarily from rock weathering but also can be introduced as a byproduct of human activities (table 1). Concentrations generally are greatest in streams draining basins underlain by rocks and soils that contain easily dissolved minerals. Dissolved-solids conentrations at all 14 monitoring stations from which data were suitable for trend analysis had no trend for water years 1980-89.

\section{DISSOLVED NITRITE PLUS NITRATE}

Nitrite and nitrate are oxidized forms of nitrogen that together normally constitute most of the dissolved nitrogen in well-aerated streams. Nitrite readily oxidizes to nitrate in natural waters; therefore, nitrate generally is by far the more abundant of the two (Hem, 1985 , p. 124). Nitrite plus nitrate concentrations at all eight monitoring stations from which data were suitable for trend analysis had no trend for water years $1980-89$, probably because municipal wastewater-treatment effluent and the tonnage of fertilizer applied in the State changed little during the analysis period (North Dakota Agricultural Statistics Service, 1981-90).

\section{TOTAL PHOSPHORUS}

The total phosphorus concentration of a water sample is a measure of the concentration of all forms of phosphorus present in the sample, dissolved and particulate. Human activities (table 1) can be important sources of phosphorus in streams. A shortened trendanalysis period was used for phosphorus because data from analyses performed in water years $1980-81$ are not comparable to data from subsequent years.

Phosphorus concentrations had an upward trend in the Missouri River at site 9, but a cause for the upward trend is unknown. No trend was detected at the other monitoring stations, probably because discharge from wastewater-treatment facilities and tonnage of fertilizer applied in the State changed little during the analysis period (North Dakota Agricultural Statistics Service, 1981-90).

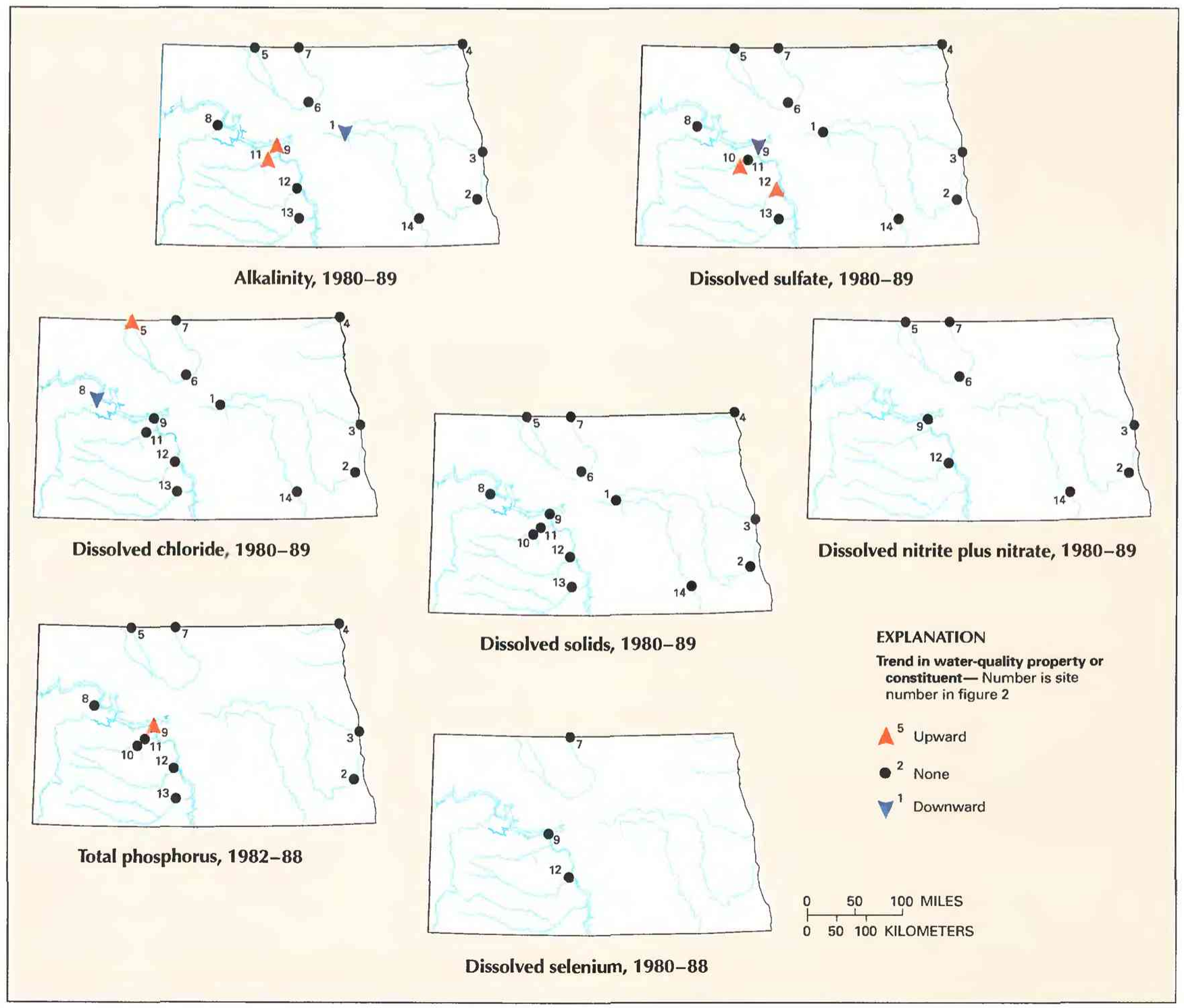

Figure 4. Trends in water quality of selected streams in North Dakota, by water years. (Source: Data from U.S. Geological Survey files.) 


\section{DISSOLVED SELENIUM}

Selenium exists in nature generally as a trace element, but soils in some arid and semiarid regions of the United States contain more than trace amounts. Selenium concentrations had no trend at the three monitoring stations from which data were suitable for trend analysis (fig. 4) and were smaller than the minimum reporting level during water years $1987-89$ at monitoring stations on the State's large rivers (fig. 3).

\section{WATER-QUALITY MANAGEMENT}

Chapter 61-28 of the North Dakota Century Code establishes the NDSDHCL as the primary State agency for the protection and maintenance of ground and surface water in North Dakota. The code directs the Department to develop comprehensive programs for the prevention, control, and reduction of pollution in waters of the State and contains the bulk of legislative authority of the agency.

The NDSDHCL, Division of Water Supply and Pollution Control (WSPC), performs specific regulatory, enforcement, and monitoring activities. These activities include development of water-quality standards and criteria for the protection of the State's waters, issuance of permits to discharge wastewater, review of the operation and maintenance of private and municipal wastewater-treatment facilities, and ambient stream water-quality monitoring.

The NDSDHCL prepares a biennial water-quality assessment report (North Dakota State Department of Health and Consolidated Laboratories, 1990) that is submitted to the EPA and to the U.S. Congress as mandated by section 305(b) of the Federal Clean Water Act. The Department reviews permits and issues related water-quality certification and is responsible for the development of the State's nonpoint-source-management program.

The NDSDHCL maintains 63 ambient water-quality monitoring stations on 36 rivers and streams. The monitoring is designed to collect baseline data used to assess water-quality trends and the effects of various land and water uses on the State's rivers and streams. Data collected also provide useful background information for discharge regulation, the Federal Clean Water Act section 401 waterquality certification process, and promulgation of State water-quality standards.

The State of North Dakota has two international rivers-the Red River of the North, which forms the boundary between North Dakota and Minnesota and flows northward into the Canadian province of Manitoba, and the Souris River, which originates in the Canadian province of Saskatchewan, flows through North Dakota, and reenters Canada at the Manitoba border. The WSPC participates in the International Red River Pollution Board and the Souris River Bilateral Water-Quality Monitoring Group. The International Red River Pollution Board was established by the International Joint Commission in 1969 to maintain continuous supervision over the quality of waters in the Red River of the North crossing the international boundary. The Souris River Bilateral Water-Quality Monitoring Group was formed to establish water-quality objectives on the Souris River at the Saskatchewan-North Dakota boundary and at the North DakotaManitoba boundary.

\section{SELECTED REFERENCES}

Anderson, J.R., 1967, Major land uses in the United States, in U.S. Geological Survey, 1970, National atlas of the United States of America: Washington, D.C., U.S. Geological Survey, p. 158-159.
Bluemle, J.P., 1977, The face of North Dakota-The geologic story: North Dakota Geological Survey Educational Series 11, 73 p.

Britton, L.J., and Greeson, P.E., eds., 1987, Methods for collection and analysis of aquatic biological and microbiological samples: U.S. Geological Survey Techniques of Water-Resources Investigations, book 5, chap. A4, $363 \mathrm{p}$.

Deutschman, M.R., and Ell, M.J., 1986, Ambient air quality, precipitation chemistry and atmospheric deposition in North Dakota, 1980-1984: North Dakota State Department of Health, Research Contract YA-553CT1-1084, $214 \mathrm{p}$.

Erickson, D.W., Holmen, O.O., and Latkovich, V.J., 1980, Flood of AprilMay 1979 in the Red River of the North basin, North Dakota and Minnesota: U.S. Geological Survey Water-Resources Investigations OpenFile Report 80-1176, scale 1:63,360.

Fenneman, N.M., 1931, Physiography of the western United States: New York, McGraw-Hill, 534 p.

1946, Physical divisions of the United States: Washington, D.C., U.S. Geological Survey special map, scale 1:7,000,000.

Fishman, M.J., and Friedman, L.C., eds., 1989, Methods for the determination of inorganic substances in water and fluvial sediments: U.S. Geological Survey Techniques of Water-Resources Investigations, book 5, chap. A1, 545 p.

Hem, J.D., 1985, Study and interpretation of the chemical characteristics of natural water (3d ed.): U.S. Geological Survey Water-Supply Paper 2254, $263 \mathrm{p}$.

Hirsch, R.M., Slack, J.R., and Smith, R.A., 1982, Techniques of trend analysis for monthly water quality data: Water Resources Research, v. 18, no. 1, p. 107-121.

Lanfear, K.J., and Alexander, R.B., 1990, Methodology to derive water-quality trends for use by the National Water Summary Program of the U.S. Geological Survey: U.S. Geological Survey Open-File Report 90-359, $10 \mathrm{p}$.

Miller, J.E. and Frink, D.L., 1984, Changes in flood response of the Red River of the North basin, North Dakota-Minnesota: U.S. Geological Survey Water-Supply Paper 2243, 103 p.

North Dakota Agricultural Statistics Service, 1981-90, North Dakota agricultural statistics: Fargo, North Dakota State University and U.S. Department of Agriculture, published annually.

North Dakota State Department of Health and Consolidated Laboratories, 1989 , Standards of water quality for the State of North Dakota: Bismarck, North Dakota State Department of Health and Consolidated Laboratories, $23 \mathrm{p}$.

1990 , The status of water quality in the State of North Dakota, 1988 1989: Bismarck, North Dakota State Department of Health and Consolidated Laboratories, Division of Water Supply and Pollution Control, $73 \mathrm{p}$.

Thelin, G.P., and Pike, R.J., 1990, Digital shaded relief map of the conterminous United States: Menlo Park, Calif., U.S. Geological Survey digital image processing, scale 1:3,500,000.

U.S. Geological Survey, 1986, National water summary 1985-Hydrologic events and surface-water resources: U.S. Geological Survey Water-Supply Paper 2300, 506 p.

1990, National water summary 1987-Hydrologic events and water supply and use: U.S. Geological Survey Water-Supply Paper 2350, $553 \mathrm{p}$.

1991, National water summary 1988-89-Hydrologic events and floods and droughts: U.S. Geological Survey Water-Supply Paper 2375, $591 \mathrm{p}$.

Ward, J.R., and Harr, C.A., eds., 1990, Methods for collection and processing of surface-water and bed-material samples for physical and chemical analyses: U.S. Geological Survey Open-File Report 90-140, 71 p. 
Prepared by Wayne R. Berkas, U.S. Geological Survey; “Water-Quality Management” section by Michael J. Ell, North Dakota State Department of Health and Consolidated Laboratories

FOR ADDITIONAL INFORMATION: District Chief, U.S. Geological Survey, 821 East Interstate Avenue, Bismarck, ND 58501 


\section{OHIO Stream Water Quality}

Ohio is bounded by two of the Nation's major waterwaysLake Erie to the north and the Ohio River to the east and south. Nearly 25,000 miles of named streams drain from Ohio into these waterways. Of the State's approximately 39 inches of annual precipitation, about 13 inches enters surface water through overland runoff and ground-water discharge (U.S. Geological Survey, 1986, p. 369). Precipitation quantities are distributed about evenly throughout the year, so that, in most areas, flow is sustained during summer when loss from evapotranspiration can be high.

Ohio withdraws about $12,000 \mathrm{Mgal} / \mathrm{d}$ (million gallons per day) of surface water (U.S. Geological Survey, 1990, p. 409). Most of this quantity ( 87.5 percent) is used in thermoelectric power generation. Of the remainder, 8.5 percent is used for public supply, 3.8 percent for industry and mining, and 0.2 percent for agriculture. About 10,000 $\mathrm{Mgal} / \mathrm{d}$ is withdrawn from Lake Erie and the Ohio River.

Abundant water resources have been a major factor in the State's development. Urban and industrial centers (fig. $1 A$ ) have developed along Lake Erie, the Ohio River, and the navigational canals and rivers that join them. Physiography also has been an important factor. The glaciated Central Lowland of western Ohio (fig. $1 B$ ) is part of the Nation's corn belt. The rugged hills of the Appalachian Plateaus in southeastern Ohio have been an abundant source of coal.

The 1990 population of Ohio was 10.8 million (U.S. Bureau of the Census 1990 decennial census files). The population has been relatively stable since 1970 , decreasing slightly from 1980 to 1984 and increasing since 1984 . More than 40 percent of Ohio's population lives within its five major metropolitan areas (fig. $1 C$ ).
Water use in Ohio is limited more by water quality than quantity. Drinking, industry, recreation, and aquatic-life habitat are among the water uses that require maintenance of designated standards of water quality. Major water-quality concerns in Ohio include contamination of streams and lakes by oxygen-demanding organic substances from sewage and industrial wastes (organic enrichment); sediment from agriculture, mining, and other activities that disturb the land surface; and trace metals and synthetic-organic substances associated with industrial or municipal waste discharge.

\section{WATER-QUALITY MONITORING}

Water-quality data obtained from analyses of water samples collected at monitoring stations are stored in the U.S. Geological Survey's (USGS) National Water Information System and the U.S. Environmental Protection Agency's (EPA) national data base known as STORET. Water-quality and streamflow data are reported by water year-the 12 months from October 1 through September 30. A water year is identified by the calendar year in which it ends. For example, water year 1991 comprises October 1, 1990, through September 30, 1991.

The data used in this summary of Ohio's stream water quality were obtained from water samples collected monthly, every 2 months, or quarterly at 10 monitoring stations at which data collection is systematic and continuing (fig. 2). Analyses of water samples collected at these stations are the basis for the discussion and graphic summary (fig. 3 ) of stream water-quality conditions during water years 1987-89 and for the discussion and graphic summary (fig. 4) of stream water-quality trends. Water samples were collected and

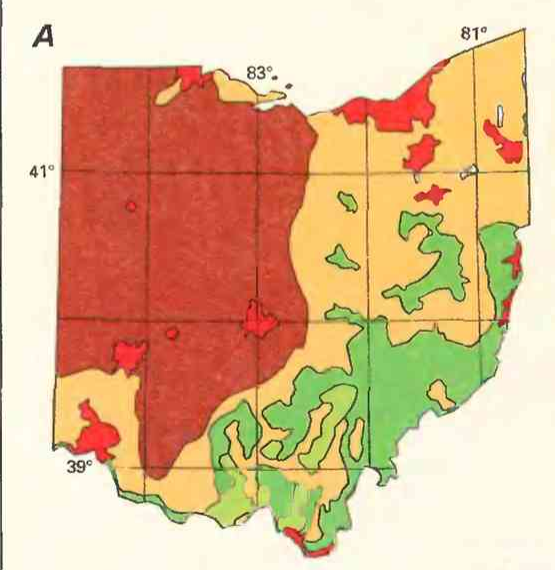

EXPLANATION

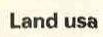

Mostly cropland

Cropland with pasture, woodland, and forest Woodland and forest with some cropland and pasture

Forest and woodland mostly ungrazed

\section{$\square$ Water body}

Urban area

Population-Each dot on the map represents 1,000 people

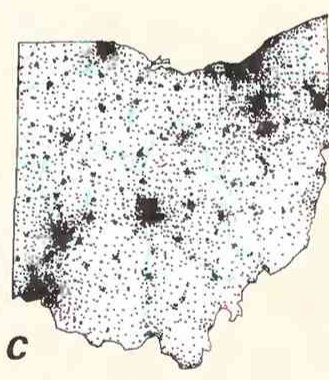

POPULATION-1990 analyzed by using standard methods approved by the USGS (Britton and Greeson, 1987; Fishman and Friedman, 1989; Ward and Harr, 1990) or by using equivalent methods. If a method of sample collection or analysis changed over time, data from an analysis were included in the evaluation of recent stream water quality or of stream water-quality trends only if the change in method did not affect the comparability of the data.

\section{WATER-QUALITY CONDITIONS}

The Ohio Environmental Protection Agency (OEPA) (1990a, p. viii) has evaluated the water quality of 7,500 miles of Ohio streams and rivers by using chemical and biological quality criteria. Data collected during 1988-89 indicate that 29 percent of the stream miles do not meet State standards for designated uses. However, many of the the water-quality conditions causing nonattainment exist in short stream segments. These
Figure 1. Land use, physiography, and population in Ohio. A, Major land uses. B, Physiographic divisions. C, Population distribution in 1990. (Sources: A, Major land uses modified from Anderson, 1967. B, Physiographic divisions from Fenneman, 1946; landforms from Thelin and Pike, 1990. C. Data from U.S. Bureau of the Census 1990 decennial census files.) 
local conditions cannot be well represented in this report because water-quality data presented herein represent either the effects of heterogeneous land use, geology, and physiography within a large drainage basin (700-7,400 square miles) or the water quality in a small, relatively undisturbed drainage basin. Major causes of nonattainment identified by the OEPA and not addressed or only partly addressed in this report include organic enrichment and habitat modification (Ohio Environmental Protection Agency, 1990a). Other contaminants of concern in Ohio, but not addressed in this report, are herbicides from agricultural runoff and toxic contamination from industrial and urban point and nonpoint sources.

The following discussion of stream water quality in Ohio is organized by river basin (fig. 3). Where physiographic and land-use characteristics in different basins are similar, the discussion of those basins is combined. Graphs in figure 3 summarize certain aspects of stream water quality in the basins for water years 1987-89. The graphs show frequency distributions of data values that represent measurements of selected physical properties of stream water and concentrations of selected constituents in stream water. These properties and constituents are $\mathrm{pH}$, dissolved oxygen, fecal coliform bacteria, dissolved sulfate, dissolved solids, dissolved nitrite plus nitrate (as nitrogen), total phosphorus (as phosphorus), and suspended sediment. The data are reported in standard $\mathrm{pH}$ units, milligrams per liter $(\mathrm{mg} / \mathrm{L})$ and colonies per 100 milliliters (col/100 mL). Sources and environmental significance of each property and constituent are described in table 1 .

Water quality at each monitoring station is the result of geological, chemical, biological, and hydrologic processes that occur

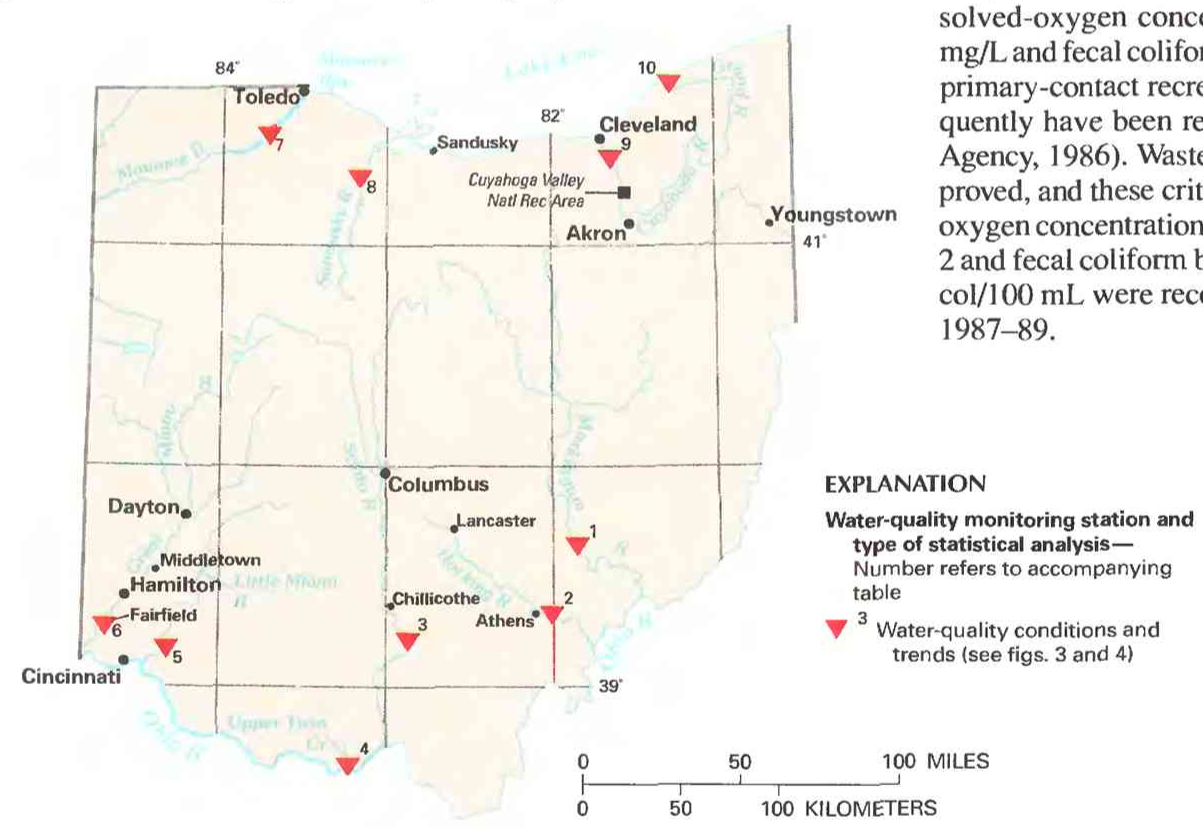

over a large area. Water-quality problems that affect aquatic life or public health only locally are not fully represented in this summary.

\section{MUSKINGUM AND HOCKING RIVERS}

The Muskingum and Hocking River basins are in the Kanawha section of the Appalachian Plateaus. The gently rolling topography of northern and western parts of this area was formed by glaciers. The unglaciated eastern and southern parts have high, rugged hills and narrow, V-shaped valleys. Bedrock consists of eastward-dipping sequences of sandstone, shale, limestone, and coal. Land cover upstream from site 1 on the Muskingum River is principally cropland, pasture, and woodland. Upstream from site 2 on the Hocking River, the basin is generally forested but has some pasture and small farms. Both basins also have light industry; active, abandoned, and reclaimed coal mines; and small urban areas.

Many abandoned mines remain from surface and underground coal extraction, an important industry in both basins. Many Muskingum and Hocking River tributaries are classified as limited warmwater habitat owing to the effects of acidic mine drainage; criteria in these streams for constituents such as $\mathrm{pH}$, dissolved solids, iron, and zinc are less stringent. Sulfate, a product of pyrite oxidation and an indicator of acidic mine drainage even in neutralized water (Helsel, 1983), is found in higher concentrations at sites 1 and 2 than at most other monitoring stations in the 10-station network (fig. 3). Although the Hocking River basin is predominantly rural, the river receives municipal wastewater from Athens, just upstream from site 2, from Lancaster, and from other small towns along the main stem. Dissolved-oxygen concentrations lower than the criterion of 4 $\mathrm{mg} / \mathrm{L}$ and fecal coliform bacteria concentrations higher than the primary-contact recreation criterion of $1,000 \mathrm{col} / 100 \mathrm{~mL}$ frequently have been reported (Ohio Environmental Protection Agency, 1986). Wastewater-treatment facilities have been improved, and these criteria usually are met; however, dissolvedoxygen concentrations lower than $4 \mathrm{mg} / \mathrm{L}$ were recorded at site 2 and fecal coliform bacteria concentrations higher than 1,000 $\mathrm{col} / 100 \mathrm{~mL}$ were recorded at sites 1 and 2 during water years $1987-89$.

Number refers to accompanying

Water-quality co

\begin{tabular}{|c|c|c|c|}
\hline $\begin{array}{l}\text { Site no. } \\
\text { on map }\end{array}$ & $\begin{array}{l}\text { USGS station } \\
\text { name and no. }\end{array}$ & $\begin{array}{l}\text { Drainage area } \\
\text { (square miles) }\end{array}$ & $\begin{array}{l}\text { Major land use } \\
\text { (see fig. 1) }\end{array}$ \\
\hline 1 & 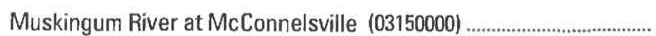 & 7,422 & Cropland with pasture, woodland, and forest. \\
\hline 2 & 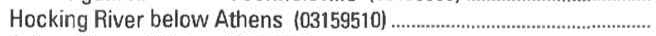 & 957 & Woodland and forest with some cropland and pasture. \\
\hline 3 & Scioto River at Higby $(03234500)$ & 5,131 & Mostly cropland. \\
\hline 4 & Upper Twin Creek at McGaw (03237280) & 12 & Mostly ungrazed forest and woodland. \\
\hline 5 & Little Miami River at Milford $(03245500)$ & 1,203 & Cropland with pasture, woodland, and forest. \\
\hline 6 & Great Miami River at New Baltimore $(03274600)$ & 3,630 & Mostly cropland. \\
\hline 7 & Maumee River at Waterville $(04193500)$ & 6,330 & Ditto. \\
\hline 8 & Sandusky River near Fremont $(04198000)$ & 1,251 & Ditto. \\
\hline 9 & Cuyahoga River at Independence $(04208000)$ & 707 & Cropland and urban areas. \\
\hline 10 & Grand River at Painesville $(04212200)$ & 701 & Cropland with pasture, woodland, and forest. \\
\hline
\end{tabular}

Figure 2. Selected water-quality monitoring stations, type of statistical analysis, and geographic features in Ohio. (Sources: Major land uses modified from Anderson, 1967; other data from U.S. Geological Survey files.) 


\section{SCIOTO RIVER}

Most of the Scioto River basin is within the flat, glaciated Till Plains of the Central Lowland. The southern one-third of the basin is unglaciated and the basin terrain grades northward from rolling hills to the rugged, wooded terrain near the Appalachian Plateaus. Land use upstream from site 3 is primarily agriculture. However, Columbus, several small urban areas on the main stem, and a paper mill in Chillicothe just upstream from site 3 discharge treated municipal and industrial wastes.

Dissolved-oxygen and fecal coliform bacteria criteria frequently were not met at site 3 in the 1970's mainly because of industrial and municipal discharges near the site. During water years $1987-89$, no concentrations of dissolved oxygen lower than the 4$\mathrm{mg} / \mathrm{L}$ criterion were measured. However, the fecal coliform bacteria criterion for secondary-contact recreation $(5,000 \mathrm{col} / 100 \mathrm{~mL})$ was exceeded at site 3 . The median fecal coliform bacteria concentration $(1,300 \mathrm{col} / 100 \mathrm{~mL})$ exceeded the criterion for primary-contact recreation.

Runoff of agricultural chemicals is an important water-quality issue in the basin. For example, Columbus, which uses the Scioto
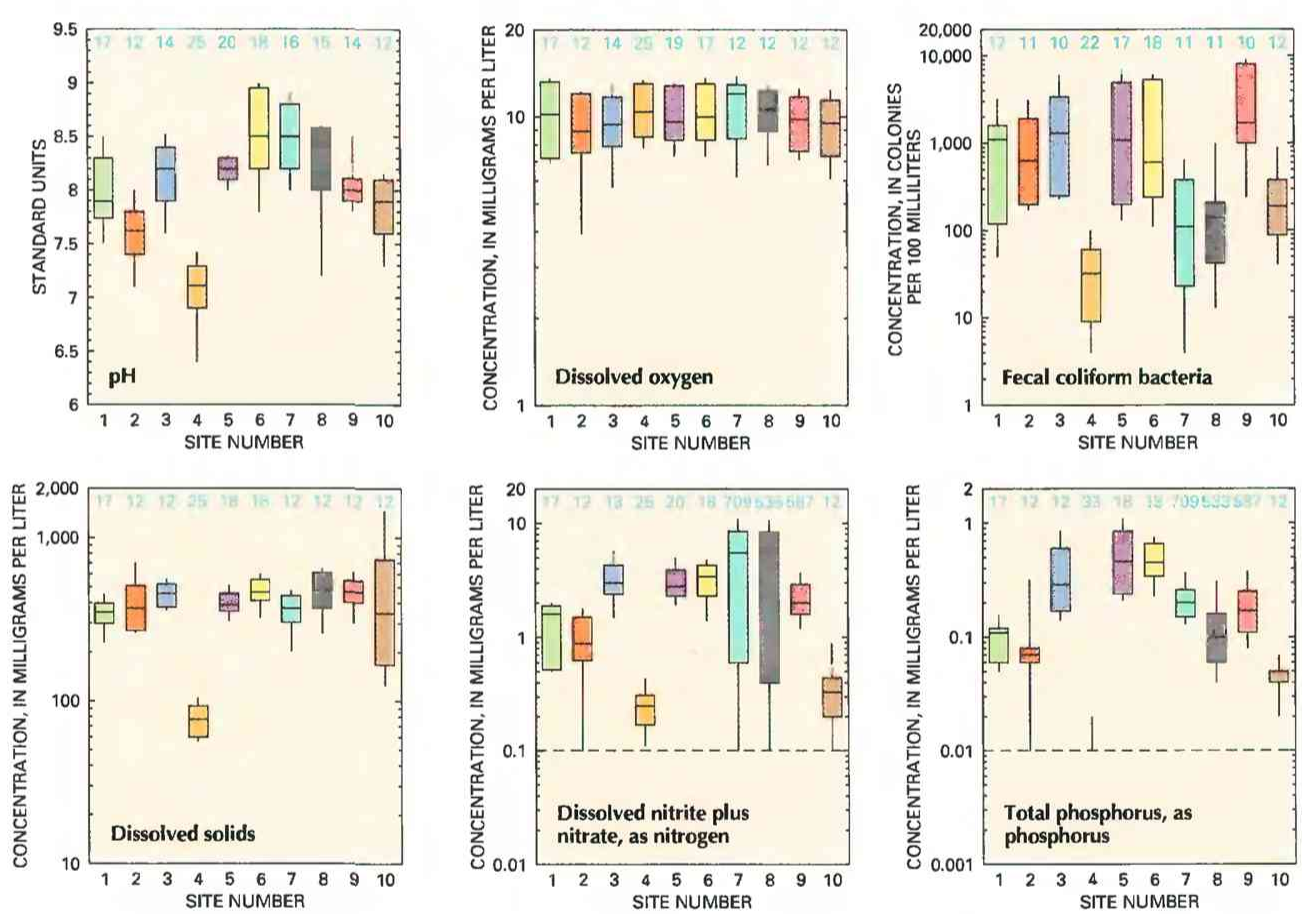
toring station at site 4 is part of the USGS Hydrologic Bench-Mark

\section{EXPLANATION}

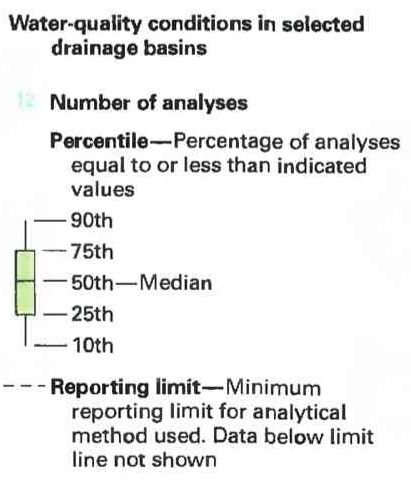

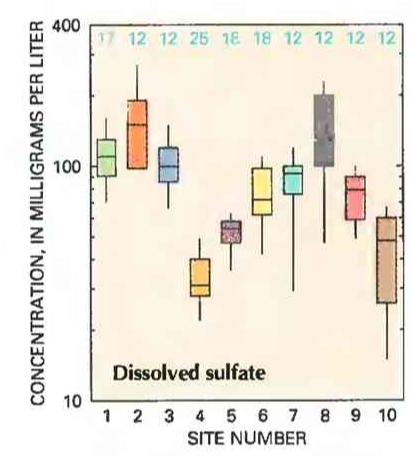
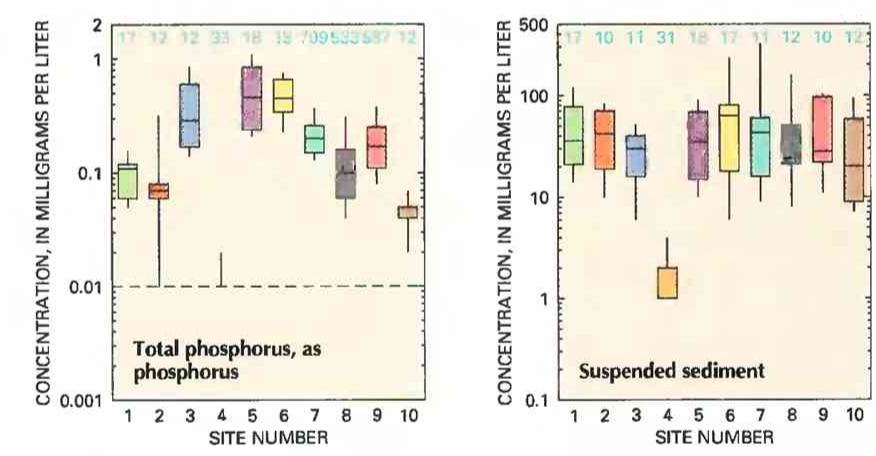

River for water supply, has issued drinking-water alerts during spring runoff because of nitrate concentrations in excess of $10 \mathrm{mg} / \mathrm{L}$ at the water intake. The median nitrite plus nitrate concentration (3.0 $\mathrm{mg} / \mathrm{L})$ and the median phosphorus concentration $(0.29 \mathrm{mg} / \mathrm{L})$, among the highest in the monitoring-station network, reflect the effect of agricultural nonpoint sources in the basin and the municipal and industrial point sources that discharge directly to the main stem.

\section{UPPER TWIN CREEK}

Upper Twin Creek drains a small area in the Kanawha section of the Appalachian Plateaus. The basin is forested and hilly and has small farms. The sandstone and shale bedrock result in surface water that is not well buffered (that is, $\mathrm{pH}$ can be greatly affected by the addition of small amounts of base or acid); the median $\mathrm{pH}$ value at site 4 was the lowest in the monitoring network (fig. 3). The moniNetwork program to monitor water-quality conditions in streams having minimal disturbance from human activities. Median concentrations of fecal coliform bacteria $(32 \mathrm{col} / 100 \mathrm{~mL})$, sulfate $(31$ $\mathrm{mg} / \mathrm{L})$, dissolved solids $(77 \mathrm{mg} / \mathrm{L})$, nitrite plus nitrate $(0.25 \mathrm{mg} / \mathrm{L})$,

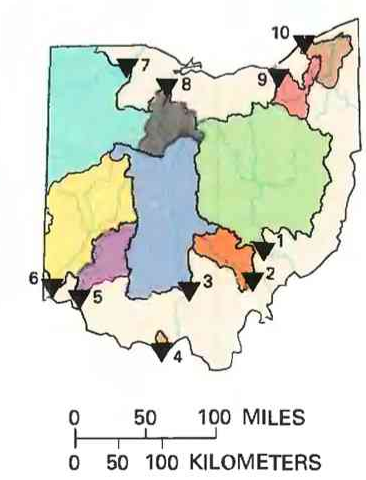

Figure 3. Water quality of selected streams in Ohio, water years 1987-89. (Source: Data from U.S. Geological Survey files.) 
Table 1. Sources and environmental significance of selected water-quality properties and constituents [Source: Compiled by the U.S. Geological Survey, Office of Water Quality]

\begin{tabular}{|c|c|c|}
\hline Property or constituent & Common sources & Environmental significance \\
\hline 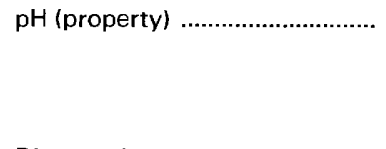 & $\begin{array}{l}\text { A measure of hydrogen-ion activity (acidity or alkalin- } \\
\text { ity); can be affected by geologic setting, biological } \\
\text { activity, municipal and industrial wastewater dis- } \\
\text { charge, and atmospheric deposition. }\end{array}$ & $\begin{array}{l}\text { Acidic water can corrode pipes and equipment; can } \\
\text { cause the release of lead and other metals from } \\
\text { distribution systems to drinking water; can affect } \\
\text { wastewater-treatment processes and taste of } \\
\text { water. }\end{array}$ \\
\hline Dissolved oxygen .............................. & $\begin{array}{l}\text { Introduced from the atmosphere; also a byproduct of } \\
\text { aquatic plants. }\end{array}$ & $\begin{array}{l}\text { Necessary for aquatic life; deficiency can result from } \\
\text { assimilation of organic wastes or rapid growth } \\
\text { and decay of algae. }\end{array}$ \\
\hline Fecal coliform bacteria ................... & $\begin{array}{l}\text { Sources include effluent from sewage-treatment } \\
\text { plants and runoff from pastures, feedlots, and ur- } \\
\text { ban areas. }\end{array}$ & $\begin{array}{l}\text { Presence indicates contamination of water by wastes } \\
\text { from humans and other warm-blooded animals. }\end{array}$ \\
\hline Sulfate & $\begin{array}{l}\text { Occurs in some rocks; also in mine runoff, industrial } \\
\text { wastewater discharge, and atmospheric deposi- } \\
\text { tion. }\end{array}$ & $\begin{array}{l}\text { Concentrations exceeding a natural, background } \\
\text { level indicate contamination from human activity; } \\
\text { in sufficient quantity, can cause water to be } \\
\text { unsuitable for public supply; can harm aquatic } \\
\text { organisms. }\end{array}$ \\
\hline Dissolved solids ................................. & $\begin{array}{l}\text { A result of rock weathering; also in agricultural runoff } \\
\text { and industrial discharge. }\end{array}$ & $\begin{array}{l}\text { In sufficient quantity, can cause water to be unsuitable } \\
\text { for public supply, agriculture, and industry; can } \\
\text { harm aquatic organisms. }\end{array}$ \\
\hline Nitrite plus nitrate & $\begin{array}{l}\text { Nonpoint sources are agricultural and urban runoff; } \\
\text { a major point source is wastewater discharge. }\end{array}$ & $\begin{array}{l}\text { Plant nutrient that, in sufficient quantity, can cause } \\
\text { algal blooms and excessive growth of higher } \\
\text { aquatic plants in bodies of water; can cause water } \\
\text { to be unsuitable for public supply. }\end{array}$ \\
\hline 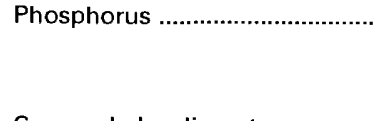 & $\begin{array}{l}\text { Occurs in some rocks and sediments; also in runoff } \\
\text { and seepage from phosphate-rock mines, agri- } \\
\text { cultural and urban runoff, and industrial and } \\
\text { municipal wastewater discharge. }\end{array}$ & $\begin{array}{l}\text { Plant nutrient that, in sufficient quantity, can cause } \\
\text { algal blooms and excessive growth of higher } \\
\text { aquatic plants in bodies of water. }\end{array}$ \\
\hline Suspended sediment ................. & $\begin{array}{l}\text { A result of rock erosion; also induced by disturbances } \\
\text { of land cover due to fires, floods, and human } \\
\text { activities such as mining, logging, construction, } \\
\text { and agriculture. }\end{array}$ & $\begin{array}{l}\text { Can be detrimental to aquatic organisms; can fill res- } \\
\text { ervoirs and impair recreational use of water. }\end{array}$ \\
\hline
\end{tabular}

phosphorus (less than $0.01 \mathrm{mg} / \mathrm{L}$ ), and suspended sediment ( 1 $\mathrm{mg} / \mathrm{L}$ ) were appreciably lower than those for the rest of the 10 network stations.

\section{LITTLE MIAMI AND GREAT MIAMI RIVERS}

The Little Miami and Great Miami River basins lie within the glaciated Till Plains of the Central Lowland. The topography of the upper basin is level to gently rolling; near the Ohio River the terrain is more hilly. Limestone, dolomite, and shale underlie the basin. The Little Miami River basin is rural, and land cover is primarily row crops, pasture, and woodland. Land cover in the Great Miami River basin is mostly row crops and some pasture and woodland, but the basin also contains some of the State's largest urban areas. Tributaries of the Little Miami and Great Miami Rivers have been designated exceptional warm-water habitats because the water quality supports a diverse biologic community. No major cities are located in the Little Miami River basin; however, suburbs of Dayton and Cincinnati extend into the basin. The lower main stem of the Great Miami River drains an urban and extensively industrialized area.

At sites 5 and 6 , fecal coliform bacteria concentrations frequently exceeded the criterion for primary-contact recreation and, often, secondary-contact recreation $(5,000 \mathrm{col} / 100 \mathrm{~mL})$. Median nitrite plus nitrate concentrations were 2.8 and $3.4 \mathrm{mg} / \mathrm{L}$, respectively. Median phosphorus concentrations for the Little Miami and Great Miami Rivers $(0.46$ and $0.45 \mathrm{mg} / \mathrm{L})$ were higher than for the eight other network sites (fig. 3). High concentrations of these constituents probably are caused by agricultural runoff and numerous municipal wastewater discharges. The Great Miami River (site 6) had the highest median suspended-sediment concentration in the monitoring network ( $60 \mathrm{mg} / \mathrm{L}$ ). Topography, soil cover, and soil type combine to make southwestern Ohio the area of greatest suspended-sediment yield in the State (Anttila and Tobin, 1978, p. 50).

\section{MAUMEE AND SANDUSKY RIVERS}

The Maumee and Sandusky River basins are in the Eastern lake section of the Central Lowland. Headwaters of the Maumee
River are in northeastern Indiana and southeastern Michigan. Paleolake Maumee, which covered much of this area during periods of glaciation, deposited a thick layer of clay, fine silt, and sand. Because the flat topography and fine-textured soils inhibit natural drainage and discourage agriculture, the land is drained by subsurface tiles and a large network of ditches. Land use in the basin is primarily row-crop agriculture. Toledo and Sandusky are downstream from sites 7 and 8. respectively. Elevated concentrations of nitrate, phosphorus, sediment, and pesticides are significant water-quality problems in these basins (Baker, 1988). The lower Maumee River has been designated an Area of Concern by the International Joint Commission on the Great Lakes because of dissolved-oxygen depletion. increased bacteria and phosphorus concentrations, and toxic substances in water and sediment. Although the quantity of phosphorus discharged into Lake Erie has decreased since the mid-1970's, further reduction in current estimated loads will be required to meet the established target load (U.S. Environmental Protection Agency, 1988, p. 16).

No major cities are upstream from either monitoring station; therefore, median fecal coliform bacteria concentrations $(110 \mathrm{col} / 100$ $\mathrm{mL}$ at site 7 and $140 \mathrm{col} / 100 \mathrm{~mL}$ at site 8 ) were relatively low (fig. 3) and were lower than the primary-contact-recreation criterion. Sulfate concentrations at site 8 (median, $130 \mathrm{mg} / \mathrm{L}$ ), which were high compared to those at most other network stations, probably were from natural sources. Ground water in the vicinity of site 8 contains high concentrations of sulfur (more than $1,000 \mathrm{mg} / \mathrm{L}$ at some sites) from bedrock containing gypsum, a calcium sulfate mineral (Breen, 1992). Water samples collected at sites 7 and 8 had high nitrite plus nitrate concentrations (medians, 5.5 and $5.4 \mathrm{mg} / \mathrm{L}$ ) compared to other network sites. Annual variability in nitrite plus nitrate concentrations is substantial (fig. 3) and is associated with runoff from cropland (Baker, 1988, p. 64). The nitrate criterion for public water supplies $(10 \mathrm{mg} / \mathrm{L})$ was exceeded at both monitoring stations. The median total-phosphorus concentration at site $7(0.20 \mathrm{mg} / \mathrm{L})$ was the highest for the Lake Erie tributaries discussed in this report and was higher than the $0.05-\mathrm{mg} / \mathrm{L}$ limit to control eutrophication that is recommended for rivers draining into lakes (U.S. Environmental Protec- 
tion Agency, 1986). However, phosphorus concentrations in these two basins were lower than in the western Ohio River tributaries, probably because of regulatory efforts to limit phosphorus loading to Lake Erie.

\section{CUYAHOGA RIVER}

The Cuyahoga River basin is in the Southern New York section of the Appalachian Plateaus and the Eastern lake section of the Central Lowland. The surficial geology of the lower basin consists of silt and clay left by a retreating glacier. The upper 24 miles of the Cuyahoga River has been classified as a State Scenic River. From cropland, pasture, woodland, and residential land in the headwaters, the river flows through the extensively urbanized and industrialized Akron and Cleveland metropolitan areas, which are separated by the Cuyahoga Valley National Recreation Area. The main stem from Akron to the mouth does not meet the designated aquatic-life-use standards owing to organic enrichment and toxic contamination from combined municipal- and storm-sewer overflows, industrial and municipal wastewater effluent, and urban nonpoint sources. The mouth and harbor of the Cuyahoga River have been designated as an Area of Concern by the International Joint Commission on the Great Lakes because of dissolved-oxygen depletion, stressed biological communities, and elevated concentrations of toxic substances, bacteria, and phosphorus.

Site 9 is between the Cuyahoga Valley National Recreation Area and Cleveland. Effluent from the Akron wastewater treatment plant, treated industrial effluents, and combined municipal- and storm-sewer overflows from the Akron-Cleveland metropolitan area have a substantial effect on river quality. The median fecal coliform bacteria concentration $(1,700 \mathrm{col} / 100 \mathrm{~mL})$ was the highest for the monitoring network (fig. 3), and measured concentrations routinely exceed criteria for recreational use - an issue of importance to the Cuyahoga Valley National Recreation Area (J.P. Debo, National Park Service, written commun., November 1989). The median nitrite plus nitrate concentration was $2.0 \mathrm{mg} / \mathrm{L}$, and median phosphorus concentration was $0.17 \mathrm{mg} / \mathrm{L}$. Sediment deposition is a continual problem in the Cuyahoga River shipping channel and harbor to Lake Erie. Although the median suspended-sediment concentration was among the lowest $(28 \mathrm{mg} / \mathrm{L})$, maximum concentrations, which generally occur during periods of high streamflow, can account for more than 90 percent of the total annual suspended-sediment discharge (Anttila and Tobin, 1978, p. 55).

\section{GRAND RIVER}

The lower part of the Grand River drains the flat Eastern lake section of the Central Lowland. The upper part of the basin drains the rolling hills of the glaciated Southern New York section of the Appalachian Plateaus. Much of the basin is in Ohio's snow belt, which receives twice as much snow as the rest of the State. The climate and sandy soil are unsuitable for grain crops but are ideal for orchards, truck farms, nurseries, and, in the headwater area, dairies. The area near Lake Erie is urban and industrialized; industrial activities include mining and processing of salt from abundant buried deposits. Runoff from abandoned chemical-industry properties and waste lagoons contributes large quantities of dissolved solids to the lower Grand River (U.S. Environmental Protection Agency, 1986). However, segments of the lower main stem have an aquatic-life-use designation of seasonal salmonid habitat and State resource water (Ohio Environmental Protection Agency, 1990b).

During water years $1987-89$, some concentrations of dissolved solids at site 10 exceeded the criterion for both public water supply (750 mg/L) and aquatic-life-use designation $(1,500 \mathrm{mg} / \mathrm{L})$ (fig. 3). Because a primary source of dissolved solids is surface runoff, concentrations differ substantially throughout the year. Values of all other properties and constituents were small compared to those at most other network stations. Median nitrite plus nitrate $(0.33$ $\mathrm{mg} / \mathrm{L})$ and median phosphorus $(0.05 \mathrm{mg} / \mathrm{L})$ concentrations were lower than at all but the bench-mark station (site 4), most likely because of the lack of row-crop agriculture in the basin. Fecal coliform bacteria concentrations (median, $190 \mathrm{col} / 100 \mathrm{~mL}$ ) were lower than the criterion for primary-contact recreation.

\section{WATER-QUALITY TRENDS}

Trend analysis is a statistical procedure used to detect changes in stream water quality at a monitoring station over time. For this report, water-quality data from 10 monitoring stations (fig. 2) were analyzed for trends by using the seasonal Kendall test (Hirsch and others, 1982), a method used extensively by the USGS. The graph (shown below) of $\mathrm{pH}$ values in the Muskingum River at site 1 illustrates the trend inferred from the data and demonstrates the variation in water quality that is common in streams.

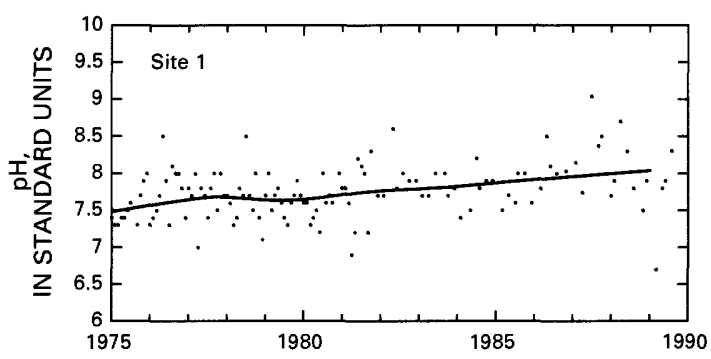

When possible, constituent-concentration data were adjusted for changes in streamflow to preclude identifying a trend in concentration that was caused only by a trend in streamflow. The data were not adjusted when (1) more than 10 percent of the samples had concentrations lower than the minimum reporting limit for the analytical method used or (2) streamflow was controlled substantially by human activities. When the concentration data could not be adjusted for streamflow, trends were determined directly from the concentration data.

Statewide trends in measurements of selected physical properties of stream water and in concentrations of selected constituents in stream water are shown on maps in figure 4. On each map, a trend is indicated at a monitoring station only if the data from that station were suitable for use in the trend analysis. For more information on the suitability criteria and on the trend-analysis procedure used for this report, see Lanfear and Alexander (1990).

$\mathrm{pH}$

The $\mathrm{pH}$ of a sample of water is a measure of its hydrogen-ion activity (effective concentration). An increase in hydrogen-ion content causes water to become more acidic but results in a lower measured $\mathrm{pH}$ value because the units of $\mathrm{pH}$ are inversely related to hydrogen-ion activity. Both natural processes and human activities (table 1) can affect $\mathrm{pH}$. The $\mathrm{pH}$ of river water in most areas not affected by pollution is between about 6.5 and 8.5 (Hem, 1985, p. 64).

The average rate of $\mathrm{pH}$ change at the seven monitoring stations at which upward trends were detected ranged from 0.023 to 0.055 standard unit per year. Smith and others (1987, p. 12), who reported similar $\mathrm{pH}$ trends in the Ohio River basin, suggested that the trends might have resulted from biological processes, such as increased rates of instream photosynthesis. Although less likely to have been a significant cause, downward trends in atmospheric deposition of sulfate and nitrate ions in Ohio (U.S. Department of Commerce, 1987) might have contributed to the upward trends in $\mathrm{pH}$.

\section{DISSOLVED OXYGEN}

The dissolved-oxygen concentration in a stream is controlled by several factors, including water temperature, air temperature and 
pressure, hydraulic characteristics of the stream, photosynthetic or respiratory activity of stream biota, and the quantity of organic material present. A trend in dissolved-oxygen concentrations commonly is directly or indirectly the result of human activities. Generally, an upward trend in dissolved-oxygen concentrations indicates improving stream water-quality conditions and a downward trend indicates deteriorating conditions.

Upward trends in dissolved-oxygen concentrations in the Scioto River at site 3, the Great Miami River at site 6, and the Cuyahoga River at site 9 might be attributable to improvements in municipal or industrial wastewater-treatment facilities located upstream from the monitoring stations (Ohio Environmental Protection Agency, 1988). The upward trends represent a decrease in organic enrichment and an improvement in the poor dissolved-oxygen conditions that have been identified as the major cause of failure to meet water-quality criteria for designated aquatic-life uses in Ohio (Ohio Environmental Protection Agency, 1990a).

\section{FECAL COLIFORM BACTERIA}

Fecal coliform bacteria are used as indicators of fecal contamination from humans and other warm-blooded animals. Such contamination can introduce disease-causing viruses and bacteria into a stream. The downward trend in fecal coliform bacteria detected in the Great Miami River at site 6 likely was due to improvements in wastewater treatment in the communities of Dayton, Fairfield, Hamilton, and Middletown.

\section{DISSOLVED SULFATE}

The major natural sources of sulfate in streams are rock weathering, volcanoes, and biochemical processes (Hem, 1985, p. 113). Human activities such as mining, waste discharge, and fossil-fuel combustion also can be important sources.

Atmospheric deposition and weathering of sulfur-bearing minerals, especially after exposure by surface coal mining, are two important sources of sulfate in surface water (Smith and others, 1987, p. 8). Surface coal mining probably was a factor in the decreasing sulfate concentration in the Hocking River at site 2 because coal mining has declined in the basin (Vanessa Tolliver, Ohio Department of Natural Resources, written commun., October 1990). Sulfur-dioxide emissions in the Ohio River basin have decreased by more than 0.6 million metric ton per year since 1970 (U.S. Department of Commerce, 1987 , p. 1-34), which might partly explain the downward trends at four other monitoring stations (sites 6, 7,9, and 10). However, it is not known why similar downward trends were not detected in the Muskingum River (site 1), Scioto River (site 3), and Little Miami River (site 5).

\section{DISSOLVED SOLIDS}

Dissolved solids in stream water result primarily from rock weathering but also can be introduced as a byproduct of human activities (table 1). Concentrations generally are greatest in streams draining basins underlain by rocks and soils that contain easily dissolved minerals.

The cause of low but significantly increasing dissolved-solids concentrations in the Scioto River at site 3 might have been increased urbanization, particularly in the Columbus metropolitan area. The downward trends in the Muskingum River at site 1 and the Hocking River at site 2 might have been the result of a decrease in acidic mine drainage. Since 1979 , more than 6,000 acres of abandoned surface mines and mine-refuse sites have been reclaimed in Ohio (Kirk Beach, Ohio Department of Natural Resources, written commun., October 1990). In addition, numerous projects to control mine drainage and restore streams in southeastern Ohio have been completed.

\section{DISSOLVED NITRITE PLUS NITRATE}

Nitrite and nitrate are oxidized forms of nitrogen that together normally constitute most of the dissolved nitrogen in well-aerated streams. Nitrite readily oxidizes to nitrate in natural waters; therefore, nitrate generally is by far the more abundant of the two (Hem, 1985 , p. 124). Nitrite plus nitrate concentrations had no trend at the 10 monitoring stations. The application of fertilizers, a major source of nitrate to Ohio streams, decreased by only 1 percent in Ohio from 1980 through 1985 (Alexander and Smith, 1990).

\section{TOTAL PHOSPHORUS}

The total phosphorus concentration of a water sample is a measure of the concentration of all forms of phosphorus present in the sample, dissolved and particulate. Human activities (table 1) can be important sources of phosphorus in streams.

The upward trend in phosphorus concentrations in the Little Miami River at site 5 might have resulted from increasing pointsource loadings from wastewater-treatment plants owing to increasing population. Several substantial expansions of existing municipal wastewater-treatment plants and additions of new wastewatertreatment plants were completed in the Little Miami River basin during 1975-88 (Diana Zimmerman, Ohio Environmental Protection Agency, oral commun., October 1990). The OEPA (1988) reported that aquatic-life uses in the lower 24 miles of the Little Miami River are threatened by increasing wastewater-treatment-plant effluent.

The two streams in which trends in phosphorus concentrations were downward (the Maumee and Cuyahoga Rivers, sites 7 and 9) (fig. 4) are in the Lake Erie drainage basin. Decreasing concentrations in these streams were likely the result of substantial reductions in application of phosphorus fertilizers in Ohio (Alexander and Smith, 1990) and of phosphorus-removal processes instituted at wastewatertreatment facilities after the Federal Water Pollution Control Act of 1972 and the Great Lakes Water Quality Agreement of 1978 (U.S. Environmental Protection Agency, 1988).

\section{SUSPENDED SEDIMENT}

Suspended sediment is a product of erosion. The erosion can be either natural or the result of land-cover disturbances related to human activities (table 1).

No trend in suspended-sediment concentration was detected at the seven monitoring stations from which data were suitable for trend analysis. The absence of a trend does not mean that sedimentrelated issues are not a problem in Ohio. The OEPA (1990a, p. 13) has stated that siltation and habitat modification were factors in 20 percent of the stream segments that failed to meet biological or waterquality criteria for designated aquatic-life uses.

\section{WATER-QUALITY MANAGEMENT}

Surface-water quality is regulated by the OEPA under the Ohio Water Pollution Control law (Chapter 6111 of the Ohio Revised Code). This statute grants broad authority to carry out the provisions of the Federal Water Pollution Control Act, which include ambient water-quality monitoring, water-quality planning activities, the $\mathrm{Na}$ tional Pollutant Discharge Elimination System permit program, and associated compliance and enforcement activities.

The OEPA develops and adopts water-quality standards for surface waters. Ohio was the first State in the Nation to adopt numerical biological criteria that are used to assess stream water quality and to determine attainment of the State's aquatic-life-use designations. Beginning in 1979 , water-quality monitoring was greatly enhanced by the completion of detailed biological and chemical water-quality surveys throughout the State. Much of this monitoring activity was in response to water-quality-management needs dictated by the waterquality standards and construction-grant programs. To date, about 


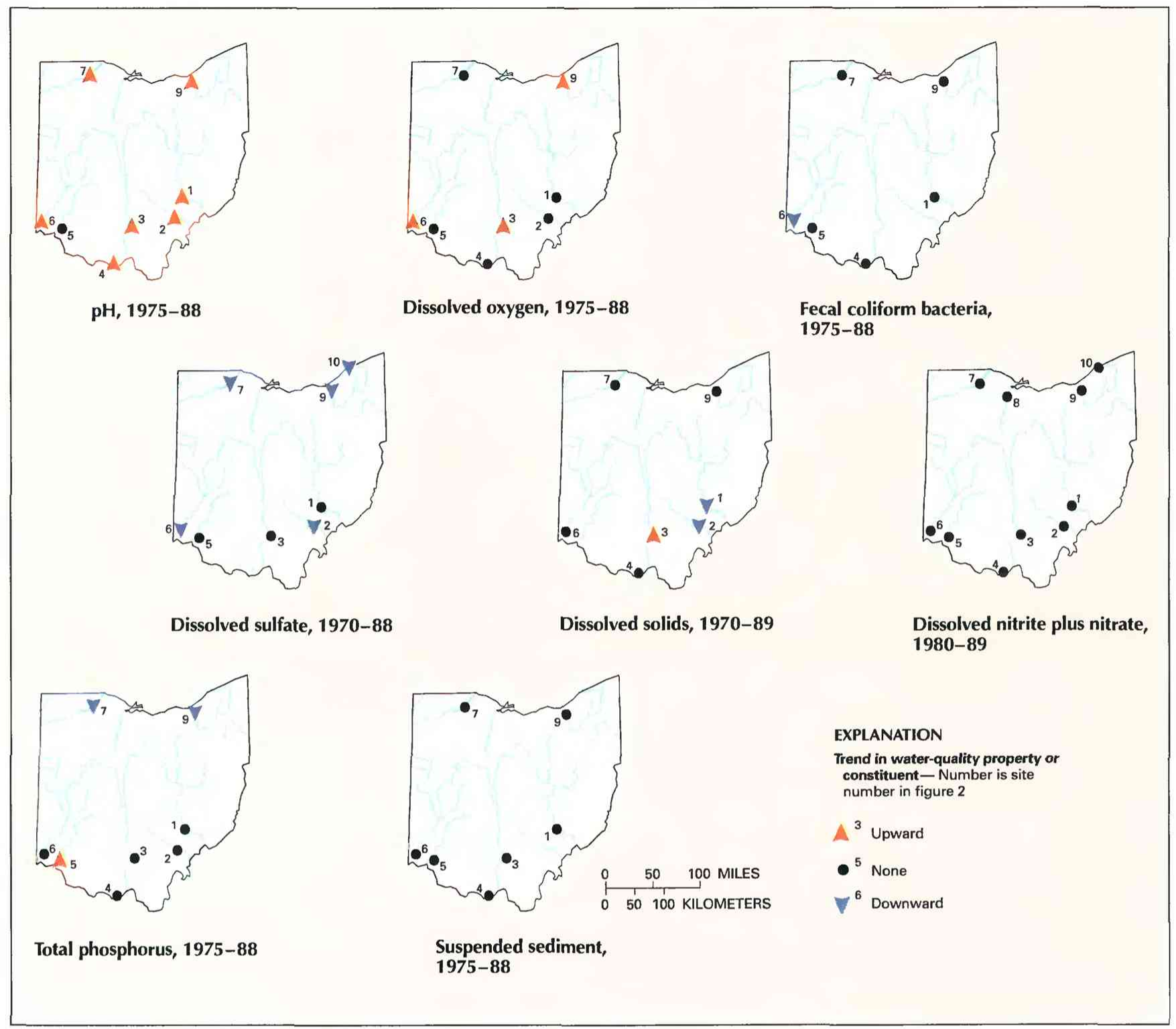

Figure 4. Trends in water quality of selected streams in Ohio, by water years. (Source: Data from U.S. Geological Survey files.)

100 surveys have been completed. Detailed water-quality survey work has declined slowly in the last 5 years in response to a decline in funding.

The OEPA prepares a biennial water-quality-assessment report (Ohio Environmental Protection Agency, 1990a) submitted to the EPA and the U.S. Congress in accordance with section 305(b) of the Federal Clean Water Act. The OEPA also has completed the nonpoint water-quality assessment required under section 319 of the act. Administration of the nonpoint water-pollution-management plan is a cooperative venture between the OEPA and the Ohio Department of Natural Resources.

The U.S. Army Corps of Engineers, OEPA, Ohio Department of Natural Resources, and local agencies cooperate with the USGS in monitoring streamflow and water quality at numerous gaging stations. The Ohio Department of Natural Resources, U.S. Army Corps of Engineers, and local conservancy districts also share water-qualitymanagement responsibilities associated with more than 20 large flood-control reservoirs in Ohio.

Ohio is a signatory State to the Ohio River Valley Water Sanitation Commission Compact and participates in water-quality moni- toring and other activities of the Commission. The State also participates in organizations having a specific interest in Great Lakes water-quality concerns, such as the Great Lakes Commission, the Council of Great Lakes Governors, and various committees of the International Joint Commission.

\section{SELECTED REFERENCES}

Alexander, R.B., and Smith, R.A., 1990, County-level estimates of nitrogen and phosphorus fertilizer use in the United States, 1945 to 1985: U.S. Geological Survey Open-File Report 90-130, 12 p.

Anderson, J.R., 1967, Major land uses in the United States, in U.S. Geological Survey, 1970, National atlas of the United States of America: Washington, D.C., U.S. Geological Survey, p. 158-159.

Anttila, P.W., and Tobin, R.L., 1978, Fluvial sediment in Ohio: U.S. Geological Survey Water-Supply Paper 2045, 58 p.

Baker. D.B., 1988, Sediment, nutrient and pesticide transport in selected lower Great Lakes tributaries, in U.S. Environmental Protection Agency, Great Lakes National Program Office: Chicago, Ill., Great Lakes National Program Office, GLNPO report no. 1, EPA-905/4-88-001, 225 p. 
Breen, K.J., 1992, Ground-water hydrology and water quality in Lucas, Sandusky, and Wood Counties, northwestern Ohio: U.S. Geological Survey Water-Resources Investigations Report 91-4024, 234 p.

Britton, L.J., and Greeson, P.E., eds., 1987, Methods for collection and analysis of aquatic biological and microbiological samples: U.S. Geological Survey Techniques of Water-Resources Investigations, book 5, chap. A4. $363 \mathrm{p}$.

Fenneman, N.M., 1946, Physical divisions of the United States: Washington, D.C., U.S. Geological Survey special map, scale 1:7,000,000.

Fishman, M.J., and Friedman, L.C., eds., 1989, Methods for the determination of inorganic substances in water and fluvial sediments: U.S. Geological Survey Techniques of Water-Resources Investigations, book 5, chap. A1, 545 p.

Helsel, D.R., 1983, Mine drainage and rock type influences on eastern Ohio stream water quality: Water Resources Bulletin, v. 19, no. 6, p. 881-887.

Hem, J.D., 1985. Study and interpretation of the chemical characteristics of natural water (3d ed.): U.S. Geological Survey Water-Supply Paper 2254 , $263 \mathrm{p}$.

Hirsch, R.M., Slack, J.R., and Smith, R.A., 1982, Techniques of trend analysis for monthly water quality data: Water Resources Research, v. 18, no. 1, p. 107-121.

Lanfear, K.J., and Alexander, R.B., 1990, Methodology to derive water-quality trends for use by the National Water Summary Program of the U.S. Geological Survey: U. S. Geological Survey Open-File Report 90-359, $10 \mathrm{p}$.

Ohio Environmental Protection Agency, 1986, 305(b) report v. II: Columbus, Ohio Environmental Protection Agency, 500 p.

1988, Ohio water quality inventory, 1988305 (b) report, v. II: Columbus, Ohio Environmental Protection Agency, 367 p.

1990a, Ohio water resource inventory, 1990 305(b) report, v. I: Columbus, Ohio Environmental Protection Agency, 78 p. 1990b, State of Ohio Water Quality Standards, chapter 3745-1 of the Administrative Code: Columbus, Ohio Environmental Protection Agency, variously paginated.

Smith, R.A., Alexander, R.B., and Wolman, M.G., 1987, Analysis and interpretation of water-quality trends in major U.S. rivers, 1974-81: U.S. Geological Survey Water-Supply Paper 2307, 25 p.

Thelin, G.P., and Pike, R.J., 1990, Digital shaded relief map of the conterminous United States: Menlo Park, Calif., U.S. Geological Survey digital image processing, scale 1:3,500,000.

U.S. Department of Commerce, 1987, National acid precipitation assessment program (NAPAP) interim assessment, the causes and effects of acidic deposition, v. 2, emissions and control: Washington, D.C.. National Technical Information Service, variously paginated.

U.S. Environmental Protection Agency, 1986, Quality criteria for water 1986: Washington, D.C., U.S. Environmental Protection Agency Office of Water Regulations and Standards, EPA 440/5-86-001, variously paginated.

1988, Five year program strategy for the Great Lakes National Program Office, FY 1989-1993: Chicago, Ill., Great Lakes National Program Office, GLNPO report no. 1-89, $84 \mathrm{p}$.

U.S. Geological Survey, 1986, National water summary 1985-Hydrologic events and surface-water resources: U.S. Geological Survey Water-Supply Paper 2300, 506 p.

1990, National water summary 1987-Hydrologic events and water supply and use: U.S. Geological Survey Water-Supply Paper 2350 , $553 \mathrm{p}$.

Ward, J.R., and Harr, C.A., eds., 1990, Methods for collection and processing of surface-water and bed-material samples for physical and chemical analyses: U.S. Geological Survey Open-File Report 90-140, 71 p.

Prepared by Carolyn J. Oblinger Childress and Gregory F. Koltun, U.S. Geological Survey; “Water-Quality Management” section by Dan Dudley, Ohio Environmental Protection Agency

FOR ADDITIONAL INFORMATION: District Chief, U.S. Geological Survey, 975 West Third Ave., Columbus, OH 43212-3192 


\section{OKLAHOMA Stream Water Quality}

Annual precipitation in Oklahoma ranges from about 16 inches in the western panhandle to about 52 inches in the pine forests of the southeast (U.S. Geological Survey, 1986, p. 375). Average annual runoff ranges from 0.2 to 20 inches from west to east. Because of the uneven distribution of the State's water resources, western Oklahoma generally relies on ground water, whereas eastern Oklahoma has abundant surface-water supplies (U.S. Geological Survey, 1990 , p. 418). Runoff from precipitation during spring and fall provides 92 percent of the State's fresh surface water. The remaining 8 percent is from surface-water inflow that originates outside of the State (U.S. Geological Survey, 1990, p. 417).

Surface water provided an average of $707 \mathrm{Mgal} / \mathrm{d}$ (million gallons per day) or 55.5 percent of the total freshwater withdrawals in 1985 . Of that quantity, 58.6 percent $(414 \mathrm{Mgal} / \mathrm{d})$ was withdrawn for public supply, 12.0 percent $(85 \mathrm{Mgal} / \mathrm{d})$ for industry and mining, 18.8 percent ( $133 \mathrm{Mgal} / \mathrm{d}$ ) for thermoelectric power generation, 9.5 percent $(67 \mathrm{Mgal} / \mathrm{d})$ for agricultural purposes, and 1.2 percent $(8.5$ $\mathrm{Mgal} / \mathrm{d}$ ) for self-supplied domestic and commercial use (U.S. Geological Survey, 1990, p. 422).

Water quality can be as important to water users as water availability. Suitability of water for beneficial uses that are designated by the State for purposes of water-quality monitoring and protection differs among streams. The water quality of some streams in the State makes them unsuitable for use as cooling waters, for propagation of fish and shellfish, and for wildlife and recreation. In general, surface water in the western part of the State is unsuitable for public supply because of large concentrations of dissolved minerals (U.S. Geological Survey, 1990, p. 418). Water quality does not restrict the use of most streams for water supply in the eastern part of the State.

The quality of Oklahoma's streams and rivers is affected by land-use and geological characteristics of the drainage basins. Land use (fig. $1 A$ ) is determined in part by physiography and climate. Western Oklahoma, which lies in the Great Plains and the Central Lowland (fig. $1 B$ ), is a mixed prairie-grass region that has been transformed by cultivation into one of the most productive wheat-producing regions in the world (Oklahoma Water Resources Board, 1990, p. 16). The Central Lowland supports cropland, pasture, and most of the larger population centers of the State (fig. 1C). The Ouachita province in eastern Oklahoma is characterized by pine forests that are logged commercially. The Ozark Plateaus province has low mountains covered by pasture and mixed forests.

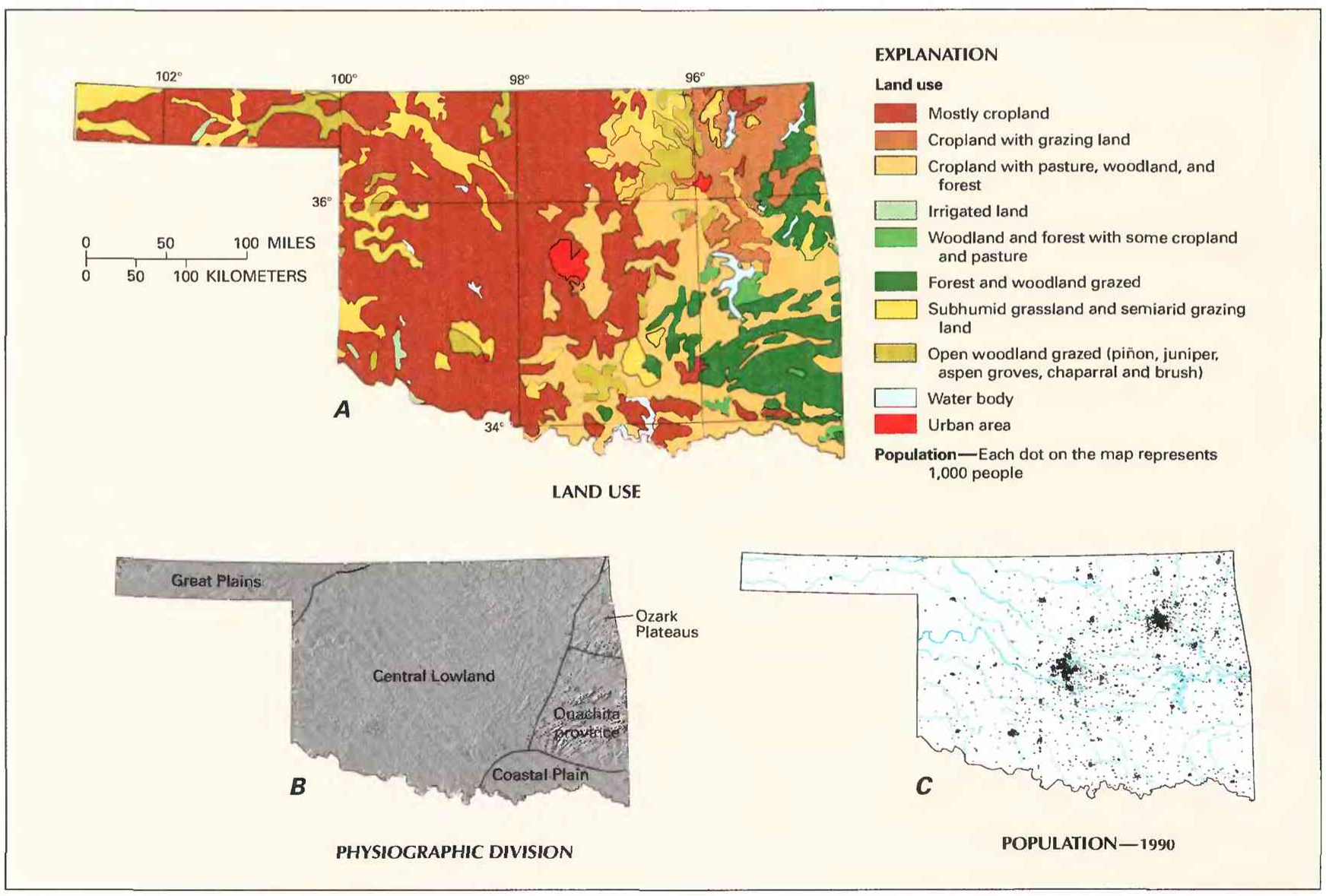

Figure 1. Land use, physiography, and population in Oklahoma. A, Major land uses. B, Physiographic divisions. $C$, Population distribution in 1990. (Sources: A, Major land uses modified from Anderson, 1967. B. Physiographic divisions from Fenneman, 1946; landforms from Thelin and Pike, 1990. C. Data from U.S. Bureau of the Census 1990 decennial census files.) 
Most of Oklahoma's population resides in the central and eastern parts of the State (fig. 1C). The State's 1990 population was 3.1 million, an increase of approximately 4 percent since 1980 (U.S. Bureau of the Census 1990 decennial census files).

\section{WATER-QUALITY MONITORING}

Water-quality data obtained from analyses of water samples collected at monitoring stations are stored in the U.S. Geological Survey's (USGS) National Water Information System and the U.S. Environmental Protection Agency's (EPA) national data base known as STORET. Water-quality and streamflow data are reported by water year-the 12 months from October 1 through September 30. A water year is identified by the calendar year in which it ends. For example, water year 1991 comprises October 1, 1990, through September 30, 1991.

The data used in this summary of Oklahoma's stream water quality were obtained from water samples collected monthly, every 2 months, or quarterly at 20 monitoring stations at which data collection is systematic and continuing (fig. 2). Analyses of water samples collected at 10 stations are the basis for the discussion and graphic summary (fig. 3) of stream water-quality conditions during water years $1987-89$, and data from all 20 stations are the basis for the discussion and graphic summary (fig. 4) of stream water-quality trends. Water samples were collected and analyzed by using standard methods approved by the USGS (Britton and Greeson, 1987; Fishman and Friedman, 1989; Ward and Harr, 1990) or by using equivalent methods. If a method of sample collection or analysis changed over time, data from an analysis were included in the evaluation of recent stream water quality or of stream water-quality trends only if the change in method did not affect the comparability of the data.

\section{WATER-QUALITY CONDITIONS}

Water-quality standards that are specific to designated beneficial uses have been promulgated by the Oklahoma Water Resources Board (1989). All of Oklahoma's streams and rivers have State-designated beneficial uses of recreation and fish and wildlife maintenance. Although 19,791 miles of streams and rivers have been

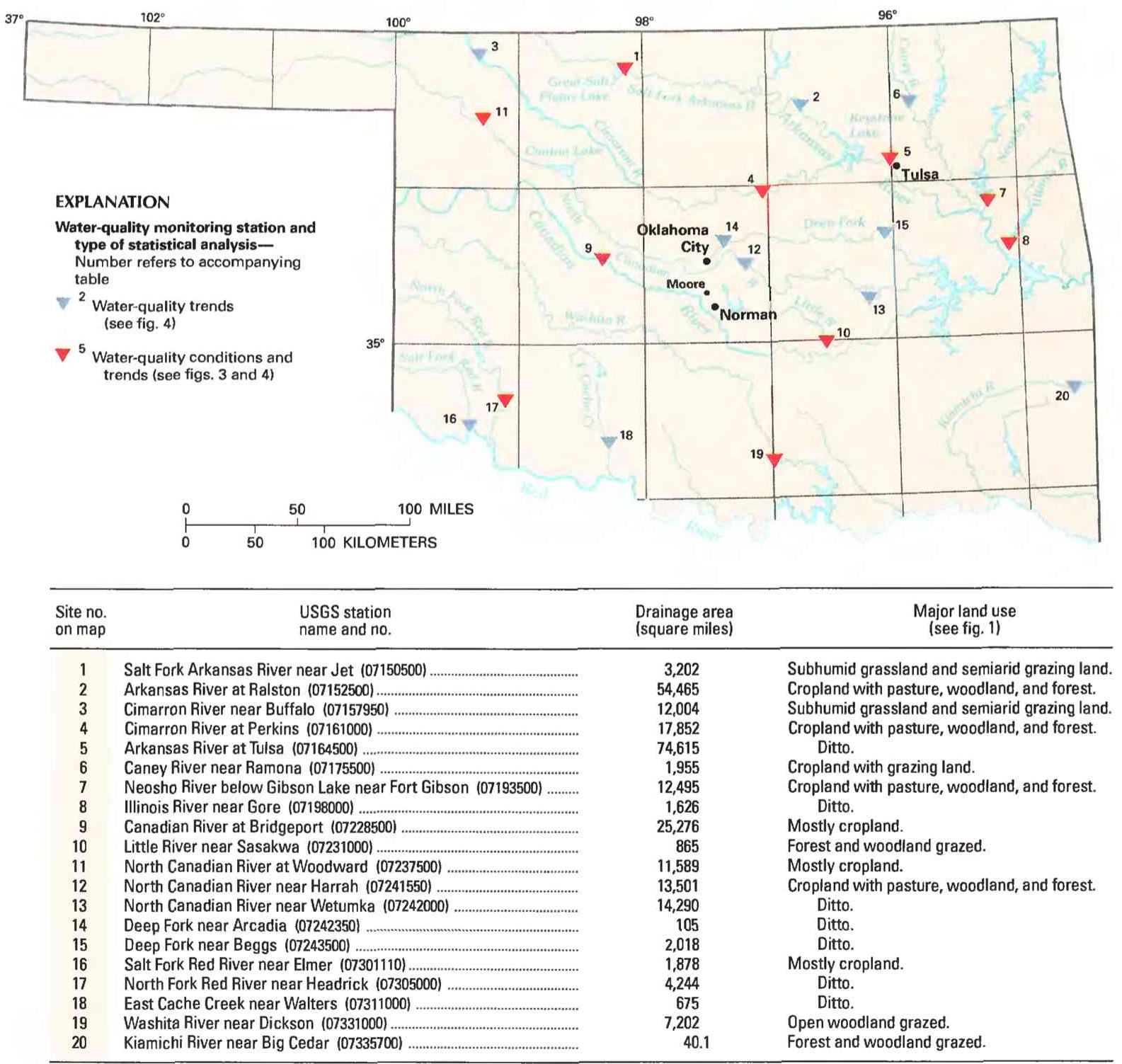

Figure 2. Selected water-quality monitoring stations, type of statistical analysis, and geographic features in Oklahoma. (Sources: Major land uses modified from Anderson, 1967; Other data from U.S. Geological Survey files.) 
directly assigned beneficial uses in the 1988 Oklahoma Water Quality Standards (Oklahoma Water Resources Board, 1989), only 4,393 miles have been assessed to determine whether they meet State standards for each designated use. Of the assessed rivers and streams, 269 miles ( 6 percent) fully support designated uses, 2,299 miles (52 percent) fully support designated uses but are threatened, and 1,825 miles ( 42 percent) partially support designated uses. A stream is classified as partially supporting designated beneficial uses if one or more of the designated beneficial uses are partially supported.

In the spring of 1990 , the State began an ambient toxicity testing program for streams having suspected toxic pollutants. Suspected pollutants identified by the Oklahoma Department of Wildlife Conservation as having caused fishkills from 1988 through 1990 include oil-well drilling wastes, sewage, poultry wastes, oil, saltwater from oil and gas extraction, pesticides, fertilizers, gasoline, diesel fuel, lawn chemicals, cattle and horse manure, nitrate, sulfuric acid, hydrogen sulfide, and dissolved metals (Oklahoma Department of Pollution Control, 1990, p. 14-17). The major sources of these contaminants are resource extraction, agricultural, municipal, and industrial sources.

The following discussion of stream water quality in Oklahoma is organized by river basin (fig. 3). Where physiographic and landuse characteristics in different basins are similar, the discussion of those basins is combined. Graphs in figure 3 summarize certain aspects of stream water quality in the basins for water years 1987-89. The graphs show frequency distributions of data values that represent concentrations of selected stream-water constituents. These constituents are dissolved oxygen, fecal coliform bacteria, dissolved sulfate, dissolved chloride, dissolved solids, dissolved nitrite plus nitrate (as nitrogen), dissolved phosphate (as phosphorus), and suspended sediment. The data are reported in milligrams per liter $(\mathrm{mg} / \mathrm{L})$ and colonies per 100 milliters $(\mathrm{col} / 100 \mathrm{~mL})$. Sources and environmental significance of each constituent are described in table 1.

Water quality at each monitoring station is the result of geological, chemical, biological, and hydrologic processes that occur over a large area. Water-quality problems that affect aquatic life or public health only locally are not fully represented in this summary.

\section{SALT FORK ARKANSAS AND CIMARRON RIVERS}

The Salt Fork Arkansas and Cimarron River basins are underlain by rocks that contain massive gypsum deposits. Natural brine seeps and springs are located throughout the basins.

Agriculture is the principal land use in the Salt Fork Arkansas River basin. Site 1 is located just downstream from the Great Salt Plains Lake reservoir. The reservoir has been partially filled with sediment, and in most places water is only about 4 feet deep. Fertilizers and pesticides from agricultural areas in the basin contribute nutrients (nitrogen and phosphorus) and organic compounds to the reservoir. The shallow depth of the reservoir allows wind mixing to keep the reservoir aerobic but also to keep nutrient- and pesticide-bearing sediment particles in suspension. The Salt Fork Arkansas River has been assessed by the Oklahoma Department of Pollution Control $(1990$, p. 3) as partially supporting designated uses in the area of site 1 because of excessive concentrations of chloride, dissolved solids, nutrients, pesticides, toxic chemicals, and suspended sediment.

Median concentrations of sulfate $(500 \mathrm{mg} / \mathrm{L})$, chloride $(920$ $\mathrm{mg} / \mathrm{L})$, and dissolved solids $(2,400 \mathrm{mg} / \mathrm{L})$ in water samples from site 1 were among the largest for the 10 monitoring stations (fig. 3). All sulfate, chloride, and dissolved-solids concentrations for water years $1987-89$ at site 1 exceeded concentrations of 250,250 , and $500 \mathrm{mg} /$ $\mathrm{L}$ recommended by the State for recreation and fish and wildlife propagation, respectively (Oklahoma Water Resources Board, 1989).

Agriculture is the principal land use, in terms of area, upstream from site 4 on the Cimarron River; however, oil production has had a significant effect on water quality (Oklahoma Conservation Com- mission, 1989). Large concentrations of chlordane from an unknown source have been detected in the stream (Oklahoma Conservation Commission, 1989). Fecal coliform bacteria concentrations have been larger than the State standard of a monthly geometric mean of $5,000 \mathrm{col} / 100 \mathrm{~mL}$ (Oklahoma Conservation Commission, 1989), perhaps owing to runoff from livestock grazing and feedlot areas. Upstream and downstream from site 4, the river has been assessed as partially supporting designated uses because of oil and grease, fecal coliform bacteria, chloride, dissolved solids, pesticides, and suspended solids (Oklahoma Conservation Commission, 1989). Many current uses and most future development of the basin are limited by natural brine seeps and springs that contribute large quantities of chloride to streams in the area and make the water unsuitable for irrigation and for industrial and commercial uses (U.S. Geological Survey, 1984, p. 191).

Samples collected at site 4 had among the largest median concentrations of fecal coliform bacteria $(180 \mathrm{col} / 100 \mathrm{~mL})$, chloride $(1,400 \mathrm{mg} / \mathrm{L})$, dissolved solids $(3,240 \mathrm{mg} / \mathrm{L})$, nitrite plus nitrate $(0.69$ $\mathrm{mg} / \mathrm{L})$, phosphate $(0.08 \mathrm{mg} / \mathrm{L})$, and suspended sediment $(126$ $\mathrm{mg} / \mathrm{L}$ ) (fig. 3). Extensive agricultural activities in the basin probably contributed to these large concentrations. Naturally occurring brines and oil-field activities upstream from site 4 also probably contributed to the large concentrations of chloride.

\section{ARKANSAS RIVER}

Much of the Arkansas River basin in Oklahoma is underlain by shale, limestone, and fine-to-coarse-grained sandstone (Bingham and Bergman, 1980). Water flowing through these rocks may dissolve large quantities of minerals, primarily sodium and sulfate. Site 5 is downstream from two major tributaries to the Arkansas River-the Salt Fork Arkansas and Cimarron Rivers. These tributaries add highly mineralized water to the Arkansas River. Water quality also is affected by oil-field activities, agriculture, and municipal wastewater-treatment discharge. Large chlordane and polychlorinated biphenyl concentrations have been detected in the river near site 5 (Oklahoma Conservation Commission, 1989). The Oklahoma Department of Pollution Control (1990) has assessed the river, both upstream and downstream from site 5, as partially supporting designated uses because of contamination by pesticides, organic compounds, and pathogenic indicators.

Samples collected at site 5 had a median suspended-sediment concentration of $21 \mathrm{mg} / \mathrm{L}$, among the smallest for the 10 monitoring stations. This level of concentration might have been the result of sediment entrapment in Keystone Lake reservoir, upstream from site 5 .

\section{NEOSHO AND ILLINOIS RIVERS}

The Neosho and Illinois Rivers are located in the Ozark Plateaus. Both rivers flow through a series of reservoirs located in low mountains that are underlain by chert, limestone, shale, and sandstone. The rivers are in one of Oklahoma's most popular tourist and recreation areas. Human activities in the two river basins adversely affect water quality.

Extensive lead and zinc mining in the Neosho River basin has increased concentrations of these trace metals in the river. The Oklahoma Department of Pollution Control has assessed the Neosho River just upstream from site 7 as fully supporting but having threatened overall designated use because of the presence of organic compounds, toxic metals, excessive $\mathrm{pH}$, and excessive suspended solids.

Median concentrations of sulfate $(34 \mathrm{mg} / \mathrm{L})$, chloride $(8.7$ $\mathrm{mg} / \mathrm{L})$, and dissolved solids $(155 \mathrm{mg} / \mathrm{L})$ in water samples from the Neosho River at site 7 were among the smallest for the 10 streams (fig. 3). The Neosho River also had the smallest median suspendedsediment concentration $(12 \mathrm{mg} / \mathrm{L})$. Site 7 is downstream from a series of large reservoirs, which might trap sediment. 

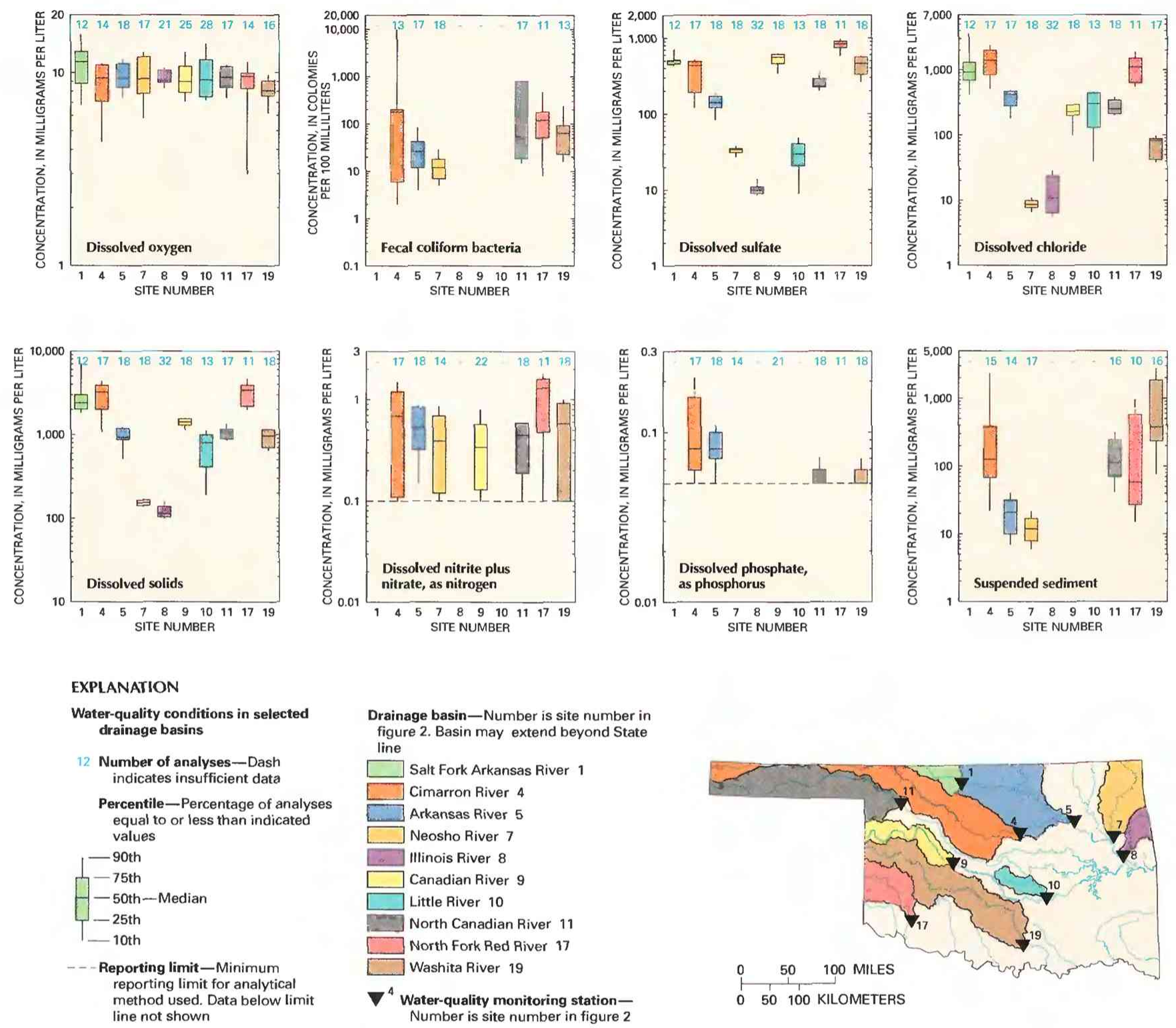

Figure 3. Water quality of selected streams in Oklahoma, water years 1987-89. (Source: Data from U.S. Geological Survey files.)

The Illinois River has been designated by the Oklahoma State Legislature as a State scenic river. However, widespread development in the Illinois River basin has led to increased nitrate concentrations contributed by nonpoint-source discharges (Oklahoma Water Resources Board, 1990, p. 36). The Illinois River has been assessed as partially supporting designated uses because of excessive nutrients, suspended solids, and organic compounds in the water. Although recent USGS data do not indicate a problem (fig. 3), the Oklahoma Conservation Commission (1989) reports violations of the State's dissolved-oxygen standard more than 20 percent of the time at site 8. These conditions affect the fishery resource and recreation in the area. As in the Neosho River, median concentrations of sulfate ( 9.9 $\mathrm{mg} / \mathrm{L})$, chloride $(11 \mathrm{mg} / \mathrm{L})$, and dissolved solids $(114 \mathrm{mg} / \mathrm{L})$ in the Illinois River at site 8 were small relative to those in most other streams (fig. 3).

\section{CANADIAN RIVER}

Upstream from site 9, the Canadian River lies entirely within the Central Lowland. The geology and land use in the basin contrib- ute to the water-quality characteristics of the river. The basin is underlain by fine-grained sandstone, dolomite, shale, and gypsum. Gypsum is a likely source of sulfate in the river. Agricultural compounds such as gypsum, ammonium sulfate, poultry-dusting powders, and sulfur-containing fungicides also might contribute sulfate to the river. The median concentration of sulfate at site $9(560 \mathrm{mg} / \mathrm{L})$ was among the largest from the 10 monitoring stations (fig. 3).

\section{LITTLE RIVER}

The headwaters of the Little River are located in central Oklahoma. The area is underlain mainly by shale and fine-grained sandstone. Land in the basin is used primarily for pasture and growing hay, but two urban areas, Moore and Norman, are near the headwaters. Human activity affects the river in the urban areas, where large concentrations of cadmium, chromium, and lead have been identified (Oklahoma Conservation Commission, 1989). The sources of these toxic metals are not known with certainty but might be industry in the urban areas of the basin. Cadmium and chromium have not been detected in excessive concentrations at site 10. The Okla- 
Table 1. Sources and environmental significance of selected water-quality constituents [Source: Compiled by the U.S. Geological Survey, Office of Water Quality]

\begin{tabular}{|c|c|c|}
\hline Constituent & Common sources & Environmental significance \\
\hline 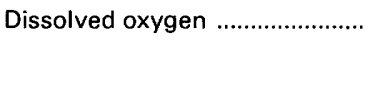 & $\begin{array}{l}\text { Introduced from the atmosphere; also a byproduct of } \\
\text { aquatic plants. }\end{array}$ & $\begin{array}{l}\text { Necessary for aquatic life; deficiency can result from } \\
\text { assimilation of organic wastes or rapid growth } \\
\text { and decay of algae. }\end{array}$ \\
\hline Fecal coliform bacteria ................ & $\begin{array}{l}\text { Sources include effluent from sewage-treatment } \\
\text { plants and runoff from pastures, feedlots, and ur- } \\
\text { ban areas. }\end{array}$ & $\begin{array}{l}\text { Presence indicates contamination of water by wastes } \\
\text { from humans and other warm-blooded animals. }\end{array}$ \\
\hline Sulfate & $\begin{array}{l}\text { Occurs in some rocks; also in mine runoff, industrial } \\
\text { wastewater discharge, and atmospheric deposi- } \\
\text { tion. }\end{array}$ & $\begin{array}{l}\text { Concentrations exceeding a natural, background } \\
\text { level indicate contamination from human activity; } \\
\text { in sufficient quantity, can cause water to be } \\
\text { unsuitable for public supply; can harm aquatic } \\
\text { organisms. }\end{array}$ \\
\hline 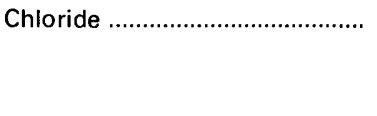 & $\begin{array}{l}\text { Occurs in some rocks and ground-water discharge; } \\
\text { also in road deicers, industrial and urban waste- } \\
\text { water discharge, and atmospheric deposition. }\end{array}$ & $\begin{array}{l}\text { Concentrations exceeding a natural, background level } \\
\text { can cause water to be unsuitable for public supply, } \\
\text { agriculture, and industry; can harm aquatic or- } \\
\text { ganisms. }\end{array}$ \\
\hline Dissolved solids ........................... & $\begin{array}{l}\text { A result of rock weathering; also in agricultural runoff } \\
\text { and industrial discharge. }\end{array}$ & $\begin{array}{l}\text { In sufficient quantity, can cause water to be unsuitable } \\
\text { for public supply, agriculture, and industry; can } \\
\text { harm aquatic organisms. }\end{array}$ \\
\hline Nitrite plus nitrate ....................... & $\begin{array}{l}\text { Nonpoint sources are agricultural and urban runoff; } \\
\text { a major point source is wastewater discharge. }\end{array}$ & $\begin{array}{l}\text { Plant nutrient that, in sufficient quantity, can cause } \\
\text { algal blooms and excessive growth of higher } \\
\text { aquatic plants in bodies of water; can cause water } \\
\text { to be unsuitable for public supply. }\end{array}$ \\
\hline 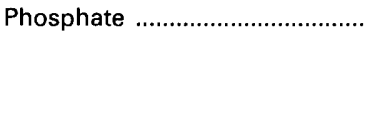 & $\begin{array}{l}\text { Occurs in some rocks and sediments; also in runoff } \\
\text { and seepage from phosphate-rock mines, agri- } \\
\text { cultural and urban runoff, and industrial and } \\
\text { municipal wastewater discharge. }\end{array}$ & $\begin{array}{l}\text { Plant nutrient that, in sufficient quantity, can cause } \\
\text { algal blooms and excessive growth of higher } \\
\text { aquatic plants in bodies of water. }\end{array}$ \\
\hline Suspended sediment ................... & $\begin{array}{l}\text { A result of rock erosion; also induced by disturbances } \\
\text { of land cover due to fires, floods, and human } \\
\text { activities such as mining, logging, construction, } \\
\text { and agriculture. }\end{array}$ & $\begin{array}{l}\text { Can be detrimental to aquatic organisms; can fill res- } \\
\text { ervoirs and impair recreational use of water. }\end{array}$ \\
\hline
\end{tabular}

homa Department of Pollution Control (1990) assessed the river upstream from site 10 as fully supporting designated uses but threatened because of pesticides and toxic metals in some reaches.

\section{NORTH CANADIAN RIVER}

The North Canadian River drains land in the Great Plains. Land uses in the basin upstream from site 11 mainly are agricultural. The Oklahoma Department of Wildlife Conservation has determined that excessive sedimentation and high turbidity levels are adversely affecting the fishery resource of Canton Lake, downstream from site 11. There also are concerns that the fishery resource is being adversely affected by agricultural runoff containing pesticides and excess nutrients from fertilizer. The area has had several fishkills, some likely caused by aerial pesticide application (Oklahoma Conservation Commission, 1989). Gypsum beds in the underlying geologic formations might have been the source of much of the sulfate (median, $230 \mathrm{mg} / \mathrm{L}$ ) and dissolved solids (median, 1,080 mg/L) in the river at site 11 during water years $1987-89$ (fig. 3). The large concentrations of fecal coliform bacteria at site $11 \mathrm{might}$ have been the result of runoff from feedlots in the basin. The Oklahoma Department of Pollution Control assessed the segment of the river downstream from site 11 as fully supporting designated uses but threatened.

\section{NORTH FORK RED RIVER}

The North Fork Red River lies within the Central Lowland in southwestern Oklahoma. The basin's geology and land use, primarily agriculture, affect stream water quality. The Oklahoma Department of Pollution Control (1990) has assessed the river downstream from site 17 as fully supporting designated uses but threatened by pesticides, metals, and suspended solids in the water. The reach upstream from site 17 was assessed as fully supporting designated uses.

Dissolution of gypsum beds contributes large quantities of sulfate to the river. Water samples from site 17 had the largest median concentrations of sulfate $(830 \mathrm{mg} / \mathrm{L})$ and dissolved solids $(3,420$ $\mathrm{mg} / \mathrm{L}$ ) for the 10 monitoring stations (fig. 3 ); the median concentration of chloride $(1,100 \mathrm{mg} / \mathrm{L})$ was the second largest. Natural brine discharges increase the chloride concentration and make several streams in southwestern Oklahoma unsuitable for municipal or irrigation use (U.S. Geological Survey, 1986, p. 381). The median concentration of nitrite plus nitrate $(1.3 \mathrm{mg} / \mathrm{L})$ was the largest for the seven stations having sufficient data for graphic presentation (fig. 3 ). Agricultural runoff in the basin might have contributed to this large concentration.

\section{WASHITA RIVER}

Located in the Central Lowland, the Washita River basin is underlain by shale, siltstone, sandstone, and interbedded gypsum deposits. Water quality in the basin is affected by its geological and landuse characteristics. The Oklahoma Department of Pollution Control (1990) reported that the river only partially supports designated uses because of excessive concentrations of chloride, nutrients, pesticides, and suspended sediment.

Solution of gypsum is the primary source of dissolved sulfate in the Washita River and limits the river's use as a public water supply (U.S. Geological Survey, 1986, p. 381). The median concentration of sulfate in water samples collected at site 19 during water years $1987-89$ was $460 \mathrm{mg} / \mathrm{L}$. Agriculture is the principal land use in the basin, and past cultivation practices have resulted in large suspendedsediment concentrations in the river upstream from site 19 (Oklahoma Water Resources Board, 1990). The median concentration of suspended sediment in water from site $19(376 \mathrm{mg} / \mathrm{L})$ was the largest for the monitoring stations that had sufficient data for statistical analysis.

\section{WATER-QUALITY TRENDS}

Trend analysis is a statistical procedure used to detect changes in stream water quality at a monitoring station over time. For this report, water-quality data from 20 monitoring stations (fig. 2) were analyzed for trends by using the seasonal Kendall test (Hirsch and 
others, 1982), a method used extensively by the USGS. The graph (shown below) of the dissolved-solids concentration in the Cimarron River at site 4 illustrates the trend inferred from the concentration data and demonstrates the variation in water quality that is common in streams.

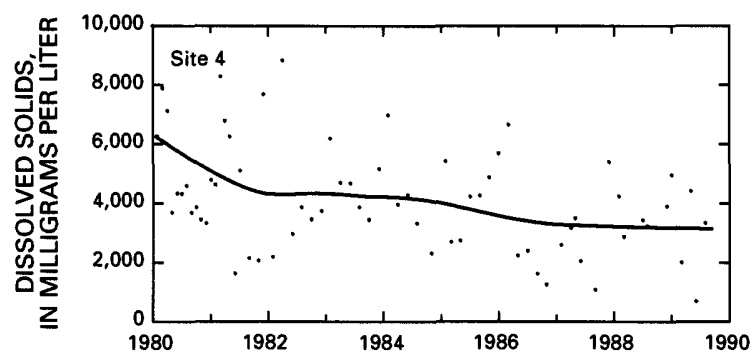

When possible, constituent-concentration data were adjusted for changes in streamflow to preclude identifying a trend in concentration that was caused only by a trend in streamflow. The data were not adjusted when (1) more than 10 percent of the samples had concentrations lower than the minimum reporting limit for the analytical method used or (2) streamflow was controlled substantially by human activities. When the concentration data could not be adjusted for streamflow, trends were determined directly from the concentration data.

Statewide trends in concentrations of selected stream-water constituents are shown on maps in figure 4 . On each map, a trend is indicated at a monitoring station only if the data from that station were suitable for use in the trend analysis. For more information on the suitability criteria and on the trend-analysis procedure used for this report, see Lanfear and Alexander (1990).

\section{DISSOLVED OXYGEN}

The dissolved-oxygen concentration in a stream is controlled by several factors, including water temperature, air temperature and pressure, hydraulic characteristics of the stream, photosynthetic or respiratory activity of stream biota, and the quantity of organic material present. A trend in dissolved-oxygen concentrations commonly is directly or indirectly the result of human activities. Generally, an upward trend in dissolved-oxygen concentrations indicates improving stream water-quality conditions and a downward trend indicates deteriorating conditions.

A cause for the upward trend in oxygen concentrations in the North Canadian River at site 12 (fig. 4) is not known. However, the trend might have resulted from a reduction in the quantity of decomposable organic material discharged to the river from wastewatertreatment plants near Oklahoma City.

\section{FECAL COLIFORM BACTERIA}

Fecal coliform bacteria are used as indicators of fecal contamination from humans and other warm-blooded animals. Such contamination can introduce disease-causing viruses and bacteria into a stream. Improvements in municipal-wastewater management techniques in the Tulsa and Oklahoma City metropolitan areas might have been at least partly responsible for the decreasing fecal coliform bacteria concentrations in the Arkansas River at site 5 and the North Canadian River at site 12 (fig. 4).

\section{DISSOLVED SULFATE}

The major natural sources of sulfate in streams are rock weathering, volcanoes, and biochemical processes (Hem, 1985, p. 113). Human activities such as mining, waste discharge, and fossil-fuel combustion also can be important sources.
No cause is known for the upward trends in sulfate concentrations in the Salt Fork Arkansas River at site 1, the Arkansas River at site 2, or the Cimarron River at site 3 (fig. 4). The increasing sulfate concentration in the Salt Fork Red River at site 16 and the Washita River at site 19 (fig. 4) could have been in part the result of increasing irrigation and return flow in the basins during a period of insufficient precipitation late in the trend-analysis period (Andy Scurlock, Oklahoma Water Resources Board, oral commun., December 1990), although county irrigation reports currently (1990) are not complete. The upward trends also could have been caused in part by changes in agricultural practices, such as increased use of sulfurcontaining fertilizers and fungicides (Oklahoma State Department of Agriculture, 1990). Concentrations decreased in the Neosho River at site 7 for unknown reasons.

\section{DISSOLVED CHLORIDE}

Chloride is present in all natural waters but usually in low concentrations (Hem, 1985, p. 118). Except in streams that receive ground-water discharge high in chloride, concentrations of greater than a few milligrams per liter generally are the result of human activities (table 1).

The upward trend in chloride concentrations in East Cache Creek at site 18 (fig. 4) might have been caused by return flow from increasing irrigation owing to insufficient rainfall. No chloride-control practices were in place to account for the downward trends at five monitoring stations, and a cause for those trends is not known.

\section{DISSOLVED SOLIDS}

Dissolved solids in stream water result primarily from rock weathering but also can be introduced as a byproduct of human activities (table 1). Concentrations generally are greatest in streams draining basins underlain by rocks and soils that contain easily dissolved minerals.

Increasing irrigation because of insufficient rainfall during the trend-analysis period probably contributed to increases in dissolvedsolids concentrations in return flow upstream from site 19 on the Washita River and possibly upstream from site 16 on the Salt Fork Red River and site 18 on the East Cache Creek (fig. 4). Causes for the downward trends in the Cimarron River at site 4 and the Neosho River at site 7 are not known.

\section{DISSOLVED NITRITE PLUS NITRATE}

Nitrite and nitrate are oxidized forms of nitrogen that together normally constitute most of the dissolved nitrogen in well-aerated streams. Nitrite readily oxidizes to nitrate in natural waters; therefore, nitrate generally is by far the more abundant of the two (Hem, 1985, p. 124).

Conflicting trends in nitrite plus nitrate concentrations were detected at the three monitoring stations on the North Canadian River. Concentrations at the upper station (site 11) had no trend, at the middle station (site 12) had an upward trend, and at the lower station (site 13) had a downward trend (fig. 4). Wastewater was transferred from another stream basin to a treatment plant on the North Canadian River basin upstream from site 12 during the trend-analysis period, and the additional effluent volume might have caused the upward trend. A definite cause for the downward trend at site 13, which occurred despite the additional wastewater in the river, is not known. The upward trends in nitrite plus nitrate concentrations in the Salt Fork Red River at site 16 and the North Fork Red River at site 17 during water years $1980-89$ closely correspond to the pattern of nitrogen fertilizer use in the State during the same time period; fertilizer use increased from 1985 to 1989 (Oklahoma State Department of Agriculture, 1990). 


\section{DISSOLVED PHOSPHATE}

Phosphate is the oxidized form of phosphorus and the only form of significance in most natural waters. Small quantities of dissolved phosphate commonly are present in streams as a result of rock weathering. Normally, concentrations are no more than a few tenths of a milligram per liter (Hem, 1985, p. 126) and usually are much lower. Higher concentrations can indicate contamination from human activities (table 1).

No cause is known for the downward trend in phosphate concentrations in the Arkansas River at site 2 (fig. 4). The downward trend in the North Canadian River at site 11, which is located in an

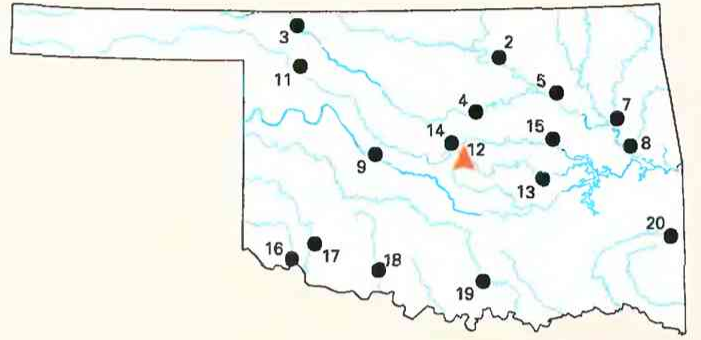

Dissolved oxygen, 1980-89

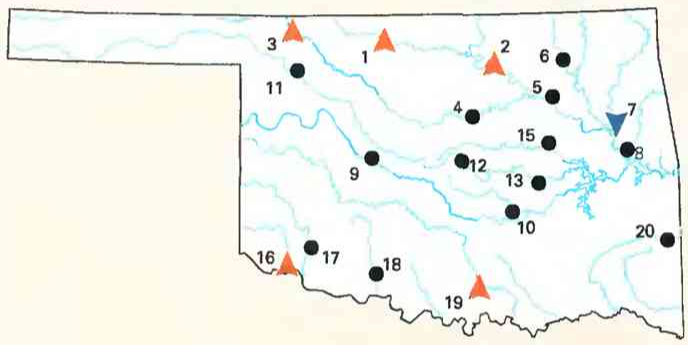

Dissolved sulfate, $1980-89$

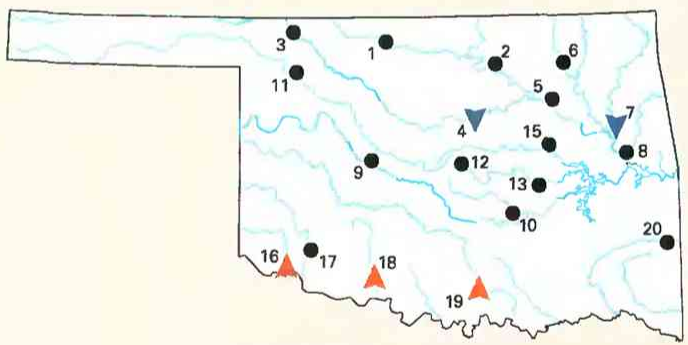

Dissolved solids, 1980-89

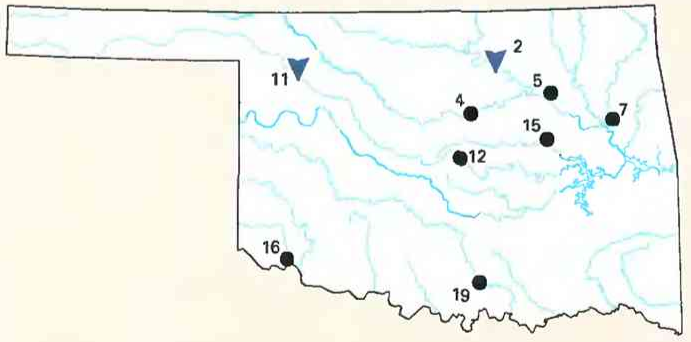

Dissolved phosphate, 1980-89

$\begin{array}{cccc}0 & 50 \quad 100 & \text { MILES } \\ & 50 & 100 & \text { KILOMETERS }\end{array}$

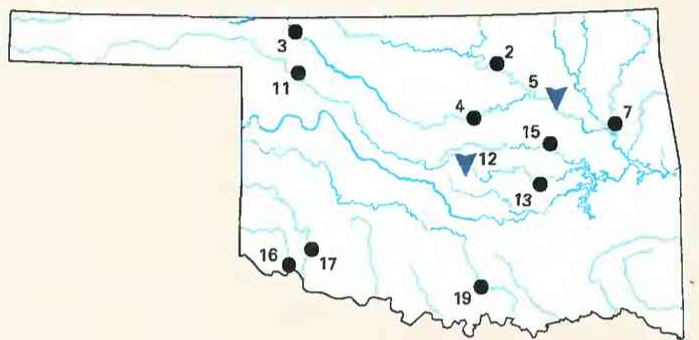

Fecal coliform bacteria, 1980-89

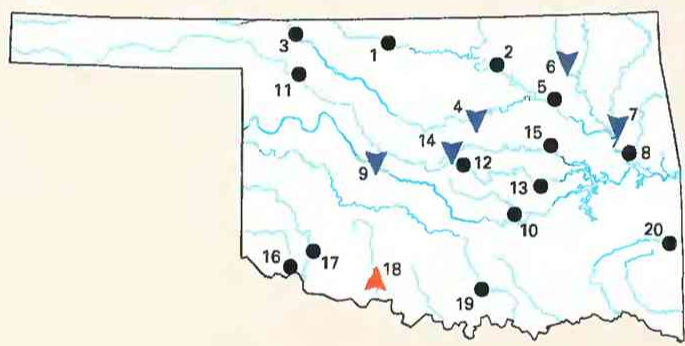

Dissolved chloride, 1980-89

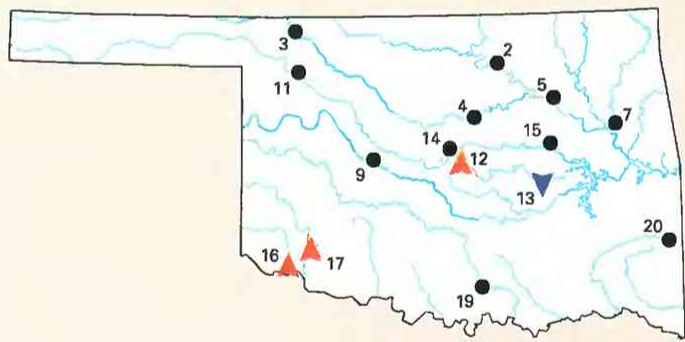

Dissolved nitrite plus nitrate, 1980-89

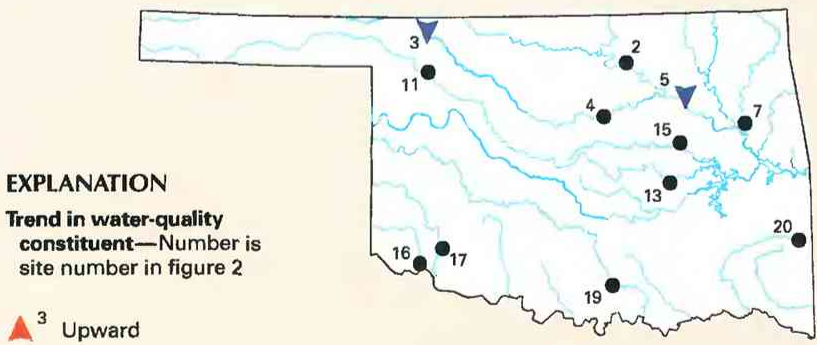

${ }^{5}$ None

$\nabla^{7}$ Downward

Figure 4. Trends in water quality of selected streams in Oklahoma, by water years. (Source: Data from U.S. Geological Survey files.) 
agricultural area. was unexpected because there was no downward trend in nitrite plus nitrate that might have accompanied a decrease in agricultural runoff.

\section{SUSPENDED SEDIMENT}

Suspended sediment is a product of erosion. The erosion can be either natural or the result of land-cover disturbances related to human activities (table 1).

The downward trend in suspended-sediment concentrations in the Cimarron River at site 3 (fig. 4) possibly was caused by changes in farming practices in the basin: land that formerly was being farmed has been planted in grass cover, and low-till farming and terracing techniques have gained popularity (Larry Caldwell. U.S. Soil Conservation Service, oral commun., December 1990). A cause for the downward trend in the Arkansas River at site 5 is not known.

\section{WATER-QUALITY MANAGEMENT}

Seven Oklahoma agencies share responsibility for protecting surface-water quality: the Oklahoma Water Resources Board. Oklahoma State Department of Health, Oklahoma State Department of Agriculture, Oklahoma Conservation Commission. Oklahoma Department of Wildlife Conservation, Oklahoma Department of Mines, and the Oklahoma Corporation Commission. The Oklahoma Pollution Control Coordinating Board coordinates the activities of the seven agencies.

The Oklahoma Water Resources Board develops and promulgates Oklahoma's water-quality standards, conducts use-attainability analyses. assesses pollution problems, certifies Federal permits, and issues permits to industrial and commercial wastewater dischargers. The Oklahoma State Department of Health, in conjunction with the EPA, Region 6, issues joint permits to municipal wastewater dischargers, operates Oklahoma's ambient water-quality trend-monitoring program, and analyzes water samples. The Oklahoma State Department of Agriculture regulates the use of agricultural chemicals, such as fertilizers and pesticides, and manages animal waste from confined feeding operations. The Oklahoma Conservation Commission administers Oklahoma's nonpoint-source pollution-management program and assesses formerly unassessed waters of the State for nonpoint-source pollution effects. The Oklahoma Water Resources Board and the Oklahoma Conservation Commission cooperate with the EPA under section 314 of the Federal Clean Water Act to identify and correct causes of inadequate lake water quality. The Oklahoma Department of Wildlife Conservation, with technical assistance from the Water Resources Board, investigates reports of fishkills and also conducts fishery management projects. The Oklahoma Department of Mines issues permits for new mines and monitors active mines. The Oklahoma Corporation Commission regulates oil and gas production activities. To enhance coordination among the seven State agencies, the Oklahoma Legislature established the Oklahoma Pollution Control Coordinating Board, which consists of the seven agency directors and four citizen members appointed by the Governor.

Oklahoma has an extensive and diverse water-quality monitoring program. Four agencies-the Oklahoma Water Resources Board, Oklahoma State Department of Health, Oklahoma Conservation Commission, and the USGS - conduct most of the water-quality monitoring in the State.

The Oklahoma Water Resources Board conducts site-specific biological assessments on State streams during Use Attainability Analysis studies. The Board also monitors lake water quality under the Lake Water Quality Assessment grant.

The Oklahoma State Department of Health operates Oklahoma's Ambient/Biotrend Monitoring Program. The monitoring network consists of 22 permanent stations, which are part of a national water-quality assessment network established by the EPA in 1973, and
78 stations at which the Department collects samples for toxic substances on a rotating basis. Since 1980,50 selected Oklahoma reservoirs have been monitored by the Department of Health for toxicants in fish flesh. In addition, fish are sampled by Department of Health staff at the 22 permanent stations and at an additional 41 rotational sites.

The Oklahoma Conservation Commission operates a statewide small-lakes monitoring program at 100 lakes. The Commission is one of Oklahoma's 1990 Clean Lake investigators and helped prepare the State's Lake Water Quality Assessment Report. As the lead technical agency for Oklahoma's Nonpoint-Source Pollution Prevention Program, the Commission monitors selected streams to assess the effects of nonpoint-source pollution.

The Oklahoma Department of Pollution Control coordinates the monitoring activities of the three State agencies. This department also prepares and submits a biennial water-quality assessment report to the U.S. Congress and the EPA (Oklahoma Department of Pollution Control, 1990), as mandated by section 305(b) of the Federal Clean Water Act.

The USGS operates a water-quality monitoring station network in cooperation with the Oklahoma Water Resources Board. the Oklahoma State Department of Health, and the Oklahoma Conservation Commission. The USGS also collects data from 16 Federal network sites-14 National Stream Quality Accounting Network stations and 2 Hydrologic Bench-Mark Network stations.

\section{SELECTED REFERENCES}

Anderson, J.R., 1967, Major land uses in the United States, in U.S. Geological Survey, 1970, National atlas of the United States of America: Washington, D.C., U.S. Geological Survey, p. 158-159.

Bingham, R.H., and Bergman, D.L., 1980. Reconnaissance of the water resources of the Enid Quadrangle, north-central Oklahoma: Oklahoma Geological Survey, Hydrologic Atlas 7, scale 1:250,000.

Britton. L.J., and Greeson. P.E., eds.. 1987, Methods for collection and analysis of aquatic biological and microbiological samples: U.S. Geological Survey Techniques of Water-Resources Investigations, book 5, chap. A4, $363 \mathrm{p}$.

Fenneman. N.M., 1946, Physical divisions of the United States: U.S. Geological Survey special map, scale 1:700,000.

Fishman, M.J., and Friedman, L.C., eds., 1989, Methods for the determination of inorganic substances in water and fluvial sediments: U.S. Geological Survey Techniques of Water-Resources Investigations. book 5. chap. Al. 545 p.

Hem, J.D. 1985, Study and interpretation of the chemical characteristics of natural water (3d ed.): U.S. Geological Survey Water-Supply Paper 2254, $263 \mathrm{p}$.

Hirsch, R.M., Slack, J.R., and Smith, R.A., 1982, Techniques of trend analysis for monthly water quality data: Water Resources Research, v. 18, no. 1, p. 107-121.

Lanfear, K.J., and Alexander, R.B., 1990, Methodology to derive water-quality trends for use by the National Water Summary Program of the U.S. Geological Survey: U.S. Geological Survey Open-File Report 90-359, $10 \mathrm{p}$.

Oklahoma Conservation Commission, 1989, Oklahoma's nonpoint-source pollution assessment report, section 319: Oklahoma City, Oklahoma Conservation Commission, variously paginated.

Oklahoma State Department of Agriculture, 1990, Tonnage distribution of fertilizer in Oklahoma counties by grade and material, annual for the period July 1. 1989 to July 1. 1990: Oklahoma City. Oklahoma State Department of Agriculture, unnumbered pages.

Oklahoma Department of Pollution Control, 1990, Oklahoma's 1990 water quality assessment report, prepared pursuant to section 305(b) of the Federal Clean Water Act: Oklahoma City, Oklahoma Department of Pollution Control, $57 \mathrm{p}$.

Oklahoma Water Resources Board, 1989, Oklahoma's water quality standards 1988: Oklahoma City, Oklahoma Water Resources Board, variously paginated.

1990, Oklahoma water atlas, 1990: Oklahoma City, Oklahoma Water Resources Board, $360 \mathrm{p}$. 
Thelin, G.P., and Pike, R.J., 1990, Digital shaded relief map of the conterminous United States: Menlo Park, Calif., U.S. Geological Survey digital image processing, scale 1:3,500,000.

U.S. Geological Survey, 1984, National water summary 1983-Hydrologic events and issues: U.S. Geological Survey Water-Supply Paper 2250, $243 \mathrm{p}$.

1986, National water summary 1985-Hydrologic events and surfacewater resources: U.S. Geological Survey Water-Supply Paper 2300, $506 \mathrm{p}$.
1990, National water summary 1987-Hydrologic events and water supply and use: U.S. Geological Survey Water-Supply Paper 2350, $553 \mathrm{p}$.

Ward, J.R., and Harr, C.A., eds., 1990, Methods for collection and processing of surface-water and bed-material samples for physical and chemical analyses: U.S. Geological Survey Open-File Report 90-140, 71 p. 
454 National Water Summary 1990-91-Stream Water Quality: STATE SUMMARIES

Prepared by Joanne K. Kurklin, U.S. Geological Survey; "Water-Quality Management” section by David Jennings, Oklahoma Department of Pollution Control

FOR ADDITIONAL INFORMATION: District Chief, U.S. Geological Survey, 202 NW 66th St., BIdg. 7, Oklahoma City, OK 73116 


\section{OREGON Stream Water Quality}

Stream water of good quality is important to the people of Oregon and to the State's economy. Generally, Oregon streams meet water-quality goals established by the Federal Clean Water Act for aquatic life and water-contact recreation. Instream water uses are fisheries, wildlife maintenance, recreation, mining, and hydroelectric power generation. Offstream water uses include public and industrial supply, irrigation, and livestock watering. In 1985, of the average 6,540 million gallons per day of freshwater withdrawn for offstream use, 89.9 percent was from surface-water sources (U.S. Geological Survey, 1990, p. 425). Public supply systems in the State used 5.6 percent of total surface water withdrawn, and withdrawals for irrigation accounted for 89.4 percent. In 1985, about three-fifths of Oregon's population relied on surface water for potable water supply (Solley and others, 1988).
The quality of Oregon's surface water primarily is affected by geology, population distribution, and land use. Land use in Oregon (fig. $1 A$ ) has been determined in large part by physiography (fig. $1 B$ ) and climate. Statewide, land use is 50 percent forest and woodland, 37 percent grazing land, 9 percent cropland, and 4 percent other uses that include urban and industrial areas, farmsteads, roads, water bodies, barren land, and alpine areas. The population distribution in Oregon, like land use, is a product of physiography and climate. As a result of the more temperate climate there, most of the State's residents live west of the Cascade Range (figs. $1 B$ and $1 C$ ), primarily in the Willamette River valley (U.S. Geological Survey, 1990, p. 425). The 1990 population was 2.8 million (U.S. Bureau of the Census 1990 decennial census files).

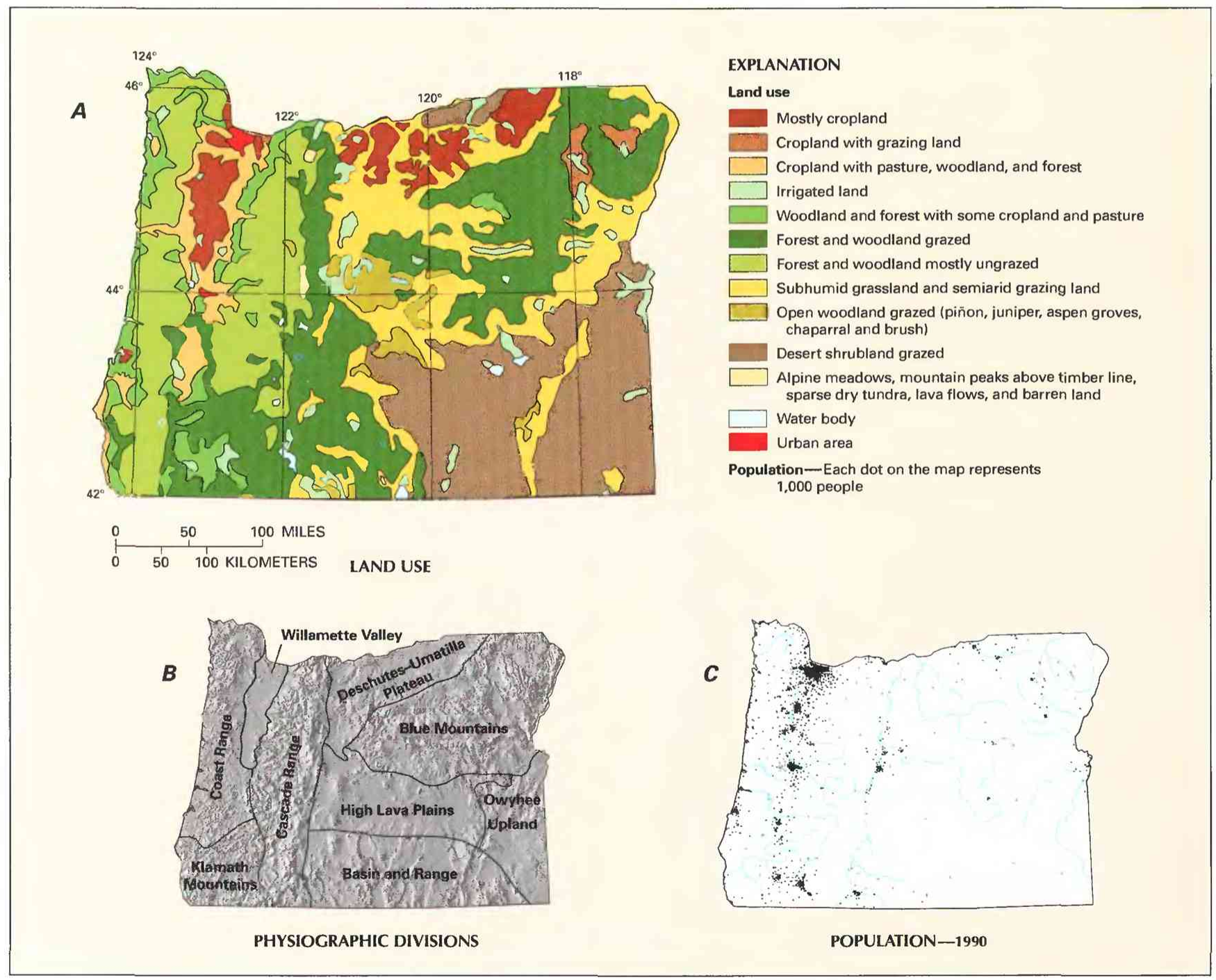

Figure 1. Land use, physiography, and population in Oregon. A, Major land uses. B, Physiographic divisions. $C$, Population distribution in 1990. (Sources: A, Major land uses modified from Anderson, 1967. B, Physiographic divisions from Dicken, 1965; landforms from Thelin and Pike, 1990. C, Data from U.S. Bureau of the Census 1990 decennial census files.) 
The Columbia and Snake Rivers, which originate in adjacent States and Canada, bring water into Oregon; all other Oregon streams originate within the State. The Cascade Range divides Oregon into two distinct climatic zones; the annual precipitation west of the Cascade Range is from 40 to 140 inches, depending on location, and east of the Cascade Range is from 10 to 20 inches. Statewide, the average annual precipitation is about 27 inches (Phillips and others, 1965). Average annual runoff is about 20 inches (Busby, 1966).

\section{WATER-QUALITY MONITORING}

Water-quality data obtained from analyses of water samples collected at monitoring stations are stored in the U.S. Geological Survey's (USGS) National Water Information System and the U.S. Environmental Protection Agency's (EPA) national data base known as STORET. Water-quality and streamflow data are reported by water year-the 12 months from October 1 through September 30. A water year is identified by the calendar year in which it ends. For example, water year 1991 comprises October 1, 1990, through September 30, 1991.

The data used in this summary of Oregon's stream water quality were obtained from water samples collected at 10 monitoring stations at which data collection is systematic and continuing (fig. 2). Analyses of water samples collected at all 10 stations are the basis for the discussion and graphic summary (fig. 3) of stream waterquality conditions during water years 1987-89, and data from 9 stations are the basis for the discussion and graphic summary (fig. 4) of stream water-quality trends. Water samples were collected and analyzed by using standard methods approved by the USGS (Britton and Greeson, 1987; Fishman and Friedman, 1989; Ward and Harr, 1990 ) or by using equivalent methods. If a method of sample collection or analysis changed over time, data from an analysis were included in the evaluation of recent stream water quality or of stream water-quality trends only if the change in method did not affect the comparability of the data.

\section{WATER-QUALITY CONDITIONS}

Oregon's surface-water resources include nearly 112,600 miles of perennial and intermittent streams; about 27,000 miles in 19 river basins have been assessed for water-quality conditions. More than one-half of these streams have water-quality problems that moderately to severely impair beneficial uses designated by the State for purposes of water-quality monitoring and protection (Oregon Department of Environmental Quality, 1990, p. 1-2).

The following discussion of stream water quality in Oregon is organized by river basin (fig. 3). Where physiographic and landuse characteristics in different basins are similar, the discussion of those basins is combined. Graphs in figure 3 summarize certain aspects of stream water quality in the basins for water years 1987-89. The graphs show frequency distributions of data values that represent concentrations of selected stream-water constituents. These constituents are dissolved oxygen. fecal coliform bacteria, dissolved sulfate, dissolved solids, dissolved nitrite plus nitrate (as nitrogen), and dissolved phosphorus (as phosphorus). The data are reported in milligrams per liter (mg/L) and colonies per 100 milliliters (col/100 $\mathrm{mL}$ ). Sources and environmental significance of each constituent are described in table 1 .

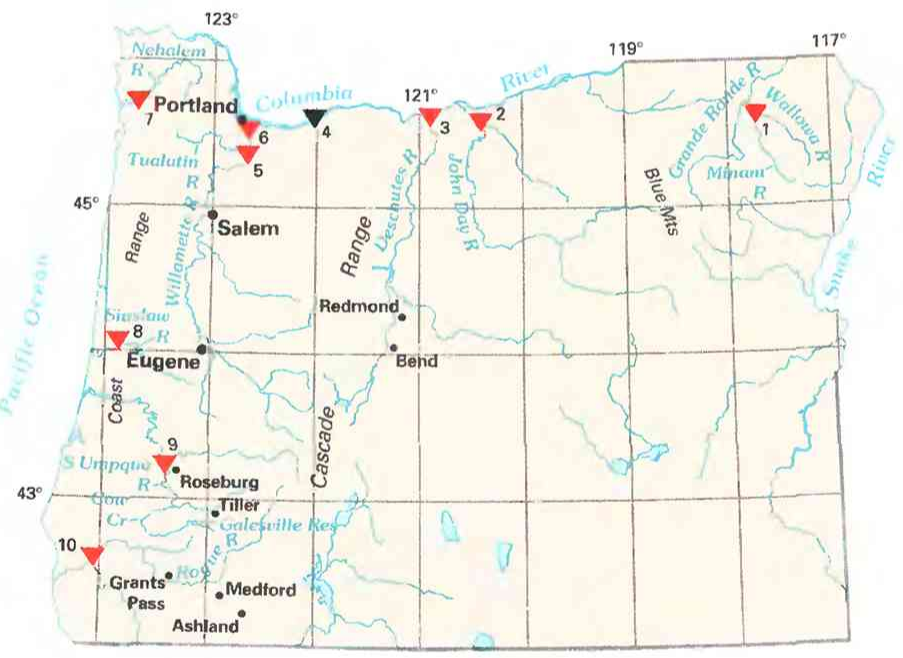

\author{
EXPLANATION \\ Water-quality monitoring station and \\ type of statistical analysis- \\ Number refers to accompanying \\ table \\ $\nabla^{4}$ Water-quality conditions \\ (see fig. 3) \\ $\nabla^{8}$ Water-quality conditions and \\ trends (see figs. 3 and 4 )
}

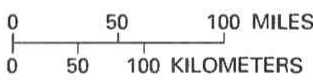

\begin{tabular}{|c|c|c|c|}
\hline $\begin{array}{l}\text { Site no. } \\
\text { on map }\end{array}$ & $\begin{array}{l}\text { USGS station } \\
\text { name and no. }\end{array}$ & $\begin{array}{l}\text { Drainage area } \\
\text { (square miles) }\end{array}$ & $\begin{array}{l}\text { Major land use } \\
\text { (see fig. 1) }\end{array}$ \\
\hline 1 & Minam River at Minam $(13331500)$ & 240 & Grazed forest and woodland; cropland with grazing land. \\
\hline 2 & John Day River at McDonald Ferry $(14044800)$ & 7,580 & Mostly cropland; subhumid grassland and semiarid grazing land. \\
\hline 3 & 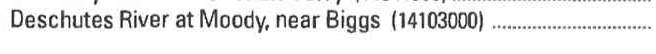 & 10,500 & $\begin{array}{l}\text { Grazed and ungrazed forest and woodland; subhumid grassland } \\
\text { and semiarid grazing land; mostly cropland; irrigated land. }\end{array}$ \\
\hline 4 & Columbia River at Warrendale $(14128910)$ & 240,000 & $\begin{array}{l}\text { Mostly cropland; subhumid grassland and semiarid grazing land; } \\
\text { grazed and ungrazed forest and woodland. }\end{array}$ \\
\hline 5 & Tualatin River at West Linn $(14207500)$ & 710 & Cropland with pasture, woodland, and forest; urban areas. \\
\hline 6 & Willamette River at Portland $(14211720)$ & 11,500 & Ditto. \\
\hline 7 & Nehalem River at Foss $(14301000)$ & 667 & $\begin{array}{l}\text { Woodland and forest with some cropland and pasture; ungrazed } \\
\text { forest and woodland. }\end{array}$ \\
\hline 8 & 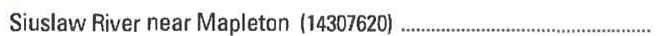 & 773 & Ditto. \\
\hline 9 & South Umpqua River near Roseburg $\{14312260\}$ & 1,760 & Cropland with pasture, woodland, and forest; urban areas. \\
\hline 10 & 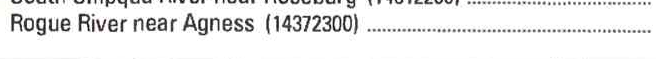 & 3,940 & $\begin{array}{l}\text { Grazed and ungrazed forest and woodland; woodland and forest } \\
\text { with some cropland and pasture; urban areas. }\end{array}$ \\
\hline
\end{tabular}

Figure 2. Selected water-quality monitoring stations, type of statistical analysis, and geographic features in Oregon. (Sources: Major land uses modified from Anderson, 1967; other data from U.S. Geological Survey files.I 
Water quality at each monitoring station is the result of geological, chemical, biological, and hydrologic processes that occur over a large area. Water-quality problems that affect aquatic life or public health only locally are not fully represented in this summary.

\section{MINAM RIVER}

The Minam River is located in the Grande Ronde River basin in northeastern Oregon and is adjacent to the Snake River basin to the east and the John Day River basin to the west. The Minam River basin is covered primarily by grazed forest and woodland and some cropland. Eighty-six percent of the cropland is irrigated and the remainder is dry farmed. The headwaters originate at high altitudes and are fed mostly by snowmelt.

Water quality at site 1 on the Minam River supports watercontact recreation, aquatic life, and esthetic water uses. Median concentrations for all the selected constituents were low at site 1, except dissolved oxygen, which had the highest median concentration
(11.7 mg/L) for all of the 10 monitored streams (fig. 3). Dissolvedoxygen concentrations generally are higher in healthy streams. Median concentrations of fecal coliform bacteria $(3 \mathrm{col} / 100 \mathrm{~mL})$, sulfate $(1.7 \mathrm{mg} / \mathrm{L})$, dissolved solids $(39 \mathrm{mg} / \mathrm{L})$, and nitrite plus nitrate (less than $0.1 \mathrm{mg} / \mathrm{L}$ ) were the lowest or among the lowest for the 10 monitoring stations (fig. 3).

Water-quality conditions in the Minam River do not characterize water-quality conditions for the entire Grande Ronde River basin. The Oregon Department of Environmental Quality (ODEQ) has reported that segments of the Grande Ronde and Wallowa Rivers do not support State-designated beneficial uses of water for aquatic life maintenance, water contact recreation, and esthetics because of high $\mathrm{pH}$ values and high concentrations of fecal coliform bacteria and nutrients (nitrogen and phosphorus). Sources are irrigation return flow, effluent from municipal sewage-treatment plants, and seepage from septic-tank and drainfield systems (Oregon Department of Environmental Quality, 1990, p. A-29).
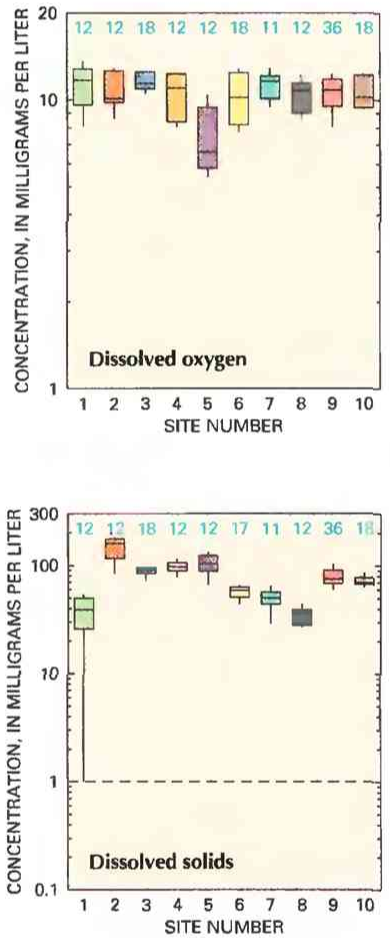

\section{EXPLANATION}

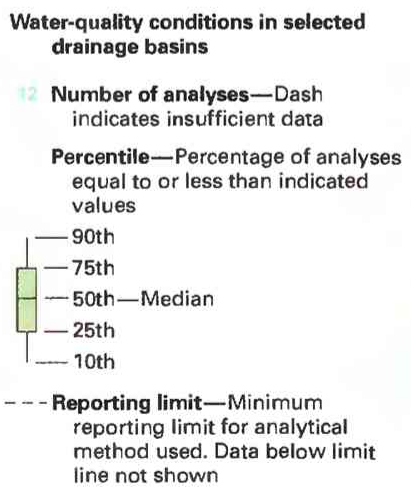

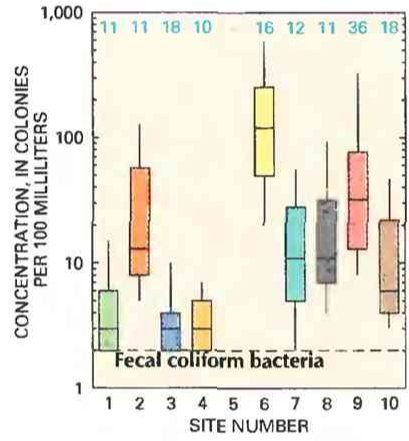
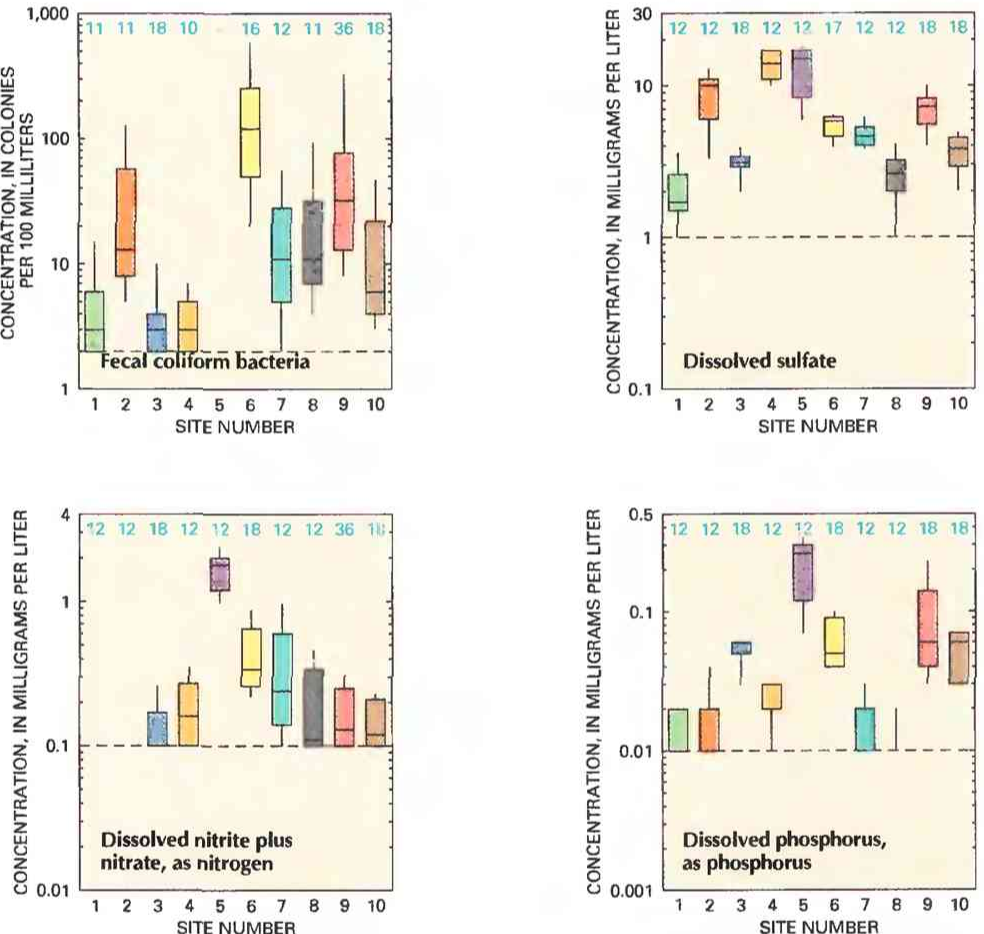

Number is site number in figure 2

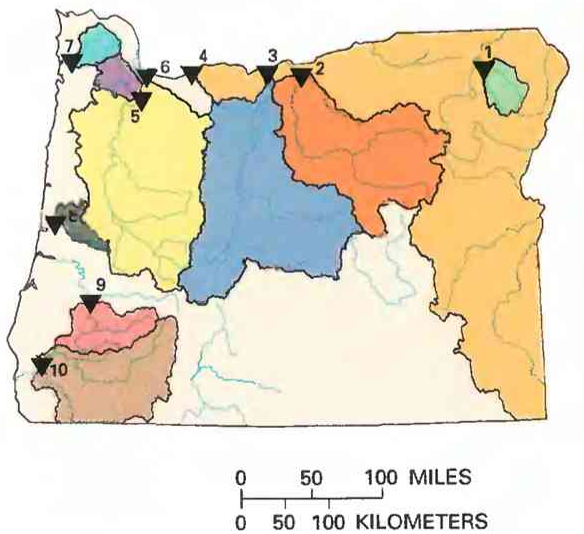

Figure 3. Water quality of selected streams in Oregon, water years 1987-89. (Source: Data from U.S. Geological Survey files.)

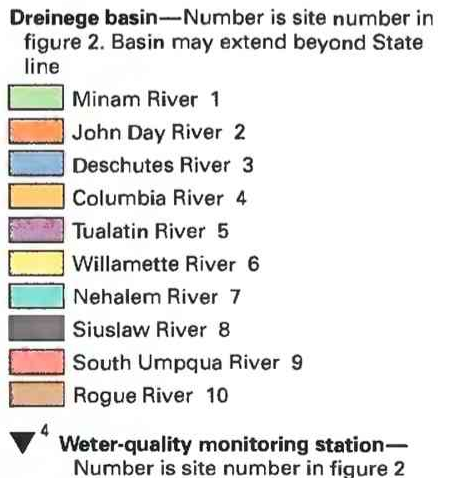




\section{JOHN DAY RIVER}

The John Day River drains about 7,580 $\mathrm{mi}^{2}$ (square miles) of north-central Oregon. The river originates in the Blue Mountains and flows northwestward to the Columbia River. Land-use activities that affect water quality upstream from site 2 are irrigation, feedlot operations, and livestock grazing.

The designated benefical uses of the John Day River for recreation, aquatic-life maintenance, and esthetic values are not fully supported during summer and early autumn owing to degraded water quality caused by agricultural runoff (Oregon Department of Environmental Quality, 1990, p. A-25). Sections of the John Day River have been classified as "water-quality limited," which indicates that those stream segments are unable to support benefical instream uses despite the presence of required treatment processes and facilities.

At site 2 , the median concentrations of sulfate $(10 \mathrm{mg} / \mathrm{L})$ and dissolved solids $(159 \mathrm{mg} / \mathrm{L})$ were the third highest and highest, respectively, for the 10 monitoring stations (fig. 3). The high values resulted from irrigation return flow, erosion from forested lands, seepage from septic and drainfield systems, and effluent from municipal sewage-treatment plants (Oregon Department of Environmental Quality, 1990, p. A-25)

\section{DESCHUTES RIVER}

The Deschutes River system drains the forested eastern slope of the Cascade Range. Annual rainfall is 10 to 12 inches in most of the basin. The basin is underlain by porous basalt that stores a large quantity of precipitation and sustains streamflows during drier parts of the year. Land cover in the basin is grazed and ungrazed forest and woodland, subhumid grassland, semiarid grazing land, and irrigated cropland. Redmond and Bend are the major urban areas. The population more than doubled in the Bend area from 1970 to 1990. Water quality upstream from site 3 , from river mile 47 to 192 , is affected by agricultural runoff, seepage from septic tank and drainfield systems, and municipal sewage-treatment plants (Oregon Department of Environmental Quality, 1990, p. A-23). Aquatic life and esthetics are affected during summer because of decreased dissolved-oxygen concentrations and increased $\mathrm{pH}$, nutrient concentrations, and algal growth.

During water years $1987-89$, concentrations of dissolved solids (median, $90 \mathrm{mg} / \mathrm{L}$ ) and phosphorus (median, $0.05 \mathrm{mg} / \mathrm{L}$ ) were among the highest for the 10 monitoring stations (fig. 3). Nonethe- less, because most of the irrigation and urbanization is located in the upper part of the basin, the full effect of those potential contaminant sources might not have been evident downstream at site 3 owing to dilution effects.

\section{COLUMBIA RIVER}

In the United States, the Columbia River has 11 dams equipped with hydroelectric power-generating facilities. This instream use of water has had detrimental effects on fisheries in the Columbia River main stem. Problems affecting fisheries include nitrogen gas supersaturation, blockage of fish migration, fishkills by turbines, and destruction of stream habitat (Oregon Department of Environmental Quality, 1990, p. A-21).

Upstream from site 4, the basin is partly forested and has some grazing land. However, the predominant land use that could affect water quality in the Columbia River is the irrigation of several million acres of agricultural land: large amounts of water return to the river as surface irrigation return flow or as ground-water seepage. Basin geology also is a contributing factor to water-quality conditions. At site 4 , the median concentrations of sulfate $(14 \mathrm{mg} / \mathrm{L})$ and dissolved solids $(97 \mathrm{mg} / \mathrm{L})$ were among the highest for the $10 \mathrm{moni}-$ toring stations (fig. 3 ).

An issue that has recently come to public attention is the presence of dioxin in the tissue of fish taken from the Columbia River. In an effort to reduce dioxin contamination in the river, the EPA will establish Total Maximum Daily Loads (TMDL's) for dioxin in effluent from point sources such as pulp and paper mills.

\section{TUALATIN RIVER}

The Tualatin River basin, located in northwestern Oregon near Portland, consists of a central plain completely surrounded by hills and mountains. Site 5 is 1.8 miles upstream from the confluence with the Willamette River. Population in the basin has grown rapidly in recent years, increasing from approximately 60,000 in 1950 to 260,000 in 1984, and is projected to double by the year 2005 .

The growing population has increased sewage-treatment-plant discharge, industrial-waste loading, and urban stormwater runoff. These larger discharges, in combination with low summer flows and small stream gradients in the lower basin, have caused serious degradation of water quality in the Tualatin River (Oregon Department of Environmental Quality, 1988). In water years 1987-89, the median

Table 1. Sources and environmental significance of selected water-quality constituents

[Source: Compiled by the U.S. Geological Survey, Office of Water Quality]

Constituent Common sources Environmental significance

Dissolved oxygen ...................... Introduced from the atmosphere; also a byproduct of aquatic plants.

Fecal coliform bacteria

Sources include effluent from sewage-treatment plants and runoff from pastures, feedlots, and urban areas.

Sulfate

Occurs in some rocks; also in mine runoff, industrial wastewater discharge, and atmospheric deposition.

Dissolved solids

A result of rock weathering; also in agricultural runoff and industrial discharge.

Nitrite plus nitrate

Nonpoint sources are agricultural and urban runoff a major point source is wastewater discharge.

Phosphorus

Occurs in some rocks and sediments; also in runoff and seepage from phosphate-rock mines, agricultural and urban runoff, and industrial and municipal wastewater discharge.
Necessary for aquatic life; deficiency can result from assimilation of organic wastes or rapid growth and decay of algae.

Presence indicates contamination of water by wastes from humans and other warm-blooded animals.

Concentrations exceeding a natural, background level indicate contamination from human activity; in sufficient quantity, can cause water to be unsuitable for public supply; can harm aquatic organisms.

In sufficient quantity, can cause water to be unsuitable for public supply, agriculture, and industry; can harm aquatic organisms.

Plant nutrient that, in sufficient quantity, can cause algal blooms and excessive growth of higher aquatic plants in bodies of water; can cause water to be unsuitable for public supply.

Plant nutrient that, in sufficient quantity, can cause algal blooms and excessive growth of higher aquatic plants in bodies of water. 
concentrations of sulfate (15 mg/L), dissolved solids (104 mg/L), nitrite plus nitrate $(1.8 \mathrm{mg} / \mathrm{L})$, and phosphorus $(0.26 \mathrm{mg} / \mathrm{L})$ were the highest or among the highest in the 10 streams, and the median dissolved-oxygen concentration $(6.6 \mathrm{mg} / \mathrm{L}$ ) was the lowest (fig. 3 ).

\section{WILLAMETTE RIVER}

The Willamette River basin encompasses much of northwestern Oregon, about 12 percent of the area of the State, and contains 65 percent of the State's population and most of its economic activity. The basin is bordered on the east by the Cascade Range and on the west by the Coast Range. Annual precipitation ranges locally from 35 to 120 inches. Estimated annual runoff for the basin is more than 24 million acre-feet. The diverse land cover in the Willamette River basin includes cropland, ungrazed forest and woodland, and urban areas.

Sources of water-quality degradation in the Willamette River basin are pulp-mill waste, municipal and industrial wastewater-treatment-plant discharge, and urban stormwater runoff. Portland has a combined storm and domestic sewage system that allows excess storm runoff to flow directly into the river whenever the capacity of the treatment plant is exceeded. Site 6 is about 13 miles from the mouth of the Willamette River in an area where the river is affected primarily by pollution sources in the lower basin. The median concentrations of fecal coliform bacteria $(120 \mathrm{col} / 100 \mathrm{~mL})$, nitrite plus nitrate $(0.34 \mathrm{mg} / \mathrm{L})$, and phosphorus $(0.05 \mathrm{mg} / \mathrm{L})$ at site 6 were the highest or among the highest for the monitoring stations from which data were sufficient for frequency analysis (fig. 3).

Sections of the Willamette River are classified by the ODEQ as water-quality limited because of excessive water temperature and excessive concentrations of fecal coliform bacteria and dioxin. The ODEQ lists the water quality in the river from mile 0 to mile 17 as occasionally not supporting water-contact recreation, aquatic-life maintenance, and fishing uses because of high concentrations of bacteria, organic compounds, and toxic metals from sewage-treatment plants, urban areas, agricultural areas, or septic tank and drainfield systems (Oregon Department of Environmental Quality, 1990 , p. A-15). The ODEQ and EPA are establishing TMDL's for dioxin in discharge to the Willamette River from pulp and paper mills (Oregon Department of Environmental Quality, 1990, p. 5-79).

\section{NEHALEM AND SIUSLAW RIVERS}

The Nehalem and Siuslaw Rivers originate on the western slope of the Coast Range and flow into the Pacific Ocean. The Coast Range mountains are composed of tuffaceous sandstone, shale, and basalt. The relatively thin soils of the coastal zone are rich in organic matter. Annual precipitation in the area ranges from 48 to 96 inches. The hydrology of the Coast Range is controlled primarily by seasonal rainfall patterns; stream discharges are large in the late autumn and winter and are small in the summer and early autumn. Streamflow in the Nehalem and Siuslaw Rivers is not regulated or diverted. Land cover primarily is forest and woodland, but there also is some cropland and grazed land. Only small population increases occurred in coastal communities from 1970 to 1985; overall increases in the basins have been less than the State average (Kimerling and Jackson, 1985).

The ODEQ has listed the Nehalem and Siuslaw Rivers as fully supporting designated beneficial uses (Oregon Department of Environmental Quality, 1990). Concentrations of the selected constituents at sites 7 and 8 (fig. 3 ) corroborate that assessment.

\section{SOUTH UMPQUA RIVER}

The South Umpqua River basin originates in the Cascade Mountains of southwestern Oregon and flows through the Coast
Range to the Pacific Ocean. The annual basinwide precipitation ranges from 40 to 80 inches. Most of the winter precipitation in the South Umpqua River basin falls as rain because about 97 percent of the basin is below 5,000 feet in altitude. Cropland, pasture, woodland, and forest cover the basin upstream from site 9. Irrigation withdrawals result in inadequate base flow in the lower basin. In October 1985, the Roseburg Urban Sanitary Authority and Douglas County (which contains the Umpqua River basin) agreed to provide water stored in Galesville Reservoir on Cow Creek to augment streamflow in the South Umpqua River to dilute treated effluent from the Roseburg treatment plant. The agreement will allow additional stored water to be released from 1987 through 2005 (Oregon Department of Environmental Quality, 1990, p. I-5).

Excessive aquatic plant growth and unpleasant odors have been noted in the South Umpqua River from Tiller (at river mile 75) to its mouth; the plant growth occurs every summer because of nutrient enrichment. Dissolved-oxygen concentrations and $\mathrm{pH}$ in the South Umpqua River near Roseburg do not meet State standards during summer; aquatic plant respiration and decay cause dissolvedoxygen depletion in the river. The ODEQ lists river miles 0 to 15 as not supporting water-contact recreation because of high fecal coliform bacteria concentrations. Water quality from river miles 15 to 47 will not support aquatic life because of high $\mathrm{pH}$ values, low dissolvedoxygen concentrations, and high concentrations of ammonia during summer and early autumn (Oregon Department of Environmental Quality, 1990, p. A-11). The ODEQ has proposed to establish TMDL's for municipal point-source discharge at river miles 8, 20, and 39 (Oregon Department of Environmental Quality, 1990, p. A-12).

At site 9, the median concentrations of fecal coliform bacteria ( $32 \mathrm{col} / 100 \mathrm{~mL}$ ) and phosphorus $(0.06 \mathrm{mg} / \mathrm{L})$ were the second highest for the monitoring network (fig. 3). Sources of these constituents include municipal sewage-treatment-plant discharge, industrialwaste discharge, and nonpoint agricultural runoff (Oregon Department of Environmental Quality, 1990, p. A-11).

\section{ROGUE RIVER}

The Rogue River system drains approximately $5,110 \mathrm{mi}^{2}$ of southwestern Oregon. The central part of the basin contains nearly all the basin's agricultural land and the major urban areas of Ashland, Grants Pass, and Medford. The northern part of the basin has a permeable pumice cover overlying lava that stores and yields large volumes of water to springs. The springs provide a steady base flow for the Rogue River. The central valley and western sections are underlain in part by less permeable metamorphic and sedimentary rocks and are subject to surface erosion.

About 90 percent of the Rogue River basin is forested land that has very dense growth in the headwater region. Agricultural land covers 7 percent of the basin and includes irrigated and nonirrigated cropland and rangeland. Limited mining also occurs in the basin, which has the potential for the production of chromium, nickel, copper, and silver (Kimerling and Jackson, 1985).

Water-quality problems in the Rogue River include seasonally high fecal coliform bacteria concentrations from point and nonpoint sources and elevated river temperatures in late summer. The ODEQ has identified a number of small streams near Medford that do not support aquatic life or water-contact uses and are listed as waterquality limited (Oregon Department of Environmental Quality, 1990, p. A-13).

Concentrations of water-quality constituents in samples collected at site 10 during water years $1987-89$ generally were low relative to those from many of the other monitoring stations (fig. 3). The median concentration of phosphorus $(0.06 \mathrm{mg} / \mathrm{L})$, however, was relatively high. Possible sources of phosphorus include municipal sewage-treatment plants, urban runoff, and agricultural runoff (Oregon Department of Environmental Quality, 1990, p. A-13). 


\section{WATER QUALITY TRENDS}

Trend analysis is a statistical procedure used to detect changes in stream water quality at a monitoring station over time. For this report, water-quality data from nine monitoring stations (fig. 2) were analyzed for trends by using the seasonal Kendall test (Hirsch and others, 1982), a method used extensively by the USGS. The graph (next page) of the dissolved-phosphorus concentration in the Tualatin River at site 5 illustrates the trend inferred from the concentration data and demonstrates the variation in water quality that is common in streams.
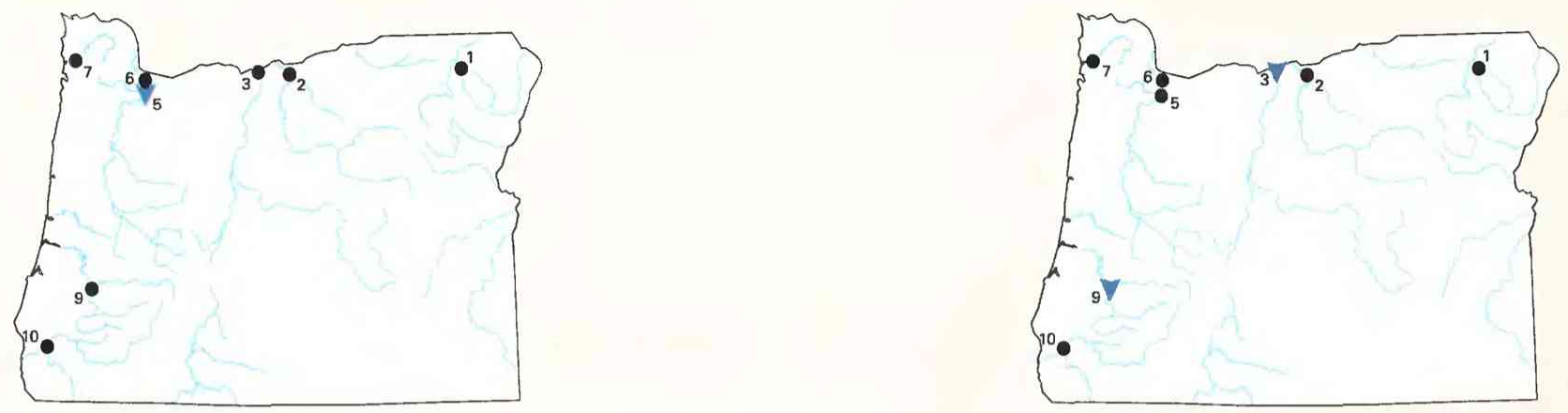

Dissolved oxygen, 1975-89

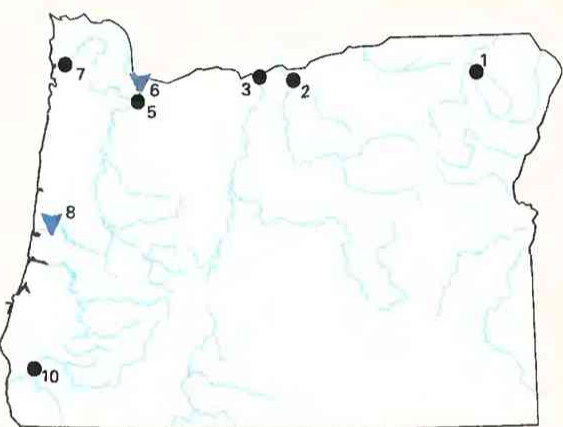

Fecal coliform bacteria, 1975-89

Dissolved sulfate, 1982-89
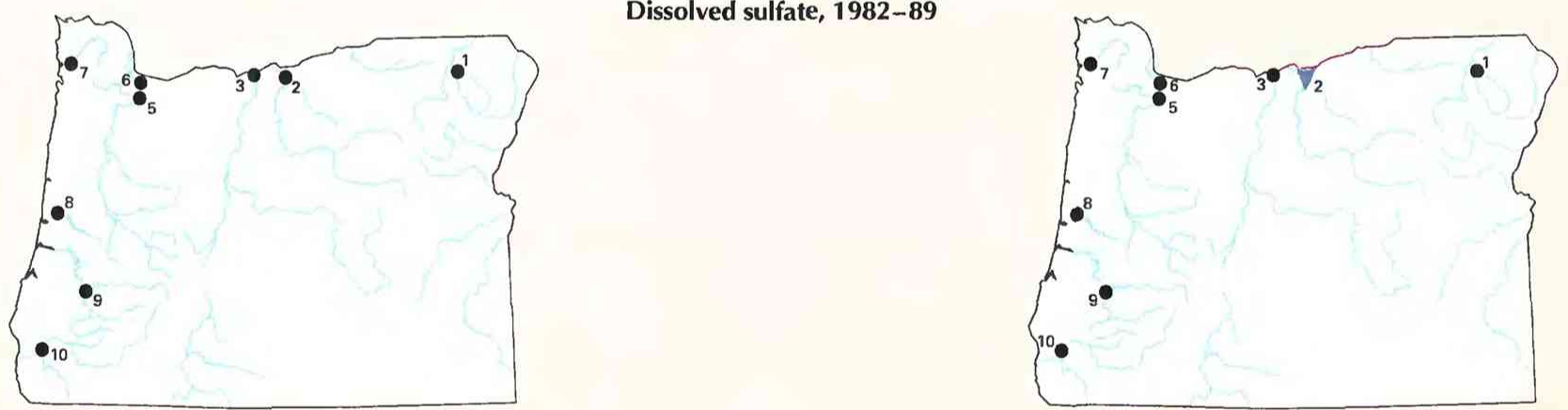

Dissolved solids, 1980-89
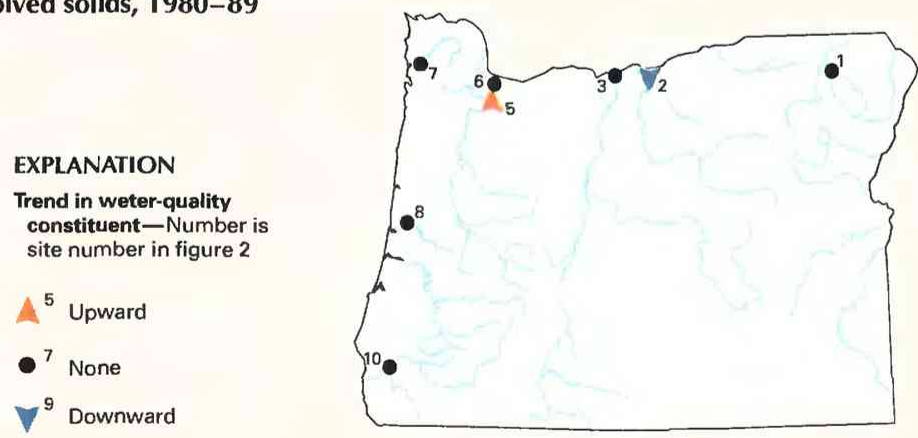

Dissolved nitrite plus nitrate, $1980-89$

Dissolved phosphorus, 1982-89

Figure 4. Trends in water quality of selected streams in Oregon, by water years. (Source: Data from U.S. Geological Survey files.) 


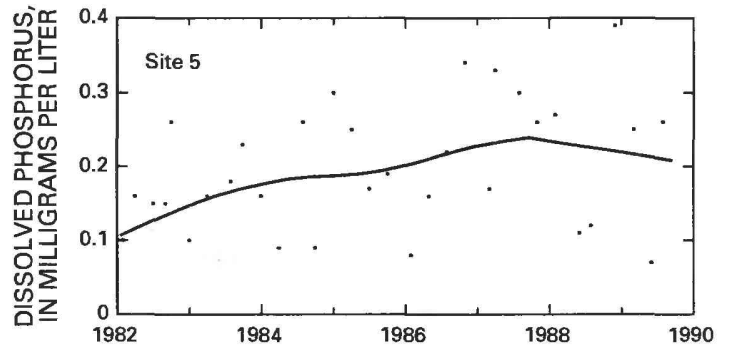

When possible, constituent-concentration data were adjusted for changes in streamflow to preclude identifying a trend in concentration that was caused only by a trend in streamflow. The data were not adjusted when (1) more than 10 percent of the samples had concentrations lower than the minimum reporting limit for the analytical method used or (2) streamflow was controlled substantially by human activities. When the concentration data could not be adjusted for streamflow, trends were determined directly from the concentration data.

Statewide trends in concentrations of selected stream-water constituents are shown on maps in figure 4. On each map, a trend is indicated at a monitoring station only if the data from that station were suitable for use in the trend analysis. For more information on the suitability criteria and on the trend-analysis procedure used for this report, see Lanfear and Alexander (1990).

\section{DISSOLVED OXYGEN}

The dissolved-oxygen concentration in a stream is controlled by several factors, including water temperature, air temperature and pressure, hydraulic characteristics of the stream, photosynthetic or respiratory activity of stream biota, and the quantity of organic material present. A trend in dissolved-oxygen concentrations commonly is directly or indirectly the result of human activities. Generally, an upward trend in dissolved-oxygen concentrations indicates improving stream water-quality conditions and a downward trend indicates deteriorating conditions.

A definite cause for the downward trend in dissolved-oxygen concentrations in the Tualatin River at site 5 is not known. Increased urban and industrial waste loads resulting from population growth can cause the depletion of dissolved oxygen in streams during decomposition of chemicals and organic matter.

\section{FECAL COLIFORM BACTERIA}

Fecal coliform bacteria are used as indicators of fecal contamination from humans and other warm-blooded animals. Such contamination can introduce disease-causing viruses and bacteria into a stream.

A cause for the downward trend in fecal coliform bacteria concentrations in the Deschutes River at site 3 is not known. The decreasing concentration in the South Umpqua River at site 9 might have been the result of dilution by streamflow augmentation from Galesville Reservoir since 1985.

\section{DISSOLVED SULFATE}

The major natural sources of sulfate in streams are rock weathering, volcanoes, and biochemical processes (Hem, 1985, p. 113). Human activities such as mining, waste discharge, and fossil-fuel combustion also can be important sources. A shortened trend-analysis period was used for sulfate because data from analyses performed prior to water year 1982 are not comparable to data from subsequent years.

The decreasing sulfate concentration in the Willamette River at site 6 could have been the result of a reduction of sulfate in indus- trial effluent. A cause for the decrease in the Siuslaw River at site 8 is not known.

\section{DISSOLVED SOLIDS}

Dissolved solids in stream water result primarily from rock weathering but also can be introduced as a byproduct of human activities (table 1). Concentrations generally are greatest in streams draining basins underlain by rocks and soils that contain easily dissolved minerals. Dissolved-solids concentrations at all nine monitoring stations from which data were suitable for trend analysis had no trend for water years $1980-89$.

\section{DISSOLVED NITRITE PLUS NITRATE}

Nitrite and nitrate are oxidized forms of nitrogen that together normally constitute most of the dissolved nitrogen in well-aerated streams. Nitrite readily oxidizes to nitrate in natural waters; therefore, nitrate generally is by far the more abundant of the two (Hem, 1985 , p. 124).

At site 2 on the John Day River, the downward trend in nitrite plus nitrate concentrations might have been caused by improvements in agricultural practices. The trend also might be related to a downward trend in the use of nitrogen fertilizers in the State from 1980 to 1985 (Alexander and Smith, 1990).

\section{DISSOLVED PHOSPHORUS}

Small quantities of dissolved phosphorus - most of it in the oxidized form, phosphate-commonly are present in streams as a result of rock weathering. Concentrations of dissolved phosphorus in natural water normally are no more than a few tenths of a milligram per liter (Hem, 1985, p. 126) and are usually much lower. Higher concentrations can indicate contamination from human activities (table 1).

In the Tualatin River at site 5, the increasing phosphorus concentration probably was the result of increased agricultural use of phosphorus fertilizer in the basin, increasing runoff from expanding urban areas, and increasing discharges from municipal sewage-treatment plants. Although a definite cause is not known, the downward trend in the John Day River at site 2 might have been the result of improved agricultural practices.

\section{WATER-QUALITY MANAGEMENT}

Stream water-quality management in the State is governed by the provisions of the Federal Clean Water Act of 1972, Oregon's Revised Statutes, and Oregon's Administrative Rules (Chapter 340). The ODEQ, under the direction of the Environmental Quality Commission, is primarily responsible for the management and protection of the designated beneficial uses of surface water through the implementation of water-quality standards. In addition, to assist in longrange water-quality planning, the ODEQ developed the State Clean Water Strategy. The Clean Water Strategy is used by the ODEQ as a guide to make decisions, establish priorities, and allocate resources.

The ODEQ prepares and submits to the EPA and the U.S. Congress the biennial water-quality assessment report mandated by section 305(b) of the Clean Water Act (Oregon Department of Environmental Quality, 1990). This report describes the status of water quality in the State.

Protection of water quality in the State is largely achieved through a permit process. In the past few years, however, criteria for issuing permits in Oregon have changed from those that are technology based to those that are water-quality based. Permit decisions for point and nonpoint discharges are made by considering the overall chemical, physical, and biological health of the receiving stream rather than being based primarily on technological requirements for the treatment facilities. The water-quality-based management ap- 
proach will place more emphasis on controlling a wider range of pollutants through the establishment of TMDL's for nutrients, metals and toxic chemicals in addition to monitoring and regulating "traditional" organic pollutants, such as biochemical oxygen demand.

The establishment of TMDL's is required by section 303 of the Federal Clean Water Act. According to the act, TMDL's are to be developed for those waters where required treatment processes are in effect, yet water-quality violations continue to occur. These waters are referred to as being water-quality limited.

The ODEQ is initiating new activities such as continuous dissolved-oxygen monitoring and intensive water-quality surveys for establishing TMDL's. Areas of the State with water-quality problems are being studied more intensively while activities in noncritical basins are being reduced.

\section{SELECTED REFERENCES}

Alexander, R.B., and Smith, R.A., 1990, County-level estimates of nitrogen and phosphorus fertilizer use in the United States, 1945 to 1985: U.S. Geological Survey Open-File Report 90-130, 12 p.

Anderson, J.R., 1967, Major land uses in the United States, in U.S. Geological Survey, 1970, National atlas of the United States of America: Washington, D.C., U.S. Geological Survey, p. 158-159.

Britton, L.J., and Greeson, P.E., eds., 1987, Methods for collection and analysis of aquatic biological and microbiological samples: U.S. Geological Survey Techniques of Water-Resources Investigations, book 5, chap. A4, $363 \mathrm{p}$.

Busby, M.W., 1966, Annual runoff in the conterminous United States: U.S. Geological Survey Hydrologic Investigations Atlas HA-212, scale $1: 750,000$.

Dicken, S.N., 1965, Oregon geography, the people, the place, and the time: Ann Arbor, Mich.: Edwards Brothers, Inc., 4th ed., 127 p.

Fishman, M.J., and Friedman, L.C., eds., 1989, Methods for the determination of inorganic substances in water and fluvial sediments: U.S. Geo- logical Survey Techniques of Water-Resources Investigations, book 5, chap. A1, 545 p.

Hem, J.D., 1985, Study and interpretation of the chemical characteristics of natural water (3d ed.): U.S. Geological Survey Water-Supply Paper 2254, $263 \mathrm{p}$.

Hirsch, R.M., Slack, J.R., and Smith, R.A., 1982, Techniques of trend analysis for monthly water-quality data: Water Resources Research, v. 18, no. 1, p. 107-121.

Kimerling, A.J., and Jackson, P.L., eds., 1985, Atlas of the Pacific Northwest: Corvallis, Oregon State University Press, 135 p.

Lanfear, K.J., and Alexander, R.B., 1990, Methodology to derive water-quality trends for use by the National Water Summary Program of the U.S. Geological Survey: U.S. Geological Survey Open-File Report 90-359, $10 \mathrm{p}$.

Oregon Department of Environmental Quality, 1988, Oregon statewide assessment of nonpoint sources of water pollution: Portland, Water Quality Division, Oregon Department of Environmental Quality, 169 p. 1990, Water quality status assessment report-The 1990 305(b) report: Portland, Oregon Department of Environmental Quality, variously paginated.

Phillips, K.N., Newcomb, R.C., Swenson, H.A., and Laird, L.B., 1965, Water for Oregon: U.S. Geological Survey Water-Supply Paper 1649, 150 p.

Solley, W.B., Merk, C.F., and Pierce, R.R., 1988, Estimated use of water in the United States in 1985: U.S. Geological Survey Circular 1004, 82 p.

Thelin, G.P., and Pike, R.J., 1990, Digital shaded relief map of the conterminous United States: Menlo Park, Calif., U.S. Geological Survey digital image processing, scale 1:3,500,000.

U.S. Geological Survey, 1990, National water summary 1987--Hydrologic events and water supply and use: U.S. Geological Survey Water-Supply Paper 2350, $553 \mathrm{p}$.

1991, National water summary 1988-89-Hydrologic events and floods and droughts: U.S. Geological Survey Water-Supply Paper 2375, $591 \mathrm{p}$.

Ward, J.R., and Harr, C.A., eds., 1990, Methods for collection and processing of surface-water and bed-material samples for physical and chemical analyses: U.S. Geological Survey Open-File Report 90-140, 71 p.

Prepared by J.M. Laenen, U.S. Geological Survey; “Water-Quality Management” section by Elizabeth Thomson, Oregon Department of Environmental Quality 


\section{PenNSYLVANiA Stream Water Quality}

Surface water is abundant in Pennsylvania. Precipitation annually ranges from 36 inches in the north and west to 48 inches in the east and provides runoff to 45,000 miles of streams (U.S. Geological Survey, 1986, p. 391). The major drainage basins are the Delaware, Susquehanna, Ohio, Potomac (main stem in Maryland), and Genesee Rivers and Lake Erie.

Pennsylvania relies on its abundant surface water to meet most water needs. However, in many streams, water-quality problems related to land use (fig. $1 A$ ) have created serious water-supply concerns. Drainage from abandoned coal mines, mostly in the Appalachian Plateaus (fig. $1 B$ ), is the primary source of water-quality degradation in Pennsylvania (Pennsylvania Department of Environmental Resources, 1990, p. 4). Other major causes of water-quality degradation include runoff from agricultural land and wastewater discharges from industrial and municipal sources in the urban areas of Philadelphia and Pittsburgh.

Surface water supplied about 13,500 million gallons per day or 94 percent of Pennsylvania's freshwater use in 1985. Surface water was used primarily for thermoelectric power generation (75.6 percent), water supply for industry and mining (14.4 percent), and public water supply (9.9 percent) (U.S. Geological Survey, 1990, p. 436). In 1985, about 58 percent of the State's population relied on public water supplies that came from surface-water sources (Solley and others, 1988). Pennsylvania's 1990 population was 11.9 millionan increase of 0.14 percent since 1980 (U.S. Bureau of the Census 1990 decennial census files). Population is distributed unevenly within the State (fig. $1 C$ ); Philadelphia and Pittsburgh have the greatest population densities. Population increases were largest in the southeastern corner of the State.

\section{WATER-QUALITY MONITORING}

Water-quality data obtained from analyses of water samples collected at monitoring stations are stored in the U.S. Geological Survey's (USGS) National Water Information System and the U.S. Environmental Protection Agency's (EPA) national data base known as STORET. Water-quality and streamflow data are reported by water year-the 12 months from October 1 through September 30. A water year is identified by the calendar year in which it ends. For example, water year 1991 comprises October 1, 1990, through September 30, 1991.

The data used in this summary of Pennsylvania's stream water quality were obtained from water samples collected at nine monitoring stations at which data collection is systematic and continuing (fig. 2). Analyses of water samples collected at all nine stations are the basis for the discussion and graphic summary (fig. 3) of stream water-quality conditions during water years 1987-89, and data from seven stations are the basis for the discussion and graphic summary (fig. 4) of stream waterquality trends. Water samples were collected and analyzed by using standard methods approved by the USGS (Britton and Greeson, 1987; Fishman and Friedman, 1989; Ward and Harr, 1990) or by using equivalent methods. If a method of sample collection or analysis changed over time, data from an analysis were included in the evaluation of recent stream water quality or of stream water-quality trends only if the change in method did not affect the comparability of the data.

\section{WATER-QUALITY CONDITIONS}

In 1989, the Pennsylvania Department of Environmental Resources (PDER) assessed 23,833 miles of rivers and streams and found that abandoned-mine drainage, a non-point source, was responsible for water-quality degradation in about 49 percent of the

4,696 miles reported as degraded
Figure 1. Land use, physiography, and population in Pennsylvania. A, Major land uses. B, Physiographic divisions. C. Population distribution in 1990. (Sources: A, Major land uses modified from Anderson, 1967. B. Physiographic divisions from Fenneman. 1946; landforms from Thelin and Pike, 1990. C, Data from U.S. Bureau of the Census 1990 decennial census files.)

\author{
Physiographic divisions \\ A. Central Lowland \\ C. Valley and Ridge \\ D. Blue Ridge \\ E. Piedmont \\ F. New England
G. Coastal Plain
}

PHYSIOGRAPHIC DIVISIONS 
(Pennsylvania Department of Environmental Resources, 1990, p. 3). The effects of degradation included acidification, increased concentrations of toxic heavy metals, and high values for turbidity and suspended solids. The toxic properties of heavy metals and acid, together with the smothering effects of iron precipitates commonly known as "yellow boy," decreased or completely eliminated biological productivity in the significantly affected streams. Municipal wastewater-treatment plants were the principal sources of point-source pollution.

The following discussion of stream water quality in Pennsylvania is organized by river basin (fig. 3 ). Where physiographic and land-use characteristics in different basins are similar, the discussion of those basins is combined. Graphs in figure 3 summarize certain aspects of stream water quality in the basins for water years $1987-$ 89 . The graphs show frequency distributions of data values that represent concentrations of selected constituents in stream water and measurements of selected physical properties of stream water. These constituents and properties are dissolved oxygen, alkalinity (as calcium carbonate), dissolved sulfate, dissolved solids, dissolved nitrite plus nitrate (as nitrogen), and dissolved phosphate (as phosphorus). The data are reported in milligrams per liter $(\mathrm{mg} / \mathrm{L})$. Sources and environmental significance of each constituent and property are described in table 1.

Water quality at each monitoring station is the result of geological, chemical, biological, and hydrologic processes that occur over a large area. Water-quality problems that affect aquatic life or public health only locally are not fully represented in this summary.

\section{SCHUYLKILL RIVER}

The Schuylkill River is one of the most extensively used rivers in the Nation (Stamer and others, 1985, p. A2). The basin has diverse land forms of four physiographic provinces - the Valley and Ridge, New England, Piedmont, and Coastal Plain. Land in the basin is largely used for agriculture, coal mining (in the upper part of the basin), industry, and urban development. The PDER (1990, p. 20) has reported that 63 stream miles in the upper Schuylkill River basin are affected by drainage from abandoned anthracite coal mines. The major sources of degradation in the basin are municipal point sources (144 miles), agriculture (98 miles), and other nonpoint sources (123 miles).

Site 1 is on a nontidal reach of the Schuylkill River and is unaffected by brackish water. Median values of alkalinity $(66 \mathrm{mg} / \mathrm{L}$ ) and dissolved solids $(194 \mathrm{mg} / \mathrm{L})$ at site 1 were the second highest for the nine monitoring stations (fig. 3); median concentrations of nitrite plus nitrate $(2.9 \mathrm{mg} / \mathrm{L})$ and phosphate $(0.14 \mathrm{mg} / \mathrm{L})$ were the highest. The high dissolved-solids concentrations probably were the result of runoff from coal mines and industrial discharges. The high nitrite plus nitrate and phosphate concentrations probably were the result of private and municipal sewage discharges and agricultural runoff.

Fish-consumption advisories were issued in November 1976, May 1983, and June 1986 for the Schuylkill River from Felix Dam upstream from Reading to the mouth (Pennsylvania Department of Environmental Resources, 1990, p. 42). Fish-tissue contamination from polychlorinated biphenyls (PCB's), chlordane, and dichloro diphenyl trichloroethane (DDT) was detected in the white sucker, carp, and American eel; anglers were warned to avoid consumption of these species at that location.

\section{SUSQUEHANNA RIVER}

The Susquehanna River basin upstream from site 2 lies within the Appalachian Plateaus and the Valley and Ridge physiographic

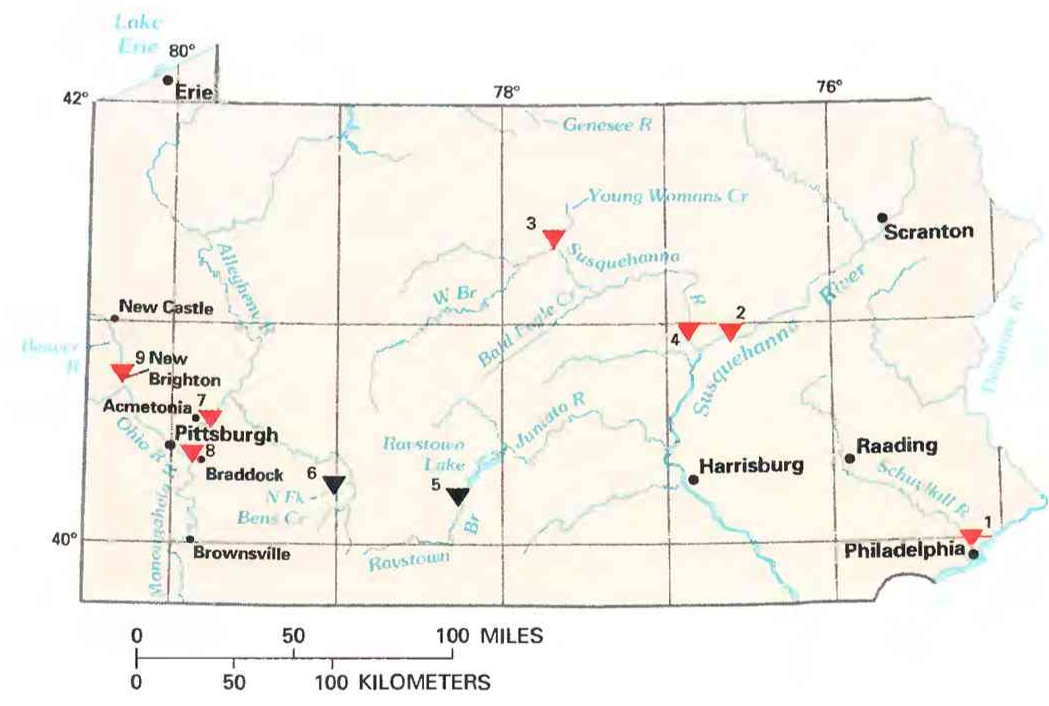

\section{EXPLANATION}

Water-quality monitoring station and typa of statistical analysis Number refers to accompanying table

$\nabla^{5}$ Water-quality conditions (see fig. 3)

$\nabla^{3}$ Water-quality conditions and trends (see figs. 3 and 4 )

\begin{tabular}{|c|c|c|c|}
\hline $\begin{array}{l}\text { Site no. } \\
\text { on map }\end{array}$ & $\begin{array}{l}\text { USGS station } \\
\text { name and no. }\end{array}$ & $\begin{array}{l}\text { Drainage area } \\
\text { (square miles) }\end{array}$ & $\begin{array}{l}\text { Major land use } \\
\text { (see fig. 1) }\end{array}$ \\
\hline 1 & Schuylkill River at Philadelphia $(01474500)$ & 1,893 & Cropland with pasture, woodland, and forest; urban areas. \\
\hline 2 & Susquehanna River at Danville $(01540500)$ & 11,220 & Cropland with pasture, woodland, and forest. \\
\hline 3 & 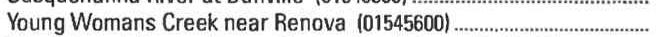 & 46.2 & Mostly ungrazed forest and woodland. \\
\hline 4 & West Branch Susquehanna River at Lewisburg (01553500) .................. & 6,847 & Ditto. \\
\hline 5 & 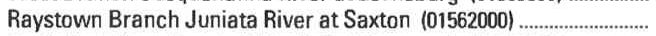 & 756 & Cropland with pasture, woodland, and forest. \\
\hline 6 & North Fork Bens Creek at North Fork Reservoir (03039925) ................. & 3.4 & Mostly ungrazed forest and woodland. \\
\hline 7 & 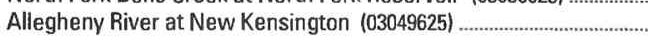 & 11,500 & Ditto. \\
\hline 8 & 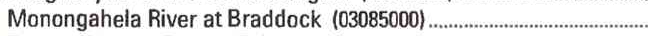 & 7,337 & Cropland with pasture, woodland, and forest; urban areas. \\
\hline 9 & Beaver River at Beaver Falls (03107500) & 3,106 & Cropland with pasture woodland, and forest. \\
\hline
\end{tabular}

Figure 2. Selected water-quality monitoring stations, type of statistical analysis, and geographic features in Pennsylvania. (Sources: Major land uses modified from Anderson, 1967; other data from U.S. Geological Survey files.) 
provinces. Land use in the basin is predominantly cropland with pasture, woodland, and forest. Drainage from abandoned anthracite coal mines is the primary cause of water-quality degradation in this basin (Pennsylvania Department of Environmental Resources, 1990, p. 21).

Median values of dissolved oxygen ( $10.2 \mathrm{mg} / \mathrm{L})$, alkalinity (41 $\mathrm{mg} / \mathrm{L})$, sulfate $(32 \mathrm{mg} / \mathrm{L})$, dissolved solids (127 mg/L), and nitrite plus nitrate $(0.80 \mathrm{mg} / \mathrm{L})$ were similar to those for the other eight monitoring stations (fig. 3). These concentrations are within water-quality standards set by the State (Pennsylvania Code, 1988, p. 93.7) and do not indicate excessive contamination in the basin.

\section{YOUNG WOMANS CREEK AND NORTH FORK BENS CREEK}

Young Womans Creek and North Fork Bens Creek are located within the Appalachian Plateaus in an area underlain primarily by sandstone, siltstone, and shale. Land in both basins is forested. Sites 3 and 6 monitor stream water quality in undisturbed, natural areas largely unaffected by direct influences of humans; both stations are used to monitor the effects of acidic precipitation on stream water quality. The water quality of these two streams is indicative of the quality of many other headwater streams draining undisturbed forested areas in Pennsylvania and can be characterized as unpolluted.

Median values of alkalinity $(7 \mathrm{mg} / \mathrm{L}$ at site $3,0.7 \mathrm{mg} / \mathrm{L}$ at site 6); sulfate (8.6 mg/L at site $3,9.4 \mathrm{mg} / \mathrm{L}$ at site 6$)$; dissolved solids $(31 \mathrm{mg} / \mathrm{L}$ at site 3$)$; and nitrite plus nitrate $(0.32 \mathrm{mg} / \mathrm{L}$ at site 3$)$ were the lowest for the nine monitoring stations (fig. 3). These values are characteristic of streams in nearly undisturbed basins that are underlain by resistant, noncarbonate rocks. The low alkalinity values indicate a limited buffering capacity that makes these streams vulnerable to the effects of acidic precipitation. The median dissolvedoxygen concentration $(11.2 \mathrm{mg} / \mathrm{L})$ at site 3 was one of the highest for the nine monitoring stations. Dissolved-oxygen concentrations generally are higher in uncontaminated streams. Dissolved-oxygen concentrations in this stream were at least 94 percent of saturation for all measurements in a study done by Hainly and Ritter (1986, p. 15).

\section{WEST BRANCH SUSOUEHANNA RIVER}

The West Branch Susquehanna River basin is located within the Appalachian Plateaus and Valley and Ridge physiographic prov-
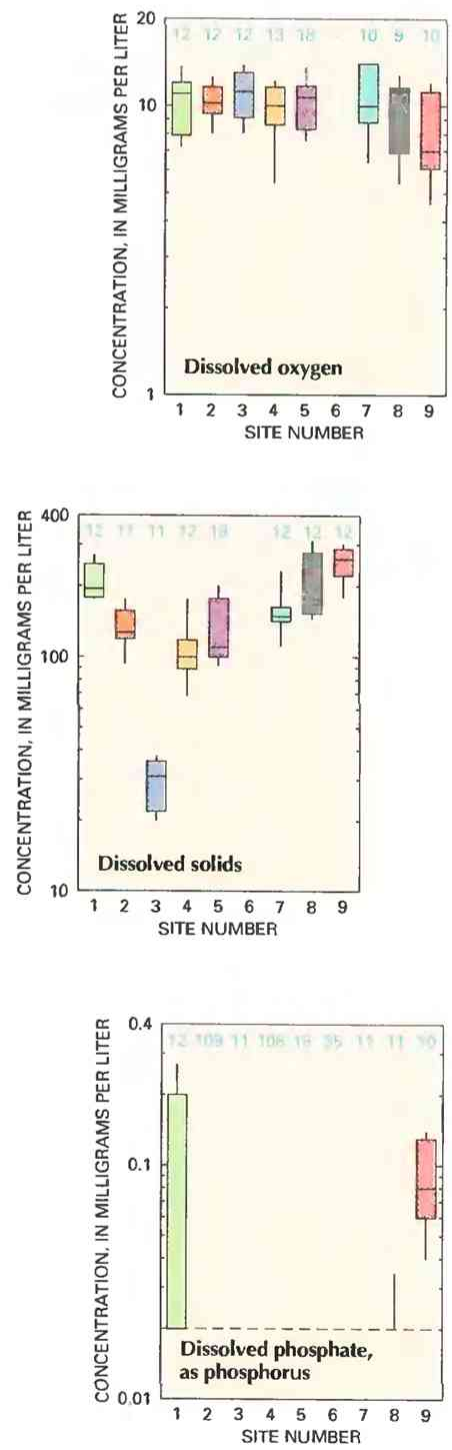
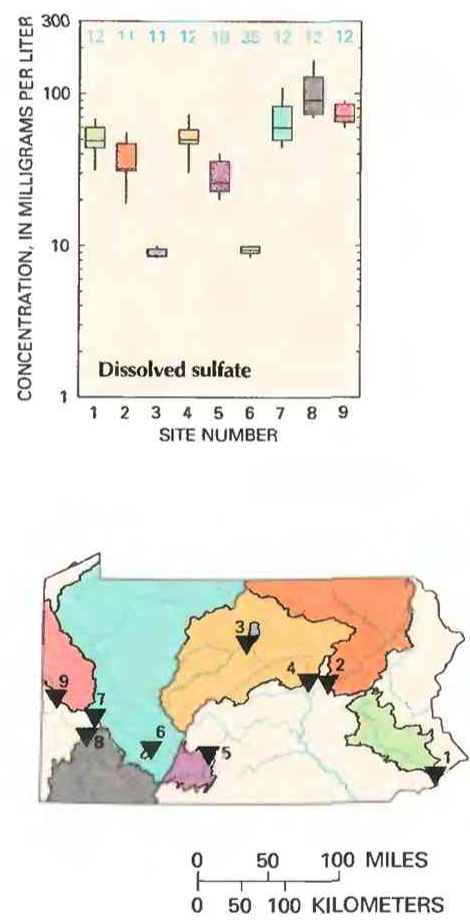

\section{EXPLANATION}

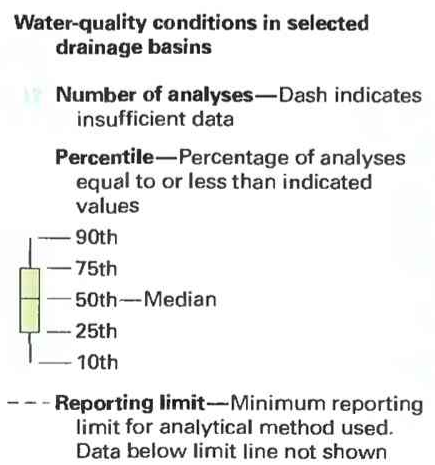

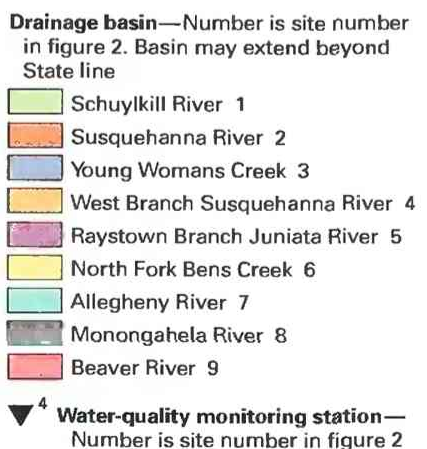

Figure 3. Water quality of selected streams in Pennsylvania, water years 1987-89. (Source: Data from U.S. Geological Survey files.) 
Table 1. Sources and environmental significance of selected water-quality constituents and properties ISource: Compiled by the U.S. Geological Survey, Office of Water Qualityl

\begin{tabular}{|c|c|c|}
\hline Constituent or property & Common sources & Environmental significance \\
\hline Dissolved oxygen ......................... & $\begin{array}{l}\text { Introduced from the atmosphere; also a byproduct of } \\
\text { aquatic plants. }\end{array}$ & $\begin{array}{l}\text { Necessary for aquatic life; deficiency can result from } \\
\text { assimilation of organic wastes or rapid growth } \\
\text { and decay of algae. }\end{array}$ \\
\hline Alkalinity (property) ......................... & $\begin{array}{l}\text { A measure of the quantity of acid-neutralizing sub- } \\
\text { stances; can be affected by geologic setting, in- } \\
\text { dustrial wastewater discharge, waste gases, and } \\
\text { runoff from surface mining. }\end{array}$ & $\begin{array}{l}\text { Sufficiently alkaline water can be unsuitable for some } \\
\text { agricultural and industrial uses. }\end{array}$ \\
\hline 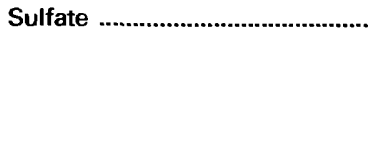 & $\begin{array}{l}\text { Occurs in some rocks; also in mine runoff, industrial } \\
\text { wastewater discharge, and atmospheric deposi- } \\
\text { tion. }\end{array}$ & $\begin{array}{l}\text { Concentrations exceeding a natural, background } \\
\text { level indicate contamination from human activity; } \\
\text { in sufficient quantity, can cause water to be } \\
\text { unsuitable for public supply; can harm aquatic } \\
\text { organisms. }\end{array}$ \\
\hline 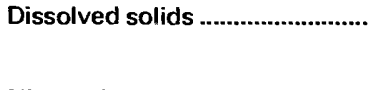 & $\begin{array}{l}\text { A result of rock weathering; also in agricultural runoff } \\
\text { and industrial discharge. }\end{array}$ & $\begin{array}{l}\text { In sufficient quantity, can cause water to be unsuitable } \\
\text { for public supply, agriculture, and industry; can } \\
\text { harm aquatic organisms. }\end{array}$ \\
\hline Nitrite plus nitrate ............................. & $\begin{array}{l}\text { Nonpoint sources are agricultural and urban runoff: } \\
\text { a major point source is wastewater discharge. }\end{array}$ & $\begin{array}{l}\text { Plant nutrient that, in sufficient quantity, can cause } \\
\text { algal blooms and excessive growth of higher } \\
\text { aquatic plants in bodies of water; can cause water } \\
\text { to be unsuitable for public supply. }\end{array}$ \\
\hline 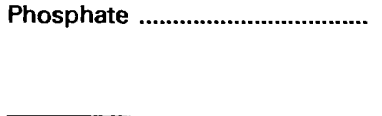 & $\begin{array}{l}\text { Occurs in some rocks and sediments; also in runoff } \\
\text { and seepage from phosphate-rock mines, agri- } \\
\text { cultural and urban runoff, and industrial and } \\
\text { municipal wastewater discharge. }\end{array}$ & $\begin{array}{l}\text { Plant nutrient that, in sufficient quantity, can cause } \\
\text { algal blooms and excessive growth of higher } \\
\text { aquatic plants in bodies of water. }\end{array}$ \\
\hline
\end{tabular}

inces. Forest covers most of the basin. Sandstone and shale are the predominant rock types in the basin, but extensive formations of limestone and dolomite are present in the Valley and Ridge province. Acidic mine drainage is a major cause of water-quality degradation in this basin. According to Hainly and others $(1989$, p. 1), the river has "...moderately good water quality in the upper reaches, poor water quality in its middle reach, and good water quality near the mouth."

The median sulfate concentration was $50 \mathrm{mg} / \mathrm{L}$ in the West Branch Susquehanna River at site 4 and the median dissolved-solids concentration was $100 \mathrm{mg} / \mathrm{L}$ (fig. 3). Alkalinity generally increases downstream in the lower reaches of the river because of the inflow of Bald Eagle Creek, which has an alkalinity of greater than 100 $\mathrm{mg} / \mathrm{L}$ (Hainly and others, 1989. p. 13). The median alkalinity at site 4 was $17 \mathrm{mg} / \mathrm{L}$.

Average concentrations of sulfate $(54 \mathrm{mg} / \mathrm{L})$ and dissolved solids (114 mg/L) in samples collected at site 4 during $1987-89$ were slightly less than the $62 \mathrm{mg} / \mathrm{L}$ and $132 \mathrm{mg} / \mathrm{L}$ reported by Hainly and others $(1989$, p. 36) for $1962-82$, and the average alkalinity of 23 $\mathrm{mg} / \mathrm{L}$ for $1987-89$ was slightly greater than the $18 \mathrm{mg} / \mathrm{L}$ reported for that period. These small differences could indicate decreased acidic drainage from mines or improvement related to changes in other sources that were also noted by Hainly and others (1989, p. 33).

\section{RAYSTOWN BRANCH JUNIATA RIVER}

The Raystown Branch Juniata River basin is in the Valley and Ridge province and is underlain principally by shale, sandstone, and limestone. Land cover upstream from site 5 is a combination of forest, cropland, and pasture. Limestone, which is abundant, is an important economic resource in the basin (Pennsylvania Department of Environmental Resources, 1988, p. 57). Raystown Branch Juniata River is the main inflow to Raystown Lake, a manmade reservoir that provides flood control, recreation, and water-quality and fisheryresource enhancement (Williams, 1976, p. 2).

The median nitrite plus nitrate concentration at site 5 (1.5 $\mathrm{mg} / \mathrm{L}$ ) was the second highest for the nine monitoring stations (fig. 3). According to the PDER (1988, p. 58), agriculture has been the major cause of water-quality problems throughout the basin because runoff from agricultural areas has contributed large quantities of nutrients and suspended solids to streams. The chemical weathering of limestone resulted in stream water at site 5 having high values of alkalinity (median, $50 \mathrm{mg} / \mathrm{L}$ ) relative to those in most other streams.

\section{ALLEGHENY RIVER}

The Allegheny River basin upstream from site 7 has the largest drainage area of the basins discussed in this report. The basin is located in the Appalachian Plateaus and is underlain primarily by sandstone and shale that contain thin beds of limestone and coal. Land cover is primarily forest and ungrazed woodland. Ninety percent of the oil and a significant part of the natural gas produced in the State come from the upper Allegheny River basin (Pennsylvania Department of Environmental Resources, 1988, p. 76). Bituminous coal is the most important mineral resource in the basin, and drainage from abandoned coal mines is the primary cause of water-quality degradation (Pennsylvania Department of Environmental Resources, 1988, p. 85).

The dissolved-solids concentrations at site 7 generally were less than $150 \mathrm{mg} / \mathrm{L}$ (fig. 3). However, sulfate concentrations, in large part a result of drainage from active and abandoned coal mines, exceeded $50 \mathrm{mg} / \mathrm{L}$ in 75 percent of the water samples. The median nitrite plus nitrate concentration $(0.62 \mathrm{mg} / \mathrm{L})$ was the second lowest for the nine monitoring stations and was similar to those in the other drainage basins where land cover is mostly forest and woodland.

Fish-consumption advisories were issued in June 1986, June 1987, and July 1989 for the Allegheny River at Lock and Dam 3 near Acmetonia (Pennsylvania Department of Environmental Resources, 1990 , p. 43). Contamination from PCB's and chlordane was discovered in carp and channel catfish tissue; anglers were warned to avoid consumption of those species at that location.

\section{MONONGAHELA RIVER}

The Monongahela River basin is located entirely within the Appalachian Plateaus. Rock types underlying the basin are primarily sandstone and shale that contain thin beds of limestone and coal. Land cover upstream from site 8 is mostly cropland with pasture, woodland, and forest. Drainage from abandoned bituminous coal mines is the largest source of water-quality degradation in the basin (Pennsylvania Department of Environmental Resources, 1990, p. 27).

The median concentration of sulfate $(91 \mathrm{mg} / \mathrm{L})$ was the highest, and the median concentration of dissolved solids $(177 \mathrm{mg} / \mathrm{L})$ was the third highest for the nine monitoring stations (fig. 3). A coalhydrology study in the early 1980's (Herb and others, 1981, p. 40) reported that many streams tributary to the upper Monongahela River 
had sulfate concentrations in excess of $400 \mathrm{mg} / \mathrm{L}$. Acidic drainage from active and abandoned coal mines is the leading cause for the high sulfate and dissolved-solids concentrations.

Fish-consumption advisories were issued in June 1986, June 1987, and July 1989 for the Monongahela River at the Maxwell Lock and Dam near Brownsville and at Lock and Dam 2 near Braddock (Pennsylvania Department of Environmental Resources, 1990, p. 43). Fish-tissue contamination from PCB's and chlordane was discovered in carp and channel catfish; anglers were warned to avoid consumption of these species.

\section{BEAVER RIVER}

The Beaver River basin is located in the Appalachian Plateaus. Land uses are predominantly agriculture and industry. Thermal and chemical pollution from industrial discharges (primarily from the steel industry near Youngstown, Ohio, and New Castle, $\mathrm{Pa}$.) are significant sources of water-quality degradation.

The median concentration of dissolved oxygen $(7.0 \mathrm{mg} / \mathrm{L})$ in the Beaver River at site 9 was the lowest for the nine monitoring stations (fig. 3). Increased water temperatures from industrial discharges have reduced the dissolved-oxygen-saturation potential, resulting in lower dissolved-oxygen concentrations. The median dissolved-solids concentration $(260 \mathrm{mg} / \mathrm{L})$ was the highest for the nine monitoring stations. Discharges from upstream industries, acidic mine drainage, and agricultural runoff were all significant contributors to the dissolved-solids concentrations.

A fish-consumption advisory was issued in June 1986 for the Beaver River at the New Brighton Dam (Pennsylvania Department of Environmental Resources, 1990, p. 43). PCB and chlordane residues were detected in carp and channel catfish; anglers were warned to avoid consumption of these species.

\section{WATER-QUALITY TRENDS}

Trend analysis is a statistical procedure used to detect changes in stream water quality at a monitoring station over time. For this report, water-quality data from seven monitoring stations (fig. 2) were analyzed for trends by using the seasonal Kendall test (Hirsch and others, 1982), a method used extensively by the USGS. The graph (shown below) of the dissolved-solids concentration in the Monongahela River at site 8 illustrates the trend inferred from the concentration data and demonstrates the variation in water quality that is common in streams.

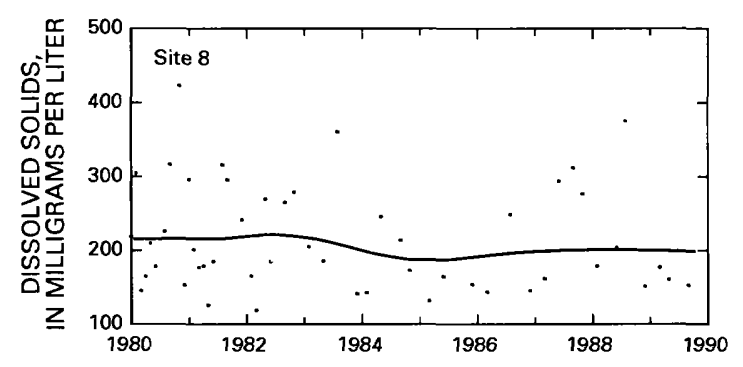

When possible, constituent-concentration data were adjusted for changes in streamflow to preclude identifying a trend in concentration that was caused only by a trend in streamflow. The data were not adjusted when (1) more than 10 percent of the samples had concentrations lower than the minimum reporting limit for the analytical method used or (2) streamflow was controlled substantially by human activities. When the concentration data could not be adjusted for streamflow, trends were determined directly from the concentration data. For more information on how the seasonal Kendall test was used in this report, see Lanfear and Alexander (1990).
Statewide trends in concentrations of selected constituents in stream water and in measurements of selected physical properties of stream water are shown on maps in figure 4. On each map, a trend is indicated at a monitoring station only if the data to be tested met criteria for the length of the period of record and the frequency of water-sample collection.

\section{DISSOLVED OXYGEN}

The dissolved-oxygen concentration in a stream is controlled by several factors, including water temperature, air temperature and pressure, hydraulic characteristics of the stream, photosynthetic or respiratory activity of stream biota, and the quantity of organic material present. A trend in dissolved-oxygen concentrations commonly is directly or indirectly the result of human activities. Generally, an upward trend in dissolved-oxygen concentrations indicates improving stream-water quality conditions and a downward trend indicates deteriorating conditions. Dissolved-oxygen concentrations had no trend at the six monitoring stations from which data met the criteria for trends analysis.

\section{ALKALINITY}

Alkalinity is a measure of the capacity of the substances dissolved in the water to neutralize acid. In most natural waters, alkalinity is produced mainly by bicarbonate and carbonate (Hem, 1985, p. 106), which are ions formed when carbon dioxide or carbonate rock dissolves in water.

A definite cause for the upward alkalinity trend in the Allegheny River at site 7 is not known. However, the trend could have been related to a decrease in coal mining throughout the drainage basin.

\section{DISSOLVED SULFATE}

The major natural sources of sulfate in streams are rock weathering, volcanoes, and biochemical processes (Hem, 1985, p. 113). Human activities such as mining, waste discharge, and fossil-fuel combustion also can be important sources.

Sulfate concentrations had no trend at six monitoring stations having data suitable for trends analysis. Although coal mining has declined significantly in the drainage basins of the Schuylkill, West Branch Susquehanna, Allegheny, Monogahela, and Beaver Rivers upstream from sites $1,4,7,8$, and 9 , continuous drainage from abandoned mines could account for the absence of downward trends in sulfate concentration.

\section{DISSOLVED SOLIDS}

Dissolved solids in stream water result primarily from rock weathering but also can be introduced as a byproduct of human activities (table 1). Concentrations generally are greatest in streams draining basins underlain by rocks and soils that contain easily dissolved minerals.

The downward trend in dissolved-solids concentrations in the Monongahela River at site 8 indicates improved water quality. A significant decline in the steel industry accompanied by a corresponding reduction in industrial discharges along the Monongahela River might have been responsible for the trend.

\section{DISSOLVED NITRITE PLUS NITRATE}

Nitrite and nitrate are oxidized forms of nitrogen that together constitute most of the dissolved nitrogen in well-aerated streams. Nitrite readily oxidizes to nitrate in natural waters; therefore, nitrate generally is by far the more abundant of the two (Hem, 1985, p. 124). 


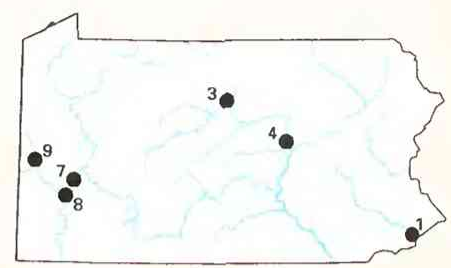

Dissolved oxygen, 1980-89

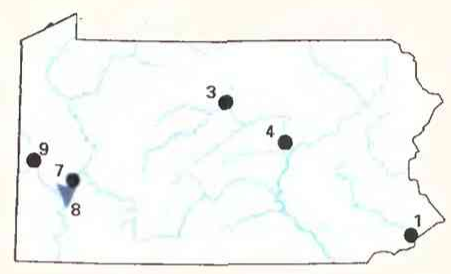

Dissolved solids, $1980-89$

$$
\begin{array}{cccc}
0 & 50 & 100 & \text { MILES } \\
0 & 1 & 100 & \text { KILOMETERS }
\end{array}
$$

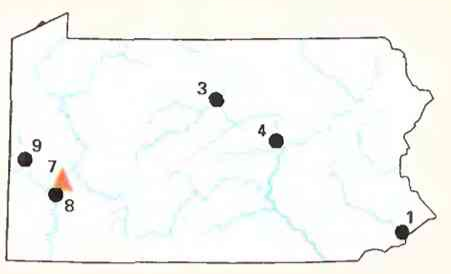

Alkalinity, 1980-89

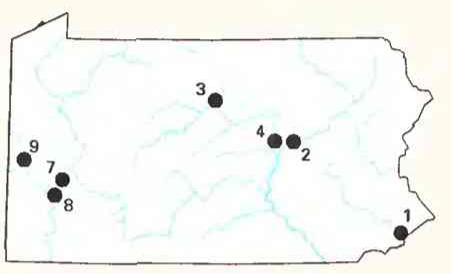

Dissolved nitrite plus nitrate, 1980-89

\section{EXPLANATION}

Trend in water-quality property or constituent-Number is site number in figure 2

$$
\begin{aligned}
& \triangle^{7} \text { Upward } \\
& \bullet^{1} \text { None } \\
& \nabla^{8} \text { Downward }
\end{aligned}
$$

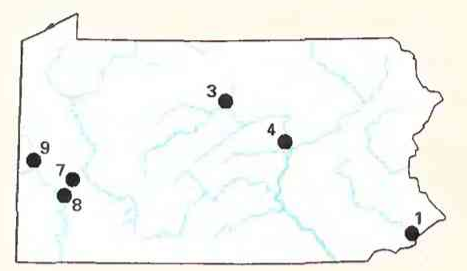

Dissolved sulfate, 1982-89

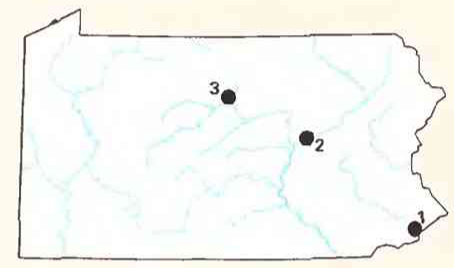

Dissolved phosphate, 1980-89

Figure 4. Trends in water quality of selected streams in Pennsylvania, by water years. (Source: Data from U.S. Geological Survey files.)

Nitrite plus nitrate concentrations had no trend for 1980-89. Nitrogen-fertilizer use in the State remained relatively constant throughout this time period (Alexander and Smith, 1990). An earlier upward trend in total nitrate concentrations at site 8 for $1974-81$ (Smith and others, 1987, p. 1609) was attributed to increased atmospheric deposition during the 1970's.

\section{DISSOLVED PHOSPHATE}

Phosphate is the oxidized form of phosphorus and the only form of significance in most natural waters. Small quantities of dissolved phosphate commonly are present in streams as a result of rock weathering. Normally, concentrations are no more than a few tenths of a milligram per liter (Hem, 1985, p. 126) and usually are much lower. Higher concentrations can indicate contamination from human activities (table 1). Phosphate concentrations had no trend at three monitoring stations. Concentrations at all of these stations were low.

\section{WATER-QUALITY MANAGEMENT}

The State's first comprehensive water-pollution-control legislation - the "Clean Streams Law"- -was enacted in 1937. This law has been strengthened by several amendments, most recently in 1989. The law provides the State with a legal framework for managing water quality.

The PDER, through its Bureau of Water Quality Management (BWQM), is the State agency responsible for enforcing laws and establishing regulations pertaining to water-quality management. Water-quality standards are described in Chapter 93, "Water-Quality Standards," of the PDER's Rules and Regulations (Pennsylvania
Code, 1988). The standards are an important element of the State's water-quality management program because they set general and specific goals for the quality of most streams. The Air and Water Quality Technical Advisory Committee, a nongovernmental organization composed of representatives from colleges and universities, businesses, and industry, advises the PDER on technical issues pertaining to water-quality standards. General policy concerning water-quality standards is provided by the central office of the PDER, but implementation of permitting, monitoring, surveillance, and enforcement is accomplished by six regional offices throughout the State.

The 168-station PDER water-quality monitoring network is designed to monitor water-quality trends in major surface waters and in smaller streams minimally affected by human activities. The USGS cooperates with the PDER in monitoring streamflow and water quality at numerous stations within the State.

Water-quality standards for some Pennsylvania waters are established under interstate agreements. For example, the Delaware River Basin Commission (DRBC), the Susquehanna River Basin Commission, the Ohio River Valley Sanitation Commission (ORSANCO), and the Interstate Commission on the Potomac River Basin are interstate agencies that have the authority to establish water-quality standards. The BWQM is an active committee participant on both the DRBC and ORSANCO. The policy of the PDER is to recommend adoption of water-quality standards that are compatible with standards of interstate agreements.

The BWQM submits a biennial water-quality assessment report (Pennsylvania Department of Environmental Resources, 1988; 1990) to the EPA, the U.S. Congress, and Pennsylvanians. This report is prepared in compliance with section 305(b) of the Federal Clean Water Act. 


\section{SELECTED REFERENCES}

Alexander, R.B., and Smith, R.A., 1990, County-level estimates of nitrogen and phosphorus fertilizer used in the United States, 1945 to 1985: U.S. Geological Survey Open-File Report 90-130, 12 p.

Anderson, J.R., 1967, Major land uses in the United States, in U.S. Geological Survey, 1970, National atlas of the United States of America: Washington, D.C., U.S. Geological Survey, p. 158-159.

Britton, L.J., and Greeson, P.E., eds., 1987, Methods for collection and analysis of aquatic biological and microbiological samples: U.S. Geological Survey Techniques of Water-Resources Investigations, book 5, chap. A4, $363 \mathrm{p}$.

Fenneman, N.M., 1946, Physical divisions of the United States: Washington, D.C., U.S. Geological Survey special map, scale 1:7,000,000.

Fishman, M.J., and Friedman, L.C., eds., 1989, Methods for the determination of inorganic substances in water and fluvial sediments: U.S. Geological Survey Techniques of Water-Resources Investigations, book 5, chap. Al, 545 p.

Hainly, R.A., and Ritter, J.R., 1986, Areal and temporal variability of selected water-quality characteristics in two hydrologic-benchmark basins in the Northeastern United States: U.S. Geological Survey Water-Resources Investigations Report 85-4025, $22 \mathrm{p}$.

Hainly, R.A., Truhlar, J.F., and Wetzel, K.L., 1989, Surface-water quality in the West Branch Susquehanna River basin, Pennsylvania: U.S. Geological Survey Water-Resources Investigations Report 85-4283, 50 p.

Hem, J.D., 1985, Study and interpretation of the chemical characteristics of natural water ( $3 \mathrm{ded}$.): U.S. Geological Survey Water-Supply Paper 2254, $263 p$.

Herb, W.J., Shaw, L.C., and Brown, D.E., 1981, Hydrology of area 5, eastern coal province, Pennsylvania, Maryland, and West Virginia: U.S. Geological Survey Open-File Report 81-538, 92 p.

Hirsch, R.M., Slack, J.R., and Smith, R.A., 1982, Techniques of trend analysis for monthly water quality data: Water Resources Research, v. 18, no. 1, p. $107-121$.

Lanfear, K.J., and Alexander, R.B., 1990, Methodology to derive water-quality trends for use by the National Water Summary Program of the U.S.
Geological Survey: U.S. Geological Survey Open-File Report 90-359, $10 \mathrm{p}$.

Pennsylvania Code, 1988, Title 25. Rules and Regulations, Part I. Department of Environmental Resources, Subpart C. Protection of natural resources, Article II. Water Resources, chap. 93.

Pennsylvania Department of Environmental Resources, 1988, Commonwealth of Pennsylvania 1988 water quality assessment: Harrisburg, Pennsylvania Department of Environmental Resources, Bureau of Water Quality Management, v. 2, 265 p.

1990, Commonwealth of Pennsylvania 1990 water quality assessment (305(b) report): Harrisburg, Pennsylvania Department of Environmental Resources, Bureau of Water Quality Management, 106 p.

Smith, R.A., Alexander, R.B., and Wolman, M.G., 1987, Water-quality trends in the Nation's rivers: Science, v. 235, p. 1,607-1,615.

Solley, W.B., Merk, C.F., and Pierce, R.R, 1988, Estimated use of water in the United States in 1985: U.S. Geological Survey Circular 1004, 82 p.

Stamer, J.K., Yorke, T.H., and Pederson, G.L., 1985, Distribution and transport of trace substances in the Schuylkill River basin from Berne to Philadelphia, Pennsylvania: U.S. Geological Survey Water-Supply Paper 2256-A, 45 p.

Thelin, G.P., and Pike, R.J., 1990, Digital shaded relief map of the conterminous United States: Menlo Park, Calif., U.S. Geological Survey digital image processing, scale 1:3,500,000.

U.S. Geological Survey, 1986, National water summary 1985-Hydrologic events and surface-water resources: U.S. Geological Survey WaterSupply Paper 2300, 506 p.

1990, National water summary 1987-Hydrologic events and water supply and use: U.S. Geological Survey Water-Supply Paper 2350. $553 \mathrm{p}$.

Ward, J.R., and Harr, C.A., eds., 1990, Methods for collection and processing of surface-water and bed-material samples for physical and chemical analyses: U.S. Geological Survey Open-File Report 90-140, 71 p.

Williams, D.R., 1976, Preimpoundment water quality of Raystown Branch Juniata River and six tributary streams, south-central Pennsylvania: U.S. Geological Survey Water-Resources Investigations Report 7657, 23 p. 
470 National Water Summary 1990-91-Stream Water Quality: STATE SUMMARIES

Prepared by Donald R. Williams

FOR ADDITIONAL INFORMATION: District Chief, U.S. Geological Survey, 840 Market street, Lemoyne, PA 17043 


\section{Puerto Rico Stream Water Quality}

Puerto Rico and its offshore islands, Vieques and Culebra, have a land area of about 3,470 square miles. The topography and geology are diverse and the surface-water resources are abundant. More than 100 streams flow to the ocean. The average annual rainfall in Puerto Rico is about 70 inches; of this amount, about 31 percent ( 22 inches) becomes surface-water runoff. The total surfacewater runoff in Puerto Rico averages about $3,700 \mathrm{Mgal} / \mathrm{d}$ (million gallons per day). Although abundant, surface-water resources are unevenly distributed; the northern part of the island has a more abundant water supply than the southern part. In 1985, surface water provided 70.7 percent of the $598 \mathrm{Mgal} / \mathrm{d}$ withdrawn for offstream use (U.S. Geological Survey, 1990, p. 444). The principal offstream surface-water uses were public supply (307 Mgal/d) and irrigation (107 $\mathrm{Mgal} / \mathrm{d})$. Surface water is the major source of freshwater throughout Puerto Rico and provides about three-quarters of the population's freshwater needs (U.S. Geological Survey, 1986, p. 399).

The quality of Puerto Rico's surface water is affected substantially by land use. The major land uses are pasture ( 35 percent) and cropland (30 percent). The major physiographic features of Puerto Rico are the Cordillera Central and Sierra de Luquillo mountain ranges that extend the length of the island. Mountains occupy about one-half of the island's land area (fig. $1 A$ ). In the mountainous areas, the principal land uses are forest reserves, pasture, and agriculture (principally coffee, banana, and citrus plantations). Only about 10 percent of the island is undeveloped (Octavio Franco, Puerto Rico Department of Natural Resources, oral commun., 1991).

Puerto Rico's 1990 population was 3.5 million, a 9-percent increase since 1980 (U.S. Bureau of the Census 1990 decennial cen-
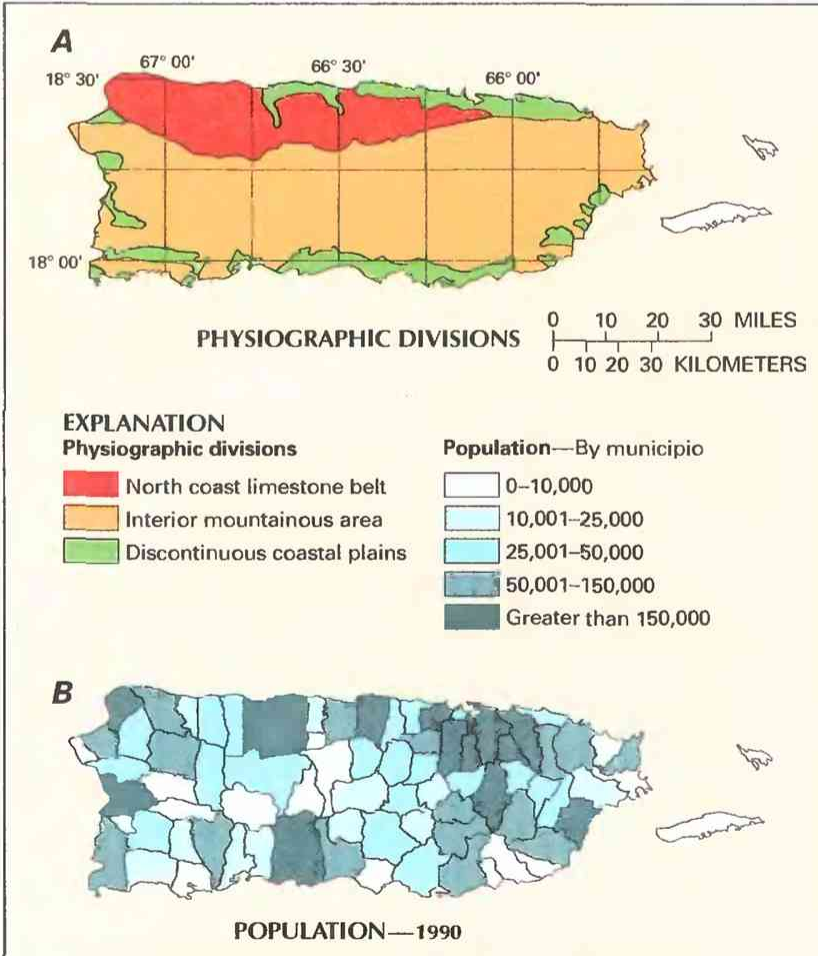

Figure 1. Physiography and population in Puerto Rico. A, Physiographic divisions. B. Population distribution in 1990. (Sources: A, Physiographic divisions from Monroe, 1980. B, Data from U.S. Bureau of the Census 1990 decennial census files.) sus files). Twenty-three percent of the population is concentrated in four major urban areas-San Juan, Ponce, Mayagüez, and Arecibo (figs. $1 B$ and 2). Estimates from the Puerto Rico Planning Board (Margarita Santini, oral commun., 1991) indicate that the population of Puerto Rico by the year 2000 will be about 3.9 million. The increasing population has had and will continue to have a significant effect on the quality of the island's water resources.

One of the most common stream water-quality problems in the island is high bacteria concentrations that result from discharges of domestic and municipal wastewater (U.S. Environmental Protection Agency, 1985). However, after appropriate treatment, the water quality of most streams in Puerto Rico meets the drinking-water standards established by the Puerto Rico Department of Health and Puerto Rico Environmental Quality Board.

\section{WATER-QUALITY MONITORING}

Water-quality data obtained from analyses of water samples collected at monitoring stations are stored in the U.S. Geological Survey's (USGS) National Water Information System and the U.S. Environmental Protection Agency's (EPA) national data base known as STORET. Water-quality and streamflow data are reported by water year - the 12 months from October 1 through September 30. A water year is identified by the calendar year in which it ends. For example, water year 1991 comprises October 1, 1990, through September 30, 1991.

The USGS, in cooperation with State and other Federal agencies, established a surface-water quality data-collection network in 1958 to assess the quality of the surface waters of Puerto Rico. At present (1990), the network consists of 57 monitoring stations on streams, 11 on lakes, 2 on lagoons, and 1 in a bay. Suspended-sediment data are collected at 22 stations.

The data used in this summary of Puerto Rico's stream water quality were obtained from water samples collected every 2 months or quarterly at four monitoring stations at which data collection is systematic and continuing (fig. 2). The four stations are part of the USGS National Stream Quality Accounting Network (NASQAN). NASQAN is a nationwide data-collection network designed to meet many of the information needs of the government agencies and other groups involved in water-quality planning and management. The four NASQAN stations in Puerto Rico are located in the basins of Río Grande de Manatí, Río de la Plata, Río Grande de Patillas, and Río Grande de Añasco. Analyses of water samples collected at these stations are the basis for the discussion and graphic summary (fig. 3) of stream water-quality conditions during water years 1987-89 and for the discussion and graphic summary (fig. 4) of stream waterquality trends. Water samples were collected and analyzed by using standard methods approved by the USGS (Britton and Greeson, 1987; Fishman and Friedman, 1989; Ward and Harr, 1990) or by using equivalent methods. If a method of sample collection or analysis changed over time, data from an analysis were included in the evaluation of recent stream water quality or of stream water-quality trends only if the change in method did not affect the comparability of the data.

\section{WATER-QUALITY CONDITIONS}

Streams in Puerto Rico have similar water quality, but concentrations of some chemical constituents differ areally and seasonally because of differences in geology, topography, land use, and 
rainfall patterns. The types of minerals dissolved in streams in Puerto Rico are common to most natural water, but minor differences in concentrations of specific ions result from differences in rock composition and dissolution rate. The concentration of dissolved solids generally increases with distance downstream. The increase probably results partly from minerals in the bedrock and partly from the addition of more highly mineralized water from tributaries, ground-water discharge, or human activities.

The sanitary condition of surface water in Puerto Rico continues to be the main water-quality problem. The low dissolved-oxygen concentrations in many streams indicate contamination by organic matter from sewage-treatment plants (Commonwealth of Puerto Rico, 1990). Concentrations of fecal coliform bacteria in nearly 85 percent of the rivers in Puerto Rico exceed the EPA-recommended standard (Commonwealth of Puerto Rico, 1990).

High concentrations of suspended sediment and deposition of sediment in lakes and streams are serious problems in many areas of Puerto Rico. The sediment results from erosion caused by intense rainfall, steep slopes, erodible soils, and some types of land use. Erosion and the transport and deposition of sediment cause significant economic and environmental problems, such as soil loss, filling or scouring of stream channels, and deposition of sediment in harbors and reservoirs.

The following discussion of stream water quality in Puerto Rico is organized by river basin (fig. 3 ). Where physiographic and land-use characteristics in different basins are similar, the discussion of those basins is combined. Graphs in figure 3 summarize certain aspects of stream water quality in the basins for water years 198789. The graphs show frequency distributions of data values that represent concentrations of selected stream-water constituents. These constituents are dissolved oxygen, fecal coliform bacteria, dissolved sulfate, dissolved solids, and dissolved nitrite plus nitrate (as nitrogen). The data are reported in milligrams per liter $(\mathrm{mg} / \mathrm{L})$ and colonies per 100 milliliters (col/100 mL). Sources and environmental significance of each constituent are described in table 1 .

Water quality at each monitoring station is the result of geological, chemical, biological, and hydrologic processes that occur over a large area. Water-quality problems that affect aquatic life or public health only locally are not fully represented in this summary.

\section{RÍO GRANDE DE MANATI AND RIOO DE LA PLATA}

Río Grande de Manatí and Río de la Plata drain areas in the northern part of the island and flow northward to the Atlantic Ocean.
Río Grande de Manatí is the largest river in Puerto Rico in which streamflow is unregulated. Río de la Plata is a regulated river used for public water supply and power generation. Excluding the difference in flow regulation, the river basins have similar characteristics. The northern parts of the Río Grande de Manatí and Río de la Plata basins are underlain by limestone that contains sinkholes, caverns, and underground streams.

Fecal contamination is the most serious water-quality problem in both rivers. Major sources of fecal contamination in the two basins include runoff from nonpoint sources such as dairy-cattle and poultry farms and point-source discharges from sewage-treatment plants in the upper basins. Concentrations of fecal coliform bacteria commonly exceed $1,000 \mathrm{col} / 100 \mathrm{~mL}$ in both rivers (fig. 3). Rocks in North Coast river basins contain small amounts of pyrite, a sulfurbearing mineral, and the oxidation of pyrite might be the source of sulfate in these rivers. However, only low concentrations of sulfate were recorded at site 1 on Río Grande de Manatí and site 2 on Río de la Plata during water years 1987-89 (fig. 3). Agricultural activities are a major source of nutrients (nitrogen and phosphorus) in these streams. Total nutrient concentrations higher than $0.5 \mathrm{mg} / \mathrm{L}$ are common in Río de la Plata (U.S. Geological Survey, 1986, p. 402). Nitrite plus nitrate concentrations in samples collected in both basins during water years 1987-89 generally were high. Erosion and sedimentation rates in the basins are high, particularly during periods of greater than average rainfall.

\section{RÍO GRANDE DE PATILLAS}

Río Grande de Patillas is in southeastern Puerto Rico. Rivers in this area generally flow from steep-sided valleys in the interior to narrow, discontinuous swamps and marshes along the coast. Geologically, the area is characterized by volcanic and intrusive rocks. Alluvium fills the valleys near the coast.

On the basis of three samples for Río Grande de Patillas, concentrations of fecal coliform bacteria during water years 1987 89 were as high as $5,600 \mathrm{col} / 100 \mathrm{~mL}$ (fig. 3). However, concentrations of from 100,000 to $1,000,000 \mathrm{col} / 100 \mathrm{~mL}$ have been recorded for the stream (U.S. geological Survey, 1986, p. 404). The sources of fecal contamination in the stream probably include urban runoff, irrigation return flow, runoff from solid-waste disposal sites, and seepage from individual septic tanks. Despite this contamination, water from the Río Grande de Patillas is suitable for most uses, including potable water supply, after disinfection at water-treatment facilities.

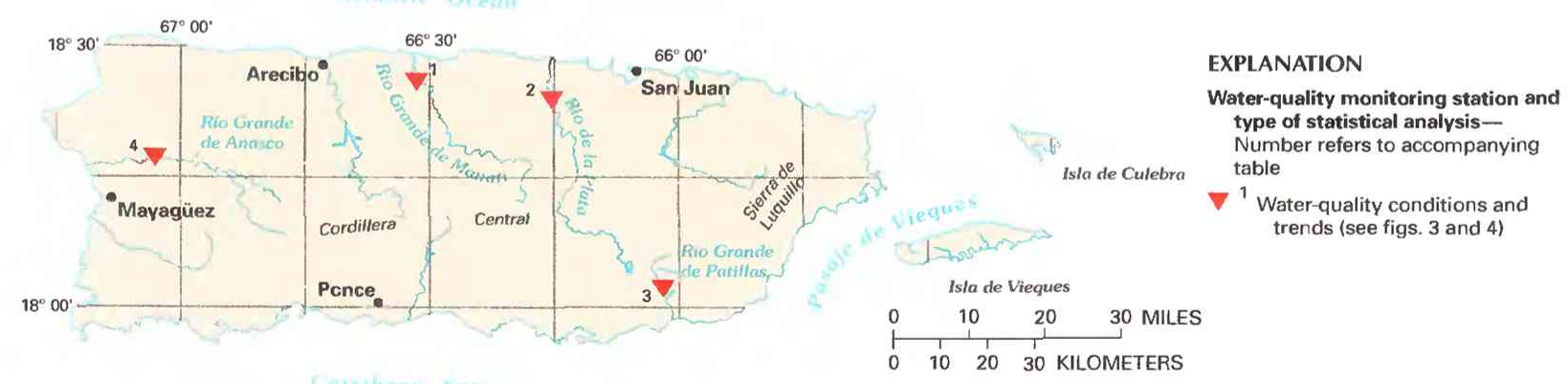

\begin{tabular}{|c|c|c|c|}
\hline 1 & Río Grande de Manatí at Hwy 2 near Manati $(50038100)$ & 197 & Cropland, pasture, and forest. \\
\hline 2 & Rio de la Plata at Hwy 2 near Toa Alta $(50046000)$ & 208 & Ditto. \\
\hline 3 & Rio Grande de Patillas near Patillas $(50092000)$ & 13.3 & Forest with some cropland and pasture. \\
\hline 4 & 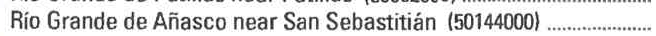 & 94.3 & Cropland, pasture, and forest. \\
\hline
\end{tabular}

Figure 2. Selected water-quality monitoring stations, type of statistical analysis, and geographic features in Puerto Rico. (Source: Data from U.S. Geological Survey files.) 
Table 1. Sources and environmental significance of selected water-quality constituents [Source: Compiled by the U.S. Geological Survey, Office of Water Quality]

\begin{tabular}{|c|c|c|}
\hline Constituent & Common sources & Environmental significance \\
\hline Dissolved oxygen ......................... & $\begin{array}{l}\text { Introduced from the atmosphere; also a byproduct of } \\
\text { aquatic plants. }\end{array}$ & $\begin{array}{l}\text { Necessary for aquatic life; deficiency can result from } \\
\text { assimilation of organic wastes or rapid growth } \\
\text { and decay of algae. }\end{array}$ \\
\hline Fecal coliform bacteria ................ & $\begin{array}{l}\text { Sources include effluent from sewage-treatment } \\
\text { plants and runoff from pastures, feedlots, and ur- } \\
\text { ban areas. }\end{array}$ & $\begin{array}{l}\text { Presence indicates contamination of water by wastes } \\
\text { from humans and other warm-blooded animals. }\end{array}$ \\
\hline 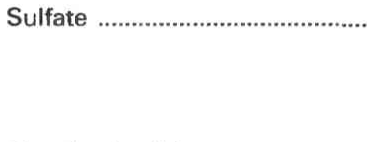 & $\begin{array}{l}\text { Occurs in some rocks; also in mine runoff, industrial } \\
\text { wastewater discharge, and atmospheric deposi- } \\
\text { tion. }\end{array}$ & $\begin{array}{l}\text { Concentrations exceeding a natural, background } \\
\text { level indicate contamination from human activity; } \\
\text { in sufficient quantity, can cause water to be } \\
\text { unsuitable for public supply; can harm aquatic } \\
\text { organisms. }\end{array}$ \\
\hline Dissolved solids ............................ & $\begin{array}{l}\text { A result of rock weathering; also in agricultural runoff } \\
\text { and industrial discharge. }\end{array}$ & $\begin{array}{l}\text { In sufficient quantity, can cause water to be unsuitable } \\
\text { for public supply, agriculture, and industry; can } \\
\text { harm aquatic organisms. }\end{array}$ \\
\hline Nitrite plus nitrate .............................. & $\begin{array}{c}\text { Nonpoint sources are agricultural and urban runoff; } \\
\text { a major point source is wastewater discharge. }\end{array}$ & $\begin{array}{l}\text { Plant nutrient that, in sufficient quantity, can cause } \\
\text { algal blooms and excessive growth of higher } \\
\text { aquatic plants in bodies of water; can cause water } \\
\text { to be unsuitable for public supply. }\end{array}$ \\
\hline
\end{tabular}

\section{RIOO GRANDE DE AÑASCO}

The Río Grande de Añasco basin, in western Puerto Rico, is characterized by broad alluvial valleys that overlie volcanic rocks and limestone lenses. The basement rocks in the lower valley are igneous rocks that have been weathered to depths of 350 feet or more below sea level. Those rocks are overlain by 250 feet or more of limestone and clay that in turn are overlain by as much as 100 feet of alluvium.

The chemical composition of surface water throughout the Río Grande de Añasco basin is similar. Differences occur only where there is contamination from sources such as seawater encroachment or sewage-treatment-plant effluent. In general, the water contains less than $250 \mathrm{mg} / \mathrm{L}$ of dissolved solids. Silica constitutes 10-20 percent of the dissolved solids, and concentrations range from 20 to 45 $\mathrm{mg} / \mathrm{L}$ (not shown). The water is a calcium-magnesium-bicarbonate type (Díaz and Jordan, 1987) and is moderately hard to very hard, but usually has less than $150 \mathrm{mg} / \mathrm{L}$ hardness as calcium carbonate. The primary water quality problems in Río Grande de Añasco are high concentrations of nutrients (U.S. Geological Survey, 1986, p. 404) and fecal coliform bacteria, which commonly range between 10,000 and $100,000 \mathrm{col} / 100 \mathrm{~mL}$ (Commonwealth of Puerto Rico, 1990). These problems were evident at site 4 during water years 1987-89 (fig. 3).

\section{WATER-OUALITY TRENDS}

Trend analysis is a statistical procedure used to detect changes in stream water quality at a monitoring station over time. For this report, water-quality data from four monitoring stations (fig. 2) were analyzed for trends by using the seasonal Kendall test (Hirsch and others, 1982), a method used extensively by the USGS. The graph
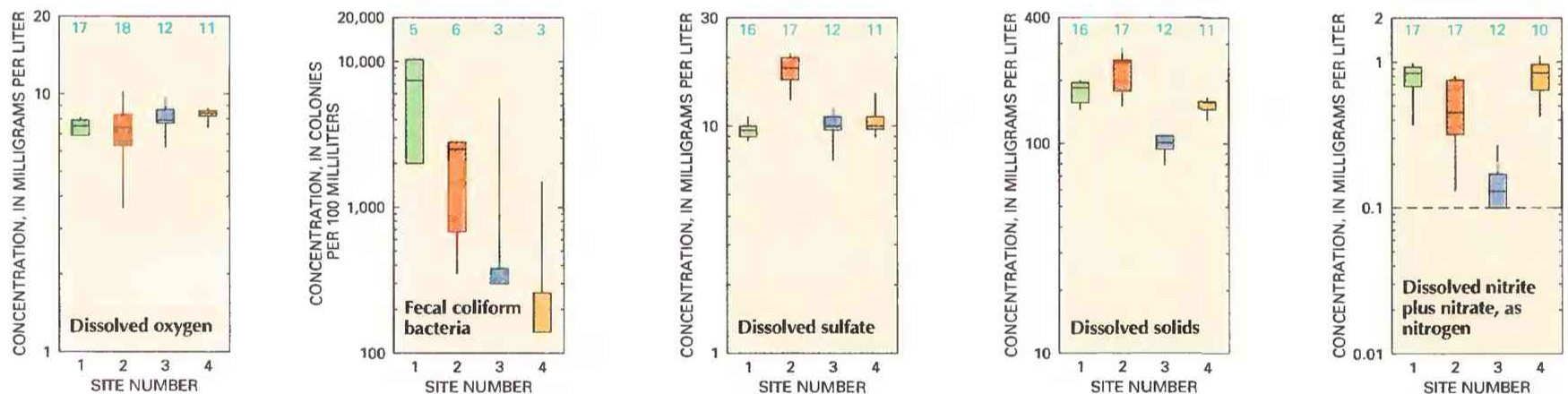

\section{EXPLANATION}

Water-quality conditions in selected
drainage basins
12 Number of analyses
Percentile-Percentage of analyses
equal to or less than indicated
values
90th
-75 th
-50 th-Median
-25 th
-10 th

-- Reporting limit-Minimum reporting
limit for analytical method used. limit for analytical method used.
Data below limit line not shown

Drainage basin-Number is site number in figure 2 .

$\square$ Río Grande de Manati 1

Río de la Plata 2

Río Grande de Patillas 3

$\square$ Río Grande de Añasco 4

$\nabla^{4}$ Water-quality monitoring stationNumber is site number in figure 2

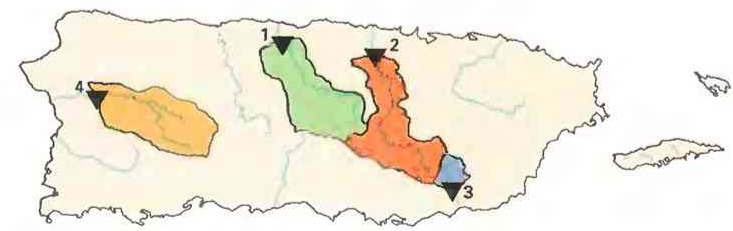

\begin{tabular}{ccccc}
0 & 10 & 20 & 30 & MILES \\
\hdashline & 1 & 1 & 1 & 1
\end{tabular}

Figure 3. Water quality of selected streams in Puerto Rico, water years 1987-89. (Source: Data from U.S. Geological Survey files.) 
(shown below) of the dissolved-oxygen concentration in Río Grande de Manatí at site 1 illustrates the trend inferred from the concentration data and demonstrates the variation in water quality that is common in streams.

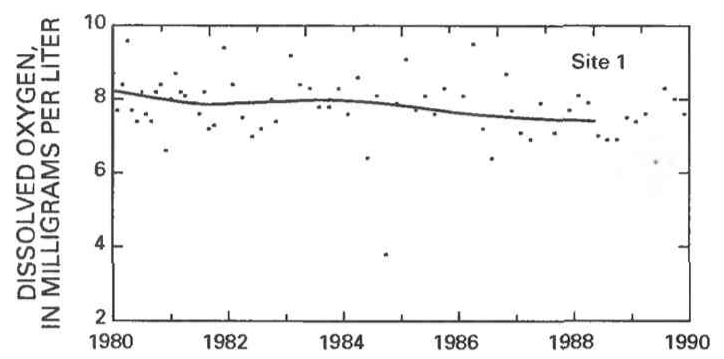

When possible, constituent-concentration data were adjusted for changes in streamflow to preclude identifying a trend in concentration that was caused only by a trend in streamflow. The data were not adjusted when (1) more than 10 percent of the samples had concentrations lower than the minimum reporting limit for the analytical method used or (2) streamflow was controlled substantially by human activities. When the concentration data could not be adjusted for streamflow, trends were determined directly from the concentration data.

Trends in concentrations of selected stream-water constituents are shown on maps in figure 4 . On each map, a trend is indicated at a monitoring station only if the data from that station were suitable for use in the trend analysis. Trends for fecal coliform bacteria concentrations are not shown because data were insufficient for trend analysis. For more information on the suitability criteria and on the trend-analysis procedure used for this report, see Lanfear and Alexander (1990).

\section{DISSOLVED OXYGEN}

The dissolved-oxygen concentration in a stream is controlled by several factors, including water temperature, air temperature and pressure, hydraulic characteristics of the stream, photosynthetic or respiratory activity of stream biota, and the quantity of organic material present. A trend in dissolved-oxygen concentrations commonly is directly or indirectly the result of human activities. Generally, an upward trend in dissolved-oxygen concentrations indicates improving stream water-quality conditions and a downward trend indicates deteriorating conditions.

A cause for the upward trend in dissolved-oxygen concentrations in Río de la Plata at site 2 (fig. 4) is not known. The slight decrease in dissolved-oxygen concentration in Río Grande de Manatí at site 1 possibly was caused by increases in inadequately treated discharge from municipal sewage-treatment plants, agricultural runoff, or both.

\section{DISSOLVED SULFATE}

The major natural sources of sulfate in streams are rock weathering, volcanoes, and biochemical processes (Hem, 1985, p. 113). Human activities such as mining, waste discharge, and fossilfuel combustion also can be important sources. A shortened trendanalysis period was used for sulfate because data from analyses performed prior to water year 1982 are not comparable with data from subsequent years. Dissolved-sulfate concentrations had no trend at the four monitoring stations (fig. 4).

\section{DISSOLVED SOLIDS}

Dissolved solids in stream water result primarily from rock weathering but also can be introduced as a byproduct of human ac-

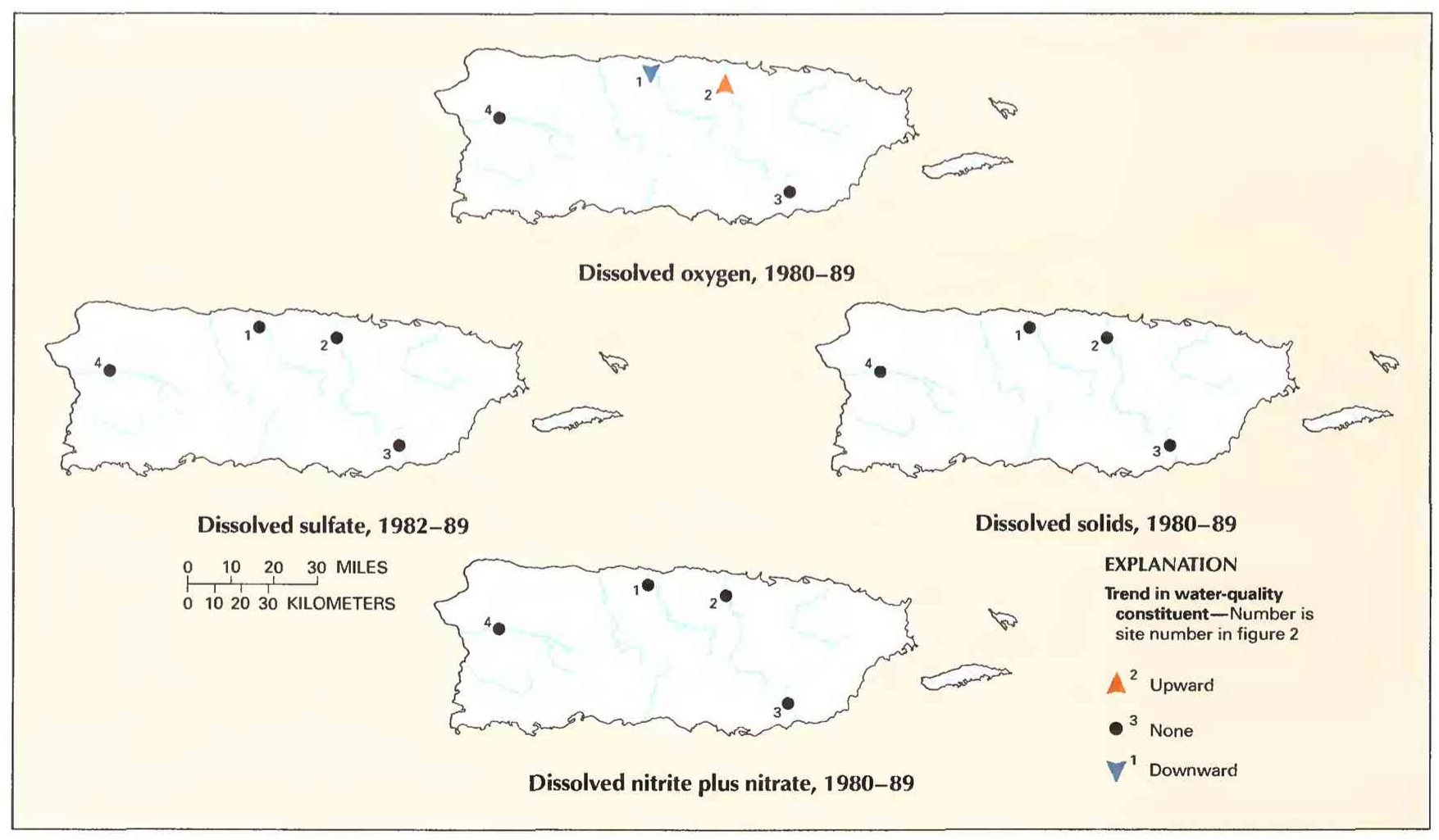

Figure 4. Trends in water quality of selected streams in Puerto Rico, by water years. (Source: Data from U.S. Geological Survey files.) 
tivities (table 1). Concentrations generally are greatest in streams draining basins underlain by rocks and soils that contain easily dissolved minerals. Dissolved-solids concentrations had no trend at the four monitoring stations (fig. 4).

\section{DISSOLVED NITRITE PLUS NITRATE}

Nitrite and nitrate are oxidized forms of nitrogen that together normally constitute most of the dissolved nitrogen in well-aerated streams. Nitrite readily oxidizes to nitrate in natural waters; therefore, nitrate generally is by far the more abundant of the two (Hem, 1985 , p. 124). Nitrite plus nitrate concentrations had no trend at the four monitoring stations (fig. 4).

\section{WATER-QUALITY MANAGEMENT}

During the last 30 years, the growth of Puerto Rico's economy and population has been among the most rapid in the Caribbean region. This growth was largely initiated by a program of industrialization that converted the island's economy from an agricultural base to an industrial base. In 1969, the Commonwealth recognized the need for an overall water-quality-management plan for Puerto Rico and entered into a cooperative effort with the Federal Water Pollution Control Administration (now EPA). The Commonwealth assumed responsibility for developing the plan and the EPA provided guidelines and necessary financial and technical assistance. Section 305(b) of the Federal Clean Water Act requires the 50 States, the Commonwealth of Puerto Rico, and several U.S. Trust Territories to submit biennial water-quality reports to EPA and the U.S. Congress. The Puerto Rico Environmental Quality Board is responsible for preparing and submitting these reports (Commonwealth of Puerto Rico, 1990) to document progress in implementing the Comprehensive Water Quality Management Plan for Puerto Rico.

The immediate objectives of the water-quality-management plan are (1) to develop water-quality standards and implement plans that will achieve instream water-quality goals and (2) to maximize the cost effectiveness of pollution abatement and related actions required to achieve water-quality goals. The long-range objective is continued water-quality improvement. The water-quality-management plan is updated through a continuing review process.

\section{SELECTED REFERENCES}

Britton, L.J., and Greeson, P.E., eds., 1987, Methods for collection and analysis of aquatic biological and microbiological samples: U.S. Geological Survey Techniques of Water-Resources Investigations, book 5, chap. A4, $363 \mathrm{p}$.

Commonwealth of Puerto Rico, 1990, Goals and progress of statewide water quality management planning for Puerto Rico 1988-89: San Juan, Commonwealth of Puerto Rico, Environmental Quality Board, variously paginated.

Díaz, J.R., and Jordan, D.G., 1987, Water resources of the Río Grande de Añasco-Lower Valley, Puerto Rico: U.S. Geological Survey Water-Resources Investigations Report 85-4237, $48 \mathrm{p}$.

Fishman, M.J., and Friedman, L.C., eds., 1989, Methods for the determination of inorganic substances in water and fluvial sediments: U.S. Geological Survey Techniques of Water-Resources Investigations, book 5 , chap. Al, 545 p.

Hem, J.D., 1985, Study and interpretation of the chemical characteristics of natural water (3d ed.): U.S. Geological Survey Water-Supply Paper 2254 , $263 \mathrm{p}$.

Hirsch, R.M., Slack, J.R., and Smith, R.A., 1982, Techniques of trend analysis for monthly water quality data: Water Resources Research, v. 18, no. 1, p. 107-121.

Lanfear, K.J. and Alexander, R.B., 1990, Methodology to derive water-quality trends for use by the National Water Summary Program of the U.S. Geological Survey: U.S. Geological Survey Open-File Report 90-359, $10 \mathrm{p}$.

Monroe, W.H., 1980, Some tropical land forms of Puerto Rico: U.S. Geological Survey Professional Paper 1159, $39 \mathrm{p}$.

U.S. Environmental Protection Agency, 1985, National water quality inventory-1984 report to Congress: Washington, D.C., Environmental Protection Agency, p. 25-26.

U.S: Geological Survey, 1986, National water summary 1985-Hydrologic events and surface-water resources: U.S. Geological Survey Water-Supply Paper 2300, 506 p.

1990, National water summary 1987-Hydrologic events and water supply and use: U.S. Geological Survey Water-Supply Paper 2350, $553 \mathrm{p}$.

Ward, J.R., and Harr, C.A., eds., 1990, Methods for collection and processing of surface-water and bed-material samples for physical and chemical analyses: U.S. Geological Survey Open-File Report 90-140, 71 p. 
Prepared by Ricardo J. Vachier

FOR ADDITIONAL INFORMATION: District Chief, U.S. Geological Survey, P.O. Box 364424, San Juan, PR 00936-4424 


\section{RHODE ISLAND Stream Water Quality}

Surface water is abundant in Rhode Island and is the State's principal source of freshwater. About one-half of the annual precipitation, which ranges from 42 to 48 inches statewide, runs off to streams (U.S. Geological Survey, 1986, p. 407). In 1985, 82 percent of the freshwater used in Rhode Island was withdrawn from surface sources, chiefly from reservoirs and other stream impoundments. Of the average 120 million gallons per day of surface water withdrawn for offstream use in 1985, 84 percent was withdrawn by public-supply systems that serve about three-quarters of the State's 1 million people; most of the remainder was withdrawn by industry (U.S. Geological Survey, 1990 , p. 447-450). The percentage of the population that uses surface water could decrease slightly during the next decade because available surface-water supplies are nearly fully committed. Fortunately, supplies of ground water, which usually is suitable for drinking with little or no treatment, are available to meet the modest increase in demand. Because the principal use of freshwater is for drinkingwater supply, future demands are likely to be driven by population growth, which has been slow. From 1980 to 1990 , the population increased by 6 percent (U.S. Bureau of the Census 1990 decennial census files).

Water quality of Rhode Island streams is affected by several factors. Among the most important are the volume and quality of wastewater discharged to streams and the amount of streamflow avail-

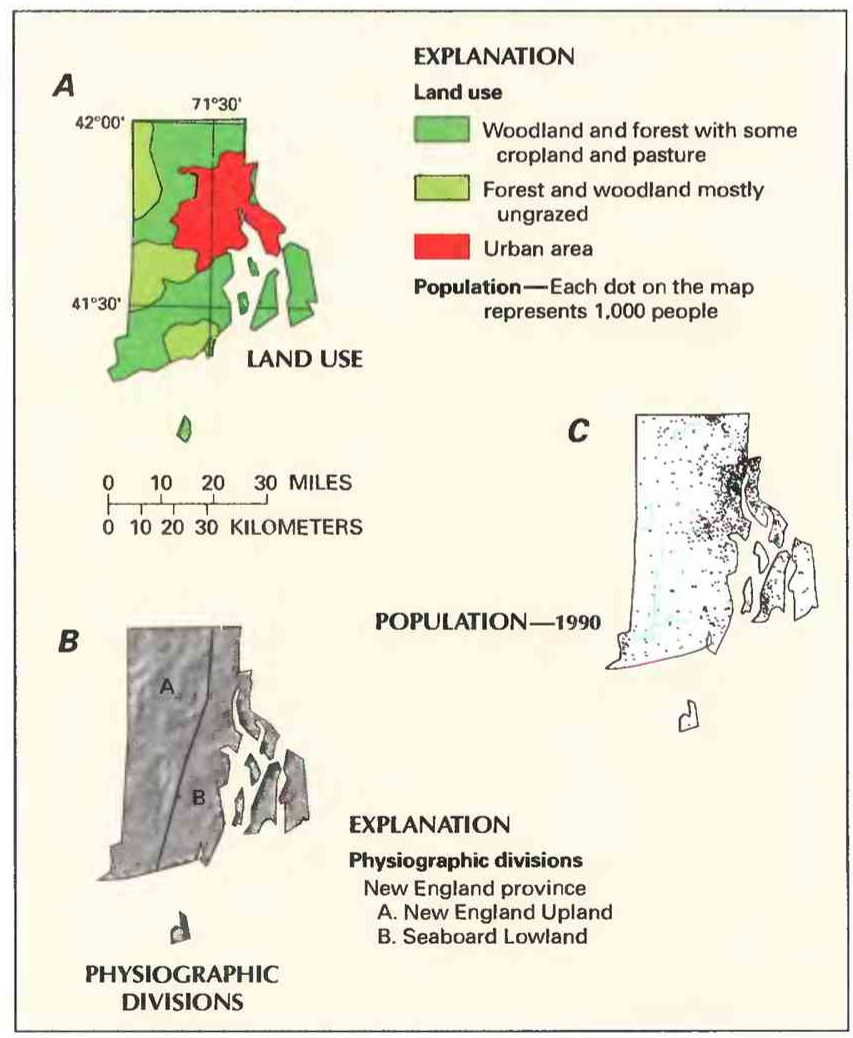

Figure 1. Land use, physiography, and population in Rhode Island. A, Major land uses. B, Physiographic divisions. C, Population distribution in 1990. (Sources: A, Major land uses modified from Anderson, 1967. $B$, Physiographic divisions from Fenneman, 1946; landforms from Thelin and Pike, 1990. C. Data from U.S. Bureau of the Census 1990 decennial census files.) able for dilution of wastewater discharges. As water resources of Rhode Island become more fully developed, reductions in streamflow could result in degradation of stream water quality, particularly in reaches that receive effluent from municipal wastewater-treatment facilities and industries. In addition to those sources, discharges from individual sewage-disposal systems and runoff from urban and agricultural areas also can affect water quality adversely.

The Rhode Island Department of Environmental Management (RIDEM) has assigned designated-use classifications to reaches of the State's major freshwater streams to provide a basis for water-quality planning and regulation. The stream reaches are classified A, B, or C. The goal for Class A reaches is that the water be suitable for drinkingwater supply. Goals for Class B reaches are that the water be suitable for public water supply (with appropriate treatment), agriculture, primary contact activities, and fish and wildlife habitat. Goals for Class $\mathbf{C}$ reaches are that the water be suitable for secondary recreational activities, fish and wildlife habitat, and industrial uses and cooling.

The quality of Rhode Island's stream water is affected by land use. The relationship between land use (fig. $1 A$ ) and stream water quality is indicated by the geographic distribution of stream classifications. The majority of Class A stream reaches are in the forested New England Upland section of western Rhode Island (fig. $1 B$ ), the area of the State having the lowest population density (fig. $1 C$ ). Conversely, the majority of Class $\mathrm{C}$ stream reaches flow through the more densely populated metropolitan areas, where streams receive contaminants contained in urban runoff, point-source discharges from municipal and industrial wastewater-treatment plants, and other pointsource wastewater discharges.

Before passage of the Federal Water Pollution Control Act Amendments of 1972, collectively known as the Federal Clean Water Act, many industries discharged untreated wastewater directly to the State's major streams, causing some reaches to be extensively contaminated. Enforcement of the provisions of the Clean Water Act and State pollution-control regulations by the RIDEM has caused some industries to close and others to reduce contaminant discharges to streams by treating wastewater or by other measures. The result has been improved water quality in many stream reaches.

\section{WATER-OUALITY MONITORING}

Water-quality data obtained from analyses of water samples collected at monitoring stations are stored in the U.S. Geological Survey's (USGS) National Water Information System and the U.S. Environmental Protection Agency's (EPA) national data base known as STORET. Water-quality and streamflow data are reported by water year-the 12 months from October 1 through September 30. A water year is identified by the calendar year in which it ends. For example, water year 1991 comprises October 1, 1990, through September 30, 1991.

The data used in this summary of Rhode Island's stream water quality were obtained from water samples collected at seven monitoring stations at which data collection is systematic and continuing (fig. 2). Analyses of water samples collected at these stations are the basis for the discussion and graphic summary (fig. 3) of stream waterquality conditions during water years 1987-89 and for the discussion and graphic summary (fig. 4) of stream water-quality trends. Water samples were collected and analyzed by using standard methods approved by the USGS (Britton and Greeson, 1987; Fishman and 
Friedman, 1989; Ward and Harr, 1990) or by using equivalent methods. If a method of sample collection or analysis changed over time, data from an analysis were included in the evaluation of recent stream water quality or of stream water-quality trends only if the change in method did not affect the comparability of the data.

\section{WATER-QUALITY CONDITIONS}

Studies by the RIDEM show that in 1989 water in most streams was suitable for public water supply with appropriate treatment. Of the 626 stream miles assessed in 1989, 42 percent were Class A, 44 percent Class B, and 14 percent Class C. Water quality in about 78 percent of the stream reaches met established criteria (Rhode Island Department of Environmental Management, 1990, p. II-2-III.A-5).

Stream water quality in sparsely populated, forested areas having little or no industrial development is affected mainly by constituents dissolved in precipitation and by constituents dissolved from soils and rocks with which water comes in contact before reaching streams. Because the bedrock, glacial deposits, and soils in Rhode Island are composed largely of relatively insoluble silicate minerals, concentrations of dissolved inorganic constituents in stream water in mostly undeveloped areas are low, typically less than $100 \mathrm{mg} / \mathrm{L}$ (milligrams per liter). Stream water in the State also generally is soft (hardness less than $60 \mathrm{mg} / \mathrm{L}$ as calcium carbonate) and slightly acidic ( $\mathrm{pH}$ values less than 7). In the more densely populated and industrialized areas, human activity has degraded stream water quality. Some stream reaches in developed areas have concentrations of dissolved solids that are sometimes as much as three times greater than in undeveloped areas.

The following discussion of stream water quality in Rhode Island is organized by river basin (fig. 3). Where physiographic and land-use characteristics in different basins are similar, the discussion of those basins is combined. Graphs in figure 3 summarize certain aspects of stream water quality in the basins for water years 1987 89 . The graphs show frequency distributions of data values that represent measurements of selected physical properties of stream water and concentrations of selected constituents in stream water. These

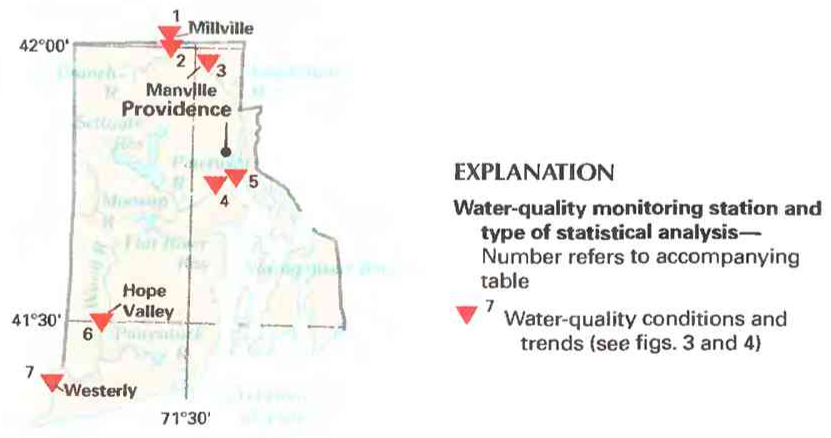

$\begin{array}{lcccc}0 & 10 & 20 & 30 \\ 0 & 10 & 20 & 30 \text { KILOMETERS }\end{array}$

properties and constituents are specific conductance, dissolved oxygen, fecal coliform bacteria, dissolved sulfate, dissolved chloride, dissolved solids, and dissolved nitrite plus nitrate (as nitrogen). The data are reported in microsiemens per centimeter at 25 degrees Celsius $(\mu \mathrm{S} / \mathrm{cm})$, milligrams per liter, and colonies per 100 milliliters $(\mathrm{col} / 100 \mathrm{~mL})$. Sources and environmental significance of each property and constituent are described in table 1 .

Some constituents discussed in this report do not have waterquality standards in the State's designated-use classification of streams. For these constituents, State and Federal drinking-water standards are provided for comparative purposes. The maximum concentration of nitrate (as nitrogen) permitted in drinking water by the Rhode Island Department of Health is $10 \mathrm{mg} / \mathrm{L}$ (Rhode Island Department of Health, 1989, p. 7). Secondary maximum contamination levels established by the EPA for sulfate $(250 \mathrm{mg} / \mathrm{L})$, chloride $(250$ $\mathrm{mg} / \mathrm{L})$, and dissolved solids $(500 \mathrm{mg} / \mathrm{L})$ are recommended for maintaining esthetic qualities and are not legally enforceable (U.S. Environmental Protection Agency, 1988a,b).

Water quality at each monitoring station is the result of geological, chemical, biological, and hydrologic processes that occur over a large area. Water-quality problems that affect aquatic life or public health only locally are not fully represented in this summary.

\section{BLACKSTONE RIVER AND BRANCH RIVER}

Sites 1 and 3 are located on the Blackstone River, which bears a Class $\mathrm{C}$ designation for its entire length in Rhode Island. Water quality at site 1 , just north of the Rhode Island-Massachusetts border at Millville, Mass., is affected by wastewater discharges from several industries and 13 municipal wastewater-treatment facilities. Water quality at site 3 in Manville is affected by several additional industrial wastewater discharges and by two other municipal wastewatertreatment facilities. Downstream from Manville, the quality of the river also is adversely affected by combined sewer and storm-drain overflow during major storms. Although only about 20 percent of the land in the Blackstone River basin is urban (K.G. Ries, U.S. Geological Survey, oral commun., August 1990), industries, wastewatertreatment facilities, and combined sewer and storm-drain overflows discharge large volumes of wastewater into the river. Water quality in the river is not in compliance with a Class $\mathrm{C}$ designation because of excessive concentrations of the trace metals cadmium, copper, and lead (Rhode Island Department of Environmental Management, 1990 , p. III.A-31). Although some water-quality problems in the Blackstone River have diminished (concentrations of some organic contaminants have decreased), the river remains a major source of trace-metal and organic-compound contamination in Narragansett Bay (Narragansett Bay Project, 1989, p. 10-15).

At site 1,90 percent of the concentrations of sulfate (21 $\mathrm{mg} / \mathrm{L}$ ), chloride (58 mg/L), and dissolved solids (173 mg/L) (fig. 3) were less than the limits established by Federal and State drinkingwater regulations. At site 3 , median values of specific conductance $(250 \mu \mathrm{S} / \mathrm{cm})$, dissolved oxygen $(10.4 \mathrm{mg} / \mathrm{L})$, fecal coliform bacteria

\begin{tabular}{|c|c|c|c|}
\hline $\begin{array}{l}\text { Site no. } \\
\text { on map }\end{array}$ & $\begin{array}{l}\text { USGS station } \\
\text { name and no. }\end{array}$ & $\begin{array}{l}\text { Drainage area } \\
\text { (square miles) }\end{array}$ & $\begin{array}{l}\text { Major land use } \\
\text { (see fig. 1) }\end{array}$ \\
\hline 1 & Blackstone River at Millville, Mass. $(01111230)$ & 277 & Woodland and forest with some cropland and pasture; urban areas. \\
\hline 2 & Branch River at Forestdale $(01111500)$ & 91.2 & Woodland and forest with some cropland and pasture. \\
\hline 3 & Blackstone River at Manville (01112900) & 416 & Woodland and forest with some cropland and pasture; urban areas. \\
\hline 4 & Pawtuxet River at Cranston (01116500) & 200 & Ditto. \\
\hline 5 & Pawtuxet River at Pawtuxet (01116617) & 231 & Ditto. \\
\hline 6 & Wood River at Hope Valley $(01118000)$ & 72.4 & Mostly ungrazed forest and woodland. \\
\hline 7 & Pawcatuck River at Westerly $(01118500)$ & 295 & Woodland and forest with some cropland and pasture; urban area. \\
\hline
\end{tabular}

Figure 2. Selected water-quality monitoring stations, type of statistical analysis, and geographic features in Rhode Island. (Sources: Major land uses modified from Anderson, 1967; other data from U.S. Geological Survey files.) 
(230 col/100 mL), sulfate $(18 \mathrm{mg} / \mathrm{L})$, and chloride $(39 \mathrm{mg} / \mathrm{L})$ were similar in magnitude to those for site 1 .

Site 2 is near the mouth of the Branch River, which enters the Blackstone River near the State boundary between sites 1 and 3 . Forest and woodland cover most of the basin upstream from site 2. The median concentration of dissolved oxygen $(10.9 \mathrm{mg} / \mathrm{L})$ for site 2 was the highest for any of the monitoring stations; the median sulfate concentration ( $12 \mathrm{mg} / \mathrm{L}$ ) was the lowest. A median dissolvedsolids concentration of about $70 \mathrm{mg} / \mathrm{L}$ can be estimated from the median value of specific conductance $(102 \mu \mathrm{S} / \mathrm{cm})$; these values indicate that water from the stream is satisfactory for most uses with respect to dissolved solids. The median value of fecal coliform bacteria $(170 \mathrm{col} / 100 \mathrm{~mL})$ was less than the limit for Class B streams (median value of $200 \mathrm{col} / 100 \mathrm{~mL}$ ). However, because of occasionally excessive concentrations of bacteria and the trace metals copper, lead, mercury, and silver, quality of water at site 2 does not support the river's Class B designated use (Rhode Island Department of Environmental Management, 1990, p. V.B.13).

\section{PAWTUXET RIVER}

The western part of the Pawtuxet River basin contains the Scituate Reservoir, which supplies drinking water to more than onehalf of the State's population, and the Flat River Reservoir, originally created for industrial regulation of streamflow but now used primarily for recreation. In this forested and little-developed upland part of the basin, stream water quality generally meets Class A or B designated-use classifications.

Downstream from the Scituate and Flat River Reservoirs, the valleys of the North and South Branches of the Pawtuxet River become progressively more populated, and the main stem of the river flows through an extensively urbanized area. Industrial wastewater discharges and contaminants in runoff from urban and agricultural areas have resulted in a Class $\mathrm{C}$ designation for much of the North and South Branches of the Pawtuxet River. In addition to the degradation from these contaminant sources, stream water quality in the main stem also is affected adversely by seepage from a closed sanitary landfill and by wastewater discharges from three municipal wastewater-treatment facilities. The main stem does not meet standards for Class $\mathrm{C}$ streams in a 12-mile reach upstream from its mouth, primarily because of excessive concentrations of heavy metals and low concentrations of dissolved oxygen (Rhode Island Department of Environmental Management, 1990, p. V.B.80).

Export of water from the basin for water supply, flow regulation by dams on the Scituate and Flat River Reservoirs, and ponded areas behind numerous unused dams downstream from the reservoirs contribute to degradation of the quality of the Pawtuxet River and its tributaries by reducing their capacity to assimilate and transport
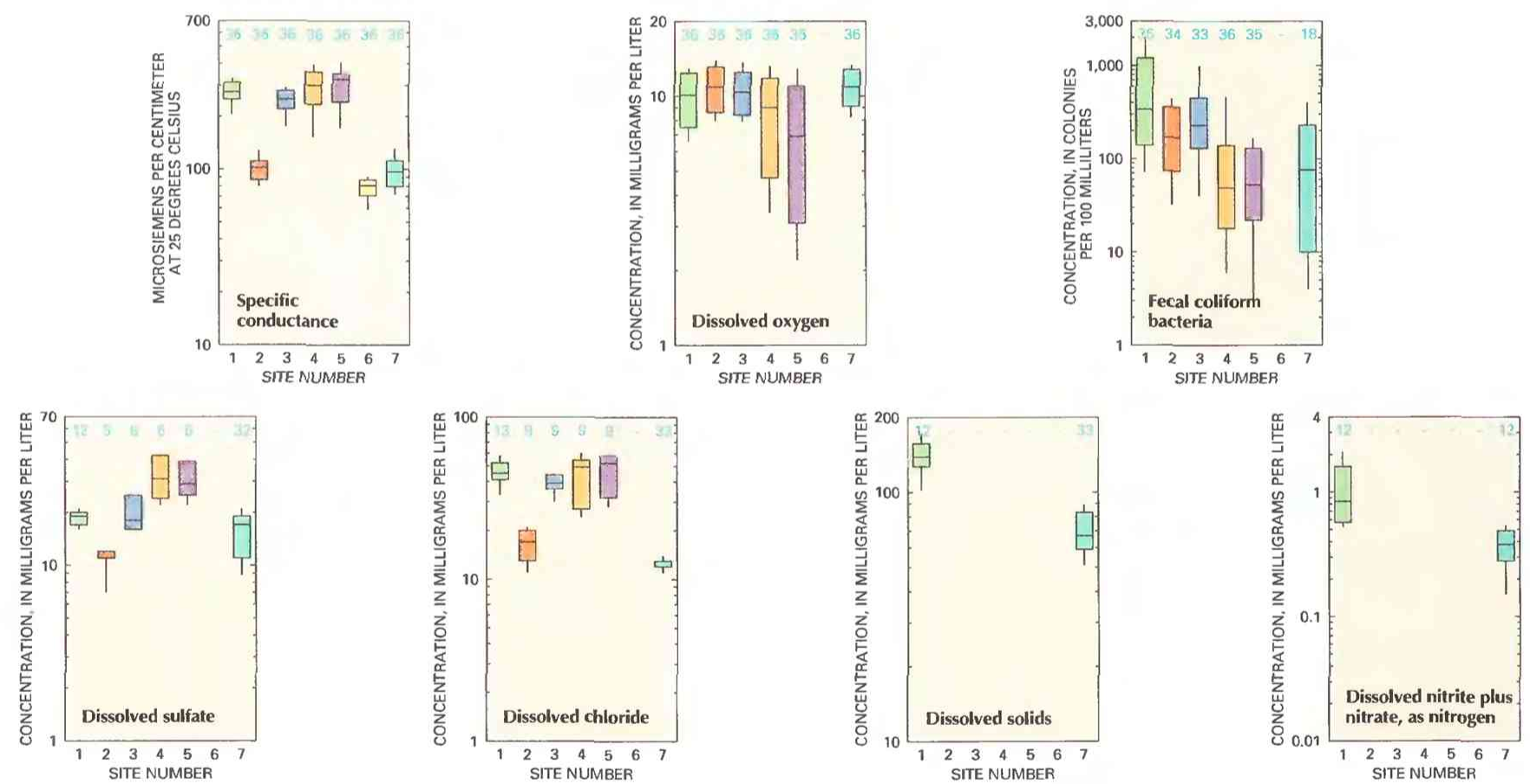

$$
\begin{aligned}
& \text { EXPLANATION } \\
& \text { Water-quality conditions in selected } \\
& \text { drainage basins } \\
& \text { Number of analyses-Dash } \\
& \text { indicates insufficient data } \\
& \text { Percentile-Percentage of analyses } \\
& \text { equal to or less than indicated } \\
& \text { values } \\
& \text {-90th } \\
& -75 \text { th } \\
& -50 \text { th-Median } \\
& -25 \text { th } \\
& -10 \text { th }
\end{aligned}
$$

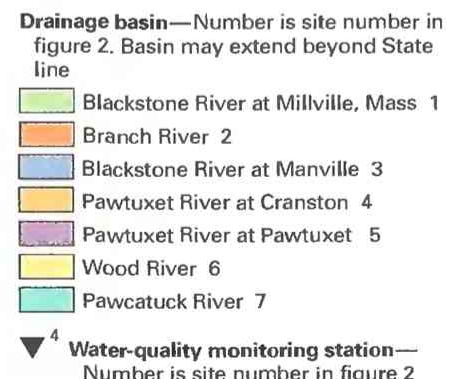

Number is site number in figure 2

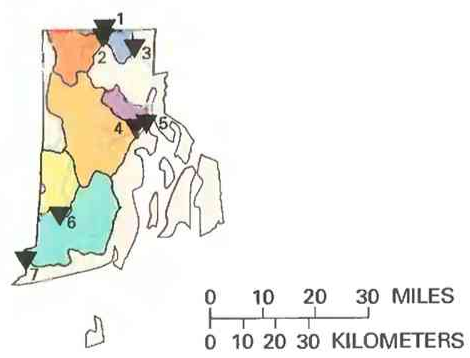

Figure 3. Water quality of selected streams in Rhode Island, water years 1987-89. (Source: Data from U.S. Geological Survey files.) 
wastes. Ponded areas behind 28 dams over a combined stream length of about 16 miles on the North and South Branches of the Pawtuxet River contribute to sediment accumulation, poor water circulation, and dissolved-oxygen depletion (Rhode Island Department of Environmental Management, 1987, p. 5).

An effort to clean the Pawtuxet River has been initiated-in 1989 the RIDEM imposed stricter limits on effluent discharges. The new restrictions are intended to make degraded reaches of the river suitable for swimming and fishing. To comply with the new discharge limits, construction of an advanced secondary wastewater-treatment facility on the river is required. The search for a site is in progress (Carlene B. Newman, Rhode Island Department of Environmental Management, Division of Water Resources, oral commun., May 1990).

Sites 4 and 5 are located on the main stem of the Pawtuxet River. Site 4 is downstream from two of the three municipal wastewater-treatment facilities; site 5 is downstream from all three. Values of most of the selected water-quality properties and constituents in samples from the Pawtuxet River indicate greater degradation of stream quality than do values in samples from other streams discussed in this report. Median specific-conductance values at site 4 (301 $\mu \mathrm{S} / \mathrm{cm})$ and at site $5(325 \mu \mathrm{S} / \mathrm{cm})$, median sulfate concentrations at site $4(31 \mathrm{mg} / \mathrm{L})$ and site $5(29 \mathrm{mg} / \mathrm{L})$, and median chloride concentrations at site $4(49 \mathrm{mg} / \mathrm{L})$ and site $5(52 \mathrm{mg} / \mathrm{L})$ exceeded values at other monitoring stations (fig. 3). Median dissolved-oxygen concentrations at site $4(9.0 \mathrm{mg} / \mathrm{L})$ and at site $5(6.9 \mathrm{mg} / \mathrm{L})$ are the lowest; more than 25 percent of the dissolved-oxygen concentrations were less than the minimum of $5 \mathrm{mg} / \mathrm{L}$ set by the RIDEM for Class $\mathrm{C}$ water (Rhode Island Department of Environmental Management, 1988, p. 14). The low median fecal coliform bacteria concentrations at site $4(49 \mathrm{col} / 100 \mathrm{~mL})$ and at site $5(53 \mathrm{col} / 100 \mathrm{~mL})$ relative to those at other monitoring stations might have been the result of chlorinated effluent discharged from wastewater-treatment facilities upstream from the monitoring stations (Briggs and Feiffer. 1986, p. 11).

\section{WOOD AND PAWCATUCK RIVERS}

The Pawcatuck River and its tributaries, which include the Wood River, form the largest drainage basin in Rhode Island, covering nearly one-fourth of the State's land area. Much of the basin is undeveloped, and the principal land covers are woodland and forest. Most segments of the Pawcatuck River and its tributaries bear designated-use classifications of $\mathrm{A}$ or $\mathrm{B}$, but a few reaches on the main stems of these rivers are designated as Class $C$ because of pointsource contamination from industrial wastewater discharges and malfunctioning individual sewage-disposal systems.

The headwaters of the Wood River drain forested upland areas that are largely State owned. Streams in this area are subject to minimal contamination and have been designated as Class A. Site 6 is in the lower Wood River basin at Hope Valley. There, the main stem is affected by malfunctioning individual sewage-disposal systems and has been designated as Class C (Rhode Island Department of Environmental Management, 1990, p. V.B.135). Of the water-quality properties and constituents selected for analysis in this report, only specific conductance was monitored at this site. The median value for specific conductance $(81 \mu \mathrm{S} / \mathrm{cm})$, which is equivalent to a median dissolved-solids concentration of about $50 \mathrm{mg} / \mathrm{L}$, was the lowest at any of the seven monitoring stations (fig. 3 ).

At site 7, near the mouth of the Pawcatuck River at Westerly, concentrations of the selected properties and constituents during water years 1987-89 were characteristic of relatively uncontaminated water. Median concentrations of these properties and constituents were as follows: specific conductance, $97 \mu \mathrm{S} / \mathrm{cm}$; dissolved oxygen, $10.9 \mathrm{mg} / \mathrm{L}$; fecal coliform bacteria, $76 \mathrm{col} / 100 \mathrm{~mL}$; sulfate, 17 $\mathrm{mg} / \mathrm{L}$; chloride, $13 \mathrm{mg} / \mathrm{L}$; dissolved solids, $67 \mathrm{mg} / \mathrm{L}$; and nitrite plus nitrate, $0.38 \mathrm{mg} / \mathrm{L}$. The median concentration of fecal coliform bacteria meets the standard for a Class B stream. Nevertheless, the segment of the Pawcatuck River that flows through Westerly (site 7) is designated as Class $\mathrm{C}$ because of industrial wastewater discharges; at site 7, the river meets the criteria for its Class $\mathrm{C}$ designated-use classification (Rhode Island Department of Environmental Management, 1990, p. V.B.126).

\section{WATER-QUALITY TRENDS}

Trend analysis is a statistical procedure used to detect changes in stream water quality at a monitoring station over time. For this report, water-quality data from seven monitoring stations (fig. 2) were analyzed for trends by using the seasonal Kendall test (Hirsch and others, 1982), a method used extensively by the USGS. The graph

Table 1. Sources and environmental significance of selected water-quality properties and constituents

[Source: Compiled by the U.S. Geological Survey, Office of Water Quality]

\begin{tabular}{|c|c|c|}
\hline Property or constituent & Common sources & Environmental significance \\
\hline $\begin{array}{l}\text { Specific conductance ..................... } \\
\text { (property) }\end{array}$ & $\begin{array}{l}\text { A measure of the electrical conductivity of water; var- } \\
\text { ies with the quantity of dissolved solids and is } \\
\text { used to approximate the dissolved-solids content. }\end{array}$ & $\begin{array}{l}\text { Dissolved solids can cause water to be unsuitable for } \\
\text { public supply, agriculture, and industry; can harm } \\
\text { aquatic organisms. }\end{array}$ \\
\hline 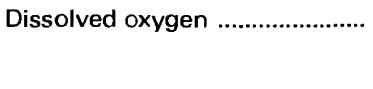 & $\begin{array}{l}\text { Introduced from the atmosphere; also a byproduct of } \\
\text { aquatic plants. }\end{array}$ & $\begin{array}{l}\text { Necessary for aquatic life; deficiency can result from } \\
\text { assimilation of organic wastes or rapid growth } \\
\text { and decay of algae. }\end{array}$ \\
\hline Fecal coliform bacteria ................ & $\begin{array}{l}\text { Sources include effluent from sewage-treatment } \\
\text { plants and runoff from pastures, feedlots, and ur- } \\
\text { ban areas. }\end{array}$ & $\begin{array}{l}\text { Presence indicates contamination of water by wastes } \\
\text { from humans and other warm-blooded animals. }\end{array}$ \\
\hline Sulfate & $\begin{array}{l}\text { Occurs in some rocks; also in mine runoff, industrial } \\
\text { wastewater discharge, and atmospheric deposi- } \\
\text { tion. }\end{array}$ & $\begin{array}{l}\text { Concentrations exceeding a natural, background } \\
\text { level indicate contamination from human activity; } \\
\text { in sufficient quantity, can cause water to be } \\
\text { unsuitable for public supply; can harm aquatic } \\
\text { organisms. }\end{array}$ \\
\hline 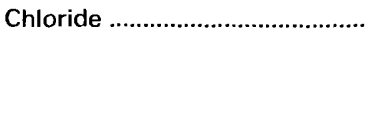 & $\begin{array}{l}\text { Occurs in some rocks and ground-water discharge; } \\
\text { also in road deicers, industrial and urban waste- } \\
\text { water discharge, and atmospheric deposition. }\end{array}$ & $\begin{array}{l}\text { Concentrations exceeding a natural, background level } \\
\text { can cause water to be unsuitable for public supply, } \\
\text { agriculture, and industry; can harm aquatic or- } \\
\text { ganisms. }\end{array}$ \\
\hline Dissolved solids ............................ & $\begin{array}{l}\text { A result of rock weathering; also in agricultural runoff } \\
\text { and industrial discharge. }\end{array}$ & $\begin{array}{l}\text { In sufficient quantity, can cause water to be unsuitable } \\
\text { for public supply, agriculture, and industry; can } \\
\text { harm aquatic organisms. }\end{array}$ \\
\hline Nitrite plus nitrate ...................... & $\begin{array}{l}\text { Nonpoint sources are agricultural and urban runoff; } \\
\text { a major point source is wastewater discharge. }\end{array}$ & $\begin{array}{l}\text { Plant nutrient that, in sufficient quantity, can cause } \\
\text { algal blooms and excessive growth of higher } \\
\text { aquatic plants in bodies of water; can cause water } \\
\text { to be unsuitable for public supply. }\end{array}$ \\
\hline
\end{tabular}


(shown below) of the dissolved-chloride concentration in the Blackstone River at site 1 illustrates the trend inferred from the concentration data and demonstrates the variation in water quality that is common in streams.

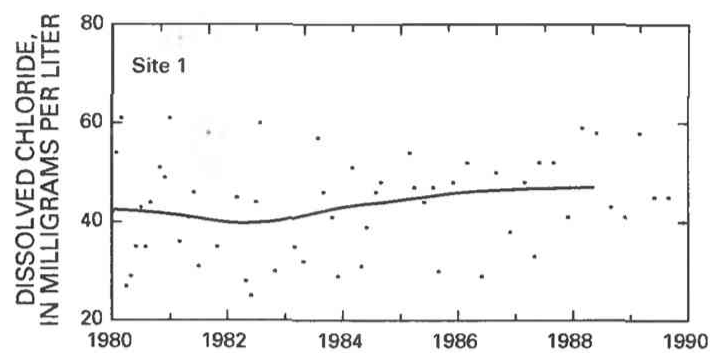

When possible, constituent-concentration data were adjusted for changes in streamflow to preclude identifying a trend in concentration that was caused only by a trend in streamflow. The data were not adjusted when (1) more than 10 percent of the samples had concentrations lower than the minimum reporting limit for the analytical method used or (2) streamflow was controlled substantially by human activities. When the concentration data could not be adjusted for streamflow, trends were determined directly from the concentration data.

Statewide trends in measurements of selected physical properties of stream water and in concentrations of selected constituents in stream water are shown on maps in figure 4. On each map, a trend is indicated at a monitoring station only if the data from that station were suitable for use in the trend analysis. For many of the selected constituents, only site 1 on the Blackstone River and site 7 on the Pawcatuck River were sampled a sufficient number of times to meet the suitability criteria. For more information on the suitability criteria and on the trend-analysis procedure used for this report, see Lanfear and Alexander (1990).

\section{SPECIFIC CONDUCTANCE}

Specific conductance is a measure of the ability of a sample of water to conduct electricity. Because specific conductance and the dissolved-solids concentration are roughly proportional in most natural waters, the specific conductance often can be used to estimate the dissolved-solids concentration (Hem, 1985, p. 66-68).

Specific-conductance values trended upward in the Blackstone, Branch, Pawtuxet, and Wood Rivers at sites 1, 2, 4, and 6 and trended downward in the Pawcatuck River at site 7 (fig. 4). Definite causes have not been determined for the upward trends. However, contaminants such as road-deicing salt in runoff from expanding urban areas might have been partly responsible. The downward trend in specific conductance at site 7 on the Pawcatuck River might have been the result of improved treatment of wastewater discharged by some industries, or a decrease in the volume of industrial wastewater discharged, or both. No trends in specific conductance were evident at site 3 on the Blackstone River or at site 5 on the Pawtuxet River. No cause has been determined for the absence of a trend in specificconductance values at sites 3 or 5 , both of which are downstream from monitoring stations where there was an upward trend.

\section{DISSOLVED OXYGEN}

The dissolved-oxygen concentration in a stream is controlled by several factors, including water temperature, air temperature and pressure, hydraulic characteristics of the stream, photosynthetic or respiratory activity of stream biota, and the quantity of organic material present. A trend in dissolved-oxygen concentrations commonly is directly or indirectly the result of human activities. Generally, an upward trend in dissolved-oxygen concentrations indicates improving stream water-quality conditions and a downward trend indicates deteriorating conditions. The upward trend in dissolved-oxygen concentrations in the Blackstone River at site 1 (fig. 4) probably was a result of improved wastewater treatment.

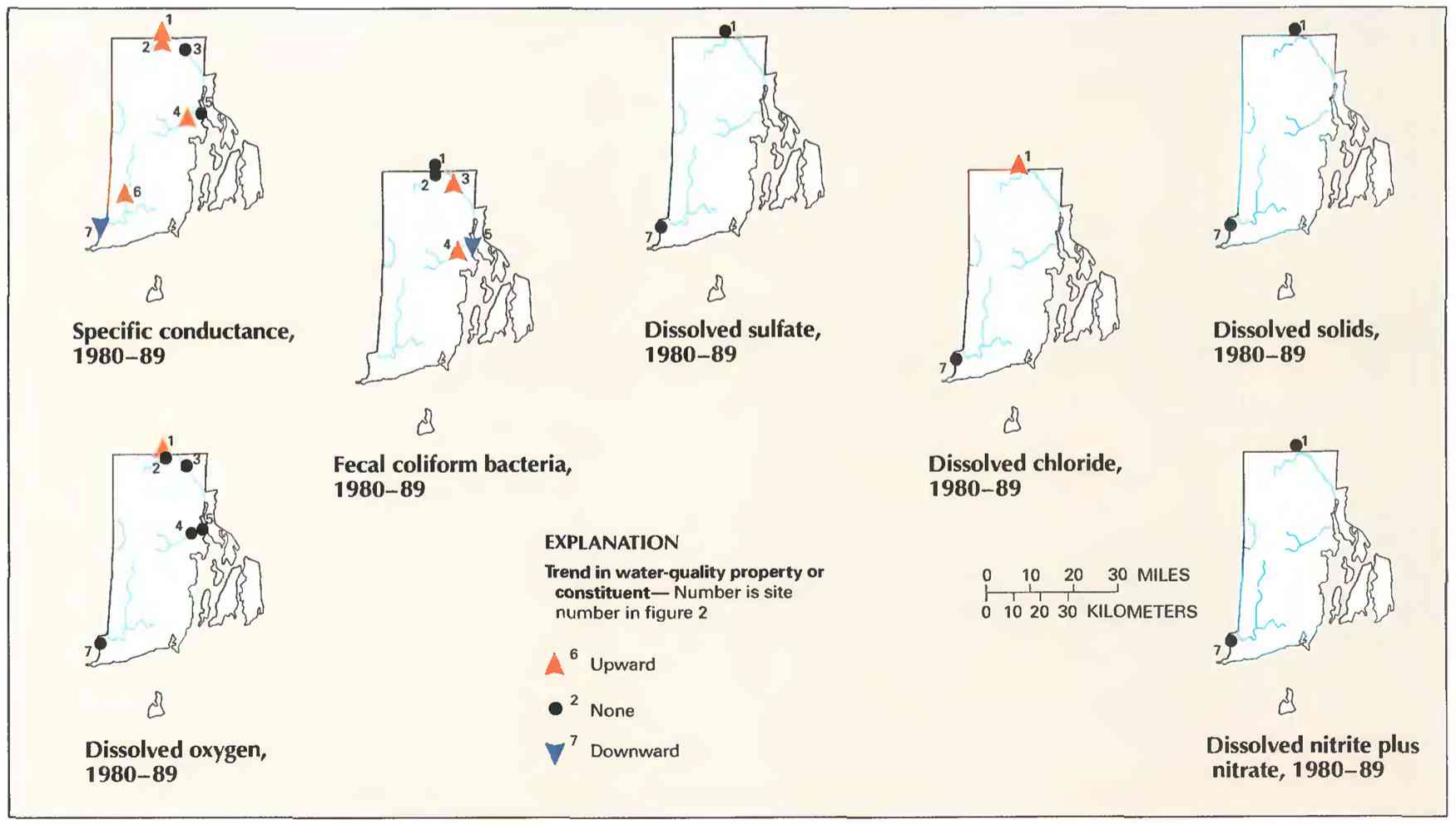

Figure 4. Trends in water quality of selected streams in Rhode Island, by water years. (Source: Data from U.S. Geological Survey files.) 


\section{FECAL COLIFORM BACTERIA}

Fecal coliform bacteria are used as indicators of fecal contamination from humans and other warm-blooded animals. Such contamination can introduce disease-causing viruses and bacteria into a stream.

The upward trend in fecal coliform bacteria concentrations in the Blackstone River at site 3 (fig. 4) might have been related to degraded water quality in tributaries that enter the Blackstone River downstream from site 1 . The disparity in trends in the Pawtuxet River at sites 4 (upward) and 5 (downward) is not easily explained but might have been the result of a complex interaction of changes in wastewater-treatment-plant effluent quality, urban runoff, and streamflow.

\section{DISSOLVED SULFATE}

The major natural sources of sulfate in streams are rock weathering, volcanoes, and biochemical processes (Hem, 1985, p. 113). Human activities such as mining, waste discharge, and fossil-fuel combustion also can be important sources. Sulfate concentrations had no trend in the Blackstone River at site 1 or the Pawcatuck River at site 7 (fig. 4).

\section{DISSOLVED CHLORIDE}

Chloride is present in all natural waters but usually in low concentrations (Hem, 1985, p. 118). Except in streams that receive ground-water discharge high in chloride, concentrations of greater than a few milligrams per liter generally are the result of human activities (table 1). The upward trend in chloride concentrations in the Blackstone River at site 1 (fig. 4) might have resulted from increasing urbanization and an associated increase in the quantity of deicing salt applied to roads.

\section{DISSOLVED SOLIDS}

Dissolved solids in stream water result primarily from rock weathering but also can be introduced as a byproduct of human activities (table 1). Concentrations generally are greatest in streams draining basins underlain by rocks and soils that contain easily dissolved minerals. Dissolved-solids concentrations had no trend at sites 1 and 7 (fig. 4).

\section{DISSOLVED NITRITE PLUS NITRATE}

Nitrite and nitrate are oxidized forms of nitrogen that together constitute most of the dissolved nitrogen in well-aerated streams. $\mathrm{Ni}$ trite readily oxidizes to nitrate in natural waters; therefore, nitrate generally is by far the more abundant of the two (Hem, 1985, p. 124). Nitrite plus nitrate concentrations had no trend at sites 1 and 7 (fig. 4).

\section{WATER-QUALITY MANAGEMENT}

The RIDEM, under Rhode Island General Laws (46-12-1), is the principal water-quality-management agency for the State and administers programs to secure, protect, and preserve rights of citizens to uncontaminated waters. The RIDEM performs specific regulatory, enforcement, and monitoring activities, which include developing water-quality standards and criteria, issuing permits to wastewater dischargers, reviewing the operation and maintenance of municipal and industrial wastewater-treatment facilities, surveying to determine compliance with effluent and water-quality standards, and monitoring of waste discharges and ambient water-quality conditions. The Rhode Island Department of Health has statutory authority to monitor the quality of water delivered by public-supply systems and to order abatement of pollution that threatens public supply.
The RIDEM is responsible for implementing the Federal Clean Water Act in Rhode Island. Section 305(b) of the act requires States to submit biennial water-quality assessment reports (Rhode Island Department of Environmental Management, 1990) to the U.S. Congress and EPA. The RIDEM prepares and submits these reports, which describe water-quality conditions of the State's surface-water bodies and document progress in achieving the goals and objectives of the Clean Water Act. In response to requirements of the Water Quality Act of 1987, the RIDEM initiated a 4-year Clean Water Strategy Program to address water-quality issues throughout Rhode Island. A Water-Quality Advisory Committee was created to oversee the program. The Committee members, which include representatives from government agencies, environmental advocacy groups, industry, and the research community, provide a broad base of interests to the program (Rhode Island Department of Environmental Management, 1989).

The RIDEM is also responsible for administering the National Pollutant Discharge Elimination System program. This program provides for the issuance of permits that require any discharges to surface water to meet water-quality-based standards.

Data for evaluating surface-water quality in Rhode Island are collected by several organizations. The RIDEM collects data used for monitoring effluent discharges, biological conditions, and a variety of chemical pollutants. The USGS, in cooperation with the RIDEM, collects data used for evaluating trends in stream water quality. The University of Rhode Island and the Narragansett Bay Project provide additional water-quality data that facilitate the monitoring and assessment of the State's stream water quality.

Rhode Island relies on surface water for most of its water-supply needs. Although some water-quality degradation is unavoidable owing to contamination resulting from certain land uses, protection of surface-water resources will continue to be an important issue for the State.

\section{SELECTED REFERENCES}

Anderson, J.R., 1967, Major land uses in the United States, in U.S. Geological Survey, 1970, National atlas of the United States of America: Washington, D.C., U.S. Geological Survey, p. 158-159.

Briggs, J.C., and Feiffer, J.S., 1986, Water quality of Rhode Island streams: U.S. Geological Survey Water-Resources Investigations Report 84 $4367,51 \mathrm{p}$.

Britton, L.J., and Greeson, P.E., eds., 1987, Methods for collection and analysis of aquatic biological and microbiological samples: U.S. Geological Survey Techniques of Water-Resources Investigations, book 5, chap. A4, $363 \mathrm{p}$.

Fenneman. N.M., 1946, Physical divisions of the United States: Washington, D.C., U.S. Geological Survey special map, scale 1:7,000,000.

Fishman, M.J., and Friedman, L.C., eds., 1989, Methods for the determination of inorganic substances in water and fluvial sediments: U.S. Geological Survey Techniques of Water-Resources Investigations, book 5 , chap. A1, 545 p.

Hem, J.D., 1985, Study and interpretation of the chemical characteristics of natural water (3d ed.): U.S. Geological Survey Water-Supply Paper 2254, $263 \mathrm{p}$.

Hirsch, R.M., Slack, J.R., and Smith, R.A., 1982, Techniques of trend analysis for monthly water quality data: Water Resources Research, v. 18, no. 1 , p. 107-121.

Lanfear, K.J., and Alexander, R.B., 1990, Methodology to derive water-quality trends for use by the National Water Summary Program of the U.S. Geological Survey: U.S. Geological Survey Open-File Report 90-359, $10 \mathrm{p}$.

Narragansett Bay Project, 1989. Pollutant trends in Narragansett Bay: Providence, R.I., Narragansett Bay Project Progress Report, 24 p.

Rhode Island Department of Environmental Management, 1987, Pawtuxet River basin non-point water quality standards review and management plan: Providence, Office of Environmental Coordination, $32 \mathrm{p}$.

1988, Water quality regulations for water pollution control: Providence, Division of Water Resources, 31 p. 
1989, State clean water strategy, Part I: Providence, Division of Water Resources, $44 \mathrm{p}$.

1990 , The state of the State's waters, Rhode Island-A report to Congress: Providence, Division of Water Resources, variously paginated.

Rhode Island Department of Health, 1989, Rules and regulations pertaining to public drinking water: Providence, State of Rhode Island and Providence Plantations, $24 \mathrm{p}$.

Thelin, G.P., and Pike, R.J., 1990, Digital shaded relief map of the conterminous United States: Menlo Park, Calif., U.S. Geological Survey digital image processing, scale 1:3,500,000.

U.S. Environmental Protection Agency, 1988a, Maximum contaminant levels (subpart B of 141, National interim primary drinking-water regulations): U.S. Code of Federal Regulations, Title 40, Parts 100 to 149 , revised July 1,1988 , p. 530-533. 1988b, Secondary maximum contaminant levels (section 143.3 of part 143, National secondary drinking-water regulations): U.S. Code of Federal Regulations, Title 40, Parts 100 to 149, revised July 1, 1988, p. 608.

U.S. Geological Survey, 1986, National water summary 1985-Hydrologic events and surface-water resources: U.S. Geological Survey WaterSupply Paper $2300,506 \mathrm{p}$.

1990, National water summary 1987-Hydrologic events and water supply and use: U.S. Geological Survey Water-Supply Paper 2350, $553 \mathrm{p}$.

Ward, J.R., and Harr, C.A., eds., 1990, Methods for collection and processing of surface-water and bed-material samples for physical and chemical analyses: U.S. Geological Survey Open-File Report 90-140, 71 p. 
Prepared by Richard W. Bell

FOR ADDITIONAL INFORMATION: Subdistrict Chief, Rhode Island Subdistrict, U.S. Geological Survey, John O. Pastore Federal Building, Room 237, Providence, RI 02903-1720 


\section{SOUTH Carolina Stream Water Quality}

South Carolina's surface-water resources are used for recreation, tourism, public supply, and industry and are a valued part of the State's economy, culture, and growth potential. Approximately 83 percent of South Carolina's surface water meets State water-quality standards for protected uses (South Carolina Department of Health and Environmental Control, 1990a).

A humid, subtropical climate provides South Carolina with an annual precipitation of more than 48 inches and an average statewide streamflow of about $33,000 \mathrm{Mgal} / \mathrm{d}$ (million gallons per day) (U.S. Geological Survey, 1986, p. 413). Offstream surface-water withdrawals in 1985 averaged $6,600 \mathrm{Mgal} / \mathrm{d}$. Principal uses included thermoelectric power generation $(5,180 \mathrm{Mgal} / \mathrm{d})$, industrial and mining activities (1,090 Mgal/d), and public supply (283 Mgal/d) (U.S. Geological Survey, 1990, p. 456).

The quality of surface water can be affected by land use, which in South Carolina is mainly forest and agriculture (fig. 1A). Climate and physiography in large part determine the land-use potential of an area. South Carolina's borders encompass parts of three physiographic provinces: the Blue Ridge. Piedmont, and Coastal Plain (fig. $1 B)$. The Blue Ridge province includes a small part of the Appalachian Mountains and consists of about $600 \mathrm{mi}^{2}$ (square miles) of rugged terrain that constitutes about 2 percent of the State's area. The Piedmont province covers roughly one-third of the State $\left(10,500 \mathrm{mi}^{2}\right)$ between the Blue Ridge and Coastal Plain provinces. The topogra- phy in this area ranges from extremely hilly in the northwestern part of the province to gently rolling in the southeastern part. The Coastal Plain province is the largest landform region in South Carolina, covering roughly two-thirds of the State $\left(20,000 \mathrm{mi}^{2}\right)$ and is separated from the Piedmont province by the Fall Line. Near the Fall Line, the topography of the Coastal Plain is hilly and difficult to distinguish from that of the Piedmont, whereas toward the Atlantic Coast, the Coastal Plain is flatter and almost featureless (Kovacik and Winberry, 1987).

More than one-half of the counties in the State are 50-90 percent forested. The mountains of the Blue Ridge province are densely forested but have narrow croplands and pastures in valleys and stream flood plains. With the decline of cotton farming from 1945 to the present, land use in the Piedmont changed from row-crop agriculture to dense forest intermixed with orchard- and pasture-related agriculture. Row-crop agriculture and forested land dominate inland parts of the Coastal Plain, and swampy flood plains along streams broaden into swampy woodlands that merge with coastal estuaries toward the Atlantic Coast (South Carolina Division of Research and Statistical Services, 1990).

The largest population centers in the State (fig. 1C and 2) are Greenville (population 640,861) in the northwest, Charleston (population 506,875) on the Coast, and Columbia (population 453,331) in the central part of the State (South Carolina Division of Research and Statistical Services, 1990). The 1990 population for South Carolina was 3.5 million, which is an 11.7percent increase from 1980 (U.S. Bureau of the Census 1990 decennial census files).

\section{WATER-QUALITY MONITORING}

Water-quality data obtained from analyses of water samples collected at monitoring stations are stored in the U.S. Geological Survey's (USGS) National Water Information System and the U.S. Environmental Protection Agency's (EPA) national data base known as STORET. Water-quality and streamflow data are reported by water year-the 12 months from October 1 through September 30. A water year is identified by the calendar year in which it ends. For example, water year 1991 comprises October 1, 1990, through September 30, 1991.

The data used in this summary of South Carolina's stream water quality were obtained from water samples collected at six monitoring stations at which data collection is systematic and continuing (fig. 2). Analyses of water samples collected at these stations are the ba-
Figure 1. Land use, physiography, and population in South Carolina. A, Major land uses. B, Physiographic divisions. C, Population distribution in 1990. (Sources: A, Major land uses modified from Anderson, 1967. B, Physiographic divisions from Fenneman, 1946; landforms from Thelin and Pike, 1990. C. Data from U.S. Bureau of the Census 1990 decennial census files.) 
sis for the discussion and graphic summary (fig. 3) of stream waterquality conditions during water years 1987-89 and for the discussion and graphic summary (fig. 4) of stream water-quality trends. Water samples were collected and analyzed by using standard methods approved by the USGS (Britton and Greeson, 1987; Fishman and Friedman, 1989; Ward and Harr, 1990) or by using equivalent methods. If a method of sample collection or analysis changed over time, data from an analysis were included in the evaluation of recent stream water quality or of stream water-quality trends only if the change in method did not affect the comparability of the data.

\section{WATER-QUALITY CONDITIONS}

The following discussion of stream water quality in South Carolina is organized by river basin (fig. 3). Where physiographic and land-use characteristics in different basins are similar, the discussion of those basins is combined. Graphs in figure 3 summarize certain aspects of stream water quality in the basins for water years 1987-89. The graphs show frequency distributions of data values that represent concentrations of selected stream-water constituents. These constituents are dissolved oxygen, fecal coliform bacteria, dissolved sulfate, dissolved solids, dissolved nitrite plus nitrate (as nitrogen), and suspended sediment. The data are reported in milligrams per liter $(\mathrm{mg} / \mathrm{L})$ and colonies per 100 milliliters $(\mathrm{col} / 100 \mathrm{~mL})$. Sources and environmental significance of each constituent are described in table 1 .

Water quality at each monitoring station is the result of geological, chemical, biological, and hydrologic processes that occur over a large area. Water-quality problems that affect aquatic life or public health only locally are not fully represented in this summary.

\section{PEE DEE RIVER}

The Pee Dee River had a long-term average discharge of $9,793 \mathrm{ft}^{3} / \mathrm{s}$ (cubic feet per second) as of water year 1989 (U.S. Geological Survey, 1989). Site 1 near the town of Peedee monitors drainage from the inner part of the Coastal Plain of northern South Carolina and from the Coastal Plain and Piedmont provinces of North Carolina. Reservoirs in North Carolina maintain flow in the Pee Dee River in South Carolina. The median concentrations of nitrite plus nitrate $(0.51 \mathrm{mg} / \mathrm{L})$ and suspended sediment $(22.0 \mathrm{mg} / \mathrm{L})$ were higher for site 1 than for the other five monitoring stations (fig. 3). These high concentrations reflect the abundant use of nitrogen fertilizers and soil erosion in agricultural areas and runoff from urbanized areas in the Pee Dee River basin (South Carolina Department of Health and Environmental Control, 1989).

\section{LYNCHES AND BLACK RIVERS}

The Lynches River is a tributary to the Pee Dee River. The Black River joins the Pee Dee River at its mouth near the Atlantic Coast. As of water year 1989, long-term average discharges of the Lynches and Black Rivers were 1,031 ft $3 / \mathrm{s}$ and $943 \mathrm{ft}^{3} / \mathrm{s}$, respectively. Data collected in the Lynches River at site 2 and the Black River at site 4 reflect conditions in the parts of these adjacent basins in which the principal land uses are agricultural. Median sulfate concentrations at sites 2 and 4 (14 and $15 \mathrm{mg} / \mathrm{L}$ ) were among the highest for the six monitoring stations, and median dissolved-solids concentrations (72 and $90 \mathrm{mg} / \mathrm{L}$ ) were the highest (fig. 3).

The rivers and their tributaries are bordered by swamps. According to Bates (1989), drainage of water rich in organic materials from swamps in the inner part of the Coastal Plain, combined with low-flow conditions and high summer temperatures, produces a poor to satisfactory rating for water quality in these rivers during summer. Periods in which dissolved-oxygen concentrations are low and fecal coliform bacteria concentrations are high can occur in spring and summer. During water years $1987-89$, the median dissolved-oxygen concentration for site $4(6.2$ $\mathrm{mg} / \mathrm{L}$ ) was the lowest for the six monitoring stations, and fecal coliform bacteria concentrations occasionally exceeded $1,000 \mathrm{col} / 100 \mathrm{~mL}$ at both monitoring stations.

\section{EXPLANATION}

Water-quality monitoring station and type of statistical analysisNumber refers to accompanying table $\nabla^{3}$ Water-quality conditions and
trends (see figs. 3 and 4 )

\section{MILES}

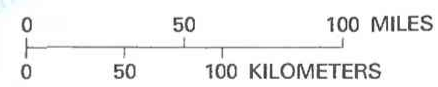

\begin{tabular}{|c|c|c|c|}
\hline $\begin{array}{l}\text { Site no. } \\
\text { on map }\end{array}$ & $\begin{array}{l}\text { USGS station } \\
\text { name and no. }\end{array}$ & $\begin{array}{l}\text { Drainage area } \\
\text { (square miles) }\end{array}$ & $\begin{array}{l}\text { Major land use } \\
\text { (see fig. 1) }\end{array}$ \\
\hline 1 & Pee Dee River at Peedee $(02131000)$ & 8,830 & Cropland with pasture, woodland, and forest. \\
\hline 2 & Lynches River at Effingham $(02132000)$ & 1,030 & Cropland with pasture, woodland, and forest; swamp. \\
\hline 3 & Scape Ore Swamp near Bishopville $(02135000)$ & 96 & Swamp; cropland with pasture, woodland, and forest. \\
\hline 4 & Black River at Kingstree $(02136000)$ & 1,252 & Cropland with pasture, woodland, and forest; swamp. \\
\hline 5 & Edisto River near Givhans $(02175000)$ & 2,730 & Ditto. \\
\hline 6 & 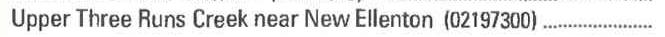 & 87 & Woodland and forest with some cropland and pasture. \\
\hline
\end{tabular}

Figure 2. Selected water-quality monitoring stations, type of statistical analysis, and geographic features in South Carolina. (Sources: Major land uses modified from Anderson, 1967; other data from U.S. Geological Survey files.) 


\section{SCAPE ORE SWAMP}

Site 3 monitors drainage from Scape Ore Swamp, the headwater for the Black River. The drainage basin is confined to the inner Coastal Plain and contains large areas of swampy woodlands as well as some agricultural land. Long-term discharge at site 3 was 102 $\mathrm{ft}^{3} / \mathrm{s}$ as of water year 1989. Ground-water discharge sustains flow during periods of reduced precipitation. Seasonal problems with dissolved oxygen and fecal coliform bacteria are worsened by low discharge (less than $20 \mathrm{ft}^{3} / \mathrm{s}$ ) in the summer (Snyder and others, 1983). Compared to those from other monitoring stations in the Pee Dee
River basin (sites 1, 2, and 4), water samples from site 3 had lower concentrations of sulfate and dissolved solids (fig. 3 ) because groundwater discharge from the extensively leached and weathered soil in the area of the inner Coastal Plain contains low concentrations of dissolved minerals.

\section{EDISTO RIVER}

The Edisto River basin lies entirely within South Carolina. Long-term average discharge as of water year 1989 was $2,584 \mathrm{ft}^{3} / \mathrm{s}$ at site 5 near Givhans. The basin upstream from site 5 is drained pre-

Table 1. Sources and environmental significance of selected water-quality constituents

[Source: Compiled by the U.S. Geological Survey, Office of Water Quality]

\begin{tabular}{|c|c|c|}
\hline Constituent & Common sources & Environmental significance \\
\hline Dissolved oxygen .......................... & $\begin{array}{l}\text { Introduced from the atmosphere; also a byproduct of } \\
\text { aquatic plants. }\end{array}$ & $\begin{array}{l}\text { Necessary for aquatic life; deficiency can result from } \\
\text { assimilation of organic wastes or rapid growth } \\
\text { and decay of algae. }\end{array}$ \\
\hline Fecal coliform bacteria ................ & $\begin{array}{l}\text { Sources include effluent from sewage-treatment } \\
\text { plants and runoff from pastures, feedlots, and ur- } \\
\text { ban areas. }\end{array}$ & $\begin{array}{l}\text { Presence indicates contamination of water by wastes } \\
\text { from humans and other warm-blooded animals. }\end{array}$ \\
\hline Sulfate & $\begin{array}{l}\text { Occurs in some rocks; also in mine runoff, industrial } \\
\text { wastewater discharge, and atmospheric deposi- } \\
\text { tion. }\end{array}$ & $\begin{array}{l}\text { Concentrations exceeding a natural, background } \\
\text { level indicate contamination from human activity; } \\
\text { in sufficient quantity, can cause water to be } \\
\text { unsuitable for public supply; can harm aquatic } \\
\text { organisms. }\end{array}$ \\
\hline 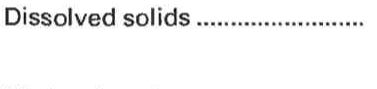 & $\begin{array}{l}\text { A result of rock weathering; also in agricultural runoff } \\
\text { and industrial discharge. }\end{array}$ & $\begin{array}{l}\text { In sufficient quantity, can cause water to be unsuitable } \\
\text { for public supply, agriculture, and industry; can } \\
\text { harm aquatic organisms. }\end{array}$ \\
\hline 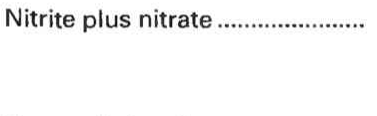 & $\begin{array}{l}\text { Nonpoint sources are agricultural and urban runoff; } \\
\text { a major point source is wastewater discharge. }\end{array}$ & $\begin{array}{l}\text { Plant nutrient that, in sufficient quantity, can cause } \\
\text { algal blooms and excessive growth of higher } \\
\text { aquatic plants in bodies of water; can cause water } \\
\text { to be unsuitable for public supply. }\end{array}$ \\
\hline Suspended sediment .................. & $\begin{array}{l}\text { A result of rock erosion; also induced by disturbances } \\
\text { of land cover due to fires, floods, and human } \\
\text { activities such as mining, logging, construction, } \\
\text { and agriculture. }\end{array}$ & $\begin{array}{l}\text { Can be detrimental to aquatic organisms; can fill res- } \\
\text { ervoirs and impair recreational use of water. }\end{array}$ \\
\hline
\end{tabular}
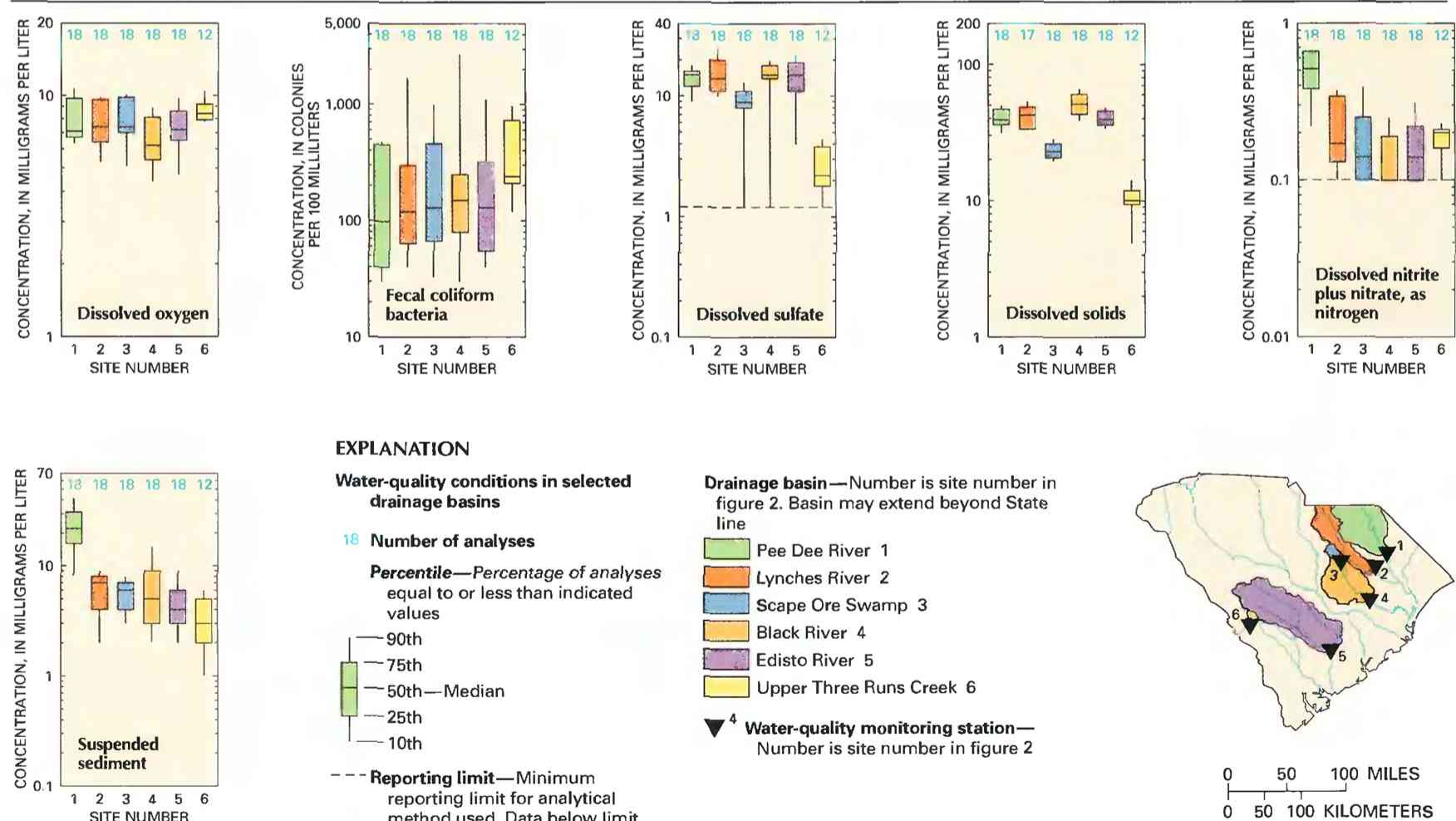

\section{EXPLANATION}

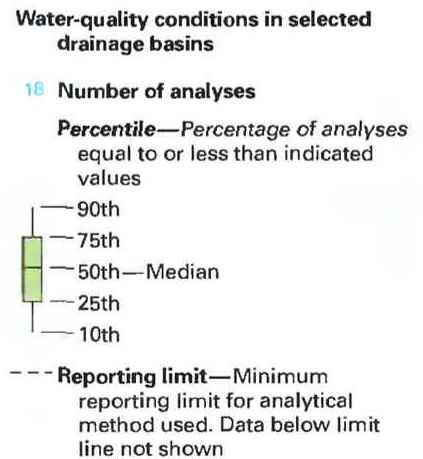
line not shown

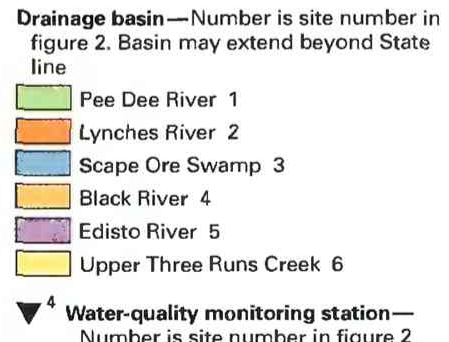

Number is site number in figure 2

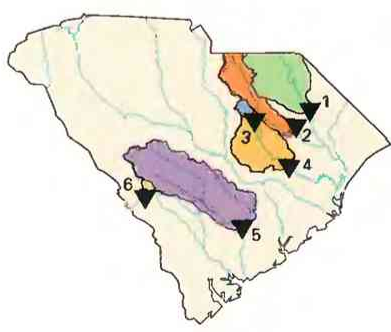

$\underbrace{0}_{0} \quad \sum_{50}^{50} 100$ KILOMETERS

Figure 3. Water quality of selected streams in South Carolina, water years 1987-89. (Source: Data from U.S. Geological Survey files.) 
dominantly by the South and North Forks of the Edisto River and Four Hole Swamp. The economy of the basin is based largely on timber and agriculture, and there is municipal and industrial development around Orangeburg. Runoff and effluent from these activities have not significantly degraded water quality in the basin, although low-flow conditions in the North Fork Edisto River and Four Hole Swamp occasionally result in low dissolved-oxygen concentrations and high concentrations of fecal coliform bacteria in spring and summer (Snyder and others, 1983). The constituent concentrations in water samples collected at site 5 are indicative of the generally undegraded condition of the Edisto River (fig. 3).

\section{UPPER THREE RUNS CREEK}

Upper Three Runs Creek is a small tributary of the Savannah River. Site 6 is near New Ellenton and the upstream boundary of the U.S. Department of Energy's Savannah River Site, which produces nuclear materials and stores hazardous and radioactive waste onsite (U.S. Geological Survey, 1984, p. 206). The basin is forested and has some agricultural activity. The small drainage area of this basin is located entirely in the inner Coastal Plain and is underlain by extensively weathered soils. Upper Three Runs Creek is regulated and had a long-term average discharge of $105 \mathrm{ft}^{3} / \mathrm{s}$ as of water year 1989 .

Concentrations of fecal coliform bacteria commonly were higher at site 6 than at sites 1-5 (fig. 3). The absence of an important human source and the abundance of wildlife in the drainage basin indicate that the origin of the fecal coliform bacteria is natural. The concentrations of dissolved constituents in ground-water discharge from the weathered soil generally are low. Consequently, concentrations of dissolved solids and sulfate in the stream are low. The low concentration of suspended sediment reflects well-established woodlands and minimal effects of agriculture on soil erosion in the drainage basin.

\section{WATER-QUALITY TRENDS}

Trend analysis is a statistical procedure used to detect changes in stream water quality at a monitoring station over time. For this report, water-quality data from six monitoring stations (fig. 2) were analyzed for trends by using the seasonal Kendall test (Hirsch and others, 1982), a method used extensively by the USGS. The graph (shown below) of the dissolved-sulfate concentration in the Pee Dee River at site 1 illustrates the trend inferred from the concentration data and demonstrates the variation in water quality that is common in streams.

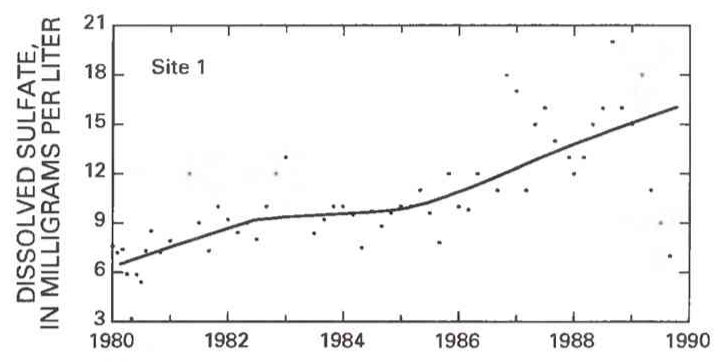

The 1980's had drier conditions than the 1970's (Guttman and Plantico, 1987; Hale and others, 1989; U.S. Geological Survey, 1991, p. 489-496). Trends in water quality during 1980-89 generally reflect the regional adjustment of stream water quality to reduced precipitation and runoff and the increasing significance of ground-water discharge during the progressively drier conditions of the 1980 's.

When possible, constituent-concentration data were adjusted for changes in streamflow to preclude identifying a trend in concentration that was caused only by a trend in streamflow. The data were not adjusted when (1) more than 10 percent of the samples had concentrations lower than the minimum reporting limit for the analytical method used or (2) streamflow was controlled substantially by human activities. When the concentration data could not be adjusted for streamflow, trends were determined directly from the concentration data.

Statewide trends in concentrations of selected stream-water constituents are shown on maps in figure 4. On each map, a trend is indicated at a monitoring station only if the data from that station were suitable for use in the trend analysis. For more information on

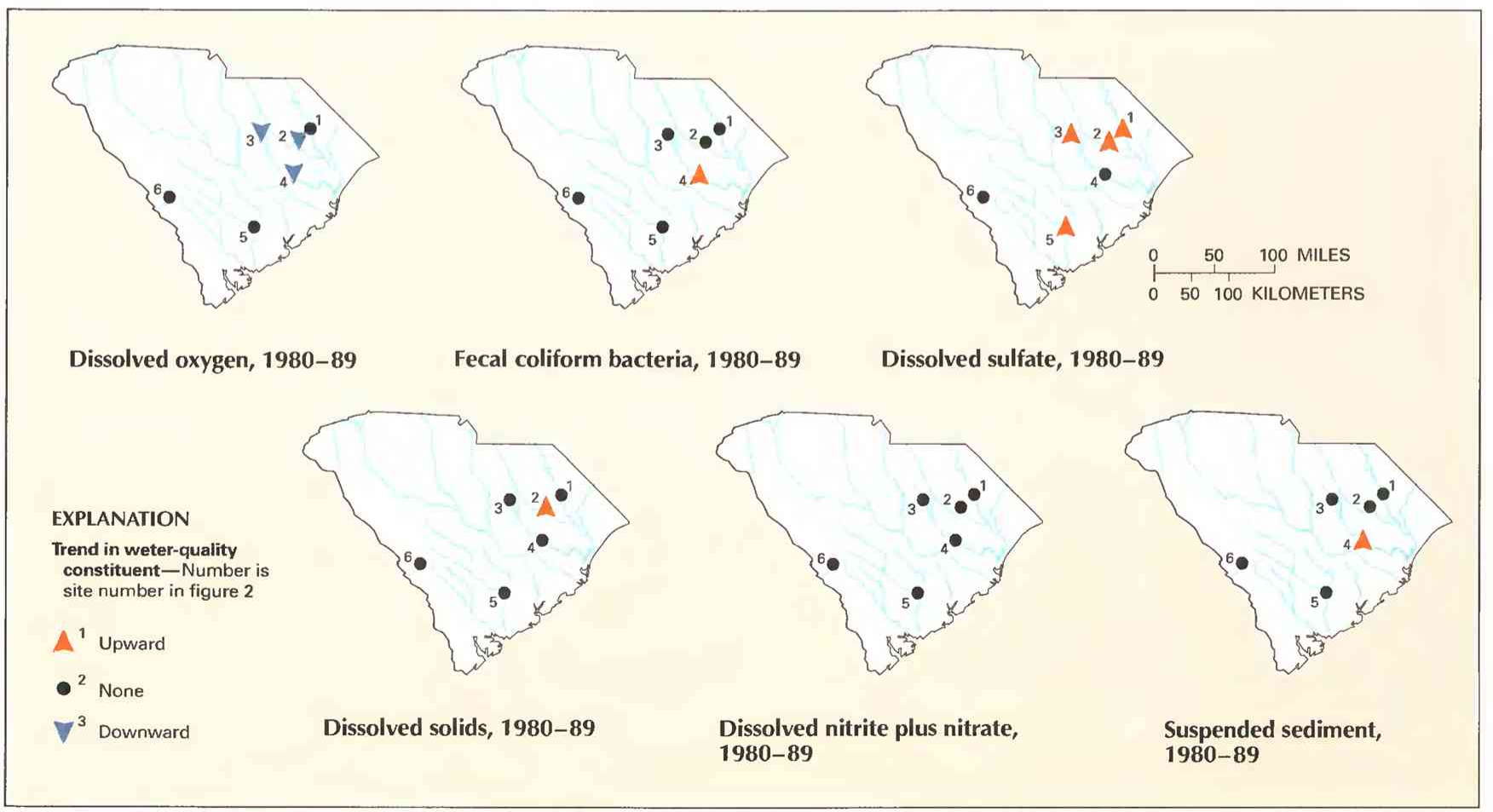

Figure 4. Trends in water quality of selected streams in South Carolina, by water years. (Source: Data from U.S. Geological Survey files.) 
the suitability criteria and on the trend-analysis procedure used for this report, see Lanfear and Alexander (1990).

\section{DISSOLVED OXYGEN}

The dissolved-oxygen concentration in a stream is controlled by several factors, including water temperature, air temperature and pressure, hydraulic characteristics of the stream, photosynthetic or respiratory activity of stream biota, and the quantity of organic material present. Generally, an upward trend in dissolved-oxygen concentrations indicates improving stream water-quality conditions and a downward trend indicates deteriorating conditions.

Concentrations of dissolved oxygen trended downward in the Lynches River, Scape Ore Swamp, and Black River at sites 2-4 (fig. 4), which are in swampy basins containing streams that are subject to low streamflow. No trends were detected in the Pee Dee and Edisto Rivers and Three Runs Creek at sites 1, 5, and 6; those streams have consistent streamflow. Concentrations generally ranged from 5 to $11 \mathrm{mg} / \mathrm{L}$ with a few values as low as $4 \mathrm{mg} / \mathrm{L}$ (fig. 3). Drought during 1985-88 (U.S. Geological Survey, 1991, p. 489-496) resulted in reduced flow and probably caused the downward trends in dissolved oxygen.

\section{FECAL COLIFORM BACTERIA}

Fecal coliform bacteria are used as indicators of fecal contamination from humans and other warm-blooded animals. Such contamination can introduce disease-causing viruses and bacteria into a stream. High concentrations of fecal coliform bacteria throughout the South Carolina Coastal Plain generally are sporadic and seasonal rather than long term.

High concentrations of fecal coliform bacteria occurred on several occasions in the Black River at site 4 during water years 1986-89 and resulted in the upward trend. The high concentrations might have been the result of increased survival of bacteria owing to lower dissolved-oxygen concentrations during the 1985-88 drought.

\section{DISSOLVED SULFATE}

The major natural sources of sulfate in streams are rock weathering, volcanoes, and biochemical processes (Hem, 1985, p. 113). Human activities such as mining, waste discharge, and fossil-fuel combustion also can be important sources.

Pyrite, a sulfur-bearing mineral, is a source of sulfate in the Coastal Plain. Upward trends in sulfate concentrations commonly are observed in the Southeastern United States and have been interpreted as the result of input from both terrestrial and atmospheric sources (Smith and others, 1987).

Sulfate concentrations had upward trends in the Pee Dee River at site 1, the Lynches River at site 2, Scape Ore Swamp at site 3, and the Edisto River at site 5. The upward trends in sulfate concentrations might reflect the greater contribution of more mineralized ground water to streamflow during the drought of the late 1980's.

Existing data on atmospheric deposition of sulfate are insufficient to allow comparison with trends in sulfate concentrations in the four streams. Precipitation in South Carolina during 1985-88 contained sulfate concentrations of between 0.5 and $4.0 \mathrm{mg} / \mathrm{L}$ but had no recognizable trend (National Atmospheric Deposition Program, 1989). Data on concentrations of sulfate in precipitation for South Carolina are not available for years prior to 1985 .

\section{DISSOLVED SOLIDS}

Dissolved solids in stream water result primarily from rock weathering but also can be introduced as a byproduct of human ac- tivities (table 1). Concentrations generally are greatest in streams draining basins underlain by rocks and soils that contain easily dissolved minerals. The upward trend in dissolved-solids concentrations in the Lynches River at site 2 (fig. 4) reflects the effects of groundwater discharge on water quality during the 1986-88 drought.

\section{DISSOLVED NITRITE PLUS NITRATE}

Nitrite and nitrate are oxidized forms of nitrogen that together constitute most of the dissolved nitrogen in well-aerated streams. Nitrite readily oxidizes to nitrate in natural waters; therefore, nitrate generally is by far the more abundant of the two (Hem, 1985, p. 124). The absence of trends for this constituent at any monitoring station (fig. 4) indicates that the net input of nitrite plus nitrate from nitrogen fertilizer, atmospheric deposition, and municipal and industrial wastewater discharge-all potential sources of nitrate (Smith and others, 1987)—did not change significantly during 1980-89.

\section{SUSPENDED SEDIMENT}

Suspended sediment is a product of erosion. The erosion can be either natural or the result of land-cover disturbances related to human activities (table 1).

Soil erosion in a basin and, consequently, the quantity of sediment contributed to streams, are affected by the extent of agriculture, urbanization, and silviculture. In five of the six monitored streams, the absence of a trend in suspended-sediment concentrations indicates an apparent equilibrium between soil erosion and the transportation and deposition of sediment in the stream channels. However, suspended-sediment concentrations trended upward in the Black River at site 4; the cause of the increasing concentrations is not known.

\section{WATER-QUALITY MANAGEMENT}

The South Carolina Department of Health and Environmental Control (SCDHEC) is responsible for monitoring water quality and regulating and enforcing policies for point- and nonpoint-source pollution in the State. The SCDHEC collects biological, physical, and chemical data from a network of 348 primary and secondary monitoring stations and prepares a biennial statewide water-quality assessment report (South Carolina Department of Health and Environmental Control, 1990a). This report is submitted to the EPA and the U.S. Congress in compliance with section 305 (b) of the Federal Clean Water Act. State water-quality standards under Regulation 61-68 of South Carolina Pollution Control Act and EPA criteria under the Federal Clean Water Act are applied when assessing the condition of surface-water resources (South Carolina Department of Health and Environmental Control, 1990b).

The SCDHEC directs the National Pollutant Discharge Elimination System program in the State to regulate the discharge of wastewater from municipal, domestic, industrial, and agricultural processing facilities. The SCDHEC also cooperates with the EPA in the Municipal Water Pollution Prevention Program to ensure that federally funded, publicly owned wastewater-treatment facilities comply with the terms of their permits.

The SCDHEC is the lead State agency on the nonpoint-source Task Force, which consists of 24 members representing Federal, State, and local agencies and environmental groups that have an interest in water quality and water resources (South Carolina Department of Health and Environmental Control, 1989). Regulatory programs for nonpoint-source pollution are administered under the State Nonpoint-Source 208 Water Quality Management Plan (South Carolina Department of Health and Environmental Control, 1990a).

The State Freshwater Wetlands Forum was established in 1989 and has recommended approaches to protect wetlands. Efforts are underway to enact a State freshwater-wetlands protection act. The 
U.S. Army Corps of Engineers currently administers a permitting program (subject to EPA approval) for dredging and filling of wetlands.

The USGS maintains 60 water-quality monitoring stations in South Carolina. The programs responsible for these stations include the USGS National Stream Quality Accounting Network, Hydrologic Bench-Mark Network, and various cooperative programs. Stream water-quality-related projects include modeling the waste-assimilating capacity of the Atlantic Intracoastal Waterway in cooperation with the Waccamaw Regional Planning and Development Commission, monitoring temperature of streams at the Savannah River Site for the U.S. Department of Energy, and modeling water quality in the Cooper River and Back River Reservoir in cooperation with the Charleston Commission of Public Works.

\section{SELECTED REFERENCES}

Anderson, J.R., 1967, Major land uses in the United States, in U.S. Geological Survey, 1970, National atlas of the United States of America: Washington, D.C., U.S. Geological Survey, p. 158-159.

Bates, Richard, 1989, Characteristics of Santee Swamp and the factors involved in fish kill episodes in upper Lake Marion, South Carolina: Columbia, South Carolina Department of Health and Environmental Control Technical Report SC P-001-90, 49 p.

Britton, L.J., and Greeson, P.E., eds., 1987, Methods for collection and analysis of aquatic biological and microbiological samples: U.S. Geological Survey Techniques of Water-Resources Investigations, book 5, chap. A4 $363 \mathrm{p}$.

Fenneman, N.M., 1946, Physical divisions of the United States: Washington, D.C., U.S. Geological Survey special map, scale 1:7,000,000.

Fishman, M.J., and Friedman, L.C., eds., 1989, Methods for the determination of inorganic substances in water and fluvial sediments: U.S. Geological Survey Techniques of Water-Resources Investigations, book 5, chap. A1, 545 p.

Guttman, N.B., and Plantico, M.S., 1987, Drought history and chances of recurrence, Southeastern Drought Symposium Proceedings, Columbia, S.C., March 4-5, 1987: South Carolina State Climatology Office Publication G-30, p. 4-7.

Hale, T.W., Hopkins, E.H., and Carter, R.F., 1989, Effects of the 1986 drought on streamflow in Alabama, Georgia, North Carolina, South Carolina, Tennessee, and Virginia: U.S. Geological Survey Water-Resources Investigations Report 89-4212, $102 \mathrm{p}$.

Hem, J.D., 1985, Study and interpretation of the chemical characteristics of natural water (3d ed.): U.S. Geological Survey Water-Supply Paper 2254, $263 \mathrm{p}$.

Hirsch, R.M., Slack, J.R., and Smith, R.A., 1982, Techniques of trend analysis for monthly water quality data: Water Resources Research, v. 18 no. 1 , p. 107-121.

Kovacik, C.F., and Winberry, John, 1987, South Carolina-A geography: Boulder, Colo., Westview Press, 235 p.
Lanfear, K.J., and Alexander, R.B., 1990, Methodology to derive water-quality trends for use by the National Water Summary Program of the U.S. Geological Survey: U.S. Geological Survey Open-File Report 90-359, $10 \mathrm{p}$.

National Atmospheric Deposition Program, 1989, NADP/NTN annual data summary-Precipitation of chemistry in the United States 1988: Fort Collins, National Trends Network Coordination Office, Natural Resource Ecology Laboratory, Colorado State University, 379 p.

Smith, R.A., Alexander, R.B., and Wolman, M.G., 1987, Analysis and interpretation of water-quality trends in major U.S. rivers, 1974-81: U.S. Geological Survey Water-Supply Paper 2307, 25 p.

Snyder, S.H., de Kozlowski, S.J., Harrigan, J.A., and others, 1983, South Carolina State water assessment: Columbia, South Carolina Water Resources Commission Report no. 140, 367 p.

South Carolina Department of Health and Environmental Control, 1989, Assessment of nonpoint source pollution for the State of South Carolina: Columbia, South Carolina Department of Health and Environmental Control, Bureau of Water Pollution Control, $147 \mathrm{p}$.

1990a, Statewide water quality assessment FY 1988-1989-Report to Congress pursuant to section 305(b) of the Federal Water Quality Act: Columbia, South Carolina Department of Health and Environmental Control, Office of Environmental Quality Control, 297 p.

1990b, Water classifications and standards (regulation 61-68), and classified waters (regulation 61-69): Columbia, South Carolina Department of Health and Environmental Control, Office of Environmental Quality Control, $58 \mathrm{p}$.

South Carolina Division of Research and Statistical Services, 1990, South Carolina statistical abstract, 1990: Columbia, South Carolina Division of Research and Statistical Services, Budget and Control Board, $308 \mathrm{p}$.

Thelin, G.P., and Pike, R.J., 1990, Digital shaded relief map of the conterminous United States: Menlo Park, Calif., U.S. Geological Survey digital image processing, scale 1:3,500,000.

U.S. Geological Survey, 1984, National water summary 1983 - Hydrologic events and issues: U.S. Geological Survey Water-Supply Paper 2250, $243 \mathrm{p}$.

1986, National water summary 1985 - Hydrologic events and surfacewater resources: U.S. Geological Survey Water-Supply Paper 2300, $506 \mathrm{p}$.

1989, Water resources data for South Carolina, water year 1989: U.S Geological Survey Water-Data Report SC-89-1 (published annually), $585 \mathrm{p}$.

1990, National water summary 1987-Hydrologic events and water supply and use: U.S. Geological Survey Water-Supply Paper 2350, $553 \mathrm{p}$.

1991, National water summary 1988-89-Hydrologic events and floods and droughts: U.S. Geological Survey Water-Supply Paper 2375, $591 \mathrm{p}$.

Ward, J.R., and Harr, C.A., eds., 1990, Methods for collection and processing of surface-water and bed-material samples for physical and chemical analyses: U.S. Geological Survey Open-File Report 90-140, 71 p.

Prepared by W.F. Falls and S.C. Lambert

FOR ADDITIONAL INFORMATION: District Chief, U.S. Geological Survey, 720 Gracern Road, Suite 129, Stephenson Center, Columbia, SC 29210-7651 


\section{SOUTH DAKOTA Stream Water Quality}

South Dakota relies on surface water for all categories of water use. Surface water supplied 63 percent ( 425 million gallons per day) of the total freshwater used in South Dakota in 1985. About 88 percent of the surface-water withdrawals were used for agricultural purposes (U.S. Geological Survey, 1990, p. 464). Surface water accounted for 77 percent of the State's freshwater use west of the Missouri River and 44 percent of freshwater use east of the Missouri River (U.S. Geological Survey, 1990, p. 459).

The quality of surface water can be affected by land use. Land use in South Dakota (fig. $1 A$ ) differs with physiography. The western two-thirds of the State is within the Great Plains province (fig. $1 B$ ), is underlain by thin soils over bedrock, and has a ranch-based economy. Within the Black Hills area, gold mining and forestry also contribute to the economy. The eastern one-third of South Dakota is in the Central Lowland province, is underlain by glacial deposits, and has a farm-based economy. The principal population centers in the State are along major rivers (figs. $1 C$ and 2). In 1990, South Dakota had a population of 696,000 -an increase of 0.76 percent since 1980 (U.S. Bureau of the Census 1990 decennial census files).

The Missouri River is the principal surface-water source in South Dakota; tributary streams within South Dakota contribute only about 12 percent of the flow leaving the State near Sioux City, Iowa. Many streams are intermittent and therefore do not provide a dependable water supply; reservoir storage is necessary to contain spring runoff and augment low flows during late summer, fall, and winter. Water quality of the tributary streams is suitable for most uses during high flows but commonly is unsuitable for many uses during low flows (U.S. Geological Survey, 1986, p. 419).

\section{WATER-QUALITY MONITORING}

Water-quality data obtained from analyses of water samples collected at monitoring stations are stored in the U.S. Geological Survey's (USGS) National Water Information System and the U.S. Environmental Protection Agency's (EPA) national data base known as STORET. Water-quality and streamflow data are reported by water year-the 12 months from October 1 through September 30. A water year is identified by the calendar year in which it ends. For example, water year 1991 comprises October 1, 1990, through September 30, 1991.

The data used in this summary of South Dakota's stream water quality were obtained from water samples collected either monthly or quarterly at 10 monitoring stations at which data collection is systematic and continuing (fig. 2). Analyses of water samples collected at 9 stations are the basis for the discussion and graphic summary (fig. 3) of stream water-quality conditions during water years 1987-89, and data from all 10 stations are the basis for the discussion and graphic summary (fig. 4) of stream water-quality trends. Water samples were collected and analyzed by using standard methods approved by the USGS (Britton and Greeson, 1987; Fishman and Friedman, 1989; Ward and Harr, 1990) or by using equivalent methods. If a method of sample collection or analysis changed over time, data from an analysis were included in the evaluation of recent stream water quality or of stream waterquality trends only if the change in method did not affect the comparability of the data.

\section{WATER-QUALITY CONDITIONS}

During 1988-89, the South Dakota Department of Environment and Natural Resources (DENR), formerly the Department of Water and Natural Resources, assessed 4,027 of the 9,937 stream miles in the State. Beneficial uses designated by the State for pur-
Figure 1. Land use, physiography, and population in South Dakota. A. Major land uses. B. Physiographic divisions. C. Population distribution in 1990. (Sources: A. Major land uses modified from Anderson, 1967. B, Physiographic divisions from Fenneman, 1946; landforms from Thelin and Pike, 1990. C, Data from U.S. Bureau of the Census 1990 decennial census files.) 
poses of water-quality monitoring and protection were not met in 26 percent of the stream miles assessed and only partially met in 44 percent of the stream miles (South Dakota Department of Water and Natural Resources, 1990, p. 4). Agriculture, urban runoff, and mining are important nonpoint sources of water-quality degradation in South Dakota streams.

The following discussion of stream water quality in South Dakota is organized by river basin (fig. 3 ). Where physiographic and land-use characteristics in different basins are similar, the discussion of those basins is combined. Graphs in figure 3 summarize certain aspects of stream water quality in the basins for water years 198789. The graphs show frequency distributions of data values that represent concentrations of selected stream-water constituents. These constituents are fecal streptococcal bacteria, dissolved sulfate, dissolved solids, dissolved nitrite plus nitrate (as nitrogen), dissolved phosphate (as phosphorus), dissolved selenium. and suspended sediment. The data are reported in colonies per 100 milliliters $(\mathrm{col} / 100$ $\mathrm{mL})$, milligrams per liter $(\mathrm{mg} / \mathrm{L})$, and micrograms per liter $(\mu \mathrm{g} / \mathrm{L})$. Sources and environmental significance of each constituent are described in table 1.

Water quality at each monitoring station is the result of geological, chemical, biological, and hydrologic processes that occur over a large area. Water-quality problems that affect aquatic life or public health only locally are not fully represented in this summary. Among the water-quality issues not discussed in this report are mer- cury in the Cheyenne River system, occasional releases of cyanide from gold mines in the Black Hills, and pesticides in streams in the eastern part of the State.

The Missouri River system drains the entire State, except for a small area (about 3 percent) in the northeastern corner. Almost the entire length of the Missouri River in South Dakota is backwater from four U.S. Army Corps of Engineers (COE) main-stem dams within the State. Water quality in several major tributaries to the Missouri River in South Dakota is discussed in this report. Tributaries for which water quality is not discussed, because of insufficient data, include the Little Missouri River (tributary to the Missouri River in North Dakota), Bad River, Vermillion River, and Keya Paha River (a tributary of the Niobrara River, which is tributary to the Missouri River in Nebraska).

\section{GRAND AND MOREAU RIVERS}

The Grand and Moreau River basins contain no large population centers. Ranching is the major economic activity in these basins; crop production is also important in the Grand River basin and to a lesser extent in the Moreau River basin.

During water years 1987-89, the Grand River contained large concentrations of sulfate (median, $660 \mathrm{mg} / \mathrm{L}$ ) and dissolved solids (median, 1,480 mg/L) at site 1 (fig. 3); most concentrations exceeded the State standards for domestic water supply (South Dakota Depart-

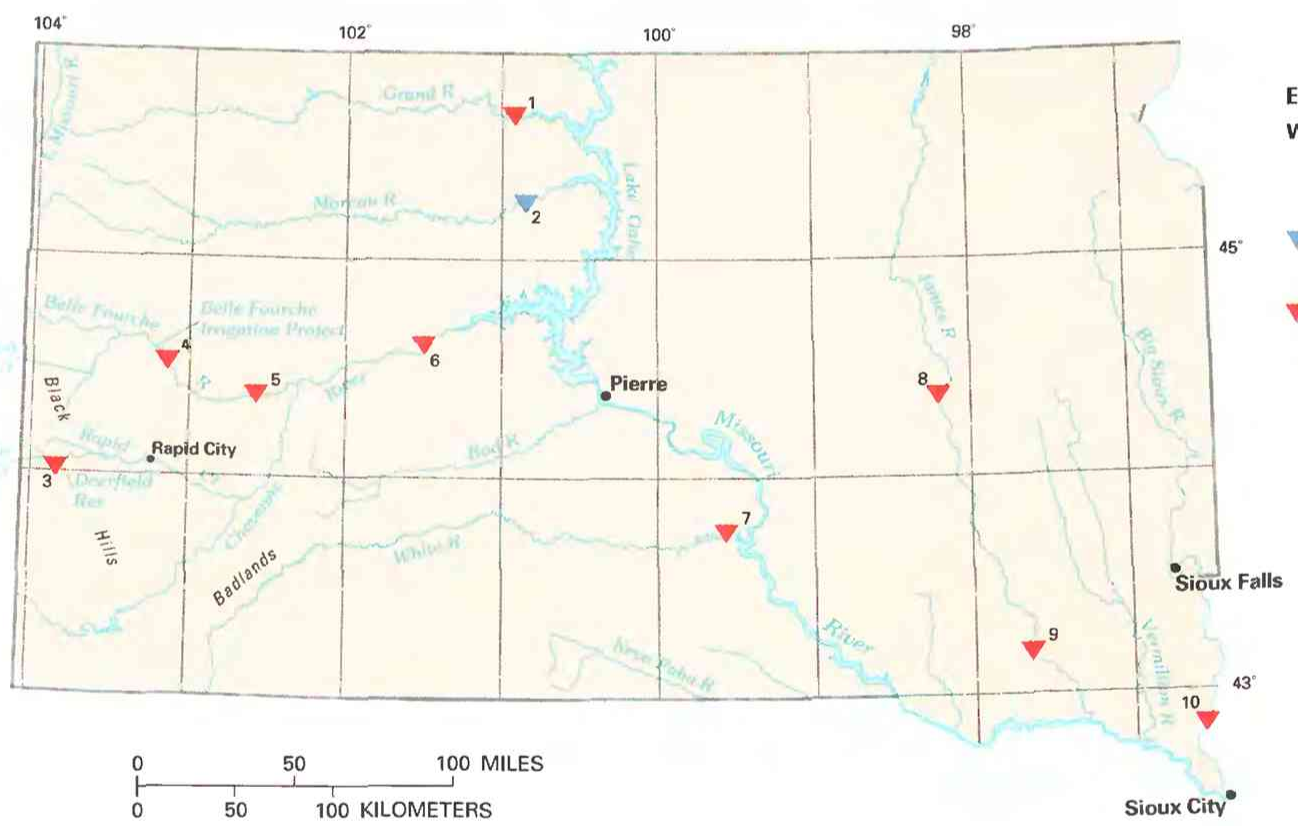

\section{EXPLANATION}

Water-quality monitoring station and type of statistical analysis-

Number refers to accompanying table

${ }^{2}$ Water-quality trends (see fig. 4)

$\nabla^{7}$ Water-quality conditions and trends (see figs. 3 and 4 )

\begin{tabular}{|c|c|c|c|}
\hline $\begin{array}{l}\text { Site no. } \\
\text { on map }\end{array}$ & $\begin{array}{l}\text { USGS station } \\
\text { name and no. }\end{array}$ & $\begin{array}{l}\text { Drainage area } \\
\text { (square miles) }\end{array}$ & $\begin{array}{l}\text { Major land use } \\
\text { (see fig. 1) }\end{array}$ \\
\hline 1 & Grand River at Little Eagle $(06357800)$ & 5,370 & $\begin{array}{l}\text { Subhumid grassland and semiarid grazing land; cropland with } \\
\text { grazing land. }\end{array}$ \\
\hline 2 & Moreau River near Whitehorse $\{06360500\}$ & 4,880 & Ditto. \\
\hline 3 & Castle Creek above Deerfield Reservoir, near Hill City (06409000) ... & 79.2 & Grazed forest and woodland. \\
\hline 4 & Belle Fourche River near Sturgis $(06437000)$ & 5,870 & Subhumid grassland and semiarid grazing land; irrigated land. \\
\hline 5 & 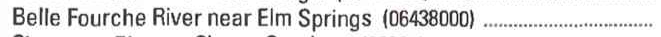 & 7,210 & Ditto. \\
\hline 6 & 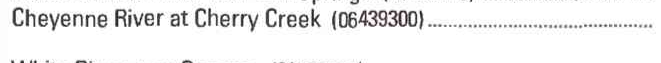 & 23,900 & $\begin{array}{l}\text { Subhumid grassland and semiarid grazing land; cropland with grazing } \\
\text { land; grazed forest and woodland. }\end{array}$ \\
\hline 7 & White River near Oacoma $(06452000)$ & 10,200 & $\begin{array}{l}\text { Subhumid grassland and semiarid grazing land; cropland with } \\
\text { grazing land. }\end{array}$ \\
\hline 8 & James River at Huron $(06476000)$ & 15,869 & Mostly cropland. \\
\hline 9 & James River near Scotland $(06478500)$ & 20,653 & Ditto. \\
\hline 10 & Big Sioux River at Akron, lowa $(06485500)$ & 8,424 & Ditto. \\
\hline
\end{tabular}

Figure 2. Selected water-quality monitoring stations, type of statistical analysis, and geographic features in South Dakota. (Sources: Major land uses modified from Anderson, 1967; other data from U.S. Geological Survey files.I 
ment of Water and Natural Resources, 1987). The Upper Cretaceous Pierre Shale, which contains gypsum, crops out adjacent to the Grand River. Dissolution of gypsum might account for the large sulfate and dissolved-solids concentrations.

\section{CASTLE CREEK}

Castle Creek is in a remote area of the Black Hills and is a headwater tributary to Rapid Creek - a tributary of the Cheyenne River. Site 3 on Castle Creek is a Hydrologic Bench-Mark Network station; the nationwide network consists of 53 surface-water stations operated by the USGS in small, pristine watersheds.

Median concentrations of fecal streptococcal bacteria $(17 \mathrm{col} /$ $100 \mathrm{~mL})$, sulfate $(7.2 \mathrm{mg} / \mathrm{L})$, dissolved solids $(249 \mathrm{mg} / \mathrm{L})$, and suspended sediment $(25 \mathrm{mg} / \mathrm{L})$ at site 3 were the smallest for any of the nine monitoring stations (fig. 3). Median concentrations of nitrite plus nitrate, phosphate, and selenium likewise were small and were at or less than the minimum reporting limit for the analytical methods used.

\section{CHEYENNE AND BELLE FOURCHE RIVERS}

The Cheyenne River enters South Dakota from Wyoming and joins the Missouri River. The Cheyenne River receives drainage from the southern Black Hills, the Plains area, the Badlands of South Dakota, and the Belle Fourche River, its main tributary. The Belle Fourche River drains the Plains area and the northern Black Hills of South Dakota and Wyoming. The average annual discharges of the Cheyenne and Belle Fourche Rivers are about equal at their confluence (Goddard, 1989, p. 5). The principal economic activity in the Plains part of the Cheyenne-Belle Fourche basin is agriculture. The major economic activity in the northern Black Hills is gold mining. Prior to December 1977, gold-mill tailings were discharged into Whitewood Creek, a tributary of the Belle Fourche River. About 20 million tons of sediment originating in gold-mill tailings is present in the flood plain of the Belle Fourche River downstream from Whitewood Creek (Marron, 1987, p. 205).

Median concentrations of sulfate and dissolved solids in the Cheyenne and Belle Fourche Rivers were larger than State standards for some designated uses (South Dakota Department of Water and Natural Resources, 1987). The median concentrations of sulfate at site $4(1,200 \mathrm{mg} / \mathrm{L})$, site $5(1,100 \mathrm{mg} / \mathrm{L})$, and site $6(1,100 \mathrm{mg} / \mathrm{L})$ (fig. 3) exceeded the State standard for domestic water supply. The large concentrations can be attributed to past runoff from gold-mill tailings that contained the mineral arsenopyrite (Goddard, 1989). Dissolution of gypsum from the Piere Shale also might be a cause of the relatively large sulfate concentrations. The median concentration
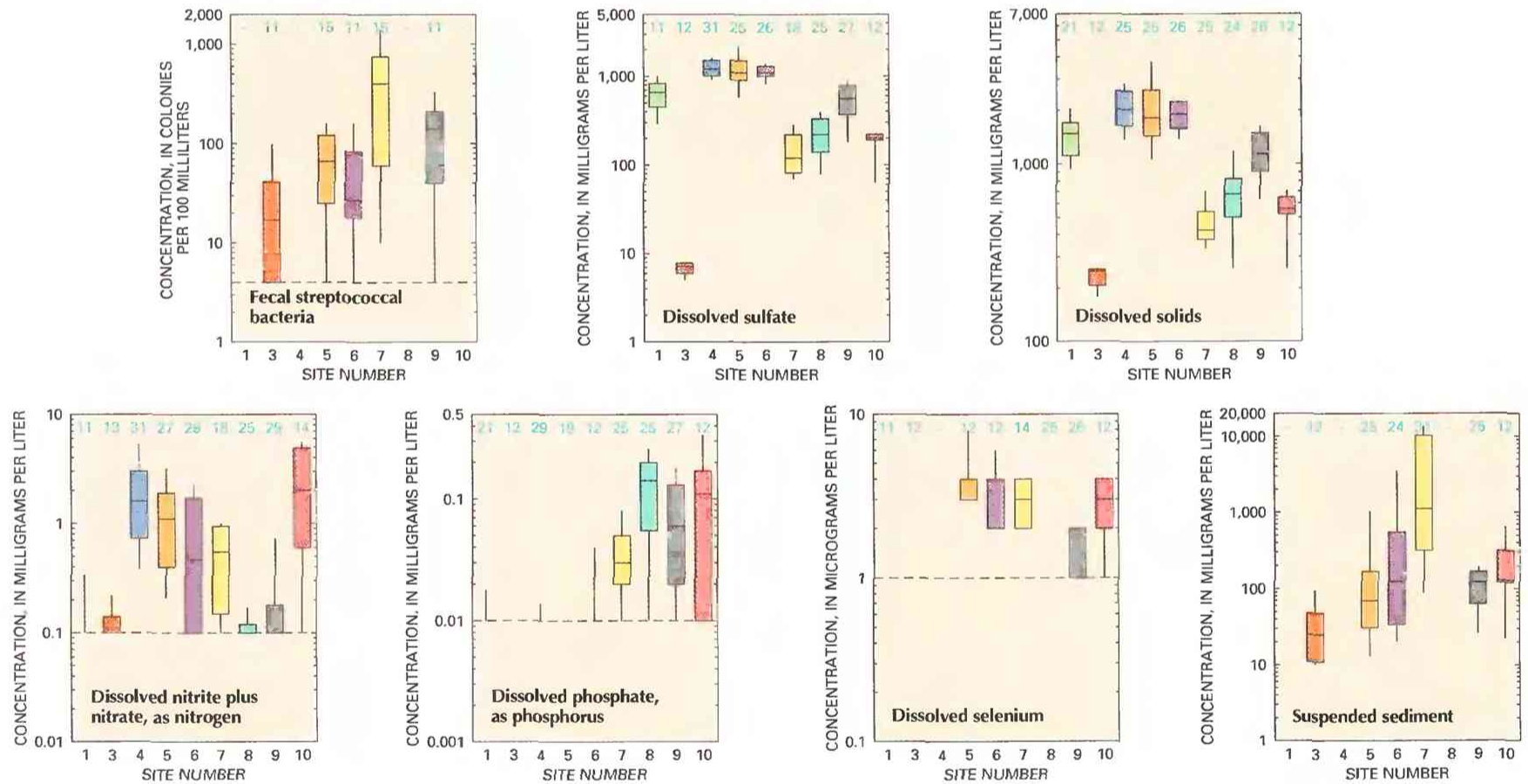

\section{EXPLANATION}
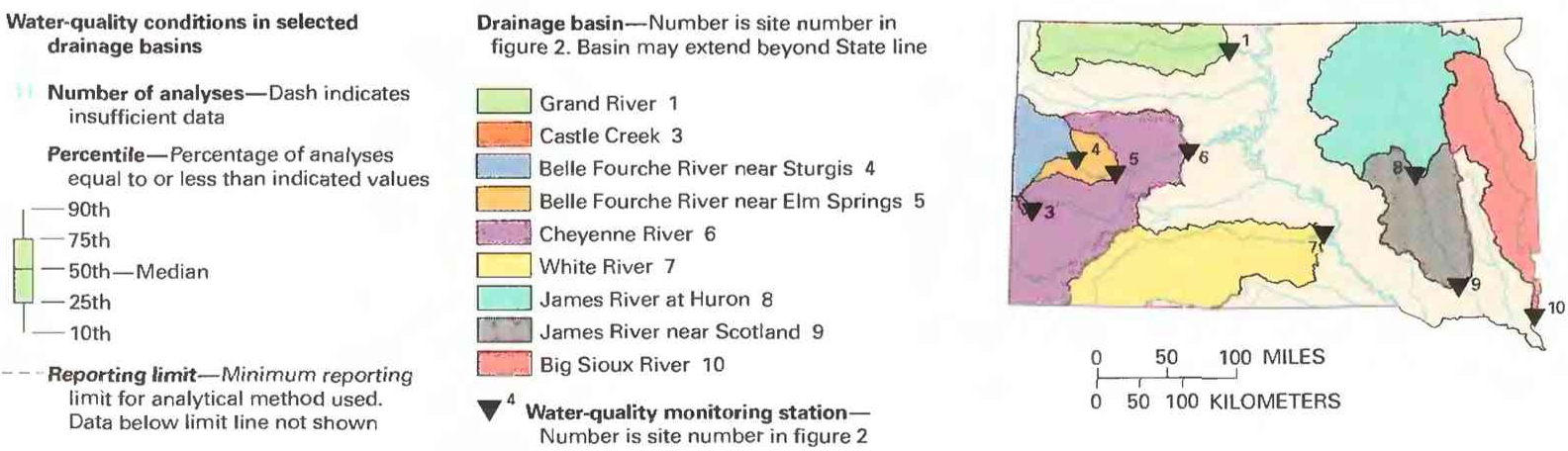

Figure 3. Water quality of selected streams in South Dakota, water years 1987-89. (Source: Data from U.S. Geological Survey files.) 
Table 1. Sources and environmental significance of selected water-quality constituents [Source: Compiled by the U.S. Geological Survey, Office of Water Quality]

\begin{tabular}{|c|c|c|}
\hline Constituent & Common sources & Environmental significance \\
\hline Fecal streptococcal bacteria ..... & $\begin{array}{l}\text { Sources include effluent from sewage-treatment } \\
\text { plants and runoff from pastures, feedlots, and ur- } \\
\text { ban areas. }\end{array}$ & $\begin{array}{l}\text { Presence indicates contamination of water by wastes } \\
\text { from humans and other warm-blooded animals. }\end{array}$ \\
\hline Sulfate & $\begin{array}{l}\text { Occurs in some rocks; also in mine runoff, industrial } \\
\text { wastewater discharge, and atmospheric deposi- } \\
\text { tion. }\end{array}$ & $\begin{array}{l}\text { Concentrations exceeding a natural, background } \\
\text { level indicate contamination from human activity; } \\
\text { in sufficient quantity, can cause water to be } \\
\text { unsuitable for public supply; can harm aquatic } \\
\text { organisms. }\end{array}$ \\
\hline 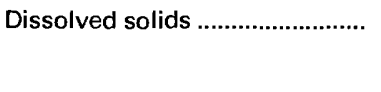 & $\begin{array}{l}\text { A result of rock weathering; also in agricultural runoff } \\
\text { and industrial discharge. }\end{array}$ & $\begin{array}{l}\text { In sufficient quantity, can cause water to be unsuitable } \\
\text { for public supply, agriculture, and industry; can } \\
\text { harm aquatic organisms. }\end{array}$ \\
\hline Nitrite plus nitrate ........................ & $\begin{array}{l}\text { Nonpoint sources are agricultural and urban runoff; } \\
\text { a major point source is wastewater discharge. }\end{array}$ & $\begin{array}{l}\text { Plant nutrient that, in sufficient quantity, can cause } \\
\text { algal blooms and excessive growth of higher } \\
\text { aquatic plants in bodies of water; can cause water } \\
\text { to be unsuitable for public supply. }\end{array}$ \\
\hline 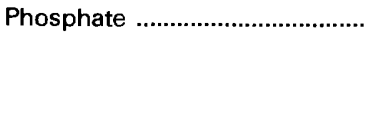 & $\begin{array}{l}\text { Occurs in some rocks and sediments; also in runoff } \\
\text { and seepage from phosphate-rock mines, agri- } \\
\text { cultural and urban runoff, and industrial and } \\
\text { municipal wastewater discharge. }\end{array}$ & $\begin{array}{l}\text { Plant nutrient that, in sufficient quantity, can cause } \\
\text { algal blooms and excessive growth of higher } \\
\text { aquatic plants in bodies of water. }\end{array}$ \\
\hline 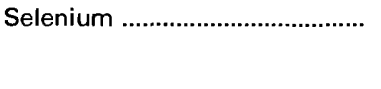 & $\begin{array}{l}\text { Occurs in some rocks and soils; can be leached from } \\
\text { arid lands by irrigation. }\end{array}$ & $\begin{array}{l}\text { Toxic in larger than trace concentrations; can cause } \\
\text { water to be unsuitable for public supply; can } \\
\text { harm aquatic organisms. }\end{array}$ \\
\hline Suspended sediment ................. & $\begin{array}{l}\text { A result of rock erosion; also induced by disturbances } \\
\text { of land cover due to fires, floods, and human } \\
\text { activities such as mining, logging, construction, } \\
\text { and agriculture. }\end{array}$ & $\begin{array}{l}\text { Can be detrimental to aquatic organisms; can fill res- } \\
\text { ervoirs and impair recreational use of water. }\end{array}$ \\
\hline
\end{tabular}

of dissolved solids $(2,027 \mathrm{mg} / \mathrm{L})$ in the Belle Fourche River at site 4 exceeded State standards for domestic water supply and for commercial and industrial use. The median concentration of dissolved solids at site $5(1,820 \mathrm{mg} / \mathrm{L})$ and site $6(1,910 \mathrm{mg} / \mathrm{L})$ exceeded the State standard for domestic water supply. The relatively large concentrations of nitrite plus nitrate at sites 4,5 , and 6 and selenium at sites 5 and 6 might have resulted from runoff from upstream irrigation.

\section{WHITE RIVER}

A large part of the White River drainage basin lies within the Badlands of South Dakota. Vegetation in the Badlands generally is sparse or absent, and the landscape is dominated by intersecting gullies cut through exposed and easily eroded claystone and siltstone. Streams draining the Badlands carry large loads of fine-grained suspended sediment. The White River at site 7 had the largest median concentration of suspended sediment $(1,110 \mathrm{mg} / \mathrm{L})$ for any of the monitoring stations (fig. 3).

The White River at site 7 had among the largest median concentrations of fecal streptococcal bacteria $(400 \mathrm{col} / 100 \mathrm{~mL})$ and of selenium $(3 \mu \mathrm{g} / \mathrm{L})$ for the nine monitoring stations. However, the concentrations did not exceed State standards. Livestock and community wastewater discharges might be sources of fecal streptococcal bacteria in the basin. Selenium in the White River might have originated in the basin soils. In western soils, selenium concentrations range from 0.039 to 1.4 micrograms per gram (Shacklette and Boergen, 1984, p. 84).

\section{JAMES AND BIG SIOUX RIVERS}

The James and Big Sioux Rivers, principal tributaries to the Missouri River in eastern South Dakota, are prairie streams that have similar characteristics. In both basins, high flows during spring and early summer can flood agricultural land, and low flows during late summer, fall, and winter can adversely affect water quality. Agricultural runoff may be a major source of pollutants in these basins. In the James River basin, nonagricultural causes of water-quality degradation include low flows in combination with small stream gradients and inadequately treated discharge from wastewater-treatment plants. A nonagricultural cause of water-quality degradation in the Big Sioux River might be urban runoff. The Big Sioux River basin contains the largest city in South Dakota (Sioux Falls) and is the most densely populated basin in the State.

Large concentrations of fecal streptococcal bacteria in the James River at site 9 (median, $140 \mathrm{col} / 100 \mathrm{~mL}$ ) might have been caused by a combination of agricultural runoff and inadequate treatment of wastewater. The James River contained large concentrations of sulfate (median, $560 \mathrm{mg} / \mathrm{L}$ ) and dissolved solids (median, 1,140 $\mathrm{mg} / \mathrm{L}$ ) that exceeded the State standards for domestic water supply (South Dakota Department of Water and Natural Resources, 1987). Large amounts of gypsum are present in the soils and underlying glacial till in the James River basin and might have been the source of the large sulfate and dissolved-solids concentrations. Large suspended-sediment concentrations in the James River at site 9 (median, $122 \mathrm{mg} / \mathrm{L}$ ) and in the Big Sioux River at site 10 (median, $128 \mathrm{mg} / \mathrm{L}$ ) probably were caused by runoff from agricultural land.

The median concentration of nitrite plus nitrate $(2.0 \mathrm{mg} / \mathrm{L})$ was larger for site 10 on the Big Sioux River than for any other monitoring station but did not exceed the State surface-water-quality standard. The Big Sioux aquifer, which is in hydraulic connection with the Big Sioux River, contains a relatively large concentration of nitrate, which might account for the larger nitrite plus nitrate concentrations in the river. Because phosphate readily precipitates or attaches to sediments, the large concentrations of dissolved phosphate (median, 0.11 $\mathrm{mg} / \mathrm{L}$ ) at site 10 probably were not caused by ground-water seepage.

\section{WATER-QUALITY TRENDS}

Trend analysis is a statistical procedure used to detect changes in stream water quality at a monitoring station over time. For this report, water-quality data from 10 monitoring stations (fig. 2) were analyzed for trends by using the seasonal Kendall test (Hirsch and others, 1982), a method used extensively by the USGS. The graph (above right) of the fecal streptococcal bacteria concentration in Castle Creek at site 3 illustrates the trend inferred from the concentration data and demonstrates the variation in water quality that is common in streams. 


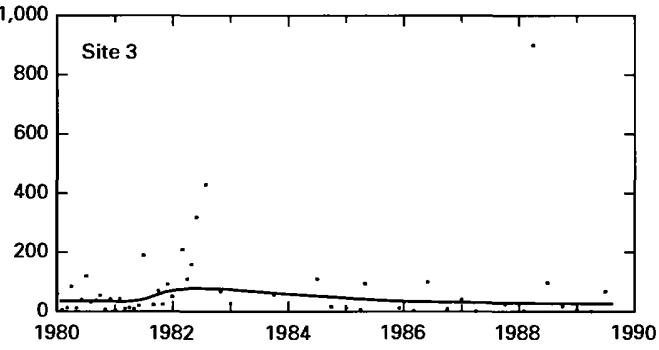

When possible, constituent-concentration data were adjusted for changes in streamflow to preclude identifying a trend in concentration that was caused only by a trend in streamflow. The data were not adjusted when (1) more than 10 percent of the samples had concentrations lower than the minimum reporting limit for the analytical method used or (2) streamflow was controlled substantially by human activities. When the concentration data could not be adjusted for streamflow, trends were determined directly from the concentration data.

Statewide trends in concentrations of selected stream-water constituents are shown on maps in figure 4. On each map, a trend is indicated at a monitoring station only if the data from that station were suitable for use in the trend analysis. For more information on the suitability criteria and on the trend-analysis procedure used for this report, see Lanfear and Alexander (1990).

\section{FECAL STREPTOCOCCAL BACTERIA}

Fecal streptococcal bacteria are indicators of fecal contamination from humans and other warm-blooded animals. The downward trend in fecal streptococcal bacteria in Castle Creek at site 3 (fig. 4) corresponds to changing land use. In 1982, the U.S. Forest Service purchased agricultural land adjacent to Castle Creek upstream from Deerfield Reservoir and returned the land to its natural state (G.C. Charles, U.S. Forest Service, oral commun., May 1990). The downward trend in fecal streptococcal bacteria concentrations probably is related to the cessation of grazing near the creek. A cause for the upward trend at site 7 on the White River is not known.

\section{DISSOLVED SULFATE}

The major natural sources of sulfate in streams are rock weathering, volcanoes, and biochemical processes (Hem, 1985, p. 113). Human activities such as mining, waste discharge, and fossil-fuel combustion also can be important sources.

A cause for the increasing sulfate concentration in the Moreau River at site 2 is not known (fig. 4). The upward trends in sulfate concentrations in the Belle Fourche River at site 5 and the Cheyenne River at site 6 might have been the result of more efficient use of irrigation water in the Belle Fourche Irrigation Project, which irrigates about 57,000 acres of the Belle Fourche River basin. The amount of water used for irrigation has decreased, and the contact time of irrigation water in soils has increased (R.A. Rahja, Agricultural Stabilization and Conservation Service, oral commun., May 1990).

\section{DISSOLVED SOLIDS}

Dissolved solids in stream water result primarily from rock weathering but also can be introduced as a byproduct of human activities (table 1). Concentrations generally are greatest in streams draining basins underlain by rocks and soils that contain easily dis- solved minerals. No significant trend in dissolved solids was detected at any of the eight monitoring stations (fig. 4).

\section{DISSOLVED NITRITE PLUS NITRATE}

Nitrite and nitrate are oxidized forms of nitrogen that together constitute most of the dissolved nitrogen in well-aerated streams. Nitrite readily oxidizes to nitrate in natural waters; therefore, nitrate generally is by far the more abundant of the two (Hem, 1985, p. 124).

No significant trend in dissolved nitrite plus nitrate was detected at any of the 10 monitoring stations (fig. 4). From 1982 to 1988, nitrogen-fertilizer use in South Dakota increased by almost 70 percent (Ranek, 1989). However, the fact that no upward trend in nitrite plus nitrate was detected at any of the monitoring stations indicates that there has been no significant change in the quantity of nitrogen fertilizer reaching South Dakota streams. During the same period (198288), nitrate concentrations have increased in some aquifers in South Dakota (Assad Barari, South Dakota Geological Survey, written commun., March 1990).

\section{DISSOLVED PHOSPHATE}

Phosphate is the oxidized form of phosphorus and the only form of significance in most natural waters. Small quantities of dissolved phosphate commonly are present in streams as a result of rock weathering. Normally, concentrations are no more than a few tenths of a milligram per liter (Hem, 1985, p. 126) and usually are much lower. Higher concentrations can indicate contamination from human activities (table 1). A shortened trend-analysis period was used for phosphorus because data from analyses performed prior to water years 1980-81 are not comparable to data for subsequent years.

From 1982 to 1988, phosphorus-fertilizer use in South Dakota increased by about 70 percent (Ranek, 1989). Nonetheless, concentrations had downward trends in the Grand River at site 1, in Castle Creek at site 3, in the Belle Fourche River at site 5, and in the White River at site 7 (fig. 4). The decreasing phosphate concentration at site 3 probably is related to the cessation of grazing near the streams, as discussed for fecal streptococcal bacteria trends. Reasons for the decreasing concentration at sites 1,5, and 7 are not known.

\section{DISSOLVED SELENIUM}

Selenium exists in nature generally as a trace element, but soils in some arid and semiarid regions of the United States contain more than trace amounts. Selenium in soils can be introduced into surface water by irrigation return flows. Although the area of irrigated land in South Dakota decreased by about 20 percent from 1980 to 1989 (Ranek, 1989), dissolved-selenium concentrations had no trend at six monitoring stations during that period (fig. 4).

\section{SUSPENDED SEDIMENT}

Suspended sediment is a product of erosion. The erosion can be either natural or the result of land-cover disturbances related to human activities (table 1).

Suspended-sediment concentration in rivers and streams is related to land use and agricultural practices in the basins. About 2.1 million acres of South Dakota cropland has been taken out of tillage farming through the Conservation Reserve Program (Randy Richards, Agricultural Stabilization and Conservation Service, written commun., May 1990). Although a decrease in suspended sediment might be expected as a result of the program, no significant trend was detected at six monitoring stations (fig. 4). 


\section{WATER-QUALITY MANAGEMENT}

State laws have established criteria for stream water quality in 11 beneficial water-use categories: domestic water supply, fish propagation (five categories), recreation (two categories), wildlife propagation and stock watering, irrigation, and commercial and industrial use. Water-quality criteria for these use categories are similar to those of the EPA and are listed in the 1987 Administrative Rules of South Dakota, Chapter 74:03:02 (South Dakota Department of Water and Natural Resources, 1987).
The State's water resources are managed through a record-andpermit system and a water plan administered by the DENR. Within the DENR, the Division of Water Rights and the Division of Environmental Regulation function as regulatory offices and provide staff to the Water Management Board. The Board performs all functions relating to water quality and control of water pollution. The Board also regulates and controls the development, conservation, and allocation of water rights according to principles of beneficial use and priority of appropriation.

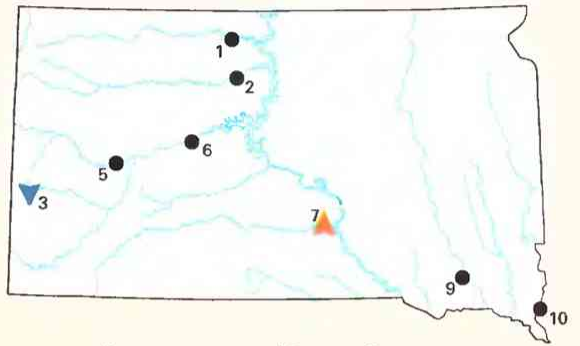

Fecal streptococcal bacteria, 1980-89

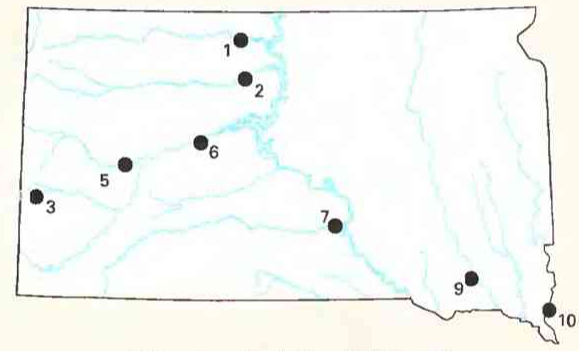

Dissolved solids, 1980-89

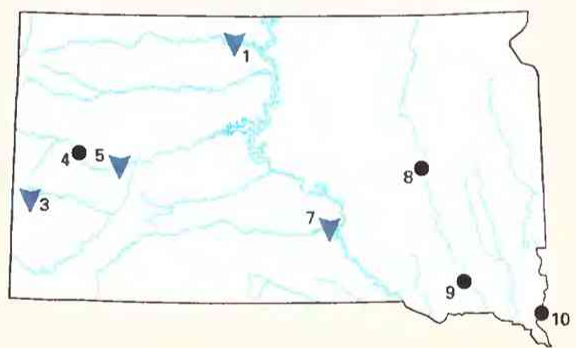

Dissolved phosphate, 1982-89

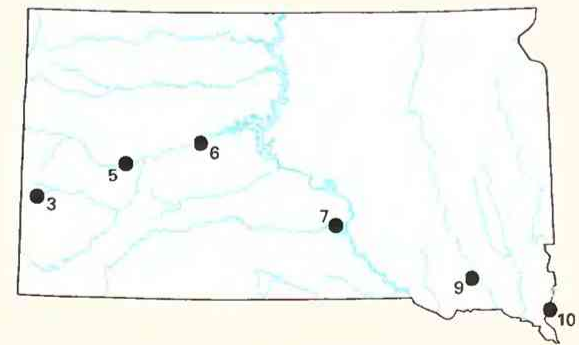

Suspended sediment, 1980-89

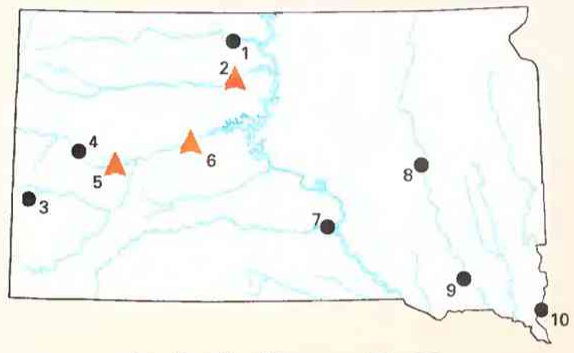

Dissolved sulfate, 1980-89

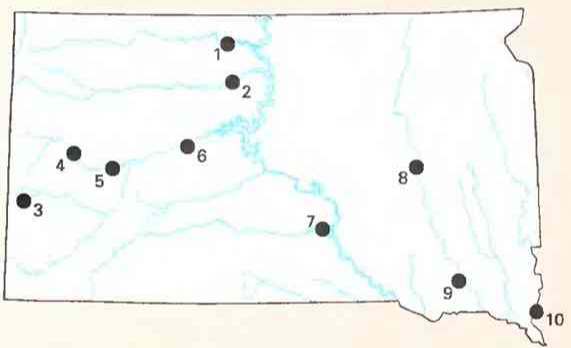

Dissolved nitrite plus nitrate, $1980-89$

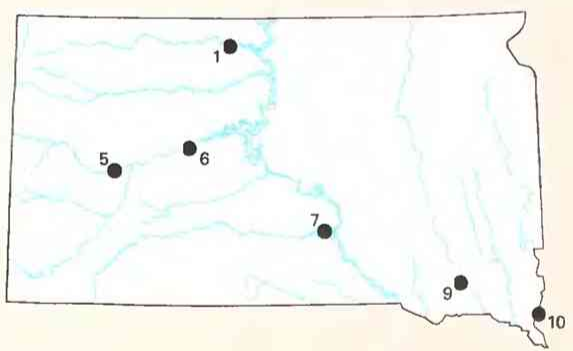

Dissolved selenium, 1980-89 $\begin{array}{r}0 \quad 50 \quad 100 \text { MILES } \\ \hline\end{array}$

$0 \quad 50 \quad 100$ KILOMETERS

\section{EXPLANATION}

Trend in water-quality constituentNumber is site number in figure 2

$$
\begin{aligned}
& \Delta^{2} \text { Upward } \\
& { }^{5} \text { None } \\
& \nabla^{3} \text { Downward }
\end{aligned}
$$

Figure 4. Trends in water quality of selected streams in South Dakota, by water years. (Source: Data from U.S. Geological Survey files.) 
The Division of Environmental Regulation reviews surfaceand ground-water-quality data to determine whether contamination is occurring or whether legal authority is required to protect the quality of water. Water quality in the State is assessed biannually in a report to the EPA and the U.S. Congress (South Dakota Department of Water and Natural Resources, 1990) mandated by Section 305(b) of the Federal Clean Water Act. This report also summarizes waterpollution-control programs. The report is based on statistical analysis of water-quality data from the DENR, EPA, COE, and the USGS; on the results of specialized investigations; and on observations from DENR personnel who collect water samples.

Two groups advise the State Board of Water and Natural Resources. The Nonpoint Source Task Force consists of representatives from Federal, State, and local agencies concerned with water and land management, and the Ground-Water Research and Advisory Group consists of representatives from the private sector.

Water-quality monitoring from 1970 to 1990 generally has increased throughout South Dakota. The increase in monitoring primarily has been in response to Federal legislation relating to general water quality, increased mining activity in the Black Hills, and concern about the increasing use of agricultural chemicals. The four agencies principally responsible for water-quality monitoring in the State-the DENR, the USGS, the COE, and the U.S. Forest Serviceincreased water-quality monitoring during the 1970's. During the 1980 's, monitoring by the DENR and the USGS has increased, monitoring by the COE remained constant, and monitoring by the U.S. Forest Service decreased (J.M. Bortnem, South Dakota Division of Environmental Regulation, written commun., March 1990).

\section{SELECTED REFERENCES}

Anderson, J.R., 1967, Major land uses in the United States, in U.S. Geological Survey, 1970, National atlas of the United States of America: Washington, D.C., U.S. Geological Survey, p. 158-159.

Britton, L.J., and Greeson, P.E., eds., 1987, Methods for collection and analysis of aquatic biological and microbiological samples: U.S. Geological Survey Techniques of Water-Resources Investigations, book 5, chap. A4, $363 \mathrm{p}$.

Fenneman, N.M., 1946, Physical divisions of the United States: Washington, D.C., U.S. Geological Survey special map, scale 1:7,000,000.

Fishman, M.J., and Friedman. L.C., eds., 1989, Methods for the determination of inorganic substances in water and fluvial sediments: U.S. Geological Survey Techniques of Water-Resources Investigations, book 5, chap. A1, 545 p.
Goddard, K.E., 1988, Gold-mill-tailings contamination of the Cheyenne River system, western South Dakota, in Mallard, G.E., ed., U.S. Geological Survey toxic substances hydrology program-Surface-water contamination: U.S. Geological Survey Open-File Report 87-764, p. 1-9. 1989, Composition, distribution, and hydrologic effects of contaminated sediments resulting from discharge of gold-milling wastes to Whitewood Creek at Lead and Deadwood, South Dakota: U.S. Geological Survey Water-Resources Investigations Report 87-4051, 76 p.

Hem, J.D., 1985, Study and interpretation of the chemical characteristics of natural water (3d ed.): U.S. Geological Survey Water-Supply Paper 2254, $263 p$.

Hirsch, R.M., Slack, J.R., and Smith, R.A., 1982, Techniques of trend analysis for monthly water quality data: Water Resources Research, v. 18, no. 1, p. 107-121.

Lanfear, K.J, and Alexander, R.B., 1990, Methodology to derive water-quality trends for use by the National Water Summary Program of the U.S. Geological Survey: U.S. Geological Survey Open-File Report 90-359, $10 \mathrm{p}$.

Marron, D.C., 1987, Floodplain storage of metal-contaminated sediments downstream of a gold mine at Lead, South Dakota, in Averett, R.C., and McKnight, D.M., eds., Chemical quality of water and the hydrologic cycle: Chelsea, Mich., Lewis Publishers, Inc., p. 193-209.

Ranek, J.C., compiler, 1989, South Dakota agricultural statistics: Sioux Falls, South Dakota Agricultural Statistics Service, 76 p.

Shacklette, H.T., and Boergen, J.B., 1984, Element concentrations in soils and other surficial materials of the conterminous United States: U.S. Geological Survey Professional Paper 1270, $105 \mathrm{p}$.

South Dakota Department of Water and Natural Resources, 1987, Administrative rules of South Dakota, South Dakota Water Quality Law, Chapter 74:03:02, Surface Water Quality Standards: Pierre, South Dakota Department of Water and Natural Resources, $29 \mathrm{p}$.

1990. The 1990 South Dakota report to Congress-The 1990 305(b) water-quality assessment: Pierre, South Dakota Department of Water and Natural Resources, $207 \mathrm{p}$.

Thelin, G.P., and Pike, R.J., 1990, Digital shaded relief map of the conterminous United States: Menlo Park, Calif., U.S. Geological Survey digital image processing, scale 1:3,500,000.

U.S. Geological Survey, 1986, National water summary 1985--Hydrologic events and surface-water resources: U.S. Geological Survey Water-Supply Paper 2300, $506 \mathrm{p}$.

1990, National water summary 1987-Hydrologic events and water supply and use: U.S. Geological Survey Water-Supply Paper 2350 $553 \mathrm{p}$.

Ward, J.R., and Harr, C.A., eds., 1990, Methods for collection and processing of surface-water and bed-material samples for physical and chemical analyses: U.S. Geological Survey Open-File Report 90-140, 71 p. 
Prepared by Thomas E. McKallip

FOR ADDITIONAL INFORMATION: District Chief, U.S. Geological Survey, 1608 Mountain View Road, Rapid City, SD 57702 


\section{TENNESSEE Stream Water Quality}

Abundant precipitation (about 48 inches annually) provides Tennessee with a large supply of stream water (U.S. Geological Survey, 1986, p. 425-430). Surface-water withdrawals for offstream use in 1985 averaged $8,010 \mathrm{Mgal} / \mathrm{d}$ (million gallons per day), or 95 percent of the combined surface- and ground-water withdrawals for offstream use. The major offstream uses of surface water were thermoelectric power generation $(6,060 \mathrm{Mgal} / \mathrm{d})$, industrial supply $(1,510$ $\mathrm{Mgal} / \mathrm{d}$ ), and public supply for domestic, commercial, and industrial use (384 Mgal/d) (U.S. Geological Survey, 1990, p. 469-472). Surface water is the principal source for public supply in central and eastern Tennessee, where ground-water resources are limited.

Most of Tennessee's stream water is suitable for all uses designated by the State (Tennessee Department of Health and Environment, 1990, p. 2). These designated uses are domestic, commercial, and industrial water supply; propagation and maintenance of aquatic life; wildlife maintenance; livestock watering; irrigation; navigation; recreation; and enjoyment of scenic and esthetic qualities (Tennessee Department of Health and Environment, 1987, p. 1). The relative importance assigned to each designated use differs within and among drainage basins.

The suitability of stream water for its designated uses can be affected by land use. Land use in Tennessee (fig. 1A) is determined in part by physiography. Rolling hills and broad flood plains in the Coastal Plain province (fig. $1 B$ ) support the greatest concentration of agricultural activity. Thin soils in the Western Valley and Cumberland Plateau are inadequate for farming; therefore, those areas remain predominantly forested. Gently rolling areas within the Valley and Ridge province, Highland Rim, Central Basin, and Sequat- chie Valley support some cropland and pasture in addition to forest. Land in the Blue Ridge province of eastern Tennessee is rugged and densely forested.

The Cumberland, Tennessee, and Mississippi Rivers are the major streams in Tennessee. In the drainage basins of the Cumberland and Tennessee Rivers, reservoirs provide flood control, navigation routes, electric power, and water supplies for growing population centers (fig. $1 C$ ) along the rivers. The State's 1990 population was 4.9 million-an increase of 6.2 percent from 1980 (U.S. Bureau of the Census 1990 decennial census files).

\section{WATER-QUALITY MONITORING}

Water-quality data obtained from analyses of water samples collected at monitoring stations are stored in the U.S. Geological Survey's (USGS) National Water Information System and the U.S. Environmental Protection Agency's (EPA) national data base known as STORET. Water-quality and streamflow data are reported by water year - the 12 months from October 1 through September 30. A water year is identified by the calendar year in which it ends. For example, water year 1991 comprises October 1, 1990, through September 30, 1991.

The data used in this summary of Tennessee's stream water quality were obtained from water samples collected at 11 monitoring stations at which data collection is systematic and continuing (fig. 2). Analyses of water samples collected at 10 stations are the basis for the discussion and graphic summary (fig. 3) of stream waterquality conditions for water years 1987-89, and data from 8 stations

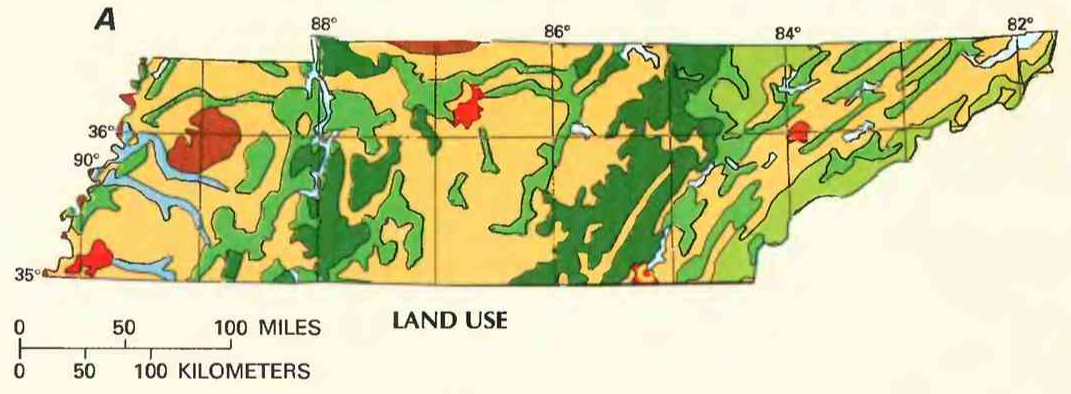

B

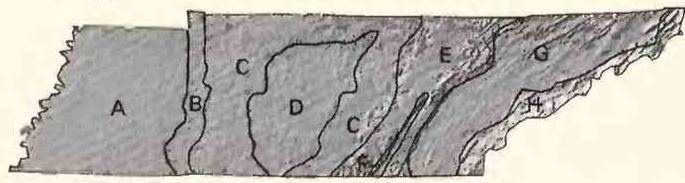

PHYSIOGRAPHIC DIVISIONS

\section{EXPLANATION}

Physiographic divisions

A. Coastal Plain province B. Western Valley

C. Highland Rim section

D. Central Basin
F. Sequatchie Valley

G.Vallay and Ridge province

H. Blue Ridge province
E. Cumberland Plateau section
EXPLANATION

Land use

Mostly cropland

Cropland with pasture, woodland, and forest

Woodland and forest with some cropland and pasture

Forest and woodland grazed

Forest and woodland mostly ungrazed

Swamp

Water body

Urban area

Population-Each dot on the map represents 1,000 people

Figure 1. Land use, physiography, and population in Tennessee. A, Major land uses. B, Physiographic divisions. $C$, Population distribution in 1990. ISources: A, Major land uses modified from Anderson, 1967. B, Physiographic divisions from Fenneman, 1946, and Miller, 1974; landforms from Thelin and Pike, 1990. C, Data from U.S. Bureau of the Census 1990 decennial census files.) 
are the basis for the discussion and graphic summary (fig. 4) of stream water-quality trends. Water samples were collected and analyzed by using standard methods approved by the U.S. Geological Survey (Britton and Greeson, 1987; Fishman and Friedman, 1989; Ward and Harr, 1990) or by using equivalent methods. If a method for sample collection or analysis changed over time, data from an analysis were included in the evaluation of recent stream water quality or of stream water-quality trends only if the change in method did not affect the comparability of the data.

\section{WATER-QUALITY CONDITIONS}

Water years 1985-88 were periods of severe drought in Tennessee, particularly in the eastern part. Precipitation during water years 1987-88 was about 75 percent of normal, and even less during the summers. Streamflow was about 50 percent of normal (U.S. Geological Survey, 1991, p. 511) and, during the summer, was dominated by ground-water discharge. In contrast. precipitation in water year 1989 was about 130 percent of normal. These extremes in precipitation substantially affected the water quality of streams and the many large reservoirs in the State (Neil E. Carriker, Tennessee Valley Authority, written commun., November 1989).

In 1990, water in 51 stream segments contained levels of toxic or other chemicals that exceeded criteria established by the Tennessee Department of Health and Environment (1990, p. 81-84) for the protection of public health. These stream segments, totaling 193 miles or about 1 percent of the 19,000 stream miles in the State, were posted by the Department as unusable or unsafe. Excessive concentrations of fecal coliform bacteria in reaches downstream from municipal sewage-treatment plants were cited as a common problem. In general, however, the major causes of degraded water quality in the State were nonpoint sources such as agricultural activities, stream channelization, mining, and urban runoff. Contamination from these sources affected more than 3,300 stream miles in 1990 (Tennessee Department of Health and Environment, 1990, p. 10). Die-offs of mussels, as well as tainted flesh, skeletal deformities, and disease in catfish, have prompted several water-quality investigations at Kentucky Lake reservoir (fig. 2). Continuing investigations have identified several potential causes, including low dissolved-oxygen concentrations during drought, siltation, industrial and municipal wastewater discharges, application of aquatic herbicides, and agricultural runoff.

The following discussion of stream water quality in Tennessee is organized by river basin (fig. 3). Where physiographic and landuse characteristics in different basins are similar, the discussion of those basins is combined. Graphs in figure 3 summarize certain aspects of stream water quality in the basins for water years 1987-89. The graphs show frequency distributions of data values that represent concentrations of selected stream-water constituents. These constituents are dissolved oxygen, fecal coliform bacteria, dissolved sulfate, dissolved solids, dissolved nitrite plus nitrate (as nitrogen), dissolved phosphorus (as phosphorus), and suspended sediment. The data are reported in milligrams per liter $(\mathrm{mg} / \mathrm{L})$ and colonies per 100 milliliters (col/100 mL). Sources and environmental significance of each constituent are described in table 1 .

Water quality at each monitoring station is the result of geological, chemical, biological, and hydrologic processes that occur over a large area. Water-quality problems that affect aquatic life or public health only locally are not fully represented in this summary.

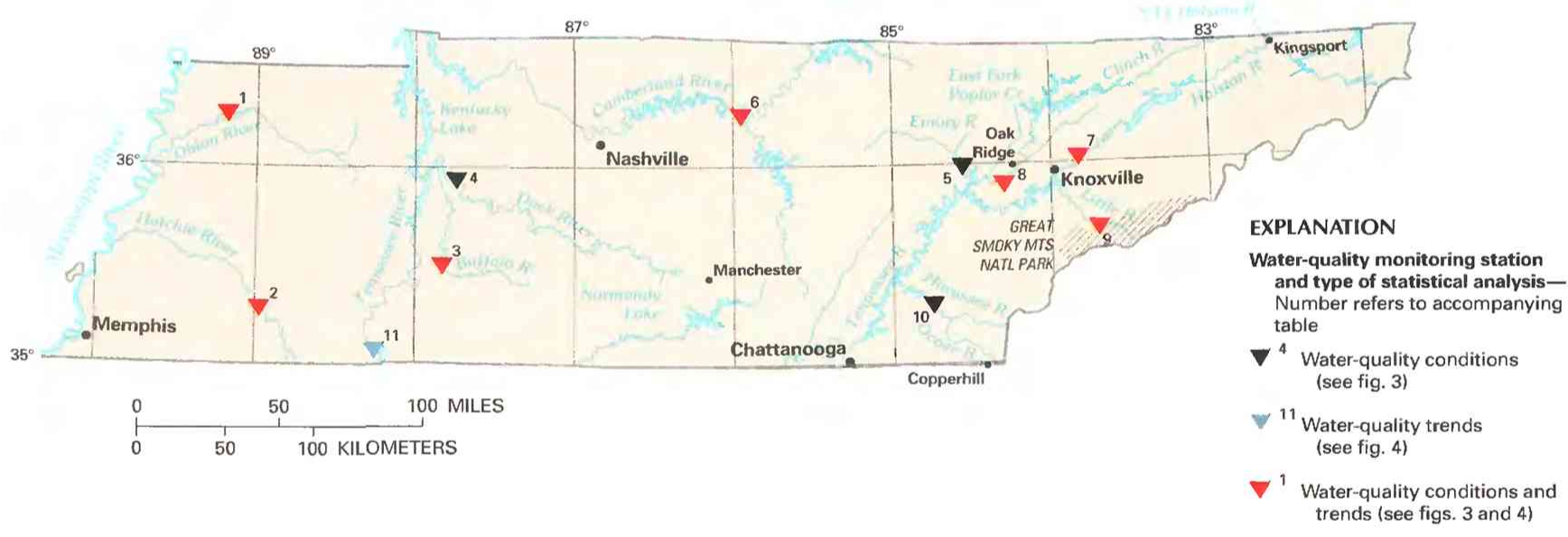

\begin{tabular}{|c|c|c|c|}
\hline $\begin{array}{l}\text { Site no. } \\
\text { on map }\end{array}$ & $\begin{array}{l}\text { USGS station } \\
\text { name and no. }\end{array}$ & $\begin{array}{l}\text { Drainage area } \\
\text { (square miles) }\end{array}$ & $\begin{array}{l}\text { Major land use } \\
\text { (see fig. 1) }\end{array}$ \\
\hline 1 & Obion River at Obion $(07026000)$ & 1,852 & Cropland with pasture, woodland, and forest; mostly cropland. \\
\hline 2 & Hatchie River at Bolivar $(07029500)$ & 1,480 & $\begin{array}{l}\text { Cropland with pasture, woodland, and forest; woodland and forest } \\
\text { with some cropland and pasture. }\end{array}$ \\
\hline 3 & Buffalo River near Flat Woods $(03604000)$ & 477 & $\begin{array}{l}\text { Grazed forest and woodland; woodland and forest with some } \\
\text { cropland and pasture. }\end{array}$ \\
\hline 4 & Duck River above Hurricane Mills' $(03603000)$ & 2,557 & Cropland with pasture, woodland, and forest. \\
\hline 5 & Emory River at Oakdale' $(03540500)$ & 764 & Grazed forest and woodland. \\
\hline 6 & Cumberland River at Carthage $(03425000)$ & 10,690 & $\begin{array}{l}\text { Grazed forest and woodland; cropland with pasture, woodland, } \\
\text { and forest. }\end{array}$ \\
\hline 7 & Holston River near Knoxville $(03495500)$ & 3,747 & Woodland and forest with some cropland and pasture. \\
\hline 8 & 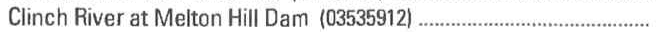 & 3,343 & Cropland with pasture, woodland, and forest. \\
\hline 9 & Little River above Townsend $(03497300)$ & 106 & Mostly ungrazed forest and woodland. \\
\hline 10 & 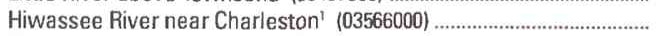 & 2,298 & Ditto. \\
\hline 11 & 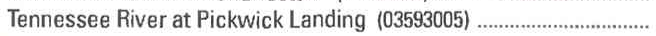 & 38,820 & Cropland with pasture, woodland, and forest. \\
\hline
\end{tabular}

'Station operated by Tennessee Valley Authority (1974).

Figure 2. Selected water-quality monitoring stations, type of statistical analysis, and geographic features in Tennessee. (Sources: Major land uses modified from Anderson, 1967; other data from U.S. Geological Survey files.) 


\section{OBION AND HATCHIE RIVERS}

The drainage basins of the Obion and Hatchie Rivers are in the Coastal Plain province, which is underlain by loess, sand, gravel, and clay. In this area, stream water contains low concentrations of dissolved minerals. However, many streams in western Tennessee carry large sediment loads because soils in the agricultural areas are easily eroded.

Upstream from site 1, streams in the Obion River drainage basin have been extensively channelized to drain wetland areas and to promote agriculture. Agriculture is the dominant land use affecting water quality in the basin. Median (50th-percentile) concentrations of nitrite plus nitrate $(0.52 \mathrm{mg} / \mathrm{L})$ and suspended sediment $(131$ $\mathrm{mg} / \mathrm{L}$ ) were higher for site 1 than for those at any other monitoring station (fig. 3). High concentrations of fecal coliform bacteria are an additional, recurring water-quality concern (Tennessee Department of Health and Environment, 1990, p. 33).

Land use in the Hatchie River drainage basin is similar to that in the nearby Obion River basin. except that the upper part of the basin, which is in Mississippi, is more heavily forested. The lack of channelization and agriculture within the flood plain adjacent to the Hatchie River main stem probably accounts for the lower median concentrations of nitrite plus nitrate $(0.23 \mathrm{mg} / \mathrm{L})$ and suspended sediment $(37 \mathrm{mg} / \mathrm{L}$ ) for site 2 compared to those in the Obion River (Tennessee Department of Health and Environment, 1990, p. 27). However, concentrations of fecal coliform bacteria at site 2 sometimes exceed the criterion of $1,000 \mathrm{col} / 100 \mathrm{~mL}$ for an individual sample that was established by the State (Tennessee Department of Health and Environment, 1987) to protect recreational water use.

\section{BUFFALO RIVER}

The Buffalo River drainage basin lies entirely within the Highland Rim. Because the limestone and overlying soils of this section have been extensively weathered, leaving little soluble material behind, streams draining these areas contain low concentrations of dissolved minerals (Tennessee Valley Authority, 1963, p. 7). As a result of the steep slopes and leached soil, land in most of the section remains forested; small cleared areas are used mainly for growing hay and grazing. Thus, water quality in the Buffalo River drainage basin upstream from site 3 has been altered only minimally by human activity. Median concentrations of nitrite plus nitrate $(0.16 \mathrm{mg} / \mathrm{L})$ and suspended sediment $(7 \mathrm{mg} / \mathrm{L})$ were among the lowest for the 10 monitoring stations (fig. 3). In some areas of the basin, however,
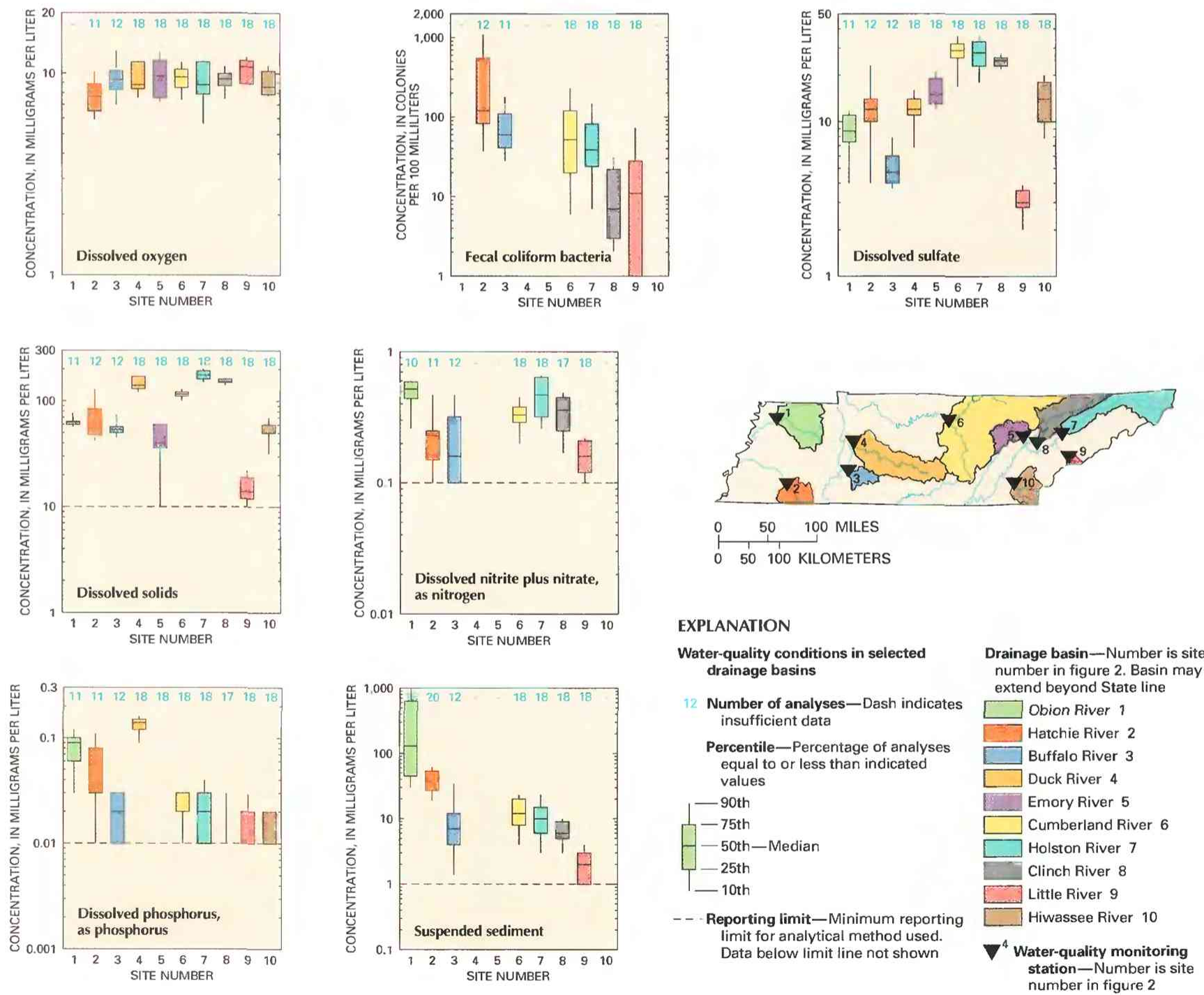

Figure 3. Water quality of selected streams in Tennessee, water years 1987-89. (Source: Data from U.S. Geological Survey and Tennessee Valley Authority files.) 
Table 1. Sources and environmental significance of selected water-quality constituents [Source: Compiled by the U.S. Geological Survey, Office of Water Quality]

\begin{tabular}{|c|c|c|}
\hline Constituent & Common sources & Environmental significance \\
\hline Dissolved oxygen ........................ & $\begin{array}{l}\text { Introduced from the atmosphere; also a byproduct of } \\
\text { aquatic plants. }\end{array}$ & $\begin{array}{l}\text { Necessary for aquatic life; deficiency can result from } \\
\text { assimilation of organic wastes or rapid growth } \\
\text { and decay of algae. }\end{array}$ \\
\hline Fecal coliform bacteria ................ & $\begin{array}{l}\text { Sources include effluent from sewage-treatment } \\
\text { plants and runoff from pastures, feedlots, and ur- } \\
\text { ban areas. }\end{array}$ & $\begin{array}{l}\text { Presence indicates contamination of water by wastes } \\
\text { from humans and other warm-blooded animals. }\end{array}$ \\
\hline Sulfate & $\begin{array}{l}\text { Occurs in some rocks; also in mine runoff, industrial } \\
\text { wastewater discharge, and atmospheric deposi- } \\
\text { tion. }\end{array}$ & $\begin{array}{l}\text { Concentrations exceeding a natural, background } \\
\text { level indicate contamination from human activity; } \\
\text { in sufficient quantity, can cause water to be } \\
\text { unsuitable for public supply; can harm aquatic } \\
\text { organisms. }\end{array}$ \\
\hline 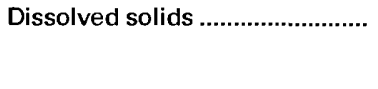 & $\begin{array}{l}\text { A result of rock weathering; also in agricultural runoff } \\
\text { and industrial discharge. }\end{array}$ & $\begin{array}{l}\text { In sufficient quantity, can cause water to be unsuitable } \\
\text { for public supply, agriculture, and industry; can } \\
\text { harm aquatic organisms. }\end{array}$ \\
\hline Nitrite plus nitrate ........................ & $\begin{array}{l}\text { Nonpoint sources are agricultural and urban runoff; } \\
\text { a major point source is wastewater discharge. }\end{array}$ & $\begin{array}{l}\text { Plant nutrient that, in sufficient quantity, can cause } \\
\text { algal blooms and excessive growth of higher } \\
\text { aquatic plants in bodies of water; can cause water } \\
\text { to be unsuitable for public supply. }\end{array}$ \\
\hline 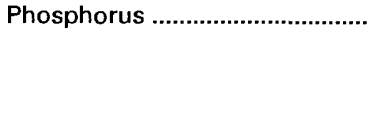 & $\begin{array}{l}\text { Occurs in some rocks and sediments; also in runoff } \\
\text { and seepage from phosphate-rock mines, agri- } \\
\text { cultural and urban runoff, and industrial and } \\
\text { municipal wastewater discharge. }\end{array}$ & $\begin{array}{l}\text { Plant nutrient that, in sufficient quantity, can cause } \\
\text { algal blooms and excessive growth of higher } \\
\text { aquatic plants in bodies of water. }\end{array}$ \\
\hline Suspended sediment .................. & $\begin{array}{l}\text { A result of rock erosion; also induced by disturbances } \\
\text { of land cover due to fires, floods, and human } \\
\text { activities such as mining, logging, construction, } \\
\text { and agriculture. }\end{array}$ & $\begin{array}{l}\text { Can be detrimental to aquatic organisms; can fill res- } \\
\text { ervoirs and impair recreational use of water. }\end{array}$ \\
\hline
\end{tabular}

streams have been contaminated by runoff from highway and allocated land development (Andrew N. Barrass, Tennessee Department of Health and Environment, written commun., November 1989).

\section{DUCK RIVER}

The Duck River basin is underlain predominantly by limestone and phosphatic limestone of the Central Basin. Chemical weathering of limestone and overlying soils in this area has not been as extensive as in the Highland Rim; consequently, streams draining this area contain high concentrations of minerals dissolved from rock and soil. Land uses in the basin upstream from site 4 are cropland, pasture. and forest.

Runoff from surface phosphate mines and cultivated soils rich in phosphorus contributes to high phosphorus concentrations in the Duck River. Recurring algal blooms and attendant dissolved-oxygen depletion caused by algal die-off and decay in Normandy Lake reservoir (fig. 2) result from large phosphorus loads in streams of this drainage basin (Tennessee Department of Health and Environment, 1990 , p. 44). Perhaps the most serious effect of high phosphorus concentrations in the Duck River is the increased phosphorus loading in Kentucky Lake and the resulting stimulation of algal growth (fig. 2). Just downstream from the mouth of the Duck River, phosphorus concentration in Kentucky Lake doubles from 0.05 to $0.10 \mathrm{mg} / \mathrm{L}$ (Neil E. Carriker, Tennessee Valley Authority, written commun., November 1989). The guideline for maximum total phosphorus concentration is $0.10 \mathrm{mg} / \mathrm{L}$ for rivers and $0.05 \mathrm{mg} / \mathrm{L}$ where streams enter lakes or reservoirs (U.S. Environmental Protection Agency, 1986). The median dissolved-phosphorus concentration for site 4 during water years $1987-89$ was $0.14 \mathrm{mg} / \mathrm{L}$ (fig. 3).

\section{EMORY AND CUMBERLAND RIVERS}

Most of the area of the drainage basins of the Emory and upper Cumberland Rivers is in the Cumberland Plateau, a highland area underlain by sandstone, shale, and conglomerate. Most streams in this area contain low concentrations of dissolved minerals. However, surface and subsurface coal mining and timber harvesting are im- portant activities in both basins. Surface mining creates spoils that erode easily and contribute sediment to streams. Moreover, minerals leached from these spoils can produce an extremely mineralized and acidic effluent. Timber harvesting can contribute additional sediment to streams through increased erosion, mainly as a result of construction and use of haul roads, skid trails, and log decks (Tennessee Department of Health and Environment, 1989, p. 3.2).

Water quality in the Emory River has been affected by surface coal mining and timber harvesting (Tennessee Department of Health and Environment, 1990, app. A15). Relative to other water bodies that have been affected by these activities, however, the Emory River at site 5 had low sulfate concentrations during 1987-89 (median, $15 \mathrm{mg} / \mathrm{L}$ ) (fig. 3).

Mining and timber harvesting have degraded the water quality in many creeks within the upper Cumberland River basin (Tennessee Department of Health and Environment, 1990, p. 53). Concentrations of sulfate (median, $29 \mathrm{mg} / \mathrm{L}$ ) and dissolved solids (median, $116 \mathrm{mg} / \mathrm{L}$ ) at site 6 were among the highest for the 10 monitoring stations (fig. 3).

\section{HOLSTON AND CLINCH RIVERS}

The drainage basins of the Holston and Clinch Rivers are mostly within the Valley and Ridge province, which is underlain by carbonate rock, sandstone, and shale that crop out alternately in long, narrow strips. Dissolution of the limestone and dolomite that underlie much of the area results in high concentrations of dissolved minerals in stream water. Five dams upstream from site 7 regulate flow of the Holston River, and two dams upstream from site 8 regulate flow of the Clinch River.

During the summer, dissolved-oxygen depletion in deep layers of water in reservoirs on the Holston River results in downstream dissolved-oxygen concentrations that are lower than the minimum criteria of $6 \mathrm{mg} / \mathrm{L}$ for cold-water fisheries and $5 \mathrm{mg} / \mathrm{L}$ for warm-water fisheries (Tennessee Department of Health and Environment, 1990, p. 77). High sulfate concentrations at site 7 (median, $28 \mathrm{mg} / \mathrm{L}$ for 1987-89) (fig. 3) result partly from discharges of saline water from natural salt deposits near Saltville, Va., to the North Fork Holston 
River. The Holston River contains water having the highest hardness values in the State. Dissolved-solids concentrations at site 7 (median, $175 \mathrm{mg} / \mathrm{L}$ ) were the highest for the 10 monitoring stations but were lower than the $500 \mathrm{mg} / \mathrm{L}$ criterion established by the State (Tennessee Department of Health and Environment, 1987) for untreated drinking water.

The headwaters of the Clinch River drain areas in the Cumberland Plateau in Tennessee and the Valley and Ridge province in Virginia. Runoff from oil and gas drilling and surface coalmining operations has increased concentrations of sulfate, certain trace elements, and suspended sediment in headwater streams (Tennessee Department of Health and Environment, 1990, p. 68). Sulfate concentrations at site 8 (median, $25 \mathrm{mg} / \mathrm{L}$ ) were among the highest for the 10 monitoring stations. Suspended-sediment concentrations were low (median, $6.0 \mathrm{mg} / \mathrm{L}$ ) compared to those in other reaches in the drainage basin primarily because sediment is trapped in the two upstream reservoirs (Trimble and Carey, 1984). The largest urban center in the drainage basin is Oak Ridge, which includes the U.S. Department of Energy Oak Ridge Reservation (fig. 2). Runoff from this area drains to East Fork Poplar Creek then enters the Clinch River downstream from site 8. Water-quality concerns in East Fork Poplar Creek and the Clinch River include increased concentrations of mercury and other metals, organic chemicals, and radionuclides resulting from activities at the Oak Ridge Reservation (Tennessee Department of Health and Environment, 1990, p. 67-68).

\section{LITTLE AND HIWASSEE RIVERS}

The drainage basins of the Little and Hiwassee Rivers are underlain mostly by crystalline and metasedimentary rocks of the Blue Ridge province. Because these siliceous rocks are relatively insoluble and surface-water drainage is rapid, streams draining this area generally contain relatively low concentrations of dissolved minerals.

Most of the drainage area upstream from site 9, on the Little River, is in the densely forested, uninhabited Great Smoky Mountains National Park (fig. 2). Consequently, water quality at site 9 has not been substantially altered by human activity, as indicated by the low concentrations of sulfate, dissolved solids, nitrite plus nitrate, and suspended sediment (fig. 3).

The headwaters of the Hiwassee River extend into the Blue Ridge province of North Carolina and Georgia; about one-fourth of the drainage basin lies within the Valley and Ridge province in Tennessee. The mineralized waters draining from that province might have contributed to the higher concentrations of sulfate and dissolved solids at site 10 compared to those in the Little River at site 9. Past copper mining and present industrial activities near Copperhill (fig. 2) have degraded water quality in several creeks and three reservoirs on the Ocoee River, the largest tributary to the Hiwassee River. This degradation has resulted in increased acidity and increased concentrations of the trace elements aluminum, cadmium, copper, lead, and zinc and of suspended sediment (Tennessee Department of Health and Environment, 1990, p. 58).

\section{WATER-QUALITY TRENDS}

Trend analysis is a statistical procedure used to detect changes in stream water quality at a monitoring station over time. For this report, water-quality data from eight monitoring stations (fig. 2) were analyzed for trends by using the seasonal Kendall test (Hirsch and others, 1982), a method used extensively by the USGS. The graph (shown above right) of the dissolved-sulfate concentration in the Clinch River at site 8 illustrates the trend inferred from the concentration data and demonstrates the variation in water quality that is common in streams.

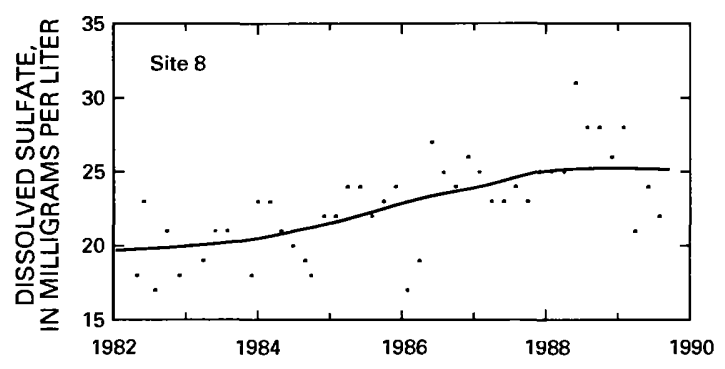

When possible, constituent-concentration data were adjusted for changes in streamflow to preclude identifying a trend in concentration that was caused only by a trend in streamflow. The data were not adjusted when (1) more than 10 percent of the samples had concentrations lower than the minimum reporting limit for the analytical method used or (2) streamflow was controlled substantially by human activities. When the concentration data could not be adjusted for streamflow, trends were determined directly from the concentration data.

Statewide trends in concentrations of selected stream-water constituents are shown on maps in figure 4 . On each map, a trend is indicated at a monitoring station only if the data from that station were suitable for use in the trend analysis. For more information on the suitability criteria and on the trend-analysis procedure used for this report, see Lanfear and Alexander (1990).

\section{DISSOLVED OXYGEN}

The dissolved-oxygen concentration in a stream is controlled by several factors, including water temperature, air temperature and pressure, hydraulic characteristics of the stream, photosynthetic or respiratory activity of stream biota, and the quantity of organic material present. A trend in dissolved-oxygen concentrations commonly is directly or indirectly the result of human activities. Generally, an upward trend in dissolved-oxygen concentrations indicates improving stream water-quality conditions and a downward trend indicates deteriorating conditions.

Dissolved-oxygen concentrations had no trend at the seven monitoring stations having data that met the criteria for trend analysis (fig. 4). Trends in dissolved-oxygen concentrations would have been expected only if the quantities of substances that require oxygen for decomposition (for example, human waste) had substantially changed during the trend-analysis period.

\section{FECAL COLIFORM BACTERIA}

Fecal coliform bacteria are used as indicators of fecal contamination from humans and other warm-blooded animals. Such contamination can introduce disease-causing viruses and bacteria into a stream.

The cause for the upward trend in fecal coliform bacteria concentrations in the Obion River at site 1 (fig. 4) is not known. Downward trends were expected because the State imposed more stringent controls on the major point source-effluent from sewagetreatment plants-during the 1980-89 trend-analysis period. The monitoring stations, however, might be too distant from sewage-treatment plants to detect the effects of wasteload changes; fecal coliform bacteria do not survive long in the stream environment.

\section{DISSOLVED SULFATE}

The major natural sources of sulfate in streams are rock weathering, volcanoes, and biochemical processes (Hem, 1985, p. 113). Human activities such as mining, waste discharge, and fossil- 


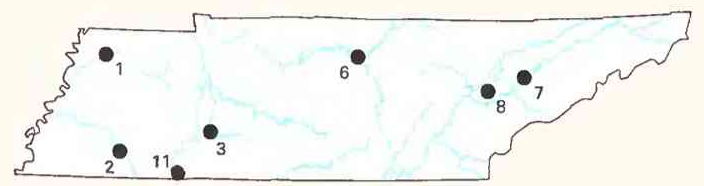

Dissolved oxygen, 1980-89

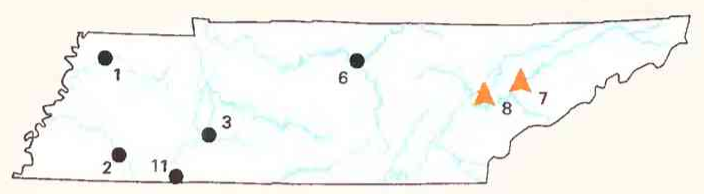

Dissolved sulfate, $1982-89$

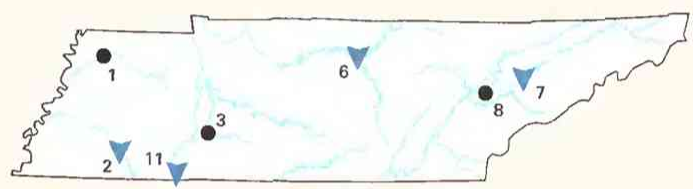

Dissolved nitrite plus nitrate, $1980-89$

\begin{tabular}{lccc}
0 & $50 \quad 100$ & MILES \\
\hdashline & 50 & 100 & KILOMETERS
\end{tabular}

\section{EXPLANATION}

Trend in water-quality constituent-

Number is site number in figure 2

$$
\begin{aligned}
& A^{7} \text { Upward } \\
& { }^{2} \text { None } \\
& \nabla^{6} \text { Downward }
\end{aligned}
$$

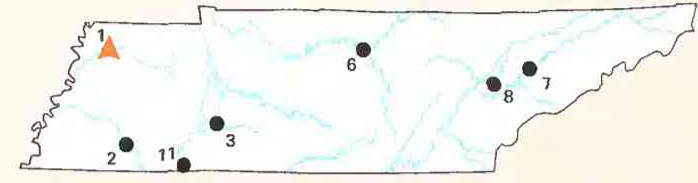

Fecal coliform bacteria, 1980-89

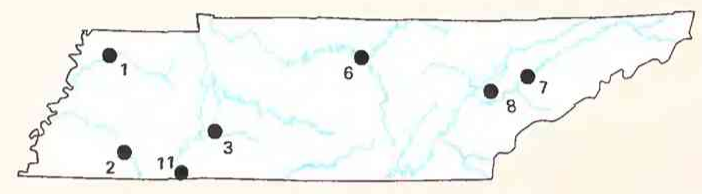

Dissolved solids, 1980-89

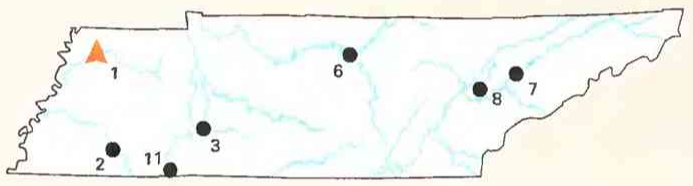

Dissolved phosphorus, 1980-89

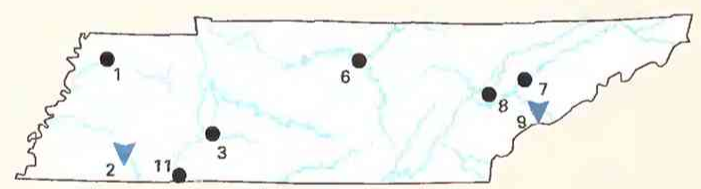

Suspended sediment, 1980-89

Figure 4. Trends in water quality of selected streams in Tennessee, by water years. (Source: Data from U.S. Geological Survey and Tennessee Valley Authority files.)

fuel combustion also can be important sources. A shortened trendanalysis period was used for sulfate because data obtained before water year 1982 are not comparable to data for subsequent years.

The cause for the upward trends in sulfate concentrations in the Holston River at site 7 and in the Clinch River at site 8 (fig. 4) is not known. Runoff from coal mines is not likely to have caused the trends because coal production decreased during 1982-89 in the drainage basins of the Holston and Clinch Rivers (Linda Johnson, U.S. Department of Labor, written commun., October 1989). Atmospheric deposition of sulfate probably did not cause the trend because atmospheric sources probably contribute too little sulfate to the Holston and Clinch Rivers to cause a detectable trend. Also, the upward trends in those two river basins during 1982-89 did not correspond with known trends in sulfur dioxide emissions (Brand Niemann, U.S. Environmental Protection Agency, oral commun., July 1990), atmospheric concentrations of sulfate (U.S. Environmental Protection Agency, 1989), or sulfate deposition (Schertz and Hirsch, 1985).

\section{DISSOLVED SOLIDS}

Dissolved solids in stream water result primarily from rock weathering but also can be introduced as a byproduct of human activities (table 1). Concentrations generally are greatest in streams draining basins underlain by rocks and soils that contain easily dissolved minerals.

Dissolved-solids concentrations had no trend at the seven monitoring stations from which data were suitable for trend analysis (fig. 4). Concentrations of some of the major inorganic components of dissolved solids (sodium, chloride, and potassium) increased slightly in Tennessee streams during this period, presumably because ground-water discharge, which generally has higher concentrations of these components than surface water, represented a large part of streamflow during the statewide drought of 1985-88 (U.S. Geological Survey, 1991, p. 505-512). However, other major components of dissolved solids (calcium, magnesium, and silica) had no change in concentration. The absence of an upward trend at the seven sta- 
tions possibly resulted from compensating reductions in loads from nonpoint sources, such as agricultural and urban areas, owing to decreased runoff during the drought.

\section{DISSOLVED NITRITE PLUS NITRATE}

Nitrite and nitrate are oxidized forms of nitrogen that together normally constitute most of the dissolved nitrogen in well-aerated streams. Nitrite readily oxidizes to nitrate in natural waters; therefore, nitrate generally is by far the more abundant of the two (Hem, 1985, p. 124).

Some of the observed trends in nitrite plus nitrate concentrations for 1980-89 (fig. 4) correspond to trends in nitrogen-fertilizer use for the same period (Tennessee Valley Authority, 1989). Nitrogen-fertilizer use declined steadily (by about 40 percent) during 1980-89 in the Hatchie River drainage basin, one of the four basins in which nitrite plus nitrate concentration decreased (at site 2). In the three river basins in which concentrations had no trend, fertilizer use likewise had no trends for the 1980-89 period. Improvements in wastewater treatment at several facilities at Kingsport and at Boone Lake reservoir (fig. 2) during 1980-89 might have contributed to the decrease in nitrite plus nitrate concentration in the Holston River at site 7. A cause for the downward trends in the Cumberland River at site 6 and the Tennessee River at site 11 is not readily apparent. The pattern of trends in nitrite plus nitrate concentrations at the seven monitoring stations does not appear to be related to downward trends in atmospheric concentrations of nitrogen oxide observed at locations throughout the State during 1980-89 (U.S. Environmental Protection Agency, 1989).

\section{DISSOLVED PHOSPHORUS}

Small quantities of dissolved phosphorus-most of it in the oxidized form, phosphate-commonly are present in streams as a result of rock weathering. Concentrations of dissolved phosphorus in natural water normally are no more than a few tenths of a milligram per liter (Hem, 1985, p. 126) and are usually much lower. Higher concentrations can indicate contamination from human activities (table 1).

Agricultural runoff is a major source of phosphorus in streams; therefore, changes in fertilizer-application rates might be expected to affect stream phosphorus concentration. The trends detected at the seven monitoring stations (fig. 4) correspond closely to trends in phosphorus-fertilizer use in the seven river basins. The increasing phosphorus concentration in the Obion River at site 1 corresponded to a steady increase in fertilizer use in the basin during 1980-89 (Tennessee Valley Authority, 1989). Phosphorus-fertilizer use in the six basins for which no trend in phosphorus concentrations was detected either remained relatively constant throughout the period (as in the Hatchie, Buffalo, and Cumberland Rivers at sites 2,3 , and 6 ) or fluctuated but had no net change (as in the Holston, Clinch, and Tennessee Rivers at sites 7, 8, and 11).

\section{SUSPENDED SEDIMENT}

Suspended sediment is a product of erosion. The erosion can be either natural or the result of land-cover disturbances related to human activities (table 1). Causes for the downward trend in the Hatchie River at site 2 and that in the Little River at site 9 (fig. 4) are not known.

\section{WATER-QUALITY MANAGEMENT}

The Tennessee Department of Environment and Conservation, formerly the Tennessee Department of Health and Environment,
Division of Water Pollution Control, administers programs and policies to secure, protect, and preserve the right of citizens to unpolluted waters. The Tennessee Water Quality Control Act of 1977 enables the Division to administer the National Pollutant Discharge Elimination System program and to inspect and regulate wastewater-treatment facilities. The Division performs specific regulatory, enforcement, and monitoring activities. These activities include developing water-quality standards and criteria, issuing permits to wastewater dischargers, reviewing the operation and maintenance of municipal and nonmunicipal waste-treatment facilities, surveying to determine compliance with effluent and water-quality standards, and monitoring of waste discharges and ambient water-quality conditions.

In compliance with section 305(b) of the Federal Clean Water Act, the Division of Water Pollution Control prepares a biennial water-quality assessment report (Tennessee Department of Health and Environment, 1990) submitted to the EPA and the U.S. Congress. The Division also reviews and certifies Federal permits related to hydrologic modifications; issues State permits for nondischarge wastewater systems and for the alteration of the State's waters, such as channel modification; and administers the Tennessee Surface Mining Law and related regulations.

The Division of Water Pollution Control is the lead agency for the development of 'Tennessee's nonpoint-source water-pollution management plan, which was implemented in 1989 (Tennessee Department of Health and Environment, 1989). The Division participates in interagency work groups and interstate organizations, including the Management Advisory Group of the nonpoint-source waterpollution program, the Kentucky Lake Task Force, the Groundwater Task Force, and the Association of State and Interstate Water Pollution Control Administrators.

The Tennessee Water Quality Control Board, established by the Water Quality Control Act, oversees the State water-management program. The Board is composed of seven members-one designee each from the Departments of Health, Environment and Conservation, and Agriculture and one representative each from industry, municipalities, conservation interests, and the public.

Because of the many reservoirs in Tennessee and their effect on stream water quality, the Tennessee Valley Authority and the U.S. Army Corps of Engineers also have significant water-quality-management responsibilities. Both Federal agencies conduct water-quality monitoring and assessment programs, and both consider stream water quality in their reservoir operations.

\section{SELECTED REFERENCES}

Anderson, J.R., 1967, Major land uses in the United States, in U.S. Geological Survey, 1970, National atlas of the United States of America: Washington, D.C., U.S. Geological Survey, p. 158-59.

Britton, L.J., and Greeson, P.E., eds., 1987, Methods for collection and analysis of aquatic biological and microbiological samples: U.S. Geological Survey Techniques of Water-Resources Investigations, book 5, chap. A4, $363 \mathrm{p}$.

Fenneman, N.M., 1946, Physical divisions of the United States: Washington, D.C., U.S. Geological Survey special map, scale 1:7,000,000.

Fishman, M.J., and Friedman, L.C., eds., 1989, Methods for the determination of inorganic substances in water and fluvial sediments: U.S. Geological Survey Techniques of Water-Resources Investigations, book 5, chap. A1, 545 p.

Hem, J.D., 1985, Study and interpretation of the chemical characteristics of natural water (3d ed.). U.S. Geological Survey Water-Supply Paper 2254 $263 \mathrm{p}$.

Hirsch, R.M., Slack, J.R., and Smith, R.A., 1982, Techniques of trend analysis for monthly water quality data: Water Resources Research, v. 18 , no. 1, p. 107-121.

Lanfear, K.J., and Alexander, R.B., 1990, Methodology to derive water-quality trends for use by the National Water Summary Program of the U.S. 
Geological Survey: U.S. Geological Survey Open-File Report 90-359, $10 \mathrm{p}$.

Miller, R.A., 1974, The geologic history of Tennessee: Tennessee Division of Geology Bulletin 74, $63 \mathrm{p}$.

Schertz, T.L., and Hirsch, R.M., 1985, Trend analysis of weekly acid rain data-1978-83: U.S. Geological Survey Water-Resources Investigations Report 85-4211, 64 p.

Tennessee Department of Health and Environment, 1987, Tennessee's water quality criteria and stream use classifications for interstate and intrastate streams: Nashville, Tenn., Water Quality Control Board, 65 p.

1989, Nonpoint source water pollution management plan for the State of Tennessee: Nashville, Tenn., Nonpoint Source Management Program, variously paginated.

1990, The status of water quality in Tennessee-The 1990 305(b) report: Nashville, Tenn., Office of Water Management, $181 \mathrm{p}$.

Tennessee Valley Authority, 1963, Mineral quality of surface water in the Tennessee River basin: Tennessee Valley Authority Division of Water Control Planning, Hydraulic Data Branch, Report 0-6392, 161 p.

1974, Tennessee Valley Authority water quality monitoring network: Tennessee Valley Authority Division of Environmental Planning Report E-WQ-74-2, $18 \mathrm{p}$.

1989, National Fertilizer Development Center computerized data base: Muscle Shoals, Ala.
Thelin, G.P., and Pike, R.J., 1990, Digital shaded relief map of the conterminous United States: Menlo Park, Calif., U.S. Geological Survey digital imaging processing, scale 1:3,500,000.

Trimble, S.W., and Carey, W.P., 1984, Sediment characteristics of Tennessee streams and reservoirs: U.S. Geological Survey Open-File Report 84 $749,32 \mathrm{p}$.

U.S. Environmental Protection Agency, 1986, Quality criteria for water, 1986: U.S. Environmental Protection Agency, EPA-440/5-86-001, variously paginated.

1989, Aerometric Information Retrieval System computerized data base: Research Triangle Park, N.C.

U.S. Geological Survey, 1986, National water summary 1985-Hydrologic events and surface-water resources: U.S. Geological Survey Water-Supply Paper $2300,506 \mathrm{p}$.

1990, National water summary 1987-Hydrologic events and water supply and use: U.S. Geological Survey Water-Supply Paper 2350, $553 \mathrm{p}$.

1991, National water summary 1988-89-Hydrologic events and floods and droughts: U.S. Geological Survey Water-Supply Paper 2375, $591 \mathrm{p}$.

Ward, J.R., and Harr, C.A., eds., 1990, Methods for collection and processing of surface-water and bed-material samples for physical and chemical analyses: U.S. Geological Survey Open-File Report 90-140, 71 p.

Prepared by Anne B. Hoos

FOR ADDITIONAL INFORMATION: District Chief, U.S. Geological Survey, 810 Broadway, Suite 500, Nashville, TN 37203 


\section{TEXAS \\ Stream Water Quality}

Texas has diverse climatic and hydrologic conditions. Annual precipitation generally decreases from east to west, ranging from 56 inches at the eastern border near Beaumont to less than 8 inches at the western border (U.S. Geological Survey, 1986, p. 432-433). Consequently, streamflow is abundant in the eastern part of the State but is scarce in the west. Presently (1990), Texas has 187 reservoirs that have a capacity of more than 5,000 acre-feet.

In 1985, surface water supplied 12,900 million gallons per day or 64 percent of freshwater withdrawals in Texas (U.S. Geological
Survey, 1990, p. 475-484). Of that quantity, 58 percent was used for thermoelectric power generation, 22 percent for irrigation, 14 percent for public supply, and 6 percent for industry and mining. Demand for freshwater in Texas varies by season, geographical area, and type of water use. Thermoelectric power generation and public-supply needs are continuous, whereas water use for irrigation is seasonal.

The water quality of a stream can be affected by the land uses in its basin. Agricultural activities are important contributors of nonpoint-source pollution; urban and industrial areas often contain

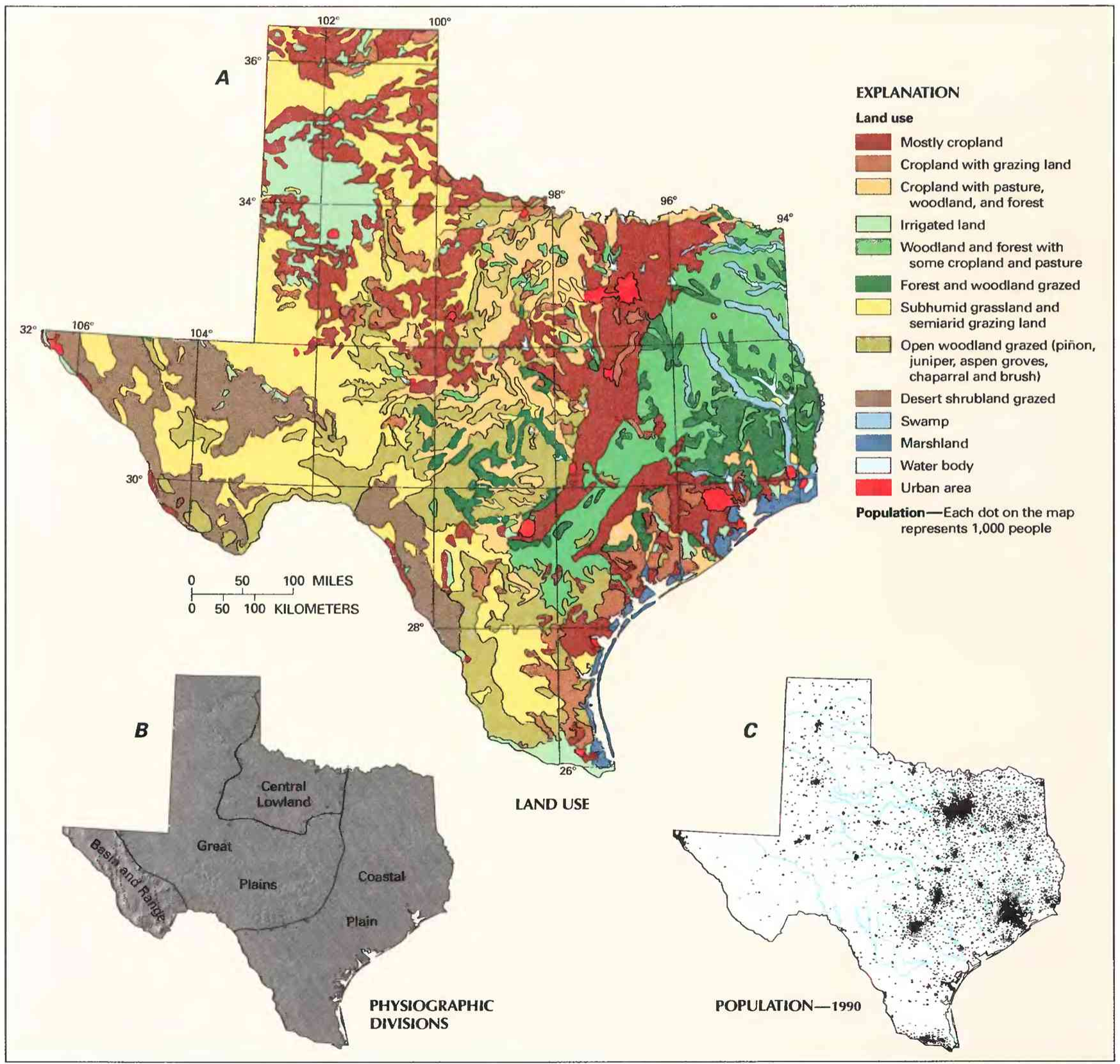

Figure 1. Land use, physiography, and population in Texas. A, Major land uses. B. Physiographic divisions. C. Population distribution in 1990. (Sources: A, Major land uses modified from Anderson, 1967. B. Physiographic divisions from Fenneman, 1946; landforms from Thelin and Pike, 1990. C, Data from U.S Bureau of the Census 1990 decennial census files.) 
many point- and nonpoint-source discharges. Land use (fig. $1 A$ ) in Texas is determined in large part by physiography (fig. $1 B$ ) and water availability.

Largely for reasons of water availability, most of Texas' population is in the eastern part of the State (fig. 1C). The 1990 population was about 17 million (U.S. Bureau of the Census 1990 decennial census files), a 52-percent increase from 1970. More than 8.5 million people relied on surface-water sources for public supply in 1985 (Solley and others, 1988, p. 13). The demand for water of adequate quality will continue to increase with the growing population.

\section{WATER-QUALITY MONITORING}

Water-quality data obtained from analyses of water samples collected at monitoring stations are stored in the U.S. Geological Survey's (USGS) National Water Information System and the U.S. En- vironmental Protection Agency's (EPA) national data base known as STORET. Water-quality and streamflow data are reported by water year - the 12 months from October 1 through September 30. A water year is identified by the calendar year in which it ends. For example, water year 1991 comprises October 1, 1990, through September 30, 1991.

The data used in this summary of Texas' stream water quality were obtained from water samples collected at 23 monitoring stations at which data collection is systematic and continuing (fig. 2). Analyses of water samples collected at 10 stations are the basis for the discussion and graphic summary (fig. 3 ) of stream water-quality conditions during water years 1987-89, and data from 20 stations are the basis for the discussion and graphic summary (fig. 4) of stream water-quality trends. Water samples were collected and analyzed by using standard methods approved by the USGS (Britton and Greeson, 1987; Fishman and Friedman, 1989; Ward and Harr, 1990) or by

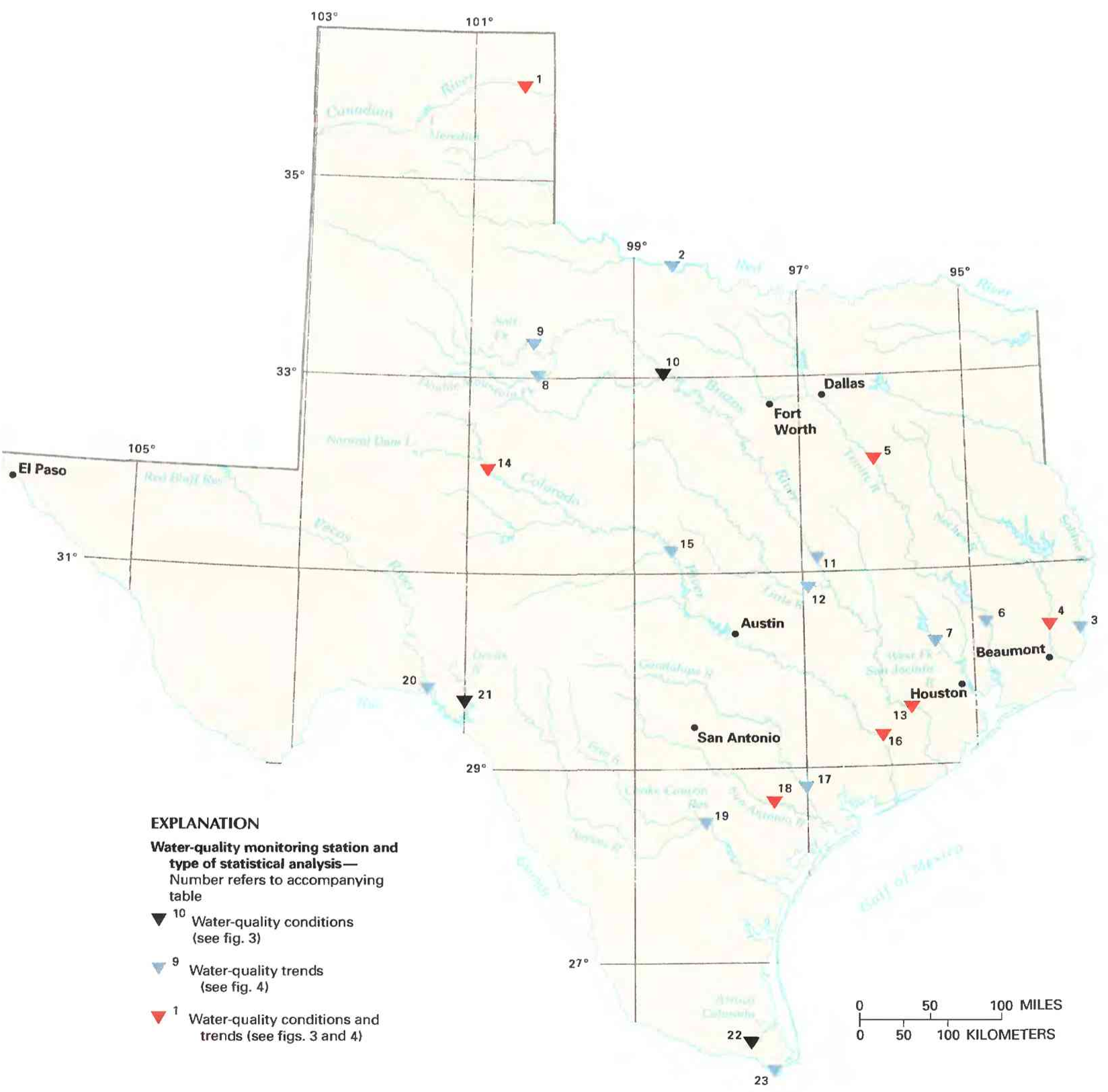

Figure 2. Selected water-quality monitoring stations, type of statistical analysis, and geographic features in Texas. (Sources: Major land uses modified from Anderson, 1967; other data from U.S. Geological Survey files.) 
using equivalent methods. If a method of sample collection or analysis changed over time, data from an analysis were included in the evaluation of recent stream water quality or of stream water-quality trends only if the change in method did not affect the comparability of the data.

\section{WATER-QUALITY CONDITIONS}

The use of water from the western reaches of many of the State's rivers is limited by natural salinity. In some locations this problem has been worsened by the residual effects of past oil and gas exploration and production activities. Other water-quality degradation that limits water use originates in the populous urban areas of Austin, Dallas-Fort Worth, Houston, and San Antonio. Recently, the quantity and quality of inflows to coastal bays and estuaries have become a major issue.

In 1990, the Texas Water Commission (1990, p. 12) assessed the water quality in more than 16,000 miles of streams. Water-quality standards for beneficial uses designated by the State for purposes of water-quality monitoring and protection were not met in 16 percent of those stream miles. Nonpoint-contamination sources such as agriculture, oil and gas exploration and production, urban runoff, erosion, individual sewage-disposal systems, and animal grazing are the origin of most contamination in streams. The remaining contamination comes from point sources, natural sources, and unknown sources.

The following discussion of stream water quality in Texas is organized by river basin (fig. 3). Graphs in figure 3 summarize certain aspects of stream water quality in the basins for water years 198789. The graphs show frequency distributions of data values that represent concentrations of selected stream-water constituents. These constituents are fecal coliform bacteria, dissolved sulfate, dissolved chloride, dissolved solids, dissolved nitrite plus nitrate (as nitrogen), total phosphorus (as phosphorus), and suspended sediment. The data are reported in colonies per 100 milliliters (col/100 mL) and milligrams per liter $(\mathrm{mg} / \mathrm{L})$. Sources and environmental significance of each constituent are described in table 1.

Water quality at each monitoring station is the result of geological, chemical, biological, and hydrologic processes that occur over a large area. Water-quality problems that affect aquatic life or public health only locally are not fully represented in this summary. One such problem not addressed in this report is contamination from organic chemicals such as herbicides used in rice farming and industrial solvents.

\section{CANADIAN RIVER}

The Canadian River originates in northeastern New Mexico and flows eastward across the Great Plains region of the Texas Panhandle, draining mostly subhumid grassland and semiarid grazing land. There are two major reservoirs in the basin. Sanford Dam, which forms Lake Meredith, the larger reservoir, has caused decreased flow at site 1 near Canadian since 1965.

Median concentrations of sulfate $(230 \mathrm{mg} / \mathrm{L})$, chloride $(720$ $\mathrm{mg} / \mathrm{L}$ ) and dissolved solids (1,770 mg/L) at site 1 (fig. 3) indicate a slightly saline water. The saline water results from contact with geologic formations that were deposited in a marine environment and comes primarily from Cottonwood Creek and brine springs near the New Mexico-Texas border (Texas Water Commission, 1990, p. 161163).

\section{NECHES RIVER}

The Neches River drains areas of forest and woodland in subhumid eastern Texas. Ten reservoirs having a capacity of 5,000 acre-feet or more store runoff from the relatively flat Texas Coastal Plain. Slow currents in some of the low-gradient, natural drainage channels of the lower reaches of the Neches River occasionally result in small dissolved-oxygen concentrations (Texas Water Commission, 1990, p. 247-248).

Smaller concentrations of the seven constituents were recorded in the Neches River at site 4 compared to those at most of the other monitoring stations (fig. 3). Dissolved-solids concentrations were relatively small (median, $101 \mathrm{mg} / \mathrm{L}$ ) because of dilution by the large quantities of rain that fall in this basin and because no source of salinity is present in the mostly fluvial sediments that underlie the drainage basin.

\begin{tabular}{|c|c|c|c|}
\hline $\begin{array}{l}\text { Site no. } \\
\text { on map }\end{array}$ & $\begin{array}{l}\text { USGS station } \\
\text { name and no. }\end{array}$ & $\begin{array}{l}\text { Drainage area } \\
\text { (square miles) }\end{array}$ & $\begin{array}{l}\text { Major land use } \\
\text { (see fig. 1) }\end{array}$ \\
\hline 1 & Canadian River near Canadian $(07228000) \ldots . . . .$. & 22,866 & Subhumid grassland and semiarid grazing land. \\
\hline 2 & Red River near Burkburnett $(07308500\}$ & 20,570 & Mostly cropland. \\
\hline 3 & Sabine River near Ruliff $\{08030500\}$ & 9,329 & Grazed forest and woodland; swamp. \\
\hline 4 & Neches River at Evadale $(08041000)$ & 7,951 & Ditto. \\
\hline 5 & Trinity River at Trinidad $(08062700)$ & 8,538 & Cropland with pasture, woodland, and forest; urban areas. \\
\hline 6 & Trinity River at Romayor (08066500) & 17,186 & Woodland and forest with some cropland and pasture. \\
\hline 7 & West Fork San Jacinto River near Conroe $(08068000)$ & 828 & Grazed forest and woodland. \\
\hline 8 & Double Mountain Fork Brazos River near Aspermont (08080500) ....... & 8,796 & Subhumid grassland and semiarid grazing land; mostly cropland. \\
\hline 9 & Salt Fork Brazos River near Aspermont $(08082000)$ & 5,130 & $\begin{array}{l}\text { Subhumid grassland and semiarid grazing land; cropland with } \\
\text { grazing land. }\end{array}$ \\
\hline 10 & Brazos River near South Bend $(08088000)$ & 22,673 & Cropland with pasture, woodland, and forest; grazed open woodland. \\
\hline 11 & Brazos River near Highbank (08098290) & 30,436 & Mostly cropland. \\
\hline 12 & Little River at Cameron $(08106500)$ & 7,065 & Ditto. \\
\hline 13 & Brazos River at Richmond $(08114000)$ & 45,007 & Mostly cropland; cropland with grazing land; urban areas. \\
\hline 14 & Colorado River above Silver $(08123850)$ & 14,910 & $\begin{array}{l}\text { Subhumid grassland and semiarid grazing land; cropland with } \\
\text { grazing land. }\end{array}$ \\
\hline 15 & Colorado River near San Saba $(08147000)$ & 31,217 & $\begin{array}{l}\text { Subhumid grassland and semiarid grazing land; cropland with pasture, } \\
\text { woodland, and forest. }\end{array}$ \\
\hline 16 & Colorado River at Wharton $(08162000)$ & 42,003 & Cropland with grazing land; irrigated land. \\
\hline 17 & Guadalupe River at Victoria $(08176500\}$ & 5,198 & Mostly cropland; woodland and forest with some cropland and pasture. \\
\hline 18 & San Antonio River at Goliad $(08188500)$ & 3,921 & $\begin{array}{l}\text { Grazed open woodland; woodland and forest with some cropland and } \\
\text { pasture; urban areas. }\end{array}$ \\
\hline 19 & Nueces River near Three Rivers (08210000) & 15,427 & Grazed open woodland; cropland with pasture, woodland, and forest. \\
\hline 20 & Pecos River near Langtry $(08447410\}$ & 35,179 & Grazed open woodland; subhumid grassland and semiarid grazing land. \\
\hline 21 & Devils River at Pafford Crossing, near Comstock $(08449400\rangle$.............. & 3,961 & $\begin{array}{l}\text { Grazed desert shrubland; subhumid grassland and semiarid } \\
\text { grazing land. }\end{array}$ \\
\hline 22 & Arroyo Colorado at Harlingen $(08470400)$ & Indeterminate & Irrigated land; cropland with grazing land; urban areas. \\
\hline 23 & Rio Grande at Brownsville $(08445000)$ & 176,333 & Irrigated land; grazed open woodland. \\
\hline
\end{tabular}

Figure 2. Selected water-quality monitoring stations, type of statistical analysis, and geographic features in Texas-Continued. 


\section{TRINITY RIVER}

The Trinity River drains cropland and pastures, large urban areas (including Dallas-Fort Worth), and land having extensive industrial development. Twenty-seven reservoirs store water for public supply and control flooding in the lower part of the river near the Gulf of Mexico. The Trinity River historically has had large values of biochemical oxygen demand and large concentrations of fecal coliform bacteria, nutrients, and suspended solids. Fishkills associated with large concentrations of contaminants and small dissolvedoxygen concentrations have occurred in the reach downstream from the Dallas-Fort Worth area (Texas Water Commission, 1990, p. 275276).

At the upstream Trinity River monitoring station (site 5), the effects of urban development on stream water are apparent (Wells and others, 1986). Median concentrations of nitrite plus nitrate (2.60 $\mathrm{mg} / \mathrm{L})$, phosphorus $(0.89 \mathrm{mg} / \mathrm{L})$, and suspended sediment (134 $\mathrm{mg} / \mathrm{L}$ ) were among the largest at the 10 stations (fig. 3). At the down- stream Trinity River monitoring station at Romayer (site 6, not shown in fig. 3), concentrations of fecal coliform bacteria $(56 \mathrm{col} / 100 \mathrm{~mL})$, the nutrients nitrite plus nitrate $(0.20 \mathrm{mg} / \mathrm{L})$ and phosphorus $(0.16$ $\mathrm{mg} / \mathrm{L})$, and suspended sediment $(13 \mathrm{mg} / \mathrm{L}$ ) were substantially smaller than those at site 5 because of dilution from runoff in the lower river basin.

\section{BRAZOS RIVER}

Almost all of the Brazos River drainage basin is in Texas. Within the State, the river system extends from the semiarid Great Plains near the New Mexico border to the Gulf of Mexico. The Brazos River drains cropland, grazing land, forest, and woodland and is regulated by 25 dams that form reservoirs that store water for irrigation, public supply, and flood control.

Water-quality data from an upstream monitoring station (site 10 ) and a downstream station (site 13) (fig. 3) illustrate the differences in water quality between the upper and lower Brazos River
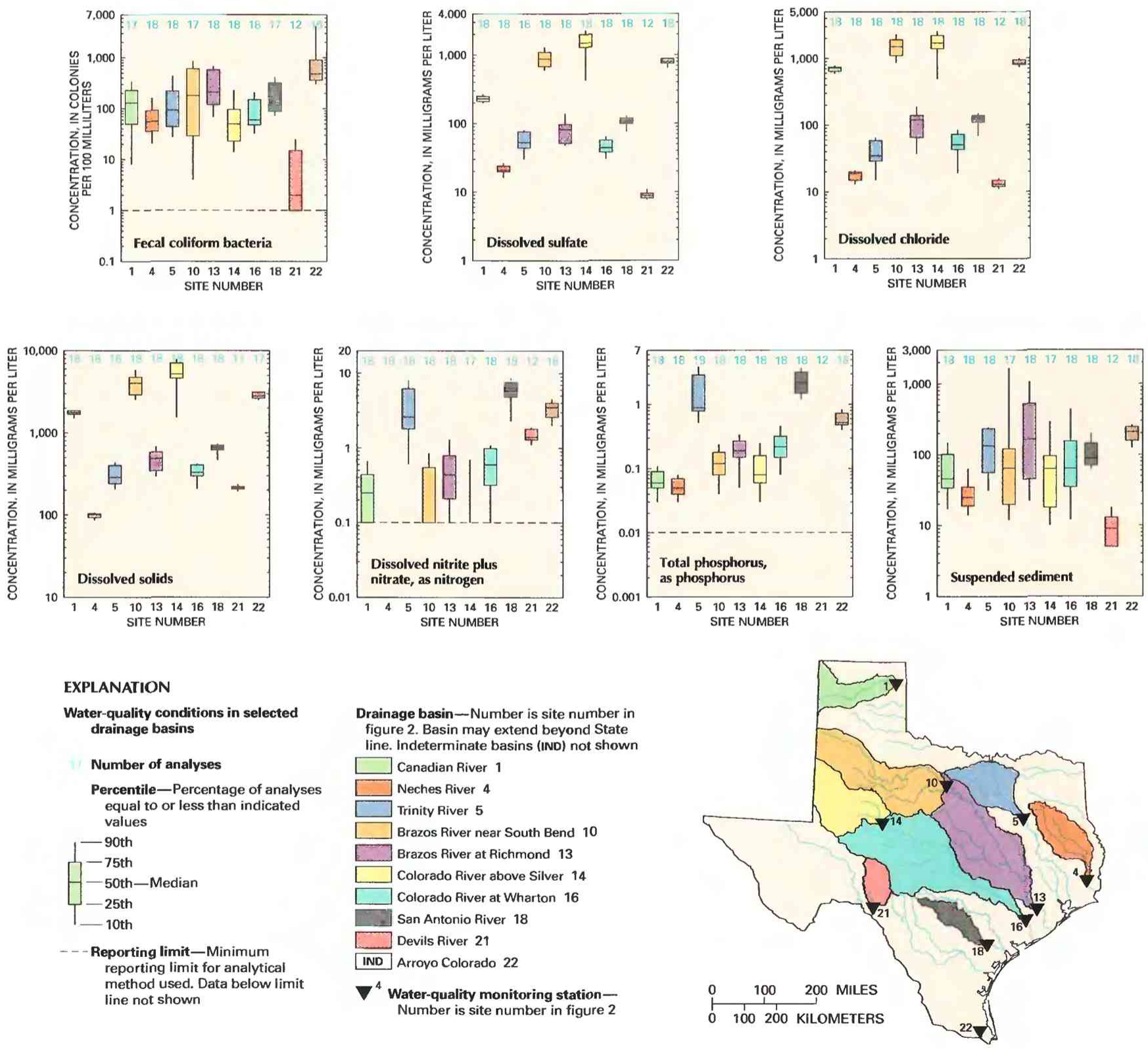

Figure 3. Water quality of selected streams in Texas, water years 1987-89. (Source: Data from U.S. Geological Survey files.) 
basin. The upper basin overlies geologic formations that generally were deposited in a marine environment and contain deposits of gypsum and salts. These deposits are sources of chloride and sulfate in stream water, and large evaporation rates and arid conditions in the upper basin concentrate the dissolved minerals. As a result, large concentrations of sulfate, chloride, and dissolved solids (medians at site 10 of $880 \mathrm{mg} / \mathrm{L}, 1,500 \mathrm{mg} / \mathrm{L}$, and $4,040 \mathrm{mg} / \mathrm{L}$, respectively, for water years 1987-89) make surface water in the upper basin unsuitable for public supply without special treatment (Texas Water Commission, 1990, p. 373). In contrast, the lower basin is in the Coastal Plain, which generally was formed in a fluvial environment, has no major natural source of salinity, and receives more rainfall. Therefore, concentrations of sulfate (median, $82 \mathrm{mg} / \mathrm{L}$ ), chloride $(120$ $\mathrm{mg} / \mathrm{L})$, and dissolved solids ( $484 \mathrm{mg} / \mathrm{L}$ ) at site 13 were considerably smaller during water years 1987-89 than at site 10. Conversely, concentrations of nitrite plus nitrate, phosphorus, and suspended sediment increased from site 10 to site 13 . The increase probably was the result of agricultural runoff and treated wastewater discharge by several municipalities along the river.

\section{COLORADO RIVER}

The Colorado River originates near the New Mexico border and flows across the State from the arid west to the more humid coastal region. The river drains subhumid grassland, semiarid grazing land, and some cropland in the upper reaches, whereas the lower basin contains woodlands, cropland, and pastures. Dams on the river form 14 major reservoirs that store water for irrigation, municipal supply, and flood control.

Geologic and climatic conditions in the Colorado River basin are similar to those of the Brazos River basin. Water quality also differs substantially between the upper and lower basins (Rawson, 1982). The median concentrations of sulfate $(1,500 \mathrm{mg} / \mathrm{L})$, chloride $(1,700 \mathrm{mg} / \mathrm{L})$, and dissolved solids $(5,200 \mathrm{mg} / \mathrm{L})$ at the upstream monitoring station (site 14) were the largest of those at the 10 waterquality monitoring stations (fig. 3). These large concentrations result from natural brine deposits and from oil-field drilling activities. As in the Brazos River, median concentrations of these three con- stituents downstream at the Coastal Plain monitoring station (site 16) were considerably smaller than those at the station located in the Great Plains. Also as in the Brazos River, the median nitrite plus nitrate concentration increased from the upstream to the downstream station (less than $0.10 \mathrm{mg} / \mathrm{L}$ at site 14 to $0.60 \mathrm{mg} / \mathrm{L}$ at site 16 ). The median phosphorus concentration increased from $0.08 \mathrm{mg} / \mathrm{L}$ to 0.22 $\mathrm{mg} / \mathrm{L}$ from the upstream to the downstream station. Agricultural runoff and wastewater-treatment-plant discharge between the monitoring stations probably caused these increases. New treatment facilities in Austin are predicted to improve water quality in the Colorado River downstream from that city (Texas Water Commission, 1990, p. 445)

\section{SAN ANTONIO RIVER}

The San Antonio River drains woodland and forest, cropland, pasture, and the San Antonio urban area. Water quality in the upper reaches of the San Antonio River historically has been affected by municipal wastewater-treatment-plant effluent and urban runoff. Median concentrations of sulfate $(100 \mathrm{mg} / \mathrm{L})$, chloride $(130 \mathrm{mg} / \mathrm{L})$, and dissolved solids $(667 \mathrm{mg} / \mathrm{L})$ at site 18 are about in the middle of the range of concentrations at the $\mathbf{1 0}$ monitoring stations (fig. 3). However, the median concentrations of nitrite plus nitrate $(5.80$ $\mathrm{mg} / \mathrm{L})$ and phosphorus $(2.20 \mathrm{mg} / \mathrm{L})$ were the largest. The water quality at this station is expected to improve after the construction of additional wastewater-treatment facilities (Texas Water Commission, 1990, p. 519).

\section{DEVILS RIVER}

The Devils River drains desert, grazed shrubland, subhumid grassland, semiarid grazing land, and grazed open woodland. Samples collected at site 21, part of the USGS Hydrologic Bench-Mark Network, had the smallest or among the smallest concentrations of all of the constituents except nitrite plus nitrate (fig. 3 ). The median nitrite plus nitrate concentration $(1.40 \mathrm{mg} / \mathrm{L})$ at site 21 was exceeded only by medians at sites 5,18 , and 22 , which are downstream from municipal wastewater-treatment plant outfalls. However, the origin

Table 1. Sources and environmental significance of selected water-quality constituents

[Source: Compiled by the U.S. Geological Survey, Office of Water Quality]

Constituent Common sources

Environmental significance

Fecal coliform bacteria

Sulfate

Chloride

Dissolved solids

Nitrite plus nitrate

Phosphorus

Suspended sediment
Sources include effluent from sewage-treatment plants and runoff from pastures, feedlots, and urban areas.

Occurs in some rocks; also in mine runoff, industrial wastewater discharge, and atmospheric deposition.

Occurs in some rocks and ground-water discharge; also in road deicers, industrial and urban wastewater discharge, and atmospheric deposition.

A result of rock weathering; also in agricultural runoff and industrial discharge.

Nonpoint sources are agricultural and urban runoff; a major point source is wastewater discharge.

Occurs in some rocks and sediments; also in runoff and seepage from phosphate-rock mines, agricultural and urban runoff, and industrial and municipal wastewater discharge.

A result of rock erosion; also induced by disturbances of land cover due to fires, floods, and human activities such as mining, logging, construction and agriculture.
Presence indicates contamination of water by wastes from humans and other warm-blooded animals.

Concentrations exceeding a natural, background level indicate contamination from human activity; in sufficient quantity, can cause water to be unsuitable for public supply; can harm aquatic organisms.

Concentrations exceeding a natural, background level can cause water to be unsuitable for public supply agriculture, and industry; can harm aquatic organisms.

In sufficient quantity, can cause water to be unsuitable for public supply, agriculture, and industry; can harm aquatic organisms.

Plant nutrient that, in sufficient quantity, can cause algal blooms and excessive growth of higher aquatic plants in bodies of water; can cause water to be unsuitable for public supply.

Plant nutrient that, in sufficient quantity, can cause algal blooms and excessive growth of higher aquatic plants in bodies of water.

Can be detrimental to aquatic organisms; can fill reservoirs and impair recreational use of water. 
of this constituent at site 21 is natural decay of mesquite plants (E.M. McPherson, U.S. Geological Survey, oral commun., August 1990).

\section{ARROYO COLORADO}

The Arroyo Colorado receives municipal and industrial wastewater-treatment- plant effluent and return flows from irrigated land. Fecal coliform bacteria and nutrient concentrations frequently are large because the flow often is predominantly composed of effluent. Median concentrations of all constituents at site 22 were the largest or among the largest at the 10 monitoring stations (fig. 3 ). The median concentration of fecal coliform bacteria $(480 \mathrm{col} / 100 \mathrm{~mL})$ was the largest for any station, and concentrations exceeded 4,000 col/100 mL in 19 percent of the water samples collected at site 22 .

\section{WATER-QUALITY TRENDS}

Trend analysis is a statistical procedure used to detect changes in stream water quality at a monitoring station over time. For this report, water-quality data from 20 monitoring stations (fig. 2) were analyzed for trends by using the seasonal Kendall test (Hirsch and others, 1982), a method used extensively by the USGS. The graph (shown below) of the dissolved-solids concentration in the Pecos River at site 20 illustrates the trend inferred from the concentration data and demonstrates the variation in water quality that is common in streams.

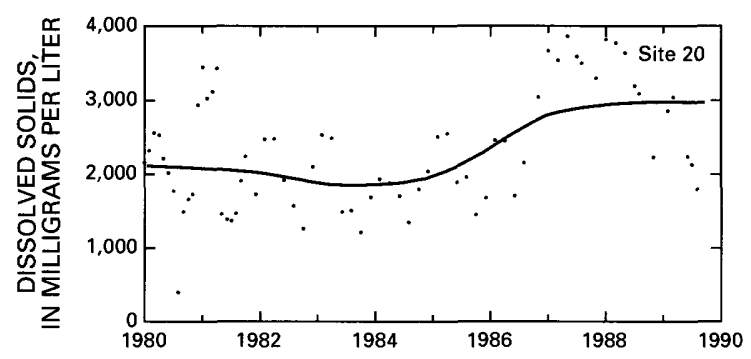

When possible, constituent-concentration data were adjusted for changes in streamflow to preclude identifying a trend in concentration that was caused only by a trend in streamflow. The data were not adjusted when (1) more than 10 percent of the samples had concentrations lower than the minimum reporting limit for the analytical method used or (2) streamflow was controlled substantially by human activities. When the concentration data could not be adjusted for streamflow, trends were determined directly from the concentration data.

Statewide trends in concentrations of selected stream-water constituents are shown on maps in figure 4. On each map, a trend is indicated at a monitoring station only if the data from that station were suitable for use in the trend analysis. For more information on the suitability criteria and on the trend-analysis procedure used for this report, see Lanfear and Alexander (1990). Additional information on water-quality trends in Texas is available in a report by Schertz (1990).

\section{FECAL COLIFORM BACTERIA}

Fecal coliform bacteria are used as indicators of fecal contamination from humans and other warm-blooded animals. Such contamination can introduce disease-causing viruses and bacteria into a stream. No trend in fecal coliform bacteria concentrations was detected at 14 monitoring stations from which data were suitable for trend analysis (fig. 4).

\section{DISSOLVED SULFATE}

The major natural sources of sulfate in streams are rock weathering, volcanoes, and biochemical processes (Hem, 1985, p. 113).
Human activities such as mining, waste discharge, and fossil-fuel combustion also can be important sources. A shortened trend-analysis period was used for sulfate because data from analyses performed before water year 1982 are not comparable to data from subsequent years.

Sulfate concentrations had upward trends in the Trinity River at site 6, the West Fork San Jacinto River at site 7, the Colorado River at site 16 , and the Pecos River at site 20 (fig. 4). A cause for the slight increase in the Trinity River at site 6 is not readily apparent. The small increase in the West Fork San Jacinto River at site 7 probably was caused by increasing effluent volume resulting from increasing population in the Houston metropolitan area. The increasing concentration at site 16 resulted mostly from releases of saline water from Natural Dam Lake in the upper Colorado River from September 1986 to August 1988 (R.M. Slade, Jr., U.S. Geological Survey, oral commun., August 1990). The increasing sulfate concentration in the Pecos River at site 20 likely was caused by increasing salinity in water released from Red Bluff Reservoir (Texas Water Commission, 1990, p. 573).

The decreasing sulfate concentration in the Nueces River at site 19 coincided with the beginning of legally required releases from Choke Canyon Reservoir in 1986. This reservoir, which is on the Frio River upstream from its confluence with the Nueces River, stores runoff from 36 percent of the Nueces River basin. The water in the reservoir consists mainly of stormwater that contains little dissolved solids. The released dilute reservoir water combines with more concentrated base flows from other tributaries in the basin to reduce variability and magnitude of stream-water concentrations in the Nueces River main stem.

Sulfate concentrations had no trend for water years 1982-89 in the Trinity River at site 5. However, a downward trend in concentrations is noticeable in graphs of data collected prior to 1982 (not shown), indicating probable wastewater-treatment improvement in the Dallas-Fort Worth area.

\section{DISSOLVED CHLORIDE}

Chloride is present in all natural waters but usually in low concentrations (Hem, 1985, p. 118). Except in streams that receive ground-water discharge high in chloride, concentrations of greater than a few milligrams per liter generally are the result of human activities (table 1).

Chloride concentrations in the Canadian River at site 1 in the Texas Panhandle and Brazos River at site 11 in central Texas had steady increases (fig. 4) that might have been a result of generally declining rainfall during the trend-analysis period. During periods of decreased rainfall and runoff, ground water, which generally contains more dissolved minerals, contributes a proportionately larger quantity of the streamflow. Concentrations at site 15 on the middle Colorado River had an upward trend because of releases of saline water from Natural Dam Lake near the end of the analysis period (R.M. Slade, Jr., U.S. Geological Survey, oral commun., August 1990). The chloride concentration in the Pecos River at site 20 increased owing to saline-water releases from Red Bluff Reservoir.

Chloride concentrations in the Neches River at site 4 had a downward trend for unknown reasons. Concentrations in the Nueces River at site 19 declined for the same reason as sulfate-stormwater releases from Choke Canyon Reservoir.

\section{DISSOLVED SOLIDS}

Dissolved solids in stream water result primarily from rock weathering but also can be introduced as a byproduct of human activities (table 1). Concentrations generally are greatest in streams draining basins underlain by rocks and soils that contain easily dissolved minerals.

Dissolved-solids concentrations had upward trends in the West Fork San Jacinto River at site 7 and the Pecos River at site 20 (fig. 4). 


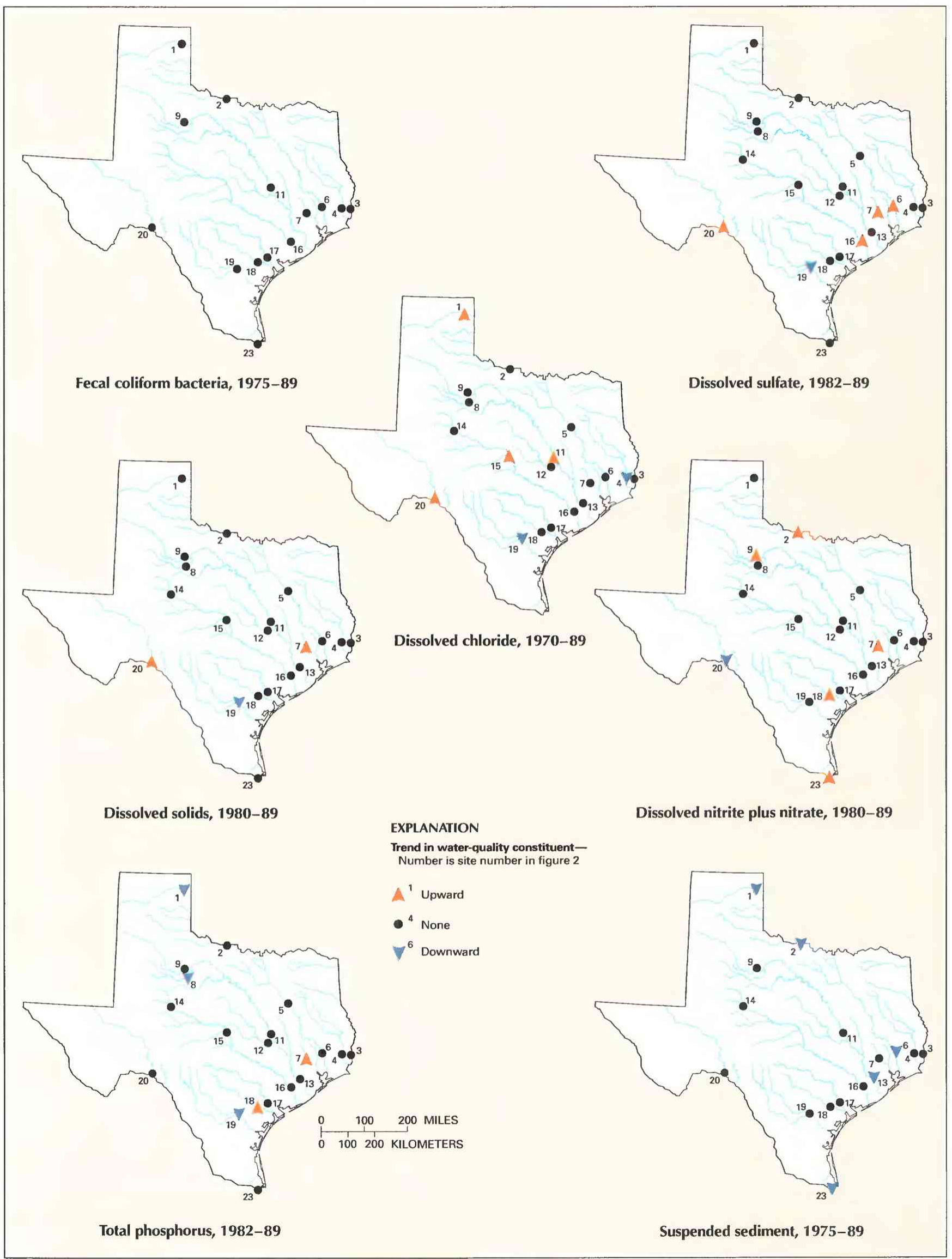

Figure 4. Trends in water quality of selected streams in Texas, by water years. (Source: Data from U.S. Geological Survey files.) 
The moderately increasing dissolved-solids concentration in the West Fork San Jacinto River probably resulted from increases in wastewater-treatment-plant discharge from urban development north of Houston (Texas Water Commission, 1990, p. 329). The large increase in dissolved-solids concentrations in the Pecos River was a result of saline-water releases from Red Bluff Reservoir. Beginning in 1986, dissolved-solids concentrations had a downward trend in the Nueces River at site 19 owing to dilution from Choke Canyon Reservoir.

\section{DISSOLVED NITRITE PLUS NITRATE}

Nitrite and nitrate are oxidized forms of nitrogen that together normally constitute most of the dissolved nitrogen in well-aerated streams. Nitrite readily oxidizes to nitrate in natural waters; therefore, nitrate generally is by far the more abundant of the two (Hem, 1985, p. 124).

The increasing concentration in the West Fork San Jacinto River at site 7 (fig. 4) is similar to the trend in sulfate and dissolvedsolids concentrations and probably is related to urban development in the Houston metropolitan area. Nitrite plus nitrate concentrations in the Salt Fork of the Brazos River at site 9 had a slight increase of unknown cause. Nitrite plus nitrate concentrations increased substantially in the San Antonio River at site 18, probably as a result of wastewater-treatment deficiencies in the San Antonio metropolitan area; these deficiencies gradually are being rectified (Texas Water Commission, 1990, p. 519). Although the upward trends in nitrite plus nitrate concentrations in the Red River at site 2 and in the Rio Grande at site 23 were statistically significant, the increases in concentrations in water samples collected during the trend-analysis period were minimal.

Nitrite plus nitrate concentrations had a downward trend in the Pecos River at site 20. The downward trend may have been the result of a reduction in nitrogen-fertilizer use in the basin.

\section{TOTAL PHOSPHORUS}

The total phosphorus concentration of a water sample is a measure of the concentration of all forms of phosphorus present in the sample, dissolved and particulate. Human activities (table 1) can be important sources of phosphorus in streams.

The increasing phosphorus concentration in the West Fork San Jacinto River at site 7 (fig. 4) probably resulted from urbanization in the Houston metropolitan area. Phosphorus concentrations in the San Antonio River at site 18 had an upward trend that probably was caused by increasing wastewater-treatment-plant effluent discharges from the San Antonio area.

Phosphorus concentrations had downward trends in the Canadian River at site 1 and in the Double Mountain Fork Brazos River at site 8 either because of reductions in fertilizer use or the upgrading of wastewater-treatment facilities. The decreasing concentration in the Nueces River at site 19 coincides with the beginning of releases from Choke Canyon Reservoir. Information concerning trends in phosphorus concentrations in Texas rivers for water years 1972-79 is provided in a report by Smith and others (1982).

\section{SUSPENDED SEDIMENT}

Suspended sediment is a product of erosion. The erosion can be either natural or the result of land-cover disturbances related to human activities (table 1).

The downward trend in suspended-sediment concentration in the Canadian River at site 1 (fig. 4) possibly was the result of decreased precipitation and runoff during the trend-analysis period. No cause is known for the substantial decrease in concentrations in the Red River at site 2 . The downward trend in suspended-sediment concentrations at site 6 possibly was caused by a 45 -percent increase in upstream reservoir storage capacity during the trend-analysis period. Suspended-sediment concentrations at the most downstream monitoring station on the Brazos River, site 13, decreased substantially during 1975-89, possibly because of a 50 -percent increase in reservoir capacity on the Brazos River basin during this period. The Rio Grande at site 23 had a small decrease in suspended sediment, possibly because of less than average precipitation and runoff for water years 1984-89.

\section{WATER-QUALITY MANAGEMENT}

The Texas Water Code provides the Texas Water Commission with the authority to administer programs and policies to secure and preserve adequate water quality for surface and ground water in the State. The code also authorizes the Commission to adopt rules and regulations necessary to conduct the duties of the Commission.

The policy of the State is to protect, restore, and maintain a quality of water consistent with public health and enjoyment and propagation and protection of terrestrial and aquatic life. The State's water-pollution-control program is based on designating desired uses for stream segments and ensuring that these uses are attained. Numerical water-quality criteria are established to protect or secure the desirable uses. Waste loads are evaluated to determine the assimilative capacity of a stream segment and to determine wastewater-treatment levels necessary to meet instream criteria for a stream segment. These treatment levels are specified in mandatory discharge permits, and compliance is monitored through inspections and self-reporting procedures. When noncompliance is detected, enforcement ensues.

The Texas water-quality inventory (Texas Water Commission, 1990 ) is prepared and submitted biennially to the U.S. Congress and the EPA by the Texas Water Commission in accordance with section 305(b) of the Federal Clean Water Act. The report evaluates water quality in Texas, progress made in restoring and maintaining water quality, and the extent to which problems remain.

The Texas Water Commission is the lead agency for development of the nonpoint-source water-pollution program. The Commission has appointed a broad-based, diverse Nonpoint-Source Advisory Committee to determine the effect of the nonpoint-source water-pollution control effort in the State. Also, the Commission is active in the Galveston Bay National Estuary Program established by the Water Quality Act of 1987 to develop Comprehensive Conservation and Management Plans for estuaries of national significance that are threatened by pollution, development, or overuse.

Surface water-quality data are collected from more than 700 sites in the State as part of the Surface Water Quality Monitoring Program, which is the responsibility of the Texas Water Commission. Sampling includes collection of physiochemical, biological, and hydrologic data. Samples are collected from 359 designated stream, reservoir, and bay segments (some have more than one sampling site) to monitor for compliance with numerical water-quality criteria. Surface water is monitored to detect long-term trends, collect data to be used in characterizing aquatic resources by ecoregion, determine reservoir-bottom water quality, evaluate effects of acid rain, and detect toxics. A citizens' water-quality monitoring program is planned. The scope of surface-water monitoring is shifting from longterm trend monitoring to site-specific intensive surveys.

\section{SELECTED REFERENCES}

Anderson, J.R., 1967, Major land uses in the United States, in U.S. Geological Survey, 1970, National atlas of the United States of America, Washington. D.C., U.S. Geological Survey, p. 158-159.

Britton, L.J., and Greeson, P.E., eds., 1987, Methods for collection and analysis of aquatic biological and microbiological samples: U.S. Geological Survey Techniques of Water-Resources Investigations, book 5, chap. A4, $363 \mathrm{p}$.

Fenneman, N.M., 1946, Physical divisions of the United States: Washington, D.C., U.S. Geological Survey special map, scale 1:7,000,000.

Fishman, M.J., and Friedman, L.C., eds., 1989, Methods for the determination of inorganic substances in water and fluvial sediments: U.S. Geological Survey Techniques of Water-Resources Investigations, book 5 , chap. A1, 545 p. 
Hem, J.D., 1985, Study and interpretation of the chemical characteristics of natural water (3d ed.): U.S. Geological Survey Water-Supply Paper 2254, $263 \mathrm{p}$.

Hirsch, R.M., Slack, J.R., and Smith, R.A., 1982, Techniques of trend analysis for monthly water quality data: Water Resources Research, v. 18, no. 1, p. $107-121$.

Lanfear, K.J., and Alexander, R.B., 1990, Methodology to derive water-quality trends for use by the National Water Summary Program of the U.S. Geological Survey: U.S. Geological Survey Open-File Report 90-359, $10 \mathrm{p}$.

Rawson, Jack, 1982, Source areas of salinity and trends of salt loads in streamflow in the upper Colorado River, Texas: U.S. Geological Survey Water-Supply Paper 2084, 36 p.

Schertz, T.L., 1990, Trends in water-quality data in Texas: U.S. Geological Survey Water-Resources Investigations Report 89-4178, 177 p.

Smith, R.A., Hirsch, R.M., and Slack, J.R., 1982, A study of trends in total phosphorus measurements at NASQAN stations: U.S. Geological Survey Water-Supply Paper $2190,34 \mathrm{p}$.

Solley, W.B., Merk, C.F., and Pierce, R.R., 1988, Estimated use of water in the United States in 1985: U.S. Geological Survey Circular 1004, 82 p.
Texas Water Commission, 1990, The State of Texas water quality inventory: Texas Water Commission LP 90-06, (10th ed.), 652 p.

Thelin, G.P., and Pike, R.J., 1990, Digital shaded relief map of the conterminous United States: Menlo Park, Calif., U.S. Geological Survey digital image processing, scale 1:3,500,000.

U.S. Geological Survey, 1986, National water summary 1985-Hydrologic events and surface-water resources: U.S. Geological Survey Water-Supply Paper 2300,506 p.

1990, National water summary 1987-Hydrologic events and water supply and use: U.S. Geological Survey Water-Supply Paper 2350, $553 \mathrm{p}$.

Ward, J.R., and Harr, C.A., eds., 1990, Methods for collection and processing of surface-water and bed-material samples for physical and chemical analyses: U.S. Geological Survey Open-File Report 90-140, 71 p.

Wells, F.C., Rawson, Jack, and Shelby, W.J., 1986, Areal and temporal variations in the quality of surface water in Hydrologic Accounting Unit 120301, upper Trinity River basin, Texas: U.S. Geological Survey WaterResources Investigations Report 85-4318, 135 p. 
516 National Water Summary 1990-91-Stream Water Quality: STATE SUMMARIES

Prepared by J.E. Veenhuis, U.S. Geological Survey; "Water-Quality Management" section by David Buzan, Texas Water Commission FOR ADDITIONAL INFORMATION: District Chief, U.S. Geological Survey, 8011 Cameron Road, Bldg. 1, Austin, TX 78753 


\section{UTAH \\ Stream Water Quality}

Utah relies on surface water for most of its freshwater supply. Surface water provided 81.1 percent of the water for offstream uses in 1985 (U.S. Geological Survey, 1990, p. 491). In 1985, surface-water withdrawals averaged 3,390 million gallons per day. Of those withdrawals, 94.5 percent was used for irrigation and 4.4 percent was used for public supply (U.S. Geological Survey, 1990, p. 493-496).

The quality of Utah's surface water is affected by natural factors, primarily the geochemistry of rocks and soils in the drainage basins, and by human-related factors, primarily land use. Many drain- age basins in more arid regions of Utah are underlain by rocks and soils containing evaporite minerals that are a major source of dissolved solids in many of the State's streams and rivers. Livestock grazing of desert shrubland, woodland, and forest is a major land use in Utah in terms of area (fig. $1 A$ ); about two-thirds of the grazed land is federally owned. Although not as areally extensive as grazing, irrigation and urbanization substantially affect stream water quality in some drainage basins.

Utah, which has an average annual precipitation of 13 inches, is the second driest State in the Nation. Precipitation varies geographically, ranging from about 5 inches on the Great Salt Lake Desert in the northwestern part of the State to about 60 inches at some locations in the mountainous regions (U.S. Geological Survey, 1986, p. 453). Annual runoff ranges from about 0.1 inch in most of the Basin and Range province (fig. $1 B$ ) to about 30 inches at some locations in the Middle Rocky Mountains. To cope with its generally arid climate, Utah has an extensive reservoir system in which an average of 7 million acre-feet of water is stored annually (U.S. Geological Survey, 1990, p. 491).

The 1990 population of Utah was 1.7 million, an increase of 17.9 percent since 1980 (U.S. Bureau of the Census 1990 decennial census files). The densely populated areas from Ogden to Provo (figs. $1 C$ and 2 ) rely on ground-water withdrawals supplemented by surface-water withdrawals for domestic use.

\section{WATER-QUALITY MONITORING}

Water-quality data obtained from analyses of water samples collected at monitoring stations are stored in the U.S. Geological Survey's (USGS) National Water Information System and the U.S. Environmental Protection Agency's (EPA) national data base known as STORET. Water-quality and streamflow data are reported by water year-the 12 months from October 1 through September 30. A water year is identified by the calendar year in which it ends. For example, water year $1991 \mathrm{com}-$ prises October 1, 1990, through September 30, 1991.

The data used in this summary of Utah's stream water qual-
Figure 1. Land use, physiography, and population in Utah. A, Major land uses. $B$, Physiographic sions. C, Population distribution in 1990. (Sources: A, Major land uses modified from Anderson, 1967. B, Physiographic divisions from Fenneman, 1946; landforms from Thelin and Pike, 1990. C. Data from U.S. Bureau of the Census 1990 decennial census files.) 
ity were obtained from water samples collected either every 2 months or quarterly at 15 monitoring stations at which data collection is systematic and continuing (fig. 2). Analyses of water samples collected at 10 stations are the basis for the discussion and graphic summary (fig. 3 ) of stream water-quality conditions during water years 1987-89, and data from all 15 stations are the basis for the discussion and graphic summary (fig. 4) of stream water-quality trends. Water samples were collected and analyzed by using standard methods approved by the USGS (Britton and Greeson, 1987; Fishman and Friedman, 1989; Ward and Harr, 1990) or by using equivalent methods. If a method of sample collection or analysis changed over time, data from an analysis were included in the evaluation of recent stream

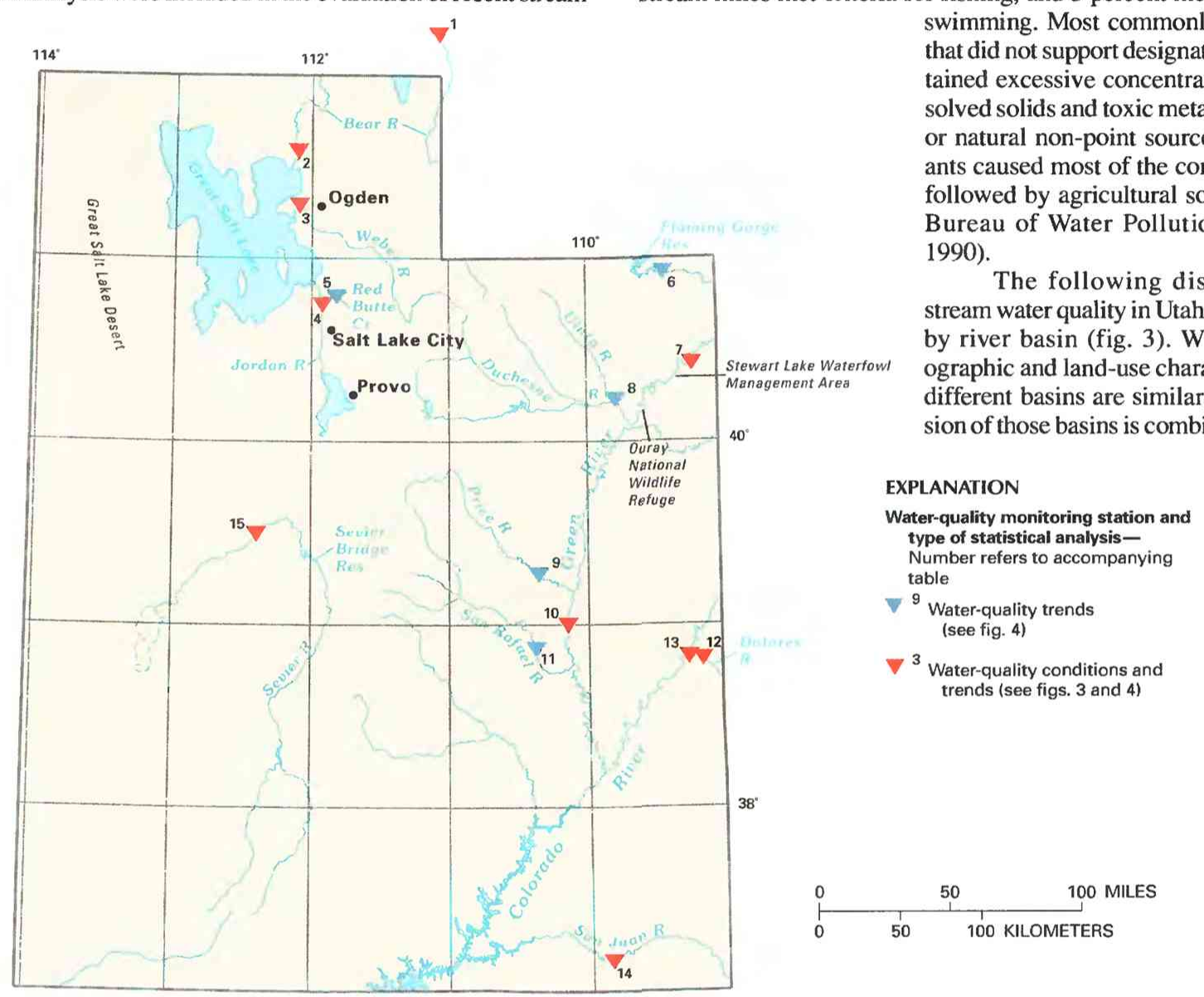

water quality or of stream water-quality trends only if the change in method did not affect the comparability of the data.

\section{WATER-QUALITY CONDITIONS}

In an assessment conducted during 1988-89, the Bureau of Water Pollution Control determined that, of the 11,779 stream miles in Utah, 15 percent supported the uses designated by the State in accordance with the Federal Clean Water Act, 48 percent partially supported designated uses, and 12 percent did not support designated uses. Twenty-five percent were not assessed. Eleven percent of the stream miles met criteria for fishing, and 3 percent met criteria for swimming. Most commonly, the rivers ( Bureau of Water Pollution Control, The following discussion of Where physiifferent basins are similar, the discussion of those basins is combined. Graphs

PLANATION

to accompanying

ater-quality conditions and

\section{(1)}


in figure 3 summarize certain aspects of stream water quality in the basins for water years 1987-89. The graphs show frequency distributions of data values that represent concentrations of selected stream-water constituents. These constituents are dissolved oxygen, dissolved sulfate, dissolved chloride, dissolved solids, dissolved nitrite plus nitrate (as nitrogen), dissolved phosphate (as phosphorus), and suspended sediment. The data are reported in milligrams per liter $(\mathrm{mg} / \mathrm{L})$. Sources and environmental significance of each constituent are described in table 1.

Water quality at each monitoring station is the result of geological, chemical, biological, and hydrologic processes that occur over a large area. Water-quality problems that affect aquatic life or public health only locally are not fully represented in this summary. For example, selenium, a naturally occurring element required in trace quantities for normal health of animals and humans, can be toxic to livestock, wildlife, and humans when ingested in larger concentrations. Selenium is present in many geologic formations in the eastern one-half of Utah. Results from a study conducted during 1986-87 indicate that selenium has caused reduced reproduction and deformities in fish and waterfowl at several sites along the Green River (Stephens and others, 1988, p. 65-66), including the Stewart
Lake Waterfowl Management Area and the Ouray National Wildlife Refuge.

\section{BEAR RIVER}

Most of the Bear River basin lies within the Middle Rocky Mountains and is underlain primarily by consolidated rocks, including quartzite, limestone, sandstone, conglomerate, and volcanic rocks. Most of these, with the exception of limestone, are not easily dissolved and contribute only small quantities of dissolved minerals to streams. Streamflow in the Bear River is regulated by dams for reservoir storage and hydroelectric power generation, diversions for irrigation, and irrigation return flows. Although grazed desert shrubland is the principal land use upstream from site 1 and grazed open woodland is the principal land use upstream from site 2 , irrigated land and cropland with grazing land are the land uses that probably most affect water quality in the Bear River.

Median concentrations of sulfate $(72 \mathrm{mg} / \mathrm{L})$, chloride $(29$ $\mathrm{mg} / \mathrm{L})$, and dissolved solids $(372 \mathrm{mg} / \mathrm{L})$ at site 1 and sulfate $(63$ $\mathrm{mg} / \mathrm{L}$ ) at site 2 were among the lowest from samples collected at the 10 monitoring stations (fig. 3). At site 2 , the median nitrite plus ni-
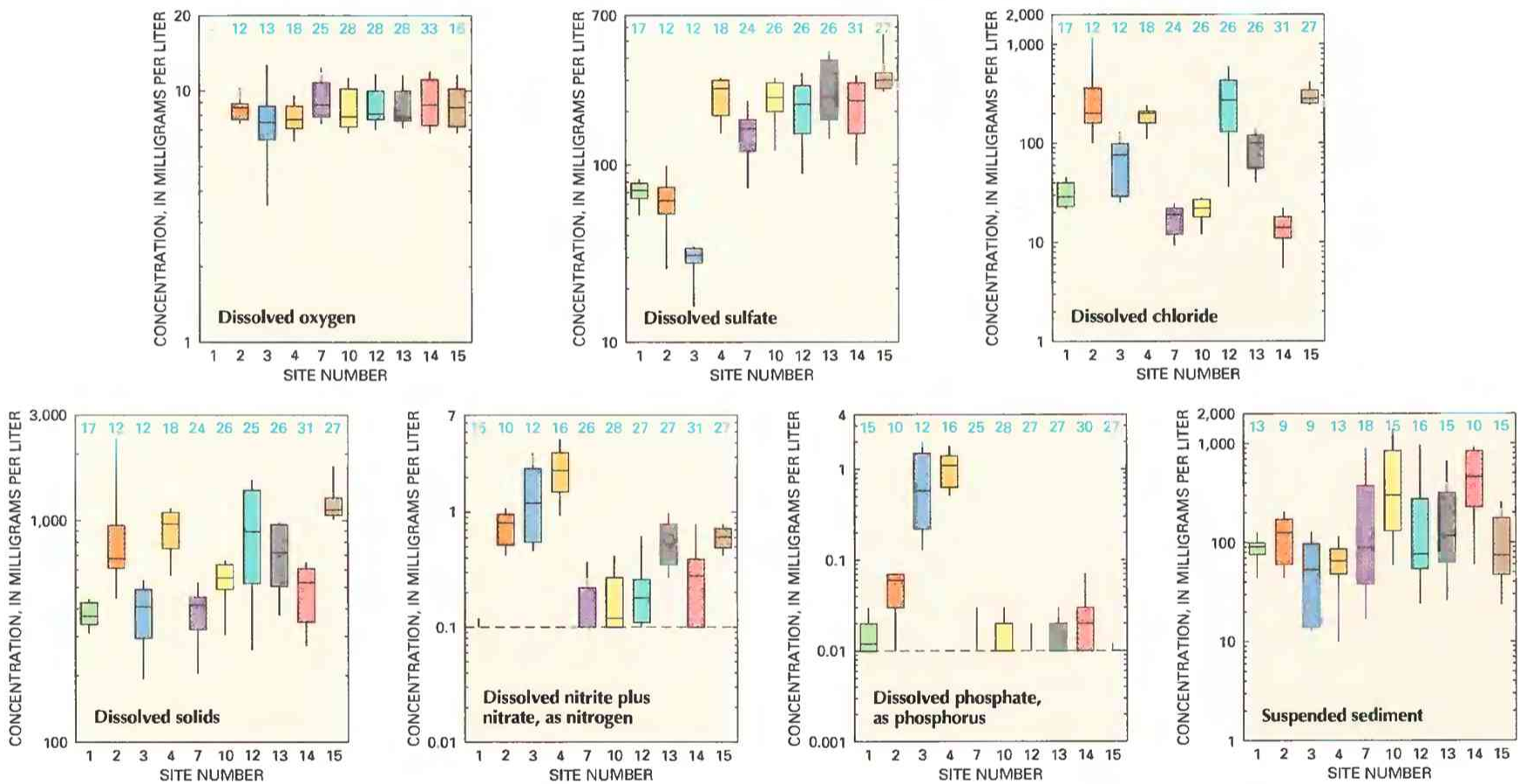

\section{EXPLANATION}

Water-quality conditions in selected
drainage basins
Number of analyses-Dash indicates
insufficient data
Percentile-Percentage of analyses
equal to or less than indicated
values
-90th
-75th
- 50th-Median
- 25th
10th
- Reporting limit-Minimum reporting
limit for analytical method used.
Data below limit line not shown

Drainage basin-Number is site number in figure 2. Basin may extend beyond State line

Bear River at Border, Wyo.

Bear River near Corinne 2

Weber River 3

Jordan River 4

Green River near Jensen 7

Green River at Green River 10

Dolores River 12

Colorado River 13

San Juan River 14

Sevier River 15

$\nabla^{4}$ Water-quelity monitoring stationNumber is site number in figure 2

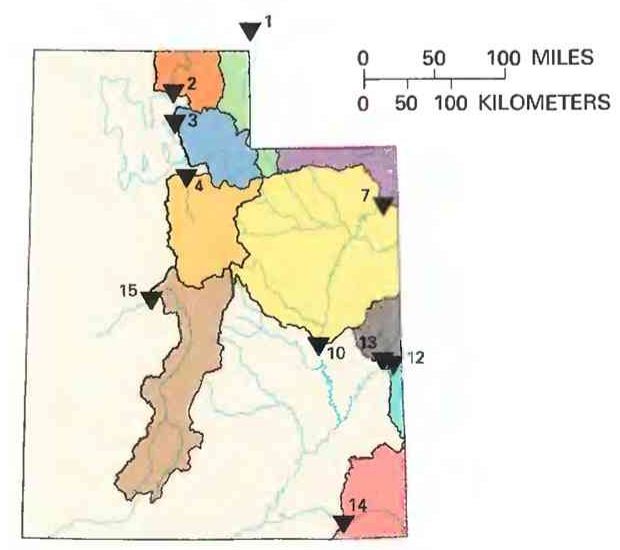

Figure 3. Water quality of selected streams in Utah, water years 1987-89. (Source: Data from U.S. Geological Survey files.) 
Table 1. Sources and environmental significance of selected water-quality constituents [Source: Compiled by the U.S. Geologıcal Survey, Office of Water Quality]

\begin{tabular}{|c|c|c|}
\hline Constituent & Common sources & Environmental significance \\
\hline Dissolved oxygen .......................... & $\begin{array}{l}\text { Introduced from the atmosphere: also a byproduct of } \\
\text { aquatic plants. }\end{array}$ & $\begin{array}{l}\text { Necessary for aquatic life; deficiency can result from } \\
\text { assimilation of organic wastes or rapid growth } \\
\text { and decay of algae. }\end{array}$ \\
\hline Sulfate & $\begin{array}{l}\text { Occurs in some rocks; also in mine runoff, industrial } \\
\text { wastewater discharge, and atmospheric deposi- } \\
\text { tion. }\end{array}$ & $\begin{array}{l}\text { Concentrations exceeding a natural, background } \\
\text { level indicate contamination from human activity; } \\
\text { in sufficient quantity, can cause water to be } \\
\text { unsuitable for public supply; can harm aquatic } \\
\text { organisms. }\end{array}$ \\
\hline 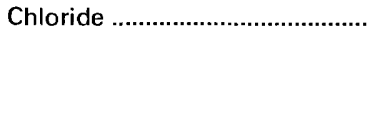 & $\begin{array}{l}\text { Occurs in some rocks and ground-water discharge; } \\
\text { also in road deicers, industrial and urban waste- } \\
\text { water discharge, and atmospheric deposition. }\end{array}$ & $\begin{array}{l}\text { Concentrations exceeding a natural, background level } \\
\text { can cause water to be unsuitable for public supply } \\
\text { agriculture, and industry; can harm aquatic or- } \\
\text { ganisms. }\end{array}$ \\
\hline Dissolved solids ........................... & $\begin{array}{l}\text { A result of rock weathering; also in agricultural runoff } \\
\text { and industrial discharge. }\end{array}$ & $\begin{array}{l}\text { In sufficient quantity, can cause water to be unsuitable } \\
\text { for public supply, agriculture, and industry; can } \\
\text { harm aquatic organisms. }\end{array}$ \\
\hline 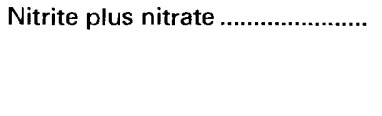 & $\begin{array}{l}\text { Nonpoint sources are agricultural and urban runoff; } \\
\text { a major point source is wastewater discharge. }\end{array}$ & $\begin{array}{l}\text { Plant nutrient that, in sufficient quantity, can cause } \\
\text { algal blooms and excessive growth of higher } \\
\text { aquatic plants in bodies of water; can cause water } \\
\text { to be unsuitable for public supply. }\end{array}$ \\
\hline 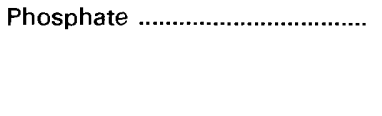 & $\begin{array}{l}\text { Occurs in some rocks and sediments; also in runoff } \\
\text { and seepage from phosphate-rock mines, agri- } \\
\text { cultural and urban runoff, and industrial and } \\
\text { municipal wastewater discharge. }\end{array}$ & $\begin{array}{l}\text { Plant nutrient that, in sufficient quantity, can cause } \\
\text { algal blooms and excessive growth of higher } \\
\text { aquatic plants in bodies of water. }\end{array}$ \\
\hline Suspended sediment .................. & $\begin{array}{l}\text { A result of rock erosion; also induced by disturbances } \\
\text { of land cover due to fires, floods, and human } \\
\text { activities such as mining, logging, construction, } \\
\text { and agriculture. }\end{array}$ & $\begin{array}{c}\text { Can be detrimental to aquatic organisms; can fill res- } \\
\text { ervoirs and impair recreational use of water. }\end{array}$ \\
\hline
\end{tabular}

trate concentration $(0.81 \mathrm{mg} / \mathrm{L})$ was the third highest. Substantial increases in concentrations of chloride, dissolved solids, nitrite plus nitrate, and phosphate from site 1 to site 2 were primarily the result of irrigation return flows that contain nutrients from fertilizers and minerals dissolved from soils.

\section{WEBER RIVER AND JORDAN RIVER}

Most of the Weber and Jordan River drainages lie within the Middle Rocky Mountains. Both rivers flow into the Great Salt Lake and are regulated by dams. Sites 3 and 4 are downstream from densely populated urban areas, and both receive effluent from wastewatertreatment plants.

Samples from the Weber River at site 3 and the Jordan River at site 4 had high median nitrite plus nitrate and phosphate concentrations (fig. 3); median phosphate concentrations at both sites exceeded the State criterion of $0.05 \mathrm{mg} / \mathrm{L}$. The consistently higher concentrations of all constituents at site 4 compared to those at site 3 were due to extensive urban development in the drainage basin upstream from site 4.

\section{COLORADO RIVER}

Upstream from site 13, the Colorado River drains an area containing many sedimentary-rock formations derived from prehistoric seas. Natural factors such as arid climate and the large salt content of the soils contribute salinity to the river. Human-related causes of increased salinity include irrigation return flows, reduced dilution owing to diversion of streamwater from tributaries for irrigation, and release of brines from mining and energy development. Almost 4 million tons of dissolved solids contributed by sources upstream from site 13 passed this monitoring station annually during 1970-87 (U.S. Department of the Interior, 1989, table 12). In addition to salinity, wastewater discharges from growing communities cause significant water-quality problems. Also, headwater streams in mineral-rich areas contribute heavy metals such as lead, zinc, and mercury, and leachates from uranium tailings contaminate some tributaries (Colorado Department of Health, 1988, p. 5-6).

The median concentration of dissolved solids at site 13 was $718 \mathrm{mg} / \mathrm{L}$ (fig. 3). Although this is lower than the State standard of $1,200 \mathrm{mg} / \mathrm{L}$ for agricultural use, the average discharge at this site is nearly 7,700 cubic feet per second. The large discharge transports a substantial quantity of dissolved solids past this monitoring station.

\section{DOLORES RIVER}

The Dolores River (site 12) joins the Colorado River near site 13. Most of the drainage basin is in Colorado, and 70 percent is federally owned. The area has been extensively mined for gold, silver, uranium, and vanadium. The Dolores River basin is underlain by extensive shale deposits that contain an abundance of evaporite minerals. The river accumulates about 200,000 tons of dissolved solids annually as it flows over a salt anticline in Paradox Valley, Colo. (U.S. Department of the Interior, 1989, p. VII-29).

The median concentration of dissolved solids at site 12 was $893 \mathrm{mg} / \mathrm{L}$, and concentrations occasionally were twice that (fig. 3). The large quantity of dissolved solids in the basin results in part from high concentrations of sulfate (median, $220 \mathrm{mg} / \mathrm{L}$ ) and chloride (median, $270 \mathrm{mg} / \mathrm{L}$ ). Contamination from these ions has impaired the quality of the water for irrigation and recreational uses (Utah Bureau of Water Pollution Control, 1988, p. 13) and prompted the planning of several projects in 1981 to reduce salinity under the Colorado River Salinity Control Program of the U.S. Bureau of Reclamation and the U.S. Soil Conservation Service. As of 1991, a major part of the McElmo Creek Unit was complete, and part of the Paradox Valley Unit was in a testing phase.

\section{SAN JUAN RIVER}

The San Juan River drains about 23,000 $\mathrm{mi}^{2}$ (square miles) in Utah, Colorado, New Mexico, and Arizona upstream from site 14. Most of the principal tributaries to the San Juan River are in Colorado. Sandstone, siltstone, and shale underlie the basin. The only major impoundment on the river is Navajo Reservoir, which was constructed in 1962 near Farmington, N. Mex.

Excessive sulfate and nitrate have slightly impaired the use of the San Juan River for public supply, and excessive dissolved solids have impaired irrigation use (Utah Bureau of Water Pollution Control, 1988, p. 16). The source of the sulfate, which constitutes 45 percent of the dissolved solids, is dissolution of gypsum deposits (Liebermann and others, 1989, p. 6, 54). 
The median concentration of suspended sediment at site 14 ( $457 \mathrm{mg} / \mathrm{L}$ ) was the highest for the 10 monitoring stations (fig. 3) and likely represents the most serious water-quality problem in the river. The average annual quantity of suspended sediment carried by the river past this location during 1970-79 was 18.2 million tons (average daily load of 5,000 tons). Nearly all the suspended sediment enters the river downstream from the Navajo Reservoir (Thompson. 1982, p. 6).

\section{GREEN RIVER}

The Green River enters Utah as the discharge from Flaming Gorge Reservoir on the Wyoming-Utah border. Tributaries to the Green River drain the Colorado Plateaus in eastern Utah and western Colorado. The area is underlain by sedimentary deposits that commonly contain evaporite minerals and abundant mineral resources, including oil, natural gas, oil shale, phosphate, gilsonite, coal, and uranium.

Upstream from site 7, urban development and agriculture are minimal, and water generally meets State standards for all uses. In the 197 miles from site 7 to site 10 , the basin size increases from about 30,000 to $45,000 \mathrm{mi}^{2}$, and the quantity of most dissolved and suspended substances increases owing to inflows from tributaries that drain easily eroded evaporite soils (fig. 3). Although phosphate concentrations did not exceed the State criterion during water years 1987-89, the warm-water fishery in the lower Green River has been adversely affected by high concentrations of phosphate (Utah Bureau of Water Pollution Control, 1988, p. 14).

\section{SEVIER RIVER}

The Sevier River basin lies mostly within the Colorado Plateaus, an area underlain primarily by volcanic rocks, sandstone, shale, and limestone. Population in the basin is sparse, and industry is minimal. Water is diverted for irrigated agriculture, which is a major land use in the basin. Site 15 is about 35 miles downstream from Sevier Bridge Reservoir.

Irrigation return flow is the largest contributor of dissolved substances to the lower reaches of the river. Median concentrations of sulfate $(300 \mathrm{mg} / \mathrm{L})$, chloride $(280 \mathrm{mg} / \mathrm{L})$, and dissolved solids $(1,120 \mathrm{mg} / \mathrm{L})$ at site 15 were the highest for any of the monitoring stations (fig. 3). The relatively low median concentrations of nitrite plus nitrate $(0.61 \mathrm{mg} / \mathrm{L}$ ) and phosphate (less than $0.01 \mathrm{mg} / \mathrm{L}$ ) indicate that contamination from fertilizers was minimal.

\section{WATER-QUALITY TRENDS}

Trend analysis is a statistical procedure used to detect changes in stream water quality at a monitoring station over time. For this report, water-quality data from 15 monitoring stations (fig. 2) were analyzed for trends by using the seasonal Kendall test (Hirsch and others, 1982), a method used extensively by the USGS. The graph (shown below) of the dissolved chloride concentration in the Bear River at site 1 illustrates the trend inferred from the concentration data and demonstrates the variation in water quality that is common in streams.

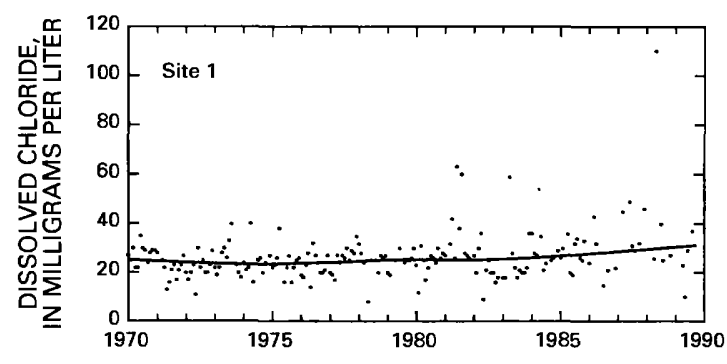

When possible, constituent-concentration data were adjusted for changes in streamflow to preclude identifying a trend in concentration that was caused only by a trend in streamflow. The data were not adjusted when (1) more than 10 percent of the samples had concentrations lower than the minimum reporting limit for the analytical method used or (2) streamflow was controlled substantially by human activities. When the concentration data could not be adjusted for streamflow, trends were determined directly from the concentration data.

Statewide trends in concentrations of selected stream-water constituents are shown on maps in figure 4. On each map, a trend is indicated at a monitoring station only if the data from that station were suitable for use in the trend analysis. For more information on the suitability criteria and on the trend-analysis procedure used for this report, see Lanfear and Alexander (1990).

\section{DISSOLVED OXYGEN}

The dissolved-oxygen concentration in a stream is controlled by several factors, including water temperature, air temperature and pressure, hydraulic characteristics of the stream, photosynthetic or respiratory activity of stream biota, and the quantity of organic material present. A trend in dissolved-oxygen concentrations commonly is directly or indirectly the result of human activities. Generally, an upward trend in dissolved-oxygen concentrations indicates improving stream water-quality conditions and a downward trend indicates deteriorating conditions.

Concentrations of dissolved oxygen trended upward in the Duchesne River at site 8 during 1970-89. The upward trend might have been the result of recent improvements in wastewater-treatment lagoons for towns that previously discharged incompletely treated waste to the Duchesne River.

The dissolved-oxygen concentration began decreasing in early 1982 at site 1 on the Bear River. Irrigated agriculture and stock grazing are major activities in this area, and increased oxygen demand caused by nutrient or organic loading in the river from runoff might have been responsible for the declines. Only 5 percent of all concentrations measured since 1970 , however, have failed to meet the State aquatic life protection standard of $6.5 \mathrm{mg} / \mathrm{L}$ (Utah Department of Health, 1988). The decrease in concentrations in the Dolores River at site 12 possibly was due to an increase in organic material entering the river upstream.

\section{DISSOLVED SULFATE}

The major natural sources of sulfate in streams are rock weathering, volcanoes, and biochemical processes (Hem, 1985, p. 113). Human activities such as mining, waste discharge, and fossil-fuel combustion also can be important sources.

The Bear River basin is affected by irrigation return flows, and the causes for increasing sulfate concentration at site 1 (fig. 4) likely are related to changes in irrigation practices. The upward trend in Red Butte Creek at site 5 possibly is related in part to atmospheric deposition; the station is in the foothills above the densely populated industrial corridor that extends north and south of Salt Lake City. Smith and Alexander (1983, p. 5) reported an upward trend in sulfate concentrations at this monitoring station for 1964-81 that was concurrent with an upward trend in atmospheric sulfur emissions for 1965-80.

The downward trends in sulfate concentrations at sites 8, 9, 11,12 , and 14 in the Upper Colorado River Basin could have been in part the result of improvements in irrigation-water management (William Harned, Utah Department of Health, oral commun., May 1990). The decreasing sulfate concentration in the Green River at site 6 probably resulted from an overall reduction in dissolved substances owing to releases of shallower, less mineralized water from Flaming Gorge Reservoir. Concentrations trended downward in the 
Duchesne River at site 8, probably owing to generally declining concentrations of dissolved substances as programs to control salinity have been implemented. The downward trend at site 14 on the San Juan River was due to dilution from increased releases from the Navajo Reservoir. The decrease at site 15 on the Sevier River might have been the result of changes in management of upstream irrigation reservoirs due at least in part to high streamflow during 198387 followed by drought conditions during 1988-89.

\section{DISSOLVED CHLORIDE}

Chloride is present in all natural waters but usually in low concentrations (Hem, 1985, p. 118). Except in streams that receive ground-water discharge high in chloride, concentrations of greater than a few milligrams per liter generally are the result of human activities (table I).

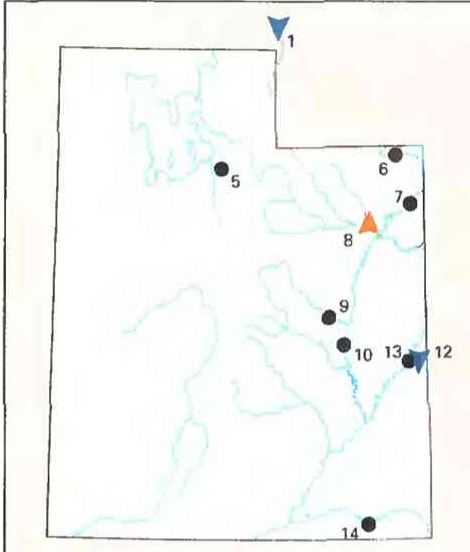

Dissolved oxygen, 1970-89

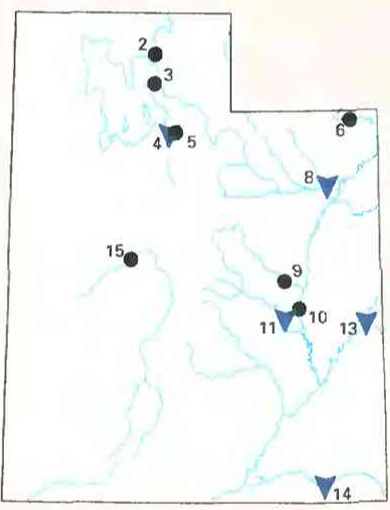

Dissolved solids, 1975-89

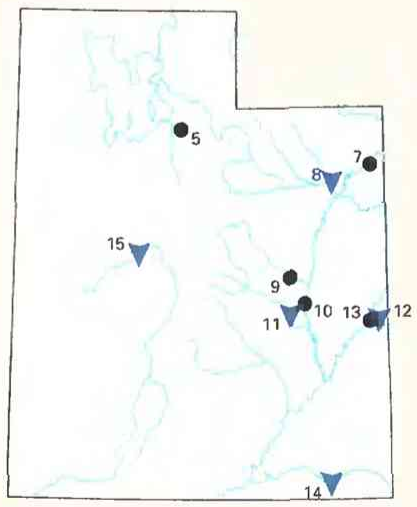

Dissolved phosphate, 1970-89

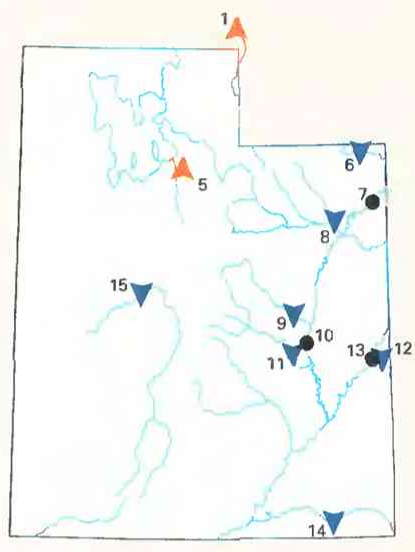

Dissolved sulfate, 1970-89

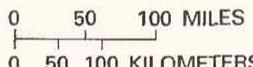

$\begin{array}{lll}0 & 50 & 100 \mathrm{KILOMETERS}\end{array}$
Dissolved nitrite plus nitrate,

1970-89

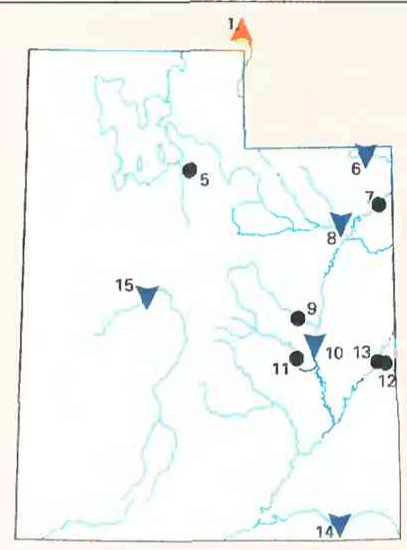

Dissolved chloride, 1970-89

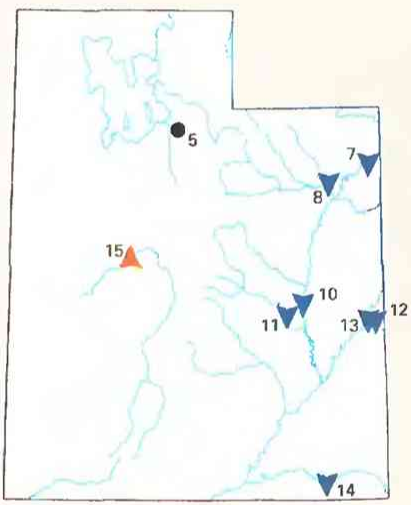

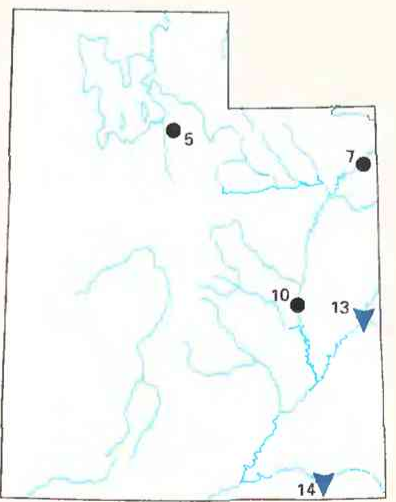

\section{EXPLANATION}

Trend in water-quality constituentNumber is site number in figure 2

$$
\begin{aligned}
& A^{1} \text { Upward } \\
& { }^{5} \text { None } \\
& \nabla^{8} \text { Downward }
\end{aligned}
$$

Figure 4. Trends in water quality of selected streams in Utah, by water years. (Source: Data from U.S. Geological Survey files.) 
The increasing chloride concentration in the Bear River at site 1 possibly was caused by an increase in irrigation return flows. Chloride concentrations trended downward in the Green River at site 6 because of a reduction in salt loading following a change in the depth of water released from Flaming Gorge Reservoir; in 1978, the outlet of the dam was raised so that warmer, less saline water would be released into the river. A downward trend in chloride concentrations at this monitoring station during 1974-81 also was noted by Smith and others (1987, fig. 3). Downward trends in the Duchesne River at site 8 and the Green River at site 10 likely were the result of generally declining concentrations of dissolved substances as programs to control salinity have been implemented. The decline at site 14 on the San Juan River was due at least in part to dilution resulting from increased releases from the Navajo Reservoir. The downward trend in the Sevier River at site 15 might have been the result of changes in management of upstream irrigation reservoirs due to high streamflow during $1983-87$, followed by drought conditions during 1988-89.

\section{DISSOLVED SOLIDS}

Dissolved solids in stream water result primarily from rock weathering but also can be introduced as a byproduct of human activities (table 1). Concentrations generally are greatest in streams draining basins underlain by rocks and soils that contain easily dissolved minerals.

Dissolved-solids concentrations trended downward during 1975-89 in the Jordan River at site 4 (fig. 4). The Jordan River flows through Salt Lake City and, as of 1984, received secondarily treated effluent from eight wastewater-treatment plants, all but one of which exceeded its capacity (Utah Bureau of Water Pollution Control, 1984, p. 117). The plants were consolidated into two regional plants during 1985-86. This consolidation improved the quality of the effluent and might have caused the downward trend in dissolved-solids concentrations.

The downward trend in the dissolved-solids concentration in the Duchesne River at site 8 possibly was due to salinity-control programs. Much of the base flow of the river at site 8 consists of irrigation return flows. In 1980, the U.S. Soil Conservation Service initiated a plan for on-farm control of salinity that has reduced the annual quantity of salt discharged to streams in the Uinta River basin by 30,100 tons; most of that reduction occurred in the Duchesne River basin (U.S. Department of the Interior, 1989, p. VII-34).

Dissolved-solids concentrations had a downward trend in the San Rafael River at site 11. The river transports large quantities of dissolved solids because of irrigation return flows from areas underlain by evaporite deposits. Although federally sponsored plans for reducing salt loading in this basin exist, none have been implemented, so the reductions in salt loading could have been due to local improvements in irrigation-water management.

Dissolved-solids concentrations had a downward trend in the Colorado River at site 13. Downward trends also were reported by Liebermann and others $(1989$, p. 32) for $1966-83$ and Kircher and others $(1984$, p. 34) for 1965-83. Projects completed from 1979 to 1985 by the Colorado River Basin Salinity Control Program in the Grand Valley of Colorado, 45 miles upstream from site 13, eliminate 63,300 tons of dissolved solids annually from the Colorado River (U.S. Department of the Interior, 1989, table VII-1). These projects likely were responsible for the decreasing concentration from 1980 to 1989.

Liebermann and others $(1989$, p. 54) reported a 14-percent decrease in the median annual flow-adjusted concentration of dissolved solids in the San Juan River at site 14 for 1964-83. Before 1968 , large dissolved-solids concentrations at site 14 were the result of lack of dilution owing to small releases of water from Navajo Reservoir upstream as the reservoir filled from 1964 to 1968 . Since 1968 , releases have been larger, providing more dilution of dissolved solids contributed downstream. The increasing dilution probably was responsible for the downward trend in dissolved-solids concentrations for 1975-89.

\section{DISSOLVED NITRITE PLUS NITRATE}

Nitrite and nitrate are oxidized forms of nitrogen that together constitute most of the dissolved nitrogen in well-aerated streams. Nitrite readily oxidizes to nitrate in natural waters; therefore, nitrate generally is by far the more abundant of the two (Hem, 1985, p. 124).

The increasing nitrite plus nitrate concentration in the Sevier River at site 15 might have been the result of increases in agricultural fertilizer use. The estimated use of nitrogen-based fertilizers increased from about 5 to 140 percent in counties upstream from this site during 1970-85 (Alexander and Smith, 1990).

All streams in which nitrite plus nitrate concentrations trended downward are in the Upper Colorado River Basin. Recent improvements in the wastewater-treatment plants in the Duchesne, Green, San Rafael, and San Juan River basins upstream from sites 8, 10, 11, and 14 might have contributed to the downward trends (William Harned, Utah Department of Health, oral commun., May 1990). The downward trend in the Dolores River at site 12 might have been the result of improvements in irrigation-water management upstream. Causes of the downward trends in the Green River at site 7 and the Colorado River at site 13 are not known. Population upstream from these sites is sparse, and human influence on stream water quality is minimal. However, changes in grazing practices or declining runoff from grazing land owing to less than average precipitation since the mid-1980's within these basins might have caused the downward trends.

\section{DISSOLVED PHOSPHATE}

Phosphate is the oxidized form of phosphorus and the only form of significance in most natural waters. Small quantities of dissolved phosphate commonly are present in streams as a result of rock weathering. Normally, concentrations are no more than a few tenths of a milligram per liter (Hem, 1985, p. 126) and usually are much lower. Higher concentrations can indicate contamination from human activities (table 1).

The cause of the downward trends at sites $8,11,12,14$, and 15 might have been an estimated 10-150-percent decline in the use of phosphorus-based fertilizers in counties upstream from those monitoring stations during 1970-85 (Alexander and Smith, 1990). The downward trends also might have been related to a nationwide decline, beginning in the early 1970 's, in production and use of phosphate-based detergents.

\section{SUSPENDED SEDIMENT}

Suspended sediment is a product of erosion. The erosion can be either natural or the result of land-cover disturbances related to human activities (table 1).

The downward trend in suspended-sediment concentrations in the Colorado River at site 13 was due to trapping of sediments in Blue Mesa Reservoir near Gunnison, Colo., and to channel adjustment following closure of the dam in 1965 . The quantity of sediment carried by the river decreased by 22 percent after the dam was closed (Thompson, 1984, p. 12). Reasons for the downward trend in concentrations of suspended sediment in the San Juan River at site 14 are not known. A study of records collected from 1914 to 1980 indicated that the Navajo Reservoir upstream from this location, completed in 1962, had no significant effect on the suspended-sediment load at site 14 (Thompson, 1982, p. 12).

\section{WATER-QUALITY MANAGEMENT}

Stream water quality in Utah is regulated by the Department of Health, Bureau of Water Pollution Control, through the Utah Water 
Pollution Control Committee, which was established under the authority of the Utah Water Pollution Control Act of 1953. The Bureau of Water Pollution Control regulates, plans, enforces, and monitors surface- and ground-water activities. These functions include developing water-quality standards and criteria, determining facility compliance with effluent and ambient water-quality standards, and monitoring facility discharges and ground and ambient waterquality conditions.

The Bureau of Water Pollution Control also is responsible for administering the Federal Clean Water Act in the State of Utah. Section 305(b) of the act requires the State to prepare biennial reports (Utah Bureau of Water Pollution Control, 1984; 1988; 1990) about the water quality in the State for the EPA and the U.S. Congress. The Bureau of Water Pollution Control is responsible for analyzing waterquality information and preparing this report. Streamflow data and water samples collected by the USGS are used in the analyses for the report.

The State of Utah cooperates with the Federal Government and six other States in the Colorado River Basin to manage the salinity of the Colorado River. The Colorado River Basin Salinity Forum was created in 1973 to address water-quality problems and recommend solutions.

The Federal Clean Water Act and other Federal and State regulations have created a greater emphasis on water-quality monitoring. The Bureau of Water Pollution Control has increased its waterquality monitoring efforts as a result of new management programs, including the Ground-Water Management Program and the Nonpoint-Source Pollution Program.

\section{SELECTED REFERENCES}

Alexander, R.B., and Smith, R.A., 1990, County-level estimates of nitrogen and phosphorus fertilizer use in the United States, 1945 to 1985: U.S. Geological Survey Open-Fite Report 90-130, 12 p.

Anderson, J.R., 1967, Major land uses in the United States, 1967, in U.S. Geological Survey, 1970, National atlas of the United States of America: Washington, D.C., U.S. Geological Survey, p. 158-159.

Britton, L.J., and Greeson, P.E., eds., 1987, Methods for collection and analysis of aquatic biological and microbiological samples: U.S. Geological Survey Techniques of Water-Resources Investigations, book 5, chap. A4, $363 \mathrm{p}$.

Colorado Department of Health, 1988, Water quality in Colorado: Denver, Water Quality Control Division, variously paginated.

Fenneman, N.M., 1946, Physical divisions of the United States: Washington, D.C., U.S. Geological Survey special map, scale 1:7,000,000.

Fishman, M.J., and Friedman, L.C., eds., 1989, Methods for the determination of inorganic substances in water and fluvial sediments: U.S. Geological Survey Techniques of Water-Resources Investigations, book 5. chap. A1, 545 p.

Hem, J.D., 1985, Study and interpretation of the chemical characteristics of natural water (3d ed.): U.S. Geological Survey Water-Supply Paper 2254, 263 p.

Hirsch, R.M., Slack, J.R., and Smith, R.A., 1982, Techniques of trend analysis for monthly water quality data: Water Resources Research, v. 18, no. 1 , p. $107-121$.
Kircher, J.E., Dinicola, R.S., and Middelburg, R.F., 1984, Trend analysis of salt load and evaluation of the frequency of water-quality measurements for the Gunnison, the Colorado, and the Dolores Rivers in Colorado and Utah: U.S. Geological Survey Water-Resources Investigations Report $84-4048,69$ p.

Lanfear, K.J., and Alexander, R.B., 1990, Methodology to derive water- quality trends for use by the National Water Summary Program of the U.S. Geological Survey: U.S. Geological Survey Open-File Report 90-359, $10 \mathrm{p}$.

Liebermann, T.D., Mueller, D.K., Kircher, J.E., and Choquette, A.F., 1989, Characteristics and trends of streamflow and dissolved solids in the upper Colorado River Basin, Arizona, Colorado, New Mexico, Utah, and Wyoming: U.S. Geological Survey Water-Supply Paper 2358, 64 p.

Smith, R.A., and Alexander, R.B., 1983, Evidence for acid-precipitation-induced trends in stream chemistry at hydrologic bench-mark stations: U.S. Geological Survey Circular 910, 12 p.

Smith, R.A., Alexander, R.B., and Wolman, M.G., 1987, Analysis and interpretation of water-quality trends in major U.S. rivers, 1974-81: U.S. Geological Survey Water-Supply Paper 2307, 25 p.

Stephens, D.W., Waddell, Bruce, and Miller, J.B., 1988, Reconnaissance investigation of water quality, bottom sediment, and biota associated with irrigation drainage in the middle Green River basin, Utah, 1986-87: U.S. Geological Survey Water-Resources Investigations Report 88-4011, $70 \mathrm{p}$.

Thelin, G.P., and Pike, R.J., 1990, Digital shaded relief map of the conterminous United States: Menlo Park, Calif., U.S. Geological Survey digital image processing, scale 1:3,500,000.

Thompson, K.R., 1982, Characteristics of suspended sediment in the San Juan River near Bluff, Utah: U.S. Geological Survey Water-Resources Investigations Report 82-4104, 21 p.

1984, Annual suspended-sediment loads in the Colorado River near Cisco, Utah, 1930-82: U.S. Geological Survey Water-Resources Investigations Report 85-4011, 19 p.

U.S. Department of the Interior, 1989, Quality of water-Colorado River basin: Washington, D.C., Progress Report no. 14, 14 variously paginated sections.

U.S. Geological Survey, 1986, National water summary 1985-Hydrologic events and surface-water resources: U.S. Geological Survey Water-Supply Paper 2300, 506 p.

1990 , National water summary 1987-Hydrologic events and water supply and use: U.S. Geological Survey Water-Supply Paper 2350, $553 \mathrm{p}$.

Utah Bureau of Water Pollution Control, 1984, State of Utah 305(b) biennial water-quality report: Salt Lake City, Utah Department of Health, 244 p. 1988, State of Utah 305(b) biennial water-quality report: Salt Lake City,

Utah Department of Health, 191 p. 1990 , State of Utah 1990 State water-quality assessment 305(b) report: Salt Lake City, Utah Department of Health, 96 p.

Utah Department of Health, 1988, Wastewater disposal regulations, part 2, standards of quality for waters of the State: Salt Lake City, Utah Water Pollution Control Board, $50 \mathrm{p}$.

Ward, J.R., and Harr, C.A., eds., 1990, Methods for collection and processing of surface-water and bed-material samples for physical and chemical analyses: U.S. Geological Survey Open-File Report 90-140, 71 p.

Prepared by Carole B. Burden and Doyle W. Stephens, U.S. Geological Survey; "Water-Quality Management” section by William Harned, Utah Department of Health

FOR ADDITIONAL INFORMATION: District Chief, U.S. Geological Survey, 1745 West 1700 South, Room 1016, Salt Lake City, UT, 84104 


\section{VERMONT Stream Water Quality}

Vermont's stream water is an important natural resource for water supply, recreation, and industrial uses. The State receives abundant year-round precipitation that assures an adequate supply of stream water. Annual precipitation ranges from 32 inches in the Lake Champlain valley to about 50 inches in the Green Mountains.

In 1985, surface water provided an average of $36 \mathrm{Mgal} / \mathrm{d}$ (million gallons per day) for public supply (U.S. Geological Survey, 1990 , p. 502) and served about 44 percent of the population (Solley and others, 1988). The largest offstream use of surface water was for industry $(51 \mathrm{Mgal} / \mathrm{d})$, whereas only 2.6 percent $(2.3 \mathrm{Mgal} / \mathrm{d})$ of surface-water withdrawals was used for agricultural purposes such as irrigation and livestock watering. Instream use for hydroelectric power generation $(8,640 \mathrm{Mgal} / \mathrm{d})$ in 1985 was greater than all other instream uses combined (U.S. Geological Survey, 1990, p. 499).

The quality of stream water can be affected by land use. Vermont is predominantly rural and agricultural (fig. $1 A$ ). Agricultural activity is greatest and urban population is largest in the Champlain physiographic section (figs. $1 B$ and $1 C$ ). The rugged Green Moun-

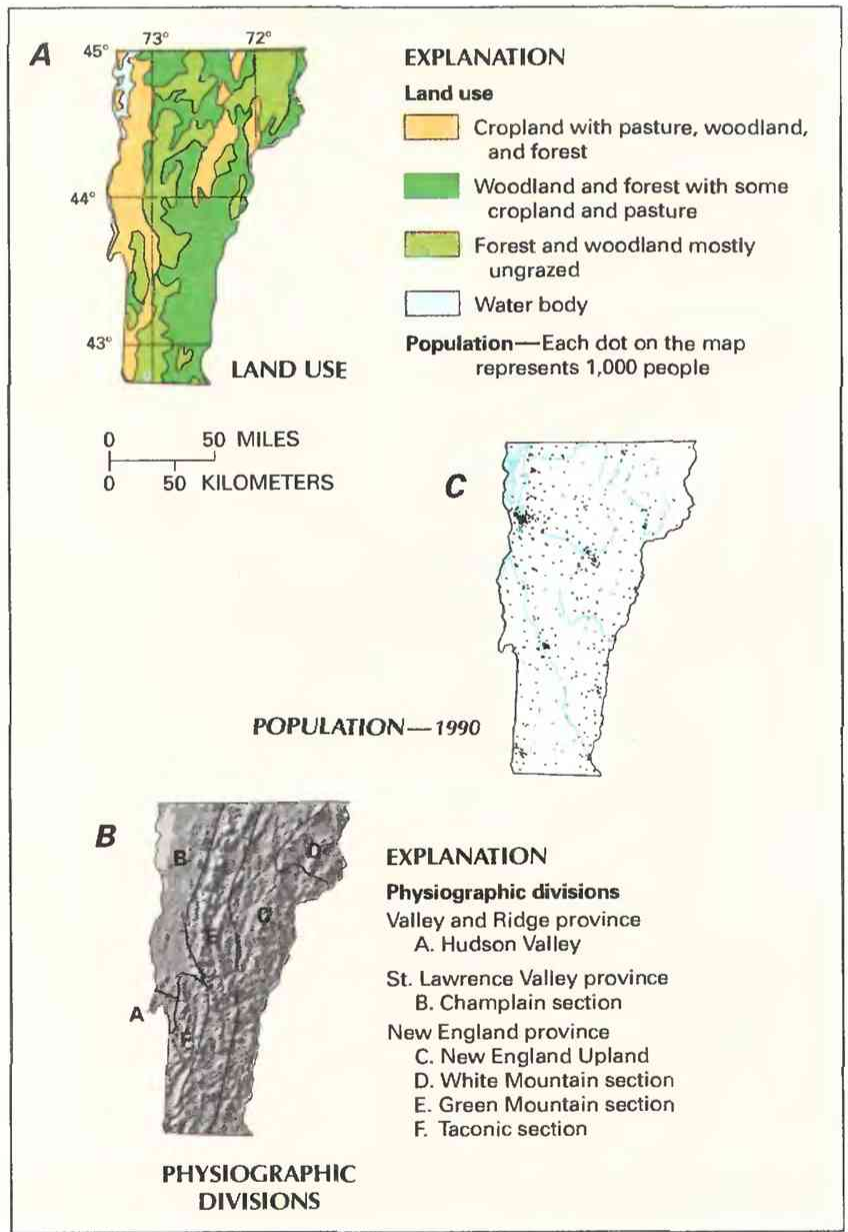

Figure 1. Land use, physiography, and population in Vermont. A Major land uses. B, Physiographic divisions. $C$, Population distribution in 1990. (Sources: A, Major land uses modified from Anderson, 1967. B, Physiographic divisions from Fenneman. 1946; landforms from Thelin and Pike. 1990 C. Data from U.S. Bureau of the Census 1990 decennial census files.) tain section is densely forested and sparsely populated. The New England Upland is wooded but has some cropland and pasture. Most State waters meet the Federal Clean Water Act goal of suitability for fishing and swimming. Of 5,266 miles of streams assessed by the Vermont Department of Environmental Conservation, 92 percent were suitable for swimming and 98 percent were suitable for fishing (Vermont Department of Environmental Conservation, 1990, p. 3).

\section{WATER-QUALITY MONITORING}

Water-quality data obtained from analyses of water samples collected at monitoring stations are stored in the U.S. Geological Survey's (USGS) National Water Information System and the U.S. Environmental Protection Agency's (EPA) national data base known as STORET. Water-quality and streamflow data are reported by water year-the 12 months from October 1 through September 30. A water year is identified by the calendar year in which it ends. For example, water year 1991 comprises October 1, 1990, through September 30, 1991.

The data used in this summary of Vermont's stream water quality were obtained from water samples collected every 2 months or quarterly at seven monitoring stations at which data collection is systematic and continuing (fig. 2). Analyses of water samples collected at two stations are the basis for the discussion and graphic summary (fig. 3) of stream water-quality conditions during water years 1987-89, and data from all seven stations are the basis for the discussion and graphic summary (fig. 4) of stream water-quality trends; however, five of those stations have only specific-conductance data. Water samples were collected and analyzed by using standard methods approved by the USGS (Britton and Greeson, 1987; Fishman and Friedman, 1989; Ward and Harr, 1990) or by using equivalent methods. If a method of sample collection or analysis changed over time, data from an analysis were included in the evaluation of recent stream water quality or of stream water-quality trends only if the change in method did not affect the comparability of the data.

\section{WATER-QUALITY CONDITIONS}

Nonpoint-source pollution is the major cause of degraded water quality in Vermont. All drainage basins in the State are affected by nonpoint-source pollution, but the types and extent of waterquality problems differ among basins. Overall, the major causes of nonpoint-source pollution of stream water are agricultural runoff, construction-site erosion, flow regulation, and streambank modification or destabilization. Natural causes of degraded water quality include streambank erosion and ponding created by beaver activity (Vermont Department of Environmental Conservation, 1990, p. 4).

In $1990,4,334$ miles ( 82 percent) of the 5,266 miles of streams and rivers assessed by the State fully supported the beneficial uses designated by the State for purposes of water-pollution control (Vermont Department of Environmental Conservation, 1990, p. 6). Water quality had improved from earlier surveys in about 56 streams because point-source pollution decreased when statewide municipal and industrial wastewater-treatment projects were completed.

The following discussion of stream water quality in Vermont is organized by river basin (fig. 3). Graphs in figure 3 summarize certain aspects of stream water quality in the basins for water years 1987-89. The graphs show frequency distributions of data values that 
represent measurements of selected physical properties of stream water and concentrations of selected constituents in stream water. These properties and constituents are specific conductance, fecal coliform bacteria, dissolved sulfate, dissolved solids, and dissolved nitrite plus nitrate (as nitrogen). The data are reported in microsiemens per centimeter at 25 degrees Celsius $(\mu \mathrm{S} / \mathrm{cm})$, colonies per 100 milliliters (col/100 mL), and milligrams per liter $(\mathrm{mg} / \mathrm{L})$. Sources and environmental significance of each property and constituent are described in table 1.

Water quality at each monitoring station is the result of geological, chemical, biological, and hydrologic processes that occur over a large area. Water-quality problems that affect aquatic life or public health only locally are not fully represented in this summary. Moreover, the monitoring-station network in Vermont lacks sufficient areal coverage to represent water-quality conditions adequately on a statewide basis. Stream-water constituents are monitored routinely only at sites 2 and 7 .

\section{CONNECTICUT RIVER}

The Connecticut River drains eastern Vermont. Because Vermont and New Hampshire each contain about one-half of the total drainage area, stream water quality is influenced by human activity and natural conditions in both States. Land use in the basin consists of silviculture and recreation in the forested uplands and cropland and pasture in the valley. The only population centers in the basin are small cities and towns. Nonetheless, municipal wastewater dis- charges and urban runoff, in addition to agricultural runoff, are pollution concerns in the Connecticut River basin.

During water years 1987-89, the median concentrations of sulfate $(12 \mathrm{mg} / \mathrm{L})$, dissolved solids $(71 \mathrm{mg} / \mathrm{L})$, and nitrite plus nitrate $(0.21 \mathrm{mg} / \mathrm{L})$ at site 2 were not excessive. These low concentrations indicate that the river is successfully assimilating much of the contaminant input from the various point and nonpoint pollution sources in the basin. However, although the median concentration of fecal coliform bacteria $(53 \mathrm{col} / 100 \mathrm{~mL})$ does not exceed State standards, concentrations were higher than $400 \mathrm{col} / 100 \mathrm{~mL}$ in 25 percent of water samples collected at site 2 .

\section{BLACK RIVER}

The Black River flows northward through the New England Upland to Lake Memphremagog along the United States-Canada border. Land use upstream from site 7 primarily is dairy farming and silviculture. Water quality in the Black River basin is affected by agricultural runoff (fertilizer and animal wastes) and erosion. Effluent from domestic septic systems sometimes results in excessively high concentrations of fecal coliform bacteria.

During water years $1987-89$, stream water in the Black River at site 7 had a median specific-conductance value of $195 \mu \mathrm{S} / \mathrm{cm}$. The median concentration of sulfate $(13 \mathrm{mg} / \mathrm{L})$ was low, and the median concentration of dissolved solids $(117 \mathrm{mg} / \mathrm{L})$ was lower than the 200 $\mathrm{mg} / \mathrm{L}$ goal established by the American Water Works for potable water (Hem, 1985, p. 212). The median concentration of nitrite plus

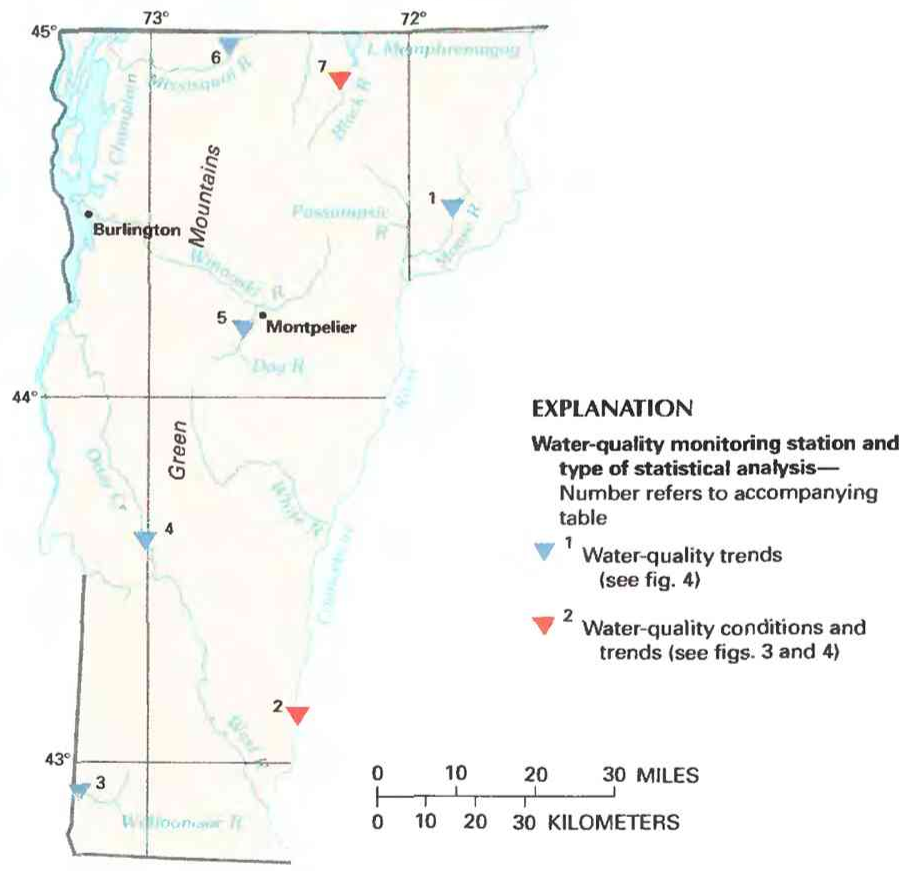

\begin{tabular}{|c|c|c|c|}
\hline $\begin{array}{l}\text { Site no. } \\
\text { on map }\end{array}$ & $\begin{array}{l}\text { USGS station } \\
\text { name and no. }\end{array}$ & $\begin{array}{l}\text { Drainage area } \\
\text { (square miles) }\end{array}$ & $\begin{array}{l}\text { Major land use } \\
\text { (see fig. 1) }\end{array}$ \\
\hline 1 & Moose River at Victory $(01134500)$ & 75.2 & Mostly ungrazed forest and woodland. \\
\hline 2 & Connecticut River at North Walpole, N.H. (01154500) & 5,493 & Woodland and forest with some cropland and pasture. \\
\hline 3 & Walloomsac River near North Bennington $(01334000)$ & 111 & Cropland with pasture, woodland, and forest. \\
\hline 4 & Otter Creek at Center Rutland $(04282000)$ & 307 & Woodland and forest with some cropland and pasture. \\
\hline 5 & Dog River at Northfield Falls (04287000) & 76.1 & Cropland with pasture, woodland, and forest. \\
\hline 6 & 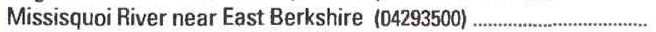 & 479 & Woodland and forest with some cropland and pasture. \\
\hline 7 & Black River at Coventry (04296000) & 122 & Ditto. \\
\hline
\end{tabular}

Figure 2. Selected water-quality monitoring stations, type of statistical analysis, and geographic features in Vermont. (Sources: Major land uses modified from Anderson, 1967; other data from U.S. Geological Survey files.) 
nitrate $(0.33 \mathrm{mg} / \mathrm{L})$ was lower than the $0.60 \mathrm{mg} / \mathrm{L}$ benchmark level for aquatic-life protection adopted by the U.S. Council on Environmental Quality (Briggs and Ficke, 1977, p. 34). Ten percent of fecal coliform bacteria concentrations exceeded $400 \mathrm{col} / 100 \mathrm{~mL}$, but the median concentration was $33 \mathrm{col} / 100 \mathrm{~mL}$.

\section{WATER-QUALITY TRENDS}

Trend analysis is a statistical procedure used to detect changes in stream water quality at a monitoring station over time. For this report, water-quality data from seven monitoring stations (fig. 2) were analyzed for trends by using the seasonal Kendall test (Hirsch and others, 1982), a method used extensively by the USGS. Specific-conductance data from all seven stations were sufficient for trend analysis, whereas data from only two stations were sufficient for analysis of the four stream-water constituents. The graph (shown below) of the dissolved-sulfate concentration in the Black River at site 7 illustrates the trend inferred from the concentration data and demonstrates the variation in water quality that is common in streams.

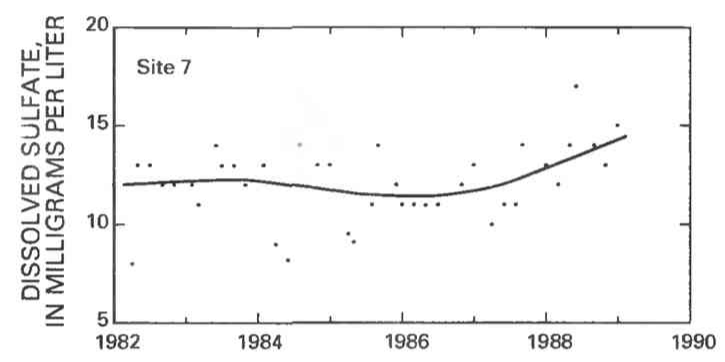

When possible, constituent-concentration data were adjusted for changes in streamflow to preclude identifying a trend in concentration that was caused only by a trend in streamflow. The data were not adjusted when (1) more than 10 percent of the samples had concentrations lower than the minimum reporting limit for the analyti- cal method used or (2) streamflow was controlled substantially by human activities. When the concentration data could not be adjusted for streamflow, trends were determined directly from the concentration data.

Statewide trends in measurements of selected physical properties of stream water and in concentrations of selected constituents in stream water are shown on maps in figure 4 . On each map, a trend is indicated at a monitoring station only if the data from that station were suitable for use in the trend analysis. For more information on the suitability criteria and on the trend-analysis procedure used for this report, see Lanfear and Alexander (1990).

\section{SPECIFIC CONDUCTANCE}

Specific conductance is a measure of the ability of a sample of water to conduct electricity. Because specific conductance and the dissolved-solids concentration are roughly proportional in most natural waters, the specific-conductance value often can be used to estimate the dissolved-solids concentration (Hem, 1985, p. 66-68). Trends in specific-conductance values generally are associated with human activities. In Vermont, upward trends in specific-conductance values resulting from increased dissolved-solids loads are attributable to sewage-treatment plant effluent, agricultural runoff, and highway deicing salts.

Upward trends in specific-conductance values detected in Otter Creek at site 4, the Dog River at site 5, and the Missisquoi River at site 6 correspond closely to upward trends in tonnage of salt applied to the State's highways (Bob Fraser, Vermont Department of Transportation, oral commun., 1990). No trends were detected in the Moose, Connecticut, Walloomsac, and Black Rivers.

\section{FECAL COLIFORM BACTERIA}

Fecal coliform bacteria are used as indicators of fecal contamination from humans and other warm-blooded animals. Such contami-
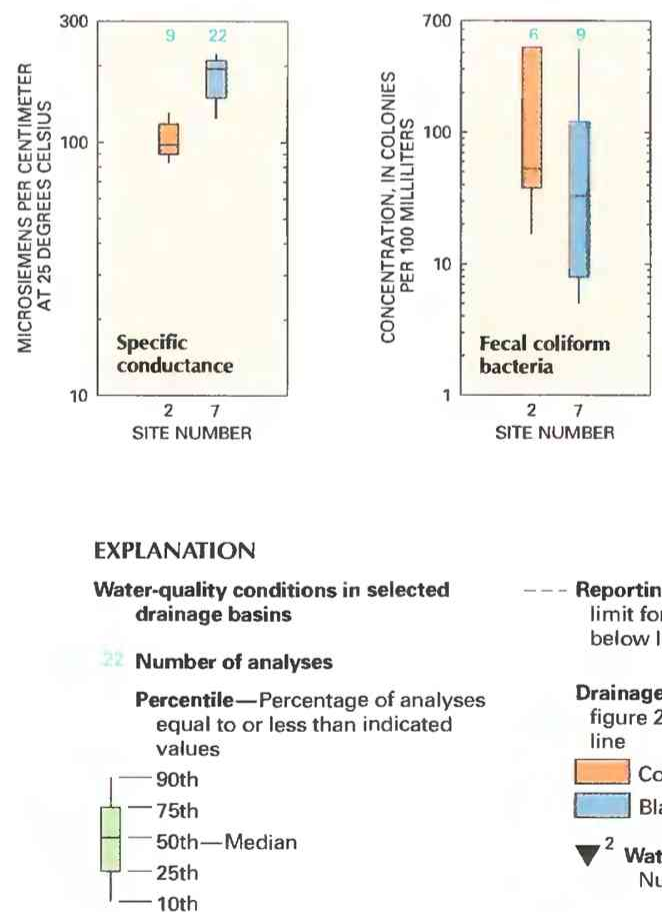
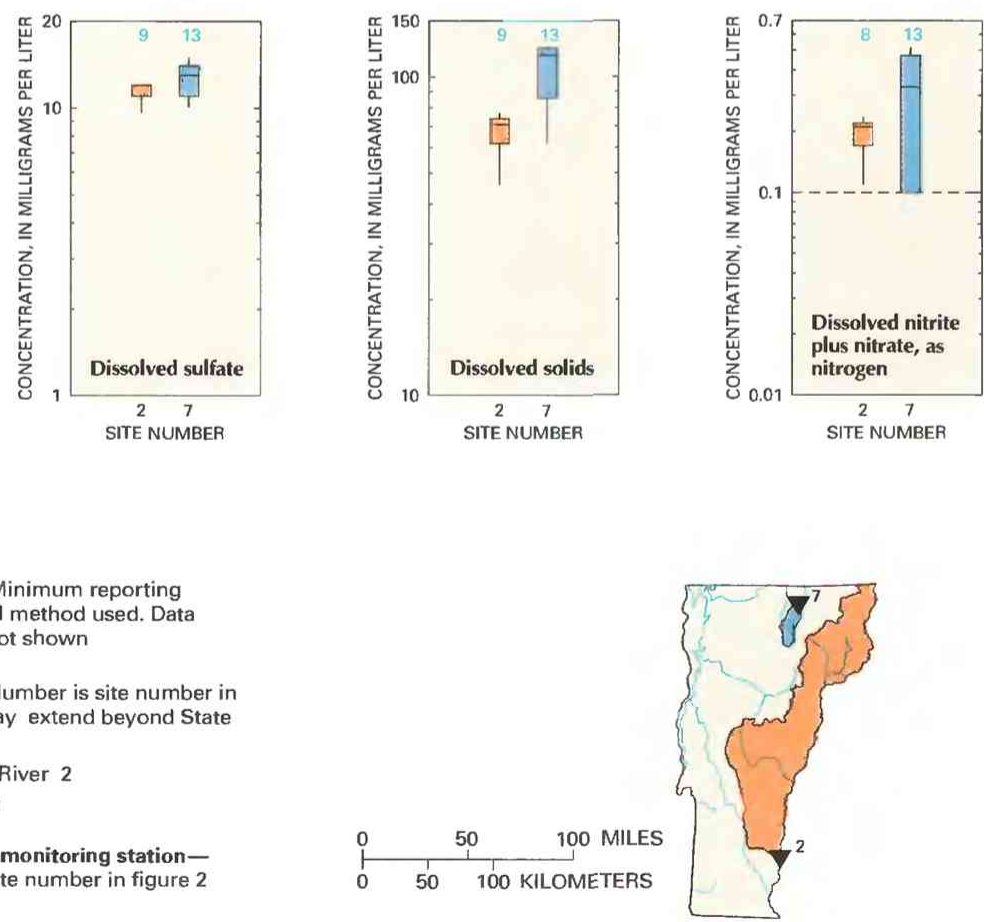

Figure 3. Water quality of selected streams in Vermont, water years 1987-89. (Source: Data from U.S. Geological Survey files.) 
Table 1. Sources and environmental significance of selected water-quality properties and constituents [Source: Compiled by the U.S. Geological Survey, Office of Water Quality]

\begin{tabular}{|c|c|c|}
\hline Property or constituent & Common sources & Environmental significance \\
\hline $\begin{array}{l}\text { Specific conductance .................. } \\
\text { (property) }\end{array}$ & $\begin{array}{l}\text { A measure of the electrical conductivity of water; var- } \\
\text { ies with the quantity of dissolved solids and is } \\
\text { used to approximate the dissolved-solids content. }\end{array}$ & $\begin{array}{l}\text { Dissolved solids can cause water to be unsuitable for } \\
\text { public supply, agriculture, and industry; can harm } \\
\text { aquatic organisms. }\end{array}$ \\
\hline Fecal coliform bacteria ............... & $\begin{array}{l}\text { Sources include effluent from sewage-treatment } \\
\text { plants and runoff from pastures, feedlots, and ur- } \\
\text { ban areas. }\end{array}$ & $\begin{array}{l}\text { Presence indicates contamination of water by wastes } \\
\text { from humans and other warm-blooded animals. }\end{array}$ \\
\hline Sulfate & $\begin{array}{l}\text { Occurs in some rocks; also in mine runoff, industrial } \\
\text { wastewater discharge, and atmospheric deposi- } \\
\text { tion. }\end{array}$ & $\begin{array}{l}\text { Concentrations exceeding a natural, background } \\
\text { level indicate contamination from human activity; } \\
\text { in sufficient quantity, can cause water to be } \\
\text { unsuitable for public supply; can harm aquatic } \\
\text { organisms. }\end{array}$ \\
\hline 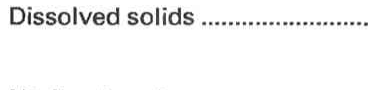 & $\begin{array}{l}\text { A result of rock weathering; also in agricultural runoff } \\
\text { and industrial discharge. }\end{array}$ & $\begin{array}{l}\text { In sufficient quantity, can cause water to be unsuitable } \\
\text { for public supply, agriculture, and industry; can } \\
\text { harm aquatic organisms. }\end{array}$ \\
\hline Nitrite plus nitrate ......................... & $\begin{array}{l}\text { Nonpoint sources are agricultural and urban runoff; } \\
\text { a major point source is wastewater discharge. }\end{array}$ & $\begin{array}{l}\text { Plant nutrient that, in sufficient quantity, can cause } \\
\text { algal blooms and excessive growth of higher } \\
\text { aquatic plants in bodies of water; can cause water } \\
\text { to be unsuitable for public supply. }\end{array}$ \\
\hline
\end{tabular}

nation can introduce disease-causing viruses and bacteria into a stream. Fecal coliform bacteria concentrations had a downward trend at site 7 on the Black River. Because agricultural runoff contributes bacteria to streams, improved feedlot and manure-management practices can decrease bacteria concentrations in stream water. No trend was detected in the Connecticut River at site 2.

\section{DISSOLVED SULFATE}

The major natural sources of sulfate in streams are rock weathering, volcanoes, and biochemical processes (Hem, 1985, p. 113). Human activities such as mining, waste discharge, and fossil-fuel combustion also can be important sources. A shortened trend-analysis period was used for sulfate because data from analyses performed prior to water year 1982 are not comparable to data from subsequent years.

Sulfate concentrations had an upward trend in the Black River at site 7 . The increase at site 7 might be attributable, at least in part, to atmospheric deposition of sulfate; concentrations in the Black
River are low, and no significant terrestrial sources of sulfate exist in the basin. The upward trend, however, does not correlate well with trends in atmospheric deposition of sulfate during 1981-88 (National Atmospheric Deposition Program, 1989, p. 56). The increasing sulfate concentration could represent a delayed response because the rate at which sulfate is transported to the stream lags behind the rate at which sulfate is initially deposited in the basin (Hem, 1985, p. 114).

\section{DISSOLVED SOLIDS}

Dissolved solids in stream water result primarily from rock weathering but also can be introduced as a byproduct of human activities (table 1). Concentrations generally are greatest in streams draining basins underlain by rocks and soils that contain easily dissolved minerals.

Concentrations of dissolved solids had no significant trend at either monitoring station. Dissolved-solids concentrations in the State's waters are relatively low because of the diluting effects of the moderate to large quantities of precipitation received.

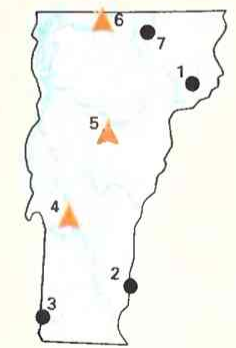

Specific conductance, 1980-89

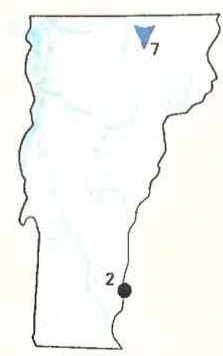

Fecal coliform bacteria, 1980-89

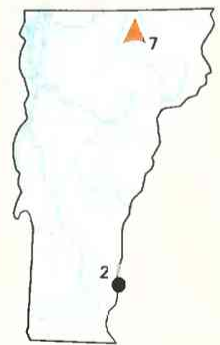

Dissolved sulfate, 1982-89

\section{EXPLANATION}

Trend in watar-quality property or constituent- Number is site number in figure 2

$$
\begin{aligned}
& A^{6} \text { Upward } \\
& 0^{3} \text { None } \\
& \nabla^{7} \text { Downward }
\end{aligned}
$$

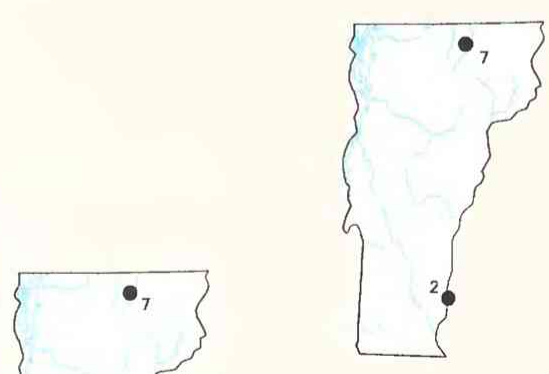

Dissolved nitrite plus nitrate, $1980-89$

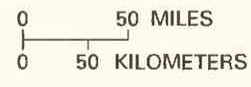

Dissolved solids, 1980-89

Figure 4. Trends in water quality of selected streams in Vermont, by water years. (Source: Data from U.S. Geological Survey files.) 


\section{DISSOLVED NITRITE PLUS NITRATE}

Nitrite and nitrate are oxidized forms of nitrogen that together normally constitute most of the dissolved nitrogen in well-aerated streams. Nitrite readily oxidizes to nitrate in natural waters; therefore, nitrate generally is by far the more abundant of the two (Hem, 1985, p. 124).

Concentrations of dissolved nitrite plus nitrate had no trend at the monitoring stations on the Connecticut and Black Rivers. Although improvements in and construction of wastewater-treatment facilities upstream from site 7 might have decreased nitrate concentrations, nonpoint sources, such as agricultural runoff and atmospheric deposition, might have offset the decreases (Smith and others, 1987, p. 1,612).

\section{WATER-QUALITY MANAGEMENT}

The Vermont Water Resource Board, through the Agency of Natural Resources, Department of Environmental Conservation, administers programs and policies to ensure that the State's water resources are protected from pollution. The EPA, in a memorandum of agreement with the State dated March 11, 1974, accepted the Vermont permit program as equivalent to the National Pollutant Discharge Elimination System program defined in section 402 of the Federal Clean Water Act. The Department of Environmental Conservation performs specific regulatory, enforcement, and monitoring activities. These activities include issuing permits to wastewater dischargers, reviewing the operation and maintenance of municipal and nonmunicipal wastewater-treatment facilities, surveying to determine compliance with effluent and water-quality standards, and monitoring of waste discharges and ambient water-quality conditions.

The Vermont Water Resources Board has statutory authority over the State's water-management program. The board is composed of five members, all of whom are lay people appointed by the Governor. The board's day-to-day responsibilities are conducted by the Executive Director. Composed of three sections-Planning and Engineering, Environmental Science, and Groundwater Management-the Vermont Agency of Natural Resources Division of Water Quality manages the State's surface and ground water through planning, engineering, technical analysis, and technical assistance; administers grants for aquatic-weed control and water-quality planning; and operates a water-quality laboratory. Through research and analysis, the division staff establishes the State's water-quality standards. The division also administers programs such as aquatic-nuisanceplant control, ground-water management, well-driller licensing, water-quality certificates, wasteload allocation, flood-plain management, lakes and ponds encroachment, wetlands protection, hydroelectric-project review, acid-rain monitoring, and chemical and biological monitoring.

The Division of Water Quality is the lead agency for the development of the State's nonpoint-source water-pollution management plan that was implemented in 1988. The division oversees Federal pass-through funds for nonpoint-source pollution-control work conducted by the Regional Planning Commission and partici- pates in a technical agricultural Best Management Practices Review Committee. Also, the division provides technical assistance to municipalities regarding lake shoreland zoning, best management practices, and protective measures. The Division of Water Quality of the Vermont Agency of Natural Resources prepares a biennial waterquality assessment report submitted to the EPA and the U.S. Congress as mandated by section 305(b) of the Federal Clean Water Act (Vermont Department of Environmental Conservation, 1990).

\section{SELECTED REFERENCES}

Anderson, J.R., 1967, Major land uses in the United States, in U.S. Geological Survey, 1970, National atlas of the United States of America: Washington, D.C., U.S. Geological Survey, p. 158-159.

Briggs, J.C., and Ficke, J.F., 1977, Quality of rivers in the United States, 1975 water year-Based on the National Stream Quality Accounting Network (NASQAN): U.S. Geological Survey Open-File Report 78-200, 436 p.

Britton, L.J., and Greeson, P.E., eds., 1987, Methods for collection and analysis of aquatic biological and microbiological samples: U.S. Geological Survey Techniques of Water-Resources Investigations, book 5, chap. A4, $363 \mathrm{p}$.

Fenneman, N.M., 1946, Physical divisions of the United States: Washington, D.C., U.S. Geological Survey special map, scale 1:7,000,000.

Fishman, M.J., and Friedman, L.C., eds., 1989, Methods for the determination of inorganic substances in water and fluvial sediments: U.S. Geological Survey Techniques of Water-Resources Investigations, book 5, chap. A1, 545 p.

Hem, J.D., 1985, Study and interpretation of the chemical characteristics of natural water (3d ed.): U.S. Geological Survey Water-Supply Paper 2254, 263 p.

Hirsch, R.M., Slack, J.R., and Smith, R.A., 1982, Techniques of trend analysis for monthly water quality data: Water Resources Research, v. 18, no. 1 , p. $107-121$.

Lanfear, K.J., and Alexander, R.B., 1990, Methodology to derive water-quality trends for use by the National Water Summary Program of the U.S. Geological Survey: U.S. Geological Survey Open-File Report 90-359, $10 \mathrm{p}$.

National Atmospheric Deposition Program, 1989, NADP/NTN annual data summary-Precipitation chemistry in the United States, 1988: Fort Collins, Natural Resource Ecology Laboratory, Colorado State University, 379 p.

Smith, R.A., Alexander, R.B., and Wolman, M.G., 1987, Water-quality trends in the Nation's rivers: Science, v. 235, p. 1,607-1,615.

Solley, W.B., Merk, C.F., and Pierce, R.R., 1988, Estimated use of water in the United States in 1985: U.S. Geological Survey Circular 1004, 82 p.

Thelin, G.P., and Pike, R.J., 1990, Digital shaded relief map of the conterminous United States: Menlo Park, Calif., U.S. Geological Survey digital image processing, scale 1:3,500,000.

U.S. Geological Survey, 1990, National water summary 1987-Hydrologic events and water supply and use: U.S. Geological Survey Water-Supply Paper 2350,553 p.

Vermont Department of Environmental Conservation, 1990, State of Vermont 1990 water quality assessment 305(b) report: Waterbury, Division of Water Quality, p. 121.

Ward, J.R., and Harr, C.A., eds., 1990, Methods for collection and processing of surface-water and bed-material samples for physical and chemical analyses: U.S. Geological Survey Open-File Report 90-140, 71 p. 
Prepared by J.C. Denner, U.S. Geological Survey; “Water-Quality Management” section by Jerome McArdle, Vermont Division of Water Quality

FOR ADDITIONAL INFORMATION: Chief, New Hampshire-Vermont Office, U.S. Geological Survey, 525 Clinton Street, Bow, NH 03304 


\section{VIRGINIA Stream Water Quality}

Virginia is a water-rich State. An annual precipitation of 42 inches, or $79,800 \mathrm{Mgal} / \mathrm{d}$ (million gallons per day) (U.S. Geological Survey, 1990 , p. 505), provides water for about 27,000 miles of perennial streams and rivers (Virginia Water Control Board, 1990a, p. i). Surface-water quality generally meets or exceeds State standards for protection of fish, shellfish, and wildlife and for recreation and water supply in most areas.

In 1985, 93 percent $(4,530 \mathrm{Mgal} / \mathrm{d})$ of the State's total freshwater withdrawals were from surface-water sources. Of this quantity, 76.4 percent $(3,460 \mathrm{Mgal} / \mathrm{d})$ was used for thermoelectric power generation, 11.1 percent $(503 \mathrm{Mgal} / \mathrm{d}$ ) for public supply, $10.9 \mathrm{per}-$ cent (494 Mgal/d) for mining and industrial activities, and 1.6 percent (72 Mgal/d) for agriculture (U.S. Geological Survey, 1990, p. 510). Surface water provided 87.1 percent of the total 579 $\mathrm{Mgal} / \mathrm{d}$ used for public supply; the remaining 12.9 percent was ground water. Surface water is the major source of public supply throughout most of the State west of the Blue Ridge province. Ground water is the primary source in many rural areas and on the Eastern Shore peninsula.

Forest, cropland, and woodland (wooded areas having little commercial value) cover most of Virginia (fig. $1 A$ ). The physiographic provinces of Virginia (fig. $1 B$ ) each have distinct geologic features and landforms that affect land use, stream characteristics, and water quality. The geology of the Appalachian Plateaus consists of sedimentary sandstone, shale, and coal. The Valley and Ridge province, also underlain by sedimentary rocks, consists of folded limestone, dolomite, shale, and sandstone; the limestone and dolo- mite are easily eroded; soils within the valleys of this area are fertile. The Blue Ridge province is underlain by crystalline bedrock that has a thin covering of weathered rock and soil; because of the rugged terrain and thin soil, the area has had little development and is mostly forested. The Piedmont province is characterized by fractured igneous and metamorphic rock and small areas of sedimentary rock; as in the Blue Ridge province, bedrock is thinly covered by weathered rock and soil. The Coastal Plain geology consists of interbedded unconsolidated sand, silt, and clay that thicken and dip gently southeastward from the Fall Line, which is the boundary between the Coastal Plain and the Piedmont province.

Water is important to the economic growth of Virginia, and many localities are seeking additional sources of water as population increases. The greatest population change in Virginia has been in northern and central Virginia, where most of the State's population is concentrated (fig. $1 C$ ), and in the southeastern coastal regions. Increases in population have been smaller in the western and Piedmont areas of the central part of the State. Virginia's 1990 population was 6.2 million (U.S. Bureau of the Census 1990 decennial census files), an increase of 16 percent from 1980 and 33 percent from 1970.

\section{WATER-QUALITY MONITORING}

Water-quality data obtained from analyses of water samples collected at monitoring stations are stored in the U.S. Geological Survey's (USGS) National Water Information System and the U.S. En-

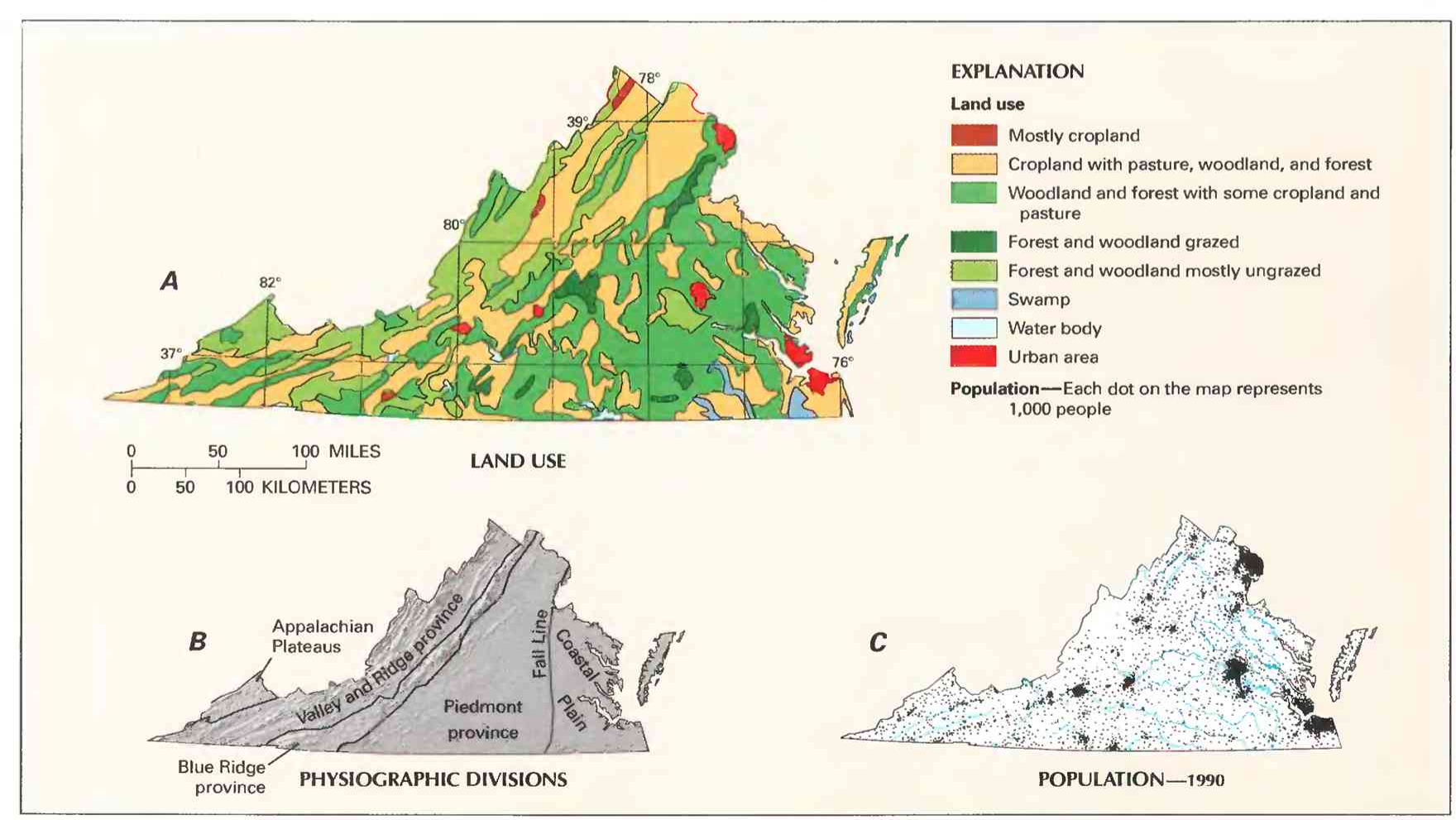

Figure 1. Land use, physiography, and population in Virginia. $A$, Major land uses. $B$, Physiographic divisions. $C$, Population distribution in 1990. (Sources: A, Major land uses modified from Anderson, 1967. B, Physiographic divisions from Fenneman, 1946; landforms from Thelin and Pike, 1990. C, Data from U.S. Bureau of the Census 1990 decennial census files. 
vironmental Protection Agency's (EPA) national data base known as STORET. Water-quality and streamflow data are reported by water year-the 12 months from October 1 through September 30. A water year is identified by the calendar year in which it ends. For example, water year 1991 comprises October 1, 1990, through September 30, 1991.

The data used in this summary of Virginia's stream water quality were obtained from water samples collected at 12 monitoring stations at which data collection is systematic and continuing (fig. 2). Analyses of water samples collected at 10 stations are the basis for the discussion and graphic summary (fig. 3) of stream waterquality conditions during water years 1987-89, and data from all 12 stations are the basis for the discussion and graphic summary (fig. 4) of stream water-quality trends. Water samples were collected and analyzed by using standard methods approved by the USGS (Britton and Greeson, 1987; Fishman and Friedman, 1989; Ward and Harr, 1990) or by using equivalent methods. If a method of sample collection or analysis changed over time, data from an analysis were included in the evaluation of recent stream water quality or of stream water-quality trends only if the change in method did not affect the comparability of the data.

\section{WATER-QUALITY CONDITIONS}

The following discussion of stream water quality in Virginia is organized by river basin (fig. 3). Where physiographic and landuse characteristics in different basins are similar, the discussion of those basins is combined. Graphs in figure 3 summarize certain aspects of stream water quality in the basins for water years 1987-89. The graphs show frequency distributions of data values that represent concentrations of selected constituents in stream water and measurements of selected physical properties of stream water. These constituents and properties are dissolved oxygen, fecal coliform bacteria, total alkalinity (as calcium carbonate), dissolved sulfate, dissolved solids, dissolved nitrite plus nitrate (as nitrogen), and dissolved phosphate (as phosphorus). The data are reported in milligrams per liter $(\mathrm{mg} / \mathrm{L})$ and colonies per 100 milliliters $(\mathrm{col} / 100 \mathrm{~mL})$. Sources and environmental significance of each constituent and property are described in table 1 .

Water quality at each monitoring station is the result of geological, chemical, biological, and hydrologic processes that occur over a large area. Water-quality problems that affect aquatic life or public health only locally are not fully represented in this summary.

In 1989, 82 percent of the length of the free-flowing streams and rivers assessed in Virginia ( 30 percent of the length of all streams and rivers) met the goals of the 1972 Federal Clean Water Act, 14 percent partially met these goals, and 4 percent did not meet these goals (Virginia Water Control Board, 1990a, p. i). The most common problem in streams that did not meet the goals was bacterial contamination, primarily in runoff from livestock operations. In 1990, 430 miles of Virginia's waters were under fish consumption advisories established by the Virginia Department of Health because of contamination from either organic compounds or metals (Virginia Water Control Board, 1990a, p. ii).

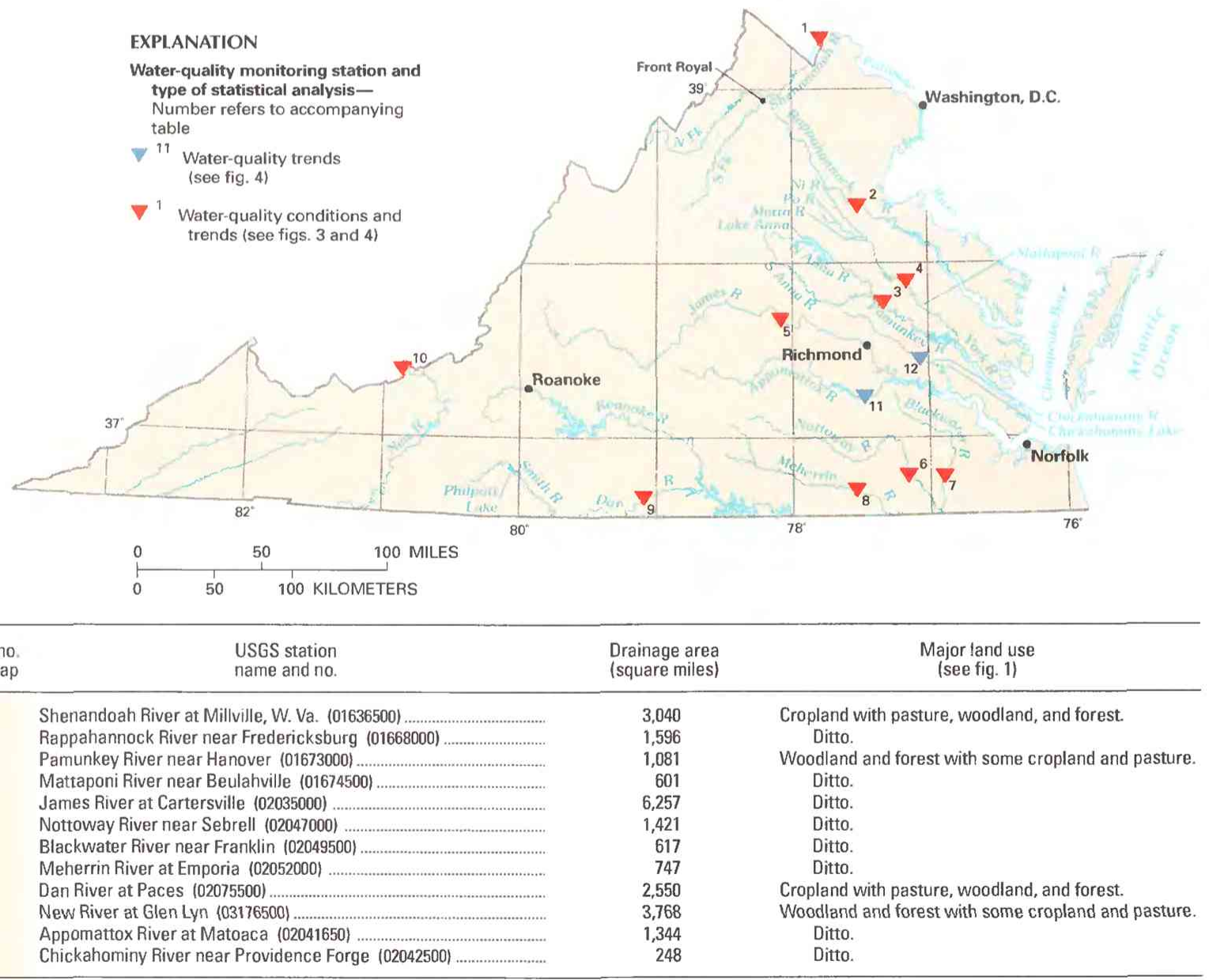

Figure 2. Selected water-quality monitoring stations, type of statistical analysis, and geographic features in Virginia. (Sources: Major land uses modified from Anderson, 1967; other data from U.S. Geological Survey files.) 


\section{SHENANDOAH RIVER}

The headwaters of the Shenandoah River are in the mountains of the Valley and Ridge province in northern Virginia. Two branches - the North Fork and the South Fork-flow northward and join at Front Royal. Thirty-seven percent of this basin is agricultural, and 6 percent is urban. Urban areas include part of the Washington, D.C., metropolitan area (Virginia Water Control Board, 1990b, p. 81).

Mercury, which has been found in fish tissue and sediments in the South Fork, has been monitored in this basin since 1977, and a health advisory regarding fish consumption in this area currently (1990) is in effect. The South Fork Shenandoah River has been contaminated with polychlorinated biphenyls ( $\mathrm{PCB}$ 's) primarily due to stormwater runoff from a manufacturing plant at Front Royal. The combined PCB and mercury contamination has resulted in health advisories for 144 miles of streams in this basin (Virginia Water Control Board, 1990b, p. 8-23).

Median concentrations of alkalinity $(121 \mathrm{mg} / \mathrm{L})$, sulfate $(51$ $\mathrm{mg} / \mathrm{L})$, and dissolved solids $(219 \mathrm{mg} / \mathrm{L})$ were higher at site 1 than at the other monitoring stations (fig. 3). These high concentrations prob- ably resulted from dissolution of limestone in the basin. The source of the high nitrite plus nitrate and fecal coliform bacteria concentrations might have been runoff from agricultural areas, wastewatertreatment plants in urban areas, or both.

\section{RAPPAHANNOCK RIVER}

The Rappahannock River flows from the eastern edge of the Blue Ridge province through the rolling hills of the Piedmont province and the Coastal Plain to Chesapeake Bay. Site 2 is located on the Fall Line, where high relief to the west results in sudden streamflow peaks during rainstorms; the river carries large loads of dissolved and suspended constituents during these high flows. About 52 percent of the basin is forest and woodland, and 35 percent is agricultural. Although only about 2 percent of the basin is urban, expansion of the Washington, D.C., suburbs is increasingly affecting this area. Two major potential water-quality problems are runoff of sediment from construction areas and increased concentrations of nutrients associated with the sediment.

Samples collected at site 2 during water years $1987-89$ had a low median concentration of fecal coliform bacteria $(18 \mathrm{col} / 100 \mathrm{~mL})$
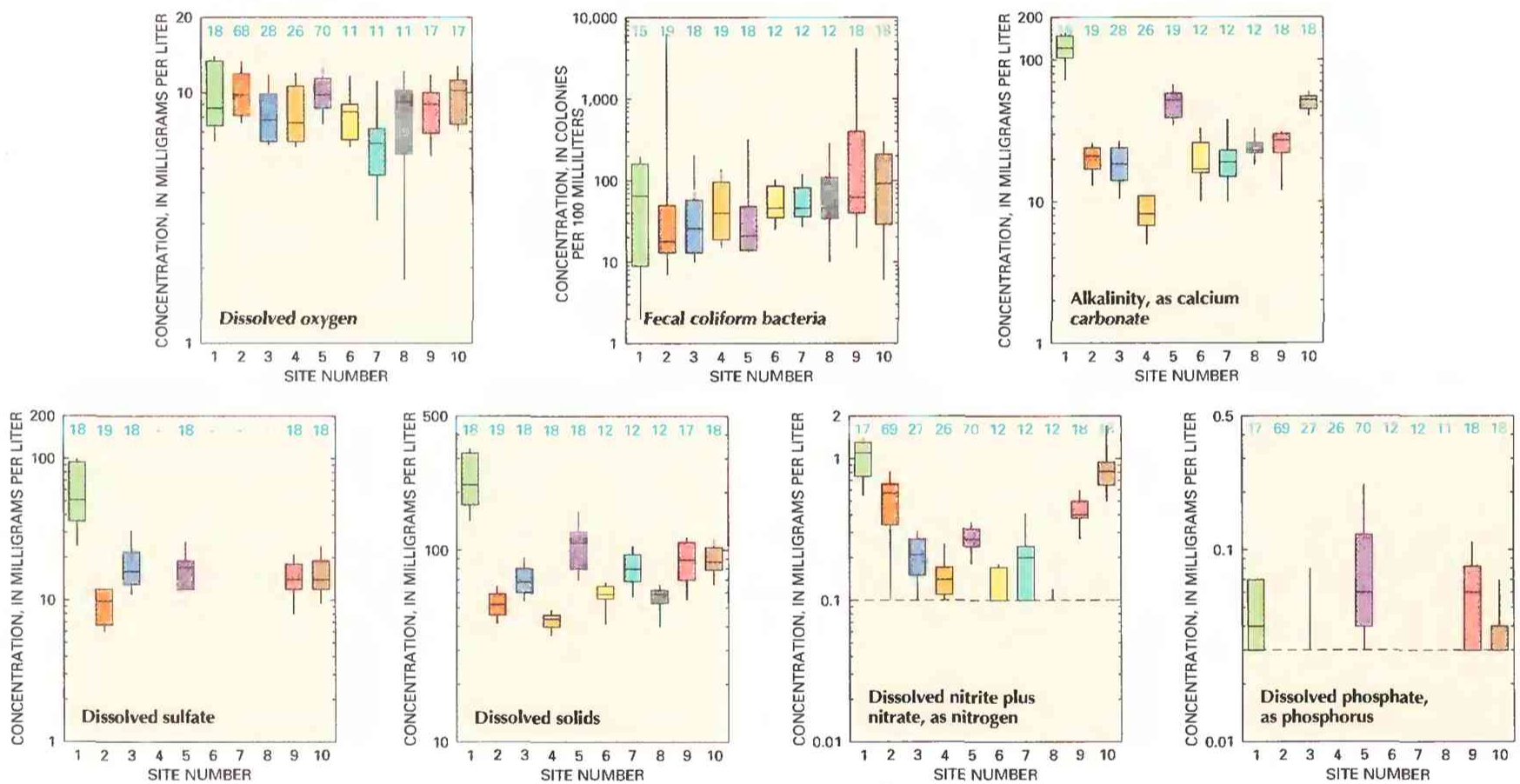

$$
\begin{aligned}
& \text { EXPLANATION } \\
& \text { Water-quality conditions in selected } \\
& \text { drainage basins } \\
& \text { Number of analyses-Dash indicates } \\
& \text { insufficient data } \\
& \text { Percentile-Percentage of analyses } \\
& \text { equal to or less than indicated } \\
& \text { values } \\
& \text { 90th } \\
& \text {-75th } \\
& \text { 25th-Median } \\
& \text { 10th } \\
& \text { Reporting limit - Minimum reporting } \\
& \text { limit for analytical method used. } \\
& \text { Data below limit line not shown }
\end{aligned}
$$

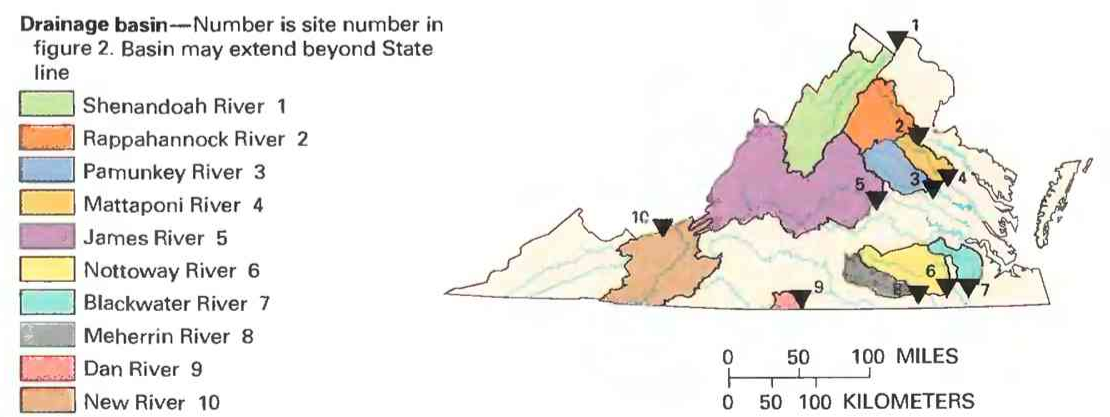

Figure 3. Water quality of selected streams in Virginia, water years 1987-89. (Source: Data from U.S. Geological Survey files.) 
Table 1. Sources and environmental significance of selected water-quality constituents and properties [Source: Compiled by the U.S. Geological Survey, Office of Water Quality]

\begin{tabular}{|c|c|c|}
\hline Constituent or property & Common sources & Environmental significance \\
\hline 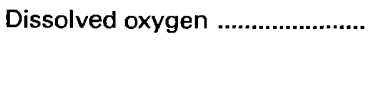 & $\begin{array}{l}\text { Introduced from the atmosphere; also a byproduct of } \\
\text { aquatic plants. }\end{array}$ & $\begin{array}{l}\text { Necessary for aquatic life; deficiency can result from } \\
\text { assimilation of organic wastes or rapid growth } \\
\text { and decay of algae. }\end{array}$ \\
\hline Fecal coliform bacteria ................ & $\begin{array}{l}\text { Sources include effluent from sewage-treatment } \\
\text { plants and runoff from pastures, feedlots, and ur- } \\
\text { ban areas. }\end{array}$ & $\begin{array}{l}\text { Presence indicates contamination of water by wastes } \\
\text { from humans and other warm-blooded animals. }\end{array}$ \\
\hline 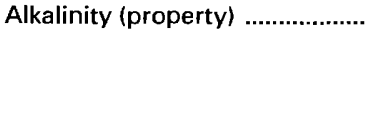 & $\begin{array}{l}\text { A measure of the quantity of acid-neutralizing sub- } \\
\text { stances; can be affected by geologic setting, in- } \\
\text { dustrial wastewater discharge, waste gases, and } \\
\text { runoff from surface mining. }\end{array}$ & $\begin{array}{l}\text { Sufficiently alkaline water can be unsuitable for some } \\
\text { agricultural and industrial uses. }\end{array}$ \\
\hline Sulfate & $\begin{array}{l}\text { Occurs in some rocks; also in mine runoff, industrial } \\
\text { wastewater discharge, and atmospheric deposi- } \\
\text { tion. }\end{array}$ & $\begin{array}{l}\text { Concentrations exceeding a natural, background } \\
\text { level indicate contamination from human activity; } \\
\text { in sufficient quantity, can cause water to be } \\
\text { unsuitable for public supply; can harm aquatic } \\
\text { organisms. }\end{array}$ \\
\hline Dissolved solids ............................ & $\begin{array}{l}\text { A result of rock weathering; also in agricultural runoff } \\
\text { and industrial discharge. }\end{array}$ & $\begin{array}{l}\text { In sufficient quantity, can cause water to be unsuitable } \\
\text { for public supply, agriculture, and industry; can } \\
\text { harm aquatic organisms. }\end{array}$ \\
\hline Nitrite plus nitrate ........................ & $\begin{array}{l}\text { Nonpoint sources are agricultural and urban runoff; } \\
\text { a major point source is wastewater discharge. }\end{array}$ & $\begin{array}{l}\text { Plant nutrient that, in sufficient quantity, can cause } \\
\text { algal blooms and excessive growth of higher } \\
\text { aquatic plants in bodies of water; can cause water } \\
\text { to be unsuitable for public supply. }\end{array}$ \\
\hline Phosphate .................................. & $\begin{array}{l}\text { Occurs in some rocks and sediments; also in runoff } \\
\text { and seepage from phosphate-rock mines, agri- } \\
\text { cultural and urban runoff, and industrial and } \\
\text { municipal wastewater discharge. }\end{array}$ & $\begin{array}{l}\text { Plant nutrient that, in sufficient quantity, can cause } \\
\text { algal blooms and excessive growth of higher } \\
\text { aquatic plants in bodies of water. }\end{array}$ \\
\hline
\end{tabular}

but also had the highest 90 th-percentile concentration of fecal coliform bacteria $(6,300 \mathrm{col} / 100 \mathrm{~mL})$. Bacteria concentrations in a single sample caused the high upper value for the frequency distribution. The sample was collected during a rainstorm that resulted in streamflow greater than would be expected 95 percent of the time.

\section{PAMUNKEY AND MATTAPONI RIVERS}

The Pamunkey River, formed by the confluence of the North and South Anna Rivers, and the Mattaponi River, formed by the confluence of the Matta, Po, and Ni Rivers, are major tributaries to the York River. The York River system has its headwaters in the Piedmont province and crosses the flatlands of the Coastal Plain to discharge into Chesapeake Bay. The area surrounding the Pamunkey and Mattaponi Rivers is largely agricultural. Part of the Mattaponi River subbasin within the Coastal Plain contains large expanses of wetlands. Water quality within the basin, with the exception of a few local problem areas, is usually above State standards for surface water. Drainage from tailings piles of a mine active during the 1920's caused excessive acidity and toxic-metals contamination in a tributary to Lake Anna on the North Anna River, which flows into the Pamunkey River upstream from site 3; although metals concentrations in the tributary have stabilized, acidity remains above normal for the area (Virginia Water Control Board, 1990b, p. 10-8). Downstream from sites 3 and 4, the Pamunkey and Mattaponi Rivers have been closed to shellfish harvesting owing to elevated levels of fecal coliform bacteria, possibly from livestock and other agricultural activities. Despite these local water-quality problems, the data from sites 3 and 4 (fig. 3) indicate that the main stems of the Pamunkey and Mattaponi Rivers have successfully assimilated much of the upstream contamination.

\section{JAMES RIVER}

The James River drains about 25 percent of the State. The main stem crosses the Valley and Ridge, Blue Ridge, Piedmont, and Coastal Plain provinces. Three-quarters of this basin is forest or woodland. About one-third of Virginia's population lives in the basin, and numerous wastewater-treatment plants discharge into the
James River and its tributaries. Water-quality problems in the James River basin include locally excessive concentrations of fecal coliform bacteria from livestock operations and urban areas. Other waterquality issues in the basin have been the presence of the pesticide kepone in sediments in the lower James River and the designation of an EPA Superfund site at an abandoned mine where fish were killed by a copper-containing leachate.

Site 5 is upstream from the Fall Line on the main stem of the James River, and water quality at the site reflects the combined effects of land use and geology in the Valley and Ridge, Blue Ridge, and Piedmont provinces. Water samples from this monitoring station had the second highest median concentration of dissolved solids $(109 \mathrm{mg} / \mathrm{L})$. These high concentrations could be from the dissolution of limestone underlying the headwaters region in the Valley and Ridge province. The median phosphate concentration at site 5 $(0.06 \mathrm{mg} / \mathrm{L})$ was the highest for any of the 10 monitoring stations. Agricultural activity in the basin possibly caused the high concentrations.

\section{NOTTOWAY, BLACKWATER, AND MEHERRIN RIVERS}

The Nottoway, Blackwater, and Meherrin Rivers join to form the Chowan River, which flows into Albemarle Sound in North Carolina. The south-central part of Virginia has relatively little relief, and areas adjacent to the rivers contain many swamps and lowlands. Flow in streams in this area is sluggish. About four-fifths of the area is forest and woodland: most of the rest is agricultural.

The lower Nottoway River is an important source of water for public supply in southeastern Virginia and is also an important recreational area. Site 6 is in a low, swampy area of the Nottoway River. The Nottoway River has dark-colored water owing to the presence of humic substances that are byproducts of natural decay of vegetation. Dissolved-oxygen concentrations have at times been lower than the State surface-water standard of $4 \mathrm{mg} / \mathrm{L}$ (Virginia Water Control Board, 1988), a natural characteristic of slow-moving streams that are rich in organic materials. Other water-quality problems in the area have included elevated concentrations of fecal coliform bacteria and toxic metals. Nonetheless, concentrations of fecal coliform bacteria and most other water-quality constituents in samples collected at site 
6 during water years 1987-89 were similar to or less than those in samples from other monitoring stations (fig. 3). Dissolved-oxygen concentrations were consistently higher than $4 \mathrm{mg} / \mathrm{L}$.

Site 7 is on the Blackwater River, so named because of its color, which is caused by the presence of humic substances. The Blackwater River is entirely within the Coastal Plain. The median dissolved-oxygen concentration at site $7(6.3 \mathrm{mg} / \mathrm{L})$ was the lowest for the 10 monitoring stations, and concentrations occasionally were lower than the State surface-water standard of $4 \mathrm{mg} / \mathrm{L}$ (fig. 3 ). Other problems in this basin include excessive nutrient concentrations and other local effects of discharge from wastewater-treatment plants (Virginia Water Control Board, 1990b, p. 12-10). However, the presence of relatively low concentrations of stream-water constituents in samples collected at site 7 during water years 1987-89 indicates that the effects of upstream local contaminant sources were assimilated by the river before the water reached the monitoring station. The Blackwater River, however, is under a fish-tissue consumption advisory owing to dioxin contamination from a paper-processing plant upstream.

Upstream from site 8, the Meherrin River basin is in the Piedmont and Coastal Plain physiographic provinces. As in the Nottoway and Blackwater River basins, this basin has localized problems of excessive concentrations of fecal coliform bacteria related to point discharges of wastewater. Dissolved-oxygen concentrations are occasionally lower than State surface-water standards ( $4 \mathrm{mg} / \mathrm{L}$ ). Constituent concentrations in samples collected at site 8 generally were low (fig. 3).

Samples collected at all three monitoring stations in the Chowan River basin had low nitrite plus nitrate and phosphate concentrations. The low concentrations might have been the result of uptake of these nutrients by plants in wetlands areas.

\section{DAN RIVER}

The Dan River is the largest tributary to the Roanoke River. The Dan River originates in the Blue Ridge province and flows southward into North Carolina before turning north to join the Roanoke River in Virginia. Philpott Lake is located on the Smith River, a tributary to the Dan River, and is used for hydroelectric power generation, flood control, and recreation. Site 9 is on the Dan River downstream from the confluence with the Smith River and upstream from the confluence with the Roanoke River. This area of the State is mostly rural, and the stream water is suitable for most uses. During water years 1987-89, the State surface-water standard for fecal coliform bacteria $(1,000 \mathrm{col} / 100 \mathrm{~mL})$ (Virginia Water Control Board, 1988) was occasionally exceeded at site 9 (fig. 3) and nitrite plus nitrate concentrations (median, $0.4 \mathrm{mg} / \mathrm{L}$ ) were relatively high, possibly because of runoff from livestock operations and areas of fertilizer application. Phosphate concentrations also were relatively high (median, $0.06 \mathrm{mg} / \mathrm{L}$ ), possibly because of runoff from fertilized cropland.

\section{NEW RIVER}

The New River flows northward from its headwaters in the Blue Ridge province in North Carolina, into the Valley and Ridge province in Virginia, and then into West Virginia. Ground-water discharge from the limestone aquifers provides a substantial part of the streamflow (Virginia Water Control Board, 1990b, p. 16-1). Site 10 is on the New River near the West Virginia border. About 55 percent of the basin is forest and woodland; the rest of the basin is largely agricultural and includes livestock operations. Water-quality problems have included excessive concentrations of fecal coliform bacteria and trace metals such as zinc, copper, lead, and iron, and, locally, acidification caused by mining activities (Virginia Water Control Board, 1990b, p. 16-8). The Virginia Water Control Board has reported that two tributaries have high concentrations of metals from iron-oxide mine tailings piled near the streams.

As at stations in other basins in the Valley and Ridge province (sites 1 and 5), water at site 10 had a relatively high median alkalinity (52 mg/L) (fig. 3) owing to the limestone and dolomite underlying the basin. At site 10, the median concentration of nitrite plus nitrate $(0.81 \mathrm{mg} / \mathrm{L})$ was the second highest for all monitoring stations. The median concentration of fecal coliform bacteria $(92 \mathrm{col} / 100 \mathrm{~mL})$ was the highest for any station.

\section{WATER-QUALITY TRENDS}

Trend analysis is a statistical procedure used to detect changes in stream water quality at a monitoring station over time. For this report, water-quality data from 12 monitoring stations (fig. 2) were analyzed for trends by using the seasonal Kendall test (Hirsch and others, 1982), a method used extensively by the USGS. The graph (shown below) of the dissolved-phosphate concentration in the James River at site 5 illustrates the trend inferred from the concentration data and demonstrates the variation in water quality that is common in streams.

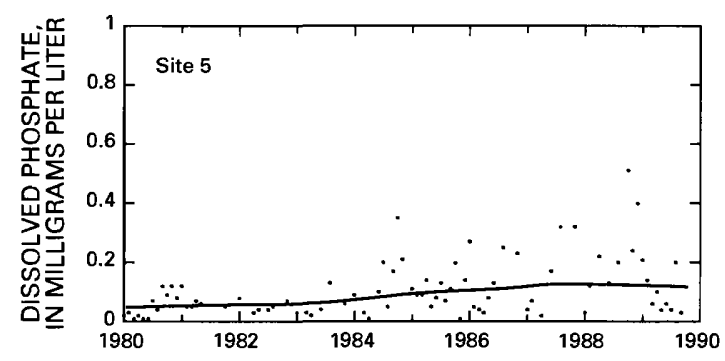

When possible, constituent-concentration data were adjusted for changes in streamflow to preclude identifying a trend in concentration that was caused only by a trend in streamflow. The data were not adjusted when (1) more than 10 percent of the samples had concentrations lower than the minimum reporting limit for the analytical method used or (2) streamflow was controlled substantially by human activities. When the concentration data could not be adjusted for streamflow, trends were determined directly from the concentration data.

Statewide trends in concentrations of selected constituents in stream water and in measurements of selected physical properties of stream water are shown on maps in figure 4. On each map, a trend is indicated at a monitoring station only if the data from that station were suitable for use in the trend analysis. For more information on the suitability criteria and on the trend-analysis procedure used for this report, see Lanfear and Alexander (1990).

\section{DISSOLVED OXYGEN}

The dissolved-oxygen concentration in a stream is controlled by several factors, including water temperature, air temperature and pressure, hydraulic characteristics of the stream, photosynthetic or respiratory activity of stream biota, and the quantity of organic material present. A trend in dissolved-oxygen concentrations commonly is directly or indirectly the result of human activities. Generally, an upward trend in dissolved-oxygen concentrations indicates improving stream water-quality conditions and a downward trend indicates deteriorating conditions.

The Meherrin River is regulated at low and medium flows. The downward trend in dissolved-oxygen concentrations at site 8 might have been a result of more frequent releases, during later years of the trend-analysis period, of water having lower concentrations of dissolved oxygen. 


\section{FECAL COLIFORM BACTERIA}

Fecal coliform bacteria are used as indicators of fecal contamination from humans and other warm-blooded animals. Such contamination can introduce disease-causing viruses and bacteria into a stream. No trends in concentrations of fecal coliform bacteria were detected at any of 11 monitoring stations from which data were suitable for trend analysis.

\section{ALKALINITY}

Alkalinity is a measure of the capacity of the substances dissolved in water to neutralize acid. In most natural waters, alkalinity is produced mainly by bicarbonate and carbonate (Hem, 1985, p. 106), which are ions formed when carbon dioxide or carbonate rock dissolves in water
The causes of the upward trends in alkalinity in the Rappahannock River at site 2 , the Pamunkey River at site 3 , and the Appomattox River at site 11 are not known, although all three rivers are in areas of increasing urban and industrial development. The trends could be a result of increasing industrial and municipal wastewater-treatment-plant effluent.

\section{DISSOLVED SULFATE}

The major natural sources of sulfate in streams are rock weathering, volcanoes, and biochemical processes (Hem, 1985, p. 113). Human activities such as mining, waste discharge, and fossil-fuel combustion also can be important sources. A shortened trend-analysis period was used for sulfate because data from analyses performed before water year 1982 are not comparable to data for subsequent years. An increasing number of wastewater-treatment plants and

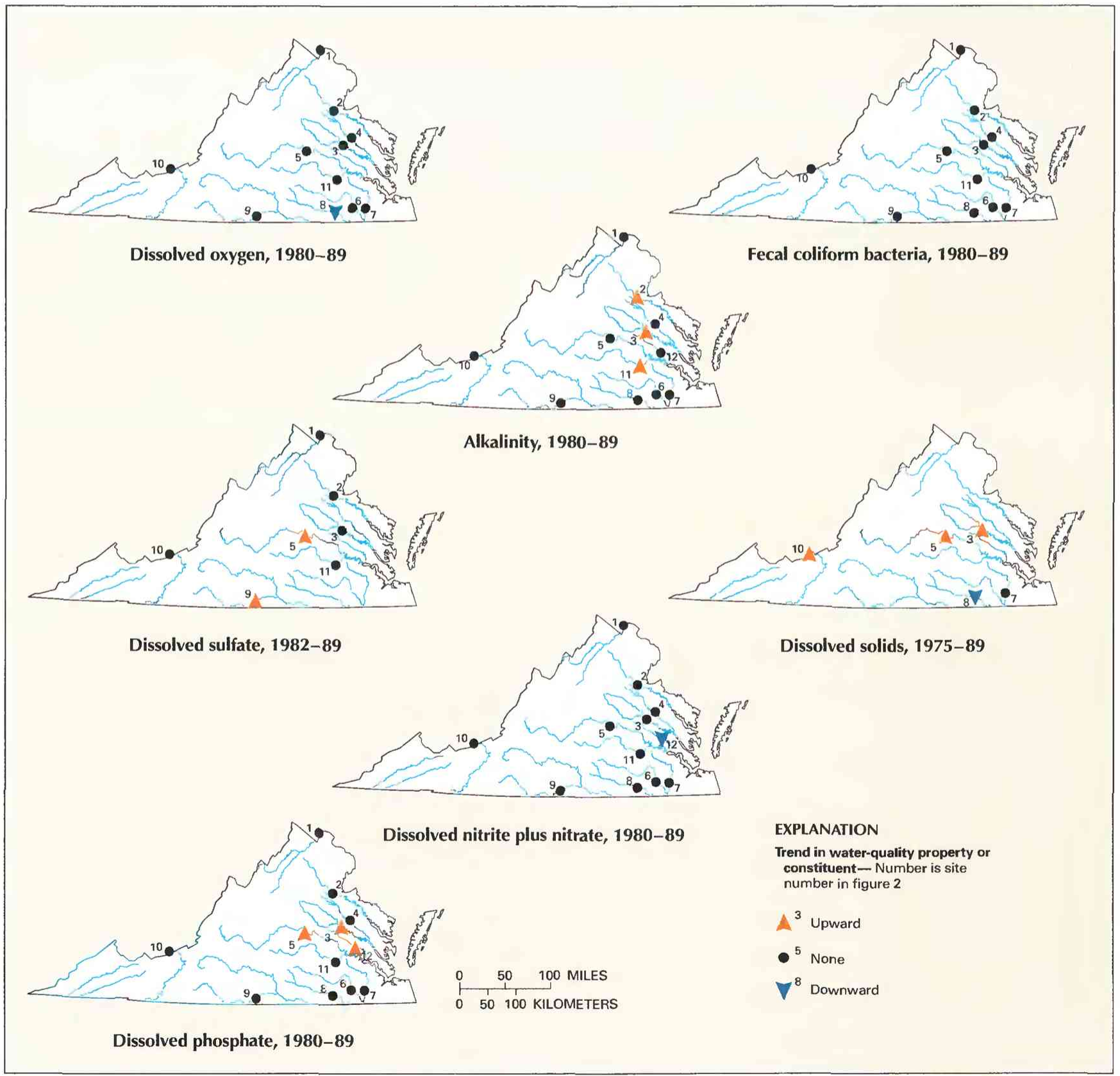

Figure 4. Trends in water quality of selected streams in Virginia, by water years. (Source: Data from U.S. Geological Survey files.) 
growth in industries such as mining that discharge wastewater into the James and Dan Rivers could have been possible causes of the upward trends in sulfate at sites 5 and 9.

\section{DISSOLVED SOLIDS}

Dissolved solids in stream water result primarily from rock weathering but also can be introduced as a byproduct of human activities (table 1). Concentrations generally are greatest in streams draining basins underlain by rocks and soils that contain easily dissolved minerals.

Upward trends in dissolved-solids concentrations in the Pamunkey River at site 3, the James River at site 5, and the New River at site 10 might have been a result of increasing agricultural activity as well as of expanding urban development. Improvement of municipal wastewater-treatment plants might have been the cause for the decreasing dissolved-solids concentrations in the Meherrin River at site 8.

\section{DISSOLVED NITRITE PLUS NITRATE}

Nitrite and nitrate are oxidized forms of nitrogen that together normally constitute most of the dissolved nitrogen in well-aerated streams. Nitrite readily oxidizes to nitrate in natural waters; therefore, nitrate generally is by far the more abundant of the two (Hem, 1985 , p. 124).

The downward trend in nitrite plus nitrate concentrations in the Chickahominy River at site 12 might have resulted from the adoption in 1971 of stringent nutrient and suspended-solids standards for the Chickahominy River basin to correct eutrophication problems in Chickahominy Lake (Louis Seivard, Virginia Water Control Board, oral commun., October 1990). Additionally, land use in this basin upstream from site 12 gradually has changed from agricultural to residential as the Richmond area has expanded, and this change could have resulted in decreased nutrient input to the streams.

\section{DISSOLVED PHOSPHATE}

Phosphate is the oxidized form of phosphorus and the only form of significance in most natural waters. Small quantities of dissolved phosphate commonly are present in streams as a result of rock weathering. Normally, concentrations are no more than a few tenths of a milligram per liter (Hem, 1985, p. 126) and usually are much lower. Higher concentrations can indicate contamination from human activities (table 1).

The upward trends in phosphate concentrations in the Pamunkey River at site 3, the James River at site 5, and the Chickahominy River at site 12 might have had one or more of several causes. Because much of the area in these basins is agricultural, agricultural activities likely are a significant source of phosphate to the streams. The upward trend at site 12 on the Chickahominy River might also have been caused by increasing urban runoff from the city and suburbs of Richmond, which have been expanding into the headwater areas of this basin. Phosphate is a common constituent of municipal and industrial wastewater discharge.

\section{WATER-QUALITY MANAGEMENT}

Surface-water allocations in Virginia are based on commonlaw riparian rights, as in most Eastern States. Virginia statutory laws direct the Virginia Water Control Board to formulate State policy and regulations that maintain the quality of the State's waters. The Virginia Water Control Board implements State and Federal stream water-quality legislation and biennially submits a water-quality-assessment report to the EPA and the U.S. Congress (Virginia Water Control Board, 1990a,b) as mandated by section 305(b) of the Federal Clean Water Act.
The Virginia Water Control Board has set water-quality standards to meet or exceed the goals of the Federal Clean Water Act. State standards protect beneficial uses that include public water supply, recreation, and the propagation of balanced populations of native aquatic organisms and wildlife.

State agencies such as the Virginia Commission of Game and Inland Fisheries, the Marine Resources Commission, and the Virginia Council on the Environment review and comment on proposed regulations. Also, the Virginia Health Department writes standards that protect designated public water supplies and shellfish waters.

Virginia has the authority to administer the National Pollutant Discharge Elimination Act as mandated by Federal and State statutory law. Permit limits for point-source discharges are set by the Virginia Water Control Board to maintain adequate water quality in receiving waters. Planning activities by the Virginia Water Control Board pursuant to section 303(e) of the Federal Clean Water Act establish wasteload allocations used to determine individual permit limits.

The Virginia Department of Conservation and Recreation, Division of Soil and Water Conservation (DSWC), has statewide responsibility to control nonpoint-source pollution in the State. The DSWC is charged with implementing the Virginia Nonpoint Source Pollution Program, a cooperative effort of State and Federal agencies.

The U.S. Army Corps of Engineers administers a program established by section 404 of the Federal Clean Water Act, which controls dredge and fill activities in navigable waters and adjacent wetlands. The Virginia water-quality certification program is administered by the Virginia Water Control Board. This certification ensures that any activities requiring a Federal permit or license, such as those required under section 404 , will not cause State water-quality standards to be violated.

Instream beneficial uses are protected by ensuring a sufficient minimum instream flow. The Virginia Water Control Board encourages conservation and reasonable use by water users. Proposed water withdrawals that require a Federal permit may be controlled by the Virginia Water Control Board to assure sufficient minimum instream flow under the water-quality certification program.

Virginia is a member of the Ohio River Sanitation Commission and the Interstate Commission on the Potomac River Basin. As a signatory State of the Chesapeake Bay Agreement, Virginia is a member of the Chesapeake Bay Commission. A part of Virginia is in the Tennessee Valley Authority (TVA) service area, and Virginia participates with the TVA in cooperative water-management activities.

The Virginia Water Control Board operates an extensive waterquality monitoring network covering all major river basins in the State. Water, sediment, and fish tissue are collected and analyzed for conventional and toxicological water-quality constituents. A network of biological monitoring stations provides an ongoing analysis of benthic-community structure. The Virginia Department of Health monitors fecal coliform bacteria concentrations in shellfish waters. The USGS and the Virginia Water Control Board cooperatively operate a network of stream gages that provide streamflow data from throughout the State

\section{SELECTED REFERENCES}

Anderson, J.R., 1967, Major land uses in the United States, in U.S. Geological Survey, 1970, National atlas of the United States of America: Washington, D.C., U.S. Geological Survey, p. 158-159.

Britton, L.J., and Greeson, P.E., eds., 1987, Methods for collection and analysis of aquatic biological and microbiological samples: U.S. Geological Survey Techniques of Water-Resources Investigations, book 5, chap. A4, $363 \mathrm{p}$.

Fenneman, N.M., 1946, Physical divisions of the United States: U.S. Geological Survey special map, scale 1:7,000,000. 
Fishman, M.J., and Friedman, L.C., eds., 1989, Methods for the determination of inorganic substances in water and fluvial sediments: U.S. Geological Survey Techniques of Water-Resources Investigations, book 5, chap. A1, 545 p.

Hem, J.D., 1985, Study and interpretation of the chemical characteristics of natural water (3d ed.): U.S. Geological Survey Water-Supply Paper 2254, 263 p.

Hirsch, R.M., Slack, J.R., and Smith, R.A., 1982, Techniques of trend analysis for monthly water quality data: Water Resources Research, v. 18, no. 1, p. $107-121$.

Lanfear, K.J., and Alexander, R.B., 1990, Methodology to derive water-quality trends for use by the National Water Summary Program of the U.S. Geological Survey: U.S. Geological Survey Open-File Report 90-359, $10 \mathrm{p}$.

Thelin, G.P., and Pike, R.J., 1990, Digital shaded relief map of the conterminous United States: Menlo Park, Calif., U.S. Geological Survey digital image processing, scale 1:3,500,000
U.S. Geological Survey, 1990, National water summary 1987-Hydrologic events and water supply and use: U.S. Geological Survey Water-Supply Paper 2350, 553 p.

Virginia Water Control Board. 1988, Water quality standards, 1988: Richmond, Virginia Water Control Board, $168 \mathrm{p}$

1990a, Virginia water quality assessment, 1990: Richmond, Virginia Water Control Board Information Bulletin 579, v. 1, variously paginated. 1990b, Virginia water quality assessment, 1990: Richmond, Virginia Water Control Board Information Bulletin 579, v. 2, variously paginated.

Ward, J.R., and Harr, C.A., eds., 1990, Methods for collection and processing of surface-water and bed-material samples for physical and chemical analyses: U.S. Geological Survey Open-File Report 90-140, 71 p.

Prepared by Donna L. Belval, U.S. Geological Survey; "Water-Quality Management" section by Louis D. Seivard, Virginia Water Control Board

FOR ADDITIONAL INFORMATION: Chief, Virginia Office, U.S. Geological Survey, 3600 West Broad Street, Room 606, Richmond, VA 23230 


\section{WASHINGTON Stream Water Quality}

Washington State has an abundance of surface water in its rivers and streams. Runoff ranges from about 10 to 160 inches in western Washington, and from about 0.2 to 20 inches in eastern Washington (U.S. Geological Survey, 1986, p. 473). Public water suppliers, a flourishing tourism industry, and the State's wildlife and cold-water fisheries depend on stream water of good quality.

In 1985, surface-water sources supplied about 83 percent (5,780 million gallons per day) of the total freshwater withdrawals in Washington (U.S. Geological Survey, 1990, p. 519). In western Washington, most of the surface water was used for public supply, whereas in eastern Washington, most was used for irrigation of agricultural land (fig. 1A). Drought beginning in November 1985 and becoming severe during 1987 and 1988 has diminished the surfacewater supply (U.S. Geological Survey, 1991, p. 551-558).

The Cascade Mountains (fig. $1 B$ ) divide Washington into a western part, which has a marine climate, and an eastern part, which has a more continental climate. This topographic and climatic division produces differences in surface-water runoff and largely determines land-use activities and population densities (fig. $1 C$ ). Of the 4.9 million people in Washington (U.S. Bureau of the Census 1990 decennial census files), about 1.9 million live in the Seattle-Everett metropolitan area (Washington State Office of Financial Management, 1990).

\section{WATER-QUALITY MONITORING}

Water-quality data obtained from analyses of water samples collected at monitoring stations are stored in the U.S. Geological Survey's (USGS) National Water Information System and the U.S. Environmental Protection Agency's (EPA) national data base known as STORET. Water-quality and streamflow data are reported by water year-the 12 months from October 1 through September 30. A water year is identified by the calendar year in which it ends. For example, water year 1991 comprises October 1, 1990, through September 30 , 1991.

The data used in this summary of Washington's stream water quality were obtained from water samples collected at 11 monitoring stations at which data collection is systematic and continuing (fig. 2). Analyses of water samples collected at 10 stations are the basis for the discussion and graphic summary (fig. 3) of stream waterquality conditions during water years $1987-89$, and data from all 11 stations are the basis for the discussion and graphic summary (fig. 4)

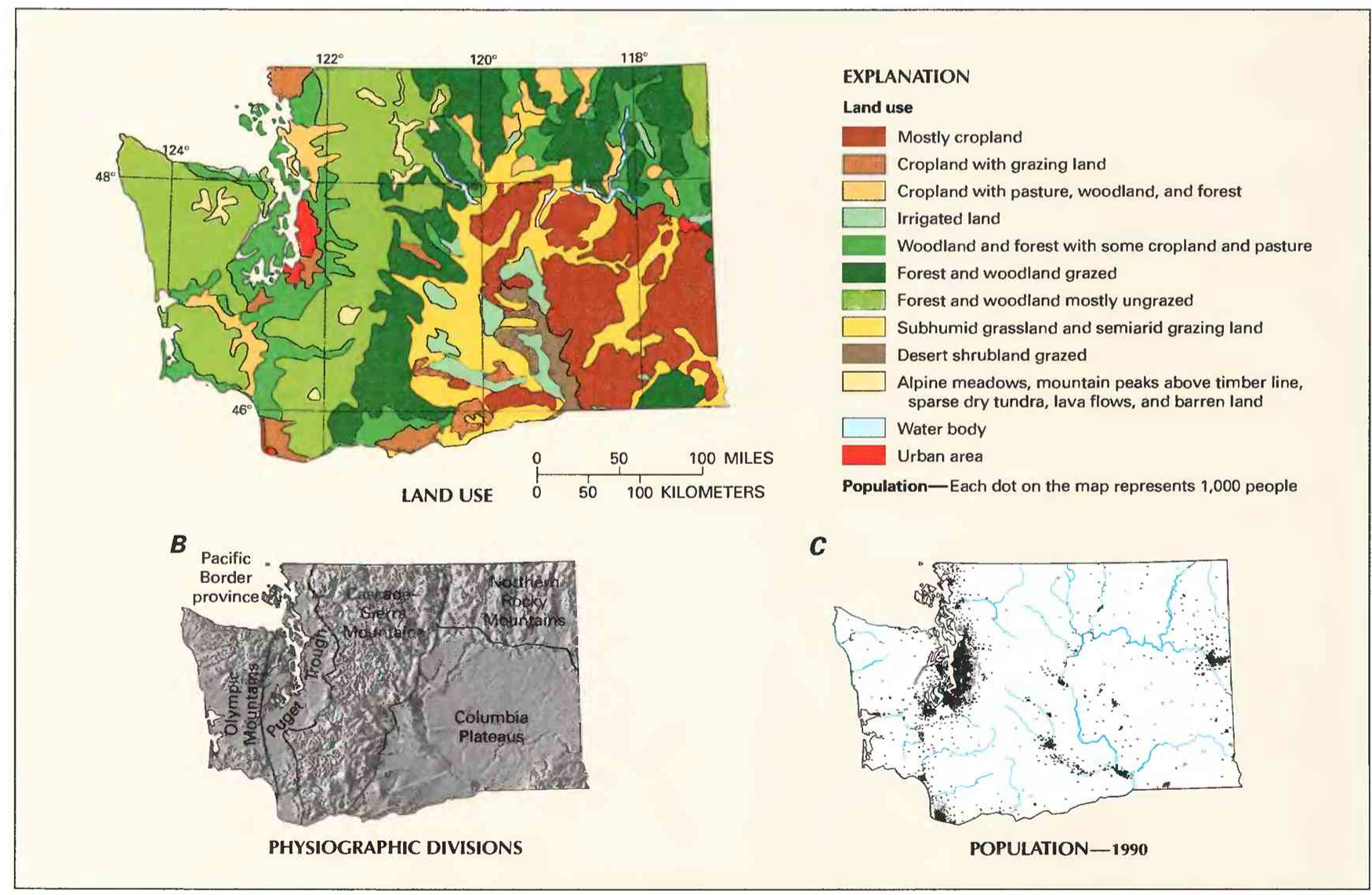

Figure 1. Land use, physiography, and population in Washington. $A$, Major land uses. $B$, Physiographic divisions. $C$, Population distribution in 1990. (Sources: A, Major land uses modified from Anderson, 1967. B, Physiographic divisions from Fenneman, 1946; landforms from Thelin and Pike, 1990. C, Data from U.S. Bureau of the Census 1990 decennial census files.) 
of stream water-quality trends. Water samples were collected and analyzed by using standard methods approved by the USGS (Britton and Greeson, 1987; Fishman and Friedman, 1989; Ward and Harr, 1990) or by using equivalent methods. If a method of sample collection or analysis changed over time, data from an analysis were included in the evaluation of recent stream water quality or of stream waterquality trends only if the change in method did not affect the comparability of the data.

\section{WATER-QUALITY CONDITIONS}

The Washington State Department of Ecology (1988, p. 1) appraised 269 river and stream segments totaling 4,621 miles or 11.4 percent of the State's total stream miles. In 15 percent of the stream miles appraised, beneficial uses of water designated by the State for purposes of water-pollution control were not supported because of water-quality degradation.

The following discussion of stream water quality in Washington is organized by river basin (fig. 3). Where physiographic and landuse characteristics in different basins are similar, the discussion of those basins is combined. Graphs in figure 3 summarize certain aspects of stream water quality in the basins for water years 1987-89.
The graphs show frequency distributions of data values that represent concentrations of selected stream-water constituents. These constituents are fecal coliform bacteria, fecal streptococcal bacteria, dissolved sulfate, dissolved solids, dissolved nitrite plus nitrate (as nitrogen), and suspended sediment. The data are reported in colonies per 100 milliliters (col/100 mL) and milligrams per liter $(\mathrm{mg} / \mathrm{L})$. Sources and environmental significance of each constituent are described in table 1.

Water quality at each monitoring station is the result of geological, chemical, biological, and hydrologic processes that occur over a large area. Water-quality problems that affect aquatic life or public health only locally are not fully represented in this summary.

\section{QUEETS AND CHEHALIS RIVERS}

The Queets and Chehalis Rivers originate in the Olympic Mountains and flow westward to the Pacific Ocean. The valleys of both rivers are underlain by Pleistocene glacial deposits that overlie marine sedimentary rocks (D.P. Dethier, U.S. Geological Survey, written commun., January 1982). Most of the two basins have mountainous terrain and are sparsely populated. The principal land use is timber harvesting; however, cropland and pastures are prevalent in the lowland reaches of the Chehalis River.

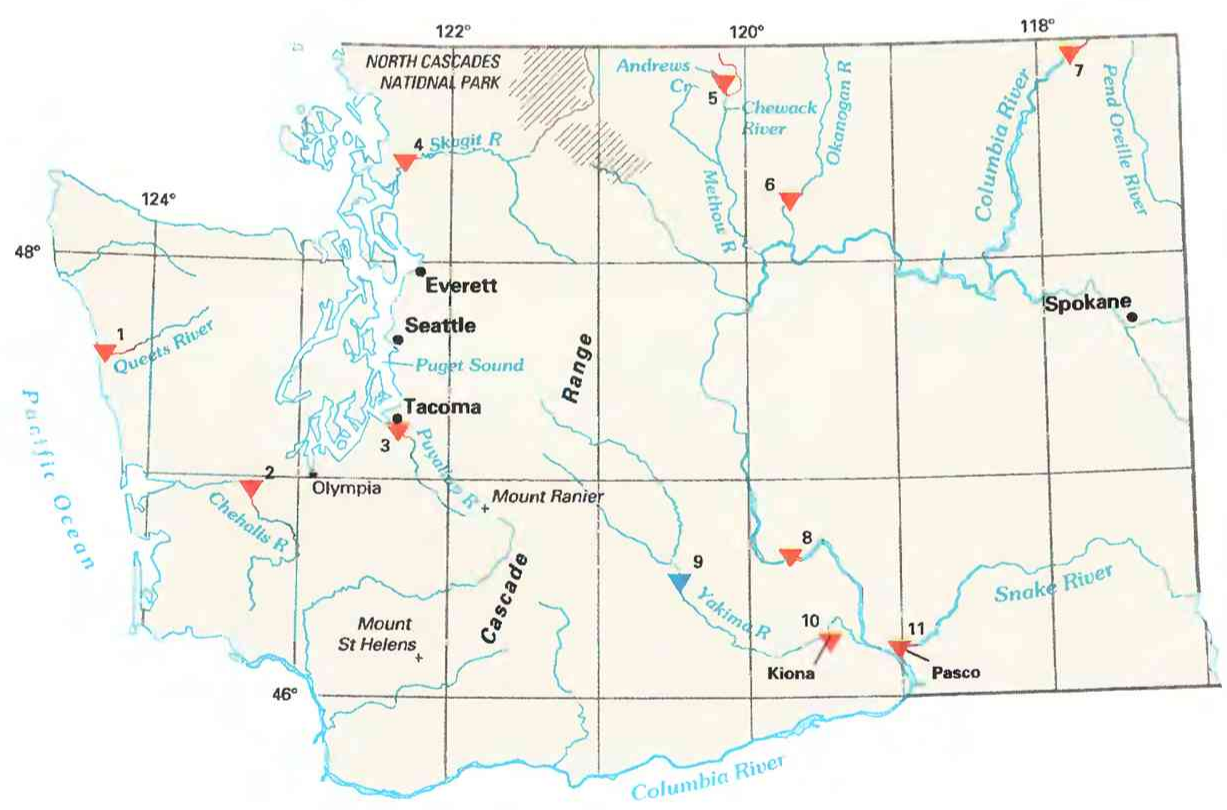

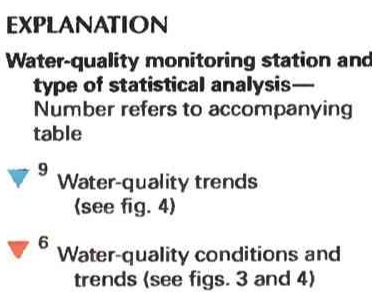
Water-quality monitoring station and type of statistical analysis-
Number refers to accompanying
table
(see fig. 4) trends (see figs. 3 and 4 )

\begin{tabular}{|c|c|c|c|}
\hline $\begin{array}{l}\text { Site no. } \\
\text { on map }\end{array}$ & $\begin{array}{l}\text { USGS station } \\
\text { name and no. }\end{array}$ & $\begin{array}{l}\text { Drainage area } \\
\text { (square miles) }\end{array}$ & $\begin{array}{l}\text { Major land use } \\
\text { (see fig. 1) }\end{array}$ \\
\hline 1 & Queets River near Clearwater $(12040500) \ldots$ & 445 & Mostly ungrazed forest and woodland. \\
\hline 2 & Chehalis River at Porter $(12031000)$ & 895 & Cropland with pasture, woodland, and forest. \\
\hline 3 & 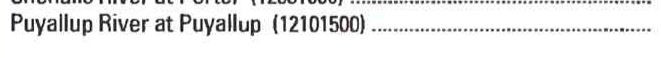 & 948 & $\begin{array}{l}\text { Cropland with grazing land; woodland and forest with some cropland } \\
\text { and pasture. }\end{array}$ \\
\hline 4 & 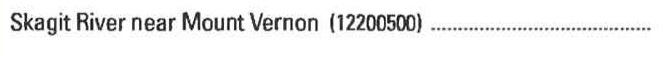 & 3,093 & $\begin{array}{l}\text { Cropland with pasture, woodland, and forest; mostly ungrazed forest } \\
\text { and woodland. }\end{array}$ \\
\hline 5 & Andrews Creek near Mazama $(12447390)$... & 22.1 & Mostly ungrazed forest and woodland. \\
\hline 6 & Okanogan River at Malott $(12447200)$ & 8,080 & Cropland with pasture, woodland, and forest; irrigated land. \\
\hline 7 & Columbia River at Northport $(12400520)$ & 60,200 & Woodland and forest with some cropland and pasture. \\
\hline 8 & $\begin{array}{l}\text { Columbia River at Vernita Bridge, near Priest Rapids Dam } \\
(12472900)\end{array}$ & 96,000 & Grazed desert shrubland; irrigated land. \\
\hline 9 & Yakima River above Ahtanum Creek, at Union Gap (12500450) ............ & 3,479 & Irrigated land; subhumid grassland and semiarid grazing land. \\
\hline 10 & 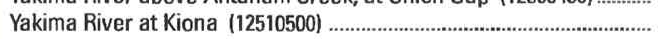 & 5,615 & Mostly cropland; irrigated land. \\
\hline 11 & Snake River at Burbank $(13353200)$ & 108,800 & Mostly cropland; subhumid grassland and semiarid grazing land. \\
\hline
\end{tabular}

Figure 2. Selected water-quality monitoring stations, type of statistical analysis, and geographic features in Washington. (Sources: Major land uses modified from Anderson, 1967; other data from U.S. Geological Survey files.) 
The Washington State Department of Ecology (1988, app. VII) reported that the designated beneficial uses of water in some parts of the Queets River are threatened by siltation, temperature, bacteria, and suspended-solids problems that are due mainly to natural causes. However, the low concentrations of dissolved solids (median, $37 \mathrm{mg} / \mathrm{L}$ ) and suspended sediment (median, $4 \mathrm{mg} / \mathrm{L}$ ) at site 1 (fig. 3) are characteristic of minimally contaminated, natural streams in western Washington. Streams in that part of the State generally have low dissolved-solids concentrations (D.P. Dethier, written commun., January 1982).

In the lower 72 miles of the Chehalis River, excessive bacteria and insufficient dissolved-oxygen concentrations degrade water quality so that the designated beneficial uses of water are only partially supported. The primary sources of these problems are municipal point sources, pastureland, animal holding areas, and septic tanks (Washington State Department of Ecology, 1988, app. VII). Concentrations of fecal coliform bacteria (median, $35 \mathrm{col} / 100 \mathrm{~mL}$ ), fecal streptococcal bacteria (median, $79 \mathrm{col} / 100 \mathrm{~mL}$ ), and nitrite plus nitrate (median, $0.56 \mathrm{mg} / \mathrm{L}$ ) at site 2 on the Chehalis River were among the highest in water samples from the monitoring stations (fig. 3). These relatively high median values corroborate the State's evaluation of the moderate water-quality problems near this site.

\section{PUYALLUP RIVER}

The Puyallup River originates on Mount Rainier as glacial meltwater and flows northwestward within the Puget Trough to Puget Sound at Tacoma. Site 3 is within the last 11 miles of levee-controlled river channel and is downstream from two sewage-treatment plants. Creosote compounds, crude oil and its refined products, and 1,1,1trichloroethane have been detected in water and sediment samples (Ebbert and others, 1987, p. 46 and 102-103).

The Washington State Department of Ecology (1988, app. VII) determined that the designated beneficial uses of water in the lower 10 miles of the river are only partially supported because of dissolvedoxygen, bacteria, metals, and siltation problems. Sources of these problems include sewage-treatment plants, channel and streambank
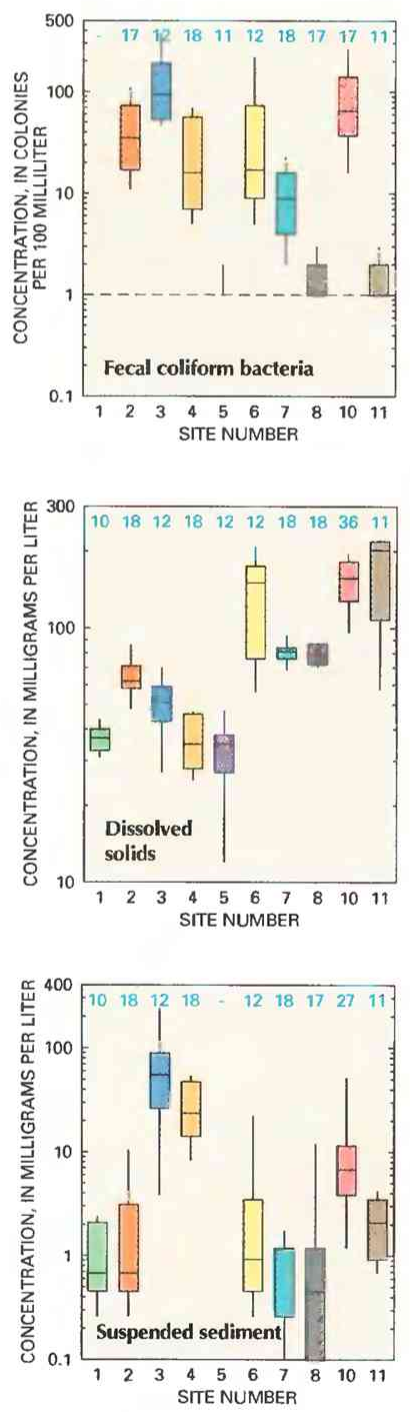
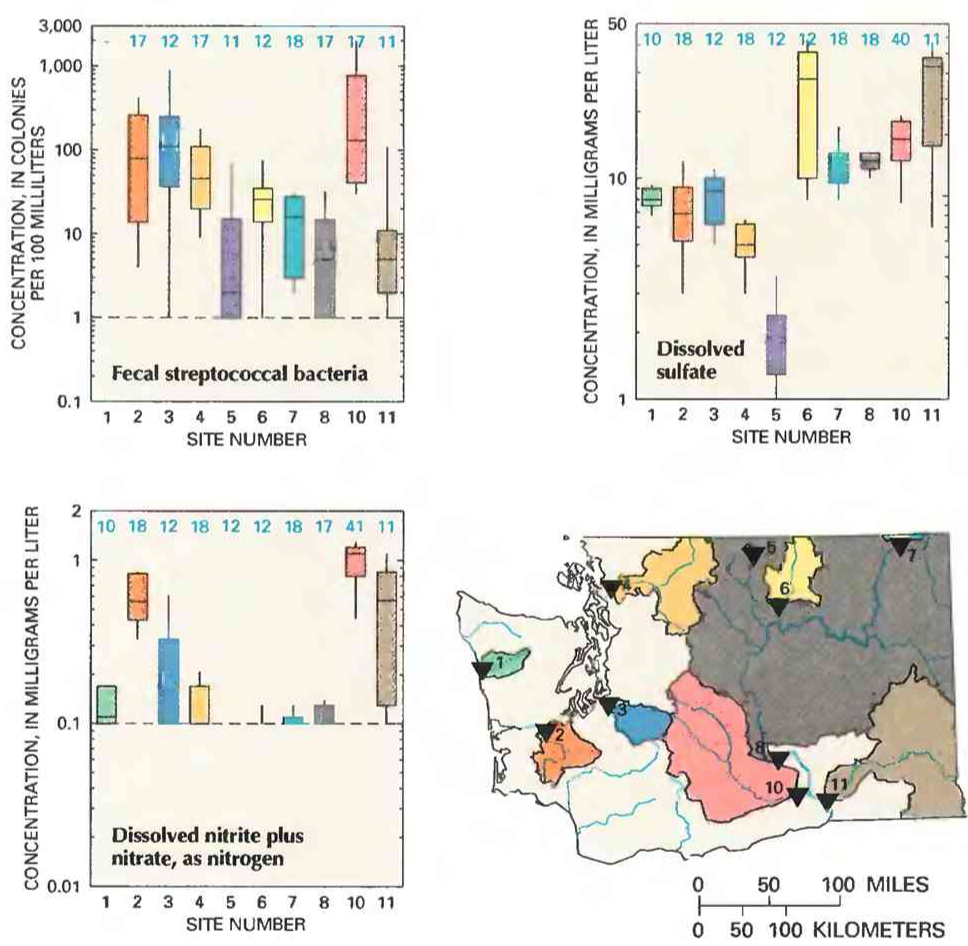

\section{EXPLANATION}

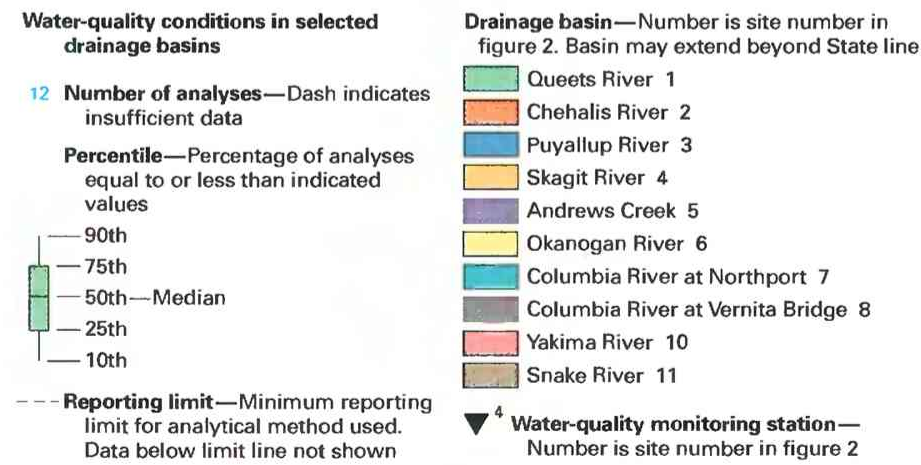

Figure 3. Water quality of selected streams in Washington, water years 1987-89. (Source: Data from U.S. Geological Survey files.) 
Table 1. Sources and environmental significance of selected water-quality constituents

[Source: Compiled by the U.S. Geological Survey, Office of Water Quality]

\begin{tabular}{|c|c|c|}
\hline Constituent & Common sources & Environmental significance \\
\hline $\begin{array}{l}\text { Fecal coliform and fecal ............. } \\
\text { streptococcal bacteria }\end{array}$ & $\begin{array}{l}\text { Sources include effluent from sewage-treatment } \\
\text { plants and run off from pastures, feedlots, and ur- } \\
\text { ban areas. }\end{array}$ & $\begin{array}{l}\text { Presence indicates contamination of water by wastes } \\
\text { from humans and other warm-blooded animals. }\end{array}$ \\
\hline 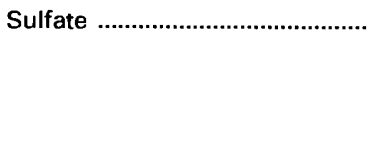 & $\begin{array}{l}\text { Occurs in some rocks; also in mine runoff, industrial } \\
\text { wastewater discharge, and atmospheric deposi- } \\
\text { tion. }\end{array}$ & $\begin{array}{l}\text { Concentrations exceeding a natural, background } \\
\text { level indicate contamination from human activity; } \\
\text { in sufficient quantity, can cause water to be } \\
\text { unsuitable for public supply; can harm aquatic } \\
\text { organisms. }\end{array}$ \\
\hline Dissolved solids ........................... & $\begin{array}{l}\text { A result of rock weathering; also in agricultural runoff } \\
\text { and industrial discharge. }\end{array}$ & $\begin{array}{l}\text { In sufficient quantity, can cause water to be unsuitable } \\
\text { for public supply, agriculture, and industry; can } \\
\text { harm aquatic organisms. }\end{array}$ \\
\hline Nitrite plus nitrate ....................... & $\begin{array}{l}\text { Nonpoint sources are agricultural and urban runoff; } \\
\text { a major point source is wastewater discharge. }\end{array}$ & $\begin{array}{l}\text { Plant nutrient that, in sufficient quantity, can cause } \\
\text { algal blooms and excessive growth of higher } \\
\text { aquatic plants in bodies of water; can cause water } \\
\text { to be unsuitable for public supply. }\end{array}$ \\
\hline Suspended sediment ................. & $\begin{array}{l}\text { A result of rock erosion; also induced by disturbances } \\
\text { of land cover due to fires, floods, and human } \\
\text { activities such as mining, logging, construction, } \\
\text { and agriculture. }\end{array}$ & $\begin{array}{l}\text { Can be detrimental to aquatic organisms; can fill res- } \\
\text { ervoirs and impair recreational use of water. }\end{array}$ \\
\hline
\end{tabular}

modifications, and urban runoff. The bacteria problem is reflected in the concentrations of fecal coliform bacteria (median, $94 \mathrm{col} / 100$ $\mathrm{mL}$ ) and fecal streptococcal bacteria (median, $110 \mathrm{col} / 100 \mathrm{~mL}$ ) (fig. 3), which were among the highest in the monitored streams. The natural, suspended glacial material in the water creates part of the sediment problem. The median concentration of suspended sediment $(96 \mathrm{mg} / \mathrm{L})$ at site 3 was the highest for the 10 monitoring stations.

\section{SKAGIT RIVER AND ANDREWS CREEK}

The Skagit River and Andrews Creek are in the northernmost part of the Cascade-Sierra Mountains. The Skagit River originates in Canada and drains the relatively inaccessible wilderness area of North Cascades National Park. Site 4 is in the last 15 miles of the Skagit River, which meanders through a glaciofluvial valley before entering Puget Sound. The major land uses upstream from site 4 are cropland with pasture, woodland, and forest. Andrews Creek (site 5) is a small tributary to the Chewack River that drains steep, forested slopes of the eastern Cascade Mountains.

The Washington State Department of Ecology (1988, app. VII) reported that the designated beneficial water uses are fully supported by the water quality in the lower 25.6 miles of the Skagit River. In general, the magnitudes of constituent concentrations at site 4 (fig. 3 ) corroborate the State's evaluation. Concentrations of sulfate (median, $5.0 \mathrm{mg} / \mathrm{L}$ ) and dissolved solids (median, $35 \mathrm{mg} / \mathrm{L}$ ) were low. However, the median suspended-sediment concentration $(52 \mathrm{mg} / \mathrm{L})$ was the second highest for the $\mathbf{1 0}$ monitoring stations. Sediment in the Skagit River basin comes from natural sources, such as erosion of glacially derived material and occasional landslides on steep mountain slopes, and human-related sources, such as sedimentation re-sulting from forestry activities.

The water quality in Andrews Creek at site 5 reflects nearly pristine conditions. Concentrations of fecal coliform bacteria (median, $1 \mathrm{col} / 100 \mathrm{~mL}$ ), fecal streptococcal bacteria (median, $2 \mathrm{col} / 100$ $\mathrm{mL}$ ), sulfate (median, $1.9 \mathrm{mg} / \mathrm{L}$ ), dissolved solids (median, 35 $\mathrm{mg} / \mathrm{L}$ ), and nitrite plus nitrate (median, $0.10 \mathrm{mg} / \mathrm{L}$ ) were among the lowest in samples from the monitoring stations (fig. 3 ).

\section{OKANOGAN AND UPPER COLUMBIA RIVERS}

The Okanogan and Columbia Rivers originate in Canada and flow southward into the Northern Rocky Mountains of northeastern Washington. This part of the State is characterized by hilly, plateaulike terrain in the Okanogan River area and mountainous land- scape in the Columbia River area. Land uses in the Okanogan River basin include irrigated and nonirrigated cropland, pasture, woodland, and forest. Land uses in the upper Columbia River basin include woodland, forest, irrigated and nonirrigated cropland, and some pasture. Metal ore deposits (Moen, 1978, map 1) support mining and smelting activities in the Columbia River basin.

Pesticides, bacteria, and suspended solids in the Okanogan River were identified by the Washington State Department of Ecology (1988, app. VII) as degrading the water quality and occasionally limiting the use of the water for designated uses. Agricultural nonpoint sources of these contaminants are partly responsible for the water-quality degradation. Solar heating of impounded water and of the river during low flows also degrades Okanogan River water quality (Washington State Department of Ecology, 1989, p. 2.17). Concentrations of sulfate (median, $28 \mathrm{mg} / \mathrm{L}$ ) and dissolved solids (median, $151 \mathrm{mg} / \mathrm{L}$ ) in water samples collected at site 6 (fig. 3) corroborate the State's assessment of Okanogan River water quality. Although bacteria concentrations were not high relative to those at the other monitoring stations, fecal coliform bacteria occasionally exceeded $200 \mathrm{col} / 100 \mathrm{~mL}$ during water years $1987-89$.

Site 7 on the Columbia River is about 20 miles downstream from a large lead-zinc smelter in Canada. The smelter has been identified as the source of several metals, including copper, in the Columbia River (Johnson and others, 1988, p. 6).

\section{LOWER COLUMBIA RIVER}

Site 8 is on the Columbia River in the Columbia Plateaus in an area where the geology is characterized by Pleistocene glacially derived materials overlying basalt. The desert shrubland near site 8 is used for grazing. Some irrigation return flows enter the river upstream from site 8; however, dilution from the large volume of streamflow (average discharge 119,200 cubic feet per second) likely controls water-quality conditions at the monitoring station. Concentrations of fecal coliform bacteria (median, $1 \mathrm{col} / 100 \mathrm{~mL}$ ), fecal streptococcal bacteria (median, $5 \mathrm{col} / 100 \mathrm{~mL}$ ), nitrite plus nitrate (median, $0.10 \mathrm{mg} / \mathrm{L}$ ), and suspended sediment (median, $3 \mathrm{mg} / \mathrm{L}$ ) were among the smallest for the 10 monitoring stations (fig. 3).

\section{YAKIMA RIVER}

The Yakima River originates in the Cascade Mountains and flows southeastward along the western limits of the Columbia Plateaus. The valleys are underlain by sandstone containing gravel, silt, 
and volcanic ash. Irrigated agriculture is a major land use throughout the Yakima basin; however, there also is some grazing land and forest.

Stream water quality in the Yakima River basin is degraded because of agricultural reuse of water. McKenzie and Rinella (1987) demonstrated that summer nitrate concentrations in the Yakima River downstream from Granger approximated concentrations observed in agricultural drains. This author determined that agricultural drains and streams near animal holding areas contain Escherichia coli bacteria sometimes exceeding $1,000 \mathrm{col} / 100 \mathrm{~mL}$ and contribute bacteria to the main stem of the Yakima River. Concentrations of fecal coliform bacteria (median, $65 \mathrm{col} / 100 \mathrm{~mL}$ ), fecal streptococcal bacteria (median, $130 \mathrm{col} / 100 \mathrm{~mL}$ ), dissolved solids (median, 160 $\mathrm{mg} / \mathrm{L}$ ), and nitrite plus nitrate (median, $1.10 \mathrm{mg} / \mathrm{L}$ ) at site 10 were among the highest in water samples from the monitoring stations (fig. 3).

Hopkins and others (1985) found dichloro diphenyl trichloroethane and polychlorinated biphenyl compounds in water samples from site 10. These and other organic chemicals also were found in fish that inhabit the lower reaches of the Yakima River (Johnson and others, 1986). Warm water temperatures caused by low flows, warmed irrigation return flows, and a lack of streambank vegetation impair use of the water for its designated beneficial uses (Washington State Department of Ecology, 1988, app. VII).

\section{SNAKE RIVER}

The Snake River flows westward through the Columbia Plateaus in the southeastern part of the State. Site 11 is 2.2 miles upstream from the confluence with the Columbia River near Pasco. Land cover in the basin includes cropland, grassland, and semiarid grazing land. Nutrient, temperature-modification, and dissolvedoxygen problems caused by upstream impoundments, irrigated agriculture, and natural conditions degrade the quality of the Snake River (Washington State Department of Ecology, 1988, app. VII).

Water samples from site 11 contained high concentrations of constituents commonly associated with agricultural runoff. Concentrations of sulfate (median, $32 \mathrm{mg} / \mathrm{L}$ ), dissolved solids (median, 202 $\mathrm{mg} / \mathrm{L}$ ), and nitrite plus nitrate (median, $0.57 \mathrm{mg} / \mathrm{L}$ ) were among the highest in samples from the monitoring stations (fig. 3).

\section{WATER-QUALITY TRENDS}

Trend analysis is a statistical procedure used to detect changes in stream water quality at monitoring station over time. For this report, water-quality data from 11 monitoring stations (fig. 2) were analyzed for trends by using the seasonal Kendall test (Hirsch and others, 1982), a method used extensively by the USGS. The graph (shown below) of the dissolved-sulfate concentration in the Puyallup River at site 3 illustrates the trend inferred from the concentration data and demonstrates the variation in water quality that is common in streams.

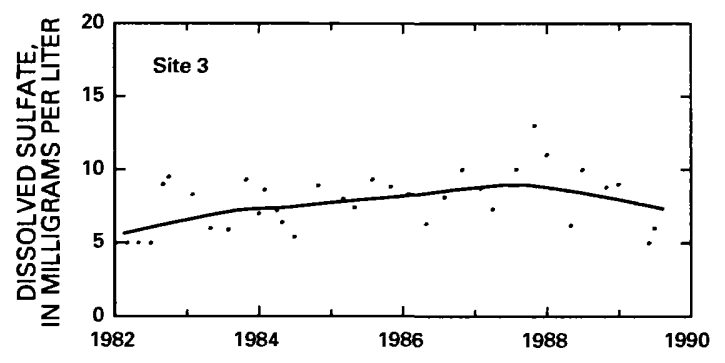

When possible, constituent-concentration data were adjusted for changes in streamflow to preclude identifying a trend in concen- tration that was caused only by a trend in streamflow. The data were not adjusted when (1) more than 10 percent of the samples had concentrations lower than the minimum reporting limit for the analytical method used or (2) streamflow was controlled substantially by human activities. When the concentration data could not be adjusted for streamflow, trends were determined directly from the concentration data.

Statewide trends in concentrations of selected stream-water constituents are shown on maps in figure 4. On each map, a trend is indicated at a monitoring station only if the data from that station were suitable for use in the trend analysis. For more information on the suitability criteria and on the trend-analysis procedure used for this report, see Lanfear and Alexander (1990).

\section{FECAL COLIFORM AND FECAL STREPTOCOCCAL BACTERIA}

Fecal coliform bacteria and fecal streptococcal bacteria are used as indicators of fecal contamination from humans and other warm-blooded animals. Such contamination can introduce diseasecausing viruses and bacteria into a stream.

Increased quantities of waste in runoff from livestock pastures could have caused the upward trend in fecal streptococcal bacteria in the Chehalis River at site 2 (fig. 4); however, a corresponding upward trend in fecal coliform bacteria from animal sources did not occur. This apparent discrepancy might be attributable to differences in survival rates between the two types of bacteria before or after they enter streams in runoff from livestock grazing or holding areas, in seepage from septic tanks, or in effluent from wastewater-treatment plants.

\section{DISSOLVED SULFATE}

The major natural sources of sulfate in streams are rock weathering, volcanoes, and biochemical processes (Hem, 1985, p. 113). Human activities such as mining, waste discharge, and fossil-fuel combustion also can be important sources. A shor tened trend-analysis period was used for sulfate because data from analyses performed before water year 1982 are not comparable to data for subsequent years.

Wastewater discharges associated with population growth could account in part for the increasing concentrations in the Chehalis River at site 2 and in the Puyallup River at site 3 (fig. 4). Also, increased automobile emissions related to population growth in the Puget Sound area might have contributed to the upward trend at site 3 .

\section{DISSOLVED SOLIDS}

Dissolved solids in stream water result primarily from rock weathering but also can be introduced as a byproduct of human activities (table 1). Concentrations generally are greatest in streams draining basins underlain by rocks and soils that contain easily dissolved minerals.

A cause for the downward trend at site 1 on the Queets River (fig. 4) is not readily apparent. At sites 9 and 10 on the Yakima River, major components of dissolved solids (such as calcium, bicarbonate, chloride, and dissolved silica) decreased, although overall dissolved-solids concentrations had no trend. These were important soluble constituents in the Mount St. Helens ash deposits from the 1980 eruptions (Klein, 1984, p. 4).

\section{DISSOLVED NITRITE PLUS NITRATE}

Nitrite and nitrate are oxidized forms of nitrogen that together normally constitute most of the dissolved nitrogen in well-aerated streams. Nitrite readily oxidizes to nitrate in natural waters; therefore, nitrate generally is by far the more abundant of the two (Hem, 


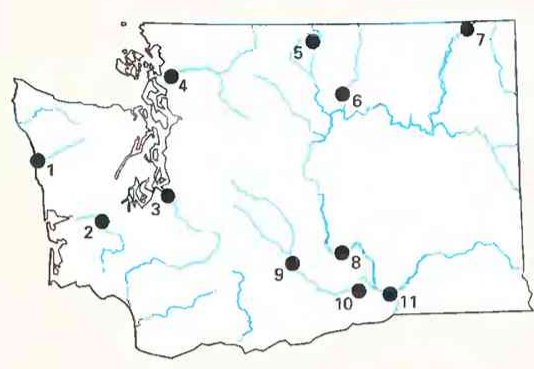

Fecal coliform bacteria, 1980-89

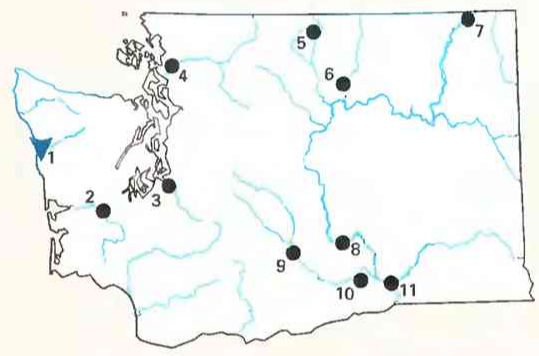

Dissolved solids, 1980-89

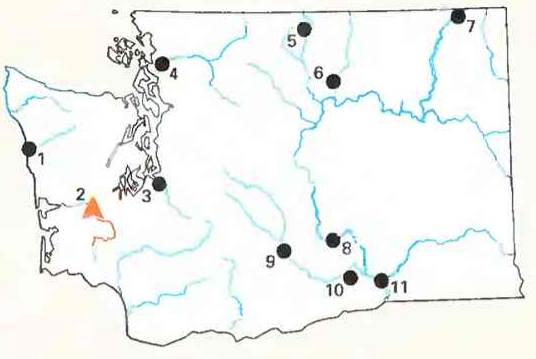

Fecal streptococcal bacteria, 1980-89

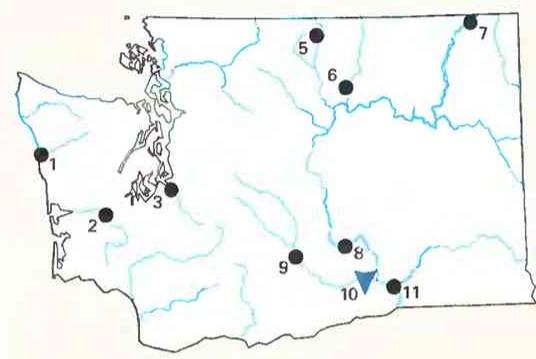

Dissolved nitrite plus nitrate, $1980-89$

$$
\stackrel{0}{\stackrel{1}{1}} \stackrel{50}{1}, 100 \text { MILES }
$$

\section{EXPLANATION}

Trend in water-quality constituentNumber is site number in figure 2

$$
\begin{aligned}
& A^{3} \text { Upward } \\
& { }^{5} \text { None } \\
& \nabla^{1} \text { Downward }
\end{aligned}
$$

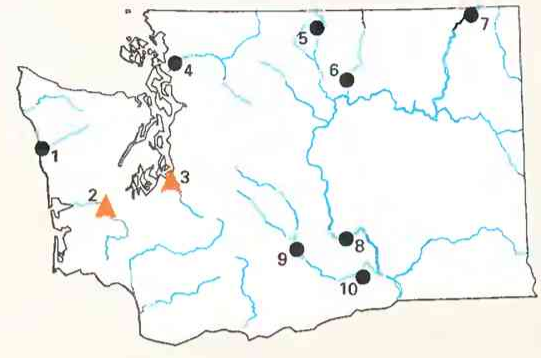

Dissolved sulfate, $1982-89$

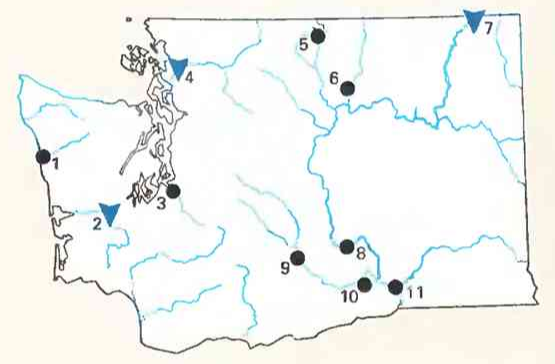

Suspended sediment, $1980-89$

Figure 4. Trends in water quality of selected streams in Washington, by water years. (Source: Data from U.S. Geological Survey files.)

1985, p. 124). The downward trend in nitrite plus nitrate concentrations in the Yakima River at site 10 (fig. 4) might be related at least in part to decreased nitrogen-fertilizer use in Washington during 1980-85 (Alexander and Smith, 1990).

\section{SUSPENDED SEDIMENT}

Suspended sediment is a product of erosion. The erosion can be either natural or the result of land-cover disturbances related to human activities (table 1).

Data from site 2 on the Chehalis and from site 7 on the Columbia River indicate that the downward trends at those localities began about 1985, which coincides approximately with the onset of drought in the State. Less than average precipitation during the drought resulted in reduced overland runoff to streams. Changes in forest-management practices or decreased logging activity also could account partly for the downward trends in the Columbia River at site 7 and in the Skagit River at site 4.

\section{WATER-QUALITY MANAGEMENT}

The Washington State Department of Ecology, as established by the Water Resources Act of 1971 (Chapter 90.54 of the Revised Code of Washington [RCW]), manages the State's surface-water resources and water quality. The Washington State Department of Ecology is the primary water-pollution-control agency and administers the Federal Clean Water Act in Washington as authorized by Chapter 90.48 of the RCW. The Washington State Department of Health administers the drinking-water protection aspects of the Federal Safe Drinking Water Act and regulates public water systems and onsite wastewater systems.

The Washington State Department of Ecology establishes water-quality standards and guidelines to ensure public health and enjoyment of water resources and to ensure the propagation and protection of fish, shellfish, and wildlife, according to Chapter 90.48 of the RCW. A water-quality monitoring program provides data needed to support the Department's role and authority. The U.S. Geological 
Survey cooperates with the Washington State Department of Ecology in monitoring streamflow.

The Washington State Department of Ecology prepares and submits to the U.S. Congress and the EPA the biennial reports mandated by section 305(b) of the Clean Water Act (Washington State Department of Ecology, 1988) that identify streams limited for use by water-quality problems and the causes and sources of the problems. The Washington State Department of Ecology also prepares the 319(b) reports that address nonpoint-source pollution as part of the February 1987 amendments to the Clean Water Act (Washington State Department of Ecology, 1989, p. 1-1).

\section{SELECTED REFERENCES}

Alexander, R.B., and Smith, R.A., 1990, County-level estimates of nitrogen and phosphorus fertilizer use in the United States, 1945 to 1985: U.S. Geological Survey Open-File Report 90-130, 12 p.

Anderson, J.R., 1967, Major land uses in the United States, in U.S. Geological Survey, 1970, National atlas of the United States of America: Washington, D.C., U.S. Geological Survey, p. 158-159.

Britton, L.J., and Greeson, P.E., eds., 1987, Methods for collection and analysis of aquatic biological and microbiological samples: U.S. Geological Survey Techniques of Water-Resources Investigations, book 5, chap. A4, $363 \mathrm{p}$.

Ebbert, J.C., Bortleson, G.C., Fuste, L.A., and Prych, E.A., 1987, Water quality in the lower Puyallup River valley and adjacent uplands, Pierce County, Washington: U.S. Geological Survey Water-Resources Investigations Report 86-4154, $199 \mathrm{p}$.

Fenneman, N.M., 1946, Physical divisions of the United States: Washington D.C., U.S. Geological Survey special map, scale 1:7,000,000.

Fishman, M.J., and Friedman, L.C., eds., 1989, Methods for the determination of inorganic substances in water and fluvial sediments: U.S. Geological Survey Techniques of Water-Resources Investigations, book 5, chap. A1, 545 p.

Hem, J.D., 1985, Study and interpretation of the chemical characteristics of natural water (3d ed.): U.S. Geological Survey Water-Supply Paper 2254, $263 \mathrm{p}$.

Hirsch, R.M., Slack, J.R., and Smith, R.A., 1982, Techniques of trend analysis for monthly water quality data: Water Resources Research, v. 18, no. 1, p. $107-121$.

Hopkins, B.S., Clark, D.K., Schlender, Mike, and Stinson, Margaret, 1985, Basic water monitoring program, fish tissue and sediment sampling for 1984: Olympia, Washington State Department of Ecology, 43 p.
Johnson, Art, Norton, Dale, and Yake, Bill, 1986, Occurrence and significance of DDT compounds and other contaminants in fish, water, and sediment from the Yakima River basin: Olympia, Washington State Department of Ecology, 89 p.

1988, An assessment of metals contamination in Lake Roosevelt: Olympia, Washington State Department of Ecology, 77 p.

Klein, J.M., 1984, Some chemical effects of the Mount St. Helens eruption on selected streams in the State of Washington: U.S. Geological Survey Circular 850-E, $26 \mathrm{p}$.

Lanfear, K.J., and Alexander, R.B., 1990, Methodology to derive water-quality trends for use by the National Water Summary Program of the U.S. Geological Survey: U.S. Geological Survey Open-File Report 90-359, $10 \mathrm{p}$.

McKenzie, S.W., and Rinella, J.F., 1987, Project description, in Surface-waterquality assessment of the Yakima River basin, Washington: U.S. Geological Survey Open-File Report 87-238, 35 p.

Moen, W.S., 1978, Mineral resource maps of Washington: Washington Department of Natural Resources, Division of Geology and Earth Resources, Map GM-22, 4 maps, scale 1:1,000,000.

Thelin, G.P., and Pike, R.J., 1990, Digital shaded relief map of the conterminous United States: Menlo Park, Calif., U.S. Geological Survey digital image processing, scale 1:3,500,000.

U.S. Geological Survey, 1986, National water summary 1985-Hydrologic events and surface-water resources: U.S. Geological Survey Water-Supply Paper $2300,506 \mathrm{p}$.

1990, National water summary 1987-Hydrologic events and water supply and use: U.S. Geological Survey Water-Supply Paper 2350, $553 \mathrm{p}$.

1991, National water summary 1988-89-Hydrologic events and floods and droughts: U.S. Geological Survey Water-Supply Paper 2375, $591 \mathrm{p}$.

Ward, J.R., and Harr, C.A., eds., 1990, Methods for collection and processing of surface-water and bed-material samples for physical and chemical analyses: U.S. Geological Survey Open-File Report 90-140, 71 p.

Washington State Department of Ecology, 1988, 1988 Statewide water quality assessment: Olympia, Washington State Department of Ecology 305(b) Report, variously paginated.

1989, Nonpoint source pollution assessment and management program: Olympia, Washington State Department of Ecology 319(b) Report, variously paginated.

Washington State Office of Financial Management, 1990, 1990 Population trends for Washington State: Olympia, Washington State Office of Financial Management Forecasting Division, 63 p. 
546 National Water Summary 1990-91-Stream Water Quality: STATE SUMMARIES

Prepared by S.S. Embrey

FOR ADDITIONAL INFORMATION: District Chief, U.S. Geological Survey, 1201 Pacific Avenue, Suite 600, Tacoma, WA 98402 


\section{WEST VIRGINIA Stream Water Quality}

West Virginia's surface-water resources include more than 9,000 rivers and streams. These waterways have become increasingly important to the State's economy as tourism and recreational industries such as whitewater rafting have begun to supplant mining and manufacturing. Under West Virginia's antidegradation policy, all surface water is classified for protection and maintenance of water quality necessary to support propagation of aquatic life and watercontact recreation (West Virginia Water Resources Board, 1990). Other State-designated uses include public water supply, agriculture, wildlife maintenance, and industrial water supply (for transportation, cooling, power production, and manufacturing). State law also provides for designation and preservation of special high-quality waters, including streams in the West Virginia Natural Streams Preservation System, federally designated Wild and Scenic Rivers, water in State and national forests, national rivers, and streams suitable for natural trout production.

Of the 28,000 stream miles in West Virginia, 17,455 were assessed in 1989 by the West Virginia Division of Natural Resources for their ability to support designated uses. On the basis of this assessment, 6.4 percent of assessed West Virginia stream miles $(1,116$ miles) were judged as not supporting designated uses, 52.6 percent ( 9,179 miles) partially supported designated uses, and 41.0 percent ( 7,160 miles) fully supported designated uses (West Virginia Department of Natural Resources, 1990). In addition, 19,812 stream miles were assessed for the Clean Water Act goals of "fishable and swimmable." These goals were attained in 18,415 miles (about 93 percent) of the total stream mileage assessed.
In 1985, West Virginia's abundant surface-water resources provided an average of 5,440 million gallons per day, or about 96 percent of the freshwater used in the State (U.S. Geological Survey, 1990, p. 527) and are the main source of domestic water supply for about one-half of the State's population (Solley and others, 1988). Major offstream uses of surface water in 1985 were thermoelectric power generation (81 percent), industrial uses (17 percent), and public supply ( 2 percent). Offstream withdrawals in 1985 were less than 9 percent of the estimated available surface-water supply.

The quality of West Virginia's surface water is related to land use (fig. $1 A$ ), geology and physiography (fig. $1 B$ ), and population distribution (fig. $1 C$ ). The State's topography is characterized primarily by the steep hills and deeply incised valleys of the Appalachian Plateaus (fig. $1 B$ ). Agricultural, commercial, and residential development is concentrated in narrow valleys, where opportunities for economic growth are limited. In many parts of the State, direct discharge of untreated domestic sewage and improperly installed or poorly maintained sewage-disposal systems have degraded local stream water quality.

Much of the State's usable land is devoted to coal mining and oil and gas extraction, all of which contribute nonpoint-source pollution to streams. Drainage from abandoned coal mines results in acidification of streams and may introduce toxic metals (aluminum, iron, manganese, and others) into a watershed. Saltwater (brine) frequently is associated with oil and gas deposits in West Virginia (Bain, 1970). Many forms of aquatic life are eliminated when improper drilling and brine-disposal methods contaminate streams with chloride. Other significant sources of nonpoint-source pollution in West Virginia streams are erosion and siltation associated with improperly conducted timber-harvesting operations.

West Virginia's population decreased from 1.9 million in 1980 to 1.8 million in 1990 (U.S. Bureau of the Census 1990 decennial census files). The resulting reductions in Federal grants for sewage-treatment facilities and the State's generally poor economic condition make enforcement of water-quality standards difficult. In spite of this difficulty, water quality in the State's rivers and streams has improved steadily in recent years, and further improvement is expected as a result of the increasing economic significance of surface water as a recreational resource.

\section{WATER-QUALITY MONITORING}

Water-quality data obtained from analyses of water samples collected at monitoring stations are stored in the U.S. Geological Survey's (USGS) National Water Information System and the U.S. Environmental Protection Agency's
Figure 1. Land use, physiography, and population in West Virginia. A, Major land uses. B, Physiographic divisions. C, Population distribution in 1990. (Sources: A, Major land uses modified from Anderson, 1967. B, Physiographic divisions from Fenneman, 1946; landforms from Thelin and Pike, 1990. C, Data from U.S. Bureau of the Census 1990 decennial census files.) 
(EPA) national data base known as STORET. Water-quality and streamflow data are reported by water year-the 12 months from October 1 through September 30. A water year is identified by the calendar year in which it ends. For example, water year 1991 comprises October 1, 1990, through September 30, 1991.

The data used in this summary of West Virginia's stream water quality were obtained from water samples collected every 2 months or quarterly at six monitoring stations at which data collection is systematic and continuing (fig. 2). Analyses of water samples collected at these stations are the basis for the discussion and graphic summary (fig. 3) of stream water-quality conditions during water years 1987-89 and for the discussion and graphic summary (fig. 4) of stream water-quality trends. Water samples were collected and analyzed by using standard methods approved by the USGS (Britton and Greeson, 1987; Fishman and Friedman, 1989; Ward and Harr, 1990) or by using equivalent methods. If a method of sample collection or analysis changed over time, data from an analysis were included in the evaluation of recent stream water quality or of stream waterquality trends only if the change in method did not affect the comparability of the data.

\section{WATER-QUALITY CONDITIONS}

Major factors affecting water quality in West Virginia streams during water years 1987-89 were siltation, abandoned-mine drainage, and nutrients originating mainly from nonpoint sources (West Virginia Department of Natural Resources, 1990). Nonpoint-source pollution problems associated with mining, oil and gas extraction, and timber-harvesting operations have been identified in the Monongahela, Big Sandy-Tug Fork, Guyandotte, Coal, Kanawha, Elk, Poctalico, and Little Kanawha River basins (fig. 2). Results of problems

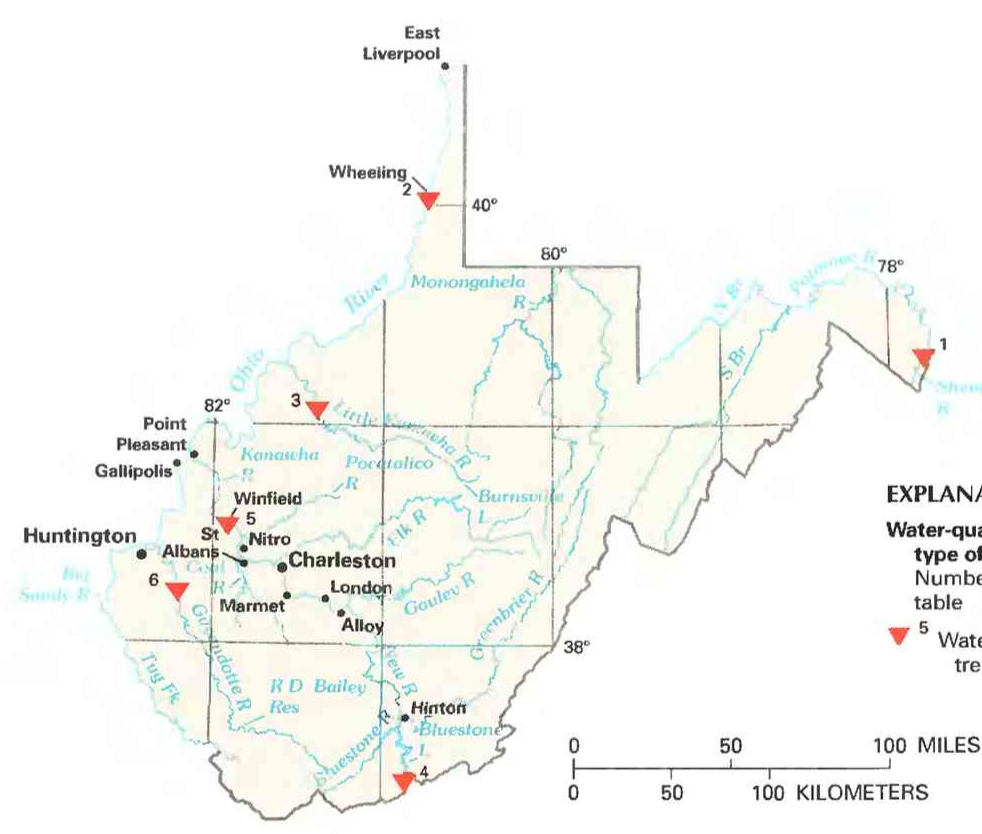

associated with industrial pollution are apparent in the Ohio, Kanawha, and Monongahela Rivers. Agricultural-waste handling and runoff are of concern in the Potomac River basin and in the New River near the Virginia-West Virginia boundary. Other water-quality concerns cited in the most recent West Virginia water-quality status assessment (West Virginia Department of Natural Resources, 1990) include (1) acidity and toxic metals in drainage from abandoned coal mines, (2) widespread lack of domestic sewage treatment, (3) inadequate funding for State environmental analytical laboratories, (4) lack of land-use policies designed to manage and protect aquatic resources, (5) chemical pollution (chloride, copper, chromium, arsenic) from unpermitted wood-treatment plants, (6) unauthorized disposal of municipal sewage sludge, and (7) development of hydroelectric power-generating facilities at several locations on the Monongahela and upper Ohio Rivers.

Abandoned-coal-mine drainage was ranked as the most serious water-quality problem in the State. Toxic metals (aluminum, iron, manganese, and others) in abandoned-mine drainage affected water quality in 2,427 miles of 477 streams. The most severely affected streams are in the Monongahela River basin. The lack of domestic sewage treatment is most evident in southwestern West Virginia, primarily in the Guyandotte and Big Sandy-Tug Fork basins, where the State standard for fecal coliform bacteria of $200 \mathrm{col} / 100 \mathrm{~mL}$ (colonies per 100 milliliters) in recreational waters and sources of public drinking-water supply was exceeded in 67 and 46 percent of samples, respectively. The problem of bacterial contamination is expected to continue because of the depressed economy in that part of the State.

Increased levels of toxic organic pollutants were noted in 7.4 percent (1,466 miles) of streams assessed during 1987-89 by the West Virginia Department of Natural Resources (1990). State monitoring for ambient levels of many toxic chemicals has been supplemented by analyses for metals, pesticides, and other compounds in tissue samples from fish collected in West Virginia streams since 1978. Many of these analyses have indicated excessive concentrations (relative to U.S. Food and Drug Administration action levels) of polychlorinated biphenyl (PCB), chlordane, and dioxin (West Virginia Department of Natural Resources, 1990). Advisories against consumption of selected fish species have been issued for the Shenandoah River, North Branch and main stem Potomac Rivers, upper Ohio River, lower Kanawha River, and two Kanawha River tributaries.

\begin{tabular}{|c|c|c|c|}
\hline $\begin{array}{l}\text { Site no. } \\
\text { on map }\end{array}$ & $\begin{array}{l}\text { USGS station } \\
\text { name and no. }\end{array}$ & $\begin{array}{l}\text { Drainage area } \\
\text { (square miles) }\end{array}$ & $\begin{array}{l}\text { Major land use } \\
\text { (see fig. 1) }\end{array}$ \\
\hline 1 & Shenandoah River at Millville $(01636500)$ & 3,040 & Mostly ungrazed forest and woodland. \\
\hline 2 & Ohio River at Benwood, near Wheeling $(03112510)$ & 25,070 & Woodland and forest with some cropland and pasture. \\
\hline 3 & Little Kanawha River at Palestine $(03155000)$ & 1,515 & Ditto. \\
\hline 4 & New River at Glen Lyn, Va. $(03176500)$ & 3,768 & Mostly ungrazed forest and woodland. \\
\hline 5 & Kanawha River at Winfield $(03201300)$ & 11,809 & Woodland and forest with some cropland and pasture. \\
\hline 6 & Guyandotte River at Branchland $(03204000)$ & 1,224 & Mostly ungrazed forest and woodland. \\
\hline
\end{tabular}

Figure 2. Selected water-quality monitoring stations, type of statistical analysis, and geographic features in West Virginia. (Sources: Major land uses modified from Anderson, 1967; other data from U.S. Geological Survey files.) 
The following discussion of stream water quality in West Virginia is organized by river basin (fig. 3). Graphs in figure 3 summarize certain aspects of stream water quality in the basins for water years 1987-89. The graphs show frequency distributions of data values that represent measurements of selected physical properties of stream water and concentrations of selected constituents in stream water. These properties and constituents are $\mathrm{pH}$, fecal coliform bacteria, dissolved sulfate, dissolved solids, dissolved nitrite plus nitrate (as nitrogen), dissolved iron, and suspendend sediment. The data are reported in standard $\mathrm{pH}$ units, colonies per 100 milliliters, milligrams per liter $(\mathrm{mg} / \mathrm{L})$, and micrograms per liter $(\mu \mathrm{g} / \mathrm{L})$. Sources and environmental significance of each property and constituent are described in table 1 .

Water quality at each monitoring station is the result of geological, chemical, biological, and hydrologic processes that occur over a large area. Water-quality problems that affect aquatic life or public health only locally are not fully represented in this summary.

\section{SHENANDOAH RIVER}

The Shenandoah River flows from Virginia northward across the easternmost tip of West Virginia's eastern panhandle and joins the Potomac River. The drainage area upstream from site 1 includes parts of Virginia and West Virginia. The basin is located in the Blue Ridge physiographic province and is characterized by mountainous terrain having long valleys and steep, northeast-trending ridges. Stream water chemistry in this part of the State is substantially affected by carbonate rocks, mainly limestone and dolomite (Hobba and others, 1972). The largely rural eastern panhandle of West Virginia is experiencing unprecedented population growth and development owing to its proximity to the Washington, D.C., metropoli$\tan$ area. The State has issued an advisory against consumption of carp, sucker, and channel catfish from the Shenandoah River because of unacceptable concentrations of PCB in tissue of these species (West Virginia Department of Natural Resources, 1990). Similar advisories are in effect for the North Branch Potomac River and Potomac River main stem because of dioxin contamination.

The predominance of carbonate rocks in the Shenandoah River basin is indicated by the highest median $\mathrm{pH}(8.2)$ and the highest median concentration of dissolved solids ( $244 \mathrm{mg} / \mathrm{L})$ for any station in the six-station monitoring network (fig. 3). Agricultural runoff has contributed to the elevated median concentration of nitrite plus nitrate $(1.1 \mathrm{mg} / \mathrm{L})$, which was greater than the background level in uncontaminated streams. In contrast, site 1 had the lowest median
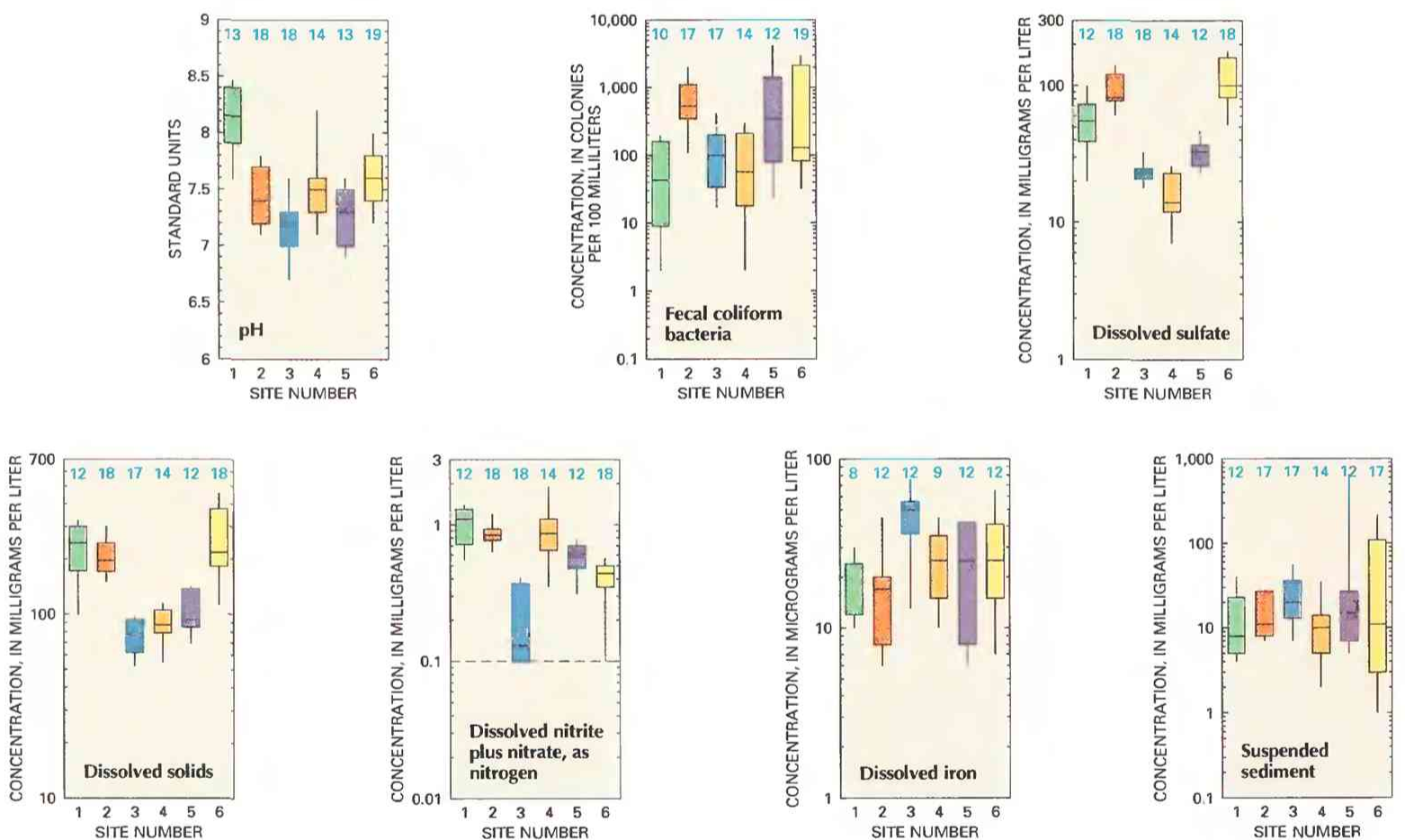

\section{EXPLANATION}
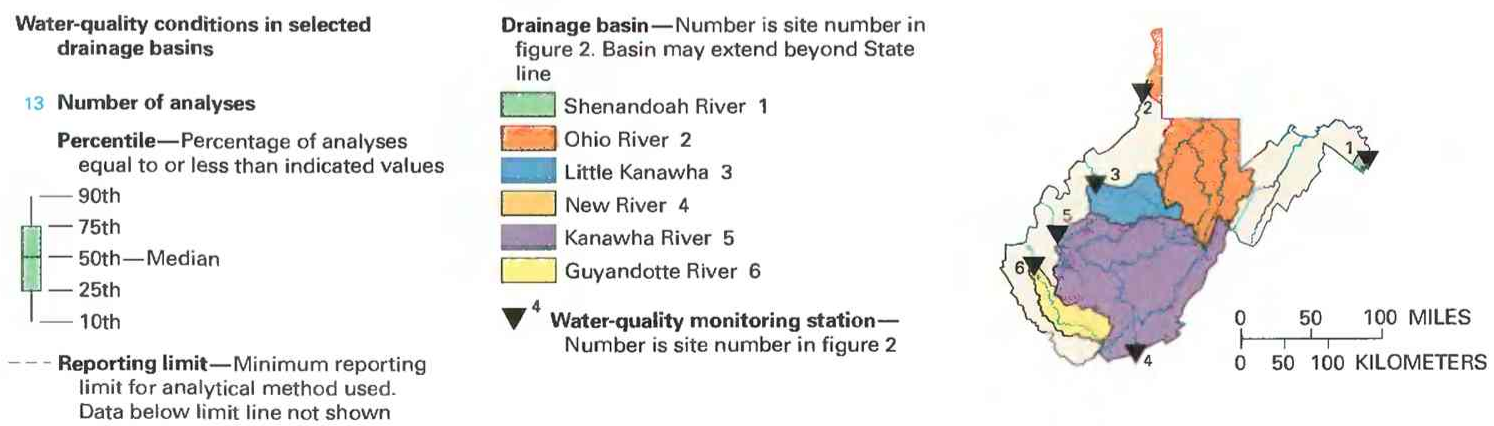

Figure 3. Water quality of selected streams in West Virginia, water years 1987-89. ISource: Data from U.S. Geological Survey files.) 
concentration of fecal coliform bacteria $(43 \mathrm{col} / 100 \mathrm{~mL}) ; 90$ percent of all fecal coliform bacteria concentrations were lower than the State standard of $200 \mathrm{col} / 100 \mathrm{~mL}$. The median concentration of dissolved iron in the Shenandoah River at site $1(12 \mu \mathrm{g} / \mathrm{L})$ was lower than those for the other monitoring stations.

\section{OHIO RIVER}

The upper Ohio River is extensively industrialized and has a long history of pollution from municipal and industrial sources (Cavanaugh and Mitsch, 1989). The 277-mile-long stream reach forming the Ohio-West Virginia State line begins at East Liverpool, Ohio, and flows southwestward through seven lock and dam structures past Huntington, W. Va. Within this reach are 10 public drinking-water intakes, 59 industrial water intakes, 15 power-generating facilities, 58 municipal waste discharges, and 150 industrial waste discharges. The river also supports recreational uses that include swimming, boating, water skiing, and sport fishing. States along the Ohio River have delegated most routine water-quality monitoring responsibilities to the Ohio River Valley Water Sanitation Commission, an interstate agency established in 1948 that consists of representatives from eight States and the Federal Government. The Commission publishes regular reports on water-quality conditions in the river and notes exceedances of individual State standards for various pollutants. Fish-consumption advisories have been in effect since mid1989 for bottom-feeding fish species because of excessive concentrations of PCB and chlordane.

The water quality during water years 1987-89 was not unusual for site 2, although there was a major diesel-fuel spill upstream on the Monongahela River in January 1988, and drought prevailed in the region during much of that year. The median fecal coliform bacteria concentration $(530 \mathrm{col} / 100 \mathrm{~mL})$ was the highest for any of the monitoring stations (fig. 3). More than 75 percent of water samples contained fecal coliform concentrations that exceeded the State standard of $200 \mathrm{col} / 100 \mathrm{~mL}$ for recreational waters, although values of as much as 2,000 col/100 $\mathrm{mL}$ are allowed in the Ohio River main stem during the nonrecreational season (West Virginia Water Resources Board, 1990). Median concentrations of sulfate $(81 \mathrm{mg} / \mathrm{L})$ and dissolved solids ( $196 \mathrm{mg} / \mathrm{L}$ ) at site 2 were high relative to those for most of the other streams, possibly because of seven coal-fired electric-power-generating facilities located within 50 miles.

\section{LITTLE KANAWHA RIVER}

The Little Kanawha River drains about 2,310 $\mathrm{mi}^{2}$ (square miles) in northwestern West Virginia. In this basin, which lies entirely within the Appalachian Plateaus, the topography ranges from steep hillsides and narrow, deeply dissected valleys in the headwaters to gently rolling terrain at the basin outlet. The basin is underlain by sedimentary rocks. Oil and gas production, timber harvesting, and farming are major land uses in the basin. Streamflow is partially regulated by five floodwater-detention reservoirs and by Burnsville Lake reservoir.

Although there is some farming and extensive oil and gas production upstream from site 3, water quality in the Little Kanawha River during 1987-89 met criteria for most uses. Concentrations of fecal coliform bacteria (median, $100 \mathrm{col} / 100 \mathrm{~mL}$ ), sulfate (median, $23 \mathrm{mg} / \mathrm{L}$ ), dissolved solids (median. $78 \mathrm{mg} / \mathrm{L}$ ), and nitrite plus nitrate (median, $0.13 \mathrm{mg} / \mathrm{L}$ ) generally were low at site 3 (fig. 3 ). The median concentrations of dissolved iron $(50 \mu \mathrm{g} / \mathrm{L})$ and suspended sediment $(20 \mathrm{mg} / \mathrm{L})$, however, were the highest for the six monitoring stations. The suspended sediment at this site might be the result of farming activities in the valleys of the middle and upper basin. Soils in the area are composed mainly of erodible shales and clays (D.M. Wood, West Virginia Division of Natural Resources, written commun., November 1990).

\section{NEW RIVER}

The New River originates in North Carolina and flows northwestward through Virginia and into West Virginia where it joins with the Gauley River to form the Kanawha River. Principal tributaries upstream from the Kanawha River confluence are the Bluestone River (drainage area, $363 \mathrm{mi}^{2}$ ) and the Greenbrier River (drainage area, 1,619 $\mathrm{mi}^{2}$ ). Much of the land in the New River basin is used for agriculture, although there are industrial sites on the river at Pearisburg, Va., about 10 river miles upstream from site 4 . Streamflow upstream from site 4 is regulated by Claytor Reservoir in Virginia. Site 4 is directly upstream from Bluestone Lake, a large impoundment on the New and Bluestone Rivers near Hinton. The most prominent water-quality problem evident at site 4 is the presence of cadmium in concentrations that occasionally exceed the State standard of $2.0 \mu \mathrm{g} / \mathrm{L}$ for water in this basin.

Table 1. Sources and environmental significance of selected water-quality properties and constituents

[Source: Compiled by the U.S. Geological Survey, Office of Water Quality]

Property or constituent Common sources Environmental significance

$\mathrm{pH}$ (property)

Fecal coliform bacteria ..............

Sulfate

Dissolved solids

Nitrite plus nitrate

Iron ......

Suspended sediment
A measure of hydrogen-ion activity (acidity or alkalinity); can be affected by geologic setting, biological activity, municipal and industrial wastewater discharge, and atmospheric deposition.

Sources include effluent from sewage-treatment plants and runoff from pastures, feedlots, and urban areas.

Occurs in some rocks; also in mine runoff, industrial wastewater discharge, and atmospheric deposition.

A result of rock weathering; also in agricultural runoff and industrial discharge.

Nonpoint sources are agricultural and urban runoff; major point source is wastewater discharge.

Occurs in some rocks; also in mine runoff.

A result of rock erosion; also induced by disturbances of land cover due to fires, floods, and human activities such as mining, logging, construction, and agriculture.
Acidic water can corrode pipes and equipment; can cause the release of lead and other metals from distribution systems to drinking water; can affect wastewater-treatment processes and taste of water.

Presence indicates contamination of water by wastes from humans and other warm-blooded animals.

Concentrations exceeding a natural, background level indicate contamination from human activity; in sufficient quantity, can cause water to be unsuitable for public supply; can harm aquatic organisms.

In sufficient quantity, can cause water to be unsuitable for public supply, agriculture, and industry; can harm aquatic organisms.

Plant nutrient that, in sufficient quantity, can cause algal blooms and excessive growth of higher aquatic plants in bodies of water; can cause water to be unsuitable for public supply.

Can affect suitability of water for public and industrial supply and can harm aquatic organisms.

Can be detrimental to aquatic organisms; can fill reservoirs and impair recreational use of water. 


\section{KANAWHA RIVER}

The Kanawha River, fourth largest tributary of the Ohio River, drains 6 percent of the total Ohio River drainage area. The Kanawha River basin encompasses more than $12,300 \mathrm{mi}^{2}$, including parts of West Virginia, Virginia, and North Carolina. The river is formed by the confluence of the New and Gauley Rivers in south-central West Virginia and then flows northwestward for 97 miles through the Appalachian Plateaus before joining the Ohio River. Navigation pools are maintained by lock and dam structures on the Ohio River near Gallipolis, Ohio, and on the Kanawha River at Winfield, Marmet, and London, W. Va. In addition to those locks and dams, flow in the Kanawha River is regulated by upstream releases from reservoirs on the New, Gauley, and Elk Rivers.

Steeply sloping terrain restricts industrial and agricultural development in the upper Kanawha River basin. Beginning at Alloy and continuing past Charleston to Nitro, the river basin is extensively industrialized and has major chemical-manufacturing complexes at South Charleston and Nitro. Also, several large municipalities discharge treated wastewater into this reach. Water-quality problems related to industrial point sources, to accidental chemical spills, and to barge, rail, and automobile traffic are common in this part of the river. Downstream from Nitro to Point Pleasant, land of the lower flood plain is used primarily for agriculture.

Since 1978, the Ohio River Valley Water Sanitation Commission has continuously monitored Kanawha River water at St. Albans for the presence of 16 volatile organic compounds, 13 of which currently are on the EPA list of priority pollutants. This monitoring has revealed high transient concentrations of several chlorinated hydrocarbons, including methylene chloride, chloroform, and carbon tetrachloride (Ohio River Valley Water Sanitation Commission, 1986).

The Kanawha River has been the subject of numerous largescale water-quality investigations, including a cooperative monitoring project involving the Kanawha Valley industrial community, the West Virginia Division of Natural Resources, and the EPA. Water samples from six stations in major areas of development along the river were analyzed for 130 priority pollutants and for short-term chronic toxicity by conducting bioassay testing on daphnid crustaceans and fathead minnows (West Virginia Department of Natural Resources, 1987). Results of the study indicated no major threat to aquatic life; toxic chemicals only occasionally were detected. Analyses of sediments and fish tissues, however, have indicated that bioaccumulation of pesticides and metals is occurring. Advisories were issued in 1986 against consumption of bottom-feeding fish in the Kanawha River because of increased concentrations of dioxin.

Site 5, downstream from the industrial complex at Nitro, monitors streamflow from a drainage area of $11,809 \mathrm{mi}^{2}$. During water years $1987-89$, concentrations of fecal coliform bacteria (median, $350 \mathrm{col} / 100 \mathrm{~mL}$ ) were relatively high (fig. 3); maximum concentrations (not shown in fig. 3) were $5,500 \mathrm{col} / 100 \mathrm{~mL}$ in February 1989 and 4,200 col/100 mL in June 1989. The State standard for recreational waters such as the Kanawha River is $200 \mathrm{col} / 100 \mathrm{~mL}$ (West Virginia Water Resources Board, 1990).

\section{GUYANDOTTE RIVER}

The Guyandotte River flows northwestward to the Ohio River and drains 1,305 $\mathrm{mi}^{2}$ of rugged terrain in the Appalachian Plateaus of southwestern West Virginia. The basin topography is marked by steep hills and deeply incised valleys. Upstream from site 6, streamflow is regulated by the R.D. Bailey Dam. The principal land use in this forested basin is coal mining, although there is some farming and manufacturing activity along the lower reaches of the river.

The most significant water-quality problem reported for the Guyandotte River during water years $1987-89$ was high concentrations of fecal coliform bacteria (West Virginia Department of Natu- ral Resources, 1990). The median concentration of fecal coliform bacteria in samples collected by the USGS at site 6 during water years $1987-89$ was $130 \mathrm{col} / 100 \mathrm{~mL}$ (fig. 3). Maximum values for this site $(3,000 \mathrm{col} / 100 \mathrm{~mL}$ in December $1987 ; 3,400 \mathrm{col} / 100 \mathrm{~mL}$ in May 1988; and 2,100 col/100 mL in July 1989) were among the highest recorded at the six monitoring stations during the period. Bacterial contamination in the basin usually is associated with domestic sewage (Bader and others, 1989). The median sulfate concentration in the Guyandotte River (100 mg/L) also was higher than for the other streams. Elevated sulfate concentrations probably are related to mining operations; small streams in the basin that drain extensively mined areas typically have sulfate concentrations that are 8-12 times higher than those of streams draining unmined areas (Ehlke and others, 1982). Sulfate concentrations are highest in the upper part of the basin where most of the coal mines are located. Metals, including copper, nickel, and zinc, commonly are detected at site 6 and probably enter the river in abandoned-mine drainage (Anderson and Youngstrom, 1976).

\section{WATER-QUALITY TRENDS}

Trend analysis is a statistical procedure used to detect changes in stream water quality at a monitoring station over time. For this report, water-quality data from six monitoring stations (fig. 2) were analyzed for trends by using the seasonal Kendall test (Hirsch and others, 1982), a method used extensively by the USGS. The graph (shown below) of the dissolved-solids concentration in the Kanawha River at site 5 illustrates the trend inferred from the concentration data and demonstrates the variation in water quality that is common in streams.

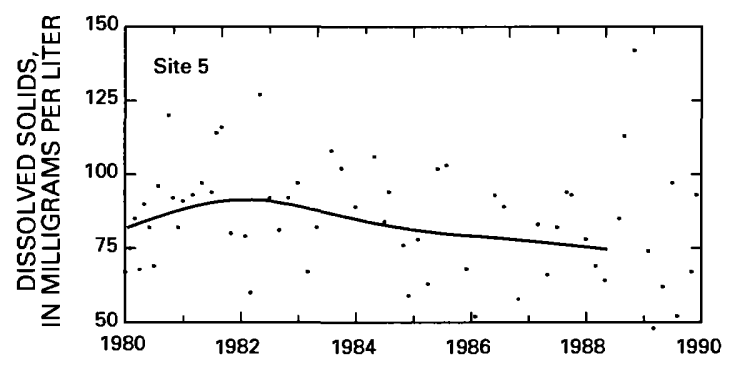

When possible, constituent-concentration data were adjusted for changes in streamflow to preclude identifying a trend in concentration that was caused only by a trend in streamflow. The data were not adjusted when (1) more than 10 percent of the samples had concentrations lower than the minimum reporting limit for the analytical method used or (2) streamflow was controlled substantially by human activities. When the concentration data could not be adjusted for streamflow, trends were determined directly from the concentration data.

Statewide trends in measurements of selected physical properties of stream water and in concentrations of selected constituents in stream water are shown on maps in figure 4. On each map, a trend is indicated at a monitoring station only if the data from that station were suitable for use in the trend analysis. For more information on the suitability criteria and on the trend-analysis procedure used for this report, see Lanfear and Alexander (1990).

\section{$\mathrm{pH}$}

The $\mathrm{pH}$ of a sample of water is a measure of its hydrogen-ion activity (effective concentration). An increase in hydrogen-ion content causes water to become more acidic but results in a lower measured $\mathrm{pH}$ value because the units of $\mathrm{pH}$ are inversely related to hydrogen-ion activity. Both natural processes and human activities 
(table 1) can affect $\mathrm{pH}$. The $\mathrm{pH}$ of river water in most areas not affected by pollution is between about 6.5 and 8.5 (Hem, 1985, p. 64).

The upward $\mathrm{pH}$ trend in the Kanawha River at site 5 (fig. 4) indicates an improvement in stream water quality. The improvement probably was the result of better wastewater treatment by both industry and municipalities in the reach of the Kanawha River from Alloy to Charleston. Smith and Alexander (1982) reported decreased concentrations of alkalinity, sulfate, chloride, potassium, dissolved solids, nitrate, phosphate, and suspended sediment at site 5 for 1974 81. The upward trend in $\mathrm{pH}$ in the Guyandotte River at site 6 is inconsistent with an increase in sulfate concentration at that location (fig. 4). If the sulfate trend is attributed to increasing contamination from abandoned-mine drainage, then $\mathrm{pH}$ should have decreased. An upward $\mathrm{pH}$ trend is more consistent with an improvement in mineeffluent treatment and mine-sealing practices. Actually, $\mathrm{pH}$ values at site 6 increased during the period from only slightly acidic to near neutral, but the cause of the increase is not known.

\section{FECAL COLIFORM BACTERIA}

Fecal coliform bacteria are used as indicators of fecal contamination from humans and other warm-blooded animals. Such contamination can introduce disease-causing viruses and bacteria into a stream.

Concentrations of fecal coliform bacteria had no trend at the six monitoring stations (fig. 4). Bacterial contamination continues to be one of the most prominent water-quality problems in West Virginia. The lack of significant improvement during 1980-89 is directly related to State and local government budgetary constraints that have limited the availability of funds for construction and improvement of wastewater-treatment facilities.

\section{DISSOLVED SULFATE}

The major natural sources of sulfate in streams are rock weathering, volcanoes, and biochemical processes (Hem, 1985, p. 113). Human activities such as mining, waste discharge, and fossil-fuel combustion also can be important sources. A shortened trend-analysis period was used for sulfate because data from analyses performed prior to water year 1982 are not comparable to data from subsequent years.

The upward trend in the Guyandotte River at site 6 probably was due to increased contamination from abandoned-mine drainage. The upward trend probably was not related to an increase in the rate of atmospheric deposition of sulfate because data from nearby sites in the Ohio River Valley indicate no related trends.

\section{DISSOLVED SOLIDS}

Dissolved solids in stream water result primarily from rock weathering but also can be introduced as a byproduct of human activities (table 1). Concentrations generally are greatest in streams draining basins underlain by rocks and soils that contain easily dissolved minerals. The downward trend in dissolved-solids concentrations in the Kanawha River at site 5 probably was related to improved erosion control and wastewater treatment and to reduced or modified application of road deicing chemicals.

\section{DISSOLVED NITRITE PLUS NITRATE}

Nitrite and nitrate are oxidized forms of nitrogen that together normally constitute most of the dissolved nitrogen in well-aerated streams. Nitrite readily oxidizes to nitrate in natural waters; there-

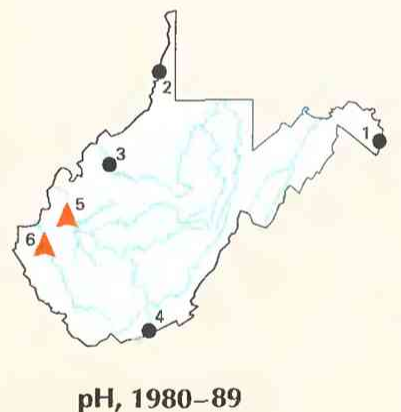

$\mathrm{pH}, 1980-89$

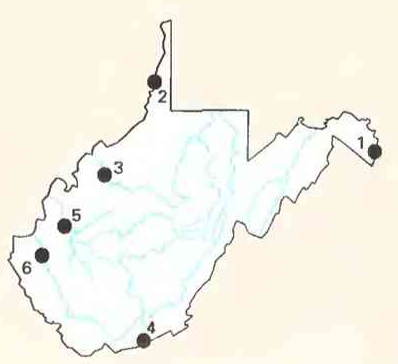

Dissolved nitrite plus nitrate, 1980-89

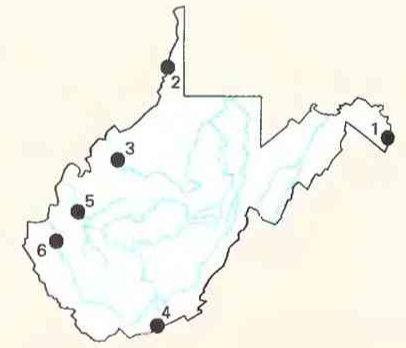

Fecal coliform bacteria, 1980-89

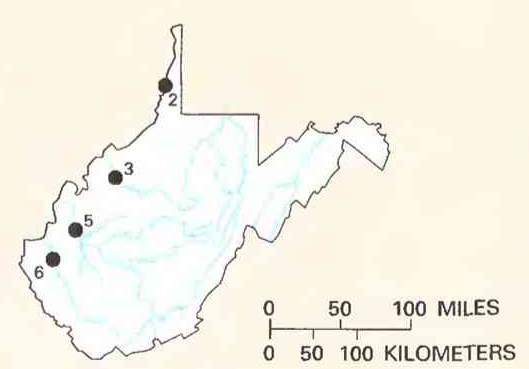

Dissolved iron, 1980-89

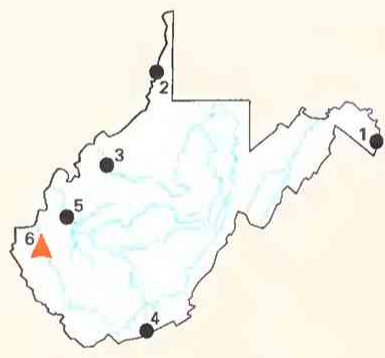

Dissolved sulfate, $1982-89$

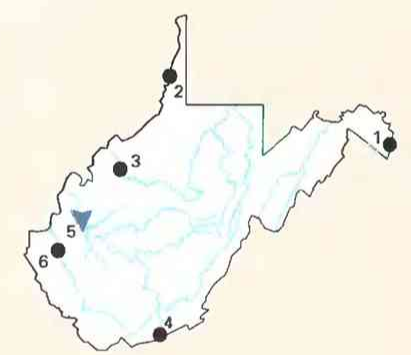

Dissolved solids, $1980-89$

\section{EXPLANATION}

Trend in water-quality property or constituent- Number is site number in figure 2

$\triangle^{6}$ Upward

${ }^{3}$ None

$\nabla^{5}$ Downward

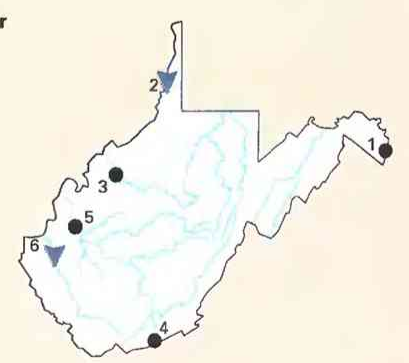

Suspended sediment, $1980-89$

Figure 4. Trends in water quality of selected streams in West Virginia, by water years. (Source: Data from U.S. Geological Survey files.) 
fore, nitrate generally is by far the more abundant of the two (Hem, 1985, p. 124).

Nitrite plus nitrate concentrations had no trend at the six monitoring stations. Smith and others (1987) reported increasing total-nitrate concentrations at several Ohio River Valley stations for the period 1974-81. Upward trends at these stations were attributed to increased atmospheric deposition of nitrate rather than to agricultural application of nitrogen fertilizer. Fertilizer application rates in West Virginia did not change significantly during 1980-85 (Alexander and Smith, 1990).

\section{DISSOLVED IRON}

Iron concentrations in natural stream water generally are low (Hem, 1985, p. 76). However, acidic drainage from abandoned coal mines and mine-spoil piles is a source of iron contamination in West Virginia streams. When this drainage enters a stream, dissolved iron is oxidized from the ferrous to the much less soluble ferric state. The ferric iron precipitates in the streambed as a yellow to orange deposit. In streams that are affected by abandoned-mine drainage, total concentrations of iron can be much larger than those of dissolved iron (Ehlke and others, 1982). Iron concentrations had no trend at the four monitoring stations from which data were suitable for trend testing (fig. 4).

\section{SUSPENDED SEDIMENT}

Suspended sediment is a product of erosion. The erosion can be either natural or the result of land-cover disturbances related to human activities (table 1).

The downward trend in suspended-sediment concentrations in the Ohio River at site 2 (fig. 4) probably was the result of a general improvement of water-quality-management practices in the basin, particularly for Ohio River tributaries upstream from the monitoring station. Cavanaugh and Mitsch (1989), using the seasonal Kendall test, were unable to detect a trend in total suspended solids during 1977-87 at an Ohio River station 54 miles upstream from site 2. However, the improvements might have occurred in the basins of several large tributaries to the reach just upstream from site 2; most of these drain forest and cropland on the Ohio side of the river. Construction of R.D. Bailey Reservoir on the Guyandotte River in the late 1970's might have decreased the suspended sediment upstream from site 6 early in the trend-analysis period. Reservoirs commonly act as sediment traps. Improved timber-harvesting and road-construction practices also might have contributed to the downward trend at site 6.

\section{WATER-QUALITY MANAGEMENT}

The West Virginia Division of Natural Resources, Water Resources Section (formerly the West Virginia Department of Natural Resources, Division of Water Resources), has the primary responsibility under State law for protection and management of water quality in West Virginia rivers and streams. Under provisions of the West Virginia Water Pollution Control Act, the Section administers the National Pollutant Discharge Elimination System permitting program, which is mandated by the EPA. This program emphasizes the use of either best available technology or water-quality-based limitations for controlling point-source discharge of pollutants from municipalities and noncoal-related industries. Coal-related discharge permits are regulated by the West Virginia Division of Environmental Protection.

The Water Resources Section inspects waste-treatment facilities, investigates complaints, and maintains surface-water quality by means of compliance inspections, ambient biological and waterquality monitoring, biological and water-quality surveys at specific sites, and effluent toxicity testing. The Section also administers the State Nonpoint Source Management Plan and prepares the 305(b) report (West Virginia Department of Natural Resources, 1990), a biennial water-quality assessment submitted to the EPA and the U.S. Congress as mandated by section 305(b) of the Federal Clean Water Act.

Regulations pursuant to the West Virginia Water Pollution Control Act are developed and promulgated by a five-member Water Resources Board. The Board works closely with the Chief of the Water Resources Section to ensure that water-quality laws and regulations are enforced. The Board also hears appeals of orders and other actions of the Section. The Permits Branch of the Section is responsible for issuing and enforcing Water Pollution Control permits for municipal and private sewage-treatment facilities and for industrial wastewater-treatment facilities.

The Division of Health is responsible for the protection of drinking-water supplies. The Division has the authority to enforce drinking-water standards for public-water systems, to issue construction and operating permits for public water systems, and to train and certify public water-supply operators.

The West Virginia Natural Streams Preservation Act of 1969 provides a mechanism for preserving and protecting selected streams for future use and enjoyment of West Virginia citizens. Under this act, streams designated by the West Virginia Legislature as protected are preserved and maintained in their current condition.

The U.S. Army Corps of Engineers, Huntington District, maintains impoundments throughout the State for flood control and recreational use and conducts water-quality monitoring and assessment programs related to these facilities. The Corps works closely with the State Water Resources Section and the Ohio River Valley Water Sanitation Commission to monitor water-quality conditions in the Ohio River main stem and several of the larger Ohio River tributaries. The Ohio River Valley Water Sanitation Commission prepares and submits to the EPA a separate 305 (b) report on waterquality conditions in the Ohio River. This document is included as an appendix in the State 305(b) report.

The USGS and the State Geological and Economic Survey also cooperate with the Water Resources Section. These Federal and State agencies jointly monitor streamflow and water quality at numerous stations in West Virginia.

\section{SELECTED REFERENCES}

Alexander, R.B., and Smith, R.A., 1990, County-level estimates of nitrogen and phosphorus fertilizer use in the United States, 1945 to 1985: U.S. Geological Survey Open-File Report 90-130, 12 p.

Anderson, J.R., 1967, Major land uses in the United States, in U.S. Geological Survey, 1970, National atlas of the United States of America: Washington, D.C., U.S. Geological Survey, p. 158-159.

Anderson, W.C., and Youngstrom, M.P., 1976, Coal pile leachate-Quantity and quality characteristics: Journal of the Sanitary Engineering Division, American Society of Civil Engineers, v. 102, p. 1,239.

Bader, J.S., Chisholm, J.L., Bragg, R.L., and Downs, S.C., 1989, Water resources of the Guyandotte River basin, West Virginia: Charleston, West Virginia Geological and Economic Survey River Basin Bulletin 7, 130 p.

Bain, G.L., 1970, Salty ground water in the Pocatalico River basin: Charleston, West Virginia Geological and Economic Survey Circular 11, 31 p.

Britton, L.J., and Greeson, P.E., eds., 1987, Methods for collection and analysis of aquatic biological and microbiological samples: U.S. Geological Survey Techniques of Water-Resources Investigations, book 5, chap. A4, $363 \mathrm{p}$.

Cavanaugh, T.M., and Mitsch, W.J., 1989, Water quality trends of the upper Ohio River from 1977 to 1987: Ohio Journal of Science, v. 89, no. 5 , p. 153-163. 
Ehlke, T.A., Bader, J.S., Puente, Celso, and Runner, G.S., 1982, Hydrology of area 12, eastern coal province, West Virginia: U.S. Geological Survey Water-Resources Investigations Open-File Report 81-902, 75 p.

Fenneman, N.M., 1946, Physical divisions of the United States: Washington, D.C., U.S. Geological Survey special map, scale 1:7,000,000.

Fishman, M.J., and Friedman, L.C., eds., 1989, Methods for the determination of inorganic substances in water and fluvial sediments: U.S. Geological Survey Techniques of Water-Resources Investigations, book 5, chap. A1, 545 p.

Hem, J.D., 1985, Study and interpretation of the chemical characteristics of natural water (3d ed.): U.S. Geological Survey Water-Supply Paper 2254, $263 \mathrm{p}$.

Hirsch, R.M., Slack, J.R., and Smith, R.A., 1982, Techniques of trend analysis for monthly water quality data: Water Resources Research, v. 18 , no. 1, p. 107-121.

Hobba, W.A., Jr., Friel, E.A., and Chesholm, J.L., 1972, Water resources of the Potomac River basin, West Virginia: Charleston, West Virginia Geological and Economic Survey River Basin Bulletin 3, 110 p.

Lanfear, K.J., and Alexander, R.B., 1990, Methodology to derive water-quality trends for use by the National Water Summary Program of the U.S Geological Survey: U.S. Geological Survey Open-File Report 90-359, $10 \mathrm{p}$.

Ohio River Valley Water Sanitation Commission, 1986, The presence of toxic substances in the Ohio River-An assessment of the results of stream monitoring for 1976 to 1985 on the Ohio River and certain of its tributaries: Cincinnati, Ohio River Valley Water Sanitation Commission, 54 p.
Smith, R.A., and Alexander, R.B., 1982, A study of trends in dissolved oxygen and fecal coliform bacteria at NASQAN stations: U.S. Geological Survey Open-File Report 82-1019, 6 p.

Smith, R.A., Alexander, R.B., and Wolman, M.G., 1987, Water-quality trends in the nation's rivers: Science, v. 235, p. 1,607-1,615.

Solley, W.B., Merk, C.F., and Pierce, R.R., 1988, Estimated use of water in the United States in 1985: U.S. Geological Survey Circular 1004, 82 p.

Thelin, G.P., and Pike, R.J., 1990, Digital shaded relief map of the conterminous United States: Menlo Park, Calif., U.S. Geological Survey digital image processing, scale 1:3,500,000.

U.S. Geological Survey, 1990, National water summary 1987-Hydrologic events and water supply and use: U.S. Geological Survey Water-Supply Paper 2350, $553 \mathrm{p}$.

Ward, J.R., and Harr, C.A., eds., 1990, Methods for collection and processing of surface-water and bed-material samples for physical and chemical analyses: U.S. Geological Survey Open-File Report 90-140, 71 p.

West Virginia Department of Natural Resources, 1987, Kanawha River cooperative monitoring project, final report: Charleston, West Virginia Department of Natural Resources, Division of Water Resources, Monitoring Branch, $86 \mathrm{p}$

1990, West Virginia water-quality status assessment 1987-1989 305(b) report: Charleston, West Virginia Department of Natural Resources, Division of Water Resources, $131 \mathrm{p}$.

West Virginia Water Resources Board, 1990, Requirements governing water quality standards, title 46, series 1, 1990: Charleston, West Virginia Water Resources Board, $20 \mathrm{p}$.

Prepared by Marcus C. Waldron

FOR ADDITIONAL INFORMATION: District Chief, U.S. Geological Survey, 603 Morris Street, Charleston, WV 25301 


\section{WESTERN PACIFIC ISLANDS Stream Water Quality}

Thousands of small volcanic islands and coral atolls dot the Western Pacific Ocean. Many of the islands belong to governmental entities that are currently or were formerly under the jurisdiction of the United States. The U.S. Geological Survey (USGS) operates streamflow and water-quality monitoring stations on several of these islands, which are referred to in this report as the Western Pacific Islands (WPI). The WPI comprises the Commonwealth of the Northern Mariana Islands (CNMI), Guam, the Republic of Palau, and the Federated States of Micronesia (FSM), which is composed of the States of Yap, Chuuk, Pohnpei, and Kosrae (fig. 1A). The CNMI, the Republic of Palau, and the FSM were jurisdictions in the former Trust Territories of the Pacific Islands.

Of the more than 2,100 islands in the WPI, only about 25 have areas that exceed $1 \mathrm{mi}^{2}$ (square mile). Landforms of the larger islands are primarily the result of volcanic activity followed by periods of erosion and sedimentation. Many of the smaller islands are coral atolls. Land use differs among islands owing to the physiography, rainfall, political factors, and diverse cultural characteristics of each island.
Streams enhance the beauty of these tropical islands and are an important source of water supply for the inhabitants. Traditionally, island inhabitants have relied on rain catchments and streams, or small stream diversions, for domestic and irrigation needs. Rainfall in the WPI ranges from about 80 to 340 inches per year, and surface-water withdrawals are about 12 million gallons per day (U.S. Geological Survey, 1986, p. 441). A growing population (fig. $1 B$ ) is increasing the demand for freshwater on the larger islands of the WPI. Ground-water supplies have been developed for the islands of Saipan, Guam, Yap, Gagil-Tamil, and Moen and are being developed for other islands of the WPI not discussed in this report.

\section{WATER-QUALITY MONITORING}

Water-quality data obtained from analyses of water samples collected at monitoring stations are stored in the USGS National Water Information System and the U.S. Environmental Protection Agency's (EPA) national data base known as STORET. Water-quality and streamflow data are reported by water year-the 12 months from

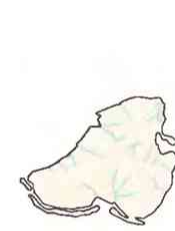

Kosrae Island Kosrae State $(7,000)$

Federated States

A

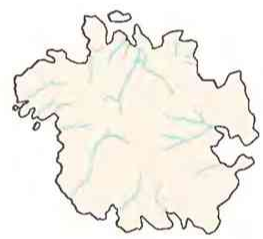

Pohnpei Island Pohnpei State $(30,000)$

Federated States of Micronesia
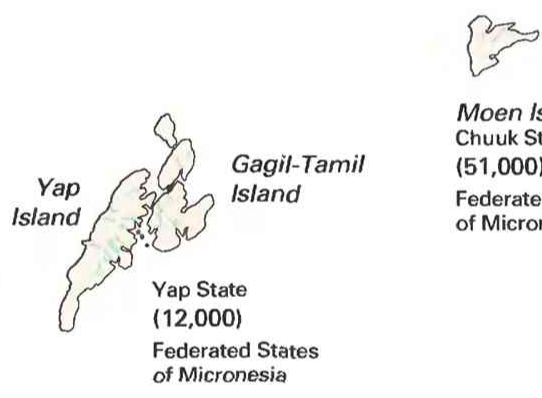

B

\section{Moen Island}

Chuuk State

$(51,000)$

Federated States

of Micronesia

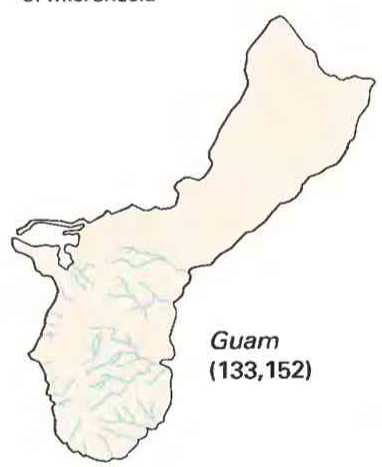

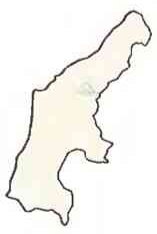

Saipan

Commonwealth of the Northern Mariana Islands $(38,896)$

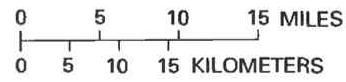

Figure 1. Island Jocations and population of the Western Pacific Islands. A, Island locations. B, 1990 population by island (given in parentheses). (Sources: A, U.S. Geological Survey files. B. Data for Guam, Babelthuap Island, and Saipan from U.S. Bureau of the Census 1990 decennial census files; projected 1990 population of remaining islands from Pacific World Directory, 1989.) 
October 1 through September 30. A water year is identified by the calendar year in which it ends. For example, water year 1991 comprises October 1, 1990, through September 30, 1991.

The data used in this summary of the WPI's stream water quality were obtained from water samples collected intermittently at eight monitoring stations on eight islands (fig. 2). Analyses of water samples collected at these stations are the basis for the discussion and graphic summary (fig. 3) of stream water quality conditions during water years $1980-89$. The frequency of data collection was not sufficient to allow an analysis of stream water quality trends.

\section{EXPLANATION}

Water-quality monitoring station and type of statistical analysisNumber refers to accompanying table

$\nabla^{1}$ Water-quality conditions (see fig. 3)

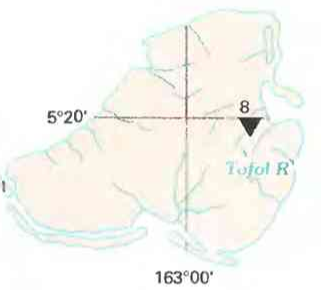

Kosrae Island Kosrae State Federated States of Micronesia

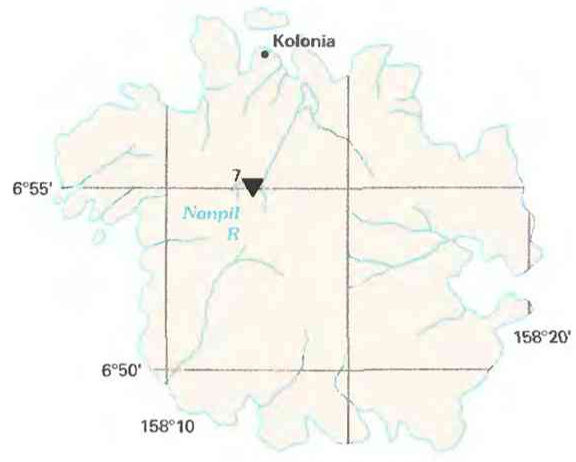

Pohnpei Island Pohnpei State Federated States of Micronesia
Water samples were collected and analyzed by using standard methods approved by the USGS (Britton and Greeson, 1987; Fishman and Friedman, 1989; Ward and Harr, 1990) or by using equivalent methods. If a method of sample collection or analysis changed over time, data from an analysis were included in the evaluation of recent stream water quality only if the change in method did not affect the comparability of the data.

\section{WATER-QUALITY CONDITIONS}

The following discussion of stream water quality in the WPI is organized by river basin (fig. 3 ). Graphs in figure 3 summarize certain aspects of stream water quality in the basins for water years 1980-89. The graphs show frequency distributions

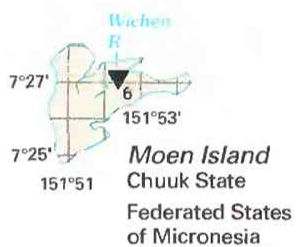

Saipan

Commonwealth of the Northern Mariana Islands $15^{\circ} 15^{\prime}$
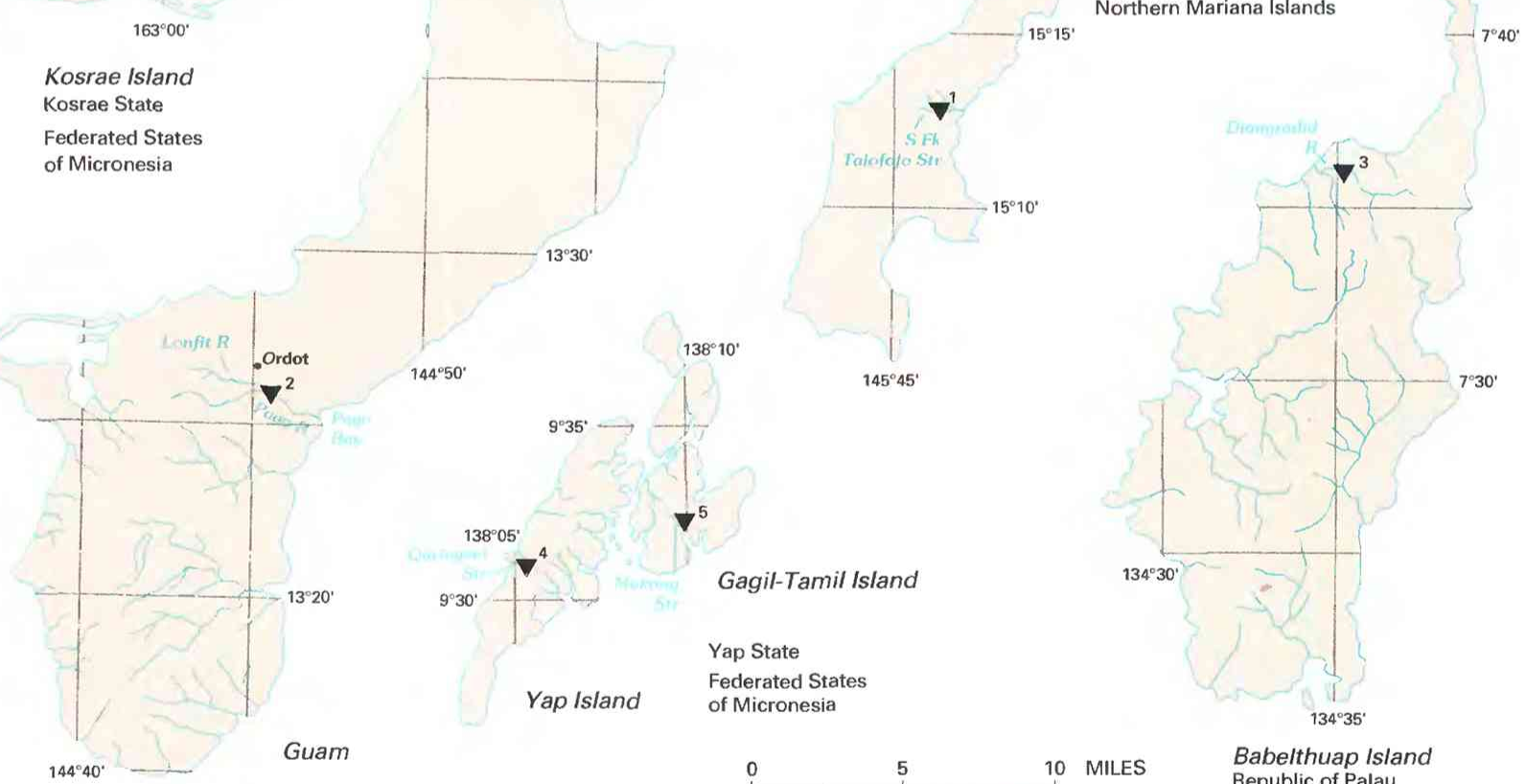

Yap Island

$$
\text { Federated States }
$$

of Micronesia

\section{Gagil-Tamil Island}
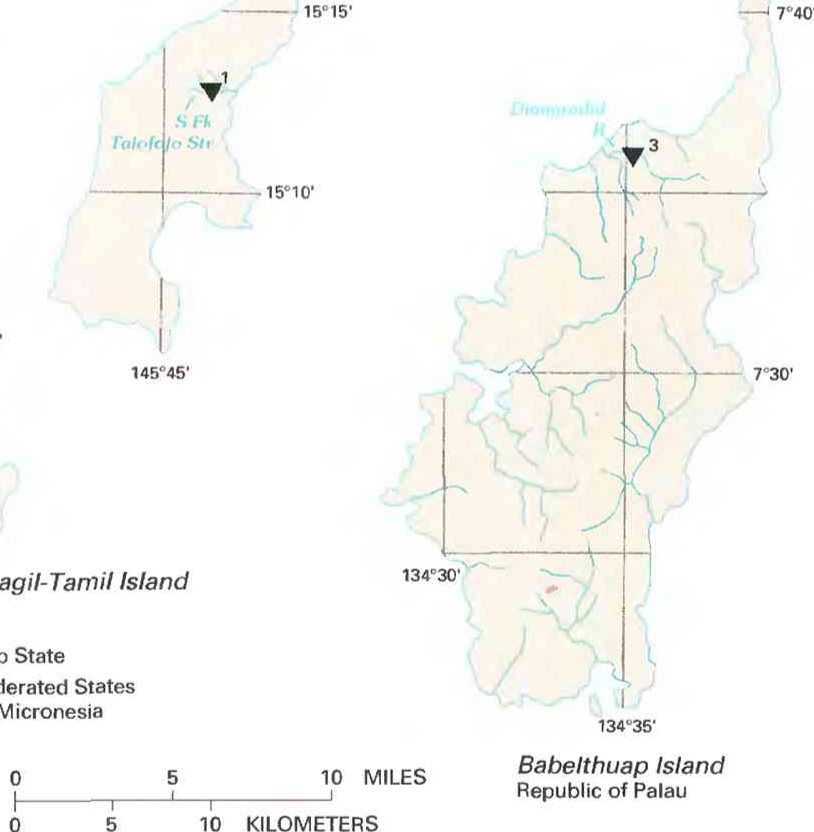

Babelthuap Island Republic of Palau

\begin{tabular}{|c|c|c|c|}
\hline $\begin{array}{l}\text { Site no. } \\
\text { on map }\end{array}$ & $\begin{array}{l}\text { USGS station } \\
\text { name and no. }\end{array}$ & $\begin{array}{l}\text { Drainage area } \\
\text { (square miles) }\end{array}$ & Major land use \\
\hline 1 & 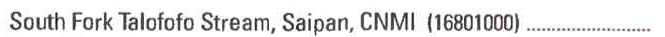 & 0.64 & Tropical woodland. \\
\hline 2 & Pago River, Guam (16865000) & 5.67 & Ditto. \\
\hline 3 & Diongradid River, Babelthuap Island, Republic of Palau (16890600). & 4.45 & Ditto \\
\hline 4 & 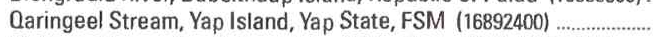 & 0.24 & Ditto. \\
\hline 5 & Mukong Stream, Gagil-Tamil Island, Yap State, FSM (16893200) ....... & 0.50 & Ditto. \\
\hline 6 & 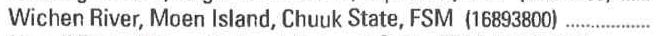 & 0.57 & Ditto. \\
\hline 7 & Nanpil River, Pohnpei Island, Pohnpei State, FSM (16897600) ........... & 3.00 & Ditto. \\
\hline 8 & 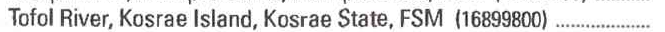 & 0.53 & Ditto. \\
\hline
\end{tabular}

Figure 2. Selected water-quality monitoring stations in the Western Pacific Islands. (Source: Data from U.S. Geological Survey files.) 
of data values that represent measurements of selected physical properties of stream water and concentrations of selected constituents in stream water. These properties and constituents are specific conductance, total hardness (as calcium carbonate), alkalinity (as calcium carbonate), dissolved sulfate, dissolved silica, dissolved solids, and dissolved nitrite plus nitrate (as nitrogen). The data are reported in microsiemens per centimeter at 25 degrees Celsius $(\mu \mathrm{S} / \mathrm{cm})$ and milligrams per liter $(\mathrm{mg} / \mathrm{L})$. Sources and environmental significance of each property and constituent are described in table 1.

Water quality at each monitoring station is the result of geological, chemical, biological, and hydrologic processes that occur over a large area. Water-quality problems that affect aquatic life or public health only locally are not fully represented in this summary.

\section{SOUTH FORK TALOFOFO STREAM, SAIPAN, CNMI}

Saipan is the largest of the 14 islands that constitute the CNMI and is composed predominantly of limestone overlying a volcanic core. Average annual rainfall on the island is about 81 inches, most of which falls from July to December (van der Brug, 1985, p. 8). Because of the permeable limestone terrane, there are few perennial streams on Saipan. Much of the rain infiltrates into aquifers and then drains to the ocean. The South Fork Talofofo Stream is one of the tributaries that drain eastern Saipan. The Talofofo Stream basin has an area of $1.43 \mathrm{mi}^{2}$ and is undeveloped; land cover is tropical woodland. Currently (1991), virtually all water supplies on Saipan are derived from ground-water sources. However, the CNMI is considering the use of surface water from the Talofofo Stream basin to augment public supplies.

Median (50th-percentile) values of specific conductance (397 $\mu \mathrm{S} / \mathrm{cm})$, total hardness $(145 \mathrm{mg} / \mathrm{L})$, sulfate $(14 \mathrm{mg} / \mathrm{L})$, silica (38 $\mathrm{mg} / \mathrm{L})$, and dissolved solids $(264 \mathrm{mg} / \mathrm{L})$ in water from site 1 were among the highest in samples collected at the eight monitoring stations (fig. 3). Water from limestone aquifers discharging into the stream contributes to these large values.

\section{PAGO RIVER, GUAM}

Guam has an area of $212 \mathrm{mi}^{2}$ and is the largest island of the WPI. Annual rainfall is about 85 inches. The northern part of the island has no streams because of the permeable limestone terrane. The southern part is underlain by volcanic rocks eroded by many streams (Ward and others, 1965, p. H7).

The Pago River drains east-central Guam and flows into Pago Bay. The northern slope of the valley along the main stem is lime-
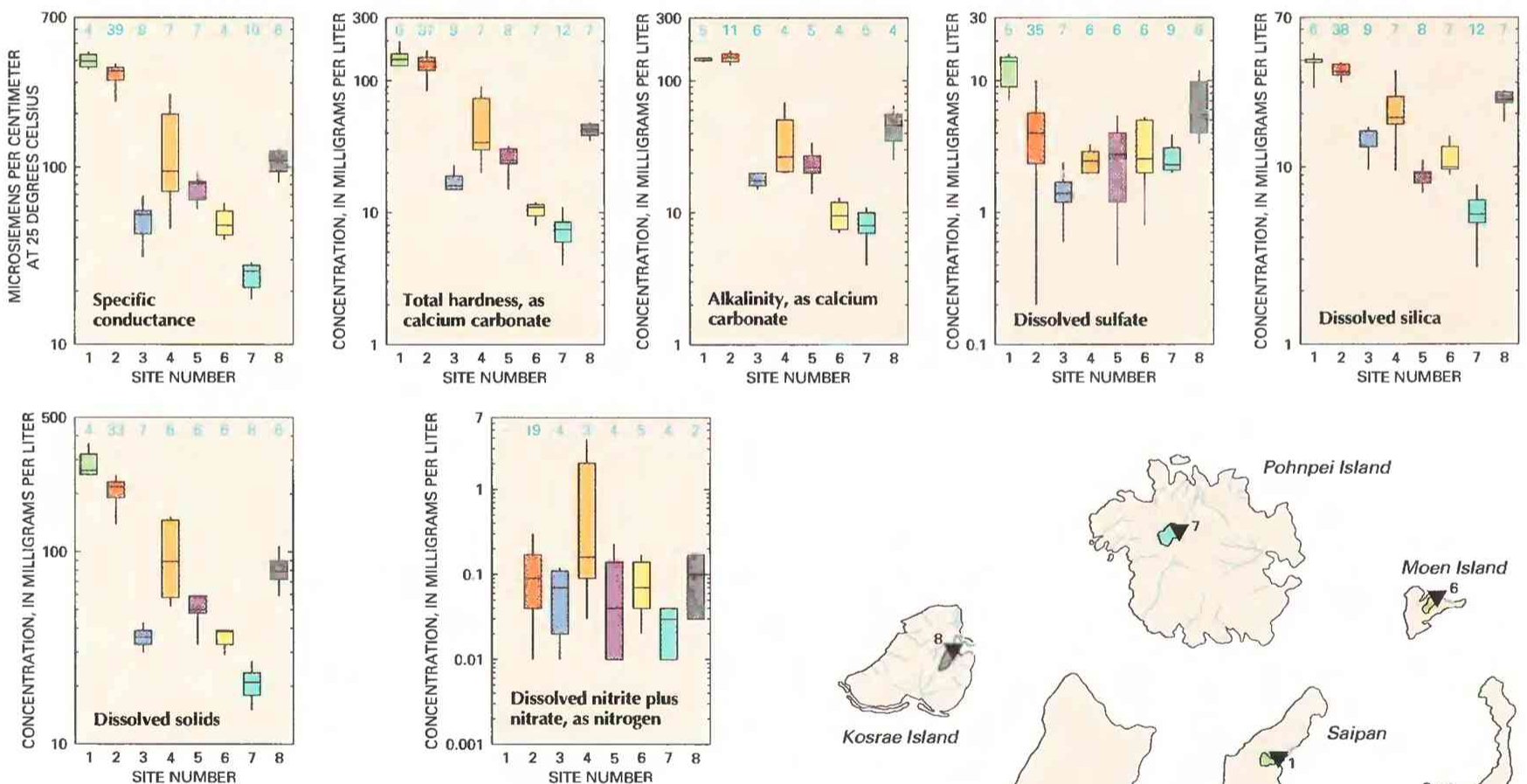

\section{EXPLANATION}

Water-quality conditions in selected
drainage basins
Number of analyses-Dash indicates
insufficient data
Percentile-Percentage of analyses
equal to or less than indicated
values
-90th
-75th
-50th-Median
-25 th
-10th

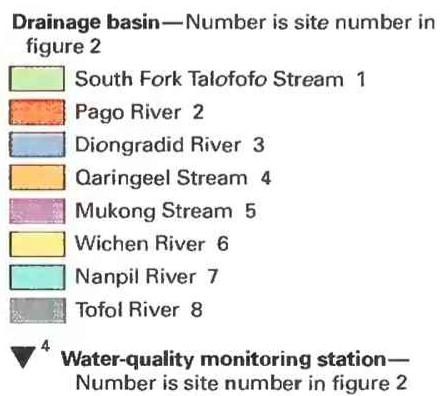

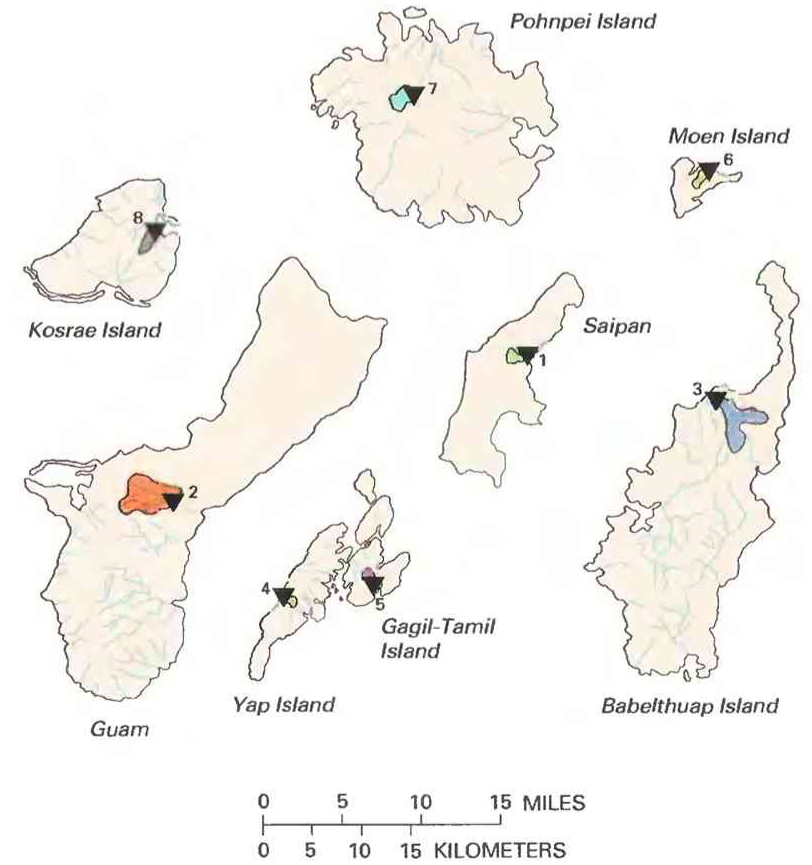

Figure 3. Water quality of selected streams in the Western Pacific Islands, water years 1980-89. (Source: Data from U.S. Geological Survey files.) 
Table 1. Sources and environmental significance of selected water-quality properties and constituents [Source: Compiled by the U.S. Geological Survey, Office of Water Quality]

\begin{tabular}{|c|c|c|}
\hline Property or constituent & Common sources & Environmental significance \\
\hline $\begin{array}{l}\text { Specific conductance ..................... } \\
\text { (property) }\end{array}$ & $\begin{array}{l}\text { A measure of the electrical conductivity of water; var- } \\
\text { ies with the quantity of dissolved solids and is } \\
\text { used to approximate the dissolved-solids content. }\end{array}$ & $\begin{array}{l}\text { Dissolved solids can cause water to be unsuitable for } \\
\text { public supply, agriculture, and industry; can harm } \\
\text { aquatic organisms. }\end{array}$ \\
\hline Hardness (property) .................... & $\begin{array}{l}\text { A characteristic of water primarily related to the concen- } \\
\text { trations of calcium and magnesium. }\end{array}$ & $\begin{array}{l}\text { Hard water causes the formation of an insoluble res- } \\
\text { idue when used with soap and scale in vessels in } \\
\text { which water has been allowed to evaporate. }\end{array}$ \\
\hline Alkalinity (property) ................................ & $\begin{array}{l}\text { A measure of the quantity of acid-neutralizing sub- } \\
\text { stances; can be affected by geologic setting, in- } \\
\text { dustrial wastewater discharge, waste gases, and } \\
\text { runoff from surface mining. }\end{array}$ & $\begin{array}{l}\text { Sufficiently alkaline water can be unsuitable for some } \\
\text { agricultural and industrial uses. }\end{array}$ \\
\hline Sulfate & $\begin{array}{l}\text { Occurs in some rocks; also in mine runoff, industrial } \\
\text { wastewater discharge, and atmospheric deposi- } \\
\text { tion. }\end{array}$ & $\begin{array}{l}\text { Concentrations exceeding a natural, background } \\
\text { level indicate contamination from human activity; } \\
\text { in sufficient quantity, can cause water to be } \\
\text { unsuitable for public supply; can harm aquatic } \\
\text { organisms. }\end{array}$ \\
\hline Silica & $\begin{array}{l}\text { In streams of tropical islands, derived from decompo- } \\
\text { sition of silicate minerals in volcanic rocks. }\end{array}$ & $\begin{array}{l}\text { Can cause water to be unsuitable for some industrial } \\
\text { applications such as boiler feed water; forms hard } \\
\text { scale. }\end{array}$ \\
\hline 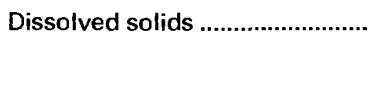 & $\begin{array}{l}\text { A result of rock weathering; also in agricultural runoff } \\
\text { and industrial discharge. }\end{array}$ & $\begin{array}{l}\text { In sufficient quantity, can cause water to be unsuitable } \\
\text { for public supply, agriculture, and industry; can } \\
\text { harm aquatic organisms. }\end{array}$ \\
\hline Nitrite plus nitrate & $\begin{array}{l}\text { Nonpoint sources are agricultural and urban runoff; } \\
\text { a major point source is wastewater discharge. }\end{array}$ & $\begin{array}{l}\text { Plant nutrient that, in sufficient quantity, can cause } \\
\text { algal blooms and excessive growth of higher } \\
\text { aquatic plants in bodies of water; can cause water } \\
\text { to be unsuitable for public supply. }\end{array}$ \\
\hline
\end{tabular}

stone; the southern slope is volcanic rock, except near the river's mouth where the river has cut through a narrow limestone plateau that borders the coast (Ward and others, 1965, p. H7). The drainage basin upstream from site 2 is covered by tropical woodland. Although the USGS gaging station at site 2 has been discontinued, the Guam Environmental Protection Agency (GEPA) continues to monitor water quality in the Pago River basin to determine the effect of a landfill on stream water quality. The landfill is a solid-waste disposal site for the civilian community on Guam and is located upstream from site 2 and north of the Lonfit River near Ordot (fig. 2). The GEPA has reported no evidence of leachate contamination from the landfill into the Lonfit River (Guam Environmental Protection Agency, 1990, p. 26).

Median values of specific conductance $(350 \mu \mathrm{S} / \mathrm{cm})$, hardness $(140 \mathrm{mg} / \mathrm{L})$, alkalinity $(150 \mathrm{mg} / \mathrm{L})$, silica $(34 \mathrm{mg} / \mathrm{L})$, and dissolved solids $(218 \mathrm{mg} / \mathrm{L})$ at site 2 were the highest or among the highest for the eight monitoring stations. Runoff from the limestone and volcanic terrane contributes to these high concentrations.

\section{DIONGRADID RIVER, BABELTHUAP ISLAND, REPUBLIC OF PALAU}

Babelthuap (153 $\left.\mathrm{mi}^{2}\right)$ is the largest island in the Republic of Palau and constitutes about 80 percent of the Republic's total land area. There are more than 350 islands in the Republic, many of which are small, uninhabited limestone islands (van der Brug, 1984a, p. 1). The Diongradid River drains northwestern Babelthuap Island. Most of the $4.45-\mathrm{mi}^{2}$ drainage basin upstream from site 3 is tropical woodland.

Stream water at site 3 is nearly free of natural or human-related contamination because human activity in the basin is minimal. The median concentration of sulfate $(1.4 \mathrm{mg} / \mathrm{L})$ in water from site 3 was the lowest, and the median concentration of dissolved solids (36 $\mathrm{mg} / \mathrm{L}$ ) was the second lowest in samples from the eight monitoring stations.

\section{QARINGEEL STREAM, YAP ISLAND, YAP STATE, FSM}

Despite an annual rainfall of 122 inches, Yap Island has no perennial streams. Streams typically do not flow during part of the dry season because drainage areas are small (less than $0.25 \mathrm{mi}^{2}$ ) and because water retention is slight. Qaringeel Stream (site 4) drains west-central Yap Island. Land cover in the basin is predominantly tropical woodland. The stream has the largest annual discharge of any on Yap Island but was dry an average of 10 weeks per year during 1969-82 (van der Brug, 1983a). Values of most water-quality properties and constituents at site 4 were in the midrange of those at the eight monitoring stations.

\section{MUKONG STREAM, GAGIL-TAMIL ISLAND, YAP STATE, FSM}

Mukong Stream drains south-central Gagil-Tamil Island. Unlike the streams on Yap Island, Mukong Stream is perennial. Deep weathering of the rocks underlying the basin allows infiltration of the 122-inch annual rainfall and slow release of water to the streams (van der Brug, 1983a, p. 20). The drainage area of Mukong Stream $\left(0.50 \mathrm{mi}^{2}\right)$ is larger than that of any other stream on Gagil-Tamil Island, and the basin is covered by tropical woodland. Values of water-quality properties and constituents at site 5 were in the midrange of those at the eight monitoring stations.

\section{WICHEN RIVER, MOEN ISLAND, CHUUK STATE, FSM}

Chuuk State (formerly known as Truk State) consists of 19 volcanic islands and at least 65 coral islets (van der Brug, 1983b, p. 3). Moen Island is the administrative, commercial, educational, and transportation center of the State. Rainfall in the area averages 144 inches per year. The Wichen River has the largest drainage basin $\left(0.57 \mathrm{mi}^{2}\right)$ on Moen Island; land cover upstream from site 6 is mostly tropical woodland. Median values of most properties and constituents at site 6 were among the lowest for the eight monitoring stations.

\section{NANPIL RIVER, POHNPEI ISLAND, POHNPEI STATE, FSM}

Pohnpei has a land area of $129 \mathrm{mi}^{2}$ and is the third largest island in the WPI. Annual rainfall is 191 inches, and monthly rainfall averages are never less than 10 inches (van der Brug, 1984b, p. 1). The Nanpil River drains the tropical woodlands of north-central Pohnpei Island. The river is one of the major sources of surface-water supply for Kolonia, Pohnpei State's capitol and largest city. 
Values of most properties and constituents at site 7 were the lowest at the eight monitoring stations. Dilution by the abundant rainfall is the primary reason for these low concentrations.

\section{TOFOL RIVER, KOSRAE ISLAND, KOSRAE STATE, FSM}

Kosrae is a volcanic island that has a land area of $42 \mathrm{mi}^{2}$. Annual rainfall in coastal areas of the island averages about 200 inches, most of which runs off as streamflow. The Tofol River drains eastern Kosrae Island, which is covered by tropical woodland upstream from site 8 .

Despite abundant rainfall, the median concentration of sulfate $(5.5 \mathrm{mg} / \mathrm{L})$ at site 8 was second largest for the eight monitoring stations. Median values of specific conductance $(109 \mu \mathrm{S} / \mathrm{cm})$, hardness $(43 \mathrm{mg} / \mathrm{L})$, alkalinity $(46 \mathrm{mg} / \mathrm{L})$, and silica $(24 \mathrm{mg} / \mathrm{L})$ at site 8 were high relative to those in other basins within volcanic terrane.

\section{WATER-QUALITY MANAGEMENT}

Stream water quality is regulated and managed by each WPI governmental entity. Regulatory agencies are established for the CNMI, Guam, and the Republic of Palau. All governments, however, follow water-quality guidelines established by the EPA.

Pursuant to section 305(b) of the Federal Clean Water Act, the Division of Environmental Quality (DEQ), Department of Public Health and Environmental Services of the CNMI, submits a biennial water-quality-assessment report to the EPA and the U.S. Congress (Commonwealth of the Northern Mariana Islands, 1990) that documents the CNMI's progress in implementing the goals and objectives of the act. The DEQ administers programs and policies to protect and preserve the environment and health of CNMl inhabitants.

Guam's water quality is monitored by the GEPA, which was created by the 1973 Guam Environmental Protection Agency Act (Title LXI, Chapter 1). The GEPA is responsible for planning and development of regulations to ensure the protection and conservation of Guam's water resources. The GEPA prepares Guam's biennial water-quality-assessment report (Guam Environmental Protection Agency, 1990). The GEPA has established a comprehensive program to manage and monitor ground- and coastal-water quality on Guam.

Water quality in the Republic of Palau is managed by the Environmental Protection Board. The board administers programs and policies to protect and preserve the environment and health of Palau inhabitants.

Prior to 1989, the FSM's water-quality management was under the direction of the Trust Territory Environmental Protection Board (1985), which represented Palau, Saipan, and other islands of the Trust Territory of the Pacific. Having achieved independent-nation status only as of October 1, 1989, the FSM's water-quality man- agement agency has not yet (1991) been identified. However, each island State has its own public works department, and these continue to set policies and monitor the quality of the water resources.

The USGS monitors surface-water quality of streams in the CNMI, the Republic of Palau, and the FSM. The monitoring is part of a cooperative program of the USGS and the island governments to evaluate water-resources availability on selected islands.

\section{SELECTED REFERENCES}

Britton, L.J., and Greeson, P.E., eds., 1987, Methods for collection and analysis of aquatic biological and microbiological samples: U.S. Geological Survey Techniques of Water-Resources Investigations, book 5, chap. A4, 363 p.

Commonwealth of the Northern Mariana Islands, 1990, Commonwealth of the Northern Mariana Islands 205(j)/305(b) water quality report, 1989 update: Saipan, Commonwealth of the Northern Mariana Islands, Division of Environmental Quality, Department of Public Health and Environmental Services, $14 \mathrm{p}$.

Fishman, M.J., and Friedman, L.C., eds., 1989, Methods for the determination of inorganic substances in water and fluvial sediments: U.S. Geological Survey Techniques of Water-Resources Investigations, book 5 , chap. Al, 545 p.

Guam Environmental Protection Agency, 1990, Territory of Guam water quality report 305(b): Harmon, Guam Environmental Protection Agency, $49 \mathrm{p}$.

Pacific World Directory, 1989: Saipan, Pacific Information Bank, 367 p.

Trust Territory Environmental Protection Board, 1985, Water quality assessment and inventory, 305(b)/205(j) report for FY 1984-85, Trust Territory of the Pacific Islands: Saipan, Trust Territory Environmental Protection Board, 13 p.

U.S. Geological Survey, 1986, National water summary 1985-Hydrologic events and surface-water resources: U.S. Geological Survey WaterSupply Paper 2300, 506 p.

van der Brug, Otto, 1983a, Water resources of the Yap Islands: U.S. Geological Survey Water-Resources Investigations Report 82-357, 187 p. $1983 \mathrm{~b}$, Water resources of the Truk Islands: U.S. Geological Survey Water-Resources Investigations Report 82-4082, 223 p. 1984a, Water resources of the Palau Islands: U.S. Geological Survey Water-Resources Investigations Report 83-4140, 223 p. $1984 \mathrm{~b}$, Water resources of the Ponape, Caroline Islands: U.S. Geological Survey Water-Resources Investigations Report 83-4139, 171 p. 1985, Compilation of water resources development and hydrologic data of Saipan, Mariana Islands: U.S. Geological Survey Water-Resources Investigations Report 84-4121, 578 p.

Ward, J.R., and Harr, C.A., eds., 1990, Methods for collection and processing of surface-water and bed-material samples for physical and chemical analyses: U.S. Geological Survey Open-File Report 90-140, 71 p.

Ward, P.E., Hoffard, S.H., and Davis, D.A., 1965, Hydrology of Guam: U.S. Geological Survey Professional Paper 403-H, 28 p. 
Prepared by Johnson J.S. Yee and Marty G. Lum, U.S. Geological Survey

FOR ADDITIONAL INFORMATION: District Chief, U.S. Geological Survey, 677 Ala Moana Blvd., Suite 415, Honolulu, HI 96813 


\section{WISCONSIN Stream Water Quality}

Wisconsin has abundant surface-water resources - more than 43,000 miles of rivers and streams and nearly 15,000 lakes. Lake Superior, Lake Michigan, and the Mississippi River form parts of the State's borders. Streams are characterized by stable base flow and low flood peaks (U.S. Geological Survey, 1986, p. 485).

The quality of stream water can be affected by land use. In Wisconsin, agricultural land uses predominate in the southern twothirds of the State, whereas woodland and forest cover much of the northern one-third (fig. $1 A$ ). The Eastern lake section of the Central Lowland (fig. $1 B$ ) contains most of the State's urban areas and population (fig. 1C). Wisconsin's population in 1990 was 4.9 million, a 4-percent increase from 1980 (U.S. Bureau of the Census 1990 decennial census files).

Surface water supplied an average of $6,170 \mathrm{Mgal} / \mathrm{d}$ (million gallons per day), or 91.5 percent of the $6,740 \mathrm{Mgal} / \mathrm{d}$ of water withdrawn in 1985 (U.S. Geological Survey, 1990a, p. 531). Thermoelectric power generation was the largest use of surface water, accounting for $5,440 \mathrm{Mgal} / \mathrm{d}$ (88.2 percent). The next largest use of surface water was for self-supplied industrial use (424 Mgal/d, 6.9 percent). Most of the remaining 4.9 percent of surface-water withdrawals (301 $\mathrm{Mgal} / \mathrm{d}$ ) was used for public supply. Other uses of surface water accounted for less than $5 \mathrm{Mgal} / \mathrm{d}$.

Public supplies from surface water serve 30 percent of Wisconsin's population (Solley and others, 1988), and all surface water used for domestic and commercial purposes comes from public suppliers. Public surface-water supplies serve some of the most densely populated areas of the State, including communities on the shores of Green Bay and Lakes Michigan, Superior, and Winnebago (fig. 2); all public surface-water supplies in those areas are obtained from these bodies of water.

\section{WATER-QUALITY MONITORING}

Water-quality data obtained from analyses of water samples collected at monitoring stations are stored in the U.S. Geological Survey's (USGS) National Water Information System and the U.S. Environmental Protection Agency's (EPA) national data base known as STORET. Water-quality and streamflow data are reported by water year-the 12 months from October 1 through September 30. A water year is identified by the calendar year in which it ends. For example, water year 1991 comprises October 1, 1990, through September 30, 1991.

The data used in this summary of Wisconsin's stream water quality were obtained from water samples collected at 10 monitoring stations at which data collection is systematic and continuing (fig. 2). Analyses of water samples collected at all 10 stations are the basis for the discussion and graphic summary (fig. 3) of stream water-quality conditions during water years 1987-89, and data from 7 stations are the basis for the discussion and graphic summary (fig. 4) of stream water-quality trends. Water samples were collected and analyzed by using standard methods approved by the USGS (Britton and Greeson, 1987; Fishman and Friedman, 1989; Ward and Harr,

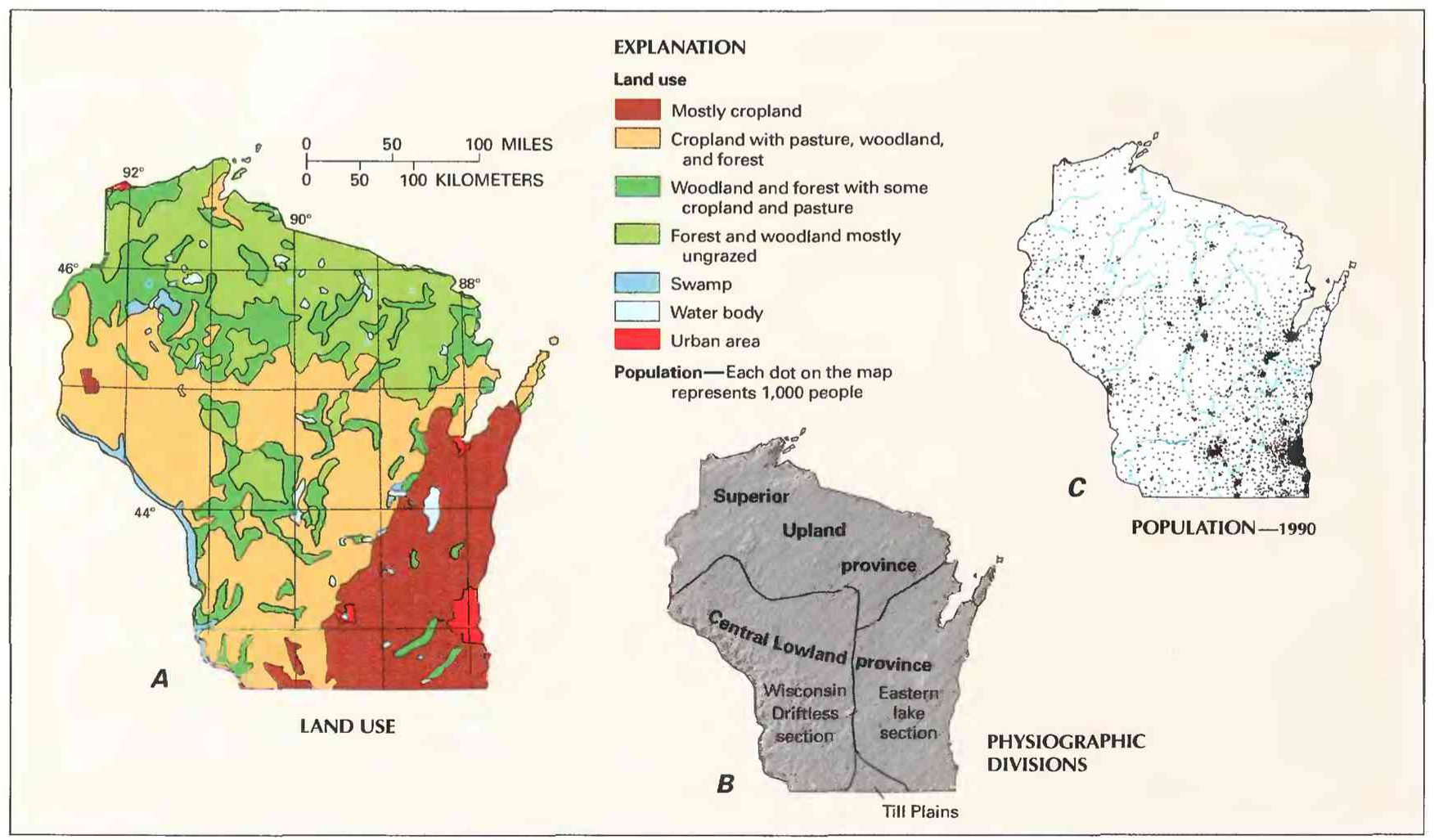

Figure 1. Land use, physiography, and population in Wisconsin. A, Major land uses. B, Physiographic divisions. $C$, Population distribution in 1990. (Sources: A, Major land uses modified from Anderson, 1967. B, Physiographic divisions from Fenneman, 1946; landforms from Thelin and Pike, 1990. C, Data from U.S. Bureau of the Census 1990 decennial census files.) 
1990) or by using equivalent methods. If a method of sample collection or analysis changed over time, data from an analysis were included in the evaluation of recent stream water quality or of stream water-quality trends only if the change in method did not affect the comparability of the data.

\section{WATER-QUALITY CONDITIONS}

Statewide surface-water-quality issues include nonpointsource contamination of streams and lakes by substances transported by overland runoff and toxic substances in fish tissue and sediments (Wisconsin Department of Natural Resources, 1990). Assessments of State streams by the Wisconsin Department of Natural Resources (DNR) indicate that siltation is the most common cause (in terms of stream miles affected) of streams not fully supporting their beneficial uses designated by the State for purposes of water-pollution control; agriculture is the most common source of water-quality problems in streams not fully supporting beneficial uses (Wisconsin Department of Natural Resources, 1990, p. 14).

The following discussion of stream water quality in Wisconsin is organized by river basin (fig. 3). Where physiographic and landuse characteristics in different basins are similar, the discussion of

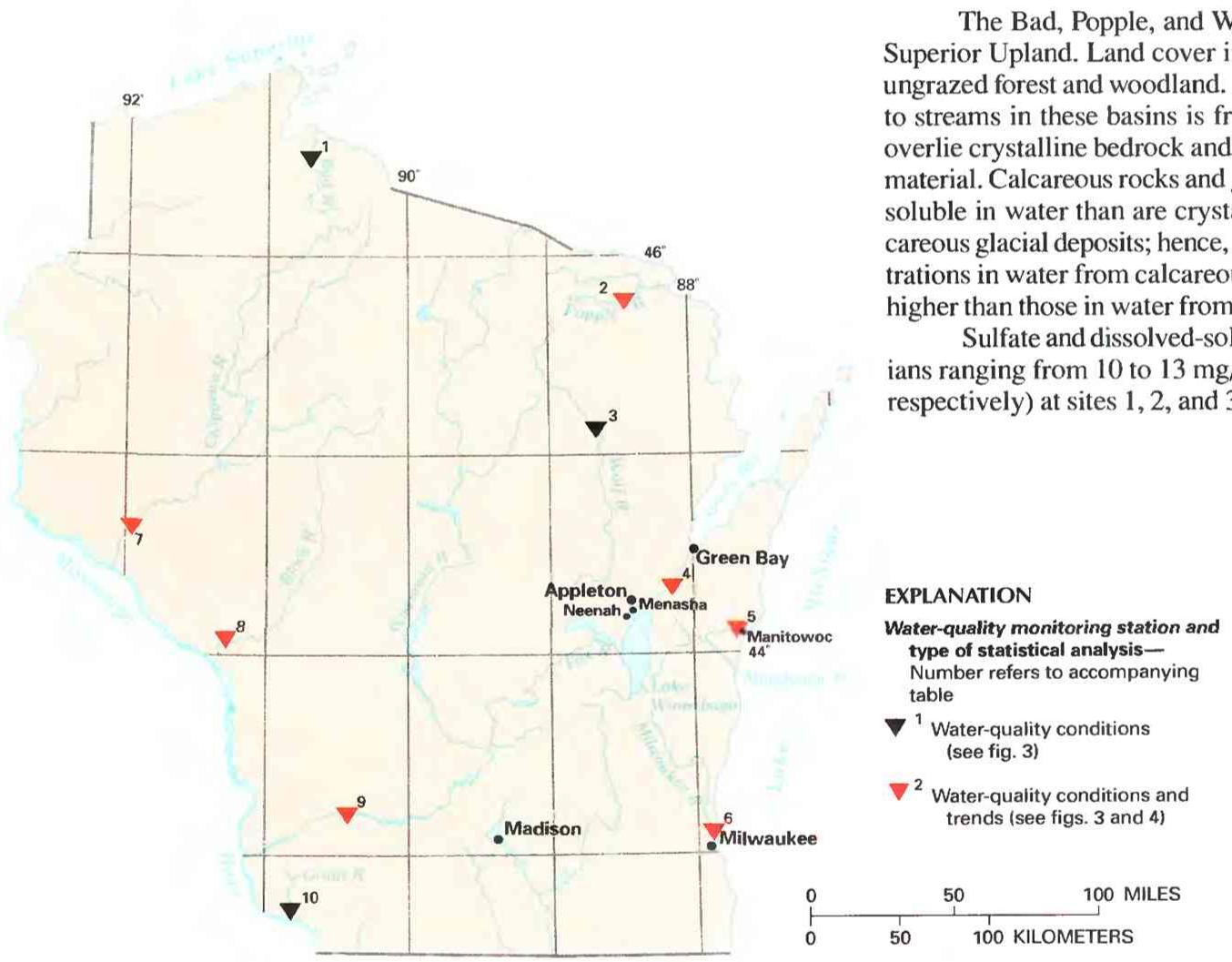

those basins is combined. Graphs in figure 3 summarize certain aspects of stream water quality in the basins for water years 1987-89. The graphs show frequency distributions of data values that represent concentrations of selected stream-water constituents. These constituents are fecal coliform bacteria, dissolved sulfate, dissolved chloride, dissolved solids, dissolved nitrite plus nitrate (as nitrogen), and suspended sediment. The data are reported in colonies per 100 milliliters $(\mathrm{col} / 100 \mathrm{~mL})$ and milligrams per liter $(\mathrm{mg} / \mathrm{L})$. Sources and environmental significance of each constituent are described in table 1.

Water quality at each monitoring station is the result of geological, chemical, biological, and hydrologic processes that occur over a large area. Water-quality problems that affect aquatic life or public health only locally are not fully represented in this summary.

Water-quality criteria and standards for Wisconsin surface waters are set according to State-designated beneficial uses of the water. These uses include propagation of fish and other aquatic life, recreational uses, water supply (public health and welfare), and wildand domestic-animal uses (Wisconsin Department of Natural Resources, 1989, p. 21-23).

\section{BAD, POPPLE, AND WOLF RIVERS}

The Bad, Popple, and Wolf Rivers lie within the Superior Upland. Land cover in the basins primarily is ungrazed forest and woodland. Ground-water discharge to streams in these basins is from glacial deposits that overlie crystalline bedrock and contain little calcareous material. Calcareous rocks and glacial deposits are more soluble in water than are crystalline rocks and noncalence, dissolved-solids concentrations in water from calcareous aquifers generally are higher than those in water from noncalcareous aquifers. ians ranging from 10 to $13 \mathrm{mg} / \mathrm{L}$ and 104 to $130 \mathrm{mg} / \mathrm{L}$, respectively) at sites 1,2 , and 3 were among the lowest

\begin{tabular}{|c|c|c|c|}
\hline $\begin{array}{l}\text { Site no. } \\
\text { on map }\end{array}$ & $\begin{array}{l}\text { USGS station } \\
\text { name and no. }\end{array}$ & $\begin{array}{l}\text { Drainage area } \\
\text { (square miles) }\end{array}$ & $\begin{array}{l}\text { Major land use } \\
\text { (see fig. 1) }\end{array}$ \\
\hline 1 & Bad River near Odanah $(04027000)$ & 597 & Mostly ungrazed forest and woodland. \\
\hline 2 & Popple River near Fence $(04063700)$ & 139 & Ditto. \\
\hline 3 & 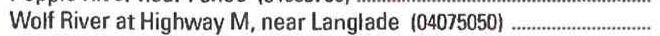 & 488 & Ditto. \\
\hline 4 & Fox River at Wrightstown $(04085000)$ & 6,050 & Cropland with pasture, woodland, and forest. \\
\hline 5 & Manitowoc River at Manitowoc $(04085427)$ & 526 & Mostly cropland. \\
\hline 6 & Milwaukee River at Milwaukee $(04087000)$ & 696 & Ditto. \\
\hline 7 & Chippewa River at Durand $(05369500)$ & 9,010 & Woodiand and forest with some cropiand and pasture. \\
\hline 8 & 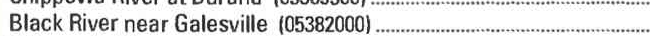 & 2,080 & Ditto. \\
\hline 9 & Wisconsin River at Muscoda (05407000) .... & 10,400 & Cropland with pasture, woodland, and forest. \\
\hline 10 & Grant River at Burton $(05413500)$ & 269 & Ditto. \\
\hline
\end{tabular}

Figure 2. Selected water-quality monitoring stations, type of statistical analysis, and geographic features in Wisconsin. (Sources: Major land uses modified from Anderson, 1967; other data from U.S. Geological Survey files.) 
at the 10 monitoring stations (fig. 3) and reflect the relatively insoluble nature of the rocks that underlie the basins. Sulfate, dissolved-solids, and chloride concentrations at sites 1, 2, and 3 were similar to those in water from shallow aquifers in the basins (Kammerer, 1984, p. 30-31). The lack of development in these basins probably is the reason for the relatively low concentrations of fecal coliform bacteria, nitrite plus nitrate, and suspended sediment at sites 1 and 2, and the low concentration of nitrite plus nitrate at site 3.

\section{FOX, MANITOWOC, AND MILWAUKEE RIVERS}

The Manitowoc, Milwaukee, and most of the Fox River drainage basins lie within the Eastern lake section of the Central Lowland. The principal land use in these basins is agriculture. In the northern headwaters area of the Fox River basin, the principal land cover is forest and woodland. The Milwaukee and Manitowoc River basins and parts of the Fox River basin have been designated by the DNR (1990, p. 169-170) as priority watersheds for implementation of measures to decrease nonpoint-source contamination of surface water. Urbanization is a minor land use in these basins in terms of area, but urban areas could disproportionately affect water quality.
Site 4 is downstream from the Appleton-Neenah-Menasha metropolitan area and sites 5 and 6 are in the upstream parts of the Manitowoc and Milwaukee urban areas.

Discharge to streams from shallow aquifers has a major effect on water quality of the Fox River (site 4), the Manitowoc River (site 5), and the Milwaukee River (site 6). Ground-water discharge upstream from sites 5 and 6 is from calcareous glacial deposits overlying dolomite bedrock; median concentrations of dissolved solids (380 mg/L and $396 \mathrm{mg} / \mathrm{L}$ ) and sulfate $(39 \mathrm{mg} / \mathrm{L})$ for both streams were higher than concentrations at the other monitoring stations (fig. 3) and were within the reported concentration ranges for sulfate and dissolved solids in water from the glacial deposits and shallow bedrock (Kammerer, 1984, p. 22-23). Median sulfate and dissolved-solids concentrations at site $4(26 \mathrm{mg} / \mathrm{L}$ and $231 \mathrm{mg} / \mathrm{L})$ were lower than those at sites 5 and 6 because of differences in the sources of ground water discharged to the streams. Ground-water discharge in the southern and eastern parts of the drainage basin upstream from site 4 is from the same terrane as at sites 5 and 6 , but ground-water discharge in the northern and western parts of the basin is from less calcareous glacial deposits that overlie sandstone. Sulfate and dissolved-solids concentrations in water from geologic units in the north and west are lower than concentrations in the south and east
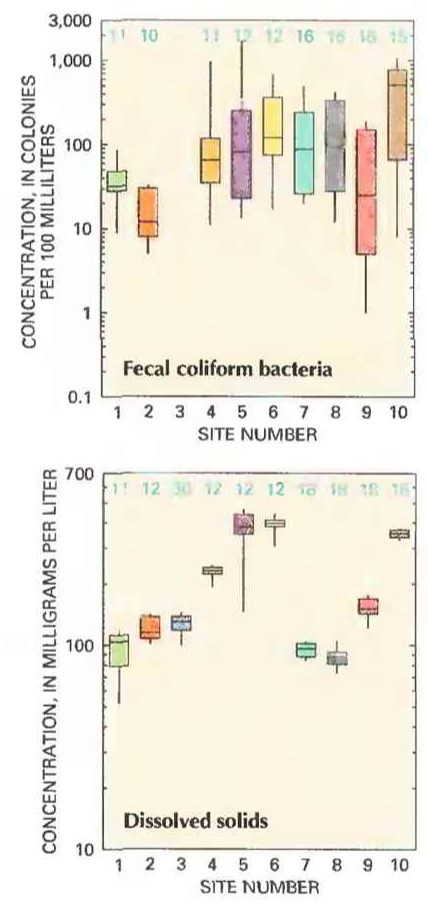

\section{EXPLANATION}

Water-quality conditions in selected
drainage basins
Number of analyses-Dash indicates
insufficient data
Percentile-Percentage of analyses
equal to or less than indicated
values
- 90th
-75 th
-50 th-Median
- 25th
10th
Reporting limit-Minimum reporting
limit for analytical method used.
Data below limit line not shown
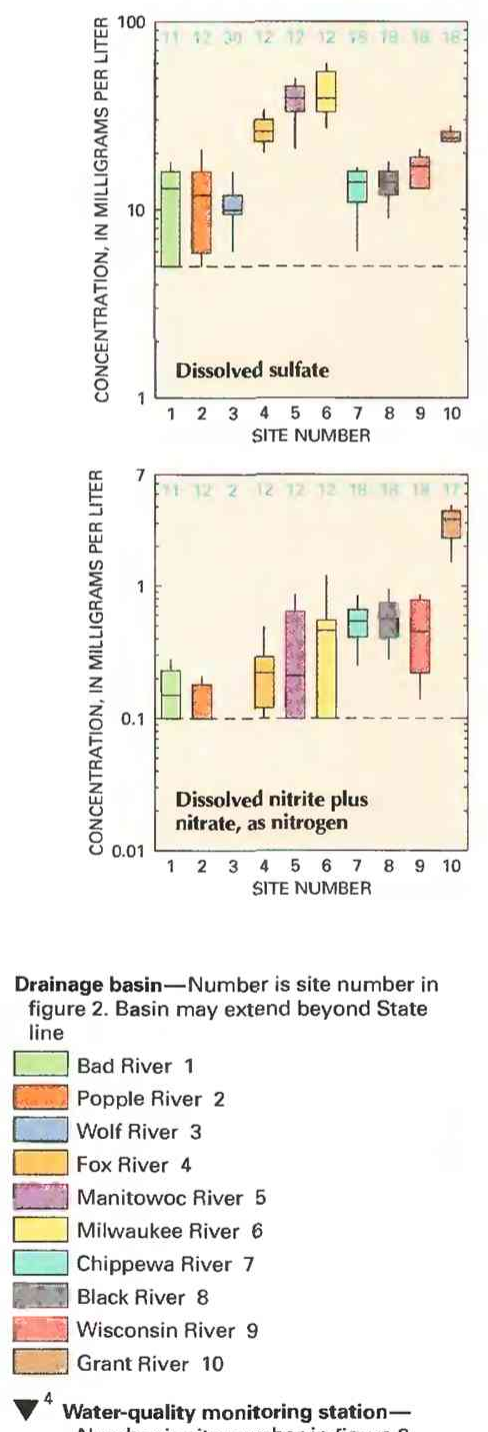
Number is site number in figure 2
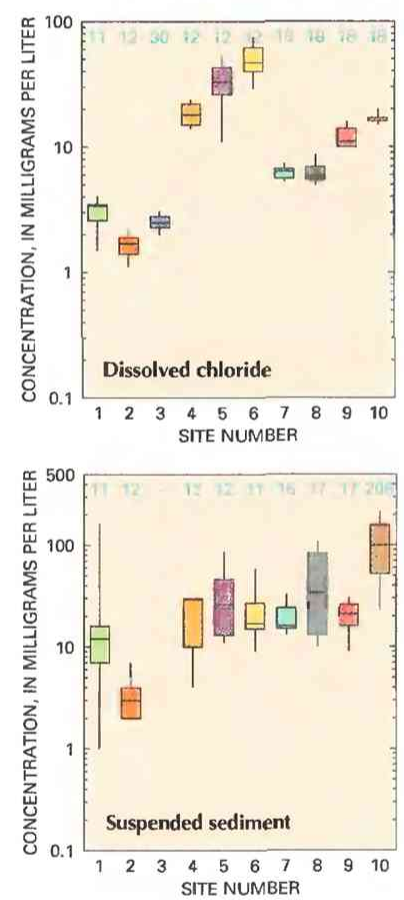

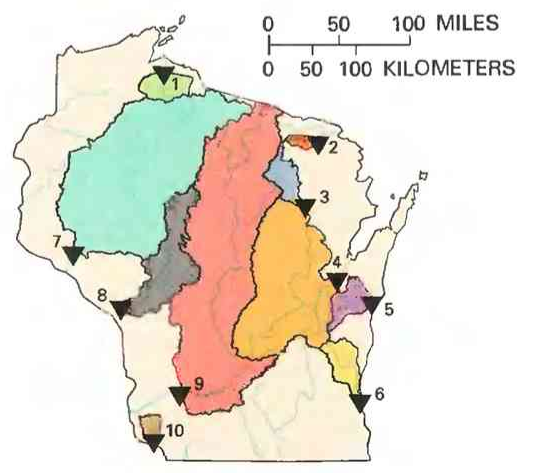

Figure 3. Water quality of selected streams in Wisconsin, water years 1987-89. (Source: Data from U.S. Geological Survey files.) 
(Kammerer, 1984, p. 22-23). Chloride concentrations at sites 4, 5 , and 6 (medians ranging from 18 to $47 \mathrm{mg} / \mathrm{L}$ ) were the highest at any of the 10 sites (fig. 3 ) and were considerably higher than the range of median chloride concentrations of $4-6 \mathrm{mg} / \mathrm{L}$ reported by Kammerer (1984, p. 22-23) for water from aquifers underlying these basins. Possible sources of the high chloride concentrations are discharges from wastewater-treatment plants and road-deicing salt. Sites 4, 5, and 6 are in or near population centers in the most densely populated areas of the State (fig. $1 C$ ). Fecal coliform bacteria and nitrite plus nitrate concentrations at sites 4,5 , and 6 were similar to concentrations at most other sites.

An important water-quality issue in the Fox River basin is contamination by polychlorinated biphenyls (PCB's) of water and sediments in the lower Fox River between Lake Winnebago and Green Bay. The distribution and transport of PCB's in the lower Fox River and Green Bay are being investigated as part of the Green Bay Mass Balance Project, a multiagency project sponsored by the Great Lakes National Program Office of the EPA.

\section{CHIPPEWA AND BLACK RIVERS}

The Chippewa and Black Rivers flow from the Superior Upland to the Wisconsin Driftless section of the Central Lowland. Both river basins are covered primarily by agricultural areas and woodland.

Sulfate, chloride, and dissolved-solids concentrations at sites 7 and 8 were low during water years $1987-89$ (medians, $14 \mathrm{mg} / \mathrm{L}$ for both sites; 6.4 and $5.9 \mathrm{mg} / \mathrm{L}$; and 96 and $88 \mathrm{mg} / \mathrm{L}$ ). These concentrations are similar to those reported for shallow ground-water discharge in these river basins (Kammerer, 1984, p. 14-15); the shallow aquifers are glacial and alluvial deposits that have little calcareous material and overlie sandstone or crystalline rocks. Fecal coliform bacteria and nitrite plus nitrate concentrations (medians, 88 and $97 \mathrm{col} / 100 \mathrm{~mL}$; 0.54 and $0.56 \mathrm{mg} / \mathrm{L}$ ) were similar to those in other basins where agriculture is an important land use.

\section{WISCONSIN RIVER}

The Wisconsin River basin upstream from site 9 includes about 20 percent of the area of the State. The river drains parts of the Superior Upland and the Wisconsin Driftless section of the Central Lowland. Agricultural areas, woodland, and forest cover most of the basin.

Water quality at site 9 is affected by land use and ground-water discharge from geologic terranes that include calcareous and

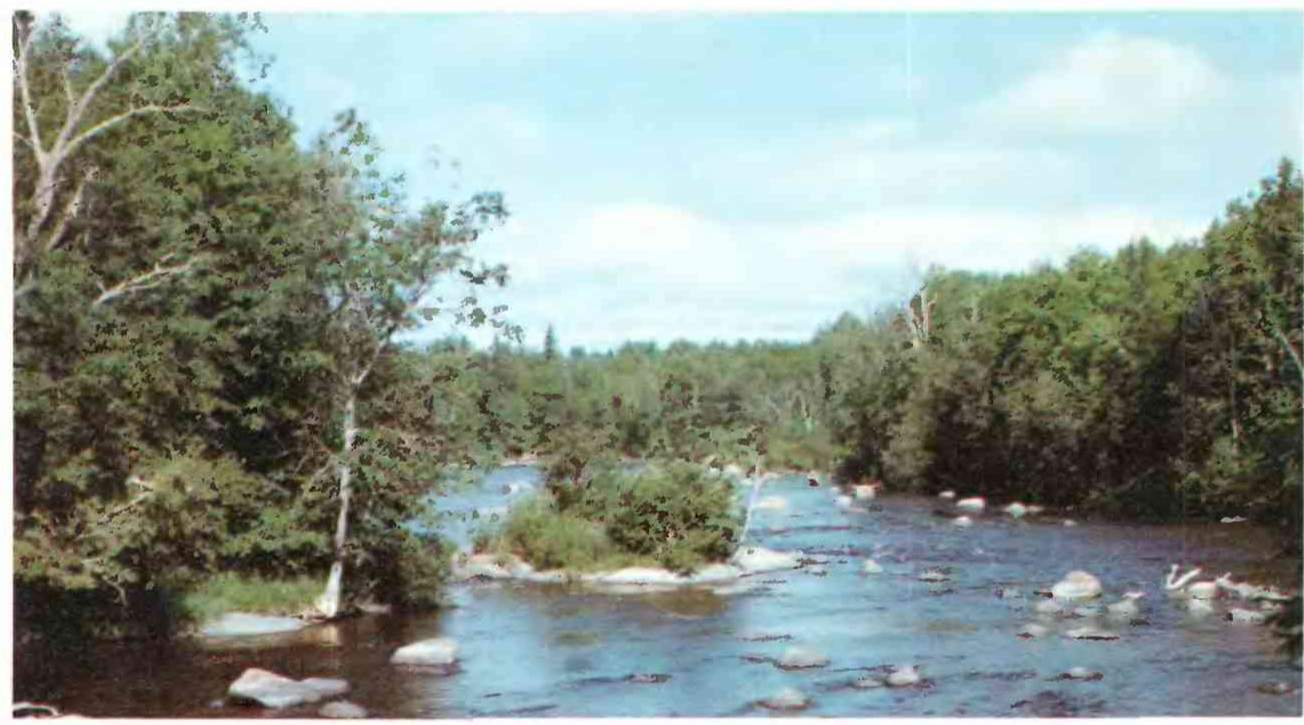

Wisconsin's Wolf River (site 3) has been designated a National Wild and Scenic River. (Photograph by Dale Cotter, U.S. Geological Survey.)

Table 1. Sources and environmental significance of selected water-quality constituents

[Source: Compiled by the U.S. Geological Survey, Office of Water Quality]

Constituent Common sources Environmental significance

Fecal coliform bacteria

Sulfate

Chloride

Dissolved solids

Nitrite plus nitrate

Suspended sediment
Sources include effluent from sewage-treatment plants and runoff from pastures, feedlots, and urban areas.

Occurs in some rocks; also in mine runoff, industrial wastewater discharge, and atmospheric deposition.

Occurs in some rocks and ground-water discharge; also in road deicers, industrial and urban wastewater discharge, and atmospheric deposition.

A result of rock weathering; also in agricultural runoff and industrial discharge.

Nonpoint sources are agricultural and urban runoff; a major point source is wastewater discharge.

A result of rock erosion; also induced by disturbances of land cover due to fires, floods, and human activities such as mining, logging, construction, and agriculture.
Presence indicates contamination of water by wastes from humans and other warm-blooded animals.

Concentrations exceeding a natural, background level indicate contamination from human activity in sufficient quantity, can cause water to be unsuitable for public supply; can harm aquatic organisms.

Concentrations exceeding a natural, background level can cause water to be unsuitable for public supply, agriculture, and industry; can harm aquatic organisms.

In sufficient quantity, can cause water to be unsuitable for public supply, agriculture, and industry; can harm aquatic organisms.

Plant nutrient that, in sufficient quantity, can cause algal blooms and excessive growth of higher aquatic plants in bodies of water; can cause water to be unsuitable for public supply.

Can be detrimental to aquatic organisms; can fill reservoirs and impair recreational use of water. 
noncalcareous glacial deposits and bedrock. The concentrations of sulfate (median, $17 \mathrm{mg} / \mathrm{L}$ ), chloride (median, $11.0 \mathrm{mg} / \mathrm{L}$ ), dissolved solids (median, $151 \mathrm{mg} / \mathrm{L}$ ), nitrite plus nitrate (median, $0.45 \mathrm{mg} / \mathrm{L}$ ), and suspended sediment (median, $21 \mathrm{mg} / \mathrm{L}$ ) at site 9 were intermediate to those at the other monitoring stations (fig. 3), reflecting the diverse geology and land use in the basin. The relatively low fecal coliform bacteria concentrations probably were due, at least in part, to bacterial die-off in the many reservoirs on the Wisconsin River in northern and central Wisconsin. Downstream, in southern Wisconsin, the fecal coliform bacteria concentration in the lower Wisconsin River is decreased by dilution from tributary streams.

\section{GRANT RIVER}

The Grant River basin is in the Wisconsin Driftless section of the Central Lowland. The basin has rugged terrain and is covered by cropland, woodland, and pasture. Most of the woodland is on steep slopes that are unsuitable for crops.

Sulfate and dissolved-solids concentrations at site 10 are similar to those in water from dolomitic and calcareous alluvial material that composes the shallow aquifers in the basin (Kammerer, 1984, p. 14-15). Chloride concentrations at site 10 (median, 16 $\mathrm{mg} / \mathrm{L}$ ) are higher than concentrations in shallow ground water in the basin (Kammerer, 1984, p. 14-15), which indicates nonpoint-source contamination of the river by chloride. Median fecal coliform bacteria, nitrite plus nitrate, and suspended-sediment concentrations at site $10(510 \mathrm{col} / 100 \mathrm{~mL}, 3.2 \mathrm{mg} / \mathrm{L}$, and $99 \mathrm{mg} / \mathrm{L})$ were higher than those for the other monitoring stations (fig. 3). These high concentrations probably were due in part to nonpoint-source contamination carried by overland runoff from agricultural land; overland runoff generally is greater in the Wisconsin Driftless section owing to the rugged terrain.

\section{WATER-QUALITY TRENDS}

Trend analysis is a statistical procedure used to detect changes in stream water quality at a monitoring station over time. For this report, water-quality data from seven monitoring stations (fig. 2) were analyzed for trends by using the seasonal Kendall test (Hirsch and others, 1982), a method used extensively by the USGS. The graph (shown below) of the dissolved-solids concentration in the Popple River at site 2 illustrates the trend inferred from the concentration data and demonstrates the variation in water quality that is common in streams.

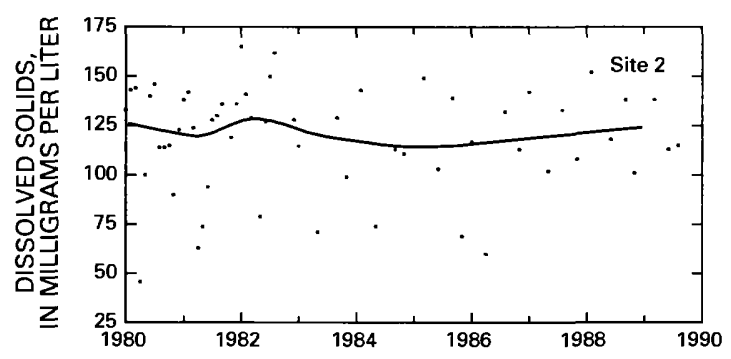

When possible, constituent-concentration data were adjusted for changes in streamflow to preclude identifying a trend in concentration that was caused only by a trend in streamflow. The data were not adjusted when (1) more than 10 percent of the samples had concentrations lower than the minimum reporting limit for the analytical method used or (2) streamflow was controlled substantially by human activities. When the concentration data could not be adjusted for streamflow, trends were determined directly from the concentration data.

Statewide trends in concentrations of selected stream-water constituents are shown on maps in figure 4 . On each map, a trend is indicated at a monitoring station only if the data from that station were suitable for use in the trend analysis. For more information on the suitability criteria and on the trend-analysis procedure used for this report, see Lanfear and Alexander (1990).

\section{FECAL COLIFORM BACTERIA}

Fecal coliform bacteria are used as indicators of fecal contamination from humans and other warm-blooded animals. Such contamination can introduce disease-causing viruses and bacteria into a stream. Concentrations of fecal coliform bacteria had no trend at the six monitoring stations from which data were suitable for trend analysis.

\section{DISSOLVED SULFATE}

The major natural sources of sulfate in streams are rock weathering, volcanoes, and biochemical processes (Hem, 1985, p. 113). Human activities such as mining, waste discharge, and fossil-fuel combustion also can be important sources. A shortened trend-analysis period was used for sulfate because data from analyses performed before water year 1982 are not comparable to data from subsequent years.

Less than normal precipitation and runoff in the Popple River at site 2, the Chippewa River at site 7, and Black River at site 8 during a drought in the late 1980's (U.S. Geological Survey, 1991, p. 567-574) probably caused the upward trends in sulfate concentrations in those streams. Sulfate concentrations late in the trendanalysis period at these locations were similar to concentrations in ground water. Ground water generally has higher concentrations of dissolved minerals than does stream water because stream water is diluted by runoff from precipitation. During drought, decreased precipitation and runoff result in reduced dilution of stream water; therefore, the chemical composition of the stream water becomes more like that of the ground water that discharges into the stream from shallow aquifers.

\section{DISSOLVED CHLORIDE}

Chloride is present in all natural waters but usually in low concentrations (Hem, 1985, p. 118). Except in streams that receive ground-water discharge high in chloride, concentrations of greater than a few milligrams per liter generally are the result of human activities (table 1).

Less than normal streamflow during 1987-88 might have caused the upward trends in chloride concentrations in the Chippewa River at site 7, the Black River at site 8, and the Wisconsin River at site 9. During periods of less than normal precipitation and runoff, ground-water and wastewater discharges are the principal sources of chloride in these rivers because less water from overland runoff is available for dilution.

\section{DISSOLVED SOLIDS}

Dissolved solids in stream water result primarily from rock weathering but also can be introduced as a byproduct of human activities (table 1). Concentrations generally are greatest in streams draining basins underlain by rocks and soils that contain easily dissolved minerals.

Dissolved-solids concentrations had no trends at six of the seven monitoring stations. A cause for the downward trend in the Manitowoc River at site 5 is not known.

\section{DISSOLVED NITRITE PLUS NITRATE}

Nitrite and nitrate are oxidized forms of nitrogen that together normally constitute most of the dissolved nitrogen in well-aerated 
streams. Nitrite readily oxidizes to nitrate in natural waters; therefore, nitrate generally is by far the more abundant of the two (Hem, 1985 , p. 124). Nitrite plus nitrate concentrations had no trend at the seven monitoring stations from which data were suitable for trend analysis.

\section{SUSPENDED SEDIMENT}

Suspended sediment is a product of erosion. The erosion can be either natural or the result of land-cover disturbances related to human activities (table 1).

Suspended-sediment concentrations had no trend at any of the seven monitoring stations. Less than average suspended-sediment loads resulting from reduced runoff during the 1988 drought were reported at several sampling sites in Wisconsin for water year 1988 (U.S. Geological Survey, 1990b, p. 10); however, the decreased suspended-sediment loads were not sufficient to cause a statistically significant downward trend in suspended-sediment concentrations.

\section{WATER-QUALITY MANAGEMENT}

The DNR is the lead agency for regulation of Wisconsin's stream water quality under provisions of the Federal Clean Water Act and State law. The DNR is responsible for water-quality assessment of streams and rivers, for fisheries management, and for development and enforcement of water-quality standards to protect aquatic life and other wild and domestic animals, to permit safe recreational use, and to protect drinking-water supplies. Pursuant to section 305(b) of the Clean Water Act, the DNR prepares a biennial water-qualityassessment report (Wisconsin Department of Natural Resources, 1990) that is submitted to the EPA and the U.S. Congress.

The DNR regulates waste discharges under provisions of the Wisconsin Pollutant Discharge Elimination System permit program (Wisconsin Department of Natural Resources, 1990, p. 69). The Nonpoint Source Pollution Abatement Program, administered by the DNR, was enacted to provide technical assistance and cost sharing for implementation of measures to decrease nonpoint-source pollu-

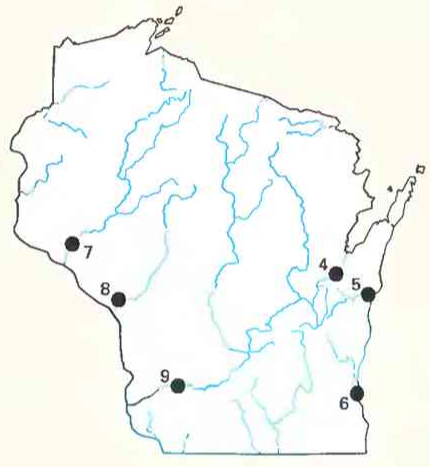

Fecal coliform bacteria, $1980-88$

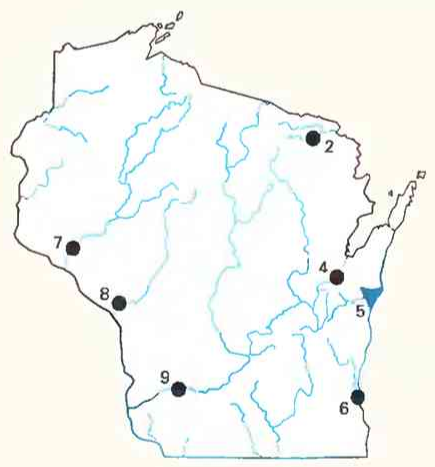

Dissolved solids, $1980-88$

\section{EXPLANATION}

Trend in water-quality constituentNumber is site number in figure 2
$\Lambda^{2}$ Upward
- ${ }^{4}$ None
$\nabla^{5}$ Downward

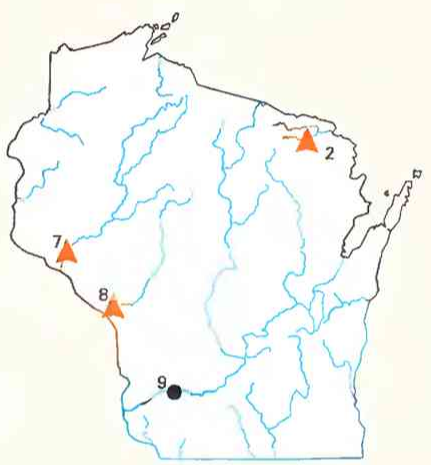

Dissolved sulfate, $1982-88$

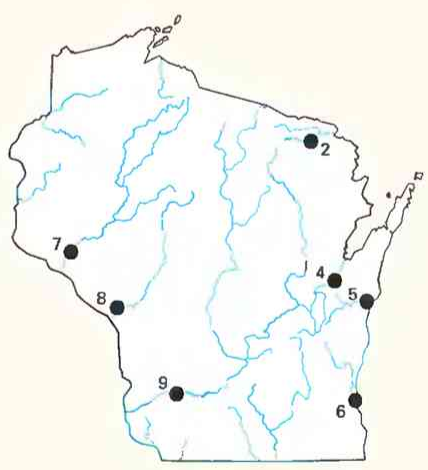

Dissolved nitrite plus nitrate, 1980-88

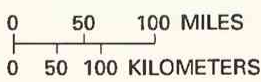

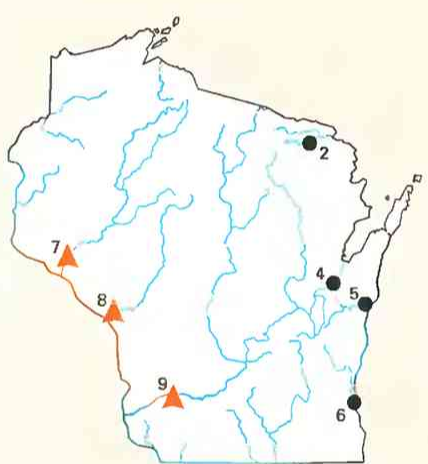

Dissolved chloride, 1980-88

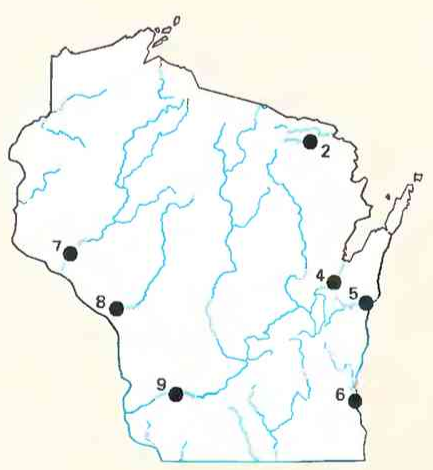

Suspended sediment, 1980-89

Figure 4. Trends in water quality of selected streams in Wisconsin, by water years. (Source: Data from U.S. Geological Survey files.) 
tion in priority watersheds (Wisconsin Department of Natural Resources, 1990 , p. 75). Responsibility for selection of priority watersheds and for planning and implementation of control measures is shared with the Wisconsin Department of Agriculture, Trade, and Consumer Protection.

The DNR regulates hydrologic modifications to stream channels under State law. Also, it reviews and certifies Federal permits for dredging and filling in State waters and for licensing of hydroelectric-power dams by the Federal Energy Regulatory Commission.

\section{SELECTED REFERENCES}

Anderson, J.R., 1967, Major land uses in the United States, in U.S. Geological Survey, 1970, National atlas of the United States of America: Washington, D.C., U.S. Geological Survey, p. 158-159.

Britton, L.J., and Greeson, P.E., eds., 1987, Methods for collection and analysis of aquatic biological and microbiological samples: U.S. Geological Survey Techniques of Water-Resources Investigations, book 5, chap. A4, $363 \mathrm{p}$.

Fenneman, N.M., 1946, Physical divisions of the United States: Washington, D.C., U.S. Geological Survey special map, scale 1:7,000,000.

Fishman, M.J., and Friedman, L.C., eds., 1989, Methods for the determination of inorganic substances in water and fluvial sediments: U.S. Geological Survey Techniques of Water-Resources Investigations, book 5 , chap. Al, 545 p.

Hem, J.D., 1985, Study and interpretation of the chemical characteristics of natural water (3d ed.): U.S. Geological Survey Water-Supply Paper 2254, $263 \mathrm{p}$.

Hirsch, R.M., Slack, J.R., and Smith, R.A., 1982, Techniques of trend analysis for monthly water quality data: Water Resources Research, v. 18, no. 1, p. $107-121$.
Kammerer, P.A., Jr., 1984, An overview of ground-water quality data in Wisconsin: U.S. Geological Survey Water-Resources Investigations Report 83-4239, $58 \mathrm{p}$.

Lanfear, K.J., and Alexander, R.B., 1990, Methodology to derive water-quality trends for use by the National Water Summary Program of the U.S. Geological Survey: U.S. Geological Survey Open-File Report 90-359, $10 \mathrm{p}$.

Solley, W.B., Merk, C.F., and Pierce, R.R., 1988, Estimated use of water in the United States in 1985: U.S. Geological Survey Circular 1004, 82 p.

Thelin, G.P., and Pike, R.J., 1990, Digital shaded relief map of the conterminous United States: Menlo Park, Calif., U.S. Geological Survey digital image processing, scale 1:3,500,000.

U.S. Geological Survey, 1986, National water summary 1985-Hydrologic events and surface-water resources: U.S. Geological Survey Water-Supply Paper 2300, $506 \mathrm{p}$.

1990 a, National water summary 1987-Hydrologic events and water supply and use: U.S. Geological Survey Water-Supply Paper 2350, $553 \mathrm{p}$.

1990b, Water resources data-Wisconsin, water year 1989: U.S. Geological Survey Water-Data Report WI-89-1, 436 p.

1991, National water summary 1988-89-Hydrologic events and floods and droughts: U.S. Geological Survey Water-Supply Paper 2375, $591 \mathrm{p}$.

Ward, J.R., and Harr, C.A., eds., 1990, Methods for collection and processing of surface-water and bed-material samples for physical and chemical analyses: U.S. Geological Survey Open-File Report 90-140, 71 p.

Wisconsin Department of Natural Resources, 1989, Wisconsin administrative code, chapter NR 102, water quality standards for Wisconsin surface waters: Madison, Register, February, 1989, no. 398, 14 p.

1990, Wisconsin water quality assessment-Report to Congress, 1990: Madison, Wisconsin Department of Natural Resources PUBL-WR-254 $90,172 \mathrm{p}$. 
Prepared by Phil A. Kammerer, Jr., and William R. Krug

FOR ADDITIONAL INFORMATION: District Chief, U.S. Geological Survey, 6417 Normandy Lane, Madison, WI 53719 


\section{WYOMING Stream Water Quality}

Surface water is the primary source of water supply in Wyoming. Surface-water withdrawals in 1985 averaged 5,700 million gallons per day; about 57 percent of the water was returned to a natural source for further use (U.S. Geological Survey, 1990, p. 540). Of the surface water withdrawn, 94 percent was used for agriculture, primarily for irrigation (U.S. Geological Survey, 1990, p. 539).

The quality of Wyoming's stream water is important to agricultural, municipal, domestic, and industrial users. Land use can substantially affect stream water quality. The primary land use in Wyoming's grassland, desert shrubland, woodlands, and forests is grazing (fig. 1A). Most irrigated cropland is along rivers and in irrigation projects throughout the State; dryland crops are grown principally in the east. Most of the streams that supply water for agriculture and other uses originate in the Middle and Southern Rocky Mountains (fig. $1 B$ ). Streams that originate in the mountains generally are perennial; streams that originate in the plains and basins generally are intermittent or ephemeral (U.S. Geological Survey, 1986, p. 493-498).
Most of Wyoming's population resides in cities and towns (fig. $1 C$ ). The State's 1990 population was about 453,600 (U.S. Bureau of the Census 1990 decennial census files), a 36-percent increase from the 1970 population but a 3.4-percent decrease since 1980 .

\section{WATER-QUALITY MONITORING}

Water-quality data obtained from analyses of water samples collected at monitoring stations in Wyoming are stored in the U.S. Geological Survey's (USGS) National Water Information System and the U.S. Environmental Protection Agency's (EPA) national data base known as STORET. Water-quality and streamflow data are reported by water year-the 12 months from October 1 through September 30. A water year is identified by the calendar year in which it ends. For example, water year 1991 comprises October 1, 1990, through September 30, 1991

The data used in this summary of Wyoming's stream water quality were obtained from water samples collected monthly, every

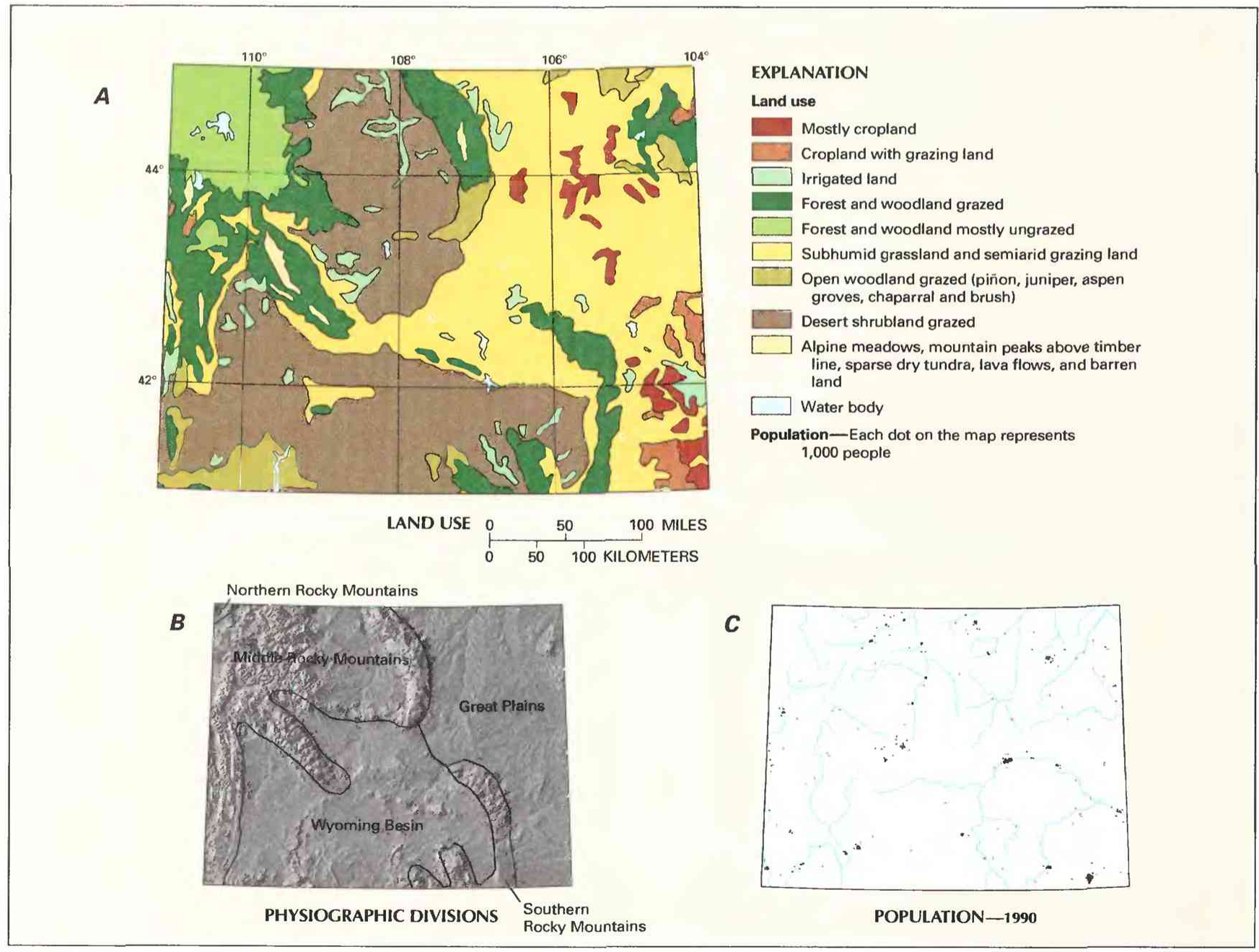

Figure 1. Land use, physiography, and population in Wyoming. A, Major land uses. B. Physiographic divisions. $C$, Population distribution in 1990. (Sources: A, Major land uses modified from Anderson, 1967. B, Physiographic divisions from Fenneman, 1946; landforms from Thelin and Pike, 1990. C, Data from U.S. Bureau of the Census 1990 decennial census files.) 
2 months, or quarterly at 19 monitoring stations at which data collection is systematic and continuing (fig. 2). Water samples are collected to analyze for many constituents, such as major dissolved ions, nutrients, trace elements, suspended sediment, radiochemicals, and herbicides. Analyses of water samples collected at 9 stations are the basis for the discussion and graphic summary (fig. 3) of stream waterquality conditions during water years $1987-89$, and data from all 19 stations are the basis for the discussion and graphic summary (fig. 4) of stream water-quality trends. Water samples were collected and analyzed by using standard methods approved by the USGS (Britton and Greeson, 1987; Fishman and Friedman, 1989; Ward and Harr, 1990 ) or by using equivalent methods. If a method of sample collection or analysis changed over time, data from an analysis were included in the evaluation of recent stream water quality or of stream water-quality trends only if the change in method did not affect the comparability of the data.

\section{WATER-QUALITY CONDITIONS}

Surface-water-quality concerns in Wyoming include salinity, nutrients, suspended sediment, and pesticides. Emphasis is placed on monitoring and abatement of nonpoint-source pollution, such as that from natural runoff and agriculture. Wyoming currently is preparing a nonpoint-source management plan, as mandated by the Section 319 Program of the EPA. Two other surface-water-quality issues of concern are acid precipitation in high-mountain areas (Wyoming

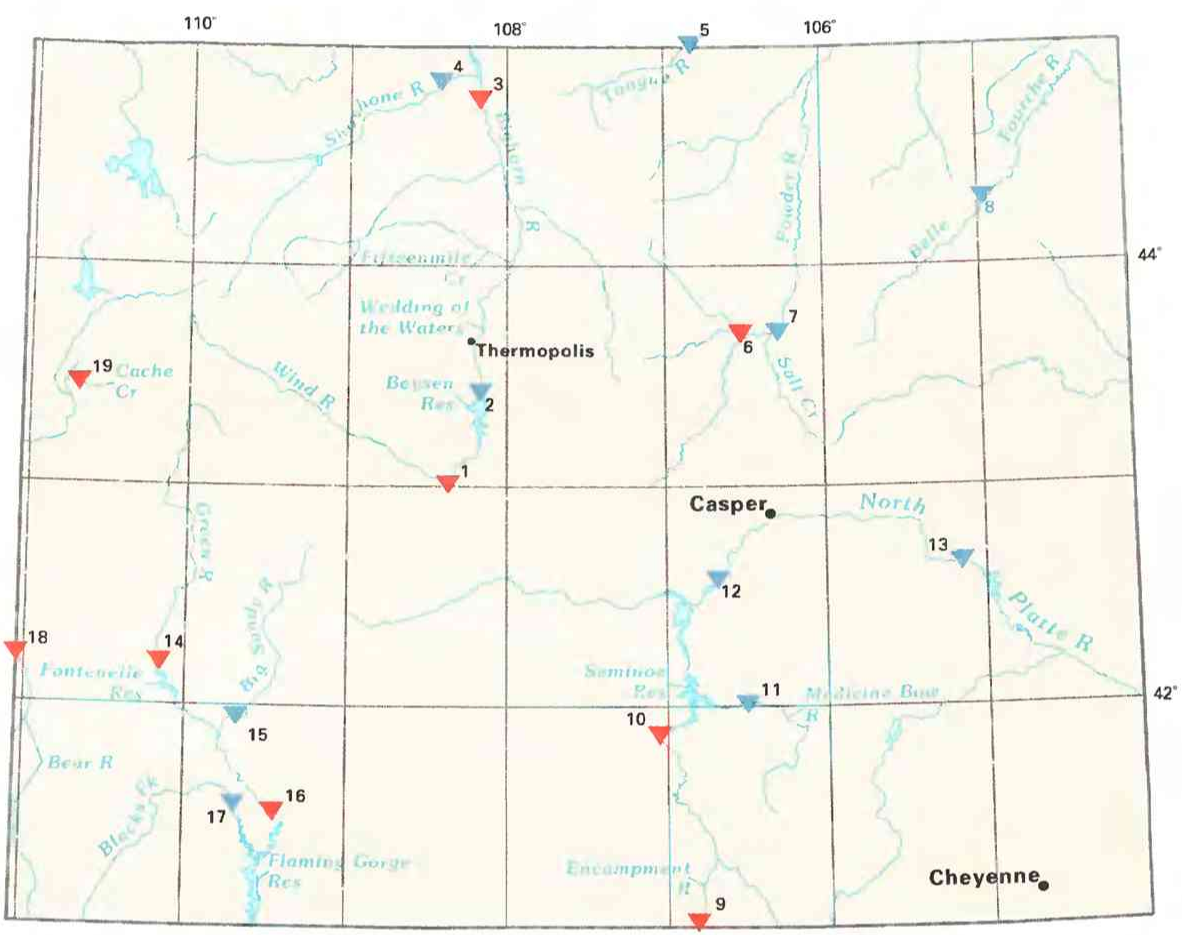

\section{EXPLANATION}

Water-quality monitoring station and type of statistical analysisNumber refers to accompanying table

$\nabla^{4}$ Water-quality trends (see fig. 4)

$\nabla^{16}$ Water-quality conditions and trends (see figs. 3 and 4)

\begin{tabular}{|c|c|c|c|}
\hline $\begin{array}{l}\text { Site no. } \\
\text { on map }\end{array}$ & $\begin{array}{l}\text { USGS station } \\
\text { name and no. }\end{array}$ & $\begin{array}{l}\text { Drainage area } \\
\text { (square miles) }\end{array}$ & $\begin{array}{l}\text { Major land use } \\
\text { (see fig. 1) }\end{array}$ \\
\hline 1 & 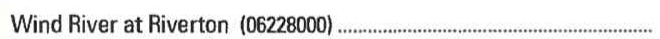 & 2,309 & Grazed forest and woodland; irrigated land. \\
\hline 2 & 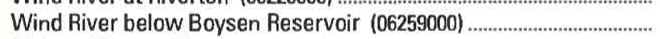 & 7,701 & Grazed desert shrubland; grazed forest and woodland. \\
\hline 3 & Bighorn River at Kane $(06279500)$ & 15,765 & Grazed desert shrubland; irrigated land. \\
\hline 4 & Shoshone River near Lovell $(06285100)$ & 2,350 & $\begin{array}{l}\text { Grazed desert shrubland; mostly ungrazed forest and woodland; } \\
\text { irrigated land. }\end{array}$ \\
\hline 5 & Tongue River at State line, near Decker, Mont. (06306300) .................. & 1,477 & Grazed forest and woodland; irrigated land. \\
\hline 6 & Powder River near Kaycee (06312500) & 980 & Subhumid grassland and semiarid grazing land. \\
\hline 7 & Powder River at Sussex (06313500) & 3,090 & Ditto. \\
\hline 8 & Belle Fourche River below Moorcroft $(06426500)$ & 1,670 & Ditto. \\
\hline 9 & $\begin{array}{l}\text { Encampment River above Hog Park Creek, near Encampment } \\
(06623800)\end{array}$ & 73 & Grazed forest and woodland. \\
\hline 10 & $\begin{array}{l}\text { North Platte River above Seminoe Reservoir, near Sinclair } \\
(06630000)\end{array}$ & 4,175 & Grazed desert shrubland; grazed forest and woodland. \\
\hline 11 & $\begin{array}{l}\text { Medicine Bow River above Seminoe Reservoir, near Hanna } \\
(06635000)\end{array}$ & 2,338 & $\begin{array}{l}\text { Grazed desert shrubland; subhumid grassland and semiarid grazing } \\
\text { land. }\end{array}$ \\
\hline 12 & North Platte River at Alcova $(06642000)$ & 10,812 & Ditto. \\
\hline 13 & North Platte River at Orin $(06652000)$ & 14,888 & $\begin{array}{l}\text { Subhumid grassland and semiarid grazing land; grazed desert } \\
\text { shrubland. }\end{array}$ \\
\hline 14 & Green River near Labarge $(09209400)$ & 3,910 & Grazed desert shrubland; irrigated land. \\
\hline 15 & Big Sandy River at Gasson Bridge, near Eden (09216050) ................... & 1,720 & Ditto. \\
\hline 16 & Green River near Green River (09217000) & 14,000 & Grazed desert shrubland. \\
\hline 17 & Blacks Fork near Little America (09224700) & 3,100 & Ditto. \\
\hline 18 & Bear River at Border $(10039500)$ & 2,486 & Grazed forest and woodland; irrigated land. \\
\hline 19 & Cache Creek near Jackson $(13018300)$ & 11 & Mostly ungrazed forest and woodland. \\
\hline
\end{tabular}

Figure 2. Selected water-quality monitoring stations, type of statistical analysis, and geographic features in Wyoming. (Sources: Major land uses modified from Anderson, 1967; other data from U.S. Geological Survey files.) 
Department of Environmental Quality, 1987) and selenium in irrigation drainage (Peterson and others, 1988).

About 82 percent of Wyoming's 19,437 stream miles fully support beneficial uses designated by the State for purposes of waterquality monitoring and protection (Wyoming Department of Environmental Quality, 1988). Streams in and near the mountains have small concentrations of dissolved constituents, but concentrations increase as the streams flow across the plains and basins. Concentration increases are the result of natural processes and of water use and reuse for irrigation, industrial, and municipal supply.

The following discussion of stream water quality in Wyoming is organized by river basin (fig. 3). Where physiographic and landuse characteristics in different basins are similar, the discussion of those basins is combined. Graphs in figure 3 summarize certain aspects of stream water quality in the basins for water years 1987-89. The graphs show frequency distributions of data values that represent measurements of selected physical properties of stream water and concentrations of selected constituents in stream water. These properties and constituents are specific conductance, fecal coliform bacteria, dissolved sulfate, dissolved solids, dissolved nitrite plus nitrate (as nitrogen), total phosphorus (as phosphorus), and suspended sediment. The data are reported in microsiemens per centimeter at 25 degrees Celsius $(\mu \mathrm{S} / \mathrm{cm})$, colonies per 100 milliliters $(\mathrm{col} / 100 \mathrm{~mL})$, and milligrams per liter (mg/L). Sources and environmental significance of each property and constituent are described in table 1.

Water quality at each monitoring station is the result of geological, chemical, biological, and hydrologic processes that occur over a large area. Water-quality problems that affect aquatic life or public health only locally are not fully represented in this summary.

\section{WIND AND BIGHORN RIVERS}

The Wind and Bighorn Rivers are the same river; the name changes from Wind River to Bighorn River at the Wedding of the Waters near Thermopolis. The river only partially supports potential water uses because of impairment by large dissolved-solids and suspended-sediment concentrations (Wyoming Department of Environmental Quality, 1991, p. 42-48).

Concentrations of fecal coliform bacteria in the rivers were among the largest at the eight monitoring stations from which data were sufficient for frequency analysis (fig. 3). Median bacteria concentrations were $42 \mathrm{col} / 100 \mathrm{~mL}$ at site 1 and $77 \mathrm{col} / 100 \mathrm{~mL}$ at site 3 .
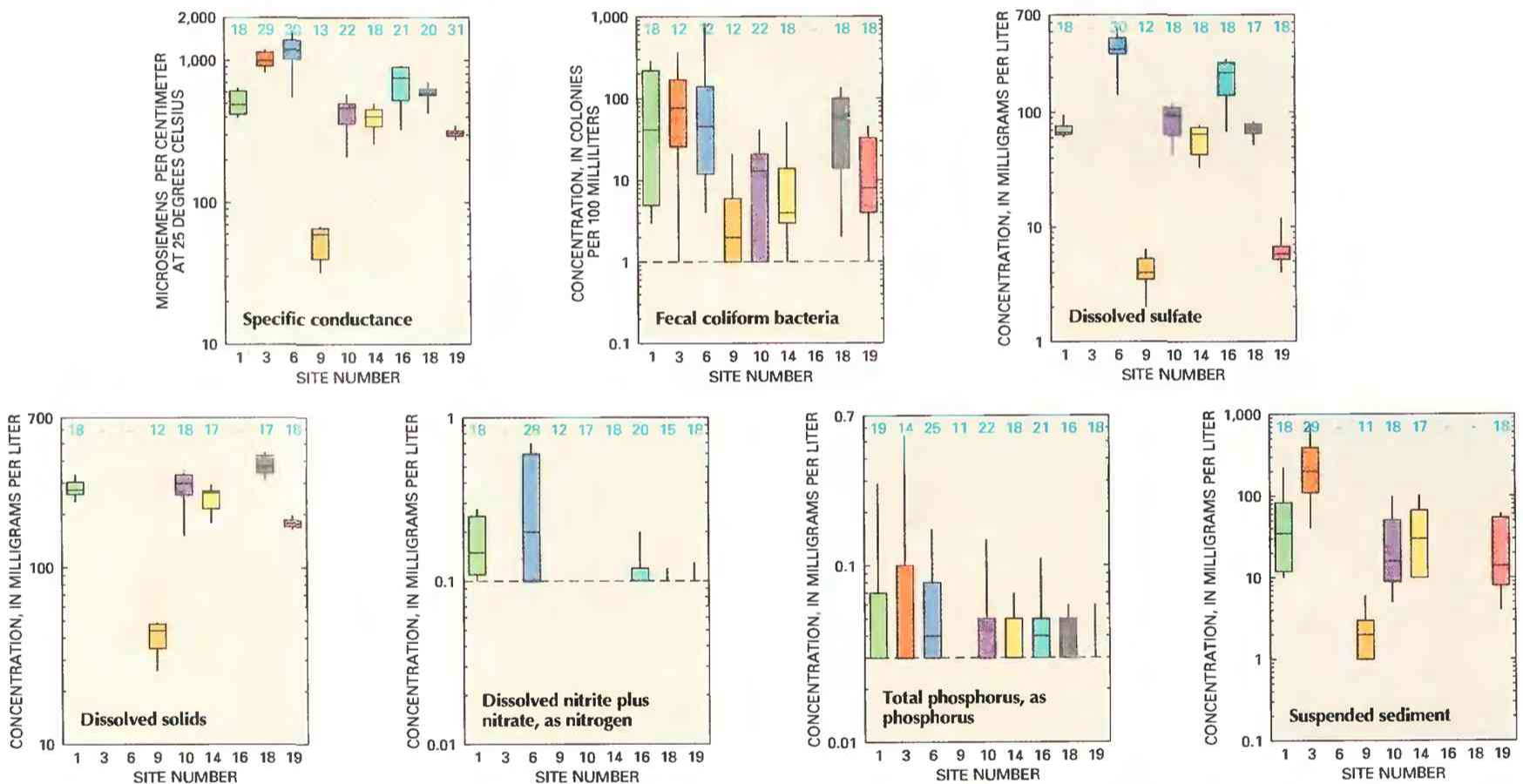

\section{EXPLANATION}

Water-quality conditions in selected drainage basins

Number of analyses-Dash indicates insufficient data

Percentile-Percentage of analyses equal to or less than indicated values

-90th

-75 th

- 50th-Median

-25th

-10th

- - Reporting limit-Minimum reporting limit for analytical method used. Data below limit line not shown
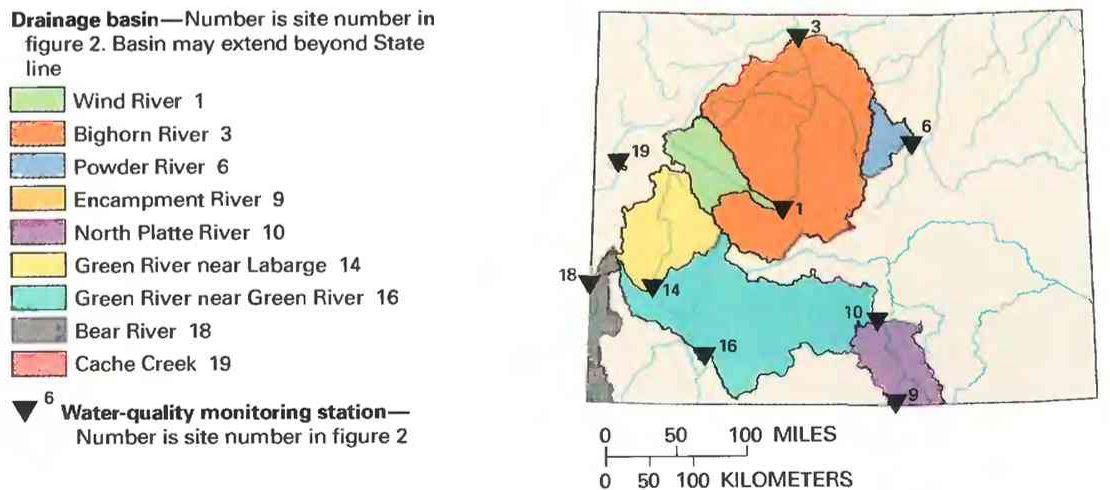

Figure 3. Water quality of selected streams in Wyoming, water years 1987-89. (Source: Data from U.S. Geological Survey files.) 
Table 1. Sources and environmental significance of selected water-quality properties and constituents [Source: Compiled by the U.S. Geological Survey, Office of Water Quality]

\begin{tabular}{|c|c|c|}
\hline Property or constituent & Common sources & Environmental significance \\
\hline 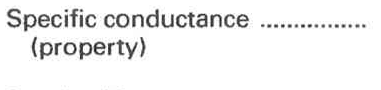 & $\begin{array}{l}\text { A measure of the electrical conductivity of water; var- } \\
\text { ies with the quantity of dissolved solids and is } \\
\text { used to approximate the dissolved-solids content. }\end{array}$ & $\begin{array}{l}\text { Dissolved solids can cause water to be unsuitable for } \\
\text { public supply, agriculture, and industry; can harm } \\
\text { aquatic organisms. }\end{array}$ \\
\hline Fecal coliform bacteria ............... & $\begin{array}{l}\text { Sources include effluent from sewage-treatment } \\
\text { plants and runoff from pastures, feedlots, and ur- } \\
\text { ban areas. }\end{array}$ & $\begin{array}{l}\text { Presence indicates contamination of water by wastes } \\
\text { from humans and other warm-blooded animals. }\end{array}$ \\
\hline Sulfate & $\begin{array}{l}\text { Occurs in some rocks; also in mine runoff, industrial } \\
\text { wastewater discharge, and atmospheric deposi- } \\
\text { tion. }\end{array}$ & $\begin{array}{l}\text { Concentrations exceeding a natural, background } \\
\text { level indicate contamination from human activity; } \\
\text { in sufficient quantity, can cause water to be } \\
\text { unsuitable for public supply; can harm aquatic } \\
\text { organisms. }\end{array}$ \\
\hline 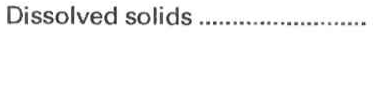 & $\begin{array}{l}\text { A result of rock weathering; also in agricultural runoff } \\
\text { and industrial discharge. }\end{array}$ & $\begin{array}{l}\text { In sufficient quantity, can cause water to be unsuitable } \\
\text { for public supply, agriculture, and industry: can } \\
\text { harm aquatic organisms. }\end{array}$ \\
\hline 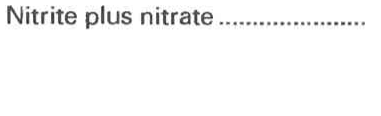 & $\begin{array}{l}\text { Nonpoint sources are agricultural and urban runoff; } \\
\text { a major point source is wastewater discharge. }\end{array}$ & $\begin{array}{l}\text { Plant nutrient that, in sufficient quantity, can cause } \\
\text { algal blooms and excessive growth of higher } \\
\text { aquatic plants in bodies of water; can cause water } \\
\text { to be unsuitable for public supply. }\end{array}$ \\
\hline 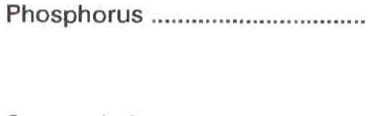 & $\begin{array}{l}\text { Occurs in some rocks and sediments; also in runoff } \\
\text { and seepage from phosphate-rock mines, agri- } \\
\text { cultural and urban runoff, and industrial and } \\
\text { municipal wastewater discharge. }\end{array}$ & $\begin{array}{l}\text { Plant nutrient that, in sufficient quantity, can cause } \\
\text { algal blooms and excessive growth of higher } \\
\text { aquatic plants in bodies of water. }\end{array}$ \\
\hline Suspended sediment .................. & $\begin{array}{l}\text { A result of rock erosion; also induced by disturbances } \\
\text { of land cover due to fires, floods, and human } \\
\text { activities such as mining, logging, construction, } \\
\text { and agriculture. }\end{array}$ & $\begin{array}{l}\text { Can be detrimental to aquatic organisms; can fill res- } \\
\text { ervoirs and impair recreational use of water. }\end{array}$ \\
\hline
\end{tabular}

The bacteria were contributed by human and livestock sources along the Wind and Bighorn Rivers and their tributaries.

In water samples collected during 1987-89, concentrations of dissolved solids increased in the downstream direction as indicated by median specific-conductance values of $490 \mu \mathrm{S} / \mathrm{cm}$ at site 1 and $1,000 \mu \mathrm{S} / \mathrm{cm}$ at site 3 . The increase in dissolved-solids concentration is caused by discharge from oil and gas development, runoff from irrigated land, and natural sources such as hot, mineralized springs and runoff from areas of outcrop that contain salt-bearing formations.

Suspended sediment is contributed to streams by natural erosion, runoff from irrigated cropland, livestock grazing in riparian zones and rangeland, road construction, and urban runoff. Sediment availability and transport are determined by a combination of soil and climatic factors. Soil in the drainage basin of Fifteenmile Creek, for example, is derived primarily from highly erodible rock formations. Suspended-sediment concentrations in water samples from the Wind and Bighorn Rivers also increased in the downstream direction, from a median concentration of $35 \mathrm{mg} / \mathrm{L}$ at site 1 to $200 \mathrm{mg} / \mathrm{L}$ at site 3 .

\section{POWDER RIVER}

The median specific-conductance value $(1,190 \mu \mathrm{S} / \mathrm{cm})$ and median sulfate concentration $(350 \mathrm{mg} / \mathrm{L})$ in water samples from the Powder River at site 6 were the largest for the nine monitoring stations (fig. 3). Much of the specific conductance and sulfate is contributed by runoff from areas of outcrop that contain salt-bearing formations. Farther downstream from site 6, dissolved-solids concentrations in the Powder River result in only partial support of potential water uses; about 25 to 30 percent of the dissolved solids in the Powder River at site 7 are contributed by Salt Creek, a tributary that joins the Powder River between sites 6 and 7 (Wyoming Department of Environmental Quality. 1988, p. 54-58). The large dissolved-solids concentration in Salt Creek is caused in part by oil and gas development.

Agricultural activities and sewage effluent also affect waterquality conditions in the Powder River. The median fecal coliform bacteria concentration was $46 \mathrm{col} / 100 \mathrm{~mL}$, third largest for the monitoring stations. Nitrite plus nitrate concentrations were larger in the

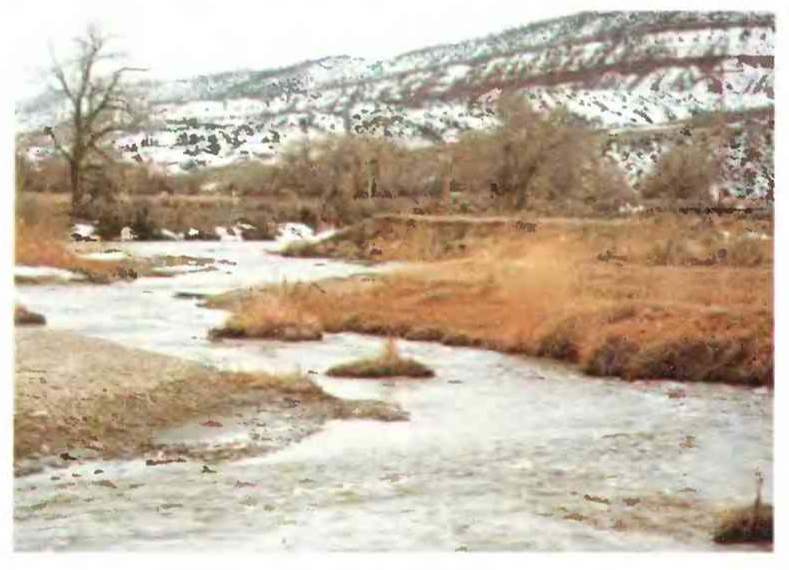

Poison Spider Creek at confluence with North Platte River. Irrigation drainage is a major source of the large selenium concentration of the creek. (David A. Peterson, U.S. Geological Survey.)

Powder River at site 6 than at any of the other monitoring stations: however, the maximum concentration was less than $1.0 \mathrm{mg} / \mathrm{L}$.

\section{ENCAMPMENT AND NORTH PLATTE RIVERS}

The Encampment River is a typical mountain stream draining a basin in which the rocks that crop out are predominantly insoluble. The relative insolubility of these rocks is reflected in the small concentrations of sulfate (median, $4.0 \mathrm{mg} / \mathrm{L}$ ), dissolved solids (median, $44 \mathrm{mg} / \mathrm{L}$ ), and suspended sediment (median, $2 \mathrm{mg} / \mathrm{L}$ ) at site 9 (fig. 3). Farther downstream, at site 10 on the main stem of the North Platte River, concentrations of sulfate (median, $93 \mathrm{mg} / \mathrm{L}$ ), dissolved solids (median, $298 \mathrm{mg} / \mathrm{L}$ ), and suspended sediment (median, 16 $\mathrm{mg} / \mathrm{L}$ ) were several times larger.

Blooms of blue-green algae and associated depletion of dissolved oxygen in Seminoe Reservoir, downstream from site 10, have been of concern (Kuhn and others, 1983, p. 60-61). For prevention and control of nuisance algae, the EPA (1986) recommends that total 
phosphate as phosphorus concentrations not exceed $0.05 \mathrm{mg} / \mathrm{L}$. Seventy-five percent of the total-phosphorus concentrations in water from site 10 were equal to or less than $0.05 \mathrm{mg} / \mathrm{L}$.

\section{GREEN RIVER}

The Green River is affected by extensive areas of irrigation along the main stem upstream from site 14, in the Big Sandy River basin, and the Blacks Fork basin. The primary sources of the dissolved solids in the Green River are irrigation return flows and natural ground-water discharge (Wyoming Department of Environmental Quality, 1988, p. 33). Seeps along the Big Sandy River contribute 88 percent of the dissolved-solids load gained in the Green River between Fontenelle Reservoir and Flaming Gorge Reservoir (DeLong, 1977, p. 25). The seeps flow from formations that contain large quantities of sodium and sulfate. As evidence of the downstream increase in dissolved solids, the median specific conductance of the Green River during 1987-89 was $405 \mu \mathrm{S} / \mathrm{cm}$ at site 14 and 755 $\mu \mathrm{S} / \mathrm{cm}$ at site 16 : the median concentration of sulfate was $65 \mathrm{mg} / \mathrm{L}$ at site 14 and $220 \mathrm{mg} / \mathrm{L}$ at site 16 .

Widespread blue-green algae blooms in the upper reaches of Flaming Gorge Reservoir, downstream from site 16, have been noted by Lowham and others (1985, p. 52-53). However, 75 percent of the total-phosphorus concentrations in the Green River at site 14 and site 16 were equal to or less than the $0.05 \mathrm{mg} / \mathrm{L}$ maximum recommended concentration of total phosphate as phosphorus for streams entering lakes and reservoirs established to prevent and control nuisance algal blooms (U.S. Environmental Protection Agency, 1986).

\section{BEAR RIVER}

The water quality of the Bear River is affected by human and livestock wastes, as indicated by the median concentration of fecal coliform bacteria of $60 \mathrm{col} / 100 \mathrm{~mL}$ at site 18 (fig. 3). However, concentrations of nutrients that generally are associated with fecal waste, such as nitrate and phosphorus, were small.

\section{CACHE CREEK}

Cache Creek is a small mountain stream that has a drainage area of 11 square miles upstream from site 19. That part of the basin is mostly undeveloped. Farther downstream, sediment from land development. urban runoff, and streambank modification and destabilization have degraded the water quality of Cache Creek (Wyoming Department of Environmental Quality, 1991, p. 177).

During water years $1987-89$, the median suspended-sediment concentration in water from site 19 was $14 \mathrm{mg} / \mathrm{L}$, much larger than the median concentration of $2 \mathrm{mg} / \mathrm{L}$ in water from site 9 on the Encampment River, also a mountain stream. Specific conductance and concentrations of fecal coliform bacteria, sulfate, and dissolved solids also were larger at site 19 than at site 9 (fig. 3). The geology of the two basins is a factor in the differing concentrations. The basin upstream from site 9 is underlain predominantly by insoluble rocks. whereas the Cache Creek basin includes more soluble conglomerate, shale, sandstone, and limestone (Love and Christiansen, 1985).

\section{WATER-QUALITY TRENDS}

Trend analysis is a statistical procedure used to detect changes in stream water quality at a monitoring station over time. For this report, water-quality data from 19 monitoring stations (fig. 2) were analyzed for trends by using the seasonal Kendall test (Hirsch and others, 1982), a method used extensively by the USGS. The graph (above right) of the dissolved-sulfate concentration in the Powder River at site 6 illustrates the trend inferred from the concentration data and demonstrates the variation in water quality that is common in streams.

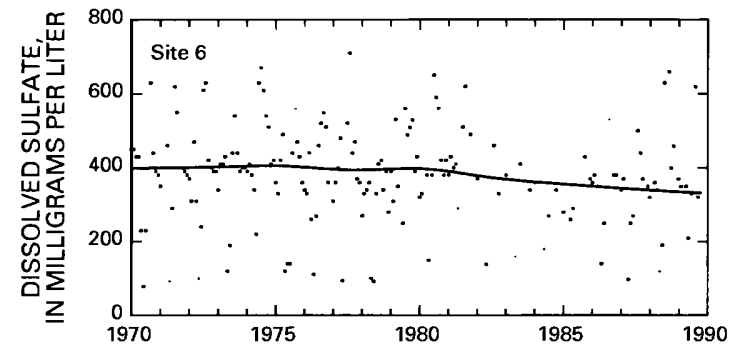

When possible, constituent-concentration data were adjusted for changes in streamflow to preclude identifying a trend in concentration that was caused only by a trend in streamflow. The data were not adjusted when (1) more than 10 percent of the samples had concentrations lower than the minimum reporting limit for the analytical method used or (2) streamflow was controlled substantially by human activities. When the concentration data could not be adjusted for streamflow, trends were determined directly from the concentration data. Most of the rivers in Wyoming are affected by dams or diversions. At three sites (sites 2, 12, and 16) the streamflow is controlled substantially by a dam upstream; therefore, the trends were determined directly from the concentration data.

Statewide trends in measurements of selected physical properties of stream water and in concentrations of selected constituents in stream water are shown on maps in figure 4. On each map, a trend is indicated at a monitoring station only if the data from that station were suitable for use in the trend analysis. For more information on the suitability criteria and on the trend-analysis procedure used for this report, see Lanfear and Alexander (1990).

\section{SPECIFIC CONDUCTANCE}

Specific conductance is a measure of the ability of a sample of water to conduct electricity. Because specific conductance and the dissolved-solids concentration are roughly proportional in most natural waters, the specific-conductance value often can be used to estimate the dissolved-solids concentration (Hem, 1985, p. 66-68).

Specific conductance had upward trends in the North Platte River at site 13 and in the Bear River at site 18 and a downward trend in the Tongue River at site 5. No definite causes are known for the trends.

\section{FECAL COLIFORM BACTERIA}

Fecal coliform bacteria are used as indicators of fecal contamination from humans and other warm-blooded animals. Such contamination can introduce disease-causing viruses and bacteria into a stream.

Upward trends in fecal coliform bacteria concentrations were detected at two sites in or near wilderness areas, site 9 on the Encampment River and site 19 on Cache Creek. Upward trends at these two stations are of particular interest because both are USGS Hydrologic Bench-Mark Network stations. Bench-mark stations have been selected in small drainage basins around the Nation to provide data from representative undeveloped watersheds. The upward trend in concentrations of fecal coliform bacteria in the Encampment River indicates a change in livestock-grazing practices (Charles Marsh, U.S. Forest Service, oral commun., September 1990). The upward trend in concentrations of fecal coliform bacteria in Cache Creek most likely was a result of greater use of the area by humans and wildlife (Gene H. Smalley, U.S. Forest Service, oral commun., September 1990). For unknown reasons, concentrations at site 10 on the North Platte River downstream from the Encampment River had a downward trend. 


\section{DISSOLVED SULFATE}

The major natural sources of sulfate in streams are rock weathering, volcanoes, and biochemical processes (Hem, 1985, p. 113). Human activities such as mining, waste discharge, and fossil-fuel combustion also can be important sources. A cause for the upward trend in sulfate concentrations in the Bear River at site 18 and the downward trends in the Wind, Shoshone, Powder, and North Platte Rivers at sites $1,4,6$, and 10 , respectively, is not known.

\section{DISSOLVED SOLIDS}

Dissolved solids in stream water result primarily from rock weathering but also can be introduced as a byproduct of human activities (table 1). Concentrations generally are greatest in streams draining basins underlain by rocks and soils that contain easily dissolved minerals.
Dissolved-solids concentrations had no significant trends during water years $1980-89$ at five monitoring stations for which data were sufficient for trend analysis (fig. 4). Liebermann and others (1989, p. 35-38) indicated no trend in dissolved-solids concentration in the Green River at site 14 for $1964-81$ or at site 16 for 1964 83, after completion of Fontenelle Reservoir upstream. However, an increase in a flow-adjusted dissolved-solids concentration of 3.1 $\mathrm{mg} / \mathrm{L}$ per year was recorded for Blacks Fork at site 17 for 1955-83 (Liebermann and others, 1989, p. 36-39). For the Bear River at site 18 , the apparent discrepancy between the upward trend in specific conductance and the absence of a trend in dissolved-solids concentrations was the result of different trend-analysis periods.

\section{DISSOLVED NITRITE PLUS NITRATE}

Nitrite and nitrate are oxidized forms of nitrogen that together constitute most of the dissolved nitrogen in well-aerated streams. Ni-

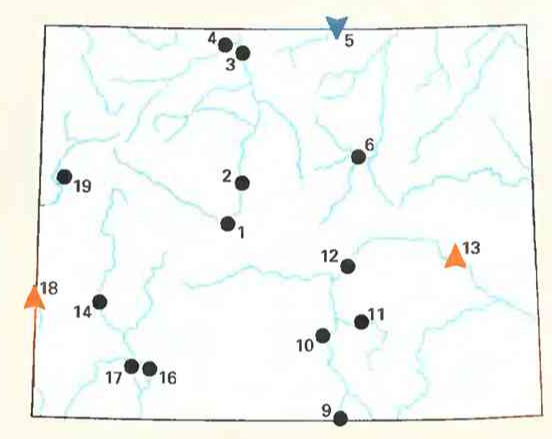

Specific conductance, $1970-89$

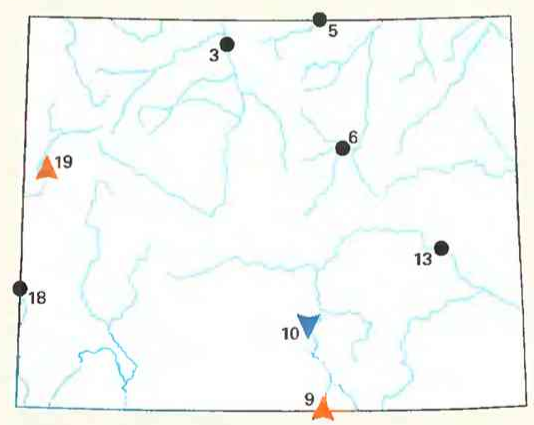

Fecal coliform bacteria, 1975-89

\section{EXPLANATION}

Trend in water-quality property or constituent-Number is site number in figure 2

$$
\begin{aligned}
& A^{1} \text { Upward } \\
& { }^{4} \text { None } \\
& \nabla^{5} \text { Downward }
\end{aligned}
$$

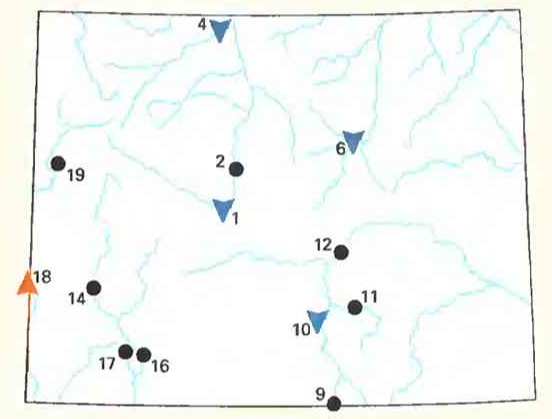

Dissolved sulfate, 1970-89

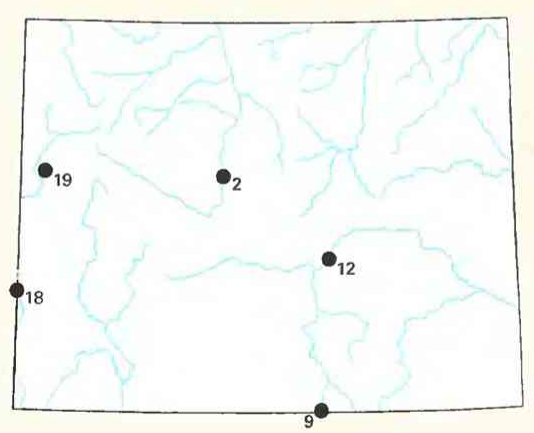

Dissolved solids, 1980-89

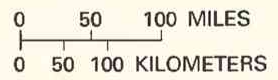

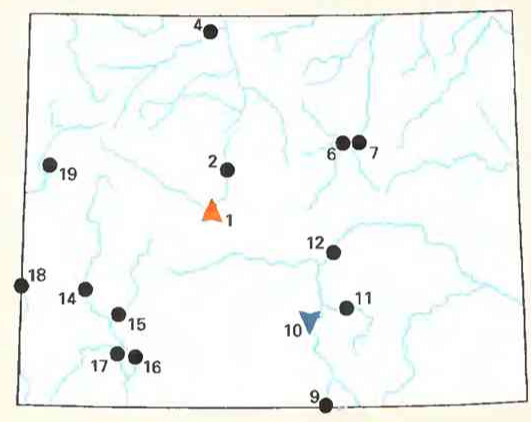

Dissolved nitrite plus nitrate, $1980-89$

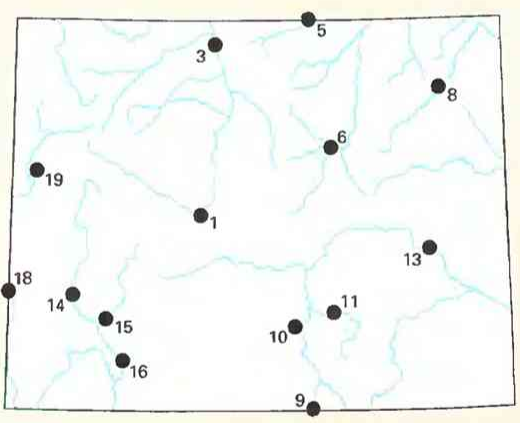

Total phosphorus, 1975-89

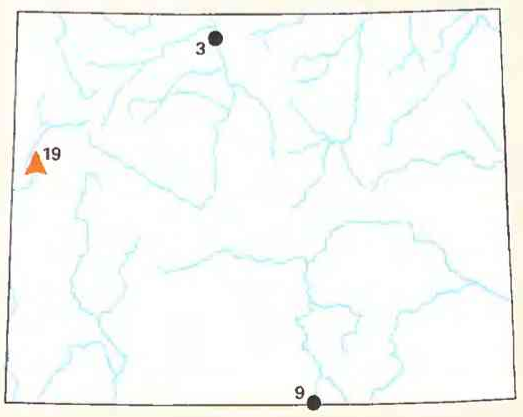

Suspended sediment, 1970-89

Figure 4. Trends in water quality of selected streams in Wyoming, by water years. (Source: Data from U.S. Geological Survey files.) 
trite readily oxidizes to nitrate in natural waters; therefore, nitrate generally is by far the more abundant of the two (Hem, 1985, p. 124).

There was an upward trend in nitrite plus nitrate concentrations at site 1 in the upstream part of the Wind River drainage basin, but there were no trends at sites 2 and 4 in the downstream part of the basin. A downward trend in dissolved nitrite plus nitrate concentrations was detected at site 10 in the upstream part of the North Platte River basin, but there was no trend farther downstream at site 12 . No definite causes for the trends are known.

\section{TOTAL PHOSPHORUS}

The total phosphorus concentration of a water sample is a measure of the concentration of all forms of phosphorus present in the sample, dissolved and particulate. Human activities (table 1) can be important sources of phosphorus in streams. An absence of upward or downward trends in phosphorus concentrations in Wyoming indicates that contributions of phosphorus to streams have remained stable or that changes in the various sources have balanced each other.

\section{SUSPENDED SEDIMENT}

Suspended sediment is a product of erosion. The erosion can be either natural or the result of land-cover disturbances related to human activities (table 1). Landslides in the Cache Creek basin during the later years of the trend-analysis period (water years 1970-89) (Gene H. Smalley, U.S. Forest Service, oral commun., September 1990) could have caused the upward trend in suspended-sediment concentrations at site 19.

\section{WATER-QUALITY MANAGEMENT}

The Wyoming Department of Environmental Quality (WDEQ) administers regulations pertaining to surface-water quality, including issuance of National Pollutant Discharge Elimination System permits and wastewater-treatment-plant licenses. Four classes of streams, ranging from Class I (best) to Class IV (worst), have been designated on the basis of criteria that include water quality, esthetics, recreation, and potential to support game and nongame fish; numeric standards for the protection of aquatic life and human health also apply to surface waters (Wyoming Department of Environmental Quality, 1990). The EPA has retained primacy for drinking-water regulations in Wyoming.

Wyoming is a member of the Colorado River Basin Salinity Control Forum and has adopted the Forum's salinity-control program (Wyoming Department of Environmental Quality, 1982). Dissolvedsolids concentrations in the Green River basin are closely monitored because the Green River is one of the major headwater streams in the Colorado River basin. The salinity-control program includes numerical standards for concentrations of dissolved solids in the Colorado River downstream from its confluence with the Green River.

Water-quality monitoring in Wyoming has increased since the early 1970 's in response to concerns about the effects of development of oil, gas, coal, uranium, and trona resources in the State. The USGS currently (1991) monitors water quality at 106 sites in Wyoming. Thirty-four of the sites are sampled in cooperation with the WDEQ in support of both point-source and nonpoint-source pollutionmonitoring programs. The monitoring network also provides data used by the WDEQ in preparation of a biennial water-quality report submitted to the EPA and the U.S. Congress (Wyoming Department of Environmental Quality, 1988, 1991) in accordance with section 305(b) of the Federal Clean Water Act. Other principal cooperators in the monitoring network are the Wyoming Department of Agriculture and the Shoshone and Arapaho Indian Tribes.

\section{SELECTED REFERENCES}

Anderson, J.R., 1967, Major land uses in the United States, in U.S. Geological Survey, 1970, National atlas of the United States of America: Washington, D.C., U.S. Geological Survey, p. 158-159.

Britton, L.J., and Greeson, P.E., eds., 1987, Methods for collection and analysis of aquatic biological and microbiological samples: U.S. Geological Survey Techniques of Water-Resources Investigations, book 5, chap. A4, $363 \mathrm{p}$.

DeLong, L.L., 1977, An analysis of salinity in streams of the Green River basin, Wyoming: U.S. Geological Survey Water-Resources Investigations Report 77-103, 32 p.

Fenneman, N.M., 1946, Physical divisions of the United States: Washington, D.C., U.S. Geological Survey special map, scale 1:7,000,000.

Fishman, M.J., and Friedman, L.C., eds., 1989, Methods for the determination of inorganic substances in water and fluvial sediments: U.S. Geological Survey Techniques of Water-Resources Investigations, book 5, chap. A1, $545 \mathrm{p}$,

Hem, J.D., 1985, Study and interpretation of the chemical characteristics of natural water (3d ed.): U.S. Geological Survey Water-Supply Paper 2254, $263 \mathrm{p}$.

Hirsch, R.M., Slack, J.R., and Smith, R.A., 1982, Techniques of trend analysis for monthly water quality data: Water Resources Research, v. 18, no. 1, p. 107-121.

Kuhn, Gerhard, Daddow, P.B., Craig, G.S., Jr., and others, 1983, Hydrology of Area 54, Northern Great Plains and Rocky Mountain Coal Provinces, Colorado and Wyoming: U.S. Geological Survey Water-Resources Investigations, Open-File Report 83-146, 95 p.

Lanfear, K.J., and Alexander, R.B., 1990, Methodology to derive water-quality trends for use by the National Water Summary Program of the U.S. Geological Survey: U.S. Geological Survey Open-File Report 90-359, $10 \mathrm{p}$.

Liebermann, T.D., Mueller, D.K., Kircher, J.E., and Choquette, A.F., 1989, Characteristics and trends of streamflow and dissolved solids in the Upper Colorado River Basin, Arizona, Colorado, New Mexico, Utah, and Wyoming: U.S. Geological Survey Water-Supply Paper 2358, 64 p.

Love, J.D., and Christiansen, A.C., 1985, Geologic map of Wyoming: U.S. Geological Survey map, scale 1:500,000.

Lowham, H.W., Peterson, D.A., Larson, L.R., and others, 1985, Hydrology of Area 52, Rocky Mountain Coal Province, Wyoming, Colorado, Idaho, and Utah: U.S. Geological Survey Water-Resources Investigations, Open-File Report 83-761, $96 \mathrm{p}$.

Peterson, D.A., Jones, W.E., and Morton, A.G., 1988, Reconnaissance investigation of water quality, bottom sediment, and biota associated with irrigation drainage in the Kendrick Reclamation Project Area, Wyoming, 1986-87: U.S. Geological Survey Water-Resources Investigations Report $87-4255,57 \mathrm{p}$.

Thelin, G.P., and Pike, R.J., 1990, Digital shaded relief map of the conterminous United States: Menlo Park, Calif., U.S. Geological Survey digital image processing, scale 1:3,500,000.

U.S. Environmental Protection Agency, 1986, Quality criteria for water 1986: Washington, D.C., EPA 440/5-86-001, unnumbered pages.

U.S. Geological Survey, 1986, National water summary 1985-Hydrologic events and surface-water resources: U.S. Geological Survey Water-Supply Paper $2300,506 \mathrm{p}$.

1990, National water summary 1987-Hydrologic events and water supply and use: U.S. Geological Survey Water-Supply Paper 2350, $553 \mathrm{p}$.

Ward, J.R., and Harr, C.A., eds., 1990, Methods for collection and processing of surface-water and bed-material samples for physical and chemical analyses: U.S. Geological Survey Open-File Report 90-140, 71 p.

Wyoming Department of Environmental Quality, 1982, Water quality rules and regulations, chapter VI-Salinity standards/criteria for the Colorado River basin: Cheyenne, Wyoming Department of Environmental Quality, 2 p.

1987, Acid rain-A report on Wyoming: Cheyenne, Wyoming Department of Environmental Quality, The Governor's Acid Rain Coordinating Committee, $12 \mathrm{p}$.

1988, Wyoming 1988 water quality assessment, 305(b) report: Cheyenne, Wyoming Department of Environmental Quality, $149 \mathrm{p}$. 
576 National Water Summary 1990-91-Stream Water Quality: STATE SUMMARIES

1990, Water quality rules and regulations, chapter I--Quality standards for Wyoming surface waters: Cheyenne, Wyoming Department of Environmental Quality, $87 \mathrm{p}$.
1991, Wyoming draft interim 1990 water quality assessment: Cheyenne, Wyoming Department of Environmental Quality, 212 p.

Prepared by David A. Peterson

FOR ADDITIONAL INFORMATION: District Chief, U.S. Geological Survey, 2617 E. Lincolnway, Suite B, Cheyenne, WY 82001 


\section{Qupplemental Information Glossary
WATER-QUALITY EQUIVALENTS AND CONVERSION FACTORS Hydrologic Unit MAPS

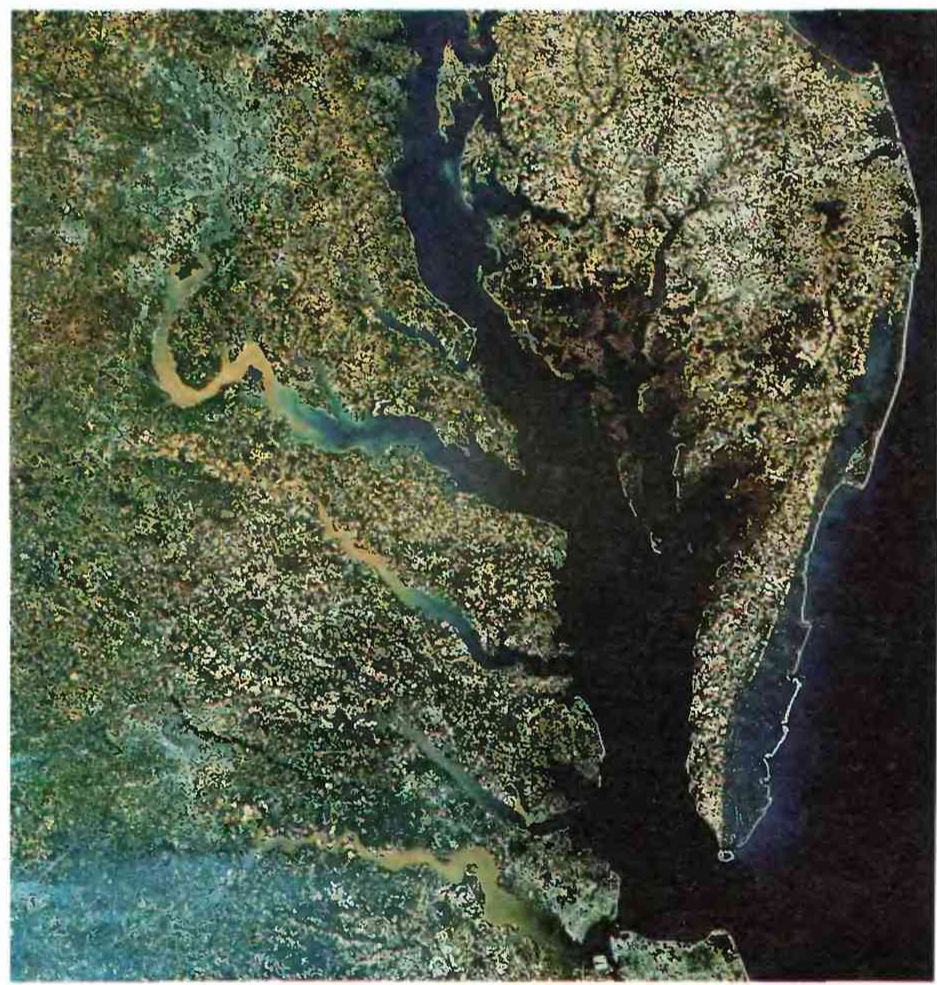

Image composited from Landsat data collected during March and April 1987 showing the Chesapeake Bay, Washington, D.C., and parts of Delaware, Maryland, and Virginia. Sediment discolors the Potomac River, which drains part of the northwestern part of the image and the Rappahannock, York, and James Rivers in Virginia. (Courtesy of the Chesapeake Bay Foundation) 


\section{GLOSSARY}

Accuracy-A degree of agreement of a measured value with the true or accepted value.

Acid rain-See Acidic precipitation.

Acidic-Acid forming; has a pH of less than 7. See also Alkaline; Basic; $\mathrm{pH}$.

Acidic precipitation-The transfer of acidic or acidifying substances from the atmosphere to the surface of the Earth, or to objects on its surface, through either wet or dry atmospheric-deposition processes. Also, precipitation that is acidic.

Acidity-The alkaline-neutralizing capacity of water.

Acre-foot (acre- $\mathrm{ft}$ ) - Volume of water required to cover 1 acre of land (43,560 square feet) to a depth of 1 foot; equivalent to 325,851 gallons.

Aerate-To supply air to water, soil, or other media.

Algal bloom-The rapid proliferation of passively floating, simple plant life, such as blue-green algae, in and on a body of water.

Alkaline-Alkaline forming; has a pH greater than 7. See also Acidic; Basic; pH.

Alkalinity - The acid-neutralizing capacity of water.

Alluvium-General term for clay, silt, sand, gravel, or other particulate rock material deposited by a stream or other running water.

Alpha (statistics) - The probability chosen as a cutoff above which a test result is declared to be indistinguishable from natural variability. It also implies the percentage of tests that can be expected to result in false declaration of trends that are due solely to natural variability.

Alpine meadow-High-mountain, relatively flat land above the timberline that is covered or predominantly covered by grasses.

Anadromous fish-Migratory species, such as salmon, shad, and striped bass, that are born in freshwater, spend most of their lives in estuary and ocean waters, and return to freshwater to spawn.

Anaerobic - The absence or near absence of oxygen.

Anion-A negatively charged ion. See also Cation; Ion.

Aquaculture-Farming of organisms that live in water, such as finfish, shellfish, and algae and other plants.

Aquatic-Relating to water.

Aquifer-A geologic formation, group of formations, or part of a formation that contains sufficient saturated permeable material to yield significant quantities of water to wells and springs.

Arid-A relatively dry climate in which annual precipitation is less than 10 inches, which generally is insufficient for crops to be grown without irrigation.

Atmospheric deposition-The transfer of substances from the atmosphere to the surface of the Earth or to objects on its surface. Transfer can be either by wet-deposition processes (rain, snow, dew, fog, frost, hail) or by dry deposition (gases, aerosols, fine to coarse particles) in the absence of water.

Atoll-A coral reef that is roughly circular in plan view, contains a shallow lagoon, and is surrounded by deep water of the open ocean.

Average-Arithmetic mean, which is the number obtained by dividing the sum of a given set of quantities by the number of quantities in the set.
Backwater-A body of water in which the flow is slowed or turned back by an obstruction such as a bridge or dam, an opposing current, or the movement of the tide.

Bacteria-Microorganisms that, in this volume, are identified as fecal coliform or fecal streptococcal bacteria; fecal enterococcal bacteria are a subgroup of fecal streptococcal bacteria. All these microorganisms are present in the gut or feces of warmblooded animals and, therefore, are indicators of possible contamination. See also Coliform bacteria.

Badlands-Topography characterized by a very fine drainage network on land surfaces having little or no vegetative cover.

Barren land-Rugged and unproductive land that is mostly devoid of vegetation because of such environmental factors as adverse climate, poor soil, or wind.

Basic-The opposite of acidic; has a $\mathrm{pH}$ of more than 7. See also Acidic; Alkaline; $\mathrm{pH}$.

Bed material-Sediment composing the streambed.

Bedload-Sediment that moves on or near the streambed and is in almost continuous contact with the bed, in contrast to sediment in suspension.

Bedrock-General term for consolidated (solid) rock that underlies soils or other unconsolidated material.

Beneficial use-A use of water that results in appreciable gain or benefit to the user, consistent with State law, which varies from one State to another.

Benthic organism-Aquatic plant or animal that lives on the bottom or near the bottom of streams, lakes, or oceans.

Bias (statistics) - A nonrandom distortion of observations, data, or calculations.

Biochemical-oxygen demand (BOD)-The amount of oxygen, measured in milligrams per liter, that is removed from aquatic environments by the life processes of microorganisms.

Biochemical process-A process characterized by, produced by, or involving chemical reactions in living organisms.

Biosphere-All living organisms of the Earth and its atmosphere.

Biota-All living organisms of an area.

Bog-Waterlogged, spongy ground consisting primarily of mosses and decaying vegetation. This type of ground is conducive to the development of peat.

Box plot-A type of graph describing the characteristics of a single group of data. The graph consists of a box showing the median and the middle half of the data, and lines extending from the box showing values outside the middle half of the data.

Brackish water-Water that contains between 1,000 and 10,000 milligrams per liter of dissolved solids. See also Brine; Saline water.

Brine-Water that contains more than 35,000 milligrams per liter of dissolved solids. See also Brackish water; Saline water

Buffered solution-A solution in which the $\mathrm{pH}$ is not 
greatly altered by the addition of moderate quantities of acidic or basic compounds.

Carbonate rock-A rock, such as limestone or dolomite, consisting chiefly of carbonate minerals.

Cataloging unit (hydrologic) - A geographic area representing part or all of a surface drainage basin, a combination of drainage basins, or a distinct hydrologic feature. It is the fourth-level classification of hydrologic units used by the U.S. Geological Survey. See also Water-resources region; waterresources subregion.

Cation-A positively charged ion. See also Anion; Ion.

Channel scour-The process of erosion by flowing water and sediment on a stream channel; results in the removal of mud, silt, and sand on the outside curve of a stream bend and the bed material of a stream channel.

Coliform bacteria - Group of several types of bacteria that are found in the alimentary tract of warmblooded animals. The bacteria commonly are used as an indicator of animal and fecal contamination of water. See also Bacteria.

Commercial water use-Water for motels, hotels, restaurants, office buildings, commercial facilities, and civilian and military institutions. The water may be obtained from a public supply or be selfsupplied. See also Public supply.

Composited water sample-Sample that results from the combining of individual samples collected at various times before chemical analysis.

Concentration-The ratio of the quantity of any substance present in a sample of a given volume or a given weight compared to the volume or weight of the sample.

Confluence-The flowing together of two or more streams; the place where a tributary joins the main stream.

Constituent-A component such as a chemical species or biological population whose magnitude in water, sediment, biota, or other matrix is determined by an analytical method.

Consumptive use - That part of water withdrawn that is evaporated, transpired, incorporated into products or crops, consumed by humans or livestock, or otherwise removed from the immediate water environment. Sometimes called water consumed.

Contamination - Change of water quality by the addition of constituents as a result of human activity or natural processes.

Contributing area-The area in a drainage basin that contributes water to streamflow or recharge to an aquifer.

Correlation coefficient-A statistic that can be used to measure the strength of a relation between two variables.

Crop out-To appear exposed and visible at the Earth's surface. See also Outcrop.

Crystalline rock-An igneous or metamorphic rock consisting wholly of relatively large mineral grains.

Cubic feet per second $\left(\mathrm{ft}^{3} / \mathrm{s}\right)$ - A unit of measurement for water discharge; 1 cubic foot per second is equal to the discharge of a stream at a rectangular cross section 1 foot wide and 1 foot deep, flowing at an average velocity of 1 foot per second. Equivalent to 448.8 gallons per minute.

Degraded-Condition of the quality of water that has been made unfit for some specified purpose.

Designated use-The use that a State determines a waterbody should have, such as the support of aquatic life and recreation in and on the water, as required under section 305(b) of the Clean Water Act.

Discharge (hydraulics) — Rate of flow, especially fluid flow; a volume of fluid passing a point per unit time, commonly expressed as cubic feet per second, million gallons per day, or gallons per minute.

Dissolved oxygen-Oxygen dissolved in water; one of the most important indicators of the condition of a waterbody. Dissolved oxygen is necessary for the life of fish and most other aquatic organisms.

Dissolved solids-Minerals and organic matter dissolved in water.

Domestic water use-Water used for household purposes, such as drinking, food preparation, bathing, washing clothes and dishes, flushing toilets, and watering lawns and gardens. Also called residential water use. The water can be obtained from a public supply or be self-supplied. See also Public supply.

Drainage basin-Land area drained by a river.

Dry deposition-See Atmospheric deposition.

Ecological-Relating to the environment of living things or to the pattern of relations between living things and their environment.

Ecosystem-A community of organisms considered together with the nonliving factors of its environment.

Effluent-A liquid that flows forth or emanates, such as a stream that flows from a lake or liquid waste that flows from a factory or sewage-treatment plant.

Enterococcal bacteria-See Bacteria.

Environmental indicators-Standard descriptors of environmental conditions, such as individual chemical or bacterial concentrations, or indices of biological community health.

Ephemeral stream-A stream or part of a stream that flows in direct response to precipitation and that receives little or no water from springs, melting snow, or other sources. Its channel is above the water table most of the time.

Erosion-Process whereby materials of the Earth's crust are loosened, dissolved, or worn away and simultaneously moved from one place to another.

Ester-Compound formed by the elimination of water and the bonding of an alcohol and an organic acid. See Organophosphate.

Estuary-Area where the current of a stream meets the ocean and where tidal effects are evident; an arm of the ocean at the lower end of a river.

Eutrophication-Process by which water becomes enriched with plant nutrients, most commonly phosphorus and nitrogen.

Evaporation-Process by which water is changed from 
the liquid to the vapor state. See also Evapotranspiration; Transpiration.

Evaporites-A class of sedimentary rocks composed primarily of minerals precipitated from a saline solution as a result of extensive or total evaporation of water.

Evapotranspiration-A collective term that includes water discharged to the atmosphere as a result of evaporation from the soil and surface waterbodies and by plant transpiration. See also Evaporation; Transpiration.

Fall line-Imaginary line or transition zone that marks the boundary between the ancient, resistant crystalline rocks of the Piedmont province of the Appalachian Mountains and the younger, softer sediments of the Atlantic Coastal Plain province in the Eastern United States. Along rivers, this line commonly is indicated by waterfalls.

Fecal coliform bacteria--See Bacteria.

Fecal streptococcal bacteria-See Bacteria.

Fishery-A place for harvesting fish or other aquatic life.

Flood plain-A strip of relatively flat-lying land that borders a stream and is underlain by sediment carried by the stream. Most flood plains are inundated by periodic floods.

Flow-Movement of a fluid.

Fluvial-Pertaining to a river or stream.

Fossil fuel-Coal, oil, or natural gas.

Frequency distribution (statistics) - A systematic arrangement of data that exhibits the division of the values of the variable into classes and that indicates the frequencies or relative frequencies that correspond to each of the classes. See also Normal distribution.

Freshwater-Water that contains less than $1,000 \mathrm{mg} / \mathrm{L}$ (milligrams per liter) of dissolved solids; generally more than $500 \mathrm{mg} / \mathrm{L}$ is considered undesirable for drinking and many industrial uses.

Geographic information system (GIS)-An organized collection of computer hardware, software, geographic data, and personnel designed to efficiently collect, store, update, manipulate, analyze, and display all forms of geographically referenced information.

Geothermal spring - Spring that acquires heat from the Earth during deep circulation along faults or fractures in the Earth's crust.

Glacial drift-A general term applied to all materials transported by a glacier and deposited directly by the ice or by running water emanating from a glacier. Includes unstratified material and stratified material. See also Moraine; Outwash; Till.

Glacial lake-A lake that derives its water, or much of its water, from the melting of glacial ice; also a lake that occupies a basin produced by glacial erosion.

Glacier-dammed lake - A lake maintained by the edge or front of a glacier that blocks the natural drainage.

Glacier-fed river-A river that receives its flow, or most of its flow, from the melting of glacial ice.

Glaciolacustrine deposits-Fine-grained sediments, such as clay, that are derived from or deposited in glacial lakes.

Ground water-In the broadest sense, all subsurface water, as distinct from surface water; as more commonly used, that part of the subsurface water in the saturated zone. See also Surface water.

Habitat modification-Change in the physical environment in which a plant or animal lives.

Hardness (water) - A property of water that causes the formation of an insoluble residue when the water is used with soap and a scale in vessels in which water has been allowed to evaporate. Due primarily to the presence of ions of calcium and magnesium. Generally expressed as milligrams per liter as calcium carbonate $\left(\mathrm{CaCO}_{3}\right)$. A general hardness scale is-

Description $\quad \begin{gathered}\text { Milligrams per liter as } \\ \text { calcium carbonate }\end{gathered}$

Soft ............................................. $0-60$

Moderately hard .........................61-120

Hard .......................................... 121-180

Very hard .......................... More than 180

Headwaters-The source, or upper part, of a stream.

Health advisory-As related to drinking water, a document that establishes nonregulatory levels of contaminants and which may be used for guidance in the absence of regulatory limits; the advisory includes acceptable contaminant concentrations in drinking water for different exposure periods. See also Maximum contaminant level; Secondary maximum contaminant level.

Heavy metals-Metallic elements, such as zinc, copper, and lead, that have atomic numbers greater than 36 in Group III through V (including transition elements) of the Periodic Table; the importance of these elements is their generally low solubility but possibly high toxicity in waters.

Herbicide-Type of pesticide designed to kill plants.

Humid-Climate where the annual precipitation is greater than 20 inches.

Hydroelectric power-Electrical energy generated by means of a power generator coupled to a turbine through which water passes.

Hydrologic modification-Change in the occurrence, circulation, distribution, or properties of water.

Hydrolyzates-A class of fine-grained sedimentary rocks, such as shale or siltstone, that contain some unaltered particles but also usually have high proportions of slightly soluble alteration products, such as clay minerals, formed during weathering of resistant silicate minerals.

Igneous rock-A rock that solidified from molten or partly molten material; igneous rocks constitute one of the three main classes into which all rocks are divided. See also Metamorphic rock; Sedimentary rock.

Impaired-Condition of the quality of water that has been adversely affected for a specific water use, such as drinking or swimming, by contamination or pollution.

Industrial water use - Water used for industrial purposes 
such as fabricating, processing, washing, and cooling; includes such industries as steel, chemical and allied products, paper and allied products, mining, and petroleum refining. The water can be obtained from a public supply or be self-supplied. See also Public supply.

Inorganic compound-A compound that contains no carbon.

Insecticide-Type of pesticide designed to kill insects. Instream use-Water use taking place within the stream channel. Examples are hydroelectric power generation, navigation, fish propagation, and recreational activities. Also called nonwithdrawal use and in-channel use.

Intermittent stream-A stream that flows only when it receives water from rainfall runoff or springs, or from some surface source such as melting snow.

Interquartile range-The range in values between the 25 th and the 75th percentile. See also Percentile.

Intrusive rock-A rock that was emplaced as magma in preexisting rock,

Ion-An atom that has lost or gained one or more electrons and has acquired an electrical charge. See also Anion; Cation.

Irrigated land-Land receiving artificially applied water for crops and pasture.

Irrigation - Generally, the controlled application of water to arable lands to supply water requirements of crops not satisfied by rainfall. See also Irrigation water use.

Irrigation return flow-The part of artificially applied water that is not consumed by evapotranspiration and that migrates to an aquifer or surface waterbody. See also Return flow.

Irrigation water use-Artificial application of water to lands to assist in the growing of crops and pastures or to maintain vegetative growth on recreational lands such as parks and golf courses. See also Irrigation.

Irrigation withdrawals - Withdrawal of water for irrigation use.

Islet-A small island.

Karst-A type of topography that results from dissolution and collapse of limestone, dolomite, or gypsum beds and is characterized by closed depressions or sinkholes, caves, and underground drainage.

Lacustrine-Pertaining to, produced by, or formed in a lake.

Lake-outburst flood-A sudden release of water from a lake, sometimes resulting in a catastrophic flood.

Lakebed-The bottom of a lake.

Land cover-The plant growth characteristic of an area.

Langelier saturation index-A commonly used index of the corrosive potential of water, based on the degree of saturation with respect to calcium carbonate.

Lava flow-A lateral, surficial outpouring of molten rock from a vent or fissure.

Leachate-A solution obtained by leaching.

Leeward-Downwind or away from the wind; the side or slope sheltered or located away from the direc- tion from which the wind is blowing. See also Windward.

Lithosphere-The solid portion of the Earth.

Livestock water use-Water for livestock watering, feed lots, dairy operations, aquaculture, and other onfarm needs. Livestock includes cattle, sheep, goats, hogs, and poultry; also animal specialties such as horses, rabbits, bees, pets, fur-bearing animals in captivity, and fish (or other aquatic fauna) in captivity.

Load-Material that is moved or carried by streams, reported as the weight of the material transported during a specified time period, such as tons per year.

Loess deposit-A widespread, homogeneous, commonly nonstratified, porous, friable, slightly coherent, usually very calcareous, fine-grained blanket soil deposit consisting predominantly of silt with some clay to fine sand.

LOWESS-A mathematical method for computing a smoothed center line whose direction and slope vary locally in response to data on a graph. Derived from the term "LOcally WEighted Scatter plot Smoothing." See also Smoothed-line scatter plot.

Main stem-The main trunk of a river or stream.

Marshland-A wetland that is intermittently exposed to flooding or is permanently flooded and that contains dense stands of emergent, non-woody, hydrophytic vegetation, which is vegetation that grows in water or on a substrate that is at least periodically deficient in oxygen.

Maximum contaminant level (MCL)-Maximum permissible level of a contaminant in water that is delivered to any user of a public water system, established by a regulatory agency such as the U.S. Environmental Protection Agency. These contaminants affect the health of people drinking the water; therefore, the levels are enforceable. See also Health advisory; Secondary maximum contaminant level.

Mean-See Average.

Median-The middle item when items are arranged according to rank.

Meltwater-Water derived from the melting of snow or ice.

Metamorphic rock-Any rock derived from preexisting rocks in response to marked changes in temperature, pressure, shearing stress, and chemical environment at depth in the Earth's crust. Metamorphic rocks constitute one of the three main classes into which all rocks are divided. See also Igneous rock; Sedimentary rock.

Million gallons per day (Mgal/d) — A rate of use or flow of water.

Minimum reporting limit (MRL) - The lowest measured concentration of a constituent that can be reliably reported using a given analytical method.

Mining water use--Water use for the extraction and processing of naturally occurring mineral-solids, such as coal and ores; liquids, such as crude petroleum; and gases, such as natural gas. Also includes uses associated with quarrying, well operations (de- 
watering), milling (crushing, screening, washing, flotation, and so forth), and other preparations customarily done at the mine site or as part of a mining activity.

Monitoring station-A site on a stream, canal, lake, or reservoir used to systematically observe the chemical quality and discharge or gage height of water, and that has a gage, recorder, or similar equipment.

Monotonic (statistics)-Increasing or decreasing, but not necessarily straight-line relation between variables.

Moraine-An accumulation of earth and stones carried and deposited by a glacier at its sides or terminus.

Mouth-The place where a stream discharges to a larger stream, a lake, or the sea.

Muskeg-Large expanses of peatlands or bogs.

NASQAN-National Stream Water Quality Accounting Network of the U.S. Geological Survey.

Navigable water-In the context of the Clean Water Act, all surface water.

NCBP - National Contaminant Biomonitoring Program of the U.S. Fish and Wildlife Service.

Noncontact water recreation-Recreational activities, such as fishing and boating, that do not result in direct contact with a waterbody. See also Primary contact water recreation.

Nonparametric tests (statistics)-Tests not requiring that data follow a normal distribution. Useful for skewed data and data having outliers. See also Outlier.

Nonpoint source of pollution-Pollution from broad areas, such as areas of fertilizer and pesticide application and leaking sewer systems, rather than from discrete points. See also Point source of pollution.

Normal distribution (statistics)-A frequency distribution that is symmetrical and follows a pattern represented by a particular mathematical equation. See also Frequency distribution.

Nutrient-Any inorganic or organic compound needed to sustain plant life.

Offstream use-Water withdrawn or diverted from a ground- or surface-water source for public-water supply, industry, irrigation, livestock, thermoelectric power generation, and other uses. Sometimes called off-channel use or withdrawal use.

Organic chemicals-See Organic material.

Organic enrichment-Increase in the organic content of water.

Organic material-Chemical compounds containing carbon. Other components include hydrogen, oxygen, chlorine, nitrogen, and other elements.

Organochlorine-Manmade organic compounds, such as pesticides and some solvents containing chlorine.

Organophosphate-A soluble fertilize material made up of organic phosphate esters, such as glucose, glycol, or sorbital.

Outcrop-That part of a geologic unit exposed at the surface of the Earth.

Outlier (statistics) - A data value of considerably higher or lower magnitude than most of the data.

Outwash-Glacially transported sediment deposited by meltwater streams beyond the edge of active glacier ice.

Parametric test (statistics) — Tests that assume that data follow a normal distribution.

Pathogen-Any living organism that causes disease.

Pathogenic organism-An organism capable of producing disease.

PCB-Polychlorinated biphenyl, a persistent, toxic, chemical contaminant of water, manufacture of which was discontinued in the United States in 1976.

Percentile-A value below which lies a given percentage of observations.

Percolation pond-A pond used to artificially recharge a ground-water system.

Perennial stream-A stream that normally has water in its channel at all times.

Pesticide-Any substance, organic or inorganic, used to kill plant or animal pests; major categories of pesticides include herbicides and insecticides.

$\mathrm{pH}$ - The logarithm of the reciprocal of the hydrogenion concentration of a solution; a measure of the acidity ( $\mathrm{pH}$ less than 7$)$ or alkalinity $(\mathrm{pH}$ greater than 7) of a solution; a pH of 7 is neutral.

Photosynthesis-Synthesis of compounds with the aid of light.

Physiographic province-A region in which the relief features or landforms differs significantly from that of adjacent regions.

Physiography — Study of the landforms of the Earth's surface.

Placer mining-The extraction and concentration of heavy metals or minerals from rock-debris deposits by various methods, generally using moving water.

Point source of pollution-Pollution originating from any discrete source, such as the outflow from a pipe, ditch, tunnel, well, concentrated animal-feeding operation, or floating craft. See also Nonpoint source of pollution.

Pollution-Presence of any substance in water or addition of any substance to water that is or could become injurious to the public health, safety, or welfare; or that is or could become injurious to domestic, commercial, industrial, agriculture, or other uses being made of the water.

Potable water-Water that is safe and palatable for human consumption.

Precipitates-A class of sedimentary rocks, such as limestone and dolomite, that is predominantly composed of calcium carbonate or calcium plus magnesium carbonate, respectively.

Precipitation-Any or all of the forms of water particles, such as rain, snow, hail, and sleet, that fall from the atmosphere and reach the ground.

Precision-The degree of agreement or uniformity of repeated measurements.

Primary contact water recreation-Activities, such as swimming, diving, water skiing, and surfing, in which there is prolonged and intimate contact with water and in which there is considerable risk of in- 
gesting water in quantities sufficient to pose a significant health hazard.

Pristine-Belonging to the earliest condition of the quality of a waterbody; unaffected by human activities.

Property of water-A measured quality that defines or describes a characteristic of water, such as hardness.

Public supply - Water withdrawn for all uses by public and private water suppliers and delivered to users that do not supply their own water. Water suppliers provide water for a variety of uses, such as domestic, commercial, thermoelectric power, industrial, and public water use. See also Commercial water use; Domestic water use; Industrial water use; Public water use; Thermoelectric power water use.

Public water use-Water supplied from a public water supply and used for such purposes as firefighting, street washing, and municipal parks and swimming pools. See also Public supply.

Quality assurance-Programs and sets of procedures, including but not limited to quality-control procedures, that are necessary to assure product quality or data reliability.

Quality control-Procedures used to regulate measurements and produce data that meet the needs of the user.

Rainfall-Quantity of water that falls as rain only. Not synonymous with precipitation.

Rating curve-A graph showing the relation between gage height and the quantity of water (volume per unit of time) flowing in a stream channel.

Reach-A continuous part of a stream between two specified points.

Reef-A ridgelike or moundlike structure, layered or massive, built of the remains of sedentary calcareous organisms, especially corals, that occurs at or near the surface of the sea.

Regulation of a stream-Artificial manipulation of the flow of a stream.

Resistates-A class of sedimentary rocks composed of chemically resistant minerals.

Resource extraction-The process of separation of a valuable metal or mineral from the total mined mass of an ore occurrence.

Return flow-Amount of water that reaches a groundor surface-water source after release from the point of use and thus becomes available for further use. Also called return water. See also Irrigation return flow.

River basin-See Drainage basin.

River mile-_See Stream mile.

Runoff-That part of precipitation that appears in surface streams. It is equivalent to streamflow unaffected by artificial diversions, storage, or other human works in or on the stream channels.

Saline water-Water that generally is considered unsuitable for human consumption or for irrigation because of its high dissolved-solids concentration. Generally expressed as milligrams per liter $(\mathrm{mg} / \mathrm{L})$ of dissolved solids. Sea water generally is considered to contain more than $35,000 \mathrm{mg} / \mathrm{L}$ of dissolved solids. A general salinity scale is-

\begin{tabular}{|c|c|}
\hline Description & Dissolved solids, \\
\hline \multicolumn{2}{|r|}{ in milligrams per il } \\
\hline Slightly ... & ....... 1,000-3,000 \\
\hline Moderatel & $\ldots .3,000-10,000$ \\
\hline Very .......... & .... $10,000-35,000$ \\
\hline Brine .... & More than 35,000 \\
\hline
\end{tabular}

Salinity-See Dissolved solids; Saline water.

Scatter plot-A graph in which data are defined by two variables $(x, y)$ that are plotted to illustrate the relation between the variables.

Sea water $\rightarrow$ See Saline water.

Seasonal Kendall test (statistics) - A nonparametric test to determine if a trend can be detected against the background variability of a set of data. It also allows for seasonal differences in data values.

Secondary maximum contaminant level (SMCL) Maximum recommended level of a contaminant in water that is delivered to any user of a public water system. These contaminants affect the esthetic quality of the water such as odor or appearance; therefore, the levels are intended as guidelines. See also Health advisory; Maximum contaminant level.

Sediment-Particles, derived from rocks or biological materials, that have been transported by a fluid or other natural processes.

Sedimentary rock-Rock resulting from the accumulation of sediment particles in layers either mechanically, by precipitation from solution, or from the remains or secretions of plants and animals. Sedimentary rocks constitute one of the three main classes into which all rocks are divided. See also Igneous rocks; Metamorphic rocks.

Self-supplied water-Water withdrawn from a surfaceor ground-water source by a user and not obtained from a public supply.

Semiarid - Climate where the annual precipitation is 1020 inches and sparse grasses are the characteristic vegetation.

Shoal-A relatively shallow place in a stream, lake, or sea.

Shrubland-Land covered predominantly with shrubs.

Siltation-The deposition or accumulation of silt (or small-grained material) in a body of water.

Silviculture-A branch of forestry dealing with the development and care of forest.

Smoothed-line scatter plot-A scatter plot that shows the central pattern of the relation between two variables. See also LOWESS.

Sodium-adsorption ratio-Index of the potential for sodium ions in water to be toxic to plants, especially crops, based on the ratio of their concentration to that of other ions.

Specific conductance-A measure of the ability of a sample of water to conduct electricity.

Spoil piles-See Spoil.

Spoil-Non-ore or other waste material removed in mining, quarrying, dredging, or excavating.

Stage-discharge curve-See Rating curve.

Standard deviation (statistics)-A measure of dispersion 
in a frequency distribution, which is equal to the square root of the mean of the squares of the deviations from the arithmetic mean of the distribution. See also Frequency distribution.

Statistics-The science that deals with uncertainty. It strives to separate patterns, such as a change in some measured variable over time, from the uncertainty inherent in all observations of natural systems.

Stream mile-A distance of 1 mile along a line connecting the midpoints of the channel of a stream.

Strip mining-See Surface mining.

Subhumid-Climate that is transitional between semiarid and humid.

Supersaturate-To increase beyond saturation.

Surface mining-Mining method whereby the overlying materials are removed to expose the ore for extraction.

Surface water-An open body of water, such as a stream or a lake. See also Ground water.

Suspended sediment-Sediment that is transported in suspension by a stream, in contrast to sediment that moves on or near the streambed.

Swamp-A forested wetland that has standing water during most or all of the growing season.

Tau (statistics)-A nonparametric correlation coefficient that measures the strength of any monotonic relation between variables; used in the seasonal Kendall test. See also Seasonal Kendall test.

Terrain-Physical features of a tract of land.

Terrane-Area or surface over which a particular rock type or group of rock types is prevalent.

Thermoelectric power water use-Water used in the process of the generation of thermoelectric power. The water can be obtained from a public supply or be self-supplied. See also Public supply.

Thermoelectric power-Electrical power generated by using fossil-fuel (coal, oil, or natural gas), geothermal, or nuclear energy.

Till-Predominantly unsorted and unstratified drift, deposited directly by and beneath a glacier without subsequent reworking by meltwater, and consisting of a heterogeneous mixture of clay, silt, sand, gravel, and boulders ranging widely in size and shape.

Titration-A method for determining volumetrically the concentration of a substance in solution by adding a standard solution of known volume and strength until a reaction is complete, usually as indicated by a change in color due to the presence of another chemical that acts as an indicator.

Trace element-A chemical element dissolved in water in minute quantities, always or almost always in concentrations less than 1 milligram of trace element in 1 liter of water.

Trace metal-A trace element that is a metal. See also Trace element.

Transpiration-Process by which water passes from the soil through living plants and into the atmosphere as vapor discharged from the plant surface. See also Evaporation; Evapotranspiration.

Transport-Movement of stream load. See also Load.
Trend analysis - The determination of whether values of a particular variable have changed over time.

Trend line-A line showing the tendency of data to increase or decrease over a period of time.

Tundra-A treeless, level or gently undulating plain, characteristic of arctic and subarctic regions, that generally has a marshy surface supporting mosses, lichens, and numerous dwarf woody plants, underlain by a dark mucky soil and permafrost (perennially frozen ground).

Turbidity-The opaqueness or reduced clarity of a fluid due to the presence of suspended matter.

Volcanic-Pertaining to the activities, structures, or rock types of a volcano.

Vollenwider index - Index of the potential eutrophication of a lake or a reservoir, based on the quantity of total phosphorus entering the waterbody per unit time, and the depth and volume of the waterbody. See also Eutrophication.

Wastewater-Water that contains dissolved or suspended solids as a result of human use.

Water use-As initially used in 1950 in the U.S. Geological Survey (USGS) 5-year water-use circulars, this term meant withdrawals of water; subsequently redefined to include consumptive use of water. With the beginning of the USGS National Water-Use Information Program (1977), the term was further defined to include return flow and offstream and instream uses.

Water year-A continuous 12-month period identified by the calendar year in which it ends, selected to present data relative to hydrologic or meteorologic phenomena during which a complete annual hydrologic cycle normally occurs. The water year used by the U.S. Geological Survey is the 12 months from October 1 through September 30.

Water-quality criteria - Limits on the concentrations of specific contaminants that can exist in the water without harming human and aquatic life. These limits are established by the U.S. Environmental Protection Agency (EPA), and States adopt these criteria or develop their own criteria subject to approval by the EPA.

Water-quality standards-Standards established by States based on a combination of the designated uses of waterbodies, State water-quality criteria, and a Federal antidegradation policy, which states that waterbodies will not be allowed to degrade from a level of water quality that protects their uses. Water-quality standards are subject to U.S. Environmental Protection Agency approval.

Water-quality-limited waterbodies-Waterbodies that will not meet State water-quality standards after implementation of nationally consistent discharge limits for individual pollutants in industrial discharges and sewage-treatment plants. These waterbodies could require additional control of discharges.

Water-resources region-Natural drainage basin or hydrologic area that contains either the drainage area of a major river or the combined drainage areas of 
a series of rivers. In the United States, there are 21 regions of which 18 are in the conterminous United States, and one each in Alaska, Hawaii, and the Caribbean. It is the first-level classification of hydrologic units used by the U.S. Geological Survey. See also Cataloging unit (hydrologic); Waterresources subregion.

Water-resources subregion-The 21 water-resources regions of the United States are subdivided into 222 subregions. Each subregion includes the area drained by a river system, a reach of river and its tributaries in that reach, a closed basin(s), or a group of streams forming a coastal drainage area. It is the second-level classification of hydrologic units used by the U.S. Geological Survey. See also Cataloging unit (hydrologic); Water-resources region.

Weathering-Process whereby earthy or rocky materials on exposure to atmospheric agents at or near the Earth's surface are changed in color, texture, composition, firmness, or form, with little or no trans- port of the loosened or altered material.

Wet deposition-See Atmospheric deposition.

Wetlands-Lands that are inundated or saturated by surface or ground water at a frequency and duration sufficient to support, and that under normal circumstances do support, a prevalence of vegetation typically adapted for life in saturated soil conditions.

Whiskers (statistics)-Lines on a box plot extending above or below the box representing values above the 75th percentile and below the 25 th percentile. See also Box plot; Percentile.

Windward-Upwind or facing the wind; the side or slope exposed or located toward the direction from which the wind is blowing. See also Leeward.

Withdrawals-Water removed from the ground or diverted from a surface-water source for use.

Yield-The weight of material transported during any given time divided by unit drainage area, such as tons per year per square mile. 


\section{WATER-QUANTITY EQUIVALENTS AND CONVERSION FACTORS}

This water-quantity equivalents and conversion factors list is for those interested in converting units in reports that contain data on water-resources availability, supply, and use. The right-hand column includes units expressed in two systems-U.S. Customary and International System (metric). Units, which are written in abbreviated form below, are spelled out in parentheses the first time that they appear.

To convert from the unit in the left-hand column to that in the right, multiply by the number in the right-hand column. Most of the quantities listed were rounded to five significant figures. However, for many purposes, the first two or three significant figures are adequate for determining many water-quantity relations, such as general comparisons of water availability with water use or calculations in which the accuracy of the original data itself does not justify more than three significant figures. Quantities shown in italics are exact equivalents-no rounding was necessary. Regarding length of time, each calendar year is assumed (for this list) to consist of 365 days.

The data in this list were adapted largely from information found in the following publications:

Chisholm, L.J., 1967, Units of weight and measure-International (Metric) and U.S. Customary: U.S. National Bureau of Standards Miscellaneous Publication 286, 251 p.

U.S.Geological Survey, 1919, Hydraulic conversion tables and convenient equivalents (2d ed.): U.S. Geological Survey WaterSupply Paper 425-C, p. C71-C94.

\begin{tabular}{|c|c|c|}
\hline U.S. CUSTOMARY & & U.S.CUSTOMARY OR METRIC \\
\hline & LENGTH & \\
\hline 1 in (inch) & $=$ & $25.4 \mathrm{~mm}$ (millimeters) \\
\hline $1 \mathrm{ft}$ (foot) & $=$ & $0.3048 \mathrm{~m}$ (meter) \\
\hline \multirow[t]{3}{*}{$1 \mathrm{mi}$ (mile, statute) } & $\begin{array}{l}= \\
=\end{array}$ & $\begin{array}{l}5,280 . \mathrm{ft} \\
1,609.344 \mathrm{~m}\end{array}$ \\
\hline & $=$ & $1.609344 \mathrm{~km}$ (kilometers) \\
\hline & AREA & \\
\hline $1 \mathrm{ft}^{2}$ (square foot) & $=$ & $0.09290304 \mathrm{~m}^{2}$ (square meter) \\
\hline 1 acre & $=$ & $43,560 . \mathrm{ft}^{2}$ \\
\hline & $=$ & $0.0015625 \mathrm{mi}^{2}$ (square mile) \\
\hline & $=$ & 0.40469 ha (hectare) \\
\hline & $=$ & $4,046.9 \mathrm{~m}^{2}$ \\
\hline $1 \mathrm{mi}^{2}$ & $=$ & 640. acres \\
\hline & & $259.00 \mathrm{ha}$ \\
\hline
\end{tabular}

VOLUME OR CAPACITY

1 qt (quart, U.S.)

1 gal (gallon, U.S.)

$1 \mathrm{Mgal}$ (million gallons)

$1 \mathrm{ft}^{3}$

$1 \mathrm{Mft}^{3}$
1 acre-ft
(volume of water $1 \mathrm{ft}$ deep covering
an area of 1 acre)

$1 \mathrm{mi}^{3}$ (cubic mile) (liquid measure)

$\begin{array}{cc}= & 0.94635 \mathrm{~L} \text { (liter) } \\ = & 231 . \mathrm{in}^{3} \text { (cubic inches) } \\ = & 0.13368 \mathrm{ft}^{3} \text { (cubic foot) } \\ = & 3.7854 \mathrm{~L} \\ = & 0.0037854 \mathrm{~m}^{3} \text { (cubic meter) } \\ = & 0.13368 \mathrm{Mft}^{3} \text { (million cubic feet) } \\ = & 3.0689 \text { acre-ft (acre-feet) } \\ = & 3,785.4 \mathrm{~m}^{3} \\ = & 1,728 . \mathrm{in}^{3} \\ = & 7.4805 \text { gal } \\ = & 28.317 \mathrm{~L} \\ = & 0.028317 \mathrm{~m}^{3} \\ = & 28,317 . \mathrm{m}^{3} \\ = & 43,560 . \mathrm{ft}^{3} \\ & \\ = & \\ = & 1,233.5 \mathrm{~m}^{3} \\ = & 1,101.1 \mathrm{billion}^{3} \text { gal } \\ = & 147.20 \mathrm{billion} \mathrm{ft}^{3} \\ = & 3.3792 \mathrm{million}^{3} \text { acre-ft } \\ = & 4.1682 \mathrm{~km}^{3} \text { (cubic kilometers) }\end{array}$


SPEED

(or, when used in a vector sense, velocity)

$\begin{array}{lll}1 \mathrm{ft} / \mathrm{s} \text { (foot per second) } & = & 0.3048 \mathrm{~m} / \mathrm{s} \text { (meter per second) } \\ & = & 0.68182 \mathrm{mi} / \mathrm{hr} \text { (mile per hour) } \\ 1 \mathrm{mi} / \mathrm{hr} & = & 1.4667 \mathrm{ft} / \mathrm{s} \\ & = & 0.44704 \mathrm{~m} / \mathrm{s}\end{array}$

VOLUME PER UNIT OF TIME

(discharge, water supply, water use, and so forth)

$1 \mathrm{gal} / \mathrm{min}$ (gallon per minute)

$1 \mathrm{Mgal} / \mathrm{d}$

1 billion gal/yr (billion gallons per year)

$1 \mathrm{ft}^{3} / \mathrm{s}$

1 acre-ft/yr

1 acre-ft/d
$0.00144 \mathrm{Mgal} / \mathrm{d}$ (million gallons per day)

$0.0022280 \mathrm{ft}^{3} / \mathrm{s}$ (cubic foot per second)

0.0044192 acre-ft/d (acre-foot per day)

$3.7854 \mathrm{~L} / \mathrm{min}$ (liters per minute)

$0.063090 \mathrm{~L} / \mathrm{s}$ (liter per second)

$694.44 \mathrm{gal} / \mathrm{min}$

$1.5472 \mathrm{ft}^{3} / \mathrm{s}$

$3.0689 \mathrm{acre}-\mathrm{ft} / \mathrm{d}$

1,120.1 acre-ft/yr (acre-feet per year)

$0.043813 \mathrm{~m}^{3} / \mathrm{s}$ (cubic meter per second)

$3,785.4 \mathrm{~m}^{3} / \mathrm{d}$ (cubic meters per day)

$0.0013817 \mathrm{~km}^{3} / \mathrm{yr}$ (cubic kilometer per year)

$2.7397 \mathrm{Mgal} / \mathrm{d}$

$448.83 \mathrm{gal} / \mathrm{min}$

$0.64632 \mathrm{Mgal} / \mathrm{d}$

$1.9835 \mathrm{acre}-\mathrm{ft} / \mathrm{d}$

$723.97 \mathrm{acre}-\mathrm{ft} / \mathrm{yr}$

$28.317 \mathrm{~L} / \mathrm{s}$

$0.028317 \mathrm{~m}^{3} / \mathrm{s}$

$2,446.6 \mathrm{~m}^{3} / \mathrm{d}$

$0.00089300 \mathrm{~km}^{3} / \mathrm{yr}$

$892.74 \mathrm{gal} / \mathrm{d}$ (gallons per day)

$0.61996 \mathrm{gal} / \mathrm{min}$

$0.0013813 \mathrm{ft}^{3} / \mathrm{s}$

$3.3794 \mathrm{~m}^{3} / \mathrm{d}$

$0.50417 \mathrm{ft}^{3} / \mathrm{s}$

VOLUME, DISCHARGE, OR USE PER UNIT OF AREA

1 in of rain or runoff

$1 \mathrm{in} / \mathrm{yr}$

$1(\mathrm{Mgal} / \mathrm{d}) / \mathrm{mi}^{2}$

$1\left(\mathrm{ft}^{3} / \mathrm{s}\right) / \mathrm{mi}^{2}$
$17.379 \mathrm{Mgal} / \mathrm{mi}^{2}$ (million gallons per square mile) 27,154. gal/acre (gallons per acre)

$25,400 . \mathrm{m}^{3} / \mathrm{km}^{2}$ (cubic meters per square kilometer)

$0.047613(\mathrm{Mgal} / \mathrm{d}) / \mathrm{mi}^{2}$

$0.073668\left(\mathrm{ft}^{3} / \mathrm{s}\right) / \mathrm{mi}^{2}$

$0.00080544\left(\mathrm{~m}^{3} / \mathrm{s}\right) / \mathrm{km}^{2}$

$21.003 \mathrm{in} / \mathrm{yr}$ (inches-of rain or runoff-per year)

$13.574 \mathrm{in} / \mathrm{yr}$

$0.010933\left(\mathrm{~m}^{3} / \mathrm{s}\right) / \mathrm{km}^{2}$ (cubic meter per second per square kilometer)

\section{MASS}

(pure water in dry air)
1 gal at $15^{\circ}$ Celsius (59 ${ }^{\circ}$ Fahrenheit)
$=$
$8.3290 \mathrm{lb}$ (pounds avoirdupois)
1 gal at $4^{\circ}$ Celsius $\left(39.2{ }^{\circ}\right.$ Fahrenheit)
$=\quad 8.3359 \mathrm{lb}$
$1 \mathrm{lb}$
1 ton, short $(2,000 \mathrm{lb})$
$\begin{array}{ll}= & 0.45359 \mathrm{~kg} \text { (kilogram) } \\ = & 0.90718 \mathrm{Mg} \text { (megagram) or ton, metric }\end{array}$

Prepared by John C. Kammerer, U.S. Geological Survey 


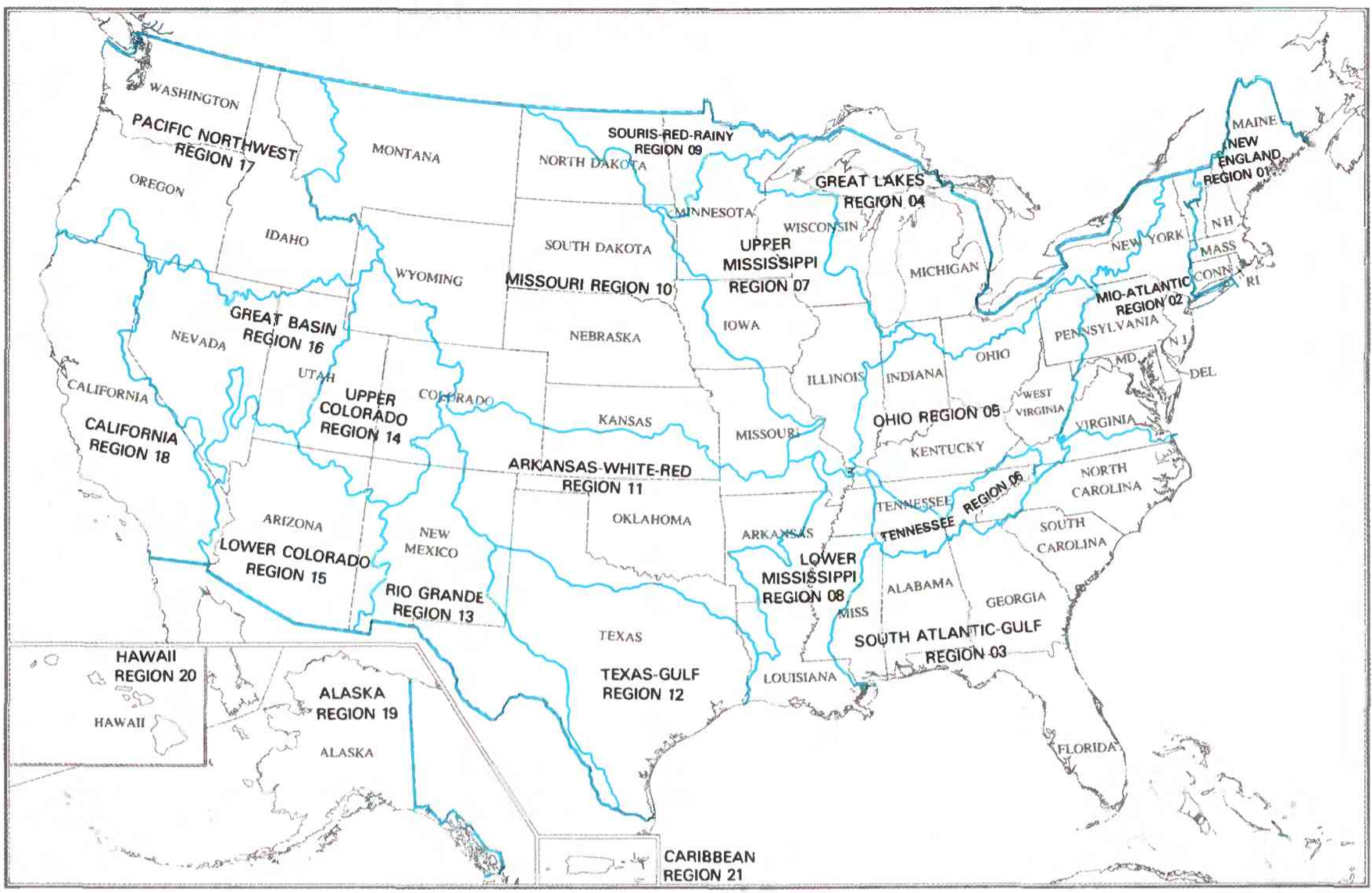

NAMES AND CODES OF THE WATER-RESOURCES REGIONS AND SUBREGIONS

NEW ENGLAND REGION (01)

0101, St. John

0102, Penobscot

0103, Kennebec

0104, Androscoggin

0105, Maine Coastal

0106, Saco

0107, Merrimack

0108, Connecticut

0109, Massachusetts-Rhode Island Coastal

0110, Connecticut Coastal

0111, St. Francois

\section{Mid-AtLANTIC REgion (02)}

0201, Richelieu

0202, Upper Hudson

0203, Lower Hudson-Long Island

0204, Delaware

0205, Susquehanna

0206, Upper Chesapeake

0207, Potomac

0208, Lower Chesapeake

\section{South AtLANTIC-GULf Region (03)}

0301, Chowan-Roanoke

0302, Neuse-Pamlico

0303, Cape Fear

0304, Pee Dee

0305, Edisto-Santee

0306, Ogeechee-Savannah

0307, Altamaha-St. Marys

0308, St. Johns

0309, Southern Florida
0310, Peace-Tampa Bay

0311, Suwannee

0312, Ochlockonee

0313, Apalachicola

0314, Choctawhatchee-Escambia

0315, Alabama

0316, Mobile-Tombigbee

0317, Pascagoula

0318, Pearl

\section{Great LAKES REgION (04)}

0401, Western Lake Superior

0402, Southern Lake Superior-Lake Superior

0403. Northwestern Lake Michigan

0404, Southwestern Lake Michigan

0405, Southeastern Lake Michigan

0406, Northeastern Lake Michigan-Lake Michigan

0407, Northwestern Lake Huron

0408, Southwestern Lake Huron-Lake Huron

0409, St. Clair-Detroit

0410, Western Lake Erie

0411, Southern Lake Erie

0412, Eastern Lake Erie-Lake Erie

0413. Southwestern Lake Ontario

0414, Southeastern Lake Ontario

0415, Northeastern Lake Ontario-Lake Ontario-St. Lawrence

\section{OHIO REgION (05)}

0501, Allegheny

0502, Monongahela

0503. Upper Ohio

0504, Muskingum
0505, Kanawha

0506, Scioto

0507, Big Sandy-Guyandotte

0508, Great Miami

0509, Middle Ohio

0510, Kentucky-Licking

0511, Green

0512, Wabash

0513, Cumberland

0514, Lower Ohio

Tennessee Region (06)

0601, Upper Tennessee

0602, Middle Tennessee-Hiwassee

0603, Middle Tennessee-Elk

0604, Lower Tennessee

UPPER MISSISSIPPI REGION (07)

0701, Mississippi Headwaters

0702, Minnesota

0703, St. Croix

0704, Upper Mississippi-Black-Root

0705, Chippewa

0706, Upper Mississippi-Maquoketa-Plum

0707. Wisconsin

0708, Upper Mississippi-lowa-SkunkWapsipinicon

0709, Rock

0710, Des Moines

0711, Upper Mississippi-Salt

0712, Upper Illinois

0713, Lower Illinois

0714, Upper Mississippi-KaskaskiaMeramec
LOWER MISSISSIPPI REGION (08)

0801, Lower Mississippi-Hatchie

0802, Lower Mississippi-St. Francis

0803, Lower Mississippi-Yazoo

0804, Lower Red-Ouachita

0805, Boeuf-Tensas

0806, Lower Mississippi-Big Black

0807, Lower Mississippi-Lake Maurepas

0808, Louisiana Coastal

0809, Lower Mississippi

Souris-RED-RAINY REgION (09)

0901, Souris

0902, Red

0903, Rainy

\section{Missourl Region (10)}

1001, Saskatchewan

1002, Missouri Headwaters

1003, Missouri-Marias

1004, Missouri-Musselshell

1005, Milk

1006, Missouri-Poplar

1007. Upper Yellowstone

1008, Big Horn

1009, Powder-Tongue

1010, Lower Yellowstone

1011, Missouri-Little Missouri

1012, Cheyenne

1013. Missouri-Oahe

1014. Missouri-White

1015. Niobrara

1016, James 


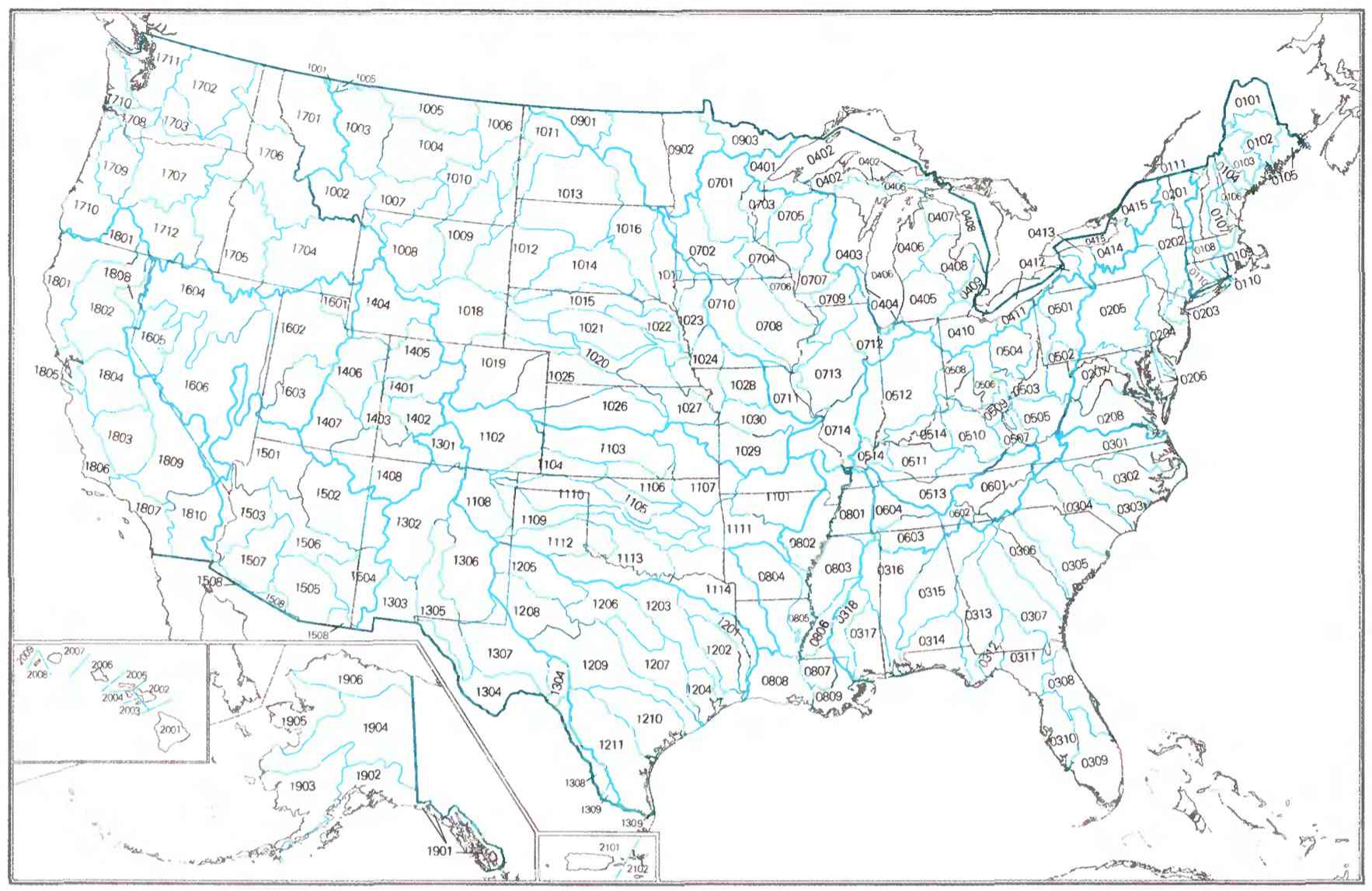

\section{NAMES AND CODES OF THE WATER-RESOURCES REGIONS AND SUBREGIONS - CONTINUED}

$\begin{array}{ll}\text { 1017, } & \text { Missouri-Big Sioux } \\ 1018, & \text { North Platte } \\ 1019, & \text { South Platte } \\ 1020, & \text { Platte } \\ 1021, & \text { Loup } \\ 1022, & \text { Elkhorn } \\ 1023 \text {, Missouri-Little Sioux } \\ 1024 \text {, Missouri-Nishnabotna } \\ 1025 \text {, Republican } \\ 1026 \text {, Smoky Hill } \\ 1027 \text {, Kansas } \\ 1028 \text {, Chariton-Grand } \\ 1029 \text {, Gasconade-Osage } \\ 1030 \text {, Lower Missouri }\end{array}$

\section{ARKANSAS-WHITE-RED REGION (11)}

1101, Upper White

1102. Upper Arkansas

1103. Middle Arkansas

1104, Upper Cimarron

1105, Lower Cimarron

1106, Arkansas-Keystone

1107, Neosho-Verdigris

1108, Upper Canadian

1109, Lower Canadian

1110, North Canadian

1111. Lower Arkansas

1112, Red Headwaters

1113, Red-Washita

1114, Red-Sulphur

TEXAs-GULF REgION (12)

1201, Sabine

1202. Neches
1203, Trinity

1204, Galveston Bay-San Jacinto

1205, Brazos Headwaters

1206. Middle Brazos

1207, Lower Brazos

1208, Upper Colorado

1209, Lower Colorado-San Bernard Coastal

1210, Central Texas Coastal

1211, Nueces-Southwestern Texas Coastal

Rio Grande REgion (13)

1301, Rio Grande Headwaters

1302. Rio Grande-Elephant Butte

1303, Rio Grande-Mimbres

1304, Rio Grande-Amistad

1305, Rio Grande Closed Basins

1306, Upper Pecos

1307. Lower Pecos

1308, Rio Grande-Falcon

1309. Lower Rio Grande

\section{UPPER COLORADO REGION (14)}

1401, Colorado Headwaters

1402. Gunnison

1403, Upper Colorado-Dolores

1404, Great Divide-Upper Green

1405. White-Yampa

1406, Lower Green

1407, Upper Colorado-Dirty Devil

1408, San Juan

LOWER Colorado Region (15)

1501, Lower Colorado-Lake Mead

1502, Little Colorado
1503, Lower Colorado

1504, Upper Gila

1505, Middle Gila

1506, Salt

1507, Lower Gila

1508, Sonora

\section{Great Basin Region (16)}

1601, Bear

1602, Great Salt Lake

1603, Escalante Desert-Sevier Lake

1604, Black Rock Desert-Humboldt

1605. Central Lahontan

1606, Central Nevada Desert Basins

\section{PACIFIC NORTHWESt REgION (17)}

1701, Kootenai-Pend Oreille-Spokane

1702. Upper Columbia

1703, Yakima

1704, Upper Snake

1705, Middle Snake

1706, Lower Snake

1707, Middle Columbia

1708, Lower Columbia

1709, Willamette

1710, Oregon-Washington Coastal

1711, Puget Sound

1712, Oregon Closed Basins

\section{CALIFORNia REgion (18)}

1801, Klamath-Northern California Coastal 1802, Sacramento
1803, Tulare-Buena Vista Lakes

1804, San Joaquin

1805, San Francisco Bay

1806, Central California Coastal

1807, Southern California Coastal

1808, North Lahontan

1809, Northern Mojave-Mono Lake

1810, Southern Mojave-Salton Sea

\section{Alaska REgion (19)}

1901, Southeast Alaska 1902, South Central Alaska

1903, Southwest Alaska

1904, Yukon

1905, Northwest Alaska

1906, Arctic Slope

\section{Hawall Region (20)}

2001, Hawaii

2002, Maui

2003, Kahoolawe

2004, Lanai

2005, Molokai

2006, Oahu

2007. Kauai

2008, Niihau

2009, Northwestern Hawaiian Islands

\section{CaribBean Region (21)}

2101, Puerto Rico

2102, Virgin Islands

2103, Caribbean Outlying Areas 


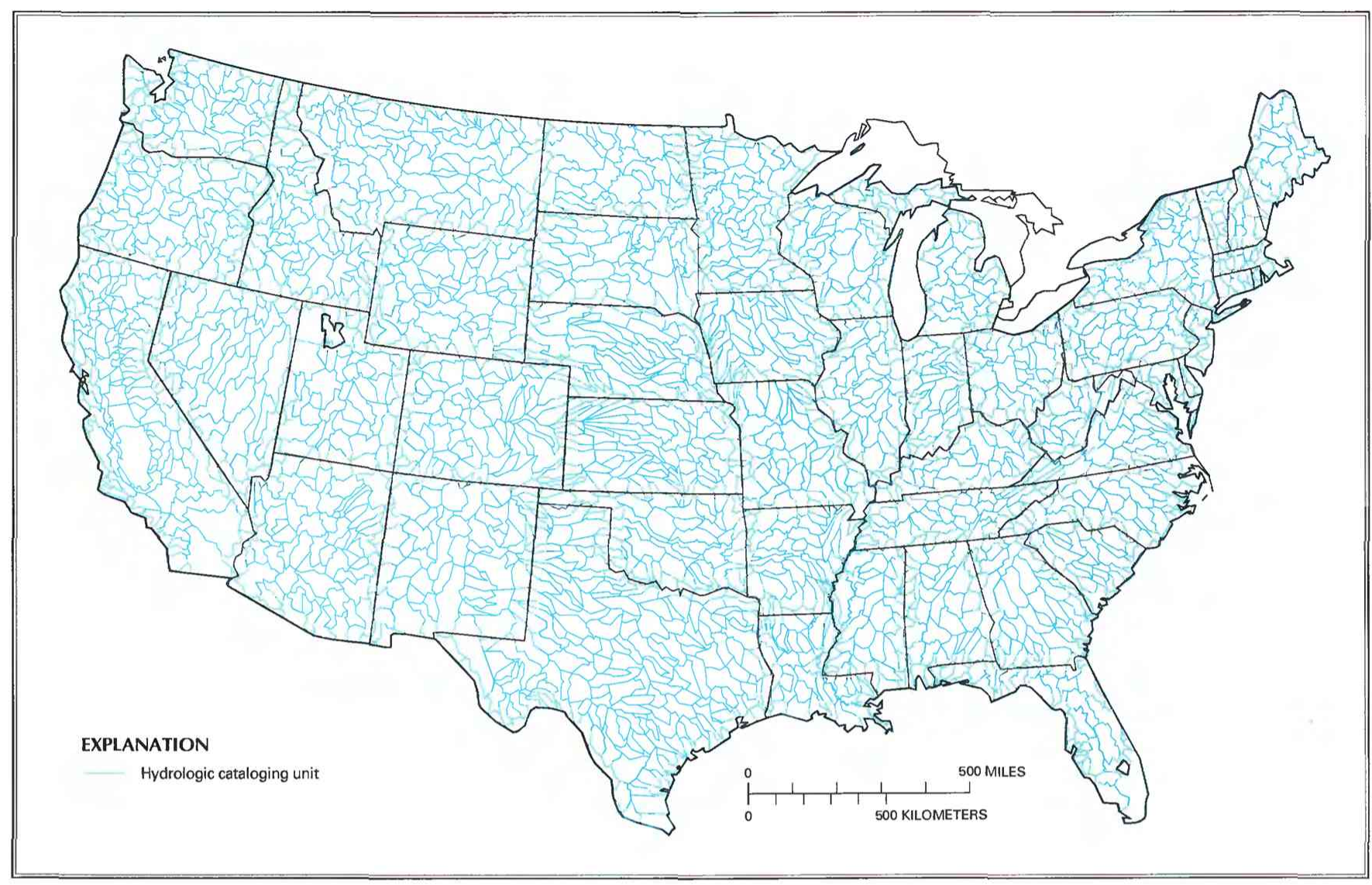

CATALOGING UNITS IN THE CONTERMINOUS UNITED STATES

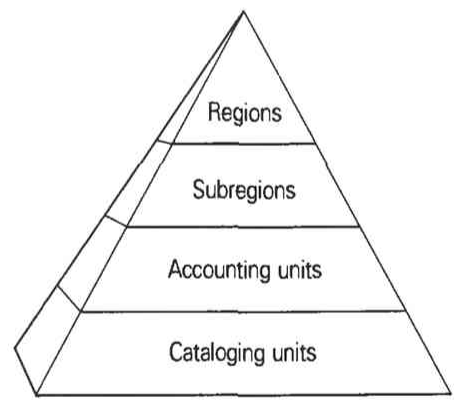

HIERACHY OF HYDROLOGIC UNITS

as used by the U.S. Geological Survey 


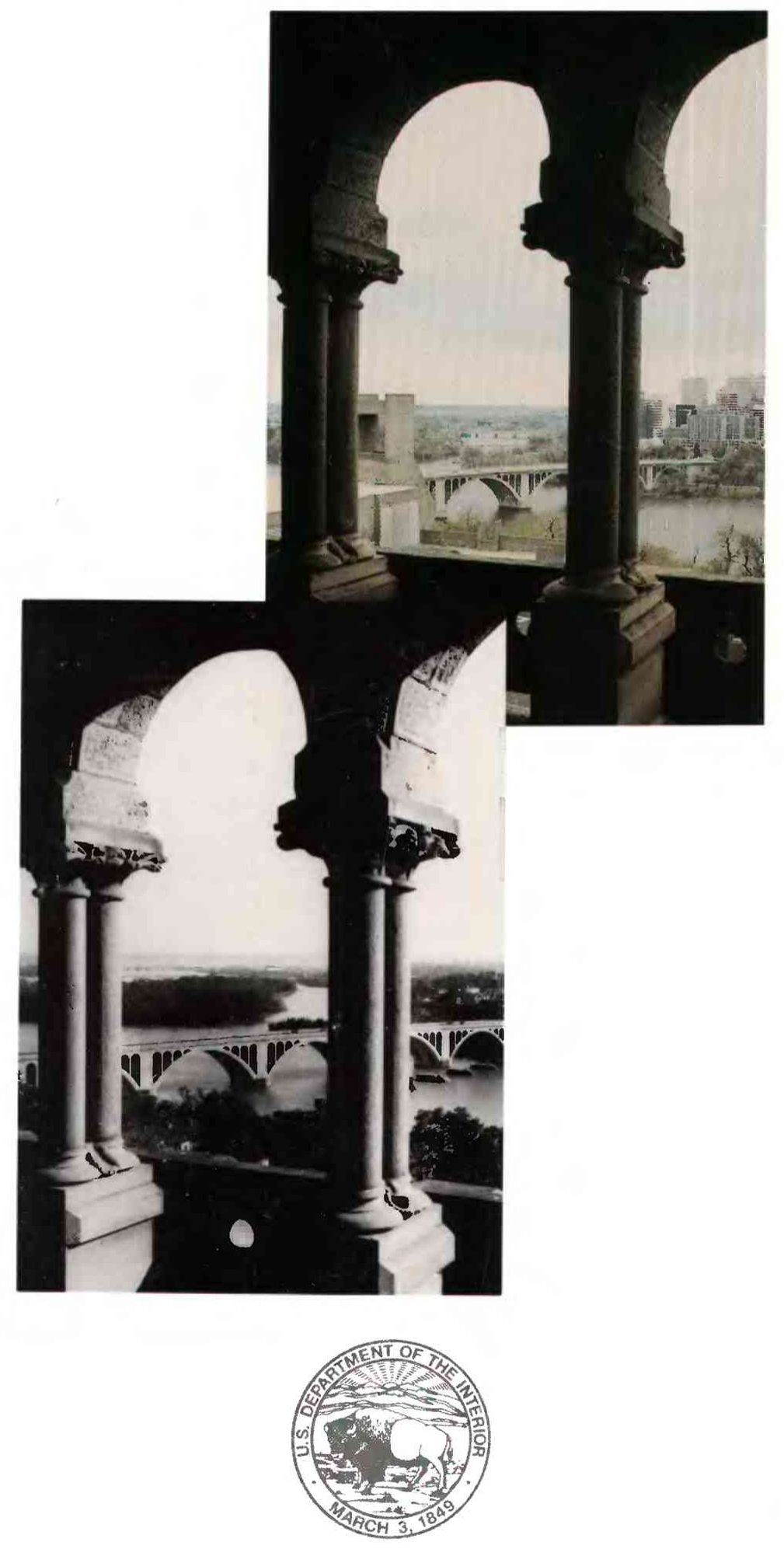

